

\section{THE CENTURY DICTIONARY}

PREPARED UNDER THE SUPERINTENDENCE OF

\section{WILLIAM DWIGHT WHITNEY, PH. D., LL. D.}

Professor of Comparative Philology and Sanskrit in Yale University

\begin{abstract}
THE plan of "The Century Dictionary" "ingeneral dictionary of the English language which shall bo serviceable for every literary and practical use ; a more complete collection of the technical terms of the various sciences, arts, trades, and professions than has yet been attempted; and the addition to the definitions proper of such related encyclopedic matter, with pictorial illustrations, as shall const a convenient book of general reforence.

About 200,000 words will be defined. The Dictionary will be a practically complete record of all the noteworthy words which have been in use since English literature has existed, especially of all that wealth of now words and of applications of old words which has sprung from the development of the thought and life of the nineteenth century. It will record not merely the written language, but the spoken language as well (that is, all important provin(in the colloquial words), and it will inelude ary) abbreviations and such foreign words and phrases as have become a familiar part of English speech.
\end{abstract}

\section{THE ETYMOLOGIES.}

The etymologies have been written anew on a nniform plan, and in accordance with the established principles of comparative philology. It has boen possible in many eases, by means etymologist, to clear up doubts or difficulties bitherto resting upon the history of particular words, to decide definitely in favor of one of sereral suggested etymologies, to discard nusereral suggested etymologies, to discard nu-
merous current errors, and to give for the first merous current errors, and to give for the first
time the history of many words of which the etymologies were previously unknown or erroneously stated. Beginning with the current accepted form of spelling, each important word has been traced back through earlier forms to its remotest known origin. The various prefixes and sufixes useful in the formation of English and suffixes useful in the formation of English
words are treated very fully in separate articles.

\section{HOMONYMS.}

Words of various origin and meaning bnt of the same spelling, have been distinguished by small superior figures $(1,2,3$, etc.). In numbering these homonyms the rule has been to give precedence to the oldest or the most familiar, or to that one which is most nearly English in origin. The superior numbers apply not so much to the individual word as to the group or root to which it belongs, hence the different grammatical uses of the same homonym are numbered alike when they are
separately entered in the Dictionary. Thus a verb and a noun of the same origin and the same present spelling receive the same superior number. But when two words of the same form and of the same radical origin now differ considerably in meaning, 80 as to be used as di.-
ferent words, they are separately numbered.

\section{THE ORTHOGRAPHY.}

Of the great body of words constituting the familiar language the spelling is determined by well-established usage, and, however accidental and unacceptable, in many cases, it this to propose improvements, or to adopt those which have been proposed and have not yet there are also considerable classes as to which usage is wavering, more than one form being usage is wavering, more than one form being
sanctioned by excellent authorities, either in
this country or Great Britain, or in both. Fa- miliar examples are words ending in or or our
(as labor, labour), in er or re (as center, centre), ize or ise (as civilize, civilise); those having a ingle or double consonant after an unacented rowel (as traveler, traceller), or spclled with $e$ or with a or a (as hemorrhage, hemorrhage); and 8o on. In such eases both forms are given,
with an expressed preference for the briefer one or the one more accordant with native analogies.

a been made to record all th varietios of popular or even educated utter ance, or to report the determinations made by different recognized authorities. It hes been necessary rather to make a selection of words o which alternative pronunciations should be ccorded, and to give preference among these ccording to the circumstances of each particuar case, in view of the general analogies and endencies of English utterance. The schem by which the pronunciation is indicated is quite imple, avoiding over-refinement in the discrimination of sounds, and being designed to be readily understood and used. (See Key to Pronunciation on back eover.)

DEFINITIONS OF COMMON WORDS.

In the preparation of the definitions of common words, there has been at hand, besides the material generally accessible to students of the language, a special collection of quotaions selected for this work from English books of all kinds and of all periods of the language hich is probably much larger than any which has hitherto been made for the use of an English dictionary, except that accumulated for th Philological Society of London. Thousands of non-technical words, many of them oceurring in the classics of the language, and thousand of meanings, many of them familiar, which have not hitherto been noticed by the dictionries, have in this way been obtained. The arrangement of the definitions historically, in the order in which the senses defined have en tered the language, has been adopted wherver possible. THE QUOTATIONS.

These form a very large collection (abou 200,000), representing all periods and branches of English literature. The classics of the language have been drawn upon, and valuable citations have been made from les famous authors in all departments of literature. American writers especially are represented in greater fullness than in any simila work. A list of authors and works (and ediions) eited will be published with the concluding part of the Dictionary.

DEFINITIONS OF TECHNICAL TERMS.

Much space has been devoted to the special erms of the various sciences, fine arts, mechanieal arts, professions, and trades, and much care has been bestowed upon their treat ment. They have been collected by an extended search through all branches of literature, with the design of providing a very complete and many-sided technical dictionary. Many thouands of words have thus been gathered which ave never before been recorded in a general dictionary, or even in special glossaries. To the biological sciences a degree of prominence has been given corresponding to the reparkable recent increase in their vocabulary. he new material in the departments of biology and zoölogy includes not less than five thoyand words and senses not recorded even in special dictionaries. In the treatment of phy- ical arts and trades, and of the philological sciences, an equally broad method has been ecelesiastical terms, the aim of the Dictionary heen to present all the special doctrines of the different divisions of the Church in such a manner as to convey to the reader the actual intent of those who accept them. In defining legal terms the design has been to offer all th information that is nceded by the general reader, and also to aid the professional reader by giving in a concise form all the important technical words and meanings. Special attention has also been paid to the definitions of the principal terms of painting, etching, engraving, and various other art-processes; of architecture, sculpturo, archæology, decorative art, ceramies, ete. ; of musical terms, nautical and military terms, etc.

\section{ENCYCLOPEDIC FEATURES.}

The inclusion of so extensive and varied a rocabulary, the introduction of special phrases and the full description of things often found essential to an intelligible definition of their names, would alone have given to this Dictionary a distinctly encyelopedic character. It has, however, been deemed desirable to go somewhat further in this direction than these conditions render strictly necessary.

Accordingly, not only have many technical matters been treated with unusual fullness, but much practical information of a kind which dictionaries have hitherto excluded has been added. The result is that "The Century Dictionary" covers to a great extent the field of the ordinary encyclopedia, with this principal difference - that the information given is for the most part distributed under the individual words and phrases with which it is connected, instead of boing collected under a few general topies. Proper names, both biographical and geographical, are of course omitted, except as they appear in derivative adjectives, as Darwinian from Darwin, or Indian from India. The alphabetical distribution of the encyclopedic matter under a large number of words will, it is believed, be found to be particularly helpful in the search for those details which are generally looked for in works of reference.

\section{ILLUSTRATIONS.}

The pictorial illustrations have been so selected and executed as to be subordinate to the text, while possessing a considerable degree of independent suggestiveness and artistic value. To secure technical accuracy, the illustrations have, as a rule, been selected by the specialists in charge of the various departments, and have in all cases been examined by them in proofs. The cuts number about six thousand.

MODE OF ISSUE, PRICE, ETC.

"The Century Dictionary" will be comprised about 6,500 quarto pages. It is published by subseription and in twenty-four parts or ections, to be finally bound into six quarto voltions will be issued about once a month. The price of the sections is $\$ 2.50$ each and no subscriptions are taken except for the entire

The plan of the Dictionary is more fully described in the preface (of which the above is in part a condensation), which accompanies the to which reference is made.

$A$ list of the abbreviations used in the etymologies and definitions, and keys to pronunciations and to signs used in the etymologies, will be found on the back cover-lining. 



$$
\begin{aligned}
& P E \\
& 1625 \\
& 24 \\
& 18892 \\
& p+2
\end{aligned}
$$




\section{appetence}

4. Instinctive inclination or natural tendency. These lacteals lave mouths, and by animal selection or appetency they The present example a preclsely contradicts th opinion that the partsotency, $i$. e., endeavour perpetuated, and impereeptibly werking its efteet through an Incal5. In inanimate things, material or chemical 5. In inan or affinity. = Syn. Sce nppetite.

attraction or affinity. $=$ Syn. See nppetite.
appetent (ap'é-tont), $a . \quad\left[<\mathrm{I}_{\text {. appeten }}(t-) s, \mathrm{ppr}\right.$. of appetere, adpetere, strive after, try to get: seo appete; ef. appclite.] 1. Desiring; very desirous; eagcrly longing.

Thirsty anil nppetent aiter glory. IIIal. Rich. III., D. 60. 2. Pertaining to desire or volition. Sir $\Pi$. Hamilton. appetibllity (ap ${ }^{\circ}$-ti-bil'i-ti), $n .[=\mathrm{F}$. appétibilite, < uppétible: see appetiblc and-bilily.] The quality of exciting
tiveness. [Rare.]

The oppetibility of the ohject.

Bramhall.

appetible (ap'o-ti-bl), a. [= F. appétible, <I. cupetibilis, desirable, < appetere: see appete and "ible.] Exciting tho appetite; worthy of being souglit for; desirable. [Rare.] Powcr both to slight the most appetible objects, and to
controul the most unruly passions.

Bramhall, Against Hobbes.

appetite (ap'-e-tīt), n. [<ME. appetit, apetite, SOF. appetit ( $\mathrm{F}$. appélit), $<\mathrm{L}$. appetitus, desire for, < appetere, adpctcre, pp. appetitus, long for, desire: see appete, appctent.] 1. An innate or acquired demand or propensity to satisfy a want; desire, especially strong desire; inclination; wish to attain some object or purpose: with for (formerly with of, to, or an infinitive) or absolntely.

She dyd it not for appetite of vengeannce. If God liad given to eagles an appetite to swim.

Jer. Taylor

As it is best to preserve our natural appetites in that tone and rlegree of strength which nature gives them, so we onght te beware of acquiring appetites which nature
never gave.
Reid, Active Powers, p. 128 .

It is the glory of God, Indeed, to conceal a thing, but not absolutely, or lor the sake of concealment. Ile does
It only till a mind and appetite for the truth la prepared. Specifically - 2. A desire to supply a bodily want or craving; a desire for food or drink. Fairest frult, that hung to the eye

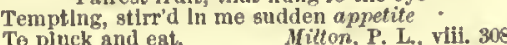
Instlnct enables a spider to entrap his prey, whlle appe
tite only leads blm to devour it when in his possession.

3. Relish for food; the capacity of taking food with pleasure.

With hounds and horus go hunt an appetite.
Pope, Imit. of Horace, I.

4. Preference; taste; liking: as, to or aceording to one's appetitc, that is, as one pleases. ing to one's appetitc, that is, as one pleas
[Rare.]-5. A thing desired. [Archaic.]

Power being the natural appetite of princes. Steift.
The mountains, and the deep and gloomy wood, The mountains, and the deep and gloomy wood,

Were then to me an appetite. Fordsworth.
6. A tendency of an inanimate thing analogous to a desire.

The air of Itself liath litte or ne appetite of ascending.
Bacon, Sylva Sylvarum. Canine appetite. See crnine, $=\mathbf{S y n}, A_{1}$ petence, appelust. To desire; long for; deeply want.

A man in his natural pertection is flerce,

ing by generation to bring forth hls semblable.

2. To satisfy the appetite or desire of.

appetition $($ ap-ē-tish'on), n. [ $\quad$ F. appétition,

R L. appetitio( $(r-)$, < appetere: see appetite.] An act of appetite; desire; craving.

We find in animals an catimative or Judicial Iaculty, an
Sir N. Hale.

The monsd is a simple sulsstance exercising perceptlve and appetitive powers, a consclous and active existent. The "simple substance " represents the objective aspect, Ulodyron, Phit. of Reflection, 11. 27.

appetitiousł (ap-ē-tish'us), a. [< appctition + -ous.] l'ertaining or agreeable to appetite; appetitive; appetizing: as, appetitious liking.

Appetitiou, passable, and toothsome Brief Descr. of Fannticks, p. 17 appetitive (a-pet'i-tiv or ap'ē-ti-tiv), a. $[=\mathrm{F}$.
appetitif, $<$ I. as if "appetitivis, < appctere: see
273

appetite and -ice.] 1. Characterized by or of no nature of appetite.

The will Is not \& hare appetitive pewer as that of the Pure spontaneity has no alternatives of imperative and 2. Appotizing.-The appetitive faculty, the aum foll anr tendencles toward ends. ppetize (ap'ë-tiz), v. t.; pret. and pp. appetizer, ppr. appetizing. [< appel(itc) $+-i z c$; sugan appetite to; awaken a craving in ; increase or whet the appetite of: as, to appetize one for his food. [Rare.]

appetizer (apj'ē-tĩ-zèr), n. That which excites or whets the appetite, as a walk; anything that gives a relish for food.

A glass of vodka, together with caviar, raw salt herring plckled mushrooms, or seme such viand as an appetizer
betore dinner.
D. $J I$. Wrallace, Russia, p. 150.

appetizing (ap'ē-tī-zing), p.a. 1. Exciting an appetite; giving a relish for food: as, "it could 2. Stimulating or awakening any desire; oxciting interest or euriosity.

Ien forget that he, too [Temnyson], was once new, un
Stedman, Vict. Poets, p. 155, Appian (ap'i-an), a. [< L. Appianus, < Appius a proper name.] Pertaining to the Appit, an aneient Roman gens, or to one of its members (Appius). Appian Way (Latin Via Appia), a cele Brundustum (Brindisi), hegun by the censer Applus Clandlus Crens, 312 B. O. It was about 350 miles in length, from 14 to 18 feet In breadth, and, likc other Roman roads, was paved with hard atone in irregular blocks, closely fitted to
gethcr and resting on a firm aubstructure. It was mad
with great care, and exists in part at the present time. applanate (ap'lä-nāt), a. [< NL. applanatus In bot., fattened ont or horizontally expanded.

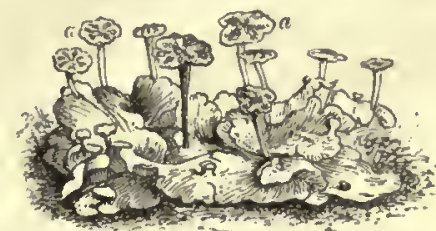

applaud (a-plâd'), $v$ [ [= F. applaudir, OF aplaudir $=\mathrm{gp}$. aplaudir $=\mathrm{Pg}$. applaudir $=\mathrm{It}$ applaudire, applaudere, < L. applaudere, LI. also applodere, clap the hands together, ap pland, $\mathrm{L}$ ad, to, + plaudere, strike, clap. Cf cxplode.] 1. trans. 1. To praise or show ap proval of by clapping the hands, acclamation, other significant sign.-2. To praise in any way By the gods, I do applaud his courage.

Can 1 do him all the mischiel Imaginable, and that easily ssfely, and successfully, and so applaud myselt in my
power, my wit, and my subtle contrivances? We applaud a sensitive honesty which shudders at any thing underhand or dlishonourable. $=$ Syn. Extol, etc. (see praise, $v$.), cheer, cry up, magnily. II. intrans. 1. To express approval by clapTo give praise; express approval.

And there he kept the Justice of the KIng

Applauded.

applauder (ă-plâ'dẻr), $n$. One who applauds, apraises, or commends.

Two hundred and eighty applauders at three shillings a applause (a-plâz'), n. $\quad[=\mathrm{Sp}$. aplauso $=\mathrm{Pg}$. It applauso, $<\mathrm{L}$. as if "applausus, n., < applausus, pp. of applaudere, applaud; ef. plausus, ap-
planse, plaudere, applaud.] 1 . A manifestation of approval by sound; enthusiastic approbation expressed by clapping the hands, acclamation, huzzas, or other means of demonstration; popular laudation.-2. Any expression of approbation, appreciation, or delight commendation; encouragement; approval.

I humbly am content with huma praise A goddess's applause would envy ralse.
Dryden, Helen to Paris, L. 126. Shall he for whose applnuse I stroveI had such reverence for his blame See with clear eye seme hid
And I be lessen'd in his love? Tennyson, In Memeriam, li.

3t. An object of approval. B. Jonson. applauseł (a-plâz' $), v$. t. [< applause, n.] To applaud; approve.

\section{apple}

And with a gencral rolce applaused his leath

Chapman, Alphonsuis, ii. 2

applauseful $\nmid$ (g-plâz'fủl), a. [< afplesuse + ul.] Abounding in plandit

All France and lritain ring with aćulamation,

And with applauseful thanks they do rejoice.

applausion $\nmid$ (a-plà'zhon), n. Appiáuse.

applausive (n̂-plâ'siv), ", [< ML. duplausirus, propitions, favorable, < L. applandere: see applaud, and ef. applatuse and plansite. 1 . Ap plauding; coutr

T'he aldicrs, as you hearl, my lord,

Dekker and il' ebster (D) Weakest Goth to the Wall, v. 1 Greet her with applausive breath. Tennyson, vision of sin.

2ł. Worthy of applanse. Chapman.

apple (ap'I), n. [< ME. apple, aplc, opplc, appel, eppel, appil, $-u l,-y l$, ¿ AS. rppel, in comp. apples NFries. aple, aeple, north. Fries. apel, = D. appel =OHG. aphal, aphol, aphul, affal, affol, afful, apful, pl. epfili, MHG. apfel, pl. epfel, öpfel, G. apfcl, pl. äpfol, = Icel. epli = Norw. dial. eple = OSw. apl, Sw. apple, äpple (in comp. äppl-) = Dan. able (Goth. not recorded), applo; user also, in connection with eye (in $G$. also absolutely), for the pupil of the eye; in AS. also poot. for ball (irenum aplum, with iron balls); in southern Norway also absolutely for jordeplc = carth-apple, potato: a common T'eut. word, ubhall $=$ W. afal, OW. abal = Corn. Bret. aval $=$ Manx ooyl) and in Slavic (OBulg. ablukk, yablüko, Bnlg. ablǔka, yablǔka = Sloven. yabelko, yabollia = Serv. yabuka = Bohem. jablo, jablko = Pol. jablho (barred $)=$ Rnss. yabloko woble =Lith, obulas = Lett. ábols, apple; bnt in all theselan The common source of all the forms has been sought in L. Abella (It. Avella), a town in Campania abounding in fruit-trees and nutg (and hencecalled malifer a, apple-bearing, by Virgil), whence nux Abellana, a filbert or hazel-nut (see the apple in partioular; cf. L. malum Persicum, the Persian apple, the peach (whence E. peach 1 , q. v.). In this view apple, like pear, peach, plum, quinec, aprieat, cherry, is of $\mathrm{L}$. (all bnt apple and pear being ult. of Gr.) origin.] 1 . The fruit of a rosaceous tree, Pyrus Malus, a native probably of central Asia. The tree is now cultivated in nearly all temperate regions, In nunierous duced Into America frem England in 1629, by the goverior of Massachusetts Bay. It is scarcely knewn in lts will
state, but as an escape from cnltivation its frult becomes small, acid, and harsh, and is known as the crnb. The cul2. The tree itself, Pyrus Malus.-3. A name popularly given to various fruits or trees having little or nothing in common with the apple. Anong them are: Adam's appie (the lime, a va-

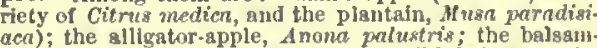
aca); the slligator-apple, Anona palustris; the balsam-
apple, Momordica Balsamina; the wild balsam-apple, rugosum; the bitter apple or colocynth, Citrullus Colorugosum; the bitter apple or colocynth, Cit rullus Colo-
cynthis; the apple of Cain, A rbutus Unedo; the cedar. (Gymnosporangium macropus); the custard-apple, species of A noma, espectally, In the West Indies, $A$.retictlata, and,
in the East Judles, $A$. squamon,; the devil's or mandrake pple, Maniragora officinalis; the egg-apple, or Jew's or niad spple, Solnnum eaculentum; the elephant- or woodthe Kel apple, Aberin Caffrn; the love-apple or tomato, Lycopersicum esculentum; the unammee-spple, Mlammea Americana; the May or Indlan apple, Podophyllum peltatum; the monkey-8pple Clusia flarn; the Otaheite apple, Spondica dulcis; the apple of Peru, Nicandro

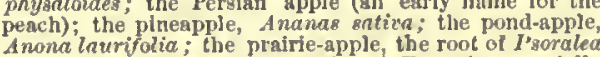
esculentn; the rose-apple, specles of Eugenia, especially E. Janabos; the seven-year apple, Genipa ciusiafolia; the alar-apple, Chrysophyllum Cainito; the sugar-apple, and other specles. The wild apples of Queensland are apple. See sbove, and Adam.-Apple of discord, a cause mythology of a golden apple thrown into an assembly of the gods by the goddess of discord (Fris), bearing the in seription, "For the fairest." A phrodite (Venus), Hera (Juno), and Psllas (Afinerva) becane compelitars for it and Its adjudication to the frst by Paris of Troy, selected by Zeus as umpire, a tiflained the jealousy of Ilera
and her hatred toward all the Trojan race that she did not

18 2

\author{
(1)
}

T 
apple

274

ccase her machinations till Troy was destroyed.- Apple
of Sodom, or Dead Sea apple. (n) A fruit sail to stow on or near the site of the Biblical sodom, described by Josepluns and other old writers as externally of fair ap nearance, bnt turning to smoke ard ashes when plncked. Nany misatisiactory attempts have becn made to accoun
for the tralitlon. (b) V'innratively, 8ome Iruitless thing onc'b desives. - IApple of the eye. (a) The pnpil.

-Dull pcople tiurn up the palins of their hands and the apples of their eyses, on beholding prose by a poet.
Blackuod's Jfag., XXII. 374. Hence- $-(b)$ Somcthing very important, precious, or dear. He kept him as the apple of his eye. Deut. xxxii. 10. Ioor Itchard was to me as an eldest son, the apple of
Scott, Old Mortality, xx my eye. Winter apple, an apple that kecps well in winter, or does apple (ap'l), $v$ [ [ $\mathrm{AS} .{ }^{*}$ applian, used only in pp. appled, appled, formed like an apple; < appel, an apple: seo the nou

give the form of an apple to. apple. The cabbage turnlp is of two kinds; one apples above
C. Marshall, Gardening.

2. To gather apples. [Rare in all uses.]

apple-berry (ap'l-ber"i), $n$. A name given in twining shrub, Billardiera scandens, of the natural order Pittosporece.

apple-butter (ap'l-but"ér), n. A sauce made

apple-butter (ap i-but cider.

apple-corer (ap'l-kör"èr), n. Any device for remeving the cores from apples.

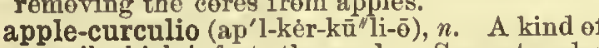
weevil which infests the apple. See eut under Anthonomus.

apple-green (ap'l-grēn), $n$. The light-green coler of certain apples, as the greening.

apple-headed (ap'l-hed"ed), a. Having a head that is round on top, between the ears, instead of flat: said of dogs.

apple-jack (ap'l-jak), n. [<apple + jack, used vaguely: sce jack ${ }^{2}$, and ef. apple-john.] A liquo distilled from cider.

apple-john (ap'l-jon), n. [< apple + John, so called, it is said, because it is ripe about considered to be in perfection when shriveled and withered.

I am withered like an old apple-John.
Shak, I Hen. IV., iii. 3

apple-mint (ap'l-mint), $n$. A European plant, a species of Mentha, M. rotundifolia.

apple-mose (ap'l-mōs), $n$. A dish made with the pulp of stewed apples and other ingredients. apple-moth (ap'l-môth), n. The Tortrix pomo nana, a lepideptereus insect, the larva of which live in apples.

apple-parer (ap'l-pãr/èr), n. A machine for apple-pie (ap'l-pi'), n. 1. A pie made ef apples variously prepared, inclosed in or covered with a species of willew-herb, Epilobium hirsutum. -Apple-ple bed, a bed made up, as a practical joke with one of the sheets doubled upward in the middle, so prevents one from getting his legs down: so called from the apple-turnover, a kind of pie in which the crust ple-pie order, an expression nsed in familiar conversation, denoting perfect ordc
was in apple-pie order.

I am just in the order which rome folks - though why ant

apple-scoop (ap'l-skëp), n. A scoop-shaped instrument formerly used in eating apples.

apple-shell (ap 1-shel), $n$. A snail-shell of the cut under Ampullariido.

apple-snail (ap'l-snāl), $n$. The snail which has apple-snail (ap'l-snal), $n$. The smail whic

apple-squiret (ap'l-skwīr), n. [Cf. apronsquire.] 1. A pimp; a kept gallant; a page whe waited on loese women.

of pages, some be court-pages, others ordinary gallant 2. A wittel.

apple-tree (ap']-trē), n. [<ME. appeltre, appittre * $^{*}$ ppeltrcón * appcltróno . usually regarded, a "corruption" of ÁS. apul der, apuldor, apuldre (the alleged *eppelder, "appeldor, "apelder, etc., not anthenticated)
$=$ OHG. aphaltra, apholtra, affoltra, affultra, conic section. [Rare.] olter, affalter = Icel. apaldr = Norw. dial. apald, apall, apal, aplc = Sw. apcl - Dan. abild, an apple-tree ; a werd still exist= Dan. abild, an apple-tree; Appledore ( $\mathrm{AS}$. Apulder, Apolder). The same termination $\odot \mathrm{c}-$ curs in AS. mapulder, mapuldor, mapuldur, mapuldern, a maple-tree: see maple-trec.] A tree (Pyrus Malus) bearing apples. Its wood is hard, durable, and fine-grained, and nuch used in turnery. Apple-t

budding. applicable.]" 1 . Capable of being applied; applicable; pertinent; suitable.

All that $\mathrm{I}$ have said of ... heathen idolatry is applia. 2. Willing to apply one's self; compliant; disposed to listen.

Apte by goodnes of witte, and appliable by readines of scham, The Scholemaster, p. 38 appliance (a-pli'ans), $n$. [< apply + -ance. $]$ rying inte practice.

The attention to fashion, the tasteful appliance of ornament in each portion of her dress, were quite in place with
Charlotte Brontë, Shirley, xvi.

2. Something applied as a means to an end, either independently or subordinately; that either independent the accomplishment of a purpese; an instrumental means, aid, or appurpese; an instrumentenance: as, the appliances of civilization, purtenance: as, the appliances of civilization, or of a trade; mechanical, chemical, or medical appliances (tools, machinery, apparatus, Diseases, deaperate grown,
By desperate appliance are reliev'd

Shak., Hamlet, iv. 3.

Material appliances have been lavishly used; arts, inventions, and machines introduced Irom abroad, manuactnres aet up, communications opened, roads made,

appliantt (a-plī'ant), a. 1. Faverably inclined docile; pliant.-2. Applicable: with to.

applicability (ap"li-kg-bil'i-ti), n. [< applica ble: see-bility.] The quality of being applicable, or fit to be applied; capability of being applied or used; pertinence.

He who has read his Aristotle will be apt to think that observation has on most points of general applicability Why need I speak of steam, the eneny of space and lime, with its enormous atrength and delicate applica-
Emerson, Works and Days applicable (ap'li-ka-bl), $a . \quad[=\mathrm{F}$. applicable $=$ It. applicabile, < L. applicarc: see apply, and ef. appliable.] Capable of being applied; fit to be applied; having relevance; suitable; appropriate; pertinent: as, this observation

The usc of logic, although potentially applicable to every matter, is ai ways actually manifested by apecial reference
to gome one. applicableness ( $\mathrm{ap}^{\prime}$ li-ka-bl-nes), $n$. The qual ty of being applicable; fitness to be applied. applicably (ap'li-ka-bli), $t d v$. In an applicable manner; fittingly.

applicancył (ap'li-kan-si), n. [< applicant, in The state of being applicable. Is. Taylor.

applicant (ap'li-kant), $n$. [< L. applican $(t-) s$, ppr. of applicare, äpply: seo apply.] One wh applies ; one who makes request; a petitioner a candidate.

The applicant for a cup of water declares limself to he
Plumtree.
the Jlcssias. applicatet (ap'li-kāt), v. t. [<I. applicatus, pp. of applicare, apply: see apply.] Te apply. The act of taith is rpplicated to the object.

applicate (ap'li-kāt), a. and n. [<L.applicatus, pp.: see the verb.] I. $a$. Applied or put to some use; practical; concrete. [Rare.]

Those applicate sciences which extend the power of man
over the element.
[8. Taylor.

Applicate number, a number applied in a concret case. II utton. [Rare.] - Applicate ordinate, in math. II. $\pi$. [< L. applicata (sc. linea, line), fem. II. $\pi$. [ L L. applicata (sc. linea, line), fem.
of applicatus: see above.] An ordinate to a

application (ap-li-kä'shen), n. [= F. application, <L. applicatio $(n-)$, a joining or attaching apply.] 1. The act of applying or putting to the act of laying on: as, the application of emellients to a diseased limb.-2. The thing or remedy applied: as, the pain was abated by the application.

\section{appliqué}

The rest [physicians] have worn me out
Shek, All'g W'll, i. 2. 3. The act of making request $\theta r^{\prime}$ of soliciting; the request so made: as, he made application to the Court of Chancery.

One Sidney gave his patronage to the applications of a poet; the other offered it unrasked. Ded. of Don Scbastian. 4. The act of putting to a special use or purpose; adaptation to a specific end.

What we buy in a broom, a mat, a wagon, a knife, is come application of good sense to a common waut.
E'merson, Compensation.

5. The act of fixing the mind on something; lese attention; devotion, as to a pursuit; assiduous efiert.

The curate, surprised to find such instances of indnstry and application in a yonng man who had never met with the least encouragement, asked him

6. The act of applying a general principle, law, or theory to a particular case; the demonstration of the relation of a general prineiple to an actual state of things; the testing of something theoretical by applying it in practice.

He laid down with clearness and accuracy the principles by which the question is to be declded, bnt he did not purSir $G$. C. Levis Cred of Karly tor 7. In law, appropriation; the act of allotting among several debts a payment inadequate te satisfy all. See appropriation, $4(b)$. - 8. In as trol., the approach of a planet te any aspect. $=$ Syn. 3. Request, solicitation, appeal, petition.-5. In

applicationert (ap-li-kā'shen-èr), n. [〈application + -erl.] One who makes an application or appeal. N. E. D.

applicative (ap'li-kầ-tiv), a. [= I. applicatif, L. applicare: see apply, applicate, and -ive.] Applying; applicatery; practical. Branihall. applicator (ap'li-kā-tor), n. [NL., < L. applicare, pp. applicatus: see apply.] It. One who ing anything, as caustic or a tent, to a deepseated part. E. H. Inight.

applicatory (ap'li-kā-tō-ri), a. and $n$. [< appliter fitted for application; serving for application ; practical: as, "applicatory infor
Wilkins, Ecclesiastes. [Rare.]

Ife therein [the Bible] morning and evening read a
hapter, with a little applicatory exposition, belore and after which he made a prayer. SIather, MIag. Chris., lii. I. Thls applicatory portion of a sermon, wherever it ocA. Phelps, Theory of Preaching, xxxil. N. E. D.

II. $n$. That which applies; a means of putting to use.

Falth is tire inward applicatory [of Christ'a death], and if there be any outward, It must be the sacraments.
Jer. Taylor, Wortly Communicant, is 4. applied (a-plid'), p.a. [< apply $\left.+-c d^{2}.\right]$ Put on; put to; directed; employed : said specifically of a science when its laws are employed and exemplified in dealing with conerete phenomena, and in this use distinguished from abstract or theoretical. Applied chemistry, logic,
mathematics, etc. Sce thie nouns.- Applled work sec appliqué.
appliedly (a-pli'ed-li), adr. By or in applicaappliedly (a-p.
tien. [Rare.]

All auperstitlon whatsoever reflecteth upon religion. It is not but in such acts as be of themselves, or appliedly, acts of religion and piety.
$B p$. Jountayu, Appeal to Crear, p. 267.

applier (a-plí'èr), n. 1. One whe applies. -2 . silk between teeth.

applimentt, $n$. Same as applyment.

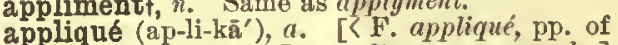
appliquer, put on, < L. applicare: see apply.] 1. In.modern dress and upholstery, applied or sewed on, or produced in this way. Thus, the gimp or pattern of soiled or injured lacc niay be sewed upon a new ground, or embroidered hawers or ay be aecured $\omega$ new alik; in such a case whe patterm or orname 2. More generally, said of one material, as metal, fixed upen anether, in ernamental werk: as, al, fixed upen another, in ernamental werk: as, an enameled disk appliqué npen a surface of filigree, an ivery figure appliqué upon a Japanese as a noun.] - Point appliqué, polut-lace in wlilch the design, after having been separately made, has been applied to the net which forms the foundation. 
applot+ (a-plot'), $v_{i} t_{\text {. }} \quad\left[<a p-\mathrm{I}+\right.$ plot $1, r_{0} \quad$ Cf. applymentt (a-pli'ment), $n_{0} \quad[<a p p l y+-m e n t$.$] appointable (a-poin'ta-bl), a . \quad[<a p p o i n t+$ alot.] 1. Literally, to divido into plots o applotment (a-plot'ment), $\%$. [ (tpplot + -nent. Cf. allotment.] A division into plots

apportionment. applumbaturet (a-plum'ba-tīir), $n$. [<ML. ap a plumbatura, $\left\langle 1_{\text {s. applumbatus, } 1 \text { lp. of applumbare, }}\right.$
solder with lead, $\langle$ all, to, + plumbare (pp. plumbutus, > plumbatura, a soldering), < ptumbum, lead: see plumb.] $A$ joining or soldering with lead. Blonent.

apply (n-pli') $x$; pret. and pp. applied, ppr.

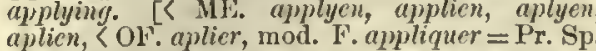

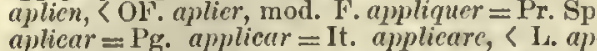
aplicar $=\mathrm{Pg}$. applicar $=1 \mathrm{It}$ applicare, $<1$. ap
plicare, attach to, apply, $<a d$, to, + plicare, fold or lay together: see ply, plicate.] I. trans. 1. To lay on; bring into physical proximity or contact: as, to apply the hand to the breast; to apply medicaments to a diseased part of the

body; to apply a match to powder.

'Beseech you, tenllerly apply to her
Some reniedies for life.
Shak., W. T., lii. 2 In the gardens of the old Afarques Spinola I saw huge

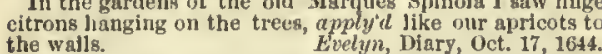
2. To bring into contact with particulars or with a particular case, as a principle, law, or rule; bring to bear upen; put inte practical operation. Quintilian applied to general literature the same prin
ciples by which he had been acenstomed to judge of the
declamations of his pupils. Macaulay, Atienian Orators,

3. To use or employ for a particular case, or devete to a particular purpose: as, to apply sum of meney to the payment of a debt. Craft against vice I must apply.

Yet there arc a aort of discontented ereatures that ljear a stingless envy to great ones, snd these will wrest the doangs of any man to their base, malieions appiment. appoggiato (àp-po-jii'tō), a. [It., supported, pp. support, prop, s I. ad, to + podium, a balcony (>It. poggio = F. pui, puy): see appui, podium. In music, literally, supported: marking note which are to be performed so that they shal without any perceptible break.

appoggiatura (åp-poj-ii-tö'rậ), n. [It., < appoggiare, prop, lean : seo appoggialo.] In music, ceding the note witl which it is connected, and taking away from that note a portion of its time. It is of two kinds: $(a)$ short, which is played a

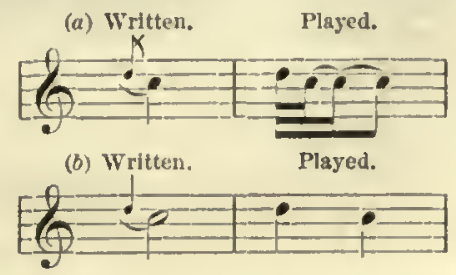

quiekly as possible, and (b) Jong, which is given its prope The long appoggiatura was eapeeiatty used by earli pianoforte conposers to avold the dlsplay of passing note.

appoint (a-point'), $v$ [Early mod. E. alse by apheresis point; < ME. appointen, apeinten, OF. apointer, prepare, settle, fix, F. appointer, refer a cause, put on a salary (cf. OF. a point to the point), $=$ Pr. apointar, apontar $=\mathrm{Sp}$ apuntar = It. appuntare, < ML. appunctare, repair, appoint, <L. ad, to, + ML. punctare, mark by a point, < L. puncta, usually punctum, point: see point.] I. trans. 1†. To make fast point: see point.] I. trans. 1†. 1 .
or firm; found; establish; secure.

When be appointed the foundations of the earth.

To constitute, ordain, or fix by decrii. 20 . der, or decision; decree; command; preseribe Thy servants are resdy to do whatsoever my lord th king shall appoint.

Unto him thou gavest commandment to love thy way which he transgreased, and immediatety thou appointeds . There be six wayes appointed hy the best jesrned men, for 3. To allot, set apart, or designate; nominate or authoritatively assign, as for a use, or to a post or office.

These were the eities appointed for all the children of
Jorat. A slip was appointed them, which ship they began im mediately to fit up, and anpply plentifinly with all manThe sncient [Hindu] law allowed the father who had no prospeet of having tegitimate sons to appoint or nominat a danghter who should bear a son to himself and not to 4. To settle; fix, name, or determine by authority or upon agreement: as, they appointe a time aud place for the meeting. -5 . In law to fix the destination of (property) by desig. nating a person or persons to take the use of an estate created by a preceding deed or will, conferring on the appointor the power se to de. Thus, a testator may give a fund to a child for life, with The donee of the power is the appointor, and those desig nated by the appointor to enjoy the fund are termed the appointee.

$6+$. To point at by way of censure; arraign as, "appoint not heavenly dispesition," Milton S. A., 1. 373. -7 . To provide with what is re quisite; equip.

You may be armed and appointed well.

II. intrans. 1t. To be in elose contiguity. 2. To have application; be applicable; have seme connection, agreement, analogy, or refer ence: as, this argument applics well to the case

Of the puzzles of the Academy, there is not one while and to Atheisn as to Deism.

Ifacaulay, Sadter's Ref. Refuted

3. To make application or request; ask; have recoursc with a view to gain something: as, to apply for an office, information, etc.-4. To give attention; turn the mind.

I have been too 11 t and too dispirited to apply to any.
thing for sone weeks yast. Ji iss Carter, Letters, II. 60.

[In all senses used with to.] Six hundred cavatry, and three thousand musketeers sll perfectty appointed, entered Antwerp at onee. 8f. To agree upen; decide upon or settle definitely.

She sat allone and gan to caste
Whereon she wolde apoynt hire at the laste. Chaucer, Troilus, ii, $69 \mathrm{I}$

$=$ Syn. 2. To preseribe, establish, direct.-3. To assign,

II intrans. I. To ordain resolvo; determ

The Iord had appointed to defeat the good counget of Ahithophel. good counget of
2 Sam. xvil. 14.

2. In law, to exereise a pewer of appointment. insensibly glide and melt inte one another

-able.] Capable of beiug appointed or constituted; subject to appointment or deeision.

Thut external ceremonieg were but exercises of religion, R. W. Dixon, li ist. Church of Eng., xvi. appointé (a-poin-tā'), a. [As if $\mathrm{F}$. , in lit seuse 'pointed': see appointec.] In her., same as niguisé.

appointee (a-poin-t $\left.\bar{e}^{\prime}\right), n . \quad\left[<\right.$ appoint $+-c e^{1}$ after $\mathrm{F}$, appoinle, pp. of appointer : see appoint.] 1. A person appointed.-2. In law, the person who benefits by the execution of a power of appointment. Sec appoint, 5.

appointer (a-poin'tér), $n$. One who nominates, appoints, ordains, or settlos. See appointor.

appointive (a-poin'tiv), a. [< appoint + -ice. $]$ . Of or pertaining to appointment; appoint ing: as, the appointive power of the President. -2. Dependent upon the exercise of the power or right to appoint; filled by appointment: opposed to clective: as, appointivo offices.

In 1873 , the question whether tho entire judiciary shoutl be appointive or eleetlve was agaln subritted to popular appointment (a-point'ment), $n$. [<MT. apoyntment, and by apheresis poyntment, < OF, apointement, F. appointement, decrec, order, in pl. of appointing, designating, or placing in office as, he erred by the appointment of unsuitable men.-2. An office held by a person appointed: as, a high appointment in the eivil service.3. Stipulation; engagement; assignation; the act of fixing by mutual agreemont: as, an $a p$. pointment to meet at six o'clock.

I shall be with her . . . by her own appointment.

4. Anything fixed or established; established order or constitution; decree; ordinance; direction; order; command: as, it is our duty to submit to the divine appointments.

Wheat, aalt, wine, and oil, aecording to the appointment Do you not think it was a merclful appointment that Dathers dic not eome to the possession of independence,

R. Choote, Addresses, p. 67.

5. Equipment, furniture, outfit, as fer a ship, an army, a soldier, etc.; whatever is appointed for use and management; accoutrements: in this sense generally used in the plural. "In besl set lorth,
In best appointment, atl our regiment

The eavaliers emulated their chief in the richness of 6. The act of preparing; preparation. [Rare.] Your best appoint ment make with speed
Shak. $\mathbf{3}$. for $\$ 1$.

$7 t$ An allowance to a person; a salary or per sion, as of a public efficer: properly used only in the plural.

An expense proportioned to his appointments and tor
chesterfield, $\mathrm{Maxims}$ is neeessary.

8. In law, the act of appointing or designating the beneficiary who is to take the use of an estate created under a precediug deed or will. See appoint, 5. - Councll of Appointment, in the govermment of the state of New York, from 1777 to 1821 a couneil, consisting of the governor and four senators
chosen by the Assembly, in whom was vested the riglt of appointment to State oftices and of removal from then.Midnight appointments, in $U$. S. politic apjointments made during the last hours of an sdministration;
specifically, those so nuade by President John Adums. appointor (a-poin'tor), $n$. [ appoint $+-a r$.
In law, one who has official or legal power of In law, one whe has official

apport $+(a-p o ̄ r t '), v . t_{0}[<\mathrm{F}$. apporter, < L. ap portare, bring to, $<a d$, to, + pertare, earry: see port ${ }^{3}$.] To bring; carry; produce.

apportert (a-pōr'tèr), u. A bringer in; one whe imports anything into a country; an introducer or proeurer.

This niakes only the apporters thembelves, their aiders
abettors, and assistanta, traitors.
Sir $M$. Hale, 11ist. Plac. Cor., xx. apportion (a-pōr'shon), v.t. [< F.apportion + portio(n-), portion, part: see portion.] To divide and assign in just proportion or accord ing to some rule; distribute proportionally allot: as, to apportion undivided rights; to apportion timo among various employments.

Boney was raised by a forced loan, which was appor(ioned among the people according to the rate at which they had been respeetively assessed to the last subsidy.
Macaulay, Nugent's IIampden.

=Syn. Dispense, Distribute, etc. See dispente. ner (Cotgrave), < ML. apportionare, $<\mathrm{L}$. ad, to 
apportionate

apportionateł (ą-pōr'shonl-āt), $\iota . t . \quad[<M L$. apportionatus, pp. of apportionare: seo apportion.] To apportion.

apportionatenessł (â-pōr'shon-āt-nes), $n$. [< of being adapted; just proportion.

The apportionateness of it to the end for which tt was apportioner (a-pōr'shon-êr), n. One wlıo ap. jortions.

apportionment (a-pōr'shon-ment), n. [< apportion +-ment; after $\mathrm{E}$. "tpportionnement, ML
apportionamentum.] 1 . The act of apportion ipportionamentum.] 1 . The act of apportioning; a dividing into portions or shares; a di-
viding and assigning of a just and equitable portion to each person interested or entitled to participato in any claim, right, property, or charge. - 2. In the United States: $(a)$ The disof Representrives, and in the houses of the differont State legislatures. In the former case a fresh apportionnent is made by Congress every ten years, aliort. apportionment is made by Congress every ten years, ahort in the latter after stated enumerations made at different the federal apportionment, Congresa deternines the pro. portion of representatives to population (one to 154,325
of the total population of the United States under the cenof the total population of the United States nnder the cen-
sus of 1880 , or 325 in al1, and the State legialatures fix the boundarles of the elective districts accordingly. (The principle of legislative apportionment according to popnlation has been more recently adopted in the other American and moat European atates, though in some it is not yet
very strictly applied.] $(b)$ The allotment of direct taxes on the basis of population: a Congressional power rarely exercised.

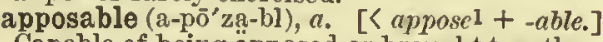
Capable of being apposed or brought together. appose ${ }^{1}\left(a-p \bar{z} z^{\prime}\right), v$. t.; pret. and pp. apposed. ppr. apposing. [<F. apposer, to lay, put, or add to, destinate, appoint, repr. L. apponere, adponere, pp. appositus, adpositus (cf. apposite), put or lay at, near, or by, apply to, add, $<a d$, to, + ponere, pp. positus, put, place, confused in ML. and Rom. with pausare, F. poser, ete.: pose, propose, repose.] 1. To put or apply (one thing) to or near to (another).

Atrides ... food aufficient

His power baving wrouglit
The king already to appose his hand.

Chapmenu and Shirley, Chabot, Admiral of France,

2. To bring near or next, as one thing to another; put side by side; arrange in juxtaposi-

\section{Each man sad looking on his appos'd object?
Dekker and Webster (?), Sir Thomas Wyat,}

appose ${ }^{2} \dagger($ a-pōz' $), v . t$. [<ME. apposen, aposen for aposer, apposer, with unacented prefix $a$
for 0 , prop. ME. oposen, opposen, $\angle \mathrm{OF}$. opposer ME. also by apheresis posen, mod. E. pose ${ }^{3}$ : see
oppose and pose oppose and pose 3 , which are now discriminated.
Appose $^{2}$, though orig. a mere variation of oppose, seems to have been regarded as depending on $\mathrm{L}$. apponere, E. apposel, in ref. to 'putting' in discussion; bring objections or difficultie before one to be answered; examine; question; pose; puzzle.

The prest and Perkyn apposed eyther other,

And I thorw here wordes awoke, and walted aboute.
Piers Plowman (B), vii. 138.

Tho the people hym apposed with a peny in the temple,

Whether thei shulde therwith worschip the kyng Sesar.
Piers Plownan (B), 1. 47.

Christ was fonnd aitting in the teniple, not to gaze on
the outward glory of tie liouse, B. but to hear and $a p$
pose the doctors.
Bip. I all, Contemplations.

Specifically-2. To examine (a sheriff) with reference to (his) accounts. See apposer.

apposerł (a-pō'zér), n. [<appose $\left.{ }^{2}+e r I.\right]$ An tions; specifically, in England, a former officer tions; specifically, in England, a former officer of the Court of Exchequer who examined the
sheriff's accounts. The office was abolished in
1833.

apposite (ap'ō-zit), a. [< L. appositus, adpositus, placed uear to, fit, suitable, pp. of apponere, adponere, put or lay at, near, or by, put to, annex, add, $\leq a d_{,}$to, + ponere, place: see appose 1 and position.] 1. Placed near to ; specifically, in bot., lying side by side, in contact, or partly united. Hence-2. Suitable; fit; appropriate; applicable; well adapted site to the case; "ready and apposite answers,"
The common church office was us'd for the King without naming the person, with aome other, apposile to the neces the time.

What intuence, they delivered with a due emphasis, and apposite rising 3†. Apt; ready in speech or answer: said of persons.

appositely (ap'o-zit-li), adv. In an apposite manner; suitably; fitly; appropriately; pertinently.

appositeness (ap'o-zit-nes), $n$. The state or quality of being apposite; fitness; propriety; suitableness.

A knowledge of the primitive sense of a word very often applicationg which we had never suspected before, and accordingly to employ it with greater propriety and appositeness. G. I. Marsh, Lectures on Eng. Lang., p. 106. Pr. appozicio $=\mathrm{Sp}$. aposicion $=\mathrm{Pg}$. apposicão $=$ It. apposiaione, <LL. appositio(n-), adpositio $(n-)$, a placing by or near, setting before, application, L. apponere, pp. appositus: see appose ${ }^{1}$, apposite.] 1. The act of adding to or together; a setting to ; application; a placing together; juxtaposition.

The apposition of new matter.

rbuthnot, Choice of Aliments.

Placing in apposition the two ends of a divided nerv

doea not re-eatablish nerroua communlcation.
II. Spencer, Frin. of Paychol., $\$ 25$.

2. In gram.: (a) The relation to a noun (or pronoun) of another noun, or in some cases by way of explanation or eharacterization. Thus, "Cicero, the famous orator, livel in the first ceutury
before Christ" " "On him, thetr second Providence, they hung." In languages that distinguish casea, the noun th apposition ts in the same case as the word to which it apposed. The sanze term is alao used nf an adjective that less close relation than the proper attributive, being a qualifying clause. Thus, "They sang Darius, great and good "; "Truth, crushed to earth, shall rise agailn." Rar $y$, it is applied to a clause, whether subatanti ive, that qualifies a noun (or pronoun) in an equivalent relation pronoun) in the same construction, under the above conditions. Kniqhts Templars lords justises, Paul the apostle, my son John's book (where gon ta also possessive, the algu of the poascadive case betng required only with the fins! term), are examples of nouns in appo-
sition; "I Jesus have gent mine angel " (Rev. xxf1. 16) is an example of a pronoun and noun in appoaltion. phrase by way of explanation or illustration of another. $N . E . D$.- Growth by apposition, in bot. growth in thicknes by the repeated formatlon of lamines
as of celluluse in the thickening of cell-walls and of starch matione

positional (ap-ō-zisl'́on-all), a. [< apposition grammatical apposition.-2. In bot., lying together and partly uniting so as to appear like a compound branch: applied to the branches of alga.

appositionally (ap-ō-zish'onn-ạl-i), adv. In apappositive in an appositional way. positif, <J. as if *appositivus, < appositus: see positif, < L. as if "appositivus, < appositus: see
apposite.] I. a. 1. Apposite; applicable.-2. In gram., placed in apposition; standing over sentence.

A ppositive to the words going immediately before.
Knatchbull, Animad. In Libros Novi Test.,

II. $n$. In gram., a word in apposition.

appositorium (a-poz-i-tó'ri-um), n.; pl. apponere, adponere, put near or by: see apposite.] A conical vessel of glass or earthenware, the nar. row end of which is placed in a receiver while the larger end receives the neck of a retort: used as a precaution against the breakage of the receiver by contact with the hot neck of a retort during distillation.

appostt, $v . t$. [<F. apposter (Cotgrave), < It. appostare, $\mathrm{LL}$. appositare, $<\mathrm{I}_{\text {. }}$ appositus: seo N. E. D.

appraisal (a-prā'zal), n. [< appraise + -al.] ment or estimation of value or worth.

pppraise (a-prāz'), v. t.; pret. and pp. appraised, ppr. appraising. [< ME. apraysen, "apreisen, and also simply praisen; preisen, praise ${ }^{2}$, q. . .), <OF. "apreiser, apretier, aprisier, apriser, price, value, praise, < LL. appretiare, value, estimate, appraise, purchase, $<$ L. ad, to, + pretium (>
OF. preis, pris), price: sce price and praise, and ef. apprizc ${ }^{2}$ and appreciate.] 1t. To value;

Hur enparel was apraysut with prynces of my3te.

2. To value in current tooney; officially set a price upon; estimate the value of: used especially of the action of a person or persons appointed for the purpose, under direction of law or by agreement of persons interested: as, to appraise the goods and estate of a deceased person, or goods taken under a distress for rent. [See note under appraiser.]-3. To estimate generally, in regard to quality, service, size, weight, etc.

Greek and Latin literature we shall examine only for the aake of appraising or deduclng the sort of ideas whicl
they had upon the aubject of style. De Quincey, style, ifi. To get at the full worth of Emerson, ... we must ap. praise him for his new snd fundamental quality of genius, were.
The Century, XXVII. 927.
mere literary accomplishment, great as these
The his

Whom Enóch took, The sickly babe

Appraised lila weight, and fondled father limbs, Tennyson, Enoch Arden.

appraisement (a-prāz'ment), $n . \quad[$ appraise + -ment.] 1. The act of setting a value upon, under some authority or appointment; appraisal. It generally implies resort to the judgment of a disinterested person.-2. The rate at which a thing is valued; the value fixed, or valuation; estimation generally.

ppraiser (â-prā'zèr), n. One who appraises, or estimates worth of any kind, intellectual, moral, or material; specifically, a person licensed and sworn to estimate and fix the value of goods or estate. [Appraise, appraiser, appraiseapprizement, sithongh the latter were formerly used by good English authors, as Lord Bacon and Bishop Hall, and are atill frequently used in the United States. pprecationł (ay-rệ-ka'shon), n. [< L. as if apprecatio $(n-)$, < apprecari, adprecari, pp. appreeatus, pray to, adore, < ad, to, + precari, pray: see pray.] Invocation of blessing; prayer: as, "fervent apprecations," Bp. Hall, Remains, p. 404

apprecatorył (ap'rẹ̄-kạ-tọ̄-ri), $a . \quad[<\mathrm{L}$. as if apprecatorius, < apprecuri: see apprecation.] of tho nature of or containing a prayer.

Not so much apprecatory as declaratory.
$B p$. IIall, Case of C

appreciable (a-prë'shi-a-bl), a. [=F. ble, < L. as if "appretiabilis, < appretiare. appreciate.] Capable of being appreciated, estimated, or percoived; neither too small nor too great to be capable of estimation or recogni tion; perceptible.

A twelfth part of the labour of making a plough is an
J.S. Mill. Apreciable quantity.
An odour which has no appreciable effect on the contl. An odour which has no appreciable effect on the con-
actousness of a man has a yery marked effect on the con
ciousness of a dog. $I I$. Spencer, Prin. of Paychol. $\$ 79$. appreciably (a-pré'sbi-a-bli), adv. To a degree that may be appreciated or estimated; percepnoticeably: as, he is approciably better.

The puffi of an approaching goods-engine scem apprecably more numerous to the ear than those of a receding
A. Daniell, Prin of Physicg, $p$. 418. appreciant (a-prē'shi-ant), a. [< L. appretian $(t-) s$, ppr. of appre
Appreciative. [Rare.]

$$
\begin{aligned}
& \text { Such was the man whom Henry, of desert } \\
& \text { Appreciant alway, choge for higheat trust. }
\end{aligned}
$$

appreciate (a-prē'shi-ät), v.; pret. and pp. $a p-$ preciated, ppr. appreciating. [<L. appretiatus, pp. of appretiare, value or estimate at a price It. appregiare, apprezzare $=\mathrm{Pg}$. apreçar $=\mathrm{Sp}$. price: see price, and ef. appraise, apprize 2.$]$ I. estimate the commercial wortl of.-2. To es teem duly; place a sufficiently high estimate on; recognize the quality or worth of: as, his great ability was not appreciated.

The sectariea of a persecuted religion are seldom in a proper temper of mind calmly to investigate or candidly appreciate the motived of their enemles. Gibbon. I pronounce that yonng man happy who is content with having acquired the skill which he had ained at, and waits willingly when the accasion of making it ap
shall arrive, knowing well that it will not loiter

3. To be fully conscious of; bo aware of; de. tect; perceive the nature or effect of.

The eye appreciates tiner differences than art can expose.
Emerson, Works and Days.

There is reason to belleve thst insects appreciate sounds
of extreme delicacy. $\quad A$. $R$. Wallace, Nat. Selec, p. 202 
Withont study of his forms of metre or his seheme of preneni the gist or the worth of a painter's or a poet
Stesignburne, Shakespeare, $p$.

4. To raise in valne; advanee the exchange, quotation, or priee of: opposed to depreciate.

Lest a sudilen peace should alpmeciate the numey. G. Lainaty.

= Syn. Value, Prize, Estecm, Ext inate, Arpreciate. Falue and estimate commonly imply a cumparison with
standard of commerctal worth : as, to value g picture at standard of commerefal worth : sa, to value s picture a
so much; to estimate its walne at so nuch. To prize ls t value highly, generally for other than pecunisy reans, we prize a hook for its contents or associations; w prize a friend for luls affection for ns. To esteem ia some. times simply to think: as, I exteem lim a scomnurel;
sometimes to value: as, I psteem it liglitiy; sometlmee sometimes to ralue: as, 1 rsteem it lightiy; somethme
to lave a high opinjon of or set a hlgh value on: As, I esteem him for his own aako; in its lighest gense il im plies moral approbation. Extimating is an act of computation or juifment, and wholiy without feeting or moral approbatlon: as, to estimate the size of a ruom, the weigh
of a atone, the literary excellence of a honk, thic claracter of a person. (See esteem, n., for comparlson of corre-
sponding nouns.) Appreciate is to set n jist vaine on sponding nouns.) Appreciate is to set n fust value on thon: as, he appreciated the quality of the work. Witi this perception maturaliy goes a corresponding intellectua
valuatlon and moral esteem: as, they knew how to appreciate his worth. Apprecinte often Implies aiso that tho thing appreciated is likeiy to be overlooked or muleresti-
mated. It is commonly used of goon things: as, I nnder mated. It is commonly used of good things: as, I nender
stood his wickedness; I realized or recomnized his folly; I appreciated his virtue or wiscion. Compare such plirases
as an apprecintive audience, a few apprecintive wolds, ap. as an appreciative a
preciation of merit.

The pearls after removal from the dead oysters ar "classed" by passing through a number of amalt bras culjenders.
sorted as to colour, weighed, and valued.
Encye. Brit., XV111. 447.

That what we have it falls out

have we prize not lo the worth.

Though men esteen thee low of parentare.

The truth is, wc think lightly of Nature's penny ahows, nd est inate what we see ly the cost of the t/ckel.
Loretl, Fireside Traveis, p. 00.

It will be soon enongh to forget them [the anclents] able us to attenil to and appreciate them.

II. intrans. To rise in value: as, publie securities appreciated. whel the debt was funded.

appreciation (â-prē-shi-ā'shon), $n$. [ = F.appréciation; from the verb: see appreciate.] 1 . The aet of setting a price or money value on real, personal, or mereantile effeets. -2 . The aet of estimating the qualities of things and giving them their due value; elear pereeption or reeoguition of the quality or worth of anything; sympathetie understanding.

What aort of theory ls that which is not based upon a connetent appreciation of Well-observed facts and thej
relations? Those who alm to be Christian teachers should be fully which nay be employed agninat it.

3. A rising in value; inerease of valuo.

The appreciation of the metal which is onr single stand ard, and the consequent decline in prices, is one of the
causea of [the] . . . depression of trade.

4. In Seots law, the appraisement or valuing of poinded or distrained goods.

appreciative (â-pré'shi-ã-tiv), a. [< appreciat $+-i v e ;=\mathbf{F}$. appréciatif, relating to valuation.] Capable of appreeiating; manifesting due appreciation: as, an appreciative andienee.

A ride in the Sonthern summer moonlight being an evero an appreciative nalure.

appreciator (a-prē'shi-ā-tor), n. [< appreciate + -ar; $=1$. appréciateur.] 1 . One who appreciates.

A ibscovery for which thero wus no permanent appreci-
ator.

2. An apparatus for determining the amount of gluten contained in a given quantity of
flour.

appreciatory (â-prē'shi-ā-tō-ri), a. [< appreciate + -ory.] Expressive of admiration; ap ive: as, appreciatory words.

appredicate (a-pred'i-kật), n. [<NL. appradi-

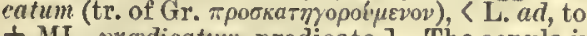
+ ML. prodicatum, prodieate.] The eopula in a proposition. See eopula.

With Aristotle, the predicate jncludes the copula; and from a hint by him, the latter has, hy sulbequent Gree logicians, been styled the appredicate.
Sir W. IJamilton, Loglc, I. 228. apprehend (ap-rē-hend'), $r$ [ [८OF. apprehendre,
inod. F'. appréhender, applehend, $=$ Pr. apprehenda" = Sp. aprehender $=\mathrm{Pg}$. apprehender the older Rom, forms being contracted. OF aprendre, apprendre, mod. F. apprendre, learn,

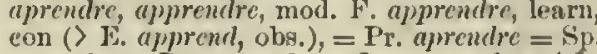
con $(>\mathrm{F}$. apprend, obs. $),=\mathrm{Pr}$. aprendre $=\mathrm{Sp}$
aprender $=\mathrm{Pg}$. aprender $=\mathrm{It}$. apprendere, $<1$ apprehendere, adprehendere, pp. apprehensus, adprehensus, contr. "pprendere, adprenelere, pp. apprensus, adprensus, lay hold upon, seize, understand, comprohend, <ad, to, + prchendere, eontr. prenderc, seize: seo prehend, prize ${ }^{\mathrm{I}}$, up prentiec, and apprise 1 , and ef. comprchend, rep-
rehend.] I. trans. 1 $t$. To lay hold of; seize upon; tako possession of.

I'hat I may opprehend that for which also 1 am appre-
I'hil. ili. 12. Apprehend your places, he shall be [ready] soon, and at
B. Joneon, Cynthia Reveis, v. 2 There is notining but luath a donble handle, or, at least, There is notining lut hath a donble handle, or, at least,
we lave two hands to apprehend it. 2. To take into eustody; make prisoner; arrest by legal warrant or authority.

The robber . . was apprehended sclling his plunder. liancock aut Adams, though removed by their friend rom the immediate vlcinty or the force sent to apprehen them, were apprised, too faithfnlly, that the work of deatl
was begun. 3. To take into the mind; seize or grasp men tally; take eognizance of. (a) To perceive; lear
by the senses. (b) To learn the character or quality of
becone accuanted or lamilinr with.

$$
\text { IIe seems to hear a Heavenly Friend, }
$$$$
\begin{aligned}
& \text { And thro' thick veils to apprehe } \\
& \text { A lahour working to an end. }
\end{aligned}
$$
Temaron, Two Volces. (c) To linaglne, especially an object of desire or dread;
form a concrete conccption of: frequently opposed to
comprehend or oftend.

Ife apprehends a world of flgures here,
But not the form of what he should attend.

Shak., I Hen. IV., I. s.

(d) To understand; take an intelligent vjew of.

This yet I apprehend not; why to those

So many and so various laws are given.

4. To antieipate; expect; especially, to entertain suspicion or fear of.

All things apprehending, nothing understanding.

0 , let my lady apprehend no feser. Shak, T. and $\mathrm{C}_{.}$, jii.

A man that apprehends death no more dreadfully, but
Shak., M. for JI., IV. 2. 5. To hold in opinion; be of opinion coneerning. See extraet.

When we would express our opinion modestly, instead of aaying, "Thls is my opinjon," or "This ia my judg ment," which has the air of dogmaticalness, we say, "I
concejve it to be thus-I imagine or apprehend it to be = Syn. 2. To catch, arrest, capture.-3. Apprehend, Com hrehend; to conceive, percejve, see, know. "We appremystcry, for instance, of the Holy Trinity - we lay hold it; but we do not take it all in, we do not compreherd it It belongs to the idea of God that he may be apwrehended though not com prehended by his reasonable creatures; he
has made them to know him, theugh not to know him ali, to apprehend though not to comprehend him." Trench. II. intrans. 1. To imagine; form a eoncrete coneeption of anything; have intellectual perception; catch the idea or meaning.

You apprehend passing ahrewdly. Shak., Much Ado, it. 1.

Put it into his hand; 'tis only there
He apprehends: he has his feeling left.

B. Jonson, The Fox, i. 1

Ilen that are in fault
Can sulutly apprehend when others ain

Beau. and F'., Majd's Tragedy, Jy, 2

To apprehend notionally is to have breadth of mind, but to be ahallow; to apprehend really is to be deep, but to be
narrow-minded. J. IJ. Nerman, Gram. of Assent, p. 32

2. To believe or be of opinion, but without positive certainty: nsed as a modest way of introdueing an opinion: as, all this is true, but we apprenend it is not to the purpose.

This, we opprehend, is a mistake.

Goldsmith, Versifficaljon

There are sentiments on some subjects witich I appre hend might be displeasing to the country".
Jeffersom, in Bancroft's Hist. Const., I. 437. 3. To be apprehensive; be in fear of a future evil.

It is worse to apprehend than to auffer.

\section{seizes or arrests.-} pprehensibility

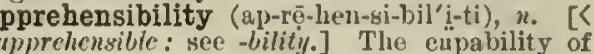
being understood, or the quality of being apprehensible.

Simplicity sni propuiar apprehenuibility will he every. apprehensible (ap)-rẹ̆-hen'si-bl), $a$. [<LL. apprelensibilis, < L. njprehensus, py. of apprehenlere, appreliend: seo apprehend.] Capable of being apprehended or understood; possible to be coneeived by the human intelleet.

It [Greck piliosoplyy so educated the intellect and con-
science as to render the Gos]el apmehensible, and, in many cases, cungenial to the mind.

G. J" Wisher, Begin. of Christianity, D. It0. apprehension (ap-rọ-hen'shon), n. [=F.appré hension, ( L. ajprehensio $(n-),<$ apprehendere, pp. apprehensus: see apprehend.] 1. The aet of seizing or taking hold of; prehension: as, the hand is the organ of apprehension. [Rare.]-2. The act of arresting or seizing by legal proeess; arrest; seizure: as, the thief, after his apprehension, escaped.

The inerease in the number of apprehensions for drunk-
Rue, Cont. Soclalism, p. 345. Kute, cont. Soclalism, p. 345 .
3. A laying hold by the mind; mental grasp; the aet or faeulty (a) of pereeiving anything by the senses; $(b)$ of learning or becoming familia with anything; (c) of forming an image in the imagination (the eommon meaning in English for three centuries, and the teehnieal meaning in the Kantian theory of cognition); $(d)$ of eatehing the meaning of anything said or written; (c) of simple apprehension (which see, below); $(f)$ of attention to something present to the imagination.

In apprehension, how like a god! Shak., Iramlet, ii. 2 They have happy wits and excellent apprehensions.
Burten, Anat. of Mel., p. 233.

To be false, and to be thougit false, is all one in respect of non who act, not according to truth, but apprehension. Apprehension then is simply an understanding of the
ldea or fact which a proposition enuuciates.
J. II. Ferman, Gram. of Assent, p. 18 . The proper administration of oul warl things will al ways
rest on a fust apprehension of their cause and origin.
Emersom, Fssays, 1st ser., p. 215 . Whatever makea a large impression upon the senses is, other things belng equal, easy of apprehention, even when
not of comprehengion.
Pop. Sci. M Q., XXVIII. 352 4. Antieipation of adversity; dread or fear of eoming evil; distrust of the future.

The acnse of death is most in apprehension.
Shak., II. for M., iti. I. As he was posseased of integrity and honour, I was under no apprehensions from throwing him naked into the am
phithestre of life.
Goldsmith, Vicar, 3 ili. Let a man front the object of his worst appreliension,
and his atoutnesa wlll commonly make his fear groundless.

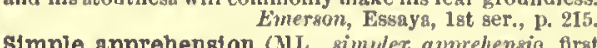
Simple apprehension (ML., simplex apprehensio, flrst
used by Jean Buridan, in the fourteenth century), in nominatistic logic, conception without judgment; the thinking of a usme as distinguislied from the thinking of a proposition: calied simple because a term is sinple compared Kamtiar philosophy, that operation of the mind by which
the nanifold of intuitlon is cullected into definite images. It is calted pure when the manifoli operated upon ja that of pure space and ime. $=5 y n$. 3. Comprehension, understandlug, idea, notlon.-4 Alarm, Apprehension, Fright,

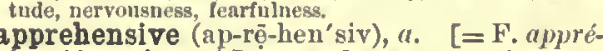
apprehensive (ap-rẹ-hen'siv), a. [= F. appre-
hensif, anxions, ( L. anprchensus, pp. of appre hensif, anxious, L L. apprchensus, pp. of appre-
hendere: see apprehend.] 1t. In the habit of seizing; ready to eateh or seize; desirous to lay hold of: used literally and figuratively. 1 shall be very apprehensice of any occasions wherein I
may do any kind offlces. 2. Quiek to learn or understand; quick of apprehension.

A good sherrls-aack ... ascends me into the brain makes it alprehenrive, quick, forgetlve, full of nimible,
fery, and delectable slapes. An understanding dullil by th' infelicity Of constant gorrow is not apprehensive
In pregnant novelty. Ford, Lady'a Trial, iv. 1. Is there a surer way of achieving the boast of Themisto cles, that he knew how to make a small State a great one, than by making it wise, bright, knowing, opprehensite,
quick-witted, ingenlous, thoughifni?
R. Choote, Aldresseg, p. 111. 3. Realizing; eonseions; cognizant. [Rare.] A man that has spent his younger years in vanity and foliy, and is, by the grace of God, appreliensive of it.
Jer. Taylor.

4. In a state of apprehension or fear; feeling alarm; fearful.

The leading retormers Gilagegan to be apprehensive for
their lives. 
apprehensive

5. Inelined to believo or suspect; snspicious: as, I am upwrehensive that he does not understand me.

He [the king] became apprehensive that his motives were
misconstrued, eveu by lis friends.
Illlem.

6. Perceptive; feeling; sensitive.

Thoughts, my tornentors, arm'd with deadly stings,

Nangle my apprehensive tenderest parts.

7. In metaph., relating to simple apprehension. It yields as a corollary that judgment, that comparison, that the cog as
hensive act. Sir W. Hamilton. Apprehensive concept, a concept withont jndgment.proposition without assent or dissent: opposed to adhesi lenowededge.

apprehensively (ap-rệ-hen'siv-li), adr. In an apprehensive manner; with apprehension. apprehensiveness (ap-rē-hen'siv-nes), $n$. state or quality of being apprehensive.

eprendt $t$ [<F apprendre <L apprendere lay hold of: see apprehend.] To lay hold of; apprehend.

apprentice (a-pren'tis), $n$. [Early mod. E. also apprentise, کME. apprentice, aprentis (and by apheresis often shortened to prontice, prentis, mod. E. prentice, q. v.), < OF. apprentis, aprentis, aprentice (Rouchi dial, apprentiehe $=$ Pr. ap prentiz $=$ Sp. Pg. aprendiz, ML. apprentieius pl.), orig. nom. of aprentif, apprentif, a learner of a trade, < apprendre, aprendre, learn, < L apprenderc, contr. from apprehendere, lay hol apprendere, contr. from apprehendere, lay hold of, understand, in ML. and Rom. also learn: see to serve some particular individual or company for a specified time, in order to learn some art trade, profession, manufacture, ete., in which his master or masters become bound to instruct him. Hence-2. A learner in any department; one only slightly versed in a subject a novice- - 3. In old English law, a barrister of less than sixteen years'standing. After this period he might be called to the rank of serjeant. - Parish, town, etc, apprentice, s person bonnd
out by the proper anthorities of a parish, town, etc., to out by the proper anthoritices of a parish, town, etc., to apprentice (a-pren'tis), $v$. t.; pret. and pp. ap prentieed, ppr. apprentieing. [< apprentiee, $n$.]
To bind to or put under the care of a master, for the purpose of instruction in some art, trade, or profession; indenture.

apprenticeaget (a-pren'tis-āj), $n$. [Also spelled apprentis (s)age, 1 . apprentisage, now appren tissage, (OF. apprentis: see ap

apprentice-box (a-pren'tis-boks), n. Same as thrift-box.

apprenticehoodt (a-pren'tis-hud), n. [< apprenice + -hood.] Apprenticeship.

Mnst I not serve a long apprenticehood
To foreign passages? apprenticeship (a-pren'tis-ship), $n$. [< apprentiee +-ship.] 1. The service or legal condi-
tion of an apprentice; the method or process of gaining knowledge of some trade, art, or profession from the instruction of a master. - 2 The term during which one is an apprentice. appressed (a-prest' $\left.{ }^{\prime}\right), a_{\text {. [ L L appressus, adpres }}$ sus (pp. of apprimere, press to, $<$ ad, to, + pre fitting closely to; apposed. A term nsed in botany and zooblogy, sild to a limited extent in geology: as, th
spikelets of s grass msy be closely oppressed to the rachi So \&lso hairs or Jeathers when closely sppoosed are said th

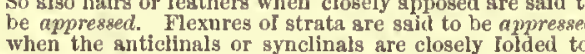
when the anticlinals or synclinals are closely Iolded th
vether, so that the opposite corresponding portions bronght in contact with each other. In botany, also writ

apprestt (a-prest'), $n_{0}$ [< $\mathrm{OF}^{2}$. apreste, apprest mod. apprét, preparation, < aprester, apprester
(mod. appréter), make ready, < L. ad, to, + prostare, make ready: see prest ${ }^{2}$, and cf. press ${ }^{2}$ impress 2 .] Preparation or provision, especially
for war, by enlisting soldiers.

Vespasian laie st Yorke making his apprests ... to go IIolinshed, Chron., Scotland (1586), p. 48.

apprâteur (a-prā-tèr'), $n$. [F., lit. a preparer, appréter, prepare: see apprest.] A rubber usering

apprisel apprizel+ (a-priz') as appraisal. prise, (aprise $\mathrm{OF}$ aprise, apprise, instruetionprop. fem. of apris, appris, pp. of aprendre, $\mathrm{F}$. apprendre, teach, learn, inform, < L. apprendere, sble estate of his debtor. ment. prizer the Greeks. mation. approbation

apprehendere: see apprehend.] Learning; in truction; information; Jore.

apprise ${ }^{1}$, apprize ${ }^{1}$ (a-prï'), $v$. $t$. ; pret. and pp. apprised, apprized, ppr. apprising, apprizing. [<F. appris, apprise ( $\langle\mathrm{L}$. apprensus), pp. of ap prendre ( $\mathrm{L}$. apprendere), teach, inform, learn see apprise I, n.] To give notice, verbal or written, to ; inform; advise: followed by of befor'o that of which notice is given: as, we will apprise the general of an intended attack

IIe hsd been repestcdly apyrised that sond Hecelay, Hist. Eng $x$

We now snd then detect in nsture slight distocstions which apprize us thst this surface on which we now stan

=Syn. Notify, scquaint, wsin, tell, mention to.

apprise ${ }^{2}, v$. $t$. See apprize 2

apprize ${ }^{1}, n$. and $v$. Sce apprise $\mathrm{I}$.

apprize ${ }^{2}$, apprise ${ }^{2}($ a-priz $), v, t$; pret. and pp. apprized, apprised, ppr. apprizing, apprising. [<ME. aprisen, < OF, apriser, aprisier (ME. also *apreiser, apretier), < LL. appretiare, value, es timate: see appreciate, appraise, and ef. prize ${ }^{2}$, priee, praise.] Same as appraise.-To apprize a

apprizement (a-priz'ment), n. [< apprize ${ }^{2}+$ -ment. Cf. appraisement.] Same as appraise-

apprizer (a-prī'zèr), n. [< apprize $2+e r 1$.

approach (a-prōch'), $v$ [ [ ME. aproehen, ap proeken, < OF. aproehier, F. approeher $=\mathrm{Pr}$. apropehar = It. approcciare, < M. appropiare, come near to, < L. ad, to, + propius ( $>$ Pr. pro$p i=\mathrm{F}$. proelie: see proehain), nearcr, compar. 1. near; advance nearer; come into presence.

$$
\begin{aligned}
& \text { He was expected then, } \\
& \text { But not approach'd. }
\end{aligned}
$$
But not approach'd. Shak., Cymbeline, il. 4.
He made signs Jor Rip to approach and assist him
Irving, Sketch-Book, p. 53 . 2. Figuratively, to draw near; approximate come near in degree: with to: as, he approaches to the character of an able statesman.

II. trans. 1. To bring near; advance: as, he approached his hand to the cup.

I . . a approached ny chsir by siy degrees to the fire. Even as a resolved general approaches lis camp . . . as 2. To come or draw near to: as, to approaeh the gate.-3. Figuratively, to come near to in quality, character, or condition; nearly equal:

Such and so extraordinary was the embrodery, that never saw snything approaching it.
Evelyn, Disry, Nov. 17, 1684. He was an admirable poet, and thought even to have
Sir II. Temple. In proportion as mankhind approach complete adjust ment of their natures to social needs, there must be fewer
and snsiler opportunities for giving sid.

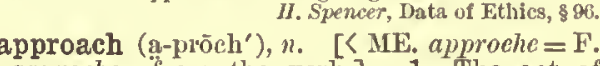
approeke; from the verb.] 1. The act of drawing near; a coming or advancing near.

Does my approach displease his grace? are my eyes
so hateIul to him? Fletcher, Wife for a Mlonth, i. 1. 2. Access; opportunity or liberty of drawing near; nearness: as, "the approaeh to kings,"
Bueon.-3. Nearness or close approximation in quality, likeness, or character.

Absolute purity of bloot, I repest, will be found no-
where; but the nearest approaches to $\mathrm{tt}$ must be lookel for smong those nstions which have played the least figure We can none the less restore or reconstruct individna old Aryan words with \& fair approach to sccursey.
J. Fiske, Evolutionist,

4. A passage or avenue by which anything i approached; any means of access or approxi-

The approaches to the city of New Ortesns, from the eastern quarter also, wtll require to be examined, and The approach by rail is through the marshes snd lagoon ther side of the Rho 5. $p l$. In fort., the works thrown up by be siegers to protect themselves in their advances toward a fortress. Compare boyau.-Counter approaches, in fort., works carried on by the besieged proach, in math., a curve along which a body descendin by the force of gravity makes equal apjpoaches to the
horizon in equal portions of time.-Method of approaches in algebre, a method of resolving certain probens by assigning limits and unaking fradual approximahort., to inarch. =Syn. 1. Approxinuation, advent. - 2, Ad approachability (a-prō-châ-bil'i-ti), n. [<appronchable: see -bility.] "Approachableness affability. Ruskin.

approachable (a-prōeha-bl), a. [< approach + -able.] Capable of being approached; accessible.

approachableness (a-prōehạ-bl-nes), n. The state or quality of being approachable; affability; friendliness.

approacher (a-prō'chér), $n$. One who approaches or draws near.

approaching (a-prō'ching), $n$. In hort., the act fing or shoot of one tree into another without cutting it from the parent stock. Also called inarching and grafting by approaeh.

approachless (a-prōch'les), a. [< approach + proached; inaccossible; forbidding.

approachment (a-prōch'ment), $n$. [< approaeh + -ment.] The act of approaching; approach; affinity; resemblance in trait or character. [Rare.]

Ice will not concrete, but in the approachment of the
sir.

approbate (ap'rọ̄-bāt), $a . \quad[<\mathrm{L}$. approbatus, pp.: see the verb.] 1†. Approved. Sir T. Elyot.-2 In Scots law, accepted. Sce the verb.

approbate (ap'rọ-bāt), $v . t$. ; pret. and pp. $a p$ probated, ppr, approbating. [< L. approbatus, pp. of approbare, assent to as good, favor, ap prove: see approve I.] 1. To express approbation of ; manifest a liking for or degree of satisfaction in; express approbation of officially, as of a person's fitness for a public office or employment; approve; pass.

The cause of this battle every man did sllow and appro. Mr. IIntchinson approbated the choice. J. Eliot. 2. To license: as, to approbate a person to preach; to approbate a man to keep a hotel or other publie house. [United States.] valid: ehiefly in the following phrase.-Approbate and reprobate, in Scots law, to attempt to take sd vantsge of one part of a deed while rejecting the rest: as
Jor exsunple, where a disposition on a destll-bed revokes a previous liege-ponstie conveyance to the prejudice of the heir st law, but still gives the estate past the heir. The
heir who abides hy the deed in so Is as it revokes the liege-ponstie deed to his prejndice, while he challenges it in the estate, is said to approbate and reprobate the deed. This, lowever, is contrary to lsw, and csunot be done; he minst elect between the two sl
low the act is csiled election. This is not an ordinary csse of election, but I consider
that it is not open to her both to approbate and reprobote
- to take benefts nnder the settlement, and by her will to dispose of property which is comprised thejein in a manner not in accordsnce with its provisions.

approbation (ap-rō-bā'shon), $n$. [〈ME. approbation, proof, < L. approbatio( $n-),<$ approbare, pp. approbatus: see approve ${ }^{1}$.] 1. The act of to something as proper or praiseworthy; sanction ; approval; commendation.

The silent approbation of one's own breast.

(i. 8 Both managers and suthors of the least merit laugh at your pretensions. The public is their critic-without whose Iair approbation they know no plsy csn rest on the
stage. If the approbation of good mon be an object fit to be pursued, it is fit to he enjoyed.
$D$. Webster, Speech, Senste, Msy $27,1834$. 2. In the Rom. Cath. Ch, the official judgment of a bishop or his representative approving the fitness of a priest for hearing confession. It is distinct from the conferring of jurisdiction or power of sbsolving, though, except in exse of danger 3. quired in England, France, etc., for the publi-
cation of a book or other writing. $-4+$. Conclusive evidence; proof. Shak,-5t. Probation; trial; novitiate.

This day my sister should the cloister enter,

And there receive her approbation.
Shak., M. for M., i. 3.

=\$yn. 1. Approbation, Approval, liking, commendstion sanction, consent, concurrence. Approbation and approval are becoming separated in meaning, approbation being
used more for the inward feeling, and approval more for the formal act. 
approbative (ap' rō-bā-tiv), $a . \quad[=\mathrm{F}$. approbatif', < L. as if "approbativus: sec npprobute
and-ive.] Approving; expressing, inplying, or and -ive.] Approving; expres

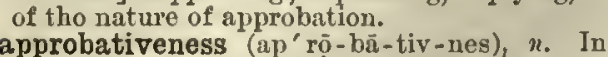
phiren., ambition; love of praise or desire for rame; pride of character; sensitiveness to the opinions of others. Fouler and Wells.

approbator (a]' rọ̄-bă-tor), $n$. [L., all approver, Supprobere, pp. appröbatus, approve: see up3rove ${ }^{1}$.] Ono who approves formally: as, [liare.]

approbatory (ap'rō-būi-tọ-1ii), a. [CMLL. approbatorins, < L. approbutio: see approbutor.] Having the nature of sanetion; eoutaining or expressing approbation.

Letters . . conflinuatory and approbatory.

approclivity $\nmid$ (ap-rọ̄-kliv'i-ti), n。 $[\langle(a p-1+p r o$ elivity.] Proelivity; incliuation; tendeney. apprompt ${ }^{1}+$ (a-prompt'), $u^{2} \cdot t_{0}$ [< L. $(a d$, to, + promptus, prompt: see prompt.] To prompt stimulate; eneourage: as, "to apprompst our in-

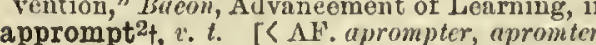

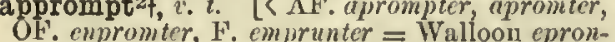
ler $=\mathrm{It}$. improntare, borrow, $=$ Wallach. inprumutà, give or take iul pledge, < LL. *impromutuare, $\langle$ in yromutum, in advaneo ( $\rangle$ Wallach. inprumeit, a pledge): L. in, in, for; promutuum, an advanee, neut. of promutuns, paid beforehand, alvanced, $<$ pro, beforehand, + mutuns, lent: seo mutual.] To borrow.

approof $t$ (a-pröf' $), n$. [Tho mod. form is related to approve as proof to proce; ME. appreffe, apref, $<$ OF aprove, aprewe, proof, trial < aprover, prove: see approvel, and ef. proof.]
1. The act of proving; trial; test. -2 . Approval or approbation.

lle was pleased a marriage feast to crown
With lis great presenee,

J. Beamenont, Psyche, x. 23

approperatet (a-prop'e-rāt), v. t. [< L. apad, to + properare, hasten, $<$ properus, quick, ad, to, + properare, hasten, < properus, quick, make, prepare: see pare, prepare.] 'To hasten. Coekeram; Johinson.

appropinquateł (ap-rō-ping'kwāt), v. [<L. appropinquatus, pp. of appropinquare, adpro-
pinquaro, $<a d$, to, + propinquare, bring near, propinquus, near: see propinquity.] I. intrans. To draw near; approach.

II. trans. To bring near.

appropinquation + (ap " rọ-ping - kwä 'shon), $n$. [R L. appropinquatio( $n$-), < appropinquare: see
appropinquate.] 1. The act of coming into near relation or proximity; a drawing nigh.

There are many wsys of our appropinquation to God.

2. The act of bringing remote things near.

appropinquet (ap-rộ-pingk'), $t^{\prime} t_{0}$ [ [ L. approiniquere: see appropinquate.] To approach get nearer to. [Rare.]

The elotted blooil withln my hose

With mortal erisis doth portend

S. Butter, lluwibras, I. III. 500

appropinquity (ap-roo-ping'kwi-ti), n. [< ap-1 + propinquity, q. v. Cf. appripinquate.]
state of being near; propinquity. [Rare.]

appropret, $v . t$. [C NE. apropven, appropren, OF. (iproprier, F. approprier $=$ Pr. apropriar $=$ $\mathrm{Sp}$. apropiar $=\mathrm{Pg}$. apropriar $=1 \mathrm{t}$. appropriave HL. appropriare, appropriate: see appropriate, .] 1. To appropriate; set apart for a specia purpose; assign; take possession of. Specifiporation.

appropriable (a-prō'pri-a-bl), a. [<LL. as i appropriabilis, < appropriare: see appropriate.] Capable of being appropriated, set apart, sequestered,

appropriamentt (a-prō'pri-â-mẹnt), n. [< LL. appropriare: seo appropriate and -ment.] Anything properly or peculiarly ono's own; a characteristie.

\section{If you ean neglect
Your owu appropruments, but praising that \\ nothers wherem youn exeel yo Ford, Lo}

appropriate (ạ-prō'pri-āt), $v_{0} t_{*}$; pret. and pp. "ppropricted, ppr, appropriating. [<LL. appropriatus, pp. of appropriare, adproprinte, make one's own, < L a dil, to, t proprius, one's own:
see proper.] 1. To take to one's self in exclu- sion of others; elain or use as by an exelusive right: ass, let no

The spirit of to to To the
divel. Miltem, 1 . L

A man is a knave who falsely, but in the paule of the ing all susplciom trom himselt, eharges you or me with having approy riated noother man's jewel. Tho ostato 1 so admitred and enviet is my own. It is

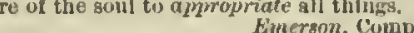

2. In general, to take for any use; put to use. In solar light the leaves of plants decompose botls carbenle anhydride sncl water, apyropriating thie carbon and the bydrogen of each for their own growth and nutrition.
IV. A. Miller, klem. of Chem., 331 . 3. To set apart for or assign to a particular purpose or use, in exelusion of all other purposes or uses: as, Congress nppropriated moro money than was needed; to appropriate a spot of ground for a garden.

The profts of that establlshment [the Post-office] has Pro of York. Siacrullay, Itist. Eng., Hil.

4. In eccles. lase, to annex, as a benefice, to an ecelesiastical corporation, for its perpetual use. appropriate (a-prō'pri-ăt), a. and $n$. [<LL. appropriatus, pp.: see the verb.] I. $a$. Set apart for a partieular use or person ; hence, bolonging peculiarly; suitable; fit; befitting; proper. It might be thought to be rather a matter of dignity
than any matter of diffidence apyroumiate to his own case. Jore appropmiate instsnees abound. Browening, Ring and Book, II. 124.

A warl ke, a refined, an Industrial society, esch evokes and requires its speeifle unslitles and produces its approo Syn. Apt, becoming, in keeping, felleltous.

II.t $n$. Peculiar charneteristic; attribute; proper function; property.

The Bible's approwriate belng ... to enlighten the yes and make wise the simple.

Boyle, Style of Holy Scripture, p. 44.

appropriately (a-prō'pri-āt-li), adv. In an appopriate or proper manner; fittingly; suitably. ppropriateness (a -prō'pri-ât-nes), $n$. The
quality of being appropriate or suitable; applicability.

A hunthg-box, a park-lodpe, may have a forest graee
and the lesuty of a pproppriatesesess. De Quincey, Style, 1 . appropriation (a-prō-pri-äshon), $u_{0}[=\mathbf{F} \cdot \alpha u$ propriation, < LLL. appropriatio(n-), < appropriating, setting apart, or assigning to a particular use or person in exclusion of all others; applieation to a special use or purpose; specifieal$y$, an act of a legislature authorizing money to be paid from the treasury for a special use.2. Anything appropriated

The speclfte appropriations made by Congress for the mints snd sssay offiees of the Unlted States daring the

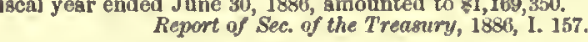

3t. Aequisition; addition.

He doth nothlng but talk of his horse; and he makes it a great appropriation to bls own good parts that he esn
shoe him himself. 4. In lawo: (a) The annexing or setting apart of a benefice to the perpetual use of a spiritual eorporation. (b) The determining to which of several debts a sum of money paid shall be applied. It the dehtor does not deslguate the appropriaarises, the ecurt may to it. - Appropriation bill, \& legislattve bill proposing appropriations of noney for sone par
ticular purpose, as for carrying on some de partment of goverument.
appropriative (a-prō'pri-āativ), a. [< appro
priate + -ive.] Appropriating; making appropriate + -ive.] Appropriating; making appropriation; having the po

appropriator (a-prō' pri-ā-tor) ,n. [< LL. as if appropriator, appropriare, appropriate.] 1. IIe knew very well that he was the ... appropriator of the money whieh... ought to have failen to his younger 2. In eeeles. lax, one who is possessed of an appropriated benefice. See appropriate, $v, 4$ approprietary (ap-rö-pri'e-tä-ri), n. [Irreg. appropriate, aft

[s approne $1+$ -able.] Capable of being approved; meriting approbation.

pprovableness (a-prö'va-bl-nes), n. [< approvable $+-n e s s.]^{3}$ The quality of being approvable. pproval (a-pröval), ". [< approce $1+-a l$. dation; sanction; ratification.

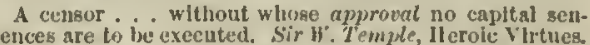
Ife was tender, Instruating, anxlous tor her ayprovet, ager to unifold limself to her. Mry. Oliphant, Hester, xxll. =Syn, Approbation, Approvat (sce approbution), acecpt-

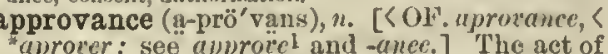
approving; approbation. [Arehaic.]

As In The people standing all abont,

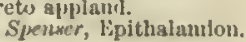

approve ${ }^{1}$ (a-pröv'), v.; pret. and $11 \%$ approced rarely pp. apuroven, after urocen), ppr. approving. [Early mod. E. also approore, (ME. aproren, appreoven, apreven, appreven, $\mathrm{COF}$. aprover, approver, approweir, appreucer, approber, ete., F. approuter $=\mathrm{Pr}$. Sp. aprobar $=\mathrm{Pg}$. approvar $=$ It. approvare, < L. approbare, allprobuere, assent to as good, approve, also show to be good, confirm, <ad to + probure < probus, good: see prove.] I. trans. 1. To make good; show to be real or true; prove; confirm; attest; corroborate.

What danned error but some sober brow

Will bless It, and approve it with s text?
Shak., M. OI V., lil. 2

Wouldst thou approve thy censtancy? Approce

First thy obedienco.

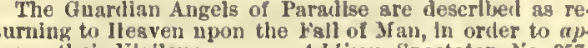
2. To show; jirove to be; demonstrate. In all things ye have approced yourselves to be elear in
2 Cor, vil, 11. 'Tis an old Jesson; Time approver It irue.

3. To sanction officially; ratify anthoritatively: as, the decision of the court martial was aparoved.

And by thy eoming certainly approve
The pledge of peace. Ford, Henour Triumphant. 4. To pronounee good; think or jud me rell of admit the proprioty or exeellence of; bo pleased with; commend: as, on trial the goods were approred; to approve the policy of the admillistration.

Yet their posterity approve their sayings. Ps. xllx. 13. The deed which closed the mertal course of theso sovereigms, I shall neither approve ner condeun.

$$
\begin{aligned}
& \text { She wore the colours I approved. } \\
& \text { Tenuyson, The Letters. }
\end{aligned}
$$

5. To manifest as worthy of approval; commend: used reflexively.

The mirseles of Christisnlty, so far from shocking nee approve themselves st once to nyy intellect snd nuy heart.
Channing, l'erfeet Life, p. 248.

6. To put to the test; prove by trial; try.

N8y, task me to my wurd; approve me, lortl.

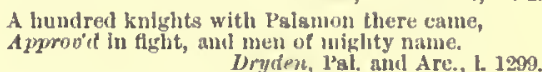

Hence - 7t. To conviet upon trial or by proof. He that is approo't in this offence Approved bill or note, in conn, a bill ur note drawn by a
solvent, trustworthy party, and to which therefore no regII intrans

II. ably; bo pleased: usually with of

I showed you s phece of lisck and white stutr, just sent
rom the dyer; which you were pleased to a approre of and rom the dyer; which you were pleased to approre of snd pprove 2 (a-pröv'), t. t.; pret. and pp. ap(NL. approbare, approvere), confused with approved, is a mod. error, due to a misunderstanding of the earlier forms; prop. approw, $<$ late ME. approwe, aprove, aproue, $<\mathrm{OF}$, aproer, approer, approuer, approner (> ML. approare, appruare, and later apprurare, approcare, as above), profit, benefit, improve, $<a$ (L. $a d)$, to, + pro, pru, prou, preu, earliest form prod ( $) \mathrm{ME}$. provo), benefit, advantage, profit: see prouc 1 and process. By a change of prefix, approve 2 has become improxe, q. v. Cf. appair, impair.] In law, to turn to one's own profit; augment the value or profits of, as of waste

As long ago as the thirteenth century the statute of Nerton had suthorized the lords of manors to approve, land as would leave enough uninelosed tor the use of the commoners.
cy. Potlock, Land Laws, p. 173. 


\section{approvedly}

approvedly (a-prö'ved-li), adv. In a manner to gain approval ; to an approved degree. approvementI (a-pröv'ment), $n$. [< approve ${ }^{1}$ $+-m e n t.] 1+$. The act of approving; approba-
tion; an expression of assent or preference.

I did nothing without your approvement. Llayward.

$$
\begin{aligned}
& \text { I am not bound } \\
& \text { To fincy your approvements, but my own }
\end{aligned}
$$

2. In lave, the act of becoming an approver or informer; the act of a prisoner who confesses, and aceuses his accomplices; the act of turning king's or state's evidence.

approvement 2 (a-pröv'ment), n. [Prop. approument (see approve ${ }^{2}$ ), < late ME. approwement, approment, aprowcment, aproument, くOF. aprocment, aproucment, aprowement (ML. approvamenta, appruciamenta, approfiamenta, pl.), aprocr, ete., profit, benefit, improve: see ap-
prove 2 and -ment. Now immovement, q. v.] In prove ${ }^{2}$ and -ment. Now improvement, q. v.] In lord of a manor of common or waste lands by inclosing and converting them to his own nse. (b) The profits of such lands.

approver I (a-prö'vèr), $n$. [ME. "approvour, usually provour, only in def. 1 ; $<$ approve $1+$ er 1 .] 1. One who approves or commends. -2 . One who proves or offers to prove; specifically, in law, one who confesses a felony, and gives evidence against his accomplice or accomplices; an informer and aceuser; one who turns king's or' state's evidence.

In the 22 Edw. III. a conmission was issued to inquire into the practice of torturing men by gaolers to compel
them to become approvers.

approver ${ }^{2} \uparrow$ (a-prö'vèr), n. [Prop. apprower (see approve 2 , < ME. apprower, approwour, approuou;, <AF. aprouour, OF." aproeor (ML. ap prouator, appruator, NL. approbator), ( aproer, etc., profit, benefit: see approve ${ }^{2}$ and -er.] One who manages a landed estate for the own

approvingly (a-prö'ving-li), adv. In a com-

mendatory manner; in such a way as to imply approval.

approximal (a-prok'si-mal), a. [< L. $a d$, to, + proximus, next, + al. Cf. approximate.] Close contiguons surfaces of adjoining teeth.

approximant (a-prok'si-mant), a. [< LL. ap proximan $(t-s$, ppr. of approximare: see approximate.] Approaching in character; approximat ing. [Rare.]

Approximant and conformant to the apostolicsl and
pure primitive church. approximate (a-prok'si-māt), $v$.; pret. and pp. approximated, ppr. approximating. [< LL. ap proximatus, pp. of approximare, $<\mathrm{L}$. ad, to, + proximare, come near, < proximus (for "propsimus), superl. of prope, near: see proximate, and ef. approach.] 1. trans. To carry or bring near; advance elosely upon; eause to approach in position, quality, character, condition, etc.

To approximate the inequality of riches to the level of

II. intrans. To come near; approach closely; figuratively, to stand in intimate relation; b remarkably similar.

It is the tendency of every dominant aystem .... to force from the apprehension which they nsturally feel, lest, in those points in which they approximate towards it, they J. II. Netoman, Development of Clrist. Doctrine, Int approximate (a-prok'si-māt), a. [ LLL. approximatus, pp.: see the verb.] 1. Near in position applied to teeth so arrsinged in the jaw that there is $n$ vacancy between them, s the teeth of man. (b) In bot. 2. Near in character; very similar: as, a state ment closely approximate to a falsehood.-3. Nearly approaching accuracy or correctness; nearly precise, perfect, or complete: as, an approximate result; approximate values.

The English must certainly rank among the more mixed nations; we csnnot claim the approximate purity of
Basques snd Albsnians. E.A. Freeman, Amer. Lects., p. 88. Approximate value or formula, in matho, one which approximately (a-prok'si-mät-li), adv. In an approximate manner; by approximation; nearly; closely.

approximation (a-prok-si-m̄̄'shon), n. $\quad[=\mathrm{F}$. approximation, $<\mathrm{LL}$ approximare: see approxiing, moving, or advancingroximating; a draw tion, degree, or relation; approach; proximity.
280

apricot

The largest capacity and the most noble dispositions are Lut an approximation to the proper standard and true
I8, Taylor. Fot directly but by suceess

cessive approximatione, do manII. Spencer, Prin, of Biol., \& 147.

2. In math. and phys.: (a) A continual approach to a true result; the process by which the value of a quantity is calculated with continually increasing exactness without erer being actually ascertained. (b) A result so obtained; a result which is not rigorously exact, but is so near the truth as to be sufficient for a given purpose. Horner's method of approximation (named for its inventor, W. G. Horner, died 1837), \& method of solving numerical equations, the moat salient features of which are That each approximate value is obtained from the last by
Taylor's theorem, and that the coefficients of the devel Taylor s theorem, and that the coefficients of the develapproximative (a-prok' si-mä-tiv), a. $[=\mathrm{F}$. approximatif, <LL. as if "approximativus, $<$ approximare: see approximate.] Approa

coming near, as to some state or result. approximatively (a-prok'si-mā-tiv-li), adv

appui, appuy (ap- $\left.\overline{-}^{\prime}\right), v . t$; pret. and pp. appuied, appuyed, ppr. appuying. [< F.appuyer, $\mathrm{OF}$. apuyer, apouier, apoier, $=\mathrm{It}$. appoggiarc (see appoggiato), <'ML. appodiarc, support prop, <L. ad, to, + podium, a support, a balcony, ete., $>$ F. pui, puy, a hill (appuye, a bal cony, ete., $>$ F. pui, puy, a hill (appuye, a bal-
cony), = It. poggio, a hill, bluff, formerly also a horse-block, etc.: see podium.] To support milit., to post, as troops, at a point of support. appui (ap-we' $\left.\bar{e}^{\prime}\right), n$. [F., a support, prop, < appuyer, support: If a vine be to climb trees that are of any great helght
there would be stays and appries set to it.
IIolland, tr. of Pliny, I. 538

2. In the mandge, a reciprocal action between the mouth of the horse and the hand of the rider, the bit and rein forming the line of communication: thus, a horse with a sensitive munication: thus, a horse with a sensitive
mouth may be said to have a good appui, and the same may be said of the rider if his hand is good.- Polnt d'appui (pwan dap-wee'), point of supon which operstions are based.

appulse (ap'uls or a-puls'), n. [<L. appulsus, adpulsus, driving to, a landing, approach, $<$ ap pulsus, adpulsus, pp. of appellere, adpellere, drive to, $\langle a d$, to, + pellcre, drive: see pulse, an against or driving upon something; active or energetic approach. [Rare.]

In all consonanta there is an appulae of the organa.

2. In astron., the approach of any planet to a conjunction with the sun or a star. - 3t. A coming to land, as of a vessel: as, "the appulse appulsion (a-pul'shon), sio $(n-),<$ appulsus: see appulsc.] The aet of striking against; collision; coneussion; shock. appulsive (a-pul'siv), $a$; [< L. appulsus: see appulse and -ivc.] Striking against; impinappulsively (a-pul'siv-li), adr. By appulsion. appurtenance (a-pêr'te-nạs), n. [A]so, less commonly, appertenance, appertinence, and, pertainance, partcnaunce, but earlier and usually appurtenaunce, apportenaunce, apurtenaunce, aportenaunce, apportenaunce, apurtenaunce, apor-
tenance, $\angle \mathrm{AF}$. apurtenance, OF. apertenance, apartenance $=$ Pr. apartenensa $=\mathrm{It}$. appartenenza, < ML. appertenentia, < LL. appertinere belong to, appertain: see appertain, appurtenant, and ance.] 1. The act, state, or fact of appertaining.-2. That which appertain s or belongs to something else; something belonging to another thing as prineipal; an adjunct; an appendage; an accessory: as, "appurtenances majesty," Barrow, Sermons, III. xiv.

The Pope with his appertinences the Prelates. Revolutions upon revolutions, each attended by its ap-
purtenance of proscriptions, Macaulay, Hallan's Const. Hist. 3. Specifically, in law, a right, privilege, or improvement belonging to a principal property, to an estate, outhouses, gardens, etc., attached to a mansion, and the like.

appurtenancef (a-pér'te-nans), v. $t . \quad$ [< appurtenance, $n$.$] To furnish with by way of appur-$ tenance; supply or equip.

The buildings sre antient, large, strong, and frir, and appertenanced witil the necessaries of wood, wster, fish.
ing, parks, and mills. $R$. Carew, Survey of Cornwall. appurtenant (a-pèr'te-nąnt), a. and $n$. [Also written, less eommonly, appertinent; < ME. appertenant, apertinent, appurtcnaunt, apurtcnant, etc., < OF. apertenant, apartenant, < LL. appertinen $(t-) s$, ppr. of appertinere, belong to, ppertain: see appertain and -ant1, and ef. appurtenance.] I. $a$. Appertaining or belonging; pertaining; incident or relating to, as a legal ight, interest, or property subsidiary to one more valuable or important.

Right of way . . a appurtenant to land.

- blackstane, Commentaries, ii. 3. A part [or land common to a trihe] is allotted in a spelal way to the chief, as appurtenant to his office, and descends from chief to chicf according to a special rule of
succesaion.

ommon appurtenant. See common,

II. $n$. A thing appertaining to another more important thing; an appurtenance; a belonging. appuy, $v$. $t$. See rppui.

aprankt (a-prank'), prep. pler. as adv. or a. [< fashion.

To set the arms a-gsmbo and $a$-prank.

J. Bulwer, Chironomia (1644), p. 104

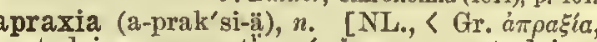
not doing, non-action, < ár.akтos, not doing, not to be done, $<\dot{a}$ - priv. $+\pi \rho a \kappa r b s$, verbal adj. of $\pi \rho a ́ \sigma \sigma \varepsilon \iota \nu$, do: see practice, praxis.] In pathol. loss of the knowledge of the nses of things.

apresst, $r . t$. An old form of oppress. Chaucer. apricate (ap'ri-kāt), $\imath$ [< L. apricatus, pp. of apricari, bask in the sun, ? apricus, open to the sun, sunny, prob. < *apericus, < apcrire, open sce aperient, and ef. April.] I. intrans. To bask in the sun. Boyle. [Rare.]

II. trans. To expose to sunlight. Dc Quincey.

aprication (ap-ri-kā'shon), $n$. [< L. aprica tio $(n-),<$ apricari: sce apricate. $]$ The act of basking in the sun; exposure to sunlight. Cockeram. [Rare.]

The luxury and beneftit of aprication, or immersion in apricitył (a-pris'i-ti), n. [<L. apricitas, < apricus, sunny: see apricate. T The warmness of the sun in winter. Cockeram.

apricockt, $n$. An old spelling of apricot.

apricot (á'pri-kot or ap'ri-kot), $n$. [Early mod. coct, etc., with term, after Ficot, abricote, abriear abricot, also, and abrecok, ote. (cf. D. abrikoos, Dan. abrikros, aprikos, G. aprikose), $(\mathrm{Pg}$. albricoque $=\mathrm{Sp}$. albaricoque, $\mathrm{OSp}$. albarcoque, albercoque, etc., = It. albercocca, albicocca (the forms in apr-, in E., G., ete., being due perhaps to a fancied connection with L. apricus, sunny (so explained by Minsheu: "q[uasi] in aprico coctus," ripened in a sunny place): see apricate), ( Ar. al-birqüq, al-burqüq, apricot, $\langle a l$, the, and

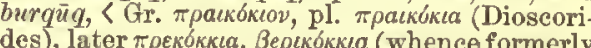
in It. berricocche, pl. - Minsheu), <I. procoqua, apricots, neut. pl. of precoquus, a form of procox, early ripe, precocious, < pre, beforehand, + coqucre, cook: see precocious and cook 1 . The vernacular Ar. name is mishmish, mushmush,

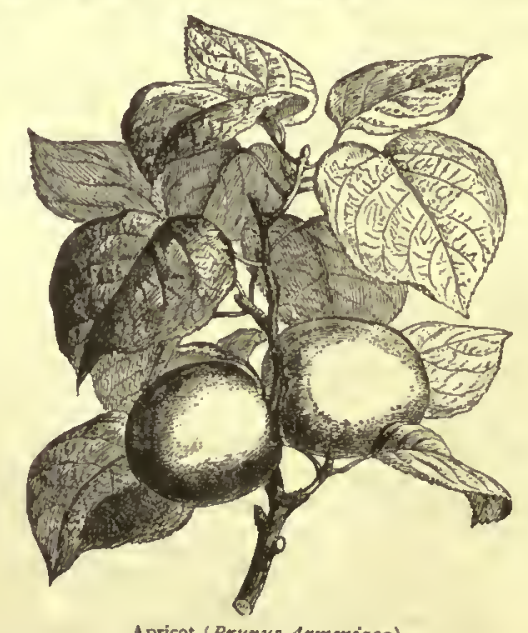

pubescent, orange-colored fruit, of a rich aromatic flavor, the produce of a tree of the plum kind, Prunus Armeniaca, natural order Rosacca. Its specific name is due to the belief that it is a native of 
apricot

It grows wild in the Ilimalayas and Northwestem Prov tnees of India, where its froit is gathered in great guant er of Ilenry VIII. 'The tree rises to the height of from 15 to 20 and even 30 lect, and its llowers appear befure 3 t upon plum-stoeks. There is a cousislerable number of va rieties, bome of them with sweet kernels which may be eaten like almonds. The wild spricot of the West Indle
is the Jommea Ainericena; that of Gulana, Ihe Courowis the JIammea Americund; that of Gulana, the

pita Guimensis. Fomnerly also spulled apricock. (As. rarely Aprclis), also and earlier Aecril Acercl, decrylle, < OF. Acrill, li. Acril $=\mathrm{Pr}$. Sp $\mathrm{Ig}$. Abril = It. Aprile = D. April = MIG Aprille, Abrille, Abrelle, Aprill, G. April = Dan. Sw. April, < L. Aprilis (se. mensis, month), April; usually, but fancifully, regarded as if <"uperilis, < uperire, open, as the month when tho earth 'opens' to produce luew fruits: see apcricnt.] The fourth mouth of the year, containing thirty days. With poets, April is the type of inconstaucy, Irom the

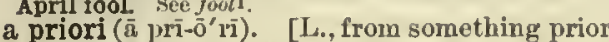
or going before: $\bar{a}$ for $a b$, from; priori, abl. of prior, neut. prius, preceding: sco prior, $a_{\text {.] }}$. From the former; from that which precedes; hence, from antecedent to cousequent, from condition to conditioned, or from cause to effect. sinee the fourleenth eentury, the phrase demonstratio
priori (intst fonnd in Albert of Suxony, died 1390) has been commonly enployed, instend of the earlicr expres alon demonstratio propter quid, to mean proof procceding
from canses or first prinelples: opposed to demonstratio a posteriori, or demonstratio quia, which proceeds from effeet to cause, and simply proves the fact without show. ug why dt must be as it is. In the eighteenth centitry de. notion to the conditions which such notion involves. since Kant, a priori, used as an sdjective and frequently plsced before the noun, has been sppitied to cognitions which, though they may eome to us in experience, hsve
their origin in the nsture of the nind, and are independent

Demonstration is perfect, when it proceedeth from the proper csuse to the effect, called of the gcholemen, Thus when we argue from the ideas we have of immen. sily, eternity, necessary existence, snd the like, that such perfections can reside but in one being, snd thence eon sp srgument a priori.

Gencral truths, which at the same time bear the characence - elcar and certsin by themselves. They are ther fore called a priori, while that which is simply tsken trom experience is sald to he, in ordinary parlance, known a
josteriori or empiricslly only.
Kant, Critlque of Pure Reason, tr. by Max Miller. is as used in a psychologicsl sense, knowledge a posterior and, consequently, is adventitious to the mind, as subse quent to, and in consequence of, the exercise of its facul
ties of observation. Knowledge $a$ priori, on the contrary, ties of observation. Knowledge a priori, on the contrary, embraces those prinelples whieh, ss the condition of th exercise of is faculties of observation and thought, are that, chronologically considered, our a priori is not ante. cedent to our a posteriori knowledge; for the internal con ditions of experience can only opersle when an object of
experience has been presented.
Sir W. Hamilton.

A priori philosopher, a philosopher who belleves in the existence of a priorl cognition in the Kantian sense of the

apriorism ( $\overline{\mathrm{a}}-\mathrm{pri \overline {- }}-\overline{\mathrm{o}}$ 'rizm), n. [< a priori, as adj., + -ism.] 1. A principle assumed as if

Unwarrsntable a-priorisms, The pure unproved as 2. A priori reasoning, as characteristic of a phase of thought or of a thinker.

apriorist (ā-prī-ón'rist), $n$. $\quad[<$ a priori, as adj + -ist. $]$ One who believes in the existence of a priori cognition in the Kantian sense of the term. Soe a priori.

Thls will be disputed by the apriorist. aprioristic (ā-prī-ō-ris'tik), a. 1. A priori.2. Having something of an a priori character: as, aprioristic reasoning or tendencies, [Rare.] apriority (a-pri-or'i-ti), $n_{0}[<$ a priori $+-i t y$.
In philos., the character of being underived from experience, or of being a priori

Aprocta (a-prok'tä), n. pl. [NL., neut. pl. of aproctus: see aproctous.] Ono of two division of the Turbellaria, in which the digestive cavity is creal, having no anal aperture: contraste aproctous (a-prok'tus), $a$. [< NL. aproctus,

Gr. $a$-priv. $+\pi p \omega k T \delta \zeta$, anus.] Having no anus specifically,

The aproctous condition, which persists in most of the Ptatyheiminthes, is passed through by these forms at an
early stage in development. Gegenbaur, Comp. Anst. (trans.), p. 162
281

apse-chapel

apron (ä'prun or a'pérn), n. [Early nod. E. also upern, apurn, earlier napron, whence, by misdividing a napron as an apron, the loss of initial , as in adder ${ }^{1}$, auger, orange, ouch, umpire, ete. OF. naperon (F. napperon), < nape, nappe ( 1 naine, a eloth, table-cloth), < L. mappa, a cloth: seo napcry, napkin, and map.] 1. A eloth: seo napery, napkin, and map.] 1. A picce of apparel made in various ways for covpletely. It is ordinarily used while at work to keep the clothes clcan or protect them from lujury, for whlch purpose it is made of cotton or linen, or for biacksmitlis, shoemakers, elc., of leather. Aprons of slik or other fine
material sre sometimes worn by ladies as sn article of dress material are sometimes worn by ladies as an article of dress
or for ornument. An apmon is also part of certain ofticial costumes, as that of an English bishop, sind that of trec-

2. Anything resembling an apron in shape or use. (a) The lesther covering used to protect the lower part of the person while ridling in an open esrriage. (b) unier side, used to cover the vent in hesvy gruns and field pieces. Also called cap. (c) A platform or flooring of the sill or lower part of $\mathrm{a}$ window. (e) $\mathrm{A}$ sirip of lead which directs the drip of s wall into a gutter. (f) A plece of leather or boarding usud to conduet loose moving mate-
rial past an opening, s. grain in a separstor. (g) Sheets of lead, or flashing, placed sboul skylights and at the in skinc covering the belly of a goose. [Provincisl.] (i) In zoöl., the sbdomen of the brachyurous or short-tailed lolded under and closely spplled to the thorax. Its whith and general slispe often distinguish the sexes.

. In ship-carp., a piece of eurved timber placed in a ship just above the foremost end of the keel, to join together the soveral pieces of tho stem. Also ealled stomach-picce. See ent under stem.-4. In mech., the piece that holds the cutting-tool of a plane.-5. Any device for protecting a surface of earth from the action of moving water. Examples of auch the action of moving water. Examples of such of the current; (b) the planking or logs placed st the basc of a sea-wall, to protect it from the scour of the waves;
(c) the platform which receives the wster that falls over apron (án prun or $\bar{a}^{\prime}$ pèrn), $v . t$. [<apron, $n$.] To put an apron on; furnish with an apron; cover as with an apron.

$$
\begin{aligned}
& \text { The cohller aproned and the parson gowned. } \\
& \text { Pope, Essay on Misn, }
\end{aligned}
$$

aproneert (ā-prun-ēr'), n. [< apron +-eer. $]$ One who wears an apron; a tradesman or shopman; a mechanic: as, "some surly apronect
Bp. Gaudcn, Tears of the Chureh, p. 238. apron-lining (a'prun-li"ning), $n$. In joinery, apron-piece of a stairease.

pron-man (à'prun-man), $n$. A man who wears apron; a laboring man or workman; aiter or bar-tender.

\section{You lave made good work,
You, and your apron-men.}

apron-piece (à'prun-pēs), $n$. In joinery, a piece of timber fixed into a wall and projecting horizontally, to support the earriage-pieces and joistings in the half-spaces or landing-places of a staircase. Also called pitching-picce.

apron-roll (a'prun-rōl), $n$. In mach., a roll
which gives motion to or which supports a traveling apron.

The upward movement of the drum prevents the ski

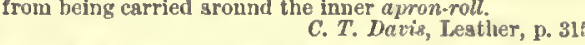
apron-squiret, n. Same as apple-squire. Nashe. (N. E. D.)

pron-string (ä'prun-string), $n$. A string by which an apron is attached to the person.woman's apron-strings, to be bound to ber as s cliild control or influence. be kept subservient to way from h control or influence: be kept subservient to her caprice.
apropos (ap-rö-pón ), adv., $a_{\text {. }}$, and $n$. [<F.apropos, to the purpose: $\dot{a}$, to, with reference to F. L. ad, to; propos, purpose, < L. propositum, a thing proposed: see purpose and propose.] I. adv. 1. To the purpose; opportunely; sea-
sonably.-2. With reference or regard; in resonably,-2. With ref

Suddenly, and a propos of nothing, asking him how it was possible for \& man to have three godmothers.
W. Black, Shandon Bells, xxxili

3. With reference to that (a thing just mentioned); by the way: used absolutely, to introduce an incidental observation.

Nir. Brown is now busy upon his work. Apropos, 1
hesrd very lstely that my friend was the suthor of that

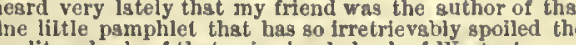
credit and gale of that vain simple book 2. In astron., same as apsis.
II. a. Opportune; seasonable; to the purose; pertinent; hapjyy: as, an ajmopos remark. III. $u$. Pertinency. [Rare.]

Aprosmictus (ap-los-mik'tus), n. [NL., < Gr.

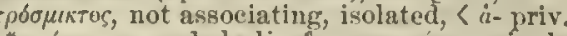

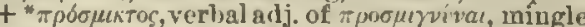

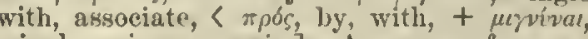
mingle, mix: see mix.] A genus of parrakeets. It inclucles $\mathrm{A}$. erythropterux, the red-wingerl par rakeel of Australia, and A. scapulatus, the king larraked. aprosopia (ap-rō-só'pi-ii), n. [NL., <Gr. ampí faces, without a face, $a$ - priv. $+\pi \rho$ tn tcrutul., absence of the greater part of the face, due to arrested development of the mandibular arch.

aproterodont (ap-rōo-ter'o-dont), a. $[<\mathrm{Gr} \cdot \dot{a}-$ priv, $+\pi \rho \delta$ Tepos, in front, + ódoís (idovr-) $=\mathrm{E}$ tooth.] In herjet. having 110 front teetli: applied to the dentition of serpents whose intermaxillaries are toothless.

aps (aps), $n$. [A dial. form of $\left.a s y)^{1}, 4 . v.\right]$ A
eommon najne for white-poplar wood, used for common name for

apse (aps), n. [CL. apsis, in the architectural sense, as in definition: sce apsis.] 1. In arch.: (a) Strictly, any reeess, or the termination f a building, of semicircular plan, covered by a semicircular vault or semi-dome; hence, a similar feature of polygonal plan. (b) In ordinary use, the termination of the choir or

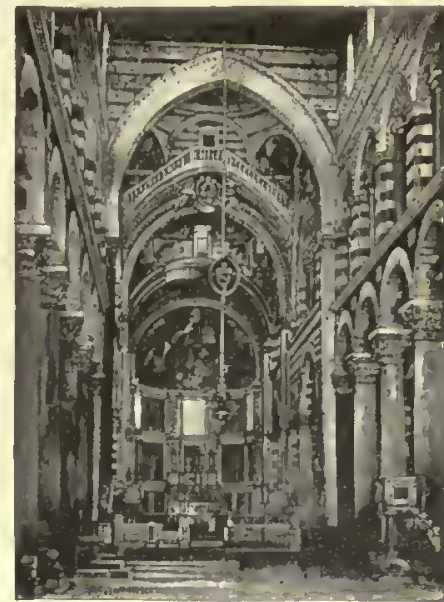

sanctuary of any church, particularly if it presents a superficial resomblanee to an apso in the stricter sense, in that it is at least approximately semicircular in plan, and vaulted: commonly cquivalent to chevet, and applied to the gular plan and not vaulted, and inchuing th apse-aisles, chapels, and any other adjunct to the ritual east end of a church. The apse in its origin was a characteristic festure of the ancient Romsn
basjijca, in which it formed the rassed tribune for the court magistrates. The throne of the questor or presiding judge
gtood in the center of the chord of the arc of the spse. When the basillcas became chrigtlan churcles, the throne was replaced by the high altar, which still occupies this church regularly have secondary spses in other positions than st the eastern end, as at the western end, at the ex. tremitles of the transepts or of
basilica and bema. Also apsis.

apse-aisle (aps'îl), $n$. An aisle which extends around an apse, continuing the lateral aisles of the choir, or choir-aisles.

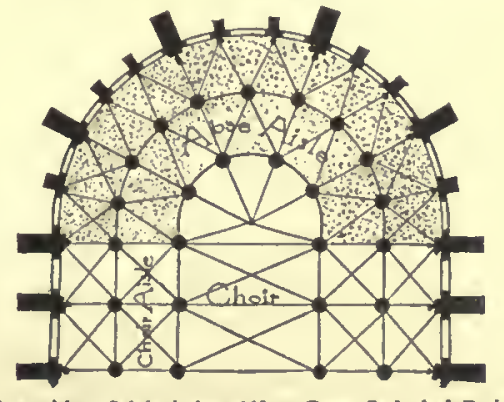

apse-chapel (aps'chap"el), n. A chapel opening upon an apse or apse-aisle. 
apselaphesis

apselaphesis (ap-sel-at-fë'sis), n. [NL., < Gr.

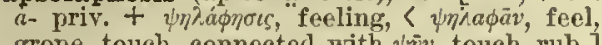
grope, touch, connected with $\psi \bar{m} \nu$, touch, rub.] bility.

apsidal (ap'si-dal), a. $[<$ apsis (apsirl-) + -al.] 1. In ustron., pertaining to the apsides. Sce upsis. - 2. In arch., of or relating to au apse; of the nature or form of an apse; terminating in an apse. The prothesis aud cliaeonicon [in Armentan churches] are
never apsidal on the outside, and seldom so on the inside.
J. M. Veale, Eastern Church, i. 174.

Apsidal chapel. (a) A chapel terninating in an apse. (b) An apse-ehapel. - Apsidal surface, in muthe, a surrnel's wave-surface is related to the cpudric surface and to its center; that is to say, on each plane section of an
original surface through a certain fixerl point the radii original surface through a certain fixed point the radii from the flred point on the perpeulicular to the asetion: then the loens of the extremlties of these lines so mes. sured is the apsidal surface.

apsidally (ap'si-dal-i), adv. In the form or manner of an apse; with an apse.

In this difficulty the architect hit upon the happy ex

Dean IJowron, Handbook of Chester Cathedral, p. 40

apsides, n. Plural of apsis.

apsidiole (ap-sid'i-öl), $n_{\text {. }}$ [F., common]y absidiole, (NI. *apsidiala, dim. of L. apsis (apsid-), apse.] A small apse; a secondary apse, as one of the apses on either side of the central or

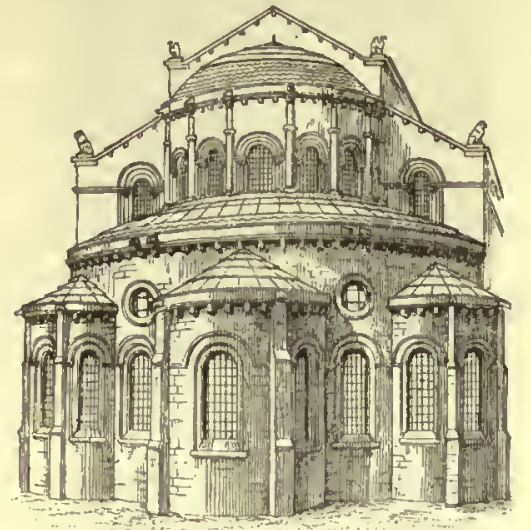

main apse in a church of triapsidal plan, or one of the apse-chapels when these project on the exterior of the church, particularly if the projection resembles an apse in shape. Also written absidiale.

apsis (ap'sis), n.; pl. apsides (ap'si-dēz). [L. (pl. apsides), also absis (pl. absides) and absida which a star describes in its orbit, a bow], < Gr.

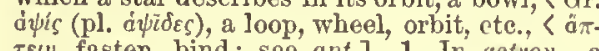
$\tau \varepsilon \omega$, fasten, bind: see apt.] 1. In astron., point is either furthest from or nearest to the body about which it revolves. The higher apsis is the polnt furthest from, and the lower apsis the point neares polnt furthest from, and the lower apsis the point nearest Ing the apsides. These terms were originally applied to apse.
2 . In arch., same as apse.-3. A reliquary or case in which the relies of saints are kept especially one of a form imitating the curve of a dome or vautt.

Sometimes written absis.

apsychical (ap-sĩ'ki-kal), a. [<Gr. $\dot{a}$-priv. + $\psi v \chi \imath{ }^{\prime} \delta s$, of the mind or soul : see $a-18$ and $p$ sychical.] 1. Not psychical; not mental or spirit ual.- 2. Not involving conscious mental action; not controlled by the mind.

apt (apt), a. [< F. apte = Pr. apte $=\mathrm{Sp} . \mathrm{Pg}$ apto = It. atto, < L. aptus, fit, fitted, prop. pp. tive apisci, apere, fasten, join (whence the incep= Gr. ámreiv, fasten, bind.] 1. Possessing the qualities necessary or proper for a certain purpose or end; fit; suited; adapted; suitable.

All the men of might, . . . strong and apt for war.

In woode and stone, not the softest, but hardest, be al-
wailes aptest. No man that putteth his hand to the plough, and looketh back, is apt for the kingdom of God.
282

The hunds that lave graspel donimion and held it hav been large and hard those from which it has slipper Loecell, Firesidc Travels, p. 251 2. Suited to its purpose; apposite ; pertinout; appropriate; becorning: as, an apt metaphor. Such apt and gracious words,
That aged ears play truant at his tales,

And youmger hearings are guite ravishe

In fitting apteat words to things.

Ternyson, in دlemorian, lxx.

Jutierous yet apt citation

Whittier, Bridal of Pennacook.

3. Having a tendency; naturally susceptible; liable; likely : as, wheat on moist land is apt to blast or be winter-killed.

It [the harbur] is gay with hundreds of small boats,

C. D. Wremer, Roundabont Jonrney, p. 135

4. Inclined; predisposed; disposed customarily; prone; realy: as, one who is too apt to slander others.

"Tis time my hard-month'd coursers to eontrol,

Apt to run riot, and transgress the goal.

What makes you thoughtless in your conduct, and apt to run into a thousand little imprudences?

Sheridan, School for Seandal, iv.

5. Ready; prompt; quick; unusually intelligent; expert; facile: as, a pupil apt to learn; an apt wit.

Strong, supple, sinew-corded, apt at amns. An apt taster knows whieh wine has the novel fiavor.
Stedman, Poets of Amerieg, p. 289.

6. Prepared; ready; willing.

I shall not find myself so apt to dis years,

Shak., J. C., lii. 1. The paymaster and the attorney stood at hand apt with 7†. Capable of easy explanation; natural credible.

That Cassio loves her, I do well believe it

That she loves him, 'tis apt, snd of great eredit.

$=$ Syn. 1. Apt, Fit. "The words apt and fit might be derivation; but apt has an active sense, and fit a passlve sense, $-\mathrm{a}$ distinetion clearly shown by 'Shakspere, when fit, 'and by Wordsworth: 'Our learts, 'hands apt, drilg thize with heaven, our' souls more fit for future glory." II. Reed, Eng. Lit. p. 106.-2. Mleet, fitting, germane, appro-
priate. -3 and 4. Apt, Likely, Lixble, Sitbject, prone priate. -3 and $4 . A p t$, Likely, Liable, Subject, prone.
$A p t$, when used in this sense of persons, Indieates plyygical tendency or inward inclination : as, apt to cateh cold ; apt
to negleet work; when used of things, it stmilarly indicates natural tendeney: as, apt to mold. Likely may sug-
gest the same idea: as, he is likely to do it: it is likely to rust; or it may express unere external jrobability or chance: as, he is likely to come at any moment. Liable
in this commection is properly ysed only of exposine to in this commection is properly 2 sed ouly of exposmre to to the danger of: as, liable to aceident: liable to be hurt censure: in such use it does not express probability of tendency, but inerely the posslbility of exposure or risk. Subject expresses what is likely to happen to a prerson or
thing, and oteasionally does liappen. Jiable to disease and subject to lisense this eonvey different ideas. The accident or circumstance; the things to whie gubject are determined by nature and constitntion. Apt
to be suddenly lll; liable, but not likely, to dle before the physieian arrives; subject to attacks of epilepsy.

Ilow apt the poor are to be proud!

It is the duty of practical good sense to hear in mind
that a certain result, though not eertain to happen, likely to happen, and that no whe man will put that likels.
hood out of sight. E. A. Freevan, Amer. Lects., Till that hour
Not liable to fear, or flight, or pain.

All human things are subject to decay,

Dryden, Jae Fleekno

5. Clever, bright, dexterous. modate, adjust, <aptus, fit, etc.: see $a p t, a$.$] To$ prepare for a definite service; fit ; suit for anticipated circumstances; adapt.

If he be mine, he shall follow and observe what I will B. Jonson, Poetaster, i. 1. That our speech be apted to necessary edifleation.
Jer. Taylo He takes his top-sail down in sueh rough storms,
And apts his sails to airs more temperate And apts his sails to airs more temperate. aptablet (ap'to-bl) a [< LI aptabitis, aptare, adapt:" see apt, $v_{.}$, and -able.] Capable ot being fitted or adapted. Sherwood.

aptatef (ap'tãt), $v . t . \quad$ [ $\mathrm{L}$. aptatus, pp. of ( $p$ -
tare, adapt: see apt, v.] To make fit.

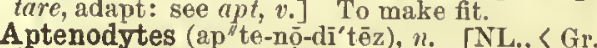
Aptenodytes (ap" te-nō-dītēz), n. [NL., < Gr.
Apteryx

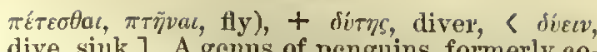
dive, sink.] A genus of penguins, formerly coextensive with the family Spheniscide, and giv usually restricted to two large species, the em peror and king penguius, $A$. imperator and $A$. rex, or $A$. forsteri and $A$. penurenti, distinguished fex, or A. for steri and A penti, distinguished from all others by their great size and long,
slender, somewhat curved bill. Both were formerly ealled the great or Patagonia penguiu, A. patachonica. Also Aptenodyta and Apteradyta.

Aptenodytidæ (ap ${ }^{\prime}$ te-nō-dit'i-dē), $n . p l l$. [NL., penguins, named from the genus Aptenadytes: penguins, named from the genus Aptenady

Aptera (ap'te-rä), n. pl. [NL. (<Gr. ä $\pi \varepsilon \rho a$, animals without wings, ártepov, the class of such animals - Aristotle), neut. pl. of apterus, a group to which various limits have been assigned. (a) In the Linnean system of classification, the seventh and last order of Insecta, ineluding "Insects" withont wings, that $\mathrm{ls}$, crustaceans, araehnldans, myriapods,
etc. In 1795 it was divided by Latreille into seven oretc. In 1795 it was divided by Latreille into seven orders: Suctoria, Thysanura, Parasita, Acephala, Entomos-
traca, Crustacea, and Myriayoda. (b) In Latreille's system traca, Crustacea, and Myriapoda. (b) In Latreile's system
of classification (I817), the fourth of nine orders of Insecta, Ineluding "wingless forms without gnathites," and containing only the fleas; the Suctoria of De Geer, the Siphnaptera of Latreille, the $A$ phaniptera of Kirby and moder (c) Loosely applied to sundry groups of whingless inseet besides fleas, as to the hatustellate and mandibulate lice tile thysanurous insects, etc. (d) In Gegenbaur's system of
classification, one of the two prime divisions of Hexapoda or Insecta (the other being Pterygota), consisting of the two orders Collembola and Thysanura, containing all apterons ametabolous insects of such forms as Podura and Lipura, Carapoder and Lepisma, ete. The name is practi. apteral (ap'te-ral), a. [As apterous $+-a l] 1$. Destitute of "wings.-2. In arch., applied to a temple or other building which has no columns on the flanks, but may have a portico at one or at each end: opposed to peripteral, surrounded by columns. See prostyle and amphiprostyle. apteran (ap'te-ran), n. [As apterous + -an.] A wingless insect; one of the Aptera.

apteria $n$. Plural of apterium.

apterial (ap-tétri-al), a. [< apterium $+-a l$. teria.

apterium (ap-tē'ri-um), n.; pl. apteria (-ä).

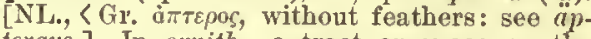
teraus.] In omith., a tract or space on the feathered tract, in distinction from a feathertract or pteryla (which see). Nitzseh; Sundevall.

apterous (ap'te-rus), a. $\quad[<\mathrm{NL}$. apterus, $<\mathrm{Gr}$. $+\pi \tau \varepsilon \rho$, wingless, without feathers, < d- priv. zoöl.: (a) Wingless; having no wings: applied both to wingless insects belonging to winged groups, and to the wingless stage of winged insects. (b) Specifically, of or pertaining to the Aptera. - 2. In bat., destitute of membranous expansions, as a stom or petiole: opposed

Apteryges (ap-ter'i-jēz), $n . \nu l$. [NL, pl. of Apteryx.] A superfamily group, made by Nowton an order, of ratite birds, based npon and including only the family Apterygide (which see). Apterygia (ap-te-rij'i-ä), n. pl. [NL. ( Gr. $\dot{\alpha}$-priv. $+\pi \tau \varepsilon \rho v y c o v$, a wing, fin: see Ptcrygia.] A group of mollusks, containing all gastropods with an intromittent male organ, and contrasting with the Pterygia, composed of the cephalopods and pteropods. Latreille, I825.

apterygian (ap-te-rij'i-an), a. [<Gr. àrípeyos, wingless (sce Aptery $x$ ), + -ian.] 1. Wingless; apterous. - 2. Pertaining to the genus Apteryx, or to the family Apterygide.

pterygidæ (ap-te-rij'i-dēe), n. $p l$. [NL., $\langle A p$ tery $x$ (Apteryg-) $+-i d a$.$] A family of ratite or$ struthious birds, of the subelass Ratite and suborder or superfamily Apteryges, constituted by the single genus Apteryx. It is eharacterized by the rudinentary condition of the wings and tail, 4 -toed anatomical peenliarities, amone them a better develop. ent the diaphragm than in any other birt.

Apterygina $\left(a^{\prime \prime} t \theta-r i-j \overline{1} ' n \bar{e}\right), n . p l$. [NL., $<d p-$ of the family Aptcrygide. The only subfam Apteryx (ap'te-riks), n. [NL. (ef. Gr. à $\pi \tau \dot{\varepsilon}-$

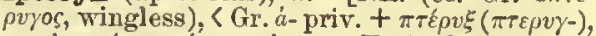
a wing, < $\pi \tau \varepsilon \rho o ̛$, a wing, = E. feather.] 1. A genus of ratite birds, constituting the family genus of ratite birds, constituting the family 


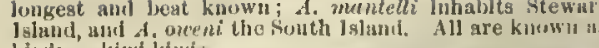
kiwis, kiwi-kiwis or kivi-kivis, from their cry. Also, in jroperiy, Apte

2. [l.e.] A birl of this genns kiwi (whicl seo) aptha (ap'thii) il. Seo uphthir. aptitude (a]'titūil), n. $[=1=$ aptitule, $\mathrm{M}$. (i) $)$ tus, upt, tit: see $a) t, a$. Cf. attitude, which is a doublet of (1) titule.] 1. The state or

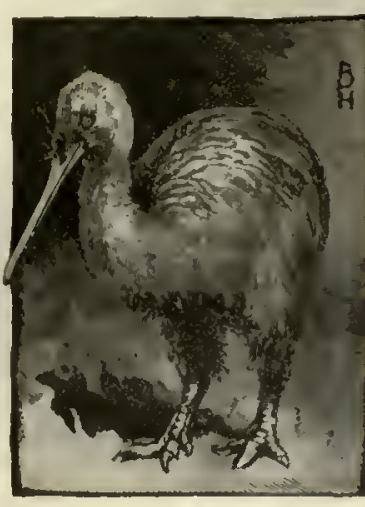

apt or tit for or suited to a purpose, place, or situation; fitness; suitableness.

Aptitule... for the end to which It was simed.

2. A natural tendency or acquired inclination; both eapacity and propensity for a certain course: as, oil has an aptitude to hurn; men acquire an aptitude to particular vices.

He that is about children should learn their nature and

locke.

Thie Americsns lave st sll times shown a remarkable

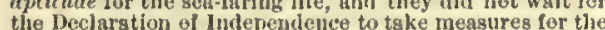
construetion of an ludependent nsvy.
Lecky, Eng. In 18th Cent, xiv.

3. Readiness in learning; teachableness quickness to u

gence; talont.

=\$yn. Facully, Capacity, etc. See genius.
aptitudinal (ap-ti-tü'(li-nal), a. [< ML, aptitulo (nptitudin-) + -al: see aptitude.] 1. Relating to an aptitude or aptitudes. -2 . Existing in possibility or capacity merely. [Rare.]Aptitudinal relation, \& relation which does not require the correlate to exist actually, but only potentislly; s, for aptitudinally (ap-tí-tí'di-nall-i), ad $v$. In an aptitudinal manner; in a way which revoals aptitude.

aptly (apt'li), adv. In au apt or suitable mannor. (a) With exact correspondence; with fitness; justly. I have fergot your name; hut, sure, that part
Was aptly fitted, snd naturally perform'd.

(b) Suitsbly ; spproprlately : of ianguage, pertinently, ap.

Words aptly cull'd and meanings well express'd

Can caln the sorrows of a wounded breast.

(c) Readily; quickly; cleverly: as, to learn aptly. aptness (apt'nes), $n$. The state or quil

being apt, in any sense of that word.

The aptness of things to their end. What shoull le the optness of blrds, in comparison of
beasts, to lmitate speech nay be inquired.
Bacon. At hls first aptnesx, the maternal love
Those rudiments of reason did Improse.

Aptornis (ap-tôr'nis), n. [NL., short for "apjtcrornis, < Gr. ärrepos, wingless (seo apterous), $+\delta \rho v s$, a bird: see ornithology.] A genus of the family liallide, related to the extant genus Ocydromus. Its remains are found In New Zealand with those of the mon. $A$. defossor and $A$. otidiformis are two aptosochromatism (ap-tō"sō-krō'ma-tizm), n

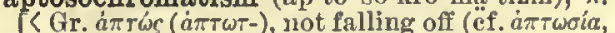
stability, firmness: see aptote), + ehromatism.] Iu ornith., chango of color of the plumage with out loss or gain of any feathers. Coues.

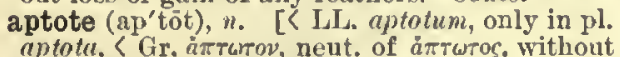
caso, undeclined, also as $\dot{a} \pi \tau \dot{s}$ ( $(\dot{a} \pi \mathrm{T} \omega \mathrm{T}-$ ), not falling, $<\dot{a}$-priv. $+\pi \tau \omega T o ́ s$, verbal adj. of $\pi i \pi \tau \varepsilon \iota \nu$, fall, whence also $\pi \tau \tilde{\omega}$ ors, ease, inflection.] In grami, a noun which has no distinction of cases; an indeclinable noun.

aptotic (ap-tot'ik), a. [<aptote $+-i c$.$] 1. Of$ or pertaining to an aptote; having no decleu-
sion.-2. Uninflected; having no grammatical inflections: said of certain languages.

aptychus (ap'ti-kus), $n_{0} ;$ pl. aptychi (-kī).

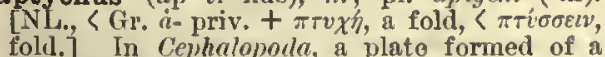
shelly substance, found in the terminal cham- her of ecrtain fossil mollusks, as ammonites, formerly comsidered to be one of the parts of different unlmuls culled trigonellites, lepadites, cte.

The Aptychi accupy the middlo of the prosterior theld hases towards its mouth. Nuthing is certainly known as to tise mature of the A ptychi ur Anaptychl.

Apulian (ın-pū'li-gn ), a. [<I. spulia, sppulia, $f_{-a n .]}$ of or pertaining to the region called Apulia, in soutliern Italy, or to its inhabitants. in Roman timen Apulia included the regron between th Apeunises and the Adriatic, sonth of the Frentani and east of Samnium, anil later also the Jlessapian jeninguia. Modem

A hill in the milst of the Apnlian plain.

Apulian pottery, as uame given to the Italio. $A$. so, Apry found in Apulia and sontheastern Itaiy generally. especially to the vases with red flgures on a lastrons hiac groimd, some of the

Apus (ā'pus), $n$. [NI., <Gr. ḋars, without feot: see apod, Apoda, ete.] 1. One of the souther constellations formed in the sixteenth century, probably by Petrus Theodori; the Bird of Paradise. I is situntel south of the Trisngul um Australe, and its brightest star is 2 A genus of branchiopodous or phyllopodous entomostracous erustacoans, typical of the family Aporlice or family Aporlicle or the form Apous) by Frisch in 1732. Like nearly ail animals which

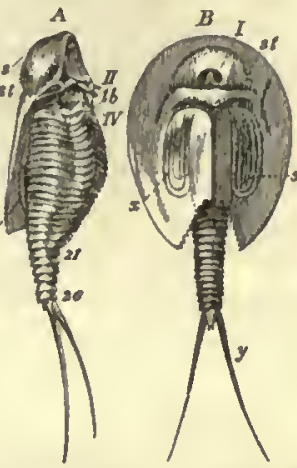
have bren iniscalled Apo.

they or havo feet, thes

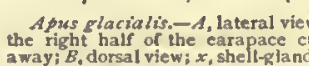

y, caldal flaments: 16 , labrum:

0 ods ranging from 11 to

palrs. The genus if

shield-like carapace, or

ho snimal. $A$. cancriformis, esilced the crah-shelle

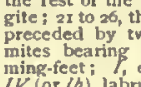
mirimp, is 2 or 3 inches leng, snd is noted for its repented months), and for the vast numerics! preponderance of the fomales, the males having been only recently discevered. ily Cypselide, estahlished by Scopoli in 1777 equivalent to Cypselus of Mlliger, 1811. (b) [l.c.] The specific name of the common swift of Europe, Cypsehis apus. -4 . [1. c.; pl. api $\left(\overline{\mathrm{a}}^{\prime} \mathrm{p} \overline{\mathrm{i}}\right)$.] In teratol., a monster destitute of poste Apusidæ (a-pū'si-dê), n.pl. [NL., irreg. $<A p m s$ +-idk: so formed to make literal

Apygia (a-pij'i-ä), n. pl. [NL., < Gr. a-priv. + $\pi v \gamma \eta$, buttock.] An order of Brachopodn: Apyrenæmata (a-pi-re-né'ma-tä), n. pl. [NI neut. pl. of apyrencmatus: së apyrenematons.] A division of animals including those in which the blood-corpuseles are not nueleated; those from nucleated cells of the blood. The term is practically the same h applicatien ss Mammatia, thongli apyrenematous (a-pī-re-nem'a-tus), $a, \quad[<N L$. apyrencematus, < Gr. a- priv. + pyrencmatus: tons; having blood which contains disks, or non-nucleated corpuseles, as a mammal.

apyretic (ap-i-ret'ik), a. [<Gr. ámiperos, with-

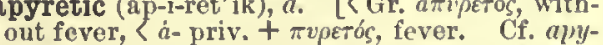
rexia.] Withont pyrexia or fevel: specifieally, in pathol., applied to thoso days in which th intermission of fever occurs in agues, and also to local affections which are not accompanied with fever.

apyrexia (ap-i-rek'si-ä), n. [NL., $<$ Gr, ámvpezio

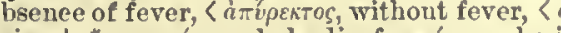
priv. $+* \pi v \rho \varepsilon \kappa \tau b s$, verbal adj. of $\pi v \rho \varepsilon \sigma \sigma \varepsilon v$, he in apyrelic.] The absence or intermission of pyrexia or fever; the interval between the paroxysms in intermittent fovers. Also apyrexy. apyrexial (ap-i-rek'si-al), a. [< apyrexia + -al.] Relating to or characterized by apyrexia; apy apyrexy (ap’i-rek-si), $n$. Same as apyrexiu. apyrotype (a-pī'rọ̄-tīp), ". [< Gr. à̃vpos, without fire (see apyruus), + type, c. v.] Printingtylo lloduced withont heat, as by means of dies apyrous (a-pi'rus), a. [र (ir. ämv/os, without tire, $\langle\dot{a}$ - priv. $+\pi \bar{i} \rho$, fire, $=\mathrm{E}$. fire: see fire and pyce] neombustible, or cauable of sustaining a strong lient without alteration of form or properties, as asbestos, mica, and talc. Apyrous hulies differ from refractury ones in remainlug uncliangerl cren under extrente heat, wh

aq. In phar., an aljbreviation of aqua.

aqua $\left(\overline{\mathrm{a}}^{\prime} \mathrm{kw}, \mathrm{i}\right), n . \quad\left[\mathrm{L}_{0}(>\right.$ lt. acquu $=\mathrm{S}]$. $\mathrm{Pg}$. agun $=1$ l. cau), = Goth. ahen, viver, = OIIG. aha, MHG. ahe (G. Aa, the name of several rivers) $=\mathrm{OS}$. alia $=\mathrm{AS}$. $c \bar{a}$ (for *cah: seo $e y$, island), water, river, $=$ OFries. $\bar{u}, \bar{c}=$ Iecl. $\bar{a}$, water, river, = Sw. $a=$ Dall. a a, a brook.] 1 . Water: " word much used in medical preseriptions written in Latin, and in phamnacy cencily, also in old chemistry, to denoto a solution, or menstruum of water.-2. In anat., some watery fluid or humor.-Aqua ammoniæ, a solution of ammenla fas in water, hising the cicuntcal propertles of an alksil hydrate.-Aquz ductus et aqua Seot la $x$, two scrvitudes, the former consistling in a right of earrying s watercourse thirough the grounds of another, sud the latter of watering eattle at s river, well, or pond in the ground of another.- Aqua fortts (strong wster), a name given to wesk snd impure nitric achl. Double aqua fortis contalns twice ss much seld as singte aqua fortis. -Aqua labyrinth, the thici of the labyrtith of the Aqua marina. See aquanarine.-Aqua mirabius whonderful water). (a) A preparens, einger, snid spirit of wine, digested lwenty-four hours, then dlatilled. Johnon. (b) A carninative cerdial prepared from ofi of pimento (silspices): also eallet spiritus pirmente. Dumglian.inder liquor), - Aqua regta or aqua regalis (royal ws. and three to four parts of hydrochlorie acld, from its yower ef clissolving geid.- Aqua Tofana, s polsonous fluid made aheut the end of the seventeenth century by s womat of fewer than 600 persons had been killed with it. It conglsted chlefly, it is supposed, of s strong solution of smsenic - Aqua vitze (water of life), an old name for alcolnol, aquæductus (â-kwē-duk'tus),, . [L.: see aque-
duct.] In anat., a canal or channel conveying a fluid, or supposed to do so. Also aqueductus. - Aquæductus cochlex, the aquedict of the cochlea, from the scala tympani of the cochles to a point fust below
the internal suilitory meat us. - Aquaductus Fallopil the aqueduet of Faliopius, a clisme ingeductus the temporat Fone, leading from the interns! anditory meatus snd enclherve. - Aquæductus Sylvil, the stuleduct of sylvius, the ventricles of the brain. Also called iter a tertio ad quarruming from the vestibule of the ear to the pusterior surmits the ductus enclolymphatlens. manalia (-li-ăa). [ML., also aquimanile, aquiminale, aquiminile, $\mathrm{LL}$. aquiminate, $\mathrm{L}$. aquamanalis, LL. also aquiminarim, < L. aqua, water,

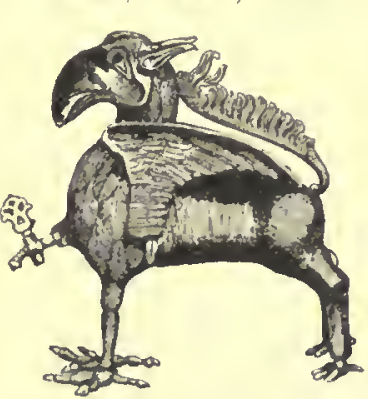
trickle, drip.] 1 . In Rom. antiq., a pitcher or vessel water, used especially for pourng water over ho hands into a basin during and The basin in ing to an ancient church cerAquemanale of copper, rath century, it emony, the priest
is filled by an opening at the top of the washed his hands
wead: the tail forms a haodle. before celebrating mass,-3. A kind of water-ewer formerly used in private houses, and frequently made in grotesque forms. The term is now used speeifically in this sense.

aquafortis (ā-kwa-fôr'tis), n. See aqua fortis, under aqua.

aquafortist (ā-kwạ-fôr'tist), n. [<aqua fortis $f-i s t$.$] One who$
fortis. $N . E$. $D$.

aquage (a'kwạj), n. [< LL. aquagium, aqueduct, < L. aqua, water, + agere, lead: see agent.] In leveling: $(a)$ The course of a mill-stream beAny watercourse. 
aquamarine

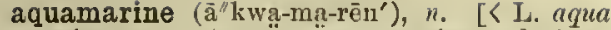
marine, sea-rwater: see aqua, marine, and aimemarinc.] 1. The finest beryl: so called from its bluish or sea-green tiut. Hence-2. A bluish-green color resembling that of the fincst beryl.

aqua-meter ( $\bar{a}^{\prime} k w a ̣-m \bar{e}^{\prime \prime}$ tér $), n$. [ 1. aqua, water, + meter.] Same as pulsometer.

aquapult (ä'kw?-pult), n. [<Is. aqua, water, $+-p u l t$, as in catapult.] A small portable forcepump.

quapuncture (a-kwa-pungk'tüur $), n$. [< L. aqua, wäter, + LI punctura, puncture.] A form of

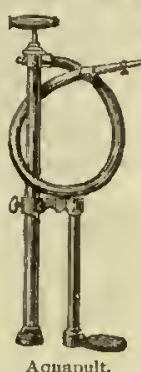
jection of a very fine stream of water against the skin. The stream, which comes from a powcrful force-pmmp, reddejs and blisters the part to which it is spplied. It is used cspecially in neuralgia and a
of the spinal cord. Also called douche filifme.

aquarelle (ak-wa-rel'), n. [F., < It. acquerella, water-color, light rain, ncquercllo, water-color, thin wine, dim. of acqua (= F. eau), < L. aqua, water: see aqua.] Water-color painting, or a painting in water-colors.

They [Frenchmen] despised it [water-color] when it was called aquarelle; they bowed down to It when it was called
peinture i la fresque. IIamerton, Grsphic Arts, $\mathrm{p}, 340$. aquarellist (ak-wa-rel'ist), n. [< aquarclle + aquarellist (ak-wa-rel'ist), n. [< aquarclle +
-ist. $]$ An artist who works in water-colors; a water-color painter.

aquaria, $n$. Plural of aquarium.

aquarian (a-kwā'ri-an), a. aud n. [<L.aquarius, pertaining to water (sce Aquarins), + -an.] $I_{\text {. }}$ a. Of or

II. $n_{\text {. }}[\mathrm{cap}$.$] [<ML. Aquarii, pl., the Aqua-$ rians, $<$ I. aquarius: seo Aquarius.] One who rians, $<$ sed water instead of wine in the eucharist: a term applied to certain Christians in Africa about the middle of the third century, who, whil it was still customary to celebrate the Lord's supper twice a day, though employing wine at the evening eucharist, substituted water for it in the morning in order that the odor of wine might not betray them during the day. They are Tstisn in Syria, cslled Hydroparastate, or Water-drink ers, and reckoned smong the Encratites, who used water in place of wine at the encharist, because they leld the latter
to be sinful, regarding it as the evil princlple or blood of the devil.

aquariculture (ā" kwa-ri-kul'tūr), n. [< I aquarium + cultura, culture.] The culture of aquatic plants in aquariums; the management of an aquarinm.

aquarium (a-kwa' ri-um), n.; pl. aquariums, aquaria (-umz, cattle, neut. of "quarius: see Aquarius.] 1. An artificial poud, cistern, or place in a garden or elsewhere for enltivating aquatic plants.2. A vessel or series of vessels, constructer chiefly of glass, filled with either fresh or salt water, and supplied with plants, rocks, etc. in which living aquatic animals are kept. Many aquariums on a large seale sre maintained in conuection

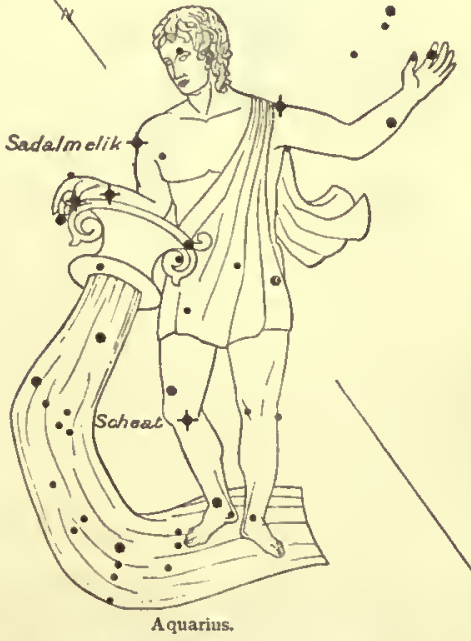

Aquarius (a-kwā'ri-us), $n$. [L., a water-bearer, one of the signs of the zodiac (Gr. videoxbos, i. $e$,
284

water-pourer); prop. adj., pertaining to water, aqua, water: see aqua.] 1. A zodiacal coustellation, supposed to represent a man standing witl his loft hand extended upward, and with his right pouring out of a vase a stream of water which flows iuto the mouth of the Southeru Fisl. It contains no star brighter than the third magnitude.-2. The Waterbearer; the eleventh sign (marked $m$ ) of the zodiac, which the sun enters about the 21st of Jannary: so called from the coustellation.

aquarter (a-kwôr'tér), $p r e p \cdot p h r$. as $a d v . \quad\left[<a^{3}\right.$ + quartcr.] Nout., on the quarter: $45^{\circ}$ abaft the beam

a quartieri (ä kwär-tẹ̄-ā'ri). [It. : $a$ (<L. $a d)$, to, with; quartievi, pl. of quarticre, a quarter, compartment: see quarter.] In coram., (decorated) in compartments: said especially of anything circular, such as a shield, the rim of a round dish, or the like, which is divided into panels or compartments by radiating lines.

aquatic (g-kwat'ik), a. and $n_{0} \quad[<\mathrm{L}$. aquaticus, aqua, water: seo aqua.] I. $a$. 1. Pertain ng to water; watery.-2. Living in or fre quenting water: as, aquatic animals; aquatic plants.-3. Practised on or in water: as, aquatic sports.-Aquatic birds, in ornith., specifically, Aves vatatores: the wading snd swimming birds, taken to gether.-Aquatic box, an secessory to the microscope generally in the form of a glass cell, in whlch slgae or ant

II. $n$. 1. A plant which grows in water. -2 $p l$. Sports or exercises practised on or in water, as rowing or swimming.

aquatical (a-kwat'i-kali), a. Same as aquatic [Rare.]

aquatilef (ak'wa-til), a. and $n . \quad[=\mathrm{F}$. aquatile, L. aquatilis, living or growing in or near wawater.

The aquatile or water frog. Sir T. Browne, Vulg. Err. II. $n$. An aquatic animal or plant.

Aquatilia (ak-wa-til'i-ä), n. pl. [NI., neut. pl. In Fieber's system of classification, a subsecIn Fieber's system of classification, a subsec-
tion of heteropterous inseets, including genuine aquatic species with concealed antennx, as distinguished from those of the section Litoralia. aquatint ('a'kwa-tint), $n_{0}$ and $a \cdot[=\mathrm{F}$. aqua tintc, aqua-tinta, < It. acqua tinta, lit. dyed water: acqua, water (see aqua); tinta, fem, of tinto (<L. tinctus), pp. of tingere, timicre, $<\mathrm{L}$. tingere, (LL. tinctus), pp. of tingere, tigncre, < L. tingere,
tint, tinge: see tint tingc.] I. $n$. 1. An etching process by which prints imitating the broad flat tints of India ink, bister, or sepia drawings are produced. It was prsetised by the Abbe St. Non in the eighteentli century, and was perfected by Jean Baptiste Ie Irince (1733-1781). In the squatint process spacp
are bitten, instead of lines as hil etching (which see).

2. An ongraving executed by the aquatint pro-

Also aquatinta.

II. a. Pertaining to this method of etehing. aquatint (a'kwa-tint), $\tau^{\prime} . t . \quad[<$ aquatint, n.] To

aquatinta (ā"kwa-tin'tï), n. Same as aquatint. quatinter ( $\left.\bar{a}^{\prime} k w a-t i n / t e ̀ r\right), n$. One who practises the art of aquatinting.

aquatinting ( $\bar{a}^{\prime} k w a$-tin $^{\prime \prime}$ ting), $n$. [Verbal $\mathrm{n}$. of aquatint.] The art or process of

aquavivarium (ā" kwa-vi-vā' aquavivaria (-ä). [< L. aqua, water, + viva rium, q. v.] Same as aquarium, 2.

aqueduct (ak'wē-dukt), $n$. [Early mod. E. also aquaduot $;=\mathbf{F}$. aqueduc, OF. aqueduct, < L. aquaductus, prop. separated, aque ductus, a conveyance of water: aquo, gert of aqua, water; ductus, conveyance, pipe, canal, < ducere, lead, convey: see aqua and duct.] 1. A conduit or channel for conducting water from one place to another. More particularly a pplied to structures of masoury and tunneling for the conducting of water from distant sources to large clities through tubulsr conduits. Aqueducts were extensively used in the Roman They were constructed of stone or wood, sometimes tun. neled through hills and carried over valleys and rivers on arches, much of the labor upon them belng uselessly expended, from \& mistaken ldes of the necessity of 8 perfectly level course. The aqueduct of Segovis, originally bnilt by the Romans, has 159 arches, is in some parts built
in two tiers 100 feet or more in height, snd is an admirable monument of anclent engineering. One of the most remonument of anclent engineering. One of the most re-
marksble aqueducts of modern times is that of $\mathbf{3 f}$ srsellles, to which city it conveys the waters of the river Durance from a distance of about 58 miles, of which 10 miles consists of tunnels, and a considersble portion is traversed by means of viaducts of grest height and length. This aqueduct was bult between 1839 and 1847 , sud supplies water
Aquila

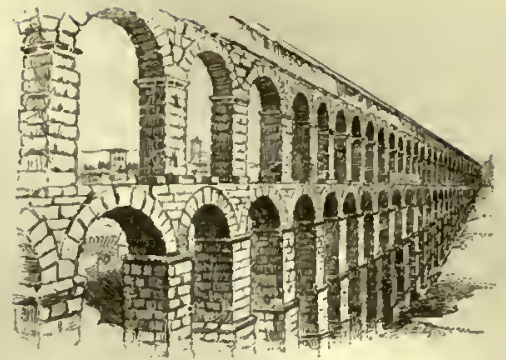

extremely arid, have become a garden from the plentifu

2. In tur., same as aqueductus.

aqueductus (ak-wẹ̄-duk'tus), $n$. [NL.] In anat., aqueityt (âkelus.

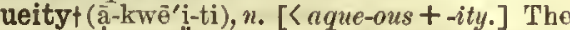
quineiple or quality of water; wateri-

Terreity, and sulphureity

Shall run together sgain, and sll be annulled. B. Jonson, Alchemist, ii. 1

aqueous (a'kwē-us), a. [< L. as if *aqueus, aqua, water: sec aqua.] Of the nature of water; abounding with water; formed by water; watery: as, an aqueous solution.-Aqueous or Watery fusion. See fusion.- Aqueous humor (of the tween the cornes and the which fills the spsce be See eye-Aqueous rocks, in geol. mechanically formed rocks, composed of matter deposited by water called sedimentary or stratified rocks.-Aqueous tint, in painting, s nearly colorless tint.-Aqueous tissue with colear sap, as ln most succulent plants. - Aqueous vapor, the invisible vapor which, taken from the surface of water by evaporation and rising into the atmosphere aqueousness ( $\left.\bar{a}^{\prime} \mathrm{kwẹ}-u s-n e s\right), n$. [<'aqucous + -ness.] The quality or state of being aqueous or watery; wateriness.

aquetta (á-kwet'tä), n. [It., prop. acquetta, dim. of acqua, water: sce aqua.] A celebrated Italian poison, more commonly ealled aqua Tofana (which sce, under aqua).

aquicultural ( $\bar{a}-\mathrm{kw} \overline{\mathrm{e}}-\mathrm{kul}$ 'tūr $-\mathrm{al}), a . \quad[<$ aquiculture $+-a l$.$] Pertaining to aquiculture.$

By the republication of these foreign papers the [Fish of whst is belng done in aquicultural entergrise in all
parts of the world.
Nature, XXX111. 38 . aquículture (à'kwè-kul-tūir), n. [= F. aquicul ture, < L. aqua, water, + cultura, culture.] Culture of the natural inhabitants of water fish-breeding; piseiculture.

aquiferous (ă-kwif'e-rus), $a$. [< L. aqua, water, + ferr $=\mathrm{E}$. bear ${ }^{1}$. ] Conveying water. Aquiferous canals, the cliannels which traverse the foot or tophorcs, opening upon the surfsce by one end, and at the cstablishing communicstion between the blood snd the surrounding water.

These aquiferous canals, as they have been termed, sppear, in miny cases, to open by their inner ends into the
blood sinnses.
II ${ }^{2}$ xley, Anat. Invert.,

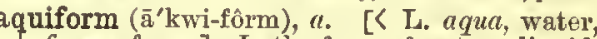
f forma, form.] In the form of water; liquid Aquila (ak'wi-lä), $n$. [L., an eagle, hence the egionary standard; prob.fem. of the rare adj.

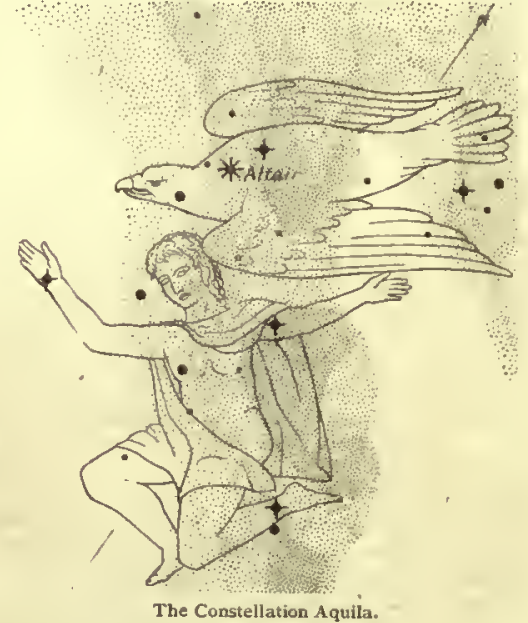

aquilus, dark-colored, dun, swartby; ef. Gr. á $\chi \lambda$ is, a mist, darkness.] 1. In ornith., a genus 
Aquila

of birds established by Brisson in 1760, but having no charactors by which it can be exactly defined. The name thas been loosely applled to eagles and other iarge diurnal raptorlai birds whilch ha ve so tooth spptied to engtes having booted taral, thew is, hivlug the goldcn eagle, $A$. ehrysaet its, of Wurvere and North A merlea the spottel cugle, A. nevera, of Asia and Europe; the it perial engle, 4. heliaca, of the simne reglon ;

2. A nertheru constellation situated in the Milky Way, nearly south of Lyra, and contain ing the bright stal Altair. It has for its outline the Hguro of a tlying eagte carrying in Its talong the boy $\mathrm{An}$ 3. [l. c.; pl. aquilu (-lō).] A reading-desk in the form of au eagle.

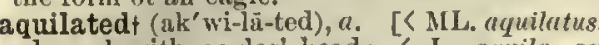
adorned with eagles' licads, < I. aquila, an eagle: soo Aquila.] In her., udorned with the heads of engles: as, a cross aquilated.

Aquilegia (ak-wi-lè'ji-li ), n. [NI. (MiL. aquilc gia, aquileiu), said to be < L. uquila, au eagle, whose claws the spurs of the petals are sup whose claws the spurs of the petals aro sup ngla, Aquilcia, a town of Austria near the Adri atic.] A gellus of acrid plants, natural or

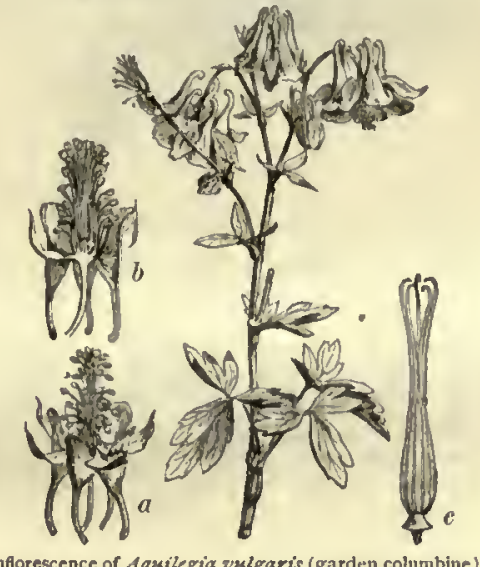

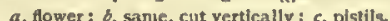

der Ranunculacea, widely distributed over the temperate parts of the northorn hemisphere. The flowers have flve flat, elliptical, colored sepals, alternating with as nuany spurred petals; the fruit consists of five follicles with numerous seeds. The gpurred petals
with incurvel hesda bave been conipared to five pigeons, the sepals representing the wings, and to this the English name columbine refers (from Latin columba, a plgeon).
Several apecies are common in euttivation, and, as they are prone to sport and hybridize, the varieties of form and cies, in aome of which, from the liocky Mountains and Mexlco, the spurs are several inchea in Jengtl.

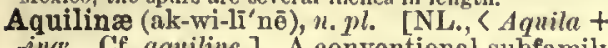
-int. Cf. aquiline.] A conventional subfamily of Falconida, containing eagles. It has no assignable technical characters. See Aquila, 1. aquiline (ak'wi-lin or -lin), $a . \quad[=\mathrm{F}$. aquilin, L. aquilinus, pertaining to au eagle, r aquila an eagle: see Aquila.] 1. Of or pertaining to the eagle.

$$
\begin{aligned}
& \text { When mortals lived } \\
& \text { Ot stronger wing, of aquiline ascent. }
\end{aligned}
$$

2. Resembling an eagle; havin i. eagle's beak ; curving; hookod ; prominent. Terribty arched and aquiline his nose.

Cotoper, Task, ji

Even before objection was made to his presence in the Board . the aquiline anggestions of $\mathrm{Jtr}$. Oakhurst's mien and countcnance not only prematurely fluttered the pigeona, but absolutely occasioned mach uneasiness ninon,
the fish-hawks. Bret Ifarte, Argonauts, p. 130 . aquilonł (ak' wi-lon), n. [< E. aquilon, <L. aqui$l o(n-)$, the north wind, Boreas; prob. $<$ aquilus, dark-colered, dun, swarthy (ef. Aquila), with allusiou to the dark, stormy weather aceom pauying the north wind.] The north wind. [Rare.]

Blow, villain, till thy sphered bins cheek Out-swell the collc of puff'd Aguilon.

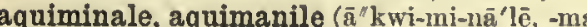
ni'le)

aquiminarium ( $\left.\overline{\mathrm{a}}^{\prime} \mathrm{kwi}-\mathrm{mi}-\mathrm{na} \overline{\mathrm{a}}^{\prime} \mathrm{ri}-\mathrm{um}\right), n_{\bullet} ; \mathrm{pl}$ aquiminaria (-ij). Same as aquemanalc

Aquitanian (ak-wi-tā'ni-an), a. [<L. Aquita nir, said to be < Celtic Aqui, name of a people, + tan, country.] Pertaining to Aquitania, on of the great divisions of ancient Gaul. Accord ing to Casar, it was bounded by the Garonue, the Pyrenees, a
285

arabesque

and the ocean. Augustus extended it as s Ronian province ond time king (lom) of Aquitaine (hell as an appanage of the English crown through internarriage for about 300 years before 1453), and finally, greatly reduced, the freneh province of Oulcine (a medieval corruption of Aquitaine)

aquitet $v, t$. An old form of acquit. Chuncer. Aquitelæ (ak-wi-tō'lō), $n_{0}, y$. [NL., < L. ufua, water, $+t c l a$, web.] A subdivision of spiders, of the family Arancidec, corresponding to the old genus Aryyroncla and to the Vayades of Walckenaer or the aquatic Tubitela of Latroille. It contains such species as the diving water-splder, Argyroneta
aquatica. So called because they spin their wels in tite water. See cat under Argyroneta.

aquocapsulitis (ā"kwō-cap-sū-lī'tis), n. [NL. L. aque, water, fluid, + capsula, box, + -itis see aqua and capsule.] Inflammation of the linings of tho

aquometer (ä-kwom'e-têr), $u$. [The aualogies] I. form would bo "aquincter, caqua, water, metrum, measuro. Cf. aquincter.] A steam pump whicl acts both by direct steann-pressur. and by vacuum. It has two workfug chinulvers, into which ateam is alternately admitted. By the condensation of the atcaun a vartial vacuum is formed, to flll which water rushes in. When the clamber fs full of water a valve pressure- or delivery-ehamber. The steam condenses a One chanber is filling white its compranion is discharging, thus keeplug uy) a continnous delivery. See pulsoineter and vacuum-primp.

aquose (a'kwōs), a. [= F. aqucux = Pg. aquoso, < L, aquosus, < aqua, water: seo aqua.] Watery; abounding in water. [Rare.]

aquosity (ä-kwos'i-ti), n. [=F.aquosite $=\mathrm{Pg}$. aquosidade, < LL" aquositas, moistness, < L aquosus: see aquose.] 1. The abstract essential qualities of water; wateriness as a quality We do not assume that a something ealled aquosity as soon ab it was formed, and then guidect the aqueous partlcles to their places in the facets of the crystal, or

Uxley, Lay Sermons, p. 136.

Life is thus only an abstraction from the propertteg of llving things, just as aquosity would be an abstractlo Irom the properties of water. New Princeton Rev., I1, 71, ure.

aquula (ak'wö-lä), n. [L., also aquola, acula, a littlo water, a little stream, dim. of aqua, water: see aqua.] In anat., a small collection of watery fluirl. -Aquula acusttea, the auditory fluid, the endolympli or perilymph of the labyrinth of the ear. arl (är), n. [< ME. ar, pl. arres, < AS. er, < J. $e r$, the name of the letter $r$; $<$, the usual asletter $R$. Also formerly.] The name

There was an $\mathrm{V}$. and thre arreg togydre in a ante Pol. Poent in Archoologia, XXIX. 31. (II alliwell.) $a r^{2}, n$. See $a r r l$

$a \mathbf{r}^{3} \phi$, ar $\mathbf{r}^{4} \phi$, etc. Obsolete forms of arc ${ }^{1}$, ere, or ar-. The assimilated form, in Latin, etc., of $a d$ beforo $r$; in older English words a restored form of Middle English and Old French $l_{-}$, the regular reduced form of Latin ar-, as in array, arrange, etc.

-arl. [ME, -ar, oceasional spelling of -erl, ere.] A suffix of nouns denoting an agent; a variant begger, etc.

-ar'. [ME. reg. -er, < OF, -er, -ier, -air, mod. $\mathrm{F}$ $-i e r,-a i r e=\mathrm{Sp} . \mathrm{Pg} .-a r i o=$ It. $-a r i o,-a j o,<\mathrm{L} .-\bar{a}-$ iu-s, fem. -är-ia, neut. -är-iu-m, a common adj. and noun suffix, = Goth. $-a r-e i-s=O H G$. -äri -ari, MHG. -arc, -er, G. $-e r=$ AS. -ere, E. er,
suffix of nouns of agent: see erl. The reg. OF' suffix of nouns of agent: see -erl. The reg. OF
form was -er, -ier, $>$ ME. -er, now restored to -ar. The usual mod. F. form is airc. In $\mathrm{E}_{\text {. }}-a r^{2}$ a an adj. suffix appears as -ary $]^{1}$, q. v.] A suftix of Latin origin, occurring in some nouns, as in bursar, mcdlar, mortar, vicar, et

ar ${ }^{3}$. [ME. reg. -or, <OF. -er, -ier, mod. F. -ier, $-\operatorname{airc}=\mathrm{Sp} . \mathrm{Pg} .-a r=\mathrm{It}$. -are, $<\mathrm{L}$. -aris, neut -are, equiv. to alis (E. -al), for which it is used when $l$ procedes: see $-a l$. 'In $\mathbf{E}$. $-a r^{3}$ also appears as -ary ${ }^{2}, \mathrm{q}$. $\mathrm{.}$.] A suffix, of Latin origin (I) of adjectives (and of nouns thence derived) being equivalent to -al, for which it is used when $l$ precedes, as in alur, polar, reqular, singular, ete. (see -al, and comparo $-a r^{2}$ ); (2) of nouns, as in altar, collar, pillar, scholar, ete. In these noums and other old words $-a r$ is an al teration (to suit the Latin) of the Mliddle English $-r$, trom old French, or (ns in scholar) from Anglo-saxon. (Brisson)"; appar. a caws, of large size and
[L., an altar.] One of the 15

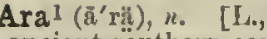
is sltuated south of the Scorpiun. It two linghtmagnitule. $\operatorname{Ara}^{2}\left(\bar{a}^{\prime} r i ̈\right), n . \quad[N L$. native Braz. name; seo def., at end.] Á genus of American birds, of the family I'sittacide, the magorgcous coloration, with very long cuncate tail and more or lessnaked face; sometimes made the type of a subfamily dine containiug the wedyetailed Ameriean par-

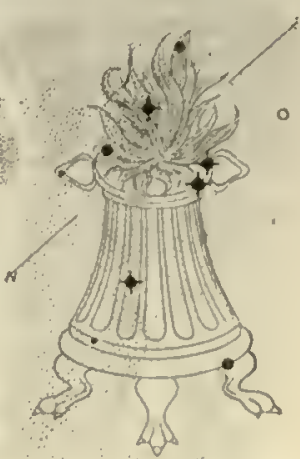

The Constellation Ar rots. Leading species are $A$. macao, the red and blue macas : A. araranena, the blue and yellow macaw ; and $A$ hacinthina, the byacinthine uacaw. It is a synonym of The related forms, arra ararauna, and crura, are severally used for specles of sections of the genus $A r a$.

Arab (ar'ab), n. and $a$. [<L. Arabs, pl. Arabcs

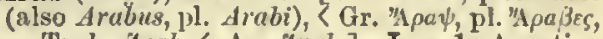
$=$ Turk. Arab, < Ar. Srab.] I. n. 1. A native of Arabia, or a member of the Arabic race (now widely spread in Asia and Africa, and formerly in southern Europe); an Arabian, whether civilized inlrabitant of a city or a dweller in the desert, eommonly known as a Bedawi (see Beclonin) or nomadic Ishmaelite.-2. A noglected outcast of the streets, particularly an outcast boy or girl, often styled a street Arab, in allusion to the wandering Arabs.

When he read about the street $A$ rabs, and of the dolngs of the young fry of thieves, he . . . whped his eyess, and
gnid. "God bless nie?"

II. $a$. Of or pertaining to the Arabs or to Arabia; Arabic; Arabian: as, an Arab steed. The delleate Arab arch of her feet.

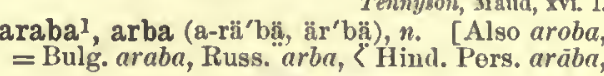

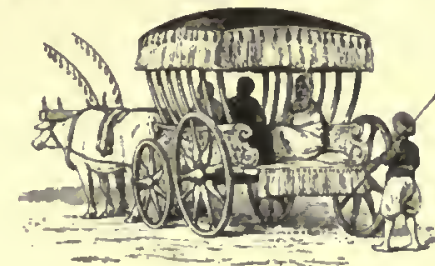

Turk. Ar. 'arabah, a cart, wheeled vehicle.] A heavy, springless wagon, usually covered with a screen as shelter from the rays of the sun, drawn by oxen or cows, and used throughout northwestern and central Asia, India, Turkey, and Russia, whercver Tatars have settled.

Not a gingle waggon is to be found in the district, and

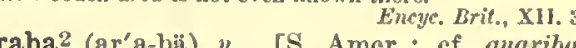
guareba, and äraguato. [S. Amer.; cf. gnaribu, ferent species of the same genus.] A howling monkey of the South American genus Mycetes, 11. stramincus. See houler.

arabesque (ar-a-besk'), $a$, and ". [Also arabesk, F. arabcsque, < It. arabesco $(=\mathrm{Sp} . \mathrm{Pg}$. ara

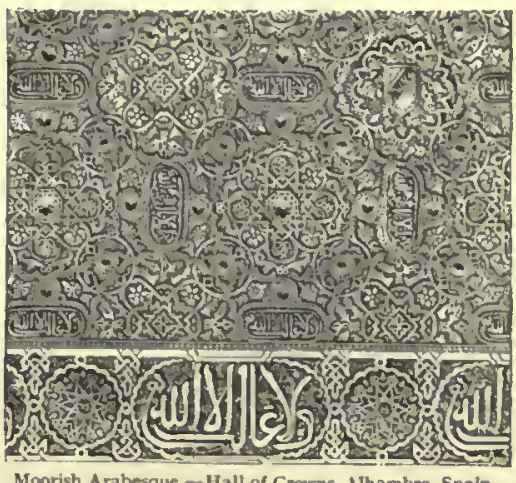

besco), < Arabo, Arab (see Arab), + esco: see esque. The arabesque style is so called becanse 
arabesque

Arabian artists brought it to high perfection, and were at one time supposed to be its originators.] I. $a$. Arabian or resembling the Alnbian in style; specifically, in art, relating to or exlibiting the variety of ornament known as uraliesque. See Il.

Some eushions disposed in the Mloorish finshion, and ornamented with arabesque necdle-work, supplicd the place
of chairs in this anartment. Scott, Kenilworth, I. vi.

II. $n$. 1. A kind of ormament of a capricious and fanciful character, consisting of lines, geometrieal figures, fruits, flowers, folingo, ete., variously combined and 8 (f) 3 gromped, and painted, inlaid, duc especially for the decoration $45 \begin{aligned} & \text { of walls and ceilings, but also } \\ & \text { for the decoration of objects }\end{aligned}$ दू. (3) 0 of any nature. In the arabesques were rigidly excluded, in accordance 350 with the requirements of their re(2 .70 mans, and the Renaissance artists,

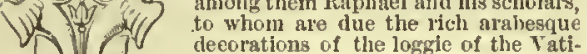
2) 5 can, laid all the kingdoms of nsture loubtedly derived the idea of pietorial हn or plastic ornsment of this kind from embroidered with natural or fabulous forms of plants snd animals, which - were brought to them by Phenicis

Cinque-cento Ara-
besue, from tomb in traders from a very early period,
Church of $S$. Pietro- 2 . In bookbinding, a term used in England for impressed or namental work on the side of the biuding, produced by the pressure of hot plates or roller upon which the pattern is engraved.

Also spelled arabesh:

arabesque (ar-ą-besk'), $v_{0} t_{0}$; pret. and pp. arabesqued, ppr. ärabesquing. [< arabesque, n.] To enrich with ornament in arabesqne.

With its vermilioned fuitial letters, so prettlly ara-
beclectic Rev.

Arabian (a-rà'bi-an), $a$. and $n_{0} \quad$ [ $<\mathrm{L}$. Arabius, taining to Arabia, or to the Arabs: as, Arabian science or philosophy.-Arabian bird, the phenix (which see); lience use

She [Imogen] is slone the Arabian bird; and I

II. $n$. 1. A native of Arabia; an Arab.2. One of a Christian sect of the third century (commonly ealled Arabici) which sprang up in cluded in Arabia. According to Ellselius, its mem. bers "asserted thst the human soul, as long as the present it would be raised again with the body at the time of the resureetion." The point was diseussed with them by
Origen, at a council, with so much foree that they were le to change their opinions.
Arabic (ar'a-bik), $a$, and $n$. [ME. Arabik, n.

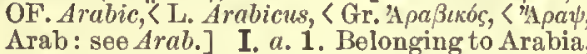
Arab: see Arab.] I, $a .1$. Belonging to Arabia Derived from certain species of acacia growing

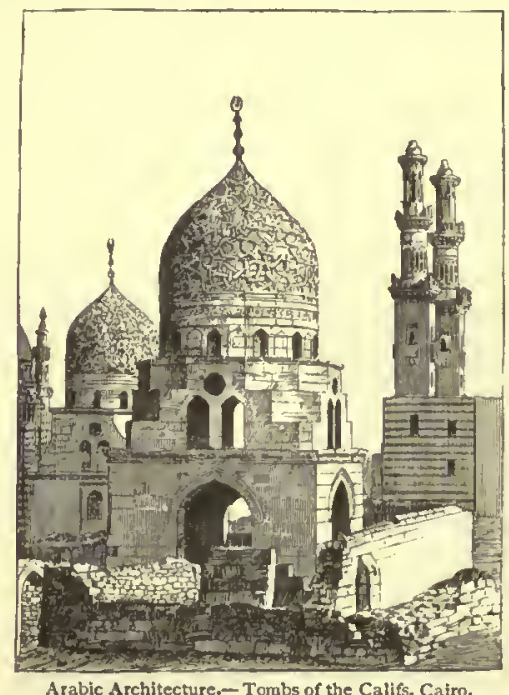

in Arabia and other casterm countries: as, gum arabic (which see, under $g u m^{2}$ ); arabic acid. See arabin.-Arablc architecture, a general term for
the Mohammedan or Nussulman, Moorish, or Sargee
286

Araceæ

styles of arehiteeture, lout applied espeeially to Egyptian
and Oriental examples. This architeeture shows in its systems of eonstruction and ornament the profonnd influenee of Persian and byzantine models, though, ss a
rule, in arehitectursl sclence it falls far behind the work of the 1yzantine masters. The ovoidoconical dome supported on pendentives is a ehirreteristic feature; the circular; the roofs sre in general flat, and supported by rehes resting on columns forming long parallel ajsles, and often surrounding a central court. The arehes ar very commonly of the horseshoe slape developed in ersia, and from the beginning show the pointed form unctive reasons, and that nether influenced the methads of building, nuwel less revolutionized the entire srt of rehitecture, as dil the adoption of the pointed areh in western Lurope. Walls, partieularly interior walls, eeilings, domes, spandrels, ete., are commonly covered with an intrieate lacework of arabesplues, usually exeented in rillion and amples of the style exist in Cairo - Arabic forthy excharacters, the numeral characters $1,2,3,4,5,6,7,8,8$, so called as having been introduced into European from rrab use. They were so in troduced in the twelt th century, and the work of Leonardo of Pisa, published in 1202, con(n)

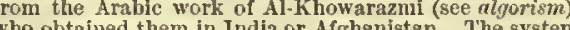
Wher certe was, whether they had been previously known in Europe without the eipher, and their history among the Arabians,

II. $n$. The language of the Arabians; a Semitic dialect, belonging (along with the Himyaritic and Abyssinian languages) to the southerm branch of the Semitic family, and generally regarded as exhibiting more ancient features than any other Semitic tongue. It is the language of the Koran, the saered language of Islam, and possesses an ing mense literature, almost wholly IJoslem and later than the time of Mohammed. Many other langtages have borrowed largely of its material, from the Persian, T'urkish, Hindu-
stani, and Mslay on thie east to the Spanish on the west. stani, and Mslay on thie east to the Spanish on the west.
Arabicalt (a-rab'i-kal), a. [ $[$ Arabic $+-a l$. Arabian; Arabic. [Rare.]

Arabically $\dagger$ (a-rab'i-kal-i), adv. According to Arabic nsage; in Arabie. N. E. D.

Arabici (a-rab'i-sī), $n_{0} p l$. See Arabian, n., 2. Arabicize (a-rab'i-sĩz), v.t; pret. and pp. Arabirender conformable to Arabic nsage.

render conformable to Arabic nsage. -bility.] Capability of being cultivated; fitness for eultivation.

A Domesday hide, which one of our latest archrologists
with good reason maintains is yariable aceording to the rabiliey or pasturability of the land. arabin, arabine (ar'a-bin), $n \cdot[<a r a b-i c$ (gum)
$\left.+-i n^{2}.\right]$ A variety ơ gum, $\left(\mathrm{C}_{6} \mathrm{H}_{10} \mathrm{O}_{5}\right)_{2}+\mathrm{H}_{2} \mathrm{O}$, soluble in cold water; arabic acid. It is the princolnal eonstituent of gum arabie, whieh consists of sslts of arabin, and is also contained in other similar substanees. $\mathrm{A}$ crystallizable sugar, $\mathrm{C}_{6} \mathrm{H}_{12} \mathrm{O}_{6}$, prepared by the action of sulphuric acid on arabin. arabinosic (ar"a-bi-nó'sik), a. [< arabinose + -ic.] Of or pertaining to arabinose.
Arabis (ar'a-bis), $n$. [NL., < Gr. Apaßis, Arabian, <A $\rho$ ißjic, Arabia, of which the more im portant species are natives.] A large genus of
plants, of the order Cruciferc; wall- or rockeress. The speeies are mostly of little interest or im-
portance; a few are eultivated for ornament in rockwork Arabism (ar'a-bizm), n. [= F. arabisme; $A r a b+-i s m$; "ef. Gr. 'A $\rho \beta \beta i \zeta \varepsilon t v$, take part with the Arabs.] An idiom or a peculiarity of the Arabic language.

Arabist (ar'a-bist), n. [= F. arabiste: $\left\langle A r^{\prime} a b\right.$ Arabist (ar'a-bist), $n$. [= F. Arabiste; Arab language, or in Arabian literature or science. Arabize (ar'a-bīz), $v \cdot t . ;$ pret. and pp. Arabized, ppr. Arabizing. [< Arab +-ize. Cf. Gr. A $\rho \alpha \beta i$

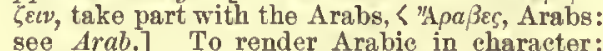
especially, to tinge with Arabisms.

These Arabs of the Sudan are not true Arslis, but to a arable (ar'a-bl), a. $\quad[<\mathrm{F}$. arable, $<\mathrm{L}$. arabilis, that ean be plowed, $<$ arare, plow, $=$ Gr. ápoì $=$ Goth. arjan = Ieel. erja $=$ AS. erian, $>$ E. ear, plow: see $\mathrm{car}^{3}$.] Fit for plowing or tillage. plow, as distinguished from grass-land, wood-land, eom-

Aracanese (ar-a-ka-nēs' or $\left.-n \bar{e} z^{\prime}\right), a$. and $n$. [ Aracan + -ese. J. I. $a$. Relating or pertaining to Aracan or to its inhabitants.

II. $n$. 1. sing. or $p l$. A native or the natives of Aracan, a division of Burma.-2. The language spoken by the inhabitants of Aracan, a dialect of Burmese.

Also spelled Arakanesc. aracanga (ar-a-kang'gï), . [Braz.: see $\mathrm{Ara}^{2}$.] A kind of macaw, l'sittacus macao (Linnæus) and blue macaw. Also aramacanga.

aracari (ar-a-käíri), n. $[=$ Ps. aracuri (NL Aracarius), from a native name. ] 1. A touean of the genus Iteroglossus, differing from the

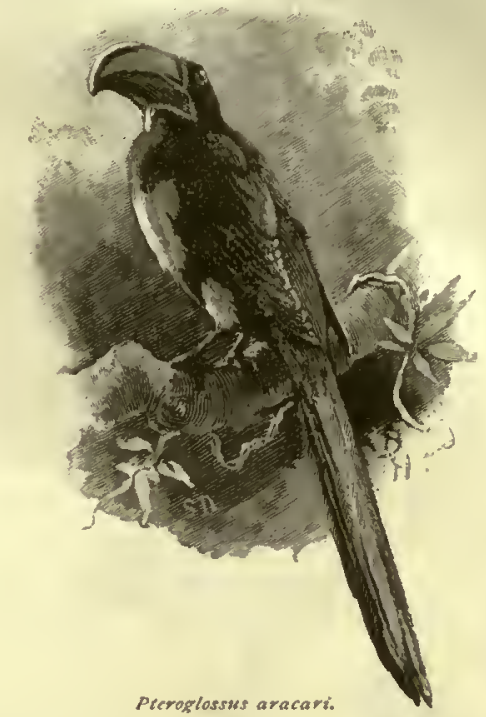

true toucan in being smaller in size, with a less developed beak, and in having more brilliant and variegated plumage. See Pteroglossus and lihamphastos. The araearis breed in the hollows of decayed trees, which they ellarge by means of their beak. The prevalling eolor of their plumage is green, often varied with spaees or bands of black, or of hrilliant red and yel-
low. They are natives of the warm parts of south America. 2. In ornith., the specifie name of one of the aracaris, Pteroglossus aracuri. It was marle a generie name by Lesson in 1828, and was Latinzed as Aracarius by Rafinesque in 1815.

Also spelled aricari.

arace $^{1}+, r^{\prime} t . \quad$ [< ME. aracen, arasen, also arachen, $\angle$ AF. aracer, OF. aracier, araehier (as if $<$ L. "abradicare), mixed with erachier, esrachic $(\bmod . \mathrm{F}$. arracher $)=$ Pr. araizar, < L. cxradicare, eradicare, uproot, eradicate. see crudi catc.] To pull up by the roots; pull away by orce; tear violently away.

The children from her arm they gonne arace.

$\operatorname{arace}^{2} t, v \cdot t$. Same as arase 1

Araceæ (ā-rā'sề-e) $), n . p l . \quad[N \mathrm{NL} .,<A r u m+$ -acck.] A natural order of monocotyledonons plants, of which the genus Armm is the type. The speeies are hermostly acauleseent from tuljerous or in the tropics often tall rooting clinbnous flowers, usual. eclous, ed upon a spadix surrounded by a
spathe, witl which it is sometimes coll. includes 98 genera within the tropics, but comparstively gegions. The large

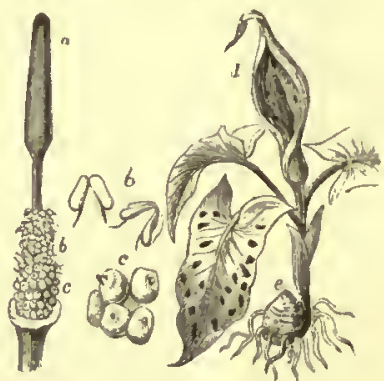

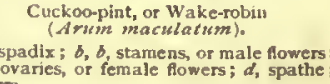

dron, Arisema, and Pothos. In temperate North Ameriea there are 10 species, belonging to 8 genera, of which the most common is the Jack-in-the-pulpit, or Indisn turnip, Ariscema triphyllum. The skunk-eablage, Symplocarpus foetidus, and the sweet-flag, Acorus calamus, are slso well-known representatives of the order. The tuherous
roots of many species abound in stareh, and furnish a wholesome food when cooked, or after the acridity has been removed by washing, as in the taro, Colocasia antiquorem, which is extensively cultivated in tropieal coun-
tries. British or Portlsnd arrowroot is manufaetured
from the roots of Arum maculatum (the wake-robin or cuekon-pint), the specles of which are natives ehiefly of tropical countries. A prineiple of acridity generally pervades the Aracece, existing in so strong a degree in sonas to render them dangerous poisons, as Diefjenbachin when it is eliewel the tongue becomes swelled by the aerid jnice, and the power of speeeh is destroyed. Many speeie are eultivsted in greenhouses, ehlefly as folinge-plants, and 


\section{Aracex}

the calla, Richardia fichiopica, is a very eommon house. araceous (ā-ra'shius), $a . \quad[<$ NL. craceus: seo Arucere.] Pertaining to the natural order of plant sraceco.

arachidic (ar-a-kid'ik), a. [< Arachis (Arachid-) $+-i c$.$] Pertaining to or derived from the earth-$

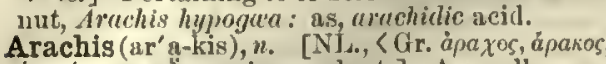
ápakis, some legrminous plant.] A small genus of loguminous plants, natives of Brazil. The genus is remarkallo in tho order for its eiongated peili. cel-like calyx-tube, anul for the nanuer in which the growing stipe of the ovary letuls downward and, attain-
fing a fength of 2 or 3 inches, pusies the ovary into the ground, where it begins to eniarge and rijent. "The bestgroundnot, which is now cultivated in nost warm elimates, and is estceneul a valuabie article of food. Its pod when mature is obiong, often contraeted in the milidle, wrinkled, of a palc-yellow color, and contalns two seeds of
the size of a hazel-nut, sweet in thavor, especinlly when

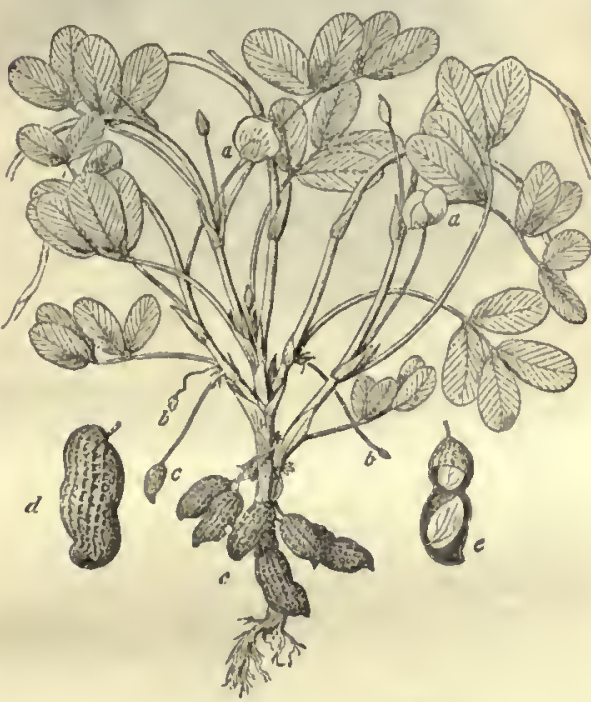
, $\delta$, ovaries on lengthened stipes; $c$, c, forming frutt:

roasted, and ylelding when pressed an oil not inferior to that of olives. The plant grows to the helght of 1 or 2 feet. -Arachis-oll, the oil expressed from the seeds of Arachis substitute for ollve-oll, and largely in soap-making.
arachnactis (ar-ak-nak'tis), n. [NI., ápáxv , a spider, + ikrís, a ray.] A name given to the free-swimming young of the gemus $E d-$ wardsia (which see). The term was used as a genus name

arachnid (a-rak'nid), n. One of the Arachnida au arachnidan.

Arachnida (a-rak'ni-dä), n. pl. $\quad\left[N L_{.},<G r\right.$ ćpá $\chi v \eta$, a spider (see Aranca), +-illa.] In zoöl. a class name used with varying signifieation. (a) In Lamarek's and Latreilie's systems of elassifieation,
one of three classes into which the Linnean Insecta wer divat Latreille's system, the second elass of articulated animsals with articulated legs, spterons and anetabolons. It was divided into two orders, Pulmonarin and T'rachearia, tir former containing the spiders and scorplons, the latter th
false scorvions, larvestmen, and mites, (c) A elass of the false scorplons, larvestmen, and mites. (c) A elass of the
plyylum Arthropoda, ineluding the spiders, scorpions, fals georpions, larvestmen, and mites, with or without it They are spterous, smetaboious, articulato animals, with
srtieulated leps. They sre deeejhalized by the blending of the liead with the therax as a cephalothorax, normally bearing 8 legs, and never more; the sntenne are trans
formed into ehelio when present; the abdomen is usually distinet but not segmented, or if segmented is not dis tinetiy separated from the eephalothorax, and lloes not transformed into appinendages being in the cyes are simpler and gen erally more than two in number; the respiratory appuratus is pulinonary or tracheal, or compounnled of these two
forms; and their mode of progression is digitigrade. Ther sre sbout 4,500 speeies, some of which are fossils occurrin in the Silurian and Carboniferous. They are now divide tra, Araneina, Acarina, Arctisca, Pyenoronida, Pentasto mida. Pascoe makes nine : Scorpiodea, Cheliferidea, Acariisca, Pentastomidea (without Pyenogonida). Synonymou with $A$ cephale, 3, and Acera,

arachnidan (a-l'ak' ni-dan), $a$. and $n$. [<Arachida $+-a n$.] I. a. Pertaining to the Arachida. II. $n$. One of the Arachnida.

arachnidia, n. Plural of arachnidium.

arachnidial (ar-ak-nid'i-al), $a . \quad[<$ r rachnidium $+-a l$.$] Of or pertaining to an arachnidium.$ which the ducts of the aracinidium enter; a spinneret.
287

Their [the glands"] ducts uit imately enter the six promiil uxiey, Anat. Invert., 11. 3\%9. Arachnidial papllia, s minute ori. an arnelunilium is poured out. arachnidium (ar-ak-nid' iumi), $n$; i pl. arachnirlia (-H). web, < aрŕx $\chi \eta$, a spiler, + dim. -idiov.] Tho cliaraeteristic organ of the Arancila, or true spiders: the glanlular anparatus by which the silky threads forming cobwob are seereted and spun out. Nun-

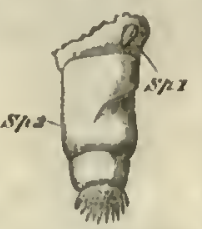
, witi

parato duets, secrete the viscid materiai wilicis hariens into silk witen exposed to the air. The giands lave been divided into flvo kimls: nciniform, ampulate, aggregate, nidina mummillo, anil diseharge through oriffees in the araclinidial papillix.

arachnitis (ar-ak-n'tis), $n$. A shortened form of aruchnoiditis.

arachnoid (a-rak'noid), $u_{0}$ and $n$. [<Gr. ápo $\chi-$ vocidńs, like a cobweb, <ápdxv7, a spider's web, a spider, + eidos, form.] I. a. 1. Of or pertaining to the trachnida? arachnidan-2 Like or likened to a coloweb: applied, iu anat. $-(a)$ to the arachnoid of the brain (see II.); $(b)$ to the hyaloid membiane or arachnoid of the eye (see II.).-Arachnotd canal, cavity, ete. sce the nouns.-Arachnoid membrane.

II. $n .1$. A kind of fossil madrepore. -2 . In anat., the serous membrane enveloping the brain and spinal cord; the middle one of the three cerebrospinal meninges, botween the dura mater and the pia mater. It was formerly re garded as eonsisting of two layers, a viseeral layer invesidura mater, the Iwo constituting a shut sac, like other serous membranes, inclosing a cavity called the arachnoid cavity, containing a serons flnid, the araehnoid fluid; but the moro modern view regards the arachnoid membrane as a single sheet external to the pis mater and attached to it, but not follewing it into the sulci and other depres. sions of the brain. What was formerly called the eavity
of the araehnofit is now termed the subdursl spaee. The araehnoil is by some regarded as simply the outernost araehnoill is ly some regarded as simply the outer

3. An old and disused name of the hyaline or hyaloid membrane within the eyeball, especially of that portion of it which contributes to form the capsule of the erystalline lens.

arachnoidal (ar-ak-noi'dgl), $a$. P Pertaining to or of the nature of the asac
of the word; arachnoid.

arachnoidea, arachnoides (ar-ak-noi' dē-dēz), $n$. [NL.] Same as arachnoid, n., 2. arachnoiditis (a-rak-noi-di' tis), n. [NL., noid membranc.

noid membranc.
arachnological (a-jak-no-loj'i-kal), a. of or pertaining to araehnology.

arachnologist (ar-ak-nol'ō-jist), n. [< arachnology $+-i s t$. ] One versed in arachnology. arachnology (ar-ak-nol'ō-ji), n. [<Gr. áá́ $\chi \nu]$

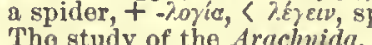

Arachnopoda (ar-ak-nop'ō-dä), n. pl. [NL.

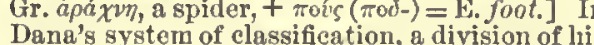
suborder Cormostomata of Entomostraca. The term corresponds with Araneiformia or Pycnogonida (which gee).

Árachnothera (a-rak-nō-thē'räi), n. [NL., $\leq \mathrm{Gr}$. dó $\chi \nu \eta$, a spider, $+\theta \eta \rho \tilde{a} \nu$, hunt.]' The typical genus of birds of the subfamily A rachnotherina There are numerous species, fnhabiting the Inio- Mals
region, sueh as $A$. Longirostris. Also Arachnolheres.

Arachnotherinæ (a-rak" "nō-thẹ-rī'nē), \#. pl. [NL., SArachnothera +-ini.] A subfamily of Nectariniida, containing mumerous speeies, chiefly East Indian and Oceanic, sometime called spider-eatchers, having long slender curved beaks like the
Drepanis, Cinnyris, ete.

arack, $\%$. See arrack.

aracouchini-resin (ar
Same as acouchi-resin.

aracuan (ar-?n-kwän'), n. [Of S. Amer, origin.] A name of one of the guans, Ortalis aracuan. Also written araucuan.

arad $\left(\operatorname{ar}^{\prime} a d\right), n_{.} \quad\left[<\right.$ Arum $\left.+-a d^{1}.\right]$ A plant of tho natural order Aracer. Lindley.

Aradidæ (a-rad'i-dē), n. pl. [NÍ., < Aradus $+-i d c c$.$] A family of heteropterons insects,$ characterized by their extremely depressed vided into Aradine and Brachyrhynchince.

\section{Araliaceæ}

The family Aradide, which contains the most depressed
Seteroutera lu existence. Aradinæ (ar-a-dīnē), n. $p / . \quad[$ [L., < Aradus + -inu:] A subfanily of Aredidu, having a comparatively long lostrum, the sterium grooved, the end of the abdomen witl a thin cleft and lobate margin, and the head with an angular process exterior to the antenne. It is a inge Group, fenersliy distributeil in Ameriea from the arctio

Aradus (ar'a-dus), n. [N'L., appar. $<$ Gr. ippedos, a rumbling (rattling), var. of apaßos, a gmashing, ehattering (rattling); ef. a $\beta a \beta c i v$, rattle, ring, as armor: in allusion to the loosc-armored appearance of the insects of this genus.] A genus of lieteropterous inseets, typieal of tho subfamily Aradino. A. crenatus is a large spocies of the United States, half an inch long.

aræometer, ete. Seo arcometer, otc.

aræostyle, $u$. Seo arcostyle.

aræosystyle, $a$. See arcosystyle.

aræotict, $\alpha$. and $n$. Sce areotic.

Aragonese (ar'?-go-nēs' or -nëz'), $a$. and $n$.

[Sp. Aragonés, [Aragon.] I. a. Pertaining

Arugon or to its inhabitants.

II $\pi_{\text {. }} \operatorname{sing}$. or $p l$. An inhabitant or the inhabitants of Aragon, one of the great divisions (formerly a kingdom) of Spain, in the northastern part.

Sometimes spelled Arragonese.

ragonite (ar'g-go-nit), n. [<Aragon, a divifon of Spain, $+-i t e^{2}$.] Calcium carbonate crystallizing in the orthorhombic system. It is idenit in erystalline furm and in compositien, but difters fron ties; for example, its specifle gravity is 2.9 , while that of calcite is 2.7. It oceurs often in transparent acicular crystals, and also as a deposit from waters carrying lime. A
white variety, having $\mathrm{s}$ delieate coraliold form, is ealled flos ferri (tlower of iron), from the fact of its oceurrence aragn (ar'a-gö), n. [Canarese aragu, Telugu sticklae. Seo sticklac.

raguato (ar-q-gw $\ddot{B}^{\prime}$ tỏ), n. [S. Amer.; cf. ara$a^{2}$.] A kind of howling monkey of Sonth America, of the genus Mycetes, M. ursinns, or the ursine howler. It is the largesi of the new-word monkeys hitherto noticed, its length being nearly 3 feet,
while the tsil resehes to even a greater length. Llke all other nembers of the family, it is charseterized by its discordant and dismai yells, which ean be heard at the araignée (a-rī-ny $\left.\bar{a}^{\prime}\right), n . \quad[\mathrm{F}$. araignée, a spider, formerly also a spider's web, < LL. "araneata, a spider's web, < L. aranea, spider: see Aranca. of several branches or galleries starting from one point, like $a$ spider's web.

araint, $n$. [Mod. only dial., also arran, arrand, ME. arain, arein, arayne, etc., irain, crayne, etc., $\angle \mathrm{OF}$. araigne, aragne, iraigne, iragne = Pr. aranha, cranha = Sp. arana $=\mathrm{Pg}$. aranha $=$ It. arayna, a spider, < L. aranea, a spider, a spider's web: see Aranca.] A spider.
Arainæ (ar-a-i'nē), n. $p l$. [NL., < Ara ${ }^{2}+$-inc.] Same as Arina.

araise (a-rāz), $\because \cdot{ }_{0}$ [< ME. araisen, areiscn, see $a-1$ and raise.] Same as raise.

[A medicine] whose simple touch
Is powerful to araine King Pepin.

rak, seo arrack.

Arakanese, $a$. and $n$. See Aracanese.

arake (a-rik ), prep. phr. as $a d v$, or $a . \quad\left[<a^{3}+\right.$ rake.] "Naut., on the rake; inclimed from the perpendicular.

araki (ar'a-ki), $n$. [Cf. arki; see arrack.] An Egyptian intoxicating drink prepared from the dibs or honey of dates; a kind of arrack.

Iiy guarilians and attendants ... used to fetch aroki in a clear glass bottle, without even the decency of a cloth, $\begin{array}{ll}\text { cidilly drunk. } & \text { R. F. Burton, El-Medinah, p. } 487 .\end{array}$ Aralia (a-rā'li-ä), n. [NL.; origin unknown.] A genus of plants with small flowers arranged in umbels, and succulent

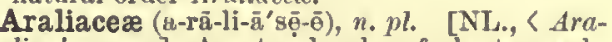
lia + -acece.] A natural order of plants nearly related to the Umbellifera, from which they are distinguished chiefly by their three- or more eelled fruit, simple epigynous disk, usually valvate corolla, and more shrubby habit. The order is most largely represented in warm and tropical seng, which is highly estemed by the Chinese as a stimu. lant, is prodlnced hy PQnax Schinseng, a plant found in northern Asia. The ginseng of North Ameriea, Aratio quinguefolia, is less valued. A species of Aralia, A. nudi-
cavtis, is used in .North America as a substitute for sarsa- 


\section{Araliaceæ}

parilla. The true rice-paper of the Clinese, obtained only
from the island of Formosa, ia made from the pith of another araliaceuns plant, Fatsia payyrifera. The order is represented in temperate North America only by the genme
Aralia, of whlch there are eight species, and by a single

araliaceous (a-rā-li-ầ'shius), a. [< NL. araliaceus.] Belonging to or resembling the Ara liacea.

Aramæan, n. See tramean.

Aramaic (ar-a-māik), $u_{\text {. and }} u_{\text {. }}$ [< LL. as if *Aramaicus, CGr. 'Apapain, JL. Aramae, propon $\mathrm{Heb}$. comprehended in the region of Damascus, and eastern Palestine southward to Arabia Petriea.] Same as Aramean.

The Aramaic specth lieman to exterrl itself beyond It
I8cac Taylor, 'The Alphabet, L 283. Aramean, Aramaan (ar-a-më'al1), $a$. and $n$ [<LL. Aramaus, < Gr. 'Apapaios:" see Aramaic.] I. $a$. Belonging or relating to the northern division of the Semitic family of languages and peoples, containing the Nesopotamian, the peoples, containing the Mesopotamian, the Syrian (extending over Palestine prior to the
Christian era), and the Nabatean; Chaldean; Chaldaic; Syrian: in distinction from the western or middle Semitic (Phenician and Hebrew) and the south Semitic (Arabic and Ethiopic).

The Aramean alplabet attained an even wider exten aion than the Aranaic 8peech, and at lengti

I raac Taylor, The Alphabet, I. 283.

II. $n$. 1. The language of the northwestern Semites, preserved in the Biblical books of Ezra and Daniel, in the Targums, and in the Peshito version of the Seriptures, together with the Christian Syriac literature.-2. An inhabitant or a native of Aramæa or Syria.

The Arameans also ... have the form "mata."
N. A. Rev., CXXV'I. 59

Arameanism (ar-â-mō'an-izm), $n . \quad[<$ Aramcan + -ism.] Samo as Aramism.

Aramidæ (a-ram'i-dē), $n . p l . \quad[N L .<$ Aramus $+-i d a$. . A family of grallatorial birds, confined to the warmer parts of America, and forming a connecting link between the cranes and
the rails, or the gruiform and ralliform birds. The principal osteological and pterylographic character are those of the cranes, while the digestive gystem and pair of syringeal muscles. The family consists of the singl genus Aramus (which gee). -ides.] A genus of American ralliform birds, of the family Rallide and subfamily Ralline; the American crakes, or small rails with short bills. The genus contains abont 20 species, chiefly of Central and
South America: It is gometimes restricted to one group of these, other names, as Porzana, Coturnicops, and Creciscus, Aramism (ar'a-mizm), $n$. [< Aram- (in Aramaic, etc.) + -ism.] An Chaldaism. Also meanism.

Aramus (ar'a-mus), $h$. [NL.; etym. nnknown.] The typical and only genus of the family Arabirds. They are ahout 2 feet long, of chocolate-brown color streaked with white, with slort and ronnded wings
a falcate flrst primary, a ghort tail of 12 feathers, and clet toes. The hinder toe is elevated, and the tarsus is scutel
late anteriorly, and as long as the bill. The bill is twice as long as the head, slender but gtrong, compressed, contracted oppoitte the linear nostrila, grooved about half it
length, and enlarged and deeurved in the ternunal portion.
A. pietus (Coues) inhabits Florida, where it is known as the limpkin; another apecies, A. scolopaceus, the scolopaceon courlan, Is fouml in the warmer parts of America. See
courlan.

Aranea (a-rā'nẹ-ä), \%. [L., a spider, a spider's

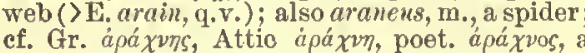

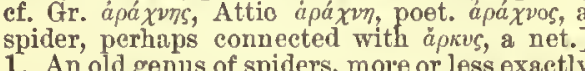
1. An old genus of spiders, more or less exactly equivalent to the modern superfamily Araneida. oje of the mollern families or genera of apiders, and has been eliminated entirely from some gystems. Aranea 2. [NL., neut. pl.] A former group of spiders, intermediate between a modern order and a intermediate bodern genus.

araneal (a-rā'nēeal), a. [<L. aranca, a spider, $+-a l$.$] Pertaining to or resembling the spider.$ araneid (a-rā'nē-id), n. Same as araneidan. Araneida (ar-ā-n̄e-'i-dä), n. pl. [NL., < A ranca class Arachnida, now usually called an order containing the spiders as distinguished from the mites, scorpions, and other arachnidans:
288

Araucaria

practically synouymous and conterminous with Dimerasomate or Pulmatrachearia. The apiders breathe by two or more pulmonary sacs, combineel or no with trachere. The abdomen is not segmented, alri is disantennx, as such, but a pair of palps; they have from 2 to

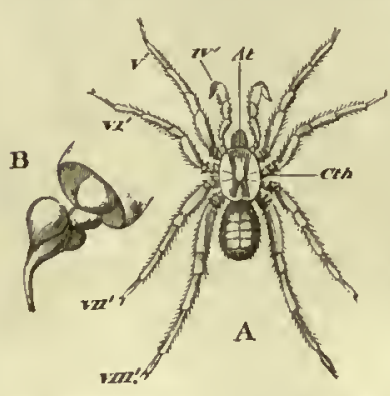

8 legs of 7 joints each. The abdomt modiffed into an arachnidinm or spinneret, the ap-
paratus by which cobweb, gossamer and other kind spun from a $8 \mathrm{e}$ eretion of glaudular organ8. There are also alway poison-glands conmouth-parts. The division of the Mygale camentaria, typical of Araneida, group varles with

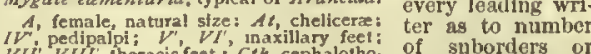

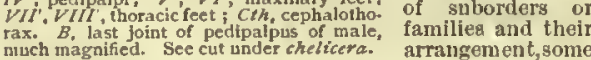
or three families, others several suborders anting but two twenty families, while the diversities of detail are endless. A prime division is into Dipmeumones, those laving two
pulmonary gacs (the great bulk of the order), and Tetro. pmeumones, with four; or according to the number of atig. (Tristicta); or according to the number of eyes, whether $2,4,6$, or 8 ; or, finally, according to the way in which they three families: Araneido, Lycosido, and Af ygalidoe. Also

Araneidæ (ar-ā-nē'i-dē), n. pl. [NL., <Aranea ] The spiders, considered as a family less spearly in ex tent the order Araneidc. In gome aystem less nearly in extent the order Araneida. In ome aystema
the tern disappears, heling conterminous with the order,
which then is divided into numerous families of other

araneidan (ar-ā-nē'i-dann), n. $\quad[<$ Araneida + an.] One of the Aravieida; any spider. Also

Araneidea

as Araneida.

raneiform (a-rā'nē-i-fôrm), $a$. [<NL. aranei-
formis, < L. aranea, a spider, + forma, form.] 1. Spider-like in form ; resembling a spider; belonging to the Araneida, as distinguished
from other arachnidans. 2 . Of or pertaining to the Araneiformia.

Araneiformes (a-rā"nẹ̄-i-fôr'mēz), n. pl. [NL., pl. of araneiform.

Araneiformia (a-rā"n $u$ ē-i-fôr'mi-ä), n. pl. [NL. neut. pl. of aranciformis: see araneiform.] A group of spider-like marine animals: synonymous with Pycnogonida (which see). They are sometimes placed with the Crustacea in an order or a aub-
class called Podosonata, gometimes in Arachnida, sometimes combined with the Arctisea in a subclass Pseudaa rudimentary unsegmented abdomen, a auctorial mouth and \& pairs of long, jointed legs, but are destitute of re-

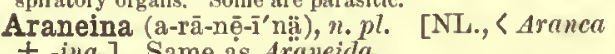
araneologist (a-rā-nēe-ol' $\overline{0}$-jist), $n . \quad[<$ aran araneology (a-ră-nẹ-ol'ō-ji), n. [<L. aranea, a spider, + Gr. - $\lambda$ oyía, $\langle\lambda \hat{\varepsilon} \gamma \varepsilon u$, speak: see-ology.] That departm

The facts . were new to the fleld of American aro

araneose (a-rā'nẹ̄-ōs), a. [< L, araneasus, full of or like spiders' webs, < aranca, a spider's web, also a spider: see Aranea.] Covered with spider's web; arachnoid.

araneous (a-rán'nê-us), $a$. [As arancosc, or after L. araneus, pertaining to a spider or to a spider's web, < aranea, a spider, spider's web: see araneose.] 1t. Full of cobwebs. -2 . Resem-
bling a cobweb; extremely thin and delicate like spider's silk or gossamer; covered with delicate tangled hairs like cobweb; arachnoid. - Araneous membrane. Same as arachnnid, $n ., 2$

arango (a-rang'gō), $n$. [A native name.] A kind of bead made of rongh carnelian, generally of a cylindrical shape. Such heads, mimported from Bombay, constituted an article of traftic.
vious to the abolition of the slave-trade.

arapaima (ar-a-pī'mä), n. [S. Amer. native name.] 1. The name of the largest known fresh-water fish, Arapaima gigas, an inhabitant of Brazil and Guiana, said to attain a length of 15 feet and a weight of 400 pounds. It is of eco- nomical importance as a food-fisl.-2. [eap.] NL.] A genus of malacopterygian abdominal fishes, of the family ostcoglossich, bor the sigas is an example. araphorostic, araphostic, $a$. See arrhaphostic. rapunga (ar-a-pung'gä), $\%$. [S. Amer. native A South American oscine passerine bird of the family Cotingide and subfamily Gymnodcrince; the bell-bird, eampanero, or averano, Chasmarhynchus niccus; one of the fruit-crows, with a long ereetile tubular process on the head, rising sometimes to the height of several inches. It is remarkable for its clcar, far. sounding notes of a peculiarly resonant or bell-like quality, are silent, and therefore readily heard at a great distance.

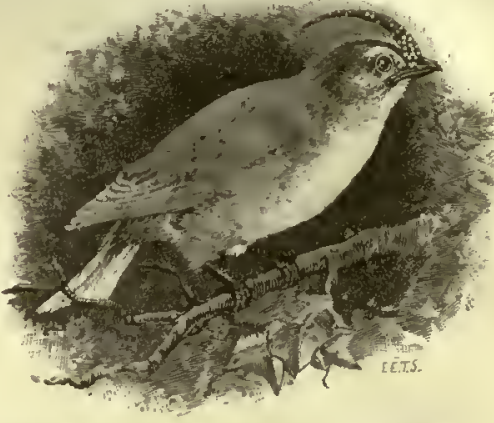

Arapunga, or Campanero (Chasmomynchus nimex). The bird is of abont the aize of a plgeon, and the plumage
of the adult ts pure white. The vative name was made a Generic term by Lesson in 1831 . The bird ta nearly related arara (a-rä'ri!), n. [Braz. Cf. Ara ${ }^{2}$.] A kind of macaw, Ara maracana.

araracanga (a-rä-rä-kang'gä), n. Same as araramboya (ar"a-ram-bō'yä), n. [Braz.] A name of the bojobi or dog-headed boa of Brazil, Xiphosama eaninum.

rarauna (ar-â-râ'nä), $n$. [Braz.] The blue and yellow macaw, Psittacus ararauna (Linnæus), now Ara ararauna.

araroba (ar-a-rón'bä), n. Same as chrysarobin. arar-tree (är'är-trë), $n$. The sandarac-tree of Moroceo, Callitris quadrivalvis. See sandaracarase $^{1}+\left(\right.$ a-rās $\left.s^{\prime}\right), v \cdot t . \quad$ [Also written aracc, $<\mathrm{OF}$. araser, raze, demolish, $<a$, to, + ras, level: see $a-11$ and rase, raze, and ef. erase.] 1. To raze; level with the ground.-2. To erase. $\operatorname{rase}^{2}+, v$. $t$. Same as aracel.

rasene, $n$. Same as arrasene.

rastra (a-ras'trä), n. Same as arrastre. aration (a-rä'shon), n. [<L.aratia( $n-),<$ arare, pp. aratis, plow
lage. [Rare.]

It would auffice to teach these four parts of agriculture; first aration, and all things belonging to it.
Coveley, Works (ed. 1710), 1I. 710. aratory (ar' gू-tọ-ri), $a . \quad[<\mathrm{ML}$. aratorius, < L. arator, plower, < arare, pp. aratus, plow: see arable.] Relating or contributing to tillage. ratrum terræ (a-rá'trum ter'ê). [ML., a plowgate of land : aratrum, a portion of land
as much as could be plowed with one plow (a special use of L. aratrum, plow, < arare, plow: see $a r a b l c)$; terro, gen. of L. terra, land.] In Scots law, a plowgate of land, consisting of drawn by eight oxen.

Araucan (a-râ'kan), $n$. Same as Araucanian.

Araucan (a-ra'kan), $n_{0}$ Same as Araucanian. cania,<Araucanos, the Äraucanians, a tribe of Indians inhabiting the southern parts of Chili.] I. $a$. Of or pertaining to Araucania, a territory in the southern part of Chili, mainly comprised in the modern provinces of Arauco and Valdivia. II. n. A native or an inhabitant of Araulcania. The aloriginal Araucanjans are a partlally civilized race who have never beenc conquiered by Europeans voluntarily gubnitted to the Chillarl government. Araucaria (ar-â-kā'ri-ñ), n. [NL., < Arauc(ania) + -aria.] A genus of Conifcre, the representative of the pine in the southern hemisphere, the islands of the Pacific. The species are large evergreen trees with verticillate sprealing branches covered eacl scale having a single large seed. The speciea hes known in cultivation is A, imbriceta (the Chili pine or nonkey-puzzle), which is quite hardy. It is a native of the mountains of gouthern Chill, where it forms vast for-
ests, and ylelds a hard, durable wood. Its seeds are eaten 
Araucaria

289

When roasted, The Joreton Bay phe of Auratralla, A. Cruniughamit, supplies a valuable timber used fn minking
furntture, in house- and boat-building, and lin other carpenter-work, A specles, A, excelsa, abotnils on Nortolk pine, under pine.
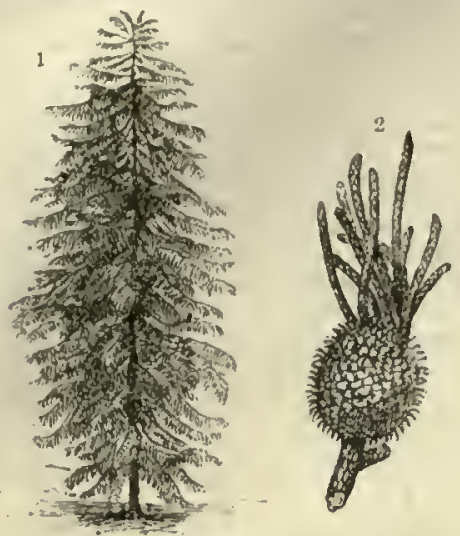

To Norfolk Istand Pine (Arascaria excelsa). 2. Cone of

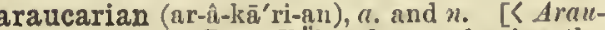
caria $+-a n$.] I. $a$. Related to or having the characters of the genus Araucaria.

II. $n$. A tree of the genus Araucaria.

The plants of which our coal-aeams are composcd apeak to us of lindls eovered with luxuriant growtha of tree-ferns
Geikie, Ice Ago, p. 94.

araucarite (a-râ'kânit), n. [< Araucaria + $-i t e^{2}$.] The name given to fragments of plant found fossilized in strata of different ages, and believed to be related to plants of the living geuns draucaria. Trunks occur In the eosl-measures to immense contferous trees, referred, thongh with som doult, to thls genus. The frults and foliage found in the Secondary rueks are certainly elosely related to the Australtan araucarlan.

araughtt. Preterit of treach.

arauha (a-ri' 0 -ii), $n$. 'The native name of a the Abrethos islands, Brazil It prease on misl even on young chlckens. it is probably the birdarba, $n$. See arabal.

arbaccio (är-bäch'iō), n. [It. dial.] A coarse cloth made in Sardinia from the wool of an Knight.

Arbacia (är-bā'si-ä), n. [NL.] The typical genus of sea-urehins of the family Arbuciadce. A. punctulate and $A$. nigra sre two apecles, occurring
respectively on the eastern and weatern eonsts of North arbaciid (air-bas'i-id), $n$. A sea-urchin of the family Arbaciide.

Arbaciidæ (är-ba-sī'i-dē), n.pl. [NL., $<A r b \iota-$ cia + -ide.] A family of desmostichous or endecyclical echinoids, or regular sea-urchins, intermediate in its general characters between Cidaride and Eelinide, and having median ambulacral spaces appearing as bare bands. The family is typified by the genus Arbueia. another genus is Coelopleurus.

arbalest, arbaiester. Seo arbalist, arbalister. arbalète (är-ba-lāt'), n. [F. < OF. arbaleste see arbalist.] Same as arbalist, 2.

arbalist, arbalest (är'ba-list, -lest), $n$. [<MF. arbelaste, arblnst, arblest, ote. (also ariceblast, arowblaste, as if connected with arow, arrow), $<$ OF. arbaleste, arbeleste, arbalestre, F. arbalete = Pr. arbalesta, albalesta, <LL. areubalista, arenballista: see areubalist.] 1. A crossbow nsed in Europe in the chase and in war throughout the middle ages. The bow was male of ateel, horn, or other material, and was of auch great atrength and atiff ness that chase, and generelly by horsemen, requined a double in the whish the arbaliater carried at hils girdle. Ifeavier ones required a kind of lever, or a windlass, or a revolving winch with a rntelet and long handle, to draw them; these ap-
pliances were aeparnte irom the arbaliat, and were carried pllances were aeparnte from the arbaliat, and were carried
alung from the aloulder or at the belt. The short and alung from the alionlder or at thie belt. The short and
heavy arrow of the arbalist was called a quarrel, from its heavy arrow of the arbalist was called a quarrel, from its
square hend, or more commonly \& bolt, as dlatinguished square hend, or more commonly a bolt, as distinguished
from the shut diseharged by the longbow. Sometimes stones (aee stone-bov') nnd leaden balls were riaed. The mis sile of the arialiat was discharged with such force as to penetrate ordinary armor, and the weapon was considered so deadly as to be prohibited by a eouncll of the ehurch cxcept in warfare against inflidels. It could, howeyer, be the attack and defeuse of fortified plaees. For slmilar weapona of other periods than tho European middle age 2 . In her, a crossbow used as a bearing. ureubalister. eree; an umpire. adjudication. f right prevsilling at the tlme. ity; discretionary. tration of exchange. sale in the dearer market. arbitrager. ute and final decision. balister, arbalester (ăr'ba-lis-tèr, -les-tér), pute which has been referred to arbitration;
[<ME. arbalester, arbalastor, arblaster, ete., the alusolute and authoritative settloment of < OF. arbalestier, <ML. arcubalistarius: see arcubalister.] One armed with the arbalist; a erossbowman; especially, a soldier earrying the arbalist of war. Also

arbiter (uir'bi-tèr), n. $[=\mathbf{F}$. arbitre, <L. arbiter, a witness, judge, lit. one who goes to see, < ar-for all, to, + betere, bitere, come.] 1. A person chosen by the parties in a conclosen by the parties in a conences; one who decides points at issuo; an arbitrator; a rel The clvilians make a difference be-
tween arbiter and arbitrator, the former being obliget to Judge according to the custonls of the law; Whereas the latter is at liberty to use

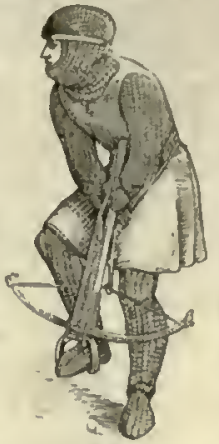
any matter.

Wait will force him to put lt to arbitrement.
Jassinger, New Way to l'ay (Jld Debts, II. 1.

Thla tax was regulated lyy a law made on purpose, and not left to the arvitrament of partinl or interested persons. 3. The decision or senteneo pronouneed by an arbiter. [In this sense axard is now inore common in legal use.]

To dlacover the grounds on which ... uage bases lts arbitraments, batnea, not acldon, our ntmost fingennity of
F. Hall, Mod. Eng., p. 31.

Sometimes spelled arbitrement.

arbitrarily (år'bi-trā-ri-li), alv. In an arbitrary manner; at will; capricionsly; without sufficient reason; in an irresponsible or despotic vay.

The Bishop of Dunkeld, who ... had opposed the gov-

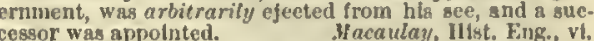

arbitrariness (är'bi-trā-ri-nes), $n$. Tho quality of being arbitrary.

late the difference in that manner which appears most just

2. In a general sense, a person who has the power of judging and determining absolutely according to his owu pleasure; one whose power of deciding and governing is not limited; ono

Our plan best, I belleve, eomblnes wisdom and praeticaarbiter for ultimate deetaion. Jefferson. Autoblog single The final arbiter of instltitiong is always the conception

$$
\text { Rae, Contenporary Socialiam, p. } 179 .
$$

Arbiter elegantiarum (cl-gan-ahl-hírum). [L.] A judgo of the elegancies; an authority In matters of taste, $=$ Syn. arbiterł (är'bi-tèr), $v . t$. [<arbiter, n.] To act as arbiter between; judge. Hall.

arbitrablet (är'bi-tra-bl), $a$. [ S Sp. arbitruble $=\mathrm{Pg}$. arbitravel, < I. as if "arbitrabilis, < arbitrari, arbitrate: seo arbitrate.] 1. Arbitrary depending on the will. Spelman.-2. Subject to arbitration; subject to the decision of an arbiter, court, judge, or other appointed author

The value of moneys is arbitrable according to the nse
of several kingdoms. Bp. /fall, Cases of Consclence, f. arbitrage (är'bi-trāj), n. [<F. arbitrage, < arbitrer, arbitrate: see arbitrate.] 1.: Arbitration. R. Cobden. [Rare.]-2. The ealculation of the relative valne at the same time, at two or more places, of stocks, bonds, or funds of any sort, including exchange, with a view to taking dvantage of favorable circumstances or differences in payments or other transactions; arbi-

Arbitrage proper Is a scparate, dlatinct, and well-defned bualness, with three nain branehea. Two of these, viz. arbitrage or arbitrallon in bullion and colns, and arbltra-
tion fn billa, alao called the arbitration of exebanges, fall tlvely. The third, arbitrage in stocks and shares, is arbiword is merly so ealled, and 80 understood, whenever the men, and It is atrictly a Stoek Exchange busloeas.

3. The business of bankers which is founded on calenlations of the temporary differences in the price of securities, and is carried on through a simultaneons purchase in the cheaper and

arbitrager (ä'bi-trạ̄-jẻr), $n$. A banker or broker whe engages in arbitrage operations.

As a rule, the arbitrage properly known as auch is the As a rule, the arbitrage properly known as auch is the
buslneas of an arbitrageur, who is almogt alwayg a nuember of a Stock Exchange or "Bourse," and hls arbitratlon with very few exceptlons are neither in bulliton nor in bilis,
but In Oovernment and other stocks and shareg.
Encyc. Brit., II. 311 rbitral (är'bi-trạl), a. [<LL. arbitralis, < I arbiter, arbiter.] "Relating to arbitration; subject to revicw and adjudication.-Decree arbtarbitrament (är-bit'ra-ment), n. [<ME. arbitrement, arbitriment, $<\mathrm{OF}$." arbitrement $=\mathrm{P}_{\mathrm{T}}$. ar bitramen $=\mathrm{Sp}$. arbitramiento $=\mathrm{Pg}$. arbitramento, <ML. arbitramentum, < L. arbitrari, arbitrate: see arbitrate.] 1. The power or right to decide for one's self or for others; the power of abso-

Liberty, and Llfe, and Death would soon

The capital City.

2. The act of deciding a dispute as an arbiter or arbitrator; tho act of settling a claim or dis-
Conaciousiness is an entaigled plexua which eannot be II. Spencer, Prin. of Paychol., 450.

arbitrarioust (är-bi-trā'ri-us), a. [< L. arbitravius: see arbitrary.] Arbitrary. Norris.

arbitrariouslył (är-bi-trā'ri-us-li), all. Arbitrarily. Barrowo.

arbitrary (är'bi-trā-ri), a. [= F. arbitraire = rius, of arbitration, hence ureertain, depending on the will < arbiter, arbiter, umpire: see arbiter.] 1. Not regulated by fixed rule or law; determinable as occasion arises; subject to individual will or judgment; discretionary. Indifferent things are left arbitrary to us. . In law, properly determinable by the choice that which should be determined according to settled rules or the relative rights or equities of the parties. Thus, whether the fulge will take and atate an account himselt, or refer it to an auditor, is a a particular person is qualifled to act as auditor is a quea3. Uncontrolled by law; using or abusing unlimited power; despotic; tyrannical.

For sure, if Dulness secs a grateful day

I'ope, Dunclad, tv. $18 \%$ Could I prevall upon my little tyrant liere to be less ar
bitrary, I should be the happiest man alive. Goldsmith, She Stoops to Conquer, v.
Arbitrary power is most easily established on the ruins 4. Not characterized by or manifesting any overruling prineiple; fixed, determincd, or performed at will; independent of rule or control. A great number of arbitrary algns, various and opposite, do constitute a language. It auch arbitrary connectlon he
instituted by men, it is an artiflial languge; if by the They perpetually sacriflee nature and reason to arbi. Iy an arbitnary proceeding, 1 mean one conducted by 5. Ungeverned by reason; hence, capricious; uncertain; unreasonable; varying; changeful: as, an arbitrary character.

My Iltappolntmenta, as a general thlug, .... had too
often been the eonsequence of arbitrary preeoneeptions.
/I. James, Jr., Little Tour, p. 253. Arbttrary constant, in math, a quantity whlch by a differential ectuation in requitred to have the same value for all values of the variable, whlle thls eonstant value re-
malns indeterninate. - Arbttrary discretton. See didcretion.-Arbitrary function, in math, a quantity wbich but whifh may vary in nny manner with these variables, eients with reapect to then.- Arbitrary homonyms.
See homonym. $=$ Syn. Caprfclous, unllmited, irresponsible, uncontrolleu, tyrannieal, domineering, Imperious. arbitrate (är'bi-trāt), $v$; ; pret. and pp. arbi-
trated, ppr. arbitrating. $[<\mathrm{I}$. arbitratus, pp. of trated, ppr. arbitrating. $[<\mathrm{L}$. arbitratus, pp. of
arbitrari $(>$ It. arbitraie $=\mathrm{Pg} . \mathrm{Sp}$. Pr. artutrar - F. arbitrer), be a witness, act as umpire, arbiter, unpire: see arbiter.] I, intrans. 1. To act as an arbitrator, or formal umpire between ontestants; mediate.

In the disputes of kings, the weaker party often appealed to the Pope, and thus gave hlm an opportunity to arbitrate
or eommand.
Hoolvey, Introd. to Inter. Law, \& \$. 2. To decide; determine; settle a question or rule otherwise indeterminate.

Some [words] become equlvocal by changing thetr aigfor eustom or caprice arbitrate[s], gulded by no law. the private oplnious or feelings of the man who attempts
to regulate. changed as long as eertain variables remain unchanged, subject only to the condition of havlng differential coefl- 
arbitrate

290

II traus, 1. "To give an anthoritative deci- arbitrort,". Seo arbitrer.

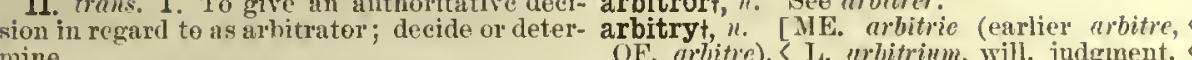
mine.

Thoughts s]eculative their nusure lopes relate;

Bint eertain issue strokes must arbitrate.

Things mist he conpured to and arbitrated by her lwi

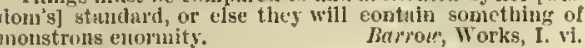
But thon, Nir Lancelot, sitting in my plaee

$$
\text { rewnysitr, 'The Last 'l'ournament. }
$$

2. Te submit te arbitration; settle by arbitration: as, to rebitrute a dispute regarding wages. determined by urbitrage: as, urbitrated rates; abitruted par of exchange.

Business men ... Were . enahed to ntiize all the Bulch, dines of I., S., D. 444.

arbitration (äl-bi-trā'shon), ". [<ME. crbitrucion, < $\mathrm{OF}^{\mathrm{F}}$, urbitration $=\mathrm{Pr}$, a bitracio, < $\mathrm{L}$. crbitratio(n-), < arbitrari, arbitrate, judge: sec "rbitratio("), crbitrate.] The hearing and determining of a
cause between parties in controversy by a person or persons chosen or agreed to by the parties. This may he done ly one person, hut it is ususl to choose more than olse. Frequently two are nominated, me ly each party, the two heing anthorized in turm ti agree upon a thiri, who is ealled the unpire (or, in Scot-
land, sometimes the orersman), and who either acts witl land, sometimes the orersinan), and who either acts with
then or is called on to decide in esse the prinary arbitrais ealled an aecard by the columou law an award prop 'rly made is binding; but the arbitrators' anthority may le revoked before a ward at the will of either party. Per maneut boards of arbitration are sometimes constituted
lyy legislative or corporate anthority but the submission of ly legislative or corporate anthority, but the
cases to their decision is al ways volnutsry.

It is not too much to hope that artitration and coneilis tion will be the lheans antopted nlike by nations and by

mdividusls, to adjust ail diterences. A, Rev., CXLII. 613.

Arbitration, in International Law, is one of the recognized nodes of terninating dispntes between indepenArbitration bond, a bont by wlich a party to a dispute tion of exchange. See arbitrage, 2.-Geneva arbitration, the settlengent by sibitration of the rlispute between the governments of the Luited States and Great Britsin coneerning the Alahams elains: 80 ealled becanse the
board of arbitrstors held their sessions at Geneva in arbitrational (är-bi-trā'shon-a1), t. 1, Perarbitrational (ar-bi-tra shon-al), $t$. 1. Per-
taining to, of the nature of, or involving arbitration: as, arlitrationul methods of settling disputes.-2. Resulting from arbitration or reference to arbitrators.

Arbitrational settlement of the Alabans elsims.

arbitrative (är'bi-trā-tiv), $a, \quad[<$ arbitrate $-i v e$.$] Of the nature of arbitration; relating to$ arbitration; having power to arbitrate: as, "h urged arbitratire tribnnals," R. J. Hinton, Eng Radical Leaders, p. 117.

arbitrator (är'bi-trā-ter'), n. [Early mod. E. also arbitratour, < ME. arbitrator, $\angle \mathrm{OF}$, arbitratour, -eur (earlier arbitrener, arbitreor: see arbitrer), < LL. arbitrutor, < arbitrari, pp. arbitratus, arbitrate: see arbitrate.] 1. A persen who decides some peint at issue between others one who formally hear's and decides a disputed cause submitted by common consent of the par-
ties to arbitration. -2 . One who has the poner ties to arbitration. -2 . One whe has the powe
of deciding or prescribing according to his own abselute pleasure; an absolute governor, president, autocrat, or arbiter. See arbiter.

And heaven's high Arbitrator sit secure. Milton, P. L., ii. 350 .
M

And that ofl eonnon arbitrator, Time,

Will one dsy end it. Shak., T. ank

$=$ Syn. 1. Umpire, Refere, ete. See judge, $n$.
arbitratorship (ar'bi -trā-ter-ship), office or function of an arbitrator. arbitratrix (air'bi-trē-triks), $n$; ipl. urbitratriecs a (är"bi-trā-trí'sēz). [LL., fem. of arbitrator: see (arbitrator.] A female arbitrator. arbitret, n. See arbitry.

arbitret, $v$. $t$. See arbiter.

arbitrement, $n$. See arbitiament.

arbitrerł (är'bi-trèr), $n$. [Early med. E. als arbitior, urbitrour, < ME. arbitrour, $\angle \mathrm{OF}$. arb. trour, arbitreour, nrbitreor, < LL. arbitrator see arbitrater.] An arbiter or arbitrater.

The arbiter of her own destiny.

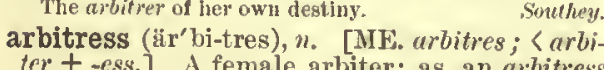
ter + ess.]

IIe aspirent to see
IIIs native Pisa quleen and arbitrens arbiter, arbiter: see arbiter.] 1. Free will discretion. - 2. Arbitration.-3. Julgment award.

arblast + n. Same as rerbalist.

arblasterf, $n$. Saine as arbulister.

arbor ${ }^{1}\left(i \mathrm{r}^{\prime} \mathrm{bor}\right), \pi$. [In the derived sonse formerly arber, arbre, $\angle \mathrm{F}$, arbre, OF. arbre, aubre

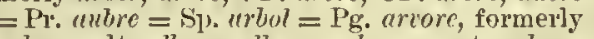
"rbor $=1$ t. albore, albere, arbere, poet. arbore,
a tree, lueam, mast, ete. $<\mathrm{L}$. arbor (ace. ara tree, beam, mast, ete., < L. arbor (ace, $a r$ beam, bar, mast, shaft, oar, ete. Cf. the similar development of berm and tree.] 1. Liter ally, a tree: nsed in this sense chiefly in botanical names. - 2. In meeh.: (a) The main support or beam of a machine. (b) The principal spindle or axis of a wheel or pinion communicating
motion to the other moving parts.-Arbor Dianæ motion to the other moving parts. - Arbor Dianse
(tree of Dians, that is, of silver: see Diana), in chem., a cautiful arthoreseent precfítate produced by silver i nereury.-Arbor Judæ, ill bot, the Juitas-tree (which see Saturn), in chem, an srloreseent irecipitste formed when a jiece of zinc is put into s solution of acetate of
lead.-Arbor vitz. See arbor vitce. - Expanding arlead. - Arbor vitæ. See arlor-vitce.-Expanding arbor, in mech, a lusandrel in a lathe provided with taper
keys or other devices for securing 8 firm holi, by varying thear sqainst the sides of the hollow of the central hole the object which is to lie operated upou.

arbor ${ }^{2}$ arbour (är'bor), n. [In Fngland the second form is usual." Early mod. E. arbor, urbour, arber, harber, harbour, harber, herber. herbor, ete., $\mathrm{MF}$. evber, erbere, herber, lerbere, <AF. erber, herber, OH, erbier, herbier, a place, covered with grass or herbage, a garlen of herbs, < ML. herbarium in same sense, earlier, in LL., a collection of dried herbs: see herbarium, of which arber ${ }^{2}$ is thns a doublet; and orchard,' and hence 'a bower of trees,' though naturally develeped frem that of 'a grass-plot' (so orehard itself. AS. zeyrt-yeurd, $i$. e., wort or herb-yard; ef. F. veryer, an orehald, < L virilarium, a garden, lit. a 'greenery'), led to an association of the word on the one hand with lewbor, MF. herbere, herberwe, ete., a sheltel, and on the other with L. arbor, a tree. 1†. A grass-plet; a lawn; a green. [Only in
[ Middle inglish.] - 2t. A garden of herbs or of $-3+$. A collection of fruit-trees; an orchard.

\section{In the garien, as I wene,
Was an arber fayre and grene,
And in the diber was a tie.} as to make a leafy roof, and usually provided with seats; formorly, any shaded walk.

Those hollies of thenuselves a shupe
is of an arbour touk.

arboraceous (är-bo-rā'shins), «. [<NL. arbo-

racens, < L. arber, a tree.] 1. Pertaining to or of the nature of a tree or trees.-2. Living
on or among trees; living in the forests; peron or among trees; l

Xot like Papuas or Buslmuen, with arboraceous habits
and half-animal clieks. Max Miller, India, ete, p. 133. arboral (är'bo-lad), a. [<arborl + -al.] Relating to trees; arboreal. [Rare.]

arborarył (är'bo-rā-ri), a. [< L. arborarius, arbor, a tree. Belonging to trees. Bailey. arboratort (är'bo-rā-ter), "u. [L., a pruner of tree.] One who plants or prunes trees. arbor-chuck (är'bor-chuk), n. See elmeh ${ }^{4}$.

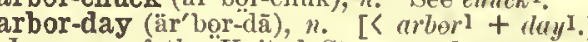
In some of the United States, a day of each year set apart by law for the general planting of trees wherever they are needed.

The Arbor-day idea. . . has heen formaliy adopted
arready hy seventeen of our States. arboreal (är-bē'rệ-âl), a. [< L. arboreus (see arboreons) $+-a l.]^{2} 1$. Pertaining to or of the natnre of trees. -2 . Living on or a

arbored ${ }^{1}$ (är'bord), $a$. [<arborI $+\ldots d^{2}$. ] Furnished with an arbor or axis.

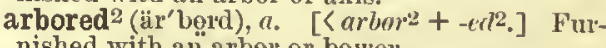
nished with an arber or bewer.

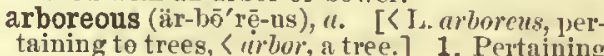
intertwined, or trained over, a latticework arborize

or belonging to trees; living on or among trees; frequenting forests; arboraceons. - 2. Having the form, constitution, and habits of a tree having mere $\theta r^{\circ}$ less the characler of a tree; arborescent. - 3. Abounding in trees; wooded. arboresce (är-be-res'), $r$. i.; pret. and Ip. $u r$ lrorescel, ppr. "urborescing. [< J. mborescre, become a tree, $<n$ mor, a tree: see $\left(r^{2} b r^{1}\right.$ and -esce.] To

put fortl branches.

arborescence (är-bo-res'ens)

11. [Carborescent: see - thece.] escent.-2. Something, as mineral or a group of crystals liaving the figure of a tree.

arborescent (ar-bo-res'ent), 11. $[<\mathrm{L}$. arborescen $(t-) s, 1) \mathrm{pr}$.

of aborescere: see arboresec.]

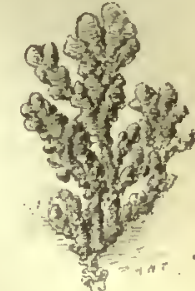

in growth, size, or appearance; having the nature and liabits of a tree; branching like a tree dendritic.

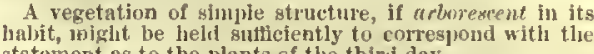
tstement as to the plants of the third day Berion the division the pedicels

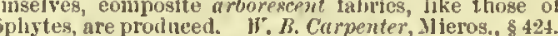
arboret ${ }^{1}$ (är'be-ret), n. [<J. arbor, a tree (see arbor 1 ), + et. Cf. F. arbret = It. alberetto, formerly allioretto, a dwarf tree.] A little tree; a slirub.

No arborelt with painted blossomes irest
And smelling sweete, but there it might be fownd

To bud ont faire, and throwe her sweete snels al arownd.

arboret? + (är'bo-ret), n. [= It. arbereto, al bercte, formerly alburcte, < L. urboretum (sce (rboretum); or perhaps regarded as a dim. of or shrubs; a small greve; planted

$$
\text { mong thick-woven arbor }
$$

$$
\text { Millon, } 1^{\prime} . \mathrm{L}^{\circ}, \mathrm{Jx} .43 \% \text {. }
$$

arboretum (ä1-be-rë'tnm), $n_{0} ; \mathrm{pl}$. arboretums, urboreta (-tumz, -tij). [L., a plantation of trees,
< arbor, a tree, +"-ctum, denoting place.] A place in which trees and shrubs, especially rare ones, are enltivated for scientific or other purposes; a botanieal tree-garden.

arborical† (är-bor'i-kal), t. [< L. urbor, a tree, + -ic-rl.] Relating to trees. Smart.

rboricole (är-ber' i-kēl), a. [=F゙. arbericele, Nl.s arbericola, < L. arbor, a tree, + colere, inhabit, dwell.] In zoöl., living in trees; of ararboricoline (är-bo-rik'ō-lin), a. In bot., growing npon trees: applied to lichens, ote.
arboricolous (är-bo-rik'ō-lus), $a$. Same as $(m-$

arboricultural (ä1" bo-ri-kul'tñr-al), a. [< $u r-$ arboriculture (är'bo-ri-kul" tür), $n . \quad[=\mathrm{F} . a r b \theta-$ viculture< L arbor a tree, + enltura, cultivariculture, < L. arbor, a tree, + enltura, cultivation: see culture.] The cultivation of trees; tivating trees and shrubs.

arboriculturist (är"bo-ri-knl'tūr-ist), $n . \quad[<a r-$ cinlture.

arboriform (är'bo-ri-fôrm), $\boldsymbol{t}$. [= F. arboriforme, < L. arber, a tree, + forma, form.] Having the form of a tree.

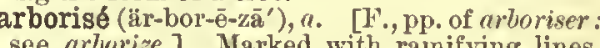
see arborize.] Marked with ramifying lines,
veins, or clondings, like the branching of trees: said of agates and other semi-precious stenes, and ef certain por'celains, lacquers, enamels, ete. arboristt (är'bo-rist), $n_{\text {. }}$ [ [ J J. arbor, a tree, + -ist; $=\mathrm{F}$, arboriste. Cf. riborize. In earlie use asseciated with arber2, herber, a garden of herbs; cf. herborist.] A enltivater of trees; one ongaged in the culture of trees: as " "our eunning arberists," Evelyn, Sylva, xxviii.

arborization (ür"be-ri-zä'shon), $n_{0} \quad[=\mathrm{F} \cdot a r$ berisation; < arborize + -ation.] 1. A growth or an appearance resembling the figure of a tree or plant, as in certain minerals or fossils. -2. In pathol., the ramification of capillary distention and injection.

arborize (är'be-rĩz), v. t.; pret. and pp. arbmizell, ppr. arborizing. [< L. arber, a tree, + -ize; = F. arborisor, only in pp.; formerly, of trees" (Cotgrave). Cf. herbarize, botanize.] To give a tree-like appearance to: as, "an ar 
arborize

horized or moss-agate," Wright. Also spelled artionise.

arborolatry (air-bo-1'ol'g-tri), $u_{0}$ [ [ L. urbor, a tree, + Gr. iarpeía, worship.] Tree-worship.

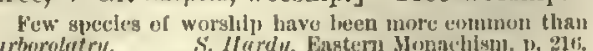
arborous (iir'bo-rus), a. [<urbor ${ }^{1}+$-ous. $]$ Consisting of or pertaining to trees.

$$
\text { trom under shally arburous punf. }
$$

Millon, $\mathrm{v}, \mathrm{l}_{\mathrm{L}, \mathrm{v}} \mathrm{v}, 137$.

arbor-vine (iir'bor-vin), no [< arborl + vine.] A species of bindwed. The spunish urbor. vine of Jamnica is an ornamental species of Jpomente, I. tuberosu.

arbor-vitæ (iir"bọr-vi'tēe, n. [L., tree of life:

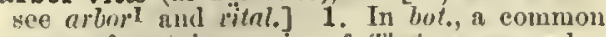
name of eertain species of Thrju, $a$ genus belonging to the natural order Coniferie. Thuje oc.

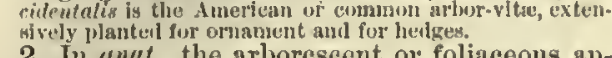
2. In unut., the arboreseent or foliaceous appearance of a section of the cerebellunn of the higher vertebrates, due to the arrangement of trast in color. See eut under corpus.-Arborvitzo uterinus, an arborescent apprearance presented by The walls of the camlal of the neck of the hamann uterus, lse-

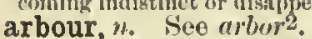

arbrier (är'bri-èr), n. [OF., also arbrean, arbret, arbrict, < arbre, a tree, beam: see arbor1.] The staff or stock of the crossbow.

arbuscle (är']us-l), n. [< L. arbuscula, a little tree, dim. of arbor, a tree.] A dwarf tree, in size between a shrub and a tree. Bradley.

arbuscular (ür-bus'kū-lïrr), a. [< L. urbuseula : see urbuscule.] Resembling an arbuseule; tufted.

arbuscule (är-bus'kül), n. [< L. urbuscula, a little treo: see urbuscle.] In zoölo, a tuft of something like an arbuscle, as the tufted branchise of an annelid; a tuft of cilia.

arbusta, $n$. Plural of arbustum.

arbustivet (iir-bus'tiv), $a,[<\mathrm{I}$. arbustivus, urbustum, a plantation of trees: sce arbustum.] Containing copses of trees or shrubs; covered with shrubs; shrubby.

arbustum (ar-bus'tum), $n_{0} ; \mathrm{pl}$. arbustums, arbuste (-tumz, -tii). [L. < arbos, arbor, a tree: see arbor ${ }^{1}$.] A copse of shmibs or trees; an orchard or arboretum.

arbute (đir'büt), $n$. [Formerly also arbut, $<\mathrm{L}$. urbutus: see arbutus.] The strawberry-tree. see arbutus, 3.

arbutean (är-bū'tẹ-an), a. [<L. arbutens, pertaining to the arbitus, < arbutus: sce arbutus.] Pertaining to the

tin), n. [ a curbu-

tin), n. [< arbuglucoside $\left(\mathrm{C}_{2+}\right.$ $\mathrm{H}_{32} \mathrm{O}_{14}+\mathrm{H}_{2} \mathrm{O}$ ) obtained from the bearberry (Arctastaphylos Uva-ursi) and other plants of other plants of ly. It forms tufts of colorless acienlar crystals soluble in whater and

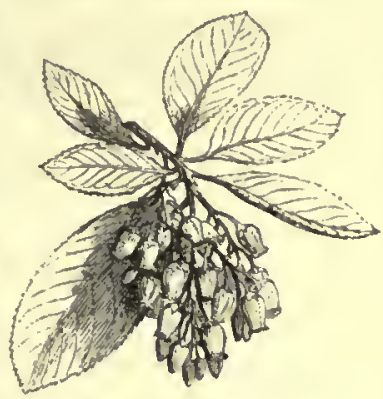

arbutus (com-

monly är-bū'tus;

as a Latin word, är'bū-tus), $n$. [Formerly also arbute, arbut $=\mathbf{F}$ arbute $=$ It. a.buto, $<\mathrm{I}$, arbu tus, the wild strawberry-tree; prob. akin to arbor, arbos, a tree.] 1. A plant of the geuus $\mathbf{A r}$ butus. - 2. The trailing arbutus (see below). 3. [cap.] A genus of evergreen shrubs or small trees of soutlern Europe and western North America, natural order Ericacce, eharacterized by a freo calyx and a many-seeded berry. The Europenn A. Unedo is called thestrawberry-tree fron its brigheseriet leries, and is cultivated for ornament of Oregon and Callomla, somelimes reaching a helght of 80 feet or more. - Tralling arbutus, the Epigeea repens, a Iragrant ericaceous creeper of the United States, blooming in the spring, and also known as Hay-forer (whileh see).
arc $^{1}$ (ärk), n. [Early mod. E. also ark; ( ME. ark, arke, $\langle\mathrm{OF}$. (and $\mathrm{F}$.) are $=\mathrm{Pl}$. are $=\mathrm{Sp} . \mathrm{Pg}$. It. arco, < L. arcus, arquus, a bow, are, areh, akin to AS. carl, > E. arroic, q. v. Doublet, archl.] 1. In geom., any part of a curved line, as of a eirele, especially one which does not inelude
point of inflection or cusp. It ls ly means of ares of a circle that all angles are measurel, the are heing de-
291

arc-cosecant

mathematies the word are is used to dennte any moular Arcadian (är-kā'ali-an), u. and $n$. [< L. Area

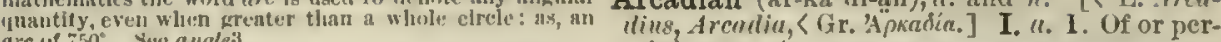
are In astron., a part of a circle traversed by taining to Althe sun or other henvenly borly; expecially, the cadia, a mounpart passed over by a star between its rising and setting.

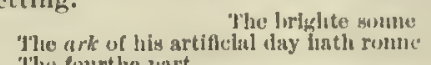

Chaveer, Prol. to Jlan of Law's 'l'uli, 1. ע.

3. In urch., an arcli. [Rare.]

$$
\text { T'urn ares of triumph tus g parylen.pate. }
$$

Arc boutant (F.), an flying buttress, - Are doubleau vanlt at rghi angles and scparatea adjolning luys (rom ceives the vaulting at the girlo of give (k.), one of liagonal rlls of a raultul buy.Complement of an arc. Sec comcentric arcs, arts wirch belong to atme center. - DIurnal are, the apparent are te guribed by the sun its setting: sometimes uaed of stars.

Elevating arc, in gun., a brass degrees and fractions of a degrec,

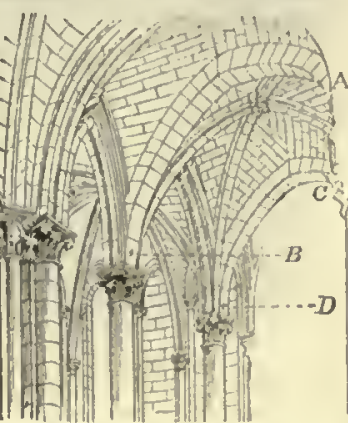
breech of a heav pose of regulating the elevation of the plece or it is to the carriage unler the trumions. the gun itgelf, a pointer Is attached the rear of the
B $<$

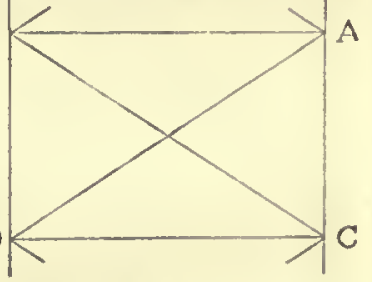
the rear of the arcs ogives: $A C, B D$, arcs formerets.
plece, and indl.
catea zero when the gun is horizentul. - Nocturnal arc

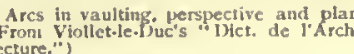
the arc described by the sun, or other heavenly body, during the night. - Simular arcs, of unequal circles, arce which or parts of their regpective efrcles. - Supplemental arcs. or parts of their regpective circles.- Supplemental arcs. of light, having the shape of an are, formed by the passage of a powerful electrical current between two earbon. proints. its length varies from a fraction of an ineh to two ineles, or even more, according to the strength of the current.
Its heat ls intense, and on thls account it ls ased for fusing very refractory substancea. It is also used for illuminat. ing purposeg.

arca (är'kii), n. [L., a ehest, box, safe; in arca (är'kij), ${ }^{\prime}$. [L., a ehest, box, safe; in
eccles. writers, the ark: see $a r^{2}$.] 1. In the early church: (a) A chest for receiving offerings of money. (b) A box or easket in which the eucharist was carried. (c) A name given by St. Gregory of Tours to an altar composed of three marble tablets, one resting horizontally on the other two, which

stand upright on the floor. Walcott, Sacred Archæol.-2. [cap.] [NL.] A genus of branch mollusks, typical of the family $t \gamma$

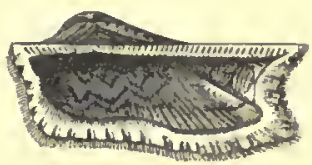

cidla (which see); the ark-shells prover.

rcabucero (Sp. pron. är"kä - bö̀-thā' rỏ), " [Sp., = harquebusier.] A musketeer; a harque-

Here in front you can see the very lint of the lunllet Fired point-blank at my heart by a spanish areabucero,
Longfellow, sules Standish,

Arcadæ (är'ka-dē), n. pl. See Arcide.

arcado (är-kâd'), $"$. [< F. arcade, < It. arcatu $=$ Sp. $\mathrm{Pg}$, arcaila, $<\mathrm{ML}$. arcata, an arcade, $<\mathrm{I}$. areus, are, bow: see arc 1 , arch $1, n$.] 1. Properly, a series of arches supported on pier's or pillars. The arcade is used especially as a screen and as a support for a wall or roof, but in all arehitecture slnce
the foman it la also commonly uged as an ornamental the foman it 18 also commonly uged as an ornamental
dressing to a wall. In this form it ls known as a blimi arcade or an arcature, and is also callesl teall-arcade.

2. A simple arehed opening in a wall. [Rare.] Specifieally, in some cities, a long arched passageway; a covered avenue, especially one that is lined with slops.

arcaded (iir-kin'ded), a. Fumished with an arcade. the licart of the Peloyonnesus, or to its in. habitants, who were n simple pastoral people, fourl of music aud dancing. Hence2. Pustoral rustic; simple; innocent. -3 . Pertaining to or charaeteristic of the Acadeiny of the Ar. eadians, an ltalian poetical (now also seifounded at

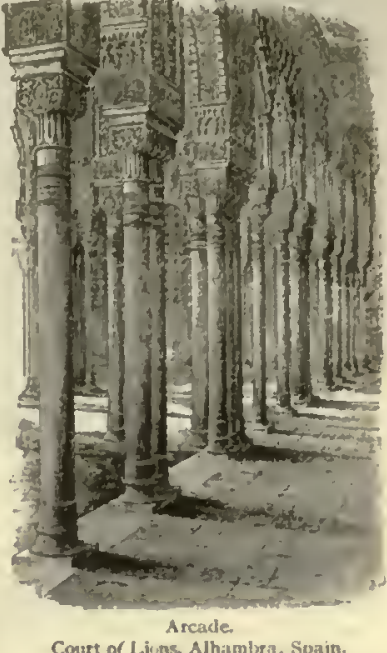
members of which was origithe aim of the nembers of which

\section{sometimes written Areulic.}

II. . 1. A native or an inhabitant of Areadia.-2. A member of the Academy of tho Arcadians. See 1.

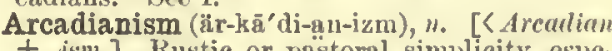
$+-i s m$.$] Rustie or pastoral simplicity, espe-$ cially as affected in literature; specifically, in teenth century, the affectation of elassic sim-

Arcadic (är-kä'dik), a. [< L. Arcadicus, < Gr. Aprrdinár.] Same as Areudiun. - Arcadic poetry, arcana, $n$. Plural of arec $m$ um.

arcane (är-kän'), a. [< L. arcamus, hidden, arcerc, shut up, arca, a chest. Cf. arenumm.] Hidden; seeret. [Rare.]

The lumlnens genlus who liul fllustrated the demonstra. tions of Enclld was penetrating inte the ercane caverns of
the calbalists.
I. D'J Joceli, Amen. of LIt., 11. 204. arcanum (iir-kä'num), $u_{+} ;$pl. arcana (-nịi). [L., nent. of arcanus, hidden, elosed, secret: see ircune.] 1. A secret; a mystery: generally used in the plurul: as, the arcana of nature. The very Areanum of pretending Rellgion in all Wars 18, That gomething nay be fonsd out in which all men Inquiries into the areana of the Godhead. N"arburton. The Arabs, with their usual activity, penetrated Into
these arcana of wealth.
Jjescott, Furl. and laa., i. 8 . 2. In alchemy, a supposed great secret of nature, which was to bo discovered by alchemieal means; the secret virtue of anything. Hence - 3. A seeret remedy reputed to be very effieacions; a marvelous elixir.-The great arcanum, the supposed art of transunting metals.
He toll us stories of a Genvese jeweller, who lad thr yreate arcanum, and hat made projectlon liefore litimser. arcature (är'kā-tūr"), ". [<ML. "areatura, arcata: seo arcaile.] In urch.: (a) An areade of small dimensions, such as a halustrade, formed by a series of little arehes. In some me. dieval churches open arcatures were lutroduced beneatl the cornlees of the external walls, not only as an ormament,
but to admit light alove the vanlting to the roof-timbers.

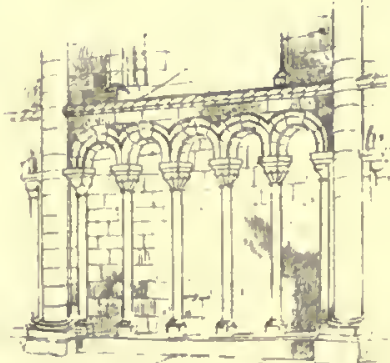

(b) A blind areade, used rather to decorate a nice, than to meet a necessity of construction. arc-cosecant (årk-kö-sē'kant), " In math., an angle regarded as a funetion of its cosecant. of Greeco in (entifie) soeiety wall-space, as beneath a row of windows or a cor 
arc-cosine

arc-cosine (ärk-kō'sin), n. In math., an angle regarded as a function of its cosine.

arc-cotangent (ärk-kō-tan'jent), $n$. In math. an angle regarded as a function of its cotangent Arcella (är-scl'ii), $n$. [NL., dim. of L. arca, a box: see trca, ark2.] A genus of amoboid protozoan organisms having a kind of carapace or shell, the type of a family Arcellita.

Arcellidæ (iir-sel'i-dē), n. pl. [NL., < Areclla + -icle.] A family of Protozoa, of the order Amoboidca, containing the genera Arcella, Difflugia, ete. the members of which are inclosed in a kind of test.

$\operatorname{arch}^{\mathrm{I}}$ (ärch), n. [<ME. arch, arche, $<\mathrm{OF}$. arch ( $\mathrm{ML}$. (trchia), mod. $\mathrm{F}$ : arche, an arch, fem. form (prob, by confusion with $\mathrm{OF}$, and $\mathrm{F}$. arehc, ark, $<\mathrm{L}$. arca: see $a r c h{ }^{2}$ ) of $\mathrm{OF}$. and F. arc, < L. arcus : see $a r c^{1}$.] 1f. In geom. any part of the cirenmference of a circle or other curve; an arc. Sce arc1, 1.-2. In arch. blocks, assembled on a eurved line in such a blocks, assembled on a curved line in such a ture is supported extraneonsly only at its two extremities. The separate blocks which compose the arch are called voussoirs or arch-stones. The extreme or lowest vonssoirs are termed springers, snd the nppermos or central one, when a single stone occupies this position,

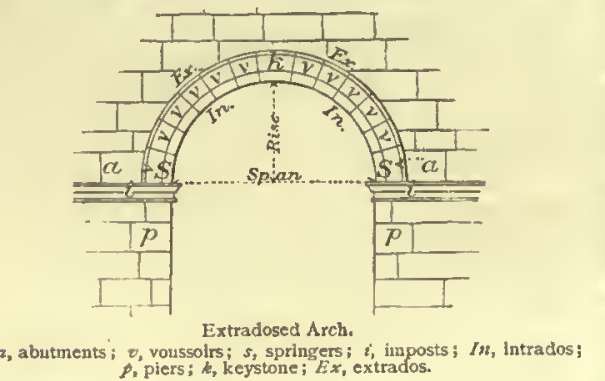

assembled voussoirs is called the intrados, and the upper or convex face the extrados, of the arch. When the curves of the intrados and extrados are concentric or parallet, the arch is said to be extradosed. The supports which afford resting and resisting points to the arch are piers or pillars, which reeeive the vertical pressure of the arch,
and abutments, which resist its lateral thrust, and which are properly portions of the wall or other structure above are properly portions of the wall or other structure above
the springing and abreast of the shoulder of the arch. The upper part of the pier npon which the arch rest (technically, the point from which it springs) is the impost. The span of an arch is the distance between its opposite imposts. The rise of an arch is the height of
the highest point of its intrados above the line of the imposts; this point is soinetimes called the under side of the crown, the highest point of the extralos being the
croun. The thrust of an arch is the pressure which it exerts outward. This pressure is pristically collected, so far as it is manifested as an active force, at a point which

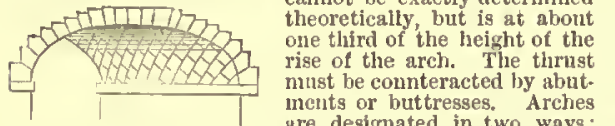

are designated in two ways: according to their properties, their nses, their position in a building, or their exclusive
employment tn a particular style of architecture. Thus,
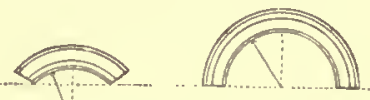

Semicircular Arch.

there are arches of equilibration, equipollent arches, arches of discharge, skew and reversed arehes, Roman, Pointed, according to the curve the intrados assumes, when thst
curve is the section of any of the geometrical solids, as
segmental, semicircular, cycloidal, elliptical, parabolical,

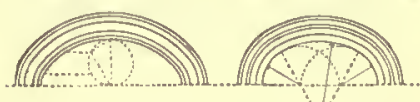

Cychoidal Arch. Elliptical Arch.

hyperbolical, or catenarian arches; or from the resem. blance of the whole contour of the curve to some familiar
object, as lancet areh and horsewhe arch; or from the

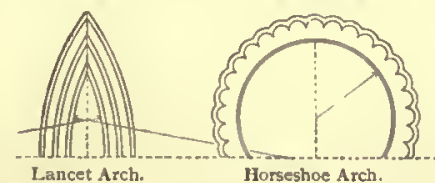

method usen in describing the curve, as equilateral, three. of its imposts higher than the other, it is said to be ramplace, to transfer pressure from wall in which it is built mere

pant. Foil arches are arches whose intrados ontlines form
a series of subordinate arcs cslled foil 8 , the points of which

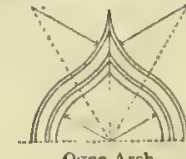

Ogee Arch.

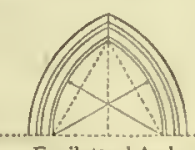

Equilateral Arcl.

are iermed cusps. A mumeral is nsually employed to designate the

3. Any place eovered with an arch or a vault like an arch: as, to pass through the arch of a bridge.-4. Any curvature in the form of an arch: as, the arch of the aorta; the $a r c h$ of an eyebrow, of the foot, of the heavens, etc.

Whercon a sapphire throne, inlaid with pure

Amber, snd colours of the showery arch.

5. In mining, a portion of a lodo left standing, either as boing too poor for profitable working or because it is needed to support the adjacent rock.-6. Tho roofing of the fire-chamber of a furnace, as a reverberatory or a glass-furnace; hence, sometimes, the fire-chamber itself. - Alveolar arch, aortic arch. See the adjectives. Arch of discharge, su extrsdosed srch built in the masonry of a wall, over a doorwsy bility on either side. An arch on discharge is generally distinly by the position of its stones, or at most by a slight projection beyond the wall-surface.- (From Viollet-le-Duc's" "
Arch of the fauces. See
del Archilecture.")

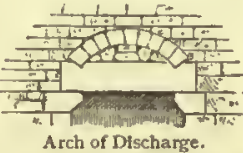
fauces. - Axillary arches. of an arch. See backing.- Basket-handle arch, an elarch, an arch of which the opening is walled up, often used as sn arch of discharge. Sec cut under arcature. - Branchial arch. See branchial. - Clustered arch, a number of arched ribs springing from one impost, a form usual in medievsl pointed vaulting. See cut lunder (clustered) col. guinal arch. See crural. - Flat arch, an arch of which HEHA wedge-shaped snd assembled in a horizontal line: used especially in brickwork, Hemal arch, hydrostatic arch. See the Flat Arch. the form of sn arch, constructed of several
bolted together: a form of arched besm. - Mandibular arch, mural arch, neural arch, etc. See the adjec. arch, mural arch, neural arch, etc. See the adjec.
tives.-Oblique arch. Same as skew arch (which sec,
below). - Pectoral arch. Same as pectoral girdle (whichl below). - Pectoral arch. Same as pectoral girdle (which (which see, under girdle). - Preoral arches, postoral arches. See the adjectives,-Recessed arch, one arch within snother. Snch arches are sometimes called donble, versed arch, an inverted arch, - Ribbed arch, an arch
composed of parallel ribs springing fronı piers or imposts. - Rough arch, an arch formed of bricks or stones ronghly arch. - Skeletal arches. See visceral arches, under vis. ceral. - Skew arch, an arch of which the axis is not perpendicular to its abutments.-Stilted arch, an arch of
which the true impost is higher than the sppsrent in-

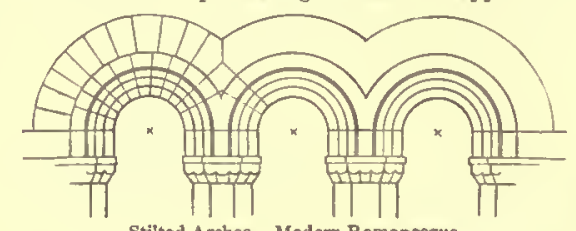

post, or of which the piers are in fact continued ghove the appare nt impost, so that a portion of the intrados on semicircular arch; ; s semicircular arch of which the rise is greater thrn the radius. - Triumphal arch, a monuration of an cvent. Such arches were first erected under

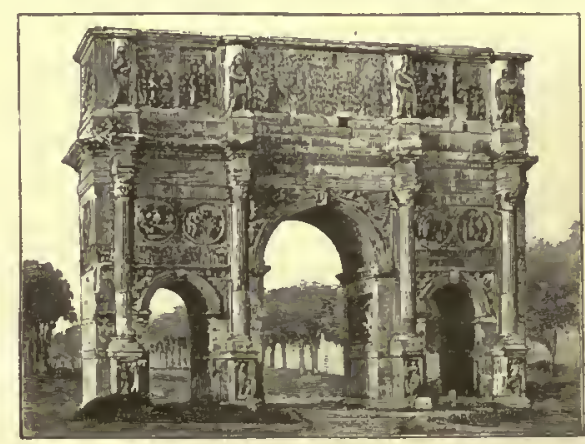

Triumphal Arch.-A rch of Constantine, Rome. archæan

the Roman emperors, and were originally temporary structures, festooned and otherwise rlecorated, standing at the entrance of a city, or in s strect, that a victorions At a later period the trimuphal arch became a richly scuiptured, massive, and permanent structure, having an archway passing through it, and often a smaller arch on either' side. 'The name is at the present day often given evergreens, banners, etc., ereeted on the occnsion of some public celebration or rejoicing. The great arch in a church which gives access to the choir-the chancel arch-is resentation of the Glory or Triumpl of Christ sometimes occupied a wall-space above this arch

statues, snd trophies, and triumphal arcs.

Gardens, and groves, prescnted to his eyes.
Milton, P. R., iv, 37

Twyer arch, sn srched opening in a snelting-furnace to tymp in a blast furuse. Sce tymp.-Vascular arches. See visceral arches, under visceral. - Visceral arches.

$\operatorname{arch}^{1}$ (üreh), $v$ [ $[\langle\operatorname{arch} 1, n$.] I. trans. 1. To cover with a vault, or span with an areh.

The proud river . . . is arched over with . . . a curions
powelle of stones.

No bridge arched thy waters save that where the trees Stretched their long arms above thee snd kissed in the
breeze.

2. To throw into the shape of au arch or vault; curve: as, the horse arches his neck.

Fine devices of arching water withont spilling. Beneath our keel the great sky arched Its liquid light and azure.

II. intrans. To form an arch or arches: as, the sky arches overhead.

The liations of the field and wood
Build on the wave, or arch beneath the savd I'ope, Essay on MIan, iii. 102. $\mathrm{ach}^{2}+$ (ärch), $n$. [< ME. arche, in Seriptura] senses, assibilated form of arc, ark, < AS. arc, carc, erc (see $a r h^{2}$ ), merged with the identical OF. arche, airche, $\left\langle\mathrm{L}\right.$. arca, a box, chest: see arc ${ }^{2}$, ark.2.] 1. A box or chest; in plural, archives. The clvile law
Holland, tr. of Livy, IX. xlvi, 349 . (N. E. D.) 2. The ark of Noah. [The common form in Liddle English.] - 3. The ark of the covenant. $\operatorname{rch}^{3}$ (ärch), $a$. and $n$. [A separate use of the prefix arch-, chief, which in many compounds as acquired, from the second member of the compound, or from the intention of the uscr, a more or less derogatory implication.] I. $a$. 1. Chief; principal; preëminent. See arch-. The tyrannous and bloody act is done;

The most arch deed of piter yet this land was guilty of.

Died that arch rebell oliver Cromwell, call'd Protector. Cromwell, call'd Protector.
Evelyn, Diary, Sept. 3,1658 .

2. Cunning; sly; shrewd; waggish; misehievous for sport; roguish: now commonly used of facial expression: as, "so arch a leer," Tatler,

He had the reputation of an arch lad at school. Sicift. So innocent-arch, so cunning-simple

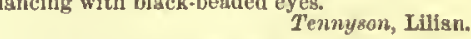
The archest chin
SIockery ever ambush'd in!

II. $+n$. A chief; a leader. [Rare.]

The noble duke my master,
Iy worthy arch and patron, comes to-night.

arch- [<ME, arch-, arche-, ete, <AS. also erce- and arce-, $=\mathrm{D}$, aarts- $=\mathrm{OHG}$ erri-, MHG. G. erz-=Sw. ärke-, erle-= Dan. cerlic-, erke $=$ Bohem. arci-, arehi- $=$ Pol. arcy-, archi$=$ Russ. arkhi- (ME. archc- also partly < OF. arce-, arche-, mod. F. arch-, archi-= Pr. Sp. Pg. arce- (Sp. sometimes arzo-) =It. arce-, arci-), < L. archi-(= Goth. ark-in arkaggilus, archangel), $<G r . a \rho \chi \chi^{-}$, a $\rho \chi$-, combining form of a $\rho \chi \delta s$, chief, $\langle a \rho \chi \varepsilon \iota \nu$, be first, begin, lead, rule, $=$ Skt. $\sqrt{ }$ arh, be worthy.] Chicf; principal: a prefix much used in composition with words both of native and of forcign origin. See $\mathrm{arch}^{3}$

archabbot ("̈rch"ab'ot), n. [<arch - + abbot. $]$ A chief abbot: applied as a specific title to the head of certain monasteries.

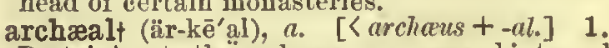
Pertaining to the archæus, or supposed internal cause of all vital phenomena. - 2. Cansed by the archrus: as, archaral diseases. See archatu. archæan (är-kē'an), $a . \quad[<\mathrm{Gr}$. ápxaios, ancient: see archeo-.] Of or relating to the oldest period of geological time: a name proposed by J. D. Dana, and now generally adopted, for a series of erystalline schists and massive rocks lying underneath the most ancient fos- 
archæan

siliferous stratificd formations. This serles is attll ealted by sonso writers azoie, because thus far it has mot
becn found to eontain any traces of life. It atso lachudes an undetermined portlon of the rocks formeriy designated us primitive, and by some writers is vaguely used to indl. archæi, n. Plural of archans.

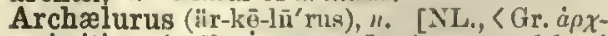
primitive, + aìovios, a cat.] A genus of fossi eats from the Miocene of North America, havinge 4 upper promolane, 3 lower premolars, and 2 lower molars. A. debilis was about as large as the puma. $f$. C. Coitis was 1879 .

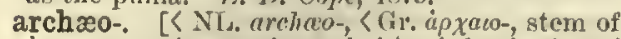
ap xaios, ancient, frimoval, $\langle a ́ \rho \chi\}$, beginning, åxetv, be first, begin, lead, rulo. Cf. arell-.] Ancient; pimoval: the first part of number of counpound seientifie worls. Also written archco-, and, rarcly, archain-

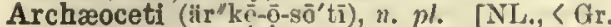
apxaios, ancient, + kijros, whale.] A suborder forms usually referred to the genus Zeuglodon (or Basilosaurus): equivalent to Zeuglodontia of some naturalists. The deutition ig, 3 fucisors canline, and 5 grinders on each sicle of each jaw, $=36$, like that of some seals. The skult is elongated and depressed,

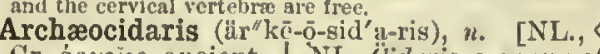
Gr. ápxaios, ancient, + NL. Cislaris, a genus of sea-urehins: sce Cidaris.] A genus of fossil sen-urchins or cidarids, from Carboniferous and Permian strata, having small hexagonal plates and long spines, either smooth or notehed and denticulated.

archæographical (är"kẹ-ē-graf'i-kal), a. Relating or pertaining to archroography.

archæography (ir-kē-og'ra-fi), n. [<Gr. i

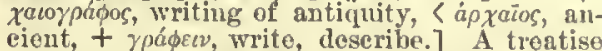
on antiquity; a deseription of antiquities in general, or of any particular branch or series. archæologian, archeologian (är/kō-ō-lō'ji-an), \%. [< archerology $+-r \mu$.$] An archicologist.$ archæologic archeologic (är/ ${ }^{\prime \prime}$ ōoō-loj'ik), archæologic, archeolog

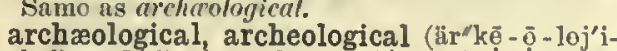

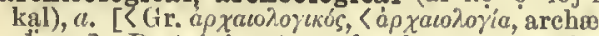
ology.] Pertaining to arehmology: as, arehaological researches.-Archæological ages or periods. See age.

archæologically, archeologically (är"kēloj'i-kal-i), adv. In an archwologieal way; in accordance with arehæology.

archæologist, archeologist (är-kệ-ol'ọ-jist), n. A sturlont of ancient monuments; one skilled iil archieology.

archæologue, archeologue (är' $k \bar{e}-\bar{o}-l o g), n$.

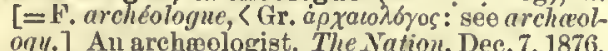
archæology, archeology (är-kê-0l' $\overline{0}-j i)$, 1870.

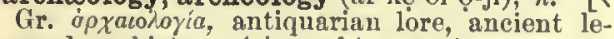
gends or history, < a $\rho \chi a c o$ o yos, antiquarian, lit.

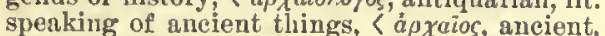
speaking of ancient things, apXaios, ancient, tiquities; that branch of knowledge which take cognizance of past civilizations, and investigates their listory in all fields, by means of the remains of art, architecture, monuments, inscriptions, literature, language, implements, customs, and all other examples whieh have survived. Arehæology is sometimes taken specificaliy in the restrieted sense of the sclence of ancient srt, inetudis architecture, sculpture, painting, ceramies, and decor serve to identity them. - Classical archæology, the chrology, the sreheology of the miditie sges. =Syn. Archoology, Antiquarianism. Antiquarianism deals with reltcs of the past rather as olj eets of mere curiosity or as
tnteresting merely on account of their antlinuity; archae ology studies them as means to a scientiflc knowiedge of the past. See paleontology.

archæonomous (är-kệ.-on'ō-mus), a. $\quad[<G r$.

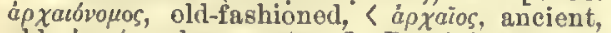
old, + vónos, law, custom.] Retaining, or deviating little from, a primitive condition; oldfashioned: especially applied by $\mathrm{S}$. Loven to echinoids of the family Clypeastrida. [Rare.] Archæopterygidæ (är-kẹ-op - to - rij' i - dē), pl. [NL., S Arehrepteryx $(-p$ teryy-) + -ille.] A Archeoptcryx, of the subclass Sourure (which see).

Archæopteryx (äi'-kē-op'te-riks), n. [NL., Gr, a $\rho \chi a i o s$, ancient, + $\pi \tau \varepsilon \rho v \xi$, a wing, a bird < $\pi \tau \varepsilon \rho \delta$, a wing, = E. feather.] A genus of fossil reptilian Mesozoic birds discovered b Andreas Wagner, in 1861, in the lithographi slates of Solenhofen in Bavaria. It is of Jurassie
293

archaist

us combining some chsracters of a lizad with those of a of a single feuther, upon which the name

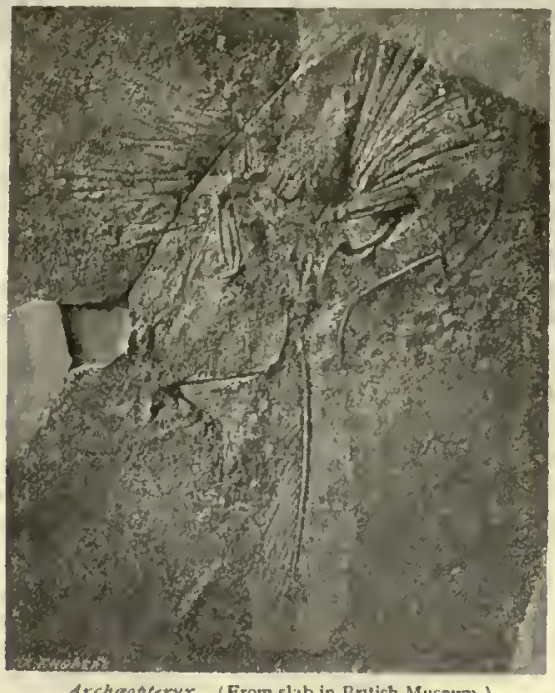

Archaopleryx. (Frorn slab in British Museum.)

lithographica was Imposed by Von Meyer. A second spect. men from the same formation and locality was named be neltiner aftirmed nor denfed, and their generde identity is only presamptive. A thiril and still more characteristio speelmen is illentieal with the second, and has furnishei many additional cliaracters. Jlembers of this genas had teeth, a long, Jlzard-11ke tall formed of many vertebre, and separate metacarpal boues, in combination with a cari-
nate stemum and other features of modern birds. It is mate stemum and other features of modern birds. It is

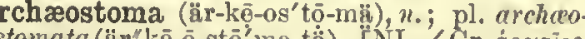
stomata (ür" kẹ-ō-stö'ma-tä). [NI., 〈Gr. ápxaios, ancient, + $\sigma r o \mu \alpha$, montl.] In biol., a primitive blastopore; a primitive unmodified enteric orifice, both oral and anal: opposed to deuteros toma. Also written archacostome.

Archæostomata ("̈r "kẹ̄-ō-stỏ' mạ - tä), n. pl. [NL., pl. of archeostomiatus: seo archioostometous.] A group of animals rotaining or supposed to retain an unaltered oral orifice or archæostoma throughout life; in some systems, a prime division of the great phylum mathelminthes, and Platylhelminthes excepting Cestoidea: distinguished from Deuterostomatu. archæostomatous (är"kē-ō-stō'man-tus), a. [< NL. archoostomatus, $<\mathrm{Gr}$. $\dot{a} \rho \chi a \tilde{i} o \check{\text {, }}$, aneient, +

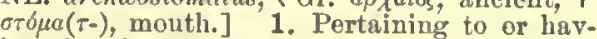
ing the characters of the Archeostomata.-2. In biol., haviug a primitive blastopore or original orifice of invagination of a blastosphere which has undergone gastrulation; re taining an arehenteric aperture, as distiu guished from any other which may be acquired state of those gastrule which are formed by emboly.

In the former [process of gastrulation by emboly] the tion of the endodern with the apterior; and the result would be the formation of an arehoeostomatous gastrula

archæostome (ür'kē-ô-stōm), $n$. Same as $u$ chacostome.

archæsthetic, archæsthetism, etc. See archesthetic, ete.

archæus (arr-ke- us), n.; pl. archeri (-i). [NL., ning, < a $\rho \chi \varepsilon \iota v$, be first: see archoo-. ] In th philosophy of Paracelsus and other spagyries, mystics, and theosophists, a spirit, or invisibl man or animal of etheroal substance, the counterpart of the visible body, within which it re sides and to which it imparts life, strength, and the power of assimilating food. The word is saic to have been used by Basil Valentine, a German chemis source of the life of plants. Paracelsus uses it with the move meaning. It is frequent in the writings of Van lle human or animal form in posge. He regards the archiol as a fluid, that is, as a semi-naterial substance, like air, and seenis to consider it a chemical constitucnt of the blood. Paracelsus had particulariy made use of the liy. pothesis of the arehreus to explah the assinilation of medicine. Van IIelmont ealls it the door-keeper of the stomach (janifor atmmachi). There are fnrther divarica tions of meaning. Also spelled archeus.

As for the many pretended intricacles in the instance of say, the Archei that formed them are no parts of tho the fuliy developed art of a
Itorse's Soul that is deari, but geveral distinct Archei ting as the Crowes cor of lis hody, so putr. Dr. II. Jiore, Antidote ogalust Athefam, anp. archaic (ïr-kī'ik), a. $\quad[=1$, archaiquc, < Gr.

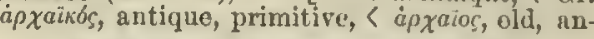

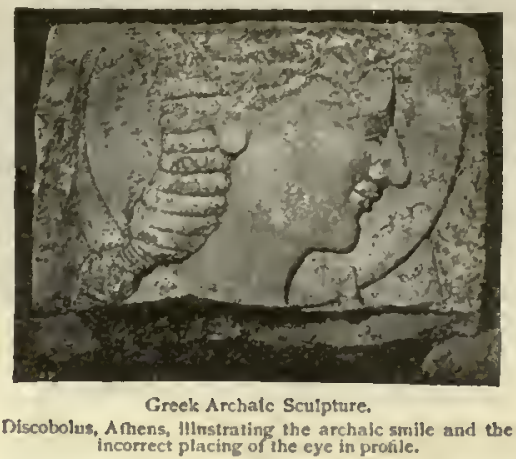

tique: sce archeco-.] Marked by tho characteristics of an earlier period; characterized by archaism; primitive; oldfaslionod; antiquated: fashonod; antiquated: phrase.

A person faniltar with the dialeet of certatn portions of
Iassacilasetts will not fail to rccomizc, in ordinary disconrse, many woris now hoted in English vocabularies which were in common use about the time of the King Shmes translation of the lible. of a glossary to nost Nev Englanders than to many Louell, Bfglow Papers, Int. There is th the best archaic colo work [of the Grecks]. which are often wanting ti Ilead, Ilistoria Numornu, [Int., 1x.

The archaic, in art, not sim. ply the quality of rudeness or ness and imperfeetion imply.
ing the promise of future ad-
yanec. Work that is merely barbarous is not property ar

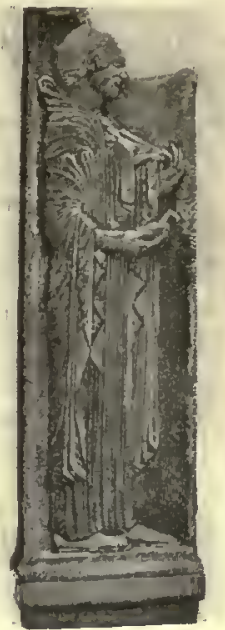

an art of sufleient torce to ave sny development, saceeeds the flrst rude attempts of a people to arrivo at graphic representation, and exhllit: finalty the archaic quality disappears little by litte as Greece ind of the lin the great art-schools, such as those of ifeee and of the lkenatssance painters, or as art sinks into sculpture of Egypt snd Mt esoprotania.

rchaical (är-kāi-kal), a. [< archaic + -al.] Relative to an early period or to a fashion long out of date; primitive; antiquated; archaic.
archaically (är-kä'i-kal-i), adc. In an archaic archaicism (är-kä'i-sizm), n. [ Ancient style or quality; archaism. $T . E . J)$. archaio-. Same as archico-. archaism (är'kā-izm), n. [= F. archaïsme, Gr. á xaïoús, an antiquated phraso or style, <e $\chi a t \zeta c t$, copy tho ancients, $\langle a \rho \chi a i o s$, old, an-
cient: sce archco-.] 1. The adoption or imitation of that which is antiquated or out of use; especially, the use of archaic words or forms of speech.-2. The quality of being archaic antiquity of style, manner, or use, as in art or literature; especially, in art, the appearance of traces of the imperfect conception or unskilfu] handling of tools and material belonging to an art before the time of its highest development. see the archaic, under archric.

A selcet vocabulary corresponding (in polnt of archaism Abulary.
De Quincey.

3. That which is archaic; especially, an antiquated or obsolete word, expression, pronuncition, or idiom.

A permissible archaim is a word or phrase that has been supplanted hy somethiag less apt, thit has not beconie
unintelfigfble. Lowell, Among ny Books, 2d ser., p. 195. Doubtless the too free 1158 of archaisms is an abuse.

archaist (är'kä-ist), n. [As archa-ism + -ist.] 1. An antiquary; an archrologist. [Rare.] $\mathbf{- 2}$. One who makes use of archaisms in art or in literary expression. IIrs. Brouning. 
archaistic (är-kī-is'tik), $a$. Imitating that which is arch atternpt to reproduco the ic; affecting archaism. In spite of the archaistic eftorts of many writers, both in forms and in voealunlary, the language [Swed.
ish] nevertheless underwent rapis changes dinfing the 16th snd 17th
centuries. Emyc. Brit., XXI. 37 . archaize ('iı' $k \bar{a}-\overline{1} z)$ ), $x$. $i$; pret. and pp. rechized, ppr. ar chaizing. [ $\langle\mathrm{Gr} \cdot \dot{a} \rho \chi a i \zeta z t v:$ se urehrisist.] To use or imitate what is arehaic; imitate an olden style; especially, to make use of archaisms in speech.

archaizer (är'kā-1̄-zèr), " One who archaiges; oule wh uffeets un archaia style.

But it may he remembered that Varro was himself something of sin

archallt, $"$. An old form of rtechit.

archamœba (är-ka-nṓbï), nrimitive, + NL. amoba.] A hypothetical primitive simple amooba supposed by Haeckel to have made its appearance in the earliest geologic period, and to have been the progenitor of all other

archamphiaster (ïr-kam-fi-as'tèr'), n. [Also urchiamphiaster, $<\mathrm{Gr}$. á $\rho \chi \iota_{-}$, first, + a $\mu \phi \hat{i}$, around, +áoth́p, star. See amphiaster.] In embryol., one of the nuclear cleavage figures developed from the germinative vesicle or primordial $11 u$. cleus at the time the polar cells or globules are expelled from an ovum, at or before the begilning of development.

The history of the esrly stages of the spindle and the Ilyatt, Proc. Bost. Soc. Nat. Ilist. (1884), p. 65. archangel (ärk'ān'jel), n. [< ME. archanyel, archnungel, etc. (in As. heán-angcl, lit. high an-
gel), < OF. archangel, archangcle, mod. F. arehange $=\mathrm{Pr}$. archangi $=\mathrm{Sp}$. areangcl $=\mathrm{Pg}$. areanjo, archanjo $=\mathrm{It}$. a reangclo $=\mathrm{D}$. a artsengel $=\mathrm{G}$. erzengel $=\mathrm{Sw}$. èkeängel = Dan. erkengel ; < LL. archangehus (= Russ. arkhongel $=$ Goth. arknggiluss), < Gr. á $\rho \chi a ́ \gamma \gamma \varepsilon \gamma_{0}$, archangel, chief angel, $\langle\alpha \rho \chi-, \quad a \rho \chi t-$,
and axgel.] 1. An angol of the highest order a ehief angel. The word occurs in two passages of th
bible, 1 Thes, iv. 16, sud Juile 9. Michael, mentioned in the lstter as sn sichangel, also in Daniel as the spiritual
prince of the Jews, and in Rev. xil. 7 as the leader of th

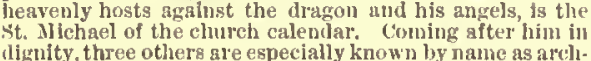
lignity, three otherg gre especially known by name as ardl-
sngels: fabriel, the heavenly interpreter aud annuncistor sngels: fabriel, the heavenly interpreter aud ammuncistor
or herald (Dan. viii. 16, ix. 21; Luke i. 19); Rrphael, the
guardian angel commenorated int the book of Tobit; and
Iriel (2 Esd. iv. 1), the flre or light of God, often men.

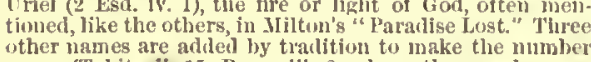

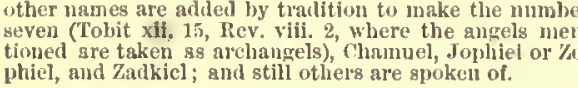
For archangels were the first and most glorious of the
wiole creation: they were the morning work of God, and had the first impressions of his image. 2. A member of the lowest but one of the nin orders of angels composing the "celestial gite, whose classification was adopted by Pope Gregory the Great, and is generally accepted by the theologians of the Roman Catholi
Church. The nime orders are: seraphim, clerul,in
thrones, dominations, virtues, powers, principaliti thrones, dominations, virtues, powers, principalities,
nrchangels, angels. 3. [ML. archingchs, archanyelica.] In bot.: (a) The name of several labiate plants, as
Stachys syluatica and species of Lamium. (b) An umbelliferous plant, Archangelica officinalis. See angerica.-4. A slim-bodied, thin-faced variety of domestic pigeon, of rather small size, with long head and beak, a peaked crest, and shoulders and tail, but coppery elsewhere. The origin of the breed is muknown : it was introduced into origin of the breed is minknown: it was introduced finto
Englanil from Ghent. The nsme is supposed to allude to the hriliancy of the plumage. The hird breeds very tru archangelic (ärk-an-jel'ik), a, [< ML. archan-

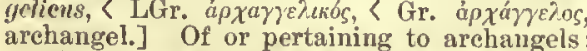
as, "archangclic pomps," Mrs. Browning. arch-apostate (äreh' a-pos'tat)
apostate.] A chief apostate. arch-apostle (ärch'a-pos'1), n. [<arch- + apos Archarchitect (ärch'in'lisi-tekt), chief apostle. architect] I'll ne'er believe that the Archarchitect With all these fires the heavenly arches decked

ch-band (äreh'band), $n$. A name given by artisans to that portion of an arch or rib which is seen below the general surface of vaulting. arch-bar (ärch'bär), n. 1. Any metallic bar' of arched shape, as the iron bar taking the place of a brick arch orer the ash-pit door of some furnaces. -2 . The upper member of a curved furnaces. - 2. The upper member of a curved the bolster of a car-truck each way to the top of the journal-boxes. It forms the compression-member of the trusswork which transmits the weight of the

of the car from the truck-holster to the ear-axles.
archbishop (ärch'bish'uj), n. [〈ME. archbisshop, archebisco], etc., <AS. arce-, arec-, ercebiscop (also herih-biscop, lit. high bishop) = OFries. alcebisko $=\mathrm{D}$. a a tsbisschop = OHG. erzibiscof G. erzbischof = Icel. erkibiskup = Dan. Sw. erkebiskop $=\mathrm{F}$. archevéque $=\mathrm{Sp}$. arzobispo $=\mathrm{Pg}$. arcebispo $=\mathrm{It}$. arcivescovo, $<\mathrm{LL}$. arcliepiscopus, < LGr. a $\rho \chi \varepsilon \pi i \sigma \kappa o \pi \%$, chief bishop, < Gr. $\dot{\alpha} \rho \chi$ chief, $+\varepsilon \pi i \sigma \kappa o \pi \circ$, bishop: see arch-and bishop.] A title used in the Christian church as early as the fourth century, and regularly given in that and the next four centuries to the bishops of the highest rank, afterward known as patriarchs. metropolitans of sces of exceptional sntliuity or dignit and was sometimes extended in later times to other of the same rank as a special distinction. In the West
from the eighth or ninth century, the title was given to from the cighth or uinth century, the title was given to
metropolitans of every class, and this fs still the use of the Roman Catlolic Church. Archbishops have certain rights of honor and jurisdietion over their suffragan bishop (that is, the bishops of the dioceses makfing up their eccle over provincial councils, recelving sppeals in certain cases etc.; but these righits, formerly very constlerable, are now
compsratively limited. At present the archbishop is not always a metropolitan, since there have long been a few title is purely honorary. See primate. The insignta of a
archlishon in the Romsn Catholie Chirch are the woole pallium, hefore receiving whlch from the pope he canno exereise the functions of his offiee, and the douhle cros
borme processlonally before him. In the Anglicsn Chure bortue processionally before him. In the Anglicsn Chure (those of Csnterbury and York, the former of whom Irelani (those of Armagh anil Dnblin, the former of whon is primate). The (hurch of Sweden has one archbishop archbishopess (ärch'bish'up-es), $n$. $\quad[<a r c h$ bishop + -ess.] The wife of an English areh archbishopric (Areh'bish'vare.]

archetischopriche, -ryh, etc., 3 AS. arcebiscoprice, arrebiscop, arehbishop, + rice, jurisdiction. Cf. bishopric.] The titular see or diocese of
an archbishop; the province over which an archbishop exercises anthority.

arch-board (ärch'bōrd), $n$, In ship-building, a plank placed across a ship's stern, immediately this board the slip's name is sometime arch-brick (ärch'brik), $n$. 1. A wedge-shaped brick used in arehed work. See eompass-brick.
-2 . A hard and partly vitrified brick, taken from one of the arehes of a brick-kiln in which the fire is made.

archbutler (är'ch'but'lèr'), $n_{.}[<$arch- + butker The G. equiv. is craschenke, 'ar'ch-skinker.'] rank in the Rontan-German empire, one of the imperial court-offiees eonnected with the elect

arch-buttress (ärch'but"res), $n$. Same as flying outtress (which see, under buttress).

等 > G. crakïmmerer, 'arch-chamberer': see cham berer.] A chief chamberlain. It was formerly the da liy the Elector of Brandenburg.

rchchancellor (äreh'chản'sel-or), n. [<archkanzler, $<\mathrm{ML}$, archicancellarins, archehancellor. A chief chancellor; formerly - (a) The title of an office in the Roman-German empire, held by the electoral archbishop of Mainz, who was actual chancellor of the empire. (b) An honorary official rank beld by the electoral archbishops of Cologne and Treves, the former nominally for Italy and the latter for Burgundy (Ganl and the kingdom of Arles). archchantert (ïreh'chàn'tèr), ". [< urch- +
ehanter. Cf. ML. archicantor, chief singer.] The chief chanter or president of the chanter: of a church; a choir-leader or precentor. archchaplain (ärch'chap'lān), n. [< rerch- + carly often the same as the papal, or later the imperial, apocrisiary, and identical with the grand almoner and archehancellor. The title hecame extinet with the Carolingian, or secoud race of kings, hefore A. 1). 1000.

archchemic (ärch'kem'ik), a. [< arch - + "the arch-chemic sun," Milton, P. I., iii. 609. [Rare.]

arch-confraternity (ärch'kon "frà-têr' $\left.1 i_{i}-t i\right), n$ In the Rom. Cath. Ch., a chief confraternity having affiliated societies and endowed with special privileges: rarely ealled arch-sndality. see confraternity.

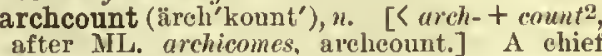
count: a title formerly given to the Count of Flanders in consequence of his great liehes and power.

archdapifer (ärch' dap'i-fér), $n$. [Modified (with E. areh-for L. archi-) from MIL. archidapifer, < L. archi- + tapifer, a food-bearer, < daps, food, feast, + ferre $=$ E. bcarl.] The title of an official rank in the Roman-German empire, held by the Elector of the Palatinate; the seneschal.

archdeacon (ärch'dē'kn), n. [<ME. urchedeken, etc., < AS. areediacon, ercelliacon = D. a artsteken = Icel. erkidjäkn = Dan. erkedegn = $\mathrm{F}$. arehidiacre $=\mathrm{Sp}$, arecdiano $=\mathrm{Pg}$. arcediago = It. archidiacono, < LL. archidiaconus, < LGr.

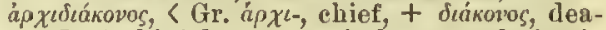
con.] A chief deacon; strictly, an ecclesiastic who has charge of the temporal and exterual administration of a diocese, with jurisdiction delegated from the bishop. The worl is found as the title of sn ecelesiastical dignitary from the fourth cer tury. In the East it is last found as applied to an eecle-
siastieal ofleer of the court of Constantinuple under the century dioce empire. In the West, from the eighth torles, over which rural archdeacons were placed, having uncler them deans or rural archpriests, charged with the supervision of the parish priests of their respective dis.
tricts; over these was the genersi or grand archdeacon of the whole diocese, who took precedence of the archpriest (which see), and held his own court with its ofhcials, disfrom the former to the latter. The rursi arcindeacons were often priests, liaving a cure of souls, as was also the grand srehdeacon from the twelfth century. The powers and privileges of this office were gradualjy restricted, and In the Roman Catholie Church, since the Council of 'Tremt,
its place is for the most part gupplied by the lusliop's viearits place is for the most part gupplied by the lisiop's vicar-
general, between whom and the pardih priests are some. times found the vicars furane, or present rural deans; survives, holds a dignity of honor. In the Church of England each bishop has the assistance of two or more archdeacons, who as his depities inspect and manage the affairs
of the diocese, and perform a varlety of duties partly secular and partly eeclesiastichl. In two dioeses of the Prothas been introdiced.- Archdeacon's court. See court.

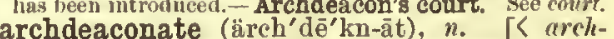
dercon +-ate 3 , after ML archidiaconatus, archdeacon's office.] The district over which an archdeacon has jurisdiction; an archdeaconry. archdeaconry (ärch'dē'kn-ri), n.; pl. arclulertconries (-riz). [< archleacon $+-r y$.$] The of-$ deacon. In the Church of Fngland every tiocese has one or more archdeaconries; every archileaconry is diarchdeaconship (ärch'dē'kn-ship), $n$. [< archdeacon + -ship.] The office of an archdeacon. archdean (ärch'dēn'), $n$. [<urch-+ dean. Cf. D. aartsdiaken, archdean.] A chief dean; a superior over other deans. [Sometimes used by Seottish writers for archdeacon.] archdeanery (ärch'dë'ne-ri), $"$.; pl. arcludeaueries (-riz). [< archdean + -ery.] The office $01^{\circ}$ jurisdiction of an archdean.

archdiocese (ärch'dī'o-sēs), $n$. [ arch - + dio. eesc, after ML archidiocosis.] The see or diocese of an archbishop.

archdruid (ärch'drö'id), $n . \quad[\langle$ arch- + druid. $]$ A chief druid.

archducal (iiı'ch'd̄̄'kal), a. [< rrchiluke; = F. archiducal: see ducal.] Pertaining to an arehduke or an arehdnchy.

In the Austrian assembly of states Vienna has as many Brougham

archduchess (äreh'duch'es), n. [< arch- + duchess, after $\mathrm{F}$. urchiduchesse. The $\mathrm{G}$. word is 
archduchess

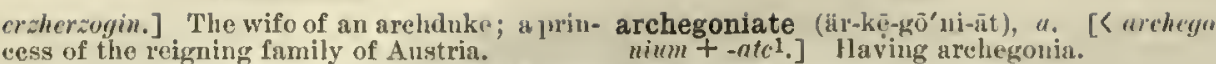
cess of the reigning family of Austria.

archduchy (iireh'duch'i), $u_{\text {. }}$; pl. archduchies (-iz). [Formerly also urchelutehy, < of. urch-

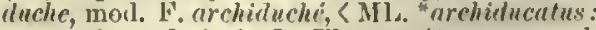
see crok-and duchy.] The tritory or rank of an arehiluke or arehduehess.

archduke (iirch'dlük'), n. [< arch- + dukt; $=$ OF. urcheche, mod. F. arehieluc, $<M \mathrm{I}_{\text {. }}$ archiduc $(-$ liue-) ( L. areli-, ehjet, + dux (duc-), duke: sec arch and eluke. The G. word is erakerag.] A title fomerly borne by some of the sovereign prinees of Austrasia, Jorraine, and Brabant, but for several centuries held exclusively by tho ruler of the urehcluehy of Austria (afterware emperor of Austria, and now of Austria-Hungary); now only a titular dignity of the prinees plinecsses. - Archduke's erown. Sce crour.

archdukedom (ärch'tink'dum), $n$. [s revelulule +- llom.] 'lhe territory or dignity of an arehduke or arehduchess; an arehdueliy.

archelt,

arche $2+, n$. See $\operatorname{arch}^{2}$

arché (hil-shn'), a. [IIeraldie F., lpp. of "areher seo treh $^{1}, x^{\prime}$.] Sime as urched, 2.

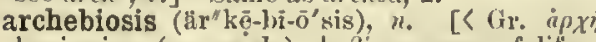
beginning (see areh-), + Biwats, way of lifo, ßoovv, pass one's life, < $\beta$ ios, life.] The origination of living from

genesis (which see)

However the question may eventuslly he decided as to the possibility of archebiosis ocenrring at the present das not be denied that archebiosis, or the orleination of diving matter in accorlance with natural laws, mist huve occurred al some epoch of the just.

arched (äl'clit), p.a. [<arehl+-cd.] 1. Mlad with an areh or curvo; covered or spanned with uu arch; laving the form of an areh; composed of an arch or arehe

"Twas pretty, though a plague,

To see him every hour; to sit and draw

Hils arelied brows, his liawklng eyc, his eurls,

In our heurt's table. Shak., All's W'ell, 1. 1 All born of unr honse have that arched instep nulle
which water ean tlow. Specifically -2. In her., applied to an ordinary both sides of which are bowed alike in the form of an areh. Also archy, arché, archy-flected, aud cnncated. - Arched beam, a heam ent, bent, or luilt In

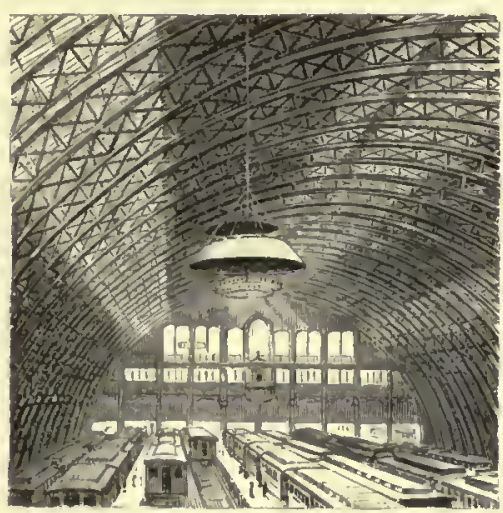

the form of an areh, usually to secure greater resistance
or previde for a Jonger span than a stralght beam would atforcl. The most injortant type of arched beam is tha such beams are malle in tmany forms, espeeially in these of several thlekuesses of timber or jilanks laid npon or alougside of one snother and bolted together, and of a truss construction in lron. The archet-bean roof of the elear, of 240 leet; that of the Grand Central station, Xew York, has a span of 199 teet 2 inches.-Arehed-beam
bridge, ete, a hrillge, etc., in which one or more of the bridge, ete, a hrilge, etc., in whieh one or more of the
principat members is a eomponnd arched beam. Se archediacret, $n$. [ME, $\angle O F$ arcediacre, archediacre, mod. F. archidiacre, i L, archidiaconus, arehdeacon: see archdeucon.] An arehdeacon. arehideacon: see

archegayt, $\ldots$. Seo asisagai.

archegone (iir' $k \bar{e}-g \bar{n} n$ ), $n$. English form of urcheyoninm.

archegonia, $n$. Pluzal of archcgonium.

archegonial (är-kē-gō'ni-nl), $a$. [<archegonium $+-a l$.$] Relating or pertaining to an archego-$ nium.

The flattened fronds . . bearing upon tiny stalks which rose from the middle veln of the leat, the temale portion
of the plant the uruegonial disks.
A female (archegroniate) prothallim Eincyse, Brit., XX. 4?

archegonium (är-kē-gö'ni-11m), и.; 11. "rrche

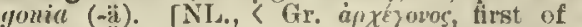
ruce, origimal, < ip $x^{\varepsilon-}$, apxi-, first (sco arehio), + góns, race: see -1wmy.] J'he pistillidium or female organ of the higliel ery ptogams, having the samo function us the pistit in tlowering plants. It is a cellular sac, containluy at the brittom cell, analogous th the embryo-sac of plizenogamems plants which is himpregnated ly spermatozooflis from the mal organ (antherldium). Front thls, after fertillzation, the alties, or a spore-cast is developed, as ln the mosses, whe new plants follow ujon tlie germination of the spores.

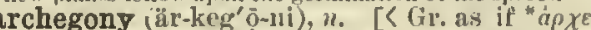
yovia, < a $x_{t}$ yove, tirst of a rnce: see archegonium.] The dloctrine of the origin of life; specitically, the cloctrine of spontaneous genera tion; arehebiosis; Hbiogenesis.

He [llaeckel] considers that, thongh the doctrine of spentaneous pencration (or archegony) has not been ments agalust it resting ou merely negative results.

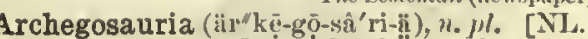
seo Archegosaurus.] is subouler or other grou of extinet labyrinthodont amplibians, typified by the genus Archegosaurns. The name is loose synonym of Leibyrinthociontice.

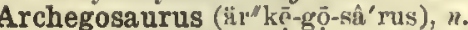

[Nlus

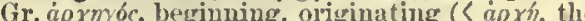

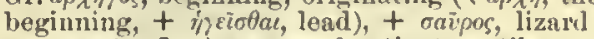
seo sanrian.] A genus of extinet reptiles reby some to bo a larval form of another animal Archelminthes (är-kel-min' thēz), n. $n$. [

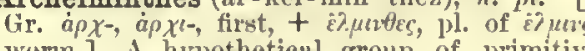
worn.] A hypothetical group of primitiv worms, the supposed progenitors of the Aca a prothelmis is the conjectured parent form. They are supposed by Jaeckel to bave leen cvolved in of the sncestors of the hunsn race. Their nearest livin relatives are considerel by him to be the Trerbellario. archelogy (är-kel'ó-ji), n. [<Gr. $\alpha \rho x \eta \dot{y}$, begin-

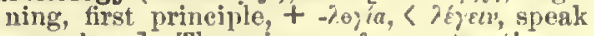
first prineiples.

Archelogy treats of principles, and should not be eor
counded with areheolugy, which treat of antigulties.

archemastry $t, n$. [Early mod. F. and ME. also urchimustry; < archi- + mastery; perhap confused with alchemistry.] Supreme skill mastery of applied seience or applied mathe inaties. I. E. D.

archemył (air'ke-mi), $n$. A variant of alchemy. Archencephala (är-ken-sef'a-lä), n. pl. [NL.

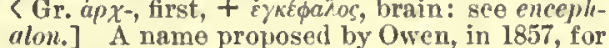
alon.] A name proposed by Owen, in 1857, for lie divided the elass Mammalia aceording to the eharacter of the brain. In this sulelass th brain attains Its maximum developnient in complexity, is deeply convoluted, largely everlaps both the eltsetory
lobes and the cerehellum, and has a well-marked hippowith the ordcr Bimand of soma, or the fanily Ifominide ineed are slared by the antliropoid apes, and the term not In nse, except as a synonym of a group of the zoölog. archencephalic (är"ken-se-fal'ik or -sef'g-lik) a. [< Archencephala $+-i c$.$] Of or pertaining$ to the Archencephola; hence, characteristic of the luuman brain alone.

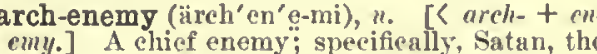
cmy.] $+-i c$.$] Pertaining to or of the nature of an$ enteron.

The periaxial portion of the archenteric space.

archenteron (är-ken'tê-ron), $n . \quad[<\mathrm{Gr} . \dot{a} \rho \chi$ first, primitive, + evтє $\rho v$, intestine: sce ent ron. The enteron (which see) in its original
or primitive undifferentinted state: opposed to metcuteron.

The hollow, which we have mentioned shove as formteron or primltlve stomach. archeo-. See archao-

IS ME areher, arehere, archice, $\angle \mathrm{OF}$. nreher, archier, F. wreher $=\mathrm{Pr}$. rer quier, arehier $=\mathrm{Sp}$, arquero $=\mathrm{Pg}$, arqueiro $=\mathrm{It}$ see-ology.] The science of, or a treatise on,

archenteric (är-ken-ter'ik), ". [< urchentern archesthetism

"rriere, < Ml. arearins, also viruurius, a bow man, <1. areus, a bow: $\sec ^{2} \operatorname{arch}^{1}$ and $a c^{1}$.] 1 Ono who uses a bow; a bowman; specifieally, in meslieval Furole, one who shot with tho longbow (which s(*0) and shaft, as distinguished from un arlalister or erossbowman. In fireek ar The archer ts generully repregented in Oriental dress an

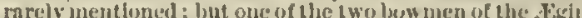
temple is iressed and arned as a Greck, and on a liasil cstan vase at Saples (Ileydemann, Yo. 8222), of gownt Cireck work, a painting rejrescnts three youthe, evielently (irceks. shooting with bows and arrows at a cock on a columi.

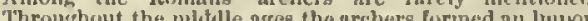
tart part of the armes of limpe: lout as an mor. drawn wholly from the pessants and turuspeople, the molility and thadr retainers were ofter suspicious of them, ancl the tree use of the bow among the common people

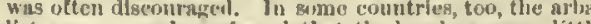
list was so much preferted that the lenglow cane little into use. In England iarge borles of archers were Inrwerc anned with some degrec of unformily with the steet eap, the gamberoun or laulperk, aud a short doulyc-edped sworl, bestdes bow and yulver. 'There 18 ino record of mounted archers in the finglish amiles, but they wer common on the contlnent ; the dukes of Burqundy maintained large borlies of thicm, sinl king Charles VI, France hal a body-guard of momted men armed with hrogantine or gambeson, and carrylug a loughow. Fron to the loody - auard of one of the later klngs of Franee whowe

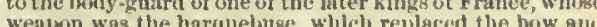
shafts, and (until the lievolutlon) to the watclumen or guards of the French citic

Same as archer-fish.-3. [cap.] The constelntion Sagittarius.

archeress (är'chér-es), $n$. [< archer +-ess.] A female areher. [Rare.]

She, therefore, glorlous archereso of heaven,

archer-fish (är'chêr-fish), u. A name given to three speeies of the genus Thxotes and fanily dian and Polynesian seas. Tro this the has heren

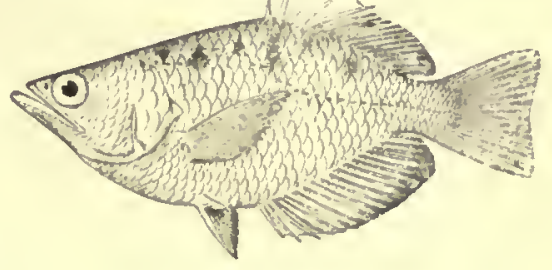

aserileel the power of shooting ilrops of water to the di to fut lutn the water, when it seizes and devours thron

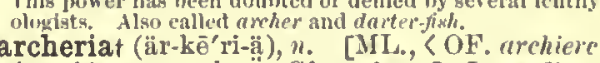
<archicr, an areher. Cf. circhery.] In medicese fort., an aperture through which archers of See loophole, and compare balistraria.

archership ("ir ehér-ship), $\mu$. Skill as an areher. archery (är'chér-i), n. [<ME. archerie, $\angle O F$ areherie, (urcher, archicr, bowman.] 1. Th" use of the bow and arrew; the praetice, art, or
skill of arehers; the art of shooting with a bou and arrow. -2. Archers collectively.

That reuison free, and burdeanx wine,

3. In old late, a service of keeping a bow for the lorl's defense.

archespore (är'kē-spōr), n. [<NL. a)chespo ium, ? Gr. ap $\chi_{\varepsilon-}$, first, + $\sigma \pi \delta \rho o s$, a seed.] I bot, a layer of small cells within the anther, to the very delicate lining of the anther-cell. The name ls also glven to a similar struetnre in some of archesthetic (är-kes-thet'ik), $a$. [<Gr. $\dot{a} \rho \chi$

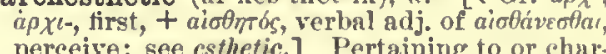
acteristic of archesthetism. Also spelled arehasthetie.

archestheticism (air-kes-thet'i-sizm), rehesthetic + -ism.] Same as arehesthetism. The hypothesis of archorstheticixm, then, malnts Ins that
eonsciousness as well as life preceded organism, and has consciousness as well as life precedert onganism, and has

archesthetism (är-kes'the-tizm), $n_{0}[$ [ archcsthetie $+-i s m$.$] The hypothesis of the primi-$ tive creative function of conseiousness; the hypothesis that conseiousness, considered as an attribnte of matter, is primitive and a cause of 


\section{archesthetism}

evolution: opposed to metesthetism (which sec). Also archasthetism, archestheticism, archastheticism.

The place of the doctrino of archersthetirm, as distin-

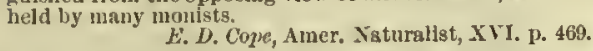
archetto (är-ket'ō), n. [It., a small arch, an arched stick, fiddlestick, < arco, an arch, bow: see $a r c h^{1}$.] An implement, consisting of a mire cutting away clay from a molded piece of pottery.

archetypal (är'kẹ-tĩ-pạl), a. $\quad$ < urchetypo + -al.] Of or pertaining to an archetype; constituting a model or pattem; original: as, "one archetypal minctical

Glorifled eyes must see by the archetypal Sun, or the Archetypal idea, a Platonjc jdea.-Archetypal world, an immsterial world supposed hy some flatonists to ha been first ereated as a jattern, according to which the archetype (ïr'kē-tīp), n. [Formerly also architype; $=\mathrm{F}$. archétype, $<\mathrm{L}$. arehctypum, $<\mathrm{Gr}$, ả $\rho \chi^{\varepsilon}-$

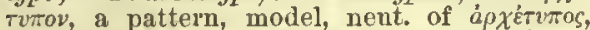
first-molded, as an oxemplar or model, <á $\rho x^{\varepsilon-}$

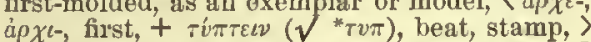
тítos, stamp, mold, pattern, type: see type.] 1. A model or first form; the original pattern or model after which a thing is made; especially, a Platonic idea, or immaterial preëxisting exemplar of a natural form.

Among the ancients, the co-existence of the Epicurean tirely different $a$ markable manner the res of vittion act Lecky, Europ. Mlorkls, 1. 160. Jan is the archetype of the animal crestion, the highest
manifestation of life. Dauron, Nat. and the Bible, p. 39 2. In coining, the standard weight by which others are adjusted: now called the prototype -3. In compar. anut., a primitive generalized plan of structure assumed to have been subsequently modified or lost by differentiation and specialization: as, the vertebrate archetype. 4. The original form from which a class of related forms in plants or animals may be supposed to have descended. Darwin.

archetypic (är-kē-tip'ik), a. [<archetype + -ic.] Same as archetypal.

archetypical (är'-kẹ-tip'i-kal), a. [< archetype. Cf. Same as archctypal. archetypically (är-kê-tip'i-kal-i), adv. In an archetypal mauner; after the mode or plan of an archetype.

archetypist (är'kē-tī-pist), n. [< archetype + -ist.]

archeus, $n$. See aichous.

arch-fiend (ürch'fēnd'), it. [<arch-+ fiend: = G. crzfeinu.] A chief fiend; specifically, the arc devil.

archi-. [L., ctc., $\left\langle\mathrm{Gr}^{\circ}\right.$ á $\rho \chi_{l-}^{-}, \dot{a} \rho \chi^{\varepsilon-}$, first, chief: prefix.] A prefix of Greek origin, the original form of arch-, first, chief. See arch-

archiamphiaster (är"ki-am-fi-as'tèr), $n$. Same as archamphiastor.

archiannelid ("ar-ki-an'e-lid), $a$. and

for pertaining to the Archiennelide.

II. $n$. One of the Archiannelida, as an annelid of the genus Polygardius. Also archiameliden. Archiannelida (är/ ki-a-nel'i-dä), n. pl. [NL., Gr. á $\rho \iota-$, first, + NL. Annelida.] A subclass or other leading division of annelids, supposed archetypal segmented worms. The best-known genus is Polygordius (which see).

archiannelidan (är."ki-a-nel'i-dan), $a$, and $n$

1. a. Pertaining to the Archiamelide.

II. n. Same as archiannetid.

archiater (är-ki-ä'tẻr), n. [= Russ, arkliyya ter $\tilde{u}=\mathrm{OHG}$. arzut , MHG. arzet, G. arzt $=\mathrm{D}$. urts, etc., a physician, < ML. archiater, < $\mathrm{L}$

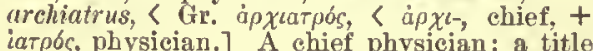
iarpós, physician.] A chief physician: a title first given by the Roman emperors to their chief physicians, and now applied on the continent of Europe to the first or body physician of cities; specifically, in Russia, the first imperial

physician.
archiblast (är'ki-blast), n. [<Gr. á $\rho \chi t-$, first, primitive, + $\beta \lambda \alpha \sigma \tau \delta$ s, germ.] In embryol.: $(a)$ The formative yolk of an egg; that which composes the germ, and in germination becomes the parablast. Wilhelm, Histology. (b) A name archiepiscopate (är/ki-ē-pis'kọ-pāt), u. [ $[11$. given by His to the epiblast.

rchiblastic (är-ki-blas'tik), a. Of, pertaining to, or derived from the archiblast: applied to those holoblastic eggs which, by equal or ar the yolk (vitellus), prodnce an archigastrula in germinating.

archiblastula (är-ki-blas'tū-lä), n.; jl. archiblastule $(-1 \bar{e})$. [NL., < Gr. á $\rho \ell_{-}$, chief, + NL. blastula.] In cmbryol., a hollow and nsually globular vesicle, the walls of which consist of a single layer of similar cells, and whi
vagination develops an archigastrula.

Yelk-division is complete and regular, and gives rise to which is provided with a flagellate cilinn.

II uxley, Anat. Invert., p. 653.

Archibuteo (är-ki-bū'tē-ō), n. [NL., < I. archiof the family Falconide, having booted tarsi.

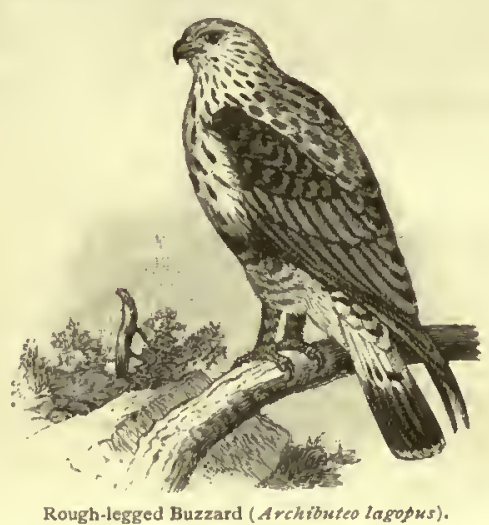

A. lagopus, the rough-legged bnzzsrd of Furope and America, is the best-known species. A. sancti-johannis is the black bizzard of America, and A. ferregin

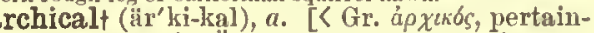
ng to rule, $\langle\dot{a} \rho \chi \ddot{\eta}$, rule, first place, beginning, < a $\rho \chi \varepsilon v$, rule, be first: see arch-.] 1. Of the nature of government; 1uling.-2. Chief; primary; primordial.

archicarp (är'ki-kärp), ${ }^{\prime}$. [<Gr. ả $\rho \chi i-$, first, + kapros, fruit.] In bot., same as ascogonium.

archicercal (är-ki-sèr'käl), a. [< Gr. à $\rho$ i-, like tail without fin-folds, as a fish; exhibiting archicer'cy, as a fish's tail.

archicercy (är'ki-sér-si), n. [See arcliccrcal.] The state of being archicereal; the primitivo condition of
J. A. Ryder.

archicytula (är-ki-sit' $\bar{n}-l a ̈$ ),$n . ;$ pl. archicytula $(-\bar{e})$. [NL., < Gr. á $\rho x i-$, chief, + NL. cytula.] in cmbryol., the parent cell or cytula which re tion of a nucleus, and which proceeds, by total and equal or palingenetic segmentation, to de and equal or palingenetic segmentation, to de
velop in succession an archimorula, archiblas velop in succession an a.
tula, and archigastrula.

Archidesmidæ (är-ki-des'mi-rlē), n. pl. [NL $<$ Arclidesma (< Gr. $\dot{c} \rho \chi^{--}$, chief, + $\delta \varepsilon \sigma \mu a$, band) zoic fossil myriapods of the archipolypodons typo.

archidiaconal (är "ki-di-ak' on-al), a. [< L. Pertaining to an archdeacon or to lis office: as, an archillinconal visitation.

This Prelate calls himself Exarch, and claims Archi.

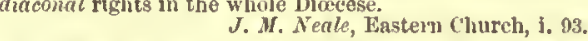
archidiaconate (är $\left.\mathrm{r}^{\prime \prime} \mathrm{ki}-\mathrm{d} \overline{\mathrm{i}}-\mathrm{ak} \mathrm{k}^{\prime} \mathrm{on}-\mathrm{a} \mathrm{t}\right), n . \quad[<\mathrm{ML}$.

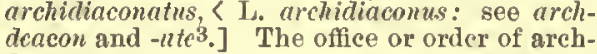
deacons.

archiepiscopacy (är $\mathrm{r}^{\prime k i}$-ẹ-pis'kō-pân-si), n. [A archiepiscop-ate + -acy. Cf. ejiscopacy.] The state or dignity of an archbishop.

archiepiscopal (är"ki-e-pis'kō-pạl), a. [<L. arcliepiscopns, archbishop: seo archbishop.] Canterbury is an archiepiscopel seo.

A Franciscan friar rode before him, hearing aloft the Aassive silver cross, the archiepiscopal standard of Toledo.
Prezcott, Ferd. and Isa., it. 21

archlepiscopality (är/ki-ē-pis-kọ-pal'în-ti), $\quad n$. [< archiepiscopal $+-i t y$.$] The dignity or stat$ archi-and cpiscopiate.] The office or jurisdiction of an arclibishop; an archbishopric.

archierey (ïr-kī'o-ri), n. [< Russ. arkhiorét,

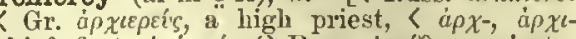

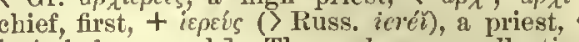
epors, holy, sacred.] The prelacy: a collectivo term for the higher orders of ecclesiasties in the Russian Chureh, including netropolitans, archbishops, and bishops. I'inkerton.

rchigastrula (är-ki-gas'trö-lä), n.; pl. archigastrula $(-1 \overline{\mathrm{e}}) . \quad\left[\mathrm{NL} .,<\mathrm{Gr}\right.$. a $\rho \chi_{t-}$, chief, + NL gastrula.] In cmbryol., a bell-gastrula; a gastrula which is bell-shaped or $^{t}$ has the form of a deep cup, resulting from that method of eggcleavage and gastrulation supposed to be primitive or palingenetic. It occurs in vartons aninals, from sponges up to the lowest vertebrates. See metcgas. trula, and cut under gastrulation.

archigraphert (är-kig'rạ-fèr'), n. [<LL. archigraphus, <Gr. áp $\chi l$ - chiëf, + $\gamma \rho a ́ \phi \varepsilon v$, write. Cf.

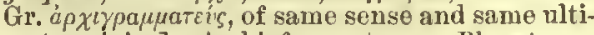

archil (är'kil), $\pi$. [Early mod. E. also archall, archel, etc., cor'upt forms of orchil (q. v.), < ME. orchell, $<\mathrm{OF}$. orchel, archeil, orseil, mod. mod. archilla $=\mathrm{Pg}$. orzella; origin undetermined.] 1. A rich violet, mauvo, or purple coloring matter obtained from certain lichens, especially the Roccella tinctoria and the fuciformis. - 2. The lichen from which the dye is obtained. See Roccella. it is bruised between stones, and mixed with quicklime o other alkaline liquor. It first becomes purplish-red in color and first state it is called archil. and in the seeond litmus. Dyer: rarely use archil by jtself, on
account of its dearness and the account of its dearness and the
perishableness of its beauty.
They employ it to give a bloom

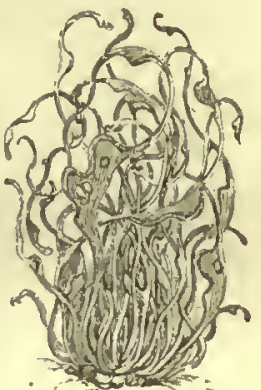

they employ it to give a bloom

and blacks; but this bloom soon decays. Archil is used for tinting the fluld employed in spirit-themometers, while litmus

Also written orehil, and formerly archall, orchal, orchel, orchella.

Archilochian (är-ki-lö'ki-an), a. [< L. Archi-

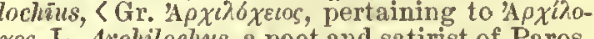
$\chi 0 s, \mathbf{L}$. Arehilochus, a poot and satirist of Paros, Archilochus, a Greek poet of Paros, noted for Archilochus, a Greek poet of Paros, noted for the bitterness and severity of his satire.
Hence-2. Severe; ill-natured: as, Archilochian bitterness.-3. In anc. pros., noting four stanzas - (1) A dactylic hexameter altermating with a penthemim (ealled a lesser Archilochian) or (2) with an iambelegus. (3). An iambic trimeter alternating with an elegiambus. (4) $A$ verse consisting of four dactyls and three $A$ verse consisting of four dactyls and three ing with an iambic trimeter catalectic.

archilowe (är'chi-lon), $n$. [Se., also archilogh and archilagh, a corrupt word; aceording to the $1 \mathrm{mp}$. Dict., < D. her-, again, + gelag (OD. ghelaegh), share of expense at an inn, = Sc. laugh, lauch, also latin, latcing, taverm-shot, reckoning: see lawing and law1.] The return which one who has been treated in an iun or tavern sometimes reckons himself bound in honor to make to tho company: when he calls for his bottle he is said to give his archilowe. [Scoteh.] I propose that this good little gentlemsin that scems
sair forlougliten, as 1 may say, in this tuilyit, sluall send for a tass of brandy, aud 1'll pay for another by wsy of
archiloue. archilute (ä $\left.\mathbf{r}^{\prime} k i-l n ̄ t\right), n . \quad\left[<a r c h i-+l u t c^{1}\right.$. Sec archlute.] Same as archlute.

archimage (är'ki-māj), . [Formerly also, as if It., arehimago, and as NI. urchimagus, q. v.] A chief magician or enchanter; a wizard.

The character of sage and archimage had fully imprinted
inself on his countenance. Brit., XIV. 462. archimagus (är-ki-mā'gus), n.; pl. archimagi $(-j i) . \quad[N L .,<\mathrm{Gr}$. a $p \chi i \mu a \gamma o s$, chief of the magi, a $\rho x<$, chief, $+\mu a \gamma_{0}$, one of the magi: see magi.] 1. The high priest of the Persian magi, or worshipers of fire.-2. A chief magician; n archimage.

archimandritate (är-ki-man'dri-tât), n. [<archimandrite $+-a t c^{3}$.] The dignity, office, or province of an arehimandrite. mate origin.] A ehief secretary. Blount. $\mathrm{F}$. orseille, < It. orcella, oricello $=$ OSp. orchillo, 

chimandrita, <LGr. ápxumavoitios (Epiphanins), chief of a monastery, $<\mathrm{Gr}$. ap $x^{t-}$, elicef, $+\mu \alpha \nu \delta \rho$, a fold, inclosure, cecles. : mon Church, an abbot-(genteral, having other abbots (leyoumenoi) with their (heyonmeni) with their perintendence; also sometimes, especially antong
the Grecks, tho alhot of a single large monastery. In Rilssia the bishois are se. lecteil (rom anony the atchi. mandrites. The title las been retalned among those who sej-
arateif from the Fastern Chinreli arateif from the Eastern chrot and sulmitted to the poino rite (tho sil-cnlled cinted ure now sulject to one proto.

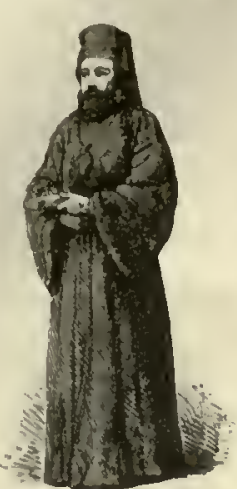
of lasslliun monks existing in sleily before the eleventh century has been minder the care of sn srchiunandrite sp Nalvatore in Messina, and it forns an exempt archimandritate humedlately dependent un tha pope. In the early W'estern Cluuroh, the word was used vagnely as ugulvalent to prelate.

Archimedean (ür"ki-mē'dẹ-an or -mē-dē'an),

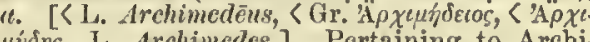
mons, 1. Archimercs.] Pcrtaining to ArchiSyracuse in the third century B. C., or to his mechanical inventions. - Archimedean drill. Sce drill.-Archimedean princtple, or princlple of Archimedes. (a) The principle of the equnilibriun of the opposite sides of the fulcrum, is in equilibrium when the weights are inversely proportlonsl to the length of the weights are inversely proportlong to the length of the
arms at wliose ends they lisag, and that tha pressure on
the fulcrum of the lever is then exactly ectual to the sum of the two welghts. (b) The hydrostatical princlple, also discovered by Archimedes, that a body immersed lin a fluid places. - Archimedean propeller, a jropeller consistin. of a continuous spilril vane on a liollow core running lengtliwiso of the vessel. It is an smpliftcation and cxtension of the screw. - Archimedean railway, a form o rallway lin which a continuous shatt rotates on pillars be screw which cngages in a pedestal attached to the cor

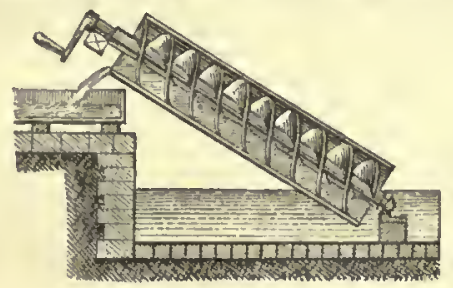

have been Invented by Archimedes. It is nigde by forming a spiral tube within, or by winding a flexthle tube spiral about, a cylinder. When the cyllnder ls placed in an inits revolution will cause the water to move up ward through ters the serew immedlately descends by ita own weight to the lowest polnt of the spiral; mit this point being alway
shifted lilgher up by the revolntion of the screw, the wate may thus be rsised to a considerable height. Also called of the thirteen solids deseribed by Archimedes, which, without being regular, have all their solid a ngles alike, al their faces resular, and not less than four faces of any onc kind: sometimes incorrectly called semi-regular solids taliedron, the truncated cubuefahedron, the icosidodeca hedron, the truncated icosahedron, the truncated dodecahedrom, the snub-cule, the rhombicosidodecahedron, the See these termi

archimonerula (är"ki-mō-ner'ö-lï), n.; pl. ar chimonerule (-lē). [NL., Gr. ce $\rho t-$, first, $+\mathrm{NL}$ moncrula.] In embryol., a term invented by Hreckel and defined by him as a cytod in which the formative and the nutritive yolk are not dis tinct. It is a specinl name for the monerula stage of holoblastic egg which undergoes palingenetic or prinuitiv of which are an archicytula, archimorula, archiblastula, and archigastrula.

archimorula (ür-ki-mor'ö-lä), $n . ;$ pl. archimoru lı $(-1 \bar{e})$. [NL. \Gr. á $\rho i-$, first, + NL. morula.] In embryol., tho morula or mulberry-mass which results from the total aud equal segmentation of the vitellus or yolk of an archicytula; a solof the vitellus or yolk of an archicytula; a solwhich proceed to develop an archiblastula and archigastrula.

archinephra, $n$. Plural of archincphron. primitive kichey. as the all archinephron kiney: as, the archincphrie duet. archinephron (ar-ki-11ef' rous), $11 . ; 1)$, arch-

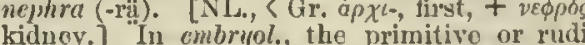
mentary, as distinguished from the final definitive, renal excretory organ of an animal; the primitive kiclney.

arching (är'ching), n. [Verbal n. of arch ${ }^{1}$.] Arched work or formation; the arehed portion of a structure.

archipelagian (är"ki-pẹ̄-lā'ji-ann), «. Samo a.s archipelagic.

archipelagic (är"ki-pệ-laj'ik), u. [< archipelusjo $f_{-i c .]}$ of or pertaining to an archipclago. The archiolagic fringe of coat

const line.

archipelago (är-ki-pel'a-gō), n. [Early mod. E. archpelago, also urchipelage and archipelagus (and abbr. archipel $=\mathrm{D}$. G. archipel, $\langle\mathrm{F}$. archipel = OSp, arcipielayo, Sp. archipielago = OPg. arcepcluyo, $\mathrm{Pg}$. archipelago (ef. Din. arkipelag, cepclayo, Pg. archipelago (ef. Din. arkipelag, arkipelagus, Russ. arkhipelayu, NGr. a $x_{t \pi k 1 a-}$ yos, ML. archipelagus), ( It. areipelago, orig. the
Egean sca, lit. the elivef gulf or sea (in distinction from minor bodies of water to which the torm pelago, ML. pelagus, was applied), (= Sp, piélergo = Pr. pelago, peyo $=\mathrm{Pr}$. peleg $)$ gulf, abyss, pool, sea, < MIL. L. pelagus, < Gr.

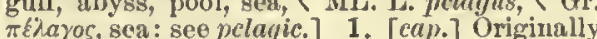
and specifically, the sea which separates Greec from Asia Minor, otherwise called the Agean sea, studded with a number of small islands. Hence, generally - 2. Any body of water abounding witl islands, or the islands themsclves collectively.

Archipolypoda (är"ki-po-lip'ō-dii), n.pl. [NL. q. v. ${ }^{a} \chi^{l-}$, first, + Polypoda, pl. of Folypus, q. V.] A group of fossil myriapods from the Britain, related to the Chilognatha, but having the tergites small and armed with large spines the sternites proportionally large and bearing supports. The Archipolypoda had two legs to esch seg ment, as in the extant biplopoda, and appear to have become extinct in the Palcozoic epoch. Three famllies have chiulida. Ir. Scudder has proposed the name Archipolypoda for
a gronp of fossil myriapods which, while closely related to
the Chilognatha, show geveral important points of dlfferStand. Nat. Ilist., II. I2

archipolypodan (är"ki-po-lip'ō-dạn), n. One
of the Archipolypodla. archipolypodous (:ir"ki-po-lip'ō-dus), a. Portaining to

polypoda.
archippus (är-kip'us), $n$. [NL., in form as Gr. archippus (är-kip'us), $n$. [NL., in form as Gr. In an architectonic manner; according to true
${ }_{A} \rho \chi \tau \pi$,
a proper name.] A butterfly, Da- stmetural principles or fitness. used as an English word.

Archiptera (är-kip'te-rï), n. pl. [NL., < Gr. tem of classification, an order of hexapodous metabolous winged insects, equiva
Pseudoncuroptera of other anthors.

archipterygium (är "kip-te-rij' $\mathrm{i}$ -

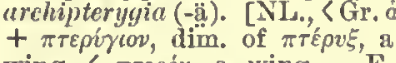
wing, < $\pi \tau \varepsilon \rho \dot{\nu}$, a wing, $=\mathbf{E}$. feather.] The archetypal form or primitive type of the skeleton of the limbs of vertebrates. most nearly approximnted in natur by the pectoral menber or fin of the been generally accepted; by others the pectoral nember of a primitive selschlan ls belleved

I have given the name of Archipte. rygium to the ground-form of the $8 \mathrm{kel}$ bearing irdle into the free sppendage. Gegenbaur, Comp. Anat. (tr.), p. 473 . archistome (är'ki-stōm), n. [< Gr. $\dot{\alpha} \rho \chi l-$, first, + $\sigma \tau \hat{b} \mu \alpha$, mouth. In zool., the primitive elongat-

The prlmitively elongated mouth of the larve of Bllateraila, with sn ex-
tended body-axls, or sny derived form

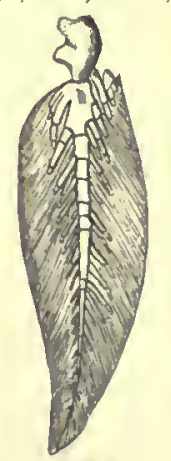
作 of the latter, or wherever there is lormed a well-deflned nenral plates or cords are developed, I would call the area thus embraced an archistome. $J$. A. Ryder, Amer. Naturallst, 18s5, p. 1117 rchitect (ïr'ki-tekt), ${ }^{\prime}, \quad[=\mathrm{F}$. architecte $=\mathrm{It}$

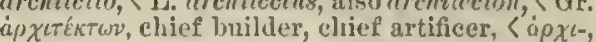

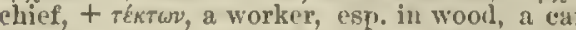
penter, joiner, builder: sce tcetonic.] 1. A person skilled in the art of building; ono who understands arehitecture, or whose profession it is to form plans and designs of buildings and superintend the excention of them. Hence2. One who plans, lesimus, or consummates any complex thing: as, the supreme Architcet of the universe; he is the architect of his own fortunes. - 3. One who eontrives, devises, or plots. Chlet nrehitect sand plotter of these wacs.

architective (ir'ki-tck-tiv), $\because, \quad[<$ architect ive.] Used in building; proper for building. architectonic (ïr"ki-tek-ton'ik), $u$, and $n$. [F. architeotonique, < I. architectonieus, < Gr.

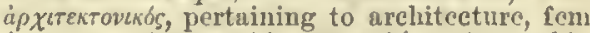

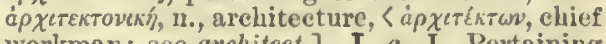
workman: see architect.] I. a. I. Pertaining to arelitecture; hence, pertaining or relating to construction or design of any kind.

The Archacologist camot fall to rcmark how severe, in a true age of art is the observance of this great A relitec pictures on Greek vascs, or the riculy enibossed snd chase work of the medisesl goldsulths are all aljusted to the form and surface allotted to then by an external necessity.
C. T. Nexton, Art snd Archeol., p. 34.

2. Skilled in architecture; expert in designing o1 constructing. - 3. Relating to the construetion of a complete and scientifically arranged theory or system of doctrine.-4. Having the same relation to something as that of an architect to his work; designing; controlling; governing; directive.

In the language of Arfstotle, whlch of these two [Culture and Religion] is the architectonic or master-art which prefunctions, as the master-lunildur preserlhes their dutics to
lis workmen? J.C. Shairp, Culture and Rellgion, p. 28. Architectonic idea See idea.-Architectonic unity the unity or union of the parts of a theory or system which II. n. 1. The scienco of architecture. Also architcetonics. -2 . In logic, the art of construeting systems.

By architectonic I understand the art of constructing syg-
(ems. Kant, Critloue of Pure Reason (tr. by \lax \ruller). Of these two sciences, . $^{\text {that which treats of those }}$ thought itsele, but of thitt which we think alsuut,. . has bcen called bididing architectonic, ln so far as it trcats of the

architectonical (är"ki-tek-ton'i-kal), a. Same

cometrical and nrchitectonical artists.

architectonically (är"ki-tek-ton'i-kal-i), adu.

architectonics (äl" ki-tek-ton'iks), n. $l$. Same as architectonic, $n ., 1$.

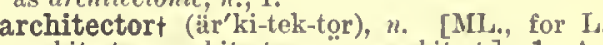
arehitectus, architecton: see arehitect.] 1. An

architect. -2 . A superintendent.

rchitectress (är'ki-tck-tres), $\eta_{0}[<$ arclitector

+ ess.] A female architect. Sir $H$. Wotton,
Reliquire. [Rare.]
architectural (ür-ki-tek'tūr-al), a. [= F.urchitcetural; $\langle$ architecture + -al. $]$ Pertaining or relating to architecture or the art of building; aceording to the principles of architecture.architecturalist (är-ki-tek'tür-a]l-ist), n. [< or connoisseur in arehitecture $N, E . D$. architecturally (är-ki-tek'tưr-âl-i), $a d v$. In an architectural manner; with regard to architectural piew.

architecture (är'ki-tek-tūin), n. [= F, archi tecture $=\mathrm{It}$. architettura, $\mathrm{L}$ L. arehitectura, < ar chitectus, architect: seearchitect. The Gr.word

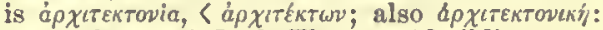
see architectonic.] 1. The art of building, speeifically of fine or beantiful building. Archltecture includes, In the widest sense, (1) the principles it science of construction, Inclnding the propertics of ma. terlals and the methouls of combining thens; and (3) the the directhng of builders and workmen. The practice of
this art requires skill In deslgn, which is the speclal prov. this art requires skill lin design, which is the specis! province of the architect, and skill in execution, which is the employs and directs. It is the function of skill in archindependent and often hostllc requirements (1) of use 


\section{architecture}

and convenience as dictated by the comilitions nt the proh-
len in hand; (2) of constructive necessity and fitness as len in hand; (2) of constructive necessity and fitness a.
letermined cither by practical experience or lyy scicntific theory; and (3) of artistic excellence both in the propor-
tions of the parts and in the decorntive treatment of details, in accordance with either the general principles and taits, in accordance with either the generat principies and
canons of good taste or thic prescriptions of custom or
tradition. it is the function of skilt fu execution practitradition. It is the function of skilt in execution practi-
eally to carry out the seheme so resigned; and this skill is exerciserl isy draftsmen, surveyors, mechanics, artithe decorative or artistic element. The most important the decorative or artistic eleme history of architecture are the Egyptian, As-
stylian, Ifellenic, Ronian, lyzantine, II Ilieval (including lwomnesque and Pointed), Renaissance, and Arabic. (See
these and other adjectives characterizing architectural these and other adjectives characterizing architectnral
styles.) The various later medieval styles are commonly (which see).

Architecture, the art of buitciing, incindes two elements, theory nud practice. The fnrmer cumprehends the fineart side proper, the body of general rules inspireet by
taste gand baset on tradition, and the science, which admits of demonstration by means of invariable and abso
lite formutuas. Practice is the application of theory to lite formulas. Practice is the application of theory to
particular ueedis; it is practice which causes the art and particular lleedis; it is practice which causes the art an

of the occasion.
Viollet-le-Duc, bict, de l'Architecture (trans.), I. 116.

We nust consider Architecture as the great law which has in all time regulated the growth and affected the form of painting and scuipture, tiil they sttain to a certain Nence Architecture and elaquence are mixed arts, whose end

duced by arehitecture as defined above. -3 . The character or style of building: as, the architecture of Paris.-4. Construction and formative design of any kind.

The formation of the first earth being a piece of divine T. Bumet, Theory of the Earth. Civil architecture, the branch of architecture liavin tary architecture, the branch of architecture which h to do with buildings for military purposes : to some exten coextensive with military engincering. - Naval arch architecture (är'ki-tek-tūr $), x, t$. [< architecare, u.] To construct; build. [Rare.]
ture This was architectur'd thus

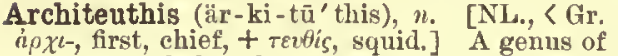
monster cephalopods, or giant squids, of the family ommastrephide, and related to $O m$ mastrephes except in size. Several species are described, as $A$.
princeps, $A$. harveyi, and $A$. megup. tera. Some specimens are sald to attain a total length of upward nt 50
feet. These animas furnish the
basis of fact for the fabulous mon-
sters known as devit-flohes. One of the giant squids, belonging, lita. 'I'he whalers have long hail accounts of the sperm whale eating being vomited by these animals in their reath fiurry, but science has recognized tinc existence of these hug
monsters for ouly a few years.

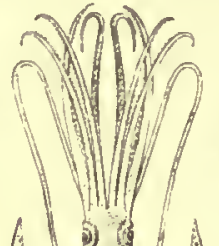
architonnerre (är-shi - to

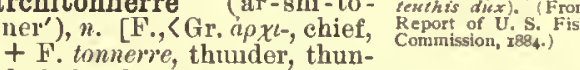
derbolt, cliamber (of a gun, etc.), < L. tonitrus, thunder.] A form of steam-gun described by Leonardo da Vinci, and supposed to liave beei devised by Archimedes, which lischarged iron

architrave (är'ki-trāv), n. [= F.architrace,
lt. architrave, < L. archi- (see archi-), chief, It. architrave, $<\mathrm{L}$. archi- (see archi-), chief, +
It. trave, $\mathrm{L}$. trabem, acc. of trabs, a beam.] 1. In arch.: (a) The lower division of an entablature; that member which rests immediately on the column and supports those portions of under entablature. (b) The oruamental molding running round the extrados of an arch. Also called archirolt. (c) Sometimes, less properly, the molded enrichments on the faces of the jambs and lintel of a door, window, or other opening. Also ealled antepagment. -2 . In fort., the master-beam, or chief supporter, in any part of a subterranean fortification.-Archltrave cornice, an entablature in which the cornice re
directly on the arelitrave, the fricze being omitted. architroch (är'ki-trok), n. [<Gr. a $\rho \chi t$, first t rpoxós, a disk, wheel, hoop: see troche.] In zool., the specialized ciliated girdle or band invertebrate embryos. E. R. Lankester.
298

It (the oral eiliated band] was probably primitively a ar to the circlet of cilin in thic Protozoa cilinta. llyatt, Proc. IBost. Noc. N. 11., 18st, p. 87. architypographer (air"ki-ti-pog " l'n-fèr), [<archi- + typographer.] The chief university printer at Oxford, an office established in 1636. ire is the director of the Oxfori press. By" Land's statutes,
"lle is to be a person well instricted in (Hreek and latin literature, and of great experience in lhilological purions of printing in the university printing office, and to take care that thie printing materials and furniture are all of the choicest in their several kinds. In works issuing rom the public press of the miversity, he is to prescribs the scale of the types, the quality of the paper, and the
size of the rnargins, and to set right the errata of the correctors, and to take diligent care in all other particuwork." If is also the ofnament and perfeetion of the upper bedel in civil law.

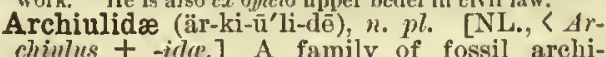
polypodons myriapods. Seudder, 1868

Archiulus (är-ki-ũ'lus), n. [NL., < Gr. á $\rho \chi t$, first, + NL. Iulus, q. v.] The typical genn of the family Archinlide.

archivat (är-ka'vä), $n, p l$.
see archive.] Archives.

[L., pl. of archivum: The Christians were able to make good what they as-
serted by appealing to those records kept in the Roman archival (är-ki'val or är'ki-val), a. [< archivc.]
[ Pertaining to archives or records; contained in records.

archive (är'kīv or -kiv), $n_{0} \quad$ [< F. archives, pl. L. archivum, also archīum (pl. archiva), a place where records are kept, the records themselves, <Gr. áp Xeĩov, a public building, hence pl. Tà ap $\chi \varepsilon \bar{a}$, the public records there kept, prop. neuter of " $\alpha \rho \chi \varepsilon i o s$, adj., pertaining to office, $\dot{a} \rho \chi \hat{\gamma}$, office, government, rule, $<\dot{\alpha} \rho \chi \varepsilon \iota v$, rule, be
first: see arch-.] 1. A place wliere public records or other historical documents are kept: now only in the plural.-2. A record or document pre served in evidence of something; in the plural, documents or records relating to the rights, privileges, claims, treaties, constitutions, etc, f a family, corporation, community, or nation. A most unpleasant archive or register.
Holland, tr. of

God hath now
sponged and made hlank of erimeful record all

Ily mortal archives, Tennyson, St. Simeon Styjites. The social conditions represented in the Homeric poems
cannot be mere figments. By the Greeks they were always regarded as perfectly real, as archives, so to speak, from which very definite claims and prerogatives were derived. =Syn. 1. Record-office, registry.-2. Registers, ehroni archivist (är' $\mathrm{r}^{\prime} \overline{\mathrm{i}}$ - or är'ki-vist), n. [= $\mathrm{F}^{\prime} \cdot \operatorname{arch} i-$ viste $=\mathrm{Sp}$. It. archivista, < ML. archivisto : see ords.

'I'ie learned archirist of the Vatican, whuse researches archivolt (är'ki-volt or -vōlt), n. $[=\mathrm{F}$. archi-

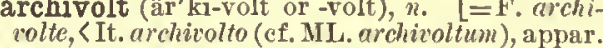
< archi-, chief, + rolto, colta, vault, arch: se archi-and ranlt, and cf, architrace; but It. arcocolto is based on arco, areh, + volto, volta, vault inc.] An or moldof the extrados; an arch-molding. Also called architrave. Archivolt is sometinies incorreetly used for
soffit. The term is applied specifically to the arches of 8offit. The term is applied specifically to the arches of
any arched construction, upon which, as upon the archisuperimposed portion of the edifice. V'rollet-le-Duc. exterior ulper edges of the arch-stones in the face of the archlute (ärch'lūt), n. [< arch- + lutel.] A large bass lute, double-necked like the theorbo and chitarronc, and differing from them in the arrangement of the longer strings. Also writarchly
coyly.

He bow'd, and archly smiled at what he said,
Civil but sly.
And the glances of the Creole And the glances of the Creole
Were still ns archly deep. Hhittier, The Slave Ships.

archmagician (ärch-ma-jish'an), n. [<arch+ magician. Cf, archimage.] A clilef magician; a great wizard.

marchmarshal (ärch-mär'shal), ". [< arch- + shal of the old German empire, a dignity which belonged to the Elector' of Saxony.

arch-mock $\nmid$ (ärch-mok'), n. [< arch- + mock.] Extrem
scorn.

\section{Archoplites}

O, 'tis the spite of lueli, the flendis arch-mock! arch-molding (ärch'mōl"diug), n. [< arch $]^{+}+$ ling.] Same as archico

archness (ärch'nes), $n . \quad\left[<a r c h \iota^{3}+-\mu\right.$ css. $]$ The quality of being areh; slyness without malice; cumning; waggishness ; roguishness ; pleasing coyness: as "dryness and rirchness of humour," J. Warton, Pope, p. 68

There was $\mathrm{n}$ mixture of sweetness and archneas in lier

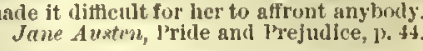

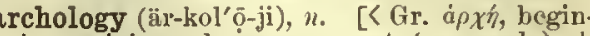

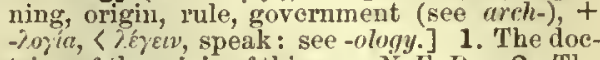
trine of the origin of things. N.E. D. - 2. The sciellco of government. N. E. D.-3. The the ory of first principles of knowledge.

archon (ïr' kon), $n$. [L., < Gr. a $\rho \chi \leftrightarrow \nu$, a rulex orig. 1 pr. of á $\rho \chi \varepsilon t \nu$, rule, be first: see $\operatorname{arch}-$. 1. A chicf magistrate of some states in ancient Greece, and particularly Athens. Aiter the aboll.
tion of the title of king in Attica there was chosen a single archon, who exercised for life essentially royal preroga-
tives. The term of ofice was atterward reduced to ten years, and in $683 \mathrm{~B}$. c. it wns made anuual, snd the dutie of the archonship were distributed among nine persons. The tirst was the archon eponymos (nane-giving archon),
whose functions were executive and judicial, snd whose name was given in official acts, ete., to the year of his service; the second was the archon basileus (nrchon king) whase duties were chiefly religious snd ceremonial; the who was, frst in fact and then nominally, cosmmsnder o the millitary power; and the remaining six were the thes-
mothete, or ndmintstrators of justice, whose most impormothetee, or ndinintstrators of justice, whose most impor-
tant duty it was to pass carefully in review, each year, the Whole body of laws of the state, in orler to make sure that had been duly canceled, and that repetition was avoided. It rested with the thesmothetie, also, to see that anl the laws of the repubitic that were in vigor were strictly en. forced, and to bring to trial any pullic official who had
fniled in bis trust. At the end of their year of oflice, all the failed in bis trust. At the end of their year of office, all the
archons, unless they were found guilty of malfeasance, by 2. In the Byzantine empire: (a) One of a number of great court officers. (b) A title as sumed by the Frankish barons who established themselves in Greece after the fourth crusade, in the thirteenth century.-3. In moder Greece, a person in authority, as a magistrate, a presiding officer of some societies, ete. -4 . Any ruler or governor,-5. In various Gnostic perior to angels, believed to be the rulers of the several heavens. According to Basilides, the great nrchon is the highest cosmikal power and the creator
of the ogdoad or ethereal world, having below him the archon who created and riles the hebiomad or lower 6. [NL.] In soöl., the human animal; man, as a momber of the group Archontia. -7. [cap.] [NI.] In entom.: (a) A genus of lepidopterons [NL.] In entom.: $(a)$ A genus of lepidopterons
insects. Hübner, 1822. (b) A genus of coleopterous insects. Kirby, 1826.

archonship (är'kon-ship), n. [<arcleon + -ship. $]$

On the expiration of the archonship of Eryxias, it was
resolved that the offee shoujd be annual, and that there resolved that the offee should be annual, and that there
should be nine persons to execute it.
$J$. Adems, Works, IV.

archont (är'kont), $n_{0} \quad[<\mathrm{NL} \cdot \operatorname{archon}(t-)$, sing of Archontic $\mathrm{q}$. v.] A member of the zoölogical group Archontia; a inan.

archontate (är'kon-tāt), n. [< archon( $t-)+$ $-a^{3}{ }^{3}$.] The office of an archon, or the term for which an archon was eleeted. N. E. 1 .

Archontia (är-kon'ti-ä), n.pl. [NL., neut. pl. f archon, < Gr. a $\rho \chi \omega \nu$, ruling: see archom.] In ome zoological systems, a prime division of mammals, represented by man alone. It is con. terminouls with the orders Archencephale of Owen, Biand with tlie family llominidae and genus Ilomo.
Archontic (är-kon'tik), n. [<LL. archonticus, <Gr. ápxovтı́́s, pertaining to archons (> LGr. oi A $\rho$ xovтtkoi, Archontics), < a $\rho \chi \omega$, ruler: see archon.] One of a sect of the fourth century, originating in Palestine, apparently an offshoot of the Ophites: so called from their belief, in common with other Gnostic sects, in archons or rulers of the several heavens. They rejected baj. tism and the encharist, identifled the God of the Jews witi the devil, and used to sprinkle their dead witb water and
oil to make them invisible and put them beyond the reach of the heavenly power

Archoplites (är-kop-lī'têzz), n. [NL., < Gr. áp xós, a leader, + ónhirns, heavy-armed: see hoplite.] A genus of pereoid fishes. A single species, A. interruytus, occurs on the Pacifie slope of Nortl
America. It resembles the rock-bass, has 7 branchiostegal rays, and attains in length of a toot or wore. Gill, 
archpillar

archpillar (ärch'pil'ạr), ". [< arch- + pillur. ] A main or prineipal pillur ; a chief supjort. Archpillar and foundatlon of humıan aociety. Ilarmar, tr. of beza's Sernous, p. 204 . archpoet (äreh'pō'et), n. [< rerch + poet; tr. of NL. archipoctr.] 1. A chief or preémine The title of archipoctin ur arrh-pwet.

Fope, The l'uet Ioaureate.

archpolitician (üreh'pol-i-tish'an), n. [ [ arrh+ politician.] A chief or leading politician u greut political leader. Bricon.

archprelate (üreh'prel'ät), $n_{0}[\langle\operatorname{arch}-+$ prelute.J A chief prelate. Hoolier.

archpresbyter (irch'pres'bi-tér), n. [< arch+ presbyter. Cf. arclipriest and Ll. archipresbyfer.] A chief presbyter. Ayliff, Parergon. + presbytery.] The absolnte dominion of pres bytery; presbytery us exercising supreme or sovereign antliority. [Rare.]

Areh-prpsbytery. . . elahning to itself a lordly power unl superintentlency, lroth over fiocks nind

willon, Eikonoklastea, 13 .

archpriest (iirch'prēst'), n. $\quad[<$ late ME. archeprest, < OF. urcheprestre, mod. F. archipretre

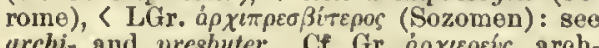
"rchi- and presbyter. Cf. Gr. á $\rho x \in \rho c k$, archpriest, chief pliest, in N. 'T. high priest: see ealled by tho Greeks prolopresbyter, and later protopope. As a title it elates from the fourth century, anl was orlginally given to the senior by ording West. The arclinifest or desu of the cathedral asslated the bislop ln solemn functions gut in his spiritual ail. ministrntion, thongh without ordingry jurlsdietton; the rural arehpriest or dem liad a lluited superintendence
over the parish prlests of lia desuery or distrlct of the dioover the parish priests of lis demery or distrlct of the dio-
cese, snd formed with them the rural chapter, as the bishop cese, and formed with them the rural chapter, as the bishop thond with other officlals, see archideacon. At present, In part, a title of honor onls, the former inties of the offle being performel by the anxlllary lishop or the dean the eathedral clapter. The dutles of the rural archpriests, since the Council of Trent, have commonly devolved on the vlcars forane, still aometimes called rural deans, or
directly on the bishop's vicar-general. In the rare case directly on the bishop's vicar-general. In the rare case
when rural arehpriests and vicars forane are found li the

archprimate (äroh'pri'māt), n. [< arch- + primate.] A ehief primate.

Milton, Chureh Gov., 1. 6.

archprophet (ärch'prof'et), $n$. [< arch- +

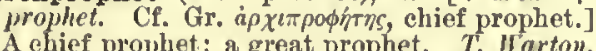
archprotestant (äreh'prot'es-tant), n. [<arch$+J^{\prime}$ rotestant.] A leading or eininent Protes-
. tant.

These archprolestants and waster minlsters of Gemnany.
Stapleton, Fortress of Faith, p. $y$.

archprotopope (ä!elı"prō'tö-pōp), n. $[<a r c h-$ + protopope.] Tho chief of the arehpriests or protopopes.

The arch protopope of Susa, where the royal restdence was.

arch-see (äreh's $\left.\bar{e}^{\prime}\right), n$. [< arch- $+8 e e^{2}$.] The see of an archbishop. Drayton.

arch-sodality (ärch'sō-dal'i-ti), $\mu .\left[<\| l^{\prime} c h-+\right.$ sodality.] An areh-eonfraternity (which see). arch-stone (äreh'stön), n. [< archl + stone. $]$ I. A wedge-shaped stone nsed in the constrnetion of an arch; a voussoir. See eut under arch.-2. A flat stone by which the opening into the chamber of some furnaces is covered. archtraitor (äreh'trā'tor), n. $\quad[<$ arch- + traitor.] A chiof traitor: sometimes applied speeifieally to the devil. Hakerill.

archtreasurer (ïreh'trez' ụr-ér), $n_{0} \quad[<$ arch- + treasurer. The G. word is erzschatzmeister.] The great treasurer of the German empire, a dignity held by the restored electorate of the Rhine Palatinate from 1648 to 1777 , and later by the Eleetor of Hanover.

archtype (ärch'tīp), $u_{0}\left[<\right.$ urch $_{-}+$type ; suggested by archetype, q. v.] An archetype. Carticright.

archvillain (ärch'vil'ân), n. [<arch- + rillain.] A desperate, confirmed villain.

$$
\text { As arch-villain keeps hlm company. }
$$

Shak, T. of $A_{*}$, v. t.

archvillaing (äreh'vil'ā-ni), " ${ }_{\dot{B}}[$ < arch- + t

archway (ärch'wã), n. [< arch1 + $w a y$.$] An$ archway (ärch'wâ), n. [< arch $1+w a y$.$] An$
entrance or a passage under an arch or vault; an opening that is closed in or covered by an
299

Arctiidæ

Through the piers ran archowy: in botls directions, so transeyt. C. E. Dorton, Cl

archwife $\nmid$ (irch'wif), $n$. [< arch- + rife.] woman of strong, masenliue physique; a hardy, woman of strong, masculino physique; a hardy, Ye archercyres, stundeth at elefence Sin ye be strong as ls a greet cumalle [cnuncl]:

Yo suffereth uat the oll yow tou offerine

Chaucer, ('lerk's T'ale, 1. 11쓰,

archwise (äreh'wiz), arlv. [<ureh] + rise?2] In the form or manner of an arels.

In the fashion of a low bent archuive. Anlife, larernous.

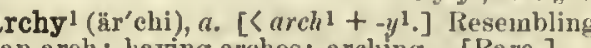
an areh; having arehes; arching. [Rare.]

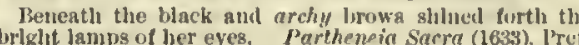
archy (air'ehi), $a . \quad[<\mathrm{F}$. as if "arclie, arehed, 10p. of "archer, v.: see archl, r.] In her., same as arched, 2

archy-flected (ïr'chi-tlek-ted), a. In her., same as archerl, 2

arcid (är'sid), n. A bivalve mollusk of the family Arcielce.

Arcidæ (air'si-dēe), $n_{0}, l_{0} \quad$ [NL., < Arca + -irl $\left.x_{0}\right]$

$A$ family of asiphonate acephalous bivalves, or lamellibranch mollusks, having equivalve shells with a long row of transverse teeth. The ismily is a large one if world.wlde distribution at the present day, and dstes back in geologic tlme to the Lower silurian. It leading genera are Arca, Aximea (or Pectunthe fanilly vary. The specles are very mumeroua. See cut under Arca. Sometimes wrongly spelled Arcala.
arcifer (är'si-fér), $n$. [< NL. areifer: see Arcifera.] An amphibian of the group Arcifert. Arcifera (är-sif' e-rä), n. $p l$. [NL., nent. pl. of arcifer (ef. ML. arcifcr, an archer), < L. arcus.
a bow (see arc $^{1}$ ) + ferre $=\mathrm{E}$. besirl.] A seetion of phaneroglossate salient amphibians, with coracoids and precoracoids connected by an arched eartilage (the epicoracoid), that of the one side overlapping that of the other. It ineludes the true toads (Bufionidce), the treetords (IIylider), and others.

arciferous (är-sif'e-rus), ". [As Arcifera + ous.] In zoöl., pertaining to or

arcifinious (är-si-fin'i-11s), $a$. [<LL arcifinins (also arcifinalis), < L. arx (arci-), a eitadel, defense, + finis, pl. fines, boundary.] 1. Serving both as a boundary and a defense: applied to rivers, monntains, the sea, ete. For. Dict.2. Having a frontier which forms a natural Nations, II. 215. N. $E . D$.

arciform (är'si-fôrm), $a$. [< L. arcus, a bow, + forma, form.] Bow-shaped; eurved; arched. -Arciform fibers, In anat, the areuate nerve-fibers, upper part of the medilla oblongata. + gerere, carry.] "Same as arefferous.

arcitenent (är-sit' $\theta-n e n t), a$. [ L L arcite$n e n(t) s$, holding a bow, $<$ areus, a bow, + tenen ( $t$ - s, ppr. of tenêre, hold: see are and tenant.] Holding or carrying a bow. Blount.
arc-light (ärklit), $n$. An electric light dnced by the voltaic are; the eleetric eurre passing between a pair of visible earbon-points slightly separated. See lectric.

arcograph (är'kō-grảf), ". [< L. areus, are, + Gr. $\gamma \rho a ́ \varepsilon \varepsilon \nu$, deseribe.] An instrument for
drawing an arc without the use of a central point. It eonsists of a thin and pliable strip of wool or
nietal, the ends of whlch are sttached to $\mathrm{n}$ straight bar, nietal, the ends of whlch are sttached to n straight lar
whlch esn he shortened or lengthened to form a ehord of whleh esn he shortened or lengthened to
the required arc. It is used as a templet.

arcosolium (är-kō-so'li-um), n.; 11. arcosoli (-ii). [ML., <L. arcus, an arch, + solium, a seat, throne.] A name given to certain recesses for of a deep niche cut in the rocky wall and arched above, a sareophagus being hown from tho roek under the areh. The flat cover of the sarcophagus may often riclily ornamented.

arc-piece (ärk'pēs), n. In mech., a piece serving to adjust the angle of elevation of a cutting-tool. arc-secant (ärk'sē'kant), $\mu$. In math., an angl regarded as a funetion of its seeant.

arc-sine (ärk'sin), $n$. In math., an angle regarded as a function of its sine.

rctt (ärkt), $v t_{0}$, See $\operatorname{art} 3$

rctalia (ärk-tā'li-ę), n. [NL., < arctic + Gr. a hia, assemblage (with an intended allusion to or zoölogical division of the waters of the globe, embracing the seas of the northerw hemispliere as far to the soutl as flonting ice descenils. Gill.

Arctalian (ärk-tä'li-anu), n. [<Aretulia.] Of or pertuiniug to Aretulin.

Arctamerican ("irk-ta-mer'i-kan), n. [<Arctic + Ameriean.] In zongeog., samo as Anglengran. as, "Anglogwan or Aretammicun realm," lill. arc-tangent (airk'tan"jent), n. In math., ai ungle regarded as a function of its tangent.

arctation (ark-tā'shon), n. [< k, aretution, L. as if "arctatio( $(n-)$, , s areture, prop. arture, lop. urctutus, artutus, driw elose, tighteu, < aretus, prop, artus, close, tight: see art: article, arm I' prop. "Nor, close, tight: see arts, article, arm in puthol., unnatural contraction of any natura opening, as of tho anus; constipation from inflammation. Also ealled arctitule.

Arctia (ärk'ti-ji), n. [NL., < Gr. גркто, a bear (in ref. to the furriness of the eaterpillars: sec

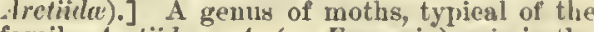
family Arctiols. A. (or Euprepia) crija is the common tiger-motl. See cut under Iuprepir. arctian (ärk'ti-an), $u$. [<Arctiat -nn.] A motl of the family irctiide.

arctic (iirk'tik), a. [Warly mod. F. also urtic. artick, ete., SMIF. artik, $<$ OF. artigue, mod. F. arctique $=\mathrm{Pr}$. artic $=\mathrm{Sp} . \mathrm{Pg}$. arctico = It. artico, < LL. arcticus, northern, < Gr. ápktek's, northerm, lit. pertaining to the Benr, < d pктоs, a bear, specifieally the constellation Ursa Major sometimes spelled a pkos, = Skt. rikshus (for "arkhas $)=\mathrm{L}$. ursus (for * wesus) $=\mathrm{Ir}$, ort a bear see vrsus.] 1. Pertaining or related to th" see vrsus.] 1. Pertaining or related to th" Little Bears; hence, pertuining or relating to the north pole or the northern polar regions northern: as, the arctic eircle, region, or sea. Ilenee-2. Cold; frigid.

I warm the traveller who goes to see the lovely Msdon. to the gusty, aretic magnificenee of the Clinrch of the
Redentore.
Jorrells, Venetlan life, lii.

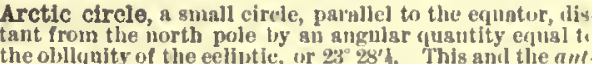
arctic clrcle are colled the polar cirrles, and witllin these
lie the trighd zones, at cvery point within whllel the

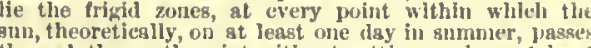
throngh the north point withont setting, and on at lenst one day in winter does not rlse; proctically, allowance mustion made for the semidimmeter sind horizontal re-
fraction of the sun. Arctic fox, a small species of fox,

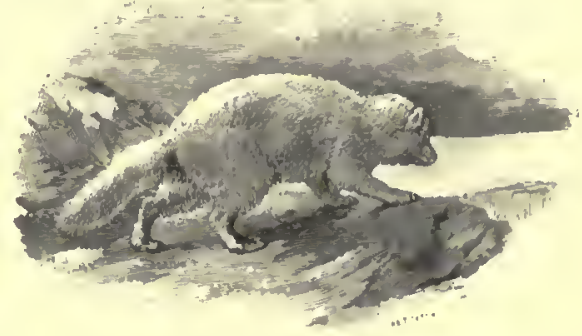

of eommerce. It is 2 feet in whentl, am its tail ia 1 foot in winter. = Syn. Hee polar.
arctic-bird (ärk'tik-bérd), $\|$. A name origi nally given by Edwards to a species of jaeger figured and deseribed by him. It has heen applitel to two speeies of Lestris or stercorarius, but is lisentifled

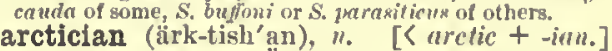
One who has investigated matters relating to the aretic regions; an aretic explorer. N. E. D. Arctictidinæ (ärk-tik-ti-dī'nē), n. $n$. [NI., rous quadrupeds, of the fanily liverrida, containing the binturongs, characterized by the prehensile tail.

Arctictis (ärk-tik'tis), n. [NL., < Gr. äpkros, bear, + iks/s, the yellow-breasted marten.] The typieal and only genus of the subfamily Aretictiarctiid (ärk'ti-id), $a$. and $n$. I. $a$. Pertaining to Arctiila : as, an arctiid moth.

II. n. One of the Arctidice; an aretian.

Arctijdæ (ärk-tī'i-dē), $n: p l$. [NL., < Arctia + -ida.] A family of lepidopterous inseets, bemoths. The types of the fanily are distingulabed in the fact that their larve are very thlckly clothed with long hairs, whence they have obtained the name of woolly bear. They feed lpon the externsl parts of plants, and linclose formationa. Sec ent under Euprejia. 


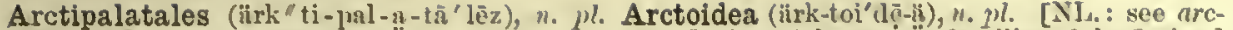
[NL.] Same as Arctipalates.

Arctipalates (ärk"ti-pan-lă'tềz), n. $m$. [NLL., <L. arctus, prop. artus, comluressed (see art ${ }^{3}$ ), + pulutum, palate.] In Sunclevall's system of elassification. a group of fringilline and tanagrine oscine passering crossbills, rice-birds, and varions other eonirostral l'asseres.

Arctisca (ark-tis'kii ) Arctisca (ark-tis kii) n. pl. [NL., dim. of Tir. apstos, a bear.] or bear-animaleules, otherwise knowu as the Tardigrada, Macrebiotida, er Colpoda, a group of mneertain value and position, formerly assoeiated with the rotifers, ated with the rotifers, but now usually con-
sidered an order of Arachnida, and loeated in the rieinity of the Acarida. They are microscopic aquntic creatures, living in moss company with rotiters. lody, witli four pairs of ed hy hooked claws, no distinction of cephalothorax and abdomen, and a suc-
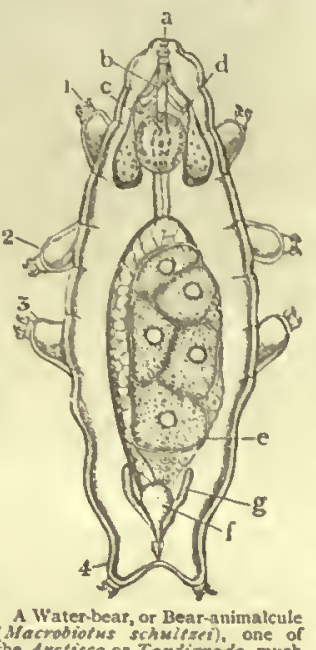

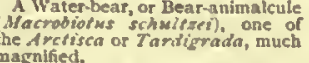

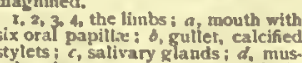

torial mouth with two
stylets, resembling that of a tick or mite. The young usin
silly hnve the same number of legs as the nidult. The

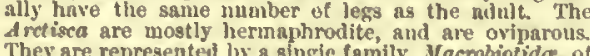
whith Macrobiotus is the lentling genus.

Arctiscon (ärk-tis'kon), $n_{0}$ [NL.: see dretisca.] The typical genus of Aretisconide

arctisconid (ärk-tis-kon'id), n. An aearid of the family Aretiscomide.

Arctisconidæ (ärk-tis-kon'i-dē), n. pl. [NL., rids with all 8 legs developed, legs of 3 joints, and without eaudal prolongations.

arctitude ("̈rk'ti-tūd), $n$. [( F. arctitude,

to arctation, q. v.] Same as arctation.

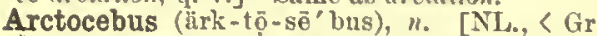
dokfos, a bear, $+\kappa^{j}, 3$ Sos, an ape: see ape and $C^{\prime} \mathrm{c}$
bus.] A remarkable genus of lemurs, having a bus.] A remarkable genus of lemurs, having a
very shert tail, small fore and hind feet, the digits partly webbed, and the index finger rudimentary. A. calabarensis, the typieal species. inlabits Old Calabar in Africa.

Arctocephalus (ärk-tọ-sef' a-lus), \#. [ŇL., Gr. ápros, a bear, + kipain, head.] A geuus Pinnipedia. The name is used in varions senses by ditferent autions: it formerly included the northern as wel as the soutthern fint-seals, but is now properly restricted
to the latter. The speciea nto communly known as sea-

Arctocyon (ärk-tos'j-on), n. [NL., 〈Gr. àpктos a bear, $+\kappa i w v$, a deg, $=$ E. lowmd.] The typica gents of the family Arctocyonida of Cenezoie
time, haviug all tho inolars tuberculate. $A$. pritime, having all tho inolars tubereulate. $A$. priknown Tertiary manınal.

arctocyonid (ärk-tọ-sī'o-nid), n. A earnivorous manmal of the family Arctocyonide.

Arctocyonidæ (ärk"tōo-si-on'i-dē), n. pl. [NL. orous quadrupeds, laving 44 teeth, the last upper premelar trituberenlate, and all the molars tuberenlate, eontaining the geuns dictocyon and its allies, plaeed by Cope in a snborder Cro odonta (whieh see).

Arctogæa (ärk-tō-jé'ij), n. [NL., < Gr. ả $\rho$ ros, a great zoölogical division of the In zoogreog. surface, comprising the Eurasian, Indian, and Ethiopiau regions: opposed to Notorger.

Arctogæal (ark-tō-jō'al), a. of or pertaining to the zoögeographiealarea known as Arclogera. In Furape, Yorth America, and Asia, the Aretogeceal
province was as distinctly characterized in the Miocene, and probably in the Eocene epoch, as it is at present

Arctogæan (ärk-tọ-jā'an), a. Same as Arctogreal.

arctoid (arrk’toid), a. [< Gr. àpкrozud̆́s, bearlike, [ápkros, a bear, + eidos, form.] Bear-like characters of the Arctoidea.

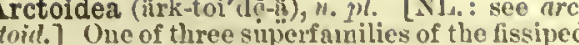
or terrestrial earuirerous manmals (the other heing Alluroiden and Cynoidea), including the bears und their relatives, as distinguisheil from the feliue and eanine members of the Fere fis-

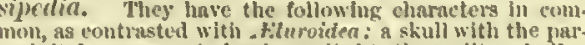
oecel pital process not chosely apprified to the andistory bulla the unastoid process prominent, projecting belind the ex.
ternal nudiltory meatus; the enrotid cannl distinet nuil in

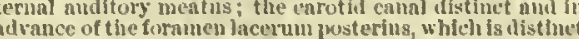
from the condylofid formuen; the glenold foramen gen. rally well defined : a large os penis; (Cowjer's glands no developed ; prostate gland not salient; nnd no intestima telidde nlone.-Arctoldea typlea, the family Urrithe

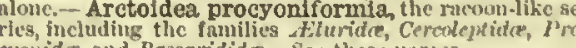

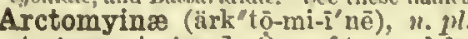

Ont whieb the squirrel family, Sciuriduc, is divisible, containing the terrestrial as distinguisleed from the arboreal members of the family, as the marmots or woodehucks, the pranie-dogs, the susliks, the ground-squirrels or spermophiles, ete. They sre generally distingulshed by larger size stonter form, shorter and less bushy tall, and terrestrin and lossorial lishits, but offer a very' easy transition

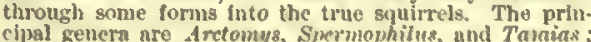

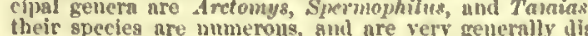
their speciea are numerous, smi are very generally dis-
trivuteil over the northern hemisphere. Also called $A$ rcto

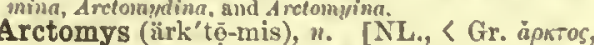

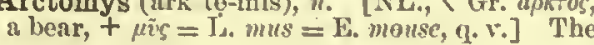

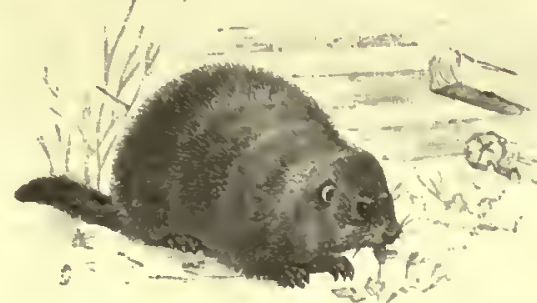$$
\text { Woodchuck (Arcromys monax) }
$$

typical genus of the subfamily Arefomyince, containing the marmots proper or woodelneks. They have the largest size, stontest form, shortest tail, and
minost completely terrestrial ant fossorinl hallits of any o

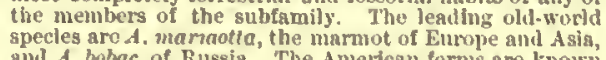
and $A$. bobac, of Russia. The American forms are know
as woodchncks, nnd are $A$. monax of the Eastern States

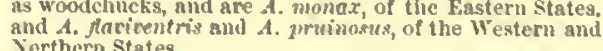
Arctopithecini (ärk "tō-pith-ē-sī' uì), n. pl. [NL., < Arctopitheces + -ini.] A synonym of insed by some as a fam

The Arelopitherini ... are small, thickly turred, long.

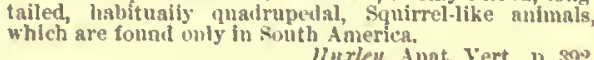
Arctopithecus ("irk" tọ-pi-thë'kus), n. [NL.

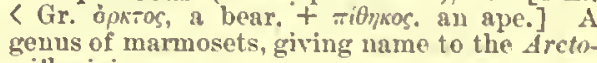
pillecini.

Arctostaphylos (ärk-tō-staf'i-les), \#. [NL., Gr. ápiros, a bear, + orapilij, a buneh of shrubs, nearly related to Arbutus, and mostly natives of California and IIexico, where the larger speeies are known as manzanita, and are sometimes from 10 to 20 feet high. The thar:berry, A. Utra-ursi, is a trailing plant, founci in the arctic valuable as furrishining an astringent tonic used chiefly in

Arctotherium (arrk-tō-thē'ri-um), n. [NL., geuns of fossil bear-like quadrupeds from the gonns of fossil bear-like quadrupeds from the generalized ursine type.

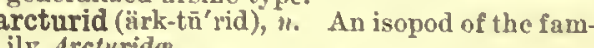
ily Areturide.

Arcturidæ (ärk-t $\overline{1}^{\prime}$ ri-dē), $n_{0}$ pl. [NL., ( Areturepresented by the genera Arcturns, Idotea, and other's: synonymons with Idoteide (which see) In Arclurider they [the youmgl are carried for some time clinging on to the sntemure of the mother.

Arcturus (ärk-tū'rus), n. [L. (> ME. Arctour, Arture, Arthurus), ( Gr. 'A рктоірое, Areturus, lit. bear-ward, < a pkтos, a bear, the Great Bear, + oủpos, ward, guard, keeper, akin to E. tearel, northern lemisphere, the fourth in orler of brightness in the enlire liensens. It is sltuntel lret ween the thighs of boottes, bethind the firent lisent, ant

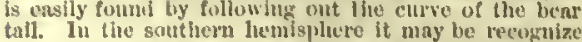

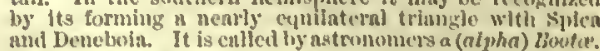
see ent muder boütes

2. [NL.] A genus of isopod erustaceans, of the fanily Itluteida or Areturilte. La trcille, 1829. arcual (irpkij-gl), "10. [<Lo arews (seo arel) + Arcuata (ür-kin-ñ'tii), n. pl. [NL., neut. pl. of 1. uremelus : sec archate.] A gromp of erabs, ineludiug those of the typieal genus Canecr. arcuate (ïr'kin-ät), a. [<L. arenatus, pp. of areuare, bencl like a bow, < arens, bow: seo $\operatorname{arc}^{1}$, $\| r_{c h}^{1}$.] Bent or curvel in the form of a bow; arehed: as, "obliquo and areuate lines," Bacen, Nut. Hist., of 1 - - Areuata fasciculus, hu

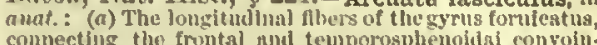
connecting the frontal und temporosphenoidai convoin-
tions of the brain as welt a interinneciate polluts. Meynert.

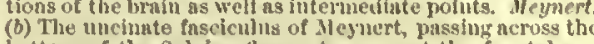

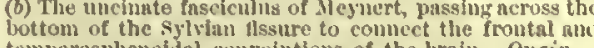
Arcuate Abers, in antot, tho horizontal nrehing filers of

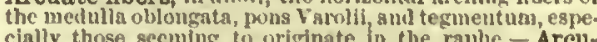
cially those secuning to originate lin the raplle.- - Areuate ligament, in anat. the tendinons nech which passes

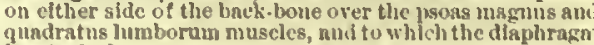
?inandratns].

arcuated (är'kū-ā-ted), n. Same as arcunte.

The Inferior edges of the mesenterics are free, and arer. ated in such a manner as to lenve a central coumnoun cham.
ber. arcuately (är'kṇ-ạt-li), adr. In an areuate manner.

arcuatilet (ür'kñ-â-til), a. [< LL. arcuatilis, bow-shaped, < arcuarc, bend like a bow: see arcuate. 5 Bent or eurved.

arcuation (är-kin-s'shon), $n$. $\quad<$ LL. arcuatio $(n-)$, an arch, lit. aeti of bending like a bow, aremarc: see arcunte.] 1 . The aet of bending, ineurvation; the state of being bent; curvedness; erookedness. - 2. A method of propagating plants by bending braneles to the ground and covering portions of them with earth; laycring (whieh see).-3. The employment of Eplstylar arcuation. See epixtylar. arcuaturet (är'kñ-ā-tür), n. [< L. as if "areuatura, < arcuere: see arewate.] The curvature of an areh. Bailey.

arcubalist (iir' kū-ba-list), n. [<ILL. arcubalista nore correetly arcuiballista, a ballista furnished with a bow, $<$ L. arens, bow, + ballista, a military engine for hurling projectiles: see ballista. balist.] Same as urbulist.

Richurd was killed lyy the French from the shot of an arcubalister ( + -erl: suggested by LI. arcuballistarius, one who used an arenbalist, < arcuballista : see ar-
cubalist, and ef, arbalist, arblaster.] Same as arbalister.

King John was espiet by a very good arenbalister, who
said that he would soon despatch the cruel tymals cubust, n. One of the numerous variants arcula, $n$. Plural of arenlum.

Arcula < L. "arculus, dim. of arcus, a bow (ef., arculum) + rostrum, a beak.] In Blyth's systein of elassification (1849), a group of birds, the hoopoes, Cpupidr, as distinguished from the Appendiarculum (ar' $\left.\mathbf{r}^{\prime} \mathrm{n}-\mathrm{ln} \mathrm{nm}\right)$, the horubills. nent. dim. of areus, a bow.] A small eireular cushion used in antiquity by persons bearing weights on their heads, to interpose between the head and the burden. Similar eushiens are still in use.

arcus ("ir'kus), ${ }^{2}$; pl. arcens. [L., a bow, an senilis. Arcus bicipita. Arcus adiposus, the arcus dinous arch thronglh which the long head of the biceps inuscle passes.- Arcus neuralis, the neural arch. See neurat,-Arcus occipitalts, a cerebral gyrus bounded above by the oceipltal portion of the interparietal fissure,

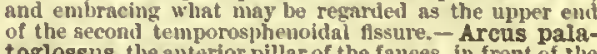
toglossus, the anterior pillar of the fauees, in front of the cous membrame covering it. Also called areus palatinus anterior.- Arcus palatopharyngeus, the pasterior plllar of the tauces, bellind the tonsil, formed by the pala

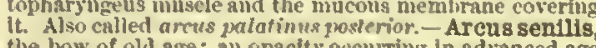
around the margin of the cornes. - Arcus superctliseris 


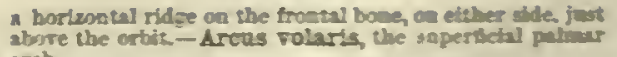

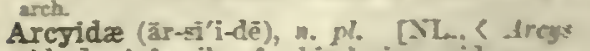
-ivhe.] A family of orbitclsrian spiders.

Arcss (är'sis), *. [NTo. \& Fr. ¿prr, a net, hunter's net, a hair-net: see arain, framea.] The typical geans of spiders of the family 1 r cyide. Also spelled drlys.

ard. [KF. ard, < OHG. (MHG. G.) hart (fre quentir as a suftix in proper names (later also in common nouns), as in Reginhart, $>O F$. $r e$ hand.] A suffix in pouns of French origin or of a French trpe. In persunal souns is esmally has sinister implication, as in lastard, comers, mally iateasive, is now scarcely felt, as in balliond, bo wand placant, standard, fantard, ete. la braggend (also the

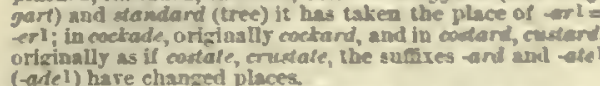
ardash (är'dash), n. [Formerle also arias, ar dass, $<F$. ardasse = Sp. arddsas, andascs, < Pers. ardan, raw silk.] The European or Levantine
name for Persian raw silk of inferior quality. It is called shiran in Persia. Benjowin, Persin and the Persians.

ardassine (är-da-sên'), n. [F., pl. ardasivines (=Sp. ardasinas, ardasimas, pl.), the finer sort of Persian silk, prop. adj.. [ardasse: see ardash.] The name under which the finest Persian silk
for weaving is imported into France. It is popularly called ablaque. Larousse.

Ardea (ä́r'dē-å̃) n. [I., a beron; of. Gr. i dios, a heron.] The typieal genus of the family

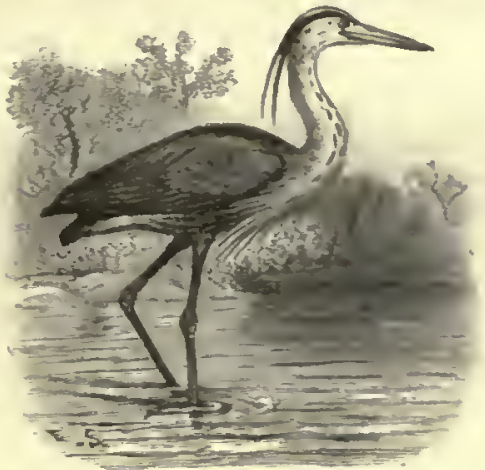

Ardeide, and formerly eoextensive with it. and night-herons ( $N$ yctiandea), or to inclute only the lar species int imately related to the common heron of kiurope
A. cinerea, such as A. goliath of Africa: $A$. herodins, the $A$. cinerea, such as $A$. goliath of Africa: $A$. herodiax, the
great blue heron of Xorlh Amerlca; $A$. occidenfafis, the great blue heron of North Amerlca; A, occiventafis, the Couth America, etc. The egrets are somet imes relerre ardeb (är'deb), $n, \quad$ [Ar. irdab, urdab (Mahn).] The prineipal Egyptian measure of capncit (not used for liquids), legally containing 40 imperial gallons, or 5.2 United States (Win-
chester) bushels, or 183.2 liters. l'mt other ariebs are in use, ranging from little more than halt the nlove time the commonest. See artabo.

Ardeidæ (är-dē'j-dē), n. pl. [NL., < Ariea + -ide.] A family of grallatorial altrieial birds, of herons. They have a comparatlvely small thin body very long legs and neck, long straight acute bill, amplo wings, short broad tail, nuked lores, pectinate molditi claws, the hlod toe not elevated, linear pervious nostrils,
and 2, 3, or 4 pairs of powder-lown tracts or pulviplumes
The family includes several genera and about 75 species, or most parts of the world, inlinbitlug sens, lakes, marshe and rivers, nesting usually In communitics In trees an bushes, where they perch with ense by means of their in-
gessorial feet, laying greenlsh whole-colored eggs, ani rearing their young in the ncst. The species prescnt in wide range of ditference in stature and colorntion, but comparatively little In form or structure, the famliy being storks, ibises, and other altriclal grallatorcs, hut only difs
tantly to the crnnes. They are divisible linto three sulb tantly to the cranes. They nre divisible into three mith cris; and Cancromina, the boatbills. The last-mamcd, der. Ardea, bittern, and bontbill.

Ardeinæ (är-dệ-1'në), $u_{0}, p l . \quad[N L .,<A r d c a+$ -ince.] The typical subfamily of Arreide, continguished from tho bitterns and boatbills. They have 12 tall-feathers, 3 pairs of powler-down feathers outer toe pot sherter than the inner, and moderately curved claws. The species are numerous, Inhabiting nearly all
parts of the world, but especially warn countries. Leal.

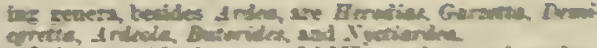

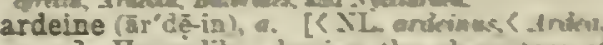
.. .] Heron-like: havin

ardeliot, ardeliont, $m$. [C L. endilia a bustardeliot, ardeliont, w. [s L ondtia a busy

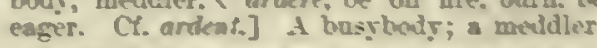
Striving lo gel thut which we had betier the withene an

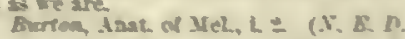
ardency (ar den-si). m. [C anicwl: see -ry.] 1. Intense heat: as, "the ervicwey of the sur," $r$. Herberl. Trarels p. Hence-2. Warmit of passion or fecling; andor: engrerness: as the andemey of lore or zeal. - 3. Lomi, a tendener of soune ships to come quickly to the wind. [lise. ardennite (amdentit), .. [R Arromes, a his wooded region of France and Belgium, $+-i c^{2}$. A silicate of manganese and aluminimm with per cent. of ranadium penturid, found in of near Ottrez in the Arlennes.

ardent (sr'dent). A. [K ME andewt, andant, ardanot, < OF, andant, burning (ppr. of amier. andoir, andre, burn), < L. arlen( (p-le, pyr, of ar dere, burn, be eager.] 1. Hot; buruing: mi hot; bence, fguratirely, ceusing a sensation of burning: as, an arien' fever, -2 . Inflammable; combustible: only in the phrase ardent spirits (which see, below).-3. Having the appearance or qualit of fire; tashing; fiere.

whth fashing danme his wrdent eres were allew. Dovien theoulone and llomerta

4. Having glowing or fiery passions or affections: as applied to the emotions themselves showing rebemence; passionate; affectionato zeslons: as, arvent lore or roms; amlent zesi Yot ardent lovers robb'd of all their miss, Sot ancient ladles when refuserl a klss, . As thou, sal vinin! for thy ravishid halr. IIs form accorved with a minul soll, In of the In, II, ש.

5t. Naut., having a tendency to gripe or come guickly to the wind: said of certain ships. quickly to tho mind: said of certain sliphswhisky, gin, rum, etc. They are all produew lig the di $=5 y n$. 3 and 4 . Ferg, Interuse, enger, keen, lervla, fervent ardently (ar'dent-li), all. [ME. ardontlicho s ardent $\left.+-1 y^{2}.\right]$ In an ardeut mnnner; with warmth; affectiountely; passionately.

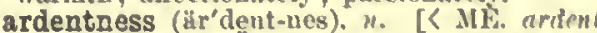
ncsse.] The state or quality of being arlent

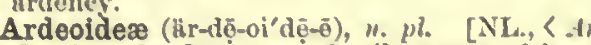
dea $t$-ridea.] A superfamily groul of horo dionino birds.

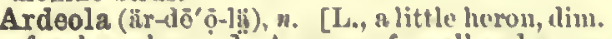
of aricu, $n$ heron.] A geuns of small and somowhat rail-like herons, the squnceo herons, of the subfamily Irdeina. The type is $A$. comata us A. ralloiden, of Europe; lint thero are several uther ajw ardert (ür'dêr), n. [E. dial. (formerly also writen ardor, ardow, ardure, as if of latin origin) prob. ( Icel. ardhr, a plow, Cf. L. uratrum, plow (see aratrum terre); Corn. (dinl.) ardu, ^ plow, ardur, a jlowman, W. ared, a plow, Gael. Ir. arach, a plowshare; all ult. from the anno root. See arnble nud

A reters; Inllowlings or plowings of gromud. Thit is the

Malliwell, Irovi, Dlet. and left fallow.

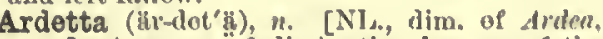
q. v.] A genus of diminutive herous, of the dwarf bittems. variegated plumage disaimllar in tho two sexcs, lninhit recty swamps and marshes, and somowhat resenulite ruil

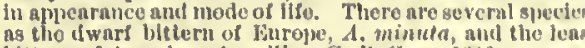
bittern of America, A. exilis. G. M. Gray, 1842.
ardish (kr'dish), $u$. [E. Inl.] A stylo of liast Indian decoration forinterior walls and cellings. it ls made at Jeypore, IBritish ludia, nul elecwhere, li, cmbedding pieces of glass in plaster, and cutting away the plaster over the glass in ornamental patterm. Tho effect
resembics a blendling of white narbio num pol lslicil silver.

rdluke (ïrd'lük), $n$. [Srid to bo Eskimo.] ame of tho grampns, Orcu gludiator.

amaer (ärd-mor'), n. [Gaol. and Ir. ardmhaor, maor, a bailifi, stoward, offleer.] The higl

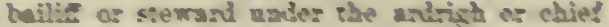
tias of ancient Striant

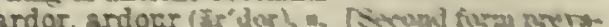

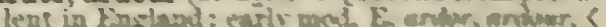

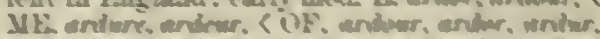

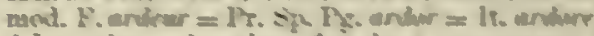

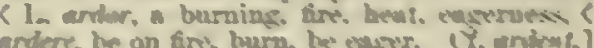

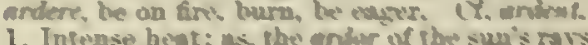
1. In In 3t. A bright or effulgui slirit. [Dietioul.]

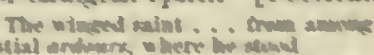

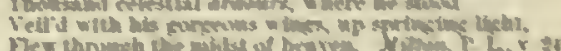

4. Warath or bent, as of the pascious aund af. fections; engurness; intousity.

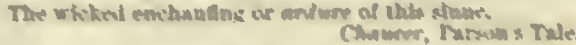

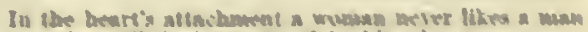

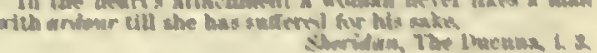

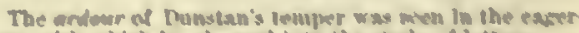

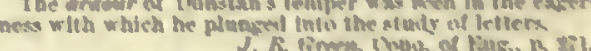

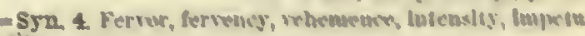
ardrish (aimini'), a. [(tanl. and Ir. andrigh, 6

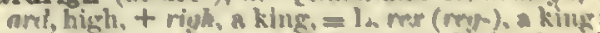
see rex.] In the esurlv history of lindand ami soutland, a chief monnoh or kinge.

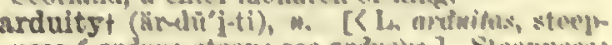
ness, [ardums, stiwll: see a riveluss.] Slewpunes diftenlty; anduonsuess. Cordernm.

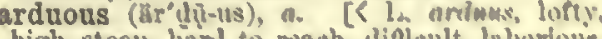
high, steep, hanl to mach, linleult. Inturroms. = Aael, lr. Com. Ilanx trrl, high.] 1, Nteep. and thenvor difleult of ascenl: hanl in alimb.

11 kh ou l'arnassus' ' wh her whas nhe Ahww'd,

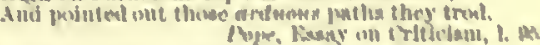

2. Attended with grout lntwr, like the ascont of acelivities; dimeult.

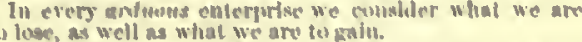

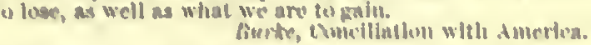
Henco-3. Eucroutlo; laborluus: said of per sons or actions: as, un mrinows stmleut; arin-

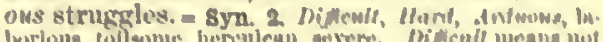

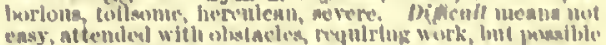

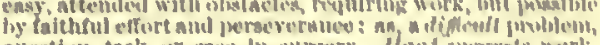

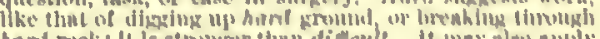

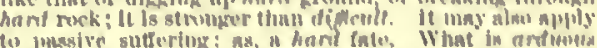

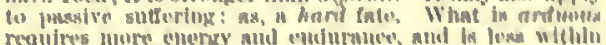

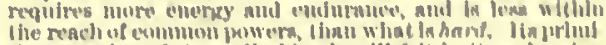

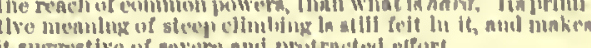

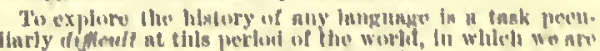

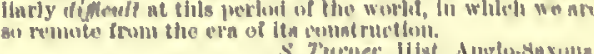

The Aard eauses they brought unto diosen, fint every

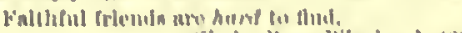

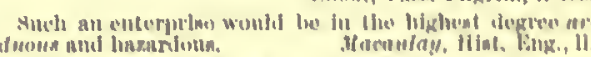

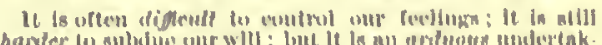

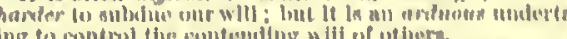

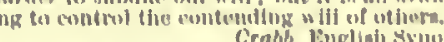

arduously (lir'dŭ-แศ-1i), ails. It แn nmluors

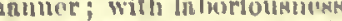

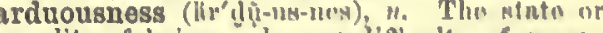
cunlity of lesing ntwhous ; linleulty of nxonarduret, 1 .

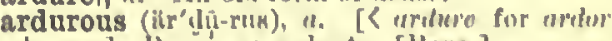
$+=0$ s.] Burning; urlout. [linro.]

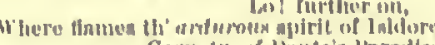
Carnis of arel (iir). Tho prenent hindientivo plurnl of the mubstantivo verb to be. Seo bo

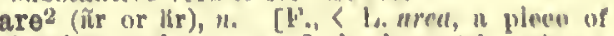
lovel ground: soe armi.] In the metrin system, $n$

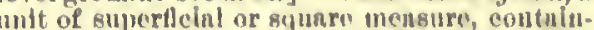
ing 100 squmre moters, or 110.6 squnro yuria. ts ablureviation is a.

a-re (li'ril'). [lt.: weo gamul.] Tho noto binmedintoly abovo the tonlo, Nt, ill llai gravi hexuchord of Cuiblo d'A ruzzo's muslenl nenle.

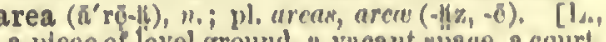
pheco of lovel ground, in viennt spince, n comir. ynrl, fleld, threshing-floor perlangs nithed to arere, bo dry; ce. arld. In Ulnt, auk vilpur

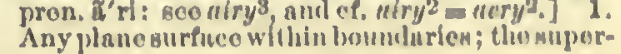


area

302

ficies of an inclosed or defined surface-space; arear' + (an-rêr' $), r . t$. [Early merl. E. also arente, the superficial contents of any figure or surface; and erronoonsly arear, < ME. areren, < AS. superficial extent. Heule-2. Auy partienlar extent of surface; regien; tract: as tho set tled area of the United States. -3 . The space or site en which a building stands; the yard at tached to or surronnding a house; specifically, arear ${ }^{2}$ (a-rêr $\left.\left.r^{\prime}\right), p r e p \cdot p h\right)$ as adr. $\left[\left\langle\alpha^{3}+v e\right.\right.$ a sunken sjace or inclosure between the base- practically equiv. to arrear ${ }^{2}$, adv.] In the ment part of a bilding and the street. - 4. A rear; to the rear. [Rare.]

bald place on the head; a disease of the hair arear't, adv. and $n$. See arrear.2.

whicli canses it to fall off and leave bald patches, area-sneak ( $\left.\overline{\mathrm{a}}{ }^{\prime} \mathrm{r} \overline{\mathrm{e}}-\mathrm{a}-\mathrm{s}-\mathrm{e} e \mathrm{k}\right), u$. A person who lurks N. F. D. - Area Celsi, atopeeis areatr (whieh see, under about the areas of dwelling-houses for the pur(alopecia).,-Area cruralls, in anat., the elural area: a pese of stealing; a sneak-thief.

term applied to that part of the surface of the base of the term applied to that part of the surface of the base of the
brain which is boumded by lines projeeted lateraty from
the pous Varolii mnl optic elinam. It may be reeognized for' convenience, but has no anntomical significsuce.
Area elliptica, in anat., the elliptical srea; the surfsee Area elliptica, in what., the elliptical srea; the surfisee
of the olivary boly of the medulla oblongata. Area emof the olivary body of the medulla oblongata. - Area em-
bryonalis, in enibryol, the entubryonje area; the central
thickened portion of thit part of the llastotermic vesicle of mamuntinn embryos which is lined with hypoblast. From this the main body of the aninat is developed, while the rest of the blastodermic vesicle goes to form the um
bilical vesicle.-Area germ inativa in embryol the gerbilical vesicle. - Area germ inativa, in embryol, the ger
minsl srea; the spot where the first rudiments of an en minsl srea; the spot where the first rudiments of an em-
bryo sppear as a little liesp of blastospheres; the germina] disk. - Area intercruralis, in anat., the intercrural area
the space between the crurs or peduneles of the brain. Also called the area interpeduncularis.-Area of a contour, the ares of its maximum orthogonal projection on a plane on the inferolatergl surface of the cerebellum, on the outer side of the area elliptica. - Area pellucida, in embryol. the elear space; the filid interior of a blasthla; 8 kind of blastocele- - Area postpontilis, in anat., the sres of the
ventral sspect of the brain belind the pous Varolii, being the ventral aspect of the metencephalon, ineluding the area elliptica and area ovalis. - Area prochiasmatica the optie ehiasu. - Area septalis, in anat, the septa whele the cross-section, in anat, the polygonal areas into vitied. Also called fields of Cohnheim.-Area vasculosa in embryol., the vaseular area about the clear space, when vitellina, in embryol., the yolk-ares beyond the vascular
area in meroblastic eggs. - Blind area, faunal area, area in meroblastle
etc. See the adjectives. areacht, $"$ [Early mod. E. also areehe, ar-
reuch, arctch (pret. araught, arraught), Se. reuch, arctch (pret. araught, arraught), Sc.
areik, etc., $\mathrm{NE}$. areehen, < AS. äraean (= OHG. areich $\bar{a}, \mathrm{MHG}$. G. erreielicn), reach, reach to, get at, $<\bar{a}-+r \vec{e} c a n$, reach: see $a-1$ and reach.] I. trans. 1. To reach; get at thing to a persen)

To whom $\mathrm{Y}$ schal areche a sop of breed.

II. intrans. Te reach; stretch; extend.

areadt, aredet (a-réd'), $v, t$. [In mod. use archaic, and of unsettled orthography; also writ-

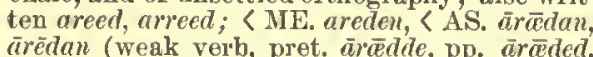

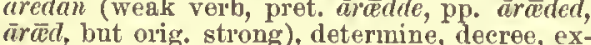
plain, interpret, read (= OHG. arrätun, MHG. erraten, G. errathen, guess, conjecture), < $\bar{a}-$ + rādan, determine, counsel, read: see $a-1$ and read, rede.] 1. To declare; tell; interpret;

Arede, good gentle swaine,

If in the dale below, or on you plaine,
Or is the village situste io a grove.

village situste in a grove.
W. Browe, Britanuia's Pastorsls, i. 3

Areed my counsel sright, and 1 will warrant thee for
the nonee.

2. To counsel; advise; direct; teach.

thut mark what I arreed thee now; A vaunt.

3. Te guess; conjectmre.

So hard this Idole was to be ared,
That Florimell herselfe in all mens vew
Shie seem'd to passe. Spenser, F. Q., IV. v. 15.

4. To pead.

tler hardly open'd look, which to aread is easie.

areadt, aredet, $u . \quad[<a r e a d, v$.$] Advice; dis-$

course; narration. $\quad$ Fayro areedes

Of tydinges stramge. Spenser, W. Q., I. ix. 28

areæ, n. Plural of area in its anatomical senses. area] (ā'rē-al), a. [<L. crealis, of a threshingfloor (cf. Mil. arealis, areale, n., an area), < area, an open space, threshing-floor, ete.: see area.] Pertaining to or of the nature of an area: as, areal interstices.

The rapid study of the areal geology of the country, in.
eluding the outlines of its eommereial problenss

Science, IV, 362

Areal coördinates, See coürdinate.
areality (ā-rề-al'i-ti $), n . \quad[<$ areal $+-i t y$.$] The$

condition or relation of anything in respect te area. I. E. I. [Rare.] areasont, $v . t$. [Early mod. F. also arraison, $<\mathrm{ME}$. araisonen, aresonen, aresumen, $\angle \mathrm{OF}$, are suner, aresoner, araisoner (mod. F. arraisonne $=\mathrm{Pr}$. arrazonar $=\mathrm{Pg}$. arrazoar $),<\mathrm{ML}$. arrationare, reason with, call to account, arraign, (I. ad, to, + ML. rationare, disconrse, reason: see reason, and ef. arraigm 1 , a doublet of areason.] To question; call to account; arraign. Love hym aresoneth. Rom. of the Rose, 1. 6224 .

areca (ar' arrequa, ereeea, also arke, arak, areck, arcque, <Pg. Sp, areea, < Malayalam ädck ka, Canarese ädike, ädiki, Tamil ädaikīy, < adai, denoting clese arrangement of the cluster, $+h \cdot \bar{a} y$, nut, fruit (Bishop Caldwell, in $N_{.} E . D_{\text {. }}$ ). The first tree of the genus Areea and its fruit (betel-nit). See next definition, and arcea-mut.-2. [eqp.] ANia and thenus of palms, natives of tropica leaves and solid, fibrens-coated nuts. There sre abont 20 species, the most important of which is the pinnig or betel-palm, $A$. Catechu, which furnishes the well-known betel-nut. It is one of the noblest palms of India, its
slender trunk rising to a lielght of 80 feet. tory, and is largely enltivsted for this purpose, the exports from Ceylon to Indis alone smounting to nearly 4,000 tons
annually. The fruit of the palm is of the slape snd size anntally. The fruit of the palm is of the slape and size
of a hen's egg, consisting of $\mathrm{a}$ thick flbrous rind inclosing of a hen's egg, eonsisting of a thick flbrons rind inclosing
a nnt like a mintmeg, with hard white albumen. This is water, snd is chewed with a little lime in a leaf of the wetel-pepper, Chaviea Betle. It is supposed to sweeten the bresth, strengthen the gunis, snd promote digestlon. aredet, areedt, $v$. and $n$. See aread.

areek (a-1'ek $\left.\mathbf{k}^{\prime}\right)$, prep. phr. as $a d v$. or $a . \quad\left[<a^{3}+\right.$ reck. ]" In a reeking condition.

A mcssenger eomes ali areek. Sucift, To Peterborough. arefaction $+($ ar-ē-fak'shon), $n$. [ $[=\mathrm{F}$. créfaction, < L. as if "arefaetio(n-),"< arefaeere, pp. arefactus, wake dry, sarere, he dry, + faeere, mak arefy $\nmid$ (ar'e-fí), $v$. t. or $i$. [ $L$. arefoeere, but with second element modified: see arefietion and $-f y$.$] To make or beceme dry.$

So doth time or age arefil. Bacon, Nat. IIist., \& 29 areisef, $v, t$. [See araise.] Same as raise. arenal' (â-rén nä), $n$. [L., sand, a sandy place, sena, ascna = Sabine fasena, sand; not relatel to arere, be dry.] 1. The inclosed space in the central part of the Roman amphitheaters. in which the combats of gladiaters or wild beasts took place. It was usually covered with sani or sawdust, to prevent the gladistors from slipping and to absorb the blood, and, for the protection of the spectawhich was often sitrmonnted by a strong grating. tion or contest of any kind: as, the arena of war or of debate.

Rival politieians contendisg in the open arena of puh. In areh., the main area of a temple, church, or other building. [Rare and incorrect.]

arena ${ }^{2}$ (är'nä) [= E. are no, i. e., are not; $n a=$ F. $n o l, q$. v.] Are not. [Seoteh.]

Things... arena keepit in mind... as they used arenaceocalcareous (ar - $\bar{\theta}-n \bar{a} " s h i e \overline{-}-k a l$ - kā'rēèns), $a$. [( arenaeeous + cileareous.] Of the na-
ture of, or consisting of, a mixture of sand and earbonate of lime.

Near Nice, in places where the great cylindrical cast-
ings . . . slound, the soil eonsists of very fne arenaceo calearevis loam. The soil eonsists of very fine arenaceo-
Damein, Veg. IIould, p. 275. arenaceous (ai'-ē-nä'shius), a. [<L. arenacens, harenaceus, sandy, < arena, harena, sand: see arenal.] 1. Sandy; abounding in saud; having the properties of sand.-2. Figuratively, dry;
arid. rruit of (ar e-kan-nnt), $n$. The betel-nut; the The nut has long been used by the Asiatics as a mastlca.

\section{Arenicoli}

An arenacenus quality in the style, which makes progress
earisone.
Lnwell, Among ny Books, 2d ser., p. 239. 3. Composed largely of sand or sandy particles. (a) In geol., spplied to rocks: as, arenacenn limestone. A rock is ssid to loe arenaceonts wilen it conmade up of sandy particles.

A reddish, soltish, somewhat arenaceote nuarly rock.

ii. 316. (b) In zoolo, specifically applied to those Foraminifere inent of foreign substances, as particles of saud or' shelly

\section{matters.}

Arenaria (ar-ē-nā'ri-äi), n. [NL., fem. sing. of (1) In (a) [l.e.] A disused specific name of Scolopaeida, as the redshank, Totanus ealidris. Scolopaeida, as the redshank, Totanus ealichis.
(b) A generic name of the turnstene, Strepsilas interpres. Brissm, 1760. (c) A generie name of the sanderling, Calidris arenaria. Meyer, 1810. (d) [l.c.] The specific name of the same. Tinueus, 1758 , and most modern writers. - 2. A genus of bivalve mollnsks, of the family Tellinide: synenymous with Scrobicularia. Miihlfeld, 1811.-3. In bot., all nuimportant genus of low herbs, of the natural order caryopleyl. lacea, allied to the chickweeds; the sandworts.

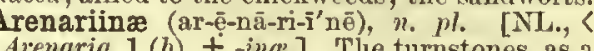
Arenaria, $1(b),+-i n a$.$] The turnstones, as a$ subfamily of Charadriide, taking name from the genus

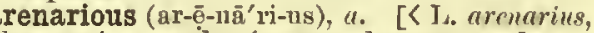
harenarius, sandy, < arena, harena, sand: see arenal.] Sandy; conuposed wholly or in part of sand: as, arenarious soil

renated (ar'ẹ-nā-ted), a. [< L. arenatus, prep. harenatus, < arena, harena, sand: see arenal. Reduced or ground into sand; mixed with sand. arenation (ar-ẹ-nā'shon), $u^{2}[<\mathrm{L}$. $\operatorname{arenatio}(n-)$, hrenatio( $n-$ ), a plastering with sand, < arenaarena harena, sand: see (renal ${ }^{1}$ ] In med, sand-bath; the application of hot sand to the body of a diseased person as a remedy.

The practice of arenation or of burying the hody in the? saud of the sea-shore $+\cdots$ is very ancient, as also that of arendalite (a-ren'da-lit), $n$. [< Arendal $\left.+-i t e^{2}.\right]$ A lime and iron epidote from Arendal in Norway, consisting of siliea, alumina, iron peroxid,
and lime. Also ealled aeantieone. See evidote. arendator, $n$. See arrendator.

reng, arenga (a-reng', -gä), $n$. [E. Ind.] A valuable sago-palm of the Indian archipelago,
Arenga saecharifera. It yields a hlsck bristly ther eseniling horsehair, which makes excellent cordsge, and

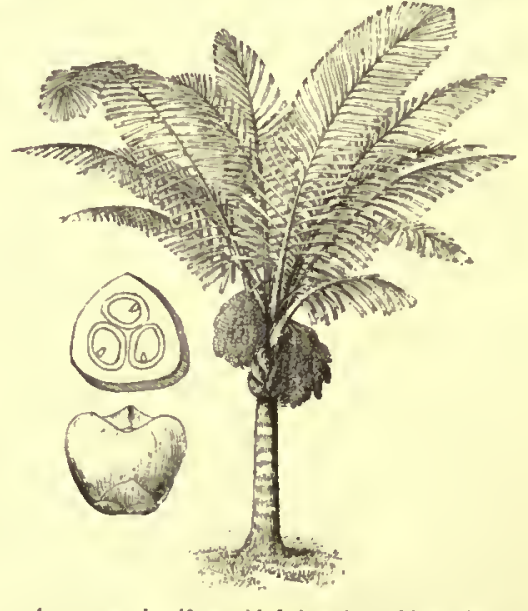

is known as gomuto or gonuti fiber. The trunk affords a conslderable smount of sago of good quality, and the lected for the sake of its sugar and for fermentation. Arenicola (ar-ê-nik'ō-lä), n. [NL., <L. arena, harena, sand, + colere, inhabit, dwell.] The typical and principal genus of the family Arenicolide (which see); the lobworms or lugworms, which live in the sand of sea-coasts. A. piscacritcm, a eommon Enropean species, much used by fist. ermen for bait, burrows a foot or two deep in the sand, is 8 or 10 inches long, with snl eyeless head, and arbuseular

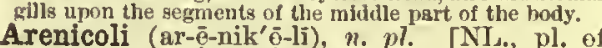
"arenieolus, as Arenicola, q. v.] A group of scarabroid beetles, corresponding to the families Geotrypirke and Trogide of Macleay. 


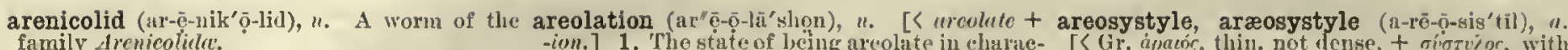
family Arenicoliele.

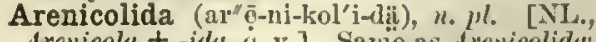
Aronicole + -idlu, i. v.] Sarno as drenicolide Arenicolidæ (al" $\bar{e}-n i-k o l$ 'i-dē), $11, p l$. [NL., Arenieule + -ielec. A family of free marine
polyehwtous or ehretopodous and notobranchiate aunelids, of wlich the genus Arenicola is tho type. Also Areniculidu, Avenocolide.

arenicolite (ar-ē-nik'ō-lit), n. $\quad[<$ Arcnienla + -ite2.] The namo given by somo praleontologists to peeuliar inalkings observed on various rocks in Wales and Newfoundlaml, and supposed to be burrows of annelids, or something similar. They huve recently lecen carefully examined iny varions geologists and lalcontologists, mld are considered l, made hy the spiny or ly water in some otlier form.

arenicolous (ar-ê-nik'ô-lus), a. [< NL. "ureni(olus: see ilvericole and -nus.] In zoöl., inhabiting saul, as certain worms. See Arevicola. arenilitict (a-ren-i-lit'ik), $\|$. [<"arenilite, $<\mathrm{I}$ arenilitict (a-ren-1-lit'ik), ".

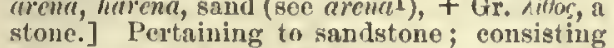
of sandstone: as, urenilitie mountains.

arenose (ar'ẹ-nōs), a. [< L. arenosus, harenosus, full of saud, < areva, harena, sand: see arenal.] Full of sand ; sandy.

arenous (ar'ệ-11us), a. [As arenose.] Sundy and-like.

arenuloust (a-ren'ī-lus), a. [< I. aremulu, lut remula, fino sind, dim. of erona, harenu, sund seo arenal.] Liko or full of fine sand.

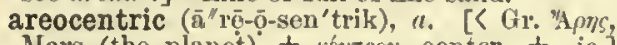

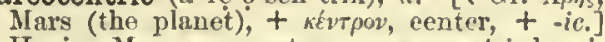
Having Mars as a conter: as, ureocentric lougi-

areographic (ā-rẹ̄-ō-graf'ik), a. [< areography

'aphy.

The areographic longitnde of the ccuter of the Oculns.

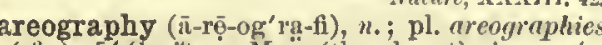

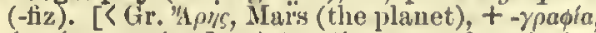
< y á́cev, write.] A treatiso on or deseription of the planet Mars.

The a reographies agree very well with cach other in re spect to the pianct's [Nars's] most inn]ortant features.

areola (a-re'⿳亠口冋-lạ̈), "1.; pl. areola (-lē). [T., \& small open place, dim. of arca: see aren.] 1 In entom., a small, generally angular, inelosed splace on a surface, as the spaces between the veinlets in the wing of a dragon-fly, or pale spaces between dark lines whieh form a network. Also areolet.-2. In bot., a term sometimes used to designato the meshes of cellular tissue or littlo distinet angular spaces on a surface.-3. In enat.: (a) Any little eell, area, or space: - 3. Tral.: (a) Any littecell, area, or in the meshes of areolar tissue and the like, in the meshes of areolar tisstie and the like, or (b) The colored cirele or halo about the nipple of the human mammary gland, pink in virgins. and brown of various shades in women who lave borno ehildren. (c) The red ring of inflamed tissue surrounding a pustule. Henee. figuratively - 4. An aureole.

with a lambent circle or golden areola about their hearls 5. In deeorative art and manufaeture, any plate, tile, or flat panel. (a) A tile of earthenware, (b) One of the etght olatcs, rectangular, with arched tops, (b) One of the etght platcs, rectangular, with arched tops, chit of the imperial crown of the liyzantine empire and Also aveole.

areolar (a-ré'ó-lär), a. [< arcola $+-a r$.$] Per-$ tainiug to an areola or to areolø; resembling an areola ; consisting of or containing areolw; full of interstices.-Areolar tissue, in anat., the light flecey or flocculent kind of ordinary connective tis. sue, such ss that usunly found beneath the skin, censistinterlaced as to include numberless areele in if meshes. Also called cellular tissue.

The cellular er areolar tixane is so called because its meshes are easily distended and thus separated into cells consequently easily hiown up witl air, or permeated hy fuid. Snch spaces, however, do not exist fut the natural condition of the body, but the whole [areolar] tissue forms II. Gray, Anat.

areolate (a-rēe' ọ-lāt), a. [< arcola $\left.+-a t e^{1}\right]$ Characterized by areolw; exhibiting areole, as the retieulated leaves of plants or the wings of
in dragon-fly.

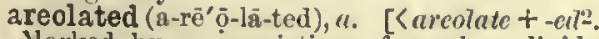
Marked by or consisting of areoln; divided into small spaces by intersecting lines. -ion.] 1. The state of leing ar'olate in characor of having an areola, or of division into areolro; the arrangement and form of areolas, in the leaves of mosses. - 2. A set of areola taken together as making something areolate.

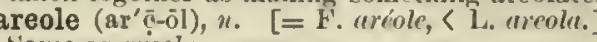
Same as areola.

areolet (ar'ê-ö-let), $1 . \quad[\langle u r e o l e+-\mu t] 1$. small areola.-2. Same as arcola, 1.

reology (ā-rē-ol'ō-ji), u. [< "ipys, Jars (the planet,+-7.0$\}$; $a,<\lambda \ell \gamma \varepsilon t \nu$, speak: see -ology. Mars.

areometer (ar-ci-om'e-tèr), n. [= F'. (triomitre,

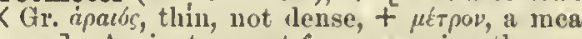
sure.] An instrument for uneasuring the speeifie gravity of liquids; a liydrometer. Also spelled ircometer.

areometric (ar" ò-ō-met'rik), ". [As areometer $+-i c$.$] ['ertaining to the areometer, or to are-$ ometry. Also spelled areometric.

reometrical (ar"ê-ê-met'ri-kal), u. Same as arcometrie. Also spelled arcoimetrical.

areometry (ar-ẹ-om'o-tri), n. [As areometer + $-y$.$] The measurement of the specific gravity$ of fluids by neaus of an areometer. Also spelled arcometry.

Areopagist (ar-ề-op'a-gist), $u_{\text {. }}$ [As Areop A $_{-}$ Areopagite (ar-êe-op'as-git), n. [< L. Areopu-

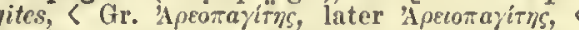
Apeiorayos: see dreopagus.] $\Lambda$ nember of the couneil of the Areopagns. Acts xvii. 34. areopagitic (ar-ê-op-n-git'ik), $a . \quad[<\mathrm{L}$. Areopagiticus, < Gr. A $\rho \varepsilon o \pi a \gamma(\tau i k b s:$

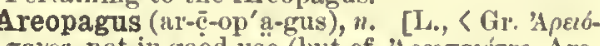
opagite), a colltr. of "A "Apecos, belonging to "A $p \eta s$, Mars (ef. Arian'1, and see Ares); $\pi a \gamma o s$, a hill.] 1. A roeky hill in Athens, situated immediately to the west of the Acropolis; benee, the sovereign tribunal or council of elders which held its sittings on this hill from unreeorded antiquity. Though medified several times in its constitution, notably by Solon snd Ephialtes, the Areopsgas aiways retained the lighest were at once religieus, political, and judicial; the scope of its aetion was this much wider than that of a supreme court of the present day, exionding not only fo jurigeliction in cases of hemiefde and some others in which religion statc, but even to the smpervision of education, and to cer

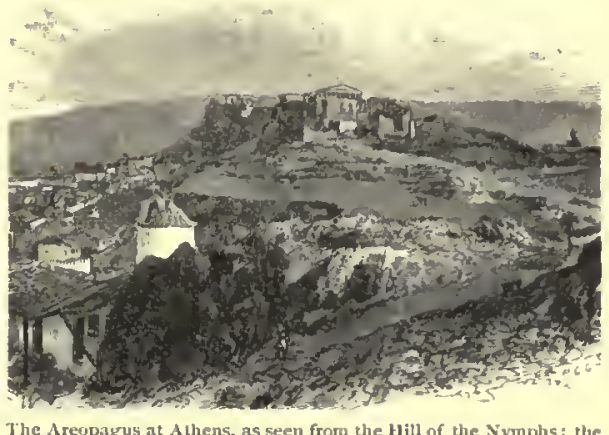

tain police and sumptuary rcgulations. In listeric times year of ottice, who had successully jroved, themiseives
guiticss of malfeasance, in accordance with the provisions gul Jaw.

The Areopagus, a primeval tribunal, hallewed by mythic associations, where trials were held under primitive forms, uniler the sanction of religion.

Hence-2. Any body, eompany, or tribunal of which the decisions, opinions, or eritioisms are final or earry great weight: as, the Areopagus of public opinion.

The Emperor, finstead of drawing the sword for LuxemLove, Bismarck, 136 reopagył (ar-ē-op' a-gi), $n$. [< Areopagus.] An reopagus or tribunal.

The ... A renpagy of hell. Sir T. Bronene, Vinlg. Err. areostyle, aræostyle (a-rē'ó-stīl), $a$. [< Ld. apart < apatós, thin not dense $t$ column, pillar: see style 2.$]$ In arch., having columns placed four diameters, or more than three diameters, apart, from eenter to center of the columus. columns standing together, $\measuredangle \sigma^{\prime} i$, together, + otitos, column: seo style ${ }^{2}$.] In areh, having columns coupled or placed in pairs, witl an interval geuerally of one diameter and a half hetween the centers of the coupled eolumns, ani of moro than three diameters betwe'n the extemal columns of the pairs, measurod from eenter to center. See ent under systyle.

areotict, aræotict (ar-ê-ot'ik), a. and $n . \quad[<\mathrm{Gr}$.

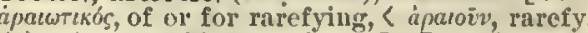
[ápatós, rare, thin, not dense.] I. $a$. In mel., attenuating the humors; efficacious in opening the pores.

II. $n$. A medieino supposed to attenuate the fluids of the body, open the pores, and inerease perspiration; an attenuant.

reret, $t . t$. See arearl.

Ares (â'rêz), ". [L., < Gr. "s/me, tho god of war: perbajs allied to $i \rho c$, strife, quarrel, discord, personified "lipts, L. His, a goddess who exeites to war, sister and companion of Ares.]
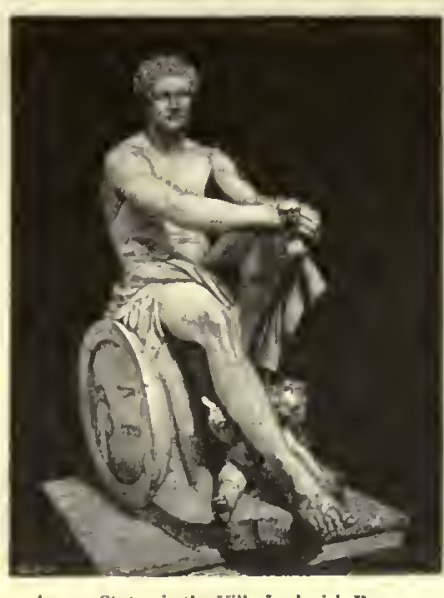

In Gr. myth., the god of war, typieal particularly of the violence, brutality, eonfusion, and destruetion it calls forth. The eorresponding Rolnan deity was Mars.

aresont, $v$. $t$. See areason. arett, arettet, $v$. $t_{\text {. }}$ [Early mod. E. also urret. irrctte, arreet, $\angle \mathrm{ME}$. arctten, $\mathrm{CO \textrm {O }}$. areter, aret ter, $\langle a(\langle\mathrm{~L} . \alpha d)$, to, + reter, $\langle\mathrm{L}$. reputare, count
see repute.] 1. To reckon; assign; ascribe with to

The charge which dod deth unto me arrett.

2. To charge; impute: with to or upon.

Ife that aretteth upon God, or blameth God of thyng of
whicll he is hym sclf gilty. Chaucer, Parson's Tale.

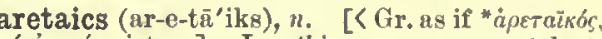

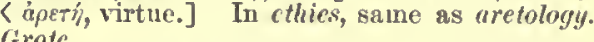

arête (a-rāt'), $n$. [F., a ridge, sharp edge, $<\mathrm{OF}$ areste, < L. arista, ear of corn, spine: see arrest ${ }^{2}$ mountain.

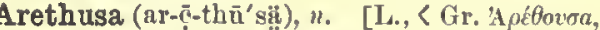
the name of several fontains, the most famous being that in the island of Ortygia at Syraeuse fabled to have been a nymph of Areadia, who being pursued by the river-god Alpheus, and changed into a stream by Artemis, disappeared under ground, passed beneath the Ionian sea, and reappeared in Ortygia; lit., tho Waterer:

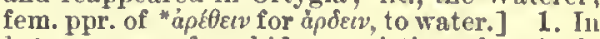
bnt., a genus of orehids, eonsisting of a single species, A. bulbost, a small swamp-plant of North Ameriea, with a handsome rosy-purple sweet-scented flower terminating a sheathed seape. - 2. In zö̈l.: (a) A genus of acalephs. A genus of reptiles. Duméril and Bibron, 1840 (d) A genus of crustreesns.

a reticelli (ä rā-tē-chel'lē). [It.: $a\left(\left\langle\mathrm{I}_{\text {. }} u d\right)\right.$, to, with; reticelli, pl. of reticello, masc., more eommonly reticclla, fem., a small net, dim. of rete, [I, rete, net: see rete.] With retieulations: applied to glassware deeorated with fine lines of opaque white buried in the transparent paste and forming net-like designs. The decoration is olitained by making the boly of the object of two thicknesses of glass in sich a manner that the spiral lines in 
Aretine

Aretine (ar'e-tin), a. $[<\mathrm{L}$. Aretinns, $<$ Aretium, the aneient name of Arezzo in Tuscany. Of or relating to the town of Arezzo in Tuseany,
or to its inhabitants. - 2. Samo as Aretinian.or to its inhabitants. -2 . Samo as Aretinian.a rcd coralline color, pale when brokel, and does not be ground, into an orange-red cals. bases in this ware are coated with a very slight glaze, whlich ia levigated and i usually of a red-eoral color; occasionally it is black, vary. thy toward azure, and soinetimes iroll-gray, or with a Aretinian (ar-e-tin' $\mathrm{i}-\mathrm{a}$ ), $a$. [See Arctinc.] Pertaining to or originated by Guido Aretino (Guido d'Arezzo), a noted Italian musieian of the eleventh century. - Aretintan syllables, the syllables ut, $r e, m i, f a, 80 t$, a (tine initial ayylables of the
lines of a Latin hy min to St. John the laptist which begin "Ut queant laxis"), chosen by (inido d'A Arezzo to name the
notes of the hexachord, $C, D, E, W$, G, A, beeaune In the notes of the hexachord, $\mathrm{C}, \mathrm{D}, \mathrm{E}, \mathrm{F}, \mathrm{G}, \mathrm{A}$, becaune in the
Gregorian melody for the hymn they fall upon these notea respectively. They are atill used, cspecially in France, a between theee notes are the aame as those between the first six tones of the nodern major senle, the ayllables have
also been used extensively as names for those tones and as guides in atudying their relations. This application ls called solmization. When thus uaed, ut la generally
clanged to do, and the syllable si (tonic aol-fa, $t \overline{\text { e }}$ ) ts added

Aretinist (ar' ${ }^{\prime}$-tin-ist), $n$. $\quad[<$ Arctino + -ist. $]$ A profligate of the stamp of Pietro Aretino, an Italian poet (I492-1557), noted for his impu-
denee and profligaey, and for the viruleuce of his satire.

aretology (ar-e-tol'ō-ji), n. [< Gr. as if "ápe-

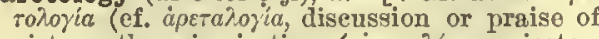

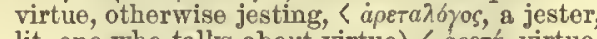
lit. one who talks about virtue), $\langle a \rho \varepsilon T h$, virtue

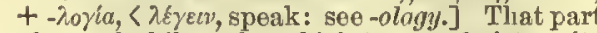
of moral philosophy which treats of virtue its nature, and the means of attaining it. Also ealled arctaics. [Rare.]

arettet, $v$. $t$.

arewt, prep. phr. as adv. An old form of araw. arfvedsonite (är'ved-son-it), $n$. [Named from eral related to hornblende, eomposed of silieates of iron and soda with a little alumina and lime. arg. In her., an abbreviation of argent.

argall (är'gal), $n$. See argall.

argal ${ }^{2} \nmid$ (är'gal), adv. A ludierous eorruption of Latin ergo, therefore.

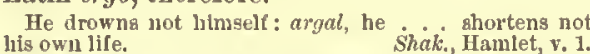

argala (är' ga-lä), n. [Anglo-Ind., also argeelah, formerly also argali, argill, hargill, repr. bird, Ardea argala (Lathan), now Leptoptilus argala, of India. (b) A similar bird of Afriea, Leptoptilus cruminiferus. Temminck. Properly called marabou. (c) [cap.] [NL.] A goneric
name of both these birds. Hadgson, 1838. See adjutant-bird, marabau.

argali (är'ga-li), n. [F., Russ., NL., etc, after the Mongolian and Tungusian name.] 1. The large wild sheep of Asia, Ovis ammon (Linnæus), nal stoek of the domestie slieep. It stands about 4 feet high at the w
enormously thick

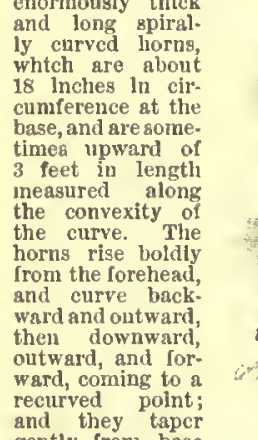

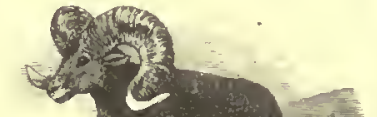
gently from base
to tip. The animal
chiefly in mountaino

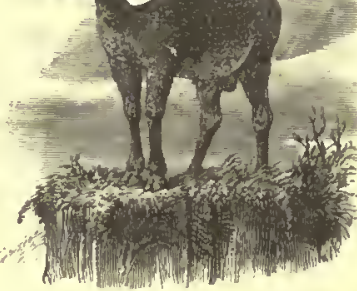

chiefly in mountainous or northerly regions and on hlocks

plateaus. 2 Some other similar wild sheep the following. - American argall, the Rocky Moun

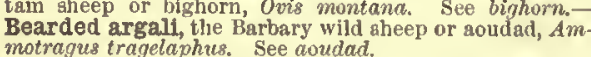
Argand gas-burner, lamp. See gas-burner, lamp.

Argantidæ (är-gan'ti-dēe), $n . p l$. Same as $A r$ argan-tree (är'gan-trē), n. [Ax. (Moroceo) ar găn, prop, arjān.] A sapotaceous tree of Moroceo, Argaria Sideroxylon, the only speeies of the genus Argania. The nuts furnish an oill, alm
304

argentometer

lar to olive-oil, which is an important artlcle of food for
the inhabitants. Its wood is reinarkable for laardness and durability.

Argas (är'gas), n. [NL., prob.<Gr. ảpyós, eontr.

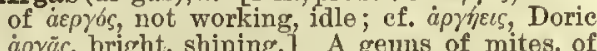
apyēs, bright, shining.] A geuns of mites, of the family lxadidee, having no eyes. The bestknown apecies is $A$. reflexus, a parasite of birits, especialiy
doves, and known as the dove-tick. Other apccies are $A$. persicus and A. nigra.

Argasidæ (är-gas'i i-dë), n.pl. [NL., 〈 Argas + $-i d c$.$] A family of tieks, named from the ge-$ us Argas. Also Argantida.

Argean (är-jē'añ), a. [<L. Argēus, pertaining to the Argo: see Arga.] 1. Pertaining to th ship Argo, or to the constellation of that name. triet of Argos) in Greeee, or to the Argives, the aneient inhabitants of Argos.

argel, arghel (är'gel), $n_{0}$. [Syrian.] The leaves of the asclepiadaeeous plant Solenostcmma ArAlso written argucl.

argema (är'je-mä), $n . ;$ pl, argcmuta (är-jem'âspeek or uleer, $\langle a \alpha \rho \gamma \delta$, white. Cf. agrimany.] 1 . A small white uleer on the eornea.-2. [cap.] In $z o \ddot{l} l$., a genus of lepidopterous inseets.

Argemone (är-je-mō'nē), n. [L., 〈Gr. $\dot{\alpha}^{\prime} \rho \gamma \varepsilon \mu \omega \omega \eta$
a kind of

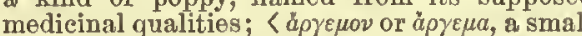
white speck in the eye: see argcma.] A small genus of plants, natural order Papareracea. The speciea are all ornamental, and natives of America, cana the Mexicans obtain an oil very useful to painters. Both yellow and white vartetiea of thth apecies are often
cultivated vunder the name of the horned or prickly

poppy.
argent (är'jent), $n$. and $a . \quad[<\mathrm{F}$. argent, $<\mathrm{L}$. argentum, silver, money, = Osean aragetom = Skt. rajata, white, silver; ef. Ir. Gael. airgiod, silver, money, eonneeted with Ir. Gael. arg, white,

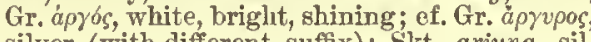
silver (with different suffix); Skt. arjuna, sil$n$. 1 . Silver, or something resembling it; formerly, in a more general sense, money.

She ahall haue the first day a whole pecke of argent.
Udall, Roister Doister, i.

With that ghe tore her robe apart, and half

The polish'd argent of her breast to aiyht
Lennyson, Fair women.
Lare.

2. In her., the metal silver: represented conventionally in uneolored drawing or engraving by a plain white surface.

Often abbreviated to $a$. , ar., or arg.

Argent comptantt, ready money.
II. a. Ifade of silver; resembling silver; bright like silver; silvery-white.

Pardon me, airy planet, that I l prize

One thought beyond thine argent luxuries!

argental (är-jen'tal), a. $[=\mathrm{F}$. argental, $<\mathrm{L}$. argentum, silver.] "Of, pertaining to, or resem-
bling silver. - Argental mercury, a native amalgam of silver

argentan (är'jen-tan), n. [< L. argentum, silver, $+-a n]$.1 . An alloy of varying proportions given as a trade-mark to German silver names see, under silver).-2. A species of Freneh point-laee.

argentate (är'jen-tāt), $a$. and $n . \quad$ [< L. argentatus, silvered, argentum, silver. 1 . a. Silgray. A. Gray.

II. $n$. In chem., a salt of argentie acid.

argentation (är-jen-tā'shon), $n$. [< L. argenoverlaying with silver.

argentea (är-jen'tẹ̄[NL., fem. of L. argenteus, silvery: sce urgenteaus.] A membrane whieh enters into the formation of the eyeball of some animals, as Cephalopoda: so ealled from its silvery color. There may be two auch membranes, In which case they
are known aa the argentec externa and argentea interna. argentei, $n$. Plural of argenteus.

argenteous (är-jen'tê̄-ns), a. [< L. argenteus, silvery, < argentum, silver.] Silvery. [Rare.] argentert, $n$. [Also written argentier, $<\mathrm{OF}$. argentier, $<$ L. argentarius, a money-changer, bankver money ] 1 ith, prop. adj., < argentum, sil2. A silversmith. A. Wilson, Hist. James I.

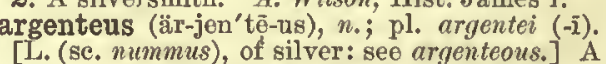
Roman silver coin, weighing about 80 grains, introduced by the emperor Caracalla, and worth argentometer (är-jen-tom'e-tèr), n. [< L. ar

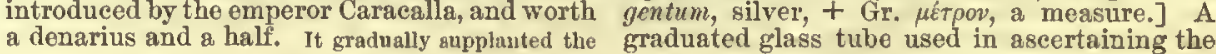

denarius from which it may be distinguished hy having the head of the emperor radiate. After a short

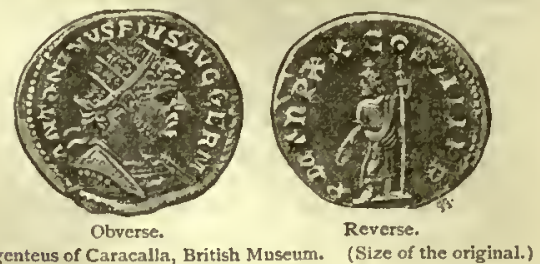

argentic (är-jen'tik), a. [< NL. argontious, 1. argentum, silver:] Containing silve

argentiert, $n$. Same as argenter.

argentiferous (är-jen-tif'e-rus), a. [< L. ar gontum, silver, + forre $=\mathbf{E}^{\circ}$. bcarl.] Produeing or containing silver: as, argentiferous ore, veins, ete.

argentifict (är-jen-tif'jk), a. [< L. argentum, dueing silver. [Rare.]

argentifyt (air-jen'ti-fī), v.t. [< L. argentum, sil-

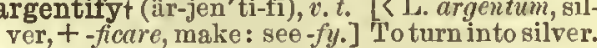
argentilla (är-jen-til'ä), $n$. [It., formed as a dim. of argento, < L. argentum, silver.] A Genoese laee, much like point d'Alençon. argentinus, pertaining to silver: see argentine.] 1. A genus of malacopterygian fishes, called from their silvery seales. A. sphyrana, of European waters, is the type.-2. [l.c.] A name given to unglazed porcelain, eoated with gold, silver, or copper by a process similar to that of electroplating.

argentine (är'jen-tin), $a$. and $n . \quad[=\mathbf{F}$. argen tin, < L. "argenitinus, pertaining to silver (as (argentum, silver.] I. a. 1. Pertaining to or resembling silver; silvery; argent.

Celestial Dian, goddeas argentine.

2. [cap.] Of or pertaining to the Rio de la rivers Paranc and Uruguay in South Ameriea, or the country ealled from it the Argentine Republie or Confederation, or Argentina.-
Argentine flowers of antimony. See antimony. Argentine flowers of antimony, See antimony. sheen of silver. It is generally formed by lnclosing delicate white ailvery incrustations of dry porcelain clay in aolid and transparent glass.
II. $n$. 1. A silvery-white slaty variety of caleite, containing a little siliea with lamina usually undulated, found in primitive roeks and frequently in metallic veins. -2 . The tetroxid or antimoniate of antimony.-3. The silvery coloring matter of the scales of fishes.-4. A
fish of the family Scopelide or Maurolicida. 5. White metal eoated with silver.-6. [cap.] A eitizen or an inhabitant of the Argentine Republic.- Sheppey argentine, Scopelus pennanti, a fish argentinid (är-jen'ti-nid), $n$. A fish of the family Argentimida, as a caplin or eulachon. Argentina + -icle.] A family of malacopterygian fishes, typified by the genus Argentina. The body is fusitor'm, covered with moderate or large acalea or wanting. The apecies were unlversally referred to the family Salmonidee hy the oldcr althors, and are still re-
tained in lt by nany, but they differ in the characters apecifed and other anatontcal pccnliarities. The chie representatives are the genera Argentina, Osmerus (in -
cluding the smelts), Nallotus (caplin), and Iypomesus. cluding the smelts), Mallotus (caplin), and Mypomesus.

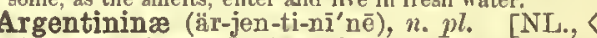
Argentina + -ince.] A subfamily of fishes, typified by the genus Argentina, referred to the family Salmanide: same as Argentinida. argentinoid (är-jen'ti-noid), $a$. Pertaining to or having the charaeters of the Argentinide. argentite (är'jen-tit), n. [< L. argentum, sil ver, $\left.+-i t e^{2}.\right]$ Silver sulphid, a blickish leadgray mineral, oceurring in erystals, in crusts, and massive. It la a valuable ore of ailver, found in the crystalline rock of many countriea. Also called $a r^{2}$ rgentobism

mulite (är-jen-tō-biz' mū-lit), $n$. (2rgentum + bismu(th) +-lite.] A native sulphid of bismuth and silver. Sometimes ealled ismuth silver. Argentina (är-jen-tī'nạ̈), $n$. [NL., fem. of L. Plata (Sp. plata, silver), the estuary of the 
quantity of silver in a solution by the admission argint, arginet, $n$. $\quad[<$ It. argine, nerhaps $<I$. of chlorid of sodium.

13y means of an argentometer the strongth of the bath car easily bo maintained at a given point.

argentous (är-jen'tus), a. [ $<\mathrm{I}$. argentosus, < aryentum, silver.] Pertaining to or containing silver: applied to a compound which contains a larger proportion of silver than the correoxonding argentic compound:

oxid, $\mathrm{Ag}_{4} \mathrm{O}$; argentic oxi, $\mathrm{N}_{2} \mathrm{O}$. silver plate, argent, silver: seo argent. 1 1 Articles formed of silver; silver plate.

Pawning bis. . argentry and jewels

2. Silvery appearance. [Rare.]

lowell, Letters, 1.2

(thering argentry

liipleles and ghuses on the confluent strean

Southey.

argentum (är-jon'tum), n. [L.: see argent. Silver. In chem., abbroviated Ag.-Argentum mosaicum, an analyam of tin, bismuth, and merenry, Arges (är'jëz), n. [NL., \& Gr. à $\rho$ hhs, bright, glaneing, a $\rho \gamma \delta \varsigma$, bright, white.] 1. A genus glancing, a pys, bright, white:] 1. A gemus ily Argide. -2. A genus of trilobites.

ily Argiduc.-2. A ge

arghool ("นr-göl'), n. Au Egyptian musical in strument, consisting of two tubes, with a monthpiece fumished with reeds. Somelimes both tulieg sre plereed with holes, sometimes only one, the other being used as a drone.

argid (är'jid), $n$. A fish of the family Argide.

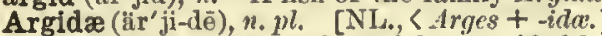
A family of nomatognathous fishes, typified by the genus Arges, related to the Loricariida, but having a naked body and only maxillary barbels. There are sbont io known specles, of smalt slze,
inhalilting the upper Andean streams and derivatlve argil ("ir'jil), n. $\quad[<\mathrm{F}$. argile, < L, argilla, white

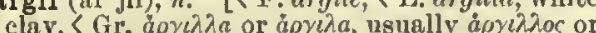

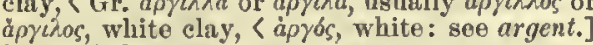

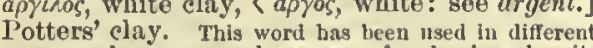
senses, and was proposed as a name for alumins when its inters as a distimetive term for clay whlch is fit for pot ters' use. argillaceous (är-ji-lä'shius), $a . \quad[<\mathrm{L}$. argillathe nature of or resembling clay. -2 . Conteining a considerable amount of clayey matter: as, argillnceous earth.-Argtllaceous rocks, rocks of sedlimentary origin, soft in texture, deposlted for the mos part in thln layers. Clay forms the basis, but with It other substances may be assoclated, as vegetable matter (car-
bonacesus shale), iron (elsyband lronstone), lime (marl), ete. When the shale is tolersbly pure it is readlly distinguished by the peculliar odor, termed argillaceores, which it emits when bresthed on.- Argtulaceous slate or schist, elay slate, s metamnorphic roek which in Scotisnd argilliferous (är-ji-lif'e-rus), a. [< L. argilla, white clay (see argil), + ferre = E. bear1.] Producing or containing clay or argil

argillite (är'ji-lit), n. [< L. argilla, white clay (see argil), +-ite ${ }^{2}$.] Argillaceous schist or slate; clay slate (which see, under cluy).

argillitic (är-ji-lit'ik), a. [< argillite + -ic.] Pertoining to argillito.

argillo (är-jil'ō), n. [< L. argilla, $<\mathrm{Gr}$. ă $\rho \gamma i \lambda \lambda o s$, white clay: sco argil.] A name given to a vitreous compound of which tiles, table-tops, door-knobs, ete., aro made.

argilloarenaceous (är-jil"ö-ar-ē-nā'shius), $a$. and sand.

argillocalcareous (är-jil "ō-kal-kā' rē-us), $a$. [ argillous + calcareous.] Consisting of clay and calcaroous earth.

argillocalcite (är-jil-ö-kal'sit), n. [<argillous + calcite. A species of calcareous earth with a largo proportion of clay; marl.

argilloferruginous (ir-jil" $\overline{0}-f \theta-r o ̈$ ji - nus), $a$. [? argillous + ferruginous.] Containing clay and iron, as a mineral.

argilloid (är-jil'oid), $a$. [ $<\mathrm{L}$. argilla (see argil) + -oid.] Having an argillaceous or clayey appearanee; like argil or clay.

Argillornis (år-ji-lôr'nis), n. [NL., < L. ar gilla, whito clay (see argil), + Gr. opves, bird. A genus of fossil birds from the London elay of Sheppey. A. longipennis (Owen), of uncertain affinitles, Is the typical species. The fossil remains Indleate a long winged bird larger thsn sn albstross, $R$. Owen, 1878 . argillous (ïr-jil'us), $a_{\text {, }}[\mathrm{KME}$, argillous, $\mathrm{OF}$, argillos, argillus, mod. F. argileux, < L. argil see aryil.] Consisting of or belonging to clay clayey. agycrem, ace. of agger, a mound: seo agger.] An emba

Argina (är-ji'nu), n.pl. [NL., < Arges + -ina.] In Güuther's ielstlyyological system, a scetion of the group IIypostomatina of the family Siluride: samo as the family Argider.

Argive (ar'giv), $a$. and $n$. [<L. Argirus, < Gr. Apyeios, pertaining to "Apyos, Argos.] I. a. Kolating to Argos, the historie eapital of Argolis or Arreia in Grecce, or to its inhabitants, or to Argolis, tho territory of Argos. The Argive to Argolis, tho territory of Argos. The Armive race is rejresentod in Iiomer as the most powerfut in

II. n. A native or an inhabitant of Argos or of Argolis; a Greek.

argle-bargle (¿ir'gl-biir'gl), $t$. $i$. [Also argiebargie, argle-bargin, etc.; a varied reduplieation of arguc.] To argue obstinately; bandy words; haggle. [Scotch.]

Argo (ür'gö), $n$. [L., < Gr. A $\rho \gamma \dot{\omega}$, name of Jasoll's ship, lit. tho swift; also a constellation named after this ship; 〈'apyós, swift, glancing, bright, white: see argcut.] 1. In Gr. myth., the name of the ship in which Jason and his the name of the ship in which Jason and his fifty-four companions sailed to Colchis in quest constellation, the largest in the heavens. It

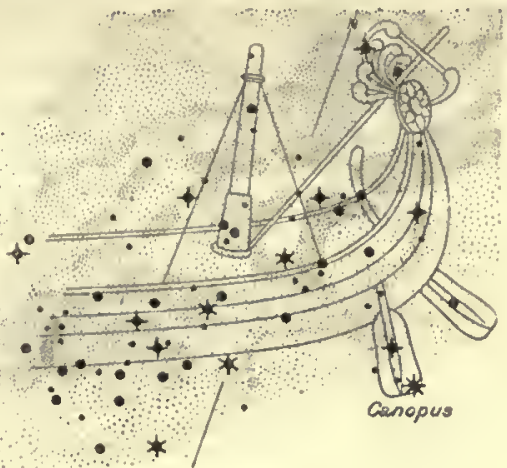

The Constellation Argo.

contains Canopus, after Sirius the brightest of the fixed stars. By modern astronomers it is commonly divlded carina, muppis, and velum, or hill, keel, stern, and sail. 3. [l. c.] In $\approx 0 o ̈ l$, the technical specific name of the paper-nautilus, Argonauta argo.-4. In conch., a genus of nudibranchiate gastropods: ynonymous with Doris. Bohadsch.

argol1 (ä $\mathbf{r}^{\prime}$ gol), $n_{\text {. }}$ [< MLE. argoil, argoyle, AF. argoil; origin unknown; appar. ult. < Gr. a ajós, white.] Unrefined or crude tartar; a hard crust, consisting of potassium bitartrate, formed fermented. It is purple or white seeording to the color of the wine. Argol ls used by dyers to dispose the stuffs to take their colors; and the purifled bltartrate, eslled cream of tartar, is used in medlcine, cooking, snd the ent of most baking.powders. Also written argal, argoll argol $^{2}$ (är'gol), n. [Mongol.] A cake of dried camel's dung, used by the Mongols as fuel. argolett, argoulett, n. [OF. argoulet; origin obscure.] A member of a French corps of light eavalry instituted by Lonis XII., similar to tho estradiots, and probably armed and drilled in partial imitation of that corps.

Take a cornet of our horse,

As many argolets, and armed pikes,

And with our carriage march swsy be fore.
Peele, Battle of Aleazar.

argoletiert, n. [OF.] Same as argolet.

Argolic (är-gol'ik), a. [< L. Argolieus, < Gr. A $\rho \gamma_{0} \lambda_{\iota \kappa}$ os, pertaining to A $\rho \gamma_{0} \lambda i s$, Argolis. See Argive.] Belonging to Argolis, the territory of Argos, a district of Greece, in Peloponnesus, between Arcadia and the Fgean sea: as, the Argolic Gulf.

Argonaut (är'gọ̄-nât), $n$. [< L. Argonauta, Gr. Aprovautys, one who sailed in the Argo, vaves, a ship: see nave ${ }^{2}$, nautical.] 1. One of the heroes who, according to the ancient Hellenic myth, sailed with Jason in the ship Argo to Colehis on the Euxine sea in quest of the golden fleece. This they secured, and Jason stso bore back with hlm snd his comrades to Iolcns, amid wer the enchantress.
Ience -2. $y$. Those who emigriated to Cali

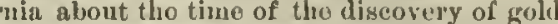
hero: as, the Argonauts of ' 49.

Nimbers of Bmall parties from (Jregon arrived leefore July (1848), but the vast borly of goldoseckers know 1 after-

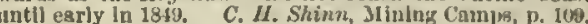

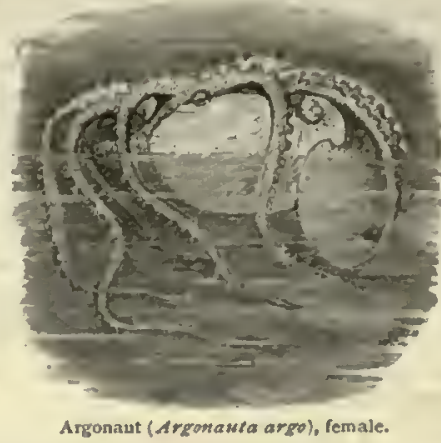

3. [l.c.] A cephalopod mollusk, known also as tho paper-nautilus and paper-sailor. The com mon Afenterrairesn species, Argonauta aryo, was fahled to be wafted by the winds. The grms are in fact con monly carried appressed to the shell, and progression effccted ehiefly backward, as with other cuttleftshes, by the ejeetion of water through the siphon.

Argonauta (är-gō-nâ'tä), \%. [L., an Argonaut: see Argonaut.] A genus of cephalopods, typical of the family Argonautida.

Argonautic (är-gō-nâ'tik), a. [< L. Argonauticus, < Argonauta, Argonaut.] Of or portain. ing to the Argonauts, or relating to their voyage to Colchis: as, the Argonautic story. See Argonaut, 1.

argonautidd (är-gō-nấtid), $n$. A cephalopod of the family Argonautido.

Argonautidæ (är-gōonâ'ti-dê), n. pl. [NI.,

Argonauta $+-i d e$.$] A family of octopod eopha-$

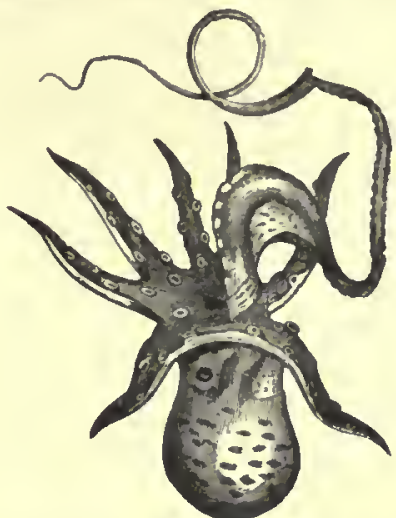

eral times smaller of with hectocotylized arm attached.

lopods, represented by the genus Argonauta, with an ovoid finless body and the two uppermost arms (in the female) expanded terminally

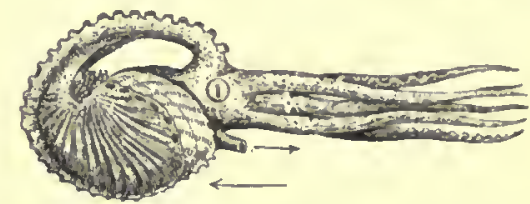

Argomanefa argo (female), swimming in the direction of the large

into broad flattish velamenta, which secrete a papery, spiral, single-chambered, involute shell. The family is pecullar in the development of the sliell. The only known genus is Argonauta. The shells, popularly
known as the argonaut, paper-nautitus, and paper-sailor, snd common as curiosities, are peeuliar to the female, are the eggs in the breeding season.

argosy (är'gö-si), n.; pl. argosies (-siz). [Early mod. E. also argosie, argosey, argozee, argosca also argose, arguze, and ragosie, rhaguse, and first in the form ragusye (see first quot.), < It Ragusea, pl. Ragusee, lit. a vessel of Ragusa (in early mod. E. also Aragousc, Arragosa), a port in Dalmatia on the east coast of the Adriatic sea, noted for its commerce.] A large merchant vesscl, especially one carrying a rich freight.

Furthermore, how acceptable a thing this may be to 
laden ships passing within or by any of the sea-limits of Dr. John Dee, Petty Navy Royal, in Arber's Englis]

There, where your argosies with portly sail

Like signiors and rich hurghers on the flood, $\%$. $\%$. 1.

By the Venetlan lsw, no slave might enter a Venetian ship, and to tread the deek of an argasy of Venice becanle
the privilege and the evldenee of freedom. argot ("ïr'gō or är'gọt), $n$. [F.; origin obscure.] The couventional slang of a class, originally that of thieves and vagabonds, devised for purposes of disguise and concealment; cant; slang.

Argot is formed .... hy the adoptlon of foreign words,
loy the absolute suppression of grammar, by grotesque tropes, wild catichresis, and allegortcal metonymy. Farrar.

Words or expressions in an ancient language, it they happen to coinelde with some modern argot or vulgarism,
take on a grotesque assoeiation which is not due at all to the phrase itscll, but which makes the phrase seen much

argoulett, $n$. See argolet.

Argozoum (är-gō-zō'um), n. [NL., appar. 〈Gr. Argozoum (ar-go-zo um), n. [NL., appar. $<$ Gr.

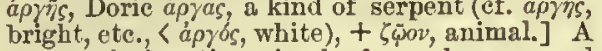
genus of gigantic animals, formerly supposed to be birds, now believed to be dinosaurian reptiles, known by their footprints in the Triassic
formation of the Connecticut valley. Hitcheock, 1818.

arguable (är'gū-a-bl), a. [< argue + -able.] Capable of being argued; admitting argument.

When men say "mere philosophy," they mean something J. R. Seeiey, Natural Religion, p. 184 argue (är'gū), v.; pret. and pp. argued, ppr. arguing. [< ME. arguen, arguwen, < OF. (and mod. F.) arguer, < L. arguere, declare, show, prove, make clear, reprove, accuse; prob. connected with Gr. a $\rho \gamma$ ós, white, bright, etc.: see argent, and cf. declare, lit. make clear.] I. intrans. 1. To bring forward reasons to support or to overthrow a proposition, an opinion, or a measure; use arguments; reason: as, A argues in favor of a measure, $\mathrm{B}$ argues against it.

Whis woman argues for her own damnation! Beau. and Fl., Knight of Malta, il.

Yet I arque not
Agalnst Heaven's hand or will, nor bate a jot

Solnets, xvil.

Paul argues thist human reason so seeking for God can
discover lils power and his divinity, and holds that the discover his power and his divinity, and holds that the
true God is not far froml every one of us.
Daweon, Nature and the Bible, p. 206. 2. To contend in argument; dispute: as, you may armue with your friend a week without convineing him.

For e'en though vanquished, he could argue still.
Goldsmith, Des. Vil., 1. 212. How finely we argue npon mistaken facts :

II. trans. 1. To debate or discuss; treat by reasoning; state the reasons for or against: as the counsel argued the cause before the Suprem Court; the cause was well argued.

$$
\begin{aligned}
& \text { To must submit } \\
& \text { To the divine deeree, not nrgue it ; } \\
& \text { And checrfully I welcome it. }
\end{aligned}
$$

Fletcher (and Massinger?), Lover's Progress, Iv.

2. To evince; render inferable or deducible show; imply: as, the order visible in the universe argues a divine cause.

$$
\begin{aligned}
& \text { Not to know me argues yourselves unknown. } \\
& \text { Milton, } \mathbf{P} \text {. L., iv. } 830 . \\
& \text { These were words, } \\
& \text { As meted by lits measure of himself, } \\
& \text { Arguing boundless forbearance. }
\end{aligned}
$$

3. To affect in any way by ar a change in the mind of, or in regard to, by persuasion or reasoning: as, to argue one ont of his purpose; to argue away a false impression.

It is a sort of poetical togic which 1 would make use of to argue you into a proteetion of this play.
Congreve, Ded. of old Batchelor. 4†. To accuse or eharge; impeach or convict: used with of.

$\begin{aligned} \text { He doth implore, } & \text { You would not argue him of arrogance. }\end{aligned}$

$$
\text { B. Jonson, Ind. to Poetaster. }
$$

I have pleaded guilty to all .... expressions of mine
which can be truly argued of obscenity,... and retract them. Dryden, Pret. to Fables. =Syn. Argue, Dispute, Debate, Diseusy, plead, expostu-
late, remonstrate. To argue is to defend one's opinion, or to exhibit reasons or proofs in fayor of some assertion or principle; it imples a process of detailed proof by one the statements or arguments of an opposing party : as, to argumentable

2. The midalo term of a syllogism. [Seo preceding note.] Argument is the bare proof or mean term which is ln-
vented loy lim that disputeth, to prove the truth of the
question; but argumentation is the whole reasoning itself, question; but argumentation is the whole reasoning itseli, tion and also the proof thereot. Argument again, argument um, - what is ussumed in order to argue somcthing, - is properly the middle notion
in a reasoning - that through which the conclusion is es. 3. A reasoning; the process by which the con 3. A reasoning; the process by which the conto be admitted and that which is doubted or supposed to need confirmation is traced or tested.

In matters of wrong arguments do confound sense, wiren In exptanation of right they do sensibly approve it.
Ford, Honour Iriumphant, ii. The probability which she easlly perceives in thing thus in their native state would be cuite lost if this aryument were managed learnedly and proposed in mood and We do not know God by argument, by reading books of
evidences or books of theology : we know hin just as we know the external world,--by experience. 4. An address or composition made for the purpose of producing belief or conviction by reasoning or persuasion.-5. A series of argumentations for and against a proposition; a debate. -6. The subject-matter or groundwork of a discourse or writing; specifically, an abstract discourse or writing; specifically, an abstract or summary of the ehief points in a book or scetion of a book: as, the arguments prefixed
to the several books of "Paradise Lost" were an afterthought.

That the whole argument fall within compass of a day's B. Jonson, Ind. to Every Jan ont of lils Humour. The abstract or argument of the plece is shortly as Iol-
Jeffrey.

7†. Matter of contention, controversy, or conversation.

And sheath'd their swords for lack of argument.
Shak., Hen. V., ili. I. It would be argument for a week, langhter for a nonth,
and a good lest forever.
Shak., 1 Hen. IV., 11. 2 . The remembrance of this small vexation

Fletcher, Rnle a wife, iii.

8. In math.: (a) Of an imaginary quantity the coefficient of the imaginary unit in its log arithm. (b) The angle or quantity on which a series of number's in a numerical table depends and with which the table is entered. If, corresponding to every degree, etc., of longitude, so that, the longitude being known, the declination minght be found opposite to it, then the longitude would be called the argument of the table. Tables of double entry liave two
arguments. In the Ptolemaic astronony, the nrgument, argunents. In the Ptolemaic astrononiy, the argument,
without quslification, is the angular distance on 1 the epicycle of a planet from the true apogee of the epicycle; and cye equation of the arfument is the angular distance, as
seen from the esrth, of a planet from the center of the epicycle, the correction to the second inequality. See equa. Induction in which the inference is made that sonrethin is true of a whole class, becsuse it is true of certsin mema mple. - Argument from exclusion, an argument in Which, alter showing that all causes but one are fnsuffi-
cient to account for a phenomenon, it is urged that the one remalning cause must be the true one.- Argument
of the latitude, the arc of the orbit reckoned from the ascending node. - Artifictal argument, contentious argument, cumulative argument. See the adjec tives. - Dilemmatic argument, one which purports to it into parts, and showing that every part has that character.-Disfunctive argument, a reasoning of the form: S is either Por Q; it is not P; hence it must be Q. - Dissentaneous argument, extrinsic argument, elc. See the adjectives. - Hyoothetical argument, an srgumen
one of whose premises is a hypothetical or conditional proposition. It is not identical with hypothetic inference founded on an fnduction. - Negative argument, an ar. gument which concludes the non-existence of a plienomenon from fts not having been observed. (For other yhrases see argumentum, place, proof.) $=$ Syn. 3. Plea, Argument "Plea should be used of the pleadings or of the arraign-
ment before the trial, not of the argument at the trial. be addressed elther to the court or to the jury." A.S. IIill, Rhetoric, p. 53 .

argument† (är'gū-ment), v. [<ME, urgumenten, < L. argumentari, adduce proof, $<$ argumentum: see argument, n.] I. intians. To argue; lebate; bring forward reasons. Chaucer.

II. trans. To make the subject of an argument or debate. N. E. D. [This, the familiar meaning of the word, probably origiCicere and almost all authorities is patio fidem, a reason causing belief of a doubtful matter. Boëlus in one place defnes it as a medium proving a con. argumenta, $n$. Plural of argumentum.

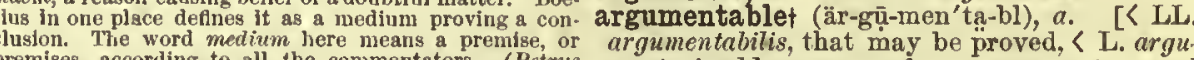
premises, according to all the commentators. (Petrus middle term of a sylloglsm, some logiclans have been led mentari, addnce as proof: see argument, $v$, and -able.] Admitting of argument; capable of being argued. 
argumental (iir-gū-men'tal), a. [<L, arpuargumental (kinumenten. longing to or consisting in argunent.

Thus they dispute, gulding their tongues' report

G. Markhain, Sir R. Grinule (Arb. reprint), 11. 40. I am at icngth recovered frou ny arymental delirlum. argumentation (äx"gū-luen-tā'shion), $n$. [= F. argumentation, < I. argumentutio $(n-),<$ aryumenturi, pp. aryumentatus, adiluce as proof: sec argument, $v$.] 1. The setting forth of reasons together with tho conclusion drawn from them; also, the premises and conclusion so set forth. Thuse schotastic forms of dilsconrse are not less lialle to Cullactes than the plainer wa Argumentation or reasoning is that operation of tho nilnd whereliy wo infer one thing, that is, one proposition, 2. $\Lambda$ course of reasoning; discussion; debate. T'le relation of his meaning to science is essential, but, in orderiy aryumentation, anhiseruent. Mop. Sei. Mo., Xxv111. 619. $=$ Syn. See reawoniug.

argumentative (iㅏ-gūi-men'tg-tiv), a. $[<\mathrm{F}$. argumentatif, < $\mathrm{I}_{\text {s. as if }}$ argumientetivus, < argumentrtus: seo argumentation.] 1. Consisting in argument; containing a plocess of reasoning; controversial: as, an argumentative discourse.

We are not to dwell upon the mental processes which composed the proof, upoil the aryumentative part of $\mathrm{rc}$ tho things proved.

\section{Showing reasons for. [Rare.]}

Another thing argumentative of Provicience is, ete.

3. Addicted to argument; disputations: as, an argumentative writer; ho is very argumentative. argumentatively (är-gū-men'tg-tiv-li), adv. In an argumentative manuer; with respect to reasoning or argiments.

Bowles, in losing his tenuper, lost also what fittle logic lie had, and contrived always to he argumentatively wrong.
Lovell, Study Windows, p. 430.

argumentativeness (är-gü-mon'ta-tiv-nes), $n$. The quality of being argumentative.

Thus was the young, vacant mind finrufshed with muct talk about Yrogress of the Specles, Dark Ages, Prejudice and the likc, 80 that ail were quickly enongh btown out
inte a atate of whily argutmentatireness.

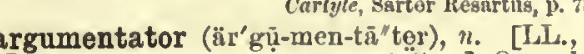
L. argumentatus: see argumentation.] One who conducts an argument; a reasoner. $N_{0}, E . D$. argumentizet (är'gü-men-tiz), $v$. [s arguas, "argumentizing philosophy," Mannyngham, Discourses, p. 34

argumentum (är-gū-men'tum), n.; pl. argnmenta (-tä). [L.: seéargument.] An argument. menta (-tä). [L.: see argument.] An argument. - Argumentum ad crumenam, an argument appenting tum ad hominem. See $a d$ hominein. - Argumentum ad 1gnorantiam, an argument based upon all alversary's invidiam, an aryument appealing to ene's hatreds o prejulicea. - Argurmentum ad judiclum, an argument addresscd to the judgment; a proof drawn Irom any of
the foundations of knowienge or probahility. - Argumenthe foundations of knowieige or probahility. - Argumen-
tum ad verecundlam (literally, sn appeal to one's noodtum ad verecundiam (literally, sn appeal to one s noot are commoniy accepted as authoritative. Also called ar gument to force; club- or lyneh-law. - Argumentum ex

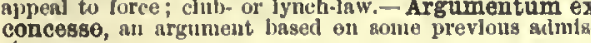
ston.

Argus (iir'gus), n. [L. < $<\mathrm{Gl}^{2}$. Ap pos, < a $\rho \gamma$ os, 1. In Grecian legend, a giant of vas and later to have eyes witheut number. Hera set him to guard the heifer Io, and after he was slain by Hermes transferred his eyes to the tail
of the peacock. Hence-2. Any observant or sharp-sighted persou: as, he is a very Argus in
watehfulness. - 3. In ornith.: (a) A genus of watehfulness, -3 . In ornith.: (a) A genus of
gallinaceous birds, of the order Gulliwe and family Phasianide, characterized by the enormous development of the secondary feathers of the wings and middlo foathers of the tail, the former being adorned with numerous ocelli, likened to the many eyes of Argus. The type is the argus-pheasant (Phasianus arpus, or Argus giganteus or pavomintex) of the Malay sichipelago. Other apectes or Aryus ocellaties of Verrean, and the Aryus bipunctatus. Other formis of the word, as a gentus name, are Argutanus
and Argusianus. (b) [l. e.] Any species of the genus Argus; an argus-phensant. The common specles has a borly only about as large as that of a barnyard hell, but sometimes neasures 5 or 8 feet in total
length, owing to the extraordinary development of the tali-fcathers. The inner feathers of the wing are 2 or
foet leng, and benutifully ocellated with metallic 1ridescent

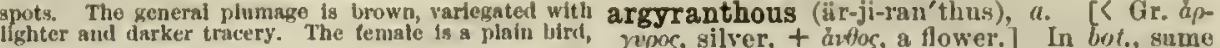

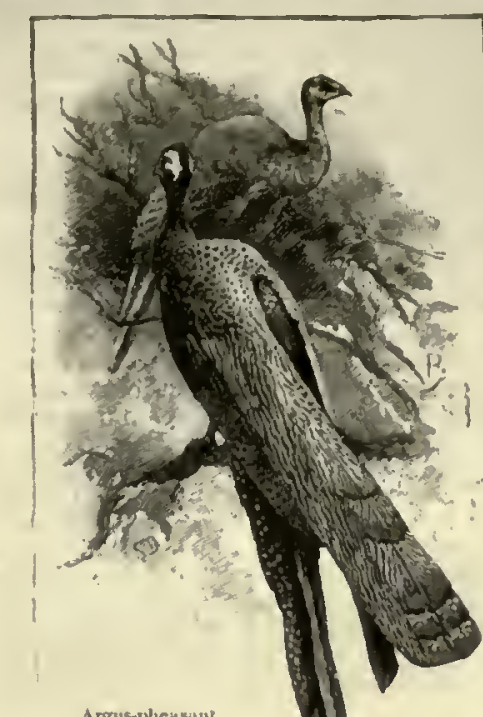

lacking tho extraordinary de. tali-feathers. 4. A genus of gastropods. Bohatseh, 1761 . 5. A genus of lepidoptereus insects. Scopoli, 1777.-6. A genus of arachnidans. Walker, 1837.-7. [l.e.] A name of certain euryalean ophiurians, or sand-stars wit branching arms. - Shetland argus, the Astrophyton (or Euryate) scttatum, or gorgon's-liead, a kind of hasket-1lsh, basket-urchin, or aenluasket, sometimes neasuring a foot of Its rays are eatimated to be some and bagket-fish.

Argus-eyed (är'gns-īd), " . igrilant: watchful; extremely observant. See Argus, 1. rgus-pheasant (är'gus-fe ant), $n$. See Argus, 3 . ärgus-shell (är'gus-shel), $n$. [ argus (with allusion to the pea coek's tail) + shell.] A gastropod of the family Cyprata, o beautifully variegated with ocellated spots. It is an inhabitant lated spots. It is an

argutationt (är-gū-tā'shou), n. [< argute, q. v. Cf. L. argutatio( $n-)$, a creaking, < argutari, pp. sharp, shrill: sce argute.] Cavil ; over-refinement in arguing; quibble; subtlety: as, "frivolons argutations," Rp. Hall, Myst. of Godliargute (ir-gūt'), a. [کL. aryutus, clear, bright, sharp, sagaeions, formally pp. of argucre, make clear: see tryuc.] 1. Sharp, as a taste; shrill, as a sound. -2 . Subtle; ingenious; sagacious; shrewd; keen.

I wili have him, continued my father, ... vigftant, The activc preacher, the restless missionury, the argute

argutely (är-gūt'li), adv. 1. Shrilly.-2. In sharp or subtle mauner; sagaciously; shrewdly. Sterne.

arguteness (är-gūt'nes), $n$. 1. Shrillness.-2 Acuteness; wittiness; sagacity; shrewdness. This [Seneca] tickles you by starts with his aryutenes,
that [Plutarch] picases you for continuance with his propriety.

Dryden, l'nutarch, p. 118

Argynnis (är-jiu'is), n. [NL., appar. orig. a misprint for "argyrius or "arfyreus, < Gr. apytpcos, silvery, < a pyvpos, silver. A genus of butcalled fritillaries, the several species of which
bave the under side of the wings marked with silvery spots. A. paphia, the silver-washed fritillary, is a typical example.

argyranthemous (är-ji-ran'thề-mus), a. [< Gir. a oyvor, silver, + ivecuov, a flower.] In bot. having silvery-white flowers. Craig, 1847. as aryyrunthemous.

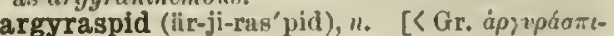
Ses, pl., lit. the silver-shielded, < a pyrpos, silver, + $i \sigma \pi i s\left(\dot{a} a \pi \omega_{-}\right)$, a shield.] A soldier of a chosen body in the arny of Alexander the Great, distinguished by earrying shields plated with silver, as a mark of honor. "lio name was retained after the time of Atexander for suldilcra of alunilar chosctu bodles In other Isscctonlan and Greek armteg,

argyria (air-jir’i-ii), n. [NL., < Gr. àprypos, sil. ver, + -ia.] Saine as aryyrism.

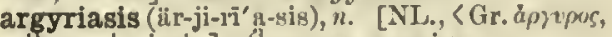
silver, + -insis.] Same as uryyrism.

argyric (är-jir'ik), a. [<Gr. apyepenós, of silver, <aproer, silver, silver money; cf. l e eruuiv. argentum: seo argent.] In elem., of silver: snmo as argentic.

argyrism (iir'ji-rizm), $n$. [(For form, cf. Gr.

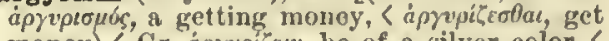
money) ( Gr. aprepilcet, bo of a silver color, ápyepos, silver, money.] A discoloration of the skin and other parts of the body due to the medicinal use for a considerable time of preparations of silver. It is causcd by the dejosition of silver or its compounda in a atate of minute aublivision in ia, aryyriaxis.

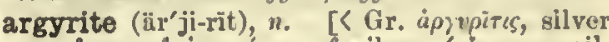
ore, fem. of aprvpirns, of silver, < \& $p\rangle$ vpos, silver.] In mineral., samo as argentite.

argyrized (är'ji-rizd), a. [<Gr. ả $\left.+-i z e+-d^{2}.\right]$ Exhibiting argyrism.

argyrodite (år-jir'ō-dīt), n. [NL., $<\mathrm{Gr}$. á $\rho \gamma y-$ $\rho \omega d \eta \varsigma$, like silver, rich in silver (< a $\rho \gamma v \rho o s$, silver, $+\varepsilon l \delta o s$, form $),+-i \ell^{2}$.] A mineral con taining silver, sulphur, and the new element germanium. It occurs in stcel-gray erystalline aggregates at Freiberg, Saxouy

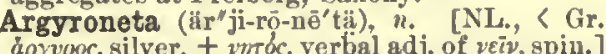
A genus of aquatic spiders, of the family Agalenide (or Araneida in a strict sense). The type of the geuns is the welling-eplder, A, aquatica, of Ev. rope, which sping a tubuliar
wel under water, líke a divwhich is then inflated witi air cartied down in bublues Argyropelecinæ (är"ji-

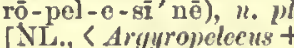
[NL., < Aroyropeleens + -ince.] A subfamily of sented by the genu Argyropelecus, with th abdominal ontline abruptly contracted in advance of the anal fin several prodneed neural

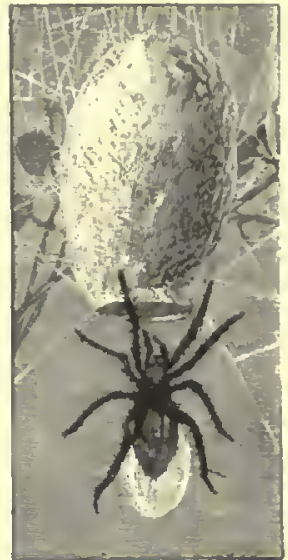
spines constituting

serriform ridge in advance of the dorsal fin, aud about nino branehiostegal rays.

Argyropelecus (är"ji-rō-pel'e-kus), $u$, [NL. typical genus of fishes of the subfamily ropelecinte: so called from the silvery color and

somewhat hatchet-like shape.
argyrose (är'ji-rōs), $u_{0}[\mathrm{~F} .,<\mathrm{Gr}$. äprpos: see argent.] In minerul., same as aryentite. arh-, in words of Greek origin. See arrhArhán (är'han), n. Same as Arhat arhapedan (är-hap'e-dan), $n$. A Syrian neasure of land, a square of 100 feet on the side. Arhat (är'hat), $n$. [< Skt. arhant, deserving,

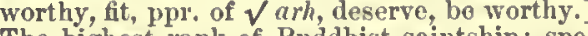
The highest rank of Buddhist saintship; specifically, one of the original five hundred diseiples of Gautama Buddha. Also Arahat, Rahat, and Arhan, Rahan.

arhatship (är'hat-ship), n. [< Arhat + ship. $]$ The state of an Arhat. Also arahatship.

The central point of primitive Buddhiam was the dostrine of Arahalship, - a syatem of ethical and mentas self cuiture, in which tielive rance was Ionnd trom all the myse
teries and sorrows of life in a change of heart to be reached
liere on earth.

arhizal, arhizous, $a$. More common but less

correct forms of arrhizal, arrhizous.

aria (á'ri- or ä'ri-ḧ), n. [It., < L. aër, air: see air ${ }^{3}$, also airl.] In music: (a) A rhythmical and metrical meledy or tune for a single voice (rarely for a monophonous instrument), having a vocal or instrumental accompaniment: dis- 
aria

tinguished from a song by being less simple and less purely lyrieal. The aria grunde is the next most claborate speeies of solo vocal music to the scena (which sec). (b) A distinct form of solo vocal music, distinguished by a elear division into three parts, lamely, a principal section, a subordinato scetion, and a repetition, with or without alterations, of the first section : otherwise known as the da capo form. (e) A solo movement, whether in strict aria opera 01 " an oratorio: as, the soprano aria "I know that my ledecmer liveth." See air3, 1.

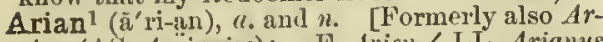
rian (AS. Arrianisc); $=$ F. Arien, < LI. Arianus (く LGr. A pelavos), < Arius, Arius (improp. Ar

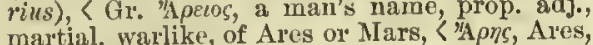
Mars: seo Arcs.] I. a. 1. Pertaining to or of the nature of the doctrines of Arius. Se

-2. Adhering to Arius or his doctrines. trines of Arius and his school. Arins was a presbyter of the church of Alexandria in the fourth century. lie leld that the Son was begotten of the Father, and there fore not coeternal nor conaubstantial with the Father, but
ereated by and subordinate to the Father, though pos. sessing a simllar nature. The name Arian is given in the ology not only to all those who adopt this particular
view of the nature of Chriat, but also to all thoae who, holding to the divine nature of Chriat, yet maintain his dependence upon and subordination to the Father in the
codthead. Aa a class the Ariana accept the Scriptures as a divinely lnspired and authoritative to be austained by its teachlngs. The doctrine of Ariug was authorilatively condemned by the Council of Nice A. D. 325, which deereed that Jeau Christ was "very God of very God; begotten, not made; o th the Faticr.

Arian $^{2}, a_{0}$ and $u$. See Aryan.

-arian. [< L. -āri-us (E. -ary, $\left.-a r^{2}\right)+-a ̈ n-u s$, H. $-a n$.$] A compound suffix of Latin origin,$ forming adjectives, and thenee nouns, from or instead of adjectives or mouns in -ary ${ }^{1}$. Worda ao formed reter sonetimes to things, as agrarian, but chiefty to persons, elther in regard to pursuit or occupation, as antiquarian, or to age, as gexagenarian, octogeand practice, as Aquarian, Millenarian, necessarian, $S u$ pratapsarian, Unitarian, humanitarian, utilitarian, etc. ur-Iatin origin, as anythingarian, nothingarint.

Arianism (a'ri-?n-izm), n. [=F. Arianisme,

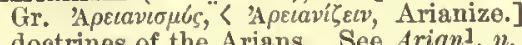

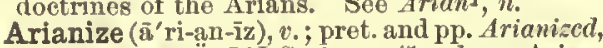
ppr. Arianizing. [<LGr.'Apezaví̌cev, be an Arian, ¿'Apecavós, Arian: see Arian ${ }^{1}$.] I. trans. To render conformable to Arianism; convert to Arianism.

II. intrans. To favor or admit the tenets of the Arians; tend toward Arianism: as, an Arianizing sect of Christians.

Arianizer ( $\left.\bar{u}^{\prime} r \dot{i}-a n-\bar{i}-z \dot{e} r\right), n$. One who favors, Arianizer ( $\bar{a}^{\prime}$ ri-an-i-zer), $n$. One who favors,
tends toward, ol converts others to Arianism. tends toward, ol convert
Arica bark. See bark 2 .

aricari (ar-i-kä'ri), n. See aracar

Aricia (a-rish'i-a), n. [NL., prob.<L. Aricia a town in Latium, now (It.) La Riccia.] The typical genus of the family Ariciide.

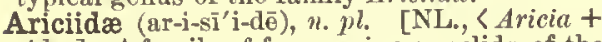
-ida.] A family of free marine annelids, of the order Chatopoda.

aricin (ar'i-sin), $n$. [<Arica, the name of a place (formerly in Peru, now in Chili) whence the bark is exported, $+-i n^{2}$.] An alkaloid found in th bark of some species of Cinchona. See bark 2 . arid (ar'id), a. [< L. aridus, dry, s arere, bo dry.] Dry; without moisture; parched with less, dull, pithless, ote.

The aril abstractions of the achoolmen were succeeded hy the fanciful viaions of the occult philosophers.
I. D'Israeli, Amen. of Lit., II. 285. As arid as a tuit of moas (a thing whose life ia in the aunshine, after long expectance of a shower. The capital defect of cold, arid naturea is the want of
Einerson, Society and Solitude. aridas (ar'i-das), n. [Native name.] A kind of taffeta, or plain smooth silk stuff without pattern, from the East Indies.

pattern, from the East Indies.
aridge (a-rij'), prep. phr. as $a d v . \quad\left[<a^{3}+\right.$ ridge. $]$ In a ridge; in or into a ridge-like position.

You're ollers quick to aet your back aridge, Lovell, Jonument to the Bridge.

aridity (a-rid'i-ti), $n . ;$ pl. aridities (-tiz), [=F. arialite, $<\mathrm{L}$. ariditas, dryness, $<$ aridus, dry: see aril.] 1. The state of being arid; dryness: want of moisture.-2. Fignratively, want want of moisture. -2 . Fignrati
interest; dryness; lifelessness.
308

The harsh arcetic mole of treating philosopliy ly the and repulsivenesa, in the rigid forma of their techuical
De Quincey, Style, iv.

I have often becn reproached with the aridity of my
Poe, Talea, I. 146. 3. Dullness of mind or situation; depression tedium.

Strike my soul with lively apprehensiona of thy excelcrees, to hear up ny apirit under the greatest aridities ridness (ar'id-nes), n. Same as aridity.

Around and between the ruiued clties, and reaching far and wide to the north and east, were blank aridness and arieæ. [NL., fem. pl. of -aricus, < L. -ari-us + $-c-u s$ : see -ary $y^{1}$ and -eous.] In bot., an ordinal termination, used by some authors in a very few cases instead of the more common -acere.

Ariel ${ }^{1}\left(\bar{a}^{\prime}\right.$ ri-el), n. [In def. 1, < LL. ariel, <Gr. a $\rho \hat{n} \hat{n},<$ Heb. aric̄, in the passage eited of un(Gesenius); clsewhere in the Old Testament as (Gesenius); clsewhere in the Old Testament as a man's name and as an appellation of Jerusalem, where it is taken as 'lion of God.' Hence, angel, and in Shakspere of an 'airy spirit' (N. E. D. ). There is an allusion in the poets' use to aërial, airy ${ }^{1}$; hence the applieation to a heavenly body and to birds.] 1 + . [l.c.] An altar. See etymology and quotation.

Forsothe the ylk ariel or anter [thilke ariel, that is the

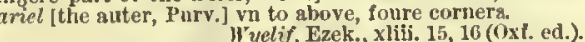
2. The innermost of the satellites of Uranus, discovered by Lassell in 1851 . It revolves about its primary in $2 \frac{1}{2}$ days. -3 . [ $[$. c. $]$ In ornith., applied to sundry birds of buoyant airy flight: as, the aricl swallow, Chelidon ariel; the ariel petrel, Proecllaria ariel; the ariel touean, Rhamphastos ariel.

$\operatorname{ariel}^{2}$ (a'ri-el), $n . \quad$ [< Ar. aryil, var. of ayyil, a stag, applied in Syria to the gazel (Dozy); cf. Ar. also $\bar{y} y \bar{l} l$, a stag.] In zoöl., an Arabian gazel, Gazclla dama.

'They are dainty little antelopes, these gazcllea and
ariels of tic Soudan.
Contemporary Revo, XLIX. 854. arierbant, $n$. See arrièrc-ban.

Aries (a' ri-êz), n. [<L. aries (ariet), OL. ares $=1 \mathrm{r}$. and Gael. reith, a ram.] 1. One of the the zodiac (marked $\Upsilon$ ), which the sun enters

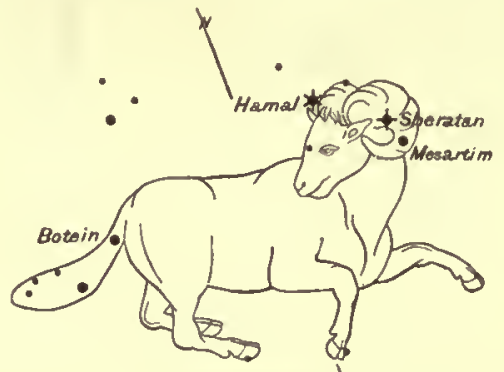

The Constelt

at the vernal equinox, Mareh 21st, and leaves April 20th. Owing to the precession of the equinoxes, aign of the aame name, which is now occupied by the

3. [NL.] In zoöl., a genus of mammals. Storr,

arietatet, v. $i . \quad[<\mathrm{L}$. arietatus, pp. of arietare, butt, as a ram, < aries (ariet), a ram: see Aries.] To push or butt like a ram. Bailey.

arietationt (ar'i-e-ta-shon), $n . \quad[<\mathrm{L}$. arieta tio $(n-),<$ arictare, butt: seo arietate. $] 1$. The act of butting like a ram. -2 . The act of battering with a battering-ram,

Ordnance do exceed all arietations and ancient inven-

3. The act of colliding or conflicting. Glanville. arietiform (ar-i-et'i-fôrm), a. [< L. Aries (Ariet), a sign of the zodiac (see Aries), + forma, form.] Having the shape of the symbol of the zodiacal sign Aries $(T)$.

arietine (ar'i-e-tin), $a_{0}[<\mathrm{L}$. arietinus, $<$ arie (ariet), a ram: see Aries.] Butting; pertaining to or having the nature of a ram.

The gap in the lence discovered by thelr arietine leader

arietta (á-ri-et'tạ̈), $n$. [It., dim. of aria, q. v.] A short song; an air, or a little air.

ariette (a-ri-et'), $u_{0} \quad[\mathrm{~F} .,<$ It. arietta, q. v. $]$ Same as arietta.

\section{Arimaspian}

She hastencd to besecch their attention unto a milltary aright (a-rit'), prep.plir. as adv. [<ME. aright arist, arilut, ete. < AS. a rilht, earlier on rillt, aright: on, E. $a^{3}$; riht, E. right: see riyht, $n$. ane a right way or form; without error or fault.

Nor can a man of passioua judge aright,

Sir J. Daries, Immortal. of Soul, iv.

These mingled seeds thy hand shall set a right,

All laid in heaps, each after ita own kind.
N'illiam Horrix, Eartlly l'aradise, I. 264.

2. To or toward the right hand. [Rare.] The affighted foemen acatter from his apear, aright, aleft.

Ariina (ar-i-i'nä), $n . p l$. [NL., < Arius + -ina.] n Günther's classification of fishes, a group of Silurida proteroptere, with the anterior and posterior nostrils close together and

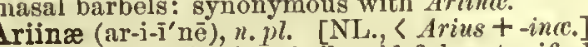
In ichth., a subfamily of siluroid fishes, typified by the genus Arius. They have a form rescmbling that of the North American catfishes, but the anterior
nosirils are close to the posterior, and the latter have no noalrils are close to the posterior, and the latter have no
barbels. Moat species have a bony occipital ahlehl, hetween which and the dorsal fin ia a amaller antedorsal

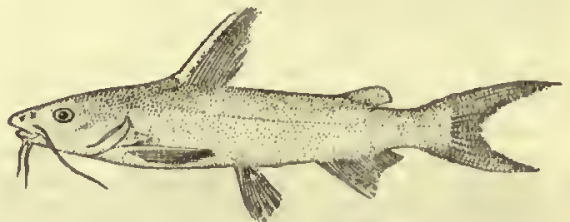

Salt-water Catish (Arius Jelis).

From Report of U. S. Fish Commission, r8s.)

1aually preaent. About 100 apeclea are known, most of which are inhabitants of the tropical or warm aeas. The aize, in their month, and there hatch then. A few reach ril (aril) $n,[=\mathrm{F}$, arille $=\mathrm{Sp}$, arill $a=\mathrm{Pg}$ It. arillo, $<\mathrm{NL}$. arillus, $<\mathrm{ML}$. arilli (pl.), dried rrapes, L L aridus, dry: see arid.] In bot., a term variously applied to the acessory eoverings or appendages of seeds. It is sometimes used in a general aense, without regard to form or place of origin, and includea the atrophiole, carumcle, and arillote (see
theae words); but it I usually llinited to a more or leas nearly complete aeed-covering which originatea from the is no funiculua. Alao arillus

ariled (ar'ild), a. Same as arillatc.

arillate (ar'i-lāt) a $\quad[<\mathrm{NL}$ arillatus < arillues: see aril ] Furnished with on aril, as the fruit of the spindle-tree.

arillated (ar'i-lā-ted), $a$. Same as arillate. arilli, $n$. Plural of arillus. arilliform (a-ril'i-fôrm), a. [<NI, arillus, aril, + L. forma, form. ] Having the form of an aril. arillode (ar'i-lod), $n$. [<NL. "arillodium, s arilsometimes applied to a form of arif which a form of aril which micropyle or raphe instead of at or be low the hilum, as in the nutmeg.

rillus (a-ril'us)

pl. arilli $(-1)$. [NL.] Samo as ari.

Arilus (ar'i-lus), $n$ [NI.] A genus of het eropterous hemipterous insects, of the family Reduviida, for merly ineluding the species of Prionidus, as the wheel-bug.

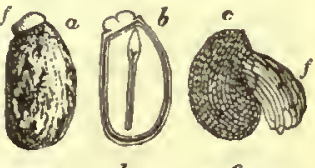
8 seed of Ricinus communis.

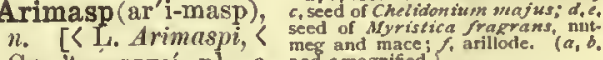

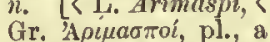
'Seythian'word, said

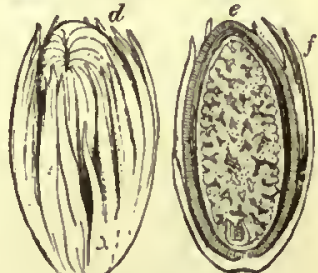

, according to Herodotus, 'Seythian,' < a $\rho \mu \mu a$, one, + $\sigma \pi \circ \bar{v}$, eye; according to Eustathius, <a $\rho$, one, $+\mu a \sigma \pi b s$, eye.] One of the Arimaspi, a mythieal tribe of Seythians, believed in antiquity to have carried off a hoard of gold which was under the guardianship of griffins. Figmres of Arimaspa occur aomelimea in Greck Arimaspian (ar-i-mas'pi-an), $n$. Same as Arimasp. 
Arimaspian

As when a gryphon litrongh the whiderness Pursues the A rimagian, who by sleattly

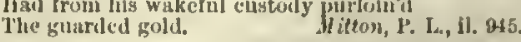
Goal or grillin, Christian or Cockney, Mlser or A rinaw.
pian. Arinæ $\left(a-1 \overline{1}^{\prime} n \bar{c}\right), n . p l . \quad\left[<A r a^{2}+-i n \alpha_{0}\right] \Lambda \mathrm{sub}$ family of birls, of tho family l'sittueith, including tho wedge-tailed macaws and parrakeets of Ameriea. See $A r^{2}$ and Conurus. Also written Aruinte.

ariolation ( $\left.\operatorname{ar}^{\prime \prime} \mathrm{i}-\overline{0}-1 \overline{\mathrm{d}}^{\prime} \operatorname{shon}\right), n$. Seo hariolation

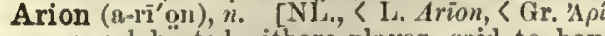
$w v$, a celebrated cithara-player, said to have been resened from trowning by a dolphin.] A genus of pulmonato gastropods, by some referred to the family limecide and subfamily Arionime, but now generally considered as the typo of a tamily Arionida, ineluding several species of slugs, of which A. ater, tho black slug, is a charaeteristic example.

In the principal genus, A rion, there is a Lrlangular por

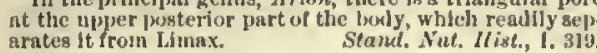
arionid (a-ri'on-id), $n$. A gastropod of the family srionider.

Arionidæ (ar-i-on'i-dē), n. pl. [NL., < Arion + -idk.] $\Lambda$ family of geophilous pulmonato gastropods, resembling the Limacida, and represented by such genera as Arion and Ariolimax. Its teclunlcal clinracters are a shell reduced to s small fla

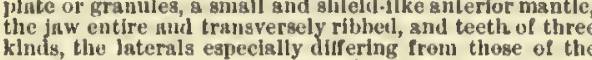
Limacilfe by their low, wide, and quadrate form. They are conf
ot slugg.

Arioninæ (ar"i-ō-ni'nēe), n. pl. [NL., < Arion $+-i n x$.$] The slugs of the genus Arion and re$ lated genera, such as Ariolinax, regarded as a subfamily of the Limacila.

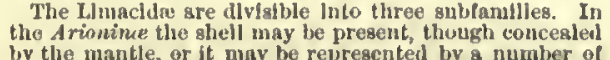
calesreous gralns sentlered through the correspondling portion of the mantle. Stand. Nat. Ilist, I. 318 ariose (ar-i-ôs'), a. [< It. arioso, q. v.] Charaeterized by melody, as distinguished from harmony. [Rare.]

Mentelssolun wants the ariose hesuly of IIandel; vocsl mcledy la not his forte; the interest of his sirs is harmonic.

arioso (ì-rẹ̄-ō'sọ̄), a. [It., < aria, air: see aria and air ${ }^{3}$.] In music, liko an air, as eontradistinguished from recitative. The word is used especiully wlth reference to recilntive passages whlch are
treated more in the sunooth and melodlens style of alrs treated more in the sinooth and melodlons style of alrs
than in the ordinury style of recitatlves. In Instrumentnl musle it indicates a flowing vocal style. Preflxed to sin lhe grent slrs of un epera.

-arious. [Accom. of L. -arius: seo-ary ${ }^{2}$ and -ous.] A suffix of Latin origin, another form of -ary 2 , but used only in adjectives, as in adversarious, arenarious, calcarious (now erroneversarious, arenarious, calcarious (now erron

arisadt, arisardt, $n$. [Origin obseure.] A long robo or tunic girded at the waist, worn by women in Seotland as
Also airisal, airisard.

arise (a-riz' arising. [ M ME. arisen, < AS. ärisan (= ONorth. arrisa $=$ OS. arisan $=\mathrm{OHG}_{\text {. }}$ ar-, ir-, ur-risan arrisa $=$ OS. arwan $=$ OHG. $a r-, i r-$, ur-risan $=$
Goth. urreisan, arise $)<\bar{a}-+$ risan, rise: $\operatorname{se\theta } a-1$ and risel.] 1. To get up from sitting, lying, or knooling, or from a posture or state of repose, as from sleep or the gravo: as, tho audienee arose and remained standing.

I will arise, and go to my tather.

The king arose very early in the morning. Dsn. ri. 19. Arise from the dead, snd Christ shall give thee light.

Isny bedles of the sainla whlch slcpt arose. Arise, he saitl, to conquering Athens go,
There fate appelnts sn end of all thy woe. here fate appoints sn end of all thy woe.
Dryden, Pal. and Arc., I. 533. I dub thee knight. Arise, Sir Ralph, De wilton's helr. Scott, Jarmion, 10

2. To get up from a sitting or session, as of a court; suspend sittings for a time; adjourn: as, tho court arose at 4 o' clock. [Archaic: seo
rise.]-3. To spring up from, or as from, the ground : ascend; mount or move from a lower to a higher plaee: as, vapors arise from humid ground.

The forests were flled with birds; snd, at the discharge Bancroft, Hist. U. S., I. 76. From right to lefl about the flashing mas A rese as splal stali, the tower ringlug. Nimrod, v. composed of the best men in the state.
309

Aristolochia

4. To come into view, as from a liding-place specifically, to appear, as the sul or a star, above the horizon: bence, to begin, or be usllered in, as the day. Arise, lalr ann, and klll the chvlous moon. While day a rises, that sweet heur of 1 rine.

v. 1 \%o.

5. To come into being or action; come into existenee or Ilay; start into prominence or aetivity; appear; eome upon tho sceno: as, a falso proplie

Now there arave up a new klug over Egypt, whlleh knew not Jonciph.

Whence heavy persecutlun shall arise

Ex. 1.8.

Milton, I'. In, xll. 531 For the mighty wind a rises, roaring gesward, and I go.
Tennyen, Lucksley IIali.

The fice of a unlversal and beneffcent Creator of tho
unlverse does not secm to arise in the mind of nam until he has been elevated by long-centhuned culture.
Daroin, Descent of Mlan, II. 377.

6. To have a beginning or origin; originate. (a) To have or take its rise, as a river; rlse, as frem source. (b) T'o result er proceed, as from a causo: as, n
of these spjaallng actilents a rise from carelessncess.

All the powers and capaclies of man, being the work of (ioil, must hsve thelr proper place in hls designs; and the vil in the world arises not from thefr nsc, lut from thel

7. To eomo or spring up incidentally, as anything requiring attention: as, other eases can be attended to as they arise.

Fortunately, the contingency to which I allude [the neE. Dicey, Vlotor

8. To rise in hostility; rebel: with agalnst. as, the men arose against their oflicers.

When he arose against me, I caught hlm by hls beard. common.] =\$yn. Arise, Itise. The cholce between these Words was primarily, and still often is, a malter of rhythm. The literal meanings, however, or those whlch seem literal, have become more assoctated with rise, and the consclously
fguratlve with a rise: as, he rose from lils clalr; the sun rose; the provlnces rose in revolt: trouble a rase. "Muslc arone ariset (a-riz'), $n$. [ ' arise, $v, i$.$] Rising.$

Upos the arise or descent of the atars.

rish (ar'ish) " [Por.] H vi. 3. measure, equal to 38.364 English inches.

aristt, $n$. [ME., < AS. ärist, êrist, érest (=Gotl. urrists), arising, (arisun, arise, + $t$, a common bed, or tho ground, or from below the horizou as, "at the somne ariste," Chaucer, Astrolabe. aristt. A shortened form of ariseth. Chaucer. arista (a-ris'tä), $n_{.} ;$pl. arista (-tê). [L, the awn or beard of grain. Cf. arrest ${ }^{2}$. 1 . In
bot., an awn (which see).- 2. In $z o o j$, an awn bot., an awn (which see). -2 . In zool., an awn or tactile filament at the end

T'he antennw ... msy. be very short and com. posed of three joints, frequently bearing a tactile hsir at
the extrenity (arista). Claus, Zool. (trans), I. 573. aristarch (ar'is-tärk), n. [< L. Aristarchus, Gr. Apíatapxos, a eritic of Alexandria, noted for his severity, espeeially in regard to the Homerie poems.] A severe eritie: as, "the aristarch johnson," Scott, Abbot, Int.

Aristarchian (ar-is-tär'ki-an), a. [< Gr. 'A $\rho$ -

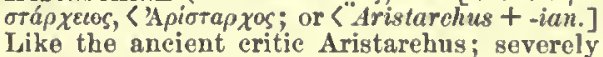
critical.

aristarchyl (ar'is-tär-ki), n.; pl. aristarchics

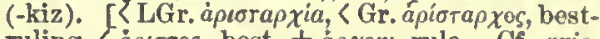
ruling, $<a \rho$ a $\sigma \tau o s$, best, $+a \rho \chi \varepsilon \iota v$, rule. Cf. aris tocracy.] Government by the best men; a b
of worthy men eonstituting a government.

oristarchy ${ }^{2} \dagger$ (ar'is-tär-ki), $n$. [< Aristarchus.] Severe eritieism like that of the aneient eritic Aristarehus. [Rare.]

Ilowbelt, the ground on whlch I would build his cllet praise (to gome of the Aristarehy s days) requires, first, an spology

ristate (a-ris'tāt), a. [< LI. aristatus, $<\mathrm{L}$. arista, awn or beard of grain.] Awued; having a pointed, beard-like process, like that of barley. See cut under barley.

ristocracy (ar-is-tok'ra-si), n. ; pl. aristocracies (-siz). [< OF aristocracie, $\mathbf{F}$, aristocratic,

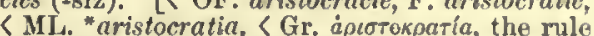

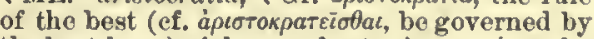
tho best-born), < a $\rho$ toros, best, + -kparia, rule, [ кpareiv, be strong, rule.] 1t. Government by the best men in the state; a governing body very few of tilis class to the exclu
guvernment becomes an ollgarcliy. tocruey of wealth or of eulture mont. iristocraey. an aristocratio manner. [Rare.] posed of aristoeratic an
[In senses $1-4,6(a)$, and 8 , risc is now moro A rese an splial stal, the tower ringling.
C. De Kay, Vlalon of Nimrod, v. composed of the best men in the state.

11e [Periander] reckoneel tlat pupular estate ... lest wise and noble senate. IIvland, tr. of Plutareh, j. 276 . 2. A form of government in which tho supreme power is oxereised by those members of the state who are distinguished by their rauk and opulenee. When the rulfug power is excrcised ly a

The a rixtocraey of Venice butli silnitced ao many slusses . Take awsy the atancllng armles, and lenve the nobless to
themselves, and in a lew ycars they wunlli uvert ur't every

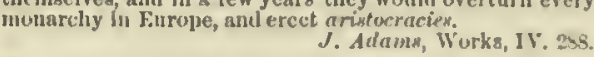
3. A body of persons lolding exeeptional preseriptive rank or privileges; speeifically, a elass of hereditary nobility; the nobles of a country and those nearly related to them.

between the aristocracy and the working peuple had sprung up a niddilo class, agricultural sud commerclal.

4. Persons noted for superiority in any eharneter or quality, taken collectivoly: as, tho aris-

aristocrat (ar'is-tọ-krat or a-ris'to-krat), n. [< $\mathbf{F}$ aristocrate, a reverse formation from the adj. aristocratique: see aristoeratic.] 1. A member of tho aristoeracy or men of rank in a community; leuce, a person having the traits supposed to be eharaeteristio of an aristocraey: as, "a born aristocrat," Mis. Brolcniug -2. One who favors an aristocracy; one who is an advocate of all aristoeratie form of govern-

aristocratic (ar"is-tō-krat'ik), a. [< F. aristocratique, <Gr. ápєбтократєкós, pertaining to aristocracy, $\zeta$ a $\rho$ бтократіa: see aristocracy.] 1. Pertaining to aristocraey or a ruling oligarehy; consisting in or pertaining to the rule of a privileged class; oligarchie: as, an uristocratie constitution; an aristoeratic government.

The Areopagus was a bolly of arisfucratic tendencles,
conslsting of those who liad served the ofice of archon; fonglsting of those who lisd served the office of archon;

2. Pertaining to, resembling, or befitting tho nobility or men of rank; resembling in manners or eharaeter tho aristocracy or higlier classes in a community: as, aristocrutie pride; aristocratic in sentiment.-3. Belonging to an

ristocratical (ar"is-tọ-krat'i-kṇl), $\alpha$. Same as

ristocratically (ar"is-tō-krat'i-kạl-i), $a d r$. In

aristocraticalness (ar/is-tē-krat'i-kąl-nes), $n$. The quality of being aristoeratic

ristocratism (ar'is-tō-krat-izm or ar-is-tok'ratizin), $n$. [ aristncrat $+-i s m$.$] A ristocratie rank,$ of being aristareter; the state or condition bership of or adherence to a privileged class.

Ariatocratism rolls in its carriage, while patriotisnn can-
not trail its cannon. aristocratize (ar-is-tok'ra-tiz), $v$. ; pret. and pp. aristocratized, ppr. aristoeratizing. [< $\mathrm{F}$. ize.] I. trans. To render aristoeratic.

II. intrans. To favor or support aristocracy.

aristocraty $\nmid$ (ar-is-tok'ra-ti), $n$. Same as arisristodemocracy (ar"is-tō-dē-mok'ran-si), n. [< aristo (cracy) + democracy.] Grovormment by sobles and the commonalty; a government eom-

Aristolochia (ar"is-tō-lö'ki-aị), n. [L., < Gr.

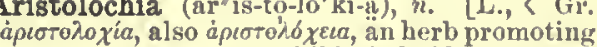

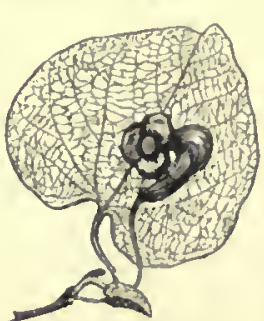

Dutchman's Pipe
(Arisfolochia Sipho)

pos

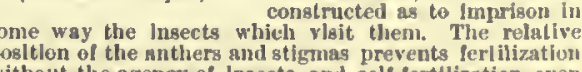
y their a agency of Insects, and self-fertllizution even proterogyny. II ow eross-ferthization is effected by en. + toxeia, child-birth: see
lockia.] A large genus of apetalous exogenous plants, the type and principal genus of the natuchiefly woody climbers, and very widely distributed. There are abont 180 specles, of which 7 are futmil
In the United States. They are remarkable for their curious Howers, wilhich vary greatly li child-birth, Sáplores, best, 


\section{Aristolochia}

trapping the insects has not heen satisflactorily explained. are usualiy of a dingy lue. A. Goldieana, of Calabar, has the largcst that are yet known, the blade of which is nearly 2 teet in lireadth. The common birthwort, $A$.
Clematitis, nud some other European species, had formerly a reputation as emmenurgogues and as facilitating tion as remedies for snake-litites, as anthelminthics, ete., and the "Irginia suskeroot, or serpentary-root, A. Ser. zentarin, is employed as a stimulating tonic and diapho-
rctic. The pipe-vine, or Dutehman's-pipe, $A$. Sipho, a na. tive of the Alleghanics, with very large cordate leaves, is

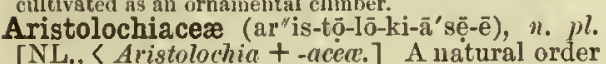
[NL., < Aristolochia +-acee. ] A natural order of apetalous dicotyledonous plants, characterepigynous stamens, and a colored, usually irregular, calyx. The principal genera are Aristolochia and Asarein, with about 200 species, herlss or woody climbers, widely distrilibuted through temperste and tropical regions
and possessing bitter and acrid properties. See Ariztolo and possessing bitter and acmit

aristolochíaceous (ar"is-tō-lō-ki-ā'shius), a. Belonging or pertaining to the Aristolochiacece. aristological (ar"is-tö-loj'i-kal),

aristologist (ar-is-tol'ô-jist), n. [< aristologn as $+-i s t$.$] One skilled in aristology. N . E . D$. aristology (ar-is-tol'ō-ji), n. [R Gr. òplotov, breakfast, $+\lambda$ yia, $\langle\lambda k$ riv, speak: see-ology.
The science of dining. T. Walker. [Rare.]

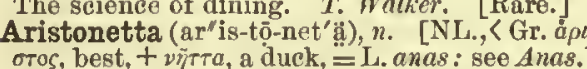
бтos, best, $+\nu \tilde{7} \tau \tau a$, a duck, =L. anas: see Anas.] A genus of sea-ducks, subfamily Fuligulince, the flesh. The type and only species is the eanvasback, $A$. vallisncria. S. F. Baird, 1858. See cut under canvasback.

Aristophanic (ar"is-tō-fan'ik), $a$, and $n . \quad[<\mathrm{L}$.

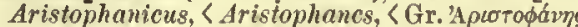
Aristophanes.] I. $a$. Pertaining to the writings or style of Aristophanes, the great comi poet of Athens; shrewd; witty.

II. $n$. [l.c.] In anc. pros., same as first PhereAric.

Aristotelean (ar-is-tot-ẹ-lē' ạn), a. Same as Aristotelian.

Aristotelian (ar"is-tō-tē'li-ann), $a$, and $n . \quad[<\mathrm{L}$.

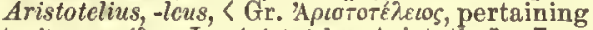

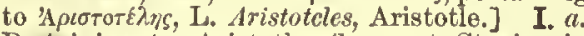
Pertaining to Aristotle (born at Stagira in Macedonia, 384 B. c., died 322 B. c.), the fathe of logic and the most influential of all philoso-
phers, or to his works, school, or philosophy. See peripatetic. - Aristoteltan logtc. (a) The logfc of Aristotle, especiaily in the plodified form taught in the mildlle ages. (b) Forms logic, based on the four propo-
sitional forms: All $\mathrm{S}$ is $\mathrm{P}$; No $\mathrm{S}$ is $\mathrm{P}$; Some $\mathrm{S}$ is $\mathrm{P}$; Som

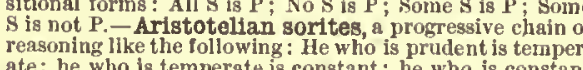
ate; he who is temperate is constant; he who is constan is unperturbed; lie who is unperturbed is without sorrow
he who is without sorrow is happy ; therefore, the proden
man is happy.

The progressive gorites has been called the conmon or
Aristutelian. This latter denomination is an error, fo
Aristotle, though certainly not ignorant of the process Aristotle, though certainty not ignorant of the process on
reasoning now called sorites, does not euter upon its cor

II. $n$. A follower of Aristotle. See peripatctic Aristotelianism (ar"is-tō-tē'li-ant-izm), n. [ [ totle, or any later modification of it telianism is a kind of metaphysical evolutionism. Its
central ides is the distinetion of act and power (Actuality and potentiality). The nature of the world as a whole, as well as every part of it, nay he illustrsted by the analog.
of the growth of a tree from a seed. The tree has a soin of heing in the seed-a potential being: it exists in it in
of bover only. That which is actualized in the perfected de.
poos pelopment from the seed - the tree-exists in act or ac
vel on tuality. This perfected development - the entelechy some natural species, and which is its form, or that ele
ment of the thing which makes it to be the kind of thing

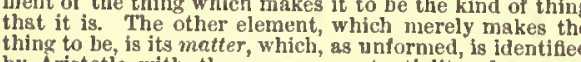
thing to be, is its matter, which, as ynformed, is identiere
by Aristatle with the power or potentiality of a germ. Every event is an act of development. Hlost events tak place under the influence of an external efficient cause,
and their chsracter is deternined by an end. Matter
forn, efficient cause, sull end are the four Aristoteling forn, efficient cause, and end are the four Aristotelian
causes or principles. But not all events are brought sbout causes or prineiples. But not all events are brought sbou
by external efilicient causes. Soune hsppen by fortuitous by external efficient causes. Some hsppen by fortuitous
gpontaneity, snd are not determined by any canses what ever. Other events come to 1 nass naturally, that is, by 8
self-determined growth. . Besides that which is moved but does not cause motion, and thst which is both noved and
causes motion, there inust needs lie a fertiven quid, which is not moved, yet calses motion; and this is God, or pure
act (actuality) without undevelopel potentiality. The soul at (actuality) with out undeveloped potentiality. The sou
is the entelechy, or perfect flower, of the body. It has and the rational. The reason is not a mere belonging of the fndividnal; it exists before the body, and, as the ac tive reason, is commonl to all persons upon the tallets of
whose passive reason it writes its dicta. Space and time are mere loglcal elements of motion. Aristotle in justly
called the tather of logic, although there were some vague
310

ark

logical doctrines betore him, and atthongh his system is arithmetician (a-rith -me -tish' an), $n . \quad[<F$ now lsrgely supersedcd. He holls the only excellent reasoning to be syllogisn, and all other kinds of reasoning $t$
be imperfect approximations to syllogism. Particula facts are first and best known to nis, but general truth are first and best known in themselves. Scicnce must set tense, to the formation of which reeson sud experience both contribute. Things are of ten classes, sulustance relations, qusntities, qualities, etc. See category. Differ ent genera are subdivided upon different principles, 80 of natures. It is possible to so collate passages from Aritotle as to make him appear as an inductive logicisn; but the whole cast of his mind was such as to lead liim to underrate the importance of induction. He lays much stress on the principle of excluded mildle, which he trest as a corollary of the princlple of contradiction; and he has a general leaning to hard and rather woodell distincthat happiness lies in the working out of one's jnwardness, and that every virtue is a golden mean between two

Aristotelic (ar"is-tō-tel'ik), a. [<LL. Aristo-

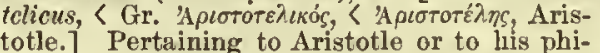
totle.]

Aristotle's lantern. See luntern.

aristulate (a-ris'tūilāt), a. [<NL. aristulatus, aring bot. having a short beard or awn. A. Gray.

arithmancy (ar'ith-man-si), $n_{0}[=$ Sp. arit cia ; contr. of urithmonancy, q. v.] Same as arithmomancy.

rithmantical (ar-ith-man'ti-kal),
pertaining to arithmancy. $\quad$ N. $E . D$.

rithmetic (a-rith'me-tik; as adjective, ar-ith met'ik), $n$. and $a$. [The ME. forms are corrupt: arsmctikc, arsmetrik, ars metrike, ete., in imulation of L. ars metrica, the metric art tricke, arithmetick, after mod. $\mathrm{F}$, and $\mathrm{L}, \mathrm{LOF}$. tricke, arithmetick, after mod. F. and $\left.\mathrm{L}_{\mathrm{S}}\right), \mathrm{KOF}$,
arismetique, mod. F. arithmétique = $\mathrm{P}$. arismetica $=\mathrm{Sp}$. arismética, now usually aritmética $=\mathrm{Pg}$. arithmetica $=\mathrm{It}$. aritmetica $=\mathrm{G}$. Sw. Dan

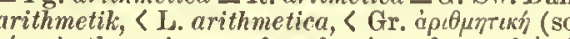
$\left.\tau^{2} \chi \nu \eta\right)$, the science of reckoning, ferm. of $\alpha \rho t \theta$

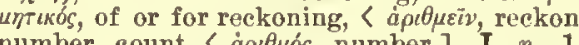
The theory of numbers; the study of tho divisibility of whole numbers, the remainders after division, ete. Also ealled therretical or higher arithmetic. -2 . The art of computation: the most the word appears earty in the sixteentli century. The ar rism (which see) or augrim, then practical arithmetic, lastly arithmetic simply, or elementary arithmetic. $\Delta b$ -

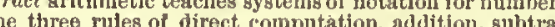
ion, and multiplication, and various rules of indirect com putation, or computation by successive approximation,
such as division, extrsction of the square and cube roots, double position, etc. Practical arithmetic teaches the $3 \dagger$ (pron. al'-ith-met'ik). An arithmetician. -Binary (or dyadic) arithmetic, decimal arithme tic, duodecimal arithmetic, etc. See the adjectives arithmetic, the simpler branclies of arithmetic adspted tions in the mind, without writing the figures. - Polticical
arithmetic, the spplication of arithmetic to politics ; staII. a. A less common form of arithmetical. arithmetical (ar-ith-met'i-kal), $a$. [= F. arith-

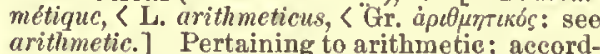
ing to the rules or methods of arithmetic Arithmetical complement, the sum which a number ample, is the arithmetical complement of $7 ; 56$ of $44 .-$ Arithmetical complement of a logarithm, the sum or number which a logarithm lacks of 10.-Arithmetica
mean. See mean. - Arithmetical progression a sea common difference, as 1,3,5,7, ete. See series.metical ratios or differences, as in the numbers 12,9,
where $12-9=9-6$. Arithmetical ratio, the differ ence between any two adjscent terms in arithmetical
progression. - Arithmetical signs, the arbitrsry synprogression, - Arithmetical signs, the arbitrary syni or the relations subsisting between them: as,,,$+-=$,
etc. Arithmetical triangle, the triangle formed by
the orderly sirangement of binomial coefflcients; thus:

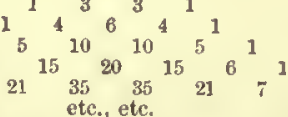

arithmetically (ar-ith-met'i-kal-i), $a d v$. According to the rules, principles, or method of
arithmetic. arithméticien, < L. arithméticus: see arithmetial.] One skilled in arithmetic.

arithmetico-geometrical (ar-ith-met"i-kō-jēọ-met'ri-kal), a. Arithmetical and geometrical: a term descriptive of a kind of mean bethe arithmetical and the geometrical means of the quantities, then the means of these means, and so on, until the two results become identical. Thus, starting with 2 and 3 , we ohtsin successive

$$
\begin{array}{lcc} 
& \text { Arithmelical. } & \text { Geometrical. } \\
\text { First pair, } & 2.5 & 2.449490 \\
\text { Second "، } & 2.474745 & 2.474615 \\
\text { Third "w } & 2.474680 & \mathbf{2 . 4 7 4 6 8 0}
\end{array}
$$

The nunbers of the last pair being sensibly equal, 2.474680 is the arithmetico-geometrical mean of 2 and 3 . This pro-
cess, invented by Gauss, is useful in calculating elliptic in

arithmocracy (ar-ith-mok'ra-si), n. [<Gr. o $\rho t \theta \mu o ́ s$, number, + -кparia, rule: see -cracy, and ef. democracy.] Rule or government by a majority. [Rare.]

A democracy of mere numbers is no democracy, but a Kingsley, Alton Locke (ed. 1854), Pre?

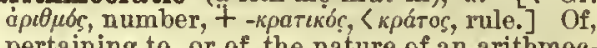
pertaining to, or of the nature of an

American democracy, being merely arithmocratic, pro and more experienced minority.
Kingsley, Aiton Locke (ed. 1862), Pref arithmograph (a-rith'mō-graif), $n$. [<Gr. á $\rho \iota$

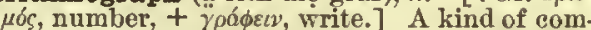
puting-machine.

arithmomancy (ạ-rith'mō-man-si), n. [Also contr. arithmancy, q. v., $<$ NL. arithmomantia,

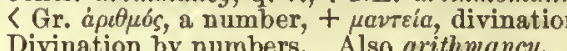
Divination by numbers. Also arithmancy.

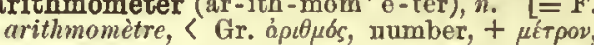
a measure.] An instrument for performing multiplication and division. The multiplicand is made to appear in one place by setting certain stops or made, so as to cause the multiplier to appear in snother place. Then the product will be found in a third place. what similar way. The best-known of these machines t arithmo-planimeter (a-rith"mö-plä-nim'e-tèr)

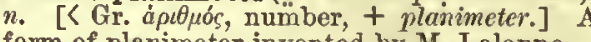
form of planimeter invented by $M$. Lalanne.

a ritorte (ä rē-tōr'te). [It.: a (< L. $a d)$, to, with; ritorte, pl. of ritorta, band, tie, sprig; cf. retort.] With bands: said of glassware glass, generally spiral, sunk in a body of transparent glass, so as to form one mass with it. arlum. [L. -àrium, neut. of -àrius (see-ary 1 , -ery), denoting a thing connected with, chiefly a place for, something, as in L. aquârium, a place for watering cattle, vivārium, a place for live fish, etc., LL. Terbărium, a collection of to as ariaryanged, or with adapted suffix -ary, original Latin nenter form of -ary ${ }^{1}$, usually in words denoting a place set apart for something, as aquarium, vivarium, herbarium, also (as Latin words) frigidarium, caldarium; but sometimes used differently, as il honorarium.

martial, warlike, < " A genus of marine catfishes, giving name to the subfamily Ariince: synonymous with Galcichthys (which see). See cut under Ariina. arius. [L.: see-arium, -ary1.] A Latin termination frequent in zoölogical and botanieal terms: sometimes used unchanged in Englisl. $\operatorname{ark}^{1} \nmid, n$. An old spelling of $a r c^{1}$, a bow, arch. OHG. arka, archa, MHG. G. arche = Icel. $\ddot{\circ} \% k=$ Dan. Sw. $a r k=$ Goth. ark $a=$ Sp. Pg. It. arca $=$ Pr. arch $a=\mathrm{OF}$, arche ( ME. arche: see areh 2 ), mod. F. arche $=$ Gael. Ir. airc $=$ W. arch $<\mathrm{L}$. arca, a chest, box, coffer (in Vulgate of Noals's ark and the ark of the covenant), ( arcere, keep, $=\mathrm{Gr}$. $\alpha$ $\rho \varepsilon i \bar{v}$, keep off, suffice.] 1. A chest, box eoffer, or other close receptacle; a bin or hutch: as, a meal-ark. [Obsolete, poetical, or dialectal.]

Then first of all forth came Sir Satyrane,

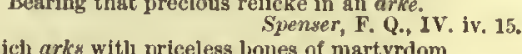
Tennyson, Bajin and Balan. tween two quantities obtained by taking botl arithmocratic (a-rith-mō-krat'ik), a. [< Gr. arc $=$ ONorth. arc, arc $=$ OFries. erke $=\mathrm{D}$. ark 
ark

2. In Scrip.: (a) The repository of the covenant or tables of the law. Thie ark was mante of slittelm-

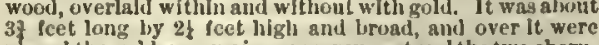
placel tho golden co veriug ur mercy-seat anilt he two cheru.

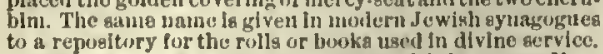
(b) The largo flonting vessel in which, aceording to the account in the Old Testament, Noals and his family wero preserved during the doluge. (e) The vessel of bulrushes in which the infant Moses was laid. -3. In the Ethiopic C'h., a sacred chest, called the tabout, serving as an altar. I must here speak of that cxtransdlinary appurtenance
of the Elhituric church, the tabout, or ark. It is the be-

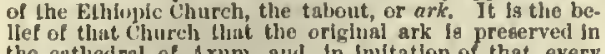
the catleciral of Axum, and, In Imitation of that, every pariah church la also frrnishcd with an ark, which ip pre-
aerved in the santuary, and forms the princlyal object in J. MV: Neale, Eastern Church, 1. 185. 4. A largo boat used on western Ameriean rivers to transport produco to market. -5 . In zoöl., a name common to the bivalve mollusks of the family Areida; an ark-shell. - 6. An Araof the family Areida; an ark-shell.- 6 . An Ara-
bian measuro of eapacity, equal to the Spanish fanega, or 58 quarts; also, a measure of threo fourths of this eapacity, or 43 quarts.

$\operatorname{ark}^{2} \downarrow$ (ärk), v. t. [ $\left[\operatorname{arll}^{2}, n_{0}\right]$ To inclose in an ark. Arkansas stone. Seo stone.

arkansite ("ar'kann-sit or är-kan'sīt), $n$. [< $A r$ kansas (one of the United States) +- -itc $^{2}$.] A variety of brookite from Magnet Covo, Arkansas. arki ("̈̈r'ki), n. [Ar. 'arqiy: seo arrack.] Samo as arraek.

arkite (ïr'kit), $n_{\text {. and }} a_{0}\left[\left\langle a r k^{2}+-i t e^{2}.\right]\right.$ I. $n$. One of the persons who were p
Noah's ark. J. Bryant. [Rare.]

II. a. Belonging to Noah's ark. J. Bryant. [Rare.]

arkose (är-kōs'), n. [F.] Feldspathic sandstone; a roek consisting essentially of more or less conselidated quartzose sand with grains or particles of orthoclase disseminated through it, and frequently containing also some miea and kaolin. The feldapar seens, In aeme casea, to have
been derlved from the dlalutegratlon of rock containlug that mineral; in others, to have resulted from the meta. morphlam of sandalone containning argillacoents material.
The rock to which the name arkose has heen given occurs Tha rock to which the name arkose has heen given occurs
chlefly lin (he Lower Sllurian, Carbonlferous, and Triasaic formallona.

ark-shell (ärk'shel), $n$. [<arli2 + shell. $] \quad$ The shell of a mollusk belenging to the family $A r-$ (which see)

arksutite ("irk'sü-tit), n. $[<$ Arksut (see def.) + -ite ${ }^{2}$.] A fluorid of aluminium, calcium, and sodium, occurrin

Arkys ("̈r'kis), n. Same as Arcys.

arle-penny, arles-penny (ärl'-, ̈̈rlz'pen'i), $n$. [< arle, arles + penmy.] Same as arles.

IIere tak' 'this gowd and never want
LEnough to gar you drink and rant,

And thls Is but an arle penny

arles (iliti), nis [North. and Se, arles (arlz), n. crlis, < ME. erles, appar. < OF. "erle, "arle,
<L. as if "arrhula, dim. (cef. OF. erre, arre, pl. erres, arres, mod. F, arrhes), < L. arrha, arra, earnest: see arrha.j 1. Earnest-money given in confirmatien of a bargain, contraet, or agreehiring of servants and with sales of goods where there is no writing and delivery is postponed. [Seoteh and north of England.] - 2. An earnest or foretaste.

Thls ure lauerd [Iord] glueth ham [them] as on erles of
the oche mede [eternal reward] that aclaal cume thrafter. the eche mede [eternal reward] that aclaal cume thrafter.

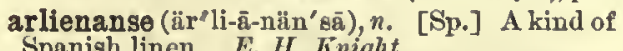
Spanish linen. E. H. Knight.

arlingt (är'ling), n. [E. dial. (ME. net found), this bird, lit. a " 'fieldling,' 'earthling' (of. elodbird, fallow-smiter); tho name also means a 'farmer': see earthling.] A species of bird; the wheatear.

Arling, a bird that appeareth not in winter; a clote
byrde; a mateh.
Baret, Alvearie. (N.E. $D$.)

$\operatorname{arm}^{1}$ (ärm), n. [ L ME. arm, <AS. earm = ONorth. $a r m=$ OS. $a r m=$ OF ries. erm, arm, Fries. $a r m=$ OD. aerm, D. $a r m=0 H G$. aram, MHG. G. arm,

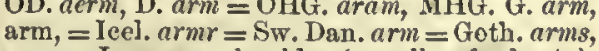
arm, = L. armus, shoulder (nsually of a brute), $=$ Gr. a $\rho \mu \phi_{s}$, joint, shoulder, allied to ápopov, joint, L, artus, limb, joint; all $<V^{*}$ ar, fit, join. ordinary language: (a) The upper limb of the human body, extending from the shoulder to the hand, and including the latter. (b) The same,
311

arm

exelusive of the hand the upper limb from the shoulder to the wrist. It is divided into upper arm, or arm proper, from the shoulder to the elbew, and lower arm, or forearm, from the elbow to the wrist.-2. In human anat., the anterior extremity from tho shoulder-joint to tho elbowjeint, represented by the extent of the humerus ; tho braehium, as distinguished from tho forearm (a) The fore limb of any vertobrate, especially when terminating in a prehensilo extremity like a hand, more or less removed from the office of locomotion; the pectoral or thoracic limb; tho diverging appendage of the seapular areh or shoulder-girdle; a fore leg, wing, peetoral fin, ete. (b) Some diverging or radiating arm of a cephalopod, the wing of a pteropod, the brachium of a brachiopod, and the ray of a starfish, sand-star, or crinoid.-4. Anything formed on tho type of the arm, or resembling an arm in shape, position, or function. (a) Any proJecting part Irom a main body, trunk, axla, cte. : as, the
arm of a lever or of the yard of a ahlp; an arm of the sea; the arm of an ancher. (b) A rall or projecting aupport at

5. Figuratively, power; might; strength; anthority: as, tho secular arm. [In this sense the word is often used in the Scriptures.]

To whom fa the arm of the Lord revealed? Is. IIi. I. Hence-6. That on which one rolies for support or assistanco; a prop; a stay.-Arm in arm,

end of ene of the long.drawn vitatas. 11 . James, Jy. Pass. Pilgrim, p. 140. Arm of a force, arm of a couple, in mech. Sce mo. ao yourg that it has to loe carrigd in the amma.- Better
armt, the right arm. Chaucer, Troilus, I1. 1650.- Oral armt, the right arm. Chaucer, Trollus, Il. 11550. - Oral armst, a practlce once obaerved amoog galiants of plerlhey mixed wllh wine and drank to the health of their IItave I not... stabb'd arms, and done all the offces Tralling arm, in mack, an arm which follows the plece to which it is at taclied.

In adapting thlo wheel to multiplex telegraphy, a trail. ing arm ia attached to tha revolvlag whee).

With open arms, cordlally; with eager welcome.

Even mitred Rocheater would nod the head,

And St. John'a gelf (great Dryden'a friend
W'ith open arms recelved one poet more.

$\operatorname{arm}^{1}+$ (ärm), $v, t . \quad[<a r m 1, n] \quad T$.$o take by the$ arm; also, to seize or bold in the arms. I k now your prize;
Thou will not loae her.

And mark him with our pikea and partiaans
A grave. Come, arm hlm. Shak., Cymbeline, 1 .

$\operatorname{arm}^{2}$ (ürm), n. $\quad[<\mathrm{pl}$. arms, < ME. armes, < OF, armes, pl. (sing. arme), $=$ Pr. armas $=\mathrm{Sp} . \mathrm{Pg}$. times arma), $<$ L. arma (neut. pl., in ML. sometimes used as fem. sing.), arms, weapons, prop. fittings, equipments; from same souree as q. v.] 1. Milit.: (a) A weapon. In thla sense most commonly used in the plural, add when used in the singular for the most part referring rather to a partlcular
kind of weapon than to an Individual plece. If the citadel of poverty and Ignorance and vice la to be

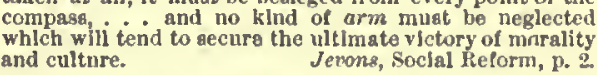
(b) pl. Armor; coverings for the body intended as defenses against weapons of war.

Three horses and three goodly auits of a rns,
And all in charge of whom? a girl: set on.
Tennyson,

(c) A branch of the military service, as eavalry or artillery: as, the enemy was strong in artilery, but we were weak in that $a r m$.

Tha Inland Britona being accustomed to rely upon thelr Infantry, and the Continental Gaula belng Ponder of the
cavalry arm.
C. Etton, Orlg. of Eng. Hat., p. 118.

Hence-2. $p l$. The use of weapons; military cupations ; war.

By aea, by land, thy matehless worth was known,
Arms thy delight, and war was all thy own

Dryden, Abs.
3. $p l$. Deeds or exploits of war. Dryden, Abs, and Achit., 1. 811. drms and the man $I$ sing. Dryden, Fnesd, I. 1.

The women crowded to the doors to gaze upon him as he pased, so much does prowess in arms delight the gen-
Irving, Knfckerbocker, p. 418. 4. In law, anything which a man takes in his hand in anger to strike or assault another. -5 . $p l$. In bot., anything that serves as a defenso to plant, as priekles, thorns, or spines. -6 . yl. In fulcoury, tho legs of a hawk from tho thigh to the foot $-7, p l$, Tho heraldic bearings of an individual or a community, consisting of somo devico in heraldie tinetures (seo tinctire) borne on a shield, generally with tho addition of a erest and sometimes with supporters. A descryption in

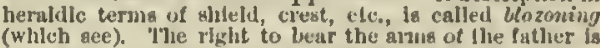

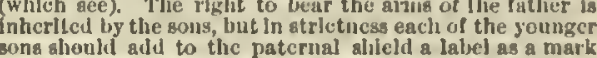
of caiency; the same right descenda to a dasghiter only 1 ?

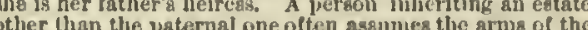
former possessor, but allould in strictnesa apply to the
proper authoritlcs. See king-al-arms, he sall, and heralds college. Arma not paternal may be classed as followa: $(a)$

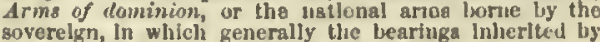
the prince as an lisdividual have come to have a certalin national character. (b) Arms of commusity, as of a correpnillic, as by the United Statea or by one of the Statea, partake of the nature of both the preceling. (c) Arims of pretension, as apectfically, those assumed iy a guverelgn
nassertion of his clalm to a rcalm not actually under hil antherlty, like the fleurs-de-lys of France, which wer borne by Engllsh sovereigns unill irol. (d) Arme of suc above. (e) Armo of assumption, or ossuntitire trms, bear. ings assumed or granted in consequence of an explolt, as

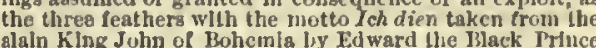
at the battle of Crécy (1346), and now borne by the Prince of Wales. (f) Arms of alliance, as where one apoua impales the arma of the other on ha or her ghield. pendage of somo publis posillon. In ail the albove cases
except (a) and (b), a private todlus dual having a righit to such arma charges them with the paternal arma hlatory of arms, see heralliry.- Abated arms. See abate. Adoptive arms. Ses adoptive. - Alusivive arms, in her., a bearing or bearings having immed late reference to

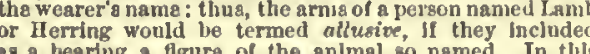
way the name De Loupe may have been given to the tirst

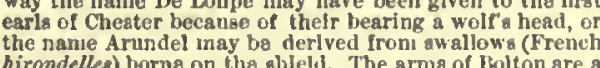
crosbbow-bolt driven through a tnn. Caatlle and Leen had

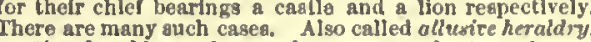
canting heraldry, rebus, and armes parlantes.-Armscarrying Act. Sé Bill of Rights, under bill.-Arms o accurately prepared bullets, and appliancera calculated
to enable theni to act with preclileil and rapidlty, and at much greater distances than ordinary weapons, The

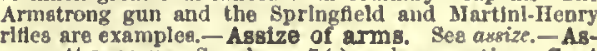

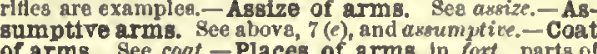
of arms. See coat.- Places of arms, in fort., parts of gles of the counterscarp. - Repeating arms, arma Ihat

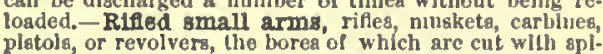
platolla, or revolvers, the borea' of which are cut will apl-
ral groovea or "rlfea." - Small arms, all weapons not

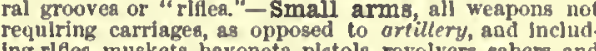
awords; alao, aporllng weapons.-Stand of arms, a com. plete set of arms for one soldier, conalsting of a musket, -To arms! a warning aequivalent to "arm! take to your
arms; make ready for balle." (Compare alarm.) -To arms ; make ready for ballle." (Compare alarm.) - To bear arms, to do milltary servlce; serve as a aoldjer.
You have been a soldler, De VItry, and borne arms.

To be in arms, to be in a stats of hestillty, or of readi-

SIr Edward Courtenay and the hanghty prelate,
With many more confederalea, are in armel

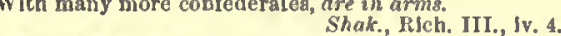

To be under arms, to be armed and in a state of readl.

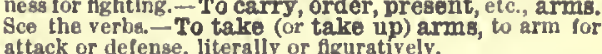
Ye wsll find It a lar eaaler field to wage war against all
the armlea that ever were or will be on earth, and all the

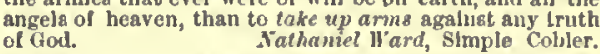

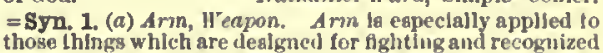
those things which are dealgned for fighting and recognized as such ; it hilelndea means of defenge as well as of oftense.
Weapon applles to any means of offense malle for the pur$\mathrm{rm}^{2}(\mathrm{arm}), v$, [<ME. armen, $<\mathrm{OF}$, armer ( $\mathrm{F}$. armer $)=\mathrm{Pr} . \mathrm{Sp} . \mathrm{Pg}$. armar $=\mathrm{It}$. armare, $<\mathrm{L}$. arms: see $\operatorname{arm}^{2}, n_{\text {.] }}$ I. trans. 1. To furnish or equip with weapons for offense or defense: as, to $\mathrm{arm}$ the militia.

On our return to Souhag we met a party of men on foot,
who were armed wilh apears, ahlelds, and daggers, and one or two wilh guna. ${ }_{R}$. Curzon, Monast. in the Levant, p. 119. 2. To cover or provide with whatever will add strength, foree, or security: as, to arm the hilt plates.-3. To furnish with means of defense; plates. -3 . To furnish with mesistance; fertify.

A mo yourselves llkewlse with the game mind. 
arm

There is no terror, Cassius, in your threats;

For 1 an armid 80 stiong in honeaty,

Shake, J. C., iv. 3.

I am arming myself against her favours wiih all my
Steele, Tatler, No. 124. 4. To provide with the requisite appliances or authority for any work or undertaking: as, arm$e d$ with axes and alpenstocks, we started out armed with a warrant. -5 . 'To fit or prepare (a thing) for any specifie purpose or effective use: as, to arm a hook in angling; to arm a dressing iu surgery. - To arm a lead, to appiy soap or grease to the rocket in the lower end of a brought up.-To arm a magnet, to fit it with an armature. See armature, 6.To arm a shot, to roll rope-yarns about a croas-bar shot
in order to facilitate ramning it home, and also to prein orter to facilitate ramning it home, and also to preit the bo

II. intrans. To provide one's self with arms, Ireapone, or moans of attack or resistance; take arms : as, the nations arm for war.

Now is it time to am.

Shak., Hen. V., iii. 7

The Belgic tribes, alarmed at the approaching danger, arm againat the universal tyrant. Motley, Dutch Republic, I. 11. armada (är-mā'dạ̈), n. [Early mod. F. also erroneously armado (also sometimes as It., armata $) ;\langle$ Sp. armada $=$ Pr. Pg. armada $=$ It. $a r$ mata = F armée (> E. army ${ }^{2}$ q. v.), lit. an marmed force, army, navy, < ML. armata, an armed force, army, navy, armed force, an army, prop. fem. of $\mathbf{L}$. armatus, pp. of armare, arm: see $\operatorname{arm}^{2}, v_{v}$, and also army, which is a doublet.] 1. A fleet of war-ships ; a squadron. The Spanish or Tnvincible Armada which consisted of 130 large ships, was aent by Elizabeth, but was repulsed, and afterward almost entirely destroyed hy atorms of

A whole amnado ol convicted aall. Shak., K. John, iii. 4. 2t. A single war-ship.-3. Any armed force an army.

Nor was the naval unworthy of the land armada. Bulwer, Athens, armadillo (är-ma-dil'ó), $n$. [Formerly also armadillio, arma(itho), dim. of armado, arm$e d$, with refbony shell. Cf. ML, armaof sea-fish.]

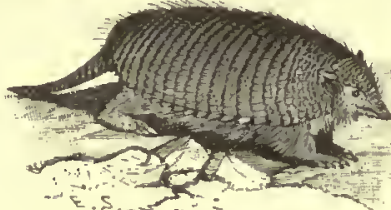

1. An Ameri-

quadruped, of the order Bruta (or Edentata) and suborder Lorieata, and of the extant families Tatusiide, Dasypodida, and Chlamydophoride, or of the extinct family Glyptodontida, having a hard shell or carapace like a coat of mail, resulting from a peculiar ossification of the integument and the confluonce of numerous small scutes. In the glyptodons the carapace was en
tire and fixed, and even in gorne cases covered the belly tire and fixed, and even in gorne cases covered the belly
as well as the back; but in all the living armadilloa the ahell is divided into an anterior, a posterior, and an en tire or variously divided midele part is conplete, the aninal can roll itsel into a ball. The teeth are numerous, bnt vary in number geba is an armadillo ol the fanily Tatusiida, the Tatusia novemeineta, the only one of the group Iound as far north as the United Staies. There are oilher species. The encouberts are the typical armadilos or the rame kabassou constitute the genus Yenurres. The kabalassou is Prio-
dontes gigas. The apars are the three-banded armadillos,
of the genus Tolypeutes. The pichiciagos constitute the of the genus Tolypeutes. The plchiciagos constitute the
family Chlamydophorido; they are the amallest and mos family Chlamydophoridas; they are the amallest and mos
peculiar forns, heing less than a foot long, while the $\mathrm{k}$ animals are mild, timid, and inoffensive, subsiating on

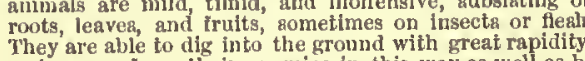
and escape from their enemies in this way as well as by
rolling up in a ball. The flesh is considered good for food. 2. In Crustacea: (a) [cap.] A genus of isopods, of the family Oniscida, including the pill bugs, which can roll themselves into a ball like the mammals called armadillos. (b) A species of this genus; a pill-bug or sow-bug; electric battery composed of copper and zinc elements riveted together, and designed to be worn as a remedy in certain diseases.

armadot, $n$. An erroneous form of armada.

armament (är'ma-ment), $n$. [<L. armamentum, usually in pl. armamenta, implements, esp.
312

Armenian

1. A bor : arm-band (ärm'band), $n$. A piece of crooked .

The whole united arinemet orece

Glover.

wa with his twenty it was necessary for lin . . . to proceed with the tiediterranean, while his guperiors, with the rest of the armament, reiurned to the Channel.

2. Munitions of war; especially, the number and weight of all the guns which a ship of war carries. Within a comparatively ahort period re-
markable changes lave occurred in the gize and welght of the armament of war.vessels. In the United States, before the civil war, the 11sual armament for hoth forts and
veasela consisted of 32-ponnders. The war led to the conreasela consisted of 32-pounders. The war led to the 50,000 pounds, and afterward of 20 -inch guns, weighing 100 , 000 pounds. Riffed cannon, which had been introluced in 1859, were aiso increased in size up to the 10-inch-bore Parrott gun throwing a 300-pound projectíle. Of other coun.
tries, the armanent of the British navy may be taken as tries, the armament of the British navy may be taken as
representative. In 1861 the "Warrior" was provided with representative. In 1861 the "Wut aince then the weight of netal has been anccessively increased up to the 80-ton guns of the "Inperdown." In Enrope preference is given to the picrcing power of elougated projectilea moving at a great velocity and fired from rifled guns. In the United Stateg reliance has unili recently been piaced upon the smashing effect of heavy spherical projectiles

armamentarium (är"ma - men - tà'ri - um), n. l. ammamentaria (-ii). [L.] An armamentary.

The physiological investigation of new remedies for th Therapeutic Gazette, 1X. 24.

armamentary (är-ma-men'ta-ri), $n$. ; pl. arma mentaries (-riz). [ $<" L$. armäntentarium, an ar senal, armory, < armamenta, equipments: see armament.] A

ariun armarius, armary.] A librarian. See extract. [Rare.]

Armarian, an offcer in the monastic librarieg who had charge of the bookg to prevent them from being injured by to keep a correct catalogu

Chanbers's Journal, No. 276, p. 239. (N. E. D.) armaryt, n. [<ME. armarie (Wyclif), < L. ar marium, a chest, safe, or closet, a repository, in ML. esp. a bookcase, library, lit. a place for arms or tools. Cf, armory ${ }^{3}$, and armory ${ }^{1}$, a difarmary was confused.] 1. A library: used by Wyclif in the plural for books, writings.

Thou ulgate, in commen

2. An armory. Leland, Itin., IV. 54. (N. E. D.) armata $^{1}+\left(a ̈ r-m \bar{a}^{\prime} t a g a n\right), n$. Obsolete form of ar Armata ${ }^{2}$ (ïr-mā'tä), n. $p l$. [NL., nout. pl. of L. armatus, armed: see armada.] A group of gephyreans having setw and a double bloodIt consists of the families Echiuride and Sternaspide.

armature (är'ma-tūr), n. [= F. armature $=\operatorname{Pr}$. Sp. Pg. armadura = It. armadura, armatura, L. armatura, armor, equipment, armed troops, L armatus, pp. of armare, arm: see arm ${ }^{2}$, Doublet, armor, q. v.] 1†. Military equipment; anat: (a) Any part or organ of an animal serving as a means of defensc or offense.

Others armed with hard ahells; others with prickles;
lawy, On Creation. It is remarkalle that man, who is endowed with rea. It is remarkable that man, who is endowed with rea-
aon, is born without amnature.
Derhain, Physico-Theology, iv. 14. (b) Any apparatus or set of organs without reference to defense; an equipmont; an appanage: as, the genital or the anal armature. All the craytishes have a complete gastric armature.
Huxley, Craytlah, $\mathrm{p} .255$. 3. In bot., the hairs, prickles, etc., covering an organ. -4 . A body of armed troops.

Raleigh, Iriat. of Word, v. 6 .

5. In arch., any system of bracing in timber or metal, as the iron rods used to sustain slender columns, to hold up canopies, etc. The term is applied especially to the iron iramework
lights are aecured in medieval windows.

6. A piece of soft iron applied simply by con tact to the two poles of a magnet or electromagnet as a means of maintaining the magnetic power undiminished. In dynamo-electric machines (whleh gee, under electric) ithe aruzature is a bar or
ring of goit iron, around which coila of insulated coppe wire have been wound. This armature is rotated rapidly in the fleld of the adjacent electromagnets. In the Holt electric machine the armature is a gitrip of varnished paper
attached to the edge of the openings or windows of the fixed plate. Also called armor.
armazine, $n$. Soe armozeen. iron attached to a rail or to a stone block fixed against the walls in barrack-rooms, to retain the soldiers' muskets when not in use.

rm-board (ärm'bōrd), $n$. A graining-board ised in leather-working, made of the outer bark f the cork-0ak, without grooves.

rm-bone (ärm'bōn), $n$. A bone of the arm or fore limb; especially, the bone of the upper arm; the humerus.

rm-chair (ärm'chãr), $n$. A chair with arms to support the elbows.

arm-chest (ärm'chest), n. 1. Naval, a box placed on the upper deck, or in the tops, to contain a ready supply of rifles, pistols, or cutlasses.2. A similar box or chest used in the military service for the transportation of small arms. armed (ärmd), $p \cdot a \cdot\left[<a r m^{2}+-c d^{2} \cdot\right]$ 1. Bearing arms; furnished with means of offense and defenso: as, an armed force or slip; "the armed
rhinoceros," Shak., Macbeth, iii. 4.-2. Supported by arms; carried on or maintained by force or readiness for military action: as, an armed inroad; armed peace or neutrality.

I shall not attempt to collect the duties and imposts by any armed invasion of any part of the country.

Lincoln, in Raymond, p. 132 . In the beaks, talons, horns, or teeth, or, of an arrow or lance, having the head, of the color specified: as, a lion gules armed or. The word is not used for the horns of a liart or an armature or a piece of iron so as to connect the poles, as a horseshoe magnet. -5 . In bot. having prickles or thorns. - Armed at all points. (a) Completely equipped with offenaive and detensive arma, according to the fashion of the time : equivalent io (b) In her., dreased in complete plate-armor, but havin the vizor open: aaid of a warrior uzed as a bearing or amporter. - Armed in flute. See fute ${ }^{2}$ - Armed neucerent realy to repel any aggression on the part of bell peace, the condition of a country which in time of peace maintains its nilitary eatablishments on a war footing,
as to be ready for war at any moment. - Armed ship as to be ready for war at any moment. - Armed ship for a partictular occasion, and armed like a ship of war. On the ramparts of the fort stood Nicholas Irving, Knickerbocker, p. 251.

Armenian (är-mē'ni-an), $a$. and $n . \quad[<\mathrm{L} . A r-$ menius, < Gr. 'Ap $\mu t v i o s$, < 'A $p \mu \varepsilon v i a$, Armenia.] I. a. Pertaining to Armenia, a former kingdom of Asia lying between the Black and Caspian Turkey, Persia, and Asiatic Russia, or to its inhabitants. - Armenian architecture, a term some-
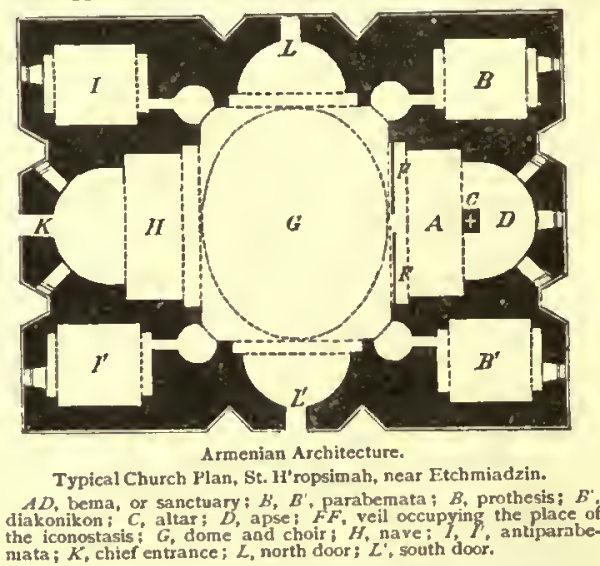

ture usual in Armenia. The typical plan of such churches western ends, having antiparabemata to corregpoud with the parabemata, and omiting the narthex. The central blue. See blue. - Armentan bole. See bole2. - Armenian cement, a cement made by soaking isinglass in wate until it becomes solt, and then mixing it with opirit in which a liftle gum mastic and ammoniacun have been dise piir precions atones, and to eement them to watch-case and other ornaments.- Armenian Churah, the ancien national church of Armenia. It maintains that it was tounded as early as $A$. D. 34 ; but while tracea or chriatian-

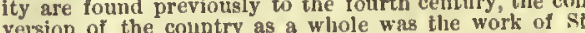
Gregory the Iluminator, who began his evangelistic la bors about the year 301 ; and from his name it is sometine known also as the Gregorian Churcli. The Arnenian Church has for the most part remained estranged fron the orthod ox Greek Church aince the latter part of the

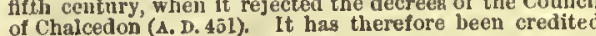


with holding YFonopluysite or Futychin doctrine, but armiak (är'myak), $n$. [< Russ. armyakin, of the thitferences arose from Armenian language to expresa the finer distinctona of Greek terninology. The Ammenian (hurch accepts all the first seven ecumenical counclls, with the exceptlon of that of Chalcolon, the doctrines of whicli they geom, how.
ever, to hold under a different phraseolugy. Their docever, to hold under a different phraseolugy. Their docbresul and of an unnuxes chalice in the eucharist. T"is prieathool is hereilitary. 'The bishops are poverned hy four putriarchs, the prinate being the cutholicos, whe resides in the monnstery of Ftelinialziln, a ghort diatance large mumber of the Armeniana have jolned the Loman Catholle Chureh and are known as United Annenians. been furned. - Armenian era, liturgy, etc. See th nouna. - Armenian stene, a sott blue carlonate of cop per: also, a commerelal nane for lupis.lazull.

II. n. 1. A native of Armenia.-2. Eecles.

Armenian language.

Armeno-Turkish (är-mē"nō-têr'kish), $n$. The Turkish languago as written by Armenians in Turkey, with letters of the Armenian alphabet. armental $\dagger$ (ïr-men'tạl), a. [< L. armentulis, $<$ armentum, old form armenta, eattle for plowing, eollectively a herd, drove; prob. contr. from "arimentum, < arare, plow: seo arable. Of or belonging to a drove or herd. Bailey.

armentinet, $a$. [ $[<$ L. armentum, a herd (see armental), + -ine.] Same as armental. Bailcy. armentoset (är-rnon'tōs), a. [< L. armentosus,

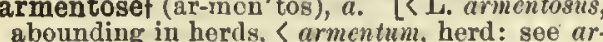
mental.] Full of great cattle; abounding with herds or beasts. Bailey.

armer (är'mér), n. [<arm $\left.{ }^{2}+-e r{ }^{\prime}.\right] \quad$ One who arms or supplies with arms; one who equips.

Builders and amners of vessels [of war

IV oolsey, Introd, to Inter. Law, 8160 .

armet (är'met), n. [F., OF. also armette, ar meret, dim, of armes, armor.] The most com plete and perfect

defensive head-eovering of the middle ages, introduced about 1450 , and remaining in use until the abandonment of the closed headpiece, more than a century later. It was lighter the basinet, and was a gulade. (See these words) It fitterl the liead well, allowed of some move. mert, and had openings It was forged in many parts, which fitted togethcured by linges, hooks, and the like, and when elosed was very rigid an

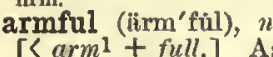
[< arml + full. ] As
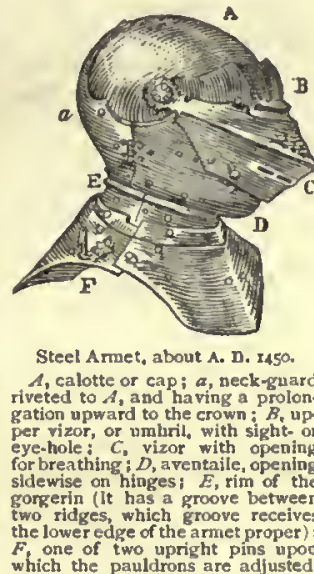
which the pauldrons are adjusted

hold; what one holds in one's arms or embrace. "Iis not the wealth of I'lutus, nor the gold

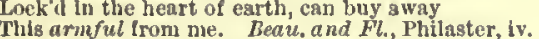
I atood where Love in brimming armfuls bore

D. G. Rossetli, Sonnets,

arm-gauntt, $a$. [An isolated form, appar. arm 1 (or $a r m$, arms) + gaunt, as if "with gaun limbs,' or 'worn with military service'; in either case a violent formation. Perhaps merely a scribe's or printer's sophistication of some wor which must be left to eonjecture.] An opithet of disputed moaning, applied by Slakspere to a
herse, and in some editions ehanged to arrogant herse, and in some editions ehanged
So he nodded,

And soberly did mount an arm-gaunt steed,

Who neigh'd so high, that what I would have apoke
Was beastly dumlid by. him. arm-greatt, a. [ME. arm-gret; $<a r m{ }^{2}+$ great.] As thick as a man's arm.

A wrethe of gold, arm-gret, of huge wighte,
Upon his heel. Chaucer, Knigbt's 'Tale, J. 1287.

arm-guards (ärm'gärdz), $n$. pl. A general name of plate-armor for the defense of the arms. It corresponds to brassart (which see) and to the French armhole (ärm'höl), $n$. [<ME. armhole, eorruptly harmole; $\left\langle a r m{ }^{1}+\right.$ hole.] 1. The eavity under the shoulder; the ampit. [Now rare.]

Tickling is most in the soles of the feet, nnd under the armholex and on the gides. The canse da the thinness of the gkin in these jarts, Jolned with the rareness of being
tonehed there.
Bacon, Nat. Ilist. 2. A hole in a garment for the arm.
Tatar origin. 1. A stuff woven of camel's hair by the Tatars.-2. In Russia, a jlain eaftan or outer garment, made of armink armiferous (är-mif'e-rus), $a$. [< L. armifer, arma, arms, + ferre $=\mathrm{E}$. bcar ${ }^{1}$.] Bearing arms. Blount.

armiger (ür'mi-jèr), n. [L., armor-bearer, < arma, arms, + gercre, bear, carry.] 1. An urin rank of the aspirants to ehivalry or knightin rank of the aspirants to ehivalry or knightings: formerly used after the proper namo by a jerson possessing such right, but no higher title: thus, "Jolın Bolton, armiger," is nearly equivalent to "John

Shakspere, armigero.

A gentleman lorn, master parson; who writes himsel armigero; in any bill, warrant, quittance, or obligation, This young armiger must be the too attrictive cyno re to our poor little malden.
$R$. D. Blackmore, Lorna Doone, 1 . armigeral (är-mij'e-ral), a. [< armiger + -al.] Of the class of squires; genteel.

I am exempted at preaent from residence, as preacher

Sydney Smith, to Franels Jefirey.

armigero (är-mij'e-rō), u. [= Sp. armigero, a squire, = Pg. armigero, a page, ?

armigerous (är-mij' $\theta-r u s), a$. ' $<$ L armiger (later, but rarely, ämigerus), bearing arms: see armiger.] Entitled to bear heraldio arms. They belunged to the armigerous purt of the popula
De Quincen, Works, VII. 4 s. armil (är'mil), n. [< late ME. armille, <OF. ar mille, < L. armilla, a bracelet, armlet, hoop, ring, dim. prob. of armus, shoulder, upper arm see $a \mathrm{rm}^{2}$.] 1. An aneient astronomieal instrument consisting of a ring fixed in the plane of the equator, sometimes erossed at right angles by another ring fixed in the plane of the me ridian. In the first ease it was an equinoctial armil, in the second
arnillary.

With the advance of geometrical conceptions there cam the hemisphere of Berosus, the equinoetlal annil, the sol stitial amnil, and the quadrant of Ptolemy - all of them couhination with sngular divisions. 2. Same as armilla, 1 .

The armil, or bracelet, was looked upon by the Anglo Saxons as one anong the badges of royalty.
Rock, Cburch of our F'athers, 1. 436, note. armilausa (är-mi-lâ'să), $n . ;$ pl. armilausa (-sē). [LL.; origin uncertain; said by Isidore to be a contr. of "armielausa, < armus, shoulder, + elauand close.] 1: A kind of Roman military tunie -2. A garment worn in England and on the Continent during the middle ages, probabl differing in shape at different times. Neyric describes it as "a body garment the prototype of the sur and even worn over the armor. armil.] 1. In archael., a bracelet or armlet: as mil.-2. In mach., an iron ring, hoop, or brace in which the gudgeons of a wheel move. - 3. I anat., the annular ligament of the wrist which binds together the tendons of the hand.-4. encireling the tibia of a bird just above the heel-joint. [Little used.]

armillary (är'mi-lạ-ri), a. [< L. armilla, an armlet, ring, etc.: seo armil.] Resembling

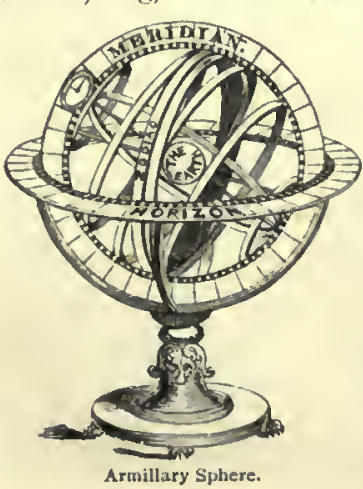
bracelet or armilla; consisting of Armillary spher aingle sphere, relative positions of the prinelpal cele whole revolves upo its axla withlit a hor zon divided into de grees and novahle a brass supporter. of armillary sphere one with the earth and one with the ginn I think geral, priestly, and swine-feeding soclet

armilla (är-mil'ä), $n . ;$ pl. armille $(\bar{e})$. [L.: see an arrangement reapectively the aphere of l'tulemy and the sphere of $\mathrm{Co}$ Ive an aecinate jepresentation of the apparent inoticms of ter having little practical nhlo. armillate (är'mi-lāt), $a$. [<I_, armillatus, $<a r-$ milla, bracelet: see armil.] Wearing a bracelet. Ash.

armillated (ür'mi-lā-ted), $a$. Wearing brace-

armilletł (är'mi-let), $n$. [<OF. armillet, dim. of rille. seo armil, armilla.] A snall armill armlet. See armilla.

armint, $n$. [Cf, armil, armilla.] A kind of oruanent for the pike. It appears to have been a
picee of stuff geweet arouni the stath, perhapis to aftori a

armine ${ }^{1}+n$. [Perhaps for *arming (of whicl, however, no recold is found for 400 years preeeding), < early ME. erming, < AS. earming, wretehed person, < curm, wretehed, miserable, poor, $=$ OS. arm = OFries. $\mathrm{orm}$, arm $=\mathrm{D}$. arm, OIIG, aram, MHG. G. $a r m=$ Ieel. $a r m r=\mathrm{Sw}$. Dan. arm = Goth. arms, wretehed, miserable. Sce yearn $\left.{ }^{2}.\right]$ A beggar; a mendieant.

Fice. A rmine, sweetheart So young sn romine? Armine, aweetheart, 1 know not what Lomdont a heggar.

armine ${ }^{2} \phi$, armined ${ }^{2}$. Obsolete forms of ermine, ermined.

arming (är'ming), $n$. [< ME. armyng; verbal n. of $\left.a r n^{2}, v_{0}\right] \quad$ 1. The act of taking arms or furthe peoplc. - 2†. In her., a coat of arms.

When the Lord Beaunont, who their arnings knew,

3. Naut.: (a) A piece of tallow placed in a cavity at the lower end of a sounding-lead to bring up a sample of the sand, mud, ete., of the sea-bottom.

On the arming from an elght-fathom cast there was a Daruin, Coral Ree $t_{8,}$ p. 11.

(b) $p l$. A kind of boarding-nettings. (c) $p l$. Red dress-eloths formerly hung fore and aft
outside the upper works on holidays: still used by some nations. Smyth.

arming-bucklet (är'ming-buk"l), n. 1. A buckle used in defensive armor. - 2. In her., such a
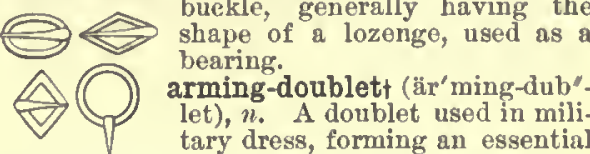
bearing arming-doublet $\uparrow\left(\right.$ är ${ }^{\prime}$ ming-dub" let), $u$. A doublet used in military dress, forming an essential part of the harness of a lightHeraldic Arming. armed foot-soldier in the middle
Buckles.
ages and later. It is prohable that It was a very close-fitting garment worn under the corse-
let. The general uge of it geems to have auggested a atyle
or cut in elegant costume, as we read of arming-doublets or cut in elegant

That every man have an arnning-doublet of histian or
Duke of Norfolk's Orders, Ilen. VIII., an. 36. An anning-doublet of crimson and yellow antill.
with threads of Venice gold.

arming-pointt (är'ming-point), $n$. A point used in fastening together parts of a suit of armor.

arming-press (är'ming-pres), $n$. A small handpower stamping-press used by bookbinders. ts earlieat employment was in stamping lieralidic arms tates this form of press is knowil as a stamping-press arming-spear† (är'ming-spèr), n. A spear used rming-sword $\nmid$ (är'ming-sōrd), n. A sword made especially for use in battle, as distinguished from one worn as a part of military dress or uniform in time of peace, and from that used in tourneys or the like.

A helmett of proofe shee strait ald provide,

Arminian (är-min'i-an), $n$, and $a$. [<NL. Arminus, $>$ Arminius, Latinized from the name I. n. 1. One of a Christian sect nen), a Protestant divine of Leyden, Netherlands $(1560-1609)$. Its members were also eslled Remonstrants, from s atatement of their vle wa in the form of They geparated from the Calvinists, objecting to their doctrine of predestination. The sect as a distinet organization is chiefly confined to the Netherlands, where it annit adherents.

2. A believer in the Arminian doctrines. Theae in opposition to conditionsl election and reprobation, 
Arminian

314

Calvin. (2) Universal redemption, or that the atonement Was made by Christ for all mankind thongh one but be.
lievers ean be partakers of its henefitts. (3) That man, in

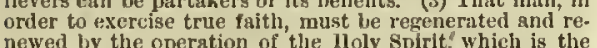
newed by the operation of the lloly spirit' 'which is the
gilt ol God. (4) That this grace is not irresistible. (5) Thst helievers are able lyy the aid of the lloly spirit to resist
stn, but that there is always in this life the prossililitity of 8in, but that there is allays in thisis life the plossililitity of
8 tall from grace, in opposition to the Calvinistic doctrine
of the of the perserersuce of the saints. l'rotestants in general these doetrines, and all oppnnents of calvinism are still

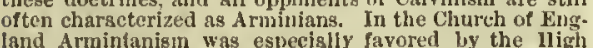
land Armintanism was especisliy favored by the 11 igh
Church party. The Jiethodilist denomination was divided Chinch party. The Methodist denomination was divided
on the subject, the foflowers of Wesley being Arminians, II. $a$. Pertaining to Arminius or to his doetrines.

Arminianism (är-min'i-an-izm), n. [< Armini-

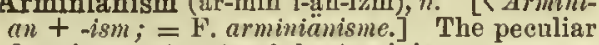
doctrines or tenets of the Arminians.

Arminianize ("̈r-min'i-an-iz), v.; pret. and pp. Arninianized, ppr. Arminianizing. [< Arminian + -ize.] I. trans. To make Arminian; tinge or permeate with Arminian doctrines.

ripo tentia, <L.armipoten $(t)$ s s: seearmipotent.] Puissance at arms. Bailey.

armipotent (är-mip'ō-tent), a. [<ME. armypotent, $<$ L. armipoten $(t-\ddot{s}$, powerful in arms, arma, arms, + poten(t-)s, powerful: see po[Rare.]

$$
\text { The temple of MIsrz armypotente. }
$$

Chaucer, Knight's Tale, 1. 1124.

The mantfold linguist and the armipotent soldier.
Shak., All's Weli, iv. 3 Who dost pluck

With hand armipotent from forth blue clouds

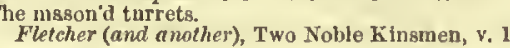

armisonant† (är-mis'ō-nant), $a$. [< L. arma, arms, $+\operatorname{sonan}(t-) s$, ppr. of sonare, sound (see sonant); suggested by armisonous, q. v.] Same as armisonous. Ash.

armisonousł (är-mis'ō-nus), a. [< L. armiso nus, < arma, arms, + sonare, sound: see sound und cf. armisonant.] Sounding or rustling with arms or armor. Bailey.

armistice (är'mis-tis), n. [< F. armistice = Sp. Pg. armistieio =It.armistizio, $<\mathrm{NL}$. armistitium, a cessation of hostilities, < arma, arms, + -stitium, < status, a standing, pp. of sistere, cause to stand, fix, reduplicated from stare, stand: see state, stand. Cf. solstice, interstice.] A

temporary suspension of hostilities by con

But, while an arnistice is an intervsl in war and supposes
a return to th, a peace is a return to a state of amity snd intercourse, tmplytug no intention to recomnence hostilithes. An armixtice again leaves the questions of the ws unsettled, but a peace implies in its terms that redress of
wrongs has been obtained or that the intention is rewrongs has been obtained, or
nounced of seeking to obtain it.

floolsey, Introd, to Inter. Lsw, § 150

armless ${ }^{1}$ (ärm'les), a. [ME. armles; $<a r m 1+$ -less.] Without arms. In zoöl., specificslly appled to the Lipobrachia, or those echinoderns, as sea-urehins and sea-cucumbers, which have no distinet raya or arms.
armless 2 (ärm'les), a. [< $\operatorname{arm}^{2}+$-less.] Destitute of weapons; defenseless.

spain lying armless and open. Howell, Letters, 1. 3 armlet (arm'let), n. [< arm $1+-l e t$, dim. suffix; suggested prob. by armillet, q. v. Cf.
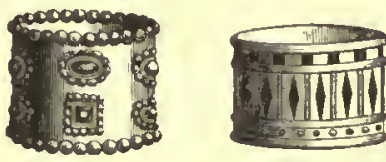

A little arm: as, an armlet of the sea.-2. An ornament specifically, metal band or ring worn up

on the upper arm. -3 . That part of a dres where the sleeve joins the shoulder.

armoire (är-mwor'), $n$. [F.: see ambry.] An ambry; a large ward robe or movable cupboard, with doors and shelves; especially, one which is inclosed or shut in with doors from base to cornice, and is simple and roomy in design.

armoirieł (är'mor-i), n. [F.] An old form of

Their great aim was to elevate their aubject by tracing Jewish and psgan antiquity.
Encyc, Brit., XI. 712 armoniact, $a$. An old corruption of ammoniae.

armor, armour (är'mor), $n$. [Second form now and more commonly armure, armor (often in pl.

armures, armu's, armeris, armeres, weapons), OF. armure, armeüre, F. armure = Sp. Pg. armedura $=$ It. armaflura, armatura, armor, < L. arma tura, armor: see armature.] 1. Defensive arms any covering worn to protect the person agains offensive weapons. All svailable materials that offe some resistance to ejge or point have, at various epoch

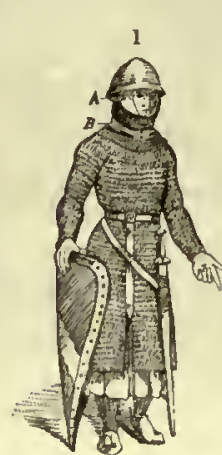

Complete Armor of 1595 -

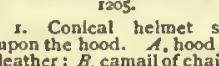

mail secured to the hood
This is here separate

the hauberk, thutgh It whas
ofien a part of it. The
hauberk of mail reaches

fore and behind : the gam
beson has a long skirt, and

divided in the same way:
the belt is only a leathe

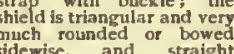

idewise, and straight
engthwise: the hose, or
chansses, are of mail, nnd

the shoes of leather. The brolgne was often worn instead of the hau-
berk; the closed heimlet, rarely. The chausses ofteo covered the feet,
replacing the shoes.

pose, as thick skins, garments of linen or of silk, stuffe with vegetable fiber, or made of many thleknesaes of ma-
terial, thin plates of horn or metal, sewed to aome textile labric and lapping over one another like acalea, etc. Usually the headptece was the first piece of armzor to be mad
in solid metal. (See helmet.) The Greeks had a solid cul rass from a very early period. (See cuirass and thorax.)
This, with the helmet and the greavea (see greave), con. stituted the whole armor of the hesvy-armed Greek warrior
of historic times. The Roman legionary was in genera similarly armed, sometimea wearing only one gresve soldtery. The Norman invaders of Englsnd in 1066 wore a contcal helmet with a nasal or strong projecting plece of
iron coming down over the nose, snd long gowns of stuff to
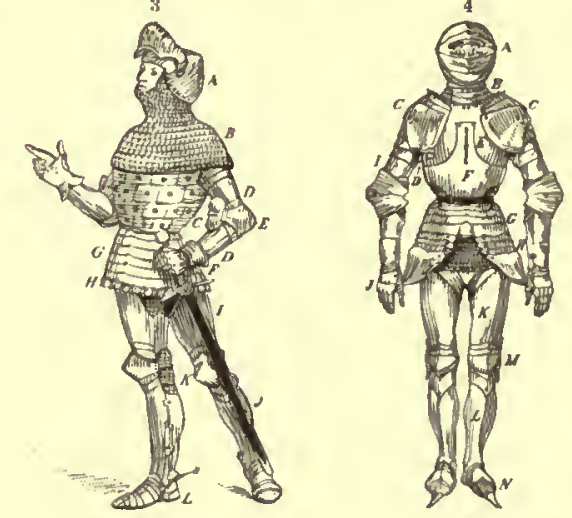

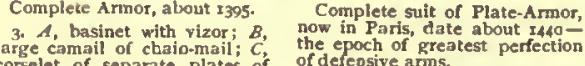
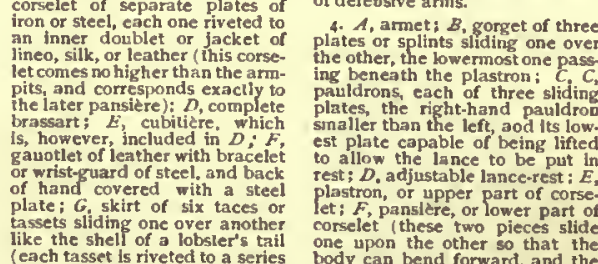

(each tasset Is riveted to a series
of vertical straps of stuff or leath
er
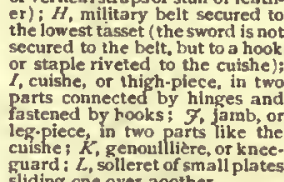

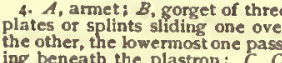
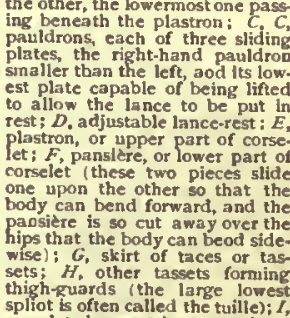

complete brassart in many pleces
perfectly articulated and forming

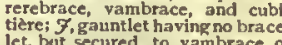

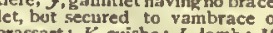

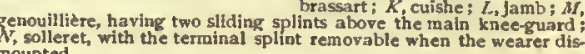

\section{armorer}

which were sewed rings or plates of metal, and the lesders had leg-coverings of siniliar make. A century later chainmaif was in common use. The knights of the time of
Richard I. of England (Cour de Lion, 1189-1199) wore a long hauberk of chain-mall, reaching to the knee or below, with long sleeves elosed at the ends so as to form gloves, and with openings in the atdes through which the hands
could be passed, leaving the gloves lianging down from or worm with shoea of stroug lesther; or somettmes long hose of leather laced or buckled like modern long gaiters A hood, called the camail, sometimes of chain-nisil, some. times of lesther, covered the head and descended to the
shonlders, and upon this rested the iron helmet, either of shonlders, and upon this rested the iron helmet, either of coniesl fnrm or rounded or acorn-shaped, withont vizor,
pressing on the head st lits lower edge, where it was often secnred to the csmail, and rising above the erown of the hesd. Very rarely in this relgn a closed helmet was used, as seen on a scal of King RIchard I.; helmets of tbis form beeame common eariy in the reign of Ilenry III. (12161272). By the time of Ilenry IV. (1399-1413) snd his invain srmor of plstes, chsin-mail being used at the junction of the limbs with the body, at the ellow-snd knee-joints, and for a hood covering the top of the corselet. Finally, under llenry VI. (1422-1461), at about the time that the reached its complete development, being forged of thin steel to fit the body and limbs, weighing not over 60 or 70 pounds in all, snd allowing of free movement. This, how. ever, was extremely costly. The armor worn in jousta snd
tonrnsments was very different after the twelifh century trom that worn in war, being hes vier, snd nether allowing the knight to dismontint without assistance nor sffording
hime sdequate protection if dismonnted. For Wsr in spite
of the general sdoption of firearms, armor, though not inof the general sdoption of firearms, armor, though not in-
vesting the whole body, continned to be worn by officerg vesting the whole body, continned to be worn by officers
snd mounted men until the close of the seventcenth cen. tury, in the wars of Louis XIV.'s reign, ald, indeed, sur corps of eavsly. (The cuts are front Viollet-le-Dne's 2. The metallic sheathing, intended as a protection against projectiles, for a ship of war or the exposed face of a fortification.-3. Figuratively, a defensive covering of any kind; that which serves as a protection or safeguard; bulwark: used in zoöl. and bot. of the protecbulwark: used in $z 0 \ddot{l}$. and bot. of the protec-
tive envelop or cover of an animal or a plant, as the scales of $a$ fish or the plates of a erocodile.

There is no armor against Iste.

Shivley.

In one apectes [hornbills] the bill armor resembles gone whst the great recurved horn of the rhinoceros,
Sci. Amer., N. S., LV. 73. In Eurape the cables contain from five to seven wires, wtth an armor of Iron wires or iron pipe.
Greer, Dict. of Electricity, p. 162

4. In magnetism, same as armature, 6. [Rare.] - Mascled armor. See mascled. - Submarine armor, a water-tight covering worn by a diver; a diving-dress. enough to permit free moventent of the hesd within, probreastplate which prevents any compression of the lungs. The remainder of the suit is of india-rubber. Pure air is pumped through a tube opening into the helmet and is
projected against the windowa, removing the molsture becomes diffused and is breathed, the impure air psssing out throngh a similar to the shoes. A signal-line affords communication witl armor, armour "(är'mor), v. t. [<armor, n.] To cover with armor or armor-plate.

The trees were yet growing and the iron unmined with Lovell, Study Windows, p. 152.

armor-bearer (är'mor-bãr"èr), $n$. In ancient and feudal times, one who carried the armor or weapons of another.

armored, armoured (är'mord), p.a. [< armor $\left.+-e d^{2}.\right]$ 1. Equipped with arms or armor.-
2. Covered with armor, as a ship or the face of a fortification; armor-plated.

The "Stonewsll" was a ram with armored aides.

Fishes [Cephalaspida] whose peculiar armoured forms

Claus, Zoölogy (trans.), p. 177

armorer, armourer (är'mor-èr). $n$. [Second form now usual in Fngland; $<$ MF. armorer, armerer, armurer, $\angle \mathrm{AF}$. armurer, $\mathrm{OF}$. armurier ( $\mathrm{F}$. armurier), < armure, armor: see armor and -er.] 1. Formerly, a maker of or an expert in armor; armor of a knight or man-at-arms, and equipped him for action.

The armourers, accomplishing the knights,
With busy hammers closing rivets up,

Riding further past an armorer"s,

Who, with back turn'd, and bow'd above his work

Sat riveting a helmet on his knec. Tennyson, Geraint

2. In modern use, a manufacturer or custodian of military arms; specifically, one who has the supervision of any collection or equipment of arms. The armorer of a shtp has charge of the arms, 
and sees that they are kejt in a eondition fit for aervice. In
the Iritish army an armorer I attached to each trooul of the liritish army an armorer 18 attached to each troopl of armor-grating (ir'mor-grā"ting), n. In unany armor-grating (ar mor-ships, especially in ironclads, ono of sevwar-ships, especially in ironclads, ond of several deep iron gratings which are fitted around
the bottom of the funmel and aeross its throat, to protect the boilers and uptakes from shot and shell during an engagement.

armorial (är-mö'ri-al), a. and $n_{0} \quad[=\mathrm{F}$. armorial; < armory ${ }^{2}+$-al. ] I. $a$. Belonging to hexaldry, or to leraldie bearings

Armurial slyna of race and birth.

Wordsserth.

Attendant on a King-at-arms,

rmortal bearings. See arn2, 7 .

He was aurromnded by his courtiers, witin their gtately retlnues, glittering In gorgeous panoply, and proucily d

aying the armoriat bearings of their aneient honges.
Prescutt, Ferd, and Isa., i. 15.

II. $n$. A book containing heraldie bearings and devices; a dictionary of tho arms rightly borne by the persons named in it.

Armoric (är-mor'ik), $a$, and $n$. [ $<\mathrm{L}$. Armorice, pl., later Armorica, sing., said to be < Celtic ar (W. $m o ́ r=I r$. and Gael. muir), tho sea, $=\mathrm{L}$. mare, sea, = E. mere, lako: see mereI.] I. $a$. Pertaining to aneient Armorica, tho region in the western extremity of France now ealled the western extremity of France

II. $n$. The language of the inhabitants of lower Brittany, one of the Celtic dialeets which have remained to the present time. It is a niemis the only other living member.

Armorican (är-mor'i-kan), $a$. and $n$. I. $a$ ame as Armoric.

II. n. A native of Armoriea or Brittany. armoried (iir'mor-id), a. [< armory ${ }^{2}+-e d^{2}$.] Decked with armorial bearings.

armorist (ä $\mathrm{r}^{\prime}$ mor-ist), $n . \quad\left[<\mathrm{H}^{\prime}\right.$, armoriste, $<$ ar moirics, coat of arms: see armory ${ }^{2}$ and $\left.-i s t.\right]$ One skilled in armory or heraldie arms.

armor-plate (ar'mor-plāt), n. A metallio plate usually of iron or steel, intended to be attached to the side of a ship or the outer wall of a fort with the view of rendering it shot-proof. A proteetion of iron for ahips was proposed in the eariy part of the present century, hint the irst practical application of the Crimean war. The gnceess of these led the French to comstruct "La oluire" the first of tire so-called ironclads, iron plates over a backing of ahout " ahlps of the aame class built by the Britlsh govermment, with 4 -inch plates over 18 inches of teak backing. The thickness of the armor has been increased as more powerful ordnance has been contrived, the plates of the "Belie-
rophon" of the British navy ranglng from 16 to 24 inchea. The armor-plate of the United States monitors varies
from 5 to 10 inches, and the backing trom 28 to 48 inches. See ironclad. - Armor-plate cradle, a device used for bending armer-plate. It is placed near the furnace, and by numerous eross-bars of iron, so placed that their upper edgca correapond to the enrve desired in the finlahed
plate. Bara are similarly placed alove the plate, and tine plate. Rara are similarly placed alove the plate, and tine forced down uper the bed-bars.-Compound steelfaced armor-plate, armor-plate made of iron faced with ateel. It is made up to 24 inches in thickneas, and the largest plates weigh aloout 50 tons. The steel face is
ordinarily about one third of the thickness of the whole plate. The two metals are wolded together by heavy armor-plated (är'mor-plā"ted), $a$. Covered or protected by iron plates, as a vessel for naval warfare; iron-clad.

warfare; iron-clad.
armor-shelf (är'mor-shelf), $n$. An iron shelf or ledge projecting from the sides of an armored the armor-plate and armor-baeking rest.

armory ${ }^{1}$ (ä́r'mor-i), $n_{.} ;$pl. armories (-iz). [In England usually spelled armoury; early mod. E. armory, armoury, armery, sometimes armary, ME. armorye, armeric, armurie, sarmure, arto (see armor and $-y$ ), but practically equiv. place for arms, arms collectively: see $a \mathrm{rm}^{2}$ and -ery. Cf. OF. armenrerie, armoiric, mod. F. armurerie, an armory, arsenal. The word has been confused to some extent with armory ${ }^{2}$.] 1. Arms or armor eollectively; a collection of arms or armor.

Blue-eyed maid, thy spear

of heaven is too little ! B. Jonson, Sejanus, iv, 5 Celestial armoury, shields, helms, and spears. dialectic a range of abatract thought, what an ammory of

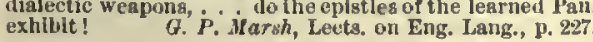

2. A place where arms and instruments of war are kept. In the United Stutes the State milltia aro nsialiy proviled w

3. A place whero arms and armor aro mado an armorer's shop; an ar

armory' (âr'mor-i), n.; pl. armories (-iz). [In England usually spelled urmoury; early mod. I: armory, armoury, armery, < lato ME. armorye, urmoiric, $\mathrm{OF}$. armoirie, armoierie, in pl. urmoiries, arms, cognizances, senteheons, < urmoier, urmoyer, urmoieor, armoirer, one who blazons arms, < armoier, armoyer (mod. F. armorier = It. armeggiare), blazon arnns, < armes, arms: see $\mathrm{arm}^{2}$. Cf. armory ${ }^{1}$.] 1. The seience of blazoning arms; the knowledgo of coat-
armor; heraldry.-2. An armorial ensign; a erest or heraldio omblem; arns.

Ilenry VII. united, ly the marriage of Elizabeth of very powerful famillea.
Sis II. Wotton, Panegyrie of Clarles I. 3t. Ensigns of war; colors.

armory ${ }^{3}+, n$. [After armory ${ }^{1}$ and F. armoire (see armoire), ult. < L. armarium, wheneo indireetly ambry and directly armary: see ambry and armary, and ef. armory $\mathbf{l}_{\text {.] }} \mathrm{A}$ eupboard; an ambry.

armosiet, $i$. A variant of armozeen.

armour, armoured, ete. See armor, ete.

armozeen, armozine (är-mọ̄-zên'), n. [Farly mod. E. also armazine, arniesine, $\angle \mathrm{OF}$. armesin, $\mathrm{F}$. armoisin $=\mathrm{It}$. ermesino, $\mathrm{ML}$. ermesi plain silk, used for women's and also for men's wear in the eighteentl century and carlier.

armpit (ärm'pit), n. [<ME. armepytt; < arm ${ }^{1}$ + pit $^{1}$.] The hollow place or eavity under the shoulder ; the axilla.

arm-rack (ärm'rak), n. A frame or fitting for the stowage of arms.

arm-rest (ïrm'rest), $n$. Something designed as a rest for the arm; specifieally, that portion of a choir-stall which is designed to support the arms of the oceupant when he is in either a leaning or a standing posture; also, the carved end of a beneb, as in a ehureh-pew.

arm-saw (arm'sâ), n. Samo as hand-saw. See

arm-scye (ärm'si ), n. Same as seye.
arm a good distance off. Dryilen.

arm's-length (armz'length), n. A spaco equal to the length of the arm.- To keep at arm'slength, figuratively, to keep off or at a distance ; not to allow to come into close contaet or tamliarity. - To work wardy.

arm-sling (ärm'sling), $n$. A sling of linen or
other fabrie for supporting the forearm when fractured or otherwise injured.

arm-span (ärm'span), $n$. The span or reach of one's arm; an arm's-length.

Not too wide for the armspan of the sllverer.
J"orkshop Receipts, 1. 313.

arm's-reach (ärmz'rēch), $n$. The reach of the the distance to which the arm can reach. as, to bo within arm's-reach.

armstrong (ärm'stroug), $n$, [ $[\langle a r m 1+$ strong. $]$ A local English naine of the common knotgrass, Polygomm arieulare.

arm-sweep (ärm'swēp), $n$. The length of reach or sweep of an arm. Browning. [Poetical.] armulett (är'mū-let), $n$. A form of armillet or of armlet. [Rare.]

armure (är'muir), n. 1t. The regular Middle English form of armor. Chaucer, - 2. A woolen
or silk fabric woven with a surface-ridge forming a small pattern, as a diamond, etc.

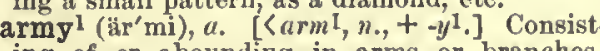
ing of or abounding in arms
branching; spreading. [Rare.]

Though large the forest's monareh throws

army ${ }^{2}$ (är'mi), n.; pl. armies (-miz). [Early mod. E. also armie, < ME. armye, armeye, armada = It. armata, < ML. armata, an armed foree, army, prop. fem. of L. armatus, pp. of armare, arm, < arma, arms: see $a_{r m}^{2}$, and ef. armada, armata, doublets of army.] 1 1. An armed expedition.

$$
\begin{aligned}
& \text { In the Grete See } \\
& \text { At many a noble armee hadde he be }
\end{aligned}
$$
war, and organized in companies, battalions, regiments, brigales, or similar divisions, under proper officers. In general, an army in modern times consists of infantry and eavalry, with artilicery, although
the unlon of the three is not essential w its constitution, designated, accordinu to thetr objects, dutles, field of oferstions, etc, as ufenxire or defenxice, covering, blockading,
besieginy, xtanding or regulur, arny of ubstruction, arnyy of besieginy, xtanding or reyulur, army of obstruction, arny of observetion, "trniy of invasion, army of acenpation, arny of
reserce, cte. 'The forces etuployed in the large war-fleet of forner times were called waral armie

The essential characteristics of an arny, hy whlch it is distinguished from other assemlilagea of armesl men, are less the will and tile power of the nation or its rulers ad its organizatlon.

3. A great number; a vast multitude.

The locuat, ... the cankerworm, and the eaterplltar, you. Joel if. 25 .

The noble army of martyrs. Book of Common Prayer. Army Acts, a series of Engllsh statntea passed each year a work tasued by the Uuited States government, the titie of the acts of Congress and the rules of the cormmander-in ehlef for the management of the army both in peace and In war.-Grand Army of the Republic. See republic. a permation Army. See salration - Standing army,

soldiers' nuiforms are made.

army-corps ("̈r'mi-kōr), n. [<armi ${ }^{2}+$ eorps; a translation of $\mathrm{F}$. corps titarmée.] A corps which is made up of several divisions, and embraces every arm of the service, thus forming an army complete in itself, and placed under the command of a general officer of higber rank than a divisional officer. In the British army three divisions make an army-corps. Sometimes abbreviated A.C. Seo dixision.

army-list (är'mi-list), $n$. 1. An English publieation (as title, Army List), issued periodically, contaiuing a list of the officers in the army, the stations of regiments, ete. In the United States thero is a similar list, ealled the Army Register.-2. Figuratively, the officers whose names are recorded in the list.

They rideand walk with halt the army-likt

and yet Thackeray, Vanity Fair, xlli1.

army-worm (är'mi-wèrm), n. A name given account of the immense numbers in which it
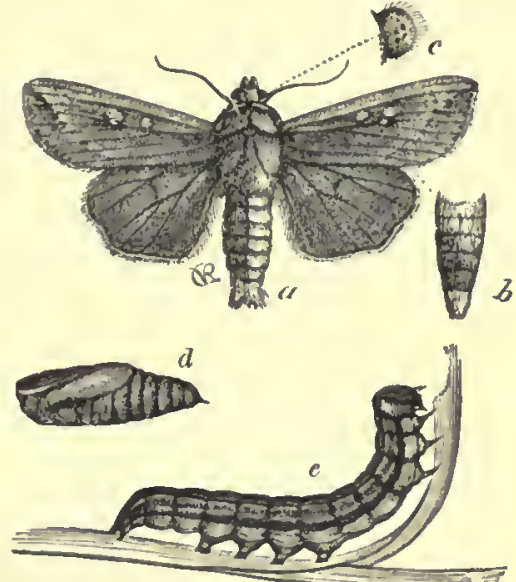

Army-rorm (Lencania unipuncta), about natural size.

a, male moth; $b$, abdomeo of fermale; $c_{\text {, eye }} d$, pupa ; $e_{0}$ cater

sometimes marches over a country, completely stripping it of all tho grasses and young grain in its way. It undergoes transformation in the ground. arn (ärn), n. [Se., perhaps a reduction of allern, aldern, of alder; or else of Gael. fearn, alder, $=$ Ir. fearn, alder, $=$ W. geern, aldertrees.] The alder, Alnus glutinosa.

arma (är'nä). n. [Hind, arna, fem. arni.] A name of the wild Indian buffalo, Bos bubalus or Bubalus arni, notable for its size and the length of its horns. Also arnee, arni. arnatto (är-nat'ō), n. Same as arnotto. Arnaut (är-nout'), n. [Also as F., Arnaout $=$ G. Armat = Serv. Arnaut, Arnautin, Bnlg. Ar

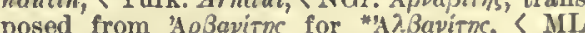

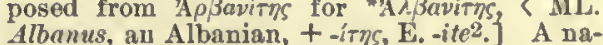

tive of Albania; an Albanian.

arnee, arnl (är'nē), n. Same as arna. 
arnica

316

arnica (är'ni-kä), n. [NL., origin unknown; perhaps a perversion of l'tamica, q. v.] 1 . genus of perennial herbs, natural order composite, natives of the northern temperate and

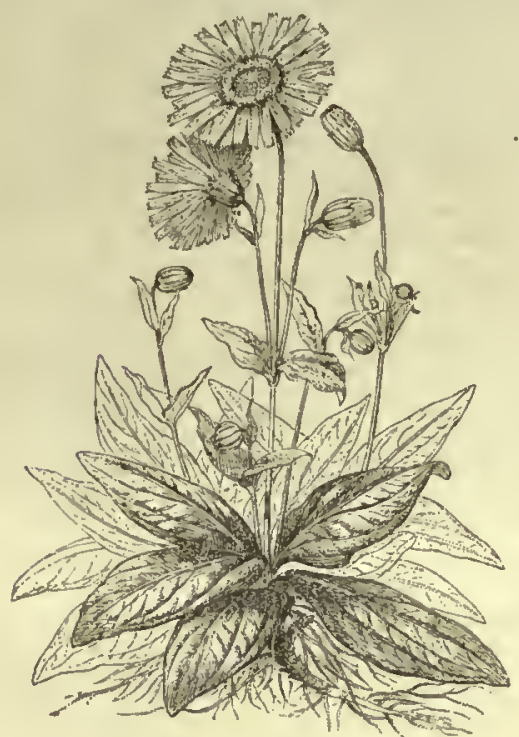

Mountan-tobacco (Arnica moneara).

aretic zones, with showy yellow flowers and opposite leaves. The most important specles, $A$. mon$\tan a$, the mountaln-tobacco of entral Europe, has long been a popular remedy in Germany. A. alpina is found specles is pecullar to the Athantic States, and a dozen others are natives of western North Americ

3. A tineture of the roots or flowers of A. montana, much used as an external application in wounds and bruises, and internally as a stimnlant in debilitated states.

arnicin, arnicine (är'ni-sin), n. [< arnica + $-i n^{2}$.] An acrid bitter prineiple in the flowers and roots of Arnica montano.

Arnoldist (är'nold-ist), $n$. [< Arnold $+-i s t$. A disciple of Arnold of Brescia, who in Italy in the twelfth century preached against the ambition and luxury of ecelesiasties, not sparing the pope himself. Ie maintained the subordination of the ecclesiastieal to the temporal power, and proclaimed the necessity of both a civil and an ecelesiastical revolution. In 1146 he put hiniself at the liead of a temporarily successful insurreetion against the temporal power of
pope. He was put to leath in 1155 . Arnold's ganglion, nerve. See the nouns. arnot, arnott, $n$. See arnut.

arnotto (är-not'o $), n$. [In various other form arnatto, anatto, anotto, anotta, annatto, annotto, annotta; prob. a native Amer. name.] 1. Bixa

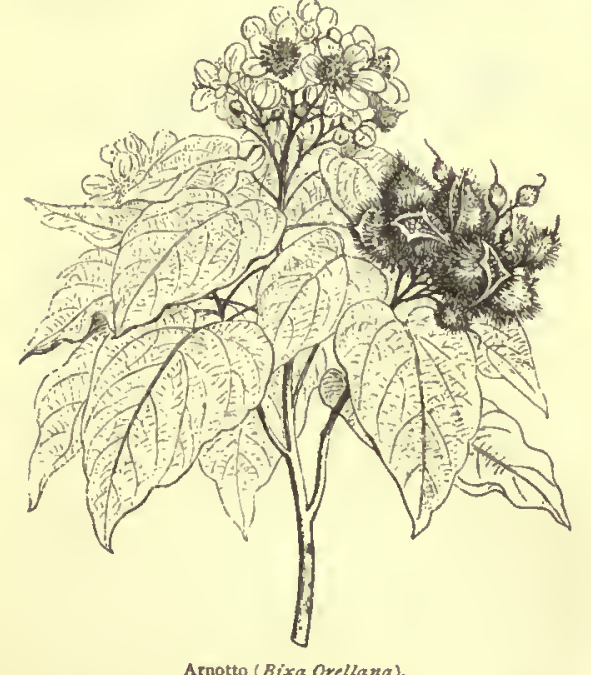

Orellana, a small tree, natural order Bixacea, native of tropical America. It is extremely common in Jamaiea and other parts of the West Indles, and has 2. The dye or coloring matter obtained from 2. The dye or coloring matter obtained from the seeds of this plant. The seeds are covered wit a reddish or reddish-yellow waxy pulp, which is dissolved In water, then dried to the consistency of putty, and made
up in rolls or folded in leaves, or drled still more and made into cakes. It is employed as a dye for silken, woolen, to simple yellows, and also as a coloring ingredient for but ter, chcese, and chocolate, and for varnishes and lacquers. arnut, arnot (är'nut, -not), $n$. [E. dial., = carthnut, q. v. Cf. arling for earthing.] earthnut (which see). Also spelled arnott. aroeira (ar-ō-ä'räi), $n$. [Braz.] The native name of a small anacardiaceous tree of Brazil Schinus tercbinthifolius, the resin obtained from which, and also the bark and leaves, are used as a remedy for rheumatism and other complaints. aroid (ar'oid), $n$. [<Arum + -oid. $]$ One of the Aroidece or Aracece.

Aroideæ (a-roi'dẹ-ēe), n.pl. [NL., < Arum + - oidece.] Same as Aracee. aroint, aroynt (a-roint'), $v$. [Found only in the sages of Shakspere, and in modern imitations, being prob. Shakspere's own adaptation (arount, being prob. Shasspere's own adaptation (aroynt, after around (see below), or with an unoriginal
introductory syllable due perhaps to forcible introductory syllable due perhaps to foreible utterance, or perhaps merely metrical, for *roynt, rynt, the diphthong oy, oi being then and still dial. often equiv. to $y, \overline{1}$ ) of an E. dial. (Cheshire) proverb, "'Rynt you, witeh,' quoth Bessie Locket to her mother," so recorded by Ray in 1693, but prob. in use in Shakspere's time. (If original with him, it could not have passed into popular speech so early as 1693.) The proverb, which bears the marks of loeal origin, from some incident long forgotten, contains a particular use of the same verb that oceurs in $\mathbf{E}$. dial. ryntyc (given by Ray in connection with the proverb), ryndia (Thoresby, 1703), rynt thec, an expression "used by milkmaids in Cheshire to a cow when she has been milked, to bid her get out of the way" (Clark and Wright, ed. Shak., l. c., note), that is, round $y c$, round thee, move round, turn about; rynd, rynt, being a dial. form of round: see round ${ }^{2}$.] I. intrans. An interjectional imperative, equivalent, in the passages

"Aroint thee, witch!" the rump-fed ronyon cries. Ie met the nlght-mare and her nine-fold
Bid her alight,

And her troth plight,

And aroint thee, witch, aroint thee!
Shak., Lear, ilt.
II. trans. To say "aroint" to; bid begone. Whiskered cats, arointed, flee

Mrs. Erowning, To F'lush, xvlii. Brouning, Two Poets.

arolium (a-rō'li-nm), n.; pl. arolia (-ij). [NL.] An appendage of the tarsus of

A short cushion [plantula] and two inembranous arolia
Pascoe, Zoöl. Class., p. 120 arolla (a-rol'ä), n. The Swiss stone-pine, Pinus cembra.

roma (a-rō'mä), n.; pl. aromas (-maz), sometimes aromata (-ma-tä). [Farly mod. E. aromate, $\angle \mathrm{ME}$. aromat, $\mathrm{OOF}$, aromat, mod. F. aro mate; mod. E. directly< L. aroma, < Gr. apw (арьнат-), any spice or sweet herb; perhaps orig

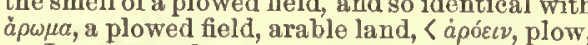
$=$ L. arare, plow: see arable.] 1†. Spice: usually in the plural, spices. $N . E . D .-2$. An odor arising from spices, plants, or other substances, more especially an agreeable odor fragrance; spicy perfume.

The air had the true northern arom

B. Taylor,

3. Figuratively, a eharacteristic but subtl quality; a pervasive eharm or flavor.

The subtle aroma of genius. Saturday Rev. A happy surprise awaits those who come to the study of the early literature of New England with the expectation of flnding it altogether arid in sentiment, or void of th

U. C. Tyler, Hist. Amer. Lit, I. 264. $=$ Syn. 2. Perfume, Fragrance, etc. See smell, $n$. aromatic (ar-ō-mat'ik), $a_{*}$ and $n$. [Early mod. E. aromatick, $-y q u e,<\mathrm{ME}$. aromatyk, $<\mathrm{OF}$. aro-
matique, < LL. aromaticus, < Gr, apwuatikós, a $\rho \mu a$, spice, sweet herb: see aroma.] I. 1. Giving out an aroma; fragrant; sweet seented; odoriferous; of spiey flavor.

Great blueberry busles hanging thick with misty blue spheres, aromatic and sweet with a sweetness no tropic
suns can give. R. T. Cooke, Somebody's Neightors, p. 291.

2. Caused by an aroma or fragrant odor.

$$
\text { Die of a rose in aromatic pain. }
$$
3. In chem., an epithet formerly applied to a
small group of organic bodies, of vegetable around

origin, which had an aromatic smell and taste; now applied to all those compounds which are derived from the hydrocarbon benzene, $\mathrm{C}_{6} \mathrm{H}_{6}$. They are distinguished from those of the fatty series by not being derived from nethane, $\mathrm{CII}_{4}$, and ly the fact that hene the aromatic hylrocarbons is easily direetly in compounds of the fatty series it is not. They gal, while contain pore carbon, also, than the compounds of the atty series-Aromatic vinegar, a volatile and powerful perfume made by adiling the essential oils of lavender, cloves, etc., and often camphor, to strong acetic a

II. n. A plant, drug, or medicine which yields a fragrant smell, as sage, certain spices and oils, ete.

aromatical (ar-ọ-mat'i-kal), a. Same as aro-

aromatically (ar-ō-mat'i-kal-i), adv. With an aromatic or agreeable odor or taste; fragrantly. romatite (a-ró'ma-tīt), n. [<L. aromatitcs, a precions stone of the smell and color of myrrh. aromatic wine, < Gr. a pwearitjs, aromatic, < a $\rho \mu \pi$, spice: see aroma.] 1. A bituminous stone, in sinell and color resembling myrrh.-2. A factitious wine, containing various aromaties. aromatization (a-rō"ma-ti-za's'shon), n. [<aromatizc + -ation.] The act of rendering aromatic ; aromatic flavoring.

aromatize (a-rō'ma-tīz), $v$. $t$. ; pret, and $\mathrm{pp}$. aromatizcd, ppr. aromatizing. '< late $\mathrm{ME}$ aromalysen, <OF aromatiser, < LL, aromatizare, <

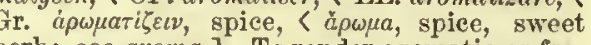
herb: see aroma.] To render aromatic or fragrant; give a spicy flavor to; perfume.

aromatizer (a-ro'ma-tī-zèr), n. One who or that which aromatizes; that which communies an aromatic quality.

Aromatizers to enrich our sallets. Evelym, Acetaria, vl. aromatous (a-rō'm@-tus), a. [< $\operatorname{aroma}(t-)+$ ous.] Containing ä aromatie prineiple; aromatic.

Aromochelyina (ar-o-mok" $\left.\mathrm{e}-\mathrm{li}-\bar{i}^{\prime} n a ̈\right), n . p l$. [NI., < Aromoehelys + -ina.] A subfamily of turtles (the stinkpots), typified by the genus Aromochelys, referred by Gray to his family Chelydrade. They have a crueiform plastron of 11 sydrade. They have a cruciform plastron of 11 shields, of which the gular pair is united and
linear. A. odorata is the common stinkpot of the United States.

Aromochelys (ar-o-mok'e-lis), n. [NL., < Gr. a pw $\mu a$, in mod. sense 'sweet smell,' $+\chi^{k} \lambda \nu, \mathbf{s}$ tortoise.] A genus of terrapins, including the stinkpot of North America, $A$. odorata, typieal of the subfamily Aromochclyina.

arondie, arondy, $a$. Variants of arrondi.

Aronhold's theorems. See theorem.
aroomt, prep. phr. as $a d v$. or $a$. [<ME. aroum, a roume, on rum: $a$, on, E. $a^{3}$, to or at; ronm, rum, space, E. roon: seo $a^{3}$ and room.] To or at a distance; abroad; apart.

$$
\text { I aroume was in the felde. }
$$

Chaucer, Hlouse of Fame, 1. 540

aroph (ar'of), $n$. [Said to be $<\mathrm{ML}$. $\operatorname{aro}(m a)$ $p h$ (ilosophorum), aroma of the philosophers. 1. A name formerly given to saffron. -2 . A chemical preparation concoeted by Paracelsus, used as a remedy for urinary ealeulus.

arose (a-rōz'). Preterit of arise.

a rotelle (ä rō-tel'le). [It. : $a(<\mathrm{L} . a d)$, to, with; rotelle, pl. of rotclla, a small wheel, disk dim. of rota, a wheel: see rota.] With disks, rondels, or rosettes: used in works on decorative art in deseribing objects so ornamented as, "an amphora with handles a rotellc" (Birch) that is, having handles which, rising above the lip of the vase, form a circular ormament, often filled with a mask.

around (a-round'), prep. phr. as $a d v$. and prep. Hence by apheresis round $2, \quad a^{3}+$ round
Hend anep. 1. adv. 1. In a circle or sphere; round about; on every side: as, a dense mist lay around. The gods of greater nations dwell around, And on the right and left the palace bound.
Dryden, tr. of Ovid's JIetamorph., 1. 223. And naught above, below, around, Of life or death, of sight or sound. Whitier, New-Fugland Legend.

2. From place to place; here and there; about as, to travel around from city to city. [U. S. -3. Abont; near: as, he waited around til the fight was over. [U. S.]

II. prep. 1. About; on all sides; encircling; encompassing.

A lambent flame arose, which gently spread
Around his brows.

Around us ever lies the enchanted land,
In marvels rlch to thine own sons dlsplayed. 
2. From placo to place; at random: as, to roan arquerite (iir'ke-rit), $n$. [< Aryeros, neal around tho eountry. [U. S.] aroura $_{2}$. See arurc.

arousal (n-rou'zal), n. [< cronse $+-a l$.$] The$ aet of a rousing or awakening; the state of being aroused or awakenod.

The aronesat and aclivity of our better nature. Hare. Cognition of these relailons [i,etween the organism and some noxions agent] will determine the arousal of some
Mind, IX.342 arouse (a-rouz'), $v$. $t_{\text {. }}$; pret. and pp. aroused, ppr. arausing. [<a.1 + rouse 1 , after arise, rise,
ete.] To excito into action; stir or put in moete.] To excito into aetion; stir or put in motion or exertion; awaken: as, to urouse attention; to arouse

Crying with full volce,
"Traitur, come out, ye are trapt at lagt, " aroused

Traitor, cono ont, yo are trapt at last, " a roused

They [the women of Goethe] aatiaty for the present, yot arouse an influite exjectation.

arouse (a-rouz'), n. [<arause, v.] Tho act of arousing; an alarm. [lare.] N. E. l)

arouser (๕̂-ren'zer), n. One who or that which arow (a-rö'), prep. pihr. as cult. [ME.' arove, a-race, a rouce, arave (early mod. F. also areve,

And ali her boncs might through her eheekeg be red.

And twenty, rank in rank, they rode arowe.

aroynt, $v$. See aroint.

in rank, they rode arowe.
Dryden, Flower and Leat, 1. 210

arpeggiation (är-pej-i-ā'shon), n. Playing ju arpeggios.

arpeggio (arr-pej'ō), n. [It., lit. harping, < arpeggiare, play on the harp, $<$ arpa, harp, < ML. sounding of tho notes of an instrumental chord in rapid suecession, either upward or (rarely) downwarl, as in harp-playing, instead of si-
multaneously. - 2. A ehord thus sounded; a broken chord.

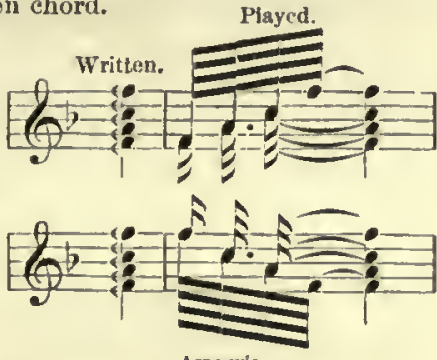

Semotimes written harpeggia. arpent (ar'pen), n. Same as arpent. arpennust (är-pen'us), $n_{. ;}$pl. arpenni $(-i)$.
[IIL., also arpennum, $-a,-i s$, ete.: see arpent.] Same as arpent. Bowvier.

arpent (air'pent; F. pron. är-pon'), n. [Early mol. E. also arpen, arpine; $<\mathrm{F}$. arpent $=\mathrm{Pr}$. arpen, aripin $=\mathrm{Sp}$. arapende, $<\mathrm{ML}$. arjennus, arpenna, arpenclus, arpendium, ete., < LL. arapennis, $\mathrm{L}$. arepennis, a word of Celtie origin. jugerum quoque arcpennem vocant." The semijugerum quoque arcpennem vocant." The semijugerum was equal to 14,400 square feet.] An
old Freneh measure for land. By a reyal edict of 1669 , it must contain 100 perches of 22 feet each (lineariy) or 48,400 square leet. 'This was ealled the arpent royal,
arpent d'ordonnance, or arpent des eaux et fortets. The 32,400 , theae beling based on perches of the arpent of Pari foliowing sre the areas in ares: arpent of Paris, 84.1897 . common arpent, 42.2083; royal arpent, 51.0720 ; English acre, $40.467 \mathrm{~s}$. The arpent ia atill used in Loutsiana, and
in the province of Quebec. Formerly also arpen, arpine.

If he be master
Of poor ten arpines of land ferty hours fonger,

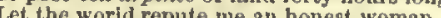
II'ebster, Devil'a Iaw-Case, bii. 3

arpentatorł (är'pen-tā-tor), n. [NL., <ML. arpentum, one of the numerons variants of $\mathrm{L}$, are peunis: see arpent.] A measurer or surveyor of land. Bowier.

arpineł (är'pin), $n$. Same as arpent.

arquata (är-kwā'tä), n. [NL., prop. arcuata, fem. of L. arcuatus: see arcunte.] An old name of the eurlew, Numenius arquatus, from its long areuate bill. Also written areuata.

arquated (ä. $\left.r^{\prime} \mathrm{kwā}-t e d\right), \alpha$. [For arcuated : see urcuate.] Shaped like a bow; arenate. [Rare.] arquebus, arquebuse, arquebusier. See har quebuse, harquebusier.
Coquimbo, a scaport town of Chili, $+-i c^{2}$. $]$ mineral silver analgam, occurring in sinall mineral silver analgam, oceurring in sinall oetahedrons and in arborescent forms. It con. tains 86 per cent. of ailver, mut ia the chief ore of the
silver-unines of Aryuros.
arquifoux (ír'ki-fö), n. Same as ulquifou.

arquifoux (är'ki-fö), n. Same as ulquifou.
$\operatorname{arr}^{1}$ (ür), n. [H. dial., <M]. arre, erre, < Ieel. $\ddot{o r r}, \ddot{\mathrm{r}}=\mathrm{Sw}$. $a r r=$ Dan. $a r, a$ serar.] A sear.

$\operatorname{arr}^{2} t, v, t . \quad[<$ HE, arren = LG. arren, vex, arre $=\Lambda \mathrm{S}$. ierre, yrre, corre, anger, as adj. angry; ef. Dan. arrig, allgry, which, howover, is arg, wieked, bad, = G. $a r g=\mathrm{AS}$. eurg, timid, cowardly.] To anger; vex; worry.

He arred loth the elergy and the laity

. Bacon, Hist. Discourse, xiv, 216. (N. k. D.)

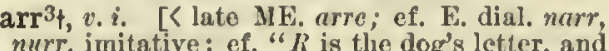
hurreth in tho sound" (B. Jonson): see hurr.] To snarl as a dog.

A dog ts . . . Ieil and ciuarrelsome, given to arre and war npon n very smali occasion. IHutareh's Morata, p. 720. arrat, $n$. Seo arrha.

arracacha (ar-a-kach'ä), n. [< Sp. arucacha (> NL. Arracacía), of S. Amer. origin.] A name given by the natives of western Sonth Ameriea to soveral kinds of plants with tuberous roots, and especially to a speeies of the nmbelliferous genus Arracacia, A. csculenta, which is extensively eultivated in the Andes, and has become naturalized in Jamaica. The roots are divided into aeveral lobea of the aize of a carrol, wislel when bolfed have a flavor between tiast of the parsnip and that of the the potato. The name is also given to a tuber-bearing species of the Oxalis, O. crenata.
arrace 1 , v. $t$. See arace $^{1}$, arase

arrace $2 t, n$. Seo arras ${ }^{1}$

arracht, $n$. See arach.

arraché (ar-a-shã'), a. [F., pp. of arracher, uproot: see arace1.] In her., torn up by the roots: applied to plants used as bearings, and to whatever has the appearance of having been to whatever has the appearance of having been
severed by violenee. Erased is now in more general use.

arrack (ar'ak ), n. [Better spelled arack, formerly arak; arae; now eommonly shortened to rack; $=\mathrm{F}$. arack $=\mathrm{Sp}$. arac $=\mathrm{Pg}$. araca, araque, Hind. arah, Tamil araku, aruki, Ar. araq 'arqüy, arraek, brandy ; <'araqa, sweat, perspire. Tho forms arak, arki (Tatar), and araki (Egyptian) are from tho same source, the namo being applieable to any spirituous liquor.] Originally tbe name of a strong liquor made in southern Asia from the fermented juiee of the date, but for strong liquors of different kinds. It is nade in Goa from the anp of the cocos-palu, and in Batavia from rice; and the arraek of enstern and northern India A Rervant brought in a silver tray, upon which were
large giasseg of the abominable apirit called arrack, each Arragonese, $n$. and $a$. See Aragonese. arrah (ar'ä), interj. A common Anglo-Irish ex-

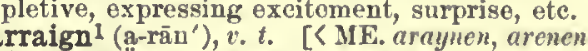
$<$ AF. arainer, areiner, arener, $<$ OF, aranier, earlier araisnicr, areisnier (later araisaner, areisoner, aresaner, ete., > ME. aresonen: see area son), $<\mathrm{ML}$. arrationare, eall to aeeount, arraign, <L. all, to, + ML. rationare, reason: see reason and ratio. Cf. deraign 1.] 1. In law, to eall to or set at the bar of a eourt, in order to plead guilty or not guilty to the inatter eharged in an indietment or information. This term is unknown in the faw forms of procedure in Engiand and scotiand are the same. Hence - 2. To eall in question for faults, before any tribumal; eall before the bar of reason or of taste; accuse or eharge in general.

They arraign'd aball aink
Beneath thy sentence.

Is there not sornething in tire pleading eye

Of the poor brute that suffers, which arraigns
The law that bids it anfter? $O . W$. Inolmes, Rights. =\$yn. Accuse, Charge, Indict. Sce accuse. arraign 1 (a-rān'), $n$. [<arraign ${ }^{2}, v$.] Arraign-
ment: $n$, the clerk of the arraigns. Blackstone. $\operatorname{arraign}^{2}+\left(a-r a ̄ n^{\prime}\right), v$. t. [Early mod. E. also arraine, araine, $\triangle \mathrm{AF}$, arraigner, arainer, the latter an error for aramer ( $>$ ML, arramare), OF aramier, aramir = Pr. aramir = OCat. arcmir, < ML. adramire, adhramire, adlehramirc, agramire, arramire, ete., <L. all, to, + "hramire, prob. orig. Also spelled ar. [Prov. Eng.] of which was supposed to be emptied at a draught.
O'Donovan, Herv, xi. with a sense sulsenuently lost in the tecluniea] ise, < Goth. hromjun, us-hranjan, erucify, lit. hang (of. OHIG. ram, MHIt. rume, ruth, $m e n=\mathrm{D}$. ruum $=\mathrm{D}$ urn. $r a m m c=\mathrm{Sw}$. ram, frame

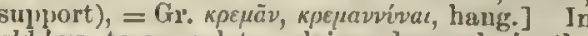
ald lue, to appeal to; elaim; deurand: in tho phrase ta arraign an assize, to lemand, and henco to instituto or lirepare, a trial or an action.

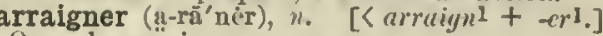
Ono who arruigns or aecuses. The ordinary namo for tho Ieonoclasts is the arraigner,
Mllinan, Latin Christimity.

Milinan, Latin Christimity.

arraignment (a-rān'nıent), n. [< arraignl + -ment.] 1. In lave, the act of arraigning; the act of ealling and setting a prisoner beforo a court to answer to an acensation. The torm usuaily lnchides calling the priaoner, sometimes requiring realing the indictment to him, and asking film wisclier he pleads guifty or not guity.

2. Aceusation before any tribunal, as that of reason, taste, ote.; a calling in question for faults; aceusation.

But this secret arraignment of tile king dill not content The sixtis salire . . a aema only an arraimment of thic

=Syn. 1. Proseention, Impeachment, indietment.

arrameurt, $n$. [AF., < arramer, aramer, < OF arramin, cramir $=$ Pr. aramir, $<$ ML, arramire, adhramire, ote., pledge, promise, appoint: see arraign 2.] A pert-officer who superintended the loading and unloading of vessels. arran (ar'anu), $n$. [E. dial.: see arain.] A spider. Alsö ealled arrand. [Prov. Eug.]

arrand ${ }^{1} \phi, n$. An old form of errani.

arrand $2+, a$. An old form of arrant.

rrand 3 (ar'and), n. Samo as arran. [Prov. Eing.]

arrange (â-rānj'), v'; pret. and pp. arranged, ppr. arranging. [K MF. arayngen, arengen, rank, arrange, $<a-(<\mathrm{L} . a d$, to $)+$ rangier, rengier, range, put into a rank, < rang, reng, rene, F. rang, a rank: see rank 2 and range.] I. trens. 1. To put in proper order; dispose or a certain eollocation to; marshal: as, to ar. range troeps for battle.

$$
\text { Arrange ine board and brim the glass. }
$$

the arrang ments (in biological finvestfgations], we find a eertain number of ldentitiea, and a certain number of variations.
L. D. Cope, Origin of the Fittest, i. 200. 2. To adjust; settle; como to an agreement or understanding regarding: as, to arrange the terms of a bargain.

Matters, therefore, were happlly arranged. The haron

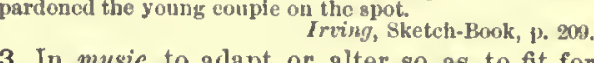
. performance by other vojees or instruments arrange an opera for the piano. = Syn. 1. To array. classify, group, ditgpose, aort.-2. 'To flx upon, determine,

II. intrans. 1. To make preparations; carry out beforehand such negotiations or make sueh disposition in regard to some matter as may bo necessary: as, to arrange about a passport, or come to an agreement or understanding in regard to something; make a settlement. We cannot arrange with our enemy in this conjuncture, without abandoning the intereat of mankind. rrangeable (a-rān'ja-bl), a. [< arrange + able.] Capable of boing arranged.

Fishes have cranta made up of bonea that are no more cleariy arrangeable tinto segments like vertebra than aro
II. Spencer, Yrin. of Biol., 210

rrangement (ą-rānj'ınent), $n$. [< F. arrangement: see arrange and -ment.] 1. The aet of arranging or putting in proper order; the state of being put in order; disposition in suitable form. Spcciflcaliy, in the fine arts, the combining of

The treedom of syntactical arrangement which was pos.

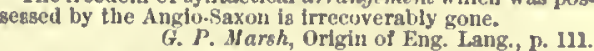

2. That which is disposed in order; a system of parts disposed in due order; any eombination of parts or materials.

The interest of that portion of aoclai arrangement is in

3 . The style or mode in which things are arranged. 


\section{arrangement}

The clonds passed slowly throngh several arrangements. De Quincey, Confessions (ed. 1862), p. 97

4. Preparatory measure or negotiation; previous disposition or plan; preparation: cominonly in the plural: as, we have made arrangements for a journey. Prevlons to his departure he made all due arrangements
with the holy fraternity of the convent for the funeral
solennities of his friend. Irving, Sketch-Book, p. 198 . An elsborate arrangement was entered in to at the sam time by the Alliel Powers, to provide for a succession to

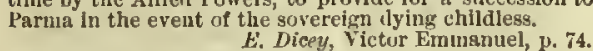
5. Final settlement; adjustment by agreement: as, the arrangement of a dispute.-6. In music: (a) The adaptation of a composition to voices or instruments, or to a purpose, for which it was not originally designed. (b) A picce so adapted; a transeriptiou: as, an orchestral arrangement of a song, an opera, or the like. $=\mathrm{Syn}$. arranger (a-rān'jêr), n. One who arranges puts in order.

arrant (ar'ant), $a$. [Early mod. E. also arraunt, arrand, a variant spelling of errant, erraunt, errand, roving, wandering, which, from its common use in the term arrant or errant thief, that is, a roving robber, ono outlawed, proused apart from its lit. sense as an opprobrious intensive with terms of abuse, as rogue, knave, traitor, fool, etc., but often also without opprotraitor, fool, etc., but often also without opprobrious force. See errant.] 1t. Wandering; an arrant preacher: especially in thief arrant or arrant thief, a roving, ontlawed robber; a highwayman. Now written errant. -2 . Notorious; manifest; unmitigated; downright: in a bad sense (derived from the noun qualified): as, an arrant rogue; an arrant eoward; arrant nonsense.

1 discover an arrant laziness in my soul. Fuller. As arrant a "Screw" Barham, Ingoldsby Legends, II. 46. It was easy to see through all his piety that he was an arrant author at the bottom.
Smollett, Gil Blas, VIII. lii. (N. E. D.) 3. Thorough; downright; genuine: in a good sense.

An arrant honest woman. Burton, Anat. Mel., p. 617. =Syn. 2. Utter, rank, consummate, perfect.

rrantly (ar'ant-li), adv. In an arrant manner; notoriously; impudently: in a bad sense. Funeral tears are as arrantly lifed ont as monrning
clokes. arrast (ar'as), n. [Early mod. E. also arrace, arrasse, < ME. arras, orig. cloth (or cloths) of Arras (F.draps d.Arras) (= It. arazzo= Pr. raz), $\langle$ Arras (F. draps d Arras) (= It. arazzo= Pr. raz), de-Calais, in the north of France, where this article was manufactured. The name Arras is corrupted from the name of the Atrebates (L.), a people of Belgie Gaul.] Tapestry; specifically, that used for hangings covering the walls of a room. The original expression cloth of Arras was prob. sbly nsed with more accuracy to distinguisli arras tapesI'll not speak another word for a King's ransom unless
the gronnd be perfumed, and covered with cloth of arras.

I have of yore made many a scrambling meal,

In corners, behind arrases, on stairs.

Beau. and H'l., Woman Hater, lii.

Arras was used precisely as a curtain; it hung (on tenters
or lines) from the rafters, or (rom some temporary stay, or lines) from the rafters, or Irom some temporary stay and was opened, held up, or drawn aside, as occasion re-
quired. Dyce, Note to Ford's Lover's Melsnclioly, it. In Arthnr's arras hall st Camelot.

Tennyson, yerlin and Vivien.

arras 2 t, $n$. [Prob. a form of orris, q. v.] A kind of powder, probably made of the root of the orris. Halliwell.

arrased (ar'ast), a. [<arras $\left.1+e d^{2}.\right]$ Hung with arras. Chapman.

arrasene (ar'a-sēn), n. [< arras $1+$-ene.] A sort of cord made with a central thread and thick velvet-like pile of wool or silk. It is used in raised embroidery. Also spelled arasene. arrastra (à-rás'trä), $n$. Same as arrastro.

arrastre (á-rás'tre), $n_{\text {. }}[\mathrm{Sp}$, lit. the act of dragging, < arrastrar, drag along the ground, creep, crawl, < $a$ - (L. al, to) + rastrar (obs.), drag, $<$ rastro, a rake, sledge, track, $=\mathrm{Pg}$. rasto, rastro, < L. rastrum, a rake, mattock, radere, pp. rasus, scrape, scratch.] A rude apparatu pp. rasus, scrape, scratch.] A rude apparatu States, for grinding and at the same time amalgamating ores containing free gold or silver.
318

arrect

To these arms masses of rock are fastened by chains and

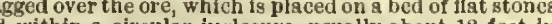
aid within s circular inclosure, usually about 12 feet in liameter. Also written arrastra, arastro.

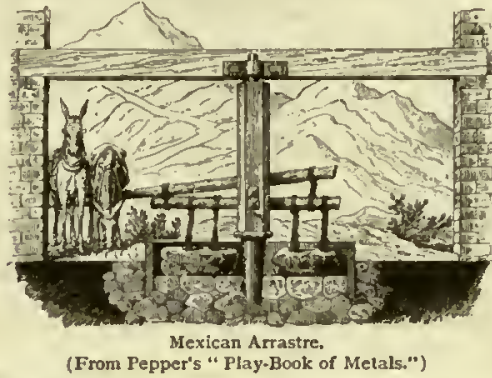

in order for the trial of a cause, or che Challenges are of two kinds ; ftrst, to the array, when seception, is taken to the whole number impaneled ; and 8. Formerly, in England, the muster of a county for military purposes; the men so mustered: as, a commission of array. See eammission.

Y. Parliament had extrenmely worried him for attempting to put in execution $\mathrm{y}^{n}$ commission of aray, and for which the rest of his collegues were hanged by $\mathrm{y}^{*}$ reluells.
Evelym, Diary, JIarch 23,1646 . Previous to the reign of Ifenry Virl., in order to protect the kingdom from domestic insinrections or the prospects of forejgn invasions, it was nsual from time to time for

9. In math., a collection of quantities arranged in a rectangular block; a matrix.-Challenge to the array. See challenge.

arraswise (ar'ass-wiz), adv. Frroneous form of arrisucise.

arratel (àr-rii'tel), n. [Pg.: see arrel.] The

Portuguese pound. It exceeds the ponnd avoirinpois by about one per cent. The following are the values In grams: Pound avoirdupois, 453.593; arratel, in Lisbo 459 ; in Funchal, 458.547 ; in Rlo de Janeiro, 458.75.

\section{arraughtt. For araught, preterit of arcach.}

array (a-rī'), v.t. [Farly mod. E. also aray, arraic, $<$ IIE. arayen, araien, areyen, $\angle \mathrm{AF}$. arayer, araier, OF. areyer, areier, areer, later aroyer, arroyer $=\mathrm{Pr}$. aredar $=\mathbf{S p}$. arrear (obs.) $=\mathrm{Pg} . a r$ reiar = It. arredare, ML. arredare, put in order, rei, rai, roi), preparation, order, of Teut. origin ef. AS. geröde, gerēde, preparation, equipmen (Icel. reidhi, rigging, harness, reidha, Implements, outfit; Sw. reda = Dan. rede, order), ger $\bar{x} d c=$ OFries. réde, rêed $=$ Goth. garaids ready, prepared: see ready. Cf. eurry. ${ }^{\mathrm{i}}$.] 1. To place or dispose in order, as troops for battle marshal; draw up in hostile order: often used figuratively.

They were more ignorant in ranging and arraying their The stronger our conviction that reason and Scripture were decidedly on the side of Protestantism, the greater
is the refuctant admiration with which we regard that system of tactics against which reason and Scripture wer 2. To deck or dress; adorn with dress, especially with dress of an ormamental kind.

Array thyself with glory and heauty.

In that wherein she deem'd she look'd her best.

And there the fallen chlef is laid,

In tasselled garbs of skins arrayed,

Whittier, Funergl Tree of Sokokis,

3. In law, to set (a jury) in order for the trial of a cause; to eall (the jury) man by man. -4

In gelid caves with horrid

Judge Trumbul

-Syn. 1. To arrange, range, marshal, draw up. -2 . Adorn, Omament, Decorate, etc. (see adorn); clothe, invest.
array (a -ră' $)$ n. [Early mod. E. also aray arraie, $\langle\mathrm{ME}$. arai, arai, araie, $<\mathrm{AF}$, arai, arrai, $\mathrm{OF}$. arrei, later aroi, F. arroi $=\mathrm{Pr}$. arrei $=\mathrm{Sp}$ arreo $=\mathrm{Pg}$. arreio =It. arredo; ef. ML. arrediun arreo $=\mathrm{Pg}$. arreio =It. arredo; cf. ML. arrediun, equipment, furniture; from the verb: see ar-
ray, v.] 1. Regular order or arrangement; disposition in regular lines; specifically, disposition of a body of men for attack or defense as, troops in battle array. - 2. An orderly col lection or assemblage; especially, a body of men in order of battle or prepared for battle hence, military foree; soldiery; troops.

A gallant array of nobles and cavaliers. Prescott. What was that mighty array which Elizabeth reviewed
Macaulay, Hist. Eng. 3. A display; an imposing series of things exhibited.

Nothing could well be loveller than this array of Dori temples and ruins of temples.

Dress; garments dispo order upon the person; raiment or apparel.

Emily ere day
Arose and dress'd herself in rich array. Dryden. ie secial art Chaucer, Minller's Tale, 1. 444.

6+. Situation; cireumstances; position; plight Thon stondest yet (quod sche) in swiche array,

That of thy lyf hastow no sewerte.
Chaucer, Wife of Bath's Tale, 1, 40.

7. In law: (a) The body of persons summoned to serve upon a jury. (b) The act of impaneling rrayal (a-rā'al), $n$. [< array $+-a l$.$] 'The$
process of arraying; muster of a force; array. N. E. D.

rrayer (a-rä'èr), n. [< ME. araier, arraiour, < - araieor, ureeor, < areer, araier, array : see list, an officer who had a commission of array to put the soldiers of a county in a condition for military service.

arrayment (a-rā'ment), n. [Early mod. E. also araienent, $\mathrm{OF}$, areement, < araier, ete., array: see array and -ment, and the abbr. form rai-
ment.] 1 . The act of arraying. $-2 \dagger$. That in which one is arrayed; raiment.

Sheep clothed in soft arraypuent.

Quarles.

arrel $n$. See $a r^{1}$

arre $2+, v$. i. See $\operatorname{arr}^{3}$

arreacht, $v$. See areach.

arrear $t, v$. See arear

arrear ${ }^{2}+($ a-rêr'), $a d v$. [Early mod. E. also arear arrere, $<\mathrm{MF}$. arere, a rere, $<\mathrm{OF}$. arere, ariere, retro ar ad $=\mathrm{Pr}$. areire, arreire, $\mathrm{ML}$. ad ward the rear; back; behind.

Forst him back recoyle and reele areare.

arrear ${ }^{2}$ (a-rēr'), n. [ME. only in phr. in ariere, in time past; $<$ arrear 2 , $a d v$. The older noun is arrearage, q. $\mathbf{v}] \quad$.1 . The state of being behind or behindhand: as, his work is in arrear. Spain, though at least a generation in arrear of England, was atter our own the frst modern Europesn country to A. $W^{\prime}$. W'ard, Eng. Dram. Lit., Int., xxvit.

The arrear consisting of between three and four thou-
sand foylin, llist. Reformation, 3. That which is behind in payment; a debt used in the plural and implying that a part of the money is already paid: as, arrears of rent, ages, or taxes.

For much I dread due payment by the Greeks
Of yesterday's arrear.
Conoper, lllad, ii.

My approval is given In order that every possible facilit may be afforded for the prompt discharge of all arrears ot
pay dne to our soldiers and sailors.

arrearage (a-rēr'āj), n. [< ME. arerage, arre rage, $<\mathrm{OF}$. arerage, arrerage, arrierage, mod. $\mathbf{F}$ arrérages, pl., < OF. arere, ariere, back: see The state or condition of being behindhand in arrears.

I have enployment for thee, such a one As shali not only psy my s

Shirley, Grateful Servant, 1. 2

2. Arrears; amount or amounts outstanding or overdue; any sum of money remaining unpaid after previous payment of a part.

The old arrearages . . . being defrayed.
Ilowell, vocal Forest.

Our pleasure is, that all arrearages
Be pald unto the captains.

$$
\text { Massinger, The Picture, if. } 2 .
$$

arrearanceł (a-rēr'ans), $n$. [< arrear ${ }^{2}+$-ance.] Same as arrearage.

arrect+ (a-rekt'), v. t. [<L. arrectus, pp. of arrigere, set up, raise, erect, $<a d$, to, + regere, keep erect.

Having large ears perpetnally exposed and arrected.

2. To direct.

Arrecting my sight towards the zodiake.

3. To impute.

Skelton, Poems, p. 9.

Therefore he arrecteth no blame ... to them. arraiment, araymen̈t, < ME. araiment, < AF. which remains unpaid, though dne: generally 
arrect

arrect, arrected (a-rekt', a-rek'ted), a. $[<\mathrm{L}$ crreetus : see the verb.] 1t. Erect; erected. -2†. Attentive, as a person listening.

$$
\text { Enger for the event, }
$$

Around the beldune all arrect they lang.

3. In bot., pointing upward; brought into an upright position. A. tiruy.

arrectary $\dagger$ (a-rek'ta-ri), $n_{0} \quad$ [< L. arrectarius, perpendieular, neut. pl. arreeturin, the npright posts of a wall, [ arrcetus, erect: see arreet.] A beam or post standing upright, as opposed to one whicli is horizontal.

The arrectery or beam of his cross. Hall, Worka, 11. 278, arrector (a-rek'tor), $n_{0}$ [NI., < I. arrigere, pp. arreelus, set up erect: seearreet, $t$.] That whieh arreets; an orector. - Arrector pili, in anat., th ning from the lower part of the hair-follicle toward the surface of the skin, and by contraction, under the influence of fright or cold, causing the hair to stand straight up or "on cud," at the anme time so ralalog the surface Jnk tion.

arreedt, v.t. Seo aread.

arrel (ar'el), n. [Sp., also arrelde (> Basque arraldea, a woight of 10 pounds); Sp. arrate Pg. arratel, a weight of 16 ounces (see arratel);
(Ar. al, the, + ratl, a weight of 12 ounces.] A weight of 4 pounds, used in Spain.

Arremon, $"$. See Arrhemon.

arrendation

rentation.

rrendator (ar'en-dā-tor), "u [Also arenckator, <Rus, arendatorü, < MÜ. arrendator, arendator, a farmer of the revenue, < arrendare, arendare, arrenture, let for a rent, farm the revenue: see arrent.] One who farms the revenues in certain Russian governments.

arrenotokous, $a$. Seo arricenotokous.

arrent (a-rent'), $v, t . \quad\left[<\mathrm{OH}^{\prime}\right.$ arrenter, arentir (ML. arrentare, arrendare, arendare), $<a\left(\mathbf{L}_{*}\right.$ ad, to + rente, rent: sce arrendator and rent.] To let for a rent; espeeially, in old Eng. law, to let out for inclosure, as land in a forest. Seo let out for

arrentation (ar-en-tā'shọ), n. [Also arrendation, < ML. arrentatio(n-), arrendatio, < arrentare, arrendure: see arrent.] In old Eng. law, the action or privilege of arrenting; the giving of permission by the lord of the manor to the tenant of land in a forest to inclose it with a small ditch and low hedge, in consideration

arreptiont (a-rep'shon), n. [< L. arreptus, pp. of arripere, suateh, seize to one's self, $<a d$, to + rapere, snateh, seizo: see rapacious, rapture.] The act of taking away.

This arreption was andden, yet Flisha sees both the charlot and the horses, and the aseent.
Bp. Ifall, Rapture of Elljah. arreptitious ${ }^{\dagger} \uparrow$ (ar-ep-tish'us), a. [<LL. arrepticius, arreptitius, seized in mind, inspired, delirious, $<\mathrm{L}$. arreptus, pp. of arripere, snateh, seize: or possessed; frantic; crack-brained; mad.

Odd, arreptitious, trantick extravagances.

lovell, Letters (1650), I. 475

arreptitious ${ }^{2} \dagger$ (ar-ep-tish'us), $a$. [As if $<\mathrm{L}$. softly to (<ad, to, + répere, creep: sce reptile), + -ilious; but appar. a mistaken def. of preceding.] Creeping or having erept in privily. Blount; Bailey.

arrest ' (a-rest'), v. t. [<ME. aresten, arresten (also by apheresis resten, $\rangle$ mod. dial. rest), OF . arester, F. arréter $=$ Pr. Sp. Pg. arrestar $=$ It. arrestare, $<\mathrm{ML}$, arrestare, stop, restrain, < L. ad, to + restare, stay back: see rest ${ }^{2}$. To stop forcibly; check or hinder the motion or action of: as, to arrest the en

Ascribing the cansea of things to secret proprietles hath
arrested and laid asleep all true inquiry. Bacon. With the progress of adaptation each [human being] beWith the progress of adaptation each human being] be-
comes so coustituted that he cannot be helped without in

II. Spencer, Data of Etliles, $\$ 90$.
apprehend by virtue of a

2. To take, seize, or apprehend by virtue of a legal warrant or official authority; take into eustody: as, to arrest one for a crime or misde-
meanor. [Shakspere most commonly construes this verb with of, like aceuse: as, "of capital treason we arrest you here," Rich. II., iv. 1.] Accorling to law no Engllshman could be arrested and govereign.

acaulay.

3. To seize and fix; engage; secure; catch take: as, to arrest the eyes or the attention.
319

arrhizous

King. If you prove it, I'll repay it back

or yleld up Aquitain. Shak., L. L. L., II. 1. Tho appearance of such a persen in the world, nnd at Buckminater. 4†. To rest or fix.

We may arrent our thanglita upon the divine mercles.

5. In Seots and admiralty lase, to seize (property) for debt or the satisfaction of $n$ claim. attach or levy upon. $=\mathrm{Syn}$. 1. To stay interruph, delay, detaln. - 2. To capture, lay holl of, take up, take
prlaner. rrest ${ }^{1}$ (A-rest'), n. [<ME. arest, < OF. arest, seppage, delay, restraint; from the verb: see arrest $\left.{ }^{1}, v.\right]$ 1. The act of stopping, or the state of being stopped; suspension of movement or action: as, an arrest of the vital functions "the stop and arrest of the air," Breon.-2 ${ }^{\prime}$ Self-restraint; self-command.

In noble corage oughte ben areste,

thing by equytee.

3. Any seizure or taking by force, physical or moral; hindrance; interruption; stoppage restraint.

To the rlcl, man wlo had promlsed linnelt ense for many yeara, it was a aad arrest that his soul was surprised
Jer. Taylor. 1 coold ... mingle my teares with you, . . but when I consider the noccsity of submitting to the div

Evelym, To his Brother, a. Evelyu. 4. In mach., any contrivance which stops or $1^{\circ} \mathrm{-}$ tards motion.

The arrest conslats of a ty vane, or egcapement with acting on tho wheel. Sci. Amer. Supp., XXII. 8974 5. In law, the taking of a person into custody of the law, usually by virtue of a warrant from authority. An arreat is made by geizlng or touching the body or otherwlse taking possession of it. By the law of purpose of enforcing the paynent of delits or preventing a defendant from eluding an ohligatlon. In criminal or the peraon charged with a crime or an offense to appea and submit to justice. In elvil cases it cannot be legally of some court, but this is often dispensed with in criminal cases. Arrest in eivil cases la of two kinds, viz., that which takes place before trial, and is called arrest on merne process, and that whlch takes place after trial and judgment, 6. In adwiralty law, the taking of a ship into custody by virtue of a warrant from a court. 7. In Seots law, attachment; seizure of propthe satisfaction of a claim.- Arrest of judgment, in las, the staying or stopping of a judgment ait ter verdict to arrest judguent for fintrinsic causes appearing upon
the face of the record, as when the declaratlon varies from the original writ, when the verdict differs nuaterially from the pleadinge, or when the case laid in the declaration is not sufficient in point of law to found an aetlon upon. The by requiring such defects to be objected to before judg arrest2 (a-rest'), $n$. [<OF, arreste, areste, mod. $\mathrm{F}$. aréte, awn, beard, fishbone, arrest, $<\mathrm{L}$. arista: see arista and arris.] A mangy tumor on the back part

arrestable (a-res'ta-b]), a. [<arrest $\left.{ }^{2}+-a b l e_{0}\right]$ 1. Liable to be arrested or apprehended.-2. the suit of a creditor of the owner, by a process in the nature of attachment or garnishment: applied to property, funds, ete.

Burgh customs still stand in the peculiar positlon of belng belther adj security.

Encyc. Brit., IV. 83 .

arrestation (ar-es-tā'shon), n. [= F. arresta tion, < ML. arrestatio $(n-),<$ arrestare, arrest:
sco arrest $\mathrm{l}, v$.$] The act of arresting; an arrest$ or seizure. [Rare.]

The arrestation of the Engliah residlog in France was II. M. Hillians, Lettera on France, I. I.

arrestee (a-rest-e é), n. [< arrest $\left.+e e^{l}.\right]$ In Seots lax, the

ment is lai

arrester, arrestor (a-res'têr, -tor), n. [ME.

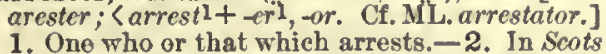
lace, the person at whose instance an arrest is made. See arrest, $n_{0}, 7$. [Arrestor is the form usual in legal documents.

arrestive (a-res'tiv), a. [=OF. arrestif; < arrest $\left.{ }^{1}+-i v e.\right]$
-2. In gram., marking an arrest, restrietion, Formerly also spelled arra. or qualifieation of thonght: applied to conjunetions like but, yet, however, ete. Bain, Eng.

arrestment (a-rost'ment), $1 . \quad[<\mathrm{OF}$, arestement, s arester, arrest: seo arrest $], v$, and ment.] 1. The act of arresting or stopliug obstruetion; stopjage.

The first effect is arrextment of the fnnctions of the The fall of man would produce an arrestinent ln the progress of the earth in that last great revolution which Datrson, Origin of World, p. 239.

2. In Scots lawo: (a) A proeess by which a ereditor may attach money or movable property which a third person holds for behoof of lis debtor. It boars a general resemblance to oreign attachment by the enstom of London. Seo attachment. (b) The arrest or detention of eriminal till he fnds eantion or surety to stand trial, or the securing of a debtor nntil he pays tho debt or gives security for its payment. Breach of arrestment. see bre

arrestor, ". Sec arrester.

arret ${ }^{1}, t, t$. See aret

$\operatorname{arret}^{2}+\left(\mathrm{a}-\mathrm{ra}^{\prime}\right.$, or $\left.\mathrm{a}-\mathrm{ret}^{\prime}\right), n \cdot[<\mathrm{F} \cdot \operatorname{arrct},<\mathrm{OF}$ arest, arrest : see arrest $\left.^{1}, n.\right]$ The decision of a ourt, tribunal, or council; a decreo published; tho edict of a sovereign prince. appliod tribunals in France.

arrha (ar'â) n.; pl, arrhce $(-\bar{e})$. [L., also ararrha (ar'â), n.; pl. arrhae (-ē). [L., also ar-
rhabo, and later arra, arrabo, < Gr. áppaßín, earnest-money. Cf. arles.] Earnest-money paid to bind a bargain or contract; a pledge.

arrhal (ar'gl), a. [<arrha +-al.] Of the na-

ture of carnest-money; given as a pledge.

arrhaphostic (ar-a-fos'tik), a. [Badly formed

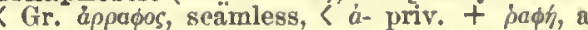
seam, < рátreıv, sew.] Seamless. Clarke. Also written a raphostie, araphorostic. [Raro.]

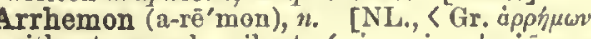

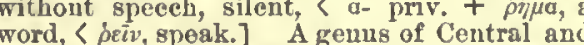
South American oseine passerine birds, of the

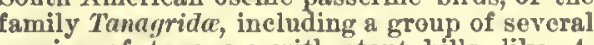
species of tanagers witl stout bills, like $A$ silens, the type. Also Arrcmon, Buarremon. Arrhemon + -ina.] A group of tanagrine birds named by Lafresnaye from the genus Arthe

arrhenotokous (ar-e-not'ō-kus), a. [Better arrhenotoeous, < Gr. а́рерот́́коs, bearing male

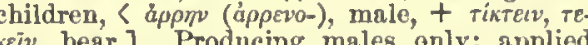
by Leuckart and Von Siebold to those parthenogenetic female inseets which produce male progeny: opposed to thelytokous. Also spelled arrenotokious.

wosed by Leuekart and Von slebold to denote those parthenogenetle females whlch prothce male and female
young respectively.
II uxley, Auat. Jnvert., p. 384.

arrhenotoky (ar-e-not'ō-ki), $n$. [As arrhenotokous $+-y$.$] The prodieing of males only: a$ form of parthenogenesis: See arrhenotokous. 年, monly in pl., 'A $\rho \rho n \phi \delta \rho \circ$ (see def.); of uncertain who were chosen annually in ancient Athens to dwell on the Acropolis and attend the priestess of Athena Polias. They played a ceremonial part in the festival of the Arrhephoria, on the night before which they bore baskets or vasea of unknown contents from the of Aphrodite in the Gardeng

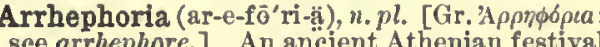
列 It was counected with the Panathenaic; festival, and was the occaslon of the ceremonial inductlon into thelr annual
office, with a splendid procession to the Acropolia, of the four young priestesses of Athena called arrephores. G Gr. ápoec (ápotv-), withont power of seenting

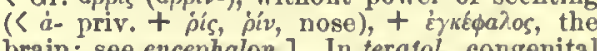
absence of one or (usually) both sides of the olfactory lobe (rhinexcephalon), accompanied with more or less dwarfing or absence of adjacent structures. Also spelled arhinencephalia.
arrhizal (a-ri'zal), $a$. [As arrhizons $+-a l$. Sarne as arrhizous.

arrhizous (a-ri'zus), a. , [< NL. arrhiaus, < Gr.

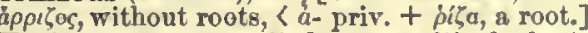
Having no root: apphied to parasitical plant which have no root, but adhere to other plants 
by uny part of their surface, and derivo their arrière-fief (a-rèr'fēf), $n$. Samo as arrière-fee. arrivanceł (a-rī'vans), n. [< arrive $+-a n c e$. nourishment from thein; also to mosses and arrière-pensée (ar-iãr"poñ-sā'), n. [F., $<a r-$ IIepatice which are lestitute of rhizoids. Also riere, rear, behind, + pensée, thought: seo penarhizal, arlizous. Arrhynchia (a-ring'ki-ä), n.pl. [NL., neut.pl. mental reservation.

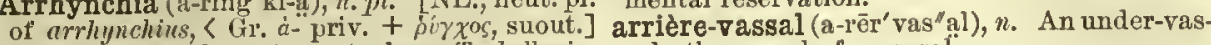
A group of the lowest proctuchous Turbellaria, sal; the vassal of a vassal.

Aaving no froutal proboscis, but provided with arrière-voussure (ar-iãr"vö-sūr'), n. A rear an anus, and presenting listinct sexes. Also vault; an arch or a vault placed within the spelled drhyuchia.

arrhythmia (a-rith'mi-ä), n. [NL., <Gr. à

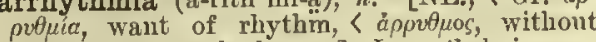
rliythm: see arrhythmous.] In pathol., irregularity. Also spelled arhythmia.-Arrhythmia arrhythmic (a-rith'mik), a. [As arrhythmous + -ic: see $a-18$ and rhythmie. $]$ Not rhythmic; wanting rhythm or regularity: used specifical ly, in pathol., of the pulse. Also spelled artiyth mec. N. L. D. arrhythmical (a-rith'mi-kal), a. Same as ar-
rhythmic. Also spelled arfiythnical.

arrhythmically (a-rith'mi-kal-i), $a d v$. In a style without rhythm. Also spelled arhythmically.

arrhythmous (a-rith'mus), a. [<Gr. å $\rho \rho \theta \mu o s$, without rhythm, out of time, $a-$ priv. $+\rho v \mu o s$, arhythmous.

arrhythmy (a-rith'mi), n. [< NL. arrhythmia, arrhythmy (a-rith mi), Al q. v.]
[Rare.]

arriage (ar'âj), $n$. [Sc., a contr. of averagc 1 , q. v. J In Seots law, an iudefinite service performed by horses, formerly required from tenphrase carriage and arriage.

It [the monastery] is aaid to have posseased nearly two thousand pounds in yearly money-rent, . . capons and wool and ale.
Scott, Monastery, Int. arridet (a-rid'), v. $t_{0}$; prot. and pp. arrided, ppr. to, smile at or upon, $<a d$, to, + ridere, laugh: see ridicule.] To please; gratify.

Fast. 'Fore heavens, hia humour arrides me exceedingly. Car. Arrides you!
F'ast. Ay, pleases me. in form, to inof the aperture ceive a charge from above, or to form an architectural junction between interior and exterior forms.

arriero (ar-ề-ā'rō), n. [Sp; $(=$

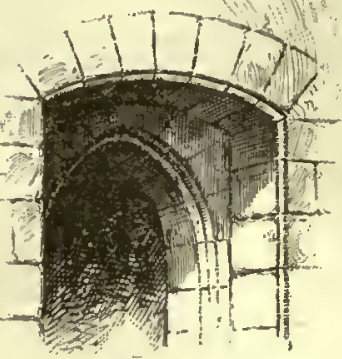

Pg. arrieiro), a

Arrière-Voussure.

(> Pr. arri = It. arri), OSp. farre, a cry used to mules and horses; prob. of Ar. origin.] A muletecr. anything that is liable to hurt (Halliwell); of grain, in ML. also a bone of a fish, exterior angle of a house: see arista and arrest ${ }^{2}$.] 1. A sharp edge, as of a squared stone or piece of or hip in which the two straight tho line, edge, faces of a body, forming an exterior angle meet; especially, the sharp ridge between two meet; especially, the sharp ridge betw

arris-fllet (ar'is-fil"ot), n. A triangular piece of wood used to raise the slates of a roof against the shaft of a chimney or a wall, to throw off the rain more effectually. Also called tiltingfillet.

The flattering The oultering ay to fetch and carry, to apring the covey lath ouly learned to fetch and carry, to apring the covey
of his master'a lusts, and to arride and deride him.

Above all thy rarities, old Oxenford, what do most ar ride and aolace me are thy repositories of mouldering
learning. arridentt (a-rī'dent), $\alpha$. [ $\mathrm{I}^{\prime}$. arriden $(t-) s$, ppr. ing. arrière (a-rēr'; F. pron. ar-iãr'), $\pi .\left[\mathrm{F}_{\text {. }}<\mathrm{OF}\right.$. ariere, arere, $>$ ME. arere, mod. E. arrear2. Ar-
riere is thus the mod. F. form of arrear stored in E. from the carlier form, or adopted afresh, in special phrases: see arrear ${ }^{2}$ and rear ${ }^{3}$.] Arreal or rear. INow rarely used except in theae words, below.) In arriere-ban, as alnown, it is hig-
torically a different word.]

An inferr'd arriere of auch storma, buch wrecks.
$W$. Whitnan, in Academy, Nov. 1S, 1882. (N, E. D.) Volant en arriere, in her., aaid of a bird represented as

arrière-ban (a-rēr'ban; $\mathrm{H}^{\prime}$. pron. ar-iãı-bò'), n. [Early mod. E. also arrier-, arrear-, arereban (also arrear-, rere-band, arrier-van, simulating $b a n d 2$ aud $\left.\operatorname{van}^{2}\right),<\mathrm{F}$. arrière-ban, $\mathrm{OF}$. ariere-ban, a corruption (due to a supposed connection with ariere, mod. arrière, rear, be-
hind) of OF. "ariban, "heriban, < ML. hari-, hind) of OF. "ariban, "heriban, <ML. hari-, heri-, ari-, are-, arri-, herebannum, etc., $<\mathrm{OHG}$.
"hariban, "heriban (MHG. herban, G. heerbann), the summoning of an army, < hari, heri (MHG her, G. heor = AS. here), army, + ban, a public call, order, decree: see har-, harry, and ban ${ }^{1}$.] sovereign to all freemen, calling them to the field with their vassals, equipment, and three months' provisions. Neglect to obey the sum mons brought fines or even loss of the fief. mons brought fines or even loss of the fief.
Hence-2. The military force thus liable to Hence-2. The military force thus liable to
be called out. Formerly written arierban. [Th misunderstanding of the frrat element (see etymology) led to the use of ban et arriere-ban, Engliah ban (or van) an arrier-ban (or $-v a n$ ), with an artiflcial distinclion, the $b a n$
beiug aupposed to refer to the immediate feudatories of the sovereign, and the arriere-ban to the vassals of the latter, or the holders of arriere-fiefs.

arrière-bras (ar-iär' brä'), $n$. Same as rercbrace. arrière-fee (a-rēr' $\mathfrak{f} \bar{e}), n$. A fee or fief de pendent on a superior fee, or a fee held of a foudatory. of a building. Gwilt.

arrish, arish (ar'ish), n. [E. dial., =ersh, dial. form of eddish, q. v.] A corn- or wheat-field
which has been harvested; stubble; eddish.

arrisiont (a-rizh'on), n. [<L. $\operatorname{arrisio}(n-),<a r$ risus, pp. of arridere, smile upon: see arride.] The act of smiling upon or at. Blount.

arris-piece (ar'is-pēs), n. In ship-carp., one of the portions of a built mast beneath the hoops. arris-rail (ar'is-rāl), $n$. In carp., a rail of triangular section, generally formed by slitting angular section, generally formed by slitting diagonally a strip of square
broadest surface forms the base.

arriswise (ar'is-wiz), $a d v$. [< arris + -vise.] 1. Diagonally: said of an ar$\Leftarrow \begin{aligned} & \text { rangement of tiles or slates so } \\ & \text { that one angle points downward. }\end{aligned}$ that one angle points downward.
jecting toward the spectator: said of any bearing of a rectangular form so placed that one gular form so placed that one
wise. Erroneously written arraswise.

arrivaget (a-ri' vāj), $n$. [ME. arryvage, aryvage, $\angle \mathrm{OF}$. arivage, mod. F. arrivage = Sp. arribaje, ML. arribatieum, arripaticun, < *arripare ( $\mathrm{OF}$. ariver), come to shore, arrive: see arrive and which happens or befalls one; lot or fate.

arrival (a-ri' val), $\pi$. [<ME. aryvaile, arrivaile, AF. arrivaille $=$ Pr. arribalh, arribetilh, arri-
val: see arrive and -al.] 1. The act of arriving as in coming to land or to the end of a journey, a reaching or coming to a destination, or some definite place.

\section{Fro thenne he goth toward Itaile \\ By ship, and there his arrivaile
Hath take, and shope him for to ride.}

2. The person or thing which arrives: as, a long list of arrivals.

To-day the Lady Psyche will harangue
The fresh arrivals.

3. The reaching or attainment of any object or strte by effort, or in natural course: as, arrival at a just conclusion. riere, rear, behind, + pensee, thought: see pen-
sice. $\mathrm{A}$ thought kept back or dissembled; a

vault; an arch opening of a windiffering from it internally, to re-

arris (ar'is), n. [Also written aris, formerly arriss, E. dial. (North.) arridge, the edge of

1. The act or fact of arriving; arrival.

Its [an animal'a] sudden arritence into growth and 2. Persons who arrive; arrivals collectively.

For every minute is expectancy Shak. (ed. Leopold), Othello, li. 1.

arrive (a-rī'), $v_{0}$; pret. and pp. arrived, ppr. arriving. [< ME. ariven, aryien, < $\mathrm{OF}$, ariver, arriver, $\mathrm{F}$, arricer $=\mathrm{Pr}$, aribar, aricar $=\mathrm{Sp} . \mathrm{Pg}$ arribar = It. arrivare, arrive, arripare, come to shore, <ML. *arribare, "arripare, reach, come to shore, earlier adripare, bring to shore, < L. ad, to, + ripa, shore, bank.] I.t trans, 1. To bring (a ship or its passengers) to shore; land. Some points of wind . . may as boon Overturn as $A r$. rive the ship. When Fortune ... had arrived me in the moat joyful

2. To reach.

Ere he arrive the happy dsle.

3. To come to; happen to.

Lest a worse woe arrive him. Mrilton, Civil Power.

II. intraus. 1. To come to or reach a certain point in the course of travel: with at: as, we arrived at Havre-de-Grace.

When at Collatium this false lord arrived, Roman dame.

2. To reach a point or stage by progressivo advance; attain to a certain result or state: with at, formerly sometimes with to: as, to $a r-$ rive at an unusual de

The Greek language was arrived to ita full perfection.

They arrive at a theory from looking at aome of the phenomena; and the remaining plienomena liey strain or
curtall to anit the theory. Macaulay, On lliatory.

3. To happen or occur: with to.

Happy ! to whom thia gloriona deali arives. Iialler. The lot of humanity is on theae children. Danger, aorrow, and pain arrive to them, as to all.
Emerson, Esays, 1st aer., p. 168. arrive $($ a-rīv'), $u . \quad[<$ arrive, v. $]$ Arrival. How shoulu I joy of thy arrive to hear! [Devonshire, Eng.]
Wonder at the afe arrive
of this aniall vessel, which all weathers drive Middleton, Triumphs of Truth.

arroba (a-rō'bä), n. [Formerly also aroba, arobe, arob, $<\mathrm{Sp}$. Pg. arroba, $<\mathrm{Ar}$. ar-rob; $<a$, the, +rob', fourth part (of a hundred-weight), weight. A Spanish and showa the number of avoirdupols and local pounds it contains and its equivalent in kllogram

\begin{tabular}{|c|c|c|c|}
\hline Places. & $\begin{array}{l}\text { Local } \\
\text { Pounds. }\end{array}$ & $\begin{array}{l}\text { Av. } \\
\text { Pounds. }\end{array}$ & Kilos. \\
\hline Saragossa. & & & \\
\hline &. .32 & 32.387 & \\
\hline 13arcelona &. .26 & 22.989 & 10.8 \\
\hline Valencía. &. .36 & 28.277 & I2,82 \\
\hline $\begin{array}{l}\text { Paraguay ............... } \\
\text { Castile, Buenos Ayrea, }\end{array}$ & .25 & 27.415 & 12.439 \\
\hline $\begin{array}{l}\text { Castile, Buenos Ayrea, } \\
\text { Chili, JIexico, ete. }\end{array}$ & $\ldots 25$ & 25.322 & 11.484 \\
\hline Alleante ............ & and 36 & 28.259 & 12.81 \\
\hline
\end{tabular}

There was also formerly in use in Valencia a small arroba 2. A measure for wine, spirits, and oil in Spanish countries, arising from the Moorish practice of weighing those liquids; the cantara. There are two measures of this name. The commoner, the in Bolivia, 16.073; in Mlalaga, 15.85; in 1lavana, 15.44; in Alicante, 11.550; In Valencia, 11.482. The arroba menor liters; it was divided into 25 libras. Wine was ald by a weight of 32 pounds to the arroba.
arrodet $\left(a-\mathrm{rod}^{\prime}\right), v$. $t$. [<. arrodere, gnaw at, s ad, to, at, + rodere, gnaw: seo rodent, and ef. corrode, erode.] To gnaw or nibble at. Bailey. arrogance (ar'o-gans), n. [< MIE. arrogance arrogance (ar'o-gans), n. [< ME. arrogance, arrogaunce, < OF. arrogance, < L. arrogantia, The condition or quality of being arrogant; a manifest feeling of personal superiority in rank, power, dignity, or estimation; the exalting of one's own worth or importance to an undue degree; pride with contempt of others; presumption.

Pride hath no other glass
To ghow itself, but prife ; for supple knees

To show itself, but pride; for supple knees
Feed arrogance, and are the proud man's fees.
Shak., T. and C., II. 3.

=Syn. Pride, Arrogance, Presumption, Asamption, lence, lordlinesa, aelf-importance, imperiousness, swagger. (See pride.) Pridc and disdain are the only words in the
list that may have a good meaning when applied to per- 
arrogance

sons: as, prite in one's country; distain of a base sugges.

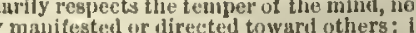
is the genersi tern for an unreasomable estimate of olle own superiority in any respect. As it cones into relation and action, it inay recelve other titles. 'Thins, arrogance is
at ity simplest, pride with contempt of others, anil is es sentially tho sace as discein. Ia action, arrayance is the homage, yower, ete. "reszemption is often used for arrogance, but moro properly expresseg a self-conceited mind
self-importint forwarlness to run risks, take diberties,
gni crowel in where one dues not deserve to be. Freani crowel in where one dues not deserve to be. Preclaims from others, and feets its pride ly seelag them yieldi. Preskmption is less seltisit than arromance, ba more concetted and headstrong. A soumption has added it ineans a disposition to du what does not belong to one to do, smil sometlmes to claim to be more than one is. IIaughtiness, like distain and luftiness, dwells upon the
interiority of others quite as much as upon Its own elevation; it is equully anplicalle to spirit and to manner.
Dixilain is a mingling of Tofty contempt with aversien, abhorrence, or indignation. Superciliousness, as ijefits its derivation, is chiefly applied to manner; it is a manifested laughtiness. Insolence is exhibited not only in maner, ghown in contemptuous or overbearing treatment of oth ers, especially ly words; frem an equal or an inferior
is an outragcous kind of impertinence. See impudence, egotisnn, and scoms.

I kuow you proud to bear your name,

Your pricle is yet no mate for mine,

Tenuyson, Lady Clara Vere de Vere.

Turbulent, discontented men of quality, in proportion as they are putfed up with personal pride and arrogance,

But most it is presumption in $\mathrm{us}$, when

we count the act of men.

Itis usual air of haughty assumption.

Scott, Waverley, xlix.

I own that there is $\mathrm{n}$ haughtiness and fle reeness in huma nature which will cause innumerable broils, place men in
what situation you plense. what sitintlon you plens.

Good natiri
and folly. of all baseness, vice,
Stcele, Tatler, No. 242 . The lofines of man shall be bowed down. I8a. if. 17. Sometimes, it is true, the giraffe stoops to mammalian levels; but there is soncthing so lofty even in its condescension that the very act of bending enhanees the haughtiness of its ereet posture, ant suggests that it does it from
policy. To be nlways keeping state, and forever in the clands, might make shorter animals accuse it of acting
uuperitiously.
$P$. Robinson, Under the Sun, p. 182 . The insolence of the agrressor is usually proportloned to
the tumeness of the sufferer. the taneness of the sufferer. Ames, Works, II. 00 1. The ounlity of being arrogant; arrorance: as, "presumptuous arrogancy," North, tr. of Plutareh, p. 77.

IIis arrogancy and his impudence, in commending his
B. Jorron, Poetaster, iv. 1. 2. A piece of arrogance; an arrogant act.

That most odious of all repulsive arrogancies-Phar

arrogant (ar'ō-gant), a. [<ME. arrogant, arrogaunt, $<\mathrm{OF}$. arroyant, $<\mathrm{L}_{\text {. }}$ arrogan $(t-) s$, assuming, arrogant, insolent, ppr. of arrogare, assume, ete.: see arrogate.] 1. Making or having the disposition to make unwarrantable claims of rank or estimation; giving one's self an undue

full of assumption: applied to persons.

Arrogant Wincliester? that hanghty prelate?

2. Charaeterized by arrogance; proceediug from an overestimate of one's importance or arrogant claims.

The speech of Themistocles, the Athenlsu, which was haughty nud arrogant, in taks, the Athen she whe large to others. Surely etiqnette was never maintsined in a more arro gant manmer at the court of Lonis XIV.

Marg. Fuller, Woman in 19th Cent., p. 268 IIIs [Lord Clarendon's] temper was sour, arrogane, and

=Syn. Anthoritative, Magisterial, Dogmatic, etc. (see ma gisteriat, proul, assuming, overbearing, presunjptuous, supercilious, lordly, eavalier, important, swelling, bluste arrogantly (ar'o-gant-li), adv. In an arrogant manner; with undue prido and eontempt of others; with haughty presumption.

Godwin and hils Sons bore themselves arroyantly and proudly towards the King, usurping to themselves equal
share in the Guvernment. arrogantness (ar'o-gant-nes), $n$. Arroganee. arrogate (ar'ọ-gāt), $\ddot{v}$. t.; pret. and pp. arro gated, ppr. arrogating. [< L. arrogatus, adrogutus, pp. of arrogare, adrogare, ask of, adopt, appropiote, assume, $\langle a d$, to, + rogare, ask: see rogation. The form adrogate is confined to the 21
321

arrow-shaped

legal sense.] 1. To elaim or demand unduly or uresumptuously; lay claim to in an overonaner: as, to arrogute power or dignity to one's self.

Who, aot content
With fair equality, fraternul state,

Over his lirethrell. Jitton, J'. L, x11. 27. A nan possessed of such warm imagination commands all nature, and arroyates possessions of whilel the uwile Fven the spiritual supremscy arrogated by the Poje was, the dark ages, productive of far more good than evil.

2. To lay elaim to on behalf of another: as to arrogite to the erown the privilege of issuing writs.

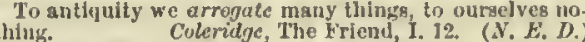
3. In liom. law, same as adrogate.

rrogation (ar-ō-gā'shen), n. [< L. arrogatio $(n-)$, a taking to one's solf, $<$ arrogarc, tako to ono's self: see arrogate, and of. adrogation. 1. The aet of arrogating, or making unjust or unwarrantable elaims or demands; tlie act

Where seltness is ex tinguished, sll manner of arrogation nuist of necessity be extinet. 2. In Rom. laio, same as adrogation.

arrogative (ar' Making unduo clair

arrollo (a-ró'lyō), $n$. Same as arroyo.

arrondi, arrondee (a-ron'di, $-\mathrm{de}), a$. [<F. ar rondi (fem. arrondic), rounded, pp. of arrondir. make round, $<a(<\mathrm{L}$. ad, to $)+$ rond, round see round ${ }^{2}$.] In her., rounded off: applied to a bearing, espeeially a cross, the extremities of which are lounded. Also written arondic, aronly. - Battled arrondi. See lailled 2. - Bend arrond, arrondissement (a-rôú-dēs'mon்), n. [F., lit. rounding, < arrondiss, stem of eertain parts of arrondir, make round: see arrondi.] In France tho largest administrative division of a department. The 87 departments are divided into 362 srron dissements. Each arroulissement is divi

arrope (a-rỏp'; Sp. pron. ä-rō'pā), n. [Sp. (= $\mathrm{Pg}$. arrobe), < arropar ( $=\mathrm{Pg}$. arrobar), mix wino clothe, $\left\langle\right.$ ar- ( $\left.<\mathrm{L}_{\text {. }} a d, \mathrm{t} \theta\right)+$ ropa $=\mathrm{Pg}$. roupa OPg. rouba, clothing, robe: sce robe.] A sort of liquor used for inereasing the body and dark euing the eolor of sherry, made by boiling down must to oule fifth or one sixth of its original quantity

arroset (a-rō'z'), $v, t$. [< F. arroser, sprinkle, water, ult. $<\mathrm{LL}$. adrurare, bedew, $<\mathrm{L}$. adl, to, rorare, distil dew, $<\operatorname{ros}\left(r_{0}\right)$, dew.] To bedew; sprinkle; wet; drench.

The blissful dew of heaven does arrose you.
Fletcher (and another), Two Noble hinsmen,

arrosiont (a-rō'zhon), n. $\quad[<\mathrm{L}$. as if "urro sio $(n-),<$ arrodere, pp. arrosus, g
rode.] A gnawing at. [Rare.]

This arrosion of the nailes, Che the property of men in
raged with choler. J. Bulwer, chirologia, D. 160. (N. $E^{\prime} . D$.

arrow (ar'o), n. [Early mod. E. also arrouce, arowe, $\mathrm{MLL}$. arow, aro, aru, arw, aruwe, arewe, arwe, < AS. (1) arice, fem. (2) earh, neut., Ieel. ör (gen. örvar), an arrow, $=$ Goth. deriv. arlucazna, a dart (Gr. $\beta \varepsilon \dot{\gamma} . \varsigma$ ), prob. orig. 'that which belongs to the bow' (a 'bow-dart' as dis tinguished from a missile thrown by hand?), "arho $=\mathrm{L}$. arquus, arcus, a bow, whenee $\mathrm{E}$ der, generally pointed, missile weapon mado to
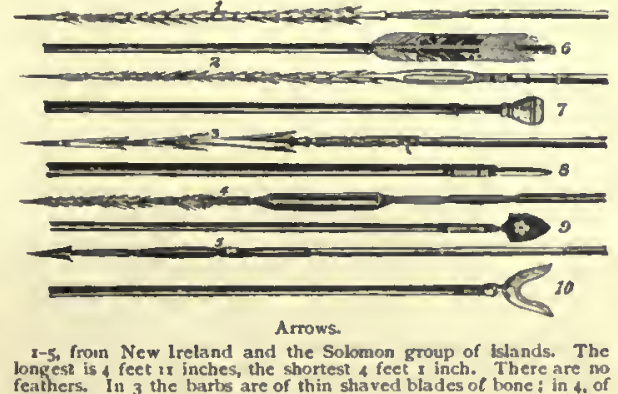

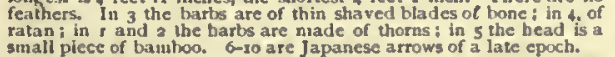

be shot from a bow. Arrows have nearly universally been made with a liglit, straight shaft of wood, fitte to remain thed in the olpject piercerl. 'These used in the middile ages rarcly
hat barbed heads; sometimes the hetmi was that, sumetimes conileal, snd itt walking-stick. The the ferrule of Nurth Aineriean ludians were of flint. obsidian, or other hard stone, or of often larbed. They were secured to the sliaft by lashings of hide or sinew. as among south Anerican Indians, are aid to be tastened lightily, so as to wound. The feathers at the butt of tie shint seem to have treen generully itsei In all ages, aud are sos set, or arc of such a form, as to give to the arrow a rotary arrow of the crosstow is ealled $\mathrm{s}$ boll or gearrel (which see)

2. Anything resembling an arrow. (a) In surv, a snisli prointed Irow rou, in a stek a sod when, lengtl. (b) II fort, a work placed at tie salient angles of a glacis, eonmunuwinds, currents, rivers. In msps, 8 of the collpass. $(d)$ An arrow shap as, an arrou-head inseription. large, arrow-shaped leaves. little arrow. Tennyson. [Poetie.] absorb poison from

ith feathers at the nock-end to steady the night, and

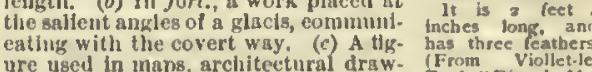
lings, etc., to lndicate direetion, as of Duce ". Dict du Mo arrow or hal1-arrow, polnting worth, serves to fix the point

arrow $\left(\operatorname{ar}^{\prime} 0\right), v . f_{0}$ [<arroic, n.] 1. 'To grow up into a long pointed stalk like an arrow.

The West Indian planter must prevent his sugar-canes
Simmond
from arroving. Colonial Mag. 2. To move swiftly, as an arrow. [Rare.] About an hour ago did we ... see that iflentieal sal
mon ... arrowing up the Tay. arrow-grass (ar'ō-grás), $n$. A commou name of plants of the genus Triglockin, especially of the eommon $T$. palustre. It is slso sometimes appiled generally to the members of the tribe Juneagithe natural orter Viachiacea. arrow-head (ar'ō-hed), $n$. and $a$. I. $n$. 1. 'Tho head of an arrow.-2. An aquatic plant of the gonus Sagittaria: so ealled from the shapo of II. $a$. Written with arrow-headed characters:

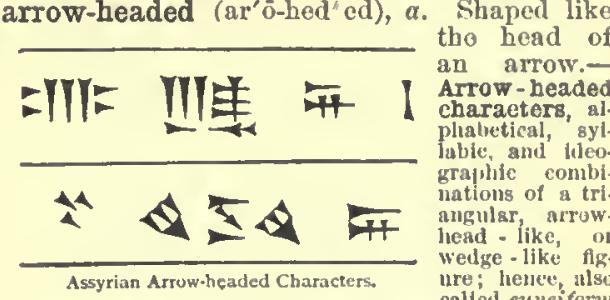
(wedge-shaped) and nail-headed characters. See cuut-

arrowleaf ( $\left.a r^{\prime} \bar{o}-1 \bar{e} f\right), n$. A South American arrowlet (ar'o-let), n. [< arrove + -let. $]$

arrowroot (ar' $\overline{0}-\mathrm{rö} t), n .[<$ arrow + root 1 wounds inflieted by poisoned arrows.] A tho horizontal rhizomes of several species of Maranta. It is much used as food and for
other purposes, and is obtrom the West In which arrowroot is mos arundinacea, hence called
the arroveroot-plant. Othe starches than that of $M$ a
ranta are occasionally sold ranta are occasionally sold
inder the name of arrow. or tapioca-meal, more usu

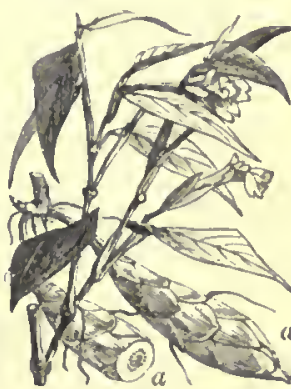
obtained from the fleshy root of Mtanihot utilissimn, sfter the polsonous juice has been renuved; East Indian ar. ronorot, from the large root-stocks of Curcuma angtst Felunbium speciosum: Englixh arrowroot fromi the of tato; Pertland arronoroot, from the corms of Arum macu latum; and Osuego arroweroot, from Indian corn. au au aurow; sagittate: applied in breny to aulobes elongated, acute, and turued downward. 
arrow-stone

arrow-stone (ar'ō-stōn), $n$. A belemnite.

arrow-tie (ar' $\overline{0}-\mathrm{t} \overline{1}), n$. [< arrow (in allusion to theop-iron used in baling cotton.

arrow-wood (ar $\left.\mathbf{r}^{\prime} \overline{0}-w u \dot{d}\right), n$. A name given in arrow-wood (ar'o-wud), $n$. A narue given in or small trees used by the Indians for making or small trees used by the Indans for making their arrows, as Viburnum dcntatum and $r$. forilla, and in the western territories Tessaria borealis. See cut under Cormus.

arrow-worm (ar'o-werm), $n$. An animal of the genus sagitla (which see) arrowy (ar'o-i), a. [<arrow $\left.+-y^{1} \cdot\right]$ Resem-
bling an arrow or arrows, as in shape or in rapidity and directness of motion.

Iron sleet of arrowoy shower
Hurtles tu the darkened air.

The lambet llatal Sisters.

The lambeat homage of his arrowy tongie.
Corper, Task, vl. 782.

The carrier-bird released
Points to one cherished apot his arrowy flight.
J. Baillie.

arroyo (a-roi'o $), n$. [Sp., OSp, arrogio, $=\mathrm{Pg}$. arroio, $\mathrm{ML}$. arrogium; cf. ML. rogium, rogia, a stream for irrigation (Diez); origin un-
known.] A watercourse; a rivulet. [Southwestern United States.] Also arrollo.

Down the arroyo, out across the mead,

By heath and hollow, sped the flying maid.

Arsacid, Arsacidan (är-sas'id, -i-dan), a. of or pertaining to the Arsacidæ, rulers of Parthia from about $250 \mathrm{~B} . \mathrm{C}_{\text {, }}$, and afterward of the Parthian empire (see Parthicm), till A. D. 2-6. The Arsacid dyuasty was founded by a chlef named Arsaces
who revolted from Antiochus II. of Syria; and all his suc cessors, about thirty, added his name to their own.
branch of the Arsacide reigned in Armenia from about branch of the Arsacid
149 B. O. to A. D. 428 .

arschin n. See arshin.

arse (är's), n. [< ME. ars, ers, < AS. ears, ars $=$ OFries. ers $=\mathrm{D}$. aars, naars $=\mathrm{OHG}$. MHG.

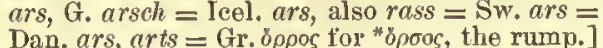
The buttocks or hind part of an animal. [Now only in vulgar use.]

arse-foott (ärs'füt), $n$. [< arse + foot, from the position of the feet in birds of the grebe family, which seem to be inserted opposite the family, Once used by writers of repute, as by Willughby and Ray, 1678.] An early British name of the great crested grebe, Podiceps or
Podicipes cristatus, and of other birds of the same genus. Also spelled arsfoot.

arsenal (är'se-nal), n. [Early mod. E. also arcenal, arsinal, ar̈cinal, arzenale, archinale, etc., from It. and F.; cf. F. arsenal, formerly arcenal $=$ It. arsenalc, arzenalc, arzanale $=5 \mathrm{p}$. $\mathrm{Pg}$. simpler form appearing in ML. arsena, It. arzend, arzand, $\mathrm{F}$. (16th cent.) arsena, arsenac, zena, arzand, F. (16th cent.) arsena, arsenac, Sp. dársena $=\mathrm{Pg}$. turacena, tarazena, tercena $=$ $\mathrm{F}$. darse, darsine, a dock; also Sp. atarazana, also atarazanal, an arsenal, rope-walk, dockyard; 〈Ar. dar -aç-cin $\bar{a} a h$, lit. house of construcindustry, < çāna'a, make, fabricate.] 1. A repository or magazine of arms and military
stores of all kinds, whether for land or naval service.-2. A public establishment where naval and military engines or warlike equip-
ments are manufactured. Hence-3. Figuratively, a repository of any kind of equipment. We can find no weapon in the whoje rich arsenal of
Comparative Anatomy which defends the truth of the Theory of Descent more powerfully than the comparison
of the internal skeletons of the various Vertebratez.

arsenate, $n$. See arseniate.

Arsenian (är-së'ni-an), $n$. One of a party in the Greek Church, in the thirteenth century, named from its leader Arsenius, patriarch of peror Michael Palreologus for putting out the eyes of John Lascaris, a minor and heir to the throne. The banishment of Arsenius, the appointment of a new patriarch, and the conforning of the emperor to to a schism between the patriarchates of Constantinople arseniasis (är-se-nī'a-sis), n. [NL., < arsen( cum) +-iasis.] In paithol., the morbid state produced by the use of arsenic. Also called arsenicism.

arseniate, arsenate (är-sē'ni-āt, ür'se-nāt), n. $[<\operatorname{arsen}(i c)+-i$-atc. $]$ A salt formed by the
combination of arsenic acid with any base. arsenic (as a noun, är'se-nik; as an adjective,
322

arson

nick, arsnick, < ME. arsenil, arsnck, < OF. arsc- arseniferous (är-se-nif'e-rus), $a_{\text {. }}$ [< arsen(ic) nic $=\mathrm{Sp}$ arsénico $=\mathrm{Pg}$. It arse - + -i-ferous.] Bearing or containing arsenic: ico, $<$ L. arsenicum, arrenicun, arrhenicum, $<\mathrm{Gr}$ a $\sigma \varepsilon v \iota \kappa o ́ v$, yellow arsenic, orpiment, lit. 'masculine,' being neut. of à $\rho \sigma \varepsilon v i k \delta s$, à $\rho \varepsilon v i k o ́ s$, maseuline, < ă $\rho \sigma m$, à $\rho \rho \eta v$, male, also strong, = Zend $a r$ shan, a man, male. The name is said to refer A yellow mineral, called specifically yellow ar A yellow mineral, called specifically yellow arsenic; the trisulphid of the element to which
it has given its name; orpiment. [The original use.] -2. Chemical symbol, As; atom ic weight, 75. A chemical element having a grayish-white color, a metallic luster, and a specific gravity of 5.727 . Under ordinary pressure it into vapor of a lemon-yeilow color. It taroishes rapidly in moist air at ordinary temperature, and heated in air is
oxidlzed to arsenic trioxid, $\mathrm{As}_{2} \mathrm{O}_{3}$. Arsenic occurs in nature oxidlzed to arsenic trioxid, $\mathrm{As}_{2} \mathrm{O}_{3}$. Arsenic occurs in nature The chief ores are the two sulphids, realgar $\left(\mathrm{As}_{2} \mathrm{~S}_{2}\right)$ and orpiment ( $\mathrm{As}_{2} \mathrm{~S}_{3}$ ), arsenical pyrites or mispickel (FesAa), arsenic of commerce is prepared in Bohemia and saxony or in England. Arsenic itself is little used in the arts. It salts, however, have great commercial importance. With

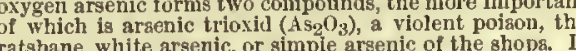
is prepared by a process of aublimation from arsenical ores, and is sold as a white crystalline powder or in glass translucent masses, which are odorless, nearly tasteleas
and glightly goluble in water. The most reliable antidote is freshly prepared hydrated seaquioxid of tron, which ginould be given in consicierable quantity after the atomach an emetic given with bland liquids, such as milk, flour an water, or white of egg and water, which serve to envelop the yoison and effect its complete ejection from the stom quantities of a paste made of chalk or magneaia and tor-oil may be used. Arsenic trloxid is used in medicin especially in the treatment of certain nervons and skin
diseasea, and in the arts as the basis for preparing arsen diseasea, and in the arts as the basis for preparing arseni-
cal salts and certain pigments, and largely in the manufacture of glass. Arsenic has two oxygen acids, whose salts are the arseniates and arsenites. Free arsenious acid is not known. Arsenic acid oceurs in commerce as a thick
acid liquid, and is largely used in the manufacture of aniline red, and sodium arsenlate is much used in cailicoprinting. Arsenic disuiphid (Asgse) occurs native as re-
algar (see realgar), and is made artificially under the naroe of ruby sulphur. Both the native and the artificially pre. atiphid $\left(\mathrm{As}_{2} \mathrm{~S}_{3}\right)$, or orpiment, also called king's yellow.
3 . The popular name of arsenic trioxid $\left(\mathrm{As}_{2} \mathrm{O}_{3}\right)$ the preparation of arsenic usually retailed in trade. See above.

II. $\iota$. Containing arsenic; specifically, conarsenious compounds. See arsenious.-Arsenic acld $\left(\mathrm{H}_{3} \mathrm{AsO}_{4}\right)$, an acid formed from arsenic oxid. - $\mathrm{Ar}-$ senic oxid, arsenic pentoxid $\left(\mathrm{As}_{2} \mathrm{O}_{5}\right)$, a compound of than of arsenious oxid. Often improperly called arsen arsenical (är-sen'i-kạl), a. [= F. arsenical; arsenic $+-a l$.$] Of or pertaining to arsenic;$ lemontite. - Arsenical minerals, a family or class of min erais in which arsenic acts the part of the electronegative
element. - Arsentcal pyrites. See arsenopyrite and lool lingite.-Arsentcal silver, an ore of ailver containing arsenicalize (är-sen'i-kall-īz), v. t. ; pret. and pp. arseniealized, ppr. arsenicalizing. [< arsenical $+-i z e$.$] To give an arsenical$
treat with arsenic; arsenicate.

The preceding [pitch] arsenicalized. Supp., XXII. 8803.
Sci. Amer. Sup.

arsenicate (är-sen'i-kāt), v. t.; pret. and pp. arsenicated, ppr. arsenicating. [< arsenic + -ate ${ }^{2}$.] To combine with arsenic;

arsenic-black (är'se-nik-blak), $n$. The name given in commerce to a mixture of powdered arsenic, charcoal, iron-filings, and lime

arsenic-furnace (är'sc-nik-fér"nās), $n$. A fur-

nace for decomposing arsenical pyrites by heat and condensing the fumes:

arsenic-glass (är'se-nik-glàs), n. Glass colored with arsenic. It is usually semi-opaque, and of an opaline-white color.

arsenicise, $v . t$. Same as arscnicate.

arsenicism (är-sen'i-sizm), n. [< arsenic + arsenitione as arseniasis.

. ar-sen 1-siz), v. $t . ;$ pret. and pp. arsencized, ppr. arsenicizing. [<arsenic +-ize.] Ure, Dict., I. 265. Also spelled arsenicise. arsenicophagy (är-sen-i-kof'a-ji), n. [< Gr. The practice of eating arsenic.

arsenide (är'se-nid or -nid), $n . \quad[<\operatorname{arsen}(i c)+$ $-i d e^{2}$.] A compound of arsenic and a metallic base. Also called arseniuret, arsenuret. as, arseniferous substances; arseniferous zinc. as, arseniferous substances; arseniferous zinc. name of a granular form of atacamite from Chili arsenious (är-sétni-us), $a$ : [<arsen(ic) $+-i-o u s$. Pertaining to or containing arsenic.-Arsenious oxygen and arsenic having a amaller proportion of oxygen
than arsenic oxid. Also called white argemic, and often arsenite (är'se-nīt), $n$. [<arsen(ic) $\left.+-i t e^{2}.\right]$ A arsenite (är'se-nit), $n$. $\left[\left\langle a r \operatorname{sen}(i c)+-i t e^{2}.\right]\right.$ A
salt formed by the union of arsenious oxid with a balt for

arseniuret, arsenuret (är-se-n̄' 'ū-ret, är-sen' ū-ret), $n . \quad[<\operatorname{arsen}(i c)+$ uret. $]$ Same as arscarseniureted, arseniuretted (är-se $-\mathrm{n}^{\prime} \bar{u}-$ reted), $a$. [<arscniuret $\left.+-e d^{2}.\right]$ Combined with arsenic so as to form an arseniuret.-Arseniureted hydrogen $\left(\mathrm{AsIl}_{3}\right)$, also called argine, a gas gener zinc, and decompoaing the alloy with stroug hydrochloric acid. It is colorless, has a fetid odor like that of garlic, and is exceedingly poisonous when breathed. The liydrogen of this compound may be replaced. wholly or in part and phosphines, as trimethyl arsine, $\left(\mathrm{CH}_{3}\right)_{3} \cdot \mathrm{As}$.

arsenoblast (är-sen'ō-blast), $n$. [< Gr. ä $\rho \sigma \eta v$, male, $+\beta \lambda$ arrós, germ.] In biol., the female element of the bisoxual nucleus of a cell; a feminonucleus. H.

arsenolite (är-sen'ō-lìt), u. [<arsen(ic) +-lite.] Native arsenic trioxid, erystallizing in isometric octahedrons.

arsenopyrite (ïr."se-nō-pi'rit), n. $\quad[<\operatorname{arsen}(i c)+$ pyrite.] A mineral containingarsenic, sulphur, and iron. Its color is tin-white, anci it commonly occurs in a massive, though sometimea in a crystallized, form.
The ordinary white arsenic is mostly obtained by roasting and is also found in Canada. Also called arrenical pyrites arsenuret, $n$. See arsenide.

arse-smart (ärs'smärt), $n_{0} \quad[<$ arse + smart, $n$. Seo smartweed.] A plant, Polygonum Hydropiper, also ealled smartweed (which see).

arsfoott, $n$. See arse-foot

arshin, arshine (är-shēn'), n. [Also spelled arsheen, Russ. arshinü, Bulg. Serv, arshin, repr. Turk. Pers. arshin; of Tatar origin.] A meaure of length in Turkey and Persia, and for(n) The Turkiah arshin was equal to nople to the meter (100 centimeters $=39.37$ inches), through the influence of the Persian arshin of 104 centimeters. The 28 inches. arsine (är'sin), $n$. [<ars(enic) $\left.+-i n e^{2}.\right]$ Arsereted).

arsis (är'sis), $n . \quad[\mathrm{L} .,<\mathrm{Gr}$, ă $\rho \sigma \iota$, a raising, elevation, < aipew, raise, lift up.] 1. In pros.: (a) Originally, the metrically unaccented part of a foot, as opposed to the thesis or part which receives the ictus or metrical stress. (b) In prevalent modern usage, that part of a foot which bears the ictus or metrical accent, as opposed to the metrically unaceented part, called the thesis. According to the original Greek usage, arsis de-
noted the raising of the foot in dancing, or of the hand in beating time, and therefore the unaccented part of the metrical foot, and thesis the fall of the foot or of the
hand in dancing or beating time, and therefore the acgreat confision in the application of these terms, some. times employing them in conformity with Greek usage, sometimes interchanging their meaning, sometimes assign: ing still other meanings to them. Some modern writers tions, as given above under $(a)$; but the meanings given
under $(b)$, and believed to be supported by the Latin writunder $(b)$, and believed to be supported by the Latin

2. In physiol. acoustics, a periodical increase in the intensity of a sound, producing a rhythmical effect.

arsmetrik $\nmid, n$. A Middle Englisl form of arithmetic. Chaucer.

arson' (är'son), n. [<OF. arson, arsoum, arsum (as if < L. "arsio, "arsion-), a burning, < arder, ardoir (pp. ars), burn, < L. ardere (pp. arsus), burn: see ardent.] In law, the malicious burning of a dwelling-house or outhouse of another. By the common law it is a felony, and if any person be in By statutes the definition has been extended 80 as to inciude the burning of other property besides that above
specifled, or of one's own property. In Scotiand called wilful fire-raising

arson $^{2}+\left(\ddot{\mathrm{r}^{\prime}} \operatorname{son}\right), n$. [<ME. arsoun, arsun, $\angle \mathrm{OF}$. areun, arzon, archon, mod. $\mathrm{F}$. arcon $=\mathrm{Sp}$. arzon
$=\mathrm{Pg}$. $\operatorname{arç\pi ̃o}=\mathrm{It}$. arciome, $\mathrm{ML}$. $\operatorname{arcio}(n-)$, also arsénico, arsenic, + dim, -ilto.] The commercial acid ( $\mathrm{H}_{\mathrm{s}} \mathrm{O}_{2}$ ) an acid formed from arsenious oxid.- 
arson

$\operatorname{arco}(n-)$, and corrujutly $\operatorname{arctio}(n-)$, a saddle-bow, [L. arcus, a bow: see arcl, archl.] A saddlebow; sometimes, a saddle.

arstt, $a d v, \Lambda$ Middle Hinglish form of erst. Chancer.

arsy-versyt (är'se-vêr-si), adt. [Also aryeiersy, arsic-tersie, arsy-jarsy, a humorons rimCf. topsy-turry, ete.] In a reverse manner or way; batekwrd; in a preposterous position; upsido down; topsy-turvy: as, "tho world goes "ric-2'ersie," Isemenuto, Passengers' Dialogues.

I wok the pen first of the huwyer, nud turuing it armyversy, ike no instrument for a ploughman, our youngster
and the rest of the faction lurst finto lnughter at the sinpliefty of my fingering. Viflefen, Father Hubbard's Taies, $\operatorname{art}^{\mathrm{I}}$ (ärt), r. [ $\mathrm{SMl}$. art, ert, <AS.eart=ONorth. urt, arth: see be.] The seeond person singular, indicative mool, prosent tense, of the verb bo (whieh see).

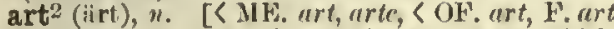

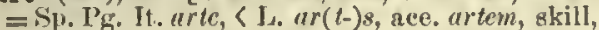
prob. orig. skill in fitting or joining; akin to artus, a joint, "trmu, anns, armus, shonlderjoint, ete., $<\sqrt{ }$ *ar, join: see aticle, arml, arme.] 1. The combination or morlifieation of things to udupt then to a given end; the em ployment of given means to effeet a purpose.

$$
\text { With each gift of nature nul of art }
$$

$$
\begin{aligned}
& \text { hre nutul of art. } \\
& \text { l'ope, Sloral Essays, f. 192. }
\end{aligned}
$$

Mr. Mill says, "Art is but the employment of the powers of nature for an enil." Yes; but the enlployment is the art. That ure or emplogment of thie natural elements is pre.
ciseiy the function of the intelligence and the will, which

difiers from unture, in its proper sense, as the nctive dif-
fers from the passive. cers from the passive.

2. Skill; doxterity; an ospeeial faeility in performing any operation, inteleetual bre or study; knaek.

There is art in roastlug eggre

Russeli had the art of writing letters that exploded like homb-shells in the midst of some controversy.

3. Artfulness; emming.

whe linth no laults, who hath the are to hide them.

Quren. Jore Mnatter, with less urt.

o art at all.

4. A system of rules and traditional methods for faeilitating the perfornanee of eertain ae tions; requaintance with sueh rules or skil in applying them, as in any mantal trade or handieraft, teehnieal profession, or plyysical aceomplishment: as, the art of building or of engraving; the healing art; the art of musie or of daneing; the practieal or the elegant arts. in this sense opposed to science.

The object of seience is knowlcilge; tho objects of ar are works. In art, truth is the means to an end; ill set ence, it fs only the end. Ifence the practical arts nre not
to be classed nunug the seiences. Theorists, by an elservation of partieulars and by gener propesitions with rewet to system a set of rules intended for the guidance of practice may be fonnded. "These rules for'm an art.
Sir G. C. Levis, Antherity in Mlatters of opinion, iii. 5. [It. arte.] An organized body of men prae tising a given trade, and earrying ont an established system of rules and traditions; a guild. The eity [Florence] was first divided into arts, in the
time of Charles I.
were at first hut i weive, These arts or companies. creased to twenty-one, and Hrrived at such power ani sithority that in a few years they wholly engrossed the govermment of the city. . . Seven of thent were called
the greater arta, and fourteen the less. A portion of the taxes was assigned to the work lbuill
ing the Duomo. 1331 , and the charge of it was committed to the Art of Wool : that is, to the corporution of the deai-
ers in wool, the rlchest and niost powerful of the Arts of Florence.
C. F. Norton, Church-huilding in Middle Ages, p. 21. 6. A branel of learning regarded as an instrument of thought, or as something the knowledge or practised: ehiefly in the plural, and in such phrases as master of arts, faeulty of arts, ete. the lionan trivium, uneranumar, logic, sud rhetoric, and the l'ythagorean quadrivimm, arthmetic, music, geometry, and astronouny. lut by art, in the middle ages, was usually

7. Fisthetics; the seienee and theory of beanty in perception and expression.

tion. Vexpression of human ente-

8. Artistic or esthetie quality; tho exhibition of the power of pereeiving the beautiful and of expressing it in artistie forms: as, a pieture

323

Artemisia

skilfully painted, but devoid of art. - 9. The -art. A sufix, another form of ard, as in bragetual prorlution or eonstuuction of objects gar.

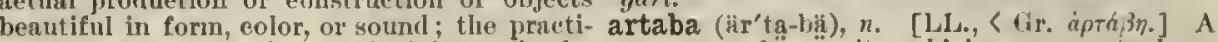
eal applieation of esthetie prineiples, as in the departments of produetion speeifieally called the finc arts (whieh see,

Notilug is hetter founded than the fanous sphorism of rhetoriciaus, that the perfection of urt consists in cons-
canule

Art and part, in Scuts lace, linstigatiun; aletment.

By art is understooc the muminte, instigation, or alvie that may have loen givell towsrds comminting the erin

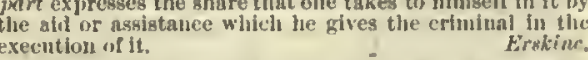

Bachelor of Arts. See bachelor. Black art, necromancy ; surcery ; the fancied power of performing wonder(111 feats by preternatiural meens, espeetslly means derived from the assistance of the powers of evil: opjposed to white
(1rt or white mayie, that is, fnnocent magic. [Bhtek art is

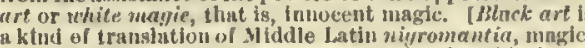
a corrupt ton, lue to confusion with Latin niger, black (see neyro), of nerowemtin, from the Grcek vexpouaveia, ne romancy. The eonfubien was assisted by the common that branch of sit which has for its primary ohject merel tile pleakure of the ey, especinlly in decorstion which silservient to architectural features or to form, as faculty of the four in the old universities; the laculty of faculty of the four in the ofd universities; the lacity of
philosophy, which hal eliarge of atudests inpon their thrst entrance and untii they took tile degree of master of arts. When a buy conlil real, write, and lial mastered the clements of Iatin gramoar, he whs eonsidered reacty to begin his stucties in logie at the university. The instruetion in the faculty of arts was shinrply sejarated from the teits preliminary to the conferring of degrees. In the luiddlo
ages the subjects of the ordinary lecturen were priscian's gramnar, thie laagoge of Porpliyry, Aristetle's Organon and the ie Divisione and three books of the Topics Boetius, wilie the exirnordinary lecinres related to rhe oric, ethics, and a little gennetry and astronomy, Fre-
quent disputations constituted the oniy exercises or the seholnrs; and the mnsters disputed in public once a week
The degrees conferred at the recommendation of the facThe degrees conferred at the recommendation of the fac-
ulty of arts were those of hachelor and master. In laar the degree of lieentinte was a distinet one intermediate was not orfolnally a degree. Uipoll the reform of the unt versities in the sixteenth century logic gave place to the humanities, and during the present century natural selence has hat a more considerable place in the instruction. Fine arta, those nrts which seek expression throngis
beautiful unodes; specilfcnlly, srehitecture, senipture,

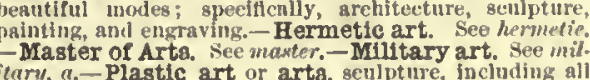
subordinate or related arts by which objects are repre sented fin the round or tn reliel. . Work of art, anything in the formintion or into the acconpilislment of which ar any one of the flne arts, hit especially of one of the in
tative lnembers of the group, as a statue or a jninting.

$$
\begin{aligned}
& \text { T'iant is lest. which lieth nearest: } \\
& \text { sisape from that thy cork of art. }
\end{aligned}
$$

= Syn. 2. Aptitnde, readiness, ndilress, tact, itlroituess,

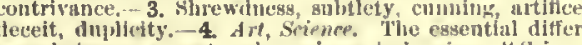
and ort neen be salit to be investigations of tritib, but urience inguires fur the sake of knowledge, art fur the sake
of production." (Karulake.) If ence, they ilifter somewint in that with which they are cuncerned. "An are directly sun upon that, and keeps it ever in its view in it teuches low ont the of her laand, regards rather the prodinct of [a] facults

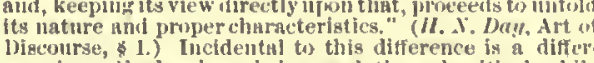
ence in method, ocience being analytie and critichl, while
nrt is synthetic and construetive. In the matter which makes up the brily of the two, an art involves the means
of diseipline in the use of the knowledge whieh nuy lanve

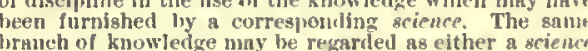
or an art. It may be viewed theoretically, as seeking, and by observntion, comparison, abstraetion, and general ization dedneing laws; or as, with more or less rclerence
to such preparatory work, franning rules whici are the
lessons of experience, and are designed to facilitate work or give it supperior excellence. The more complete the a second ary $18 \mathrm{se}$ of the woril seience by which it. stands for an art that thiss rests upon a seience, as in the following: The lundanientał conception of the oceupation of the architect emhraces the two ldeas of weience and ort. Ar-
ehitecture as an urt is the work of the skilled hand; as a ehitecture as an wrt is the work of the skilled hand; as a
science, it is that of the informed and cultifated brain.

$\operatorname{art}^{3}+, \imath t_{\text {. }}$ [ME. arten, orten, $<\mathrm{OF}$. arter $=\mathrm{Sp}$ $\operatorname{artar}($ obs. $)=\mathrm{Pg}$. arctar $=\mathrm{It}$. artare, $<\mathrm{L}$. ar tare, ML. often erroneonsly arctare, compress, eontraet, draw elose, < artus, drawn close, prop. article, arm ${ }^{2}$, ete.] 1. To foree; cornpel; constrain.

Love arted me to do niy observanuce

2. To induee; incite.

What to arten hire to tove he sought.

Also written aret.

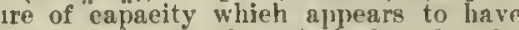
originated in Egypt, whero it had under the Pharaohs a eapacity of 36.176 liters. A P'erstan monsure of the same nume had, sccording tu lierimlotis,
ahout the game capscity. The ltomans reducerl its vol. ume to 27.192 liters (according to sonse, to 23.23 or 29.34 evitently been, doubled, having respectively ots.oms and rtamia

tomus, 1

us, 1. Artamidæ (iir-tam'i-dē), n. pl. [NL., < Artamus + -ille.] A family of oscine lranseriue birds, the swallow-ahrikes or wood-swallows, elosely thet family. and loblyesian. Leading lornus, besilea Artams, are artamockest, n. "The moeking-bird, Mimus polyglottus.

Artnmeckes, the linguist, a hirl that innitateth snd uscth the sounuls s nil tones of almost nll the bircls in the colnt.
trie.

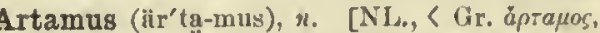
a butcher, a cook.] 1. 'Tho typieal genus of the fumily Artamicla, and nearly conterminous therewith. Ticillot, 1816. Also ealled Artumin. -2 . A genns of arachnidans. Koch, 1837. artedt (är'ted), a. [<art $\left.+-c t^{2}.\right]$ Skilled.

Those that are thoronghly arted in navigation.

Felthura, liesolven (ed. 1070), I. xil.

ike au arled uunted Feltham, Resulves (cil

artifuct. artefactum (ïr-tê-fak'tum), ". Same as urtifact.

artelriet, n. A Middle English form of arlillery.

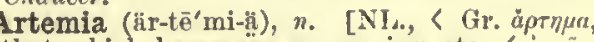
that which hangs, as an ear-ring, etc. <a hang upon, fasten to.] A genus of phyllopod the family Jranchipolider. The animals are motable us inhabiting saline waters, the other forms of the group us inhahiting saline waters, the other torns of the groll
heing found in (resh water. A. saline, a cummon britisli Artemis (är'tẹ-mis), ". [I., <Gr. "Apreurs. The origin of tho name is undetermined.] 1. In Gr. myth., one of the great Olynpian deities, danghter of Zeus (Jupiter) and Leto (Iatona) and twin sister of Apollo. She may le regarded an a feminine lorm of A Apollo. She chustised evit with her was not ecmnected with poetry or divination, but, lik

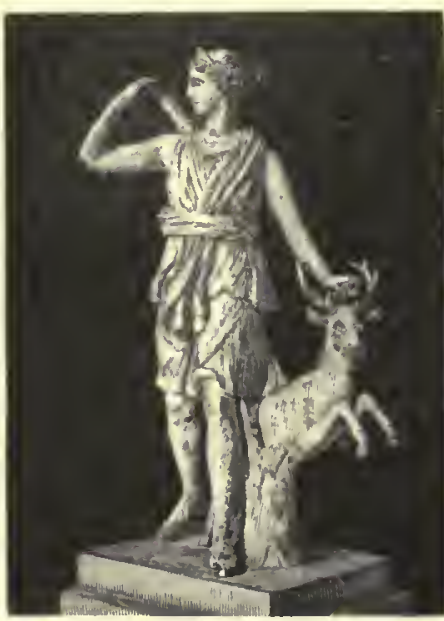

inthority over the moon, which loctonged more phrtientar is represented as a virgin of noble and severe beanty, tal huntress or nomutain goddess. She was identified by the 2. [NL.] In zoöl.: (a) A genus of siphonate 2. [NL.] In zool.: (a) A genus of siphonate lamellibraneh bivalves, of the family Ienerida.
having the pallial margin sinuous. (b) A genus of eoleopterous inseets. Mulsant, 1851.-Epheslan Artemia. See Dian

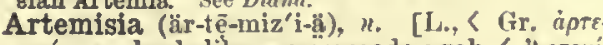
ucóa, an herb like wormwood; prob. $<$ Apreni olos, pertaining to sptems: see Artemis.] A very large genus of plants, of the natural orde of the northern hemisphere. The genus is alliel to 
Artemisia

324

the tansy (Tanacetum), and consists of low shrubs and
herios, with small discoid, often pendnlous, heads panicu. lately arranged, and all bitter aronatics. "Iherc are over regions west of the Mlississippi. Of the foreign spectes, th common wornwwod, $A$. A Lsinthium, was formerly minch the peculiar ingredient in the French liqueur absinthe. $A$ ufacture of a similar liqueur, génepi. Worninseed or santonica consists of the small unexpanded fowerobuls of $A$. pauciflora, extensively collected on the steppes of 'Turkes. of gartens, $A$. Abrotanum, and the tarragon, $A$. Dracuncullus, have a fragrant aronatic odor. Of the numerous
North American speeies, the best known are A. tridentata and $A$. can $\alpha$, which are the sage-brush of the western platns, the first especially covering large areas in the val

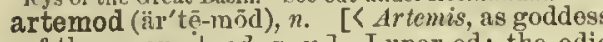
of the moon, + od, q. v.] Lunar od; the od foree of tho moon. Baron von Reichevbaeh.

artert (är'tèr), n. [<OF. artre, a moth; artre grise de bois, a wooul-louse (Cotgrave); also arte, and artiron, artison, artuison, nod. F. artison, a wood-worm. Cf. art-10orm.] A woodworm. Also ealled art-xorm.

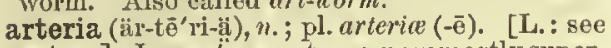
crtery.] In anat., an artery: now mostly superseded by the English form of the word. Some of the prinuipal arterics in the names of which the Latin form is still used are: Arteria anastomotica, one of the branches of the brachial or femoral artery, forming anastomose retince, the central proper artery of the cochlea or of the ref the ascending transverse, and descending colon respectively; arteria comes, a companion artery of a nerve, as the phrenic and selatic; arteria coronaria ventrieuli, the proper gastric artery, a branch of the coliac axis; arteria dorsalis hallucis, indicis, linguae, penis, pedis, pollicis,
scapulce, the dorsal artery of the great toe, index finger, tongue, penis, foot, thumb, and shoulder-blade respective $1 \mathrm{y}$; arteria gastro-duodenalis, arteria gastro-epiploica, two arteries of the stomach and associate parts; arteria innominata, inuominate artery, or anonyma, the first great arterial bianch of the arch of the aorta, on the right side arteria pancreatica magna, parva, arterice pancreatica. duodenales, superior et inferior, large and sniall pancreatic
arteries, and the superior and inferior arteries of the pau. ereas and duodenum; arteria princeps cervicis, pollici the neck, and the principal artery of the tlumb, respectively; arteria profunda humeri, superior et inferior, certcis, femuris, the superior and luferior deep branchcs of the
braehial artery, the deep cervical branch of the first intercostal artery, and the deep branch of the femoral artery, tery, the continuation of the abdoninal aorta after giving artery of the hall of the thumb, a branch of the radial, usually eontinuons witls the superfletal palmar arch; $a r$. traverases the root of the neck and ends in the posterior
gcayular artery. - Arteria aspera, the asper or rough
artery that is, the windpipe or trachea.

arteriact (är-té'ri-ak), $a$. and $n$. [ [ Gr. ápr

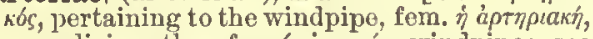
a medicine therefor, < a $\rho \tau \eta \rho i ́ a$, windpipe: see
artery.] I. $a$. Of or pertaining to the wind-

II. $n$. A medicine preseribed in diseases of the windpipe. Dunglison.

arterial (är-tés'ri-al), a. $[=1$. artéricl, $<\mathrm{NL}$. arterialis, < L. arieria, artery: sce artery.] 1. Of or pertaining to an artery or to the arteries: as, arterial action. -2 . Contained in an artery: as, arterial blood.-3. Having a main channel and many branches or ramifications, like the arteries: as, arterial drainage. - Arterial blood, blood as it passes through the arteries after having been
oxygenated in the lungs. It is distinguished from venous blood particularly by its lighter florid-red color, due to the
presence of oxygen.-Arterial cone. ( $($ ) The upper left presence of axygen.- Arterial cone. ( $(a)$ The upper left monary artery leads. Also called infundibulum. (b) In
ichth., the elongated conical ventricle of the heart, whieh is continuous with the bulbus arteriosuz, and is distin. guished therefrom by the presence of valves between the two.-Arterial duct (ductus arteriosns), the portion of
any primitive aortic arch which serves to connect and furnish communication between a branchial artery and a
branchial vein.- Arterial navigation, navigation by means of connected or branehing channels of inland water, arterialisation, arterialise. See arterialization, arterialize.

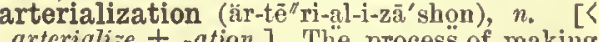
arterialize the conversion of venous into arterial arterial; the conversion of venous into arterial
blood, during its passage through the lungs, by blood, during its passage through the lungs, by
the elimination of carbon dioxid and the absorption of oxygen from the air. Also spclled arterialisation.

arterialize (är-té'ri-al-iz), $v . \ell$; pret. and pp. $-i z e ;=\mathrm{F}$. artérialiser.] To convert (venous blood) into arterial blood by the action of oxy gen in the lungs. Also spelled arterialise. arterially (är-tē'ri-ạl-i), adv. In the manner of an artery; by means of arteries. calillaries. artery. intima. the arteries. of the arteries. or windpipe. arthrocacology

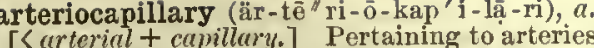
and capillaries.-Arteriocapillary fibrosis, the in

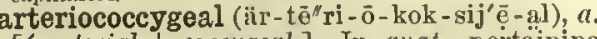
[ arterial + eoceygeal.] In anat., peitaining 0 arteries and to the coceyx: specifically applied to the glomerulus arteriococeygeus, or Luschka's gland. See glard and glomerulus. arteriogram (ïr-té-ri-ō-gram), n. [<Gr. i $\rho \tau \eta$ $\rho^{\prime} a$, artery, + $\gamma \rho \dot{\alpha} \mu \mu a$, a writing.] A sphygmographic tracing or pulse-curve from an

a sphygmogram taken from an artery.

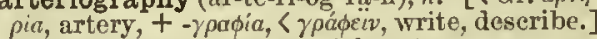
A description of the arterial system.

arteriola (är-tēe-ríō-lá), n.; pl. arteriole (-lē). [NL.] In anat., a little artery; an arteriole. Arteriolw rectæe small straight arteries supplying the rteriole (är-tó'ri-ōl), n. [= F.artériole, $<\mathrm{NL}$. arteriola, dim. of L. arteria, artery.] A smal

The minute arteries, the arterioles of some distant organ
ike the brain. $\quad$ B. W. Richardson, Prevent. Nled., p. 407 .

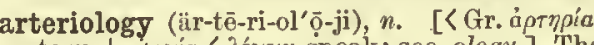

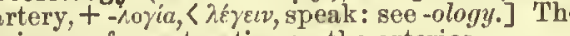
seience of or a treatise on the arteries.

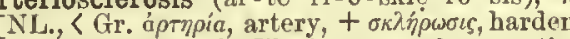
ing: see sclerosis.] The increase of connectiv tissue in the walls of arteries, especially in the

arteriotome (är-tē'ri-ō-tōm), n. [ $n_{\text {. Gr. as if }}$ instrument for dissecting an artery.

arteriotomy (är-tê-ri-ot'o $\overline{0}-m i), n$. [<LL. arte

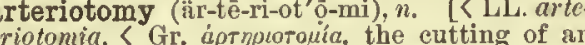

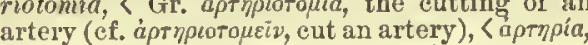
artery, + to $\mu \delta \delta$, verbal adj. of тé $\mu \nu \varepsilon i \nu, \tau a \mu \varepsilon i \nu$, ent.] 1. In surg., the opening of an artery by the lancet or other instrument, for the pnrpose of letting blood.-2. That part of the science

arteriovenous (är-tēen ri-ō-ve' nus), a. [< L. ar-

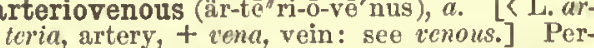
trining to an artery and a vein.-Arteriovenous

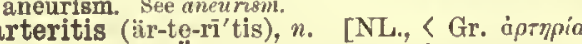
artery, $+-i t i s$.$] Inflammation of an artery o$

artery (är'te-ri), m.; pl, artevies (-riz). [<ME. arterie (carly mod. E. also arter, artere, artier, arture, ete., $\angle \mathrm{OF}$. artere, mod. F. artere $=$ Pr. Sp

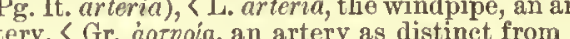
tery, Gr. a $\rho \tau \eta \rho i a$, an artery as distinet from a
veiu; but commonly the arteries were regarded as air-ducts (the name being supposed to come from ahp, air), because found empty after
death, and seem to have been conceived as ramifications of the windpipe; orig. the windpipo; pcrhaps < aipe $v, \dot{\alpha} \varepsilon i \rho \varepsilon v$, raise, lift up; ef.
aorta, from the same source.] 1t. The trachea

Under the artcry or windpipe is the mouth of the
Sir II. IIolland.

2. One of a system of cylindrical, membranous, elastic, and muscular vessels or tubes, which the body by ramifications which as they proceed diminish in size and increase in number, and terminate in minute capillaries which unite the ends of the arteries with the beginnings of the veins. There are two prineipal arteries: the aorto
which rises frons the left ventricle of the heart and raniwhich rises from the left ventricle of the heart and ramilungs, to mindergo arierialization. Most arteries are conposed of three conts: an outer or fibrous, of condensed nerves; a nistule well supplied with blood-vessels an and dense, composed, from without inward, of an elasti and dense, composed, from without inward, of an elastic alventitia; the middle, the (tunica) media; the inner, the (tunica) intima. The arteries in the luman body which liave received special nanes are about 350 in number finger to microscopic dimensions. communication, as in drainage. - Artery-claw, a locking foreeps for holding an artery. - Artery of the Axtllary artery, coronary artery, nutrient artery, artery (äl'te-ri), $v$. $t$.; pret. and pp. arteried, ppr. arterying. [< artery, n.] To supply with arteries; figuratively, to traverse like arteries.
Great rivers that arteried every State. Artesian (är-ténian), a. [<F, artésien, propArtesium, in France.] Pertaining to Artois,

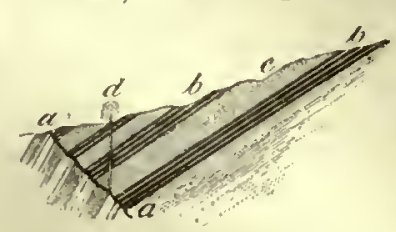
an ancient province of northern France, corresponding to the modern department of Pas-de calais. - Arteusually without capital letter)given

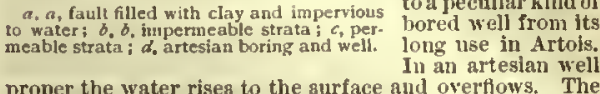

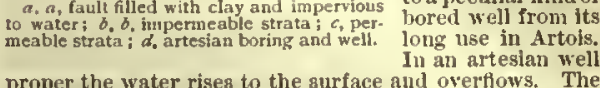
proper the water rises to the surface and overfiows. The
geological eonditions permitting thia are not general, since
it is necessary that the reglon should have a more or less it is necessary that the region should have a more or less complete basin-atrueture, and that there should be a series
of permeable covered by impermeable beds. In the United of permeable covered by impermeable beds. In the United
states any deep bored well is called artesian, even if the water has to be pumped from a conaiderable depth. Artesian wells vary in depth trom less than for petroleum. artful (ärt'fúl), a. [< art $\left.{ }^{2}+-f u l.\right] \quad 1$. Done with or characterized by art or skill. [Rare.] Our yaalms with artful terms inseribed.
Milton, P. K., jv. 335.

No one thinks when he looks at a plant, what restless activity is at work within it, for the cells perform their
artful labor in atillness. Pop. Sci. Mio., XXII. 185. 2t. Artificial, as opposed to natural; produced or producing by art: as, "too artful a writer," Dryden, Life of Virgil.-3. Skilful. (a) Of persons, skilful in adapting means to ends ; adroit. (b) Of things, skilfully adapted; ingenious clever. Hence-4. Cunning; crafty; practis ing or characterized by art or stratagem: as Fair to no purpose, artful to no end.

=Syn. 4. Cunning, Artful, Sly, etc. (Bee cunning), deceitful, pnlitic, shifty, insidious artfully (ït'full-i), $a d v$. In an artful manuer. (a) With art or skill : as, colors artfully distributed on the ningly.

Whether this motion was honestly made by the oppo-
aition... or artfully made lyy the courtiers, Oit is now inposisble to diacover. artfulness (ärt'fủl-nes), $n$. The quality of being artful; craft; ennning; address. arthen† (är'then), a. An old form of earthen. arthra, $n$. Plural of arthron.

arthral (ar'thrạl), $a . \quad[$ artheron $+-a l$.$] of or$ pertaining to an arthron or articulation; articnlar: as, "the arthral surface of the ilium," Wilder and Gage.

arthralgia (är-thral'ji-ä), n. [NL., <Gr. ả $\rho \theta \rho o \nu$, joint, $+a \lambda$ ros, pain.] Pain in a joint; specifiarthralgic (ar-thral'jik), $a$. Pertaining to arthralgia

arthrembolus (är-threm 'bō-lus), n. [NL.,

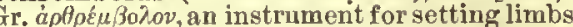
$<$ a $\rho \rho 0$, a joint, $+\dot{\varepsilon} \mu \beta 0 \lambda \dot{n}$, a putting in place, the setting of a limb, $\langle\dot{\varepsilon} u \beta a$ a $\lambda \varepsilon \varepsilon v$, thrust in: see embolus.] In surg., an instrument formerly used in the reduction of dislocations. Dunglison.

arthria, $n$. Plural of arthrium.

arthritic (är-thrit'ik), a. [(ME. artetike, < OF. artetique $<\mathrm{I}$. arthritiens, < Gr. à $\theta_{\rho} \rho \tau \iota \kappa b s$, of the joints, gouty, < a cally to the gout; affecting the joints.

$$
\begin{aligned}
& \text { Pangs arthritic, that infest the toe } \\
& \text { Of libertine excess. Corper, The Task, } 1 .
\end{aligned}
$$

arthritical (är-thrit'i-kal), $a$. Same as $a r-$ arthritis (ur-thri' tis), n. [L., < Gr. ả $\rho \theta^{\prime} \rho \bar{\tau} \iota s$ (se. vóøos, disease), joint-disease, gout, prop. fem. adj., of the joints, $\langle$ a $\rho \theta \rho 0 v$, a joint: see arthron.] Inflammation of a joint.-Arthritis deformans, rheumatoid arthritis in whity is produced. See rheumatoid.

arthrium (är'thri-um), n.; pl. artliria (-ä). Nl., <Gr. as if *à $\rho$ piov, dim. of á $\rho \theta \rho o v$, a joint.] n entom. the minute penultimate tarsal joint of many Coleoptera.

arthrobranchia (är-thrô-brang' ki-ä), n.; pl. arthrobranchice $(-\bar{\theta})$. [NL., $\langle\mathrm{Gr}$, a $\rho \theta \rho o v$, a joint, + $\beta \rho \sigma \gamma \chi \chi$, gills.] In Crustaeea, a distinet respiratory appendage of the maxillipeds. Huxley. arthrocace (är-throk'a-sē), $n$. [NL., < Gr. a $\rho-$ Caries of a joint. Billroth.

arthrocacology (är"thrō-ka-kol'ō-ji), n. [<arthrocace + -ology. q. v.] The sum of human knowledge concerning diseases of the joints. 
arthroderm

arthroderm (iir'thrō-dèm), n. [<Gr. äpopov, a joint, $+\delta \varepsilon p \mu a$, skin.] Tho erust or body-wal or the integument of an insect. A. S. Puchari. arthrodia (är-thrō'di-äi), $n_{\circ} ;$ pl. arthrodire $(-\bar{e})$. [Nl., < Gr. a $\rho \rho \omega \delta i a, a$ particnlar kind of artic-

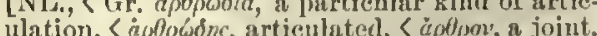
+ cidos, form.] \ gliding joint; a movablo articulation formed by plane or nenrly plane surfaces which slide upon ench other to somo extent, as in tho articulations of tho carpus: a form of diarthrosis. Also enlled adturticulation. Double arthrodia. Same as amphitharthroris.

arthrodial (ïr-tlırō'di-nl), ". [< arthrodia + -al.] 1. J'ertnining to or characterized by an arthrodia. - 2. Of or pertaining to arthrosis ; parts, especially of limbs. - Arthrodial apophyparts, especially of limbs. - Arthrodial apophypleurite which
cavity of a limb.

The endoplenrite... dividea Into three apophyres,

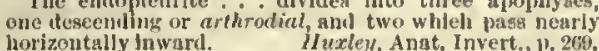

arthrodic (ïr-throd'ik), $a$. Samo as arthrodial. arthrodynia (iir-thrö-din'i-i), n. [NI., < Gr. arptoov, a joint, + dofivn, pain.] Pain in a joint; artluralgia.

arthrodynic (är-thrô-dlin'ik), a. [<arthrodynia + ic.] Relating to artlirodynia, or pain in a joint; arthralgic.

Arthrogastra (iir-thrō-gas'trị), n. $p l$. [NL., Gir. àpopov, a joint, + jaornp, bolly.] A division of the class Arachnida, inchinding tho scorpions and mites. See cut under Scorpionile.

and mites. See cut under Scorpionule.
Thie Arlirogastra, or scorplons and jreudo-scorplons,

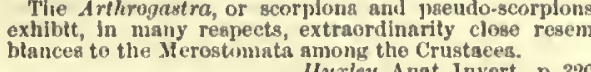

II uxiey, Anat. Invert., p. 320.
Arthrogastres (iir-thrō-gas'trēz), $n . p l$. [NL. Arthrogastres ("ir-thrō-gas'trēz), n.pl. [
as Arthrogastra.] Samo as Arthrogasira.

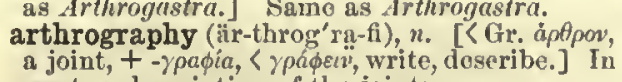
anat., a deseription of the joints.

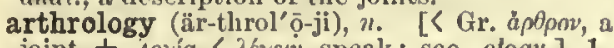
joint, +-coyía, < $\lambda \xi_{\text {reiv }}$, speak : seo -ology.] 1. Tho knowledgo of tho joints ; that part of anatomy which relates to the joints.-2t. Finger speoch for tho doaf and dumb; dactylology.

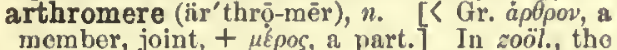
momber, joint, $+\mu \varepsilon \rho \circ$, a part. $]$ In zool., tho ulate animal is composed; a zoönulc, zoönite, or somite of an articulated invertebrato animal. The typical arthromere eonsists of a tergite, a pair of pleces, and an under plece.
arthron (är' thron), $n$; pl. arthra (-thrịi). [NL. arthron (är'thron), $n$. ; pl. arthra (-thrị). [NL.,
$<$ Gr. a 0 opov, a joint (of the body); in grammar, tho articlo; akin to equiv. L. artus: see artus tion of any kind.

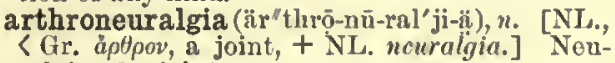
ralgia of a joint.

arthropathy (är-throp'a-thi), n. [<Gr. ápopov a joint, $+\pi a ́$ os, suffering.] Disease of a joint. arthrophragm (är'thrō-fram), n. [<Gr. ápopov,

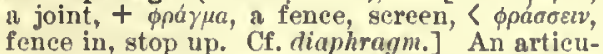
lar diaphragm; a septum or partition between cortain articulations, as in the crawfish. Seo oxtract.

All four apodemeg lie In the ventral half of the somite are two nearer the transverse geries; conseinently there dosternites, and two further off, whleh are the endoplen-
rites, The former lie st the inner, and the latter at the onter ends of the prititions or arthrophrayms. bietweel the srticnlar envities for the hasal joints of the
Ilmbs, and they gpring partly from the latter and partly Ilmbs, and they spring partly from the latter and partly

arthropleura (ïr-tlırō-plö'rüi), n.; pl. arthro pleure (-rê). [NL.] Same as arthropleure. arthropleure (iir'thrō-plör), n. [<NL. arthro pleura, < Gr. apopov, a joint, + $\pi \lambda \varepsilon v \rho a ́$, side.] Tho ploural, lateral, or limb-bearing portion portion of any arthromere between the tergite and tho stornite.

arthropod (iir'thrō-pod), n. and $a$. [<NL.arthro-

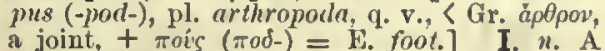
a joint, $+\pi$ oirs $(\pi 0 \delta-)=$ E. foot.] I. $n$. A jointed invertebrato anin
one of tho Arthropoda.

II. a. Arthropodons; pertaining to or having the characters of the Arthropoda. Among the Crustacea the simplest atage
pod body is aeen in the N $\mathrm{N}_{3}$ uplius-form.
325

artichoke

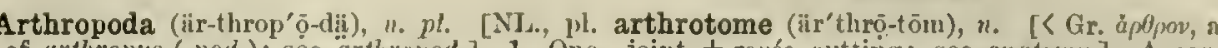
of arthropus (-pad-): seo arthropod. ] 1. One joint, tropos, cutting: seo anatomy. $\mathrm{A}$ carof two primodivisions (Anarthropoda being the tilage-knifo; a strong senlpel, two-edged for a other) Into which a subkingclom Annulosn has part of its cutting lengt h, and having a ronghan wived. It containg bitateral segmentell anttot the "arteulated animals with articulated legs" of C'n-

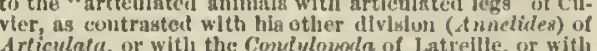
the finathopoda or Arthrozed of Bonde other naturatists. . In molo modern and exact usage, ono of the phyla, subkingdoms, or muin types of tho Metuzou, containing the articulated, invertebrate, non-ciliatel animals with articulated limbs, a ganglionic nervous system, oviparons eproduction, and generally separate sexes. Tour great elasses I raspeta, If yriapola, A rachnida, and Crustceea, nund contalns the vast majority (nbout four fittis) of the snimal

The Arthropodu, with more than 200,000 specles, vary to sirel an extent that tittle can bo gaili sppilicalle to the whoto grotup. of all Invertehrata tliey are the most alvances in the development of the organk peculise to anlinal life, manifestert in tho powers of locomotlon, and in the Jastlucts whleh aro so varled and so wenterfit in the
ingect elass.
['areoe, Zoob. Class., p. 70 . arthropodan (iir-throp'ō-dạn), a. [< arthropod +-an.] Samo as arthropodous. arthropodous (är-tlirop'ó-dus), $a$. [<arthropod
+- ous.] Of or pertaining to tho Arthropoda: $+-o u s$.$] Of or pertaining to tho Arthropoda;$
having jointed legs (among invertebrates); conhaving jointed legs (among invertebrates); con-
dylopodous; arthrozoic. Also gnathopodous. Arthropomata (är-thrô-pó 'man-tịi), n. pl. [NL.

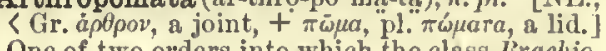
One of two orders into which tho class lirachiopoda is generally divided, the other being Iyopomata:

arthropomatous (är-thrō-pō'ma-tus), $a$. [ Arthropomata + -ous.] Pertaining to Arthropteridæ (ïr-throp-ter'i-ilē), n. pl. [NI, SArthropterus + -idle.] A family of heteropterous insects, chiefly of the Orient, Africa, and the Pacific islands, inclnding a large number of flat wide forms, mostly of a polished black color variously marked with yellow.

thropterus, adj. < Gr. ápopoiv, a joint, $+\pi \tau \varepsilon \rho \delta b$, a wing, fin.] Having jointed rays, as a fin of a fish. Arthropterus (är-throp'te-r'us), n. [NI.: see arthropterous.] 1. The typical genus of tho family Arthropteride. Maclea. arthroses, $n$. Plural of arthrosis.

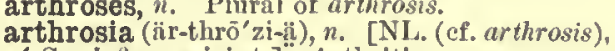

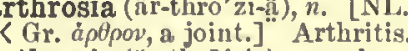

rthrosis (ir-thrō'sis), $n_{0} ;$ pl. arthroses (-sēz).

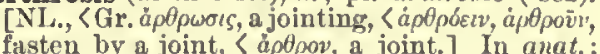
(a) A suture; an articulation; a joining or jointing of bones or cartilages otherwise than by ankylosis. Arthrosis is divisjble into three jrincipal eategorles: (1) Symsrthrosis ; (2) amphisrtlurosis; (3) ttar-
thresis. See these words. (b) The result of articnlation; a joint ; an arthron; a node.

arthrospore (är'thrō-spōr), n. [<Gr. äpopov, a joint, $+a \pi b$ pos, seed.] In bot., ene of a number of spores united together in the form of a string of various low fungi and alga.

arthrosporic (är-thrọ-spor'ik), a. Same as arthrosporous.

arthrosporous (är-thros'pō-rns), $a .\left[<N L_{\text {. }} a r-\right.$
throsporus: see arthospore and -ous.] Produeing arthrospores.

rthrosterigma (ĭr" thrō-stē-rig' mï), n.; pl. arthrosteriymata (-ma-tï). [NL.. < Gr. ápepor,

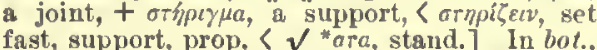
the jointed sterigma which occurs in the spermagonium of many lichens.

Arthrostraca (är-thros'tra-kị), n. $p l$. [NI... Gr. àp 0 pov, a joint, + borpäкö, a shell.] 1. In Gegenbaur's system of classification, one of two
prime divisions of malacostracons crustaceans prime divisions of malacostracons crustaceans approximately to tho edriophthalmons or ses sile-eyed crustaceans of other authors, and divided into the threo orders Ampliporla, La modipoda, and Isopoda.-2. In Burmeister's system of classification, one of three orders of Crustacca (tho other two boing Aspidostraca and Thoracostraca), divided into nine lesser and $T h$

groups.
arthrostracous (är-thros'tra-kus), $a$. Pertaining to or having the characters of tho Arthrostraca. continuors witli the blade. jolnts, and other ruugh work.

Any thilck-bladet sealnel may be qroutid Into a tolcrable joint, + rouh, a cutting: sce cumtomy.] In ury., incision into a joint.

Arthrozoa (iir-thrō-zō'in), n. pl. [NT., < Gr.

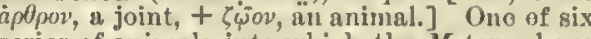
series of animals into which tho Metezod havo been divided: equivalent to Arthropoda together witl Nevetoscolices and probably Chatognathe.

arthrozoic (iir-thrō-zö'ik), $a$. lelating to or having the characters of the Arthrozoa.-Arthrozolc series, a grsulaton of anlmals represented by the to the highest arthropods. IItixley.

Arthurian (är-thü'ri-an), «. [< Arthur, ML. form Arthurus, representing W. Artur.] of or pertaining to King Artlum, one of the last Celtic eliefs of Britain (the hero of a great literature of poctic fable, and whose actual existence has been questioned), or to the legends conneeted with him and his knights of tho Round Table.

Arthurian legend Is not, and never has been, to the Engllah wational nind what the myth which guppled the snb-
jeeta of Attlc tragedy were to the Greek. artiad (iir'ti-ad), $n$. and $a$. [<Gr. ăor $+-a l^{1}$.] I. n. 1. In chem., an atom whose quantivalence is expressel by an even number, rissud.-2. In zoö., an even-toed ungulato quadruped; a cloven-footed ruminant animal; ono of tho Artioulactyla: opposed to perissal. Soe cut under Artiodactyla.

II. $a$. In chcm., having the nature of an artiad: as, oxygen is an artiad eloment.

artichoke (är'ti-chōk), n. [Introdnced in tho 16th eentury, the two normal forms (after tho

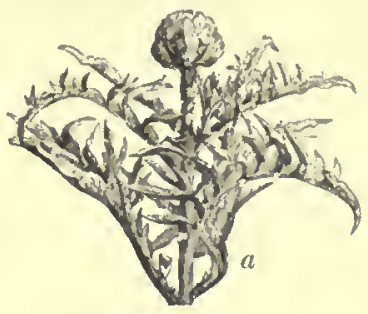

It.) artichockic, ar

chichock, mixing

with artichon, ar-

tichove, artichan, artichault, etc., aumerous forms, varying initially harti-, harte-, archi-, archy-, arch-, and terminally -chok, -cholic.

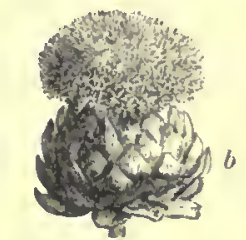
-chough, -chooke, ete. (simulating garden, $\mathrm{F}$ chule, as if that which 'cliokes' tho garef. D. artisjok: ef. D. artisjok, a. top of plant: b. flowering head. ärtskockit, G. artischocke, Russ. artishokin, Bohem. artichak, artychol, Pol. karczock, with F. artichaut (formerly also artichau, -chaul, -chaud, -chou, ete.), ML. articoccus, articoctus, articactus, all from Sp. or chicioce, arciocco, also arciciofjo, archicioffo, for "alcarcioffo; also simply carcioeco, carcioffo, mod. It carciofto, carcinfo, $\mathrm{S} p$. alcarchofa, now alcachofa, alcichofera, $\mathrm{Pg}$. alcachofra, $<\mathrm{Sp}$. Ar. al-kharshōfa (Pedro do Alenlá), rl-kharshüf (Bocthor), < Ar. at, the, + liharshofa, kharshñf with initial $k h a, 7$ th letter), also harshinf (in Bagdad - Newman), harshaf (Freytag; Pers. ter), an artichoke. The Ar. ardi-shauki (Diez), crlushauke (in Aleppo-Newman), Pers. ardushähi, Hind. hathi chak, are adaptations of the European forms (appar. simnlating Ar. arih.

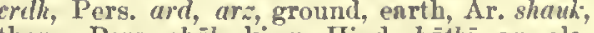
thorn, Pers. shäh, king, Hind. häthi, an elephant).] The Cynara Scolymus, a plant of the natural order Composita, somewhat resembling a thistle, with large divided prickly leaves. The ereet flower-stem terminstes In a large round hesd of nufowers, "The fles lyy bases of the scales with the large recep tacle are used as tood. Artlchokea were introduced into rthrotomy (iir-throt'ō-mi), [<Gr. a as the atoms of sulphur, oxygen, ete. See pe- 


\section{artichoke}

Enrope early in the sixtenth century,- Jerusalem arti-

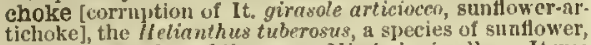
tichoke], the flitinthe of Caniala and the upper Mississippi valley. It was culiverouts louts, and was introduced at an esrly date into Europe, where it is raised in considerable quantities as an saticle of food. The plant was long believed to be a
native of brazil, sind it is unly recently that its true origin article (är'ti-kl), n. [C ME. article, <OF. article, $\mathrm{F}$. article $=\mathrm{sp}$. articulo $=\mathbf{P g}$. articulo (in anat. and bot.), artigo = It. articolo, articulo, L. articulus, a joint, limb, member, part, division, the article in grammar, a point of time; prop. dim. of artus, a joint, akin to Gr. a phpov, a art 2 , ete.] 1 1 . A joint connecting two parts of the body -2 One of the parts thus conneeted; a jointed segment or part.

The first pair of legs [of the whip-scorpion] is the longest, snd the tarsal joint is lroken up into a long series nf 3. In bot., the name formerly given to that part of a stalk or stem which is between two joints. Henee -4. A separate member or portion of anything. In partienlar- $(\alpha)$ A clause, item, point, or particular in a contract, treaty, or other formal agreement; a condition or stipulation in a contract or bargain: as, articles of association; articles of apprentieeship.

$$
\text { Against our articles. }
$$

Junson, Alchenist, $\mathrm{v}$

(b) A distinet proposition in a connected series one of the particulars constituting a system: as, the

A Minister should preach according to the Articles of Cried amen to nyy crecd's one article. Setden, Table-Talk, p. 72 (II 250 (c) A separate clause or provision of a statute: as, the act of the six articles (see below). $(d)$ A distinet charge or count: as, articles of impeachment. (e) A distinet item in an account or a list. $(f)$ One of a series of regulations: as, on a specific topic forming an independent tion of a book or literary publication, especially of a newspaper, magazine, review, or other periodical: as, an article on war, or on earthquakes and their causes.-6. A material thing as part of a class, or, absolutely, a particular substance or commodity: as, an article of
merchandise; an article of clothing; salt is a necessary article.-7. A particular immaterial thing; a matter.

Where nature has bestowed a show of nice attention in 1 have seen men, who ln this vain artict, perhaps might
l'ank ahve you. 8t. A concern; a piece of business; a smbject. -9. A point or nick of time joining two sucressive periods; a juncture; a moment; the moment or very moment. [Now rare or obso-
lete except in the phrase in the article of deatl (which see, below).]

$$
\begin{aligned}
& \text { Could my breatl } \\
& \text { Now execute 'em, they should not enjoy } \\
& \text { An article of time. } \quad \text { B. Jonson, Cat }
\end{aligned}
$$

coming to Hick's Hall upor the articte of my Lord Russel's trial was said to have had no little in menee on the jury and all the beneh to his prejudiee.

$$
\begin{aligned}
& \text { An infirm butlding just in the articte of falling. } \\
& \text { Wollaston, Relig. of Nat., v. } 99 .
\end{aligned}
$$
10t. The number 10, or any number ending in a cipher.-11. In gram., a word used attributively to limit the application of a noun to
one individual or set of individuals, and also to indieate whether the nouu used signifie indefinitely one or any one of the class which it names, or definitely a specific object of thought. The two articles are regarded as a distinct part of speech. They are in English an (betore conso-
nant-sounds $a$ ) and the. An was originally the same word as one, and in meaning is an unemphatic any; it singles member of the elass being capable of serving as example article. The was originally a demonstrative pronoun out a particular individual or set of individuals, and is consequently known as the definite article. Articles class of pronouns. Some languages, as Latin, have no articles; others, as Hebrew and Greek, have the definite
article only. The indefinite article is always of later formation than the definite. [The name article is a trans the Greek grammarians to the one article of that lan guage (the definite), on account of its frequent use after
the manner of a relative to join an adjectlve to a noun :
326

articulate

as, aring o a yatos, literally. man the good, for (the) man sociation, or articles of incorporation, the certif cate filed, in conformity with a general lsw, by person who desire to becoune a corporstion, and setting forth the rules and conditions upon which the association or cor-
porstion is fonnded.-Articles of Confederation. Se confederation.. - Articles of faith, the main or essentia binding statement of snch points as held by a particnla church or denomination: a doctrinal creed.- Articles of tmpeachment, the accusations in writing which form the basis of sn impeachment trisl. They take the place tion or complaint in civil, actions.-. Articles of Perth, flve articles agreed upon at a General Assembly of th
Church of Scotland convened by Janies VI. in 1618, en: joining certain episcopal observanees, such as the ohsery. ance of feast-days, kneeling at the Lord's supper, ete They were ratifled by the Seotch Parliament in 1621, snd and the people. - Articles of the peace, an ohligation to keep the peace for a certaio tine, under s peualty, an
with or withont sureties, imposed upon an individua with or withollt sitreties, imposed upon an individual there is just cause to fear that the party complsined harm, or procure a third person to do it.- Articles of Schmalkald, articles of Protestant faith draw up by Lnther, and sulmmitted to a meeting of electors, princes, and states st Schmalkald (or Schnalkalden), Germany, in 1537, lesigned to ghow how far the Protestants wer willing to go fin order to avoid a ruptiue with Ronie. ment snd discipline of the army aod nsvy. In Great passed every year. The articles of war of the United States are 128 in number; anything relating to the arnyy not in established regulations, issued from time to time by the War Department, copies of which are furmished and read to the troops.-City article.

As he [T. J. K. Oliphant] views mstters, we have been As hesily going down hill, in the article of our mother-
F. Ifall, $\mathbf{N}$. A. Rev., CXIX. 321. In the article of death (Latin, in articulo mortis), In the article of death, I give you my thanks, and prsy
Steele, Tatler, No. 8. Lords of the Articles. See lord. - Marriage articles. randum.-The Five Articles and the Five Points, statements of the distinctive doctrines of the Arminians
and Calvinists respectlvely, the former promulgated in and Calvinists respectlvely, the former promingated in 1010 in opposition to the restrictive principles of the
latter, which were sustained by the synod of Dort in
1619 , and are the following: partieular predestination, limited atonement, natural insbility, irresistible grace, and the perseverance of saints. The discussion of these lifferences at that time is sometimes ealled the quine
quarticutar controversy. - The Lambeth Articles, nine
articles drawn up in 595 at Lsmbeth, England, intended
to enbody the Cslvinistic doctrine respecting predesto embody the Cslvinistic doctrine respecting predessess no eccleslastical anthority.- The Six Articles, impotimes called the "whip with six strings" articles
passed in 1539 , in the reign of Heury ViII. They decreed the aeknowledgment of transubstantiation, the
sufficiency of conmunuton in one kind, the obligation of vows of ehastity, the propriety of private masses, celibacy of the clergy, and auricular confession. Acceptance
of these six doctrines was made olligatory on all persons under the severest penalties. The act, however, was - The Thirty-nine Articles, a statement of the particular points of doctrine, thirty-nine in number, maintained by the Church of England, first framed by an ecclesiand promulgated in thirty.nine articles by a convocation
held in Lonion in $1562-63$. With some alterations they were adoptet by the Episcopal Church of Ireland in with certain modifications, by the Protestant Eplscopal Church of the United States in 1801. - The Twenty-five
Articles, the doctrinal basis of the Methoulist Episcopal
Church, substantlally the Thirty-nine Articles of the Church of England, with the omission of the 3d, 8th, 13th, 15th, 1hey were originally framed by John Wesley, and, with held, in 178

article (är'ti-kl), v.; pret. and pp. articled, ppr.
articling. [< article, n.] I. trans. 1. To state in detail; particnlarize; speeify. [Rare.]
[Ro

If all his errors and follies were articled agalust hiou.
Jer. Taylor, Holy Living (ed. 1727), p.

2. To accuse or charge by an exhibition of articles or accusations. [Rare.]

What I have orticled against this fellow
I justify for truth. If iddlet on, Spanish Glysy, v. 1.

3. To bind by articles of covenaut or stipulation: as, to article au apprentice.

II. + intrans. To agree by articles; stipulate. Came Sir John Kiviet to article with me about his briekThey have su articled with us. Then he articled with her that he should go away when
Selden, Table-Talk. articular (är-tik'ū-lär), $a$, and $n$. [<L. articularis, pertaining to the joints, < articulus, a joint: see article.] I, $a$. 1. Belonging to or
affecting an articulation or joint; entering into he composition of an articulation: as, the aricular surface of a bone; an articulur eartilage an articular disease. - 2. In zoöl., artienlate; specifically, of or pertaining to the Articulata. [Rare.] - Articular bone. Same as articulare.-Arront of the glenoid fossa; the preslenoid process.- Arcular process of the lower Jaw, the process which I. $n$. Same as articulare.

articnlare (är-tik-ū-lā'rē), $n_{\circ} ;$ pl. articulariı (-ri-ï). [NL nent, of L articularis : see articutar. $\mathrm{A}$ bone of the lower jaw of vertebrates below mammals, by means of which the jaw or mandible articulates with its suspensorium. See euts under acrodont, Cyclodus, and Gal. ince.

articularly (är-tik'ū-lär-li), adv. 1. ln an aricular manner.-2. Artic

articulary (är-tik'

Articulated by a clublile articulary heal with the mas
Encyc. Brit., XII. 64?

Articulata (är-tik-ī-lā'tä), $n . p l$. [NL., nent. pl. of L. articulatus, jointed: see articulate.] In zoöt., a name variously applied. (a) In Cuvier's system of classiffeation, the third prime division of the in wbich the hody is made np of a serles of rings (metameres), is endoweil with a ganglionated nervons system and possesses distinet respiratory organs. It is divided jolla, and Annelides. This division corresponils to the Anrulosa of some zoölogists, but neither of these terms is now recognized by lesding naturalists. Cuvier's first hropoda, while his Ammeticles are referred to another phy. lum, Vermes. (b) One of two orders of Brachiopoda, sometimes styled the Arthropomata (which see), the other order being called Inarticutata. It corresponds to the arthropomatous Brachiopoda, containing those brachioporls in
which the shell is hinged, the nuantle-lobes are not entirely free, and the intestine is crecal. (c) One of two divisions of cyclostomatous polyznans, containing the families Salione of two divisions of cyclostomatous polyzoans, represented hy the family Crisiidne. Also called Radicata. $(e)$
One of two divisions of crinoids, the other betng Tessel. articulate (är-tik' ū-lāt), r.; pret. and pp. ar ticulated, ppr. articulating. [< L. articulatus, pp. of articulare, divide into joints or members, article, ete. : see article. . I trans. 1. To joint; unite by means of a joint: as, two pieces loosely articulated together. See articulation, 2.

Plants ... have many ways of articulating thelr parts
with one another.
II. Spencer, Prin. of Biol., 8215. The delicate skeleton of adinirably articulated and related parts which underlies and sustains every true work of art, and keeps it from sinking on itselt a shapeless heap, Lowell, study Windows, ]1, 123. 2. To utter articulately; produce after the manner of human speech.

The logmatist knows not by what art he directs his

To ntter in aistinet syllables To formulate or set forth in articles; draw up or state nnder separate heads.

These things, indeed, you have articnlated,
Proclain'd at narket-crosses, read in ehurch

=Syn. 2 and 3. Pronounce, Enunciate, ete, (sec utter)

II. intrans. 1. To form an artienlation (with); connect (with): as, the ulna articulates with the humerus. - 2. To utter articulate sounds ; ntter distinet syllables or words: as, to articulate distinctly.

It was the eager, inarticulate, unimstructed mind of the whole Norse people, longing only to become articulate, to
gorlyle.

3t. To enter into negotiations; treat; come to or make terms.

The best, send us to Rom

The best, with whom we nıy articulate,
For their own good, and ours. Shak., Cor., 1. 9.

articulate (är-tik'í-lāt), a. and $n$. [< L. $a r-$ ticulatus, jointed, distinct (applied partieularly to utterance), pp. of articulare: see articulate, $r$.$] I. a$. 1. Jointed; segmented; artieulated: as, an articulatc limb; an articulate animal.2. Specifically, having the character of the $A r$ ticulata.-3. Jointed by syllabie division; divided into distinct successive parts, like joints, by the altermation of opener and closer sounds, or the intervention of consonantal utterances (sometimes also of pause or hiatus) between vowel sounds: said of human speech-utterance, as distinguished from other sounds made by 


\section{articulate}

human organs, and from the sounds inade by the lower animals. The terms articulate, artipututinn, etc., ns applied to juman ntterance, are not seldon tended were that of the physical organs of utterance, a narrowing or clusing of the organs at aome polnt or po sueh action, however, belongs to all utterance, articulat or inarticulate Heriee-4. Clen1; distinet.

La Fossense's roice was naturally solt ani low, yet 'twas The aentiment of Right, once very low anil indistinct, but ever more articulate, because it is the volee of the

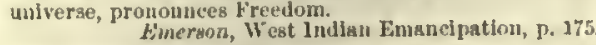
5. Formulated or expressed in artieles, or in separate particulars. [Rare.]

Total changes of party nnd articuiate opinion. Carlyle. 6t. Consisting of tens: as, articulate numbers Articulate adjudication. See ar

articulately (ür-tik' û-lật-li), adv. 1. Iu a joint ed manner; by joints: as, parts of a body ar liculately uniterl.-2. In an artieulate inanner with distinct utterance of syllables or words.

Is it for nothing the wind sounds almost articulate metimes - sings as 1 have lately heard it aing at night

3. Artiele by article; in detail.

1 had articuiately set down in writing our polntas
Fuller, Cli. Hist., ix. 110

articulateness (är-tik' ū-lạt-nes), $n$. The qual ity or eondition of being artieulate.

articulation (är-tik-ū-lä'slon ), $n$. [< L. articulatio $(n-)$, a putting forth of new joints, as a vine, a disease of the vine at the joints, lit. a joint a disease of the vine at artieulate: see articu late.] 1. The aet of articulating, or the state of being articulated. (a) The aet of putting together so as to form a joint or joints. (b) The uttering of articulate sounds, -2 . In a eonerete sense: (a) In anat., a joint, as the joiring or juncturo of bones or of tho movable segments of an artliropod. The articulations of bone are of three kinds : (1) Diarthrosis, or a movable eonne ball-and-sacket foint: arthrodia or the gliding joint : ginglymus, or the himge-jofint; the trochoid, or the wheel-an axle joint, otherwise ealled diarthrosis rotatorius; and the condyloid, or saddle-joint. (2) Synarthrosik, immovahie (aee these words). (3) Amphinethosis, an articulation with tra. (b) In bot.: (1) A joint; a place where separation takes plaee spontaneously, as at the separation takes plaee spontaneously, as at the as a leaf or the pedicel of a flower, or easily, as at the divisions of the stem of the horsetail. (2) A node: applied either to the thiekened jointlike part of the stem where a leaf is plaeed or to the spaee between two such points. (c) In gram., an articulate sound or ut teranee; espeeially, a eonsonant, as ordinarily affeeting and marking syllabic division.-Acromloclavicular articulation. See ncromioclavicular:- Articulation of a science, the system upon which its parts are put toin while the deaf and diumb are taught to apeak.-Cla-
vate articulation. See ciarate.-Harmonic articu-

articulative (ïr-tik'ū-lä-tiv), a. [< articulate $+-i v e$.$] Pertaining or relating to articulation.$

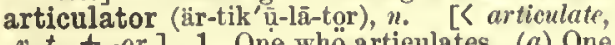
$\left.v_{.} t_{0},+-o r_{.}\right]$1. One who artieulates. $(a)$ One who utters or pronounees words. $(b)$ One who apparatus for obtaining the correct artieulatios apparatus for obtaining the eorrect artieulation for preventing or euring stammering. -4. An attaehment to the telephone, producing regularity of vibrations and smoothness of tone.

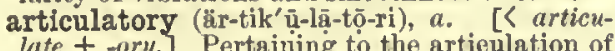
late +

articulus (är-tik'ū-lus), $n . ;$ pl. articuli (-lī).

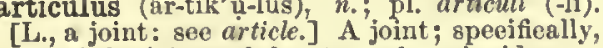
one of the joints of the stem of a erinoid.

artiert, n. An old form of artery. Marlowo.

artifact (är'ti-fakt), $n$. and $a . \quad\left[<L_{0} \cdot \operatorname{ar}(t-) s\right.$, art, + factus, made: see fact.] I. n. 1. Anything mado by art; an artificial produe

Also artefactum.

II. a. Not natural, but produced by manipulation, as some microseopic feature in a hardened tissue.

Also spelled artefact. [Rare in all senses.] artifex (är'ti-feks), n. [L.: see artifice. ] An artifieer. [Rare.]

artifice (ür'ti-fis), $n, \quad[<F$, artifice, skill, cunning, < L. artificium, a craft, employmont, art,

\section{artificially}

It lu piefure] tuturm nuture: artipicial strite

Shak., T, of $\mathrm{A}$., i. 1.

mung (ef. artifex (urtific-), artist, muster in make.] 1t. The art of making.

Strabo aftirmeth the Britons were so simple, that though they had not the artifice of eheese
Sir $T$. Broune, Yuly. Err., p. 312

2†. An ingenious or skilfully contrived work. The inaterial universe, which is the artifice of Got, the rtifice of the best mechanis Cud worth, Morality, iv. 2,13 3. Skill in desiguing and omploying expedients; artful contrivanee; address; triekery.

Ifla [Congreve's] plots are cumstructed without inuehart 4. A erafty deviee; $"$ in ingenious expedient trick; shift; piceo of finesse.

Titose who were eonscious of guilt employed numerom artifices for the purpose of a verting inquiry.

=Syn. Artifice, Manoutuer, Stratagern, Wile, Trick, Ruse, inesse, device, contrivanee, cunning, craft, deception, heat, fraud, guile, imposition, dodge, suhterfuge, doubleto compass an end by decelving others, not necensarily, owever, with evil inteut Thes all iniply manageme and adiress. An artifice in prepared with art or care; is eraftily devised. II anoeucer suggests something ninre elaborate or fntricate, a carefully contrived movement of course of action for a definite purpose; it is the quiet or to carry a polut. Strafagem is, like manoever, a fgura to carry a polut. Stratagen is, like manoeuver, a figura wile is upon a smaller, a device to deceive one who th the object of an imagined warfare, so that we may catch him at a disadvantage and discomfit him, or, more gener alty, a carefully prepared plan to carry one's point witl
snother - to eapture it or him, so to apeak. A wite may snother-to eapture it or him, so to gpeak, A wiie may and most dishonorable of these words; it may be a lo the purpose of cheating, or something as bad. A ruse a deception of some elaborateness, intended to co:er one intentiona, help one to escape from a predlcament, ete. to happen, without spparent interference on our part Finesse is subtlety in action; it fis a more

A favorite artifice [with Venetian beggars] is to a] proach Clarity with a alice of polenta in one hand, an with the other extended, implore a soldo to buy cheese
to eat with tlie polenta.
Hoveils, Venetian Life, xx. Pope completely suceeeded [in startling the public] by D. Israeli, Quar. of Auth., II. 100 This goid mist coin a stratagem,

Which, cunningly effected, wilt beget

Slink., Tit. And., il.

Women's hypocrisics! their subtle viles,

Betraying amiles, feigned tears, ineonstaucles :

But, Valentine being gone, I'll quickly cross,
By some sly trick, binnt. Thurio's dult proceeding.

The departure of the Malurattas was a ruse. . Their objeet in leaving the Carnatic wss to blind Chunder
Sahib, and in this they fully auceeeded. [Sont]uc] was not provided with the uanal means whilch

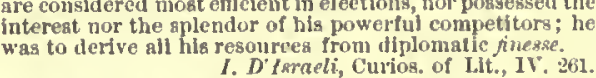
artificer (är-tif'i-sèr), n. [< ME. artificer (cf. mod. F. artificier, maker of fireworks, $(M$ artifiarius, artist, artisan), L. artificium see artifice and -er1.] 1. A maker; a construe-
tor; a skilful or artistie worker; a handicraftman; a meehanic.

But till some geniua as universat as Aristutle shall
arise, who can penetrate into all arta and aclences without the practice of them, I shall think it reasonable that the jndgment of an artificer in his own art ahould be preferahle
to the opinion of another man, at least whell he is not to the opinion of another man, at least
bribed by interest, or prejudiced by mallee.

$$
\begin{aligned}
& \text { Dryden, Ded. of All } \\
& \text { with their artificers. }
\end{aligned}
$$

$$
\begin{aligned}
& \text { R. } J \text {. Stevenson, The Dynamiter, p. } 25 \\
& \text {. Sticers. }
\end{aligned}
$$

2. One who eontrives or devises; au inventor especially, an inventor of erafty" or fraudulent iv. 121; "artificer of lies," Dryden; "let you alone, eunning artificer," B. Jonson.-3. Milit. a soldier-mechanie attached to the artillery and engineer service, whose duty it is to eonstruct and repair military materials. $-4 \nmid$. One who uses artifice; an artful or wily person. - Artificers' knot, a knot conalsting of two hali-hitehes rtificial (är-ti-fish'al), $a$ and $n$.

ficial< 1 artificialis, of or belong ficial, $<$. artifeialus, of or belonging to art, artificium, art, skill, theory, 8ystem, etc.: see artifice.] I. $a_{.}$1t. Of or pertaining to art; in 2. Contrived with skill or art; artistically done or represented; elaborate. soune birls builh highly artificiai nest. Cromes. 3. Made or contrived by art, or by humau 8kill and labor: opposed to natural: as,
ficial heat or light; an artificial magnet. That is the yattern of his fatiler's glory: To make another rirtificial nature. And change nil other seasona finto Dekker and L'ord, Sun's Darling, iv. I.

All artificial sources of light depend upon the develop4. Made in imitation of or as a substitute for that whieh is natural or real: as, artificial pearl. or diamonds; artificial flowers,-5. Feigned. fietitious; assumed; affeeted; constrained; not genuine or patural: said of things.

Wet my cheeks with artificiai tears,

Shak., 3 Ilen.
0 iet them [the linnets] no'er with artifciai note,

But sing what Ileaven Inspires, and wander where they wlli.

The while artificiai dialect of books has come into plisy
De Quincey, Style,

6. Full of affeetation; not natural: said of per80ns.

Citles force growth, and make men talkative and enter-
taining, but they make them artificial. Emeraon, Farming

7ł. Artful; subtle; crafty ; ingenious.

We, Ilermin, like two artificini gods

Have, with our neediea, created both one flower. Artlfctal argument, in thet., an argument invented by which are called inartificinl arguments or proofs.-Artiliclal caoutchouc. See caoutchouc. - Artincial cinnabar. See cinnabar. - Artificlal clasaification, in nat. of resemblance or difference, witbout reference to nat tu ral atinities, the chiel objeet being convenience au.
facllity of deternination.- Artifleial day. Sec day. Artificial gems, imitationa of gems, made of a kind of capable of produeing tho deatred color.-Artinctal harmony. See harmony. - Artincial horizon. See hmiIrom the heavenly bodles. - Artis cial lines, on a sector or seale, lines so contrived as to represent the logarith-
mise sines and tangents, which, by the help of the line of
numbers, sotve with toleralle exactness questions in trigononetry, navigation, etc- Artificlal marble. See Artifictal mineral, a mineral made in the laboratory, not by processes of nature alone.-Artifictal mother. See brooder. - Artificlal numbers, logarithms. - Artificial
person. See yerson.-Artificial printing, a method of printing from an etched plate in which the print owes nere or less of its tone to the way in winich the ink has with a stiff rag, or by wiping with the rag only. In arti. creasing or diminishing the pressure, and hy varlety of inf.-Artificial aines, tangenta, etc., the Jugarithms of -4 and 5. Sham, pretended, вpirious.-4-6. Unatural,

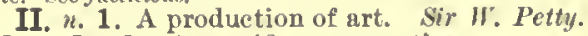
[Rare.] - 2†. An artifieer; an artisan.

No, air, ye are decelved, I am no peasant; 1 am Bunch
the boteher : peasants le plonghmen, 1 am an artificial.

artificiality (är-ti-fish-i-al'i-ti), $u . ;$ pl. artificialities (-tiz). [< artificial $+-i t y]$.1 . The quality of beit

It is a curious commentary on the artificiality of ous lives, that men must be disguised and masked before they ality, and display the true featurea of their nature.
Loweil, Freside Travela,

2. That which is artifieial; an artificial thing or eharaeteristic.

rtificialize (är-ti-fish'al-iz), $r . t$; pret. and pp. artificialized, ppr. artificializing. [< artificial + -ize.] To render artificial. [Rare.]

It has a rificialized large portlons of mankind.

artificially (är-ti-figh'ąl-i), adv. 1. In an artifieial manner; by art or hnman skill and contrivance.

The entire spot, elurch, mankion, cottagea, and people, form a piece of snelent England
from the intrusion of modern ways.

2t. With good contrivanee; with skill or ingenuity.

A grove of atately trees, amongst which are sheept,
hepherda and wild beasts, cut very artificially in a gres The spider'a web, finely and avelyn, Diary, Oct. If Tillotson, Sermons, 1. $x$
Wet my cheeks with artificiai tears, 
artificially

3. Artfully ; craftily. [Rare.]

There was not, perlagis, in all England a person who unclerstout more artificialy to disguise lier passions than
the late queen. Surit, Clange in Queen's Ministry. artificialness (ar-ti-fish'gl-nes), $n$. 'The quality of being artificial.

artificioust (är-ti-fish'us), a. [ $[<]$. artifieieux, $<$ L. artifiensus, made with art, artificial, < artificium: art, ete.: sce artifice.] Same as artifieinl.

artilizef ("ir'ti-liz), $\imath^{\prime} t_{0}$; pret. and pp. artilized ppr.artilizing. [<OF.artialiser, make artificial (Cotgrave), as it < *artial, adj., < art $+-i a l$ see $a r t,-a l,-i z e$, and ef. natur-al-ize. Cf. also OF. artiller, fortify, equip, also prepare or do with art: see artiller.] To give an appearane of art to; render artificial. [Rare.]

If I was a plailosopher, says Nlontaigne, I would nsturalize art, insteanl of attilizing nature. The expression ing
odd, bit the sense is good. artillert, $n$. [ME., also arteller, $<\mathrm{OF}$. artiller artillier, arteiller (also articulier, after the ML $=$ Sp. artillero $=\mathrm{Pg}$ artilheiro $=\mathrm{It}$ artigliere =Sp. artillero $=\mathrm{Pg}$. artilheiro $=\mathrm{It}$. artigliere us (ef. OH. artiller, artillier, fortify, equip, provide with artillery, also prepare or do with art, $=$ Sp. artillar $=$ Pg. artilhar $=$ It. artigliare provide with artillery, < ML. "artieulare), dim. of L. $\operatorname{ar}(t-) s$, art. Cf. engine and gin 4 , ult. $<$ L. ingenium, genins, skill. The word has also been referred to $\mathrm{L}_{\text {. }}$ artieulus $(>\mathrm{OF}$, arteil artoil), a joint, dim. of $L$. artus, a joint, which is closely related.] A maker of implements of is closely related.] A male

artillerist (är-til'e-rist), n. [<artillery $+-i s t$. 1. A person skilled in designing and construct ing artillery.

Our artillerists hsve paid more attention ... to the de i. A. l'roctor, Light science, p. 25.

2. One skilled in the use of artillery; a gun ner; an artilleryman.

artillery (ïr-til'e-ri), n. [< ME. artylerye, ar tylrie, artilrie, artelrie, etc., $<$ OF. artillerie,
arteillerie $=\mathrm{Pr}$. artilheria $=\mathrm{Sp}$. artilleria $=\mathrm{Pg}$. artilharia $=\mathrm{It}$. artiglieria (ML. reflex artilla ria, artilleria), <ML. as if *articularia, fem. ab stract to "artieularius : sce artiller and -ery.] 1t. Implements of war: in this sense formerly with a plural.

With tourcs suche as lisve castiles and other maner ed

Chaucer, Tale of Melibens. In particular - 2†. Engines for diseharging missles, as eatapults, bows, crossbow's, slings, cte. And Jonsthan gave his artillery unto his lad, and said
unto him, Go, carry then to the city. The Parthians, having all their hope in artillery, over3. In modern use, properly, all firearms dis charged from earriages, in contradistinction to small arms, which are discharged from the hand; cannon; ordnance. Guns, howitzers, and mortars are the three kinds of artillery employcd in the light and heavg artillery, according to their charscter, and principal use. See phrases below.

Hence-4. The particular troops employed in the service of such firearms. -5 . The scicnee nance.-Artillery fire. See fre.-Fleld-artulery. Same ss light artillery, but often used syeciflcally for foot tillery, artillery designed for very rapid evolutions, th cunners being either all mounted or accustomed to ride up onl the ammunition-chests when the pieces are to be dragged
from one part of the fleld to another. - Foot-artillery, istinguished from horse-artillery It is used in tion with infsintry. - Heavy artinery, all artillery not formed into batteries or equipped for field evolutions; it is divided into siege and sea-coast artillery.-Horse-ar-
tillery, light field- or machine-guns, of which the canholleers in manceuvering or marching are mounted on artillery, artillery for service in the fleld. It is organized bers according to its special function, and with machineguns, and includes fying artillery, foot- or field-artillery, horse-artitery, and mountaill-artillery. Also eslled feldcher, used in mountain warfare, and monnted elther on Park of artillery. See park.- Royal regiment of arbelonging to the British army. This force is divided int a number of hrigadcs, which in respect of size would co respond with the reginents into which the other forces
are divided.- Sea-coast artillery, artillery consisting of guns of the heaviest caliber, used for the arniament of per msnent works chiefly on the sen-coast. Tibeir carriages do systems of mounting are use I witis such artillery, nsme-
328

artless

arriage - Siege-artillery, artillery used in attacking peratinns in war, wheunted on carringes for transport tion; when employed in the defense of fleld-works it is ometimes called garrison-artillery. - Train of artillery mumber of pieces nt ordnance, monnted on eart
with all their turniture, and ready for marching.

artillery-carriage (är-til'ẹ-ri-kar"āj), $n$. See

rtillery-level ("ir-til'ce-ri-lev"cl), n. An instrument for indicating the angle of elevation which it is desired to give to a piece of artillery in aiming. It is made to stand on the plece, and by the axis of the piece with the horizon.

artilleryman (iir-til'e-ri-man), $n . ;$ pl. artillery men (-men). [s artillery + man.] One who serves a piece of artillery or cannon; a soldier in the artillery cerps.

artillery-plant (ir-til'e-ri-plant), $n$. A name given to some cultivated species of Piler, as $I^{2}$. serpyllifolia and $P$. muscosa, natives of tropieal America. The name las allusion to the forcible discharge of the pollen from the anthers by the sudden artimorantico (är-ti-mōr-än-tē'kộ), n. An alloy imitating old gold, composed of tin, bismuth, sulphur, and copper.

artiodactyl, artiodactyle (är"ti-ō-dak'til), $a$ and $n$. [ [ NL. artiodaetylus, < Gr. áprıos, even in exactly, just now, $<\sqrt{ } * a \rho$, join, fit, redupl.

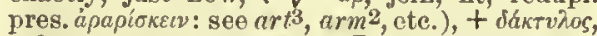
a finger, tee: sce daetyl.] I. $a$. Of or pertaining to the Artiodactyla; cloven-footed; even ing to the Artiodactyla; clor

II. $n$. One of the Artiorlactyla.

Artiodactyla (är"ti-ō-dak'ti-lï), n, pl. [NL., neut. pl. of artiolaetylus : seo artiodaetyl. ] An order or a suborder of ungulate or hoofed mammals which are cloven-footed or even-toed and have hoofs in pairs (either two or four), as all ruminants (Bovide, Cervide, etc.) and hog-like ungulates (Hippopotamida, Suida, ete.): opposed to odd-toed ungulates or Perissodactyla, as the horse, rhinoceros, tapir, etc. The chsrac. the two serles named, though various extinct forms go far toward bidging over the gap between them. The func-
tionsl diglts of the Artiodactzla sre the third and fourth of the typical pentadactyl foot, forming the pair of large true hoofs, in addition to which there unsy be present a
pair (second and ffith) of smaller hoofed digits, the false hoofs. The metscarpals and metatarsals are correspond fngly modifled, in typicsl cases by the reduction of the lat larged third and fourth into a stont single canon-bone.
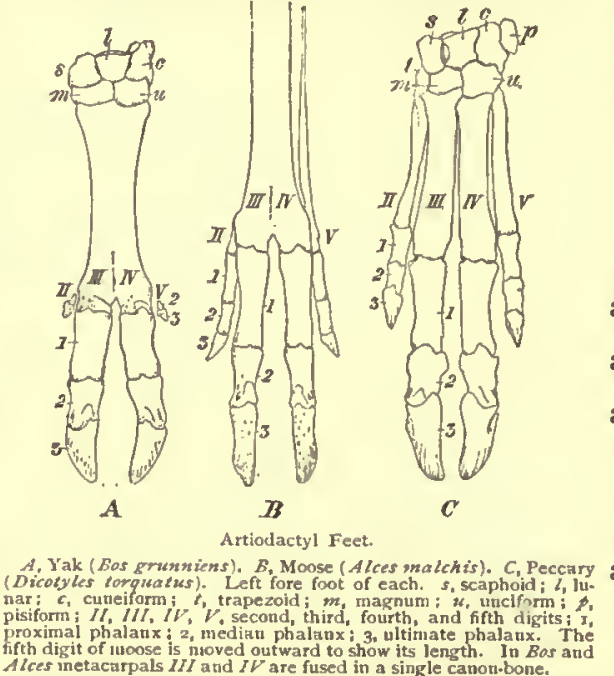

There are also modiflcations of the carpal and tarsal bones. tebre are, in general, 19: dor'sal 12-15, lumbar 7-4. The premaxillsry hones are inore or less flattened toward their is more or less subdivinted bear no teetil. The stomach is more or less subdivided and complex. This group in
cludes all the ungulate (not the solidungulate, however) cludes all the ungulate (not the solidnugulate, however)
animals domesticated from time immemorial, as the ruminants and the pigs, all the wild ruminsits, as the deer and artiodactyle, $a$. and $n$. See artiodaetyl.

artiodactylous (är"ti-ō-dak'ti-lus), a. [As artiodaetyl +-ous.] Same as artiodaetyl.

artisan (är'ti-zan, in Fingland often ar-ti-zan'), n. $[$ Also artizän; $<$ F. artisan, earlier artisien,
artist, $=$ Sp. artesano $=$ Pg. artesão $=$ It, artigiano (ML. reflex artesanus), < ML. * artitianus, L. artitus, skilled, pp. of artire instruct in arts, < $\operatorname{ar}(t-) s$, art, skill: seo art2.] 1. One killed in any art, mystery, or trade; a handiraftsman; a mechanic.

The painter who is content with the praise of the world in respect to wliat does not satisfy himself, is not an artist,
but an artisan. The soldier was on a sudden converted into an artisan and, instead of wsr, the csmp echoed with the sounds of
pesceful lahor. $2 \nmid$. One skilled in a fine art; an artist. Best and happiest artisan,
Best of painters.

Guardian.

artist (är'tist), $n . \quad[<\mathrm{F}$, artiste $=\mathrm{Sp} . \mathrm{Pg}$. It. ar tista, < ML, artista, < L ar $(t-) s$, art: see art $^{2}$ and -ist.] 1 . A person of especial skill or ability in any field; one who is highly accomplished especially, one versed in the liberal arts.

The wise and fool, the artist and unren

Shak., T. and C., 1. 3

Some will make me the pattern of ignorance for mak ing this Scaliger [Julius Cresar] the pattern of the genera] artist, whose own son Joseph might liave been hls father
in many arts. 2. One skilled in a trade; one who is master of a manual art; a good workman in any trade: as, a tonsorial artist. [Obsolete, collequial, or vulgar.]

When I made thls an artist undertook to initate it, but "You shall have no cause to rue the delay," said the gmith, " for your horse ghall be better fed in the mesntravel." With this the artist left the and nat and siter a few minutes intervsl. Seott, Kenilworth, Ix. 3. One who practises any one, or any branch, of the fine arts; specifically, a painter or a seulptor.

Miss Sharp's father was an artist, and lin thst quality had given lessous of drawing in M iss $P$.'s sehool.
Thackeray, Yanity Fair, J. it. Love, unperceived,

A more ideal artist he than all,

Came, drew your pencil from you. sions, as an actor, a tenor, or a dancer. -5 . In $-6+$. One whe practises artifice; a trickster. artiste (är-tēst'), $n$. [F., an artist : see artist.] One who is peculiarly dexterous or skilful in the practice of some art not one of the fine arts; one who makes an art of his employment, as a dancel, a hair-dresser, or a cook same as artist, 2 and 4.

artistic (är-tis'tik), a. [< $\mathrm{N}^{\prime}$ artistique, <artiste: sec artist and -ie.] Pertaining to art in any formity with art or with an art; displaying perfection of design or conception and execution. specifically, pertaining to or elaracterized by art in the esthetic sense; pertaining to onc of the fine arts.

To be artistic, tlust is, to excite the feeling of besuty cffectuslly, the notcs [of a song] must not be sll forte or ous the grsdations - supposing these are such as to satisfy Artistic printing, in etehing, same as artificial print

artistical (är-tis'ti-kal), a. 1. Same as artistie. -2t. Produced by art; artificial.

artistically (är-tis'ti-kăl-i), $a d v$. In an artistic manner.

artist-like ("är'tist-lik), a. 1. Befitting an artist.-2. Executed in the manner of an artist; conformable to the rules of art.

To thls day, though we have more flintshed irswings, we list sre more artist-like.

artistry (är'tis-tri), $n$. [< artist + -ry : see -ery. $]$

1. Artistic pursuits collectively. Browning.quality.

The scene overhowered lyy these heavenly frescoes, J. James, Jr., Trans. Sketches, p. 203.

Artium Baccalaureus (är'ti-um bak-a-lâ'rë-

us). [NIL.. NI.] Bachelor of Arts. See bäehelor.

Artium Magister (är'ti-um mạ-jis'tèr). [ML.,

NL.] Master of Arts. See master.

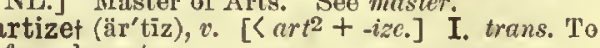
form by art.

II. intrans. To live by or exercise an art. Florio.

artless (ärt'les), a. [<art2 + -less. $]$ 1. Unilfui; wanting art, knowledge, or skill.

The high-shoed plowman, should he quit the land,

Artless of stars, and of the moving sand.

Dryden, tr. of Persius, Satires, v. 249.

In early times very little that resembles modern joinery
was known; every part was rude, and joined in the most 
2. Withont knowledgo of art; ignorant of the art-union (iirt'ī-nyon), n. An association or arval', arvel (ïr'vil, -ve]), $n$. and a. [Now fine arts. [lare.]

And as for Mr. Ruskin's worid of art heing n place where he may take life casily, wo to the luckiess mortal wanderer soun beglns to lewk back with inthite longing to the lost jaralise of the urtest.

3. Showing ne artistie skill ; inartistic; rude. [iare.]

IIni it been n practice of the Saxons to get up these assemblages of crless und massy pillirs, thore specimen

4. Tree from guile, eraft, or stratagem; simplo; sineero; unaffeeted; undesigning; unsophisti cated: as, an artless mind.

The littlo artless Resey wajbled on her pretiy ditties.

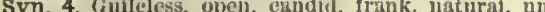
fected, ingenumus, sinple-ninded, mive, honest.

artlessly (iirt'les-li), arlv. In an artless manner. (a) Withont art or skill. [Raro.] (b) Without guile; naturally; sinecrely; unaffectedly.

Soune buds she arranged with $\mathrm{n}$ vast deal of eare,

To look ns if artlexsly twincd in lier hair.

artlessness (iirt'les-res), mo 'The qu boing artless; simplicity; sincerity ; unaffeetedness.

artlył (iirt'li), a. [< art $\left.{ }^{2}+-l^{1} \cdot\right]$ Artistic; skiltul; artful. [Rare.]

Their artly and pleasing relation.

artocarpad (är-tọ-kär'pad), $n$. A member of the tribo Artocarpece. Linalley.

Artocarpeæ (äı-tộ-kär'pê-ê), n. pl. [NL., <Artocarpus, q. v.] A tribe of trees or shrubs under the natural order Urticacea, but by some botanists rotained as a distinet order, charaeterized gonerally by a milky juieo, small unisexual flowors numerous upon a fleshy receptacle, ereet anthers, and pendulous ovules. There are about 25 genera, Inelnding the fig (Ficus), the
cow-tree(Brosimum), the upas (Antiaris), the india-rubber tree of Central Ameriea (Castilloa), snd the breadiruit (Arlucarpus). The tribe is mostly trepleal, and is reprein soutliem Florida.

artocarpous, artocarpeous (är-tọ-kär'pus, -pō-ns), $a$. [< NI. Artocarpus + -ous, -cous, q. v.] Relating to the Artocarpea, or to the breadfruit-

tree.

Artocarpus (:ir-tọ̄-kär'pus), n. [NI., < Gr. aptos, bread (of unknown origin), $+\kappa a \rho \pi \delta \varsigma$,
fruit.] A gonns of tropieal trees, natural order Uruit.] A gonus of tropieal trees, natural order Urticacec, tribe Artocarpece. Mlany species are bar yield valunble timber, called angili-urood. The mos important apecles is $A$. incisa, the breadfruit-tree of the jack-trec, $A$. integrifolia, is the bread Iruit of tropieal Asla,

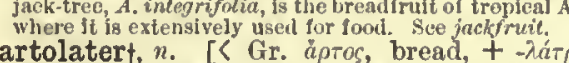

worship. See artolatry.] A worshiper of bread. artolatrył (är-tol'a-tri), n. [<Gr. a $\rho$ ros, bread, artolatryt (ar-tol diptri), Tho worship of bread, especially in the mass or eucharist.

artole $\left(a r^{\prime}\right.$ tō-lē), n. An East Indian weight, equal to 90 grains troy.

artophorion (är-tō-fó'ri-on), n.; pl. artophoria (-a). [Gr. aproфoptov, a pyx, a bread-basket

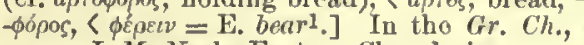
pyx. J. M. Ncale, Eastern Church, i.

artotype (ï ${ }^{\prime}$ tō-tip), n. [Irreg. < art2 + type.] A form of photelithograph printed in ink from a photographic plate in bichromated gelatin. artotypy (är'tō-ti-pi), n. Tho art or procoss of making artotypes.

Artotyrite (är-tō-tínit), n. [<LI. Artolyrito, pl., <Gr. aprórupos, bread and cheese, 〈à seet in the primitive ehurch who used bread and eheese in the eucharist, alleging that the first oblations of man were the fruits of tho earth and tho produce of their floeks. They admitted women to the priesthood and to the episeopate.

artsman (airts'man), $n_{.} ; \mathrm{pl}$. artsmen (-men). [〈art's, poss, of ärt 2 , man. Cf. craftsman.] $A$ man skilled in an art or in the arts; espe cially, a learned man; a scholar. [Archaie.] The pith of all seienees which maketh the artsman differ from the inexpert is in the middle proposition.
Bacon, Advancement of Learning, iI. xilj. \& 2. The irlumphs of an artaman
O'er all Infrnitieg.

If crsinger, Enuperor of the East, iv. 4.

No ar/sman is literally withent conscious and aystema. tized, aelected knowledge, which is sclence; and no aclen-
tifle man can remain slisolutely lnoperative.
Dr. J. Brovon, Spare Hours, 3il scr., p. 195. soeiety the object of which is to cultivate art, to aid in extending tho knowlerlge of and love for the arts of design, ol to give encouragement and aid to artists. The method cupluyed ly associa of works of art by lot anong subseribers to ther funits this distrif)utton beluk the clief inducement for subsertio. tipon. Snch art-unions were at one time numerous in the

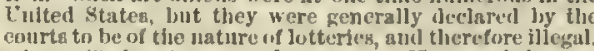
artus (iir'tus), $n_{*} ;$ pl. artus. [L., a joint, a limb: see articlc.] In anat., a limb; a niember an extremity.-Artus abdominalis, artus pelvcus, artus posticus, the al,dominal, pelvie, or hind limb. ectoral liml

art-wormt, $u$. [As art(er) + uorm.] Samo as arter.

Arum (ā'rum), n. [L., also aron, < Grr. àpow, the wake-robin.] 1. A genus of plants, natura

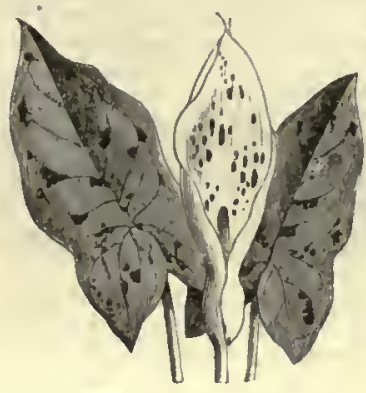
tives of Europo bordering on the Mediterranean. The ouly British spe (wake-robin, enekon pinders), the root of which yiclds a starel known as Portland see also ent under 2. $[l . c$.$] A name$ given in the plants belonging to the order Aracce, but not to the gonus Arum (although some of them wero formerly so elassed), as the arrow-arum (Pcltandra Virginica), tho dragon-arum (Arisama Dracontium), and tho water-arum (Calla palustris).

Arundelian (ar-und $\bar{e}^{-}$lyau $), a$. Pertaining to an Earl of Arundel, particularly to Thomas How ard, Earl of Arundol and of Norfolk (1592-1646). - Arundeltan or Arundel marbles. See marble. arundiferous (ar-un-dif'e-rus), a. [<L. aruneane, + ferre $=$ E. bearl.] Produeing reeds or

arundinaceous (a-run-di-nā'shius), a. [< L. arundinaceus, harundinaceus, like a reed, 3 haundo (-din-), a reed, cane.] Pertaining to a reed; resembling a reed or cane.

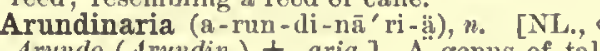
Arundo (Arundin-) + -aria.] A genus of tall woody grasses, allied to the bamboo, including about 25 species of America and Asia. $A$. macroxperma, the cane of the senthern United States,
and $A$. tecta, the amall or switch cane, are the only lombusaceous species tbat are found in Nortl America north of Mexico. The eane ranges frem Texas to Kentucky and Virginia, ocenpying rich river-boitoms and forming dense

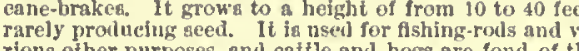
young plants and the seeds

arundineous (ar-un-din'e- -us), a. [< L. arundineus, harundincus, reedy, like a reed. (harund (-din-), a reed.] Resembling a reed; reedy.

Arundinicola (a-run-di-nik'ó-lii ), n. [NL. L. arundo, harundo (-din-), reed, + colere, inhabit.] A genns of South Ameriean elama$A$. leucocephala and $A$. dominicrna are two Brazilian speeies. Lafresnaye, 1839.

arundinose (a-run'di-nōs), $a$. [C L. arundinosus, better harundinosus, ahounding in reeds, harundo (-din-), a reed.] Abounding in reeds. Arundo (a-run'dō), $n$. [L. arundo, better $k n-$ rundo, a reed.] A genus of tall reedy grasses, with large, dense flowering panieles. There nie
6 or 7 speeies, whdely distributed over the globe, of which A. Donax is the most common, a native of the senth of
Einrope, Egypt, and the East, and alse found in the Finrope, Egypt, and the East, and alse found in the warmer parts of America. It is sometimes eulitivatel,
nud attalns a heighi of 0 or 10 feet, or even more, with
hroad and loug leaven hroad and long leaven. Its canes or atems are imported from spail

arura (a-rö'rä), n. [<Gr. å $\rho o v \rho$, tilled or arablo land, ground, a measure of land in Egypt, apóciv, plow, = I. arare, plow: see arable.] An ancient Egyptian measuro of surface, aceording to Herodetus the square of 100 cubits, which would be 27.35 ares, or 0.676 of an English aere. Under Roman ruje in Egypt another arura was estabished, cyual to 2 jngera, which was $f_{9} 6$ of the old arura. Also spelled aroura.

ruspex, aruspice (a-rus'peks, -pis), $n_{.} ; \mathrm{pl}$ aruspices (-pi-sëz). See haruspcx.

aruspicy (a-ris'pi-si), n. See haruspicy.
, also arvil aud aterill, fomnerly artall, rell, S ME. artell (ef. equiv, W. artcyl, appar. adated from the F.), appar. SIcel.erfol=OSw. anot = Dan. arröl, a wake, a funeral feast (ef. leel. erfi and erfilh(t-iildr, tho same), (Ieol. arf (Asw. $a r f=$ Dan. $a r v=$ AS. erfe, yrfe), inheritanee, $+0 l$, an alo, a feast: see alc, and of ridlal.] I. $\pi$. A funeral feast; a wake.

II. a. Conneeted with or relating to funeral elobrations.

the marringe and aroal gatherings aftre the aummer.

arval2 (iir'val), a. [<I. arralis, < arvum, a fielo] prop. nent. of arrus, that has been plowed, arare, plow: see arable.] Pertaiuing or relating to a rable or plowed land. - Arval Brethren or Brothers (Latin, 1 ratres A roales), a college nominally of twelve priests in anclent liome, who offered sacriflees, With a fixed cercmonlal, to the rural goddess Dia. The ists of then never give more than nine names, but the
college was suj'pwsed to have leen lustituted fiy Ronnlus

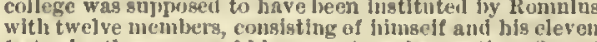
fuster-brothers, cons of hla uurse Acca Laurentia. One of their prineipai duties was the anutual prirormance of the public amlarvalia on the horders of the comntry, at the sme time with the private ones.

arvel, $m$. and $a$. Seo areall.

Arvicola (är-vik'ō-lịi), n. [NL., < L. arvum, field, arable land (see arval2), + colerc, inhabit.] The central and typieal genus of the subfamily Arvicolino, eontaining the great bulk of tho species which have perennial yrismatic molars,

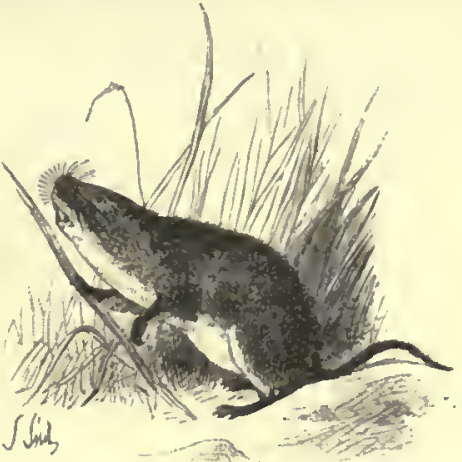

ungrooved ineisors, and no special peeuliarity of tho tail or elaws. The best-known specics are the hater-vole and flejd-vole of Enroje, $A$. amphilvine and arvicolid (är-vik'ō-lid), \#. Same as arvicoline. Arvicolidæ (är-vi-kol'i-dē), n. $p l$. [NL., $<A r$ vicola + -idec.] The Arricolina, rated as a famrvicolinase, 1840.

Arvicoln + -ina. $]$ Ono of soveral subfamilies into which the family Muride is divided. It contains those murine rodents which (exeept Erotomys) prismatie, rootlens melars, with the crowns and serrate periphery; ineisols uanally lroader trangversely than in
the opposite direction; the root of the under incisor some times causing a pretuberance on the inmer side of the
mandibular ratmus between the eondyloil process and
the strons haunulate angle of the nualible, whlch latter attalns the level of the nolar crowns; the zygonata high and the nasul bones not produced leyend the premaxijlaries; and the dental formula of 16 teeth, there leeing t any canines or premelars. The Arviceline are specially eharacteristic of the northern hemisplhere, and are very
abundnint in hlgh latitudea. They inelude all kinds of voles or fleld-mice properly so called, the water-rai of Enrope, the mendow-mice of America, the lenmings, the

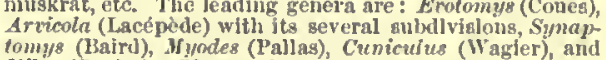
$F^{\prime} i b e r($ Cnvier). The gpeles are very numerons.
arvicoline (är-vik'o-lin), $a$. and $n$. [<NL. arvicolinus: see Articolinc.] I. $a$. 1. Inhabiting he Arvicoline

II. 1 . A rodent of the subfamily Areicoline. Also called arvicolid.

rvicolous (är-vik'ọ-lus), a. Same as arricoine, 1 .

arwet, $n$. A Middlo Finglish form of arrow.

ary (ãr'i or er’i), a. [Formerly also ery, a modieation of e er a for ever a (with exer in a gennow regenge) toward any, of which ary is nary.] Any: as, I haven't seen ary one of them. [Prov, Eng. and U. S.] 
-ary

330

-ary1. [L. -ürius (fem. -äria, neut. -arium), $>$ It. -ario, atjo, Sp. Pg. -ario, OF, reg. -air, usually - ier, -er $>$ s.

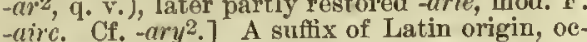
-airc. Cf. -ary ${ }^{2}$.] A suffix of Latin origin, occurring (1) in adjectives, as in arbitrary, con(2) in nouns denoting either ( $a$ ) persons, as untiquary, apotheeary, notary, secretary, ete., or $(b)$ things, as books, writings, etc., as in dictionary, glossary, breviary, diary, vocabulary, formulary, etc., or $(c)$ places, repositories, etc., as in apuary, granate.

-ary ${ }^{2},[\mathrm{~L}$. -aris (neut. -äre), > It. -are, Sp. Pg. $-a r, O F$. reg. -er, -ier (>ME. -er, mod. E. restored a $-a r^{3}$ q. v.), later -aire, mixed with -aire, E. -ary 1 .] A suffix of Latin origin, another form of -ar ${ }^{3}$, occurring in adjectives, as auxiliary, some of which are also used as nouns, as enuxili ary, capillery, military, ete.

Arya (âr'yä), n. [Skt.Ārya: see Aryan.] Same

But besldes these Aryas there were also the Dasyus, plexion and constsntly at war with tlie Aryas.

Aryan (är'yan or ar'ian), $a$. and $n$. [Also written Arian, after L. Arianus, belonging to Ariana or Aria, Gr. 'Apeía, A $A$ ía, or 'A $\rho$ ea, the easterm part of ancient Persia, < Skt. Arya, the name by which the Sanskrit-speaking immigrants into India the Sanskrit-speaking immigrants into India called themselves, in distinction from the abo-
rigines of the country, whom they called Dasyu, Sidra, ete. The ancient Persians gave them selves the same title (OPers. Ariya, Zend Ai$r y a)$; and it appears in the name of their country, Airyana or Irän: see Iranic. There are no traces of the word to be found outside of these two races. Its origin is obscure and disputed there is no probability that it has anything to do with a root "ar, plow.] I. $a$. Of or pertaining to the Aryans or to their speech. See II. Our faith, our chstomis, our language, were sll but frag
ments of the primitive Aryan stock common to Rome an Germany. $\quad$ E. A. Freeman, Amer. Leets., y. 118

II. n. 1. A member of the eastern or Asiati division of the Indo-European family, occupythe Bay of Bengal, in the two subdivisions of Persia, or Iran, and India. IThis is the older, minre scicntific, and still widely current use of the word. 2. An Indo-European or Indo-German or Ja phetite; a member of that section of the hu man race which includes the Hindus and Irani ans (Persians) as its eastern or Asiatic division and the Greeks, Italians, Celts, Slavonians, and Germans or Teutons as its western or European division. The languages of all these branches
or gromps of peoples are skin; that is to say, they sre te secndants of one original tongue, onee spoken in a linited
loeality by a single community, hut where or when it i Many words still live in India and England that have ern Aryans, and these are witnesses not to be shsken by any cross-examination. The terms for God, for lonse, fo and tears, for axe and tree, identical in all the Indo-Euro pean idions, are like the watchwords of soldiers. We with the lips of a Greek, a Germsn, or an Indian, we ree-
ognize hin ss one of ourselvea. There was a time when the ancestors of the Celts, the Germans, the Slavonians, the Greeks and Italians, the Persians and Hindus, wer living together beneath the same roof, separate from the Aryandic (är-yan'dik), a. Originating with Aryandes, Persian satrap of Egypt, condemne that of the great king himself.-Aryandic coin Aryanize (är'yan-iz or ar'ian-izz), v. t.; pret. and pp. Aryanized, ppr. Aryanizing. [<'Aryan appearance; impart Aryan peculiarities to. [Rare.]

European artists who have not lived umong the Afriean
racc sometimes try their hands at a pretty negress, bu race sometimes try their hands at a pretty negress, bu
they always Aryanize the type.

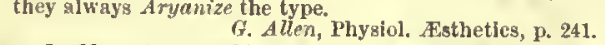

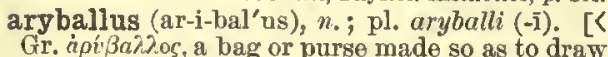
Gr. apt' $\beta a \lambda \lambda . o s$, a bag or purse made
elose, a vessel so shaped.] In archieol., a form of Greek vase. Probably in ancient times this name
was applied to a large vase with a was applied to a large vase with a
small neck, used for carrying water to small neck, used for carrying water to
the bath. In modern archæological nomenclature, It generally denotes 9 small vase shaped like a ball, with a
abort peck and a small oriflce sur-

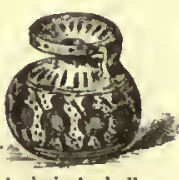
Same as aryteno-epiylottic. rounded by a broad flat rim, used like the alabastrum in ryepiglottic (ar"i-ep-i-glot'ik), a. [<ary(tenoid) + epiglottic.] Same as aryteno-cpiglottic. Folds of mucous nembrane, extending from the epiglottis to the arytenoid eartilages, are the aryepiglottic
Iigaments.

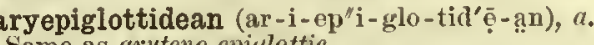

aryteno-epiglottic (ar-i-tē"nō-cp-i-glot'ik), a aryteno(id) + epiglottic.] In anat., pertain ing to the arytenoid cartilages and the epiglot tis.-Aryteno-epiglottic fold, one of two folds of mu-
cous membrane passing from the tips of the arytenoid cous membrane passing from the tips of the arytenoid esrtilages and the

of the epiglottis. aryteno-epiglottidean (ar-i-tē" nō-ep"i-glo-
tid'ệ-an), $a$. [< aryteno-epiglottideus + -an.] Samo as aryteno-epiglottic.

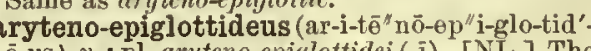
e-us), $n$.; pl. aryteno-epiglottidei ( $(-\mathrm{i})$. [NL.] The name of one of two pairs of small muscles of the larynx extending from the arytenoid cartilages to or toward the epiglottis.-Aryteno-epiglotti cartilages and spreading cut upon the laryngeal poneh, cartilages and spreading cut upon the laryngeal poneh,
which is compressed by the sction of the muscle. Also
called compressor saceuli laryngis.- Aryteno-epiglottlcalled compressor sacculi laryngis.-Aryteno-epiglott1apex of the grytenoll cartilages

arytenoglottidean (ar-i-té, ${ }^{\prime \prime}$ nō-glo-tid'ẹ-an ), a. Same as aryteno-epiglottic.

arytenoid (ar-i-té' noid), a. and $n$. [<NL. ury teenoides, < Gr. ápvтavoeidis, < ápítauva, fem. form of ápvip, a ladle or cup (〈apícu, draw water), + cldos, form.] I. ". Ladle- or cup-shaped: iu of the larynx, and also to the muscles connected with these cartilages. - Arytenold cartilages. nold muscle. Aryme as arytenoideus.

II. $n$. An arytenoid cartilage. tenoid.

arytenoideus ( $\mathrm{ar}^{\prime /} \mathrm{i}$-tẹ-noi'dẹ-us), $n_{\text {。 }}$; pl. arytenoidei $(-1)$. [NL.: see rrytenoid.] The aryteroid muscle, a muscle of the larynx passing from one to the other. - Arytenoldeus major, the arytenoidens.-Arytenoideus minor. Bame as aryte. noideus obliquus.- Arytenoideus obliquus, two small
oblique budles of muscular thers crossing behind the oblique buudles of muscular flbers crossing hehind the
arytenoid cartilages, regarded as parts of the aryteno-epi-
glottidean muscles. - Arytenoideus transversus, the glottidean m

as ${ }^{1}(\mathrm{az}), a d v ., c o n j .$, and mon. [ $<\mathrm{ME} . a s$, ase, als, alse, also, alsa, alsiru, al so, al swa, < AS. alswā, ealswā, eal swā (= OS. alsō $=$ OFries. us, ase, asa, als, alse, alsa $=\mathrm{D}$. als $=\mathrm{OHG}$.
alsō, MHG. alsō, alse, G. also, als), lit. ‘all so, wholly so, quite so, just so, being the demonstrative adv. so, qualified by the intensive adv. all. As a demonstrative, the word retains its the word, through weakening of force and accent, has been reduced to as. As is thus hiscent, has been reduced to $a s . A s$ is thus his torically $s o$ with an absorbed intensive, whose tional uses of so, the differences being only idiomatical. The peculiar form and uses of as have arisen out of the correlation so . . so (AS. suc W $s w \bar{a}$, or, without separation, $s w \bar{a} s w \bar{a})$, in The second term passed into the relative use and the first, remaining demonstrative, was strengthened by the adv, all (AS. eal swe

$s u \bar{a})$. The sccond term, as a relative, became weak in accent, and, after assuming the prefix all in conformity to the first, was gradually reduced, through also, alsc, als, asc, to as, to which, in turn, the first term in many constructions conformed. The resulting correlations so

so, so ... as, us . . so, as . . as, through ellipsis of one or the other term, extending often ellipsis of one or the other term, extending often to the whole clause, present in mod. E. a com-
plication of constructions which cannot be fully exhibited except at great length, and in connection with the earlier uses. They are also involved with the kindred correlations such ... as (sueh being historically so, with an absorbcd relational suffix) and same . as, in which the relative conj. as varies with that, and lead to the use of as as a simple relative pronoun.]
1. adv. (demonstrative or antecedent). The antecedent in the correlation as ... so, or as .. as: In that degree; to that extent; so far. The

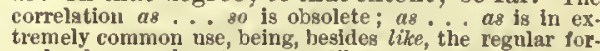
mula of comparison to express likeness or equality : as, as
black $a \&$ jet, as cold $a s$ ice, as wise as Solomon, etc.; the

\section{as}

verb in the relative clanse, when the sume as in the prin. cipal clause, being nsuslly omitted : as, it is
ice (sc. is); come $a s$ soon as yon can (ac. come).

He was al 80 [var. also, ald, $a s$ ] fresche $a s$ is tile moneth
of Hai.

Lo ! whiche sleightes and subtiltees

In wommen ben! for sy as bisy as bees
Ben they, vs sely men for to deeeyve.
Chaucer, Squire's Tale, Prol., 1. 4.

We [Americaus] use these words [faith and hope] as if they were as obsolete as Selah and Amell.
Emerson, Man the Reformer.

The relstive elsuse is often omitted, especially in collowill do $a s$ well (sc. as that); I would $a$ s lief walk (sc. $a s$ ridc). The bod man shall attend $a s$ bad a master.

The bad man shall attend $a g$ bad a master.
Fletcher, Wife for 9 Ylonth, v. 3. I will be temperste

In speaking, and as just in bearing.
Beau, and F'., Philaster, iv. 3.

These scruples to many perhaps seem pretended, to others, upon as good grounds, may secm real.
Milton, Elkonoklastes, xi.

The appointment of a regular wit has long ceased to be
part of the econemy of a morning paper. Editors flnd their own jokes, or ilo as well without them.
Lamb, Newapapers 35 Years Ago.

II. comj. (conjunctive or relative adr.). 1. The sequent in the correlations as ... as, so pressing quantity, degree, proportion, manner, ete. The relative uses are as exhibited in I. (where see examples). Through ellipsis of the anter
into many peculiar idiomatic plurases.

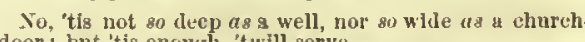
door; bnt 'tis enough, 'twill serve. Shak., R. and J., iii. 1. His resolutions were as fained as his rowa were frus.
If ilton, Eikonoklastes, $x \times v$.

The results of this eamplign were as honorable to Spain re they were disastrous and liumiliating to Lonis
the Tweelfth. Prescott, Ferd. and Isa., ii. 13. The clanses may be transposed for emphasis.

As thy days, 80 shall tliy strength be. Dent. xxxiii. 25.

As It is in particular persons, wo it is in nations.

The antecedent as is often, and so is ususlly, omitted : as,
blsck as jet; cold as ice; do as you like.

The motions of his spirit are dull as night,

Shak, ,1. of V., v. I desire no titles,

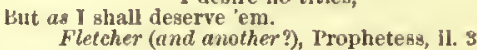

Black it stood as night,
Fierce as ten furies, terrible as hell. P. I., 11,671

I live $a * I$ did, I think $a * I$ did, I love you as I did.

It is fin criticism, as in ull other Sciences and Speculs

In parenthetical elauses involving a concessfon, the rela tive as (the antecedent being onitted) may be equivalent Trite as the counsel was, ... in this emergency it ws.
to me as if an angel had spoken. Seither the arguments nor entresties of his iriends hacked $a$ they were by the avowed wishes of his sover-
eign, could overcome his scruples. Prescott, Ferd. and Isa., 3i. 5 In parenthetical clauses involving a contrast or negation

Had I but time, ( $a s$ this fell sergeant, Death, Is strict In his arrest,) 0 , I could tell you,-
Shat let it he. Hamlet, $v$, ?

I must confess I lov'd her; as who would not? Feteher, Loyal Subject, v. 7 .

In subordinate clauses involving a supposition, as is con the ordinary forms. This use is now rare or only poetical except in the independent phrase as it were. (Sce phrases

It lifted np its hesd, and did address
Itself to motion, like $a g$ it wonld speas.

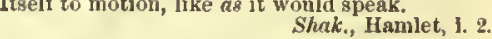

And all at once thelr breath drew in, Coleridge, Ancient $\mathbf{1 l a r i n e r , ~ 1 . ~} 165$.

The young lamba bound

As to the tabor's aound.
Word ox orth, Intimations of Immortality.

The clause introduced by as may be reduced by ellipsis of its verb and other elements to one or two important words, or adverbial phrase in the principal clause and an advert or adverbial phrase constituting the snbordinate clause. It guffees me to say ... that men here, as elsewhere, (b) Between the principal verb or its subjeet and the subpredicate appusitive or factitive object after the principal 
verb, an meaning ' "ufter the ananter' of," " the smue as, " like, rese as one man; sll these things were an nothing to hlm

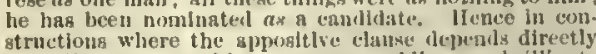
spon the nom: ho reputathon an a geholat stands high: and go in ruening phases of a general subject: as, Washiagton en a get. eral: man an a thinker. The constmetion us a cquasl.

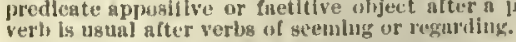

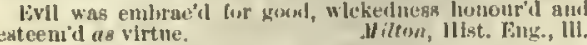

Howker, Fucclcm. $\mathbf{P} 0$

This gentleman was known to his comtemprorites as Han of fortume, and as the anthor of two suceessful plays

cur age is lewalled ax the age of Introversion.

Silnolar.

The subordinate clamse Introduced lyy $a_{n}$ is often not de

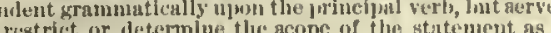

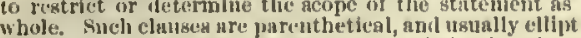
eal, some of thern, as rex tesual and as a rule, linving ulmost the filionatleal unlty of an aslverblal pluruse.

The stree ts were narrow, a* ls usual li, Moorlsh and Ara aties. Irring, Granada, 1.

In certain emplatic formulas, an ('evell as") Intronluees solemn at testation ("as truly or" surely as ) or aljuration

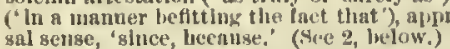

But truly $\alpha$ s the Lurd live th, and ax thy gonl IIveth the But trily $\alpha^{a}$ the Lord live th, and ax thy gonl /liveth, thete.
but a step betw wen me and cleath. Now, as you are a koman, tell me true.

A* ever thou lov'st valour, or' wear'st ambs

A* ever thou toval valour,

Bear., and $F^{\prime} l$., Knight of Maltn, Iv.

2. Of reasou: Since; because; inasmuch as.

He who wonld persinale 138 of hls sorrow for the sins of other mell, as they are slna, not as they ure slnd againg

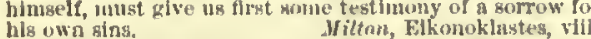
As the wind was fuvoralle, 1 hal an opportunity of sur.
$B p$. berlectey. 3. Of time: When; while ; during tho time that And whistled $a *$ he went for want of thought. An duy liroke, the scene of slaughter unfolded Its hor4. Of purpose or result: The cousequent in the correlations so . . as, such . . . vis: To such a degree that; in such a manner that: followe by an infinitive or, formerly, by a finite verl (but in the latter construction that has taken the place of $a s$ )

So घany exanuples as filled xw. bookes. The relations are no nucertain $a \times$ they require a great Bacom.
Indeed the prospect of atfairs here 18 mo strange anl Indeed the prospect of atrairs here 18 mo strange an-
melanelioly, as wonld rnake any one lleslrous of withdraw-

With a depth so great as to make it a day's Jomruey from the rear to the van, and a front 80 narrow $a$ to congist it
one gun and one Jorsenon. Kinglake, Crimea, III, ix.

5. Of mere continuation, introdueing a clans in explanation or amplification of a word or statement in the principal clause, especially in giving example

Wluter hlrls, as woolcocks and fieldlares.

A simple idea ls elte idea; $a$ sweet, bltter.

6. In dependent elauses: That. Formuerly was often attached, like that, to the adverbs there, then, where, when, etc, to make them distlnctly relative. These
forms are now obsolete, except whereat, whlch remsins in forms are now obsolete, except whereat, whlch remains in
deflected sense. See whereas. From thls Interchang with that followed the use of as for that, in introducin an object clause aster say, knowe, think, etc, varying with as I do', and I don't know ag I do,
the accent. [Coljoq., Xew Eng.]

"Dunnow'z I know':" the nearest Lovell, Introd. to Biglow Papers, 2d ser.

7. After comparatives: Than. [Now only prov. Eng.; ef. G. als, the regular construction afte comparatives.]

now way the herte lo more contryte and meke as whan of very contryclon. . . we aske mercy and forgyuedess of
almyghty god?
Bither, L. 210. Darkness Itself is no more opposite to light as the tions were diametricall to their worts. . Parly of Beasts, p. 4 .

I rather like hlm as otherwise. Scott, St. Ronan's Well. 8. Before certain advorbs and adverbial uhrases, including plepositional phrases: Even: just restricting the application to a particular point as, as now, as then, as yet, as here, as there, etc. [Now only
phrases below.] There is no cluristian duty that is not to be geasoned and
set off with elieerishne
$\$ 31$

asarone

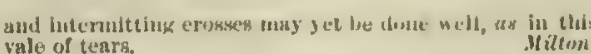

Betore punislnuent lee wax tis he heurl $n \times$ to-morrow.

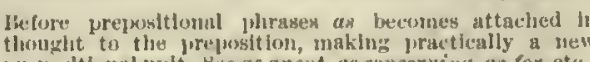
prepoult fomal unit. see as aneut, as evncerniny, dis for, etc.

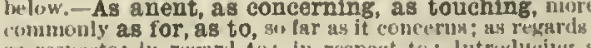
as vespects; fu regurd to: in respect

And in regarl of ranses now in land,

An touching rinnet.

sir. A. Juck! Juck : what tlithk you of bloming, leve. Alse. An to that, sir, I am quite ludliffercut. If I cau

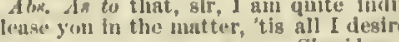

As 1f, as though, an it would be 1f, or sumpoging that.

it seemed to the attriglited Inliabitunts un if the flend of the air had come nlom the whes of the winel, and pos Irring, (irunala, It. 21.

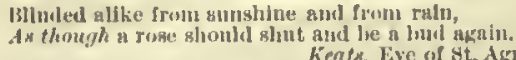

As It were, as if It were so: In sume sort ; su tos gpeak: : parcathetical clause indleating that a statement or $\mathrm{com}$ rect for the purpose intendel.

lirutiss, that expell'd the kings out of leome, was for the time forc't to be, $a \&$ it urere, a king himgelf till matter's Milton, I'relatical Finlscopacy. Aa much, what amounts to the same thing; the same. But if youl lankh at my rute carriage
in jeace, I'll dio as much for you in war When yeit come thither. Bean. and

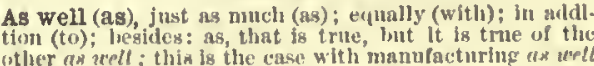
a* with agricultural interest.

In order to convi Was necegsary to fin
J/ncaudny, Lord Bacon.

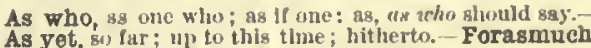
inasmuch. Sce these words.

III. rel. prom. That; who; which: after such suine and introduciug an attributive clause: as, he did not look for such a result as that he traveled the same ronte "s I dicl.

They fear religion with such a fear as loves not.
Jilton, (lhurch-Governotot, il,

In this use alse formerly after that, this, what; new dia

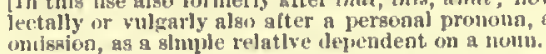
That gentleness
And shew of love $a \times$ I was wout to have.
Shak. J. C.,

Inder these hand conelitions, an this time
Is like to lny upon us.

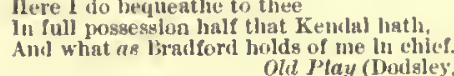

Take the low an stauds in the first fire-place.

$a s^{2}(a z), r . \quad$ An olsolete and dialectal or colloquial form of has: in colloquial speech ofter

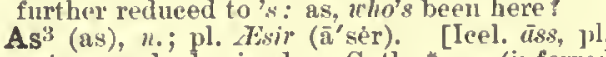
As (as), n.; pl. Wsir, a god, demigod, = Goth. "nns (inferred from the Latinized plural form in Jornandes about A. D. 552: "Gothi proceres suos quasi qui fortuna vilice bant non pares lonines sed semideos, in est anses, voeavere the name of the rune for $\bar{o}$, and twice in doubtful gen. pl. esst?; otherwise compound names, $=\mathrm{OHG}$. " in like compounds: AS. Osuold, Oswald, Osric ( = OHG Ansarih), Osrie, Oskinc, Oswin, Osbeorn = Icel. Ábjörn, Osborn, OHG. Anselm, Anselm, ete.] In the gods, the inhabitants of Asgard. See Asgard.

ast (as), $n_{0} ; \mathrm{pl}$, asses (as'ez). [L., a unit, one pound of money. ete., usually derived from us s, said to be the
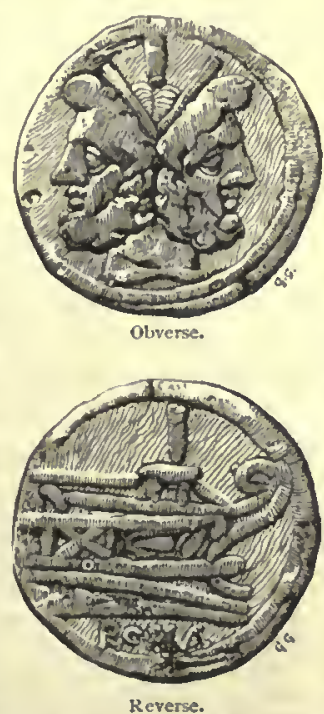

Roman As in the British Museum
'Inrentine furn of tir. rit, une; but this deriva tion is rery doubtfu]. See ace.] 2. In Latin, un integer; a wholo or single thing; ('s]recially, gerts. Thus, tho juof weight. 12 onnees (1. uncir, twelfthis): the

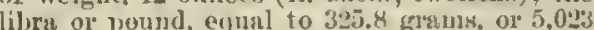
grains.-3. A copluer coin, the nnit of the carly inonetary systen of Rome. It was lirst colned in the fourtl (arcorrling to Bommsen, the flith) (entur

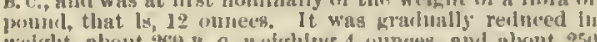

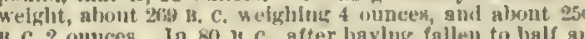
. In 80 2s. C., after havlug fallen to hale ga fornilng the divisloms of the a* were sumber semper (half of

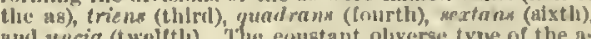
und whria (twelfth). The ecmatant olverse type of the as
las the double head of Janus; the reverse, a prow: It suldivislons hore varlous devlees. Colnk struck on the

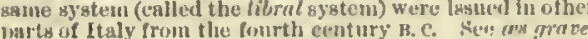
under ap.

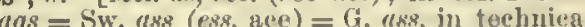
senso < L. 118 : set $\left(18^{4}.\right]$ 1t. Obsolete form of see chucer-2. In old Swedislı and Dutel unit of weight, equal to 4.8042 centigrams, or about three quarters of a troy grain. See as diceat and as: 3 .

As. Chemieal symbol of arkenic.

. S. An abbreviation of Anglom Sraxon.

as-1. [L. as-, assimilated form of ad-befor's s stored to r.s-, as in assent, ressign, etc.] An assimilated form of al- before $x$, th in assimi late, assert, assume, ete.

as-2. [I. $a b$-, redueed in $\mathrm{OF}$, and $\mathrm{MF}$. betore a consonant to 11 , erroneously restored to $a_{s-}$ before $s_{\text {. }}$ ] An erroneonsly restored form of $a$-, originally Latin $a b$, in as.

as-3. [MF. and OF. as-, var. of os-, $<1$. cs-: see $c s_{-}, x_{-}$. A variant of $e x_{-}$, Latin $c x_{-}$, in cessurt assay, astonish, obsoleto ascripe, risehere, assenm. ple, ete.; now represented alse, or only, by csus in cseape, exelew, or $\mathrm{s}$, as in serrpe, sample. See $c 8-1$

asa (as'ä), n. $\left[N l_{.},<\right.$Pers. äza, mastic: see nally nsed separately witl the Latin adjectives dulcis and fetirla (foetirlu), now joined to them as a prefix. See below. Also spelled assa. asadulcis (as-a-dul'sis), n. [NL., lit. sweet
gum, <ast, gum, + L. tulcis, sweet.] The letser gum, < ast, gum, + L. Iulcis, sweet.] The lase
or lascr cyrenaicum of the anejents, a very highly esteemed drug, usmally supposed to have been a gummy aceretion from Thiprsia Garganica, an umbelliferous plant of northeris Afriea and sonthern Europe. It was helleved by

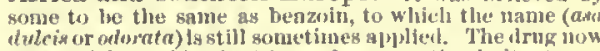
ohtannel from this plant is used as an active Irritant.

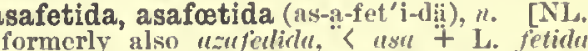
fortida, fem. of fiticlus, foetidlus, stinking: see asa and fetirl.] A fetid inspissated sap froll Persia and $\Lambda$ fghanistan, the concrete juie from the roots of several large unbelliferou plants of the genus Firnla, especially $F$. Sar thex (Narthex Asufictila) and $F$. Sicorodosmu (Scorodosma factisla). The drug las a powerful and perslstent allaciuss odor and litter acrifl taste, and consists of resin, gum, and an essential oil which eontaing
gulphur. It is isset as an antlgpasmodic, and ln Indla snd

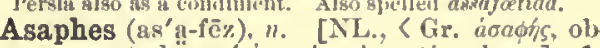

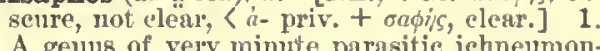
A genus of very minute parasitic ichneumonaphids, so destructive to crous a check, the fontale punctures the wingless female aphlids with her ovi hecones a maggot, and eats out the inglde of the aphld. 1837. asar (ä'sạ̈r), ${ }^{\prime}$. [Pers.] A Persian gold eoin, equal in value to about $\$ 1.60$.

asarabacca (as" a-ra-bak'ä), n. [Formerly also usaraback, and emoneonsly osarabece < L aso rum (see Asarum) + bacea, buca, berry.] A common name of a kuropean plant, a ipeciex of Asarum, A. Einoparm. See Asarum. Also spelled asarabica.

asarin, asarine (as'g-rin), $1 . \quad$ [s Asarum + $\left.-i n^{2}{ }^{2} \mathrm{H}_{26} \mathrm{O}_{5}\right)$ obtained from the plant Asarum Euro peum having an aromatic taste and smell like camphor.-2. A bitter principle obtained from the plant Astrum Europerum.

asarone (as' g̣-rōn), n. [<Asarum + one.] Same as asarin, 1. 
Asarum

Asarum (as'a-rum), n. [L., $<\mathrm{Gr}$. à $\sigma a p n$, asaplants, natural order Aristolochiacea, low, stemless herbs, with dullbrownish flowers and aromatic root-stock. Tire lew apecies are natives of the asaraliace, $A$. Europoeum, was formerly used as a purgative and an emetic. The common Anerican species, $A$.
Canadense, is known as wild ginger or snakeroot. Fiv Alleghanies snd Sierra Ne asbestic (as-bes'tik), a [< asbestos $+-i c.] \mathrm{Re}-$ lating to or containing

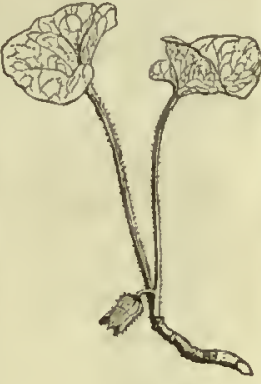

also ashestous. \\ 332}

Ascalaphidæ (as-ka-laf'i-dēe, $n . p l$. [NL., Ascalaphus + -ide.] A family of planipennine neuropterous insects, related to the ant-lions (Myrmeleontide), and characterized by long clavate antennx and a comparatively short
body. It corresponds to the genus Ascalaphus of Fabricius.

Ascalaphus (as-kal'ag-fus), $n$. [NL., < Gr. ảoкáhados, an unknown bird, supposed to be a kind of owl.] 1. The typical genus of the family Ascalaphide. - 2. [l.c.] The specific name of a horned owl, Bubo ascalaphus, of Enropo and Africa.

Ascalopax (as-kal'ō-paks), n. [NL. Cf. Gr.

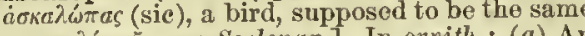
as $\sigma \kappa 0 \lambda \sigma \pi a \xi:$ see Sculopax.] In ornitli.: (a) An
old form of Scolopax. (b) A symonym of Galold for

ascan (as'kan), a. [<ascus $+-a n$.$] of or per-$ taining to an ascus. N. $E . D$

asbestiform (as-bes'ti-fôrm), a. [< L. asbestos + forma, shape.] Having the form or appearance of asbestos.

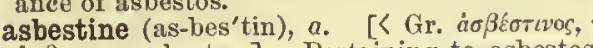
$\dot{a} \sigma \beta \varepsilon \sigma \mathrm{ros}$, asbestos.] Pertaining to asbestos, or partaking of its nature and qualities; incombustible.

asbestinite (as-bes'tin-it), n. [< asbestine + $-i t e^{2}$. Actinolite or strahlstein.-Calciferous asbestinite, a variety of steatite.

asbestoid (as-bes'toid),

[< asbestos + -oid. $]$ Resembling asbestos.

asbestos, asbestus (as-bes'tos, -tus), n. [Also asbest ( $\mathrm{F}$. asbeste), abbest, abcst ( $(\mathrm{OF}$. abeste), also, and in ME., asbeston, abeston, abiston, a beston, etc., and in other corrupt forms (in earlier use only in sense 1), ( L. asbestos, used by Pliny in ref. to the mineral asbestos, which he believed to be regetable (see def. 2), < Gr. $\dot{a} \sigma \beta \varepsilon \sigma \tau o s$, applied by Dioseorides to unslaked lime, lit. inextinguishable, unquenchable, $<\dot{\alpha}$ priv. $+\sigma \beta \varepsilon \sigma \tau \delta \varsigma$, verbal adj. of $\sigma \beta \varepsilon v v i v a t$, extinguish, quench.] 1+. A fabulous stone, which, once set on fire, could not be quenched: a notion in heating quicklime.

$$
\begin{aligned}
& \text { My mind is like to the Asbeston stone, } \\
& \text { Which, if it once be heat In flames of tire, } \\
& \text { Denieth to becommen cold again. }
\end{aligned}
$$

2. A supposed kind of flax, alleged to be incombustible. [An erroneous notion of the mineral. See 3.] -3. A fibrous variety of amphibole or hornblende, composed of separabl flaments, with a silky luster; also, in popnlar use, a similar variety of serpentine called chrysotile. Its fibers are sometimes delicate, flexible to a powder are-soft to the toluh. Its colors are various shades of white, gray, or green, passing into brown, red,
or black. It is inconbustible, and is therefore used for making lamp-wicks, paper, fremen's elothing, building
materinls, twine, and rope for packing stenm-joints and pistons; it is also prepared as a cement for protectilig proofing purposes. It is nilned in Canada, Vernont, Vir ginia, South Carolina, and in Staten Island, New York. sre loose, like tlax or silky wool. Ligniform asbestos, or
mountain-wood, is a variety presenting an irregular fila. mountain-wood, is a variety presenting an irregular hla
mentous structure, like wood. Other varieties of hornpaper, and fossil flax. A fne variety is ealled anciantus (which see). stove with asbestos spread over the bumers, so as to form an incandescent radiator.

asbestous (as-bes'tus), a. [< asbestos + -ous. $]$ Same as asbestic.

asbestus, $n$. See asbestos.

asbolan, asbolane (as'bộ-lan, -lān), n. [ [<Gr.

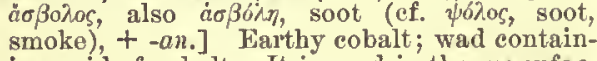
ing oxid of cobalt. It is used in the manufacture of smalt. Also called asbolitc.

asbolin, asboline (as'bō-lin), $n$. [As asbol-an $\left.+-i n^{2}\right]$ An oil-like, nitrogenous matter, acrid and bitter, obtained from the soot of wood. asbolite (as'bō-lit), n. [As asbol-an + -ite ${ }^{2}$.] Same as asbolan.

Ascalabota (as"ka-la-bö'tä), n. pl. [NL.: see Ascalabotes.] One of the major groups of the Lacertilia, consisting of the geckos alone. See
Gecco and Gecconider. Also called Nyctisauria. Ascalabotes (as"ka-la-bö'tëz), n. [NL., < Gr.

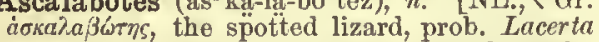
gecko.] A genus of nyctisaurian lizards, of the family Geccotidee or Gecconide. A. fascicularis is sometimes known by the name tarentola. The genurs was originally, as ured by Cuvier, coextensive with
or with the modern superfamily A scalabota. ascancel $\downarrow$, adr. See asliance $\dot{\text { See asliance }}{ }^{2}$.

ascance 2 t, ascancest, conj.

ascantt, ade. See askant.

ascarid (as'ka-rid), $n_{\text {. }}$ One of the Ascarille. Ascaridæ (as-kal'i-dē), n. $p l$. [NL., < Ascaris matoda and class Nemathelmintha, containing several genera of round-worms, or threadworms, which are intestinal parasites of man and other animals. They have a cylindrical elastic body, tapering toward each end, and a trivalved head. under Oxyurit.

Ascaris (as'ka-ris), n. [NL., < Gr. áбкapis, a worm in the intestines.] 1. A genus of roundworms, typical of the family Ascarida, infesting the small intestines. 'I7te best-known species, $A$ lumbricoides, is so called from its resemblance to all eartil worm in size, shape, and genersl sppearance. It has conoidal head, with trilahiate terminal mouth, and a fliiform penis ; the genital pore of the female is in the anterior part of the hody. The female attains a length of

2. [l.c.; pl. ascarides (as-kar'i-dèz).] A threadworm or pinworm of the rectum, formerly ent genus, Oxyuris (which see). ascend (a-send'), v. [< ME. ascenden, assenden, L. ascendere, adscondere, go up, climb up to, to, scandere, climb: see scan, and ef. lescend, transcend.] I. intrans. 1. To move up ward; mount; go up; rise, whet
water, or upon a inaterial object:

$$
\begin{aligned}
& \text { In our proper motion we ascend } \\
& \text { Tp to our native seat: descent and fall } \\
& \text { To us is adverse. }
\end{aligned}
$$

2. To rise, in a figurative sense; proceed from an inferior to a superior degree, from mean to noble objects, from particulars to generals, By these steps we shall ascend to more just ideas of the Tis sometines questioned whether morals have not deEinerson, Works and Days. 3. 'To slope upward.-4. To go backward in the order of time; proceed from modern to remotest antiquity. $-\mathbf{5}$. To rise, as a star; appear ahove the horizon.

\section{II igher yet that star ascends.
Sir J. Bouring, Watchman, Tell}

6. In music, to rise in pitch; pass from any tone to one more acute. $=$ Syn. To mount, soar, climb.

II. trans. 1. To go or move upward upon; climb: as, to ascend a hill or ladder; to ascend a tree.

We returned to the great tower, and ascended the stecn Hight of steps which led to its door of entrance.
$R$. Curzon, Honast. in the Levant, p. 77. 2. To move upward along; go toward the source of: as, to ascend a river.=Syn. To mount, ascendable (a-sen'da-bl), $a .[<a s c e n d+-a b l e$. Capable of being ascended. Also written ascendible.

ascendance, ascendence (a-sen'dans, -dẹns), . Same as ascendancy. [R̈are.]

Fear liad too much ascendance on the mind.

iplding, Joseph Andrews, ix

ascendancy, ascendency (ạ-sen'dạn-si, -dennsi), $n$. [< ascendant, -ent, +-ancy,-eney.]. The state of being in the ascendant; governing or controlling influence; domination.

The great Latin war, the war in which the flrst Decius gave himiseli for Rome, marks the last struggle of Rome's
E. A. Freeman, Amer. Lects., p. 31 . placed in this genus, now referred to a differ-

ascaunce ${ }^{1}$, adv. See astoni. See askance ${ }^{2}$. ascending

Syn. Infueace, Authority, Ascendancy, etc. (see author-

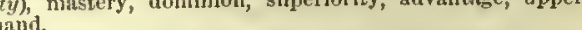
scendant, ascendent (a-sen'dant, -dent), $a$. and $n$. [< $11 \mathrm{E}$. asccndent, assendent, $\mathrm{n}$. (the form oscendant being later, after $\mathrm{F}$. (ascendant), < L. ascenden $(t-) s$, ppr. of ascenderc, go up, rise, ascend: see ascend.] I. a. 1. Proeeeding upward; rising; monnting.-2. Superior; predominant; surpassing: as, "an ascendant spirit over him," South.-3.

The constellation of Pegasus ... is abont that time as4. In bat., saine as ascending. - 5. In her., rising or issuing upward (the reverse of $i s s u$ ant): as, rays of the sun ascendant from the bottom of the shield, from a fesse, ete.

II. $n .1$. In astrol., the point of the ecliptic or the sign of the zodiac that is situated on the eastern horizon at any particular moment, as at the moment of birth or of the propounding of any question; the horoscope. The house of the arcendant includes that part of the zodiac which extends from $5^{\circ}$ above the horizon to $25^{\circ}$ below it. The lord of the arcendant is the planet thist rules the ascendant. This planet is generally the significator of the querent, and the to be in the ascendant signities to have commanding power or luffuence, to occupy a ruling position; and lord of the ascendanl, one who has possession of such power or
fluence: as, to rute, for a while, lord of the ascendant.

The assendenl sothly, as wel in alte natiuitez as in questiouns and elecciouns of tymes, is a thing which that thise Astrologiens gretly obseruen; wher-fore me semeth conspecial declaratioun. The assendent sothly, to take it at the largest, is thilke degree that assendeth at sny of thise forselde tymes npon the est Orisonte; and there-fore, gif that any planet assende at that same tyme in thilke lor. horoscope. Sciences that were then in their highest ascendant.
Sir $\boldsymbol{W}$. Temple. Marlborough lad not, when Popery was in the ascen dant, crossed hinself, shrived himself, done pensnce,
taken the communion in one kind, and, as soon as a turn taken the communion in one kind, and, as soon as a turn
of tortume came, apostatized back again.

2. Superiority or commanding influence; predominance: especially in the phrase to gain the ascendant over one.

Wlat star I know not, but some star, I find, Dryden, tr. of Persius, Satires, v.
Don sing. Goldsmith, Voltalre.
Gold

The secular authority, long unduly depressed, regalned The secular authority, long unduly
the ascendant with startling rapidity. acaulay, Von Ranke.

3. An ancestor, or one who precedes in genealogy or degrees of kindred: opposed to descendant.

The succession of ascendauts of the deceased, of his male If any survived him.

4. In arch., one of the two sides or vertical members of the chambranle of a door or window. ascendence, ascendency, ascendent. See as cerdance, ete.

ascender (a-sen'dèr), $n$. 1. One who ascends. -2. An ascending letter. See ascending.

ascendible (a-sen'di-bl), $a$. [ $<\mathbf{L}$. asccndibilis (also, from pp. ascensus, IL. ascensibilis), <
ascendere, ascend: see ascend and -ible, and cf. ascendable.] Same as ascendable.

ascending (a-sen'ding), $p, a, 1$. Proceeding from a lower position to a higher; rising; moving upward; figuratively, proceeding from the less to the greater; proceeding from a later to an earlier time; rising from grave to acute. -2 . In bot., growing upward, as the stem of a plant, which is called the ascending axis. comnonly restricted to the sense of growing up obliquely or in a curve from the base, in distinction from erect, and from See paralysis.-Ascending latitude, the latitude of a letter, in type-foumding, a letter which resches to the extreme upper part of the hody of the type. In Roman types of the minuscule or " "lower-case. "form the ascendascending letters,-Ascending node, that point of a planet's orbit at whtch it passes the ecliptic to proced ing ovule, in bot, an ovute that is sttached above the base of the ovary and directed npward.- Ascending rhythm, in pros., a rhythm or movement composed of feet in which the metrieally accented part (commonly called the arsis) follows the metrically unaccented part (eommoply ealied the thesis), as an iambic or anspestic rhythm: dactylic.-Ascending signs, the signs Capricornus, Aquarius, lisces, Aries, Taurus, and Genini : so called because pole, which is to our view elevated.-Ascending vespole, which in anat, those vessels which carry the blood upward
or toward the superior parts of the body. 
ascension

ascension (a-sen'shọn), n. [< ME. ascensioun , Leccnsio $(n-)$, a rising, asconsion, < asccnalcre, pp. ascensus, rise, asceml : see ascend.] 1. The act of ascending; a rising ; specifically, the bodily passing from carth to heaven of Christ, in the presenee of his diseiples (Mark xvi. 19; Luke xxiv. 50,51; Acts i. 1-11).-2. [cap.] The day on which the ascen sion of Christ is cornmemorated in the churel Ascension day. $-3 \uparrow$. That which rises or as cends; a fume.

Ilen err in the theory of Incbriatlon, concelving the brain doth only suffer trom vapourons axcensions from

4. In astron., the rising of a star or point abov the horizon on the celestial sphere. -5 . A going back in time, or in the order of genealogical succession; ascent.-Apparent right ascension. See apparent.-Ascension day, the fortleth rlay siter Easter, on which the ascenslon of Christ is con
memoraterl; sometimes called Moly Thursday. - Oblique ascensiont, of a star, in estron., an arc of the equstor in tercepted between the vernsl equinox or first point of (a) the star, - Right ascenbion. (a) In old astron., vertlcal rising.

The signes of riht assencioun ben fro the heued of esn cer to ye ende of sagittare, and thise signes artsell mor ipriht.

(b) In mod. astron., the right ascension of a star or point if the sphere is the arc of the equator intercepted betweell it eircle of deelination and the vernal equinox or thrs polnt of Arles, reckoned toward the esst. This mesnlng is derived
from the conception of sn observer at a point on the earth's from the conception of an observer at a point

ascensional (a-sen'shon-al), a. [< asccnsion + al.] Relating to ascension or ascent; ascending or rising up.

That Idea [of the gun-cotton rocket] was to place a dist or short cylinder of the gun-cotson wh be employed to carry the disk to an elevation of 1,000 feet or thereabouts.
Tyndall, Pop. Set. Mlo., XIII. 28

Ascensional differencet, in astron., the difference be tween the rlght and the oblique ascenslon of the sari
polnt on the surface of the sphere: used ehleily as ex pressing the difference betweell the time of the rising
setting of a lodly and six o'clock, or six hours from its morldiun passage.

ascensive (a-son'siv), $a_{0}, \quad\left[<\mathbf{L}_{\text {. ascensus (pp. of }}\right.$ ascendere: sce asccnd) + -ivc.] 1. Characterized by an ascending movement; tending to ascend; rising; tending to rise, or causing to rise. Sir T. Browne.-2. In gram., increas ing force; intensive; augmentative. [Rare.] ascent (a-sent'), $n$. [<asccnd; formed like dc The act of rising or ascending; upward moy ment: as, the ascent of vapors, or of a balloon. To him with swift ascent he up return'd.

Hence-2. A rising from a lower to a higher state, degree, or grade; advancement.

As to the genesls of man and the universe, the less $\mathrm{cul}$ tured trlbes claimed to be an ascent from hirds, flishes, 3. The act of climbing or traveling up; the act of advancing from a lower to a higher position; a going up, as up a mountain, river, stairway, ete.-4. An eminence; a hill or high place.

Depressed valleys and swelling ascents. Bentley. 5. The way by which one ascends; the means of ascending; aeclivity; upward slope.

$$
\begin{aligned}
& \text { It was a rock .. } \\
& \text { Conspicuous far; winding with one ascent. } \\
& \text { Milton, } \mathbf{Y}^{\prime} \text {. L., iv. } 545 \\
& \text { Next the proud palace of Salerno stood }
\end{aligned}
$$

A mount of rough ascent, sud thick with wood.
Dryden, Sig. and Guis., I. 102 Clambering up the very steep ascent, 1 took my plat
upon the ramparts to wateh the sunrise over the plain.
O'Donovan, Merv, xxiv. 6. The angle made by an ascending line or surface with the horizontal line or plane: as, the road has an escent of five degrees.-7. A procceding upward or bac

The ascents from particulsr to general are all successive, and each step of this arcent rerguires time and labour.

Line of ascent, in genealogy, ancestry.

They [aneient nludu law-teachers] say hardly anything of deseent or ascent.

Maine, Early Law mul Custom, p. 112 ascertain (as-er-tān'), $v, t$, [Early unod. $\mathrm{E}$, and late ME. uscertuine, assertuinc, assartainc,-taync, ete., with asser-, ascer-, ju erroneous simulation of words like assent, ascend, otc., earlier ME. accrtainen, acerteinch, $<\mathrm{OF}$, accrtwiner, accrtciner, make certuin, $<a$, to, + ccrtain, certain: see $a-11$ and certain. The word is thus etymologieally $a_{-11}+$ certain, and was so pronouneed in early mod. E.] 1. To make certain; deter- mine; define or reduce to precision by removingt, obscurity,

The two first lines of the following book scem to ascerIn 1635 he [Moyle] was chosen to represent the horongh Saltash In parliament; a circumstance which racer to that perled. Malone, note in Dryden's Life of Laclan. We must Jook somewhat deeper, would we learn why s of those multiplied editions which have ascertainet it

2. To find out hy trial, examination, or experiment so as to know as certain; aequire an as curate knowledge of : as, to ascertain the wejght of a eommorlity or the purity of a metal. To pass to ascertrined facts, there actually sre worl
which were ventured many getieratlons ago, but, for som

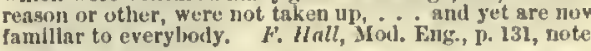
3. To make sure of; insure. [Arehaic.]

The minlstry, in order to ascertain a majority in the Ifouse of Lords, persinuled the queen to create twelv new peers.

4†. To mako certain or suro; certify; assure inform. [Rare.]

1 am desirons of srranging with you such just and prac ticable conditions as will axcertain to you the
whieh you will recelve my part of your debts. MInncer assured them that the design was npproved of
by llesven, and that the Aluighty had in a dresm ascertained him of its effect

5. To establish with certainty; render invariable, or not subject to eaprice ; fix. • [Rarc.]

The mildness and prectsion of their laws asecrtaimed th rule and measure of taxstlon.

Giblon.

ascertainable (as-êr-tä'na-bl), a. [< asccrtai $+-a b l e] .1 \uparrow$. Capable of being determined o madocertain. - 2. Capable of being ascertaincd or found out by trial, experiment, investigation, inquiry, etc.

ascertainer (as-èr-tã'nêr), n. One who asce tains.

ascertainment (as-ér-tān'ment), n. [< ascer tain $+-m e n t$. $]$ 1. The act of fixing or determining; a redueing to certainty. [Arehaic.] 2 . The act of attaining certainty ; the acquire ment of certain knowledge concerning some thing; a finding out.

Our sncestors guided their course by the stars, withou knowing much sbout the stars; the ascertainment of few relative positions suffled.
G. II. Lewes, Probs. of Life and Mind, I. i. \& a. We can procecd in the ascertainment of internal trutl.
as we proceed th the ascertainment of external ones.

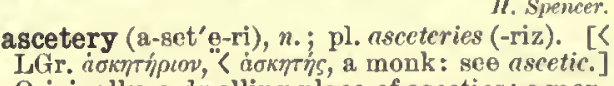
Originally, a dwelling-place of ascetics; a monastery; now, in certain religious houses, a eomreading.

ascetic (a-set'jk), $\pi$. and $n . \quad[<$ Gr. á $\sigma \kappa \eta \tau \iota k \sigma ́ s, a$ cetic, laborious; as noun, a hermit, an ascetic cetic, laborious; as noun, a hermit, an ascetic:
áokmths, one who exercises, an athlete, eccles. monk or hermit, < d $\sigma \kappa \varepsilon i \nu$, work, exercise, eceles. mortify the body.] I. a. 1. Practising specia acts of self-denial as a religious exercise; seek ing holiness through self-mortification; hence petites and passions.

He was for his life so exact and temperate that I hane heard he had never been surprised by excesse, belug aseetic Genlus is al ways ascetic; and piety and love. Appetlte
shows to the fner souls as a disease.
Emerson, Fssays, Ist ger., 210. IIence-2. Unduly strict or rigid in religious ercises or mortifications; severe; austere. A constant ascetic course of the severest sbstinence snd
South, Sermons (ed. 1737), II. 3L. Tacaulay, Dryden. 3. Pertaining to or resembling the ascetics.

II. $n .1$. In the early Christian church, one who practised unusual self-denial and devotion; in modern usage, also one who retires from the custonnary business of life and engages in pious exereises; a hermit; a recluse.

He that preaches to man should understand what is in
man; and that skill can scarce be attained by an ascetic in his solitudes.
Atterbury. 2. $p l$. [cap.] The title of certain books on d vout excreises: as, the Ascetics of St. Basil.

ascetical (a-set'j-kal), $a . \quad[<$ ascctic $+-a l$. and the mortifieation of the body as a means of attrining virtue and holiness; ascetic. - Ascetiattaining virtue and holiness; ascetic.-Asceti- of virtne and perfection and the means ly whlch they

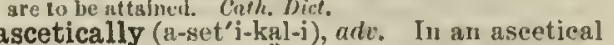
manner; by tho praetice of asceticism; as an uscetic; to or toward asceticisn : as, persons asectically inelined.

asceticism (a-sct'i-sizm), $n$. [<asectic + -ism. $]$ 1. The life or practice of an ascetic; tho principles and historie course of the asceties. In an-

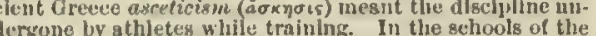
itolcs the same worl was aullied ti the controllins of the appetites and 1 prosions and the practice of virtue. Anwmg Clirtstians, through contact with the Alexundrian school
of philosoing, the wort early came lito use witl a siml. of philosopily, the worl early esme lito use with a sim lar meaning, nanely, the habitual use of self-discipline, communitles among the Jews. The object of this dise. ts passlons and desires as the stronglold of evil In. herent in man since the fall of Adam, the means used beling fasting, cellhacy, peverty, penance, and solitude, centuries into monastleksm. Simllar and even greater austerltles have beell practised Irom very early times by wany arnong various pagsin nations ging in connection ism, cte. 1nder the infinence of the idea that natter is essentisily evil, and that an approseh lo ldeal good or an escape tron the evlls of exlstene
subululng ur torturing the borly. Asceticism again - Including under this term . . all
efforts to wltherrsw from the world in orler to cultivate a lijgliser degree of sanetily - belongs naturally to a soclety and easy.
and 2. In theol., the theory or systematic exposition of the means, whether negative, as self-denial and abstinence, or positive, as the exereise of natural and Cliristian virtues, by which a completo conformity with the divine will may be attained. See ascctical theology, under ascetical. $=$ Syn. Self-sacrifice, Austerity, ete. See self-denial.
ascham (as'kam), 1 . [After Roger Ascham, who in 1545 published "Toxophilus," a celebrated treatiso on archery.] A cupboard or case to contain bows and sometimes arrows anc. Brit.

Aschiza (as-kízä), n. $j l$. [NL., < Gr. á- priv. $+\sigma x i \zeta a$, a cleft: sce schism.] In Braner's system of elassification, a division of eyclorhaphous dipterous insects or flies, of the suborder Cyclorhapha, containing the families Syrphida, Intypezide, Phoride, and Pipunculide, thus Aschizopoda (as-ki-zop'ó-dạ),$n . p t_{*}$ [NL., Gr. $\dot{a}-$ priv. $+\sigma x i \zeta a$, a cleft, $+\pi$ ous $(\pi o d-)=\mathrm{E}$.
foot.] A division of maerurous decapodous crustaceans, embracing most of the group, as distinguished from tho Schisopoda or opossumhrimps.

asci, n. Plnial of ascus.

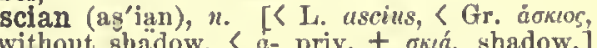
A person who easts no shadow at noon. The mlabitants of the torrld zone alone fulfil this condition, Ascidia (a-sid'i-ä), $n$.,$l$. [NL., pl. of Ascidium, - vi lid invertebrates with the Tertebrata: the tunicates, tuniearies, or sea-squirts, otherthe tunicates, tuniearies, or sea-squirts, other-
wise callod Tunicata, Ascozoa, Crochorda, or Protovertcbrata (in part); the asuidians. They

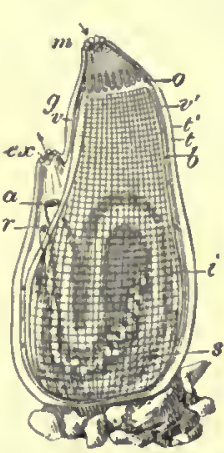
sre asymmetrical marine anlmals,
glmple or compound, fixed or free, with a monogsanglionle nervous The integument is a leathery sac, with two orifices, oral and anal. The young are free-swhining and ditlon show traces of vertebrate aftinities In the possesslon of a uro-
ehord, or notochurd of the tall, a ne family, the Appendiculari idoe. They are found at low.water mark on the sea-beach, and, at-
tached to stones, shells, and fixed objects, are dredged trom deep water. An ascidisn presents externally the appearance of a wime-
jar or double-necked bol tle, the
one aperture of the lottle corresponding to the month and the other to the vent or excretory $a$, ternination of trtes- sperture. A feature in the or-
tine: $b$, branchial sac; ganlzation of these animals is

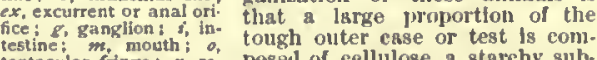
predacular fringe: $r$, re: pesed of eellulose, a starchy sub

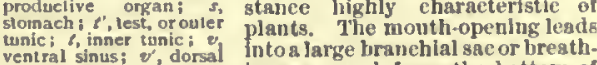
into a Jarge branchial sac or breath-
ing-aae; and from the bottom of this gae the digestive system, conststing of stomach and intestine, is continued, the in testlne opening Into a seeond sac, the atrial ehanber.
Thls latter eavity upens externslly by the secomil aper-
ture of the body, and also ernlts the effete water which 
Ascidia

has been nsed in lreathing. A single nerrous mass asciferous (a-sif'eor ganglion represents the nervous system, this mass beand female reproductive organs exist in each ascldian. 'These animuals misy he single or simple, sccial, or conipound. In social ascidians the peduncles of a number of ind -
viduals are united into a connon tubmlar atem, wlth partial common circulation of bloot. The species a more or less gelatinons, and some are used as food in
China and on the shores of the Mediternumen. The Ascidia are divisible into two order's not wcll defined, called Biphura and Axcidioida, and by other names, one
containing the Salpide and Dotiolide, the other the rest containing the Salpide and Doliolide, the other the rest
of the class. Also written Ascidine. See cuts under $A p$

2. [Used as a singular.] Less preper form

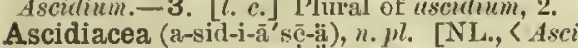

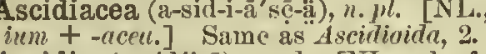
Ascidix (a-sia' $\mathrm{i}-\overline{\mathrm{e}}), n_{*}, \eta_{\text {. }}$ [NL., pl. of Ascintin .] 1. In Gegenbaur's system of classification a division of Acopu, embraeing the true ascidians as distinguished from the Pyresomatide, Doliolidec, and salpidr. It contains three groups, Simplices, Socialex, and Co

2. Same as Ascidia, 1.

ascidian (a-sidl'i-an), $a$. and $n_{0} \quad[<$ secillum + an.] I.

II. $n$. sea-squirt.

(a-sid-i-ấ,

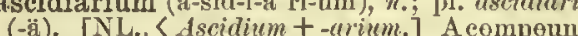
ascidian, censisting of twe or mele individual ascidiezoöids. See eut under cyathozoöid.

It [a fixed ascidian] may remain simple, or it may de verium, consisting of many acopotnd organism or $A x c i$ -

IIuxiey, Anat. Invert., 1. 514. Shaped like a small bettle, or like an ascidian. Ascidicola (as-i-dik'ó-lï), $n$. [NL., S Ascidirm Ascidicola (as-i-dik o-lï), $n$. [NL., S Ascidirem
+ L. colere, inhabit.] The typical genus of the + L. colere, inhabit.

Ascidicolidæ (a-sid-i-kol'i-dē), n.pl. [NL., <As cidicola $+-i d a$.$] A family of copepod entemes$ tracous crustaceans, parasitic upen aseidians. ascidiform (a-sid'i-fêrm), $a . \quad[<$ Ascidium $+\mathrm{L}$ forma, shape.] 1. Shaped like an aseidian; ascidian; related to the Ascidic.

Also ascidiiform.

ascidiid (a-sid'i-id), n. One of the Ascillida. Ascidiidæ (as-i-di'i-dē), $n_{0} p l$. [NL., < Ascidia, $2,+-i d w$.$] A family of solitary ascidians,$ the atrial 6-lobed, the branchinl sae not folded, the tentacles simple, and the genitalia in clese connection with the mantle. It is the typical family of the ascidians proper, including the simple form, as Mol Irom the social and componnd forms, and contains many

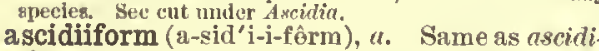
form.

ascidioid (a-sid'i-oid), "1. [<Ascidium + -oid. Of or resembling an aseidian: as, an ascidibic form. Huxley

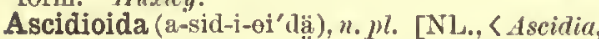
Ascidium, + oida.] 1. Same as Ascidia, Asco$z \theta a$, or Tunicata, as a elass or phylum of ani-
mals. - 2. All order of Ascidia, conterminous mals. - 2. All order of Ascidia, centerminous ascidiology (a-sid-i-ol'́-ji), $n$. [<Ascidium + - - logy. $]$ That department of zooblogy which treats of the ascidians or tunicates.

ascidiozoỏid (a-sid" $\mathrm{i}-\overline{0}-z \bar{\theta}^{\prime}$ eid), n. [< Asciclium organ pound ascidian or aseidiarium (which see) pound ascidian or aseidiarium (which
See cuts under cyathozeöid and Doliolide.

In the compound or aocial Tunicata, many arcidiozoöids,
which are united by a common test into an arcidiarinm, which are united by a common test into an ascidiarinm, are produced by gemmation from a aolitary metamor-
phosed larva.
H $u x l e y$, Anat. Invert., p. 522.

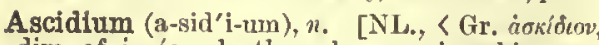
dim. ef $\dot{a} \sigma \kappa o ́ s$, a leatlern bag, a wine-skin: see ascus.] 1. [Also less prep. dscidia.] A genus of tunicates, typical of the principal family of the class Ascidia, some of whose species are knewn as sea-squirts: synonymeus with Phallnsia. - 2. [1.c.; pl. ascidia (-ä). $]$ In bot.: $(a)$

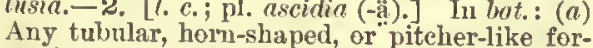
mation, arising usually from the unien of the margins of a leaf or other ergan, or frem the dispropertienate grewth of some part. The as cidium ordinarily known as a pitcher, as in the pitcher-
plants (Nepenthex) and side-saddle flowers (Sarracenia) often covered by a lit, and contains a secreted fuid in which insects are drownet and macerated. The smal. aquatic sacs of species of tricularia are also asc
see cut in next column. (b) Same as (iscus, 1. rus), a. [S NL. as cus, q. v., + L. ferre ing asci.

There is a parallelism (etween the frnctification of lichens and the axciferon

Eneyc. Brit., XIY. 557. ascigerous (a-sij)erus ), a. [< NI. äs$c u s, q . \mathrm{v},{ }^{+} \mathrm{L}_{0} g c-$ bearing asei, as liehens and ascomy. cetous fungi. See ascus, and compare uerosporous.

ascites $(a-s i ̄ t e ̄ z), n$ [L., < Gr. áokím, a kind of drepsy, < $\dot{a} \sigma \kappa \delta s$, a leatlieru bag, a bladder: : see ascus.] In pathol. the belly. scititio
334

ascus.] In pathol., Maout and Deçaisne's "Traité géné

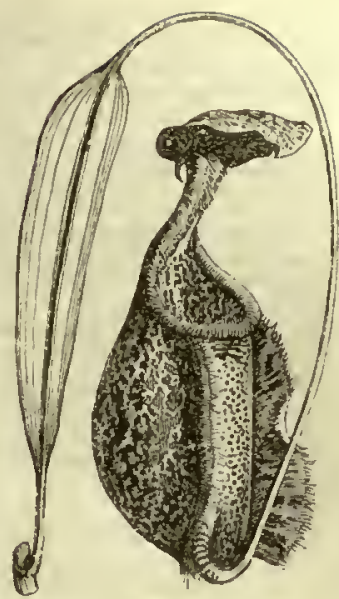

ascribable

ascitic (a-sit'ik), $a$. Relating to ascites; drep-

(a-sit'i-kal), a. Same as ascitic.

asclent (as-klent'), alv. A Scotel form of aslant. asclepiad (as-klē'pi-ad), n. [<L. Asclepiadenm asclepiad (as-kle pi-ad), n. [<L. Asclepiaden

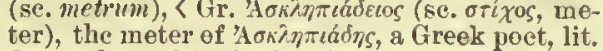
descendant of Asclepius, 〈'A $\sigma \kappa i n \pi t o ́ s$, Aselepius: see Asclepias.] 1. [cap.] In anc. pros., an Aselepiadie (verse or line). - 2. In bot., a member of the order Asclepiatacere.-3. [cap.] One of Asclepiads (which

Asclepiadaceæ (as-klē"pi-a - dlā'sē-ē), n. $p$ l. [Nl., $<$ Asclcpias ( $a d l-)+$-acce. $]$ A natmal orlen in waxy masses, the pellinia attached in pairs to glandular appendages of the stigma, the frui a pair of follieles, and the seed cornose. They are
manly tropical, many of them African and Indian twining mainly tropical, many of them African and Indian twining
slruls, usually with milky juice, which often has gtront

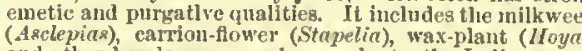

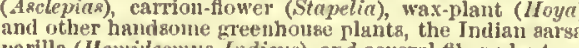
parilla (Hemilesmus Indieus), and aeveral fiber-plants, as specles of Calor ropis and Marsdenia, a species of the latter asclepiadaceous (as-klē" pi-a-dä'shius)

lenging to the Asclepiarlacere.

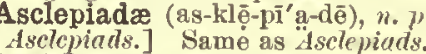

[NL.: see Asclepiadean (as-klē" pi-a-dé,'an)

clepiatēus (see tsclepiad) + -añ.] In anc. pros. censisting or composed of Asclejiadies.

In hia combinations of the Asclppiadean [meter] we note
the grave and thoughtfui temperance of tone which pervades those in whicli the three Asclepiadean lines are con-
bined with one Glyconic. Asclepladean strophe, a airophe or atanza composed of Asclepiadics with or without other verses, such as Gl

Asclepiadic (as-klē-pi-ad'ik), $u_{\text {. and }} n_{\text {. }}$ [<asclcpiad $+-i c$.] I. a. Of or pertaining to

II. $n$. In anc. pros., a verse consisting of a spondee, two (or three) cheriambi, and an iambus; or, aceerding to ether authorities, a legaoedie verse consisting of a basis, three cyclie dac tyls, of which the secend is syncepated (or fiv eyclie dactyls, of which the second and fourth are syncepated), and a trochaic dipody catalec-
tic. The shorter form is called the lesser, the tic. The sherter ferm is calle
longer the greater, Asclepiadic.

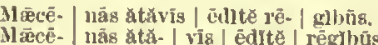

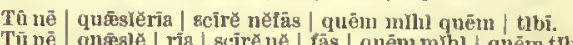

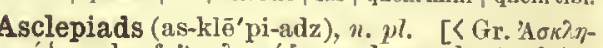

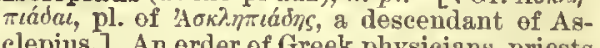
clepius.] An order of Greek physicians. priests of Aselepius or Asculapius, the god of medicine, whose descendants they elaimed to be. They practised medicine under the reputed inspiration of thiat deity, and were bound by oath not to reveal the From these primltive clinical recorda, the half-priestly, half-philosophic caste of the Asclepiads compiled the data upon which the earlieat generaliaationa of medicine, as an inductive geience, were hased.

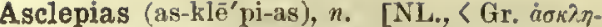

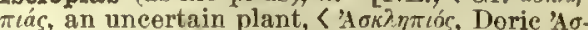

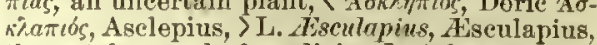
the tutelary god of medicine.] A large genus of North American herbs, natural order Asclepiadacea, pepularly known as milkweed or silkweed. The plants are pereuntal herbs with milky jnice, mostly upriglt with opposite or verticillate leaves, the flowers in umbels, and the seeds tufted with long silky
lairs. Of the more than 70 apecles, nearly 50 are found lairs, of the more than 70 apecles, nearly 50 are found
within the United states. The butterfly-weer or pleurisyroot, $A$. tuberosa, has diaphoretle and mild purgative propcurassacica, is a powerful emetic. Some of the specie afford an excellent fiber.

ascocarp (as'kō-kärp), n. [< Gr. a iokós, a bag ef asei and ascophores.

ascogenous (as-kioj'e-11us), a. [< Gr. áokós, a bag (see uscus), + -revis, preducing: see -ge-
nous.] In bot., yroducing asei: applied to the nous.] In bot., producing asei: applied to the ascemyceteus fungi.

ascogone (as'kn̄-gồn), $n$. Same as ascogonium. (-ii) - rovos, preducing: sce -gony. $]$ The female organ in certain of the lower eryptogams, which after fertilization develops asei. Also called carpogonium and urchicary.

Ascomycetes (as "kẹ-mī-sē'tēz), n. pl. [NL., <

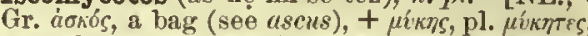
a mushreem, akin te L. muchs: see mucus.] A family of fungi characterized by the formation of free spores within elongated cells (asei), often asseciated with alternation of genoration. acopic yeast-1ungi or forments, various mildews, ergot, the anbierranean truftlea, the morels, helvellas, ete., which represent the several orders Saccharomycetes, Perisporiacece, Pyrenomycetes, Tuberaceve, and Discomycetes. II Pst
ot the lichena are now alao generally considered as he-

ascomycetous (as" kō-mi-sé'tus), $a$. [< Ascomycctes + -ons.] Of or pertaining to the Ascomy-

Ascomyzon (as-kồ-mīzen), n. [NL., < Gr. áo-

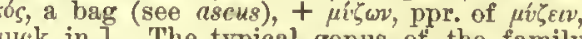
the family Ascomyzontidæ (as "kẹ-mī-zon'ti-dē), n. pl. [NL., $\left\{\right.$ Ascomyzon $\left.(t-)+-i d e_{0}\right]$ A family of parasitic epizoio crustaceans, of the order Siphonoascon (as'ken), n.; pl. ascens, ascenes (-ken\%, as-kō'nēz). [NL., < Gr. áonós, a bag: see ascars.] One of the Ascones; a sponge having the charneter's of the Ascenes.

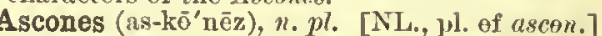
A grenp of the lowest and simplest chalksponges, having a ventricle with walls se thin that the inhalent peres epen directly into the ventrieular cavity: distinguished from Leucones and Sycones. See Olynthus.

Asconidæ (as-kon'i-dē), n. pl. [NL., $\langle$ ascon + idle.] A family of Calcispongia, the same as ascophore (as'kō-fêr'), n. [<Gr. áokoфópos, bear-

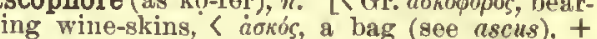

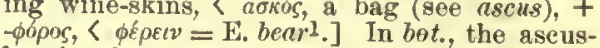
$\phi o \rho o s,<\phi \varepsilon \rho \varepsilon v=\mathrm{E}$. bearl.] In $b \theta t$., the aseus-
bearing form or stage of develepment in some greups of the Ascomycetes. See cut under

ascophorous (as-kef' $+-\theta u s$.$] In bot., bearing an aseus or asci:$ applied to the hyphre in lichens, which develep asei at the end of the branches.

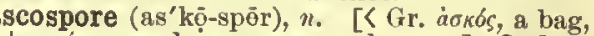
+ otopos, seed: see ascus and spere.] In bot., ne of a cluster of speres berne within an aseus.

The claracteristic form of reproduction of the Aacomy. cetea is by ascospores formed within asci by free cell-1or-
mation.
Encyc. Brit., IX. 833.

ascosporous (as-kos'pō-rus), a. [As ascospore. + -ous.] Having ascesperes: as, "ascesperrus ungi," Encyc. Brit., IV. 162.

Ascozoa (as-kē-zō'in), n. $p l$. [NL., < Gr. áonós, a

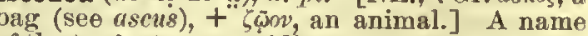
of the tunicates or ascidians: synenymous with Ascidiu, 1 (which see).

ascozoan (as-kē-zō'an), $n$. [< Ascozoa + -an.] One of the Ascozon; an ascidian or tunicate. ascozoic (as-kē-zē'ik), $\alpha$. [< Ascozoa + -ic. $]$ Of ol pertaining to the Ascozon; tunicate; asidian

ascribable (as-kri'ba-bl), a. [< ascribe $+-a b l e$. Capable of being aseribed or attributed; at-
tributable. 
335

ascribe (as-kmin') [< Gr. dokews, without a ppr. ascribing. [Altored to ascribe (after L.) cup, $\dot{i}$-priv. $+\sigma \kappa i \phi o s, a$

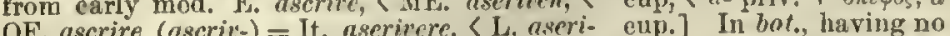
OF. ascrire (ascric-) = It. aserivere, < L. aseri- eup. In bol., having no bere, annex by writing, add to a writing, enroll, scyphi: applicd to liehens , attritute, $<$, to, inc: appenil (one's name) to a dorument, etc.; ing; appent

The aseritring of my name wonld .... have substracted frum... the wetght of those discourses. 2†. To inseribe or derlicate. The secound pillor ralled lorica, being ascribed to lier 3t. To enroll or register. Ile would long since have been ancribed s memher there. 4. To attribute, impute, or refer, as to a causo 4. To attribute, impute, or refer, as to a causo or source; assign; setdown: a

This speech is, I think, the finest that is ancribed to

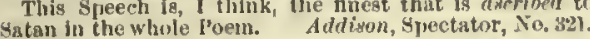
But ruany atrocie us proceedings must, joulitiess, he as. cribed to heated imagination, to perverted princilile, to a

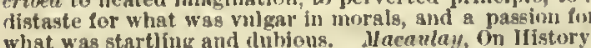
5. To attribute, as a quality or an appurtenanee; consider or allege to belong.

I ... will aserike dighteousneks to my IIakur.

xxxiti. 3.

They have ascribed unto Ihavid tell thonsands, and to
gatm. xvill. 8 . me they have ascribed but thousands.
$=$ Syn. Attribute, Refer, etc. See attribute.

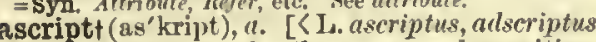
pp. of ascribere, adscribere, annex by writing: scription (us-krip'shon), 2 [ L I aseriptio(n-), ascription (") kript cascribere, up, uscriptus, add to a writing: seo ascribe.] 1. The aet of aseribing, imputing, or aflirning to belong, to be due, ete.

Selt-sbnegations often repeated imply on the part of the
actor a tacit uscription. of relative selfishness to others why profit by the self-abnegthor.

II. Spencer, Data of Ethics,

2. An expression aseribing; words in whieh one aseribes.

Offering up the areriptions justly due to llim for snch

Also rarely adscription.

Also rarely adscription.
ascriptitious (as-krip-tish'us), a. [<L. ascrip-

ticius, on'olled as a eitizen, soldier, ete. (ascri)

ticii servi, slaves bound to the soil), (ascriptus,

pp. of ascribere, enroll: see ascribe, aseript.] villeins under the feudal system, who were annexed to the freehold and transferable with it

-2. Added, as to a list; emrolled.

An ctscriptifiots and supernumersry god.

Also rarely adseriptitious.

$$
\text { Farinden, Sermens, p. }
$$

ascryt, $v$. [Ear.]y mod. E., < ME. ascrien, ascryen, escrier, mod. F. ecrier $),<$ es- $(<\mathrm{L}$. ex $)$, out, crier, ery. Cf. escry, and by apheresis sery. donblet of ascry: see as-3, es-1, and cry.] I rans. 1. To eall forth

hallenge--2. To desery.

ascryt, $n$. [<asery, e.] Outery; clamor; shouting.

$$
\text { Ascry aros at sksmyssh sl withoute. }
$$

$$
\text { Chaucer, Troilus, ii, } 61
$$

ascula (as'kū-lï), $n_{\circ} ;$ pl. asculce (-lē). [NI. sponges (as Olynthus, sycan, Halipbysema) in which, after ceasing to be a free-swimming which, after ceasing to be a free-swimming form by the development of spienlw in the eetoderm, or other modifieations, it beeome attached to some support. Hacckel. - 2. Th first period of attachment of certain sponges. namely, that in which the sponge has lost or is losing its collar, opening the primitive cloaeal collar, and forming the first central eavity without lateral ampullie. It corresponds to the protospougian stage of Hacekel. Hyatt.

ascus (as'kus), n.; pl. asei (as'i). [NL., < Gr. iøкós, a leathern bug, bottle, bladder, wine-skin : see Ascidium, Ascidia, ete.] 1. In bot., the spore-case of lichens and ascomycetous fungi, ronsisting of a single cell, usually the swollen terminal eell of a braneh of a hypha, from the protoplasm of which the spores (typically 8) are produced. Also ealled ascidium and theor. -2 In archeal., same as askos.

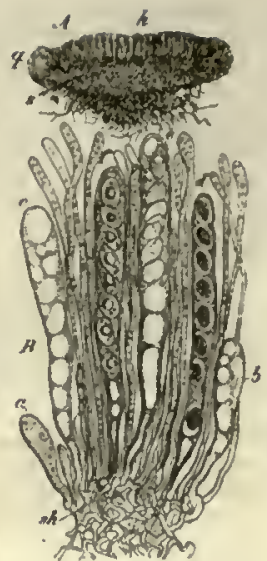

Asci.
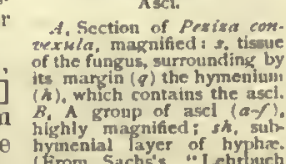
effects of earthquakeeffects of earthquake-

contrivanees designed to secure stability, as of lighthouses and other struetures during eartl quakes: as, aseismatic joints; aseismatic tables. aseity (a-sé' $\mathrm{j}-\mathrm{t} \mathrm{i}), n . \quad[=\mathrm{F}$. aséité, $<\mathrm{ML}$. ascitas, aseity (a-se being of one's self, independent existence, < L. $a$ se, of one's self: $a$ for $a b$, of istence, < L. a se, of one's self: $a$ for $a b$, of.
from; se, self: see se.] The mode of being of that whieh is underived from anything else independent existenee; existence by self-origi nation.

By what myslerious light have you discovered that axc. is entail'il on matter?

The absolute belug and aveity of (ion. Aselli, n. Plural of Avellus,

asellid (a-sel'id), $u$. An isopod of the family

Asellidæ (a-sel'i-dê), n. $m$. [NI., < Asellus + A family of isoporlons erustaceans, of which the genus Asellus is the type. It also con tsins the gemms Limnoria, of which the species $L$. ter

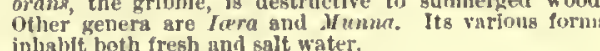
Aseilota (as-e-lóntậ), no pl. [

Aselins (a-sel'us), n. [L., din. of asinus, an Asellus (a-sel'us), $n_{\text {. }}[\mathrm{L} .$, dim. of asinus, an
ass: see assl.] 1. [Pl. Aselli (-i).] A name ass: see ass'] ${ }^{1}$. $[\mathrm{Pl}$. Asell $(-1)$.$] A nam$ given to each of the two stars $\gamma$ and $\delta$ Caneri lation. - 2. [NL.] The typieal genus of the family Asellida. A. aquaticus, the wate

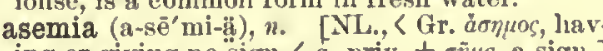
ing or giving no sign, < a- priv. + $\sigma \tilde{\eta} \mu \Omega$, a sigu.] understanding any sign or symbol of thought understanding any sign or symbol of thought
whether spoken, written, or aeted. Also called asymbalia.

asepsis (a-sep'sis), n. [NL., < Ar. $\dot{a}$ - priv. + $\sigma \eta \psi \psi$
of disease, putrefaction.] Absence of living g asepta (a-sep'tä), n. pl. [NI., neut. pl. of aseptus, 3 Gr. a antros, not liable to deen

ascptic. ] Things not liable to putrefy.
aseptic (a-sep'tik), a. [<Gr. áontros, not liable

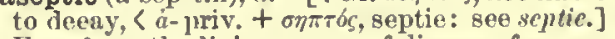
Free from the living germs of disease, fermenasepticity (as-ep-tis'i-ti)

The character or quality of being aseptie.

These are shsence of damil soil, aseplicity of the nir
and dryuess of the stmesphere. Nexs, XiLII asepticize (a-sep'ti-sīz), v. t.; pret. and pp asepticized, ppr. asepticizing. [< aseptic + -ize.] To render free from living ger

sexual (a-sek' sū-al), a. [< Gr. á- priv. $(a-18)$ + sexual.] 1. Not sexual; not sexed; having no sex, as a species or other gronp of animals which liave no sexual system or organs.-2. Nenter; being of neither sex, as some indi-
viduals of species in which other individuals are male or female, or as some stages in the growth of individuals which later develop into male or female.-3. Effected or produced by other than sexual processes; agamic; agamoofretic: as, asexuat reproduction. ash

Little eolonfes of these parasites, the Cunine, ultimately

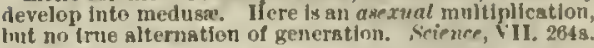
Asexual reproduction, siny process of propingation that many of the cry\}thos sms, by celf-division, ete., And in phe asexually (a-sek'sû-乡l-i), "ult. In an aspxual munner; agamieally; aganogunetically.

For what are the phrmomena of Agamogenesis, stater generally" An Imiregrated exg ifwelops into an asexual

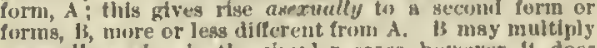
anexually agaln : In the simpler cases, huwever, it doe unteri engs from whence $A$ once noro yriwes.

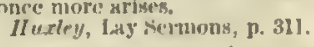

Asgard (as'gïrd), n. [<Icel.āsgardlur, < $\bar{\imath} s s_{1}$, god, + gurlhr, an inelosure $=\mathrm{E}$. yart ${ }^{2}$ : see $A s^{3}$,
gurth 1 , and yorl'.] In Nirse myth., the abode of the twelve gods and twenty-six gorldesses. and of heroes slain in battle, formed of the nyehrows of the giant Yimel. In the miflst of Asgard were the plain of Ida (Indsvollr), where the goids sssemseveral gods and gurldesses had thelr uwn dwellings, and sathala (Odin's hal), (Hodsheirn (the specisl hall of the gorls), and Vingoit (that of the goddesaes) were cummon biligard (the earth) by the bridge lifrost.

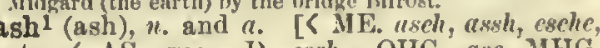
ete., $<$ AS. ase = I). esch = OHG. asc, MIIt, asch, m., G. esche, $\mathrm{t}_{\text {, }}=$ Ieel. ask $r=\mathrm{Dan}$. Sw. ask = OBulg. yasikn= Ijith. usis, the ash.] I. $n$ 1. In bat.: (a) The popular name of trees belonging to the genus Fraxinus (whieh see). The common ash of Furope, $\boldsymbol{F}$. exeetrior, is native through the greater part of Furope, northern difica, and some parts
of Asia. It is a handsome ornamental tree, and is exceed ingly valuable for its timber, which is close-grained and remsrkshly tongh and elastic. It was therefore in early
times the chief material in the construct fon of lows an

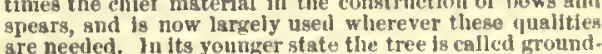
sre needed. In th younger state the tree is called ground ash, and a variety is weli known in cuitivation as weep
ing-ash. The flowering ash, $F$. Ornus, is a smalt tree of sonthern Europe, sometimes cnitivated for ornament. It
ylelds a sacciarine exudstion, which forns the best kmown the United states several specles of the genus are cum monly known under the name, as the black ash, groum

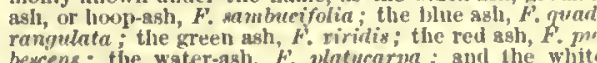
bexcens; the wster-ash, $F$ platycarpa; snd the white
ash, $F$. Americana. The last is the mist vilualle; it. wood elosely resenibles that of the Europesu ash, and adjunct) of varions trees or shrubs of other genera, generally from some resemblance in foliage or qualities of the woor to the eommon ash. (See below.) (c) Also, in parts of Fngland, the name of some herbaecous plants, chicfy Eyapadiun Poduyraria and Angeliea sylrestris, and the sweet ash, Anthriscus sylrestris.-2. The wood of the ash-tree; henee, something The wood of the ash-tree; hence, somethin

$$
\text { My grained ash a hunired times hath broke. }
$$

Ash of Jerusalem, an old Finglish nsme for woad or

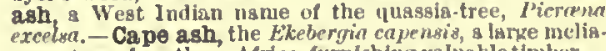

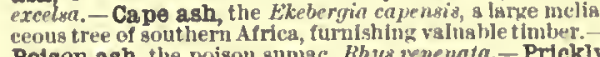
Polson ash, the poison sumsc, Rhus venewata. - Prickiy camum, I. Clava-Herculis, the laiter also called sea-(xh), Quaking ash, in scotlsnd, the aspen.-Red ash, of Aus
tralis, the Alphitoria excelsa, a tall rhamnaceous tree with
very hard wood.-Wild ash, sn old English narne for the very hard wood.- W1ld ash, an old English narne for the
mountaln-ash.- - Yellow ash, a legurainous tree of the nited States, Cladrastis tinctoria. See yellow-tcond. (Fee II. $a$. Pertaining to or like the ash; made of ash. (ash), n. [E. dial. pl. axen, be, as, ass, pl. asses; <ML. ash, ashe, asche, aiscbe, csehe, asse, aske, axe, pl. ashes, asches, askes, axes, and with older terin. ashen, aschen, aslien, axen, < AS. asce, asce, axe, pl. ascan, useath, axan, axun, = D. asel $=\mathrm{OHG}$. asga, aseu, MHG. asche, esehe, G. asche = Ieel. Sw. ash $n=$ Dan. aske = Gotl. azga, ash.] 1. What remains of a body that. azga, ash. 1 . What remalo of a bony that is burned; the ineombustible residue of organim after eombustion; in common usage, any incombustible residue of materials used as fuel: usually in the plural. As a commercial term, the word generally means the ashes of vegetsble suhstances, frum which are extracted the al
ash, pearlash, kelp, barilla, etc. The ash of tobacco. Donne, Polyderon (1631), N. 142.

A residne censisting of earbon, or carhon and $a x h$. UTr. 2. Fine material thrown out of a voleano in oruption. It is not, like orlinary ashes, a residunum of the combustion of a substance containing earbonsceong mingled with inorganic nister, but from the actusl tearing asunder of 
ash

the not fully consoliclated materlal hy the expanslve force ashen ${ }^{2}$ (ash'en or ash'n), $a . \quad\left[<a s h^{2}+-e n^{2}\right.$. of the gascs which it colltains, ancl in part from meehan-cal pulverization by friction in the elrmmey of the rolca-
no. Larger particles are called capilli; colserent matses of still larger size, scorice, cindcrs, and as a stratifited form. Rocks of this character have been called igneo-

and pluto-neptumian. See lave, rolcano, and the remains of the human body when burued; henee, a dead body or corpse; mortal remains.

Poor key-coll figure of a holy king:

Thou blootless remnant of that royal blood!

Black ashes, crude sota.-Blue ashes. See blue.Clavellated áshes. See clavellated. - Dust and ashes, af cheep humiliation : as, "I which ambut bust and ashes,

Gent. xvii. 27. - Ultramarine ashes. See ultramerine.
ash2 ash ${ }^{2}$ (ash), v. $t$.

They ash and powder their pericraniums.

2. To convert into ashes.

IIovell, Letters, iv. 5 The folled filter paper brought into a scorifter and

ashame (a-shäm'), v. [< (1) ME. asehamen, ashamen, < AS. äseamian, äsceamian (= MHG. irseamen, ersehemen, G. erschämen); mixed with (2) AE. yshamen, yschamen, < AS. gescamian, gesceamian, geseomian (= Goth. gastaman, refl.), and (3) ME. ofsehamen, < AS. "ofscamian (the AS. $g e-($ E. $a-6)$, or AS. of $-($ E. $a-4)$, respeetively, and shame, $v$.$] I.t intrans. To feel shame; be$ ashamed.

II. trans. To shame; make ashamed. [Now rarely used except in the past participle ashamed, with the foree of an adjective.]

It should humble, ashame and grieve us.

11. 417

ashamed (a-shãmd'), p.a. [<(1) ME. ashamed, aschamed, AS. aseamod, mixed with (2) ME. sehamed, s AS. *ofseamod; pp. of the preeeding sehamed, < AS. "of seamod; pp. of the preceding
verb.] 1. Affeeted or touched by shame; abashed or confused by guilt or a conviction of some wrong action, indeeorous eonduet, or other imbropriety: or by a dependent clause with that.

They shall be turned baek, they

y ashamed

I feel sufficiently my folly's penance,
And an asham'd; that shame a thousand sorrows

Those who base their hopes for the futme on the glorious revelations of the Bible need not le ashamed of it
story of the past. Dawson, Nature and the Bible, p. 181

"Ashamed am I that I should tell it the".

My pride is broken: men lave seen my fall.

2. Reluetant through fear of shame: followed by an infinitive: as, I am ashamed to offer it it is so little.

I cannot dig, to beg I am ashamed. Luke xvi. 3. He was not ashamed to answer that he could not live ont
Macaulay, Hist. Eng.
He royal sinile. ashamedly (a-shā'med-li), adv. With shame. ashamedness (a-shā'med-nes), $n$. The state of being ashamed.

Ashantee, Ashanti (a-shan'tēe), $n$, and $\alpha$. [Native name.] I. $n$. A native or an inhabitant of Ashantee, a state in western Afriea.

Ashantee, a state in western Afriea.

ash-barberry (ash'bärs ber-i), n. A name given to pinnate-leafed spocies of barberry (Berberis) belonging to the section Mahonit.

ash-bead (ash'bèd), $n$. In the manufacture of varuish, a layer of ashes placed near the fire over which the gum is melted. The pot containing the gum is placed upon the ashes when the heat become too great, or when the varnish is ready for mixing.

ash-bin (ash'bin), $n$. A receptacle for ashes and other refuse.

ash-cake (ash'kāk), $n$. A cake baked on or in hot ashes.

ash-candles (ash'kan"dlz), n. pl. Ash-keys: an English name of the fruit of the European ash-tree, Fraxinus excelsior.

ash-color (ash'kul"or), $n$. The color of ashes a clear, neutral gray.

ash-colored (ash'kul"ord), $a$. Of the eolor of ashes; cinerous.

ashen 1 (ash'en or ash'n), a. [< ME. *aschen,

AS. * rescen (Bosworth), (ase, ash: see ush 1 and

-en ${ }^{2}$.] Pertaining to the ash-tree or its timber; made of ash.

Fis ashen spear, that quivered as it flew.
Dryden, tr. of Ovid's Jetamorpl., xil. 494
Consisting of or resembling ashes; ash-colored: "the ashen hre of age," Scott, Marmion, vi. 14.

ashen ${ }^{3}+, n$. Obsolete plural of $a s h^{2}$. Chaucer. ashery' (ash' $\mathrm{\theta}-\mathrm{ri}$ ), n.; pl. asheries (-riz) $\left.\operatorname{sh}^{2}+-c r y.\right]^{-1}$ 1. A place for ashes; an ashash.

ashet (ash'et), n. [Se., earlier asset, < F. assiette, a plate.] A large platter or dish, generlly of an oval shape, on which meat is brough ally of an oval shape, on

sh-fire (ash'fir), $n$. A slow fire of live coals banked or covered with ashes, used in chemica operations, and by baker's and others.

ash-fly (ash'fli), n. 'The oak-fly, Cynips querensfolii.

sh-furnace (ash'fër" nạs), n. A kind of furnace or oven in which the materials for glass-making are firtted.

ash-hole (ash'hōl), $n$. A repository for ashes: the lower part of a furnace; an ash-bin.

shine (a-shin'), prep. phr. as $a d v$. o1 $a$. $\quad\left[<a^{3}\right.$ + shinc.] Shining; bright; luminous.

His hard leatures . . . all agrin and ashine with glee.

Ashkenazic (ash-kē-naz'ik), a. Pertaining or 292.

Ashkenazim (ash-kẹ-naz'im), n. pl. [Heb.] German-Polish Jews, as distinguished from the Sephardim or Spanish-Portuguese Jews. They form about 90 per eent, of the Jewish race, and differ Irom but not in doctrine.

sh-key (ash'kē), n. $\quad\left[\left\langle a s h^{1}+k e y^{1}\right.\right.$. Cf. $m a-$ ple-licy.] The key or samara of the ash-tree;
the periearp of the ash; in her. (in the plural), a representation of the keys or

samaras of the ash-tree, used as a

hoko (ash-kō'kō), $n$. A native

ame in Abyssinia of the cony, a

species of Hyrax. Bruce. Also

eony, 2.

See ashler.

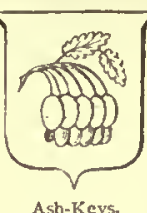

ash-leach (ash'lēch), n. A hopper in which ashes are placed during the proeess of the

ashler, ashlar (ash'ler, -lär), $n$. [Ear]y mod. $\mathrm{E}$. also astler, asler, ete., $<\mathrm{ME}$. asheler, ascheler, achiler, $\angle \mathrm{OF}$, aiseler, ashler, $\angle \mathrm{OF}$, aiselle, aisscle, aisselle, < ML. assella, a little board or shiugle (cf. L. assula, a ehip, shingle), dim. of L. assis ( $>$ It. asse = F, ais), a board, plank, also spelled axis, and the same word as axis, axis: seo axis and astel.] 1. A block of building-stone, rough as it is brought from the quarry; sueh stones

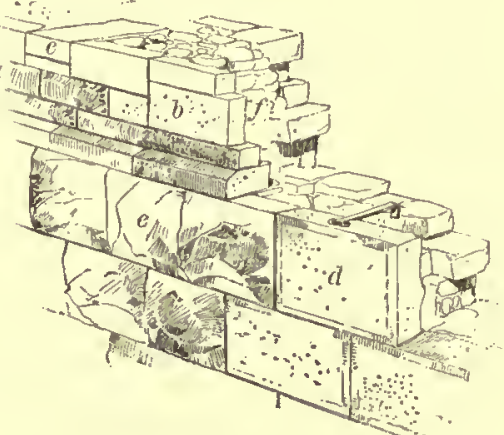

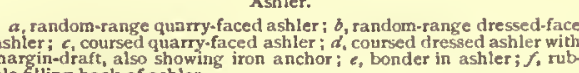

as distinguished from a stone which is of irregular shape; such stones colleetively.

Ashlar stones, or ashlars as they are commonly called, are made of various sizes on the surface, as the eharacter
of the ediffee nay require.
Encyc. Brit., IV. 471.

3. Masonry constructed of ashler. When the courses are not regular, but broken up by the use of thenes of different thicknesses, it is ealled broken ashler or ran-
dom-range ashler. Small ashler employs stones of less than one foot in breadth. Bastard ashler is an ashler face acked with rubble or other inferior work, as in all course when it is smoothed on the exposed face; tooled proper when the tooling is in grooves; random-tooled, when cut
without regularity; chiseled or bonsted, when wrought with hole. - 2. A manufactory of potash or pearl-

Also called ash-candles.
Asiarch

narrow tool; pointed, when wrought with a tool still arrower, rusticated, or quarry-faced, when the joint ment when tooled ohliquely fn alternate directions; and nigged, when dressed with a pointed hammer.

The ashler buttress braves its force, cott, Cadyow Castle.

Droved ashler, a scotch name for ashler of Inferior ashlering (ash'ler-ing), n. [< ashler $\left.+-i n g{ }^{1}.\right]$ 1. In earp., short upright pieces to which laths . are nalled, oxtendrets.-2. In masonry, ashler used as a facing to the body of a wall; bastarl ashler.

ashore (a-shōr'); prep. phr. as $a d v$. or $a . \quad\left[<a^{3}\right.$ + shore ${ }^{1}$. 1 . On shore; on or to the land adjacent to water: as, bring the goods ashore; the ship was driven ashore. - 2. On land: opposed to aboard or afloat: as, the eaptain of he ship remained ashore.

ash-pit (ash'pit), n. 1. A place of deposit for ashes and house-rubbish generally. -2 . The place where the einders fall under a furnace
or fireplace.

ash-plate (ash'plāt), $n$. The rear plate of a shrafi (ash-raf'i), n. [Pers. ashrafi.] A Persian gold eoin, weighing rather more than 53 grains, and worth about $\$ 2.43$.

ash-shoot (ash'shöt), n. A tube leading upward from the stoke-hole of a ship to the deek, through which the ashes are lifted. The shoot is also utilized as a ventilating shaft.

Ashtaroth (ash'ta-roth), $n$. [Heb.] Plural of Ashtoreth.

Ashtoreth (ash'tō-reth), n. [Written Astoreth by Milton: a Heb., orig. Phenician, name, equivalent to the Assyrian Ishtar.] Same as Astarte. Ashura (ash'ö-rä), n. [Ar. 'ashir, tenth, <'ashara, ten.] A voluntary fast-day observed by the Mohammedans on the 10th day of the month Muharram. Hughes.

Ash Wednesday (ash wenz'dā). [ME. asche-, ask-, ax-lcednestay; $a s h^{2}$ and $W$ ivedresday.] The first day of Lent. It is named from a custom in the Western Clmrch of sprinkliug ashes on the heads of penitents admitted to penance on that day. The origination of this ceremony is generally attributed to Gregory the
Great. According to the present rite in the Roman CathGreat. According to the present rite in the Romaly Cath-
olic Church, the ashes are consecrated on the altar, sprinkled with boly water, signed with the cross, and then strewn on the heads of the elergy and people, the priest repeating, "Memento quod cinis es, et in cinerem reverteris ashweed (ash'wëd), n. [Formerly also ashieaish-veed: $<a s h 1+$ ueed 1.$]$ Tho goutwort, Agopodium Podagruria.

ashy (ash'i), a. [ME. asshy, asky; <ash $\left.{ }^{2}+-y.\right]$ 1. Belonging to, consisting of, or resembling ashes; henee, ash-colored; pale.

A timely-parted ghost,
of ashy semblance, meagre, pale, and bloodles

2. Sprinkled with ashes. Chaueer.

Asian (ā'shian or $\left.\bar{a}^{\prime} z h i a n\right), a$. [< L. Asianus,

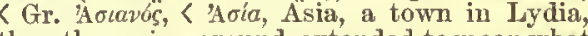
then the region around, extendod to mean what is now known as Asia Minor; in Pliny Asia is used, as now for the whole eontinent. The origin of the name Aoía is unknown.] Pertaining to Asia, a continent extending from Europe eastward to the Pacific ocean, and from the frozen ocean on the north to the Indian ocean on the south.

Asianic (ā-shi- or ā-zhi-an'ik), a. [< Asian + -ie.] 1. Of or pertaining to Asia Minor.

A syllabic writing, evidently of immense antiquity, which prevailed throughout the whole of Asia Mfinor, and 2. Pertaining to or characterized by Asianism, or a florid and inflated style of literature.

Asianism (ā'shian- or $\left.\bar{a}^{\prime} z h i a n-i z m\right), n$. [<Asian $+-i s m$.$] A florid and inflated style of oratory$ or rhetorical treatment, such as was eharaeteristic of the Asiatie Greeks in the three eenturies preeeding the Christian era.

Asiarch ('a'shi-ärk), $n$. [< LI. 'Asiarcha, < Gr.

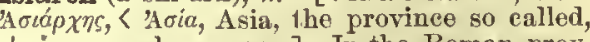
$+a \rho \chi \varepsilon \varepsilon \nu$, rule, govern.] In the Roman province of Asia, one of the presidents of the provineial games. The Asiarchs were chosen annually, expense. It was probably the policy of the Romans to encourage
eentralisation in the religious organisation of their prov. Inces, and the titles "Archiereus of Asia" and Asiarch were probably introduced by them into Asia Minor.
C. T. Nercton, Art and Arcliæol., p. 165. 


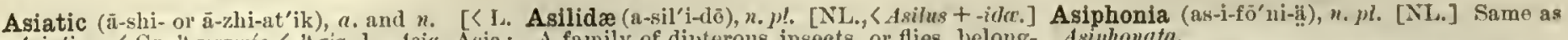

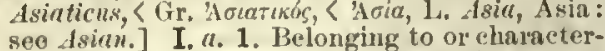
istic of Asia or its inhabitauts. - 2. Characterized by Asianism.- Aslatic cholera See cholern. II. $n$. A native of Asia.

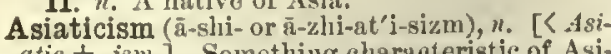
atic $+-i s m$.$] Something charaeteristic of Asi-$ aties; speeifically, Asiatic, as distinguished [Rare.]

The great struggle between lrotertantism and Arioti

Asiaticization (ii-slii- or $\overline{\mathrm{i}}$-zhi-at"i-si-ză'shon), n. [S Astaticize + -ation.] Tho act of rendering Asiatic, or of pormeating with Asiaticism. [liare.]

The Asiaticization of Furopean hlte.

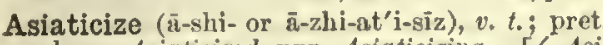
and pp. Asiaticized, ppr. Asiaticizing. [ $[$ Asi-
atic + -ize. $]$ To render Asiatie; tinge or imbue with Asiatic ideas, customs, ete. [Rare.]

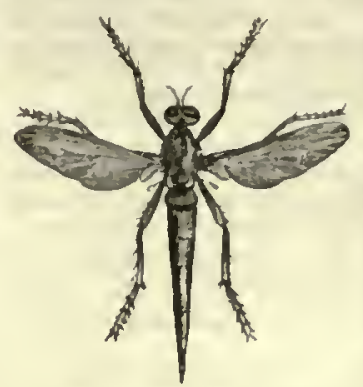

Robber-fly (Asilus sericent culmination of the Ariaticizing tendency in Europe, sa in France, and Spain, and Italy, aml in half of Germany.

Asida (as'i-dii), $n$. [NI.] The typieal gonus of beetles of the subfamily Asidina, eontaining numerous wingless species witl ovate bodies, inhabiting desert regions of Furope and Nortl America.

aside (a-sid'), mep. phr. as adr. and prep. MlE. aside, a side, on side, on syd (also with ad$o n, a^{3}$, and side ${ }^{1}$.] I. $a d r^{2}$ 1. On or to one side; to ol' at a short distanee; apart; away from some normal direction or position: as, to turu or stand aside; to draw a eurtain aside. Thou shalt set axide that whlch is full. $2 \mathrm{Kl}$. Wr. 4.
lle took lim aside fron the multitude. The flames were blown aside.

Dryden, Pal, ain Arc, 1. 1639.

2. Apart or separately (from); in a state of withdrawal or exclusion (from). [A use of aside for apart nearly or quite peeuliar to the United States.]

I give thee love as God gives light, from prayer.

That we agree with him [Emerson], or that lie always agrees with himself, is aside from the question.
Lotell, Stully Windows

3. Out of one's thoughts, eonsideration, or regard ; away; off : as, to lay aside one's animosity; to put one's cares aside. Withont laylug axide that danntless valour which had
been the terror of every land from the Fibe to the 1 yyre-
Meea.
Macalay, 11 tst. Eng. 1 . neea.
Books can only revenl us to ourselves, aurl as oiten as they do na this service, we lay them aside.

No man can put abstract notions nore entlrely nsicte l. 4. So as not to be heard by some one present: chiofly a dramatic use. Thus, on the stage, to utter a speech aside, is to utter it in such a manner that it is as-
aumed not to be heard by the other characters, or to be heard only by those for whim it is intended. o dear, madam, you are not to say that to her face! Sheridan, The Critic, lit.

II. wep. By tho side of; beside. [Rare, except in old English and Scoteh.]

[lere slake your thirst aride their livelicst rlll. Landor. aside (a-sid'), n. [< aside, $\left.a d v^{*}\right]$ Something spoken and not heard, or supjosed not to be heard, by some one or more present ; especially, a remark uttered by an actor on tho stage, and assumed not to bo lieard by the other characfor whom it is intended.

for whom it is intended. $<(\mathrm{Gr}, \dot{a}$ - priv, $+\sigma i \delta \varepsilon$ pirns, of iron: see $a-18$ and siderite. $]$ A meteorio stone which contains no metallie iron. See meteorite.

Asidinæ (as-i-dī'nē), n. $)$. [NL., <Asidu + -ina.] A subfamily of atraeheliato hetromefied by the genus Asida.

Asilici (a-sil'i-sī), $n_{0} p l$. [NL., < Asilus.] A name given by Latreille to a group of tetraehretons braehycerous dipterous insects, corresponding most nearly to the modern family Asilide, or hornet-tlies. I atreille divfled the Linnean genus $A$ this fellow.

Also spelled assinego. Axiphouida.
A family of dipterous inseets, or flies, belongiug to the group Tetrachete of the suborder
Brachycera; the hornet-1lies, very active, predacious, and voracious, preying upon other inAsilus (a-si'lus), $n$. [NL., < L. asilus, a gadgellus of two-winged

Asiphoniata $\left.\left(\mathrm{as}-\mathrm{i}-\mathrm{f} \overline{-}-\mathrm{ni}-\mathrm{a}^{\prime} \mathrm{tạ}\right), n, p\right]$. [NL.] Samo as Asiphonata.

asiphoniate (as-i-fō'ni-āt), a. Same as rsipho-

Asiphonida (as-i-fon'i-dạ̈), n. $\mu l$. [NI.] Same is Asiphonatu.

asis. Seo-iasis.

Asilide, popularly asitia (a-sish'iă), n. [N1., < Gr. dotria, want known as ornet- of food or of appetite, <actros, without food, flies, robber-flies, $\dot{n}$-priv. + ciros, food.] Loss of appetite; Joathor hawk-flies. They ing of food.

are large, ratlier slen. ask (ásk), $^{2}$. [E. dial. also $u x$ and ass (pret. derroug nurkably strong heak sen, eshen, esscn, transposed axcn, acsen, acsien, with whleh they pierce oxien, < AS. äseian, often transposed äcsian, $\vec{a} x$ their prey. They de $i a n, a h s i a n .=O S$. éseon $=$ Orries. äskia $=\mathrm{D}$. stroy caterplllars, grass. cischen = OIIG. eiscōn, MIHG, eischen, G. eischen, hoppers, and even heischen = Sw, äska = Dan. aske, ask (ef.

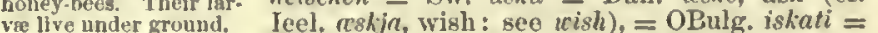
2. In ormith.: (a) Bohem. jiskati = Russ, iskati = Lith. jeshkoti [i.c.] An old name $=$ Lett. cshiat, seek; ef. Skt. $\sqrt{ }$ ish, seek, de(Gesner, 1555, to sire.] I. trans. 1. To request; seek by words Brisson, 1760) of to obtain; petition for: commonly with of, in

he willow-warbler, Plylloscopus trochilus. (b) the sense of from, before tho person to whom
A genus of such warblers. Bechstein, 1802. genus of such warblers. Bechstein, 1802.

Asimina (a-sim'i-nạa), n. [NL. (ef. Canadian F. aciminc, the fruit; aciminier, the tree), asimina, the northern Algonkin corruption of southern Illinois rassimina (pl.), the name of
the fruit, prob., as Dr. Trumbull suggests, rassa, a sleeve, + min, pl. mina, fruit; from its shape.] An anonaceous genus of shrub of the Atlantie and Gulf States, including half dozen species. ot theae the most widely distriluted a the common papaw, $\boldsymbol{A}$. triluba, which beconses a smal the and bears a large edihle frult. The others are lo cles arc also crellterl to .lexico and the West lndies. asinarył (as'i-nä-ri), a. [< L. asinarius, <

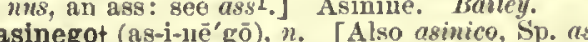
ico, a little ass, dim, of $\mathrm{Sp} . \mathrm{Pg}$, asno, $\mathrm{L}$. as mus: $\sec a s s 1$.$] 1. A little ass.-2. A foolish$

Thou sodderi-witted lord! thou hast no more brain flan have in mine elbows; an assinego may tutor thee.

asinine (as'i-nīn or -nin), a. [<L. asininus, < (tsinus, an ass: see $a s^{1}$.] 1 . Belonging to or
characteristic of the ass. - 2. Having the qualiies attributed to the ass; stupid; obstinate obtrusively silly; offensively awkward.

$$
\text { Thla one act. . proclaims his axinine nature. }
$$

The gravest historians of the Tetherlands often relieved the niost asinine gambols. asininity (as-i-nin'i-ti), $n . \quad[<$ asinine $+-i t y$.
Cf. ML. asinites, stupidity.] The quality of Cf. ML. asimitas, stupidity.
being asinine; obstinate stupidity.

$$
\begin{array}{r}
\text { The elephant's discourse } \\
\text { Will neutralize the atupid a a sininity. } \\
\text { The Century, }
\end{array}
$$

asinus (as'i-nus), $\|$. [L.. an ass: see (lissl.] In zoö.: (a) Speeifically, the ass, Einus asinis. (b) [caj.] Generically, a subgenus of Equus, including the asses, as the hemione, onager, quagga, zebra, ete.

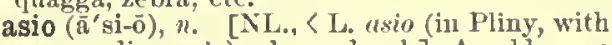
var. reading axio), a horned owl.] An old name of a horned owl. It was made a gemns by Brisson, 1760 , having as type the common long-eared owl of Europe,
A. of urs, and the name has been given with little diacrimimation to sundry horned or eared owls. Wow nsually: $(a)$
[cop.] A genus compreliending only $A$. ot $x$ and its mo. [ccp,] A genus comprelending only $A$, of ux and its in. accipitrinus, the short-eared owl, etc. See cut mider owl.
(b) The speciflc name of the snall red or gray owl of Nortli Auerica, Strix asio (Linnæus), now Scops asio.
Asiphonata (a-sī-fō-na'tä), n. pl. [NL., neut. pl. of asiphonatus: seo asiphonate. ${ }_{\text {An }}$ order of acephalous lamellibranchiate mollusks, colltaining headless bivalves without respiratory taining headless bivalves without respiratory tubes or siphons like those whieh in the
siphonata eonvey water from the gills, and having the lobes of the mantle free. Most of the Ariphonata are fixed, the foot being smajl or wanting, and many secrete a byssus. The order inclules hn valuable to man, as oystera, pearl-oysters, scallops, mus. Synouy wous with Atrachia. Also A siphonia, Asiphoniatn,

asiphonate (a-si'fō-nāt), $a_{0}[<\mathrm{NL}$. asijhonatus, (Gr. $\dot{a}$ - priv. + oi $\phi w$, sipbon: see $a-2 s$ and siphonate.] Not possessing a respiratory tubo or siphon: opposed to siphonate; specifieally, of or pertaining to the Asiphonata. H.
Nicholson. Also asiphoniate and csiphonate.
Ask counael . . of God. Judgea xwil. 5.

2. To demand, expeet, or elaim: with for: as, what price do you ask, or ask for it ?

Ask me never so muclı dowry. Gen, xxxiv. 12

3. To solieit from; request of : with a personal desired: as, I ask you a great favor; to ask one for a drink of water.

1 came near, ... and asked hlm the truth of all this.
Dan. vii. 10

4. To require as necessary or useful ; demand exaet.

The exigence of a state axks a jauch longer time to con-
Addison.t the dealgn to maturity. To find the medium oaks some slare of wit, Cocper, Conversation.

5. To interrogate or inquire of; put a question to.

6. To inquire concerning; seek to be informed

about: as, to ask the way; to ask a question.

Ilere kennell'd in a brake she finds a hound,

Aud asks the weary caitiff for his master.

7. To invite: as, to ash guests to a wedding or entertainment.- To ask in church, to publish banns of marriage. [1'he verh ash is nsed in this phrase
becunse the publication is reslly an inquiry whether any one can state any valid olj,ection to the marriage. = Syn. IBeseerl, Enitreat, Crave, Supplirate, Implore, Importume. Ask la the generie word in this list; it implies neither that
wlat is usked mnst lie rendered, nor, on the other band, that it would he a fuver. Demand, chatm, and require ask imperatively or anthoritatively; the other's call for a favor
with different degrees of urgency or lumility. Beseech, with different degrees of uryency or limility. Beseech, urgency ; erne, supplicate, and implore injply. great urgen. cy and great dependence or lumility. Request is a little
more formal or carcfully chil than axh : as, your atten-
dance is requested. Deg is primarily to ask as a bepgar: sometimes, by the hyperbole of social usage, to sak as a
favor, real or professed : as, I beg your pardon. Demaad and clain more often refer to things; require appliea more the whole ; he required me to come ; he reguired some proof to back my demand and sulstantiste my clam
Solicit la nrrent, but legs 80 than the words that follow it: as, he solicited my vote. Beseech is most appllealle to the nct of asking on the grouml of pure favor. Entreat inmples into polite forns of speech, and in that ise robbed of most of its Porec. Supplicate and implore are, flgnratwely, or tesperate appeal, perhaps in many words. To imporwith urgency, lut perhaps withont especial ilependence or humility.

$$
\text { To axk and have, command and be oheyed. }
$$$$
\text { To-niglit we holl a solemn supper, sir }
$$

Aml l'll requexf your presence. Shak., Jacbeth, iil. 1. Theae matters conld not be thus carri'd without a beyg'd and borrow'd force from worldly authority.

It is cunly when the reasonable and the practicable are denled that men demand the unreasousble and lmpracti-
Loverell, Democracy.$$
\text { (ame not to ns, of us to claim the prize, }
$$

Curselvea will send it after. Tennyson, Lancelot and Elaine.

The guards opened the doors, we were told that we could proceed no further, and were required to alight. The port ... was crowded with those who hastened to solicit permission to share in the enterprise.
Bancroft, IIIat. U. S., I. 40. object, and with or without for before the thing

Ife is of age, ask him. John ix. 21. continued apyeal or representations of a moving kind. 
ask

1 Iis eyes, hís silence, did besech Filliam Mforris, Earthly Paradise, 11. 114. Lest I ghould fear and fall, and miss Thee a Who art not nissed by any that entreat.

Time, the avenger! unto thee I lift Byron, Childe Ilarold, iv. 130 . We have petitioned, we have remonatrated, we have supplicated, we have prostrated ourselves before the throne,
and have implored its interposition to arrest the tyranand have hands of the ministry and Parliament.
Patrick IIenry. 1)il they hear me, would they listen, did they pity ne supphall I heed then in their anguish? shall I hrook to ho
supplicated?

Implore your help in these pathetic atraing.
Pope, Imit. of II Iorace, II. 1. 232.

Importune him for ny moneys; be not ceas'd
With alight denial.

5 and 6. Ask, Inquire, Question, Interrogate. Ask is here alao the generic word; it is simple and inlormal. Inquire may be used in the endeavor to be civil, or it may expreas a to) the causes of discontent. To question in this sense implies the asking of a aeries of questions, it being supposed that the truth is hard to get at, through ignorance, earentially the same as question, but more formal : as, to question a child or servant about his conduct; to interrogate a witness, an applicant for office, etc. Questioning or interrogation might be reaented where asking, asking
a question, or inquiring would meet with a friendly response.

If we encountered a man of rare intellect, we ahould $k$ him what books he read.

I promis'd to inquire carefully

bout a schoolmaster for the fair Bianca. But since I heard him make reply la many a weary hour
$T$ were well to question him, and try If yet he keeps the power.

lentryson, The Talking Oak To question and [to] interrogate [are] to ask repeatedly, and in the latter case more authoritatively than in the
former.
Crabb, English Synonymea, p. 102.

II. intrans. 1. To request or petition: with for before the thing requested: as, ask for bread. Yonr committee ask for candor and justice; they do Szimner, Prison Disciplinc.

Explore the thought, explain the asking eye.

2. To inquire or make inquiry; put a question often followed by after or about, formerly also by of.

Wherefore is it that thou dost ask after my name?

ask ${ }^{2}$ (ask), $n_{0}$ [E. dial. also asker, ascar, askerd askard < aske, spelled once arske, < AS. atthexe (found but once, in a gloss), appar. contr. from * agithexe $=\mathrm{OS}$. egithassa $=\mathrm{OD}$. eggedisse, egdis, later heghdisse, haeghdisse, now hagedis, haagdis (simulating $\mathrm{D}$. haag $=\mathrm{E}$. hay ${ }^{2}$, hedge) $=\mathrm{OHG}$. egidehsa, $\mathrm{MHG}$. egedehse, $\mathrm{G}$. eidechse, a newt; appar. a compound, but of uncertain for mation; perhaps < AS. "agi, cge $=$ OS. egi $=$ OHG. -dehsa, repr. a Teut. $V^{*}$ thalss, make, fashion (seen also in $\mathrm{OHG}$. MHG. dahs, G. dachs, a badger, OHG. dehsala, MHG. dehsel, a hatehet,

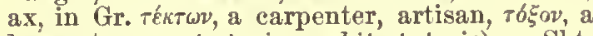
bow, etc.: see tectonic, architect, toxic), = Skt. $\sqrt{ }$ taksh, make, fashion; the seuse 'awe- or
fear-maker' suiting the popular dread of lizards and other reptiles.] A newt. [Prov. Eng. and Scotch.] aska (ảs'kä), $n$. [Russ. asika.] A warm cap by the Russian peasantry.

askance ${ }^{1}$ (a-skans ${ }^{\prime}$ ), adv. [First in early mod. askance (a-skans'), adv. [First in early mod. E., also written ascance, askaunce, ascaunce, the earliest recorded form (Palsgrave, 1530) sanche; with a later variant askiant, q.v. Origin uncertain. Cf. asquint, asklent, aslant, and askew, askite.] Sidewise; obliquely; out of the corner of the eye; askant.

But Ruatum ey'd askance the kneeling youth.
M. Arnold, Solrab and Rustum. So ahe, and turn'd askance a wiutry eye. askance ${ }^{1}$ (a-skans'), v. t.; pret. and pp. askanced,
ppr. askancing. [< askance 1 , adv.] To turn ppr. askancing. [< ashance
aside, as the eyes. [Rare.]

, how are they wrapp'd in with infamiea
That Irom their own misdeeds reskance their eyes!
Shak., Lucrece, 1.637

askance $2 \nmid$, askances $\nmid, a d v$. and comj. [Early mod. E. ascances, ashaunces, < ME. ascancc, as
338

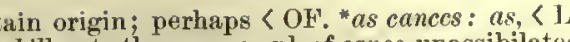
ad illas, to the; cances, pl. of cance, unassibilated (Pieard) form of cheance, $>\mathrm{ME}$. chance, chaunce, E. chance. Cf. perchance.] I. adv. Perhaps. Aseaunce that eraft is no lyght to lere?

Chaueer, Yeomanl' Tale, 1. 838.

II. conj. As if; as if (saying).

And wroot the names
d scaunce [var. axkaunce that he wolde for hem preye.
Chaucer, Stummoner'a Tale, 1. 37.

lieeping a countenance ascances she understood him
Sir $P$. Sidney, Arcadia.

Therewith he raysed his heavy head alight,
Askcounces, $\mathrm{Ha}$ ! indeed and thinkest thon so.

Gascoigne, Flowera. ( $\boldsymbol{V}^{\mathrm{V}}$. L. D. $)$

askant (a-skant'), adv. [Early mod. E. also ascant, askaunt, ascaunt, later form of askancel
Cf. aslant or asquint.] Sidewise ; askance.

With an eye askant.

Corcper, Iliad, xi. 65 .

asker ${ }^{1}$ (ás'kèr), n. [ME. asker, askere; < ask1 + -erl.] One who asks; a petitioner; an iuquirer.

To give to every asker. Hammond, Workz, 1. 99. Every asker being aatisfled.

gby, The Nature of Bodiea.

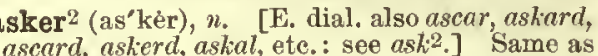
ask $^{2}$. [Prov. Eng.]

askew (a-skü'), adv. [Early mod. E. also askuc, ascue, a sliew; appar. $<a^{3}+$ skew, q. v. Cf. equiv. Icel. $\bar{a} s k \bar{a}$.$] In an oblique position;$ obliquely; awry; out of the proper position or arrangement; hence, askance; sidelong.

When ye lowre, or Jooke on me askew,

Spenser, Sonnets, vil. He [Kepler] found that this planet [Mars] moved in an ellipse or oval curve round the aun, which was aituated
rather askew near the middle. inppar. $<a^{3}+$ skite, askilet, $p r e p . p h r$ as $a d v$. [Appar. $a^{3}+$ skite, appar. of Scand. origin, repr. by AS. sceolh,
sceol-, scyl- (cf. in comp. sceolh-êge, scyl-ègede sceol-, scyl- (cf. in comp. sceolh-êge, scyl-ègede
$=$ Icel. shjoleygr = Sw. skelögd = Dan. skelöjet, squint-eyed) $=$ Icel. skjalgr $=\mathrm{Sw}$. dial. shjaly $=$ D. schecl = OHG. scelah (scelh-), MHG. schelch, schel, G. schecl, schel, oblique, squinting; hence Icel. skala $=\mathrm{Sw}$. shela $=$ Dan. skete, make a wry face.] Askant. Bp. Hall.

asking (ás'king), n. [< IE. askinge, axungc, etc.,, AS. äscung, āxung, <äscian, ask: see ash $k^{1}$.] 1. The making of a request; a petition: as, it
may be had for the asking. - 2. Proclamation or publication in church of banns of marriage. Sce to ash in church, under ask ${ }^{I}$.

askingly (ás'king-li), adv. In an entreating [Rare.]

Ilow askingly its footsteps toward me bend!
It acems to gay, "And have I then one Iriend?"

asklent (as-klent'), $a d v$. A Scotch form of aslont.

askos (as'kos), n. [Gr. dokós, a wino-skin: see more or less elosely the form of a wine-skin. Such vases, of Etruscan or Greek workmanship, are of not uncommon oceurrence in Italy, and are often provided with a foot and a handle. Also ascus.

land, probably a plethra (which see)

aslakeł (a-slāk $\left.\mathbf{k}^{\prime}\right), i$. and $t$. [< ME. aslaken, <AS. asslacian, slacken, loosen, remit, $\langle\bar{a}-+$ slacian, slake: see $a-1$ and slake.] 1. To abate diminish.

The water schal aslake and gon away.
Chaucer, Niller's Tale, 1. 367.

Shal ... thy hauty lookes quench my kindeled lone, or thy gailant shew oglake my good wil?

2. To moderate; mitigate; appease; satisfy. Atte laste arlaked was his mood.

Chaucer, Knight's Tale, 1. 90\%

When mourning altars, purgd with enimies lite,

The black infernalt Furies doen aslake.

The beast that prowla about in search of blood,

Wr reptile that within the treacherons brake Southey, Paraguay, i. 14.

aslani (as-lä'ni), n. [Turk., < aslan, arslan, a lion.] A Turkish silver coin, worth from 115 to 120 aspers. See asper ${ }^{2}$

aslant (a-slánt'), prep. phr. as adv. or $a_{.}$, and prep. [ML. aslante, o slante, aslonte, earlier asklent, asclent.] I. adv. or $a$. In a slanting or sloping direction; oblique; obliquely; not perpendicularly or at right angles. asocial

The ahait drove through his neck aslant. Dryden As with hia winga aslant

Lomafellow, Skeleton in Armor.

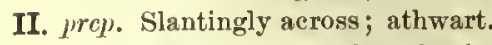
There is a willow growa aslant a brook.
Shak., Hamlet, iv. 7 The swelling upland where the side-Jong sun Aslant the wooded grove at evening goes.
Lonffellow, spirit of Poetry.

asleep (a-slēp'), prep. phr. as $a d v$ or $a$. [Also on sleep (Acts xiii. 36); MIE. aslepe, aslape, onslape, etc., < AS. on släpe, in sleep; < as t fall asleep.

IIe [Sisera] was faat asleep. Judges iv. 21. By whispering winds goon lull'd asleep.
Milton, L'Allegro, I. 116. And there within the hollow lay
Aslaug the golden headed child,

Ileep and rosy.
William Morris, Earthly Paradise, III. 32.

2. Figuratively - (a) Dead; in or into a state of death: chiefly in the Scriptures and religious literature.

Concerning thenu which are asleep, ... aorrow not.

(b) Dormant; inactive; idle.

During this inquiaition Julia' a tongue
Was not asleep. Byron, Dou Juan, i. 145.

3. Having a peculiar numb feeling, accompanied by or passing off with a prickly tingling sensation. This condition ia produced usually by prolonged presaure on the nerve-trink
most frcquent in the arms and legs.

IJia legge ' $\dot{U}$ dall, tr. of Erasmus's A pophthegms, p. 235.
stiff. 4. Naut., said of sails when the wind is just strong enough to distend them and prevent them from shaking.

aslope (a-slōp'), pp., or prep. phr. as $a d v$. or $a$. ¿late ME. a slope, either $\left\langle a^{3}+\right.$ slope, $n$., or else for aslope, aslopen, 'slipped away,' üslopen, pp. of äslüpan, slip away, $\langle\bar{a}$ - + slüpan, slip: see $a-1$ and slopc, $a$. and $n$., and slip. Cf. alight ${ }^{1}$, of similar double formation.] In or into an inclined or slanting position or direction; with leaning or inclination; deflected from the perpendicular; with declivity or descent, as a hill.

Set them not upright, but aslope. Bacon, Essays.

aslugt (a-slug'), adv. $\left[<a^{3}+\operatorname{slug}^{1}.\right]$ In a

sluggish manner. [Rare.]

That comea aslug araing lis boat

Fotherby, Atheomastix, it. 12.

asm. [<Gr, $-a \sigma \mu \delta \varsigma,<-a ́ \zeta \varepsilon \iota v$, after - - , equiv. to $-\iota \sigma \mu \sigma c,<-i \zeta \varepsilon v$ : see-ism, and ef. -ast.] A suffix of Greek origin, occurring instead of -ism after $-i-$, as in enthusiasm, miasm, etc.

smanite (as'man-it), $n$. A form of siliea found in some meteorites. It has been aupposed identical with tridymite

Asmannshäuser (ås-mảnz-hoi'zèr), n. A brand of wines made at Asmannshausen, in Nassau on the Rhine. Theae wines are both red and white, the ormer being in eapecial repute for its excellent flavor and asmatography† (as-ma-tog'ra-fi), n. [< LGr.

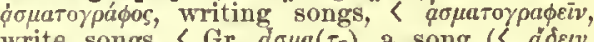
write songs, < Gr. do $\sigma \mu a(\tau-)$, a song ( $\angle d \varepsilon \varepsilon v$,

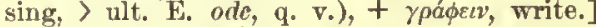
The art of composing songs.

asmear (a-smēr'), prep. phr. as $a d v$. or $a . \quad\left[<a^{3}\right.$ + smear.] Smeared over; bedaubed.

I came into Snithfleld, and the shameful place, being all asmear with fith, and fat, and blood, and foam, aeemed to
atick to me. Asmonean, Asmonæan (as-mō̄-né'añ), $a$. and $n$. [< LL. Asmomaus or Asmoneus, representing Heb. Khasmonu.] I. a. Pertaining to Asmoneus or Asmoneus, a reputed ancestor of Mattathias, the first of the Maceabees and the father of Judas Maccaboeus, who lived about $165 \mathrm{~B}$. c.; hence, pertaining to the Maccabees. See

II. $n$. One of the family of Asmoneus; a Maccabean.

asoak (a-sök'), prep. phr. as $a d v$. or $a$. [< $a^{3}$ dition; thoroughly wet.

social (a-sō'shal), a. [<Gr. $\dot{a}$ - priv. $(a-18)+$ social.] Unsocial; antagonistic to society.

As new morbid elements are formed in the disintegrat. ing processea of disease, the ravages of which they there upon accelerate; so new products of an asocial or antisocial kind are tormed in the retrograde mo
the human kind. 
asomatous

$3: 39$

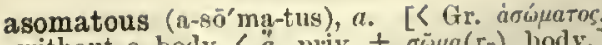

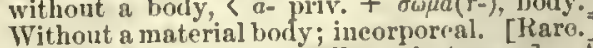
Asopia (a-sóp pi-ä), $n$. [N1. ; ef. dsopuss.] genus of pyralid moths. A. fariualis is the meal-moth.

Asopinæ (as-ō-pi'nē), n. pl. [NI.. < Asopus + ina.] A subfamily of heteropterous insoets

Asopus (s-sō'pus), n. [N]., uppar. < L. AsöAsopus (a-so pus), n. river-god.] A genns of hoteropterous inseets, of the family I'enta tomide.

asor (as'or), n. [Heb.] A ten-stringed musieal instrument of the Hebrews, played with a plectrum, and smpposed to have borno some refust., p. 39.

$\operatorname{asp}^{1}$ (asp), n. [< ME. (isp), uspe, espe, < $\mathrm{AS}$. "asp, (sipe, aspe, espe, transposed aps, = D. esp =
oll, aspa, MHG. aspe, G. espe = leel. osp, asp, cspi, aspen wood. = Dan. Sw. asp, asp; origin unknown. The E. form aspen is prop. an adj.: seo (uspen.] A European tree of the poplar family, Papulus trcmula. In Americs a simflar specien, 1.' tremulnides, is known as tho quaking asp, or aspen. The white poplar, $l^{\prime}$. alba, is slse semetines

$\operatorname{asp}^{2}$ (asp), n. [In MF. as L., aspis; $\mathrm{OH}^{2}$ aspe = Pr. aspic (> F. aspic, > F. aspie', q. v.) $=$ Sp.

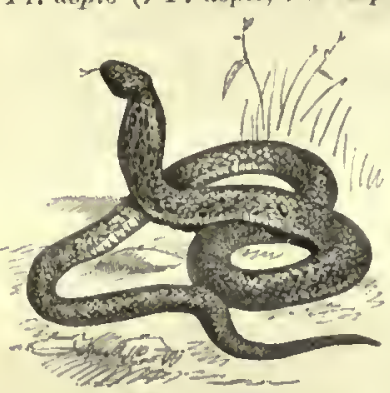

aspin, aspide $=$ Pg. It. aspie, a pid-), < (tr. aaris pid-), <Gr. aares Egyptian viper.] 1. A very nolis sercelebrated in eonneetion with tho story of Cleopatra's suieido. It ta idcntiAsp (Naja haje). probability with the herned viper, of the genus Cerastes, a snako sbont 1 whehcs long. The namo has also been conmonly applied t the Naja haje, s specles attainhg s length of 3 of 4 leet dians. It is of 8 inottled green hougit less se thrn that of the true cobra This serpest is of frepuent occurrence along the Nile, and is Egypt, represented commonly in art as 8 part of the hea and often connected with their emblems, as \& symboi of royal power. In arehreology it is 2 . The common viper or adder of Europe, a feebly poisonous serpent, formerly named l'ipera communis, now l'clias berus, of

the family Fiperida. See name of sundry otleer poisonous serpents.

Aspic and aspick aro obsolete or poetie forms.

Aspalacidæ (as-pa-las'i-dề), n. pl. Same a spalacidex.

Aspalacinæ (as-pal-â-sī'nē), $n . p l$. Same as acino.

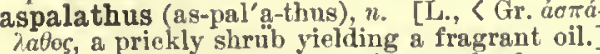
1. An unknown aromatie thorny shrub mentioned in the Apoerypha and by some of the old herbalists.

I gave a sweet smeli like cinnsmon snd aspalathus.

2. [cap.] The South Afriean broom, a large genus of Afriean plants, natural order Leguminose, with small heath-like leaves, and generally with yellow flowers.

Aspalax (as'pa-laks), n. Same as Spolax.

asparagi (as-par'a-jī), n. pl. [NL., pl. of asparagus.] In bot., scaly shoots from under paragus.] In bot., scaly shoots from und ground, as in asparagus. Also called turions.
asparagic (as-pa-raj'ik), a. [< asparagus + -ic.] Same as ispartic.

asparagin, asparagine (as-par'a-jin), $u_{0}$ [ [< asparagus $+-i n^{2},-i n c^{2}$.] A erystallized snbstance $\left(\mathrm{C}_{4} \mathrm{H}_{8} \mathrm{~N}_{2} \mathrm{O}_{3}\right)$ found in tho juice of asparagus, bcets, and ather vegetables, in the spronts of cereals, and in leguminous seeds during germination. It is an amide of aspartic acid, name in aonve parts of En

\section{aspen}

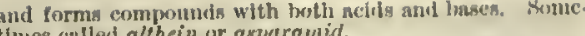
thres willed athein or anpetranit.

asparaginous (as-1)!-raj'i-nus), «. [< aspart gus $\left.+-i n^{2}+-o u s.\right]^{*}$ Belonging to aspuragus resembling asparagus; speoifieally, having tenler edible shoots like thoso of asparagus: as asparaginous plants.

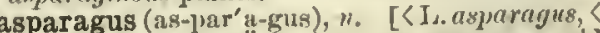
asparagus (as-par'a-gus), n. [ I _.asparagus,

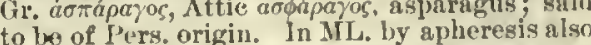
to baragus, sparagi, $>$ It. sparagio, OF. esperage, early mod. 1\%. speraye, sparage, speruch. The IIL. Corm sparagus was in E. altered by popula etymology into sparegrass and sparrouc-gras (sometimes simply grass), which were until recently in good literary uso.] 1. A plant of the cents Asparagus, espeoially 1 . officinalis.-2 [cup.] A largo genus of plants of the old world, [cup.] A largo genus of plants of the old wiliacer. Tlist which is culted in natural order Litiacer. Thist which is cuitivated

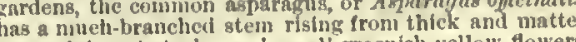
perennint root-stocks, and small grecnish-yellow flower hranelicets growing in clusters in the axils of the true but cnlodike leaves. The roots have a bit terish nuscliagino tastc, and the stalk la in some degree apcrient and deo struent, but not very efficncions. The part eatell is the turlon, or young ahoot covered with scaleg in place of ceaves. The speragin. - French or Prussian asparagus,

sparagus-bean (as-par'a-gus-bēn), n. Soo bean 1 , 1.

sparagus-beetle (as-par'g-gus-bë/tl), n. A me given to two speeies of leaf-beetles (Criocerides) of the genus Crioceris, $C$. asparagi (Linnæus) and $U$. duodecimpunetata (Linnaus), which prey upon the asparagus-plant. loth specics were imported ints, the United State日 Both the beetles
and their larve feet upon the but the damage is principaliy
done by the larre. C. asparagi is lackish benesth, reddish and the elytra yellowish spots of

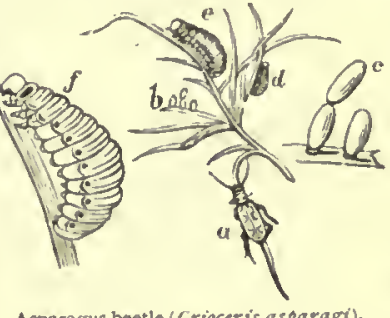
duodecimpunctrea is nesrly unifornly reddish, the elytrit
hoving twelve smill black spots. The larve of the two gpeeies resemble each other closely; they sre nearly cylin. of a dirty oijve-green color.

asparagus-stone (as-par' a-gus-stōn), $\mu$. yellows]-green variety of tho mineral apatite, ocenring in Spain in small trusparent erystals.

asparamide (as-par'a-mid), $n . \quad[<$ aspar(agin) + amide.] Same as usparagin.

asparginic (as-pär-jin'ik), a. [<aspar(a)gin + -ic.] Samo as aspartic.

asparmate (as-pär'mät), n. [< aspar(a)m(idle

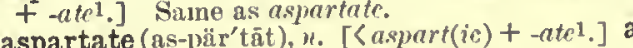
aspartate (as-pär'tāt), $"$.

aspartic (as-piïr'tik), a. [<aspar(agin) + -t-ic. $]$ Pertaining to or obtained from asparagin. Also asparagie, asparginic.-Aspartio act crystalline acid derlved from aspsragin.
aspet, $n$. An old spelling of $a s p^{1}$ and $a s p^{2}$ aspect (as'pekt, formerly as-pekt'), n. [< MF aspect, < L. aspectus, seeing, look, appearance, + specere, look: seo spccics and spy.] 1. Th spcere, look: seo spceing at anything; view gaze; glanee; look. [Archaie.]

$$
\text { Some other mistress hath thy' sweet axpects. }
$$

Lis aspect was hent on the ground.

Meeting the cold aspect of Duty:

. IItimex, Autocrat,

2. Countenance; look or partieular appearane of the face; mien; air: as, a mild or sever aspect.

Wiser princes patron the arts, sud esrry an indulgent
aspect unto scholars. Sir T. Brozone, Religh Medici, ii. 3 . Yet, had his aspect nothing of severe,

But such a tace as promis'd htm sincere. Dryden, Character of Good Prison, I. 12.

3. Appearanee to the eye or mind And then our arms, like to a muzzled bear,

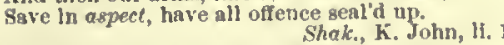

IIow aweet, how fair, snd lovely her aspects are ! licr eyes, like bright Eoan flsmes, ahoot through me.
Fletcher (and another ?), Prophetess, jil.
What of cullegiate axpect has that flne lilizalpethan hall, 4. One of tho ways in which a thing may bo viewod or eontemplated: as, to present an oljjeet or a subjeet in its truo espret; in a doublo (sipect; a favorablo aspect.

Somncthing loltier, more as\}ment,

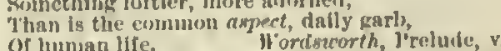

Indoubtedly wo have a right to make new words, s.

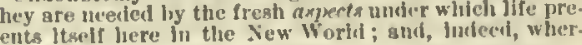
ever a language la alive, jt grown.
lonewl, Jutrod. to Jiglow lapers, 1 st aer. 5. Practical bearing or reference. [Ruro.]

The asject of atonement is obviously toward creatures, working effects on them, not on Goot.

Gillert, Christ, A tonement, p, 16\%. (X. K.: D).

6. Yiew eommanded; jrospect; ontlook.

This town has a good axpect towarl the hill from whences

Now used in this senнe msinly witi reference to the points of the compass: as, a house has $\mathrm{n}$ southern anpect or ex-

posure. I astrol., the relative positions of the plants as they appear at any given timo to an observer upon the earth; the combined look of the heavenly bodies from the eartl.. The aspects are nine fil number: (1) aemisextile, s difference of longl-
tule of $30^{\circ} ;$ (2) semisquare, of $45^{\circ} ;$ (3) sextlle, of $60^{\circ} ;(4)$ tude of $30^{\circ} ;(2)$ semisquare, of $45^{\circ} ;(3)$ sextle, of $30^{\circ} ;(4)$ $20^{\circ}$; (7) sesquighadrste, of $135^{\circ}$; (8) bfinuintile, of $144^{\circ}$ (9) opposition, of $180^{\circ}$. To these may he adden same longi. tude. Geod aspects sre the semisextile, aextile, quintlle, trine, snd blquintile. Dad aspects are the senisquare, square, sesquiquadirate, and opposition. Jindane azpects nre guch as are formed by the houses in horary as

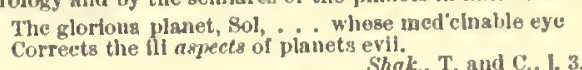

We, thnt behold the sad axpects of henven,

leading sense-bilinded men, fcel grief enoug

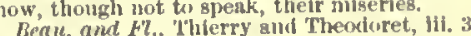

8. In her., the position of an animal with referenee to the speetator.-Ambulacral aspect. See ambulacral. - Aspect of a plane, in math., the directionol its normisl. - In full aspect. Same as affront, - In trian aspect, in a position betw aspectt (as-pekt'), v. t. [< L. aspecture, look at , look at: see aspect, $n$. To behold; look upon.

Happy in their mistakes those people whom Sir it. Temple, tr. of Luen, in Heroic Virtue. aspectable (as-pek'tag-bl), a. [< L. aspectubilis that may bo seen, < aspectare, see, look at: see

What is in this arpectabe world? Rav, Creation.

2. Fair or fit to be seen.

Tia Hitorta, the aspect

Rare in botlı senses.]

Broveriin, Ring and Book, I. 57

[Rare in

spectant (as-pek'tant), a. [< I. aspcrtan $(t-) s$, as affronté, 2.

aspected (as-pek'ted), $p, a . \quad\left[<\right.$ aspect $\left.+-e d^{2}.\right]$

$1+$. Looked at; viewel. -2 . Having an aspeet or look. [Rare.]

Your lawyer's face, a contracted, a gnbtile, and intrieate face, full of quirks and turnings, a labyrinthesn
angularly, now circulsrly, every wsy aspected. aspecting (as-pek'ting), p.a. [Ppr. of aspect.]
Same as affronté, 2.

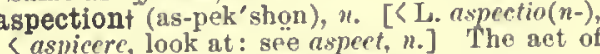
viewing or looking upon; view.

A Moorish queen, upon aspection of the picture of An-
dromedn, conceived and brought forth 8 fsir one.

aspector (as-pek'tor), $n . \quad[<\mathrm{L}$. as if " (espector <aspicerc, look at : see aspeet, n.] A beholder a spectator. J. Davies. [Rare.]

The first-nentioned [gaivanism] may eontract a muscle,

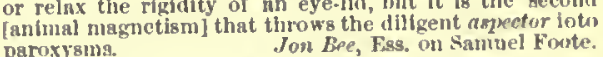
aspen (as' pen), $a$, and $" \quad[<\mathrm{MLE}$ aspen, $<\mathrm{AS}$. "espen (not authentieaterl; = OFries. cspen $=$ cespen (not anthentioater ; = OFries. cspen =

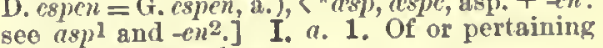
to the tree named asp.

2. Tremulous, liko an aspen-leaf; quivering:

II. $n$. [A mod. substantive use of the adj., prob. due to sueh phrases as aspen leaf, aspen trce, aspen wood, ete., regarded as compounds;
ef. linden for lind.] Same as asp $1^{1}$ [Aspen is 
aspen

340

the usual form in poetry, and is also eommon Asperifoliæ (as" per-i-fón'li-ē), n.pl. [NL., fem.
pl. of asperifolius: see asperifolious.] in prose.] liis hand did quake
And tremble like a leafe of Aspin greene.
Spenser, F. Q., I. ix. 51. Only the pattering aspen Made a sound of growing rain.

Lovell, Singing Leaves,

asper ${ }^{1} \dagger$ (as' pér), $a . \quad[<$ ME. aspre, aspere, <OF' aspre, < l. asper, rough; origin undetermined.] All base notes . . . give an asper sound.

asper ${ }^{1}$ (as' pèr), $\ldots$. [Short for tor spiritus asper, a translation of Gr. $\pi v e v i \mu a$ dazí, rough breathsign (c) placed before or over an initial vowel or $\rho$ to show that it is aspirated, that is, pronounced as if $l$ preceded it; the rough breathing. Thus, os $=$ hos; pis $=$ hris. [In Latin, and lience in modern, words derived from the Greek, aspirated $r$ is represented by $r h$, as in
ing gilent in the modern pronunciation.]

asper $^{2}$ (as'pèr), $n .[=\mathbf{F}$, aspre $=\mathrm{It}$. aspero, $<$ IIL. asperus, asprus, asperum, asprum, < MGG.

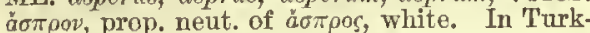
ish this coin is called aqeha, lit. whitish, $<a q$, white, $+-c h a,-j a$, equiv. to $E_{0}-i s h{ }^{1}$.] An old Egyptian and Turkish silver coin: now only a money of account. A piaster ls conaidered equal to 100 good agpera or 120 current oncs. One curr
is equal to four ninths of a United States mill.

Demanded of me,
For what I valued at 80 many aspers,

A thousand ducats.
Massinger, The Rene

aspera (as'pe-rä), n. [NL., fem. of L. asper, rough.] Same as asper-artery.

asper-artery (as'perr-är"te-ri), n. [< L. aspera arteria, or arteria aspera, à tr. of Gr. a a $\rho$ tpoia toaarteria, or arteria asplera, a tr. of Gr trachea.] The trachea or windpipe. Coues.

asperate (as'pe-rāt), v, $t_{\text {. }} \quad[<\mathrm{L}$. asperatus, $\mathrm{pp}$. of asperare, roughen, 〈 asper, rough: see asper 1 . To make rough
ete. [Rare.]

The level surface of clear water being by agltation as.

asperation (as-pe-rà'shonn), n. [< usperate + -ion.] A making rough. Bailey.

asperge (as-pèrj'), v. t.; pret. and pp. asperged, ppr. asperging. [= F. asperger, < L. aspergere, sparse, and ef. asperse.] To sprinkle.

Each thing in order, as before,
His pious hands array

His pious hands array,

sperge the shrine; and then once more

Bulwer, tr. of Schiller's Fridolin.

aspergeoiret, $n_{\text {. }}$ [OF., also kspergoir (mod. F'. aspersoir); cf. ML. aspergerinm; < L. aspergeSame as aspersorium, 1 .

asperges (as-pèr'jēz), n. [LL., prop. second pers. sing. future ind. of L. aspergere, sprinkle: see asperge.] In the Rom. Cath. Ch.: (a) An antiphon, taken from the IIiserere, intoned by the celebrant aud sung by the choir before the solemn mass on Sundays, during which the priest sprinkles with holy water the altar, clergy, and people. With some modifications, the same rite is practised in the Greek and Oriby the priest during the antiphon.

aspergill (as' pèr-jil), n. [< ML. aspergillus, q. v.] Same as asplersorium, 1.

aspergilla, $n$. Plural of aspergillum.

aspergilli, n. Plural of aspergillus.

aspergilliform (as-pèr-jil'i-fôrm), $a . \quad[<\mathrm{ML}$ aspergillus, q. v., $+\mathrm{L}$. forma, shape.] 1 .
Shaped like an aspergillus or sprinkler.-2. In bot., brush-shaped; made up of numerou spreading hairs.

aspergillum (as-pèr-jil'um), n.; pl. aspergille (-tid). [ML.: see aspergillus.] 1. Same as aspersorium, 1.-2. [eap.] [NL.] A genus of mollusks, the watering-pot shells, of a family Aspergillicia: a synonym of Brechites. Lamarck, 1799

aspergillus (as-pèr-jil'us), $n_{.} ;$pl. aspergilli (-i) . [ML. (in sense 1), < L. aspergere, sprinkle (see um, 1.-2. [eap.] [N1.] A genus of hyphomy cetous fungi, including several of the common molds. Some of the species have been found to be only it is probable that the same is true of all. Several have been detected in the human ear and in diseased lungz.
See cut under Eurotium. pl. of asperifoli

asperifoliate (as"pèr-i-fón'li-ât), a. [< NL. asperifoliatus, < L. asper, rough, + folium, leaf : see asper I and foliate.] Having leaves rough to the touch. foliate.

asperity (as-per'i-ti), n.; pl. asperities (-tiz). sperity (as-per i-ti), n.; pl. asperities (-tiz). asprete, mod. F. Apreté and aspérité, < L. asporita $(t-)$, roughness, < asper, rough : seo asper I. 1. Roughness of surface; unevenness: opposed to smoothness.

The pores and asperities of dry bodies. Four thougand pioneers were gent in advance... to Four thougand pioneers were sent in advance. . . to
conquer, in some degree, the asperitieg of the roadl.
Irving, Granada, p. 320.

2. Roughness of sound; harshness of pronunciation.

Those dissonances and asperities which atill adhered to
our diction. T. Warton, Hist. of Eng. Poetry, iii. 62.

3. Harshness of taste; sourness.

The asperity of tarturous salts. Bp. Berkeley, Siriz, \&86. 4. Roughness or ruggedness of temper; crabbedness; bitterness ; severity : as, to chide one with asperity; "asperity of character," Landar. It could only have been the atrong political feeling of Warton which could have induced
prose of Milton with such asperity. A royalist, .... without any of that political asperity
which is as unwomanly as a long beard.

5. Disagreeableness; unpleasantness; difficul ty : as, "the acclivities and asperities of duty," Barrow, Sermons, III. xlii.

The allurements of praise and the asperities of cengure. =Syn. 4. Acrimony, Harshness, etc. See acrimony. asprely, < ME. asperly; $<$ asper $\left.1+-l y^{2}.\right]$ Roughly; sharply; vigorously.

Enforced their enemies to strike on land, and there as. sanlted them so axprely. Sir T. Elyot, The Governour, i. 17 aspermatism (as-pér'ma-tizm), ${ }^{\prime \prime} \quad[<\mathrm{Gr} . \dot{a}-$
priv. $+\sigma \pi \varepsilon \varepsilon \mu a(t-)$, seed, $+-i s m.]{ }_{1}$. Absence priv. $+\sigma \pi \varepsilon \rho \mu a(\tau-)$, seed, $+-i s m$.$] 1. Absence$
of seminal secretion. -2 . The non-emission of semen in the sexual orgasm, owing to its reflux into the bladder.

aspermatous (as-pèr'mą-tus), a. Same as (sivermous.

aspermous (as-pè1'mus), a. [<NL. aspermus,

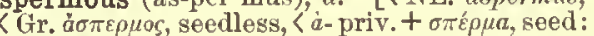
see sperm.] In bot., destitute of seed.

aspernationt (as-pèr-nā'shon), n. [ $[\mathrm{L}$. aspernutio( $n-),<$ aspernari, pp. aspernatus, disdain, spurn, neglect, $<a b$, from, + spernari, despise, 2. Neglect; disregard. Joknson.

aspernesst, $n$. [ME. asprenesse; < $\iota s]$

-ness.] Harshness; severity. Chaueer.
asperousł (as'pér-us), a. [< L. asper, rough sperous $\nmid$ (as'per-us), $a$. [< L. asper, rough
(see asper1), t -ous.] Rough to the touch; uneven; harsh; severe.

asperse (as-pérs's, v. $v$.; pret. and pp. aspersed. ppr. aspersing. [<L. aspersus, pp. of aspergere, sprinkle; scatter over.

Asperse and sprinkle the attendants. The mouners returning from a Roman funeral, aspersed with water and stepping over fire, were by this double pri-
cess made pure. 2. To bespatter with foul reports or false and injurious charges; tarnish in point of reputation or good name; slander; calumniate.

With blackest crimes aspersed. Couper, Iliad, vi. What perplexed ns most, was to think who could be 80
base as to asperse the character of a fanily so harmless as our's.
Goldsmith, Vicar, xiv. =Syn. 2. Asperse, Defame, Calumniate, Slander, Malign,
Traduce, Libel, r'ilify, decry, depreciate, disparage, slur, run down, lampoon, biacken. These worda are all descriptive of attempts to injure reputation by false statements. They all apply primarily and chletly to persons. There is
often little or no difference between them. Asperse is, often little or no difference between them. Asperse is,
literally, to bespatter, as with nud or dirt; it sometimes implies injury to reputation by indireet insinuation. De fame is, literally, to lower the fame or repute of, to bring toward infamy, to make charges that are more open and lign represent the most deliberate and deadly assaults upon reputation. The calumniator is most often the in-
ventor of the falsehoods he circulates. The slanderer is ventor of the falsehoods he circulates. The slanderer is
less inventive and more secret, his work being generaly most mischievous of the injured person. The maligner most mischievous, malicious, or malign in his motives
To traduce is to misrepresent, to show in an odious light. asperifolious (as"pèr-i-fö'li-us), a. [<NL. as-

I. D' Trrael, Quar. of Auch., p. 261.

asphalt

Libel and slander are the words most used in speaking of njury to reputation in its relation to the possble recov. the pecuniary loss by defamation: libel is strictly ettected the pebuty lossile slander is strictly by word of mouth. Vilify is, literally, to make one (seem) vile; it suggests a defamation of the coarser and more abuaive sort. Sce I am not sure ... whether 1 ought not to eall you out

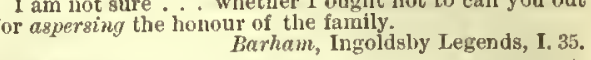
Whenever yoll would ruin a person or a government,

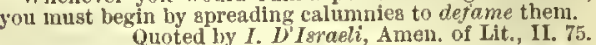
one trade or art, even those that ghould be the most liberal, make it their business to disdain and calumniate
another. Thou sittest and speakest against thy lurother; thou You malign our senators, for that
They are not anch as you.

If 1 am

"Tis but the fate of place, and the rough brak

That virtue must go through.

Shak., Hen. VIII., i. 2.

IIis [Dr. Kendrick'\&] virulent attack on Johnsou's Shakegpeare may be preserved for its total want of literary decency. Ile libelled all the genius of the age, and was
prout of doing it. $\quad$ I. D'Irraeli, Cal. of Auth., p. 217. When I find the first of men, in rank and genius, hating one another, and becoming slanderers and liars in order to any barbarous people for more barbariam. aspersed (as-pèrst'), p. a. In her., same as semé.

asperser (as-pèr'sèr), n. 1. An aspersorium. -2. One who asperses or vilifies another aspersion (as-pèr'shon), $n$. [ $[=$ F , aspersion, < sprinkle: see asperse, asperge.] 1. A sprinkling, as of or with water.

No sweet aspersion slall the leavens let fall

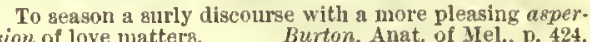
Ximenes, unable to administer the rite to each individ. ually, was obliged to adopt the expedient familiar to the
chriatian missionaries of christening them en masse by aspersion; scattering the consecrated drops from a nop or hysop, as it was called, which he twirled over the
heads of the multitude. Prescott, Ferd. and Isa., ii. 6.

2. The making of calumnious reports, imputations, or charges; a derogatory assertion or criticism; calumny; censure.

There, sir, an attack upon my language! what do you think of that? - an aspersion upon my parts of speech!
Sheridan, The Rivals, iii. 3.

Every candid critic wonlt be ashamed to cast wholesale axpersions on the entire botly of professional teachers.
Grote, Hist. Greece, 11. 6r. aspersive (as-pèr'siv), $a . \quad[<$ asperse $+-i v e$. Tending to asperse; defamatory; calumnious; slanderous.

aspersively (as-pèr'siv-li), acle: In an aspersive manner; by way of aspersion. aspersoir (as-per-swor'), n. [F

aspersorium (as-pèr-sō' ri-um), n.; pl. aspersoria (-ä). [MIL., <L. aspergere, pp. aspersus, besprii-

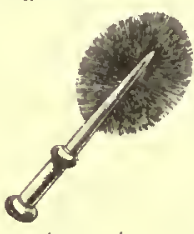
klo: see asperse.] 1. A brush, or oftener a metallic instru ment, used by the priest in Roman Catholic churches for sprinkling holy water. Also called aspergillus, aspergillum, aspergitl. - 2. A holy-watel Glossary [Not in common Niddle Latin use.]

spersory (as-pèr'sō-ri), a. [< asperse + -ory. Cf. aspersorium.] Tending to asperse; defamaasphalt (as'falt or as-falt'), 1 . [Also written as F., asphalte, and as NL., asphaltum, formerly also asphaltus, $-0 s,-u$, and as $1 \mathrm{t}$, asjualto; in ME. spelled aspalt, once aspaltoun; <OF. "aspalt $=$ Pr. asphalt $=$ Sp. asfalto $=$ It. aspalto asfalto, $<\mathrm{Gr}$, abaj ros, asphalt, bitumen; a wor of undetermined foreign origin.] 1. Same as asphaltucm. - 2, A bituminous material, employed for the covering of roofs and arehes, for the lining of tanks, for pavement and flooring, and as a cement. See asphaltum. In the United States the substance so named is commonly made of ref use tar from gas-houses, mixed willed asphaltic cement.

3. A thick solution of the finest asphaltum in spirits of turpentine, used by opticians. It is used for naking cells on pieces of glass, in which objects may be preserved in liquid, for examination with the microscope. - Asphalt-furnace, a portable furnace in which asphalt stone, asphalt rock. See asphalt um.-Asphalt tiling the form of flooring-tiles. - Asphait varnish, a black var. 
asphalt

nish composed of 3 parts of nupialt, 4 of bolled linseed-
will, and from 15 to 18 of oil of turpentine. - Mexican asphalt. sime as chaçminte.

asphalt (as-falt') $v . t$. [<asphalt, n.] To cover or treat with asphalt.

asphalter (as-fal'tẻr), n. One who covers (as a path or a roof) with asphalt.

asphaltic (as-fal'tik), a. [<rosphult $+-i c$.$] of$ the nature of or containing asphalt; bituminous. - Asphaltic cement or asphaltle mastic. sum

asphalting (us-fal'ting), $n$. The process of eovering or paving with asplualt.

In Parls . . a anhaltiny is still extensively jructiced in the more sjuclonts thorcughtar's.

asphaltite (as-fal'tit), a. $[<$ L. Asphaltites, term applied especially to tho Dead Sea; Asphaltic ; bituminous.

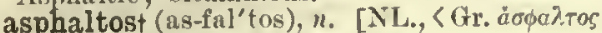
seo asphalt.] Same as asphalt.

asphaltotype (as-fal'tō-tī]), $\pi, \quad[<\mathrm{Gr}$. àoba) asphaltotype (as-fal'tö-tip), $n$. [ $\quad$ Gr. a $\sigma \phi a \%$ -

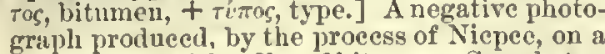
plate coated witl a filın of bitnmen. Sce photog raphy.

asphaltum (as-fal'tum), n. [NL. : see asphalt.] One of the so-ealled bituminous substances which aro widely diffused over tho earth, and are of great practical importance. See bitumen and bituminolls. The asphaitums of various localities differ from encl other considerahly in ehemical cornposition, as is proved by their different chenical reactions. They all
agree, lowever, in being nnorphous, in having the lister and general nppenrunce of jiteh (whence the name of min. eral pich, often applien to them, in meling at alout the temperature of boiling water, and in taking the when
heated and burning with a hright but amoky tlame. 'l'hey differ exsentinilly frum conl in heing more or less aoluble in varions reagent, such as oil of turpentine, ether, aud alco-
hof. Asplaltum seems, in most cases at least, to have resulted froun the hardening of the more liquid forms of bituminots snbstinces, namcly, maltha and petroleum,
which have ouzed ont upon the aurface and become in. spissated lyy oxygenation or esaporation of their nore volatiie portious, or by hoth causes combined. The most interesting locality of asphaltumz is the so-called "pitchlake " in the island of Trinilad, about a mile and a half in
circunference, and flle with asphaltum, which near the circumiclence, and flled with asphaltum, which near the
shorc fa quitc solici, but nearer the center, in places, ta soft ani bubbling. Host of what is called asphnltum congists of this insterial more or leas mixell with sand o uther nincral substruces. Asphaltum is extenaively used in a variety of ways, nnd eepecially for pavements, foot-
walks, and roofing. For this purpose the naterial is pre. pared by nixing it while hot with aand or fine gravel, or by calsing it to be absorbed by paper. Ccrtain kind
of asplaatic rock, or asphalts (F. asphatte), as they ar or other \&peetial purposes. 'The localities of Seysel in mportant of this kind. At each of tinese the arphalte conaists of limestone impregnated with lituminous toaterin to the amnount of from 4 to 16 per cent. This roek, especially that from Val de Travers, has the remarkable propiy durable and elastic road way, and is, although expensive, extensively used for that purpose in Paris and ofher large crumbles to possder, in which condition it is compressed in molis into biocks, or aimply spread over the aurface roller, when, after cooling, it assumes a condition ciosely reaenibling that of the original rock.
tha, and petroleun. Also asphalt.

aspheterism (as-fet'e-rizm), n. [< Gr. á-priv.

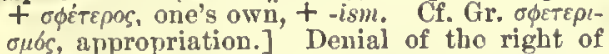
private property; the principle of communism. Southey. [Rare.]

aspheterize (as-fet'e-riz), $v_{\text {. }} i$; pret. and pp. aspheterized, ppr. aspheterizing. [<Gr. $\alpha$ - priv.

$+\sigma \phi \varepsilon \tau \varepsilon \rho s$, one's own, + -izc. Cf. spheterizc.]
To practise aspheterism. Coleridge. [Rare.] To practise aspheterism. Coleridge. [Rare.]
asphodel (as'fō-dol), n. [< L. asphodelus, <Gr.

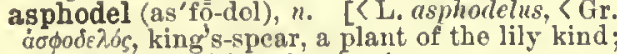
as adj., no申odzios $\lambda \varepsilon \mu \omega \nu$, in of the dead; origin unknown. The E. forms affodil, daffodil, daffodilly, ete., are corrupdil.] A name of various species of Asphodelus, a genus of plants, natural order Liliacea. llatives of sonthern Europe. The yellow asphodel or king' 8 -spear, best-known apecies, thongh ot fiers are sometimes cultivated for ornament.
The asphodel of tlie earler English and French poets is the daffodil, Nirciszu. Psendo-narcissus. In $G r$. myth. the sons covering the meadowa of IJades. It recejvel thia at tribution, perhaps, because in Greek lands it is a very common weed, plentiful in barren and deacrt places an

3.41

Aspila

The banks of axphodel that liorler the river of life. og-asphodel, the name of specles of Narthecium, $N$.

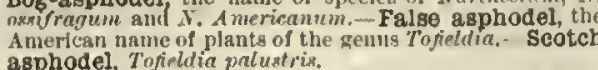

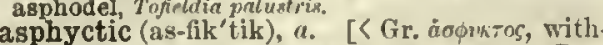
out pnlsation (see asphyxia), + -ic.] 1. Per taining to asphyxia.-2. Pulseless.

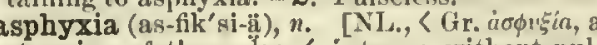
stopping of the pulse, $<$ aбovктоs, without pulsation, < $a$-priv. $+\sigma \phi i \zeta \varepsilon v\left(V^{*} \sigma \phi v \gamma\right)$, pulsate, throb.] 1t. Originally, absence of pulse.-2. gen and excess of carbon dioxid in the blood, brought about by any sufficient interference with respiration, as in choking, drowning, or paralysis of the museles of respiration. Als asphyxy. - Local asphyxda. See Raynaud's disease. asphyxial (as-fik'si-al), a. [< asphyxia t -al.
Relating to asphyxia; resulting from or indicating asphyxia: as, asphyxial symptoms.

asphyxiant (as-fik'si-gnt), n. [< (lsphyxia + $-\left(i n t^{1}\right.$.] Any poisonons chemical substance which produces asphyxia.

asphyxiate (as-fik'si-āt), $v, t$; pret. and pp. as phyxiatel, ppr. asphyxiating. [< asphyxia + doprive of oxygen to the extent of produeing death or very serions symptoms.

The deprivation of oxygen, and the accumulation of carbonle acid, cause injury long before the asphyxiating asphyxiation (as-fik-si-ấ,'shon), $n$. [< asphyxi ate + -ion.] The aet of eansing asphyxia; ate + -ion.] The
state of asphyxia.

asphyxiative (as-fik'si-ā-tiv), a. [<asphyxiute $+-i v e$.$] \quad Suffocating; producing asphyxia or$ suffocation.

asphyxy (as-fik'si),n, See asphyxia.

aspic', aspick (as'pik), n. [Early mod. E. also aspike - < F aspic, Pr. aspic, < L. aspis (aspid-) an asp: sec $a s p^{2}$.] 1. A venomous serpent same as $a s p^{2}$, but used chiefly in poetry.

$$
\begin{aligned}
& \text { They ahall find } \\
& \text { That, to a woman of her hopes be }
\end{aligned}
$$

That, to a woman of her hopes beguil'

$$
\text { A viper trod on, or an aspic, 's mild. }
$$

Thereto she pointed with a laugh
Showing the aspick' 8 bite. Tennyson, Fair IV

24. A piece of ordnance of small caliber.

aspic ${ }^{2}$ (as'pik), n. [Early mod. E. aspiche, F. aspic, in hiile aspic for huile de spic (so first in E., "oil of aspicke"); spic, lavender spike, orig. spikenard: see splke. lavender.

aspic ${ }^{3}$ (as'pik), $n$. [F.; perhaps < aspic, an asn (see aspic1), with allusion to its coolness there being a French proverbial saying, "Cold as an aspic" (Littré); or perhaps from the (supposed) custom of flavoring or seasoning this dish with spikes of lavender: see aspic ${ }^{2}$.] In meat-jelly containing fowl, game, fish, etc. aspick, $n$. See aspic1.

aspiculate (as-pik'ū-lät), a. Same as aspiculous.

aspiculous (as-pik'ū-lus), a. [<Gr. $a$ - priv. + L. spiculum, a point: see spieulum.] Having no

Aspidisca (as-pi-dis'kä), n. [NL., < Gr. áoml-

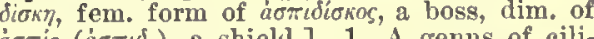
$a \sigma \pi \iota c_{\text {(n) }}(a \sigma \pi \iota \delta-)$, a shield.] 1. A genus of ciliEhrenberg, 1830.-2. A genus of lepidopterous insects

Aspidiscidæ (as-pi-dis'i-dê), n. $p l$. [NL.,
Aspidisca, 1, +-ide.] A family of hypotrichous Aspidisca,
Ciliata.

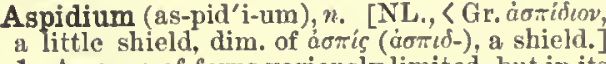
1. A genus of ferns varionsly limited, but in its broad sense including all those in which the dot-like sori are covered by a roundish, peltate, or reniform indusium. Those with a reniform iniusium, attached by the sinus, are often separated as the genus Nephrodizm. When the indusium is abortive of of Polypodium. The genus is cosmopolitan, fneluding nearly 300 species, which vary greatiy in size, texture venation, and division of the fronds. About 40 apecies are found within the United Statea. The common apecies are usulally

shield-fern.
2. A genus of hymenopterous insects. Also Aspidion.

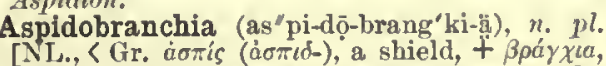
gills.] A group of prosobranchiate gastropods, pidoglossa, or Chiastoneura. It includes such families as Fissurellirle, Haliotinle, ete. Also Aspirlobranchiatr.

Aspidochirotæ (as" pi-dō-kī-rō'tē), n.pl. [Nl,

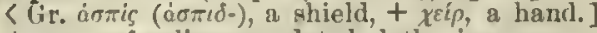
A group of ordinary pedate holothurians or seacucumbers, with peltate tentacles: couivalent to the family IIolothuriirla: contrasted with Dentrochirotie (which see). Also spelled Aspinlocheirotu.

In the Aspidochirute, or liolothurlans with disk- or shiedi-ghaper tentacles furnished with tentacular anpulise, the left reapiratory tree is bonnd to the hody-walls, theru are no retractor muacles to the pharyux, and Cuvierin organa are present. These are the highest type Stand, Nat. Ilist., I, 182. aspldochirote (as"pi-dō-ki'rōt), a. Pertaining or belonging to the Aspidochirotre. Also spelled aspidocheirote.

Aspidogaster (as"pi-dō-gas'tér), n. [NI., < Gr. $a \sigma \pi l \zeta(n \sigma \pi \iota d-)$, a shicld, + jaothp, stomach.] A grematoda, or Aluke-worms, paramussel. A. conchicola is an example. See cut under Trematorla.

Aspidoglossa (as"pi-dō-glos'å̆), n. [NL., < Gr.

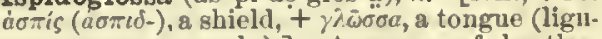

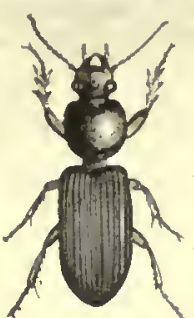
la).] A genus of beetles, family Carabita, of Scaritimi. Abont 20 splectes are known, moatly from Central or lata (Chandler), ocenra in the more Southern portion of the of the Rocky Jiountains. It is an elongate, convex, and shin. It is an elongate, convex, and shin. with very stont fossorial tra. Its color is black with a green. lali tinge, but the antennae, legs, and apex of the elytra are redlish. It
is found on moiat gromul, where it Aspidonectes (as " pi - dōnek'tēz), n. [NL., < Gr. àaris

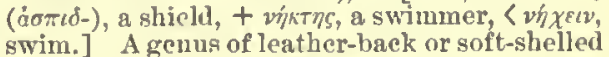
turtles. A. spi.

nifer is a convoracious specit: Aspidophora (as-pi-dof' rỉ), n. jil. pl. of aspirlo phorus, all.

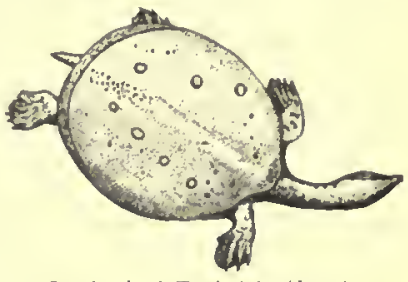

rus. 1. In Tra

reille's syatem of classification, a section of his phyllopodous branchiopods, containing the genera Apus and Lepidurus, and equivalent to tho modern family Apodide of the order I hyllopoda. Also Aspidiplera.-2. In Allman's system of classification, a suborder of polyzonus coustituted for the

Aspidophorus (as-pi-dof'ō-rus), $n$. [NL., < Gr.

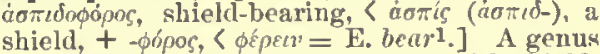
of acanthopterygian fishes armed with shieldlike seales: synonymons with Agomus. . A fish of the family Aspidorhynchille.

Aspidorhynchidæ (as"pi-dō-ring'ki-dē), n.pl. [NL., S Aspinlormynchus, $1,+$-ida. I Gunther system of classification, a family of lepidosteoid ganoid scales, a series of cnlargod seales along the sides, jaws prolonged iuto a beak, the vertebral column homocercal, the fins furnished with fulera. and the dorsal fin opposite the anal. Tho species are

Aspidorhynchus (as"pi-dō-ring'kus), n. [NL.

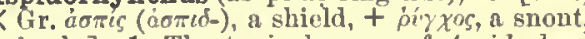
a beak.] 1. The typical genus of Aspidorhyn-
chida. Agassia, 1833.-2. A genus of reptiles. -3. A genus of worms.

Aspidostraca (as-pi-dos'tra-kä), n. pl. [NL.

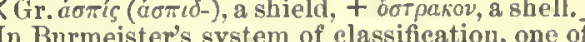
three orders of Crustacea, divided into five suborders called Parasita, Lophyropoda, Phyllopoda, Cirripcdia, and Pocilopoda. See these words.

aspiet, $v$. $t$. A Middle English form of espy.

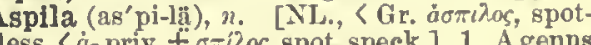


Aspila

of moths, family Noetuider, founded by Guénéc. The larve are sino
is a beautiful moth with olivaceous tore wings, marked with
three distinct pale lines, relieved by shades. 2. A genus of coleopterous insects.

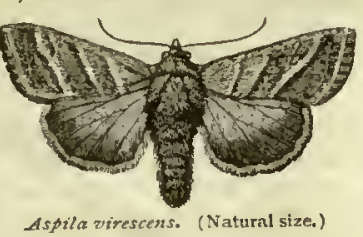

spinet (as'pill Aspilavirescens. (Natural size.) or -pin), $a$. [Irreg. $\langle a s)^{2}+-i n e^{1}$. $]$ of or pertaining

aspirant (a-spir'ant or as'pi-rạnt), $n$. and $a$ [R F. aspirant, a eandidate (prop. ppr.), < I aspiran $(t-) s$, ppr. of aspirare ( $>$ F. aspiver), as pire: see aspire.] I. $n$. One who aspires; one who seeks advancement, elevation, or preference.

Our young aspirant to the name and honours of an Eng. "Deauty and extroordinary goodness" were her dowry

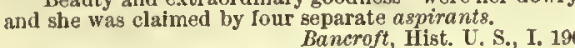

II. a. 1. Aspiring; ambitious: as, "our as pirant souls," Mrs. Browning.-2. Ascending; pirnting both uses.]

aspirate (as'pi-rāt), v.; pret. and pp. aspirated, ppr. aspirating. [ [ L. aspiratus, pp. of aspirare, give the $h$-sound to, breathe or blow upon: see aspire.] I. trans. 1. To pronounce with a breathing or an audible emission of breath; pronounce with such a sound as that of the letter $h$ : as, we aspirate the words horse and house, but not hour and honor; cockney often aspirate words beginning with a vowel. Such mutes as were originally aspirated - that is to say, had an audible bit of an $h$ pronounced after thern.

2. To remove by aspiration.-Aspirating winnowing-machine, one in which asplration or suction

II. intrans. To be uttered with an aspirate or strong breathing. [Rare.]

Where a vowel ends a word, the next begins either with a consonant, or what is its equivalent ; for our $w$ and $h$
arpirate. aspirate (as'pi-rạ̄t), a. and $n$. [<L. aspiratus, pp.: see the verb.] I. $a$. Pronounced with the aspirate or rough breathing; pronounced with the $h$-sound, or with a strong emission of breath.

The Zend often showing an aspirate mute where the The versa.
J. Hadley, Essays, p. 172 IIolder, Elem. of Speecli.

II. $n$. An aspirated sound, or a sound like II. bined, or which corresponds historically to a sound of this nature: thus, the Sanskrit $k h, g h$, $b h$, ete., and the Greek $e h, t h, p h(\chi, \theta, \phi)$ aro ealled aspirates, as are also the English $f, t h$, which are more properly ealled breathings or spirants; also, a character or combination of characters representing a sound thus described, as the letter $h$, the Greek rough breathing, etc. aspirated (as pi-rā-ted), p. a. Same as aspirate.

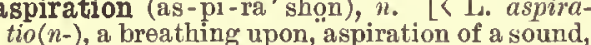
the aspirate letter $h$, < aspirare: see aspirate, $v$.$] 1. The act of aspirating or breathing; a$ breath.

Fanned with continued hreezes, and gentle aspirations
of wind.

2. An aspirated sound; a phonetic breathing. The $h$, the pure aspiration, is an expulsion of flatus vowel, semivowel, or nasal.
Whitney, Life and Growth of Lang., p. 67. The Latin grammarian Priscian, about $500 \mathrm{~A}$. D., tells us that the sound then expressed by $f$ was originally sig-
nifled by $p$ with an aspiration (that is, by ph).
J. IIadley, Essays, p. 172 .

3. The act of aspiring or ardently desiring; an ardent wish or desire, chiefly after what is elevated or spiritual.

She ... Peels neither inclination to pleasure nor aspi
ration after virtue. All Emerson's aspirations were toward greatness of haracter, greatness of wisiom, nobility of soul.

4t. Aid; inspiration; countenance.

To God's honour, .... without the arpiration and help ir $T$. More, Works, p.

5. The act of removing a fluid, as pus or serum, from some cavity of the body, by means of a
342

asprino

hollow needle or trocar connected with a suetion-syringe.-6. Suction; the act or proces of drawing air through (by some method of ex haustion), as opposed to the act or pro For cleaning grain there are other kinds of apparatus in air through the grain, is now extensively employed.
Encyc. Brit., IX

=Syn. 3. Longing, yearning. aspirator (as'pi-rā-tor), n. [NL., < L. aspirare breathe or blow upon: see aspirate and aspire. 1. An apparatus for ereating a vacuum by the action of a moving fluid. A common form is that of a simple vessel fllled with water and connected with the receptacle to be drained of air. On permitting the
to eseape below, a partial vacuum is formed above it.

to eseape below, a partial vacuum is formed above it low needle, or trocar, connected with a suctionsyringe, used in removing fluids from the eavities of the body.-3. A form of winnowingmachine employing aspiration instead of blast. See aspiration, 6 .

aspiratory (a-spiría-tọ-ri), a. [< L. as if *as piratorius, < aspirare, breathe upon: see aspied to the inbaling of air.

aspire (a-spir'), $v^{\prime}$; pret. and pp. aspired, ppr Sp. Pg. aspirar = It. aspirare, < I. aspirare, ac spirare, breathe or blow upon, desire to reach, ad, to, + spirare, breathe, blow : see spirit. Cf. conspire, expire, inspire, perspire, respire, suspire, transpire.] I.t trans. 1. To breathe to or into. To spreade his beames vpon vs, and aspire hys breth
into vs. 2. To breathe forth or exhale. Shenstone.

Whose notes the alr aspire

Egyptian or the Thracian lyre.

3. To breathe after; seek with eagerness to at tain to; long or try to reach; attempt.

Who dare aspire this journey? Donne, Poems, p. 18

4. [See II., 2.] To mount or soar to; attain. That gallant spirit hath aspir' $d$ the clouds.
Shak., R. and

Come, there was never any great thing yet

Aspired, but by violence or Iraud.

B. Jonson, Catiline, iii. 3

II. intrans. 1. To be eagerly desirous; aim mbitiously, especially at something great or noblo; be ambitious: followed by an object noble; be ambitious: followed by an object with to or after, or by an infinitive

Aspiring to be gods, if angels fell,

Aspiring to be angels, men rebel.
Pope, Essay on Man, i. 127. He aspired to see

His native Pisa queen and arbitress
Of cities.

2. [Partly influenced by association with spire.]

To rise up as an exhalation, or as smoke or fire; hence, to mount or ascend; tower up or rise high.

As thonghts do blow them, higher and higher.
Shak., $\mathbf{H}$. W. of $\mathbf{W}$., $\mathbf{v} .5$,

aspiret (a-spīr'),n. [<aspire, v.] Aspiration; ardent wish or desire.

And mock the fondling for his mad aspire. Chapman. aspirement + (a-spir ment), n. [< aspir

$$
\begin{aligned}
& \text { By which aspirement she her wings displays. } \\
& \text { Ant. Brewer (?), Lingua, }
\end{aligned}
$$

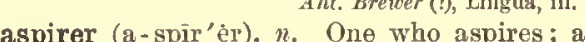
aspirant. an ardent desire, as of power, importance, or excellence; ambitious; soaring: as, "aspiring nobles," Macaulay, Hist. Eng., i.

Aspiring beggary is wretchedness itself. Ere he flled with loves, hopes, longings, this aspiring heart 2. Rising; towering or soaring.

To sore destruction dooms the aspiring wall.
Pope, lliad,

aspiringly (a-spī'ing-li), $a d v$. In an aspiring manner; soaringly; ambitiously.

aspiringness (a-spin'ing-nes), $n$. The state of being aspiring; ambitiousness. [Rare.]

aspis (as'pis), n. [NL., <Gr. áomic, an asp, the Egyptian cobra: see asp 2.$]$ 1. Same as $a s p^{2}$
or aspic 1 . Also used as a generie term.-2. or aspic1. Also used as a generie term.-2. mar.-3. [eap.] A genus of lepidopterous insects. Treitsehke, 1829. aspish (as'pish), a. $\left[<a s p^{2}+{ }_{-i s h}\right]$ of or
pertaining to asps; snaky. N. E.D. Aspisoma (as-pi-sōmä̈), $n$. [NI., irreg. < Gr. South American fireflies, of the family Telephovide, belonging to the malacodermatous division of pentamerous Coleoptera. A. lineatum is the common firefly of the Amazon region. Asplanchna (as-plangk'nạ̈), n. [NI., < Gr.

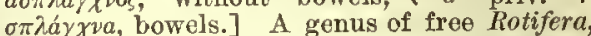
having a rounded sae-like body, devoid of apnendes and possessing neither anns nor intestine, whence the name. The genus is typieal of the family Asplanehrido.

asplanchnic (as-plangk'nik), a. [< Gr. $\dot{a} \sigma \pi \lambda a \gamma \chi \nu 0$, without bowels (see Asplanehna), + anenterous.

asplanchnid (as-plangk'nid), $n$. A rotifer of the family Asplanelmido.

Asplanchnidæ (as-plangk'ni-dē), n. pl. [NI. SAsplanehna $+-i d c e$.$] A family of rotifers hav-$ ing the trochal disk rounded, the wreath single and marginal, the trophi incudate, and no in testine, anus, or foot. Asplanelna is the leading genus.

Asplenium (ass-plë'ni-um), $n$. [NL., 〈Gr. $\dot{a} \sigma \pi \lambda \eta \dot{-}$

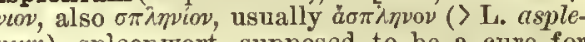
num), spleenwort, supposed to be a cure for the spleon, $\langle\dot{a}$-euphonic $+\sigma \pi \lambda \eta \nu$, spleen: see spleen.] A genus of ferms characterized by spleen.] A genus of ferms characterized by linear or oblong sori lying on the veins (which
are free in most species) and obliquely to the costa, the involucre being conformable to the sorus and opening toward the costa when single. It is the largest gelus of the order (Filices) excepting
Polupodium, and its species are found in all parts of the Polypodium, and its species are found in all parts of the
world, wherever ferns grow. It includes very varied world, wherever ferns grow. It includes very varied
forms. Iany of the species are evergreen, and some are cultivated for their beauty. Among the more conimon (A. Fil genterally known as spleen wort, are thic lady-1er distributed around the globe, wall-rue (A. Ruta-muraria), and ebony spleenwort (A. ebeneum).

aspodilt, $n$. An obsolete and corrupt form of asphodel (Asphodelus ramosus). Also aspodfower. Holme, 1688.

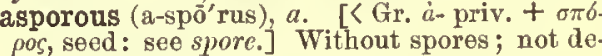
veloping spores.

In the case of the simplest and most minute Schizomy. cetes (Mllococcus, etc.) no definite spores have been discovered; any one of the vegetative micrococel may commence a new series of cells by growth and division. We
may call these forms asporone, at any rate provisionally. asport (as-pört'), v. t. [< L. asportare, carry away, $<a b s$, away (see $a b-\rangle,+$ portare, earry.] To carry away; especially,
ously. N. $E$. $D$. [Rare.]

asportation (as-pór-tā'shon), $u$. [<L, asportatio $(n-)$, a carrying away, $\ddot{<}$ asportare, pp. asporatus: see asport.] 1. A carrying away or off. [Rare.]

Aubrey, whose "Miscellanies" were published in 1696 , had no doubts whatever as to the physical asportation of
the witch.
Lowell, Among my Books, 1st ser., p. 115 . 2. In criminal law, the felonious removal of goods from the place where they were deposited. It may be theft, though the goods be not carried from the house or apartment.

aspret, $a$. A Middle English form of asper ${ }^{1}$.

Aspredinx (as-prē-dīnēe ), n. pl. [NI., $<A s-$
predo + -ina.] Same as Aspredinina or $A s-$ predo + -ina.] Same as
predinidae. Swainson, 1839.

aspredinid (as-pred'i-nid), $n$. A fish of the family Aspredinida.

Aspredinidæ (as-prē-diu'i-dē), n. pl. [NL., < Aspredo (-din-) + -idee.] A family of nematognathous fishes, exemplified by the genus $A s$ predo, containing a fow fresh-water catishes of South America. They have no operculum, no adipose fin, no splne in the dorsal fin, reduced gill-openings,
small eyes and mouth, and 6 to 8 barbels. The skin is

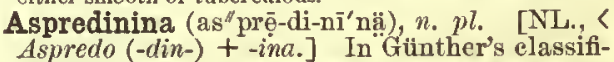
Aspredo (-din-) + -ina.] In Günther's classifi-
eation of fishes, a group of Silurida proteropodes, with the anterior and posterior nostrils remote from each other, the lower lip not reverted, and the humerocubital process much developed and prolonged: synonymous with the family Aspredinida.

Aspredo (as-prē'dō), n. [NL., < I. aspredo, roughness, < asper, rough: see asper1.] A genus of nematognathous fishes, typical of the family Aspredinida.

asprelyt, adv. See asperly.

asprenesst, $n$. See asperness.

asprino (äs-pré'nō), n. [It., prop. dim. of as- 
white wine made in the neigliborhood of Rome. tives of South Africa, especially the \%ulus and The best-known quality is sparkling.

aspy $\nmid, n$, and $v$. A Middle English form of espy. asquat (a-skwot'), prep. plir. as all, or $a$.
$a^{3}+$ squat.] In or into a squattiug posture. Siltlug asquat between my mother and sister. Richardson.

asquint (a-skwint'), prep. phr. as adv. or a. [< Mk. asquint, a squynte, appar. $<a^{3}+"$ squint (ef? I). schuinte, slopo, slant); but squint is not found in ME., the mod. form squint, ade. and $a$., hav- as ing come by apheresis from asquint: see squint.] 1. To or out at the corner or angle of tho eye obliquely; toward one side; not in

Who look asquint or slunt their eyes.

\author{
Survint
}

Edifices, . . With all their costllness, looking some-
what aryuint on the visitor, as if questioning his right to what asquint on the visitor, as if questioning his right to
enter then.. 2. In the condition of squinting; oblique.

The eye is muddy snd some limes asquint. Emerson, Wssays, 1st ser., p. 126. (N. k., D)

asquirm (a-skwèrm'), prep. phr. as adt. or $a$. [ $\mathrm{a}^{3}+$ squirm.] On tho squirm; squirming.

ass ${ }^{1}$ (ás), 2. [< ME. as, ass, asse, < AS. assa, m. (fem.assen, not "asse), an isolated form, perhaps adapted from ONorth. assald, asall, asal (which is from the Celtic), the earlier form, of the common Tout. typo, beiug esol, esul $=$ OS. esil = D. ezel ( $>$ E. easel, q. v.) = ÖHG. esil, MHG. G. esel (> Dan. esel, asel) = Goth. asilus (ef. Ir. and Gael. asal = Manx assyl, and OBulg. osìlü = Bohem. osel = Pol. osiel, osiol (barred $l)=$ Russ. osclu $=$ Lith. asilas = OPruss. asilis), prob. the same, with variant termination, as Icel. asni. m., asma, fem., = Sw. asna = Dan. asen (ef. W $a s y n=$ Corn. $a s e n=$ Bret. $a z e n)$; all appar. (the Slav, and Lith. forms through Teut.) ( L. asinus (> lt. asino $=\mathrm{Sp} . \mathrm{Pg} . a s n o=\mathrm{Pr}$, asne $=\mathrm{OH}$ nus ( > lt. asino $=\mathrm{Sp}$. Pg. asno $=$ Pr. asne $=\mathrm{OF}$.
asne, F. ane) $=\mathrm{Gr}$. ovos (orig. "dovos 9 ), an ass; perhaps ult. of Semitio origin; ef. Heb. äthōn, a sho-ass. Cf. G. assel, esp. in eomp. keller-asse (also keller-esel), a wood-louse, so named from its color, < I. asellus, a little ass, dim. of asinus; cf. Gr. ovos, a wood-louse.] 1. A solidungulato quadruped of the family Equide, the Equus asinus. This sulms has long ears, s short mane, and s tsil ored, with a biack cross over the shoulders, formed by a longiludinal and a transverse tark streak. The tame or domestlc ass is patient, and carries a heavy burden. It i slow, but very sure-footed, and for this reason very useful on rough, steep, and hiliy ground. The ass is supposed Abyssinla), where vast troops roam over the grest desert in a wild state. The wild ass is a fine fleet snimal, an is prized as venison is with us. The domesticated ass has becone the type of obstinscy and stupidity. See jackass. as the dziggetai or hemione, onager, etc -3 . dull, heavy, stupid fellow; a dolt; a fool; a blockhead.

If this be not a tit of some violent affectiou, $I$ am an
ass in understanding.
$H^{\prime}$ ord, Love's Sacrifice, $j \mathrm{it}, 2$ 4. A post in the bridge of a pulp-vat on which the mold is placed to drain.-Asses' bridge (pon asinorum), s name humorously glven to the fifth propo
sition of the first book of Euclid's Elements of Geometry. See pony asinorum. - Feast of asses. See feast. Cancer on either sicle of liners $y$ and of ass $^{2}$ (äs), n. [Seoteh form of $a s^{2}$.] Ashes.

ass $^{2}$ (as), n. [Seoteh form of $a s h^{2}$.] Ashes. ass $^{3}$ (ïs), $n$. A unit of weight in use in differ-
ent parts of Germany until the adoption of the ent parts of Germany until the adoption of the
metric system. It was equal to 5 centigrams, or three quarters of a grain troy.

assacu (as'a-kö), $n$. [Braz.] A euphorbiaceous tree of South America, Hura erepitans, the bark and sap of which eontaiu a very acrid poisonous prineiple. Applied to the skin the milky sap produces a pustular eruption; the natlves prepare fronl It a poison ous drink, also used as an anthelmintic. The seeds sl. as a remedy for elephantiasis, and the pounded leaves ar used for rhemmatism.

assafetida, $n$. See asafetida.

assagal (as'a-gi), $n$. [A]so written assegai, assagay, asseguy, and formerly assagaic, azagaia (also zagaye, zagaie, $<$ F. zagaie), and early mod. E. archegaye (< F.archegaie, archigaie, areigaye); \& F. azegaye, azagaye, < Pg. azagaia, Sp. azagaya (Sp. formerly also without the art., zagaya, It. zagaglia, F. zagaie, above), < Ar. az-zaghäyah, < al, the, + zaghayah, a spear: a native Berber word. Cf. lancegay.] A slender spear or lance of hard wood, usually having an iron ing-spear or javelin used in battle by the ua- tives of Sonth Africa, especiu

assagai (as'a-gi), $v$. $t$. [( assagai, n.] To strik or kill with an assagai. Also spelled asseyai.

Upon a signsl the Zulus rushel upon thelr unarned guests, snd aragagied them to the last mant.

assagal-wood (as'a-gī-wud), $n$. The wood of a cornaceous treo of sonthern Africa, Curtisia faginea, of which tho Zulus make their spears. assail (ás-sii'i), allv. [It., very, much, enough, [31L. ad satis: L. ad, to; salis, enough. See asseth, assets.] In music, very: as, al

$\operatorname{assai2}^{2}\left(\mathrm{a}-\mathrm{si}^{\prime}\right), n$. [Braz.] A nativo namo is Brazil of several species of palms of the geuus Eulerpe (which seo). The axwai-rani (that is ssise enterpe) is the Geonma Camana. Aseati is a drink yreparcd from the nuts of $k$. oleracea.

assail (a-sã $\left.]^{\prime}\right), t . t . \quad[<\mathrm{MF}$. assailen, asailen (later often by apheresis saile), $\left\langle\mathrm{OH}^{2}\right.$. asaillir asalir, later assaillir $=$ Pr. asalir, assalhir $=\mathrm{It}$. as salire, ( ML. assalire, adsalire, assail, for I. as silire, adsilire, leap upon, < ad, to, + salire, leap silire, adsilire, leap upon, $<a d$, to, + salire, leap,
jump, rush forth: seo salient. Cf. assault.] 1. jump, rush forth: see salient. Cf. assault.]

With greedy force he gan the lort t' assail. Spenser.

The covert of some enclosed ground in the rear ensbled party to steal round snd agrail then unexpectedly in 2 . To attack with reasoning, arguments, censure, abuse, eriticism, appeals, entreaties, o anything that bears upon the mind or feelings as, to clssail an obnoxious person with jeers. The prince next assailed the baron upon the subject of
settlug hils estate on his dainghter.

The reslly effcient weapons with which the philosopher vaugehical morality. Macaulay, Von Ranke. The metsphysical doctrine assailed by Ilume tended, when carried to its logical extreme, to identify reslity
with reason.
Lesic Stephen, Eng. Thought, i. 54

3. To fall upon; bring something to bear upon or against; come in contact with: as, the ship was assailed by a severe storm.

$$
\begin{gathered}
\text { Stt down awhile, } \\
\text { Anú let us once again assail your ears. }
\end{gathered}
$$

When tronble did thee sore assail, words. Set upon and fall upon hsve the vlgor of short and famlliar words, snd they express s sudden, energetic are to altack vehemently snd perhaps suddenly. Asacul is the stronger of the two, and is especially used of at tacks with persunal violence, as with fists, stones, etc. Al contests sud struggies of any kind. against an army of wlder nationslity than had ever before
attacked Egypt. $I I . S$. Osborn, Ancient Egypt, p. 74

He iook'd, and more amazed
Than if seven men had set upon him,

The malden standing in the dewy light.
Tennyson, Lancelot gnd Eisine.

Iy lord is weary with the fight before,

And they will fall upon him ungwres.

The Indignation which arms Ilself with secrel forees
does nol swaken until we sre pricked snd stung and sorely does nol swaken until we sre pricked and stung and sorely
assailed. but only to find that the defenders had raised a mor R. W. Dixon, Hist. Church of Eng., 1II. ot. assailable (a-sa' la -bl), $a$. [< assail + -able. $]$
Capable of being assailed, attacked, or iuvaded. He lived among a generation of sinners, whose con-
sciences were not assailable by smooth circumlocutions, snd whose vices required the scourge snd the hot iron.
Jfhipple, Ess. and Rev., II. 80. ppr. of assaillir: see assail aud -ant $\left.{ }^{1}\right]$ I. $a .1$. Milton.-2. In her., same as salient.

II. $\pi$. One who assails, attacks, or assaults.

The wise man throws himself on the side of his a asait-
ants. It is more hls interest than it is theirs to find his assaller (a-sā'lèr), n. [〈 ME. assailour, assailyour, $($ OF. assailled

assailment (a-sāl'ment), n. [< assail + -ment.] An assault; än attack. [Rare.]

Ilis nost frequent asscilinent was the headache.

Johnson,

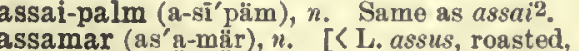
amarus, bitter.] "A bitter substance produced by roasting in the air such substances as sugar, iiest minster Rev., CXXVI. 173 =Syn. 1. Attack, Set upon, Fall upon, Astail, Assault.

This king's [Jienephtah's] first experience in war wa

Then they argaulted one of the gates, which they burned:
but only to find that the defenders had raised a mort

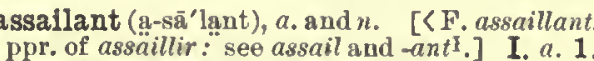
weak point. Emerson, Compensation. meat, bread, grain, etc, until they turn brown. Baron ton Reichenbach.

Assamese (as-?-mēs' or -mëz'), u, and $n$. [< Assum t-ese.] I. a. Pertaining to Assam or sinliabitants.

II. $n$. sing. and $p l$. A native or the ratives of Assam, an eastern provinco of British India adjoining Burma and Tibet.

assapant, assapanic (as-a-pan', -ik), n. [N. Amer. lnd.] The native name of the American flying-squirrel, Sciuropterus voluecllu. Also assapaniel; assaphan.

assart (a-sairt'), v.t. [< AF. assurter, OF. essarter, ( ML. exartare, exsartare (freq. of "exsarire), grub up, <ex, out, + sartare for "saritare, freq. of L. sarire, surrire, pp. sarritus, hoe, weed, grub.] In king. law, to grub up (trees and bushes); clear (wood-land).

assart (a-särt'), $n$. [Now also essart; < AF. ussart, OF essart ( $>$ law L assarta, assurtus, essartum), ( MIL. exartum, prop. neut. of "exar lus, pp. of "exarire, "exsarire: see assart, $v$.] In Eng. lavo: (a) The act of grubbing up trees and bushes in a forest. This act, as deshroying thlckets and coverts, was in some circumstances forbidden by law.
(b) A tree grubbed up by the roots. (c) A piece of land cleared, as by grubbing.

In those districts, and in many ollers in the nelghibourhood, the copyhold lands which have been reclainned from the furest-waste are known as "agsart-lands."
C. Eiton, Origins of Eng. Hist., p. 192

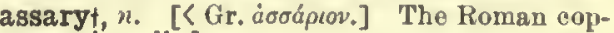
per eoin ealled as.

assassin (a-sas'in), n. [< F. assassin $=\mathrm{Pr}$, as sassin $=\mathrm{Sp}$. asesino $=\mathrm{Pg}$. It. assassino, < ML. assassinus, prop. one of the Assassini, Assasini, Assessini, Aseisini (also Asasi, Hatssasi ; ef. OF Assacis, Hassasis, MGr. Xaoioto, pl., from tho Ar. sing.), ( Ar. Washshäshin and Hashishiyyin, the order or sect of the Assassins, lit. hashisheaters (so called because the agents selected to do murdor were first intoxieated with hashish), pl. of hashshäsh and hashishiyy, hashish eater, < hashish, hashish: see hashish.] 1. [eap.] One of tho Assassins, a military and religious order in Syria, founded in Persia by Hassan ben Sabbah about the year 1090 . A colony nigrated from Persia to Syris, settled in varions plsces, wilt their chief sest on the mountalns of Lebanon, and becsme remarkable tor their secret murders in blind obedlence to the wlll of Judsism, Christianity and was a componnd of Mlagianlan, of thelr creed was that the Holy spirit resided in their The chiel of the sect is best known by the denomlnation old man of the mountain (Arabic sheikh al-jebal, chlef of the mountains). Thiese bsrbarous chleftains and their followers sprcad terror smong instions far and near for as
most two centuries. In the time of ile crusades they most two centuries. In the time of lle crusades they mustered to the number of 50,000 , snd presented a form-
dable obstacle to the srms of the christlans. They were 2. One who undertakes, for a reward previous ly agreed on, to put another person to deatl ly agreed on, to put another person to death kills, or attempts to kill, by treacherous vio'ence; a murderer.-3t. [With allusion to its ration worn in front. Ladies Diet., London, 1694.

assassin† (a-sas'in), v. t. [<F. assussiner, assassinate, worry, vex $=\mathrm{It}$. assassinare, assassinate, [ML. assassinare; from the noun.] To murder; assassinate.

IVith him that assassines his parents.

assassinacy $\nmid$ (â-sas' $\mathrm{i}-\mu \mathrm{a}-\mathrm{ai}$ ), $n$. [< assassina(te) $-c y$.$] The act of assassinating. Jlammond.$ nant, ppr. of assassiner: see assassin, v.] An

assassinate (a-sas'i-nāt), v.; pret. and pp. as sassinated, ppr. assassinating. [<ML. assassi-
natus, pp. of assassinare: see assassin, v.] I. natus, pp. of assassinare: see assassin, $v$.] I. or secret assault; murder by sudden or treach erous violence.

Help, nelghbours, my house is broken open,

Dryden.

2†. To assault; maltreat.

Such usage as your honourable lords
Afford ne, axsarsinated and betray' Mitton, S. A., 1. 1109

3. Figuratively, to blight or destroy treacherously; overthrow by foul or unfair means: as, to assassinate a person's character or repuation. = Syn. 1. Slay, Murder, ete. See kill.

II. intrans. To commit murder by assassina-

Where now no thieves assassinate.

Sandys, Paraphrase of Judges, 
assassinate $\left(\right.$ ă-sas'i-nāt), $n_{0}$ [ [ $\mathrm{F}$. assassinat, assaultant (a-sâl'tant), a. [<OF. assaultant, assassination, $<$ ML. assassinatus, $<$ assassinare: ous assault.

If I had made an assassinate upon your father.

2. An assassin.

Seize him for one of the arsarsinates.

\author{
nc, ii. 1.
}

assassination (a-sas-i-11ā'shon), n. [< assassinatc + -ion.] The act of assassinating; the act, especially of a hired emissary, of killing or murdering by surprise or secret assault; murder by treacherous violence.

assassinative (a-sas'i-nā-tiv), $\alpha_{0} \quad[<$ assassinate assassinative (a-se.] Inclined to assassinate. Carlyle.

assassinator (a-sas'i-nā-tor), n. 1. An assassin, -2. In canon law, one who hires another to kill a third person by surprise or secret assanlt. He loses the right of aanctuary and all other ecclesiastical immunity, and is smbjected to excomnimica.
tion, and, by the letter of the law, to conflscation of goods tion, and, by the letter of the law, to conflscation of goods
or even to deprivation of personal rights, lncluding that or even to deprivation of personal rights, lncluding that
of security of life: these penalties could be imposed even when the attempted assassination fell short of its effect. The law was frat made against those employing inffdels to extended to Christians as against any person, whetler Christian or not, who was allowed to live in the atate. The peculiar malice of the crime was placed in its being
gecret murder for hire. Technically it was unknown to aecret murde

assassinous $\nmid$ (gू-sas'i-nus), a. [< assassin + -ous.] Murderous; treacherous.

To smother them in the basest and most aszassinous assationt (a-sā'shon), n. [ [ F. assation, <ML. "assatio( $n-),<$ LL. assare, roast, < L. assus, roasted, perhaps for arsus, pp. of ardere, burn, be on fire.] A roasting.

Assation is a concoction of the inward moisture by heat.

assault (a-sâlt'), $n$. [The $l$ has been restored, as in fault, vault, ete.; ( ME. assaut, asaut, asaute (also by apheresis saut, later sault), OF. assaut, assalt, asalt, F. assaut $=$ Pr. assaut $=$ Sp. asalto $=\mathrm{Pg}$. It. assalto, $<\mathrm{ML}$. assaltus, assault, attack, [assalire, assail: see assail.] 1. An attack or violent onset with physical means; an onsiaught; especially, a suddon and vigorous attack on a fortified post.

$$
\begin{gathered}
\text { Able to resiat } \\
\text { Satan's assaults, and quench his flery dart }
\end{gathered}
$$
In milltary art ... more is oltentimes effected by reguJ'ashington, in Bancrolt's Hist. Const., I. 45 Specifically-2. In law, an unlawful attack upon the person of another ; an attempt or offer to do violence to another, coupled with present ability to effect it, but irrespective of whether the person is touched or not, as by lifting the fist or a cane in a threatening manner. It the person is struck, the act is called assault and battery. In 3. An attack with other than physical force, as by means of legislative measures, by arguments, invective, appeals, etc.: as, an assault upon the constitution of government; an assault upon one's reputation.

I would have thought her spirit had been lnvincible Assault of or at arms, the attack made upon each othe by the opposite parties in fencing or in military exercises assault (a-sâlt'), v. $t$. [く late MLE. assaute asaute (and by apheresis saute, later sault), $<\mathrm{OF}$ asauter, later assaulter $=\mathrm{Sp}$. asaltar $=\mathrm{Pg}$. as saltar $=1$ l. assaltare, $<\mathrm{M} \mathrm{L}$. assaltare, $<\mathrm{L}$. ad, to, upon, + saltare, leap: see the noun.] 1. To attack by plysical means; fall upon with violence or with a hostile intention: as, to assault a man, a house, a town.

look in npon me then, and speak with me, Shake, othello. v.

Specifically-2. In law, to attempt or offer to do violence to another, with present ability to accomplish it. See assault, n.,2.-3. To attack with other than physical force; assail with argu ments, complaints, hostile words, etc.

$$
\begin{aligned}
& \text { The cries of babes new-born } \\
& \text { A saault his ears. }
\end{aligned}
$$

Dryden

= Syn. Attack, Set rpon, etc. (see assail); to storm. Se

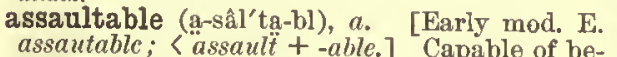
assautablc; $<$; The 28th day of October the walls were made low, and
the town assaultable.
IIall, Henry VIII., an. 15. Is the breach massinger, I aid of Honour, it. assaulter (a-sâl'tèr), $n$. One who assaults or violently attacks; an assailant.

assautt, $n$. Older spelling of assault.

assay (a-sā'), $n$. [< MF. assay, assai, asaye, asaie (and by apheresis say), $\angle \mathrm{OF}$, assai, assay= Pr. assai, assag= Cat. assatg=Sp. asayo=It.assaggio, saggio; also, with variatiou of the same prefix, OF. essai ( $>$ F. essay, q. v.) = Pr. essai $=$ Cat. ensatg $=$ Sp. ensayo $=\mathbf{P g}$. ensaio (MI. reflex assagium, assaia, essagiun, essayum), < LL. exagium, a weighing (cf. exâmen (for "exagmen), a weighing, examination), ( * cxageve, exigere, weigh, try, prove, measure, examine: see exanen, examine, and exigent, and ef. the doublet essay. For the prefix, see $\left.a s^{-3}, e s-1, e x-.\right] 1$ t. Examination; trial; attempt; essay.

Neither is it enough to have taken a slender taste or
Udall, Prel. to Luke. This cannot be,
By no assay of reason. Shak., othello, i. 3. He hath made an assay of her virtue.

Shak., M. for M., iil.

Hence-2†. Trial by danger; risk; adventure. Throngh many hard assayes which did betide. Spenser, F. Q., II. i. 35.

3t. Trial; tribulation; affliction.

She heard with patience all unto the end, Spenser, F, Q., I. vij. 27

4. The trial of the purity, weight, etc., of metals or metallic substances, as ores and alloys; any operation or experiment for ascerore or a mineral, or in coin or bullion. See as6. In law, an examination of weights and measures by the standard. Cowell. -7. Formerly, the act or custom of tasting the food or drink in tended for another, as a king, before presenting it.-_ 8t. Value; ascertained purity: as, "stones of rich assay," Spenser, F. Q., IV. x. 15.-Annual assay, an annual official trial of gold and ailver coin of colnage is maintained.-At all assayst. ( $(\alpha)$ At every trial or in every juncture: always. (b) At all hazards
ready for every event.-Cup of assay, the small cup with in assay ${ }^{\dagger}$, make the trial or experiment. $=$ Syn. 4. Assay ssay (a-sā'), v. [< ME. assayen, asaycn, asaien (later also by apheresis sayc, say), <OF. assayer, asaier = Pr. assaiar, assatjar = Sp. asayar = It. assaggiare; also, with variation of the same prefix, OF. essayer ( $>\mathrm{E}$. essay, q. V.) $=\mathrm{Pr}$. essaiar, ensaiar $=$ Cat. ensajar $=\mathrm{Sp}$. ensayar examine by trial ; put to test or trial; try the effect or merit of
lete or poetical.]

$$
\begin{aligned}
& \text { Solt words to his flerce passion she aszay'd. } \\
& \text { Here, too, our shepherd-pipes we first assay'd. } \\
& \text { M. A mold, Thy }
\end{aligned}
$$

Specifically -2. To make trial of or analyze as an ore or metallic compound, with the view of determining the proportion of a particula metal present in it.-3. To attempt; endeavor essay: often with an infinitive as object.

The first part I have told you in the three sermons past in which I have assayed to set forth my plough, to prove
what 1 conld do. Latimer, Sermon of the Plough.

$$
\begin{aligned}
& \text { She hath asray'd as much as may be proved. } \\
& \text { Shak., Venus and Adonis, }
\end{aligned}
$$

[Hen. V1II.] effected no more than what lis own pro essors desired and assayed in agea past.

[In this sense essay is now commonly used.] 4 . To endeavor to influence.

Implore her in my voice, that she make friends 5†. To affect; move.

$$
\text { When the hart is ill assayde. }
$$

II intrans. To make om try. [Now more commonly essay.] assayable (a-sā'a-bl), a. [< assay Capable of being assayed or tested.

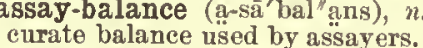

curate balance used by assayers. assayer (a-sā'ér), n. [< ME. assayer, assaior,
assaiour, $\mathrm{AF}$. assaior, assaiour: see assay and - $r^{1}$.] it. One who tries, tests, or attempts. 2. One who assays metals; one who examines metallic ores or alloys for the purpose of determining the quantity of any particular metal,
Same as assailant, 1. Which the assay of wine, etc., was made. (See 7.)-Put Pg. ensaiar; from the noun.] I. trans. 1. To
Specifically - 3. An officer of the mint, whose duty is to test bullion and coin.

assay-furnace (ฉ̊-sā'fẻr"nās), $n$. A simple form of furnar.

assaying (a-sā'ing), $n$. The act or art of testng metals, ores, or alloys in order to ascertain the quantity of goid or silver or any other metal present in them. There are two modes of as saying, one of which is sometimes employed to corroborate
the other. The one is called the humid or vet process, in which the solntion of the nuetals is effected by means of acids, after which those sought for are precipitated by proper reagents. The other is called the dry process, and is performed by the agency of fire. The first is generally employed for the purpose of estimating the gutantity of gold
or silver in an alloy, and the second is chiefly applied to res. Tests are also made by comparison of speciffc grayties, and by the color of the streak or trace made by rubarticle of silver or gold plate is assayed at Goldsmiths' llall previously to being sold, in order to determine the exact richness of the metal of which It is made. See hall-mark. sayer; a chief officer appointed to try the weigh aud fineness of the precious metals. - 2 . officer appointed, in the provincial period in Massachusetts, to test the quality of potash and Massachusetts, to test the quality of potash and pearlash intended for export, or the composition of the worms and still-heads used in
asse ${ }^{1}+n$. Obsolete spelling of $a s s^{1}$.

asse $^{2}$ (as), $n$. A name of the caama, a small African fox, Fulpes caama.

assealt, $v, t$. [ ME. asselen, aselen, var. of enselen: seo enseal.] Same as enseal.

ss-ear (às'ēr), $n$. An old name for the comfrey, symphytum officinale.

assectation $\nmid$ (as-ek-tā'shon), $n$. [< L. assect tio(n-), attendance, < asscctari, pp. assectatus, attend upon, < ad, to, + sectari, follow, attend, freq. of sequi, follow: see sequent.] Atteudance or waiting upon; a following. Blount; Bailey. assecuranceł (as-ẹ-kūr'anns), n. [< ML. assecurantia, assurance, <

Those assecurances which they give in the Popish assecurationt (as $\left.{ }^{\prime} \bar{e}-k \bar{u}-r^{\prime} \operatorname{sh} g n\right), n . \quad[<M L$. assecuratio( $n-)$, assecurare, pp. assecuratus, as-
sure: see assecme.] Assurance; a making secure or sure.

Ilow lar then reaches this assecuration' go far as to ex
lude all lears, all doubting?
Bp. Hall, Sermons, xliii. assecuret (as-ē-kür'), v.t. [< ML. assecurare, assure, < L. ad, to + securus, secure, sure Doublet, assure, q. v.] To make secure; make sure or certain.

Sin is not helped but by belng arsecured of pardon.
Ilooker, Eccles. Pol., vi. 6.

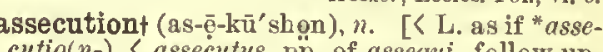
cutio $(n-),<$ assecutus, $\ddot{p}_{\mathrm{p}}$ of asserqu, follow up, quent.] An obtaining or acquiring.

His first [beneflce] . . . is Immediately void by his asse-
Ayliffe, Parergon, p. 115. assegai, $n$. and $v$. See assagai.

asseget, $v$. and $n$. Seo assiege.

asseizet, $i, t$. To seizc. Mfarlove. [Rare.] asself $\left(a-s e l f^{\prime}\right), r . t$. [<us-1 + self.] 1 . To take to one's self; appropriate; adopt.-2. To asuses.]

assemblage (ạ-sem'blāj), n. [<F. assemblage, assembler, assemble: see assemblc ${ }^{1}$ and -age.] 1. The act of assembling or the state of being assembled; association.

A collection of indiviolning grace. 2. A collection of individuals or of particular things: as, an assemblage of noted men; an as semblage of various materials. -3 . The act of fitting together, as parts of a machine; in carp. and joinery, a union of parts or pieces by fram ing, dovetailing, etc. See assembling. The exterior plank [i. $e$, planking] of our large wooden
war ships was divided into a number of distinct $a 8 s e m$ blages, each having a special designation.
Thearle, Jiaval Arch., \$ 212 assemblance ${ }^{1}+$ (a-sem'blans), $n$. [COF. assemblance $=$ It. assembranza: sce assemb
-ance.] An assemblage; an assembly.

To weete the cause of their assemblaunce wide. 政, 21 assemblance ${ }^{2} \uparrow$ (a-sem'blans), n. [< OF. assembtance (Roquefort), <"assembler, resemble: see assemble ${ }^{2}$ and -ance.] Representation; likeness; semblance.

Care I for the ... big assemblance of a man? Give me
the spirit.

assemblationt, $n$. A gathering; a meeting.

Roger North, Examen. [Rare.] 


\section{assemble}

assemble ${ }^{1}$ (an-sen'bl), $x$; pret. and pp. assembled, ppr. assembling. [र $\mathrm{Ml} \%$ assemben, nsemassambler = Pr. assemblar, asemblar, asemlur = assambler $=$ Pr. assiemblar, ascmblar, asfmlar =
OSp. asemblar $=$ It. assemblare, assembrave, MIs. assimulare, bring together (in L. the same

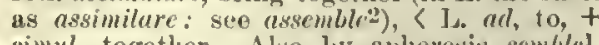
simul, together. Also by apheresis scmble.1.

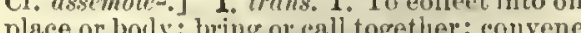
congregate.

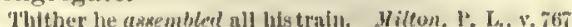
2. To fit together. See nssembling, 2.-3t. To join or eouple, as one with another, or as in sexual intercourse. = Syn. 1. To convene, collcet, cot

II. intruns. 1. 'To meet or come together eonvene, as a number of individuals: as, "the ehurls assemble," Dryten, Anneid, vii.-2†. 'To meot in battle; fight. $=$ Sym. 1. To gather, get to assemble $+\left(\right.$ a-sem'bl) $n . \quad\left[\left\langle\right.\right.$ asscmblel $^{1} r$. Cf. nssembly.] Än assenbly.

assemble ${ }^{2}+\left(a-\mathrm{sm}^{\prime} b \mathrm{~b}\right), v, t$. [Lato Mk. assam ble ; <OF, nssembler; of. Pg. assemelhur, assimi lar $=\mathrm{It}$. assimigliare, resemble; $<\mathrm{J}$. assimularc, assimilare, make like, consider like, com-
pare, $<$ ad, to, + similis, liko (related to simul, together; cf. asscmble 1 ): seo (rssimilute. Also by apheresis semble ${ }^{2}$.] 1 . To be similar to; resemhle.

For the world nxxembleth the gee.

\section{2. 'To liken or compare.}

llues may be azsembled to piltch.

assembler (a-sem'blèr), $n$. 1. One who assem bles.-2. Speeifically, a workman who assem maehine, as of a watch. See assembling, 2. $-3+$. One who takes part in an assembly; a member of an assembly.

assembling (a-sem'bling), $n$. 1. A eolleeting or meeting together. Not lorsaking the asyembling of ourselves together, as
the manner of gome ls.

ehines and instruments, sneh as sewing-machines, guns, mieroseopes, watehes, ete., espeeially when duplieate parts are so exaetly male as to bo interchangeable.

assembling-bolt ( $a$-sem'bling - bōlt), $n$. A serew-bolt for holding together the several parts of a maehize or tool.

assembly (a-sem'bli), $n_{\text {; }}$; pl. assemblies (-bliz) [< IIE. assemble, assemblayc, assemblec, $\angle \mathrm{OF}$. assemblec, $\mathbf{F}$. assemblé (= Sp. asamblea $=\mathrm{Pg}$. asscmblea), neeting, eoming together, < asscmsembling, or the state of being assembled or sembling, or the ste

A Triemnlal Bill enforced the asembly of the llonses
every three yeara, and bound the sheriffs and citizens to every three yeara, and bound the sheriffs and citizens to
proceed to electlon if the Royal writ falled to almmon

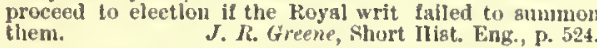
2. A company of persons gathered togetlier in the same place, and nsually for the same purpose, whetler religions, p

At length there issued from the grove behint

A fuir asaembly of the fente kind. Dryden, klower and Leal, ?. 154

Another assembly, composed of representatives chosen
by the people in all parts, vives lree access to the whole na. by the people in all parts, yives lree access to the whole na. tion, and communleates all its wants, knowledge, projects
and wlahes to government. J. Adams, Works, IV. 288 . The Popular Axzendily and the Popular Court of Justice are In principle the same institution; they are gatheriogs of the fremen of the community for different publle
purposea. 3. Specifieally- $(a)$ [cap.] The name given to the lower house of the legislature in several of the United States and in some of the British eolonies. (b) A eompany of persons of both sexes met for daneing; a ball; espeeially, a ball the expenses of which are defray ed by the subseriptions of those who take part in it. IIerglrls .... appeared perseveringly at the WInchester'
and Southainpton nesemblies: they penetrated to Cowes for the race-balls and regalta-galeties there.

4. Milit.: (1) The second beating of the drum before a mareh, upon whieh the soldier's strike their teuts. (b) A drum-beat or bugle-eall to briug troops togetlier at an appointed place.

Lagache ... thought it best to teat the loyaity of the

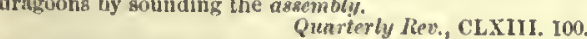
5 t. An assemblage or eolleetion of inanimate objeets.
To Venlce herself, or to any of the Ifthle nuxembly at
Horell, Letters, I. 1. Assembly of Divines at Westminster, commonly eall

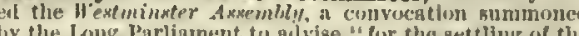
by the Long Parlianent to alvise "for the settling of the

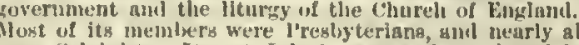
were Calvinists. It met July J, let3, and cont inued it (c8sions tlli kehruary 22, 1649. The chled fruits of its la aion of Fuithe and the of lablile Worshlp, the Confe-

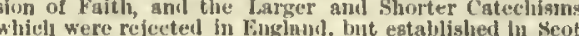
- Black Assembly ta the Unlyersity of ('un the grent connsoention, - General Assembly. (a) The lifhest eccleslastieal tribunal of churches of the Irealyte. rian orler, mcetlng annunliy, anil composed of ministen ant ruling eliers delegated by each breshytury withln
their respective national bunns. (b) In many of the their respective nalional bunnls. (b) In many of the
Enited states, the colleetlve title of the legistatnre. (c) In New Jersey, the lower house of the legislature.-Legtslative Assembly. (a) The enllective title of the ling Inture in the state of (Oregun and the territoriea of the inited States; also, the tinle of the lower lonse or of the slnglo legislative holy hn many of the British colonles. (b) In F'rench hirt., the legislative boulles of 1791-2, 1849-51, as Jistinguished from the Natinnal Asgembly of 1789-1791.
National Assembly, in French hist., the frot of the revolut lonary assemblies, lin session 1789-1791. The State Juneral, elected in 1789 , were opened Mlay 5,1789 , and 1 sembly and ahsorbed the two remaining estates. Its clilef work was the formation of the constil
also called the Constituent Axwembly.

assemblyman (a-sem'bli-man), $n_{.} ;$pl. assemblymen (-men). [C assembly + man.] A member of a legislative assembly. [U. S.]

assembly-room (a-sem'bli-röm), n. A room in which porsons assemble, espeeially for dancing. See assembly.

assen $^{1} t, n$. An obsolete plural of ass L. Chaueer. assen $2 t, n$. An obsolete plural of $a s h^{2}$.

assent (u-seut'), $v$ [ [ ME. aswenten, asenten (later also by apheresis sente), < of. asenter, assenter (< L. assentari, alsentari. irreg. freq. of assentiri), also assentir, F. assentir, < L. assenti re, more frequently deponent, assentiri, assent to, approve, consent, $\langle$ ad, to, + sentire, feel, $\rangle$ F. sent, now spelled improp. secnt: see secnt and sense, and ef. consent, dissent, and resent.] I. in trans. To admit a proposition as true; express an agreement of the mind to what is alleged or
proposed; coneur; acquiesce: with to before an objeet.

The Jews also nsyented, aaylng that these things were so,

We cannot aracnl to a propoaition without some Intell. gent apprehenslon of it; whereas we need not unilerstan

\section{Syn. To agree, subseribe.}

$$
\text { Infer lt. Jereman, Gram. of Assent, p. 6. }
$$
IJere wyles wolle it wel assente.

assent (a-sent'), $n . \quad[<\mathrm{ME}$. assent, asent, < as senten, asenten, the verb: see assent, $t$.] 1. The aet of the mind in admitting or agreeing to the Faith is the nexent to any proposition on the eredit of the iproposer.

Locke.

2. Consent; concurrence; aequieseenee; agree-
ment to a proposal: as, the bill before the house has the assent of a great majority of the mem bers.

Without the king's axkent or knowledige,
You wrought to be a legate. Shak., llen. VIII., ill.

No parish-business in the place could atlr,
Without lirection or axsent lrom her.
Crabbe, The Parish Register.

3. Accord; agreement; approval.

Virtue engages his axsent,
But Pleasure wina hls heart Cocper, il uman Frailty.

Too many people read this ribalily with assent and ad-
mlration. 4t. Opinion.

Thou art oon of his axsent.

Chauer, Partonie Tale, 1. 200 aovereign In l'urliangent to a bill whleh has passed both houses, alter which it hecomea law. This assent may be given in two ways: ( $a$ ) In person, when the sovereign comes
to the House of Peers, the Commena are sent lor, and the to the House of Peers, the Commona are sent for and the assent is deelared In Norman-French by the clerk of the signed by the sovereign, and notifled in hls or her ahsence. A money-bill, or bill of suplly, passed by the Honse o Commonis, is presented by the Speaker tor the royal assent. anee, adherence. Aswent is prinarily an act of the under standing ; consent la diatinctly the act of the wlil: as, I ter apeaks of justlfying falth as the assenting trug. Bax understanding and the consenting trust of the will. As-
sent is not yet altogether excluded trom the fheld of the
will, but tends to express a feebler action of the will than will, but tends to express a feebler aetion of the will than it fornerly clid, or than consent does. Compare Luke xxlil.
24 (nargin) "Pilate assented that it should be as they re-
yulred," with the formal consent in the royal assent to a bill. Concurrence is a running of mindla in the same chana state or act of quifel snbmission to a dectsion, an act, or the prevalence of an opinlon, beeanse it is near enough to one's wishes, or not worth resisting, ur limpos
sist, but not becanse it lo cutirely acceptahl]c.

Axsent I have described to be a mental asserion: in lts ry nature then it is of the mind, and nut of the lips.

If any faction of men will reutulre the axsent and consent. of other ment to a sust mumber of disgutalule and uninst ameng the frat of them, an! uterly renounce all cliristian conmunbou with all that sliall not glve that awarnt and compent, we look upon those to be separatlats; we dare not to be so narrow.spirit

C. Nither, Jiag. Chris, Int. to IIL

The necessity, under whlch the jury la placed, to agree unanimonsly, in orier to fiml a veritet Calhoun, works, I. a?

The show man rulos his trow Impulsively, . . but fnel

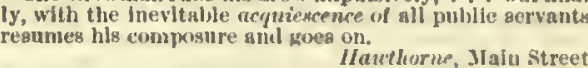
Hauthorme, Main Street.
and $\%$. [S ME. as assentantt (a-sen'tant), $a$. and $n$. [ $\mathrm{Me}$. $a$ s assenter: see assent, $t_{0}$, and $-t m \mathrm{I}$. Donblet, assenter: see assent, $t$., and $-t m l \mathrm{l}$. Do
assentient.] I. a. Assonting; agrecing.

II. $n$. (nne who assents or agrees.

assentation (as-en-t犃shon), n。 [< L. assentutio $(n-)$, tlattery, servile assent, < assentari pp. assentatus, flatter, assent in everything. sent, $v$.] The act of assenting; especially, ob
The sequions assent to the opinion of another; flattery; adulation.

It la a fearful presage of ruin when the prophets com.
pire In agsentation.
Bp. II all, Death of Ahah. Worls amoeth and aweeter-gounded are to be used rather than rough or harsh, as adore for worshlp, ossen. assentatort (as'en-tā-tor), n. [< I. assentalor (assentari, flatter: see assentation.] One who assents or consents; especially, one who as sents obscquiously; a flatterer. sir $T$. Elyot. assentatorilyt (ạ-sen'ta-tō-ri-li), adr. In the manner of an assentator
sequionsness. Bricon.

assentatorył (a-sen'ta-tō-ri), a. $\quad[<\mathrm{L}$. "assentatorius (implied in adv. assentatorie), < assentator, a flatterer: see assentator.] Pertaining to or eharaet

assenter (a-sen'tér), $n$. One who assents. See

assentient (a-sen'shicnt), $a$. and $n$. $\quad[<\mathrm{L}$. as

sentien(t-)s, ppr. of as̈entiri, assent : see assent, $v$.] I. $a$.

II. $n$. One who assents; an assenter. Forth British Rer.

assentingly (a-sen'ting-li), wlt. In a manner expressing assent; by agreement.

assentive (a-sen'tiv), a. [< assent + -ire. Giving assent; complying. savage. [Rare.] assentment+ (a-sent"ment), n. [<OF. (assente-
mont, <Ml. assentimenium, assent, < L. assentiri, assent: see assent, r., and -ment.] Assent agreement. Sir 1 . Bronche.

assentor (g-sen'tor), $n$. $\quad[<a s s e n t+-n r$; the nsual legal form; ef. asspnter.] One who assents; specifieally, one of the eiglit voters who indorse the nomination, by a proposer and seeonder, of a candidate for eleetion to the Parliament of Great Britain aud Ireland, as required by law.

assert (a-sẻrt'), v. t. [< L. assertus, pp. (1IL. a.ssertare, freq.) of asserere, adserere, join to, adserere aliquem manu (or simply adserere) in libertntem or in servitutem, declare one free or slave by laying hands upon him, hence free from, proteet, defend, lay elaim to, assert, declare, $\{a d$, to, + serere, join, range in a row,
Gr. eipetv, bind, fasten: see series and serricl.] 1t. To bring (into freedom); set (free). [Th original Latin use, usserere in libertutem.]

The people of Irraet, heing lately oppresser in Egypt.
were asserted ly God into a state of liberty.

2. To vindieate, maintain, or defend by word or measures; support the cause or elaims of vindieate a claim or titlo to: now used only of immaterial objects or reflexively: as, to assert our right

I could and would nyzelf assert the British from hts pen. often, in the parting hour, Oer colduess and disdaln s.ott, Iarmlon, 


\section{assert}

3. To stat declare.

There is no proof of what is a commonly agserted, that II uxley, Anat. Vert., p. 419.

To assert one's self, to assume and defend one'a rights, claims, or anthority ; exert one's influence; $80 \mathrm{~m}$

'The natural strength and firmness of his natnre began to assert itself. George Eliot, Jint on the Hoss, il. 2. While the struggle between the Emperor and the Pope
absurbed the strength of both, it became possible for the people to assert themselves.
II. Spencer, Prin. of Soclol., \$ 498. = Syn. 2. Assert, Defend, Maintain, Vindicate. Assert supports a cause or claim aggressively: its meaning is well
brought out in the expression, aszert yoursel $f$; that is, make your influence felt. To defend is primarily to drive
back assaults. To maintain is to hold up to the full back assaults. To maintain is to hold up to the full ancient cnstoms, liberties, rights. To vindicate is to resdicate the waya of God to man," Pope, Essay on Man, i. 16.

And as my vassals, to their ntmost might,

Assist my person, and assert my right.
Dryden, Pal. and Are, 1. 1,000.

It is time now to draw homeward; and to think rather of defending myself, than assaulting others.
Dryden, Pref. to IIock Astrologer. I will maintain

1 will maintain
My truth and honour firmly. Shak., Lear, v. 3. If it should at any time so happen that theae rights the courts to protect and vindicate them.

$D$. liebster, Convention to Revise the Const., 1821. 3. Assert, Affirm, Declare, Aver, Asseverate (see declare),
allege, protest, avow, lay down. (See protest.) Assert seems to expect doubt or contradiction of what one says. Affirm strengthens a statement by resting it upon one's repitation lor knowledge or veracity: as, "she [Rho-
d a] constantly affirmed that it was even so," Acts xii. 15 . Dectare makes public, clear, or emphatle, eapecially against contradiction. Aver is posit
erate is positive and solemn.

We can arsert without assenting.

$J$. II. Newman, aram, of Assent, p. 11.

It is a pure impertinence to affirm with oracular assur. ance what might perhaps be admisaible as a suggestion offered with the due diffidence of modest and gennine
acholarship.

Our Hebrew songs and harps, in Babylon

That pleased so well oun victors' ear, declare
That rather Greece from us these arts derived.

Ifitton, P. R., 1v, 337.

Then all averred I had killed the bird fog and mist. It is impossible to calculate the good that such a work
would have done if half which is asseverated lad only been assertable (âsér'tạ-bl), $a, \quad[<a s s e r t+-a b l e$. Capable of being asserted or maintained. Also assertible.

assertationł (as-èr-tā'shon), $n$. [<ML. assertatio $(n$-) < assertare, pp. assertatus, assert. see assert.] An assertion. Sir T. More.

assertative (â-sér'ta-tiv), a. [<assert +-ative. $]$ assertative

asserter (â-sèr'tèr), n. 1. One who asserts or maintains; a champion or vindicator.

Harmodius and Aristogiton had assassinated Hipparchus from mere private revenge; but they were now called
asserters of pubjic liberty. $J$. Adams, Works, IV. 488. 2. One who asserts or declares; one who makes a positive declaration.

Also assertor.

assertible, $a$. [<assert + -ible. $]$ See assertable. assertion (à-sér'shon), $n$. [< L. assertio( $n$-), declaration, $<$ asserere, assert: see assert. $] 1+$.
The act of setting free; liberation. -2 . The action of maintaining a cause or a claim: as, the assertion of one's rights. -3 . The act of stating something to be true.

A seertion unsupported by fact is nugatory. Junius.

4. A positive declaration or averment; an unsupported statement or affirmation: as, his as sertion proved to be false.

An assertion is as distinct from a conclusion as a word J. H. Neuman, Gram. of Assent, p.

The capacity of Jelly [protoplasm] to guide forces, which
Professor Huxley aaya is a fact of the profoundegt slgniffcance to lim, is not a fact at all, but merely an assertion.
Beale, Protoplasm, p. 85. $=$ Syn. 2. Vindication, defense, maintenance. -3 and 4 . assertional (a-sér'shon-al), $a . \quad$ [< assertion + -al.] Pertaining to or of the nature of an assertion; containing an assertion. [Rare.]

assertive (a-sér'tiv), $a$. [<MII. *assertious (imasserere: see assert and -ive.] Positive; dogmatic; affirming confidently; peremptory; af firmative.

Proposing them not in a confident and assertive form,
but as probabilities and hypotheses.
346

asseveration

ssertively (a-sèr'tiv-li), adv. In an assertive

assertiveness (a-serr'tiv-nes), $n$. The quality

of being asscrtive, or self-assertive.

As for this agsertiveness, one should admire it; it tend 11'. Shepherd, Prairie Experiences, p. 114. assertor (a-sćr'tor), n. [< L. assertor, declarer, advocate, defender, < asserere: see assert. Seo asserter.

assertorial (as-ér-tō'ri-gl), a. [< LL. asserto rius (see assertory) + -ai.] Asserting a fact as true, but not holding it to be necessary. See assertory, the common form.

assertorially (as-ér-tō'ri-ạl-i), $a d v$. In an asertorial manner ; as an äscrtion.

ssertoric, assertorical (as-ér-tor'ik, -i-kal), a. [< assertor $+-i c$, -ic-al.] Asserting; assertory assertive: as, an assertorie judgment. See as sertory.

assertory (â-sér'tōori), a. [< LL. assertorius, taining; declaratory; affirmative; assertive.

We have not here to do with a promissory oath: Bp. Ilall, Cases of Conseience, ii.

An Asertory Oath is made to a Man before God, and I An Assertory Oath is made to a Jian betore Assertory proposition, in fogic, a proposition stat

assertress (â-sér'tres), n. [< asserter + -ess.]

A female who asserts.

sserveł (a-sẻrv'), v.t. [< L. asservire, serve, hid, $<a d$, to, + servire, serve:

asservilet (a-sèr'vil), $v$. t. [< as-1 + semile. asservilet (a-sèr'vil), $v$. $t$. [< as-1
To render servile or obsequious.

[1] am weary of asserviling myself to every man's charity.
Bacon, y, 240 (Ord MS.). asses, n. Plural of $a s^{4}$ and of ass $I$

assess (a-ses'), v.t. [< late MIE. assesse, also accesse (whence by apheresis sess, cess), ( OF. as sesser, < ML. assessare, fix a rate, impose a tax, assessor to a judge, in $\mathrm{ML}$. fix a rate, impose tax, assess (ef. assessor), $\langle$ L. ad, to, + sedere, sit, tax, assess (cf. assessor), L L. ad, to, + sedere, sit,
$=$ E. sit. Cf. assize.] 1. To set, fix, or eliarge a certain sum upon, by way of tax: as, to asses each individual in due proportion.

His method of raising supplies was to order some rich courtier to pay a anm, and then sell this order to som
speculator with the power of torturing the person assessed.

2. To estimate the value or amount of (property or income) as a basis for taxation.-3. To set, fix, or determine: as,

assesst (a-ses'́), n. [〈assess, $\left.v_{0}\right] \quad$ Assessment. assessable (a-ses'a-bl), a. [< assess + -able.] Capable of being assessed: liable to assessment.

assessably (a-ses'a-bli), adv. By assessment. assession $\left(a-\operatorname{sesh}_{0}^{\prime} \mathrm{n}\right), n . \quad[<\mathbf{L} . \operatorname{assessio}(n-)$, sitting by or near, < assidere, sit by or near: see assess, v.] A sitting beside or together; a session. [Rare.]

assessionary (a-sesh'on-ā-ri), a. [< assession $+-a r y$.$] Of or pertaining to an assession or to$ assessors: as, "at the assessionary court," $I$. Carew, Survey of Cornwall. [Rare.]

assessment (a-ses'ment), $n$. [<ML. assessa-
mentum, < assessare, assess : see assess and -ment. Also by apheresis sessment.] 1. The act of assessing, determining, or adjusting the amount of taxation, charge, damages, ete., to be paid by an individual, a company, or a community. -2. The amount so determined; the tax or specific sum charged upon a person or proppay corporate debts. -3 . An official valuation pay corporate debts. -3 . An official valuation of property, profits, or income, for purposes of
taxation.-4. The value thus ascertained or assigned.-Commissioners of estimate and assess ment. See commissioner. - Polltical assessments, in the United States, contribntions of money levied by political committees npon the office-holders and candidate
belonging to their respective parties, in order to defra belonging to their respective parties, in order to defray
the expenses of a political canvass, - Union Assessment Acts, English statutes of 1862 (25 and 26 Vict.
1864 (27 and 28 Vict. c. 39 ), and 1880 (43 and 44 Vlet. which relate to the poor-rates and secure a uniform valnaSee tax.

assessor (a-ses'or), n. [Early mod. E. also assessour, ¿ ME. assessour, < OF. assessour, mod. $\mathrm{F}$. assesseur $=\mathrm{Pr}$. assessor $=\mathrm{Sp}$. asesor $=\mathbf{P g}$. assessor = It. assessore, < L. assessor, an assistant judge, in MI. also an assessor of taxes, lit. one who sits by another, < assidere, sit by: see one who sits by another, < assidere, sit by: see
assident, assess.] 1. One who sits by another; hence, one who shares another's position, rank, or dignity; an associate in office.

Don Quixote, $\%$. or his assezsors, the curate and the
barber.

2. An inferior officer of justice, who sits to assist a judge as a law authority; in Scotland the legal adviser of a magistrate, with judicial powers.

Minos the strict inquisitor appears

And lives and crimes with his agsessors hears.

3. In England a person chosen to assist the mayor and aldermen of a borough in matters concerning elections.-4. In some universities, as the Scoteh, the title of the elected mcm bers of the university court or supreme governing body of the university.-5. One appointed to make assessments, especially for purposes of taxation.-Assessor of the vice-chancellor, in Finglish universities, a depnity of the vice-chancellor ap pointed by him to hear causes and to be his

assessorial (as-e-só'ri-al), a. [<assessor + -ial.]

Pertaining to an assessor, or to a court of as-

sessors.

assessorship (a-ses'or-ship), n. [< assessor + ship.] The office of assessor.

Be this as it may, his progress from the passive Auacul. tatorship towards any active Askessorship is evidently of
the slowest. Cariyle, Sartor Resartus, p. 86. asset (as'et), n. See assets.

asseth,$+ n$. [ME., also aseth, aseeth, asethe, assethe, assetz, etc. (= Sc. assyth), < OF. asset, aset, asez, assez, in the phrase fere aset, aset fere (< L. (ad) satis facere), make amends, lit. do enough: see asset, assets, the same word, of later and difsee asset, assets, the same word, of later an
ferent use in E.] Satisfaction; amends.

We may noghte be assoylede of the treapase bot if make

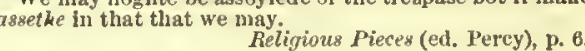
Yit never shal make his richesse Asseth uito his greedynesse.

assets (as'cts), n. pl., orig. sing. [ [ $\mathrm{AF}$. assetz, asetz (OF. assez, asez, asset, aset, mod. F. assez $=$ Pr. assatz = OSp. asaz = Pg. assaz, assas = have <ML. ad satis, lit. up to enough, equiv, to L. satis, enough: sce satisfy.] 1. In law: (a) Suffisatis, enough: sce satisfy.] 1. In law: (a) Suffian executor or heir to pay the debts or legacies of the testator or ancestor to satisfy elaims against it. (b) Any goods or property or right of action properly available for the payment of a bankmipt's or a deceased person's obligations or debts: generally used to signify resourees for the payment of debts, etc. Assets are real or personal. Reat assets are lands such aa descend to the ancestor; personal assets are the money or goods of the deceased or insolvent, or debts due to him, which come he is to coliect or convert into money.

2. Property in general ; all that one owus, considered as applicable to the payment of his debts: as, his assets are much greater than his liabilities. - 3. [As a singular, asset.] Any portion of one's property or effects so con-Equitable assets. See equitable.-Marshaling assets. sert strongly, speak in earnest, < ad, to, + severus, earnest, serious, severe: see severe.] To asseverate.

Anselnuns. . not only assevereth it, but also endeavoureth ... to set out the true . . proportion of it.
Fotherby, Atheomastix, p. 317.

asseverate (a-sev'èr-āt), $x . t$. ; pret. and pp. asseverated, ppr. asseveraling. [ $[\mathrm{L}$. asseveratus,
pp. of asseverare: see assever.] To affirm or aver positively, or with solemnity.

Charity nigh choke

Ere 8 wallow what they both asseverate;

Though down the gullet falth may feel it go.
Brouning, Ring and Book, I. 85.

$=\$ y n$. Aszert, Affirm, Declare, ete. (zee aszert); to say, allege, protest, insist, maintain.
asseveration (a-sev-e-rá'shon), $n$. $\quad[<\mathbf{L}$. asseveratio $(n-)$, an earnest declaration, $<$ asseverare, pp. asseveratus, assever: see assever.] 1. The act of asseverating; positive affirmation or assertion; solemn declaration.

"My God!" eried the monk, with a warmth of asseveraian which reemed not to belong to him.
Sterne, Sentimental Journey, p. 21. 2. That which is asseverated; an emphatic assertion.

He [Leeds] denied with the most solenn asseverations that he had taken any money for himaelf. 
asseverative

asseverative (a-sev'èr-â-tiv), a. [< assecerate $+-i v e$.$] Pertuiniug to or eharacterized by$ asseveration.

Jean Thompson lockent at his wile, whose apmlanse lue prized, anil she answered by an asseveratine toss of the
hesel. asseveratory (a-sev'èr-ñ-tō-ri), a. [< assceer ate $+-o r y$.$] or the nature of an assoveratiou$ solemnly or positively affirming or averring. After divers warm and axae teratory answers made by $31 \mathrm{r}$ tkins, the captaln stopped short tin lis walk.

ass-head (is'hed), n. One who is dull, like th ass; one slow of approhensiou; a blockhead. Whil you hely an ass-head, and a coxcomb, and s knsve?
shak., 'T. X., v. 1. assibilate (a-sib'i-lāt), r. t.; pret. and pp. assibilated, plur. assibilating. [< L. "assibilatus, pp. of assibilare, whisper at or to, $\langle a d$, to, + sibiof assibilare, whisper at or to, $\langle a d$, to, + sibi-
lare, whisper: see sibilant. The E. senso of lare, whisper: see sibilant. The E. sense of
assibilate depends on that of sibilant.] To renassibilate depends on that of sibilant.] To ren-
der sibilant, as a sound; ehange into a sibilant or lissing sound; alter, as a sound, by the phonetic procens ealled assibilation. The term may be applied to the whole

assibilation (a-8ib-i-lä'shon), $n . \quad[<$ assibilate. $]$ The aet of making sibilant; specifieally, in philol., the chango of a dental or guttural (or a labial) mute into a sibilant $(s, z, s h, z h, \mathrm{ch}=t s h$ $j=d z h)$, or into a sound approaching that of a sibilant, as for instance a palatal. This clange usually results from a tendency to accominodate the nunte to an immediately succeedings $e^{i}$, or $y$ aound. Thus, $t$ is prononnced of in the French nation and $s h$ In the Finglits nation. Simllarly, the Engl sh $t$ approaches or assume
the sound of ch betore the $y$-sound contalned in long $u$ in

Assidean (as-i-dē'an), $n$. [Also Assidaran, Asi as if 'assiduous Aoidaio, repr. Heb. lasidim, lit pious ones (usually translated "saints" in the English Bible) (hasad (initial heth), bo pious. The form Chasi dean is approximated to the Heb.] 1. One of a sect of orthodox Jews, opposed to Greek innovations. They were anong the first to foin Mstathlas, the father of the Mfaccabees, in delending the purity of their reilgion and the libertles of their country.
2. One of a mystical sect of Polish Jews which originated in the eighteenth century.

Also ealled Chasidean.

assident (as'i-dent), $a$. [< L. assiden $(t-) s, p p{ }^{*}$. of assidere, sit by or near, $<a d$, to, + sedere E. sit. See assess and assiduous.] Aceompanying; concomitant.- Assldent or accessory signs or symptoms, in pathol, signs or symptoms such as usil. aliy, though not invarialsly, attend a disease : dist

assiduateł (a-sid' în-āt), a. [< LL. *assiduatus, pp. of assiduare, apply constantly, < L. assiduus, ual; assiduous.

$$
\begin{array}{r}
\text { By love's assiduate care sud lndustry. } \\
\text { Middleton, Micro-Cyn }
\end{array}
$$

assiduity (as-i-dū'j-ti), n.; pl. assiduities (-tiz) $\left[=F^{3}\right.$. assiduité, < L. Le assiduita $(t) s$, < assirluus: see assiduous.] 1. Constant or elose application to any business or oceupation; diligence. I have, with much pains and assiduity, qualifled mysell By marvellons assiduity, he [Pickering] was able to lea. two lives, one produclng the fruits of esrth, the other
those of immortsllty. 2. Solicitous care of a person or persons; constant personal attention: usually in the plural. Far from thelr natlve home, no tender assidrities of iriendshlp... relieve their thirst, or close their eyes in
death.
II all, MIodern Infidelity.

Hence-3t. Sycophantic attention; servility. The obsequlonsness and assiduity of the court. -Syn. 1. Industry, Assiduity, Application, Ditigence, Constancy, Perseverance, Persistence, care, attention,
wrtchifulness, sedutonsness, patence. Diligence in labor often conveys the tdea of quickness. Industry keeps a
work, lcavlug no time idie. Assiduity (literslly, a sittin wown to work) stleka quietly to a particular task, with th determinst lon to succeed in spite of Its difficulty, or to ge It done In splte of Its length. Application, Jliterally, bends itsely to its work, and la, more speeiflcally than assiduity,
a steady concentration of one's powers of body and mind as steady concentration of one's powers of boly and inlnd gence is, literally, fondness for one's work, and 80 , by a natural transfer, industry that is alert. Constancy is the on in any particular course or work; it goes more deeply
into character than the others. Perseverance suggests obInto character than the others. Pergeterance suggests ob-
stacles from without or within which are steaslily met and is morally neutral. Persistence may be good, but is more often anl evil perseverance, as obstinacy or a derefusal on the part of others. We speak of plodding in
347

\section{assigmation}

duntry, patient axxiduiry, steady application, grest dili gence, unshaken coustancy, undanuted perse

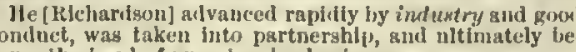
ane the inead of an extensive business. Ile was distluguished among his fellow students .. hy the assiduity with which he often prolonged his studies fy
Macaulay, Addilson.

A man of judgment and application wlll succeed Incon prably hetter fin composing tite Talles to his own writ Diligence and accuracy are the only merita whilch an
istoricat writer may agcrlie to himseif.

$$
\begin{aligned}
& \text { The careful search } \\
& \text { Is made with all due ditigerice } \\
& \text { Shak., Peric }
\end{aligned}
$$
Shak., Pericies, IIL. (cho.

True conseancy no fime, no prower can move. Gray. All the performances of human $8 \mathrm{rt}$, gt which we look with prstse or wonder, are instances of the reslstless force
of persencrance. Full-arm'd upon his charger all day long

Sat by the walls, and no one open'd to him. Temmyson, Pelleas and Eitarre.

assiduous (a-sid'ū-us), $a$. [ $\mathrm{L}$. assiduus, sit ting down to, constantly occupied, unremitting, [ assidere, sit at or near: see assident.] 1 . Constant in applieation; attentive; devoted assiduous physician or nurse.

The most assiduons tale-bearers ... are often halt af the Tongue.

2. Constant; unremitting: applied to actions In some places the deep sand conld with dithiculty be

$$
\begin{aligned}
& \text { To wesry him wlth my assiduous eries. } \\
& \text { Milton, P. L, xi. } 810 .
\end{aligned}
$$
IIIs charaeter, ... as displayed in his works, repays = Syn. 1. Sedulous, diligent, active, bnsy, constant, pa-
tient, persevering, laborious, unceasing, indefatigahle, un tiring. See assiduity

assiduously (a-sid'u-us-li), $a d v$. In an assidu ous manner; diligont

Many persons have attained a marvellons proficlency in falsehood, and tell lles as assiduonusly as s friar does his
wheads. assiduousness (a-sid'ñ-us-nes), $n$. The qual ity of being assiduous; constant or diligent ap plication. = Syn. See comprrison under assiduity.

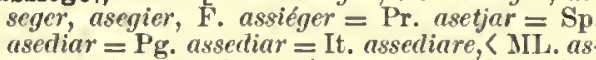

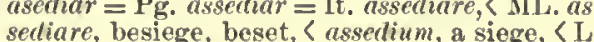
all, to, by, + -sedium, as in L.obsirlium, a siege (ob, before, in front of ), ( sedere
besiege and siege.] To besicge.

The Grekes... the cite long a

On th' other syde, th" asxieged Castles ward

Thelr stedfast stonds aidd mightily maintaine.

assiegeł, $n$. [< assiege, $v.] \mathrm{A}$ siege.

Al the assege of The hes. Chaucer, Trotilus, ii. 107.

assiegementt, $u$. [<assiego + -ment. $]$ A siege or state of siege; a beleaguering.

assientist (as-e-en'tist), n. [C Sp. asentista, asiento: see assiento.] One connected with the
furnishing of slaves by assiento. Boneroft. assiento (as-ē-en'tō), n. [< Sp. asiento, for rerly assiento, a seat, seat in a court, a con$\mathrm{Pg}$. assentar = It. assentare), place in a seat, adjust, make an agreement, < $M L$. as if "assedentare, cause to sit, < L. ad, to, $+\operatorname{seden}(t-) s$, ppr. contract made by Spain with foreign powers or merchants for the supply of African slaves to its American possessions. The last asslento, held Wha ahrogatcrt or relinction

<Sign $($ a-sin $), v . t . \quad[<\mathrm{ME}$. assignen, asignen,
< assigner, asigner, < L. assignare, mark out, appoint, assign, distribute, allot, < ad, to + signare, mark, < signum, mark, sign: see tion or appropriation; apportion; allot.

The priests had a portion assigned then. Gen. xlvii. 22 Mr. Buckle's fundamental error lay in the attempt to
assion distinct parts to elements of human msture that th assign distinct parts to elements of human nsture that th
reality csunot be separated. $J$. F iske, Evolntionist, p. 217. To each [province] was assigned a governor experienced In the law who dealt with taxation and finance.

2. To point out; show; designate; specify. All as the Dwarle the way to her axyynd. Spenser, F. Q., I. vil. 28
It la not easy to assign a period more eventiul. With the help of the scale of numbers, then, any ayhiched continuous quantity will serve as a standard hy W. $K$. Cliford, Lectures, I. 33 s.

3. To give, furnish, or specify: as, to assign a reason for anything. -4 . To appoint; select for a duty or oftice: as, the officer assigned to the eharge of a military department.

Knights assigued to enforce the oath of peace and the hue and cry spyear as esrly as the year 1195 . Their des-

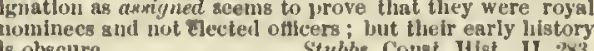

5. To ascribe; attribute; refer.

There are many causes to which one may auvign thia
Steele, Spectator, No. 4is. 6. In lav: (a) To transfer or mako over to another the right one has in any object, as in an estate, chose in action, or reversion, especially in trust for the sccurity of ereditors: rarely applied to testamentary transfers. (b) To show or set forth with partieularity: as, to assign error in a writ; to assign false judgment. (e) To point out or substantiate as a charge: as, perjury cannot be assigned on an oatli taken without the jurisdiction of the offeer adminis. tering it.-To assign dower, to allot or portion out to $f x$ the boumlaries of the wldow's ghare in an estate. To assign in bankruptcy, to transfer jroperty to an veat it in assignees for the benent of the creditors. $=S \mathrm{yn}$ 1. Dispenue, Distribute, etc. (see digpense). -3 . Adduce,
Allege, etc. (see adduce); to determine, give, nsme, present assignt (a-sin'), n.1 [< assign, v.] 1. Assign ment; appointment. -2. Design; purpose; ob ject.

\section{IIe alnid at hlgh designs, and so attalu'd
The high assign: to which his sirit ainid.} Ford, Fane's Jiemoriai.

assign (a-sin'), n.2 [The same, with loss of the final syllable, as assignee, < ME. assigne (threo
syllables), <OF. assigne, prop. pp. of assigner, assign: see assigm, $v$.] 1. A person to whom the property or interest of another is or may be transferred: as, a deed to a man and his heir and assigns.

Scrooge was his sole executor, his sole adninistrator, hils

The excluaive right of frequenting all the countries thist might be found was reserved to them [John Calot and his [Assign is a lorosder word than assignee. The assignees of a person are nsually understoor to mean those who take a person include sll who actuire title under his transfer,

appurteng pertaining to something olse; a Six French rapiers and pontards, with their asmigna, as assignability (a-si-na-bil'i-ti), $n_{0}$ [ [ assigna ble: see-bility. ] Capability of being assigned. assignable (a-si'na-bl), a. [= F. assignable; or bill.-2. Capable of being specified, shown, designated, or expressed with precision : as, an assignable reason; an assignable magnitude.

His [s soldier's] fighting condition was needed not on one or two days consecutively, but on many days, and not or period perhaps of nonths. While on the one land industry is limited by capital, 80 of giving, additional employnent to fndustry : and thi 3. Capablo of being attributed; attributable. 4. In law, predicable; capable of being pointed out or substantiated: as, perjury is not assigna ble of testimony on an immaterial point assigmably (a-sī'nạ-bli), $a d v$. In an assignable assignat (as'ig-nat; F. pron. a-sē-nyä'), n. [F. <L. assignatus, pp, of assignare, assign, allot. see assign, $\ell$.] 1. One of the notes formin the paper eurrency issued in Frunce during the revolution from 1789 to 1796 . The assignats were based on the security of the conflscated church tands, sn afterward of all the national domalns and other property.
They were issued to the amount of over forty. five bitilion francs, and before they were withdrawn deterio
Jess than one three-hundredth of their face value.

2 . In French law, the assignment of an annuity an an estate, by which the annuity is based on the security of the latter: now little used. assigmation (as-ig-na'shon), $n$. [ $=\mathrm{F}_{\text {. assigna }}$ tion, < L. assignatio ( $n-)$, assignment, allotment, The act of assigning or allotting; the act of fix ing or specifying.

The assignation of particular nsmes to denote particular 


\section{assignation}

348

2. An appointment of time and place for meet ing: used chietly of love-meetings, and now generally in a bad sense. -3 . The legal transis made; an assignment. $-4 \nmid$. Paper currency a bill; an assignat.

assignee (as-i-nét), n. [< F. assigné, pp. of assigner, assign: see assign, $\imath^{\circ}$.] A person to whom a transfer of some right or interest is made, either for his own enjoyment or in trust. An assignee may take title hy act of the previous owner or ly operation of law, as in the case of an administrator: Sec
note inder assign 2 , 3. - Assignee in bankruptey, or assignee in insolvency, a person to whoin is transferrel the title to the estate of a liankrupt or insolvent, for the purpose of

assigner (a-si'nér), $n$. One who assigns, appoints, or allots. See assignor. [Rare.]

assignment (â-sin'mẹnt), $n_{0}$ [< ME. assignement, < OF. assignement, < ML. assignamentum, [ L. assignare: see assign, $x_{0}$, and -ment.] 1 . The act of apportioning or allotting; allotment. - 2. The act of setting apart, appointment.-2. The act of setting

The only thing that maketh any place puhlic is the publi
Hooker. 3. That which has been assigned, as a particular task or duty.-4. Specifically, in law: $(a)$ The transference of a right or an interest. See assign, $v, 6(a) . \quad(b)$ A pointing ont or setting assign, $v ., 6(a) . \quad(b)$ A pointing ont or setting writing by which an interest is transferred. writing by which an interest is transferred.sum allowed.-7. Formerly, in Australia, the allotting of convicts as unpaid servants to colonists, in order to relieve the authorities of the expense of the conviet establishments.

The expense of the Australian convict establislument was enornous, and some change in systen was thevitab assignments, in other words, of freely lending the convict to any one who would relieve the authorities of the bur-
densome charge.
Encyc. Brit., XIX. 750. Assignment of dower. See as8ign, vo-Assignment of errors. See prror.-General assignment (more Sully assignment for benefit of creditors), an assigminent
of all the assignor's property not exempt irom execution, in trust to pay his creditors. - New assignment, of setting the defendant right where the latter, throug misapprehension of the real cause of complaint as stated
in the declaration, had been led to apply his plea to a dis. in the declaration, had been led to apply his plea to a dis ferent matter from that which the plai

assignor (as-i-nô $\mathbf{r}^{\prime}$ ), n. In law, one who makes an assignment, or assigns an interest. assilag (as'i-lag), n. [E. dial.] A local British name of the petrel, Procellaria pelagica. Mrontaru.

assimilability (a-sim/i-la-bil'i-ti), n。 [< assimilable: see-bility.] The quality of being assimilable. Coleridge.

assimilable (a-sin'i-la-bl), $a$. and $n$. [< ML. assimilabilis, that can be made like, $<$ L. assimilare: see assimilate.] I. a. Capable of being assimilated, in any sense of that word.

II. $n$. That which ean be assimilated. [Rare.]

Meeting no assimilables wherein to re-act their natures.
Sir T. Broume, Vulg. Err., vii. 19.

assimilate (a-sim'i-lāt), $v$; pret. and pp. assimilated, ppr. assimilating. [< L. assimilatus, pp. of assimilare, adsimilare, mixed with assimulare, of assimilare, adsimilare, mixed with assimulare, quently imitat $\theta$, feign, simulate; $<a d$, to, + similis, like (related to simul, together): see simulate, similar. 'To an erroneous supposition 'make like,' and assimulare for the sense 'counterfeit, is due the existence of the corresponding E. forms assimilate and assimulate, with the same distinction of sense: see assimulate. Cf. assemble ${ }^{2}$, also nlt. < L. assimilare.] I. trans. 1. To make alike; cause to resemble.

Fast falls a fleecy shower; the downy flakes

Assimilate all objects. Coicper, Task, iv. 328. A monse's squeak trarimilates itself in thought with
sounds of high pitch, snd not with sounds ike the bellow ing of a bull. II. Spencer, Prin. of Psychol., \$ 114. cordant, in sound; bring to or toward agreement in mode of utterance: said of alphabetic sounds as affected by other neighboring sounds, generally (but not always) in the same word. See assimilation, $(d) .-3$. To compare; liken; class.

He assinilated the relation between teacher and pupil
to that between two lovers or two intimate friends. to that between two lovers or two intimate Iriends.
Grote, Hist. Greece, 11.67. 4. To convert into a substance suitable for ab-
sorption by an animal or vegetable system; ab- orb and incorporate into the system; incorpoate with organic tissues: as, to assimilate food. Hence, in general, to alumopriate and incorporate, as the
body does food : as, stich ideas cannot he assimilated lyy the mind.

5. To bring into conformity; adapt.

By religion the trutlis thus oltained [from theology are urned over in the nind and assimilated by the imagina6. To conform to; make one's own; adopt.

The ease with which she assimilates the city hife when in , making it a part of her imaginative

Varg. Fuller, Woman in 10th Cent., p. 274.

II. intrans. 1. To become similar; become ke something or somebody else; halmonize.

Do but put them in relationship, and no division int, castes, no differences of wealth, can prevent men from
IIssimilating.
II. Spencer, Social Statics, p. 254 A people whose diffcrences of religion, language, and generat habits made them not only incapalle of a 8 similat

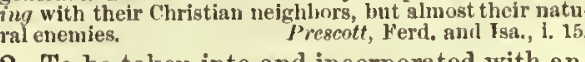
2. To be taken into and incorporated with anther body; be converted into the s

For whatsoever asximilateh not to flesh turneth either 3. To perform the act of converting anything. 3. To perform the act of converting anything, as food, into the substance of that which conbeasts," Baeon, Nat. Hist., $\$ 680$.

No organs whlch are destitute of chlorophyll can aysimi
Saeds, Botany (trans.) D. 620 .

assimilateness (a-sim'i-lāt-nes), n. [<"assimi late, $a$. (< L. assimilatus, pp.), + -ness.] Likeuess. Bailey.

assimilation (a-sim-i-lā'shon), $n$ : $[=\mathrm{F}$. assimi lation, < L. assimilatio $(n-)$, assimulatio $(n-)$, , being similar, $<$ assimilare, assimulare: see as similate.] The act or process of assimilating or of being assimilated. Speciffcally - $(a)$ The act of process of making or becoming like or identical; the act of It is as well the instinct as duty of our nature to aspire
to an assimilation with God. Decay of Christ. l'iety. In this long stillness the finsion of conquerors and con quered, the Christianization and civilization of the for France beside him, went steadily on. (b) In physiol., the act or process by which organisms convert and absorb nutriment, so that it hecomes part of the

To these preparatory changes, which fit the crucle foon materials for protoplasmic food, the general name of as
similation has been given.
Bessey, Botany, p. 178 Plants and animals increase by crsimilation and trans. (c) In pathol., the supposed conversion, according to a ohsolete theory, of the fluids of the body to the nature of
any morbifte matter. (d) In philol, the act or process by like, another neighboring sound; a lightening of the effort of utterance by lessening or removing the dliscorin contignous words. The kinds and degrees of assinila torical chang varions, and in the phonetic form of words. Examples are assimilate from L. ad-similare, correction from L. con rectio, impend from $\mathrm{L}$. in-pendere, $\mathrm{L}$. rectus from reg-tus, rex (reks) from reg-s, $\mathbf{F}$. legg (pronounced legz), reaped (pronounced reapt), and so on.- Littis assimilations, in
oxford, a meeting of the masters and tw'o proctors, called by the vice-chancellor, in the congregation house, on til
linging of the little bell. This meeting is anthorized ringing of the little bell. This meeting is anthorized to read, approve, and seat any letters concerning the pnblic of Convocation, and also to set seal to
tion, and to despateh minor matters.

ssimilative (a-sim'i-là-tiv), a. [= F, assimila tif; < assimilate + -ive.] Characterized by as similation; capable of assimilating or of caus ing assimilation: as, assimilative substances or organs.

The desert birds are still nore remarkably protected by
their assimilative hues. A. R. Wallace, Nat. Selec., p. 50 their assimilative hues. A. R. Wallace, Nat. Selec., p. 50. Sted man, Pocts of America, p. 184. assimilatory (å-sim'i-lā-tō-ri), a. [く assimilate + -ory. $]$ Tending to assimilate; producing gans.

The assimilatory cells, though the most important menmeans, essential to the welfare of the body corporate.
S. B. Ierrick, Plant Life,

Assiminia (as-i-min'i-ä), $n$ : [NL.] A genus of gastropodous mollusks, giving name to tho family Assiminiida, by some referred to the family Littorinide, or periwinkles. Also spelled Assiminea.

ssiminiid (as-i-min'i-id), n. A gastropod of the family Assiminiide.

Assiminildæ (as"i-mi-nī'i-dē), n. pl. [NL., assistance

gastropods, typified by the genus Assiminia. connate with the tentacles. The shell is conical, with an oral aperturc. Progression is effected by a looping move ment, the rostrum and smalt foot being aiternately applied
to the ground. The species are of small size, and tcres. trial or anuphibions.

assimulatet (a-sim' $\bar{u}-l a \bar{t}$ ), $v$. $t$. ; pret. and pp. as simulated, ppr.assiminlating. [< L. assimulatus, pp. of assimulare, adsimulare, also assimilare, udsimilare, make alike, feign, connterfeit, ete. see assimilate. Cf. assemble ${ }^{2}$, also ult. < L. assimulare.] To feign; simulate. Coles, 1717.

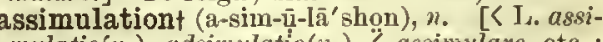
mulatio(n-), adsimulatio(n-), $<$ assimulare, ete. see assimulate.] A counterfeiting; simulation. assinegot, $n$. See asinega.

ssis (as'is; F. pron. a-s-' $\bar{e}^{\prime}$ ), a. [F., pp. of as seoir, sit: see assize.] In her., sitting; same as

assiset, $n$, and $v$. $t$. See assize.

assiser, $n$. See assizer.

assish (ás'ish), a. [<ass $\left.{ }^{1}+-i s h 1.\right]$ Pertaining to or resembling an ass; asinine; absurdly stupid or obstinate: as, "the assish kind," Lidall, Lake xix.; "an assish phrase," Mrs. Corden Clarke.

assisor, $n$. See assizer.

assist (a-sist'), $" . \quad$ [ $<$ F. assister (= Sp. asistir $=$ Pg. assistir $=$ It. assistere), help, attend, etc., $<\mathrm{L}$. assistere, stand at or by, < ad, at, to, + sistere, place, stand, a redupl. form of stare, stand: see stand. Cf. eonsist, desist, insist, persist, resist.] I. truns. 1 t. To ath
at or with; take part with.

The king and prince at prayers! let's arsist them.

2. To help; aid; suceor; give support to in som undertaking or effort, or in time of distress.

Assist her in whatsoever business sle hath need of you,

Soon after Christianity had achieved its triumph, the principle whlch had assisted it began to corrupt it.

3. To be associated with as an assistant. $=$ syn 2. To secund, back, support, further, sustain.
friend, relieve.
II. intrans. 1. To lend aid or help.

In every turn of state, without meddling on either side he [Lord Leicester] has glways been favourable and assis God
men, that they night mutually assist to the support of
each other. 2. To be present, as at a public meeting; take part, as in a ceremony or discussion. [A Gallicism.] It wouth require the pen of Tacitus (if Tacitus had as-
isted at this assembly) to describe the varions emotions
Gibbon. In our age all the nation may be said to axzint at every detiheration of the Lords and Commons.
Maculay, Hist. Eng., vi.

3. In euehre, to order the adoption of the suit to which the card turned up as trump belongs, wealer.

assistance (a-sis'tans), $n$. [Early mod. F. and ME. assistence later, after $\mathrm{F}$, assistance, $<\mathrm{MI}$ assistentia, < L. assistere: see assist and assistant.] 1. (a) A being present; presence; at tendance. (b) The persons present; spectators; audience. [In these uses obsolete, or in aid : furtherance; succor; a contribution in aid, by bodily strength or other means. Where we do reign, we will alone uphold, Without the assistance of a mortal hand.

3†. An assistant or helper; assistants colleetively.

Wat Tyler [was] killed by valiant Walworth . Fuand
his assistance. . . Joln Cavendish.

Hence, specifically - 4. In Eng. common lavo and Amer. colonial law, a general name for a somewhat undefined body of subordinate parish or town officers or auxiliaries, apparently including, as sometimes used, the ex-officers, in their customary function of advisers.- Court of assistance. See court. - Divine assistance, in Cartesian philosophy, the act of God in moving the body when
the sout forms a volition. Sec occasionalism. - Writ of assistance. (a) A writ commanding the sheriff to pht in assistance of the execution of the decree. $(b)$ In Amer hist., a writ issued by a superior colonlal court, on alleged precedents of the English Conrt of Exchequer, authorizing any officers of the crown, in the process of executing the acts of trade, to summon assistance and enter and search chisetts, defeated in 761 , was one of the abuses which ter to the revolution. = Syn. 2. Aid, support, hacking, rellef 
assistant (a-gis'tant), "t. and $n$. [Early mod. k. and $11 \mathrm{~F}$, essistent, later, after $\mathrm{F}$., assistant $=\mathrm{Sp}$. asistcnte $=\mathrm{Pg}$. It. "Issistente, < I. assis$\operatorname{ten}(t-) s$, ppr. of assistere : see assist and ant ${ }^{1}$ -ent.] I. $a .1$. Standing by; prosent; uecompanying.

('hrist
with 148.

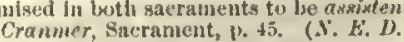

No prophane thing ought to have nceesse, mothing to be aswivent but sage and Christianly Admonition, hrotherly 2. Present to help; helpful; aiding or fitted to aid and support; auxiliary: with to.

Iintually and greatiy assistent to cach other.

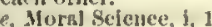

Asalstant engine, a atenu or hydraulic motor used to fontrol tire reversing gear of a marine engine, or to tur
the shatt when the matin engine is ai rest. Sce engine.form. Nec form.

II. $n$. 1t. One who stands by; a bystunder one who takes part in anything: usually in the plural.

The growing clrcumference was obsurved with astunish-
ment by the assistants. Gibon, Decllne and Yal1, 11. 11. 2. One whe stands by to help; one who helps a helper; an anxiliary; speeifically, one who is associated with another as an auxiliary in ear rying on some systematic work or undertaking, rying on some systematic work or undertaking, the harbor-master and lis assistunts; a book the harbor-master and his assistants; a book-
kceper's assistant. -3 . An ofticial auxiliary to the father-general of the Jesuits. Erroneous ly called adjutant-general. $-4+$. [Sp. asistente.]
The ohief officer of justice at Seville.

The assistant aits to-morrow.

5. In the Massaclunsetts Bay and Plymouth colonice, one of the electerl councilors who coust tuted the governor's council and the upper hous of the legislature. The number of assistants in the former was eighteen; in the latter, origi nally five, later seven.-6. In clyeiny, a substance, such as tartaric acid, acetate of lime, or sulphate of soda, added to the dye-bath, to offect a brightening of the color.-Court of As sistanta. See currt.

assistantlył (a-sis'tant-li), adv. In a manne to give aid. Sternhold.

assistantship (a-8is'tnit-ship), $n$. The oflice or position of assistant

assistencyt (a-sis'ten-вi), n. Holpfulness; as sistance.

assister (a-sig'tèr), $n$. 1. One who stands by one who takes part in anything, as a public ceremony or assembly. [Archaje.] - 2. An as sistant.

Also spelled assistor.

assistless (a-sist'les), $a_{0}$ [ [ assist + -less. Cf. resistles

Stupint he stares, and all araint

Jope, Iliad, xvi. 970

assistor (å-sis'tôr), $n$. [< ussist + -or. $]$ Same as assister: used in learl doeuments.

assize (a-sì') , n. [〈 ME. assize, assisc, tsise, (tssys, also corruptly acisc, accise (> mod. crcise, q. v.), and by apheresis sise, sysc ( $>$ mod. E. size, q. v.) ; $\left(\mathrm{OH}^{\circ}\right.$. assise, asisc, a sitting, session, esp. of a court, julgment, appointment, settlement, asis, scoir, < L lessidere, sit by as assistant or assess scoir, , hence in $\mathrm{ML}_{\text {. }}$. and OF., ete., appoint, settle assess, etc.: see assident, assess.] It. Originally, a sitting or session of in legislative body or court.

Frequent assizes were held, ant as of old, when the sword
of jusilce was ahnryened, the recuipts of the 'Treanury in Stubbr, Const. lilst., \& 68

Hence-2t. An ediet, ordinanee, or enactment made at such a session or sitting, or issued by sueli a body. Speciffeally, in Euy. hist.: (a) An ordiof general consumition mestid in market: as, the assize of general consumistion sold in market: as, the assize

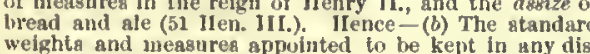
weights and measures appointed to be kept in uny dis-
trict: as, the cuatoly of the asxize. (c) In a more genera gense, measurement; dimensiong; a measure of rating.

$$
\begin{gathered}
\text { l aaw a stately frame, } \\
\text { An hundreil cubits high by jugt assize. }
\end{gathered}
$$

$$
\text { Spenser, Vysions of Belluy, st. }
$$

3. A jury, or trial by jury: now used only in Scotland with reference to criminal causes. See grand assizc, below.-4t. A name given to certain writs commanding juries to be sumdisseizin, the ancient common-law remedy for the recovery of the possession of lands. -5 t. The verdict of a jury in such a case.-6. The at least one of the judges of the auperior courts directed to take the assizes or verdiets of a partieular jury (anciently ealled the assize), in eaeh of the counties of Finglind and Wales (with ing), for the purpose of trying issues nisi prin and jail-delivery for eriminal eases: popularly called the assizes. [This is the only sense in which the word is now used in law.] The conmisalon by which as sizes are held is cither general or special. A generai cont.

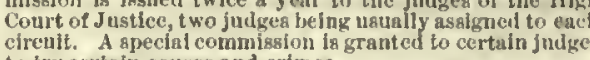
the try certain caunes

7. In a more general sense, any eourt or session of a court of justico. -8 t. Situation; plaee.9. Judguent: as, the last or great
is, the last judgrnent or last day).

times spelled assise.

Assize of arms, the name under which reference Engilsh history, reciuiring all freemen to provide, aceori. ing to their estate and degree, arma to enalile them to keep the preace and to serve in the fleld, and also providing for assizes or asaesaments by juried of the equilmment $r$ inte of 1181 (27 Herson. II.) for this purpose.

In 1181, he [1ienry II.] issued the As*ize of Arms, hy which he alrected the whole of the freenen of the conn. means, and the inquiry by onth of legal juries to deter
mine the liability of each. Asaize of Clareudon, sis Engliah ordinance issued it ministration of justice.-Assize of Northampton, al

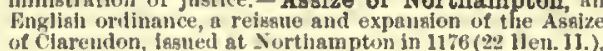
of Ciareudon, fasmed at Sorthampton in 1176 (22) llen. II.) drawin uip in the form of instructiong to the judges. The

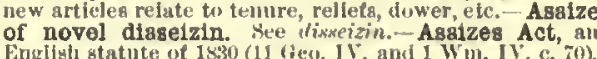
nftecting the constitution of the common-law courts in Engluni and W'ales and the pratetice in then. - Assizes anthority of Godfrey de phuilion, the throt erusading hing of Jernsalem, and in torce muler the Christian sov. juristiction over the noblity, the gecond over the com mon peopte. Both were concelved with a wfstom and

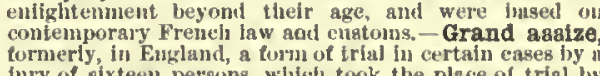
jury of aixteen perauns, which took the place of trial by
jndicisi combat. It was almolished in 1839 . - Maiden assize. See muiden. - Maritime Asaizes of Jerusalem,
hody of muritinc lawa cougtituting a part of the Asaize:

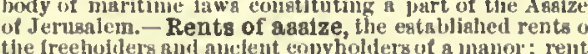
which eamot lee ehauged.

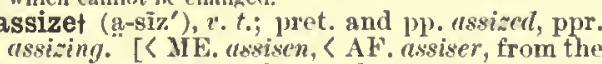
noun: seo assize, 1.$]$ It. In a general mense, noun: seo assiz
to fix; appoint.

$$
\text { 'jinu shat have diny and thue ax*ixed. }
$$

2 t. To fix the rate of; assess, as taxes.-3. To fix the weight, measure, or priee of, by an ordinance or athoritutive regulation.

The liberty of arxizing breat has been naed at l'iyder-

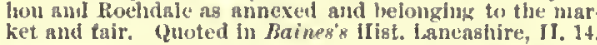
assizement (a-siz'ment), " [< assize, $r$., + -inent.] An inspection of weights and rncaized by statute.

assizer (a-si'zèr), n. [< ME. assisour (and by apheresis sisnur, $\rangle$ mod. E. sizar, q. vo $),\left\langle A \mathrm{~F}^{3}\right.$ I. In Eng. hist., a member of a grand assize (whicl see, under assize).-2. In Seotland, a juror. - 3t. One who had eustody of the assize or standards of weight and measure; one who cles of general consumption.

Also spelled assizor, assiser, assisor.

assize-sermon (a-sīz' gér $\left.\mathbf{r}^{\prime \prime} \operatorname{mon}\right), n$. In England, a sermon preached to the judges, barristers, and others attending the assizes.

assizor, $n$. See assizer.

assobert, v.t. [< ME. assobren, < L. as- for ador make sober.

And thus I rede, thon assobre

$$
\text { of such a grace. }
$$

associability (a-s $\overrightarrow{0}-s h i a-b i] '$ i-ti), $n$. [< associa ble: sce-bility.] 1. The quality of boing assoeiable.

The associability of feelings with thore of their ow rang, group within group, corresponds to the general ar gub-divisions.

II. Speneer, Prin. of Psyehol., \$116.

2. In pathol., the property of suffering changes by sympathy, or of being affected by the condi-
tion of other parts of the body.
L. as if "associabilis, < associare, associate: sec associate.] 1. Capalle of beiug joined or associated; capable of forming part of a combination $0 \mathrm{r}^{\circ}$ association.

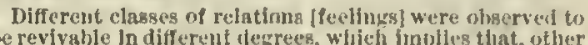
things equal, they are associnble in different degreer.
II. Spereer, I'rin. of Psychol., $11 \%$.

2. Capable of being made an associate; com panionable; social. -3 . In puthol., liable to be affected sympathetically, or to receive from ather parts like feeliugs and affections.

associableness (â-8ón'shia-bl-nes), $n$. Associaliility.

associate (a-so'shi-ăt), $x^{\prime}$; pret. and pl\%. alssuej ated, ppr. associating. [< R. associatus, Pp. of associare, join to, unite with, $\langle a d$, to, + sociare, join, < socius, joined with, allicd, following (as a noun, a companion): seo snciul.] I. trans. 1. To join in company, as a friend, companion, partner, eonfederate, or the like; join or eonneet rith (formerly sometimes by to): as, to asso ciatc others with us in business or in an enterprise; particles of earthy unatter associated with other substances.

IIe anccuedel In asucciating his Hane insciparably with ome names which will last as lung as our language.
Maca ulay.

Just ns the older female deities were associated in theit woralip weth hearen and the heaveniy bodies, with season wothe year and a vith sacred

2r. To keep company witlı; attend.

Friendy should associnte friculs in urlef and woe.

I'o-morrow 1 will associate you to conrt myseif.

3. To make an associate of; admit to associs tion or membership: with to: as, "he was associated to the Royal Aeademy," Southey. [Rare.]

\section{Associated functions. See finction.}

II. intraws. 1. To have intercourse; be an associate or assoeiates: implying intimaey: as congenial minds are disposed to associate.

It was once degraviation Intensiffed for a Norman to axso

2. To join in or form a confederacy or associa-

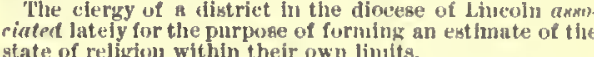
state of religion within their own linits.
Sydisy Smill, in Lady Itoliand, iil

3. In general, to unite, as in aetion, with a person or thing, or to coexist in organie dependence, as the parts of the body.

ssociate (a-so'shi-at), a. and $n$. [< L. associl $f u s, \mathrm{pp}$ : : see the verb.] I. a. I. Joined in in-
terest, object or purpose, office or employment; combined together; joined with another or others: as, an associate judge or professor; "my associate powers," Milton, P. 1., x. 395.-2. In associate movements, that is, movement 8 which oceur sympathetieally, in eonsequence of preoceur sympathetieally, in eonsequence of preis associated with eontraction of the pupils.

II. и. I. A eompanion; one who is on term fintimacy with anotler; a mate; a fellow.

Sole Eve, aronciale sole, to me beyond
Compare above ail living creatires denr Jilton, H. L ix, m.

2. A partner in interest, as in business; a confederate; an aeeompliee; an ally: as, "their defender and his associates," Hooker - 3. One who shares an office or a position of authority or responsibility; a colleague or coadjutor.of membership in an association or institution: as, an Associate of the Royal Academy, or of the National Acadomy of Design.-5. Anythin usually accompanying or assoeiated with another.

The one [iden] no sooner ... comes luto the umderatandilng than its associale appears with it.
Locke, 11uman Understanding, il. 33 $=$ Syn. 1 aad 2. Akxociate, Friend, Companion, Conradr,
Fellow, Partner, Ally, Colleague, Coadjutor, Confederate. Aszociate is the most general word for persons who are con nected in life, work, etc.; it is apecial only in suggesting an alliance of nome permanence. Friend is the most general word for persong who, through community of lite or atherthrown together, but are not uniled by any atrong tie;
hence it is not a good gynonym for husbrnd or wife. "Many men may be admitted as companions who would 
associate

p. 197. Comrade denotes a close companion; it implies
freedom of intereourse and a good degree of friendship: freedom of intereourse and a good degree of friendship: signiflcation of agreeable companionship, the later mean-
ings having overshadowed it: as, "a lettre felave schulde ings having overshadowed it: as, "a hettre felawe schulde low-helper, fellow hip. Fellow in this connection may mean one wbo naturally would be or is a companion: as, who takes part with others, especially in business or in any kind of joint ownership. Formerly ally was nearly chiefly to states or rulers in their public eapacity: as, the
allies in the Crimean war. A colleaque is an assoclate fo some specific purpose or in sonse office; it is, like coadjutor, properly applicable only to one engaged ln labor or
busincss regarded as especially dignifled: as, Senators and $\mathrm{B}$ were colleagres ; Luther and his coadjutors. A connow usually, when applied to private relations, for a bad object

A nice and subtle happiness, I sec

of thy associates, Adsm! Milton, P. L., viii. 401.

Thou shalt never find a friend in thy young years whose conditions and qualities will please thee alter thon comest

One that has well digested his knowledge, both of books and men, has little enjoyment but in the company of a
few select companions.

Thus he moved the Prince
To langhter and lis comrades to spplause Tennyson, Geraint.

I and $\mathrm{my}$ fellows
Are ministers of fate. Shak., Tempest, iil. 3 .

Mygelf and other noble friends
Are partners in the business. The allies, after conquering together, return thanks to God separately each after his own form of worship.

The patricians prevalled upon some of the tribunes to issent from their colleagues. J. Adoms, Worka, 1V. 534 Whose political aagacity, like that of his 111
adjutor, read the fate and interests of nations. Story, Speech, Cambridge, Aug. 31, 1826

1 had forgot that foul conspiracy

of the beast Caliban, and his confederates

associateship (a-sō'shi-āt-ship), n. [< associate + ship.] The position or office of an associate. [Rare.]

association (ạ-sō-și-ā'shọn), n. [= F. association, < MIL. assaciatio(n-), a society, < L. associare, associate: see associate, v.] 1. The act of associating or the state of being associated.

(a) Connection of persons or things; union.

Self-denial is a kind of holy association with forl.

There are many objects, of great value to mave, cannot be attained by unconnected individuals, but must be attained, if attained at all, by association.
D. W'ebster, Speech, Pittsburgh, July, 1833. The very common association between seelng clearly und seeing narrowly is a law or a frailty of onr nature not (b) A union or connection of ideas. See as sociation of ideas, below.

The words which we usc are so enwrapped in an atmo-
spliere of subtle associations that they are liable to sway the direction of our thonghts in ways of which $w \mathrm{c}$ are
of ten unconscions. Fiske, Idea of 0 od, p. 151 2. An organized union of persons for a common purpose; a body of persons acting to gether for the promotion of some object of mutual interest or advantage; a partnership corporation, or society: as, the Association for the Advancement of Science; a political or charitable association.

The old company ... was sble, with the help of its T'ary friends, to present the rival association from obtain-
ing sinilar privileges.
Macaulay, Hist. Eng., xx. Articles of association or incorporation see article. Associatlon of ddeas (an expression Invented by Locke), or mental assoclation, in psychol., the tendency
of a sensation, perception, feeling, volition, or thought to rccall to eonscionsness others which have previougly coexisted in consclouaness with it or with states similar to it. Thus, the name of a friend is assoeiated with his per sonal appearance, age, place of residence, and so on; ; and the sound of the name brings into eonsclonsness involun-
tarily one or more of these assoeiated ideas. The special tarily one or more of these associated ideas. The special
lrues of a sociation, though rarionsly stated by psycholo gists, are usually admitted to he those of contiguity and similarity; that is, ideas recall ideas which have oecurred along with them, and slso those which are gimler to thern. These are called the principles of objective and
subjective associntion. The doctrine of associstion has played an important part in the history of modern English psychology and philosophy. The phrase, intrinsic and extrinsic association, might be
lntrodnced very appropriately to distinguish assoclations
founded on intrinsic resemblauces of mental states from founded on intrinsic resemblauces of mental states from
those which merely imply the extrinsic accident of simnl
taneous occurrence in congciousness. T. Clarke Murray. Association philosophy, the doctrine put forward by
Hobbes, Hume, Hartley, J $_{\text {smes IIll, and others, that the }}$ operations of the mind are to be explained chiefiy by the evangelical. - Free Religious Association. See free. Indissoluble or inseparable association, an associa tion of ldeas so strong that we cannot think one witbout
also thinking the other.- Voluntary assoclation, In law, a socicty which is unincorporated, lint is not a part nership, ln that the menthers are not agenta for one an-
other.=Syn. 2. Combination, company, club, lodge, fra-

sociational (â-sō-şi-ā'shon-â), a. [< asso1. Portaining to an association. 2. Pertaining to the psychological doctrine of association or associationism.

associationalism (ân-sō-si - $\bar{a}^{\prime} \operatorname{shon}$ - ạl - izm), $n$. Same as associationism.

associationalist (â-sō-si-ā'shon-ạl-ist), $n$. and Same as associationist.

associationism (â-sō-sí-ā'sbon-izm), $n_{0}$ [< $a s-$ soeiation $+-i s m$.] 1 . The psyehologieal theory which regards the laws of association as the fundamental laws of mental action and development. See association of ideas, under as sociation.-2. Same as Fourierism.

Also associationalism.

associationist (a-sō-si-ñ'shon-ist), n. and $a$. [< association + -ist. ] I. $n$. 1. One who adrocates the psychologieal doctrine of associationism. tion advocated hy Fourier and known as Fonricrism (which see).

II. $a$. Pertaining to associationism, in either ense of that word.

Also associationalis

associative (â-sō'shi-ā-tiv), a. [< associate + sociation; capable of associating; tending to associate or unite; characterized by association: as, "the associative faculty," Hugh Miller. Onomatoperia, in addition to lts awkwardness, has
nelther associative nor etymological application to words gonnds.

2. In math. gives the same result whether it first unites two quantities $A$ and $B$, and then unites the unites $B$ and $C$, and then unites the result to A, the order of the quantities being preserved. Thus, addition and multiplication are sald to be associa.

\section{$(a+b)+c=a+(b+c)$}

In the same gense, mathematiclans often use the expressions asgociative formuln, nespciative principle. - Associa

associativeness (ạ-sō'shi-ä-tiv-nes), n. The property of being as

mathematical sense. that which ässociates or connects together. 2 . An associate or partner in any scheme; a confederate.

Our late associntors and conspirators have made a third
copy of the League. Dryden, Post. to II ist. of League assoguet, n. [< F. assogue, < Sp. azogue (in same sense), lit. quicksilver: see azogue.] A
Spanish galleon transporting quicksilver to America for use in the inines.

assoill (a-soil' $), v . t$. [< ME. assoilen, asoilen, assoilien, asoilien, assoylen, etc., = Sc. assoilzic, formerly assoilyie, assoilze (where $l z, l_{3}, l_{y}$ represent the $\mathrm{F}$. Il monillees), ( $\mathrm{OF}$. assoiler, assaitlier, asolier, also asoldre, assoldre, assoudre, ete., $<$ L. absolvere, absolve, loosen: seo absolve, of which assoil is thus a doublet.] 1t. To solve: clear up.

To assoil this seeming difficulty. solve. [Archaic.]

At my own tribunal stand a*soil' $d$.

$$
\text { To some bishop we will wend, }
$$

To be assoiled at his hand. Percy's Reliques.

3t. To remove; dispel.

Seeking him that should her paine aysmyle.

assoil ${ }^{2}+\left(a-s o i l^{\prime}\right), v . t . \quad[<a s-1+$ soill. $]$ To soil;

Whate'er he be
Can with unthankfulness agroil me, let him

Wig ont mine eyes, and sing my name in verse.
Fletcher (and another), Queen of Corinth, iil. 1. assoilmentt (a-soil'ment), n. $[<$ assoill + -ment.] The act of assoiling; absolution. More. forms of assoill.

Ood assoilzic him for the sin of bloodshed.

assonance (as'ö-nans), $n . \quad[<F$. assonance (= Sp. asonancia $=\mathrm{Pg}^{\mathrm{g}}$ assonancia $),<$ assonant see assonant, a.] 1. Resemblance of sounds. The disagreeable assonance of "sheath " and "gheathed."
The combination of calleneed sentences with antitheti. cal alliteration, intersprinkled with as8onances of every was by hin [Lyly] flab ofspring, the nicalled for pur, A. W'. Ward, Eng, Dram Lrose. Homer, like Dante and Shakespeare, like all who really fond of playing with assonances,

Specifically-2. In pros., a species of imperfeet rime, or rather a substitute for rimo, especially. common in Spanish poetry, consisting in using the same vowel-sound with different consonants, and requiring the use of the same vowels in the assonant words from the last accented vowel to the end of the word: thus, man and hat, penitent and retiecnee, are cxamples of assonance in English.

There are some traces of the employment of rhyme and assonance in mere popular literature at a very remote
period. 3. Agreement or harmony of things. [Rare.] = Syn. Paromomasia, etc. Sec yu

assonanced (as'ō-nanst), a. [< assonanec + $-c d^{2}$.] Characterized by assonance; assonant. Tho lines are, in the earlier examples, argonnneed, that is to say, the vowel sonnd of the last syllablca is

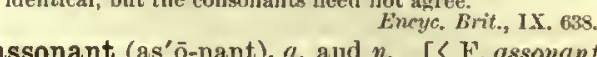
(= sp. asonontent $n_{0} \quad[<\mathrm{F}$, assonant ( see nssonate and sonant.] I. a. 1. Having a see assonate and sonant.] I. $a$.
resemblance of artieulate sounds.

Landor's blank verse . . is . . terse, yet fluent, as.
sonant, harnonious.

2. In pros., pertaining to or characterized by

II. n. 1. A word resembling another in sound. Specifically -2. In pros, a word forming an assonance with another word. See as

ssonantal (as-ō-nan'tạl), $a$. Of or pertaining to assonance; of the nature of an assonant. ssonantic (as-ō-nan'tik), $a$. Same as assonantal.

assonate (as'ọ-nāt), $\imath$. i.; pret. and pp. asso nated, ppr. assonating. [< L. assonare, sound to, respond to, $<a d$, to, + somare, sound: sec sonant.] To correspond in sound; rime in assonance; he assonant.

assort (â-sôrt'), $x$. [< late ME. assorte, < OF. assorter $=$ OIt. assortare, < ML. assortare (mod. F. assortir $=\mathrm{Sp}$. asortir = It. assortire, $<\mathrm{MI}$. as if "assortire, after L. sortiri, east lots, allot, distribute, select: see sort, $v$ ) ; $\left(\mathrm{L}_{\mathrm{ad}}\right.$, to + $\operatorname{sor}(t-) s$, lot, condition, sort: see sort.] I. trans. 1. To separate and distribute into classes, sorts, or kinds ; part into lots; arrange; classify: as, to assort goods.-2. To furnish with a suitable assortment or variety of goods; make up of articles likely to suit a demand: as, to Burke. - 3. To make of the same sort; adapt or suit.

No way aroorted to those with whom they must asso-

II. intrans. 1. To agree in sort or kind; he

ceordant or matchod: $\mathrm{as}$, the two kinds assort well or ill.-2. To associate; consort.

Asort no more with the menials of the goddess. Bulwer.

assorted (a-sôr'ted), p.a. 1. Consisting of selected kínds; arranged in sorts or varieties. Our cargo was an aszorted one; that is, it consisted of R. II. Drna, Jr, Before the Maat, p. 85 2. Matehed; fitted; suited : as, a well-assorted pair.

assortment (a-sôrt'ment), n. $[<$ assort + -ment. Cf. F. assortiment, < assortir.] 1. The act of assorting or distributing into sorts, kinds, or classes, or of selecting and suiting. - 2. A collection of things assorted: as, an assortment of goods ; "an assortment of paintings," Coxe. 3. A class or group into which objects are assorted.

Those classes and as8ortments
species. Adam Smith, Mor. Sent., II. $407(1797)$. (N. E. D. $)$ assott (a-sot'), $r$. [<ME. assoten, < OF. assoter, asoter, < $a$ (L. ad, to $)+$ sot, foolish: gee sot.] fool.

II. trans. To infatuate; deceive; befool.

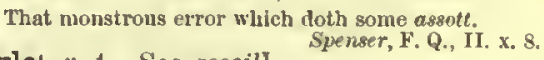

assoylet, $\imath, t$. See assoill.

ass's-ear (às'ez-ēr), $n$. A fine iridescent shell, 
buttons, for inlaying woolwork, and for other purposes. ass's-foot (ás'ez-fut), $n$. Same as colthfont.

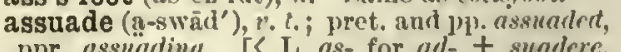
ppr. assundiny. " [ L L. as- for al- + suadere,

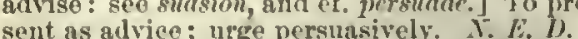
assuage (a-swij'), $v_{0}$; pret. anct $\mathrm{pl}$. assuaged,

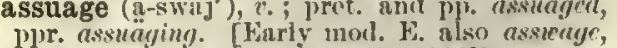
plir. assuaging. Ghares mol. H. also assienge,

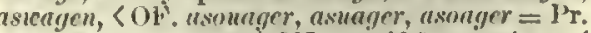
assuatiar, asuminr, ? ViI. an if "nsshatiare, $\mathrm{I}_{\mathrm{s}}$ ad, to, + suaris, sweet: see sume and sireet. viare, ete.] I. trans. To seften, in a figurntive sense; nllay; mitigate, ense, or lessen, as pain or grief; motlerate; appease or paeify, as passion or tumult.

Yet he wlti stroug perswasions her exsicaged,

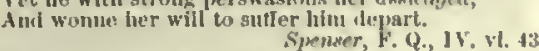

Refreshing wintis the summer's heats axm iv,

Addison.

For the first lime in history, she (the churchl lusplred thousands to dervet their cutitre llives, throngh satertice and danger, th the single oblect of nxitunging the suffer.
ings of himanilly. =Syn. Alteriate, Retieve, Mtrigate, etc. (see nllerinte); to appease, thollify, temprer (ace lists under alleriale and

II. intrans. To abate or subside; grow less: as, "let thin liert assuage," Gover; "the water assicalyed," Gon, viii. 1.

assuagement (å-swåj'ment), n. [< OF, asmegcment, < asuager: see nssumge and -ment.] I. The act of assuaging; mitigation; abate Spenser.-2. An alleviative; a sedative. allays: that which mitigates or abates. assuasive $\left(\mathrm{a}-\mathrm{s} w \bar{a}^{\prime}\right.$ 'siv), $a$. and $\eta_{0} \quad[<a s-1+$ assuasive (a-swa siv), a. and no suasice, as in persuasite, with reference to as-
swage.] I. a. Softening; mitigating; tranuquiizing; soothing. [Rare.] Musle her solt askutasive volce applles. Pope, St. Cecilla's Day, 1.

II. n. A soothing medicine er applieation. assubjugatet (a-sub'jö-gñt), $v_{0} t_{0}$. [ $\left\{a s^{-1}+s u b-\right.$ jugnte.] To reduee to subjugation; put into
low er unworthy position; debase. [Rare.] No, thls thrice worthy and right villinut lorl

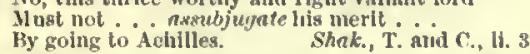
assuefaction (as-we ê-fak'shon), $n$. [< L. as if "assuefactio(n-), < aisuefuecere, p1). assuefaetus, make accustomed to, habituate, $<$ assuetus, pp. of assuescere, aceustom (see assuete) + facere. make.] The act of aecustoming; the state of being accustomed; use; habituation.

Right and left, as part Inservient unto the motive lacul. ty, are differenced by degrees, iny use, and axtuef faction.

assuetet, a. [< L. assuetus, pp. of assupsecre accustom, habituate, $<$ ad, to + suescere, inceptive of "suere, be wont: see enstom.] Acenstomed; practised. Blount.

assuetudet (as'wēe-tūd), n. [<L. "sssuetudo, enstom, < nssuetus, pp.: see assuete. Cf. desuctom, S nssuetus, ppi: see assucte.

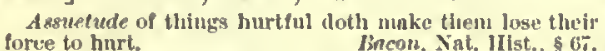
assumable (a-sũ'ma-b]), a. [<assume + -able. $]$ Capable of being assumed or taken for granted. assumably (a-su'ma-bli), adr. As may bo as sumed; presumabli.

The Macfarlnne Illghinders,
bly with target and broadsword.

$x$.

assume (â-sūm'), v.; pret. and pp. assumcel ppr. assuming. [< L. assumere, take to one' self, take up, receive, aceept, claim, assume, $a d$, to, + sumere, take, contr. from "subimere, sub, under, + emere, take, buy: see emption, tion or association; adopt; take in; admit: as, "Enoch and Elias were assumed up into henven," "Abp. Abbot. See assumption, 5. [Arehaic.] The sixth was a young knight... asinumed into tha
bonourable company. 2. To take upen ene's self; undertake: as, to assume the responsibility of a proceeding; to assume office; to assume an obligation.

Assteme thy winged throne, thon Yesper of our throng!
Shelley, Adonals, st. 46. Among those subject kings whom the Assyrians had established in Egypt the descendants of the first Nech psiumed, after the trili of Nineveh, the position of Inde3. Te take or put on oue's self; iuvest one's self with: as, to assume the garb of a mendi- caut, or the figure of an animal ; to nssume a severe aspeet; "to
ton, P. L., iii. 30 ;.

They say the devil ean axmume henver "s irightness, And so Hipear to tempt 11. Fiteteher, Lanyal sulueet, iil. Varuline ... had persuaded Mrs, Jryor to nuxume her Charlotte Bronte, Shlrley, $\mathrm{xx}$.

soclety never oxamert the military tyine lu Finglant

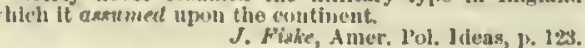
Wheat inickly axumes new lialilts of life.

Darvin, Var, of Animals and i'lants, p. 383.

4. To apply to one's self; appropriate.

Ifis majegty might well axtume the complnint of hing
Clarendon.

IIIs Holluess the lonpe, by virtue of belng Chrial's vicegerent lyoul enrth, ptously anxumed to hlumself a right to dispesse of the territories of inflileis as he thonght tti.

IIastings had cessed to ilfference his arma as a cadet,
bincyc. Jirit. XI. 687 . 5. To take for granted or without preof; sunposo as a fact; postulate: as, to nssume a priniplo in reasoning.

Generally it may be axoumert that rhetoric will not aurTre the age of the ecremonlous in naanners and the gorIf the step from mechanics to chenistry is knowin, has feell proved, and is admitted, timat from chemistry to 1 it

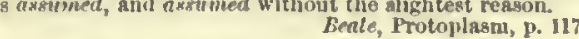
6. To take fictitiously; pretend to possess; take in appearance: as, to assume the garb of humility.

\section{7†. To elaim.}

Like a boid chanpion I asrume the lists.

Syn. 6. To affect, felgn, connterfelt.

II. intrans. To bo arrogant; elaim more than is due; presume.

assumedly (a-sū'med-li), adv. As is or may b assumed or taken for granted; prosumably. assumentt (a-su'ment), n. [CLL. assumientum, a piece sowed on, $<\mathrm{L}$. assuere, sew on, $\langle a d$, to,+ suere, sew, = E. seic, q. r.] A piece sewed on a patch; an addition.

The nasument or additlon Dr. Sarshall never could tmi uywhere but in this Auglo-Saxonlck transiation.

assumer (a-sū'mér), n. One who assumes; a arrogant person.

These hlgh nwemers ant pretenders to reason. South To swenr nt the niention of araugaers and pretenders to assuming (a-sū'ming), p.a. Taking or dis posed to tako upon one's self more than is just disposed to at tribute to one's self undue importance; hanghty; arrogant.

Ilis haugitty looks mul his a*xuminy als Goldxwilh, The Bee,

=Syn. Bold, forward, presuming, gelf-conflient. sumingt (a-su'ming), $h$. Presumptiou.

The valn assumings of sone. $\quad$ B. Jonkon, Poetaster. assumingiy (a-sū'ming-li), all. In an assuming manner; arrogant.ly.

ssumpsit (a-sump'sit), n. [L., he undertook third pers. siug. perf. ind. of assumere, assume, undertake: see assume.] In lav: (a) Au ae through the breach of a simple contract (that is, a promise net under seal), in which the plaintiff alleges that the defendant assumpsi that is, promised or undertook, to perforin the aet specified. In England and In most of the Cnited States thls, like the other common-law formo of action
has been superselei by statute. Hence - $(b)$ An ac tionable promise, express or implied by law. assumptt (a-sumpt'), $t^{*} t$. [< L. assumptus, pp. of assumere, take up: see assume.]
up; raise. See assume, $v$. t., 1.

she was nestmpled lnto the clond

Inil, Hen. VIH., an,

2. To assume, as a proposition or premise.

Supposition axrumpted is when a manlfest supposit ton disputer will assumpt this assertlon, which salth that o false thlngs there ls no certaln knowledge, and truth
not known but of true thlngs.

3. To assume, as a property, attribute, ete.

I do grant lt to le Clirst's true body and fesh by a property of the nature abtumpted to the Goulhead; yea, and w Ridley, in R. W. Dixon's Jist. Chureh of Eng., xvi., note.
4. To take to one's self; put on; assume.

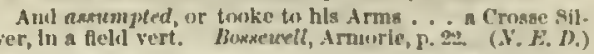
assumptt (a-sumpt'), n. [<L. (18sumptum, neut. of assumplus, lp., assumed: see $(18 s u m) t, x$.] That whieh is assumed; an assumption.

The sum of all your camumpes.

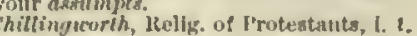
assumption (a-8ump'shon), n. [< ML $\%$ assumpcioun, assumptionn of the Virgin Mary), < Ml, assumptio(n-), a taking "1 (into leaven); I., a aking up, adoption, tho minor proposition of a syllogism; (assumere, pl. assumptus, take Il), ete.: sce asiume.] I. The aet of taking to oue's self; a taking npon one's self; undertaking.

Sluce the Aammption of our tlegh, wo know what ahape
to picturo God In.

to picturo God ln. Selden, Tahle-Tinik, p. Sis.

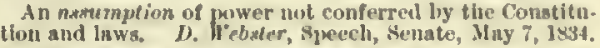
2. Tho act of taking for granted, or suplosing without proof; supposition.

The asmumption of a final eause in the stmeture of eacls rause for every event.

3. The thing supposed; \& postulato or propoition assumed.

Let well-welghed conaicierationa, not stlft and percuup-

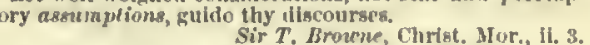

In fact, the puttlng of llmils to human conceptiou mnst always involve the axxumption that our previous exjerition which we have already seen reason to refuct.

4. In logic, the minor premise in a categorical syllegism.

Stlll nore objectlonahle are the correiallve terms prop-

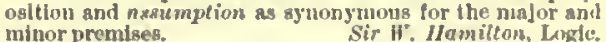
This uae of the word, originating with Clcero (IAatln ns. rumptio), was revived in the sixteenth century, and is coll 5. The taking up of persom into

. specifieally, the traditional anticipated resur-
rection or bodily taking up into heaven of the Virgin Mary after her death, eelebrated by the Roman Catholie, Greek, and Oriental churehes by the feast of the Assumption on the 15th of August. -6. Adoption, or making use of.

It is evilent that the prose psalms of our liturgy were of their words and combinntions. 7. In lac, the agreement of the transferee of property to pay obligations of the tmansferror which are chargeable on it. -8 . A conceited dispositiou, characterized by a tendeney to claim moro thau is one's duo; presumption.

The prlest, however arrogant his azmmption, makes a
II. Spencer, Ithit of Soctol., \& 343 .

Arms of assumption. See am 2, 7, and assumplive clause - Deed of assumption, in Scots tarn, a deel exe cuted by trustees under a trist deed or ilced of sittlement, assuning a new trustee or trustees. = Syn, 2 ani 3 . ConJecture, hypothesig, theory, postulate.- - . I'ride, P'resilf-confidence, self-conceit, lace.

assumptious (a-sump'shus), a. [<assumption + -ous. Cf. presumptuous.] Assuming; presumptuous. [Rare.]

assumptive (a-sump'tiv), a. [<I. assumptivus, taken in addition, assumptus, $\mathrm{pp}$. of assumere, ing assumed; assumed.

Writing under an assumptive eharacter.

Wycheriy, Plain Dealer, Pre?

2. Marked or characterizel by assumptions.

Trivlal, scholastic, anl axmumptire methowis.
G. S. Hall, German Culture, p. 312 Assumptive arms, In her.: (a) Formerly, arms not pa ternal, assunedi in consequence of an exploit. (b) Xnw, arms which a person has a right, with the approbatlon of
his soverelgn and of the heralds, to assume. (c) Arruorial his soverelgn and of the heralds, to assume. (c) Artuorial
bearings lmproperly agsumedi. [Rare in last use.] Als"

assumptively (a-sump'tiv-li), adv. In an assumptive or assumed manner; by way of assumption.

assurable (a-shör'a-bl), a. [〈assure + able.] Capable of being assured; suitable for insurance: as, an assurable preperty.

assurance (a-shör'ans), n. [〈ME. assuraunec, OF. asseiirance, $\mathbf{F}$. assurance $=\mathbf{S p}$. asegurun$z a=\mathrm{It}$. assecuranza ( $=$ F. asseeurance, q. v.) ML. asscenrantia, < assecurare, assure: se ssure and -ance.] 1. The act of assuring; fermal or eamest statement intended to produce belief or conviction; a positive declara-
tien intended te give cenfidence: as, I trusted to his assurances. 


\section{assurance}

Plight me the full asszerance of your faith.

2. Pledge; guaranty; surety.

You should procure him better assurance than Barlolph; he would not take his bond and yours; he liked
Sliak., 2 ILen. IV i i 3t. Affiance; betrothal.

The day of their assurance drew uigh. I am sure
I never courted yon, nor gave you tokens

Beau, and $\boldsymbol{F} l$, Coxcomb, tii. 1.

4. In lux, documentary evidence of the title or right of possession of property. -5 . Insurance; a contract for the payment of a snm on the occurrence of a certain event, as loss or death.

Recent writers lave sought to establish distinctlons of a novel character between them [assurance and insurance]. One of these is that a person insures his life, his honse, of
his shlps, and the office assures to him in each of thes his ships, and the office assures to him in each of these cases a sum of money payable in certain contingencies.
Another is that cssurance represents the principle and Another is that assurance represents the principle and
Encyc, Brit., XIII, 169. 6. Certain proof; clear evidence; positive demonstration; undeniable grounds for belief o trust; assuredness.

Whereot he hath given assurance unto all men, in thist
he hath raised him from the desd. A form, indeet,
Where every god did seem to set his sesl,

To give the world assurance of a man. 1 feel desires

That give assurance of their own success

And that, infus'd from Hesv'n, must thither tend.

brightness, like thst of the cyes of some smaller animals, which gives assurance of life, bnt of a life foreig
and unintelligible.
Lovell, study Windows, p. 44. 7. Firm persuasion; full confidence or trust freedom from doubt; certain expectation; the utmost certainty.

Let us draw near with a true hent, in full asxurance of
laith.

I'll make axsurance double sure,

There lhave prevailed very wictely. among mankind the sad tradition of a lost or forfeited life of perfection ance of a future life of perfection and happiness. Maudsley, Body and Will, p. I97.

Kspecially - 8. Firmness of mind; undonbting teadiness; intrepidity; courage.

Brave men meet dsnger with askurance. Kinolle. He is wanting in neither personal coursge, asxurance, then in the service of vice. 9. Freedom from timidity or bashfulnéss; landable confidence; self-reliance.

Conversation with the world will give them knowledge I have heen often surprised that you, who have seen so site share of assurcerice. . cunld uever yet acipuire a requi.

10. Excess of boldness; impudence: as, his as urance is intolerable.

Immoderate assurance is perfect licentiousness.
Shenstone.

Upou my soul, Jack, thou art a very Impudent fellow o do youl justice, I think I never saw a piece of more con
summate assurance! Sheridan, The Rivals, Chamber of assurance. See chamber.-Collateral assurance. See collateral. - Common assurances.

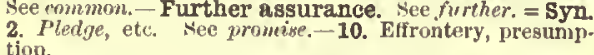
assure (a-shör'), $v$; ; pret. and pp. assured, ppr. assuring. [C ME. assuren, asuren, asseuren, OF. aseirer, $\bmod$. F. assurer $=\mathrm{Pr}$. assegurar = Sp. asegurar $=$ Pg. assegurar $=$ It. asseeurare (= E. assecure, q. v.), < ML. assecurare, assure, < L. ad, to, + securus ( $>$ OF. segur, seïr), secure, sure: see secure, sure.] I. trans. 1. To make sure or certain; convince or make confident, as by a promise, declaration, or other evidence: as, to assure a person of one's favor or love. It is idle to propose remedies before we are assured of
the disesse. Strift, Advancenent of Religion. "T is a vast privilege for a Cliristian to be a*sured that C. Mather, Mag. Chris., iv.
C.

And, for I sm a man, I dare not do

Browning, Ring and Book, 1. 94

2. To declare solemnly to; assert earnestly to endeavor to convinee by assertion: as, I assur you I am speaking the truth.

I lare assure thee that no enemy
Shall ever take allve the noble Brutur.

Shak., J. C., v. 4

They are reconmended ly people of consequence, I as
Sheridan, The Critic, $i$. I.
xure you.
352

Astacidæ

3. To sceure or confirm; make sure to be or to continue; give certainty or stability to: as, to assure a person's position or possessions. This shsll assure ny coustant loyslty. IIen. VI, iii.

My penance hath not slacken'd, though my pardon
No way assured.
Mitton, S, A., l. 739. So irresistible an suthority cannot be reflected on with. out the most awful reverence, even by those whose piety
I. Rogers 4. To free from obscurity, ambiguity, or un certainty.

Wss lent, not to assure our doubtill way, But guide us upward to a better diy.

Dryden, Religlo LaicL

5. To embolden; make confident.

And herchy we .. shall assure our hearts before hin.

6†. To affiance; betroth.

Thls drudge, or diviner, laid elaim to me; ealled me Dromio; swore I was assured to her.

7. To insure, as against loss. $=$ Syn. Insure, A Axure II. intraus. 1. To confide; trust.

Therfore as frend flllych in me axxure.

Chaveer, Troilus, 1. 680

2. 'To promise; pledge one's self. Chauccr.

assured (a-shörd"), p. a. 1. Certain; sure; inence," Bacon, Nat. Hist.

We dare not leave his fortunes, Fletcher, Ilunorous Lleutenant,

In history, as in tragedy, the master's hand has not ye come to Its full stretch sind skill; its touch is not yet wholly assured, Its work not yet wholly blameless.

2. Bold; confident; self-possessed.

II looked frank, unconstralned, something asxured, but ot borderiug upon assurance.
Sterne, Tristram Shandy, ii. 15. lie . came forth with sn assured slr and bade left 3t. Affianced. Shak.-4. Insured; having one' life or goods insured.

assuredly (a-shör'ed-li), ndl. 1. Certuinly; dubitably.

Assuredly Solomontly son shall reign. I ki. i. 13
2. With assurance; contidently; impudently. The more Actions of depth and danger are considcred,
The less assuredly they are pertormed.

assuredness (a-shör'ed-nes), $\pi$. The stato of being assured; certainty; full confidence. assurer (a-shör'ér), n. 1 . One who or that which assures, or gives assurance; specifically, out a poliey of insurance; one who is assured. assurgency (a-sér'jen-si), $n$. [< assurgent.]

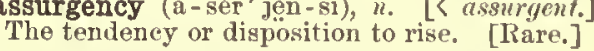
The continual assurgency of the spinit through the loody. assurgent (a-sér'jent), $a . \quad\left[<\mathrm{L}\right.$. assurgen $(t-), s_{\text {, }}$ ppr. of assurgere, rise up, ascend, $<$ ad, to, + surgere, rise: see surge.] Rising; aseending specifically - (a) In her, spplied to s bearing when cte rising in a curve to an erect position; ascending. Alsu
adsugent. - Assurgent leaves, lesves first bent down,
but rising erect toward the apex. but rising erect toward the apex.
assuringly (a-shör'ing-ji), adv. In an assuring

manner; in a way to give confidence.
asswaget, $v$. An old spelling of assuage.

Assyrian (a-sir'i-an), $a$. and $n$. [< L. Assyrius.

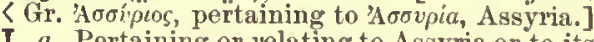
I. a. Pertaining or relating to Assyria or to its inhabitants. - Assyrian architecture, the most inportant branch of the architecture of Mesopotania, de-
veloped in Assyrin during the period of its supremacy. Its
chief monuments were the roys chief monuments were the poys I palsces, which were of dried briek on grest mound of clay, of whici they have now
virtually become a part owing to the disintegrating inftu. virtually become a part, owing to the disintegrating influ. rials. They were never more than one or two stories high rials. They were never more than one or two stories high, consisted chiefiy of corridors and long, narrow halls, either and surrounding open eourts. The entranees were of imposing height and width, ornamented with colosssl stone
figures of winged human-headed bulls or lions, or other figures of winged human-headed bulls or lions, or other
mythological conceptions. The interior walls were comwhich were carved in low relief the remarkalle slabs, on sculptures which have preserved the record of Assyrian triumphs, charscter, and customis. Color in somewlist subdued tints was generally employed upon the sculptures and the wsll-spaces. The temple, in Assyria, was sulb ordinate to the palace, the opposite being the case in Baby
lonia.-Assyrian art, one of the later branches of 31 eso
potamisn art, parallel to the later Babylonlan potamisn art, parallel to the later Babylonian. It most senlptured srchitecturs] decoration in low reliet. Ju its

Assyrian Sculpture. first period, culminating in the ninth century B. C., it displsyed grcat vigor and truth in its interpretation of nature, particnlarly in its portrayal of anisual forms. Later tt sutard tlie end of the seventl century B. c. Its lumman

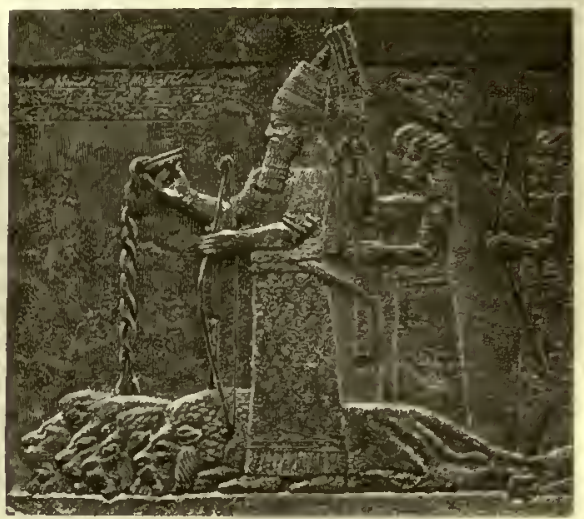

Relief from Koyunjik, in the British Museum. King Assur-banl-pal
pouring a libation. About 625 B. C.

heary and conventional. It is marked by grest minuteness of detail, ornaments, texture of fabrics, etc, being carefilly rendered. In nietal-work of all kinds the Assyrian

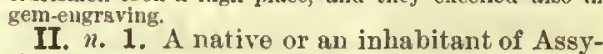
II. n. 1. A native or an inhabitant of AssyTigris, long at the head of the powerful Assyrian empire, including Babylonia and other neighboring countries. - 2. The language of the Assyrians, which has been preserved by and largely recovered from their euneiform inscriptions. See cuneiform.

Assyrological (a-sir" $1-\overline{0}-{ }_{0} j^{\prime} \mathrm{i}-\mathrm{kal}$ ), $a$. Pertaining to Assyriology.

The latest results of Asxyriological research. Assyriologist (a-sip-i-ol'ō-jist), $u$. [ [ Assyri-
ology $+-i s t.] \mathrm{A}$ student of Assyriology; one ology + -ist.] $\mathrm{A}$ stud
versed in Assyriology.

Assyriologue (a-sir' i-0.0-log), n. [= F. Assyrio

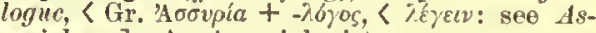
syriology.] An Assyriologist.

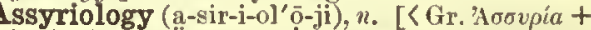

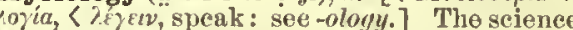
of Assyrian antiquitics; that branch of knowledge which includes the history, language, ete., of ancient Assyria.

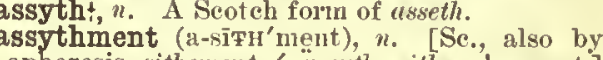
apheresis sithement, < $\quad$ ss:yth, sithe, + -ment.] In Scots lav, an indemnification lue from a person guilty of murder to tlie murdered. Where the criminal has sufferel the yensity of the law, nu
vlainn for thsstlument ast. $[<\mathrm{Gr} .-a \sigma \tau i, \mathrm{~s}$, [<Gr. $-a \sigma \tau i s$, cyuiv. to -torns, A suffix of Greek origin, occurring instead of -ist after $-i-$ as in chilust, enthusiast, etc.

astacian (as - tā' shian), $n$. [< Astet cus + -ian.] An animal of the genus Astacida, as a craw fish or lobster.

stacid (as'ta-sid), $n$ One of the Astacide. Astacidæ (as-tas'i dē), n. pl. [NI Structure of the Crawfish (Astacis).

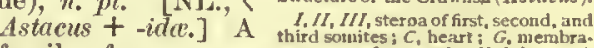
family of maerurons nous part of stomach: $l b$, labrum : decapod crustaceans represented by the crawfish and lobster. Among fluviatile forms, tacus and Cambarus, the former contsining the tilis, and the latter numerous species of Forth
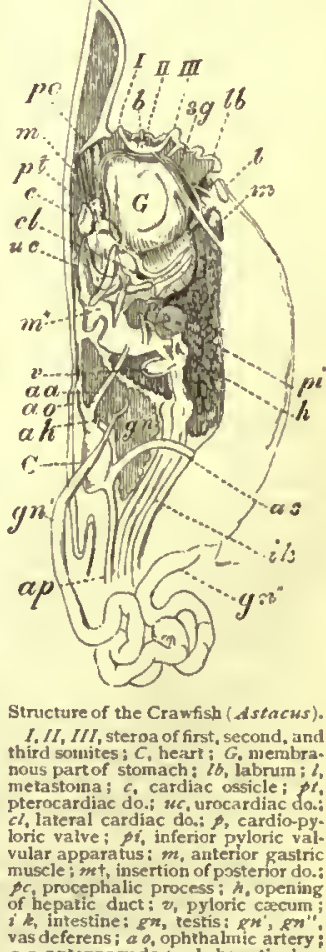

$a$, antennary do.it $a$, , hepatic do. $a s$, sternal do.; $a$, , superior abdomi
nal do.: $b$, cereleral ganglia ; $s g$, azy 
Amerlea, among them the blind erawftsh of the 11 smmoth

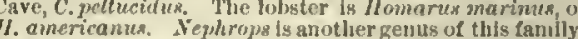
ce cut under Astacu.

Astacina (as-tn-si'nị), n. pl. [N].., < Astucus $+-i n a.] \quad \Lambda$ group of inacrurous decapod erus taceans corresionling nore or less nearly wit Astacini or Astacide.

astacine (as'ta-sin), $a$. and $n$. $\quad[<$ Astcens + -inet.] I. a. Yaving the charueters of a cruwfish; pertaining to the Astacile.

II. $n$. One of tho Astucille, as a crawfish.

The problem whether the crustacen in yuestion was to solve.

Also astacoial.

Astacini (ns-ta-si'ni), n, pl. [NI $I_{0,}<$ Astacu + -ini. In Latreilln's system of classification, the third section of macrurons decapod erustaceans, containing a number of forms now distributed in severat families and at least tw suborlers. If is sulseetion of llie same name corre-

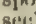

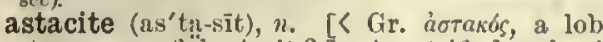
ster, a erawtish, $+-i t c^{2}$.] A petrified or fossil crawfish, or other similar crustaceous animal Also cistacolite.

astacoid (as'ta-koil), $a$. and $n$. [< Astucus + oill.] Same as astacinc. Huxley.

Astacoidea (as-ta-koi'dồ-ä), $n, p l$. [NL., $<A s$ taeus + villea.] "A superfamily group or series of macrureus decapod erustaceans.

astacolite (as-tak'o-lit), n, [< Gr. a arakós, a lobster, a crawfish, $+\lambda i \theta o s$, a stone.] Samo as astacite.

Astacus (as'ta-kus), n. [NL., < Gr. абтакb́, a lobster, a crawfisl..] The typical genus of the

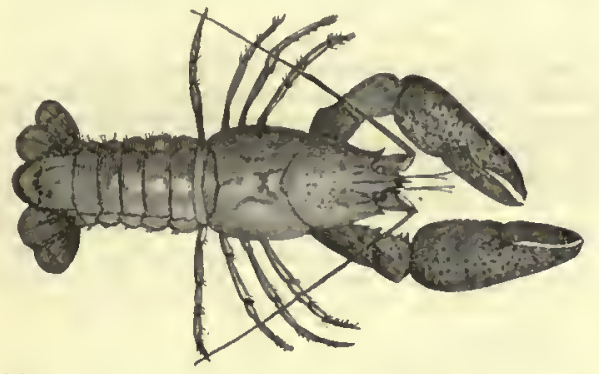

family Astacilce, and one of the two leading genera of fluviatile erawfishes, the other being Cambarus.

astarboard (n-stär'bōrd), prep. plur. as adv. $\left[<a^{3}+\right.$ starboard. $]$ At or to the starbeard or right-hand side of a ship when looking forward. astare (a-stãr' $)$, prep. plur. as adv. or $a$. [< $a^{3}$ + stare ${ }^{1}$.] Staring.

astartt (a-stärt'), v. [< $1 \mathrm{E}$. asterten, asteorten, asturten, startle, start up, eseape, $<a-(<\mathrm{AS} . \bar{a}-$ + sterten, etc., start: see $a-1$ and start. ${ }^{3}$ I. trans. 1. To eseape; eseape from.

Every tere which that Creseyde asterte.
Chaveer, Trollus, ii. 1070.

2. To cause to start; startle.

Fo daunger there the shepheard esn astert.

II. intrans. 1. Te start up.

Out of her hed she did astart,
As one with vew of gliastly feends affirigh

2. To be cseaped from.

And who hadide the herte,

Chnucer, Death of Blanche, I. 1153.

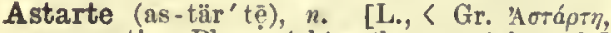
representing Phen. Ashtareth: see Ashtorcth.] 1. The principal female divinity of the Phenicians, preperly a chaste deity, goddess of the moon or of the heavens, but frequently confounded with the unchaste Ashera. She was the same as the Assyrian Istar. Also called Ashtoreth (Ash.
tareth. Astoreth), and, ineorrectly, Ashtoroth (Ashtarolh), a plural form of Ashtoreth.

$$
\begin{aligned}
& \text { Yooned Ashtaroth, } \\
& \text { Hesven's ctueen and mother both. }
\end{aligned}
$$

$$
\text { Nilton, Nativity, 1. } 200 .
$$

Came Astoreth, whon whe these in troop

A tarte, queetl of hearent, whth crescent hor

2. The moon

Axtarte s hediamonded crescent

23

3. [NL.] A genus of bivalve shells, formerly of In pathol., defective secretion of sebaceous great coxtent and referred to the type of a family Astar. tirlie.

Astartidæ(as-tär'ti-clēe), $n$. 1). $\left[N \mathrm{I}_{\text {s. }},<\right.$ Astarte, $3,+$ zöllogical classitiegtion a fumily of limyarion, valves, witl solif equal valves, an cxterual ligavalves, an cxterual ligaalso lateral teeth on each

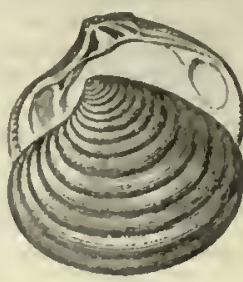
matter by the glands of the skin. asteer (a-stêr'), prep. phr. as arte, or a. [Se., $=$ astir, $q . v$.$] In or into a stato of stir; stir-$
ring. [Scotch.]

asteism (as'tề-izm), n. [<Gr. áoteīouós, clever

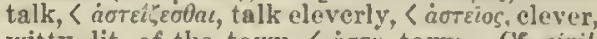
witty, lit. of the town, < icri, town. Cf. eivil <1. ciris, a citizon; urbanc, < I. urbs, a city. In rhet., polite irosy; a polite and ingenious manner of deriding another.

astel (as'tel), $n . \quad[<\mathrm{MH}$. ratelle, $<\mathrm{OF}$, astelle $=$ l'r. astela, < I. "astella, for astula, a form of assula, a thin board, a shingle, dim. of assis, a board: see ashler.] A ceiling of boards overtire, the muscular sears ovate, and a distinet head in a mining-drift, designed to proteet tho pedal sear abovo the anterior inuscular one. men when at work from falling rocks. [Eng.] The tyjical species aro chiefty milluabltants of the northern seas, but ment. licrs of the sume canily as comin mosi other sens. Astasia (as-tã'si-ḥ̊̂) unsteadiness, inconstancy, < dotatos, unsteady: see ustutic.] A genus of elistomatens flagellate infusorians, typical of the

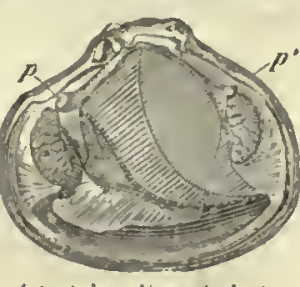
asterl (as'tèr), n. [L. < Gr, icoth, a star (ulso a plant, prob. Aster sticus; cf. do-pov (> L. astrum), a star, a constellation, usually in pl. ár $\rho a$, tho stars), = E. star, q. v.] 1+. $\Lambda$ star [Rare.]-2. A plant of the genus Aster. -3 [cap.] [NL.] A large genus of plants, natural order Compositre, natives of Europe, Asia, and America, but chiefly of North America, about 120 species occurring in the United States. They are nostly perenniul, dowering in late sminer and They are nostly porennial, dowering in late summer sind land sicliaelmas or Cliristmas dalsles. The ray-fowers vary from white to like-blue or purple, the center being yellow, changing somettmes to purple. Stany of the species resenible one another closely, snd in no genus is the 4. A name of plants of some allied genera, as the Cape aster (Agathara amelloides), the China aster (Callistephus Chinensis), the false aster (Boltonia), the golden aster (Chrysopsis), and the white-topped aster (Scrincarpus).-5. In biol., a karyokinetic figure intervening iu time betweeu the rosette and the diaster during the changes in the nucleus of a cell. See diaster and liaryokincsis.

Aster ${ }^{2}$ (as'tèr), $n$. In ornith., same as Astur.

aster. [L. -aster, dim. suffix, as in parasitaster, a bit of a parasite, Antoniaster, a líttle Antony, oleaster, wild olive, pinuster, wild pine, surdaster, deafish, etc.] A suffix of Latin origin, forming contemptuous diminutives, as in criticuster, poctaster. It occurs without reeognized diminutive force in pinaster, olcaster (which see).

Asteracanthiidæ (as"te-rğ-kan-th'̈ $i-d e \bar{e}), n . p l$. Hence-2. In phys., having no tendeney to [NL., S Asteracanthion +-ide.] A family of
take a definite (fixed) position; without diree- ordinary starfishes, of the order Asteroidea.
tive power: used especially of a magnetic nee- Asteracanthion (as"te-ra-kan'thi-on), $n$. [NL.,

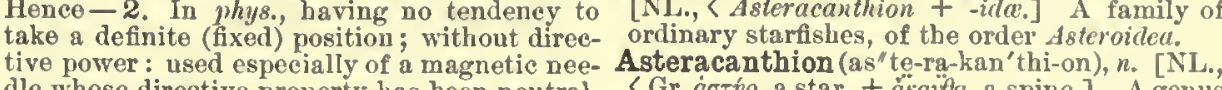
tive power: used especially of a magnetic nee-

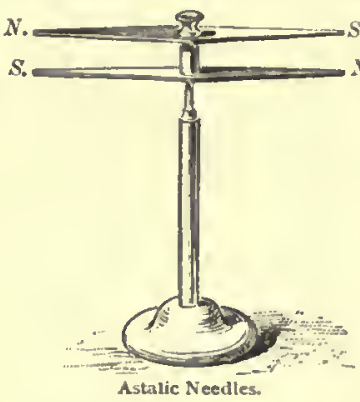
be rendered astatic in varions ways, but
most sjumply by the proximity of another ncedle of the same in to it, sud with the poles reversed, the belng adjacent to the sonth pole of the
other. In thls posi. tion the needles neuand are therufore unt sffected by the mag though they are still sulbject to the influ.
sul ence of an electrlc current properly situated. Such needles were formerly employed in the electrle telegraph, and they form an essential part of the astatic galvanometer.
astatically (as-tat i-kal-i), adv. In an astatic astaticall

astaticism (as-tat'i-sizm), n. [<astatic $+-i s m$. The state or quality of being astatic.

The nominal sensitiveness of a galvanometer can be in.

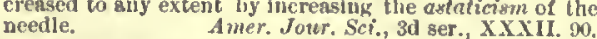
astatize (as'ta-tiz), v. $t$; ; pret, and pp. astatized, ppr. astatizing. [<astat-ic $+-i z c$.$] To render$ astatic.

The deflexion of a properly astatized needle suspended
insinle the globe.

astatizer (as'ta-tī-zér), n. A device for rendering the needle of a galvanometer astatic astay (a-stā'), prep. ph" as $a d v$ or $a$. $\left[<a^{3}\right.$ + stayl.] Naut., said of the anchor when, in heaving in, the cable forms such an angle with the surface of the water as to appear to be in a line with the stays of the ship.

asteatodes (as-tē-a,-tódēz), n. [NL., < Gr. $\dot{a}-$

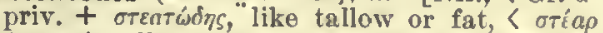
(бтеतт-), tallow or fat, + cidos, form.] Same as asteatosis.

asteatosis (as-tō-a-tō'sis), n. [NL., < Gr. ì- tét'ri-ā-ted), $a$.

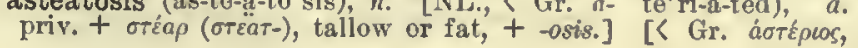

of starfishes, typical of the family Asteracan

thiida. A. rubens is a common British speeies,

the "five-finger" of the oystermeu.

Asteracanthus (as" te-ra-kau'thus), n. [NL., <

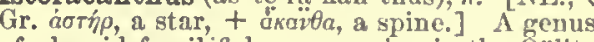

of placoid fossil "fishes, eccurring in tho Ölite and Iias formations.

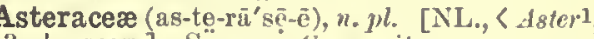
, +acer.] Same as compositco.

steria (as-tē'ri-a), n. [L.,〈Gr. ¿َoríp, a star. Cf. Asterias.] A variety of sapphire, not perfectly transparent, but showing, when cut round, a stellar opalescence in the directiou of the vertical axis of the crystal. Also called oculus cati.

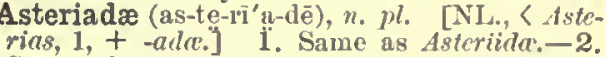
Some other aud major group of starfishes.

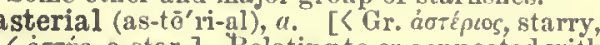
the stars.

If the dleep learn'd atterial quacks
l'alnt Time to life in almanacks, l'aint Time to life in almanack
He lias on brow a loek of l hair, But all his liead leside is laire. T. IVard, Fingland's Reformation, D. 298

asterialite (as-tē'ri-a-līt), n. [< Asterias, 1, + -lite.] A fossil starfish.

Asterias (as-tè'ri-as), $n$. [NL., SI., asterias, 1. The pias, a fis starfishes which is typical of the family Astcriila. - 2. $[l, c$. In ornith., an name of the goshawk, goosehawk, or starhawk. See ds-

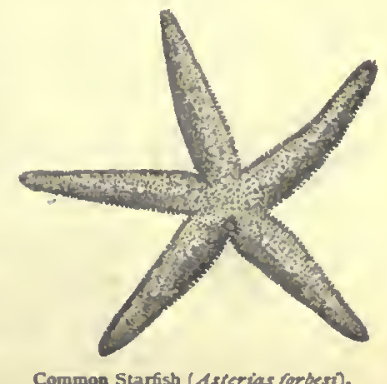




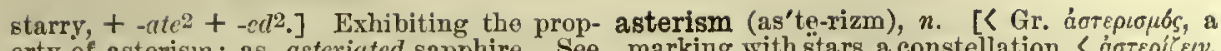
erty of asterisin: as, asteriated sapphire. See asterism, 4.

asterid (as'te-ricl), n. [<Astericle. ] A starfish; a member of the genus Asterias, or family $A s-$ terinde, or same other division of the order $A s$ Asterida (as-ter'i-diin), n.pl. [NL., < Asterias, 1, $+-i d a$.$] In Gegenbaur's system of classifica-$
tion, an order of the class Asteroida, including tion, an order of the

the typical startishes. $+-i d x$. ] I. Same as Asteriidre-2. Some superfamily group of startishes, more or less ox actly equivalent to Asteroidea (which see).

asteridan (as-ter'i-dan), n. Same as asterid.

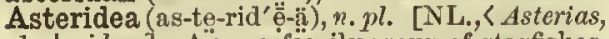

$1,+-i d c a$.$] A superfamily group of starfislies.$ (a) More or less nearly the same 88 sn order Asteroidea (a) More or less learly the same s8 sn order Asteroidea, noderms. (b) Jore or less nearly the same as s class Asteroidea or Stellerida, distinguishing the stsrfshes and
sand-stars (ophlurians) together from other echinoderms. asteridian (as-te-rid'i-an), $n$. and $a . \quad[<$ asterid + -ian.] I. n. Same as asterid.

II. $a$. Of or pertaining to the Astcriidle.

The asteridian affinities of the class [Brachiopoda] hsve asteriid (as-té-ri-id), n. A starfish of the fam ily Asteriida.

Asteriidæ (as-te-rī'i-dē), n. pl. [NL., < Aste rias, $1,+-i d c e$.$] A family of echinoderms, of$ the order Asteroidea the starfishes, class Asteroidea or Stelle rida, represented by such genera as $A s-$ terias or Astropecten and Luidia, having four rows of pedicollate feet in each ray. Also Asterida, and, less correctly, Asteriado.

Asterina (as-te-rī'

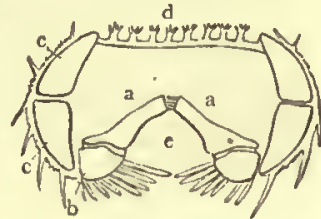
, as-te-ri - nal ossicles; $d$, paxillax upon antanåơh $\rho$, a star, + -ina.] The typical genus of starfishes of the family Asterinida. A. gibbosa is the gibbous starlet.

Asterina Is a large genus, almost world-wide in its dis tribution. The skeleton is formed of Imbricated or overasterinid (as-ter'i-nid), $n$. A starlet of the family Asterinida.

Asterinidæ (as-te-rin'i-dē), $n . p l$. [NL., <Asing the starlets of the genera Asterina, Asteriscus, Goniaster, et.

asterion (as-tétri-on), n. [NL., < Gr. áoréplos

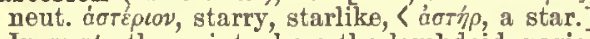
In anat., the point where the lambdoid, parietomastoid, and oceipitomastoid sutures of the skull meet.

Asteriscus (as-te-ris'kus), n. [NI., < Gr. áarepíко, a little stä: see asterish.] 1. A genus mous with Palmipes. The species are known as sea-stars. - 2. [l. c.] An otolith lodged, in most fishes, in a diverticulum of the vestibule, beneath the ampulla of the posterior canal.
asterisk (as'te-risk), $n$. [<LL. asteriscus, $<\mathrm{Gr}$.

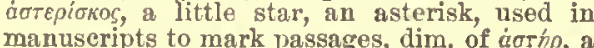

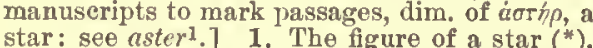
star: see asterl.] 1 . The figure of a star $\left(^{*}\right)$,
used in printing and writing $-($ ( ) as a reference to a passage or note in the margin; (b) to distinguish words or phrases as conjectural, theoretical, unverified, obscure, or as having some other specified charaeter; (c) to mark the omission of words or letters; and $(d)$ arbitrarily, as a
mark of classification. -2 . Something in the shape of or resembling an asterisk.

The lanthorn is in the centre of an asterisk of gisdes, cut througin the wood of sil the country round, four of
five in a quarter. Roger North, Lord Guilford, I. 258. 3. In the $G r$. Ch., a frame consisting of two arches of metal, crossing each other at right

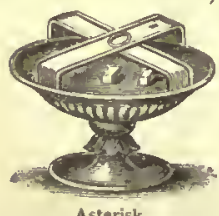
angles, placed on the paten and over the prepared bread of the eucharist to prevent contact with the covering veil.

The asterisk ... folds snd mo folds for the purpose of being more
conveniently put away. Its use is conveniently put away. Its use is
to prevent the vell of the disk from
dissrrsuging the order of the portions; ifs nystical mesning . .
Wise Jen to the Infant Saviour. J. M. Neale, Eastern Church, i. 350, note. mark with stars, < $\dot{\alpha} \sigma \eta \dot{p} \rho$, a star, = E. star.] 1 . A group of stars: formerly oquivalent to constellation, but now appropriated to any small cluster of stars, whether a part of a constellation or not.

All set in number and in perfect form,

Chapman, Blind Beggar.

Any one who studies the heavens will recognize the fact that the larger constellations hsve been robbed of thei R. A. Proctor, I.ight Scienee, p. 335.

2. An asterisk, or mark of reference. [Rare.] -3. Three asterisks placed thus, ***, or thus, * *, before a passage, to direct attention to it. -4. An optical property exhibited by some luminous ficure when viewed by reflected light, as the asteriated sapphire, or by transmitted light, as some kinds of phlogopite. In the former case it is due to certsin peculiarities of internal structure
in the latter to the inclusion of symmetrically arranged in the latter to the

astern (a-stêrn'), prep. phr. as adv. or $a$. [< $a^{3}+$ stern $^{2}$.] 1. At or toward the hinder part of a ship: as, to go astern.-2. Behind, at any indefinite distance: as, the ship was far astern of us.

Csptain Terry ... put oft in his boat at sunset for his R. II. Dana, Jr., Before the MLast, p. 36 3. Iu the direction of the stern; backward; back; to the rear: said of a ship: as, the current drove us far astern. - To back astern, to move stern foremost; go astern: said of a ship.-To be astern of the reckoning, to be behind the position given
vessel by the reckoning. - To fall astern. See fall. asternal (a-stèr'nal), a. [< Gr. $a$ - priv. + otદ́pvov, sternum.] 1. Having no sternum or breast-bone, as a serpent. [Rare.]-2. Not
reaching to or connected with the sternum: as, asternal ribs, that is, floating ribs, ribs which do not articulate with the breast-bone.

Asterodactylidæ (as"te-rō-dak-til'i-dề)

[NL., < Asterodactylus + -idke.] A family of salient amphibians: synonymous with Pipide (which see). Also Asterodactyloide and Astro. dactylida.

Asterodactylus (as"te-rō-dak'ti-lus), $n$. [NL., of salient amphibians: synonymous with Pipa (which see).

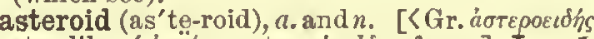

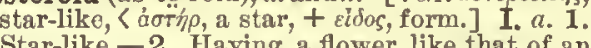

aster. $n$. 1. One of the small plarets, 280 or more in uumber, between the orbits of Mars and Jupiter: more aceurately ealled planetoids. See
planetoid. -2 . One of the Asteroidea; a starfish, in a wide sense.

Asteroida (as-te-roi'dä), n.pl. [NL., 〈Gr. árepoeton's, star-like: see astcroid.] 1. In Gegennoderms, the sea-stals or starfishes, consisting of the orders Asterida, Brisingida, Ophiurida, and Euryalida. -2 . Same as Alcyonaria.

asteroidal (as-te-roi'dal), a. [S asteroid (or Asteroida $+-a i l$.$] 1. Resembling a star. -$ 2. Pertaining to the asteroids.-3. PertainAsteroidea (as-te-roi'dẹ-ä), n.pl. [NL., <Gr.

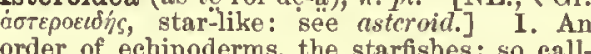
ed from their star-like form. They have a more or

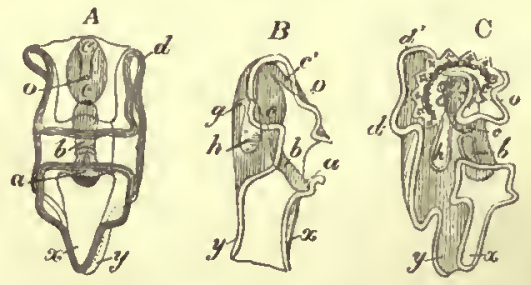

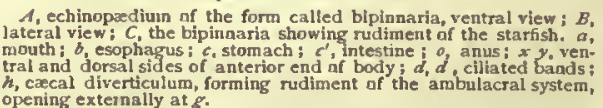

less lobed or pentagonal disk; lobes continuous with the disk, receiving prolongations of the viscera, and lesring gbors1 msdreporic body. The group includes severs famllies, as Brisingida, Pterasterida, Astropectinida, A8. ferinida, Goniasteridce, Linckiida, snd Asteriida, or the tharfishes proper ss distinguished from the sand-stars and They have s coriaceous skin, in which are implanted spines or tubercles. The body is expanded into arms, the unde surface of which is marked with grooves, Tadiating from the center, and pierced with rows of holes, whence issue Most have 5 arms or rays, but some have more, varying from 8 to 30 . They have the power of reproducing these arms if they are broken off; and if on entire arm, with a small portion of the body attached to it, is torn off, it form a new and perfect animal. The mouth is in the inferior center of the rays, is not provided with teeth, and leads intestine snd snus proy or may not be present. 'J'he sul. mals feed chiefly on mollusic

2. A class of echinoderms, containing the sand-stars or ophiurians together with the starfishes, and more or less exactly equivalent to Stellerida (which see).-3. Same as Alcynaria.

Asterolepis (as-te-rol'e-pis), n. [NI., < Gr. arip, a star, +

ienis, a seale.] gautie primitive fishes, now found only in a fossil state in Sandstone. Sands t one. From their reseem that these times have at- $x$, hyoid plate of Asteroleptis, sogth natura tained the jength

asterophrydid (as"tẹ-rof'ri-did), $n$. One of the Asterophrydide.

Asterophrydidæ (as "te-rō-frid'i-dē), n. $p l$. NL., ? Asterophrys $+-i d e^{\text {.] }}$ A family of arciferous salient amplibians with maxillary teeth, dilated sacral diapophyses (the coceyx being connected with one or two condyles or sacral vertebræ), and opisthocelian vertebre. It is a small group of toad-like animals.

Asterophrys (as-to-rof'ris), n. [NL., < Gr.

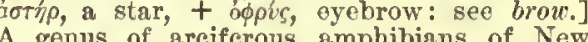
Guinea, typical of the family Asterophrydide. asterophyllite (as "t $\left.\theta-r \bar{o}-f^{\prime}{ }^{\prime} i t\right), n . \quad[K N L$. Asterophyllites.] A member of the genus Asterophyllites.

Asterophyllites (as"tẹ-rō-fi-lì'tēz), n. [NL.,

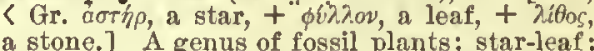
so ealled from the stellated disposition of the leaves around the branches. They abound in the Coll-measures, and are believ

astertt, $v$. See astart.

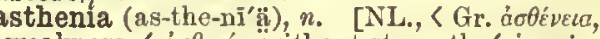
weakness, <a a $\sigma \varepsilon v i s$, without strength, < $\dot{a}$-priv. want of strength. Also astheny. - 2. [eap.] In coöl. a genus of insects.

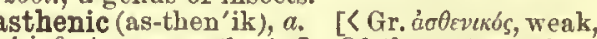
ácocvís: see asthenia.] Of the nature of asthenia; characterized by or suffering from asthenia or debility; weak.

asthenologyt (as-the-nol'ō-ji), n. [< Gr. a $\sigma \theta \varepsilon-$

whs, weak (see asthenia), + - hoyia, $<\lambda \in \gamma E w$, speak: see-ology.] The doctrine of diseases connected with debility.

sthenopia (as-the-nō'pi-ii), n. [NL., < Gr. dotev's, weak (see asthenia), +" $\omega \psi(\dot{\omega} \pi-)$, eye.] Weakness of the eyes. Two forns are especially importsnt (a) accommodat ive asthenopia, which is the result of the ex hsustion of the ciliary muscle, as in hypermetropia; and
(b) museular asthenopia, which is the result of some ex (b) museular asthenopia, which is the result of some ex-
lanstion of the external muscles of the eye, usually the internal rectus.

asthenopic (as-the-nop'ik), $a$. Pertaining to, resembling, or suffering from asthenopia.

For resding, the manifest hypernetropia should be corrected, the strength of the glasses being incressed as often Encye. Brit., XVII. 785.

Asthenurus (as-the-nū'rus), n. [NL., < Gr.

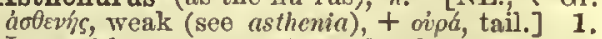
In ornith, a genus of woodpeckers: synonyichth., a genus of fishes.

astheny (as'the-ni), n. Same as asthenia, 1. sthma (ast'mä or as'mä), $n$. [Early mod. F. also astma, asma, < MF. asma, asmy, <ML. asma, asthma, $\langle$ Gr. $\dot{a} \sigma \theta \mu a$, asthma, panting, $\langle a ̉ \zeta \varepsilon v v$, also

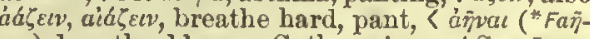
vai), breathe, blow, = Goth. waian = AS. waw wan $=$ OHG. wajan, MHG. wajen, G. wehen = Skt. 
asthma

air ${ }^{\mathrm{I}}$, aura, anla, atmo-, ete., and in Tout., wind2, q. v.] A paroxysmal disorder of respiration, rales, a feeling of constriction in tho ehest, and cough. The essential feature of the attacks is the contraction of the brotichlat tube through spasta of the minto other dysmucic conditions, - Hay asthma same as hay fever (which gee, under fever)

asthmatic (ast-or as-1nat'ik), $a$. and $n$. [< L.

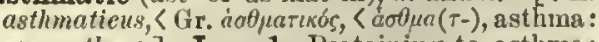
see asthma.] I. a. 1. Pertaining to astlıma: as, asthmatie symptoms.-2. Affected by asthma: as, an asthmutie patient. Ife reads fromt paper and book,
In a low and huaky nuthmntic tone.

II. n. A person troubled with asthma.

asthmatical (ast-or as-mat'i-kạl), $a$. Samo

as asthmatic.
asthmatically (ast- $\alpha r^{\prime}$ as-mat'i-kal-i), adv. In an asthmatic manner; as an asthmatic.

Asthmatos (ast'ma-tos), n. [NL., < Gr. a oo$\mu a(\tau-)$, panting, asthma: see asthma.] $\Lambda$ genus of cilioflagellato infusorians, having at the anterior end a single flagellum in the midst anterior end a single flagellum in the midst of the mese In cases of hay tever, and is anpposed to caus

astichous (as'ti-kus), a. [<NL. astichns, < Gr. a-priv. + orixos, a row.] In bot. and zoöl., not arranged in ranks or rows.

astigmatic (as-tig-mat'ik), a. [< Gr. 'd-priv. $+\sigma r i \gamma \mu a(\tau-)$, a point, +-ie: soo $a-18$, stigma, and stigmatic.

astigmation

astigmatism.

astigmatism (as-tig'ma-tizm), $n$. [Also astig-

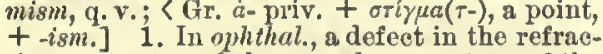
tive apparatus of the eye, the eurvature of the refracting surfaces being greater along certain meridians than along others, so that rays of light proeeeding from an external point do not converge to a point upon the retina, but to a line.-2. A similar defect in a lens.

astigmism (as-tig'mizm), $n$. [See astigmatisn which is "etymologically the better word," which is "etymologically the better word,
notwithstanding the extraet.] Same as astigmatism.

The late ernincnt scholar, Dr. Whewell, who had origl. nally suggeated the word astigmıatism, .... approves of astigmism as being etymologicslly the better word.
Quoted in $N$. and $Q$., 7th ser., II. 344.

astigmometer (as-tig-mom'e-tér), n. [< astig-

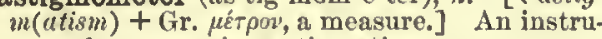
ment for measuring astigmatism.

Zehender deseribes a new astignnometer, consigting of
two pasteboard tulbes, one of which fitted into the othe and could be revolved around its long axls. N. Y. Med. Jour., XL. 218 astigmometry (as-tig-mom'e-tri), n. [< astigmeasurement of astigmatism.

astipulateł (as-tip' $\bar{u}-l a \bar{t}$ ), v. [<L. astipulatus, pp. of astipulari, adstipulari, agree with, $\leq a d$ to, + stipulari, stipulate: seo stipulate.] I. in trans. To make a stipulation; agree.

All, but an bateful Eplcurus, have astipulated to thita
truth.

II. trans. To assent or agree to.

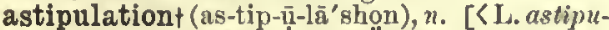
latio(n-), < astipulari, adstipulari, agree with. see astipulate.] 1. Agreement; concurrenee.

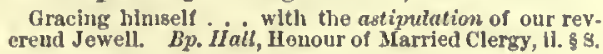
2. Assent.

astir (a-stêr'), prep. phr. as adv. or $a . \quad[=$ Se. stir; on the move; stirring; aetive.

For the Nantes youth, the Angers youth, all Brittany Permeated and timged and all astir with the principle

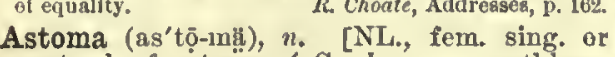
neut. pl. of astomus, < Gr. dorouos, mouthless: see astonous.] 1. [NL., fem. sing.] A spuriof acarines of the family Trombidida, retained as a distinetive name of this stage.-2. [NL. neut. pl.] In Cuvier's system of elassification, a general name for those acalephs or metion, a general name for those aealephs or mefications of tho pedunele, and no eavities for the ovaries. [Not in use.]

Astomata (as-to'ma-tä), n. pl. [NL., neut. pl. two groups into whieh the Protozoa are divided, with reference to the presenee or absence of a
355

\section{Astræacea}

mouth, in which the month is wanting. The Ghizopode. See P'rotozon.

astomatous (as-tóman-tus), a. [<NL. astomatus, < Gr. $\dot{a}$ - priv. + бт́ं $u a(T-)$, mouth.] 1. Not possessing a mouth; speeifically, belouging or pertaining to the Astomata.-2. In bot., witlout an aperture; speeifieally, without stomata or breathing-pores.

astomous (as tō-mus), a. [<NL. astomus, < Gr. dorouos, moutliless, <'a-priv. + orópa, mouth.] Without a stoma or mouth; astomatous: apopen regularly by an opereulum, but bursts irregnlarly, as in $I^{\prime}$ hascum and its allies. A. Ciray. astont, astonet, astunt, $v$. $t$. [K MIE. astonen, asastont, astonef, astunf, $v \cdot t$. [ $[$ MIE. astonen, as-
tunen, astoonen, astowen (later and rarely astunen, astoonen, astouncn (later and rarely as-
toyuc), also astonien, astunien (whence later and med. astony, q. v., and by extension astonish, q v.), oftenest in the pp. astoned, astuned, astouned (whenco in mod. E. a new inf. astound, q. v.), also astonicd (see astony); of uncertain origin: either (1) in the earlier normal form *astunicn, $<$ AS. "astumian (not found), $<\bar{a}-+$ stunian, re-
sound (not verified in the later sense of 'stun with a noise,' stun in this sense being possibly by apheresis from astun); ef. Swiss stiuncn, ? NHG. staunen (in comp. erstauncn = AS. "ästunian 9 ), astonish; or (2) $(\mathrm{OF}$. estoner, estuner, estonner, mod. F. étonner, stum, astonish, < I. as if "extonare, equiv. to attonare, chiefly in pp. attonitus, strike with a thunderbolt, stun, astonish, $<e x$, out $(a d$, to $)$, + tonare, thunder: see as-3, ex-, and thundcr. The indieations point te an orig. AS. word, merged in ME. with the tionally equiv. OF. word. The forms aston, astone, astun, astony, astonish, and astownd are thus variations of the same word. The normal mod. form is astun (a-stun'), or with further development astound, the only form, besides as tonish, in actual use.] To confound; astonish amaze; bewilder; dismay. Chaueer. On the solid ground
IIe fell rebounding breathlcss, and astunn'd
His trunk extcoded lay.

astoniedness $\nmid n . \quad[<$ astonicd $+-n e 8 s$.$] The$ state of being astonished. astonish (arston'ish), $v, t$. [First in early mod. E.; either $<$ aston, astone, or astony, $+-i s h^{2}$, used (as in distinguish and extinguish) in imitation of words like abolish, banish, eherish, etc., where -ish represents -iss- in certain parts of F. verbs; or perhaps from an actual of. "estonishment (Palsgrave).] 1†. To stun, as with blow; benumb; give a stupefying shoek to. Or as a thunder-clap, or cannons" noyge, Sir J. Davies, Ininortal. of Soul.
.

The knaves that lay in walt behind rose up and rolled down two huge stones, whereof the one amote the king
upon the head, the other astonished his shoulder.
Holland, tr. of Livy, xllt. 15 2t. To stun or strike dumb with sudden fear; confound.

$$
\begin{aligned}
& \text { It is the part of men to fear and tremble, } \\
& \text { When the mort mighty gods, by tokens, send } \\
& \text { Such dreadful heralds to astonish us. }
\end{aligned}
$$

3. To strike or impress with wonder, surprise, admiration; surprise; amaze.

Thou hast astomish'd me with thy high terma. The student of Nature wonders the more and is aston ished the less, the more conversant he becomes with her
operations.
If $u x l e y$, Lay Sermons, 1.260. What shall we say of the ocean telegraph, that exten
sion of the eye and ear, whose sudden performanee astonsion of the eye and ear, whose sudden perfornanee aston.
ished mankind?
Emerson, Works and Days. =\$yn. 3. Surprise, Amaze, etc. (see surprise); startle,

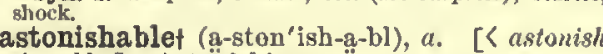
+ able.] Astonishing.

astonishedly (a-ston'isht-li), $a d v$. In an astonished manner. [Rare.]

astonisher (a-ston

astonishing (a-ston'ish-ing), $p$ a Causing or fitted to cause astonishment; amazing ; wonderful. = Syn. Anıazing, surprising, wonderful, marveløu. astonishingly (a-ston'ish-ing-li), $a d v$. In au
astonishing manner; to an astonishing degree. astonishingness (a-ston'ish-ing-nes), $n$. The quality of exeiting astonishment. [Rare.]

astonishment (a-ston'ish-ment), n. [< astonish + -ment. Cf. OF. estonissement (Palsgrave).] of being stunded or benumbed.
A coldness and astonishment in his lolns, as folk say. (b†) Confusion of mind from sudden fear or otber eno; consternation.

Axtonishment is that state of the soul in which all its (eł) Passion; excltement ; Irenzy.

Furlous ever I koew thec to be

Spenser. (d) Great surprise or wonder; amazement.

We lound, with no less wonder to us than astonishmen to themselves, that they were the two valfuut and famous
brothers.

2. A eause or matter of consternation.

Thou shalt become an axtonishment, a pruverh, and a

Those Imaged, to the pride of kings and priests,

A dark yet mighty talth, a lower as wids

But an estosish wh

Shelley, Prometheus Unhound, III. 4.

=\$yn. 1. Amazement, adiulration, awe

astony (as-ton'i), $v$. t.; pret. and pp. astonled, ppr. astonying. [< ME. astonien, rarely astu: see aston.] 1f. To stun, as with a blow. The captain of the II elots ... strake Palladias upon the side of his head that he recled axtonied.

2. To astonish; terrify; eonfound. [Obsolete or archaic.]

And when 1 heard this tling, I rent my garmcut and my mantle, . . . and sat down astonied. Ezra ix. 3 . Aatonying with their suddenness both their fricnds and
Knolter
their eventes. And I astonicd fell and coula not pray. Afro Browing. astoret, $x$. t. [< ME. astoren (and by apheresis storen, > mod. E. store), (OF. estorer, estaurer, $<\mathrm{L}$. instaurare, repair, renew: seo instauration and store.] To store; furnish with stores. Ful riche he was astored prively.

Astoreth (as'tō-reth), n. [See Ashtoreth.] Same as Astarte.

astound $\nmid$ (a-stound'), p. a. [Early mod. E. also astown', < ME. astouned, astoned, astumed, $\mathrm{pl}$. of astounen, astonen, astunen, astonish: see aston, astony, and ef. astound, $v$.] Astonished confounded. See aston.

The elf
Upstarted lightly.

astound (a-stound ${ }^{\prime}$ ), $v$. [As an inf. this form is late, being due in part to the pp. astound, astouned, and in part perhaps to the frequent dissimilated gemination of fiual $-n$ into $-n d$, as in sound for soun, ete.; so dial. droucnet for drown, pp. drownded for drowned.] I. trans. To astonish greatly; strike dumb with amazement; amaze; alarm.

These thoughts nay startle well, but not astoumd
The virtuous mind.
Mitton, Conus, 1.

In the architecture and cmbellishnents of the chamber

Poe, Tales, I. 375

= Syn. Surprise, Astonish, A maze, etc. (8ve surprize); con-
tound, atagger, dumfounder, atupefy, shock.
II. intrans. To cause astonishment; amaze

The lightnings flash a larger curve, and nore

astounding (a-stoun'ding), $p, a$. Causing fitted to eause surprise or wonder; eausing amazement; highly astonishing.

The third s your soldler'a face, a menacing and artound-
B. Jongon, Cyntbia's Revelg. ing facc.
His [Comte'g] astounding gelf-concelt was more akin to that which msy be seen in lunatic asylums than to any-

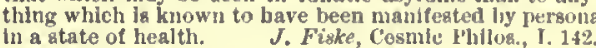
astoundingly (a-stoun'ding-li), adv. In an asteunding or amazing manner; amazingly. astoundment (a-stound'ment), $u_{0} \quad[<$ astound + -ment.] Amäzement. [Rare.]

To the astoundinent of the young urchins, nyy contem astraddle (a-strad'1), prep. $p h r$. as $a d r$ or $a$. $\left[<a^{3}+\right.$ straddlc: see straddle. $]$ In a straddling pesition; with one leg on each side of something; astride: as, to sit astraddle.

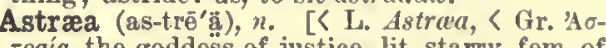
rpaia, the godaess of justice, lit. starry, fem. of A name sometimes given to the sigu Virgo. 2. The 5th planetoid, discovered at Driesen by 2. The 5th planetoid, discovered at Driesen by
Henke in 1845.-3. [NL.] In zoöl., a genus of fixed coralligenous zoöphytes, or stone-corals, typieal of the family Astreide, or star-corals. eo star-coral.

Also spelled Astrea. Astræacea (as-trē-è'sē-ä), n. pl. [NL., < As-
traea + -acea.] In Verrill's system of elassifi- 


\section{Astræacea}

eation, the third suborder of the order Madreporaria. The techuieal eharacters are: poiyps mostly ding; tentacles usually welf developed, long, subeylindri
eal, limited in number, in multiples of six, encireling the eal, limited in number, in multiples of six, encireling th
disk; the eoral mural, septal, and enilotheeal, with vertical and eentrifugal growth, producing turbinsted forms
which are often elongated. Ihe families refersed to the order as thus definetl are 8: Lithophyllide, Meandrinidre, E'uxmillider, Caryophyllida, Stylinide, Astra
nide, Stylophorida', Also written Astreacea.

astræan (as-tré' an), a. 1. Sce astrcan.-2. limhedded in the hase of this eliff of coral limeston were two dome-shaped masses of Astrcan coral. astræid (as-t $x^{\prime} \mathrm{id}$ ), $a$. and $n$. I, $a$. Samo as astrcun, 2.

The large astreid and brain corals imbedded in the up. imbedded some 15 or 20 feet below.

II. $n$. A coral of the family Astroides.

Astræidæ (as-tr'é'i-dēe), n, pl. [NT., $<$ Astra + -idk.] A family of aporose selerodermatons stone-corals, of the order Sclerodermata, class Actinozoa; tho star-corals: so ealled from the radiated or star-like arrangement of their tentacles. The fandly is a large snd important one,
containing several geners, the snimals of whieh largely contribute to the formation of coral reefs. Its limit astræiform (as-tré'i-fôrm), $a$ [< NJ. Astrcea + L. forma, form.] Resembling a star-eoral having the characters of the Astraidee or starhaving the eharacters of the Astraide or starVI. 383.

astragal (as'tra-gal), n. [< astragahs, q. v. 1. In arch.: (a) $\ddot{\AA}$ small convex molding cut string of beads, of in classical arehitecture, especially in egg-and-dart molding and between th faees of different pro jeetion of Ionie and Corinthian epistyle and coffering beams. (b) A small plain convex molding, usually with a fillet beneath it, sometimes between two fillets, used between the eapital and the shaft of elassie orders, except the Greek Doric, and in many other positions in elassic, medieval, and later styles. See cut under column. Also called bead.-2. A convex
molding encireling a eannon near the mouth: not present on modern guns.-3. In carp., one window. -4 . In anat., the astragalus.

astragalar (as-trag'a-lẹir), a. [< astragalus + -ar.] Pertaining to the astragalus.

astragali, $n$. Plural of astragalus.

Astragalinus (as-trag-a-li'nus), $n$. [NL., < as-
tragalus $+-i n u s$.$] An old and disused name of$ some European siskin, linnet, or thistle-bird. In 1851 it was used by J. Cabsnis as a genus same of the finch or thistle-lird of the United Ststes, A. psattrin, the astragalocalcanea, $n$. Plural of-astragalocalastragalocalcaneal (as-trag"a-lō-kal-kā'nē-ạl), a. Pertaining to the astragalocaleaneum. astragalocalcaneum (as-trag "a-lö-kaI-kä'nêum), $n_{.} ; \mathrm{pl}$. astragalocalcanca (-ä). [< astragásenting both the astragalns and the calcaneum, as in lizards and birds. It is supposed as so to include the navieulare, in some eases at least, and thus to reprelizards, as members of the genus Varanus, it is very iarge, perfeetly distinet, extended transversely, hut little back. astragaloid (as-trag'a-loid), a. [< astragalus + -oid.] In anat., of "or pertaining to the astragalus.

astragalomancy (as-tr'ag'ag-lọ̄-man-si), n. [<

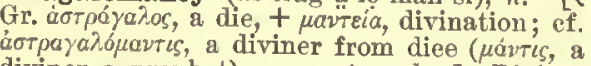
diviner, a prophet): see astragalus.] Divingtion by means of huckle-bones or diee.

astragalonavicular (as-trag"a-lō-nä-vik' प̄ -lärr), $a$. and $n$. [Castragalus + navicular.] I, $a$. An tiles, as a erocodile, supposed to represent an astragalus and a navieular bone combined.

The tarsus presents, proximally, an astragalo-navicula
[I uxley, Anat. Vert., p. 220.

II. $n$. A bone of the tarsus. See I.

The distal end of the astragalo-navicular. astragaloscaphoid (as-trag"a-lo-skaf'oid), $a$. [rastragulus + scuphoid.] Pertaining to both bone; connecting these two bones: as, the astragaloscaphoial ligament.

astragalotibial (as-trag"a-lō-tib'i-al), a. [< stragalotibial (as-trag"a-lo-tib'i-al), $a \cdot[<$
astragalus + tibial.] Pertaining to both the astragalns and the tibia: as, astragalotibial articulation.

astragal-plane (as'trị-gạl-plān), $n$. In joinery, a bench-

astragal-tool (as'tra-gal-töl), n. A turningchisel with a concave face for cutting astragals. astragalus (as-trag'a-lus), n.; pl. "rstragali

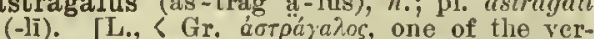
tebre, the ball of the ankle-joint, a die, an arehitectural molding, a leguminous plant arehitectural molding, a leguminous plant; prob. from same root as orrev, a bone. Cf.
osteo-.] 1. In anat., the tibiale, or innermost one of the proximal row of tarsal bones. In mammals it articulates with the tibia and enters into tle the tibia for ankle-joint; in birds it is ankylosed witl the tibia, forming unore or less of the tibial ennlyles, and joint or hcel-joint. In man and some other mamms Is it is known as the talus, huckle-bone, snkie-bone, or slingbone, being the uppermost bone of the tarsus, suil chiefiy or entirely reeeiving the weight of the body, in so far as
this is borne upon the foot or hind foot. See euts under Dromeeus, foot and hock 1 .

2. [cap.] [NL.] A very large genus of plants, natural order Leguminose, mostly low herbs, found in all parts of the world except Australia and Sonth Afriea.

in the old world, and about 200 in Nortli Ameries, ehiefly west of the Mlississippi. Very few are of any value. $A$. of Asla Minor, Syria, snd Persis, are the souree of the gum of Asla Minor, Syria, snd Persis, are the souree of the gum yieid $\mathrm{s}$ sort of manna. A. Baticus is euitivated in sone parts of Europe for its seeds, which are used as a substitute for coffee. In the United States several species are known

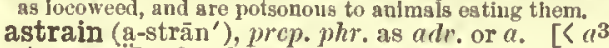
+ strain.] On the strain; straining.

astrakhan (as'tra-kan), n. [<Astralihan (Russ. Astrakhanu), a city and government (province) of Russia.] 1. A name given to skins with a curled wool (the pelts of young lambs) obtained lough fabrie with a long and elosely eurled pile in imitation of the fur.

astrakhanite (as'tra-kan-it), ". [< Astrakluen $+-i t e^{2}$.] A variet
lakes of Astrakhan.

astral (as'tral), a. and $n . \quad[<\mathrm{LL}$. astralis, < L. astrum, a star, <Gr. áorpov, a star, a constellation, $\langle\alpha \sigma \sigma h \rho$, a star, = E. star: see asterl and
star.] I. a. 1. Belonging to the stars; starry. Astral showers eovered the heavens.

2. Specifieally, in theosophy, an epithet deserip tive of a supersensible substance supposed to pervade all space and enter into all bodies; odie ; biogenie.-Astral body, in theosophy, a living an astrsl. Astral fluid, of; i biogen. See these words which is eonmected with the wick-tube by two snall tubes which is eonnected with the wick-tube by two smali tubes
These tubes offer the only obstruction to the passage of all rays which fall between the reservoir and the stem of construetion belng thins in grest messure avoided. - Astral spirts, spirits believed, in the niddie ages, to peo
ple the stars. They were variotsly eonceived as tallen an gels, sonls of departed men, or spirits originating in fire, and hovering

II. $n$. In thcosophy, an astral form or body.

Two or more astrats will mske this journey together.

astrand (a-strand'), prep. phr. as ad ${ }^{\prime}$ or $a$. [

The tail silp, whose lofty prore
Shall never stem the billows more

Shall never stem the billows in
Deserted by her gailant band,

Amid the breakers lies astrand.

astrangef, $x . t$. An old spelling of estrange. Astrapæus (as-tra-pé'us), n. [NL., < Gr.

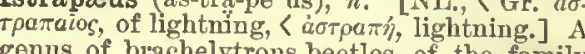
genus of birache

astraphobia (as-tra-fóbi-ậ), $n$. [NL., < Gr

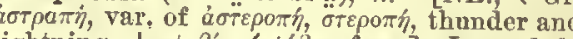
lightning, + $\phi \circ \beta_{i} a,<\phi \delta \beta \circ$, fear.] In pathol. morbid dread of thunder and lightning.

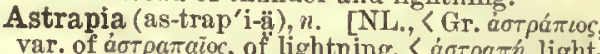
var. of árparaios, of lightning, < $\alpha \sigma \tau \rho a \pi \gamma$, light-
ning. New Gninea, sometimes loceted in the fards of Sturnide next to Manucodia, sometimes referred to the Paradiseide, having a very long gradu- ated tail, like a magpie's, paired lateral crests on the head, and the whole plumage brilliantly irideseent. A nigra, or A. quluris, is the paradise-ple, astraughtł (as-trât' '), $m$. $a$. [Substituted for distraught, q. v.] Distracted; distraught; ghast. Golding.

straunget (as-trânj'), $v \cdot t$. An old form of estrangc.

astrayt (a-strā'), v. i. [< ME. astraicn, only in pp. astraied (after OF. cstraic, estruyé, whenec also appar. the ME. adj. : see astray, a.), or by apheresis straien ( $>$ E. stray), < OI'. cstraier, stray, prob. = Pr. cstraguar, < late ML. extravagare, < L. cxtra, without, out, + vagarc, wander: seo extracagant. See cstray and stray, which are donblets of astray.] To go out of the right way; go astray; stray.

stray (a-strā'), adv. and $a . \quad$ [< ME. astraly, astruie, astraye (also, and earlier in recorded date, by expansion and adaptation, o strai, on stray, on the straye; mod. E. as if $a^{3}+$ stray), also astrayey, < $O F$. cstraié, cstrayé, strayed (ef. MF. astraied), pp. of estraier, cstrayer, go astray: see astray, $v$. The word is thus orig. a p. a., later assimilated to the form of a prep. phr. like asleep, ete. Cf. alight 1 and aslope.] Out of the right way or proper place, either literally or figuratively; wandering.

Thou shait not see thy brother's ox or lis sheep go
Deut. xxii. 1 .

The guides would purposely lead the Castilians astray,
and involve them in morasses. Bencroft, Hist. U. S., I.42, With eyes astray, she told meehanic bead Louell, Cathedral.

astref, $n$. [E. dial. anster, in austerland, q. v., early mod. E. astirc, "asterc, <ME. "astre, $\mathrm{OOF}$. astre, aistre ( $\mathrm{ML}$ astrum), mod. F. Atrc, a hearth; origin unknown.] A hearth; a home. Astrea, $n$. See Astrac.

astrean (as-tré'an), a. [< L. *astrcus, < Gr.

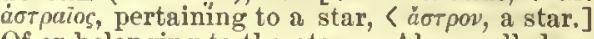
Of or belonging to the stars. Also spelled astraan. [Rare.]

Every Star In Ifeaven is eoioniz'd and replenisin'd with astreated (as'trēe-a-ted), p.u. [< LL. as if "astrcatus, pp. of "astrcarc, only in ppr.astreans, gleam like a star, < astrum, a star: see astral.] Astreidæ, n. $p l$. See Astraide.

astrelabiet, $n$. One of varions Middle English spellings of astrolabe.

Astrelata (as-trel'a-tä), $n$. See CEstrclata.

strict (as-trikt'), $\ddot{v} . t_{0}$ [<L. astrictus, pp. of astringere, draw close: see astringe. $]$ 1†. To bind fast; confine. Hall.-2. In Scots law,
to limit. See astriction, 3.-3. To constriet; to limit. See astriet
contraet. [Rare.]

The solld parts were to be relaxed or astricted.

4. To constrain; restrict. [Rare.]

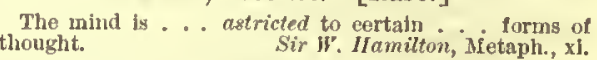

Formerly also adstrict.

astrictt (as-trikt'), $a_{.}$[< L. astrictus, pp.: see the verb.] Brought into small compass ; compendious ; coneise.

astricted (as-trik'ted), $\mu^{\prime} a$. Restricted. See astriction, 3. Formerly also adstricted.

astriction (as-trik'shon), n. [< L. astrictio(n-) a power of contraeting, < astringcre, pp. astricobligation.

Of marriage lie is the author and the witness; yet what will not follow any divine astriction more this good of elther party. Miltom, Divoree, xlit. (Ord Mts.) 2. In med.: (a) The a et of binding close or compressing with ligatures. (b) A contraetion of parts by applieations; the stopping of liemorrhages. (c) Constipation.-3. In Scots lav, the obligation imposed by the servitude of thirlage, by which certain lands are restricted to the use of a particular mill for the grinding of grain. See thirlage.

trictive (as-trik'tiv), a [ L astrictus, pp. (see astrict) + -ive $;=\overline{\mathrm{F}}$. astrictif. $] 1$ Binding; obligatory. -2 . Tending to contract or draw together; astringent; styptie.

Being sodden, it is astrictive, and will strengthen a wesk
tomach.

Formerly also adstrictive.

astrictiveness (as-trik'tiv-nes), $n . \quad[$ <astrictive $+-n e s s$.$] The quality of being astrietive.$ Formerly also adstricliveness. 
astrictoryt (ass-trik'tô-ri), a. [<L. retrietorius, theory of the ereation or evolution of the bincling, < astrietus, l'p. of astringere: se astride. Astringent; binding; apt to bind. astride (a-strid'), mep, phr. as all. or a. [< $a^{3}$
+ stricle. With one leg on each side of some objeet; witl the legs wido apart.

Placel astride whon the bars of the ialisats.

astriferoust (as-trit" star-bearing, (astruin, a star, + ferre star-bearing, ( astrum, a star, + ferre = F.
bearl.] Bearing or containing stars. Blount. astrigeroust (as-trij'e-rus), a. [<I. astriger, star-bearing, < astrum, a star, + gerere, bear.] Bearing sturs. Bailey.

astrild (as'trild), n. [< Astrilda, Estrella: neo Estretda.] A bird of the genus Fistrclila (which seo): as, the gray astrild, Estrelda cinerea.

astringe (as-trinj'), $v$, ; pret. and pp. astringed, ppr. astringing. [Farly mod. F. also adstringe, L. astringcre, adstringere, draw elose, eontraet, < ad, to, + stringere, bind fast, strain: seo astriet, and stringent, striet, and strain.] stivet. [Rare.]

Which contraction. . astringeth the molsture of the braln, and therehy acndeth tears litto the eyesture of the 2†. Figuratively, to obligo; eonstrain; bind by obligation.

II. intrans. To beeome solid; congeal. Hol-

astringency (as-trin'jen-si), n. [=F. astrinyenee; < ustringent: see -enee, -eney.] The property in eertain substanees by which they eause contraction of soft or relaxed parts of tho body: as, the astringeney of aeids or bitters. astringent (as-trin'jont), $a$. and $n .[=\mathrm{F}$, astringent, $<\mathrm{L}$. astringen $(i-) s$, alstringen $(t-) s, p p r$. of astringere, adstringere, draw elose, contract: see astringe.] I. a. Binding; eontracting; eonstrietive; styptie.

strengthening and ast ringent die

Arbuthnot, Alinents.

II. n. A substanee which contracts the tissues and eanals of the body, condensing the soft solids, and thereby eheeking or diminishing exeessivo discharges, as of blood. The chlet astringents are the minerni acils, nlum, lime-water, chalk, aits of copper, zinc, Iron, lead, and silver, and snion astringents owe their efficacy to the presence of tannin.

gent manner.

astringer (as'trin-jèr), neo austringer.

astrite (as'trit), n. [< LL. astrites, also aster tes, < Gr. dorepirns, a brilliant precious stone,
$\dot{\alpha} \sigma \mathrm{Th}$, a star: seeaster 1 .] Any radiated or starlike fossil, as one of the detachod articulation of fossil oncrinites; star-stone. Seo encrinite. Also asterite and astroite.

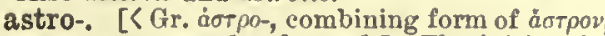
a star: see astral and aster 1.$]$ The initial ele ment in many componnd scientifie terms of Greek origin, meaning star.

Astrocaryum (as-trō-kā'ri-um), n. [NL., < Gr.

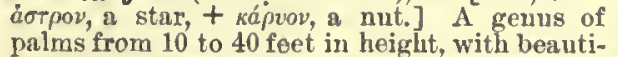
ful pinnated leaves, inhabiting the tropical parts of Amorica. The stemis are covered with stiff and sharp spincs, often a loot in length. The seed is Inclosed in a perlcarp. The eattle of the upper Amazon fced on the is nutheh tised for bows and for other purposes, and the fiter of the lcaves of A. Tucuma are used for flahlng-nets. astrofelt, astrophelt, $n$. [Found only in Spenmanipulated form of asphodel (affodil, daffodil) simulating L. astrum, a star, and fel, gall ('bit ter'). In the second instanee the name is professedly taken from "Astrophel" (Sir Philip Sidney), the subject of the elegy of that name and of another elegy (by Matthow Roydon) printed with it; in the latter also written $A s$. trophill "Our Astrophill did Stella love"), as if ? Gr. aroov, L. astrum, a star ("Stella" "star-

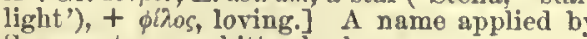
Spenser to some bitter herb.

Iy little flocke, whom carst I lov'd so well,

And wont to feede witis finest grasse that $g$

Feele ye hencefoorth on hitter Aat rofell,

Spenser, Daphnaicla,
That hearbe of some Starlight is eald by name,

Pithers lenthin, though not so weli:

from this day forth do call it Astrophel.

$$
\text { Spenser, Astrophel, } 1 .
$$

astrogeny (as-troj'e-ni), n. [< Gr. dorpov, a astrologized, ppr. astrologizing. [< astrology +

star, $+-\gamma \varepsilon v e c$, generation: see -geny.] The -i=e.] I. intrans. To praetise astrology. celestial bodies; stellar cosmogony. II. Speneer. Also astrogomy.

astrognosy (as-trog'nö-si), $n . \quad[<$ Gr. à $\sigma \tau p m$ Kular, f yvwois, knowledge: see cmostie. stars, in respreet to their names, magnitudes, situations, etc.

astrogonic (as-trō-gon'ik), $a$. Of or jertaining o astrogony or astrogeny

astrogony (as-trog'ō-11i), n. [< Gr. dorpon, a star, + -rovic, generation: seo $-y m y$.$] Samo$ as ustrogeny.

astrography (as-trog'ra-fi), $n$. [<Gr. ăorpov, a description of, or tho art of describing or map ping, the stars.

stroid (as'troid), n. [< Gr. dorpozidis, staxlike, $<\dot{a} \sigma r \rho o v$, a star, + fibos, form, likeness. Af. asteroid.] 1. In her, same as mullet.-2. A plane curve of the sixth class and fourth or-
der, having two conjugato diameters of a eonie and the lino at infinity as infleetional tangents. astroite (as'trọ-it), n. [< L. astroites (Pliny), an unknown preeious stone, $<$ Gr. "áotpoltzs,

astrolabe (as'trō-lāb), n. [Early mod. E. also astrolaby, asiroloby, etc. $<\mathrm{MI}$. astrolabe, astrolabie, astrelabie, astrolabre, ete., $<\mathrm{OH}^{*}$. astrelabe mod. F. astrolabe, MI. astrolabium, < Gr.

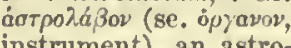
instrument), an astro-

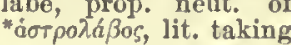
stars, < dorpov, a star, +

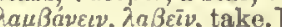
1. An obsolete astronomical instrument of for taking the altitude and for the solution, of other problems in astronomy. The nume was applied to any Instru-

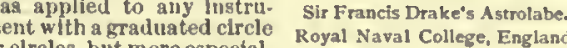
Iy to one intended to be held in the hand Some astrolabes wcre armillary splierea of complicatcd const ructlon, whlle others were plsnispheres intended to measure th
altitude only. One of the most important uses of the as trolabe was in navigatlon, for which it was superseded by

$$
\text { If It does, I'll burn my aztrolabe. }
$$

2. A stereographic projection of the sphere either upon the plane of the equator, the eye or upon the plane of the meridian, the eyo being in the point of intersection of the equinoctial and the horizon.

astrolabyt, $n$. Same as astrolabe.

astrolatry (as-trol'n-tri), n. [= F. astrolatric Gr. árpov, a star, + haspeía, worship: see la-
iria. Cf. idolatry.] Worship of the heavenly bodies, as stars, the sun, ete.

astrolithology (as"trō-li-thol'ō-ji), n. [< Gr

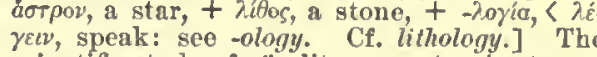
seientific study of aërolites or meteoric stones. astrologer (as-trol'ó-jèr), n. [< MF. astrolo$g e r$, -ere (with suffix -er as in astronomer, ete.

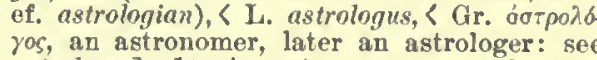
astrology.] 1t. An astronomer; an observe of the stars.

A worthy astrologer, by perspective glasses, hath found in
the stars many things unknown to the nneients. Kaleigh.

2. One who professes to determine the influene of the stars on persons, events, qualities, ete.

Astrologers that future fates foreshow.

Pope. astrologiant (as-trō-ló $\mathrm{ji}-\mathrm{an}), n . \quad[\mathrm{ML}$. astro
logien, $\mathrm{OF}$, astrologien $=\mathrm{Pr}$, astrologian < LI astrologia, astrology; L., astronomy: see astrol $o g y$ and $-a n$.] Same as astrologer.

astrologic (as-trōoloj'ik), $a$. Same as astrological: as, "no astrologie wizard," Dryden.

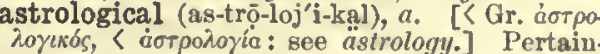
ing to astrology; professing or practising as trology.

astrologically (as-trō-loj'i-kal-i), adv. In an astrological manner; by means of or aceordin to astrology. different forms, used
II. trans. To aseertain by means of astrology. Also spelled astroloyise.
atrologuet astrologuet (as'trō-log) $n$. [Early mod. E. gus $<$ astroloy, $<\mathrm{F}$. astrologue, $<\mathrm{L}$. astrolotrologer. I' '́rfey.

astrology (as-trol'ö-ji), n. [< ME. astrology, Astrolonie, < OH. astrologic $=\mathrm{Sp}$. astrologia $=$

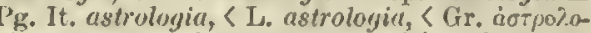

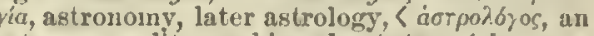
astronomer, lit. speaking about stars, < $\dot{\dot{\alpha} \sigma}$ poov, a star, $+\lambda \ell \gamma \varepsilon v$, speak: seo-oloyy.] 1. The seience or doctrine of tho stars; practical astronomy; astronomy in its earliest form. The term ls now restricted in meaning to the preudo-selence or art properly cnlied whundere astrolopy, whlich assumea that the tons at certain times, a direct infuence upost buman tions at certain times, a direct inffuence upon human given case what thls influence is, and this to foreteli planet becler which lie was born, as saturuine from Sat. urn, fooval from Jupiter, mencurial from Xereury etc. and the virtues of herbs, gema, and mediclnea were aujp

2t. An old namo for the plant bistort, l'olygonum Bistorta. - Horary astrology, that lirancl of the art which ahow's how to answer questions by the figure of the heavens at the moment when the fuestion arises Judicial astrology, that branch of astrology which pro-
fesses to foretell human affairs. The practice of fudicial astrology was forbldden under the sevcrest penaitlea by the Jewish, Roman, snd eanon lawa, ad inplylng filolatry or hereay (equivslent to hlgh (reason), snd falling under the greater cxcommurleation, - Natural astrology, (a) Astrology applled to determining the destiny of a person That branch of satrology which professes to predlct natural efreets, as changes of the weather, winda, atorma, Astrolophida (as-trō-lof'i-dä), n. [NL., < Gr. dorpov, a star, $+\lambda$ ópos, a erest, + -idlu. $\mathrm{A}$
genus of radiolarians, represonting a speeial family, the Astrolophidide

Astrolophididx (as " trō- $\overline{0}-\mathrm{fid}$ ' $\mathrm{i}-\mathrm{de}$ ), $n, p l$. acantharian madiolarians with a skeleton ing a varying number of spieules irregularly distributed, consisting of the genera Astrolophida and Litholophida: synonymous with Aetinellida. Hacehel.

astromancy (as'trō-man-si), n。 [< Gr. áotpo-

Divination by means of the stars; nstrology. astrometeorological (as" trō-me é" tệ-ō-rō-loj'i kal), $a$. Of or pertaining to astrometeorology.

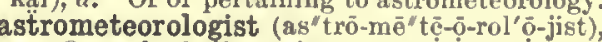
$n$. One who believes in or practises astrome-

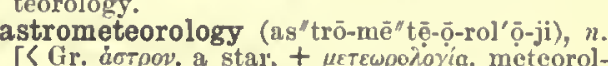
ogy: see meteorology.] 1 . The pretended art of foretelling the weather and its changes from stars: a branch of natural astrology. - 2. Prognostication of the weather from the appearance of tho heavenly bodies.

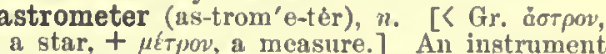
a star, $+\mu \varepsilon \tau_{p} 0 N$, a measure.] An ingtrument
designed to measure the relation, brightness, or apparent magnitudo of the stars. It was inthe moon, or some other object of recognized brightues:
ls brought Into direct comparison with a star, 80 that star and imnge are scen in the same direction. isy adjusthy brightness to the star, and by measuring this distance, the
luster of the otar is readily detcrmines. astrometry (as-trom'e-tri), n. [< Gr. ajorpov,

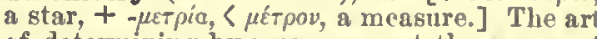
of determining by measurement tho apparent relativo magnitudo of the stars.

Astronesthes (as-trō-nes'thēz), n. [NL., irreg. genus of fishes of the family Astronesthida. Astronesthidæ (as-trō-ues'thi-dē), n. $p l$. [NL. < Astronesthes + -ida.] A family of fishes, represented by tho genus Astronesthes. They have claviform boty; the supramaxillaries as well as intermaxbarbel is developed; the dorsal fin is in allauce of the ana, and there is an allpose fin.

oner (as-tron'ō-mér), n. [ [ME. astronastronomian), < L. astronomia: see astronomy astronomian), L. astronomia: see astronomy versed in astronomy; a scientific observer of the stars; a student of the laws of the heavenly bodies, or the principles by which their motions are regulated, with their various phenomena. -2 . An astrologer: as, "astronomer Royal, the official tithe of the astronomer in charge of any
one of the royal observatorics of Great Britain, especially of the Greenwich observatory. 
use: obtained or made by means of the astrophotometer.

$\mathrm{P} r$. astromomian, < $\mathrm{NL}$. as if *astronomianus, $<$ L. astronomia: see astronomy and -an.] An astron
stars.

Astronomians canue from the East. I'yclif, Mat. ii. 1. astronomic (as-trọ-nom'ik), a. [= $\mathrm{F}$. astrono-

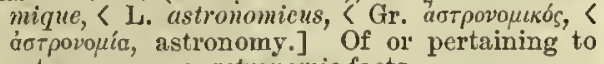

astronomy : as, astronomic facts.

astronomical (as-trọ-nom'i-kạl), a. [< astronomic $+-a l$. Pertaining or related to astronomy; connected with or relating to astronomic obscrvation or research.-Astronomical chronolofy. Sec chronolagy. - Astronomical clock, a clrok day, horizon, etc. See the nouns. - Astronomical lantern, a lampl liaving a glass or paper acreen on which a
celestial map is drawn.--Astronomical signs, the aigns of the zodiac. - Astronomical year. See year.

astronomically (as-trọ-nom'i-kạl-i), adv. In an astronomical manner; by means of astron-
omy, or according to astronomic principles or methods.

astronomiconł (as-trō-nom'i-kon), n. [< Gr.

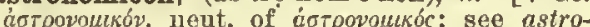
nomic.] A treatise on the stars.

astronomics (as-trō-nom'iks), $n$.

tronomie: seo-ies.] Astronomy.

The lawa of Gravitation, Statics, Acoustics, Chemics, Optics, Pnemmatics, Magnetics, Astronomics . . . are a G. D. Boardman, Creative Week, p. 310, App.

astronomize (as-tron'ō-miz), v. i. ' pret. and pp. astronomizcd, ppr. astronomizing. [< Gr.

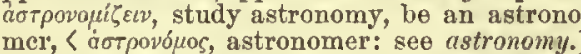
To study astronomy; apply the prineiples of To study astronomy; apply the prin
astronomy. Also spelled astronomise.

They astronomized in caves.
Sir $T$.

Sir T. Browne, Christ. Mor., ii. ?

astronomy (as-tron' $\overline{0}-\mathrm{mi}$ ), n. [C ME. astronomie, astronemic (also contr. astrony), $<\mathrm{OF}$, astronomie, < L. astronomia, < Gr. dotpovouír, astronranging' (with ref. to classifying or mapping

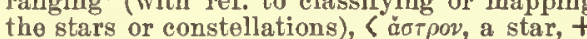
$v \varepsilon \mu \varepsilon v$, distribute, arrange: see nome.] 1. The seience which deseribes the heavenly bodies and explains their apparent motions, ete. That part of the acience which gives a description of the mo-
tiona, flgures, periods of revolution, and other phenomena tions, figures, periods of revolution, snd other phenomena
of the heavenly bodies is called descriptive astronomy; that part which teaches how to observe their motions, flgures, necessary instruments, is called practical astronomy; and that part whlch explains the causes of their motonia, and
demonatrates the laws by which those causes operate, is termed physical astronomy.
$2 \uparrow$. Astrological skill.

Not from the stars do I my judgment pluck,

Nautical astronomy. See natical. Shat.

Astropecten (as-trọ-pek'ten), n. [NL. < Gr. árpov, star, + L. picten, comb: see Pecten.] A pectinide.

Astropectinidæ (as "trō-pek-tin'i-dē), n. pl. [NL., (Astropecten (-tin-) + -ida.] A family of starfishes, typified by the genus Astropecten. They have a doraal akeleton formed of raised ossiclea and Burface, no anus, no interbrachial aystem, snd the ambu-
lacra bierial snd conic. The family includes the genera
Astropecten, Luidia, and Ctenodiscus. astrophelt, $n$. See astrofel.

Astrophiura (as"trō-fi-ü'rä), n. [NL., < Gr. ă $\sigma$ pov, a star, + NL. Ophiura, q. v.] A genus of sand-stars representing a generalized form, typical of the family Astrophiurido.

Astrophiuridæ (as"trō-fi-̄̄' ri-dē), n. pl. [NL. CAstrophiura +-idle.] A family of sand-stars,
order Ophiuroidea, typified by Astrophiura. They have arms, with an ophinroid disk, included in a pen. tagonal body, a very hroad interbrachial cavity, ambula-
crat pores acparated by septs perpendicular to the rays,
and the oral armature without teeth.

astrophotography (as'trō-fọ-tog'rạ-fi), n. [< Gr. dorpov, a star, + photography.] "The application of photography to the delineation or
record of solar spots, the moon's disk, the record of solar spots, the moon's disk, the
planets, and the constellations, and to other astronomical ends.

astrophotometer (as"trō-fō-tom'e-tér), $n$.

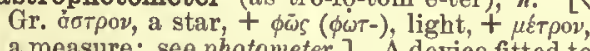
a telescope for comparing the brightness of star with a standard light.

astrophotometrical (as'trō-fō-tō-met'ri-kal), a. Pertaining to the astrophotometer or its strophyllite (as-trō-fil'it), n. [< Gr. ăorpon, a star, $+\phi u \lambda \lambda . o v$, a leaf, $+-i t c^{2}$.] A mineral of a bronze- or gold-yellow color and micaceous
structure, sometimes found in tabular triclinic erystals. It is a ailicate of iron and manganese, with potassiun, rodium, and also some titanium. It is found

astrophysical (as-trō-fiz'i-kăl), $a$. [<Gr. à $\sigma \tau p o v$, star, + фuotkós, physical: seo physical.] Per-

We need, and onght to have, a continuous record of the state of the solar aurface, such ss it is hoped may be seC. A. Young, The Sun, p. I60.
C. Astrophytidæ (as-trō-fit'i-dê), n. pl. [NL., < Astrophyton $+-i$ ice. $]$ A family of ophiurians, of the order Ophiuroidea, containing those which have branching arms. It corresponds to the Euryalea.

Astrophyton (as-trof'i-ton), $n$. [NL., < Gr. of the family Astrophytide, containing tho gorgon'shead, basket-fish, or sea-bas Astrorhiza (as-trō-ri'zä).

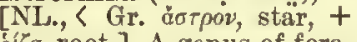
ica, root.] A genus of fordminiferous rhizopods, typidee and the subfamily Astrodre and the subfamily Astro-
rhizina. The species are of considerable sizo.
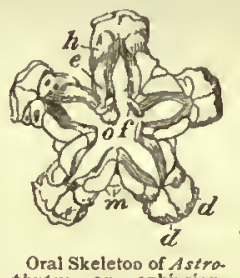
$\mathrm{d} \bar{\theta}), n \cdot p l$. [NL., SAstrorhiza $+-i$ la. A family of rhizopods with the test invariably peristomial plates; $0, p$ size and monothalamous, often branched or radiate, sometimes segmented by constriction
of the walls, but seldom or never truly septate. The polythalamous forms are never symmetrical.

Astrorhizinæ (as"trō-ri-zīnēe),n.pl. [NL. zide, characterized by thick walls composed of sand or mud but slightly cemented.

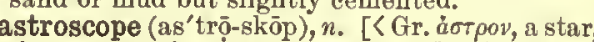
$+\sigma \kappa o \pi \varepsilon i \nu$, view: see astroscopy.] An astronomieal instrument composed of two cones on the surfaces of which the constellations with their stars are delineated. It was forme
used as a substitute for the celestial globe. astroscopy $\nmid$ (as-tros'kô-pi), n. [< MGr. dंorpo-

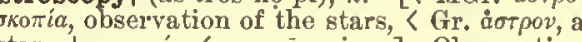

astrotheology (as"trō-thē-ol'o-j-ji), n. [<Gr.

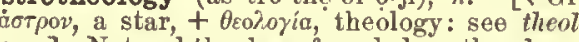
ogy.] Natural theology founded on the observation of the celestial bodies. Derham. astructivet (as-truk'tiv), a. [< L. astructus, pp. of astruere, build in addition, add ( $\angle a d$, to, tive.] Building up; erecting; constructive: opposed to destructive.

The true method of Christian practice is frat destructive "Cease to do evil, learn to do well." astrut (a-strut'), prep. phr. as adv. or a. [ME. astrut, astrout, astrote, o strut, on strut;
strut.] Strutting; pompous. [Rare.] Inflated and astrut with self-conceit

astucious (as-tū'shus), a. [ C F. astucieux, 268 tute, < astuce, astuteness, < L. astutia, astuteness, < astutus, astute: see astute.] Astu
subtle; designing. Also spelled astutious.

Lonis... like all astucious persons, was as desiron Lonis, . . like all astucious persons, was as deairons
of looking into the hearts of othera as of concealing his own.
Scott, Quentin Durward, ix astuciously (as-țu'shus-li), adv. Astutely.

But marked you not how astuciously the good father
.. eluded the questions? Scott, The Abbot, II. Xv. astucity (as-tū'si-ti), n. [< astuci-ous + -ty.] The quality of being astute; astuteness.

With astucity, with awiftness, with audscity.

astunt, v. $t$. See aston. Astur (as'tèr), n. [LL. astur, ML. also astor, austur, etc., a goshawk: see austringer. $]$ A
genus of hawks, formerly called star-hawks or goose-hawks, now goshawks, of large size, with short rounded wings, loug tail, moderately long legs, and the beak festooned but not toothed. taining to astronomical physies. oтpov, star, + фvróv, plant.] The typieal geuus

Astrorhizidæ (as-trō-riz' istar, $+-\sigma \kappa o$ is A. atricapillus; there are other species, grading in size
down to the apecies of Accipiter, so that the limits of the

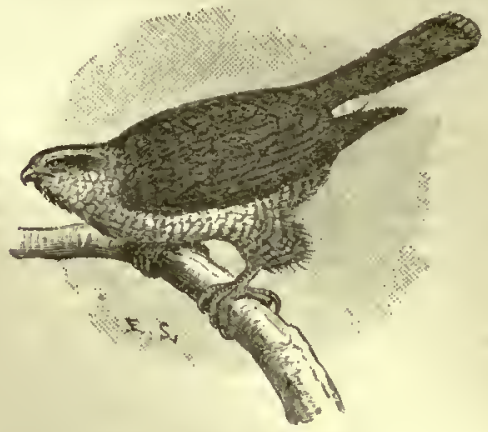

genus are indefinite. The wort has been used with mucl
latitude for various liawk and hawk-like birds. Also

Asturian (as-tū'ri-an), $a$ and $n$. [<Sp. Asturiano, < Asturias, Asturia, < L. Asturia, the country of tho Astures, in Hispania Tarracoer in Astur, an Asturian. Cf. Astura, a riv ing to ancient Asturia or modern Asturias, a northwestern province of Spain, on the bay of Biscay.

II. $n$. A native or an inhabitant of Asturia. Asturina (as - tụ -rī'nä),$n$. [NL., < Astur + -ina.] A genus of comparatively small Amer iean hawks, of the buteonine division, the adults of which have somewhat the pattern of plumage of the goshawks, to which, however, they are not specially related: synonymous with Asturisca (Sundovall, 1872). One species, A. plagiata, occurs in the United States, and there are several others Asturing (as-tī- $\bar{n}$ 'n $\bar{\theta})$,

[NL., < Astur + having the group of hawk synonymous with Accipitrino. The name is naed with great latitude, and is incapable of exact definition. In Sundevall's classiffcation, for example, it is a family of asturine (as'tér-in), $a$. and $n$. [< NL. asturi-

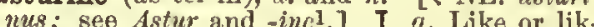
ened to a hawk, especially of the genus Astur ceipitrine.

\section{turina.}

Asturisca (as-tū-ris'kä), n. [NL., < Astur + dim. -isca.] Same as Asturina.

astute (as-tuit'), $a$. . [< L. astutus, cunning, cratty, astus, eunning, eraft.] Of keen peneation or discernment; cunning; sagacious.

That astute little lady of Curzon Street. Thackeray. Nlighty clever you gentlemen think you are!
Acute and astute, why are you not also omniscient?

Acute and astute, why sre you not also omniscient?
Charlotte Bronté, Shirley,

=Syn. Sagacious, Sage, Knowing, Astute, Subtle. Saga cious and sage are used only in good sensea, and when apoften penet the knouling man has wide knowledge an often penetration. The word knouring has slso a humor-
ous cast: as, he gave me a knowing wink; it may be uaed
ironically: as, he is a little too knouning, that ia, he thinks ironically : as, he is a little too knouring, that ia, he thinks more than one has a right to know; it sometimes sllggest a diaposition to make Ill use of knowledge: as, s knowing leer. Astute is often the same as sagacious, but is aua row ahrewdneza, alyness, or cunning. il it often of a nar sagacity that knows how to be silent; ;it is frequently spplied to looks. Subtle, in its good aense, limplies great acuteness, delicacy, or refinement in mental action: ar, a subtle reasoner. For its bad aense, see cunning.

Another effect of public inatability is the unreasonable advantage it gives to the sagacious, the enterprising, and the monicd few, over the ind ustrioua and uninformed masa
of the people. Let time, that makea you homely, make you sage. Not every one, knowing as he may be, knows when his
question is answered. No ambasado wetern Courts, Table po No ambassadors to Western Courts were so instructed,
so decorous, so proud, go astute as the Yenetian anbas-
sadors.
D. G. Mitchell, Bound Tougether, Ji. A subtle disputsnt on creeds.

Byron, Napoleon Bonaparte.

astutely (as-tūt'li), adv. In an astuto manner ; shrewdly; sharply; cunningly.

astuteness (as-tūt'nes), n. The quality of being astute; cunning; shrewdness.

All so smooth and fair,
Even Paul's astuteness suiffed no harm i' the wortd. Browning, Ring and Book, I. 145

astylar (a-sti'lär $), a$, [< Gr. åotvìos, without pillars or columns $\left(\langle\dot{a}-\text { priv. }+\sigma \tau \bar{v}\rangle_{0}\right.$, a column: see style $\left.\left.{ }^{2}\right),+-a r.\right]$ In arch., having no columns. 


\section{astyllen}

astyllent (as-til'en), n. [W. dial, ; etym. ob- aswought, adv. or a., orig. p. a. [ME., also senre.] A small temporary dam or partition, uswogh, cswowe, iswowe, iswoze, $<\mathrm{AS}$. yeswöyen, mado either of branches or twigs interlaeed, or senseless, swooned (ef. geswognung, swooning); perliaps sometimes of a simplo pieco of board, and nsed either to check the flow of water

attle on tho surface. [Eng.]

asunder (n-sun'dér), prep. phr. as adv. [<ME.

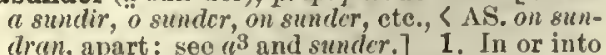
dren, apart: seo $\iota^{3}$ and sunder.] 1. In or into position or in dircetion: snid of two or more things: as, widlo as the poles asunder.

The vangusrid and rear-guard were ahove halt' a league anumler, wlth the cavalgadia between them. Irving, (irangda, p. 78. 2. In or into a divided state; into separato parts; in pieces: as, to toar, rend, break, burst, or ent asunder.

"the Lord. . . hath eut asunder the eoris of the wieked. What a plaguing thing it is to have a mas's misd torn

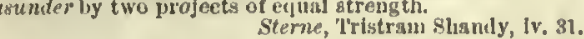
Ties the strongest, infiuencea thie sweetest, seem falling asurder as snoking Hax. $\quad R$. Choate, Addresses, p. 405. 3. Soparately; apart. [Archaic.]

It was impossible to know them asund

Defoe, Piague, p. 204.

asura (as'ö-rậ), n. [<Skt. asura, spiritual; as a noun, a spirit, later a demon (Hind. asur); $\left\langle\sqrt{ } a s\right.$, be, with which are connected $\mathrm{E}_{0}$ am, are: soe be, cris.]. In IIndu mythol., one of u elass of demons in perpetual hostility to the gods:

aswail (as'wāl), n. [H. Ind.] The native name of tho sloth-bear of India, Molursus or Prochilus

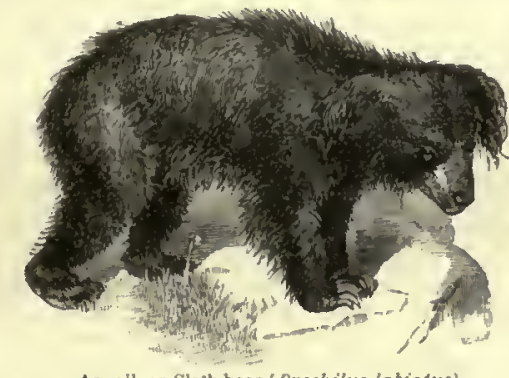

labiatus. It is an uncoutl, unwieldy animal, with very long blaek lisir, and inoffensive when, its exceeding gensitiveness to heat, it couthes itself to its den durfing the day. It never eats vertebrate snlmals
except when pressel by lunger, jts ususl diet consisting exeept when pressed hy lunger, its ususl diet consisting
of roots, bees' nests, grubs, analls, ants, ete. Its flesh is of roots, bees' nests, grubs, snsils, snts, ete. Its flesh is
used tor food, ant its lat is highly valued for the lubriegtion of the delicate steel-work in gun-loeks. When capform many curious tricks.

aswarm (a-swârm'), prep. phr. as $a d v$. or $a$. [s $\left.a^{3}+s w a r m.\right]$ In a swarm; swarming.

Carnival-time, - anotlier providence

Browing, ling and Book, II. 73.

aswasht, prep. phr. as adv. or $a$. [Early mod. "sicash, of obscure origin.] Slantingly; aslant; oblique; (of looking) askant and with seorn. Cotgrave.

asway (a-swä), prep. phr. as adv. or $a$. [< $a^{3}$ + sway. In a swaying state; roeking from slde to side.

aswevet, $t$. $t$. [ME. asueven, stupefy, < AS. $\overline{a s w e b b a n, ~ s o o t h e, ~ s t i l l, ~ p u t ~ t o ~ d e a t h, ~}<\bar{a}-$, intensive, + swebban, put to sleep, < swefan, slecp: sce sweven.] To stupofy, as by terror. So antonyed and asoeved,
Was gvery vertu in my lieved.

Chawer, liouse of Fame, 1. 549

aswim (a-swim'), prep. phr, as adv. or $a$. [< $a^{3}+$ swim.] Swimming; overflowing; afloat,
aswing (a-swing'), prep. phr. as adv. or $a$. [< $a^{3}+$ scing.] In a swinging state; asway. aswoon (a-swön'), prep. plir. as $a d v$. or $a$.

ME. aswoun, aswown, astioune, astoicne, also a surowe, on swoune, in srooune, taken, as in mod. F., as prep. with uoun $\left(a^{3}+\right.$ swoon $)$, but originating in aswowen for iswowon, the fuller form of astcowe, iswowe, orig. pp.: see aswough. Cf. aslope, alight1.] In a swoon.

And with this word slie teli to ground

$$
\begin{aligned}
& \text { Beeause } 1 \text { fell arwoon, } \\
& \text { I think you'll do the like. }
\end{aligned}
$$

I think you'll do the like. aswooned (a-swönd'), adv. or $a$. [< ME. $a$ suroned, isurnuned, oceasional var. of aswoune, ete.: see aswoon and aswound.] Aswoon. aswoundt, $p r e \eta$. $p h r$, as $a d v$. or $a . \quad\left[<a^{3}+\right.$ scound for swoon: see sicouml, and cof asuroon, (swooned.] In a swoon; aswoon.

sylet $\left(\mathrm{a}-\mathrm{sil}^{\prime}\right), n_{0} \quad[<\mathrm{MH}$. asile, < $\mathrm{F}$. usile, < L. rsylum: sce asylum.] An old form of asylum. asylum (a-si'lum), n. [< L. asylum, a sanetuary, asylum, く Gr. åoviov, au asylum, uout of ávios, safo from violence, $<\dot{a}$ - priv, $+\sigma \dot{v} \lambda \eta$, also ounov, a right of scizure, perbaps related to $\sigma \kappa i \bar{\lambda} o v=$ L. spolium, spoil: see spoil.] 1. A sanctuary or place of refuge where eriminals and debtors formerly sought shelter from jins tice, and from whicli they could not be taken without saerilege.

Se sacred wss the church to nome that it hal the rigit af an asylum or sanctuary. Aytiffe, Parergon.

IIence-2. Inviolable shelter; protection from pursuit or arrest; security of tho person: as, the right of asylum, that is, of furnishing such protection. Jlost Greclan temples hal sndentiy this right, and the custom, following Jewish snalogles, passed modern legislation has nearly everywhers ended the cus tom. (See zanctuary.) In international law, the right of asylun was formeriy elaimed for the lionses of ambas. sadors. The term now apeeifieally signifies the right of one state to reeeive and shelter persona aecused of erimes,
or eapecislly of poiltical offenses, committel in snother. or expecisliy of

3. Any place of retreat and security.

Farth has no other axylum for them than its own cold Specifically -4. An institution for reeeiving, maintaining, and, so far as possible, ametiorating the condition of persons suffering from fortunes: as, an asylum for the blind, for the deaf and dumb, for the insane, cte.; a magdealen asylum.

asymbolia (as-im-bō'li-ä), n. [NL., < Gr. a priv. + oí $\mu$ 3aiov, symbol.] Same as asemia. asymmetral $\nmid$ (a-sim'e-tral ), a. Same as asymmetrous.

asymmetric (as-i-met'rik), $a . \quad[<G r . \dot{a}-$ priv. $(a-18)+$ symmetric. Cf. asymmetrous.] Destitute of symmetry; not symmetrieal.-Asymmetric system, ln crystal., same as triclinic gystem whont a plane of symuetry. See crystallography. Many substances centrin an asymmetric carbon atom symmetrical (as-i-met'ri-kal), $a$. [< Gr.

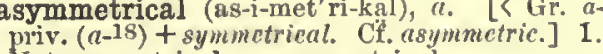
Not symmetrical; unsymmetrical.

In some Cetaees, the bones ahout the region of the nese are unerually developed, and the skuil becomes axymmet-
rical.
Huxtey, Anat. Vert., p. 30. 2t. In math., not having commensurability; incommensurable.-3. Inharmonious; not reeoneilable. Boyle. [Rare.]

asymmetrically (as-i-met'ri-kal-i), adv. In an asymmetric manner; without symmetry.

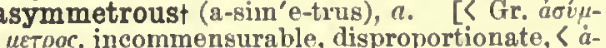

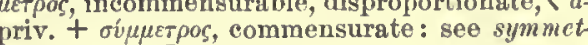
ric.] I. Ineommensu-

2. Asymmetrical.

Also asymmetral.

symmetry (a-sim' $\mathrm{A}-\mathrm{tri})$ n.; pl. asymuetries (-triz).

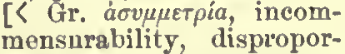

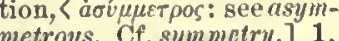
Want of symmetry or proportion.

In the Flat-fishes (Plenronee tidac, the skuil becomes ao eomipletely distorted that the tw ons side of the body. . In certain of these flshes, the rest of the skull snd factal bones, the spine, and even the limbs, partake in this asymme-
try. II $2 \uparrow$. The want of a common measure between two quantities; incommensurability. Barrono.

asymphynote $(a-\operatorname{sim}$ ' $\mathrm{fi}$ -

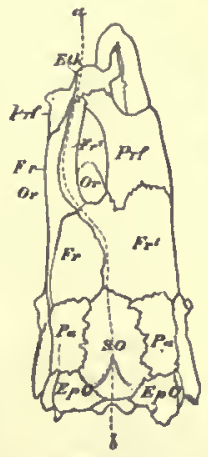

nót), $a$. [< Gr. a- priv.

(a-1S) + symphynote.] Not

soldered together at the back, that is, at the hingo: the opposito of symphynoto (which see): the ehurehes hat wiklely extended rights of asylum, but asystaton

aprlied to those unios or river-mussels which have the hinge free und the valves consequently movable, as is usual in tho genus Unio. Ir. Israc lea.

asymptote (as'inl-tót), $a_{0}$ and $n_{0} \quad[<\mathrm{Gr}, \dot{a} a \dot{y} \mu-$ , not close, not fulling together, $\langle\dot{a}$ - jriv.

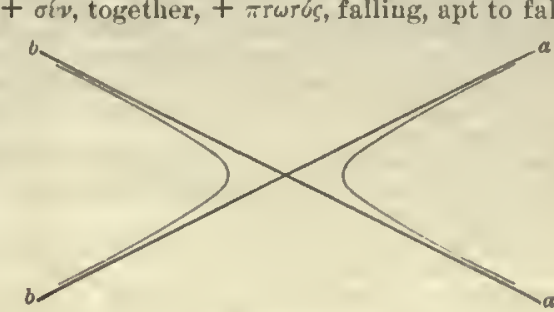

$a b, a b$, Asymptotes.

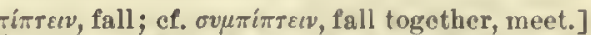
I. $a$. In math., approaching indefinitely close. s a line to a curve, but never meeting. See II. II. $n$. A straight line whose distance from a curve is less than any assignable quantity, but which does not incet the eurve at any finite distance from the origin. The asymptote is often defined as the tangent to the eurve st an infuite diatanes, and this deflultion snswers for Jucltdean space i fut, in vlew of non-Euelidesn liypotheses, it is prefersble to define it as a eammon chord of the eurye and the al
(which see), and thus as not neeessarly a tangent.

asymptotic (as-im-tot'ik), $a$. Same as asymptotical.

asymptotical (as-im-tot'i-kal), $a_{0} \quad[<$ asymptotic $+a l$.$] Belonging to or having the char-$ acter of an asymptote; approaching indefinitey near, but never meeting.

In these perpetusl lines and eurves ran the asymplotical negotiation from beginning to end - gnil 80 it might have Motley, Iutch Republie, III. 455.

Asymptotical lines or curves, lines or

asymptotically (as-im-tot'i-kal-i), $a d v$. In an asymptotical manner; in a manner so as gradually to approach indefinitely near, though never to meet. The theory is not a thing complete from the first, but a
thing which grows, as it were, axymptoticalty towsrds
certainty. M. Airchin, Statics, I. 180

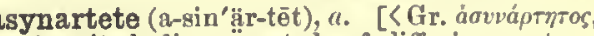
not united, disconnected, of differing meters,

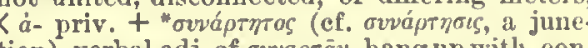
tion), verbal adj. of ovva $\rho \bar{a} v$, hang up with, eonnect, < oív, together, + ápià, join, fasten, rearthritic, article, armi, etc.] 1. Disconneeted; not fitted or adjusted. - 2. In anc. pros.: $(a)$ With interior catalexis at the ond of a colon; procatalectic or dieatalectie: as, an usynartetc verse, meter, or period. (b) Composed of cola of different kinds of feet ; episynthetic. [I'sed in this latter sense (b) hy most modern writers sinee hent-
ley, the former genae (a), however, being restored by some
writers in sceordance with sncient guthority.] Also axymsynchronism (a-sin'krō-nizm), n. [< Gr. àapriv. $(a-18)+$ synchronism.] Want of synclironism or correspondenee in time. asynchronous (a-sin'krō-nus), $a . \quad$ [<Gr. $\dot{a}-$
priv. $(a .1 \mathrm{~s})+$ synchronows.] Not coineiding

asyndetic (as-in-det'ik), a. [<asyndeton $+-i c$. Pertaining to or characterized by asyndeton. asyndeton (a-sin'de-ton), $n$. [L., < Gr. áaiv

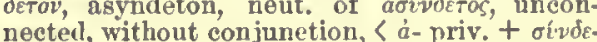
nectel, without conjunetion, $a$ - priv. + oivdeoiv, together, + deiv, bind.] In rhet., a figure of speech consisting in the omission of connectives, as in the following passage:

Heal the siek, cleanse the lepers, raise the dend, east It is the opposite of polysyruleton, which is a nultiplica. asyntactic (as-in-tak'tik), a. [<Gr. áбívтакто,, not ranged together, ungrammatical (<就 priv,

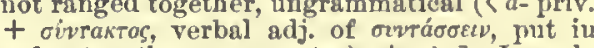
order together: see syntax), + -ic.] Loosely put together; irregular; ungrammatical. $N$ E. $D$.

asystatonł (a-sis'ta-ton), n. [< Gr. àcioraros, incoherent, incongruons, $<\dot{a}$ - priv, + fíotaros, verbal adj. of ovvotáva, hold together, < oiv, with, + iorával, cause to stand, mid. ioraofal, stand.] The sophism of the liar (which see, un (ler liar). Formerly erroneously assistation. 
asystaton

Assistation [asystaton] is a kind of cavlling not consisting of any sure ground, as if a man ahould say that le doth
hold his peace or lyeth or knoweth nothing, another by hold his peace or lyeth or knoweth nothing, another by and by might cavil thereof in this sort, krgo, he that asystole (a-sis'tō-lēe; $n$. [NL., < Gr. $\dot{a}$ - priv. + ovoro $\lambda \dot{\eta}$, systole.] In pethol., that coudition in which a dilated and enfeebled heart remain coutinuously filled with blood on account of th inability of the left ventricle to diseharge more than a small part of its contents. Also ealle asystolism.

asystolic (as-is-tol'ik), a. [< asystole + -ic.] fected with asystole.

asystolism (a-sis'tō-lizm), n. $\quad[<$ asystolc + asystolism (a-sis tọ -lizm)

asyzygetic (a-siz-i-jet'ik), a. [< Gr. $a$ - priv. $(a-18)+$ syzygetic. $]$ Not connocted by a syzygetic relation.

at (at), prep. [<ME. at, sometimos att, atte, ct, $<$ AS. $c t=$ OS. $a t=$ OFries. ct (in combination also $a t, i t)=\mathrm{OHG}$. $a z=\mathrm{Icel}$. $a t$, mod. $a t h=\mathrm{Sw}$. $a t=$ Dan. $a d=$ Goth. $a t=\mathrm{L} . a d$ ( $>$ It. $a=\mathrm{Sp} . a$ $=\overline{\mathrm{P}} \cdot a=\mathrm{F} . \dot{a})$, to, at, = Skt. adhi, unto, on. F Pg. $a=$. $a$, to nearly equiv. to $l o$, without the orig. implication of motion. In many con the orig. implication of motion. In mauy constructions the two prepositions interchange. In many E. dialects at has partly, and in Seand. hand in G. to $(z u)$ has wholly displaced at. In L. and Rom. the form cognate with at covers all the uses of to as well as of $a t$, and extends partly over the field of uith.] A preposition of extremely various use, primarily meaning to, without implication, in itself, of motion. contact, contiguity, or eoineidenee, actial or approxitive position than other prepositions, it may In different construetions assume their offiee, and so beeonie equlvalent, aceording to the context, to in, on, near, by, about, 1. Of simple local position: $(a)$ With verbs of rest (be, live, etc.): In, on, near, by, ete., aeeording to the context: denoting usually a place conceived of as a mere point: as, at the center, at the top, at the corner, at the river, at the north pole, at No. 48 Main street, ete. so with llames of tow us, etc.: as, at stratford, at Lexington,
etc.; but if the city is of great size in is conmonly used as, in London, in Paris, in New York; unless, again, the eity eial interests eenter at New York. The place implied by at may be left indeterminate, with a referenee rather to con-
dition than to mere location: as, at sehool, at college, at dition than to mere location: as, at sehool, at college, at
court, at sea, etc. At may also express personal proximity: as, at one'g side, at one' a lieels, at one's elbow, etc.
At hand, near by, has lost its personal reference. I don't believe there's a eirculating library in Bath 1 Muley Abul Hassan, at the head of a powerful foree,
hast luming from Granada. He [Don Juan de Vera] was armed ot all point, gallantly mounted, and followed by a moderate but well-ap-
pointed retinue. (b) With verbs of motion: (1) Through, by (implying a starting-point or a point where a thing to go out at the baek door. (2) From (implying a source from which a thing comes or where it is sought): as, to reeeive ill treatment at their hands. (3) To, toward (implying a stopping-point, a position attained or aimed at): as, to come at, to get $a t$, to aim at, fire at, shoot $a t$, drive at, point at, look at, shout at, reach it implies effort direeted toward a thing.

No doubt hit they will sonne answer that all these
things they seeke at God's hands.

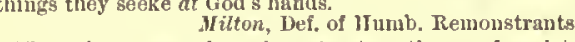
There is no way of eoming at a true theory of acelety but by inquiring into the nature of its component indi-
viduals.
II. Syencer, Social Staties, p. 28 What you can drive at, unless you mean to quarrel with
me, I eannot coneeive! Sheridan, The Kivals, iv. 3. In spite of his former aubmissions and promizes, Lati-

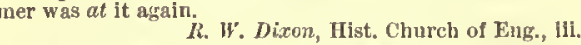
Who but Henry eould have been aware of what his fathe 2. Of eircumstantial position, state, condition manner, environment, ete., in a great variety of relations developed from the local sense: as, at dinner, at play, at work, at service, at right angles, at full lengtli, at odds, at ease, at war, at peaee, at will, at pleasure, at diseretion ate.

They let her goe at will, and wander waies unknowne. I have brought you a new aong will make you laugh, Though you were ot your prayers.
Fletcher (and another), False One, 1, 1.
360

ataxia

Really, sir, you have the advantage of me:-I don't re- ataman (at'a-man), n. [Russ. atamanü= Pol. Sheridan, The Rivala, v. 2 Suecess would place a rieh town at thelr mercy.

The ship in which he [Goldsmith] had taken his passage having got a fair wind while he was at a party of pleasure, 3. Of relative position: implying a point in an actual or possible series, and hence used of degree, price, time, order, oceasion, ete.: as, at the beginning, at the third house from the cor ner, at nine years of age, at seventy degrees in the shade, at four dollars a yard, at ten eents a pound, at half past six, at midnight, at first, at last, ete.

I'll take them at your own priee. . At present, if you please, we'll drop the subject. Sheridan, The Duenna, i.

In passing through the gate of Elvira, however, he ac-
ad eidentally broke his lanee againat the areh. At this, cer vil omen. Irving, Granada, p. 108. In all uses, especially in those last mentioned, at is very frequent in idlomatieal phrases: as, at all, at most, at least, at last, at length, at any rate, at stake, at one, of

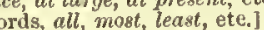

4t. With the infinitive: To.

\section{Faire gan him pray}

Minot, Poems (ed. Ritson), p. 40

Now ouly dialeetal, but common In Middle Engllsh, an the regular use in Seandinavian, to which the English us do. See ado.1

t (at), pron. and eonj. An obsolete and diaectal form of that.

t-1. [ME. at-, < AS. at-, being the prop. at, E. $a t$, in comp. with a rerb (with the accent on accent on the prefix).] A plefix of Anglo-Saxo origin, meaning at, close to, to: common in Iiddle English, but now obsolete. A relie of it properly a prefix, but is the preposition merged with its objeet. [L. at-, assimilated form of ad-before $t$ in $O F$. and $M E$. reg. reduced to $a$, later re stored to at-, as in attain, attainder, cte.] A attend, etc.

ata ${ }^{1}$ [L. $-\bar{a} t a$, fem. sing. of $-\bar{a} t u s=\mathrm{E} .-e d^{2}$ : seo $-a t 1^{1}$, and ef. -ade ${ }^{1}$.] A suffix in Now Latin (and Italian) nouns, some of which are found in English, as armata.

ata2. [L. -äta, neut. pl. of -ätus = E. $-e d^{2}:$ see $-a t c l^{1}$. A suffix in Now Latin names of zoölogieal divisions, properly adjectives, agreoing with animalia understood: as, Articulata, jo

ed animals; Annulata, ringed animals, atc. ataballe = F. attabale $=$ It. ataballo, $<\mathrm{Sp}$. ata$b a l,=$ Pg. alabale, $<$ Ar. at-tabl, $<$ ' $a l$, the, + tabl, drum: see tabor, tambour, and timbal.] A Moorish tambour.

Don John gave orders for trumpet and atabal to sound
Prescott.

atacamite (a-tak'a-mīt), n. [<Atacama + -itc ${ }^{2}$; having been first found in Atacama, a province of Chili.] A mineral consisting of the hydrated oxyehlorid of copper. It exists abundantly in some
parta of south America, as Ataeama, in Australia, near parta of South America, as Ataeama, in Australia, near Ambriz on the west eoast of Afriea, and in Arizona in the
western United States. It occurs massive, or in small prisniatic cryatals of a bright enierald-green or blaekls nillo. It alao appears on eopper long exposed to the air or gea-water.

atactic (a-tak'tik), a. [< Gr. àraктos, without

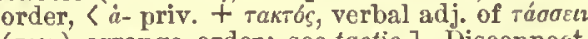
$(\tau a \gamma-)$, arrange, order: see tactic.] Disconnect ed; without arrangement or order: in gram. [Rare.]

Poreelaln Iragea of "Josh" will find niches in Protes tant meeting-houses; New England aneestral tahleta will be inseribed in perpendieular eolumus of atactic charac

at-aftert, prep. [ME., $<a t+a f t e r$.$] After.$

At-after aoper fille they in trete

Chaucer, Franklin'a Tale, 3. 492

atagas, $n$. [See attagas.] Same as attagen.

atagen, $n$. Seo attagen.

ataghan (at'a-gan), n. Same as yataghan.

atak (at'ak), n. [Native name.] The harp seal of Greenland, Pagophilus groenlandicus.

ataket, $v$. t. [ME., $<a-1+t a k e$.$] To overtake.$ At Boughton under Blee us gan atake

A. man, that elothed was in clothea blake. hetman.

Any member could be ehosen chief of his kurén, and D. M. Wallare, Russia, p. 356.

tamasco (at-a-mas'kō), n. [Amer. Ind.] An amaryllidaceous bulbous plant, Zephyranthes Atamasco, of the southern United States, with a low scape bearing a single white, lily-like flower. atamasco-lily (at-a-mas'kö-lil/ij), n. Same as atomasco.

taraxia (at-a-rak'si-ą), n. [< Gr. áapa Fia,

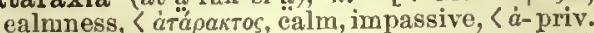

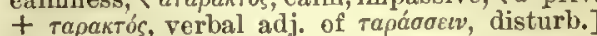
Freedom from the passions; ealmness of mind stoieal indifference: a term used by the Stoics and Skepties.

Thelr utoraxia and freedom from passionate disturbGotans's Ataraxia is supreme and utter immolnty. quietism which determines nothing, denle

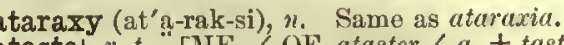
tastet, $v . t$. [ME., < OF. atrister, $<$ ataunt (a-tânt'), ad'. [<ME. a taunt, atount, < OF. autant, altant (mod. F. autant), as much, so much, $<a l$, another (thing) (<L. aliud, neut of alius, other), + tant, so much, < L. tantum, neut. of tantus, so mueh.] 1†. As much as possible.

A dronglew [var. dronken] fole that sparythe for no disTo drynk et-taunte til he slepe at tahille. Naut., with all sails set; fully rigged.-All with all the upper masts and y ards aloft.

ataunto (a-tân'tō), adv. Same as ataunt, 2 atavic (a-tav'ik), a. [= F.atarique; < L. atavus (see atavism) + -ic.] Pertaining to atavism; charaeterized by or exhibiting atavism; re-

versionary. atavism (at'a-vizm), n. $[=\mathbf{F}$. atarisne, < L. atavus, a great-grandfather's grandfather, an origin, + avus, a grandfather) $+-i s m$.$] . In$ biol. reversion, through the influence of hercdity, to ancestral eharacters; resemblance exhibited by a given organism to some remote ncestor: the return to an early or original type by its modified deseendants; restoration f structural characters whieh have been lost or obscured. Atavism, to some slight exteht, is witnesaed In the human race, when ehildren exhibit some peeuliarity has skipped one or more generations.

of the $13.6 \%$ of ehildren born with eyes of other than the parental eolor, a part must be attributed to atavism,
that ia, to internittent heredity.
Science, IV, 367 . 2. In pathol, the recurrence of any peculiarity or disease of an ancestor in remote generations. ic. Pertaining to or charaeterized by atavism;

Theoretieally we may decompose that force which determines linman actions and, through them, social phenomena, Into ita two component forees, the social and the
rtavistic intluenee.
$N . A . R e v ., C X X .275$. atavistically (at-a-vis'ti-kal-i), adv. In an atavistic manner; in atavistic examples.

But, after the lapse of thonsands of years, the fuslona are incounplete, and the aneient types crop out atavisti. ataxaphasia (a-tak-sa-fā'ziä), $n$. [NI., irreg.

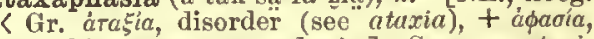
speechlessness : see aphasia.] Samo as ataxic apllasia. Seo aphasia.

ataxia (a-tak'si-ä), n. [NL. < Gr. àra $\xi^{\prime} a$, dis-

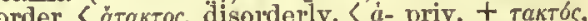
verbal adj. of táacciv, order, arrange: see tactic.] In pathol., irregularity in the functions of the body or in the eourse of a disease; specifically, inability to coördinate voluntary movements. Also ataxy.-Frtedrich's ataxia, a form of ataxia naually affecting zeveral members of a fainfly and developing at an early age. Usually it begins in the legs and extends to the armis, is aeeomylanied with jerky movements of the head, disturbanee of articulation, oss of knec-jerk, and is eharacterized anatomically by Also ealled hereditary ataxia. - Locomotor ataxia, a disease eharacterized elinleally by want of power to eoör dinate voluntary movementa, by violent ahooting palns, espeeially in the legs, absenee of knee-jerk, atrophy of the optic nerve, parnesthesia and anesthesia in certain parts,
dysuria, and functional sexual disorders; anatomieally, by a aclerosis of the postero-external columna of the
apinal called progressive locomotor ataxia and apinal eord. nothing. J. Owen, Evenings with Skeptiea, I. 416

But now is tyme that thou drynke and atast[e] gome softe 
ataxic (a-tak'sik), a. $[<$ ataxia $+-i c$.$] In$ pathol, of or pertaining to ataxia; elaraeter irregular.

Soon ataxic nervolis symptoms declared themseives.

Ataxic aphasia. Sec apharia - Ataxde fever, a tem applicd by l'inel to fevers at tenicul with great weakness.

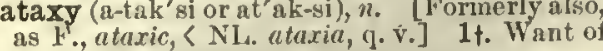
order; disturbance.

Three ways of clurch government 1 lave lienril of, and no niore; the Fpiscopal, the J'resbyterin, nut that new-

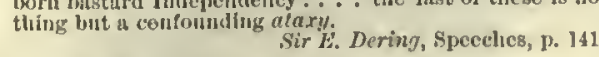

2. In pathol., same as ataxia.

2. In pathol, same as atasir, atucir, < Ar. "at-

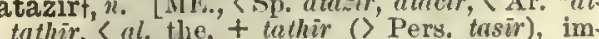
pression, effeet, intluenee, < athara, leave mark, athar, ethr, a nark, traee, footstep.] In as trol, aceording to modern authorities, the (evil) influenee of a star upon other stars or men. But the Arabian astroluger Iraly distinetly states (Comment. on Ptolemy's Opus Quadripartitum, lii. 10) that it menr
the direetion of hiyleg. Ihis, necording to the nethod of the direction of hiyleg. This, according to the

\section{Infortunat ascendent tortuons,}

of which the lord is helpless fsile, allas

Out of his angle into the derkest hous

Chaucer, IIan of Law's Tale, 1. 172. (Skeat.)

atche (at'ehe), n. [Turk. aqcha: see under asper2.] A small Turkish coin, somewhat loss than a eont in value.

atchison (aeh'i-son), n. [Se.; also spelled ntcheson; ' Atchison, a Se. form of Athinson, name of an Englishman wlio was master of the Seottish mint in the reign of James VI. (James I. of England).] A billon coin, or rather a eopper coin washed with silver, struck in Seotland in the reign of James VI., of the value of eight pennies Scots, or two thirds of an English penny. Jamicson.

atchorn, $n$. An obsolete or dialectal form of acorn.

ate $^{1}$ (et or āt). Preterit of cat.

Ate $^{2}\left(\bar{a}^{\prime} \mathrm{t} \overline{\mathrm{e}}\right), n$. [<Gr. 'A $\tau \eta$, a personifieation of ¿่Ty, infatuation, reekless impulse, siu, ruiu,

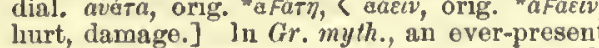
evil genius leading men on to erime; the goddess of blundering misehief; a personifieation of the reekless blindness and moral distortion inflicted by the gods in retribution for presumption and wickedness, typifying the selfperpetuating nature of evil.

-ate. [ME. reg. - at, $<$ OF, -at, a later "learned"

form of vernaeular $-e(-\dot{e})$, fem. $-e c(-b c)$, = Sp. Pg. -ado, fom. -ada, =It. -ato, fem. -ata, < L. -ätus, fem. -ātu, neut. -ätum (stem -āto-), pp. and adj. suffix, being -tu-s (= Gr. $\left.-\tau 0-s=\mathbf{E} .-l^{2},-c d^{2}\right)$, added to stem of verbs in $-\bar{a}-r c$ (It. -are, Sp. Pg. -ado,-ato, $-c c,-1$, ete. Latin adjectives and partieiples in -atus were usable as nouns, in mase. of persons, as lcgätus, one deputed, a legate, ML. prolatus, one preferred, a prelate, ete., in neut. of things, as mandatum, a thing eommanded, a mandate, ote. Seo $-a t c^{2}$ and -ate 3 .] A suffix of Latin origin: ( $a$ ) In adjeetives, where $-e d^{2},-d^{2},-t^{2}$, in perfeet partieiples and partieipial adjeetives, the native Fnglish suffix being often added to -ate when a verb in $-a t e^{2}$ exists, as in desalate or desolat-ed, accumulate or accumulat-ed, situate or situat-ed, ote. In many In. stances the adjectlve is not aecompanled by s verb In -ate,
as innate, ornate, temperate, ete.; this is especialiy true of botanical descriptives, ns acuminate cremate, curpidate, sons, as legatc, dclegate, rcprobate, ete. or of things, as mandate, precipitate, etc.; espeeially, in chem., in nouns denoting a salt formed by the action of an acid on a base, as in acetate, nitrate, sulphate, etc., the suffix being added to the stem (often shortened) of the name of the aeid. The corresponding New Latin ferms are acetatum, nitra. tum, sulphatum, etc., hut eften erroneously astas, nitras, ate?. [L. -älus, -àta, -ätum, pp. suflix of verbs in -ä-re (see -atcl), with supine in -atum (stem $-\bar{a} t u-)$, to which, instead of the pp. stem, such verbs are often referred. In this dietionary E. verbs in -ate (and so verbs in -etc, -ite) are reg. reforred to the L. pp. -atus (-etus, -itus), reg. reforred to the L. pp. -atus (-etus, -itus), formed aecording to the L. pp. stem, though with the foree of the inf. From L. partieiples
in -tus $(-\bar{a}-t u s$, of the 1st conjugation, $-\bar{e}-t u s$, $-i$-tus, of the $2 \mathrm{~d},-t u s,-s u s$, of the $3 \mathrm{~d},-i-t u s$, of the 4tli), and from thenee-fomed frequentatives, whiel beeame very 11 merous in $\mathrm{LL}$. and
ML., arose many verbs in $\mathrm{OF}$. and $\mathrm{Nll}$.., based, or appar. based, on I. participles, coineiding thus witl adjectives and nouns from sucl participles. These, with verbs of other origin agreeing in form with adjeetives, have made it a rule in E. that any adj. may bo male a verb; henee adjectives in -ate aro usually aceompanied by a verb in atc at and new verbs from $L$. verbs of a verb in -atc $c^{2}$, and new verbs from $L_{\text {. verbs of }}$ whether a corresponding adj. oxists or not and $-a t e^{2}$, as a recognized verb-formative, may be suffixed to other stems of any origin, as in felicitate, capacitate, substantiate, assassmate, camphorate, ete., based on felicity, capacity, substance, ete, of Latin origin, assatsin, caniphor, anee of verbs in ate over adjectives in -ate sueb verbs are in this dietionary placed before the adjectives, even when the adjeetives are of earlier date.] A suffix of Latin origin, a common formative in verbs taken from the Latin, as in accumulatc, imitatc, militate, ete., or formed in English, cither on Iutin stems, as in felicitate, capacitatc, ete., or on stems of other oritate, cupacitatc, ete.,

gin. See etymology. form of vernacular $-e(-\dot{e})$ (as in duche, E. duch-y, q. v.), = Sp. Pg. -ado = It. -ato, $<\mathrm{L}$. - -atus (stem -atu-), forming nouns of the 4th deelension from nouns, but formed as if from verbs in $-\bar{a}-r e$, with suffix -tu-, parallel with -to-, suffix of $p$ p. (henee the similarity to pp. -ätus, E. -atel, q. v.), as in consulätus, magisträtus, pontificātus, senātus, LI. cpiscopatus, ete., with senses as in eorresponding E. words.] A suffix of Latin origin, denating offiee, an offiee, a body of of fieers, as in consulate, pontificute, decemvirate, scnate (Latin scnätus, from sencx, an old man), episcopatc, etc., and sometimes a single offieer, as magistrate (Latin magistrātus, properly magistraey, also a magistrate), the suffix in the las use being cquivalent to -ate 1 in legate, otc., and to -ate 4 in primate, ote.

-ate ${ }^{4}$. [< L. -as (-at), as in magnas (gen. magno tis) (parallel to magnatus), primas (prop. adj.) alent to $-a t e 1$ in nouns, and $-a t e^{3}$ (in magistrate) as in magnate, primatc, and (in Latin plural

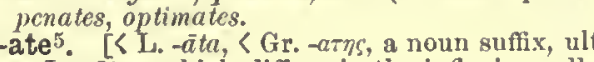
$=\mathrm{L}_{\mathrm{i}}-$ atus, which differs in the inflexive syll ble.] A suffix of Greek origin, oeeurring umfelt in pirate (which see).

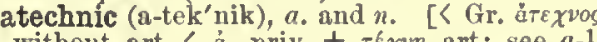
without art, $<-$ priv, $+\tau \varepsilon \chi \nu \eta$, art: see a-1 edge, especially of art.

II. $n$. A person without technieal knowledge II. $n$. A person

In every fine srt there is minch which fo illegible by
atechnics, and this is due to the habits of linterpretation
into whlch artists always fall.
North British Rev.

atechnical (a-tek'ni-kal), a. Free from toehniality; popular: as, atechnical treatment of teehnieal subject.

atechny (a-tek'ni), n. $[=\mathbf{F}$. atechnic, < Gr. art; unskilfulness. $N . E, D$.

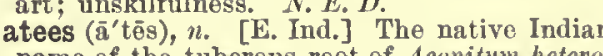
name of the tuberous root of Aconitum heterophyllum, whieh is used as an antiperiodie an a tonic. In some sections the same name is give

atef (ätef), n. [Egypt.] Father: an aneient Egyptian title and component of proper names. Also written atf.-Atef-crown, in Elyypt. antiq., s symbolie hesd. dress unlformly borne by the deities
Klnum snd Osiris, sometimes by other gods, sueh as Sebek, Thoth assumed by kings, ss the Rameses. It censisted regularly of the tsl conical white cnp of upper Egypt, plumes, and having the solar disk and urseus in front, and was prol ably emblemstic of the sovereignty light, truth, and divinity. The conleal cap is sometimes omitted in works of srt. The atef is eften mentioned in the "llook of the Desd, and is frequently represented

ategart, $n$. See atgar.

telectasis (at-e-lek'ta-sis)

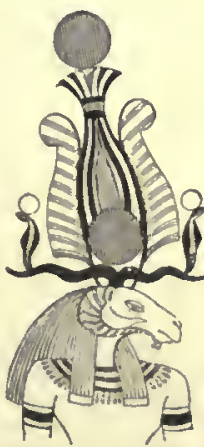

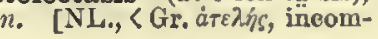

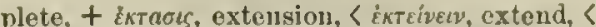
$\kappa, \dot{\xi}$, out + reivet, stretch, $=$ L. cxtendere: sec extoni.] Imporfect dilatation. especially of the air-eells of the luugs of newly born elildren. There is a cluss of cases in which a clild is buru slive, hut Its lungs remain in the foctal condition, $i_{\text {. }}$, they present no suluegrance of having received air by the act
of breathing. 'These nre cases of atclectasis. atelectatic (at"e-lek-tat'ik), $a$. [< atclcctisi $(-t a t)+-i c$.$] Pertaining to or charaeterized$ by ateleetasis.

ateleocephalous (a-tel" $\left.\overline{\mathrm{c}}-\overline{\mathrm{o}}-\mathrm{sef}^{\prime} \mathrm{n}-\mathrm{lus}\right), a$. [<Gr.

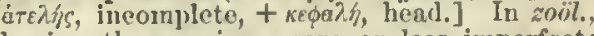
having the eranium more or less imperfet: sajd of eertain fishes: opposed to teleocephalons. ateleopodid (a-tel-ê-op ô-did), $n$. A fish of the family A telcopodidic.

Ateleopodidæ (a-tel"ē-0-pod'i-alè), n. pl. [NL. $<$ Ateleopus $(-$ pod -$)+$-ide.] $\Lambda$ family of teleoeephalous fishes, represented by the genus Atclcopus. It is cliaracterized by an elongnted tail, ts]erIng backward lut provided with \& parrow camial tin, sntemedlan anus, moderate suborbitals, Inferior month, thoracic ventral fins reduced to donble or slmple filnment, a short anterior corsal fin only, and a lung anal fin con-

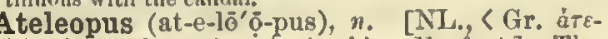

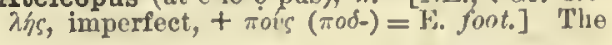

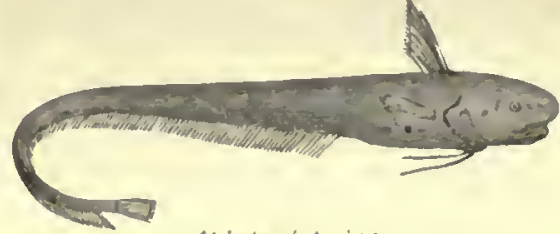

typieal genus of fishes of the family Atelcopoateleost (a-tel'- -0 -ot), $n$. A fisl of the subelass Atelcostei.

Ateleostei (a-tel-ē-os'tēe-1), n.pl. [NL., < Gr

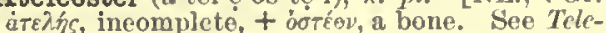
ostei.] $\Lambda$ subelass of fishes contrasting with the Teleostci and distinguished by the reduction of the bones of the skull and branehial skeleton, proposed for the order Lyonicri.

ateleosteous (a-tel-ệ-os'tẹ̄-us), $a$. Pertaining to or having the eharaeters of the Atelcostei.

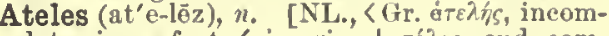
plete, imperfeet, $<$ - - priv. $+\tau k$ es, end, completion.] A genus of Ameriean platyrrine
monkeys, of the family Cebide and subfamily Cebina; the spider-monkeys or sapajons, with attenuate bodies, very long slender limbs, and long powerfully prehensile tails : so ealled beeause the thumb is rudimentary. There are seversl species, smoug them the northermmost represents-
tives of the Quedrumana in America. Also called Atelo. atelier (at-e-lyā'), n. [F.. formerly attclier, hastelier; of disputed origiu.] A workshop; specifically, the

Modern seulptors . . too often cxecute colnssil works wholly different from those of the site for which the statue ateline (at'e-lin), n. [<G1. árcins, imperfeet, $+-i n c^{2}$.] An oxyehlorid of eopper allied to from the alteration of the copper oxid tenorite.

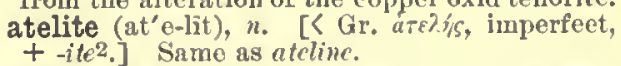
Atellan (a-tel' an), $a$. and $n . \quad[<$ L. Atellamus, pertaining to Atclla, an ancient town of the Osei, in Campania; hence fabula (or fabclla) taining to or resembling in eharneter the farces or dramas called fabute Atcllame; fareieal; ribald. See II. Also spelled Atellune.

Their... Atellen way of wit. high conedy and its parody. ... They were not performed by regular actors (histriones), but by leman citi-

II. $n .1$. One of a elass of farees or dramatic pieces (fabule Atollane) in vogue among the ancient Osei, and early introdueed into Kome. The personages of these pieces were slways the same, and
the wit was very broad. It is probable that their perthe wit was very brosd. It is probuble that their per-
petuation in rural districts was tise origin of l'unchinello 2. A satirieal or licentions drama : as, "Atellans and laseivious songs," Burton, Anat. of Mel., p. 425 .

Atellane (a-tel'ān), a. Same as Atellan. 
atelocardia (at"e-lō-kär'di-ä), n. [NL., < Gr. athalline (a-thal'in), a. [< Gr. $\dot{a}$ - priv. + tol., imperfect develepment of the heart.

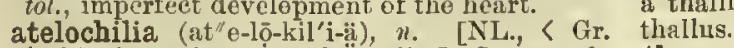

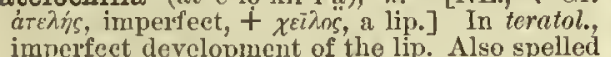
imperfect deverilia.

Atelochirus (at" e-lō-kī'rus), $n_{\text {. }}[\mathrm{NL}$., $<\mathrm{Gr}$. $\dot{\alpha} \tau \varepsilon \dot{\lambda} y_{s}$, imperfect, $+x \varepsilon i \rho$, hand.] Same as Ateles. Also spelled Ateloeheirus.

atelo-encephalia (at " $\left.\theta-1 \bar{e}-\mathrm{en}-\mathrm{se}-\mathrm{f} \mathrm{f}^{\prime} \mathrm{li}-\mathrm{ii}\right), n$.

athamantin (ath-a-man'tin), $n . \quad[<$ Athumanta (see def.) $+-i n^{2}, j$ In ehem, a substance $\left(\mathrm{C}_{24}\right.$ $\mathrm{H}_{30} \mathrm{O}_{7}$ ) produced from the root and seeds of of the same genus of European and Asiatic umbelliferons lierbs. It has a raneid soapy odor atelo-encephalia (at "e-lo-en-se-fáli-ii), $n$. and a slightly bitter acrid taste. H. Watt. brain: see eneephalon.] In teratol., imperfect development of the enecphalen.

ateloglossia (at" c-lộ-glos'i-în), n. [NL., < Gr. athamauntt, $n_{0}$. An old forin of addamant. immortality (> ML. athancesia, tansy), < $\dot{\alpha} \theta \dot{a}-$
im

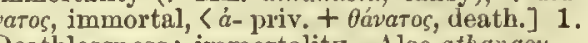
$\dot{a} \tau \hat{\lambda} \eta \bar{c}$, imperfeet, $+\gamma^{2} \bar{\omega} \sigma \sigma$, tongue.] In tera- Deathlessness; immortality. Also athanasy. tol., imperfeet development of the tongue.

atelognathia (at"e-log-nā'thi-în), n. [NL.,

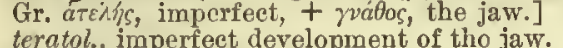
atelomyelia (at" $\left.\mathrm{e}-\mathrm{l} \overline{\mathrm{o}}-\mathrm{m} \mathrm{i}-\overline{\mathrm{e}}^{\prime} \mathrm{li}-\mathrm{i}\right), n$. $n$ [NL. $<\mathrm{Gr}$. atrelomys imperfect, $+\mu v \varepsilon \lambda \delta s$, marrow.] In tero

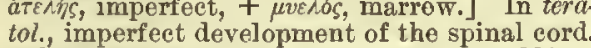
ateloprosopia (at ${ }^{\prime \prime}$-lōopro-sō'pi-äi), n. [NL.,

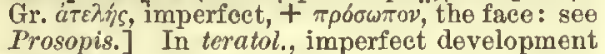
of the face.

atelorachidia (at" $\theta-10$-ra-kid'i-ä), n. [NL., <

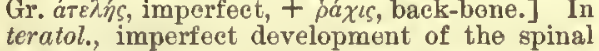
teratol.,

Atelornis (at-e-lôr'nis), $n_{0}$ [NL., < Gr. á $\tau \varepsilon \lambda \eta \zeta$, imperfeet, + opvis, bird.] A genus of Madagascan ground-rollers, family Coraciide and subfamily Brachypteraciince. A. pittoides is a typical speeies, of gor

noeturnal habits.

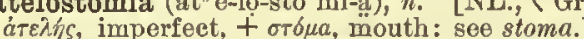
In teratol, imperfeet development of the mouth. a tempo, a tempo primo (ä tem'pọ, prếmộ). [It., lit. to time, to the first time: a, <L. ad, to;
tempo, < L. tempus, time (see tempo) p primo L. primus, first: see prime.] In musie, a direction, after any change of movement, as by acceleration or rotardation, that the original timo be restored. See a battuta.

a tempo giusto (ä tem'pọ̄ jös'tộ). [It., lit. to just time: a tempo (see a tempo); giusto, <L. justus, just: see just ${ }^{1}$.] In music, a direction to sing or play in an equal, jnst, or strict time It is seldom used except when the time has been inter.
rupted, as during a recitative, to suit the action and pas.

Ateuchus (a-tī'kns), $n$. [NL., lit. without ar mor, in allusion to the absence of a seutellum,

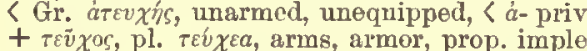
ments, S Tev Xevv, make, produce.] A genus of lamellieorn beetles, of the family Searabaide.

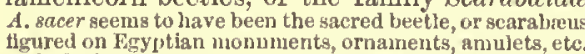
and oi which a tigure, either in porcelain or earved out of
stone, rarely a gen, was placed in the bosom of every stoue, rarely a gein, was placed in the bosom of
mummy, as a symbol of aud prayer for resurrection. atf (ätf), $n$. Same as atef?.

atgart, $n$. [Also improp. ategar, repr. AS. at-

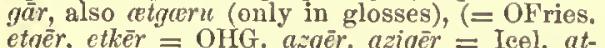
geirr), a spear, < (tet-, appar, the prep. at, at + gär, a spear: see garr, garfish, gore 2 .] A kind of spear or lance formerly in nse.

Athabaskan (atll-a-bas'kan), $a$, and $n$. I. $a$ Belenging to a certain great family of Nerth pying a vast extent of country south frem the Eskimo region, between Hudson's Bay and the Roeky Mountains, with outlying members also west of the monntains, as far sonth

II. $n . \mathrm{A}$ member or the language of this family.

Also spelled Athabasean, Athapaskan.

athalamous (a-thal'a-mus), $a$.

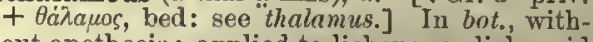
out apothecia: applied to lichens, or liehenoid growths, the fruetification of which is unknown. Athalia (a-thā'li-ị̂), n. [NL., named with allusion to the devastation produced by its larve, $\langle$ Gr. $\dot{a} \theta a \lambda \hat{n} \zeta$ or $\dot{a} \theta a \dot{\lambda} \lambda \dot{\eta} \zeta$, not verdant, withered, $\langle\dot{\alpha}$-priv. $+\theta \dot{a} \lambda \lambda \varepsilon \nu \nu$, be fresh or luxuriant.] A genus of saw-flies, or Terebrantia, of the orde spinaruin or $A$, centifolia is the turnitip saw-fly of E.
whose larve occasionally devastate turnip-fields.

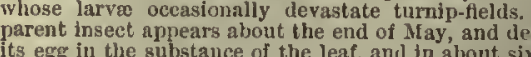
Its egg in the substance of the leaf, and in abont six day
the larve are hatehed. Within a few days the vegetation
on which they appear is laid whaste by their eating the sol 2t. The herb tansy. See tansy.

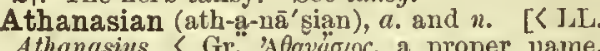
Athanasius, ( Gr. AAaväros, a proper name, abavaros, immortal.] 1. a. Pertaining to andria.-Athanasian creed, a creed formerly ascribed to Athanasius, but whose real authorship is unk unownibed opposed to Arianism) and of the incarnation, and contans what are known as the "damnatory clauses" in the concluding formulas of the two parts, viz. "Whosoever will be saved, before all things it is necessary that he should
hold the catholic faith; whtelh faith, except every one do keep whole and undeflied, without doubt he shall perlsh verlastingly"; and "Thls is the catholic fiath; which ex
cept a man believe faithfully he cannot be saved." Thi creed is retained in the service of the Clurech of En
but not in that of the American Eniscopal Church

II. $n$. A follower of Athanasius or a believer $n$ his ereed.

Athanasianism (ath-a-nā'siạn-izm), n. [< Athanasian $+-i s m$.$] . The prin$

Athanasianist (ath-a-nã' gian-ist), $u . \quad[<A$ the nasian $+-i s t$.] An Äthanasian.

athanasy (a-than'a-si), n. Same as a thanasia, 1 Time l,rings to chscure anthors an odd kind of repara.
tion, an immortallty not of love and interest and admira. tion, but of euriosity merely. . . Is not then a scholas.
tic $a$ tharuery better than none? Louell, Study Windows, p. 346 athanor (ath'a-nôr), $n$. [Late ME. also athenor for conveying water, $<$ Ar. at-tannür, $<a l$, the + tannur, <Heb. or Aramaic tannur, an oven or furnace, $\langle n \bar{u} r$, fire.] A self-feeding digesting firnace formerly used by alehemists. It was o made as to maintain a uniform and durable heat.

Athecata (ath-ē-kā'tä), $n_{0} p l$. [NL., neut. pl. of athecatus, not sheathed: see athecate.] A which are not sheathed, that is, have no gonangia and no hydrothecs: a synonym of rymnobiastea (which see)

(ath' $\bar{e}-k \bar{t} t)$, a. [<NL. atheeatus, < Gr. $a$-priv. + $0 \hat{\eta} \kappa \eta$, a sheath: see theea.] Not
sheathed; specifically, of or pertaining to the Atheeata.

atheism (a'thẹ-izm), n. $[=$ F. cthéisme $=P g$ atheismo $=\mathrm{Sp}$. It. ateismo, ( NL. "utheismus, Gr. $a \dot{\theta} \varepsilon a s$, withont a god, denying the gods, $\langle\dot{a}$ was $\left.\dot{a} \theta \varepsilon \dot{\sigma} \sigma \eta \zeta_{s}.\right]$ 1. The doctrine that there is no God; denial of the existenee of God.

Atheigm is a disbelief in the existence of God-that is,
disbelief in any regularity lin the universe to which man disbelief in any regularity in the univ
must conform himself under penalties.

The denial of their that the great first cause is a supreme, intelligent, righteous person. - 3. A practical indifference to and disregard of God; godlessness IIn the first sense above given, atheism is to be discrimi and from agnosticism, which denies the possibility of pos atheist $\left(\bar{a}^{\prime}\right.$ thẹ-ist), n. and $a .[=\mathbf{F}$. atheiste $=$ Pg. atheista = Sp. It. ateista, < NL." "utheista,
〈Gr. àteos: see atheism.] I. I. 1. One who denies the existence of God, or of a supreme intelligent being.

\section{Well, nonarchies may own religion's name,
But states are atheists in theirv very frume.
Drydent, Prov. to Amboyna, 1. 22} By night an atheint half believes a God.

2. A godless man; one who disregards his duty
to God.=Syn. Shevtic, Deist, etc. See infulel. II. $a$. Godless ; atheistic: as, "the atheist crew," Milton, P. L., vi. 370.
atheistic (ā-thọ-is'tik), $a . \quad[<$

Pertaining to or charaeteristic of atheists; involving, containing, or tending to atheism: as,
atheistic doctrines or beliefs; an atheistic ten- deney.-2. Denying the existence of God; godess; impions: applied to persons: as, "athestie Gainsayers," Ray, Works of Creation.
= syn. Godlesy, Unjodly, etc. See irrelinious. atheistical (âa-thê-is'ti-kal), a. Marked by or' manifesting atheism; atheistic.

I was present, very seldom going to the publiq theaters or many reasows, now as they were ahuscd to an atheit.
Evelyn, Diary, Oct. 18, 1666 . atheistically (a- -thē-is'ti-kal-i), udv. In an theistic manner; impiously.

I entreat sucls as are atheistically inelined to consider
these tlungs these tlings

atheisticalness (ā-thẹ-is'ti-kall-nes), n. The quality of being atheistic; irreligiousness.

Purge out of alt hearts protaneness and atheisticalness.
IIamnomd, Works, I. 500 . atheize (a'thẹ̄-iz), v.; pret. and pp. atheized, pr. atheining. [〈Gr. àeos (see atheism) + -ize.] ot intrans. To discourso as an atheist.

We slall now make diligent seareh and inquiry, to see we can find any other philosophers who atheized betor Cuduorth, Infellectual System,
II. trans. To render atheistic. [Rare.]

They endeavoured to atheize one another. Bp. Berkeley, Minute Philosopher, 1 .

atheizer (à'thē-i-zèr), $n$. Ono who atheizes, or renders atheistic. Cudworth. [Rare.]

athel1 $1^{1+}, n$. [Early ME., < AS. cethelu, athelo, pl., deriv.) $=\mathrm{D}$. adel $=\mathrm{OHG}$. adal, MHG. aclel, race, family, ancestry, esp. noble ancestry, nobility, G. adel, nobility, = Icel. adhal, nature, disposition, family, origin, in comp. chief-, head(mod. also nobility, = Sw. Dan. adel, nobility, a sense due to the $\left.\mathrm{G}_{0}\right),=$ Goth. "athal (as in the proper name "Athalareiks (> ML. A thalarieus) = AS. Athelric) ; not found ontside of Teut. rimony (see ethel). In mod. E. only in proper names, historical or in actual use, of AS. or OHG. origin, as Ethel, Ethelbert, Athelbert= Albert, Ethelred, Audrey (St. Audrey, > taudry, q. v.), ete.] Race; family; ancestry; noble ancestry; nobility; honer.

Her wes Arthur the king athelen bidaled [deprived].

athel ${ }^{2}+, a$. and $n$. [ME., also ethel, cethel, and prop. athele, ethele, athele (in northern writers often hathel, ete.), $<$ AS. cethele, ethele $=\mathrm{OS}$.
edili $=$ OFries. ethel, exlel $=\mathrm{D}$. edel $=\mathrm{OHG}$.

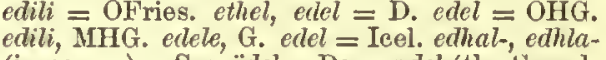
(in comp.) = Sw. ärlel = Dan. axdel (the Seand. after $G$.), noble, of noble family (from the excellent.

Lutcle children in the cradele,
Both chorles an ek athele.

II. A noble; a chief; often simply a

His hathel on hors watz thenue

Sir Gawayne and the Grene Knight (ed. Morris), 1. 2005. atheling (ath'el-ing), $n$. [In mod. use, as a historical term, also writteu eilheling and atheling, repr. ME. atheling, < AS. cetheling (= OS. edhiling $=$ OFries, etheling, elling $=\mathrm{OHG}$. adaling, ML. adalingus, adelingus $),<$ eethelu, noble family (see athell), + -ing, a patronymic suffix. The Aethelinga $\bar{q}$, lit. princes' island.] In AngloSaxon hisi.: $(a)$ A erown prince or heir apparent; one of the royal family. (b) A nobleman. originally none but Anglo-saxon princes were called or ncurest heir to the throne to which, however, lie did not necessarily succeed ; but the ferm who afterward ex-
tended to all who held noble rank. Also writtell etheling, cetheling.

An English community [A. D, 500-600] knew but two orders of men, the ccorl or the freeman, and the eorl or the
noblc. The freeman was the base of the village society. IIe was the "free-necked man," whose long hair tloated sometimes called, the village was the eorl, or, as he was

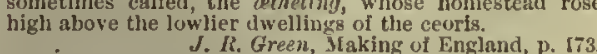
One or two rebellions are mentioned, headed by dithe lings or ment of the ruyal housc. Athena (a-thë'nä), n. Same as Athene, 1 . Athenæum, Atheneum (ath-ê-n $\left.\bar{\theta}^{\prime} u m\right), n$. [L Alhencenm, < Gr. 'Atrivacov, a temple of Athene, <'A $\theta$ inn, Athene: see Athene.] 1. A temple or a place dedieated to Athene, or Minerva; spe-
cifically, an institution founded at Rome by Hadrian for tho prometion of literary and seientifie stndics, and imitated in the provinees.- 
ern times, an institution for the encouragement athericerous (ath-ō-ris' $\theta-$-rus), $a_{0} \quad[<A$ therieera of literature and art, often possessing a library for the use of those entitled to its privileges.

Athene (a-thè'nē), n. [L., also Athena, \& Gr.

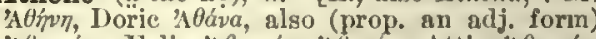

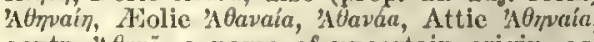
contr. A $\theta$ wä, a namo of unecrtain origin, asGr. wyth, the goddless of knowledge, arts, sei-

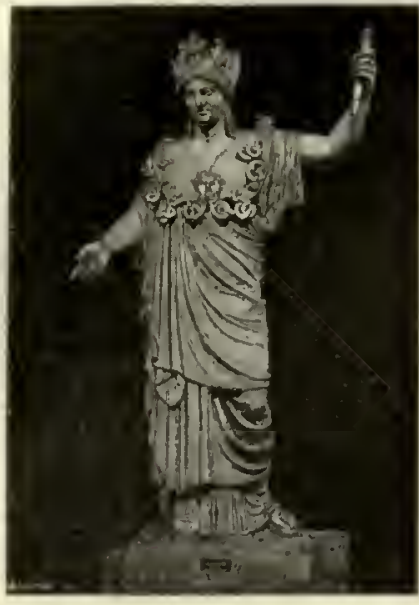

enees, and righteous war; particularly, the tute lary deity of Athens: identified by the Romans with Minerva. She personifled the clear upyer air a weil as mental clesrness and acuteness, embodyng the the agris symbolizing the dark storm,-cloud, and armed with the resistess spcar - the shaft of lightning. Also Athena. 2. [NL.] In ornith., an extensive genus of owls related to $A$, noetua of Europe, including smal earless species. The nsme is used by different suthor with grent latitude, and is not susceptible of exact definiAtheneum, $\%$. See Athenceum.

Athenian (a-the' nj-an), $a$. and $n$. [<L. as if -Athenianus, equivalent to Athenionsis, Athe na, < Gr. 'A $\theta$ inval, Athens, traditionally named after AO'mp, Athene.] I. $a$. Pertaining to Athens, anciently the metropolis of Attiea in Greece, and now the eapital of the kingdom of Greece. A native or citicen of Athens.

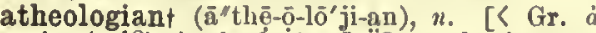
priv. $(a-18)+$ theologian.] "One who is not theologian; one who has no knowledge of theology; an iguorant theologian. They ... [the Jesnits] are the only atheolorians whose
leads entertsin no otlier object but the tunult of realms.
Sir J. Maynoard, Answer to Doleman, ix.

atheological (文"thē-ō-loj'i-kal), $a$. [< Gr. priv. $(a-18)+$ theoloyical.] Untheological; contrary to theology. In the curt a theologicat phrase of the Persian Lucretius,
one tling is cert ain, and the rcst is lies."

atheologyt (ā-thē-ol'ō-ji) $n$ [S Gis. $(n-18)$ t theology. Cf. atheous.] 1. Laek or absence of theological knowledge; opposition to theology. -2 . Atheism.

Seversl of our learned members have written many proatheoloyy seened yet wanting

atheous ( $\overline{\mathrm{a}}^{\prime}$ thē-us), a. $\quad[=\mathrm{Pg} \cdot$ atheo $=\mathrm{Sp}$. It.

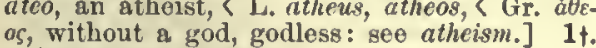
Atheistio; ungodly.

The hypocrite or atheous priest. Nilton, R. R, 1. 487. 2. Having no reference to God; irrespective of divine existence or power.

"All plysical science, properly so called, is compelled by its very nsture to take no account of the being of God eeases to be physical science." And so, colning a dis. criminating word to express this, he the Bishop of Carlislel would sny that sctence was atheous, and therefore

Athericera (ath-ē-ris'e-rii), n. $p l . \quad\left[N L_{0},\langle\mathrm{Gr}\right.$. atip $\rho$, awn or beard of ä ear of eorn, $+\kappa \varepsilon \rho a \varsigma, a$ horm.] In Latreille's system of elassification, the fifth fanily of dipterous insects, nearly equivalent to the dichotous division of brachycerous Diptera, but including the Syrplida. The division corresponded to the Linuesu geners Conops the bot-fies and drune-ties with the flies proper. [Not in athericerous (ath-ō-ris' e-rus), $a_{0}[\langle$ Atheriecr ricera.

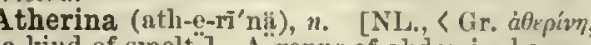
a kind of smelt.] $A$ genus of abdominal acanrinide, containing the sand-sinelts. $A$ rrestruter the common British athurine or samelesmelt, is a flsh shout 6 inclics long, used as food.

atherine (ath'e-rin), n. [< Atherinc.] A fish of the genus Atherina; a sand-smelt.

atherinid (ath-e-rin'id), n. $\Lambda$ fisll of the family Atherinida.

Atherinidæ (ath-e-rin'i-dō), n. $p$. [N $L_{.}$, Atherina + -illa.] The atherines or sancsmolts; a family of abdorninal aeanthoptery riu fishes, typified by the genus Atherina, to which varying limits havo been ascribed by different writers. In Ginther's system the Atherinide are fanily of Accuthopterygii mugiliformes, having vertclir in increased number and the dentition feeble or of moderate strength, and including the tetragonurids as wetl as
the aticrinids proper. In more recent systems they are fsnilly of Percesoces with more than 24 vertebre, cycloidin scales doral fins two in puuber and sepsebte, ayd feebl dentition. The species are mostly amall: thosc found in Anerica are known as friars, ar are confounded with the

atherinidan (ath-e-rin'i-dnn), n. A fish of the family Atherinide; an atherinid. Sir J. lieharilson.

Atherinina (ath" $\mathrm{e}-\mathrm{ri}-\mathrm{ni}$ 'nä), n. nl. [NL., Atherina + -ina. "In Günther's classifieation of fishes, the first subfamily of Atherinidt, eharacterized by feeble dentition, cyeloidal scales, the separation of the first dorsal fin from the second, the presence of an air-bladder, and the absence of pyloric appendages: sane as Athe rivida of recent systems.

atherinoid (ath'e-ri-noid), $a$. and $n$. $[<$ Atherina + -oid. $]$ I." $a$. Having the eharacters of II. $n$. A fish of the family Atherinide; an therinid.

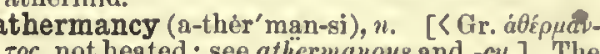
ToS, not heated: see athermanous and $-c y$.$] The$ power or property of stopping radiant heat; impermeableness to radiant heat.

sponds to opacity in the case of light.

thermanous (a-ther'ma-nus), $a_{0}$ [ $<\mathrm{Gr}$. (cf. a $\theta \dot{\varepsilon} \rho \mu a v \sigma_{\sigma}$, not heated), < $\theta \varepsilon \rho \mu$ ós, hot $(\theta \varepsilon \rho \mu \eta$, heat): see thermo-.] Impermeable to radiant heat; having the power of stopping radiant heat; opaque to heat.

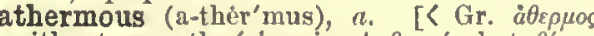
without warmth, < $a$ - priv. +

atheroma (ath-e-ró'mä), n.; pl. atheromat

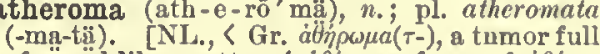
of gruel-like matter, $<\dot{a} \theta \hat{m} p \eta$, a form of á $\theta \dot{a} \rho m$ groats or meal, a porridge made therefrom.] 1 . mors, the contents of which have the appen ance of bread-sauce. -2 . The formation of thickened patehes of the inner coat of an a tery (much more rarely of a vein), eonstitutmass exhibiting fat-globules, fatty acid erystals, eholesterin, moro or less caleareous matter, ete. The endothelisl film separating tints from the

atheromatous (ath-e-rō'mg-tus), $a . \quad[<$ atheatheroma; having the qualitios of atheroma. atherome (ath'e-rōm), n. Same as atheroma. Atherura (ath-e-rö'rï), $n$. [NL., s Gr. ám $\rho$, th beard of an ear of corn, + avoá, tail. $]$ A genus of hystrieomorph rodents, of the family Hystricide; tho brush-tailed poreupines: so called because the tail ends in a peneil of flattened scaly bristles. The best-known species are A, fasci
culata, the Malacca porcupine of India, and the African A. africana. There are seversl others. Aso Atherurus.

atherure (ath'e-rör), n. [< Atherura.] brush-tailed porcupine; a species of the genus Atherura.

Atherurus (ath-e-rö'rus), $n$. Same as Alhemira.

atheticize (a-thet'i-siz), v. $t$; pret. and pp. atheticized, ppr. atheticizing. [Irreg. 〈Gradoctos,
set aside, invalid, + -ic + -ize. Cf. athetize.] set aside, invalid, $+-i c+$
Same as athetize. Bererley. tized, ppr. athetizing. [< Gr. äbcein, set aside, reject as spurious $(<\dot{a} \theta \varepsilon r o s$, set aside, invalid, without place or position, $<\dot{a}$ - priv. $+\theta \varepsilon \tau \delta \zeta$, verbal adj. of $+t-\theta t-v a l$, put, place: see thesis, ote.), +-ize.] To set aside; reject as spurious. Osmeri under the same of smelts. Also atherome.

athetize (ath'e-tiz), $v$. t.; pret. and pp. athe-

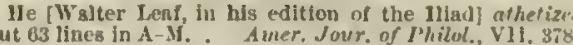
thetoid (ath'e-toid), $a$. of or resembliug athotosis: as, athetoid movements.

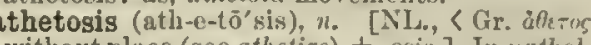
without pluee (sco athetize), + -osis.] In yathol., a condition in which the liands and feet caunot be maintained in any position in which they aro placed, but continually perform in voluntary, slow, irregular movements.

athinkt, v. impers. [IIE. athinle, reduced form of ofthinke, $\mathrm{AS}$. ofthyncan, impers. < of- + thynean, seem: see $a^{-4}$ and think.] To repent grievo.-Me athinketht, it repeuts ule.

$$
\text { Me athinketh that I schal reherce it here }
$$
athirst (ạ-thérst'), a. [< MH. athurst, also athrestc and afurst, contr. from ofthurst, of thyrst, < AS. ofthyrsted, very thirsty, pp. of of thyrstan, thirst, < of- (intensive) + thyrstan, pp. thyrsted, thirst: $\sec a_{-4}^{-4}$ and thirst, v.] 1 . hirsty; wanting drink.

When thou art athirst, go unto the vessels, and drink.

2. Figuratively, having a keen appetite or de sire.

$$
\begin{aligned}
& \text { Their bonnding liearts alike } \\
& \text { Athirst for battle. }
\end{aligned}
$$

athlete (ath'let) 11 , $<$ L athleta < Gr. Th, a combatant, contestant in the games,

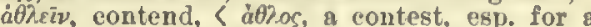
prize (neut. $2 \theta \lambda .0 v$, the prize of eontest), contr.

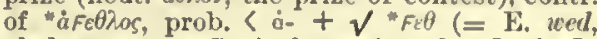
pledge: see $u e d)+$ formative $-\lambda 0$ - s.] 1. In Gr. antiq., one who contended for a prize in the public games. Hence-2. Any one trained to exereises of agility and strength; one accomand activity.

$$
\begin{aligned}
& \text { Ilere rose an athlete, strong to break or bind } \\
& \text { All force in bonds thnt ningit cndure. }
\end{aligned}
$$

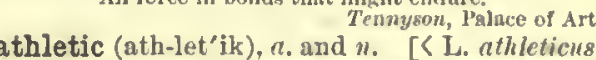

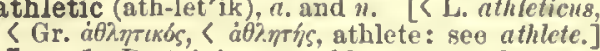

I. a. 1. Pertaining to athletes or to the exercises practised by them: as, athletic sports. Hence-2. Strong; robu That athletic somudness and vigour of constitution
which is seen in cottages, where Nature is cook and Ne-

II. $n$. An athlete. [Rare.]

rether. athleticism (ath-let'j-sizm), n. [< athletie + $-i s m$.] The act or practice of engaging in athletic exercises; devotion to athletic

athletics (ath-let'iks), n. [Plural of athletie.] The art or practice of athletic games or exercises; the system of rules or principles em-
ployed for physical training, as in lunning, ployed for physieal training, as in lunning rowing, boxing, gymnasties, ete.
athletism (ath'lê-tizm), $n_{0}[<$ athlete $+-i s m$. The character or profession of an athlet
Athole brose. See brose. Athorybia (ath-ō-rib'i-ạj), n. [NL., $<$ Gr. a priv. + type of the family Athorybi ide. A. rosacea inhabits the Meditertanean.

Athorybiadæ (ath" "ō-ri-bi'a dē), $u . p l$. Same as Athorybiine. thorybiidæ (atlı"ô-ri-bi'ide), n.pl. [NL., (Athorybia sophorous oceanie Hydrozoa, of the order Siphonophorn. having a bundle of hydro- preumatoph ming-column, and resembling a larval stage of some other Physophora.

athreet, prep. phr. as adv. [ME., also a thre; athrepsia (a-threp'si-ä) par. Chucer. priv. + $\theta \rho \varepsilon \dot{\psi} \iota \varsigma$, nourishment, < $\tau \rho \varepsilon \phi \varepsilon v$, nourish.] In pathol., a profound disturbance of nutrition in children, due to negleet of hygiene and insufficient or improper food.

athrob (a-throb $)^{\prime}$, prep. phr. as $a d v$ or $a$. [< $a^{3}$
+ throb.] ln or into a throbbing or palpitating state or manner; throbbing.

[Lansuagel is a mere dead hody without a soul till some nun of genius set its arrcsted pulses once more athrob.
Lovell, Study Wtudows, p. 258 .

thwart (a-thwârt), prep. phr. as ndv. and prep. [Early mod. E. also athirt, Sc. athourt, athort, 


\section{athwart}

364

[MIE. athwart; $<a^{3}+$ thwart. Cf. orerthwart.] I. reln. 1. Crosswise; from side to side; transversely.

IIe crus'd to he drawn out and pav'd fonr main roads others atherert. 2. In opposition to the proper or expected course; in a manner to cross and perpl
crossly; wrongly; wrongfully. [Rare.]

The baby beats the nurse, and quite athwart
Goes all decorum.
Shak., M. for II., t. 4.

II. prep. 1. Across; from side to side of.

A jine,
Rock-rooted, stretched athvart the vacancy

Rock-rooted, stretched athwart the vacancy
Its swinging boughs.
Shelley, Alastor.

The Fosse Way was one of the two great lines of comminnication which ran $a$ thruart Britain from the northeast to Taut, acress the line of a ship's course.3. In opposition to; against; contrary to.

I have seen this present work, snd flnd nothing athwart the Catholick faith and good manners. Athwart hawse, said of a ship when she lies or sails across
tance.

We soon saw two sails to windward, going directly

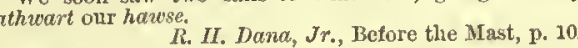
Athwart the forefoot, said of the flight of a cannon ball fired across a ship's

athwartships (a-thwârt'ships), prep. phr. as adv. [< altwwart + ship + adr. gen. suffix $-s$.] Athwart the ship; erosswise of the ship.

The foretopsail, which had been double reefed, split in two athwartships, just below the reef-band, from earing
to earing.
R. II. Dana, Jr., Before the MIast, p. 254 athymiat (a-thim' i-ä), n. [<Gr. áavuía, want of courage or spirit, $<$ a $\theta v \mu s$, wanting courage or spirit, $<\dot{a}$-priv. + ovuós, courage, spirit, breath [ $\theta$ íru, rush, rage, be eager.] Lowness of spirits: despondeney; melancholy.

-atic ${ }^{1}$. [ $[\langle\mathrm{F}$. -atique (vernacularly-age, $\rangle \mathrm{E} .-a g c$ q. v.) $=$ Sp. Pg. It. -atico, < L. -aticus, a com-
pound adj. suffix, being -ic-us, E. $-i c$, suffixed to a pp. stem in -at-: sce $-a t e^{1},-i c$, and -agc. A compound suffix of some adjectives of Lati origin, as aquatic, erratic, lymplatic, ete., some of which are also used as nouns, as fancer

- atic $^{2}$. [ $\mathrm{F}$. -atique $=\mathrm{Sp}$. Pg. It. -atieo, < I -aticus, $<\mathrm{Gr} .-a \tau-\imath \kappa-b \varsigma$, being $-\iota \kappa-\sigma \varsigma$, E. $-i c$, suffixed to a noun stom in -aT-, nom. $-a$, or $-a \rho$, or $-a \tau-\eta 75$ of adjectives taken from or formed after Greek, as grammatic, hepatic, pneumatic, some accompanying English nouns in $-m a$ or $-m$, as dre matic, problematie, ete., or in -ate 5 , as piratic otc. [M [ 0 ost adjectives of this termination, and also son ending in -aticl, may take (often preferably) the addition
al syllable - al, with very slight if any change of meaning. -atile. $\left[=\mathrm{F} .-a t i l e,\left\langle\mathrm{~L}_{\text {. }}-\bar{a}\right.\right.$ tilis, a compound adj. suffix, being -ilis, E. -ite or -le, suffixed to a pp. stem in -at-: see $-a t e^{1}$ and -ile.] A suffix of fluviatile, ets.

atilt (a-tilt'), prep. phr. as $a d t$. or $a . \quad\left[<a^{3}+\right.$ tilt 1 , $\left.\varkappa_{0}.\right]$ 1. 'Tilted up; set on tilt, literally or figuratively.

Speak; if not, this stand
Of roygl blood shall be albroach, atilt, snd run
Even to the lees of houour.
Beau, and Fl. Plilaster, The little bird sits at his door in the sun,
Atilt like a blossont smong the leaves.

2. In the manner of a tilter; in the position or with the action of a man making a thrust: as, to ride or run atilt.

atimy (at'i-mi), n. [<Gr. ácı́ía, disgrace, loss of civil rights, dishonor, $\ \dot{a} \tau \iota \mu$ os, dishonored, deprived of eivil rights, $<a$-priv. $+\tau \iota h$, honor,
$\tau i \varepsilon v$, honor.] In $G r$. antiq., disgrace; suspension of the civil rights of a person in punfranchisement; degradation. It was perpetual and total (sometimes hereditary), or temporary, or partial and
affecting only certain privileges of the citizen. It often in-ation. $[<\mathrm{F}$, -ation $=\mathrm{Sp}$, -acion $=\mathrm{Pg}$. -ação $=\mathrm{lt}$. -azione, < L. -ātios $n-$, acc. -ätiōnem, being -tio(n-), E. -tion, q. v., suffixed to the stem of verbs in $-\bar{a}-r e$, or, in other words, $-i o(n-)$, E. -ion, suffixed to the pp. stem -ät-, E. -atel, of verbs in $-\bar{a}-r e$ : see-tion, -ion, and -ate 1 . The reg. OF. form of this suffix was -aisun, -eisun, later -aison, etc. (later restored -ation, ME. -ation, -esun, etc., which exists, unrecognized, in oriSometimes writ tez), n. pl. [<Gr. Atlantëan, son, venison, which have differentiated doublets in oration, venation (obs.).] A suffix of Latin origin, oceurring in nouns of action, ete. These nouns are properly ahstract nonns equivalent to the Latin, as citation, commendation, creation, education liberation, etc., and formed in Iatin (commendetio, etc.) from the verbs represcnted in English either by forms without suffix (from the Latin infinitive), as cite, commend, etc., or by forms in -ate (from the Latin perfect particlple), as creatc, educate, liberate; or (b) formed in modern speech, whether from verbs without suffix, as in fixation,
quotation, etc., from fix, quote, etc., or from verbs in -ate, quotation, etc., from fix, quote, etc., or from verbs in -ate,
as concentration, desiccation, from concentrate, desiccate, etc., or from verbs of non-Latin origin, as starvation, firtation, these being the earlicst formations (in the middie of the cightecnth century) in ation from verbs of native origin (starve, flirt). Some words in ation have no
accompanying verb in English, as constellation, lunation, negation, ete.

atious. [<-ati(on) + -ous, like-itious, <-iti(on) + -ous.] A compound adjective suffix, consisting of -ous added to a redueed form of -ation, and serving to form adjoctives from nouns

tion.

atiptoe (a-tip'tō), prep. phr. as adx. or $a . \quad[<$ $a^{3}+$ tiptoe.] 1. On tiptoe. - 2. Figurativel in a state of high expectation or eagerness.

ative. $[=\mathrm{F}$-atif, fem. -ative, < L. $-\bar{a}$-ivus,
being-ivus, E. -ive, suffixed to the pp. stem in being-ivus, E. -ive, suffixed to the pp. stem in suffix of Latin origin, consisting of -ive added to the stem represented by -ate 2 , and accompanying verbs with suffix -ate ${ }^{2}$, as in demonstrative, relative, ete., from demonstrate, rclate, ete., or verbs without a suffix, as in laudative, ete. verbs without a suffx, as in lanthout corresponding verbs in English, as in amative, horlative, lucrative, etc. : especially frequent in grammatical terms, as in vocative, locative, ablative, ete., all used also as nouns. It Is also found in a few other nouns, as in prerogative, donative. It is added tive, and used in colloquin or or slang expressions like go ahead-ative. English formations in ative, from verbs th

Atlanta (at-lan'tä), n. [NI., < I. Atlanticus, Atlantic: see Attantic, a.] A genus of molthe twisted visceral sac inclosed in a dextral spiral shell, and the foot provided with an oper culum. A. peroni is a Mediterranean species. atlantad (at-ada.] In anat., toward the atlas, or the upper part of the body.

atlantal (at-lan'tal), a. [< NL. atlantalis, atlas $1,3, q . \vee$.$] In anat., of or pertaining to th$ atlas. - Atlantal foramen (forsmen atlantale), a hole the transmission of the suboccipital nerve and vertebral (1)

Atlantean (at-lan-tē'an), a. [< L. Atlanteus, Gr. 'A $\tau \lambda$ ávтcios, pertaining to "A $\tau \lambda a s$, Atlas; 'A

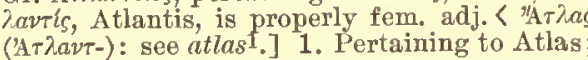
resembling Atlas.

$$
\begin{aligned}
& \text { Sage he stood, } \\
& \text { With Atlantean shonlders, fit to bear } \\
& \text { The weight of mightiest monarchies. }
\end{aligned}
$$

2. Pertaining to the island Atlantis of Plato and Strabo, fabled to exist in the ocean of the far West, or to
Bacon's ideal Bacon's ideal that name. ten Atlantian. tlantes (at-lan ATrace, Atlas: see atlas 1.] In areh. figures or half fig ures of men used in place of col umns or pilasters, to support They were called tel. nisns. Femsle figure so employed sre cal tlantian (at

Atlantic (at-lan' tik), $a$. and $n$. Gr. 'Aт havтlkós,

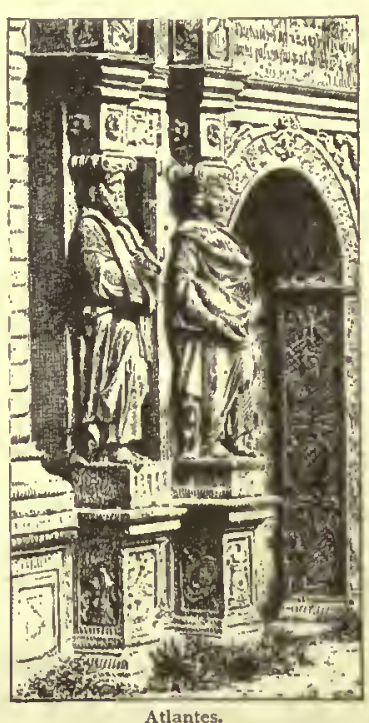
Baden. atlas

pertaining to Atlas, $<" A-\lambda a s$ ('A 7 avt-), Atlas, (1) titan (see atlas 1 ), or (2) the mountain-range northwestorn Africa named from the Titan, being regarded as the pillar of heavell ; tò A $\mathrm{A} \tau$ -

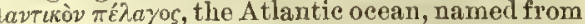
Mount Atlas.] I. a. 1. Portaining to or deseended from Atlas: as, "the seven Atlantie Sisters" (the Pleiades), Milton, P. I., x. 674.2. Appellative of or pertaining to that division of the ocean which lies between Europe and Africa on the east and America on the west.

II $n$. The Atlantic ocean.

lantid (at-lan'tid), n. A heteropod mollusk of the family Atlantide.

Atlantidæ (at-lan'ti-dē), n. pl. [NL., < Gr.

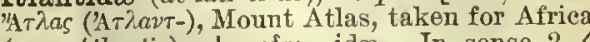
(sce Atlantie), + -idau, -idw. In sense 2, Atlanta (q. v.) $+-i d a$.$] 1. One of the three$ great divisions into which some ethnologists divide the human race, including the tribes of Africa and the Semitic peoples of Asia.-2. A family of heteropodous mollusks, typified by the genus Atlanta. They are free-swimming pelagic forms, of warm seas, with a small, thin, keeled, spiral
shell and calcareous opercnlum. Besides the type, At lanta, the family contains the genns Oxygyrus. Atlantides (at-lan'ti-dēz), n. pl. $\quad[\mathrm{L} .,<\mathrm{Gr}$.

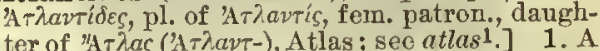
name given to the Pleiades, which were fabled to be the seven daughters of Atlas who were the legendary island of Atlantis.

Atlantis (at-lan'tis), n. $\quad[\mathrm{L} .,<$ Gr. AThavтís: stlantic. 1 A mythical islaud of vast extent, mentioned by Plato and other ancient writers, and placed by them in the far West.

atlanto-epistropheal (at - lan "tō-ep"i-strō$\left.\mathrm{f}^{\prime} \mathrm{al}\right), a$. [< atlas (atlant-) + epistrophous + strophæus or axis.

atlanto-occipital (at-lan"tō-ok-sip'i-tal), a. [< atlas (atlant-) + occiput (occipit-) +"-al.] In anat., pertaining to the atlas and the occipital bone.

atlanto-odontoid (at-lan"tō-ō-don'toid), $a$. [< atlas (atlant-) + odontoid.] In anat., pertaining atlantosaurid (at-lan-tö-sấrid), n. A dinosaurian reptile of the family Atlantosauride.

Atlantosauridæ (at-lan-tō-sâ' ri-dē), n. pl. [NI., < Atlantosaurus + ille.] A family of sauropodous dinosaurian reptiles with a pituitary canal, the ischia directed downward and meeting at the middle, a hollow sacrum, and the anterior and caudal vertebræ exeavated by lateral cavities. It is a group of gigantic Juras sic herbirorous lizards. O. C. Mlarsh.

Atlantosaurus (at-lan-tō-sâ'rus), $n$. [NL.,

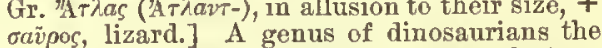
species of which were of gigantic size; the type of the family Atlantosauride.

$\operatorname{atlas}^{1}$ (at'las), n. [ = F. Sp. Pg. atlas $=$ It. atlante $=\mathrm{G}$. Dan. Sw. atlas, atlas (def. 4 ), $<\mathbf{I}$.

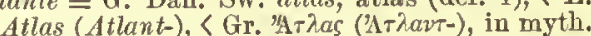
alder family of gods, who bore up the pillars of heaven; later, one of the bore up the pillars of heaven; later, one of the
Titans, condemned to bear up the heavens, or, in other forms of the legend, the earth: the name was also given to Mount Atlas (seo $\mathrm{At}$ lantic), to a statue serving as a column (def. 2), and to one of the cervical vertebre (def. 3 ); appar. $\left\langle\dot{a}\right.$ - euphonic $+V^{*} \tau \lambda a(\tau \lambda \bar{\eta} v a \iota)$, endure, $=L . V$.tla, in tlatus, latus, pp. (associated wollere, ferre $=$ E. bear , hold up, carry), and in tollcre, 1. [cap.] One who supports a heavy burden; a mainstay; a 'pillar.'-2. [Pl, atlantes (at-lan'tēz).] A male human figure serving as a column or pilaster. See atlantos.-3. [NL.] In anat., the first eervical vertebra, by which the skull arspinal column: so spinal column: so called because it supports the head, to uphold the sky. It is one of the most modified and specialized of the vertebra, of
ten having no centrum, ss such, but a hypspophysis instead, large lateral.masses, and the other processes smal

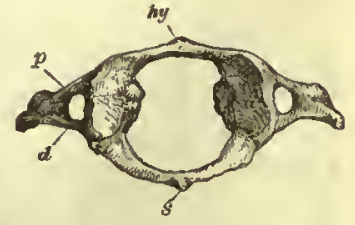

Human Atlas

s, rudiment of neural spine in the
neiral arch, $d$, tubercular process, or

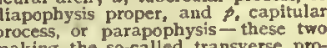
cess, and ine so-called the verteersarterial
foraneus $k y$, hypapophysis, in place oraneu; $h y$, hyp
of a centrum, $a$, a
occipital condyle. 
or wanting. The general form of the hone is annular; it atmosphere (at'mos-fēr), $n . \quad[=\mathrm{F}$. atmospliere revolves about a pivol furnished by the odontold pror'ess liead upen the neck. It lo contuouly ankyloged with the (n)

4. A bollud colleetion of maps. The word was first used in this sense by Jlercator in the alxteenth century, acnted as bearing a globe on hls shoulders, was given on the title-pagro of sucl: works.

Ileneo-5. A volumo of plates or tables illustrativo or explanutory of somo subject. -6 . A size of writing-or drawing-paper, 26 by 33 or A size of writing- or arawing-pajer, 34 inehes. -7 . [NL.] In cntom, a large lamellibeetle, Chalcosoma atles, about 3 inehes long, and of a brilliant metallic-green color.

atlas' (at'las), $\pi . \quad[=$ Sp. ntlas $=$ G. atluss $=$ Sw. atlas = Dun. atlas, atlask, satin, < Ilind. atlas, < Ar. atles, satin, < atlus, smooth, bare, blank, S tulasa, mako smooth, lelete.] A kind of satin: a worl formerly used in the Levant of satin: a w

atlas-folio (at"lans-fō' $] \mathrm{i} o \overline{0}), n$. [<atlns $1,6,+$ folio.] A large square folio sizo of books.

atlo-axoid (nt"lō-ak'soirl), $a$. In anat., of or pertaining to the atlas and axis, the first and second eervieal vertebræ.-Atlo-axold ligament, one of thre lichments, unterior interal, and poment, connected with both tho uxis nni the allas.

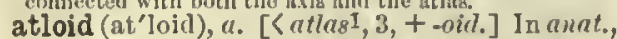
of or pertaining to the atlas; atlantal: usually as the seeond element of a eompound: as, oecinito-atioid ligaments.

atmidometer (at-mi-dom'e-tér), n. [<Gr. äruis

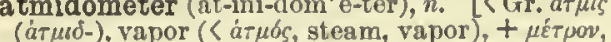

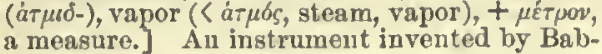
ington for measuring the evaporation from water, ice, or snow. E. H. Kniglit. See atmometer.

atmo-. [<Gr. ár $\mu \delta s$, vapor, steam (=Skt. ätman, breath, $=$ AS. $\bar{a}$ thm $=$ OS. athom $=$ OFries. $\bar{e} t h$ $m a=\mathrm{D}$. adlem = OHG. àlum, ātum, MIHG, atem, aten, G. atem, athem, odem, also (prop. dial.) ofen, breath), perhaps from the root repr. by Skt. $\sqrt{ } u^{\prime}$, Gr. $a \dot{m} v a \iota\left(V^{*} F a\right)$, blow, and so related

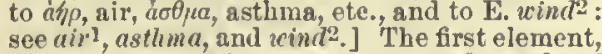
meaning vapor, in some compound words of Greek oricin.

atmological (at-mō-loj'i-kal), a. [< atmology Pertaining to atmology.

A classiffeation of clouds can then only be consistent
and intelligthle when it rests on thelr at molorical condl. and intelligthle when it rests on their at nolorical condl.
tions.

atmologist (at-mol'ō-jist), n. [< atmology + $-i s t$.] One skilled in atmology; a student of atmology.

The atmoloyists of the last century.

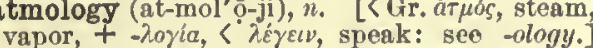
That branch of seionee which treats of the laws and phenomena of aqueous vapor.

The relations of leat and moisture give rlse to another
extendive colleetlon of laws and princlples, which I glail treat of in connection with themistics, and slasll term at atmolysation, ete. See atmolyzation, ete.

atmolysis (at-mol'i-sis), n. [〈Gr. ár $\mu \delta$, vapor, $+\lambda \hat{c} \sigma \iota$, a loosing, < $\lambda \varepsilon \varepsilon v$, looso.] A method of separating mixed gases or vapors of unequa diffusibility by eonfining the mixture in a vesin a vacuum. See atmolyzer. This nethod was first made known in 1863 by 1 tz 118 scoverer, Proleasor $T$. Gra. atmolyzation (at"mō-li-zā'shon), n. The separation of mixed gases by atmolysis. Also at nolysation.

atmolyze (at'mō-lĩz), $v$. $t$.; pret. and pp. atmolyzed, ppr, atmolyzing. [s atmolysis. Cf. an alyzc, <analysis.] To separate, as gases or vapors, by atmolysis. Also atmolyse.

atmolyzer (at'mö-li-zér), $n$. An instrument for separating gases. It consists of a porous plye 8115 rominded by an sir-tight cylinder connected with an aspi-
rator, the lighter pases passing through the pores of the
pipe, the heavier remnining in it. Also atmotyser. pipe, the heavier remnining in it. Also atmolyser.
atmometer (at-mom'e-tér), n. [< Gr. ar $\mu \delta s^{2}$. vapor, $+\mu \varepsilon r \rho o \nu$, a meastre.] An instrument, invented by Sir John Leslie, for measuring the amount of evaporation from a humid surface in a given time; an evaporometer. It consists of a thin hollow ball ol porous earthenware, to which is jolned a graduated glass tube. The ball and the tube are filled
witl water, the lop of the tulhe is closed, and the instru-
inent is exposed to the free gction of the alr. As the inent is exposed to the free action of the alr. As the lemoved in the form of vapor by the air, the extent of evaporation is g
graduated tube.
= J'g. atmosphera $=$ Sno. atmosfera = It. atmosera $=\mathrm{Sw}$, atmosfer $=$ Dan. atmosfare $=\mathrm{G}$. at mosphiüe, \& NL. atmosphara, < Gr. dituos, vajor, t opipa, sphere: see sphere.] 1. The aërifom fluid which surrounds the earth, and extends to an undetermincd lieight above its surface; the air. It ts a mecianicul mixture of 79 parts by voluthe of nltegen snd 21 of axyzen, with s trace of carbon dioxte and organic matler. The composillon of the mormal atmonear towis it usually contains impuritles, sueli as aulplu. fic acd, hydrochloric acld, ete. The movements of the

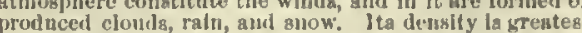
at the earth's aurface, and decreasea as the lielglit atove the earth lncreoses. The atmos]phere, like other bodics grnvitates toward the earth, and therefore las welght and
exerts presaure. It a a vernge welkht at the level of the exerts presaure. Its a vernge welght at the le
acn is alyout 15 pounds (14.7) to the aquare lich.

2. A eonventional unit of atmospherie pressure An atmosphere is in Finglish use the pressure of a vertical cotumn of 30 inches of inercury at tho freezing-polnt
at London; In French use it is the pressure of 760 inlill. meters of mercury at llie freezing-point at l'aria. For the shoointe atmosphere in the C. G. S. (centlmeter-gramsecond) system, aee absolute. The weiglit of the atmo-
splhere to the square luch fa commonly enoployed as a conas the welght of llinulds, the force of ateain, etc.: thus,

The apparnlus ... was of great simplieity, all of glass, capable of resisting the pressinse of many atnonjheres.
Science, VIII. 56. 3. The gaseous envelop surrounding any of tho heavenly bodies.

No sonnd, either loud or soft, could be heard hy any Inhabitant of the moon, leeause the moon practlcally has
jo atmogphere.
J. N. Lockyer, spect. Anal., l1. 22 4. Any gaseous medium: as, "an atmosphere of cold oxygen," Miller.

For an afmogphere of any gas gt nniform tenyerature,
the hetghit at which the density would be haived is the helght of the homogetheons atmosphere for that gas, mul-
tiplied by .69315; the gas ls assunued to obey Boyle'a law. J. D. Eiverett, Unita and I'hya, Const., p. 41. via, ete., surionnding a body: as, an electrieal atmosphere. - 6. Figuratively, intellectual or moral environment; pervading influenee. By the hearth the chlldren sit

ennyson, In Miemoriam, xx.

Absolute atmosphere. See absolute-Electric attmospheric (at-mos-fer'ik), $a_{0}$ [< atmosphere + -ic. Cf. spherical.] 1. Pertaining to, existing
in, or consisting of tho atmosphere: as, atmoin, or consisting of the
spheric air or vapors.

Quarantine cannot keep out an atmogyheric disease.

2. Dependent on the atmosphere.

3. Caused, produced, or operated on by the atmosphere: as, rust is an almospheric effect.Atrmospheric churn, a churn of various forms, in which atmospheric sir is driven inlo the milk in order to agitate upon the nillk in ageregating the oleaginous globules. Atmospheric currents. See current.- Atmospheric
engine, a variety of stean-engine in which the ateam is
adnitted only to the under gide of the piston sud for the

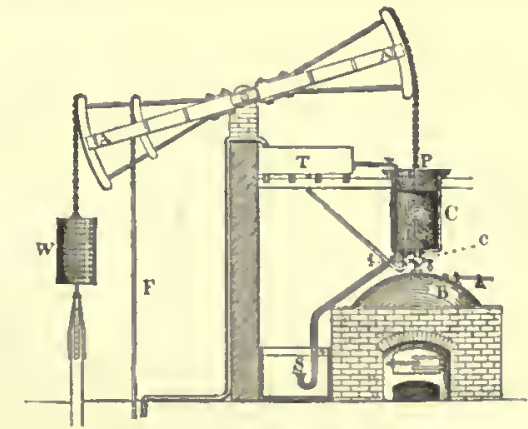

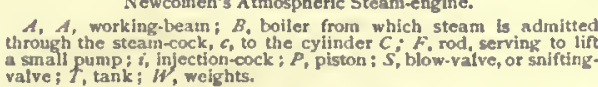
up-stroke, the down-stroke belng effected by the pres-
sure of the atmosphere caused by the formation of a sure of the atmosphere caused by the formation of a
vacuum under the piston through the condensation of vscuum under the piston through the condensallon of
the stean. This engine, Invented by Papin in 1695, was first made a practical guccess by Newcomen, and was
subsequently grestly improved by Watt, tlirough the addition of $\mathrm{s}$ separate condeuser and alr-pump.-Atmo spheric governor, an spparatus for controlling the move-
neents of machlnery by the nse of alr under pressure.
Atmospherlc hammer. (a) A hammer driven by nieans steain. See steam-hammer. (b) A hanmer in which an at-
mospherle spring ts enployed. The hanmer-hesd ts conamt a variable quantlty of aypeous Vapor, ambionia, ozone, splhere to the square luch is commonly entployed as a con-
venient unft for pressures arising from other entzes, snch iressure ln a steam-boller of 3 otmospher
surc equal to 45 ponuds per square lnch. of compressed air, as the steam-hamuser is operaled by nected hy a rod with a platon working In a cyilnder to
which afr is adimitcell st tise cculer of its length. A recip. roesting motion is given to the cylinder, and liy means
of the air confined hetween fits other end and the piston a correspondlug motion is given to the piston-heat con steam-jresure, a llue drawn ty the jencif when the stean is ahut off from the pisten of the lindicater, anil

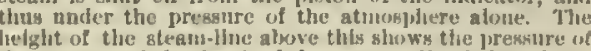
the stenn, and the depth of the vaetum-1ine betow shows

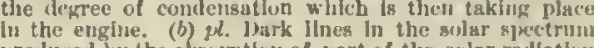
produced ly the absorption of part of the solar radiatlon tho terestrial atmosphere. seo slectruu.

In addition to the linea of Frambingler, Inlubilably belonging to the aun, thero are many other dark lises in the ton of the terrestrial atmogshere, and are therefore called atmonpheric lines. Lowmel, Jight (trans.), p. 166. Atmospherle pressure. See atmosphere 2-Atmothe auctionl-pifo by stmospheric pressure- Atmospheric railway, a railway an constructed that the notive jowe is derlved from the pressure of the atmospliere acting on a piston working in a contlnuous lron tube of inlforn created by exhansting the air from that end of the tulne towsrd which it ta desirer that the plston should advance, or by forclug in alr buhind it, or by foth nuthods at once. prrpose of a rallway, though it la successfully worken

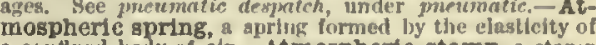
operated in the of air.-Atmospheric stamp, a atanip (which aee, alove). -Atmospheric ttdes, dinmal oscllis thona of the atmosphere, propluced by the attractions of the sun and moon, like the fides of the ocean, and inditmospherical (at-mos-fer'i-kall), $a$. Same as atmospheric.

atmospherically (at-mos-fer'i-kal-i), $a d v$. As, or as regards, the atmosphere; by atmospheric force or influeuce.

atmostea, ". Plural of atmostcon.

al.] Pertaining to an atmosteon; pneumatic, as a bone.

atmosteon (at-mos'tề-on), n.; pl. almostea (-ĩi) [NL. < Gr. á $\mu \delta \varsigma$, air, + botéov, bone.] In ormith., an air-bone; a seleroskeletal ossification of a membranous tube or eanal conveying air into the interior of a bone of a bird.

The siphon-like tule which conveys air Irom the onter
ear-passage to the hollow of the miandlile may osslfy,

. resulting in a neat tubuhr " air-bone" or at worteon,

atocha-grass (a-tō'chä-grås), n. [Sp. atocha, esparto-grass.] A name sometimes given to the esparto-grass, Stipa tcracissime.

atok (a-tok'), n. [Peruv.] The native name of in Peru, originally deseribed by Humboldt as Gulo quitensis. Also ealled zorra.

atoll (a-tol' or at'ol), $u$. [Formerly atollon; the name of such islands in the Maldive group; prob. Malayalam adal, elosing, uniting
(Yule).] A coral island, consisting of a strip or ring of coral surrounding a central lagoon. Snch lslands are very coumon in the Paciftc ocean. They
often present an exceedingly jicturesque sppearance, a compratlvely narrow atrip of coral rock thinly coated nut-, pandsnus-, and breadfrut-trees, indelosing a large still aheet of water, Maually of consideralile cleptl, and often
well supplled with flsh. The circle of coral 18 sometimes conplete, showlug no apparent conmunieation between the inclosed lagoon and the surround ing sen; but generally
it is interrupted, snd presents one or nore openlngs suita. atollont, $n$. See atoll. atom (at'om), n. [Early mod. E. also atome, sometimes atomie, $>\mathrm{E}$. sing. atomic, atomy $\mathrm{I}, \mathrm{q}$. v.), $<\mathrm{ME}$. attome, atome, $<\mathrm{F}$. atome $=\mathrm{Sp}$. átomo $=$ Pg. It. atomo $=\mathrm{G}$. Dan. Sw. atom, < L, atomus, < Gr. äropos, an atom, prop. adj., indivisible, adj. of $\tau \xi \mu \nu \varepsilon v, \tau a \mu \varepsilon i v$, cut : see tome.] 1. An extremely minute particle of matter: a term used generally witl certain philosophic or scientifie limitations. (a) A liypotletical particle of matter 8 ininute as to admit of bo divlslon; an ultimate indivtsible
particle of matter. Sce atomic phitorophy, under atomic. No atoms casually together hurl' Dryden the efrcumstances considered; a moleeule.

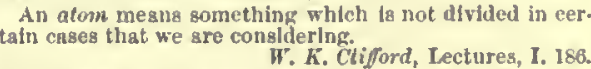
(c) In chem. snd physics, the unit of natter; the amallest
mass of an element that exists in sny molecule. The
number of klnds of atons 18 the same as the number of number of klnds of atoms lo the same as the number of
the elements. All atoms of the game elenent liave the game conatast welght. They are for the most part combined with other atoms, elther of the anme or of a different
kind, forming molecules, and are Indivizible hy chemical 
atom

366

force. The atom is sometimes called the chemical unit, in tisthetion which can exhibit all the propertics of that matter; but atom is also sometimcs uscd as syonymons with molected
in this aense.
Hence-2. Anything extremely small; a miHence-2. Anything extremely small; a minute quantity: as, he has not an atom of sense. about th of a second. -4. Anything indivisible an individual. $=$ Syn. Molecule, ete. See particle.

atom $\nmid\left(a^{\prime} \circ \mathrm{m}\right), v . t_{0}$. [< atom, $n$.] 'To reduce to atoms; atomize.

And atour'd mists turn instantly to hail

Drayton, Elegies,

atomatic (at-o-mat'ik), a. [< atom + -atic. $]$ Same as atomic.

atomic (a-tom'ik), $a \quad[<$ atom $+-i c ;=F$, atomique.]

The atomic constitution of bodies.
IY'heurell, Hial. Scientiflc Ideas The gods, the gods!

If all be atoms, how then should the gods,

, follow the great laso ?

F heats of bodies, the product of the apecific heats of bodie into their atomic weights. These products are nearly the atomic conposition, though the productin of the specific heats into the atomitc weights may differ in different ciasse
of conipounds.-Atomic or atomistic philosophy, a ays tem of philosophy, founded by Lencippus and Democritus. which taught that the nltimate constituents of all thing are indivisible particles or atoms, whtch differ from one
another in form and position; whether also in quality of diverse combination and motions of these atoms all thing diverse combination and motions or these atoms al things
including the soul, were aupposed to arise. The atomistc
philosophy was perfected in its details by the Epicureans particularly by Lucretius, and was the first complete sy em of materialism. It is the basis of the modern phyz cal atomic theory, but, apart from the numerous special modicat that the ancient atomism was a plilisosophy of the universe, while nodern atonismis is, primarily at least, merely a physical theory of the inner structure of natter, con-
structed for the convenlence of phy yical research. Atomit theory, or doctrine of definite proportions, in chem. the hypothesis that all cbernical conbinations take place
between the ultimate particles or atoma of bodies, and etween the nitimate particles or atoma of bodies, an
that these unite either atom with atom or in proportions expressed by sorme ainuple multiple of the number of atoms qunantity of an element in the solid atate proportional to its atomic weight, and expressed hy the quotient of the
specific gravity divided by the atomic weight. - A tomic specific gravity divided by the atomic weight.-A Atomic
weight, in chem., the number expreasing the relative weight of one atom of an element compared with the weigh the lighteat, at present known. The atomic weighta of the other elementa, therefore, express how many times the atoms of these elements are heavier than the atom atomical (a-tom'i-kal), a. Same as atomic. atomically" (a-tom'i-kal-i), $a d r^{\prime}$. In an atomi manner; from an atomic point of view; atomician (at-o-mish'ann), n. $[<$ atomic + -ian. An adlerent of the atomic philosophy or the ory. See atomic.

atomicismt (a-tom'i-sizm), n. [<atomic + -ism. $]$ Atomism.

atomicity (at-o-mis'i-ti), n. [<atomic $+-i t y$. In chem., same as equivalency and quantivalency. The number of londs posacssed by an element, or it afomicity, is apparently, at least, not a fixed and inva
riable quantity.
E. Frankland, Exper. in Chem., p. 9. atomisation, etc. See atomization, etc.

atomism (at'om-izm), n. [< atom - $_{-i s m ;}=\mathrm{F}$. atomisme $=\mathrm{Sp} . \mathrm{Pg}$. It. atomismo.] 1. The metaphysical or the physical theory of atoms;
atomic philosophy or atomic theory. See atomic. Atomizin also is inconcelvable; for this supposes atoms, Sir W'. Hamilton, Metaphys., II. 528, App The result of atomism in any form, dealing with an
subject, is that the principle of uniformity is luunted dow into the elementa of things: it is resolved into the nut formity of these elcments or atoms, and of the relation
of those which are next to each other. 2. The state of existing as an atom or a unit, of being composed of atoms or units; individnalism.

atomist (at'om-ist), $n_{0}$ and $a . \quad[<$ atom $+-i s t$ $=\mathrm{F}$. atomiste $=\mathrm{Sp}$. Pg. It. atomista. $]$ I. n. One who holds to or expounds the atomic philosophy or the atomic theory.

II. $a$. Same as a tomistic.

The more closely we follow the atomist doctrine to it atarting-point, and spread leefore us the necessary outfl for its journey of deduction, the larger do fta demand
appear.

atomistic (at-o-mis'tik), a. [< atomist $+-i c$. 1. Pertaining to atomism or the atomists.
It is the ohject of the mechanical atomistic philosophy to confound synthesis with synartesis.

2. Consisting of atoms.-Atomistic phtlosophy. atomistical (at-o-mis'ti-kal), a. Same as atomistic.

atomistically (at-0-mis'ti-kal-i), adv. In an atomistie manner; as composed of distinct atoms. atomization (at"om-i-zä'shon), n. [< atomize + -ation.] The process of atomizing or the state of being atomized; specifically, in med. the rednction of liquids to the form of spray for inhalation or for application to the throat or nasal passages, and

atomize (at'om-iz), v.; pret. and $\mathrm{pp}$. atomized, ppr, atomizing. [< atom $+-i z e$.$] I.t intrans.$ o speculate respecting atoms. Cudworth.

II. trans. To rednce to atoms; reduce to very mall particles, as a liquid ; spray.

Also spelled atomise.

atomizer (at'om-1-zèr), $n$. One who or that which atomizes or rednces to atoms or very small particles; specifieally, an apparatus dosigned to rednce a liquid to spray for disinfecting, cooling, perfuming, medicinal, and other purposes. Also spelled atomiser.

atomology (at $\left.-0-\mathrm{mol}^{\prime} \overline{0}-\mathrm{ji}\right), n$. [< Gr. ăтo $\mu \circ$, atom, $+-\lambda o \gamma i a,\langle\rangle \varepsilon \dot{\gamma} \varepsilon v$, speak: see-ology.] The
metaphysical doctrine of atoms. See atomic. atomyl (at'om-i), n.; pl. atomies (-iz). [Early mod. F. also a tomie, attomye, < atomie, prop. atomi, pl. of atomus, prop. the $\mathbf{L}$. form then in current use along with atom, the form atomy being regarded appar. as a dim. Cf. atomy2.] 1. An atom; a mote.

Should he or heli
Affront me in the passage of my fate

I'd crush them into atomies. From the onter day,
Betwixt the elose-set iviea came a broad Arowded with driving atomies. Tennyson, Lover's Tale, il.

2. A tiny being; a pygmy. Drawn with a team of little atomies.

Epicurus makes them [gouls] swarrns of atomies, Which do by chance into our bodies flee.
Sir $J$. Davies, Immortal. of soul. atomy ${ }^{2}$ (at'om-i), n.; pl. atomies (-iz). [Formerly also atamy and natomy, for anatomy, omy; a skeleton. - 2. A very lean person; walking skeleton.

Thou atomy, thon. Shak. (ed. Leopoid), 2 Hen. IV., v. 4 atonable (a-tō'nạ-bl), a. [< atone + -able. $]$ Capable of being atoned for; reconcilable. atonet, prep. phr. as adv. [ME., also attone, earlier atoon, aton, at one, at on, lit. at one, agreed. In mod, nse written as two words, at and see at and one. In at-one, as in allone tion (ōn), the nsnal pronunciation (wun) being a modern (16th century) corruption, which has not affected the compounds.] 1. At one; reconciled.

Make the wel at on with him . . and Ired the of the
Eome. Aton he was with the king. King Ilorn If gentil men, or othere of his contree,

2. Together; at once. Chancer, Clerk's Tale, l. 381. All his sences seend berefte attone.

atone (a-tôn') $v$; pret. and pp atoning. [<atone, adv., q. v.] $\dot{\mathbf{I}}_{\text {. intrans. } 1 \mathrm{t} .}$ To be at one; agree; be in accordance; accord. IIe and Aufidius can no more atone,
Than violentest contrariety. Shak.,

2. To make reparation, amends, or satisfaction, as for an offense or a crime, or for an offender: with for.

The murdcrer fell, and bloot atoned for blood. Pope. The ministry not atoning for their forner conduct by
Juning. So it aometimes happens that a single bright and genrous act serves to atone for the abuse of years.
$J$. F. Clarke, Self-culture, p. 81.

3. To make np, as for errors or deficiencies; a set-off or palliative.

Or where the pictures for the page atane,

And Quarles is aav'd hy beantiea not hia own.

II.t trans. 1. To bring into concord; reconcile, as parties at variance. atonement

To atone them, for the love Iould do much Shak., Othello, iv. 1 I am just ai that hour

Upon some late conceived

V'ebster, Cure for a Cuckold, i. 2 Tigers and lions, boars and raging bulls, Hlath he aton'd with leopards and wolves.

2. To put in accordance; harmonize. To atone your fears

3. To unite in forming. The Four Elements, who Joined
With the Four knowu Complexiona, have aton'd A noble league, and severally put on

Dekker and Ford, The Sun'a Darling, v. 1

4. To conciliate; appease.

So heaven, atoned, shall dying Greece reatore.
Pope, 1liad, 1. 89.

5. To expiato; answer or make satisfaction for. Soon ahould yon boasters cease their haughty strife, Although atome as a transitive verb is essentially ohsolete, it is used occasionally by moderu writers in several of the senses above given.]

atone-maker $\nmid, n$. [< atone, adv., +maker. $]$ One who makes reconeiliation or atonement. reconciler; a mediator.

One God, one mediatour, that is to say, aduocate, inter. Tyndale, Worka, p. $15 \mathrm{~s}$.

tonement (a-tön'ment), n. [< atone, v., + -ment; but the noun is fonnd earlier than the verb, arising perhaps from the phrase at onement: sce onement.] 1t. Reconciliation after enmity or controversy; settlement, as of a difference; concord.

II auying more regarde to their old variannce than their
ewe attonement. Sir T. More, Degerfp. of Rich. III. If we do now make our atonement weli,
Our peace will, like a brokes limb nuited, Grow stronger for the breaking.

2. Satisfaction or reparation made for wrong or injury, either by giving some equivalent or by doing or suffering something which is received in lien of an eqnivalent.

0 when did a morning shin So rich in atomesnent as thia Ternyson, Maud, xix. ?

3. In theol, the reconciliation of God and man by means of the life, sufferings, and death of hrist.

For God was in Christ, and made agrement bitwene the worlue and hym sylfe, and imputed not their aynnes vnto them; and hath committed to vs the preachynge of the
atonement.
Tyndale, 2 Cor. v. I9. When we were enemies we were reconciled to dod by the death of his Son; . . We also joy in God through our atorement. Christ, by whom we have now received th Thia doctrine asaumes that sin has made a apiritual aepa ration between God and the human soul Different ay ciliation, and therelore nse the word atonement with dilferent meanings. The early father's generally atated the doctrine in the terma of Scripture, and it was not until the time of the Relormation that the differences in philosoph lcal atatement were elearly marked. The modern statelows: (a) A reparation or aatiafaction for sin made by the lieu of the punishment to which the sinner was juatly amenable. Such satisfaction is regarded as necesary either (1) to satisly the justice of God, and so make forgiveness poasible, or (2) to aatialy the law of God, produce the public impression which punishment would have
produced, and so make forgiveness safe. The former f produced, and so make forgiveness safe. The former is
known as the satisfaction, the latter as the governmental

The word atonement, in its original aenae, always de some duty or the lion with which, when supposed to be complete, the per-
son injured ought reasonably to be contented, and to demand of the offender nothing more on account of his
transgression.
Duight, Theology, iv. Taking the term atonement in its technical aignifleation to denote the aatisfaction of divine juatice for the sin of man, by the substituted penal sufferings of the Son of God, we shall find a slower scientific unfolding of this truths of Chriatianity. Shedd, Hist. Christian Doctrine, $\mathbf{} .1$ (b) The entrance of God into humanity, that le may with himself. Suppoaing the Father's will to be a will to all good;
the Soll of Cod, being one with him, and Lord of man, to obey and fuln in our flesh that will by entering into the lowest condition into which man had fallen through their sin; this Mlan to be, for this reason, an object of cency to be fully drawn ont hy the death of the cross; ever offered, the entire surrender of the whole apirit and 
atonement

367

atrioventricular

body to God; is not this in the lighliest sense atonement inim reconciled to mun? Maturice, Theol. Essays. It [the new theology] holds to the atmement as a divin act null jrotegs of cthicnl and practien inijort- not a struggle of the worli, lint $\mathrm{n}$ compreliensible furce in the actual redemption of the world frou its evil

T. T. Munger, thie Fredom of Finth.

The majority of orthodox ilivines, whetler in the Roman Cintholic or the I'rotestant elumeches, ordinarily hold on
of the above views or a comblination formed from them. of the above views or a combination formed from them

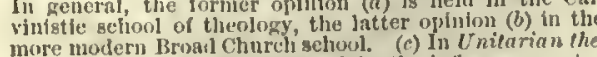
ology, the moral result produced liy the influenee exerted on mankind by the life and denth of clurist, lealling men to repentance and to God. This is sometlim.
nurat infuesce theory of the atonement.

Even though we ghould reject all the orthodox theories abont atonement, we may aceept the fuet. We enn be

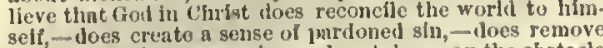
the weight of transgression, - does tnke nway the obstae thour cunscience, - loes hielp us into a living faith, liope, (i) In Nevo Church (Swedenhorgian) theology, the union and aceord of thesh and sinirit in man, and so the union and aceord of ninn
tho fudividual.

T'his is what is understood in the New Chureh by the atonement, or at-one-ment, . A I linging nt one of the human and the divine, or, is the apostle says, "making in
hifmsell of twain one new nuan." And the purpose of thts atonement was, that the Lord might ever after be able to loing our external or natural at one with our internal spirtunl man - goodness at one with truth in our minds,

B. $F$. Barrett, Doetrine of the New Chureh. Doetrine of blood atonement, the dactrine, attributed to the Mormon Church, that the ktlling of an apostate of
of one in danger of apostasy is a deed of love, sinee it makes of one in danger of apostasy is a deed of love, since it make
ntonement for the sin of apostasy, and so mnkes possibi
God's forciveness of tt. atoner (a-t.o'nér), $n$. One who makes atonemeut.

atonest, adv. [Early mod. H. and ME., prop. separate, at oncs: now written at once:

and once.] 1. At once; immediately.

Love me al atones. Chaucer, Miller's Tale, 1. 94.

2. At one and the same time.

Curlons enditing and hard sentence is ful hevy atoues atonic (a-ton'ik), $a$. and $n$. [< Gr. árovos, (a) not stretehed, relaxed, languid, <a- priv. +

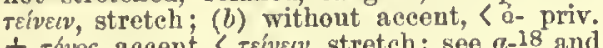
+ róvos, accent, < reivecv, stretch: see $a-18$ and
tonic.] I. a. 1. In pathol., characterized by atony, or disease.-2. In philol.: (a) Unaecented. (b) Produced by the breath alone; surd.-Atonle dyspepsia, defective digestion, independent of inflanma-

II other reeognizable lesions of the digestive oryans. organie exeitement or irritation. [Rare.]-2. In philol.: (a) A word or syllable that has no accent.

A siugle nnaceented syllable is ealled an atonic.
$F^{\prime} . A . M a r c h$, Anglo-Saxun Grammar, p. 202. (b) An elementary sound produeed by the breath; a surd consonant; a breathing.

atony (at'ó-ni), n. $[=\mathrm{F}$. atonic, < NL. atonia, < Gr. árovio, languor, < àrovos, languid: see
atonic.] In pathol., a want of tone; defeet of musenlar power; weakness of any organ, partieularly of one that is eontractile; debility. -Atony of the bladder, in pathol. loss by the muscinlar thers in the walls of

atop (a-top $\mathrm{p}^{\prime}$, prep. phr. as $a d v$ or $a . \quad\left[<u^{3}+\right.$

top.] "On or at the top.

"Tis but to shew thint you ean piree sometime

Your molesty a-top of all your virtues

Despots atop, a wild elan below,

Such is the Gaul from long ago;

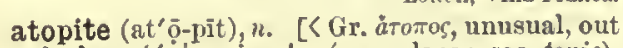
of plaee (< a- priv. + tónos, plaee: see topic), in Sweden in yellow or brown isometrie oetaliedrons.

-ator. [i. - a ator, term. of nouns of agent, being

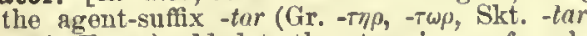
- lär) (E. -or) added to the stem in - $a$ of verbs in $-\bar{a}-r e$. This termination was reg. redueed
in $\mathrm{OF}$. to -cor, -cour, whenee in ME. -eour (as in saccour, mod. E. saviour), commonly -or, -our, mod. E. -or, -cr, as in appcllor, arbitror or tither, cecuscr, ete., from l. nouns in origin.] A termination of nouns of agent origin.] A termination of nouns of agent taken direetly from the Latin, as creator, eduLatin, as detonator, corrugator, ete., from verbs of the Latin first eonjugation, which have in derived from nouns without an internediate verb, us glad. iator, wenctor. in -aitor.] A termination of adjectives, of Latin origin, in form from nouns in alor, but in senso often to be referred to the original verb, as ill amatory, accuscitory, rleclamatory, exclamatory, nugatory, ote. When trom English noun in atur, the termination is -ator +-inl, as semaloriat, ete.
atour ${ }^{1}$ (a-tor'), prep. and alv. [Sc., also written altour, atower, < IIE. (Scoteli) atour, atoure, al-oure, $<$ at + aur, oucr, over: see at and over; for the eombination, ef. at-aftcr.] I. prep. 1 . Of place, ever.-2. Of number or quantity, ver; beyond; more than.

II. adk. Over and above; besides. - By and atour (prep. and ndv.), also by atour (ndv), over nu atour ${ }^{2}+n$. See attour

atrabilarian (at"ra-bi-lä'ri-gul), $a$, and n. Ml. atrabilarins, 2 L. atra bilis, blaek bile:
see atrabile and bile 2 .] I. $a$. Affected with see atrabile and bile ${ }^{2}$. I. $a$. Affected witheholy, which the ancients attributed to black bile; atrabilious.

The alrabilarian constitution, or a blnck, viscous,

II. $n$. A person of an atrabiliar temperament; hypoehondriae. Disracli.

atrabilarious (at"ra-bi-lā'ri-us), a. [< MI atrabilarins: see alrabilarian.] Same as atra-
bilarian.

Christopher Glowry, Esquire, ... Was naturally of an phantoms of indigestion whieh are conmonly called blue
Peacock, Nightmare Abbey, 1 atrabilariousness $\dagger$ (at"ra-bi-lä'ri-us-nes), The state or quality of being atrabilious melancholy.

atrabilet, $n$. [ $[$ F. alrabile, formerly atrebile $=$ Sp. atrabilis $=\mathbf{P g}$. atrabilis $=\mathrm{It}$. atrabile,,

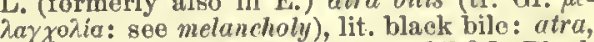
fem. of $a$ ter, blaek; bilis, bile: see bile 2 .] Blaek bile; melancholy: from the supposition that melancholy is duo to a preponderanee of the so-ealled "black bile," an imagin

trabiliar, atrabiliary (at-rạ-bil'i-är, -â-ri), $a$.

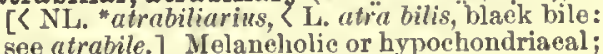
atrabilious. Seo atrabile.

Complexion of a multiplex atrabiliar character, the flus Atrabiliary capsules, glands. See capsule, gland.

trabilious (at-ra-bil'ius), a. [<L. atra bilis: see atrabile, and ef. bilious.] Affeeted as if by
blaek bile; melancholic or hypoeliondriaeal; splenetie. See atrabile.

A hard-faced, atrabilious, earnest-eyed race, stiff from
long wrestling with the Lord in prayer, and who had long wrestling with the Lord in prayer, and who had
tanght Satan to dreal the new Puritan hug.
Lowelf, Biglow Papers. atracheate (a-tra' 'kē-āt), a. [NI. atrachcatus, (Gr. $\dot{a}$-priv. $(a-18)+$ NL. trachea.] Having no trachere or spiraeles, as some artliropods, such as erustaceans.

Atrachelia (at-ra-k- $\left.\left.\bar{\theta}^{\prime}\right] i-a ̈\right), n . \mu l$. [NL., < Gr.

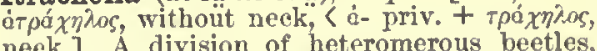
having the head not exserted nor narrowed be hind, the antennæe livear or subelavate, and the claws undivided, sometimes serrate or peetinate: opposed to Trachelida. The group is chtefly composed of the family Tenebrionida, whlch me plantsurd no lower wings.
atracheliate (at-ra-kë'li-àt), «. [ Atrochelia

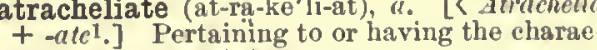
$\left.+-a t c^{1}.\right]$ Pertaining
ters of the Atrachelia.

Atrachia (a-tráki-ä), n. pl. [NL., < Gr. a yriv. + rpaxeia, trachea: see trachea.] A di-
vision of Lamellibranchiata: a synonym of Asiphonate (whieh seo).

atractaspidid (at-rak-tas'pi-did),

Atractaspididæ (a-trak - ta-spid' $\mathrm{i}-\mathrm{de}), n . j$. [NL., < Atractaspi(d-)s + -ida.] A family of venomous African serpents, suborder Solenoglypha (sometimes referred to $I$

Atractaspis (at-rak-tas'pis), ". [NL., < Gr. átpaktos, a snindle, an arrow, + aotis, a serpent: see asp ${ }^{2}$.] A genus of venomous serpents, laris and A. corpulcritus are two Afriean speeies, from Angola and Liberia respectively.

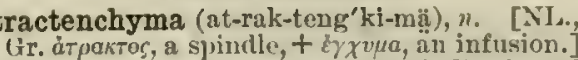

In bot., a tissue composed of spindle-shaned cells.

trament (at'ra-inent), n. [< I. atramentum, lack ink, < uter, black.] Blacking; ink; any black fluid, as the ink of the euttlctish.

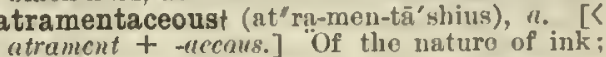
black as ink. Derham.

atramental (at-ra-men'tal), ". [< "trument [Rare.] Also atramentous.

[Taro. Also atramentarious (at"ra-men-ta' ri-us), a. [<I.

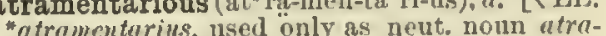
"atramcntarius, used only as neut. nown atriu mentarium, all inkstand, L L. atramentum, ink: ink. Thus the sulphate of iron, or cojpuerns, is ealled atramentarious from its use in the manufseture of ink. atramentous (at-rạ-men'tus), a. [< atrament -ous.] Same as atramental.

Whenever provoked hy anger or labour, sn atramentouk guality of most malignant nature was Beell to distill from
Sicift, Battle of the $1600 \mathrm{k}$. atred t, a. [< L. ater, black, + ed?2. Cf. Is. atratus, elothed in black.] Tinged with a black color.

Fellow eholer or atred.

Whitaker, 31 inol of the Grape, p. 76. tredet, r. t. [ME., < at-, from, + reden, adsee read, retc.] To surpass in counsel. Sien may the olde atrenne, but nat atrede.
Chavcer, Knigit's Tale,

atrent, $v, t$ [< ME atronen, < at-, from, + rennen, run.] To outrun. Chaucer.

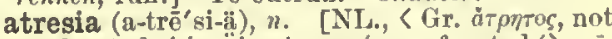
perforated, $\langle\dot{a}$-priv. $+\tau \rho \eta r \delta s$, perforated (\rangle$\tau \rho \vec{\eta}-$ ors, opening, orifiee), verbal adj. of $\tau \varepsilon \tau \rho$ aivelv $\left(V^{\text {* }} \tau \rho \alpha\right)$, bore, pierce.] The state or eondition sence of a natural opening or passage: ehicfly used in medieine and surgery.

atresial (a-tré'si-al), a. Characterized by tresia; imperforate.

tria, $n$. Plural of atrium.

atrial (a’tri-g̣l), $a .[<$ atrium $+-a l$.$] or or$ pertaining to an atrium.- Atrial aperture, opening, or ordace, the communication of the atrisi cavity
with the extertor. It forms one of the two apertures (the other being the oral) with which asetilisus or sen-squirts are provided, and throngh whteh water may lie $\mathrm{squ}$.
by the contraction of the museular walls of the body. by the contraction of the museular wall
euts under Appendicularia, Dotiolidoe,
Atrial canal, the eavity of an atriuu. Esch stigma leads into a finmel-shaped atrial cannl.

Atrial membrane, the tiliril tunic of ascidians; $n$ ifeli ate membrane of two layers, parietsl ant viseral, like The atrial membrane forms n bilobed sac, one lohe ex-
tending on each side of the phnrynx, and opens outward tending on each side of the phmrynx, and opens outwar

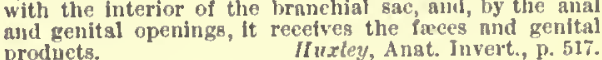

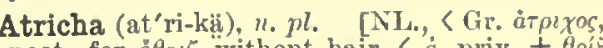
poet. for $a \theta_{\rho} \xi \xi$, withont hair, $<a-p r i v,+\theta \rho i \xi$
$(\tau \rho i x-)$, hair.] 1. $\Lambda$ division of the Nematarhyncha, containing those forms which are devoid of cilia, as the genus Echinoderes. They are distingulshed from Gastratricha, which are ciliated on 2. A name given to certain protozoans, or lobose rhizopods having no permanent pro-

Atrichia (a-trik'i-ä), n. [NI., < Gr. àr $\rho$ xos, poet. for $a \theta \rho l \xi$, without liair: see Atricha.] 1 . clivale $A$. clamosi is the serub-bird of Anstralia. J. Gould, 1844. Also called Atrichornis. -2. A genus of dipterous inseets.

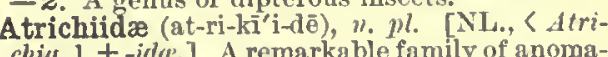
lous oscine passerine birds, forming with Menuridle one of the major groups of birds, Passeres abnormales. It contnins the Australian seruh-birds of the genus Atriclia, which have tise syrinx differently
constructed from that of normal osches. Also ealied

Atrichornis (at-ri-kôr'nis), ".. [NL., < Gr. atpcxos, without hair (see

Atrichornithidæ (at"ri-kôr-nith'i-dē), n. $p l$

Atrichornithidæ (at"ri-kôr-nith'i-dē), n. $p l$. Atrichiida.

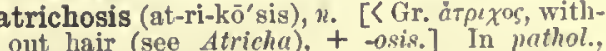
out hair (see Atricha),

atrioventricular ( $\bar{a}^{\prime \prime}$ tri - $\overline{-}$-ven-trik 'ü-lär $), u$. [< atrium, $3,+$ tentricular.] Pertaining to the 

atrial, or auricular, and ventrieular cavities of
the heart: as, the etrioventriculer valve.

atrip (a-trip'), $m^{\prime}(p)$. pler. as adv. or $a . \quad\left[<a^{3}+\right.$ trip $\left.1, n_{0}\right]$ Naut.: (a) Just raised from the Hound in weighing: said of an anchor. $(b)$ for trimming: sairl of sails. (c) Swayer up. realy to liave tho stops eut for erossing: said of yards. $(d)$

Atriplex (at'ri-pleks), n. [L., also atriplexum,

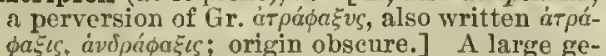
$\phi a_{s} \iota s, a ́ v \delta p a ́ \phi \alpha \xi \iota s ;$ origin obscure.] A large ge-
nus of plants, natural order Chenopodiucece, mostly mealy or scurfy herbs or low shrubs, growing usually in saline localities, and of very littlo importaneo. The garien orach, A. hortensis, is cultivated to some extent as a salad, and a variety with
criman foliage for ornament. A number of ahrubly spe. cies are very freytuent in the dry and alkaline portions of weatern North America, and are generally known as

atrium ( $\bar{a}^{\prime}$ tri-um), n.; pl. atrin (-ä). $\quad\left[\mathrm{L}_{.}\right.$, in senses 1 and 2 , also a have been orig. the kitelien, and so ealled beeause blackened with smoke, < ater, black; but perhaps the reference is to the hearth or fireplace in the atrium, the namo being connected with eedes, orig. a fireplace (ef. $\mathbf{E}$. oast), Rom. arch., the entrance-hall, the most impor-

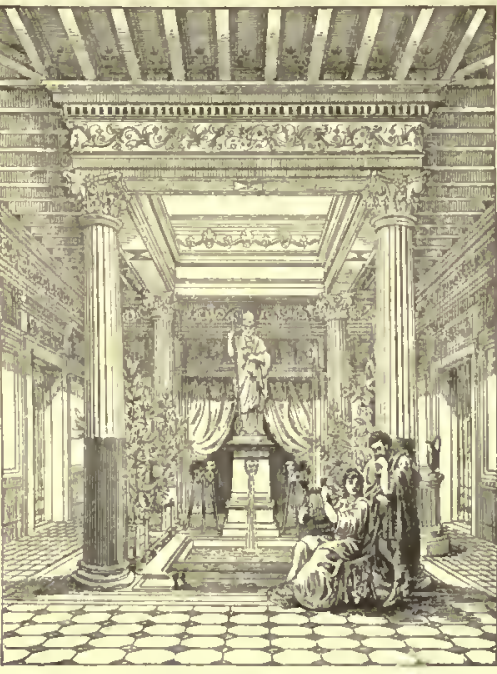

tant and usually the most splendid apartment of the house. At an early period, and later among the poor, the atrinm was used not only as a ceremonial roon, poses, as cooking and dining. In it were placed the ancetral images and heirlooms, the marriage-conch, the focus
or hearth, sad generaily a amall altar. Later, among th or hearth, snd generaily a amall altar. Later, among the kitchen and dining-roon, chapel of the larea, etc., it was lighted by an opening in the roof, called the compluvium, toward which the roof sioped, ao as to condnct the rain2. A hall or court resembling in arrangement an atrium proper, as at the entrance of some elassical or early Christian public buildings, ete.-3. [NL.] In cmat., an auricle of the heart, or some equivalent venous eardiac carity.

In all the other vertebrates [than Amphioxus] there is a heart with at fewest three chambers (aimus venosus,

4. [NI 4.] In zoöl.: (a) Tho chamber or eavity and with the eavity of the alimentary canal. See atrial, and cut under Tunicata.

The atrium, into which the frees and genital prodncts
are poured.
Ifuxley, Anat. Invert., p. 514. (b) A membranous saceular diverticulum of the ear in fishes: as, the atrium sinus imparis, a membranous sae given off from the sinus auditorius impar of fishes, and conneeted in various torius impar of fishes, and
ways with the air-bladder.

atrocet, a. $[<\mathrm{F}$. atroce, $<\mathrm{L}$. atrox (ace. atro$(\mathrm{em})$, cruel : see atrocious.] Atrocious.

atroceruleous (at-rō-sē-rö'lē-us), a. [<L. ater, black, + caruleus, bluo: see cerulean.] of deep blackish-blue color, as an inseet.

atrocha (at'rō-kä), n. pl. [NL., neut. pl. of atrochus: see atrochones.] 1. Ciliated embryos of the polyehrotous annelids, in which the eilia form a broad zone around the body, leav- ing each end free of cilia, excepting, in som eases, a tuft on the head. See mesotrocha, telcotrocha.-2. [cup.] In Rotifera, a group of wheol-animalcnles having no eilia and the lobes ers.

trochous (at'rō-kus), a. [< NL. atrockus,

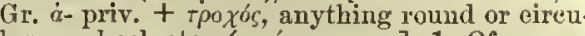
lar, a wheel, ete., $\langle\tau \rho \varepsilon \hat{\varepsilon} \chi \imath v$, run.] 1. Of or pertaining to atrocha; having eilia disposed as in those annelidan larvo ealled atroch $a_{-}-2$ Wheelless, as a rotifer.

trocious (a-trō'shus), a. [<L. atrox (atroc-) muel, fieree, horrible, $<$ ater, black: see atroce and -ous.] 1. Manifesting or characterized by atroeity; extremely heinous, criminal

Revelations .... ao atrocious that nothing in history
De Quincey. approaches then. In spite of the eanon law, which forbade a churehman t
take any part in matters of blood, the archbiahoy signe the warrant for the atrocious aentence. $2 \nmid$. Very grievous; violent: as, atrocious distempers.-3. Very bad; execrable: as, an atrocious pun, [Colloq. $]=$ Syn, 1. il'icked, Scandalous Shocking, F'layrant, lleinone, Infainous, Outrageou, olica, , Monstrous, horrible, villain calling for atrong shhorrenee. Because they sre use with feefing, the reeognition of their differenees is not al ways practicable. F'zayrant and heinous are fisardly applscalle to persons; the others apply to peraons or things
lvicked is the generic word, and is the ilghtest where ai Nicked is the generic word, and is the fightest where ani
are atrong; it is the one that is most common in a pliayfui are atrong; it is the one that is most common in a pliayfni
use, yet it is at times an intense word, as foreible as any of the others, thongh less definite. Scandalous mean offensive to decency, and so disgraceful. That which is shoeking, fiterally, gives a audden and heavy biow, and hence produces a corresponding feeling of horror or dis gust, or both. That which is flagrant, literally, flames into notice, and henee is giaring, atriking, snd so notori.
ons, enornona in bauneas. Il einous meana hateful, and hence argravated. That whiel is infa mones is worthy of a 作 rageous means attended witl oot on for haseness, out dong ontrage, especially out raging decency, going beyond all hounds like the acts of a madnan. Atrocious is primarily flerc or cruel, savage, bloody, and wicked, enormously wicked,
hence violating the first principles of humanity or of
human nature. That which is monstrous is so had as to he out of the course of nature; a prodigy or miracle badness. See abandoned, criminal, irreligions, and nefaAa even here they talked at Almesbury

About the good King and his wicked Queen.

So the king arose and went

To smoke the scandalous hive of those wild bee

Tennyson, Holy Grail. In thia dreadful manner was one who had been tiil the
of an excellent eharacter hurried on, from a aingle, an aeeningiy alight, indulgence, into the depth of the groas. The offenaes which prompt atrong invective have been far more numerous and fagrant in his [Syines Smith' The ohject of this society [Abolition] is now, as it has addreased to their hearta and consciences, by argument addreased to their hearta and consciences, that alave-
loolding is a heinous crime. Ir. Phillips, Speechea, p. 98. There is no crime more infamous than the violation

$$
\begin{aligned}
& \text { Thia ill day Johnson. ropin. } \\
& \text { A most outrageous fit of madness took him. }
\end{aligned}
$$

It is a war base in its object, atrocious in ita beginnin. atropinism (at'rō-pin-izm), $n . \quad[<$ atropin +

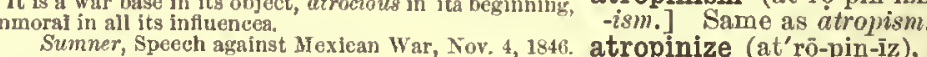

Pliny agsures ws that the moat monstrous of ali criminals atropinized, pp. atropinizing. $t$.; pret. and pp. was the man who first devised the luxurious enstoni of -ize.] To poison or affect with atropin. Also wearing golden rings. Lecky, Enrop. Iorale, If. 15i. sometimes spelled atropinise. atrociously (a-trō'shus-li), adv. In an atro- atropism (at'rō-pizm), $n$. [< atropia $+-i s m$.
cions manner; with great cruelty or wieked- The morbid state produeed by atropin, charaecions manner; with great cruelty or wicked-

atrociousness (a-trō'shus-nes), $n$. The state or quality of being atrocious; atrocity.

The atrociousnegs of the crime misde ani men look with
an evil eye upon the claim of any privilege which might revent the severest justice.

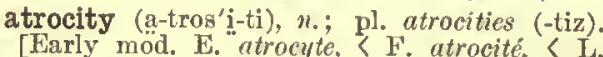
[Early mod. E. atrocyte, < F. atrocite, < L.
atrocita $(t-) s$, cruelty, batefulness, < atrox, cruel, ete.: see atrocious.] 1. The state or quality of being atrocious; enormous wickedness; extreme eriminality or eruelty.

They deaired justice might be done upon offenders, as
the atrocity of their crimea deserved. Burke was the oniy man in England in wlom the prose sion as weli as a fixed principle.
atrocity was a fixed pas2. A speeifie act of extreme heinousness or eruelty; an atroeious deed. The atrocities which attend victory.
Atropa (at'rō-pä), n. [NI, < Gr. "Aтpotos, one the Fates, who eut the thread of life, lit. the pérecv, turn: see tropo.] A genus of plants, natural order Solanacce, of a single speeies, $A$ f Europe and western Asia. See belladonna. atropal (at'rọ-pal), $a$. [<

not to bo turned: see in bot. ted), a. [< atrophy + [Rare.]

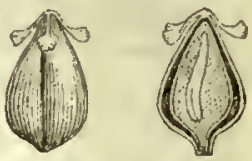
Fruit of Dock (Ratmex).
Section shows erect (atropal)
seeda (From Le Maout and
Decaisne's "Traité généra$$
\begin{aligned}
& \text { Decaisne's " "Traité génénáral } \\
& \text { de Botanique") }
\end{aligned}
$$

[<atrophy $+-i c$.$] Pertaining to atrophy; elıar-$ acterized by atrophy; exhibiting or undergoic organ.

Exhibiting or affected with $\left[\right.$ [ atrophy $\left.+-e d^{2}.\right]$

In many instances special muscies, or gets of muscios, B. W. Richard8on, Prevent. Med., p. 232. D. \& own atrophiced faculties of toving.
E. Phelps, Beyond the Gates, p. 105. (at'rō-fi), n. [= F. atrophic, < LL.atro-

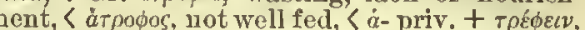
a a pasting of the body, or municates no nutriment to the mernbers; there is an Macaulay, Mitford's IIist. Greece. by the operation of eauses either external to or inherent in the organism.- Brown atrophy, a phicel as a reanlt of vaivular diaease or of old age. The brown, and its fibers contain pignent, accumulated eapeatrophy (at'rō atrophy. ppr. atrophying. [< atrophy, n.] To waste Colin Clont's Calendar, p. 121. atropia (a-trō'pi-ii), n. [NL, < Atropa.] p. I20. atropic (a-trop'ik), a. [< atropia + ic. $]$ of or pertaining to atropin.

pina, < Atropa + -ina: soo-in2.] line alkaloid $\left(\mathrm{C}_{17} \mathrm{H}_{23} \mathrm{NO}_{3}\right)$ obtained from the deadly nightshade, Atropa Belladonna. It is very poisonous, and produces temporary dila-
tation of the pupil. Also atropina and atropia. atropina (at-rọ-pìn'na $), n$. [NL.] Same as $a t-$ terized by dilated pupil, frequent pulse, dryness of mouth and skin, hallueinations, axi delirium. Also atropinism.

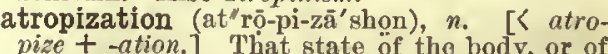
pize + -ation.] That state of the body, or of of atropin.

atropize (at'rō-piz), r. t.; pret. and pp. atropized, ppr, atropizing. [< atropia +-ize.] To add atropin to; affect with atropin. [Gr. 'Arpotos, one of the Fates: see Atropa.]
1. A genus of neuropterous insects, of the family Psocida: synonymous with Troctes. A. pulsatorius ahares with certain beetlea the popular name
of death-watch, and is a great pest in entomological collec. 2. A genus of venomous serpents. Wagler, 1830. [Not in use.]-3. A genus of lepidopterous insects. Okicn, 1815.

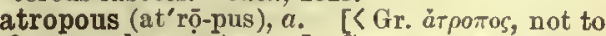
be turned: see Atropa.] Same as atropal ovule. Also atropous.
trophiated (a-trō'fi-a There is no demand for the lahour of the poor; the

Atropos (at'rọ-pos), n. [NL., < L. Atropos, 
atrous (a'trus), a. [< L. ater, black, + -ous.] Intensely blaek. [Rare.]

atry (a-tri'), prep. phr. as adv. or a. [Appar. so arrauged that the bow is kept to the gea. - said of a ship in a gale.

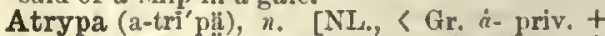
трӥлa, a hole.] A genus of uraehiopors, typical of the family Atrypidec. Daman, 1828. atrypid (a-trítpid), $n$. A brachiopod of the family Atrypicte.

Atrypidæ (a-trip'i-dē), n. $p l$. [NL., $<$ Atrypn
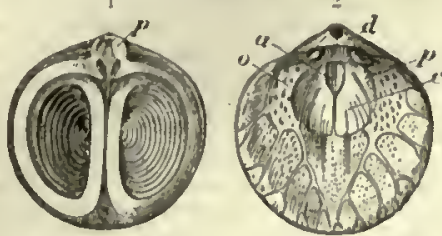

Atryparedicularis.

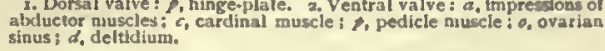

brachiopods with the brachial appendages rigid and apirally coiled toward the center of the shell, and eomplotely supported by spiral lamelle, the valves generally subovate or tri lobed, the foramen bencath a produeed beak stance fibrous and impunetate.

Atta (at'i), n. [NL., <L. Atta, a aurname for Atta (at' ${ }_{\text {. }}$, n. [NL.,
persons who walk on the tips of their shoes ef. atta $=$ Gr. arta, a childiah word for father, used familiarly in addressing an old man. Cf. Goth. atla, father.] A genus of hymenopterous

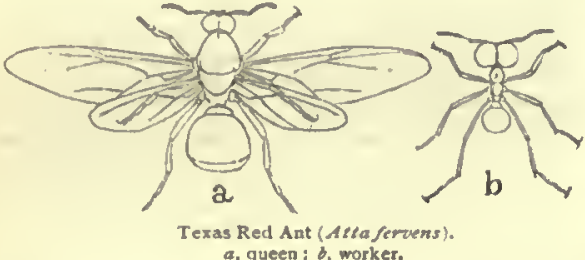

insects, of the auborter Heterogyna and family Formicide, or ants. They have very short palps, anc Weat Iadian specles called the visting ant, and A. fervens is the red ant of Texas.

attaball, $n$. Sce atabal.

attacca (ât-tak'kaji). [It., impv, of attaccare join, fasten, tie, $=\mathrm{F}$. attacher: see attach and attack.] In music, begin! a direetion to pro eeed with a suceeeding movement immediately, without pauso.

attach (a-treh'), v. [< ME. attachen, atachen (only in the legal sense, the lit. sense being of mod. adoption), ( OF. atacher, atachier, later and ataquer, mod. F. attaquer, > E. attack, q. v.) (= Pr. attacar $=\mathrm{Sp} . \mathrm{Pg}$. atacar = It. attaccare: Pr. attacar $=\mathrm{Sp} . \mathrm{Pg}$. atacar = It. attaccare: $\mathrm{see}$ attacca), fasten, join, lit. trek to, $a-(<\mathrm{L}$. ad,
to) +" tac (not found in OF.), Genevese tache Sp. Pg. tacha = It. tacca, < Bret. tach, a nail, = lr. taca, a nail, peg, = Gael. tacaid, a nail, taek, law, to take by legal anthority. arreat in person: now a ppled only to arrest of a perily: by civil process to answer for a contempt of court or dis regard of its maniate, but form
with for, also formerly with of.

Thero were two or three altached for the sane robbery.
Latimer, 4 th Bermen bet. Edw. VI., 1549. of capltal treason I astach you both. to be held for the aatisfactlon of the judgment that nas $2 \uparrow$. To lay hold of; seize.

Then, homeward, every wan attach the hand
of hils tair mlatreas.

3. To take, seize, or lay hold on, by moral foree, as by affeetion or interest; fasten or bind by moral influenco; win: as, his kindnes atteched $\mathrm{us}$ all to him.

Songs, garlanils, flowers,
And charming aymphonlea attach 'd the beart

Milton, P. L, xi. 695

4. To tack or fix to; fasten in any manner, as one thing to another, by either natural or artificial means; bind; tie; cause to adhere.
The next group consists of these Rotifern which seldon or never attach themselves by the foot, lunt swhn freel such temperaments... attach themselves, like barSuch temperaments ... attach themselves, like bat-
uaclea, to what seema permanent. Loucell, Firesicie Travely, J. 67. 5. Figuratively, to conneet; associato: as, to attuch a partieular gignificaneo to a word.

lle attaches very little Importance to the invention of
gunpowder.

6. To join to or with in actlon or function connect as an associate or adjunct; adjoin for duty or coupanionship: as, an officer is at tached to sueh a ahip, regiment, battalion, ete. tached to such a ahip, regiment, battalion, ete.
our regiment ia attached to the lat brigade; this man is attached to my service; he attached himself to me for the entire journey.- Attached

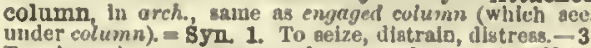
To win, gatn over, evgage, clarm, endear one's selt to

II. intrans. 1. To adhere; pertain, as a gnality or cireumatanee; belong or be incident with to.

The fame of each diacovery rightly attaclees to the minc that made the furmula which contains all the details, and
not to the usanufacturers who now make their galu by it
Lineraon, success

$T o$ the healthful performance of each function of mind II. Spencer, Social Statics, p. 02 2. To be fixed or fastened; reat as an appur tenance: with on or upon.

Blame attached upon Lord Aberdeen'a Cabluet for yield
Kinglake, Crimea, I, 491 , $(N, E, D$. 3. To eome into operation; take or have effect. After the rikk [in marine insurance] has once com
menced, the whole premlum la earned, even though the menced, the whole premlum la earned, even though the
voyage ahould not be prosecuted. But if the risk "polley ahould not attach," the premium must be returnes attach $\nmid($ a-tach $), n . \quad[<$ attach, v. $]$ 1. An at nont.

I am made the unwilling instrunent
of your attach and apprehension.

2. An attack. Heyreood, Woman Kllied with KJodness.

attachable (a-tach'a-bl), a. [<attuch +-able. 1. Capable of being attached, legally or other wise; liable to be taken by writ or precept.2. Capable of being fastened or conjoincd as an adjunet or attribute.

attaché (a-ta-shä), n. [F., prop. pp. of at tacher, attach: see attach.]. Ono attached to another, as a part of his suite or as one of his attendants; apecifically, one attached

George Gaunt and I were intimate lo early life : howa my Juntor when wo were attaches at Pumpernickel to
ghackeray, Vanity Fair, xlvil.

attachedly (a-tach'ed-li), adv. With attach ment. [Rare.]

attachment (a-tach'ment), n. [< ME. attach ment (in sense 1), < attachen, attach; in other senses < F. attuchement, < attacher: sce attach. 1. The act of attaching; speeifieally, in law, a taking of the person, goods, or estute by a writ or precept in a civil action, to secure a debt or punish for contempt. In American usage, attoch ment, when used in reference to property, means the taking
of the defendant's property into cuatody by the law, liy a gummary proceas fronl a court, in advance of the trial of the merts of the case, as security for the payment of any
judgment that may be recoverei. The grounds of grant ing it are ususily evidence of fraud or trandulent disposa. of property, or apprehenaion of absconding, etc. Whel the person finto custody to answer to as eharge of contempt of court. Foreign attachment Is the taking, from the
hands or control of a third person within the jurisdiction, an the money or goods or riglat of action of a debtor
who is not withtn the furtadiction. Any person who has who is not within the furtadiction. Any person who has agent, sttorney, factor, or trustee of the debtor; and an attachment served on sech person binds the property in The process of foreign attachment has extated from time imnemerial In London, Bristol, Exeter, Inneaster, and
some other towns in England, and lyy the Conmon Law some other towns in England, and ly the Common Law
Procedure Act of 1854 has been made general. It is also Procedure Act of 1854 has been made general. It is als ment, and in New England as trusee procenh

2 . The writ or proeess direeting the person or estate of a person to be taken, for the purposes above stated.-3. The act or state of being attached, fastened on, or connected. -4 . Close adherenee or affection; regard; any passion or affection that binds a person to another person or to a thing. The attochment of the people to the luatitutiona and the
inwa under whleh they live is
the glory, and the aafety of the land. once the atrength, the glory, and the aafety of the land.
Gladstone, Might of Right, p. 270. ('romwell hal to deternnine whether he would gut to army. . . to save a prince whom no engagerment coutd The heredilary attachments of these kiugs [Fanglish] lay in Anjou and Acuitaine far more than in Fingland, or even 5. That whlch attaehes one thing to another, a a person to an object: ns, the attacliments of or a person to an object: as, the attachments of which is attaclied to a princijal object; an adjunet: as, the aolian attacliment to the piano; an attachment to a aewing-machine.-Eollan

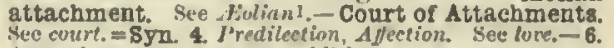
Appenclage, aypurtenance, addition.

attachment-screw (a-tach'ment-skrö), n. A binding-serew.

attack (a-tak'), $\bullet$. [Forner]y also attacque, attaquc; ? F. attaquer, OF. ataquer, unassibilated form (perhaps < Pr. attacar or It. attaccare) of attacher, join, fasten: seo athech.] I. trans. 1. To agsault : fall upon with force; assail, as with foree and arms; begin hostilities against. The strong tribe, in which war bas become an art, attack and conquer their neighbers, and teach them their

2. To endeavor to injure, overthrow, or bring into diseredit by any act or proposal, or by unfriendly words or writing, whether by eatire calumny, criticism, or argument: aa, to attacl a religious belief or a legialative measure; to attack a man or his opinions in a newspaper.

The people'a intereat is the only object that we have any right whatever to consider in decluing the queatton, whether or not the present state of things shall be auh-
brougham. 3. To make an onset or attempt upon, in a general sense; begin action upon or in regard to; set about or upon: as, to attack a picee of work or a problem, or (hnmorously) the dinner. 4. To begin to affeet; come or fall upon; seize said of diseases and other dest ructive agencies: as, yesterday he was attacked by fever; earies attacked the bones; locusts attached the creles. Speeifically -5 . In chem., to eause to decompose or diasolve.

The bodiea are of a sillceous character, for they are not $=$ Syn. 1. Set upon, Fall upon, etc, (aee assuil), assault, II. intrans. To make an attack or onaot: s, the enemy attacked with great boldness.

Those that attack generally get the victory. Cane, Campalgn

attack (a-tak'), n. [= F, attaque; from the verb.] 1. A falling on with force or violence, or with ealumny, satire, or criticism; an onzet ; an assault.

I wish that he [Jir. Sumner] may know the shudder of terror whtch ran through al
tidiugs of thls brutal attack.

2. Battle generally; fight. [Rare.]

The hattel hung time tin even scale

The hattel hung $;$ till satan, . . .

Saw where the sword of Mllchael smote, and fell d

3. An onset of any kind; the initial movement in any active proceeding or contest, as a game of chess, cricket, etc.; in music, specifically, the act (with referenco to the manner) of beginning a piece, passage, or phrage, especially
by an orcheatra. -4 . The aggressive part of the art of fencing: opposed to defonse.

Aitack are made In three ways:- first, by a quick
thruat proceedling merely from the wriat, the arm at the same time being elevated and advanced, with the point directed towards the adversary's hreast ; secondly, by
what is technically ealted an extenslon; and lastly, by 5. A seizure by a disease; the onset of a dis. ease. - Attack of a sioge, an assault upon an enemy"
feld or permanent fortificatlons, by means of parallels, galleries, saps, trenches, mines, enflaling, eounter., of breschlng-battertes, or by atorming partles, - To deliver
an attack. See deliverl. = Syn. 1. Charge, Onslaught, etc. attackable (a-tak'a-bl), a. [< attack + able = F. attaquable.] "Capable of being attacked; assailable.

attacker (a-tak'èr), n. One who attacks or assaults; an assailant.

attagas (at'a-gas), n. [NL., < Gr. árrayär, a bird deseribëd as of a reddish eolor and apotted on the back; prob. a kind of partridge. See attagen.] Same as attagen.

attagen (at'ag-jen), $n$. [L., also attagena, < Gr. aттау $\dot{v}$, also аттаY from the árrayāc), prob. a kind of grouse, the franeolin, elassed with the partridge, pheasant, 
attagen

370

ete.] 1. Properly, the common partridge of attainableness (a-ta'na-bl-nes), n. The qualEurope, now known as Perdix eincrea. - 2. A ity of being attainable.

name given to various other Furopean birds. (a) Used indiscrininately by early writers Lor sundry gaa.
linaceous birds of Europe, as grouse, ptarnigan, parlinnaceous birds of Europe, as grouse, ptarnigan, par-
tridges, francolins, Pteroctes acchata, etc. (b) Used by Moehring, 1752, lor the frigate-bird or nan-ol-war, bird,
Tachypetes aquila, and adopted by G. R. Gray, 1871, in the Tachypretes aquila, and sdopted by G. R. Gray, 1 s71, in the
spelling Atagen, as the generic name of these hirds:

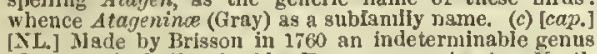
of grouse, including, besides European species, two North Anerican birds called Attagen americana and Attagen
pensilvanice. (d) Applied by Cuvier (1817) to the sandpersitvanice. (d) Applied by Clyier (1817) to the sand-
grouse of the genus Syrrhaptes (111iver, 1811 , the only specles of which known to Civier was Pallas's sand-grouse

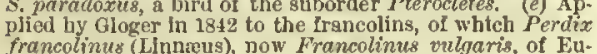

rope, etc., is the type.
Also atagen, attagas, atagas.

Attageninæ (at" "a-je-ni'në), n.pl. [NL., < Attagen, $2(b)+$ + inc. Atagemine is the form used tion (1871), a subfamily of totipalmato birds, named from Moeluring's genus Attagen (1752), equivalent to the family taehypetida of authors equivalent to the family Taehypetida of authors
in general; the frigate-birds or man-of-war in general; the frigate-
birds. See Tachypetide.

attaghant, n. Same as yataghan.

attain (n-tān' $\left.{ }^{\prime}\right), v$. [< MLE. attainen, atteinen, attaindryt, $n$. An obsolete form of attainder. atainen, ateinen, ete., < OF. ataindre, ateindre attainduret, $n$. [A mixture of attainder and (atrign-, ateign-), $\mathrm{F}$. atteindre $=\mathrm{Pr}$. ateigner, attainture.] An obsolete form of attainder.

atenher $=$ It. attignere, attingere, attain, $<$ I. at- attainment (a-tān'ment), $n . \quad[<$ attain + -ment. $]$ tingere, touch upon, attain, $<a d$, to, + tangere, 1 . The act of attaining; the act of arriving at touch: see tangent. Cf. attainder and attaint. touch: see tangent. Cf. attainder and attaint.] I. trans. 1t. To touch; strike; hit. -2 t. To touch upon; mention.-3†. To conviot; con-
demn. Compare attaint, vo, 3-5. - 4 . To come so near as to touch; reach, achieve, or aceomplish (an end or objeet) by continued effort; come into possession of; aequire; gain.

$$
\begin{aligned}
& \text { Ends we seek we never shall attrin. } \\
& M \text {. Arnold, Self- }
\end{aligned}
$$

5. To come to or arrive at (a place); reach (a place, time, or state)

canaan he now attcins.

He has scarce attained the age of thirt

To reach in excellence or degree; equal.

So the first precedent, il it be good, is seldom attaine
by imltation 7t. To overtake; come up with: as, "not at know; experience." Chaveer. $=$ Syn. 4. Attain, ob know; experience. Chaueer. $=$ Syn. 4. Attain, Ob

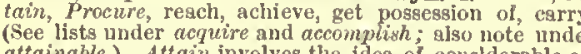
attainable.) Attain involves the idea of consldersble ef.
lort, while obtain does not necessarily imply effort at nil and procure only a small degree of it: thus, we may ob tain property by thheritance, we may procure a book h purchase, but we can attain an cnd only by exertiol
Attain generally has higher or more abstract objects tha obtain or procure: as, to obtain an office or a patent; to
procure a chair: to attain eninence: attain one's end. procure a chair; to attain ensinence; attain one's end
In these cases it would be ludicrons to use attain in place

The Khans, or story-tellers in Ispahan, attain a control ling power over their sucieince, keeping them lor many Einergon,
Sonte pray for riches; riches they obtain

But, watch'd by robbers, for their wealth are slain.

Have you a catalogite
Of all the voices that wh have provert'd
Set down by the poill?

II intrans 1. To reacly; come or anive motion, bodily or mental exertion, or efforts of any kind: followed by to or unto.

Such knowjedge is too wonderfnl for me; it is high;
can not attrinounto it. 2t. To pertain; have relation. Chaneer. attaint (a-tān'), n. $[<$ attain, v. $]$ Something attainability (n-tā-

ble: : attainable (a-tán na-bl), $a_{0}[<$ attain $+-a b l e$. Capable of being attained.

He [Plato] quits the normal for the attrinable. De Quincey, Plato. All that is said of the wise man by Stoic, or oriental or modern essayist, describes to each reader lis own ldea
his unattained but attainable seli.
Emerson, 1 listory. IAttainable was lormerly sometimes used where obtainable or procurable wolld now be prelerred, as in the follow

The kind and quality of lood and liquor, the species of hibitation, Iurniture, and clothing, to which the conmmon
peopie of each conntry are habituated, mist be attainablc
with ease and certsinty.
Palcy.

Generai Howe would not pernit them Iclothes and not attainable in the country.

$=$ Syn. Practicable, feastble, possible, within reach. dere, < OF. ataindre, ntcindre, attain, tonch pon, affect, accuse, attack, attaint, convict; stain, or corruption has been nected with this word: see attaint. 1 . The act of attainting, or the state of being attainted; outlawry pronounced in respect of treason or as, a bill of attainder; to remove an cluded forleiture of lands, tenements, and liereditaments, incapability of suing in a court of justice, or of performing any of the duties or enjoying any of the priv ing the person affected incapsble of tnheriting property

An act of attainder was carried against him, as one who
had been indicted for piracy and murder, and had fled Bancroft, HIst. U. S., I. 188.
(rom justice. 2. A bringing under some disgrace, stain, or tation; the state of being in dishono So to the laws at large I write my name:
And he that breaks them in the least degre

r reaching; the act of obtaining by exertion or effort.

The attainment ol every desired object.
Sir W. Jones, Hitópadéss 2. That which is attained, or obtained by ex ertion; acquisition; acquirement.

Formerly the natural impulse of every man was, sponbooks was a secondary attainment not made without
effort. Snatterers, whose attainmenfy just suffice to elevate
them Irom the insignificance of dunces to the dignity of
hores.
Macaulay, Mill on Government. =Syn. 2. Acquirement, Acquisitions, etc. See acquir

attainort, n. [s attuin + or, after AF. attei gnour.] One of the jurors in the process called attaint (a-tānt'), $v$.

en, atteinten, p. of ataynen, ete., after OF. ateint, pp. of atein pp. of ataymen, ete., after OF. ateint, pp. of ateinously associated with taint, stain, corruption, ously associated with taint, stain, corruption,
to which some of the senses are due.] 1t. To touch; hit in tilting.-2†. To attain; ascertain. -3t. To convict (a jury) of having given a pass judgment on, as on ore found guilty crime, as felony or treason, involving forfeiture of civil privileges.

1 dare undertake, that at this day there are more at taynted landes, concealed from lier Majestie, then she
bath now possessions in all Ireland. Spenser, Present State
I must offend belore I be attainted. Shate.

No attainder of treason shall work corruption of blood,
or forfeiture except during the life of the person attainted? Constitution of $U$. $S_{\text {., }}$ iii. 3 5t. To aecuse: with of: as, to attaint a person

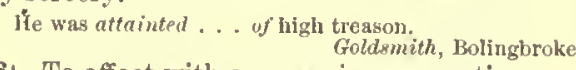

6t. To affect with any passion or emotion.

This nohle woman . . attainted with extreme sorrow:
Historia Anglica (trans.)

7. To taint; disgrace; cloud with infamy tain; corrupt.

Lest she with blame her honour should attaint.

That the pleasure is of an inlerior order, can no more attaint the idea or model of the composition, than it can
inpeach the excellence of an epigram that it is not a
trsgedy.
De Quincey, Rhetoric.

attaint (a-tānt'), p.a. [The older pp. of attaint, $v$.] 1. Attainted; convicted.-2. Tainted; corrupted; infected; attacked.

My tender youth was never yet attaint
With any passion.

Auterfoits attaint. See auterfoit

ttaint (a-tānt'), n. [< attaint, v.] 1t. The act of touching or hitting; specifically, in tilt ing, a hit. [Arehaic.]

"Youn, reverend sir," said the knight, "have in the en

2. A blow or wound on the leg of a horse cansed by overreaching. - 3. An ancient legal process the legal consequence of judgment of death or attask

instituted for reversing a falso verdict given by a jury; conviction of a jury for giving such a verdict. -4 . In old law: (a) A conviction. (b) Impeachment. - 5t. Infection; injurious or deloterious action.

The narrow-eating sickness, whose attaint

6. Attainder. It was a point of honour with his [Bismarck's] Govern-
ment that the captive royslists should at every cost a]-

7. A stain, spot, or taint; hence, a disgrace an imputation involving dishonor.

Shak., C. of E., iii. ?

attaintmentł (a-tānt'ment), n. $\quad[<$ 'attaint + -ment.] The act or statë of being attainted or affected with attainder; conviction; arrest; impeachment.

When thls man was attalnted there, snd they lad liberty to say nay to his attaintment if they would, sure I am ward. Latimer, quoted in Dixon's Hist. Church of Eng. for-

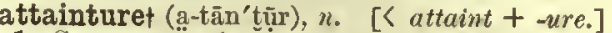

1. Same as attaintment. Her attainture will be Humphrey's Iall

2. Imputation; stain. Withont the least attainture of your valour.

Chapman, Byron's Tragedy, ii., 1

attake,$+ v . t$. See atake.

attal (at'al), n. Same as attle

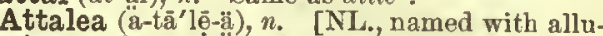
sion to the beauty of the trees, < L. Attalus, Gr. "Artanos, Attalus, the name of three kings of Pergamum; Attalus I. and II. were noted for their wealth and liberality.] A genus of palms, allied to the cocoanut, natives of tropical Amcrica, and distinguished by the fact that the nut contains three cells, each inclosing a single seed. There are about 20 species. The nuts, which hang in great clusters, are egg-shaped, with a very The pinnate leaves are very large, and are often used for stalks of $A$. furifera are made into ropes and broom The seeds are mits called coquilla-nuts; they are 3 or 4
inches long, lrown in color, hard, and of sufficlent thickinches long, lrown in color, hard, and of sufficient thick-
ness to be turned into door-handles, small cups, etc. The ness to be trurned into door-liandles, small cups, etc. The
cohme palm, $A$. Cohune, is the largest paln that is found in Guatemsla and Honduras.

attalica (a-tal'i-kä), $n_{.} p l$. [I., nent. pl. of Attalicus, [ Attalus, S Gr. "Artahos.] Cloth of gold: a name derived from its supposed intro attaman (at'a-man), n. Same as hetman.

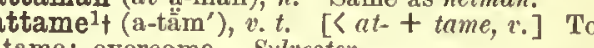
tame; overcome. Sylvester.

attame ${ }^{2}+v . t$. [< ME. attamen, atamen, open, broach, begin, injure, < LL. attaminare, touch, attack, dishonor, $<$ L. ad, to, $+{ }^{*}$ taminare, touch: see eontaminate.] 1. To broach or open cask, etc.). Chaucer.-2. To begin; venture upon; undertake.

Ryght anon his tale he hath attamed.
Chaucer, Prol. to Ninn's Priest's

attaminatet (a-tam'i-nāt), v. $t$ [< I attominatus, pp. of attaminare, contaminate: see at natus, pp. of attaminare, contaminate
tame $\left.e^{2}.\right]$ To contaminate. Blount.

attap (at'ap), n. [Native name; also written atap and adap.] The Stipa frutieans, a nearly stemless palm of the tidal forests of the East Indian archipelago. Its smooth pinnste leaves are Irom 15 to 30 leet long, very thick and strong, and are ex
tensfvely used for thatching.

The rool is thatehed with the comnon Buttam attap

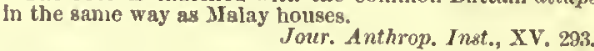

attaqnet, $v$, and $n$. A former spelling of attaek attar (at'är), n. [Also written atar, ottar, and otto; < Pers. 'atar, Hind. atr, < Ar. "itr, fragrance, perfume, esp. of roses (Pers. 'atar-gül, grance, perfume, esp. of roses (Pers. 'atar-gul,
attar of roses), <'atara, smell sweet.] In the East Indies, a general term for a perfume from flowers. In Europe it generally denotes only the attar or otto of roses, an essential oil miade in Turkey and various other eastern conntries, chiefly from the
damask rose, Rosa Damascena. The yleld Is very small damask rose, Rasa Damascena. The yleld Is very small,
150 pounds of rose-leaves yielding less than an ounce of 150 pounds of rose-leaves ylelding less than an ounce of Kazanilik, on the southern side of th Balkan mountains, in Eastern Rumelia. The pure oi well-known perfume, but the odor is agreesble only when diffused, being too powerful when it is concentrated. It ls largely used in the scenting of snuff. Also written ot

attask $\dagger\left(a-t a \dot{s k} k^{\prime}\right), v . t . \quad[<a t-+t a s k$.$] To task;$ tax; reprove; blame.

You are nuch more altask'd for want of wisdom,
Than prais'd for harmful milduess. Shak., Lear, i. 4. 
attastet, $v$. [MF. ataste, < OF. ataster, taste, < soe tcmpt.] 1. To make an effort to effect or $a \cdot($ L. $a d)+$ taster, tasto: soo taste.] I. trans. To taste. Chaucer.

II. intrans. To tasto (of). Ye shullen ataste both thowe and slieo Lydyate.
Of thilke water. attet. Middle English assimilation of at the Chaveer.

Attelabidæ (at-e-lab'i-dē), n. $p l . \quad\left[N L_{.},<d t\right.$ tabus + idae. A family of rhynchophorou betles. Seo ittelabine.

Attelabinæ (at" $0-1 a-b \bar{i}^{\prime} n e \overline{)}, n . p l$. [NL., < Atte labus + -ine.] A subfamily of Cureulionida typificd by the genus Aticlabus, containin weevils with the abdomen alike in both sexes, the mandibles pincer-liko, the elytra without a fold on the innor surface, and no labium. Tho gronp is sometimes raised to the

family under tlio namo Attelabida.

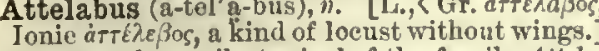
A genus of weevils, typical of the family Attela bide. A. rhois is a roddish pubescent speeles with a short probosels infesting the

parts of the United States, $v . t$. [<ME. attempren, atempren, < OF. atemprer, < L. attemperare, fit, adjust, accommodate, < ad, to, + temperar, control, moderate, temper: see temper, $v]$.1 . To reduce, modify, or moderate by mixture: as, to attemper spirits by diluting them with water. Nobility nttempers sovereignty.

2. To soften, mollify, or moderate: as, to attemper justice with clemency.

Those smillung eyea attemp'ring every ray.
Pope, Floiga to Abelard, 1. 63. Those [influences] which, in older and more normally constituted communities, modily and attemper Mammon.

3. To mix in just proportion; regulate.

God hath so attempered the blood and bodles of fishes.
Ray, Works of Creation. Ray, Works
Pure of blame,

In praise and in diapralse the sante,
A man of well-attemper'd trame.

Tennysom, Duke of Wellington.

4. To accommodato; fit or make suitable. The joyous birdea, shrouded in chearefull sinade,

Thelr notca unto the volce attempred sweet.
Spenser, F. Q., II. xil. 71.

Arts attemered to the lyre. Spenser, H. Q., 11. Pope [In all

attemperament (a-tem' pér-a-ment), n. A tempering or mixing in due proportions. Also at temperment.

attemperancet (a-tem'pèr-ans), n. [<ME. at temperaunce, < OF. atempränce, < atemprer, attemper. Cf. temperanec.] Temperance.

temper. Cf. temperanec.] Temperance.
attemperate (a-tem'pér-āt), v. t.; pret. and p. attemperated, ppr. attemperating. [< L. pp. attemperated, ppr. attemperating. [< L. attemper.] if. To attemper; regulate.

If any one do . . . attemperate his actions accordingly.
Bnrrow, Nath. Lectures, Iv.

2. In breaing and distilling, to regulate the temperature of, as the wort.

attemperatet (a-tem'pèr-ät), p.a. [< L. at temperatus, pp.: see the verb.] 1. Tempered; proportioned; suited.

IIope nust be proportioned and attemperate to the
promise.
IIammond, Pract. Catechlsm. 2. Moderate; equable; mild: applied to climate.

attemperation (a-tem-pe-rā'shon), n. $[<a t$ temperate, v.] 1 $\nmid$. The act of attempering, regulating, adjusting, or accommodating. $B a-$ con.-2. Tho act of regulating the temperature of the wort in brewing and distilling

attemperator (a-tem'pèr-ã-tor), n. [< attemperate, $\left.v_{.},+-o r.\right]$ In brewing and distilling, a contrivance for regulating the temperature of the wort during the progress of fermentation. attemperlyt, adv. See attemprely.

attemperlyt, adv. Seo attemprely. $\quad[<$ attemper + -ment.] Same as attemperament.

attempret, $a$. [ME., also atempre, < OF. atempre, pp. of atempier, attemper: see attemper.]

Atenpre diete was all hire phyaike.

attemprelyt, adv. [ME, also attomperly, < attempre $\left.+-l y,-1 y^{2}.\right]$ In a temperate mannor. Chaucer.

attempt (a-tempt'), $v . t . \quad[<\mathrm{OF}$. atempter, attenter, mod. F. attenter $=$ Pr. attentar $\overline{\overline{\mathrm{S}} \text { S. }}$. atentar $=\mathrm{Pg}$. attentar $=\mathrm{It}$. attentare, $<\mathrm{L}$. at temptare, more correctly attentare, try, solicit, sad, to, + temintare, more correctly tentarc, try: do; endeavor to perform; undertako; essay as, to attempt a bold flight. The wise and prudent conquer diffeulties by daring to
nitennpt then. Something attempted, something done, Longfellow, Village Blacksmith. 2. To venture upon: as, to attempt the sea.3t. To make trial of ; prove; test: as, "wellattempted plate," Fairfax.-4 4. To try with af flictions. Jer. Taylor. $-5 \nmid$. To endeavor to obain or attract.

Thia man of thine attempts her love. Shak., T. of A., I.

6. To try to win or seduce; tempt; entice.

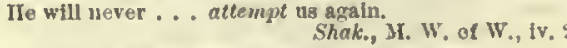

\section{It made tbe laughter of an afternoon,} Tennyson, Jlerlin and Vivien.

7. To attack; make an effort against; assail : $\therefore$, to attempt the encmy's camp; to attempt a person's lifo.

Mugter
Our soldierg up ; we"ll gtand upon our guard

For we alasll be nttermpted. Beau, and Fl. Thierry and Theodoret, 1.

Caluniny never dared to suspect her morals, or atcenpt er character.

= Syn. 1. Attempt, Esaray, Undertake, Endearor, Strive, Struggle, seek, aim. Thie tislicized words agree in expressing the beginuing of a task, physical or intellectusl, which of rder of strength. Alcmipt is to try with sonie efror one or aftalned, and sometimes simply to attempt: a "which the Egyptians assaying to do were drowned, ILeb. xl. 29. Undertake ts, literally, to take a tnsk upon with care and effert. Endeavor is to try with more earneatness, labor, or exertion. Strive la to work isrd an to the extent of fatigue, pain, or exlaustion. The firs three words are noro sppropriste for a single None are very violent against it [writing plays in verse
but those who elther have not attenpted $\mathrm{tt}$, or whe hav aucceded til in their attempt.

Dryden, Ded. of Ess. on Dram. Poeay. Instinct led him [Tennyson] to construct lits machinery I will . . . undertake one of Hercules" labours

Shak., Sinch Ado, ti. 3 In what I dil endeavour, it is no vanity to say, I have
Dryden, Annus Mirabills. A certain truth possesses us, which we in all ways serive o limed soul, that, struggling to be free, putting forth of effort in the performance or certain; essay, trial, or endeavor; effort.

$$
\begin{aligned}
& \text { The attempt, and not the deed, } \\
& \text { Shak. Mracbeth, 11, } 2
\end{aligned}
$$

By his blindness malm'd for high autempts.

2. An effort to accomplish something by foree or violenco; an attack or assault : as, an attempt upon one's life.

Forelgu attempts against a state and kingdom

Ford, Perkin Warbeck, 1.

3t. Temptation.

The attempt itself intended by our foe.
For he who tempts, though in vain, at lcast asperses
The tempted with dishonour foul. Milton, $P . \mathrm{L}_{\omega}, \mathrm{ix}, 295$

The tempted with dishonour foul. Milton, P. I., ix. 295 . 4. In law, an act done in part execution of a golicitation or preparation, without \& step taken toward the actual commission, is not a criminal netempt. $=\mathrm{Syn}$. Undertaking, effort, endeavor, enterprise, experiment. temptability (a-temp-ta-bilis-ti), $n$. [र ating attemptable.-2. A thing that may be ating attemptable.-
tempted. [Rare.]

Short way ahend of us it is all dim; an unwound skein of possibilitles, of apprehensions, attemptrbilities, vaguettemptable (a-temp'ta-bl), a. [< attempt + -able. Capable of being attempted, tried, or $_{\text {attacked; fikely to yield to an attempt or at- }}$ tack.

Less attemptible than any the rarest of our ladies in attemptate† (a-temp'tãt), n. [<OF. attemptat, mod. F. attentat: seo attentate.] An attempt or endeavor; especjally, a violent or criminal attempt or attack; assault; outrage. attempt (a-tempt'), n. [< attempt, v.] 1. A
For tho better detense of his highness's loving subjects the sanie shires in ease of any invasion or other atten. Somerget, ingoted in Dixon's Hist. Church of Eng., xv., note. attempter (n-temp'tèr), n. 1. One who attempts, tries, or endeavors. -2 . One who at tacks or assails; an assailant.

Agninst the alfempter of thy Finther's throne.

3†. A tempter. Milton.

attemptive (a-temp'tiv), a. [<attempt + -ive.] leady to attempt; enterprising; venturous. Danicl.

attend (a-tend'), $v_{0}$ [<OF, atendre, $\mathrm{H}_{\text {. attendre }}$ wait, retlex. expect, $=\mathrm{Sp}$. atender $=\mathrm{Pg}$. attender $=$ It. attendere, < L. attendere, streteh toward, give heed to, $<a d$, to, + tendere, stretch: seo tend, and cf, attempt.] I. trans. 1. To fix the mind upon; listen to; havo regard or pay heed to ; consider. [Archaic. Seo II., 1.]

The diligent pllot... doth not attend the unskilful
Sir P. Sidney. The erow doth sing as sweetly as the lark Their hunger thus appeased, their care attends

2. To accompany or be present with, as a companion, minister, or servant, or for tho fulfilment of any duty; wait upon.

$$
\begin{aligned}
& \text { The fit had charge sick persons to attend. } \\
& \text { Spenser, F. Q., I. X. } 41 . \\
& \text { Let one attend htm with a silver bason. } \\
& \text { Shak., T. of the S., Ind., I. } \\
& \text { You shall have men and horses to nttend yon, }
\end{aligned}
$$
ind money in your purse.

Fleteher, Rule a Wife, ii. 3

3. To be present at or in for purposes of dnty, business, curiosity, pleasure, ete. : as, to attend meeting. - 4. To accompany or follow in immediato sequence, especially with a causal connection: said of things: as, a cold attended with fever; a measure attended with bad results. A correspondent revolution in things will attend the 5ł. To wait or stay for ; expect, as a person or an event.

Thy intercepter, . . bloody as the hmiter, attends thee
Shak., T. N., lli. 4. The trumpets, next the gate, in order placid, dttend the sign to sotund the martial hlast.

6t. To be in store for; await. The state that altends sll men after this. Locke.

One tate altends us, and one conmon grave.
Dryden, tr. of Lucretius, ilt. 304.

II. intrans. 1. To give attention; pay regard or heed: followed by to: as, my son, attend to $\mathrm{my}$ words.

Attend to the volee of my supplications. 2's. Ixxxvi, 6 . It will be snfficient for me if 1 discover many Besutfes

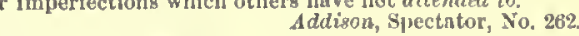
2. To be present, in pursuance of duty, business, or pleasure; especially, act as an attendant: absolutely, or with on or upon, or at: $\mathbf{a s ,}$ who attends herol to attend upon a committee; to attend at sucl a church. Hence-3. To fix the mind in worship: with on or upon.

That ye may attend upon the Lord without distraction.

4. To be consequent; wait: with on or upon. It is good that a certain portion of disgrace shonld constantly attend on ceriain bal actions. 5†. To stay; wait; delay.

For this perfection she must yet altend

Till to her Maker ahe cspoused be.
Sir J. Darieg, I mnortal. of Soul.

ttendt (a-tend'), n. [<attend, r.] Attendance. Stars have made your tortunes climb so high,

To give attend on Rasni"s excellence. attendance (a-ten'dans), n. [< ME. attendaunce, $<\mathrm{OF}$. atendäce $=\mathrm{Pr}$, atendensa, ML. attendentia, $<\mathrm{L}$. attenden $(t-) s$, ppr. of attendere: see attend and -ance.] 1. The act of attending or attending on. (a) The set of waiting on or serving; the state of being present for purpo No man gave attendance at the altar. Ifeb. vil. 13. Lindamira, a lady whose . Constant ntlendance at
church three times \& day had utterly defeated many malielous attacks upon her reputation.
Fielding, Joscph Andrews. The other, after many years" allendance upon the duke, was now one of the bed-chamber to the prince. Clarendon.

(bt) Attention ; regard; careful application of mind.
He called ... for redress of the attemptates conimitted

Give attendance to reading.

(ct) A waiting on, as in expectation.

1 Tim. Iv. 13. 
attendance

372

That which canseth bitterness in death is the languish- attentatet, attentatt (a-ten'tāt, -tat), $n$. [< F. ling attendance and expectation thereof ere it come.

2. The body of persons attending for any purpose: as, a large attendanee is requested.

The attendance of the 'lurieg was scanty, as no impor-
. Ifaculay, li ist. Eng., xv.

3t. Attendants collectively; persons waiting on one to render him servico; a train; a retinue. -To dance attendance. See dance. attendancył (a-ten dan-si),
a train or retinue. Fuller.

of honour another part is attendancy; and therefore, in the visions of the glory of God, angela are apoken of as his attendants. 2. Relation; relative position.

To name lands by the attendaney they have to other
lands nore notoriuus. Bacon, Mlaxims of the Law, xxiv. attendant (a-ten'dant), $a$. and $n, \quad[<\mathrm{F}$. attendant ( = It. attendonte), ppr. of attendre, wait:

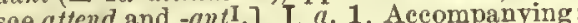
being present or in attendance.

Other anns perhaps,
With their attendant moons, thon wilt descry.
Milton, P. L, vili. 149.

2. Accompanying, connected, or immediately following as eonsequential: as, intemperance, with all its attendant evils. Those bodily pains and sufferings which o. are but
too trequently attendant upon any disorder of the Iancy.
Barham, Ingoldsby Legenda, I. 183.

3t. In law, depending on or comnected with H. Th lave or some person; owing duty or service. -Attendant keys, in music, aame as relative keys.

see relative.

II. $n$. 1. One who attends or accompantes belongs to a train or retinue; a follower.

Brave attendants near him. Shak., T. of the S., Ind., i The Furieg, they gaid, are attendants on justice, and it the sun in heaven should transgress his path, they would
Emergon, Compensation. Eunish him.
Emergon, Compensation. of another, as a suitor or the like.

To give an attendant quick despatch is a civility

Specifically - 3. In law, one who owes a duty or service to, or depends on, another. -4 . One who is present, as at a public meeting, for any purpose.

IIe wa

5. That which aceompanies or is consequent on anything.

He that early arriveth unto the parts and prudence of age, is happily old without the uncomfortable attendants
of it. Sir T. Browne, Letter to a Friend. An extrene jealousy of power is the attendant on all popular revolutions, and has seldom been without it Master attendant, an ofheer of an Fnglish dockyard, generally a statf conmander, whuse cuty it is to inspect maorings, nove and gecure vessels, carre tant. attender (a-ten'dèr), n. 1. One who attends or gives heed.

Attending to conduct, to judgment, makes the attemle

M. Amold, Literature and Dogma,

2. An attendant; a companion.

attendingly (a-ten'ding-li), adv. With attention; attentively.

attendmentf (a-tend'ment), n. $\quad[<$ attend + "ment.] An accompanying circumstance: as, "uneomfortable attendments

Browne, Vulg. Err., vii. 16.

attenaresst (a-ten'dres), $n$. [< attender + -ess. $]$

A female attendant. Fuller.

attentt (a-tont'), $\therefore t$. [A later form of attempt, after the orig. L. attentare: see attempt.] To attempt. Quarles.

attentt (a-tent'), $a$, and $n$. [< L. attentus, pp. tive; intent: as, "an attent ear," Shak., Ham let, i. 2.

Let thine ears be attent. 2 Chron. vi. 40

Whylest thus he talkt, the knight with greedy eare

Spenser, F. Q., VI. ix. 26
.

II. n. $[<\mathrm{ME}$. attente, atente, < OF. atente, mod. F. attente $=\mathrm{Pr}$. atenta, prop. pp., $<\mathrm{L}$. attenta, fem. of attent.

So being clad unto the fields he went

And kept her sheepe with dilligent attent.
Spenser, F. Q., VI. ix, 37. attentat, crime, $\backslash M L$. attentatum, crime, attempt, neut. of $\mathrm{L}$. attentatus, pp. of attenta$r e$, attempt: see attempt.] 1. A criminal attempt.

Aff riglited at so damuable an attcntate.

T'ime's Storehouse, p. 154 (Odd 11S.)

2. In law: (a) A proceeding in a court of judicature after an inhibition is decreed. (b) A thing done after an extra-judicial appeal. (e)

by an inferior judge.

attention (a-ten'shon), $n$. [< ME. attencioun (F. attention), < L. ättentio( $n-)$, < attendere, pp. attentus, attend, give heed to: see attend.] 1 . Active direction of the mind upon an object of sense or of thought, giving it relative or absoute prominence: it may he either voluntary or nvolumtary.

When the ideas that offer themselves are taken notice of, and, as it were, registered in the memory, it is atten-
Lion. In the relation of events, and the dellneation of characterk, they have pasd little attention to facts, to the costume of the times of whlch they preterd to treat, or to
the general princlples of human nature. the general princlple of human nature. Macalay, On IIistory. A trained pianist will play a new plece of music at sight, and perhaps have 80 much attention to spare that
he can talk with you at the same time.

2. The power or faculty of mental concentration.

In the childbool of our race and of each one of na, the attention was called forth by the actions npon us of exter 3. Consideration; observant care; notice: as, your letter has just arrived, and will receive early attention. -4. Civility or courtesy, or an act of civility or courtesy: as, attention to a stranger; in the plural, acts of courtesy indicating regard: as, his attentions to the lady cating regard: as, his attentions to the lady tionary word used as a preparative to a command to execute some mancuver: as, attention, company! right face ! = Syn. 1, Not'ce, heed, ence. if "attentivus, < attendere, pp. attentus, attend: see attend, attent, and -ice.] 1. Characterized by or of the nature of attention; heedful; intent; observant; regarding with eare; mindful : as, an attentive ear

Like Cato, give his little aenate lawa, And git attentive to his own applause. They know the King to have been always their most at 2. Characterized by consideration or observant eare; assiduous in ministering to the comfort or pleasure of others; polite; courteous : s, attentive to the ladies.

Ilerbert proved one of the most attentive guards on the G. A. Sala.
$=$ Syn. Regardiul, watch $r u l$, clrcumspect, wary, careful,

ttentively (a-ten'tiv-li), $a d v . \quad$ [< attentive + $-l y^{2} ;$ ME. attentifly (Wyelif).] In an attentive manner

attentiveness (a-ten'tiv-nes), $n$. The state of being attentive; heedfulness; attention.

attently $\dagger$ (a-tent'li), adv. Attentively. Barrow. attentor $\dagger$ (a-ten'tor), n. [< L. as if "attentor

(cf. ML, attensor, an observer), < attendere, pp. atten tus, attend.] A listener.

Let ballad.rhymers tire their galled wita

To gross attentors by their hired writs.

attenuant (a-ten' témuant, < L. attenian( $t-) s$, ppr. of attenuare, make thin: see attenuate.] 1. $a$. Attenuating; making thin, as fluids; diluting; rendering less dense and viseid.

Things that be attenuant. Holland, tr, of Plntarch, p. 642

II. $n$. A medicine which increases the fluidity of the humors; a diluent.

attenuate (a-ten' $\bar{u}-\bar{a} t), v . ;$ pret. and pp. attenuated, ppr. attenuating. [< L. attemuatus, pp. $=\mathrm{Sp} . \mathrm{Pr}$. atenuar = F. atténuer), make thin, weaken, lessen, $<a \bar{d}$, to, + tenuare, make thin, [tenuis, thin, = E. thin, q. v.] I. trans. 1. To make thin or slender; reduce in thickness; wear or draw down: as, an attcnuated thread wear or
or wire. thoughtiful, alert

Scorns to their patrons, naking juiceless mirth atter

He plties his long, clanmy, attenuatcd fingers.
Lamb, The Convalescent. 2. To reduce by comminution or attrition; nake small or fine: as, extremely attenuated particles of dust or flour.

This uninterrupted motion must attcnuatc and wear
Chaptal (trans.), 1791. 3. To make thin or rare; reduce in density; nerease the fluidity or rarity of.

The earliest conception of a zoul is that of an atteruated
duplicate of the body, capable of detachment from the body, yet generally reaident in it.

Trans, Amer. Philol. Asx., XV. 37.

The finer part belonging to the juice of grapes, being atteruated and aubtilized, was changed into an ardent
aplrit. 4. To lessen in complexity or intensity; reduce in strength or energy; simplify; weaken: as, the attenuated remedies of the homeopathists.

To undersell our rivals... has led the manufactnrer to attenuate his processes, in the allotment of taskz, to
I8. Taylor. If correctly reported, Pasteur fs convinced that he has dicoved micans by which the virus of hydrophobia cau aed virus, individuals may be rendered, for the time being, insusceptible to the disease. Science, VI. 399.

5. Figuratively, to weaken or rednce in force, effect, or value; render meager or jejune; fine down.

We may reject and reject till we attenteate history Into

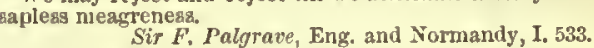
Men of taste are so often aftenuatcd by their refluements, and dwarfed by the overgrown accuracy and pol sh of their attainments. Mentschikof tried to attenuate the extent and effect of 6t. To lessen; diminish: said of number. Howell.

II. intrans. 1. To become thin, slender, or ; diminish; lessen.

The attention attenuales as its sphere contracts. Coleridge.

2. In brexing and distilling, to undergo the process of attennation. See attenuation, 4 .

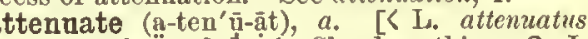
pp.: see the verb.] 1. Slendor; thin. -2. In bot., tapering gradually to a narrow extremity. -3. Of thin consistency; dilnte; rarefied.

Splrits attenuate, which the cold doth congeal and co. A geries of captivating bubbles, each more alry and
agulate. anescent, each more attenuate and fantastic, than it

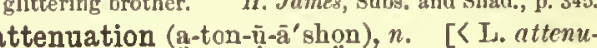
atio $(n-),<$ attenuare: see attenuate, $v$. $]$ 1. The act or process of making slender, thin, or lean the state of being thin; emaciation; reduced thickness or proportions.

Age had worn to the extreme of attennation a face that

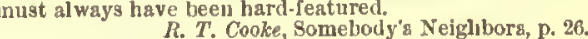

2. The act of making fine by comminution or attrition.

The action of the air facilitates the attenuation of these
Chaptal (trans.), 1791.

3. The act or process of lessening in complex ity or intensity; reduction of force, strength, or energy; specifically, in homcopathy, the reduction of the active principle of medicines to minnte or infinitesimal doses. -4. The act of making thin or thinner, as a fluid, or the state of being thin or thinned; diminution of density or viscidity: as, the attenuation of the humors; specifically, in brewing and distilling, the thinning or clarifying of saccharine worts by the conversion of the sugar into alcohol and carbonic acid.

The decrease In densilty [of the beer-wortal is called at-
Thausing, Beer (trank.), p. 707.
enuation.

Thausing, Beer (trans.), p. 707.
tenuation.

attor, (at er), n. $\bar{e} t a r, \overline{e t t a r}=\mathrm{D}$. etter $=\mathrm{OHG}$. citar, eitter, $\mathrm{MHG}$. G. citer, poison, pus, = Icel. eitr = SW. etter $=$ Dain. edder, adder, poison, connected with OHG. MlHG. eiz, a boil, sore; ef. Gr. oidos, oid $\mu a$, a tumor, swelling: see odema.] Poison; venom; pus. Holland.

atter ${ }^{2}+\left(a-\right.$ ter $\left.^{\prime}\right), v . t . \quad[<\mathrm{F}$. atterrer, < ML. atterrare, prostrate, east down, carry earth from one place to another, < I. ad, to, + terra, earth. Cf. inter.] To place upon or in the earth; cast down to the earth; humble; subdue. Also written atterr.

Atterrs the stubborn and attracts the prone.
Sylvesler, tr. of Du Bartas. 

atterateł, atterationł. Seo atterrate, atterra- attestive (a-tes'tiv), $u_{0}\left[<a t t e s t+-i r e_{0}\right]$ Giv-
ing attestation; attesting. attercop (at'êr-kop), $n$ 。 $[=$ Sc. ctterectp); $<\mathrm{ME}$. attercop, attereoppe, < $\mathbf{\Lambda}$ S. ättereoppe (= Dan. edderhop), a spider, $s$ ator, poison (seo atterl) + "coppe, < cop, heal, round lump, or copp, a eup : seo coll, cobuerb, cop ${ }^{1}$, and cup.] 1. A spider. [Old and prev. Eng.]-2. Figuratively, a peovish, testy, ill-natured peraon. [North. Eng.]

atterlył (at'er-li), a. [<ME. atterlich, < AS. ätor lic ( $=$ OHG. eitarlih ), poisonons, $<$ àtur, poison + -lie: soe atter ${ }^{1}$ and $-y^{1}$.] Poisonous; attery. atterminal, $a$. Seo ariterminal.

atterrt, $\imath . t$. See citter ${ }^{2}$

atterratet, atterateł (at'e-rāt), v. t. [<ML. atterratus, pp. of atterrare, carry earth from one place to another: sec atler2.] To fill up one place to another: $80 e$ atler ${ }^{2}$.]
with earth, especially with alluvium. Alterated by land bronght down liy floods. Ray, Disc. of World,

atterration $\nmid$, atteration atterrate, atterate.] The process of filling up by alluvial deposits.

atterył, attrył, a. [< ME. attri, < $\mathrm{AS}$. ättrig,

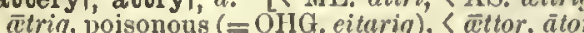
poison: seo alterl.] Poisonous; pernicious. Than cometh also of Ire attry anger.

attest (a-test') Sp. $=$ Sp. alestar $=\mathrm{Pg}$. attestar $=\mathrm{It}$. attcstare, $<\mathrm{L}$. attestari, bear witness to, $\langle a d$, to, + testari I. trans. 1. To bear witness to; certify; affirm to be true or genuine; declare the truth of in words or writing; especially, affirm in an official capacity: as, to attest the truth of a writing to attcst a copy of a document.

The most monstroua fables. Giattested with tho ut
moat aolemity. Goldsmith, citizen of the World, xvi Thils sale of a tract, twelve miles square, was formaliy
attested at Manliattan.
Baneroft, Hist. U. S., 1I. 44. 2. 'To make evident; vouch for; give proof or evidonce of ; manifest.

The birds their notes renew, and bleattng herds

Atlest their joy, that hill and valley rings.

The rancor of the disease attest the strengti of Eimerson, Conduct of Life.

3. To call to witness; invoke as knowing or conscions. [Obsolete or archaic.]

The sacred atreams which heaven'a Imperlal atate

4. To put upon oath; swear in.

If a proposed recruit, when taken betore a justice of the paying a fine of twenty shillings, popularly called smart money, het in attested, and after that, red and puntabed as a de Attesting witness, a person who signs his nume to an the inaker or makers, $=5 \mathrm{sn}$. 1. To confirm, corroborate,

aupport, authenticate, prove.
II. intrans. To bear witness ; make an at testation: with to: as, to attest to a statemen or a document.

attest (a-test'), n. [<attest,v.] Witness; testimony; attestation. (Now chlefiy used at the end thenticating it by his slguature.]

There is a credence in my heart,

An esperance se oliatinately atrong,
Thint doth Invert the atrest of eyes and ears
Shak., $T$. and

attestation (at-es-tā'shon), n. [< F. altesta- tion, < LL. attestatio $(n-)^{\circ}<\mathrm{L}$. attestari, pp. attestatus: see attest, $v$.$] 1. The act of attest-$ ing; a declaration, verbal or written, in support of a fact; evidence; testimony.

The applanse of the crowd makea the head giddy, but the attestation of a reasonable nam makes the heart glad. I would not willingly apare the attertation which they took pleasure in rendering to each other's characters.

2. The administration of an oath, as to a mili tary recruit. See attest, 4 .-Attestation clause a clanse uanally appended to wllls, after the slgnature of the teatator and before that of the witnesseg, recitlng the
due performance of the formalitles required by the law.

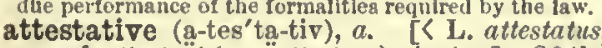
pp. of attestari (see attest, $\left.v_{0}\right)$, +-ive.] Of th naturo of attestation; corroborative: as, attestative evidence.

attestator (at'es-tā-tor), n. [= It. attestature, see altest, $v$.$] An attester.$

attester, attestor (a-tes'têr -tor'), $n$. Onowho attests or vouches for. [Altestor is the common form in legal phraseology.] ing attestation; attesting. [Rare.]

attestor, $n$. Seo attester. Atthis (at'this), n. [NI., < Gr. Arois, Attic, At
tica.] A gonus of diminutive linmmins-birls

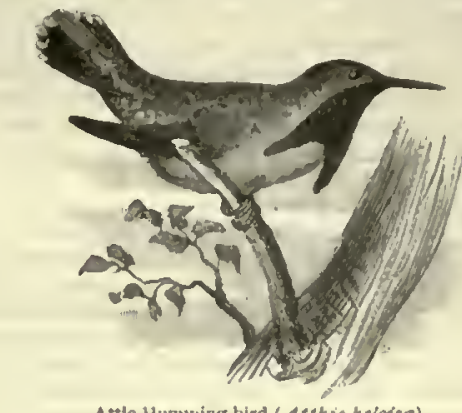

having tho nuetallic seales of the throat prolongod into a ruff, as in A. heloise, the Attic humming-bird of tho southwestorn United States.

Attic ${ }^{1}$ (at'ik), $a$ and $n . \quad[=\mathrm{F}$. dttique $=\mathrm{Sp}$. Ati$c 0=$ Pg. It. Attico, < L., Atticus, ? Gr. Art skós Attic, Athenian, <Arrıkí, Attica, a province of

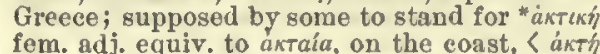
coast, prop. headland, promontory; ' $\mathrm{A} \times \mathrm{T}$, is tho ancient name of the headland of the Pirmus.

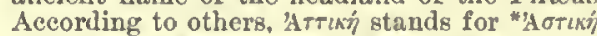
< árv, eity: see asteism.] I, a. Pertaining to Aartv, city: see asteism.] I. a. Pertaining to nian; marked by such qualities as were characteristic of the Athenians. - Attic base, In arch a base uned properly with the lonlc order, consisting of an upper torua, a scotta, and a lower torus, separated by
fliets. Sec cut under base. - Attic dlalect, the dialect flliets. Sec cut under base. - Attic dialect, the dialect of
Greek used by the anctent Athenians, and regarded as the standard of the language. It was a aubdlivion of th it Is distlnguished from the lonic by a more frequen retention of an original $a(a)$ sound, and by Its a vold ance of hitus, espectally tlurough contraction. Ita chied hiterature belongs to the fifth and fourth centuries $B$. C
As written daring the greater part of the former cenAs written daring the greater part of the former cen
tury, It Is known as old Attic; in Its transitlon to the IIext century, as middle Attic; and during the greater part into the Koine or common dialect, the general Greek o the Alexandrine and Roman periods, departing nore of less from Its former classic standard. - Attic faith, invio lable falth. - Atttc hummer, a humming-bird of the ge nus Atthis.-Attic salt, wit of \& dry, lelleate, and reflne II. n. 1. A native or an inhabitant of Attiea the territory of the anciont Athenian state, now an eparchy of the kingdom of Greece; an
Athenian. -2. The Attic dialect; Attic Greek. attic ${ }^{2}$ (at'ik), n. $[=\mathrm{F}$. attique $=\mathrm{Sp}$. ático $=$

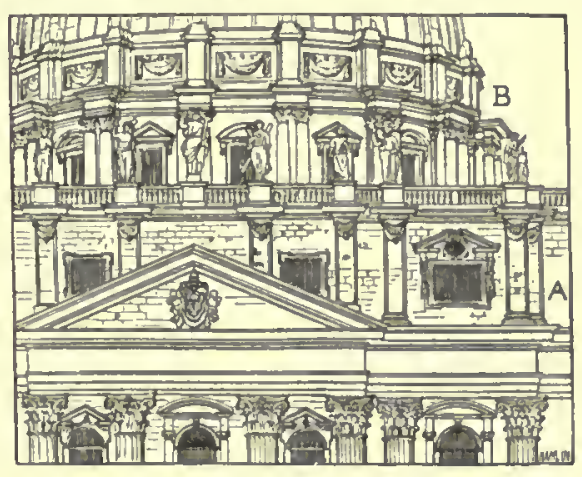

$A$, attic of the main edifice; $B$, attic of the dome.

Atticl, and extract bolow.] 1. In arch., a low story surmounting an entablaturo or the mail The term fatticl appears to have been Introduced by the of conveylng [(falaely) the fdea that the leature to which manner.

Audsley. Dict. of Architecture.

A room in the uppermost part of a house,

Byrn, Beppo, st. 78

Atttc order, a name aometimes given to small pillars o Atticalł (at'i-kal), a. [< Attie $1+-a l$.$] Per$ taining to Attica or Atbens; Attic; pure; elassical. Hammond. lellenic.-Attic style, a pure, chaste, and clegant stylc. architects of the seventeenth century, with the intention mediately beneath the roof or leads; a garret

They atare not on the stars Irom out thelr attics. atticet, $v . t$. [Farly mod. F. also attise, < MF atisen, alysen, $<\mathrm{OF}$. alisier, atieier, atiser, morl $\mathrm{F}$. attiser $=\mathrm{Pr}$. Sp. atizar $=\mathrm{Pg}$. aticar $=\mathrm{It}$ uttizare, < J. as if "uttilure, stir the firc, < ud, to, + titio(n-), a fircbrand; ef. ML. litionuri $=$ gato; alluro; entico.

atticementt, n. Instigation; enticenent. Cax-

Atticise, $v$. See Attieize.

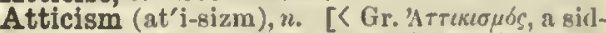
ing with Athens, Attic style, < Arrikileiv, At tieizo: see Atticize.] 1. A peculiarity of style or idiom belonging to the treek language as userl by tho Athenians; Attic eleganee of diction; conciso and elegant oxpression.

They thought themselves galiant men, and I thought them foold, they made sport, and 1 laught, they misprowere out, and I hist. Mliton, Apology for Smectynunus. An elegant alticism which oceurs Luke xill. 9: "If It bear 2. A siding with, or favoring the cause of, the Athenians

Put to death by Padaritus for alticion. Iodbes, tr. of Thucydldes, vllt. 38

Atticist (at'i-sist), n. Ono who affects Attic style.

Atticize (at'i-siz), $\iota_{0}$; pret. and pp. Atticizer, ppr. Atticining. [ $=\mathrm{L}$. Atticissure, < Gr. ATTkíclv, side with tho Athenians, speak Attic, [Arrıós, Attic, Athenian: see Atticl.] I. into Attic Greek - 2. To favor or side with tho Athenians. Dean Smith.

II. trans. To make coliformable to the language or idiom of Attica.

Also spelled Atticise.

attid (at'id), n. A jumping-spider; a member of tho family Attick.

Attidæ (at'i-rlē), n. pl. [NI., < Attus + -icla. $]$ with of saltigrado dipneumonons arancids eyes usually in throe transverse rows; the jumping-spiders. Their chlef characteristic la that the medisn foremoat pair of eyes are much larger and the wels, but capture their prey lyy leaping upou it. The Attidian (a-tid'i-gn), $a$. of or pertaining to the ancient town of Attidium in Umbria.- At tidian Brethren, a corporation of twelve priests In anclent Umbria, who had authority over a conalderable the Umbrian Inscriptlons on wlich are records of their attiguous $\uparrow$ (a-tig' $\bar{u}-\mathrm{us}), a . \quad\left[<\mathrm{I}_{\text {. }}\right.$ attiguus touching, contiguous, < attigere, older form of
attingere, touch: seo altinge, and cf. contiguous.] Near; adjoining; contiguous.

attiguousness (a-tig' $\left.g^{\prime}-u s-n e s\right), n$. The quality or state of being attiguous. Bailey.

attihawmeg (at-i-hâ'meg), $n$ 。 [Amer. Ind.] A kind of whitefish, of the genus Corcgoms and family Salmonide, abundant in the great lakes of North America, and a delicious foodfisl.

Attila (at'i-lị:), n. [NL., named from Attila, king of tho "Huns.] In ornith., a genus of Sonth American tyrant flyeatchers, family Tyrannida, sometimes giving name to a subfamily Attitina. d. cinerea is the type, and about I2 other species are included in the gemus.

attinget (a-tivj'), r. $t . \quad[<\mathrm{L}$. attingere, older form attigere, touch, borler upon, be near, $<a d$, to, + tangere, touch: see tangent.] To tonch; come in contact witli; hence, affect; influence. attiring. [Also by aphercsis tire (see tirt attiring. [Also by aphercsis tire (see tirc ${ }^{4}$ ); (= Pr. aticirar), put in order, arrange, dress a tire (= Pr. a ticira), in order, in a row: a (< L. ad $)$, to ; tire, tiere $(=\mathrm{Pr}$. ticira, tiera $=\mathrm{It}$. dress ; clotho; array; adorn.

With the linen mitre sliall he [Aaronl le altired.

His ahoulders large a mantle dill altire,

$$
\text { The woman whe attired her head. }
$$

attire (a-tï') $n$. [Also by apheresis tire (sce tire $\left.n^{2}\right)$; $<$ NIE. atire, atir, atyr, dress, equip-
ment; from the verb.] 1. Dress; clothes; garb; apparel.

Conkummate Earth in her rich attire II ilton, P, In, vili, 501. 
2t. A dress or costume; an article of apparel. attollens (a-tol'enz), ppr. used as $n_{.} ; \mathrm{pl}$. attolShow me, my women, like a queen :- go fetch

3. pl. In her., the herns of a hart, when used as a bearing.- $4 \nmid$. In bot., the stamens collectively.

Grew speaks of the attire, or the stamens, as being the
Encyc. Brit. IV $=$ Syn. 1. Raiment, array, costume, suit, toilet, wardrobe. attired (a-tîrd'), p. a. In her., having horns: thus, "a hart gules attircd or" means a red stao having horms of gold: used only of the hart and buck. See armed, 3.

attirement (a-tir'ment), $n . \quad[<$ attire +- ment. $]$ Dress; apparel; attíre. [Obsolete or rare.] attirer (a-tir with attire.

attirewoman (a-tīr'wùm"an), n.; pl. attirewomen (-wim"en). Same as itrewoman.

attiring (a-tir'ing), $n, 1$. The act of dressing or decking.-2†. Attire; dress; array.

$$
\text { Each tree in his best attiring. }
$$
Sir P. Sidney, Astrophel and Stella.

Specifically -3t. A head-dress. Huloct.-4. The attires of a stag.

attitlet, $v . t . \quad[<\mathrm{ME}$, attitlen, < OF, atitcler, later atitrer, mod. F, attitrer, < LL. attitulare, name, entitle, < L. ad, to, + LL. titulare, give a title, < L. titulus, title: see title. Cf. entitle.] To name; name after. Gover.

attitude (at'i-tūd), n. [<F. attitude, < It. attitudine, attitude, aptness, < ML. aptitudo (aptitudin-), aptitude: see aptitude.] 1. Posture or position of the body, or the manner in which its parts are disposed; especially, a posture or position as indicating emotion, purpose, etc. or as appropriate to the performance of som act.

The demon sits on his furious horse as heedlessly as if he were reposing on a clasir.... The attitude of Fanst

$$
\begin{gathered}
\text { There sat my lords, } \\
\text { Here sit they now, so msy tbey ever sit } \\
\text { ln easier attitude than suits my hantch! } \\
\text { Browning, Ring and Book, I. } 237
\end{gathered}
$$

Hence-2. Any condition of things or relation of persons viewed as the expression of, or as affecting, feeling, opinion, intentions, etc. England, though she ocessionslly took a menacing att
iude, remsined inactive. Nacaulay, Hist. Eng. it If we were to estimate the altitude of ecciesiastics to pose that they ascribed to then a direct Divine inspirstion, and exalted the Imperisl dignity to \&n extent that wa
before unknown.
Lecky, Europ. NIorals, II. 277 To strike an attitude, to assume an emotionsl posture or pose in a theatrical minner, snd not as the instinctive attitudinal (at-i-tū'di-nal), a. [< attitude (It attitudine $)+-a l$.$] Pertaining or relating to$ attitude.

attitudinarian (at"i-tū-di-nā'ri-an), $n . \quad[<a t t$ tude (It. attitudine) +-arian.] One whostudies or practises attitudes.

Attitudinarians and face-makers; these accompan
every word with a peculiar griniace and gesture attitudinarianism (at"j-tū-di-n $\overline{\mathrm{a}}$ 'ri-an-ism), $n$ The use of affected attitudes; insincerity of

expression.
attitudinise, attitudiniser. See attitudinize,
attinizer.

attitudinize (at-i-tū'di-nīz), $v_{\text {. }}$ i.; pret. and pp. attitudine) +-ine.] 1. To pose; strike or prac tise attitudes.

Maris, who is the most picturesque flgure, was put to
attitudinize at the harp.
Mrg. II. More, Coelebs, ix. 2. To be affected in deportment or speech. Also spelled attitudinise.

attitudinizer (at-i-tū'di-ni-zèr'), n. One whe poses, or strikes attitudes. Also spelled atti-

attle (at'1), n. [Also written attal, addle, adall, origin uncertain; perhaps the same as addleI,
filth, mud, mire: sec addle 1 .] Dirt; filth, filth, mud, mire: sec addle 1 .] Dirt; filth; rubbish; specifically, the refuse or worthless rock which remains after the ore has been sc-
lected from the material obtained by miniug a term originally Cornish, but extensively used in other mining regions in both England and America

attle $\mathrm{e}^{2}$ (at'1), $v$. An obselete form of ettle I.

attole (à-tón $\bar{l} \bar{a}), n$. [Mex.] The Mexican name of a favorite dish prepared from wheat, maize, and various other nutritious seeds, which are
parched and finely powdered, and then made into a gruel with boiling water. see attollent.] In anat., an attollent muscle; a levator. - Attollens aurem, a muscle which jrises the ear, or tends to do so.-Attollens oculi, an old name of ttollent (a-tol'ent) a and ( ppr. of attollere, lift up, raise, $<a d$, to, + tollere, lift, related to tolcrare, bear: see tolcrate.] I. $a$. Lifting up; raising: as, an attollent muscle. II. $n$. A muscle which raises some part, the ear; a levator; an attollens.

attollentes, $n$. Plural of atlollens.

attonable, $a$. See atonable.

attonet, $a d v$. See atonc.

ttorn (a-tèrn'), v. [Early mod. E. also atturn <OF. attorner, atorner, aturner, utourner (> MI attornare), transfer into the power of another, $<a\left(<\mathrm{L}_{0} a d\right)$, to, + tourner, turner, tum: see turn. Cf. attorney.] I. trans. 1. To turn over to another; transfer; assign.-2. In old Eng. law, to turn or transfer, as homage or service, to a now possessor, and accept tenancy under to a

II. intrans. 1. In feulal law, to turn or trans fer homage and service from one lord to another. This was the act of feudatories, vassals, or tenants npo the alienation of the estate.

. In modern law, to acknowledge being th tenant of one who was not the landlord originally, but claims to have become such.

attorney ${ }^{1}$ (a-tër'ni), n. [Early mod. E. also atturney, aiturny; < $\mathrm{ME}$. atturny, attourncy, tornatus), pp. of atomer, aturner, transfer into the power of another: see attorn.] 1 . One who is appointed by another to act in his place or stead; a proxy.

I will attend my husband, be his nurse

Diet his sickness, for it is my office,

Specifically -2. In law, one who is appointed or admitted in the place of another to transact any business for him. An attorney in fact, sometime called a private attorney, is an attorney anthorized to mak contracts and do other acts for his principsi, out of court
For this purpose a written authority is usus], but verbs anthority is in generai sufficient. For the performanc of some scts, however, as conveyance of land, transfer of
stock, etc., a formsl power of attorney is necessary. A stock, etc., a formsl power of attorney is necessary. An person qualifled to appesr for snother before $\mathrm{s}$ court of The term was formerly applied especialiy to those practis. ing before the supreme courts of common lsw, those prac tising in chancery being eslled solicitors. Under the pres ent English system, all persons practising before the supreme courts at Westminster are calied solicitors. In ehalf of their clients, this being the part of the barrister to institnte sctions on behalf of their clients and tak necessary stcps for defending them; to funtsh counse their pleadings; to practise conveyancing; to prepare lega deeds snd instruments of all kinds; and generally to ad vise with and act for their elients in all matters connected
with law. An attorney, whether private or public, nay be special, and limited to a particular act or scts. United states the term barrister is not used, the designation of a fully qualifled lswyer being attorney and coun
selor at law. When employed simply to present s csuse in court, an attorney is termed counsel. In Scotlan. there is no class of practitioners of the law who take the
name of attorneys. See advocate, I. 3. The general supervisor or manager of a plantation. [British West Indies.] - District atin Jamaica to species of Clusia, woody vines which twine

To perform by proxy.

Their encoun ters, though not personsl, have been royally
Shak., W. T., i. 1. 2. To employ as a proxy.

$$
\begin{aligned}
& \text { Aftorneyed at your service. } \\
& \text { sm stili }
\end{aligned}
$$
attraction.

attorney ${ }^{2}$ (a-tér'ni), n. [Early mod. E. also prop. fem. attorn: see attorn, and ef. attorney1.] The appointment of another to act in one's stead; the act of naming an attorney: now used only in the following phrase.-Letter, warrant, or power of attorney, an instrument by which one peras to execute a deed, to coliect rents or debts, to sell

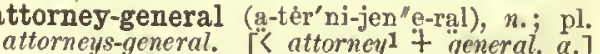
1. The first ministerial law-officer of a state. He has general powers to act in all legsl proceedings in legal sdviser of the executive. In England the attorneyaturneye, aturne, < OF. atorne, attorne (MI. at Aut will have no attorney but myseir.
Shak., C.
General is specislly appointed by letters patent. In the the President has the general management of the departnents of justice throughout the conntry, advises the President and departments on questions of law, and appears for the government in the Supreme Court and Court of
Claims. The individual Statcs of the Union also have Che

2. In England, the title of the king's (or queen's) attorney in the duchies of Lancaster and Cornwall and the county palatine of Dnvham. $N$. E. D.-3. Formerly, an attorney having general authority from his principal.

attorney-generalship (a-tér'ni-jen"e-ral-ship), or term of service as attorney-general.

attorneyism (a-tér'ni-izm), n. [< attorney ${ }^{1}+$

$-i s m$. ] The practices of attorneys; the unserupulous practices frequently attributed to attorneys or lawyers. Carlyle.

attorneyship (a-tèr'ni-ship), n. [< attorncy $1+$ -ship.] The office of an attorney, or the period during which the office is held; agency for another.

Marriage is a matter of more worth Shak., 2 Hen. VI., v.

attornment (a-tèrn'ment), n. [<OF. attornement (ML attornamentum) < attorner: see at torn and -ment.] In old Eng. lav, the act of a feudatory, vassal, or tenant, by which he consented, upon the alienation of an estate, to receive a new lord or superior, and transferred to him his homage and service; the agreement of a tenant to acknowledge as his landlord one who was not originally such, but claimed to have become such.

The necessity for attornment was done sway with by
4 Anne, c. 16 . Digby, Real Prop., v. \& 3, 227. (N. E. D.) attour ${ }^{1}$, prep. and adv. See atour 1

attour $^{2} t$, atour ${ }^{2} t, n$. [ME., also aturn, < OF. atour, older form atoum, aturn, dress, attire, atourner, atomer, turn, prepare, same as atorner, attorn: see attorn.] Attire; dress; specifically, head-dress: as, "her rich attour," Rom. of the Rosc, 1.3718.

attract (a-trakt'), v. [< L. attractus, pp. of attrahere, draw to, attract, $<a d$, to + trahere, draw: see tract1.] I. trans. 1t. To draw in, to, or toward by direct mechanical agency or action of any kind.-2. To draw to or toward (itself) by inherent physical force; cause to gravitate toward or cohere with.

It is a universsl physical law that every particle of the II. $L$. Carpenter, Energy in Nature,
p.

3. To draw by other than physiçal influence invite or allure; win: as, to attract attention; to attract admirers.

$$
\begin{aligned}
& \text { Adorn'd } \\
& \text { She was indeed, snd lovely, to attract }
\end{aligned}
$$

She was indeed, snd lovely, to attract
Thy love.
Milton, P. L., x. I5e At ses, everything that breaks the monotony of the sur-

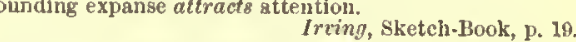

1. intrans. 1. To possess or exert the power attract as: as, is a property of matter to winning: as, his manuers are calculated to at traet.

attractt (a-trakt'), n. [< attract, v.] Attraction; in plural, attractive qualities; charms. What migical attracts and graces! S. Butler, Hudibras, III. i. 1037 attractability (a-trak-ta-bil'i-ti), n. [<attractable : see -bility.]. The quality of being at traction.

Thou wijt not find a corpuscle destitute of that ustura] attractable (a-trak'ta-bl), a. [< attract + -able.] Capable of being attracted; subject to attracter (a-trak'tèr), n. One who or that which attracts. Also spelled attractor. attractict, attractical $\dagger$ (a-trak'tik, -ti-kal), a. $[<$ attract $+-i c$, -ical. $]$ Having power to attract; attractive.

Some stones are endued with an electriesl or attractical Ray, Works of Creation (1714), p. 93.
virtue, Having the power to attract; attractive.

attractingly (a-trak'ting-li), adv. By way of attraction; so as to attract.

ttraction (a-trak'shon), n. [= F. attraction, < L. attractio $(n-)$, $<$ attrahere, attract: see attract.] 1. The act, power, or property of attracting. Specifically - $(a)$ In phys., the force through which particles of nistter are attracted or draw 


\section{attraction}

toward one another, according to their diatinec. such at whether a a minal action which in some form all botiles, whether at yeat or in motion, exert ulyon one another. The In certrin cases tend to Inite, ao as to furn a new body or botica, ia calted chemical afinity; that which binda to - gether the moleenlea of the game body is enlier colerion last-nanied forcea is cajillary attraction, by which tiquid tend to rise th tine tubca or stuall intersilices of purcun bodics. In ail the cases mentioned the loree nct oniy
through very amall distances. When bodies tend to come through very amal distances. When budies tend to com inversely as the square of the distunce, and the force prom portions to the niass, the attraetion is ealied grovitation, as when the earth attraets and is attraeted by a Iniling body, or attracts and is nttricted by the moon, etc; or
maynetism, as when exerted between the unlike poles of maynetism, as when exerted between the unlike poles of
a nagnet; or eleotricity, as when disainliarly clectriffet a dies attract one another. seo capilary, chemical, power or act of alluring, winning, or engaging; allurement; enticenent: fss, the attraction of beauty or elo
quence.

Setting the attraction of my good parts aside, I have no
other clinma.
Shak., M. W. of W., if. 2.

2. That which attracts feeling or desire; charm; au allurement.

She, queationless, with her aweet hannony,

Shek. Pericles, v.

It is probable that pollen was aborigtanlly the aole at Ition to inseet.

Dimoin, Crosa nud Self Fertllisation, p. 402

Center of attraction. See center.- Heterogeneou attraction. See heterogeneous. - Molocular attrac-
tion. Seo molecular $=$ Syn. 2. Attractiveness, lascinaattractionaily (a-trak'shon-al-i), adv. By means of attraction.

The advance and retreat of the water react attractionaly upen the piummet in a very rnarked degree

attractive (a-trak'tiv), $a_{\text {, and }} n_{0} .[=\mathbf{F}$. attrac tif, - ive, $=\mathrm{It}$. attrattivo, $<\mathrm{L}$. as if attructivus: seo attract and -ive.] I. a. 1t. Having the power or faculty of drawing in, to, or toward by mechanical agency or action.-2. Having the quality of attracting by inherent foree causing to gravitate to or toward: as, the at tractive force of bodies.

A repulaive force ta poaltive; an atcractive, which d. between two masaes, la negative.

3. Having the power of charming or alluring by agreeablo qualities; inviting; engaging; onticing.

For contempiation he and valour form'd, Yilton, $P$. L, iv. 290,

For hera was one of thoae attractive faces,

That when you gaze upon them, never lail
To bid you look again.

II. $n$. That which draws or incites; allure ment; charm.

$$
\text { Is a most main attractive. }
$$

The rospel ajeaks notheg but atractiver and im tion.

attractively (â-trak'tiv-li), adv. In an attrac tive manner; with the power of attraeting or drawing to: as, to smile attractively.

attractiveness (a-trak'tiv-nes), $n$. The quality of being attractive or engaging.

The sane attractivenesg in richea.

South, Sermons, VII, xiv.

attractivity (a-trak-tiv'i-ti), n. [< attractive + -ity.] Attractive power or influence.

attractor, n. Seo attracter.

attrahens (at'ra-henz), ppr., used also as $n$, pl. uttrahentes (ät-ra-hen'tēz). [NL. < L.attrehens, ppr.: see attrahent.] In anat., drawing forward, or that which draws forward; attrahent: the opposite of rctrahens. Chlefly in the phrase attrahens auren, the name of a amall muscie who attrahent (at'ra-hent), $a$. and $n$. $\quad[<\mathbf{L}$. attra hen(t-)s, ppr. of attrahere, attract: see attract.] I. a. 1. Drawing

II. $n .1 \uparrow$. That which draws to or attracts, as a magnet. Glanville. -2 . In med., an application that attracts fluids to the part where it is applied, as a blister or a rubefacient; an opispastic.

attrahentes, $n$. Plural of attrakens.

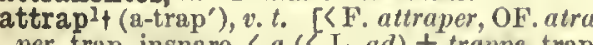
per, trap, insnare, $<a(<\mathrm{L} . a d)+$ trappe, trap see trapl.] To insnare.

He [Richard III.] was not attrapped either with net or

attrap ${ }^{2} \uparrow\left(\mathrm{a}-\operatorname{trap}^{\prime}\right), v . t . \quad\left[<a t^{2}+t_{\mathrm{rap}}{ }^{3}, v_{\text {. }}\right]$ To furnish with trappings; deck.

375

For all hils armour was like anlvage weed With oaken leaves attrabt, and all his ateerl Spenser, F. Q., IV. Iv, 38

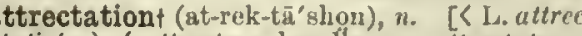
tatio(n), < attrectare, haudle, pp. attrectatus, ad, to, + tractare, handle, freq. of trahere, pp.
tractus, draw. Cf, attract.] A touching; a bnndling; frequent manipulation.

attributable (a-trib'u-ta-b]), a. [< attribute + -able.] Capable of boing or liablo to bo asribed, imputed, or attributed; ascribablo; im putablo:

II ibernation, although a reault of coid, is not it jumefiato consequence, but is attributable to that deprivation Sir J. E Tennent, Ceylon, Ii. 4 .

attribute (a-trib'int), v. t.; prot. and pp. attributed, ppr. attributing. [< 1. attributus, pp. of attribuere, assign, $<$ ad, to, + tribuere, give, as pute; consider as belonging or as due; assign. The luerit of aervlee is seldon attributed to the true

Shat, All' Well, iil. 0. Narrow vlewa of religton tend wattribute to Gorl an arbitrary and capricious action, not in harmony with either Ile does not heaitate to attribute the digease from which they autfered to those depressing moral influences to which
they were subjected. O. W. Holmen, oll Vol. of Life, p. 2. The burning of New York was generally attributed to =\$yn. Attribute, Aecribe, Refer, Impute, Charge, have
two meanlugs in eommon: they may assign some attribute, two meanings in eommon: they may assign some attribute, connect different things, as an elfect with its canse. Refer
is the weakeat. Attribute in atronger : as, to attribute on niscience to God; to altribute failure to incompetence. Ascribe, being moat manifeatiy flgurative, ia the atrongeat and moat conmon; it ta rarely used in a bad aense. Tha not alwaya bad: as, to impule folly to a man. To impute

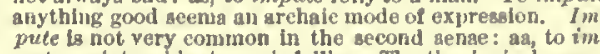
pute one' in troublea to ooe'a follies. The theological mean pute one impute, that of laying to a person'a aecount some bit little the popular use of the word. That whlch l charged, in elther of the gensen named, ia bad: an, "Hi their youth and inexperience. The word ia a atrong on

The singular excellence to which eloquence attalned at thena is to be mainly attributed to the influence which Macaulay, Atheninn Orator. I have never yet encountered that bitter apirit of bi
utry whjch is so frequently ascribed to Mohammedang.

The salts, preduminant in itulck lime, we refer rather The Balts, predominant in "tuick lime, we refer rathe
Boyle, Colour
Bixiviate than acid. I dealre that what I have said may not be impuled t their direction.
Franklin, Life, p. 38.

What you have charg'd me with, that have I done,

attribute (at'ri-būt), n. [<J.attributum, predieate, attribute, lit. what is aseribed, neut. o attributus, pp. of attribuere, ascribe, attribute: ieated or affirmed of a subject; a predicato; a aceident.

A predicate, the exact limits of which are not deterIt may be called an attribute, and conveys not the whol oature of the subject, but toune one qualty belonging to it.

The term attribute simply direets the attention to the act that we attribute to, or alf
that we distingulah fron) itself.

2. A character inseparable from its subject.

By this word attribute is meant something which ia fin. as that whlch conatitutea it, and whjeh is thus opposed t.

Some neeessary marks beiong to things as reasona of of otizer marka. . . . The tatter are called attributes.

3. A characteristic or distinguishing mark; especially, an exeellent or lofty quality or trait s, wisdom and goodness aro his attributes.

Serv. ... with him the mortal Venua, the heart-blood beauty, love'a invisible soul.

Pan. Who, my cousin Creasida?

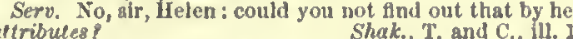

The term attribuce is a word properly convertible with quality, for every quatity is an attribute, and every attrdintinetion in their application. Attribute ta consideres as a word of loftier signiffennee, and is, therefore, col Thus, for example, it would be felt as indecorous to apeas of the qualities of God, anul as ridiculona to talk of the
attributes of matter. Sir H. Hamilton, JIetsph., I, 151. attrition

4. In tho fine arts, a syentsol of office, character, or personality: thus, the eagle is the attribut of Jupiter.

The ladier la a striking attribute lor the pntriareh Jacob,
and the harp for King bavid. Persephone is recognised by the lolty modlus, or corn. mensire, on her head, the altribute of the Chithonian
deitiea.
C. T. Steaton, Art and Archeol., $\beta .87$ 5†. Reputation; honor.

Huch attilnue he hath; and nutch the reason
Why we ascrtbe it to hin. Shak, T. and C., li, s.

6. In gram., an attributivo word; a word denoting an attribute.- - symbolical attributes. See qualily. tion < L attributio $(n-)$ " autribuere attribute seo attribute, $c_{\text {.] }}$ 1. The aet of attributing, in any sense; aseription.

II a [ [Oolin] relative personality fs sladowed forth by the attribution to ilim of love, anger, and other humnn feel-
Ings and mentlments.
Davoson, Org. of World, p. 12.

2. That which is ascribed; attribute.

If apeaking truth,
In this the age, were not thought flattery,

Snch attribution shoult the Donglas ha

Should wo so generai current through the world.

3. Authority or function granted, as to a ruler, minister, or court.

It is not deairablo that to the ever-growing attribution of the government so delicate a funetion ahould be superattributive (a-trib' $\bar{u}-t i v), a$. and $n . \quad[=F$ attributif, < L., as if "attributicus, < attribuere c. Pertaining to or havutire use or relation of certain words; attributive qualitics or insignia; an attributive judgment (in logic).-2. In gram., pertaining to or expressing an attribute; used (as a word) in direet description without predication: $a \mathrm{~s}$, a bad pey, a burning house, a ruined man. An at tributive word la to be distingulshed Irom a predicative tive: as, the pell, lad as it In, might be worse; thia man, ruined by a nother's miaconduet, is in miaery. All adjectiv worda, as proper adjectivea, adjective jronouna, an participlen, may be used attributively; also nouna: as,
yine table; a gold ring ; my hunter frlend; the young sol
dier.boy. The relation of an adverb to the gdjective qual. fled by it is alao by gome called attributive.

II. $n$. In gram.y a word expressing an at tributo; an adjective, or a phrase or elause deseribes a noun without being part of the assertion or prodieation made about it.

attributively (a-trib'ü-tiv-li), adr. In au at tributive manner; specifically, in gram., as
attribute or attributivo; in direct ascription of quality or eireumstance without predication.

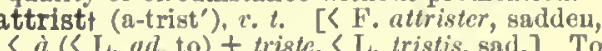
rieve; salden.

IIow then could I write when it was Imposalble hut to altrist you! when I could apeak of nothing but unparal-
leied horror. attrite (a-trīt'), $u . \quad[<\mathrm{L}$. nttrifus, pp. of at terere, rub away, wear, < ad, to, + terere, rub Sce trite.] 1+. Worm by rubbing or friction. repentant. See attrition, 3 .

lie that was atr rite being, by virtue of this [the prleat's] bsolution, made contrite and justified.

attriteness $\uparrow$ (u-trit'nes), $n$. The state of being attrite ; the state of being much woru.

attrition (a-trish'on), $n_{0}\left[=\mathrm{I}^{\prime}\right.$. attrition, $<\mathrm{LL}$. attritio $(n-)$, a rubbing, $<\mathrm{L}$. attritus, pp. of atte rere, rub: see attrite.] 1. The rubbing of one thing against another; mutual friction: as, the alorasion of coins by atfrition.-2. The act of wearing away by rubbing; the state of being worn down or smoothed by friction; abrasion. The change of the aliment is clfected by the attrition of the inward stomach and dissolvent liyuor assiated with There were people trained by altrition with many influ3. In theol., imperfect contrition or repentance, with real detestation of sin, and a true purpos of amendment, arising from those supernatural motives of faith which are lower than eharity or the true love of God for his own infinite perfections. Suel motlvea are a love of juatice for Its ow sake, the intrinsic ahamefulness of sin, the lear of divine punishment, etc. Attrition remits ain oniy when conple
mented by the grace conferred through aaeramental abmoiution. See contrition.
luted by the grace conte 
attrition

376

auction

Attrition by virtue of the keys ia made contrition. attrition-mill (a-trish' on-mil), n. A mill, ized by the mutual attrition of its partic and by frictional euntact with the sides.

attritus (a-tri'tus), n. [L., a rubbing on, an inflammation caused by rubbiug, < attritus, pp. of atterere: see attrite. For the sense here given, ef. detritus.] Matter reduced to powder by attrition. Carlyle.

attryt, $a$. See attery.

attune (a-tūn'), $v$. $t$.; pret. and pp. attuned, ppr. attuning. [< at-2 + tune, q. v. $]$ 1. To tune or accordant: as, to attune the voice to a harp.

And tongues, attuned to cursea, roar'd applause.

2. Figuratively, to arrange fitly; make accordant; bring into harmony: as, to attune our aims to the divine will.

The landscape around... Was one to attune thelr Though my ear was attuned, the songster was tardy.

\section{To make musical. [Rare.]}

Breathing the smell of field and provernal airs,

Breathing thic smell of field and grove, attune
The trembling leaves.

attune (a-tūn'), n. [< attune, v.] Harmony of sounds; accord. Mirs. Browning. attunement (a-tün'ment), n. [<attune + -ment.]
The act of attuning. [Rare.]

atturnt, $r$. An obsolete spelling of attorn.

atturney $\dagger, n$. An obsolete spelling of attorney.

Attus (at'us), n. [NL.; cf. Atta.] I. A genus of spiders, typical of the family Attida.-2. A genus of heminterous insects.

attypic, attypical (a-tip'ik, -i-kal), $a$. [<at-? + typie, -al. $]$ In zoöl., of the particular character acquired, or in process of acquisition, by specialization, from a more generalized type, as from
etypical

Attypical characters are those to the acquisition of
which, as a natter of fact, we find that forms, in thell

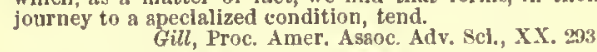

attypically (a-tip'i-kạl-i), adv. In an attypic

atumble (a-tum'bl), prep. phr. as $u d l^{2} . \quad\left[<a^{3}+\right.$ tumble.] In a tumbling condition.

-atus ${ }^{1}$. [L. -ätus, fem. -äta, neut. -ätum: see -atel.j A Latin termination, the original of $-a t e^{1},-a t e^{2},-a d c^{1},-e e^{1}$, ete., the suffix of perfeet participles of the Latin first conjugation, and quently in New Latin speeific namos in botany, zoölogy, etc.

-atus ${ }^{2}$. '[L. -atus (-atu-), in nouns of the 4th de elension, $<-\bar{a} t$, pp. stem (see-atus 1 ), + stem vowel $-u$-. The Eng. form of this suffix is -ate

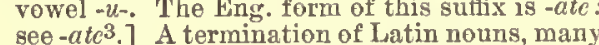
of which have been adopted unaltered in English, as apparatus, aftlatus, flatus, ete. Such nouns, if they have a plural, retain the Latiu form (L.
-ätüs), as apparatus, or, rarely, take an English plural, a

atwaint (a-twān'), adv. [< MIE. atwayne a-tweyne; $\left\langle a^{3}+\right.$ twain. Cf. atuin and atwo.
In twain; asunder.

A fickle maid full pale,
Tearing of papers, breaking rings a-twain,

Storming her world with sorrow' a wind and rain.

atwee] (at-wël'). [Sc., appar. contr. from $I$ wat veel, I know well: wat $=\mathrm{E}$. wot; weel $=\mathrm{E}$. well.] I wot well. [Scotch.]

Atweel I would fain tell hlm. Seott, Antiquary, xxxiv. atween (a-twēu'), prop. and adv. [< ME. q.veene, atwene; $\mathrm{q}$.] Betweeu; in or into an intervening space. [Old English and Scotch.]

But he, right well aware, his rige to ward

Spenser, F. Q., V1. xii. 30

atwint, acke. [ME., also atwinne; $<a^{3}+t w i n$. Cf. atwain.] Apart; asunder.

Thy wif and thou most hangen fer a-tuinne.
Chaucer, Mriller's Tale, 1. 403.

atwirl (a-twérl' ${ }^{\prime}$ ), prep. plir. as adv. or $a . \quad\left[<a^{3}\right.$ + tuirl.] In a twirl; twirling.

Sat by her door with her wheel atwirl.

Whittier. The Wreck of Rivermont

atwist (a-twist'), prep. phr. as adv. or $a . \quad\left[<a^{3}\right.$

atwitet, $v . t$. [Early mod. E. also attwite, $<\mathrm{MF}$.

atwiten, <AS. cetwitan, < at, at, + witren, blame sce wite. Hence by apheresis mod. E. twit.] To blame; reproach; twit.

[< $a^{3}+$ twitter.] In a twitter.

atwixt, atwixent, atwixtt, prep. [ME. atcix, atwixen, atwixe, atwixt, etc.; $<a-+-t w i x e n$, twixt equiv. to bctwixen, betwixt, q.v.] Betwixt; between.

Atwixen aonne and see. Chaucer, Troilus, v. 886. atwot, arlv. [ME., < AS. on twa $\bar{a}$, on tū : see $a^{3}$ and two.] In two.

An axe to smite the cord atwo.

Chaucer, Miller's Tale, 1. 383.

Atwood's machine. See machine.

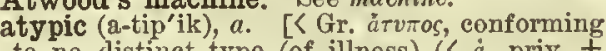
to no distinet type (of illness) ( $<\dot{a}$ - priv. + Tíros, type), +-ic: see $a-18$ and typic.] 1 . Having no distinet typical eharacter; not typicing a loss of typical characters. Dana.

atypical (a-tip'i-kal), a.

[< atypic + al.] Same as atypie. atypically (a-tip'i-kall-i) adv. In an atypic mannor.

Atypinæ (at-i-pī'nē), $n$. pl. [NL., $<$ Atypus, $1,+$ Theraphoside or Myga Theraphoside or Mygadevelopment of six spinners, typified by the ge nus Atypus.

Atypus (at'i-pus), $n$.

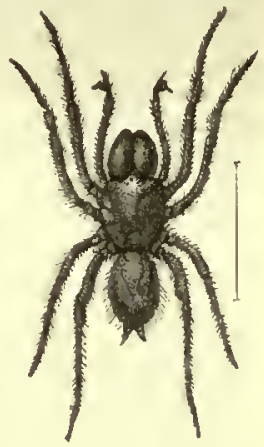

forming to no distinet

type, $<\dot{\alpha}$ - priv. + títos, shows natural size. $)$

type: see type.] 1. A genus of spiders, of the family Theraphosida or Mygalida, having six arachnidial mammilla or spinnerets. A. piceux is a Enropean apecies which digs a hole in the ground and
lines it with sllk. The genns with some authors gives name to a aubfamlly Atypina.

2. A genus 0

Gunther, 1860 . au ${ }^{1}$. [ ME. $a u, a w$, or a before a guttural, nasal,
or $l(a z, a h$, $a l$ (aul), ete.), of AS. or OF. or L. origin.] A common English digraph representing generally the sound of "broad a" (â), but often also ä. It occurs only exceptionally, and by conformation with Romanic analogies, in words of Anglo Saxon origin, as in aught, taught, daughter, haulma = halm,
baulk=balk (and fornerly as a variant, medially, with au baulk = balk (and fornierly as a variant, medially, with au, as in baul, hauk, etc., for baul, hawk, etc.). In words of or $a$ before a wasal, as in aunt, haunch, launch, etc. (bnt in most aucl words now unually simpllfied to $a$, as in yrand, grant, lance, ctc.). It is frequcntly of Latin origin, as in audit, cause, laud, etc., or of Greek origin, as in caus-
tic. In words from recent French it may have the present F. solnd (o) as in heuteur, au fait, etc. In words of Gercal value $(\dot{a}+1)$, corresponding to English $0 u$ in analyt in sauerlraut, ablaut, vimlaut. Formerly a $u$ and $a w$ wer insed almost indifferently; but now au is never final in English worda, while aw is rarely medial, except in a few familiar worda, as in hawk, bawl, but regularly final, as in $\mathbf{u u}^{2}(\bar{\theta}) . \quad[\mathrm{F} .,<\mathrm{OF}, a u, o, o u$, earlier $a l$, contr. of $a l c=\mathrm{Sp} . \mathrm{Pg}$; $a l=\mathrm{It}$. all, allo, $<\mathrm{L}$. ad illum (m.) or ad illud (neut.): ad, to, with aec. of ille, that, "in Rom. the def. art. 'thc.' The corresp. fem, is $\dot{a} l a, q . v$.$] To the; at the ; with$ oceurring in some phrases frequently used in English, as au fait, au fond, au revoir, ete.

Au. The chemical symbol of gold (L., aurum)

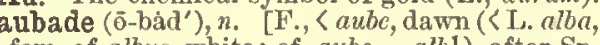
fem. of albus, white; ef. aube = alb1), after Sp. troubadour and similar music, a song or piece to be performed in the open air in the early morning, usually addressed to some speciá person; a musical announcement of dawn. person; a m

Sang his aubade with lusty voice and clear. his aubade with lusty voice and clesr.
Longfellow, Wayside Inn, Emma and Eginhard.

2. In modern musie, a rarely used title for a short instrumental composition in lyric style.
aubain (ē-bān'; F. pron. ō-bañ'), $n$. [F. $\langle$ 'ML. albanus, an alicn, <L. alibi, elsewhere, +'-anus. see alibi.] A non-naturalized foreigner, subject to the right of aubaine. $\quad N . E . D$.

aubaine (ō-bān'), n. [F., 〈aubain: see aubain.] Succession to the goods of a stranger not nat uralized. The droit d'aubaine In France was a right of
the king to the goods of an alien dying within his realm,
There be lingered till the crowing cock, aucht2 (ächt he king gtanding in the place of the heirs. This right aubet, $n . \quad[\mathbf{F} .,<\mathrm{L}$. alba, alb: see alb1.] Obsolete form of alb1. Fuller.

auberge (Â'bèrj; F. pron. ō-bārzh'), n. [F., $\mathrm{OF}$. alberge $(=\mathrm{Pr}$. alberc $=\mathrm{Sp}$. albergue $=\mathrm{It}$. albergo, an inn), earlier helberge, orig. herberge, a military station, $<\mathrm{MHG}$. herberge, OHG. heriberga, a camp, lodging, G. herberge, an inn: see ubergine (ấbẻr-jin; F. pron. ō-bār-zhēn'), $n$. [F., dim. of auberge, alberge, a kind of peach, $<$ [F., dim. of auberge, albcrge, a kind of peach,
Sp. albérchigo, alberchiga (= $\mathrm{Pg}$. alperche), a Sp. alberchigo, alberchiga $(=\mathrm{Pg}$. alperche $)$ a
peach, $<\mathrm{Ar}$. al, the, $+\mathrm{Sp}$. persigo, prisco $=\mathrm{Pg}$. peach, < Ar. al, the, + Sp. persigo, prisco $=\mathrm{Pg}$.
peccgo $=\mathrm{F}$. péche (\rangle $\mathrm{E}$. peaeh 1$),\langle\mathrm{L}$. persicum: seo peach 1 . The Sp. forms touch those of apricot: see aprieot.] The fruit of the egg-plant, Solanum Melongena; the brinjal.

aubergist, aubergiste (â'bér-jist; F. pron. ōbār-zhēst"), n. [< F, aubergiste, inn-keeper, auberge: see auberge.] The keeper of an anberge; an inn-keeper; a tavern-keeper; a landlord or landiady: as, "the aubcrgiste at Terni," Smollett.

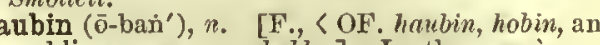
ambling nag: see hobby.] In the manège, a kind of broken gait, between an amble and a gallop, commonly called a "Canterbury gallop," and accounted a defect.

auburn (â'bẻrn), $a$. and $n$. [Early mod. F. auborn, abourne (also abrown, abroun, abrune, simulating brown) < ME auburne, auburne (defined "citrinus," i. e., eitron-colored, in Prompt. Parv.), < OF. auborne, alborne = It. alburno auburn, < ML. alburnus, whitish, < L. albus, white. Cf. alburn, alburnum.] I. a. Originally, whitish or flaxen-colored; now, reddishbrown: generally applied to hair.

That whitlsh colour of a woman's hair called an áburm

II. $"$. An auburn color.

He's white-haired,
Not wanton white, but such a nanly colour,

(1v. 2

A. U. C. Abbreviation of Latin $a b$ urbe eondita or anno urbis condite (which see)

Auchenia (â-ké'ni-ăg), n. [NL. (Illiger, 1811), <Gr. avं $i v$, neck: in allusion to the long neek of the llama.] A genus of ruminants, of the family camelida, representing in the new world the camels of the old, but having no bump. The genus incluilea four luportant and well-known qual(A.llana), the guanaco ( $A$.huanaco), the alpaca ( $\boldsymbol{A}$. pacos), and the vicugna $(A$, vicugna). The scond of these is by some auppored to be the wild stock of the llama, which

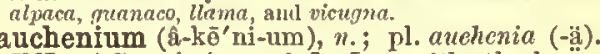
[NI., <Gr. aixir, neck.] In ornith., the lower back part of the neek; the seruff of the neck just below the nape. Illiger; Sundcrall. [Little used.]

Auchenorhynchi (â-kẻ-nọ-riug 'kī), n.pl. [NL.,

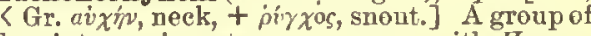
homipterous insects: synonymous with Honopter.

+ lot, part. Cf. firlot.] In Scotland, a measure equal to the eighth part of a boll.

aucht 1 (âcht), v. Same as aught ${ }^{2}$. [Seoteh.]

au courant ( $\overline{0}$ kö-rou'). [F.: $a u$, with the (see $a u^{2}$ ); courant, eurrent (see courant, current).] Literally, in the current, that is, of events well informed in regard to any event or subject. auctificialt, $a$. Same as auctive. Coles.

auction (âk'shon), n. [<I. arctio( $n-)$, an increasing, a sale by auction, < augere, pp. auetus, inerease, = F. eke, v., q. v.] 1t. The act of inereasing public sale in which each bidder offers an increase on the previous bid, the highest bidder becoming the purehaser. Called in Scotland a roup. Goods may he aad to he sold either at or by auction, the in Great Britaln.

The old books would have been worth nothlng at an 3t. The property or goods put up for sale at auction.

Ask you why Phryne the whole auction buys? Pope, Moral Essays, iii. 119. Auction by Inch of candle, an old method of selling by anction, atill sometinuea practised, in which a small plece of candle is lighted at the beginning of a aale, and the highest bld made before the 
auction

auction (âk'shon), v. t. [< auction, n.] To sell by auction: commonly used with off

A catalogue deala with articles to be auctiuned The Anericans, V11. 134

auctionary (âk'shọn-ậ-1'i), ". [< L. auctionarius, < auctio( $(n-)$, ain auction. Cf, unetioneer.] Pertaining or lelating to an auetion or public sale.

\section{Witl auctionury lanmuer In thy hand.}

Drydest, ir. of Juvenal's satires, vi.

auctioneer (âk-shon-ề" $\left.\iota^{\prime}\right), n . \quad[$ auction + -eer. Cf. L. uuctionarius, under auctionary.] One whose business is to offer goods or property for sale by auction; the erier who ealls for bich anl strikes the bargain at an auction; a bids anl strikes the bargail at an auetion; a person liecnsed to clispose of goods

auctioneer (âk-sliou-ēr'), $v, t$. [〈uuclionecr, $n]$ 'l'o sell by auction.

Fistates are landlscales, gaz'd upon awhile,

Then advertis'l, anuf auctioneer't a way.

auction-pitch (âk'shon-piteh), n. See pitch auction-pool (âk'shon-pöl), $n$. In bettiny, pool in which the lingest bidder has the first clioice, the second, third, etc., choiees being clioice, the second, third, etc., choiees being
then sold, and the remainder, comprising those most unlikely to win, being "bunched" and sold as "the field," the

tire pool thus formed.

auctivet (âk'tiv), $u . \quad[<$ L. auctus, pp. of auycre, increase (see auction), + -ive. $]$ Increasing; serving to inereaso. Coles, 1717.

auctort, $n$. An obsolete form of author.

auctorial (ak-tō'ri-gl), a. [< L. unctor (seo author) +-ial. Cf. authorial.] Of or pertaning to an author.

There is more than people think in the gratifleation of wlll be handisomely placed lefore the public.
The Century.

auctourt, $n$. An obsolete form of author

aucuba (â'kū-bă), n. [NL., prob. \Jap. aoki green, $+b a=h a$, a leaf.] 1. A shrub of the genus Aucuba.-2. [cap.] A genus of plants, natural order Cornacea, eonsisting of six speeies from eastern Asia. They are branciting shrul with smooth opposite leaves and amall unisexual flowers
A. Japonica has leng been in cultivation, and is prized fo A. Japonica lias leng been in cultivation, and is prized for

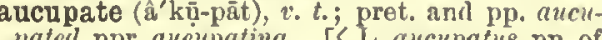
pated, ppr. aucupating. [<1, aucupatus, pp. of aucupari, go bird-catching, < auceps (aucup-),
a bird-cateher, contr. of "aviceps, $<$ avis, a birl (see Aves), + capere, take: see capable.] Literally, to go bird-catehing; henee, to lie in wait for; hunt after; gain by eraft.

To aucupate beneflees by cajoling the Patrone.

aucupationł (â-kū-pā'shon), n. [<L. aucupatio( $n$-), < aucupari: see aincupalc. ] 1. The art or practiee of taking birds; fowling; bird-catching. Blount.-2. Hunting in general. Bullokar. aud (âd), $a$. [Cf. auld.] $\Lambda$ dialeetal form of old. [North. Eug. and Seoteh.]

audacious (a-dả'shus), a. [= l'. audacicux, aulace, boldness, < I. audacia, boldness, < au dax (auduc-), bold, < autérc, be bold, daro.] 1 Bold or daring; spirited; adventurous; intrepid. She that shall be my wife, must be accomplished with courtiy and aulacious ornamenta.

\section{Her sparkling eyes with manly vigour slone,}

Blg was her voice, audacious was her tone.
Dryden, tr. of Ovid's Iphia and Ianthe. since the day when Jiartin Linther posted his audacion heresies on the church-door at Wittenilierg, a M"eat chang 2. Unrestrained by law, religion, or propriety eharacterized by eontempt or defiance of th principles of law or merality; presumptuousl wicked; shamoless; insolent; impndent: as, an audacious traitor; an audacious ealumny "audacious cruelty," Shak., 1 Hen. IV., iv. 3 $=$ Syn. 1. Intrepid, foolhardy, rash.-2. Shamelese, u.
sbashed, preaumptuoun. audaciously ( $\hat{a}-d \bar{a}$ 'shus-li), $a d v$. In an auda-

eious man

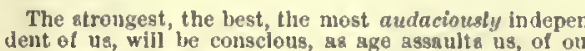
weakness and lielplessness.

h. $T$. Corke, Somebody's Nelghbors, p. 260. audaciousness (â-da's'slus-nes), $n$. The quality of being audacious; bolduess; reckless daring; impudence; audacity.

audacity (ấ-das'i-ti), n. i pl. audacitics (-tiz)
377

audit

ness, < audax (undac-), bold: seo audacious.] 1. Boldness; daring; confidence; intrepidity. The freedon and audacity necesary in the commeres inen.

Tatler. No Ionter sang these Norse sea-kings; but Agnmem-
hen's was a smali audacity, and of anall frnit in the werld to sone of them-to Rolrs of sormandy for fit.

2. Reckless daring; venturesomeness

A tonch of andacily, siltogether short of effroutery, and far less appreaching to vulgarlty, gave as it were a wlidi-
nesg to all ihat ghe illd. The Abbut, iv. 3. Audaciousness; presumptuous impudenee; effrontery: in a bad sense, and often implying a contempt of law or moral restraint: as, "arrogant audacity," Joyc, Expos. of Daniel, vii.4. An audacious person or act. [Rare.] $=\$ \mathrm{Syn} .2$.

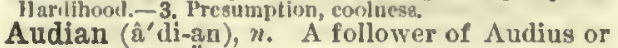
Audrus, a Syrian layman in Mesopotamia, who in the fourth century founded a seet liolding anthropomorphitie views, and was irregularly ordained a bishop.

Audianism ( $\hat{a}^{\prime}$ di-an-izm), n. The pecnliar doctrinal system of Audius and the Audians. In addition to strict asceticlsm, it conslated niainly in a fiteral luterpretation of Gen. I. 20, 27, res

audibility (Âdi-bil'i-ti), n. [ [ audivle: see bility.] The quality of being audible.

The note itself is possthly too feelle for aud ibility.

audible ( $\left.\hat{a}^{\prime} \mathrm{di}-\mathrm{bl}\right), a$, and $\pi$. [< NL. audibilis, that may be heard, < L. audire, liear: see audient.] I. $a$. Cajable of being heard; perceiv able by the ear; loud enough to be heard: as an audible voice or whisper.

To man'a eares not audible.

Sir T. Mare.

Even that atubborn churcli whlch has held its ow against zo many governuents, searce dared to utter al
audihle murmur.
Macaulay, Hlat. Eng., I. II. $u$. That which may be heard.

"isibles are swiftlier carried to the aenae than audible. audibleness (â'di-bl-nes), $n$. Audibility. audibly (ádi-bli), adv. In an audible manner so as to be heard.

audience ( $\hat{a} \cdot d i-e n s), n . \quad[<M E$. audicnee, $<O H$ audience (vernäcularly oianec), mod. F. audi encc $=\mathrm{Sp} . \mathrm{Pg}$. audiencia $=\mathrm{It}$. audicnza, audienzia, < L. audientia, attention, hearing, audien $(t-) s$, ppr. of audire, hear: see audient.] 1. The act or state of hoaring or attending to vords or sounds; tho act of listening.

$$
\begin{aligned}
& \text { Hig look } \\
& \text { Drew audience, and attention gilil as night. } \\
& \text { Milton, } P \text {. L. }
\end{aligned}
$$

2. Liberty or opportnnity of being heard; liberty or opportunity of speaking with or before, as before an assembly or a court of law; speeifieally, admission of an ambassador, envoy, or other applicant to a formal interview with a overeign or other high offieer of government. Were it reason to give men audience, pleading for th
overtlirow of that which their own deed hath ratiffed?

That day Sir Lancelot st the palace craved
Audience of Guinevere. 3. A hearing; an interview or confereuce. This conversation was not ended under fle audiences
each of geveral houra. Strift, Gulliver's Travels, It. 6 . 4. An auditory; an assembly of hearers.

$$
\begin{aligned}
& \text { Stlli govern thon nyy soug, } \\
& \text { Urania, and fit audicace fnd, though few. }
\end{aligned}
$$
Ilitton, 1 '. L., vil. 3

5. [Sp. audiencia, commonly used in English writing without translation.] In Spain and Spanish countries, a name given to certain courts, also collectively to certain law-offieer appointed to instituto a judicial inquiry.

Among those of the former class was the president
Deza, with the members of the audience, and the civil anthoritles in Gransda. Prencot. 6. In England, an abbreviation for

audience-chamber (ấdi-ens-ehäm"bèr), n. An apartment for an audieoce or a formal meeting. audience-court ( $\hat{a}^{\prime}$ di-ens-kört), $n$. An ecclesi audience-court ( $a$ di-ens-kort), $n$. An ecclesi
astical eourt, now disused, held by the archastical eourt, now disused, held by the arch
bishops of Canterbury and York or by auditor in their bohalf. Thst held by the Archblshop of Can terbury had equal authority with the Court of
though of leas diguity, and Is now merged in it though of lea diguity, and Is now merged in it.
audiencia (Sp. pron. ou-dê-en-the $\bar{e}^{\prime} \mathrm{a}$ ), Seo audience, 5 .$$
\text { See audience, } 5 .
$$

adiendo et terminando (â-di-en' dō et tèr-m nan'dō). [ML., for hearing and deciding; dat. ger. of L. audire, hear (see audient), and of terminare, end, deeide (see terminate). Cf. oyer and taining to audiometry. terminer, unler oyer.] In inu, a writ or conlmission to certain persons for appeasing and punisling any insurreetion or great riot. udient (a'di-(nt), a. und $n$. [< L. uudien(t-)s, DIr. of audire ( $>$ it. udire $=\mathrm{Sp}$. oir $=\mathrm{Pg}$. ourir $=\mathrm{Pl}$, ausir = OF. odir, oir (AF, oyer, $>\mathrm{E}$. oyer, q. v.), mod. H. ouir), hear; ef. Gr. aictv, hear: see heur and eurl.] 'I. $u$. Hearing; listening. Irs. Brononing.

II. $n, 1 . \Lambda$ learer.

The atdients uf her sad story felt great motiona both of Shelton, tr. of bon Quixote, Iv. 2.

2. In the early church: (a) One not yet baptized, but receiving instruction preparatory to laptism; a catechumen of the first stage. Such laptism; a catochumen of the first stage. Such which followed. (b) In the Eastern Church, aeeording to the systematic classification of penitents in force at the elose of the third century, but becoming obsoleto early in the fifth, one of the second elass of publie penitents, occupying a station higher than that of the weepers and lower than that of the prostrates. Tire audienta were not allowed to enter the body of the cintrch, but heard the opening prayers and sermon standing In the narthex, whicin was aiso the llaee of the cate-
climmens, and like them, had to depart before tlie offer. chmmens, and, hike them, had to depart be ore the offeraudile (â'dil), $n$. [Irrep.<L. audire, hear (seo aulicnt $),+-i l e$.$] One in whose mind auditory$ images are predominant, or especially distinct. Stricker, a motile, declarea tibat it la inposslble to rep-
resent to ourseives other vowels whlle pronounclug any
partlcular one, gRy $a$ : he can only relreaent them as partlcular one, ony a: he can only relreaent them as I. Pauihan an audile, declares he can easily do wliat Stricker declarea inpossihle, for he can easily de what anditory images of $i$ and $u$ while the notor presentation audiometer (Â-di-om'e-tér), n. [Irreg. <L. $a u$. lirc, hear, + metrum, < Gr. $\mu k \tau$ ov, a measure.] An instrument designed to gage the power of hearing and record it upon an arbitrary seale. audiometric ( $\hat{\mathrm{A}}$ "di-ō-met'rik), $a$. Of or per-

andiometry (â-di-om'e-tri), n. [As auliomete $+-y$.$] The testing of the sense of hearing,$ audiphone (ấdi-fōn), n. [Irreg. < L. audire, hear, + Gr. фwví, a sound.] An instrument for counteracting deafness by collecting the sonndwaves and transmitting the vibrations to tho auditory nerves through the bony part of the head. It consists of a diaphragm, or plate, whlch ia held audit (â'dit), $n$. [< L. auditus, a hearing, <audire, pp. auditus, hear: see audient.] 1t. Audience; hearing.

With his Orisons 1 meddle not, for hee appeals to a high
A
Milton, Eikonoklastes,

Whose seeks an audit here

game or Hlsh.
Couper, T'ask, Iv. 610

2. Official examination and verification of aecounts or claims; an examination into accounts or dealings with money or property; especially, an examination of accounts by proper officers, or persons appointed for that pulpose, who compare the eharges with the vouchers, examine witnesses, aud state the result.

The rule of insisting on a proper audit of accenth was a
corollary Irom the practice of appropriating the aupplies to particular purpesea. Stubbo, Const. llist., \$ 804 . Hence-3. A calling to account; an examination into one's actions.

You must prepare agalugt to-morrow for your last auf-
Scott.

4. An account or a statement of account; a balnee-sheet.

And, how hia a udit stands, who knows, save heaven?

5t. A periodical auditing or settlement of aecounts; hence, receipts; revenues.

I knew a nobleman In England that had the greatest alieep-master, a great timber-man, dc. Bacon, Rlches. Commissioners of audit, formerly called auditors of all public accountants to account for noney or stores i truated to them, and to cleck the sccomnts of the ord-
nance, army, and navy, and the land revenue. The es.
tabllahment consiats of a chairman and flve conimisslouers, a secretary, and nunierous aubordlnates. andit of; examine and verify by reference to

vouchers, as an account or aceounts: as, to audit the accounts of a treasurer.

In 1408 the commons, who objected to making a grant intil the accounts of the last grant were atcdiced, wer Stubbs, Const. Hlst., 60 . 
audit

The commission under the convention with the Repullic of New Granada closed its session without having ardited and passed upon all the clalm in waymond, p. 311.
nuitted to it.

II. intrans. To examine iuto the correctness of an account; act as an auditor.

Let Hocus audit; he knows how the money was disbursed.

A specially excellent

audit-ale ( $\hat{a}^{\prime}$ dit-āl), $n$. A specially excellent English universities, originally for use on auditday. It was formerly a custons in all the colleges to make a grest feast on the day on which the college accounts
were audited, snd the very best sle was hrought out for the occasion. The sudit-ale was first broached on that day every year.

Observing from the goose on the table and the auditale which was circling in the loving-cup that it was s ferst.

audita querela (â-dī'tä kwe-rē'lä). [L. (NL.), the complaint having been heard: audita, fem. of auditus, pp. of audire, hear; querela, complaint: see audient and quarrell.] In law, a form of action in which the judgment debtor strives to recall or prevent execution on a judgment to which he claims a valid defense; the writ by which such act

audit-house (ấdit-hous), n. A building or room appended to an English eathedral, in which the bu

is transacted.

audition (â-dish'ọn), n. [< L. auditio(n-), a hearing, listening, $<$ audire, pp. auditus, hear: see audient. . 1. The act of hearing; a hearing or listening; the sensation from an impression on the auditory nerve by the vibrations of the air produced by a sonorous body. It is genersily admitted that the audition of speech in
the telephone is the result of repetitions, by the dia-
herate phragm in the receiving instrume

Quoted in G. B. Prescott's Elect. Invent., p. 288, 2. The sense of hearing; hearing, as a physiocial senses.-3. Something heard. [Rare.]

I went to hear it [the Cock-Lane Ghost], for it is not sn
apparition, but sn audition. Walpole, Letters, II. 333. ossicles of audition. See ossicle.

auditive (ấdi-tiv), a. $[<\mathrm{F}$. auditif, $<\mathrm{L}$. as if "auditivus, < auditus, pp. of audire, hear: see ing: concerned with the power of hearing; auditory.

His heart is fixed and busily taken up in some object, inaster, the heart, lose the set of that auditive organ by some suspension, till the heart hath done with them.

audit-office (â'dit-of/is), n. An office where accounts are andited: as, a railway audit-ofjice, specifically, in England, the office where the commissiouers fer auditing the public aceounts
of the United Kingdom transact their business. The imperial audit-effice is under the immediate contrel of the lords of the treasury.

auditor ( $\hat{\mathrm{a}}^{\prime}$ di-tor), $n$. [<ME. auditour (AF. anditour, Or. a hearer, in ML., specifieally, a judge, commis sioner, notary, examiner of accounts, ete., audire, hear: see audient and audit.] 1. A
hearer; one who listens to what is said; member of an auditery.

What, a play toward? I'I he an auditor; '
An actor too, perhaps. I was infinitely delighted with the station of a humble
auditor in such conversations Swift, Gulliver's Travels, iv. 10. pointed and antherized to $2 .-3$. A person appor accounts, compare the charges with the vouchers, examine parties and witnesses, allow or rejeet charges, and state the result. It is nsugl with courts to refer accounts involved in litigstion
to suditors, in some jurisdictions called referces or comis the basis of the judgment. Sonetimes an auditor is a standing officer of political or corporpte bodies. State or
municipal auditors are persons spointed or elccted to mumicipal auditors are persons appointed or elccted to examine the public accounts as they sccrue, or at such
intervals sa may be designated. In the United States gov ernment there are six auditiors of the tressury. The first
suditor has charge of the accounts of the civil service. suditor has charge of the accounts of the civil service,
customs, judiciary, public debt, etc.; the second, those of customs, judiciary, public debt, etc.; the second, those of
Indisn affirs and some of those of the army; the third, those of the quartermaster-genersl, engineer corps, com-
nissary-genersl, war claims, etc.; the fourth, those of the nasy; the fitht, those of the internal-revenue office, cen-
sus, patent-office, snd state department; and the sixth, sus, patent-office, snd state department; and the sixth,
those of the postooffice department.
4. One of certain officers of bigh rank at the 4. One of certain officers of high rank at the papal court: so called from their connection
with business treated of in audiences with the
378

auger

pope: as, auditor of the apostolie chamber; au fond (o fôn). [F.: $a u$, at the $\left(\operatorname{see} a u^{2}\right)$; fond, auditor of the pope; auditors of the Roman bottom: see fund.] At bottom; essentially. rota (which see). - Auditor of the Court of Ses10n, in scotiand, a crown otticer to whom strits in which costs may be taxed.-Auditors of the Exchequer. See commissioners of audit, nnder audit.

uditoria, n. Plural of auditorium.

aditorial (â-di-tō'ri-gl), a. [Cf. LL. auditori alis, pertaining to a school (auditorium), ML. unditorialis seholasticus, an advocate; $<$ LL. aditorius, auditory, < L. auditor, a hearer [Rare.]-2. Of or pertaining to an auditor of accounts, or to audits.

auditorium (Â-di-tố'ri-um), n.; pl. auditoriums, auditoria $(-\mathrm{umz},-a$ ). $\quad$ [L., a court of justice, a hall of audience, a school, assembled hearors, in ML. also a reception-room in a monasing: see auditory, a. $]$ 1. In a church, theater, ing: see auditory, $a$ like, the space allotted to public hall, or the like, the space allotsed an apartment for receiving visitors; a parlor or reception-room.

auditorship (â'di-tor-ship), n. The office of auditor.

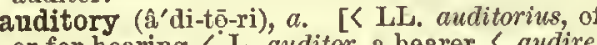
or for hearing, $<\mathrm{L}$. auditor, a hearer, $<$ audire, pp. auditus, hear: see audient.] 1. Pertaining ing: as, the auditory nerve.-2. Pertaining to ing: as, the auditory nerve.-2. Pertaining te an auditorium; designed for an audience: as,
the auditory part of a theater. [Rare.] - Auditory artery, a branch of the basitar artery which \& conpanies the anditory nerve ald supplies the labyrint
of the ear. - Auditory canal, the mestus auditorius ex ternus and internus. cephaloy crest, anditory The terninations of the anditory nerves either form the
auditory plate, which is a thickened portion of the epl-
thelium, thelium, from which the celis send hair-like processes
(auditory hairs) (Sepia); or an auditory crest, which genrally takes a curved direction, and which is likewtse covered by modified epithelinm.

Cells bearing or developet into which sre to be regarded ss the peripheral end-oryans of the vestibular branches of the auditiory nerve. Auditory duct (dnctus cochlearis or ductns anditorius), and the to the interval between the membrana tecAuditory nerve, the special perve of hearing, which enters the ear-parts by the mestus suditorins internus,
and is distributed to the membrsnous labyrinth. In Willis's enumerstion it was known as the portio mollis of the seventh cranisl nerve; now it is genersily reckoned as the eighth cranial nerve. Also called the acoustic nerve.
see cut nunder brain. - Auditory ossicles. See osicle.
- Auditory process, or external auditory process, the projecting border of the externsl suditory meatus to
which the cartilage of the ear is attached. Auditory vesicie, the vesicle formed in the embryo by the involution of the epiblast on either side of the head; the rudi. auditory foramen. See foramen. tory (â di-tọ-ri) [<L. auditorium: see anditorium.] 1 . An audience; an assembly of heare

He had not the popular wsy of preaching, nor is in any measure fit for our plsine and vulggr auditorie, as his
Dreelym, Diary, 31 ar. 5,1673 . Having entered his court, he [Bacon] addressed the
splendid auditory in $\mathrm{s}$ grave and dignified speech. 2. A place for hearing or for the accommodation of hearers; an auditorium; specifically, in a chureh, the nave, in which

When Agrippa and Bernice entered into the auditory.

3t. A bench on which a judge sits to hear causes. - 4 . A lecture-room; a philosophical school. N. E. D.

uditress (âdi-tres), $n . \quad[<$ auditor $+-e s s$.

Adsm relsting, she sole anditress.

ilton $\mathbf{P}$. $\mathrm{L}$, vili. 51.

anditual (â-diț'ụ-al), a. [< L. auditus (auditu-), hearing (see audit, n.), +-al.] Relating to hearing; auditery. Coleridge.
auf $t(\hat{\mathrm{f}} \mathrm{f}), n$. The older form of oaf.

A neer changeling, a very monster, sn auf imperfect. an fait ( $\bar{o}$ fā). [F.; lit., to the point or fact: $a u$, to the (see $a u^{2}$; ; fait, < L. factum, fact: see feat and fact.] Up to the mark; fully skilled or accomplished; expert; possessing or showby at or in: as, he is quite au fait at the game. The nstives [of Maites] seemed quite au fait in the
mattcr of monetary transsctions snd exchsnges.
Lady Brassey, Voyage of Sunbeam, I. xiii.
Petrarch was timid. Laura was a woman of sense, and C. D. Warner, Routudabout Journey, p. 9

auget, augest, auxt, $n$. [It. Sp. Pg. auge, acme, summit, ML. anges, aux, < Ar. Pers. auj, top, summit, altitude, zenith, ascendant of a plan et.] In old astron.: (a) Properly, the apogee (b) planet, or the longitude of the apogee. nation or point of culmination.

Augean (â-jē'an), a. [< L. Augeas, Augias, Gr. Aviýas, Aìycias, king of Elis (see def.), according to one tradition a son of the Sun and Naupidame; prob. < avyं, splendor, sunlight. of or pertaining to Augeas or Augeias, one of the Argonauts, and afterward king of Elis, or resembling his stables; hence, very filthy.Augean stable, in Gr. myth, a stable in which this king
kept 3,000 oxent, nnd which had lot been cleaned for thirty years, oo that the task of cleaning it had come to be
dcemed impracticable. IIfrcules accomplished the task the stable. Hence, cleansing the Augean stable has be ssnces, abuses, and the like.

auger (â'gèr), n. [Initial $n$ has been lost, as in adder, umpire, ote.; early mod. E. also augre, augor, etc., and, with orig. $n$, nauger, $<\mathrm{ME}$, nauger, naugor, earlier navegor, $<$ AS. nafogär, kafcgār $(=\mathrm{D}$. avegaar, eveger, egger $=\mathrm{LG}$. na viger, näviger $=\mathrm{OHG}$. nabagề, nabigē $r$, transber, G. näber, neber = Icel. nafarr (for *naf geirr P), Sw. nafvare (for "nafgare); ef. Finn. napakaira, < Teut.), < nafu, nave, + gār, a orer, spear: see nave ${ }^{1}$, gar 1 , and gore ${ }^{2}$. An instrument for boring holes larger than

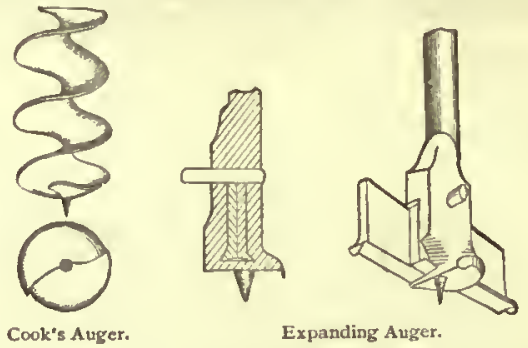

those bored by a bit or gimlet. It consists of an iron shank ending in a steel bit, sud a handle placed at
right angles with the slsnk. The sugers formerly nade

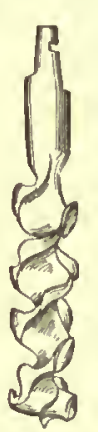
with a stralght chsnnel or groove sre called pod-augers; sugers of the modern form1, with
spiral channels, sre called screv-augers. The ordinsry screw-suger is forged as a parsuleled blade of steel, which is twisted while red-hot. The end terminstes in a worm, hy which the suger is gradually drawn into the work, like
the gimiet. Another form is thst of a cylindri. cal shatt, sround which is brazed a single fin or rib, the end being mide into a worm, and rical mortise is formed for the reception of a detached cutter, which exastly resembles the chisel-edge of the center-bit. Expanding au gers have cntters susceptible of radial adjust-
ment for boring holes of different sizes. In the slott ing-auger, ised for channels, mortises, etc. the cutting lips are upon the side of the ange as well as at the end, and the piece to be groov-
ed is fed against them laternlly. Ifortises are cut by cansing the anger to penetrate to the proper depth, snd then feeding the work laterally to the required length. The two rounded
ends of the mortise are then squared with chisel. The square-hole auger is an anger revolving within a rectangular tube or boring, whose lower edge is square circumscribing the round hole soil. Such an insetting posts is called a post-hole ascertaining the nsture of the sub-
soil, the presence soil, the presence ter, etc., is calle earth-boring auger. Augers for the lat ter use are of va-
rious kinds, but they sll consist of they sll consist of which two or more
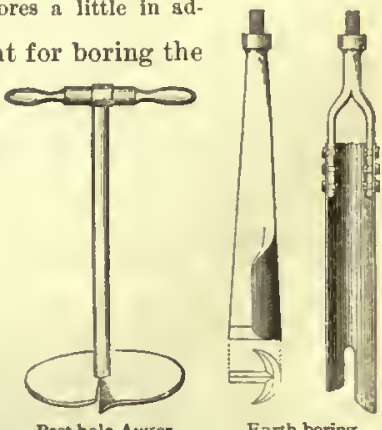

men csn work the instrument; the bit, month, or cutting picce; snd rods for connecting the handle with the bit of cutting piece.-Annular auger. See anmular. in s single day, by torning the river Alphens through oosed nagibēr, MHG. nabeger, negeber, neg-

2. An instrument for boring the 
auger-bit

auger-bit ( $\hat{a}^{\prime}$ gerl-bit), ${ }^{\prime}$. $\Lambda$ small auger used with a braco or bit-stock.

auger-faucet ( $\hat{u}^{\prime} g \dot{e} r-f \hat{a}^{\prime}$ set) $), n$. A faueet with an auger attaelred. By means of the auger a hele is bored siearly through the wood of the cask, or the like, in which the fancet is to be inserted, and the faucet is then the fatiet by a rack and pinion.

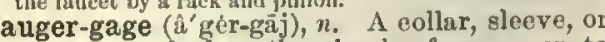
elamp attached to the shank of an auger, to prevent it from penetrating beyond the dosired point.

auger-hole (Ágèr-höl), n. A hole mado by an

Ilid in an auger-hole.

Shak., Macbeth, 11. 3.

auger-shell ( $\hat{a}^{\prime}$ ger-shol), $n$. A shell of tho genus Terebra and family Tcrebrille. Seo ou under Terebra.

auger-stem (â'ger-stem), n. 'The iron rod or bar to which the bit is attached in rope-drilling. auger-twister ( $\hat{u}^{\prime}$ gèr-twis"tèr), $n$. A machine for twisting the blanks for serew-angors.

augest, $n$. Soe alige.

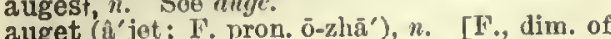

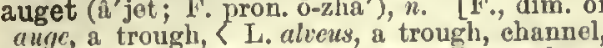
hollow: see alveus.] Milit., a small trough extending from the ehamber of a mine to the extremity of a gallery, to proteet from dampnes a saucisson or tube filled with powder.

augh (â; Se. pron. àch), interj. [Cf. $a u$, ah oh.] An exclamation of disgust. [U. S. and Seoteh.]

aught1. (ût), $n$. or pron. [In two forms: (1)

aught, < ME. aught, auzht, auht, aght, azt, aht, $<$ AS. awiht, awuht, with vowel shortened from oght, ozt, oht, <AS. äwiht, āivuht, eontr. äht, with labialized rowel, ôviht, owuht (= OS. èowih $=$ OFries. $\bar{a}$ wet, $\bar{a} c t=\mathrm{D}$. iets $=\overline{\mathrm{OHG}}$. cowilht ioxiht, iewiht, MHG. icht, iht, iewet, iet $\rangle,\langle a \vec{a}$ ever, in comp. a generalizing prefix, + wiht over, in eomp. a gent, 'over a whit': see ay and whit, wight, and ef. the negative naught nought, 'never a whit.' 'There is no essentia difference between the two spellings aught and ought; the former is now preferred.] Anything whatever; any part: used in interroga tive, negative, and eonditional sentenees. Is tirere aught elae, my friends, I can do for you?

$$
\text { Untaith in aught is want of faith in all. }
$$$$
\text { and Vivien. }
$$

aughtl + (ât), adv. [< ME. aught, ete.; prop. aee. of the noun.] In any respect; in any way; at all; by any chanee.

Can he aught telle a mery tale or tweye?
Chaucer, Prol. to Canon's Yeoman's Tale, 1. 44.

Thereon mused he
If that the chlldes moder were aught ahe

That was his wyl.

aught $2 t, v$. An obsolete form of ought 2 .

aught ${ }^{3} \nmid(a \hat{t}), n$. [Now only in Se., written aucht (äeht), < ME. aught, aughte, auehte, aght, auhte,

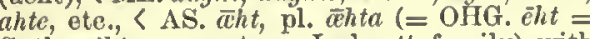
Goth. aihts, property, = Icel. cett, family), with formative - $t$, < a alan (pret. āhte), have, hold, own: see ought 2 and owe.] Possession; property.

The sureat gear in their aught.

aught4 (Ât, ächt), $a$, and ". An obsolete or dialectal form of eight

aughtwhereł (ât'hwãr), adv. [<aught,$a d v .,+$ where.] Anywhere. Chaucer.

augite $\left(\hat{\mathrm{A}}^{\prime} \mathrm{j} \mathrm{j} \mathrm{t}\right), n . \quad\left[=\mathrm{F}_{\text {. }}\right.$ augite, $<\mathrm{L}$. augites, a precious stone, < Gr. "avyitms, < àvin, brightness, sunlight.] The dark-green to black variety of pyroxene eharacteristic of basie eruptive rocks like basalt. It differs from other varleties of pyroxene in containing a considerable proportion of whole species see ingroxen.

augitic (Â-jit'ik), a. [<augite $+-i e$.$] Pertain-$ ing to augite; resembling augite, or partaking of its nature and characters; composed of or containing augite.-Augitic porphyry, a rock with a dark-gray or greenish base, contain

auglettet, n. An obsolete form of aglet.

augment (âg'ment), n. [<ME. augment, < OF'

augment $=\mathrm{Pg}$. augmento $=\mathrm{Sp}$. It. aumento, augment $=\mathrm{Pg}$. augmento $=\mathrm{Sp}$. It. augmentum, inerease, growth, < augere, increase: see auetion.] 1t. Increase; enlargement by addition; augmentation.

Thls augment of the tree. I. Iralton, Complete Angler. 2. In gram., an addition at the beginning of certain past indieative tenses of the verb in a
part of the Indo-European languages. In San.
379

augur

skrit it is always d.; In Greek it is $\ell$-( $(2)$ before a conse-
nant (syllabie augment), but an hutial vowel is lcngthened (n-, i. (tenpora' augment). The sane nsme is sometinea given to other preflxed inflectienal glements,
as to tho ge of the German perfect jarticiple (gebracht, rought

Another form, which we may call the preterito-present unites the augment of the past and the ending of the
Amer. Jour. Philot., VII. 354. 3. In pathol, the period of a fever between it commeneoment and its height. [Rare.]

augment (âg-ment'), v. [< ME. augmenten, F. augmenter, earlier aumenter $=\mathbf{S p}$. aumentar $=\mathrm{Pg}$. augmentar $=$ It. aumentire, < LL. augmentare, increase, < L. augmentum, an inerease: see augment, n.] I. trans, 1. To increase; enlarge in size or extent; swell: as, to augments an ovil.

To augment your lieap of wealth.

F'letcher (and a wother), Eilder Brother, i. 2 Though fortine change, his constant spouse renains: Augments his joya or mitigates his pains.

The gencrai distreas did but augnent the piety and conIrm the fortitude of the coloniats. 2. In graw., to add an angment to.

II ost [Greek] verbo beginning with a consonant augmen the inperfect and aorist by prefixing

In ler to make an honorable addition to, a coat of arms.

IInry V1II. granted to the earl of Surrey to augment his arma with a demillion, gules, pierced thirough the Augmented interval. See interval. - Augmented surace, a term first uaed by Rankine to denote an 1mmerse face of a veasel to give, when aubstituted for the actual quantity in eatimationa of the apeed of

II. intrans. To beeome greatcr in size, monnt, degree, etc.; increase; grow larger.

The winds redouble and the atreama augment.

IIer fears augmented as her comforts fled. Crabbe, Tales of the Hal

augmentable (âg-men'ta-bl), a. [< augment $+a b l e$.$] Capable of bïing augmented or in-$ ereased.

augmentation (âg-men-tā'shọn), $n$. [< ML. 促 $(n-)$, LL. augmentare, pp. augmenatus, augment: see augment, v.] 1. The aet of increasing or making larger by addition, expansion, or dilatation; the aet of adding to or enlarging; the state or condition of being made larger.

Escon, holding that this laethod was insufficient and published his Novum Organon.
IIhewell, Nov. Org. Renovatum, Pref.

2. That by which anything is augmented; an addition: as, the augmentation amounted to $\$ 500$ a year.

He does smile his face into more lines than are in the new map with the augmentation of the Indiea.

Specifieally-3. In musie, where mueh repetition and imitation of themes is required, the

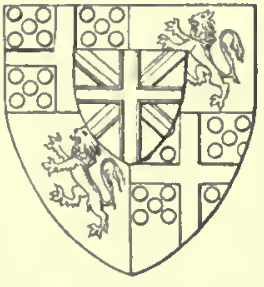
modifieation of a theme or subjeet by systematieally inereasing the original time-value of all it notes. -4 . In her., an additional charge to a coatarmor, granted as a mark of honor to an armiger. It is borne on sin ordinary or aubordinary in such a way as the paternal coat, aod in an cient times was more rarely Arms of first Duke or wel. used as an addition to the bear
lington with the augmenta.
tion granted to him, viz. An ings on the fleld. Also called tion granted to him, viz, An
Inescutcheon of Ringland.
(From Boutelif, in Herald. 5. In pathol., same as augment, 3.- Augmentation Court, in England, a court establiahed by Henry preasion of monasteriea. It was dissolved on the accession of Queen Mary. - By augmentation, tn England, a phrase an officer'a appolntwent had been conferred by the crea tlon of a new patent, not by the purchase of an old one.Process of augmentation, in scotland, a process in the teind court, raised by the minister of a parish against the
titular and heritors, for the purpose of obtaining an ang mentation of his stipend.

augmentationer (Âg-men-tä'shon-êr), n. A offieer belonging to the Augmentation Court (which see, under augmentation).

Ilere now I speak to you my masters, minters, augmen-
Lationers.
Latimer, $2 \mathrm{~d}$ Sermon bef. Edw. VI., 1550. ortnitous incidents, suc the creaking of a chalr, augmentative (âg-men'ta-tiv), $u$. and $n . \quad[=\mathrm{F}$. augmentatif, <LL. as if "eugmentatious, <augmentare, pp. augmentatus: see augment, $v$.] menting.-2. In gram., expressing augmentaveyed: applied both to words and to affixes liich efreet this.

II. $n$. A word formed to express increased intensity of tho idea eonvoyed by it, or an affix hich serves this purpose.

Also augmentive.

ugmentatively (Ag-men'ta-tiv-li), adv. So as to augment or inerease; in the manner of an augment.

angmenter (âg-1nen'tér), n. One who or that which augments.

augmentive (ag-men'tiv), a. and n. [< augment + -ice.] Same as augnentative.

augmentless (âg'ment-les), a. [< augment + -less.] Without an augment.

Additional fornta - agisisam, agăsis, agasit, and the augmentlegs gisisisns - are found throughout the Brah augoert, augret, $n$. Obsolete spellings of auger. augoert, augret, n. Olidasolete English form of algorism. augrim $\nmid, n$. A Middle English form of algorism. in arithmetieal ealeulations, some standing for units, others for tens, ete.

His augrim-stoones, leyen faire apart.

Augsburg Confession. Sce confession.

(âne lier auger, of uncertain origin, perhaps (avis, a bird (cf. au-spex and au-cupation), + -gur, connected with garrire, talk, ehatter.] 1. Among the ancient Romans, a functionary whose duty it was to observe and to interpret, aceording to traditional rules, the auspiees, or reputed natural signs concerning future events. These ausplces were atud-
led, witha fixed ceremonial in the foliowing classea of phenomena: (1) signa from the heavena inciuding ther meteorological maai lestations; (2) signs from the direction of flight or (3) aigna from the manne kept for this purpose; igits from the movement 5) evil omens frent variou as the fall of any ebject, when these were about to begin. The official or pubilic augurs, who constituted a college, probaluly founded by Numa, were originally three in number. By the time of
Tarquin they had been increased to gix. After $300 \mathrm{~B}$. c. the number became nine, of whom five nust be plebelins. including his own official membership in hls character ut perpetual chief priest and dictator; and teward the close of the empire the number was stijl further increased. The augurs wore the ancerdotal pratexta, or toga with 8 the curved rod called the liturs, with which they marked out the limits of the tempium or boundary within which Betore any public buainess or ceremeny was undertaken or whether unfavorable omens demanded interruption of delay; they conducted the inauguration or exaugurstien of priests, temples, and places, such as new aettlements, snd fixed the times of movahle festivals. In the engrav.
ing, the figure holda the litums in his right hand, while Hen to foretell future events by omens; a soothsayer; a prophet; one who bodes, forebodes, or portends.

$$
\begin{aligned}
& \text { Augur of } 111 \text {, whose tongue was never teund } \\
& \text { Without a priestly curse or boding gound. }
\end{aligned}
$$

augur (â'gér), $\iota . \quad[=\mathrm{F}$. augurer $=\mathrm{Sp} . \mathrm{Pg}$. au gurar = It. augurare, <L. augurari; from the noun.] I. trans. 1. To prognostieate from signs, omens, or indieations; predict; anticipate: with a personal subject.

$$
\text { I did augur all this to him beforehand. }
$$

I augur everything from the approbation the proposal 2. To betoken; forebode: with a non-personal or impersonal subjeet.

Sooth was my prophecy of fear;

Syn 2 To portend, preage, toreshadow, be ominous or. 
augur

380

II. intrans. 1. To conjecture from signs or mens.

My power's a crescent, and my cuuguring lope
Says it will come to the full. Shak., A. and C., it. 1. 2. To be a sign; bode: with $u$ ell or ill.

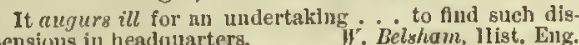
augural (Á'gū-rạl), a. [<L. auguralis, pertaining to an angui', ( augur, angur. ] Pertaining to an augur, or to the duties or profession of an augur; of or pertaining to divinat

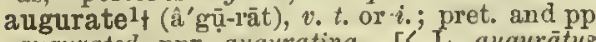
augurated, ppr. augurating. [< L. augurātus, p. of angurari, augur: see augur, $v$., and -ate ${ }^{2}$. To conjecture or foretell by angury; predict act as an augur.

I augurated truly the fuprovement they would receive
Warburton, To II urd, Letters, cil. augurate ${ }^{2}$ (â'gụ-rāt), u. [< L. auguratus, the atice of augur, $<$ augur: see augur, $n$., and $-a e^{3}$.] The office of augur; angurship.

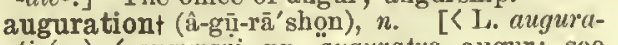
tio(n-), < augurari, pp. auguratus, augur: see augur, $r$.] The practice of angury, or the foretelling of events by signs or omens: as, "tripudiary auguratians," Sir T. Brawne, Vulg. Eirr., i. 11

augure ${ }^{1} \uparrow, n$. [For *auger, for *algere, appar. D. aalgeer, aalger, clger, < aal (= E. eel) + -ger eel-spear.

augure ${ }^{2}+, u$. [Also augur, < OF. augure, < I. angurium: see augury.] Angury.

augurert (â'gèr-ér), $n_{0}$ An augur. Shak.

augurial (â-gī'ri-ạl), a. [< L. augurialis, collateral form of auguralis: see augural.]
pertaining to angurs or angury; augural.

As for the divination or decision from the staff, it is an
Sir T. Browne, Vulg. Err.

augurism† (âgèr-izm), n. [< augur + -ism. $]$

Augury.

auguristt ( $\hat{a}^{\prime}$ gèr-ist), n. [<augur $+-i s t$. Cf. augurize.] An augur.

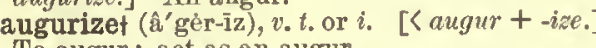
To augur; wet as an augur.

auguroust (á'gèr-ıs), a. [< augur + -ous. $]$ Predicting; foretelling; foreboding.$$
\text { Presaging in their augurous hearts. }
$$

Chapman, Iliad, xvili. 19

augurship (â'gèr-ship), n. [< augur + -ship. $]$ The office or period of office of an augur. augury (águl-ri), n.; pl. auguries (-17z). [<ME

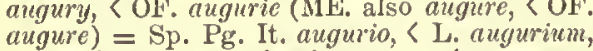
divination, prognostication, omen, $<$ augur, angur: see augur, n.] 1. The art or practice of foretelling events by signs or omens.

She knew by augury divine.

The throne and sceptre of Ithaca were to be disposed by augury, by the wlll of Jove, signifed by some omen.

2. That which forebodes; that from which a prediction is drawn; an omen or siguificant token.

Sad auguries of winter thence she drew. 1 lasl this interchange of sentiment ... as an augury
that. . the peace and friendship which now exist beween the two nations will he . . . perpetual.

3. Figuratively, indication; presage; promise. His diligence at school . . gave augury of his futur = Syn. Portent, Sign, etc. See omen.

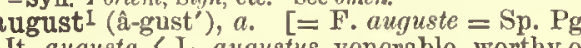
It. augusto, < L. augustus, venerable, worthy of honor (assumed as a title by Octavius Cæesar and his suecessors), perhaps orig. ' consecrated by augury,' < augur, angur (ef. rabust, < L. raaugere, increase, extol: see auction.] 1. Inspiring reverence and admiration; majestic solemily grand or stately; sublime; magnif cent; imposing.

There is on earth a yet auguster thing

Wither.

That august face of Truth. Whittier, Eve of Election. This was an extensive and magnificent structure, the
creation of the prince's own eccentric yet august taste.

2. Venerable; worshipful; eminent. $=$ Syn. State. ly, etc. (see majestic), swful, imposing.
August2 (â'gust), $n$. [<ME. Aug

August2 (a gust), $n$. [< ME. August, Augst, also Aust, after OF. Aaust, mod. F. Aout $=\mathrm{Sp} . \mathrm{Pg}$.
It. Agasta $=\mathrm{D}$. Augustus $=$ G. Dan. August $=\mathrm{Sw}$.

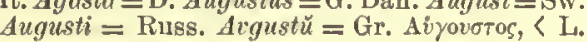
See month. known.

alacanthid

Augustus (sc. mensis, month), Angust; so named by the emperor Angustus Cosar (see august 1 ) in his own honor, following the example of Julius month, July. The earlier name of Angust wa Sextilis ( $<$ sextus $=$ E. sixth, it being the sixth month in the old calendar).] The eighth month of the year, containing thirty-one days, reckoned the first month of autumn in Great Britain, but the last of summer in the United States.

august2 (â'gust), v. t. [= F. aaûter, ripen, = Sp. agastar, bo parehed, dial. plow land in Angust, pasture cattle on stubble in summer (sce agostadera); from August ${ }^{2}, n$.] 1 1 ipen; bring to fruition. [Poetical.] IIe for . . dear natjons toiled, Bailey, Mystic, l. 55. (N. E. D.)

augusta (â-gus'tậ), n. [See august ${ }^{1}$.] A name given in Central America to a valuablo timberree, the botanical relations of which are un-

augustal (â-gus'tạl), $n$. [<L. Augustalis, relating to Augustus, the title assumed by the emperors, < augustus, venerable: see august ${ }^{I}$.] 1. onder the ancient Roman empire: (a) A priest of tho lares at the cross-roads, an office first
established by Augustus. (b) A pricst of a college or brotherhood (sodales Augustales) of members of the imperial house and some othe persons of high rank, whose duty it was to maintain the religions rites of the Julian family: institnted by Tiberius. (c) A member of private college or corporation, of which there were many in Rome and throughont the provinces, formed to do reverence, by religious ceremonies and otherwise, to the memory of Augustus, and, at a later date, to pay divine honors to the reigning emperor also. The office aasessment of certain public dues, and the giving to the public of stated feasts and shows. The augustals wore dis-
tinctive ornaments, had places of honor in the theaters, tinctive ornaments, had places of honor in the theaters,
and enjoyed other privlleges. (d) Under the early and enjoyed other privlleges. $(d)$ Under the early of the legion.-2. The name of an Italian gold

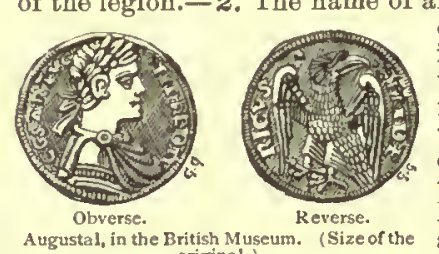
ing from 30 to 40 grains, issued in century by the emperor Froderick II. as king of Si-
cily. It bears a resemblance to gold coins of the ancient Roman empire.

augustalis (â-gus-tā'lis), n.; pl. augustales (-lèz). Same as augustal,

Augustan (â-gus'tañ), a. [< L. Augustanus pertaining to Augustus, or to cities named Augusta: sce August2.] 1. Pertaining to the Emperor Augustus (31 B. C. to A. D. 14): as, the Augustan age. The Augustan age was the most brilliant period in Roman literature; hence the phrase erary history of otlier countries. Thus the reign of Lonis
XIV. has been called the Augustan age of French litera XIV. has been called the Augustan age of French literation in English.

2. Pertaining to the town Angusta Vindelicorum, now Augsburg, in Bavaria: as, the $A$ u gustan Confession, commonly called the Angsgustan Confession, commonly cal

Augustin, Augustine (â-gus'tin or â'guss-tin) n. [< L. Augustinus, a proper name, < Augus
tus, name of Roman emperors: see August ${ }^{2}$ The name Austin is a contraction of Augustin.] A name formerly given to a momber of one of the monastic fraternities following the rule of St. Augustine. See Augustinian.-Augustine disputation, a disputation

Augustinian (â-gus-tin'i-an), $a$. and $n$. [<L. Augustinus, Angustine.] I. $a$. Relating or pertaining to St. Augustine or his doctrines, or o the order of monks following his rule.

II. n. 1. A member of one of several religious orders deriving their name and rule from St. Angustine. The regular canons of St. Augustine, or Austin Canons, were introduced into Great Britain soon
gfter 1100, and had houses at Pontefract, Scone, Holyrood, etc. The hermits of St. Augustine, or Austin Friars, now known as Angustinians, form one of the four mendicant
orders of the Roman Catholic Church; they were gathered orders of the Rontan Catholic Church; they were gathere
into one body from several congregations in the middle of known as the barefooted Augustinians. There have also heen various congregations of nuns called by this name, and many other's follow the rule of St. Augustine, as the 2. In theol., one who adopts the vicws of St. Angustine, especially his doctrines of predestination and irresistible grace. Sce grace. -3 . One of a sect of the sixteenth contury, which maintained that the gates of heaven will not be open till the general resurrection.

Augustinianism (â-gus-tin'i-an-izm), n. [< Augustinian $+-i s m$.
Angustine. 1 . The rules and practice of the Augustinians.

augustly. (â-gust'li), $a d v$. In an august manner; majestically.

augustness (â-gust'nes), $n$. The quality of being august

He was daunted at the augustness of such an assembly.

$\operatorname{auk}^{1}$ (âk), $n$. [Also written awk, E. dial. alk, < Icel. alla, ällo $a=\mathrm{Sw}$, alk $a=$ Dan. alk; > NL. Al$c a, q . v$.$] A diving bird belonging to the fam-$ ized by having 3 toes, webbed feet, and short wings and tail. Originally the wame was specifically applied to the great ank, or garefowl, Alea inqpennis, which became extinct about 1844, notable as the largest bird of the family and the only one deprived of thic power of flight by reason of the 8mallness of its wings, though theae wcre as perfectly formed as in other birds. It was aboult 30
inches long, the length of the wing being only about 6 inches. 1ta color was dark-brown nbove and whilte below both a last of the vorth arctlo circle, and south on the American side to Massachusetts. The name came to be also specifically applied to the razor-bllled auk, Alca or Utamania torda, a similar but much analler species, about 15 inches long, with a white line lnstead of a spot before the eye; and flisally. as a book-nane, it was made synonymous with Alcidos rhinoceros auk (Ceratorhina monocerata), the crested auk (Simorhy nchus cristatellus), etc. - but other special namea are usually found for most of the birds of this family, a puffin, murre, guillemot, dovekie, auklet, ete. There are auk $^{2}$, $a$. Samo as ark.

auklet (âk'let), n. [< auk+dim. -let.] A lit auk. Speciffcally applied to several small species of

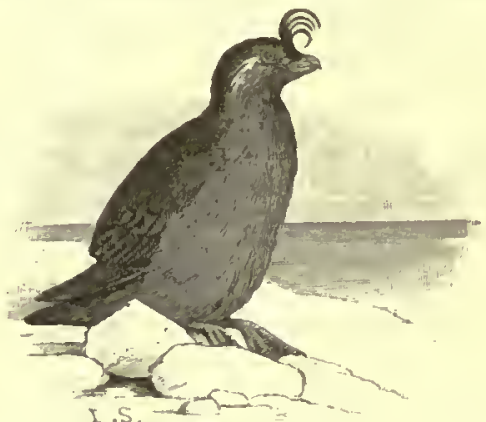

Alcidae, of the genera Simorhynchux, Ombric, and Ptychorhamphus, as the erested auklet, Simorhynchus cris. Alcutian auklet, Ptychorhamphus aleuticus.
aul (âl), $n$. [F. dial., "a reduetion of alder 1.$]$ The alder.

When the bud of the anl is as big as the trout's eye,

Then that fish is in reason in the river $W$ ye.

aula (Ẩ'lä), n.; pl. aulce (-lē). [L., a hall, court, <Gr. aivi, a hall, a court, orig. an open court, prob. as being open to the air, <áñal, blow: seo airl, aura, and asthma; ef. aì $\delta s, a$ pipe, flute.] 1. A court or hall.-2. [NL.] In anat. the anterior portion of the third ventricle of the brain, corresponding to the cavity of the primitive prosencephalon; a mesal portion of the common ventricular eavity of the brain; in the amphibian brain, the ventricle of the unpaired cerebral rudiment.-3. [NL.] In $z o o ̈ l$., the cavity of a colony of infusorians, as members of Falvox or Eudorina. A. Hyatt.Aula Regla or Regis (Royal or King'a Court), a court whence the name. It was composed of the great officers of state resilent in the palace, of the king's justiciars, and the greater barons. It formed an ndvisory body consulted

Aulacantha (â-la-kan'thä), $n$. [NL., < Gr.

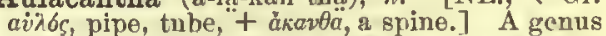
of radiolarians, ropresenting a peculiar family, the Aulacanthide. Hacekel, 1860.

aulacanthid (â-la-kan'thid), $n$. A radiolarian of the family Aulacanthida. 
Aulacanthidæ (â-la-kan'thi-dēe), n.pl. [NI., < Aulacantha + -iffe.] A family of tripyleans or acantharian radiolarians, with a skeleton consisting of a superficial pallium of five tangential tubes and a number of strong ratial spicules, siniple or branehed, which pierce the mantle. 'liney are deep-sea organisms, and are divided Into a miniber of genera, as $A$ uffecanth

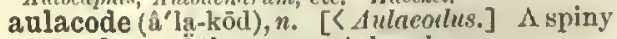
grounl-pat of the genus dulacorlus.

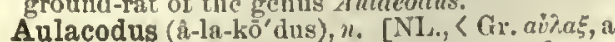
furrose, + idoirs, tootl. ] I. $\mathrm{A}$ genus of rodents,

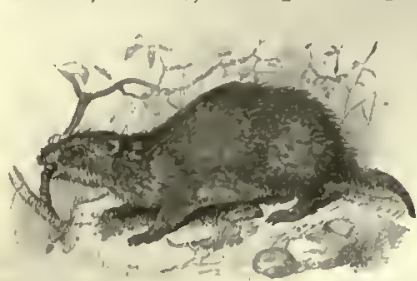
of the family of the family ()clodlontide and subfamily Echimyione Afriean pecies, $A$. Swinder's aulacode, the ground-pig. It Ground-pig (Aulacadus swinderianus).
ro a large Dur.
rowing animal, about 2 feet long, with a atont body, ahort limbs, ears, anc
tall, llattenci and ehanncled bristly hairs like spines, and tali, lattence and el

2. A geans of coleopterons insects. Eschscholt $\tilde{*}^{\prime}, \mathrm{I} 83^{\circ}$.

aulæ, n. Plnral of culu.

aularian (Â-lä'ri-an), $a$. and $u$. [<ML. aularis,

L. cula, hall.] "I. a. Relating to a hall.

II. n. At English universities, especially Oxford, a mem

a collegian.

rian. Same as aularian.

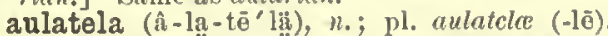

[NL., irreg. <"aulu (see aula) + L. tela, a web.]

In anat., the atrophied or membranous joof of the anla. See aula, 2.

aulbet, $n$. An obsolete form of $a l b^{1}$.

auld (âld), a. [Se., = E. old, q. v.] old.

Take thinc auld cloak aboit thee. Quoted In Silak., Othello, ii. 3.

Auld birkie. Sce birkie.-Auld lang syne. [Auld = E. phrase denoting days or timce long since past, especially phrase denoting days or timce long since past, especially women s toongs were made, as the poets and some other report, whlch seldom ceane wagging." Gerar

Auldana (âl-dā'nï), $n$. An Australian red wine. auld-farand, auld-farrant (âld-fä'raud, -rant), a. [Se., < auld + farand.] Having the ways or thoughts of an old person; resembling an old or at least a grown-up person; henee, sagacious ; wily; knowing more than was expected most frequently applied to children. [Scoteh.] most frequently applied to children. [Scotch.]
aulen (âl'len), $a$. [E. dial., a reduction of al-

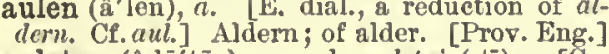
auletes ( $\left(\hat{a}-1 \bar{e}^{\prime} t \bar{e} z\right), n_{\text {. }}$; pl. auletai $(-\mathrm{t} \bar{z})$ [Gr.

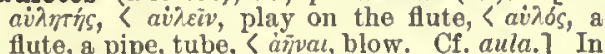
ancient Greece, a flute-player.

Before him on the right gtand an auletes

auletic (Â-let'ik), a. [<L. auleticus, <Gr. $a \dot{v}\rangle$ Tixós, of or for the flute (ef. aùnrís, a flutePertaining to instruments of the flute kind.

It is true that tho ancicnts also had an instrumental music scparate from poetry; but whlle this in modern musical art, it was conflned in antiquity to the kithariatic
and autetic nones.
J. Jadley, Easays, p. 90.

auletris (â-] $\bar{e}^{\prime}$ tris), $n . ;$ pl. auletrides (-tri-dëz).

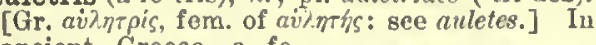
ancient Greee,

In the centre an auletris, Cat. of lases in Brit.
cif useum, II. 15.

aulic (â'lik), $a$. and $n$. [< L. aulicus, < Gr. avi

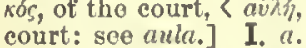
1. Pertaining to a royal court. In ths old German empire, the Aulic Council was the personal council of the
emperor, and ono of the two emperor, and ono of the two aupreme courts of the em-
pire which decided without pire which decided withous under a definite constitution in 1559 , modiffed in 1654 . I

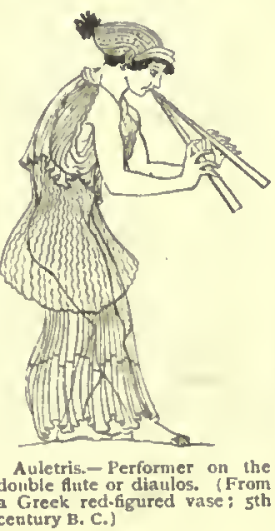

finally consisted of a presidcnt, a vicc-president, and $\operatorname{aum}^{1}$ (âm), $\%$. A dialectal form of $c l m$. [North. ightecu conncilors, six of whom were l'rotestants; the Ling.

tle others. The Aulic Cotucll consed to exist on the ex. aum² (âm), n. Sec aam.

tinction of the German empire lin 1800 . The title is now $a^{3} \mathrm{~m}^{3}$ (âm), n. A dialectal form of alum. [North. given to the Council of State of the Emperor of Austria. Eng.]

2. [ $<$ aulu, 2.] In unat., of or pertaining to the aula. Willer.

aum $4, n$. Seo om.

II. $n$. Formerly, in the University of Paris, the ceremony of conferring the degree of doetor in theology, ineluding a liarangue by the chancellor and a disputation upon a thesis a written and defended by the candidate: so ealled becanse it was held in the great hall of the arehbishoprie.

nlical (a'li-kal), a. Samo as aulie, I

alicism (ấli-sizm), n. [< aulic +-ism.] A ulin (ân), $n$. [Also written allin, allen, allan; aceording to Edmonston (Shetland Gloss.) Icel. "alinn, a parasite" (ef. the speeific name marasiticus), prop. one fed, being pp. of ela, bear, nourish, feed: sec alie 1 and all.] The aretic gull, stercorarius parasiticus, also callaretic gull, stercorarius parasiticus, also callskait-blvd. See scouty-aulin and skait-bird.

alin-scouty (â'lin-skou"ti), n. Same as aulin. auliplexus (Â-li-plok'sns), n.; pl. auliplexus or auliplexuses (-ez). [NL., $<$ ainla, $2,+$ plexus.] In anat, the aulie portion of the diaplexus; that part of the choroid plexus which is in the aula. See aulu, 2. Willer and Gage, Anat. Tech., p. 473 .

Tech., p. 473.

aulmonieret, $n$. See aumónière.

ulnt, $n$. See aune.

alnagef, $n$. See alnage.

aulophyte (â'lō-fit), $n$. [< Gr, aì̀.ó, a pipe,

tube + $\phi v \delta^{\prime} v$ a plant.] A plant living within another, but chiefly for shelter, not parasitically, as some minnte algre.

Aulopora (औौ-lop'ọ-rạ̈), n. [NL., < Gr. avìss, a pipe, $+\pi$ pos, a pore.] A genus of fossil selesoname to a family Auloporido.

alorhynchid (ấ-lọ-ring'kid), n. A fish of the family Aulovhymehidee.

Alorhynchidæ (â-lō-ring'ki-dē), n.pl. [NL. Aulorhynchus + ide.] A family of hemibranchiate fishes, with an elongated subeylindrical body, elongated tubiform snout, sides with rows of bony shields, and subthoracie Aulorhynchus (â-lō-ring'kus), n. [NL.,

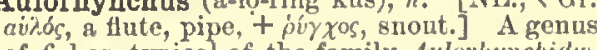
of fishes, typical of the family Aulorinnchider. of fishes, typical of the family Aulorinnchidu. A. Aaridus, the only known species,
the Pacific eoast of the United States.

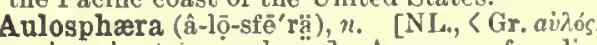
a pipe, + opaipa, sphere.] A genus of radio-
larians, typical of the family Aulospharide.

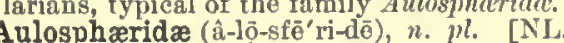

dulosphara + -ida.] A family of tripylean or acantharian radiolarians, with a fenestrated shell composed in a peculiar fashion of hollow tubes. It is a group of several deep-sea genera, as Aulosphava, Aulophlegma, ete. Haechel. Aulostoma (â-los'tọ-mä), n. [NL. (prop. fem. of Aulostomus; ef. Aulostomus), < Gr. avios, a A genus of fishes, typical of the family Aulostomide. Also Aulostomus.

Aulostomatidx (

Same as Aulostomidie. aulostomid (â-los'tōo

Aulostomidæx (â-lō-stō'mi-dē), n. $p l$. [NL., Aulostoma +-ide. ] A family of hemibranchiate fishes, typified by the genus Aulostoma,

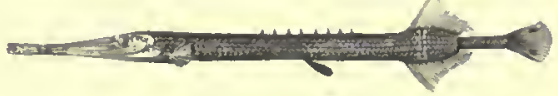

with a long compressed body, elongated tubi form snout, imbricated ctenoid scales, numerous dorsal spines, and abdominal spineless ventral fins. Several speeies are known as inhabitants of tropical and warm seas. Also Aulostomatida.

aulostomidan (Â-lō-stō'mi-dann), $a$, and $n$. I. a. Pertaining to or having the characters of the Aulostomida.

II. $n$. A fish of the family Aulostomida; an aulostomid. Sir J. Richardson.

Aulostomus (â-los'tọ-mus), $n$. [NL., mase. seo Aulostoma.] Same as Aulostoma. umailt, $n$. and $r$. An obsolete form of amel. aumbryt, $n$. An obsolete form of ambry.

aumelett $n$. An obsolete form of ouclet. aumener $l_{t} n$. An obsolete form of almonerr. aumener $2, n$. An obsolete form of almoner2. aumery $\dagger, n$. An obsolete form of a mbry.

umone $\left(a^{\prime}\right.$ mōn $), n . \quad[<1:$ aumbne, <OF. almosne, <LI. clecniosyna, alms: see ulms and almoin.] In law, alms. - Tenure in aumone, a ten.

umônière, aulmoniere (ô-mō-ni-ãr $\left.^{\prime}\right), n$. [F. see almoner.' A pouch or purse, often richly embroidered, carried at the girdle by persons of rase name is also given to a bag or poucl similarly worn by women at the present day.

umuce, $n$. Sce amice 2

uncelt, $n$. [Early mod. F. also aneel, < MF. ancel, auncelle, aunselle, also auncere, aunsere, AF. auncelle, aunsellc, appar. (by mistaking the initial $l$ for tho article $l, l a)$ for "lanncelle, It. lancella, a little balance, dim. of lance, balance, < I, lanx acc laneem, a plate, a seale of a balanee: sce lance ${ }^{2}$, launec ${ }^{2}$, and balanee. $A$ kind of balance for weighing anciently used in England, apparently that variety of the steelyard commonly known as the Danish steelyard, which has a morable fulcrum and a fixed weight, the forefinger often serving as the fulcrum. It was very inaccurate, and was thercfore prohih ited by gtatute. In many parts of Fingland the terin cun cel-zceight is still used to gignify wejglit, an of $\mathrm{m}$
has been estininted by the hand withont Bcalca. undert, $n$. A dialcetal form of undern.

aundiron,$+ n$. An obsolete form of andiron. aune (on), $\mu$. [F., < ol. whe, ell: sec alnage
and $e l l$. and ell.] A Fied a standard measure by the meter. The nse of the aune metrique, nourelle, us ustells, equal at different places: at Rouen it was the same as the Eng. inches; at Calals, es! Inches. Formerly written auln. see angel.] Obsolete forms of angel. aunt (änt), n. [< ME, aunte, aunt, < OF, ante, auntc $(\mathrm{F}$, tante $)=$ Pr. amel $a=\mathrm{It}$. dial. $a m i d o$ ameta, <I. umita, aunt; ef. Icel. amma, grandmother: see amma1. For the change of $m t$ to $n t$, ef. antl.] 1. The sister of one's father or mother; also, in address or familiar use, the wife of one's nncle.-2†. Formerly nsed by alnmni of Oxford and Cambridge as a title old woman; an old gossip.

$$
\text { The wisest aunt telling the saddeat talc. }
$$

4t. A procuress; a loose woman.

Summer songs for me and my aunte Aunt Sally (a) In Englani, a favorite gamc at race clay plpe is placed in the mouth or uose. The game conor other nissiles at it. $(b)$ The liead so usecl.
auntert, $n$. Tho common Middle Ellglish form of adrenture, $n$.

auntert, auntret, $v, i$, and $t$. The common

Middle English forms of adventure, $v$.

$$
\text { I wol arise and auntre it hy my fay. }
$$

auntie, 1 . See aunty.

auntroust, $a$. The common Middle Englisl form of adrenturous. Chaneer.

aunty, auntie (än'ti), n. Familiar diminntive forms of cunt.

aura $^{1}$ (â'rï), n. [L., a breeze, a breath of air, the air, Gr. aipa, air in motion, a breeze, 1. A supposed influence, foree, or imponderable matter proceeding from a body and surfrom all living things, to consist of the subtlo essence of the individnal, and to be a means of manifesting what is called animal magnetism, and also a medium for the operation of alleged mesmeric, clairvoyant, and somnambulic powers. Also ealled nere-aura, or nervaura. Hence-2. Figuratively, atmosphere; air; character, ete. The use of the aune metrique, nourelle, (1)" ustelle, equal
to 11 meters or 471 English inches, catal,ished in 1812 , was
forbidden after 1839 . The old measure of this nane varled rounding it as an atmosphere; speeifieally, an imponderablo substance supposed to emanate 
aura

He [Rosacti] appreciated to a generous extent the poetry of present younger writers, but failed to see in aura that characterize work that will atand the stresa of
time The personal aura which aurounded hin [S. Bowles] is young men in the was now

Charles $G$. Whiting, in Merriam's Life of Bowles, II. 69 3. A peculiar sensation resembling that produced by a current of air. See epileptic aura, below.-Electric aura, a aupposed electric fluid euraasting from an electrifled body, and forming s sort of at Epileptic aura (aura epileptica), primarily, a aenaation, the head, preceding an attack of epilepsy; in a more general aense, any diaturbance of consciousness or local mo- Hysteric aura, a similar aenation preceding an at aura 2 (â'rä), n. [NL., appar. adapted (with ref. to aura 1 ) from a S. Amer, native name. The form ouroua is given by Barrère as the native name in Guiana.] An old native name of any South American vulture excepting the condor; South American vulture excepting the condor;
an urubu, tzopilotl, gallinazo, turkey-buzzard, or carrion-crow. It was early Latinized in the form regina aurarum, was adopted by Linneus aa the apecific name of his Vultur aura, and ia now used as the apecific name of the twits

aural' (Áral), a. [< L. aura (see aura $\left.\left.{ }^{1}\right)+-a l.\right]$

Pertaining to the air or to an aura.

aural 2 (â'rạl), a. [<L. auris, $=$ E. ear $1,+-a l$. 1. Relating to the ear: as, the aural orifice aural surgery.-2. Perceived by the ear learned by hearing; auricular.

That aural acquaintance with Latin phrases which the unlearned might pick up from pulpit quotations conwhen they saw written Latin. George Eliot, Romola, Ixiii. auramine (ân-min), n. [< aurum + amine. A coal-tar color used in dyeing. It is the bydro chlorid of tetra-methyl-diamido-benzo-phenon-imide. I
yields a pure and brilliant yellow on cotton, wool, and silk, aurantia (Â-ran'shi-ä), n. [NL., < aurantium, an orange: see orange.] A coal-tar color used in dyeing. It is the ammonium salt of hexa-nitro-diphenyl. amine. It produces shades of orange, but is only applied

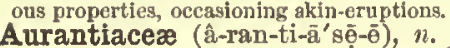

aurantium, an orange (see orange), + -acece. See Aurantica.

aurantiaceous (â-ran-ti-â'shius), a. [< NL aurantiaceus: see above.] Of or belonging to the Aurantiacce.

Aurantieæ (â-ran-tīe ē-ê), n. $p l$. [NL., $\langle a u r a n$

tium (see orange) $\left.+-\dot{e} e_{0}\right]$ A tribe in the natu ral order Rutacew, trees or shrubs, distinguished from the rest of the order by their perfect flowers and by their fruit, a large berry with exalbuminons seeds. It has often been classed as a geners, indigenous to tropical Asia, of which the most
familiar are Citrus, yielding the orange, etc.; Limonia, the Iamiliar are Citrus, yielding the orange, etc.; Limonia, th

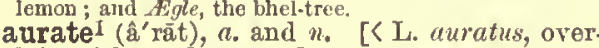
laid with gold, of gold, pp. of aurare, overlay I. a. Resembling gold; gold-colored; gilded [Rare.]

II. n. 1. A kind of pear.-2. A combination of auric acid with a base: as, potassium aurate. aurate $^{2}$ (â'rāt), a. [<L. auris, $=\mathrm{E}_{\text {. carI, }}+$ -atel. Equiv. to aurited, q.v.] Eared; having ears, as the scallop-shell.
aurated $^{1}$, aurated 2 (â'rä-ted), a. Same as aurate 1 , aurate 2 .

auré (ó-rä'), $a$. [Heraldic $\mathrm{F} .,=$ aurate $^{1}$.] In her., sprinkled with drops or spots of gold. Otherwise termed gutté d"o: See gutté.

aureate (啇'rē-āt), a. [Farly mod. F. aureat, LL. aureatus, adorned with gold, < L. aureus, golden, < aurum, gold: see aurum.]
gilded; golden-yellow, as a flower.

gilded; golden-yellow, as a
aurei, $n$. Plural of aureus.

aureity (â-ré'in-ti), n. [< aurc-ous + -ity. $]$ The peculiar properties of gold; goldenness. Coleridge.

aurelia (â-ré']y:ä), $n$. [NL., 〈 It. aurelia, chrys< L. "aurelius (only as a

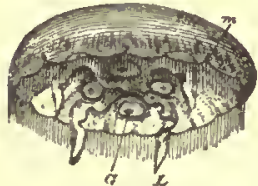
proper name, Aurelius, earlier Ausclius, a Roman family), < aurum gold: see aurum.] 1t. In entom., the nymph, chrys alis, or pupa of a lepi chrysalis.-2. [cap.] A

$G$, genital chaniber; $L$, pro-
longed angle of the mouth
$m$, one of the lithocysts. phorous Hydromedusa

382

auricular

typical of the family Aureliide, characterized by having branched radial vessels and the edge of the disk fringed with small tentacles. A. aurita is the type-speciea, found in Europesn seas, the old
Medusa aurita of Linnoua. A. flavidula occurs on th coast of North America. The name is aynonymous with
Medusa regarded as a genus and in its most reatricted Medue.

In the atudy of the aunfish (Aurelia) we are able to see poop. Sci.Mo., July, 1878, p. 318.
group and polyps as a group.

3. The adult state of any medusa, or the perfected stage of a medusiform zoöid.

aurelian (ầ-ré'lyan), $a$. and $n . \quad$ [< aurelia, $1,+$ -an.] I.t a. In entom., like or pertaining to the aurelia: as, the aurelian form of an inseet. of lepidopterous insects only.

With the exception of a few Aurelians, as the atudents of Lepidoptera were then [1853] termed, as the atudenta

Aureliidæ (â-l'ê--li'i-dê), n. pl. [NL., < Awelia, $2+-i d a$.$] A family of pelagic Discophora,$ containing the genus Aurelia.

aureola (â-ré'ō-lä), n. [L., fem. of aurcolus, of gold, dim. of aureus, of gold, < aurum, gold :

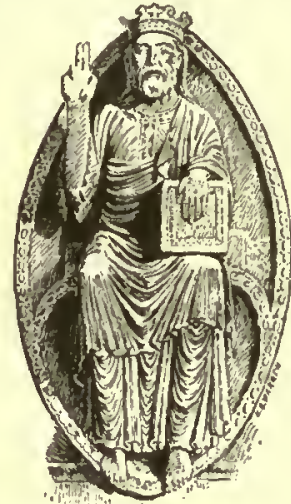
resentations of the Deity, the Virgin Mary, saints, martyrs, etc., radiance or luminous al eloud emanating from and surrounding the whole figure. If the fig-
ure is represented in an erect position, the sureola is usually oval, or of the form known as the vesica piscis (fish'a bladder); if the figure is aiting, the aureols often approachea a circular form Aureola, nimbus, and glory are frequently confounded though See nimbus and glory.

There are some poets whom we picture to our-
gelves as aurrounded with Stedman, Vict. P'oetz, p. 114

from tympanum of portal of St.
Trophme, Arles, France; szth 2 . Anything resem-
century.
bling an aureola. Spe.
elfically-(a) In astron., the ring of light seen around tlic

from tympanum of portal of St.
Trophime, Arles, France; 12th 2. Anything resem-
century.
bling an aureola. Spc-
eiflcally-(a) In astron., the ring of light seen around tlic eiflcally - (a) In astron., the ring of light seen around the
moon in total eclipses of the sun. (b) In meteor., a kind moon in totgl eclipses of the sun. (b) In meteor., a kint bank or dew-covered graas: often observed by sëronanta on the upper aurface of clouda. Also called a glory. to the essential bliss of heaven as a recompense for a special spiritual victory gained by the person to whom it is attributed: as, the aureolu of virgins, martyrs, doctors, otc.

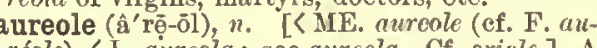
réole), < L. aureola: see aureola. Cf. oriole.] A figure or an object; an aureola.

$$
\begin{aligned}
& \text { Fair shines the gilded aureole } \\
& \text { In which our highest painters place } \\
& \text { Some living woman'a aimple face. }
\end{aligned}
$$

round the grisly fighter's ber the Roseth, Jenny. bent! $\quad$ ifhittier, Brown of Osaawatomie. When the electric arc is produced between carbons in
vacuo a beautiful glow is obtained, the negative pole being aurrounded by a blue aureole, and the positive by a atrat-
ified pale-blue light. A. Daniell, Prin. of Physica, p. 583 . aureole (ấrệ-ōl), v. t.; pret. and pp. aureoled ppr. aureoling. $[<$ aurcole, n.] To surround or invest with an aureole.

ureolin (â-ré'ọ-lin), n. [< L. aureolus, dim. of aureus, golden, yellow (see aureous), $+-i n^{2}$. A trade-name for the pigment cobalt yellow (which see, under yellow)

aureosin (ấré'ó-sin), n. [< L. aurum, gold, + eosin.] A coal-tar color used in dyeing. It is a chlorinated fluorcacein (which aee). It dyes light-rose
ahades on ailk, giving a greenish-yellow reffection. aureous ( $\hat{a}^{\prime}$ rể-us), a. [<L. aurens, of gold, goldyellow eolor.

aures, $n$. Plural of auris, 1.

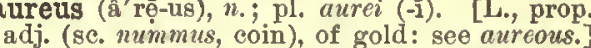
A Rold coin equivalent to 100 sesdenarii, first minted in thefirst cen and issued

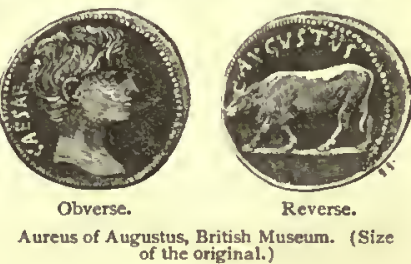

nder the empire till the reign of Constantine ., who substituted for it the gold solidus. In the timie of Augustus the aurens weighed about 120 grain and was worth about

u revoir ( $\overline{0}$ ré-vwor'). [F.: $a u$ (see $\left.a u^{2}\right) ; r e-$ oir, < L, reviderc, seo again, < re-, again, + videre see: lit. to the reseeing (inf. used as n.).] Until we meet again; good-by for the present.

auri-argentiferous (ấl'ri-är-jen-tif' $\theta$-rus), a. [< L. aurum, gold, + argentum, silver, + ferre = ing or containing both gold and silver.

There are found in the lower levels pockets of auriauric I (â'rik), a. [<L. aurum, gold (see aurum),

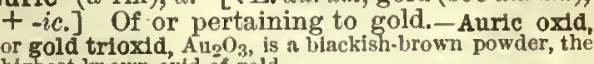
auric ${ }^{2}$ (â'rik), a. [<aura $\left.{ }^{1}+-i c.\right]$ of or pertaining to the aura; aural. See aura ${ }^{I}$. aurichalc (â'ri-kalk), n. See oriehalc.

aurichalcite (â-ri-kal'sit), n. - [< L. aurichatcum (see orichalc) + -ite 2 .] A hydrous carbonate of copper and zinc occurring in transparent verdigris-green to sky-blue ncedle-shaped crystals, also in laminated or granular masses. When reduced it yields a gold-colored alloy of copper and singular in containing calcis

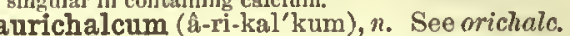

uricle (â'ri-kl), n. [<L. auricula, the external ear, the ear, dim. of auris = E. earl, q. v.] 1 The pinna of the external ear; that part of tho organ of hearing which projects from the side of the head. See pinna, and eut under car. Also auricula.-2. A chamber or one of the chambers of the heart into which the blood comes from the veins, and from which it passes into the ventricle or one of the ventricles. In the mammalian, avian, and reptílian heart there are two used in a more apecial aense to designate an ear-like portion or appendage (appendix auriculse) of esch of these chambers; the remainder is then distinguiahed as the
sinus. The right auricle receives venous blood from the sinus. The right auricle receives venous blood from the
venæe cava; the left auricle receives arterial blood from the lungs tirongh the pulmonary veins. See cuts under 3. Something, or some part of a thing, like or likened to an ear: variously applied, chiefly in botany, zoölogy, and comparative anatomy. Specifically-(a) In entom, an appendage of the planta o See auricula, 4. (c) In bot., an ear-ahsped or ear-like appendage; the infiated lower lobe or appendage of the 4. An instrument applied to the ears to assist in hearing; a kind of ear-trumpet.

auricled (ấri-kld), a. [< auricle +-ed2.] Having ears or auricles; having appendages resembling ears; in bot., same as auriculate.

auricomous (â-rik'ō-mus), a. [< L. auricomus, with golden hair, < aurum, gold, + coma, hair: yellow-haired.

auricula (Â-rik' ụ-lä̈), n.; pl. auricula (-lē). [L., the extemal ear, the ear: see auricle.] 1. In bot, a garden flower derived from the yellow Primula Auricula, found native in the Swiss Alps, and sometimes called bear's-ear from the shape of its leaves. It has been cultivated for cen-
turieg by fioriats, who have gucceeded in raising from turiea by fioriats, who have succeeded in raising from 2. Same as auricle, 1.-3. [cap.] [NL.] In $z 00 \ddot{7}$., a genus of phytophagous or plant-eating pulmonate gastropods, typical of the family Auriculida. A. juda and $A$. mide are examples. They In echinoderms, one of the perforated processes into which the ambnlacral and sometimes the interambulacral plates are produced, and which arch over the interior of the ambulacra, as in the typical echini, or sea-urchins. See cut under Echinoidea.

uricular (â-rik' ù-lậr), $a$. and $n$.

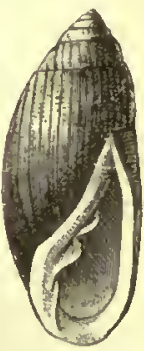
the ear: see auricle.] I. $a$. 1. Per- Ear-shell (Aurt. taining to the ear, or to the auri-

cle of the ear; aural: as, the auricular nerve. -2. Used in connection with the ear: as, an
auricular tube (which see, below).-3. Addressed to the ear; privately confided to one's ear, especially the ear of a priest: as, auricular confession.-4. Recognized or perceived by the ear; andible.

You shall ... by an auricular assurance have your
Shatisfaction. Lear, 1. 2 


\section{auricular}

5†. Communieated or known by report; hearsay.

Auricular traditions and lejgned testimonles.

Bacom, Nat, IItsto, 320.

6. Known or obtained by the sense of hearing as, auricular evideneo.-7. Ear-shaped; aurieulate; auriform: as, the auricular articulating surface of the human ilium. -8 . In cehinoderms, of or pertaining to the aurieule: as, all internal auricular process.-9. Pertaining to the suricle of the beart. - Anterior suricular arterles, two or more branclics of the temporal artery sup-
plyling tire external ear. Anterlor auricular veins, amall velus from the external ear emptying into the tem poral vein. - Aurlcular feathers, lin ornith., the speeial set of feathers, usually of peculiar struetnre, which overif
and defend the onter openling of the car. - Aurlcular finger, the iittie finger: an called from the fact that it is most easily lntrodueed into the enr. - Auricular foramen, the ular nerves, varlous snail nerves derived frou the great auricular, tho anriculotemporal, the facial, the second cervical, the small or sometimea the large occipital, and the vagus nerves, which supply the fntegument and other
parts of the external ear and its vieinity. - Auricular point, In anat, the center of tho auricular foramen.juricular radil, in craniom., radil drawn from the proprojections of other points of the skull. See craniometry. the nse of deaf persons, or extending between different parts of a bulluing for the convey ance of messages. - Auric ular witness, a witness who reiates what lio has henrd. nal maxillary artery, supplying the external meatus of the enr.-Great suricular nerve, the aurteniar's magnus, a nerve arising from the aecond and third cervical nerves, and distributed to the external ear and adjacent parts. - Posterlor aurjcular artery, a branch of the external carotid artery, supplying parts in the region of the ear.Postsrior auricular vein, a vetn which, deseending be-
hlnd the pinna of the ear from the side of the liead, jolns

II. $n .1$. pl. In ornith., the anricular feathers.-2. The auricular or little finger. Soe auricular finger, above.

auriculares, $n$. Plural of auricularis.

auricularia (Â-rik-ūi-lā'ri-ä), n. [NL., < auricula, $4,+$-aria.] 1. [Pl. auricularia $(-\bar{e})$.$] A$ term applied to an carly stage of the development of the embryo of certaiu echinoderms, as those of the genera Hotothuria, Synapta, ete. when it is eiliated. See Holathuridca. [It is a generic name given by Muller through a mis-
take as to the nsture of these larve.] -2 . take as to the nature of these larvo.]-2. [cap.] In conch., a generie name variously acephalous mollusks; $(b)$ by Fabricius for genus of gastropods.

auricularian (â-rik-ñ-lā'ri-an), a. [< auricularia $+-a n$.$] of or pertaining to an aurieuls-$ ria; echinopæedi

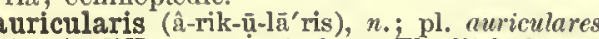
(-rēz). [NL.: see ciuricular.] The little finger. See auricular finger, under auricular.

auricularly (â-rik' ú-lär-li), adv. 1. In an auricular manmer; specifically, in a secret msnner; by whispers.

These will aoon confess, and that not a uricularly, but in 2. By means of auricles.

auriculate, auriculated (â-rik' ū-lāt, -lā-ted), a. [S NL. auriculatus, < L. auricula: sce auauricle; suriform. -2 . Having ears; provided with ears auricles, or ear-like parts: in bot. said of a lesf with a pair of small blunt projec tions or ears at the base.-Aurlculate antenno, In entom., antenne in which one of the basal jointa is $e x-$ panded lateraliy in a concave plate, as In certain aquati laterally at the humeral angles tnto a free lobe. family Auriculidie.

Auriculidæ (â-ri-kū'li-dē), n. pl. [NL., < $A u$ ricula, $3,+-i d c$.$] A family of pulmonate gas$ tropods with contractile tentacles, eyes sessile at the inuer or hinder bases of the tents-
cles, rugose teguments, and a spiral shell whose psititions are generally absorbed, and whose columella is plicated. The family la divided into subfamilies and many genera. Some of the apecles frequent banks, generally withlin tide-limits, others marshes and wet woods, and a few (of the genua Carychium)

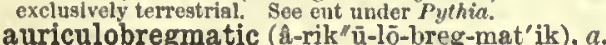

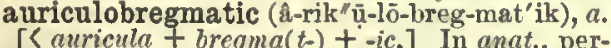
taining to the auricular point and the bregms. - Aurlculobregmatle line, a line drawn from the profeetlou of the alricular polnts on the median plane of the akull to the bregnta, See craniometry. ris), 11 . [NL., < auricula + orbicularis. ] A musele of the hedgehog connecting the pinna of the ear with the orbicularis panniculi, which it antagonizes.
383

aurochs

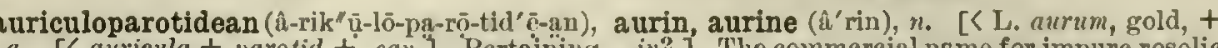
a. [< aurieula + paratid + can.] Pertainiug -in'2.] The commereial nsmo for impure rosolic to the auricle of the ear and the parotid gland: specifieally applied to a nerve whieh supplies ose parts.

uriculotemporal (â - rik" $\bar{u}-1 \overline{0}-$ tem $^{\prime}$ pọ - rạl), $a$. [s auricula f temporal.] Pertaining to tho ear and the temporal region: specifically applied to a branch of the inferior maxillary nerve which supplies the external ear and adjacent regions. är), $a$. [< auricula + icntricular.] Pertaining both to the aurieles and to tho ventricles of the heart: as, the anriculoventricular orifice. See cut nnder heurt. - Auriculoventricular valves. Seo walt

ariferous (^̂-rif'e-rus), a. [< L. aurifer, goldbearing, < aurum, gold, + ferrc $=$.. bearl.]
Yiolding or producing gold; containing gold: as, auriferous quartz; auriferous strata.

Mountalns big with mines,
Whenee many a bursting atream auriferous play. Thomson, summer, 1. 64s

aurific (â-rif'ik), a. [< L. aurum, gold, + facere, mako.] Capable of transmuting subtances into gold; gold-making.

Some experiments made with an aurife powder.

(the The poctor, cixxxyL

auriflamma, auriflamme (Â-ri-flam' ä, $\hat{a}$ 'riflam), $n$. [ ML. auriflamma, lit. goldeñ flame, <L. aurum, gold, + flamma, flame.] The aneient royal banner of France. See oriflamme. uriform (a'ri-fôrm), a. [< L. auris, the ear, + forma, form. ] Far-shaped; having the form of the external human ear: as, an auriform shell.

aurifrisia (Â-ri-friz'i-än), n. Same ss auriphryaurifrisiate (â-ri-friz'i-āt), a. Same as auriphrygiate.

aurify (Ári-fi), $v . t$. and $i$.; pret. and pp. auri-

fied, ppr. aurifying. [< 广. aurum, gold, + fafied, ppr. aurifying. [ $\left[\begin{array}{l}\text { L. aurum, gold, }+f a- \\ \text { cere, make: see }-f y .]\end{array}\right.$ gold.

Auriga (â-ri'gä), n. [L., t charioteer; as constellation, the Wagoner; perbaps < aurca, the mouth: see $\left.0 s^{1}\right)+$ agcre, drive; otherwise <"aurus (not found, supposed to mean ' a horse,' = Gr. avoos, swift) + agere, drive: see act, $\left.v_{.}\right]$1. A northern constellation contain-

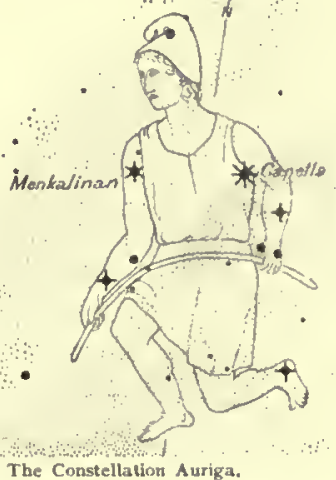

ing the splendid star Cspella; the Charioteer or Wagoner. It is supposed to represent a chariotee on hia left shoulder, this belng doubtless an ancient con2. [l.c.] [NL.] A name of the fourth lobe of the liver. [Rare.]

aurigal (Â-rī'gal), a. [< LL. aurigalis, < L auriga: see Auriga.] or carriage. [Rare.]

aurigation (â-ri-gè 'shon), n. [< L. auriga tio(n-), < aurigarc, pp. aurigatus, bo a driver, < tice of driving a chariot or coach. [Rsre.]
[Ret

If a man indulges in the vicious habit of aleeping, al the skill in aurigation of Apollo himaelf, with the horses of Aurora to exeeute bls notlons, avall him nothtrg.
De Quincey, Eng. Mail-Coach. aurigerous ( $\left.\mathrm{A}-\mathrm{rij} \mathbf{j}^{\prime} \mathrm{\theta}-\mathrm{rus}\right), a$. [ [ L. aurum, gold, + gerere, besr.] "Gold-bearing.

arigraphy (A-rig'rag-fi), n. ¿< ML. aurigraphia, < aurigraphus, one who writes in golden
characters, < l. aurum, gold, + Gr. yoá $\phi \varepsilon v$,

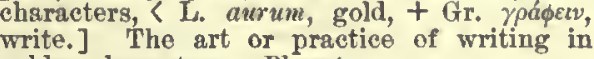
golden characters. Blount.

aurilave (A'ri-lav), $u$. [< L. auris, the ear, + lavare, wash: sce auricle and lave ${ }^{2}$.] An earbrush. E. H. Knight. (which sec, uuder rosnlic), onc of tho coslar colors. In its pure state it forms ruby.red erystal with a blue flnoreseence. Owing to its fugltiveness, it is coes and woolens and for plginents. It prosuces orangeed colors.

A urine dyes slades more inclining to orange than coral.
Inoorkshoy leceipts, $2 \mathrm{~d}$ acr., p. 228 . uriphrygia (ht-ri-frij'i-ii), n. [<ML. "auriphry gia, auritrifia, also apelled aurifrisia, aurifresia, also au-

rifrynium, also

simply phry-

gium, frigixm,

gold ombroid

ery, < L. aurum

Phrygium, lit.

hrygian gold were noted for

their skill in

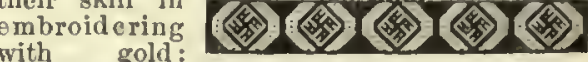

see aurum Miter with Auriphrygia, or Auriphryglate

souree, through the French, come orfrays, or fray, orphrey, q. v.] Properly, gold embroidery; eccles., an ornamental band on various vestments; an orphrey: nsed espeeially of the orphrey of a miter, which is a richly adorned band around its lower edge. Also aurifrisia. auriphrygiate (â-ri-frij'i-ăt), $a$. [<ML. "auri phrygiatus, auriphrigiatus, aurifrisiatus, auriEmbroidered with gold; provided with an auriphrygia. Also aurifrisiate.

Nor wore he mitre liere, preclous or auriphrygiate.

uripigment, auripigmentum (Â-ri-pig'ment, A."ri-pig-men'tum), n. [L. auripigmentum, ${ }^{\prime}$ aurum, gold, + pigmentum, pigment: see aurum and pigment. From the L., through F., comes orpiment.] Same as orpiment.

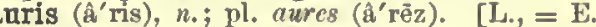
carl, q. v.] 1. In zoöl. snd anat., sn esr; the outer ear or suricle.-2. [cap.] [NI.] In conch., a genus of ear-shells: synonymous with Haliotis.

auriscalp (án' ri-skalp), n. [< auriscalpium.] pick; cal operations on the car.

auriscalpium (Â-1'i-skal'pi-um), n.; pl. auriscalpia (-ä). [NL., < L. auris, = E. ear1, + scalpere, scrape, scrateh: seo scalpel.] 1. Samo ss aurisealp. -2 . [cap.] In conch., a genus of bivalve mollusks.

auriscope (â'ri-skōp), n. $\quad\left[<\mathrm{L} \cdot\right.$ auris $_{1}=\mathrm{E} \cdot$ earl $^{1}$

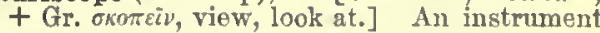
for exsmining and exploring the ear. auriscopy (âtris'kō-pi), n. [< I. auris, = E

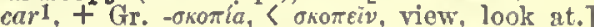
The use of the auriscope. One who trests disorders of the ear; an otologist.

In England the medical profession is divided into phy-
sieians, surgeons, apotheearies, aeeoneheurs, oeullats, au

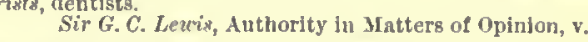
aurite ( $\hat{a}^{\prime}$ rit), $a$. Same as aurited.

aurited (ári-ted), $a_{0}[<\mathrm{L}$. auritus, $=$ E. eared, auris $=$ E. earl. . Cf, aurated 2 In bot. snd zool., eared; auriculate; having lobes or appendages like an ear.

aurivorous (â-1iv'ō-rus), a. [<L. aurum, gold,
+ vorare, devour.] Gold-devouring. Walpole. aurocephalons (â-rō-sef'a-lus), $a$. [< L. aurum,

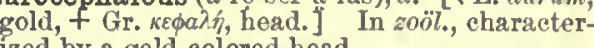
ized by a gold-colored head.

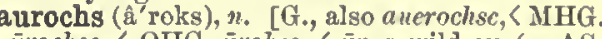
urochse, $<\mathrm{OHG}$. ürohso, $<\bar{u}$, wild ox (= AS. $\bar{u} r=$ Icel. $\bar{u} r r ;$ ef. L. $u r^{\circ} u s=\mathrm{Gr}$. ov́ $\rho \circ s$, from and urus.] A species of wild ox or buffalo, the bonasos of Aristotle, bison of Pliny, the Enropean bison, Bos or Bison bonasus of modern naturalists. This anlmal was once abundant in many bearly exterminated it, and were it not for the protection afforded hy the emperor of Russin to a few herda which crox, and, wrongly, auroch and aurock. See urus.

The relationships of the aurochs to the American bison, aurist ( $\hat{\mathrm{E}}^{\prime}$ rist $), n_{0}\left[\left(<\mathrm{L}\right.\right.$. auris, $=\mathrm{E}$. ear $\left.^{\mathrm{I}},+-i s t.\right]$ Teut.,+ ohso, G, ochse, ochs $=\mathrm{E}$. ox: see urox casus it rould of Lithiranla and of Kuban in the Cau- 


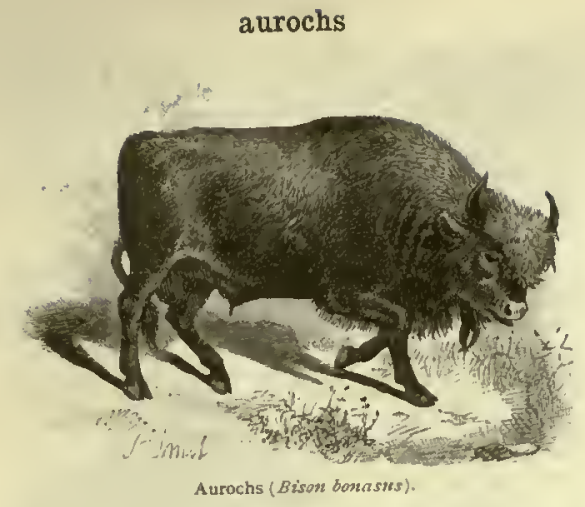

which some anthors have assumed to exist. . . The aturochs is rather larger, with a smaller thorax, lsrger and
stronger pelvis, longer snd thicker tail, snd less shsggy fore parts.
Aurocores (â-rok'ō-rēz), n. $n l$. [NL., < L. aurum, gold, + Gr. ko $\iota s$, a bug.] Isiterally, the gold-bugs; a group of heteropterous hemipterous insects, the same as Geocores, the name Aurocores being considered more appropriate by Westwood, who proposed it as a substitute. See Geocores.

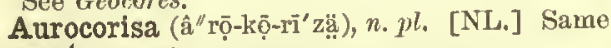
as Aurocores.

aurocyanide (â-rọ-sī'ânid or -nīd), $n$. [< L. eurum, gold, + E. cycinide.] In chem., a double cyanide, one of the bases of which is gold: as, potassium aurocyanide, $\mathrm{KAu}(\mathrm{CN})_{4}$.

aurora (Â-rō'rä), n. [L., the dawn, the goddess of the dawn, earlier *Ausosa, = Gr. a $36 \rho$ (Laconian), avás (Álic), ás (Doric), ibs (Ionic), conian), avas (Avolic), aws (Doddess of dawn (related $\tilde{\varepsilon} \omega \zeta$ (Attic), the dawn, goddess of dawn (related to aipiov, to-morrow $),=$ Skt. ushas, ushasa,
dawn, $(\sqrt{ }$ ush, burn, $=\mathrm{Gr}$. aiciv $=\mathrm{L}$. urere, burn. To the same source are referred L. aurum, gold, auster, south wind, Gr. incos, the sun, E. east, etc.: see cast.] 1. The rising light of the morning; the dawn of day, or morning twilight.2. [cay.] In Rom. myth., the goddess of the dawn: called Eos by the Greeks. The poets repre. fingers dropping gentle dew. (the polar lights).

The most probable theory of the aurora is that origi-
nslly due to franklin, namely, thst it is due to electric disclarges in the upper air.
S. P. Thompron, Elem. Lessons in Elect. snd Mag., p. 264. 4. A reddish color produced hy dyeing with arnotto.-Aurora australis, the aurora of the southerm hemisphere, a phenomenon similar to the aurora of dswn; the northern lights or streamers; a luminous meteoric plemomenon appearing at night: It usually mini-
fests itself by streams of light ascending tuward the zenith from a dusky line of cloud or haze, a few degrees above the horizon, and stretching from the nith its ends on the horizon. Sometimes it appears in detached places; at other times it covers almost the whole sky. As the streans of
light have a tremulous motion, they are called in many places "the merry dancers." They assume many shapes and a variety of colurs, from a pale red or yellow to a they serve to illuminate the earth and cheer the gloom o the long winter night. The appearance of the aurora borealis so exsctly resembles the effects of grtificial electri
city that there is every reason to believe that their csuse are identical. When electricity passes throngl rarefe air it exhibits a diffused luminons stream which has al the characteristic appearances of the anrora, and hence casioned by the passsge of elthoctiglt under conditions not regions of the atmosphere, al The connection of the an.
as yet entirely understood. The
roral displays with disturbances of the magnetic ueedle is now regsrded as an ascertained fact. The aurora boreali is said to be frequently accompanied by sound, which i variously described as resenbling the rustling of pieces
of silk agalnst each other, or the sound of wind against the fiame of a candle. The spectrum of the aurora is pethe fiame of a cande.
culiar in consisting of a prominent line in the greenish-
yellow (citron line), which has not been identified with any known substance; also occasionally a sharp line fin the red and some otliers less prominent have been ob. auroral (â-rō'rạ), a. [< aurara + -al.] 1. Ot or pertaining to the dawn.

Those steady discharges of auroral light to the zenith
along innumerable conducting lines come, it is thought, to equalize the electric conditions of the air.

2. Resembling the dawn in color, beauty, ete. hence, roseate.

$$
\begin{aligned}
& \text { Her cheeks suffused with an auroral blush. } \\
& \text { Longfellow, Falcon of Federigo, }
\end{aligned}
$$

3. Pertaining or relating to the polar aurora resembling an aurora.
384

auspicious

(ân'kul-tā-tor'-ship), n. [<ausNo auroral exhibition can be called complete withont auscultatorship (as them [streaners], snd in their htut and originated.
Edinberght Rev., CLXIV. 429

4. In geol., appellative of the second of Professer H. D. Rogers's fifteen divisions of the Paleozoic strata in Pennsylvania. As applied ly him, it included all the divisions of the Lower Silurian group, according to the now genersily adopted nomenature of the Yew York Geologicsl Survey.

aurorally (ấ-rō'rạl-i), adv. 1. As the dawn; reately: as, "to blush aurorally," Browning, Red Cotton Night-cap, 1, 117.-2. In the manner of the polar aurora.

aurora-shell (â-ró'rï-shel), n. The shell of the Huliotidce; an ear-shell, sea-ear, ormer, or abalone (which see). See also Haliotis.

aurorean (â-rō'rē-an), a. [< aurora + ean.] Belonging to or resembling the dawn. At tender eyedswn of aurorean love.

$$
\text { heats, Ode to Psychc. }
$$

aurotellurite (Â-rō-te]' $\bar{u}-1 \bar{i} t), n$. [< L. aurum gold, + NL. tcllurium $+-i t e^{2}$ : see aurum and and silver; sylvanite.

urous (â'rus), a. [< L. aurum, gold, + -ans. Cf. LL. aurosus, golden.] of or pertaining to gold: in chem., a term applied to an oxid of gold $\left(\mathrm{Au}_{2} \mathrm{O}\right)$ whose molecule contains two a tom less of oxygen than auric oxid. See auric 1 . aurum (â'rum), $n . \quad$ [L. (= Sabine ausum), in colloq. speech orum ( $>$ It. Sp. oro $=$ Pg. ouro $=$ F. or: see or 3 ), gold; related to aurora, aurecal symbol is Au.-Aurum fulminans, gold dissolved in aqua regia or nitromuristic achl, snd precipitated by brown-yellow or orange color, and when exposed to a moderste heat, or struck, detonates with considersble noise. It is probsbly an smmonium aurste, $\mathrm{Au}\left(\mathrm{NH}_{4}\right) \mathrm{O}_{0 .}$. $\mathrm{NH}_{3 .}$ - Aurum graphicum, the mineral sylvanite. - Aurum mosalcum or musivum, mosaic gold, a yellow per and ainc, used both in the mass and as a bronzing a cordial or medicine formerly nucli esteemed. It was ssid to consist of "Gold itsel, thatally reduced, without Corrosive, into s blood-red, gummie or Honey-like subdrunk; or some rich Cor

Ionsr. Roupel sent me a small phial of his aurum pota. Monsr. Roupel sent me a small plial of his aurum pota.
bile, with a letter shewing the way of administering it, and $y^{\circ}$ stupendous cures it had don st Paris.

auscult (âs-kult'), v. t. [< L. auscultare, listen: see auscultatc.] Same as auscultatc. [Rar'e.]

auscultate (âs'kul-tāt), $v$. $t_{\text {. }}$; pret. and pp. tus, pp. of auscultare, listen.] To listen to give ear to; specifically, in pathol., to examir by auscultation.

auscultation (âs-kul-tā'shọn), n. [〈L, ruscultatio(n-), a listening, < miscultare, listen: ser auscultate.] 1. The act of listening or learkening. [Rare.]

Yoll slinl hear what deserves attentive auscultution.

2. In pathol., a method of distinguishing the state of the internal parts of the body, particularly of the thorax and abdomen, by observing the sounds arising in the part, either through the direct application of the ear to the actjacent external surface (immediate ausculta-
tion) or by applying the stethoscope over the part and listening through it (mediate auscultation). See stcthoscopc. Anscultation may be used with more or less sdvantage in all cases where morbin
sounds are proluced, but its general applications are auscultation of respiration; auscultation of the voice; auscultation of the cough; auscultation of sounds foreigi
to all these, but sometimes accompanying thens a ascul auscultative (âs-kul'ta-tiv), $a$. [< auscultate + -ive.] Pertaining to or of the nature of auscultation.

auscultator (âs'kul-tā-tor), u. [L., a listener, specifically, one who pructises auscultation.2. An instrument used in listening to the seund within the thoras; a stethoscope.-3. In Germany, a member of a college of officials who attends its sessions as a student but is not en1869 , one who had passed the first examination

and begun his judicial

IIis first Law-Examination he has come through trisum need not lavve frightened bim: but though he i hereby "an Auscultator of respectability," what avails it
Carlyle, Sartor Resartus, p. 85 . cultater, 3 , + -ship.] The office of or period of
service as auscultator. Carlylc, Sartor Resarservice as *auscultatorius, < auscultritor.] Pertaining to auscultation; auscultative.

auset, adv. Obsolete dialectal form of also. unsier, $n$. A dialectal form of osier.

auslaut (ous'lout), u. [G., < aus, denoting completion or termination (= E. out), + laut completion or termination $(=$ E. out $),+$ laut,
a sound $(=\mathrm{E}$. lour $)$. Cf. inlaut, ablaut, umlaut. In plitol., the final sound of a word. name of italy, prop. applied to middlo and given to the primitive inhahitants of middle and lower Italy, of or pertaining to Italy or the Italians. Longfellow. [Poetical.]

auspex (âs'peks), n.; pl. auspices (âs'pi-sēz). [L. auspcx (auspic-), a diviner, contr. < "arispex, < avis, a bird, + specerc (spiccre), view see species.] One who divines by observing the motions, cries, etc., of birds; a diviner in general; an augur.

auspicalt (âs'pi-kal), a. [< L. auspicalis, < pertaining to omens or auspices. Blount. auspicate (âs'pi-kät), $v$. t.; pret. and pp. auspicated, ppr. auspicating. [< L. auspicatus, p. of auspicari, make a beginning for the sake of a good omen, begin, prop. take the auspices, act as auspex, < auspex, a diviner: see auspex. Cf. anigu
show.

Long mast thou live, and see me thus appear.

As ominous s comet, from my splere

So lasting glory to Augustus' state.
B. Jonson, King 3 ames's Coronation Entertainment.

There are yet other special suguries of this great change, ment of all international Prepsrations for War.

2. To initiate or inaugurate with ceremonies calculated to insure good luck. This meaning of the word was borrowed from the Ronan prsctice of takiless. If we are consclons of our situation, and glow with zeal onght to auspicate all our public proceedings on America with the old warning of the Church, Sursum corda! To auspicate... the ... concern and set it agolng
Lamb, Ellistonlang. 3. To begin or introduce in a favorable or auspicious manner. [Rare.]

The London company merits the prnise of having ans. auspicator (ầ'pi-kā-tọr), n. [<L. as if "auspicator, < auspicari: seë auspicate.] An augur. auspicatory (âs'pi-kä-tō-ri), $a$. [< $a$

auspice (âs'pis), $n_{0}$ [R F. auspice, pl. auspices, $<\mathrm{I}$. anspicium, divination from the flight of birds, a sign, omen, < auspex, a diviner: see cuspex.] 1. An augury from birds; an omen or a sign in general: as, to take the auspices an auspice of good fortune.

The tribunes were at first elected in the curix, wher the vote of the poorest citizen was equal to that of the
most wealthy. But, even liere, the patricians, besides most wealthy. But, even liere, the patricians, besides We then strive, as lar as our poor philosophy can do it,
to read the country's reverend auspices. 2. Protection or lead; favoring or propitious influence; patronage: especially in the phrase under the auspices (of).

$$
\begin{aligned}
& \text { Great father Mars, and greater Jove, } \\
& \text { By whose ligh auspice Rome hsth stood } \\
& \text { B. Jomson, Catil }
\end{aligned}
$$
3. A cireumstance or conjunction of circumA A hegun under the fairest auspices. [In all senses

auspices, $n$. Plural of auspex and of auspice. auspicial (âs-pish'al), $a$. [< L. auspicium, auspice, $+-a l$.$] 1. Relating to auspices or$ tunate; auspicious. [Rare.]

auspicious (âs-pish'us), a. [< I. auspicium, anspice, $+-o u s$.$] 1. Of good omen; betoken-$ ing success, or a favorable issue; prognosticating good ; favorable. Auspicious omens from the past and the present cheer
us for the future. Sumner, True Grandeur of Nations. 2. Prosperous; fortunate: applied to persons. auscultatory (âs-kul'ta-tẹ-rí), $a_{0}$ [ $[<\mathrm{L}$. as if

Ausonian (â-só'ni-ạn), a. [<L. Ausomia, poet lower Italy, 2 Ausones (Gr. Aivoves), a nante anspex, diviner:" see cuspex.] Anspicatory; nearly always used in the plural.] 
ausplclous

Arespicious clitel! thy race in times to come

Favorable; kind; propitious: applied to persons or things.

Fortunc Jlay upon tlyy proapcrous lielm,

Shak., All's Well, lil.

No day conld be more auspicious to the undertaking.

4†. Showing joy; happy. [Rare.]

With voe auspricious and one divjphlug eye

ak., itamict, 1.2

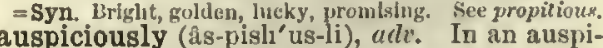
cious manner; witl favorable omeus ; happily : prosperously; favorably; propitiously.

I looked tor ruin; and encrease of honour
J sects mo auspiciously. Middleton, Witch, iv.

auspiciousness (âs-pish'us-nes), $n$. The quality of being anspicious; a state of fair promiso; prosperity.

auster (âs'tèr), $n$. [L., the south wind; akin to aurorn, the dawn, and urere, burn: see curora and aurum.] 1. The south wind (commonly with a capital, as a proper name): as, "drizzly duster," Thomson, Castle of Indolence, lxxvi. Hence-2†. The south.

austere (Âs-tēr'), $a$. [< ME. austere, < OF. austere, < L. austerus, harsh, sour, tart, severe,

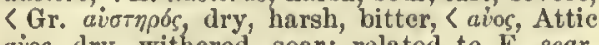
aios, dry, withered, sear; relatod to E. sear, sere, dry: soo searl, serel.] 1. Sour; harsh; rough to the taste: applied to things: as, austere fruit or wine; "sloes austere," Cowper, Task, i. 122 . An austere prape
That hast no jutce but what is verjuice lin him !
B. Jonson, Staple of News, v. 1.

2. Severe; harsh ; rigid ; rigorous ; stern : applied to persons and things: as, an austere master; an allstere look.

A atern lady, and anstere, not only in her manners, acter of her undorstaniling and morals.

Sceret Socletleg,

But what ohiefly diatinguished the army of Cromwell from otlier armiles was the austere morality and the fea 3. Grave; sober; serions: as, austere deportment.

There lived a Lady, wise, austere, and nlce, Priest and sage, with golemn browg austere.
Whittier, Last Walk in Autum

4. Severely simple; unadorned. $=$ Syn. 2. Austere, Severe, Stern, I Iard, Harsh, Strict, 8on's dealings with himiself or with others. A A ustere is the
most Individual word In the list; It still guggesta the ety. most Individual word in the list ; It still auggesta the et mologlosl senze of dryness and hardness of nature. A
appliod to manner of life, it himplies gelf-mortifleation, re. tusal of pleasure, or the self.infliction of pain, for the purpose of gelt'dlscipline. The austere man may treat reaponding gort. Thero is no suggestion of hypocrisy or
gell-righteonsness in the word, nor does it go so far as aell-righteousnese in the word, nor does it go so tar a
ascettcisn (gee gelf-denial). Severe starts from the noascetcism (see self-denial). Severe starts from the nothrough a whde range, coverhig most of the meanings in taclal expresston, applies to almost anything to which severe can apply. IIard Is of the samo character, but starts to mean diffeult to endure, unfeeling, etc. IIargh pr marlly expresses physical roughness, as a hargh touch, and retalns some ingurative auggestion akm to that idea. Stri
to drawn close, tense not relaxed, observhng exact rul
for one's self or requirng such observance from others. Bigorens means, literally, atiff, and hence allowing abatement or mitigation: inflexible; nnsparing. Rigud is the game as rigorous, but with somewhat more of the ort. final flgurativeness than in rigorous; both are opposed to sary, overwrought, or narrow-minded strictness than rigorous. We speak of austere morality; a severe aspeot, judgment; harsh enforcement of liws; strict rules, disc pline, represslon of imlschlef ; rigorous justice;

Je [Plutaroh] was not so artatere as to desplae riches but being in possession of a large fortune, he Jived, though

For in their looks divine
The image of their glorlous IIaker shone,

Truth, wistom, sanctitude severe and pur

Severe, but in true filial freedom placed.
Milton, P. L., IV, 298

Wrapped in lils sad-colored cloak, the Day like a Puritan Stern in the foyless field, rebuking the lingering color. B. Taytor, llume Pot

Whose heart the accuvtom'd gight of death makes hard.

Be sometimes jovely like a bride,

And put thy harsher nouods aside,

25

Tennyson, In Jenoriam, IIr.
385

Austromalayan

Strict statutes and moat biting laws.

ve heard

Your grace hath ta'on great pains to yually
Iis rigorous course.

Sternly jie pronounced austerely (Âs-têr'li), adv. In an austero manner; soverely; rigidly; harshly.

$$
\begin{aligned}
& \text { Whatever } \\
& \text { Of purity. }
\end{aligned}
$$

Jilion, 1 .

In the wonder whother a door so grimly bolted and cheerful overcharges for caudles and service. Houclln, Venetlan Life, li.

austereness (As-tēr'nes), n. [ME. austernesse (Wrelif); < anstere + -ness.] The state or quality of being austere; harshness in taste; severity in manners; austerity.

Towards his prince, in things ladifferent

To use th' a ustereness of a censuring Cato

Fletcher (and others), Bloody Brother, v, 1.

usterity (âs-ter' $\mathrm{i}-\mathrm{ti}$ ), n.; pl. ansterities (-tiz). [< ME. austerite, "< OF. austerite, $F_{\text {. austérite, }}$ ₹MIL. austerita $(t-) s,<\mathrm{L}$. austerus, austere: see
austere.] 1†. Harshness or astringency of taste. The sweetneng of the ripened fruit is not the less do felous for the austerity of its erude state. IIorsley, Sermona, II. xxvill.

2. Severity of manner, lifo, oto.; rigor; strict ness; harshness of treatment or demeanor.

But the ausferity of Dante will not condegcend to the conventlonal elegance whteh makes the charm of French.
Lowell, Among my Book8, $2 \mathrm{~d}$ ser., p. 23 . There is no show of mercy in hlm. II carricd lis aus. terity beyond the bounds of humanity. 3. Severe or rigorous simplicity; absence of adornment or luxury.

The Baptist we know was a atrict mall, remarkable for austerity and set order of llite.

4. Severe or ascetie practices: chiefly in the plural: as, the austerities of the Flagellants.

The austerities and the blameless purity of Ximenes life had given him a reputation for aanctity throughon
Ppain. = Syn. Self-sacrifice, Asceticism, etc. (see self-denial) austerland (âs'tèr-land), n. [E. dial., ("auster $=$ astre, hearth (see astre), + land.] Land which had a house upon it in ancient times. Elton,
Origins of Eng. Hist. p. 191. [Local Eng.] Austin (as'tin), a. [R ME. Austyn, contr. of Augustin, q. v.] Samo as Augustinian: as

Austin frial's. See Augustiu.
anstral (Âs'tral), a. [< ME. austral $=$ F. Sp. Pg. austral = It. australe, < L. australis, sout ern, [ auster, the south wind: see auster.] Southern; lying in or pertaining to the south: as, austral lands; the austral signs of the zodiac.-Austral pole, the name given by French anthors called the north pole by English and American writers. So also, what to termed the sonth pole by the latter is termed
the boreal pole by the former. - Austral s1gns, the las Australasia (âs-tra-lä́'shä or -zhä), n. [NL., Austral, southern (ê. Australian), +Asia.] 1 In geog., a general name for Australia, Papua Tasmania, and the neighboring islands.-2. In zoögeog., a division comprising the islands and Austrogoca.

Australasian (âs-tră-lä'shan or -zhan), a, and n. [< Australasia $+-a n$.$] I. a. 1. Relating to$ Australasia.-2. In zoögeog., of or pertaining to that primary faunal area of the earth's line (which separates Celebes from Borneo and Lombok from Bali) to Tasmania.

II. n. A native or an inhabitant of Australasi australene (âs'tra-lēn), n. $\quad[<\mathrm{L}$. australis, in Pinus australis, the American southern pine the chief source of the turpentine.] A liquid of English and Ameriean oil of turpentine, ob tained by neutralizing turpentine-oil with an lation. It is dextrogyrate.

Australian (âs-tràllian), $a$. and $u . \quad[<A u s t r a$ lia, the NL. term for the earlier Australis terra lit. southern land: see austral.] I. a. Pertaining to Australia, a large island, often classed as a continent, south of Asia.-Australian II. See beech 1.

11. n. A native or an inhabitant of Australia: specifically, a member of the aboriginal race of Australia.

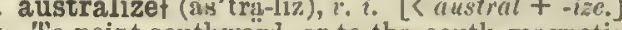

Australioid (Ass-trā'li-oid), a. and $n_{0}$ [< Austrulia + -oid.] I. ". In ethnol., of the type of
the aborigines of Australia and of some of the native races of tho Decean. The Australiold race lorm a group of tlte leciotrichi (which Bec), laving dark II. $n$. $A$ member of the Australioid groul

Also Australoid. jole, as a magnet.

They [atecl and iron] do scptentrlonate at one extreme, Sir T. Brovene, Vulg. Err., H. 2.

ustraloid (As'tra-loid), a and $n$. Australioid. Austrasian ( $\hat{t} s-\ddot{r}^{-} \bar{c}^{\text {sian }}$ or -zinu), $a$, and $n$. I a. Of or belonging to Austrasia, the eastern or Teutonic portion of the Frankish empire under the Merovingians.

The A ustrasian domination was more parely Germanic

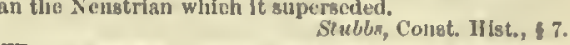

II. $n$. A native or an inhabitant of Austrasia. ustrian' (âs'tri-qn), $a$. and $u$. [< Auslria, a tria, lit. enstem kingrini, G. Ocsterreieh, Austo the western dominions of Charlemagne), OHG. östar, eastern, + vihhi $=\mathrm{AS}$. rice, kingdom, E. -rie in bishopric, otc.: seo east and -rie.] tria, or to the Cisleithan division of the dual Austro-Hungarian monarchy, or to the collecive dominions of the house of Hapsburg.

II. n. 1. A native or an inhabitant of the arcliduchy of Austria, the nucleus of the Hapsof Upper and Lower Austria.-2. A native or an inhabitant of the Cisleithan division of Austria-Hungary, which comprises all the crown lands of the dual cmpire except Hungary, Croatia with Slavonia, and Fiume.-3. A native or an inhabitant of any part of the dominions of the house of Hapsburg, known since 1867 as Austria-Hungary.

ustrian't (Âs'tri-an), $a$ [ 'L, auster, the south wind, south (see auster), + -ian.] Southern; austral.

austrineł (âs'trin), a. [< L. austrinus, southern, < auster, the south wind: see auster.]

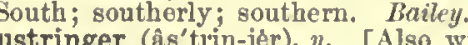

ger (âs'trin-jêr), $n$. [Also written osiIF astreger, (autrucier, autoursier - Roquefort) (ML. reflex business it was to breed and fly goshawks, < "austrueus, austureus, astruco, astureo, austurgo, usturgo, asturgius, ostorius, ete., variations (perof ostrich, q. v.) of austur, (cstur, astor, LI. astur (> It. astore $=\mathrm{Pg}$. açor = OSp. aztor, Sp. azor - Pr. austor = OF. austour, ostor, hostur, mod. $\overline{\bar{F}}$. autour), a goshawk: seo Astur. The $n$ is inserted, as in porringer, passenger, messenger, ete.] A keeper and trainer of goshawks. Austrocolumbia (Âs "trō-kō-lum'bi-ä), $n$. Columbia, applicd to America.] In zoögeog., a primary division of the earth's land-surface with reference to its fauna, which consists of all the American continent south of Mexico. Austrocolumbian (âs trō-kō-lum'bi-ân), a. "[< Austrocolumbia.] Of or pertaining to Austro Austrogæa (âs-trọ-jō'ậ), n. [NL., < L. auster the south wind, south, + Gr. yaia, the earth.] In zoögeog, tliat prime zoölogical division or prises Australia and its immediately outlying islands, and the Austromalayan archipelago. It is bounded on the west by Wallace's line, and Ineludes I'apna or Jew Gutnea and the Solomon islands on the east and Tasmania on the sonth. $+-a n$.$] Of or pertaining to Austrogæa: as, the$ ustrogacan fauna.

Anstromalaya (âs"trō-mā-lā'yä), n. [NL.,
L. auster, the south wind, + NL. Malayn.] L. auster, the south wind, + NL. Malayn.]
In zoögcog., the first subregion of the great Australasian region, including Papua and the islands zoölogically pertaining thereto. On the west the boundary passes between Borneo and Celebes, eastward it extends to include San Christoval. It lieg en

Austromalayan (âs" trỏ-mā-lā' yan), a. [< Austromalaya $+-a n$.$] Of or pertaining to$ Austromalaya. I. a. Of or pertaining to the arehduchy of Ausburg dominions, comprising the crown lands astorerius), < MIL. "austrucarius, one whose 


\section{austromancy}

austromancy (âs'trọ-man-si), n. [< L. auster, the south wind, + Grir. $\mu a v \tau \varepsilon i a$, divination, $<\mu a \nu-$ Divination from observation of the winds.

aut-. See auto-

autacanthid (â-ta-kan'thid), a. [<Gr. airos, self, $+\dot{\alpha} \kappa c \nu \theta a$, spine, $+-i l l$.$] In z o o ̈ l .$, having self, $+\dot{d} \kappa a \nu \theta a$, spine, $+-i c l$. In $z o o l .$,
the greater number of the intermediate spines the greater number of the intermediate spines integument: applied to a starfish: opposed to typacanthirl.

autæsthesy, autesthesy (â-tes'thē-si), n. [<

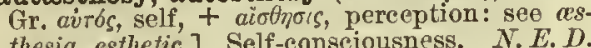

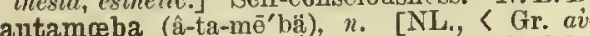

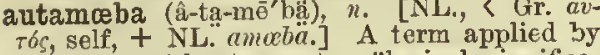
Tos, self, + Nackel, without exact zoölogical significaHaeckel, without exact zoological signitication, to any simple amœeba form regarded as
the nearest living representative of a hypothe nearest living representative of a h

autantitypy (â-tan-tit'i-pi), n. [< Gr. avibs,

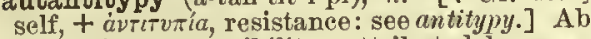
solute incompressibility: attributed by many metaphysicians to matter.

Autarachnæ (â-tạ-rak'nē), $n \cdot p l$. [NL., < Gr. aútos, self, + áá $a v \eta$, spider.] In Gegenbaur's avtos, sel, + assification, a division of Arachnida the arachnids themselves, or Arachnida proper, consisting of spiders, scorpions, mites, etc., as distinguished from the Pseudarachne (Tardigrada, Pyonogonida). Gegenbaur divldes the Autarachne into four groups: Arthrogastres, Aranea, Acarina, and Lingatulina. See these words.
autarchy 1 (â'tär-ki), n.; pl. autarchies (-kiz)

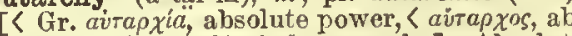

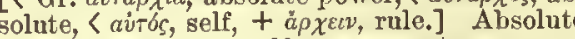
power; autocracy; self-government.

A certain government called an autarchy, of which he makes God the only judge. $J$. Washington, tr. of Miltou's Def. Pop. autarchy' ${ }^{2}+\left(\hat{a}^{\prime}\right.$ tär-ki), n. [Prop. *autarcy, < Gr.

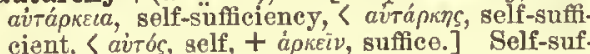
ficiency; independence.

[Conscience is] In man the principal part of God's image, and that by which man resembleth most the autarehy
and self-sufficiency of God. $\quad$ S. Ward, Sermons, p. 98 . autemt, n. [Obsolete slang.] A church. autert, $n$. Middle English form of altar. Chau-

auter droit (ō'tèr diwo or droi). [OF. (mod. $\mathrm{F}$. autre droit): auter, autrc, altre, etc., < L. alter, other; droit, <ML. drictum, direetum,

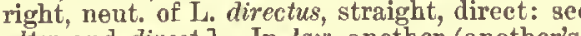
alter and direet.] In law, another (another's) right: thus, one who acts not on his own behalf, but as trustee or represe
said to act in auter droit.

auterfoits (ō-tèr-fwo' or -foi'), $a d v$. [OF. (mod. F. autrefois), at another time, < auter, autre altre (see auter aroit), + foits, fois $=\mathrm{Pr}$. fes $=$ It. vece, time, turn, ' L. vice, in place of, in turn: see vice ${ }^{2}$, vicar.] In law, formerly: a term introduced into the plea of former trial as a bar to a second prosecution for the same offense.Auterfolits acquit (formerly acquitted), the plea of former acquittal.-Auterfoits attaint (101merny attainted) ly convicted), the plea of former conviction.
auter vie (ón $\bar{o}^{\prime}$ vēe. [OF.: auter (see auter droit) vie, < L vita, life: see vital.] In law, another (another's) life. - Tenant pour auter vie, authentic (â-then'tik), a. and $n$. [Early mod. E. also authenlick, autentic, ete. < ME. autenE. also authentick, autentic, ete., $<$ ME. autenthentique, being changed, like the $\mathrm{E}$. word, to suit the L. spelling) $=\mathrm{Pg}$. authentico $=\mathrm{Sp}$. auténtico $=$ It. autentico, $₹ \mathrm{LL}$. authenticus, Gr. aifevrik 6 , warranted, authentic, original,

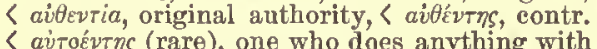
his own hand, the real author of any act, avibs

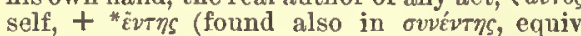
to ovvepyos, a fellow-workman), of uncertain

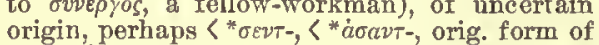
origin, perhaps $<* \sigma \varepsilon \nu T-,{ }^{*} a \sigma a \nu T-$, orig. form of
Ionie $\varepsilon \omega \nu$, Attic $\omega \nu\left(=\mathrm{J}_{\text {. }}\right.$ ens, ${ }^{\operatorname{sens}}$ ), ppr. of Ionie $\varepsilon \omega v$, Attic $\omega v\left(=\mathrm{I}\right.$. ens, $\left.{ }^{*} \operatorname{sens}\right)$, ppr. of
$\varepsilon i v a^{\prime}$, be: see ens, be $e^{1}$. Cf. effendi, also ult. $<\mathrm{Gr}$. av่Ávins.] I. a. 1t. Having anthority; possessing inher

Men ought to fly all pedantisms, and not rashly to nse
all words that are met with in every English writer, all words that are met with in every English writer,
whether authentic or not. Phillips. 2. Real; of genuine origin; being what it purports to bo: opposed to pretcnded or imaginary, fictitious, counterfeit, apocryphal, or unauthorized: as, authentic documents.
386

author

As there ls but one God, but one hope, but one anchor. age for man-so also there can be but one authentic fion.
De Quincey, Essenes, iii. 3. In law, executed with all due formalities; executed by the proper person and legally attested before the proper authorities : as, an authentic deed. -4 . Entitled to acceptance or authentic deed.-4. Entitled to acceptance or credit, credibility, or authority: as, an authentic tale, book, writer.

Origen, a most $a$ uthentic author in this point.
Brevint, Saul and Samuel, p. 77. of the manner in which the ruin of Nineveh was ought about we have nowhere any authentic record.
Von Ranke, Univ. Mist. (trans.), p. 82 That this mere dream is grown a stable truth To-night's feast makes authentic.

Browning, In a Balcouy.

5t. Original; first-hand, as opposed to copied or transcribed. - 6. Own; proper; properly belonging to one's self. [Árchaic.]

It were extreme partiality and injustice, the flat denial and overthrow of herself [J usticel, to put her own authen
tic sword into the hand of an unjust and wicked man.

Millon, Eikonoklastea, xxvii.

IIen are ephemeral or evanescent, but whatever page
the authentic soul of man has touclied with her Immortal. izing finger, no matter how long ago, ls still young and

7. In music, having an immediate relation to the key-note or tonic: in distinetion from plagal which has a corresponding relation to the fifth or dominant in the octave below the key-note. - Authentic act, In civil law, an act or deed performed before and attested by a notary or other proper magis. trate. - Authentic cadence, same as perfect cadence
(which see, under cadence). - Authentic melodieB. Se melody. Authentic modes or tonea. See mode. $=$ Syn. 2 and 4 A A thentic, Genuine, correct, trustworthy, relia book, authentic indicates that it is reliable as narratin real facts; genuine, that we have it as it left its author
hands: as, an authentic history ; a genuine text. $A u$ hendic is thrs equivalent to trustwortliy, reliable; genuine, to unadulterated. The " Memolrs of a Cavalier" is a genuine work of Defoe's, for it was written by him auming the tone of real biography that it "deceived even
the great Chatham into clting the volume as an authentic the great Chatham into clting the volume as an authentic
narrative "(Backus, Revision of Shaw'a Eng. Lit., p. 250). A genuine book ls that which was written by the person which name it bears; $\ldots$ matters of an authentic book is that which relates matters of fact as they really happened.
A book may be authentic without being genuine, and
genuine without leing authentic.
Bp. Watson.

II.t n. [< LI. authenticum, ML. also authen tica, the original (of a document), neut. or fem. of authenticus: see I.] 1. An authoritative or genuine document or book.-2. An original as opposed to a copy or transeript.

Authentics and transcripts. Fuller, Church Hist., I. 42 The Authentica, in civil lav, a Latin translation from made by an anonymous author. So called as an unthe epitome made by Julian.

authentical (â-then'ti-kal), a. Same as authen The hopes thou dost conceive
or thy qulck death, and of thy future life

$\begin{array}{ll}\text { Are not authentical. } & \text { B. Jonson, Poetaster, iv. }\end{array}$ His testimony will he authentical. Beau. and $F^{\prime}$. This, the squire confessed, with some little hesitation,
was a pheasant pie, though a peacock pie was certainly thie Irving, Sketch-Book, p. 277 authentically (â-then'ti-kal-i), adv. In an authentic manner. (a) With the requisite or genuine authority. (b) With certainty.

IIe [Coleridge] was the man of all his generation to hom we should most unhesitatingly allow the distin time to time by some infuence that made hinm better and
greater than himself.
Lovell, Coleridge. (c) Actually; really.

Not yet authentically decided. Sir T. Broune, Vulg. Err. authenticalness (â-then'ti-kal-nes), n, 1. Th quality of being authentic or trustworthy; th quality of being of good authority; authenticity.

They did not at all rely on the authenticalness thereof.
Barrow, Works, I. 35?

2. The quality of being genuine or what it purports to be; genuineness; anthenticity.

Nothing can be more pleasant than to aee virtuosos
about a cabinet of medals, descanting upon the value, about a cabinet of medals, descanting upon the value,

[In both uses obsolete or obsolescent.]

uthenticate (â-then'ti-kät), $v$. $t$.; pret. and pp. authenticated, ppr. authenticating. [<ML. au-
thenticatus, pp. of authenticare, confirm, < LL. thenticatus, pp. of authenticare, confirm, < LL.
authenticus, authentic: seo authentic.] 1. To render anthentic; give anthority to by the proof, attestation, or formalities required by law or sufficient to entitle to credit.
The kingserves only as a notary to authenticate the cholce
judges. Precisely as our researches are fortunate, they authen-
icate themselves as privileged; and in such a chase all
De Quincey, Fssenes, i. He fording in the ceature after selfhood, in order that the latter... may effectually aspire to the knowledge and obedience of those laws of Divine order which alone give hin rest.
H. Janes, Subs, and Shad., p. 61.

2. To prove authentic; establish as correct or genuine.

I have authenticated two portraits of that prince. Walpole, Anecdotes of Painting, I. ii. There is little more left for Bihlical research. The few places which can be authenticated are now generally ac-
B. Taylor, Lands of the Saracen, 1.72 . On June 18,1838 , about 3,000 volumes, and in 1858,265 ther volumes of non-parochial registers, were authenti-
$\boldsymbol{N}$. and Q., 7 th ser., III. 305.

3. To establish as true or worthy of belief: as, to authenticate a statement.

One of the hest authenticated ghost stories in existence. Mem. of $R$. II. Barham, in Ingoldsby Legends authenticatet (â-then'ti-kāt), a. [く ML. au-
thenticatus, pp.: see the verb.] Anthenticated. authentication (â-then-ti-ka's'shon), n. [<au thenticate + -ion.] The act of authenticating, verifying, or establishing the authoritativeness, genuineness, validity, credibility, or truth of anything; speeifically, in law, the official attestation of a written instrument.

The authentication of every little detail in the text.
The American, VIII. 315.

authenticity (â-then-tis'i-ti), n. [< anthentic $+-i t y ;=\mathrm{F}$. authenticite. $]$ The quality of being authentic, or entitled to acceptance as authoritative, authenticity of the Seriptures or of a document; the authenticity of a portrait; the authenticity of a statement.

We compare the narrative with the account of the times when it was composed, and are left satisfled with the au Milman, Latin Christianlty, 1. 3.

athenticlył (â-then'tik-li), adv. Authenti-

ally.

He could learn no way so authenticly as from thls testl

authenticness (â-then 'tik-nes), n. Authenticity. [Rare.]

The authenticnes of that decree.

author (â'thor), $n$. [Early mod. E. also authour auctour, auctor, and prop. autor, (ME. autour, autor (later auctour or auctor, after the L.) $<\mathrm{AF}$. autour, OF. autor, later and mod. $\mathrm{F}$. auteur $=\mathrm{Pr}$. auctor, actor $=\mathrm{Sp} . \mathrm{Pg}$. autor $=\mathrm{It}$ autore, $<\mathrm{L}$. auctor (in ML., and hence in $\mathrm{E}$. corruptly author, prob. through the influence of LL. authenticus and its derivatives; ef. ML authorisare, anthorize, confirm, var. authoricare, synonymous with authenticarc, confirm authorabilis, synonymous with authenticus, ete.), an originator, (augere, cause to grow, increase: see auction.] 1. The beginner, former, or first mover of anyihing; he to whom something owes its origin; originator ereator; efficient cause: as, God is the author of the universe.

The law, the author ... whereot ls ... God. The serpent autor was, Eve did proceed;
Adam not autor, auctor was indeed. He was become the Authour of a Sect ever after to be
Selden, Table-Talk, p. 33 . Thus King Latinng In the third degree 2. Cause: applied to things. [Rare.]

That which is the strength of their anity shall prove Shak., A. and C., ii. 6.

3. The original composer of a book or writing of any kind, as distinguished from a compiler, translator, editor, or copyist.

An author has the choice of his own thoughts, which a Often used elliptically for the literary producitself: as, the statement occurs in Pliny and other ancient authors.]-4t. An editor: s, the author of the Gentleman's Magazine. [Rare.] - 5t. A person who authorizes a statement; an authority; an informant. Look upon him;

Such holy men are authors of no fables.

6. In Scots law, one from whom a title to property is derived either by inheritance or otherwise; especially, one from whom title is de- 
author

rived by purehase or otherwise than by way of deseent.

authort (a'thor), \&. t. [s author, n.] 1. To eusion; effeet; do.

Execrable slanghter! what hand hath authored it? That he thus wisely und wo witi nued nuch

That he thus wisely and witi nced consents
'To what 1 uuthor for your country's good,

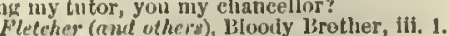

2. To bo authority for'; youch for. More of lifu l dare not authm.

authoress ( $\hat{\imath}^{\prime}$ thor-es), $n$. [Larly mod. L. also authourcss, anthresse, cuctresse, ructrice, < late IIE. auctorice: see author and-ess.] A female
author, in uny sense of that word. [Author is commonly used for both sexes, exeept in case of special diserimination.]

authorhood (it'thor-hủd), $\hat{e}_{\text {. }}$ [< author + hood.] 'L'he state of being an author (of books); tho provinee of an author; authorship.

authorial (Â-tho'rri-n]), a. [< author + -ial. Cf. auctoriul.] Pertaining to an anthor (of books). Also rutorial.

IIust we then bow to authorial dignity, and kiss hands

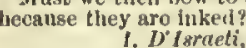

D' Iraeti, Lit. Char. Men of Genius, p. 345.

authorisable, authorisation, ete. See authorizable, ete.

authorism ( $\hat{a}^{\prime}$ thor-izm), n. [<author $\left.+-i s m.\right]$ Authorship; the position or eharacter of an au thor. [Rare.]

Ife [Burke] is a sensible man, but has not worn oft hit authorism yet, and thinks there is nothing so charming
in writers, suci to be one. authoritarian (â-thor-i-tä'ri-an), a. and $n . \quad[<$ authority +- arian. $]$ I. a. Favoring the prinvidual freedom.

The loyslists, who aympathized mest atrongly with .

II. $n$. One who supports the prineiple of anthority, as opposed to that of individual freedom.

By looking only at the beginning and end of his career, an imaglnary Napeleon has been obta

Encyc. Brit., XV1I. 220

authoritative (â-thor' i-tā-tiv), $a_{0}$ [ [ authority + -ative. Cf. ML. auctoritatious. $]$ 1. Having of authority. entitled to eredence or obedieneo as, "anthoritative teaching," Barrow.

The Law of Duty renains indeed autheritative, bnt its y 80 awful and unique as formerly.

Anselm was compelled to publish an autheritative editien of his Monolegium, becanse ao many copies of it were

in circulation from notes of lectures.
C. 1 . Pearsou, Early and Mid. Ager of Eng., xxxr.

2. Having an air of authority; positive; peremptory; dictatorial.

The mock anthoritative manner of the one and the in-
sipid mirth of the other. sipid mirth of the other. Swift, Examiner. Dogmatic and autharitative by nature and educat ion, he
hardly comprehended the mesning of toleration in mat. hardiy comprehended the mesning of toleration in mat-
ters of religion.
Whipple, Ess. and Rev., II. 90. -Syn. 2. Authoritative, Magisterial, etc. (see magisterial),

authoritativelg (â-thor'i-tä-tiv-lí), adv. In an authoritative manner. (a) With due authority.

I think it [the law of repetition] is even more autharitetively present in the minds of most great composers thas
the law of principality. (b) With a show of authority.

authoritativeness (â-thor'i-tā-tiv-nes), $n$. The quality of being authoritative; an aeting by autherity; anthoritative appearance.

authority' (Â-thor' i-ti), n.; pl. authorities (-tiz). [Early mod. E. also autoritic, auctoritie, ete., $\mathrm{ME}$. autorite, auctorite, $<\mathrm{OF}$. autoritct, F. autorite $=\mathrm{Pr}$. auctorital $=\mathrm{Sp}$. autoridad $=\mathrm{Pg}$. autoridadc $=$ It. auloriti, $S$ L. auctorita $(t-))$, counsel, will, decree, liberty, power, weight, authority, < auctor, author, originator: see an thor.] 1. Power or admitted right to command or to act, whether original or delegated: as, the authority of a prinee over subjeets and of parents over children; the authority of an agent to aet for his prineipal. In lav, an authority Is general when it extends to all acts, or all connected
with a particular employment, and apecial when confined to a single act.

Fy what authority doest thou these things, and who
Ilark xi. 28 .

If law, authority, and power deny not,
It will go hard with poor Antonio.

Shat $x$ of $v$, iil

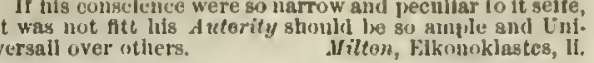
2. The power derived from opinion, respeet, or long-established reputation; influence conferred by eharaeter, onlee, station, mental superiority, or the like; credit: as, the authorit of age or example; the authority of Aristotle. But the mortallest eneny unto knowledge, snd that wich hati done the greatcst execution upon truth, hath beene a percuptury sulhesion unto A uthurity, sud espe. Antiquities. For (as every capacity may obnerve), most nen of Ages present, so auperstitiontaly do look upen Ages jast, that tire Authorities of tile one exceed the rea-
sons of the other. Sir T. Brome, Vulg. Err. (1646), 1. 20.

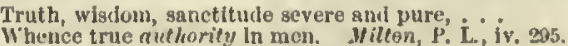
†. Power in a general sense.

The ... corrigible authority of this lies in our wills.

4. A person or persons, or a body, exereising power or command: generally in the plural: as, the civil and military authoritics.-5. Tho outward marks of authority; especially, the expression of authority in tho eountenanee.

Kent. You liave tirat in your countennnoe which I would Lear. What's that?

Shat Lear, 1. 4.

6. That to which or one to whom an appeal or referenee may be made in support of any opinion, action, or eourse of eonduct. (a) Testimony; Something I hrve heard ef this, which I would be giad to
timd liy so aweet an atutherity confinned. Sir P. Sinney.

$$
\text { Jesus, If Itassiah, Son of Geen declared, }
$$

And on that high a uthority bad believed.

(b) Weight of testlmony ; credibility : as, a historian

The registers of the Engliah Peerage are of far highe athority thsn any other atatistioal doeumenta.
Macrulay, Sadler's Law of Popnlation. c) One who possesses sdequate knowled ge el a subject, snd whese opinlons or staternents nowy be relled on; an expert; a standard ant hor or his writt This practice wo may learn, from a better and nure
ancient authority then any heathen writer hsth to give
118. Milton, Church.Government, l'ref. (d) In law, a precedent; a judicial declsion; sn oftelal Thieves for their robbery hsve a uthority, When judges ateal themg ho cuthorily,

Argument from authority. Same as argumentum ad verecundiam (which sce, under argumentum). - Constituted authorities, the magistrates or governors of $n$
nation, people, municipality, etc. - General authority, tho suthority of a general agent, intended to apply to a gnikhed from specisl instances, thongh it may be ifnited to a particular business and to a particular place. = Syn.
1. Rule, deminion, government; warraut, permisslon, anthorizstion.-2. Infuence, Autherity, Ascendancy, Control, Stoay, Demination, nusy sll spply to persons ol: ence and autherity imply meral power; the others msy arrsuged in the order of their strength. Inf weruce msy werd exprcssea the extent to whlch one affecta the conhinct or character of others slmply by their deference $t$ him on acconnt of his station, wealth, sbility, character,
etc. A uthority is, in this connection, influence smountetc. Authority is, in this connection, influence smountof age, wisdom, experience. It is presunishly rightfnl, some weight or powcr. Ascendaney is overmasterlng in-

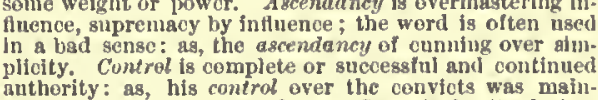
antherity: as, his control aver the cenvits was main-
tained witheut resort to force. Suvy is, by its derivatained without regort to force. Stray is, by its deriva
tien, control over that which may be vewed as a weighty
or nassive object; hence, a solit or powerful or controlor massive object; hence, a solid or powerful or control.
ling intinence. Domination, as it may be sn absolnte snd tyranuical rule, may also be sn abselute and tyrannicsl inthence or assendancy: as, he was really under the dum
netion of these whem he thought his aervsts or tools. Youm for the man of amplest influence, Yet clearest of nmbitious crime.

Tennyson, Duke of Wellington,

In the aboolute authority sccorded [by the Romsus] the father over the children we may trace the same
of discipline that proved ao formidable in the fleld. Lecky, Europ. Mlorals, I. 181. The application of gunpowder to the art of war has for ilization and barbariam, in favor of the former.

Gevernment has a genemal superintend Gevernment. . has a general buperintending control
over all the action and over all the publlely propagated
doctrines of men.
Burke, Unitarians, Ilay 11, 1792 . Ilorrible forms of worship that of old

Ileld, o'er the shuddering realms, unquestioned suny.

They ruse and took arms to resist Ordogno, son of AIfonan III., whose domination was too severe for them. uthorizable (Áthor-ī-za-bl), a. [Farly mod. auctorizuble; < IL. anthorisubilis, anetoriabihis, ote., s auctorizarc: see authorize and "ule.] That may be authorized: as, "a cenAlso spelled anthorisable.

uthorization ( $\mathrm{a}^{\prime \prime}$ thor-i-zĩ'shon), $u . \quad[=\mathrm{F} \cdot u u-$ torisation, < ML." auctorizatio(in-), < auctorizure, pp. anctorizatus: seo authorize.] The net of authorizing; the aet of giving authority or legal power; establishment by authority: as, "the anthorization of laws," Motlcy. Also spelled uthorisation.

uthorize ( $\hat{\mathrm{a}}^{\prime}$ thor-iz), $t . t$. ; pret, and pp. authorized, ppr, anthorizing. [Early mod. F. also auctorizc, $\mathrm{ME}$. auctorisen, aulorisen, $\angle \mathrm{OF}$. anctoriser, later authoriser, mod. F. autoriser = Pr. authorisur $=$ Sp. autorizar $=\mathrm{Pg}$. autorisar = It. autorizzurc, <ML. auclorisure, auctorizare, whorisave, ete., < L. auctor, author: seo author and $-i z c$.$] 1. To give authority, warrant, or$ legal power to; empower (a person): as, to f a iz commissioners to settlo the boundary of a state.-2. To give authority for; approve of and permit;

The report of the commission was takcn into immediate consideration by the estates. They resolved, withent one
dissentient voice, that the order signed by Willism dld not aw horize the slaughter of Glencoe.

The money, then, is borrowed on the credit of the United States-ant act which Congresa alone is competent to au.
thorize.
D. Hebster, Speech, Senste, May $7,1834$. $3 \nmid$. To make authoritative or valid; legalize; validate.

\section{Our undertakings to the ignorant people,
As if what we do were by lier conmind.}

4. To establish by anthority or usage: as, an authorized idiom.-5. To warrant; voueh for. [Rare.]

womsu's story, st a whinter's flre,

Bt. To support (one's of)

The Historian . authorizing hituself, for the mest Sir I'. Sidney, Det.
Also spelled authorise.

authorizer (â'thor-ī-zér), $n$, One who author-

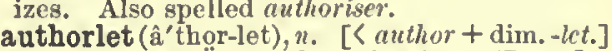
athorlet (â'thor-let), $n$. [< authort dim.-let.]
A petty author. Blackioood's Mag. [Rare.] A petty author. Blackwood's Mfag. [Rare.]
authorling (â'thor-ling), n. [<author + dim. ling.] A petty anthor. [Rare.] Oh then poer arthorling! Reseh s little lieeper Into the
hunan hesrt! authorly (âthor-li), a. [s author $\left.+-l y{ }^{1}.\right]$
longing to an author; authorial. [Rare.] longing to an author; authori

Counper, Letter to Unwh.

authorship (âthor-slip), n. [<author +-ship.] 1. The souree or cause of anything that may be said to have an author; origination; eausation: as, the aulhorship of an invention or of a politieal movement; a book whose author-
ship is unknown.-2. The state of being an author; the oeeupation of writing books.

If the formslists of this sert were erected Into palentees edly see such writing in our dsys as would either wholly such as were the product of our own nation.
Shaftesbury, Characters (ed. 1869), I. 347. auto (ou'tō), n. [Sp. Pg., < L. actus, an aet: ee act, n.] 1. In spanish litcrature, a play. The miracle-plays of the people attained a high degree
of excellence in the autos or sacred Clristmas pinys of of excellence in the autos or sacred Clristmas pirys of
Gil Vicente (14-0-1536). 2. In Spanish law: (a) An order; a decreo; ? sentenee; a deeision. (b) pl. The pleadings and proeeedings in a lawsurt. -3 . An auto de fe. ato-. [<Gr. airo- (before a vowel ait-, which before a rough breathing beeomes ai $\theta-$ ), stem
of airos, self (myself, thyself, himself, ete.).] of avios, self (myself, thyself, himself, ete.).] meaning self, of itself (natural), of one's self (independently), of nothing but ..., ete. very eommon in English and other modern languages, especially in seientifie terms.

autobiographer (â" tō-bī-og'ră-fe̊r), $n$. [<Gr. aecount of his own life.

"And yet, o man born of Woman," cries the Autobiog. rapher, with one of his sudden whirls, "wherein is nyy
case peculiar?"
Carlyle, Sartor Ressrtns, p. 58. 
autobiographic

autobiographic (â-tọ-bī-ọ-graf'ik), a. Of the utobiography.

The writinga of Dante . . are all .... autobiographic autobiographical (â-tō-bì-ọ-graf'i-kạl), a. 1. of or pertaining to autobiography; characterized by an autobiographic tendency.

It ever remains doubtful whether he is laughing in his chal thines ol dars.

2. Same as autobiographic.

a utobiographically (â- tō - bī-ọ-graf'i -kạl-i) adv. In an antobiographic manner.

autobiographist ( $\hat{a}^{\prime \prime}$ tō-bī-og'rạ-fist), $n$. [<autobiograph

[Rare.] autobiography (â"tö-bi-og'rạ-fi), $n_{\text {. ; pl. auto- }}$ biographics (-tiz). [<Gr. avtos, self, + biogra-
phy.] A biography or memoir of a person written by himself.

autocarpian, autocarpic (â-tọ-kär'pi-ạn, -pik) a. Same as autocarports.

autocarpous (â-tọ̄-kår'pus), a. [< Gr. avitós self (in comp. sometimes, as here, meaning 'o

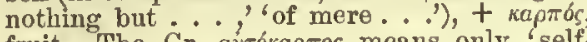

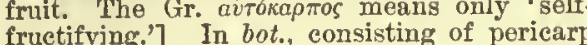
alone; having no adnate parts (Gray) : applied to fruits which are free from the perianth. Same as superior.

autocephalic (ất tō-se-fal'ik or â-tō-sef'ạ-lik) a. [As autoccphal-ous $+-i c$.$] Autocephälous;$

autocephalous (â-tō-sef'a-lus), a. [<LGr.aìo-

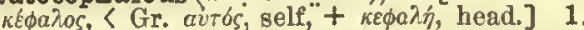
Having a head or chief of its own; independent of jurisdiction: applied to a ehurch.

The Rissian Church became autocephalous, and its pa-
triarch had immense power.
Encyc. Brit., XI. 157. 2. Acting as an independent head; having primary jurisdiction: as, an autocephalous bishop or metropolitan.

We have aeen Greece proclaim Its Holy Governing Sy autochronograph (â-tọ-kron'ō-gràf), $n$. [<Gr. aurbs, self, + chronograph.] An instrument ing time.

autochthon (â-tok'thon), $u_{0} ;$ pl. autochthons, autochthones (-thons, -tho-nēz). [< L. autochthoncs, pl., < Gr. "aìtó $\chi \omega \omega \nu$, pl. av่т6 $\chi 0$ oves, aborigines, primitive inhabitants, lit. sprung from rigines, primitive inhabitants, lit. sprung from Athenians and some other Greeks that they sprang originally from the soil on which they
lived), (avros, self, $+\chi \theta \dot{\omega} v$, land, earth. 1 . Literally, one sprung from the land ho inhabits hence, one of the primitive inhabitants of a country; a member of the race found in habitant.

Whoever the artist may have been, it [a atatue] is un doubtedly a very able conception, the figure geeming t
rise from the earth just as an autochthon would be though rise from the earth just as an autochthon would be though
to rise.
A. S. II urray, Greek Sculpture, 1. 224, note. Their own traditions appear to have made them [th that they believed the re-peopling of the earth after the food to have begun in their country.
G. Rawlingon, Origin of Nationa, p. 6 \% 2. $p l$. The primitive animals or plants of country or region, especially in geological time. [Rare.]

autochthonal (â-tok'tho-nal), $a$. [<autochthon + -al.] Autochthonic; ahoriginal: as, autoch- an

thonal peoples.
autochthones, $n$. Plural of autochthon.

autochthonic (â-tok-thon'ik), a. [< autoch thon $+-i c$.$] Of or pertaining to an autoch$ thon; native to or sprung from the soil; aboriginal ; indigenous.

The aborigines of the country [were] driven, like the
Bheels and other autochthonic Indians, tnto the eastern and aoutheastern wilds borderting upon the ocean.
R. F. Burton, El-Mledinah,

We may, however, venture the agaertion that the Eakim is of autochthonic origin in Asia.
Arc. Cruise of the Corwin, 1881, p. 30. autochthonism (â-tok'tho-nizm), n. [< autoch thon $+-i s m$.] Birth from the soil.

According to the Scythians, Targitaus lived jnst a thou
aand years before the year 513 B. c. - a legend which, taken aand years before the year 513 B. c. - a legend which, take
with the tradition of autochthonism, ndicates a much earlter date for the immigration of the Scythians than we Encyc. Brit., XXI. 576

autochthonous (â-tok'tho-nus), a. [< autoch indigenous; sprung from the soil; aboriginal. I apeak here ${ }_{\text {of }}$ of ancient reltgions only, of what are
388 not of those founded in later times by individual pro-
pheta or reformers. One would almost be inclincd to think from Herr Stalir' account of the inatter, that Lessing had been an autoch
thonors btrth of the German soil, without intellectual an
cestry or helpful ktndred.

Lowcll, Among my Books, 1st ger., p. 30 .

2. In pathol., not extraneous; originating at the place where found.

autochthonously (â-tok' tho-nus-li), adv. In an utochthonous manner.

The larger number of maladies do not arise autocht thoautochthony (â-tok'tho-ni), n. [< autochthon $+-y$.$] The condition of being autochthonous.$ The practice of describing legendary heroes and men of ancient lineage as earth-born, $y \eta \gamma \in v \in i s$, atrengthened great iy the doctrine of autochthony, and nowhere so mucli as
in Attica.
Encyc. Brit., III. 141. autoclave (â'tō-k]āv), n. [F., self-rogulating, a digester, < Gr. avitó, self, + L. clavis, a key (or clavus, a nail i).] A kind of stewpan, the lid of which is kept close and steam-tight by the steam proceeding from the contents of the pan. It is all application to culinary purposes of $\mathrm{Pa}$ pin's digester. See digcstor.

autocracy (â-tok'ra-si), n.; pl, autocracics (-siz) [ $\mathrm{F}$. autocratic, "< Gr. avтonpáteca, absolute power, < aivoкрат\}彳, absolute, ruling by one's self: see autocrat.] 1t. The power of deterderived power; self-government; self-rule.

Man's will, that great aeat of freedora, that, with a kind of autocracy and anpremacy within itself, commands its

It [the divine will] moves, not by tho external impulse or inclination of objects, bint deternines itself by an ab.

2. Uncontrolled or unlimited authority over others, invested in a single person; the govern ment or power of an absolute monarch.

At least from the days of Hildebrand the mind of Europe had become famtiarized with the assertion of those claima which in their latent algnificance amounted to an Nilman, Latin Christianity, ix. 3ł. In med., action of the vital powers toward tho preservation of the individual. $=\$ \mathrm{Syn}$. 2. Tyr-

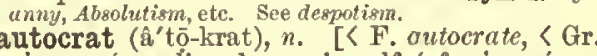
airokparhs, ruling by one's self (cf. aírokpátwp, кри́тоร, power, < крати́s, strong, = Gotb. hardus = E. hard: see hard.] 1. An absolute prince or sovereign; a ruler or monarch who holds and exercises the powers of government as by inherent right, not subject to restrictions: as, "the autocrat of all the Russias," a title assumed
by the emperor of Russia. - 2. One who is invested with or assumes unlimited authority in any relation: as, "The Autocrat of the Break autocratic (ê-tō-krat'ik), a. '[< autocrat + -ic.] Pertaining to or of the nature of autocracy. absolute; holding independent and unlimited powers of government.

The Russian government is autocratic, jnasmuch as over the poaition of the Mongolian khans, who from the thir-
teenth to the fifteenth century held the Rusian people in

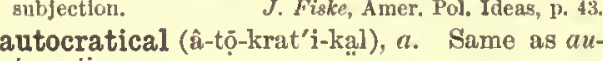
autocratically (â-tō-krat'i-kal-i), adv. In an autocratic manner.

autocrator (â-tok'rạ-tor), n. [<Gr. avirokpárs one's own master, an absolute ruler: see
tocrat.] An autocrat; a dictator. [Rare.]

The picturesque spiked Macedonian helmet with \&
goat'a horn and cheek-piece which occuples the reverse goat"a horn and cheek-piece which occuples the reverse
[of a coin], on which is written after "King Tryphon" the lof a coin], on which is written after "King Tryphon" the
strange title autocrator.
Encyc. Brit., XVII. 649. autocratorical ( $\hat{a}^{\prime \prime}$ tō-krâ-tor'i-kąl), a. [< Gr.

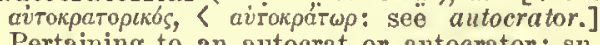
preme; absolute: as, autocratorical power. [Rare.]

autocratrice (â-tok'ra-tris), u. [F.] Same as

autocratrix (Â-tok'ra-triks), n.; pl. autocratrices

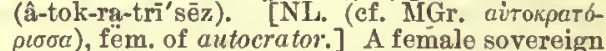
who is independent and absolute: a title sometimes given to a reigning empress of Russia.

atocratship (â'tō-krat-ship), n. [< autocrat auto da fe (ou'tō dä fā); pl. autos da fe (on'tōs). [Pg. auto da fé $=\mathrm{Sp}$. auto de fe $\left(\mathrm{Pg}_{\text {. }}\right.$ da, $<$ de a,
where $a$ is the fem. art., $\langle\mathbf{L}$. illa $)$.] Same as autogenic

auto dc fc. [This Portugueae form, commonly written auto da ye or auto.daffe, was the first introdnced, and ha becto

auto de fe (on'to da lâ); pl. autos dc fo (ou'tōs) [Sp., lit. act (judicial process, judgment) of faith: auto, < L. actum, an act; $d c,<\mathrm{L}$. de, from, of ; $f c=\mathrm{Pg} . f \dot{e},<\mathbf{L}$. fidcm, ace. of fides, da fe.] The public declaration of the judgment passed on accused persons who had been tried before the courts of the Spanish Inquisition, and by extension the infliction of such penalties as bad been prescribed in the sentence. The declaration of judgment was usually made with nuch solemnity, in an open place, and tncluded the acquittals, reception to retraction, official admonition, and petency of the court. These crimes were public profesaion of hereay, apostasy, witchcraft, aeduction hy ecclesiastics, bigany, unnatural crimes, church-robhery, blas phemy, usury, and, in general, crimes of or against the brought from prizon, dressed in the sanbenito, or robe of defamed criminals, which was worked with a cross an other deaigns, aometimes with grotesqute scen es of infernal
characters or torments, ant varied in its color and patterm pased ordance with the aeverity or the cor to cifed, and ita punishment declared, after which all were delivered up to the civil officiala. IJere the auto proper fintshed; but as the execution of those penalties that were of capital or corporal nature immediately followed, the name was extended to this part, as applied to which it has
hecome popularly accepted. Such punishments were floging or burning according to the prescriptions of the imperial or Carollne code.

autodidact (â'tō-di-dakt"), n. [<Gr, avirodíak ros, self-tanght, < avrbs, self, + didakrós, verba]

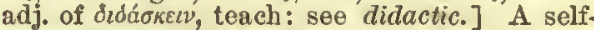
taught person. [Rare.]

autodidactic (â"tō-di-dak'tik), a. [< autodidact $+-i c$.$] Self-taught. [Rare.]$

He [Jlenzel] was from the beginning an auto-didactic
realiat: he drew and painted as he saw - not as other taught htm how they had seen.
Contemporary Rec, XLIX. 293. autodynamic (â"tō-di-nam'ik), a. [<Gr. aìrodvapos, powerful of itself, < avtas, self, + diva $\mu t s$, power: see dynamic.] Having power or force in itself. - Autodynamic elevator, a hydraulic machine in which the welght of a falling colnmn of wate tirat of the first.

autœcious (A-tē'shus), a. [< Gr. airós, self, + olkos, dwelling.] In bryology, having both male and female inflorescence on the samo plant monocions. Three modifications are cladautøeious, goniautœeious, and rhizautœeious. Also written autoicous.

autogamous (â-tog'a-mus), a. [< Gr. airós, married.] Self-fertilized: applied to flower which are fertilized by their own pollen, in distinction from anemophilous and entom ophilous flowers, in which one flower is fertilized by pollen from another through the intervention of the wind or of inseets.

autogamy (â-tog' â-mi), n. [< Gr. aitós, self,

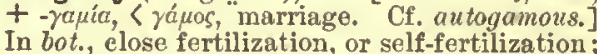
the fertilization of a flower by its own pollen. See alloganey.

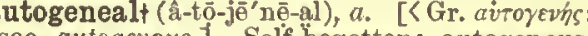
see outogenous.] Self-begotten; autogenous.

autogeneous (â-tộ-jē'nệ-us), a. Same as auto-

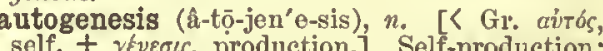
self, $+\gamma \varepsilon v \varepsilon \sigma \iota$, production.] Self-production; parent organisms; $(b)$ in tissues, of parent tissues; and (c) in disease, of previous cases of ymotic disease.

autogenetic (â" tōoj-jẹ-net'ik), a. [<autogenesis: see genetic.] Self-producing; pertaining to auogenesis.

There was no doubt . . . of the existence of autogenetio
Brit. Med. Jour., No. 1319

autogenetically (â"tō-jē-net'i-kal-i), advv. By antogenesis, or autogenetic processes.

Some aeptic poison, either from without or autogeneti-
cally, might cause the aame. Brit. Nled. Jour., Xo. 1319.

autogenic (â-tō-jen'ik), a. [As autogen-ous $+-i c$.$] Self-produced; independent of a me-$ dium: specifically applied to a process of soldering in which pieces of metal are united by fusing the parts to be joined. See antogenous.

Platinum workers. have long learned to nnite two platinum aeanis by the autogenic process - the local fiame.
Encyc. Brit., XIX. 190. 
autogenous

389

autogenous (A-toj'e-nus), a. [<Gr. aíogevís, auto-inoculable (â"tō-in-ok' solf-producod, < aurb́s, self, $+\gamma \varepsilon v o s, k i n d$, race, avibs, sclf, + inocutuble.] Possessing the power offspring: see gcnus, genous.] 1. Self-pro- of auto-inoculation; capable of being propaduced; self-generated; coming forth independently. Specifically, in anat., endegenous: applied to those procesaea or parts of a bone which arlso fron an
independent or gejarate center of ossilleation, as diatin. gutalied from merg exogenuis outgrowtis. Thus, the epiplyses of a bone are aulogenous; a pophyses may be cither autogenous or exogenous.

The centrum and several of the apophyses of a vertch re autugenou, while other apophyseg are exogenous.

\section{Samo as autogenie.}

Also autogeneous.

Autogenous soldering, the process of uniting pleces of metal hy the fusion of yitrt of their own substance, with. ont the usa of a apecial sulder. It is performed by meang
of the atrolydrogen or oxyliydrogen blowpipe and uy clec-

autogenously (â-toj'c-nus-li), ad $v$. 1. In an autogenous inanner.

The anterior, or more properly inferior, bar of the tranaverse process of tho seventh, and occasionaliy of some of the other cervical vertebre In Man, Is autogenouzly devel-
oped. 2. By the autogenous process of soldering. This battery is constructed of a caac of insulite, having a lid of the same materlal autogenously soldered in. J. W. Queen, Elect. Catalogue, 1883, p. 10.

autogeny (Â-toj'e-ni), n. [< Gr. avroyeviss (seo any; spontaneous generation.

autogony (â-tog' produced, self-producing, <aviró, self, + -yovos, produced: see-gony.] The generation of simple organisms from a lifeless fluid; abiogenesis. autograph (a'tō-grál), $a$. and $n$. [CF. autographe, < L. autographus, < Gr. avisypaфos, writ-

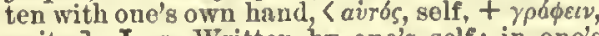
write.] 1. a. Written by one's self; in on

own handwriting: as, an autograph letter.

II. $\mu$. [<F; autographe, < Hu, autographum. $]$ 1. A person's own handwriting; something
written by a person's own hand; an original manuseript or signature.

Autographs of famous names were to bo acen in fadad
ink on sone of their fly leavea. Uarthorne, Old JIange, 1. 2. Au autographic press (which see, under press).

autograph (átō-gráf), v. t. [<autograph, n.] autograph (a'tōgraf), $v$. t. $[<$ autograph, $n$. one's autograph on or in. -3 . To copy or produce in autogranh, or by an autograplic process. See autographic.

Annonncements and notices of various kinds, whether printed, engraved, lithographed, or autographed.

It contains 80 autographed pagea out of the 1,100 of which the whole work will conais.

autographalt (Â-tog'rạ-fal), $a$. [< autograph

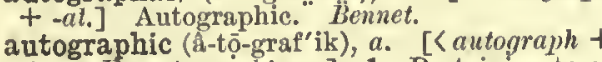
$-i c ;=\mathrm{F}$. autographique.] 1. Pertaining to or of furnished by one's own handwriting: as, autographic authority; autographic evidence. autographic authority; autographic evidence. tography: as, autographic ink; autographie paper.-3. Self-recording: applied to a form of telegraph. See below.-Autographic press. See press. - Autographic process. (a) In the fine arts, any served in mechanical reproductions, as in an antotype or a plioto-engraving. (b) A general term applled to thos drawing is made with a peculiar ink, and then transferred to the atone, plate, or other matrf from which it is to be printed.- Autographic telegraph, an instrument lor transmitting a telegraphle despatch written in ingulating ink upon a metalite paper, and reproducing it with aluso luta exactness on another prepared paper. The inatru-
ment may be used for transmitting portraits or other fig ures, diagrams, etc.
autographical (â-tō-graf'j-kal), a. Same as au tographic.

autographically (â-tō-graf'i-kâl-i), $a d v$. In an autographic manner; by mealis of autographic writings; in autograph.

And had "shaken hands autographicatly" with him
acruss the Atlantic.
D. Mill, Life of Irvlng, p. 150. autography (â-tog'ra-fi), $n .[<$ autograph $+-y ;$
$=F$. autographic. $]$. The act of writing with one's own hand; autographic writing. - 2. That department of diplomaties, or the study and decipherment of old writings, which is concerned with autographs. -3 . $\AA$ process in lithography by which copies of a writing, drawing, etc., are produced in facsimile.

autoicous (â-toi'kus), a. Same as antoccious.

auto-inoculability (Â"tö-jn-ok" ü-la-bil'i-ti), n. [< auto-inoculablo: seo -bility.] Capacity for auto-inoculation. of auto-inoculation; capable of being propa-

uto-inoculation (â"tö-in-ok-ụ--lā'shon), n. [< of a healthy part of the body with the virus a chancroid.

a to-insufflator (â-tō-in'suf-lā-tor r), n. [< Gr. airós, self, + insuglator.] An instrument used for administering to one's self a unedicinal powder.

utokinesyt, $n$. [< LGr, avirostvpoía, Gr. airoкívnots, self-movement, < airokim seo autokinctical.] Self-movement; spontaneous motion. Cudcorth.

autokinetical $\nmid$ (â"tō-ki-net'i-kal) $), a_{*},[<G r$.

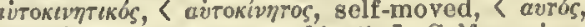
self, + אiveiv, movo: seekinetic.] Self-moving. Dr. II. More.

autolaryngoscope ( $\hat{\text { A }}$ " tō-lą-ring' gộ-skôp), $n$. [<Gr. avtos, self, + laryngoscope.] An instrument, consisting of a combiuation of mirrors, II. Knight.

autolaryngoscopy (â"tō-lar-ing-gos'kō-pi), $n$. [<Gr. autor, scif, t laryngoscupy.] The juspection of one's own larynx by means of an autolaryngoscope.

autolatry (ĥ-tol'a-tri), n. [<Gr. airos, self, + iarpeia, worship. J Self-worship.

autology (â-tol'ộ-ji), n. [<Gr, avirb́s, self, +

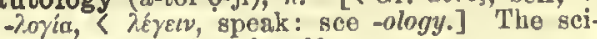

Autolytus (â-tol'i-tus), n. [NL., < Gr. airths self, $+\lambda v \tau \delta \zeta$, verba] adj. of 'ívetv, loose.] A ge nus of chetopodous annelids, of the famijy syl

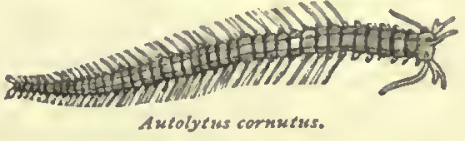

lide: a synonym of Syllis. A. prolifer is an asexua? form, the opposite gexual forms of which have been called automat, $n$. An erroneously
of automata. See automaton.

$$
\begin{aligned}
& \text { It is an automa, runs under water } \\
& \text { With a anug noae, and has a nimlile tail }
\end{aligned}
$$

Srade like an augur.

automalite, $n$. See automolite. -al.] Same as automatic. [Rare.]

automath (Â'tō-math), n. [< Gr. airo $\mu a \theta n$ s,

self-taught, < ávirós, self, + $\mu a v \theta a ́ v \varepsilon t v, \mu a \theta \varepsilon i \nu$, learn: see mathen
taught. [Rare.]

automatic (Â-tō-mat'ik), a. [<Gr. airóparos, self-moving (soe automaton), +-ic.] 1. Acting as an automaton. (a) Having the power of gelfmotlon; self-acting : as, automatic machlnery. (b) Done posed to voluntasy.

2. Conducted or carried on by self-acting maIt is in our modern cotton and flax mlita that automatic operationa are displayed to most advantage.

3. In physiol.: (a) Not voluntary; not under the control of, or not effected by, volition: said of certain museular actions.

Let me briefly notice aome of our other automatic ac the back of the throat, the "gwallow" laya hold of the footl or the drink brought to it by the muncles of the
month and carries this down into the stomach. We are mouth and carries thia down into the stomach. We are
quite nnconsclena of its passage thither unless wa have quite nnconsclona of its passage thither unless we hav ordinary. This is an instance of purely automatic action. In anlmais, too, to a far greater extent than in plants, to different parts of the organian or to the whole of It. (b) Not reflex: said, for example, of certain activities of ganglion-cells.-Automatic brake. See brake. - Automatic coupling see coupling.- Automatic mallet. Same as dentai hammer (whlch aee under hism, 2 .

automatical (â-tō-mat'i-kal), a. 1. Same a automatic.-2. Having reference to or connected with automatic things.

automatically (â-tọ-mat'i-kal-i), adv. 1. In an auto: ir. aviśs, self, + inoculation.] The inoculation entific study of one's self.

automata, ${ }^{n}$. Plural of automaton. 11 automatzc activity which always realdes in protoplas

\section{automatous}

Ilo went on rowing idly, laals aufomatically. We know that a frequently repeated act of muscular aklli finally comes to be done alnost automatixaly and 2. By automatic means; by its own action.

in automatically working machine.

Sci. Amer., N. S., LV. 55. Autonatically keeping its temperatnre miform.
Jour. Franklin / nat., CXX1., Supus. automaticity ( $\hat{a}^{\prime \prime}$ tō-ma-tis' f being automatic: automatic action. Martin, Human Body ( $3 d$ ed.), p. 23 .

Human Borly ( $3 d$ ed.), p. 23 . -ism. Cf. Gr. avтouariojı́s, that which lappens of itself, a cliance.] 1. Automatic or involuntary action: in pathol., sometimes specifically applied to such purposeless actions as are of

In consldering the borly as the instrument of the mind, 1 ghall alow you, flrst, tho large amount of automatism
W. B. Carpenter. The Inperfectiona in sensation, and the inhibition on the moral facultica luposed by alcohollc anseathesia, go the characteristlca of automatism; but the semblances of autumatism are so almilar to conacloss rationality that they diagulse the actual incompetency of the noral
Aliest. aud Neurol., VI. 40. 2. The doctrine that animals, especially those below man, are automata, in the sense that al the phenomena exhibited by them are results of physical laws; especially, the doctrine of Descartes that animals aro devoid of consciousness.-3. The faculty of independently originating action or motion. [From the origina] sense of automaton.] N. $E$. $D$.

automatist (â-tom'a-tist), n. [< automaton +

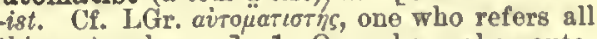
things to chance.] 1. One who makes auto(sometimes including man) are automata. See automatism, 2.

Thongh not a declared automatist, however, Mr. Spencer
is by virtile of hia general phillosopliy a necessarian. automatize (Â-tom'a-tĩz), $v$. $t_{0}$; pret. and pp. automatized, ppr. automatizing. [< automaton + -ize. Cf. Gr. avrouaríctv, act of one's self chance.] To make an automaton or a selfactiug machine of.

A God-created man, all but abnegating the character of man ; forced to exist, automatised, numuny-wise, . . as automaton (â-tom' a-ton), n.; pl. automata, automatong (-tị, -tonz). [Formerly also automatum, < L. automaton, automatum, < Gr. airb $\mu \mathrm{\sigma}-$ rov, neut. of airof $\mu$ ros, acting of one's self, self-

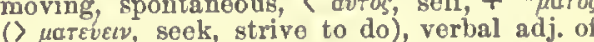

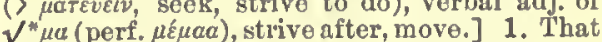
which is self-moving, or has the power of spontaneous movement, but is not conscious.

So great and adnirable an automaton as the world.
Boyle, Works, V. 251.

Specifically-2. A self-acting machine, or one which is actuated in such a manner as to carry on for some time certain movements without the aid of external impulse. In this respect clocks and watchea, with a vast number of other machtnes, may denotes an apparatus in which the purposely concealed power is made to fimitate tha voluntary or meclanical mo-
tions ol living beings, such as men, horsea, birda, flshes, etc.

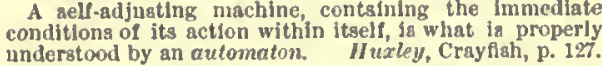
3. A living being acting mechanically or as a mere machine, especially without conscious ness; a person or an animal whose actions are purely involuntary or mechanical. See bestial automaton, below.

Obedience,
Bane of all genlus, virtue, freedom, trutls,

Mlakes alaves of men, and of the humant Irams

4. A person who acts in a monotonous routine manner, without active iutelligence, especially without being fully aware of what he is doing. - Automaton balance, a machine for weighing plan chets and coin, and sortlug the pleces antomatlcally, acautomaton, In the Carteslan philosophy, a brute, as snp. posed to bedevild of consciousness and sensibility. - Spirsuluject to necessity.

automatoust (â-tom'g-tus), a. [<Gr. avibuaros, automatic (see autömaton), + ous.] Automatic.

Clocks or automatous organa, whereby we now distinguish of tlme, have fonnd no mention In any ancient
Sir T. Brouters, Vulg. Err., v. 18 


\section{autometric}

autometric (â-

autometry (ầ-toln' $\theta$-tri), n. [く Gr. củtós, self,

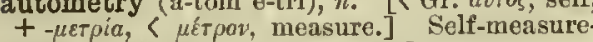
ment; self-estimation. I. $E$. D.

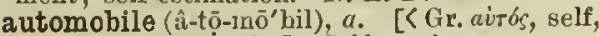
+ L. mobilis, mobile.] Self-moving.

An auto-mabile car, with isolated rails. Greer, Dict of Elect, 18

Our authorities are still in the dark as to what call ac tually be done witic autonobile torpedoes deserter, prop. adj., going of [<Gr. avtouahos, a self, + sometimes given to gahnite, from the fact that it contains a large proportion of zine oxid, though it has no resemblance to an ore. See gahnite. Also snelled automalite.

automorphic (â-tō-môr'fik), a. [<Gr. avióreopautomorphic (â-tō-mor' self-formed, natural (taken as 'formed upon one's own self or pattern'), (avibs, self, $+\mu o \rho-$ $\phi y^{\prime}$, form.] Framed or conceived after the pat tern or form of one's self.

The conception whlch any one frames of another's mind is nevitably more or less after the pattern of his own which the has to frame a conception differs from his ow his automorphic Interpretation is likely to be wide of the
truth.
II. Spencer, Study of Soclol, p. I14. automorphically (â-tō-mốr'fi-kal-i), adv. In an automorphic manner. H. Spencer.

automorphism (t̂-tōomôr'fizm), $n$. [As automorph-ic $+-i s m$.] The aseription of one's own characteristies to another, or the habit of jndging others or explaining their acts by means of analogies furnished by the knowledge of one's self.

autonomic (â-tō-nom'ik), a. [As autonom-ons $+-i c$.$] Relating to antonomy; having the$ power of self-government; autonomous; selfgoverning; independent.

Reason is thus ever autonomic, earrying Its awn law
within itself. autonomist (â-ton'ō-mist), n. $[<$ autonomy + -ist.] One who advocates or favors the principle of autonomy; one who desires home rule, or self-government of the commu
he belongs, or of any community.

The party of the Irreconcilables lin Alsace-Lorraine those who subordinated tlie qrestion of nationality to that
of bome rule. Bismarck, II. 385 . autonomous (â-ton'ō-mus), a. [<Gr. aviróvouas, independent, of one's own free will, $<$ avtos,
self, + vé $\mu \varepsilon v v$, hold sway, $>v 6 \mu$ s, law: see nome.] self, $+\nu \varepsilon \mu \varepsilon \iota v$, hold sway, $>v b \mu$, law: see nome.
1. Of or pertaining to autonomy or an autonomy.-2. Independent in government; having the right of self-government.

The few brave men who seven years back first un-
sheathed their yataghans annd the liills of Iferzegovina
did not carry with them a scheme for. did not carry with them a schem
province of Eastern Roumelia.

3. Subject to its own laws; specifically, in biol. independent of any other organism. not a form or stage of development of some other organ ism.

autonomously (â-ton' $\bar{o}$-mus-li), $a d v$. In an au tonomous manner; from one's own choice.

We must know and autonomously will to follow non-
egoistic absolute ends as essentialiy our ends.

autonomy (Â-ton' $\bar{o}-\mathrm{mi}), n_{\text {; }}$; pl. autonomies $(-\mathrm{miz})$. [<Gr. aviravapia, independence, < av̉rónopas, independent: see autonomous.] 1. The power or right of self-govermment, whether in and makes its own laws, or in an individual who acts according to his own will.

There was nothing in the treaty of Adrianople that
really interfered with the autonomy of the Circassians.
Lathain, Vationalities of Europe, I. xxx That which is autonomy objectively will be self-deter
mlnation subjectlyely. Maudsley, Body and Will, p. 189. 2. A self-governing community.-3. An autonomous condition; the condition of being subject only to its own laws; especially, in biol., organic independence.

The government of the Arabs nay be ealled almost an
autonomy.
R. $\boldsymbol{F}^{\prime}$. Burton, El-Jledinah, p. 341. autonomy. R. $\boldsymbol{H}^{\prime}$. Burton, El-3ledinah, p. 341. Given the basis of good mental nutrition and respiration
In a suitable soclal atmosphere, and there take place from time to time spontaneous y ariations testifying to the at

onomy of the organism. Maudsley, Body

4. In the philos. of Kant, the doctrine that the moral law is one which reason imposes upon and sense-experience, and is therefore absolute
390

autostylic

and immutable: opposed to heteronomy (which see).

autonym (â'tō-nim), n. [<Gr. airós, self, + al. ovpa, name.] 1. One's own name; real name: opposed to pseudonym and anomym. book published under the author's real name.

-3. The self-same name; one and the same name for two or moro things; a homonym. [Rare.]

autopathic (â-tō-path'ik), a. [< autopathy + -ic.] In pathol., dependent on the original structure and developmental tendencies of the ic: applied to certain forms of disease.

It is Impossible, says SImon, absolutely to exclude au topathic diseased states; there nay be some such, mostly developmental, whlch "are actual caprices and spontane. ties of Jife, without any exterior causation whatsoever."
Encyc. Brit., XVIII. 362

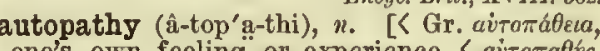

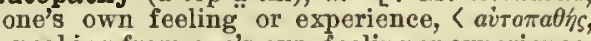
speaking from one's own feeling or experience,

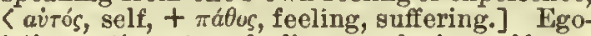
istic sentiment or feeling; exclusive self-consideration. Dr. H. More. See extract.

We have In the word sympathy a term representing the altrulstic sentiments as subjective feelings. No correword autopathy, could it be adopted in thls sense, wonld doubtless be found useful. L. F. Ward, Dynam. Sociol., II. 371. Autophagi (â-tof'a-jî), n. pl. [NL., pl. of autophagus, self-feeding: see autophagous.] In are able to run about and feed themselves as soon as they are hatched: synonymous with Ptilopades or Dasypades.

autophagous (â-tof'a-gus), a. [<NL, autopha gus, self-feeding, < G̈r. aviroфáyos, self-devourSelf-devouring.-2. Self-feeding; capable of feeding itself, as a precocial bird: equivalent in application (but not in meaning) to hesthogenous or ptilopodic, and opposed in meaning to heterophagous (which see) autophagy (â-tof'a-ji), $n$. [ $=\mathrm{F}$. antophagic;
as autophag-ous $+-y$.$] The act of feeding$ upon one's self.
autophoby (ấtō-fō-bi), n. [<Gr. avisós, self, + -фoßia, fear: see -phobia.j Fear of referring to one's self; fear of being egotistical. Hare. [Rare.]

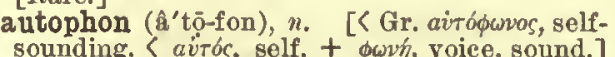
sounding, < aútos, self, + $\phi \omega \nu \eta$, voice, sound.] A form of barrel-organ, of which the tunes are board cut to correspond with the desired notes. E. H. Knight.

autophony (t̂̀-tof'ō-ni), n. [< NL. autophonia (in form as if < Gr. avtoduvia, the voice itself) <Gr. aviódwros, self-sounding: see autophon.] In auscultation, the character of the sound of placed against the chest of the patient. When there is a large cavity this sound unay be rendered of greater intensity than is nomal. autophthalmoscope (ê-tof - thal ' mộ-skōp), [< Gr. airbs, self, + ophthalmoscope.] An in-
strument by which one may inspect the interior of one's own eyes.

autophyllogeny ( $\hat{a} "$ toō-fi-loj'e-ni), n. [<Gr. ai

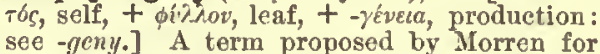
the abnormal growth of leaves from leaves. autopisty (â'tō-pis-ti), n. [< Gr. avio $\pi \iota c T 0$ ble, worthy of belief, $<\pi \varepsilon i \theta \varepsilon v, \pi \iota \theta \varepsilon i v$, persuade. Worthiness of belief from internal evidence; the quality of credibility existing in a statement itself, independently of external evidence or corroboration. [Rare.]

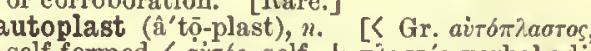
self-formed, < aviós, self, $+\pi \lambda a a \tau o ́ s$, verbal adj. of $\pi$ raacetv, form.] In embryol., an autogenous spontaneously in the yolk of fission or the regular process of cleavage of the fission or the regular p.
vitellus. See extract.

In addition to the layer of eleavage cells whlch consists of more than one stratum of cells in the future embryonic area as opposed to the yelk-sac area, additional celis are
formed in the mass of residual yelk apparently by an In dependent process of regregation, each ceil having an In rate origin, whence they are termed autoplast8.
$E$. $R$. Lankester, Encyc. Brit., X VI. 682. autoplastic (â-tọ̄-plas'tik), a. Pertaining to

autoplasty (â'tọ-plas-ti), n. [As autoplast companied with loss of substance are repaired by means of healthy portions of tissue taken from another part of the patient, and made to supply the deficieney. See rhinoplasty. utopolygraph (â-tō-pol'i-grảf), $n$. [〈Gr. aưos self, + polyyraph.] An

autopsiat (ti-top'si-êt),

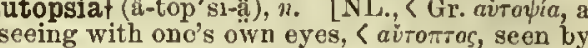

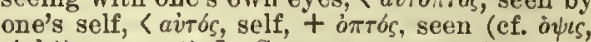
sight): see optic.] Same as autopsy, 1.

It is no small undertaking for a man . To begin a
atural history from lis own autousia.

autopsic (â-top'sik), a. [< autopsia + -ic.] 1. Same as autoptic. -2 . In med., pertaining to or obtained by means of an autopsy.

Undonbtedly the late King of Bavaria was insane, and the autopsic and the combined ante-mortem testlunolny to
lis insanity" was not more conflrmatory of mental dehis insanity was not more confirnatory of mental deagement than that given in the history of Gulteau. A utopsic notes of cases of cellulitis Thoinas, Med. Dict., p. 491

autopsical (â-top'si-kal), a. Same as autopsic. Basing hls opinton on the autopsical examination of fever patients.
Ziemssen, Cyc. of Med. (trans.), Supp., p. 561. utopsically (â-top'si-kal-i), $a d v$. Same as autoptically.

autopsy (ấtop-si), $n$. [< autopsia, q. v.] 1 A seeing for one's self; personal ocular obser-
vation, inspection, or examination. Specifically-2. In pathol. and anat., dissection and inspection of a dead body to discover the canse of death, or the site and character of the disease of which the person died; post-mortem examination; a post-mortem.

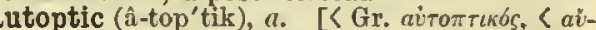
rortos, seen by one's self: see autopsia.] Seen with one's own eyes; relating to or based on antopsy or personal observation: as, autoptic evidence. Also written autopsic.

autoptical (â-top'ti-kal), a. Same as autoptic. Oral tradition or autoptical memoirs. Schaff, Hist. Christ. Ch., I. 882 utoptically (Â-top'ti-kgl-i), adv. In an autoptic manner; by ocular view or one's own observation. Also written autopsically.

That the galaxy is a meteor, was the account of Aris , but the telescope hath autoptically confinted it.

utort, $n$. An obsolete form of author.

utorialt, $a$. An obsolete form of authorial. autorityt $n$. An obsolete form of anthority. autoschediasm (â-tō-skē' di-azm), n. [< Gr.

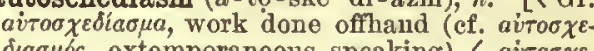

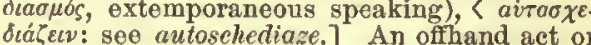
performance; something hastily improvised. autoschediastic ( $\hat{a}^{\prime \prime}$ tō-ské-di-as'tik), a. [< Gr.

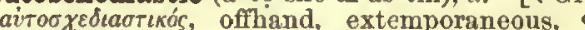

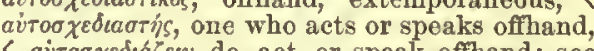
< aivoa $\chi \varepsilon \delta e a ́ \zeta \varepsilon e v$, do, act, or speak offhand: see autoschediazc.] Slight; hasty; not fully considered; done hastily or on the spur of the moment.

atoschediastical ( $\hat{\mathrm{a}}^{\prime \prime} \mathrm{tō}-\mathrm{skē}-\mathrm{di}-\mathrm{as}$ 'ti - kal), $a$ Same as autoschediastic. Dean Martin. autoschediaze (â-tō-ske' $\bar{e}^{\prime} \mathrm{d}-\bar{a} z$ ), $v$. $i . ;$ pret. and pp. autoschediazcd, ppr. autoschediazing. [ $<\mathrm{Gr}$.

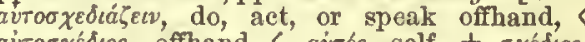

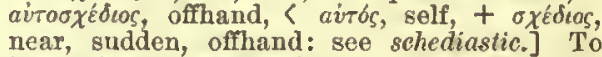
improvise or extemporize.

autoscope ( $\hat{\mathrm{a}}^{\prime}$ tō-skōp), n. [<Gr. airbs, self, +

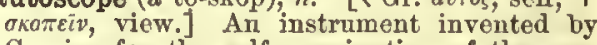
Coceius for the self-examination of the eye. Syd. Soc. $L c x$.

autoscopy (â-tos'kō-pi), n. [< Gr. airbs, self, $+-\sigma \kappa о \pi i a,<$ бкотвiv, view.] In med., the ex-
amination of one's self, as by the autoscope or the antolaryngoseope.

utositarius (ấ $(-\bar{i})$. [NL., as autosite, q. v., + -arius.] In teratol., either part of a double monster which is formed by the junction of two equally developed individuals, as by means of the umbilicus.

utosite ( $\hat{\mathrm{a}}^{\prime}$ tō-sīt), n. $\quad[<\mathrm{Gr}$. aúrócatros, bringing one's own provisions, < airbs, self, + airos, food.] In teratol., that twin in an unequal donble monster which furnishes nutriment to the other, the latter being ealled the parasite or parasitic tucin.

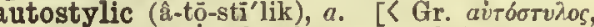
resting on natural columis, < aviós, self, +
orṽnos, column: see style 2 .] In anat., having 
no separate suspensorium or distinct suspensory apparatus of the lewer jaw.

An autogtylic skull, that is, a skull without separate
Bncyc. Brit., XIl. 646 . The oldest representatives of the sclachlan order had meither hyostylic nor an

$$
\text { A. S. Woulucard, I'roe. Zoobl. Soc., 3886, 1. 211) }
$$

autotemna, $n$. Plural of autotemnon.

autotemnic (Â-tō-tem'nik), a. [<autotemnon + -ic.] Same as intolemnous. Ilyalt.

autotemnon (â-tō-tem'nou), n.; pl. antotenna (-nii). [NL irreg. (better" "antotomon) < Gr. aitós, self + réuueiv, taueiv, ent.] In biol. cell considererl as an organism eapable of self division. [Rare.]

We caunot nse the woris enilryo and larva, which be propose to diesignate the cell as an autotemnon, in contras IIhyo, whicls is more specialized.
Ilyat, I'roc. Isost. Soo. Nat. Hist., 18s4, p. 143. autotemnous (â-tō-tem'nus), a. [Irreg. < Gr.

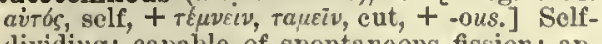
clividing; capable of spontaneons fission: ap itself by fission and not by impregnation. Commen tissue-cells of all kinds are autotemnons, as are spernatocysts and spermatozoa, and also ova that divide before the union of male and fernale nuclei. Division pratozonts are antotemnous while growing hy fisson, but ure embryos or form-spores therealter. Also aututennic. very God, sairós, self, + Oés, God.] 1. The doctrine of the self-existence of God; specifieally, the ascription of self-existence to the second person of the Trinity. [IRare.]-2. Assumption of divine powers; self-deifieation excessive self-esteem. Ninetcenth Century.

autotheist ( $\hat{a}^{\prime}$ tō-the-ist), n. [< autothe-isin + $\left.-i s t_{.}\right] 1$. One who believes in antotheism. - 2 . One who ascribes
divine powers.

IIe begins to mistake more and more the voice of that very tlesh of his, which he fancles he has cenquered, for autotheist. autotomic (â-tọ-tom'ik), a. [<Gr. aỉós, self,

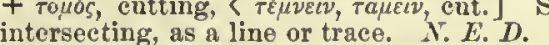

intersecting, as a line or trace. Tíros, a stamp, type.] 1. The trade-name of a certain photographic process for producing permanent prints in a carbon pigment. It is much ture made by this process. - 3. A copy; a re production in facsimile. Kingsley.

autotype (ấtọ-tip), v. t.; pret. and pp. autotyped, ppr. autotyping. [< autolypc, n.] To
reproduce by means of the autotype process, reproduce by

autotyplc (â-tọ-tip'ik), a. Pertaining to an autotype, or produced by the antotype process. avtós, selt, + typography.] Any process by means of which drawings, manuseripts, ete., can be transferred directly to a plate or inaterial from which impressions can be taken; especially, a process by which antographs executed in a special ink are transferred to a plate of
zine, which is then etched and prepared for printing on an ordinary press. See zincography. autrefois, adv. See auterfoits.

autumn (ấtum), n. [Early mod. E. also autome, $<\mathrm{ME}$. autumpne, $\mathrm{OFF}$. outompne, mod. F. automne $=\mathrm{Sp}$. otono $=\mathrm{Pg}$. outono $=\mathrm{It}$. autunno, < I. antumnus, less correctly auctumnus, autumn, perhaps related to accre, be well, Skt. $\sqrt{ } a v$, satisfy' one's self. The old derivation from augerc, inerease, is not now aceepted.] 1. The third season of the year, or the season as being the time of the falling of the leaves. Astronomically it begins at the autuminal equinox, abont the $22 \mathrm{~d}$ of September, when the sun enters Libra, and ends st the winter solstice, about the 21st of December, when the sum enters Capricorn. In popular language autumn is regarded in North America as comprising September, October, and November, but in Great Britain, Augusi, SepFiguratively -2. A period of maturity, or of incipient decay, abatement, or decline: as, the autumn of life.

Di: Preston was now entering linto the autumn of the
duke's lavour.
Fuller.

autumnal (â-tum'ngl), a. and $n$. $\quad[<\mathrm{L}$. autumnalis, auctumnalis, <autumnus: see autumn and -al.] I. a. 1. Belonging to autumn; produced or gathered in autumn: as, autumnal fruits.

'The little stunted hushes, on the snow-streaked slopes, were sil dyed with autumnal purples and erimsons.
II. James, Jr., Trsns. Sketches, p. 249.
Figuratively - 2. Belonging to a period corresponding to autumn in tile year; hence, past the middle stage of life: as, "an cutumnal matron," Inothorne. - Autumnal equinox, the time winent the sun crosses the ertnator as lie proceeds south-
warl. This happens aloont the $22 \mathrm{~d}$ of September. See quinox.-Autumnal plumage, in ornith, the piumsuse che lird leaves the nest is exchanged fur another; th plunage of an annotine; also, that sulsequently accuined ach autumin by such biris as molt at that yeason 28 wel as in spring, or have what is termed the double molt.-
Autumnal signs, the slgris Lihra, Scorpio, and sagit-
tarius, through which the sun passes during the autumn, ically cousidered.

II. n. $\Lambda$ plant that flowers in autumu. autumn-bells ( $\hat{\Omega}^{\prime}$ tum-belz), $n$. A name given to a Furopean gentian, Gentiane I'neumonanthe,
from its bell-shaped flowers and their season of opening.

autumnian (â-tum'ni-gn ), a. [< autumn + -inn.] Antumnal. [Rare.

\section{Jlethinks already
I grasp best part of the autumnian blessing.} Muldleton, Michaelmas Term, Ind.

autumnity (Â-tum'ni-ti), n. [< L. autummitas, the seasen of autumn, harvest, < autummus, antumn.] The season of antumn; quality or
dition characteristic of autumn. [Iare.]

Draughts of sweet autumnity. Bp. IIall, satires, lii. 1. atunite ( $\hat{a}^{\prime}$ tun-it), n. [< Autun, \& city in Burgundy, France, $+-i t c^{2}$.] A native hydrous phosphate of uranium and calcium, occurring in tabular erystals, nearly square in form, and of a citron or sulphur-yellow eolor. It is usually found with other uranium minerals, often as a result of the decomposition of uraninite or pitch-blende. It is
closely relsted to the phosphate of uranium and copper corbernite or copper uranite, in distinction from which is called lime uranite, and also simply uranite. aturgy (â'tèr-ji), n. [< Gr, avтoupyia, < airos, self, + eprov, work. Cf. chirurgeon.] Wor
with one's own hands; self-action. [Rare.] Auvergnat (F. pron. $\overline{0}$-vār-nyä'), $n_{\text {. }}[\mathbf{F} .,<$ Aucergne.] 1. A native or an inhabitant of part of France, nearly corresponding to the modern departments of Cantal and Puy-deDôme.-2. A French wine of a deep-red color, made near Orleans: so called from the name made near Orleans: so

auxt, n. See augc.

uxanometer (ấk-sa-nom'e-têr), n. [Irreg. Gr. aígávetv, grow, f $\mu \dot{\varepsilon}$ rov, measure.] An inrecording, the growth of plants. In the are auxa. nometer this is dene with the aid of an index moving ove a vertical arc of a circle.

Auxerre $\left(\overline{0}-z \bar{a} \mathbf{r}^{\prime}\right), n$. [F.] A general name near the city of Auxcrre, in the department of Yonne.

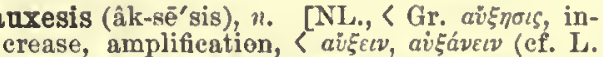

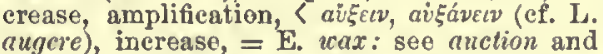
wax 1.] 1. In rhet., amplification; exaggeration; hyperbole; the use of a more unusual proper word.-2. In matl., the ratio in which the element of a figure has to be magnified to the element of a figure has to be magnified to of a conformable figure.

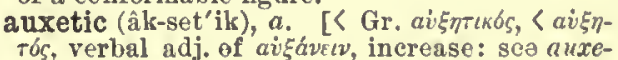
sis.] Pertaining to auxesis; amplifying; increasing.

Dr.

uxetically (âk-set'i-kal-i), adv. By or amplification.

auxiliant (âg-zil'iant), a. [< L. anxilian(t-)s,

ppr. of auxiliari, help: see auxiliate.

anxiliar (âg-zil'iă̊r), $a$. and $n$. [ [L. auxiliaris helping, aiding, $<$ auxilium, help, aid, < auger increase.] I. a. Helping; auxiliary.

Ostorius, though yet not strengthen'd with his Legions causes the auxiliar Bands, his T'roops also allighting, to There Athens sat, as In the foretime, on her citadel rock, in sighi of her auxiliar sea, crowned, garlsnded,
wanton. Choate, Adldresses, p. 180 . II. $n$. An auxiliary: usually in the plural, auxiliary troops.

My auxiliars and allies. Sir II, Taylor, Ph. vsn Art., II., v. Mighty were the auxiliars which then stood Upon our side, we who were streng in love Bliss was it in that dswn to be alli

Wordsworth, French Revolution.

[Arehaic in both uses.] uxiliarly (âg-zil'iłị-li), udk. By means of aid uxiliary (âg-zil iặ-ri), a. and $n$. [<L. auxiiuritu, equiv. to auxiliaris, lelping: see auxil$a r$.$] I. a$. Ilelping; aiding; assisting; giving support or suceor; lienee, subsidiary; additional: as, auxiliary troops; auxiliary engines. - Auxlliary blshop, auxdliary buffer-8pring, auxilconic section, 8 circle laving its center at the center a conic, wilich it tuuches at the extremities of the quanverse dlaneter. - Auxdliary quantity, in math., a as may ho done in eynations or irigonometry. - Auxdliary scales, in music, the slx keys or scules, consist fug of any key najor, with its relative minor, and the gttendant keys of esch. - Auxdliary serew. Seo screw.- Auxdliary verb a vert., $\$$.

II. $n_{;}$; p]. anxiliaries (-riz). [ $\quad$ L. auxiliarius, 11.] 1. A helper; un assistant; a confederate in some action, enterprise, or undertaking; an aid of any kind.

Aquatiut is seldom practiced by itselt; it is rather an Specifieally-2. pl. Foreign troops in the service of a nation at war.

The Fleisns often engaged as auxiliaries in the wars of ther states, on pretence of asserting tine cause of religion.

3. In gram., a verb used in forming, with the infinitive and participles of other verbs, plirases having the valuo of, or a value analogons to that of, modes and tenses: thus, I do love, I have loved, I shall love, I am loved.-4. In math., an auxiliary quantity (which see, under I.).

uxiliatet (âg-zil'iät), $t \cdot t$. [< L. anxiliatus, pp. of muxiliari, help, < auxilium, help: see auxiliar.] To aid or assist.

He [Day] then fell into s disputation with Cranmer and
Goodrich, in which he repeatedi his former Scripture, and $R$. IV. Dixon, Ilist. Church of Tng., xvil. auxiliatorył (âg-zil'iā-tō-ri), $a$. and $n$. [< $[$. as if "auxiliatorius, $<$ auxilintor, a helper, < I. $a$. Helping; aiding; auxiliary.

$$
\text { Masses both auxiliatory sni expiatory. }
$$

II $n$ A help ; an aid; in the plureal, aud

There were no such auxiliatories within the walls.
B. Watson, Ilist. Philip 11. auxometer (ak-som'e-tèr), n. [Irreg. < Gr. aü $\varepsilon v v$, increase, $+\mu \varepsilon t \rho o v$, measure. Cf, auxa-
nometer.] An instrument for measuring the magnifying powers of an optical instrument. auxospore (âk' sō-spōr), n. [Irreg. 〈 Gr. ai $\varepsilon \varepsilon v$, grow, + $\sigma \pi \sigma \rho \circ$, seed, offspring.] In the Diatoasexually, by the growth of the protoplasm attended by renewal of the silicious envelop, or sexually, by the union of the contents of two eparate cells.

uxotonic (âk-sō-ton'ik), a. [Irreg. $\langle\mathrm{Gr}, a \ddot{\xi} \xi \varepsilon c \nu$, grow, + roves, tension, tone. in bot. Determined by plants which are the result of growth, in distinction from those of matured organs influencer by stimulation. See allassotonic.

चa ${ }^{1}$ (ä'vă), n. [Also called lava, kace; a native name.] A fermeuted drink used in the
South Sea islands, made from the roots of the Piper methysticunt. See kara.

$\operatorname{ava}^{2}\left(a^{\prime} v a ̈\right), n$. A name of the topaz hummingbird, Topaza pella.

ava' (a-vấ $)$, adv. Seoteh for of $a^{\prime}$, that is, of all, frequently used in the sense of at all.

avadavat (av"a-da-vat'), $n$. Same as amaln-

vat.
lemur, or long-tailed indri, of Madagascar, Atohis laniger; the ampongue.

Avahis (av'ag-his), $n$. [NL., < arahi.] A genus woolly lemnr of Madagasear, A. laniger: a synwony of Microrhynchus (which see).

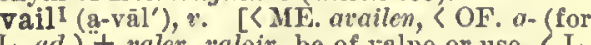
L. ad-) + valer, valoir, be of valne or use, $\mathrm{L}_{\text {. }}$. I. intrans. 1. To have value or use; be of service or advantage; give profit: as, wealth avails little to a castaway.

The effectual fervent prayer of a righteous man a raileth

2. To have force or efficacy; serve for a purpese; give aid toward an end: as, his eries availed to bring relief.

The thing to be taught hss a nailed to obscure or evel to annililiate for their eyes every anxiely as to the mode
of tesching.
De Quincey. Style, i. 
3t. To take or draw advantage; make use or availment (a-väl'ment), $u_{0} \quad[<$ axaill, v., + vance, alvantage, ete. $]$ A prefix of French oriprofit.

availment (a-väl'ment), $n$ [ [ araill, v., +
-ment.] Profit; efficacy; successful issue. Bailey. [Rare.]

But how out of this can ahe avail Shak, M. for M., Ili. 1.

II. trans. 1. To be for the advantage of assist or profit:

Yet all this availeth me nothing.

Esther v. 13.

Ali the songs and newspapers and money-snbscription and vituperations of such as do not think with us, wil

"God save ns!" cried the captsin,

li"hittier, The Jantle of St. Johu De 3latha

2t. To promote; prosper; assist: said of things. Ileantime he voyaged to explore the will of Jove on high Dodona a holy hill,

3. To advantage; profit; give the benefit to: used reflexively, with of: as, he availed himself of the opportunity. [Often used colloquially

without the pronoun.

Then shall they aeek $\mathrm{t}$ ' avail themselves of names,
Places and tities.
Milton, F. L., xii. 515.

The theatre asails itself of the best talent of poet, of The theatre a wails itself of the best talent of poet,
painter, and of amateur of taste, to make the ensemble of
Energon, Misc.,

To avail one's self byt, to avall one'a self of.

And my peculiar profit persusded me, sometimes, to
Sanford.

avail ${ }^{1}$ (a-vāl'), n. [< ME. availe, < availen: see avail, v.] 1. Advantage, profit, or benefit, in a general sense; also,

The aunil or a desthod Thy pardon; I but speak for thine avail. apeak for thine avail.

2. Efficacy for a purpose; advantage to an object or end: now used chiefly in negative phrases, or sentences of negative import: as, of little or no avail; I doubt whether it will be of much avail.

But Cranstoun's lance, of more avail,

Pierced through, like siik, the Borierer's msil

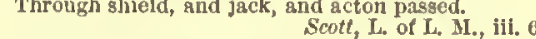

3. $p l$. Profits or proceeds: as, the avails of a sale by auction.-Avail of marriage, in Seots law, a sum payable to the auperior by the heir of a deceased ward-vassal on his becoming marriagea
2. Use, utility, service.-3. Returns

avail ${ }^{2}+, v$ See avale.

availability (a-vā-la-bil'i-ti), n. [< available see -bility.] "The state of being available; suitableness for the accomplishment of a given purpose; capability of advantageous use or for office, or of a proposed method.

available (a-vā'la-b]), a. [< ME. araylable; avail $1+-a \ddot{b l e .}$ ] 1. Profitable; advantageous having efficacy.

Those who will consult him [Fourier] for no other res

son, might do so to see how the energies of Wonin may lable in the pecuniary way.

2. Having sufficient power, force, or efficacy for the object; valid.

Laws human are available by consent. Hooker.

She knows no commendation is more available with

3. B. Jonson, Cynthia'a Revela, v. 3. Capable of being used or employed with disposal: as, his resources were not available disposal: as,
at the time.

The whole army is called 700,000 men, but of these only
80,000 can be reckoned available. 80,000 can be reckoned available. Brougham. We do not choose our own candidate, no, nor any other
man's first choice, - but only the a vailable candidate

Advailable is a rare and obsolete form.

availableness (a-vī'la-bl-nes), n. 1. The state of being available; capability of being used;

[Rare.]

The efflcacy, or availableness, ... or suitableneas of Sir $\boldsymbol{M}$. Ifale, Orig. of Mankind, p. 225.

2. Competent power; legal force; validity as, the availableness of a title.

availably (a-va'la bli), adv. In an available manner; so as to be used with efficacy; profitably; advantageously; validly; efficaciously. manner ; successfully.

It [the Bible] is worahipped with a positive idolatry, in pleada availingly with the man of letters and the besity Faber, in Dublin Rev.. June, 1853 . aval1 ( $\bar{a}^{\prime}$ val), a. [< L. avus, grandfather, + al.] Relating to grandparents.

The rare opportunities of anthentic verification of spe-
cial parcntsi or a val recollections.
Science, III. 345 .

aval' ${ }^{2}\left(a-\mathrm{val}^{\prime}\right), n$. [F., an indorsement, guaranty, < $\dot{a} v a l$, at the bottom: see arale.] In promissory note.

avalanche (av'á-lánch), n. [< F. avalanche (also atalange), "dial. form (Swiss etalanche) of *avalance (ML. avalantia), lit. descent, < avaler, let fall down: see avale and -ance.] 1. The fall or sliding down of a mass of snow or ice from a mountain-slope. The sllding down of ordiuary snow is, in high snow-covered nountsins, al cvent of frequent occurrence, and is generally not dangerons or destructive, since it miostly takes place high above habitatious and foreste. Partly consolidated snow, op névé, however, is sometimes set in motiou in large quantities, and such an occurrence may be productive of very serious injury, especially to the forests below. Snali gla and fail into the valley below; such events sre sare, but have sometimes been attended by very disastrous results. The more terrible catastrophes which have occurred, snd by which, eapecislly th the Alps, whole villages have been
buried, have been due to the allding down of a portion of the rock itself of which the mountain was formed. Thes "rock-svalanches," as they are sometimes calied, are more slip, land-siule.

Around his [Sont Blanc's] waist are forests braced, The avalanche in his hand;

Tre pain, that in

Hence - 2. Anything resembling an avalanche in suddenness and destructiveness: as, an avaanche of misfortunes.

avale (a-vāl') $^{\prime}$, . [<ME. avalen, auvalen, < OF avaler, avaller $(=\mathrm{Pr}$. avalar $=\mathrm{OIt}$. avallare $)$ come down, let down, $<a$ val, downward, < I ad vallem, lit. to the valley : $a d$, to; rallem, ace. of valles, valley, valo: see vale. Cf. anount, L. ad montem, to the hill ; down, adown, < AS. down; fall.

$$
\text { A iayn from hevene gan avale. }
$$

They ... from their sweaty Coursers did abale.

II. trans. 1. To lower; uncover; take off, as a vizor or hood. Chaueer.

IIadid men were cleped thanne the Lolardis, that woid Capgrave's Chron., D. 245, an, 1387. Quoted in $G_{.}$.

2. To let down; lower, as a sail; cause to descend: as, "hath his saile avaled," Gover, Conf. Amant., viii.

$$
\begin{gathered}
\text { By that, the welked Pholus gan availe } \\
\text { His weary wine. Spenser, Shep. } \\
\text { Thou seest my lowly saile, } \\
\text { That frowsrd fortune doth ever availe. }
\end{gathered}
$$
Spenser, Shep. Cs]., Sept.

3. To make low or abject; depress; degrade. avalite (av'a-līt), n. [< Avala (see def.) + -ite ${ }^{2}$. A silicate containing chromium, occurring in emerald-green scales at the mercury-mines of Mount Avala, near Belgrade.

Avallon (a-va-lôn'), n. [F.] A French wine of good quality, named from the town of Avallon in the department of Yonne. There are aev. eral varieties, named locally from the various vineyards.
These wines are free from sweetness, and are often sold ander the nsme of Chablis. ${ }^{1} t, v$. A Middle English form of advance. avance $2 t, n$. Obsolete form of avens.

avaneh (a-vä'ne), n. A light scarf or sash, generally of silk, worn in Asia Minor and Syria as a girdle, or twisted around the tarboosh to form the turban.

avania (a-va',ni-ing), n. [Formerly also avarria, <NGr. áßavia, Turk. Ar. awām, also awāri, also 'awān, 'awānia; origin uncertain.] An imposilence" (Marsh); specifically (as applied by Christians), an extortionate exaction or tax levied by the Turks. N.E.D.

avanious (a-va'ni-us), a. [< avania + ous.] Extortionate.

avant† (a-vänt'), n. [Abbr. of avant-garde, q. $\nabla$.$] The front of an army; the van.$

avant- $[<\mathrm{F}$. avant $=\mathrm{Pr}$. avant $=$ It. avante, avanti, before, < LL. abante, i. e., ab ante, from before: see $a b$ - and ante-, and cf. avaunt 1 , adCanada, an act of suretyship or guaranty on a

\section{To descend; dismount.} avaria, also aveny, $<\mathrm{F}$. avanie $=\mathrm{It} . \mathrm{Pg}$. avania tax; government exaction: "aid, "benero gin, meaning before, fore. Also shortened to vant-, van-.

avantaget, $n$. A Middle English form of ac vantage.

avant-bras (a-ron'brä), n. A piece of platearmor, generally ealled in English vambrace (which see). See brassart.

avant-courier (a-vïnt'kö"ri-ér; often, as F., a-von'kö-riā'), $n_{\text {. }}$ [Formerly atant-courrier, -currier, -coureur, $\mathbf{F}$. acant-coureur, acant-courrier, m. (cf. avant-courriere, f.), < avant, before, + courcur, courrier, conrier: see courier.] 1. One despatched in advanee to give notice of tho approach of another or others. - 2†. $p l$. The scouts, skimmishers, or advance-guard of an army. $N . E, I$.

avanterst, n. pl. [ME., also arancers, < OF. avant, before: see avant-.] Portions of th numbles of a deer which lie near the neck. Ryuez hit vp radly, rizt to the byzt, Voydez out the a-vanters, \& verayly ther-afte Sir Gauayne and the Green Knight (E. E. T. S.), I. 1342. Then iresse the 11omhles, fyrste that ye recke, Boke of $S t$ th to the neck.

vant-fossé (a-von' fos- $\bar{a}^{\prime}$ ), n. [F., < avant, before, + fosse, a ditch: see fosse.] "In fort., the ditch of the counterscarp next to the country, dug at the foot of the glacis. Wilhelm, Mil. Dict. avant-gardet (a-vänt'gärd; F' pron. a-von' gärd), n. [< F.avant-garde, < avant, before, + garde, guard: see vangilard.] Advance-guard. vantplat (a-von'plä), $n$. Same as vamplate. vanturin, avanturine (a-van'tụ̂-rin), $n$. and a. See avcnturit.

avarice (av'a-ris), n. [< ME. avarice, < OF avarice (F. arariee), < L. avaritia, < acarus, wish, desire.] An inordinate desire of gaining and possessing wealth; covetousness; cupidity; greediness, or insatiable desire of gain. So for a good eld gentlemsnly vice I think I must take up with avarice. Byron, Don Juan, i. 210

= Syn. A varice, Covetousness, Cupidity, penuriousness, of the natural inatinct of possession. A varice, literally come limited, except in figno only a sordid and mastering dealre to get wealth. Covet. ousness and cupridity are not limited to wealth, but may have for their olject anything that can be deaired, cupidity being directed especisliy toward material things. Covet. lience the prohibition in the tenth commandment (Ex. Xx. I7). Cupidity is more active than the others, less grovel covetousness may wish for without trying to get. See pe-

In my most ill-compoa'd affection, such

A atanchless avarice, that, were I king,

I should cut off the noblea for their lands.

I would not have you to think that my deaire of having When covetousness. When this continent was first discovered, it became an
oljject of cupidity to the smbition of many of the nations olyject of cupidity to the ambition of many of the nations
of Europe.
Story, Speech, Ssien, Sept. 18, 1828.

avaricious (av-a-rish'us), a. [<ME.avaricious <F.ataricieux, < avarice. Cf. avarous.] Characterized by avarice; greedy of gain; immoderately desirous of accumulating property; eager to acquire or possess. Luxurious, avaricious, false, deceitful.

scheth, iv. 3. Liberal of everything e]se, he [Walpole] was a varicious
Macaulay, Horace Walpole.

avariciously (av-a-rish'us-li), adv. In an avaricious manner; with inordinate desire of gaining wealth; covetously.

Each is contented with his own possessions, nor avariciously endeavonrs to heap up more than ta necessary for
his own subsistence.
Goldsmith, Essay, xvi.

variciousness (av-a -rish'us-nes), n. The quality of being avaricious; insatiable or inorvaroust, $a$. [ME, avarous, averous, < OF averos, avcrus (extended form as if $<$ aver, possession: see aver 2 ); ef. aver, avar, mod. $\mathbf{F}$. avare, (L. avarus, greedy: see avarice.] Covetous; avaricious: as, "the erle avarous," Piers Plowman.

vast (a-väst'), interj. [Prob. (D. hou' vast, houd väst $=$ E. hold fast, i. e., hold on, wait a while. Cf. D. houvast = E. holdfast, a erampiron.] Naut., stop! hold! cease! stay! [Sometimes used colloquially.]

Avast hailing! Don't you know me, mother Partlett? 
avast

Avast heaving (naut.), the cry to arrest the capstan curs in lieaving the cable.

avatar (av-g-tär' or av'a-tiir), n. [<Skt.avatära descent, <äa, down, $+\sqrt{ }$ tar, eross over, pass througl.] 1. In Hindu myth., the descent of a deity to tho earth in an incarnato form or somo manifest shape; tho incarnation of a god.

Threo of the Avaturas or incaruations of Vishuu are connected with a rleiuge, ... Vishnis in each case regeuing
manktad fron destriction by water.
Ifax Müller, India, 1. 144. Hence-2. A remarkable appearanee, manifestation, or embodiment of any kind; a de-
seent into a lower sphere; an adorablo or wonderful exhibition of an abstraet idea, prineiplo ete., in eonerete form: as, "The Irish "ratar" (a poem by Byron oll a visit of Feorne IV. to Ireland); "the aratur of mathematics," Musson, Milton, 1. 226. [Carjyle is] the lwost shining avatar of wlifm the world
has ever seen.

avatara (av-?-tii'riin), n. Same as avatar.

avauncet, $n$. An obsoleto form of advance.

avaunt' (a-vänt' or -vânt'), all'. and interj. [HL < OF avanl, forward, LI. abonte, lit. from bofore: see avant-.] I.t adv. Forward. And with that word came Irede avaunt. Rome of the Rose, 1. 3958

II. interj. Away! begone! depart! an exclamation of contempt or abhorrence.

Avarnt, thou hateful villain, get thee gone

avaunt It, n. [< avaunt ${ }^{1}$, interj.] Dismissal.

To give her the avaunt? It ls a pity

Shak, IIen. Vul., it.

avaunt $2+, v, i$. [A modifieation of avancel $=$ advance, due to influence of avaunt $\left.{ }^{1}, a d v.\right]$ To advanee.

A vaunting in great bravery. Spenzer, F, Q., II. lii. 6.

avaunt ${ }^{3}$, $v$. [ME. ataunten, avanten, < OF acanter, avaunter, $<a-+$ vanter, vaunter, vaunt: see vaunt, $v$.] I. trans. To praise highly; vaunt; make renowned.

$$
\text { Do you favour you to awounte. }
$$

II intrans. or reflexire. To boast; brag; speak or express vauntingly.

"Thanne," quod she, "I dar me wel avaunte, Let now the papists atcunt themseloes !

Cranmer, Ans, to Gardiner, p. 333

$\operatorname{avaunt}^{3} \mathrm{t}, n$. [ME. aveunt; < avaunt ${ }^{3}, v$.] A boast; a vaunt.- To make avaunt, to assert con avauntancet, $n$. [ME., < avaunten: see avaunt ${ }^{3}$ $v$., and -ance. Cf. OF. vantance, < vanter, vaunt. Boasting.

avaunter $t$, avauntour $\nmid, n$. [< ME. avauntour, avaunter, $\mathrm{OF}$ avantour, -eor, < avanter: $\mathrm{se}$ avaunt $\left.{ }^{3}, v.\right]$ i boaster.

He is not nyce
Chaucer, Trollus, ill. 724.

avauntryt, n. [ME., also avauntaric, $<\mathrm{OF}$ *avanterie, found only as vanterie: see avaunt3 $v$.] Same as avauntance.

avdp. An abbreviation of avoirclupois.

ave (ă'vë or ä've), interj. [I., haill orig. impv.

of averc, be well, be of good cheer; esp. in LT. phrase Ave Maria, hail Mary! in allusion to Hail! Also, farewell!

$$
\text { "And "Ave, Ave, Ave" said, }
$$

$$
\text { Tennyzon, In MLemorlam, Ivil. }
$$

Ave Maria, the Hail Mary, a devotion or prayer used in the Westerm Church. In the older form it consists of the salntation of the angel Gabriel to the Virgin Mary
when he announced to her the fucarnation (Luke 1. 28) togetier wlth the words of Elizabeth to Mlary (Luke l. 42 . Thla form of the Hail Mary was used as an anthem in both century. It came into wide noe as a devotion in the elevent century. It came into wide neas a "Holy MIary, Mother dod, pray for as, "etc., were first iatroduced in the fitteent centiry, and first authorized for dally use in the brcviary

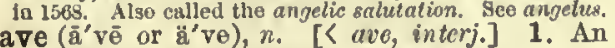
Ave Maria (whieh soe, under ave, interj.).

Nine hundred Pater nosters every day,

Spenser, F. Q., I. Ili. I3
S

\section{A salutation.}

Their loud applause and aves rehement.

Shak., M. for Mr., L. I.

avel (av'el), n. [E. dial., appar. due to a confusion of ME. avene (Prompt. Parv.), for acene, awn (cf. Dan. arne, awn), with E. dial. ail2, ME. aile, eile, <AS. egl, awn, beard of grain. dit? and awn are from the same root, differing only in the suftix.] The awn or beard of barley. veler (av'el-ér), $n$. A maehino for renioving the avels or awns of barley from the grain; ummeler. K. II. Knight.

velingest, auv. [Liarly mod. F., < avclong + adv, geu. suffix -es, the term. being assimilated to -lings, $q_{\text {. }} v_{\text {. }}$ ] In an oblong or oval sliape. avell (a-ve $\left.]^{\prime}\right)$, v. $t_{\text {. }}\left[\left\langle\mathrm{I}_{4}\right.\right.$. avellere, pull away, $<a b$, away, + vellere, pluck, tear.] To pull way. Sir T. Brounc.

vellan, a. See avellane. lanus: see avellane.] Relating to tho filbert. avellane, avellan (a-vel'ān, -an, or av'el-ān, -an), $a$. [< OF. atchane, L L. Arellana (se. nux, nut), earlier Abellaw, the fil. bert, lit. the nut of Avella, Abella, a town in Campania abounding in fruit-trees and nuts, now Avella. Cr. apple.] In ler resembling a filbert: In her., resembling a noert: specifically said of a eross each of whoso arms resembles the sometimes blazoned as four

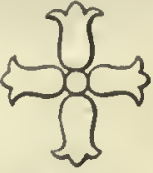

erts coujoined in cross.

velongt, a. [E. dial. welang, oval, < ME. atelonge, awelonge, < Icel, aflangr $=\mathrm{Sw}$. aflang $=$ Dan. aflang (the prefix being assimilated to af $=$ E. off), < L. oblongus, oblong: see oblong. Oblong or oval; drawn out of a square or circle. Ave-Marył ( $\bar{a}^{\prime}$ 'vē-mā"ri), $n$. Same
Maria (whieh sce, under ave, interj.). lie told of Salntes and Popea, and evermor Spenser, F. Q., I. I. 35 I could never hear the Ave-Mary bell without an eleva.
tion, or think it a anfficlent warrant because they errei in one circumstance for

Sir T. Browne, Religio Mredicl, I. \& 3

Avena (a-vē'nä), n. [L., 0ats.] A genus of plants, natural order Graminea, oharaeterized by having large membranous onter glumes, which inelose two or three perfeet flowers, back with a long, bent, and twisted awn on the back of the lower palet. The species are natives of
temperate and cold regions. Some are usefnl pasturegrasses, but by far the most important apecies is $A$. sativa the cultivated oat. See oat.

avenaceous (av-ē-nā'shius), a. [< L. areno ceus $<$ avena bling oats.

avenage (av'ē-nāj), n. [<OF, avenage, <avene, oats, < I. avena, oats.] In old lav, a certain quantity of oats paid by a tenant to a landlor in lieu of rent or other duty.

avenarył (av'è-nā-ri), n. [< L. avenarius, avena, oats.] Same as avener.

avenauntt, a. [ME., also avenant, avenand, ete., < OF. (and mod. F.) avenant, comely, eonvenient, ppr. of avenir, come, suit, become, nient, eomely, and becoming.] 1. Beeoming well-looking.

Clere browne ghe was, and thereto bright

2. Convenient; suitable.

Dyghttes his dowblettez for dukes and erles, Morte Arthure (ed. Perry, E. E. T. S.), 1. 2627. avener (av'ē-nèr), n. [ME. avener, avenere, OF. avenier, < L. avenarius: see avenary.] In
feudal law, a ehief offieer of the stable, whose duty it was to provide oats. Also spelled ave nor.

avenge (a-venj'), $v$; pret. and pp. avenged ppr. avenging. [<ME. avengen, < OF. avengier, $a-\left(<L_{0} a d\right.$, to + vengier, revenge, take vensee vindicate, and ef. revenge and exngence.] I. trans. 1. To vindieato by inflicting pain o evil on the wrong-doer; exeeute justice or vengeance on behalf of: with a person as object. Avenge me of mine adversar Luke xvili. A venge, 0 Lord, thy alaighter'd saints, whose bones
Lie acatter'd on the Aiplne mountains cold.

2. To take satisfaction for by pain or punishment inflicted on the injuring party; deal punishment on account of: with a thing as object. He will avenge the blood of his servants.

$$
\begin{aligned}
& \text { Never, till Cresar'a three-aod-thirty wounds } \\
& \text { Be well aveng'd. }
\end{aligned}
$$

I thought ten thonsand swords must have leaped from thelr acabbarda to avenge even a look that threatened her
wlth lnsult. But the age of chivalry ls gone.
Burke, Rev. in France.
$3 \nmid$. To take revenge on ; treat or deal with regefully.

It Cain silali be avenged sevenfold, truly Lamech geven$=$ Syn. Arenge, Revenge. Until lately these words were (ivns under onch . to tile infliction of patin or evif to gratify resentful feclings, or the deaire of retaliation for seme real or fancled wrons poctic use sometimes returos to the earifer freelom In the 1 will avenge this insult, noble Qucen. If you polaon us, do we not die? and if you wrong us,
Shake, Xi. of V., iil. I.

II. intrans. To execute vengeance; infliet retaliatory pain or injury on a wrong-doer.

Thou shalt not a renge nor bear any grudge against the The avenging horror of a conscluns mind,

And seca no end of punislment and woe.

arenget (a-venj'), n. [< arenge, $]$ 1. Tevengo; retaliation.

$$
\text { T'hat avenge by you decreed. }
$$

penser, F. Q., IV. vi. s

2. Punishment; vongeanco takeu.

Why doth mine hand from thlne arenge abstaine? [<avenge +-ance

avengeancet (â-ven'jans), $n$. [ [avenge + -ance, after vengeance.] The act of avenging; venips, Cyder, ii. 49 .

avengeful (ạ-venj'fủl), $a . \quad\left[<\right.$ avenge, $n_{.},+$-ful, after revengeful.]

areangement (o-venj'ment), n. [K aucnge + -ment.] The aet of avenging; vengeance; punishment; satisfaction taken. [Rare.]

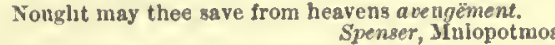

God's acengement of his repulse at II Iull.

venger (a-ven'jèr), n. One who avenges or kes vengeanee.

The Lord is the avenger of all such. $\quad 1$ Thes. $1 \mathrm{v} .6$. Brutns, thou salnt of the avenger's order.

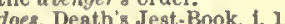

avengeress (a-ven'jèr-es), n. [<avenger + ess. $]$ A female avenger. [Rare.]

That cruell Queene avengeresse.
Spenser, F. Q., III. vili. 20.

aveniform (a-vē'ni-fôrm), a. [< L, arena, oats,

+ forma, form.] Resembling a grain of oats. Thomas, Med. Dict.

avenin (a-ve'́nin), n. [<L.avena, oats, + -in ${ }^{2}$. A nitrogenous proteid substance found in oats, legumin and gluten.

avenious (a-véni-us), $a$. Same as avenous. avenort, n. See arener.

avenous (a-vē'nus), a. [< Gr. a- priv. + I vena, vein.] In bot., wanting veins or nerves, as the leaves of certain plants. Also aveniaus. avens (av'enz), n. [' ME. avans, avance, ataunce, arence, MI. avancia, acencia, atantia, avens, harefoot; origin obscure.] The popugenus Geum. The common or yellow avens, or herb. bennet, is $G$. urbanum; the purple or water avens, $G$. aventaile, aventail (av'ẹn-tāl), n. [< ME. aventayle, < OF. estentail, air-hole, < estenter (mod. F. éventer), < L. cx, out, + ventus, wind.] In fap or adjustable part of the hood of mail, which when unfastened allowed the hood to drop upon the shoulders. (b) The movable front of the helmet. Aventine (av'en-tin), and $n$. [< L. Ärentinus.] I. a. Appellative of one of
the seven hills on whieh Rome was built. According to a iegend, it was called Mons

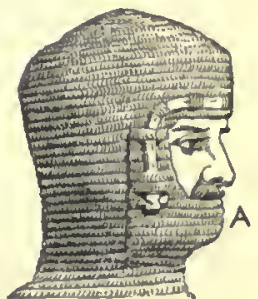

Aventaile (def, a) from an aborlginal king Aventinns who was buried there;
II. $n$. A post of defense or safety; seeurity; defense.

Into the castle' 5 tower,
That only A ventine that now is left us.

My strong A dentine is

That great Domltian. . . wlll once return, Massinger, Roman Actor, 1. l. 
aventre

aventret, $r$. t. $[<$ It. arentare, throw, shoot, dart, < a (< L. ad, to ) + vento, wind; ef. Pr.
ventar = OF. venter, cast to the wind: see vent.] To throw, as a spear or dart. IIer mortsli speare

She mightily a rentrell towards one,
And downe him smot. Spenser, F. Q., III. i. 28. aventuret, $u$. [The older form of adventure, q. v.] Adventure; chance; accident; specifically, in ald law, a mischance causing a person's death witho

aventurin, aventurine (a-ven'tū-riil), $n$. and a. [< F. aventurine, < It. aventurino, < avtentura, chance: see adventure, u.] I. n. 1. A sort of opaque golden-brown glass filled with specks or drops of a bright gold-eolor and of
different sizes, used, under the name of goldstone, for various ornaments. 1ts preparation wa stone, for various ornaments. Its preparation a dropping a quintity

2. A variety of feldspar, usually oligoclase, spangled with seales of hematite, göthite, or mica. It is often callod sunstone. The most highly prized variety is obtained in Russia. 3. A similar variety of quartz containing spangles of miea or other mineral. -4. A kind of sealing-wax, of a translucent browh color and abounding in gold specks or particles.-Chrome aventurin, a glass made hy freely adding chromste of potash to the other nater.

II. $a$. Having the appearance of aventurin as, aventurin laequer, etc.- Aventurin glaze, s glaze for porcelsin. It

Also written avanturin, avanturine.

aventuroust (a-ven'tūị-rus), $a$. Obsolete form of adventurous.

avenue (av'e-nū), n. [Formerly also advenue avenew, < $\mathrm{F}$." avenue, orig. pp. fem. of avenir, L. advenire, come to, < ad, to, + venire, come Cf. advene. 1 . A passage; a way or an openpassage by which a thing is or may be intropassage by which a thich
duced or approached.

Good guards were set up at sll the a rentees of the city
to keep sll people from going out. 2. A roadway of approach to a country-house, particularly when straight, of considerable side; a drive in a private country-place; walk in a garden or demain of some pretensions as to style or size.

A long avenue wound and crcled from the ontermost gate through an untrimmed woodland,
II. James, Jr., Pass, Piigrim, p. 45

3. A street; properly, a wide street planted with trees and often with turfed spacos on either side, or a garden or shaded promenad ete. in the names of the longest and general ete., in the names of the longest and generalAvenue, but in some American cities without special leference to the character of the street.
4. Figuratively, means of access or attainment.

There sre no aventes to the public service opened for aver ${ }^{1}$ (a-vér'), $v . t$; pret. and pp. averred, ppr. averring. [Early mod. E. also aterr, < I1 averren, $\mathrm{COF}$. averrer, averer, mod. F. avérer $=$
$\mathrm{Pr}$. averar $=\mathrm{It}$. avverare, $\mathrm{ML}$. adverare, make true, prove true, be true, <L. ad, to, +verus, true: see verify, verity, etc.] 1t. To assert the true.-3. To affirm with confidence; declare in a positive or peremptory manner.

And I aver that, to this day, I have done no offeial set in mere deference to my sbstract judgment and feeling
on slavery. 4. In law, to avouch or verify; offer to verify; allege as a fact. See averment. - 5. To assert
the existence of; offer in evidence. [Archaic.] Averring notes
of chamber-hangings, pictures, this her brscelet.

=Syn. 3. Affirm, Declare, etc. (see assert), say, sllege, pro$\operatorname{aver}^{2}$ (a'vẻr), u. [Se. aver, aiver (def. 3); ME. aver, avere, aveyr (later also avoir, havoir, havor, havour, after later OF.), ( $\mathrm{OF}$. aver, aveir, later avoir, mod. F. avoir = Sp. averes, haveres, pl., now haber, $=\dot{P}_{\mathrm{g}}$. haveres, pl., = It. avere (ML. averum, averium, avere, aver), substance, property, stock, lit. 'having,' being the noun use of the inf., OF. aver, aveir, ete., < L.
habere, have: see have. From its use as a col-
394

leetive sing. arose its nse in the plural, in the special scuse of stock, cattle, whence a new sing: (ML. averia, averius, as well as averum, averium), a beast
property; estate.

Marchaunt he was of gret avoir
Seujn Sages, 1. 2205, in Weber's Mletr. 2t. pl. Live stock; cattle; domestic animals.3. A beast of burden; a draft-ox or draft-
horse; an old horse. [North. Eng. and Seoteh.] An inch of a nag is worth a span of an aver.

II Ray, Proverbs (1678), p. 30 average ${ }^{1}$ (av' $\left._{\text {erạj }}\right), n . \quad[=$ Sc. avarage, contr. arrage, arage, now arriage, esp; in the combination arriage and carriage; < late ME. ave rage, earlier only in $\mathrm{ML}$. averagium or $\mathrm{OF}$. averuge, appar. the same, with suffix -age, as ML. acera, a kind of service mentioned in Domesday Book: nsually referred to acer, a beast doubtful, arera being more prob. a reflex, simulating aver, of OF. ovre, avre, mod. F. avvre, L. opera, work: see opera, ure ${ }^{2}$, mancuver.] In old law, a kind of service owed by tenants to their superior. The nature of the service is not elear. It is usually explsined as service done with beasts of bur den, but this

average ${ }^{2}\left(a v^{\prime}\right.$ erạj), n. and $a$. [Early mod. E.also averige, averidge, avaridge, $<$ late $\mathrm{IIE}$. average the same, with suffix -age (found only in E. an Anglo-I. averagium), as late ME. averays (for averys ?), ( F. avaris, "decay of wares or merchandise, leaking of wines, also the charges of the carriage or measuring thereon, also the fees or veils of a cook, etc." (Cotgrave), sing. prop. avaric $=$ Sp. areria $=$ Pg. It. avaria, in Mi $\mathrm{L}$. ava via, averia; ef. MD. avarij, D. haverij $=\mathrm{G}$. hafe rei, haverie $=$ Dan. havari $=\mathrm{Sw}$, haveri, from Rom. Origin disputed; the orig. sense, 'a duty on goods.' suggests a connection with MI. ave ria, goods, property: see $a v e{ }^{2}$. Perhaps avauia, through its appar. more orig. form avaria, is to be referred to the same source: see avania.] I. $x_{.}$. (at) A duty or tax upon goods. (b) A small charge payable by the shippers of good to the master of the ship, over and above the freight, for his care of the goods. Hence the clanse, in bills of lading, "paying so mueh (c) A small charge paid by the master on aceount of the ship and eargo, such as pilotage, towage, etc.: called more specifically petty average (d) A loss, or the sum paid on account of a loss (d) A loss, or the sum paid on account of a loss
(such as that of an anchor), when the general safety is not in question, and which falls on the owner of the particular property lost called more specifically particular average. ship's freight and cargo, in proportion to thei several interests, to make good a loss that has been sustained or an expense incurred for the general safety of the ship and cargo. This, of property is jucurred, either by cutting awsy the mast f property is iucurted, either by cutting awsy the mast who have goods on board or property in the ship (or the age, that is, according to the proportionate value of the cootls of each on board. Average in this sense is also calle (a) ber of different sums or quantities, obtained by adding them together and dividing the result by the number of quantities added; an arithmetical mean proportion. Thus, if four persons age loss by the four is $\$ 25$. Hence-3. Any medial amount, estimate, or general statement based on a comparison of a number of divers specific cases; a medium.

A like nnmber of men, through varions kinds and degrees of ill-snccess, reveal a mental capscity that is nuore
or less below the average. J. Fiske, Evolutionist, p. 177 . Yet I have no doult that thst people's rulers sre as wise as the average of civilized rulers. Average boud. See bondl. - Upon or on an average,
taking the aritlinetical niean of several unequal numbers or quantities; taking the arithmeticsl mean deduced from a great number of examples. equal. female births are tolerably
Buckle, Civilization, I. iv.

\section{Syn, 2 and 3, Mredium, etc. See mean,}

II. a. 1. Equal in amount to the sum of all the particular quantities of the same sort divided by the number of them: as, the average
yield of wheat to the acre; the average price of anything for a year.
Avernian

I departed, . convinced that, . Whatever the ratio of population, the average amount of luman nsture to the square wile is the same the world over.
Lowell, Yireside Travels, p. 93. Hence-2. Of medium character, quality, etc.; midway between extremes; ordinary.

They all [the Palseocosnic skeletons] represent a race equal to that of the averaye modern European.
Dawron, Nature and the Bible, p. 174. The average intellect of five liundred persons, tsken as
they come, is not very ligh. 0 . if. Holmes, Autocrat, vi.

We mortals cross the ocean of thils world

Each in his arerage cahin of a life-

The hest's not big, the worst yields ellow-room.

3. Estimated in accordance with the rules of average: as, the loss was made good by an average contribution.-Average curvature. See market vsiue of a ton of tough-cake copper. It fornierly market vsiue of a ton of tough-cake copper. It formenty the snelters to the miners for o
[Cornwall.]=\$yn. See mean, $n$.

average ${ }^{2}$ (av'e-rajj), v. t.; ; pret. and pp. averaged ppr. averaging. [< average $\left.2, n_{.}\right] \quad$ 1. To find the arithmetical mean of, as unequal sums or in, as an arithmetical mean term; amount to as a mean sum or quantity: as, wheat averages 56 pounds to the bushel.

These spsrs average 10 feet in length. Belknap. 3. To divide among a number proportionally divide the total amount of by the number of equal shares: as, to average a loss.

The permanent averaged price on all kinds of commoni-

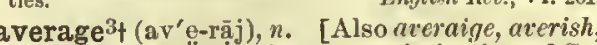
prob. an expaüsion (in reverse imitation of Sc. arriage, arrage, for average 1 ) of arrish, ersh see arrish, ersh, eddish.] The stubble and grass left in corn-fields after harvest.

In these monthes after the cornne bee innede it is meete to putt draughte horses and oxen into the averish.
Quoted in Archceologia, xiil. 379. average-adjuster (av'e-rạjj-ạ-jus"tẻr), n. An accountant who is employed ill cases of general average to ascertaiu and state the sum which each of the parties interested has to pay in order to make up the loss sustained by some for the general go

averagely (av'e-rāj-li), adv. In an average or medial

Which tends to render living more diffeult for every veragely situsted indivjdual in the conmunity. average-stater, average-taker (av'e-rāj-stā" tẻr, -tä"kèr), n. Same as aver(ige-adjuster. averano (av-e-rä'nō), $n_{0}$ [Appar. S. Amer.] A name of the birds of the genus ChasmorhynAmerican fruit-crows of the family Cotingido and subfamily Gymnoderina, as $C$. variegatus, the averano of Buffon, and the arapunga. See eut under arapunga.

avercake, $n$. See havercake.

avercornt, $n$. [Appar. S ater (repr. ML. avera (see uverage 1 ), a kind of service) + corn.] In old law, corn paid by a tenant to his superior as rent or in lien of service. This word, like aver. land and averpenny, is not known in vernacular use, and averdant (a-vẻr'dant), a. [See verdant.] In her., covered with green herbage: chiefly applied to a mount in base.

averish $+($ av'e-rish), $n$. Same as average 3 averland (ä'vèr-land), $n$. [See avercorn.] In old law, land subject to the service called average. See average 1 .

averment (a-vèr'ment), u. [<aver $1+$-ment.] 1. The act of averring; affirmation; positive Publishing averments and innuendoes. 2t. Verification; establishment by evidence. Bacon, - 3. In law, an allegation or statement as a fact: commonly nsed of statements in a pleading which the party thereby professes to be ready to prove.

Avernian (a-vèr'ni-an), a. [<L. Al'ernus (sc. ( G Gro y Campania in Italy, looked upon by the ancients as an entrance to hell. From its waters mophitic vapors arose, which were supposed to kill birds that attempted to fly over it. 
averpenny

averpennyt (a'ver-pen"i), $n$. [See atercorn.]
In old luw, money paid by a tonaut to his lord in lieu of the service called twerage.

averrable (â-vèr'ạ-bl), $a .[\langle a c e r 1+-a b l e] 1$. Capablo of being verified or proved.-2. Capable of being averred, asserted, or deelared.

Averrhoa (av-e-rō'a $), n$. [NL., named from Aierrhoës, Avcrioës: see Alerroist.] A genus of snall trees, natural order fercniaeea, tribe Oxalilew, containing two East Indian speeies, cultivated for their very acid fruit. The bllm. bi, A. Biliwbi, is often pirkled or eandfed, and its juice removea the atain of lron-rust and other spots from linen
The curambola, $A$. Carambola, ta also nsed as food.

Averroism, Averrhoism (av-e-rō'izin), $n$. Averrhoës $+-i s m$.] The doctrines held by Averrhoës and his followers. See Avcrroist.

The patricians of Ventce and the lccturers of Padua mate A verroism synonymous with doubt and criticism in theol ing, and with anreasm against the hierarchy.
Bncyc. Brit., 1II. 151.

Averroist, Averrhoist (av-o-rō'ist), n. [< Alerrioes or Acerroes + -ist. Acerroes is a of Averrhoës, a celebrated Arabian philosopher of Averrhoës, a celebrated Arabian philosopher and commentator on Aristotle, who was born
at Cordova about A. D. 1126, and died 1198 . at Cordova about A. D. 1126, and dicd 1198.
The phlloaphy of the Averolst8 was little more than The philoaphy of the Averrolsts was little more than an imperfect interpretation ol

Averrolstic (av"e-rō-is'tik), $\ell_{0}$ [< Averroist + -ie.] Of or pertaining to the Averroists or their doctrines.

The Averroistic achool, mainly composed of physicists

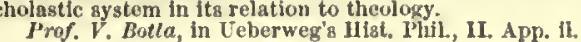
averruncatef (av-e-rung ${ }^{\prime} k_{a}$ ), $v . t$. ; pret. and pp. averruncated, ppr. acerruncating. [< L. acerruncatus, $\mathrm{pp}$. of averruncare, avert, remove, an ancient word peculiar to the language of religion, $<\bar{a}$ for $a \bar{b}$, from, + verruncare, turn. Henee erroneously averruncate, averuncate (Coekeram), aberuncate (Bailey and John. soil), "to weed," "to pull up by the roots," from an erroneously assumed L. "aberuncare, runcare, uproot, weed.] 1. 'To avert or ward off. [Obsolete or rare.]

But aure some mischlef will come of it,

Unless by providential wit

Butler, Hudibras, 1. 1. 758

2. [Improp.: see etym.] 'To weed; pull up by

averruncation $\dagger$ (av "e-rung - ka 'shon), $n$. [<
averruncate.
1. The act of averting or warding off (evils). [Obsolete or rare.]

Avernuncation of epldemical diseases by telesmas.

2. [Improp.] A rooting up; extirpation; removal.

averruncator (av'e-rung-kä/tor), n. [< aver runeate + -or; also spelled
aberuneate.] See aberuncator.

aversant (ävèr'sant), $a$. [< L. aversan(t-)s ppr. of acersari, turm away, $\langle\vec{a}$ for $a b$, away, + versari, turil. Cf. aversc.] In her., turned to show the back: said of right hand. Also called dorsed. aversation (av-èr-sā'shon), n. [< L aversatio $(n-),<$ aversari, pp, aversatus: see aversant, aversari, pp. atersatus: see aversant.] Aversion; a turning
away from. [Obsolete or rare.] I had an aversation to thia voyage Chapman, Revenge of Bussy d'A mbois, tii. Certainly for a king himself to charge his aubjects wit high treason, and so velhemently to prosecnte them in his
own cause as to do the offlce of a gesrcher, argued in him no great avergation from ahedding blood.

Milton, Eikonoklastes, ix. Some men have a natural aversation to aeme vices or averse (a-vèrs'), a. [< L. aversus, pp. of avertere, turn away: see avert.] 1. Turned away from anything; turned baekward; averted.

Earth ..... with her part a verse
From the sun'a beam.

The tracks arerse a lying notice gave,

Dryden, Eneid, vill

Hence-2. Specifically: (a) In bot., turned away from the entral axis: opposed to adverse away from the eentral axis: opposed to adverse
(which see). (b) In ornith., set back or turned away from: applicd to pygopodous or rumpfooted birds, whose legs are set so far back
that the erect posture is necessitated, as in the case of the loon, grebe, or auk.-3. Disliking utwilling; having reluctance.

395

Averge alike to flatter, or offend,

Popre, Essay on C'riticism, 1. 743. Aa $31 \mathrm{r}$. WJimot knew that I could make a very handsome settlement on my son, he was not averse to the matel.
Grohlm

4. Unfavorable; indisposed; adverse.

Some much arerse I found and wondrous liarsh,

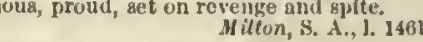

And Pallas now averse refubed her aid. Dryden. TThia word and its derivatives are now regularly followed modern from: but the literal mesuing is ignored, the affection of the ninid gignifled by the word being regarded as exerted loward the object of dialike. Similarly, the kindred term contrary, repugnant, etc., are also followed by to.] $=5 y n$. 3. A verse, Retuctant, disinchined, backward, slow, lonth,
opposed. A verne implles habitual dislike or unwilliugness, though not of a very strong character, and is nearly aynonymous with disinclimed: as, a verne to study, to active pursuits. Reluetant, literally, atruggling back from, inpiles some degree of atruggle either with others who are inciting 11 s on, or between our own inclination and some atrong motive, aa sensc of duty, whether it operates as an
iniveling or as a restraining inflnence. See antipathy.

A verse to pure democracy, yet firm in his regard for ex isting popular libertiea. Bancroft, 11 ít. U. S., I. 27 . I would force from the reluctanc lips of the Secretary

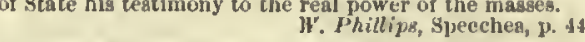
4. Adverke, Inimical, etc. See hostile.

see the adj.] To turn away, $[<\mathrm{L}$. acersus : son.

$$
\begin{aligned}
& \text { Wise Pallas' shleld } \\
& \text { (By which, my face aversed, in open field } \\
& \text { I glew the Gorgon). }
\end{aligned}
$$

B. Jonson, Masque of Qucers.

aversely (a-vèrs'li), $a d v$. 1. In the reverse or opposite direction; backward.-2. With aversion or repugnance; unwillingly. [Rare in both senses.]

averseness (a-vers'nes), n. [< averse $+-n c s s$.
The state of boing averse; opposition of mind: dislike; unwillingness; backwardness.

aversion (a-vér'shon), $n . \quad[<\mathrm{L}$. aversio $(n-),<$ turning : see avcrse, $a_{\text {., }}$ and avert.]

A figurative speech called apostrophe, which is an aver. sion of spcech from one thing. $2 \nmid$. The act of averting or warding off. -3 . An averted state of the mind or feelings; opposi. dislike; antipathy: used absolutely or with to sometimes with from, for, or toward.

His aversion towards the house of York.

Adhesion to vice, and aversion from goodness.
$B p$. Atterbury.

A atate for which they have so great an aversion.
Addison.

An aversion to a atanding army in time of peace hat
lang been one of the strongeat of English gentiments. lang been one of the strongeat of English sentiments.
Lecky, Eng. in 18th Cent., iis. 4ł. Opposition or eontrariety of nature: ap plied to inanimate substances.

Magneala, notwithstanding thla aversion to aolution, 5. A cause of dislike; an object of repugnance. Had I no preference for any one else, the choice you have made would be ny aversion, Sheridan, The Rivals, 1. $=$ Syn. 3. Iatred, Dislike, Antipathy (see antipathy)
unwillingness, ahrinking, hesitation, diarelish, distaste,

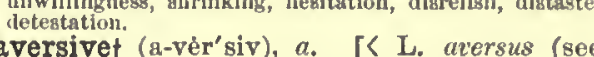
averse, a.) + -ive.] Averse; turning away. Those atrong-bent humours, which aversive grew.
Daniel, Civil Wars, vil. 7 aversivelył (n-vér'siv-li), adv. With aversion;
baekwardly. Chapman.

avert (a-vèrt'), $v . \quad[<\mathrm{L}$. avertere, turn away, $a$ for $a b$, from, away, + verterc, turn: see versc version, acerse, etc. Cf. advert, convert, divert evert, invert, pervert, revert, subvert, ete.] I. off or away: as, to avert the eyes from an object: now seldom with a personal objeet.

When athelats and protane persona do hear of ao many them from the church.

To associate Himself with aome persong and to aver 2†. To give a turn or direetion to; direct.

$$
\text { Avert your liking a more worthier way, }
$$

Than on a wetch whom satire la ashat

3. To ward off; prevent the oceurrence or happening of (evil or something threatened).

Belleving in the divine goodness, we must necessarily greater evils.
Avesta

4†. To oppose; view with aversiou.

The uature of mankind doth certaluly avert both kilnw locety Christ. I'iety (16087), vi. \& 9, 25\%. (N. B. D.)

II. intrans. To turn away. [Rare.] Arerting from our nelghlihur's gens.

rhomsun, spiring, 1, 301.

vertebrated (a-vèr'tī-briā-ted), a. [ $\quad$ Gr. $\dot{a}$ priv. $(a-18)+$ iertcbratel.] Evertelsrated; inertebrate.

Tho Lituman clasaiflcation of arertebrated animals.
G. Johnston (cu. of Cuvier, 184:D), p. 330 .

averted (a-ves $\left.r^{\prime} t e d\right), p, u, 1$. Turned away or When food was l, rought to them, her aliare To his urerted lips thie chill did bear.

etsian, v. 30

2. Specifieally, in anat. dracing, having the head of the object turned to tho top of the figure. Wilder.

averter (a-vér'tér), $n$. One who or that which averts or turns away.

Averters and purgers muat go tuguther, as tending all to
the same purvose, to divert this rebellious lunnour Imel the same purpose, to divert this rebellious humour [mel Burton, Anat. of Mel., p. $40 \%$.

avertible (a-vèr'ti-bl), $a_{0}$ [< avert $\left.+-i b l e.\right]$ "tiertible evils," Kinglalie.

avertiment, $n$. An erroneous form of adver tisement. Milton.

Aves $\left(\bar{a}^{\prime}\right.$ vēz), n. jl. [L., pl. of aris, a bird; ef. Skt. $v i=$ Zend $v i$, a bird. Cf. also ovum and eygl.] Birds; feathered animals, considered as a class of vertebrates, next after mammals sometimes united with Reptilia in a superelass Sauropsida, distinguished on the one hand from Mammalia, and on the other from Ichthyopsida, or amphibians and fishes together. Avea are de with feathers, a kind of exoakeleton no other animals possess; hot bluod; conspleteiy double circulation; perfxed lungs; a air-passages prolonged into various air-
sacs, even into the interfor of some of the bones of the skeletoll; ovlparous reproduetlon; eggs large and mero-
blastic, with coplous food-yolk and albumen and a hard which are modifed as wings, and generally subaerve fligh by means of their large feathers, the distal aegment of the limb being compressed and rednced, with not more thau 3 digita, usuaily not unguiculate; the metacarpals more
or less ankyloged as a rule, and the free carpals normally only 2 in adult life ; a large breast-bone, usually carinate, and great pectoral muscles; numerous dorselumbar, sa
cral, and urosacral vertebre ankyloged into a sacrarium ilia greatly produced forward, and ilia and isclia back ward, normally without median symphyses: perforate with an iliac antitrochanter, and the fibula ineomplet below; the astragalus ankylosed with the tibla, and assist-
ing in forning the tibial conclylea ; mediotarsal ankieand not more than 4 digits, the phalangea of which are and not more than 4 digits, the plialangea of which are forms, the Jaws being she athad in horn. dergone little modification since their first sppearsnce in the Jurassic age; their classiffeation ia consequently dif. (1766) divided them into 6 orders: Accipitres, Pica, $A n$ seres, Grallo, Gallina, and Passeres, C'uvier's arrange-
ment (1817) was similar, with the 6 orders Accipitres, A aystem said to have been originally proposed by Kirby, recognized Natatores, Grallatores, Cursores, Rasores, Scan sores, Inseasores, and Raptores as orders. The latest arti-
ficlal system is that of Sundevall (1872-3), with the orders Oscines, Volucres, Accipitres, Galline, Grallatores, Nata.
tores, Proceres, and Saurura, 42 aubordinate groups, and tores, Proceres, and Saurura, 42 aubordinate groups, and Savirura, Latita, and Carinata; the luller Into 4 gubor Egithornatho, and 16 guperfamily groups-an arrangement very different from any preceding wine. The diaprimary division by Jiarsh into Odontolece, Odontotorma, to recent birds. In 1884 Couea divided all birda into 5 bra, carinate aternum, aeparate metacarpals, and long, concave vertebrs, carinate aternum, ankylubed metacarpals, and short tall ; (3) Odontolcoe, with tecth in grooves, heterocolous vertebræ, rndinentary wings, ratite ster-
num, and short tall; (4) Ratito, without teeth, with het num, and ahort tall; (4) Ratita, without teeth, with hetank toeth with hearpala, alo developed wings, ankylosed metacarpals, and short tail. The Carinate include all living birds, except the few atrit. thious or ratite birda. For the carinate aubclass or order, adopted. One of these, Paxseres, includes a large majority
of all birls. The genera or subgenera of birda in use now usually estinated at about 10,000. See bird and Sauroy-

Avesta (a-ves'tä), $n$. The saered writings attributed to Zoroaster. See Zend-Aresta. 
Avestan (a-ves'tan), $a$. and $n$. [<Aveste $+-a n$. Bolonging to the Avesta.

II. $n$. The language of tho Avesta; Zend. avestruz (a-ves-tröz'), $u$. [Pg., also abcstruz, = Sp. revestru, ostrich: seo rstrich.] A name of tho Soutli American ostrich, Rhoa americana. aviador (av"i-qu-dōr'), $n$. [Amer. Sp., < Sp. aviar, to provido articles for a journey, prepare, $<a(<\mathrm{L} . a d)$, to, $+v i \alpha,<\mathrm{L}$. via, way, prictor of a mine money and supplies for workpring it.

Mineral avindores, or provider of goods and provisions, Quoted in Joury's Arizona and Sonora, p. 126. avian (ấvi-g̣n), a. and $n$. [< L. avis, a bird, + -rin.] I. a. Of or pertaining to Aves, or birds ; ornithic.

The furcuhum is distinctly avian.

II. $n$. A member of tho class Aves; a birl:

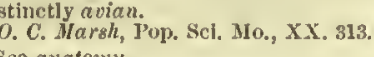
s, "this anciont arian," Coues.

aviary (ā'vi-â-ri), n.; pl. aviavies (-riz). [<L. aviarium, an aviary, neut. of aviarius, of birds, <avis, bird: see Aves.] A large eage, building, or inclosure in which birds aro reared or kept. avicula (a-vik'u-lä), n. [L., dim. of avis, a bird.] 1. A little bird; henco, any ungrown bird; a nost-

ling, fiedgling,

[cap.] [NL.:

in allusion to

the wing-like

expansion of

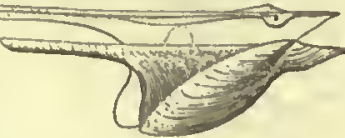

the hinge.] In

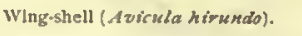

作 rundo is the type

avicular (a-vik'ñ-lär), a. [< I avieularius, n

a bird-keeper, prop. adj., pertaining to birds, avicula, a littlo bird: see aricula.] Pertaining to birds Thomas, Med. Dict.

avicularia, $n$. Plural of avicularium.
avicularian (a-vik-ñ-lā'ri-an), $a$. Of or pertaining to an avicularium.

avicularium (a-vik-ū-lä'ri-um), $n_{0} ;$ pl. avicularia (-ä). [NL, neut. of L, avicnlarius, adj.
see avicular.] In $\approx 000$. a singular sma]] prehensilo process, rcsembling a bird's head, with a movable mandible, which snaps incessantly, larium, vibracularium.

In the avicularia, a large adductor muscle which tak its origin from the greater part of the inner surface of the

aviculid (a-vik' $\left.\tilde{u}_{-}\right] \mathrm{ld}$ ), $n$. A bivalve of the fam aviculid (a-viciculida.

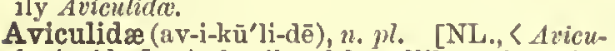
$l a+-i l a$.$] A family of lamollibranchs, with$ oblique inequivalve shells, having an outer prismatic cellular layer and imner nacreous pletely opon mantlo. There are geveral genera bo sides Avicula, the type, among them Meleagrina, which the Indian ocean and Persian gult and the Gulf of Mexic. aviculoid (a-vik' ü-loid), $a . \quad[<$ Avicula + -oid. $]$ Resembling the Aviculide: as, "an aviouloi shell," Amer. Jour. Sci., 3d ser., XXXI. 140. Aviculopecten (a-vik" ü-]ō-pok'ten), n. [NL. [Avicula + Pectcn.] Á genus of fossil bivalve mollusks: so called becauso it combines characters of the genera Avicula and Pcctch. Spe cies occur in the Silurian and Carboniferons rocks.

aviculture (的'vi-kul-tīr), n. [<L. avis, a bird, + cultura, culture.] The care of birds; the rearing or

avid (av'id), a. [< L. avidus, greedy, eager, <averc, wish. Cf. avarice.] Eager; greedy. A vid of gold, yct greedier of renown. Southey. The voluptuons soul of Mirabesus was not more avid of pleasire than tho valn, amhitions soul of Robeapierre wa
of applause.
G. 11 . Lever, Rohespierre, avidioust (a-vid'i-ns), a. [Expanded form for "avidous, [ L. avidns: seo avid.] Same as
avid: as, "avidious greedinesse," Bp. Balc, Seleet Works (1849), p. 418

avidiouslyt (a-vid'i-us-li), $a d v$. In an avid o ; with greediness. Nothing is more avidionily desired than is the swee
Beace of uod. Bp. Bale, Image of the Two Churches.

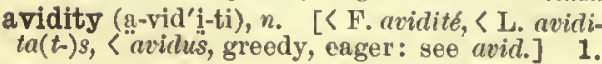

Grecdiness ; strong appctite: applied to the applied to the mind.

Avidity to know the eauses of things is the parent

= Syn. 2. Earnestness, Zeal, etc. See eagerness.
viet (a-vi $\left.\bar{i}^{\prime}\right)$, prep. phr. as adv. $\quad\left[\left\langle\boldsymbol{a}^{3}+v i e\right.\right.$ atter fr. a l'envi, in emulation, emulously: see ric.] Iimulously.

They atrive avic one with another in varicty of colours.

aiewł $\left(a-v \bar{u}^{\prime}\right), v . t$. [Far]y mod. E. also advicw, adicice, < late MU, arcice, < a- ad-, + vewe, view. Cf. OH. avuor, uvener, follow with the eye (aveunent, a view), $<a$, to, + vue, view, sight.] To view or inspect; survey; reconnoiter.

avifauna (ä'vi-fâ-nä), n.; 1 l. arifauna (-nē). [NL., < L. atis, a bird (sce Aves), + fauna, q. v.] 1. A collective name for the birds of any given locality or geographical area; the fauna of a region or district so far as concerns birds. of a region or district so far as concerns birds.
-2 . A treatiso upon the birds of a given region.

Vifaunal (ä'vi-fâ-nal), a. [<avifauna.] Of or pertaining to an avifauna.

aviform (ă'vi-fôrm), $a$. [< L. avis, a bird, + ture a morphological sense.

Avignon berry. See berry 1 .

avileł (a-vil' ), v. t. [ME. avilen, < OF. aviler, F. avilir $=$ Pr. Sp. avilar $=$ It. avvilire, avvilar $<\mathrm{L}$. as if "advilare, "advilire, <ad, to, + vilis, vile: see vilc.] To make vile; treat as vile deprecinte; debase.

Wsnt makes us know the price of what we avile.

avilement $+n$. [<OF' avilcment (mod. F.avilis sement): see avile and -ment.] The act of reudering vile, or of treating as vile.

avine (ā'vin), a. [< L. avis, a bird, + -inel. Same as avian.

avireptilian (ä"vi-rep-til'i-ann), $a_{0} \quad[<\mathbf{L}$ aris, bird, + reptilis, reptile, $\left.+-t n_{0}\right]$ Combinin avian and reptilian characters; sauropsidan, s a bird. [Rare.]

The hesd is in a stage of avi-reptilian transition.
\[ \text {. W. Shufeldt, in The Century, XXXI. } 355 . \] avist, $n$. An obsolete form of advicc.

avisand $t, a$. Advising; giving advice.

avisandum, $n$. See avizandum.

aviset, $n$. and $v$. An obsolete form of advicc,

avised (a-vist'), a. [Se., prop. "vised, < F. vis face, $+e d^{2}$, with unorig. a-developed in comp.
Faced: only in composition: as, black avised, dark-complexioned; lang-avised, long-faced. [Scotch.]

aviseful $\dagger$ (a-viz'fúl), $u$. [Also arizefull ; < avise, $=$ advise, + -ful.] Circumspect. Sponser.

avisementt (â-viz'ment), $n$. Obsoleto form of I think there never
Harrlage was managed with a more avisement.

avisiont, n. [ME, also avisiun, -oun, $<\mathrm{OF}$, ati sion, avisiun (=Pr.arision), for vision; confused with aris, advice, counsel.] Vision. Chancer.
avisot, $n$. [<Sp. aviso, advice, etc.: seeadvice.] 1. Advice; intelligenco.

I had yours, ... and besides your avisos, I mast thank you tor the rich flourishes wherewith your letter was em-
broidered.
Ilovell, Letters, il. 68 .

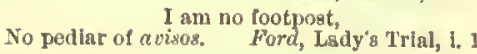
2. An advice-or despateh-boat.

avital (av'i-tal), a. [<L. aritus, pertaining to a grandfather (< aus, a grandfather), $+-a l$. I sncered Just now at avital aimplicity.
C. Reade, Love no

avivage (a-vi-väzh'), n. In dyeing, the etc., $x$ of clearing a fabric of superfluons coloring matter after it has left the vats, and of reviving and brightening the colors.

When the dyeing process is continued for moro than six houls tite colours produced stand cleartng (avivage) less well than when the time has been shorter.
Crookes, Dyelng and Calico-printing, p. 301. avizandum (av-i-zan'dum), n. [Law L., also avisandum, gerund of avisarc, < F. atiser, consider, advise: sce advisc.] In Scots law, private consideration. To make avizand um with \& cause is to rcmove it from the public court to the private considers.
tion of the fudge. Also spelled avisand tum. avize ${ }^{\mathrm{I}}+v$. An obsolete form of advise.
Avize $^{2}$ (a-vëz'), $n$. A sparkling wino named rom the village of Avize, in the department of Marne, France. See champagne. avocado (av-ō-kä'dō), $n$. [Corrupted from Mexean name.] Tho alligator-pear, the fruit of Persea gratissime, natural order Lauracee, a tree common in tropVest Indies, It is lrom 1 to 2 pounds in weight, is reen or purple color, and 8 highly estecmed, thoug rather as s vegetal)le than as
s fruit. The pulpis firm and marrow-like, whence the ruit is sometinıes known a vegetable marrow or mid. is saill to be eqnal to paln. oil for soap. The tree is an vergreen, growing to the
hcight of 30 feet. Also av ato, arigat

vocat (aY-ō-kär), n.

$[\mathrm{F} .,<\mathrm{L}$. idlvocritus:

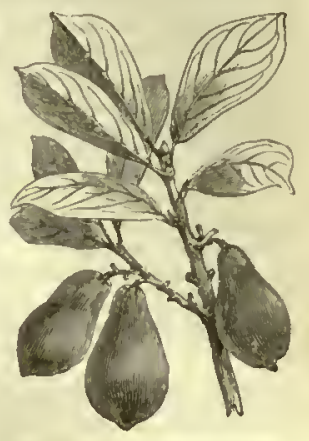

Arocado, or Alligator-pear

see acluocate, $n$.$] An advocato; a lawyer.$

avocate (av'ọ-kât), v. $t_{\text {; }}$ pret. and pp. arocated, ppr. avocating. [< L. avocatus, pp. of arocare, call away, $<a$ for $a b$, away, + rocare, call: see voice and vocal.] 1t. To call off or away.

One... who avocateth his mind trom other occupa-
Barron, Works, III. xxit.

2. To remove authoritatively from an inferio to a enperior court. [Arehaic.]

Seeing ... the cause avocated to Rome.

avocation (av-ō-kä'shon), n. [ $<\mathrm{L}$. avocatio $(n-)$ a calling off, interruption, $<$ arocarc, call off sce avocate.] 1t. The act of calling aside or diverting from some object or employment. God does irequently infect into the soul blessed im2. The authoritative removal of a case or process from an inferior to a superior court.

The pope's a vocation of the process to Rome, by which made evident, and the disgrace of Wolsey, took place in 3t. The state of being called, or of wandering
aside or away; a diversion of the thoughts. It not from virtuo, Irom its gravest ways,
The soul with pleasing avoca tion strays.

Hence - Parmell, To an 0id Beanty. one's which calls one away from one's proper business; a smbordinate or oceaoccupation; a diversion or distraction. Hesven is his vocation, and therefore he counts earthly
Fuller, Jloly State iv Visits, business, cards, and I know not how many other avacations. do succed one another ao thlek, that in converse with his own thoughts.
Boyle, Occasional Reflections, ii. 6. 5. A person's regular business or occupation; vocation; calling. [An improper though comnon use of the word.

Docs it not require time for an individual, thrust out of avocation, to gain admittance to another?
Godwin, The Enquirer, p. 190. The sncicnt a vocation of picking pockets.

In a few hours, sbove thirty thousand men left hmith. lart, and retarned to their ordinary avocations. The wandering avocation of a shepherd. Buckle, Civilization, II, avocativet (a-vok'a-tiv), $a$. and $n$. [< avocatc + II. n. That which calls aside; a dissuasive. II. n. That which calls aside; a dissuasive. Barrono, The Creed.

avocato (av-ō-kä'tō), n. Same as arocado.

a vocatory (a-vok'a-tō-ri), a. [< arocate + -ory.] Calling off; recalling.- Letters avocatory, letters by which the subjects of a sovereign are recalled fron a abstahn or desist irom illegal acts.

avocet, $n$. See avoset.

Avocetta (av-o-set'iij), u. [NL.: see avoset.] 1. A genus of birds, the avosets: a synonym See cut under aroset. -2 . A genus of humming-birds. Agassiz. Also dvocettula.

Avogadro's law. Seo law.

avoid (a-void'), $v$ [< ME. aroiden, aroyden, AF. avoider, OF. csuridier, estcudier, empty out, <es-(<I. cx, out) + vuidicr, veudier, < L. viduare, empty, < vidurs, cmpty: see roid, $a$., which has influenced avoid in some of its senses.] I. trans. 1. To make void; annul; make of no effect: chiefly used in legal phraseology: as, 


\section{avoid}

this grant cannot be aroided without injustice to the grantee. $-2 t$. To empty.

A coud thou thl trenchere. Sabees Rook, p. 23. 3t. To eject; throw out; drive out.

And y! he avoyde hem [swine golug at large] nol, or pul hem ln warde, att warning made, . . lie that is so in deSinglish Giliz (E. E. T. S.), p. 39s.

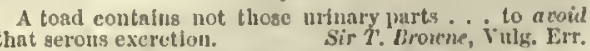
4†. To quit; evacuate; depart from.

Anl then the both marres to chanige their places, then A coid the gallery. Shak., llen. vIII., $v, 1$ That prince should command him to avoid the comntry.

5. To shuu; keep away from; esclew: as, to aroid expense, danger, or bad company.

The best way to acoill controverstes aboul worls is to use worls in their proper aclises. 6t. To get rid of; get out or elear of.

I will no longer endure it, though yet I know no wiso
Shak., As you Like it, I. 1.

= Syn. 5. To esenpe, elinde, evade, keep elenr of.

II.t intraus. 1. To become void, vaennt, or empty.

Bishoprieks are not included under beneflees: so that 1 a person takes a blshoprlek, it does not azuid by force cliat law of plurnlities, but by the anclent conmon law.

\section{To retire; withdraw.}

David a vouled out of hls presence. 1 Sam. xwlil. 11. Aroid, my soul's vexation! Satan, lience is Altered, iv. Let him avoid, then,

And lenve our walk. Fletcher and Roxcley, Iaid in the sill, i.

avoidable (a-voi'da-bl), a. [< avoid + able. $]$ 1. Liable to be anuulled or to becomo void; voidablo. [Rare.] - 2. Capable of being avoided, shunned, escaped, or prevented.

avoidably (â-voi dạ-bli), ade. In an avoidable manner.

avoidance (a-voi'dans), $u$. [〈ME. ntoidannee, atoidans; < aroid $f$-ance. $]$ 1. The act of annulling or making void; annulment.

The obsequious elergy of France ... pronouneed at once the aroidance of the marrlsge. 2. The act of hecoming, or the state of being, vacant; especially, the state of a bonefice when it becomes void by death, deprivation, resignation, or preferment of the incumbent; vacancy. Wolsey,.... on every avoidance of St. Peter's chair, was sitting down tliereon, when suddenly some one or 3. The act of avoiding or shunning anything disagreeable or unwelcome. -4 . A retiring from or leaving a place.-5t. An emptying out; that by which a fluid is carried off; an outlot.

Avoidances anci draluings of water.

Bacon.

Confession and avoldance. See confession.- Plea in avoldance, in lac, a plea which, whthout denying the
plnintifl's allegation, sets up sone new fsct evading its effeet, ss where the pla hintiff alleges a debt snd the do avoider (a-voi'dér), n. 1. One who avoids, shuns, or esceapes.

Good sir, steal away: you were wont to be a curlous

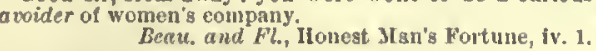
2ł. That which empties.

avoidless (a-void'les), $a$. [< avoid + -less. $]$ That cannot be avoided; inevitable: as, "avoidless ruin," Dennis, Letters. [Rare.]

avoir. An ahbreviation of acoirdupois.

avoirdupois (av"or-dū-poiz'), n. [Prop. averdepois, early mod. E. arerdepois, averdupois, haverdupois, -poise, < ME. aver de poiz, avoir de pois, acer de peis (later also-paise, -pase), $\angle O F$. aecr de pes, areir de peis (equiv, to ML. averia penderis), lit. goods of weight: ater, goods (see arer ${ }^{2}$ ); de. <L. de, of; pes, peis, later pois (mod. F. poils, by mistaken reference to L. pondus, weight $)=$ Pr. pes, pens = It. peso, < L. pensum, weight, < pendere, weigh: see poise, pensum, weight, < pendere, weigh: see poise, penpound contains 16 ounces. It was introducel into pound contains 16 ounces. It was fntroduced into England from IBayonne sbout A. D. 1300, and is substantial-
ly the Spanish system. In avolrdupois weight 7,000 troy sTsIns (formerly, and now in the Unlted States, approxiin troy weiglt the pound e belng the same in both cases; hence, 175 pounds troy are equal to 144 pounds avoirlupois. The pound avoirlugols is the standard weight of Great Britain, and is equal to
453.6 grans in the French suetric system. Avolrlupois
welght is used in determining the weiglits of all comuouli.
397

ties exeept gems snd the preclous metals. It is reekoned
as follows: 1 ton Cwt. Qrs. Pounds, Ounces. Drams. liundredwelglt $=20=80=2240=35840=573440$
$=4=112=1792=28672$ quarter 1 loun

In the United Stales the hundredweight is now commenly 100 poums, and the ton 2,000 pounds, walled the whore ton 2. The weight of anything according to the avoirdupois system : as, his acoirlupois was 150 pounds. [Colloq.]

Also written averdupois, and often abbreviated to aroir. and $a v d p$.

avoket (a-vōk'), v. $t_{\text {. }} \quad$ [<I. atocare, call away: seo arocate. Cf. convolie, evolic, imroke, provolic, reroke.] To call away or back. Bp. Burnet.

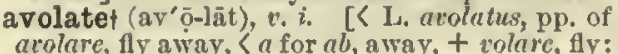
avolare, fly away, < a for $a b$, away, + volare, fly: sce colant.] Toflyoff; escape; exhule. Boyle. tio( $n-)$, s avolarc: see avolate. J The act of flying away; flight; escape; exhalation; evaporation.

The avolation of the favillous partleles.

roli (ì-พō'lē), $n$. [It.] In glas:-blocing cially in Venetian work, the small cirenlar piece which covers the junction of the bowl and the stem in a drinking-glass.

voncet, $v$ Variant of arunee ${ }^{1}$, obsoleto form of adrunce.

avoset, arocet (av'ō-set), $u$. [Also as NL.

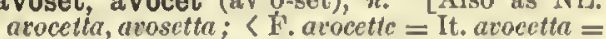
arocetha, avosetta; Sp. avocetic = It. avoeetta = the genus Recurvirostra, family liccurvirostride, and order Limicola, characterjed by extreme

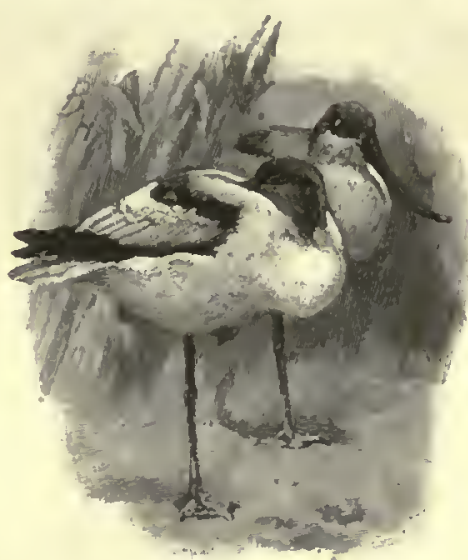

European Avoset (Recurvirostra avoctra).

slenderness and upward eurvature of the bill, and by very long legs and webbed toes. In the lat ter characteristlc it differs from most wading birds. Its he end of the tail, and its coloration ls chiefly black and White, the legs being
The svoset of Europe is $R$. a a pocetta; that of the United
States is $R$. americana, distingulshed by the chestuntbrowll coloratlon of the hend. The former is somet Im 2. A humming-bird of the genus Avocetta. avouch (a-vouch'), $v$ [< ME. arouchen (rare) $\checkmark \mathrm{AF}$. advoncher, OF. awoehier, acoelier, a partly restored form, after the L., of acoer, avoucr, affirm, declare, avow, orig. call upon to defend 1. advocare: seo adrocate, avot', and vouch.] I. trans. 1. To affirm or acknowledge openly

Thon hast avovehed the Lord this day to be thy Gorl And the Lord hath a vouched thee thls day to be hl
Deut. xxvi. 17, is Nelther indeed would 1 have thought that any auch an
tlquities conld lisve been a vouched for the Irish.

$$
\text { If this whlch he avouches does appear. }
$$

$$
\text { Shak, M sebeth, v. S. }
$$

1 speak whst history a rouches, that the meehanlcs, as a elass, were prime agents in all the measures of the revolu-
tlon.
Everete, Orations, 1. 363 . 2. To admit, confess, or avow.

The first time that 1 have heard one with a beard on his
Scott, Betrothed, iii. Jillon in his prose works frequently avouches the pecnliar affeetlon to the Itallan literature and language whlch he bore.

Trench, Eng. Past and Preseut, iil. 119. (N. E. D.) 3. To maintain, vindicate, or justify; make good; answer for; establish; guaranteo; substantiate. avowal

wlll avouch, in presence of the Shak., IRich. III., I. 3. We might be disposed to question its authenticlty if it were uot arouched by the full evidence lin lis favour.
It ilman, Latlu Chrtstianlty, Iv. 7. 4t. To appeal to, or cite as proof or warrant: to arouch the authorities on any subject.

II. intrans. To give assurance or guaranty; ouch: as, "I can wouch for lier rejutation," I) foe, Mrs. Veal.

avouch $\nmid($ a-vouch' $), n$. [<atouch, $v^{*}$.] Evidence; testimony; assurance.

Without the sensible and true arouch
Of mine own eyes.
shak., llamlet, 1.

avouchable (a-vou'cha-b]), $a$. [< arouch + -able. Capable of being avouched.

avoucher (a-vou'cher), $n$. One who avouches. avouchment (a-vouch'ment), $n$. [< atouch + -ment.] The aet of avouching; declaration; avowal; acknowledgment.

lyy laying the foundation of lis defence on the abouch. ment of that which is so manlfestly untruc, ho hath given s worse foll to his own cause than when lila whole forces
were at any time overthrown. Milton, Eifkonoklastes, i. avoué (a-vö-ä), n. [F., < OF. aroue (pp. of avouer, anoer), <L. advocatus, advocate, patron: scearowee, adrorce, and advocate.] In France, originally, a protector of a church or religious community; now, a ministerial officer whose duty it is to represent parties before the tribunals and to draw up acts of procedure.

nals and to draw up acts

avouret, $n$. See avoucer2.

avow'l (a-vou'), v. [Early mod. E. also advoin, after the L. ; $<$ ME. aroucen, arouch, <OF arouer atoer $=$ Pr. avoar, < L. advocare, call to, call upon, lience to call as a wituess, defender, patron or advocate, own as such: see atouch (from later OF.) and advoke and advocato (directly from L.), doublets of avow ${ }^{\mathrm{I}}$. This verb, in $\mathrm{E}$. and $\mathrm{F}$., was partly confused with the now obsolete avoit ; ef. the similar confusion of $a l$ low ${ }^{1}$ and allow ${ }^{2}$.] I. trans. 1t. To own or acknowledge obligation or relation to, as a person: as, he avowed him for his son.-2 t. To $^{2}$ sanetion; approve.-3. To declare openly, of ten with a view to justify, maintain, or defend: as, to avowo one's prineiples.

If there loe one amongst the talr'st of Greee .
That loves litin nistress nore than in confesslon.

Anl dare avow lier beanty and lier worth

In other arms then hort to him this ehallenge.

"Wster, verdure, and a beantlful face," says an old Arab proverb, "are three thlugs which delight the lieart," and the Sylians avono that all three are to be fotmd 11
Damiascus.
B. Taylor, Lands of the Saracen, p. 126. 4. Specifically, in lax, to acknowledge and justify, as when the distrainer of goods defends in an action of replevin, and avous tho taking, but insists that such taking was legal. See acourry, 1.-5. To admit or confess openono's self a convert.

Left to myself, I must avore, I strove

Syn. 3. To aftirm, assert, profess,-5. Admu, Conjesx,

II. intrans. In lac, to jnstify or maintain an ct done, specifically a distress for rent taken in one's own right. N. E. D.

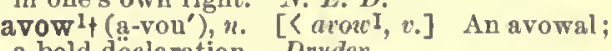
a bold declaration. Dryden.

vow ${ }^{2}+($ a-vou'), $v$;Early mod. E., also advow (after the L.); ; ME. avouen, arowen, $<$ OF. atouer, arocr, later adwouer, $<$ MIL. as if adiolare,
$=$ OF. toer, vocier, $>$ E. vow, q. v. This verb was = OF. toer, vouer, $>$ E. vow, q. v. This verb was partly confused with avow 1 , q. v.] I. trans. 1. by a row; row. 3 . To vow to do or keep; romise; undertake.

II. intrans. To bind one's self by a vow; make a vow; vow.

avow $2 \nmid$ (a-von'), n. [ME. atowe, avou; from the verb.] A vow; a promise. I make avoice to my God here I will make mine avote to do her as ill a turn.

avowable (a-von'a-bl), a. [< avow $+-a b l e$. Capable of being avowed or openly acknowledged with confidence.

avowably (a-vou'a-bli), adr. In an avowable manner. Imp. Dict.

vowal (a-vou'al), n. [< arowl + al. $]$ A

open declaration; a frank acknowledgment.

Ilis ... a voural of such . . il prineiples. 
avowance

avowance (a-vou'gnns), n. [<avow $+-r n c e$. 1. The act of avowing; avowal.-2ł. Justifiindicatiou.

Can my arova nce of king-murdering be collected trom ansthing here written ly me?
Fvoller. lace, tho defendañt in replevin, who avows the distress of the goods, and justifies the taking. avowed (a-voud'), p.a. Declared; open.

I was thine open, thine aroved enemy. Masinger. avowedly (a-vou'ed-li), $a d v$. In an avowed o open manner; with frank acknowledgment.

avoweet, $n$. [AIso adrowce, q. v. ; < MIE. avowe, eritus: see adrowee, adroeate.] An advocat ol patron; in law, same as adrowee.

avower ${ }^{1}$ (a-vou'èr), $u$. [<avoı $\left.{ }^{1}+-e r^{1}.\right]$ Ono avower (a-vou er), $n$. [<aco

avower ${ }^{2}, n$. [Álso alvouer, avoure; < OF. avouer, inf. used as a noun: seeavow ${ }^{1}$.] Avowal. IIe bad lim stand $t$ ' abide the bitter stoure

of his sore vengeaunce, or to make a voure.
Spenser, F. Q., VI. iii. 48.

avowry (a-vou'ri), n. [< ME. avowerie, avoucrie, acknowledgment, authority, $\angle O F$ avoucrie, avoerie, < avouer, avoer', avow: sce avow and goods, who, in an action of replevin, avowed and goods, who, in an action of replevin, avowed and justified the taking by maintaining that he took
them in his own right: thus distinguished from them in his own right: thus distinguished from maintained that he took them in the right of another as his bailiff or servant.-2 + . A patron saint chosen for one's advoeacy in heaven: often applied to a picture or representation of the patron saiut, and hence the cognizance by which a knight was known, because the representation of his patron saint borne on his pennon bccame such a cognizance.

Therefore away with these avourics; let God alone be ur awovory. Within this circle and close to the corpse were carried the four banners - two before, two belinin - of the dead person's avowries, which were smali suuare vanes beaten and fastened flag-wise upon stave

avowtryt, etc. See advoutry, etc.

voyt, interj. [< OF, avoi, avoy, interj.] An

exclamation of surprise or remonstrance. Avoy, (nnod she, fy on yow herteless.

avoyer (a-voi'er), n. [Also advoyer; <F. avoyer, prob. <ML. *advocarius, equiv, to advocntus, protector, patron; cf. ML. advocaria, tribute pair for protection, the protection itself: see advocate. I In French Switzerland, the early title of the chief magistrates of the cantons. In Bern the chief magistrates of the

the title was used until 1794 .
avulset (a-vuls'), v.t. [< L. avulsus, pp. of avellere, pluck off: see avell.] To pluck or pull off. Shenstone.

avulsion (a-vul'shon), n. [< L. avulsio(n-), avulsus, pp. of avellere, pluck off: see avell.] ing or violent separation.

The thronging elusters thin

By kind avulsion. J Philips, Cyder, i. 24. On condition of everiasting avulsion from Grest Britain. 2t. A fragment torn off.-3. In law, the sud den removal of soil from the land of one man and its deposit upon the land of another by the action of water.

avuncular (a-vung'kụ-lạ̈r), a. [く L. avunculus, uncle, dim. of avus, grandfather: see unele. Of or pertaining to an uncle.

In these rare instances the law of pedigree, whether di-
rect or abuncular, gives way. Clive had passed the avrencular banking.house in the city, without caring to face his relations there.

$a w^{1}+, n$. and $r$. See ave 1 . (I. it.

$a w^{2}$, interj. [Cf. augh, al, oh.] An exclame tion of surprise, disgust, or remonstrance. [Colloq.]

aw. $[(\mathrm{I})<\mathrm{ME} . a w, a u, a g, a z$ (awe, etc.) $<\mathrm{AS}$ $a g$ (aga, agu, etc.) that is, a followed by the guttural $g ;(2)<M 1 \mathrm{E}$. aw, au (are, ete.), < AS. aw (awu, ete.) (or $\bar{c} u, e a w)$, that is, $a$ (or $\overline{\bar{e}}, e d$ ) followed by the labial $w ;(3)<\mathrm{ME}$, aw, $a u, a v$ <AS. (ete.) af $(a v) ;(4)$ of other origin.] A common English digraph (pron. â), formerly interchangeable in most instances with au (which see), but now the regular form when final, and when medial before $l, l$, and $n$. Historicslly it

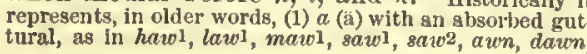

398

awald

c.; (2), (3), $a$ (a) with an alsorber labial ( $w$ or $v$ ), as in $a w l$, claw, raw, awk1, hawk 1 , crowel, etc.: (4) $a$, au, or o awn, pawn, pawl, bawl, etc. In later words often a mere accicht of spelling.

awa (a-wâ'), adv. A Scotch form of areay.

awabi (a-wâ'bè),$n$. [Jap.] The Japanese abalone, or sea-ear, Haliotis gigantea, a shellfish found in great quantity on the southern shores of Japan and much used as food. The hell is extensively used for inlaying In lacquer-work, aul in other ornanentation. See abalone.

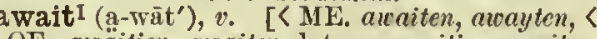
$\mathrm{OF}$. awaitier, awaiter, later aguaitier, aguiter, wateh for, lie in wait, $<a$, to, + waitier, later gluatier, gaitier, gaiter (mod. F. guetter), wateh, wait: see $a-11$, wait, and watch.] I. trans. 1t. To watch for; lie in wait for. Your lil-meaning politician lord Under pretence of hridal friends and guests, Appointed to aurit me thirty spies.

2. To wait for; look for or expect. Betwixt these rocky plllars Gabriel sat, Milton, P. L., iv. 550

All throngh life I have awaited the fulfilment of a prophecy.

3. To be in store for; attend; be ready for: as, a glorious reward awaits the good. Let ail good things await
IIim who cares not to be great. Tennyson, Duke of We

II.t intrans. To watch; give heed. Auaitynge on the reyn th he it heere. Ther is ful many an eye and many an ere
A waitymg on a lord, and he noot where Chaucer, Summoner's Tale, 1. 352.

wait' + (a-wãt'), n. [<ME. await, aroayt, 〈OF. await, later aguait, agait, ete., mod. F. aguets, Watch, ambush; from t
ing; watch; ambush.

The lyoun sit in his await aiwsy
To slen the Innocent If that he may.

Chaucer, Friar's Trale, 1. 359.
Themselves they set

There in avait with themselves they set

To have in awaitt, to keep a watch on.

Fortune was first trend and sithen foo,

But haue hir in aucat tor ener Chaucer, Blonk

wait2t (a-māt') prep. phr. as a wait, n.] In wait. Tyndale.

waiter (a-wa'tér), n. [< ME. acayter, awa tour (cf. OF. aguaiteor, agnetteur): see await lies in wait.

Yef he be a prive awaitouer yhid, snd reloysetly lym to
rauysshe by wyles, thon shalt seyne him lyke to the fos rauysshe by wyles, thon shalt seyne hin lyke to the fox
whetpes. wake (a-wāk'), $v_{\bullet}$; pret. awoke, awaked, pp. awokc, awaked, ppr. awaking. [In this verb ar merged two orig. different but closely related forms: (I) ME. awaken (strong verb; pret. awoke, awok, pp. awaken, awake), < AS. "äicacan, onl in pret. $\bar{a} w \bar{o} e, \mathrm{pp} . \bar{a} w a c e n$, the pres. being sup plied by äcrecnan with formative $-n$ (whence prop. mod. E. awaken, q. v.), earlier *omacan (pret. onucoe, pres. onwaenan, etc.), < $\bar{a}$-, orig. on-, + *uacun, wacnan, wake; (2) ME, awaken ancakien (weak verb; pret. awaked, pp. awaked) < AS. aroacian (pret. āwacode, pp. äwacod) (= cacian, wake, watch. The above were intrans., the trans. form being ME. accechen, AS. areeccan (= OS, awekkian = OHG. arvec chan, irwecchen, MHG. G. erwecken), $<\bar{a}-+$ ceccan, trans., wake, arouse. 'The forms var as those of the simple verb: see $a_{-2}^{2}, a_{-1}$, an wake.] I. intrans. 1. To cease to sleep; com out of a state of natural sleep.

Jscoll arcaked out of his sleep.

Gen. xxviil. 16

2. To come into being or action as if from sleep.

Now with his wakening senses, hunger too linilliam Al resemolf from a state tion; be invigorated with new life; becom alive: as, to awake from sloth; to awake to the consciousness of a great loss.

A wake, 0 sword, against my shepherd. wake to righteousness.

And at his word the choral hymns aurake.

Zecih xiii. 7

. 32 or poetical.]
Nourish the cause of his a waking. Shak., W. T., ii. 3.

The purple flowers droop: the golden bee Tennyson, Enone.

II. trans. 1. To arouse from sleep.

uro that I may a veake him out of sleep. John xi. 11. 2. To arouse from a state resembling sleep, as from death, stupor, or inaction; put into action or new life: as, to aurake the dead; to (ueake the dormant faculties.

Iy master is awak'd by great occasion
To call upon his own. Shak, T. of A., i. 2.

Thou dost awake something that troubles me,

And says, I fov'd thee once.

=Syn. 2. To wake, excite, stir up, csll forth, stimulate, spur (up).

awake (a-wäk'), a. [Formerly also awaken, <

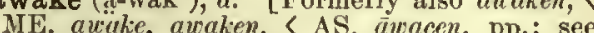
the verb.] Roused from sleep; not sleeping; in a state of vigilance or action.

It is my love that keeps mine eye awake.

Sornets, $1 x i$

awakement (a-wāk'meut), n. [< awake, v., + -ment.] The act of awakeniug, or the state of ligion. [Rare.] Imp. Dict.

awaken (a-wā'kn), $v$. [<ME, awakenen, awakmen <A $\bar{a}$. $n c n$, As. awacnan, pres. used with strong
pret. $\bar{a} w \bar{o} c$ (seo awake, $v$. ), also āwacnian (pret. äwocenede, pp. àxacned), awake; orig. intrans., but in mod. use more commonly trans.: see awake, $v$.$] I. intrans. 1. To become awake;$ cease to sleep; be roused from sleep or a state resembling sleep: as, to atcaken early.

A music of preparation, of awakening suspense - a muDe Quincey. 2. To come into being or action as if from lecp: as, hope awakened in his breast.

II. trans. 1. To rouse from sleep or a state incering sleep; cause to revive from a state of inaction.

$$
\begin{aligned}
& \text { Satan in his next subordluate } \\
& \text { A wakening, thins to him in secret spake. } \\
& \text { Milton, P. L. }
\end{aligned}
$$$$
\text { I offer'd to auraken his regard }
$$

I offer'd to a waken his regard
For his private friends.

2. To call into being or action.

Such a reverse in a man's life arcakens a better principle
than curiosity. [Awaken is chiefly used in figurative or transferred ap-
plicattons, aveake being preferred in the sense of arousing rom actual sleep.l

awakenable (a-wa' $\mathbf{k n}-\mathrm{a}-\mathrm{bl}), a . \quad$ [< awaken +
-able. Capable of being awakened. Carlyle. awakener (a-wãk'nèr), $n$. One who or that which awakens or arouses from sleep or inaction.

Tyough not the safest of guides in politics or practical philosophy, his [Carlyle's] value as an inspirer and $\alpha 200$. Lowell, Study Windows, p. 149

awakening (a-wãk'ning), n. 1. The act of

of her aurakening minte ere the time

Shak. (some editions), R. and J., v.

2. An arousing from what is like sleep; a revival of interest in, or attention to, what has been neglected.

It was a sign of a grest arakening of the human mind when theologians thought it both their duty and their
privilege to philosophize. Stille, Stud. Med. Ilist., p. 384.

Especially - 3. A revival of religion, either in an individual or in a community: a use of the word derived from the Scripture symbol of sin as death or sleep, and conversion as resurrection or awakening.- The great awakening, the great revival of religion in New England brough awakening (a-wāk'ning), p. a. Rousing; alarming: as, an axakening sermon.

awakeningly (ạ-wāk'ning-li), $a d x$. In a manner to awaken.

wakenment (a-wa'kn-ment), n. [< aroaken of being awakened; specifically, a religious revival. [Rare.]

awald, awalt (äwald, ä'walt), $a$. and $n$. [Se. awald, awalt (äwald, ä'walt), $a$. and $n$. [Se.,
also written awelled, acart (and by simulation awkvard); origin uncertain. Cf. AS. vecaltan, waltan, roll, "äwaltan, pret. ätcelte, roll: see walter, valty, welter.] 1. a. Lying helplessly on the back: said of a sheep when unable,

rough sickness or fatness, to get up.

II. $n$. A sheep so lying. 
awane (a-wān'), prep. phr. as adv. [< $n^{3}+$ awater (n-wâtér), prep.phr. as ade. [< $u^{3}+$ wanc. On the wane; waning.

awanting (â-wân'ting), a. [P'rop. a phrase, absent; missing: not used attributively.

In either case criticism was required, and critidsm was
rereantiny.

awapet, $t ;$ See awhape.

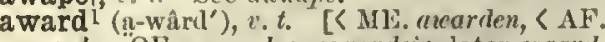
"weverter, OF, eswarter, estcardeir, later esgarlcr, esguariler, esgarleiv = Sp. esyuardar (obs.) cr, esguaticr, esgariets = Sp. esyuardar (obs.) = It. syuarlare, look at, consider, decide, adjudge, Mardure, gnarlarc, observo, regard, guarl : see carll, guard, and reyurl.] 1. 'To adjulge to be due; assign or bestow as of right; give by judicial determination or deliberate judgment, especially upou arbitration or umpirage: as, to awarl the prizes at a school examination the arbitrators nourled lim heavy damages. A pound of that same mcrchant's flesh is thine The court aucrids it, and the law doth give it.

To the woman who conld conquer, a triumph was 2t. To senteneo; adjudge or determino the doom of.

est ... the aupreme hing of kings ... a war Sher of you to be tho other's end.
Slak., Rieh. III., 3i. I.

A wards you to be tranded to the frout B. Jonzon, Poetaster, v.

3. In a general sense, to permit the possession of; allow; allot; yield.

The clinld had many more Inxuries and indulgences
Than had been averded to his father.

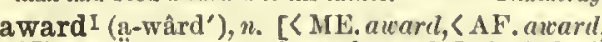
OF. esicurt, esguart; from the verb.] 1. A decision after examination and deliberation; a judieial sentoneo; especially, tho decision of arbitrators on points submitted to them
document containing such a decision.

We cannot expect an eqnitalle arrard where the Judge

is mite a party.
2. That which is awarded or assigned by sueh a decision, as a medal for merit, or a sum o money as damages, eto.-Geneva award. See Alaaward $\left.{ }^{2}+, v . t . \quad[<a-11+\operatorname{seard}].\right] \quad$ 1. To guard. -2. To ward off. Exelyn.

awarder (a-wâr'dèr), ". One who awards or' as signs as of right; a judge, arbitrator, or umpire aware (a-wãr'), a. [< ME. aware, itcar, icare, year, 〈 AS. gewer (=OHG. giwar, MHG. gewar, G. gevahr), (ge- + weer, wary, cautious: see $a-6, g e-$, and icarc 1.$]$ 1t. Watchful; vigilant on one's guard.

I have laid a snare for thee, and thon art also taken,
babylon, and thou wast not azeare. Are you all arcare of . tale-henring and evil-speak 2. Apprised; cognizant; in possession of in2. Apprised; cognizant; in possession of information: I wus ao distimetly made aware of the presence of some-
thing kindred to ne... that I thought ne place could
ever be strange to me again. Specifically-3. Informed by sight or other sens

Then Enid was ateare of three tall knights

On horscback, wholly arm'd, behind a rock,
In shadow, waitlug.

= Syn. 2. Aroare, Conscious (see cont

awareness (a-wãr'nes), $n$. The state of being waro.

Recognition of reality in our view is not aum remesk.

This conscionsness I apeak of is not a direct perception Nero I'rinceton Rev., II. 178 .

awarnt (a-wârn'), v'. t. [<a-twarn.] Towarn. Every lird and beast awamed made + cash.] ing from the surface of the level with or emergwaves break over it, as wreekage, or an anchor when hove up to the surface, or rock, spit, or bank just apnearing above the water.

The wrecks are floating almost arcash, presenting little (b) Covered with wator; kept wet: as, the deeks were constantly awash. (c) Washing alout; tossed about by the waves.

awaste (a-wäst'), prep. phr. as adv. [< $a^{3}+$ instc.] Wasting; going to waste or decay. Awata ware, pottery. See voare. cater.] On the water.

Wave (a-wāv'), prop. phr. as adt. [< $a^{3}+$

way (a-wä'), prcp. phr. as alr. [<Mk. ancay, "zoey, ruce, oucuy, o wey, on rcuy, ete., < As. axeg, earlier on $u e g$, lit. on way: see $a^{3}$ and
way.] 1. On the way; onward; on ; along: as, eome arcay.

Mifstress, you must come areay to your father. Shak., As youl like it, 1. 2

2. From this or that plaee; off : as, to go, run, flee, or sail arcay.

Ife roae and ran away. Shak., Pass. I'ilgrim, Iv. It ad we kias'd the fringe of his beard and we pray"d as we nd the Ifoly juan tic as Temmyson, voyage of Macldune. sent: as, ho is away from home; I found him alvay on a vaeation.

Thyself away art preaent still with me;

Shak sonnets, xivil.

4. From contact or adherence; off: as, to elear away obstruetions; ent acay the broken spars.

Betore the golden tresses of the dead

5. Removed; apart; remote: as, away from tho subject.

$$
\text { Quite aury Irom anght vulgar and extern. }
$$

Bronening, King and Book, II. 129

6. From one's possession or keeping: as, to
give atcay one's books or money; throw axcuy give acay one's books or mon
a vorn-out or disearded thing.

O there, perchance, when all our wars are done,

Tennyan, Holy Grail.

7. From one's immediate presence, attention, or use; aside: as, put or lay arcay your work; put away your fear or the summer.

These slispositlens, which of late trat avay

Thesc lispositions, which of late transport you
Srorn what you riglitly are.

8. From this or that direction; in another or the other direction: as, turn your eyes ascay; ho turned away.

Often, where clear-stemu'd platans guari The boat-head down a broad cana the village is six miles accay.

Mirthful sayings, children of the place,
That have no meaning half a league airay.

An hour avay, I pulled up, and atood for some time at the edge of a meadow.
II. James, Jr., Trans. Sketches, p. I36. 10. From one state or condition to another; out of existence; to an ond; to nothing: as to pass, wear, wasto, fade, pine, or die away; continual dropping wears aroay stone; the im age soon faded away; the wind died away at sunset; she pined axuy with consumption.

The new philosophy represented by Locke, in ita conf dence and pride taking a parting look at the old philosophy, repreaented by the acholastic lliscusslons, passiog McCosh, Locke's Theory of Knowledge, p. 16. Without adducing one fact, withont taking the tronlyle to perplex the question by one aophism, he [3r. MIll]]
placldly dogmatises array the interest of one half of the himan race. 11. Gone; vanished; departed : as, here's a
health to them that's avay. [Chiefly prov. Eng. and Seoteh.]-12. On: continuously; steadily; without interruption: as, he worked away; he kept pegging away; and hence often as an intensive: as, to fire away, eat awoy, laugh away, snore aicay. consent, caught fire and were blazing a way to their dear

13. Often used elliptically, with a verb (as go, get) suppressed, and simulating an imperative: as, (go) acay! (get) away! we must away; whither away so fast?

Away, old man ! give me thy hand, anay! Love hath wings, and will arcay. Waller. tray, auday, there is no danger in him. Beau and $E^{\prime}$ in him.

Away back, far back; loog ago: as, away back in the years before the war; a way baek in 1844. [Collog. often way back.]-Away with. (a) Uacd as an

A way with this man, and release nuto us Barabbas. ave.] On the wave; waving. 3. From one's own or acenstomed place; ab

As if ail the chlmneys in Great Britain had, by on aweel

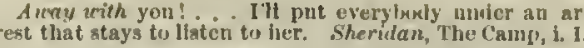
(b) An ellintieal expression for " get on with; accommolate one'a aelf to; endure. IAr haic.

Some agayne atfirme that he retorned in to his countrey lut partly fer that lie coulde not a way with the fashons of lils countroy folk, and partly for that his minde and aff ce-
thon was aitogether set and fixed unon ctopia, they sily lon was aitogether set and flxed ifon Ctopia, they sit
that he inathe taken his yoyage thetherwardc agnyne. Sir T. Ifore, Ltopia

Shal. She never coulit away with mo.

mo. Fal. Never, never; she would al ways say ahe eould not
Shak, 2 Iten. IV., Iit. 2 I could never away trith that atiff-necked generation,
B. Jomson, Bartholomew Fair, I. I.

Far away, far and away. (a) At a great diatance Ot all the men whon sile had ever been, he waa far array
the nicest and best. Right away, atraightway ; at once; Immcilately ; forthwith.-Say a way, say on; proceed with your reioarks. [U. S. and prov. Eng.] - To bear away, explain away, away-going ( $n$-wä'gō" ing), $a$. and $n$. I. $a$. Going away; dëparting; leaving: as, an awaygoing tenant. - A way-going crops, crops suwn durln the last year of a tenancy, lut not ripe until atter the ex

II. $n$. A going away; departure.

awaywardt (a-wa'wịrd), adv. [ME., also auci

ward, ete. ; ; away + -rard.] Turned aside. Goicer.

awbert, ". [< F. aubour, OF. aubour, also au ur (Cotgrave), laburnum, appar. < L. albur bum: see alburnum and laburnum.] The lather, Remark. Provid., p. 232. (N. E. D.) awe 1 (â), n. [Also, more prop., aio (like lac, awe (â), n. [Also, more prop., aio (like lave,
haic, ote.), < ME. atc, awe, algh, aghe, aze, < Ice]. agi $=$ Dan. ave = AS. as if "aga, the same with diff. formative as AS. egc, Mí. eze, eghe, oye, aye, ay, = OHG. agi, cgi, MHG. ege = Goth. agis, fear, <" agan, fear (in ppr. "agonds, with negative unagands, nnfearing); perhaps akin to $\mathrm{Gr}$. à $\chi \circ$, anguish. Cf. $\left.a s k^{2}.\right]$ 1. Dread; fear, as of something evil.

I had as lief not be as live to be
In azce of such a thing as I myselt.

In every form of reverument, the mules ata ave of the people. 2. Fear mingled with admiration or reverence reverential foar; feeling inspired by something sublime, not necessarily partaking of the nature of foar or dread.

Stand in auce, and gin not.

P8. iv. 4

The [Egyptian] deitiea repreaenting the great forces of nature, and shronded by mysterious aymbols, excited

To feel once more, in placid awe.

The strong Imagination roll

A aphere of stars about my nou

wen influence.

By my sceptre's awe I make a vow.

Shak, Rith. II. i, 1

$=$ Syn. Reverence, I'eneration, etc. Sce reverence, $r$.
We

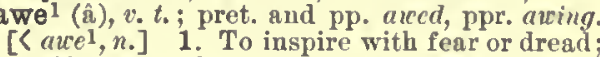
terrify; control or restrain by the influenee of fear.

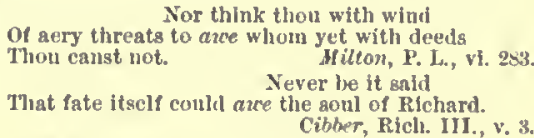

2. To strike with awe, reverence, or respect;

influenee by exciting profound respect or rev-

$\mathrm{we}^{2}(\hat{\mathrm{a}}), v . t .[\mathrm{Se} .,=\mathrm{E}$. ovce. To owe. [Seoteh.] $\mathrm{we}^{3}$ (a)), n. [Sc. also are, early mod. E. also aw, ave, ace, alve; origin obscure.] 1. One of the float-boards of an undershot water-wheel, on which the water aets.-2. One of the sails of a wiudmill.

weary (a-wēr'i), a. [<a-expletive + veary. $]$

Weary; tired. [Archaie or poetical.] She said, "I am areary, aneary,

Tennyson, Marlana. And all his people toli him that their horsea were Ticknor, Span. Lit., I. 6 t. aweather (a-weqH'er), prep. phr. as adv. or a. [< $a^{3}+$ weather. $]$ On the weather side, or toposed to alco.

weel (a-wēl') $a d v$, [Sc. < $a$ for $a h, o h,+$ $x e e l=E$. 1cell.] Oh well; very well; well then. A meel, if your honour thinks I'm safe - the story is just 


\section{aween}

aweent, v.t. [<ME. awencn, <a- + wenen, <AS. wernan, think, ween: see $a-1$ and ween.] To ween; suppose.

The Jewes out of Jurselem awenden he were wode [mad].

aweigh (a-wa' $)$, prep. phr. as $a d v$. or $a . \quad\left[<a^{3}\right.$ + weigh.] Naut., atrip. The anchor is aweigh when it is just drawn from its hold in the ground and hangs

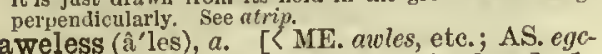
lé́s, Wanting awe or reverence; void of deferential fear.

Lordes bene lawles,

A Prophecy, etc., l. 16 (E, E. T'. S., extrs ser., VIII. i. 85 ),

The aweless lion could not wage the fight

2. Wanting the power of inspiring reverence or awe.

The innocent and awless throne. Shak., Rich. IIl., ii. 4. Also spelled awless.

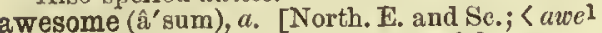
+ -some.] 1. Inspiring awe; awful: as, an awesome sight.

"An awsome place," answered the blind womsn, "as ever living creature took reftige in." Scott, old Mortslity, xliii. The Wizard, on his part, minfully stuck up for his the Devil was really no joke, Kinglake, Eothen, p. 168
Kind to do so was an avesome crime.

2. Evidencing or expressive of terror.

He did gie an avesome glance up st tbe auld castle.

Also spelled awsome.

awe-strike ( $\hat{A}^{\prime}$ strik), v.t. To strike with awe. [Rare.]

awe-struck (â'struk), p.a. Impressed or struck

awful (â'fül), a. [〈ME, awful, agheful, aghful ; AS. egeful, < ege, awe (see awe 1 ), $+-f u l]$.1 . Striking or inspiring with awe; filling with dread, or dread mingled with profound reverence: as, the auful majesty of Jehovah; the awful approach of death.

Her fathers' God belore her moved,
An awf ul guide in smoke and flame. Scott, when Israel, of the

d beloved.

The awful mysteries of the world unseerl. J. Caird. 2. Of a dreadful character; causing fear or ter; I heard an awful shriek.

$$
\begin{aligned}
& \text { Or it she slept, she drean'd } \\
& \text { An avenul dream. }
\end{aligned}
$$

3t. Inspiring or commanding respect, reverence, or obedience.

An awful rule and right supremacy.
Shak., T. of the $S$

A parish priest was of the pilgrim train;

An awful, reverend, sind religious manl.

She wonld, npon accasions, trest them with freedom; yet her demeanour was so awoful, that they durst not fail
in the least point of respect. Swift, Death of Stella.

4. Expressive of or indicating deep awe, as for the Deity.

Towards him they bend
With awful reverence prone. Al ilton, P. L., ii. 478.

A wful prostration, like Pascal's, before the divine idea.

5t. Impressed with or exhibiting respect or reverence, as for authority; law-abiding; respectful in the extreme.

Thrust from the company of awful men.
Shak., T. G. of V., iv. 1.

How dare thy joints forget
To pay their awful dnty to

onr presence?
Shak., Rich. II., iii. 3.

6. Having some character in an extreme or noticeable degree; excessive; very great; extraordinary; preposterous: as, he is an awful
dandy; that is an awful bonnet. [Colloq. and vulgar.]

Pot-pie is the favorite dish, and woodsmen, sharp-set, are awful eaters.
Carleton, New Purchase, I. 182. (Bartlett.) $=$ Syn. 1 and 2. Awful, Dreadful, Fearful, Frightful, solThe first four of these words are often loosely or colloquially nsed to express dislike, detestation, or horror but should in the main retain the sane distinction Thus awful is full of awe, full of that which inspires awe, exciting a feeling of deep solemnity and reverence, often with a certsin admixtnre of fear, acting especially upon the imagination (see reverence, $n_{\text {. }}$ ); the suggestion may shift in all degrees from awe to borror: as, an awfu spires dresd, thst is, an oppressive fear of coming evil, lumpressing tear: as, "a certain fearful looking for of
400

\section{awkwardly}

inspiring fright or sudden snd almost paralyzing lear. An $\operatorname{awk}^{1} \dagger$ (âk), adv. [< auki1,a.] Awkwardly; auful sight; a dreadful disaster; a fearful leap; a fright- wrongly.

Abash'd the Devil stood,

Professors ringing as awi as the hells. Milton, P. L., iv. 846. awk ${ }^{2}, n$. See $a u k^{1}$.

he smoothness of flattery cannot save us in this rugged awkerd, awkert (ák'kèd, -kèrt), $a$. A dialecaveward. [Prov. Eng.]

0 Lord! methought what pain it was to drown!

What sights of ugly death within mine eyes

Tethought I saw a thoulsand fean

Shak., Rich. III., i. 4.

There was a fearful, sullen sound of rushing waves and ken surges. awklyt (âk'li), adv. [ME awlely. $<a w k^{1}+$ $-l y^{2}$.] In the wrong direction; left- or backhandedly. Henee- $(a)$ Awkwardly; clumsily.

Their music, frightful as the serpents' hiss,
Shakk, 2 Henl. VI., ili. awklyt (âk'li); $a$. [< avk $k^{1}+-l y 1$ Cf. As (ONorth.) afulic, perverse: see awk.1.] Perverse; nntoward.

awknesst (âk'nes), n. [〈awki + -ness. $]$ The state of being awk or awkward.

awfully (ấful-i), $a d v$. In an awful manner. (a) Dreadfully; terribly. (b) With solemn impressiveness;
sublimely; majestically. (c) With \& Leeling of awe or reverential fear; reverently. (d) Excessively; extreme[s; very :

You'll be avfully glad to get rid of me.

wkward (âk'wärd), adv. [Early mod. E. or dial. also aukward, awkwart, awkard, awkerd, awkert, etc., ME. awkwarde, aukward, etc. transversely, sidewise, perversely; < awk $1+$ -ward.] 1t. In the wrong direction; in the wrong way; backward.

The emperour thane egerly at Arthure he strykez A wkwarde on the umbrere [vizorl and egerly hym hittez.

2ł. Asquint.-3. Awkwardly; clumsily. [Now only prov. Eng.] awe, fear, or horror; impressive solemnity or sublimity; dreadfulness; terribleness: as, th awfulness of the sacred place, or of a casualty. Contrasts which move, now our lsughter at their incon gruity, and now onr terror at their awfulness. J. Caird. awe; reverence; awe.

A help to prsyer producing in us reverence and awfulwgrimt, n. A Middle English form of algo-

awhapet, $v . t$. [Revived by Spenser from a ME. verb found only in pp. avchaped, awaped, terrified, confounded; a word of uncertain To confound; terrify. Also awape.

Not fulliche alle awhaped

Ont of the temple slle esiliche he wente.
Chaucer, 'Troilus, 1. 310.

A wilde and sslvage man,

All overgrowne with hair, that could awhape

awheels (a-hwēlz'), prep. phr. as $a d v . \quad\left[<a^{3}+\right.$ wheels.] On wheels. B. Jonson.

while (a-hwil'), adv., prop. adv. phr. [<ME. For a space of time; for some time; for a short time.

Counsel may stop awhile whst will not stay.

The company were sll sorry to separate so soon,

and stood a-while looking bsck on the wster, npon which [A while is properly two words, as it has to be written when an adjective is used, as $a$ little while, and as it is by for.] prep. phr. as adv. [< $a^{3}+$ wide, after afar, ete.] Wide; widoly.

They opened their month a wide [wide in anthorized verwing (a-wing'), prep. phr. as a. or adv. [<a + wing.] On the wing.

"Tis time his fortune be a-ving; high time, sir.
Fletcher, Humorous Lieutenan

Toving specks, wlich he thought might be ships in flight or pursuit, or they might be white birds awing.

awk' (âk), a. [< ME. awke, auke, < ONorth. * afuh (in afutice, perverse) (= Icel. öfugr, öfigr (for *afugr $)=\mathrm{Sw}$. afvig $=\mathrm{OS}$. abhuh, abhoh $=$ OHG. abuh, abah, abeh, $\mathrm{MHG}$. ebich, ebech, G. dial. abicht, abech, abäch, äbich, äbig = MD. avesch, aefsch, awkward, contrary, perverse, D. aafsch, crafty, artful), lit. 'off'ward,' < af', AS. of, E. off, away, with a suffix of variable form and obseure origin. Cf. Goth. ibuks, back, backward, in which ib-, like the prefix in $i b$ dalja, descent, declivity, is perhaps a var. of $" a b$, af thus making $i b u k s=$ OS, $a \bar{b} h u h$, ete., $=$ E. $a w k$. .] 1 1 . Turned in the opposite direction; directed the wrong way; backhanded: as, "an awk stroke," Palsgrave.-2†. Iuft; left-handed. on the ark or left hand.

Holland, tr. of Plutarch, p. 717.

3t. Wrong; erroneous; perverse: as, the awh end of a rod.

Confuting . . the avk opinions of the Stoics.

of Mornay's Trueness of Christ. Religion.

4. Awkward to use; clumsy: as, an awk tool. [Prov. Eng.] - 5†. Strange; singular; distinguished.

off elders of alde tyme and of thelre aroke dedys, myghty. Morte Arthure (ed. Perry, E. E. T. S.), 1. 13.
myey were lele in theire lawe, and lovede God wkward (âk'wặrd), a. [Early mod. E. or dia]. also aukward, aickwart, awkard, awkerd, ete. awkward, adv.] 1t. Turned the wrong way backhanded.-2†. Perverted; perverso.

They with arkward Judgment put the chlef point of 'Tis no sinister nor no awkvard claim.

3ł. Untoward; adverse.

Twice by awkward wind from England's bank

Drove back agsin unto my native clime.
Shak, 2 Hen. VI., iii. 2

4. Ill adapted for use or handling; unbandy in operation; clumsy: as, awkward instruments or contrivances. -5 . Wanting dexterity or skill in action or movement; clumsy in doing anything, as in using tools or implements; bungling.

So true that he was awkwoard at a trick. Dryden. 6. Ungraceful in action or person; ungainly; couth: as, awhward ges

Drop'd an aukword conrt'sy to the Knight.

7. Embarrassed; not at ease: used in relation to persons: as, an awoward feeling. -8 . Not easily dealt with; troublesome; vexatious; requiring caution: as, an awkeard predicament. [Colloq.]

Between the weir and the trees it is an arokward spot, Froude, Sketches, p. 241 .

t. Unlucky.

The beast long struggled as being like to prove
An awkward sacrifice. -Syn. 5 and 6. A whward, Clumsy, Ungainly, Uncouth, Bungling, unhsndy, inexpert, nnskntul, inapt, lubberly, generally spplied to want of ease and grace or skill in bodi. iy movement, especially of the arms or legs: as, an aukward gait; a awoward in the use of a tool. Clumsy starts from the notion of hesviness, and consequent unwieldiness or a whwardness in use; it is applicsble to the whole body or o any part of it, even when still: as, a clumsy flgure; clumsy hands. This difference is siso found in the figurs the use of the words: a clumsy excuse is one that is pat good, but is not gracefully presented. Ungainly, literslly nnhandsome, not pleasing to the eye, is applied generally to swkwardness of appearance. Uncouth, literally um. known, unconmmon, and so, by a bit of human conceit, uninstructed, untrained, unrefined, sometimes even rude,
bsrbarous: as uncouth phrases, manners. Bungling, osrbarous: as uncouth phrases, manners. Bungling, wardness, in either literal or flgurative use: as, he made bungling work of it.

With ridiculous and awkward action .
Shak., T. and C., i. 3.

Besides Hepzibah's disadvantages of person, there was on uncouthness pervading all her deeds; a clumsy some thing, that conld but ill adspt itself for use, and not at all

Who would liave predicted that the prince of Grecian eloquence should have been found in a stammering orphan, of feeble lungs and ungainly carriage, deprived of educaIany uncouth phrases and forgotten words seemed to her no less a vailable than cormmon forms.
Stedman, Vict. Poets, p. 126. IIe mnst be a bungling gamester who cannot win.

wkwardly (âk'wärd-]i), adv. In an awkward manner. (a) Clumsily; without dexterity or grace in action; in a rude or bungling manner; inelegantly. (b) Fmbarras
situated. 
awkwardness (âk'wärd-nes), $n$. The state or awoke (a-wök'). P'reterit and last participle öxa, ax; from the noun.] To shạe or trim ruality of being awkward. (a) Cinmsiness; un- an

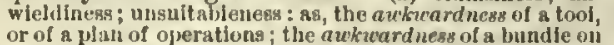
sccount of its aizo or shape. (b) Lack of akilli or dexterity in action. (c) Luck of ease in action ; ungracefuiness.
(t) An awkward eircumstance or feciling; embarrassment unpleasmitness; ineonveniene.

awl (âl), n. [Warly mod. H. also aul, all, and by misdivision (a naul for an awl) nawl, mul, nall,

Mk. nal. The earlier forms are of four types:

(1) Ml\%. aule, eacle, mul, < AS. accel, aucul; (2)

ME. oule, onel, oucl, owul, < AS. ärel, areul; (3)

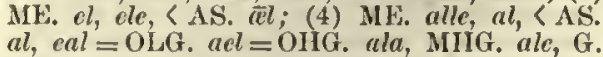
al, eal =OLG. acl =OHG. ala, MIIG. ale, G.
ahle =Icel. alr, an awl; with added formative, OHG. alansa, alunsa, "alasna (> ML. alesna, It. lesina $=\mathrm{Sp}$. lesna, alesna $=$ Pr. alena $=\mathrm{OF}$. alcsne, $\mathrm{F}$. aléue $)=\mathrm{OD}$. uelsene, elseno $(\bmod . \mathrm{D}$ cls), > Se. elsin, elson, Shetland alison, an awl Cf. Skt. ārī̄, an awl..] 1.

A pointed instrument for piereing small holes in leather, wood, ete., as the bent-pointed arcl of the shoemaker and saddler aud avel of the joiner.-2. The

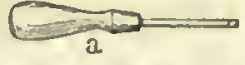
a. Brad.awl; b. Sewlng.

popilijay or green woodpe

viridis. [Loeal, British.] awl-bird (âl'bèrd), n. Same as avl, 2. Montagu. awl-clip (âl'klip), n. A device for holding blanks, memoranda, ete., eonsisting of an aw on file are thrust upon the pin.

awless, $a$. See aveless.

awl-shaped (âl'shāpt), a. 1. Having the shape of an awl. - 2. In bot., slender and tapering toward the extremity from a broadish base, as a leaf; subulate.

awl-tree (âl'trēe), n. [< avol, repr. Hind. äl (see $a l^{1}$, al-root $),+$ tree. $]$ Same as al1.

awlwort (âl' wert), $n$. The popular name of the Subularia aquatica: so ealled from its awlshaped leaves (Latin subula, an awl). It is a very found in Errope, Siberia, and North Ameriea. awm (îm), n. Same as aant.

awmbrył (âm'bri), n. Samo as ambry.

awmous ( $\hat{l}^{\prime}$ mus), $n$. A Seoteh form of alms.

aWn' (ân), n. [E. dial. also ang; < ME. awone, aune, avene, earlier agun, < AS. "agun (not reeorded; the ME. may be from the Seand.) = OHG. agana, MHG. agene, agne, ane, G. ahne (also agen), awn, = Ieel. ögn, pl. agnar, = Sw. agn, only in pl. agnar, = Dan. avne $=$ Goth.

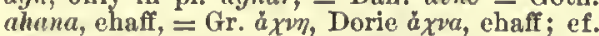
(with diff. formative) Gr. a a xvoov, ehaff, L. acus (with diff. formative) Gr. axvoov, ehaff, L. acus eór (contr. of "ahur = ONorth. ehcr, ahher), $\mathrm{E}$ ear $^{2}$ (of corn) (see ait', avel, acerose, and ear ${ }^{2}$ ) ult. <" $a k$, be sharp. But it is possible that two orig. different words, meaning ' $a w n$ ' and 'ehaff' respectively, have here run together.] In bot., a bristle-shaped terminal or dorsal appendage, such as the beard of wheat, barley, and many grasses.

$\mathrm{awn}^{2}, a$. and $v$. An obsolete or dialectal form of oion.

awned (ând), $a$. [<awn1 + -ed ${ }^{2}$.] Having awns applied to leaves, leaf-stalks, ete., bearing a long rigid spine, as in barley, ete.

awner (â'nêr), n. A machine for removing the avels or awns from grain; an aveler; $a$ hummeler. See hummeling-machine.

awning (â'ning), $n$. [First recorded in the 17th eentury, in naut. use; of undetermined origin, but appar. (with suffix -ing 2 ) "aicn, prob. a naut. reduction of $\mathrm{F}$. aurent, "a penthouse of eloth before a shop-window" (Cotgrave), OF auvant, ML, auranna (also spelled auventus, appar. in simulation of L. rentus, wind), of unknown origin.] A movable roof-like eovering of eanvas or other eloth spread over any place, or in front of a window, door, ete., as a protection from the sun's rays.

Compact, with tuciel marbles, boss'd with length

Of elassie frieze, with ample arenings gay. Tennyson, Princess, it.

It was very hot, and sitting under the avoning turned out to be the ple

Lady Brassey, Yoyage of Sunbeam, L. I.

Backbone of an awning. See brekbone. To house awnless (ân'los), a. [<aon $1+-l e s s$.$] With-$ out awns or beard.

awny ( $\left.\hat{\imath}^{\prime} n i\right), a$. [ $\left\langle u c u^{I}+-y^{1}\right.$.] Having awns; bearded; bristly. awork $\nmid$ (a-werk'), prepl. phr. as ade. [<ME. acerke; $a^{3}+$ work.] At work; in a state of bor or action.

"'were s good mirtil now to set him a-veork

Middleton, Ciaste Maid, 1. 1.

The bad will have hut small matter whereon to set their aworking (n-wèr'king), prep. phr as adv. [< $a^{3}$ + working.] At work; in or into a state of working or action.

Adventure which might them a vever met

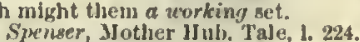

awreakt, v. t. [<ME. atcreken, < $\mathrm{AS}$. ätrecan < $\overline{-}$ - + crecan, wreak: see $a-1$ and creak.] To wreak; take vengeanee on; avenge.

Ne were lever than al this toun Chaucer, Mililer's Tale, 1. 566 .

awrong $\nmid$ (a-rông $\left.g^{\prime}\right), p r e p . p h r$, as $a d v$. [< $a^{3}+$ wrong. Cf. aright, a moch.

If 1 ainid

$$
\text { Alorong, 'twas in an envy of tily gaodines. }
$$

Ford, Lady'a Trla, jil. 3

wry (a-ri'), prep. phr. as adv. or a. [< ME acry, awrye, on wry: $<a^{3}+$ wry.] 1. Turned or twisted toward one side; not in a straight glanee or look awry; the lady's eap is awry.

If alre stepa, looks, or moves aury. Spectator, No, 66. 2. Figuratively, away from the line of truth or right reason; perverse or perversely.

$$
\begin{gathered}
\text { Nuch of the noul they talk, but all avery. } \\
\text { Milton, } \mathrm{P} \text {. J. }
\end{gathered}
$$$$
\text { The prince's counselg all axry do ko. }
$$

Ther. Xxxil.

To go (run, etep, tread, walk) awry. (a) Of persons : badly or untowardly; go wrong.
awsk (âsk), $n$. A dialeetal form of $a s k^{2}$.

awsome, $a$. See awesome

$a x^{1}, a x e^{1}(a k s), n$. [The reg. mod. spelling is $a x$, $\mathrm{ME}$. $a x$, also $a x c, c x, a x,<\mathrm{AS}$. $a x$, also $c a x,=$ ONorth. acasa, acase $=\mathrm{OS}$. accus $=\mathrm{OD}$. akes, D. aks, a akse, aaks, $=\mathrm{OHG}$. acchts, achus, MHG, ackes, axt, G. ax, axt = Icel. ox, oxi Sw. $y x a=$ Dan. $0 x c=$ L. ascia, ax, mattoek akin to Gr. $\dot{a} \xi i m$, ax.] An instrument used for hewing timber and chopping wood, and also

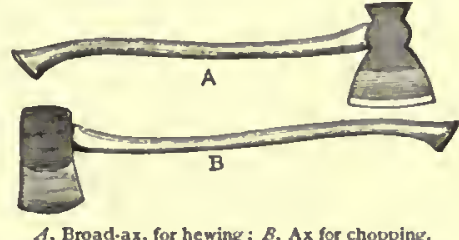

as a weapon of offense. The moderu ax consigts of a head of iron, with an arehing edge of ateel, and a helve or handle. The edge is in the plane of the sweep of

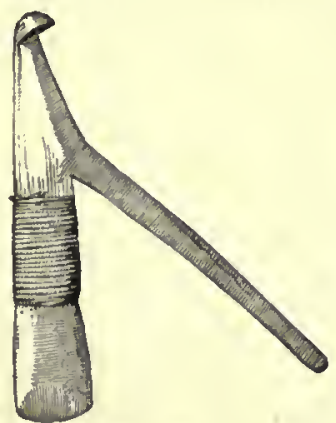

Ax of Jadeite from New lreland.

among the Arabs and Yoors. A light ax was common prehistoric and ancient remiains, and in use by harbarous told by trankiln), aome privute purpose to subserve, or
selfish end to attain.-Bullhead ax, a pole-ax with a selnsh end to attain.- Bulluead ax, s pole-ax with - Sacred ax, a name given by col. lectors of Chinese poreelain to an em. blem or mark aupposed to resemble forming part of the decoration of certain pleces anid to be assigned to war.
riors. - To put the ax in the helve, The find out a puzzle.

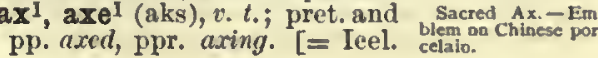
hrearms. It was uked by wn ancestors and of the art. The northern naRoman enpire used reapon, and ita use premiddle age日 in Europe. atone, or entirely of copper or bronze, are found amon told by tranklin), An axe private purpose to silo a story an ax, and found either alone or as with an ax.

$a \mathbf{x}^{2}+, a x e^{2}+$ (aks), n. [<ME. $a x, a x c$ (in comp.), $c x, c x c$, also $u s$, , AS. cux, $c x=$ OD. usse, D. as $=\mathrm{OlIG}$. ahse, $\mathrm{MHG}$. ahse, G. achse = Dan. $a x$

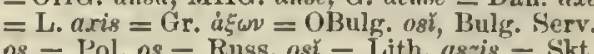

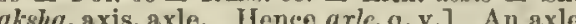
an axis.

$\mathbf{x}^{3}, \mathbf{x y}^{3}$ (aks), $v, t$. Obsolete or dialeetal forms Por I wol axe if It hir wille be

axal (ak'sgl), a. Same as axial.

Chaveer. axel, $n$. and $v$. See $a x^{1}$

axe $e^{2}, n$. See $a x^{2}$

$a x e^{3}, r$. See $a x^{3}$

axe "aks), $n$. An Englisl name of a native species of Lobelia, L. urens.

axed (akst), $a$. [<ax $x^{1}+e^{2}$.] In masonry, dressed with a stone harnmer to a smooth surface.

Good effect is olstained by the contrast of axed and pol.
Lincye, Brit., IV, 474. axes, $n$. Plural of $a x$ and of axis.

axfitch, n. [Also written axvitch, axfetch; $a x^{1}+$ fitch. This and the other names axscer, acoort, hatchet-fitch, and NL. Securigera, refe to the ax-shaped seed.] A leguminous plant. Securigera coronilla. Cotgrave.

ax-form (aks'fôrm), a. Same as ax-shapel.

ax-head (aks'hed), $n$. The head or iron of an ax. Aneient ax-heads, formed of stone and sometimes of bronze, are ealled celts.

axial (ak'si-al), a. [<axis + al. $]$ 1. Pertaining to or of the vature of an axis.

From central development we pass insensilly to that higher kind of development for which axial seems the 2. Situated in an axis or in the axis.-3. In ant., pertaining to the somatic as distinguished from the membral portions of the body; not appendieular. Axial parts or organs are, in general, divided into epaxial, hypaxial, and paraxial, according
as they are situated over, under, or alongside the spinal 4. In gcol., forming the axis, eentral dominating portion, or erest of a mountain-range.

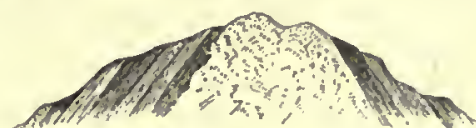

Section of mountain showing anticllinal structure with a xial nass

The central or axiai portions of many mountain-range consist of crystalline, azoje, or arehrean rocks; this is especially true

Sometimes axal.

Axtal canal, in ertnolds, the central eanal within the hard perisoma of the atem, extending the Jength of the
latter and filled with a soft solid substance.-Axial cavity, in Aetinozor, the cavity conmon to the gaatrie sac circle, a eircle having its center on the axis of a curve. which the magnetic force passeg from one pole of a horseshoe magnet to the other. - Axial plane, in crystal., plane containing (1) two of the erystallographic axes, or rotation, rotation upon an axis.-Axial okeleton, the the skeleton of the limb

axially (ak'si-al-i), $a d v$. In a line with or in ireeks it was looked Asiatic nations, and so axis.

There are many Transparent 0l,jeets, however, whose peeuliar features ean only be made ont when they are vewed ly light tranamitted through them obliqnely in
stead of axially.
U. B. Carpenter, SHerog, 8145 . axiferous (ak-8if'e-rus), $a$. [< L. axis, axis, + ferre = E. bcarl.] In bot, eonsisting of an axis only, without leaves or other appendages: applied by 'Turpin to fungi and algre, considered as eonsisting essentially of an axis merely. axiform (ak'si-fốrm), a. [< L. axis, axis, + forma, shape.] In the form of an axis. xifugal (ak-sif'ū-gal), a. [< L. axis, axis, + fugcre, fleo, $+-a l$.$] Centrifugal. [Rare.]$ ril (ak'sil), n. [< I, arilla, dim. (ef. àla for "axla, dim.) of axis, axis, armpit : see ala, aisle, axis ${ }^{1}$, and axle.] 1. The armpit, or axilla (whieh see). gle formed between the upper side of a leaf and the stem or braneh to which it is attached; in eryptogams is attached, in eryptogams, branehing of a frond.

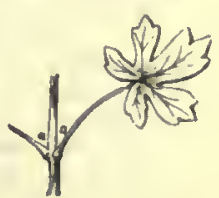


axile

axile (ak'sil), $\pi . \quad[<\mathrm{L}$. as if *arilis, < axis: ser axis1.] 1. Of or belonging to an axis of the axis: axial. -2 . Situated in an axis or the axis, as an embryo which lies in the axis of a seed. A large sinus, which separates the axile portion of the in of the proboth

Ifuxley, Anat. Invert., p. 555.

3. Iu $\approx 0 \ddot{1} l .$, axial, with reference to ovarian or3. Ins an: opposed in this sense to periphcral.

This mass becontes differentiated into an axile cord of protophismic snbstance, - the rhachis, - and peripheral umasses, ... which are the developing ova.

axilla (ak-sil'ịi), n.; pl. axillce $(-\bar{\theta})$. [L.: see rxil.]. In anait., the armpit; a region of the body in the recess between the npper arm (or in birds the upper part of the wing) and the side of the chest beneath the shoulder. It is pyramidal In shape, its apex corresponding to the inter val hetween the scaleni muscles opposite thermometer, a clinical thermometer : so named because it is placed in the axilla in oliserning the temp atnre of a person.

axillant (ak-sil'ant), $a$. [<axil $+a n t^{1}$. $]$ Forming an axil, as a leaf
axil it is. [Rale.] For him the tree is a colony of phytons, each heing a
lud with its axillant leat and fraction of the stem and
root.
Encyc. Brit., XVI. 841. axillar (ak'si-lär), $a$. and $n$. [< NL. axillaris, <L. axilla, axil: see axil.] I. a. Same as $a x$ illary.

II. $n$. In ormith., one of the under wing-covorts of a bird, growing from the axilla or armpit, and distinguished from the under coverts in general by being the innermost feathers linmost always longer, stiffer, and narrower than the rest. Commonly used in the plural.

axillary (ak'si-1ā-ri), $a_{0}$ and $\mu_{0}$ [As axillar: see $\left.-a r^{3},-a r y^{2}.\right]$ I. a. 1. In anat., pertaining to the axillary boundaries; the cxillary vessels. -2 . In the arthropod animals, pertaining to an In the arthropod animals, pertaining to an articulation or joint: said of parts which are attached to the point of union of two joints bot., pertaining to or growing frow the axil (of plants). See cut under wxil.- Axillary arches, in anat, nursular slips which sometimes pass from the latis tion, acros the axilla, to terminate in the tendon of the
pectoralis major (grester pectoral muscle), in the coracohrachialis, or otherwise. - Axdllary artery, the contin
nation of the subclavian artery, after it lias passed the nower horder of the flrst rib, as far as the lower border of It is divided lnto three portions, that above, that lochind It is divided lnto three portions, that above, that lehind
and that lelow the pectoralis minor (smaller pectors])
muscle, and gives off numerous brancles, thoracic, sub scapular, and circumflex, - Axillary feathers, in ornith. the axillars. See cxille", n.-Axillary nerve, the dirforced by the vene comites of the brachlal artery an ther veins, and ending in the subclavian.

axine $\left(a k^{\prime} \sin \right), a$. and $n .\left[\left\langle a x i s^{2}+-i n e^{1}.\right]\right.$ I.

a. Of or pertaining to the group of deer of which the axis, or spotted Indian hog-deer, is II. $n$. A deer of the axine group.

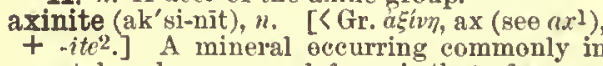
erystals, whose general form is that of a very oblique rhomb, so flattened that some of it edges become thin and sharp like the edge of an ax (whence its name), also sometimes found in lamellar masses. It is a silicate of aluminim fron, and manganese and calcium, with 5 per cent, of borol
trioxid, and is commonly of a clove-brown or plum-l)tue

axinomancy (ak'sin-or ak-sin'ō-man-si), ax, + $\mu a v r \varepsilon i a$ divination: see Mantis.] An ancient kind of divination for the detection of crime by means of an ax or axes. One form consisted in poising an ux on a bar, and repeating the
names of persons suspected. If the ax moved at the name of any one, he was pronouncel guilty. For another form

[Jet] was mureover enployed in the form of divination
called axinomancy. Laid on a latchet made hot, it was stated not to consume if the desires of the consulting party were destined to be futflled.

axinometry, " See axonometry.

axiolite (ak'si-ō-lit), $n_{0} \quad[<\mathrm{L}$. axis, axis, + Gr. crystal-fibers and preducts of devitrification, occurring in certain rocks like rhyolite. Axi lites resemble spherulites, except that their arrangement
is divergent from a line instead of from a point. to2

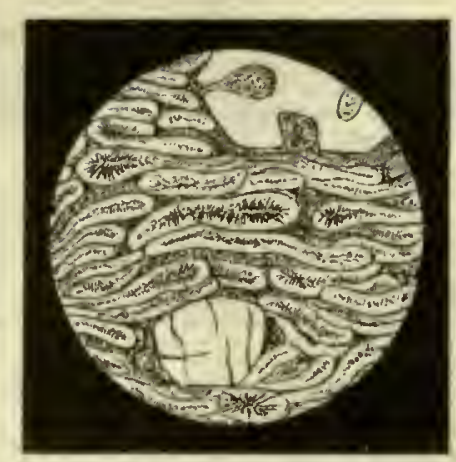

Axiolite. - Specinem of rhyolite from Virginis Range, Nevada,

(Froun Zirkel's "Microscopical Petrography.") axis

Many controversies arise loulding the axiommtic charac.
ter of the law. 2. Full of axioms or maxims; aphoristic.

The most axiomatic of English poets,

axiomatical (ak"si-ō-mat'i-kal), axiomatical (ak"s of the nature of an axiom; axiomatic. -2 . Of or pertaining to axioms or received first principles: linglroke $-3 \mathrm{t}$. In logie, of, pertaining to, or of the uature of a proposition, whether true or false.

axiomatically (ak"si-ō-mat'i-kall-i), rede. In an axiomatic manner. (a) By the use of axioms: as an axiom or axiomatic truth. (bł) In logie, in the form of a simple proposition. See rxiom, 3 . axiometer (ak-sj-om'e-tér), n. [< L. axis, axis, +metram, a measure.] An instrument for showing the position of the tiller of a vessel which uses a steering-wheel.

axiolitic (ak"si-ộ-lit'ik), $a$. Of, pertaining to, or of the nature of axiolite.

axiom (ak'si-om), n. [< L. axioma, < Gr. ásiwaa that which is thought fit, a requisite, that which a pupil is required to know beforehand, a selfevident principle, $\langle\dot{a} \xi$ coiv, think fit or worthy, require, demand, < a slos, worthy, fit, lit. weigh ing as much as, of like value, $\left\langle\dot{a} \gamma^{\prime}(v)\right.$, drive lead, also weigh, $=$ L. agere, drive, do, ete. : se demonstrable, theoretical, and general propodemonstrable, theoretical, and general propo-
sition to which every one who apprehends it meaning must assent. The Greek word was prob ably applied by Plato (though it does not occur in hi ialogues in this sense) to ceriain first premiscs of msth term. It was exiended by Aristotle to simllar principles supposed to underlie other branches of knowledge. The ish translations, are twelve in number, viz: (1) Things which are equal to the same are equal to one another. (2) If equals be addeci to equals, the wholes are equsl. (3) If equals be taken from equals, the remainders are eyual. (4)
If equals the added to unequals, the wholes are nnequal. If equals loe added to unequals, the wholes are nnequal.
(5) If equals be taken from unequals, the remainders are nnequal. (6) Things which are donble of the same are
equal to one another. (7) Things which are halves of the same are equal to one anotler. (S) Magnitudes whlich coincide with one another, that is, which exactly fill the same space, are cgual to one anothcr. (9) The whole
is grester than its part. (10) Two straight lines cannot nclose a space. (11) All right angles are equal to one nother. (12) If a straight line meets two straight lines it taken together less than two right angles, these straight lines, being continually proluced, ghall at length meet than two right angles. Only the first three of these are miversally acknowledged to be authentic, though the
latest editor, Heílerg, allows the elghth and ninth also. Euclid gives hesiles a list of pogtulates, which, gs given Euclid gives hesiles a list of post ulates, which, gs give
in English translations, are : (1) Let it le granted that a traight line may be drawn from any one point to any produced to any length in a straight line. (3) And that a circle may be described from any center, at any distanc the eleventh and twelith sxioms formed originally the axiom nppears as the sixth postnlate. It would thus premise which was asked to he taken for granted, an premse which "as asked to he taken for granted, and would be already familiar. This agrees with Aristotle definition of an axiom as a principle which he who would
learn must bring of himself. The Leibuitzians distinlearn must bring of himself. The Leibuitzians distin cording to Kant, gn axiom is a necessary and general syncording to Kant, an axiom is a necessary and general synspace or time and rests directly on intuition, and is thu
self-evident. He refnsed the name to the genuine "com mon notions" of Euclid, holdng these to be analytics propositions. Hodern mathematicians seem to regard the properties of space, so that the longer the list, providen fectly has the design been fulfilled. Many eninent mathe maticians hold that there is no reason to thilik these axioms to l,e exactly true, but that they must be assumed
to be slightly erroneous one way or the other; although experience shows that they approximate so nearly to the gible to measure the amount of their error. A slmilar
doctrine is held ly sono thinkers concerning metaphysi
cal axioms, such as the axiom that every event is determined by

2. Any higher proposition, obtained by generalization and induction from the observation general fact; an empirical law. This use origi nated with Bacon, influenced probably by the employ. ment of axiom lyy the stoics to mean any proposition. 3t. In logic, a proposition, whether true or false a use of the term which originated with Zene the Stoic. = Syn. 1. Maxim, Truism, etc. See aphorism.

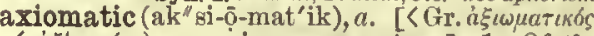

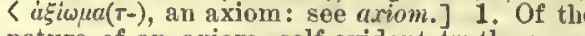
nature of an axiom, self-evident truth, ol re ceived principle; self-evident.

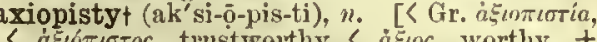
< a

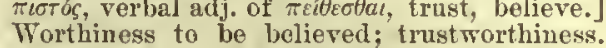
Imp. Dict.

$\operatorname{axis}^{1}$ (ak'sis), n.; pl. axes (-sēz). [L., axle, axis pole of tho earth; poet., the heavens; also, a board or plank (see asher); = AS. eax, E. $a x^{2}$, axle: see $a x^{2}$, axle.] 1. The motionless, or relatively motionless, imaginary line about which a rotating body, snch as the earth, turns: speeifically called in this sense the axis of revolution or rotation (which see, below).

$$
\text { On their own axis as the planets run, }
$$

Yet make at once their circle round the siu. of any mechanical piece intended to turn in The weightines of the wheele doth settle it ypon hi 3. In anut.: $(u)$ The socond cervical vertebra: so called because the atlas turus upon it a about a pirot or axis, bearing the lead with it

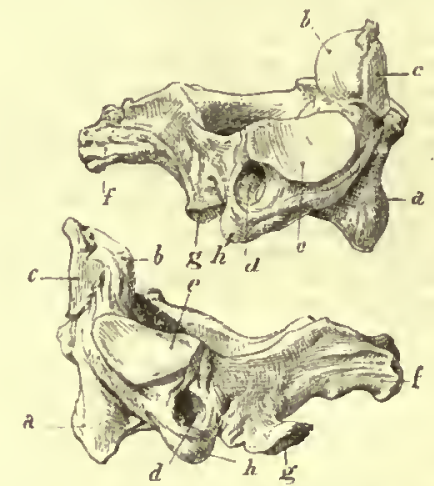

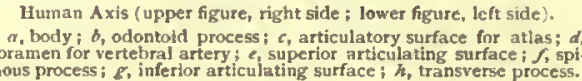

It is usually distingnished from the other vertebre by lar ing an odontoid or tooth-like process, furnishing the pisot
about which the atlas turns: hence called the toothed verabout which the atlas turns: hence called the toothed ver.
tebra (vertebra dentata), or the odontoid vertebra (vertebra odontoldea). (b) The odentoid process of the axis. (c) The entire vertebral column. (d) The central or axial nervous system of a vertebrate: as, the cerebrospinal axis. (e) The columella or modielus of the cochlea. (f) A short thick aitery which immediately divides into several (g) Ihe axis-cylinder of a nerve. ( $h$ ) Same a lution; the central line of any syumetrical, nearly symmetrical, body: as, the uxis of a cyl inder, of the eye, etc.-5. Any line with reference to which the physical properties of a body, especially its elasticity, are symmetrical. -6 . In Trilobita, specifically, the tergum; the me dian cenvex portion of a thoracic somite, intervening between the pleura or flattened lateral portions of the thorax. See cut under Trilobita. -7. In coneh., the imaginary line or space around which the whorls of a spiral shell turn. -8. In bot., the stem; the central part or longitudinal support on which organs or part. are arranged. The root has sometimes been called the desecnding uxis. A. Gray.

In many cases the florat axis is prolonged beyond one or more circles of tioral organs, and the stem again assumes
the ordinary leaf-bearing form. branches: as, the celiac axis; the thyroid axis. 
9. In geng. aud grol., the central or dominating region of a mountain-chain, or the line which follows the crest of a range and thus indientes the position of the most conspieuous portion of the uplift. In a folited region, or one in

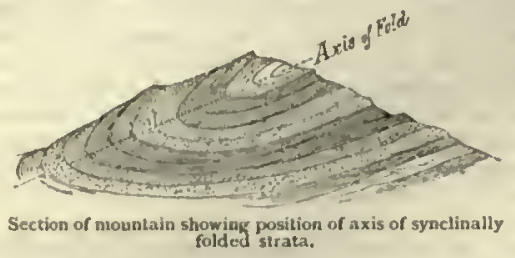

which the strata liave been bent into anticlinals and gyn. enche toward wich the strata ineline.
10. In cualytieal geom. any fixed line of reference used to determine the position of a point or series of points (line, surface) in space.-Ant1clinal axis, in geel. See anticlinal.-Axes of an ellipsoid, its maximum ani nunimum diameters and tire disnseter jerpendicular to these. Axes of coördinates, or coordinate axes, in anniytical geom., fixed lines on which or parsilel to which an elcment (abseissa or ordilight-elasticity, the tiree directions at right sngles to one another in a hiaxial crystal in winich the elasticjty of value. In \& trinetric (orthorhombic) crystal they coln. clive with the crystallographjo axes; in a monoclinic crystai one coincides with the orthoilagonal axis, the others lie in the plano of symmetry. In a triclinic crystal there Axd of a beam of light, the midule ray of the beam. to the center of the base. Ads of a conic, a diameter perpendicnlar to the chords it bisects. - Axls of a cryssumed for convenience to define the position of the planes of the crystal, and to exhibit its symmeiry. See
crystnllogmphy.-Axds of a curve, a right line dividing it into two symmetrical parts, so ns to bisect every chord centia of a eylinder, a straight line drawn from the afinity, the axis of homology of figures homologieal by aflinity. Axis of a gun or piece, the mildile line of the througin the optical center of the lens, and perpendicular to both its surfaces.-Axis of a magnet, the imaginary line which connects the north and south poles of the face of the sphere. $-\mathbf{A x d}$ of a spherical, concave or convex mirror, a straight line which passes through the geonetrical and optical centers of the nujror.-A Ads of of all the glasses in the tube. Axis of collineation, in math, a line which correspouds to jtself in a projective in a solidi body such that a longitu dinat stralin in tliat di rection produces a stress precisely opposed to the strain. respect to winich sombe kind of symmetry exists in the line upon which corresponding lines of two figures in a pendulum, a right line passing through the center about which it vibrates, and perpendicular to the plane the plane of a perspective representation cnts suy plsne version in gcumetry, any line considered as perpendichlar to and bisecting the distance between two inverse points. to Axis of refraction, a straight dinedrawn perpendicular of incidence of the retracted ray. Some crystals have two axes of refraction.- Axds of rotation, the imaginary line
about which all the parts of a rotating body turn.-Axis of similitude of three circles a line passing through two intersectiuns of corresponding pairs of common of simflitude slso necessarily passes through a third sucl point, but this fact is not essential to its definition.-
Axis of aymmetry, \& line on both or all sides of which tine parts of a body or magnitude sre symmetrically disposed.-Axis of the earth, the gtraight line connecting tation.-Axis of the eye, a straight line passing through axis. - Axds of the Ionie capital, a line prassing perpendicularly through the middle of the eye of the volute.Axis of the world, the imaginary axis passing througl the celestial poles. - Axis of vision. See visual axis, bepoint midway between the occipital condyles, through the and presphenoid, in the floor of the cerebral cavity. II uxley. See cut under crrniofacial. - Basifactal axds,
ur faclal axds, a straight line drawn from the anterior extrentity of the premaxilia to the anterior extremity of the hasicranial sxis (which see, shove): not to be conthe abdominal aortac axis. (a) A short, thick branch of and immediately dividing into the gastric, hepatic, and splenio artertes. (b) The sympathetic plexus which surrounds this artery. - Cerebrosplnal axds. Bee cerebro-
spinal. Conjugate or minor axis, in geon., an axis, especially of a hyperbola, perpendicular to the transverse axis. The term was origlnally nsed fin the plural for a pair

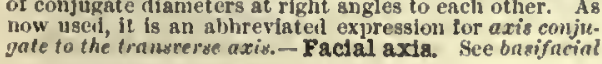

nxis, ahove. - Harmonte axis. See harmmic - Instantaneous axds, the axis sbout which a body is rotating at considered in only two dimensions or when a point of the body is fixcl; ; in other cases it would lie an inaccurate axis, that line about which a body is rotating and along
which it is simultaneousiy sliding at any instant. Fvery which it is simultaneousiy sliding at any instant. Every
rigiti hody at every instant of its notion has such an ins. rigid hody st every instant of its notion has such an ins-
stantaneous sliding axis.- Macrodiagonal axis, magstantaneous silding axis.-Macrodiagonal axis, mag-
notic axis. See the arijectives.-Neural axis, in anut. ccrebrospinal systcni. - Neutral ads, jn mech.: $(a)$ of a beam, the pisne in which the tensile and compressiug thing. (b) Of a dellected bar, the line alons whicls there is neither extension nor compresslon.- Optic axds, the axis
of tive eye (which sec, above) - Orthogonal or prinetpal of tire eye (which sec, above). - Orthogonal or prinefpal
metatatic axes, tiree axes in a boty such that, if a cuhe metatatic axes, tirree axcs in a boty such that, it a chbe there be a linear elongation along one of them and an stress wili result rounil llie third axis on planes normal to the first iwo - Radical axis of two circles, tive line
joining their points of intersection. This ine is real even when the circles do not really intersect, the dilference of when the circles do not really intersect, the difierence of
its dilstance from the two centers being projortions to the in arche, the axis of a twisted columu gpiraily drawn in order to trace the circunvolutions without. - Synclinal axis, in geot. See rynclinal. - Tectonle axes, in crys.
tal. the lines aiong which the minute crystals are arranged in the fornation of a complex crystalline grow th. branch at sngles of $60^{\circ}$, their directions leeing paralic to the sidcs of an octahcirsi face. - The prineipal axes of inertia of a body, those iines passing through its cenmum and a minimum, togeiher with the third line perpendicular to these at their intersection. - The princtpal axes of stress in a iody, the directions of the three
conjugate normal stresses. - Thyroid axis, a short, thick conjugate normai stresses. - Thyrotd axis, a short, thich
branch from the subclavian artery, dividing almost im mediately into the fuferfor thyroid, suprascapular, and transversalis colli. - Transverse or major axis, in conic the ellipse it is the longest diameter; in the hyperbola it is the shortest; snd in the parahola it is, fike ail the other the strsight line passing through the center of the pnpit
and the middie of the macula lutea. It docs oot coincide and the middie of the macula lutea. It docs oot coincide
with the optic axis. Also called visual line, or axis of vision.-Zone axds. See zone.

E. Ind. origin.] 1. A A kind of East Indian deer, Cervus axis, of which there are several varieties, perhaps species. The body is spottod with white. Also called axis-dcer, spotted deer, and hog-deer.-2. [eap.] [NL.] A genus of xis-cylinder (ak'sis-sil'in-dèr)

列, white nerventissue in a nerve-fiber. It is the es. sential nart of the nerve, and is the only part found at jits origin and termibation. In cross-section, a bundle of nerve-fibers appears like a hunch of lead pencils, the axis-
cylinder corresponding to the lead. Also called band-axis axis-deer (ak'sis-dẻr), $n$. Samo as axis², 1. axisymmetric (ak"si-si-met'ri

axle (ak's1), n. [Early mod. E. also axel, axell axile, < MF. axel, axil (ehiefly in comp, axel, tree, $\mathrm{q} . \mathrm{v}$; not in AS., where only the primitive $a x$, eax occurs: see $\left.a x^{2}\right)=$ Icel. öxull, m., $=$
Sw. Dan. axel, axle; not found in this sense in the other languages, where its place is supplied by the primitive $a x^{2}$, but ult. = ME. axl, exl, As. eaxl, cxel $\equiv$ OHG. ahsala, MHG. ahsrl, $\mathrm{O}$ achsel $=$ Ieel. $\ddot{o x l}, \mathrm{f} .,=$ Sw. Dan, axel $=$ Norw. okst, aksl, axel, the sloulder, =L. ala (for *axaxilla); with formative $-l,<a x^{2}$ (L. axis, ete. axle (the shoulder-joint being the axle or axis on which tho arm turns): see $a x^{2}$.] 1. The pin or spindle on which a wheel revolves, or which forms the axis of the wheel and revolves with it.
Properly, the sxle of a carriage-, cart-, or wagon-wheel is
the round arm of the axletree or axle-bsr whicin is inserted in the lubb or nave, but the name is sometimes extended to 2 . An axis, as of the earth.

Whether

Ile [the sun] from the east his flaning roal begin,

Or she [the earth] from west her silent course sdvan Witly inoffensive pace that spinning sleeps
On her solt axte.
Milton, P. $\mathrm{L}_{\text {, }}$ vili. 165.

Axle stop-key, a plate upon the end of the axle of a rallto take the wear. - Blind axle, an axle that does not communicate power; a desd axle. - Collinge axle, in cuach building, an axle the box of which is secured upon the
amm by two nuts gerewed right and left.-Compound some other locking arrangement. - Dead axlo, one which does not lmpart motion; a blind axle : opposed to a lice axle or drivinf-axle.-Dipping the axie, in coach-building,
bending the end of the axle so that the wheel shall strike seuarely upon the ground. - Driving-axle, in locomotive engines, the axle which receives the power from the steam-piston transmitted through the piston-rod and con mecting-rod. The resr end of the latter is connected with crank-pins upon the driving-wheels st its ends.-
Leading axle, in Britisi locomotives, an axle of a wheel in tront of the wriving-wheeis, - Mall axlo, in coach build.
ing, sn axle which is sccured by a plate 8 it its back instesd of a nut on the end.

The commonest kind of oil axie is called the mail, he. canse the pecnilar mode of fastening was first used in
the mali cosches. J. it. Burgers, Coach-Bnliding, 1 . 72 . Teleacopic axie, an exicnsion-axic which permits the running-wheels of a raiiroad-car to be slipped in or ont, thils making then adlaptable to tracks of dilterent page. rle-adjuster (ak'sl-a-jus"tèr), n. A machine for straightening axlës; a machine used in giving to the spindle its proper line of dircefion relatively to the axletrco.

axle-arm ( $\left.a k^{\prime} s l-a i r m\right), n$. The spindle on the end of an axle on which the box of the wheel slips, or one of the two pivots on which the axle itself turns. See seeond eut under axls. box.

xle-bar (ak'sl-bir), $"$. The bar of an axle.

axle-block (ak'sl-blok), $n$. The block placer upon the axle of a vehicle to form a seat for the spring when it is depressed.

zle-box (ak'sl-boks), n. The box which contains the bearings for the spindle of an axle, or tho journal of an axle, as of a carriage-wheel, a railroad-ear wheel, ete. tho bushing or metal lining of the hub whicl forms the rotatory bearing of the axle of a vehicle.-Axle-box guides, an axle-box.- Radial axlabox, in a rail rosid-ear, a sild.
ing axle-box, so arranged that,
with its fellow, it maintains with its fellow, it maintains the axle in a position radisal to

ever its direction

axle-clip ( $\mathrm{kk}^{\prime} \mathrm{s}$ -

klip), n. A which unites some other part of a vohiele to clip tie, the erosiand secures the xle-collar (ak'sl-kol " ïr),
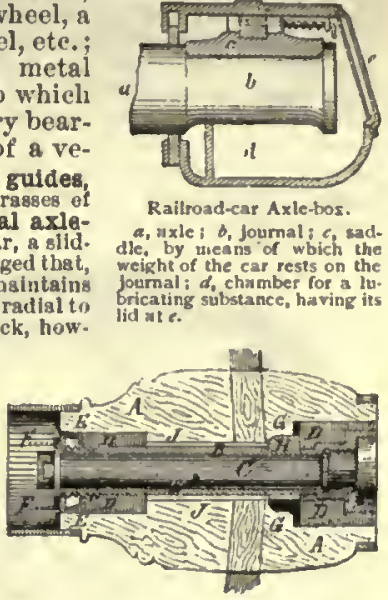
weight of the car rests on the
jornal i $d_{1}$ chamber for a tus $n$. The collar lateral pressure from the wheel or bearing.

axled (ak'sld), a. Furnished with an axle or

axle-gage (ak'sl-gāj), n. A wheelwright's instrument for giving to the spindle of an axle its proper swing and gather.

axle-guard (ak'sl-gärd), n. 'Those parts of a
railroad-car in which the axle-box plays vertically under the yield and reaction of the carwhich are bolted to the frame and to all the ends of the axle-guards, to strengthen them. A hook in front of the axle of a carriage, to which is attached the stay-chain connecting the axle and the double-

axle-nut (ak'sl-nut), n. A serew-not fitter to the end of the arm of an axle to keop the wheel 4 place.

xle-packing (ak'gl-pak"ing), " . The guard or material placed abont an axle to exclude dust.

axle-pin (ak'sl-pin), n. Same as lineh-pin. axle-saddle (ak'sl-sad"1), $n$. A saddle-shaped clip, used in securing a spring to an axle. axle-seat (ak'sl-sēt), $n$. The hole in a rail coad-car wheel which receives the arm of the

xle-skein (ak'sl-skān), ". A band, strip, or thimble of metal placed on a wooden axle-arm to prevent the wood from wearing rapidly.

axle-sleeve (ak'sl-slēv), " . A sleevo plaeed the ends should the axle be broken.

axle-tooth (ak'sl-töth), n. [E. dial., also assle-, $a=1 e-$ assal-tooth, early mod. E. axel- axilltooth, (late ME. axyltothe (= Dan. axel-tand); " axel (Shetland yackle) (< Ieel. jaxl = Norw. jaksle, jakle $=\mathrm{Sw}$. dial. jäkkel, jäksl $=\mathrm{Dau}$. axel), a jaw-tooth, grinder, + tooth.] A grindor: a molar. [Prov. Eng.] 

axletree (ak'sl-trē), n. [< ME. axel-tree, axil- ax-shaped (aks'shāpt), $a$. In bot., shaped like
tre, ete. (= Iecl. öxul-trē), $\langle$ axel + tree. Cf. $a x$ - an ax or a hatchet; dolabriform.

trec. ] 1. A bar or beam fixed erosswise under ax-stone (aks'stōn), $n$. A mineral found chiefly the body of a earriage, having rounded axles at the ends for a pair of wheels to revolve on.

Be hem turnethe alle the firmament, right as dothe a wheel, that turneth be his axille tree.
Maundeville (ed. IIalliwell), p. 182 24. An axis.

axle-yoke (ak'sl-yōk), n. A plate beneath an axle through which the ends of the saddle-clip pass. It serves as a washer-plate for the nuts upon the ends of the saddle-elip.

axman, axeman (aks'man), $n_{\text {.; }}$ pl. axmen, axemen (-men). 1. One who wields an ax; one employed in chopping; a woodman.

Axemen were put to work getting out timber for bridges, and cutting fuel for the locomotives when the road was
completed. $U . S$. Grant, in The Century, XXXI. 138. 2. Formerly, a soldier whose weapon was an ax. We hear nothing of any prisoners being taken, nothing of any of the axemen taking to fight. $E$. A. Freeman, old Eng. Hist., p. 336. ax-master (aks'mảs"tèr), $n$. A name given in Honduras to a tree with very hard wood. Its genus is not known.

Axminster carpet. See carpet.

axoid (ak'soid), a. [< axis $1+$-oid. $]$ of or pertaining to the axis: used in anatomical terms, ligament. See axis 1,3 .

Axolotes (ak-sō-lō'tềz), n. A Latinized form of axolotl, used as a generie name. See Siredon.

axolotl (ak'sō-lotl), n. [Mex.] A urodele or tailed amphibian found in Mexico, which is

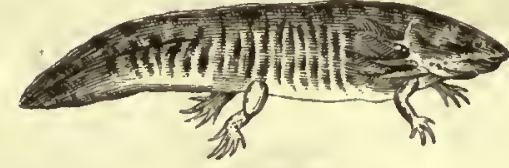

to retain its gills throughout life, breeding in the larval state. From this clrcumstance the sulimal was made the type of a distinct genus, Siredon,
and was placed with Proteus, Siren, etce, in the tamily
proteideo, under the name of Siredon pisciforme. An.

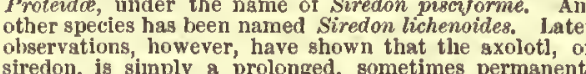
siredon, is sinply a prolonged, sometimes permanent
stage like thrt which all the specles of salanıandrine of the family Amblystomidae pass through, and that the
animal is reterable to the genus Amblystoma. Axolotil animal is referable to the genus Amblystoma. Axolotls
are common in lakes and lagoons in Mexico, like the varias mud-puppies, water-dogs, ete. They have the appearas mud-puppies, water-dogg, etc. They have the appear-
ance of gigantic tadpoles ghout to turn into frogs, belng
from 6 to 9 inches lons from 6 to 9 inches long, with a large conpressed tsil, 4 legs, gill-tufts on esch side of the neck, and obtuse Hlat.
tened head. They are marketable in Mexico, where they are sald to be deemed a luxury ss an article of food.

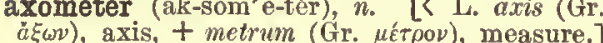
an instrument used in adjusting the height of the bridge of a pair of spectacles, to bring the centers of the lenses in line horizontally with the centers of the pupils of the eyes.

axon (ak'son), n.; pl. axones (-ề). [ [Gr. à $\xi \omega v$ axis: see axis ${ }^{2}, a x^{2}$.] In anat. the body-axis the mesal, longitudinal, skeletal axis of the body, represented in Branehiostoma and em bryos by a membranogelatinous notochord, and in most adult vertebrates by the cartilaginous or osseous centra of the vertebre and the base
of the skull. Wilder, N. Y. Med. Jour., Aug. 2,1884 , p. 113. Also ealled axis. Jour., Aug. Axonia (ak-só'ni-ä), n. pl. [NL., $\langle\mathrm{Gr}$. d $\xi \omega \nu$ having definite axes: the opposite of $A$ naxonia. The $A$ xonia are divided into Homaxorita, having all axe equal, as spherical and polyhedral forms, and Protaxonia having one main axis about which o ther ares are arranged
The latter are again subdivided into Monaxonia and Stauraxomia. See these words.

axonometry (ak-sō-nom'e-tri), $n$. [Irreg.< Gr. å $\xi \omega v$, axis, $+\mu k \tau p o v$, measure.] The art of when the coördinates of points in them are given. Also written axinometry.

axospermous (ak-sō-spèr'mus)

axis, axis, + Gr. $\sigma \pi \varepsilon \rho \mu a$, seed.] In bot., an epithet axile placentation, the attachment of the seeds being toward the axis.

axotomous (ak-sot'ō-mus), a. [< L. axis (Gr.

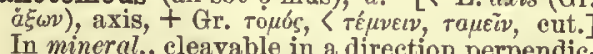
ular to the axis.

axseed $\dagger, n$. [<axl + seed. $] \quad$ Same as axfitch. in New Zealand and the South Sea islands, and ined by the natives for axes and other entting nephrite and jade.

xtree (aks'trē), $n$. [Sc., also aixtree, extree, $\mathrm{ME}$. axtre, extre, axtreo, $<$ AS. *eaxtréoio, $<$ eax An axletrec. [Obsolete, except in Scotland.] A large pyn in maner of an extre Chaucer, Astrolabe, D.

Thunder and earthquakes raging, and the rocks Tumbling from down their scyts like nighty blocks As though in sunder heav'ns huge axtree brak Drayton, Poems (ed. IIslliwell), p. 219.

axunge (ak'sunj), n. [<F. axunge, now axonge, < L. axungia, grease, fat, wagon-grease, < axis, axle, + ungere, grease: see unguent.] The internal fat of the body, especially of pigs and reese; fat; lard.

xungious (ak-sun'ji-ns), $a$. [< axunge + -ious. $]$ axvitch $t$, axwort,$+ n$. Same as axfiteh. $a y^{1}, \operatorname{ayg}^{1}(\vec{a}), a d v$. [く ME. ay, aye, $a i, e i$ (i

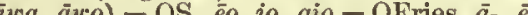
comp. $),=\mathrm{OHG}$. io, $\bar{e} o, \mathrm{MHG} . i e, j e, \mathrm{G} . j e=\mathrm{Icel}$ $e i, e y($ as above $)=$ Goth. aiw $=$ Gr. áei, lonic aic

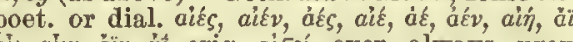
ail, aliv, äiv, ìt, orig. aifeí, ever, always, prop. acc. (in Gr. locative) of a noun, AS. $\bar{\alpha}, \bar{a} w$ (orig. "a $w$ ), existence, law, marriage, $=\mathrm{OSS}^{-\bar{e} o}$, law, OFries. $\bar{a}, \bar{e}, \bar{e} w e, \bar{e} w a$, law, $=$ OHG. $\vec{c} v a, \mathrm{MHG}$ ece, eternity, law, mantage, nity, = L. avum, OL aevom (whence ult. E. age eternal, q. v.); ef. Gr. ai $\omega v$, *aif $\omega v$ (with unorig. formative v), an age, an eon (see eon); orig. appar. a going, a course, with formative $-v$ $\left\langle v^{*} i\right.$, Skt. $i$, Gr. $i-\varepsilon v a \iota=\mathrm{L}$. $i-r e$, go: see iter ever in whoever, whatever, ete.), and, fused with ge-, exists unrecognized in eaeh, either. With the negative it exists in nay and no 1 , which are elated to each other as the simple $u y$ and obs.) $o$. The spelling $a y$, like nay, is historEver; always; for ever ; continually; for an E. dial.]

Care for the Conscience, \& kepe ft ai clene.
The A B C of Ariatotle (E. E. T. S., extra ser., vJII. 1. 65) Let this pernicious hour
Stand aye accursed in the calendar

2†. Ever: indefinitely, after if

Behold the man ! and tell me, Britomart,
If ay more goodly creature thou didst see

If ay more goodly creature thou didst see?
Spenser, F. Q., III. iil. 32

For ay, for ever: sometimes strengthened by combination

The soul, though made in time, survives for ay;

$\operatorname{ay}^{2}(\bar{a})$, interj. [Also aye, eigh (and, in this use, , ), < ME. $e y, e i$; a mere interj., of no definite history, but it may be regarded, formally, as a
variant of ME. $a$, E. $a h$, oh. In the poetical ay me, prob. in imitation of OF aymi, $\mathrm{Sp}$. ay de mi, It. ahime; ef. F. ahi, ai, Sp. ay, It ahi ah: see $a h, O$, oh, and ef. $c h$.$] Ah! O! oh!$ an exclamation expressing surprise, interest, regret, ete., according to the manner of utterance. [North. Fng. and Scoteh.] - Ay me! ah

Ay me! that thankes so much should faile of mee

$\mathrm{y}^{3}, a d v$. or interj. Seo aye ${ }^{3}$.

$\mathrm{ay}^{3}, n$. See aye

$\mathrm{Ay}^{5}(\bar{a}), n$. A sparkling wine taking its name from the town of $\mathrm{Ay}$ in the department of Marne, France. See champagne.

ay6. [(1) <ME. ay, ai, ey, ei, ez, ete., < AS. $a g$ eg, $\bar{x} g, \bar{e} g$, etc.; (2) of other origin: see under ai.] A common English digraph (pron. $\bar{a}$ ), with $a i$, but now the regular form when final oceurring medially only in certain positions. Historically lt represents, (1) in words of Anglo-Saxon origin, $a(a)$ or $e$ with an albsorbed guttural, as in clay, day 1 ,
lay 1 , may 1, say 1 , stay 1 , etc.; (2) in words of Scandinavian, Romanic, Latin, or other origin, various diphthongs, ai
$e i$, etc., as in $a y 1$, nay, ray $1, r^{2}{ }^{2}$, atay ${ }^{2}$, etc. In recent $\mathrm{E} . a x^{2}+$ treów, E. tree, beam. Cf, axletree.] Lard-like ; fat; greasy. Sir T. Browne. Ormulum $a z 3$ ), prop. a northern form (< Icel.ei , the native form being ME. oo, o, earlier $a$ zing prefix (somewhat like the related suffi ically and analogically the proper one.] 1 . words it is the ordinary representative of the sound ayah (áy'ä), n. [Anglo-Ind., <Hind., etc., ayya, $\bar{a} y \bar{a},<\mathrm{Pg}$. aia (=Sp. ay $a=\mathrm{It}$. aja), nurse, governess, fem. of aio (= Sp. ayo=It. ajo), tutor of uncertain origin.] In the East Indies, native waiting-woman or lady's-maid; a nurse. ayapana (ä-y:̈̈-pä'nä), n. [Braz.] The native name of Eupatorium triplinere, a Brazilian plant, natural order Compositce, at one time bolieved to be a panacea. It is still considered to have some valuable medicinal properties.

ayaya, $n$. See aiaia.

aye $(\bar{a}), a d v$. See $a y^{1}$.

aye $^{2}(\bar{a})$, interj. See $a y^{2}$

aye $^{3}$, ay $^{3}$ (äi or i $)$, adv. or interj. [Formerly also ai, ey, but at its first appearance, in the Elizaciated in puns with the pronoun $I$ ) history unknown; possibly orig. a dial. form of ay, ever, always, worn down to a mere particle of assent. Hardly, as commonly supposed, a corruption of yea. The spelling aye is preferred, as making a distinction like that in eye from words in $-a y,-e y$ with the reg. pron. $\bar{a}$, as in bay, bey, gray, grey, cte.] 1. Yes; yea: a word expressing assent, or au affirmative answer to a question: opposed to no. It is common in disectal and nautical language, and is the regular word used in voting "yes" in Congress, the IIouse of Commons, and
other legislative bodies. In Congress the official terms, as in the Constitution, are yea and nay; but the more sonorous aye and no are preferred in making response. 2 . Yes; yea; even so; truly: indieating as-
sent to what has been said, and introducing a further or stronger statement.

$$
\begin{aligned}
& \text { What ! am I not your klng? } \\
& \text { If ay, then am I not to be obey'd? }
\end{aligned}
$$

$$
\begin{aligned}
& \text { to be obey'd? } \\
& \text { Beau and } F l \text {. }
\end{aligned}
$$

$F l$., Philaster, Iv. 2. The champions, ay, and exemplary too, of classical
learning. Story, Speech, Cambridge, Aug. 31, 1826. 3. Indeed: suggesting slight surprise, interrogation, anger, or reproach, or simple attention, according to the mode of pronuneiation. Aye, aye, naut.: (a) The phrase by which comprehen. $\operatorname{aye}^{3}, \operatorname{ay}^{3}($ äi or $\overline{1}), n$. [<aye, adv. or interj.] An affirmative answer or vote in deliberative bodies.-The ayes and noes, the yeas and nays. ( $(a)$ The afirmative and negative votes. (b) Those who so vote. phrase The ayes have it, in deliberative iodies, the that the affirmative votes are in a majority.

Another was the late Speaker Trevor, who had, from the chair, put the question, whether he was or was not a rogue,
and had been forced to pronounce that the A yes had it.
Mlacaulay, II ist. Eng., xxili. aye $^{4}+, n$. See ey 1 .

aye-aye $\left(\overline{\mathrm{I}}^{\prime} \overline{\mathrm{i}}\right), n . \quad[<\mathrm{F}$. aye-aye, <Malagasy aiay, also dial. ahay, haihay, prob. of imitative origin (ef. $a i$ and $a i-a i$ ). Reduplication is characteristic of imitative names, particularly in native languages.] A name of a remarkable lemurine

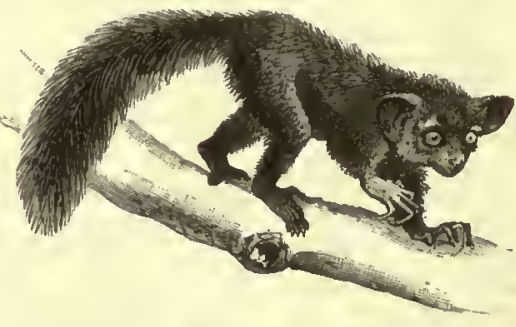

quadruped of Madagascar, of the suborder Prosimia, family Daubentonitda (or Chiromyida), the Daubentonia (or Chiromys) madagaseariensis, which combines a rodent-like dentition with the general characters of the lemurs. It was originally relerred to the Rodentio, and was described as a species of Sciurus, or squirrel. It is a small
squirrel.like animal (so far as its long bushy tail, general squirrel.like animal (so far as its long bushy tail, general
configuration, and si'boreal habits ntay warsnt the comconfiguration, and siboreal habits nay wartant the com-
parison), with large thin ears opening forward, great eyes parison), with large thin ears opening forward, great eyes The thumb is not apposable, in which respect it is unlike the lnner digit of the foot. The animal is nocturnal, arboreal, and peculiar to Madagascar. Its economy is still inperfectly known. The mesningless name aye-aye was pede. The genus is usually called by the name Chiromys, given by Cuvier in, 1800 , but this is antedated by DouSee Daubentonia.

ayeint, $a d v$. and prep. An old form of again.

ayelt, $n$. See ayle.

ayelp (a-yelp'), prep. phr. as adv. [<a3 yelp. $]$

On the yelp; yelping. Browning.

ayent, adv, and prep. An old form of again. 
ayenbite

405

ayenbitet, $n_{.}$[Ml\%., \& ayen, again, + bite (a translation of LL. remorsus, remorse): see aguin and bite.] Remorse. [The "Ayenlite of Inwyt" (iRemorse of Conbeicnec) is the title of a well-known old English religious work adapterl from tho French.]
ayenee (å-ye-nề (which see)

ayenst, ayenstt, prep. Obsolete forms of reyainst.

ayenwardt, atle. An obsolete form of again-

ayenyeftet, n. [ME., < ayen, again, baek, + yefte, gift: see ayain and gift.] A reeompeuse. Ayenbite of Inwyt.

ay-green, aye-green ( $\bar{u}^{\prime}$ grēn), $u$. [ $\left\langle\iota^{1}+\right.$ green. Cr. etryneon and sempervin.

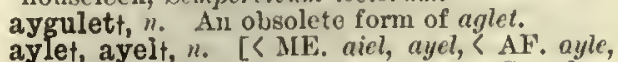
OF. aiel, wiol, $\mathrm{F}$. aieul $=\mathrm{Pr}$. atiol $=$ Sp. abue$10=1$ t. arolo, < LL. "ariolus, dim. of arius, for L. arus, graudfather.] A grandfather. See besayle.

I an thin ayet, ready at thy wille.

Chaucer, Kuight'a Tale, 1. 1619

aylet (a'let), u. [Cf. ailette. ] In her., a bird represented as sable, beaked and legged gules. Also known as the sea-sicallow and as tho Cormish chowyh.

aymantt, aymont, $n$. [<OF. aymant, aimant = Pr. ayman, aziman, adiman, < ML. *adimas (arlimant-), var. of L. aulamas (adamant-), adaunant; a diamond.

aymet, intcrj. See ay me! under $a y^{2}$.

Aymees and hearty heigh-hoen

Are aaliads fit for aoldiers.

aymerst, $n . p l$. Obsolete form of embers.

aymontt, $n$. See aymant.

ayni-wood ( $\overline{1}^{\prime}$ ni-wid), $n$. The timber of the Terminalia tomentosa, a combretaceous tree of solithern India.

ayont (a-yont'), prep. [Sc., = E. beyond, with prefix $a$-instead of be-: see beyond.] Beyond. Some wee ahort hour ayone the twal.

Burns, Death and Doctor 11 ornbook

ayr (ãr), n. [Se, also air, < leel. eyrr, mod. eyri, the gravelly bank of a river, a small tongue of land running into the sea (= Sw. or = Dan. öre, seen in plaee-names, as in Elsinore, Dan. Helsingör, Ieel. as if "ILelsingja-eyrr), (aurr, clay, mud, $=$ Norw. aur $=$ AS. eár, earth, ground, used also as the name of the runic sand-bank. Also spelled air. [Seoteh.]

ayrant (ar'ant), a. [Also eyrant, a ppr. form,. In her, seated on its nest or aery: said of bird of proy when thus represented as a bearing.

Ayr stone. See stone.

ayuntamiento (ä-yön"täi-mi-en'tō), n. [Sp., OSp. ayuntar, < ML. "adjunctare, < ad, to, + "junctare (> Sp. juntar, join), <L. jungere, pp. and Spanish Ameriea, a eorporation or body of magistrates in a city or town; a town couneil, usially composed of alealdes, regidors, and nsialy composed of at

ay-wordt (a'wèrd), $\cdots$. [A form, appar. an error appearing in some editions of Shakspere, spegive naywora, q. v.] A byword.

az. In her., an abbreviation of azure.

azale (a-zāl'), n. [Appar. < azalea. Cf. azalein.]

abtained by extraeting ing temperature. It is no longer used.

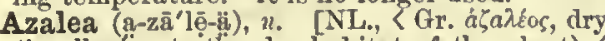
(in allusion to the dry habitat of the plant), $a \zeta \varepsilon v v$, dry up, pareh.] 1. A genus of eriea2. [l.c.] A plant or flower belonging to this genus. See Rhododendron.-3. $[l . c$.$] A name$ of a species of plants of the genus Loiselearia, the Alpine azalea, $L$. procumbens.

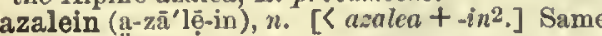
as rosaniline.

azan (a-zän'), n. [Ar.] In Mohammedan coun tries, the call to publie prayers, proelaimed by the crier from tho minaret of the mosque.

When thcir crier, a amail wizen-faced man, began the Azan, we received it with a shout of derision, and aone, tunity of martyrdon. $\quad$ R. $F$. Burton, El-Miedinal, p. 133. azarin (az' a-rin), $n$. A coal-tar color of the aro-group used iu dyeing. It is applied only to cot- thol-azo-dichlor-phcuol and anmoninm bisulphite. It dyes the

azarole (az'?a-rōl), n. [Also azerolc; $<\mathrm{F}$. azarole, azerole $=1$ t. tzzeruolo $=$ Sp. acerolo, azurolo $=\mathrm{Pg}$. azarolı (NL. azarolus), < Ar. az-zirūr, < al, tho, + zu'rur, azarole.] The Neapolitan wedlar, a speeies of thom, Crakegus Azaro

azedarach (a-zed'a-rak), n. [< F.azddarac = p. acclaruque, prob. tlirough Ar., < Pers. äzäe dirakht, lit. free (noble) tree: azuid, free; dirakht, tree.] 1. An ornamental Fast Indian tree, Melia Azedarach, cultivated in southern Europe and Ameriea, and also known as bealtree, pride of India, ete. See Melia.-2. A azedaraeh. It is an emetie and a eathartic, and is used as a vemnifuge.

aziam (az'iam), n. [Russ, azyamǔ.] A full

long outside garment, without plaits, made of a coarse gray cloth; at Astrakhan, a sheepskin coat eovered with eloth. [Russian.]

azimuth (az'i-muth), n. [<ME. azymuth, azimut,

$\langle\mathrm{OH}$. azimut $=\mathrm{Sp}$. azimut $=\mathrm{Pg}$. azimuth $=\mathrm{It}$. azcimutto, $>\mathrm{Ar}$, as-sumüt, <al, the, + sumüt, pl. of samt, way or path, point orquarter of the horizon. From the same word is derived zenith, q. v.] In astron., an arc of the horizon intereepted beeirele passing through the conter of a celestial object. The azimnth and altitude of a stargive its exact position in the sky. azimuth circle. muth compass a compasa placed part of a ahip on the provided with vanes screws, and other apparatus for obof herveniy and ter. estrial objects.Azimuth whose atyle or angles to the plane of the horizon. The ahadow marks circles intersecting one another in the zenith and nadir. and cutting the horizon at right angles. - Magnetic az1muth, an arc of the horizon intercepted between the azimuth or vertical circle pasaing througin the center of found by observing the object with an azimuth compasa. Pertaining to the azimuth; used in taking azimuths.

azimuthally (az'i-muth-al-i), $a d v$. In the manner of

Turning azimuthally in either direction.

Nature, $\mathrm{XXX} 502$

azo-. A eurt form of azote in compounds. Azo-compound, a compound intermediate between a by partial reduction, or from the latter by partial oxida-

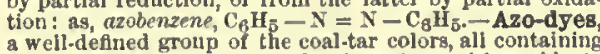
the diatomic gronp $-\mathrm{N}=\mathrm{N}-$, bound on either aide to
a benzene radical. They may be prepared hy reduction of a benzene radical. They may be prepared by reduction of diazo-compounds with phenols or aminea of the aromatic brightly colored bodies; but they are not coloring mat. ters, since they do not posses the property of combining
with either acids or bases. The azo-dyea are the amido. or hydroxyl-derivatives of aimple azo-compounds, and ar diatingulahed as amidoazo- and oxyazo-dyes. In dyeing,
the amiloazo-dyea can either be used as anch or in the the amiloazo-dyea can either be used as anch or in the
form of their auphonic acids, while the oxyazo-dyea
nearly always contain aulpho-groups.

azobenzene (az-ō-ben'zēn), n. $\quad[<a z o(t e)+$ benzene. $\mathrm{A}$ erystalline substance, $\left(\mathrm{C}_{6} \mathrm{H}_{5}\right)_{2} \mathrm{~N}_{2}$,
obtained by the aetion of redueing agents upon nitrobenzene. Also called azobenzol and azobenzide.

azobenzol (az-ō-ben'zōl), n. $\quad[<a z o(t e)+b e n-$ zol.] Same as azobenzcne.

azo-blue (az'ō-blö), $n$. A coal-tar eolor used for dyeing cotton, and fast to soap and acids. It ia a dark-biue powder soluble in water, and is formed by the
sction of tetraza-ditolyl chlorid on beta-paphthol-sulphonate of potash.

azodiphenyl (az"ō-di-fen'il), n. Same as Coupier's blue (which see, under blue).

azo-erythrin (az"ó-e-rith'rin), n. [<azo(te)+ crythrin.] A coloring principle obtained from the arehil of commeree.

azogue (Sp. pron. ä-thō'gā), n. [Sp., $=\mathbf{P g}$. azongue, quieksilver, < Sp. Ar. azaouga, < Ar.

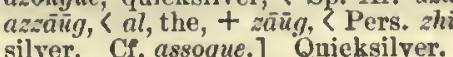

azotized

Alf the different kinds of silver are called [in Mexico]

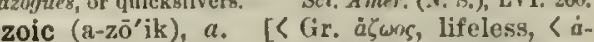
zoic (ą-zo'ik), a. [< Gir. aswhs, lifeless, < apriv. $+\zeta \omega m$, life, < $\zeta a \varepsilon t v, \zeta \bar{\eta}$, live.] Destitute
of organic life: in geol., applied to rocks which are destitute of any fossil remains or other evidenee of the existenee of life at the period of their deposition. The " azoic system " or geries of with the associated uustratifled or massive ones, which inderlie unconformably, or are otherwiae shown to be older than the Yotsdam andatone, or the lowest group
of rocks which has up to the present time been proved to of rocks which has up to the present ti

The dredge was sent down at each succesive station, but with very poor reanit; and Ur. Carpenter was driven ond a few hundred fathoina is nearly azoic.
Sir C. W. Thomson, Depttita of the Sca, p. I92

The cnormously thick azoic siaty and other rocks, which onstitute the Laurentian and Cambrian formations, may be to a great extent the metanorphoed products of For
miniferal life.
IIuxtey, Anat. Invert., p. $8 \%$ azolitmin (az-ō-lit'min), n. $\quad[<a z o(t e)+$ litmus $+-i n^{2}$.] A deep blood-red coloring matter obtained from litmus.

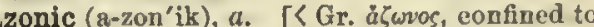
no zone or region, < a. priv. $+\zeta \omega v \hat{\text { a }}$ a zone.]

Not confined to any partieular zone or region; not loeal. Emerson.

zoöspermatism (a-zō-ō-spèr'ma-tizm), n. [<

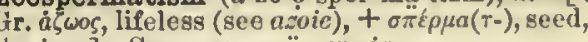
+ -ism.] Same as azoöspermia.

azoöspermia (a-zōōo-spér'mi-ä), n. [NI, : see of vitality of the spermatozoa, or their absence from the semen.

azor (a'zor), $n$. A kind of beaver eloth, made azor (äzor), $n$.

Azorian (ạ-zó'ri-?nn), a. and $n$. [< Sp. Azores Pg. Açorcs, so named from the abundanee of hawks or buzzards there, < Sp. azor, Pg. acor, longing or relating to the Azores, or to their inhabitants.

II. $n$. A native or an inhabitant of the Azores, a group of islands situated in the Atlantic oeean
about 800 miles west of Portugal, to which eountry they belong.

azorite (az'ō-rit), $n$. A mineral erystallizing in tetragonal crystals, found in a granitie roek in the Azores. Its ehemieal nat azotatet (az'ó-tāt), $n$. [< azot-ic + -atel.] A
compound formed by the union of nitrie or azotie aeid with a base; nitrate.

azote (az'ōt), n. [= F.azote, < NL. azotum,

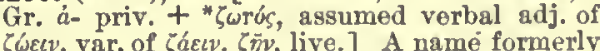
given to nitrogen, because it is unfit for resp? ration.

Lavoisier suggested the propriety of giving to thit fon]
kind of air [air robbed of its oxygen] the name of kind of air [air robbed of its oxygen] the name of Azote has been auperseded elsewhere by the term 1 hitrogen.
Ih $x$ ley, Physiog., p. 79.

azoted (az'ō-ted), $a . \quad\left[<a z o t e+-e d^{2}.\right]$ Nitrocenized.

Aa anlmais are fed on animal diet or on azoted gub-
Aitkin, Jied. Dict. (6th ed.), II. 1061 . azotht (az'oth), n. [Also $a z o t$ and $a z 0 o k ;$ a eor ruption of the Ar. original of azogue, q. v.] 1. In alchemy, mereury, as the assumed first prin-
eiple of all metals. -2 . The universal speeifie or panaeea of Paraeelsus.

azotic (a-zot'ik), a. [< azote +-ic.] Pertaining to azote; fatal to animal life.-Azotic acid or nitrogen gas. An azotized body. See azotized.

azotin (az'ō-tin), n. [< azote $\left.+-i n^{2}.\right] \quad$ An explosive compound eonsisting of 15.23 parts of carbon, 11.43 of sulphur, 69.05 of saltpeter, and 4.29 of petroleum.

azotise, azotised. See azotize, azotized.

azotite (az'ó-tit), $n$. [<azote $+-i t^{2}$. $]$ A salt

base: synonymous with nitrite.

azotize (az'ō-tiz), $v$. t.; pret. and pp. azotized, ppr azotizing. [< azote + -ize.] To nitrogenize. Also spelled azotise.

azotized (az'ö-tizd), $p . a$. Imbued with azote or nitrogen. Also spolled azotised.

It has been maintained, on the basis of carefully-conducted experiments, ... that the amount of work don by an aninial may be grester than can be accounted for by the ultimate

IV. B. Carpenter, in Corr. and Conaerv. of Forces, p. 431. Organic coupounda whlch contain nitrogen are frequently termed azotized substances.
W. A. Afiller, Elen. of Chen., \& 339. 


\section{azotometer}

azotometer (az-ō-tom'e-tèr), n. $\quad[<a z o t e+\mathrm{Gr}$ 

An azotometer containing a concentrated solution of poAmer. Jour. Sci., 3i ger., XXX. $5 \%$

azotous (a-zōtus), $a$. [<azote + -ous. $]$ Nitrous: as, azotous (= nitrous) acid.

azoturia (az-ō-tü'ri-äj), n. [NL., <azote + I. ur-ina, urine: see urea.] In pathol., a condition in which there is an excess of urea excreted.

Azrael, Azrail (az'rā-el, -il), $n$. [Heb. Azraēl, ef of men's souls from their bodies.

The second trumpet blast will be that of "Extermination," at the sound of which the lives of all creatures wIII 'n an linstant be extinguished, the last to dle being
Azrael, the angel of death. Religions of the World, p. 304 .

Aztec (az'tek), $n$. and $a$. [< Azteca, tho native wame. Cf. Aztlan, the legendary but unknown region from which the.Aztecs came; said to be < aztatl, heron, + tlan or titlan, place.] I. $n$. A member of one of the leading aboriginal A member of one of the leading aboriginal tribes of Mexico, which was dominant on the iuvasion under Cortes in 1519 .

II. $a$. Of or pertaining to the Aztees.

Aztecan (az'tek-an), $a$. Of or pertaining to the Aztecs; Aztec.

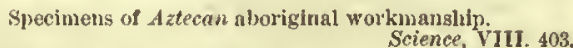

azulejo (Sp. pron. "̈̈-thö-]ā'hō), $n$. [Sp., $\leq a z u l$, blue: see azure.] An carthenware tile of Spanish manufacture, painted and enameled in rich colors, especially one having a metallic luster. [This use of the word, whjeh is general among English eollectors and writers on decoration, fa apparently founded
on the assumption that the word in the original Spsnish on the assumption that the

azulene (az'ụ-lèn), n. [< Sp. Pg. azul, blue, azure, + -ene.] A vegetable principle which imparts a blue color to many of the volatile oils. It 18 a volatile liquid, with an intensely blue vapor. The
formula $\mathrm{C}_{16} \mathrm{H}_{26}$ O lias been given to it. Also called cert. azulin (az'ū-lin), $u$. [< Sp. Pg. azul, blue azure, $+-i i^{2}$. ] A coal-tar color formerly used in dyeing. It was prepared by heating coralline snd aniline together, and produced blue colors

azulmin (az-ul'min), n. $[<a z($ ure $)+u l m(i c)+$ $-i n^{2}$.] A name given to the brown ulmie nitrogenous substance which is formed by the spontar

azumbre (Sp. pron. ä-thöm'brā), n. [Sp.] A

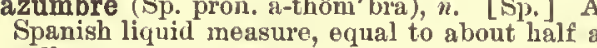
gallon.

azure (azh'ụ̂r or' à'zhūr), n. and $a$. [< ME. azure, asure, asur, < Ö̈. azur, asur, F. azur = Pr. azur = OSp. azur, Sp. Yg. azul=It. azzurro, azzuolo, <MI. azura, azurim, ete., also lazur, lazurius, lazulus, an azure-colored stone, lapis

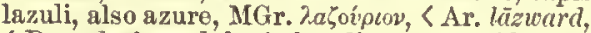
<Pers. lazhward, lapis lazuli, azure: said to be named from the mines of Lajuurd. The initial $l$ is supposed to have been lost in the Romanic forms through confusion with the definite article, F. le, $l$, etc.] I. n. 1t. Lapis lazuli.

But natheles this markis hath doon mak Broches and ringea, for Grisildis Ba

Chaucer, Clerk's' Tsle, 1. 254

2. The fine blue color of the sky: as, "ber eyes a bashful azure," Tennyson, The Brook. If ... the air were absolutely pure and devoid of mat-
ter foregn to it, the azure of the aky would no longer lo Spottiswoode, Polarisation, p. 82 A little speck of azure has widened in the western heap-
Mlawthorn, Twlce-Told Tales, 1.
406

azzy

3. A name formerly applied to several sky. colored or blue pigments, but now used for cobalt blue (which see, under bluc). It has been applied to-(a) that made from lapis lazull, called genuof eobalt, and reducing this to a powder: in grains the ze of zand, this is called smalt; $(c)$ an artificially pr 4. The sky, or blue vault of heaven.

on henven's azuret

Milton, P. L., i. 297

5. In her., the tincture blue, which in uneolored drawings or engravings is

represeuted by shading in horito $a z$

II. a. Rescmbling the clear blue color of the sky; sky-blue. - Azure blue. See ilue.-Azure re. See azurite, 1.

zare (azh'ür or $\left.\bar{a}^{\prime} z h \bar{u}{ }^{\prime}\right), r$. $t$. prot. and pp. azurcd, ppr. azur-
ing. $[<$ azure, a. $]$ To color blue. 'Twixt the green sea and the azur'd vault. Shak, Tempest, v.

azure-stone (azh'ür-stōn), $n$. Same as $a z u-$ rite, 1.

zurine (azh'ū-rin), a. and $n_{0}$ [< ML. azurinus, < azura, azme: see azure.] I. $a_{\text {. Azure. }}$ Hakluyt.

II. $n$. 1. An English book-name of a fisl which is a variety of the rudd; the blue roach. -2. A bird of the genus Malurus (which see) -3. A bluish-black shade produced in printing with aniline black, formed by treating the fabric with ammonia after the black is completely developed.

azurite (azh'î-rīt), n. [く azure + -ite $\left.{ }^{2}.\right] 1$ A blue mineral, a hydrous earbonate of copper. It has been used as a pigntent, under the name of monn near Lyons, France, whenee it has been called chessyltit and Chessy copper; It is also obtained in fine crystals at the Longfellow mine in Arizona. Also called azure copper ore, azure-stone, blue copty

zurn (azh'ūrn or $\left.\bar{a}^{\prime} z h \bar{u}{ }^{\prime} n\right), a$. [<azure $+-e x^{2}$ Cf. golden.] "Of a blue color.

The azurn aheen of turkis blue.

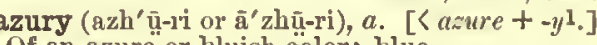

Of an azure or bluish eolor; blue.

Azygobranchia (az"i-gō-brang'ki-ä), n. $p l$ [NL., < Gr. ácvyos, not joined (see azygous), + ppayxıa, gills.] A division of streptoneurous gastropods, by which the Seutibranchia, the Ctecontrasted with the Zygobranchia. See extract. All the remaining Gasteropoda eontrast with the Zygobrsinchia in the fact that the torsion of the body lias cills, and for this reason Dr. Lankester liss arzanged theen under one ordinal head, Azygobranchin. Stand. Nist., 1. 320 azygobranchiate (az"i-gọ-brang'ki-āt), a. [< Azygobranchia + -ate ${ }^{1}$.] Pertaining to or having the characters of the Azygobranchia.

azygomatous (az-i-gom'a-tus), a. $\quad[<\mathrm{Gr}$. priv. $(a-18)+$ zygomatic.] Having no \%ygomata; destitute of zygom

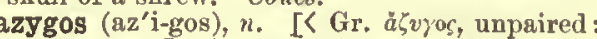
see azygous.] An azygous part, as a muscle, vein, ete.-Azygos pharyngis, a smsll muscle arising from the pharyngeal spine of the basilar process of the back of the pharynx and inserted into the raphe. - Azygos uvula, the fleahy substanee of the uvula, supposed to be a single symmetrical muscle, lnt really composed
of paired halves.

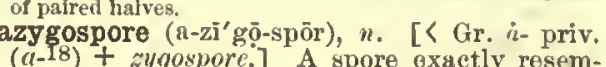
Latin controversialiats. bling a zygospore, but produced partlenogenetically by an isolated reproductive organ in some members of the order Zygomycetes of the lower fungi.

azygous (az'i-gus), a, [<Gr. à vy os, unpaired, E. yoke.] Having no fellow; not being one of a pair ; single : in anat. applied to several parts, as inuscles, veins, bones, etc., that are apparently single, or have no symmetrical fellow.-Azygous artery. an artery of the knee-foint, nsually eoming from the popliteal, but gometimes from onle of the superfor articnone on the right alde and two on the left. The right per lumbar vertebre, passes up into the thorax to the right of the aorta, snd, receiving the eight inferior right intercostal veins, the lesaer azygous veins, the left anpe-
fior intercostal vein, the right bronchisl veln, and some esophageal and mediastinal branches, empties into the lover or vena cava juat above the pericarcium. The left veins, enters the thorax, receives the four or flve lower leit intercostal veins and some egophas tinal branches, and empties usually into the right azygous vein, but zometimes into the left innoninate vein. The left upper azygous vein is derived from the left intercosta veing, which lo between those that empty juto the lef anperior intereostal trunk and those that empty into the luer. It communicates above with the left anperior jnter. costal vein and below with the right azygons veln

azym, azyme (az'im), n. [< LL. azymus, also azymon, unleavened bread, < Gr. a $\zeta \mu$ os, neut.

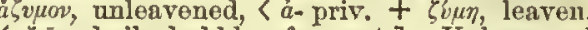

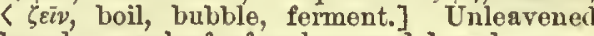
bread, or a loaf of unleavened bread; especially, the bread eaten among the Jews at the time of the Passover, or that used in part of the Christian church for cousecration in the eucharist: generally in the plural. In the Weat ern Chile hazyms seem to have been ured as far back a positive testimony goes, but the evidence either for of against their use in the earlier centuries is very scanty.

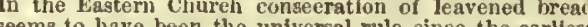
times the earlieat Latin Chureh doea not hold that the use of lesvened The controversy letween the Eastern and Western churches as to azyns turn mainly on the question whether the Last Supper was within the period of unleavened bresd, and whether therefor the holy comminson was institited with azyma or not. We have ghunued the obscurity of the papists in their azymes, tunjek, \&c Rome prescribes nothing to other nations on the point merely laying down that the blessed Sacrament may mor secrated in Azymes. zymic (a-zim'ik), a. [<azym+-ie.] of or pertaining to unleavened bread; unleavened; azymous

Azymite (az'i-mit), n. [<ML, azymita, < MGr a mrend for conseeration in the euebarist; especially, a designation applied by controversialists of the Greek Chureh to a member of the Latin or Western Chureh, or to an adherent of the Armenian or of the Maronite Church, which also use azyms. See azym. The terms Fermentarians and Prozymites have sometimes

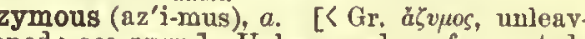
ened : seo azym.] Unleavened; unfermented as, sea-biscuit is azymous. [Rare.]

azzimina (iit-si-mē'nä), $u$. [It.] Decoration by damaskeening of the finer sort, especially in gold or silver and in elaborate designs. Also called agemina.

azzle-tooth (az']-töth), n. [See axle-tooth.] Same as axle-looth. Hallizell; Dunglison. [Prov. Eng.]

azzy, $u_{*}$ [E. dial.] A wayward child. Hallillawthom, Twice-Told Tales, 1. (a-18) + zygospore.] A spore oxaetly resem- well. [Prov. Eug. (Yorkshire).]

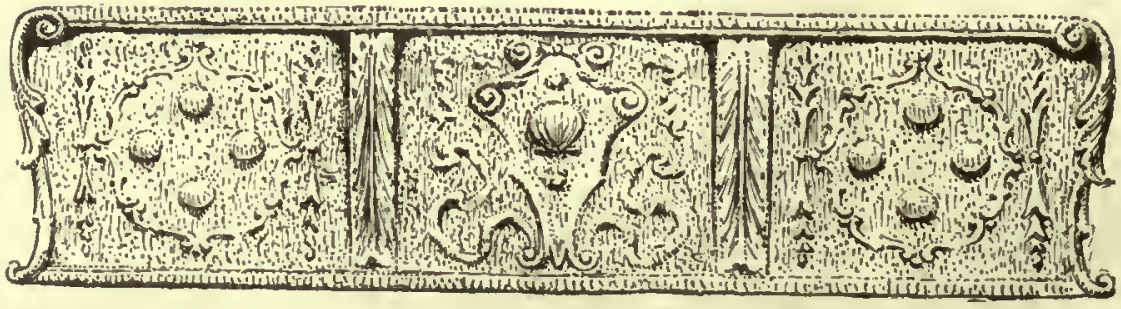




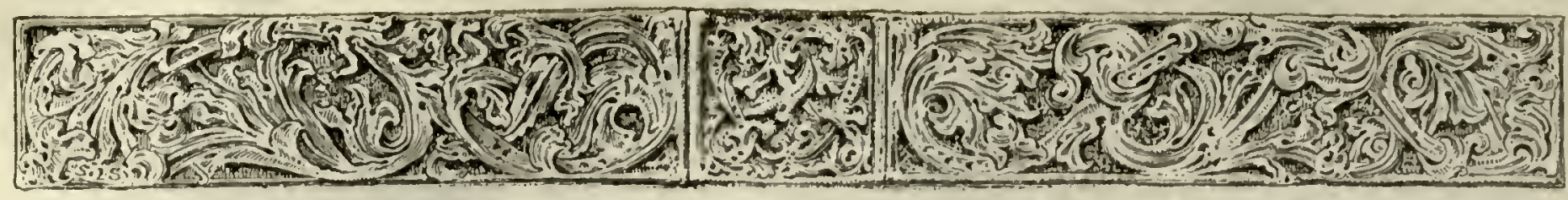

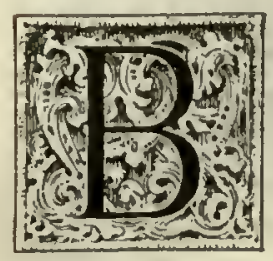
1. The second letter in ba2 (bâ), r.t. [lmitative of the sound.] To lull liabet, as it was in the lium. [Seoteh.] Phenician, and has beon in inost other alphabets derived from the Phenician. (See d.) The name beth, meaning house; from this comes the cireek riame, beta.
The Pleniclan beth, witli sonie early Greek nud Latin forms of $b$, and wlth the ancient Figyptian elinuacters, hiferutic and hieroglyphic, from which
the others nre by many authorlties sulposed to be ulti. mately derived, are given helow:

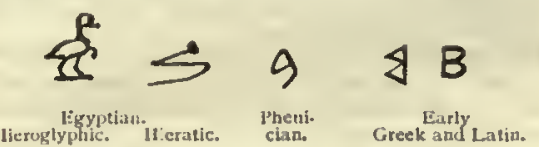

The value of the clinracter is the aame In all these alyha bets. It is a labial sonant (or voiceni) mute (or stup, or cleck); that fa, it is madle with the lips alone, by a com.
plete closure cutting off all exlt of breath from the mouth, plete clositre entting off all exlt of breath from the mouth, cherds, the eurrent of nir necessary to produce this being "The corresponding aurd (or voleeless) mute is $\mu_{\text {. }}$ (See $\mu$, $B$ las nothing of that varfety of pronunciation. ghown by most Fnclish letters; int it is sometimes silent, as when thal after $m$, lis lemtb, limb $t_{\text {omb }}$, thumb, and in a few modern graphic insertion, and was never pronounced (in. the English forms); e.g., limb, thumb, tebt, doube. In the fumianental or Germanic part of our language a $b$ comes from a nore original asyirate found in Sanskrit as $b h$, in (ireek as $\phi(p h)$, In Latin usually ns $f$. Examples are:

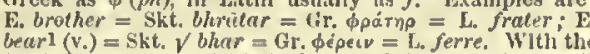
Englishi $b$ eorresponds that of nest of ule other Gemmanle
dialects. In tho original Indo-Eurovean or Aryan lan. alaces.

2. As a numeral, B was used by the Hebrew and Greeks, as now by the Arabians, for 2.3. As a symbol: (u) In musie, the seventh tone, or "leading tone," of the model diatonio scale, or scale of C. $\mathbf{B}$ was the last tone to be allopted lute the molern major aeale. It was the first note to bo modl. flerl by lowering its pitch a semitone; its two forms, the

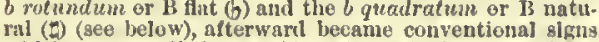
which were applied as accillentals to all the notes of the scale. See accidentul, n., 1. In Italian and Freneh the aame nete is anlled si. In Germun use $B$ denotes $\mathbf{B}$ flut (b) In elicm., the symbol of boron. (e) In ornith. the accessory femorocaudal muscle, one of the chicf elassificatory mascles of the leg. A. II. furrod. (d) In math., see $A, 2(c)$ (e) Iu abstract reasoning, suppositions, ete., the seeond or other person or thing mentioned: as, if strike $B$. ( $f$ ) In general, the second in any se-
ries: as, Company $\mathrm{B}$ (of a regiment), sehedule $B$, ete. ; in the form $b$, or $b$, the second colum of a page, in a book printed in columus. - 4. As an abbreviation, B. stauds for - (a) Bachelor (or Middle Latin Bacculaureus), in B. A. or A B., B. C. E., B. D., B. L., B. M., ete. Seo these abbreviations. (b) In dates, before, as in B. C. or B. C., and born, as in b.1813. ( $(e)$ Iu a ship's log-book, in tho form b., blue shy. (d) In hydrometric measurements, Baumé: as, $8^{\circ} \mathrm{B}$. See
Buumés hylrometcr, under hydrometer. Also Bé. B, or B flat, au English humorous euphemism for be" (Cimer lectularius), - B cancellatum, in music, the sharp: so called heeause it was origginally indicated by cressing or
tancellng the synbel of $\mathbf{B}$ ifuadratum. $-\mathbf{B}$ quadratum, cancellng the symbol of $\mathbf{B}$ ruadratum, - B quadratum, to denote B nutural in clistlnetion from B flat: nww nsed as the natural. See aecidental, $n$. , - B rotundum, in musie, literally romind $B$, a modifled form (b) of the Ronnan letter b first nsed to lenote $B$ flat, as distingulshed from B quadratum: It is now the conventional algn of the fiat. See aecidental, $1,, 1 .-$ Not to know B from a bull's
foot, or a broomstick, or a battled ore, to be very li. literate or very ignerant: jopular alliterative com

$\mathrm{ba}^{1}+, v, t$. [Perhaps a humorous initation of smack; but ef. OF. baer, beer, open the mouth, gape (see buy4), and buss, kiss.] To kiss. Let me ba thy cheke.

\section{l'il bu the lat}

Ba. The chemical symbol of barium.

II. Vichelsus

ba' (bâ), n. [Se., = E. bull1. Ct, $a^{8}$.] A ball. [Seoteli.]

B. A. An abbreviation of - (a) Bachelor of $A \cdot t s$. See A. B. and bachelor. (b) Bachelor of Agriculture: same as B. Ayr. (c) British Associasuch phrases as $B$. A. wit. See unit.

baa (bai), $\tau$. $i$. [Imitative of the sound. Cf. L. bee, the sound made by a sheep (Yarro), L.
balure, bleat, Gr. $\beta \lambda \eta \chi \eta$, Doric $\beta$ ha $\chi^{\alpha}$, a bleat-

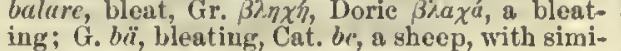
lar forms in many languages.] To ery or bleat as a sheep.

$$
\text { Like a laub, whoae dam away ls set }
$$

Ue treble bags for help.

baa (bä), n. [<baa, $\left.x_{0}\right]$ The ery or bleating of a sheep or lamb.

baag-nouk, $n$. A weapon for secret attack nser among the Mahrattas in India, consisting of short, sharp, curving steel blades, seeured to a strap of plate passing across the paln of the hand, and so arranged as not to wound the the hand inflicts a terriblo wound. Heb. Bi⿱ïl, orig. 'lord,' or 'owner,' applied to any deity, then to a particular deity; pl. worshiped, especially by the Phenicians and their descendants the Carthaginians, with muel license and sensuality. Baal was derived from the Babylonlan Bel, a deity of a mnel higher tyje, and was
merged in the Tyrian IIelkarth. In its original generic aense of 'lord,' the name was applied to many diftercint livinsties, or, with yuallifying epitbets, to the aame divinity regarded in different aspeets and as exerclsing differhimself, while Baal-berith (the covenant-lurd) was the goxl
of the shechenites, and Baat-zebub (the fly ged) the idel of of the Shechenites, and Baat-zebub (the fly.ged) the idel of
the I'hillistines at Ekron. Baal-peor (lord of the opening) mosl. brew, Phenlcian, and Carthaginian names of persons and

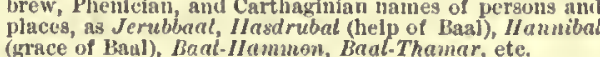
Baalism (bā'al-izm), n. [< Baal + -ism.] Th orship of Baal; gross idolatry of any kind.

His seven thousand whose knees were not suppleal with Baalist (bā'gn]-ist), ${ }^{2}$ [ [ Baal + -ist.] A wor sliper of Baal; a Baalite.

Baalite (bā'al-ît), \#. [< Baal + -ite $\left.{ }^{2}.\right]$ A wolshiper of Bäal; hence, a worshiper of heathen gods in gen

These Bcalites of pelt.

Baanite (bā'an-it), n. [<Bannes $\left.+-i t e^{2}\right]$ follower of Baanes, a Paulician of the eightl century.

aar, $"$. see bahar.

$\mathrm{ab}^{1}$ (bab), $u_{0}$ [Se. and E. dial., = E. $b o b^{1}, q_{0}$ A coekit hat with a bab of blue ribbands at it. Seot. 2. A bob, as used in fishing.

Besildes these eel-scts, however, the Norfolk Broadme also fish for eels with babw, which ean hardly be called babl (bab), $v$. $i . \quad[$ F. dial., $=b o b l, i$.$] To fisl$ with a bob. See bobl

$\mathrm{bab}^{2}$ (bab), n. [E. dial., = babe, (1. v.] A babe [Prov. Eng.]

Bab $^{3}$ (bab), M. [Ar. Pers. bäb, a gate or door forming part of many easteru plaee-names, as Bab-el-mandeb.] 1. The title assumed by the founder of Babism. - 2. A Babist; an adherent of or a believer in Babism.

babal (bä'bai'), $x$. A ehild's variant of papa. baba2 (ba-bä'), n. [F.] A light kind of fruit cake, of Polish origin.

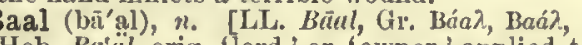

father. Cf. bibu. " [Turk. and Ar. bäbă applied (a) by tributary Arabs to the Turks (b) to the nshers of the seraglio, and (e) to the Patriareh of Alexaudria.

babacoote, 1 . Same as babakoto.

babakoto (bä-bä-kō'tō), ». [Native name.] A name of the indri or short-tailed woolly lemu' of Madagasear, Inelris or Lichunotus brevicute-

abber (bab'ér), n. [E. dial., = bobber1.] Ont who fishes with a bob; a bobber.

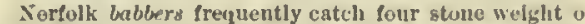
cels to a buat per night, especially in the spawning
groumls. abbinf, \%. All obsolete form of barin.

babbitting (bab'it-ing), n. [Verbal n. of "bab bitt, v., < Babbitt (metal).] 1. The operation of lining shells or bushings for a bearing witl Babbitt metal; henee, commonly, the similar use of auy antifriction alloy-2. Babbitt meta!. - Babbitting jig, a tuol used to holi bearing lower in luing metal, as the Babbltt, is belng poured in. - Babbitting lade, an iron lalle used to pour the Babbit chlnery.

babblative (bab'la-tiv), $a$. [Formerly also bubto babbling.

Argumentatjve, babblatice, and unpleasant to me.

babble (bab'1), ${ }^{\prime}$; pret. and pp. babbled, ppr'. babbling. [< ME. babelen, bablen = D. babbc$l e n=\mathrm{LG}$. babbclen = Icel. babbla = Dan. bable = G. bappeln, bappern, babble (ef. F. babiller, ehatter); all perhaps imitative, with treg. sutfix -l, from the redupl. syllable ba: see $b a^{2}$.] I. intrans. 1. To utter words imperfectly or
distinctly, as ehildren do; prattle; jabber. I babled for you, as balies for the moon,
Vague brightness. Tenmyson, Prlnee

2. To talk idly, irrationally, or thoughtlessly chatter or prato heedlessly or mischievously.

\section{The people, when they met.
Began to scoff and Jeer aml bable of lim.}

3. To make a continuous murmuring souml, as a stream; repeat a sound frequently and in-

The babling echo mocks the hountis.
Shak., T. of A., il. 3
The bubbling rumel crispeth. Tennyson, Clarlbel.
II. trans. 1. To utter incoherently or witl

II. trans. 1. To utter incoherently

These [woris\} he used to babble indifferently in all cou.

2. To uttel foolishly or thoughtlessly; let out by babbling or prating: as, to babble a plot or

babble (bab'1), *. [<babblc, $v$. I Inartieulato speech, such as that of an infant; idle talk Iaking prattle; murmur, as of a strean. Xaking werry in orld tones, and a babble of outlanillsi:
Words. An extruordinary fnecsant babble of rapid prayer from babblement (bab'l-ment), $n$. $\quad$ < babble + -mont.] Idlo talk; seuseless prate; unmeaning words.

Deluled all this whlle with mgged notlons and babble babbler (bab'ler), n. 1. One who babbles; an idle talker; an irrational prater; one who say things heedlessly or misehievously. Cum, No blabbing, as you lo
Sir Grey. Sone of our blood fere ever babblers (ireat babblerw, or talkers, are not fit for trust.

2. In ornith.: (a) A name of various old-world lentirostral oseine passerine birls more or les: nearly related to thrushes. (b) $\mu l$. The family 
babbler

Timaliide or subfamily Timaline of Turdide, an uncertain group of generally short-winged and short-tailed birds, definaljle by no common
characters. 1t contains $\mathrm{s}$ great number of birls not characters. It contains \& great number of birls no
satisfactorily located elsewhere, and has becn called "the
ornithological waste-basket."

3. In hunting, a dog that yelps or gives tongue too much when in the field.

After a fox has leen found, the babbler announces the fact for the next ten minutes, and repests Encyc. Brii., XII. 315. babblerg ${ }^{1}+, n$. [< babble + -ry. Cf. F. babillerie (Cotgrave), babble.

babblery ${ }^{2}+u_{\text {. }} \quad$ [Early mod. E. babblerie, bablerie, appar. for babery or baublery.] Something worthless; worthless things eollectively. Narcs.

Other toyes, fantasies, and bableries, whereof the world
ful, are suffered to be printed. Stubbes, Anat. of Aluses. babbling (bab'ling), n. [Verbal n. of babble, v.] Foolish talk.

Avoiding profane and vain babblings. I Tim. vi. 20. babblingly (bab'ling-li), adv. In a babbling manner; with babblement; pratingly.

babblishlyt (bab'lish-li), adv. Babblingly. babbly (bab'li), a. [< babble + -y.] Full of babble; chattering.

babby (bab'i), $n$. [F. dial., = baby, q. v.] $\mathbf{A}$ baby. [Prov. Fing.] babe (bāb), $n$. [< ME. babe, prob. abbr. of
earlier baban; origin obscure, perhaps nlt. imiearlier baban; origin obscure, perhaps nlt. imi-
tative; cf. $b a^{2}$. The Celtic words (W. Gael. Ir. Corn. baban = Manx baban, bab, a babe, ehild; regarded by Skeat after Williams (Lex. Cornu-Brit.) as a mutation of *maban, dim. of W. mab, a son, = Gael. Ir. Manx mac, a son, $=$ Goth. magus, a boy, = AS. magu, a son, related to may 1 , may ${ }^{2}$, might) are late, and may be from F.] 1. An infant; a young elild may be from E.] 1. An infant;

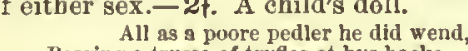

Bearing a trusse of tryfles at hys backe,

As bells, and baber, and glasses, in hys packe.

3. One whe is like a babe in any respect; persen of infantine or childish character or ability: as, he is a mere babe in that man's a recent convert to Christisnity (1 Cor. liit. 1). as babyllood. Udall.

Babel (bā'bel), n. [LL. Babel, <Heb. Bäbel, re ferred in Genesis to the notion of 'confusion'; but perhaps < Assyrian bãb-ilu, lit. gate of God, or $b \bar{a} b-i l i$, gate of the gods, < $b \bar{a} b$, gate, +ilu = Heb. el, God: see Elohim and Allah. 1 1. The Semitic name of the eity (Babylon) where, according to Gen. ix., the construction of a tower where the confusion of tongues took place. See Babylonian. Hence-2. A lofty structure.and vonfusion, as a great city or a riotous assemblage.

"Tis pleasant, through the loopholes of retreat,

To peep st such s world - to see the stir
of the great Babel, and not feel the crowd.

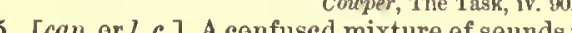
confusion; disorder.

That babel of strange heathen lsnguages.

Babel quartz. See quartz.

baberyt (bā' bèr-i), $n$ [< ME. babery, earlier babeuric, babeuwrie, etc., appar. cormut forms of baboymrie, baboonery (see baboonery); but in later use < babe + ery.] 1. Grotesque ornamentation in art or architecture,
human figures or other decorations.

\section{As baberuryes and pynacles,}

Ymageries and tsbernscles, 2. Finery to please a child; any trifling toy for children: as, "painted babery," Sir P. Sidney, babiant, babiont, ant forms of baboon, q. v.] A baboon. $B$. Jonson; Massinger.

babillard (bab'i-lärd), $n$. [F., < babiller, chatter: see babble.] The chatterer: a name bor-
rowed from the French by Rennie for the lesser white-throat, Sylvia curruca of Europe, la fauvette babillarde of Buffon. [Rare.]

babingtonite (bab'ing-ton-it), n. [After the mineralogist William Bäbington (1756-1833).] A vitreous dark-green or black mineral of the pyroxene group, oceurring in small brilliant

triclinie erystals in beds of magnetic iron ore and in veins of quartz and feldspar. It

Babington's-curse (bab'ing-tonz-kèrs), $n$. The water-weed, Elodea Canadensis: so ealled in Fngland from the false supposition that it was introduced there by the botanist Charles Babington (born about 1808)

babiont, $n$. See babian.

abir (bä'bër), ${ }^{\prime}$. A Syrian name for the papyabirussa, babiroussa (bab-í-rö'sä), $n$. [Also formerlybabirusa, barbirousa, etc. (NL. babirus$s a)$, [Malay $b \bar{a} b i$, hog, + rissa, deer.] 1. The East Indian wild hog or horned hog. The upper

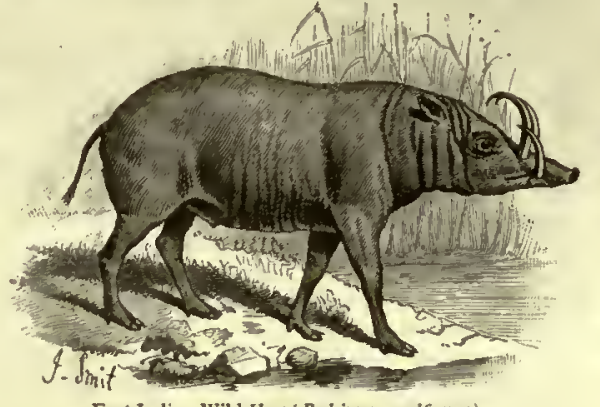

East Indian Wild Hog (Badirussa a burno).

caniues of the boar are sometimes 12 inches In length, an nesrly resch the forehead; the lower pair partake of the same extent, nor do they pierce the lips. The tusks of sow are nuch smaller. The general appesrance of the animal is that of a hog, but the legs are longer and the pelage is less liristly. The babirussa is gregarious snd herblvo rous, like the rest of the pig tribe, an

2. [cap.] A genns of setiferous pachydermatous ungulate quadrupeds, of the order Artiodactyla, or even-toed ungulates, and family Suide ontaining only the babirussa.

Also spelled babyrussa, babyroussa.

babisht (bā'bish), a. [<babe + -ish $\left.{ }^{2}\right]$ Like a babe; babyish.

If he be bashful and will soon blush, they call him a babishlyt (bā'bish-li) Ascham, The Scholemaster, I. babishlył (bā'bis
babe; babyishly.

babishnesst (bā' bish-nes), n. Babyishness childishness.

Babism (bäb'ism), n. [< Pers. Bābi, Babism ( $b \bar{a} b$, a gate, the name assumed by the founde of the sect, who elaimed that no one could come to know God except through him : see $B a b^{3}$ ), $+-i s m$.$] A religious, political, and social sys-$ em founded in Persia about 1843 by Seyd Mo hammed Ali, a native of Shiraz, who pretended to be descended from Mohammed. It is a panthe istic off shoot of Iolrammedsmism, tinctured with Gnos-
tlc, Buddhistic, and Jewish ideas. It inculcstes a high morality; dlscountenances polygamy ; forbids concubinage asceticism, and mendicancy; recognizes the equslity
the sexes; and encoursges the practice of chsrity, hosp tslity, and slostinence from intoricants of all kinds.
Babist (bäb'ist), n. [<Pers. Bābi (see Babism) + -ist.] A believer in Babism

bablah (bab'lï), $n$. [See babul.] The pod of several species of Acacia, especially of A. Arabica, which comes from the Fast and from Senegal under the name of neb-neb. It contalns gsllic acjd and tannin, and has been used in dyeing cotton for producling various shades of drab. The seeds sre said to Egypt for dyelng norocco. Álso called babool, babul, and babulah. See cut under acacia.

bable ${ }^{1}$, bable $2+, n$. See bauble 1, bauble ${ }^{2}$.

$\mathrm{Bable}^{3}$ (bä'blā), $n$. A dialect of Spanish, spo ken in Asturias. Encyc. Brit., II. 824.

baboo $n$. See babus

babool, $n$. Same as bablah. baboon (ba-bön'), n. [Farly mod. E. also ba-
boone, babounc, babound (also babion, babian (

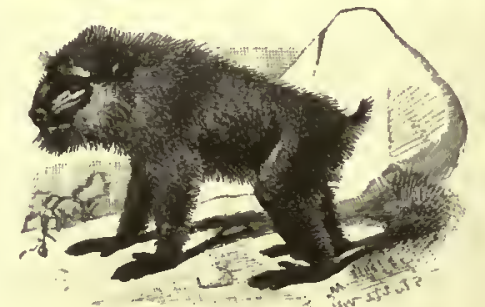

Baboon (Cynocephalus maimon).
F. babion), and batian, after D. bariaan, LG. bavian, > Dan, bavian, G. pavian), < ME. babewyne, babwyn, babwen, baboyne, etc., < OF. babuin, baboin, babouin, babion, mod. F babowin $=\mathrm{Sp}$. Pg. babuino $=1$ t. babbuino; ML. babevynus, babervynas, babuynus, babouinus. The OF. forms appeal to be the oldest. The origin of the name is unknown. The Ar. maimun is prob. from the European word.] A quadrumanous animal of the old world, of the subfamily Cynopithecince, and especially of either of the genera Cynoccphalus (or Papio) and Mandrilla (or $A$ formon). The bahoon las a large prominent muz. zle and a low racial angle, constituting a physiognomy
to which the term "dog.faced" has been applied. It
has cheek-pouches, large canlne teeth, tail nsnally short has cheek-pouches, large canlne teeth, tail nsinally ghort
(whence the term "pig-tailed "spplied to some), anl large are ischisi callosities, often gayly colored. 1ts fore ant hind limbs are proportionate, so that the snimal can go animals, some equaling a mastifi in size and weight, and are smong the most sullen, intractable, ferocious, and filthy brites of the order to which they belong. Mlosi of them sre Atrican, and they are 11sulaly gregarions, going in large etc. Among those which have speclal names are the ann. mana which loelong technically to the same group as the baboons do not usinally take the name, as the hlack ape of Celebes, Cynopithecus niger, and the Barbary ape, Inuts ecandatus; while some monkeys of other groups are baboonery (ba-bön' e-1i), n.; pl. baboonerics (-riz). [< baboon +-ony.] 1+. Same as babery, 1.-2. A collection of baboons. - 3. Baboonish (ba-bön'isl

Like a baboon; charaeteristiof

A serles of babronish chuckles and grins.

Pop. Sci. M/o., XXIX. 660.

baboosh (ba-bösh'), ". [Also babouche, after F. babouche (usually pl., babouchcs) = Sp.babucha (pl. babuchas), ২ Är. bäbūish, ২ Pers. päpōsh, a lipper, < $p \bar{a},=$ F. foot, + pōsl, covering; ef. puarters cover.] A kind of slipper without Babouvism (ba-bö'vizm), n. [< F. babourisme, <Babeuf (Babouf) + -isme.] The communistic Babeuf (Babouf) + -isme.] The communistic system promulgated by the French socialist Its fundamental principles were summed up in the senhapplness consists in equslity." By "equality " was mesnt asolnte uniformity in dress, food, clementary education, and that of the people were to have unlimited powers to divide the product of the fnilustry of all, sccording to the needs and requlrements of each. A great conspiracy was organized goveriment based on these principles, but it was hetrayed to the Directory In Misy, 1796,
in Miay, 1797. Also Bavouism?

Babouvist (ba-bö'vist), $n$. [< F. babouviste: see Babouvism.] A follower of the French socialist Babeuf, or an adherent of Babouvism. babu (ba-bö́), $n$. [Also (as E.) baboo; <Hind. $b \bar{a} b u$, a title of respect; in Canarese it means father. Cf. baba.] A Hindu title of address, equivalent to sir or $\mathbf{M r}$., given to gentlemen, clerks, etc.: formerly applied in some parts of Hindustan to certain persons of distinction. "In Bengal and elsewhere, among Anglo.Indians, it is often used with a slight savor of disparagement, as characterizlng a superficially cultlvated but too often effeminate Bengsil; and from the extenslve employment of the
class to which the term was applied as a title in the csclass to which the tern was applied as a title in the cs-
pactity of clerks in Englisl offices, the word has come often pacity of clerks in English offices, the word has come often babuina (bab-ū-1'nä), n. [NL., fem, of babuimus: see baboon.] A female baboon.

The depravity of an old babuina, or female Bhunder
Pop. Sci. $3 / 0$, XX. 393 . babul (ba-böl'), n. [Also written babool, babu$l a h$, repr. Hind. băbùl, a species of Acacia.] Same as bablah.

baby (bā'bi), $n$. and $a$. [Also dial. babby; early babe.] I. n.; pl. babies (-biz). 1. An infant or young ehild of either sex; a babe.

I knew them all as babies, snd now they're elderly men. 2t. A doll.

The archdnke saw that Perk!n would prove a runagate and it was the part of children to tall out gbout babies.

These [boxes] are to have Folding-Doors, which being opend, you are to behold $\mathrm{s}$ Baby dress d out in som

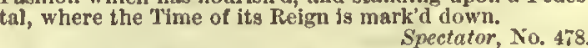
3t. [Cf. E. pupil, < L. pupilla, a girl, the pupi of the eve.] The minute reflection which a persen sees of himself in the pupil of another's eye. There are many allusions to this in our older poets; 
baby

hence auch phrases as to took babies in one's eyes, nsed with

To look gay babies in No more foxt

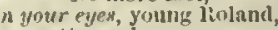

fletcher, Woman'a Prize, v.

lint wee cannot ao passe the centre of the Fye, which Weo call l'upilla, (1uasi l'ulura, the babie in the eye, the

4. One who is like a baby; a childish person.

'I'hough he be grave with years, he's a great baby.

Baby act, a colloptial name for the legal defense of infancy. Ilence - To plead the baby act. (a) To plead that a contract is vold becume made during one's minor-
tty. (b) To attempt to excuac excessive or feigned ignorance or stupidity on the ground of professed inexperience [Collowillal in both nses.] - Bartholomew baby, a kin ot doll aold orlginaliy at Bartholom

It nlso tells furmers what ntanner of wife they shall cluose; not one trickt up with riblhens and knots itke a
Barthotomerv buby.

II. u. 1. Babyish; infantino; pertaining to au infant.

Ye consclence-stricken craven, rock to reat

Your baby hearts. Shelley, The Cenci, iv.

Moulded thy baby thonght, Tennyson, Fletinore.

engine. [Collog.]

baby (ba'bi), $r$. $t$; prot. and pp. babied, ppr.

babying. [<baby, n.] To treat like a young child.

At best it babies 118 with enlless toys, Yoteng, Night 'Thoughts, vi. 521 .

baby-farm (bā'bi-färm), n. A place where chilbaby-farm (bä bi-furm), $n$. A placo

baby-farmer (bā'bi-fiir"mèr), n. One who re

ceives and contracts to care for the infants of those who, for any reason, may be unable of unwilling to bring up their owu children. baby-farming (bā'bi-fïr'ming), n. 'The busi-

babyhood (bā'bi-hudd), n. [<baby + -hood. $]$ The state of being a baby; infancy.

baby-house (ba'́bi-hous), $n$. A toy house for children's dolls.

babyish (bā'bi-ish), a. [<baby +-ishl.] Like a baby ; childish.

babyishness (bā'bi-ish-nes), n. The quality of being like a baby; extreme childishness.

babyism (bā'bi-izm), n. [<baby + -ism. $] 1$. The state of being a baby; babyhood. Jeffrey. Babyisms and dear diminutivea. Texnyron, Aylmer's Fleld.

The egotism, the babyism, and the inconaistency of thi

baby-jumper (bā'bi-jum"pér), n. [< baby + jumper.] A basket or sling in which a small child may be fastened, having an adjustable elastic cord which permits a dancing motion when the child's feet touch the floor.

Babylonian (bab-i-lō'ni-au), $a$, and

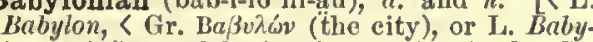
lonia, <Gr. Baßvievia (the province), the Gr form of the Semitic namo Babel or Bābilu (IIeb. Bäbel). See Bubel. The original Acea dian name of the city was Ca-dimirra.] I. $a$ 1. Pertaining to Babylon, the eapital of the ancient kingdom of Babylonia, or to the kingdom itself. Ruins of the city, in the form of three large monnds, exist near lfillah on the

2. Like the confusion of tongues at Babel $(=$ Babylon); mixed; confused.

This formal error [of applying the word "force" to al kinds of power, living or dead has hecome a Pandora' Quoted in IF, R. Grove's Corr. of Forces, p. 333.

3t. [From a former common identification by Protestants of the "scarlet woman," "Baby lon the great, the mother of harlots and abomi-
nations" (Rev. xvii. 5), with the Papacy.] (a) nations" (Rev. xvii. 5), with the Papacy.] (a)
Popish. (b) Scarlet. - Babylontan art, a subdivi. sion of Mesopotarnian ast; the later development of Chal dean art as practized at Babylon, both prior to the Assyrian
domination, whlch began in the eleventl century B. O. and culninated in the ninth century, and after the restoration of the Babylonian kingdom, under Nabopolassar, about $600 \mathrm{~B}$. C. The sarchitecture of Babylon, like that of As. material of construction the sum dried brick, and held in general to the thick walls and massive forms which wer imposed by this friable material. Stone was much mor gcarce in Balyyionla than in Assyria; hence Balyylonla decoration adhered in the matn to painting on a auriace often formeng pictorial subjects of great size and variety, for exteriors. In Babylonia, contrary to Assyrian practice, the temple, rlsing pyramilally in atagea, each as color, was the most important development of architecture, the royal palace being gnthordinated to it. The gcar-
city of stone rendered sculpture scanty; but the gem-ent-
409

bacchante

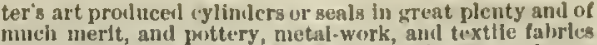
attained gTcat perlectlon. See Mesolwefunian art, and con pare Chaldean art and Assyrion arl, under the sdjectives, - Babylontan quartz. Same as liabel quartz (whit of of numeratlon, which originated in liabylonia.

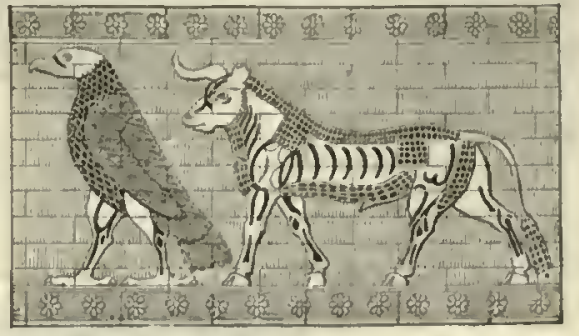

Babylonlan Art-- Deasgn In enameled brick work, from a pal)
(From Clark-Relher's "Ilistory of Ancient Art.")

II. "1. 1. An inluabitant of Babylonia; Chaldean.-2. An astrologer: so used from the faet that the Clialdeans were remarkable I. 3 .

Babylonic (bab-i-lon'ík), a. [< I. Babylonicus, [Bubylon: seo Babylonian.] 1. Pertaining to Babylon, or made there: as, Babylonic gar ments, earpets, or hangings.-2. Tumultuous disorderly. Sir $J$. Harington.

Babylonicalt (bab-i-lon'i-kal), a. Samo as

Babylonish (bab-i-lō'nish), a. [< Babylon + -ish.] 1. Belonging to or mado at Babylon.2. Babel-like; confused.

Worls which were a perfect Babylonish jargon to the
bewlliered Yan Winkle. Jroing, Sketch-Book, po 59. 3t. Popish. See Babylonian, a., 3.

Babylonite (bab'i-lon-it), " [< Babylon + ter. Sce arrow-headed and euneiform.

baby-pin (bā'bi-pin), $n$. A safety-pin.

babyrussa, babyroussa, $n$. Seo babirussa.

abyship (ba'bi-ship), n. [< baby + -ship. $]$ Tho state of being a baby; babybood.

baby-walker (bā'bi-wâ."kèr), $n$. A frame, moving on easters, in which a child may be supported white learning to walk

bac't, $n$. An obsolete spelling of back?

bacaba-palm (ba-kä’bä-päm), n. $\quad[<\mathrm{S}$. Amer. bacaba + E. palm.] A palm of northern Brazil, Enocarpus distichus, with a tall trunk and widely spreading pinnate leaves. The drupaceous frults are used by the native for making a pleassnt drink,
and the kernels furnish an oll reaembling that of the olive. bacbakiri (bak-ba-ké'ri), n. [Native name.] A name of an African shrike, Telephonus guttu-

baccalaurean (bak-a-1árē-an), a. [<ML. baccalaureus: see baccalaureatc.] Of, pertaining
to, or befitting a bachelor.

That quiet, comfortable, baccalcurian habltatlon, ov Dr. J. Broven, Spare Hours, 3 ser.

baccalaureate (bak-â-lâ'rē-āt), $n$, and $a$. [ NL. NL. bacealaureatus, < bacealaureus, a corruption (simulating L. bacea, berry, and laurus, lacel) of ML. bacealarius, a bachelor, on versity: see bachelor.] I. $n$. 1. The university degree of bachelor.-2. A baccalaurcate sermon (which see, below)

II. $a$. Pertaining to the university degree of bachelor.-Baccalaureate sermon, a farewell aermon Baccanarist (bak-r-när'ist), $n$. In the Rom. Cath. Ch. a member of a society founded in Italy by ono Baccanari after the suppression of the Jesuits in 1773 , with the object of restoring that order under a new name and form. The society was merged in the reëstablished order of Jesuits in 1814.

baccara, baccarat (bak-ą-rä'), n. [F; ; origin unknown.] A French game of cards played by any number of betters and a banker, and with one or more packs of cards, according to the number of players. Fach better deposits a stake, and all atakes are duplicated by the banker, after which self. The atm is to decide each individinal bet by com held by the banker. The court hy each better with that the others according to the spots. The counts range in valne by series of $9,19,29,8,18,28$, ete., 9 beating any
other count. A pluyer may call for more cards, but at other count. A pluyer may call for more cards, but a his bet. If a player s cards count 9 he declares it, when cialm the amount of their bets, and the bunker takea the liferent, court-cards and tems nut countfug.

baccaret, interj. Seo backeri.c.

baccarinine (ba-kar'i-nin), n. $\quad[$ licucharis + $-i n c^{2}$.] An alkaloin obtained from buccharis eorrijolia.

baccate (bak'ät), a. [< L. baerntus, lucalus, sot with pearls, lit. berried, < becen, briec, a berry, a pearl: seo bayl.] ln bot.: (a) I'ulyy and berry-like: applied to fruits. See bcrryl. (b) Bearing berries; berricl.

baccated (bak'ä-ted), a. [< breeritc $\left.+-e d^{2}.\right]$ 1. Set or adorned with pearls. Bailey. -2 llaving many berries. Bailey.

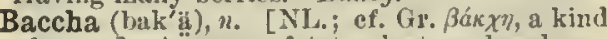
of pear.] A genus of tetrachatous brachycerous dipterous insects, of the family Syrphide. bacchanal (bak'a-nal), $a$ and $n$. [< L. bacchanatis, pertaining tö Bacelus: sce Bacelus.] I. a. 1. Characterized by intenperato drinking; riotous; noisy: as, "bcecharal feasts," Crouley, Deliberatu Answer, fol. 26 (1587). 2. Relating to

II. $n .1$. One who celebrated the bacehanalia; a votary of Bacchus. Hence-2. One who indulges in drunken revels; one who is noisy and riotous; a drunkard: as, "each bold bacehanal," Byron, Don Juan, iii. 86 . Eacli with the merry wink of a practiced bacchanal.
T. Winthrop, Cecll Dreeme,

3. pl. Same as bacchanalia.

In this masquerade of mirth and love,

Ilistook the bliss of heaven for bacchanals above.

Also bacehanalian.

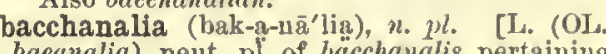
baeanalia), nout. pl. of bacchanalis, pertaining antiq. a festival in honol of Bacehus. These festivals became the occasion of great excesses, and were forbidden by the senate in $186 \mathrm{~B}$. C -2. Any festivitios characterized by jottity and good-fellowship, particularly if somewhat boisterous, aud accompanied by much winedrinking.

The morning after the bacchanalia in the saloon of the

3. Drunken orgies; riotous disorders; muthless and shameless excesses; unbounded license.

Plunging without restraiat or aliame into the Bacche malia of degpotism, the king [John] continued to plllaye,
to banlah, and to slay. Sir K. Creasy, Eng. Cougt., p. 110 . bacchanalian (bak-a-nā'lian), a. and ". [<
bacehanalia + -an.] Same as breehanal. [The bacehanalia + -an.] Same as breehanal.
more common form of the adjective.]

Ev'n bacchanatian matness basits

Coscyer, Progress of Error, 1. 56.

Sculptures of the Lacectualians. Stuketer.

bacchanalianism (bak-a-nä'liann-izm), n. [< baeehanalian $+-i$ sm.] The practice of bacchabacchanalianly (bak-a-nă'lian-li), adv. In bacehanatian inanner.

bacchant (bak'ant), $a$. and $n$. [< L.bacchan(t-)s, ppr. of bacehari, celebrato the feast of Bacchus, [Bacchus, Bacehus. Cf. brechante.] I. a. Worshiping Bacehus; reveling.

$$
\begin{aligned}
& \text { Over his ahoulder with a bacchant alr } \\
& \text { Pregentel the o'erflowing cup. }
\end{aligned}
$$

II. n. 1. A priest, priestess, or votary of Bacchus; a bacchanal.

They appear in a state of intoxication, and are the bace 2. One addicted to intemperance or riotous revelry.-3. A name given in Germany, in the fourteenth, fifteenth, and sixteenth centuries, to waudering scholars who traveled from one institution of learning to another. These hac chants frequently had younger stulents under their profor them, etc

bacclante (bak'ant, ba-kant', or ba-kan'te), ${ }^{\prime}$. pl. bacchantes (bak'antz; usually, as if L., babacchante $=\mathrm{It}$. baceante, $<\mathrm{L}$. bacehan $(t-) s$ (ace. baechantem), pl. baechantes, used, as a nour only in fem. (equiv, to Baccher), prop. ppr. of bacchari, celebrate the feast of Bacehus. In mod. use also mase.: see bacchent. The E. form, prop. bacchant, usually follows the F. spelling, and often the F. accent (ba-kant'). The pl. is usually in the L. form, whence the irreg. sing. in 3 syllables (ba-kan'te).] 1. In antiq. a priestess of Bacchus, or a woman who joined in the celebration of the festivals of Bacchus; 
bacchante

a woman inspired with the bacehic frenyy Guide tho revel of frenzied Bacchantes.

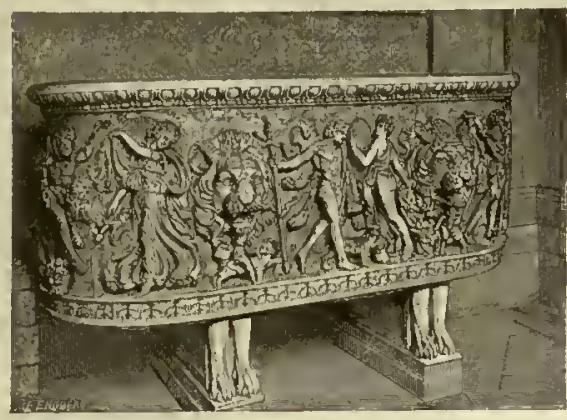

Mythological festival of Bacchus, fro
sarcophagus in the Vatican Museunt.

2. A woman addicted to intemperance or riot ons revelry; a female bacchanal.

bacchantic (ba-kan'tik), a. [<bacchant +-ic.]

of or lesombling a bacchant or bacchanal; bac chanalian ; riotous; jovial.

It is the feeblest band [of music]; and yet it is subject to spurts

C. D. Wamer, Whiter on the Nile, p. 103. I hardly know what of bacehantic joyousness I had not sttributed to them [the Italians] on their holidays.
[Iowells, Venetian Life, xviii.

baccharict, $n$. A corrupt form of Bacharach. Baccharis (bak'a-ris), ${ }^{2}$ [NL. <L, bacchar, better spelled baccaris, brccar, < Gr. Báккарьs (some-

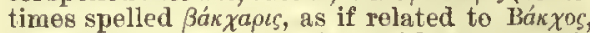
Bacehns), an unknown plant with an aromatic

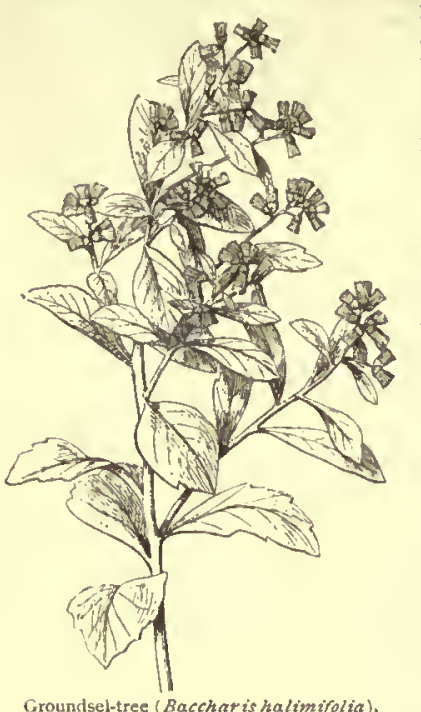

root yielding

to be a Lydian word.] A very large geof the plants of the natura yosito, somewhat nearly allied to Eni geron, but with dice or yellowish flowers, and the leaves with a resin oussecretion. lyey are mosttimes small tropieal an South Ameri. A in the United Andes extensive plateans are cuvered with them. Sulor realnous species. A decoction from the groundsel-tree
of the West Indies and Atlantic cosst of North America, B. halimifolia, is oceasionally used as a remedy in disense baccharoid (bak'a-roid)

[< Baceharis + -oid.] Resembling in some respect the groml
of composite plants of which the genns Baccharis is the type.

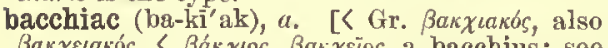
bacchius.] Pertaining to or consisting of bacchii.

Bacchic (bak'ik), a. [<L. Bacelicus, < Gr. Bak $\chi \varkappa \delta \zeta,<\mathrm{B} a ́ \kappa \chi \alpha \varsigma$, Bacchus: see Bacchus.] 1. Re-
lating to or in honor of Bacchus; connected lating to or in honor of Bacchus; connected
with bacchanalian rites or revelries. [Often without a capital.]

The bacchic orgia were celebrated on the tops of hills
and desolate wild places.

2. Jovial; drunken; a Bacchic reveler. - 3. [l. c.] Same as bucchiac. Bacchic amphora or vase, in arehreol, a Greek or the myths or the festivals of Breehus. Also called Diony siac amphora or vase. An example is shown in the cut of a decorsted smphora, under amphora.

Bacchicalt (bak'i-kal), a. Same as Bacchic: as, "bacclical enthiusiasm," J. Spencer, Vulgar Prophecies, p. 78.

bacchius (ba-kîus), n.; pl, bacchii (-i). [1,
410

ucs), a metrical foot: so named, it is said, from its use in hymms in honor of Bacchus.] In mos, a foot composed of one sliort and two long syllables, with the ictus on the first long, as in ăvā'rī, ăbōve'bōard. Sec antibucchius and homiolic. I Before the Alexandrine period Bax xeios

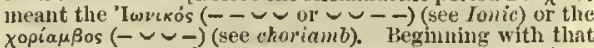

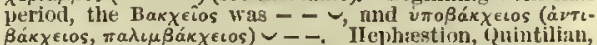

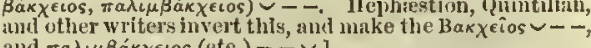

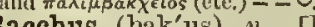

(bir. Bakxos, anone of lis followers or priests. Also called "Iak of his followers or priests. Also called "IakXos, prob. related to $a x \varepsilon v$, shout, with allu-
sion to the noisy manner in which the festival sion to the noisy manner in which the festival
of Dionysus was celebrated.] In classical myll. a name of Dionysus, the son of Seus (Jupiter) and god of wine, persod of wine, per sonifying both its good and its bad qualities. It was the current liame of this god among the Rowas especially eharac. where his festivali were eelelrated on the
slopea of Nount Citheslopes of Nount Cithrethose of the neighboring Parnassis. In At somewhat savage cult of Bacelus underwent a metamorphosis, and reached ita lighest expression in the choin which origiluated edy and for whifeh were written most of the masterpieces of Greek
literature. Bacchus was held to have tauglit

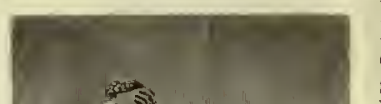
(he and and the preparation ot whe. In esrly art, and less comnonly nfter the age of Phidias, ally completely draped. After the time of Praxiteles he appears almost univergally, except in archaistie examples, in the type of a beardless youth, of gracetul and rounded A mong his uanal attrihutes are the vine, the ivy, the thyr:-
aus, the wine-cup, and the panther. See Dionysia, meenad, thiasus.

acciferous (bak-sif'e-rus), $a_{0}$ [< L. baccifer,

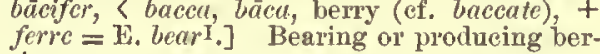

bacciform (bak'si-fôrm), a. [< L, bacca, bāca, a berry, + forma, shape.] Shaped like a berry. baca, berry, + vorare, eat, devour.] Eating or subsisting on beries: as, baccivorous birds. senses.

Bacharach (bak'a-rak), $n$. A brand of Rline wine made at Bacharach, a small town in Rhenish Prussia, on the left bank of the Rhine, 23 miles sonth of Coblentz. Formerly also backarach, bachrack, backrag, baccharic, etc.

Im for no tongues but dry'd ones, such ns wil

Give a fhe relisht to my backrag. Jayne, City Match. Good backrack... to drink down in liealths to this
Fletcher, Beggar's Busl, v. 2. bachel (bak'el), n. [See bacile.] A grain-meafrrom $\frac{7}{8}$ of a bushel to $1 \frac{1}{2}$ bushels, according to the locality. Also bacile.

bachelert, $n$. An obsolete form of bachelor. bacheleriat, $n$. [ML., also bacelleria, ete.: see bachelery.] In old recerds, the commonalty or yeomanry, in centradistinction to the barouage.

bachelery $\dagger, n$. [ME., also bachelevie, bachelry,

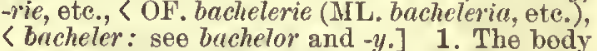
of young aspirants for knighthood.

$$
\text { And of his retenue the bachelrye }
$$

2. The whole body of knights.

Chaucer, Clerk' ${ }^{2}$ Tale, 1, 214. Th:s Phebus that was flour of bachilrie.

Chencer, Maneiple's Tale, 1. 21.

bachelor (bach'e-lor), n. [Early mod. E. also bacheler, batcheler, batchelor, -ar, -our, batchler,

etc.; < ME. bacheler, bachiler, bachler, ete.,

(a) $\mathrm{OF}$. bacheler $=\mathrm{It}$. baccalare $=\mathrm{Pr}$, bacalar,

\section{bachelorism}

S MIL. baccularis; (b) later OF. bucluclier, ba eliticr, ete, $\mathrm{I}^{\mathrm{T}}$. bachclier $=\mathrm{Pr}$, bachallier $=\mathrm{Su}$ bachiller = It, becenlliere < MIL baccalarins, bacchalarius, ete. (later baecolaurcus: : see baccalcurcate), a bachelor. Origin nncertain. snpposed by some to be orig. connected witl ML. baccalarius, the holder, as vassal of : superior vassal, of a farm called baceulariu, perhaps < bacea, tor L. vaeca, a cow. By others the OF. bacheler, in the assumed orig. sense of 'a young man,' is comnected with OF brcele, bricelle, bacliele, bachelle (with dim. bacclettc, bachelotc), a young woman, a female servant, bacheleric, youth, bacelage, apprenticeship, courtship, etc., words erroneously referred to a Celtic origin (W. bach, little, bechau, a little giri, bachgen, a boy, a child). The history of the forms mentioned above is not elear. Perhaps several independent words have become contused in form.] 1. Formerly, a person in the first or probationary stage of knighthood; a knight not powerful enough to display his banner in the field, and who therefore fol lowed the banner of another; a knight of low rank. See knight bacleclor, under knight.

I seke after a segge [man] that I seigh ons,

Piers Plaeman (B), xvi. 179.

With him ther was his sone, a yong Squyer,

A Chaveer, Gen. Prol. to C. T., 1. 79.

"Community of the bachelors of England," that is, no doubt, the body of knights - the tenants in chivalry, the landowners below the rank of the baronage. 2. In universities and colleges: $(\alpha)$ Before the fifteenth century, a young man in apprenticeship for the degree of master in one of the higher faculties, that is, of theology, law, or medicinc. (b) In modern use, a person who has taken the first degree (bacealaureate) in the liberal arts and sciences, or in divinity, law, medicine, ete. at a college or university: as, a bachclor of arts; a bachelor of science. See baccalaureatc. Origiually, a bachelor hal not neees garily takell auy degree whatever; but after the fourteentl tion, was also applied to a determinant, or young man who had taken the lowest degree in the faeuity of arts. Thi degree seems to have been conferred not by the elancelnot acconpanied by any regular diploma, but teatimonia letters were furnished if desired. In order to be admitted
to the degree, it was requisite for the esndidate to be fourleen years of age, to have followed a three yearg: course in logic in the university, and also to sinstain a disputation, called the determinance. There were in the middle ages consisted of the ordinary biblies and cursors, the dity of the former being to rend and expound the Bible from beginuing to end, and that of the latter to give one course of leetures upon a book of the Old and another upon a
book of the New 'Testament, which books they ehose at pook of the New 'Testament, which books they ehose at called sententiary bachelors, hecause they publicly read Lombard. It was not, however, till late in the Peter the century that any bachelor was permitted to leeture on the Sentences. According to the law, the lectures of the sententiary bachelorg had to include the reading of the text o the author, and the explanation of it phrase by phrase ;
and they were forbidden to trench upon questions of logic
and netaphysics. They also made certsin acts ealled had completely thinshed the exposition of the Sentences lie beame a formed bachelor (baceclarius formatus), and lad still to contimme his theological atudies for three years as a master.

3. A man of any age wbo has not been married. It was my turquoise: I had it of Leal when I was a monkeyg.
Shak., JI. of V., iil. I. 4t. A woman who has not been married.

He wonld keep you
A bachelor atill, by keeping of your portion

bachelor still, by keeping of your portion,

But in a sickness. B. Jonzon, slagnetick Lady, 1i. 1.

5. In London livery companies, a person not yet admitted to the livery. -6. A local name in the United States of a fish. Pomoxis anmularis, of the Mississippi valley; a crappie. Sometimes incorrectly spelled batchelor.
Budge, bachelors. See budgez. - Knight bachelor.

bachelorhood (bach'e-lor-hủd), $n$. [<bachelor + -hood. $]$ The state or condition of being a bachelor or unmarried man.

I can lancy nothing more cruel after a long easy life of bachelorhood than to have to sit day after day with a dull
lrandsome woman opposite. Thackeray, Newcomes, II. Ii. Keeping in bachelorhood those least likely to be long. lived. II. Spencer, study of Sociol., p. 95 . bachelorism (bach'e-lor-izm), $n . \quad$ [< bachelor bachelorhood. - 2. A trait or habit peculiar to a bacheler. 
bachelor's-buttons

bachelor's-buttons (bael' 0 -lor\%-but'uz), $u . \mu l$. [Said to be so named beeause eountry youths used to earry the flower in their poekets to divine their sueeess with their sweethearts.] 1. The popular name of several plants, as tho double-flowered variety of Lyclinis diurna (the red eampion), Centaurca nigra (knapweed) but ehiofly the double-flowered varieties of Ranunculus uconitifolius (white baehelor's-buttons) and Lumuculus acris (yellow baehelor'sbuttons). The mane is also glven to the rasged-robm

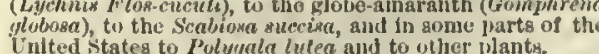
Unilted states to Polyyala lutea and to other plantr.
2. A namo for tho seeds of Strychinos N vomica, formerly used for poisoning rats. Dun glison.

bachelorship (baeh'e-lor-ship), ". $\quad[<$ bachelor + -ship.] The stato or condition of being a baehelor in any sense; the rank or degree of a baehelor in any sense; the rank or degree

bachelor; the unmarried
bachle 1 . See buchle!.

bachle $2, t r t$. An obsolete Seoteh form of bafte baclle (bi-ehö'le), n.; pl. bacili $(-\bar{e})$. [It., IL. bricile, baceile, bachilc, a basin, a dry mensuro; ef. bacinus, baceinus, baechinus, bachinus, a basin, a dry measure: see busin.] 1. I ceram., a basin or deep dish: in use in Englisl for an oinamental vessel of Italian make and of that shape, espeeially for a vessel of enameled and lustered pottery.-2. In metrology, sanio as bachel.

bacillar (bas'i-jịr), a. [<L. bacillum or NL. bacillus, q. v., +-ar.] 1. Belonging or pertaining to the genus Bacillus. - 2. Resembling in form a short rod or bacillus; baeilliform. As applied to the valves of dlatoms, it indicates that their greates dimension is in a direction parallel to the line of juncture thercfore rod-llke. See cut under bacillus.

Bacillaria (bas-i-la'ri-lík), n. [NL., < bacillus + -turia.] A genus of mieroseopic alga, belong ing to the elass Diatomacerc. They cunast of slender reetangular segments, arranged in tabular or oblhtue serieg. The compound segments of frustules are inces
sautly glipping lackward and forward over each other l'hey are frequent on the custs of Great Britain.

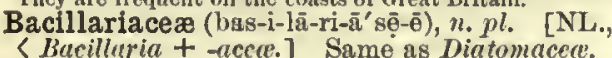
bacillary (bas'i-lã-ri), a. [< bocillus + -ary. 1. Pertaining to or eonsisting of baeilli; geterized by the presenee or ageney of baeilli. -2 . Haviug the form of small rods.-Bacllary bacilli, $n$. Plural of bacillus.

bacillian (ba-sil'i-an), a. [< bacillus + -ian. $]$ Pertaining to or of the nature of a breillus: as, "bacillian parasites," $\boldsymbol{B}$. W. Richardson. bacillicide (ba-sil'i-sid), n. [<NL. bacillus + L. -ciclu, < cadere, kill.] A substanee emgermicide.

A combluatlon of lime with chlorine, perhapg the best ery genterally employed.

baclllicidic (ba-sil-i-sid'ik), a. [<bacillicide + -ic.] Destructive to baeilli.

bacilliculture (ba-sil'i-kul-tūr), n. [<NL. bacillus + L. cultura, enlture.] The cultivation of baeteria in vegetable or animal infusious or otherwise, for purposes of investigation.

bacilliform (ba-sil'i-fôrm), $a$. [SNL. bacillus bacilliform (ba-sil i-form), $a_{0}$ [CNL. bacillus
$+\mathrm{L}$. forma, form.] Of the form of a small rod; rod-shaped; baeillar in form.

bacillus (ba-sil'us), $n_{\text {; }}$; pl. bacilli (-ī). [NL., a partieular use of LL. bacillus, L. bacillum, a a stiek, staff; ef. Gr. ßákтрov, a staff, perhaps akin to $\beta$ aivecv, go, =

1. venire $=$ E. come.]

rod or rod-like body,

as one of the rods o

the retina. -2 . An individual of the genus Bacillus.genus of the mieroseopieal vegetable organisms known as bacteria, having the form of very slender straight filaments, short or of moderate length, and consisting of one or more elongated eylindrieal joints. Several forms, or apecies, are rec-
ugnized. Of tliewe, $B$. sub.

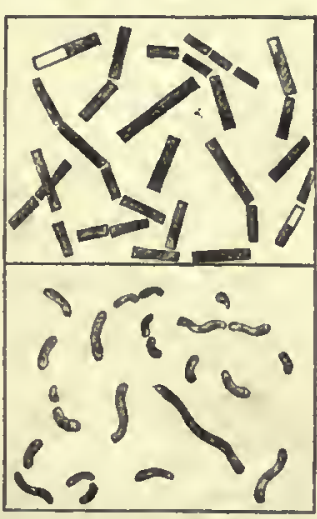

Bacillws, hlghly magaified. - Up
per figure, B. anthracus; lower fig
$+11$

lilis is found in remect, and is thes agent in lutyrle fer mentatlon; 13 . Cut thracis causes the disease known as anlifch molluce pitrefaction. other afvecieg are believed bocillns, which is asserted to and chulera. The comma course of the Iast-named dlseasc, is peculiar in havfuk a more or less curved form. See Baeterimu and Schizo

4. [cap.] In cutom., a genus of orthopteron alkorial inseets, of the family I'husmider; the ong round figure like a stick. made up into bacint, $n$. An obsolete form of brsin.

bacint, $n$. An obsolete form of brisin.

bacino (bi-chè'nō), $n_{0} ;$ pl. bacini $(-n \bar{e})$. [lt., a basin : see basin.] In cermu, one of the dishe of riehly eolored pottery which are found buil into the walls of eertain medieval buildings in Italy, espeeially at Pesaro, Pisa, Rome, and Bologna.

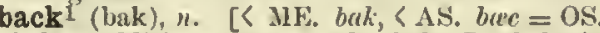
bak $=$ OFries. bek $=$ M11). bak (D. bak - i comp.) = LG. bak (also in eomp., bak-, ) G. buck- in eomp., also separately, back, foreeastle) = Ieel.' Sw. bak = Dau, buy, baek. Cf. AS. hryey, back, F. riclye.] 1. The whol hinder part of the human body, opposite the front and between tho sides, or the upper part of the body of most animals; technieally the spinal, dorsal, or tergal portion, surfaee, ol aspeet of the trunk, extending from the or aspeet of the trunk, extending from the buttoeks, hams, or bifureation of the bouly a the legs; the tergum; the dorsum; the nota um.-2. The corresponding or related portio of any part or organ of the body; the posterior aspect of a thing; the part olposite to or furthest from the frout, or in any way eorrelated with the baek of the trunk: as, the back of the head, neek, arm, leg; the back of the hand; the back of the mouth. -3 . Anything resem bling the back in position. (a) As belug beluln or furthest from the face or front, like the back ln man

Trees set upon the backs of clumneys do ripen frnits
Bacom, Nat. Ilist.

(b) As being behind, or in the furthest distance, with reference to the apectator, apeaker, acene of action, etc. : as,

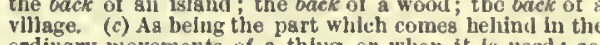
ordinary mevements of a thing, or when it is used: as and especlally the outer sud upper, portlen of s thinger like the back of one of the lower aninials: as, the buck o
a hand-rall; the back of a rafter. (e) The ridge of a lilly. The mountains huge applear
Emergent, and their broad bare backs upheave.
Myilfon, P. L., vi.

O'er the long vacky of the bushlegs downs. Tennyron, Lancelot and Elaine.

( $f$ ) As belng that whlch supports the Ifbs: as, the back of
a shlp (namely, the keel and keelsen). See broken-backed. (g) The upright hind part of a chalr, serving as a support for the back. (h) In bot., the outer ainle of an orgal, al
the alde turned away fron! tile axis : as, the back of a feat or of a carpel.

4. By syneedoehe, the whole body, with refer-
enee to elothing, beeause the baek is usually most fully eovered: as, he has not elothes to his back.

I bought you a dozen of shirts to your back.
Shak., I Ilen. IV., lii.

5t. Clothing; a garment to cover the baek. And owre bakkes that nioth-eaten be.

6. $p l$. In the leather trade, the thiekest and best-tanned hides. $-7 \nmid$. The address of a letter, formerly written on the back of the letter source.

Should have a back, or accend, that might hold,

9. In ship-bwilding, a timber bolted on the after end of the rudder, to eomplete its form. -10 . In metal-mining, the portion of the lode whieh lies between any level or stope and the one next above it, or the surfaee. Generally, the backs are the unstoped portions of the lode, as far as laid open, and ready to be mined or stoped.-11. In coal-mining: $(a)$ Same as face. going on.-12. In foot-ball, a position behind the lino of rushers, or a player in this position: ealled quarter-back, half-back, three-quarters back; or full-back, aecording to the distance from the rushers.-Back and belly. (a) Before and behind; all over: as, to bent a person back and belly. (b) (to keep lim in clothes and food). [Vulgar.]-Back and breast, the usual term in the seventeenth century for
the bedy-arnor of the perioul. It conslated of a soltc the body-armor of the periont. It conslated of a goltc
breastplate in one plece, generafly cousidered bullet- back

proxf, and a lighter backifiece, the two secured toggethin $r$ Aer the arms, dsuaily by strajes and buekles. Armet with back and brekst, liend filece and linacelets Back and edget, wiolly; completely.

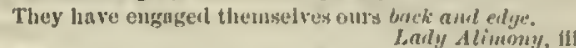

Back of a book, that part of thu cover to which the tw: - Back of a bow, in oichers, the exterlor alde of a taw,

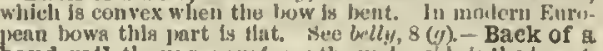

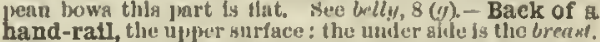
- Back of a hip-rafter, thic upper c'lge of the rafte.

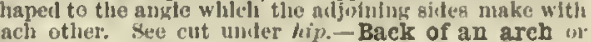
vault, the extrulos, or onter curve or face, see tirst cut under arch. - Back of a roof-rafter, lts upper sur.
face.-Baek of a slate in ronfing, thu ujper ur w wather - back or a wh to the ash- rrame, extentilng to the fior.-Backs and cutters, uing in lines more or less parallel to thio strike of the atrats, and forming the "back" of the quurry, and the back, In gecret, or when one is absent.

I confess, Mtr. Surface, I cannet hear to hear people at. tacked behwd heir backn; and when ugly cireunstauces come out against our acyualntance, I own I al ways love
to thituk the begt. Sherielan, School for Seandas, 1. I. Lazy-back, a hlyl back-bar ln a carringe-seat. It is gome- Mitered baek, lu bookbinding, a back having Hines, isnally in guld, comnected and mitered in square panels y means of cross. lines beck having two the cold, on its outer edget, rumuling oft at top and lottons. Distingulshed from the mitered bick (which see). - Smali
of the baek, the loins; the relus. - The back of beyond. sec beyond. To be on another's back to he sovere ol one for any fault or fooliali act; elilde; ridicule. [Colloq; To be on one's (own) back, to be at the end of one's
resources; be aground. [Collofi.]-To bow down the back, to sulmit to opjrresslou. Rom. xl. I0.- To break Serip.: (a) To forget and forgive. 1s. xxxvili, 17, (b) " 1 "o

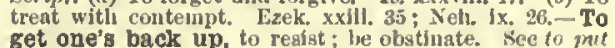

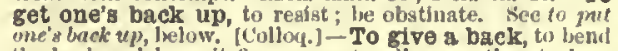
one's back up, lelow, (Collop.) - To give a back, to bend
the back and keep it firm go as to allow another to leap over one lyy placj ny his hands upon the hack, or to mount
uj, to snythlug. [Collowt.] - To make a baek. Samie as to give a back.-To put or get one's back up, to shuw metaphor probahly taken fron the hablits of frightened or angry cats. [Collorl.] - To see the back of, to get rill of.

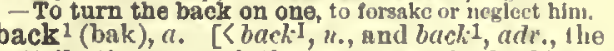
attributivo use of the noun, as in buckibone, mingling witl that of the $a d v$, as in back yarel, the yard whieh is baek, back spring, a spring thero is no definite dividing line between the separate adj. use and the use in eomposition.] 1. Lying or being behind; opposite to the front hinder; rear: as, the back part of anything; a
back dool ol window; back stairs; the back sill of a field.

I will take away mine hand, and thon slalt gee my bac
Jarts : but my face ghall not be secn.
Ex. sxxili, o:

Henee-2. Away from the front position o rank; remote in plaee or eondition; far in the rear, literally or figuratively: as, the back set tlements of a country.

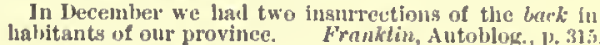
3. In a baekwarl direetion; returning in the direetion whenee it eame: as, a back stroke; back water. [In this sense properly with hyphen.]-4. In arrear; overdue: as, buck pay or rents.-Back action. Seo action.-Back cylinderbead, that head of a cylinder through which the piston-
rod pases in locometives : the opposite heas in atationary back $^{1}$ (buk), adr. [By apheresis for abuch, n.] 1. To or tow urd tho rear; bsekwsed the reverse direetion: as, to step or shrink back; the tido flowed back.

All shrank back aghast, and left the denonncer of woe
atandlug alone in the centre of the hall. 2. From forward motion or progress; from ad vaneing or advaneement; in a state of restraint hindranee, or retardation: with sueh verbs as eulty; the poliee kept back the erowd.

The Lord hath kept thee back from honour.

3. To or toward one's (its or their) original starting-point, place, or condition: as, to go back to the eity, to one's old oeeupation, to oue's former belief.

I must liear anawer back
How you excuse my brother. Shak., Ad you Like it, Eate.

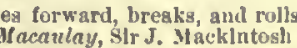

4. From a present, usual, or natural position in a direetion oppesite to some other, expressed 
back

or understood; backward: as, to bend bact one's finger; to force back the bolt of a door.

The angel of the Lord . . came and rolled back the
Mlat, xxviit. 2 5. To or toward times or thiugs past; back ward in time: as, to look back on former ages. Oln, that constant Time

Fletcher (and another), Love's Cure, v. 3. Volnmes of this form dated back two hundred years or The existence of this language [Singhalcse] has been taken y Goldschmidt of the Archeological Survey. Indies, p. 62 6. From the proper destination or purpose as, to keep back despatehes.

A certain man named Ananias, with Sapphira his wifc a possession, and kept bach part or the pricc. $\mathrm{v}, \mathrm{I}$

7. Away from an undertaking, engagement, or promise.

ve heen aurprised in an unguarded hour,

But must not now go back.

8. In a position of retirement or withdrawal off; aloof: absolutely or with from: as, th house stands a little back from the road.

$$
\begin{aligned}
& \text { Somewhat back from the village atrect } \\
& \text { Stands the old-fashioned country-geat. }
\end{aligned}
$$

Longfellow, old clock

9. Behind in position, literally or figuratively, or as regards progress made: absolutely or with of: as, the hills back of the town; the feeling back of his words; a few pages back.10. Past in time; ago; since: as, a little back. [Colloq.]

This precaution, still more salutary than offenstve, has for some years back been onitted.

11. Again; in return : as, to answer back; to pay back a loan.

"Ruth-daughter Ruth!" the outlaw shrieks,

But no sound comes back - he lis gtanding aloue.

To and backt, forward and backward ; to and fro.

Thls common body,
Like to a vagabond flag upon the streami,
Goes to and back, lackeying the varying tide.

To beat, draw, fall, hang, etc, back. See the verls. in senses I., 9-11, and II., <back', adv.] ' I. trans. 1. To furnish with a back or backing; strengthen or support at the back: as, to a book; to back an electrotype-plate; to back the armor-plates of a war-vessel with teak. $2+$. To cover the back of; elothe.

'To breke beggeris bred and bakken hem with clothli.
Piers Ilownan (A), xi. 18.

3. To support or aid, as with practical assistance, money, authority, influence, ete.; second or strengthen; reinforce : often with $u p:$ as, in his efforts he was backcd by many influenSucces still follows him and backs his crimes.

The men of the northern Danelaw found themselve
backed, not only by their brethren from Ireland, but by the mass of atates around then.

Hence-4. In sporting, to recognize and support by standing or dropping: said of dogs which follow the lead of a dog on point.

Both dogs went off finely; soon after helng put down backed by Gath.

Forest and Stream, XXI. 418.

5. To act or wager in favor of; express confidence in the sucess or superiority of: as, to
back a horse in a race, or one of the parties in an argument.

1 back him at a rebus or a charade againgt the best rhymer in the kingdon. Sheridan, School for Scandal, 3. 1. They [Bedouina] are fond of backing themselves with
wagers, and will ghoot for a gheep, the loser inviting his rriends to a feast. R. F. Burton, El-Medtnah, p. 336 6. To get upon the back of; mount: as, to ack a horse.

And hust the phonix through the Arabian desert

And he has reached the northern plain Shirley, Grateful Servant, iv. 5.

And backed his fire-fly steed again.
$J . R$. Drake, Culprit Fay, p. 58.

7. To write something on the back of; address, of; adjoin in the rear; form a back or background to.

Peering That length of cloistral roof, ij'ordsworth, Near Aquapendente.
412

\section{backbone}

That snug and comfortable retreat which generally backs back-balance (bak'bal" ans), 1 . A weight used .

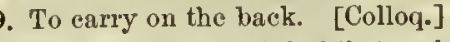
If the men are expected to back the traps for any consid ly admissible artieles are, etc.

0. To causo to move backward; propel backward: as, to back a horse; to back a boat 11. To reverse the action of: as, to back a stationary engine.-12. In coal-mining, to throw back into the gob or waste, as the small slack made in holing or undercutting the coal. Greslcy. [Leicestershire, Eng.] - To back a chain or rope, to attach a preventer to it 80 as to reduce the gtrain upon it. - To back an anchor. gail. - To back a warrant, to gign or indorse a warran issued in another county to apprehend an offender. - To back (a spindle) off, in cotton-spinning, to reverse th winding the last few coils of the thread about the cop, in winding the last lew coils of the thread about the cop, in
order to prepare for its proper distribution upon the col when the mule-carriage returns. - To back the oars, t the worming, in rope-making, to flll the interstices between the strands of a rope, thus mak ing the aurface even.- To back up. (a) To lend support, aid, or assistance to; stand by ; give countenance to: as,
to back up one's friende. (b) To move or force backward as, to back up a carriage. (c) To reverse, as an engine or a press. $(d)$ In electrotyping, to atrengthen, as the thi of type, an engraved plate, etc., by depositing upon it back type-metal to a certain thickness. (e) In base-bal and g!milar games, to stand behind, as another player, in order to stop and return any balla that may pass him : as, the ccnter-field backs up the second-base. - To back
water, to propel a boat in the opposite direction to that in which the prow is pointed, by reversing the action of the rowing in the case of a

II. intrans. [<back $\left.{ }^{1}, a d v.\right]$ 1. To move or go backward: as, the horse backed; the train backcd.-2. To move in the reverse direction: said specifically of the wind, in contradistinction to haul (which see), when it ehanges in a manner contrary to tho usual circuit. In the northern hemighere, on the polar aide of the trade-winds,
the usual circuit of changes in the wind is from east by the gouth to weat, and so on to the north. In the same latitudes in the aouthern lemisphere the reverse uaually takes place. The backtigg of the wind is regarded as an indication of bad weather.-To back and eil. (a) To get when the wind is againat the tide and there is no room for tacking, by alternately fllting and backing the salls 80 as
to make the ship shoot from one gide of the channel to to make the ship shoot from one gide of the channel to
the other whlle being carried on by the tide. ITencethe other whlle being carred on by the tide. Irence
(b) To be vacllating or irresolute; ahlly-ahally.-To back
astern. See astern. - To back down, to recede from position; abaudon an argument or opinion; give tn.-To

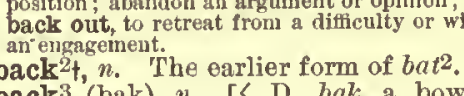

back $^{3}$ (bak), n. [< D, bak, a bowl, tray, = brewer's or distiller's back, also a ferryboat; cf. Bret. bak, bag, a boat, ML. bacus, baccus, a ferry-boat, bacca, a bowl ('vas aquabaccus, a ferry-boat, bacca, a bowl ('vas aqua-
rium'); origin uncertain. Cf. basin, from the rium'); origin uncertain. Cf. basin, from the ry-boat, especially one adapted for carrying vehicles, and worked by a chain or rope fastened on cach side of the stream. - 2. A large cistern or vat used by brewers, distillers, dyers, -3. A kind of wooden trough for holding or carrying fuel, ashes, ete.; a coal-scuttle: commonly in the diminutive form bakey. [Seoteh.] Narrowly escaping breaking my ahins on a turf back.

backache (bak'āk), n. Any dull or continuous pain in the back.

backache-brake (bak'āk-brāk), n. A næme of the lady-fern, Asplcnium Filix-foemina.

backache-root (bak'āk-röt), $n$. The button snakeroot, Liatris spicata.

back-action (bak'ak"shọn), a. In marine cngin. having the connections between the piston-rod and crank reversed: as, a back-action steamengine. See action.

backarack, $n$. See Bacharach.

backaret, interj. [Perhaps for back there. The spelling baccarc, orig. bacare, in the passage of Shakspere has led to the fancy that the word is dog-Latin, based on E. back.] Stand back! go hack! Ah, backare, quod Mortimer to his sowe.
Udall, Roister Doister. Backare, quoth Mortimer to his sow, gee
Mortimer's gow speaketh as good Latyn as hee.
Ileywoor. [A proverbial saying, derived apparently from aome loca] anecdote.] as a counterbalance for an ecentric, or an occentric pulley or goar.

back-band (bak'hand), $n$. A broad strap or ehain passing over tho saddle of a cart- or carriage-horse, and used to support the shafts. Called in Scotland a riguiddie.

ack-bar (bak'bär), n. The horizontal bar in heavy kettle was liung over the fire.

ackbeart (bak'bãr), n. In old Eng. forest law, llegally. See backcarry.

backbite (bak'bit), v.; pret. backbit, pp. backbitten, backbit, ppr. backbiting. [< ME. bukbitcn, earlier bacbiten (= Icel. bakbita (Haldorsen), appar. from E.), ( bac, bak, n., the back, or, more prob., < bak, adv. (though this, the apheretic form of $a b a k$, aback, is not found in ME. except in comp. and deriv.), + biten, bite seo back 1 and bite.] I. trans. To injure morally in a manner comparable to biting from behiud; attack the character or reputation of secretly; censure, slander, or speak evil of in absence: rarely with a thing as object. And eke the verae of tamons Poets witt
Ile does backebite. Spenser, F. Q., J. iv. 32 Ile does backebite. Spenser, F. Q., J. iv. 32 Most untruelye and maliciously doe these evill tonge
backbite and slaunder the aacred ashes of that personage bsent.

To be prynces in pryde and pouerte to dispige,

Piers Plowman (B), ii. 80. Te that backbiteth not with his tongue. P\&. xv. 3. They are arrant knaves, and will backbite.
Shak., 2 Hen. JV., v. t backbiter (bak'bi'tèr), $n$. One who slanders, calumniates, or speaky ill of the absent.

Satirists describe the age, and backbiters assign their deTennyson, Merlin and Vivien. backbiting (bak'bī"ting), n. [ME. bacbiting, bacbitung; verbal $n$. of backbite.] The act of slandering the absent; secret calumny.

Envyings, wraths, atrifes, backbitings, whisperings.

backbitingly (bak'bī"ting-li), adv. With backbiting.

back-block (bak'blok), n. In piano-making, see vrest-block.

backboard (bak'bōrd), n. [<back'1, n., +board. The AS. baebord (=D.LG. bakboord $(>$ G. backbord, $\mathrm{F}$, babord $)=$ Dan. bagbord = Icel. bak bordh, also bakbordhi) means 'larboard.'] A board for the back; a board placed at the back or serving as the back of something. Specillcally(a) A hoard placed across the atern-sheets of a boat to anp-
poction port the baeks of the occupants. (b) A small strip of wood $A$ carcful and undeviating uae of the backboard .... is ecommended as neccssary to the acquircment of that dignified deportment and carriage 80 requisite for every
young lady of fashlon. (c) A board used in a lathe to sustain the ptllars supporting the puppet-bar. $(d)$ In English [Yorkghire] coal-minback-bond (bak'bond), $n$. In Scots law, a deed attaching a qualification or condition to the terms of a conveyance or other instrument.

backbone (bak'bōn'), $n$. [ME. bakbonc, bakbon, bacbon; <back
+ bone 1 .] 1. The bone of the middle line of the back; th spine; the vertebral column; the vertehro collectively. -2 . Something rescmbling a backbone in appearance, position, or office: as, the Apennines are the backbone of Italy.

The plutocrata, shippers, merchants
and others who are the backbone of the and others who are the backbone of the ervative party Leader

3. Figuratively, firmness; stability of purpose; decision of character; resolution; mora principle.

The civilization is cheap and weak science in it.
$J$. Clarke, self.Culture, p. 202. Backbone of an awning, a rope sewed to the middle of a ship s awning,
- and extending fore and aft, to strength-
en it and afford tt support. - To the

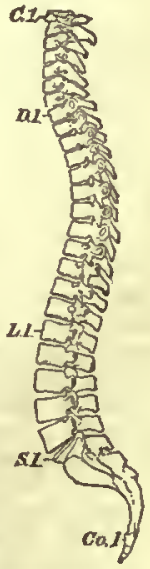

C.r. first cervical vertebra i $D . I_{1}$, first
dorsal vertebra; $L . x_{3}$ first lumbar vertebra,
S. I, first sacral ver.
tebin: C., first cocthe old English open fireplace, on which the

II. intrans. To slander or speak evil of the Face-flatterers and sackbiters are the sames 
backbone, to the utmost extent of one' a power or nature; one for earrying ashes or cinders; a liod or

Jolly okt Burbo, ataunch to the backlome.

A true-blue Tory to the backbone.

$$
\text { Bullicer }
$$

mpeli, ti. 1.

Game to the backlone.

r. II ughes

backboned (bak'bönd'), a. Vertebrated; fur-

backcap (bak'kap), $v$. $t$. To depreciate or disbackcap (bak'kap), v. $t$
parage. [U. S. slang.]

parage. [U. S. slang.] law, the crime of laving game on the back, as deor unlawfully killed. Seo bachbcar.

back-casing (bak'kñ"sing), $n$. II mining, a wall or lining of dry bricks, nsed in sinking through sand or gravel. Within it the permanent wall of the shaft is hinilt up, after the bed-rock or stoneJeas has been reached.

back-cast (bak'kast), $u_{0}$ [< back1, adv., + ctist, n.] 1. A cast or throw back.-2. A backward stroke, or a stroke driving one back; lience, figuratively, any discouragement or lence, figuratively, any discourage
canse of relapse or failure. [Scotch.]

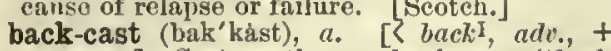
east, $p p$.] Cast or thrown back: as, "backcast thoughts," Joanna Baillie.

back-center (bak'sen"tér), $n$. In a lathe, the point of the back or dead spindle of the tailstock. It gupports that end of the pieee whlch is to he turned. The front center is that part of the live spindle lathe, the serew which gived longitulinal motion to the

back-chain (bak'chān), $n$. A chain that passes over the saddle of a horse's harness to support tho shafts of a cart or wagon.

back-cloth (bak'kloth), $n$, I. In calico-print ing, a reinforeing eloth used to support a fab-

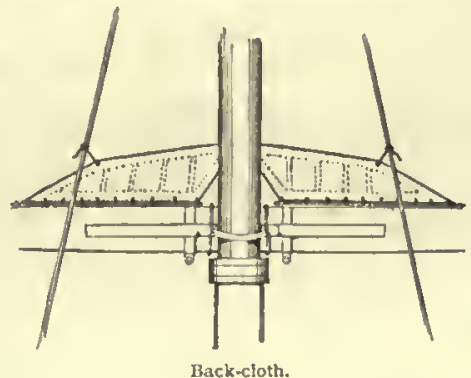

ric which is being printed.-2. Naut., a triangular piece of canvas fastened in the middle of a topsail-yard to facil

backed (bakt), p. a. [<back ${ }^{1}, n$. or $v_{.}+{ }^{2}+e d^{2}$. $]$ In composition, having a back (with the qual ity or characteristic noted in the first par of the word): as, a high-backed chair; hump backed; broad-backed.

Oid riekety tableg and ehairs broken-back'd. Thackeray.

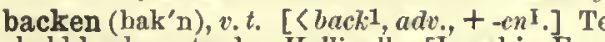
loold back; retard. IIallizell. [Local in Eng. and U. S.

back-end (bak'end), $n$. The latter end or part; especially (Scotch), the latter part of autumn. The hedgea will do, I cllpped them w' my ain hands

backer ${ }^{1}\left(\right.$ bak $\left.^{\prime} e ̀ r\right), n . \quad\left[<b a c l^{I}, v_{0}+-c r\right.$ I. $] 1$. One who backs or gets on the back: as, a backer of untamed horses. - 2. One who backs or supports, or who aids and abets, another in an undertaking, especially in any trial of skill, agility, or strength; also, one who bets or son, horse, etc., in a contest; one who indorses the notes or sustains the credit of another. The local combinations and their political backers found

3. In arch., a narrow slate laid on the back of a broad square-headed one, where the slates begin to diminish in width.-4. Naut., a strap of rope or sennit fastened to a yard-arm to secure the head-earings of a sail.

backer ${ }^{2}+a d v$. [<back1, $\left.a d v .,+-e r^{2}.\right]$ Same as

backermoret, adv. [ME., a double compar., backer ${ }^{2}+$ more. Cf. furthermore, hindermost ete.] More or further back.

With that anon I went me backirmore.

backermostt, a. supcrl. [< backer'2 + -most.] Backinost.

backet (bak' et), n. [< F. baquet, trough, dim. of bac: seebuch ${ }^{3}$.] A troingh or box, especially coal-scuttle. [Scotch.]

backfall (bak'fâl), n. I. In wrestling, a fall or trip-up in which a wrestler is thrown upon his back.-2. In music, an obsolete melodic decoration, nearly like the modern long apuoggiatura: ealled a double backfall when prolonged.
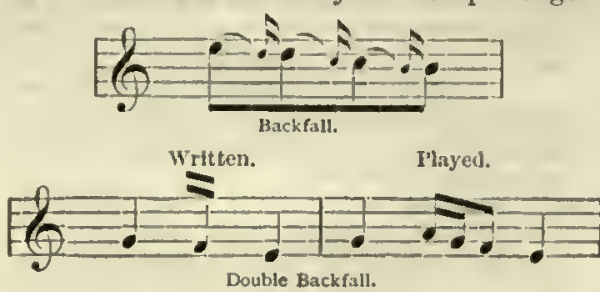

3. In organ-building, a lever whose front end is raised by the motion of a digital or peda transmitted through a stieker (which see), it back end being correspondingly depressed: a device for transforming upward motion into downward.

backfallerł (bak'fálèr), n. [<backI, ade., + gade.

Onfas, with many lyke backfallers from God, fled into

cyllet (bak'fil'et), mo' margin of a groin, or of a door-or window-jamb, when it projects beyond the face of the wall Such margins are said to be back-filleted. back-flap (bak'flap), $n$. That part of a windowin the window-casing.

back-frame (bak'frām), $n$. An internally gear ed wheel supporting the twisting pinions or whirlers of a rope-making machine.

back-friend (bak'frend), $n$. [ $\left[<b^{\prime} a c k, a_{.},+\right.$
fricnd.] 1 t. A false or pretended friend; secret enemy.

Let him take heed I prove not lis back.friend. ers, as aome who are backfriends to both would mall clously insinuate.

2. A friend at one's back; a backer. [Rare.] back-game (bak'gām), n. [<back' $a^{1},+$ +game. 1. A game

backgammon (bak-gam'on), n. [Also formerly bagganimon - < back I a t gammon I (seo gammon I and game ${ }^{1}$ ); appar. so called because in certain circumstances the pieces are
obliged to go back and reënter. The reason of the name is not certain, but the formation is clear. Cf. back-game.] 1. A game played by the purpose, with pieces or men, dice-boxes, the purpose, with pieces or men, dice-boxes,
and dice. The board is in two parts, usually hinged together, on which twenty-four spaces, called points, ar ments are nuade in accordance with the numbers turned up by the diee, the objeet of eael player being to advance or remeve them entirely from the board.

2. A single bout at backgammon won by player before his opponent has advanced all of his men from the first six points.

ackgammon (bak-gam'on), v. $t$. To beat by n., 2.

backgammon-board (bak-gam 'on - bōrd), $n$ The board or table on which the game of backgammon is played.

back-gear (hak'gêr), $n$. The variable speedgear in the headstock of a power-lathe.

ackground (bak'ground), n. 1. The ground at the back or behind, as opposed to the front situation in the rear of thoso objects, considerations, ete., which engage the attention; subordinate or secondary position in contradistinetion to principal or important position; place out of sight: used both literally (of physical objects) and figuratively: as, there were mountains in were kept in the background.

A huaband somewhere in the background. Thackeray. Forbearance and mercy to enemiea are not unknow to the 0ld Testament : lint they are in the backgrouend.

Specifically -2 . The part of a pieture represented as furthest from the spectator's oye: opposed to foreground. In pietures of which th foreground possesees the ehief interest, the background is ground, to which it is kept anbordinate in color, ete. foreserving no other purpose than that of a mere acreen or settlug behind the objeets in whicli the futerest is concen- trated: as, a portrait with a landscape background; roup of figures with buildisigs ln the backyround. I

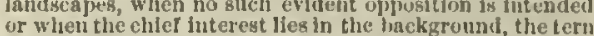
dinfance is properly used to denote the more distant planes
lin the pleture, as ilatinguished from the foregroud and the middle distance.

Ilere we see the rude and simple expellent by whteh, to atune for the want of aerial perspective, the vasepainters indieated the backgromil of their eompositions. Figures more dlstant from the eye are ulways representent gented or standfing on a higher level than fignres in the
loreground.
C. T. Sewton, Art and Archioul., p. 358 . The leafless trees become splires of flame in the sunset, with the biue cast for thiclr background.

3. In photog., the plain or decorated sereens, properties, ete., placed behind the subject in taking portraits, especially in regular gallerywork, in order to form an appropriato setting in tlie finisher picture.

ackhand (bak hand), $n$, and $a$, I $n, 1$. Writ ug which slopes backward or to the left: as he writes backlhand.-2t. In lemis, the position behind the principal player. No, faith, that'a odds at tennia, my lord; not but if
your Jadyship pleases, I'l endeaveur to keep your backhand a little, tho upon my sonl you thay safcly set me up
at the line.

II. a. Backhanded; unfavorable; unfair: as, a baekliand intluence.

backhanded (bnk'han"ded), $a$. 1. With the back of the hand: as, a backhanded blow. -2 . Done or effected with the hand turned backward, crosswise, or in any oblique direction marked by a backward slope, direction, or of fect: as, buchlhanded writing; a backhunded stroke in sword-play or lawn-tennis. In the Jat ter game a backjlanded stroke is one that causes the liall Hence-3. Figuratively, oblique in meaning indirect; equivocal; ambiguous; sareastic: as, a backhanded compliment. -4 . Twisted in the opposite way from the usual method: said of a rope.

One part plain-laid and the other backhanded rope.

backhandedly (bak'han"ded-li), adv. With the liand directed backwarl: as, to strike backhandedly.

backhandedness (bak'han"ded-nes), $n$. The stato of being backhanded; unfairness.

backhander (bak'han"dér), $n$. A blow with the back

backhead (bak'bed), $n$. I. The back part of the head: opposed to forclical.-2t. False hair worn on the back of the head.

ackhouse ${ }^{I}$ (bak'hous), $n_{\text {. }}$ [ $<$ back ${ }^{\mathrm{I}}, a_{.},+$ bouse.] A building behind or back from the main or front building; hence, in country backhouse $2 t, n$. Same as bakehouse.

backing (bak'ing), $n$. [Verbal n. of back ${ }^{\mathrm{I}}$, .] 1. Support, physical or molal; supporters or backers collectively. $-2+$. The address of a letter.-3. Something placed at or attached to the back of something else to support, strengthen, or finish it; the act of providing anytling with such a support. Espeetaly - (a) A layer or lay. armor-clad ghips are bolted. (b) $A$ heavy plating of woot, or wood and iron, supporting the armor-ptates of fortifications or ef targets from behind; a thiek bed of rammed
sand or conerete placel behind armored works or targets. The conerete might be faced with a comparatively thin
steel plate which would explode the ghell, and go gave the c) In bookhiuling, the eurving of the back of aewe (c) In wookbinding, the eurving of the baek of aewed shect so that the book will not be thieker at the baek than at the fore edge; (2) to make a gecure rest in the arehed grove
at either side for the cover: (8) to nake the hack flexible, 80 that the leaves of the book glaall be flat when open. Backing is done by beating with a hammer er rolling with a machine. (d) In weaving, the web of eoarser or at ronger sat In, Brussels carpet, ete. (e) In photog, a coating of
dull, dark plgment, plaeed on the back of the semsitize plate in some elasses of work to absorb llght that might otherwise pass through the film, be reflected again upon it from the baek of the glass, and eause an effect of blur.
ring. Such a backing is useful in taking pietures in the direction of the chief light, or those in which some portions of the fleld are very highly flluminated while of her adjeining them are dark. (D In printing, the printing of uaed to back up or strengthen an electrotype. (h) In theat., that portion of a aeene on a atage whieh is revealed through an open door or window:- Backing of an arch, backing-boards (bak'ing-bỏrdz), n. $\eta^{\prime}$. In bookbinding, boards of hard wood, faced witl steel, which are nsed in pairs for the purpose of elamping togetler the sewed sheots of an 
backing-boards

unbound book while the lack is leeing monderl with a hammer.

backing-deals (bak'ing-dēlz), n. $\%$. In Enylish cocl-mining, boards or planks placed be-
hind the eurbs of a shaft, to keep the earth hind the eurbs
behind in place.

backing-hammer (bak'ing-ham"èr), n. A hammer used in beating into shape the backs of books.

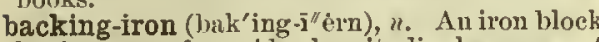
having upon four sides longitudinal grooves of differeut widths aud depths, suitable to different sizes of books, and used in shaping their backs. backing-metal (bak'ing-met"al), $n$. A composition of type-metal, in which lead is the chief sition of type-metal, in which lead is the chief
ingredient, which is poured into an electrotypeshell of copper to form the backing of the clectrotype-plate.

backing-pan (bak'ing-pan), n. A pan in which electrotype-shells are placed face downward, while the molten metal with

backed is poured over them. backings (bak'ingz), n. $n$. The refuse of wool or flax after it is dressed; the

back-joint (bak'joint), $n$. In masonry, a rebate such as that made on the inner side of a chim neypiece to receive a slip.

backlash (bak'lash), n. 1. In mcch., the jarring roaction of each of a pair of wheels upon the other, produced by irregularities of velocity power is not uniform.-2. In coal-mining, the backward suction of the air-current after an explosion of fire-damp. - Backlash of a screw, the play between a serew and its nut when the latter is loosely
fitted.-Backlash-spring, a spring fitted 10 a machine to fitted.- Backlash-spring, a spring fitted to a machine
keep the moving parts in contact and prevent hacklash. keep the moving parts in contact and prevent hacklash.
backless (bak'les), a. [< bachi, $\left.n_{.},+-l e s s.\right]$ backless (bakles), a, Without a back: as, backless benches.

backling, backlings (bak'ling, -lingz), adt. [Sc. backlins, < AS. bacling, in adv, phrase on brecling, back, behind; < bace, baek, + -ling, ad back-lining (bak'li' "ning), $n$. In windows, piece of sash-frame parallel to the pulleypiece and next to the jamb on each side.

back-link (bak'lingk), $n$. In engines, one of the links in a parallel motion which conneet the air-pump rod to the beam.

backlog (bak'log), $n$. A large $\log$ placed at the back of an open wood-fire to sustain combustion and concentrate the heat.

Yew people know how to make a wood fire, but every
hody thinks he ol' she does. You want, tirst, a large back loy, which does not rest on the andirons.

backlook (bak'lukk), $n$. Retrospcctive view: as, to take a buchlook. [Rare.]

as, to take a bueklook. [Rare.]
back-lye (bak'li), $\eta_{0}\left[\right.$ [ back $^{1}+l y c$ for $\left.l i e^{1}.\right]$ In coal-mining, a siding or shunt on an underground railway, Gresley. [North. Eng.] back-mill (bak'mil), $n$. A fulling-mill. Ire, Dict.

back-mold (bak'mōld), n. In reversing molding, that part of the mold which backmost (bak'mōst), a. superl. [ [ back-1, adt.
+ -most. Cf. backermore. $]$ Hindmost: opposed to foremost. [Rare.]

back-overman (bak'o"vèr-man), $n$. In coulmining, a man whose duty it is to see to the safety of a district of underground workings, and of the men working in it, during the backshift. Greslcy. [North. Fing.]

back-painting (bak'päsı"ting), n. A method of applying varnish colors to mezzotint prints affixed to glass, in such a mann

backpiece (bak'pēs), $n$. A piece at the back of something; specifically, a piece of armo which coverod the back and was connected with the breastplate by straps and buckles, hooks, and the

backplate (bak'plāt), $n$. Same as bachpiece.

back-pressure (bak'presh"ür), n. Pressur. backward or in the reverse of the nomnal diree tion; specifically,

the resistance of

the atmosphere or the action of the piston of a steamengime. - Back-pressure valve, in mach,, a
valve placed within sulpply-pipe or over an
inlet-orifice, to prevent

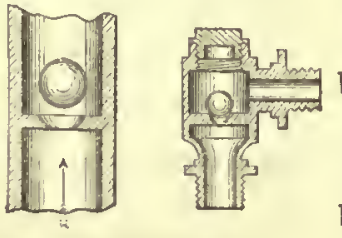

414

backstay

the hackward flow of a fluid or gas when the pressure in the normal direction falls below that in

chamber to which the fluid is supplied.

back-rackett (bak' rak" et), $n$. The returi of ball in tennis; henee, figuratively, a eounter charge.

Hox. Why, are not delits letter than words, sir? lints, Are not words lromises, and as
Iloa. He plays at back-racket with me.

Middleton, Trick to Catch the old one, Iv. 4.

back-raking (bak'rā"king), n. In forriery, an operation by which hardencd freces are withdrawn from the rectum.

back-rent (bak'rent), $n$. 1. Arrears of rent.2. In Scots lav, a rent paid subsequently to reaping. Thus, when a tenant entering with a leaso
is allowed to reap and sell his first crop before paying his rent, the rent in this case is termed a back-rent, in con cradistinction

back-rest (bak'rest), n. A guide attached to the slide-rest of a lathe and placed in contact with the work to steady it in turning.

back-returnł (bak'rẹ-térn"), n. A going or coming back; return.

$$
\text { I Iarry's back-return again to France. }
$$

The back-return of Charon's hoat.

$$
\text { Shok., Hen. V., v. (cho). }
$$

Marlone.

backrope (bak'loop), n. Naut.: (a) The rope the dolphin-striker to each side of the bows of a ship. (b) A sinall rope attached to the hook of the cat-block or fish-hook, to facilitate hooking it on the anchor.-Martingale backropes. see martingale.

back-saw (bak'sâ), n. A saw the web of which is stiffened by a metallic back of greater substance. Such saws have specific names according to their use, as tenon-saw, dovetail-

back-scraper (bak'skrä"pèr), $n$. Same as buckseratcher.

back-scratcher (bak'skrach" èr), n. 1. An implement for scratehing the back, generally made of bone or ivory, in the form
liand fixed to a long slender handle.

A back-scratcher of which the hand was ivory and the
Southey, Tho Doutor, jv.

2. A toy of wood or bone having a thin tongue which presses upon a toothed wheel, on the principle of a watehman's rattle: when it is rubbed on the back of a person, it produces a sound like the tearing of eloth.

backset (bak'set), $v$, [<back.1, $a d v_{v},+\operatorname{set}^{1}$ .] I.t trans. To set upon in the rear.

The lsraelites... [were] kackset with Pharanh's whole

II. intrans. To plow again, in the autumn, prairie-land which las been plowed for the first time in the preceding spring. [Wester] U. S.]

backset (bak'set), $n_{\text {. }} \quad\left[\left\langle b a c h^{1}, a\right.\right.$ or $u d v_{\text {. }},+$ set ${ }^{1}$ $\left.r .01^{\circ} n.\right]$ 1. A setting back or backward, as th result of some untoward cireumstance or opposing agency; a check to progress; retardation, or the losing of ground; a relapse: as, he set which appeared to be fatal.-2. An eddy or counter-current in flowing water.

Of conrse much of this was slack water, or the backset
Iarper's Mfag., LXV. 612. back-settler (bak'set"lèr), $n$. One inluabiting the back settlements of a country.

backsheesh, $n$. See bakshish.

back-shift (bak'shift), $n$. [<bacli, a., + shift. In coal-mining, a second shift or relay of hewers who begin eutting the coal after another set have begun to draw it, at the same place.
backside (bak'sid'), $n$. [< ME. baksilc: $<$. thing; the 1. The back part or aspect of anythat which is presented to a spectator. [Properly two words in this use. See back, $a ., 1$. Specifically -2 . The hind part of an animal the rnmp: often (vulgarly) in the plural. -3 . The back premises, back yard, or out-buildings attached to a dwelling; also, the privy. [Obsolete or dialectal.] N. E. D.

back-sight (bak'sit), $n$. 1. In surveying, the reading of a leveling-rod, taken when looking back to a station which has been passed. All other readings are called foresights, -2 . The pear sight of a gun.

back-skin (bak'skin), $n$. A leather dress used by miners when at work in wet places. back-slang (bak'slang), $n . \quad[<h n c k$, $n$. or $a d v$,
+ slang. Cf. palindrome.] A species of slang which the words are pronounced or written backward, or as nearly so as the skill of the speaker or writer, or the possibility of pronouneing the word, will permit: thus, penny becomes ycrmep; woman, namor, and so on.

backslide (bak-slíd'), $x . \dot{\imath}$.; pret. buckstid (sometimes backslided), pp. backslid, backslidden (sometimes brekstidled), ppr. backsliding. [< back $, a d v^{\circ},+$ slide. ] To slide back, in a figurative sense; apostatize; turn from the faith; lepart from or abandon religious principles or practices.

I have fallen lack to my earnal temper, from the holy

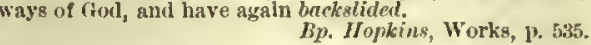

When persons have been professors of religion, and have for varions reasols backblidden and declined luto a

backslider (bak-sli'dèr), n. One who back slides. (a) An apostate; one who falls from the faith
and practice of religion. Prov. xiv. 14. (b) One wlio neglects lis religious rowrs and falls into habits of sin. in principle or practice; a lapse in or abandonment of religious obligation; apostasy.

Our backslidings are many: we have simed against
Jliee.

backslidingness (bak-slī' ding-nes), $n$. The

te of backsliding.

back-spear, $x$. $t$. See back-speer. speed-gear of a lathe, which can be brought into action on the fore-speed, so that second series of speeds of the spindle are thereby obtained.

back-speer (bak'spēr), v. $t$. [Se., also written gach-spcar, -speir, <ack, ack., + specr, ask, [Scoteh.]

back-splinting (bak'splin "ting), $n$. In coalmining, a system of working coal over the goaf and across the packs of a lower one got in advance upon the long-wall method. Gresley.

back-spring (bak'spring), n. 1. A spring final slit near its upper coge, thus leaving strip of nnsupported metal which by elastic pressnre springs the bolt into its place when it is left by the key. -2 . The spring at the rear of the body of a vehicle; specifically, a C-sprin which rides up at the back of the carriage, the body of the latter being suspended from the forward end. -3 . A spring backward.

back-staff (bak'stä), $n$. An instrument formerly used for measuring the sun's altitude at sea: so called because in using it the observer turned his back to the sum.

backstair, backstairs (bak'stãr, -stã ‘\%), n and $n$. I. $n$. A stair or stairs in the baek part of a house; private st
words. See bach $1, a ., 1$.

II. $a .1$. Of or pertaining to stairs in the back part of a house: as, a backstair entrance.-2. Indirect; underhand; unfair; intriguing: as, backstair influence.

IIe's like a brekstair minister at eourt, who, whllst tho

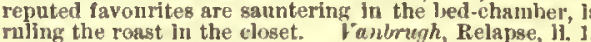
Is he not a back-stairs favourite - one that can do what le pleases with those that do what they please?

back-stall (bak'stâl), $n$. The thief who walks behind the chief operator in a garrote-robbery to conceal him when at work and make off with the booty. ['Thieves' slang.] See garrote.

backstand (bak'stand), $\%$. Support; something to fall baek upon.

A sure staye and a stedfast backetande at home.
[Iall, Iien. VII.

backstay (bak'stā), n. 1. In printing, a strap of leather used to eheck the carriage of a printing-press. - 2. In coul-mining, a forked bar of wrought-iron attached to the back of the mine-car when ascending an inclined plane, for the purpose of stopping the car in case of accident. [Yorkshire, Eng.] -3. A rod extending from the perch to the outer end of the rear axle of a carriage. -4 . One of the thaps of a ful spring placed at the back of the powerblade to keep the two -6. In metal-turning an adjustable support for -6. In metal-turning, an adjustable support for long ropes extending backward from the heads of all masts above the lower mast and fastened 


\section{backstay}

on each side of the ship to the chain-plates serving to support the masts. - Backstay-stoola, planking er picces of Iron projecting from the side of a
ship, to which tho backstays are lamile fast. T'hey serve the sarae purpese for the backstays that tho channels do for the hrouds. - Traveling backstays, barkstays titted with

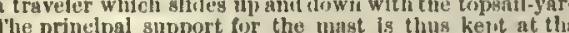
phe principal support wor the mast is thus keld at

back-step (buk'step), $n$. A rearwarl movement of a squad or body of troops, without ehange of front.

backster ${ }^{1}+n$. Sece baxter.

backster' (buk'ster), n. [Etym. uneertain.] A tlat piece of wood or cork fastened on the feet for walking over loose beneh. $\quad \mathrm{N} . \mathrm{K} . \mathrm{I}$.

backstitch (bak'stieh), n. A method of sewing in which encl stitch overlaps or doubles baek on the preceding one, the needle entering behind the tiread at the end of the stiteh already mudo and coming ont in fiont of it.

backstitch (bak'stieh), $v$. $t$. and $i$. To sew with stitches which overlap each other. See buckstitch, $n$.

backstone (bak'stōn), n. [E. dial., = unkestone, [batic + stonc.] The heated stone on which oat-eake is baked. [l'rov. Eng. and Seoteh.]

back-stop (bak'stop), ". In basc-ball, a fence placed a sliort distance behind the eatcher to stop the ball if he fails to eateh it.

back-strap (bak'strap), u. A broad strap passing along the middle of a horse's back from the upper liame-strap to the erupper or a point of junetion with the hip-straps in a wagon-halness, and in a earriage-harness from the gigsaddle to the erupper. E. $\boldsymbol{H}$. $\boldsymbol{K}$ wight.

back-strapped (bak'strapt), $p, a$. Carried by head-winds to the baek of a cape or promontory said of a slip.

back-stream (bak'strem), n. A current rumning against the regular eourse of the stream an up-stream.

back-string (bak'atring), $n$. A leading-string by which a ehild is supported or guided from behind.

The back-kf ring and the lubl. Concyer, Task, Is. 22s.

back-stroke (bak'gtrōk), ". I. A blow or stroke in retum.-2. A backhanded stroke; a back-hander.

.Yy uncic Toly never took this back-stroke of my father"s

back-swimmer (bak'swim"ér), n. Same bnat-fly.

back-sword (bak'sörd), . 1. A sword with one sharp edge, used for entting rather thau thrusting, sometimes curved, and frequently straight. It rolally had a basket-hllt, and was the straight. It rsually had a basket-hllt, and was the common weupon of citizens and country leople when the
rapier and giterward tize small-sword were worn by 2. A eudgel fitted with a basket-hilt, used for a particular kind of single-stiek play.-3. A cudgel-play in which the back-sword (in sense 2 ) is used, peculiar to eertain counties of England, and still kept $u p$ at festivals and the lik in the atternpt to preserve old eustoms. The gunrit is with the left arm, and the object of ench lllaye
is to break the skin of hls adversary's forchead so as to

draw llookl.
back-tack (bak'tak), $n$. In Scots laic, a tack or lease connected with wadsets or mortgages by which the possession of the land is returned to the proprietor on payment of a rent corresponding to

back-tool (bak'töl), n. Any tool, either fillet ol' roll, used by bookbinders in decorating the curved surfaee of the back of a book.

back-trick $\nmid$ (bak'trik), ". A caper backward in dancing.

I have the bock-trick simply as strong as any man in
Itigria.

backward, backwards (bak'wärd, -wärdz), adv. [< ME. baknard, bacward, adv., by apheresis for abackward, < abak, adv., back, + -icard, -ucurds.] 1. In the direetion of the back: as, to throw the arms buckicard.-2. With the
baek first in the direction of motion: as, to baek first in the direction of m
walk backucurd; "to fall backitarl.

Ife [EJ]] fell fron off the seat backecard, i sam. and his
neck brake. Thun wilt Shake, R. and J., i. 3.

3. In the direction from which one has come; toward that which is or has been left behind: as, he glaneed backicard. -4 . Toward bygone times or events; toward that whieh is past in time: as, to look backirard to the last eentury. The lights of inemory backn

Ifhittier,

415

Baconian

5. In $o r^{\circ}$ by reflection; retlexively. The mini cun bachraril cast

[mul herself her understanding light.

6. In time past; ago.

kome reigns backirarul.

7. In an opposite or contrary direction.

For crery two steps they mude forwards and npwards

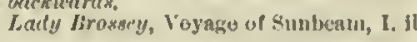

8. In an opposite or reverse order; from the nd toward the beginning; in an order contrar a the natural order: as, to read or spell beckcurd; hence, perversely; in a wrong or pererse manner.

Inerer yet saw man,
ILow wise, how nollile, young, how rarely featuril,

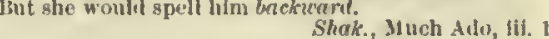
The posigel of Christ is real backurds, when that world a merit to abandus.

$$
\text { C. E.. Nirton, Travel ani stndy in Italy, p. 4i. }
$$

From a better to a worse state; retrogresively.

The work went backwarl; and the mure he strove
T" alvance the snit, the farther from her love. I) ryden. Backward and forward, to and fro.-To ring bells backward, to gfvo sn alarn by ringing the bells of

The bells they ring backurarl, the drumis they are beat.

backward (back'wånd), a. [<backvarl, ad 1. Directed to the back or rear: as, "a backcard look," Shak., Sonnets, lix.-2. heversed; returning; direeted to or toward the original starting-point: as, a backward movement or joumey.

$$
\begin{aligned}
& \text { And now they do re-stem } \\
& \text { T'heir kackward conrsc. } \\
& \text { Shak., Othellu, 1, s. }
\end{aligned}
$$

3. Done in reverse order; done in an ordex contrary to the natural order, as in repeating a sentence from the end to the beginning.

$$
\begin{aligned}
& \text { Withont his rod reversed, } \\
& \text { A Iml backeard mutters of dissevering power, }
\end{aligned}
$$

Aml backcard mutters of dissevering power,
We cannot tree the lady. Hiltou, Comn, 1. 817.

4. Being in, or placed at, the baek.

Four legs and two veices. . His forward volce now
is to speak well of his friend; his backerard volce is tter foul speeches, and to detract. Shak., Tempest, ii. 5. Slow; sluggish; unprogressivo; unadvaneed behind in progress: as, a backicard learner. Brigandage survives only in out-of-the-way corners of
the most backuerd countries of Christendom, such a
spain snd Slcily.
J. Fiske, Evolutionist, p. 220. 6 . Late; behind in time; coming after some thing olse, or after the usual time: as, backicar fruits; the season is backicard.

A dry, cold, backuard spring, easterly winds.

7. Holding back; arerse; reluetant; h ng. The mind is brekward to undergo the fatigne of welgh-
ling every argument.

For wiser brutes were backurard to be slave. Pope, Windsor Furest, 1. 50.

8. Timid; bashful; retiring in disposition already past.

Flies uneonsclous o'er each backerard year.
Byron, Childe Hsrold,

backward† (bak'wärd), $u$. [< backicard, a.]

The things or state behind or past.

$$
\text { In the dark backuard and abysm of time? }
$$

backward $\nmid$ (bak'wärd), $t$. $t . \quad[<b a c k$ ward, ad $v$. obstruct; keep baek; retard ; delay.

Doth clug and backrard us. IIamand, Sermons, xv.

backwardation (bak-wịir-dā'shon), n. [< back vard, v., + -ation.] Ö̈ the Loudon Stoek Exchange, the premium paid by a seller of stock for the privilege of postponing its delivery to the buyer until th

backwardly (bak'wärd-li), adl. 1. In a backward direetion.

The mandille is extremely massive and has a beckourd

II uxley, Aust. Vert., p. 32i.
tantly; aversely; per2. Unwillin
versely; ill.

\section{I was the first mos
That e'er recelv'd gift from him;}

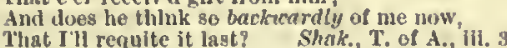
backwardness (bak'wïrd-nes), $n$. The state or quality of being backward. (a) Baekward stal rarduess of the spring. (b) l'nwillingruess; reluctance; Our backung

backwards, ally. See backwarl.

back-washed (bak'wosht), $\boldsymbol{~}$. Cleansed from oil, as wool after combing.

back-water (bak'wîn"tér), ". 1†. Water flowing in from behind. - 2. Wnter thrown back by the turning of a water-whecl or the parddes of steamboats, ete. -3 . Water held or forcerl back, as in a mill-race or in a tributary stream, in conseyuence of some obstruetion, as a dam or llood. -4 . An artifieial neeumulation of water obtained at high tide and reserved in reservoirs, to bo discharged at low tide for clearing off deposits in channel-berls and tideways. -5 . A ereek or arm of the sea which runs parallel to the coast, having only a narrow slip of land with the latter by barred entranees.

Enteriug the menth of the Mlorelub, an extensive buck. water Into which fall the Piri-Bazaar and other strearas. e come aloagslue a fairly constincted quay.

backwood (bak'wuld), $n$. That portion of a earpenter's plano which is immediately behind tho plane-iron. - To drive the backwood up to drive the wedge of \& plane tow tlghtly. When this is cluste at the angle of the inouth ani sole.

ackwoods (bak'wuddz'), n. pl. Wooded or partially uneleared and unsettled distriets in the remote parts of a new country; hence, in the United States and Canada, any rough or thinly settled region far from the centers of popuation.

The very ease with which books contalung the world's best Ilterature were obtalnable ia the backuools nuade our II [Count Tolstol] put into my lianids a letter fron some ann llving in a village in the breckeoods of Perungylyania. backwoodsman (bak'wúdz'man), "1.; pl. backroodsmen (-men). An inhabitant of the backvoods.

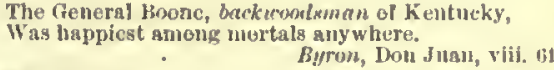

backworm (bak'wêrm), ". A small worm genhawks. See filander 1 .

backwort (bak'wẻrt), . The comfrey, symphytum officinale.

back-wounding (bak'wön"ding), a. Wounding at the back or behind one's buek; backbiting; calumny," Shak., M. for M., iii. 2.

bacon (b'̄'kon or -kn), n. [Warly mod. E. a]so bakon, baken, < ME. bacon, bacoun, bakonn, OF. bacon $=$ Pr. bacon, < ML. baco $(n-)$, bacon, side of bacon, shoulder, ham, also a swine, OHG. Wahho, bacho, MHG. bache, side of baeon, ham, G. bache, a wild sow (obs. or dial., a ham),
$=$ MD. bakc, bacon, ham, a swine, (OHG. "bah, ete., = AS. bac, E. back. : see back 1.] 1. Hog's flesh, espeeially the back and sides, salted or pickled and dried, usually in smoke.-2†. Pork. -3t. A hog; hence, a grossly fat person. -4 t. A rustic; a clown: in allusion to the fact that rural population. $\quad$ N. E. $I$.

On, bacons, on! Shak, I litn. IV., ii. But here I say the Turks were mueh laistaken,
11ho, lating hogs, yet wished to sace their bacon.

Byrou, Don Juan, vii. 4. acon-beetle (bä'kon-bē"ti), "1. A species of mestide, order Coleopten, whose larvo are very destmuctive to stuffed animal in museums. The larvæ are briry, and whitish-brown in color.

Baconian (bā-kō'nian), $a$. and $n$. [< Franeis Bacon, born I56I, died 16:6.] I. $a$. Pertaining to Francis Bacon, Baron Verulam, eommonly as, the Baconian philosophy. - Baconian method, a tern often. though incorrectly, ap

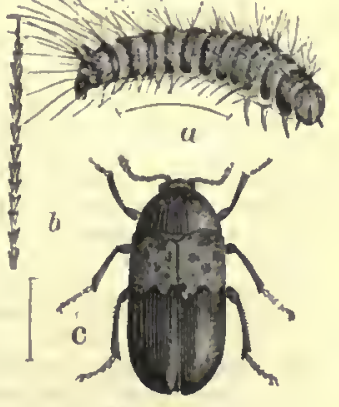

Bacon-Beetle, larva; o, one of its barbed hairs:
beetle. Hair-lines show natural 


\section{Baconian}

induction (which see) as developed hy modern seicnce, on
the supposition that lacon was mainly instrumental in bringine this incthod into general use.

II. n. 1. An adherent of the Baconian philosopliy,-2. One who lolds the theory that Bacon wrote the plays usually attributed to Shaksperc.

Baconism (bä'kon-izm), n. [< Bacon + -ism.] The philosophy of Francis Bacon, or the general spirit of his writings.

These socictics are schools of Baconism, designed to embody all that was of valne in the thought and spirt in seience, with, of course, a recommendation of induction and of the indinctive sciences for their value in the arts of
Wright.

baconize (bā'kon-iz), v. t. ; pret. and pp. baconiscd, ppr. baconizing. $[\langle$ bacon $+-i z c$.$] To make$ into or like bacon; smoke, as bacon.

baconweed (ba'tkon-wēd), n. The pigweed, Chenopodium album.

bacony (bā'kon-i), a. [<bacon $\left.+-\left.y\right|^{1}.\right]$ Like bacon; lardaceous.

bacteria (bak-té'ri-ä), $n$. [NL.: see bacterium.] 1. Plural of bacterium, 1.-2. [cap.] A genus of gressorial orthopterous insects, of the family Plasmidce; the stick-insects or walking-sticks. B. sarmentose

Phasmida.

Bacteriaceæ (bak-tē-ri-ā'sẹ-ē), n. pl. [NL., Bactcrium +-acco.] A group of the simplest microscopic fungi, more usually called Schizomyectcs, the achlorophyllous divisiou of the Sclizosporce of Cohn, or of the Schizophyta of more recent authorities. They exhibit a great vsriety of lorms, and are subdivided accordingiy into-(1) Sphaerobacteria, which are spherical, as in Micrococcus;
(2) Microbactera, which are elliptical or shortly cylindricai, as in Bacterium, the only genus; (3) Desmobacterix, Spirobacterio in which the flaments are baore or ; (4) coiled, as in Spirillum.

bacterial (bak-té'ri-al), a. [<bacterium + -al. $]$ Pertaining to or resembling bacteria; of the nature of or caused by bacteria: as, a bacterial parasite in the blood; bacterial organisms; bacterial infusions.

The issue of a bacterial affection is either the death of
the pstient, or the death and elimination of the bacteris. Ziegler, Psthol. Anat (trans.), 1.287.

bacterian (bak-té' ri-an), $a$. Same as bacterial. bactericidal (bak-tè'ri-sì-dăl), a. [< bacteribactericide (bak-tëri-sīd), n. [CNL. bacterium has the property of destroying bacteria.

A bactericide of great setivity. Therapeutic Gaz., VIII. 561 .

Bacterides (bak-ter'i-dēz), $n . p l$. [NL., prop *Bacteridce, $<$ Bacterium +-ides, -ide.] A name sometimes given indefinitely to a group of miterium (which see).

bacteriform (bak-tè'ri-fôrm), a. [< NL. bac-

terium + L. forma, form.] Of the form of bacteria; l'esembling bacteria.

bacterioid (bak-tē'ri-oid), $a$. [< bacterium + -oid.] Resembling or closely allied to bacteria.

bacteriological (bak-tē"ri-ō-loj'i-kạl), a. Of or bacteriologist (bak-tē-ri-ol'ō-jist), $n, \quad[<b a c$ teriology + -ist. $]$ One skilled in bacteriology. bacteriology (bak-tē-ri-ol'ō̄-ji), $u$. [< NL. bactc-

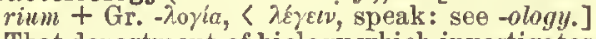
That department of biology which investigates bactcria and other microbes, especially their life-history and agenc
tific study of bacteria.

Bacteriology is now a natural science of sufficient inlpygiene, etiology, and pathologicsl anatomy.

bacterioscopic (bak-t $\bar{\theta}^{\prime \prime}$ ri-ō-skop'ik), $a$. [<bacterioscopy $+-i c$.] Relating or pertaining to the discovery or observation of bacteria.

bacterioscopy (bak-tē-ri-os'kō-pi), n. [< NL. bacterium + Gr. $-\sigma \kappa o \pi i a,<\sigma \kappa o \pi \varepsilon i \nu$, vier.

bacteriotherapeutic (bak-té" "ri-ō-ther-a-pu's tik), $a$. [< bacterium + therapeutic. ] Pertaining to bacteriotherapy.

Dr. Ballagi has carefully followed the bacteriotherapeutic
details advised by Cantani in eight esses of advanced phthi. sis with moderate fever. If edical News, XLIX, 41. bacteriotherapy (bak-tē"ri-ō-ther'a-pi), n. [< N. into the system for the cure of disease. 'Imus in into the systein for the cure of disease. 'Thus in
phthisis inlalations containing Bacterium termo have
been employed, with the idea that the bacterium de- troyed the Bacillus tuberculosis which is characteristic of acteritic (bak-tō-rit'ik), a. [<bactcrium + -it- see-itis.] Characterized or caused by the resence of bacteria.

acterium (bak-tē'ri-um), n.; pl. bacteria (-ä)

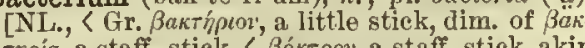

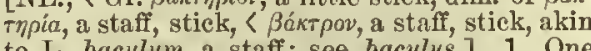
to L. baculum, a staff: see baculus.] 1. One of the micro-organisms which are concerned iu the putrefactive processes, and are known as Schizomyectes, or fission fungi, in distinction from Saccharomycctcs, or budding fungi, which produce aleoholic fermentation. Their true charse ter was long in doubt, but they are now generally regarded as the lowest forms of vegetable life, and are known to muand even of true sporangin. They consist of exceedingly minute sphcrical, oblong, or cylindrical cells, with out chlorophyl, multipiy by transverse division, and may iu pitrefaction, fermentation, and disease have been th subject in recent years of much study and discussion. the imuch renains in dould, but there is no question the importance of these investigations from a sanitary
point of view. 1t also sppears to have been demonstrated that the bacteris which exist in the soil are active in for the food of plants, converting the nitrogenous matte of organic origin into soluble nitrates. The geners an species have been variously deftned, and are necessarily geners usually recognized are The groujss and prineipal cells, concerved in certain fermentations and found in connection with spccial contagious discases; the rod-bac te.; and the spiral filiform bacteria, Vibrio, Spirillum ete. of the genus Micrococcus, M. diphtheriticus is considered to be the specisl cause of diphtheris, and $M$. vac
cince of smalipox. See Bacteriacee, and cut under bacillus. 2. [cap.] A genus of microscopic fungi, conisting of a single short cylindrical or elliptical cell, or of two such cells united end to end, and capable of spontaneous movement. The best-known species, $\boldsymbol{B}$. termo, is the prime cause of pntreaction, occurring early in all infusions of animal and veg. table substances and multiplying with great rapidity. Bactrian (bak'tri-an), $a$. and $n$. [< L. Bactrienus (Gr. Baктрiavós), < Bactria, < Gr. Baктрí (also Báktpa, ( Pers. Bäkhtar), a province so called.] 1. a. Of or pertaining to Bactria o Bactriana, an ancient country of central Asia
with its capital, Bactra, on the site of the nooderm Balkh. It became a province of the Pcrsian empir under Cyrus, and from about 255 to about 126 B. O. was

II. . A native or an inhabitant of Bactria.

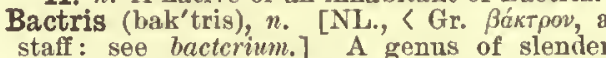
palms, consisting of about 40 species, found bout rivers and in marshy places in America within the tropics. The stems are generally covered

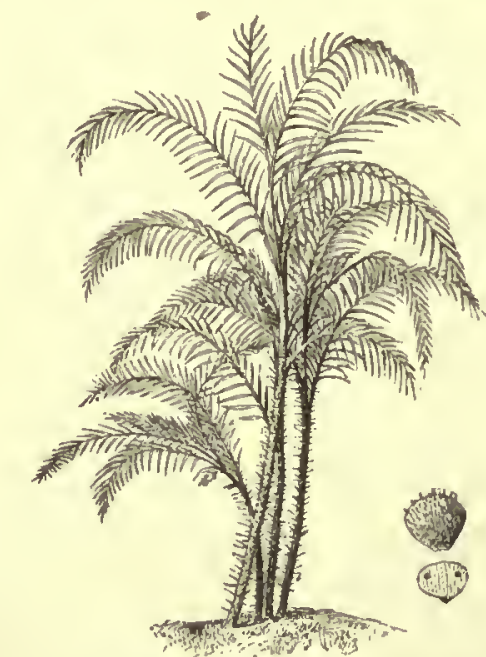

\section{Bactris acanthocatpa, with fruit, and out deprived of its husk.
the dots upon the latter showing position of ernbryos.}

with spines, and the leaves are pinnate, thongh occasio fibrous pulp inclosing a hard black nut. The kernel of $B$. major is eaten in Cartagena. The stems of $B$. minor ar used for walking-sticks, under the
baculi, $n$. Plural of baculus.

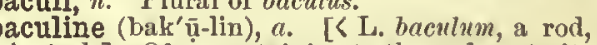
$\left.+-i n e^{1}.\right]$ Of or pertaining to the rod, or to its use in punishment by flogging.

baculite (bak'ü-lit), $n$. and $a$. [< NL. Baculites, q. v.] I. $n$. A fossil cephalopod of the genus Baculites; staff-stone.

\section{bad}

II a. Pertaining to or containing baculites. Also baculitic.-Baculite limestone, a name given to which it contains.

Baculites (bak-ūi-lī’tēz), n. [NL., < L. baculum, a staff, + -itcs: see $\left.-i t c^{2}.\right]$ A genus of poly thalamous or many-chambered cephalopods, belonging to the family Ammonitide. The species are known only in a fossil state, having become extinct at the close of the Cretaceous period. The shell is straight, more or less compressed, conical, and
very much elongated. The chambers are slmuous and pierced by a marginal siphon. The external ehamber is consicierabiy larger than the rest. There are about 20 species, found from the Neoconian to the Chalk formstion. baculitic (

baculometry (bak-ū-lom'e-tri),

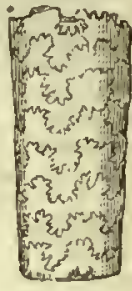

11. [< L. baculum, a stafí + Gr a measure.] The measurement of heights or distances by means of staves. Phillips.

baculus (bak'tu-lus), $u_{0}$; pl. baculi (-li). [L. more commonly neut. baculum, a stick, staff scepter, etc.; cf. LI. dim. bacillus (see bacil lus); akin to Gr. Bákroov, a rod, staff: see bac tcrium.] 1. A divining-rod.-2. A long staff or cruteh upon which worshipers were formerly psalms.-3. [cap.] [NL.] A genus of crusta-

badl (bad), $a$. and $n$. [< ME. bad, badde, bad, worthless, wicked, prob. a generalized adj. use (with loss of $-l$, as in iIE. muche for muchel, <AS. mycel, much; ME. lyte for lytel, < AS lytel, little; ME. wenchc for wenchel, $<\mathrm{AS}$. wen cel: see much, micklc, lite, lytc, littlc, and wench) of a noun, "bacldel, < AS. baddel (twice, in glosses), with equiv. deriv. badlling (suffix -ing ${ }^{3}$, an effeminate person, a hermaphrodite, with formative -el, < "bed = OHG. "bad, pad, a hermaphrodite (Leo). This word appears to exist also in some AS. local names, but traces elscwhere are slight; cf. AS. "bede, "pede, immatura," negative "or-bede, "or-pede, adultus," in glosses. This etymology, first suggested by Leo, is uncertain, but it is the only one that fairly satisfies the phonetic and historical conditions; the word can have no connection, as suggested, with Goth. bauths, deaf and dumb, with $G$. böse, bad, or with Corn. bad, Ir. Gael. baodh, foolish, ete. The orig. word, AS. baddcl, ME. "baddcl, on account of its sinister import, is scarcely found in literature, but, like other words of similar sense, it prob. flourished in vulgar speech as an indefinite term of abuse, and at length, divested of its original meaning, emerged in literary use as a mere adj, badde, equiv. to the older cvil. (Cf. the similar development of the adj. wicked, ME. wicked, wiktied, earlier wicke, wiklic, from the noun AS. wicca, m., a witeh, wizard, hence an evil person: see wiched ${ }^{1}$.) The adj. first appears at the end of the 13th century, and does not become common till the 15 th century. In high literary us $\theta$ it is comparatively rare, as against cril, till the 18 th century. In the English Bible bad occurs but rarely, and only in the familiar antithesis with good. Bad was formerly compared reg. badder, badelest, but has now taken from evil the irreg. comparison worse, worst.] I. a.; compar. worsc, superl. worst (1. Evil; ill; vicous; man; bad conduct; a bad life; a bad heart; bad influence, ete.

$$
\begin{gathered}
\text { Wisest men } \\
\text { Ilsve err'd, and by bad women been deceived. }
\end{gathered}
$$

2. Offensive; disagreeable; troublesome ; painful; grievous: as, bad treatment; a bad temper; it is too bad that you had to wait so long. The old soldiers of James were generslly in a very bad
Macaulay. 3. Hurtful; noxious; having an injurious or unfavorable tendency or effect: with for: as, bad air or bad food ; late hours are bad for the health; this step would be lad for your reputation or prospects.

Reading was bad for his eycs; writing made his hesi

4. IIl; in ill health; sick; in unsound condition: as, to feel bad; to be bad with rhenmatism; a bad hand or leg. [Colloq.]

I have beell, tliree days ago, bad again with a gpitting 
5. Not good ; dofective; worthless; poor; of 2. A mark, token, or deviee worn by scrvants, no valuo: as, bad coinl a bad crop; a bad picee of work; bad heaith. l'erjutles are common us bud pence.

6. Incorroct; faulty: as, a bed aim; bad English ; a bad pronuneiation.

$$
\text { Call, if you will, bud rliynulng a disease. }
$$

7. Not valid; not sound: as, a bud elaim; a bat pilea.

"Yon hind better gett a porter's knot, and carry trunks." Nor was the ndvice Gad?; for a porter wals likely to be as

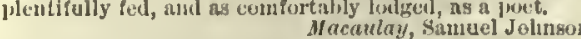

8. Unfavorable; unfortunate: as, bad nows; bad suecess.

Perplex'd nul troubled at hls bad success

The templer stood, nor liad what to reply.

[Dud is the ordhary smtithesis of good, in all its senses,

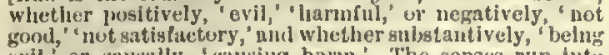
cvil, or cirusally, "chasing ham.' The senses run int the context.j-Bad blood bad consclence, ete. See the heuns. - Bad form, condect not in sccordance with goed tiste or proprlety, or not in keeplng with the preseut
conventional usnge; s slightly vulgar; not very refined. [sliung.]

They are taught that to beceme emotional or enthusl-
astle uver nuything is bed form. N. A. Rev., CXLII. 621. In bad odor. Seo odor. -With a bad grace. See grace.

II. $n$. That which is bad. (a) A bad condition: as, to go to the bad (see below). (b) A bad thing: as, there are $b a d s$ and goods among them. -To the bad. (a) To ruln, financlal or morsl : $\mathrm{ks}$, gilue of the account; in arrear or deflelt: as, I am now 8100 to the bad.

bad ${ }^{2}$ (bad). Preterit of bid.

badak-tapa (bad'ak-tap'ä), n. [Malay.] The Malay name of the rhinoceros of Sumatra.

badaneh (ba-dä'ne), $n$. The tunic worn by the
ligyptian ealifs, made of the very finest quality of linen. The weight of the garment was only 2 ounces, baddam (bad'am), $n$. A species of bitter al mond imported into some parts of India from Persia, and used as.money, with a value of about half a cent. baddert (bad'ér), a. Old comparative of bad.
See badl.

Lewerl peple . . demen gladly to the badder ende.

Were it badder, It is not the worst. Lyly, Euphues.

badderlocks (bad'èr-loks), $n$. [Supposed, withont evidence, to stand for Balder's loeks. Cf. balder-brac.] A name given in Scotland to the edible seaweed Alaria esculenta. The plsnt is ollve-green, belonging to the order Laminariacee, snd has into a mlirib. The stipe bears ribless leaflets along its sldes. Also ealled henware, and ln the Orkney Islsnds honey-ware: in psrts of Irelsnil, murlin

baddestt (bad'est), $a$. Old superlative of bad. e bad1.

The baddest among the enrdinals is ehosen pope.
Sir $E$. Sandys, Siste of Religion.

baddish (bad'ish), a. [<badl $\left.+\cdot i s h^{1}.\right]$ Some-

what bad; of inferior character or quality.

II wrote badd ish verses.

Jefrey.

A suuffy, babbling, baddish fellow.

baddock (bad'ok), n. [E.dial. Cf. badoek.] A local Fnglish name of the coalfish.

bade (bad). Preterit of bid.

badelaire (ba-de-lãr' $r^{\prime}, n$. [F., formerly baude-

laire: see badelar.] 'In her., a curved sword or cutlas used as a bearing.

badelart, n. [< F. badclaire (ML. baclelare, badarellus). Cf. basclard, baslard.] A short curved sword. Urquhart, tr. of Rabelais.

badge1 (baj), n. [< ML. badge, bagge, bage (also bagy, early mod. Se. bagie, badlgie, bawgy), later in ML. bagea, bagia, OF. bage (rare) Origin unknown; perhaps < ML. baga, a ring, < OS. $b \bar{a} g, b \bar{g} g=\Lambda \mathrm{S}$. beág, beáh, a ring, ornament, ME. bez, beigh, ete., mod. E. bec ${ }^{2}, q$. v.] 1. A token or cognizance worm in allusion to 1. A token or cognizance worn in allusion to or achiovements. The baige in the middle ages was net necessarlly heraldic, though in many cases it was se lected from one or mero of the heraldic bearings, and it is not bound by heralds' rules. Thus, the white hart of deseribel in the language of blazon. A flgure for a badge inght also be ehosen arbitrarlly, as the hoar of Richard iIf. Balges selectedl as personnl tokens have often become ivales.

IIIs gorgeous cellar hung sul aw?

Vrought with the badge of Scotinnd's erown.

$2 \pi$ retainers, partizans, or followers, as a sign o nembers of an association to indicate the members of

On his hreast a liforilte crosse lae lore,

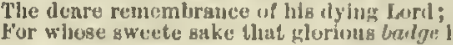

s'penser, r'. Q., I. i. .

3. The mark or token of anything. Swect mercy is nebllity's trme baufor

Shake, 'iii. And., 1, 2

Zeal for orthodoxy becane a badye of Spantsh patriot ism nfter the leng struggle, first with Aring, and then 4. Naut.: (a) A carved ornament formerly placed on ships, near the stern, and often containing the represontation of a window. (b) A lnark of good conduet awarded in the United States naval service to for sobriety and obediher., the sucient distunctive nets. (See breronet.) It is the cingrom of Uister and is thes blazooed: arg., asinister hand sppaumee, couped st the wrist, gules. This may be
frore upon a eanton or $8 \mathrm{n}$ in escuteheon, snd on that part of the besrer's armorial shleld which is most convenient. Sometlmes callel the blood: hand of Ulster.- Corps different United States srningcerps during tlie elvll war of one from another.

adge ${ }^{I}$ (baj), $v$. $t$.; pret. and pp. badlged, ppr. To mark or distinguish with a badge or as with a badge. [Rare.]

Their hands and laces were all badg'd with blood.

badge $2+$ (baj), $v . i$. [Early mod. E. also bagge appar. the source of badger's as a noun of agent ( $\left.b a d g c^{2}+-e r 1\right)$, but the verb appears later than the noun and is prob. a reverse deriv. of badger ${ }^{3}$.] To hawk for salo; buy up, as provision

grade. $n$. See badgir.

adgeless(baj'les), $a$. [<badgc $1+$-less. $]$ Having no badge.

$$
\begin{aligned}
& \text { Some badgetess blue upon his back. } \\
& \text { Bp. Hall, Sa }
\end{aligned}
$$

badgeman (baj'man), n.; pl. badgemen (-men). [<badgel + man.] A man who wears a badge; specifically, in England, an almshouseman: so
called because a special dress or badge is worn to indicate that the wearer belongs to a particular foundation.

Ile ruits the gay and rich, the young and free,
Among the badgemen with s lusige to be. Crabse. badger $^{1}$ (baj'èr), n. [<balgc $\left.{ }^{1}, n_{.},+e r^{1}.\right]$ A badgeman; one entitled or reguired by law to
wear a badge, as the police, licensed porters, wear a badge, as the police, licensed porters,
and others. and others.

gadger ${ }^{2}$ (baj'èr), n. [Early mod. E. also badgerd, bagcard (mod. dial. also barlget, q. v.), prob.
$\left\langle\right.$ badge ${ }^{2}$ (in allusion to tho white stripes on its forehead) $+-\operatorname{ard}($ rednced to $-e r$ ) or $-e r 1$ (ox-

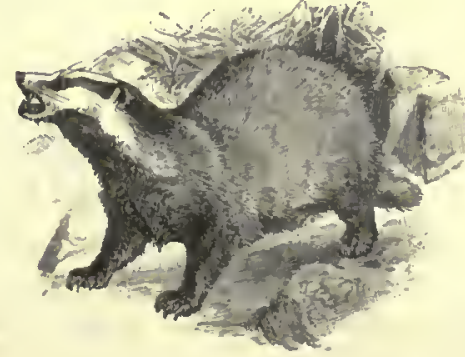

tended to -arl, as in braggard, braggart, for bragger, standard, a tree, for staniler, etc.), being thus identical with badger1. Cf. F. bluireau, a badger, OF. blariau, a badger, ¿ OFlem. seamen distinguished ence.-Badge of Ulster, In
01). Llacr, bald, blure, blacre, 1). Uluar, a white spot on the foreliead; cf. also the equiv. namo bauson.] 1. A fossorial plantigralo eamivorous mammal, of the family 1/ustetide and subfamily Melinet. (For its techulcal chnrueters, sec Mteli

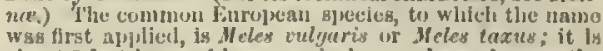
alnut 2 fect lohlg, of heavy anil clumsy sliaje, low on the legs, witle a short thick tail, a lon!s smove and ling claw: ilark limbs, and biack and whilte strlyes on the lieal. Thi animal Inhabits temjerate and bortherly portsons of lid rope and Asia. Its flesh is useil as fock, its pele in furri ery, and lis lanir for zunklug shuving-bruslics and Llie kiml of artints bruslies called batlyers, in n state of nature
the nul mal is less fetld than sone of the other specles. The American lnulger, Taxidea americana, rosermbles the foregolug, but differy lin the dental formula and some other technleal cliaracters; it is a common anlunal in the western watersherl, it is very gliundant. The Inilan halger is Aretunyx colheris; it ls also called sand-bear and bear-piy. The Javancse skunk (so ealled from lts extreme fetldness), sce cut under teledu. The ratel, honey-balger, or cup badfer, Mellivora capensis, ts nesrly relsted, thimgl, bethe Mellivorime. spread vulgar error that the lews of the laskect nre shorte on one slle than on the other; henec, "the eneventh'ggid We are not brulgers,

For our legs are one as long as the other.
Lyly, Midas, i. 2

2. (a) An artists' brush made of badgers' hair, used for blending or eausing the pigments to melt or shade into ono another and for imparting smoothuess. (b) A flat brush used for removing dust from a polished surfaco in some photographic and other elemical operations, etc.-3. The Lutraria vuluaris, a common conchiferous or bivalve mollusk of northern Enrope. It is especially used as bait for the cod. -4. A sobriquet of a resident of Wisconsin, ealled the Badyer State, in allusion to the abundance of badgers in it.-Drawing the badger. badger ${ }^{2}$ (baj'er), v. $t$. [< bndger $2, n$.] 1. To attack, as the badger is attacked when being drawn or baited; bait; worry; pester.

Inconslstent professors, who seemed to lave badgered Careline F'vx, Jourual, p. 542. When one has to be badyered like this, one wanls a drop 2. To beat down in a bargain. [Prov. Eng.] Halliwell. = Syn. Pester, "Worry, ete. See lease.
badger $^{3}$ (baj'er $), n$. [< late ME. bager, of obseure origin, perhaps an assibilated form (arising from its legal use, in an AF'. or L. form) of bagger (which does not oceur in the lit. sense $<b a g^{1}+-e r^{1}$. Cf. pedder, pedler, peddler, < ped, a basket, pannier.] One who buys corn and other provisions to sell them elsewhere; a hawker; a huckster; a cadger. Badgers were required to take out a license, snd were nniler certain legal
restrictions as to regrating or forestalling the inarket. [Nuw only prov. Eng.] rous sport formerly common, and still praetised to some extent, generally as an attraetion to
public bouses of the lowest sort. A badger is nut into a barrel, and one or more degs are put in to drag hin out. When this is etfected lie 18 returnet to hls harrel. to be similarly assniled by a fresh set of tlogs. The bulger badgering (baj'er-ing), $n$. [ [ badger $\left.3+-i n g{ }^{1} \cdot\right]$
In England, the practice of buying eorn or viet. uals in one place and selling them in another for profit : once restrieted by statute.

badger-legged (baj'ér-legd), a. [<ballger ${ }^{2}+$ other: in allusion to the common but erroneous supposition that the badger's legs on one side are shorter than those on the other.

IIis body erooked all over, big-bellied, badner-lenged, aod
lils comjlexien swarthy.

badgerly (baj'èr-li), a. [< badger $\left.2+-l y{ }^{1}.\right]$ Badger-like; grizzled or gray in color.

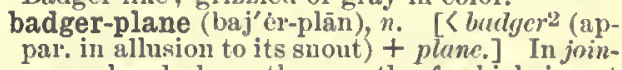
ery, a liand-plane the mouth of which is eut obliquely from side to sicle, so that it ean work close up to a corner in making a rabbet or inking.

badger's-bane (baj'èrz-bān), $n$. A variety of wolf's-bane, Aconitum lycoctonum.

badget (baj'et), n. [E. dial.; appar., like bad$g^{2} r^{2}<b a d g c{ }^{1}$, in allusion to the whito stripes on the badger's forehead. The same allusion holds for a cart-horse; ef. ball'3.] 1. Same as ballyer ${ }^{2}, 1 .-2$. A common name for a carthorse. Hallicell. [Prov. Eng.] 
badgir (bäd'gēr), n. [Pers. bāagir, 〈bül, wind, bads (badz), n. pl. [E. dial.] The husks of

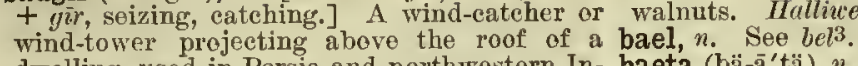

dwelling, used in Persia and northwestern In- baeta (bä-ā'tä), $n_{\text {. }}$ [Pg. baeta, baicta $=$ Sp. ba dia. Thre ladgirs are built like large climmeys, of wicker- yeta, baize: sce baize.] A plain woolen stuff
work and plaster, with openiniss toward the quarter of the manufactured in Spain and Portugal. Simprevailing wind, they are sometimes also made movable
or adjustable. See reind-8ail. Also written badgeer.

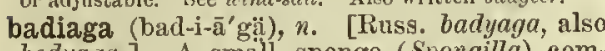
bodyaga.] A small sponge (Spongilla) common in the north of Europe, the powder of bricises

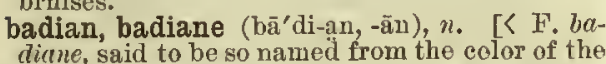
capsules, < L. badius, bay: seebay ${ }^{6}$.] The fruit of Illicium anisatum, the Chinese anise-tree. It abounds in a volatile oil which pives it an aro-
matic flavor and odor. On this account it is much used in China and India as a condiment, and ls
imported lnto France for flavor-

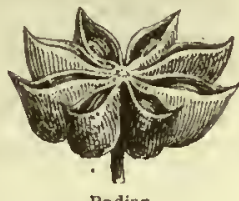

badigeon (ba-dij'on), $n$. [F.: origin unknown 1. A mixture of plaster and freestone, ground to A mixture and sifted, used by sculptors to fill the small holes and repair the defects of the stones used by them.-2. A mixture of sawdust and glue, or of whiting and glue, used by jeiners to fill up defects in their work. -3 . A preparation or wash for coloring houses, or for giving plaster the appearance of stone, consisting of powdered stone, sawdust, slaked lime, alum, and other ingredients. - 4. A preparation of tallow and chalk used by coopers.

badinage (had-i-näzlı' or bad'i-nạjj), n. [F.

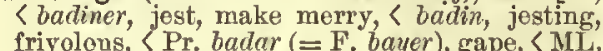
frivolous, < Pr. badar ( $=$ F. bayer), gape, < ML.,
badare, gape: see bay4.] Light playfnl hanter er raillery.

He seems most to have indulged himself only in an ele

=\$yn. Raillery, banter.

badinerie (ba-de'-ne-rē), $n$. [F., <badiner, jest seo badinage.] Light or playful discourse nonsense; badinage. [Rare.]

The fund of sensible discourse is limited; that of jest
and badinerie is infnite. Shenstone, Works, II. 240 .

badineurt (had-i-nèr'), n. [F., < badiner, jest : see badinage.] One who indulges in badinage; a trifler.

Rehuke him for it, as a divine, if you like it, or as a
badineur, if you think that more effectual. badineur, if you think that more effectual.
Pope, To Swift (Ord MS.).

badious (bā'di-us), a. [< L. badius, bay : see bay $\left.{ }^{6}.\right]$ Of a bay color; reddish-brown; chest nut. [Rare.]

badling (bad'ling), ${ }^{\prime}$. [E. dial., appar. 〈 bad1 bedling: manish man. $N . \mathbb{L}$. D. - 2. A worthless person. Halliwell. [North. Eing.]

badly (bad'li), adv. [ME. badly, baddeliehe $<$ bacl $1+-l y^{2}$.] In a bad manner. (a) Wickedly wrongly; in an evil or an improper manner: as, the boys
behaved badly. (b) Grievously; dangerously ; severely: behaved badly. (b) Grievously; dangelously; severely
as, badly wounded. (c) In a manner which falls below a fully; inperfectly; defectively; poorly; not well: as, the work was badly doule. (d) Incorrectly; fanltily : as, to as, the army fared badly. - Badly off. See off.
badmash, $n$. Same as budmash.

badminton (had'min-ton), n. [< Badminton, in Gloncestershire, England, a seat of the dnke of Beaufort.] 1. An English outdoor game, similar to lawn-tennis, but played with shuttlecocks. - 2. A summer beverage, properly a claret-cup made with soda-water iustead of
plain water and flavored with cucumber. plain

Soothed or stimulated by fragrant cheroots or beakers
of Badminton. Disraeli, Lothair, xxx, $(N . E . D$.

[With or without a capital in either sense.]

badness (bad'nes), n. [< bad + -ness.] The state of heing bad, evil, vicious, depraved, wrong, improper, erroneous, etc.; want or deficieney of good qualities, physical or moral the roads, etc. See bad1.

"The badness of men," a Jewish writer emphatlcally de. Lecky, Europ. Morals, II. 357

badoch (bad'ech), n. [Sc. Cf. baddoek.] A Seotch and local English name of one of the jaegers or skua gulls, Stercorarius parasiticus, a
predatory marine bird of the family Larido. monds.

Bætis (bē'tis), n. [NL., < L. Bretis, Gr. Baĩtı, a river in Spain, now called Guadalquivir.] A genus of agnathous nelropterous insects, of the family Iphemeride, or giving name to a gromp
Botida, eontaining numerous species with Batida, containing

wrings and 2 setæ.

rtylus (bë'ti-lus), n. [L., also botulus, bctu

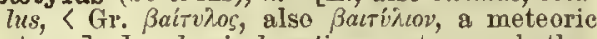
stone.]. In classical antiq; a stone, whether meteoric or artificially shaped, which was venerated as of divine origin, or honored as a symbol of divinity. Snch stones were preferably of conical form, and somctimes bore certain natural symbois, not consiclered material. Thus, the stone preserved on the omphalos at Delphl, reputed to be the one swallowed ly Kronos (Saturn) through Rhea's stratagem in place of the infant Zeus (Jove), was of spherical shape. Among the most celebrated of these sacred stones were those of Pa-
phos in Cyprus, of Zells Kasios at Seleucia, and of Zeus phos in Cyprus, of Zelis Kasios at Seleucia, and of Zeus
Teleios at Tegea in Arcadia. See abadir. Also written

baff 1 , v. $i$. [ [ ME. baffen $=$ D. and LG. baffen $=$ MHG. baffen, beffen, G. batien, bäfzen = Dan. bjoffe = Sw. bjebba, hark; appar. imitative. Cf.
dial. buff, bark, and yaff.] To bark; yelp.To say neither baff nor bufft, to say nothing

baff' (baf), r. i. [Se., also beff. Cf. OF. baffe To beat; strike; specifically, in the game of golf, to hit the ground with the club when striking at the ball. [Scotch.]

a heavy thump.

baff-ends (baf'endz), n. pl. [<baff (dial) baff-ends (baf'endz), n. pl. $[<b a f f$ (dial.), per-
haps for baft, behind (see baf $\left.t^{1}\right)$, + end. $]$ In coal-mining, long wooden wedges for adjusting tuhbing-plates, or cribs, in sinking shafts during the operation of fixing the tubbing. Gres- haffling

ley. [Eng.]

Houndes for the hauk beth fizters and grete baffers.

baffeta (baf'e-tä), n. Same as baft ${ }^{2}$.

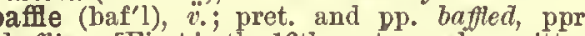
bafling. [First in the 16th century, also written bafful, baffol; origin uncertain. The senses point to two or more independent sources: ef. (1) Sc. bauehle, baehle, disgrace, treat with contempt (see bauehle ${ }^{2}$; (2) $\mathrm{F}$. bafouer, earlier baffouer, disgrace, revile, scoff at, deceive, befler, also beffer, deceive, moek, = Pr. bafar $=\mathrm{Sp}$. be-
$\mathrm{far}=\mathrm{It}$. beffare, mock, deride ; ef. OF. befe, beffe $=$ Pr. baf $a=$ OSp. bafa, Sp. befa $=$ It. beffa, beffe, mockery; cf. Pr. baf, an interj. of disdain; cf. Sc. baffle, a trifle, nonsense, appar. <OF. beffe, trifling, mockery (see ahove). Cf. MHG. beffen, bark: see baff I.] I. trans. 1t. To disgrace ; treat with mockery or centumely; To disgrace; treat with mockery or centumely;
held up as an object of scorn or contempt; insult; specifically, to subject to indignities, as a recreant knight or traitor.

The whoke kingdom took notlce of me for a bafled,
whipped fellow, Bear, and Fl, King and No King jii. You on your knees have curs'it that virtuous maiden And me for loving her; yet do you now

Thus baffle me to my face. Mrddleton and Dekker, Roaring Girl, i. 1 .

Justice [in "Mensure for Measure"] is not merety evad-
ed or ignored or even defied: she ls both in the older and the newer sense of the word directly and dellberately the newer sense of the word directly and dellberately
baffled; buffeted, outraged, insulted, struck in the face.
Sumburne, Shakespeart, p. 203 .

2t. To hoodwink; cheat.

Alas, poor fool! how have they bafled thee

3. Te circumvent by interposing ahstacles or difficulties; defeat the efforts, purpose, or suecess of ; frustrate; check; foil; thwart; disconcert; confound: as, the fox baffled his pursuers; to baffle curiosity or endeavor. I. D'Israeli, Amen. of Lit., IT. 239 CaIculations so difficult as to have baffed ... the most
Prescoit Prescolt.
I never watched Robert in my life but my scrutiny was I never watched Robert in my life but my scrutiny was
presently beffed by finding he was watehing me. 4. To beat about, as the wind or sronte, Shirley, xv. 4. To beat about, as the wind or stray cattle together. = syn. 3. Foil, Thwart, etc. See frustrate. bjoffe = Sw. bjebba, hark; appar. imitative. Cf.

To paint lightning, and to give it no motion, is the
II. intrans. 1t. To practise deceit; shuffe. quibble.

Do we not palpably baffe when, in respect to God, we pretend to deny ourselves, yet, upon urgent occasion, al-
Darrow, Works, 1.437 . 2. To struggle ineffectually; strive in vain: as, the ship baffed with the gale.-3. In eoal mining, to brush out or mix fire-damp with air, to such an extent as to render it non-explosive. baffle (baf'l), n. [<bafle, v.] 1†. Disgrace; firont.-2t. Defeat; discomfiture.

It is the skill of the disputant that keeps off a baffe.

3. Same as baffler, 2.

bafflement (bat'l-ment), n. [<baffle + -ment.] The state of being baffled, frustrated, or thwarted in one's endeavors; want of suecess after repeated attempts. [Rare.]

Assoclated in bis mind with baflement and defeat.

baffle-plate (haf'l-plāt), $n$. A metal plate used to direct the flames and gas of a furnace to different parts of a steam-hoiler, so that all portions ef it will be evenly heated; a deflector.

baffler (baf'lér), $n . \quad 1$. One who or that which baffles.

Experience, that grcat baffer of speculation.

2. A pertition in a furmace so placed a kine, Steam Fingine, $\$ 304$. Also baffe.-3. In eoal-mining, the lever with which the throttlevalve of a winding-engine is worked. [North Stafferdshire, Eng.]

baffling (baf'ling), p.a. Frustrating; disconcerting: confusing; perplexing: as, a bafling wind, that is, one which frequently shifts from one point to another.

Those are the true bafting prejudices for man, which he never suspects for prejudices. De Quincey, Ferodotus. bafflingly (baf'ling-li), adv. In a haffling bafflingness (baf'ling-nes), $n$. The quality of

baff-week (baf'wēk), n. [E. dial., < baff, perhaps for baft, behind (see baftI), + week.] In coal-mining, the week next after pay-week, when wages are paid onee a fortnight. [Eng.]
baft 1 (bäft), adv. and prep. [<ME. baft, bafte, baften, biaften, $<\mathrm{AS}$. boflon, beaftan, be aftan, $<b e, \mathrm{by},+a f t a n$, aft: see be-2 and $a f t$, and ef. abaft.] I. adv. Behind; in the rear; naut., ahaft. [Archaic.]

\section{II.t prep. Behind.}

aft ${ }^{2}$, bafta (baft, baf'tä), $n$. [Formerly also baftah, baffeta, boffeta; K Hind. bäfta, a kind of cotton cleth, baft, weaving, a web, < Pers. baft, wrought, woven.] A fine cotton fabric of Oriental manufacture; especially, a plain muslin, of which the Surat manufacture is said to be the best. The bafts of Dacca in British India are an are sald to be manufactured from European thread, The are sald to be manufactured from European thread. The Also baffeta.

bag ${ }^{1}$ (hag), n. [< ME. bog, bagge, of uncertain origin, perhaps < Icel. baggi, a bag, pack, bundle (cf. the older böggr, a bag), appar., with assimilation, < *balgr, belgr, skin, bellows, = bale, G. balg, a skin, = D. balg, skin, belly, = bale, G. balg, a skin, = D. balg, skin, belly, $=$
AS. brelg, belg, baclig, belig, a bag, > mod. E. belly and bellows: see belly, where other forms are given, and bellows. Cf. OF. bague = Pr. bagua =It. dial. baga, a bundle, baggage, ML. baga, a bag, chest, baggage, helongings, appar. from the Tent. or the similar Celtic forms.] 1. A small sack; a portable roceptacle or repository of leather, eloth, paper, or other flexible material, capable of being closed at the mouth a wallet; a pouch: as, a flour-bag; a carpet-bag or traveling-bag; a mail-bag. Specifically-2. A purse or meney-hag.

He was a thlef, and had the bag. 3t. A small silken peuch in which the back hair of the.wig was curled away.

A bob wig and a black silken bag tied to it. Addison.

4. What is contained in a bag; in hunting, the animals bagged or ohtained in an expedition or a day's sport.

The bag is not the sole aim of a day afield. Stream, $\mathrm{XXI}, 2$

5. A sac or receptacle in animal bodies containing some fluid or other substance: as, the heney-bag of a bee.-6. An udder.

The cow is sacriflced to her bag, the ox to his girloln. 
7. $p l$. The stomach. [Seoteli and north. Fing.] -8. pl. Trousers. [Vulgar.] -9. The middle part of a large liaul-seine: the two parts on the sides are ealled wings. - 10. A flue in a poreclain-oven whieh ascends on the inner side, and onter's tho oven lighl up, so as to heat the upper part.-11. A customary measuro of capacily, generally from 2 to 4 bushels. -12 . In coulmining, a quantity of fire-damps suddenly given off from the coal; also, the cavity from which the gas is cunittel: formerly used to include eavities containing a large amount of water. - Bag and baggage, all onc

Come, slepheris lut us make all honouratue retreat

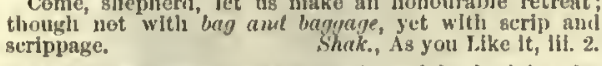

ement used th dredging fur ba

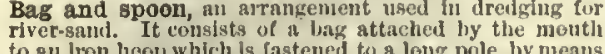

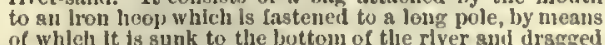
of whleht it is sunk to the bottom of the river and dragged
along ao thiat the buag is tilledi.-Bag of bones, a very slong so that the bag is illledt.-Ba
lean person or antmal. [Il unoreus.]

Such a limping bay of bones as I was!

Dickens. Bag of foulness, In a coal-sean, a cavity fillcd wlth firedamp.-To bear the
mand of the nuoney.

These are court-admirers,
And ever eelio hilm that bears the bag.

"letcher (and another), Eider Brother, 1. 2. To bring to bag. See bring. - To give one the bag.

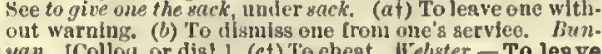

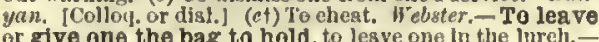
or give one the bag to hold, to lesve one
To let the cat out of the bag. See cat 1 .

bag1 (bag), $v_{-}$; pret. and pp. bagged, ppr. bagging. [KME. baggen, intrans.; from the noun.] loosely like a bag.

IIts trill and neek-cleth hung limp under his bagging 3 . 'To grow big with ehild.

Then Venus ahortly bagged, snd
Ere long was Cupld bred.

"arner, Alblon's England, vI. 148.

II. trans. 1. To put into a bag: as, to bag hops.-2. To distond like a bag; swell.

Llow loth an unwelcome dropsy bag up his eyer.
Bp. Hatl, Works, II. 408. 3. To secure as game; shoot, entrap, or otherwise lay hold of: as, to bag thirty brace of grouse. The disputes of I talians are very troll things, and I will
accordingly bag the one which is now imminent as a
spectmen.
Lovell, Fireside Travels, p. 245 . 4. To make off with; steal. [Colloq.]

bag ${ }^{2}$ (bag), $v$. $t$.; pret. and pp. bagged, ppr. bagging. [स. dial., also bagge, badge; origiu obscure.] To cut with a reaping-hook or scyth.

bagana (ba-gid'nij), n. [Abyssinian.] An Abyssinian lyro with ten

bagara (bag'a-rii), n. [Cf. Bagarius. ] A scimnoid fish of California, Menticirrus undulatus, rclated to the kingfish of the eastern United States.

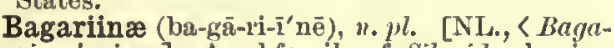
rines + -ince. A A subfamily of Silurida, having the head uaked above, and the anterior and

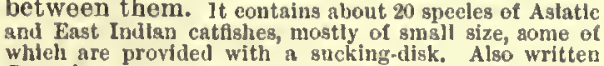
Bagarine.

Bagarius (ba-gä'ri-us), n. [NL. Cf. Bagrìs.] Bagariine.

The first appearanee of Sllurolds is indlcated by some

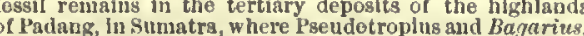
types well represented in the lifing a launa, have beeni found.
Dr. A. Gunther, Study of Fishes.

bagasse (ba-gas'), n. [= F. bagasse, also bagace, <Sp. bagazo (= $\mathrm{Pg}$. bagaço), the refuse of sugarcaue, grapes, olives, efe, which have been
pressed, prob. a dial. var. of bagage, trash. pressed, prob. a dial. var. of bagage, trash
lumber; baggage: see baggage ${ }^{1}$ and baggage ${ }^{2}$. The sugar-cane after it has been crushed and the juice extracted; ; cane-trash. It is used as fuel in hesting the boilers and pans in the sugar-manulactorg,
and somettmes as manure. Also ealled bagazo, megass, and somettmes
and megasse.

When they have finlshed grinding the cane, they form the refuse of the staiks (whicls they eall bagasse) into great piles and set fire to them.

bagatelle (bag-a-tel'), $n$. [Formerly also bagatel, baggatelle (älso bagatcllo), < F. bagatclle $=$ Sp.bagatela $=\mathrm{Pg}$. bagatella, $<$ Itt. bagattella, dim.
of dial. bagatta, bagata, a trifle, prob.<ML. baga

(It. dial. baga, OF. bague), a bundle: seo bag 1 and bayga

leaps of linir rings and cypher'il sesls There is a pleasure arising from the perusal of the very
bagatelles of men renowneil for thelr ksuwledge and geGolsmith, Critlelsms. The [cremation] furnace can not be creeted hits the country for less than from three to five thousand clollars - B mere bagatelle compared wlth the cost of aume of our
l'ometerites. Sci. Mo., XXII. 862 2. A game played on a table having at one end nine holes, into which balls are to be struck with a billiard-eue.

agatelle-board (bag-a-tel'bōrd), n. A portable boart on which bagatelle is played.

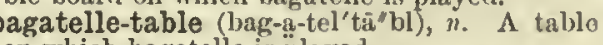
on which bagatello is played.

bagatinet, $n$ [< It. bugattino: see bagattino.] Same as bagattino.

Expeet no lower price, tor by the baunce of my trunt, I

bagattino (båg-at-tén $\left.\bar{e}^{\prime} \overline{0}\right), n . ;$; pl. baggatini (-nō). [It., dim. of dial. bagatta, a triflo: see bayutelle.] $A$ copper coin of Vonico, worth about half $a$ cent.

bagaty (bag'a-ti), n. [Also baggety; origin not ascertained.] A name of the female lumpfish, Cyelopterus lumpus. agazo (Sp. pron. bä-gia'thō), n. [Sp., $=\mathrm{Pg}$.

bagaco: seo bagasse.] Same as bagfasse. the mouth of a bag; a bag-fastener.

ag-fastener (bag'fás"nér), n. A device made of wire, twine, rope, etc., for closing the mouths of bags.

bag-filler (bag'fill"èr), n. A funnel used in filling bags.

ag-filter (bag'fil"tẻr), $n$. A filter usud in sugar-refining to clear saccharine solutions of feculencies and impurities suspended in them. It consists of a gerles of alevea or atraners through which the solutions pass inte one or more flannel bags, whence bag-fox (bag'foks), $n$. A fox kept in confinement, and slipped from a bag when no other game for a hunt can be had.

To have a sort of bag.fox to turn out, when fresh game
cannot be had.
Miss Ferrier, Inheritance, I. $x$. bagful (bag'fül), $u$. [<bagl + full. $]$ As much as a bag will hold, of whatever sizo: as, three bagfuls of wool.

aggage I (bag'ạjj), $n$. and $a$. [<ME.bagyage, bagage, $<\mathrm{OF}$. bagage, baggage, esp. of an army, also the baggage-train, including the attendants, mod. F. bagage, baggage (= Pr. bagalge $=\mathrm{Sp}$. bagage, baggage, esp. of an army, a beast of burden, formerly also refuse, lumber, trash, = Pg. bagagem, baggage, carriage; ef. It. bagaglia, bagaglie, baggage), $<$ OF. baguer, tie up, pack bundle, pack, usually in pl. bagnes, baggage, belongings: see bag 1 and -age. Cf. baggagc. ] I. $n$. 1. The bags, trunks, valises, satchels, packages, ote., and their contents, which a traveler requires or takes with him on a journey: now usually called luggage in Great Britain. In law, bsg. gage Ineludes whatever the passenger takes with hlin for wsints of the psrtienlar class to which he belongs with referenee either to the immediate neeessities or to the ultimate purpose of the Journey. (Chief Justice Cockburn.) Sounting the baronet's baggage on the ront of the
Thackeray. IJaving dispatched my baggage by water to Altdort. We were told to get our baggage in order and embark
for ditarantine. B. Taylor, Lands of the Saracen, p. 18. Specifically-2. The portable equipment, illluding the tents, clothing, utensils, and other necessaries, of an army or other moving body of men; impedimenta.- $3 \nmid$. Trash; rubbish; efuse.

In the stomacke is engendered great abundanee of Touchstone of Complexions, p. 118. Bag and bagsage. See bagl.

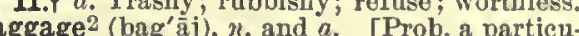

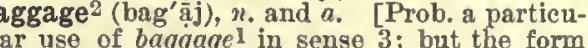
and sense agree closely with F. bagasse, strumpot, also bojasse, baiasse $=$ Pr. baguassa, prob. S. bagasa (obs.) = Pg. bagaxa = It. bagascia, a strumpet; of uncertain origin; associated a strumpet; of uncertain origin; associated gasse, Sp. bagazo, ete., refuse, trash, which is, again, prob. a var. (in Sp.) of bagage, baggage: see baggage 1 and bagasse. But there are indi-
I. 3. 1. A worthless person, especially a wortlless wornan; a strumpet.

A spark of imlignation dill rise in her not to sutfer such You are a baggagr, and not worthy of a inan.

Shirley, Lwe Tricks, t. 1. 2. A playful, saucy young woman: a flirt: usually in conjunction with such qualifying words as cumning, sly, saucy, ete. [l'umiliar.] Tell them they are two arrant lictle baggagen, and that $I$ am this moment in $\mathrm{s}$ most violent passion with thom.

II. $u$. Wortlless; vile: said of persons: as, a bagyage fellow.

baggage-car (bag' āj-kür), n. $\Lambda$ railroad-car built for heavy loads and high speed, and user for earrying the baggage of tho passengers on a train. [U. S. and Canada.]

baggage-check (bag'äj-chek), $n$. A tag or labc to be attacherl to each article of a traveler: baggage, indicating its destination, and also usually the point of departure and the company which issues it. A duplleate is given to the traveler, on the presentatlon of wh.
ed. [U. S. and Canads.]

baggaged (bag'ãjd), a. [E. dial., appar. < bayguge $1+-e d^{2}$.] Niad; bewitclied. [Prov. Eng.] baggageman (bag'ด् j-man), $n_{. ;}$pl. baggagemen -men). A man who handles baggago; especially, one who earries or throws it into a baggage-car.

baggage-master (bag'âj-más"tèr), n. An officer of an express, railroad, or stenmship company whose duty is to look after the baggage intrusted to the company's caro.

baggagert (bag'āj-ér), n. [< baggagel + cerl. $]$ One who carries baggage; specifically, one wy

The whole camp fled anain, the victuallers and baj-

The whole camp fled amain, the victuallers and bay
gagers forsaking their csmps.

lialeigh, Ulst. of World, III. X. s. s.

for transferring baggage at a railroad station, for transferring bagg

aggala, baglo (bag'a-li;, bag'lō), n. [Ar.] A

two-masted Arab boà used for trading in the

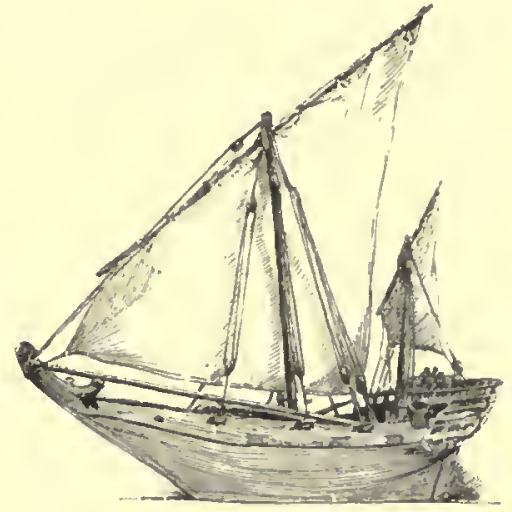

Bagrala. - From model in South Kensington Museun, London.

Indian ocean, between the Malabar coast and the Red Sea. Iarge numbers of bagralas trade between Mluseat, the Red ses, snd Indla, making one royage eaeh
way ammuslty with the nonsoons. They are generally of and are remsrksble for the elevation of the stern, which bagget, v. i. [ME., found only twice, in the apparent sense of 'squint,' or 'look aside'; adv. baggingly, q. v. Origin obscure.] A word of doubtful meaning, probably, to squint or look aside.

False fortune . . . that bagyeth foule, and looketh taire.
Chaucer, Death of Blanche, 1. 621.

bagged (bagd), $p . a$. 1. Hanging in bags or lack folds.

In a robe of russet and white mixt, full and bagged.
$B . J$ Jonson, Jlasine of Heauty.

2. Provided with bags. -3 . Retained in the bags after filtration: applied to crude sperm or other matter remaining in the filtering-bags after the process of bagging.

agger (bag'ér), n. [<bagl, $v_{.},+-c r^{\mathrm{I}}$. Only One who bags or incloses in a bag.

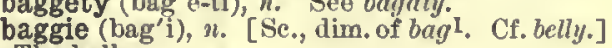
The belly.

A guid New-ycar I wish thee, Maggie!

Burns, Farmer to his Auld Jiare IIagrie. 
baggily

baggily (bag'i-li), act. In a loose or baggy way. The state or quality of being baggy.

There was a bagginess alont the tronsers which indi. caterl the work-a-day costume of a man of might.

bagging ${ }^{1}$ (bag'ing), $n$. [Verbal n. of bag ${ }^{1}$.] 1 . Tho ast of putting into bags. -2 . Filtration through enuvas bags.

Separation of "brown paraffin scale" is effected hy bag. ging and pressing.

Ure, Dicto, 111. 511. The first opcration needed to fit apermaceti for use is
tecluically termed bagging. The evinde spermu oil, as lirouglit in ly the whalera, is placed in a reservoir, at the bars lived with linen, and temporarily closed at the bottom by tying cords rond the mouth

W. $L$. Corpenter, Soap and Candles, p. 241.

3. Any coarse woven fabric of hemp, ete., out of which bags are made, or which is used for covering cotton-bales and for similar purposes. 列 the northern counties eaten between regular meals; now, especially in Laucashire, an afternoon meal, "arternoo tea" in a substantial form. N. E. D.

bagging ${ }^{2}$ (bag'ing), $n$. [Verbal n. of $b a g^{2}$.] A method of reaping corn or pulse by chopping it with a hook.

bagginglyt, adv. [NE., < bagge, q.v.] With a leering expression. Rom. of the Rose.
bagging-time (bag'ing-tìm), n. [E. dial., bagging + time.] Lunch-time.

bagging + time. Luneh-time.

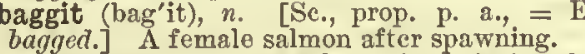
baggy (bag'i), a. [<bag $+-y^{1}$.] Having the appearance of a bag; bulging out loosely like a bag; puffy: as, a baggy umbrella ; a baggy face. We untwisted our turbans, kicked off our baggy trowHe looked like a Hindoo ldol, with his heavy-lidded or bs and baggy cheeks. bag-holder (bag'hōl'dèr), n. A contrivance for supporting a bag and holding it open during the process of filling it.

Bagimont's Roll. See roll.

baglo, bagla, $n$. See baggala.

bag-machine (bag'ma-shēu"), n. A machin for making paper bags.

bagman (bag'man), n.; pl. bagmen (-men) One who carries a bag; especially, one who travels on horseback earrying samples or wares in saddle-bags: a name formerly given to commercial travelers, but now used only as a term of moderate contempt.

bagne (F. pron. bany), n. [F.] Same a bagnio, 3 .

bag-net (bag'net), n. An interwoven not in the form of a bag for catching or landing fish. form of bayonet.

bagnio (ban'yō), $n$. [Early mod. E. also bagno, bagnio (ban'yō), n. (Early nod. E. also bagno,

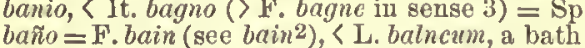
see balneum.] 1. A bath; a house for bathine cupping, sweating, and otherwise cleansing th body.-2. A brothel; a stew.-3. In the Turkish empire, a prison in general; in France, for merly, one of the great prisons (bagnes) substi tuted for the galleys, now superseded by transportation: perhaps so called from the former us of ancient baths in Constantinople as prisons, Bagnolian (bag-nó'li-an), n. [From Bagnols, in the department of Gard, France, where the heresy had its rise.] One of a sect of Freneh heretics of the eighth century, who rejecte the whole of the Old and part of tho. New Testament, and generally held the doctrines of the Manicheans. The name was again applied in the thirteenth century to some of the Cathari. They were also called

Bagnolenses.

bag-nut (bag'nut), n. The bladder-nut of Europe, Staphylea pinnata.

bagonet (bag'ọ-net), $n$. [Cf. bagnet.] An obsolete or dialectal form of bayonet.

bagpipe (bag'pip), n.
[ME. baggepipe; $\langle$ bag + pipe.] A musical wind-instrument consisting of a leathern bag, which receives the air from the mouth, or

pipes, into which the Old English Bagpipe.

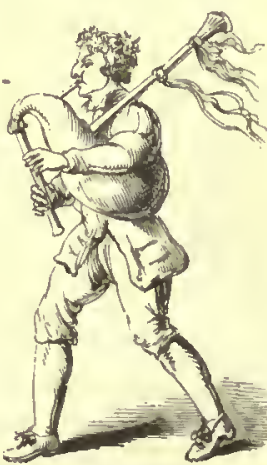

420

bahut

air is pressed from the bag by tho performer's elbow. It originated in the liast, was known to the tle middle agea, and is still used in many eastern coun ties, as well as among the country people of Polani. Wtaly, the south of france and in Scotland and lreland Scotland especially Celtie Scotland, its orivin and 11 seem to belonif to the Celtic race in cenerat in known form it has four pipes. One of these, called the chanter, has a double reed nud eight finger-holes, ao that melodies may be played upon it. Its compass nay be ap-

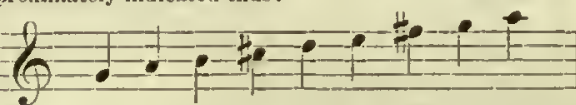

There are three other pipes, called drones, with a single eed, which give a contimnous sound, and are tuned in arious ways. There are aeveral kinds of bagpipes, as
he Scotch (Ilighland and Lowland), whicl is the most huportant, most characteristic, best known, and perhap, the oldest; the Einglish, or perhaps more properly North

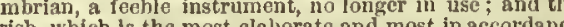
with modem ideas of nusical accuracy. The word is now used chietly in the plural, espectally in scotland.

bagnipe (bag'pip), $v$. t.: pret. and pp. bagpiped,

, $<$ bagipe, n.] pagpiped, esemble a bagpipe.-To bagpipe the mizzen lesemble a bagpipe. - To bagpipe the mizzen
(naut.), to lay it aback by bringing the sheet to the miz.

bagpiper (bag'pï"pér), n. [ME. baggepipere ; agpipe $+-r^{1}$.] One who plays on a bagpipe.

Laugh, like parrota, at a bagpiper. Shak., M. of V., 1.1.

bag-press (bag'pres), $n$. A press

in whieh the materials to be

pressed are inclosed in sacks or

bags of linen or hair. It is used in

the expressing of oil from seeds.

bag-pudding (bag'pud"ing), $n$. A

poiled in a bag.

bag-pump (bag'pump), $n$. A form

of bellows-pump in wlich there

is an elastic bag, distended at in-

tervals by rings, fastened at one

end to the bottom of the piston- Bar-pump.

valve-disk.

B. Agr. An abbreviation of Bach

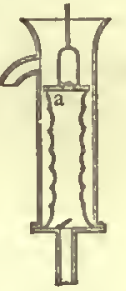

clor of Agriculture, a title confe

agrationite (ba-gra $\bar{a}^{\prime}$ shon-it), n. [After P. R. Bagration: see -itc ${ }^{2}$.] A mineral from the Ural, resembling some forms

bag-reef (bag'rëf), $n$. The lowest reef of fore-and-aft sail, er the first reef of a topsail. Bagrinæ (ba-grī'nē), $n$. pl. [NL., < Bagrus + ince.] A subtamily of catfishes, of the family Silurida. They have the anterior and posterior no trlls remote from one another, the latter being provided isthmus; ; a a ort anal fin; ; i long adipose fin ; and a ghort dorsal fin in front of the ventral fins. There are many pecica, mostly Asiatic and East Indian.

bag-room (bag'röm), $n$. A room on a man-ofwar where the elothing-bags of the erew aro stored. Luce.

Bagrus (bag'rus), n. [NL., < Sp. Pg. bagre tish, silurus bagre.] The typical genus of catfishes of the subfamily Bagrince. Two spe-
cies, attaining a length of 5 or 6 feet, are found in the Nile.

Bagshot beds. See bedl.

bag-trousers (bag'trou"zèrz), $n . p l$. The cover ing for the legs worn by men in the Levant, an it consiats of an undivided bas with two loles in the bottom, througl which the feet are passed. It is drawn up anklea, or above them, and is commonly so full as nearly to reach the ground in falling over the feet. The trouse of the women are more commonly made with two legs,
like Enropean drawers or trousers. See petticoat-trousers baguet, baguette (ba-get'), n. [<F. baguette, a wand, rod, stick, < It. bacchetta, a rod, stick, dim of bacchio, a rod, pole< < baculum. rod, stick: sce baculus.] In arch., a small convex semicircular molding: usually called when plain a bead, when enriched with foliage a chaplet.

bag-wig (bag'wig), $n$. A wig the back hair of which was inclosed in a bag. See bag 1,3 .

Expect at every turn to come upon intriguing spectres in bag-wigs, immense hoops and patches. bagwigged (bag'wigd), $a$. Wearing a bag-wig. bag-worm (bag'wêrm), $n$. Tho larva of lepidopterous insect, Thyridopteryx ephemere formis (Harris), common throughout the more nerthern part of the United States. called bag-worm because it apins a silken bag for Ita pro- tection, and moves with it hanging downward; it has male insect has well-developed wings, but the ferale is apterous, and lays her eggs within the puparinm.

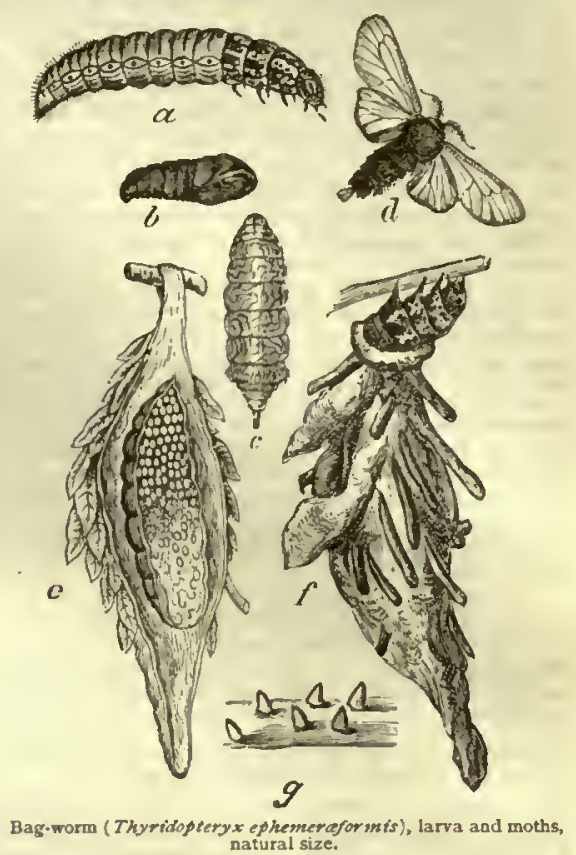

a. larva; $b$, male chrysalis; $c$, female moth; d d male moth; $e_{\text {, fe- }}$
male chrysalis in bag (sectlonal view); $f$, caterpillar and bag; $g$.
very young caterpillars in their bags.

bagwynt, $n$. In her., a fabulous beast, like an antelopo with a horse's tail. Cussans.

bah (bä), interj. [< F. bah, interj. of contempt.] An exclamation expressing contempt, disgust, or ineredulity.

Twenty-five years ago the vlle ejaculation bah ? was utbahadur (ba-hâ'dör), $n$. [Hind. băhadur, brave, gallant; as a noun, a hero, champion.] A title of respect commonly affixed to the names of European officers in Indian documents, or used in ceremonious mention by natives: as, Jones Sahib Bahadur. It may be compared to the phrase "gallant offeer" of parliamentary It was conferred as a title of honor by the Great Mogul,
and by other native princes. Yule and Burnell, AngloInd. Gloskary.

Bahama grass, sponge, etc. See the nouns.

bahar (ba-här'), n. [Also baar, barr, barre; < Ar. ing con cording to the substances weighed. In Mlozam. bique it is ahout 250 pounds, in Mocha 450 ponnda, in Susure of capacity. of an East Indian deer; the spotted deer of the Sunderbunds or swampy parts of the Ganges delta; the Rucervus duvaucelli.

bahut' (ba-höt'), n. [F., formerly also bahu, ahus, bahuee (= Pr. bane = Pg. bahú, bahúl = Sp. baul=It. baule), a chest, trunk, with arehed top, prob. < MHG. belwuot, behut, a keeping, guarding, a magazine, < bchuoten, behieten, $G$. huoten, MHG. hüeten, G. hüten, keep, = E. heed, v. $v$ 1. A chest, eften with an arched or convex top, and frequently covered with leather, richly carved, or otherwise ornamented. Such

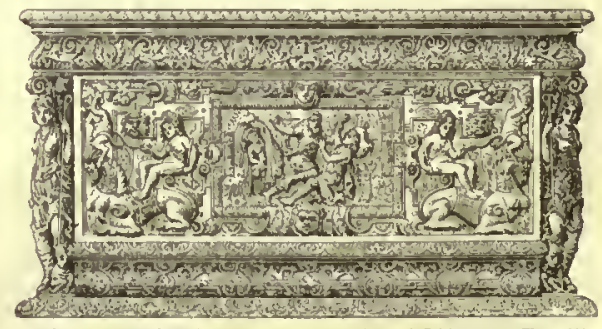

Bahut. - French r6th century work. (From "L'Art pour Tous.") chests were a universal and very important article of fur2. An ornamental cabinet, especially one having doors. See cabinet.-3,-In areh: (a) The convex erowning course of a wall or parapet. Victor Gay. (b) In great medieval buildings, a low wall supporting the roof behind the gut- 


\section{bahut}

ter and balustrade or parapet erowing the main walls. This wall serves both to prevent fufltrm

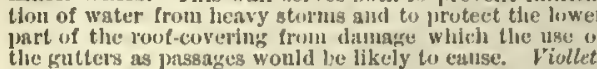
the kr

bahut ${ }^{2}, n$. [<F. Lahutte. Cf. bahut $\left.{ }^{1}\right]$ Adress for masquerading; a domino. N. E. D.

Baianism (bä'yạn-izm), 1 . [From Miehel Buiws, or de Buy, its äuthor.] A systom of religiou opinions, regarded as un anticipation of Jansonism, found in part or construetively in the writings of lsaius (Michel do Bay, 1513-1589) of the University of Louvain. As condemnal by Plus and Gregory XIII., its cllief polnts are: that or before the tall, net an alditional gift of Gorl; that Arlam eould have mertted eternal 11 le as a matter of strict fins. tice; that man as fallen was mulitatcel in nature and capsble of sin only; anil that all works are sinful unless done
from pure love of (ind. latus sulunitied to the conden-

baicht, $n$. An obsolete form of batch ${ }^{2}$. Ray (IIalliwell).

baid (bāl). [North. Eng. and Se., = E. bodle $e^{3}$.] $\Lambda$ proterit of bile.

baidak (bi'diik), $n$. [Russ, bañakit.] A riverboat used on the Drieper and its aftuents. It is from 100 to 150 feet long, and will earry from 175 to

baidar (bì'där), n. [Native name.] A eanoe used by the inhabitants of tho Aleutian and Kurile islands in the pursuit of otters and whales. It is from 18 to 25 feet long,
and propelled by from 6 to 12 paddles.

baiet, $n$. and $a$. Obsolete form of $b a y^{1}, b a y^{2}$ ete.

baierine (bīe-rin), n. [<G. Baiern, Bavaria, $+-i n e^{2}$.] A name given by Beudant to eolumbite obtained in Bavaria.

baiest, $n$. An obsolete form of baize.

baignet, $n$, and $v$. See bain ${ }^{2}$.

baignoire (bả-nwor' ), n. [F., a bath-tub, a box in a theater, <baigner, bathe: see bain2.] A box in a tleater on the same level as the stalls. Sometimes written baignoir.

The twelve baignoirg and the thirty-six bexes of the IIarper's Mlag., LXViI. 884

baikalite (bī'kal-it), n. [< Baikal (Bäakhal said to mean 'abundant water'), a lake in southern Siberia, $+-i t e^{2}$.] A dark-greeu variety of pyroxene, oeeurring in erystals with a lamellar
strueture like that of salite near Lake Baikal in southern Siberia.

bail ${ }^{1}$ (bāl), $n$. [Sometimes improp, bale; ear]y *begel "bygel (not recorded; ef. byge, a bend turn, beáh (> E.bee ${ }^{2}$, a ring) (=D. beugel, a lioop, turn, beah ( $\mathrm{E}$. bee ${ }^{2}$, a ring $)$ ( = D. bengel, a lioop, ring, bow, stirrup, handle, $=$ MLG. bogel, bog-
gel, LG. bögel, a bow, ring, $=\mathrm{G}$. biegel, buigel, a bow, bent pieee of wood or metal, stirrup, Dan. böjle, a bow, bar, boom-iron, $=$ Sw. bögel, bygel, a bow, hoop, ring, stirrup, = Ieel. bygill, a (= G. biegen = Ieel. bjüga, ete.), bow, bend, in part from the causative bygan, bégan, ME. beizen, beien, ete., mod. E. dial. bay $(=\mathrm{G}$. beugen = Ieel. beygja, ete.: see bay ${ }^{9}$ ), bend: see bow ${ }^{1}$,

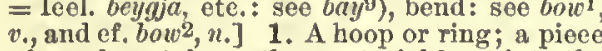
of wood, metal, or other material bent into tho form of a eirele or half-eirele, as a hoop for supporting the tilt of a boat, the eover of a wagon or eradle, ete. Specifieally - 2. Tho hoop form ing the handle of a kettle or bueket.-3. One of the iron yokes which serve to suspend a lifeear from the hawser on which it runs. - 4. A stout iron yoke plaeed over heary guns and fitting elosely over the ends of the trunnions, to which it is attached by pins in the axis of the trunnions: used to raise the gun by means of the gin. Farrow, Mil. Eneye.-5. An arehed support of a millstone.-6†.

bail ${ }^{1}$ (bãl), v. $t$. [<bail,$\left.n.\right]$ To provide with a bail; hoop.

bail' (bāl), v. t. [< ME. "baylen, < OF, bailler, baillier, bailier $=$ Pr. bailar, carry, eonduet, eontrol, reeeive, keep in eustody, give, delivor, conduct, eontrol, rule, < bajulus, a bearer, carrier, porter, in ML. (> It. bailo, balio $=\mathrm{Pg}$. bailio $=$ Sp. Pr. baile $=$ OF. bail, with ML. reflex baillus, balius, ete.) a governor, administrator, tutor, guardian, fem. bajula ( $>$ OF. baille, ete. tutor, guardian, fem. bajula (> OF. baille, ete., verb, iu its eustomary senses, is rather from the noun: see bail $2, n$.] 1. In law: (a) To de liver, as goods, without transferenee of ownership, on an agreement, expressed or implied,
421

\section{bailed}

that they shall be returned or aceounted for. see bailment.

If cloth be delivered (or in onr lagal dlalect, baitel) to a

(b) To set free, deliver, or liberato from anest and imprisonment, upon security given that the person bailed shall appear and answer in conr or satisfy tho julgment given: applied to tho aetion of the magistrate or the surety. 1he ma Glistrate is sadd to bait a jerson (or to admit him to bai
when heliberates him from arrest or imprisonment, upo lond given with suretes. The surety is also said to laid T'it. let me be thelr bail. .

Shak., Tit. And., il. 4

When they [the judges] had baild the twelve lishops the Ilouse of Commens, in grest lndignation, cansed then

2. Figuratively, to release; liberate.

Ne none there was to reskne lier, ne none to brite.
Syenter, F, Q., IV. ix. 7.

3. To be security for; seeure; protect.

We can bail him from the eruclty
Of misconstruction. To ball out, to preeure the release of (a person) by acting sccurity from (s person) that ho will keep the peaee.
baill ${ }^{2}$ (băl), n. [Garly mod. E. also bayle, bnte, (ME. bayle, baill (ML. ballium, balinm), $<\mathrm{OF}$ bail, power, eontrol, enstody, charge, jurisdie tion, also delivery, < bailler, bailier, eonduet. eontrol, ete, deliver. Tho noun is thus historieally from the verb, though in 1 s. the verb in some of its senses depends on the noun: see bail $2, v$.] 1†. Power; eustody; jurisdietion. So did Dians and her maydens all within their baile.

2. The keeping of a person in nominal eustody on seeurity that he shall appear in court at a speeified time. The person is gaid to be admitted to thought of as the security given. See 3 .
3. Seeurity given to obtain the release of a prisoner from eustody, pending final deeision in the aetion against him. In clvil cases a person thereupen be released from eustedy. In eriminal eases the defendant has also this right, as a rule, when the
crime charged is a mere misdemeaner. Whether to bail crime charged is a mere misclemeaner. Whether to bal cretion of the judge, and in some states bail is always de
nied to one helil for a crime pnnishable with death. TJie seeurity is in the form of a bond exeented by responsible sureties, providing tliat the defcndant shall appear at the named in the bond. The person balled is regarded as bu surcties, whe uny therefore selze snd surrender him a
sny time. In eivil eases there are several kinds of ball at Common law, the ehief belng common bait and special bait. to tho sheriff on a batl-bond cntered into by two persons,
on eondition that the defendant appear at the day and i on eondition that the defendant appear at the day and in
sail, bail above, or bait to the action, is given by persens who undertake generally, after sppearance of a defen dant, that if he be condemned in the aetion he shall salisfy in seotiani, bail in civil eases is eslled caution (which see) 4. Figuratively, security; guaranty.

Donbtless this man hath bail enough to be no Adulterer
dIitton, Tetracherden, Works (1738), 1. 251 .

5. Liberation on bail: as, to grant bail. -6 . The person or persons who provide bail, and
thus obtain the temporary release of a prisoner thus obtain the temporary release of a prisoner.
persens who make a business of furnishing bail on pay.
ment of a fee often frequent Jaw-eourts. Formeriy guch ment of a fee often frequent law-courts. Formeriy such pation; henee the term straw bail, used
titions or irrespensible professlenal bail.

The bait must be real substantial bondsmen.

Tho attorney whispered to Mr. Piekwiek that he wa only a bail. "A bail?" "Yes, ny dear sir, half-R-doze
of em here. "Bail you to any ameunt and only charge
half-a-crown."
Dickens, Piek wiek Papers Where those mysterious persenages whe were wont in
the old times to perambulate the great saloon of the futile lootsteps, Westminster IIsll, witl straws in their shoes, and whose occupation is not by any mesng gone now-s
days, sre always in sttendanee in s philanthrople eager ness to render servlee to suffering humanity - or in othe words, to beeome bail where bail is wante

[Bail, being an abstract noun applicable to persons only by ellipsis, is not used in the plurral. - Bail a longues years, termed also an emphyteutic lease, whereby the les gee enjoys for the term all the rights attaehed to the qual ity of proprietor, and can dispose of the property subject to the rights of the lessor. - On batl, on guaranties dnly
given for the appcarance or production of a prisoner in conrt at the proper time: as, he was liberated on bail His [Somerset's] friends sttempted to obtaln his release
on bail. To admit to ball, or to take ball for, to release upon seeurity given. See alove, 2,- To find ball, to proenre
persons to act as ball. - To go bail. (a) To act as ball or surety. (b) To vonch (for a thing): as, Ill go bail for that. - To hold to bail, to ollige to find hail or go to fall.
To perfect or justify ball, to prove hy the outh of the ersou furnishing lanil thut, over and aluve his delots, he bail'3 (bāl), $x$. [Early morl. F. also bayle (still sometimes used archaically in def. 6), < ME. bayle, baile, bail, a larrier, palisale, prob. also a bar (=1). Flem. bulie, a bar, 1'ail), ২ Ol', bail buile, baille, a barrier, palisade, prob. also (as in mod. F. diul. bail) a bar, cross-bar (cf. Ieel. bayull, an episeopal staff, (rozier), prob. ( L. baculum, baeulus, a stick, lod, staff (see baculus, and ef. bailt, < MLd. "bacula) : see bait ${ }^{3}, v$. and ef. deriv. balleys. The noun baik in some pear to depend ult. on that of a bar, or erossbar.] 1t. A bar; a eross-bar.

Set them nppon some perarche or bayle of wood that they maye liy that meanes the better keepe their feather unliroken and esehue the dragging of their tralnes upon
the ground.

Turberville, lioeke of Falconrle, p. 358, (N. $\left.E_{0}, D_{0}\right)$

2. In cricket, one of the two little bars or stieks about 4 inches long, which are laid on the tops of tho stumps, one end resting in the groovo of one stump, and the other iu that of the next. Since they inll with the lightest blow, th
cate when the stumng have been struck.

Oid Bailey gravely sets up the middle stump again, nud puts the bails on, T. Hughes, Tom Brown at Rugby, 11.8 3. A bar or pole to separate horses in a stable. -4. A framework for securing tho head of a 5. [The earliest uso in E.] Milit.: (a) pl. The outer wall or line of defenses, originally often made of stakes; barriers; palisades. See palisade. Heneo-(b) The space inelosed by the outer wall; the outer court of a castle or a fortified post: in this sense usually ealled bailey. See bailcy -6 . A certain limit in a forest.

bail3 (bäl), v.t. [Ėarly mod. E. also bale; appar. baill. bailier, inelose, shut in, bar, appar. sense, direetly ' bail $\left.3, n_{.}, 5.\right]$ 1. To bar in confine. [Rare.]-2. To provide with a bail confino. [Rare.]-2. To provide with a bail.
- To bail up. (a) To secure the head (ol a eow) in a bail atory to rolbbing; order to throw up the arms. [Austrulla.]
[ = MLG. balge, ballige, balleie, ${ }^{2}$, [ M E. beyle $=\mathbf{D}$. balic bueket, = G. Dan. balje = Sw. balja, a tub, It. baglia, a tub, bueket, < $\mathrm{F}$. baille, naut. a tub, bucket, pail, prob. < MT. "bacula, a bueket or tub (ef. bacula, a sinall boat), dim. of baca, bacea, a tub: see baek ${ }^{3}$. Cf. bail 3 , prob. < L. baculum.] $A$ bueket; a pail; espeeially, a
bueket or other small vessel used to dip water out of a boat.

bail 4 (bāl), $v$. [Also less prop. bule; early mod. E. baile, bayle (=D. balien, vit-balien $)$; from the noun.] I. trans. To remove (water), or free basin, or othor small vessel: usually with out.

II. intruns. To remove water,

bail $\overline{5}_{t}$, ete. Obsolete and less proper spelling of balel, ete.

bailable (bā'la-bl), a. [Farly mod. E. also 1. Capable of being delivered; deliverable. 2. Capable of being set free upon giving bond with sureties; capable of being admitted to as, a bailable offense.

bailage (bā'lāj), n. [Also bailiage, balliage, as $v$, and -age.] A duty imposed upon the de$v$, and age.] A duty imposed upon the de-
livery of goods; an aneient duty reeeived by the eity of London for all goods and merehandise brought into or carried out of the port. Chambers.

baill-bond (bāl'bond), $n$. A bond or obligation given by a prisoner and his surety to inthe return of the writ.

bail-dockt (bãl'dok),n. [Prob. $\left\langle\right.$ bail3 + dock $^{3}$. Formerly, at the Old Bailey in London, a smail room taken from one of the corners of the tain malefaetors were placed during trial. Also spelled bale-doek.

Penn and Mead, for their stont defence at their trial, were dragged into the bale-dock, and the Recorder yroceeded to eharge the jury during their detention there, bailed + (bāld), p. a. [< bail $\left.+e d^{2}.\right]$ Provided with a bail; hooped and covered, as a wagon. 
bailee

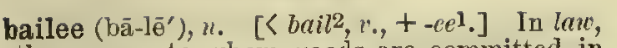
the person to whom goods are committed in bailment. He has a temporary possession of
them and a qualified property in them for such

purpose only.
bailer ${ }^{1}, n$. [<bail $\left.l^{2}+-e r^{1}.\right]$ See builor.

bailer' (bā'lér), $n$. [<built + er 1.$]$ i. One who bails out water, or frees a boat from water. -2. A vessel nsed for bailing water.

For river or lake work $\Omega$ sponge and baler may be suffleient, but for sea cruising and efrective puning should be
fitted. Also baler.

bailey ${ }^{1}$ (bā'li), n. [Early mod. E. also baily, bailic, < ME. baily, bailie, baillie, bailly, baili, ete., an extended form (prob. after the IL. balium,

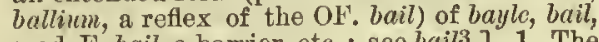
mod. E. bail, a barrier, ete.: see bail3.] 1. The external wall of defense about a feudal castle
(see bail 3 ); by extension, any of the circuits of (see bail 3 ); by exteusion, any of the circuits of
wall other than a keep or donjon, that is, any line of defense other than the innermost one. -2 . As used by later writers, the outer court or base-court of a castle; by extension, any court of a defensive post used with a distinctive epithet. The inner bailey contained the stables and often thie cliapel, etc., and communicated directly with the keep
the outer baitey, when there were only two more commonily contained the chapel and sometimes a tilt-yard, exerciseground, or the like. The entranceway to a castle, aiter passing the defenses of the barbican, led first into the outer hailey and thence into the inner bailey; but it was usual
for the keep to have also a separate communication with for the keep to have also a separate communication with
the exterior. [The word is still retained ln some proper nal court of Iondon, so called from the ancieut bailey of the city wall between Lud Gate and New Gate, within which it was situated.]

Also ballium.

bailey ${ }^{2}, n$. See bailie ${ }^{2}$

bailiage $1, n$. See bailagc.

bailiage $e^{2}$, bailliage (bā'li-āj), $n$. [Formerly also baillage, baliage, and balliage (ef. ML. bal liagium, baillagium, baliaticum), < $\mathrm{F}$. bailliage (=Pr.bailiatge $=\mathrm{Sp}$. bailiage), $\langle$ bailli, abailiff bailie, + -age.] The jurisdiction or district of a bailiff or bailli; a bailiwick: now used chiefl French or to Swiss bailiwicks.

At first four bailliages were created.

The several orders [in France] met in their bailliages in 1789 , to choose their representatives [in the Assembly]

bailiary, $n$. See bailiery. bailie $^{2}$ (bā'li), $n$. [Now only as Se, also spelled baillie, baily, early mod. E. also baily, bailey, bayley, ete., < ME. baylie, bayly, baillic, baili, baill $\langle\mathrm{OF}$. bailli, earlier baillif, $\rangle \mathrm{E}$. bailiff, of which bailie 2 is thus a doublet: see bailif:] 1†. A
bailiff.-2. In Scotland: (at) The chief magisbailiff.-2. In Scotland: (at) The chief magis trate of a barony or part of a county, having
fumctions equivalent to those of a sheriff. $(b)$ A municipalofficer or magistrate, corresponding to an aldermau in Englaud. He possesses a certai jurisdiction by common law as well as hy statute. The
criminal jurisdiction of the provost and ballies of royal burghs extends to breaches of the peace, drunkenness,
adulteration of articles of diet, thefts not of an aggra vated character, and other ofienses of a less serious na-
ture. Formerly, a person appointed by precept of sasine $t$ give infeftment in land (a legal formality now abolished) was also called a bailie.

bailiery, bailiary (bä'li-e-ri, -ā-ri), n. [Early <bailli: see bailic ${ }^{2}$ and -ery.] In Scots law, a bailie's jurisdiction. Also bailliery, bailliary. Letter of baillery, a conmission by which a heritable a haron bailie, with the nsual powers, to liold courts, apbailiff (ba'tlif), n. [Farly mod. E. also bayliff, baliffe, bailive, etc., < ME. bailif, baillif, balyf, etc. (ML. ballivus), < OF. baillif (later bailli
E. bailie ${ }^{2}, q$. v.), <ML. *bajulivus, prop. adj., E. bailie ${ }^{2}$, q. v.), $<\mathrm{ML}$. *bajulivus, prop. adj.,
bajulus, an administrator, manager, guardian, tutor, etc., in L. a carrier, porter: see bail2, v.] 1. A subordinate civil officer or functionary. There are in England several kinds of bailiffs, whose offices differ whdely, but all agree in this, that the keeping or pro-
teetion of something belongs to them. 'The sherift is the sovereigu's bailiff, and his county is a bailiwick. The name is also applied to the chief magistrates of some having the conservation of the peace in hundreds and in some special jurisdictions, as Westminster, and to the returning-officers in the same. But the officials conmonsherifis officers, who execute processes, etc., and bailiffs of liberties, appointed hy the lords in
jurisdictions to perform similar functions.

2. An overseer or under-steward on an estate appointed to manage forests, direct husbandry operations, collect rents, etc. Also called a bailiff of forests, or bailiff in lusbandry.-3. An officer of the Kuights of St. John of Jerusalem. above, 2.-High balliff, in England: $(a)$ T'le chief ofltcer of certain corporations. (b) The officer of a county court. (c) The officer who serves writs and the like in of the sheriff. - Special bajliff, a person named by a party in a civil suit for the purpose of executing some particular process therein, aud appointed by the sherift on the appliofficer eniployed in protecting a river from poacliers and from being fished at othe permitted by law.

bailiffrył (bā'lif-ri), n. [Early mod. E. also bailivery; < bailiff $+-\rightarrow y$.$] The office or juris$ dietion of a bailiff bailiffship (bā'lif-ship), $n . \quad[<$ bailiff + -ship. $]$
The office of bailiff.

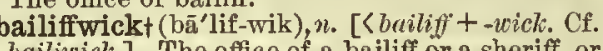
bailiwick.] The office of a bailiff or a sheriff, or bailing-machine (bã' ling-ma-shēn "), n. A bailing-machine (ba- ling - ma

bailiwick (bā'li-wik), n. [<ME. bailic-, bayly-, ete., +-wikc, ete.; <bailic ${ }^{2}+$-wick.] The coun ty within which a sheriff exercises his office the precinets in which a bailiff has jurisdiction the limits of a bailiff's authority, as (in Eng which a bailiff is appointed.

There is a proper officer allreadye appoynted for these it is to It is to walke continuallye up and downe his balywick, bailliage, $n$. [F.] See bailiage ${ }^{2}$.

baillielt, $n$. See bailey 1 .

baillie2t, $n$. See bailic ${ }^{2}$.

baillie-brushkie (bā"li-brush'ki), n. [Native name in Alaska.] The parrakeet-anklet, Pha leris or Ombria psittacula. H. W. Elliott.

bailliery, bailliary, $n$. See bailiery.

baillon ( $\mathrm{F}$. pron. ba-lyôn' '), n. [< F. baillon, gag, of uncertain origin; either (1) dim. (as if ¿L. *baculo, *baculon-) of $\mathrm{OF}$. baille, bail, a bar,
barrier (seebail3); or (2), written baillon, $<$ bailler, OF. baailler, baailer = Pr. badaillar = Cat badallar = It. sbadigliare, gape (cf. ML. badal lum, a gag), < ML. badare, gape, open the of cork or other material used to keep the mouth open during operations, dental or surgical, in the mouth.

bailloné (ba-lyo-nā'), a. [<F. baillonné, pp. of bdillonner, gag, < baillon, a gag: see baillon.] of an animal used as a bearing.

bailment (bãl'ment), $n$. [Early mod. E. also bailement, < OF. baillement, $<$ bailler, deliver or legal relation which is constituted by the or legal relation which is constituted by the
delivery of goods without transference of ownership, on an agreement expressed or implied that they be returned or accounted for, as a loan, a consignment, a delivery to a carrier, a pledge, a deposit for safe keeping, or a letting on hire.-2. The act of bailing a prisoner o uments relating to such a bailing.

bailo (bä'i-1ō), n. [It., < ML. bajulus, a manager, administrator, guardian, ete.: seo $b_{a i l^{2}}, v$. toman Porte. N. E. D.

bailor, bailer ${ }^{1}$ (bà'lor, -lèr), $n_{\text {. }}\left[\left\langle\right.\right.$ bail $^{2}, v^{\prime}$, + -or, -erl.] In law, one who delivers goods to another in bailment. See bailment, 1 .

bail-piece (bāl'pēs), $n$. In law, a certificat issued to a person by a court attesting

bail-scoop (bāl'sköp), n. [<bailt + scoop. $]$ A scoop pivoted at one end, fitted with valves, and so arranged that a large quantity of water may be raised by it through a short distance used in draining and irrigating.

bailsman (bãlz'man), $n_{*} ;$ pl. bailsmen (-men). [< bails, poss. of bail $2, n .,+$ man.] One who gives bail for another; a surety or bail.

baily ${ }^{1}+\left(\mathrm{ba} \bar{z}^{\prime} l i\right), n$. Obsolete spelling of bailey baily't (bā'li), $n$. The regular English spell ing of the word now used only in the Scoteh spelling bailie. See bailie 2 .

Lausanne is under the canton of Berne, governed by Addison, Travels in Italy.

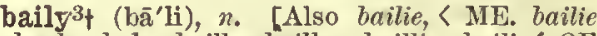
bayly, baly, bailly, baillye, baillie, baili, < OF. bailie, baillie = Pr. bailia $=\mathrm{Sp}$. bailia $=$ It. hali (ML. balia, ballia, bailia, baillia, baylia, bayllia) ML. bajulia, the jurisdiction or office of a bai- iff, < bajulus, an administrator, governor, bailiff: see bail 2 and bailiff, bailie ${ }^{2}$.] 1. The jurisdiction, authority, or office of a bailifi or bailie; hence, jurisdiction or authority, especially as delegated; stewardship.-2. The district of a bailiff or bailie; a bailiwick.

Baily's beads. See bcad. bain 1 (bãn), a. [Now only E. dial, also written
bane, < IIE. bayne, bayn, bcyn, <'Icel. bcina, bane, MF. bayne, bayn, bcyn, < Icel. bcinn, straight, direct, hospitable, $=$ Norw. bein,
straight, direct, easy to deal with.] 1. Direet; near; short: as, that way's the bainest (bancst). near; short: as, that way's the bainest

Bc thou buxom and right bayn.

3t. Limber; pliant; flexible.

bain l (bān), adv. [E. dial., also bane, < ME.

bayn, bain; from the adj.] 1. Near by; at

hand. [Prov. Eng.]-2†. Readily; willingly.

The berne besily and bane blenkit hem about.
Gawan and Gologras, i. 6 (in Pinkerton's Scottish Poems)

bain²+ (bān), n. [Early mod. E. also bane, < MIE.

bayne, baine, $\angle \mathrm{OF}$. and $\mathrm{F}$. bain $=\mathrm{Pr}$. banh $=\mathrm{Sp}$.

baño $=\mathrm{Pg}$. banko = It. bagno (> F. bagne, $\mathrm{E}$ bagnio, q. v. < <. balneum, a bath, bath-house: see balneum.] 1. A bath, in any of the senses of that word.-2. A bagnio or brothel.

bain't (bãn), $v$ [<ME. baynen, < OF. baigner =

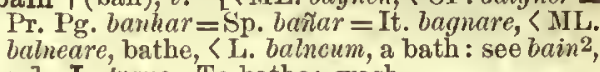
n.] I. trans. To bathe; wash.

He that in Furotas' silver glide

II. Intrans. To bathe one's self; take bain ${ }^{3}$, ete. Obsolete spelling of bane, bone, ete. bainbergł (bãn'bêrg), n. [Appar. F., <G. "beinberg (not found) $=\mathrm{AS}$. bünbeorg, bänberge, bangebeorg, also ealled scanegebeorg, lit. 'bonebeorh, 'neck-guard,' hauberk: see hauberli), < bān, bone (= G. bein, leg), or scanca, shank, leg, + beorgan, protect.] A name given to the plate-armor of the leg below the knee, when first introduced. It was worm over the chain-

Baines's act. See act.

bainie (bā'ni), $a$. Seotch form of bony.

bain-marie (F' pron. bańma-ré $\left.\bar{e}^{\prime}\right), n$. [1'., formerly bain de Marie, $\mathrm{ML}$. balneum fanciful name, perhaps in al Iusion to the 'gentle' heat. The second element is some. times erroneonsly referred ing heated containplaced in order to heat its contents gently, or with more regularity and evenness than if the heat were applied directly to the second vessel: used in solne operations of cooking, manufac-

bainst, $2 \%, p l$. Another spelling of banes, obsolete form of banns. Spcnser.

baiocco, bajocco (bä-yok'kọ), n.; pl. baiocchi bajocchi $(-\mathrm{ke})$. [Formerly in E. baiock, byok

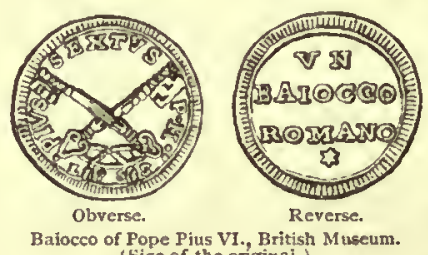
ocque, ba oque), < It. baiocco, ba jocco, a small coin, so ealled from its color, $<$ baio,
bajo, brown bay: $\quad$ see

small coin of the former Papal States, struck in both silver and copper, worth about a cent.

Bairam (bī-räm', bī'rä̀m), n. [Formerly bayram, beyram, <Turk. bairäm, bayrām, bciram, Pers, bairām.] The name of two festivals in the Mohammedan year, distinguished as the lesser and the greater. The lesser Bairam follows immedi ately after the fast strictly kept during the ninth month Ramadan, in the first three days of the tenth month, and
ls devoted to feasting, rejoicing, visiting, and gifts, very
much as our Christmas holiday season is spent, The greater Bairam occurs on the tenth day of the iwelfth month, and is everywhere observed with the slauchter of sheep and general festivity by those at home, simultane ously with the great sacrificial feast at II ecca concluding the ceremonies of the annual pilgrimage by the hadjis. bairmant, $n$. See bareman. 
bairn

bairn (bärn), n. [Sc. form of the reg. E. barn ${ }^{2}$ (now only dial.), < ME. bam, bern, $\ \Lambda$ S. beam (= OS. barn $=$ Olries. barn $=$ OD. baren = barn), a ehild, < beran, E. bearl.] A chill; a son or daughter. See barn'2. [North. Ling. and Seotch.]

T'hink, like gond Cliristians, on your bairns and wives.

As she annunciated to her bairns the upshot of hor practical experience, ahe pulled from her pocket the jor tions of tape which showed the fength and breadtl of the
vartons roouns at the hospltal house.

Bairns' part of gear. In Scuts law, sane as legitim.

bairnliness (bãrn'li-nes), n. [<"bairnly (<bairn being a child or like a child. [S'oteh.]

bairntime (bãrn'tin), n. [Sc., < ME. burn team, barn-tem, ete., < AS.bearn-team (= OFies. barn-täm) teím, fanily: seo bairn and tean.] A family of children. [Old Eng. and Scoteh.]

Thae hennle baimutime Ileav'n fias lent.

Buens, A Drean.

bairnwort (bãrn'wêrt), n. $\Lambda$ name for the common English daisy, Bellis perennis.

baisemaint (bā $z^{\prime}$ mãn), $n$. [ [ $\mathrm{H} .,<$ baiser, kiss (<L. basiare, kiss, < basinm, a kiss), + main, LL. mamus, hand.] A kissing of the hands; in the plural, compliments; respeets.

baisementt, $n$. Same as baiscmain.

bait ${ }^{1}$ (bāt), v. [< ME. baiten, beiten, bayten, beyten (= OF. beter, bait, in comp, abeter, urge as with hounds or hawks, bait, as a hook (= Sw. beta = Dan. bede, bait, = AS. betan, also Sw. beta = Dan. bede, bait, = AS. bàtan, also gebātan, bridle, curb (ef. bätian, bait, ‘ bāt, bait), = MD. leeten = OHG. beizen, beizzen, MHG. G. beizen, bait), lit. cause to bite, ( bite $=$ AS. bitan, E. bite: see bite. In senses 5 and trans. 1f. To cause to bite; set on (a dog) to bito or worry (another animal).-2. To provoke and harass by setting on dogs; set a dog or dogs to worry or fight with for sport, as an a bull or a bear.

We'll bait thy bears to death. Shak., 2 Hen. VI., v. I

3. To set upon, as a dog upon a eaptive animal; hence, to harass in any way; annoy; nag; badger; worry.

As chatned beare whom eruell doga dloe bait.

Ilow oft have I been baited by these peets,

And dare not be revenged.

Marlowe, Edward 11., i1.

Baited thus to vexalfon, I assum'd

4. To feed; give a portion of food and drink to especially upon a journey: as, to bait horses.

The Sunne, that measures heaven anl day long,

At ulght doth baite his atcedes the Ocean waves emong.
Spenser, F. Q., 1. I. 3.

5. To put a bait on or in: as, to bait a hook line, snare, or trap.

llany oorts of figles feed upon insects, as is well know

6†. To allure by a bait; eateh; captivate: as "to bait fish," Shak., M. of V., iii. I.

Do their gay vestments his affectiona bait?

But thls day she baited
A stranger, a grave knight, with tier loose eyes. W. Jonson, Volpone,

II. intrans. 1†. To act in a worrying or harassing manner.-2. To take food; feed. -3 . To stop at an inn, while on a journoy, to

Thenee baiting at Newmarket, atepping In at Audiey End to see that house againe, I slept at Bishops Strotford,
and the next day home. Lvelyn, Diary, Sept. 13, 1677 bait (bảt), n. [< ME. bait, bayte, beite, beyte, (Ieel. beita, f., bait (ef. beit, neut., a pasture) (= AS. bãt, bait, = MHG. bciz, beize, hunting), < beita, feed, bait: see the verb. The $\mathrm{E}$. noun is in part directly from the E. verb.] 1. Any substance, as an attractive morsel of food placed on a hook or in a trap to allure fish or other animals to swallow tho hook or to enter the trap, and thereby be caught; specifically, worms, small fishes, etc., used in fishing. Henee

-2. An allurement; enticement; temptation. 1 do not like that ring from him to her, Inean to wamert F'leteher, Loyal subject, Ii. 2

Their riper years were knowne to be unmor'd with the
423

bakey

The chtef lail which attractert a neely sycophant to the

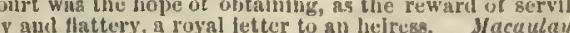
3. A portion of food and drink; a slight o informal repast. (a) Refreslunent taken or a journey, ly man or beast.

If you grow dry lefore you end your tusiness, pray take B. Jimson,

(b) A luneheon; food eaten by a laborer durin his shift. [rood eaten by a laborer durfreshment or rest in the courso of a journey.

The telfousness of a Iwo hours' bait at l'etty France, in Wilch there was nuthing to be done bint to eat withon being hinngry, and loiter alout withont anything to see 5ł. A refreshment or refresher.

A pleasannt companfon is a brit in a journy.
Lyly, linphuea, Anat. of Wit, p. 103. 6ł. A basty meal; a snack.

lle rather look a bait than made a meal at the inns of

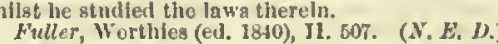
7. Short for uhitebait

bait2t, ete. All obsolete form of batel, ete.

bait-box (bāt'boks), $\cdots$. 1. $\Lambda$ small box in fish. - 2. A tauk in which bait for fish is taken to the fishing-ground.

baiter (bä'tèr), $n$. One who baits or wolries (animals); hence, a tormentor; a tease.

baith (bätli), a., pran., or conj. $\Lambda$ Seoteh form of bath.

baiting (bā'ting), n. [< ME. baitiuy, bayting, ete.: verbal $n$. of baitl.] 1. The act of worrying a chained or confined animal with dogs. Hence-2. The act of worrying and harassing persistent amnoyanee. -3 . The act of halting on a journey for rest and food for either man or beast. -4 . The act of furnisbing 2 trap, look, ete., with bait.

ean fishermen for cutting mackerel, salted herrings, ete., into small pieces for bait. It consist of a roller armed with knives and in elosed in an uprigin bait-poke (bāt'pōk), ". In conl-mining, bag in which bait or luncheon is carried ints the mine.

aittle (b. $\left.\overline{\mathbf{a}}^{\prime} \mathrm{tl}\right), a$. A Scotch form of battle 3 . baitylos, $n$. See batylus.

baize (băz), n. [Farly mod. E. also bays, bayes, bense, baies, $<$ OF. buies (Godefroy), pl., also in sing. baye (Cotgrave), baize (whence also $\mathrm{D}$. baai, LG. baje $\left(>\mathrm{G} . b_{0}\right)=\mathrm{Sw} . b_{0 j}=\mathrm{Dan} . b a$ = Russ. baika, baize; ef. dim. sp. bayeta $=$ Pg. baeta $=$ It. bajetta, baize), < bai (= Sp. bayo Pg. baia $=$ It. bajo), bay-colored. The word is
thus prop. pl. of bay 6 , formerly used also in the singular: see bay 6.] 1. $\Lambda$ coarse woolen stuf with a nap on one side, and dyed in plain colors usually red or green. Baize (or bay) was first mannfactured in England in 1561, under letters patent lssued to eertain refugees from the Netherlands, who had attlen Baize is now ehjefly used for linings, table-covers, eurtain

and finer material, and was used for clothing. See bay. 2. Any artiele, as a table-cover, a eurtain, etc.,
made of baize; specifically, in theaters, the plain eurtain lowered at the end of a play.

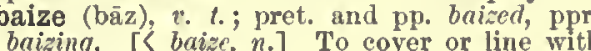

bajadere, $n$. See bayadere.

bajdarka, $n$. Same as bidarkee.

Bajimont's Roll. See Bagimant's Roll, under

bajjerkeit (baj'ér-kît), n. [< Beng. bajraki (Hunter).] A name of the Iranis pentadactyla or bajocco, n. See baiocco.

bajra ${ }^{1}$ (buj'räi), n. [Hind. and Beng. bajrā.] Same as budgero.

bajra2, bajri (baj'rạ̈, -rệ), n. [Also written bajree, bajerce, bajury, repr. Hind. bäjra or bājri also bäjrā; bäjiri prop. denotes a smaller kjnd which ripens earlier.] A species of millet Pennisetum typhoideum, much used in the East bajulateł (baj'tu-lāt), v.t. [<L. bajulatus, pp. earry to some other place, as in badgering (which seo).

bake (bāk), v.; pret. and pp. baked, ppr, bak ing. [<ME. baken, <AS. bacan (pret. böe, pp. bacen $)=\mathrm{D}$. bakken $=\mathrm{LG}$. bukken = Fries. bach = OHG. bacchan, $\mathrm{MHG}$, baehen, G. baeken =
icel, baka = Sw. baka = Dan, bane, bako, prob. = Gr. фwyetr, roast, parch.] 1. trans. 1. To cook by dry heat in a closed place, such as an oven: primarily used of this manner of cooking bread, but afterward applied to potatoes, apples, etc., and also tlesh and fislı: to bo distinguisherl from roast (which see)

1 inve brebed firead upun the coals. 1sa, xliv. 10 2. To harden by lieat, either in an oven, kiln, or furmace, or by the sun's heat: us, to balie brieks or pottery. $-3 \nmid$. To harden by cold.

They buke their aides upon the cold hard stuste.

$$
\begin{aligned}
& \text { The carth } \\
& \text { When it is bak'd with frost. }
\end{aligned}
$$

Shak., Tenupest, 1.2

II. intrchs. 1. To do tho work of baking.

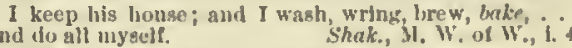

2. To undergo the yrocess of baking.

bake (bāk), n. [<bake, $v^{\circ}$ Cf. batch1.] A baking.

After this Esan fluished the oven, and accomplishell a bakeboard (bāk'bōrd), n. $\Lambda$ board on which dongh is kneaded and rolled out in making bread.

baked-apple (bākt'ap'l), n. $\Lambda$ name given in Labrador to the dried frut of the Rubus Chamemorus, or eloudberry.

baked-meatt, bake-meat (bākt'-, bāk'mēt), n. [Prop, baked meat: $[$ baled + meat.] 1. Food prepared by baking; a dish of baked meat or lood

In the uppermast liaket there was of all manner of Thrift, thrift, lloratio : the funeral bak'd meats

Dit coldly furnials forti the marrlage tabiea.

2. A meat-pie.

Should know what towl gpeak as if a man

vebster, White Devll, Iv.

bakehouse (bāk'hous), n. [E. dial. also backhouse; < ME. bak-hanse, bachouse (= I,G. back$h u s),\langle$ AS. bechüs, $<$ bacan, bake, + hüs, liouse.] A building or an apartment used for the pre-

paring and baking of bread, ete.

bakent (bä'kn). An obsoleto past participle of bake.

baker (bā'kẻr), n. [< ME. baker, bakere < AS. bacere (= OS. bakkeri $=\mathrm{D}$. bakke ${ }^{\circ}=\mathrm{G}$. baicker, becker $=$ Icel. bakari $=$ Sw. bagare $=$ Dan. ba ger), ( bacan, bake: see bake and -erl. Hence bakester, backsterl, baxter.] 1. One who bakes; specifieally, one whoso business it is to make used in baking. [U.S.] - 3. The popular name of the flesh-fly, Sarcaphaga carnuria.-Bakers dozen, thirteen reckoned as a dozen. It was euatomary the extra plece heing called among baker a the in-bread o to-bread. Brewer says the eustom originated when heavy penaltica were inflicted for short weights, loskers plyhg the extra bread to seeure themselves - Bakers 1tch, baek of the hand. It often appears in l,akers. - Bakers' salt, allbcarbonale of ammonia, or amelling-saits, 80 called minufacture of some of the flner kinds of loread.

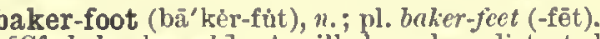
[Cf. buker-legged.] An ill-shaped or distorted foot: as, "bow-legs and baker-feet," Jer. Taylar (३), Artif. Handsomeness (1662), p. 79. baker-kneed (bā'kèr-nēd), a. Same as bakerbaker-legged (bā'kẻr-legd), a. Disfigured by having erooked legs, or legs that bend inward at the knees.

bakery (bā'kèr-i), n.; pl. bakervies (-iz). [< bake + -ery.] 1. The trade of a baker. [Rare.] 2. A place used for making bread, ete., or for
the sale of bakers' goods; a bakehouse or baker's establishment: a baker's shop.

bakestert, n. [Also backster, baxter (whence the propername Baxter), (ME. bakestere, bacster, baxter, usually masc., $\mathrm{AS}$. bacestre (fem. in form, but mase. in use), a baker, < bacan, bake, + -cs-tre, E. -ster.] A baker; properly, a female baker: "brewesteres and bakesteres, Piers Plotman. In Scotland commonly written baxter: as, baxter wives.

bakestone (bāk'stōn), n. [E. dial., also backstone.] A flat stone or slate on which cakes are baked. [Prov. Eng.]

bakey (bâ'ki), n. [Se., also bukie and baikie, dim. of back $3, n_{0}$.] A square wooden vessel narrower at the bottom than at the top, and with a handle on eaeh of two opposite sides, used for earrying coals, ashes, ete.; a wooden coal-seuttle. Also spelled bakic and baikie. See back 3 , 3. [Scoteh.] 
bakhshish

bakhshish, $n$. Seo brlishish.

baking (bâ' king), $n$. [Verbal n. of bake.] 1 . The act of baking. -2 . The quantity baked at onee: as, a baking of breal. Also ealled balic and batch.

baking-powder (bā'king-pou "dẻr), n. Any powder used as a substitute for yeast in raising bread, eakes, etc. 13aking-powders are composed of

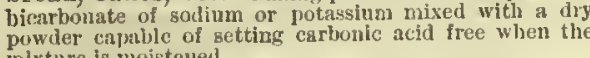

bakshish, bakhshish (bak'shēsh), n. [Also backshish, backshecsh, bukshish, etc., <Turk. Ar. Hind. bakhshish, < Pers. bakhshishh, a present, $<$ bakilshiclan, give.] in the East, a present or gratuity in money.

We pronised lim tacksheesh for a sight of the sacred hook. B. Taylor, Lands of the Saracen, p. 94. "Bakhshish," says a modern writcr, "is a fee or luresent which the Arabs (he here means the thyphisis, claimo thll occasions for services you render them, as well as for services they have rendered youl. This balkshish, in fact,
is a sort of alms or tribnte, which the poor Arab befieves linsclf entitled to clain from every respectable-lookla bakufu (bak'ú-fö), $n$. [< Jap. baku, curtain, + $f u$, office.] Curtain-government, that is, the government or couneil of the former shoguns of Japan: so called in allusion to the curtain used in time of war to screen off that part of the camp occupied by tho general or shogun. See shogun.

On the 3rd of June the Shôgun hsd an andience of the Mikado. IIts majesty"s speech on the occasion was as to govern the cumpire in pesce, and on the other to subjubal (bâl), n. [Formerlȳ alse ball, < Corn. bal, a mine (Pryce), a cluster of mines (Borlase).] A mine. [Cornwall.]

bal. An abbreviation of balance.

balaam (bā'lam), $n$. [In allusion to Balaam and his "dumb ass speaking with man's voice" (Num. xxii. 28-30; 2 Pet. ii. 16).] 1. Matter serted in a newspaper to fill space. [Euglish printers' eant.]

Balat $m$ is the cant name for asinine paragraphs about monstrons produetions of nature and the like, kept stand ling in type to be insed whenever the real news of the das

2. Same as balkam-box.

Bring in Balaam, and ylaee him on the table. balaam-box, balaam-basket (bā'lam-bolss, - An editor's depository for worthless mattor, rejected writings, ete.

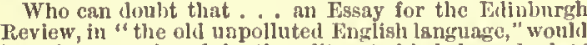
(he editor, to his balaam-ba sket

Balaamitet (bā'lam-īt), n. [< Balaam (Num. xxii.) $+-i t e^{2}$.] One who makes a profession of
religion for the sake of gain: in allusion to the prophet Balaam.

Balaamiticalt (bā-lam-it'i-kal), a. Pertaining to or eharaeteristic of a Balaamite.

Bala beds. Seo bed 1 .

balachan (bal'a-chan), $n$. Same as bulachon

balachong (bal'a-ehong), $n$. [< Malay bäla chān.] A substänee composed of small fishes or shrimps pounded up with salt and spices,
and then dried. It is much nsed in the East and then dried. for rice. Also balachan, Irikechoung,

baladine, $n$. See balladin.

Balæna (ba-lē'nä), n. $[1$. Gr. $\phi a \lambda a c v a$, more correctly whale.] typieal genus of whalebone whales, of the amily Balcenidee, having the bre ankylosed, the fore limbs pentadactyl, the head enormons with long blaek

elastic baleen,

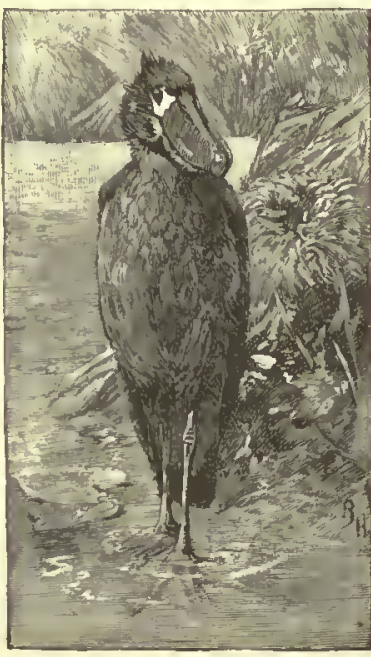

424

balance

ont furrews, and no dorsal fin. It contains the (rechland or aretic whale, $B$. mysticetus, and several and Balamide.

Balæniceps (ba-lē'ni-seps), $u_{0} \quad$ [NL., < L. balena, a whale, +-ceps, < cuput, head.] A genus of grallatorial altricial birds, of which the type and only known member is the shoebill or whalehead of Africa, B. rex, comparatively lately diseovered on the upper part of the White Nile. The genus is the type of a family Balcenicipida, of somewhat uneertain position, probably near vanlted beak, which is nuch longer than the head. Little is known of its labits and economy. It is a large specles, standing upward of 3 feet high. The bill soneWhat rescmbles that of the boat-billed hero

Balænicipidæ (ba-lē-ni-sip'i-dê), n. pl. [NL. Balcniceps (-cip-) $+-i d a$.$] A family of birds,$ of which the genus Balaniceps is the type and only known representative. It helongs to the altricirl or herodionine scries of wading birds,

balænid (bal'ê-nid), $n$. A eetacean of the famly lialcenide; any right whale.

Balænidæ (ba-lē'ni-dē), n. pl. [NL. < Balana + ida.] A family of right whales, or true whale hone whales, typi-

fied by the genera

Balona and $B a$ -

lenoptera, having

teeth. Teeth are,

however, present in
the fetus, thought they

never cut the gum.

vided into two sec-

tions, the smooth

by smoothness of skin

and the absence of a

Greenland or right

whale, Baltena me fur.

rowed whales, in which
the skin is furrowed

and the ilorsal fin is

prescint, as the fimners
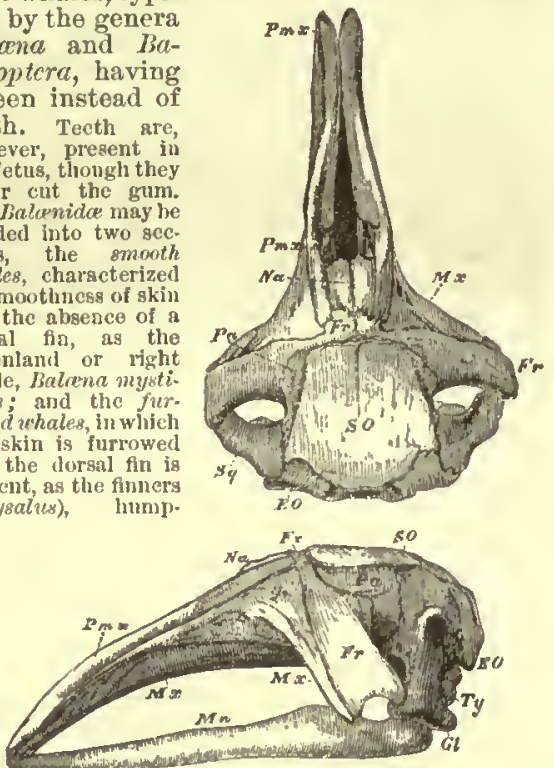

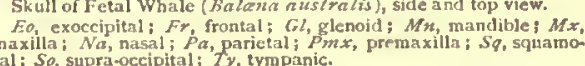

hacked whales (Megaptere), and rorquals or piked whales (Balenoptera). The term is sometimes restrifted to the

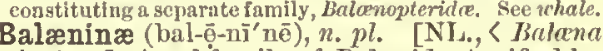
$+-i n a$.$] A subfamily of Balnenidce, typified by$ the genus Balana, eontaining only the smooth right whales. See Jaloenide.

Balænoidea (bal-ẹ-noi'dẹ-ä), n. pl. [NL., One of the three primary groups into which the cetacea are divisible, Phocodontia. It ombraees the right whalos (Balcena) and the fin-whales (Balanoptera etc.).

Balænoptera (bal-ē-nop'te-rä), n. [NL., < L. balana, a whale, + Gr. $\pi \tau \varepsilon \rho o v$, a wing. A ge eral species of piked whales, rorquals, finners, finbacks, or razor-backs, so called from their long, sharp, falcate dorsal fn. They are found in all seas. Soine are very large, as $B$. sibbaldi, which attain is short and coarse; the skin of the throst is folded; the head is small, flat, and pointed; the body is long and slender; snd the cervical vertebra are free. Conmon Atlan-
tic species are $B$. musculus and $B$. borealis. The whale balænopterid (bal-ề-nop'te-rid), $n$. A cetacean of the family Balanopteridice.

Balænopteridæ (bal " $\overline{\mathrm{e}}-\mathrm{nop}-\mathrm{ter}^{\prime} \mathrm{i}-\mathrm{d} \overline{\mathrm{e}}$ ), n. $n l$. [NL., Balanoptera + -idle.] The furrowed whalebone whales; a family of mysticete cetaceans, typified by the genus Balcenoptera, having the throat plicated, the dorsal fin developed, the cervical vertebræ free or incompletely anky losed, tho flippers with only 4 digits, and the baleon short and coarse. It contains the lmmpbacked
and the finner whales, sometimes respectively made types and the finner whales, sometimes respectively made types
Balænopterinæ (bal-ē-nop-tê-rī'nē), n. pl. [NL., < Balanoptera + -inc.] "A subfamily of whalebone whales, typified by the genus Balenoptcra. (a) A subfamily of Brelonida, ineluding the furrowerl as distinguished from the smooth right whales or Butceninoe. (b) A subfanily or Balanopterida, in ancked whales or Megayterince, laving a high, crcct, falcate dorsal fin, and digits of notive name.] A musical instrument of tho Senegambian negroes, over gourds to increase their resonance. Its compass is two octaves.

alalaika (bal-a-lì'kä̈), n. $\quad[=\mathbf{F}$, balaleik $a=\mathrm{G}$. balalailia, repr. Russ. balalaika.] A musical instrument of very ancient Slavic origin, common among the Russians and Tatars, and, according to Niebuhr, also in Egypt and Arabia. It is of the guitar kind, and has two, three, or four strings, the gijssies of eastern Europe.

The dances of the gipsies, accompanied by the nusle of the balalaika, and clapping of hands.

Bala limestone. See linestone.

balance (bal'ans), n. [ [ ME. balance, balaunce, early mod. F." also ballance, belaunce, ete., $\angle \mathrm{OF}$. balance, F. balance $=$ Pr. balansa $=$ Sp, balanza, Jance $=$ Pg. balança $=$ in libra bilunx, a balaneo having two seales, in libra bilanx, a balance having two seales, balance. See $b i-2$, tance ${ }^{2}$, launce ${ }^{2}$, and aumecl.] 1. An instrument for determining the weight of bodies as compared with an assumed unitmass. In its simplest and most selentific form it consists of a horizontal lever, having its fulcrum (which is a knile-edge) just above the center of gravity of the whole balance, and carrying two pans suspeuded as delieatcly as possible (nreferably from knifeedges) at equal distances tongue-pointer or index (a slender rod) rigidly attached to the midale of the beam or lever, snd extending vertically np or down. Except in coarse balanees, there is a divided scale, over which the end of the tongue noves in the oseillations of the balance. All delicate balances arc protected vanees for steadying the pans, and often for removing the vanees for steadying the pans, and often for removing the
knives from their berings and for replacing them. Exccedingly delicate balances are sometimes inclosed in vacunm-chambers, and have machinery for clianging the weiphts. In using the balance, the substance to be weighed is placed in one pan or scale sad the welghts sre put in until the pointer oscillates at equal distances to one side and the other of the position at has when the scales are tained by moving a ninute welght, or rider, to different points on the decimally graduated bear whe fo diferent the beam of a balance of precision. It is so formed as to combine stiffress with lightness, and there are varlous ad. justments for moving the center of gravity, the knife-edges,
cte. Other things being cqual, the greater the length of

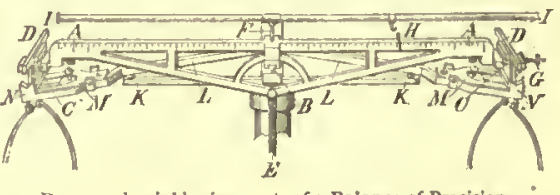

$A$, beam; $B$, knife-edge on which it turns; $C, C$, knife-edges fixed

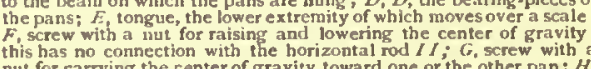
nut for carrying the center of gravity toward one or the other pan: ${ }^{2}$
a rider, or litte weight, whose value depends on its position on the beam, which it stradales; $Y J$, rod sliding horizantally, with a hook to
take up and set down the rider: $K K$, piece which raises and lowers
the levers, $L, L ; L, L$, levers to take the beam and pans simultane

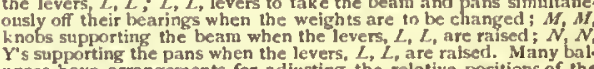
Y's supporting the pans when the levers,,$L$, are ratsed. Many ba
inces have arrangements for adjusting the relative positions of the
three knives, but these are discarded in the larger balances.

the arms and the smaller the distance of the center of gravity below the center of suspension, the greater will be the deviation produced with a given slight addition to either scale. The degree of sensibility to be desired de pends upon the use to which the instrument is to be put gis will indicate $\mathrm{a}$ difference of weight of a tentl or hundredth of a milligram.

I have in equal balance justly weigh'd

What wrongs our arms may do, what wrongs we suffer.
Shak., 2 lien. IV., iv. i.

2. Any apparatus for weighing, as a steelFard or a spring-balance.-3. One of the scales of a balance; in the plural, seales.

And I heheld, and lo a black horse; and he that sat on
him had a pair of lalances in his hand.
Rev. vi. 5 .

Take \& pinte of air; and weigh it against a pinte of wa ter, and you will see the ballance of the last go down a
main. Digby, Nat. Bodies, iil. 19. (N. K. D.) 4. The act of weighing mentally; the act of comparing or estimating two things as in a balance. 
balance

Upon a fair balance of the advnntiges on either sildc.
Bp. Atterbur 5. An equivalent or equalizing weight; that which is put into one seale to oflset the weight in the other; the wejght necessary to make up tho difference betwoen two nuequal weiglits; a counterpoise, literally or figuratively. Specifically - 6. In mining, a countorioise or counterweight used in such a way as to assist the ongino in lifting the load.-7. The part of a engine in lifting the load.-7. The part of a
elock or wateh which regulates tho beats: formerly, a pin oscillating on its center, and thus resembling the beam of a balunee; now, a wheel. See balunec-lohecl. -8 . Tho arithmetical differenco between the two sides of an account: as, to strike a balanee. -9 . Tho sum or amount necessary to balance the two sides of an ae. count, usually spoken of as a delit or a credit bulunco: as, I liavo still a balunce at my banker's; a bulance still due.-10. A surplus; a remainder; the rest; tho residue; what remains or is left over: as, ho bequeathed the balance of his estate to A. I3.; tho balance of a meal. [A eolloquial use, of eommereial origin.] -11 . A balauced condition; a stato of equilibrium or equipoise: as, to loso one's balance.

$$
\text { IIts credit now til doubtill ballaunce houg. }
$$

Spener, 1.09 .31 .3

12. IIamonions arrangement or adjustment; just proportion, especially in the arts of design. -13. [cap.] In restron., a sign of the zodiac, the equinox in September.-Aërostattc balance. See airostatic. - Automaton balance. Seo automatom. and su oppostition of forces among nstions formlng part of one system, sncli that no stste shnil be hn a position, elther other state or intcrere with its independene. (Ortolan.
The lendiug rule by wlitch it lias been souglit to effect thi in Kanrope las been to oppose every new srrangemen of one of the greater powers or to liminish that of another. The meaning of the balance of pourer is this: that sny Furopesn state may be restruined from pursulug plans of acquisition, or making preparatlons looking towarts (12ture ncquisitions, which are Juilged to be liazardous to

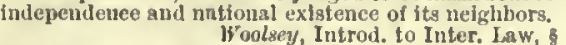
Balance of probabflities, the excess of reasons for be ratio of the chances in favor of a proposition to the chances agsinst it. - Balance of trade, the difference betwee and imported Into a conntry. The balance is sail to be favorable for or in favor of a eountry when the value when the valuc of its imports exceeds thst of its exports.Bent-lever balance. See tanyent-batance. Compen-
sation balance. Sec compensation. - Danish balance,
a weighing spparatus semewhat resenbling the stcelyar. but differing from it in hav. ing the fulcrum movable, the weight belng at one end
and tho load at the other; the loop by whlch it is suspended is ghifted along the (he weight of the

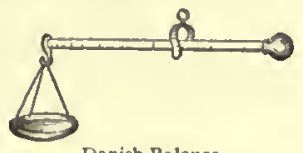
sinhstanee in the scale-pan is the enstrument is in equilibrinm. - Electric balance. See absolute elect rometer, under electrometer; differential galva nometer, under galvanometer; indretion.balance; I" Heat
stone's iridge, under resistance. - Expanstve balance, eompensation-balance in watches, consiating of a com
pound ritm whose outer and funer porttons are made of metals having different rates of expanslon by heat. Thi arrangenent serves to counteract the effeets of variation of temperature upon the speed of the watch. - False bal

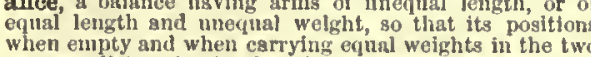
when empty and when carrying equnal weights in the two grus are different. - Hydraulic balance. See hydraulic ric balance. see hygrometric-Roberval's balance,
bslance havlng two horizonttal beans one over the other, connected at thetr extremltles hy joints to vertical picces so that the whole forms n linked parallelogrsm. The scale It makes tt a matter of indifference at what point on th pan the objeet to bo weighed, or the counterpoise, placed. An inproved folm of this balaneo is commonly ance, a steelyard (whleh see). - Spring-balance, s con serving the amount of deflection or compresslon which prodluces upon a helieal steel spring properly ad Justed sn fittel with an tindex working against a graduated sesle
Another form of spring.bslance is made in the shape of the letter $\mathrm{C}$, the upper end belng suspended by a rlng whereby the object is suspended. As the bow opens a fun Wer traverses a graduated are and registers the weight.Thermic or actinic balance. Same as bolometer. - To preponderate: often used figuratively. South; Drydert.

She wolde not tonde
To holde no wight in balaunce

By halfe worde ne by countenan

Chateer, Death of Blanehe, I. 1020.
425

To lay in balance, to put uy as a pledke or security.

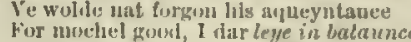

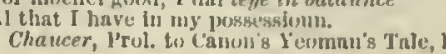

To pay a balance, to pay the difference and make tw aceomits equal.- Torsion-balance, an Instrument for neasuring certaln electrital fores ani the intensity of
nagnets. It consist of of nuaguetic needle suspended liy silk thread or a very the wlre in \& ylass cylinder, het to be neasurel is applicid to one side of the eylinder either inslide or outsinc, and its intensity is indleated by the amount of deftectlon of the suspenilert needle, which s csilsed to exert a forco of torslon on the threal or wire
which supports it. (See also alloy-lalance, assay.bal. ance, coin-balance, micrometer-balance, millstonebalunce.) $=$ Syn. 10. See remainter.

balance (bal'ans), $v$; pret. and $\mathrm{pp}$. balaneed,
ppr. bulancing. $\quad[=\mathrm{F}$. bnluneer $=$ Pr. bulansar = Sp. balenzar (obs.), balancear $=\mathrm{Pg}$. balangar $=$ It. bilanciare, balanee; from the noun.] I. trans. 1. To weigh; especially, to weigh or eonsider in the mind; ponder over.

In the menn whlle I will go for the sald Insirument, and till my return youl may ballance this Matter in your
own Diseretion. Congreve, Way of the World, $v .0$.

$$
\begin{aligned}
& \text { She balancel this a llitle, } \\
& \text { And told me slie woulil answer us to-lay. } \\
& \text { Tennysom, Princes, }
\end{aligned}
$$

$$
\text { Tennysom, Priuccas, III. } 149 .
$$

2. 'To estimate the relative weiglit or importance of, as two or ruore things; make a comparison between

Balance the goot and evll of things. Sir R. L'Estrange.

3. To bring into a state of equipoise or equilibrium; arrange or adjust (the several parts of a thing) symmetrically: as, to balance the several parts of a machine or a painting.-4. To keep in equilibrium or equipoise; poi
steady: as, to balanee a pole on one's ehin.

I camot give due action to ny words, Shak., 2 IleI. VI., v.

The madds of Niszareth, as they trooped to fill $o$. W. Holmes, The Hother's Secret. 5. To scrve as a counterpoise to ; connter-
balance; offset: as, the ups and downs of life balance each otler.

One expression in the lettcr must check and balance the
other. In the case of $n$ precislon steel-yard, it Is best so to dts tribute the mass of the beam that the right srm balances
the left one.
Encye. Brit., III. 262 . 6. To bring into a state of equality; make equal; offset (one thing with another)

$$
\begin{aligned}
& \text { To balance fortume by a just expense, } \\
& \begin{array}{l}
\text { With splendour, charity; with plenty, health. } \\
\text { Pope, Mloral Fsssy, iif. } 223 .
\end{array} \\
& \begin{array}{l}
\text { Like souis that batance Joy and pain. } \\
\text { Tennyson, Lancelot and Gulncvere. }
\end{array} \\
& \begin{array}{l}
\text { Weariness was balanced with delight. } \\
\text { Hilliam Morris, Eartlly Paradise, I. 240. }
\end{array}
\end{aligned}
$$

7. To uso as a counterpoise or set-off.

Is it a rule of oratory to balance the style ngainst the Sydney Smith, in Lady IIolland, iit.

The ... wistion which balanced Fyypt against Assyrin
I'lesey, Minor l'rophets, 1. 47. 8. To sway up and down, liko the arms of Ifculcy stands,
Tuning his volce, and balancing his hands.

9. To settle by paying what remains due on an aecount; equalize or adjust.

Though I am very well satisfled that it is not in my
power to balance accounts with my $\$$ aker, I an resolverl, power to balance accounts with my 31 aker, I am resolverl,
however, to turn all my endeavours that way.
Addisen, spectator.

10. To examine or compare by summations, etc., so as to show how assets and liabilities or debits and eredits stand: as, let us balance ou weather) by reefing witl a balance-reef. - Balanced copula. See comula. - To balance books, to clos II. intrans. 1. To have an equality or equivlence in weight, parts, etc.; be in a state of equipoise; be evenly adjusted: as, the two things exactly balance; I cannot make the ac count balance. - 2. To oscillate like the

He would not balance nor $\mathrm{crr}$ in the determinst hla cholce.

3. In dancing, to move forward and backward, or in opposite directions, like the arms of a balance; especially, to set to a partner.-4. To of an account or accounts. balance-plow

Ol! who would enst sud balanee nt a desk,

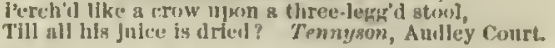
balance-bar (bal'anıs-bär), $n$. Sume as bulunce-

balance-barometer (bal'ans-bą-roin"c-tèr), $n$. barometer cousisting of a beän balanced ou pivot, and formed, on opposite sides of the pivot, of materials differing greatly in specific gravity. The lulks of the parts on eillier sile of the

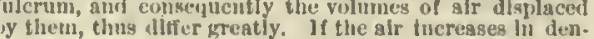
y them, this allifer greatly. If the air tuereases ln dendiferably exceeds tts effeet upon the smanller: the former therefore rises. If the alr lecomes lighter, the reverse balance-beam (bal'ans-bēm), n. 1. Tho beam f a balance.-2. $A$ long beam attaclied to a lrawbridge, the gate of a canal-lock, ete., serving partially to counterbalance its weight, and used in opening and closing it. Also called bulance-bar

balance-bob (bal'ans-bob), $n$. A beam, bent lever, or bob, rocking or oseillating on an axis, and having at one end a counterpoise, while the other is attached to the rod of a Cornish pumping-engino. It is designed to relleve the stratn n the cngine and rod resulting from lifting a heavy luad. alance-book (bal'ans - bủk), $n$. In com., a book iu which the aidjnsted debtor and ereditor aceounts have been posted from the ledger. alance-bridge (bal'ans-brij), $n$. A bridge in which the overhang beyond an abutment is counterbalaneod either by means of heavy woights connocted with it by chains rumning over pulleys, or by a portion of the roadway which extends backward from the abutment. See bascule-brillge.

balance-crane (bal'ans-krān), $n$. A crane in which the load is counterbalaneed iu whole or in part by a weight, swinging witl tho load, but placed upon the opposite side of the pintle or post.

balance-dynamometer (bal'ans-di-na-mom'eprinciple of the steolyard is used to estimato the number of foot-pounds of power. The apparatus is attrched hetweenl two pnlleys, of which onc re. operated by means of Joose pulleys, upon which the belts are shifted when it is desired to test the power. Also balance-electrometer (bal'ans-ë-lek-trom'etèr), $n$. A form of absolute elëctrometer. See clcetrometer.

balance-engine (bal'ans-en"jin), n. A steam engine which lias two pistons acting in oppobalance-fish (bal'ans-fish), $n$. A name of the hammerbead, or hammer-headerl shark, sphyrna malleus: so ealled because the sides of the head resemblo the arms of a balance. Also head.

balance-frame (bal'ans-f'àm), $n$. One of two frames of a ship which are of equal weight and at equal distances from its center' of gravity.
balance-gate (bal'ans-găt), $\pi . \quad 1$. A gate either so supported in the middle, or so counterweighted, that its weight may rest vertically upon the gate-post instead of linging upon ono
side of it.-2. In luydraulics, a gatehaving erpual areas upon each side of the snpporting equal that the action of a current may not impede its

balance-level (bal'ans-lev"el), n. A builders' or surveyors' instrüment, eonsisting of a bar exactly balanced and suspended by a cord, and earrying two sights which show the line of level. Sometlmes the bar is placed nt riglit angles to a telescope ls sometimes substituted for the bar and slghts. +- ment. $]$ The aet of balaneing, or the state of being balaneed. [Rare.]

The law of compensation or balancement in which the stamens were greatly developed, and to bu in which the stamens were greatly developed, and to be
increased in length in those wlich hail their stamens but
little developel. balance-pit (bal'ans-pit), $n$. In mining, the counterpoise moves.

balance-plow (bal'ans-plou), $n$. A plow in which two sets of plow-bodies and colters are attached to an iron frame moving on a fulerum, one set at either extremity, and pointing in different direetions. The balance-plow is intended 


\section{balance-plow}

to he used without turning, and is so arranged as to east
all the furrows in the same direction, the one part of the frame being raised ont of the ground when moving in one direction, and the other when moving in the opposite. It is the front part of the rame, or that furthest the driver sits, which is clevated, the plowing apparat ground and doing the work. Balance-plows are used in steam-plowing. Uenerally two, three, or four sets of plowbodies and eolters are attached to either extrenity,

balancer (bal'ant-sèr), $n$. 1. Oñe who balance or weighs; a weigher of things in or as in a balance.

The nicest of our modern critical balancers.
Dateson, Orig. of World, p. 59. 2. An acrobat; one who balanees himself.3. One who or that which keeps a thing or things in equilibrium; that which maintains or helps to maintain something in a state of balance or equipoise.-4. Specifically, in entom. a halter (which see); a poiser ; the small organ supposed to be useful in balancing the body one of a pair of slender processes with clubbed ends placed near the insertion of the wings, especially of dipterous insects. -5 . In herpet., an elongate cylindrical rod protruding from front of the gills: permanently retained in certain forms, as the crecilias and some sala manders. H. D. Cope.

balance-reef (bal'ans-rēf), $n$. Naut., a reefband crossing a säil diagonally. A balance-reef

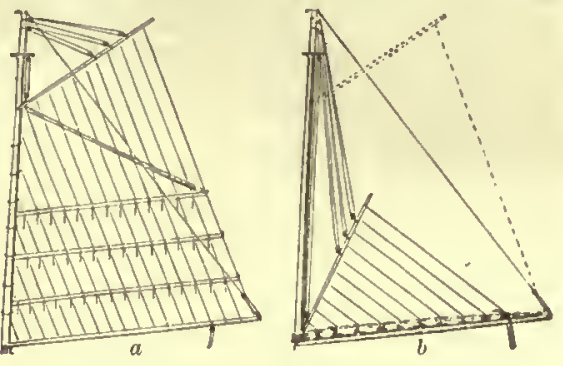

$\alpha$, sail before reefing ; $b$, balance-reefed sall.

is generally placed in all gaff-sajls, the band running from the throat to the clew. Esther the upper or the lower half

balance-rudder (bal'ạns-rud"èr), $n$. A rudder supported on a skeg or projection from the keel, about one third of its surface being forward of and two thirds abaft its vertical axis of motion. See rudder. balance-rynd (bal' ans-rīnd), $n$. An iro bar stretched aeress the eye of a revoly support the stone upon the top of its spindle.

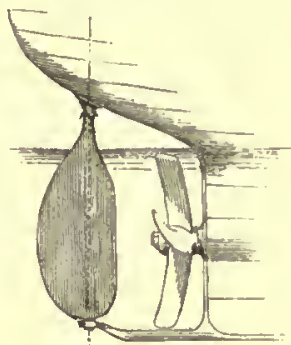

balance-sections (bal'ans-sek"shonz), n. $n$. In ship-bnilding, a pair of sections, one near each after the midslip section and the water-line are determined.

balance-sheet (bal'ans-shèt), $n$. A statement made by merchants and others to show the true state of a particular business. A balance sineet should exlibit all the balances of debits and credit also the value of the merchandise, and the result of the wets and liabilities and tile profts and losses of a com
pany. (Mar'sh, Bank Book-keeping.)

the reserve bof publish balance-sheets professing to show

balanostep, Ioney and sl ech. of Lxchange, p. 320 . (balans-step), $n$. In milit. tactics, an exercise in squad-drill intended to teach the primciples of marching.

balance-thermometer (bal'ans-thèr-mom"etèr), $n$. A device in which mercury inclosed in a balauced tube is caused to make one or the
other of the ends preponderate, thereby opening or closing a wiudow or damper, or touching an alarm.

balance-valve (bal'ans-valv), $\boldsymbol{n}$. A valve in which the fluid is admitted to both sides, and acts with nearly equal pressure in opposite directions, but with an excess in the directio of the seat sufficient to keep the valve in contact with it when closed. It is a construction de aigned to permit the operation of a valve by a slight agle stem, the fluid being admitted eitler between the wo disks or above the upper and helow the lower. On slight excess of pressure tending to close the valve, or to
keep it pressed to its seat.

balance-vise (bal'ạs-vis), $n$. A small tailvise used by watchmakers.

alance-wheel (bal'ans-hwèl), $n$. 1. A wheel in a watch or chronometer which by the reguarity of its motion delermines the beat or trike.-2. Figuratively, whatever serves for the regulation or coördination of movements.

These are in themselves very ohjectionable; the true regulators, the proper balance-wheels, are those which

Balance-wheel engine, a watchmakers' instrument, used in the construction of the balance-wheel,- Balance-wheel file, a watchmakers' file with three sides, one convex and cut, the others plane and amootl. It is irsed in working in the sector openings of a balance-wheel.rim is formed of two metals of difterent expansive powers a arranged that the change of size of the wheel, as the temperatiue rises or falls, is compenated for by the cliange in position of the parts of the rim.

balandra (ba-lan'drä), $n$. [Sp. Pg. balandra $=\mathrm{F}$. bélandre, <D. bîlander, > E. bilander: see bilander.] A small coasting vessel used in South America.

balandrana (ba-lan'drạ-nä), n. [ML.; OF balandran, F. balandras = Sp. balandran = It palandrano, palandrana; origin unknown.] A wide cloak or mantle used as an additional garment by travelers and others in the twelfth and thirteenth centuries. Also called supertotus.

balanid (bal'an-nid), $n$. A cirriped of the family Balanida.

Balanidæ (ba-lan'i-dē), n. pl. [NL., < Balanus $+-i d c$.$] A family of sessile thoracic cirripeds,$ of which the genus Balanus is the type. The peduncle is alssent or rudimentary, the operculum is Jated. The species are commonly called acorn-shells or
sea-acorns, and often share the name barnacle with the spectes of Lepas. They are found all over the world, adhering closely to submerged rocks, timber, etc. Als balaniferous (bal-a-nif'e-rus), a. [<L. balanus (<Gr. Bá7avos), an acorn, + ferre $=\mathrm{E}$. bear ${ }^{1}$. Bearing, yielding, or producing acorns.

Balaninus (bal-ag-ni'nus), n. [NL., <L. balanus (〈Gr. ßáiavos), an acorm, + -inus.] A genus of rhy nchophorous beetles, of the nida or weevils: the nut-weevils. B. nueum is the weevil of hazels and filberts: $B$. glandium and $B$. rectus, of acorns. balanism (bal'anizm), n. [< Gr. Báhavos, an acorn, a suppository, + a doral view: $b$, laterect

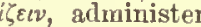
a suppesitory.]

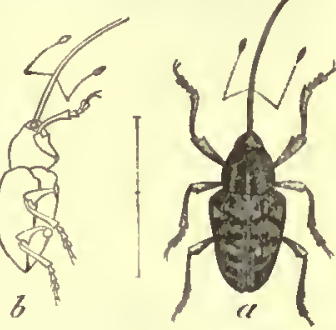

n med., the application of a suppository or balanite (bal'a-nit), $n$. [< L. balanites: see Balanites.] 1 $1{ }^{\circ}$. A kind of precious ston

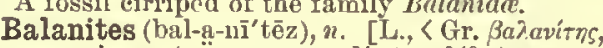
precious stone, prop. adj. (sc. $\lambda i \theta_{0}$ os), acorn-

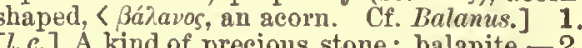
[NL. [N. A simarubaceous genus of plants, ineluding two species, spiny shrubs or small trees, naand tropieal drier parts of India, western Asia, the pulp of which is sometimes used in ane-seedcd drupe, silk. The oily seeds, as well as the lark and subacil leaves of the Jindian species, $B$. Roxburgh ii, are employed in nativ

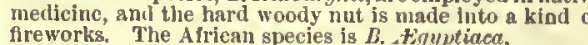
3. [NL.] A genus of fossil cirripeds, of th amily Balanide.

balanitis (bal-a-nī'tis), n. [NL., < Gr. ßánavos, acorn, glans penis, + -itis.] In pathol., inflammation of the glans penis.

balanoglossid (bal" a-nọ-glos'id), $n$. A mem ber of the family Balanoglossida.

alanoglossidæ (bal " a -nọ-glos'i - dē), n. $p l$ NL., [ Balanoglossus + -ida:] The farnily of invertebrates represented by the genus Bala

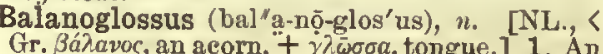

extraordinary genus of invertebrate animals, the type not only of a family, Balanoglosside but also of an order or even a distinct class of animals, Enteropnensta (which see). It is related in its mode of development to the echinoderms, in some
respects to the ascidians, and is usually classed with the
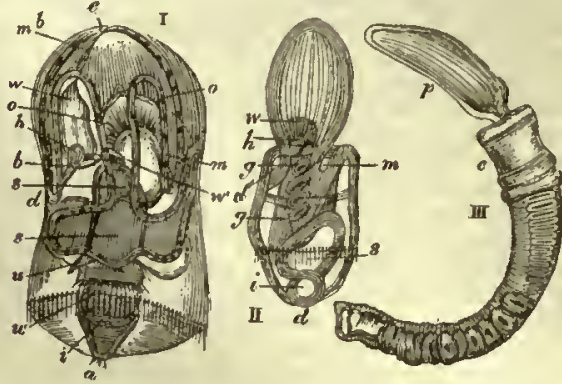

Balanoglossis.

I. The Tornaria larva, about $x \cdot 72$ of an inch long, enlanged, side

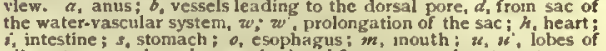

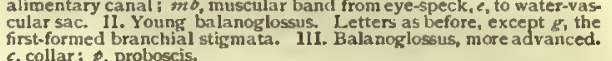

Vermes. The members of this genus are elongated, footless, soft-hodied worms, with the moutl at one end of the body and the anus at the other. The fore part of the body presents a kind of collar surrounding a constriction from which aprings a long hollow proboscis-like organ, whence
the name Balc noglossus, this organ being like a tongue the name Balanoglossus, this organ being like a tonguc
somewhat acorn-shaped, proceeding from within the collar like an acorn from its cup. On the portion of the body from which the proboscis aprings there is a flattened are with a longltudinal series of branchial apertures, communicating with branchial sacs comnected with the alimenof this relation of the respiratory to the alimentary canal, Huxley associates Balanoglossus with Tunicate (or ascldi ans) as membcrs of a pharyngopneustal aeries. 'the larval regarded as an echinoderm fron its great resemblance to the larva of a atartish.

2. [l. e.] A member of the genus Balanoglossus. balanoid (bal'a-noid), $a$. and $n$. [< Gr. $\beta a \lambda a-$

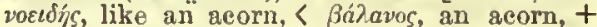
cídos, form.] I. a. Resembling an acorn: specifically applied to the acom-shells of the family Balanida. See cut under Balamus.

II. $n$. An acorn-shell; a cirriped of the family Balanida.

Balanoidea (bal-ag-noi'dẹ-ä), $n_{0} p l$. [NL., < $B a-$ lanus + -oidea. Cf.balanoil.] Same as Balanida.

Balanophoraceæ (bal" n-nō-fō-rā'sē-ē), n. $p l$

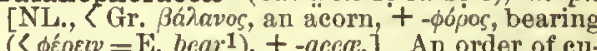
$\left(\left\langle\phi \varepsilon \rho \varepsilon v=\right.\right.$ E. $\left.\left.b e a r^{-1}\right),+-a c c a.\right] \quad$ An order of $e u$ rious apetalous leafiess plants, related to the mistletoe, but parasitic upon the roots instead of the branches of other plants. From their simple structure, they were formerly thouglit to be allied to the fungi. There are about 40 known specles, grouped into 14
genera, natives of the tropics. They are generally of a
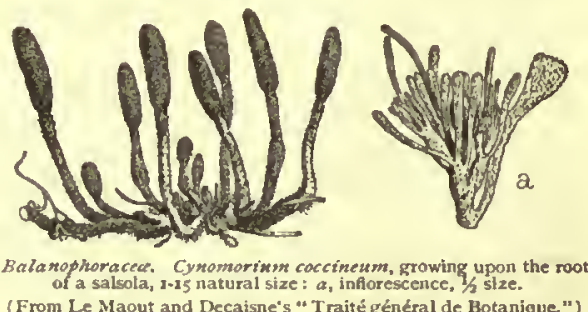

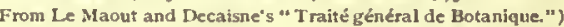

bright yellow or red color. Their small flowers, in most thexual, are aggregated into dense masses. The lantt (belled, with a single seed.

balare, bleat. Cf. baa.] Bleating.

The balant and latrant noises of that sort of people.

Balanus (bal'a-nus), $n$. [L., <Gr. ßá> avoc, an acorn. Cf. L. glans, an acorn: see gland.] The typical genus of sessile cirripeds of the family Balanida; the acorn-shells or sea-acorns, called barnacles, except in Great Britain, where the peduncu lated Lepadida have that name. B. tintimabulum is the representative species. The ahel

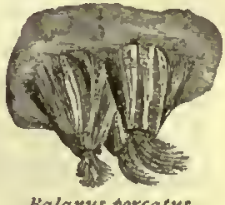
consists of 6 plates, with an oper

culum of 4 valves. Colonies are to be fonnd on rocks left dry at low water, on ships, on timber, on lobsters and other lusks. They differ from the meinbers of the gemms $L$ epoin having a symmetrical shell and in being lestitute of a 


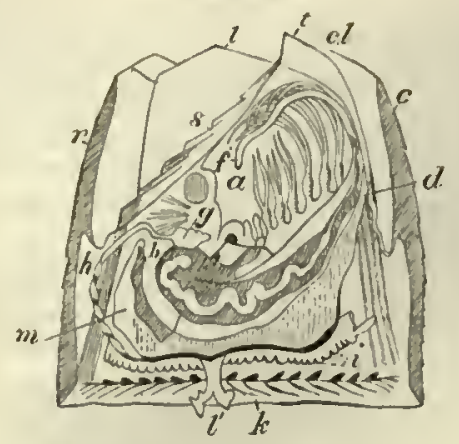

Diagranumatic section of A corn-shell (Balarus).

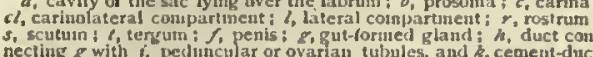

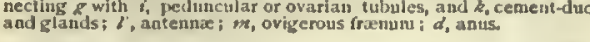

tence, at which period they are not flxed, but move alout by means of swimming-fcet, aud possces large atalkerl eyes, both feet and eyes disappearing wh

balas', balass (bal'as, ba-las'), n. [Early mod. F. also ballas, ete.,"< ME. balas, baluce, bulays, ete., < OF. balais, balai $=\mathrm{Pr}$. balays, balach $=\mathrm{Sp}$. balax $=\mathrm{Pg}$. balache $=$ It. balascio, kind of ruby, ¿ Pers. Ballakhshän, a country in eentral Asia north of the Hindu Kush mountains (called Zalasian by Mareo Polo), where this ruby is found.] A variety of spinel nuby, of a pale rose-red eolor, sometimes inelining to orange. See spincl. Usually ealled balas-ruby.

William of Wykeham ... bequeathed to hla auccesso tifleal ring, with a sapphtre stone, gurrounded with four balas-rnebies, and two amanl diamonds and eleven pearis.

balas' (bal'as), $n_{\text {: }}$ ['Turk.] A long dagger intended for thiusting rather than eutting, used by the Turks; a Turkish yataghan. R. F. Burton.

balase ${ }^{1} f, n$. See balas $I$

balase $2 t, n$. See ballast.

balass, $"$ See bulust.

balata (bal'a-tä), $n$. Same as balata-gum.

balata-gum "(bal' ga-tä-gum), n. The inspissated juice of a sapotaeeous tree, Mimusops globosa of tropieal America from the Antilles to Guiana. It is intermediate in character letween caontchonc and
gutta-percha, and trom its great strength is egpeclally ancing

balata-tree (bal'a-tä-trē), n. A large sapotaecous tree of the West Indies, Bumclia retusa, the wood of which is very hard. See bullytree.

balatront (bal'an-tron), n. [<I/. balatro(n-), a babbler, jester, buffoon, prob. for *blatero(n-), blaterare babble.] A buffoon. Cockram.

balatronic (bal-?-tron'ik), a. Of or pertaining to buffoons. Säla. [Rare.]

balansta (ba-lâs'tặ), n. [NI., < L. balunstium: see Balaustion.] Ä fruit like the pomegranate, sueculent within and many-seeded, with a firm rind, and tipped with the persistent lobes of the ealyx.

balaustine (ba-lâs'tin), a. [< L. balaustium (< Gr. $\beta a \lambda a v o r t o v$, the flower of the wild pomegranate) $\left.+-i n e^{1}.\right]$ Pertaining to the wild pome granate-treo.- Balaustine flowers, the dried flower of the pomegranate, used in medictne as an astringent.
Balaustion (ba-lâs'ti-on), n. [NL.; ef. L.

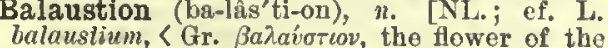
balauslium, < Gr. $\beta a \lambda a i \sigma \tau o v$, the flower of the
wild pomegranate. Cf. baluster.] A genus of myrtaceous plants, of a single speeies, B. pul cherrimum, a shrub iuhabiting sonthwestern Australia. It bears numerous flowers resembling in shape and color those of the dwarl pomegranate.

balausty $\dagger$ (ba-lâs'ti), n. [< I. balaustium : see Balaustion.] Samo as balaustinc floters.

balayeuse (bal-ā-yèz'), $n$. [F., fem. of balayeur a sweeper, < balayer, sweep, < balai, OF. bale balcis, a broom, dial. the broom-plant, $>\mathrm{ME}$ baleis, a rod.] A strip of plaited muslin or laee plaeed inside of tho bottom of women's dresses to proteet them from the floor.

balaynf, $\pi$. An obsolete form of balcen.

balayst, $u$. An obsolete form of balas $I$.

bal-boy (bâl'boi), $n$. A boy working in a mine. Ure, Diet., I. 280. [Cornish.]

Balbriggan hoslery. See hosiery.

balbusard (bal'bü-särd), $n$. [F', also balbuzard.] A name of the osprey or bald buzzard, Pandion halinëtus. It was taken in 1828 by Fleming
as a genus wane in the form Balbueardus. [Not in use.]
427

\section{Balder-brae}

balbutiatef (bal-bü'slii-āt), $v$. i. $\quad[<\mathrm{L}$. as if "Zalbuticte for balbutirc, stammer, < balbus stammering.] To stammor in speaking.

balbutient† (bal-bū'shi-ent), a. [<L. balbutien $(t-) s$, ppr. of balbutire, stammer: see balbutinte.] Stammering.

balbuties (bal-bū'shi-êz), n. [NL., <1. balbus, stammering. Cf. balbutiate.] 1. Stammering. -2. A vicious and ineomplete pronuneiation in which almost all the eonsonants are replaeed by $b$ and $l$. Dunylison.

bal-captain (bâl'kap"tặn), n. A mino-eajtain. [Cornisli.]

balcont, balconet, $n$. $[\langle\mathrm{r}$. bulcon, $<\mathrm{It}$. balcone, a balcony: see balcony.] i balcony or gallery. r'epys.

balconet (bal-kō-net'), n. [A]so balconette, baleon, balcony, + et, -ctte. Cf. It. dim. bal conatu.] A low ormamental railing to a door or window, projeeting but the threshold or sill.

alconied (bal' kō-nid), $a$. IInving a baleony or baleonies.

The house was Roger North, Ex [amcu, Iit. 7 . balcony (bal' kō-ni, until reeently bal-kóconics (-niz) [Formerly also balcone, balconic, balcony, ete. (sometimes balcon, after $\mathrm{F}$. baleone, Sit. balbeam, seaffold, s OHG. balko

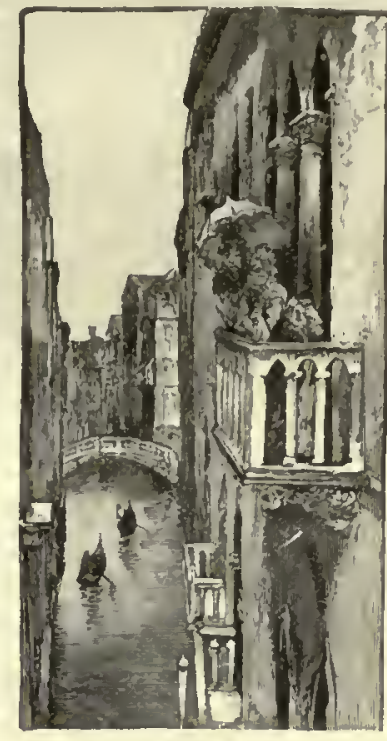
balcho, a seaffold, $=\mathrm{E}$. balk, a beam, ete.: see balk.1,n.] 1. A stage or platform projecting from the wall of a building within or without, supported by columns, pillars, or eonsoles, and encompassed with a balustrade, railing, or parapet. Outer balconies are eommon before windows, and inner ones in ball-rooms, publie halls, ete.

The fourtsh of trumpets and kettledrums Irom a ligh balcony, which overlooked the hall, anmounced the en.
trance of the maskers. Scott, Kentlwortl, I1, xwili. 2. In theaters, a gallery oceupying various positions. In some theaters it is a raised tier of geats sur rounding the parcuette; in others it takes the place of the
dress-clrcle; and in others atill it is the gallery immedibald I (bâld), a. and $n$. [Early mod. F. also balle, bauldc, bal't, balld, < ME. balde, belde, earlier balled, ballid, ballede, bald; of uneertain origin, (1) by some regarded as identical with origin, (1) by some regarded as identical with
the ral'e early ME. ballede, in the apparent sense of rotund, eorpulent, applied to the body, lit. 'balled,' round like a ball (< ball $1+$ $\left.-e d^{2}\right)$, and henee, perhaps, of the liead, smooth, hairless; otherwise (2) perhaps < ball, a white streak or spot (a word of Celtie origin not found in ME., but prob. then existent: see ball3), + -ede, an adj. suffix eonneeted with $-e l^{2}$.] I. $a$. 1. Wanting hair, as the head, in some part
(usually the top, or front and top) where it naturally grows; partly or wholly deprived of hair on the head, as a person.

His heed was ballid and achon as eny glas.

Cæear, . . because his head was bald, covered that de

2. Without the natural or usual eovering of the head or top; bareheaded: as, a bald oak; a bald mountain.

No question asked him by any of the aenators, but they
atand bald before him. Blanc:

Coleridge, Chamouni.

3. Destitute of beard or awn: as, bald wheat. -4. Wanting force or meaning; meager; paltry: as, a bald sermon; a bald truism.-5. Destitute of appropriate ornament; too bare, plain,
or literal; unadorned; inelogant: as, "a bald trauslation," Longfellow, Hyperion, iii. 6.
He [Milt on! conld story to a plain stylc, sometimes even acaulay, siliton Ghastly thro the drizzling raft Tennysв 3. Bare; open; undisguised.

A bald egotim which is yuite alove and lxyond selfish7. Having white on tho fae or head: specifcally applied to several birds: as, the ball buzzard, eagle, ete.

II. n. A natural ineadow or grassy plain oceurring on the rounded summit of a ligh mountain: a term in use in the southern extension of the Appalachian rauges, where n number of tho highest knobs have their dome-shaped tops entirely bare of troes.

baldl $f$ (bâld), r. t. [<bald $1, a$.$] To mako bald;$ deprivo of hair.

bald ${ }^{2}+$, a. An obsolete and dialectal form of bold. It is retained ln this apelling as an element in certahil proper namea of Anglosaxon or old lligh German orifin: as, Baldvir, Archibald, Lihelbeld, etc.

baldachin (bal'da-kin), $\pi$. [In def. 1 also formerly bullakin, balklkin, and earlier bundetin, g. V.; in def. 2 also buldaquin, and, as It. or Sp., baldacchino, baldaquino ; < $\mathbf{F}$. baldaquin = Sp. boldaquino $=\mathrm{Pg}$. baldaquim, < It. baltacchino (Ml. ballakinus, ete.), a canopy, Baldacco, It form of Bardail (Ar. Banhiad) where a rich eloth used for such eanopies was manufaetured.] 1†. Samo as baudekin.-2. A eanopy of various kinds. (a) A portalule decorative covering, borne in eercmonlal processions as a gign of rank or dignity i particularly, the dals-like canopy cartied over die pope, whelits aupported on elght polea and carned portable canopy borne over the eucharist carried processionally, as on the feast of Corpus Chriati. (c) A stationary covering, of baudekin, silk, or other rich atuff, stretched dais; sometimes, that of a bed with curtains. (d) A fixed
dater

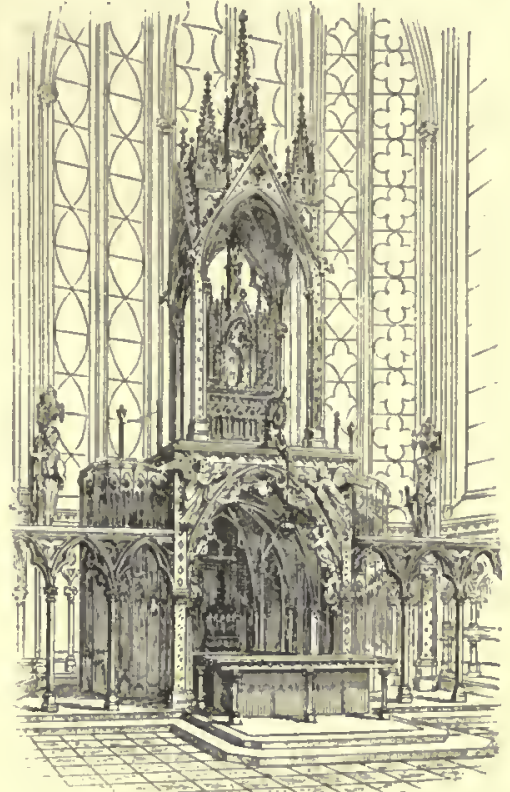

Double Baldachin--Shrine of the Crown of Thorns, high altar of
the Sainte Chapelle, Paris; 13 th century.

canopy, often of metal or atone, above the isolated high altar in many churches, expectaily in Italy and the East. Fron chain the vessel containing the Host; but this usage has gitions than over ators as over tomls shyines, otcer pobaldachino (bal-da-ké'nō), n. [< It. baldacchino.] Same as baldachin.

baldaquin (bal'da-kin), $\pi$. See baldachin.

baldaret, $n$. [Origin obseure; some suppose an allusion to the rod Balder and his restoration to life.] An old name of the amaranth, Amavantus caudatus.

bald-coot (bâld'köt), n. See baldicoot.

baldekint $n$. An obsolete form of baldachin.

balden (bal'den), $x^{\prime} t_{\text {. }}$ and $i_{\text {. }}[\langle$ bald $l+e n l]$. To make or beeome bald. [Rare.]

Balder-brae, Balder's-brae (bÂl'dè- bôl' dèrz-brā), n. [North. E. ( Ieel, Balders-brē (Cotula fctida) $=$ Norw. baldur-braa, ballebraa (Pyrethrum inodorum), that is, as also in E. Balder's broso; also eorruptly bald eyebrow. From Balder, a Norse divinity, son of Odin.] An old name for the mayweed, Anthomis Cotula. 


\section{balderdash}

balderdash (bâl'dér-dash), n. [First in sense 1; of obseure origin, appar, dinl. or slang: according to one conjecture, $<$ Dinn. bulder, noise, clatter (from a verb repr. by Sw. dial. ballra, Norw. baldra, bellow, prattle, = Icel. reft. baldrast, ballrast, clatter; ef. D. LG. balderen, roar, thunder), + dash, repr. Dan. daske, slap, flap: soo desh. But the word may be merely one of the numerous popular formations, of no defiperiod.] 1†. A jumbled mixture of frotby liquors.

$$
\text { To drink such balderdash or boumy-clalbber. }
$$

2. Senseless prate; an unmeaning or nonsensical jumble of words; trashy talk or writing. 1 heard him charge this pullication with vibalilly, scur. Iforne Tooke, T'rial, p. 25. balderdash (bâl'dèr-dash), v. t. [< balderdash, n.] To jumble and adulterate (liquors); henee, to mix with inferior ingredients; adulterate: with with before the adulteran
dash wine with cidor. [Rare.]

The wine-merchants of vice brew and balderdash and even inix it witl pigeon's dung and ynieklime.

Balder's-brae, n. See Balder-brae.

bald-faced (bâld'fāst), $a$. Having a white face or white on the face: said of animals: $0 s_{2}$ bald-fuced stag.

baldhead (bâld'hed), n. 1. A man bald on the head. 2 Ki. ii. 23.-2. The name of a breed of domestic pigeons.-3. A name of the fruitcrows (Cotingide) of South America, of the genus Gymnocephalus. G. calvus is the capuchin baldhead.

bald-headed (bâld'hed"ed), a. Having a bald head.-Bald-headed eagle. See eagle.

baldicoot (bâl'di-köt), n. [Also baldecoot, baldcoot $<$ bald $\mathbb{1}^{1}$ coot; the syllable $-i$ - is meaningless.] 1. The common coot, Fulica atra. ingless.] 1 . Figuratively, a monk, on account of his somber raiment and shaven crown.

Princesses that $a$. demean themselves to hob and
nol, with these blaek baldicoots. baldly (bâld'li), adv. Kingsley, Saint's Tragedy, iii. t. sense of that word.

baldmoney (bâld'mun'i), n. [Early mod. E. also baldimomie, baudmoney, ete., < ME. buldmony, baldemoyn, baldemoyne, baldemoin, an early name of gentian; origin unknown.] 1 . $A$ name of varions species of gentian.- 2 . $A$ name for the mew or spignel, an umbelliferons plant of Europe, Meum athamenticun.

balduness (bâld'nes), n. [< MIE. ballednesse; bald ${ }^{1}+-n e s s$.] The state or quality of being bald. (n) Laek of hair or natural covering on the heal
or top; absenee or loss of hair. (b) Deficiency of alyure priate oruanentit, as in writing. meaness or inelegance
want of ornament: as, batdness of styles wait of ornament: as, baldness of style.

Laldness of alluslon and barbanity of versification.

baldpate (bâld'pāt), n. 1. A person with bald head.

Come hither, goodman baldpate.

2. In ornith a kind of duck with white on tho head; a widgeon, Marcea penelope and $\boldsymbol{M}$. americana. See cut under vidgeon.

baldpate, bald-pated (bâld'pāt, -pā"ted), $a$. Lacking hair on the pate; shorn of hair.

You bald-pated, lying rascal. Shak, M. for M., v. I

baldrib (bâld'rib), n. 1. A joint of pork cut from nearer tho rump than the spare-rib, and consisting of a rib from wlich the fat has been removed.

$$
\text { Baldrib, griskin, chine, or chop. }
$$

Hence - 2. Figuratively, a [Rare.]

Faith, thou art such a spring baldrib, all the mistresses
in the town will never set thee up. baldric (bâl'drik), $n$. [Formerly also baudrick, ete., < ME. baudrik, bawdrik, bauderik, etc., earlier baudry, < OF. baudrei, baldrei, baldret (later baudroy and, with added suffix, baudrier) $=\operatorname{Pr}$, baudrat (ML. baldringus), appar. $<\mathrm{MHG}$. balderich, a girdle, perhaps < OHG. balz $=\mathrm{E}$. belt, < L. balteus: see belt.] 1. A belt, or an ornament resembling a belt.

$$
\begin{aligned}
& \text { A palmer's anice wrapt him round, } \\
& \text { With a wrought Spanish baldricks bor }
\end{aligned}
$$

In particular - (at) a belt wong. Ii. 19, In particular- $(a \dagger)$ A belt worn round the waist, as the moman cingulum, or military belt. (b) A jeweled ornament worn round the neek by both ladies and gentlemen
in the sixtecnth century. $\boldsymbol{N}$. Morris. (ct) Figuratively,

\section{balin}

the zediac. Spenser. (d) A belt worn over the right or left shonlder, erossing the body diagonally to the waist or below it, either simply as an ornament or to suspend a uaissance times, were sometimes richly dlecorated and maissance times, were sometimes richly

Athwart his brest a bauldrick brave he ware

rave. And from his blazon'd baldric slung Tennyson, Lady of Shalott, iii.

$2 t$. The leather thong or gear by which the clapper of a church-bell was formerly suspended. In the earliest accounts the baldrichs of the bells are "leathers."
"led to eo nomine, but later on they are called
N. eud Q., 7th ser., 11. 405. Also spelled baldrick.

baldric-wise (bâl'drik-wiz), adv. [<baldric + wise.2. After the manner of a baldric; over one shoulder and hanging down to the waist.
balductumt, $n$. [Also balduchtum, < ML. balducte, eurd, hot milk curdled with ale or wine, a posset.] Balderdash; trash.

aldwin bit. See bit

baldy (bâl'di), n. [<bald $\left.1+\operatorname{dim}_{\text {- }} y.\right]$ A nickname for a bald-headed person. [Colloq.]

bale ${ }^{1}$ (bāl), n. ['MIE. balc, baluoc, balu, baluw, balu, cte., $<$ As. balu, bealu, bealo (bcaho-, bcalow-) =OS. balu=OFries. balu-, bale- (in comp.) $=\mathrm{OHG}$. balo = Icel. böl (not in mod. G. Sw. Dan.), evil, calamity; prop. neut. of the adj. MLG. bal- (in comp.), Goth. balws (in comp. and deriv.), cvil, dire.] Evil; woe; calamity; misery; that which causes ruin, destruction, or sorrow. [Long obsolete until recently revived in poetry. It occurs especis

\section{For now this day thou art my bate,}

Iy boote when thou shold bec.

Robin IIood, in Percy's Reliques.

Yett still he strove to cloke his inwarl bate.

Brought hither from their homes to work our b., ix. 16.

A touch, and bliss is turned to bale. Southey.

bale ${ }^{2}$ (bāl), n. [Se. also beal, bail; < ME. balc,

baile, belle (ehiefly northern; the reg. southern

ME. would be *bele, *bel, giving mod. E. *beal or

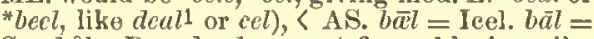
Sw. $b a l=$ Dan. baal, a great fire, a blazing pile,

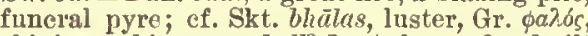
funcral pyre; ef. Skt. ohalas, luster, Gr. фanos, shining, white: see balls.] A large fire built out of doors and burning freely; a bonfire. Spe-
cifically-(a) A funeral pile or pyre. iobsolete and poetcifically-(a) A funeral pile or pyre. [Obsolete and poet-
leal.] (b) A signal-fire; a beaeon. See beacon and bale-fire. On Penchryst glow's a bale of fire

Prlesthaughswire.

bale ${ }^{3}$ (bāl), n. [<ME. bale, $<\mathrm{OF}$. bale, balle= Pr. Sp. Pg. bala = It. balla, <ML. bala, balla, , ball, a round bundle, a package, $\angle O H G$. balla.
valla, MHG. balle, a ball: see ball 1 , of whi $\mathrm{h}$ bale is a doublet.] 1. A large bundle or package of merchandise prepared for transportation, either in a cloth cover, corded or banded, or without cover, but complessed and secured by transverso bands, wires, or withes and longitudinal slats. The chicr articles of merchandise that are baled are cotton, wool, and hay. The weight of a bale of American cotton is between 400 and 500 pounds, vary. 1. 1 hindredweight, a bale of Spanish wood $2 \mathrm{t}$ hundredweinht, a bale of caraway-seeds 3 himndredweight, a bal
of Hocha eoffee 303 pounds, \& bale of thread 100 bolts. $2 \nmid$. A pair or set of dice.

it is a false die of the same bale, but not the same cut.
Sir. T. Overbury, Characters.

I have a erew of angels prisoners in my pocket, an none but a good bale of dice can fetch them out.
Widdleton, Blurt, Master-Const

bale ${ }^{3}$ (bāl), $v . t$; ; pret. and pp. baled, ppr. baling. [<bale $3, n$.$] To make up into a bale or bales.$

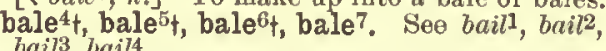

Balearian (bal-ē-ā'ri-an), a. Same as Balearic. Balearic (bal-ée-ar' $\mathrm{ik}$ ), a. [<L. Balearicus,

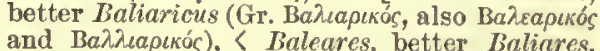

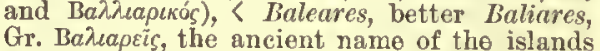
and of their inhabitants, lit, according to the common tradition, the slingers, < Gr. Bád $\lambda \varepsilon \iota \nu$, throw, sling.] Pertaining to the islands Majorca, Minorea, Iviza, ete., in the Mediterranean sea, called the Balearic islands. - Balearic crane. Balearica (bal-ê-ar'i-kä), n. [NL., fem. sing. of 1. Balearicus: see Balearic.] A genus of cranes, family Gruido, including the crowned cranes, $B$. paronina and $B$. regulorum. They ow ish feathers resemhling a miniature wisp-brom. The heal is also variegated with black featler's aml rcd naked blaekish, with much whitc on the wings. The total length is alont 4 feet. "These eranes occur in varions parts of Africa, as well as in the islands to which they owe their rame, and one species has occasionally been found in En-

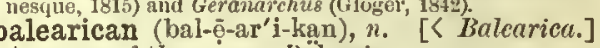
A crane of the genus Bälearica.

baleen (ba-lēn'), n. [< ME. balene, baleync, a

whale, $<$ OF. balene, F. baleine, < 1. balena, a

whale: see Balana.] 1t. A whale.-2†. The

sea-bream. - 3. Whalebonc in its natural state: a name given by whale-fisliers.

The horny " teeth" of the Lampreys, and of Omithorhyn. chus, appear to be ecderonic structures, homologrons with the baleen of the Cetacea, with the palatal plates of the
Sirenia, or the beaks of Birds and Reptiles, and not with

aleen-knife (ba-lēn'nîf), $n$. A double-handled knife with a curved blade, used for splitting whalebone.

bale-fire (bāl'fūr), n. [< ME. balefyre, < AS. fire.] 1. A large firo in the open air; particularly, the fire of a funcinl pile.

The festival lof the death of the earth in winter] was - kept by the lighting of great fres, called bale-fires.

2. A beacon-or signal-fire.

Sweet 'Teviot! on thy silver tide

The glaring bale-fires blaze no more.

iv. I.

baleful (bāl'fül), a. [<ME. baleful, baluful, <

AS. bealuf'ull, bealofull, < bealu, bcalo, bale, + -full, -ful: sce bale 1 and -ful.] 1. Full of hurtful or malign influence; destruetive; pernicious; noxious; direful; deadly: as "baleful breath," Dryden; "baleful drugs," Milton, Comus, 1. 225.

And when he weeps, as you think for his vices,
"Tis but as killing drops from baleful yew-trees,

"Tis but as killing drops from baleful yew-trees,

Fletcher, Valeutinlan, iii. I

This lustful, treacherous, and baleful woman. He reminded him that the baleful horoscope of Abdal-

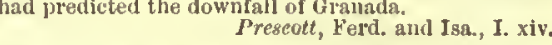

2. Fraught with bale; full of calamity or misfortune; disastrons; wretched ; miserable.

Ah! Jucklesse babe, borne under eruel starre,

And in dead parents balefull ashes lored.
Spenser, F. Q., II. ii. 2.

That baleful burning night,
When subtle Greeks surprls'd King Priam's Troy.
Shak., Tit. And, v.

balefully (bāl'fńl-i), adv. [ME. balfully, baillfully; <baleful $+-l y^{2}$.] In a baleful manner.

(a) Calamitously; perniciously ; noxionsly. (b) Miserably; unläppily ; painfully.

alefulness (bāl ful-nes), n. The state or

Their blisse he turn'd to balefulnesse

Spenser, F. Q., II. xii. 83.

ale-hook (bāl'húk), n. 1. A large liook suspended from the chain of a crane or winch, for use in lifting bales.-2. A smaller hand-hook used in handling unwieldy bales, boxes, and packages.

baleine (ba-lān'), n. [F., lit. a whale: see baleen.] A movable platform for the support
of dumping-wagons, used in France in building railroad embankments.

baleist, n. [Early mod. E. balys, < ME. baleys, balcis, < OF. baleis, balei, mod. I'. balai, a broom, besom, dial. also broom, genesta; ef Bret. balaen, a broom, besom, balan, broom, genesta.] A rod; a twig.

baleless (bāl'les), a. [〈ME. baleles, <AS. bealuleás, bealolevis, < bealu, bealo, bale, +-leás, -less: see bale 1 and -less.] Harmless; imnocent.

who bales, or makes up bales or bundles.

baler ${ }^{2}, n$. See bailer 2 .

balest, $n$. A Middle English form of balus ${ }^{1}$.

alestert, $n$. Soe balister 1

bale-tie (băl'tì), n. A contrivance for joining

the ends of the straps used in baling cotton, hay, ete.

aliki (ba-lé'kē), $n$. [Russ.] The back-picees of the sturgeon, salted and smoked in Russia for home use and exportation.

balint, n. [Irreg. < L. balin, ace. of balis, < Gr.

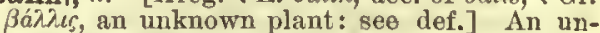
known plant, supposed to have wonderful meicinal virtues. $D$. $E . D$.

Having th' herbe balin in his wounds infus's. 
baline (ba-lên'), $u$. [l', preking-eloth; ; ef. balin, winnowing-cloth.
vas used for packing. vas used for packing. enger, ete., < OF. bullengier, bullenjer, baleinier, orig. a whale-ship (= Ig. buleciro, a whaler, a a whale: sce bulcert.] A small sea), (oing warvessel in use in the fifteenth aml sixteenth centuries, and supposed to havo been a kind of sloop witlout forecastle.

III February, 1417, tho king posscssed six great slipgs, eighit barg's, and ten balingers, stubbs, Const. 11 ist., \& 650 .

baling-press (bä'ling-pres), n. A power-press employed for eompressing soft or tibrous materials, as raw cotton, hay, and cotton an woolen goods, into bales for transportation.

balisaur (bal'i-sâr), n. [< Ilind, bēlusūr, sandhog, < bälu (Beng. büli), samu, + sür, th hog (cf. Skt. sükura, a hog).] The common Indian balger, Arctomyx colluris, of the family Mustelitke and subfamily Meline. It resembles the com mon European balger of the genus ASelex, but ls larger
and is, from its technical characteristles, placed in and is, from its technical characteristles placed in
different genus. It is a true barlger, one ol several mem bers of the Meline. Sce bads

balise, $n$. Seo balize.

balista, $n$. So bellista. balister ${ }^{1}+$ (bal'is-ter), $n$. [< MIE. balester, < OF. balestier, < LL. bellistarius, ono who makes crossbows, a crossbowman, < L. ballista, a
crossbow. Cf. arcubalister.] A crossbowman. balister ${ }^{2}+$ (bal'is-tèr), $n$. [<OF, balestre, < IIL balistra, a var. of I. ballista, a crossbow (ef. MIL, balistarius areus, a crossbow): see ballista. An arbalist or crossbow. Also spelled ballister. Balistes (ba-lis'tēz), n. [NL., <L. balista, better ballista, the military engine; so called for the same reason as they are called trigger-fish:

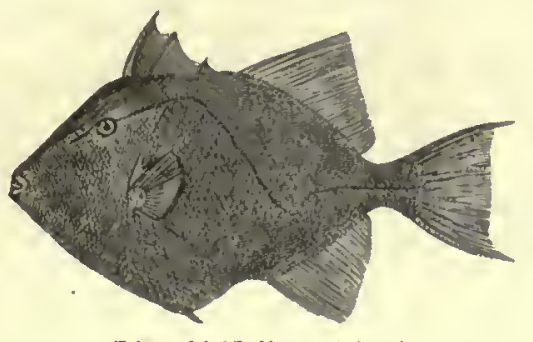

see def.] A genus of plectognath fishes, typical of the family Balistida, containing such species as $B$. capriscus. They sre known as trigger-fish, be cause one large snd sharp first ray of the dorsal til cannot be pressed down until the second ray is depressed, whie
the first shuts down as does the hammer of a gun when the balistid (ba-lis'tid), n. A fish of the family Batistide.

Balistidæ (ba-lis'ti-dē), n. pl. [NL., < Baliste + -ida.] A family of fishes, typified by th genus Balistes, adopted by different author with various limits. (a) In Bonaparte's early system
1832, a famlly embracing the Balistidae, Triacenthide, anc Ostraciontida, and thus equivalent to the Sclerodermes Cuvier. (b) In Bonaparte's later systems (1840, ete.), a fam-
ily embracing the Balistidoe and Triacanthida, thus cquiv alcnt to the suborier Sclerodermi of Gill. (c) In Swainson's systen, a farmily including sll the plectoguath fishes with reduced rhomblforn or nore or less spiniform dermal sppendages; a compressed body; teeth few in number snd more or less compressed; a long pelvis, compresse times coocealed; snd no paired ventral fins or spines The species are numerous in tropicsl and subtropical scas, and are divided into three sulbsmilies, the Balistina, cies are known as trigger-fish, file-fish, et.

Balistina (ba]-is-ti'nä.), n. pl. [NL., < Raliste $+-i n a$.$] In Günther's classification of fishes,$ the second group of his family Sclerodermi, identical with the family Balistide of recent anthors. Balistinæ (bal-is-tī'nē), n. $p l$. [NL。, $\langle$ Bnlistes $\left.+-i n x_{0}\right]$ 1. A subfamily of balistoid fishes having few vertebrw (17), an anterior dor'sal fin consisting of 3 (rarely 2) spines, of which the first is enlarged and the second locks it in erection, branchial apertures behind the eyes, a compressed ovate form, and rhombiform scales. The most common English mames of the specles
are file-fish and trigger-fish. The flesh is generaliy lut
little esteemed, and may even be poisonous ; lut in some places, as in Bermuda, one of the species of the genes Balistcs is highly estecncel and localiy called turbot. The
skin is used for filing and ss a substitute for sandpaper.

2. In early systems of classification, a subfamily embracing tho Balistida and Triacan- thider, and equivalent to the suborder Sclerodermi of Gill. - 3 . In some systenis, a sulifan-
ily equivalent to the family Julistide of Gill. ily equivalent to the family Julistide of Gill. Bulistince.

balistoid (ba-lis'toid), $u_{0}$ and $u_{\text {. }} \quad$ [< Julistes + -oid.] I. $a$. I'ertaining to or liaving the chareters of the bulistida.

II. $n$. A balistid.

balistraria (bal-is-trā'ri-ị), n. [ML., < bnlisra, a form of lallista, a crossbow: seo balister2.] In old fort.: (a) A loopliole or aperturo in the wall of a fortification, or in a wooden hoarding temporarily put up for defense, through which erossbowmen might discharge their bolts. Sce loophole, and comparo archeria. (b) A room in which balisters or crossbows wero kept.

balize, balise (ba-löz'), n. $\quad[<\mathrm{F}$. Ualise $=\mathrm{Sp}$ 'g. baliza, Sp. also balisa, valiza, a beacon, buoy, sea-mark; origin unkmown.] A sea-mark or beacon at the mouth of a river or the entrance to a harbor; a barrel-butoy, a pole surmounted by a peculiar flag or other object, etc. balki, baulk (bâk), n. [<ME. balk, balkc, <AS. balca, a ridge, $=$ OS. balco $=$ OFries. balka
OD. balke, $\mathrm{D}$. ball $=$ MLG. balke, a beam, balance, corn-loft, LG. balke, corn-loft, $=$ OIIG. ance, corn-loft, LG. balke, corn-loft, $=$ OIIG.
baleho, balko $>$ It. balco, a beam, $>$ balcone, $>$ E. baleho, balko (>It. balco, a benm, $>$ baleone, $>\mathrm{F}$.
baleony, q. v.), MHG. ballie, G. balle, ballien, a beam, bar; also, with diff. formative, $\Lambda \mathrm{S}$. balc (once), a ridge, = Icel. bällir, bölkr $=\mathrm{Sw}$. ball = Norw, balk, bolk, beam, bar, partition, division, = Dan. balk, ridge, partition; AS. bolca, gangway, = Icel. bjalki = Sw. bjällke, bjelke= gangway, = Icel. bjalki $=$ Sw. Sw. bjalke, ajelke =haps akin to Gr. $\phi a ́ \lambda a \gamma \xi$, a beam, pole, log, trunk, block: see phalanx.] 1. A ridgo; especially, a ridge left unplowed in the body of a field, or between fields; an uncultivated strip of land serving as a boundary, often between pieces of ground held by different tenants. The latter use originated in the open-ficld gystem (which see, under feeld.
[Commo in provincial English and Scotcl.]

Dlkeres snd delueres dipged vp the balkes.

Green balks snd furrow'd lands.

The properiy consisted of 2,752 acres, whith were vided into 3,509 strips of land set st every possible angl from nine to thirty leet wile snd about nine or tell cliain 2. A piece missed in plowing Hence-3t. An omission; an exception.

The mal steele sbout dotlı fiercely fly,
sparing wight, ne lesving any balkc. 4. A blunder; a failure or miscarriage: as, to
make a balk; you have made a bad balk of it [Now chicfly colloq.] Hence-5. In base-ball a motion made by the pitcher as if to pitch the ball, but without actually doing so.-6r. A barrier in one's way; an obstaele or stumbling ment.

A balk to the confldence of the bold undertaker. South. 8. In coal-mining, a more or less sudden thinning out, for a certain distance, of a bed of timber of considerable iength and thickness. Specifically-(a) A cross-beam in the rool of a house whieh joned one-story houses of Scotland, J reland, and the North of England these tie-beams were often exposed, and boards
or peeled saplings called calers were laid across then, or peeled saplings called calers were laid across then exposed tie-beams or from the callers
suspended. [Prov. Eug. and Scotch.]

Tubbes hanging in the balkes.

The stiffest balk bends more Carlyle Irench all joists creak

(b) Milit., one of the besms connecting the successive supports of a trestle-bridge or loatesu-bridge. (c) In carp., a foor, ete.; a square log.

[Obsolete, except cxept balk-line (bâk'līn), n. In billiards, a diagonal in dialectal usage.] - 11. In billiards, the space line cutting off a corner, or a straight line cutbetween the cushion of the table and the balk- ting off a uniform space on each side (generally line. A ball inside this space is said to bo in 14 inches), from the main field of the table.
balk.-12. A long wooden or iron table on balk-staff' (bak'stàf), $n$. A quarter-staff. which paper is laid in the press-room of a print balky (bâ'ki), $a$. [ [ $b a l h^{1}, r_{.},+y$.] Given to ing-office.-13. A set of stout stakes sur- balking; apt to stop abrupt]y and obstinately rounded by netting or wickerwork for catching refuse to move: as, a balky horse. [U. S.] fish. N. E. D. [Prov. Eug.]-14. The stout ball1 (bâl), n. [Early mod. F. also balle, somerope at the top of fishing-nets by which they times baule, baule, <ME. bal, ball, balle, either

are fastened one to another in a fleet. [In from Icel. (see below) or" $<$ As. "beallu or Cornwall, balch.] N. E. D.

balk I, baulk (bâk), v. [< ME. balken, make a beallue, L. ballock, ]it. a little ball: see ballock) balk in land, that is, leave a strip or ridgo of $=$ D. bal = Flem. bal, ILG. bal, LG. ball, a land unplowed, $<$ balk, a ridge: see hall $1, n$. Cf. To make a balk or rirlge in plowiug; nake a loaving a strip) unplowed.

$$
\text { I'alladi }
$$

Tence - 2 $\uparrow$. To leave untouched generally; pass over; negleet; shum. To place a balk in tho way of; he
inder; thwart; frustrate; disappoint.

Jy Sport is slways balkt, or cut short - I stumble over Alike to the citizcn and to the lcglsiator, fiome experisalks calculation. $I I$. Spencer, Sins of Legisistors, ii.

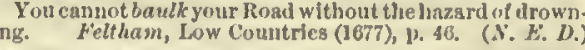
[Rare.]

Ten thousand bold Scots, two-gnd-twenty knights, On Ilolmedon's plalus. Shak., I IIEn. JV., I. I Some editors read bah' $d$ in this passage.] =\$yn. II. intrans. 1. To stop short in one's course, s at a balk or obstacle: as, the horse balked; England, but in common use in the United But to occasion him to further talke,

To feed her humour with his plessing style,

Spenser, F. Q., III. Ii. 12. Manton, Works (1653), IV. 227. (N. K, D.)
Mot divide and boulk with God.

balk ${ }^{2}$ (bâk), v. $i$, [Prob. < ME. "balken (not belchen, belch, vociferate) (AS, beleian, shout, $=$ Fries. balckien $=$ Flem. and D. balken, bawl, bray; cf. Flem. and D. bulken = LG. bölken, bellow. The AS. form, which ocenrs but one in this sense, is by some identified with the ative, bealcettan, belcettan, > ME. balken, belken, out offensive implication, belch out, vociferate utter (words, hymns, etc.); so $M \mathrm{M}_{\text {. bolken, mod. }}$
dial. bouk, bolie, bock, etc.: see belch, belk, bolk All these words are prob. based on the same nify to fishing-boats the direction taken by tho shoals of herrings or pilehards, as seen from bawling or shouting, subsequently by signals. N. E. D. [Local, Eng.] also Balcan; = F. Balcan $=$ G. Ballan, [Formerly name appar. of Slavic origin.] Of or pertainembracing European Turkey, Greece, Bulgaria the balker (bâ'ker), n. [<balk1, v., + err.] Ono balker ${ }^{2}\left(b \hat{a}^{\prime} k e ́ r\right), n$. [<balk $\left.{ }^{2}+-c r i\right]$ A man stationed on a cliff or an eminence to look out the direction taken by them. [Local, Eng.] The pilcharda are pursued by a lifger fish, called a
pluslier, who leapetil above water and isewrayeth then to balkish $\nmid$ (bâ'kish), a. [< balk', $\left.n_{0},+-i s h.\right]$ urrowy; ridged; uneven.

gry and balkish way. "bealla (not found, but evideneed by the dim. belchen, E. bclk, belch, used also, in AS. ehiefly, (ans, a mountain-range crossing 
ball

ball, = OHG. "bul, m., ballo, pallo, m., balla palla, f., MHG. bal, balle, m., G. ball, m., a ball, ballen, m., a hale, packagc, = Icel.böll $=$ Norw.
ball, ball, = Sw. boll, ball, beil, bale, = Dan. bal, billiard-ball, balde, ball (in anat.), balle, bale, bold, playing-ball; not found in Goth. Henee (from OHG.) ML. balla, palla, bala, a ball, a bale, > It. balla, palla, a ball (now distinguished: balla, a bale, palla, a ball), Sp. Pg. Pr. bala, a ball, a bale, $=$ F. balle, OF. balle, bale, a ball, a
bale, > D. baal = OFlem. bale, Flem. bal, MILG. bale, > D. baal = OFlem. bale, Flem. bal, Mndle:
bale $=\mathrm{ME}$. bale, E. bale, prop. a round bundle bale $=$ ME. bale, E. bale, prop. a round bunde:
see bale ${ }^{3}$. Appar. a native Teut. word, akin te boll1, bovol1, q. v., and to L. follis, a wind-bag, an inflated ball for playing, $>$ ult. E. fool : see fool 1 and folliele, etc. The Gr. $\pi \dot{a} \lambda \lambda a$, a ball, is appar. a different word, but it may be the source A spberical or appreximately spherical bedy; a sphere; a glebe: as, a ball of snew, of thread, of twine, etc. Specifically-2. A reund or nearly round body, of different materials and sizes, for use in variens games, as base-ball, feet-ball, ericket, tennis, billiards, etc.-3. A or any medification of it.-4. A toss er threw of a ball in a game: as, a swift ball; a high or low ball. -5 . In basc-ball, a pitch such that the ball fails to pass ever the home-plate net higher than the sheulder ner lower than the knees of the striker: as, the piteher is allowed five balls by the rules of the game.-6. A small spherical body of wood or ivory used in voting
by ballot. See ballot 1 and blackball. - 7 . The missile or projectile thrown from a firearm or other engine of war; a bullet er cannen-ball, whether spherical (as originally) or cenical or eylindrical (as now commenly); in artillery, a solid projectile, as distinguished from a hollow one called a shell (which see).-8. Projectiles, and more particularly bullets, cellectively: as, te supply a regiment with powder and ball; the troops were ordered to lead with ball. $-\mathbf{9}$. In printing, a reunded mass or cushien of hair or woel, covered with soft leather or skin, and fastened to a stoek called a ball-stock, used (generally in pairs, one for each hand) befere the invention of the reller to ink type on the press: invention of the reller to ink type on the press:
still in use by wood-engravers, but made of smaller size, and with a silk instead of a leather face. A similar ball is used in inking the blocks In calico-printing. That used by engravers in apreading an 10. A clew or cep of thread, twine, or yarn.11f. A spherical piece of seap.

Then slee said to her maids, bring me oil and waahing
balls, and slrut the garden doors, that I may wash me. For my part, I'll go snd get a sweet ball, and wash m hands of it. Middleton, Blurt, Master-Constable, ii. 1. metal., one of the masses of iron, weighing about 80 pounds, into which, in the process of converting pig-iron inte wrought-iren by puddling, the iron in the reverberatery furnace is made up as seon as it begins to assume a pasty condition. As last as the iron is balled it is taken out of the furnace, and is first ham-
mered or squeezed, and then rolled into bara of any

14. In med., a belus; a large pill : now only in veterinary medicine.-15. In pyrotechnics, a globular mass of combustible ingredients, or a case filled with them, designed to set fire to something or to give forth light, etc.; a fireball.-16. In cabinet-worl, the composition of sheemakers' wax used in waxing black-work. human bedy, that is reunded er pretuberant: as, the ball of the eye; the ball of the thumb; the ball of a dumb-bell; the ball of a pendulum, that is, the bob or weight at the bettem.

Is the ball of his sight much more dear to him?

18t. The central hellew of the palm of the hand. - 19. The central part of an animal's foet.-20. A testicle: generally in the plural. [Vulgar.]-21. A hand-toel with a reunded end arranged for cutting hellow forms. - 22. A round valve in an inclosed chamber, operated a ball-valve. - 23. In lapidary-work, a small spherical grinder of lead used in hellewing out the under side of certain stenes, as carbuncles, to make them thinner and thus more transparent.-24. The globe; the earth. [New rare.] Julius and Anthony, those lords of all,
430

Ye gods, what justice rules the ball ?

Pope, Chorus to Brutus, 1. 25.

A globe representing the earth is a common symbol of
sovereignty; lience bacon has the phrase to hold the ball

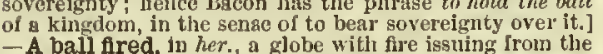
A ball fred, in her, a globe with fire issuing from the
top. When it is intended to represent the fire issuing lin more places than one, it is so expressed ln the blazon : as,
ball fived in four places.-Ball and socket, min inball fired in four places.- Ball and socket, an inhorizontally, obiliquely, or vertically, used in managing surveying and astronomical instruments. - Ball-andsocket coupling, a ball-and-socket joint used for a revolving rod or shait, prineipaliy to change the direction of the line of transmission of motion, but sometimes to allow
for any yielding of the aupports which would bring the shafting out of line.- - Ball-and-socket hanger, a hanger
in which the box or bearing is attacleed to the bracket or pendant by a spherical aegment-joint to allow frac a of the shaft or rod, or other cause which may birng the ahaft out of line and thus occasion excessive friction and wear,-Ball-and-socket joint, a natural or an artificis joint formed by a ball or knob working in a socket. In anat. it is s kind of grticuemplitied in the hip-joint and slioul
der-joint. Also called cup-and-ball joint. -Ball-and-socket pillow-bleck, in mech., a pillow-block which, within certain limits, can accommodate itself to the

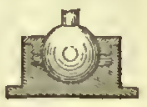
lum, a bob. See bob1.- Ball of the eye. See eyeball. Ball of the foot, the protuberant part of the sole at the basea of the other toes, upon which the body rests when the heel is elevated. - Ball of the thumb, the palm; the volar or thenar eminence. - Ball soda, crude sods.-Golden balls. See golden.- Venetian ball, in ball. = Syn. Sphere, ete. See glabe.

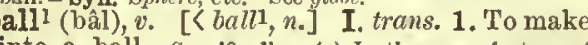
into a ball. Specifically - ( $a)$ In the manufacture of
cotton, to wlnd lnto balls. (b) In metal., to heat in a fur-

2. Te surround in a compact eluster, as bees when they surreund the queen bee.

This is more spt to happen when a strange queen is ntroduced to a colony, but sometimes a colony will ball their own queen if unusually excited or disturbed. . . If not soon released, the qlleen dies and is thrown out of queen for the purpose of protecting her Irom the attacks II. intrans. 1. To form or gather inte a ball, as snow on hor'ses' hoofs, or mud on the feet.2. To remain in a selid mass instead of scattering: said of shot discharged frem a gun.form the bail preparatory to rolling. (b) To fsil; mis.

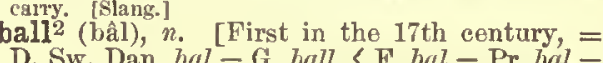
D. Sw. Dan. bal $=\mathrm{G}$. ball, $\langle\mathrm{F}$. bal $=\mathrm{Pr}$. bal $=$
$\mathrm{Sp} . \mathrm{Pg}$. baile $=1 \mathrm{t}$. ballo (ML. ballus), dancing, a dance; from the verb, F. baller, OF. baler ME. balen, rare $)=$ Pr. ballar $=$ Sp. Pg. bailar =It. ballare, <LL. ballare, dance, < Gr. (in Sicily and Italy) $\beta a \lambda \lambda i \zeta \varepsilon \iota v$, dance, jump about, appar. $\langle\beta a \lambda \lambda \varepsilon v$, threw.
dance; daneing.

They had got a Calf of Gold and were Dancing sbout it But it was a Dismal Ball, and they paid dear for their
Junket.
Penn, Add, to Prot., p. 19, (N,E, D.

2. A social assembly of persens of both sexes for the purpose of dancing.

In various talk th' Instructive lours they pass' $\mathrm{d}$,

, $R$. of the L., ill. 12 aelf at a ball, she longed to dance, but she had not an acquaintance in the room.
Jane Austen, Northanger Abley, p. To open the bali, to begin the dancing; hence, flgurgball ${ }^{2}$ (bâl), v. i. [<ball $\left.{ }^{2}, u_{.}\right]$Te take part in a ball; dance. [Rare.]

It is the temperature that sets people dancing and ballball ${ }^{3}+$ (bâl), n. [Not found in ME., but perhaps existent, as the pessible source of the balleard $1, q . v_{.} ;<W$. bal, having a white streak on the ferehead, as a horse, bali, a white streak, $=$ Bret. bal, a white mark on an animal's face,
$=$ Ir. Gael. bal, a spet, mark, freckle. Cf. Gr.

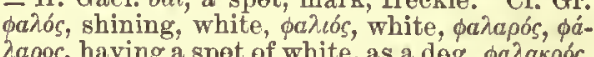

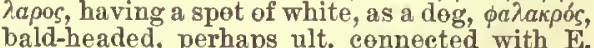
bald-headed, perhaps ult. connected with E.
bale $^{2}$, a fire. Hence preb. bald 1 and ballard ${ }^{1}$.] 1. A white streak or spot.

The ii. propertyea of a bauson [badger]. The fyrste
is to haue a whyte rase or a ball in the foreheed; the seconde, to haue a whyte fote.
Fitzherbert, Husbandry, 8 73. (N. E. D.)

2. A horse or nag (originally, white-faced): used appellatively, like dun, bayard. ball ${ }^{\dagger}, v$. An obselete form of bawli.

\section{balladry}

ball ${ }^{5}+n$. An obsolete form of $b a l$.

[It., a bundle, package, bale:

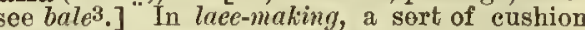
used by the Maltese lacc-makers.

allacet, $n$. An obsolete form of ballast.

ballad (bal'ad), $n$. [Early mod. E. also ballade, alse (after "It.) ballat, ballatt, ballet, ballette, balette (with term. conformed to -et ; cf. saled, formerly sallet), Sc. corruptly ballant; < ME. balade, $<\mathrm{OF}$. balade, mod. ballade, a dancingsong, < Pr. Pg. ballada= OSp. balada = It. bal lata, a dance, a dancing-seng, < ballare, dance: see ball2 2 , a d A cing-seng, < ballarc, dance: paniment to a dance.-2†. The tnne to which such a song is sung.-3. A short narrative peem, especially one adapted for singing; a poem partly epic and partly lyric. As applied to the minstrelsy of the borters of Englund and Scotland, and of Scandinavia and Spain, the ballad is a rort of minor epic, reciting in verse more or less mide the exploits of warriors, the adventures of lovers, and the mysteries of
fairyland, desigued to he rehearsed in musical recitatjve .

Roundel, balades, and virelay. Gover, Conf. Amant. The ballad .... is the lyrically dramatic expression of actions and events in the lives of others.
W. Sharp, D. G. Rossetti, p. 355.

4. In music, originally, a short and simplo vecal melody, often adapted te mere than one stanza of poetry and having a simple instrumental accompaniment. The term is sometimes and more loosely to more elalorate compositions in which balladt (bal'ad), v. [Early mod. E. also ballat, ballet; from the neun.] I. intrans. Te make or sing ballads.

There envious libellers ballad against them.
Dome, Juvenilla, I.

II. trans. To celebrate in a ballad. Rlyymers ballad us out o' ture.

She has told all : I shall be bailated. IIeynood, A Challenge, iii. 1. I make but repetition Of what is ordinary and Rysito talk,
And ballated, and would be play'd o the stage.
Jebster, White Devil.

ballade (ba-làd'), n. [F.: see ballad, n.] 1. A peem consisting of one or mere triplets each larmed of stanzas of seven or eight lines, the last line being a refrain cemmon to all the stanzas.-2. A pecm divided inte stanzas havor eight.- Ballade royal, a ballade in which each llne ballader (bal'ad-ér), n. [Early mod. F. also ballater, balletter; < ballad, v., +-er-1.] A writer or singer of ballads; a balladist.

balladic (ba-lad'ik), a. [<ballad +-ie. $]$ Of, pertaining to, or of the nature of ballads.
balladical (ba-lad'i-kal), $a$. Same as balladie. balladiert, $n$. [<ballad + ier: see-eer.] A

ladin, recently also baladine; $<\mathrm{F}$, balladin, new baladin, m., baladine, $f$. < ballade, a ballad. ballad.] 1t. A theatrical dancer.-2. A female public dancer. [Rare.]

$$
\begin{aligned}
& \text { The first breathlng woman's elueek, } \\
& \text { First dancer's, gipsy's, or street baladine's. }
\end{aligned}
$$

3t. A ballad-maker.

balladism (bal'ad-izm), n. [<ballad $+-i s m$. The characteristic quality of ballads. N. $E$. $D$. balladist (bal'ad-ist), $n_{\text {. [ [ ballad }+-i s t .]}$ balladize (bal'ad-iz), $r$; ; pret. and pp. balladized, ppr. balladizing. [' ballad $+-i z e.] \mathrm{I}$. trans. To convert inte the form of a ballad; make a ballad of or about.

II. intrans. To make ballads.

alladling (bal'ad-ling), n. $\quad[<$ ballad + -ling. $]$ allad-maker (bal'ad-mā"kér), n. A writer of ballads. Shat.

alladmonger (bal'ad-mung"ge̊r), $n$. A dealer ballads; an inferier poet; a poetaster.

I had rather be a kltten and ery mew,

Than one of these same metre ballad-mongers.
Shak., I Hen. IV., bii. I.

To make herself the pipe and balladinonger of a clrcle! to aoothe her light heart with catches and glees!
Sheridan, The Rivals, Ji. 1.

ballad-opera (bal'ạd-op"e-rä), n. An opera in which ballads or popular songs are sung. balletry ballatry: ballad $+-r y$. Poetry the ballad kind; the style of ballads. 


\section{balladry}

What though the greedy iry
He taken witi lalse baits of worded balladry

And think it poesy?

B. Jomean, Vunderwoods, xli. The viliages also must have their visitors to inquire what lectures the bagpipe and the rebec reads, even to tite
ballatry and the gannt of every municipal tiddler.

ballad-singer (bal' ad-sing "ér), n. A person whose empleyment ëonsists in singing ballads in publie.

ballahou (bal' $q-h_{1}$ ) $), n$. [Prob. of nativo origin.] 1. A fast-sailing two-masted vessel, rigged with high fore-and-aft sails, much used in the West Indies. The foremast rakes forward, the mainmast aft.-2. A term of derision applied to an ill-conditioned, slovenly ship.

ballam (bal'am), n. [Native name, prob. same as Malayalam vallam, a large basket for storing grain, a dam.] A sort of canoo hollowed out of timber, iu which Singhalese pearl-fishers wash out the pearls from pearl-oysters.

ballan (bal'au), $n$. [Appar. \& Gael. and Ir. ballach, spotted, speekled, (Gael. and Ir. bal, a spot, speek: see ball ${ }^{3}$.] A fish, the ballan-wrasse. balland (bal'and), $n$. [Origin unknown.] In mining, pulverized lead ore, after separation from its gangue. [North. Fing.]

ballant (bal'ant), $n$. [Se., a corruption of ballad.] A ballad.

They're dying to rliyme ower jrayers, and ballants, and

ballan-wrasse (bal'an-ras) n. The most geueral Finglish name of the Labrus maculatus, a fish of the family Labrida.

ballaragt, v. $t$. An obsolete form of bullyrag. You vainly thought to ballarag us.

[ME +-ard.]' A bald-headed person; a baldhead. And seornede to hym saying, stye up, ballurd! ["Go
up, thou baidhead," in authorized version.]

ballard $^{2} \dagger_{1} \ldots$. [Origin unknown.] $A$ kind of musieal instiument. Purchas, Pilgrims. (N. E. $D_{.}$)

ballast, ballaset, $n$. and $v$. See ballast.

ballast (bal'ast), $n$. [Early mod. E. also balast, balcst, balist, and, with loss of $t$, ballas, ballass, ballasse, ballace, ballesse, balase, ete. (not in MIE.), = F. balast $=\mathrm{G}$. ballast (> Pol. balast = last, Flem. ballas, Dan. ballast, Sw. ballast, barlast, OSw. ODan. barlast, the last being appar. the orig. form, $<$ bar = E. bare, mere, + last $=\mathbf{E}$ last, load or weight; but the first element is uncertain. The Dan. baglast, 'back-load,' D. obs. balglast, 'belly-load,' appear to be due to popular etymology. The explanation of ballast as $<$
MIL. bal-, = AS. balu, bad, evil (see bale $)$, last, load, that is, unprofitable curgo, is not satisfactory.] 1. Weight carried by a ship or boat for the purpose of insuring the proper stability, both to avoid risk of eapsizing and to secure the greatest effeetiveness of the propelling power. A usual modern form of ballast is water whieit is pumped in or out of compartments arranged to receive it; lead is also much used, especially for craft of
moderate size, and is often run into a space left for it be. tween the plates of the keel, or east into plates of appropriate form and bolted to the exterior of the keel. Gravel, stones, pig-iron, and other weighty materials are in com-
mon use as bailast, in cases where the requisite weight cannot be found in the regular cargo Itseis.

So rich shall be the rubbish of our barks,

Ta'en liere for ballars to the ports of France,

Greene, Oriando Furioso.
Bags of sand placed in the ear of a balloon to steady it and to enable the aëronaut to lighten the balleon, when neeessary to effeet a rise, by throwing part of the sand ont. -3 , Gravel, broken stones, slag, or similar material (usually ealled road-metal), placed between the sleepers or ties of a railread, to prevent them from shifting, and generally to give solidity to the road. The name is also given to the stones, burnt elay,

Depressions frequently occur in concrete flooring when balleala beed dewn.

4. Figuratively, that whieh gives stability or steadiness, mental, moral, or political.

Those that are of solid and sober natures have more of
the ballagi than of the aall.
Breon, Vain Glory.

There men have not ballast eneugh of humllity and fear.

Ballast-plants, piants that grew upon the baliast of a ship after it has been diseharged, from the seeds that may aceidentaliy be brought with it. - In ballast, withont
431

ballimong

ballast (bal'ast), 1. $\ell$. [liarly mod. E. also balast, and with loss of $t$, bellas (pret. and pp. ballased, sometimes ballast, ballasing) ballasse, ballace, balase, ete. =G. D. Flem. LG. ballasten $=$ Dan. ballaste, baylaste $=$ Siv. barasta; from the neun.] 1. To place ballast in or on; furnish with ballast: as, to ballast a a railroad. See the noun.

The road was 80 perfectly ballasted with atone that we

2. Figuratively: $(a)$ To give steadiness to; keep steady.

Tia clarity muat ballast the heart.

II ammond, Sermons, p. 011 .

(b) To serve as a counterpoise to; keep down y counteraetion.

Now you have given me virtue for my gulide
And with true honeur ballogled my pride.

3t. To load; freight. -4 . To load or weigh down.

When his belly is well ballaced, and his brain rigged a

B. Jonson, Ind. to Every Man in his II umour.

These ycllow rasenls [coins] must serve to ballost my

ballastt (bal'ast), $p p$. Ballasted.

Who aent whole armadas of carracks to he Latlast.

IInlks of burden great,

Which brandimart rebated rom his eoast,
And sent them home ballast with litlle wealth.

Greene, Orlando Furioso.

allastage (bal'as-tāj), n. [< ballast + -age. $]$ 1. An old right of the admiralty in all the royal rivel's of Great Britain to levy a rate paid for the privilege of taking ballast, as from gravel-bed, ete.

ballast-engine (bal'ast-en"jin), n. A steamengine used for dredging a river or drawing earth and ballast on a railroad.

ballast-getter (bal'ast-get"èr), n. One whe is mployed in proeuring ballast for ships.

I now come to the nature of the ballast labeur itgelf. This is divisible fnto three classes : that performed by the
ballage-getters, or these who are engaged in raising it from the bed of the Thamea; by the ballast-lighters, or thoae the

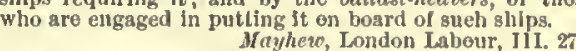

allast-hammer (bal'ast-ham"er), n. Adoublefaced, long-handled hammer used in laying railroad-traeks.

allast-heaver (bal' ast-hēe'vèr), n. 1. One who is employed in putting ballast on board ships. See extract under ballast-getter. -2 . A dredging-machine for raising ballast from a river-bed; a ballast-lighter.

allast-hole (bal'ast-hōl), n. Same as ballast-

allasting (bal'as-ting), $n$. 1. The aet of furnishing witl baillast, as a ship or railıoad. . Ballast; that which is used for ballast, gravel or broken stones, cinders, or other material used for the eovering of roads or to form the uppe

ballast-lighter (bal'ạst-li”tèr), n. $\quad[\langle$ ballast + lighter2.] 1. A person employed in conveyng ballast for ships. See extract under balast-getter.-2. A large flat-bottomed barge for receiving and transporting ballast, or for removing salld, silt, ashes, or other deposits dredged from the beds of rivers and the bottorns of harbors, doeks, ete.

ballast-port (bal'ast-pōrt), n. A largo square port in the side of a merchant-ship serving for ealled ballast-kole.

ballast-trim (bal'agst-trim), $n$. The state of a ship when she is merely in ballast or has no eargo on board: as, she is in ballast-trim.

allatt, $n$. and $v$. An obsolete form of ballad. ballatoon (bal-a-tön'), $n$. A heavy boat employed in Russia in the transportation of tim ballatorium (bal-a-tó'ri-um), $n$.; pl. ballatori

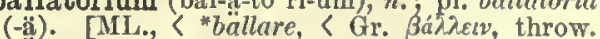
cif. balista, ballista, ete.] The forecastle or the stern-castle of a medieval ship of war: so called because it was a position of vantage from which missiles were discharged.

ballatryt, $n$. An obsolete form of balladry. method of lessening friction by causing a shaft balliage, $n$. See bailage.

to rest upon or to be surrounded by balls partly balliard'st, $n$. $p l$. Billiards. Spenser. contained in sockets, each ball being loose, ballimongt(bal'i-mong), n. [Origin unknown.]
and turning with the shaft. and turning with the shaft.
It necesary, ball bearings can be piseed mpon the crank. ball-block (bal'blok), $n$. In printing with balls, the slab or plate which holds tho ink. which see, under bluc).

all-callber (bal'kal" j-bér), ". A ring-gago for lling ther of gun-shot.

all-cartridge (bâl'kïr."trij), ". A cartridgo contridge or a blenk cortriluse.

all-caster (bâl'küs"tér), ". A easter for tho legs of furniture, ete, havinu a ball iustead of an ordinary roller.

all-cock (bal'kok), $n$. A hollow sphere or ball of a lever, which turns the stop-eock regulates the supply of water. The ball, floating in tho water of \& tank or cistern, rises and
falls wití it, sliutting off the flow when tho water has reached a certain

alledt, $a$. An obsolete form of bald 1 .

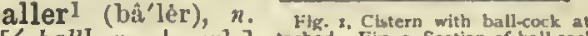
One who or that on larger rcaice: Section of ball-eock which forms any- lever which being raised shuts the

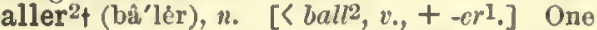

who takes part in a ball for dancing.

allerina (bảl-lā-ré'nä), $n_{0} ;$ pl. ballerlnas, bal lerine (-näz, -nā). [It., fem, of ballerino(pl. ballerine), a dancer, (ballare, dance: seo ball2.] A female ballet-dancer.

ballet1 (bal'et), $n$. [< OF. balette, a little ball dim. of bale, balle, a ball: see ball 1 and -et. $]$ Little ball: in her., a bearing in eoats of arms plates, burts, ete.

allet2 (bal'ā, formerly and still sometimes bal'et), $n$. [First in the 17th century, also ballat, ballette, balette, balet, < F. ballet (= It. $b_{a l l}^{2}$ and -et.] 1. A specticular dance, more or less elaborate in steps, poses, and costumes, in which a number of performers, chietly females, take part. It is led or conduetel by one or to an operatie or other dramatie representatiou 2. A complete pantomime or theatrical representation, in which a story is told, and actions, charaeters, and passions are represented, by gestures and grouping, accompanied by characteristic or illustrative music, daneing, and often rich seenery and decorations.-3. The corps of dancers who perform ballets. 年 (bing or in a ballet. [Rare.]

II ballets to her: " Will you cotue down here and dance?" ballet ${ }^{3}+, n$. and $v$. An obsolete form of ballad. balletryt, $n$. An obsolete form of balladry. mont resembling a ball placed in a circular

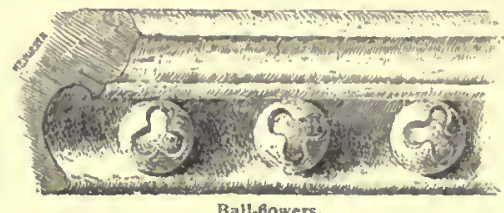

flower, the three petals of which form a eup round it. Thls ornament is usually found inserted in a and of the decorated styie of the thirteenth century. three (York cathedrai), and tralls of different sizes and ball-grinder (bâl'grin”dèr), n. A pulverizer or disintegrator formed by balls of metal inlosed in a rotating eylinder. The material to crushed is broken by the attrition of the olling balls.

all-gudgeon (bâl'guj "on), n. A spherical udgeon, permitting a lateral deflection of the level, and letting it on thing into balls. balletto), dim. of $b a l=I t$. ballo, a dance: see 
balling

432

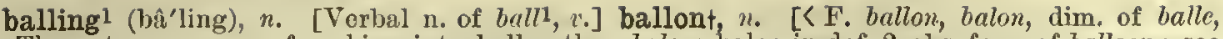
The act or process of making into balls; the bale, a bale; in def. 2 , obs. form of balloon: see act of assuming the forn of a ball; specifieally, in the process of puddling, the forming of the iron into balls or round

balling ${ }^{2}$ (bâ'ling), $x$. [Verbal n. of ball $2, v$.] The frequenting of balls; daneing. [Rare.]

balling-furnace (bâ'ling-fèr"nặs), n. [< balling, verbal n. of ball $1, v_{\text {. }}+$ f fumace.] I. A furnace in which piles or fagots of metal are placed to be heated preparatory to rolling. ratory furnace used in alkali-works.

balling-gun (bâ'ling-gun), $n$. An instrument for administering to lorses medieine rolled into balls. It consiats of a tuhe from which the air is partially exhausted; the ball is hell on the end of the tube hy atmospherie pressure, and is releasell by a pis
when fairly within tle esophagus.
. II. Knight.

balling-iron (bầ'ling-ï'èrn), $n$. A hook-shaped tool for removing snow from the fect of a loorse. balling-machine (bâ'ling-mâ-shēn"), $n$. A machine for balling cotton thread.

balling-tool (bâ'ling-töl), $n$. The tool used in collecting into a mass the iron in a puddlingfurnace preparatory to taking it to the hammer or squeezer; a rabble.

ball-ironstone (bâl'1'"èrn-stōn), $n$. In English mining, nodular iron ore. Also called ball-mine and ball-vein.

ballisedt, $a$. [Appar. for "pallised, < F. palissé, pp. of palisser, surround with pales: see paliWotton. (N.E.D.)

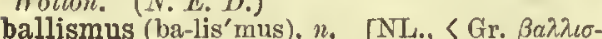
$\mu \delta ́ s$, a jumping about, daneing, < $\beta a \lambda \lambda i \zeta \varepsilon \varepsilon v$, jump about, danee: see ball2.] In pathol., a name which has been given to chorea, to paralysis agitans, and to other forms of tremor.

ballist (bal'ist), n. [Early mod. E. also balist, Same as ballista. [Rare.]

ballista, balista (ba-lis'taï), n.; pl. ballistae, balistae (-tê). [L., oceasionally (in gloss.) ballistra,

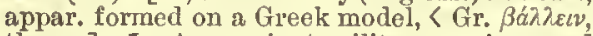
throw.] 1. An ancient military engine used for throwing missiles. The different references to It are contradictory, as it is leseribed as acting by mean
of a bow, but also as throwlng large stonea ratlier than of a bow, but also as throwng large stonea ratlier than
darts. An attempt has ben made to reconcile these atatements by repreaenting the engine as composed of a
strong shaft, rotating on one of its ends, and having at the other end a receptacle for the missile; this shaft would be thrown forward by the recoil of a ateel bow, and atopped gaddenly against a tranaom, thus releasing the milssile.
Thronghont the midlle ages the tern is nsed in Latin writings for military enginea of different kinds. See tres. buchet, mangonel, eanble, petronel, pierriere, and cate tante. When used as a hearing in heraldry, the ballista is repre. generally two upright posta with a movable bar between
them, allown loaded at one end. 2. [NL.] In anat., the astragalus, a bone of the tarsus.

ballistic (ba-lis'tik), $a$. [< ballista +-ic.] Pertaining to ballisties, or the scientific construetion and use of projectiles. - Ballistic curve, the retical or parabelic path. - Ballistictic galvanometer. See galvanometer. - Ballistíc pendulum, an apparatua of militiary projectiles and consecuently the the veloeity force of gunpowiler. A piece of orinanee is fired against a castirron case filled with bega of sand, which forms the
ball of a pendulum, and the pereussion casses the pendit. is measured on a eopper are by ant index earrying at ver18 measured on a coppcr arc by all index carrying a ver.
nier, and the amount of vibration forms a measure of the nier, and the amount of vibration forms a measure of the
foree or velocity of the ball. The ballistic pendulum is
now nearly auperseded by various forms of npparatus for

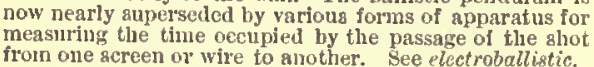
from one acreen or wire to another. See elcetroballistic.
ballistics (ba-lis'tiks), $n$. [Pl. of ballistie: -ics.] 1. The scienee or art of discharging large missiles by the use of the ballista or other engine.-2. The science of the motion of proballium (bal'i-um), n. [MI.: see bail ${ }^{3}$ and bailey1.] 1. Same as bail $l^{3}, 5 .-2$. Same as bailey ${ }^{1}$. ball-joint (bâl'joint), $n_{0}$. A jointed connection in which one of the connected pieces has a ballshaped extremity, fitting a eup-shaped socket

ball-lever (bâl'lev"ér), $n$. The lever of a ball-

ball-mine (bâl'mīn), n. Same as ball-ironstone. ball-mounting (bâl'monn"ting), n。 A kind of harness-mounting having a ball where a ring is fastened to tho base.

ballock (bal'ok), n. [<ME. ballok, balluk, balok, CAS. bealluc, $<$ "bcallu or *bealla, a ball, + dim.
$-u c$ : seo ball 1,20 , and -ock. $]$ A testicle. [Ob$-u c$ : see ball 1,20,
solete or vulgar.] balloon1.] 1. A balo of paper, ete.-2. Same as balloom $1,1,2$.

balloon ${ }^{1}$ (ba-lön'), $n$, [In some senses also balone, ballone, < It. ballone, pallone, a large ball, a foot-ball (now distinguished: ballone, a large bale, pallone, a foot-ball, balloon) (=Sp. balon, a foot-ball, a large bale, = Pg. balão, a balloon, = F bullom, a fardle or small pack, balon, " a little ball or pack, also a foot-ball or foot-ball, balloon, swelling hill), aug. (in $\mathrm{H}$ prop. dirn.) of balle, ete., a ball, bale: see used in playing certinin games; a game played b with such a ball. It was tossed to and fro by either hand or foot, the hand being defended by a guard (bal. oon-brasser). Sce foot-ball

"Tis easier aport than the baloon.

II eynood.

It was my elivied lot to lead the winning party at th wondrous match at ballon, made betwixt the divine Aa. trophel (our matchleas Sidney) and the right honourable
my very good Lord of Oxford. Scot, Mlonastery, II. iit. 2. In chem., a round vessel with a shor't neck, used as a receiver in distillation; a glass receiver of a spherical form.-3. In arch., a ball or globe on the top of a pillar. -4 . In pyrotechnics, a ball of pasteboard or a kind of bomb stuffed with combustibles, which, bursting like a bomb, exhibits sparks of fire like stars. - 5. In weating, a cylindrical reel on which sized dried by rapid revolution in a heated chamber -6. A bag or hollow vesscl filled with hydrogen gas or lieated air, or any other gaseous to rise and float in the atmosphere. It is of sllk or other light material, varnished with eaontehonc dissolved in turpentime. A network of twine envelops the whlel a car, usually consisting of a large wicker basket, is which a car, 11sually consisting of a large wicker basket, is opened and closed at pleasure by meana of a string, and aëronant wishea to ascend, he throws ont aonje of the hallast; if to descend, he opena the valve. Balloons have been suceessfnlly used for military purposes (see captive medium of conmmication with the outside world. balloon and inclosing words which are represented as issuing from the month of a spcaker. - Captive balloon, a balloon anchored or attached to the gronnd by means of a rope, which may be either perbe raised at pleasure. Such balloons have been employed for nillitary reeonnoissance. - Steering balloon, a bal. by M. Dupny de Lome during the siege of Parls in 1871. The rudder is said to be able to defiect the narachine $11^{\circ}$ to either side of the direct line in which the wind is blow.
ing, so that a balloon leaving Paris winh the wind straight for Brussels could be landed at eitler London or Cologne.
balloon ${ }^{2}$ (bal'ó-on), n. [Also balloen, balon, name.] A state barge of Siam, made in fanciful imitation of a sea-monster, and having 70 to 100 oars on a side.

balloon-ball $\nmid$ (ba-lön'bâl), $n$. Same as bal-

I'll nake him the balloon-ball of the churches,
And botli the aides ghall toss him. Middleton, Game at Chesa, ii.

balloon-boiler (ba-lön'boi ${ }^{\prime \prime}$ lèr), $n$. A stcam-
boiler having form somewhat resembling that of a balloon.

balloon-brassert, n. $[<$ balloonl + brasser, a
form of bracer, after $\mathrm{F}$. brassard, also brassal form of bracer, after F. brassard, also brassal (Cotgrave): see def.] A brace or guard of to protect the hand and arm.

ballooned (ba-lönd'), a. Swelled out like a balloon. aëronaut.

fish of the order Plectognathi and A globefish; a

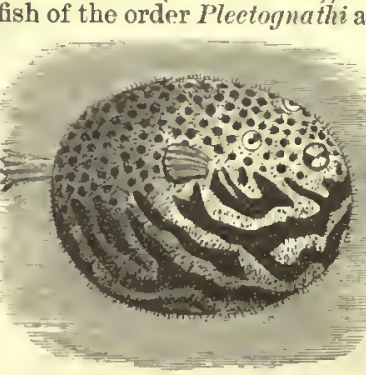
suborder Gymnodontes, as thetropical Tctus, or striped spine-belly, or a species of one of tho genera Triodo and Diodon. So called becanse
has the power has the power of which is retaine Balloon-fish (Tetrodon tineatus). the esophagus, balloon" (Cotgrave), now ballon (after It.), a ballong $=\mathrm{Sp}$. balon $=\mathrm{Pg}$. balão; from the native

ballooner (ba-lö'ne̊r), n. A balloouist; an ballot

and thus of llowing itself up into a nearly spherleal alape like a balloon. The ivory-like tips of the jawbones cleft above and below, as in Tetrodon, give the fish the appearGymnodontida.

allooning (ba-lö'ning), n. [<balloon $\left.{ }^{2}+-i n g^{2}.\right]$ 1. The art or practice of ascending in and of managing balloons. - 2. In political and stockexchange slang, the operation of booming a eandidate, or of inflitious favorable reports.

Ballooning indeed Jeffersom, Corresponballoonist (ba-lö'nist), n. [< balloon $1+-i s t$.$] One$ who asconds iu a naut.

alloon-jib löu'jib), n. angular sail made of light canvas, used only by yachts

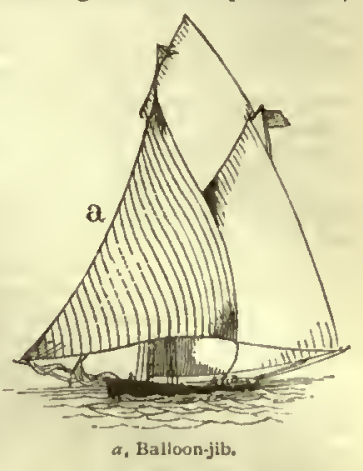
and in light winds, set between the forotopmast-head and the end of the jib-boom.

alloon-net (ba-lön'net), $n$. A kind of woven ace in which the weft-threads are twisted in a peculiar manner round the warps. E.H. Kinight. balloonry (ba-lön'ri), $\pi$. [ balloon $+-r y$.
The art or plactice of ascending in a balloon. The art or priat

balloon-sail (ba-lön'sāl), n. Light canvas uscil in yachts, as the balloon-jib, the spinnaker, alloon-topsails and -foresails, and the sliadow. ail and water-sail.

balloon-vine (ba-lön'vīn), n. A herbaceous climbing plant, Cardiospermum Halicacabum,

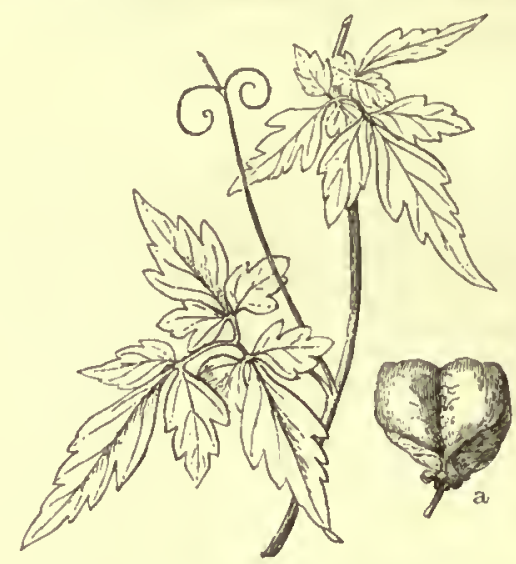

Ballooth-vine (Cardiospermum Halicacabum).
apsule or pod, about one half natural size. (From Gray's

natural order Sapindacec, found in all tropical countries. It bears a large, 3-celled, bladderlike pod. Also called heartsced.

ballot' (bal'ot), $n$. [First in the 16th century, It. ballotta $=\mathrm{F}$. ballotte, balotte, a little ball, esp. as nsed for voting, a vote, suffrage, $=\mathrm{Sp}$. ball: see ball and -ot.] 1. A little ball nsed in voting. Hence-2. A ticket or slip of paper, sometimes called a voting-paper, used for the same purpose, on which is printed or written an expression of the elector's choice as between candidates or propositions to be voted for.- 3. A method of secret roting by means of small balls, or of printed or written ballots, ballot-box. In the former case, each peraon who is and one black, places a white hall in the box if he is in avor of the resolution proposed, as the admission of a erson to membership in a club, or a hlack ball it he is ophored to it. Hence, to blackbrall a person is to vote against papers are 0 folled as to prevent the ballots or votingfrom being diaclosed, and are nsually handed to an anthorized officer ealled an finspector of eleetions, to be depositel in the box io the voter'a preaence. The ballot is now employed in all popular elections in the United the voting is viva voce), throughout the United $K$ ingdom the voting ls viva roce), throughout the United Kingdon tary elections tin Germany, France, Bejgium, Italy, and moat other conntriea of continental Europe.

4. A casting of ballots; a vote by ballot; also the whole number of votes cast or recorded: 
ballot

433

as, a ballot was taken on the resolution; thero ballow ${ }^{3}, u$. A worl used only by Shakspere was a large bullot. -5 . A method of drawing in tho passage cited, in the folio of $16 \% 3$, where lots by taking out sinali balls, ol the like, from a box; hence, lot-liawing. N. L. I. I.- Tsaue-

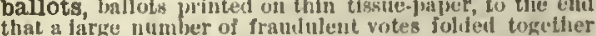
may be anumgrged lints the ballot.hox without detectioni.- To cast a ballot, to deposit in a ballot-lowx, or jresent
for deposit, a lasilut or vuting-paper.-To cast the ballot, to recoril, as if aseertiained by ballot, lhe vote of an
gssembly or meeling. The seeretary is often linstrueted

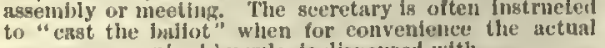
process, as reynifret lyy rule, is dispensect with. bullet; < It. bullottere $=\mathrm{F}$. ballotter, earlierbulot ter, = Ste buloter, vote by ballot; from the $t e r,=S$ Sulotar, vote by ballot; from the
noun.] I, intrens. 1. To decide unon a quesnoun.] I. inlruns. 1. To decide upon a queslots; take a ballot or a voto by ballot: often with for in the sense of 'in relation to': as, to ballot for members of a club. See the neun.

The Jindges... would never take their halls to ballot ba The convention dit not ballot until its third day. G. S. Merrinm, S. Jowiles, i1. 185.

2. To bound, as in the bore of a cannon: as, spherical projectiles ballot in the bore of the pieee. - 3. To seleet by lot; draw lots (for): as, to ballot for places.

II.t trans. 1. To vote for or against by ballot; ehoose or eleet by ballot.

None of the competitors arriviug at a 6 fiflectent number

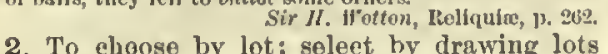
for.

Pensanis . . . who will not be balloted for soldters.

ballot ${ }^{2}$ (bal'ot), n. [ $<F$, ballot, a bale, prop. a small balo, dim. of balle, a bale: see bale 3 and $-o t$, and ef. the ult, identical ballot ${ }^{1}$.] A small bale, weighing from 70 to 120 pounds.

Alpaes is inmorted in inllots, hales of sbont 70 lbs.
Draperg Dict.

Ballota (ba-1ōtai), n. [NL. (L. ballote), < Gr.

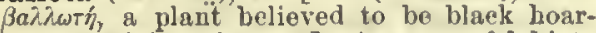
hound, origin unknown.] A genus of labiate plauts, of abont 25 speeies, mostly natives of plauts, of abont 25 specion. The blsck hoartound, the Mediterranean region. The blsek hoarhound, B. nigra, sometimes used jil

ballotade, ballottade (bal-ō-tãd' or -täd'), n. [< F. ballottade (Sp. balotada), < ballotter, toss, prob. ( ballotte, a little ball: see ballot 1 , In the manege, a leap of a horse in which all four legs are bent without jerking out the hind ones. Also spelled balotade.

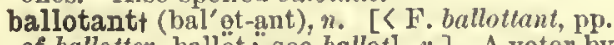
of ballotter, ballot: see ballot $t^{1}, r$.] A voter by ballot. J. Harrington. [Rare.]

ballotationt (bal-o-tä'shon), $n_{0}\left[<\right.$ bullot ${ }^{1}+$ -ation, after It. ballottazione.] A voting by ballot; a balloting. [Rare.]

Thie election of the Duke of Venice is one of the most intrieate and eurions forms in the world, eonsiating of tell
geveral bnllotations.

ballot-box (bal'ot-boks), n. A box for reeeiving ballots.

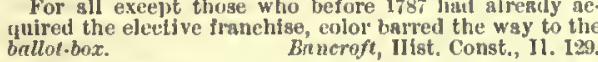

balloter (bal'ot-ér), n. 1. One who ballots or votes by ballot. - 2. A mechauieal deviee for reeeiving, counting, and reeording ballots. The ballotint, $n$. [ $[$ ballot $1+-i n$, irreg. used. The by ballot. J. Herrington. [Rare.]

balloting (bal'ot-ing), $n$. [Verbal n. of ballot ${ }^{1}$, v.] 1. The aet of easting or taking a ballot: as, the balloting began at 2 o'elock.-2. A speeifie instanee in which a ballot is taken; a vote

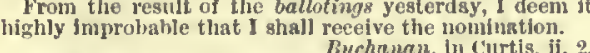

ballotist (bal'ot-ist), n. $\left[\left\langle\right.\right.$ ballot $\left.^{1}+-i s t.\right]$ An adrocate of voting by ballot.

adrocate of voting by ballot.

ballottement (ba-lot'ment), n. [F., a tessing, <ballotter, toss: see billotade.] In obstet., a method of testing pregnaney.

ballow ${ }^{1}$, a. [Appar. ¿ME. balove, bahec, bal 30 balgh, round, rounded, smooth, appar. < AS. epithet of uneertain meaning, in the following passage: tho apparent etymology suggests passage: 'tho apparent

The ballow nag outsirips the winls in cliase.
Drnyton, Poiyolbion, jii, 40. (N. K. D.)

ballow ${ }^{2}$ (bal'ō), n. [Etym. unknown.] Naut., deep water inside a shoal or bar. Smyth, Sailor's Word-Book. (I. E. D.) the quarto editions have battero and bat; it is, like battero, apprarently a misprint for batton, tom, batuon, buton, and bat 1

Keepe oul, ... or les try whitier your costaril or ny ball-proof (bâl'pröf), a. Capable of resisting ball-rack (lakl'rak), n. In printing, the raek whieh lield tho balls formerly used in inking. all-room (bâl'röm), $n$. A room expressly dowhicli suell cntertainments aro given.

all-screw (băl'skrö), n. A serow wlich ea e attaclied to the end of the ramrod of a gun, for the purpose of extraeting a bullet from the barrel.

all-seater (bâl'sō'têr), $n$. A tool used in fitting the ball of a cartridge aeeurately in line with the axis of the shell.

ball-stock (bâl'stok), $n$. In printing, formorly, stoek somewhat hollow at one end, to which he ball was attaehed, and which sorved as a

ball-train (bal'trān), $n$. A set of rolls for rolling pudders" balls or loops into bars.

ball-trimmer (bâl'trim"ér), $"$. A lathe for fin-

ball-trolly (bâl'tiol"i), $n$. A small iron truck used in conveying the balls of puddled irom from tho puddling-furnace to the tilt-hammer or squeezer. E. II. Tnight.

allustred + (oal'us-térd), $a$. Same as balkstered. Drylen.

all-valve (bâl'valv), $n$. A valve formed by a globe resting upon a concave eireular seat. t is litten by the upward pressure of the finth. and de ball-cock.

ball-vein (bâl'vān), $n$. Same as ball-ironstone. bally (bal'i), n. [Repr. Ir. Gael. baile, Manx balley, a town, village.] A town: an olement in many plaee-names in Iroland: as, Ballywal.

The old tribal division of the ballys into "quarters "and "tates" lias left distinct and numerous

$$
\text { Secbohm, Eng. Vill. Communilies, p. } 2223 .
$$

alm (bäm), n. [The spelling has been altered to bring it nearer balsam; early mod. E. also baulm, baum, SME. baume, baume, basme, bame,
<OF. bausme, basme, mod. F. baume = Pr. basmic = Sp. bálsamo = Pg. It. balsamo, < L. balsamum,

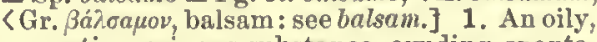
aromatie, resinous substanee, exuding spontadron; hence, by extension, any aromatic or odoriferous exudation from trees or shrubs, whether spontaneous or after ineision; balsam. And sweetest bresth of woodland balm.

2t. An aromatic preparation used in embalming the dead. See embalm.-3. Any aromatic or fragrant ointment, whether for ceremonial or for medicinal use, as for healing wounds or soothing pain. (For the ecelesiastical use, see balsam.

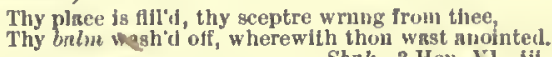

4. Aromatic fragrance; sweet odor.-5. Anything whieh heals, soothes, or mitigates pain. Sleep, that knits up the ravell'd slenve of care,
The death of eaeh dsy's dife, sore ls bour's bstil, Balm of hurt minds, great nature's second eours. Shale., Siacbeth, fi. 2
lle wounded spirit with the balm of pity.

6. A tree that yields balm; especially, a tree of the genus Balsamodendron. -7 . One of several aromatic plants of the natural order Labiatce, particularly plants of the genus Melissa. The garden. or lemon-balm, bee-balm, or balni-mint is M. officinalis. Plants of other geners so nsmed are the American gardens, Monarda didyma; the horse-bs Im, Col linsonia Cnnadensis; the fleld-balm, Nepeta Cataria; the
Moluccs balm, Moluccella lavis; : and the sweet bslm, some-Abraham's-balm, an old nsme for sn I islisu williow. Balm of Gllead. $(n)$ 'Balm or balsan of ILece, or of Syria, an oleo-resin, once of grest repute and silil esteemed in the East for its fragrance and medicinai properties. Mixed with oil, it eousititutes the chrism of the homan Catholic phara (Bnlsamodendron) Opobalsa mum, whieh slso yields myrri. It is now produced, so far as is known, only in Arsbia. (b) A ragrant resin from Sonth Anierica. Sec ulus balsamvera, the buds of whieh are coated in spring balls from firearms; impenotrable by bullets. handle. See ballı, 9. ter upper town; Ballycastle, cast balneary

wilh an oiorous butsam ; also oceasionally tho halsam-tir,

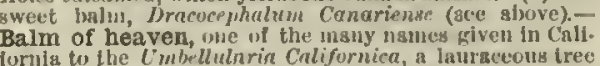
balm (baim), $v$. t. [< Ml. banmen, bamen, < baume, balm. Cf. OF. embaumer, combalm: see embulin.] 1. To embalm.

Shrouded in cloth of state!
Balm'll and entreasur'd with full hags of spices:
Shick., l'ericies, iil. 2

2. To anoint as with balm or with anything Trant or medicinal.

Belm his loul hend in warm distilled waters.

3. To soothe; mitigate; assuage; leal.

Oppressed nature sleeps:-
This rest might yet have baln'd thy loroken senses.
Shnk., Lesr, ifi. 0.

[Obsolete or archaic in all uses.]

almalden (bal'mā"dn), n. [< bal + maiden.] girl or young wolna

iuwall, Eingland.

The smoek-1roek is a survival of a plonghman's dress,

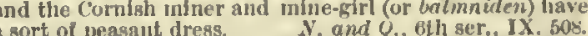
balm-cricket (bìm'krik"et), n. [Earlier brumcricket, appar. a half translation of $\mathrm{G}$. baumgrille, tree-erieket, < baum, a tree (= E. beam), + grillc, a ericket: see

The bilm-cricket carols clear

In the green that folda thy grave.

balmert (bï'mér), n. One who or that which

13leod must be my hody's only balmer, Raleigh, The Pligrimgre.

balmify (bä'mi-fī), $\imath, t_{.} ;$pret. and pp. balmified, ppr. balmifying. [< balm $+-i-f y$ : see $-f y$. To render balmy. [Rare.]

The fluitl have been entirely sweetened and balmified.
G. Cheyne, Eng. Mslacly, p. 306.

balmily (bämi-li), adv. In a balmy mauner.

balminess (bä'mi-nes), $n$. The state or quality of being balmy.

balm-mint (bäm'mint), $n$. Same as gardenbalm. See balm, 7

balmony (bal'mộ-ni), n. [Appar. a var. of baldmoncy.] A namo sometimes given in the United States to the plant snakchead, Chelone glabra. usur a ral as an adjective and ith out as a noun) to various artieles of dress possessing unusual strength and weight, in imitation of the materials or style of thoso worn out of doors by Queen Victoria, or the members of her fanily, during visits to the roya residence at Balmoral, in Aberdeenshire, Seotland.- Balmoral boots, sloes or ankie-hoots that laee balmornls. - Balmoral petticoat, a woolen pelicicost,

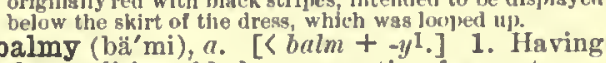
balmy (bä'mi), $a .\left[<b a l m+-y^{1}.\right] 1$. Havin
the qualities of balm; aromatic; fragrant.

o balmy breaih, that cloth almost persunde
Justice to break her sword! Shak, Othello, v. And I would be the necklace, Upon her bolmy bosom,
with her laughter or her sig. Produeing balm: as, "the balmy tree," l'ope, Windsor Forest, 1. 30.-3. Soft; soothing; assuaging; refreshing.

Now with the drops of this most balmuy time
Sy love looks frest.
Shak., Sonnets, evii.

Tirel nature's sweet restorer, baluny sleep.

4. Of healing virtue; healing: as, balmy medi-

balnea $n$. Plural of balneum.

balnealt (bal'uẹ̄-gl), a. [<L. balweum, a (warm) bath (see balneum), $+-a l$. The L. adj. is balnearis or balncarius.] Of or pertaining to a vi. 35.

balneary (bal'nē-ă-ri), a. and $n$. [<L. balnearivs, pertaining to a bath (neut. pl. balnearia, bathing-room), (balneum, a bath: see balneum.] I. $a$. Of or pertaining to baths or bathing.

The French do not treat their heaches as we do oursas places for a glance, a dip, or a trot, places animsted JI. Jamen, $J_{n, \text { Portraits of Places, p. } 142}$
II. $n . ;$ pl. balnearies (-riz). A room or prosion of any kind for bathing.

The balnearies and bs 
balneation

balneationł (bal-nē-ā'shọ), $n_{\text {. [K ML. balne- }}$ see balnoum.] The act of bathing.

Balneation, washings, and fomentations.

balneatory (bal'nẹ-a-tōo-ri), a. [< L. balneatorius, < balneator, a bath-keeper, $<$ balneum, a
bath: sce balneum.] Of or pertaining to a bath or bath-keeper.

All the reflnements of the antigue balneatory art.

balneot, $\%$. [For bagnio, after I. balneum.] Same as bagnio, 1.

Then began Cluristian churches... to ontahlne . . the Balneos and Theatres of free Citfes balneography (bal-nē-og'rạ-fi), $n_{0}$ [< L. bal

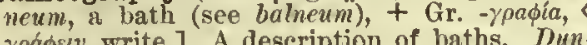

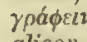

balneological (bal-nē-ō-loj'i-kal), a. Of or perbalneological (bal-nẹ

balneology (bal-nē-ol'o-ji), n. [< L. balneum,

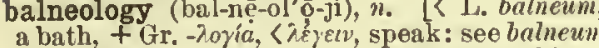

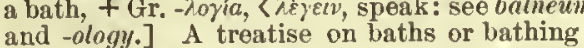
the use of baths and bathing as a departmen of therapentics.

Among our medical schools balneology as n subject of syatematic study is entirely neglected. IIarper's Mag., LXIX. 438

balneotherapeutics (bal"nē-ē-ther-a-pu'tiks) [C L. balneum, bath (see balneum), + thera peutics.] Balneotherapy.

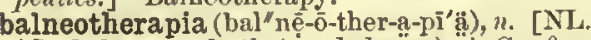
$<\mathrm{L}$. balneum, a batlı (see balneum), + Gr. $\theta \varepsilon \rho 0-$

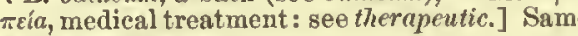
as balneotherapy.

balneotherapy (bal"nē-o-ther'a-pi), n. [Engdisease by baths; water-cure.

Balneotherapy, or bathing, and treatment by medica-

balneum (bal'uē-um), u. ; pl. balnea (-⿳厶.⿲丿丨丶 ). [L. fuller form balineum, < Gr. Baiaveiov, a bath, vio and bain 2 , q. v.] In cliem., a vessel filled with water or sand, in which another vessel is placed to be heated; a bath. See bath 1,8 .

balolo (ba-lō'lō), $n$. A sea-worm found in the South Pacific ocean. See palolo.

The balolo is a smalt sea-womn, long and thlu as ordinary vermicelli. Some are fully a yard long, others about an inch. 1t has a jointed body and many legs, and live balont, balonet, $n$. See balloon 1 .

balonea (ba-1ó'nẹe-ạa), $n$. [See ralonia.] A name for an oak, Quereus Egilops, large quantities of the cups of which are exported from the ralonia.

baloot, interj. and $n$. See balor.

balotade, n. See bullotale.

balowt, baloot, interj. and n. [Nursery sylla bles.] ' I. interj. An utterance used in lulling to sleep.

Hee balou! my sweet wee Donth. Bums, Song.

II. n. 1. A lullaby.-2. A song containing this word. N.E. D.

bals. An abbreviation of the Latin balsamum, that is, balsam, used in medical prescriptions. balsa, balza (bâl'sä, -zä), \%. [〈Sp. Pg. balsa(〉 F. balse, balze), < Peruv. balza, a kind of light porous wood used in Peru for constructing rafts.] 1. The native name of the Ochroma Lagome, a bombaceous tree common in the forests upon the coasts of tropical America. The wood is very soft and light, and is used for stopping
bottles, as well as in the construction of rafts which take 2. A kind of raft or float much used on the
its name. west coast of South America for crossing lakes or rivers, for landing through the surf, and by fishermen. It is there formed of two inflsted cylinders of teas l-skin or bullock's hide, joined by a sort of ptatform on which the passengers or goods are placed. In the cylluders of india-rubber, or long casks of metal or wood, gecured together in pairs by a framework, and used as
life-saving raft or for crosging heary surf. See life-reft. balsam (bâl'sam), n. [Early mod. E. also balsem, balsum, bälsome (in ME. only as balm, q.v.), $<$ AS. balsam, balzam, < L. balsamum, < Gr. Bát

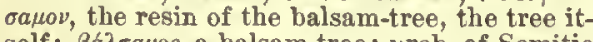
self; $\beta a \lambda \sigma a \mu \rho$, a balsam-tree; prob. of Semitic origin: seebaim.] 1. An oily, aromatic, resinous substance, exuding spontanoously from trees of the genus Balsamodendron; hence, by exof the genus Balsamodendron; hence, by ex-
434

balsamy

from trees or shrubs, whether spoutaneons or after incision; balm. A great varicty of substances pass under this uame; but in chemlstry the term is con-
fluel to vegetsble juices, whether they remain liyuid or spontaneously become solld, which conslst of resins mixed with gumg or volatile oils, the resins being produced from
the ofls lyy oxilation. A balsan is thus intermediate be tween a volatife ofl and a resin. It is sululle in atcohol and ether, and capalle of yicliling benzoic acid. The balsams are either liquid or solid : of the former are the lyatm of Gilead and the balsams of copaibs, Pcru, anct Toln (ge below); of the latter, benzoin, dracron's hloot, and stor'sx.
The bassam used in the Roman Catholic Church in the conThe balsam used in the Roman Catholic Churels in the con-
fection of chrigm is, by the rubrics, that of Syria or IIecca. fection of chrism is, by the rubrics, that of Syria or Ilecca; macte by the popea for the use of the balsans of Brazil Tolu, Peru, etc.

Many of the resins occur in planta dissolver in ethereal injured, it flowg out, and becomes thick, or. even solid. oul exposure to the alr, partly from evaporation of the Golvent oil, snd partly by its oxidstion.

Stricker, Organic Chemfstry, p. 732 $2 \nmid$. An aromatic preparation used for embalming the dead. - 3. Any aromatic fragrant oint ment, whether for ceremonial or for medicina use, as for healing wounds or soothing pain.4. Figurativ

Is this the balsam that the usuring senate as not the people's blessing . . a batsan to thy blood? $5+$. In alchemy, a healthful preservative essence, of oily penetrative nature, conceived by Paracelsus to exist in all organic bodies. $N$. E. $D .-$ 6. A tree yielding an aromatic, oily resin. In the United Stateg the name is often applled generally to

7. The Impatiens balsamina, a familiar flowering annual, of Eastern origin, cultivated in many
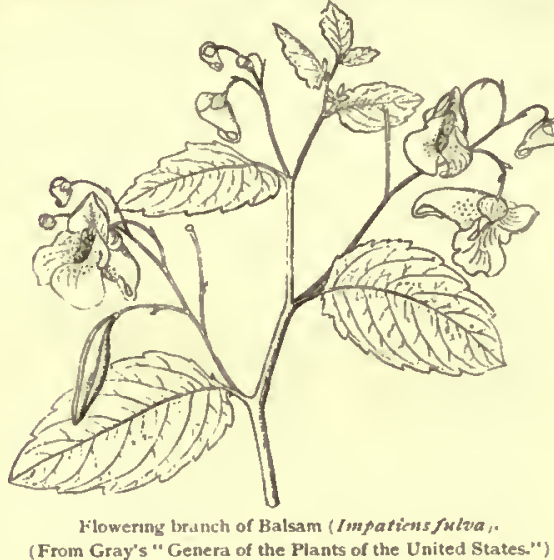

varieties, often called garden-balsam, and in the United States lady's-slipper; also, the native Enropean species, I. Noli-me-tangere, and the AmerIn medical preseriptions abbreviated to bals. Balsam of Mecca, balın of Gitesd. See balm. - Balsam of Peru, the product of Alyroxylon Pereire, a leguminon the manufacture of sosps, and in medichne as a stimnlat ing ofntment snit for the relief of astlums and coughin.Balsam of Saturn, a solution of leat acetate in turpen-
tine, concentrated ly evaporation and nilxed with camphor, fornerly used to hasten the cicatrizatlon of wounds Tateg of Colombia), \& jrodnct of Mf yroxylon Toluifera closely allied to $M$. Pereince (see above) It has an agreeable flavor, snd is used in medicine as an expectorant an stinulant, though its properties are not important. It closely resembles balsam of Peru. - Broad-leafed balsam, of the West Indiek, a small tree betonging to the ing an aromatic balsam, which is derivel chiefly from th berries. - Canada balsam, a trangparent liquid resin or turpentine obtsined by puncturing the vesleles which form under the bark of the balsam-fir, Abies baisamea of North
America. It is much valued for mounting objects for the ufferoscope, as it remafus permanently transparent, and
it is also used in making varnlgh. The principal supply is trom Cansda. Other forms of turpentlne from European confferous trees are sometimes called balxams. - Copal ambar Styracifua, very similsr to storax and used for simitar purposes. - Yellow balsam, of Jansica, Croton Aarens, an aromstic euphorbiaceous shruh, covered with a copaiba, gurjun, and lagam.)

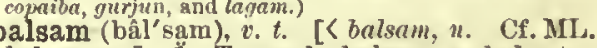
balsamare.] 1. To apply balsam or balm to; anoiut with balm or balsam.

The gifts of our young and flourisling age are very Bp. Hacket, Abp. Willitams, i. 5i.

\section{To erabaln. [Rare.]}

We had him batsamed aul sent hone.

balsam-apple (bâl'sam-ap"1), n. An annua cucurbitaceous plant of tropical regions, $\boldsymbol{M}_{0}$ mordica Balsamina, beariug a sinall warty fruit of a red or orauge color. Proth the fritt and the root ure actively purgative. - Wild balsam-apple, of the
United States, an annual vine, Echinocystis louata, of the orfler Cucurbitacece, bearing numerong white flowers an a filwous fruit opening at the summit.

alsamation (bâl-sâ-mā'shọ), n. [<ML. bal samatio $(n-)$, , <alsamare, pp. balsamatus, to balsam, <L. balsamum, balsam.] The act of rendering balsamic. [Rare.]

balsam-bog (bâl'sam-bog), $n$. A curious nmbelliferous plant of the Falkland islands, forming lord hemispherical hillocks often from to 4 feet in height. It yields a gum which has been used in medicine.

balsam-herb (bâl'sạm-èrb), n. A name given in Jamaica to Dianthere reptans, an acantha-

balsamic (bâl-or bal-sam'ik), $a$ and $n$. [< bah som $+-i c$.$] I. a. 1. Pertaining to or of the na-$ ture of balsam: as, balsamic juices. -2 . Yielding balsam: as, balsamic pine.-3. Having the fragrance of balsam ; aromatic ; balmy. The new.leaved butternut And quivering poplar to the roving lreez

Bryant, OJd Man'a Connsel.

4. Having the healing or soothing qualities of balsam; healing; soothing; mild: as, balsamic remedies. $-5+$. Of or pertaining to the balsam of the alchemists. See balsam, 5 .

II. n. Any warm, stimulating, demuleent medicine, of a smooth and oily consistence.

balsamicalt (bâl-or' bal-sam'i-kal), $a$. Same as bulsamic.

The batzamical humour of my blood.

balsamically (bâl- or bal-sam'i-kạl-i), adv. In a balsamic manner; as a balsam.

balsamiferous (bâl-or bal-sa-mif'e-rus), [< L.balsamum, balsam, + ferre $=$ E. bear ${ }^{1}$. and shrubs which yield balsam.

balsamina (bâl-sâ-mi'nä), n [NL.: see balsaminc.] Same as balsamine.

balsamine (bâl'sam-in), $\pi$. [< F. balsamine Sp. Pg. It. balsämina, < NL. balsamina (< Gr.

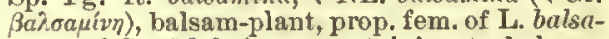
minus, < Gr. * $\beta a \lambda \sigma \alpha u$ os, pertaining to balsam,

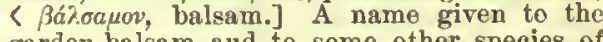
garden-balsam and to some other species of the genus Impatiens (which see).

balsamitict (bâl-sa-mit'ik), a. [<MI. "balsamiticus (ef. $11 \mathrm{~L}$. bälsamaticus), < L. balsamum.] Balsamic.

balsamito (bal-sâ-më'tō), n. [In form Sp. or Pg.; cf. Sp. balsainita ( $=$ Pg. balsamita), tansy, bitter taste, the odor of the Tonquin bean, and a light sherry-color, produced by digesting the fruit of the balsam of Peru in rum. It is used as a medleine, and also as sul application to sloughing sores, espectalty to those caused by the chigoe. samized, ppr. balsamizing. [< balsam + -ize.] To render balsamic.

balsamous (bâl'sam-us), a. [< balsam + -ous.] Having the qualities of balsam; abounding in balsam; consisting of balsam.

Sow the ranical molsture is not the tallow or fat of antmals, but an ofly and baleamones substance.

balsam-root (bâl'sạm-röt), u. A name given California to species of Balsumorrhiza, a geins of low, coarse, peremnial composite plants, allied to the suntlower. They have deep thick roots Whicli cuntain a terebinthinate balsam. These roots are balsam-tree (bâl'sam-trē), " A name giren to many of the balsam-bearing trees of the ropies (see balsam), and to the mastic-tree, Pistacia Lentiscus. In North America it is applled to Popelus balsamifera, and on the westem coast to $P$. the east (the latter tree betng dintinguined a and in the Rocky Monntains and west warl to $A$. concolor balsam-weed (bâl'sam kēd), $n$. A name of the common everlastings of the United States, Gnaphalium decurrens and G. polycephalum. They are also called sicect balsam, on account of their balsamic fragrance.

balsamy (bâl'sam-i), a. [< balsam + - - $y^{1}$.] Balsam-like; balmy. 
baltel, $"$. Plural of bulteus.

balter, r. [Farly mod. F. baulter, bolter (in blowl-boltered, q. vo), now only dial. bunter, ME. balleren, prob. of Scand. origin; ef. Dan baltre, var. of boltre, roll, tminble, gambol.
intrens. 1t. To tumble; dance elumsily.

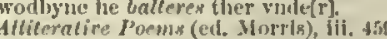

2. To becomo tangled or matted. [Prov. Eng.] It. [a goat's heard] battereph snd cluttereth linto kitents

II. trans. 1. To tread down in n clumsy mastner. [Prov. Fing.] -2t. To tangle; clot; mat, as the hais.

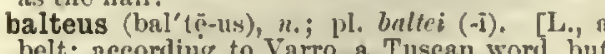
belt: necording to Varro, a Tusean word, but perhajs of Celic origin: see belt.] 1. In lioworn over the shonlder to support a sword, shield, or quiver.-2. In areh.: $(a)$ A band perpendieular to the axis in the lateral part of the volute of an Ionic pulvinated capital. (b) One of the passages dividing the auditorium of ancient loman theaters and amphitheaters horizontally into upper and lower zones, and afforling aceess to the different eunei, or wedgeshaped divisions of the auditoriun, without disturbing persous oecupying seats. Such a passago had usnally tho form of $n$ wide step.

Baltic (bal'tik), a. [< Nl. Baticus, prob. Lith. bultus, white, balti, be white.] AppellaLith. baltas, white, lilti, be white.] Appella-
tive of or pertaining to the sea which separates Sweden from Denuark, Germany, and Russia; siturted on or bordering the Baltie sea: as, the Baltic islands; the Baltic coasts.

Baltimore bird, oriole. See oriole.

baltimorite (bal'ti-mör-it), $n$. [< Baltimore, the chief eity in Maryland, $\left.+-i e^{2}.\right]$ A variety of serpentine from Baro Hills, MIaryland.

balu (bä'lö), n. [Native name.] A kinil of wildeat, Felis sumatrana, native in Sumatra.

Baluchi (ba-lö'chē), n. [Pers. Baluehi, Beluchi.] 1. A native or an inhabitant of Balnehistan, a country lying to the east of Persia and between Afghanistan and the Arabian sea; specifieally, a member of one of the tribes dominant tribe, the Bralioes - 2. The language dominant tribe, the Bralioes. - 2. Tho language
spoken by the Baluchis and by over 300,000 spoken by the Baluchis and by over 300,000
British subjects inhabiting Sind and the Panjâb. It belongs to the Iranle branch of the Aryan tamily of languages. It has no literature and wilten ehargeter of Its own, Arable chsractera having been used for such
works in Baluehi as have recently appeared. works in Baluehi as have reeently appeared.

baluster (bal'us-tèr), n. [Also balluster, ballister (and corruptly bannister, banister, q. v.), laustro ( $=\mathrm{Sp}$. Pg. balaustre), a baluster, small pillar, so called from a fancied resemblance to the flower of the wild pomegranate, < balausto, balausta, balaustra $=$ Sp. balanstra, balaustrin $=\mathrm{Pg}$. balaustia $=\mathrm{F}$. balauste, formerly also bu lustre, < L. balaustium, < Gr. Bahavoriov, the flower of the wild pomegranate-tree. Cf. Balaustion.] 1. In arch. and building, a smal

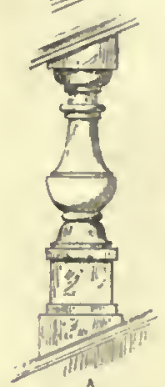

A
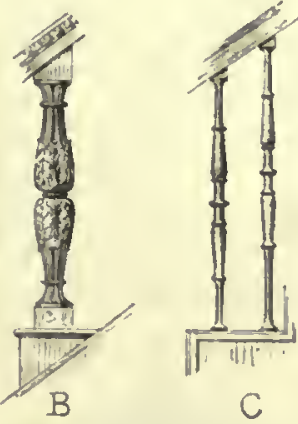

C
B, from church of Santa Trinith des. Monte, Rome: B, (rom pulpit-
staiss, Duomo of Sienai $C$ (bronze), from Casa de Pilatos, Sevilie.

forms, but typically strongly swelled outward at some point between the base and the top or capital, and eommonly vase- or urn-shaped, used in series to support the rail of a railing o balustrade. The baluster, as distluguislienl from a sunal! columu serving the sanie purpose, originateal in the srchi.
tecture of the Renalssanee. Sow often ealled ba nister. 2. In areh., the lateral part of the volute of the Ionie capital. Also bolster. balustered (bal'ns-terd), $a$. [<baluster + ed $\left.t^{2}.\right]$
Furnished with balusters.

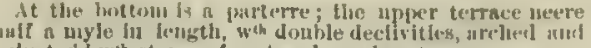
binelyna, Diary, Fitb. 27, 104t. baluster-shaft (bal'us-tẻr-sláft), "1. A form of pillar ocenring in so-ealled Angln-tiaxon architecture, ant in work intluenced by it as late as the twelfth century. It serves esjecially in: sepraration of witi rom its ruile reserm. binuee in shape to a angt ty:

aluster-stem

(bal'us-tèr - stem)

n. The stem of a

goblet, chalice,

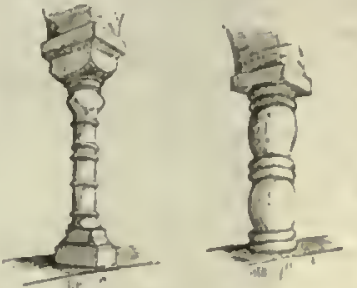

13:Inster. shiofs

St. Althans Cathetral, England.

ther similar vessel when of the bulging shape elaracteristic of a balnster.

balustrade (bal-us-tràd'), n. [<F'. balustrade, t. balaustratu $(=\mathrm{S})$. $\mathrm{Pg}$. buluustrada), a balnstrade, prop. adj. fein., furuished with balusters [balaustro, a baluster.] In areh., strietly, barrier ol railing consisting of a horizonta

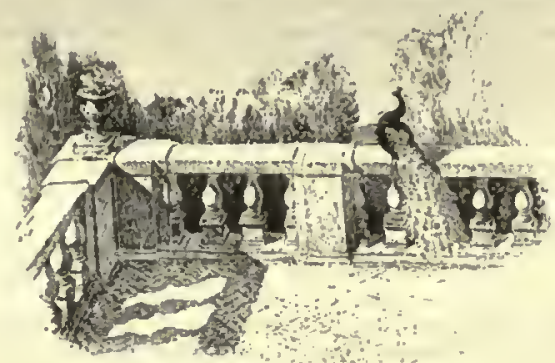

Balustrade- - From the Vilita d'Este, Tivoll, Italy.

member resting on a series of balusters; but commonly, an ornamental railing or pierced parapet of any kind, whether serving as a barrier or merely as a decorativo feature, and whether composed of balusters or not. Broal-hased filglts of marble stalrs Raul up with gollen balustrade. raluian Nights balustraded (bal-us-trā'ded), a. [< balustrad $\left.+-d^{2}.\right]$ Furnished with a balnstrade or bal ustrades.

I like the balustraded terraces, the smin-proof laurel Walka, the vase and atatuea. balustrading (bal-us-tı'a'ding), n. $\quad[<$ balus balustrade-work.

The upper [floor] was terraced and detended by atrong balysaur, $n$. See balisaur.

balza, $n$. See balsa.

alzant, n. [F., < It. balzano, white-footed white-spotted, = OF. bansan, bausant: see banbalzarine (bal-za-rēu'), $n$. [Origin obseure.] A light mixed fabric of cotton and wool for women's dresses, commonly userl for summe gowns before the introduction of barege.

bam (bam), r.; pret. and pp. bammed, pler. bamming. [A slang word, formerly also bamb either an abbr., or the aouree of the first syllable, of bamboozle, q. v.] I. trans. To bam boozle; cheat; hoax; wheedle. [Slang.]

This is some conspiracy, I suppose, to bam, to clrouse

II. intrans. To practise hoaxing or imposi tion. [Slang.]

bam (bam), n. [<bam, v. $]$ A cheat; a hoax an imposition. [Slang.]

It was all a bam, madam, a acene we thouglit proper to To relleve the tellum he kept plying them with al
manner of bams.

bamalip (bam'a-lip), n. [An artifieial term.] In logic, a muemonio word denoting a mood of the fourth figure, containing syllogisms with universal affirmative premises and a particular affirmative conclusion: as, All greyhonnds ar dogs; but all dogs are quadmueds; therefore, some quadmupeds are greyhounds. Six of the that the nool is to be reduced to barbara (willeh see): a thiat the major premise is a universal aftirnative: $m$, that
the prenises are to be transposed in redicling if to the the prenises are to be transposed in redicing it to the
first figure; $a$, thit the minor premise is universal at.
Ammative; $i$, that the conciuston la s part fenlar affinuacive: to be converted per accidena to give the oouchuston of

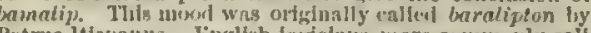

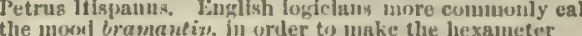

tramantfi, campues, dimaris, fesqun, Iresisin.

bamalipton (bam-4!-lip'ton), n. [Au artificial temn.] $A$ inool of syllogism, differing from baralipt on only in haviug the nanes of the inajor and minor premises trunsposed. The une was fuventerl by Jodoc Trutfeler of Vimenneli, $n$ teacher of
luther, who died lub 151 .

bambara (ban'bu-rii), n [An artifieial term.] A moorl of stllogisin, differing from barbari only in liaving the names of the major and ninor premises transposed. Tho name was invented by Jodoe Trutfeder. Seo bamalipton. bambino (bam-bō'nō), n.; pl. bambini (-11ề). [lt., a child, dim. of bambo, childish, simplo; ef. bimbn, a chilal, Sp. bambarria, a child, $\mathrm{A}$ foolish man, Austrian bams, child. I'rob. of mitative origin, and so far related to $\mathrm{Gr}$. $\beta a \mu$ Baiverv, ehatter with the teeth, also stammer;

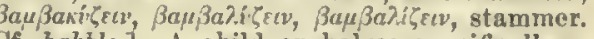
Cf. babble.] $\Lambda$ ehill or baby; speeifieally, $\mathrm{n}$ figure of tho Child Jestus. It is commonly repre sented as in the manger at

in unany Romnn Catholic churehes throngliont the world from Christmas to Epiphany, the effeet being of sngels, of the shepheris ftiesisgr, ete. The whol together ls commonly calla suljuect of pojpular devot. Franeis of Asstsi in the early part of the thirteent century. The famous banColl at Rome is of ollvewood, and was inade ln Ini
estine by a Franeiscan lay brother some lime before the seventeenth century it is in repute for miracu. riclily deeorated lyy the
faithful. In the fine arts falthful. In the flne arts
thls subjeet has been often glazed terra-eotta reliers of

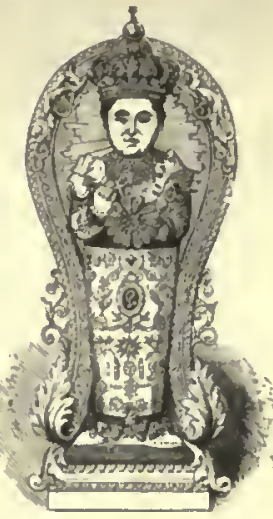
bambocciade (bam-boch-i-äd' $)$, n. [A]so bamboceiate, aud bamboreiatu (after It.) $;\left\langle\mathbf{F}^{*}\right.$ bambochade, (It, bamboeciatr, grotesque painting, earicature, < bamboccio, a little elild, puppet, simpleton (like bambino, a din. of bambo, childish, simple: see bambino); said to have been a niekname given to Pieter van Laer (17th eentury), a painter of such scenes.] In painting, games, a village festival, rollieking peasanta drinking and smoking, and kindred subjects. Teniers is the greal master of this atyle, and in Britiah art bamboo (bam-bö́), n. [Also bambu, and formerly also bambou, bambor, bambo, and (after. D.) bambonse, bambus'; = D. bamboes $=G$. Dan. bambus = Sw. bambu= Pol. Bohem. bambus = Russ. bambuk $u=\mathbf{F}$. bambn $=$ Sp. bambi $=\mathrm{Pg}$. bamibu (first recorded as mambu) = It. bambi (NL.bambusa); from the native E. Ind. name, Malay and Jav. bumbu, Canarese banbu or bantu. The orig. language is uneertain.] 1. (a) The common name of the arboreseent grasses belonging to the genus Bambusa (which see) and its allies. (b) In the West Indies, a tall elimbing grass of tho genus Panicum, $P$. diraricatum. (c) In Queensland, a coarse grass, Stipa mieranthn.-2. A stick or cane from the stem of the bamboo. - 3. In pottery, a name given to a cane-eolored biscuit made by Wedgwood.Pondicherry to 3 ? meters, - 5. In Sumatra, a measure of capacity: in Beucoolen, equal to the United States (Winchester) gallon; in Achin, to 5 pints. - Bamboo books, a collection of ancient Clanese writings, ehiefly hiatorieal, said to have been dis. writings were engraved on allps of bamboo, as was cus tomary in China before the inveution of paper. - Sacred Damboo, the Nandina domesfica, a handsonse evergreen lerberidaceons shrub, besring red berriea, and extensively

bamboo (bam-bö'), $x, t$, [< bamboo, n. ] To beat with a bamboo; punish by flogging with smooth lath of bamboo; bastinado.

amboo-brier (bam-bö'bri'èr), $n$. The greenbrier of the United States, Smilax rotundifolia, a tall thorny elimber. 
bamboo-partridge

bamboo-partridge (bam-bö' pär "trij),,.$\Lambda$ (bambicold.

bamboo-rat (bam-bö'rat), $n$. A species of rodent animal of the size of a rabbit, belonging to the genus Rhizomys, found in Malacea.

bamboozle (bam-bö́zl), $t_{0}$; pret. and pp. bamboavled, por, bemboozling. Mentioned by Swift in 1710 among "certain words invented by some pretty fellows, such as banter, bamboazle, country pretty fellows, such asich are now struggling for put, .... some of which are no); appar. a slang the vogue" (Tatler, No. 230); appar. a slang word, of no definite origin, connected with pears a little later: see bam. Cf. Sc. bambaze, bumbaze, confuse, stupefy, bazed, based, basit, confused, stupid.] I. trans. 1. To hoax; deceive; trick; impose upon.

All the people upon earth, excepting these two or three worthy gentlenel, are imposed upon, cheated, bubbled,

Americang gre neither to be dragooned nor bamboozled
Franllin, Life, p. 514 . out of their liberty. It's supposed by tlits trick

Barham, Ingoldsby Legends, II. 203. 2. To perplex; mystify.

II. intrans. To use trickery; practise cheating. bamboozler (bam-bö'zlër), $n$. One who bamboozles; a cheat; one who plays tricks upon another.

There are a set of fellows they eall banterers and bam-

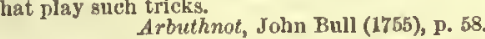
bambosh (bam'bosh), n. [<bam + bosh, prob. [Slang.] T, $E, D$

bamboula (bam-bö'lä), n. [Creole F., < F bambou, bamboo.] 1. A small drum consisting of a section of bamboo covered at one end with sheepskin, formerly in use among slaves in Louisiana.-2. A dance pert

Bambusa (bam-bī'sä), n. [NI., through D. bamboes, G. bambus, etc., < F. Ind. bambu: seo bamboes, G. bambus, etc., bamboo. ] A genus of arborescent grasses, of
the tribe Bambusere (which see), of about 25 wellthe tribe Bambusere (which see), of about 25 well-
known species,

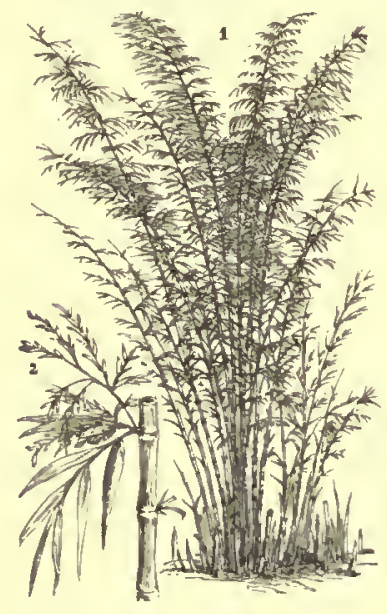

I, Bamboo (Ba, mbusa zutgraris), show.
ing its mode of growth; ; , flowers, leaves
and stem on a larger scale. natives of southorn and eastern Asia, onespecies only being cosmopolitan. This species, the common garis, is nowher as indigenous, but is naturaand is cultivated extensively in the Indies, and South he spccies are spnose at the joints, The stems attain ven 120 feet, with dismetcr, in th larger specles, made of the sten and leaves of the various specics of ndtes and Asia are innumerable. llouses and their furniture, the masts, sails, and rigging of ships, rafts, bridges, ferces, kets, mats, pipe-stems, and in fact nearly sil srticles of o dinary us, are made entirely or in part from this material.
The seeds and young shoots are used as food, and the leaves bambusaceous (bam-bū-sā'shius), $a$. [< Bambusa + -aceous.] Resembling the bamboo; be longing to the gramineous tribe Bambuseo.

Bambuseæ (bam-bū'sē-ē), n.pl. [NL., $<$ Bambu $s a+-e c$.$] A tribe of grasses, of great economi$ importance, including nearly 200 species in may be considered the type. They are mostly con thed to the warmer regions of the globe, though some are the sea. They are gregarious in habit, and have woody,
tall, and often arborescent stems, hollow between the joints, the taller specles reaching an extreme helght of 120 feet, with a diameter of 6 or 8 inches. MIost of the specie flower but rarely, but the flowering of any species, whe it oceurs, is usually general, sud the consequent harvest bamboos of tropical America belong to seversl genera (chiefly Arthrostylidium, Chusquea, and Guadua), some species attaining nearly the size of those of the old world, eral of the Indian geners sre berry-bearing, the species
436

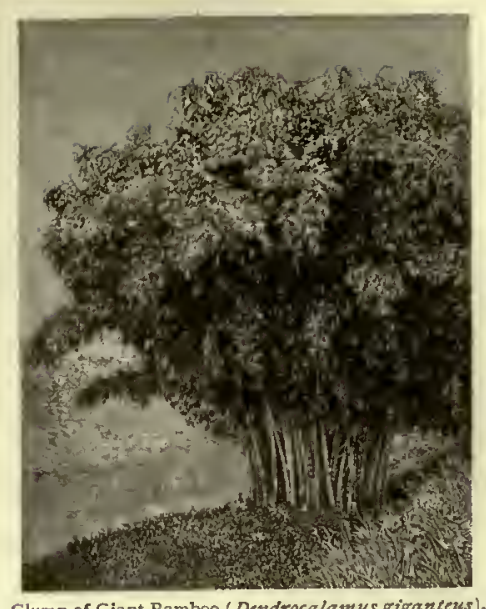

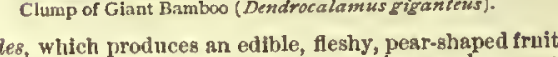
from 3 to 5 inclies long. The same species, as also some others, yiclds the tabasheer (which see), a secretion in the Bambusicola (bam $\left.-\mathrm{bu}-\operatorname{sik}^{\prime} \overline{0}-1 a \mathrm{u}\right), n_{\text {. }}$ [NL., < bambusa, bamboo, + I. colere, inhabit.] A genus of gallinaceous birds of Asia, the bamboo-

partridges. B. thoraeiea is a Chin

bambusicoline (bam-bü-sik'ō-lin), a. [< NL. bambusicolinus, < bambusa, bamboo, + L. colere, inhabit: seo -ine1.] Inhabiting cane-brakes; living in bamboo-grass: said of sundry animals, as certain partridges, rats, etc.

bamia (bā'mi-ä), n. A fish of the family silurida, taken in the Red Sea. In a dried state it is much nsed as food by sailors.

bamlite (bam'lit), n. [< Bamle +-ite1.] A va. riety of fibrolite from Bamle, Norway.

an $^{1}$ (ban), $v$.; pret. and pp.banned, ppr.banning. < ME. bannen, < AS. bannan, bonnan, summon, in comp. äbannan, summon, gebannan, summon, command, proclaim, = OFries. banna, banna, command, proclaim, = OD. bannen, prohibit, bannan MHG. G. bannen, banish, expel, exorcise, = Icel. banna, forbid, curse, refl. swear, = Sw. banna, reprove, chide, refl. curse, swear, = recorded), orig. appar. 'proclaim or announce, subsequently "command or forbid under a peualty,' prob. akin to I. fari, say, speak (> ult. E. fable, fame, fate, otc. ), =Gr. фával, speak, say (> ult. E. aphasia, aphemia, euphemism, etc.); make appear, show, shine, Skt. $\sqrt{ }$ bha $a$, appear, shine. The Ml. verb bannire, summon, proelaim, banish, is formally from the noun: see banish. 'The sense of 'curse' is appar. due to scand. nse.] I. trans. 1†. To summon; call out. Pharaon bannede vt his here. Gen. and Ex., 1. 3213. 2. To anathematize; pronounce an ecelesiastical curse upon; place under a ban.

It is hard to admire the man [Henry VIll.] who was burning and banning Lutherans at home, while he was
trying to ally himself with them abrosd. 3. To curse; execrate.

Hiere upon my knees, striking the earth,

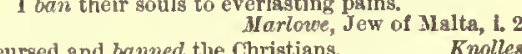

4. To prohibit; interdict; proseribe. Knolle.

The religion of the immense majority . . . was banned

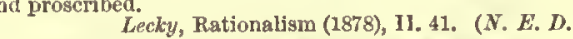
Working his best with beads and cross to ban

The enemy that comes in like a tiood.
Browning, Ring and Book, I. 46.

II. intrans. To curse; utter curses or maledictions.

And curst, and band, and blasphemies forth threw. ban 1 (ban), n. [<ME. ban, banne, bane; partl identical with iban, < AS. gebann, proclamation, decree, $=$ (without prefix) OS. ban = OFries $b a n, b o n=O D . b a n=O H G$. MHG. ban, bann, G. bann, proclamation (of command or prohibition), = lcel. bann = Sw. bann = Dan. ban, band partly (in the form ban, bane) $<\mathrm{OF}$. $b a n=\mathrm{Pr}$. partly (in the form ban, bane) $<\mathrm{OF}$. ban $=\mathrm{Pr}$.
ban $=\mathrm{Sp} . \mathrm{Pg}$. It. banda, $<\mathrm{MI}$. bannum, bannus, also bandum, proclamation, summons, edict, proscription, banishment, excommunication, etc., from the Teut. (OHG.) form, which is from

\section{banana}

the verb: see banI, v., and cf. banish.] 1. In feudal times: $(a)$ A public proclamation or edict; especially, a proclamation summoning to arms. (b) The

See arriere-ban, 2. of the fiefs were called upon for nilitary services in sub(c) A proclarnation made at the head of a body f troops, or in the cantonments of an army, by of troops, or in the canto trumpet, to announce the apnointment of an officer or the punishment of a soldier, to enforce discipline, etc. In modcrn tinies these proclamations are publis

2. A proclamation or notice given in a church of an intended marriage: generally used in the plural, bans, usually spelled banns (which see). -3. An edict of interdiction; a sentence of outlawry. Thus, to put a prince under the ban of the empire was to divest hin of his dignities, and to interdict all intercourse and all offices of humanity with the offender. Sometimes whole citles have been put un

4. Interdiction; authoritative prohibition. $\mathbf{- 5}$. A formal ceclesiastical denunciation; curse; excommunication; anathema.-6. A malediction; expression of execration; curse.

ller fyrie eyes with furious sparkes did stare,
And with blasphemous bannes high God in peeces tare.
Spenser, F. Q., III. vil. 38. Spenser, F. Q., III. vil. 38.

7. A pecuniary mulet or penalty laid upon a delinqueut for the bishop, in addition to other mulet paid to the bishop, in addition to other penalties, for certain erimes connected with

ban² (ban), n. [Croatian ban = Bulg. Serv. ban, Hung. ban, [Pers. bān, a Jord, master.] A title formerly given to the military ehiefs who cuarded the southern marches of Hungary (the Banat), but now only to the govemor of Croatia and Slavonia, who is appointed by the emperor of Austria as king of Hungary, and is responsible to the landtag of Croatia and Slavonia. ban ${ }^{3}$ (ban), n. [Cf. banana.] A fine sort of muslin made in the East Indies from the leafstalk fibers of the banana.

banali (ban'al), a. [Formerly also bannal, F. bannal (Cotgrave), now banal $=$ Pr. banal, <ML. bannalis, pertaining to compulsory fendal service: applied especially to mills, wells, ovens, ete., used in common by people of the lower classes, upon the command of a fendal superior; hence, common, commonplace; $\langle$ ban mum, command, proclamation: see ban $1, n$.] 1. Subject to manorial rights; used in common: as, a banal mill or oven. See banal trite; stale.

Too much of what [England] gives us from her painters Too much of what [England] gives us from her painters
of modcrn life is familiar, tawdiy, banal.
Fortnightly Rev. (N. S.), XXXII. 76. banal2 (ban'al), a. [<ban't $+a l$.$] Of or per-$ taining to a ban, or provineial governor: as, the royal banal court at Agram. See ban2. [<F. banalité, <banal: see banall.] 1. lu ole Fronch and French-Canadian law, the right by which a lord compelled his vassals to grind at his mill, bake at his oven, etc.: applied also to the regions within which this right was exercised. -2. The state of being banal, trite, or stale; commonplaceness; triviality.-3. Anything common, trite, or trivial; a commonplace. He has a good sense that enalles hin to see through
the banalities of English political life and to shrink from
involving his own existence in such littleness. Lanier, The English Fovel, p. 253
banana (ba-nan'ä), $n$. [Also formerly banano (tree); = F. banane, < Sp. Pg. banana, the fruit of the banana-tree, Sp. banano (Pg. bananeira, F. bananier), the tree itself; eited in the 16th

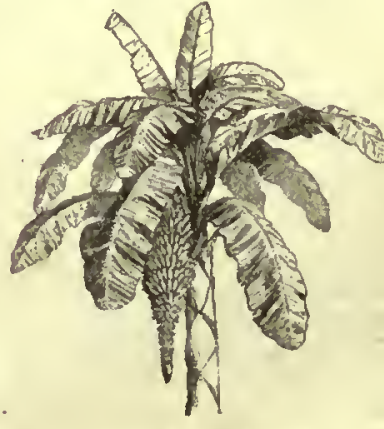

Banana (Musa sapientum). contury as the native name in Guinea, but the plant is probably a native of the East Indies.] An endogenous plant of the genus $M u$ now eultivated foritsfruit everywhere in the tropies. The stem - like trunk, pact sheathing lear. stalks, grows to a
helght usually of 8 
banana

or 10 feet, bearing its ohlong frult in a dense clnster 2 or 3 feet long and sometines welghing 70 or 80 ponnds. "Th

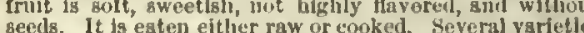
are cullivated, differing In size, color, and fluvor. After frulling the stem decays, or Is enl down, and new slioot spring from the root and produce a new eroj in s few monthis. The filher of the stem and leaves is of littlo value.
The plantain, Af. parudisiaca, is probably only a variety
of the sume speeles. See $\$$ usa and plantain.-Banana essence, sn nrtificisl frult-essence used for fiavoring je acetate and hutyric ether.-Mexican banana, a nani somethes given to a species of l'ucea, y baccata, of northery Nlexico snd the alljace

banana-bird (ba-num'h-berd), $n$. A namegive by early writers to soveral West Indian and tropical Ameriean species of the large gonus Icterus, which contains tho American orioles or hangnests, more or less nearly related to the Baltimore bird, fetorus galbula. Thus, under thls name, Fdwards deseribes a specles, afterward the 1 an. name, Fdwards deserities a spectes, afterward the 1 an nana of Lifunens (1766). The Icterus leucopteryx of Jamalcs ta niso one of the spectes which liave borne the name. One section of the genus Jcterus has been named Banani. vorus from the implled habif (of lonnana-eating) of the
birds composing it; the type of thls ls the commen or chird-orlole of the United States, Icterus smurius.

banana-eater (ba-nan' ị̂-ê" tér), n. A plantain cater; a bird of the gonus Musophaga.

banana-quit (ba-nan'ạ̈-kwit), $n$. A name of the black and yellow honey-creeper, Corthiola favcola, and other species of hirds of the same genus.

bananist (ba-11an'ist), $n$. $\quad[<$ banana + -ist. $]$ A banana-bird: a name given to various birds besides those of the genus Icterus, as, for example, to Corlhiola bananivora of San Domingo. bananivorous (ban-a-niv'ō-rus), a. [< banana + J. vorare, eat.] Feeding upon bananas.

banat, banate (ban'at, -āt), n. [Also bannat; $\left.<b a n^{2}+-a t,-a t c^{3}.\right]$ 1. In Hungary, a border province ruled by a ban; the territory or juris banat in southeastern Hungary, distinctively banat in southeastern Hungary, distinctively in $1860 .-2$. The office of a ban.

banatite (ban'a-tit), n. [< Banat $\left.+-i t c^{2}\right]$ A name given by Von Cotta to a variety of dio rite oceurring in the Banat, Ifungary.

banausic (ba-râ'sik), a. [< Gr. Bavavousos, of or for mechanies, < $\beta a v a v a i a$, the practice of a mechanical art, the habits of a mechanic, ßávavos, mechanical, $<$ a vivos, a furnace, forge.] Merely mechanieal; eharacteristic of mechanics or a mechanic. [Rare.]

By this term [Anterteanjsms] he [Du Bols-Reymond] eral, whlch are more specincally expressed in makin meney-getting the prime object of life, In love of display,

G.S. Ilall, Germsn Cullure, p. 149 cus), bench: seobankl.] In law, a seat or bench of justice.-A court in banc, s court in whlch the full bench of Judges is present : as, before the contrt in banc.or by a querum of them.- Days in banc. See dayl. legged.] A saber more curved than usual, if in imitation of the simitar; specifieally, the saber of this form worn by officers of the first

French republic and empire, during 1792-1810.

bancal $^{2}$ (bang'kal), n. [E. Ind.] $A$ weight equal to about 1 pound, used in India.

banco (bang'kō), $\mu$. [It., a bank, bench, counter, < ML. bancus: see bank.1.] In com., the money in which the banks of some countrie keep or kept their accounts, in contradistinction to the current money of the place. The distincthon was more necessary when the currency conslsted, as mark. See mark banco, under mark. bond, bonde ( $>$ mod. E. bond, the same word, now partly diseriminated in use), < AS. "bane $=\mathrm{OS}$. band = OFries. band $=\mathrm{D}$. band $=\mathrm{OHG}$ MHG, bant, G. band = Icel. Sw, band = Dan baand, a band, a tie, a neut. noun (in D, and G. also masc.), developing in later use a great variety of particular senses, and merged in MF. with the synonymous bend, bende, bende, < AS with the slightly different bande, bend, and strip, hoop, etc., derived through the F. from the same ult. source, namely, Teut. (AS., etc.) biudan (pret. band), E. bind: see bind, bend1, bend 2 , bend ${ }^{3}$, and $\mathrm{ef}^{\text {. bond }} 2$, band 2 , band 3 .] 1 . Anything which binds the person or the limbs, and serves to restrain or to deprive of liberty; a shackle, manacle, or fetter: usually in the plural.

437

band

And thuraoh-neelioh put bin In bands st Riblah.

And andilenly there was a preat enrthinake, so that the

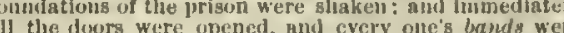
boaed. Dol. In ehsins of adlamant?

B. Jouson, Alchemist, iv. 1 .

2. That by whieh loose things of tho samo or a sinilar kind aro bound together. Speciflenlly - (a) The tie of straw used in londing shen es of whent or othe grain. (b) In bookbinding, elle of the eoris, tajes, or

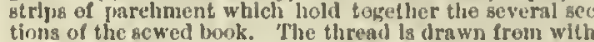
In each sectlon areunil or over the hand

3. That whicl connects; a connecting piece, or means of connection; that whieh connect or unites the several parts of a complex thing. The body, by folnts and bands... knit together, in

Ile (hoje) ls a flatterer,
A parasite, a keeper roack of denth,
Whio gently would disolve the ban Siluk., Kich. 11., il.

specifically - $(a \nmid)$ In logic, the copula. [Rare.]

A simple Axlome is that, the baul whereof is a Verbe.
T. Spencer (IO2s), Loglek, p. J60. (N. $E . D$.)

(b) The metallic aleeve which bincls the barrel and stock of a musket together. (c) One of two pieces of Jron fasA lesden eame. Sce came2. (et) A hyphen.

4. A binding or uniting power or influence: as bremel of union. [Now usually bond.]

1 drew them with cords of a man, with bands of love.
Ilos, xl. Land of my sires! what urortal hand Can e'er untle the fillal band
That knits me to thy rugged at rand

5. An obligation imposing reciprocal, legal, o moral duties: as, the nuptial bands. [Now usually bond.]

Ifere'a eight that must take hands,

To join in Hymen'a band.

Bt. A binding promise or agreement; a bou or security given.

Adr. Tell me, was he sirested on a band?

Shak., C. of E., 1v.
S. S. Not on a band, but on stronger thling.

Yon know iny debts are many more than meat

Fletcher (and another), Noble Gentleman, I.

7t. A surety; a bondsman.

Since faith could get no credit at his hand

I sent hlm word to ceme snd sue my band.

8t. A covenant or league. [Scoteh.]-False bands, In bookbinding, strips of leather or strsnds books, and afterward molded in high relfef to give the sppessance of bands of nnuaual thlckness or strength.Raised bands, In bookbinding, strips of leather or braded
cord of unusual thiekness, fastened on the outside of the sewed sheets of a hook -hack, making a notlceable profec
tlon on the back, snd intended to give Increased strength to sewin

band 2 (band), n. [< ME. bande, < OF. bande, banda, renda $=\mathrm{Pg}$. banda $=$ It. banda an bcnda, dial. binda, a band, strip, side, etc. in various particular sonses, $\angle \mathrm{OHG}$. binda binta, MHG. G. bindc, f., a band, fillet, tie = Dan. bind, neut., a band, tie, ete.), < OHG bintun, MHG. G. binden, ete., = AS. binden, $\mathrm{E}$ bind. The word is thus ult. cognate with bind. The word is thus ult. cognate with
band ${ }^{\prime}$ and with bendl, with which it has been mixed, but it differs in its orig. formation: see band1, bend, and the doublet bend?2.] 1 . A flat strip of any material, but especially of a a fllet: as, a rubber band; a band around th head; a hat-band.

$$
\text { A alngle band of gold about her halr. }
$$

2. Anything resembling a band in form or func tion. (a) A bandage; speclfcally, a swaddling-band. Henry the Sixth, in infant bands crown'd king
of france and England. Of France and England. Shak., Hen. V., v. 2 (b) A border or strip on an srticle of dress serving to strengthen it or to confine It, si st the walst, neek, of
wrist: as, a walstband; a wristband; s sueck-band. Naut.: (1) A strip of canvas sewed across a sail to
strengthen it. (2) An tren hoop reund a gpar. (d) In nach., a belt, cord, or chain for transmilting power. Such communicating motion from ene to the other. (e) In projection: slso called facia, face, or plinth. (2) A tab let or atring-course esrried around a tower or other part decorslion separated from the general wall-anrfsce by
parallel lines. (g) A more or less broad space erossing a

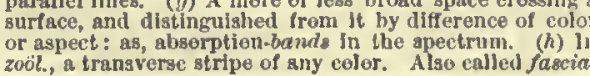

3. The form of collar commonly worn by men and women in the seventcenth eentury in west ern Europe. Is $w$ ss ertginally starched, and fixed in a half.erect position, nearly like the rufr, which it surperaeded, snd was often of lace and of immense size. After.
ward it was turned down over the shoulders, and ealled a falling-brend.

This band
Shews not my neck eneugh.
B. Jonsen, Volpone, lil. 2.

Klashg your finger that liath the ruhy or playing with

The next that mounted the Stage was sn linder-Citizen of the lath, a rerson remarkable annong the inferior p'eo. ple of that Place for his great Wiadom and his Broa
lkand.

4. The linen oruunent worn about the nock, with the ends hanging down in front, by certain Protestant elergymen. II was preserihed hy Qneen Elizabeth as a part of the every-day dress of Angliean 5. In mining, a layer of rock interstratified with the coal; sometimes, as in Cumberland, Eng land, tho coal itself. - Band of rock, a phrase sornethines used for bed of rock. See blackbond.- Gastroparleband 3 (band), $n$. [Early mod. F. also bend, late MF. bande, also bende, $\angle \mathrm{OF}$. and $\mathbf{F}$. bunde = Pr. Sp. It. banda (ML. bandum, bandus; 80 $\mathrm{G}$. bande, $\mathrm{D}$. bande, now bende, Dan. bande, $\mathrm{Sw}$ band, after Rom.), a band or company, < OHG. bant, OS. OFries., etc., band, a band or tie, the sense of 'company' being developed first in Rom. see band 1 band2 and of the doublet bend ${ }^{3}$.] 1. A company of persons, especially a body of armed men; a company of soldiers or of persons united for any purpose.

$$
\begin{aligned}
& \text { We few, we happy few, we band of brothers. } \\
& \text { Shak., llen. } V .
\end{aligned}
$$

My lord of Sonierset, linite
Your troops of horsemen with his bands of foot

Originally there were ususlly in each conslderable soclety [of Jiethodists] four bands, the members of whleh were composed of narried suld another of unmarried men, one of married and another of unmsrrled women. All the menibers of society, however, were not of necessity inem-
bers of bands. Did not Sexer Felipe tell you that he had positively en siged the ssme band of shearers we had last sutumn, 2. In music, a eompany of musicians playing various instruments in of micom playing manner of an orchestra: most frequently ap plied to a company of musicians playing suc instruments as may be uscel in marehing.-3. A collection of animals of any kind, as a drove ern U. S.]

In Californls every collectien of animals of sny sort 18 called a band. A herd of esttle, a flock of sheep, s party oeen in numbers is known as a band, and it is regarded as s sure sign of being " tenderfoot" to use any other term.

Knights of the band. See knight-Muitary band, band ${ }^{3}$ (band), v. [< band $\left.{ }^{3}, n.\right] \quad$ I. trans. To unite in a troop, eompany, or confederacy: generally reflexive.

They band themselves with the prevslent things of this world to overrun the weak thlngs whieh Christ hath made
cholee to work by. Miton, Chureh-Government, 1i. 3. Among the sons of morn, what multtudes
Were bauded to oppese his ligh deeree.
Milton, P. L.

Band them Into puebles : make then work; and, above

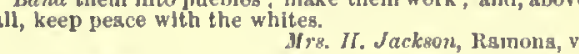

II. intrans. To unite; associate; confederate for some common purpose.

Wilh them great Aslur slso band.

Vilton, Ps. Jxxxill, 29.

The grest lords
Banded, and so brake ent in open was.

The weak will band agahnst her when she beconies too band4 (band), n. [Loeal E., perhaps a particular use of band2, a strip, or possibly of early mod. E. bande, $<$ ME. bande, var. of bonde, bound, limit: see bound.] A ridge of a hill: commonly applied in the English lake district to a long ridge-like hill of minor height, or to a long narrow sloping offshoot from a higher hill or mountain. $N . E . D$.

band ${ }^{5}+$. An obsolete 01 Scoteh preterit of bind. band $6+$ (band), $v$. $t$. [Same as ban ${ }^{2}$, after MI.
and It. bandire, a form of ML. bannire, banish, 
band

bau: see bani, banish. Otherwise taken, in the interdict; banish.

Sweete love such lewdnes bands from his falre conmanee.

band $7 \dagger, v$. Same as bandy 1 .

band 8 (band), $n_{*}$ [Native name.] A weight equal to about 2 ounecs troy, in use in wester Africa for weigling gold-dust. Simmonds.

bandage (ban'dāj), $n_{\text {. [ }}$ [ F. bandage, < bande, a band, strip: see band ${ }^{2}$ and age.] 1. A strip, band, or swatle of cotton eloth, or other
soft woven material, used in dressing aud bindsoft woven material, used in dressing aud binding up wounds, stopping hemorrhages, joining
fractured and dislocated bones, etc. -2 . A band or ligature in geveral; that which is bound over something else.

Zeal too had a place among the rest, with a bandage

3. In arch, an iron ring or a chain bound around the springing of a dome, the cireumference of a tower, or some similar part of a building, to tie it together.

bandage (ban'dāj), v. t.; pret. and pp. bandaged, ppr. bandaging. [< bandage, n.] To hind up or dress, as a wound, a fractured limb, ete. with a roller or bandage; cover with a bandage for the purpose of binding or conccaling: as, to bandage the eyes.

bandager (ban'dāj-èr), $n$. One who bandages or binds up wounds, ete.

bandagist (ban'dāj-ist), $n . \quad[<F$. bandagiste $<$ bandage: see bardage and -ist.] A maker of bandages, especially for hernia.

bandal, $n$. See bandle 2 .

bandal, ( S strong outer fiber of the abaca or Musa textilis of Manila, made into cordage, especially into the well-known Manila white rope.

bandalore, bandelore (ban'da-lōr, -de-lō'), $u^{\prime}$. [Origin obseure. Cf. bandore ${ }^{1}$.] 1. A kind of present century. See quiz.-2. Same as bandore1.

bandana, bandanna (ban-dan'ä), $n$. [First in for'm bandanno, later bandanna, prob, through Pg., < Hind. bañdhnu, "a mode of dyeing in which the cloth is tied in different places to prevent the parts from receiving the dye" bindh, a cord, ligature, tie, band, ult. $=\mathbf{E}$. . A large handkerchief, dyed blue, where the stuff has been pressed to prevent it from receiving the dye.-2. A stylo of calico-printing in imitation of bandana handkerchiefs, white spots being produced on a
red or dark-colored ground by discharging the

band-axis (band'ak"sis), n. Same as axiseylinder.

band-bird (band'berd), $x$. A name of the African collared finch, smadina faseiata.

bandbox (band'boks), n. A light box made of pasteboard or thin flexible pieces of wood and paper, for holding eajs, bonnets, or other light articles of attire: so called because originally made to contain the starehed bands commonly worn in the seventeenth century. See

She deposited by her side a eapacious bomllox, in which,
as is the custom annong travelers of her sex, she carried a bandboxical (band'bok"si-kal), a. [<bandbox $+-i e a l$.$] Of the size or appearance of a band-$ bex: as, bandboxieal rooms. [Colloq.]

band-brake (band'brāk), $n$. A form of brake used to prevent or to control the revolution of a shaft. It consists of a pulley secured upon the shaft, the circumference of which is embraced by a strap or
band, usually of netal, whieh is capable of being adjusted
to any desired degree of tirhtness. band-coupling (band'kup"ling), n. Any device for uniting together the ends of a band.

band-driver (band'dnī"vèr), $n$. A tool used for correcting irregularities in the bands of machinery. E. H. Kright.

bandé (boń-da'), a. [F., pp. of bander, band: see band $\left.{ }^{2}, v.\right]$ "In hor., bendy dexter, as dis-

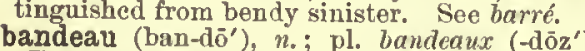
[F., $<$ OF. bandel, m., dim. of bande, band: se $\theta$ roumd the head; a head-band; especially, a ribbon worn by girls and women above the forehead.-2. A horizontal band or ring forming a part of the headpiece of armor.

438

\section{bandoleer}

Around the edge of this cap was a stiff bandeau of
Scott, Ivanhose. banded ${ }^{1}$ (ban'ded), p. a. $\left[<\right.$ band $\left.{ }^{1}+-a d^{2}.\right]$ Bound or fastened with a band.

banded ${ }^{2}$ (ban'ded), p. $a$. $\left[<b a n d^{2}+-e d l^{2}.\right]$ Haviug bands; crossed or encircled by a band or bands; specifically, in her., encireled with a band, often of a different color from the sheaf or bundle which it surrounds : as, a bundle of or bundle which it surrounds : as, a bundle of
lances proper, banded gules, or tbe like.-Banded column. See column. - Banded mall, a kind of mallarmor shown in works of art of the thirteenth century, in
which the rings are arranged in bands running around the arms, body, ete. Between the rows of rings there are ness as the rings. This mail is found represented not only in the minfatures of manuscripts, but also in life-size
eftigies in stone; but it is not defnitely known how it
wasmade. - Banded was made.-Banded
structure. (a) In structure. (a) In geol., the structure tinctly divided into layers of different color, iexture, term implie narily, something tratifleation and is applicable chiefly to volcanic masses. (b)

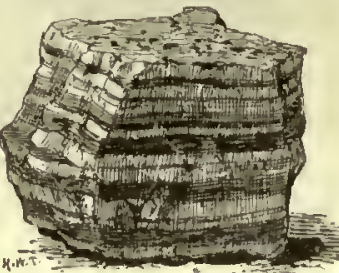

Banded Structure $(b)_{0}-$ Onyx. tructure of a min

ral made up of a series of layers, usually parailel and difThough banded Europe stood her foesThe star of Brandenburg arose.

(Oil, Int.

bandel $t$, bandle ${ }^{I}, n$. [< OF. bandel, m., bandele, bandelle, $\mathrm{f}$., dim. of bande, a strip: bandelet, $n$. Same as bandlet.

bandeliert, $n$. See bandoleer.

bandelore, $n$. See bandalore.

andert (ban'dér), n. One who bands or as ociates with others; a member of a band or confederacy.

$$
\begin{aligned}
& \text { Yorke and his banders proutly pressed in } \\
& \text { To challenge the crown by title of sight. } \\
& \text { Mir. for Mags., p. } 352
\end{aligned}
$$

You are to watch every atterupt which is made ... to
open any communication with any of the lords who may have become banders in the west. Seotl, Abbot, I. xx.
banderet (ban'de-ret), $n$ [Swiss $\mathrm{F},=\mathrm{F}$. Lanneret, E. bannerë̈ 2 , q. v.] A Swiss army com ander.

banderilla (ban-de-rēl'yậ), $u_{0}$ [Sp., dim. of andera, banner: sce banner.] A small dartlike javelin ornamented with a banderole, us banderillero (ban-de-rēl-yā'rō), $n$. [Sp., < banderilla: sec band

banderole, banderol (ban'de-rōl, -rol), $n$ [Early mod. E. also bandrol, bandroll, ete. bannerol, banerol, etc., < F. banderole (OF. banerolle), < It. banderuola, banderola (= Sp. banderola), a little banner, dim. of bandier (= Sp. bandera $=\mathrm{F}$. bamière), a banner: see
banner.] 1. A small flag or streamer. cally-(a) A small ornamental or streamer carried on the

Then take my banderol of red

Mine, and none but mine, shail honour thee,
And safe conduct thec. Greene, Oylando Fi

From the extremity fluttereen a small bonderobo. From the extremity ... . fluttered a small banderole or (b) In her., a streamer affixed immediately beneath the rook on the top of the staff of $n$ bishop, and folding over

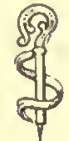

का Heraldic the staff. (c) A long narrow streamer with cleft 2. A band of various form adapted to receive an inscription, used in decorative senlpture and other decorative iod.

Also written bannerol.

band-fish (band'fish), $n$. An English name of (a) the Cepola rubescens, a species of the family Cepolide, more specifically ealled red band-fish (b) the oar-fish, Regalecus glesne. Also called snake-fish.

bandful (band'fúl; by miners, bon'tl), n. [< arricd up or down in the mine a load of men chain-loops attached to the hoisting-rope os was customary before the introduction of the cage and man-engine. [S. Staffordshire, Eng.]
bandicoot (ban'di-köt), n. [Cf. G. bandikit, from E.; said to be a corruption of the Telugu name pandi-kokk'u, lit. pig-rat.] 1. The Anglo-
Indiau name of the Mus giganteus of Hardwicke, a large Indian rat, upward of 2 feet long including the tail, and weighing 2 or 3 pounds. It is very abnudant in some regions, a great
pest in the rice-flelds and gardens, and is said to be good 2. The Anglo-Australian name of any marsupial animal of the family F'eramelida. Also called bandieoot rat.

bandie (ban'di), $n$. [Local Sc.] The stickleback: a name eurrent around Moray Frith, Scotland.

bandikai (ban'di-kā), $n$. One of the names of the Abclmoschus esculentus. See Abelmoschus. bandileer (ban-di-lēr'), n. Same as bandoleer. banding-machine (ban'ding-mâ-shēn"), n. A blocking-machine for forming the band of a hat.

banding-plane (bau'ding-plān), $u$. A plane used for eutting out grooves and inlaying strings and bands in straight and circular work. It bears a gencral resemblance to the plane called a plow.

banding-ring (ban'ding-ring), $n$. In hat-making, a ring which passes over the body of a hat, keeping jt pressed to the hat-block. Its lower' edge is at the band, or angle formed by the body and the brim.

bandit (ban'dit), n.; pl. bandits, banditli (ban'dits, ban-dit'i). [Early mod. E, bandetto later anditto, bandito, bandite, etc., pl. bandetti, banditti, banditi, banditty, and with added F. pl.banditties, etc.; < It. bandito (pl. banditi), a bandit, pp. of bandire, S ML. bandire, bannire, banish, outlaw: see ban 1 , banish.] 1t. An outlaw; one who is proseribed. Hence-2. A lawless or desperate fellow; a brigand; a robber; especially, one of an organized band of lawless marauders.

The Ripon men brought down the half-outlawed bandits rom the Archbishop'a liberty of Tynedale.

=Syn. 2. Brigand, etc. See robber.

banditt (ban'dit), v. $t$. To outlaw; proseribe; banish.

banditti, $n$. 1. Plural of bandit, banditto.-2†. Used as a singular.] A band or company of bandits. Sometimes written banditty.

anditto (ban-dit'ō), n.; pl. banditti (-i). [It. bandito: see bandit.] A bandit.

A Roman sworder and banditto [originally printed bandetto] $\begin{aligned} \text { slave } & \\ \text { Iurther } & \end{aligned}$ That ruthless hearse of her dear spouse

and-lacing (band'la' 'sing), mo Strips leather used in fastening together the ends of a band or belt used in driving machinery.

bandle ${ }^{1} t, n$. See bandel.

bandle ${ }^{2}$ (ban'dl), $n$. [Also sometimes bandal, CIr. and Gael. bannlamh, a cubit, < bann, a meahalf a yard in length, used in the southern and half a yard in length, used

bandle-linen (ban'dl-lin"en), $n$. A coarse homemade Irish linen of narrow width.

bandlet (band'let), $n$. [KF. bandelette, dim. of any little band or flat molding, as that which erowns the Doric architrave: a fillet or listel. 2. A small band for encircling anything: as, an india-rubber bandlet.

Also bandelet.

band-master (band'mảs'tèr), $n$. The leader or

band-mounting (band'moun"ting), $n$. In harness-making, a style of harness-mounting in edges.

band-nippers (band'nip"èrz), $n$. sing. and $p l$. An instrument used in bookbinding to draw the leather on the back close to the sides of the bands.

bandog (ban'dog), n. [ME. band dogge, ete.; in England generally a mastiff, usually kept chained.

They pray 11 s that it would please us to let them atil hale us, and worry us with thelr band-dogg, and Pursul The keeper entered leading his bandog, a large biood. hound, tied in a leam or band, from which he takes his

bandoleer (ban-dō-lēr'), n. [Early mod. E. also bandaleer, bandeleer, bandileer, -ier, etc., (=Sp. bandolera), a shoulder-belt, $<$ "bandola 
bandoleer

(ef. bundolo, head of a skein), dim. of burla $=\mathrm{Sp}$. banda $=\mathrm{F}$. bandc), a band, sash: see bund2.] 1 $\dagger$. A broad belt or baldric worn over the shoulder and aeross the breast, and used for suspending a wallet by the side.

1 lhrew mhe arms, Itke a scarl or banditees", cross the lientelant a mel ancholy losom.
Middleton, The Black Book. The baillie now came bustling fu, liessed In his hlue cont and bandabalterdicrs. Scott, Nonaslery, I. x. Sipecifically -2 . Such a belt Specifeally - 2. Such a belt woru by soldicrs; a shoulderbelt from whi

The dengrer is sluek in the assh, and a bandoteer slung over the shoulder carrles their eartrldge-euse, powder lask, fliut and stcel, prining-horn,

taandoleer. and other necessariea.

Hence - 3. A ncarly eylindrical case of copper or other material formerly used to contain a charge of powder. A number of these were glnng to of eharging the harqueluase, or hi moderil times the And, as Sym Hall stood by the fire, Scott, L, of Lo $\mathbf{X}$, iii. 21.

Also spelled bandileer, bandalier, bandelier. bandoleer-fruit (banl-dō-lēr'fröt), $n$. The berries of Zanomia Indica, an Indian cucurbitaceous vine bearing a fleshy fruit with winged seeds.

bandoline (ban'dō-lin), $n$. [Origin obscure apper a perhaps based on band ${ }^{2}$. appar. a trade-name, perhapsea, originally obtainod mainly from quince-seeds, used to impart glossiness to the hair, or to fix it in any particular form.

bandoline (ban'dō-lin), $v$. ; pret. and pp. bandolined, ppr. bandolining. $[\langle$ bandoline, n. $]$ I. trans. To apply bandoline to, as the hair; rentrans. To apply bandoline to, as the hair; rendor stiff, as the mustache, by applying basdoline. Diekens.

bandont, n. [Early mod. E., < ME. bandon, bandoun, bandun, etc., < OF. bandon, < ML. "bando(n-) for bandum, bannum, proclamation, command, edict, ban: see ban $1, n$., and cf. $a b a n-$ don.] Jurisdiction; power of disposal; dis-

bandont, $v$. t. [Early mod. E., < late ME. ban done, by apheresis for abandan, q. v.] To abandon.

bandore ${ }^{I}$ (ban-dōr'), n. [Also formerly bandora bandurion, after Sp. or Pg.: Sp. bandurria and bandola, formerly pandurria, $=\mathrm{Pg}$. bandurra $=$ It. mandora ( $>$ F. mandore) and mandola (dim. mandolino, $>$ E. mandoline), and pandora, pan dura; variously corrupted (as also E. banjo, q v.), < LL. pandura, pandurium, < Gr. mavdoũpa,

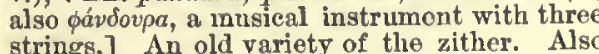
called bandalore.

Sound lute, bandora, gittern

Afiddleton, Your Fivo Gallants, v.

bandore 2 , n. [For "banda, i. e., bandeau, < F bandean, $\mathbf{a}$ band, in the particular sense of widow's head-dress: see bandeau.] A widow' veil for covering the head and band-pulley (band'pull"i), $n$. A flat or slightly crown-faced pulley.

band-robin (band'rob'in) In lat-maloing a piece of eloth saturated with cement, bound and ironed around the body of a hat to hold the brim firm$1 y$ in its place.

bandrolt, $n$. An obsolete form of banderole.

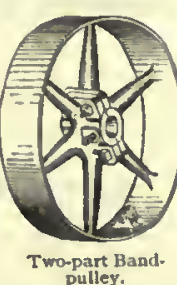

band-saw (band'sâ) ". An endless narrow band or ribbon of steel with a serrated edge, passing over two large wheels, which give a contintrous uniform motion instead of the reciprocating action of the jig-saw. It was invented by William Newberry of London. Also called belt-suw and endless sav.

band-setter (band'set"èr), n. A tool used for shaving off the surface of a band-wheel so that the band-saw can be foreed on. It has a broml

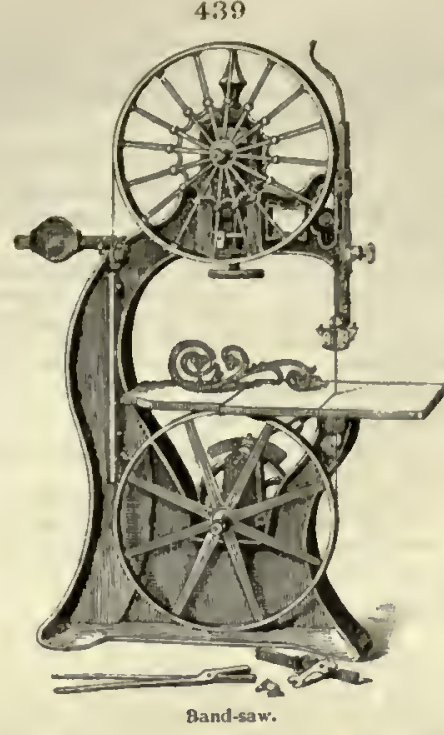

bane

To cive and take; excliange, esuecially contentionsly: as, to bandy compliments; to bandy words, reproaches, ete.

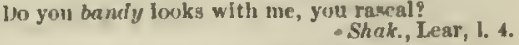
Worda with your mightliness.

Jfansinger, Eanperor of the East, iv. 3.

Mlschlef, spirit, and glee spsrkled all over her face as she thus bandied words with the old Cossaek, who almost equally enjoyed tise tilt. Charlote Bronte, Stirley, xil. 5†. To discuss; debate.

0 , what a thing is man,

To bandy factlons of distemper'd passlong

Agalnat the sacred Provldence ahove lim!
Ford, Lover'g Melanclioly, v. J.

6t. To band together; leaguo: ehiofly roflexive. All the klugg of the earth bandy themselves to fight with

II intrans. 1t. To bound, as a ball that is truek. - 2 . To form a band or league. - 3 . To contend; strive, whether in emulation or in enmity.

One fit to landy witl tliy lawless sons.

bandy ${ }^{l}$ (ban'di), n. $\left[<\right.$ bandy ${ }^{I}, t$. ; appar. for bandy-club, elub used at bandy; but see bandy 1 a.] 1t. A particular manner of playing tennis, the nature of which is not now known.-2 A stroke with a racket, or a ball so struck; a return at tennis. N. E. D. - 3. A game played with a bent club, better known as hockey, and, in the United States, shinny in the game of hockey or bandy-ball; a shinny or shinty.

bandy 1 (ban'di), a. [Appar. attrib. use of bandy $1, n$, a bent club, but some refer both to F. bande, pp. of bander, bend a bow, < bande, a band. The second sense seems to rest on bend ${ }^{\text {. }] ~ 1 . ~ H a v i n g ~ a ~ b e n d ~ o r ~ c r o o k ~ o u t w a r d: ~}$ said of a person's legs: as, his legs are quite bandy.

\section{Nor make a scruple to expose
Your bandy lez, or crooked noge.}

Your bandy leg, or crooked noge.

2†. Limp; without sufficient substance: said of bad cloth.

bandy ${ }^{2}$ (ban'di), a. [< band $2+-y$; but $c$ f. $\mathbf{F}$ bande, pp. of bander, bend, and bendy.] Marked with bands or stripes.

bandy ${ }^{3}$ (ban'di), $n$. [Anglo-Ind., < Telugu bandi, Tamil randi, vandil.] A kind of cart or buggy much used in India. See extracts.

A buggy being a one-horse vehiele ... (at Madras the eall it a band $y$ ).

Stocqueler, IIandbook of Brit. Indla, p. 109. (N. E. D.) The trsmew ork of bandies is made of Jlght wood, but of wood as strong as posslble. Above it la spread a semicireular awning of hamboos aupportlng mats of cloth or can.
vas. The bandy is a cross.country vehlele, and as a rule vas. The bandy is a cross-eountry vehlele, and as a rule
possesseg no springs of any kind. The conveyance ls bandy-ball (ban'di-bâl), $n$. [ $\left[<\right.$ bandy ${ }^{1}, n .,+$
ball ${ }^{1}$. 1 . The ball used in the game of bandy ball1.] 1. The ball used in the gan bandy-jig (ban'di-jig), $n$. [〈bandy $y^{1}, a .,+j i g^{1}$. A burlesque dance performed with the toes and knees turned in. IIayher.

bandy-legged (ban'di-legd or -leg"ed), $a$. [< bandy, a., + leg $+e d^{2}$.] Having bandy or bandy $1, a .,+$ leg $+-e d^{2}$.

bandyman (ban'di-man), n. bandymen (-men). [<bandy ${ }^{3}+$ man.] In British India a man engaged in driving a bandy. When also, as all over India, our white kinsmen speak
of bandymen and bandles, the word thus angljelzed is
simply the old 'l'smilian one. bane1 (bān), n. [Early modl. E. also, less prop., bane baine: 1 ME. bane, <AS. bana, bona, a bain, baine; $\mathrm{ME}$. bane, $\mathrm{AS}$. bana, bona, a slayer, murderer, $=$ OS. bano= OFries, bona $=$ OHG. bano, MHG. bane, ban = Icel.bant = Sw. Dau. bane, death, murder (not in Goth); akin

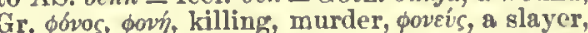

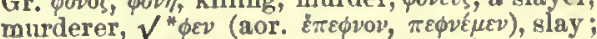
ef. $\sqrt{ }$ " $\phi a$, slay, $\phi a \tau b$, verbal adj. in eomp., of death, as a man or an animal.

$$
\begin{gathered}
\text { He overcame tlis beeate and was lifs bane. } \\
\text { Chatcer, Good Women, 1. 2147. }
\end{gathered}
$$

Lest Rome herself be bane unto herself,

And shi

2†. To toss aside; drive or send off.

If the Earth had been bandied out of one Vortex into
another. Dr. II. More, Div. Dinl., 3. 17. (N. E. D.)

3. To toss about, as from man to man; pass from one to another, or back and forth.

Let not... known truth . . . be bandied in disputa. But now her wary ears did hear "illiam Mforris, Earllhly Paradise, 1II. 275. especially, poison of a deadly quality.

A sword and a dacker he wore by hlla gide,

of manye a man the bane. 
bane

Hence-3. Any fatal cause of mischief, injury, or destruction: as, vice is the bane of society. Bane of the poor! it wounds their weaker mind
To miss one favour which their neighthours find Crabbe, The Parish Register. Thonghts with better thoughts at strile, The most famtliar bane of lite.

4. Ruin; destruction.

The cup of deception spiced and tempered to their bane. 5t. Death: usually with such verbs as catch, get, take: as, to catch one's bane.

$$
\begin{aligned}
& \text { She catch'd her bane o' th' water. } \\
& \text { Middleton, Chast }
\end{aligned}
$$

6. A disease in sheep, more eommonly ealled the rot. $=$ syn. 3. Pest, curse, scourge.

bane ${ }^{1} \nmid($ bān $), v . t$.
poison. -2 . To injure; ruin. For minors have not only baned families but ruined
realins. bane $^{2}$ (bān), $n$. Seoteh form of bone1.

bane ${ }^{3} t, n$. An obsolete form of banl, especially in plural banes, now banns (which see).

bane $4 t, a$. An obsolete form of bain 1 .

bane $e^{5}, n$. and $v$. An obsolete form of bain ${ }^{2}$.

baneberry (bān'ber $\left.{ }^{\prime \prime} \mathrm{i}\right), n$. [<bane ${ }^{\mathbf{I}}+$ berry $^{1}$. $]$ The common name of plants of the genus Actca: so called because of their nauseou poisonous berries. Also called herb-christopher. Ser Aetoca.

baneful (bān'ful), a. [<bane $1+-f u l$.$] De-$ structive; pernicious; poisonons: as, "baneful wrath," Chapman, Iliad, i. 1; "Zaneful hem

lock," Garth, The Dispensary, ii.

Like baneful herbs the gazer's cye they seize,

Rush to the head, and poison where they please.

=Syn. Hurtful, harmiful, nischlevous, deadly.

banefully (bān'fúl-i), adv. In a baneful man ner; perniciously; destruetively.

banefulness (bän'fúl-nes), $n$. The quality of being baneful or hurtful; poisonousness.

banewort (bān'wẻrt), n. A name applied to two plants: (a) Atropa Belladonna, or deadly nightshade; (b) Ranunculus Flamnula, or lesser spearwort, from the supposition that it is a bane to sheep.

bang ${ }^{1}$ (bang), $v_{0}$ [Early mod. E. also bangue; not found in ME., but prob. existent; of native or Scand. origin, = LG. bangen, freq. bangeln, a bell, MHG. bengel, a club, G. bengel, a club, clown, , = Ieel. banga = OSw. banga, hammer, = Norw. banka = Dan. banke, beat. In popular apprehension the word is imitative.] $\mathbf{I}$. trans. 1. To beat,
thump; cudgel.

He having got some iron out of the earth, put it into his

. Locke. 2. To beat or handle roughly in any way; feat: often with about: as, to bang the furniture about.

The deaperate tempest hath so bang'd the Turks What galleys have we bang'd, and sunk, and taken, What galleys have we bang'd, and sunk, and taken,
Whose only franghts were flre and atern deflance.

3. To produce a loud noise from or by, as in slamming a door, and the like: as, he went out and banged the door behind him.

Twa unlucky redcoats. . . banged aff a gun at him.

4. To beat in any quality or action; surpass excel. [Colloq.]

The practical denial of the common brotherhood of the
same famlly bangs heathenism.
J. Mill.

That bangs Banagher, and Banagher bangs the world.

II. intrans. 1. To strike violently or noisily thump: usually with against.

Now there are certain particles or small masses of matter which we know to bang ugainst one another according
to certain laws.
$W^{*} \cdot K$. Clifford, Lectures, I. 177 .

2. To resound with elashing noises.

$$
\begin{aligned}
& \text { The maid and page renew'd their strite, } \\
& \text { The palace bang'd and buzz'd and clackt. }
\end{aligned}
$$

$$
\text { Tennyson, Day-Dream }
$$

3. To spring or move with sudden energy o impetus; bounce: as, he banged up at once. bang ${ }^{1}$ (bang), $n$. [= Icol. bang $=$ Sw. bang, hammering, $=$ Norw. Dan. bank, a beating; from the verb.] 1. A heavy, resounding blow; a The very first blow that the forester gave
II made his broad weapun cry twang;
440

Twas over the head, lie fell down for dead, o, that was a damuable bong

Robin Hood and the Ranger, hu Child's Ballads, v. 209. I heard aeveral bangs or buffets ... given to the eagle
that held the ring of nyy hox in his beak that held the ring of my hox in his beak,
Sroift, Gulliver's Thavels. 2. A loud, sudden, explosive noise, as the dis charge of a gun or cannon, the slamming of a door, etc.

The steps of a fine-belozenged carriage were let down
Thackeray, Newcomes, II
witl a bang.

IIe made lis exlt, clearing the stairs at a stride or two and making the house shake with the bang of the front 3. A sudden, impetuous movement; an energetic dash or bounce: as, he got up with a bang. 4. A stick; a club. [North. Eug.]=Syn. 1 see thump.

bang (bang), adv. [Adverbial use of bang ${ }^{1}, v$ or $n$.$] With a sudden or violent blow or elap;$ or go: as, bang went the guns.

A 32lb, shot struck 13 bang on the quarter.
Tom Cringle's Log, Blackwood's Mag., XXXII. 31. bang $^{2}$ (bang), v. t. $\quad[<b a n g 1, a d v$; ; to cut the hair 'bang off.'] To cut across: used of hair.
(a) To cut (the hair) so as to form a fringe over the forehead: a common fashion with girls and young women.

He was bareheaded, hls hair banged even with his eye.
brows in front.
The Century, XXV. 192. (b) To dock (a horse's tail).

bang ${ }^{2}$ (bang), $n$. [<bang ${ }^{2}, v$. $]$ The front hair cut so as to hang evenly over the forehead: often in the plural: as, to wear bangs.

bang ${ }^{3}, n$. See bhang.

bang-beggar (bang'beg/är), n. $\quad\left[<b^{\prime}\right.$ ang ${ }^{1}, v_{.},+$ obj. beggar.] 1. A strong staff. -2. A constable or beadle. [Seotch and prov. Eng.]

bangerts (ban'gèrts), $n$. [E. dial., possibly kind of stopping used to hold [Eng.]

banghy (bang'i), n. [Hind. banghi.] 1. In the East Indies, a sort of bamboo pole or yoke carried on a person's shoulder with a load sus-
pended at each end. Hence-2. A parcelpost; a carrier.

banghy-post (bang'i-pōst), n. Same as bang$h y, 2$

banghy-wallah (bang' $\mathrm{i}$-wal "ä), n. [< Hind. banghi (see banghy) + -wāta (in comp.), -man.] banging (bang'ing), a. [Prop. ppr. of bang 1 .
[ Cf. thumping, whopping.] Huge; great; surpassing in size. [Vulgar.]

bangle $1+$ (bang'gl), $v$. [Prob. freq. of bang $\mathrm{I}, v$.]
I. trans. 1. To beat about or down, as eorn by the wind. [Prov. Eng.]-2. To waste by lit tle and little; squander carelessly; fritter.

It we bangle away the legacy of peace left us by Christ,$$
\text { II hole Duty of Man. }
$$

II. intrans, 1n falconry, to beat about in the air; flutter: said of a hawk which does not rise steadily and then swoop down upon its prey.-2. To flap or hang down loosely, as a hat-brim or an animal's ear.

bangle ${ }^{2}$ (bang'gl), $n_{.}$[< Hind. bangri, a brace-

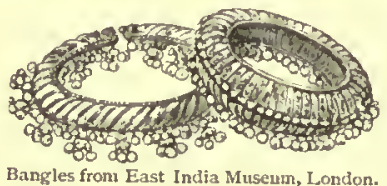
upon the arms and ankles in India and Africa. Hence2. A bracelet without a clasp; a ring-bracelet, small ornaments suspended from it.

We hear too often of Bertha's vartous dresses, and 3. Naut, The American, VI. 124

bangle-ear (bang'gl-ēr), $n$. [< bangle $1+$ ear 1 . garded as an imperfection.

bangle-eared (bang'gl-ērd), $a$. [Also bangledeared; as bangle-ear $+-e d^{2}$.] Flap-eared, like a spaniel.

bangling† (bang'gling), n. [Verbal n. of banBangorian (bang-gó'ri-an), a. [< Bangor, a bishop's see. The name is W., lit. 'high peak, < ban, peak, prominenee, + gor, high.] Relating to Bangor, a bishop's see in North TWales. Bangorian controversy, a controversy atirred up by a

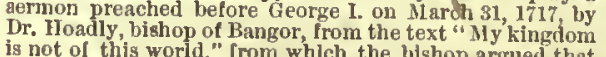
Christ had not delegated judiclal and disciplinary powers banish

to the Clnistian ministry. Convocation declared that Hoadly's teaching tended to subvert an government in the chirch or chist, reduciug his kinglom to anarehy, and has about to proceed against him when the king prorogation as olten as it lad to be stmmoned agaln.

bang-pitcher $\nmid$ (bang'pich"èr), n. $\quad\left[\left\langle b^{\prime} a n g 1, v\right.\right.$, obj. pitcher.] A drunkard.

bangsring (bangz'ring), $n$. Same as banxring. bangster (bang'stèr), n. [< bangl, v., + -ster. A violent fellow who carries everything befor him; hence, a victor or champion. [Seotch.] Eng.]

bangue, $n$. See bhang.

bang-up (bang'up), $a$. or $a d v$. $\quad\left[<b a n g^{1}, v\right.$ or $a d v$. implying energy or dash, + up, implying completeness.] In fine style; in the best manner; complete; perfect: as, a bang-up entertainment; "task bang-up," Scott, Diary, Sept. 8, 1826 (in Lockhart's Life). [Slang.]

bangy, $n$. See banghy.

(ban'ian), n. [Formerly Pg. banian, prob., through Ar. banyān, < Hind. banya (also banik), Beng. baniya, banya, benya, a trader, merehant, Gujarati vaniyo, a man of the trading caste, < Skt. vanij, a merchant, possibly < $\sqrt{ }$ pan, buy, bargain.] 1. A Hindu trader or merchant, especially of the provinee of Guzerat; one engaged in commerce generally, but more particularly one of the great traders of western India, as in the seaports of Bombay, Kurrachee, ete., who carry on a large trade with the interior of Asia by means of caravans, and with Africa by vessels. They form a class of the easte Valsya, wear a peculiar dress, and are the use of fleah.

The Banians would eat nothing that had life. Their priesta were called vertecs, and wore white clothes, which charity, and kept nothing till the next day.

2. In British India, originally, a cotton shirt worn by the Hindus. Hence- $(a)$ Any undergarment, even of the elastic web made in England. (b) Any loose or easy dress worn in the house, especially one modeled on the native dress of the Hindus. - Bantan days, originally two days in the week, and afterward one, in which sallors in the British navy had no fleal-meat served out to them. Ban-
lan days are now abolished, but the term is stil applied ays of poor fare.

banian 2 , banyan ${ }^{2}$ (ban'ian), $n$. [Fol banianor bamyan-tree, that is, banians' tree, tree of the banians or Hindu merchants ; orig. applied to an individual tree of this species at Gombroon, a port of the Persian gulf, and then extended to all trees of the species, from their frequent use as market-places. The native Hind. name for the tree is bar, Skt. vata (cerebral $t$ ), the banian-tree.] An East Indian

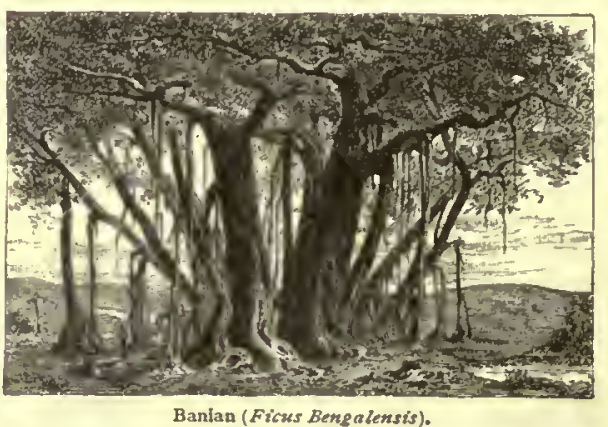

fig-tree, Fieus Bengalensis, natural order Urticaeece, remarkable for the area which individual trees cover through the development of roots from the branches, which descend to the ground and become trumks for the support and nourishment of the extending erown. It is exof rapid growth, Irequently covering a space 100 yards in diameter and reachlng a height of 80 or 100 teet. The truit is of the size of a cherry. As in some otiter tropical ground, but usually in the crowns of palms or other trees, where they bave been deposited hy birds. Roots are sent down to the ground, and they embrace and finally kill the nurse-palm. The tree furnishes lac, the bark is made into cordage, the milky juice yields a bird.lime, and the
leaves are lashioned into platers. The wood ia soft and

banie (bā'ni), a. A Scotch form of bory.

banish (ban'ish), v. t. [< ME. banishen, banysen, $\angle$ OF. banir, bannir (baniss-), mod. F. bannir $=$ Osp. Pg. bandir = It. bandire, ML. bannire, 
banish

bandire, proclaim, ban, banisl, < bannun, bandum, bau: see ban $1, n$. and $v$.] 1t. To outlaw put under ban.

$$
\begin{aligned}
& \text { When he had in Lougl-leven been } \\
& \text { Many a montli aud many a day: } \\
& \text {, a banysghed man. }
\end{aligned}
$$

2. To condemn to exile by political or judicial authority; expel from or relegate to a country or a place, either permanently or for a time: often with objectives of both person and place: banished to Tomi.

From this instant, banish him our We, Shak, Rich. II., i. 3, Thou knowest what it is to be banished thy native country, to be over-ruled, as well as to rule and git upon
the throne.
R. Barclay, Pref. to An Apology. 3. To send or drive away; expel; dismiss: witl a persou or thing as object: as, to banish sorrow; to banish an obnoxions person firom one's presence or thoughts.

These evils thou repeat'st upon thyself.

Shak., Macbeth, Jv, 3

You have aiready banished siavery from thia common. "Syn. Banish, Exile, Expel, expstriate, put sway, are all used of removal by physical or moral compulalon; they literslly, to put out of a community or country by ban or civin interdiet, nind istance. To exile ta atmply to ciste ively ; it emphrasizes the Idea of leaving home, while banish emphasizes rather that of being forced by some su. thortty to leave it: as, the bitterness of exile; baniahed to Siberia. Expel, iiterally, to drive out, means primity
rily to cast out forcibly and vlolently, and accondarily with disgrace: as, to expel from th

Banished from Rome I what's banished but set tree

From dalty contact with the things I loathe?

The Intrigues of Richelien compelted her [Mary of Me

dicis] to exile herseif, and live an unhappy fugitlve.

When the French Revolution of February, 1848, broke out, Iarx was expelled without circumstance from Brus-

banisher (ban'ish-ér), $n$. One who banishes. To be full quit of those my banishers

banishment (ban'ish-ment), n. $[<$ banish + -ment, after $\mathrm{F}$. bannissement.] 1. The act of banishing or compelling a citizen to leave his country or place of residence by political or judieial authority.

Ife secured himself by the banishment of his enemies.

2. The state of being banished; enforced absence; expulsion; exile, in either a legal or a is worse than death.

Six frozen winters gpent, Shak, Ricli. II., t. 3.

Fields whose thrifty occupssts sbide

As in a dear aud chosen banishment, Wordsworth, Sonuets, iit. 21.

3. The act of driving away or dispelling: as, the banishment of care from the mind.

banister, bannister (ban'is-tér), n. Corrupt forms of baluster.

He struggled to ascend the pulpit atairs, holding hard banister-cross (ban'is-tèr-krôs), $n$. In her., seo cross-banister.

\section{banjert (ban'jér), $n$. See banjo.}

banjo (ban'jö), $n$. [Negro pron. of banjore, a corruption (in another form banjer) of ban-

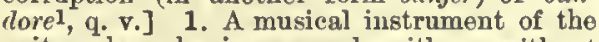
guitar class, having a neck witl or without frets, and a circular body covered in front with tightly stretched parchment, like a tambourine. It has trom five to nhe strings, of which the melouly. string, the higlsest in pitch, hut placed outside of the low
eat of the otliers, is played by the thumb. As in the gut est of the otlers, is played by the thumb. As in the gut
tar, the pitch of the strings is fixed by atopping them with the left hand, while the right hand produces the tone by plncking or atriking. It is a favorite instrument antong used by other per so

2. A banjo-frame (which see)

banjo-frame (ban'jō-frām), $n$. A rectangular frame of metal, fitted in the stern of a ship, for earrying and hoisting or lowering a twobladed serew-propeller. It worka in guldes in the

441

bank

stern-post and rudder-prost, and enables the serew to he bank ${ }^{l}$ (bangk), $v . \quad\left[\left\langle b a u k^{-1}, n\right.\right.$. $]$ I. trans. 1 . lifted ont of the water when it in combected to the shaft when banjoist (ban'jộ-ist), $n$. [s banjo + ist.] One who plays the banjo. bank (bangk), $n_{\text {. }}$ [< ME. bank, bane, banke, also bonk, bonc, bonke, AS. "banca (found only uce, in a gloss, in comp. ió-banca, a coneh, lit. 'hecl-bench': see hock'), the ME. being perhaps from the cognato Icel. $k i$, a bank (of a river, of a chasm, of clouds, etc.), ridge or eminence, Sw. backe = Dan. bakke, a hill, hillock, ris-

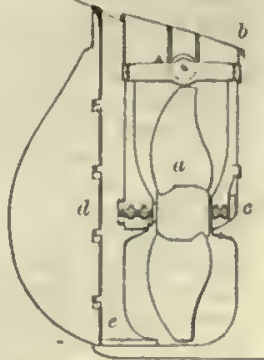

Banjo-frame. a. two-bladed screw; 8 , pur coupling connecting screw wlit

with weak suffix, cognate with AS. benc, etc. H. bench, with orig. strong suffix: seo bench. bench, ete., from Teut.; so the distinct bank ${ }^{2}$ ult. a doublet of bench.] 1. A mound, pile, or ridge of earth raised above the surrounding plain; an artificial embankment, espccially for nilitary use.

They cast up a bank agalnat the city. 2 Sam. xx. 15. 2. Any steep acclivity, as one rising from a river, a lake, or the sea, or forming the side of plain.

Tiber trenbled undernesth her banks. Shak., J. C., i. 1, Moored against the grassy bank of the brin
the black ships were taking in hides and furg.

G. W. Cable, Creoles of Louisiana, p. 104

3. An elevation or rising ground in the sea or the bed of a river, composed of sand or other soil, and either partly above water or covered everywhere with shoal water; a shoal; a shallow: as, the banks of Newfoundland; the Dog ger bank in the North Sea.-4t. A bench or long seat; also, a stage or platform to speak from. See mountebank.

Per. Who be these, sir? $P$. Fellows, to mount a bank. Did your instructor In the dear tongues never discourse to you
of the Italian mountebanks?
B. Jonson, Volpone, if. 1. The heads of the couches were towards the walls; sod go far as one can gather from the vague descriptiong which Ved as a bank to slt upon.
W. K. Sullivan, Int. to O'Curry's Anc. Irish, p. ccexlix. 5. A bench in a galley for rowers; hence, the number of rowers seated on one bench. A galley was double-banked when there were two tiers or rows of were three tters, and so on. In modern phraseology, a boat
is single-banked when the oars are pulled each by one man, the men sitting one upon s seat and alternately on oppoaite atdes of s boat; it ta double-banked when two men ait
upon one seat, each man with an oar. An osr is single. banked when worked by one man, and double-bsnked Mesntime the king with gifts a ressel stores,

6t. In lav, the bench or seat upon which the judges sat. See banc.-7. A bench or row of keys in an organ or similar instrument.8. In carp., a loug piece of timber, especially -9. In coal-mining: (a) The surface around the mouth of a shaft: in this sense nearly synony mous with the Cornish grass, to bank being the same as to grass. (b) In England, the wholo or one end or side of a working-place under ground. (c) In Pennsylvania, a coal-working opened by
water-level drifts. Penn. Geol. Surv. Glossary. (d) In England (Cumberland), a large heap or stack of coal on the surface. Gresley.-10. The support of the moving carriage of a printing-press.-11. In the fire-chamber of a glassfurnace, one of the banked-up parts which support the melting-pots. - 12. In printing: $(a)$ The table used by a hand-pressman for his unprinted paper and his printed sheets. (b) A the galleys for use in collecting and proving the type set: mainly used in newspaper composing-rooms. - 13. In thread or yarn manufacture, a creel in which rows of bobbins are held. - Bank of clouds, a mass of clouds appearing as if piled up in the form of a bank. - Bank oll, menhaden-oll.taut points in the line of $\mathrm{a}$ work, or purchased for use wilhere $a$ sufficlent quantity for the needed flllings is not
furnishel by the cuttings.
To raise a mound or dike about; inclose, defend, or fortify with a bank; embank: as, to ank a river. -2 . To form into a bank or heap leap or lile: with up: as, to benk up the snow. -3. To lio around or encirele, as a bank; couto; hem in as a bank.

Hurutug saukls that bank the shrubly vaieg.

4t. To pass by tho banks or fortificatious of.

llave I not heard these islanders slout out

"Vive fe roy" as I have bauk' $d$ their towna?

To bank a are, to cover up a firo with aslies, snd use other meuns, as closing the dampers and ash-pit door, to coming extinguished.

Towards the afternoon a nlce breeze sprang up, snd we

were able to bank fires and sait. To bank out, in coal-mining, to stack, as coal, on the II. intrans. 1t. To border upon. -2 , To in pinge upon the banking-pins of a watch: sail of the escapement.

ank ${ }^{2}$ (bangk); n. [Early mod. E. also banke, banque, < late Mis. banke, < $\mathrm{F}$. banque, < It banca $(=\mathrm{F}$. bauche $=$ Pr. Sp. Pg. banea, $<\mathrm{ML}$. banca, f.), a bench, esp. (in It. and thence in other lauguages) a money-changer's bench or table, later a bank; cf. lt. Sp. Yg. banco = P'r. F. banc, < ML. bancus, m., a bank, bench, bank 1.] 1†. A money-dealer's table, counter, or shop.

Excbangers of Money male the temple to be the market
and the banke. Theae establtshed their banks or tables in the forum, like ordinary bankers.
A rnold, IIlst. Rome, II. xxvtt. 72, (V. E. D.) 2†. A sum of monoy, especially a sum to draw upon, as in a loan-bank.-3. In games of tor of the gaming-table, or the person plays against all the others, has before him. the funds of a gaming establishment; a fund in certain games at cards: as, a faro-bank. -4 . An institntion for receiving and lending money. The banking institntfons of the United States may be vate banks or bankers, and loan and trust companies.
Yational banks were Arst anthorized by \& law of the United States enacted in 1863 , for a term of twenty years.
In 1864 another act was adopted (allowing the líke tern of. twenty years), which was thereafter known as the National Bank Act. In 1883 they were authorized to
continue twenty years longer. They recelve, lend, and transmit money, and issue notes which are nsed as money, with the government, and their operations are subject to Currency. State banks perform the game tunctions except taxed 10 per cent. by Congress in 1865 , in order to cause thetr retirement, whteh was speedily accomplished. Pri-
vate banks an.] bankers carry on the aane business as State banks. Somettmes one person constitutes a pirivate form s partnerslip. Loan and trust companies are incor. fixed perfod, and loan them on the pledge of stocks, bonds, largely on the promises of the borrowers; they have ais a cspital which is subscribed sind paid by the stoekholders.
Savings-loanks recelve montey and lend it chiefly on the sectrity of resl estate. See batinga-bank. In Europe with the fiseal departments of the governments of their respective contres, Bas of issue are such as issue notes tlat cir-
culste as currency. In London and for gixty-five niles culate as currency. In London and for gixty-five miles $\mathbf{5}$. The office in which the transactions of a banking company ale conducted. - Bank-charter Act, an Engl lah statite of 1844 (7 and 8 Vict., c. 32) defining of notcs and the amount of bullion reserve. Its object notea, which it accomplished by fixing a limit to the the issue of noteg hy other banks. Also known as the
Peel Act, snd Sir Robert J'eel's Act. - Bank discount. See discount.- Bank men, in $U$. $S$. hist., supporters of dent Jsckson. Two institutions have been chartered by their aeat in Philadelplila, and intimately connected with the national finances. The charter of the first, granted In 1791, expired in 1811 , ita renewal having been refused. The second lasted from 1816 to 1836 under the national
cliarter, and was continued for a time as a State bank. The opposition of President Jackson to the renewal of It: It in 1833 , led to a violent political contest, in which his conrse was ultimately sustained. - Bank of issne, a bank or banklng company duly autborized by law to issue banknoter of tts own.- Bank post-bill. See bill3. - Days in banc. See day1. - National Bank Act, sn act of Con-
gress of Is64, provilug for the organization throughout the 
bank

United States of banks whose circulating notes were re-
quired to be secured by a deposit of United States bonds, which resultei, as was intendel, in proviling a market
for a very latge government loan, and at the sane time a seenre currency equally acceptable in all parts of the country- Penny-banks Act, an Finglish statite of 1859 ( 22
and 23 Vict., c. 53) suthorizing the investing of the funds of penny savings-banks, clinritable soctetics, etc., in the inoney of establishled savings-banks. - To break the
bank, to will, as in faro, from the management a certsin sum which has heen fixed upen us the limit which the bank is willing to luse in a single day. - To play against
the bank, to take the risks of a game, as rotge-et-neir or

bank $^{2}$ (bangk), $v$ : [< bank ${ }^{2}, n$. $] \quad \mathbf{I}$, intrans To have an account with a banker; deposit money in a bank; transact business with a bank or as a bauk; exereise the trade or profession of a banker.

I bank with one of uy sons' fathers-in-law, and the other
Thackeray.

II. trans. To lay up on deposit in a bank as, he banked $\$ 500^{\circ}$

banka (bang'kạ̈), $u$. [Native.] A passengerboat without outrigger, used on the river and harbor at Manila. It is hewn from s single log of
woed from 16 to 23 feet long, and carvies three or four

bankable (bang'ka-bl), a. [<bank2, $x_{.},+$-able. $]$ Receivable as eash by a bank, as bank-notes, checks, and other securities for money.

bank-account (bangk'an-kount"), n. A sum deposited in a bank to be drawn out on the written order of the depositor.

bank-bait (bangk'bāt), $n$. A name of May-flies. A grest many tall into the water a prey to fishes, and st that time [May], especially at Dordreclit, the roach is
noted as being peculiarly fat and good. Hence the name bank-bait (in some parts of France, la manne)

$E$. $P$. Wright, Anim. Lite, j. 485

bank-bill (bangk'bil), $n$. 1. A note or bil drawn by one bank on another, and payable
either on demand or at some future specified date. - 2. In the United States and some parts of England, a bank-note (which see)

bank-book (bangk'búk), $n$. The pass-book in which an officer of a bank enters the debits and credits of a customer. The intials of the teller or accountsnt of the bank sffixed to the sums entered in the receipt.

bank-credit (bangk'kred/it), $n$. A credit with a bank, by which, on propel' security given to the bank, a person receives liberty to draw to

a certain extent agreed upon: in Scotland also a distinctive feature of Scotch banking. a distinctive feature of Scotch banking.
banker ${ }^{1}$ (bang'kèr), $n$. [ bank $k^{-1}, n$. or $v_{*}$, in various senses, $+-e r^{1}$.] 1 . A vessel employed land. J. O. Adanis, -2 The bench or table upon which bricklayers and stone-masons prepare and shape their material; a banket. -3 . In cular platform turning on wheels so that the work can be revolved to expose any portion to the light. -4 . A covering for a bonch or seat, made of tapestry, rich stuff, or embroidered cloth. - 5. A hanging for a church wall the ends of an altar. - 6. A ditcher; one engaged in embanking.

The discovery was made by some bankers (men who

treeman, Life of W. Kirby, p. 155 7. In hunting, a horse which can jump on and D.-8. In Australia, a river full to the brim. N. E. D.

banker ${ }^{2}$ (baug'kèr), n. [<bank2, v., +-erl.] 1. One who keeps a bank; one who traffies in bills of exchange, etc. - 2 . The funds of a gaming establishment; in games of chance, that player who deposits a certain sum of money against which bets are made, or that player who for the sake of convenience receives and pays out bets won and lost.-Banker's note, a prominsery note

bankeress (bang'kèr-es), n. [<banker ${ }^{2}+$-ess. $]$ A female banker; a banker's wife. Thackeray. [Rare.] The late Countess of Jersey was only received on suffer-
snce in seme houses in Vienns, becsuse she was a bauk-
eress.
The American, V. 200 .

bankerless (bang'kèr-les), a. [< banker ${ }^{2}$ -less.] Without bankers. Quarterly Rev.

bankeroutt, $n_{.}, a_{.}$, and $v$. An obsolete form of bankrupt.

banket,$+ n$. and $r$. An obsolete forn of banquet.
442

banket2 (bang'ket), $n_{\text {. }} \quad\left[<b^{2} a n k 1\right.$, a bench, + layers cut their bricks to the size proper for the place into which they are about to lay thein. [Eng.]

bank-fence (bangk'fens), $n$. A fence made of a bank of earth.

bank-game (bangk'gām), 'n. In billiarls, a in which only bank-shots count.

upper -head (bangk'hed), $n$. In coal-mining, the engine. [Fing.]

bank-holiday (bangk'hol'i-dä), $n$. In Great Britain, a secular day on which the law exempts the parties to negotiable paper from the obligation of presentment, payment, ete., and consequently allows banks to be closed. Its effect on such paper differs from that of Sunday in the fact that the laws establishing such holidsys nsually, if not always, provide that paper falling due ou such day is
psysble on the next following secular day, while paper entitled hy commerclal usage to days of grace, and fallin 1871, the bank.holidays in England snd Ireland are Easte Monday, Whit Joudsy, the flrst Monday in August, and the 26th of December' (boxing-day); in Scotland, New
Year's day, the first Monday In Msy, the first Monday th

bank-hook (bangk'hük), n. 1. A large form of fish-hook for eatching cod, used on the banks of Newfoundland.-2. In coal-mining, the iron hook with which the banksman draws the loaded tubs off the cage. [Eng.]

bankingl (bang' king), n. [Verbal n. of bank ${ }^{1}$, $v$.$] 1. The act of raising a mound or bank, or$ of inclosing with a bank.-2. The bank or mound raised; anything piled up to serve as a bank, as a raised odging of wax on a plate that
is to be treated with acids for etching. -3 . A general term for fishing as practised on the banks of Nowfoundland.-4. In coal-mining, the sorting or loading of coals "at bank," or at the mouth of the shaft. [Eng.]

banking ${ }^{2}$ (bang'king), $n$. and $a$. I. $n$. [Verbal n. of bank $k^{2}, v$.] The business or employment of The term banking was then [1742] spplied only to the
ssue of notes and the taking up of money on bills on de. issue of notes and the taking up of money on bills on de
mand.
W. Bagehot, Lombrard Street, $\mathrm{p}$.

II. a. Pertaining to or conducted by a bank as, bonking operations.

parallel edges and a triangular section.

banking-pin (bang'king-pin), $n$. In a watch, one of two pins serving

ments of the escapement.

banking-wax (bang'king-waks), $n$. A composition of beeswax, common piteh, Burgundy poured into cold water, used in etching to form a border around the plate, to prevent the overflow of the acid.

bankless (bangk'les), $a . \quad[<$ bank $1+$-less. $]$ sea," Davies.

bank-level (bangk'lev"el), $n$. In coal-mining,
thelevel heading from which the bank is worked. [Yorkshire, Eng.]

bank-martin (bangk'mär"tin), n. Same as bank-swalloro.

bank-note (bangk'nōt), $n$. A promissory note bank authorized by law, and intended to a culate as money. In the United States frequently called bank-bill. - Bank-note paper, psper used for bank-notes and government bonds. It is msde
in such $\mathrm{s}$ way thst it is very difficult to imitate it, and in such \& way thst it is very difficult to imitate it, and for pressing bank-110tes and arranging them in packages.
banko-ware (bang'kö-wãr), . A Japanese unglazed stoneware made near Kuwana the Tokaido. It is very light and durable, is made in molds of irregular shapes, snd decorated with figures in bank-plate (bangk'plāt), $n$. In coal-mining, one of the cast-iron plates with which the face at the mouth of the shaft or the bank is floored. [Eng.]

bank-post (bangk'pōst), $n . \quad\left[<\right.$ bank ${ }^{2}+p_{0 s} t^{2}$, n.] A large size of letter-paper, ranging in weight from $5 \frac{1}{2}$ to 10 pounds to the ream. bankrout (bangk rout), $n_{.}, a_{.}$, and $v$. One of torms of bankrupt.

$$
\begin{gathered}
\text { Being bank-rout both of weslth snd worth. } \\
\text { Chapman, Byren's Trage }
\end{gathered}
$$
play the bank-rowtes with books; snd since 1 or other much time with this age, I would be glsd, as God shall

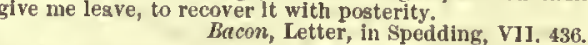
bankrupt (bangk' rupt), $n$. and $a$. [Early mod.
E. bankrout, bankerout, banqueroute, ete. ]ater

\section{bankruptcy}

bunqucroupt, and finally bankrupt (in imitation of L. $v u p t u s),<$ F. banqueroutte, now bunque route (> banquer'outtier, a bankrupt), orig. in $\mathbf{E}$. banke rota (def. 1), < It. banca rotta (ML. as if * banca rupta), bankruptey, lit. broken bank or bench: banca, < NL. banca, < MHG. banc, bank (see bank.1, bank2); rotta, fem. of rotto, broken, wrecked, < L. ruptus, broken (in ML also as a noun, a bankrupt). It is said to have been the eustom in Italy to break the bench or counter of a money-changer upon his failure; but the allusion is prob. figurative, like break crash 1, smash, similarly used in English. Seo bank 1 , bank 2 , rupture, rout ${ }^{2}$.] I. $n$. 1t. The breaking up of a trader's business due to his inability to meet his obligations; bankruptcy. -2. An insolvent person whose property is creditors in accordance with the provisions of a system of laws called bankrupt, bankruptcy, or insolvcnt laws. See bankruptcy. In particular-(a†) In old law, a trader who secretes himself, or does certsil (bt) A fugitive from his creditors; one who by extrava. gance and reckless expenditure had breught himself into a state of inselveucy and had abscended, or retired linto a place of sanctuary. (c) In mod. law, any person who upon his own petition or tlist of his creditors is adjudged
insolvent by a bankruptcy court. His estate msy be ad. of thered by an assignee or trustee, under the direction 3. In popular language, a hopelessly insolvent person; one who is notoriously unable to pay his debts; hence, one who is unable to satisfy just claims of any kind made upon him.

$$
\begin{aligned}
& \text { What a bankru } \\
& \text { of a full stuck of blessings. }
\end{aligned}
$$

Cessionary bankrupt. See cessionary.

II. $a .1$. In the state of one who has committed an act of bankruptey, or is insolvent; subject to or under legal process because of insolvency. -2. Unable to pay just debts, or to meet one's obligations; insolvent.

I'illo. The king 's grown bankrupt, like a breken man.

Hors. He hath not meney for these Irish wars,

Shak, Rich. II, ii, The beggared, the bankrupt seclety, not only proved
gble to meet sll its obllgstlons, but ... grew richer and Macaulay, Il ist. Eng, xix 3. Figuratively, at the end of one's resources: as, to be bankrupt in thanks.

To lend to him whou see? he has tears

of sorrow has made bankrupt of such treasur.

Bankrupt laws. Same as bankruptcy laws (which see,

bankrupt (bangk'rupt), $v$. [ trans. 1 . To make insolvent; render unable to

meet just claims.

We cast off the care of all future thrift because we are
already bankrupted.

Iron-clads, unere than anything else, bankrupted Turkey.

2†. To reduce to beggary; exhaust the reources of.

Fat psunches have lean pstes; and dsinty bits Shak., L. L. L., I. 1.

II.† intrans. To become bankrupt; fail or me insolvent.

bankruptcy (bangk'rupt-si), n. [<bankrupt + solvent; inability to pay all debts; failure in trade. In law, speciffcally, the status of a person or cerporstion thst by reason of insolvency has been adjudt

2. Figuratively, utter wreck; ruin. - Act of bankruptey, in law, an act the commlssion of which by a debong acts of bankruptcy sre the assignment of his prep.
erty by a debter to a trustee for the beneflt of his cred. itors; the making of a transfer of any of his property in it to evsde legal process; departing from the country, of remsining out of it, in order to defeat or delsy creditors non-payment of debts under certain other circunstauces defined by the law as lndicsting inselvency.- Assignee in bankruptcy. See asgignee. - Bankruptcy commisenpowered, subject to the supervision, of the court, to $\mathrm{ln}$ vestigate and sdjudicate upon the affairs of bankrupts.Bankruptey laws, the statutory regulations under which the preperty of an insolvent may be distributed smong
hts creditors, with the double object of enforctng s cemplete discovery snd an equitable distribution of the propand fron future molestation by his creditors. Fermerly, only a trader could be made s bankrupt under the bank. ruptcy laws, otlier persons who were nnable to nueet their inligations being insolvents. The distlnction was sbolished
in the United States in 1841 and in Great Britsln ln 1869 . In the United States in 1841 and in Great Britsin In 1869. hankruptcy laws which slall be nniform throughout the 
bankruptcy

courts. Laws having simllar obfects, but less eflenclons ires a eral bankruptcy law. These are termed insolvent la er. In Fuglanil lankinptcy laws have existed frem the time of llemy VIII. 'lle principal acts are: 34 and 35 J (en). Whe, the lord cliancellor and other ligh oftcers to gelze their estates and divlde them among the crelitors; 13 Eliz., $c$ 7, restrieting bankruptcy to tradcts, and preseriling cer-

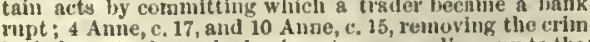

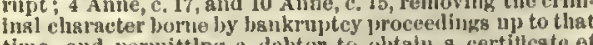
time, snd permittlng \& debtor to whtaln a certificate e liavlng cenferiued to the requirements of the lankrupt own bankruptcy, and lintroduciug the prineiple of privat settlements lietween debtors and crealifurs; 1 asd 2 Wn. six commissioners slong with four judges, as a court of re-

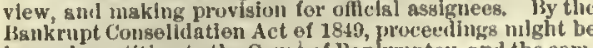
Bankrupt Conselidatien Act of 1849 , proceedings might be
legun by petition to the Court of Bankrmptey, and the cem. inssioners were suthorized to a warl certificates accordlns to the merit of the bankruptcy. The bankruptey act of 1901 (24 and 25 Vict., c. 134) alsolished 8pecis! lepislation relating to insolvent debtors, and permitteil pcrsons othe
thsm traders to svall themselves of the reliel afforded by the bankinptcy court. In I863 ( 32 snd 33 Vict., c., 71) the a new Court of Bsnkinutey was eatablished, and provlsten we creditors. The Court of Bankruptcy was also strlppen of its criminal jurisdictlon, the criminal clanses betn placed in snother atatute, the Debtors Act, whlch aholished imprisonment for deht except In certain casea, In
1883 (46 and 47 Vict., c. 52, taking effect Jail. 1, 1884) the English lnukruptcy acts were amended and consolldater. In the United states the sulbject has becn, except durim the periods of the operation of the Unitcits ststes banksuptcy acts, left to the Imperfect legnlation of divel's there is no United States act conflething, provide for the distribution of an insolvent's property, nay discharge him "from inprisonment for debt, and may discharge lim, if a zen thereof contracted while such State law was in force, ao far as to make the dlscliarge a protection fin the court of the sime state. The first United States lingkrup law on a consolidation of then existing Fnglish statutes, and was tu force from June 2,1800 , till Dec, 19, 1803. The aec
ond, the act of 1841 (5 Stat. at $\mathrm{L}_{\text {L }}$ p. 440), was in forc ond, the act of 1841 (5 Stat. at $\mathrm{L}_{\text {, }}$ p. 4.40), was in force
front Feb. 1, 1842, till March 3,1843 . The third, the act of 1807 (14 Stat. at $\mathrm{L}_{4}, \mathrm{p} .517$ ), repeatedly amended, an finally revised in the Unied states Revised Statites, tic. nt $\mathrm{L}_{2}, \mathrm{p}, 178$ ), was in force from June 1 , 1807, t1ll Sept. $1_{\text {, }}$ flduclary capacity, are not discharged by the bankruptcy laws.-Commission of bankruptcy, a comminston formerly issiled by the English lord chancellor, appolnting and empowering certsin persons to examine into the in bankruptey. See discharge. - Flat in bankruptcy. see fiat. - Fraudulent bankruptey. See fraudulent. - Involuntary bankruptcy, bankruptey adjudged on the petition of creditors, showing csise why the bank hls assets. - Voluntary bankruptey, bankmptcy asl-
judged on the petition of the delotor, Indlcatlug hls desire

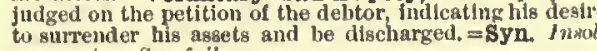

bankruptism + (bangk'rup-tizm), $n, \quad[<$ bank-

bankruptly $\nmid$ (bangk'rupt-li), adv. Like a bankrupt.

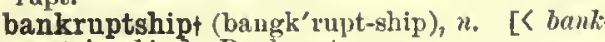
rept + -ship. Bankruptey.

bankrupturet (bangk'lup-tūil'), $n$. $[<$ bankrupt + -ure; after rupture.] Bankruptey.
bankshall (bangk'shal), $u$. [Anglo-Ind., for merly also banksall, saul, -soll, reps. Malay bangsāl, Beng. bankçā, bankaçāà, lit, hall of trade, < Skt, vanij ( $>$ Beng. Hind., ete., banih (= Gr. ka iá =E. hall : see hall); or perhaps Skt. bihandaçäla, a storehouse, < bhända, wares, ware, a vessel, pot, + cála, as above.] 1. In office of harbor-master or other port authority, - 2. In Java, a large hall of andience in a princely residence, without regular walls, but supported by wooden pillars. Yule and Burnell. bank-shot (bangk'shot), $n$. In billiards, a shot which makes the ene-ball touch the eushion before hitting any other ball.

Banksia (bangk'si-ä), n. [NL., named after' Sir Joseph Banks (1743-1820).] A genus of shrubs or trees, for the most part of small size, ern extra-tropical Australia and 'Tasmania, where with other shrubs of the same order they constitute most of the so-called "scrub." The foliage is hard and dry, and extremely variable in form, foliage is liard and dry, and extremely variable in form,
and the flowers forn close cylndrical heads resembllng
bettle-bruslies. Slany apecles have been cultivated in Furopean conservatories and gardens.

banksman (bangks' mạn), $m_{\text {; }}$ pl. banksmen (-men). [<banks, poss. of bamk', + man.] In conl-mining, a man in attendance at the mouth

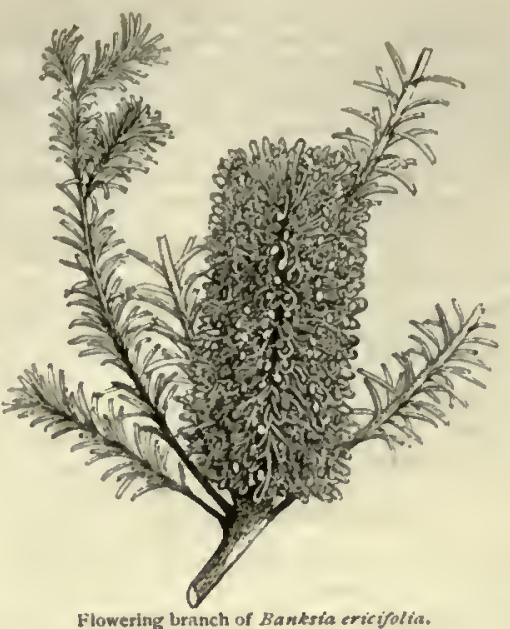

of the shaft, who superintends the sorting and loading of the coal. [Eng.] Circsley.

bank-stock (bangk'stok), u. Tho capital of a bank. In lingland the term is applled chiefly to the joint-stock banks is divided into shsre ank-swallow (bangk'swol"ö), n. Hirumlo or (ntile riparia, a very common bird of Eu-

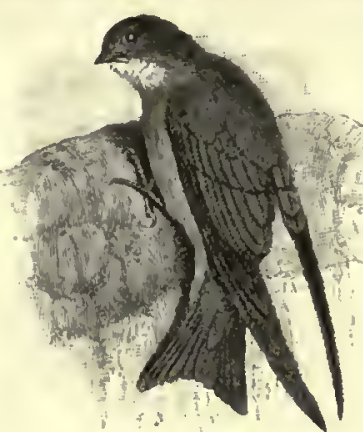
rope, Asia ea, of the reallo its labit of its labit of burrowing in its nest. It is a small swal above and whit gray collar. In numerous, hui. ireds or thousands gather to breed in conbank may loe ridlled with their holes, which are excnbank-work (bangk'wèrk), $n$. In coal-mining a method of working coal in use in South
Yorkshire, England, and in some of the North Welsl collieries, combining some of the peenliatities of the pillar system with those of the long-wall system.

banky (bang'ki), a. [<bank.I + -y. $]$ Full o banks oz ridges ; ridgy; hilly. [Rare.]

banlieue (ban'lū), n. [F. (in ML. banlenco, bamum leuce), < ban, command, jurisdiction, + lieuc, league, also an indefinite extent of territory. Cf. G. bann-meile in same sonse: see
ban 1 and league 2 .] The territory without the walls, but within the legal limits, of a town city. Sometimes erroneously spelled banliew, as if from French lien, a place.

bannat (ban'at), $n$. Scoteh form of bonnet. bannat $2, n$. See bonat.

banner (ban'èr), n. and a. [< ME. baner, banere, $\left\langle\mathrm{Ol}^{\prime}\right.$, banere, baniere, F. banniere, bandière $=$ Pr. bandicira, bannieira $=\mathrm{Sp}$. bandera $=$ (banderia after Rom.), < bendum, a standard, <Goth. bandica, bandwo, a sign, token, prob
akin to E. bind and band, q. v.] I. $n$. 1. The picce of cloth, attached to the npper part of pole or staff, which in former times served as the standard of a sovereign, lord, or knight, after which he and his followers marched to war, and which served as a rallying-point in try, army, troop, ete.; a standard or ensigi.

Terrible as an army with bamers.

Cant. vi.

Irng out our banners on the outward walls

The cry is still, "They come Shak., Nacheth,

2. In her, a square flag which in the middle ages was the ensign of a knight banneret. Instances are related of a knight companion being made promotlon being the tearing off of the points of his pennom, leaving the tlag scuare. In modern usage, any squsre flat most familiar instance is the royal banner of Englant commonly ealled the royal standarl; int other herald the Garter and the lijgher volility.

\section{banner-stone}

3. An ensigu or thag bearing a badge or enblem, as of a society or order, and borne in processions. linmers wero early nsed In the procesby ('onstantine. It consisted of a soluare cloth suspended

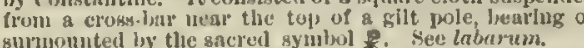
4. liguratively, anything displayed us a profession of prineiples.

'l'hou hast glven a benner tu them that fear thee, that it
may the dlsplanyed hec'suse of the truth.
Ps $\mid x, 4$.

See ensign, flag, pennon, and standard.

5. In bot the vexillum or npper petal of a papilionaceous tlower. Also ealled the standird.-6. One of eight divisions into which the Munchus are marshated, each with distinguishing flag or banner. Fenr of the flafes are plaln (red, yellow, white, or blue), the other four having a margln of a thiferent color. Hence, the Mlan-
chus are known collectively as the chus are kuown collectively as the II. $a$. Leading or foremost panded lkanner, with ex in regarl to some particular wer: , ala i c, keet. majority to a politiea] party, ete.

I am reminderl that there is an Alleghany City as well as an Alleglany county, the forner the banner town, and the latter the banner county, perhajs, of the world.
Linevin, in Raymond, p. 84. banneralt, $n$. A corrupt form of bannerol, 2. bannered'(ban'érd), $"$ [< banner $+-e l^{2}$.] 1

Furnished with or bearing a banner; displaying bauners.

A bemmer'd host Afilton, J. I., II. 885

. Borne or blazoned on a banner.

bannerer (ban'èl-ér), n. A standard-bearer ono carries a banner.

banneretI (ban'ér-et), ". [Also bannerette, MIE. banneret, banerett, $\angle \mathrm{OF}$, baneret, bancretle, dim. of bonere, banner: see

The banner, a banderolo. dissuade me from believing thee a vessel of too grest a

banneret ${ }^{2}$ (ban'er-et), n. [<ME. baneret, <OF. baneret, danneret, < banere, a banner (see banner) + + ct, $<\mathrm{L}$. - atus $\left(\right.$ see - ate $\left.^{1}\right)=\mathrm{E}$. $-\mathrm{ed}^{2}$; lit., ner) $+-e t,\left\langle\mathrm{~L}\right.$. -atus (see $\left.-a t e^{1}\right)=\mathrm{E}$. $-d^{2}$; lit.,
one bannered: see banner aud $-e d^{2}$.] 1. One who is bannered or entitled to a banner; specifieally, a knight of a certain grade in the military hierarehy of the middle ages. Origiually the right to display a bauner (as ilistinguished from a pennon)
was linited to those who could bring a certain array or followers hito the fleld, and who had also been dulbed of feudalism became confused by the employment of pain soldicrs, the right of dlsphaying a bamner became more and a vletory or a notalle achievement a bamneret clect, carry. Ing his pennon in his hand, was, it Is said, conducted be. tween two knighits of note, and presented to the king or it squsre. Hc was then called a knight of the square flag. Sir Richard Croftes, who was made banneret st

2. Formerly, the title of magistrates of the second rank in some Swiss eantons, and also of certain officers of some of the Italian republics. Jlelchlor Stumnthal, . . Banneret of Berne.

[In Solothmri] on the death of an avoyer, the brinneret bannerless (bau'èr-les), $a . \quad[<$ banner + -less.] Having no banne1. J. II. Jesse. bannerman (ban'èr-man), $1 . ;$ pl. bannermen
(-men). 1. A standard-bearer; a bannerer.2. A person belonging to one of the eight banners into which the IIauchus are marshaled. Seo bnuner, 6.

bannerol (ban'e-rōl), n. [See banderole. 'This is the usual spelling in sense 2.] 1. Same as anderole - 2. In England, a banner, about a yard square, borne at the funerals of prominent men, and placed over the tomb. It bears the arms of the ancestors and alliances of the deceased, painted on silk. Also

banner-plant (ban'ér-plant), $n$. A name given to some cultivated species of Anthurium, natural order Aracea, in wbich the bright-searlet spathe is broadly expanded at right angles to the spadix. banner-roll (ban'ér-rōl), $n$. An erroneous form of bannerol, 2 .

banner-stone (ban'èr-stōn), $n$. A name sometimes given, not very aptly, to certain stone 


\section{banner-stone}

are supposed to have been woru as ornaments in prelistoric times, or held in the hand as badges of authority. They have an eye for the insertion of a handle.

Some banner-stones of atrlped slate have been found in Choillo ba [New York]

Smithsonian Rep., 1881, p. 657
banner-vane (ban'èr-vān), $n$. A weather-vane having the shape of a banner, balanced by a weight on the other side of the staff.

bannet (ban'et), n. [Se., = E. bonnet. $]$ A bonnet. Scolt.

bannimust, $n$. [< ML. bannimus, we banish, lst pers. pl. pres. ind. of bannire, banish: see banish.] Same as bannition.

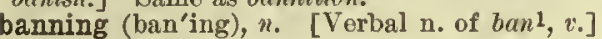
The act of uttering a ban or curse; an execration or eursing of another.

Espeeially when the names of the infernal fiends or unlucky gonles are used in auch bannings.
IIolland, tr. of Pliny, xxvii.

bannition t(ba-nish'on), n. [<ML. bannitio(n-), $<$ bannire, banish: see banish, and ef. abannition.] The act of banishing or the state of being banished; expulsion, especially from a university.

You will take order, when he comes ont of the cartle to gend him out of the unjversity too by bannition.
Abp. Laud, Remains, II. 191.

bannock (ban'ok), $n$. [Se., $<\mathrm{ME}$. bannok, <AS. bannuc, <Gael. bannach, also bonnach, = Ir. boin neog, a cake.] A thick cake made of oatmeal, barley-meal, or pease-meal, baked on the emb
or on an iron plate or griddle over the fire.

Bannoks is better nor na kin bread.

annoc-fluke (ban'ok-flök), [Sc. p. 364. nock + fluke $e^{2}$. A Seoteh name of the common turbot.

banns (banz), n. pl. [Formerly bannes, often banes, mod. more correctly bans, pl of bant, $q . v$. The spelling banns is now usual in this sense.] 1. The proclamation of intended marriage in order that those who know of any impediment thereto may state it to the proper authorities. Banns were made a part of ecclesiastical legialation by the fourth Council of the Lateran, $\mathbf{A}_{\text {. }}$ I. Trent. In the Roman Catholic Clurch the celebration of marriage without previous proclamstion of the banns,
unless by apecial diapensation, is gravely illicit, but not unless by apecial diapensation, is gravely illicit, but not
invalid. The proclamation is made by the parial priest of each contraeting party, on three consecutive festivals
during public nass. The proclamation of banns is no during public mass. The proclamation of banns is $\mathrm{n}$ $2 \uparrow$. The proclamation or prologue of a play Banes or Prologue [to] the Fall of Lucifer.

To bld or ask the bannst, to publish the banns. If all parties be pleased, $a s k$ their banns, 'tis a match.

To forbid the banns, to make formal objection to an A better fate did Maria deaerve than to have her. banns
forbid.
Steme, Tristram Shandy, ix. 24 . bannut (ban'nt), n. [F. dial., also written bannet, < late ME. bannenote (in comp. bannenotetre, glossed avetana, filbert); <"ban, "banne (origin unknown) + nut.] A walnut, the fruit of Juglans regia (bannit-tree). [Obsolete
[Ob dialectal.

banquet (bang'kwet), $n$. [Earlier banket, < F.
banquet (= It. banchetto $=\mathrm{Sp}$. banquete) feast, orig. a littlonchetto $=\mathrm{Sp}$. banquete , (=lt. Sp. banco), a bench or table: see bant and banquette.] 1. A feast; a rich entertainment of food and drink.

A napkin of fine linen to be laid on the table at the
coronation banquet.

2†. A light entertainment at the end of a feast;

a dessert; a refection at which wine is drunk.

We'll dine in the great room; bnt let the music

And banquet be prepared liere.

There were all the daintieg not only of the git. of what art could add, venison, plain solid meate, fowle bak'd and boil'd meats, banquet (derert) in exceedin Evelyn, Diary, Oct. 27,1685 .
3†. A slight repast between meals: sometimes 3†. A slight repast between meals
ealled running banquet. $\quad$ N. E. D.

The running banquet of two beadles.

Shake, Henry vilI., v.

4†. In fort., same as banquette, 1.-5. A small rod-shaped part of a horse's bridle coming under the eye.=Syn. 1. Feast, Festival, ete. See feast. banqueter; from the noun.] I. trans. To trea with a feast or rich entertainment.

You exceed In entertainment;
Banquet our eyes too? Shirley, The Traitor, iil.
444

Just in time to banquet
The illustrions company assembled there. Coleridge.

II. intrans. 1. To feast; regale one's self ith good eating and drinking; fare daintily. The mind ahall banquet, though the body pine. Were it a draught for Juno when she banquets Irould not taste thy treasonous offer. ilton, Comus, 1. 701.

2†. To take part in a light refection after a feast. See banquet, n., 2.

Then was the banqueting-chamber in the tilt-yard at Greenwich furnished for the entertainnent of these anquetantt (bang'kwet-ant), n. G. Cavendish. quetant, ppr. of banqueter: see banquet, v.] One who banquets; a banqueter. Are there not beside
Other great banquetants?
Chamman,

banqueter (bang'kwet-ér), n. 1. A guest at banquet; a feaster.

Great banqueters do seldom great exploits, Cotgrave. 2 t. One who provides feasts or rich entertain ments.

anquet-hall (bang'kwet-hâl), ' $n$. A hall in which banquets are held. Also called banquet ing-liall.

The fair Peleïan banquet-hall. Tennyson, Enone.

banquet-house (bang'kwet-hous), $n$. A ban ueting-house.

A banquet-house salutes the southern sky.

Dryden

banqueting (bang'kwet-ing), n. The act of feasting; luxurious living; rich entertajnment; feast.

Excess of wine, revellings, banquetings. 1 Pet. iv. 3 banqueting-hall (bang'kwet-ing-hâl), $n$. Same banquet-hall.

anqueting-house (bang'kwet-ing-hous), $n$. A use where banquets are given.

In a banqueting-house, among certain pleasant trees, th anquette (bong-ket'), n. [F., fem. dim. of banc, a bench: see bank ${ }^{2}$, and ef. banquet.] 1 . (a) In fort., a raised way or foot-bank, rumning along the inside of a parapet breast-high above it, on which riflemen stand to fire upon the enemy. (b) In medieval fort., an advaneed earthwork or palisaded defense outside of th ditch. The space between the ditch and the parapet
was wide enough for a line of goldiers, but too narrow to was wide enough for a line of goldiers, but too narrow to
allow of its being fortified if occupied by the besieger .

. The footway of a bridge when raised above he carriageway.-3. A bench for passengers, or the space oceupied by benches, on the top
of a French diligence, and hence of any public vehicle.-4. A sidewalk. [Common in the sonthern and southwestern United States.] Standing outside on the banmette, he bowed - not to D
ulossy, but to the balcony of the big red-brick front. G. $W$. Cable, old Creole Days, p.

Banquette slope, in fort, an incline connecting the work, - Banquette tread, the level surface of the ban bans, $n . p l$. See bamns.

banshee (ban'shē), $n$. [<Gael. ban-sith, Ir. bean sidhe, lit. woman of the fairies, < Gael. ban, Ir. bean, woman, + sith, Ir. sigh, sighe, sighidh (the final consonant being scarcely sounded), fairy.] A type of female fairy believed in Ireland and some parts of Scotland to attach herself to a particular house, and to foretell by
each appearance the death of one of the family. Also benslie, benshi.

The banshee is a species of aristocratie fairy, who, in the
ahape of 8 little hideous old woman, has been hnown to appear, and heard to aing in a mouruful aupernatural voice under the windows of great housea, to warn the family
that gome of them were goon to die. In the last century every great family in Ireland had a banshee, who attended every great family in Ireland had a banshee, who attended
regularly, but latterly their vigits and songs have been dis
continued. banstickle (ban'stik-1), $n$. [Sc., < IE. banstickle, $<$ bane, < AS. bãn, bone, q. v., + stickle, < AS. sticels, prickle. Cf. stickleback.] A name of the three-spined stickleback.

bant (bant), $v_{i} i$. [Ludicrously fomned from the phrase "the Banting system," the proper name of an assumed verb bant.] To practise bantingism (which see).

bantam (ban'tamn), $n$. and $a$. [So named, prob. from Bantam, in Java.] I. $n_{0}$ 1. A general name for a number of varieties of the common hen
possessing the eharacteristic of very diminu-

\section{Bantu}

tive size. Slany of these varieties are the exact counter. ize, and in size, of the corresponding breeds of full gelection and breeding of amall specimens from these ull-sized breeds. Thero are other varieties, however, as the Japanese and the Sebright bantams, which do not re. the African, game (in the sever'al colors), Japanese, Pekin, Polizh, and Sebright bantams.

II a Pertaining to or resembling the bantam; of the breed of the bantam; hence, diminutive; puny; absurdly combative, or fussy and consequential.

Bantam-work (ban'tam-wèrk), $n$. An old name for carved work, painted in party-colors, imported from the Fast Indies; "a kind of Indian painting and carving on wood, resembling Japan-work, only more gay," Chambers's Cyc., Supp., 1753.

banteng (ban'teng), $u$. [Native name; also spel]ed banting.] A species of ox, Bosbanteng or $k$. sondaicus, a local race in the Malay archipelago. banter (ban'tèr), $v . t$. [First in the latter part of the 17th century; regarded then as slang.] with jokes or jests; make fun of; rally.

The magistrate took it that he bantered him, and bade Not succeeding in bantering me out of my epistolary
proprieties.
Blackwood's Mag., XXIII. 384. So home we went, and all the livelong way

With solemn jibe did Eustace banter me.

2. To impose upon or eheat, originally in a jesting or bantering way; bamboozle. [Archaic.] somebody had heen bantering him with an impoaition.

3. To challenge; invite to a contest. [Southorn and western U. S.] = Syn. Banter, Rally, quiz, ease, joke. We banter another in good humor chefly for omethe or she has done or neglected to do, whether only affords a gubject for a jaugh or smile at his or jer expense, or causes a blush not altogether painful. Rally, literally to rail, generally implies some degree of sarcasm or pungency

$$
\begin{aligned}
& \text { The aort of moek-heroic giganlegque } \\
& \text { With which we banter'd little Lilla first. } \\
& \text { Tennyson, Princesa, Concluaion. } \\
& \text { Lest yon think } 1 \text { rally more than teach, } \\
& \text { or praise malignly arts I cannot reacl. }
\end{aligned}
$$

banter (ban'tèr), $n$. [<banter, v.] 1. A joking or jesting; good-humored ridicule or raillery; it or humor; pleasantry.

When wit has any mixture of raillery, it is but calling It banter and the work Is done.
Swift, Tale of a Tub, Author's Apol. Mir. Adams made his contribution to the service of the which makes a dinner of herbs more digeatible than stalled ox without it. 2. A challenge to a match or contest; the mateh or contest itself. [Southern. and western U. S.]

banterer (ban'tèr-èr), n. 1. One who banters or assails with good-humored jests or pleas[Archaic.]

Ilis dress, his gait, his accent, ... . marked him out as an excellent subject for the operations of gwindlers and
banterers. bantery (ban'ter-i), a. Full of banter or goodhumored raillery. Carlyle.

banting $1, n$. See banteng.

banting ${ }^{2}$ (ban'ting), $n$. [Verbal n. of bant, $v_{\text {. }}$ ] go through a course of banting.

bantingism (ban'ting-izm), William Banting.] A course of dict for re ducing corpulence, adopted and recommended in 1863 by William Banting, a merchant of London. The dietary recommended was the use of lean bantling (bant'ling), n. [Perhaps a corruption of *bandling, meaning a child in swaddling elothes, < band 2 , a wrapping, + -ling, dim. suffix, as in foundling, fondling, nurseling, ete.; more prob. for *bankling, < G. bänkling, a bastard, < LG. bankert, < bank, bench equiv. G. bankert A young child; an infant: a term earrying with it a shade of contempt.

It"s a rickety gort of bantling, I'm told

That'll die of old age when it s seven years old.

Bantu (ban'tö), $n$. [A native name, lit. 'people.'] A name sometimes applied to the Soutl 


\section{Bantu}

African faraily of tongues. The most marked pe. culisrity of these languages is their prevailing une of preThose of them that border on tho 11 ottentut employ clicks or clucks as alphabetic clements. Alse calleil Chu. banxring (bangks'ring), $n$. [Native namo.] A name of a squirrel-like insectivorous mammal of Java, tho Tupaia javanica. Also called bangsring and sinsring. Seo Tupaitede.

banyan ${ }^{1}, n$. Seo banian 1 .

banyan ${ }^{2}$, banyan-tree, $n$. Seo banion ${ }^{2}$

baobab (ba'ó-bab), n. [Formerly also baho$b a b$; a nativo African name.] An Afriean tree, the Aclansonia eligitata, belonging to the tribe Bombacere, natural order Matiacer, also called the Ethiopian sour-gourd, and in South Afriea the eream-of-tartar tree. It is a native of tropleal Africa, and has been introduced and naturallzed in varfous trees in the world, being often tound 30 leet in diameter, though it grows to a height of only trom 40 to 70 feet. "The
branclies glinot out from 60 to 70 fcet, bearing a dense

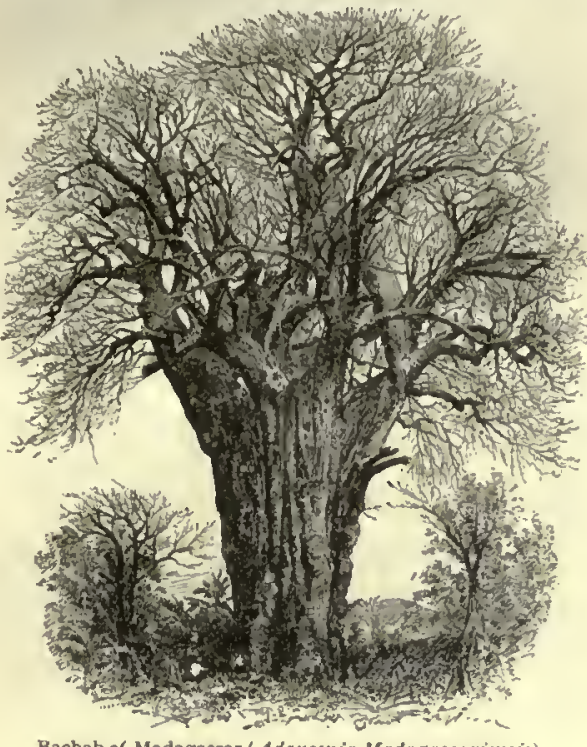
mass of deciduous lesves, ,omewhat aimilar to those of
the horse-chestnut. The white flowers are from 4 to
Inchea broad, and the oblong gourd-like truit, about foot in length, is esten by monkeys, and hence is called
monkey-bread (which gee). The juice of the iruit mixed with sugar is much esteemed as a beverago; and the pulp,
which is pleasantly actd, is esten, ani is employed 8 . which is pleasantly acid, is esten, and is employed as
remedy in Egyptian dysentery. The dried and powdered mucilaginous burk and leaves are used by the negroes under the name of lato, on their lood, like pepper, to dimin. inh perspiration; and the atrong flber of the bark is made this genus are the Australlan aour-gonrd or cream-of-tarta tree, Adansonia Gregori, which differs chlefly in it

bap (bap), n. [Sc.; origin unknown.] A roll of bread of various shapes, costing generally a halfpenny or a penny.

The young baker who brings the baps in the mornings,

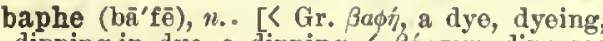
dipping in dye, a dipping, < $\beta a \pi \tau \varepsilon \iota$, dip: see minating anoient mannscripts.

Baphomet (baf'ō-met), n. [F. Baphomet; $\mathrm{Pr}$. Bafomet, OSp. Míafomat, regarded as a corrup tion of Mahomet. Cf. Mahound and Mammet.] The imaginary idol or symbol which the Tem plars were accused of worshiping. By some mot Gnoaticism, snd the word Brphomet has had given to it the signiffeation of bnptism of wisdom (as if < Gr. Bad baptism, $+\mu \eta \bar{r} t s$, wisdon), brptiam of fire; in other words,
the Gnostic brptism, a species of spiritual llumination. may be a manipulated lorm of JKahomet, 8 name which took atrange shnpes in the middle ages. Of or pertaining to Baphomet, or to the rites in which it was supposed to be employed.

It is from thia hour that I incline to date my spiritual
new-birth or Baphometic Fire-baptlam ; perhspa I directly new-birth or Baphometic fire-baptlsm, perhapa I directly

Bapta (bap'tä), n. [NL., <Gr. $\beta a \pi \tau \delta s$, dipped dyed, verbal adj. of $\beta a ́ \pi \tau \varepsilon v$, dip.] A genus of geometrid motlis. The white pinion-spotted noth baptise, $v$. $t$. See baptize.

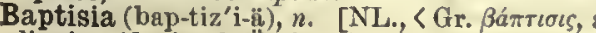
dipping (dyeing? êf. $\beta a \pi \tau o ́ s$, dyed), $<\beta a \pi \tau^{\prime} \zeta \varepsilon(v$,
445

baptistic

dip, dye.] A genus of leguminous plants of the United States east of the Mississippi. They are herbaccots, and turn black In drying. The oot in medicine as a jaxative, and in farser luses as a ca thartic and emetic. Smns species, especially the blue-flow-

aptism (bap'tizm), n. [C ME. baptisme (usually and earlier buptim, baptym, baptem), $<\mathrm{OH}$ baptesme, bapteme, batesme, bateme (mod. bapteme), < LL. breptisma, < (ir. Bántioua, also

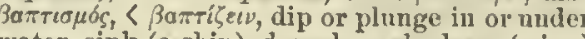
water, sink (a ship), drench, soak, draw (wine) by lipping with a eup; in N. T. and ecel. baptize.] 1. A saerament or ordinance of the Cliristiau ehureh, instituted by Christ as an initiatory rite, consisting in the immersion of the person in water, or in the application of wate to the person by affusion or by sprinkling, by an antliorized administrator, "in tho name of the Father, and of the Son, and of the Holy Ghost." I'he proper aignifleation of the rite, the proper aubjecis ters of dispute in the Christian cburch. In I'rotestant churchea it is gencrally regarled as in symbol of purifica-
tion, a rite of initiation into the vialhle clumreh of Christ, and a sign ratifylug God's covenant with his people. In th Roman Catholic Church baptisun fo the sscrament of initistion into the clumrch of Christ, consisting essentially in the application of water to the person baptized by one baving the intention of conferring the sacrament, snd who pro in the name of the Fsther, and of the son, and of the Ilol Ghost." "TheGreek formula, "The servantof God ia baptize in the name," etc., Is also recogaized as valid. In all branche of the church a layman may, in case of necessity, administe bsptiam. In the Roman Catholic, Greek, and moat Prote tant churches, Intant ehildren are admitted to baptlsm but among the various Baptist denominstions only thoa are admitted who give credible evidence of possessing formed by immersion, which they, also, it is generally pcs mode. This is also the common mode in the Faster churches; in the Weatern churches apriukling or pourlng with water, regarding Chriatian baptism as apiritual only. Baptism is not only a sign of profession, and mark of dif that bo not christened, but it ia also acerned from others thon or New-Birth, whereby, as by an instrument, they tha receive Baptism rightly are grafted into the Church; the promiaes of the forgiveness of ain, and of our adoption to and sealed. Falth ia confirmed, and Grace increased by irtue of prayer unto (iod.

Ch. of Eng. and Prot. Epis. Ch. llevers and their children as the bign of clesnsing to bellevers and their chlldren, as the sign of clesnsing from
sin, of uuion to Christ, snd of the impartation of the Ifol

2. Any ceremonial alution intended as a sign 2. Any ceremonial ablution intended as a sign administered by John the Baptist, or that administered to proselytes by the anciont Jews the baptism or christening of bells, ships, and other objeets in the Roman Catholio Chureh, ete. The publicana juatifled God, being baptized with the Baptism for the dead, the baptiam of a living perso Thatead of and for the sake ol one who has died unbaptized. by the ehurch, is on record in a number of individus cases among the early Christians, snd is slso ssid to hat been a custom of several snclent aects, the Eblonites, Mar
clonites, and others. In modern times it has been revive: hy the Mormons. This practice liss been supposed by mations of the passage have been glven. - Baptism of
blood, martyrdom for the sake of Cliriat, regarded as aup blood, martyrdom for the sake of Cliriat, regarded as aupplying the absence of the sacrament of bsptism.- - Baptism
of desire, the virtue or grace of baptism recelved by a unable to obtsin it.-Baptism of fire. (a) The gitt of separately from tha outer lorm. (b) Martyrdom.- Clinic or clinical baptism, baptlsm on a sick-bed. In the esriy
church this was allowed only in case of impending death, and was sometimes refused even then, except to persous
already candidates. Such baptism was recognized as already candidates. Such baptism was recognized as
valid ; but a person ao baptized was not ordinarily eligible to orders, perhaps becsuse it was judged that fear had induced the reception of the asacrament. - Conditional Catholic snd Anglican churchea, baptism administered to persons in respect to whom it is doubtful whether they doubtinl valldity. The condition is then regularly ingertvate baptism, baptism conferred in the home or elscsolemn baptism in the church. - Seal of baptism, ( $a$
The rite of unction in baptism. ( $)$ Saale as baptisma baptismal (bap-tiz'mal), a. [<baptism + -al; = F. baptismal.] Pertaining to baptism: as, "the baptismal vow," Iammond.-Baptismal character, a spiritual and indelible mark attaching to the souls
of baptized Christlans from their reeeptlon of the sacrament. This term is used officlally by the Roman Catholic Church, and also by theologians of the Greek, Orl
ental, and Anglicen churehes, to express the doctrine of those churches that a baptized person can for good or tor cannot be repeated withont saerllege. Also called the seat, or the neal of brytimn. See brptism.-Baptismal Baptismal regeneration, the doct rive of thaptisn. fon of original mud actual sin, and the new birth into the ife of sanctifying grace, in and throngh the sicrament a smrall metal vessel in the glope of a scallop.shcll, uned to take water from the font snd pour it upon the head of the candidate In lantfgn. - Baptismal vows, the prom. baptismally (bap-tiz'mal-i), adv. In or through baptism; by neans of baptism.

baptist (bap'tist), n. [< ME. baptist (only in reference to John the Baptist), < LI. baptista,

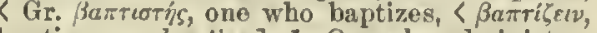
baptizo: see baptize.] 1. Ono who administers baptisin: tho title (with a capital letter) of John, the forerunner of Clirist.

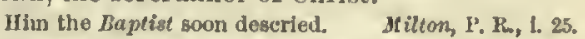
2. [cap.] A member or an adherent of one of those Cliristiau denominations which maintain that baptisna can bo administered only npon a lersonal profession of Christian faith. Generdoctrine has been held Broptists are Immersionists. This than church; but the Baptists as a diatinet denominstion date from the epoch of the Reformation and were originally called Anabaptist by their opponenta. In the Wuited States the Baptists owe their origin to Roger Williams, who was originally a minister of the Church of
England. The princlpal Baptist denominat ion are the Baptists, sometimes called Catvinist Baptists, from their Calvinistic theology; Freevill Baptists, who are Arminian in theology and open conmunionists in practice; German Baptists, popularly cailed Durkers; General Baptists, a and hold to a general atonement (opposed to P'articular Baptists, Who are Calvinistic); Old-School Baptists, some-
tumes cslled Anti-Mission or IIard-Shell Baptists, from their extreme Calvinism, which leads them to oppose all getive measures lor the conversion of the world (a sect
numbering 40,000); Seventh-Day Baptists, who keep the seventh day, instead of the frst, as the sabbsth; Six. constitute their crea (they practise "in principles which and reluse communion to all who do not); Diseiples of denomination gTowing out of the labors of Alessuder Campbell, and separately organtzed in 1827; A Hebren Winebrenner), who maintain the washing of feet Joh ordinance ol perpetual obligation; snd Christians, or the Christian Connection, an American sect of Unitarian Bap-
tists founded about 1800. The Baptists are conpregational in polity, and generally Calvinistic or semi-Calvinistic i baptlamby bymersion as a prerequisite to communion, and position is with few expents of the United States. The former are popularly called openbaptistery, baptistry (bap'tis-tér-i,-tri), $n . ; \mathrm{pl}$ baptisteries, baptistries (-iz, -triz). [< L. baptis(1) in ecel. sense)

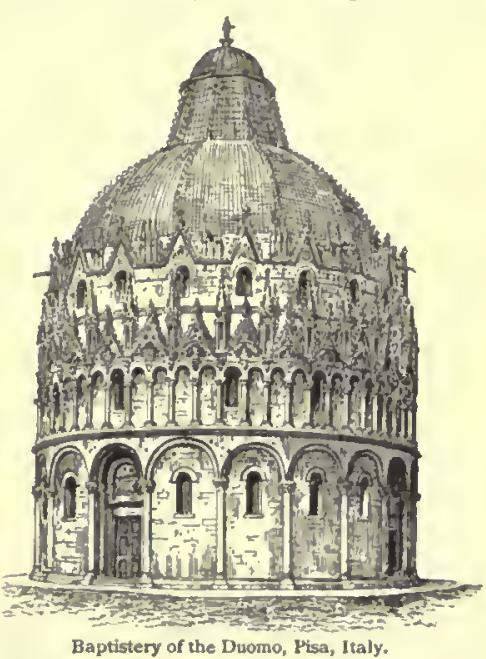

tizc.] A building or a portion of a building in which is administered the rite of baptism. In the early Christian church the baptistery was distinct from the church-building, and was situsted uear its west end ; began to be absorbed in the church, within the baptistery was placed, not far from the western door. The detached baptiatery was, however, olten preserved, especlally in that of St. John Lateran in Itome, and those of the cathe drals of Pisa, Forence, etc. As a separate building tho baptistery was often of considerable size and great archicomety. Hedicated to St. John the lkaptist. Soo font and baptismal.

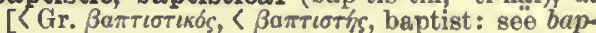




\section{baptistic}

tist.] Pertaining to baptism, or (with a capital) to the doctrine of the Baptists.

This baptistical profession, which he ignerantly laugheth at, is attested by fathers, by councils, by liturgies.
Abp. Bramhall, Schism Guarded, p. 205.

Baptistically (bap-tis'ti-kal-i), adr. Accorling to Baptist doctrine; in the manner of the Baptists.

baptizable (bap-tī'za-bl), a. $\quad[<$ baptize + -able.] 'That may be baptized. [Rare.]

As for the condition limiting persons beptizable, which is actual bclieving, this also Bp. Gauden, Tears of the Clurch, p. 284.

baptizationt (bap-ti-za'shon), n. [<LL. baptizatio $(n-),<$ baptizare, baptize: see bap

If they had been lay persens, their baptizations were baptize (bap-tiz'), $v . t$.; pret. and pp. baptized, ppr. baptizing. [< ME. baptizen, < LL. baptizare, $<\mathrm{Gr} . \beta a \pi \tau i \zeta \varepsilon v$, dip in or under water, baptize, < $\beta a ́ \pi \tau \varepsilon v$, dip in water. See etym. of baptism.] 1. To administor the rite of baptism to. See baptism.

None [in Yucatan] might marry whe hal not been bap.

2. To christen; name; denominate: with allusion to the naming of infants at baptism.

Call me but love, and I'll be new baptiz'd

Henceforth 1 never will be Romeo.

Sometimes spelled baptise.

baptizement (bap-tīz'ment), n. $\quad[<$ baptize + -ment.] The act of baptizing; baptism. [Rare. baptizer (bap-ti'zèr), n. One wha baptizes.

On the part of the baptizer, baptism was a form of re-
Rees, Cyc., Baptism.

baqnet (ba-kä'), $n$. [F.: see backet.] A small tub or trough.

barl (bär), n. [<ME. barr, barre, < OF. barre, F. barre $=$ Pr. Sp. Pg. It. barra, < ML. barra, of unknown origin. The Celtic words, Bret. barren, a bar, a branch, W. bar, a bar, rail, Gael. and Ir. barra, a bar, spike, Corn. bara (v.), bar, as well as MHG. bar, barre, a barrier, G. barre, Dan. barre, a bar, ingot, Russ. bar $\breve{u}$, bar (of a harbor), are from the ML., Rom., or E. Hence barrier, barrister, barricade, barrace, embar, embarrass, debar, debarrass, etc.] 1. A piece of wood, metal, or other solid matter, long in proportion to its thickness, used for some mechanical purpose; a rod: as, a capstan-bar; the bars of a grate; the splinter-bar of a vehicle; especially, such a piece of wood or metal used as an obstruction or guard: as, the bars of a fence or gate; the bar of a door or window.-2. Anything which obstruets, stacle; a barrier.

Nust I new bars to my own joy create? Dryden. The Incapacity to breed under confinement is one of the

Daruin, Var. of Animals and Plants, I. 21.
3. A barrier - (a) At the entrance to a eity, or between the eity proper and its suburbs; hence, the gate at which the barrier was placed in former times, as Temple Bar in London, now

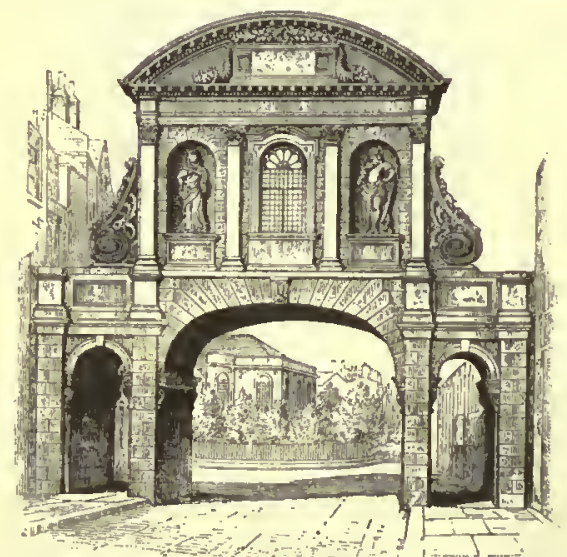

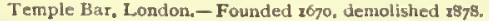

removed, and the existing medieval bars of York. (b) At a toll-house; a toll-gate. Also called toll-bar. -4 . An aceumulation forming a bank obstructive to navigation or to the flow
of water. (a) A bank of saud, of water. (a) A bank of sand, gravel, or earth forming
a shoal in any body of water; 3 bank or shoal at the
446

baraket

mouth of a river or harhor, ohstmeting entrance er ren

Ie rose at dawn, and, fired with hope,

Tennyson, Thi Sailer Boy.

(b) A narrow point ef land jutting out into the water. (c) In placer-mining, an accunulation of sand or gravci in or 5. In lav: (a) The railing inclosing the place which counsel occupy in courts of justice. [Hence the phrase at the bar of the court signi[Hence the phrase Or en the bench the knetty laws untie. Dryden.

(b) The place in court where prisoners are stationed for arraignment, trial, or sentence.

The great duke

Came to the bar; where to his accusations (e) The practising members of the legal profession in a given community; all those who have the right to plead in a court; counsel or barristers in geueral, or those present in court. It is the bench, the magistracy, the bar - the professlon as a profession .... - a class, a body, of which I meal
exclusively to speak.
R. Choate, Addresses, p. 137. The storm of invective which burst upon him from bar,

(d) $\Lambda$ stoppage or defeat in an action or suit by countervailing the alleged right of action.6. In Fngland, a railing or barrier which sepof either honse of Parliament, beyond which none but members and clerks are admitted.

these bars counsel stand when pleading befere the houre, and to the same bar witnesses and such as have been ordered into custody for bresches of privilege are bre ught.
In the houses of Congress, the bar, fer the latter purpose, In the houses of Congress, the bar, fer the

7. Figuratively, any tribunal: as, the bar of public opinion; the bar of God.-8. That portion of a tavern, inn, coffee-house; or the like, where liquors, ete., are set out; the counter
over which articles are served in such an establishment.

I was under some apprehension that they would appeal to me; and therefore laid down my penny at the bar,.

\section{A band or stripe: as, a bar of light.}

The long, slender bars of cloud float like flahes in the

10. In farriery, the upper part of the gums of horse between the grinders and tusks, which hears no teeth, and to which the bit is fitted.11. In music, a line drawn perpendicularly of time and marking the place of the strong

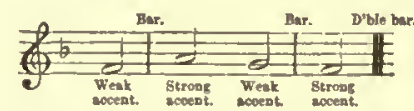

accent; hence, the space and notes included between two such lines; the portion of mnsic represented by the included notes. See also double bar, below.

Whistling a randent bar of Benny Doon.

12. In com.: (a) An ingot, a lump, or a wedge, as of gold or silver, from the mines, run in a bar-iron about half a pound in weight, used as a medium of traffic with African negroes. - 13 . In printing: (a) The lever by which the pressure is applied in a hand-press. (b) The middle cross-piece of a printers chase. -14 . In her., a horizontal stripe crossing the field, narrower than the fesse, and oceupying usually one fifth or less of the field: one of the nine ordinaries.
It is rare that one bar only is used It is rare that one bar only is used; but smaller, thcy are called barrulets. See barry 2 and baruise.

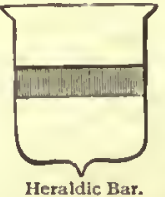

15. In a bridle, the mouthpiece plate in the form of a segment, with its upper or chord edge horizontal, and secured in a ring. If the plate has a vertical slot in it, it is called a slit baris a bar-sight or open bead-sight.

17. In saddlery, one of the side pieces connecting the pommel and cantle of a saddle.-Accented parts of a bar. See accent, v.t.-Bar of ground, a term used in Cornwall, England, and elsenear to or crossing the lode, and of a different character from that adjacent to it.- Bar sinister, a phrase erro-
Thackeray falls into the cemmon error of describing "a
ar-sinister" as a mark of bastardy. A bar in heraldry, being herizoutal, cannot be dexter or simister; a bend may be either. N. and Q., 7th ser., III. 46. Bar super, in apiculture, a case or crate in which the or thin Dict. ar. Same as baston, 1 (c).-Blank bar, in lare, a ple in bar which in an actien of trespass is put in to compel the plaintiff to assign the certain place where the trospas was committed; a common bar. It is mest used by the the place is conmonly ascertained in the declaration. Blount.-Branchial bar. See branchial. - Double bar in mure, two bars placed together at the conclusion of a movement or strain. If two or four dots are added to it, the strain on that side should be repested.- Equalizingbar. (a) In a car-truck, a wroughtit-Irou beam which besupon the top of the jonrnal-boxes on the same side of the the car and the the car upon that side rest npon the center of this bar, In yehicle a bar to ench end of whiel a whippletree is attached. It is pivoted at the middle, and is used to qualize the draft of two horses harnessed abreast. Also alled evener and doubletree. - Father of the bar. See father. - Hordzontal bar, a round bar placed horizontally at some distance above the ground, on when sthletes cercise. - Landing-bar, in lace-making, a shuttle-box; cast. driven into the pattem and struck lightly with a hammer to loosen it from its mold, se that it cun be withdrawn. - Parallel bars, a pair of bars raised about 4 to 6 feet above the ground and placed about a foot and a half apart, ased in gymnastics to develop the minseles of the arms, chest, etc.-Plea in bar, in law, a plea of matter or such cor abatement. - Splinter-bar, in coach-building, the bar of to the bar. See call. - Trial at bar, a trial in one of the superier courts before all the judges of the court in which the action is brought, or a quorum sufficient to
make a full court. $=\$$. 2 snd 3 . Earricade, etc. See

$a^{1}$ (bär), v. t.; pret. and pp. barred, ppr. [< ME. barren, < OF. barrer $=\mathrm{Px}$. noun.] 1. To fasten with a bar, or as with a bar.

Every door is barr"d with gold, and opens but to golden keys.
Tennyson, Iocksley Hall. New to sll hepe her heart is barred and cold.
Longfellow, Blind Girl of Castel-Cuille, fi.

2. To hinder; obstruct; prevent; prohibit; restrain.

Bar his access to the king you cannet

The houses of the country were all scattered, and yet not so far off as that it barrel mutual succour. Sir P. Sidney.

Though the law ef arms deth bar

'The use of venem'd shet in war.

3. To except; exclude by exception.

Nay, but I bar to-night ; you shall not gage me
By what we do to-night.
Shak. NI. of V., ii. 2. 4. To provide with a bar or bars; mark with bars; cross with one or more stripes or lines. A Ceynt she wercd, barred al of silke
Chaucer, Miller's He bars his surfaces with horizental lines of colour, the
Ruskin. 5. To make into bars. [Rare.] - To bar a vein, in farriery, to open the skin sbove a vein in a herse's leg, disengaging it, tying it both ahove and below, and strikto stop malignant humors. Johnson.-To bar dower.
See dower2.-To bar an entail See entail. See dower2,-To bar an entall. See entail.
barl (bär), vrep. [Prop. impv. of bar ${ }^{1}, v ., 3$; cf. barring.] "Except; omitting; but: as, to offer to bet two to one against any horse bar one. bar $^{2}$ (bär), n. [< F. bar, "the fish called a
base " (Cotgrave): see base ${ }^{5}$.] An acanthopterygian European fish, Sciane aquila. Also called maigre.

bar ${ }^{3}, a$. An ebselete (Middle Fnglish) or dialectal form of bare 1

bar ${ }^{4}$. A Middle English preterit of bear 1 bar $^{5}$ (bär), $n$. A dialectal form of bear ${ }^{2}$. [U.S.] bar $6+, n$. A Middle English form of baron. baracan, $n$. See barraean.

baræsthesiometer, $n$. See baresthesiometer. baragouin (ba-rä-gwan' or -gwin'), n. [F., said to be < Bret. bara, bread, + guin, wine, or guenn, white, "in reference to the astonishment of Breton soldiers at the sight of white bread"; but this reads like a popular etymology, with the usual fictitious anecdote appended. The word may be merely imitative.] Unintelligible jargon; language so altered in sound or sense as not to be generally understood.

baraket (bar'a-ket), n. [Heb.] In Jewish antiq., the third jewel in the first row in the breastplate of the high priest: it is thought to be the garnet. 
baralipton

baralipton (bar-a-lip'ton), $n$. [An artifieial used in tho phrase tn fire in barb, in barbete, or term. 1. In lagic, a mnemonic name of an in which the two premises are universa] affirmatives and tho conclusion is a rartieular affirmative: as, Lvery animal is a substance; every man is an animal; therefore, some substanee is a man. The name was probably in vented by Petrus Hispanus. See bamalip and coleopterous insocts.

baranco (ba-rang'kō), $n$. Sumo as barranca.

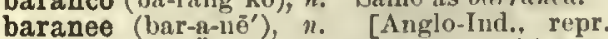
barane birani, lit. keeping off the rain, $<$ birin, rain.] A eloak made of felterl woolen eloth, used in India.

baraniline (ba-ran 'i-lin), n. [< Gr. Bapes, heavy, + anilive.] A name given by Reiman to heavy aniline oil, to distinguish it from the light aniline oil or kuphaniline.

barathea-cloth (bar-a-thè'ä-klôth), $n$. 1. A barb2+ (bärb), $n$. [A corruption of bard2 perwoolen eloth made at Leeds, England -2. A laps by eonfusion with berbl a beard, or beth silk, either plain or twilled, made in Fingland. Also spelled barrathea-cloth.

barathrum (bar'a-thrum), $u . ;$ pl. barathro

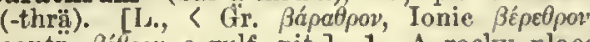
contr. $\beta \varepsilon \dot{\theta} \theta$ ov, a gulf, pit.] 1. A rocky plaee or pit outside the walls of ancient Atlens, into whieh eriminals were thrown.-2 + . The abyss hell.

He will eat a leg of mutton whlle I an in my porridge,

. his beliy is like Barathemem. Jonson, I'vetaster, Jii. I. 3t. Anything that swallows up or devours; the belly; an insatiable glutton or extortioner.

Yout come
To scour your dirty naw with the goud cheer,
Which will be damn'd in your lean barathrum, Which will be damn'd in you

Shirley, The Weddiog, ii. 3

You barathrum of the ahambles! barato (bä-rï'tō), n. [Sp., as in def., lit. eheapness, low priee, bargain, barato, eheap: see barrat.] A portion of a gamester's winnings giveu "for luek" to the bystanders. N.E. $D$. barbe = Pr. Sp. Pg. It. barba, <L. barba, beard see beard.] 1. A beard; anything which re sembles a beard or grows in the place of it.

The barbel, so called by reason of his barbs, or wattle
In his month.

2. In bot., a terminal tuft of hairs; a beard more usually, a retrorse tooth or double tooth

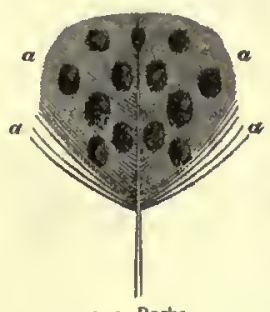
prickle.-3. In ornith one of the processes, of the first order, given of by the rachis of a feather. The vame [of a feather] con sists of a series of appressed, Iinear laminie or plates, set ob. liquely on the rliachis by their a varying open angle, ending in a free point; each such narrow acute plate is called a barb.

4. One of the sharp points projecting backward from the penetrating extremity of an arrow, fish-hook, or other instrument lo

llaving two points or barbs

Aseham, Toxophllus (Arluer), p. 135.

5. A linen eovering for the throat and breast sometimes also for the lower part of the faee, worn by women throughout the middle ages in western Europe. It was at times peeuliar to nuns or wornen in mourning. Do wey your barbe and slew

$$
\text { youre face bare. }
$$

B. Alond or sn of laee, or other fine material, worn by women at the neck or as a headdress. - 7. Same as barbel, 3.-8. In her., one of the five leaves of the ealyx which projeet beyond and between the petals of the heraldic rose. See barbed $1,3,-9$.
A bur or roitghness pro-

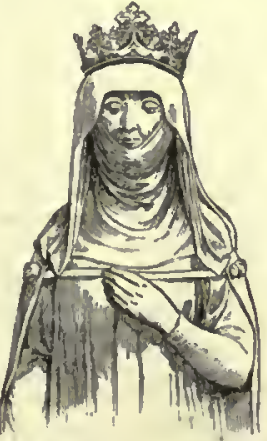
dueed in the course of metal-working, as in coining and engraving.-10, A military term pet instead of through the embrasures.

Also spelled barlse.

arb] (biirb), $v$. [< OH', burber, slave, < barbe, vearl. In $F_{\text {se }}$ the vorb is now generally re garded as formed from barber, like peddle from peddler, and is used only colloquially.] I.
trans. 1. To shave; dress the beard. [Now only eolloq.] - 2 $\downarrow$. To pare or shave close to the surface; mow

The stoophing scytheman, that doth barb the fleld.

3t. To elip, as gold. B. Jonson-4. To furnish with barbs, as an arrow, fish-hook, spear or other instrument.

II. intrans. To shavo.

To sir A. Smith"s, it behg now nighit, and there up to morrow.

Pem/s, Diary, II. 329.

a Barbary bard2,

II left his loltie steed with golden sel]

Spenser, F. Q., 11. i1. 11

Their horses were naked, without any barbs, for allelt many bruinght barbe, few regarded to put them on.
Sir J. Ilayneard, Folw. VI., p. 32 barb $^{2}+$ (bäirb), r. $t$. [< barb $\left.{ }^{2}, n_{\text {. }}\right]$ Samo as bard ${ }^{2}, *$

A lirave courser trapped and barbed. Berbed with frontlet of steel, I trow, Aubl with Jedwood-axe at saldle- low. Seett I of I y i t connection with $\mathrm{L}$. barba, a beard), < Barbarie, breed introdueed by the Moors into Spain from Barbary and Moroeco, and remarkable for speed, enduranee, and doeility. In Spain this noble race has degenerated
tive country.

The inportance of improving our studs by an infusion of new bleod was strongly felt; and with this view a con siderable number of barbs had lately been broughit int
the country.
Macaulay, IItst. Fng., ill 2. A breed of domestic pigeons having a short broad beak, classed by Darwin with the earrier and runts. Also called barb-pigean, Barbar pigeon, and Barbary carrier.-3. A seiænoid fish. See kingfish.

barbacant, $n$. See barbican 1

barbacou (bär'ba-kö), n. [<F' burbacou, irreg. barbu, a barbet, $f$ (tur) acan or (cou)cou, euckoo.] A name given by Le Vaillant to the American barbets of the family Bucconide, to distinguish thom from the barbets proper of the famil Capitonida. The South American barbacou are the birds of the genera Monasa and Cbel doptera.

barbacue, $n$. See barbecue.

Barbadian (bär-bà'di-an), $a$. and $n$. [<Barbados, the Barbados, a name said to be due to $\mathrm{Pg}$. as barbadas, the bearded, applied by the Portuguese to the Iudian fig-trees growing there.] ed Barbadocs)

II. $u$. An inhabitant of Barbados, the most eastern island of the West Indies, belonging to treat Britain.

Barbados cherry, leg, nut, tar, ete. See the nouns.

Barbados-pride (bür-bā'dōz-prīd), ". 1. priekly leguminous shrub, Casalpinia puleherrima, of tropical regions, planted for hedges as well as for the beauty of its flowers. Also Indies, a handsome flowering leguminous tree, Adenanthera paronina, introdueed from the East Indies.

barba Hispanica (bär'bä his-pan'i-kä), " [NL., lit. Spanish beard.] A name given to the plant Tillandsia usneoides. See lang-moss.
barbaloin (bär'ba-lo-in or -loin), $n$. A noutral substanee $\left(\mathrm{C}_{34} \dot{\mathrm{H}}_{36} \mathrm{O}_{14}+\mathrm{H}_{2} \mathrm{O}\right)$ erystallizing in tufts of small yellow prisms, extracted from Barbados aloes.

barbart (bär'bär), $a$. and $n$. [Early mod. F also barbare, <ME. barbar, OF, barbare, < L uarbarus: see barbarous.] I. a. Barbarous.

II. $n$. A barbarian.

barbara (bär'ba-rä), $n$. In logic, a mnemonic name of a syllogism of the first figure, all whose parts are universal affirmative propositions: as, All men are mortal; all the patri- barb 3 (bärb), $n$. [< F. barbe, a Barbary horse (IIL. eavallus de barba, indicating a supposed

\section{barbarlanism}

arehs (Enoch, Elijah, ete.) aro men; hence, all patriarehs are mortal. It is the type of all sylly. Lisiu. This name is believed to have been invented by
Petrus llispanus (l'ope John XXI., dled 1277), glthough l'rantl thinks the work of Willain of Shyrwoilc (dlect barbaresque (bir-ba-resk'), $a$. and $n$. [< $F$. barbaresque, of Barbary, Sp. I'g. bnrbaresen = It. barbaresen (obs.), of lbarbary, barharous: Charaeteristic of or appropriate to barhariank barbarous in style. [Rare.]

Our Furopean and Jast Ind lan colos are the basest of all ase products from rude barlaresque habdicraft.

2. [cap.] of or pertaining to Barlary in nortlern Arriea.

II. . [c(i).] A native of Barbary. Jefferson. [Rare.

barbari (bär'ba-1ī), n. In logic, the mnemonic name of a kind of syllogism the premises of which are those of a syllogism in barbara (which see), whilo tho conclusion is only a partieular instead of a universal affirmative: as, All wnen are mortal; all kings aro men; henee, some kings aro mortal. This kind of sylloglsu was his followers, Alhert al kaxons. See moxl

barbarian (bär-bā'ri-an), n. and $\boldsymbol{t}_{\text {. }}$ [<F. barbarien, < barbarie, < I., barbaria, barbarousuess (see barbary), < barbarus, barbarous, a barbarian: see barburous and -ian.] I. $n$. 1. A for eigner; one whose language and eustoms differ from those of the spenker or writer. [This is the uniform meaning of the word in the New Testament.]

Therefore if I know not the meaning of the volce, I ghal! be unto him that speaketh a barbarian, and he that speak
eth shall be a barberian nuto me.
C Cor. xiv. I1 It is well kuown that many of the Roman Emperor were burbariaus who had heen auccessful soldiers in the
Imperial army.
Stille, Stud. Med. IIst., p. 50 . Imperial army. Stille, Stiud. Med. Hiat., p. 50 . With the Greeka, onc not a Greck was a barbarian; with or its civilization, and especially a person belongiog to one of the northern nations who overthrew the empire: outsinte of Italy. Among the Chinese, one who is not Chinaman, and eqpecially a Furopean or an American, commonly spoken of as a arestern barbarian. The treaties
with the chinese government, huwever, stipulate that the

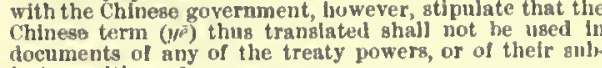
2. One outside the pale of Christian eiviliza tion.-3. A man in a rude, savage state; an tion.-3. A man in

There wers his young barbarians all at play,
There was their Dacian mother - he, their sire,

4. An uncultured person; one who has no sympathy with eulture; a philistine.-5. A eruel, savage, brutal person; one destitute of pity or humanity: as, "thou fell barbarian," Philips.6t. [eap.] A native of Barbary.=Syn. Heathen, II. a. 1. Foreign ; of another or outside na ion; henee, non-Hellenic, non-Roman, nonChristian, uon-Chinese, ete.

Thou art bought and sold among throse of any wit, lik
barbarian slave. 2. Of or pertaining to savages; rudo; uneivized.-3. Cruel; inhnman; barbarous.

The storny rage and hate of a barbarian tyrant.
Mfacaulay, Hist. Fing., xxili 4t. $[c a p$.$] of or belonging to Barbary. =\mathbf{S y n}$. Barbarian, Barbarates, Barbaric, unlettered, uncultivated. intutored, ignorant. Barbarian applies to whatever pereference to its moral aspects. Barbarous properly ex. presses the bad side of harbarian life and character, espe(barbariana for dornment, magniffence, noise, etc., but it is not comvated taste: as, berbaric music; ba rbaric splendor. Bar. barian and barbaric are now strietly conflued to the meanings named above.

This barbarian tongus ralsea him far above what he ould have become lhad lie never learned to speak at all.
Whitney, Life and Growth of Lang., is. The boast of the barbarion freeman was that a true equality, founded on the supposed commun posscssion of honor, courage, devotion, had al ways bech recognized
among them as their nost jrecions inheritance.

O barbarous and lloody spectacle Shak., 2 Ilev. Vir., iv. Something of indescribable barbaric magnificence.
IIorells, Venetian Life, II.

barbarianism (bär-bā'ri-ạn-izm), n. [< barbarian + -ism.] The state or condition of being barbarian. 


\section{barbarianize}

barbarianize (bär-bā'ri-ân-īz), $\imath \cdot t$; pret. and pp. barburianized, ppr.

barbaric (bär-bar'ik), a. [< I. barbaricus, < Gr. $\beta a \rho \beta a \rho \iota k o ́ s$, foreign, barbaric, < $\beta a ́ \rho \beta a p o s$, barbarous: see barbarous.] 1†. Foreign. The gorgeous east with richest hand

Showers on her kings Barbaric pesrl and gold.
Milton, I. L, il.

2. Uncivilized ; baxbarian : as, "barbaric or Gothic invader's," T. Narton, On Milton's Smaller Poems.-3. Of, pertaining to, or characteristic of barbarians or their art; hence, ornate without being in accordance with

cultivated taste; wildly rich or magnificent. We are hy no means insensible . . to the wild and
berburic melody.

His plans were hold and fiery, and his conceptions
Poe, Tales, I. 341. = \$yn. Barbarian, Barbarous, Barbaric. See burbarian. barbarically (bär-bar'i-kal-i), $a d v$. In a barbaric manner; after the fashion of barbarians or uncivilized persons.

barbaris (bär' ba-ris), $n$. In logic, a mnemonic barbaris (bar syllogistic mood baralipton: used name for the syllogistic mood Saralipton

barbarisation, barbarise. See barbarization, barbarize.

barbarism (bär'ba-rizm), n. [= F. barbarisme,

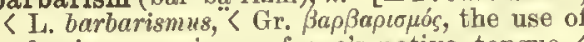
a foreign, or misuse of one's native, tongue, $\beta a \rho \beta a \rho i \zeta \varepsilon l v$, speak like a foreigner or barbarian: see barbarize.] 1. An offense against purity of style or language; originally, the mixing of foreign words and phrases in Latin or Greek; foreign words and phrases in Latin or Greek; hence, the use of words or forms not made ac-
cording to the accepted usages of a language: cording to the accepted usages of a language:
limited by some modern writers on rhetoric to an offense against the accepted rules of deri vation or inflection, as hisn or hern for his oher, gooses for gcese, goodest for best, pled for pleaded, proven for proved.-2. A word or form so used; an expression not made in accordanco with the proper usages of a langnage. The Greeks were the first that branded a foreign term
In any of their writers with the odlous name of barbarism.

A barbarism may be in one word; a soleeism must be

3. An uneivilized state or condition; want of civilization; rudeness of life resulting from ignorance or want of eulture.

Times of barbarism and ignorance.
Dryden, tr. of Dufressoy's Art of Painting, Pref.

Divers great monarchies have risen from barbarism $t$

4†. An act of barbarity; an ontrage.

A helnons barbarism... against the honour of mar-

$=$ Syn. 1. Burbaribm, Solecism, etc. See impropriety.

barbarity (bär-bar'i-ti), n.; pl.barbarities (-tiz).
[< barbarous.] 1. Brutal or inhuman conduct barbarousness; savageness; eruelty.

Another ground of violent ontery against the lndians is
their barbarity to the vanquished.
Irving, Sketch-Book, 1. 34s

2. An act of cruelty or inhumanity; a barbarous deed: as, the barbarities of war or of savage life.-3†. Barbarism.

The barburity and narrowness of modern tongues.

barbarization (bär-ba-ri-zā'shọ), n. [< bar barize + -ation.] The aet of rendering barbarons; a reduction to barbarism, or to a sons and communities. Also spelled barbarisa sons a

barbarize (bär'ba-riz), $v_{\text {. }}$; pret. and pp. bar barized, ppr. barburizing. = F. barbariser, LL. barbarizare, < Gr. $\beta a \rho \beta a \rho i \zeta \in \imath ?$, speak like foreigner or barbarian, hold with the barbarians, < $\beta a ́ \rho \beta a \rho o c$, foreign, barbarian. See bar-
barous.] I. intrans. 1. To speak or write like a barbarian or foreigner; use barbarisms in speech or writing.

The ill habit which they got of wretched barbarizing

2. To become barbarous. [Rare.]

The Roman Empire was burbarizing rapldly

II. trans. 1. To corrupt (language, art, ete.) recintroducing impurities, or by

He [Inigo Jones] barbariged the aneient eathedral o of Pointed arehitecture. Encyc. Brit. II. 443.

2. 'To render barbarous.
448

barbel

Nicleous changes have barbnrized France.
Burke, To a Noble Lord. To hahitual residents amoug the Alps this absence of social duties and advantages may be barbarising, evell
brutalising. $J$. A. Symonds, Italy snd Greee, p. 301. Also spelled barbarise.

barbarous (bär'ba-rns), a. [Earlier barbar, q. จ.; < L. barbarüs, < Gr. $\beta$ áp $\beta a \rho o s$, foreign, uncivilized: applied orig. to one whose language was unintelligible. Cf. Skt. barbara, stammering, in pl. foreigners; L. balbus, stammering: see balbuties and booby; cf. babble.] 1. Foreign; not classical or pure; abounding in barbarisms; of or pertaining to an illiterate people: applied to language, originally to languages $w$

A wholly barbarous use of the word.

Ruskin, Pol. Econ., Art. ix.

2. Speaking a foreigu language; foreign; outlandish: applied to people. [Ärehaic.] See barbarian, $n ., 1$.

The lsland was called Mlelits. And the barbarous people shewed ns no little kindness: for they kindled a fire snd

3. Characterized by or showing ignorance of arts and civilization; uneivilized; rude; wild ; savage: as, barbarous peoples, nations, or countries; barbarous habits or customs.

Thou art a Roman; be not barbarous.

Shak., Tit. And., i. 2.

What we most require is the setual exsnination by community, whose Aryan pedigree is reasonably pure.

4. Pertaining to or characteristic of barbarians: adapted to tho taste of barbarians; barbaric; of outlandish character.

Emetrius, king of Inde, a mlghty name,

On a bay courser, goodly to behold

the trappings of his horse emboss'd with barbarous gold.

Pyrrhus, seeing the Romans marshal their army with some art and skill, sald, with surprise, "These barbarians
lave nothing borbarous in their discipline."

5. Cruel; ferocious; inluman: as, barbarous treatment.

By their barbarous usage he died within a few days, to
the grief of all that knew him.

6. Harsh-sounding, like the speech of barbarians: as, wild and barbarous musie.

A barbarous noise environs me. Milton, Somets, vii. = Syn. Barbarian, Barbarous, Barbaric (see barbarian);
barbarously (bär'ba-rus-li), adv. In a barbarous manner; as a barbarian. (a) Imperfeetly ; without regard to purity of speeeh: with
foreign or unclassical words and phrases.

IIow barbareusly we yet spesk and write, your lordship knows, and I am suffieiently sensible in my own Fnglish. Morlern Frenel, the most polite of languages is barbarously vulgar if enmpared with the Latin out of whieh it has been corrupted, or even with Italian.

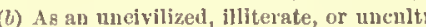
avagely; cruelly; ferocionsly; inhumanly.

The Finglish law touehing forgery leeame, st a later
periol, barbarously severe. Wfacaulay, Ifist. Eng., xxiii. barbarousness (bair'bạ-rus-nes), $n$. The state or quality of being barbarous. $(n)$ Rud

It is much degenerated, as tonching the pureness of (c) Cruelty; inhmmanity; barbsrity.

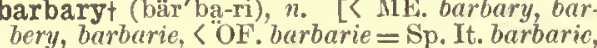
bery, barbarie, $<\mathrm{OF}$. barbarie $=\mathrm{Sp}$. It. barbaric, foreign country, barbarism, < barbarus, < Gr.

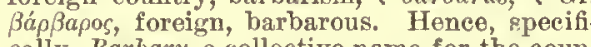
cally, Barbary, a collective name for the countries on the north and northwest coasts of berei; Ar. Barbariyan, < Barbar, Berber, the Berbers, people of Barbary in northern Af

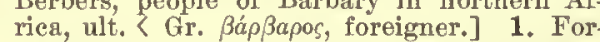
eign or barbarous nationality; paganism; heaeign or barbarous nationality; paganism; hea-
thenism.-2. Barbarity; barbarism.-3. Bar-

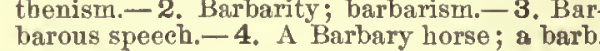
See barb 3 , 1 .

$$
\text { Pin-buttoeked, like your are ill-built, }
$$

Barbary ape, gum, ete. See the nouns.

Barbary horse. Same as barb ${ }^{3}, 1$.

barbastel, barbastelle (bär'bas-tel or bär-bastel ), n. [ < F. barbastelle = It. barbastello, 〈I. barba, beard.] A common European species of long-eared bat, Barbastellus com
claubentoni, or Plecotus barbastellus.

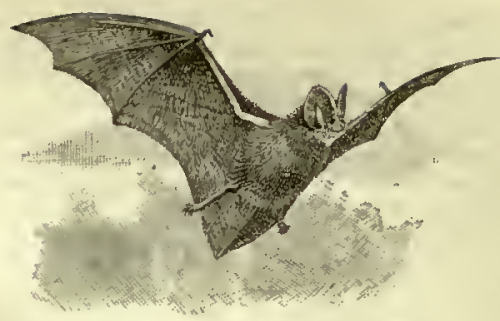

Long-eared Bat (Barbasteltus commusnis)

barbate (bär'bāt), a. [<L. barbatus, bearded, $<$ barba, beard: see barb1.] 1. Furnished with barbs-2. In bote bearded; furnished with long and weak hairs. - 3. In zoöl., bearded; having a tuft of hair or feathers on the chin; in entom., bordered by long hairs.

barbatedt (bär'bā-ted), a. Barbed or bearded; barbate: as, "a dart uncommonly barbated," T. Warton, Hist. of Kiddington, p. 63.

arbatula (bär-bat' ū-lä), n. [NL., fem. of $\mathbf{L}$. arbatutus, dim. of burbatus, bearded: see barbate.] A genus of African scansorial barbets, the barbions, of the family Megalcemiale or Capitonide.

barb-bolt (bärb'bōlt), n. A bolt whose edges are jagged to prevent it from being withdrawn from that into which it is driven; a rag-bolt.

arbe $1, n$. See barb1.

arbe ${ }^{2}, n$. Same as bard ${ }^{2}$. Rumonsch barba, arbe ${ }^{3}$ (bärb), $\ldots$. [F., It., and Rumonseh barba, ing a beard, < L. barba, beard: see barbl.] A superior teacher or ecclesiastic among the Vaudois.

barbecue (bär'bẹ-kū), n. [Also barbacue, and formerly barbicue, barbecu, borbecu = Sp. barbacoa, < Haytian barbacoa, a framework of sticks et upon posts. In Cuba barbacoa designates a platform or floor in the top story of country houses where fruits and grain are kept.] 1. A wooden framework used for supporting over a fire meat or fish to be smoked or dried.-2. An iron frame on which large joints are placed for broiling, or on which whole animals are roasted; a large gridiron.-3. The careass of an ox, hog, or other animal, roasted whole.

A kid that had been cooked in a hole in the ground, wlth embers upon It. . . This is callet a "barbacoa"-a tar.
becue. 4. A large social or political entertainment in the open air, at which animals are roasted whole, and feasting on a generous scale is indulged in. [U.S.] -5 . An open floor or ter race smoothly covered with plaster or asphalt on which to dry coffee-beans, etc.

barbecue (bär'bề-kū), v. t.; pret. and pp. barbecucd, ppr. barbecuing. [ barbecue, n.] 1. To eure by smoking or drying on a barbecuo (which see).-2. To dress and roast whole, as an ox or a hog, by splitting it to the backbone, and roasting it on a gridiron.

Rieh puddings and big, sud a barbecued plg.

barbed $^{1}$ (bärbd), p. a. [<barbl, v. or $n_{.},+$ $-e d^{2}$.] 1 t. Shaved; trimmed; having the beard row, the point of a fish-hook, and the like: as, row, the point of a fish-hook, and the like: as, 546 ; "a barbed proboscis," Sir E. Tennent, Ceylon, ii. 7 .

And, with the same strong hard
That flung the barbed spear, he tilled the land.

3. In her.: (a) Having barbs: said of the rose used as a bearing. The barbs are commonly colored green, and the blazon is a rose gules barbed proper. (b) Having gills or wattles, as a cock: as, a cock sable, barbed or (that is, a wattled. (e) Having the ends made with barbs like those of an arrow-head: said especially of a cross of this form. Also called bearded. a cross of this form. Also called bearded.-
Barbed bolt. See bolt 1 - Barbed shot, a shot having Barbed bolt. See bolt 1, - Barbed shot, a shot having twlsted to woith Barbed wire, in pelined or woven into the strands, or a single wire furnished with sharp points or barbs: used for fenees, and so made fo barbed ${ }^{2}$ (bärbd), p. $a$. [ $\left[\left\langle a r b^{2}, v .,+-e d^{2}\right.\right.$. Prop. barded, q. v.] Same as bardca.

barbel (bär'bel), n. [ME. barbelle, barbylle, OF. barbel ( $\mathrm{F}$. barbeau), < ML. barbellus, dim. of barbus, a barbel (fish), < barba, beard: see barb1. In the sense of an appendage, barbel is rather < NL. barbella: see barbella, and ef. 
larbule.] 1. The eommon English namo of the barber-snrgery (bär'bèr-sèr "jèr-i), n. The fish Tiarbus vulyaris, also extended to other spe- oeeupation or praetiee of a barber-surgeon; cies of the genus Barbus.-2. A small eylindrieal vermiform proeess appended to the mout of certain fishes, serving as an organ of touch. 3. A knot of superfluous flesh growing in the elannel of a horse's mouth. Also barble and barb. barbella (biir-bel'ị̂), n.; pl. barbella $(-\overline{\mathrm{e}})$. [NL., bel, 2, 3.] A small barb or bristle.

barbellate (bilr-bel'āt), $a$. [<NL. barbellatus, <NL. barbella, a. v.] Having small bristles or barbules: used ehiefly in botany. Also barbulate.

barbellula (bair-bel'ū-lị), n.; pl. barbellula (-lē). [NL., dim. of bäbella, q. v.] A vory small barb or bristle.

barbellulate (bdr-bel'ụ̂-lāt), $a$. [<NL. barbe lulatus, < barbellula, q. v.] Having very small bristles or barbules.

barber (bäir'bér'), $\%$. [Early mod. E. also berbour, < (a) ME. Garbour, barbor, barbur, < $\mathrm{AF}$ burbour, OF. barbcor" ( $\mathrm{L}$. as if "barbator, "barbare, shave: see barbl, $v$.); mixed with (b) ME. barber, ( OF. barbier, F. barbier = It. bar biere, $<\mathrm{L}$, as if "barbarius, $<\mathrm{L}$. barba, a beard seo barbl, u.] 1. Ono whose oceunation is to shave the beard and ent and dress the hair.2. Same as surgcon-fish.-Barber's basin, a basin or howl formerly used in ahaving, laving a broad rim tomer, who lield it, while the barber made the iather with his haud and applled it directly: atill in use ill gomc part of Europe as a hurber's sign.- - Barber's pole, a pole atrijed spirsity with alternate lands of colors, gencrally
red or hlack and white, and often, in Europe, having brass basin at the end, placed as a gign at the door of with which the arm of $\mathrm{s}$ person who has been bied is bound up, and originally indicsted that the barber conbined minor surgical operations witls his other work. and dress the hair of.

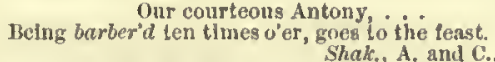

barbera (bär-bā'rịi), n. [It.] An Italian ver wine, made in

grapes so ealled.

barber-boat (bär'bèr-bōt), $n$. A small boat like a eanoe, in nse at Canton in the south of China: probably so called beeause in the oarly days of trade with China native barbers use sueh boats in going about among the shipping. barber-chirurgeont (bär'bẻr-kì-rèr jọn), n. A

IIe put inInself into a barber-chirurgeon's hands, who, ly

inti applications, rarefled the tumour, Surgery.

barberess (barrber-es), n. [< barbcr + ess. $]$

barber-fish (bär'bèr-fish), $\mu$. In ichth., Teuthi corulcus or some other fish of the family Tcuthidide.

barbermonger (bär'bèr-mung"gèr), $n$. A man who frequents the barber's shop, or prides himsolf on being dressed by a barbor; a fop. Shak.

barberry (bär'ber-i), n.; pl. barberries (-iz). [Also berberry, early mod. E also barbery baibary, berbery (the term. simulating berry $\mathbf{1}$ ), , ME. barbere (ef. F. berberis, formerly berberc) $=\mathrm{Sp}$. berberis = It. berberi, $(\mathrm{ML}$. berberis, barbaris, of uneertain origin. The Ar. barbāris, Pers. barbāri, are from the ML.] 1. A shrub of the genus Berberis, $B$. vulgaris, bearing raeemes of yellow ill-smelling flowers, whieh produee red elongated berries of a pleasantly acid flavor, a native of Furope and extensively naturalized in New England. From the root of the barberry a yeilow coloring msitcr is obtained, whlch when rendered brown hy alkalis is uned in the nianufacture of moroceo
leather. In Engiand also cslled pepperidge or piprage. 2. The fruit of this shrub.

barberry-fungus (bär'ber-i-fung "gus), n. A fungus whieh attaeks the leaves of the eommon barberry, formerly known as Ecidium Berberidis, but now proved to be the reeidiospor stage of the red and blaek rust (Puccinia gra minis) whieh is found upon wheat, oats, other kinds of grain, and varions speeies of grass. Also ealled barberry-rust or barberry-clustercups. See cut under Iuccinia.

barber-surgeon (bär'bèr-sẻr"jon), n. Formerly, ono who united the praetiee of surgery with that of a barber; hence, an inferior praetitioner of surgery.

That the whole compenany of baber alie brands,

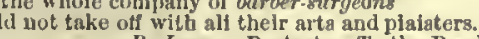

29 titioner of surgery.

Slits it into four, that he may the leetter come at it with

barbery ${ }^{1}$ (bair'bèr-i), n. [Warly mot. E. also

barbery ${ }^{1}$ (bair'bèr-i), n. [Warly mot. E. also barbary (ME. barborcry), < OF. barberic, < barbier, a barber: seo barber and -ery.] 1t. A a barber. [Raro.]

The nnion of aurgery and barbery was psrt ially dlssolved 1540 (32 Ilenry VIII., c. 42), the barbers belng conflute tooth-drawing.

$N$, and Q., 7 th ser, 11 . 196. barb1.]. 1. A small beard.-2. A part of the helnet in use in the sixteentli century; eitbe (a) the fixed beaver or mentonnièro, or (b) the lower part of the vizor when made in two pieees, so that oither eould be raised without tho other. Compare barbutc. Also spelled barbelt.

barbet ${ }^{2}$ (bïr'bet), n. [< F. barbet (prob. for barbe), < OF. barbet, < L. barbatus, bearded. Cf. barbute.] 1. A variety of dog having long
curly hair; a poodle.-2. In ornith., any bird of the families Capitonidce (or Megalamicle) and Bucconide. It ia a book-name which has followed the generic names Capito and Bucco in their various appliea fions to mumerous zygodactyl birds with large heads, stou hills, and prominent rictal vibrisse, inhabiting hoth the old cal meaning. - Fissirostral barbets, the puff-birds; the
hirds of the family Bucconid ce (which see). They are confined to America, beiong to the three icading gencra, kuceo, Momisa, and Cheludopter $a$, and incinde the biris words.) They are clogely reiated to the facamars or Gal bullide, but have no special affinity with the acsnaoria larbets. - Scansorial barbets, the barbets proper; the birds of the family Capitonidas (which aee). They are
chlefly birds of the old world, of the leading genera I'o. gonias (or Pogonorhynchus), Megaloma, Calorhamphus, birds known as bartions and hapbleans; but they also

includo the South American genua Cayito.
barbett, $n$. See barbet 1 .

barbette (bär-bet'), $n$. [F., fem. dim. of barbe, [L. barba, beard. Cf. barbet1.] The platform of through embrasures.-Barbette-carrlage, a car. riage which eievatea a gun autificitly to ensble it to be fred over the paranet, and lowers it again behind the
parapet after the decharge. See gun-earriage. - Barbette gun, or battery, one gun, or several, nounted in ironelad, carrying heavy guns which are fired over the bette. See barb1,

barb-feathers (bärb' fecr "èrz), n. pl. Tls feathers under the beak of a hawk.

barbicanl (bär'bi-kan), n. [Farly mod. E. also barbacan, ete., <" ME. barbican, berbikan, barbygan, ete., < OF. barbicanc, barbaquenne, mod. F. barbicane $=$ Pr. Sp. barbicana $=\mathrm{Pg}$. mod. F. barbicane $=$ Pr. Sp. barbicana $=$ Pg. bacana, "barbacanus, a barbiean: supposed to be
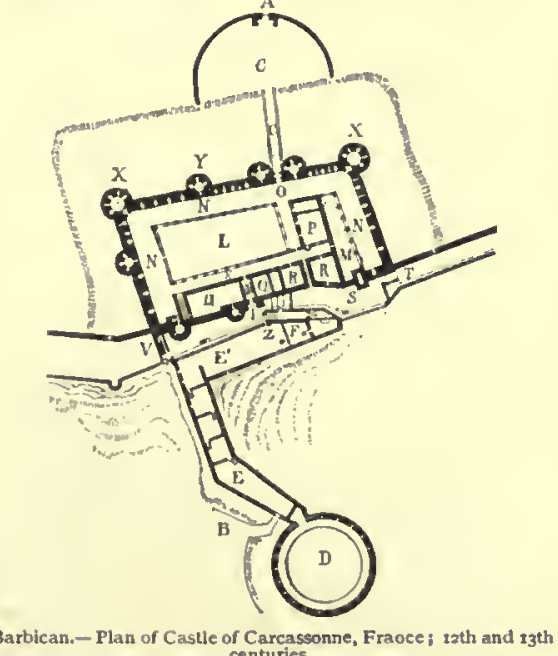

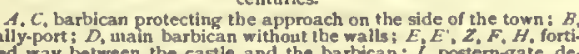

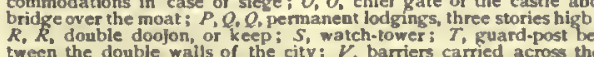
tween the double walls of the city i $V$, barriers carried across the
space intervening between the city walls; $X, Y$, $X$, towers connected
by curtains, (From Viollet-le-Duc's " Dict. de f Architecture.") barbery ${ }^{2}+n$. Seo barberry.

barbet ${ }^{\prime}$ (biir'bet), $n$. [<' F. barbettc, OF. bar bete, dim. of barbe, < L. barda, a beard: see or breastwork of a fortifieation, from whiel

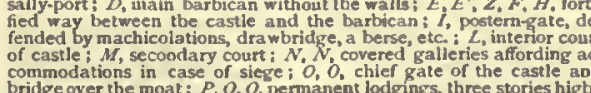

of Ar. or Pers, origin, introdueed into Europe by the erusaders; cf. Ar. l'ers. bab-hitannh, a gatelouse, gateway with a tower.] 1. In medieval fort., an outwork of a eastlo or fortified place. (a) Properly, a post in which a force could be sheltered so such a work frequently supplicd an advantike ous means or taking an assalfant in the flank, and, while comnunicallig with the main post, aeldom contalued the chlict cntrance to it. (b) An outlost of any nature, as a bridgcprove or adefense ontside of the moat protecting the ap-
proach the drawbridge ; algo a gateway-tower throughi which the main entrance was carricl.

Witjıln the Bartican a Porter sate

Dsy and night duely keeping watch and ward.

Ie leats a body of men elose under the outer barter of the barbicas.

2. A loophole. [Rare and obsolete.]

Ife cansed certnin barbecan or loop-holes to be plerecul
throngh the walla.
Ifolland, tr. of Livy, rxiv, 34.

throngh the walla. Ifolland, tr. of Livy, rxiv, 3t. diseharge of water.

barbican ${ }^{2}$ (biir'bi-kgnu), . [Apuar, a nado word, based (like bïrbion, $q . v_{0}$ ) on $\mathrm{F}$. barbe, a beard.] A seanserial barbet of the family Capitonida and subfamily P'ogonorhynchine, ol' the genus l'ogonias in a broad sense. The barbicans are all Afriean, like the barbions.

barbicel (bär'bi-sel), n. [< NL. "barbicelle, dim. of L. barba, a beard. Cf. barbcl.] In ornith., a fringing proeess of the third order of a feather; a fringe of a barbule; one of the proeesses with whieh a barbule is fringed, differing from a liamulus or hooklet in not being reeurved.

barbiers (bär'bêrz), $n$. [See def.] A paralytic disease formerly very eommon in India, and see), or to be another form of that discase. barbigerous (bair-bij'e-rus), $a$. [< L. barbiger (< barba, bearl, + gerere, carry) + -ous.] Bearded; wearing a beard: in bot., applied to petals that are hairy all over.

barbion (bär'bi-on), $n$. [< F. barbion ( 8 ),
barbe, a beard. Cf. barbet ${ }^{2}$.] Ar Afriean sean sorial barbet of the genus Barbatula, family Megalcemide or Capitonider.

barbiton, barbitos (bär'bi-ton, -tos), n.; pl.

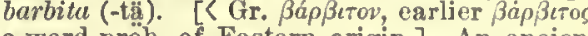
a word prob. of Eastern origin.] An aneient Greek musieal instrument of the lyre kind.

barble, $n$. See barbel, 3.

barbolet, $n$. A very heavy battle-ax. barbotine (bür'bō-tin), ". [F., wornwood, seIndian vegetable produet, the ehiof eonstituent of whieh are wax, gum, and bitter extraet. Sinmonds. - 2. Worm-seed. Simmonds.-3. In ceram., same as slip.

barb-pigeon (bärb' pij"on), $n$. Same as barb3, 2. barbret, $a$. See barbar.

barbu (bär'bū), n. [F., < barbe: see barl1.] 1. A name, derivel from Buffon and othe1 of the senses of the latter, as applied to bird either of the family Bucconida or family Capitonicle. See these words, and barbet ${ }^{2}-2$. $p l$ The birds of the family Capitonide alone, as distinguished from the Bucconida.

barbula (bär'bū-lạ̈), n. ; pl. barbulce (-lè). [I., a little beard, a small barb: see barbulc.] 1. Same as barbule, 1.-2. [cap.] [NL.] A large genus of true mosses eharacterized by terininal, ereet fruit, and a peristome of long filform segments spirally twisted to the left.3. [cap.] [NL.] A genus of bivalve mol lusk

barbulate (bär'bū-lāt), a. Same as barbellate. barbule (bär'būl), n. [< L. barbula, dim. of barba, beard.] 1. A small barb, as of a plant a little beard. Also barbula. -2. In ornith., one of a proeesses fringing the barbs of a feather.

As the rhachis [ot a feather] go does each barh besis its vanes o the gecond order, or littie vanea, Cones, Key to N. A. Birds, p. 84

3. The part of a helmet

which protects the ebeeks $a, a$, Barbs; $\delta, \delta$, Rarbule and ehin.

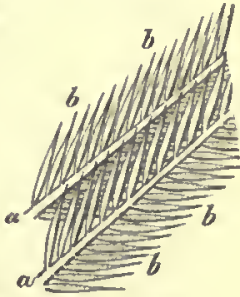

Barbus (bär'bns), n. [NL., < L. barbus, a barbel, < barba, beard: see barbcl.] An extensive cenus of eyprinoid fishes, eontaining the barbels, typified by the common barbel of Europe 


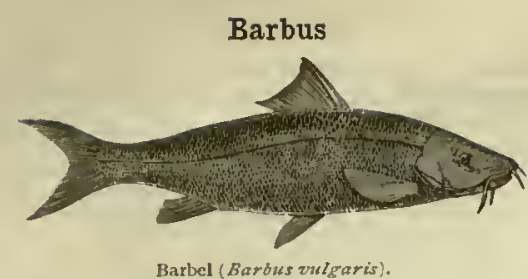

B. vulgaris: used with varying latitude by different writers. mod. F. barbu, bearded, < barbe, beard.] 1. A mod. F. barbu, bearded, b barbe, beard. stcel cap without vizor, but covering the cheeks and ears, used in the fifteenth century and
later by foot-soldiers, archers, ete., and by the common people in times of danger.-2. A manat-arms: from the name of the helmet worn by heavily arıed men.

barcal (bär'k:3), n. A fish of the family Ophiocephalide (Ophiocephalus barea), living in the fresh waters of Bengal

barca ${ }^{2}$ (bar' kij), n. [It., Sp., bark : see bark 3.] A boat, skiff, or barge. N. $E . D$. - Barea longa (lit. long boat), a flishing-boat, common

Barcan (bär'kan), $a$, of or pertaining to Barca, a vilayet of the Turkish empire, in northern
Africa, lying to the north of the Libyan desert, and between Egypt and the gulf ef Sidra.

$$
\begin{gathered}
\text { Take the wings } \\
\text { of morning, pieree the Barcan wilderness } \\
\text { Bryant, Thas }
\end{gathered}
$$

Bryant, Thanatopsis.

barcarole (bär'kạ-rōl), $n$. [<It. barcaroto, barcaruolo, a boatman (fem. barearuola, $>$ F. barcarolle, $>$ E. barcarolc, a boatman's seng), barch, a bark, barge: see $b_{a r k}{ }^{3}$.] 1. An Italian boatman.-2. A simple song or melody sung by Venetian gondoliers.-3. A piece of instrumental such a song.

Also spelled barearolle.

barce (bärs), n. [Another spelling of barse, q. v.] An English (Yorkshiro) name of the

barcelonat (bär-sē-lō'nä), $n$. [Named from Barcelona, a city in Spain.] A neck-eloth of soft silk.

The author of Wsverley entered; ;. a donble barcelon
Scotet

barcenite (bär'se-nīt), n. [After Prof. Mariano Barcena, of Mexico.] A hydrous antimoniate of mereury from Huitzuco, Mexico, deniate of mercury from Huitzuco, Mexico,
rived from the alteration of livingstonite.

B. Arch. An abbreviation of Bachelor of Architeeture, a degree granted by some colleges and schools in the United States.

Barclayite (bä:r'klā-ît), $n$. Same as Berean, barcon, barcone (bür'kon, bär-kō'ne), $n$. [' It. barcone, aug. of barca, $\ddot{a}$ bark: see barks.]

bar-cutter (bär'kut"èr), $n$. A shearing-machine

which cuts metallic bars inte lengths. $\quad E . H$. Knight.
bard1 (bärd) n. [Formerly also barth, bardh bard 1 (bärd), n. [Formerly also barth, bardh ( W.), and Se. baird ( Gael.); = F. barde = Sp. Pg. It. bardo, < LL. bardus, Gr. Bápdos; bard $=$ Corn. bardh $=$ Bret. barz, a poet.] 1. A poet and singer among the ancient Celts; one whose occupation was to compose and sing verses in honor of the heroic achievements of princes and brave men, aud on other subjects, generally to the accompaniment of the harp. The Welsh bards formed a hereditary order regucalled eisteddfods, which after a long suspension were re
vived in the eighteenth century. (See eistedd food.) Ther vived in the eighteenth century. (See eisteddjod.) There
waa alao a hereditary gitd of bards in Ireland, many of

There is amongest the Irish a certayne kind of people
called $B$ ards, which are to them insteede called Burt 8 , which are to them insteede of poetts, whose profesioni is to sett foorth the prayses and disprayea of
men in theyr poems and rimes. Spenser, State of Ireland. 2t. Formerly, in Seotland, a strolling musician; a minstrel: classed with vagabonds, as an object of penal laws.

All vagabundis, fullis \{fools, bardis, acudlaris, snd alclike Kenneth's Stat, in Sir J. Bslfour's Pra

3. In modern use, a poet: as, the bard of Avon (Shakspere); the Ayrshire bard (Burns).

$$
\begin{aligned}
& \text { Bard, who with some diviner sit } \\
& \text { Ifaat tonchel the bard's true lyre, a nation's hear }
\end{aligned}
$$

4. [See def. 2 and bardy, and ef. skald, scalch, a poet, as related to scold.] A scold: applied
only to women. [Shetland.]

450

bare bard 2 (baird), u. [Also corruptly burb2, formerly
barde, $<\mathrm{H}$. barde (= It. Sp. Pg. burda), the trappings of a horse, the deof a war-horse. Cf. OF. bardelle (see bardelle), $\mathbf{F}$ dial. aubarde, Sp. $\mathrm{Pg}$, albarde a pack. albarda, Ar. al-barda'all, <al, the, + barda'all, a pad of wool placed under a sadule, pack-sadale. seems to have

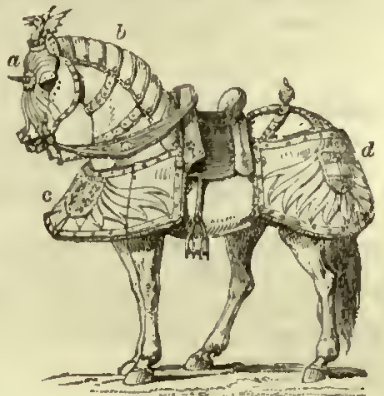
been influenced by Icel. bardl

the beak or prow of a ship of war, the brim of a helmet, orig. a beard, = E. beard (see beard). hence the variations of form, barde and barbc.] 1. Any ene of the pieces of defensive armor nsed in medieval Europe to protect the horse. There is no record of any general uae of such armor in antiquity or before the fifteenth century. IIonsings of different kinds of stuff, sometinies quilted snd wadded in exposed parts, the sadule with ita appurtenances, and occsionally a
chamfroll, were all the defense provided for horsea nntil chamfroli, were all the defense provided for horses until that time. The piece of armor most coninionly used afte

poitrel. The croupiere, or part covering the haunches, was added st the close of the fifteenth century; but after the wars of the Roses the bards resched their fullest development, and the upper part of the body of the horse was

Hence-2. $p l$. The housings of a horse, used in teurneys, justs, and processions during the later middle ages. They were most commonly of stuff woven or embroidered with the arms of the rider.

The bases and bardes of their horae were grene gattyn.

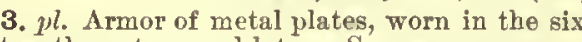
teenth century and later. Seo armor.

mleat French man-at-armes with all his barls.
Florio, tr. of Montaigne, II. ix. 225. (N. $E . D)$

bard 2 (bärd), $v . t$. $\quad\left[\left\langle\right.\right.$ bard $\left.{ }^{2}, n_{0}\right] \quad$ To caparison with bards, as a horse; to furnish or accoutre with armor, as a man.

Fitteen hundred men

barded and richly trapped.
Store, Edw. IV an, 14 .

Above the foaming tide, I ween,

Scarce half the charger's neck was seen

For he was bavded from counter to tali,
And the rider was armed complete in mai

bard ${ }^{3}$ (bärd), n. [<F. barde $(=\mathrm{Pg}$.barda $=\mathrm{Sp}$ albard $a$, a strip of bacon; a particular use of barde, trappings: see bard ${ }^{2}$.] A strip of bacon used to cover a fowl or meat in roasting.

bard ${ }^{3}$ (bärd), v.t. [ [< bard $\left.d^{3}, n.\right]$ To cover with thin bacon, as a bird or meat to be roasted.

bardasht (bär'dash), n. [< F. bavdache, < S

bardaxa = It. barlascia, < Ar. bardaj, slave, captive.] A boy kept for unnatural purposes. arde 1 , barde $2, n$. Sce band1, bard 2

barded (bäl'ded), p. a. [ $\left[<\right.$ barl $l^{2}+-e d l^{2}$. Cf.
barbed $\left.{ }^{2}.\right]$ Furnished with or elad in armor said of a war-horse.

bardelleł (bär-del'), n. [< OF', bardelle (=It bardella), dim. of barde: sce bard ${ }^{2}$.] A pack saddle made of cloth, stuffed with straw, and tied down tightly with pack-thread.

Bardesanism (bär-des'a-nizm), n. [< Barde sanes $+-i s m$.] The doctrinal system of tho Bardesanists.

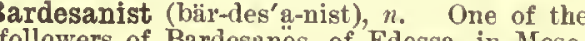
followers of Bardesanës, of Edessa, in Mesopotamia, in the secend and third centuries. He is said to have tsught doctrines resembling those of the Gnostic Vatentinus, namely: a self-existent principle of punishment; and thst therefore a body was not assunne y Christ in his incsrnation, and is not to be raised at the resprreetlon. Recent discusaions have ahown, howeve question. There are still extant Syriac hymns and prose worka ascribed to Bardesanes.

$+-i e^{2}$.] A Bardesanist.

He [Mani] looked upon what he conaldered to be Chris tianity proper, that la, Christianity as it had been deve perhaps Bardesanites, as a comparatively valuable and sound religion.

Eneyc. Brit., XV. 485

bardic (bär'dik), $a . \quad[<b a r d l+-i c$.$] of, per-$ taining to, or of the character of a bard or
Here, in the open air - in "the eye of light sul the face of the sun," to use thie bardic style - the deerees
nounced, and the Druids harangued the people

barding (biir'ding), n. [< bard ${ }^{2}+-i n \mathbf{I}^{1}$.] Horse-armor in general: nsually in the plural. See bard $^{2}, 1$.

bardish (bür'dish), a. [<barl1 +-ishl.] Pertaining to or characteristic of bards: as, "bardish impostures," Selden, Drayton's Polyolbion. bardism (bär'dizm), n. [<bard + -ism.] The seience of bards; bardic principles or methods. bardlet (bärd'let), $n$. [<bardl + -let.] A bardling.

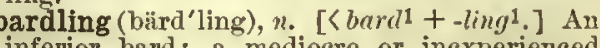
inferior bard; a medioere or incxperienced poet.

The forte of bardlings is the foille of a bard.

rdocucullus (bär"dō-kū-kul'us), n.; pl. barlocuculli (-1). [NL.] A kind of cowled cloak anciently worn by some Gallic peasants, and adopted by Romans and monks. See cucullus.

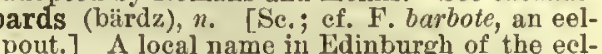
pout, Zoarecs viviparus.

ardship (bärd'ship), n. [< bardI + -ship.] bard.

The Captaln . . a allowed a particular respect for my bardy (bär'di), $a$. [< bard ${ }^{1}$, in the depreciative senses (defs. 2 and 4$),+-y^{1}$.] Bold-faced; defiant; audacious. [Scotch.]

bare1' (bãr), a. [<ME. bare, bar, < AS. bar = OS. $b a r=$ OFries. ber $=$ D. baar $=\mathrm{OHG}$. MHG. bar, G. bar, baar=Iecl, berr $=\mathrm{Sw}$. Dan, bar = OBulg. bosú = Litlı. basus, bosus, bare; orig. meaning prob. 'shining'; ef. Skt. $\sqrt{ }$ bha $\bar{\alpha}$, shine.] 1. Naked; without covering: as, bare arms; the trees are bare.

Wou wast naked ani bure, Ezek, xvi. 7. More fowl in cities than on mountains bare

2. With the head uncevered. In numel, Dara. ered or devold of any adornment, auch as a diadem or

When once thy foot enters the clunrch, be bare.

llerbert, Chureh Porch.

Thou atanlest bare to him now, workest for him.

Burton, Anat. of Mfl., p. 357.

3. Open to view; unconcealed; undisguised.

Bare in tlyy guilt, how fonl muat thou appear! rent; unfurnished: as, bare walls. -5 t. Plain simple; unadorned; withont polish.

Yet was their manners then but bare and plain.

6. Threadless; napless.

It appears, by their bare liveries,

Shat., T. G. of V. Ii.

7. Poer; destitute; indigent; empty; unfurnished; unprovided with what is necessary or comfortable: absolutely or with of.

I have made Fsan bare.

Jer. xllx. 10.

Upon lher death, when her nearest friencls thought her very bare, her execntors fonnd in her strong lox about
S150 in gold.

"Tlo" your violence ahould leave them bare

Dryllen, tr: of Juvenal'a Satires.

8. Empty; valueless; paltry; worthless.

Not what we give, but what we share-

Lovell, Sir Lannfal.

9. Mere; scarcely or just sufficient: as, the bare necessaries of life; a bare subsistence.

Pray you, cast off these fellowa, as unfitting

For your bare knowledge, and far nore your company.
Beau. and Fl., Scornful Lady, jv, 2.

10. Unaccompanied; without addition; simple.

It was a bare petition of a state. Shak., Cor., v, I 11. Unaderned; without literary or artistic effect; bald ; meager.

Much has yet to be done to make even the bare annals
of the time coherent.
Athenceum, Io. 3067, p. 170.

12. In bcer-making, not completely covered by the bubbles formed in fermentation: said of the surface of beer.-13t. Raw; excoriated.

How many flyes in whottest aommers day

14t. Leau; spare.
Spenser, F. Q., VI, x1, 48 
bare

Fal. Fon their laneness, I ans sure they never leamed

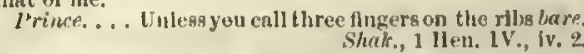
Bare contract, In faw, an uncouditionsl promilse or sur-

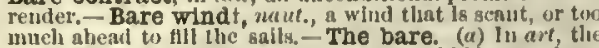
much ahead to fill the sails. - The bare. (a) In art, the nude. [ltare.] (bt) I'he uncuvered
the body; the sulsstance, [liure.]

You have touchest the very bare of truth. Markfon. To lay bare, to uncuver; expose to vlew or to know ledge, as something hilden (11 a sccret of ming kind.in a gale of winl. $=$ Syn. See mere.

bareI (bãr), $v$. t.; pret. and $1 \mathrm{p}$. bared, ppr. buring. [SME. baren, <AS. burian (in comp. äburiun), also beriun (= OIIG. barin = Icel. ber' $($ ), make bare, < bur, bare: see lure $1, a$.]
1. To make bare; uneover; divest of covering: as, to bure one's head or one's breast.

IIe bared an ancient ank of all her loughs. Inytron That ary wretehed life of seemed to bare

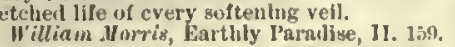

2. 'To diseloso; make manifest; lay bare: as, to barc the secrets of the grave. [Xreliaie.] bare 2 (bĩr). Old preterit of bea $i^{1}$.

Barea (bā'rề-l̨i), n. pl. [Gr., neut. pl. of Bapis, $\beta$ apéa, heavy.] An Aristotclian group of birls, correspouding to the Isinnean Gallinc,

bareback (bĩ'bak), a. and atr. I. a. Using or performing on a barebaeked lorse: as, a barcback rider.

II. ade. On a barebacked horse: ar, to risle barcback.

barebacked (bãr'bakt), $a$. IIaving the luek uneovered; unsaddled, as a lor'se.

barebind, $n$. See bearline.

barebone (bãr'bōn), 1 . A very lean jerson. [Rare.]

Here cuntes lean Jack, there comes bare-bone. IV., il. A.

bareboned (bãr'bōncl), a. Having tho bones bare or scantily eovered with flesh; so lean that the borres show their forms.

lint now that fair fresh mirror, dim and old,

Shows me a bareboned death by time outworin.
Shak., Lucrece, I. 1761.

barefaced (bãr'fāst), a. 1. With the fnee uncovered; not masked.

Then you will play barefaced. Shak, 3. X. D., 1. 2 2. Undisguised; unreserved; without eoneeal[Obsolete or archaic in this use.]

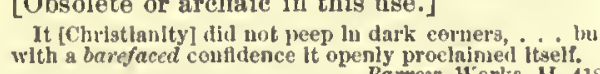

3. Undisguised or open, in a bad sense; henee shameless; impudent; audaeious: as, a barefaced falsehood.

See the barefaced vlllaln, how he cheats, lies, perjures
robs, murders! A wretch, ... guilty of . berefaced inconstancy.

barefacedly (bãr'fäst-li), adv. In a barefaeed manner; without disguise or reserve; openly; mauner; witbout disguise
shamelessly; impudently.

Some profitgate wretehes own it too barefacedly. Lack

Barefacelly unjust. Carlyle, Fred, the Gt., IV. xii. II.

barefacedness (bãr'fāst-nes), n. 1. Openness. barefit (bãr'fit), $a$. Barefoot or barefooted. barefit (bär

barefoot (bãr'füt), a, and ade. [< ME. bare fote, barfot, < AS. burfot $(=$ OFries. berföt $=$
D. burrevoct $=$ Leel. berfattr $),<$ bur, bare, + fót, foot.] I. a. Having the feet bare; without shoes and stoekings.

Going to find s barefoot brother out,

Shak., R. Bnd J., v. Blessings on thee, little msu,
Barefoot boy, wlth cheek of tan!

II. adt. With tho feet bare. ter, Bareloot Boy.

must dance barefoot.

Shak., T, of the S., ii. 1.

barefooted (bãr'füt-ed), a. [<barefoot $+-c d^{1}$. $]$ Having the feet bare. - Barefooted Augustinians. See Alugustinion. - Barefooted Carmelites.

barege (ba-rāzh'), n. [< F. barègc, so called from Buregcs, a watering-plaee in the Pyrenees. See def.] A thin gauze-like fabric for women's dresses, usually made of silk and worsted, but, in the inferior sorts, with cotton in plaee of silk. In reality bareges were never made in the village irom being at lagneres-de-Bigore in the Pyrenees. (sec bricge), the springs of which yield the sub- stance, $\left.+-i n^{2}\right]$ A transparent, gelatinous algo growing in thermal sulylinr-springs, to whieh they impart the flavor and odor of lleslbroth. IBaregin is Itself odorless and tasteless. It contalns, when dry, from 30 to 80 per cent. of minerul matler from $y$ ti 12 per cent. of nitrogels.

bare-gnawn (bũr'11âsı), đ. Cinawed or t"ateı bare. Shak., Lear, v. 3

barehanded (bãr' lası "ded), ". 1. With nu covered hands. -2 . Destitute of menns; will no aid but one's owu hands: as, le begun life barchoniled.

bareheaded (bãr'led"ed), $a$. IInving the lest meovered, espeeially as a token of respeet.

first, you shall swear never to uame my lord, Fletcher (and another"), (queun of Corinth, iv. 1. Din belug flrst lromght before the court, Riuley stomil bareheadedness (bũr'hed" ed-nes), n. The state of being barelreaded.

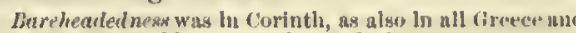
liouse, a token of honour and auperiority.

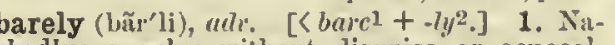
kedly; openly; without disguise or coneeal. ment,-2. Seantily; poorly: as, a man barely elad, or a room barcly furnished.-3. Only just; 110 more than; with nothing over or to just; 10 more than; with nothin
spare: $1 \mathrm{~s}$, she is burly sixteen.

In prying lis dehts a man lutrely does lits duty.

Goldomith, The jec, No. 3. Fox himself burely succeedel in retalning lils seat lor 4. Merely; only. [Arehaic.]

It la not barely a man's abridgment in his external ne baremant (bãr'man), n. [Se., also bairman; bare $1+$ man.] A bankrupt. [Seoteh.] bareness (bã r'nes), $n$. The state of being bare. (a) Want or deffeiency of elothing or covering ; laked uess, (b) Defleleney of appropriate covering, equlpment
furniture, ornament, etc.: as, "old Decenber" bereness, lurniture, ormament,
Shak., Sonnets, xcvil.

\section{To make old barenesg pleturesune,
And tuft witl grass a feuthl tower.}

Tennyson, In Jlemorlan, exxull.

(c) Leanness. [Rure.] (d) Poverty; intigence.

Stript of . Its Priveleges, and made like the prinitive
Chourch, Sor its Barenean. bare-picked (bãr'pikt), $a$. Picked bare; stripped of all flesh, as a bone.

The brere-picked bone of majesty. Shak., K. Julu, Iv.

bare-pump (bãr'pump), n. A pump for drawing liquor from a eask: used in vinegar-works, ealled bar-pump.

bare-ribbed (bãr'ribd), $u$. With bare ribs like a skeletou: as, "bare-ribbed death," Shak., K. John, v. 2

bares, $n$. Plural of baris,

baresark (bãr'särk), $\mu$. [く barel + sark; a lit. translation of berserker, Ieel. berserkr; in the supposed sense of 'bare shirt'; but se berserker.] A berserk or berserker.

Many of Harold' brothers in arms fell, and on his own ship every man before the must, except hils band of Bar
sarks, was elther wounded or slaln. baresark (bãr'särk), adv. In a shirt only without armor.

I will go baresark to-morrow to the war. aresthesiometer (bar-es-thē-si-om'e-tèr), n.

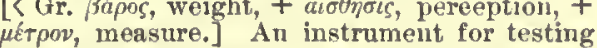
the sense of pressure. Also spelled barcsthesiometer.

baret, $n$. See barret ${ }^{2}$

bare-worn (bãr'wōrn), a. Worn bare; naked: as, "the bare-1eorn common," Goldsmith, Des. Vil.

(bärf), n. Same as borgh.

bar-fee (bär'fê), $n$. In English lav, a fee of 20 pence, which every prisoner acquitted (at the bar-fish (bär'fish), $n$. Same as calico-bass.

bar-frame (bär'främ), $n$. The frame supporting the ends of the grate-bars in furnaces.
barful (bür'ful), a. [<barl $+-f u l$.$] Full$ obstruetions or impediments. [Rare.]

I'tl do my best
To weo yeur lady : [A side] yet, s brerful strife hita wife. Shak., T. X., 1.4.

bargain (bär'gän), n. [< ME. bargain, bargayne, bargeyn, bargen, etc., $<\mathrm{OF}$. bargainc,
bargaigne = Pr. barganh, barganha = Pg. bar-
! $a n h a=\mathrm{It}$. bargugna (Pr. also barganl = It. bargagno), < ML. "burcania, "bareanium, a bargain, traftic; cef. betrgnin, 1'. Origin unkuown supposed by Diez and others to be from $11 \mathrm{~L}$ burcu, a boat, bark, or barge, but evideneo is wanting.] 1t. The act of discussing the terms of a proposed agreement; barguining. jll give thrice sommeh lu

To any well-oleservlng frlenl

lint in the way of bergatin, mark ye me,

Shak., I Ilen. IV., III, t.

2f. A eontention or eontest for the mastery or ipler lıand; a struggle.

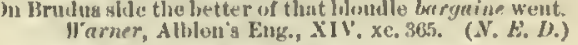
3. A contract or an agreement between two or more parties; a compact settling that somothing sliall be doue; specifieally, a contraet by whieh one party binds himself to transfer the right to some property for a eonsiderntion, and the other party binds himself to reeeive tho property and puy the considerution.

$$
\text { 'To clap this royal bergain uy, of peace. }
$$

Rive Int if you do relnse to marry me,

Souli glve yomirself to thls most faithilul ghepheril ?

'he. So th the bargain. Shak., As youl Like it, v. t.

"Our fathers," sald one orator, "sold thelr klng fur sunthern gold, unt we still lie uniler the reproach of that
Jacaulay, Jilst. Fong., vi. 4. The outeome of an agreement as regards one of the parties; that which is accuired by bargaining; the thing purehased or stipulated for: as, look at ny barguin; a bad baryain; " a losing baryain," Junius, Letters, $v$

she was toos fond of her most fllthy bargain.

5. Something bought or sold at a low price; an advantageous purchase.

If you have a taste for palntligg, egad, you shull haves
em a bargain. Bargain and sale, or, more fully, deed of hargain aml conveyance of land: so ealled because it Is expressed as 4 sale for a pecunlary censideratlons agreed on, belng thus
distingulshed on the one hand from a tuitclalm, which is a relcase, and on the otlier hand from the old conveyance gain, a bargsin sealed by the partles drinking over it.Into the bargain

Faith, Cliarleg, thlis is the most convenient thlng you conld have found for the business, for twill serv

To beat a bargain to barraln ; hache bargain. to buy cheaply. - To buy the bargain deart. to pay dearly for $\mathrm{a}$ thing.- To make the best of a bad bargain, to do the best one cant in untoward clrcunt.

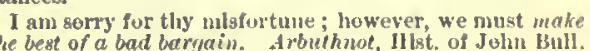
To sell a bargaint, to entrap one hito asking innocent questions, so as to give

The bey hath sold hlm a kargain. Shak., L. L. L., ili. 1. I see hin ogle still, and hear hlm chat Selling facetious bargains, and propoundling

Dryden, Prol. to Prophetess, 1.40.
. No mald at coult is less aslanid.

To strike a Swift. or an agreement, originally by ztriking or shaking bands. bargain (bür'gān), r. [CME. bargainen, bargaynen, etc. $<\mathrm{OF}$ burgaigner $(\mathrm{F}$. barquiquer $)=\mathrm{Pr}$. $\mathrm{Pg}$. baryanhar = 1t. bargagnore, $<\mathrm{ML}$. barcanave, traffie, trade, <"barcania, traffie: see the oun.] I. intruns. 1. To treat about a transaction; make terms.

The thrity atate will baryain ere they flglit. Dryden. 2. To come to or make an agreement; stipuate; make or strike a bargain: with a person. for an objeet: as, he bargained with the proeers for a daily supply.

So worthless peasants brirgain for their' wlves

I allglited, and haviug bargained with nyy hoat for 20 cownea a moneth, I caused a gool flre to be made in my
Evelym, Diary, Nov. 4,1644 .

II. trans. 1. To arrange beforehand by negotiation and agreement.

$$
\begin{aligned}
& \text { "Tls bargainid } \\
& \text { That she shall }
\end{aligned}
$$
Shak in company.

$2 \nmid$. To agree to buy or sell. - To bargaln away, to part with or lose as the reault of a bargain.

The helr . . . had somehow bargained a way the estate.
George Eliot, Felix Holt, Int.

bargain-chop (bär'gạ̄n-chop), $n$. A kind of gambling "option" on opium to arrive, formerly common among foreign traders in China. 
bargainee

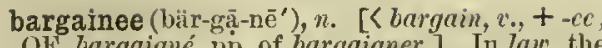
party to party ton.

bargainer (bär'gān-èr), n. [ME. barganar <bargaill, $v_{0}+$-er1.] $^{-1}$ One who bargains or stipulates; speeifically, in luw, the party in a contract who stipulates to sell and convey property to anser sense also spelled bargainor.

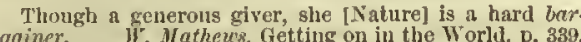
bargainman (bär'gān-man), n.; pl. bargainmen (-men). In coal-mining, a man who does bar(-men). In coal-mining, a
gail-work. [North. Eng.]

bargainor (bär' gạnn-ọ), n. In lax, same as bargainer.

bargain-work (bär'gạ̄n-wèrk), $n$. In coal-mining, any underground work done by contract. [North. Eng.]

bargander (bär'gan-dèr), $n$. A local (Norfolk, England) form of bergander.

bargarett, $u_{\text {. A }}$ a variant of bergeret.

barge ${ }^{1}$ (bärj), n. [< ME. barge, < OF. bargc (ML. reflex bargia) = Pr. barga, < ML. barga, appar. a var. of LI. barca, a ba

His barge ycleped was the IIaudeleyne.

Chaucer, Gen. Prol. to C. T., 1. 410.

2. A flat-bottomed vessel of burden used in loading and unloading ships, and, on river's and canals, for

By the margin, wlllow-veil'd,
slide the heavy barges trail'd

By slow horses. Tennyson, Lady of Shalott. 3. A long, double-banked beat, spacious and of elegant construction, for the use of flagofficers of ships of war. - 4. A practice-boat monlya long, narrow, lap-streak boat, somewhat wider and stronger than a shell, and thus better fitted for rough water. [U. S.] -5 . A boat for passengers or freight, two-decked, but without sails or power, and in service towed by a steam boat or tug: used for pleasure-exeursions and for the transportation of hay and other bulky merchandise. [U. S.] - 6. A pleasure-boat;

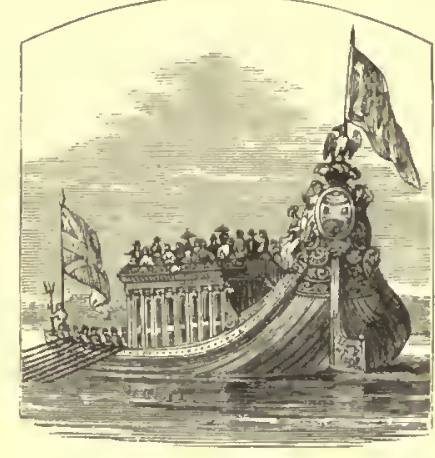

State Barge. apartments, canopied and cushioned, decorated slate which is exposed to the weather. Weale. apartments, eanopied and cushioned, decorated slate which is exposed to the weather. Weale.
with banners and draperies, and propelled by Barí2 (bä'rē), $n$. [It.] A wine grown near Bari, a numerous body of oarsmen: used by soverpageants, as the marriage of the Adriatio at Venice and the Lord Mayor's parade at London.

The barge she sat in, like a burnish'd throne,

7. In New England, a large wagon, coach, omnibus for carrying pienic parties or conveying passengers to and from hotels, etc.

Marcia watched him drive off toward the station in the
hotel Large.

barge $^{1}$ (bärj), $v$. t.; pret. and pp. barged, ppr. barging. [<barge $1, n$.] To cal'ry or transport barge ${ }^{2}$ (bärzh), $n$. [F.] A book-name of the godwit.

barge-board (bärj'bōrd), n. [Hardly, as has been suggested, a corruption of verge-board, gallows.] In arch. Cf. ML. bargus, a kind of vance of a gable and underneath the bargecourse, where the reof extends over the wall, either covering the rafter that would otherwise be visible, or occupying its place. The earliest barce-boards date from the fourteenth century; many
452

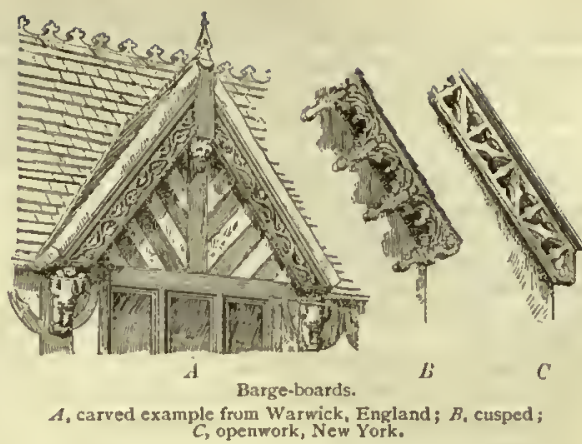

decorated, being cusped, Ienthered, paneled, pierced with After the medieval period barge-boards gradually becone. barge-couple (bärj'kup"1), . [Cf. barge-board.] In arch. one of tho rafters placed under the barge-course, which serve as grounds for the barge-boards, and carry the plastering or
bearding of the soffits. Also called barge-rafter. barge-course (bärj'kōrs), n. [Cf. barge-board.] projects beyond the principal rafters in buildings where there is a gable. (b) The coping of bargee (bär-jēé $), n$. [< barge $\left.e^{1}+e c.\right]$ One of

argeman (bärj man), $n_{.}$; pl. bargemen (-men). an employed on a barge; an oarsman.

Spenser, F. Q., VII. vii. 35.
S.

barge-master (bärj'mảs"tèr), $n$. The master or owtler of a barge conveying goods for hi
barger (bür'jer), n. A bargeman. [Rare.]

The Londou bargers. R. Careve, Sirvey of Cornwall. barge-rafter (bärj'råf"tér), $n$. Same as bargcbargerett, $n$. See bcrgeret.

bargh (bärf), n. [E. dial., also written barf, row 1 , of which bargh is a dial. form: see bar row ${ }^{1}$.] 1. A low ridge or hill.-2 - A road up
a hill. Ray.-3†. A mine. [Prov. Eng. in all barghmotet, $n$. See barmote.

bar-gown (bïr'goun), n. The gown or dress of a lawyer.

barguest (bär'gest), n. [Also barghest, bargest, Sc. barghaist; perhaps < G. berggeist, mountain (or mine) spirit, gnome. Cf. barghmote, barmotc. Ritson says the ghost was so called from appearing near bars or stiles.] A kind of hobgoblin, slirit, or ghost beileved in in the one is supposed to prognosticate death or some great calamity.

II understood Greek, Latin, and IIebrew, and therefore, according to lis brother Wilfrld, needed not to care
for ghaist or bar-ghaikt, devil or dohbie. barhal (bär'hal), $n$. [E. Ind.] Same as burrhel. The barhal, or blue wild sheep [inhabits the llimals on the Adriatic coast of ltaly.

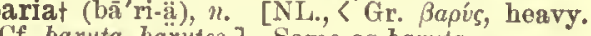
Cr. baryta, barytes.] Same as baryta.

aric (bar'ik), a. [In sense 1, < Gr. Bápos, weight, Same as barametric. -2. Of or pertaining to barium; derived from barium: as, baric iodide barilla (ba-ril'ä), n. [= $\mathbf{F}$. barille, $<$ Sp. barril$l a=$ Pg. barritha, impure soda, also the plant from which it is derived.] The commercial name of the impure carbonate and sulphate of soda imported from Spain and the Levant, and obtained from several fleshy plants growing by the sea or in saline localities, mostly belonging to the chenopodiaceous genera Salsola, Salicornia, and Chenopodium. The plants are dried and burned, sud the incinerated ashea constitute bsrilla. This was once the chief aource of carbonate of soda, but is now
used principally in the manufacture of soap and class. used principally in the manufacture of soap and glass.
British barilla is the crude aods-ash left trom common galt in the manufacture of carbonste of soda.

barillet (bar'i-let), n. [F., dim. of baril, a barrel.]. 1. The barrel or ease containing the mainspring of a wateh or spring-elock.-2. The funnel of a sucking-pump.

baring (bãr'ing), $n$. [Verbal $\mathrm{n}$. of barel, v.] In bricklaying: (a) A part of the tiling which bark

been removed for the purpose of getting at the underlying rock.

bar-iron (bär'ì"èrn), n. Wrought-iron rolled into the form of bars. See iron.

baris (bar'is), $\pi_{0}$; pl. bares (-ēz). [<Gr. Bãpes a boat: see bark 3.$]$ 1. In Emypt. antiq.: $(a)$ A flat-bottomed j 1 . In Lypt. antiq.: (a) A frat-bottomed boat, used for transporting term for the Egyptian makhen. (b) The sacred

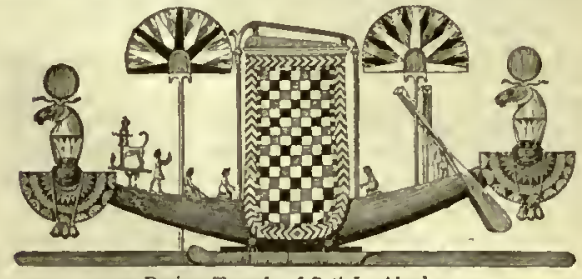

Baris.-Temple of Seti I., Abydos

boat, represented in art as bearing an enthroned deity or some symbolical or venerated object. -2. [cap.] [NL.] A genus of rhynchophorous beetles, of the family Curculionido, or weevils. B. lignarius feeds upon the elm.

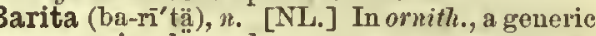
name variously used. (a) In Cuvier's system of classification (1817), a genus of ahrikes or Laniida: a syuonym of Cracticus (Vjeillot), of prior date. [Disused.] (b) Trans. ferred by Temminck in 1820 to the Australian and Papusn manucodes. See Manucodia. [Disused.1 (c) Transferred
by Swainson in 1837 to, and used by Vigors and others Ior, the Australisn and Papuan cassieans, or corvine birds o the moderu genera Gymnorhina and Strepera, of which the piping-crow of Australia (Gymnorhina or Barita of the word, and the above-noted trausfers of the name account for the common statemcut that the genus Barita is sometimes classed with the
the Corvida. [Not now in nse.]

baritah (ba-ri $\bar{n}^{-1}$ ), n. A name of the Australian birds of the genus Barita.

barite (bā'rit), n. $\left[\left\langle\operatorname{bar}(i u m)+-i t e^{2}\right.\right.$. $]$ Native barium sulphate: also ealled barytes and heavyspar, because of its high specifie gravity. It oc. curs in orthorhombic cryatals, commonly tabular, and transparent, and varies in color from white to yellow, gray, red, blue, or brown. There are also massive varietiea, columusr, granular, snd compact, rcsembling marble. It is a common mineral in metallic veint and beds. It is terito Also betente, barytine.

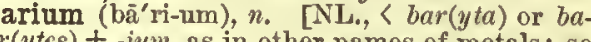
$r(y$ tes $)+-i u m$, as in other names of metals; so named by Davy.] Chemical symbol, $\mathrm{Ba}$; atomic weight, 137.1. A chemical element belonging to the group of metals whose oxids are the alkaline earths. It is oblained as a ailver.white powder, melting-point is about that of cast-iron. It does not occur native, but is found abundantly in combinatlon in the minerals barite, barium aulphate, and witherite or barium carbonate, and less conmonly in several other min-
erals. Barium combines with most geids to form salts whlch are more or less aoluble in water, sud these soluble salts, together with the carbonate, are active poisons.formed by precipitating any solubie salt of barinm with chromate of potasaium. It finds a linited use as a plgnent both for painting and for calico-printing, under

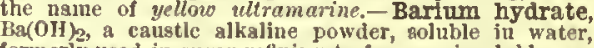
formerly used in sugar-lefining to form an ingoluble saccharine componnd.- - Barium nitrate, $\mathrm{Ba}\left(\mathrm{NO}_{3}\right)_{2}$, a subfre, anl to extengively in pyrotechny for producing red - Barlum oxdd. See baryta.-Barlum sulphate, or heavy-spar, Baso $_{4}$, the commonest of the barjum minerals. almost perfectly insoluble in water. Artifcially prepared harium aulphate to used as a pigment, under the nante of bark 1 (bärk), v. [< ME. barken, berken, borken, AS. beorcan (strong verb, pp. borcen, > borcian, bark, weak verb) = Icel. berkja (weak verb), bark, bluster. Supposed by some to be orig. another form of AS. brecan (pp. bracen), break, snap. Cf. Icel. brakta, bleat, = Norw. brakta, brcka $=$ Sw. bräka = Dan. braegc, bleat.] I. intrans. 1. To utter an abrupt explosive cry: said of a dog, and hence of other animals.

No dog shall rouse thee, though a thousand bark.
Shak., Venus and Adonis, 1. 240

2. Figuratively, to clamor; pursue with unreasonable clamor or reproach: usually followed by at.

Vile is the vengeaunce on the ashes cold, Spenser, F. Q., II. vili. 13.

The lank hungry belly barks for food. 3. To cough. [Colloq.]-To bark at the moon, to clamor or agitate to no purpose.-To bark up the wrong tree, to nistake one's object; attack or pursue
another than the person or thing intended, as wlien a dog 


\section{bark}

ly barking brings the lunter to a tree other than that in II truns, 1. To utter or give fortl with.] bark. -2 . Te break out with: as, to barl: out flawe.

bark $^{1}$ (biirk), n. [<bark-1, v.] The abrupt explosivo cry of a dog; hence, o ery resembling thut of the dog, uttered by some other animals. -His bark is worse than his bite, little jarm is por. teuted by his angry threats, finitinding, ete., as iny ti

bark ${ }^{2}$ (bärk), n. [< MF. barlie, bark, burc, < late AS bare< <el bionlor (en barl.ar) $=$ Sw bark $=$ Dan. burk = M1,G. LG. borke (> G. borke), bark. Possibly connector with Ieel. bjarga = AS. beorgan = G. bergen, ete, eover, proteet: see burys. The older E. Worl for 'bark' is rind.] 1. Generally, the eovering of the woody stems, branehes, aud roots of plants, as distinet and separable from the wood itself. In its strictest
acientiflc sense it is limiled to the dry and dead portion of inis covering, ns fonnd on exogenons piants, which nstaily consists of psrenchyma or soft celluhar tissue, cork, mul bast, in varying proportions. See baxt 1 , corkl, and
ppidermis. It is very diverse and often complieated lin strncture, varying in these respects with the species upoul
which it is foind; but it is usualty srranged in annular concentric layers. As these become distended by the thickening of the stem, the onter litycrs often crack and ure graduaiiy cast off. In the bark the medicinnl and other peenllar propertiea of the plant are nsislly alun. dant, especinlly tamnin and many alksloids. The younger inner bark, liter, or bast. See cilt nnier bast.

2. Specifieally - (a) In phar., Peruvian or Jesuits' bark (see Cinchona). (b) In tanning, oak and hemloek barks. - Alstonia bark, a bitter bark obtained from tile Alstomia echolaris, an apocyna-
ceous ferest-tre of the trepics of the old wordd. It ig ised in India as a tonic and antiperiodic. The Alatonia or stonia constricta.- Angostura or Cusparia bark, the product of a rutaceous shrub, Galipea Cusparia, of tite dysentery, and chronic dian'hea. It was formerly prized as a febrifuge, and is new nuch used in making on kind of bitters. Its uae in medicine was discontinued for a Inlse Angesturn bsrk, obtained from the nux-vonica tre

which produced fatal effects. Alse Angnestura bark.Arlca bark. Same as Cuscn bark. - Ashy crown bark, bark. See bebeeru.-Bitter bark. See Georgia bark.bark. Sce boldo.-Bollvian or calisaya bark, the bark of Cinchona Catisaya. - Canella bark See Canella1.Carabay a bark, the bark of Cinchona elliptica. - Carib-
bean or West Indian bark, the bark of a rubinccous tree, Hxostemma Caribbeum, nearly sllied to the genns as a substitute for cincinous bark.-Carolina bark. See Georgia bark, - Carthagena bark, a general name for of Seutin America, generslly of inferior quality. - Cascara amarga or Honduras bark, a bitter bnrk, said to be obtained from /icramnia antidesma, a sinstrubsceous tree

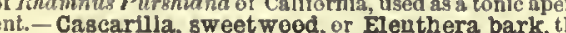
bark of ('roton bileuteria, arood, or Elenthera bark, the hnmas. It is an aromatic, bitter tonic. Cassta bark. Sce Cassia. China bark, Peruylan bark, (a) See Cin-
chmm. (b) The bark of Coscarilla (Buezu) hexandra, rubiaceons tree of the western coast of Soltit America, Which is useci ss a substitute for cinchons. -Clove-bark.
Same as clove-cassia (which see, under cassic).-Colombian bark, the bark ol Cinchona pitayensis, C. laneifolia, Holarrhent antidysenterica, nn arborescent composite of Indik, where it is of considerable repute as a remedy for Tellicherry brrk, - Coquetta bark, the hark of Cinchona wancifolin.-Crown bark Same as loxa bark.-Cullia-
wan bark, a valuable aromatic, pungent bark, the pro-
duce of Cinnamomum or Laurus Cutiluwan, a tree of the Mieluccas, uscful in indigestion, disrrher, etc. Sometimes several specles of the rubrea bark, a bark obtained from cal South Arverica, largely imported into Fingland for the manufacture of quinine. Cusco bark, the bark of Cin-
choma pubescers, variant Pelleteriana. Also called Arica bark.-Cusparia bark See Angostura bark.-Doom bark, the bark of Erythrophlaum Guineense.-Dounwest coast of Africa, possessing tonic, febrifugsl, and other medicinal proporties. The best-known kind is the pro. Elenthera bark. See cascrilla bark. - Elk bark, the Essential salt of bark, an aqueous extract of clnchon Essential aalt of bark, an aqueous extract of clnchens
hark. - False loxa bark, the bark of Cinchona IIum Guiana - Florida bark See Georgin bark. - Freneh a rubiaceons tree of tropical South Ameriea, having feb. thngena baik, - Georgia, bitter, Carolina, or Florida ceoua tree of the southern Unitel Statea, having the same
properties as French Guiana bark. - Honduras bark. properties as French Guiann bark. - Honduras bark. of Cinchone prerpurea. - Indian barberry bark, the as a tonic and in the treatnient of fevers, diarrhea, ete. Indian bark, the bark of Mragnotia glauca. Alao called Jamalca bark, the lork of Cinchond II umboldtiana.Jits' bark, l'eruvian bark. - Jesuits' Bark Act, an
453

Finglish atatute of 1808 forbiduling the exportation of the bark of Cinchour l'erviviaun, $C$, nitida, and C. mi cranthn. - Loxa bark, the bark of Cinchonir oficiunlis. Also called crown bark. - Malambo bark, an nromntic

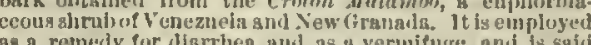
as a remedy for diarrhen and as $t$ vermifuyce, nnif is saif ation of splices.- Mancona bark, the bark of H'ryllirophlarum Guinenue. Maracalbo bark, the hark of CinMelia Indica, useci in lndia as a tomic and sntiperiudic. - Mezereon bark, this bark of Diphne Atezereum. It is eiy in yenerest, - Neem bark, the bark of Azrderacher Indica. - New bark the bark of Cascarill c oblongifolia. - Nim bark,

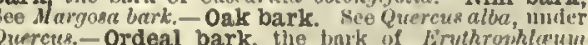
Quercus.-Ordeal bark, the brik of Frythrophla'um Cinchona ofpcinalis, C. nitida, C. mucrentha, C. merpuerea, choma macrocaly $x$, variant, J'alton. - Peruvian bark. See china bark. - Pitaya bark, the bark of Cinchana pitayensis. - Quebracho bark, the hark of Aspidosperma Qne. bracho, an apocynsceons tree of Brazil. It contains several of dyspnea.- Red bark, the bark of Cinchonc succinibro. Rohun bark, a bitter astringent luark, from Soymula febr ngr, a nelinceons tree of India, where it is used as an as of Cinchona cordifolia. - St. Lucla bark, the burk of Exastemma furibumda. - Samadera bark, the imner bark of a iree belonging to the Simarnbacex, growing in Ceyion. It is intedscly bitter.-Santa Ana bark, the hark of Cinbark slipped from Santa Minrtha. - Sassy bark, tîe bark

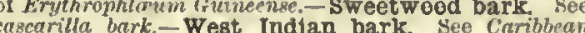
bark. - Wild-eherry bark, the hark of Prenens Virginiana.- Winter's bark, an astringeut pungent, bark ob
tnined from a niggneliaceons tree, Drinys If interi, nativ of the mountains of western Anerica from Mexico to Cape liern. It is a stinulating tonic and antiscerbuilic demiron corticosum and Canella abbe of the Wes: Indies ark $^{2}$ (bärk), $r . t . \quad[=$ Sw. bark $a=$ Dan. barke tan ; from the noun.] 1. To strip off the bark of, or remeve a cirele of bark from, as a tree; peel; specifieally, to scrape off the outer or
dead bark of. See barking ${ }^{2}, 1$.

$$
\text { That overtopp't titen alit. }
$$

Hence-2. To strip or rub of the outer eov. ering of (anything, as the skin): as, to bark

So after getting np [the tree] threc or lour fcet, down 3. To eover or inelose with bark: as, to bark house. - 4t. To eover, as the bark does house. -4 t.

A most instant tetter bark'd ahout,
Most lazar.jike, with vite and losthsome crust,

5. To apply bark to, as in the proeess of tanning; tan. - 6. To eolor with an infusion or -7. To kill (game) by the coneussion of bullet whieh strikes the bark of a limb at the the flying bark. Barking off squirrels is a delightinl sport, and in my
opinion requires a greater degree of sccuracy than sny
other. I flrst witnessed this near Hrankfort. The performer was the celebrated Daniel Boone. bark $^{3}$ (bärk), n. [Also barque, after $\mathbf{F}$. ME. barkc, barque, $<\mathrm{F}$. barque $=$ Pr. Sp. Pg. It bark = Teel. barki, 〈LL.barca (ML. also barga, $>\mathrm{OF}$. barge, > E. barge $e^{1}$ q. v.), regarded by some as a syneopated form of au assumed LI. *barica, a quasi-adj. formation, < L. baris, Gr. $\beta \bar{a} \rho \imath s,<$ Egypt. (Coptie) bari, a flat-bottomed
beat used in Egypt; but more prob. of Celtie or even of Teut. origin.] 1. Naut., a threemasted vessel, fore-and-aft rigged on the mizzenmast, the other two masts being square-
rigged.-2. A vessel of any kind, espeeially rigged.-2. A vessel of an

0 ateer my bark to Erin's ial

barkantine, barkentine (bär'kan-tēn, -kentên), n. [ [ bark ${ }^{3}$, on type of brigantine 1.$]$ three-masted vessel, with the foremast aquare rigged, and the mainmast and mizzenmast fore bark-bed (bärk'bed), $n$. In hort, a bed formed of the spent bark that has been used by tanners. The luark is placed in $a$ lrick pit in a glazed liouse Artiffeial warmth and dampness gre produced by the termentation of the bark. Also called bark-stove. growth by having the bark too firm or elose.

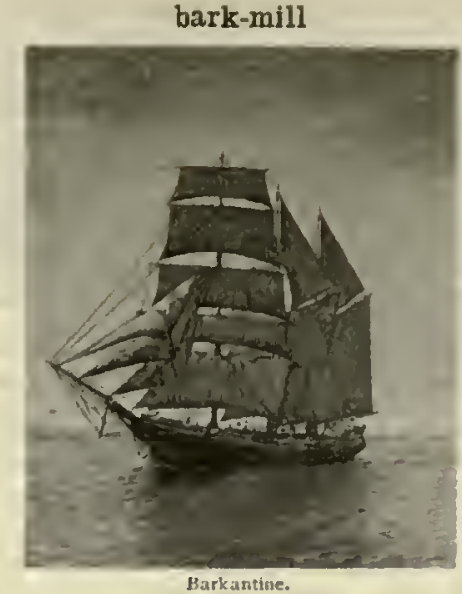

barkeeper (bär'kē"pèr), $n$. One wlıo has charge of the bar of an inn or other place of public entertaimment; a bartendel.

arken' (bär'ken or-kn), v. [Se.; $\left\langle b a r k^{2}+-e n I\right.$, as in harlen, stifjen, etc.] I. intrans. To beeome lart; form a crust.

The best way's to let the liood barken on the cut-

II. trans. To tan (or dye) with bark.

Fille used to iro]p me tumble the bundies o barkened barken ${ }^{2}$ (bär'ken or -kn), a. [< bark' + cen'2] Consisting or made of bark: as," "barken knots," Whittier. [Rare.]

barkentine, $n$. See barkantine.

barker ${ }^{I}$ (bür'kèr), n. [<barkI, v., + erl.] 1. An animal tluat barks; a person whe elamors unreasonably.

They are ratier encmies of my fmue than me, theae
B. Jonson, Discoveries. 2. The spotted redshank, Totanus fuscus. Albill; Montagu. [Prov. Eng.] - 3. A person stationed at the door of a bouse wliere anctions of inferior goods are held, to invite strangers to enter; a touter; a tout. [Cant.] -4. A pistol. [Slang.]-5. A lower-deek gun in a ship.

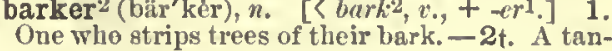

Barker's mill. See mill1.

barkery (bär'kèr-i), $n$; pl. barkcries (-iz). [s

bark is kept.
bark-feeder (bärk'fē" lèr), n. A bark-eating insect or animal.

barking ${ }^{1}$ (bär'king), $n$. [Verbal n. of bar $h^{\cdot 1}, r$.] The uttering of an abrupt explosive ery, as that of a dog.

barking ${ }^{2}$ (bär'king), $n$. [Verbal n. of bark2, $v$.] 1. proeess of stripping bark from trees, of kill it, or of seraping dead bark from fruit-tree to promote their growth. -2 . The operation of tanning leather with bark; also, the operation of dyeing fabries with an infusion of bark. arking-ax (biir'king-aks), ". An ax used in barking-bill (bär'king-bil), n. A sharp-pointed instrument used to make transverse cuts proeess of stripping them. ppr. of bark. + bird $l^{1}$.] The name of a rockwren, Pteroptochus or Hylactes tormi, of the island of Chiløë: also said to be applied to anther and smaller speeies, $r$. rubecula. The name is ane, in either ease, to the slinilarity of the cry of the
birds to the yelping of a puppy. Darin. Also called

barking-iron ${ }^{1}$ (biir'king-i"èrn), n. [< barking, ppr. of burk

barking-iron ${ }^{2}$ (bür'king-ī"èrn), $n$. [<barking ${ }^{2}$ + iron.] An instrument for removing the bark barking-mallet (bär'king-mal"et) $n$. ner with a wedge-shaped edge, used in barking trees.

arklak (bär'klak), n. A myrtaceous tree of barkless (bärk'les), a. [<bark'2+-less.] Destitute of bark.

bark-louse (biirk'lous), $n$. A minute inseet of the genus $A$ phis that infests trees; an aphid. bark einal purposes. 
barkometer (bär-kom'e-tèr), $n$. [Irreg. 〈bark'2 barley-bree, barley-broo (bär'li-brē, -brö), $n$. barm-clothł, $n$. An apron. Chaucer.

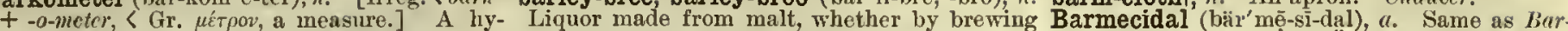

drometer used by tanner's in ascertaining the or distillation; ale or whisky. [Seoteh.] strength of infusions of bark, or ooze.

by boiling barley and meat with vegetables. [Ścotch.]-2. Ale or beer: used jocosely, and also in contempt, as in the extract.

A drench for sur-rein'l jndes, their barley broth, Decoct their colli blood to atuch valiant heat? or Broussonctia papyrifera, a tree common southeastern Asia and Oceanica. Most of the paper used in Japan is of this kind.

bark-pit (birk'pit), n. A tan-pit, or pit for (

barkstone (bärk'stōn), $n$. The concrete musky beaver; castor; castorcum

bark-stove (bürk'stōv), $n$. Same as bark-bed. bark-tanned (bärk'tand), $a$. Tanned by the slow action of oak, hemlock, or other barks, wholly or in part by ehemicals.

barky (bär'ki), a. [<bark $+-y^{1}$.] Consisting of bark; containing bark; covered with bark.

The barky fingera of tile eim. Shak., M. N. D., iv. 1.

bar-lathe (bär'lämH), $n$. A lathe with a single beam, usually having a triangular section, on which the beads or puppets slide.

barley ${ }^{\prime}$ (bär'li), n. [Early mod. E. also barly, barlye, sc. barlick; < ME. barly, berley, barlich, < late AS. barlic, barley, appar. < bere, $\mathrm{E}$. bear', barley, + lic, E. -ly $y^{1}$; the word appears Icel. barlak, and W. barlys, Icel. barlak, and W. barlys,
barley (as if < bara, bread, + llysiau, llysau, plants, herbs), Corn. barliz, are from E.] the plant yielding it, belong ing to the genus Hordeum natural order Gramince Thatis grain order Gas been cultivea. from the very earliest times, when from tormed an important article of
food, as it stilf does where other cerenla cannot be ralsed. It is
jargely employed for feeding ani mala, but its clilef $115 \mathrm{se}$ is in the
manufacture of fermented liguors manufacture of fermented liguors
ag beer, ale, and porter, and
whisky, o whisky, No other grain can be
cultivated throngh so great a rauge of cllmate, for it matures in Lsp.
land, Norway, sud Iceland, in 65 and $70^{\circ}$ north latitude, and at aut
altitude of 11,000 feet in the Andes altitude of 11,000 feet in the Andes
and Himalaya. The only cultivat. eld apecies that las been founc barley, II. distichon, a native of western Aaia, but in cultivation in
prehistoric times, as was also the six-rowed apecies, ar winter borley,
II. hexastichon. of later origin

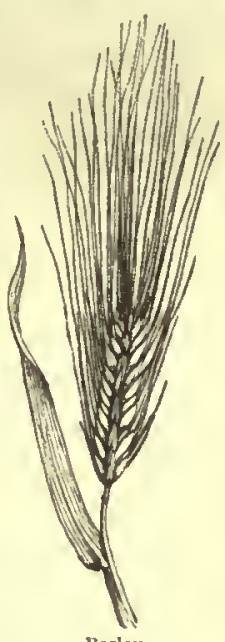

is the common four-rowed apecies,
spring or summer barley, $I I$. rut

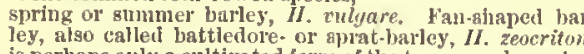

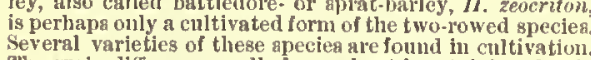
The grain differs generanly from whent in retaining closely its husks; it is also gomewliat less nutritions and palata-
ble as an article of food. See IItordcum.- Caustic bar-
ley ley, an early mame for the seeds of Sehoenocaulon offiei.
nale, called veratrin.- Mouse, wall, way, or wid bariey, Ilor-
deum murinum, $\mathrm{a}$ grass or little val we. - Patent barley, the farlua obtained by grinding pearl-briley. - Pearr-bar-
ley, the grain deprived of hnsk and pellicle and conyletely rounded hy grinding. It is ansed in making broths ant
lu aoupa.-Scotch, pot, or bulled barley, the grain de. barley ${ }^{2}$ (bär'li), n. [A corruption of parley, q. v.] A cry used by children in ecrtain games when a trice

barley-bigg (bär'li-big), n. Same as bigg.
barley-bird (bär'li-berd), \%. [< barlcy ${ }^{1}+$ bird; applied to various birds which appear about the time of sowing barley.] 1. A name of the name of some small bird: said to be either the siskin (Chrysomitris spinus) or the nightingale (Dautins phitomela). [Eng.]

barley-brake, barley-break (bär'li-brāk), $n$. [Se. barley-brneks, barla-brcizis; < barley (unother' source) + break.] An old or from some by six persons, three of each sex, formed into couples. Three contiguous plots of ground were chosen, and one couphe, placed in the middle plot, attempted to
catch the plot was called h hll, whence the alluslond in old plays to
"the last couple in liell." Slie went abroad thereby
At barley-brake lier aweet awift feet to try. Sir P. Sidney, Arcadia, 1 Play at barley-break in my bones. A thousand ague Massinger, Parliament of Love, iv. barleycorn (bär'lj-kôrm), n. 1. A grain of barley. A statute of Edward II. (A. D. 1324) makes 3. A measure equal to the breadth of a fine grain of barley, about 0.155 inch.- John or Sir John Barleycorn, a humorous personliftcation of the antiquity.

$$
\begin{aligned}
& \text { John Barleycom was a hero hold } \\
& \text { of nowle enterprtse, } \\
& \text { For, if you do but taste his blood, } \\
& \text { "Twill make your conrnge rise. }
\end{aligned}
$$

barley-fever (bär'li-fō" vèr), n. [< barley ${ }^{1}$ (as caused by intemperance. [North. Eng.]

barley-fork (bär'li-fôrk), $n$. A hand-fork with a guard at the root of the tines, used for gathering up stalks of barley.

barleyhood (bär'li-húd), $n$. A fit of drunkenness, or of ill humor brought on by drinking. [Cliefly Scotch.]

barley-islandt (bär'li-i"lañd), $n$. An alchouse.

barley-meal (bär'li-mēl), $n$. Meal or flour made from barley.

barley-milkt (bä̈r'li-milk), n. Gruel made with barley or barley-meal.

barley-sick (bär'li-sik), $a$ : [< barley' (see bur ley-fever) + sick.] Intoxicated. [Scoteh.] barley-sugar (bür'li-shùg"èr), $n$. Sugar boiled comes brittle and candied.

barley-water (bär'li-wâ"tèr), n. A decoction of barley used as a demulcent nutritious drink in fevers, and in inflammations of the air-passages and of the alimentary canal.

barley-wine (bär'li-win), $n$. Ale or beer. tened to a heavy window as a convenience in lifting it. a pole, $\left\langle\right.$ biu $a=$ E. bea $v^{1}$, q. v.] A pole. bar-loom (bär'löm), $n$. A ribbon-loom. barmIt, $n$. [ME. baime, barm, berm, benm (ONorth. barm = OS. OFries. OHG. barm $=$ Ieel. bam $=\mathrm{Sw}$. Dan. burm = Goth. bams), the bosoln, with formative $-m,<$ beran, E. bearl, q. v.] The bosom; the lap.

barm² (bairm), n. [< ME. barme, berme, < AS. beorma = Fries. berme, barm = MIG. berm, harm, IG. borme, barme, barm ( $\mathrm{G}$. bärme) $=$ Sw. baima = Dan. besme; prob. alkin to I. fermentum, yeast, < fercue, boil: see ferment, $n$.] The scum or foam rising upon beer or other mait liquors when fermenting; yeast. $1 t$ is used as leaven in iread to make it swell, causing it to hecome
8ofter, lighter, and more delicate. It may he used fin 8ofter, lighter, and more delicate. It may lhe lused
liquors to make them ferment or work. It is a fungus, barm ${ }^{3}$ (bärm), $n$. Samo as berm.

\section{Barmacide, $n$ and $a$. See Barmecide.}

bar-magnet (bär'mag"net), $n$. All artificial steel magnet made in the form of a straiglit and rather slender ba

barmaid (bär'mād), $n$. A maid or woman who attends the bar of an inn or other place of refreshment. barmaster (bär'más"tér), $n$. [Reduced from earlier barghmaster, barge master, prob. < G. bergmeister, a surveyor of mines, $\langle$ beig, a hill, a mine (= E. barroic: see barrow and baryh), + meister $=\mathrm{E}$. master. A number of $\mathbf{E}$. min-
ing terms are of $\mathrm{G}$. origin. Cf. barmote. mining, the title of an officer who acts as manager, agent, and surveyor, representing the interests of the proprieter or 'lord,' and at the same time looking after those of the miner. Also called bailifi, bergmaster, and burghmaster. [Derbyshire, Eng.] Ir. bairigen breac, speckled cake: bairigen, spotted.] A currant-bun. [Anglo-Irish.] of ar "three barley-corns round and dry" the definition of an (formerly in a decoction of barley) till it be-

bar-lift (bär'lift), $n$. A short metal bar fas-

barlingt, n. [North. E. and Sc., < sw. bürling

A barrister.

barmbrack (bärm'brak), 1 . [A corruption of

\section{mecide.}

Barmecide, Barmacide (bär'ınệ-sīd, -ma-sī $n$. and $a$. [< one of the Barmecidre (a Latinized form, with patronymic suffix -ida) or Barmecides, a noble Persian family founded by Barmek or Barmak, and having great powe under the Abbasside califs.] I. $m$. One who offers imaginary food or illusory benefits: in allusion to the story, told in the Arabian Nights, of a member of the Barmecide family of Bagdad, whe on one occasion placed a succession of empty dishes before a beggar, pretending that they contained a sumptuous repast, a fiction which the beggar humoronsly accepted.

II. a. Like, or like the entertainment of, the Barmecide of the story; hence, unreal, sham, illusory, etc.: as, "my Barmecide friend," Thackeray; a Barmecide foast or repast.

It is a Barmecide Feast; a pleasant field for the inagi

barmilian (bär-mil'yạn), n. [Origin unknown.]

An old name for a kind of fustian goods largely exported from England. E. H. Knight.

bar-mining (bär'min'ning), $n$. In placer-mining, the washing of the sand or gravel in the bed of a stream, when laid bare by the diminution of the stream at low water, or by building a flume, and thus carrying the water to one side of the channel. The latter method is more commonly called fluming. [California.]

barmkin (bärm'kin), $n$. [Also spelled barmkyn, barnekin, barnkyn; <ME. barmeken, barnehynch; origin uncertain; possibly < barm ${ }^{3}=$ lerm, brim, border, edge (the forms in barnbeing then corruptions), + -kin; but more prob. all corruptions of barbican.] The rampart or outer fortification of a castle. [Low]and Scoteh and North. Eng.

$$
\text { And broad and bloody roae the sim, }
$$

And on the barmkyn ahone.

Oul ballal, Lord Soulis he aat in Hernita

And he called on a page, who was witty and ange,

And he called on a page, who
To go to the barmkin high.

J. Leyden, Lord Souffa, in X. and Q., 6 th ser., XI. 380. Battlements and barmkins and alf tle oticer appurte-
ances of Strength, as such places were calfed. barmote (bär'mōt), $n$. [A reduction of earlier bargemote, also barghmote and berghmote, < G. berg, a hill, mine, + $\mathrm{E}$. mote, meeting. Cf. barmaster.] A court established in the roign of Edward III. and held twice a year in Derbyshire, Fngland, in which matters connected with mining are considered. Also written bergmote. barmy (bär'mi), $a . \quad\left[<b^{\prime} a m^{2}+-y^{1}\right.$. $]$ Containing or resembling barm or yeast; frothy.

$$
\text { of windy cider and of bormy beer. }
$$

Divden, tr. of Virgit's Georgica, iil.

Tilou barmie froth! thou jottle-aie,

barmy-brained (bür'mi-brānd), a Light-

lieaded; giddy.

$\operatorname{arn}^{1}$ (bärn), n. [< ME. barn, bern, < AS. bern, contr. of berern, bere-ern, as in ONorth., bere, barley (E. bear ${ }^{3}$, + ern, a place.] A grain, hay, flax, or other farm-produce. In America barns also usually contain stabling for horses and cattle.

barn ${ }^{I}$ (bairn), $v, t$. [<barn $1, n$.] To store up (1. 859.

Hen. ... often barn up the chaff, and bum up the
graill. barn $^{2}+, n$. [Early mod. and dial. E., $<$ Sc. bairn, q. v., $<$ ME. becm, bern, < AS. bearn, a child. See bairn.] A child.

Mercy on '8, a barn; a very pretty barn! A jooy or a
Shak., W. T., iil. 8.

barnabee (bär'nạ-bē), n. [E. dial. (Suffolk); prob. in allusion to Barnaby day. See Baraby-bright.] The lady-bird.

Barnabite (bär'na-bit), n. [= F. Barnabite, < LL. Barmabas, < Gr. Bapváßas, a Hebrew name translated "son of consolation" (Acts iv. 36), more accurately "son of exhortation" or "son of prophecy."] In the Rom. Cath. Ch., a member of a religious congregation properly styled "Regular Clerks of the Congregation of St. Paul," but having their popular desionation from the church of St. Barnabas in Milan, which was granted to them in 1545, soon after the foundation of the congregation. Their prineipal house is now in Rome.

barnabyt (bär'na-bi), $n$. [Prob. connected with the celebration of Barnaby day, < Barna- 
barnaby

by, formerly also Barnabie, < F. Barnabé, < LL. Jarnabas, Barnabas: see Burnabitc.] An old daneo to a quiek inovement.

Bonnce: erles the porthole - ont they fly,

Antice

Barnaby-bright (bär' 11ạ-bi-brit), n. [Also Barnaby bright, Barnaby the bright, and (scott, L. of L. M., iv, 4) St. Barnabright; also ealled Long Barnaby, in lef. to the coincidenee of Barnaby day with tho summer solstice. ${ }^{2}$ Tho Juy of which in old style was the day of tho June, which in

Bamaby-bright, the longest day aud the shortest night.

This day the sumne is lu his chlefest hlght,
Witl Barnaby the bright.

Fithatamion, 1. 200

Barnaby day. Same as Barnaby-bright.

barnacle ${ }^{1}$ (biir-na-kl), n. [Also barniele, bernacle; (ME. barnahylle, bernakill, bernacle, appar. a dim. of the earlier bernake, bernak, bernack, bernekle; ef. OF. bernaque (MIL. bernaea, berneke), later $\mathrm{F}$. bernache, mod. barnache, barnacle $=\mathrm{Sp}$. bernache $=\mathrm{Pg}$. bernaca, berna cha, bernicha = It. bernacla, later MIL. or NL. bermicla, bernecla, bernacula; G. bernikel-gans, Dan, bernakel-guas. Ultimate origin unknown. The word seems to have arisen in England. The oldest ME. form, bernekke, could be simply 'bare-neck,' with a possible allusion to the large white patehes on the bird's neck and hear. If this were a popular desiguation, it could easily, when taken into book-language and Latinized, assume tlie above and the other numer ous corrupt forms (ML. bernicha, bernecha, beruescha, bernesta, ete.) in which it appears. Th loss of a knowledge of its meaning would assist the growth of the fables connected with the word.] 1. A species of wild goose, Auser ber

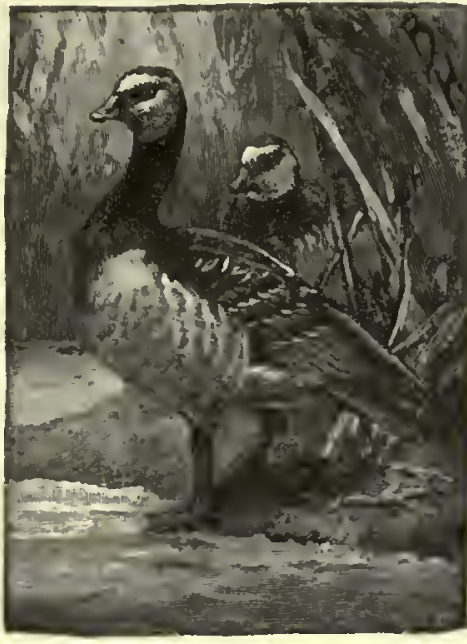

Bamacle-goose (Bernicla leweopsis).

nicla or Bernicla leucopsis, also ealled barnacleyoose or bernacle-goose. It is one of several speele of the genus Bernicla, inhabiting the northern parts of Europe, and occasionlaity appesring as s straggler in North genus Anser proper, has dark-brown or blaekish upper parts, and s black neek snd head, with large whlte patches.
It is related to the eommon wild googe of North Anerieg B. canadensis, and atlll more elosely to the brent- or brant goose, Bernicla brenta. This bird, whieli was known in th enrious popular fable, not yet extinet, being believed to be bred trom s tree growing on the ses-shore, either from the fruit of the tree or as itself the trult henee ealted treegoose), or from a shell-flsh which grew on
(lef. 2), or (rom rotting wood in the water.

So rotten planks of broken alilps do elınge To Barnacles.

T'was first a green tree, then a broken lull, now a flying Gill. 2. A species of stalked cirriped, Lepas anatifera, of the family Lepadida, found hanging in elusters by the long pedunclo to the bottoms of ships, to floating timber, or to submerged wood from its support and turn into a goose (see def. 1). The name is sometimes extended or transferred to various other eirripeds, as the sessile aenrn-shells or ae bulum. See Balanus. This is the usual sense of the word, except in Great Britaln.

A barnacle may be said to be a cmistacean fixed by its heal, and kicking the food into lts mouth with its legs.
$45 \div$

baroco

3. Auything resembling a barnacle (in sense 2). (a) Any anomalous yrowth or extraneous adherlug niatter or arrangement tent. gress.

Compulsory pllot.
age, the three months" extra pay to erews discharged in foreign lands, and ploymeut of ency tuent ofticinls for the shipment of sallar in American perts, are all barnacles which impedo the progress of our con

merelal marine.

MIarine, 1). 181.

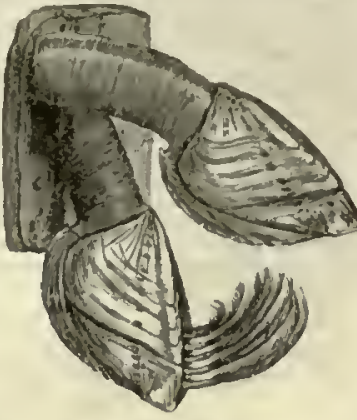

(b) A person holiling

Barmacle (Lepas amalifern)

plsee or position ne who is a useless ar ineompetent fixture in an oftlce
or enployment; a foltower whe will not be dismisset or shaken of

4t. [Cf. barnarl.] A decoy swindler. [Cant.] barnacle ${ }^{1}$ (bär'na-kl), $t$. $t$.; prot. and pp. bar nacled, ppr. barnacling. $[<$ baruaele $1, n$.$] To$ fix or atta ely as a barmacle upon the bottom of a ship. [liare.]

IIe barnacled himsell to Gershon, now, and slijpped with rthys, xxiv. barnacle ${ }^{2}$ (bär'na-kl), n. [Also barniele, bernicle; <ME. barnikylle, byrnacie, bernacle ( $(\mathrm{OH}$ bcrnicle, an instrument of torture), appar. adim. of the earlier bernake, bernak, bernae, $\mathrm{SOl}$. bernac, a bamacle (def. 1); origin unknown. The word branks, of v., has a similar meaning, but no connection can be made out. The sense of 'spectacles' easily arises from the original sense; but some conneet barnacles in this sense with OF. bericle, mod. F' besicle, eye-glass (< IL. "bericulus, dim. of berillus, beryllus, beryl see beryl and brills), or with mod. F. dial. berniques, spectacles.] 1. A kind of bit or muzzle used to restrain an unruly horse or ass; now (usually in the plural), aul instrument consisting of two branches joined at one end with a hinge, placed on a horse's nose to restrain him while being shod, bled, or dressed.

A seourge to an hors and a bernacle lbridle, A. V.] to an
W'yclif, Irov, xxvi,
asse.

Hence-2. An inst rument of torture applied in a similar way to persons.-3. $n l$. Spectacles. [Colloq.]

What d'ye laek? What d'ye laek? Clocks, wstches, bar
nacles 7 What d'ye laek, air? What d'ye laek, madan?

barnacle 2 (bär'na-kl), $\imath$. t.; pret. and pp. barnacled, ppr. barnacling. [<baruacle ${ }^{2}, n$.] To apply barnacles to: as, to barnacle a hor'se.

barnacle-goose (biir'na-kl-gös), n. [Formerly also abbr. bargoose; < barnacle $1,1,+$ goose. Same as barnacle1.

barnard $\nmid$ (bär'nậrd), n. [Also bernard; perhaps for berner, $\ddot{q} \cdot v$.$] One of a gang of swin-$ dlers who acted as a decoy.

Barnburner (bärn'bèr"nèr), $n$. [In reference to the story of a farmer who burned his barn to get rid of the rats.] A member of the more progressive of the two factions into which the Democratic party in the State of Now York was long divided, tho other faction being ealled the Hunkers. The Barnburners opposed the extension of the eanal system, and after 1846 they opposed the ex
tension of slavery in the Territorfes. In a few years most tension of slavery in the Territories.

The Internsl refomn of a party cannot be carried out by crrupt lesders. One of the main objeets of the reformerg was to break the influence of the latter, and to this eharging them with a readiness to burn the bullding with the vermin, in defanlt of a less radiegl means of purifles
tlon. barncock (bäru'kok), $n$. A loeal Scoteh name of the turbot: so ealled on account of its round shape. Day.

barn-door (bürı'dōr'), $n$. The door of at barn. - Barn-door fowl, a mongrel or eross-bred s

bar-net (bär'net), $\pi$. A net plaeed aeross a stream to guide fish into a wing-pond.

barney (bair'ni), ". [Perhaps from tho prope name Barney for Bainaby, fomerly very common as a Christian name, and still common among the Irish. But in $3 d$ sense cf. blarmey. 1. In mining, a small car used in the anthracite region of Pennsylvania on inelined planes and slopes to push the mine-car up the slope

A prize-fight. [Slang.]-3. Humbug. barney-pit (bär'ni-pit), $n$. In the anthracite baroco' (ba-rō'kō), $n$. [An artifieial name in- a slope or plane into which the barney runs, order to allow the mine-car to run in ove it to the foot of the plane. barn-gallon (bärn'gal"on), $n$. A measure containing two imperial gallons of milk; a double gallon.

barn-grass (biim'grås), $n$. The common cock spur-grass, I'anicum Crus-galli.

barnbardtite (baim'här-tit), n. [< Burnharlt, nume of the owner of land in Nortl Carolina whero it is found, + -itc2.] A sulphid of copper and iron oceurring massive and of a bronzeyellow color in North Caroling and elsewhere. barnman (bärn'munn), n.; pl. barnmen (-mell) A laboler in a barn; a thresher.

Butrnman, sower, hayward, and woodw'sril were alike
serfs.

barn-owl (birn'oul), n. 1. The comrnon white oul, Strix flammea or Aluco flammeus: 80 ealled from being often found in bams, where it is useful as a destroyer of mice. Its conspecies or varletles inhalilt nesrly all temperate regions of the glolye cola. Also csiled church-oul.

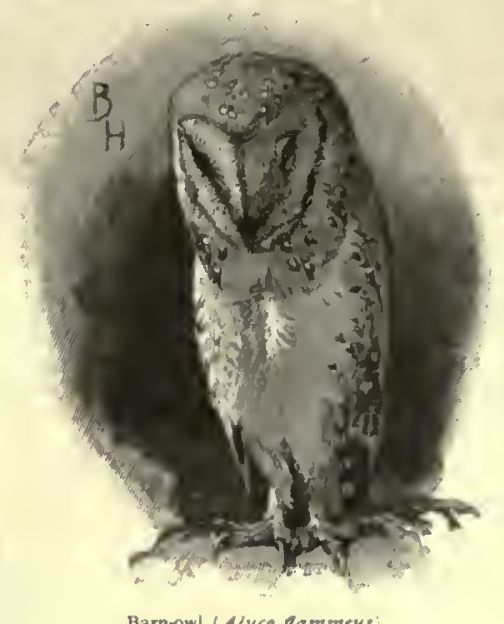

2. $p l$. The owls of the barn-owl type, genera strix or Aluco and Phodilus, which differ so decidedly from all other owls that naturalist now consider them types of a distinet family. See otel and Alucomide.

barns-breaking (bärnz'brā"king), ${ }^{\circ}$ [SS., i allusion to the act of breaking open a baru to action; an idle frolic.

There is blood on your hand, and your elathes are tom. What barns-breaking have you been at? Yon have bee barn-stormer (bärn'stôr"mèr'), n. A strolling player; an actor who plays "in the provinees." barn-storming (bärn'stốr"ming), n. [In allustrolling actors often played.] The practice of acting in barns, as strolling plavers; hence, the praetice of playing "upon the road" or "in the provinces."

barn-swallow (bärn'swol"ō), n. The common swallow of the United States, Hirundo horreogastra: so ealled because it habitbarns. The upper parts sre dark steelblue, the lower parts perfeet collar, snd the tail deeply forked and spotted with white. representstive of the Europe.

barn-yard (birm'värd), n. A yard surrounding or adjoining a barn.- -

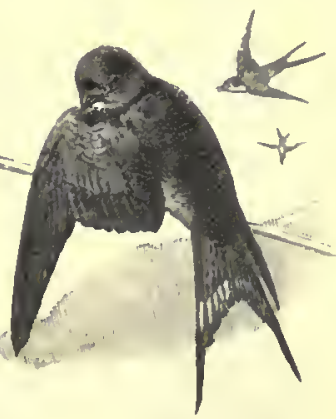

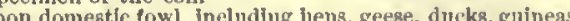
and turkeys; apeeiflesilty, a mongrel or cross-bred apeelbaro L. gravis, heavy: see arave ${ }^{3}$.] An element in certain compound scientific terms, implying aviness.

baroco ${ }^{1}$ (ba-rō'kō), $n$. [An artifieial name in-
vented by Petrus Hispanus.] In logie, tlie rom or $H$. erythro- 
baroco

mnomonic name of a mood of syllogism in the second figure, having a universal affirmative major premise, a particular negative minor Every true patriot is a friend to religion; some great statesmen are not friends to religion therefore, some great statesmen are not true patriots. Five of the six letter's that conpose the word bara; $a$, that the major prenise is universal affirmative o, that the minor premise is partieular negative; $c$, that the syllogism is to he reduced per impossibile (see reduc-
tion); and 0 , that the eonclusion is particular negative.

baroco ${ }^{2}$, barocco (ba-rō'kō), a. [It. baroeco.] Same as baroque.

barogram (bar'ö-gram), $n$. The record traced by a barograph.

barograph (bar'ö-graf), n. [<Gr. Bápos, weight,

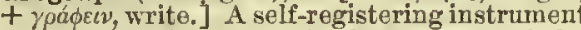
for recording variations in the pressure of the atmosphere. It is made by attaehing to the lever of a counterpoised barometer an arm with a pencil in eontact with a sheet of paper, and moved uniformly by cloekwork. The result is a continnous trace, whose clanges of form a ray of light is made to traverse the upper part of the a raper the rising and talline the mercury in the barometer calsing the beam of licht to be increased or dinin. ished in width, thus showing the changes in the baroneter by the continueus photographic reeord of the paper. In slill another form the movement of the mereury-eolumm
is used to elose an electrie eircuit and thus repert its barographic (bar-ō-graf'ik), a. [< barograph $+-i e$.$] Of or pertaining to a barograph; fur-$ nished by the barograph: as, barographic reeords.

baroko, $n$. See baroco 1 .

barolite (bar'ō-lit), n. [<Gr. ßápos, weight, + barology (ba-rol'ó-ji), n. [<Gr. ßápos, weight, $+-\lambda o \gamma i a,<\lambda \varepsilon$ recv, speak: see -ology. $]$ The sci$+-\lambda$ yia, $\langle\lambda \varepsilon \gamma \varepsilon t v$, speak: see -ology.
ence of weight or of the gravity of bodies.

baromacrometer (bar" e-tẻr), n. [< Gr. Kápos, weight, +

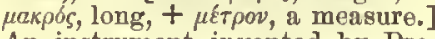
fessor Stein for ascertaining the weight and the length of new-born infauts.

barometer (ba-roun'e-tér), n. $\quad$ c< Gr. Bapos, weight, $+\mu \varepsilon \tau \rho o \nu$, a mea-
sure.] An instrument for measursure.] An instrument for measuratmosphere, invented by Evangelista Torricelli, an Italian mathematician and physicist, in I643. The simplest form of this instrument is a
glass tube over 30 inehes long, sealed at one end, and then fllled with mereury. When dipping into a enp or etstern of mereury, the column sinks, leaving a vaeumm at th
top, till the pressure of the atmosphere on
eaeh unit of surface of the mercury in the cistern equals the weiglit of the column th the tube over each unit of surface of the cury outside, when the pressure of the

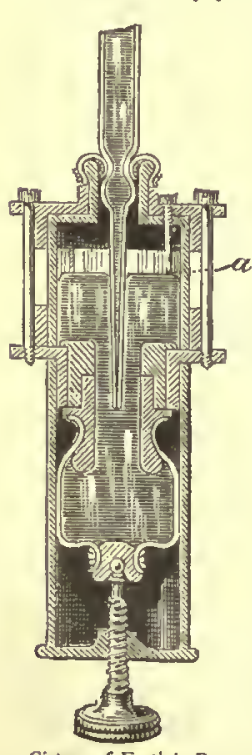
Cistern of Fortin's Barom. legs represents the pressure of
eter. a, extremity of iwory
pointer marking the zero of the atmosphere. The wheel ba.
the scale.
rometer uanally consists of $a$ ais. on a graduated seale. Barome ters of this form
are ealled cis. They are the Barometer. rough mereurisl barometer frequently used is Fortin's ba adjustable, the zero of the seale colneiding with the extremit
of an ivory pointer ( $a$ in secoll warl from the top of the cistern-box. The bottom of the by a screw working agains cury ean be raised or low. tonehes the point of the index this operation must be per tion. 'The siphon barometer eo $a$ bent tube, general of uniform bore, having two unequal legs. The longer leg,
whieh must be more than 30 Winches long, is closed, while the shorter leg is open; the diffe
456

phon barometer having a float resting on the surface of the float passing over a pulley, and having a weight at its
extremity as a counterpoise to the float. As the mercury extremity as a counterpoise to the float. As the mercury
rises and falls the thread turns the pulley whieh moves the index of the dial. The barometer is used in many nary applications are (1) to the prediction of the weather, and (2) to the deternination of the elevation of stations above the sea-level. - Aneroid barometer, a
portable instrument, invented by $\mathbf{1 1}$. Vidi of Paris, for inportable instrument, invented by $\mathbf{1 1}$. Vidi of Paris, for inmereury or other fluid. It consists of a eireular metallie box
which is exhausted of air, and of which the corrugated diaphragms are held in. air, and of which the corrugated diaThe varying pressure of the atmosphere eauses a variatio multiplied by delicate levers and a fne chain wound around a pinion, actuates an index-pointer which moves over a graduated seale. Bolrdon's metallic barometer is an anc-
roid barometer consisting of a flattened, curved tuhe, $\mathrm{ex}-\mathrm{f}$
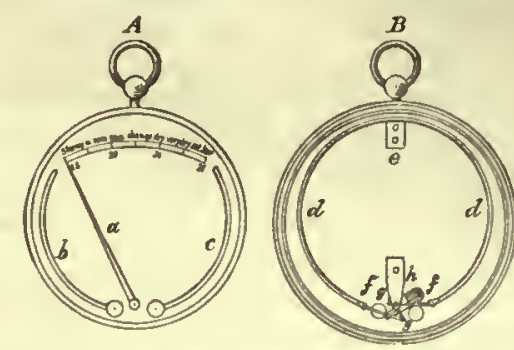

Bourdon's Metallic Barometer.

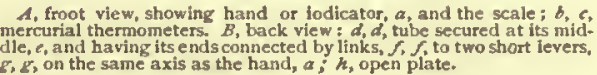

hausted of air and having one end fixed and the other geared to an index-pointer which traverses a graduated arc. The curvature of the tube is affeeted by variations in the apondingly on the dial.- Marine barometer, a cistern heing suspended by the tube to lessen the oscillationg of the mercury Pumping of the barometer, an unsteadiness in the barometrie eolumn, due to a gusty wind.- Self-registerof the barometer, the height of the barometer corrected the freezing-point of water, for variations of gravity, for seale, etc. The United States Signal Office also corrects barometer-flowers (ba-rom'e-tèr-flou"èrz), $p l$. Artificial flowers colored with chlorid of cobalt. In dry air they are blue, and in moist air they turn pink.

barometer-gage (ba-rom'e-tèr-gāj), n. An appa atus attached to the boiler of a steam-engine, to condenser, or to some othe

chamber in which a more or to be formed, to indicate th state of the vacuum. In one plunged in a basin of merenry and um-chamber. Another common orm is a U-tube partially filled
with mercury, and having one end open to the air and the other con-
neeted with the vacuun-ehamber. Any exhaustion in the chamber eauses the mercury to rise in the
leg conneeted with it and to fall in the other. The fluetuations are
noted upon a seale placed between

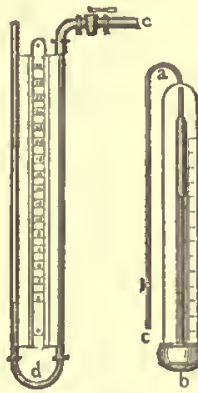

\section{barometric (bar-ō-met'rik),} a. Pertaining to, made with, or indicated by a barometer. as, barometrie errors; barometric experiments or measurements; barometrie changes. Also baric. Barometric depression. See depression.- - Barometric
trough, an area of low barometer. See barometer Tornadoes are more frequent when the major axes of east and southwest, than when they trend east and west.

barometrical (bar-ō-met'ri-kal), a. Pertaining to or of the nature of a barometer; baro metric.-Barometrical aërometer. See aérometer.
barometrically (bar-ō-met'ri-kal-i), adv. By means of a barometer.

barometrograph (bar-ō-met'rō-gråf), n. [s

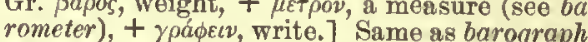
barometrography (bar " $\overline{0}-m e t-r o g$ ' ra-fi), $n$. [As barometrograph $+-y$.$] The science of the$
barometer; also, the art of making barometric bservations.

barometry (ba-rom'e-tri), n. [As barometer + baronet

tions, or the like.

A scrap of parehment hung loy geometry

Can, like the stars, foretell the we Swift, Grub Street Elegy.

barometz (bar'ō-mets), $n$. [Appar. an erroneous transliteration of Russ. baranetsü, clubmoss, connected with baranŭ, a ram, sheep.] The decumbent eaudex of the fern Dicksonia Barometz, also called Agmus Seythicus, the Scythian or Tatarian lamb. See Agnus Scythi. eus, under agmus. Also written boramez.

baromotor (bar'ō-mō-tor), n. [< Gr. ßápos, weight, + L. motor.] "A portable haud-and foot-power having two treadles connecting with cranks on a fly-shaft. E. $H$. Knight.

baron (bar'on), $n$. [Early mod. E. also barron, (orig. ace. of ber) $=$ Pr. bar, ace. baron, baro $=$ Sp. varon $=$ Pg. varão $=$ It. barone, prop. a man (It, now a vagabond), then specifically one who was a 'man' or vassal of the king or other term as a title, F. buron, fem. baronne, whence, from F. or E., in other languages, Sp. baron, Pg. barão, It, barone, G. Dan. Sw. baron, Icel. barün, Russ. baronŭ, ete.; <ML. baro(n-), a man (L. homo or vir), hence, in particular uses, vassal, servant, freeman, husband. Origin uncertain; by some connected through 'servant' with L. baro $(n-)$, a simpleton, blockhead, dunce.] 1. In Great Britain, the title of a nobleman holding the lowest rank in the peerage; a member of the baronage: as, IBaron Arumdell of Wardour; a Seoteh baron. The ehildren of barong lave the Litle "IIonorable." Originally the harons, being the fendatories of princes, were in ancient records the word barons comprehends all the nobility. All auch in England liad in early times a right o sit in Parliament. Anciently barons were greater, such as beld their lands of the king in capite, or lesser, acrvice in capite. "The present barons are-(1) Baroms y presoripton, for that they and their aneestors have mmemorially sat in the Upper House. (2) Barons by and thcir heirs, male or otherwise. (3) Barons by tenure, holding the title as annexed to land." (Wharton.) For. merly, when all barons were not summoned to sit in Par. liament, the name of barons by writ was given to those whe actually were so summoned. Barons in the peerages of Seotland and Ireland have seats in peer. The word baron was no duced from the continent under the Torman princes. The eoronet of cold eirele, with six balls er large pear on its edge, and wilh the eap, ete., as 2. A title of the judges or off cers of the English Court of Ex-

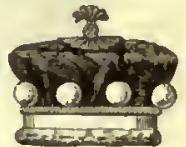

lish Banet of ang
lish chequer, hence called barons of the Exehequer, the president of the court being called chicf baron.-3. In law and her, a husband: as, baron and feme, husband and wife.-4. On the continent of Gurope, especially in France and Germany, a member of the lowest order of hereditary nobility: in Germany, same as Freilerr:Baron of beef, in cookery, two girloins not eut asunder.
- Barons of the Cinque Ports, members of the British House of Comm Romney, Hastings, Hythe, Winehelsea, and Rye. barunage, barnağe, $<\mathrm{OF}$. barnage, bamaige, $\mathrm{F}$. baronnage $=$ Pr. barnatge $=$ It. baronaggio, barnaggio (ML. reflex baronagium) < ML "baronaticum, $\langle$ baro $(n-)$ : see baron and -oge.] 1. The whole body of British barons; formerly, the nobility or peerage in general.

The baronage is llfvided ao narrowly that the aummena a ministry or of a dynasty. Stubbs, Const. Hist. \&ase. 2. The dignity or rank of a baron.-3t. The land which gives title to a baron; a barony. baron-court (bar'on-kōrt), n. See court-baron. baroness (bar'on-es), n. [< ME. baronesse, baronys, < OF. "barnesse, baronnesse $=\mathrm{Pr}$. It baronessa (ML. baronissa): see baron and -ess.] The wife of a baron, or (in a few eases in England) a lady holding a baronial title as a peeress in her own right.

baronet (bar'on-et), $n$, [<ME, baronet, baronete (ML. baronettus, F. baronnet, G. baronet, Russ. baronetŭ, after E.), <baron + -et.] 1t. A lesser or inferior baron. In this use the word had not the speeiflc sense that it received in the time of Jamies
I. "Aecording to Spenser ('State of Ireland'), orfginally applied to gentlemen, not barons by tenurc, summene heirs of barons summoned by writ in their fathers life 
time. Appliest in Jreland to the holder of a small burony. Ile had sod many Barrons in his Partinent, as were
alde to waight downe the cleargye and theyr fremdes; the which Barrons, they say, were not sfterwardes Lorles, lait only Barronetis, as sundrye of them doe yet retayne the 2. A British titlo of hereditary rank or degree of honor next below that of a baron, and thus not conferring a peerige; the only titlo of hereditary knighthood. A baronet is designated S1 So-and-sar, lart. (Christian name aud surname being given), and ranks above sil knights except those of the Garter patent. The order was founded by James I. In 1611 , professedly to promote the English and Seotch colonization
of Uister, for which esch barunet paid $\& 1,080$. The ori-

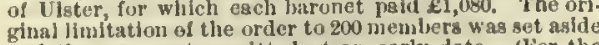
ginal linitation of the order to 200 meminers was set aside lanige if the order, see badge of Clster, under badge 1 , hand the hlooly hand of Uister. See badge of Uhres. under boulge 1 - - Baronets of Ireland, an order of knights teenth year n! his reign (1619), for the ssme purpose sn with the sane privileges fn Ircland as had heen conferre Scotland, an order Instituted by Charles I. of Pngland in 1625. The nominal object was the settlement of Nova Scotia, and patents were granted under the great seal of Scotlani, as thase of the Ulster loaronets had been granted under the grent seal of Finglsnd. Aiter the unlon of the
crowns in 1707 the baronets of seotland chargerl their crowns in 1707 the bsronets of Scotland chsrged their
arms with the badge of Ulster, and became baronets of the United Kingdom. The baroncts or scotland ast osten called Noras

baronet (bar'on-et), $v$. $t$. To raise to the rank of baronet: generally in the passive: as, he expects to be baroneted.

baronetage (bar'on-et-âj]), n. [< baronct + age, on type of baronage.] 1. The baronets as a

baronetcy (bar'on-et-si), n. [< baronet $+-e y$. The title and dignity of a baronet.

baronial (ba-róni-al), a. [<baron + -ial. Cf. IIl. baronalis.] Pertaining to a baron or barony, or to the order of barons: as, baronial possessions; the baronial dignity.

baronism (bar'on-izm), $n$. [< baron $+-i s m$.] Feudalism; the baronial system.

The spirlt of Norman baronism on one side, and the spinit of Anglo-saxon freedem on the other.
If arper'8 Mag., LXJX. 422

baronnette (bar-on-et'), $n$. [F., dim. of baronne, fem. of baron, baron.] A little baroness; baron's daughter: sometimes used for the wife of a baronet. N. L. $D$.

baronrył (bar'on-ri), $n_{*}$; pl. baronries (-riz) [< ME. barunric, < OF. baronnerie : see baron
and -ry.] $1 . \Lambda$ barony; the domain of a baron. -2. The rank or dignity of a baron.-3. Barons collectively.

barony (bar'on-i), n.; pl. baronies (-iz). [< M1. baronie,"< OF.baronie, barunie (F. baron nie), (ML. baronia, < baro $(n-)$, a baron.] 1 . The rank or dignity of a baron.-2. The domain of a baron; the territory or lordship of baron.-3. In Scotland, a large freehold estate, even though the proprietor is not a baron. -4 . In Ireland, a territorial division corresponding nearly to the English hundred, and supposed to have been originally the distrin the island. Whatever the regnlar troops spared was devonred by
hands of marauders who overran almost every baromy in
the islsnd.
Macaulay. Ilist. Eng., xil. 5. Formerly, the tenure by which a baron held of his superior, namely, military or other honorable service. -6t. The body of barons and other peers; the baronage.-Burgh of barony. baroque (ba-rōk'), a. and $n$. [Also baroco; $=\mathrm{G}$. Dan. barol, $<\mathrm{F}$. baroquc, barroque $=$ It. barocco, $<\mathrm{Pg}$. barroco $=\mathrm{Sp}$. barrueco, irregular, bizarre, esp. in arehitecture, orig. irregular-shaped, a applied to a pearl. Origin uncertain; perhaps, with some eonfusion with other words, < L. verruca, a steep place, a height; hence, a wart, an
oxerescenee on precious stones.]
I. $a .1$. Odd; bizarre; corrupt and fantastic in style.

The Oncidlum leucochlum is by no means the mest eccentric or baroque member of the fsnilly of orchths. Hsppy the artist whose women-friends or relatives are sttire which charseterize so miny of our native canvases,
especially in genre subjects. The Centwry, XXV. 575 . 2. Specifically, in arch., applied to a style of decoration which prevailed in Europe during a great part of tho eighteenth century, and may of the seventeenth century. It is nearly equivalent forms, particularly in church architecture, sult tta con. barra' + (bar'ii), $n$. [ML., a bar: see barl.] A less scrolls and insrganic shell-work. Also callect, some. bal" or

times, the Jestit style, from the many and remarkahly Wfolf. (har'ai), n. [Pg., a particular use of

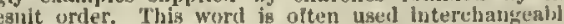
th rocuco but rucoco is preferaliy reserved fur ornument the same pertod, partienlarly in France, whilch, thongh

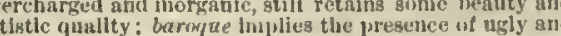

Sometimes written barnco, barneeo, barock: Baroque pearl, a rough pearl of irregular or conturt Min. Sinch pearls are frecuncintly ntillzed to form lrotic

II. n. 1. An object of irregular and peeuliar orm, especially in ornamental art

On the scroll hamdle is a pearl baroque of Septume rlit Ing on a delphin. S. $K$. Loan lixhibition, 186i. 2. Ornament, design, etc., of the style and period called baroque. See I., 2.

The mad extravsqances of the baroque, a style, if style t can be called, which declared war axalust the stralicht ine, erased logic in construction from its grammar of art C. C. Perking, I taltan Sculjuture, 1. 364.

baroscope (bar'ó-skēp), n. [<Gr. ßápos, weight,

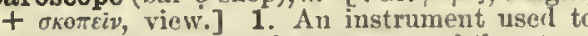
indicate changes in the pressure of the atmosphere without measuring its absolute weight. See weather-glass and storm-glass. - 2. A piece of physical apparatus used to demonstrate the upward pressure of the air. It consists of a lnrg hody of small density attached to the beam of a balasice and exactly balanced hy a small weight. When this exhausted, the arm of the balance to which the larg boly ts attached tips down, since the ppward pressur

baroscopic (bar-ō-skop'ik), $a$. [< baroscope + $-i c$.$] Pertaining to or deternined by the baro$

baroscopical (bar-ō-skop'i-kal), a. Same as

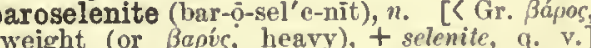
Same as barite.

Barosma (ba-ros'main), n. [NL., also Baryosma,

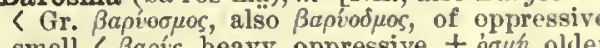

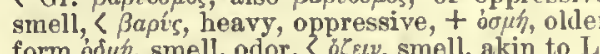
form od $\mu \eta$, smer.] A genus of shrubs, natural orde Rutacce, natives of the Cape of Good Hope, pos sessing a strong, heavy odor. The lesves of severs

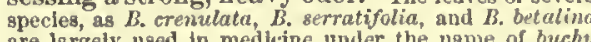
chiefly in disorders of the vrinogenital orgsns. In Cap. barouche (ba-rösh'), $n$. [Spelled as if $\mathrm{F}$., bu taken direetly $<\mathrm{G}$. dial. barutsche, $<\mathrm{It}$. baroccio biroccio (with term. assimilated to that of car roccio, a ehariot) $=$ Sp. barrocho, orig. a twewheeled vehicle, < LL. birota, a cabriolet, orig.

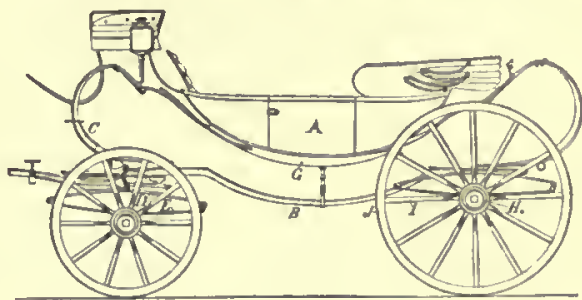

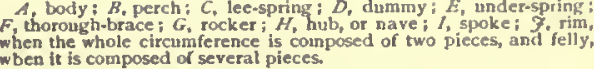

fem. of the adj. birotus, two-wheeled, < I. bis, double, + rota, a wheel.] A large four-wheeled earriage with a falling or folding top over th back seat, and the seats arranged as in a coaeh. barouche.] A small kind of barouche.

aroxyton (ba-rok'si-ton), n. [< Gr. Bapís, heavy, + ofviovos, sharp-sounding.] A brass instrument of music invented in 1853 , having a nearly three octaves below middle C: oeeasion ally used in military bands.

bar-post (bär'pōst), $n$. One of the posts driven into the

gate.

bar-pump (bär'pump), $n$. Same as bare-pump. arque, $n$. See bark ${ }^{3}$.

arr $1, n$. Obsolete spelling of bar ${ }^{1}$

barr2 (bär), v. i. [Also bary; < F. barrir, <L barrire,

barr ${ }^{3}, n$. See bahar. barra, a bar (ef. F. yurd, rod, pereh, similarly used): sec burt.] A portugueselinear measure, equal to 1.25 yards, used for eloths of varions kind lare, eipalilo of being barred or stayed.

barra-boat (bar'ii-bot), $n$. [Named from the island of Jirura in the Hebrides.] A vessel carrying ten or twolve men, used in the Hebrides. It is cxtremely slisry fore snd aft, sud has no floor, the barracan (bar'a-kan), n. [< F. barracan, bara can, now bourä̈an = I'r. barracan $=$ Sp. barragan (wlienee also F. barragan) = Pg. barregane = It. baraeane $=1$ ). burkan $=\mathrm{MH}$ ( . barchant, burchat G. barchent, fustian, berkan, barracan, $=$ Pol. barchen, baralian (ML. barenents), <Turk barrakan, < Ar. barrakīn, barkēn, a kind of blaek gown, < P'ers. barak, a stuff made of eamel's hair.] A thick, strong stuff made in the Lovant, properly of eamel's hair. The namo Is used thronghout the liedlterranean countries; the use of it hy Byron ("the striped white gauze baracan thst lound her" Don Juan, 11. 70) and others to denote a dellcate material is apprarently an error. A

can, barrakan, barrafon, also barrais, barres, barres, <OH. burras, a barrier, < barrc, a bar: soe bar ${ }^{1}$, and ef. cmbarrass, debarrass.] 1. A barrier or outwork in front of a fortress.-2. The bar of a tribunal. [Raro.]-3. A hindrance or ob-
struetion. [Raro.]-4. The iuclosure within which knightly encounters took place. Hence -5. Hostility; contention; strife. N. E. D. of uncertain origin. Some compare Gael. and Ir. barrachad, a hut or booth; Gael. barrach, top branches of trees; Bret. barrek, full of branehes, <bar, a branch: see bar1.] 1. A bulding for lodging soldiers, especially in garrison; a permanent building or range of buildings in which both officers and men are lodged in fortified towns or other places.

He [Bishop IIall] lived to see his esthedral converted T. Warton, llist. Eng. Poetry, IV. 2.
2. A largo building, or a eollection of huts or Win a eormmon inelosure, in which large numbers of men are lodged.

Nost of the quarrymen are Bretons, and live in wooden
Ansterl, Channel Islands, 1.6 . The rail way has come close unler the wallis of the chatesn, while an ugly barrack has sprung up en the other side.
Contemporary Rev., L. 329.

[In both senses generally in the plural.] -3 . A straw-thatched roof supported by four posts, under which hay is kept, and which is capable of being raised or lowered at pleasure. In Maryland, and perhaps elsew here, the word is used for or hay, [U, S.]-Barrack allowance, a speciflc quanlititibls reainents ststlonied in barmeks. - Barrack casemate, a bomb-proof casemate for shelter and suppties. barrack-master (bar'ak-mais"tèr), $n$. The officer who superintends the barracks of soldiers. - Barrack-master general, an officer who superintends sccommodation to the requirements. [Fng.]
[ barc $1,+$ hleed $=$ E. cloth.] A home-made woolen blanket without nap. [Peculiar to those parts of New York originally settled by the Duteh, and now little used, if at all.]

barracoon (bar-a-kön'), n. [< Sp. barracon used in the West Indies) = Pg. "barracão, aug. of Sp. Pg. burraca, barrack: see barrack.] A barrack or an inelosure containing sheds in which negro slaves were temporarily detained; a slave-pen or slave-depot. Barracoons formerly existed st various points on the west coast of Africa, slso of large but low-roofed wooden sheds, snd were sometimes provided with defensive works, in order to resist attack
from the British forces engaged in bresking up the slave-
trade.

barracouta (bar-a-kö'tä), n. A corrupt form of barrackda.

arracuda (bar-a-kö'dä), n. [Native name.] A large voracious fish, Sphyrana picuda, of the
West Indian and neighboring seas. It belongs to the pereh family, and is from 6 to 10 feet in length.

barrad, barraid (bar'ad, -ād), n. [<Ir. bairread, brircud, $<\mathrm{F}$. barret ${ }^{2}$, q. v., or from the F. origi-

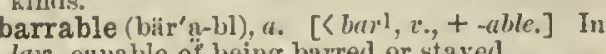

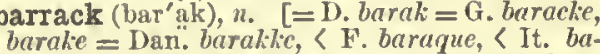
racca $=\mathrm{Sp}$. Pg. barraca, a tent, soldier's hut 
barrad

nal.] A conical cap of very ancient origin, century.

barragant (bar'a-gan), n. Samo as barracan.

barrage (bär'ạj), n. [F., a bar, barrier, dam, < burrer, bar, obstruet, < barre, bar, obstrue-
tion: see bar ${ }^{1}$ and -age.] 1 . The act of barring; specifically, the formation of an artificial obstruetion in a watereourse, in order to increase the deptli of the water, to facilitate irrigation, thus formed. especinlly, one of those on the river Nile in Egypt.

barragon $\nmid$ (bar'an-gon), $n$. Same as barraean. Barragons - a genteel corleel stuff much in vogue at that
time for sunmer wear.
Gillert White, selloorne, v. 14 barragudo (bar-ạ-gö'dō), n. [S. Amer.] A native Indian name of a large South American monkey of the genus Lagothix.

barraid, $n$. See barrad.

barrakant, $n$. See barracan.

barramunda (bar-a-mun'dï), $n$. [Native Australian.] An Australian fish, Ceratodus forsteri, of the order Dipnoi, representative of a suborder Monopneumone. It attains a length of 6 feet, and its flesh is esteemed for food. See Ceratodus.

barranca (ba-rang'kä), n. [Sp., also barranco $=$ Pg. barranco.] À deep ravine, mountaingorge, or defile: a word frequently used by raphy and travel.

Oply in the valleys of erosion, true barancos, into which

barras ${ }^{1}+\left(b^{\prime} r^{\prime} a s\right), n$. [Origin obscure.] A coarse linen fabric originally imported from Holland The word was in use in the seventeenth century. barras $^{2}$ (bar'as; F. pron. ba-ri'i'), n. [F., < barre, a bar, in ref. to its appearance on the
tree. I The French name for the turpentine obtained in the south of France from Pinus Pinaster. Also called galipot.

barratt, n. [<ME. barrat, barret, barat, baret, <OF. barat (= Pr. barat = Sp. barato (obs. $)=$ It. baratto), m., also barate $=\mathrm{Pr}$, barata $=\mathrm{Sp}$. burata (obs.), f. (ML baratus, baratum, and be rata), of uneertain origin; orig. appar. traffic, dealing (as in the E. deriv. barter, q. v.), then fraudulent dealing, fraud, etc. In sense 3 , of. Icel. barātta, fight, strife, trouble.] 1. Fraud How he has in greste barett bene sithe

3. Contention; strife.

barratt, $v . i$. [Also barret; < barrat, n.] To barrathea-cloth, $n$. See barathea-cloth.

barrator (bar'a-tor), n. [<ME. barator, baritor, bareter, baratour, bavatur, etc., $<\mathrm{AF}$. *baratour, OF. barateor $(=$ Pr. barctador $=$ It. barattatore ML. barratctor), ( barater, barter, cheat, deceive, < barat, ete., barter: see barrat.]. 1t. In old law, one who buys or sells ecelesiastical preferment; a simonist. - 2. In Seots lave, a judge who takes a bribe. -3 . One who buys or sells offices of state.-4. Oue who commits barratry one who, being the master of a ship or one of its officers or seamen, commits any fraud or fraudulent act in the management of the ship or
cargo, by which the owner, freighters, or insurers are injured, as by running away with the ship, sinking or deserting lier, wilful deviation from the fixed course, or embezzlement of the cargo.-5t. A quarrelsome, brawling person; a rowdy. - 6. One who frequently exeites others to lawsuits or quarrels; a common nover and maintainer of suits and controver-
sies; an encourager of litigation between other sies; an encourager of litigation between other See barratry, 4

Will th not reflect as much on thy charscter, Nic, to turn thy neighbours?
Arbuthot, 11 ist. of Joln Bull. Also spelled barrater, and, especially in the last sense, barretor:

barratoust (bar'g-tus), a. [< NE. baratous, OF. barateus, $<$ ba

The world is too full of litigions and barratous pennes.

barratrous (bar'a-trus), a. [<barratry + -ous. $]$ Of the nature of "or characterized by barratry fraudulent. Also spelled barretrous.

trous or frouduraspellod barretrously.

barratry (bar'g-tri), n. [< ME. barratrie,
458

barrel-organ

barataria), (barat: see barrat and -ry.] 1 . The purchase or sale of ecclesiastical prefer -2. In old Scots law, the taking of bribes by a judge - 3. The fraud or offense committed by a barrator. See barrator, 4.-4. A vexatious and persistent inciting of others to lawsuits and litigation; a stirring up and maintaining of controversies and litigation. 'This is a crimial offense at common law.

Also barrctry, ospecially in the last sense.

barré (ba-rā'), a. [F.,pp. of barrer, bar, < barre bar: seo bar1.] 1. In her., divided by a bend sinister: the reverse of bendwisc or bandé. [This French term is used because English heraldry las no single

2. In music for the guitar or lute, barred: conreying a direction to press with the forefinger of the left hand across all the strings, in order to raise their pitch, a

barred (bärd), p. a. 1. Secured with a bar or bars: as, "the elose-barred portal," Scott, Abbot, xix.-2. Furnished or made with bars: as, a five-barred gate.-3. Obstructed by a bar, as a harbor.-4. Striped; streaked: used especially of textile fabries: as, "barred al of silk," Chaucer, Miller's Tale.-5. In music: (a) Mark
ed off by bars. (b) Same as barré, 2.-6. In her. same as barry ${ }^{2}$.

barrel (bar'el), n. [< ME. barel, barcle, barayt, barril $=$ It. barile $=$ G. F. baril $=$ Pr. Sp. Pg. Russ. barilo $=$ Pol. baryla (barred $l$ ) $=$ NGr. ßapéne, < ML. barile, barillus, barellus, baurilis a barrel. Origin uncertain ; perhaps connected with bar1. The Celtic words, W. baril = Gael. baraill = Ir. bairile = Manx barrel = Corn. balliar, are of $\mathrm{E}$. origin.] 1. A vessel or cask of a cylindrical form, generally bulging in the middle, usually made of wooden staves bound together with hoops, and having flat parallel heads. -2. As a measure of capacity, the quantity of anything, liquid or solid, which a barrel should contain. In English metrology there were four prtm.
cipsl ktnds of barrels: the wtne-barrei of 31 , whe gallons; the London ale-barrel of 32 beer gallons; the country aleand becr-barrel of 34 beer gallons; snd the London beerbarrel of 36 beer gallons. The wine.barrel was legalized Under George III. the barrel of ale or beer for town and country was made 36 gallons. Oil, spirits, tar, and pork
were measured hy the wine-barrel ; vinegar, by the barrel of 34 gallons. A barrel of eels or herrings contsined 30 weer IV. this was made 42 gallonis. Salnon snd spruce rel of beef, wet codfsh, or honey contsined 32 wine gallons; but honey was sometimes sold by barrels of $42 \mathrm{gal}$. lons of 12 pounds each. By a statute of George IIl., a
barrel of fish was made 38 wine gallons; but a barrel of
salt pilcliards or mackerel measured 50 gsllons. The barsalt pilchards or mackerel measured 50 gsllons. The bar.
rel of apples, cosl, or nuts contsined 3 Winchester bush. rel of spples, cosl, or nuts contsined 3 Willchester bush-
els, each of 8 gallons, dry messure. The barrel of sncho-
vies contained 16 pounds; of gunpowiter, 100 pounds; of vies contained 16 pounds; of glunpowder, 100 pounds; of
raisins, 1 liundredweight; of candles, 120 pounds; of bs.
rilla, potash, or butter, 2 hundred weitht rilla, potash, or butter, 2 hundred weight (hut only 100 chap, 256 pounds. A barrel of plates, by a statute of grent variety of other barrels in Scotlsnd and Ireland. In United States the barrel in liquid neasure is commonly $31 \frac{1}{2}$ galions, and for solid substances it is generally a unit
of weight, a barrel of four, for exsmple, being 196 pounds,
and a barrel of beef or pork 200 pounds. In Haine 8 harand a barrel of beef or pork 200 pounds. In Haine s har-
rel of fish is by law 200 pounds. In Louisiana $\mathrm{g}$ barrel in dry measure is 31 bushels. The bushels vary in different troduction of the metric system, there were many barre In each state of 1 taly the barile for wine was a little The barril of Normandy was abont 60 Paris pintes. The baral of Miontpelier was 253 liters; the barrallon of Bar.
celona, 30 liters; the baril of Riga, 1374 liters. The bar. rique was commonly larger than the baril. The abbrev 3. Th obl., pi. bols.

3. The contents of a barrel : sometimes, like bottle, used to signify intoxicating drink. -4 . The money (especially when the sum is large) paign, for campaign expenses, political camfor corrupt purposes: hence, a barrel campaign is one in which monoy is lavishly employed to bribe voters: in this sense often written and pronounced barl (bärl), in humorous imitation pronounced barl (bärl), in humorous imitation
of vulgar speech. [U. S. political slang.]5. Anything resembling a barrel; a drum or cylinder. In particular- $(a)$ The drum or roller in a portion of s capstan, about which the rope wiads, between the drumbead at the top and the pawl.rim at the bottom.
See cut under capstan. (c) In the steering spparatus of a ship, the cylinder on which the tiller-ropes or -chains a ship, the cylinder on which the tiller-ropes or -chains
sre wound. (d) The rim in a drum or pulley about which in the barrel-organ opens the key-yslves, and in the mu.
sical box sets in vibration the teeth of the steel counb by arrel-loom (bar'el-löm), which the soumd is producet. (f) The cylindrical portion of a boller between the firc-box snd the snoke-box, containg the tubes or thes. (g) The body or trunk of Lofty is his neck,

Singleton, tr. of Virgil, I. 151.

(h) The cylindrical case in a watch, withia which the (i) The chamer of a pur in (i) The chamber of a pump, in which the piston works. vibrating portion of a bell between the lower tlickened part or sound-bow and the top or cannon. (l) The hard, proper or quils of the stem of a feather, the ealataus part of the hit of a sword which 18 grasped by the hand. (n) The metal tube of a gun.- Barrel of the ear, the rel, tumbling-barrel, a tumbling-box, or vessel mounted on a shaft and made to revolve, for the purpose of polishing or cleaning by attrition materials placed witlin it, and for cutting shellac, etc. - Slack barrel, a coopered vessel
slisped like a cask, but not made water-tight, being in-

barrel (bar'cl), v. $t$; ; pret. and pp. barreled or barrelled, ppr. barreling or barrelling. [<barrel, n.] To put or pack in a barrel or barrels: as, to barrel beef, pork, or fish.

Stale . . butter, and such, I fear, it is loy the being
barrelled up so long. barrel-bayonet (bar'el-bā"ō-net), n. A bayonet, formerly used, fitted to a haft which was inserted into the barrel of the gun. See plugbayonet.

barrel-bellied (bar' el-bel "id), a. Having a barrel-bolt (bar'el-bōlt) or barrel-shaped belly. ing in a eylindrical easing.

barrel-bulk (bar'ol-bulk), Naut, a measure of capacity for freight, equal to 5 cubic feet. Eight barrel-bulks, or 40 cubic feet, are eqnivalent to one ton by measurement.

barrel-curb (bar'el-kerb), $n$. An open cylinder, $3 \frac{1}{2}$ or 4 feet in length, formed of strips of used as a mold in well-sinking to ribs of elm, cavation cylindrical.

barrel-drain (bar'el-drān), $n$. A cylindrical

barreled, barrelled (bar'eld), p.a. 1. Packed, stowed, or stored away in barrels: as, barreled butter. - 2. Inclosed in a cylinder or barrol: as, barreled bolts.-3. Having a barrel or barrels of a kind or number indicated: used chiefly in composition: as, a double-barreled gun. Barreled crossbow. See crossbon.

arrel-filler (bar'el-fil"èr), n. An apparatus or filling barrels, provided with an automatic arrangement, generally in the nature of a float, for cutting off the supply of liquid in time to prevent overflow.

og-fish or rudder-fish), n. A name of the formis, of the family Stromateidle.

They are slmost always found in the vicinity of floating lience the fishermen call them barrel-fish, though the most
ususl name is rudder-fish. Stand. barrel-gage (bar'el-gāj), n. An automatic device to indicate when a barrel is full, or to shut off the supply and prevent overflow.

arrel-hooks (bar'el-hükz), n. pl. A pair of iron hooks for lifting bar-

barrelled, $p$. $a$. See barrelcd.

barrel-lifter (bar'el - lif " tèr), $n$. A hand-tool for liftng a barrel by the chines. $n$. 1. A loom in which o be woven is determined by a chain of perforated cards passing over a drum or barrel. See Jaequard oom, under loom.-2. A

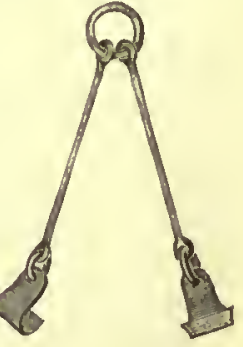

loom in which pins pro

jecting from a revolving barrel determine the levation and depression of the warp-threads. barrel-organ (bar'el-ôr "gan), n. An organ with a cylinder or barrel turned by a crank and furmished with pegs or staples, which, when the barrel revolves, open a series of ralves admitting currents of air from a bellows actuated by the same motion to a set of pipes, thus producing a tune either in melody or in harmony. In snother form of the instrument wires like those of the piano are acted on insterd of pipes. Many it is chiefly applied to the hand-organs carried alout by 
barrel-pen

barrel-pen (bar'el-pen), n. A pen with a eylindrieal shank adapting it to slip upon a round lolder.

barrel-pier (bar'el-pēr), ". A support for a military bridge torned of empty easks or barrels joined together in a raft, in the absenee of pontoons or boats. The rafts of harrels for the abunt. strens or body of water to le croseced, anit those forming the wiers are anchored at jroper intervals between the

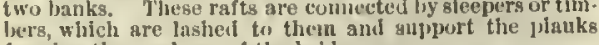

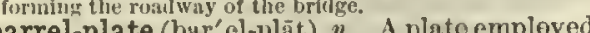
arrel-pa mble and hold the barrels in place abent the axis. The Gatling gun lias a tront and a renr barrel-plate, the barrels passing

barrel-saw (bar'el-sâ), n. A eylinder with a serrated edge, or a band-saw bent into a circle and fitted to a eylindrieal frame, used for eutting barrel-staves, fellies, the eurved work in furniture, ete.

barrel-screw (bar'el-skrö), n. A powerful apparatus censisting of two large poppets or male screws, moved by levers inserted inte their heads upon a bank of plank, with a female serew at each end: of great use in starting a launch. Also ealled bect-screxs.

barrel-setter (bar'el-set"èr), $n$. A cylindrieal maudrel used for straightening the barrel or truing the bore of a firearm.

barrel-shaped (bar'el-shāpt), a. Having the form of a barrel, that is, of a short eylinder with bulging sides: used especially in deseribwith bulging sides: used espee
ing the oggs of certain insects.

barrel-vault (bar'el-vâlt), ${ }^{2}$. A plain, semieylindrical vault, much used by aneient arehiteets, and employed generally by medieval vaulting at the elose of the eleventh century.

barrel-vise (bar'el-vis), u. A benelı-vise whose jaws are greoved longitudinally, adapted for holding a gun-barrel or other similar object. barrel-work (bar'el-wèrk), $n$. In mining, pieces of native copper large enongh to be sorted out by hand and shipped in barrels, but not large enough to come under the head of mass copper. The latter is sent to the smelting works aster being cut, if neeessary, into pieces of manageable sizc
without being barreled. [Lake superior

barren (bar'en), $a$. and $n$. [Early mod. E. also barraine, < ME. barein, barain, $<\mathrm{OF}$. "barain, brahain, brehaing, fem. baraine, baraigne, brchaigne, mod. F. bréhaigne, barren: origin unknown. The Bret. brechagn, sterile, is from $\mathrm{F}$.] I. a. 1. Ineapable of predueing or that does ne produce its kind : applied to animals and plants. There shall not be msle or female barren among you.

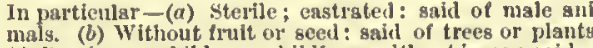
(c) Bearing no childrent; childiess; withesut issue : said of The name of Abram's wife was Sarail, . . . Thlt Sarai was
barren; s sle had no ehild.

For aye to be in shady cloister mew'd,
To live a barren sister all your life.

(d) Not bearing or pregnant at the

2. Producing little or no vegetation; unproductive; unfruitful; sterile: applied to land.

Another rocky valley yswnel beneath us, and anothe barren stony liil rose up beyond.
R. Curzon, Honast. in the Levant, p. 144.

3. In mining, unpreductive; unprofitable: applied to roeks.-4. Void of vital germs.

It is partieularly diffecult to protect a liquid from all germs, or to deatroy sil those which hisve penetrated it
lowever, it is possible, and the lifquid is then said to be 5. Mentally unproductive; unresponsive; dull stupid. [Rare.]

There be of them, that will themselves laugh, to set on me quantity of barren spectators to laugin to. Shak, Hamlet, iii. 2. 6. Devoid; lacking; wanting: with of: as, hill barren of trees; a mind barrch of ideas. Our latest letters from Amuriea are
April, and are extremely barres of news

Jefrerson, Correspondence, 1. 242 .

It is impossible to look without smazement on a mind lacaulay, Petrarch.

7. Not producing or leading to anything; profitless ; fruitless: as, barrcu tears; a barren attacliment. - 8. Destitute of interest or attraction; unsuggestive; uninstruetive; bald; bare as, a barren list of names.
459

But it [Dnomo of Florence) is impresslve within from vust open spaces, anil from the statciy ancl almple, C. E. Vorton, Church-builifing in Middle Ages, p. 22:3. Barren flowers, sineh as for any reason produce no seed.
- Barren ground, un produetive beils nt rock: insell, - Barren ground, unproduetive bets of rock: nsen,

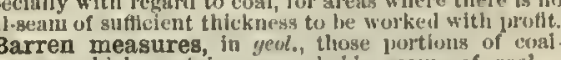
Barren measures, in yeol, those portions of coal Barren stgns, in asfrol, , fenini, Leo, and Virgo,- BarII. $u$. A tract or region of more or less unproductive land, partly or entirely treeless. I'le term is best known in the Uniterl Statc9 as the name of a distrlct in Kentucky, "the larrens," underlald l,y soll, whieh was nearly or quite trecless when that state began to be settled by the whites, but which at present, where not eultivated, is 1nartly covered with trees. In less, grass-covered areas, once the beds of lakes, but nuw feslecated and in most eases the exaet conuterpart of va rous traets existing in the western Unitcd States, and there generally called prairies, but sonetimes hnles. The pine-iarrens of the sontheru Atlantie States are sandy plains on whieh is a valuable
leated pine, Pimus palustris.

The "pine barren" ig traversed hy several exeelfent rosds, and a morning ride or drive whilie the delicate haz stili lingers aumeng the forest of stems, and the air 18 full of the fresin scent of the pine woods, is not easily for.
gotten. T'o fertilize expeclatiy the barrens of surrey and leerk barrent (bar'en), t. t. [<barren, a.] To render barren or unproductive.

barrener (bar'en-er), $n_{\text {. }}$ [< barren, a., 1 (d).] A eow not in calf for the year.

barrenly (bar'en-li), adv. Unfruitfully.

barrenness (bar'en-nes), n. [<ME. bareynesse, barynes, etc.; [ barren $+-n e s s$.$] The state$
or quality of being barren. (a) Incapability of pro-
ereation; want of the power of eonception.

I pray'd for children, and thought barrenness
In wediock in reproach.
Miltom, $\$$. A., 1. 3: III wedilock a reproach. Anton, s. A., 1. s. as, the barrenuess of the land. (c) Want of the power o jrodneing anything; want of instruetiveness, snggestive ness, interest, or the like;
nesz of invention," Dryden.

And this lesda me to wonder why Ligideins and many thers should ery up the barremess of the French plots ahove the variety and copiousness of the Fnglisio. Poesy.
Dryden, Ess. on Iraru. Posy. The barrennes of his feliow students forced hin generally into other company at his hours of entertainment.
Johnon, Rambler, No, 19.

(d) Defect of emotion, sensibility, or ferveney.

The grestest saints sometimes are fervent, suld some-
Jer. Taylum

barren-spirited (bar'en-spir"i-ted), "a. Of a oor or mean spirit. Shak, J C. iv. 1.

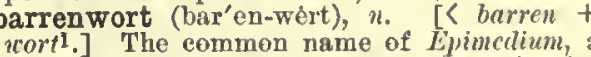

genus of low herbaceous plants, natural order Bcrberidacere, having ereeping roets and man stalks, each of which has three flowers. Tly only European species is $\boldsymbol{E}^{2}$. clpinum. Speeies oecur also Vancouveria hexamlra, a vearly allied specles found in

barreten. ${ }^{1} \nmid, n . \quad[<\mathrm{F}$. barrettc $(=\mathrm{Sp}$. barrcta), dim of barrc, a bar: see barl.] A little bar. barret ${ }^{2}$ (bar'et), $\cdots$. [Also baret, < F. barrett $=$ Pr. barreta, berrcta $=\mathrm{Sp}$. birreta $=\mathrm{It}$. ber retta: see biretta and birrus.] 1. Same as di relta.-2. A sort of ancient military cap harret 3 t. $n$. See barrat.

barret-cap (bar'et-kap), n. Same as barret ${ }^{2}, 2$ Old England's sign, St. Geurge's crusg,
IIIs barret-cap did graee.

barretero (bar-e-tā' rō), n. [Sp. < barreta dim. of barra, a bar, erowbar: seobarret and barl.] A miner who wields a crowbar, wedge or piek.

The ores .... are 80 solt that
throw down many tons a day.

L. II onitton, Mex. Ilandbook, p. 73

barretor, barretry, ete. See barrator, ete.

barr-fsh (bär'fish), $n$. [Cf. bar2.] A name of fish. See ent under crappic.

arricade (bar-i-kād'), n. [First in the form barricado (after Sp.), < F. barricade = It. barricata, < Sp. Pg. barricada, a barrieade, lit. made of barrels, $<$ barrica $(=\mathrm{F}$. barrique $)$, a barrel, prob. ¿barra, a bar: see barl, and ef. trees, earth, paving-stones, palisades, wagons, or anything that can obstruct the progress of an enemy or serve for defense or security. barrier

Jis'n tho thrice arsin
The red foul-fury of the seine marricuden with dead

2. A temporary barricer of any kind designed to obstruct passage into or throngh a space intencled to be kept fyee for a particular use.There must be such a barricale as would greatly amnoy or absolutely stop the currents of the atmosphere. Depham.

4t. In waval arch., a strong wooden rail, suported by stanclions, extending across the foremost part of the duarter-lrek, in ships of war nd backed witli ropes, mats, pieces of old eable and full hammocks, as a protection agaiust small shot in time of action. $=$ Syn. Bar, etc. See

barricade (bar-i-käd') , t. : pret. and pp. bar ricadcel, ppr. barriending. [< barricade, n.] 1. To obstiuct or block (a path or passage) witl a barricale. -2 . To block or render impassable.

Yow all the pavement sounds with trampling feet,

Gay, Trivia, ill hern in.

Ite is ao barricallo' $d$ in his louse,

Chapman, Jevenge of Linsy D'A mbols, I. I.

Also formerly barricado.

arricader (bar-j-ka $\bar{a}^{\prime} d e r$ ), $n$. One whe barri-

barricadot (bar-i-kä'dō), $n$, and $v$. Same as barricade: the older form in English use.

Shiall I lave a barricado made against my friends, to be harred of any pieasure they can bring in to me?

barricot, w. [<Sp. Pg. barrica, a eask, barre] seo barricade.] A small barrel or keg.

barrier (bar'i-êr), ". [Ear]y mod. E. also bar ier, baryer (with term. accom. to mod. F.) (ME. barjere, barcre, $\mathrm{AF}$. barreve, OF. bar viere, $\mathbf{F}$. barricre $=\mathrm{Pr}$. It. barricra $=\mathrm{Sp}$. barvera $=$ Pg. barreira (ML. reflex barrera), <ML. "barraria, a barrier, <barra, a bar: see barli.] 1. In fort., anything, as a palisade or stockade, designed to obstruct entrance inte a fortified place.-2. $p l$. The palisades or railing surrounding the gronnd where tourneys and justs were earied on; henee, the sports themselves (formerly sonetimes with the plural in a singular sense).

$$
\begin{aligned}
& \text { Deny ne not to stay } \\
& \text { To see a barriers prepared to-night. }
\end{aligned}
$$

he young Earl of Essex and

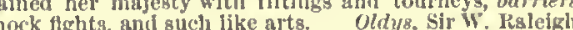
3. Any obstruetion; anything which hinder approach, attack, or progress; anything standing in the way; an obstacle: as, to build a tntional barricrs.

Constantly strengthening the barriers opposed to our A barrier to defend us trom popery.

4.4 fortiress or fortified town on of a country.

The rtueen is guarsintee of the Duteh, having possession
of the barrier, and the revenues thereof, before a peace.

5. A limit or boundary of any kind; a line of separation.

1 was persuaded that when onee that nice barrier which
narked the loundsries of what we owed to eael othe ghould be thrown down, it might be propped agaln, but
eould never be restored. A. II r milton, Works, I. 233.

6. The gate, in towns on the continent of Enepe, at which lecal revenue duties are collected. -7. In China, a subordinate customs station placed on an inland trade-route for the collection of duties on goods in transit.-8. In coalbetween two eellieries, for seeurity against the aceidents whieh might occur in eonsequence of communieation between them. [Eng.] - Barrer Act, the name given to an act passed by the General that no change esn be made in the laws of the ehurch without first being submitted to nll the presbyteries for least a majority of them. The Barrier Aet is held both $y$ the Tistahilished and by the Free Chureh as of high im. portanee, and analogous regulations have been adopted ref.- Barrier system, in North of England coal-mining, solid masses or barriers of coal are left between the working-plaees. - Barrter treaty, a treaty flxing the frontier of a country; espeetally, the treaty signed st Antwerp, 
barrier

Jands, determining the relations of the Dutch and the Austrians in the strategic towns of the Low Countries. Sral, and takes allnost all the many figurative meanings.
Barrier is also full in flgurative nieaning. Barricade is Barrier is also full in flgurative nieaning. Barricade is conflned strictly to obstructions set with the speciflc intenliy spirit beats her mortal bars. The barriers which they builded from the soil

The karricades at their leisure, and The Milanese threw up barricades at their leisure, and stili the Austrian governmerial anthority.
of this deflance of the Victor Iinmanuel, p. 77.

barrier (bar'i-êr), v.t. [< barrier, n.] 'T'o shut in or off with a barrier.

barrier-gate (bar'i-èr-gāt), $n$. A gate which closes the entrance through a stockade or barrier.

barrigudo (bar-i-gö'dō), n. [Sp. Pg., big-bellied, ২barriga, belly; of uncertain origin.] The Brazilian name for several monkeys of the genus Lagothrix. They are the largest of South American monkeys, one measuring 53 inches in length, of which the tail constituted 26 .

barring ${ }^{1}$ (bär'ing), $n$. [Verbal n. of bar1.] In mining, timber used for supporting the roof or sides of shafts. [Fing.]

barring ${ }^{2}$ (bär'ing), ppr. as prep. [Prop. ppr. of barl.] Excepting; leaving out of the account; apart from: as, barring accidents, I shall be apart from: as,
there. [Colloq.]

Little writing-deaks, constructed after the fashion of those used by the judges of the land, barring the French

barring-out (bär'ing-out'), $n$. Exclusion from a place by means of locks or bars; specifically, the act of excluding a sehoolmaster from school by barricading the doors and windows: a boyish sport indulged in at Christmas in Great Britain, for mischief in parts of the United States.

Revolts, repulilica, revolutions, most

No graver than a achoolboys' barring-out

Tennyson, Princess, Conclusion.

barris (bar'is), $n$. A name given on the Guinea coast to the chimpanzee, and also to the mandrill.

barrister (bar'is-tèr), n. [First in the 16th century, written barrester, barester, later bar$\left(\right.$ bar ${ }^{-1}$ n.) + -ster, the term. being appar. assimilated to that of sophister, etc.] A counselor or an advocate learned in the law, admitted to plead at the bar in protection and defense of elients: called in full a barrister at law. The term is more especially used in England and trem in Scotland being advocate and in the alone are admitted to plead in the superior courts. The mast previously have belonged to one of the inns of court, without the bar, and queen's (or king

jeante at leno, who pleathe After applying himself to the study of the law Bacon
was admitted in his twenty-second year (1582) as an $U$ tter Inner barrister. Same as bencher, 1. bar-roll (bär'rōl), n. A bookbinders' tool, of circular form, that makes a

bar-room (bär'röm), n. A room in a public house, hotel, restaurant, or other place of resort, containing a bar or counter where liquors or other refreshments are served.

barrowl (bar'o),$n$. [Early mod. E. also barow, barrough (mod. dial. bargh, barf, q. v., also berry $^{2}$ ); ( $\mathrm{ME}$. berw, beru 3 , ber 3 , bergh, beoruh (also, with vowel appar. affected by association with other words, borw, borgh, burgh, etc. whence the mod. form with differentiated meaning burrow2, q. v.), ( AS. beorg, beorh

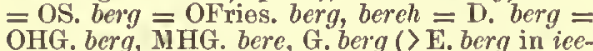
berg $)=\mathrm{Sw}$. berg $=$ Dan. bjorg = Goth." bairg (in deriv. bairgahei, a mountainous district), a hill, mountain, = Icel. berg, bjarg, a rock, precipice, $=$ OIr. brigh, Ir. bri =W. bre = Bret. bre, a mountain, hill (ef. W. bry, high), = OBulg. brêgŭ $=$ Serv. brijeg $=$ Bohem. breh $=$ Pol. br $z$ eg $=$ Russ. beregu, shore, bank; cf. Zend berezanh, a height, berezant, high, $=$ Skt. brilhant, strong,
mighty, lofty, ppr. of $\sqrt{ }$ brih, barh, bo thick, be strong. The orig. notion is that of a height and there is no connection with AS. beargan, etc., cover: see buryl.] 1t. A hill or mountain: originally applied to hills or mountains of any height, even the greatest, but later restricted to lower elevations. In this sense the word survives only in provincial use or as a part of local names in England.-2. A mound;
a heap. [Prov. Eng.] In particular-3. A

460

\section{bars-gemel}

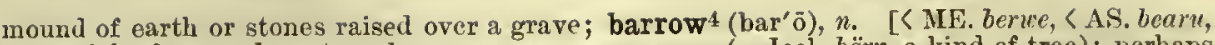
a sepulchral mound; a tumulus. Barrows are a grove (=Icel. börr, a kind of trec); perhaps among the most important monuments of primitive an-
tiquity. They are found in fireat Britain and other dis-

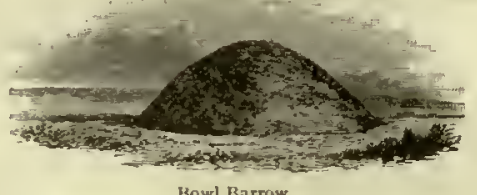

Bowl Barrow

tricts of Europe, and in North America and Asia. They and construction, as long, broal, bowl, bell, cone, etc., bar. rows. In the more ancient barrows the bodies are found ons of stone or bone beside them. In barrows of later
date the implements are of bronze, and sometimes, though

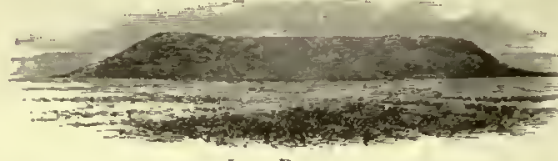

Long Barrow.

rarely, of iron, while the remains are often inclosed in a stone or earthenware cist and doubled up. Where the
body was burned the ashes were tusualiy deposited in an urn. Barrow-burial is supposed not to have been aban-
doned in Great Britain until the eighth century. In Engdoned in Great Britain until the eighth century. In Fngmost abound. Stone barrows in Scotland are called crirns. The numerous barrows of North America are generally or distinguished as burial-nounds.

Whilst the term tumulus is almost excluaively used in speaking of the sepulchral mounds of the ancient Greeks, their camps and stations, to serve as land-marks an watching-stations, it is used indifferently with the word inhabitants of this and other northeru countries.

A long street climbs to one tall-tower'd mill ;
And ligh in heaven behind it a gray down
With Danish barrows. Tennyson, Enoch Arden

4. A burrow or warren. See burrox ${ }^{2}$, berry ${ }^{2}$. The coney-barrow of Lincoln's Inn is now covered by barrow ${ }^{2}\left(\right.$ bar' $\left.^{\prime}\right), n$. [< ME. barrow, baraw, barowe, barewe, barwe, $<$ AS. "bearwe (a form row (ef. D berrie, MHG. bere, a hand-barro MHG. rade-ber, G. radberge, radbürge, dial. radeberre, a wheelbarrow, Icel. barar, mod. börur, pl., a bier, Sw. bar, barrow, bier, Dan. baare,

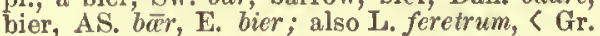
фepsтроy, a litter, bior, all from the same ult. source), (beran, bear: see bear $\mathbf{l}$ and bier.] 1. A frame used by two or more men in carrying a load; formerly, any such frame, as a stretcher or bier; specifically, a flat rectangular frame of dles (in Fngland called trams) at both ends, by which it is carried: nsually called a hand-barrow.-2. A similar frame, generally used in the form of a shallow box with either flaring or upright siles, and supported in front formerly by two wheels, now by a single small wheel inserted between the front shafts, and pnshed by one man, who supports the end opposite to the wheel by means of the rear shafts: usually larger size, resting on an axle between two large wheels, and pushed or pulled by means of shafts at one end; a hand-cart: as, a costermonger's barrow. [Local Eng. (London) and Scotch.]-4. A barrowful; the load carried in or on a barrow.

Ilave I lived to be carried in a basket, like a ba,row
butcher's offal ; and to be thrown in the Thames? Shak., M. W. of W., iit. 5 .
5. In salt-works, a wicker case in which the salt is put to drain. -6. The egg-caso of a skate or a ray: so called from its resemblance to a hand-barrow.

barrow ${ }^{2}$ (bar'o), $v$. $t$. [< barrow $\left.{ }^{2}, n.\right]$ To
wheel or convey in a barrow: as, to barrow wheel or con

barrow ${ }^{3}$ (bar'o), n. [< MF. barow, barowe, baru, < AS. bearg, bearh $=$ Fries. baerg $=\mathrm{D}$. barg, berg = OHG. barg, barug, MHG. bare, G. connected, as sometimes suggested, with $\mathbf{L}$. verres, a boar. Skt. varāka, a boar. Cf. hog, of the same orig. sense.] A castrated boar. Also called barrow-pig or barrow-hag. [Now chiefly prov. Eng.]

I say "gentle," though this barrow grunt at the word. rig. a fruit-bearing trec, < beran = Icel. bera, bear.] A wood or grovo: a word surviving only in English local names, as Barraw-inFurness, Barroutield.

barrow ${ }^{5}$ (bar'o), n. [E. dial., also barry, barbarrow (bar'o), n. [E. dial., also barry, bargaie. Origin obscure, perhaps ult. ( As. betect.] Same as barrow-eoat. gan, cover, protect.
barrow-coat (bar'o-kot), $n$. [E. dial., also barricoat; < barrow ${ }^{5}+$ coat.] A square or oblong piece of flannel, wrapped round an infant's body below the arms, the part extending beyond the feet being turned up and pinned. Also called barraw and barry.

arrowman (bar'ō-man), n.; pl. barrovemen (-men). A man employed in wheeling a barrow; specifically, in eoal-mining, ono who conveys the coal in a wheelbarrow from the point where it is mined to the trolleyway or tramway on which it is earried to the place whero it is raised to the surface.

barrow-pig (bar'ō-pig), n. Same as barrow ${ }^{3}$.

A barrow-pig, that is, one which has been gelded.
Dryden, Pintarch, II. 397.

barrow-pump (bar'ö-pump), n. A combined suction- and force-pump mounted on a twowheeled barrow.

barrow-tram (bar'ō-tram), n. The tram or haft of a wheelbarrow; hence, jocularly, a raw-boned fellow.

Sit down there, and gather your wind and your senses, ye black barrow-tram o' the kirk that ye are. Are ye fou barrow-truck (bar'o-truk), n. A two-wheeled hand-truck; especially, such a truck for uso in moving baggage or freight.

barrowway (bar'ō-wã), $n$. In coal-mining, an underground road on which coal is transported from the place where it is mined to the tramway. [Hing.]

barrulée (bar-ö-là'), $a$. In her., same as barruly. barrulet (bar'ö-let), $n$. [Also barrulette, dim. of AF. "barrule, dim. of OF. barre, a bar: see bar1.] In her., a diminutive of the bar, generally considered as being one fourth of its width. It is never used alone. Also written barrelet. See barruletty.

barruletty (bar'ö-let-i), $a$. [< barrulet.] In her divided into barrulets: said of the heraldic field. See barry ${ }^{2}$ and barruly.

barruly (bar'ö-li), a, [< AF. barrule, <*bar( In her., divided into bars or barrulets: said of the field when divided into not less than eight parts; if the number is much greater, it is called barruletty. Also barrulée.

barry ${ }^{1}$ (bar'i), n. Same as barrow-eoat. [Prov. Eng.]

$\operatorname{arry}^{2}$ (bä'ri), a. [< F. barré, pp. of barrer,

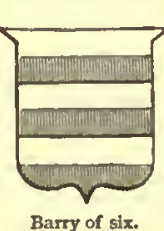
v.] In her., divided into ba said of the heraldic field. The number of divisions is always even and pieces, barry of six, etc.; if there are barmily and barruletty may be employed. Also barred.-Barry bendy. divided into lozenges hy the in tersectlon of lines drawn barwise and bendwise. dexter; when bendy ginister, it is writ barry.-Barry paly, divided hoth barwise and palewise, Barry pily, divided both barwise and diagonally, the division forming piles across the fleld. It is more properiy blazoned as of piles barwise, the number being mentioned. - Barry wavy, divided into waving bands of gen erally horizontal direction: aaid of the fleid. This charge like is to be depicted as afloat. Barsac (bär'sak), $n$. [F.] A general name for the white wines made in Barsae, department of Gironde, France. All the Barsac wines are sweetish; but they have a certain bitterness, and sometimes a
tarry or resinous flavor, which prevents thetr being lus. tarry

arse (bärs), $n$. [The original form of the word now corrupted to bass (see bass 1 ) ; <ME. barse, AS bars, bears, perch $=\mathrm{D}$. baars = MHG. bars, G. barseh, OHG. (with added formative) bersich, a perch; prob. akin to birse, bristle, q. v. Cf. Sw. and Dan. aborre, perch.] The common perch. [Local Eng. (Westmoreland).

ars-gemel (bärz'jem"el), n. pl. [<bars + gemel, q. v.] In her. [reed very near to gether, having more of the fiel above and below them than between them.

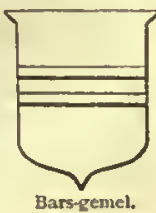


bar-shear

bar-shear (biir'slēer), n. A machine for cutting metal bars. It consists of a very strong frame havlug a laxed lower lilude and a vertical

bar-shoe (bür'shö), $n$. A kind of horseshoe having a bar across the nsual opening at the heel to protect a tender frog from injury.

bar-shooting (bär'shö"ting), $n$. The practice of slooting wild fowl from the bars of rivers and bays.

bar-shot (bilr'shot), n. 1. Double-learled shot, consisting of a bar with a half-ball or round head at each end, formerly used for destroying masts and rigging in navil warface. -2 . In

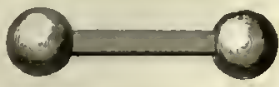
connected by a shert bar like a dumb-bell.

bar-sight (bir'sit), $n$. A form of rifle-sight. see bar 16.

barsowite (bair'so-wit), n. $\quad[<B$ arsow (skoi) + -ite ${ }^{2}$.] $\Lambda$ mineral ocenrring as the gangue of blue corundum at Barsowskoi or Barsovskoi in the Ural. Its true nature is uncertain, but it may bo identical with anorthite.

Bart. The contraction of baronet appended to a 11 me: as, Sir John Doe, Bart

bar-tailed (bär'tāld), $a$. Having the tail barred crosswise with different colors: as, the bartailer godwit, Limosa lipponica. See cut under Limosa.

bartender (bär'ten"dèr), n. A barkeeper; a waiter in a bar-room who serves out drinks and refreshments.

barter (bür'tér), v. [< late ME. bartren for *burton "bareten (tho jnserted $r$ being due perhaps to the suffix of the $\mathrm{OF}$. infinitive, or to dependence on the noun barator, bareter, ete. sce barrator), ( OF. bareter, barater, barter, truck, cheat, < barat, barate, barete, barter, cheating: see barrat.] I. intrans. To traffic or tracle by exchanging one commodity for anmoncy.

II. trans. 1. To give (one thing or commodity) for another of equivalent or supposed equivalent valne: with a person, for (formerly
with) a thing: as, to barter one's jewels for bread.

As my falth has once beon glven to you, I never will
Sherter it with gnether. Rute people who were willing to barter costly furs for
trifles. 2. To exchange, in general.-To barter away, to dispose of by barter, espectally in an unwise or dishonornble way; bargain away: as, to barter away human rights
for the patrenage of the great. IIte also bartered avay plums

Ior ruts. Locke.

barter (bär'tér), n. [<barter, v. ] 1. The act of exchanging; specifically, the act or practice of traficking by exchange of commedities.

All government, indeed cvery human bencfit and enjoy. ment, every virtue, and every prudent act, lo founded ou Burke, Concillation with America, $17 \%$ Artlele is excluanged for article without the use of moncy or credit. Thila is gimple bart

$$
\text { D. IF'ebster, Speech, Senate, Mareh 18, } 1834 .
$$

2. The thing given in exchange.-3. An arithmetical rule by which the values of different goods are ascertained and compared. $=$ Syn. 1 . barterer (bär'tér-ér), n. One who barters or traffics by exchanging commodities.

barterył (biir'tèr-i), n. [< barter $\left.+-y_{0}\right]$ Ex change of commodities in trade; barter.

It is a recejved opinjon that, in most anclent agea, there was only bartery or exehange of ... commodities amengs

barth (bärth), n. [E. dial., of obscure origin. Cf. berth2.] A warm inclosed place of shelter for young eattle.

Bartholomew baby, day, etc. See the nouns. Bartholomew-tide (bär-thol' $\overline{0}-m \bar{u}-t \bar{i} d), n$. The senson near St. Bartholomew's day (August 24). See $d a y^{1}$

Like flien at Bartholomew-tide, blund Shak., IIen. V., v. 2

Bartholomite (bar-thol'ọ-mît), n. [<Bartholomow $+-i t e^{2}$.] 1. $\Lambda$ member of the community took refuge in the West and wero assigned the
chureh of St. Bartholomew, in Genoa, in 1307. The community was finally suppressed in 1650 . -2 . One of a congregation of secular priests following a rule drawn up by Bartholomew IIolzhasen, in Germany, in 1640. They spread

to ITungary, Poland, and Spain, bnt, meler this

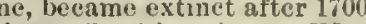

artizan (bär'ti-zạn), n. [Not found before Sir W. Scott who uses the prob. adapted frou a corrupt se. sp)elling (ber tisene) of bretticing, bratticing: sce bratticing.] In arch., a small verhanging turret, piereed with loopholes or embrasures, or witl both, and projecting gencrally from an angle at the top of a tower, or froln the parapet of

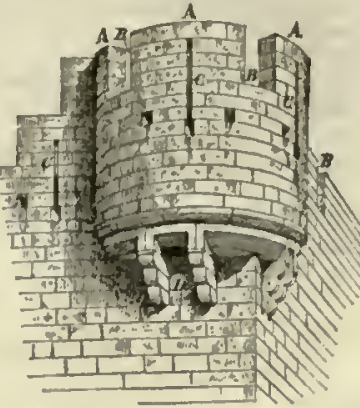

Bartizan.- Carcassonne, France.

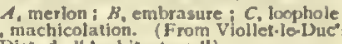

fortification-wall. On hattlement and bartizan Gleamed axe, and apear, and partisan.

Ic pass'd the court-gate, nid he ope'd the towcr-grate, And he neunted the narrow atal

the bartizan-acat, where, witl mids that on her walt, Scott, Eve of Saint John, artizaned (bä1'ti-zand), $a$. Furnished with a bartizan or bartizans. Scott.

Bartolist (bär'tō-list), n. $\Lambda$ student of Baring a famous It

bartonł (bär'ton), $n$. [< $\Lambda \mathrm{S}$. (ONorth.) bere-tūn, courtyard, manor, threshing-floor, < bere, bar ley, + tün, inclosure: see bear ${ }^{3}$, barley ${ }^{1}$, and ley, + tün, inclesure: see bear ${ }^{3}$, barley 1 , and
town, and ef. barn 1 .] 1. The demain lands of a manor, not rented, but retained for the use of the lord of the manor. Also called berwick. -2. A farm-yard.

Spacions bartons, elcan, well-wall'd around, Southey, I'oet'a Pilgrimnge, ill. 41.

artram, n. See bertram.

Bartramia (bär-trā'mi-ä), n. [NL., after the naturalist William Bartran (1739-1823).] A genus of sandpipers the type of which is Tringa bartramia of Wilson, now Bartramia longicau-

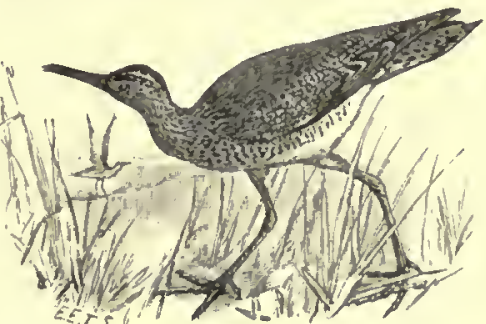

Bartram's Sandpiper, or Upland Plover (Bartramia longicauda)

a, a common species of North America, variously called Bartram's sanlpiper, upland plover, prairie pigeon, and quailly. It belougs to pecullar for the length and graduatien of its tail.
baru (ba-rón'), $n$. [Malay name.] A fine woolly baru (ba-ró ), $n$. [Malay name.] A fine woolly
substance, used for ealking ships, stufting eushions, ete., found at the base of the leaves of the Arenga saceharifera, a sago-palm of the East Indies.

baruria (ba-rö'ri-ä), n. [NL., < Gr. Bapér, heavy, + oupov, urine.] In pathol., a morbid condition of the body eharacterized by

barutine (bar'ö-tin), n. [Prob. of Pers. origin.] $\Lambda$ kind of silk manufactured in Persia. Simmonds.

barvel, barvell (bär'vel), . $_{\text {. [ }}$ [ dial., perhaps a corruption of "barm-fell, <barm1, lap, [Prov. Fing.]

barways (bär'wāz), adv. In her., same as bar-

ar-weir (bär'wēr), n. A weir which rises and falls with the tide, placed in a stream to prevent the return seaward of any fish which may have passed it.

barwin (bär'win), ". [Cf. Ir. Gael. bar, the sea.] A name applied in Connty Antrim, centroclontus. barwise (bär'wiz), adv. [<bar1 +- ise $^{2}$. $]$ In
her., in the direction of the bar, that is, hori- zontally aeross the field: said of tho divisions of the field, and also of any bearing; thus, a sword burreise is a sword berue horizontally. Also barkays.

barwood (bir'wúl), n. [Prob. so called beequse exported in bars; ef. logrood.] A red dyewood obtained from Sierra Leone aud Angela, Africa. It is the prodnet of the treo Baphice nitida, and is found in commerco as a rongh rect powder, iroulucen whter, hut yields about 23 per ecnt. to alcoholic infusion It is used for dyeing cotton yarua the hrilliant orange-red
known as mock Turkey red or barkood red, - Barwood spirits. Same as tin spinitn (whicl see, under tin).

bary-. [Is, etc., < Gr. Bapís, lieavy, = L. gravis, heavy, $>$ F. grave 4 , q. v.] An element in many words of Greek origin, meaning heavy, dull, hard, rlificult, cte.

barycentric (bar-i-sen'trik), a. [< Gr. Bapis, heavy, $+\kappa \varepsilon v \tau p o v$, ecnter.] Of or pertaining to the center of gravity.- Barycentric calculus, an application to geometry of the mecinanleal theory of the as metrleal or debcriptlve geonctrical propertiea are to bmincerticte.

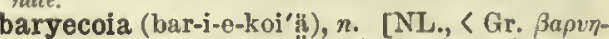
koia, hardness of hearing, < $\beta$ apvinoos, hard of

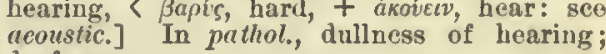
deafness.

baryglossia (bar-i-glos'i-ä), n. [NI., < Gr.

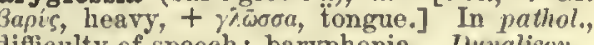
difficulty of speech; baryphonia. Dunglison. barylite (bar'i-lit), n. [<Gr. Bapers, heavy, + hilos, stone.] A silicate of aluminium and barium occurring in white eleavable masses in Sweden.

baryphonia (bar-i-fón'ni-ä), n. [NL. (ef. Gr. Bapvowvia, a deep voice, < $3 a \rho i \phi w \nu o s$, with a deep voice), < Gr. $\beta a \rho u s$, heavy, hard,

baryta (ba-ríntai ), $n$. [NL., formerly also barita, < barytes, q. v.] Barium oxid, BaO: also called heavy earth, because it is the heaviest of the earths, its specific gravity being 4.7. It is a gray powiler having a sharp, eanstic, alkalme taste, and a atrong afthity for water, with which it combines to form whlch are poisonous, except the aulphiatc, whllch is quite insoluble in the juices of the atomach. "The carbonate of baryta is much used in the preparatien of beet-root Formerly ealled baria. - Baryta-water, a solution of the hydrate of barium in water, used as a reagent in chemical barytes (ba-rì'tēz), n. [NL., < Gr. ßapítns, weight, heaviness, < $\beta$ apir, lieavy; the term. being associated with that of minerals in -ites, $-i t e^{2}$.] 1+. Baryta. -2 . The native snlphate of eral barite or heavy-spar. It is gometimes mineil
and ground in a nill, and used to adulterate white lead,
to weight paper, cte. See barife. barytic (ba-rit'ik), $a$. Pertaining to, formed of, or containing baryta.

barytine (bar'i-tin), n. [< barytes $+-i n e^{2}$. $]$ barytocalcite (ba-rī-tō-kal'sīt), n. [< baryta + calcite.] A mineral consisting of the carbomonoclinic crystals, also massive, of a white, grayish, greenish, or yellew color.

barytocelestite (ba-r" "tō-sē-les'tît), n. [<bataining some barium sulphate.

barytone (bar'i-tōn), $a$. and $n$. [Also baritone, It. baritono, < Gr. Bapítovor, deep-toned, with

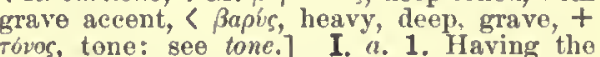
rovos, tone: see tone.] I. a. 1. Having the between a bass and a tenor: ats, a barytone voice. See II.

The volce [of the IIejazi] in atrong nud elenr, but rather barytone than basa: In anger it beeomea a ahrill chattering R. $F^{*}$. Burton, Et-1letinal, p. 318 (theoretical) grave aceent on the last syllable (see grave, a.); having the last syllable unaccented: as, a barytone word, such as tónor. ( $b$ ) Causing a word to be without accent on the final syllable: as, a barytone suffix.

II. n. 1. In music: (a) A male voice, the compass of which partakes of the bass and the tenor, but which does not descend se low as the one nor rise so high as the other. It range is treble. The quality ia that of a high bass rather than that of a low tenor. Frequently applied to the person possess. ing a volce of this uquality: as, signor 8. is a great ba rytone. IIaunting harmonies hover arouud us, deep and eternal like the undying barytone of the aea. 


\section{barytone}

(b) A stringed instrument played with a bow, (b) A sting the viola da gamba, called in Italian viola di bardone or bordone. It had sometimes 6 , nsually 7 , gut atrings, stopped by the flingers of the left steel, running under the finger-board. Thiese were sometimes plucked with the thumb of the left band. The iilstrunent was a great favurite in the eighteenth century, and nuch musio was composed egpeeially for it. It is
now obsolete. (c) 'The name nsually given to the smaller brass sax-horn in Bb or C. - 2 . In Gr. gram., a word which has the last syllable unaccented.

barytone (bar'i-tōn), $v$. t.; pret. and pp. barytoned, ppr. barytoning. [< barytone, $n$.$] In G r$. gram., to pronounce or write without ace the last syllable: as, to barytone a word.

barytrope (bar'i-trōp), n. [<Gr. ßapús, heavy, $+\tau \rho b \pi$ os, a turning: see trope. ] A curvo deslides down an incline having this form, the pressure on the incline will follow a given law. basal (bā'sal), $a$. and $n$. [< $\left.b a s c^{2}+-a l.\right]$ I. $a$. 1. Of or pertaining to the base; constituting the base; fundamental.

The basal thea of Bishop Butler's profound treatise, T'ire A Religion.

G. D. Boardman, Creative Week, p. 28.

2. Pertaining to the base of a part or organ. (a) On or near the base: as, a basal mark. (b) basal joints of an insect's antenna. -3 . In ichth. of or pertaining to the basalia. See basale.

The Elasmobranchil possess three basal cartilages, which The Ilastrobranchil possess three basal cartilages, which
articulste with the pectoral arcl.
Huxley, Anst. Vert., p. 38. Basal cell. (a) A cell st the base of the segmented ovim of some embryos, as aponges : the opposite of apical cell. (b) In the wings of Dipterce, one of the elongate cells near the base of the wing between the second and fifth or second and sixth longitudinal veins; they are numbered, the first
being the one nearest the costal margin.-Basal cleavage, in crystal., cleavage in the direction of a basal plane. age, in cryst feld, area, or space, a portion of an insect's wing lying at the base, but very diversely defned in the different groups. In the Lepidoptera it occupies the
whole width of the wing for about one fourth of tts length, and in the fore wings of the Noctudice ts limited externally by the anterior or extra-basilar cross-line. In the dragon-flies it is a sinsll space at the extreme base of the Whing, between the median and strbmedian veins, alt
bounded extertorly by the arc or areulus, a small crossbounded exteriorly by the arc or areulus, a shatr crosa
vein. In other groups $t$ is generally an indeterminate portion occupying about one third of the wing. - Basal tuid moths, s line extending lrom the costal horder of the
anterior wing, near the base, halt way across the surface. - Basal plane, in crystal., a plane parallel to the lateral or horizontal sxes.- Basa valve, that valve in bivslves
by which they adiere to other substances.
II. $n$. 1. One of the basal joints of the branches of a crinoid, bearing the radials. -2 . In $i c h t h$., the basisphenoid. [Rarc.]

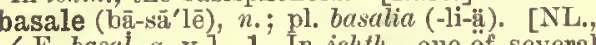
< E. basal, q. . .] 1. In ichth., one of several cartilages which may compose the basis of the pectoral limb of a fish, and to which the series of radialia, or radial cartilages, is attached: as, the propterygial basale; the mesopterygial and metapterygial basalia. See pterygiun, and cut under scapulocoracoid.-2. One of the bones which form the base for the pectoral fiu;
actinost. -3 . In crinoids, same as besal, 1 .

A central picce, which probably represents the basalic
II uxley, Anat. Invert., p. 500. basal-nerved (bā'sal-nèrvd), $a$. Iu bot., descriptive of leaves the nerves of which all proceed from the base.

basalt (ba-sâlt' or bas'âlt), n. [F'irst in E. as L., basaltes; = F. basalte, < L. basaltes, a dark and very hard species of marble in Ethiopia; said to be an Afriean word (Pliny).] A
volcanic rock occurring widely, and consisting of a triclinic feldspar, together with augite and magnetite or titaniferous iron. Olivin and nephelin are also oiten
found in the basalts, eapecially the for: iner. Apatite, leucite, and haiiyne are
occasionally present. The basalts have ocen varioubly elased by different
writers. Basalt proper is the dark, compact variety, breaking with a splintery fracture. Under the name dolerite are included all the more
coarsely crystallized varieties in which the component minerals can be made
out with the naked eye, while anamesite is the name given to those varie

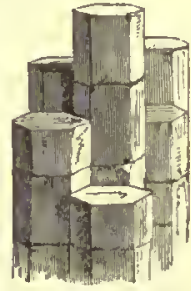
Colutmar Basalt. basalt has almost always been the last rock to be emitte from the volcanic orifice. The cooling of lava often gives which sre focastonally extremely regular in form snd Which sre occastonally extremely regilar in form snd of and in greater perfectness than any other rock ; bence cui,) Remarkable formations of columnar basalt exist in
462

northeast coast of Irolanl, and Fingal's Cave in the island of Stafia, Scotland.- Basalt Ware, a kind of stoneware made by Josiah Wedgwood and his ancessorg, flumblout the paste, and has a dull gloss: hence also called black avere. Articles made of it are much admired,

basaltic (ba-sâl'tik), a. [<basalt + -ic.] Pertaining to basalt ; formed of or containing basnlt; of the nature of or resembling basalt: as, basaltie lava.

asaltiform (ba-sâl'ti-fôrm), a. [< L. basaltes, basalt, + forma, shape.] Of the form of prismatic basalt; columnar.

asalting (bạ-sâl'ting), $n . \quad[<$ basult + -ing I. $]$ A process of making paving- and buil

basaltoid (bâ-sâl'toid), a. [< basalt +-oid.]

Allied in appearance or nature to basalt; reAllied in appear

sembling basalt.

basan, basane (baz' an, ba-zän'), $n_{\text {. }}$ [Also bazan, basin, bazin, and more corruptly basil, badana (ML. bedanc), a tanned sheepskin, $<$ Ar. bitānah, lining.] Sheepskin tanned in oak- or lareh-bark, and used for bookbinding, etc. It is distinguished from roan, which is tanued in sumac.

asanite (bas'a-nit), n. [< L. basanites (sc.

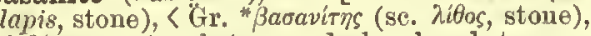

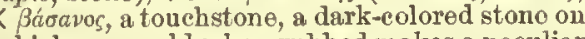
whicls pure gold when rubbed makes a peculiar mark; origin uncertain.] A silicious rock or jasper, of a velvety-black color, used as a touchstone for determining the amount of alloy in gold. The touchstone was formerly extensively used, but is now much less common. See touchstone and touch-necdle.

[ [F, blue-stocking: bus, bas-bleu (bä-blè'), n. [F., blue-stocking: bus, abbr. of bas de chausses, nether-stock, stock-
ing (see basc 1 ); bleu, blue: a translation of the E. term.] Same as blue-stocking, 1.

as-chevaliert, $n$. [A fictitious term, based on a false etymology of bachelor; < F. bas, low, One of a class of low or inferior knights, by bare tenure of a military fee, as distinguished from bannerets and baronets. Phillips, 1706. frow bannerets and baronets. Phillips, 1706.
[A spurious term, without historical support.] ascinet, $n$. See basinet.

Bascuencet, $n$. The Basque language.

basculation (bas-kū-lā'shon), $n$. [< F. bascu-

ler, swing, see-saw, < bascüle: see bascule.] In pathol., the movement by which a

uterus is swung bascule (bas'kül), n. [ ' $\mathrm{F}$. bascule, swing, poise, balance, see-saw, formerly baculc, appar. poise, balance, see-saw, formerly baculc, appar. posteriors.] 1 . An arrangement in bridges A form of bailing-scoop.

bascule-bridge (bas'kül-brij), $n$. A drawbridge floor of the foor of the the counterpoise descends into a pit pre the commonest form of me bridge. See ba ance-briage.

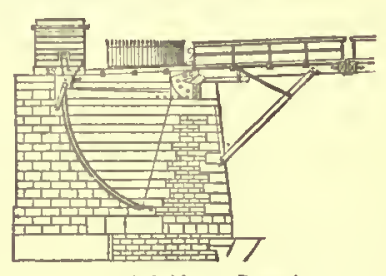
base ${ }^{1}$ (băs),

and $n_{\text {. }}$ [Early mod. E. also bace; < ME. base, fem., = Pr. bas = Sp. bojo= Pg. baixo=It. basso, low, < LL. bassus, low, short, thick; in classical L. found only as a cognomen, Bassus, 'Short.' Perhaps of Celtic origin; cf. W. bas, = Corn. bas = Bret. baz, shallow; W. basu, make shallow, lower; Corn. basse, fall, lower, abate shallow, lower; Corn. basse, fall, lower, abate; sic, now generally bass: see bass. As a noun, base of this origin (the lower part) is confused with base ${ }^{2}$ (the supporting part).] I. a. 1. Tow;
of small height : applied to things. [Archaic.] The cedar stoolss not to the base shrub'a foot.
Shak., Lucrece, 1. 664.

Hence - 2. In bot., of low or lowly growth: as, base broom; base rocket.-3. Low in place, position, or degree. [Archaic.]

By that same hole an entraunce, darke and bace,

Wescends to hell.
Spenser, F. Q., I. v. 31. llen acting gregariously are slways in extremes; as they are one moment capable of higher courage, 80 they are lisble, the next, to buser depression. base

4. Of little value; coarse in quality; worthess, absolutely or comparatively: as, the batse metals (so called in contrast with the noble or precious inetals).

The harvest white plumb is a base plumb. Often has the vein of gold displaycd itself amil the Hence-5. Fraudulcutly debased in value; spurious; false: as, basc coin.

They were compelled to accept base money in exchange or those commoditles they were forced to sell.

6. Low in scale or rank; of humble origin, grade, or station; wanting dignity or estimidtion; mean; lowly: as, base menials.

Bare things of the world, and things whlch are despised, "Tis the plague of great ones;
Prcrogatived are they less than the base. Shak., Othello, iii. 3.

7. Suitable to or characteristic of a low conition; depressed; abjoct: as, base servility. I ain fire and air: my other elements
I give to baser lite. $\quad$ Shak., A. and C., v. 2.

8. Of mean spirit; morally low; withont dignity of sentiment: said of persons.

Base is the glave that pays. Shak., Hen. V., it. I.

The buse gud abject multitude. Junius.

9. Showing or proceeding from a mean spirit: said of things.

$$
\text { Him that ntterd nothing base. }
$$
The one base thing in the universe - to receive favors 10. Of illegitimate birth; borm out of wedlock. Why bastard? wherefore base? Shak, Lear, 1. 9 .

I din'tl with $\mathrm{S}^{\mathrm{r}}$ Robe Paston, stnce Earle of Yarmouth, and saw the Duke of Vernenille, base brother to the $Q$.
Mother.

11. Deep; grave: applied to sounds: as, the base tones of a viol. See buss 3 .

The sllver sounding matruments did meet of the wsters fall.
Spenser, F. Q. II. xil. 71.

12. In old Eng. law, not held or holding by honorable tenure: as, a base estate, that is, an estate held by services not honorable nor in ow and the tenant a base tenant.13. Not classical or refined: as, "base Latin," Fuller.

No Husea alde me needes heretoo to call;

Rase is the atyle, and matter meane witliall.

Base bullion. See bullion.-Base court. See broecourt.- Base fee, infeftment, right, etc. see the nouns - Base metals. Sce metal. = Syn. Imoule, vulgar, plegrovellng, servile, slavish, menial, rascally, villainous. vaist to the knee, worn during the first half of the sixteenth century. In civil costume it was ap ed to the girdle; it was also worn 2t. A skirt of plate - armor, corrugated or ly, as if in imitation of the preceding. See lamboys. - 3t. The skirt of a Troman's outer Base of rich stuff, the border embroidered garment. The

throughout the seventeenth and part of the eighteenth century. - 4t. An apron.

$$
\begin{aligned}
& \text { With gauntlets blne and bases white. } \\
& \text { S. Butler, IIudibras, I. ii. } 769 .
\end{aligned}
$$

Bakers in their linen bases. Marston.

5t. The housing of a horse: used in the sixteenth and seventeenth centuries.

The bases and bardes oi their horse were grene gattyn. Or to describe races and games,

Buses and tinsel trappings, gorgeons knight 6. In music, same as bass 3

ase It (bãs), v. t. [< bascl, a., but in first sense < $\mathrm{F}$. baisser, lower, <bas, low, base. Cf. abasc.] 1. To let down; abase; lower. state. 
2. To lower in claracter, condition, or rank degrade; debase.-3. To reduce the value of [iRare.]

Mctuls which we camnot baxe.

Lincon,

base $^{2}$ (bās), n. [< MF. base, bus, buas, < OF base, $\mathrm{F}$. buse, < l. bresis, < Gr. Bárıs, a going, a stepping, a step, pedestal, foot, base, $\langle\sqrt{*} \beta a$ 1. The bottom of anything, consiclered as it support, or tho part of the thing itself, or separate feature, on which tho thing stands or rests: as, the bise of a colimn; the base of a mountaili.

lor want like thine - a hog without a base -
Ingnitfs all gatns I gather for the place. Against the beses of the aonthern hllls.

Lateel, Under tles whllows.

Ience - 2. $\Lambda$ fundamental prineiplo or ground work; foundation; basis.

Antonlo never yet was thlef, or pirate,

Though, I confess, on base and ground enough,

nereby" he undermineth the baxe of rellgion.

Drowne, Yulg. Err.

3. In areh., specifically - $(a)$ The lowest meinber of a wall, either projocting beyond the face of the portion of the wall above it, or differing otherwise from it in construetion, and often resting on a plinth, with or withont in tervening moldings. (b) The member on which

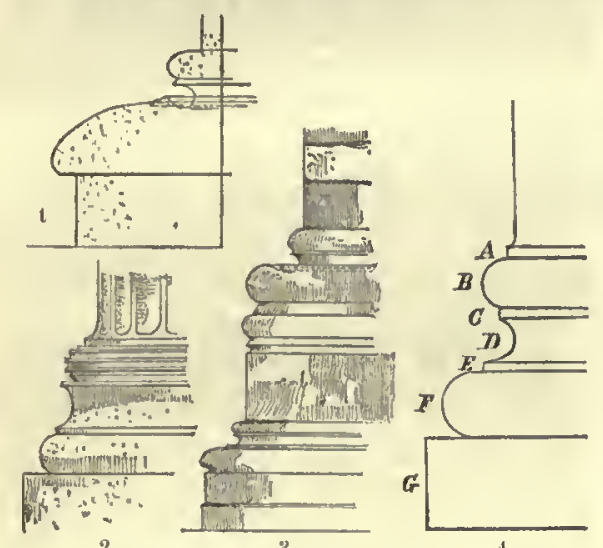

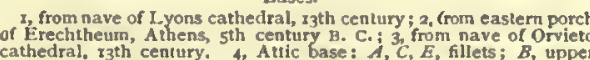
cathedral, r3th century. 4 , Attic base: $A, C, E$, fillets; $B$, upper
torus; $D$, scotia ; $F$, lower torus; $G$, plthih, or stylobate.

the shaft rests in columans of nearly all styles. It appears in most Egyptian forms, but is not present in on the stylobate. In purely Ifellenle examples of the lonic and Corint hian the base conalsts of vartous combina thons of moldings on a cirenlar plan, without the awk. ward aquare plinth wlich was universally adopted by th
Ronnans, and was generally retained in the elaboratel
molded bases of byzantine and medleval archttecture 4. (a) In $z o o ̂ l$. and bot., the extremity opposite to the apex; the point of attrehment, or tho part of an organ which is nearost its point of at tachment: $\mathrm{as}$, tho base of a leaf; the basc of a shell. "The point of attachment of an anther, however, is sometimes at tho apex. (b) In zoöl. also, that part or extremity of anything by which it is attached to anotlier of higher value or significance.-5. In chem., a eompound substanee which unites with an aeid to form a salt. The term is applled to the hydroxids of the metals, to certain metallic oxids, and to groups of atoms contalning one or more hydroxyl gruups (OH) in which hydrogen is re
placeable by an actu radtcal. 8. In phar., the prineipal ingredient of any compound preparation. - 7. In erystal., same as basal plane (which see, under basal). -8 . In the ground-1nass of a rock. This may possess a ccr. taln amount of structure, lendering it disthet from glass, while not crystalline, when it is known as a microfelsitic base. If a true glass, it may be, according to the amount of devitriftcation products plesent, microlitic, globulitic, or glassy. In some recent andesitic lavas It possensea a peculiar appearance, ao similar to felt that it is known as a
felt-like base. The term mamua (whlch gee) has also been felt-like base. The term mamua (whlch see)

9. In dentistry, the setting for artificial teeth. - 10. In dycing a substance that has an affinity for both tho eloth and the coloring matter a mordant. - 11. In fort., the exterior side of the polygon, or that imaginary line which is drawn from the point or salient angle of one bastion to the point of the next. - 12. In geom. the line or surface forming that part of a figure
463

base-line

on which it is supposed to stand; the side opposite to lie apox. The base of a hyperthola or

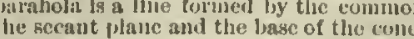

13. In arith. and alycbra, a number from the different powers of which all numbers are coneeived as produced. The base of a syatem of arith metical notation fo a mumber the multiples of whose

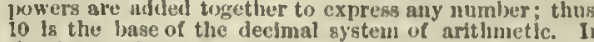
the theory of numbers, the base of an hidex is a number which, betng raised to the power represented by the index, gives a number congruent to the munber whose index
la spoken of. The base of a systcm of fogaritlims is the 18 spoken of. The base of a system of logaritlims is the
munber which, ralsed to the power indleated hy the log arither, gives the number to which the liggarithun belongs. The Napnerias base, or baso of the Napiertan systeru of

$$
1+1+1+\frac{1}{2.3}+\frac{1}{2.3 .4}+\frac{1}{2.3 .4 .5}+\text { etc. }
$$

14. In her., the lower part of the field, the charges in which aro said to be in base. It Is sometimes consifered as diviled Into dexter, sinfster, and

15. Milit.: (a) A tract of country protected by fortifieations, strong by natural advantages, or for any other reason comparatively secure, from which the operations of an army proeeed or from which supplies are obtained: ealled
distinctively the base of operations or the base of supply.

Base, in millitary operations, is almply a secure starting. point, or rather tract of country belind, in which an army ia In comparattve aafety, and in which the stores and
reserves of men lor the force are situated. Saturday Rev. (b) The rounded hinder portion of a gun, generally ealled the base of the brecch. (c) A small light eannon used in the sixteenth and seventeenth eenturies. - 16. In surv., same as base line. -17 . The place from which racers or tilters start; a starting-post.

To thelr appointed base they went.

Dryden, Fincld,

18. An old game, played in various ways in some of which it is still practised, and in all of which there are certain spaces marked out, beyond or off which any player is liable to be touched with the hand or struek with a ball by a player on the enemy's side. Forms of thla game are known under the names of prisoners' base, rounders, wational game of the United States.
Alter a course at Barley-break or $D$ (te B. Jonson, Sad shepherd, i. ?

19. One of the spaces marked off in the game of base or prisoners" base. See 18. - 20. In bascball, one of the four corners of the diamond. See base-ball.-21. That part of an eleetromagnetie apparatus which contains the helix switeh, and first and seeondary binding-posts -Altern base, Attic base, clc. See the adjectives, prisoner. - To bid the organic. - Prisoners' base. Se challenge to a game challenge to a triai of lexterity, gkili, or of the game, to trial of any kind; challenge generally.

To bid the wind a base he now prepares.

Shak., Ve

We will find comfort, money, men, and triends, Marloze, Edw. II., it.

base ${ }^{2}$ (bäs), $v . t$; pret. and pp. based, ppr. bas ing. [< base $\left.{ }^{2}, n_{.}\right]$1. To form a foundation for. [Rare.] -2. To use as a groundwork or on or upon: as, all sound paper currency must be based on coin or bullion; he bases his arguments upon false premises.

It is on the understanding, and not on the sentiment, of hation that alt ante legisiation must be based.
Louell, Study Whndow, p. 165.

base ${ }^{3}$ (bãs), $n$. Another form of bass 1 and barsc. [Loeal Eng. (Cumberland).

base-bag (bàs'bag), n. In base-ball, one of the bags of ten used to inark first, second, and third base.

base-ball (bās'bâl'), n. 1. A game of ball played by eighteen persons, nine on a side. scuare plot of ground called the diamond, with sldes 90
leet long, is marked off, at the cormers of whlch are the bases, known as home or home base (B), first base (D), secand base (E), and third base (F). The players on one side
take their posttlons in the field, the catcher $(A)$ just behind take their positlons in the field, the catcher (A) just behind
the home base, the pitcher (C) at a dlatance of 50 feet frorn the home base, the pitcher (C) at a dlatance of 50 leet fror three brsemen near first, second, and third base, the short known as right (II), center (I), and left (J), at some dis
known tance behlnd and on each aide of the second hase. The piteher pliches the ball over the home plate to the catcher. One of the other slde, whlch is sald to be in, or at the brt, takes a position lyy the hoine base, and tries to strike the
ball as it passes bim, It lie knocks it linto the alr, and olle standing on first bas of the other sidce catches it thefure it reacises the groumd, the striker is out or cauyll oute, that $f_{3}$, retirea frum the home to first or from home to third or tron thoned indeffnitely, it is a foul, und dues not comnt at all, minless it is canght before it tonches the gromid, in whell ease tlee
striker ts ont. Shonli] it strike linside these lines the batter ruas to firs loase, and their or lnter to hase. It he reaclees liom liase he acores a run.
Should the ball be thrown to and eanght by a playe cceils in reactiog it or should the batter or touched with the ball ! the hande of any of hil adversarice whife rumin I $\quad H$ is out One player atter anuther of the slule whicli "In" goes to the bat untll three men have been put out. Thla constitutes an inning. N mo tnnings for each side make a game, and that aldu wlifch succecds In making the reater numher of rums wins the camis.

ball with which this game is played.

ase-board (bās'bōrd), n. A line of boarding around tho interior walls of a room, next to the floor.

ase-born (bās'bôrn), $a$. Of baso or low birth born out of wedloek; of low or mean parentage or origin; spurions.

Thy base-born thlld, thy bale of allame.

Gay.

It ta jnatly expected that they ahould loring forth a baxe.

base-bred (bãs'bred), $a$. Of low or base breed

ing; mean; of discreditable origin.

As little soula thelr base-bred taneles feel. J. Baillie.

base-broom (bās'bröm), n. $\Lambda$ name given to Genista tinetoria, with referenee to its low staturo.

ase-burner (bās'bèr"nèr), A stove or furace eonstructed on the base-burning princi-

base-burning (bās'bèr"ning), $a$. Burning at the base.-Base-burning furnace or stove, a fur. is renewed from a self-act ing hopper or chamber above. base-conrt (bās'kōrt), n. 1. A secondary or inferior court or yard, generally at the back of a house, opposed to the chief court or main quadranglo; a farm-yard.-2. In Eing. law, a inferior eonrt of justice, but a court of record, as a court-baron, court-leet, etc.

asedt (bāst), $a . \quad\left[\left\langle b a s c^{1}, n_{.},+-c l^{2}.\right]\right.$ Weal-

Based In lawny velvet. Hall, 11en. V111., an.

ase-dance (bãs'dàns), n. A slow dance in time, resembling the minuet.

When the aad Morrls ls doone, then the gentillmen to every of them to taike oon lyy thand, and dannce such se daunces as is apointed theym.

Basedow's disease. See discase.

base-hearted (bäs'här"ted), $a$. Having a base

treacherous heart; deccitful.

baselardt, $"$. Same as baskard.
baseless (bās'les), $a . \quad\left[<\right.$ basc $^{2}+$-less.] Witl out a base; having no foundation or support.

LAke the baseless fabric of thls vision,
The cloud-capp'd towers, the gorgeons palaces

The aolemn temples, the great globe itself,

Yea, all which it inherit, ahail dissolve;

A ud, like thls Inaubstanttal pageant faded,
Leave not a rack behlnd. Shak., Tenjpest,

baselessness (bās'les-nes), $n$. The quality of

being baseless, or without foundation ; groundlessness.

The baselessness of this hypothesis has been shown.

base-line (bās'līn), n. 1. A line adopted as a base or foundation from which future operations are carried on, or on which they depend or rest. (a) In perspect., the bottom line of a picture, in whlch the loremoat vertical plane of delineation cuts the ground-plane, on which the wljects repregented in ing a alde of a triangle, the adjacent angles of which bein

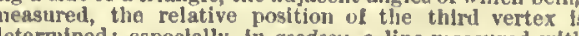
the utmost prectsion to serve as the orine measured with triangles, and as the foundation for the computation of the length of their sides. In the process of triangulation, the angles of tbese triangles and the length of a aingle alde (the base or base-line) being known, the lengtha of all cal are measured, each being from 3 to 10 milles hase-lines length. 


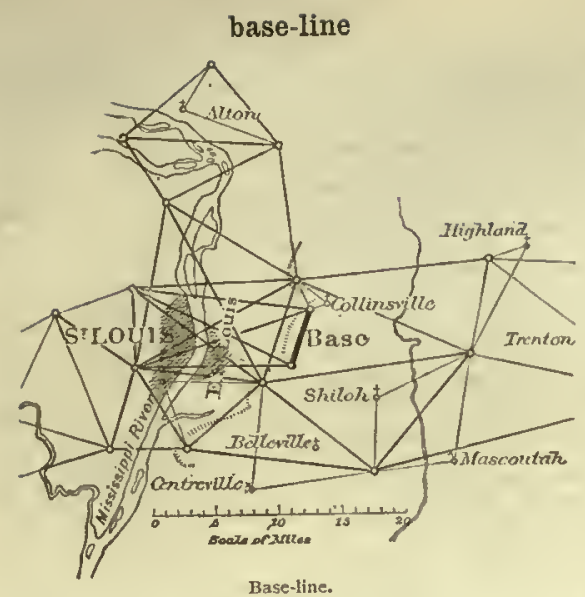

(c) Milit., a line, as of frontter, aea-coast, or forts, takes by an army as the base of operations, from which moveand nen are gent to the front, and to whieh the army may retreat in ease of disaster. Also called base.

2. A line traced round a cannon behind the vent. -3 . In the game of lawn-tennis, the ond line of the court the line from which the player serves the ball. - 4. In base-ball, the line connecting one base with the next.

basely (bā's'li), adv. 1 , In a base manner; meanly; dishonorably.

But basely ylelded wom arr'd he hath not, yined upon eompromis

v'd with blows.

2. In a base or mean condition; illegitimately; in bastardy.

Two Mitylene brethren, basely bori.

3t. At a low rate; eheaply. Them that deaire to look lig, and to live basely.

Knolles.

baseman (bās'man), n.; pl. basemen (-men). Any one of the three players who in the game of base-ball

basement (bàs'ment), n. [= MLG. basement, basiment, basment, base, pedestal; ef. F. soubassement, formerly sous-bassement, < sous, under (<L. subtus, < sub, under), + *bassement (in der (< L. subtus, sub, under), + "bassement (in form after It. bassamento, abasement): sce base tion; a base. [Rare.]

Up from its deep reservoirs, from the mysterious base-
ments of the monntain, wells the ailent strean.

J. A. Symonds, Italy and Greece, p. 322. 2. In artion of the elevation of a structure which performs the function in portions which come above it; especially, the substructure of a columnar or arehed construction, but also the lowest member in the design of a wall, ete. Compare bnse 2,3 .

It [the tomb] eonsisted of a aquare basement surrounded?
by a Dorie peristyle with engaged columns, and surnounted by a Dorie peristyle with engaged columns, and surmolnted by a pyramid, on the apex of which was placed the lion as
the epithema, or erowning ornament.

(b) A floor or story which is wholly or in part beneath the surface of the ground, but is usually, as distinguished from a cellar, well lighted, and fitted up and used for lionsehold or other usual purposes.-3. The aet of basing, or the state of being based. [Rare.]-Basement membrane, in anat, a delicate membrane, formed of thatmenbranes, and covers that of aecreting glanda. Also ealled membrana propria.-Basement tissue, the sul)-
atanee of basement membrane.-English basement, the atanee of basement membrane. - English basement, the
entrance-story of a eity house when it is on the level of [U. S.] See extract.

But the most conspienous importation from Britain Was the houke New Yorkers call the Kinglizh bagement and Its drawing-rooms upstairs, as distinguished from the Dutch type with ita "ligh stoop" givlng immediate ae-

basement-story (bās'ment-stō" ri), n. Same as basement, 2 (b).

base-minded (bãs'minn"ded), a. Of a low spirit base-mindedly (bās'min" ded-li), adv. In a base-mindedly (bās'min" ded-li), adv.

base-minded or dishonorable manner. ornamental molding at the base of any architectural feature, as a colnmn, pedestal, or especially a wall.

basent, $a$. [Appar. one of Spenser's made words Cf. Se. bazed, stupefied; D. verber
Extended as with astonishment.
Stare on him with ling Iookes basen wite. Spenser, Mother Il ub. Tale, 1. 670 baseness (bās'nes), $n$. [< basel + -ness. $] 1$. The state or condition of being base or low in seale; mean

Baseness of birth is a great disparagement to some nien. Ile mixhng with his proper sphere,

Tennyson, In $\$$ is emorian, $1 \mathrm{x}$

2. That which is baso or low; anything of an imoble grade or quality; meanness, as of r'elation or employment.

$$
\begin{gathered}
\text { Some kinds of baseness } \\
\text { Are nobly isndergone. Shak., Tempest, lii. 1. }
\end{gathered}
$$

3ł. Illegitimacy of birth; bastardy. write fair. Why brand they us Shatk., Lear, 1. 2

4. The state or quality of being morally mean or vile; vileness; worthlessness.

Villains,
Whose baseness all disgraceful worls made one
Caunot express!
Beau. and $F l .$, Knight of Malta, iv. 4.
Equal baseness lived in sleeker timea,
T'ennyson, Prineess, v. Tennyson, Prineess, $v$

5. Of metals: (a) Liability to rust: opposed the result of having been alloyed with a cheaper metal; spuriousness.

We alledged the fraudulen tobtaininghia patent, the bras ness of his metal, and the prodigiona aum to be eoined. 6ł. Deepness of sound.

Swift

The baseness or trebleness of toner.

basenett, $n$. See basinet. Bacon, Nat. Hiat., s 184

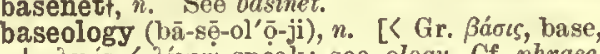

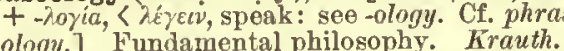
base-plate (bās'plāt), n. 1. The foundationplate of metal on which a heavy piece of machinery, as a steam-engine, stands; the bedchinery, as a steabe-ball, one of the plates formerly often used to mark the bases; hence, by merly often used to mark the

extension, one of the bases. metal directly in front of the base of the breech in old pieces of ordnance, connected with the body of the gun by a concave molding.

base-rocket (bās' rok" et), $n$. A species of mimonetto Reseda lutea: so called from its ocket-like leaves and low stature.

ase-running (bās'run"ing), $n$. In base-ball, the act of running from bas.

base-spirited (bâs'spir"i-ted), $a$. Having a base or mean spirit; mean; cowardly.

apprehension regarded as imitative (cf. bang. dash, smash, ete.), but prob. of Scand. origin, assibilated form of bash (now obs.; ef. dial. basking, a sound thrashing), ( Dan. baske, slap, drub, Sw. basa, whip, drub, beat.] I. trans. To strike with a heavy blow; beat violently;
knoek out of shape. [Colloq. and prov. Eng.] A woman, a whelp, and a walnut-tree,
'Ihe more youl bash 'en the better they be.

(he proverbial saying. The above proverb lefers to the praetice of beating wal. proceeding which was thought to inerease thetr produc-

II. intrans. To strike; knock. [Colloq. and prov. Eng.]

ash ${ }^{1}$ (bash), n. [Cf. Dan. bask, a blow, Sw. bas, whipping, beating; from the verb.] A [Colloq. and prov. Eng.]

bash ${ }^{2} \uparrow$ (bash), $v$ [<ME. basshen, basehen, baisen, by apheresis for abashen, ete., abash: see abash.] I. trans.

She that bash'd the sum-god with her eyes.

. and Eng.

II. intrans. 1. To be daunted, dismayed, or confounded.

Inia countenamnee was bold, and bashed not Spenser, F. Q., 11. Iv. 37.
Sp.

Make Venus' leman, arm'd in all his ponip,
Bash at the brightness of your hardy looks.
Greene and Lodge, Looking Glass for Lond. and Fng. 2. To be abashed or ashamed; be put out of countenance.

bash $^{3}$ (bash), v. $t$. [E. dial.; perhaps another use of bashI.] In eoal-mining, to fill with rub-

\section{bashlyk}

bish (space from which coal lias been taken). [S. Wales.]

bashaw (ba-shâ'), $n_{\text {. }}$ [Early mod. E. also bassaw, basha, baeha (1. baeha, It. bassa, bascia,

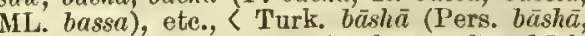
$b \bar{a} d s h \bar{a} h$ ), another form (perhaps after $b \bar{a} s h$, head, chiof) of pāsh $\ddot{a},<$ Pers. pādshāh, a govrnor, prineo, king: seo pasha.] 1. Same as pasha. -2 . A grandee; an important personpasha.-2. A grandee; an important person-
age; a bigwig. [Colloq.] - Bashaw of three tails, a bashaw or pasha of the rank inclieated by that 'Tis a very fine thing to be father-in-law

To a very magnifleent three-tailed Bashazo! G. Colman the Younger, Blue Beard, ii. 5 .

ashful (bash'fủl), $a .\left[<b a s h{ }^{2}+-f u l.\right] 1 \phi$. Wanting in self-posscssion; fearful; dismayed. Aud baskful Ilenry depos'd, whose cowardice

Hath made us bywords to our enemies. Shak., 3 Hen. VI., 1. 1

2. Easily put to confusion; modest to excess; diffident; shy; sheepish. [Formerly used also in the sense of modest, unassuming, as a term of commendation.]

Come, you pernicious asa [to the page], you bashful fool, must you be blushing? wherefore blush you now?

3. Indieative of, accompanied with, or proceeding from bashfulness.

The refusal which hla consin had steadfastly given him

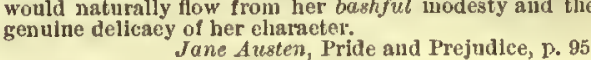
4†. Exeiting bashfulness or shame.

A woman yet must blush when bash ful ia the ease.

bashfully (bash'ful-i), adv. 1†. Withont selfpossession; with misgivings.-2. In a bashful, modest, or shy manner.

bashfulness (bash'full-nes), $n$. The quality of being bashful; excessive or extreme modesty; timorous shyness; want of confidence. [Formerly, like bashful, a term of commendation, equivalent to modesty.

He full of bashfulness and truth.

Fairfax, tr. of Tasso's Godfrey of Bulloigne, i1.

We have in England a partieular bashfulness in every-
thing that regards religion. Addison, Speetator, No. 458

-Syn. Bashfulness, Mfodesty, Diffidence, Shyness, Coy ness, timldity, alleepishness. Bashfulness, literally readiness to be abashed, designates timidity and a disturbed state of feeling at meeting with others, or being brought
into any pronilnenee. It la natural and not unbecoming to the young, but with advanelng years seems a defeet; is orten a translent stat it is either' \& proper and be coning distrust of one's seif and one's powers, or a highminded freedom from assuranee and assumption; it is always an exeellenee, unleas explieitly aaid to be excessive. Diffidence is a defeet; it is an undue diatrust of self, with duty. Shyness is almply a constitutional allinking from contact with others; it is the result of sensitiveness. Coyness la shyness where advances are made by others; a

Yet unask"d,
nlis bash fulness and tenderness at war,

Ilis bashfulness and tende
Ile aet himself bealde her.

Tennyson, Enoch Arden. It is to be noted that modesty in a man is never to be
allowed as a good quality, but a weakness, if it suppresaea hls virtue, when he has at the same time a mind to exert
himaelf.
Sir $R$. Steele, Tatler, No. 52. As an aetor, Mr. Cunuingham obtained little reputatlon, for hls diffidence was too great to be overeome.

For the very cause of shyness is an over-anxiety as to what people are thinking of you; a morbid attention to Whately, Bacon's Essay of Discourae.

The laugh that guidea thee to the mark,

And hides but to be found again. Dryden, tr. of Horace, I. ix. 36

bashi-bazouk (bash'i-ba-zök'), n. ['Turk. bashi-bozuq, one who is in no particular dress or uniform, an irregular soldier or civilian, < bashi, head, head-dress, dress and appearance, + bozuq, spoilt, disorderly, bad, < boz, spoil, damage, destroy.] A volunteer and irregular auxiliary, serving in connection with the Turkish army for maintenance, but without pay or uniform. Basht-bazouks are generally mounted, and beealse unpald frequently resort to pillage. They are also at the command of minicipal governors, tbrough the country they expeet not only to be "found," but to be suitably rewarded with bakshish.

bashlesst (bash'les), a. [<bash ${ }^{2}+$-less. Cf. ashful.] Shameless; unblushing. Spenser.

ashlyk (bash'lik), $n$. [Also bashlik, repr. Russ. bashluiku, a Cancasian hood or cowl.] A sort of hood or head-covering with long ends, usuof hood or head-covering with long ends, usually made in one piece, worn in Russia. The 
bashlyk

ornamented with silver or allver.gilt galloon. A similar
article to whlch this name has loen glvell is worn by article to whlch this name has leeen glvell is worn by
women in the United Statea as a IIght eovering for the head.

11 anging hetween the aheulders, and knotted ground the ing bad weather, this hood befing of a crinson color. I considered thint a Iight fur and a bashlyk-a eloth hood which protects the ears - wonlid be quite suthictent
to keep out the cold.
D. M. W'allace, Russin, p. 21

Bashmuric (bash-mö'rik), $n$. A dialect of Coptic, named from the district Bashmur of Lowe Egypt, in the eastern part of the Delta: as, the Bashmuric version of the Now Testament. Also Basmuric.

basi-. The combining form, in various scientifie terms, of Latin basis (Gr. ßáoıs), base. Seo basis.

basia (bā'zi-ti), n. pl. [Lit. kisses; pl. of $\mathbf{L}$. basium, a kiss.] A name for erotie verses or amorous writings of any kind; auscreontics sapphies: as, the basia of Bonnefous and Seeundug. basial (ba' zi-âl), a. [〈L. basium, a kiss, $+-a l$.]
lelating to or consisting of a kiss. [Rare.]

The Inneccnt gnety of h/s sister-In-Iaw expressed itself Quarterty Rev.

basi-alveolar (bā"si-al-vēōō-lär ), a. [<basion + alveolar.] In craniom., pertaining to tho basion and the alveolar point. Also basio-alveolar.Basi-alveolar length, the distance between the brilon and the al veolar point.- Basl-alveolar line, the lino joln. Ing the binsion and the alveolar point. Sce craniometry.
basiation (bä-zi-ä'shon), n. [<L. basiatio( $n-$ ), [basiarc, pp. basiatus, kiss, <basium, a kiss.] Kissing. [Rare.]

basiator (bā'zi-ä-tor), n. [NL., <L. basiator, kisser, < basiare, kiss: see basiation.] The orbieular musele of the mouth.

biculuris oris and oscularis.

basibrachial (bā-si-brā'ki-al) n. In some mollusks, a piece like an invorted $T$, which forms a support to the base of the "arms" of the fore foot. basibracteolate (bā-si-brak' tê-ō-lät), a. [S L. basis, a -atel.] In bot., having bracts at the base: applied especially to the involuere of a compoto the involuere of a comporounded at the base by a serie Head of Dandetion.

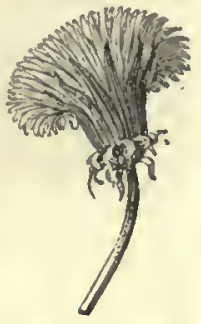

(bä-si-brang'ki-all), $a$. and $n$. [ L. basis, a base, + branchia, gills, + al. $]$ gills or branchim, or to the corresponding visceral arches of abranchiate vertebrates.

II. n. A bone or cartilage forming the base of a branchia, gill-arch, or visceral arch. In birds, the hastbranchial is the single median plece of the hyod apparatus usually ealled urohyol. In typical fishes
there are three baslbranchials in a longltudinal row, beneath the foremost of which is the urohyal, and in front the glessohysi

basic (bä'sik), a. [<base $\left.e^{2}-i c.\right]$ 1. Relat ing to a base; of the nature of a base; fundamental.

Thla besic princlple runs throngh the literature of the past from the days of the Zend A vesta.

2. In chem.: (a) Performing the office of a base in a salt. (b) Having the base in excess; having more than one equivalent of the base for each equivalent of acid.-3. In geol., containing a relatively small amount of silica: ap plied to crystalline rocks, as basalt: opposed to acidic. -4. In anat., basal; basilar.-Bastc alum. See alum, - Basic blue. See blue - Basio line, in the spectrum, a name given by Lockyer to theae lines in under increase of temperature, become more conspleuous while the others disappear. Certaln of these lines being common to the spectra of two substancea(e. g., cadminin and Iron), It is inferred that they may helong to a common perature.-Basic lining, a lining fitted to the interfor of a Hessemer converter having a tendency to absorb the phosphorua in the melted metal.- Basic process, a prointreduelug Into the lining composition of the Bessemer converter and into the cliarges linis or other earthy base, which absorbs phosphorus and other Impuritles In tho pig-lron, and pcrmits the iss of eheap grales of metal for process.-Basic water, water when, as in rome cases, it

répas, horn.] In Crustacea, the second joint of the antema, or long feeler, sueceediug the coxocerite. In the erawfish (Astacus) it bears the scaphecerite 30
465

Basllian

(considered to represent an exopodite) and tsehtocerite. basicity (bā-sis'i-ti), n. [<basic + ity. $]$ In chem.: (a) The stato of being a base, or of playing tho part of a base in eombination. (b) 'l'ho power of an acid Another way in which acida may be classlfled has refer-
enee to their basicity: they may be divileel into noueII. Wats, Dict. of Chem., I. 16. basicranial (bã-8i-krä'ni-al), a. [< T. basis, a
base, + NL. cretnium + -al.] Pcrtaining to the base of the skull. - Basicranial axds. See axisl.

basidia, $n$. Plural of basidium.

basidigital (bä-si-dij'i-tal), a. [<L. basis, \& base, + digitus, finger, $f$-al.] In unat., of or pertaining to the bases of the digits: applied to the metacarpal and metatarsal bones.

Fach digt has a proximal basi-digitat . . . bone, upon Iuxley, Anat. Vert., p. s1.

basidigitale (bā"gi-dij-í-tā'lē), n.; pl. basidigitalia (-li-a). [NL.: sce basidigital.] One of the basidigital bones; a metacarpal or metatarsal bone.

Basidiomycetes (bā-sid"i-ō-mī-sē'tēz), n, pl.

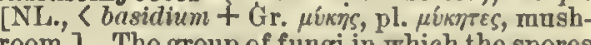
room.] Tho group of fungi in which the spores eetes, Gasteromycetes, and most of the larger fungi known as mushrooms and toadstools. See cut under basidium.

basidiomycetous (bạ-sid ${ }^{\prime} \mathrm{i}-\overline{0}-\mathrm{m}-\mathrm{i}-\mathrm{s} \bar{e}^{\prime}$ tus), $a . \quad[<$ Basidiomyeetes + -oits.] Belonging to or hav ing the characters of the Basidiomycetes.

basidiospore (bā-sid'i-ō-spōr), n. [<NL. basi diun + Gr. oropá, seed.] A spore borne on a basidium.

basidiosporous

(bä-sid-i-os'pō-

sidiospore +

-ous.] Produ-

eing spores by

ns of ba-

sidia.

basidium (bā-
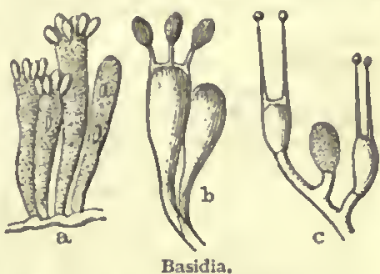

pl. basidia (-i)

NL., dim. of

Aparicus; $c$, of Lycoperdorlat ceftofs; 8,0

Gr. Báoıs, a base.] In bot., an enlarged cell in basidiomycetous fungi, arising from the hyme-

nium, and producing by abstriction spores borne

upon slender projections at its summit.

basifacial (bä-si-fã'shiạl), a. [<L. basis, base + facics, face, $+-a l$.$] . Relating to the base of$ the face, or of the ficial, as distinguished from plied to an anterior evertebral region of the base of the primordial skull, corresponding to the situation of the trabeculæ cranii, and consequently in advance of the notochordal region known as the basicranial. See cut under craniofacial.

This section of the primordlal skull may be con venlently termed the basifacial region, the trabeculse forming a

Sutton, Proc. Zoöl. Soc., 1885, p. 577.

\section{Basifaclal axis. See axisl}

see-ation.] In chen., the act of basifying

basifier (bâ'si-fi-ér), n. In chem., that which

basifies, or converts into a salifiable base.

fisixed (bä'si-fikst), a. [< L. basis, base, + base or lower end, as an

anther upon the filament.

basifugal (bạ-sif' ù-gal), $a$.

[< L. basis, a base, + fugerc, flce.] Receding from the growth of leaves which are developed from the base upward

Two extreme cases may thereaithourheloselyconnected by intermediate forns : the predom. inantly basifugal or aplcal, and

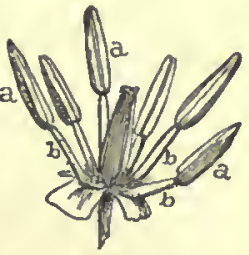

Sachs, Botany (trans.), p. 138.

basify (bā'si-fí), v, t.; pret, and pp. basified, ppr. basifying. [C L. basis, a base, + facere, make: see $-f y$.] In chem., to convert into a salifiable base.

basigynium (bā-si-jjin'i-um), n.; pl. basi-

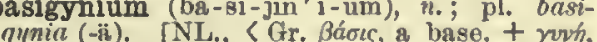
a female.] In bot., a stalk rising above the baso of the flower, and bearing the ovary at its phore (which sec) hyoid bone or liyoid arch. summit, as in plants of the genus Cleome. Also called podogynium, or woro frequently gyro-

asihyal (bā-si-hī'al), n. and $a_{\text {. }}$ [C I. brsis, a anat the distal bouy element of theseend postoral visceral arch, or hyoidean apparatus, represent in human automy by the so-callecl body of the hyoid bone, bearing two pairs of horns or cornua; in general, the basis or body proper of tho hyoid areh; tho basihyoid. Seo cut under skull. -2 . In ichth., the segment of the branchiostegal areh next to tho basibranchial and urohyal. It is generally double, or posod of two pieces on erch sido.

II. $a$. Relating to the basis or body of the

basihyoid (bā-si-hī'oid), $a$, and $n$. [< I. basis, a base, $+\mathbf{F}$. hyoll. $]$ I. $a$. Of or pertaining to he basiliyal.

II. $n$. Samo as basihyal.

asili (baz'il), n, [Early mod. E. also bazil, bassel, < $M \mathrm{E}$. basile, < OH. basile, mod. F. basilie = t, basilieo, < ML. basilieum, busilicon (ef. I. basilisca, a plant, also called regula, mentioned as an antidote for the bito of the basilisk: see

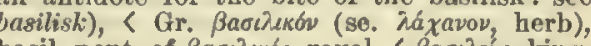

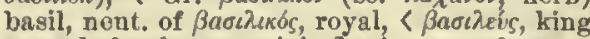
a word of unknown origin.] A name of several labiate plants, espocially of the gonus Ocymum. 0 . basilicum, a native of India, is much used in cookery, especially in France, and is known as sweet or cominot
basil. Bush or lesser hasil is 0 . minimum. The holy basil of India, 0 . sanctum, is eonsidered sacred to Vishnu, and fokaries are made of its wood. For the wild, otone, or the name is given to other aromatic labiates, eqpeclally to speeles of Pyeranthemum.

The anclents had a curious notion relative to the plant basil ( 0 . basillcum), viz, that there is a property In baril they are bred In the brains of nien. He once called her his basil plant; and when ahe asked for an explanatlon, gald that basil was a plant which had flourished wonderiuliy on a murdered man'a bralms.

Basil-oll an aromatic ofl obtained from the roots of the basil 2 t, $n$. [Early mod. E. (def. 1) bassil, < OF basile, mod. $\mathrm{H}$. basilic, a basilisk: see basilisk.] 1. A large cannon throwing a heavy shot. Seo basilisk, 4.-2. [Perhaps in allusion to a canankle of a prisoner.

basil ${ }^{3}+$ (baz'il), n. A corruption of bezel.

basil4 (baz'il), $n$. A corruption of basan. basilad (bas'i-lad), adv. [R NL. basil(aris) (see

bnsilar $\left.+-a d^{3}.\right]$ To or toward the base.

basilar (bas'i-lär), a. [ $[\mathrm{F}$. basilairc, < NL. basilaris, <L. basis, a base.] Relating to or situated at the base, espceially of the skull.and Jying on the basllar process of the ocelpital bone. and lying on the basilar process of the ocelpital bone.a dellcate nembrane stretching from the lamina spiralis cochlea, and supports the organ that portion of the occlpital bone which liea in front of the
foramen nuagnum.- - Bastlar Begment, the compound and the body of a centiped immediately aucceeding the cephnllc
segment. It bears several pairs of appendager, and has been four merpholngical somites.Basilar Blnus, or basilar plexus, the trangverse ainus. process of the occlpital bone

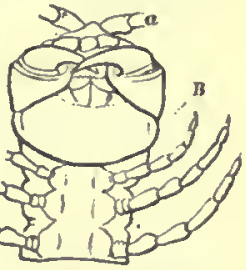

and the body of the sphenold. - Basilar vein, a vei aseending from the base of the brain on the outer gide of basilary (bas' $\mathrm{i}-\mathrm{l} \overline{\mathrm{a}}-\mathrm{ri}$ ), a. Same as basilar. basilateral (bā-si-lat'ê-ral), a. [< L. basis, \& base, + latus (later-), síde, + -al.] Situated at the side of the base. Also basolateral. Basileuterus (bas-j-lū'te-rus), n. [NL., with

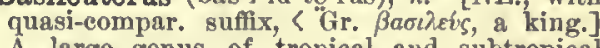
A large genus of tropical and subtropical Ameriean oseine passerine birds, of the family Mniotiltide and subfamily Setophaginc; group of pretty fly-eatehing warblers related to the common American redstart. Several of the Iexicm specles reach the lower Rlo Grande, but moat are Jexienn specles reneh the lower Rlo Grande, but moat are

Basilian (ba-sil'i-an), $a$. and $n$. [<LL. Basilius, Basil the Great (died A. D. 379), ( Gr. Barinecos, lit. kingly, s $\beta a \sigma i$ revs, king.] I. a. Relating 
Baxing

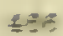

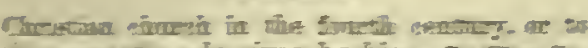

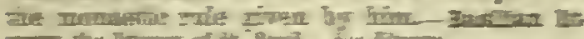
स्द्र

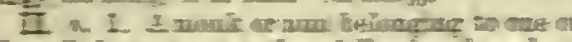

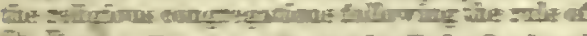

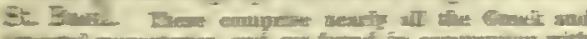
D-ine Dis

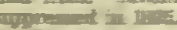

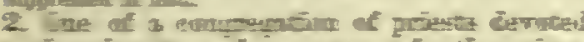

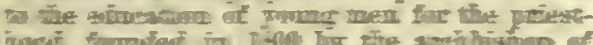

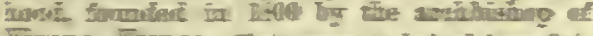

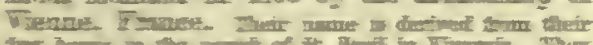

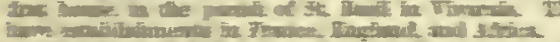

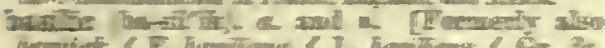

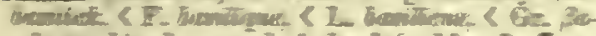

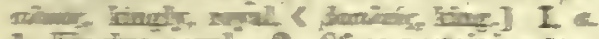

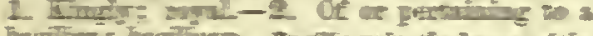

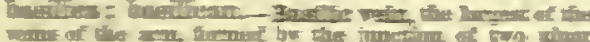

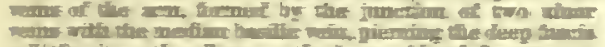

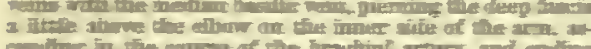

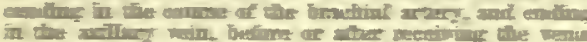

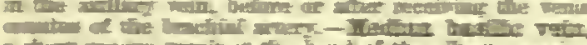

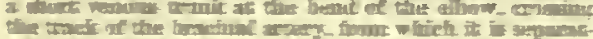

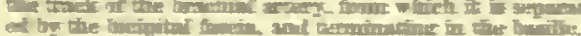

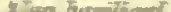

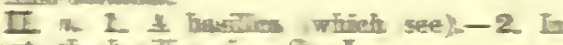
anat the betrille whire Set I

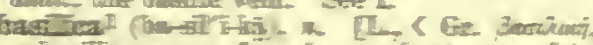

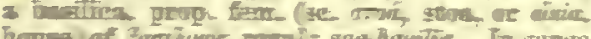

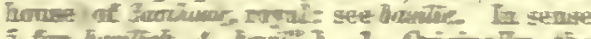

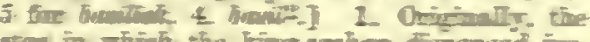

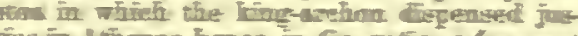

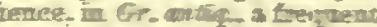

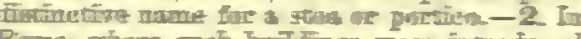

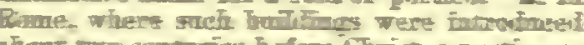

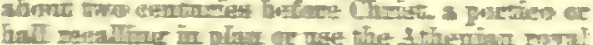

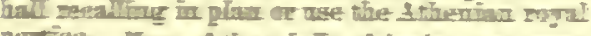

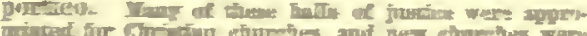

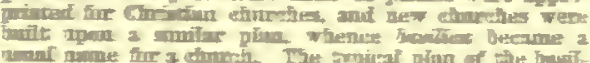

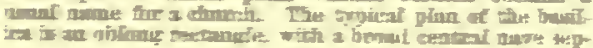

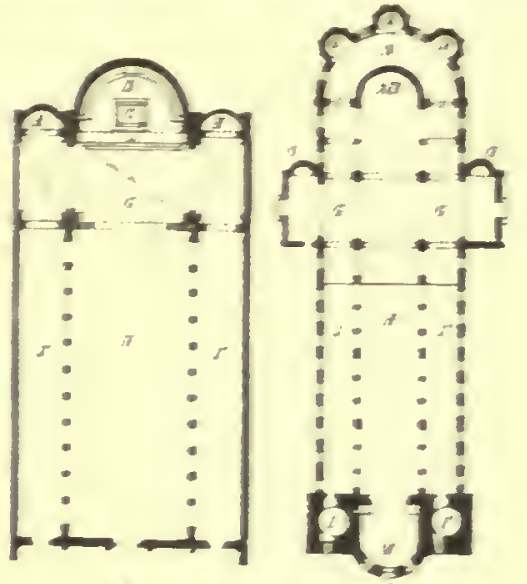

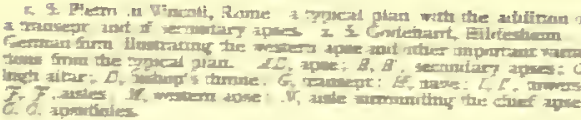

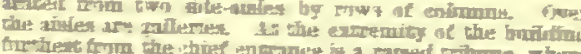

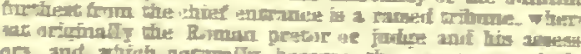

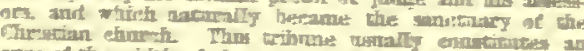

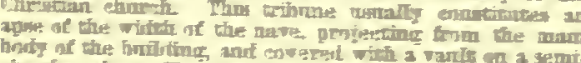

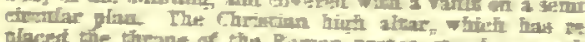

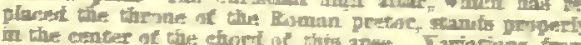

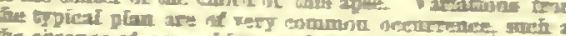

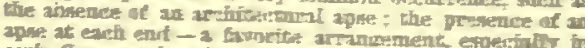

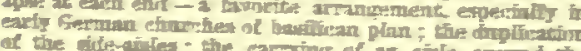

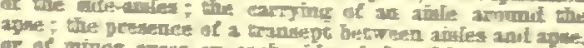

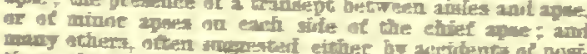

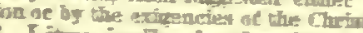
3. Liturzieally, in the Esmo Cath. $\mathrm{Ct}_{-}$, thile enafecred by the poge na a earseh withow ret-

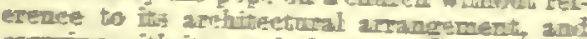
torryiug with it certain honors and peivileges.

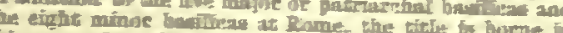

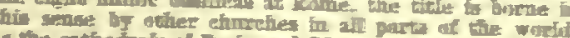

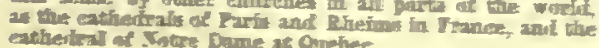

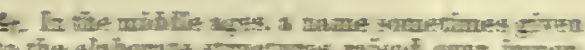

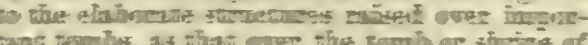

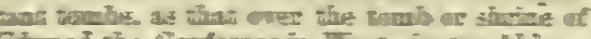

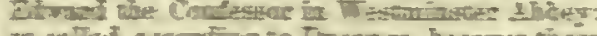

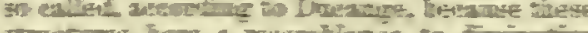

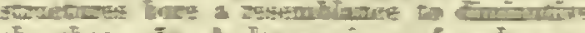

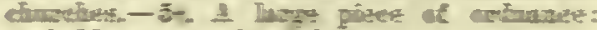

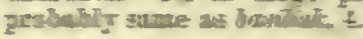

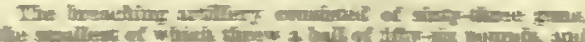

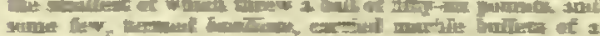

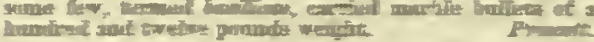

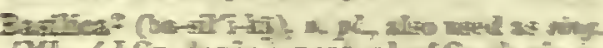

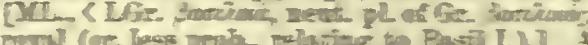

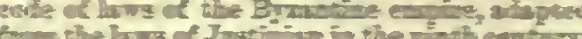

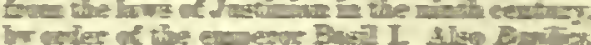

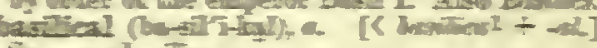
Same as bentis.

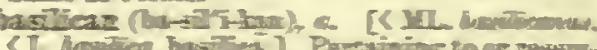

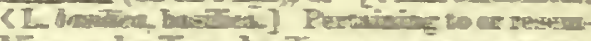

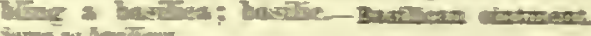

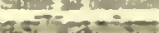

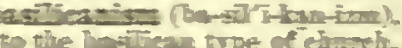

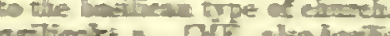

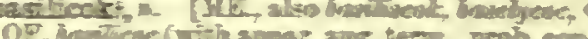

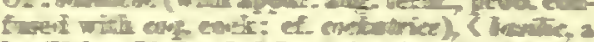

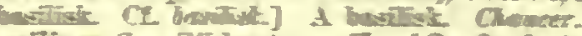

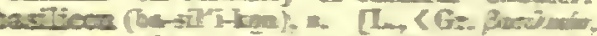

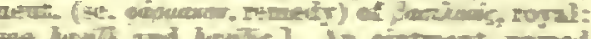

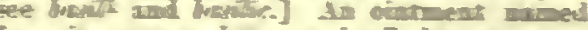

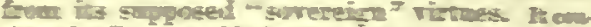

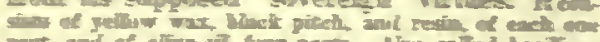

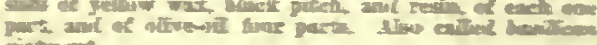

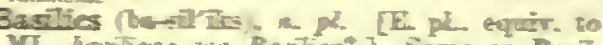

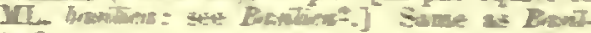

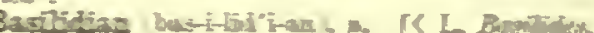

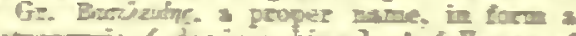

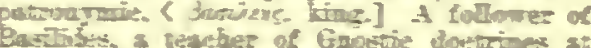

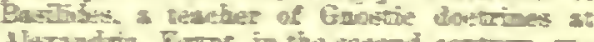

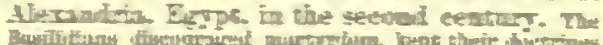

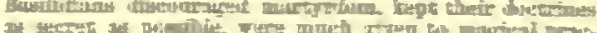

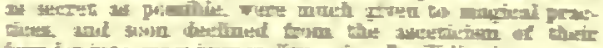

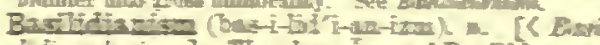

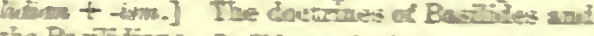

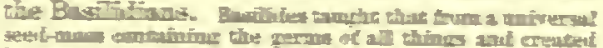

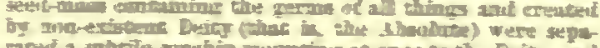

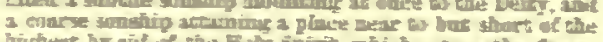

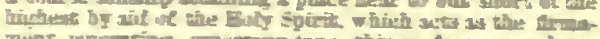

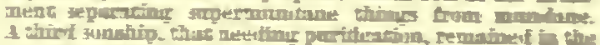

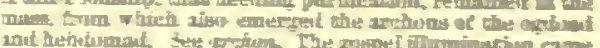

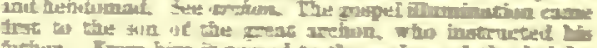

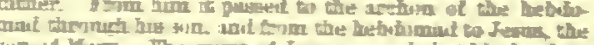

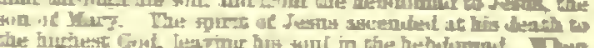

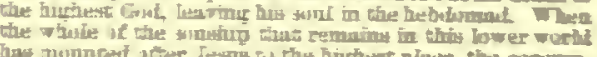

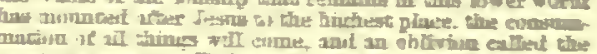

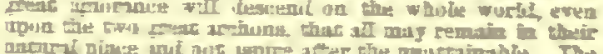

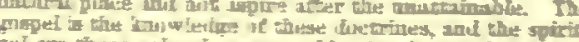

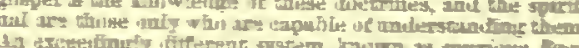

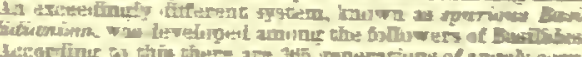

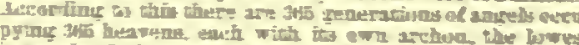

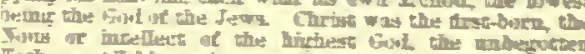

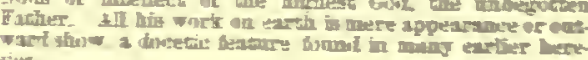

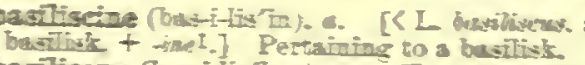

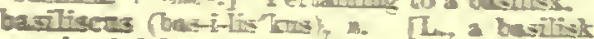
gete brentik] 1t. \& besitisk-2t. [NL] Io

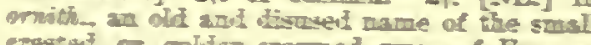
entestes of golden-erowned wren of Elope.

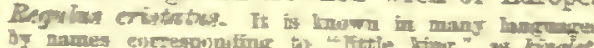

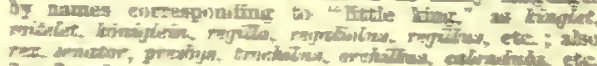
3. [exp.] [KTL] A geans of sarrian reptiles

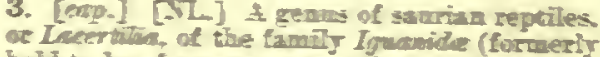
beli to be of geaice exteat than now), charseterized escedtially by the presence of a contia toras median docial erext along the beck and

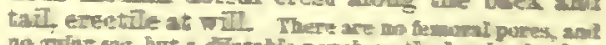

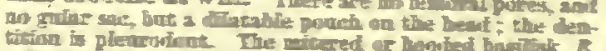

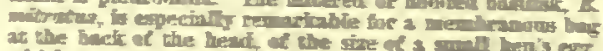

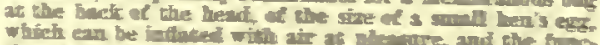

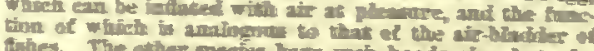

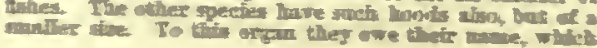

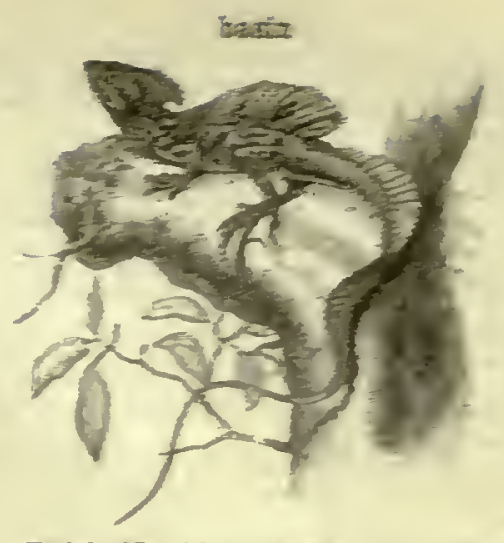

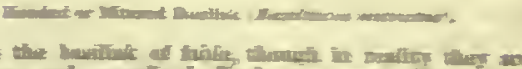

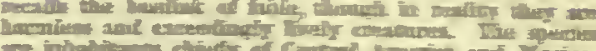

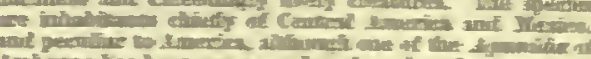

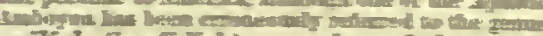

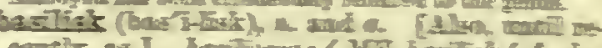

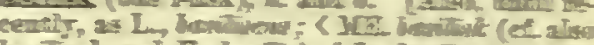

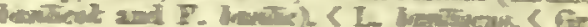

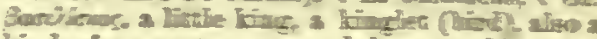

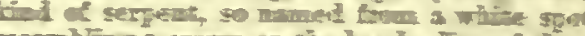

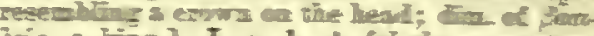

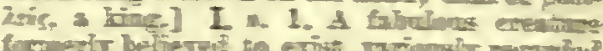

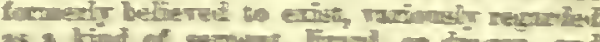

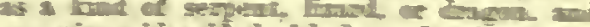

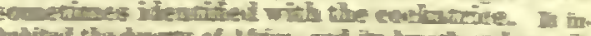

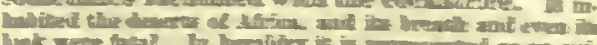

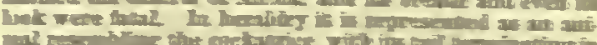

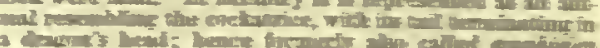

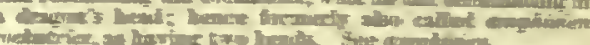

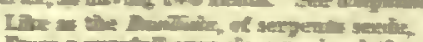

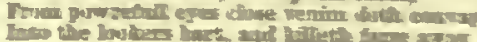

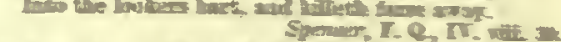

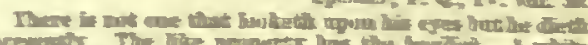

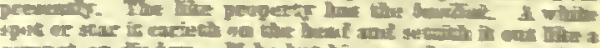

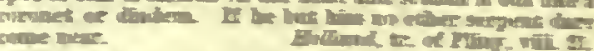

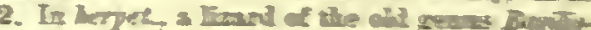

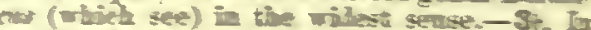

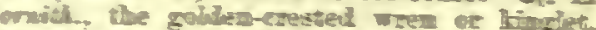

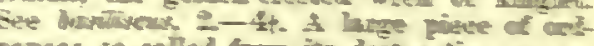

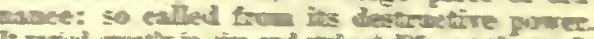

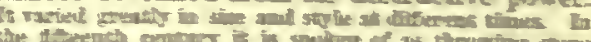

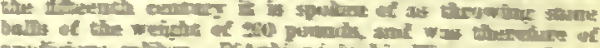

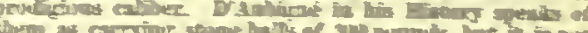

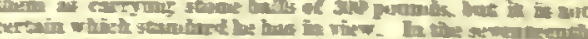

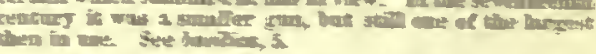

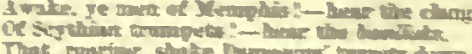

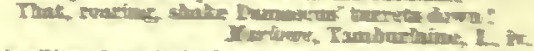

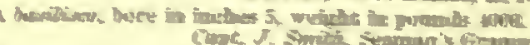

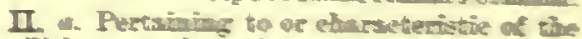
basilisk: as a haviniti ere or hok (a ghapp

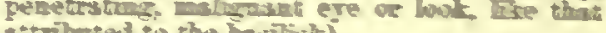

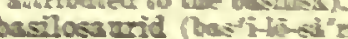

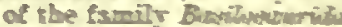

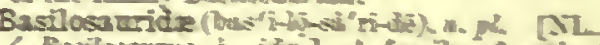

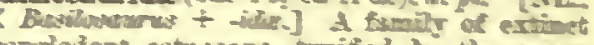

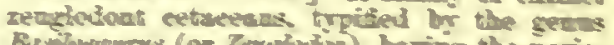

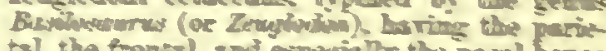

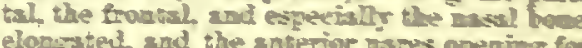

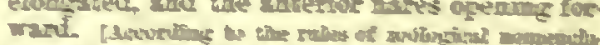

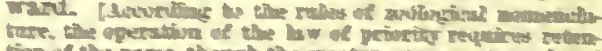

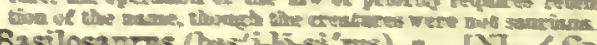

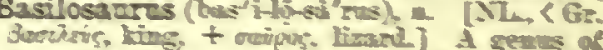
hrye fossi cetaceass trom the ivene of the

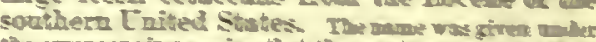

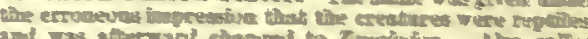

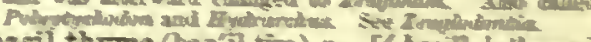

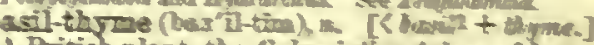

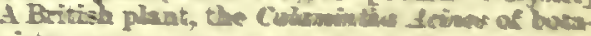

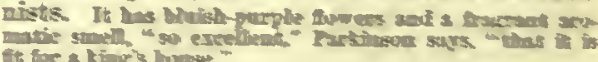

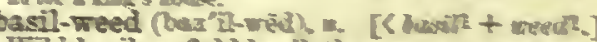
Wild basil, or feld-basil, the eomom nowe fo

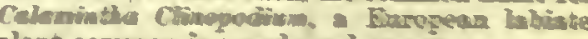
plact coosmon in wroeds and eepers.

basio (bo'ss) a [Eurty mod E also havm.

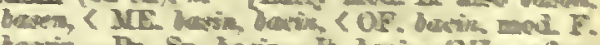

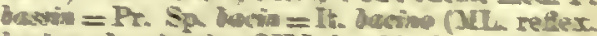

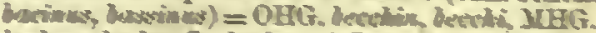

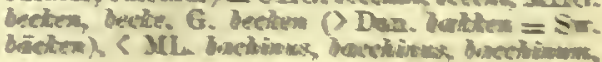


appar. for "baccinus, "baccinun, prop. an adj. basinerved (bā'si-nérrd), a. [K L. basis, a Educards; Huxley. See also cut under endopto-

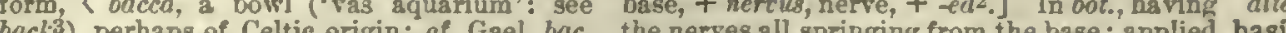
a hollow, a hook, crook = wi. back, a hook, Bret. bak, bag, a shallow boat: $\sec$ back ${ }^{3}$. Hence basinet.] 1. A circalar dish or vessel of greater width than depth, contracting to-
ward the bottom, and used chiefly to hold water or other liquid, especially for washing, but also for rarions other purposes.

Let one attend him with a silver bawom,

Foll of rose-wster, and beatrew'd with flowerh,

2. As much as a basin will hold; a basinful.3. In the arts and manuf.: (a) In hat-making, a vessel filled with boiling water in which the loose mat of felted fur formed on the cone for a hat-body is dipped in the process of basining (see basin, $t$. t.), in order to shrink it to the proper size. Also ealled sizing-kiettle. (b) A properve piece of metal on whieh glass-grinders form their convex glasses. (c) The seale or form their convex glasses. (c) The scale or seale-dish of a balanee when concare. $-4 \nmid$. A
pair of hollow metal dishes clashed together like esmbals to produce sound: formerly beaten when infamous persons were exposed in a eart 28 a punishment. - 5. A basin-shaped ressel hung by chains from the roof of a chureh, with a pricket in the middle for the serges. See a brass or latten basin within to eatch the waxdroppings. - 6ł. The hollow part of a plate or dish.

Silver dithes and plates . . . In the edges and basins of
which was placed ... gold medals. 7. A natural or artificial reservoir for water. (a) A pond; s bay; : dock for ships (b) In a canal, spece which enables boats to trm, or to lie and nnioad,
without obseructing the pasage of olber boata (c) The

8. In geog.: (a) The area drained by a river. The termu is ordinarily nsed only when spealing of a

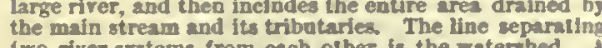
tho river-grstems srom each ol her is the watershed. cloped barin is an area which has no outlet to the sea. In Cordilileran region which has no such outlet, comprisios bios an area of about 225,000 square miles. (b) A basinshaped depression or hollow ; a cireular or oval ralley.- 9. In geol., an area over which the stratified formations are so disposed as to show that they were deposited in guccession within a basin-shaped depression of the original sura basin-shaped depression of the original surhave a general dip toward a common center, especially near the edges of the area. In some instances the basin structure is very marked, as in the case of
the Yorest of Dean and lode coal-delds. Sometimes, how. ever, a mere synclinal depression of the strats is called a
lasin; and this is especially the case in the Appalachian basin; and thers is especially the case in the A ppalachian Irom the main body of the coal-bearing strata, may
called a basin. The geological basins of London and Paris are espectilly know and interesting The rocks ol both are sometimes given to that part of the series which is inter-
mediate in age between Eocene and 3 llocene. The importaot member of the Iondon basin - the "London eisy" is absent from the Paris basin. The 3 ilddle Focene is represented in the Paris basin by an extremein fonsiliferous
rock, the Calcouire groustier (which see). The Tertiary of

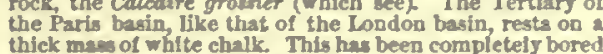

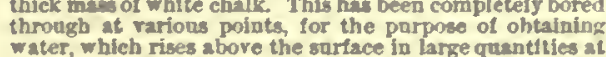
Water, which rises abore the surface in large quantities
the wellis of Grenelle end Pasy, and at ofther points. 10. In anat.: (a) The third ventriele of the brain. (b) [Cf. F. bassin in same sense.] The pelvis.-11. In entom., a lange concavity in a surface; specifically, a concave portion of the metathoracic segment over the base of the
abdomen. The basin of the antenna is a concarty in which the antenna is inserted, often limited on the tinger wide by accuring as in the anta

Formerly also spelled bason.

Barber's basin. See barber.

basin (ba'su), $x$. $t$. [ [ basin, n.] In hat-making, to harden or shrink to the proper size, as a hatbody in the process of felting, by dipping in the basin of bot water, wrapping in the basining-
cloth (which see), and rolling on a table. Also spelled bason.

The hat is bouned, or readered tolerably arm.

Ure, Dict, 11. ist.

basinasal (bā-si-nā'zạl), a. [ک basion + nasion $+-a l$.$] In craniom., pertaining to the basion$
and the nasion. - Bastnasal length, the diatance be

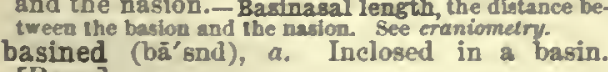
basined
[Rare.] to leaves.

basinet, basnet (bas'i-net, bas'net), n. [Also bassinet, bascinet, < ME basinet, basenet banet fish, p. I64. vacenct, bacynet, < OF bacinet (F basipterygial (bā-sip-te-rij'i-gl), a. [<L. basis. bacinct $=\mathrm{Sp}$. Pg. bacinete $=\mathrm{It}$. basinet $=\mathrm{Pr}$. of bacin, a basin, a belmet in the form of a basin : seebasin and -et.] A steel cap, original.
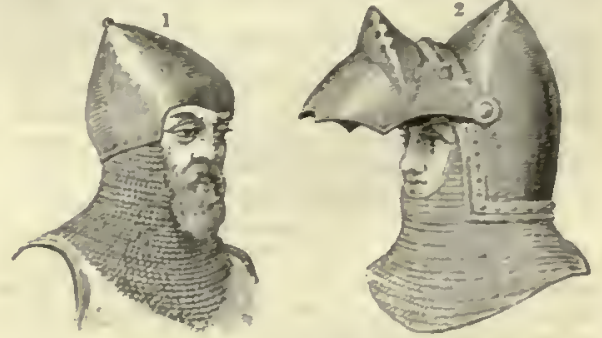

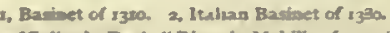

(Fro Violleble-Duces " Dict. du Mobilier frangain"

ly of very simple form, named from its resem. blance to a little basin. It was ordinarly worn lone; bat in baftle the heary heimet or heanme was phocd over it resting npon the ammor of the neck and ncconnt of its great weight, the basinet was furnished with a vizor. If was the commonest form of headplece during the thirteenth and fourteenth centuries, and so continued until the iniroduction of the

"So, youngster," gaid he, lookfing af Glendinnfing, and seeing hit military dreas, "s thon hast ta'en the bamet al

basinful (bä'sn-fúl), $n$. As much as a basin will hold.

basining-cloth (bās'ning-klôth), $n_{\text {. }}$ [< basinonsin, $\tau_{.},+$cloth.] In hat making, the eloth in which a hat-body as taken from the cone is wrapped after dipping in the basin, and rolled

basin-trap (bā'sn-trap), n. A seal or trap placed in the waste-pipe of a set basin to prerent the escape of sewer-gas.

basin-wrench (bä'sn-rench), n. A plumbers' wrench, having the jaws presented on one side, for working in contracted spaces.

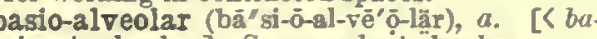
sion + alreolar.] Same as basi-alreolar. L. basis, a base, + occiput (occipit-), oceiput, + -al.] I. a. Pertaining to the base of the occipot, or to the basilar process of the oecipital bone.-Basdoccipltal tooth, atroth aitached to a procarp and tench

II. $n$. The centrum of the first (hindmost) cranial segment, forming the basis of the compound occipital bone, called in buman anatomy the basilar process of the occipital, which anteriorly articulates or ankyloses with the part the foramen magnum. Its normal union with two exoccipitals and a sopraoccipital constitutes the thus Crotalus, Emz, and Gallina.
basioglossus (ba'́si-ô-glos'us), n. [< L. basis, a base, + Gr. ri wrar, tongue.] That portion of body of the hyoid bone.

basion (bā'si-on), $n$. [NL.] In anat., the middle of the anterior margin of the foramen magnum. See eut under craniometry.

basiophthalmite( bä' si-of-thal'mīt), n. [<Gr. Bács, a base, + ospaifućs, eye.] The proximal or mite or peduncle of the eye of a stalk-eyed erustacesn, the other joint being the podoph thalmite. See cut under stalk-eyed.

basipetal (bā-sip'e-tal), a. [< L. basis, a base + petere, seek, $+-a l$.] Direeted towand the base; in bot., developing from the apex downward: applied to growth in the leaf when the rachis or midvein is developed first, then the leaflets or lobes in succession from the top downพard.

basipodite (bā-sip" ō-dit) , n. [<Gr. Báors, a base, The proximal joint of the limb of an arthropod animal, by which the limb is articulated with the body. Dunman. (b) The second joint of a developed endopodite, between the coxopo-
dite (protopodite) and the isehiopodite. Mrifme-

\section{a base, + pterygial.] "Situate
the fin, as of a cephalopod.}

In Sepis, along the whole bese-ifne of each lateral fin of the mantie, is a "barri-pleryyial cartilage." basipterygoid (bä-sip-ter'i-goid), $a$. and $n$. [< L. bavis, a base, + pterygoid.] I. a. Pertaining or related to the base of the pterygoid bone, or the sphenoid.-Basiptery gold processes, in the anatomy of biris, processes which are or may bo ticulate, or may articulate, with the pterjgoid bones. See

II. n. A lateral bone or process of bone at the base of the skull, developed in connection or relation with sphenoidal and pterygoid elements.

basirhinal (bā-si-ri'nal), a. [〈Gr. Hécu, a base, + pis, jiv, nose, + -al.] Situated at the base of the rhineneephalon: spplied to a fissure of the brain called by Wilder postrhinal. Oncen.

basirostral (bā-si-ros'tral), a. [( L. basis, a base, + rostrum, beak, $+-a l$.] of, pertaining to, or situsted at the base of the beak or bill of a bird: as, basirostral bristles.

basis (bä'sis), $n_{0}$; pl. bases (-8èz). [ $\mathrm{L}_{0},<\mathrm{Gr}$. Brors, a going, step, foundation: see base 2 .] a thing stands or on which anything is reared a foundation, groundwork, or supporting principle: now most commonly used of immaterial ciple:

Build ne thy fortunes apon the baris of ralonr. Challenge me the Connt's youth to dight with him; hurt him
in eieven places. Who bulids a monomeot, the baris jasper, And the main body brick?

Good health is the basis of all pbysical, intellectnal, moral, and apiritual derelopment. 2. In arch., same as base $e^{2}, 3 .-3 \nmid$. A pedestal. Observing an English inscription npon the banis, we 4. The principal constituent of a compound; a fundamental ingredient. -5 . Milit. same as base ${ }^{2}$, $15(a) .-6$. In crystal. and petrog. same as basal plane (which see, under basal). -7. In bot. and conch., same as base $2,4 .-8$. basilar part of anything: as, basis cranii, the base of the skull. -8 . In pros., a trochee or itg substitute preceding the dactyls of a logacedic series. An appareat spondee or lambas, a Pong syllahie of three times, or even a pyrrhic, tri. msy be prefixed to it. The basis is sometimes donble (Gotifried Hermann). Io ancient Greek writers on metrics the meaning of Bécis is: (a) That part of the foot which takes the onmarie (Ictus); the oirss. (b) A series ol stitnting s single foot or s dipody ; a measure.]-Eolic basiscopic (bā-si-skop'ik), a. [< Gr. ßáou, a base, $f$ cкопгiv, view, $+-i c$.$] Looking toward$ the base; on the side toward the base. basisolute (bā-sis'ō-lūt), a. [< L. basis, a base, + solutus, free, loosed: see solution.] In bot., said of leares.

basisphenoid (bā-si-sfé'noid), $a$. and $n$. [ $b a n$ sis $f$ sphenoid.] I. a. In anat., pertaining to the body or basis of the compoand sphenoid

II. n. In anat, the centrum of the second eranial segment, or basis, of the compound sphenoid bone, represented in human anatomy by the greater part of the body of the sphenoid (all that part behind the sella turcica), as distinguished from its wings and pterygoid processes, situated in the basicranial axis of the skull, between the basioccipital and the presphenoid. It is always combined with other sphepoldal elements, and frequently ankyloses also with the basisphenoidal (bñ'si-sfệ-noi'dal), a. Same as basisphennid.

basistt (bā'sist), $n$. [(base1 + -ist.] A singer of bass.

basisylvian (bā-si-sil'vi-an), a. [< L. baxis, a base, + Sylrius, an anatomist after whom the aqueduct of Sylvius in the brain is named.] Appellative of one of the lateral fissures of the brain. 
basitemporal

basitemporal (bā-si-tem'pō-rạl), $a$. and $n$. [< L. basis, a base, + tempora, temples.] I. $a$. the skull.

II. n. A membrane-bone developed at the base of the skull of many vertebrates, as birds, opposite the temporal region, underlying the true basis cranii (which is developed from cartilage), and on the same plane as the parasphenoid. $W . K$. Parker.

basivertebral (bā-si-vèr'tẹ--bral), a. [< basis + vertebral.] Pertaining to the body or centrum of a vertebra; central in a vertebra: as, basivertebral veins.

bask ${ }^{1}$ (båsk), $v$. [<ME.basken, <Icel. *badhask, now badlhast, bathe one's self, < badlha, =E bathe, + silk $=G$. sich, reflex. pron., one's self;

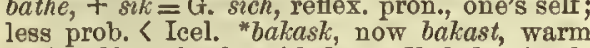
one's self at the fire, $<$ baka, $=\mathrm{E}$. bake, + sik, one's self at the fire, baka, = $\mathrm{E}$. bake, + sik,
as above. Cf. Sw. dial. basa sig i solen, bask in the sun; badfisk, fishes basking in the sun; LG. sich baken, warm one's self in the sun, lit. bake

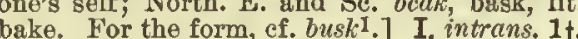
To bathe, especially in warm water (and hence in blood, ete.)

Basked and baththed in their wylde burblyng. 2. To lie in or be exposed to a pleasant 2. To lie in or be exposed to a pleasant of anything: as, to bask in the sunshine.

She desires no ssles of the bleat, no qujet reats of the just, To rest in a golden grove, or to bask in a aummer aky.
Tennyson, Wagen.

3. Figuratively, to be at ease and thriving under benign or gratifying influences: as, to bask in the favor of a king or of one's lady-love.

Mlerely to $b a s k$ and ripen is aometimes The atudent'a wiser busineag: Loweell, Under the Willowe

II. trans. To expose to genial warmth; suffuse with agreeable heat.

As I do live by lood, I met a fool Who laid him down, and bask' $d$ him in the sun,

Basks at the fire his hairy gtrength

Milten, $\mathbf{L}$ Ailiegro, 1. 112

bask ${ }^{1}(b a d s k), n$. [<bask1, v.] Emitted warmth a genial radiation or suffusion. [Rare.]

Milton and La Fontaine did not write in the bask of bask ${ }^{2}$, a. [Se., prop. baisk, <ME. bask, baisk

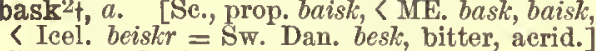
Bitter. [Old Eng. and Scoteh.] bask ${ }^{3} \dagger$ (bảsk), v. [E. dial., obs.: see bash ${ }^{1}$. $]$
Same as bash'1.

basket (bảs'ket), n. [< ME. basket; of unknown origin. The Celtic words, W. basged, Corn. basced, Ir. basceid, Grel. bascaid (ef. W. basg, a netting or piece of wickerwork), are mod. and from Eng. The supposed original, L. bascauda, which is mentioned by Martial as ing-tub or brazen vessel, and is prob. not connected with basket.] 1. A vessel made of twigs, rushes, thin strips of wood, or other flexible materials, interwoven in a great variety of forms, and used for many purposes.

$$
\text { Wude baskets }
$$
2. The contents of a basket; as much as a basket will hold: as, a basket of fish.

Do ye not ... . remember the five loaver of the five thou3. A measure for fruit, equal in the United States to three fifths of a bushel, and in Great Britain to about two bushels.-4. Figuratively, that which is gathered or placed in a basket

Blesaed shali be thy basket and thy store. Dent. xxriit 5. In old stage-eoaches, the two outside seats facing each other behind. Itz [London's] fopperies come down not only as inside
pasaeogers, but in the very barket.

Goldsmith, she Stoops to Conquer, i. 1.

6. In hat-making, a wickerwork or wire screen of an oval shape, for receiving the filaments of hair which are deposited on it in the operation of bowing.-7. Alitit., a gabion (which see).8. A protection of wiekerwork for the handle of a sword-stick.- -9 . In arch., the echinus or aeanthus-leaves.-10. In ichth., the gill-support in the lamprey (Petromyzon). It consists of
468

Basquish

of the backbone and connected hy cross.bars. - Basket-

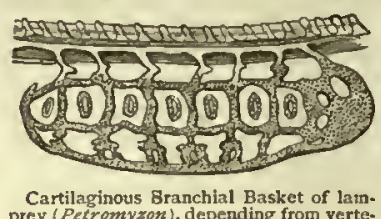
sket. Sce Marper of the bas ret, the flnest of number. - To be ket, to remain unchosen or to the Cartilaginous Branchial Basket of larn-
ey $($ Petromyysor $)$, depending from verteapples, the worst to the basket + , to go to prison, with apecial reference to the alms-bagket on which prisoners io The public jails were formerly dependent for aupport.

basket (bas'ket), v. to 1 . To put in a basket.

All that come ahall be basketed in time, and conveyed 2. To cover or protect with basketwork.

Basketed bottlex of Zem Zem water appeared atanding in basket-beagle (bảs'ket-bē"lgl), n. A beagle used in hunting a hare that was slipped from a basket to be coursed.

Gray-headed aportsmen, who had aunk from fox-hound
to basket-beagles and coursing. Scott, St. Ronan'a Well, $i$. basket-button (bás'ket-but ${ }^{\prime n}$ ), n. A metal button with a pattern resembling basketwork. Dickens.

basket-carriage (bảs'ket-kar"āj), n. A light earriage

basket-couching(bás' ket-kou"ching), $n$. A kind of embroidery; a titch used in embroi dery. See couching. basket-fern (bảs'ketfêrn) $n$. The eommon male fern, Aspidium Filix-mas, from the basket-like form of its growth.

basket-fish (bás'ketfish), $n$. A kind of Me

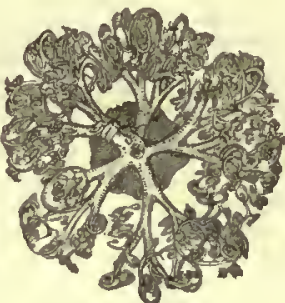

Basket-fish
Astrophy for agassizi). dusa's-head or ophiurian, Astrophyton agassizi a euryalean sand-star of the family Astrophytido, found on the coast of New England: so named by Governor John Winthrop of Conneeticut, about 1670 . The name is given to other species of the aame genus, ali alike remarkabie for the extraordi. nary aubdiviaion of the rayg into minute tendrila, which
have been eatimated to number 80,000 . Astrophytom scu
tatum is also called the shetland argua. Also called bas ket +urchin and sea-basket.

"Until a better Engliah name be found for it, why may it not be cailed . . a a basket-fish, or a net-fikh, or a purse of Connecticut first chriatened it

basketful (bảs'ket-fúl), $n$. As mnch as a basket will hold.

asket-grate (bás'ket-grāt), n. A grate with bars at bottom, front, and sides.

slipped from a basket to be coursed in the hare sence of other game.

basket-hilt (bas'ket-hilt), n. A hilt, as of a sword, which

Would my aword had a close basket-hilt, to hoid wine and the blade would make knivea

You see where his viol hangs by his basket-hilt aword.

Steele, spectator, No. 109

basket-hilted (bàs

basket-hoop (bás'ket-höp), n. A name in Jamaica of Croton lucidus, an aromatic euphorbiaceous shrub.

basket-lizard (bás'ket-liz"ärd), n. A bookname of lizards of the genus Gerrhosaurus, hav ing a coloration resembling wickerwork.

basket-of-gold (bàs'ket-ov-gōld'), $n$. The yellow alyssum, Alyssum saxatile.

basket-palm (bảs'ket-päm), n. The talipotpalm

basketry (bảs'ket-ri), $n$. [<basket + -ry.] Basketwork or basketware; basket-making

basket-urchin (bas'ket-èr"chin), $n$. Samo as basket-fish.

basket-withe (bás'ket-with), $n$. A twining shrub of tropical America, Tournefortia volubilis, natural order Boraginacea.

basket-wood (bás'ket-wưd), n. A tall woody elimber of the West Indies, Serjania polyphylla, for slender, suppl basketwork (bảs'ket-wèrk), n. Wiekerwork; anything made in the form or manner of a bas ket; specifically, in fort., work composed of withes and stakes interwoven, as in wicker construetions of gabions, fascines, hurdles, ete.

asket-worm (bás'ket-wèrm), $n$. Same as g-worm.

askingt (bàs'king), n. [E. dial., verbal n. of bask ${ }^{3}$.] A sound thrashing. [Prov. Eng.] basking-shark (bảs'king-shärk), $n$. A popular name of the Cetorhinus maximus (or Selacho max$(m a)$, one of the largest of the sharks. It is an inhabitant of the northern seas, and has been known to reach the length of 40 leet. It Irequently comes to the aurface and basks in the sunshine. Its food consista chiefly of
amall animals, which are atrained from the water by a pe-

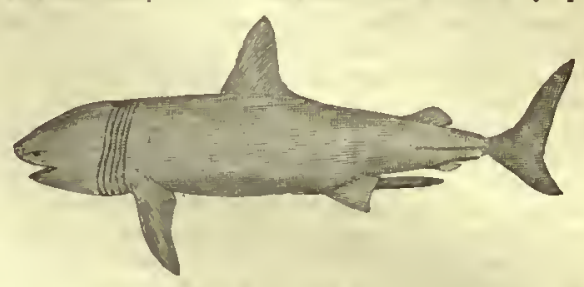

Basking- or Bone-shark (Cetorhinws maximus).

culiar development of the gill-structureq. The liver is very large and yields a great quantity of oil, as much as twelve other popular names are bone-shark by which it ia gen. crally known along the American coast), homer or hoe mother, sailfish, and sunfish. See Cetorhinidos.

baslard (bas'] iäd), $n$. [<ME. baselard, baslard, baselarde, < AF. baselard, < OF. basalart (ML. bassilardus, basalardus), appar. < base, a short knifo or saber; but ef. OF. baselaire, bazelaire, badclaire, a short sword: see badelaire.] An ornamental dagger worn in the fifteenth century, hanging at the girdle in front. Baslarda were conaidered indispenanble to all having claim to gentility. In

There is no man worth a leke, Be he aturdy, be he meke,
But he bere a baselard.

Basmuric, $n$. Seo Bashmuric.

basnet, $n$. See basinet.

basolateral (bā-sọ-lat'ê-rạl), a. Same as bast.

Baso-lateral angle [of the acutum]. Darwin.

(bā-som-ä-tof' ọ-rạ̈), n. $p l$

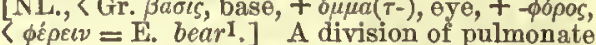
gastropodous mollusks, including those which have the eyes at the base of the tentacles, as in the families Auriculida, Limnaida, ete.: opposed to Stylommatophora. See cut under Limasommatophorous (bā-som - a - tof' $\bar{o}$ - rus), $a$ In conch., having eyes at the base of the tentacles, as a pond-snail ; specifically, pertaining to the Basommatophora.

bason, $n$. and $v$. t. Same as basin.

Basque ${ }^{1}$ (bảsk), n. and $a$. [Also Bask; < F. Basque = Sp. Pg. Basco; ult. = F. Gascon (see ants of Vasconia, Gaseony, one of the inhabitheir language Eskuara.] I. $n$. 1. One of a race of unknown origin inhabiting the Basque provinces and other parts of Spain in the neighborhood of the Pyrenees, and part of the department of Basses-Pyrénées, France. - 2. The language of the Basques, supposed to represent the tongue of the ancient Iberians, the primitive inhabitants of Spain. No connection between it and any other language has as yet been made out. Like the tongues of America, it is highly polysynthetic. It is aupposed to represent the tongue of a race existing in European tribea

II. $a$. Pertaining to the Basques or their language

asque ${ }^{2}$ (bàsk), n. [< F. basque, appar, with (at) The short skirt of the body-garment worn by both sexes. (b) A kind of short-skirted jacket worn by women, forming the upper part of a dress: probably so called because it was worn by the Basques.-2†. A dish of minced mutton, mixed with bread-crumbs, eggs, etc., mutton, mixed with

basqued (báskt), $a$. Furnished with or having a basque, as a woman's dress.

basquine (bas-kēn'), n. $\quad\left[<\mathrm{F}^{\prime}\right.$. basquinc, <Sp. basquiña, < Basco, Basque.] An outer petticoat worn by Basque and Spanish women.

Basquisht (bảsk'ish), a. and n. [= G. Baskisch; $<$ Basque + -ishI.] Basque; the Basque language. 
bas-relief

bas-relief (bä-rẻ-lèf', bås-rẹ-lēf'), $n_{\text {. [For- }}$ merly base relief: < I. bas-relief, < It, bassnrelief: seo basel and relief.] low relief; in sculp., a form of relief in which the figures or

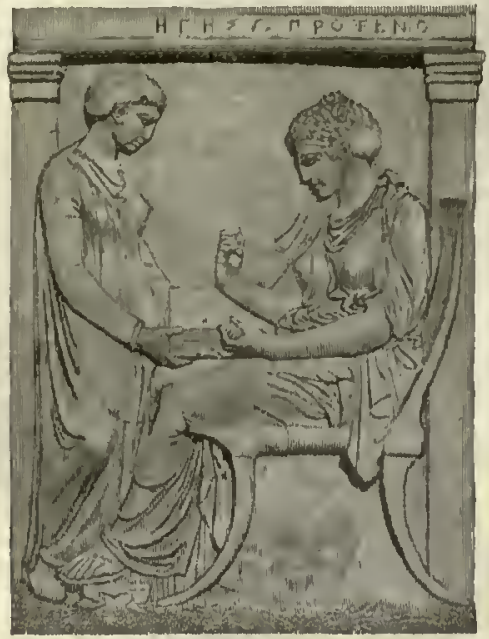

Bas-relief. - Tomistone of Hegeso, daughter of Proxello
Sacred Way, Athens; 4 th century B. C.

otlier objects represented project very slightly from the ground. The most artistic examyles of bss relief often present to the observer tise ilingion that thei carving has congiderable projeetion. A bas-reliet, or a
work in bas-reliet, fa a piece of seulpture in this form. Work in bas-rellet, is s piece of sempture in this form.
Commure alto-ritievo and mezzo-ritievo. Also bass-relief,

bassl (bảs), $n$. [Early mod. E. bas, base, < MIE. base, bace, a corruption of barse: see barse.] Originally, the perch, but now restricted to fishes more or less like the true perch. (a) In

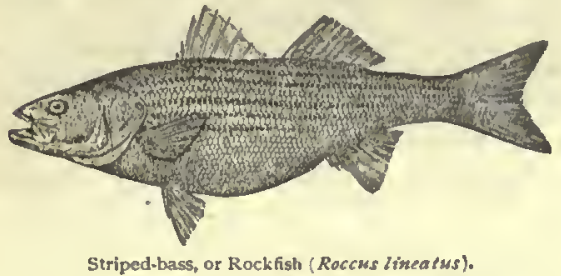

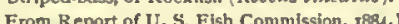

England, the Labrax lupus, sn acsnthopteryglan flsh with a compressed fuslform contour, two dorsal flus, the first with 9 spines, the secoud with trom 12 to 14 rays, a general grayishor greeniah color, relleved by small blackspots, and Englial-apeaking countries, the name of various flahes, generally distinguiahed by a qualifying prefix, as black

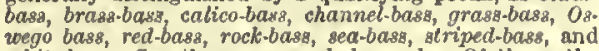
wego bass, red-bass, rock-bass, sea-bass, st riped-bass, and
whitc-bass. See the compounded words. Of these the nearest American relstion of the Enropesn bass is the basse.

bass ${ }^{2}$ (bảs), n. [A corruption of bast1, q. ₹.] 1. Same as bast.-2 . The American linden or lime-tree, Tilia Amerieana. See basswood.3. A mat made of bass or bast; a bass-mat hence, any thick mat or matting; formerly, a straw hassock or cushion.

Targets consial of straw basses with painted canvas
Encyc. Bril., II. 370 . taces aewed on them. Encyc. Bril., II. 376. base (the spelling bass being mod., after It. basso, and the pron. being that of base), < ME. base bace, bas, < OF. bas, fem. bassc, low: see basel.] I. a. In music, low; deep; grave.-Bass clarinet, clef, cornet. See the nouns. - Bass counter, the two bases which is tsken by voices or Instruments of the lowest range, as the second-bass voices (bassi profundi) and the violoncelios.- Bass or Turkish drum. Se druml. - Bass horn, staff. See the nouns.-Bass
string, the name populariy given to the loweat string in string, the name populariy given to the loweal string in
stringed lnstrumenta. - Bass viol. See viol. - Bass voice a volee adapted for ainging bass; tho lowest nalo voice, 政 $\mathbf{F}^{\prime}$ below the bass ataff to middie $\mathbf{C}$, the note on the frst ledger-line above it

II. n. 1. In music, the lowest part in the harmony of a musical composition, whether vocal or instrumental. According to some it la the fundamen tal or most importsnt part, while others regard the meloly or highest part in that light. Nexi to the melody, th movements, and the richest in effect.

2. A male voice of the lowest or gravest kind, having a compass of about two octaves from the second $F$ below middle $C$, or lower.-3. A
469

singer having such a voico. -4. A musical instrument of any class having a deep, grave tono, excelled in gravity only by the contraclef).-Aibertl bass, a hass consiating of arpegglua or menico Alberti of Venfe, who died ill 1739 .

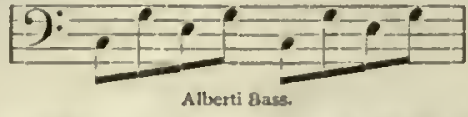

Double bass. Sce double-bass.-Drone bass. See drone bans.-Figured bass, a bass part luving the sccomplany. the notes: the moat snccessful aystem of shorthand acoring at pregent in use umong organists anc pianists. Also called continued mental bass. See fundamertal. - Ground base a fundannental bass cunslsting of 4 or 8 bars which are continually repested duriug the wholo movemeni. Aiso ealled bresso-ostinato. - Murky
bass. Sec murky. Supposed

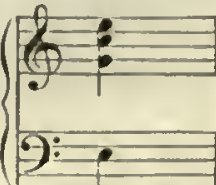

Supposed Bass. bass, in music, the lowest note in sn inverted chorl, as contradlstinotion to $\mathrm{C}$, which is considered the real bass, roet, or generator of the chord. (See also thorough-bass.)

bass $^{3}$ (bās), v. $\left[<b a s s^{3}, n.\right] \quad$ I. trans. 1. To sing or play the bass part of; accompany with the bass. [Rare.] -2. To sound in a deep tone. [Rare.]

That deep snd dreadful organ-plpe, pronounc'd

The vame of Proaper; it dif bass my treapass.

Shak., Tenpest, ili. 3 .

II. intrans. To take the bass part in a concert

od piece of musie: as, he basses very steadily.
bass $^{4}$ (bās), $n$. [Origin uncertain; perhaps for base (formerly also bas), coal.] In coal-mining, black carbonaceons shale.

bass $^{5}+$ (bas), $v . t$. [< late ME. basse; cf. OF. baisier, mod. F. baiser, < L. basiare, kiss, < basi $u m$, a kiss. Cf. $b a^{1}$ and $\left.b u s s^{1}.\right]$ To kiss.

bass + (bas), n. [<ME. basse, a kiss; prob. from the verb; ef. Lasium, a kiss.] A kiss; buss. Court of Love.

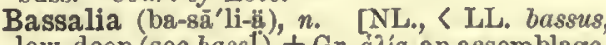
low, deep (see base $\left.{ }^{1}\right),+$ Gr. a $i a$, an assemblage, with an intended allusion to $a \lambda s$, sea.] In $z 00-$ geog., the deep-sea realm; a zoölogical division, in a vertical direction, of the waters of the globe. The depth is not fixed, but depends upon tempersture and consequently upon fatitude, Bassalis being deepeat in tropical regiona, and more shallow or even super-
ficlal toward or at elther pole. Bassalian (ba-sa'li-an), $a$. Pertaining to the deep-sea realm called Bassalia.

The ichthyological peculiaritiea of the Bassatian realm, as he has proposed to call the deep-aes region. Science, III. 505.

Bassano ware. See majolica.

assaricyon (bas-g-ris'i-on), $n$. [NL., < Gr.

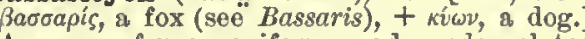
A genus of procyoniform quadrupeds, related nal form, but having the skull and teeth more like those of the racoons and coatis. B. gabbi of Costa Rica is the type. Another species from Eevador is $B$. alleni.

Bassaricyonidæ (bas-a-ris-i-on 'i-dē), n. $p l$ [NL., S Bassaricyon +-ida.] An

the lamily Bassaridida, Coues.
Bassarididæe (bas-a-rid'i-dê), n. pl. [NL. < $<B a s-$ sari $(d-)+-i d c$.$] A family of American car-$ nivorous quadrupeds, of the aretoid series of the order Fera, suborder Fissipedia, and section Arctoidea procyoniformia, most nearly related to the racoons (Procyonidas), having some $\mathrm{su}-$ perficial resemblance to the civets and genets, new world the numerous viverrine quadrupeds of the old. It is constituted by the genera Bassaris (or Bassariscus) and Bassaricyon.

Bassaris (bas'a-ris), n. [NL., < Gr. Baorapis, ó́pa, a fox, a Thracian bacchanal.] 1. The typical genus of the family Bassarididae (which see). B. astuta is the type-species, inhsbiting the southwestern United States snd. Miexico, where it is cahlel
mountain-cat and cacomixl. It is a prelty and inteill. mountain-cat and crcomixl. It is a prelty and inteil coon in some respects, but slemderer, and with a long common lenur. It is frequently tamed,

2. [l. $e_{\text {. }}$ ] An animal of this genus: as, the ring-tailed bassaris. Also called bassarisk. -3 A genus of lepidopterous insects. [The use of the word in entomology antedates that in mam malogy.]

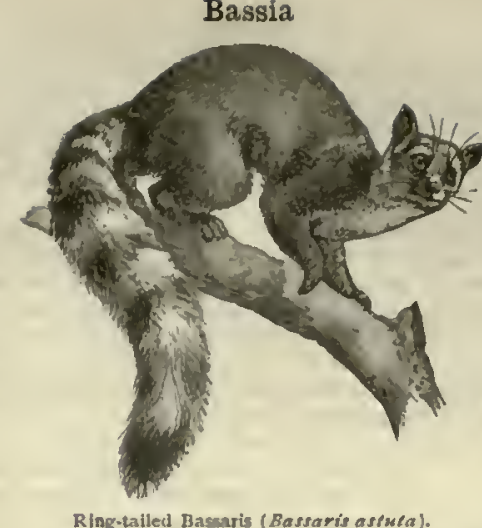

Bassariscus (bas-a-ris'kus), n. [NiL. (Coues, 1887), < Gr. Bacoa $\rho$ is, a fox (sce Bassaris), with lim. suffix.] Same as Ibassaris, I.

bassarisk (bas' a-risk), n. [<NI. Bassariscus.] Same as bassaris, 2. Coues.

bass-bar (bās'bär), $n$. In instruments of the violin class, an oblong wooden 'bar, running longtliwise within tho instrument, designed to strengthen it and enable it to resist the pressure of the bridge and tho tension of tho strings. basse, $n$. Seo bassl.

bassel $\psi_{\uparrow}, n$. An obsolete form of basilı.

bassel2 $t, n$. Same as basan.

basse-lisse (bas-lēs'), a. [F'., low warp, <basse, fem. of bas, low (sce basel), + lisse, also lice warp, < L. licium, the thrum or leash, a thread of the web.] Wrought with the warp in the usual horizontal position, as distinguished from that which is wrought with the warp placed in a perpendicular, and described as haute-lisse. applied to tapestry.

bassenett, $n$. An obsolete form of basinct.

basset ('bas'et or ba-set'), $n$. [<F. bassette, It. bassetta, basset, orig. fem. of bassetto, somowhat low, dim. of basso, low: see basel.] A game of cards resembling faro, invented in Venice, and popular throughout Europe during the eighteenth century and the latter part of the serenteenth.

We went to the Chelto de San Felice, to see the noble men snd their ladies at basset, a game at esrda which is much used, but they play not in public, and sli that have
inclination to it sre in masquerside, without speaking one

Some dress, some dance, some play, not to forget

Your piquet partiea, snd your desr basset.

basset ${ }^{2}$ (bas'et), $n$. and $a$. [Origin obscure perhaps $<$ OF. basset ( $=$ It. bassetto), somewhat
low, dim. of bas, low: see basset ${ }^{1}$.] I. $n$. In geol, and mining, an outcrop.

II. $a$. In geol. and mining, outeropping.-Basset edges, the outcrop, or outcroppling edgea, of a seriea of strslified beds.

The inalde [ridge In St. Helens] is much steeper, and is slmost preclpitous; it la lormed of the basset edges of the Darvin, Geol. Ohaervations, i. 4. and mining, to appear at the surface; crop out: said of the edges of strata.

basset-horn (bas'et-hôrn). $n$. [< basset, for It. bassetto, somewhat low (see baeset1) t horn tr. It. corno di bassetto.] A musical instrument of the clarinet class, having a single reed and a long twice-bent wooden tube; really the tenor clarinet, being intermediate between the clarinet proper and the bass clarinet. Its compass is four octaves and

basseting (bas'et-ing), $p, a$, and $n$, [< basset ${ }^{2}$ $+-i n g$.$] I. p. a$. In geol. and mining, outeropping. ock on the surface of a stratum, or series of strata.

bassetto, bassette (ba-set'ō, ba-set'), n. [<It. bassetto, somewhat low: see basset ${ }^{1}$.] A small bass viol with three strings: now obsolete.

Bassia (bas'i-ä) n. [NL named in honor of Ferdinando Bassi (died 1774), an Italian physician and writer on botany.] A genus of tropical trees found in the East Indies and Africa, natural order Sapotaceo. Several species are valualle for the ofl ylelded by the seeda and for thelr fleshy flowers which are iargely used as food in central India, and yiel s coarse spirti by dotilstion. The mah wa-tree, B. LatiThe me or illupl, $B$. longifolia, ia a large evergreen tree fulws-butter. The lark, leaves, snd ofl of these trees are 


\section{Bassia}

used tn rheumatic and cutaneous disease 3 , and the timber is hard and very durable.-Bassia, oll, all aromatic oll used for illumination and in the mannfacture of soap.

bassie (bas'i), n. [Sc., prob. dim. var. of basin.] A basin-shaped wooden vessel for holding meal. Hoga.

bassinet (bas'i-net), n. [ $<\mathrm{OH}$. bacinet, a basinet; also, as in defs. 2 and 3 , mod. F. bussinet, dim. of bassin, basin: see basin, basinct.] 1†. Same as basinet. - 2. A wicker basket with a covering or hood over one end, serving as a cradle for young children.-3. A name given to several common Europcan species of Ranunculus.-4†. The pan of a harquebuse or musket. See pan. bass-mat (bås'mat), $n$. A mat made of bass or bast; specifically, a matting made of bast, used for packing furncing countries: in the latter sense, usually in the plural.

basso ${ }^{1}$ (bås'ọ ), a. or $n$. [It., = E. bass $\left.{ }^{3}.\right] 1$. In music, th

sings bass.
basso $2 t, n$. An obsolete form of bashaw. Marbasso

bassockt, n. [Cf. "bass, bassock," biacketed as synonyms in Bailey, 1731 and later, where in 1706 and 1708 , the second form is printed hassock. Bassock, though a possible dim. of bass', is prob. a mere misprint for hassock.] A hassock. See etymology.

basso-continuo (bás' $\overline{0}-k o n-t \bar{e}^{\prime}$ nö-ō), n. [It. basso = E. bass 3 ; continuo, < L. continuus, continuous.] Same as figured bass (which see, un der bass ${ }^{3}$.

basso-di-camera (bás'ō-dē-kam'e-rä), $n$. [It.: basso $=\mathrm{E}$. bass $;$;i, < L. dc, of; camera, < L camera, chamber: see canera.]. A double-bass or contra-basso, reduced in size and power, but not in compass, and thus adapted to smal or private rooms. It has cour atrings, of the same
quality as those of the violoncello, but all proportlonally quality as those of the violoncella, but all proportionaly
thicker. boon.-Basson quinte (kaht), a dauble-reed instrument soon.-Basson quinte (kant), a double-reed instrument

bassoon (ba-sön'), $n, \quad$ [< F. basson, < It. bassone, a bassoon, aug. of basso, low: see base 1 ,
bass 3 , basso'. 1 . A musical instrument of the boe class, having a double reed, a long, curved metallic mouthpiece, and a doubled wooden tube or body. fron 15 below the bass staff. Its diameter at the botton is about 2 inchea, and for convenience of carriage it is divided into two or a bundle. It serves tor the bass among wood 2. A reed-pipe stop in an organ, having a quality of tone resembling that of the bassoon.

bassoonist (ba-sön'ist), $n$. [ $[<b a s-$
soon $+-i s t$.$] A performer on the$ soon +

basso-ostinato (bås'o-os-ti-nä'tō̄), $n$. [It., lit. obstinate bass: basso $=\mathrm{E}$. bass ${ }^{3}$; ostinato $=$ E. obstinate, q.. Same as ground bass (which see,

basso-profondo (bås'ō-prō-fon'dọ),

n. [It.: basso = E. bass ; profondo,
<L. profundus, deep, profound: see profound.] In music: (a) The lowest bass voice, having compass of about two octaves rising from $D$ below the bass-staff.

roice of this compass.

bassora gum. See $g u m^{2}$ 'ilevo (bàs'ō-rē-lyà'vō), n. See basrelief.

bassorin (bas'ō-rin), n. [< Bassora, also writte Bassorah, Bussorah, or Basra, a city in Asiati Turkey.] A gum $\left(\mathrm{C}_{6} \mathrm{H}_{10} \mathrm{O}_{5}\right)$ insoluble in water the essential constituent of gum tragacanth and of cherry and plum gum

bass-relief (bas'rê-lēef'), $n$. Same as bas-relief. bass-rope (bảs'rōp), n. [<bass ${ }^{2}+$ rope.] A lope or cord made from bass or bast, used for tying cigars and for other purposes.

basswood (bás'wid), $n$. [<bass 2 wood.] The common name of the American linden or lime-tree, Tilia Americana. The white basswood is T. heterophylla. Also ealled bass.

bast1 (bast), n. [Also corruptly bass ${ }^{2}$, q. v.; = Icel. Sw. bast (neut.) = Dan. bast; origin uncertain; perhaps connected with besom, q. v.]

1. The strong inner fibrous bark of various
470

baste

ees, especially of species of linden (Tilia), of which the Russia matting of commerce is made. Cuba bast, used for tying up cigars, etc., is the inner hark of a malvaceons tree, Paritium elatum. 2. In bot., a tissue, other or containing ver larrow, long, and tough flexible cells, calle bast-cells or bast-fibers, and occurring most abundantly in the inner bark of dicotyledons.

softer portion ly.

he cambium has been called $80 f$ are the essential textile fibers that are derived from the bark of plants, as flax, hemp
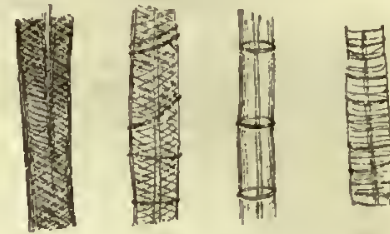

3. A rope or

cord made of or mats. See bass 2,3 .

bast $2+, n$. and $a$. [Early mod. E., < ME. bast, baste, < OF. bast, mod. F. bat (cf. batt, bathorse, etc. $)=$ Pr. bast $=$ Sp. It. basto, $\langle\mathrm{ML}$. bastum a pack-saddle (see bastard), prob. MHG. bast = E. bast ${ }^{1}$, bass $^{2}$. Cf. bass ${ }^{2}$, a cush ion.] I. n. Bastardy.- Son of bast $t$, a bastard. II. a. Bastard ; illegitimate.

asta I (bàs'tä), interj. [It., = Sp. basta, orig. mpv. of It. bastare, $=$ Pr. Sp. Pg. bastar, suffice, satisfy, < Sp. Pg. basto, copious, thick, gross.] Enough! stop! (a term not uncommon in old dramatists). Basta ; content thee; for 1 have it full.

Shak. T. of the S., l. 1 .

basta2 (bás'tä), n. [Appar. a fem. form of basto, the ace of clubs: see basto.] In the game the third trump.

bastantt, $a$. [< F. bastant, < It. bastante (= Sp. Pg. bastante), ppr. of bastare, suffice: see basta1.] Sufficient; able (to do something).

OFries. baster $d=\mathrm{G}$. bastard $=$ Icel. bastardhr)

< OF. bastard, bastart (F. batard $=\mathrm{Pr}$. bastard

$=\mathrm{Sp} . \mathrm{Pg}$. It. bastardo; ML. bastardus), a bastard, prob. < bast (E. bat $=$ Pr. bast $=$ Sp. It. basto: see bast ${ }^{2}$ ), a pack-saddle, + -ard; equiv. to OF. fils de bas, fils de bast, a bastard, lit. son of a pack-sadale: see bast ${ }^{2}$ and $-a v d$, and cf. bantling. The first known application of the word was to William the Conqueror, who was called William the Bastard beforo the conquest, and, indeed, called himself so ("Ego A natural child; a child begotten and born out of wedlock; an illegitimate or spurious child. By the civil and canon laws (a rule adopted also in many child by the marriage of the parents at any luture time. But by the lawa of England a clitid, to be legitimate,
must at least be loorn aiter the lawful marriage; it doe not require that the child shall be begotten in wed
lock, but it is indispensable that It ghould be born after marriage, no matter how short the time, the law presuning it to be the child of the husband. The only legal in capacity of a bastard ls that he cannot be heir or next of kin to any one save lis own issue. Inheritance trom the hiaintenance of a bastard in the first instance devolves on the child In prelerence to the father. In the United State the lather may be compelled to provide support.

2. In sugar-refining: (a) A large mold into which sugar is drained. (b) An impure, coarse brown sugar made from the refuse syrup of previous boilings. - 3t. An animal of inferio previous boilings. - 3t. An animal of inferior cloth, probably of inferior quality, or of unusual width, or both. $-5 t$. A kind of war-vesse used in the middle ages, probably of unusual
size.-6t. In the seventeenth century, a small cannon, otherwise known as a bastard culverin sh wine resembling muscadel; any kind of weetened wine.

We ghall have all the world drink brown and white Shak., M. for M., ill. 2.
bastard. Why, this now, whlch you account so choice, were
counted but as a cup of bastard at the Groyne, or at Port 8. In falcomry, a kind of hawk. -9. [Sp. bas. tar a bastard, a short, thick-bodied snake, etc.] A local name of Kemp's gulf-turtle, Thalassochelys (Colpochelys) kempi, of the Gul of Mexico. - Speclal bastard, a child born before the of Mexico.- Speclal
II. a. 1. Begotten and bori out of wellock; II. 1. 1. Begrate a bustarl child. - 2t. Mongrel hybrid: as, a bastard brood.-3t. Unauthorzed; unrecognized: as, "bastarl officers beore God," Inox, First Blast (Arber), p. 48 (N. E. I.) - 4. Spurious; not genuine; false; supposititious ; adulterate: as, "bastard hope," Temple.

['They] at the hest attain but to some bastard piece of

5. Having the appearance of being geuuine; resembling in some degree: an cpitbet applied especially in botany, zoölogy, medicine, etc., to things which resemble, but are not identical with, the things named: as, bastard mahogany, bastard pimpernel, bastard caddis, bastard marble, bastard measles, ete." See phrases below. Also bastardly. -6. Of abnormal or irregular shape or size; of unusual make or proportions: applied to guns, ships, swords: as, bastard culverin, bastard galley, etc. See phrases. tard culverin, bastard galley, etc. See phrases. - Bastard Baltimoret, bastard orlolet, the orchardbeston, 1 (c).-Bastard branch, a shoot or sucker springing up of its owa accord from the root of a tree, or where Bastard cod. Sameas green-cod,2.-Bastard culverint. see culverin.-Bastard file, a fle of a grade betweel smooth and raugh. - Bastard limestone, an inpure siliclous limestone, Incapable of beiog converted into quick. chineel. - Bastard musket. See musket. - Bastard plover, a name for the lapwing, Vanellus cristatus. the rough dab, Ifimponlossoides limandoides, - Bastard senna. Same as bladder-senna.- Bastard sole. (a) A local English name of the smear-dab, Cynicoglossa microcephala. (b) A local English name (in Weymouth) of in plastering. See stucco, - Bastard sugar. Same a brevlated litle of a book on an otherwise blank page precedlng the full title-page. - Bastard turbot, the brill. In printing, type with a face larger or smaller than that proper to the aize of the body, as bourgeois on a l)revier one which is a near approach to a apur-wheel.-Bas-
tard winet, wine which is neither sweet nor sour.-Bastard wing. Same as alula.

bastardt (bas'tärd), v. t. [< bastard, n.] To declare to be a bastard; stigmatize as a bas tard; bastardize. [Rare.]

IIave I ever cozened any frienda of yours of thelr land? ught their possessions? . . . bastarded their Issue?

To brestard our children, Bp. Eurnet, Records, Il, il.

astardiceł (bas'tär-dis), n. [< F. bastardise (I6th century), now batardise, < OF. bastard, bastard.] Bastardy. Chapman.

bastardismt (bas'tär-dizm), n. [< bastard + -isin.] Bastardy.

bastardize (bas'tär-dīz), v.; pret. and pp. bas tardizcd, ppr. bastarlizing. [< bastard + -ize.] I. trans. 1. To declare or prov

The law is ao indulgent as not to bastardize the child if born, though not begotten, in lawful wedlock.
Blackstone, Com., 1. xvi. 2t. To beget out of wedlock. Shak-3. To render mongrel or hybrid; make degenerate; debase: as, "a bastardized race of the

II. intrans. To become degenerate. Also spelled bastardise.

bastardlyt (bas'tärd-li), a. [<bastard + -ly' $\left.\mathbf{1}^{\mathbf{1}}\right]$

Shak., 2 Hen. IV., ii. 1

2. Spurious; counterfeit.

A furtive simulation, and a bastardly kind of adoption.

3. Degenerate; debased.-4. Same as bastard, a., 5 .

bastardy (bas'tär-di), $n$. $[<$ bastard $+-y$. Cf. or begotten and born out of lawful wedlock.
Born in bastardy.
Shak., 2 IIen. VI., tii. 2

They blot my name with hateful bastardy.

2 . The act of begetting a bastard.-3. A ju-

dicial proceeding to determine the paternity

of a bastard child and compel its father to

support it.-Declarator of bastardy In Scotslare, an action instituted in the Court of Session by the donatory
in a gitt of bastardy, for the purpose of having it declared
that the land or the effects which belonged to the deceased thastard belong to the donatory, in virtue of the gift trom the crown.- Gift of bastardy, in Scots lawe, a gift from the crown of the heritable or movable effects of a bastar wisposed of his property in liege-ponstie.

basteI (bāst), v. $t$.; pret. and pp. bastcd, ppr. basting. [First known in pret. or pp. baste 
baist, basit, perlhaps with orig. int." "base", $<\mathrm{Sw}$. basa, atrike, beat, whip (ef. bashl, bask 3 ) somo comparo Icel. beysta, beyrsta = Sw, bó ta = Dan. böste, beat, drub, generally associated with börste (= Sw, borste), brush, < bürste a brush, bristle, = Sw. borste, a brusl, borst, bristle. Others take bustel to be a fig. uso of baste ${ }^{2}$; ef. anoint in sense of

Mlno liat atruek down Creel'a hoy in the dirt, with hi new anti un, and the boy.... was In a pltiful takjug and

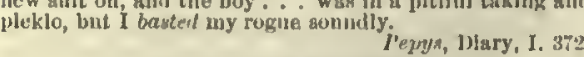

A stick, or atool, or anytulng that roumij dld sle

And baste lier lord and master most confoupdedly.

baste ${ }^{2}$ (bãst), $v$. t.; prot. and pp. basted, ppr. basting. [Origin unknown; tho word first or curs in the 16th eentury. Cf. baste ${ }^{1}$.] 1. To with melted fat, gravy, etc., to improve the flavor or prevent burning.

The fat of roasted mutton falling on the birds win acrve
So kente them. Down ran the wino late the rosi,

Which malc hila liorse's flanka to smoke

2. To mark (aheep) with tar. [Prov, Tug.]

baste ${ }^{3}$ (bāst), v. t.; prot. and pp. basted, p)r.
besting. [CME. basten, < OF. bastir, I' batir

$=\mathrm{Sp}$. bastear $=$ It. imbastire, baste, sew (ef.
$\mathrm{Sp}$. Pg. It. basta, basting), prob. < OHG. besten, patel (MIIG. besten, lace, tie, OFries. besten, baste), < bast, bast, the fibors of which wero used for thread: see bast ${ }^{1}$.] To sew glightly; fasten together with long stitehes, as the parts of a garment, for trying on or fitting, or for making.

The body of yonr discourse ls sometime guarded [trim. med] with fragmente, and the guards [trimmlugs are lut

baste 4 (bāst), n. [Another spelling of beast, rotaining the former pronunciation of that word.] In card-playing, same as beast, 7 .

bastel-houset, n. [< ME. bastel, bastele, bastile (see bastile) + house.] A fortified honse, especially one built in an outlying and exposed position. See border-tower.

baster ${ }^{1}$ (büs'tér), n. [<bensteI + -erl. $]$ 1. One who bastes or beats with a stiek.-2. A blow with a stiek or other weapon. [Colloq.]
baster $^{2}$ (bās'tér), n. [< baste ${ }^{2}+$ er $]$. One who bastes meat

baster ${ }^{3}$ (bās'tér), n. [< bastes $\left.+e r^{1}.\right]$ On who bastes or joins the parts of a garment loosely with long stitches; also, an attaehment

basterna (bas-tér'nại), $n$. [LL.] 1. A sort of litter or sedan, borne by two mnles, used by the Romans.-2. An ox-eart or wagon used

by the early Freneh kings,
bastida (bas-té'dă $), n$. [ML., also bastita: see bastite.] Same as bastide.

bastide (bas-tēd $\left.{ }^{\prime}\right), n$. [F., a farm-house, a fortress, < Pr. bastida, \ ML. bastida, prop. bas tita, lit. a building, prop. fem. of bastitus, pp. of bastire, build, see bastile, bastion.] It. $\bar{A}$ small forti fied building, often of timber, eorresponding nearly to a moderu blockhouse.-2†. A tem. porary or movable hint or tower erected for besieging purposes. Sce bastile, 4.-3. A small farm-houso or country dwelling in the sonth of seilles.

bastile, bastille (bas-tēl'), n. [In spelling and

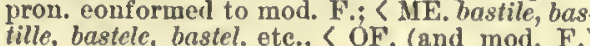
bastille, < MIL. bastile, pl. bastilie, a tower, for tress, < bastire (> OF. bastir, F. batir = Pr. OSp. bastir = It. bastire), build, of unknown origin reforred by Diez to Gr. ßacráčctv, raise, support.] 1. A bridge-tower, gate-tower, outlying defense, or eitadel.

At veh brugge a berfray on basteles wyse,

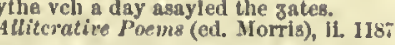

2. In Frevel hist., a fortress used as a state prison. Many French citlea had bastliles of this kind in Paris, called buecifically the Bastille. Porte St. Antolae, and its erection was begum by Charle $v$. In 1369. J'lis, belng of pecullar atrength, remalned after the other medleval fortiffeatloas of the clty had been removed, and its use as a prlson for jersone coll-
flued at the arbjtrary will of thie klug or hia ministers thed at the arbltrary will of the klug or hia ministers ahed by the popnlace July 14 , 17S9, and was demollishell

shortly afterward. There were delivereel from the prisen been conflued at the demand of lits fumlly.

In Iaris la Bastile ls, as our Tower, the elilef prison of kingalom. That rock.fortress, Tyranny's strongliold, whilcli they
Carlyle, French Rcr. I. Jv. S.

Ienee - 3. I3y extension, any prison, especially one conducted In an arbitrary or oppressive way.

The modern hospltal for the Jasanc, especially the man he ute and corporate humes, conducted as they aro wit enrulshing only reatrsint belinid the lars.

Alien. and Veurol, vil. 700

4. A movable tower used by the besiegers of a stroug place, whother for approaehing the walls (see bclfry) or as a defonse and protection for the besiegers.

bastile, bastille (baa-tēl'), $v$. t. ; pret. and pp. bnstilcd or bastilled, ppr. bastiling or bastilling. [< bastile, n.] To eonfino in a bastilo; in prison.

bastillion $\nmid$ (bas-til'yon), ". [< OF'. bastillon, dim. of bastille: 80e bustile.] 1 small fortress or castlo.

bastiment (bas'ti-ment), n. [S OF' bastiment (F. batiment $=$ Sp. "berstimento), a building, strueture, ship, [ baslir, build: soo bastile. ] 1 . Military

bastimentoł (bas-ti-men'tö), n. [Sp.] Same as bastiment, 3 .

$$
\begin{aligned}
& \text { Then the brattimentos never } \\
& \text { Ilad our fonl diahonour seen, } \\
& \text { Nor the sen the sad reeeiver } \\
& \text { of this gallant traln bad been }
\end{aligned}
$$

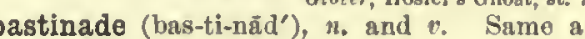

\section{bastinado.}

bastinado (bas-ti-nä'dō), $n$. [Formeriy also bastonado (-ada, -ade) = F. bastonnade, $<\mathrm{Sp}$ beastonada, also bastonazo (= It. bostonata), a $=$ It. bastone, a stick, cudgel : seo baston, baton.] 1. A blow or beating with a stiek or endgel, especially on the soles of the feet or on the buttoeks; a eudgeling.

Ile brags be will gi' me the bastinado, as I hear.- How he the bastinado? IIow came he by that word, trow ? nay, lndeed

2. A mode of punishment in some Orientel countries, especíally Turkey, Persia, and China, in whieh blows with a stiek or lath of bamboo are inflieted on the soles of the feet or on the buttoeks. - 3. A stiek or eudgel; the jmplebastinado (bas-ti-nā'dõ), $v_{0} t$. [< bastinado, $\left.n.\right]$ To beat with a stiek or eudgel; specifieally, to beat on the buttoeks or the soles of tho feet. as a judieial punishment.

The Sallee rover, who threatened to bastinado a Chrls
tlan captive to death. basting ${ }^{1}$ (bäs'ting), $n$. [Verbal n. of baste ${ }^{1}$.] A cudgeling; a beating.

A gool basting. . . was a averelgn remedy lor aea-sickbasting ${ }^{2}$ (bās'ting), n. [Verbal $n$. of baste2.] 1. The moistening of meat that is being roasted with its own fat, butter, ete.-2. The gravy, melted fat, butter, etc., used in moistening roasting beef, ete. -3 . In candle-making, the proeess of pouring melted wax over the wicks. basting 3 (bās'ting), $n$. [Verbal n. of baste ${ }^{3}$.] 1. The act of sewing together with long, loose basting-machine (bäs 'ting-ma-shēn.

sowing-machine used for basting together pieces of fabries, to make a continuons piece for bleaching, dyeing, ote

bastion (bas tion), n. [< F. bastion, < It. bas tione (= Sp. bastion), < bestire = OF. bastir

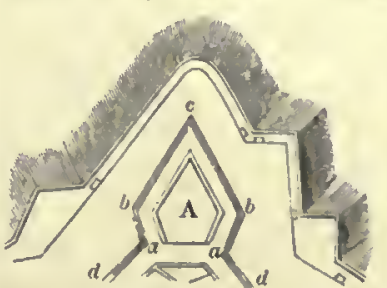

A

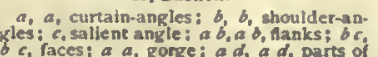
ete., build: see
bastile.] In fort., a mass of earth, faced with sods, briek, or stones, standing out from which it is a prineipal part. A baation conglsts
of two fanks, each commanding and cent curtain, or that portion of the wal cxtending from owe hastlon to another, and $t$ wo faces makn ng with each other the outworks and ground before the fortincation. The merspace between lhe two flauks is the gorge, or entrance point at thic foot of tho rampart as mucls as prasilt) uade of the place. Formeriy called bulueark. Ant copples round the dreary weat,
A loomlung brestion frlnged with fre. Tennysm, In Mtemorlam, xv.

To our right was a long embattled line, with many
(') lonvern, Mterv, xvil. Center of a bastton, a polnt at the mildle of the gorge, whence the captial line proceeda. It Is lu gencral at the sugle of the Inner polygua. - Detached bastion, In fort. a bastlon whlch is se

Farrono, Mil. Fneyc. ury ${ }^{2}$.] Pertrining to or eonsisting of bastions: as, systems of bastionary fortifieation.

bastioned (bas'tiond), a. [< bastion + ed ${ }^{2}$. $]$ Provided with or defended by bastions.

$$
\text { Bastion'd with pyramlds of glowing }
$$

Keats, IIyperion, 1. From the bastion'd walls,

Like threaded spiders, one by one, we dropt.

Basttoned fort, \& fort having I wo or more lasil lons con. works, - Bastloned front. Nee front. In fort. a small bomb-proof chamber plaeed in a position tlanking the diteh of a lunette or redoubt. Bastlonets are usually placed at the sallent angles of redonbts, and are furnilghed with loopholes fo bastite (bas'tit), n. [<Baste (see def.) $+-i c^{2}$.] A serpentinous mineral oceurring embedded in A serpentinous mineral oceurring embedded in and probably derived from the alteration of a variety of enstatite (bronzite). It often show: a bastnasite (bast'nā-sit), n. [< Bastnäs (see def.) $+-i e^{2}$.] A fluoearbonato of cerium, lanthanum, and didymium from the Bastnas mine, Sweden. It also occurs as an alteration product of tysonite near Pike's Peak, Colorado. basto (bas'tō), n. [< It. Sp. Pg. basto, aco of elubs; cf. It. bastone $=\mathrm{Sp}$. baston $=\mathrm{Pg}$. bastão, a stick, elnb: seo baston.] In card-playing, the ace of clubs in quadrille and ombre.

In Spauls] cards clubs are really represented by "cluba," for whlch basto is the Spanish word. In certain games, e. Oo. Onbre, the ace of cluba playa an important part,
and is enipluatjcally called basto.

bastonł (bas'ton), n. [< ME. baston, bastun, OF. baston, F. báton $=\mathrm{Sp}$. baston $=\mathrm{Pg}$. bastão = It. bastonc, < ML. "basto( $n$-), a stiek, club, cudgel. Origin unknown. The word appears in

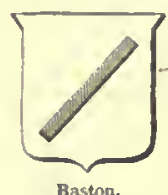
E. also as baton, batoon, batton batten ${ }^{2}$ : see these forms.] 1. A stiek, staff, or cudgel; a baton. spectfically - (a) A nuace of wood uaed in used in war. It was nanally ahaped linto g handle, and had a guard like a aword.
(b) A leading ataff of enaign of conmuad. Sec baton, a. (c) In her, a bendlet ainlareach the edge of the fleld: It is generalty considered in
Engliab heraldry a mark of lilegitimacy. [N1I]] used in thls bense. 1 Also buton and bastard bar. cially in tho bases of columns; a torus. -3 . A servant of the warden of the Fleet, who attended tho king's courts as an offieer, earrying a red truncheon. It was hta duty to take to ward sucl priaoners as had been conmitted by the court, and also to go out of prison by baston was to go at large in the cuatody ast-palm (bast'päm), n. Two species of Brazilian palms which yield the piassaba fiber, a coarse fiber from the sheathing-bases of the leat-stalks, used for eordage, brooms, ete. The Bahla bast-palm la the Attalea funvera (see Attalea); that

Bastramia (bas-trā'mi-ä), $n$. [NL.] A genns of mosses, of the tribe Bastrumiece. It has erect, fruit, which is a nearly spherjca] capsnle.
bast-tree (bast'trê), n. [MIE. baste-tre; < bast1 + tree.] A tree furnishing bast, in Europe especially the linden, Tilia Europar. See bast1. basyl, basyle (bâ'sil), n. [< Gr. ßáoıs, a base, $+v \lambda \eta$, substanee.] In eliem., a name given by Graham to the electropositivo constituent of a salt.

basylous (bā'si-lus), a. [< basyl + -ous. $]$ In chem. of the nature of or relating to a basyl, or electropositive constituent of a salt.

The name of the electro-negatlve Ingredient . belng
that wllleh is placed first as the geneje term whilat that that willeh is placed first as the generic term, whllat that
of the electro-positjve or bantous elenent followa as indlof the electro-positive or bamtous element folluwa as indl-
catlng the apecies. W. A. Jiller, Elem. of chelu, \& 591 . 
bat

bati (bat), n. [< ME. bat, battc, botte, the earliest recorded forms being dat. sing. botte, nom. pl. botten (nom. sing. "bat, "bot?), pointing to an AS. "bat (gen. dat. "battc), given by Somner, but not authenticated, appar. < Ir. Gael. bat, bata, a staff, eudgel. But in part at least the word rests on $\mathrm{OF}$. batte, F. batte, a rammer, a wand, appar. < battre, beat: see batter 1 . Some of the noun senses are from the verb (see bat v.), while others are perhaps from orig. diff. sourees.] 1. A

$$
\begin{aligned}
& \text { A handsome bat he held, } \\
& \text { On which he leaned, as one farre in eldic. }
\end{aligned}
$$

Spenser, Mlother Hub. Tale, 1. 217.

2. The wooden club with which the players in base-ball, cricket, and similar games bat or drive the ball. That nsed in base-ball is a round ta. pering gtick of varying size and welght to suit the strength the broad end of an oar, and fo provided with a round 3. A batsman or batter.

W. is the best bat left.

T. Iughes, Tom Brown's School-Days, if. 8.

4. A blow as with a bat or baton: as, he received a bat in the face. [Colloq.] - 5. A tool made of beech, used by plumbers in dressing and flatting sheet-lead. -6 . A rammer used scutching hemp or flax.-8. A piece of briek having one end entire; hence, any portion of a briek; a brickbat.--9. A kind of sun-dried brick. Southey.-10. Shale; hardened clay, but not fire-clay: same as bind, 2. Penn. Surv. Glossary. Also spelled batt.-11. In hat-maling, a felted mass of fur, or of hair and wool. Two such masses are required to form the body of a hat. Also spelled batt.

One half of the intended hat, called a bat, is bowed at a 12. A continuous wad of cotton from the batting-machine, ready for earding; also, a sheet of cotton wadding or batting. See batting.-13. In ceram.: (a) A flexible sheet of biseuit.

Batt or bat is ... a plate of gelatine, used in printing ing, the impresaion ts traniserred from an engraved copper plate to a lat of gelatine or glue, whence tit is printed dusted over the print, adheres to the oiled aurface, and the porcelain is then fired at a low temperature.
Ure, Dict., I. 298.

(b) A shelf or slab of baked clay used to support pieces of bisenit which have been painted, 14. Rate; speed; style. [Scoteh and prov.
[Set Eng. ] - At the bat, in the position of the batter or to wield the bat. - To oarry one's bat. See carry.- To go on a bat, to go off for a drunken carouzal or apree. bat1 (bat), v.; pret. and pp. batted, ppr. batting. [< late ME. batten, beat with a stiek, < batte, a perhaps regarded as imitative of a heavy, dull blow; ef. pat.] I. trans. To beat; hit; strike. Especially - (a) In base-ball and similar games, to knock required thickness, as unbaked clay, preparat

ing on the block or throwing on the whel.

similar games, to attempt unsuccessfully to knock, as a ball; strike at but niss.

bat $^{2}$ (bat), n. [A corruption of earlier back, bak, Sc. back, bake (also bakie-bird, bawkie-bird), aftenbakke, orani, backe, Dan. bakke, in comp. natt-bakka night-jor $S$, black $a,=$ Icel. blaka, in comp. ledhr-blaka, bat lit. leather-flapper, $<$ blaka, flutter, flap. The lit. leather-flapper,
orig. form is uneertain. Cf. ML. blatta, blacta, batta, a bat, another applieation of I. blatta, an insect that shuns the light, a cockroach: see Blatta 1 . For the change of $k$ to $t$, ef. E. makie ${ }^{2}=$ trani. The AS. name of the bat is hreerenus $>$ F. rercmouse. The G. name is fledermaus; ef E. flittcrmouse.] A wing-handed, wing-footed
flying mammal, of the order Cliroptera (whiel flying mammal, of the order Chiroptera (which
see). The apecies are npward of 450 in number, nearly
cosmopolitan, but largest, most varied in character, and cosmopolitan, but largest, most varied in character, and countries. The gpecies of temperate eountriez, as of the and of such uniform characters that they give little ide of the extent and diversity of the order in warmer regions. Bats are the most aerial or volitant of all aulimals
even more 80 than birds or fnsects, for they have scarcely even more so than birdi or insects, for they have scarcely
any other means of locomotion than flying. They aro
472

\section{bate}

nocturnal and erepuscular, passing most of the daytime in dusky retreats, where they gather sometimes in almost downward by their hind feet. In aize they range irom less than the size of a nouse to large forms with sone five feet spread of wing. The body is usually softly furry; the

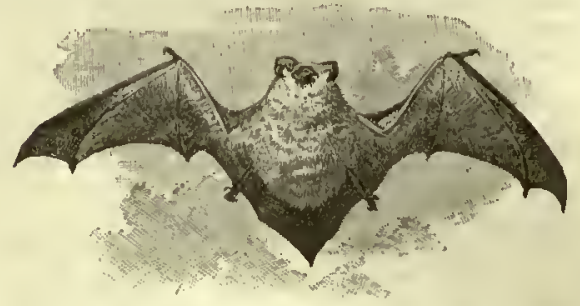

Hoary Bat (Lasinrus proinosu,

are Insectivorous and carnivorous, and constitute the anl. order Animalivora or Insectivora; of these, a few pres Diphylla, suck the blood of large animals; but the great bats of South America called vampires are chicfly frugivorous. See Desmodontes, Vampyri. The old-wori cies, constituting the family Pteropodidee and suborder Frugivora. See cut under fying-fox. " The physiognomy
of many of the bata is groteaque, owing to the extraordi nary appendages of the gnout, especially tn the fanilies and leaf-nosed and Phyllostomatida, or horsegloee bat and much complexity of detail, and, like the various ap pendagea of the face, and the wing-membranes themselves serve as tactile organs of extreme delicacy, even to the exof bats are commonly given to representations of evil ge ii and demons, as those of lírds are attached to goo ments is one of the fruit-bata, the Cynonycteris ogyptiaca The Hebrew narne of the bat of the Old Testament, atal leph, is now used in the form Atalapha for a genus of
American bats. The commonest apecies of the United States are the small brown bat, Vespertilio subulatus, an the red bat, Lasiurus noveboracensis. Among European us communis), the oreillard (Plecotus auritus) horseshoe bats (Rhinolophus hipposideros and $R$. ferroe played, that is, with the wings opened, and is often calle by ita older name reremouse. - Bat's wing, in anat. See
ala vespertilionis, under ala. - Bat's-Wing burner. See burner.- Bulldog bats, the molossold chiropterans. ots (Vat)

taken in a prob. now or flutter, as in the phrase to bat the eyes, that is, wink. [Prov. Eng. and U. S.]

You hol' your head ligh; don't you bat your eyes to
The Century, XXVII. 146. bat4 (bat or bâ), $n$. [ك F. bat, < OF, bast, a
pack-saddle: see bast ${ }^{3}$.] A pack-saddle: only in composition, as bathorse, batman, ete. bat's (bat), $n$. See batz.

bat 6 (bat), n. [Hind. $b \bar{a} t$, a weight, a measure of weight.] Same as tical.

bat7, $n$. A measure of land formerly used in South Wales; a perch of 11 feet square.

batablet (bà'ta-bl), a. [Also bateablc; short for debatable, as batc ${ }^{3}$ for dcbate. See dcbatablc.] A shortened form of debatable, as in batable ground, batable land. Seo debatable.

As we crossed the Batable Jaud.

Border ballad.

battle 1 battlerillert

batara (bà-tä'räa), n. [S. Amer.] A name of birds of Sonth America, of the subfamily Tham nophilina and family Formicariida; specifically, the Thamnophilus cinercus (Vieillot). It was used as a generic name by Leason in 1831, and by Sclater in 1858 , other Thamnophiline, under the name Batara cinerea also by Temminck, 1820, as a generic name of species of batardeau (ba-tär-dō'), n.; pl. batardeaus $\left(-\mathrm{doz} z^{\prime}\right)$ [F., dike, dam, coffer-dam, formerly bastardeau, dim. of $\mathrm{OF}$. bastard, dike, perhaps a casing of piles made water-tight, fixed in the a easing of piles made water-tight, fixed in the
bed of a river to exclude the water from the site of the pier or other work while it is being constructed. -2 . In fort, a wall, generally furnished with a sluice-gate, built across a moat or ditch, to retain the water in those parts of the ditch which require to be inundated.

batata (bả-tä'tä), n. [Sp. Pg. batata, <Haytian batata, the native name of the sweet potato; potato.] The sweet potato. The products of both China and Japan are here [Loo-
choo] cultivated, eapecially batatas and the gugar-cane.
J. J. Rein, Japan (trans.), p. 532.
Batavian (ba-tā'vi-an), $a$. and n. [<L. Bato via, the country of tho Batavi, a people anciently inhabiting an island (Batarorum Insula or Batavia) formed by the rivers Rhine, Waal, and Maas, and the ocean.] I. a. 1. Pertaining to the ancient Batavia, or by extension to the Netherlands or their iuhabitants, the Dutch.-2. Pertaining to Batavia, the chief city of the island of Java, and th eapital of the Dutch possessions in the East.

II. $n$. 1. A native of the Netherlands; a Dutehman.-2, A native of Batavia in Java.

bat-bolt (bat'bōlt), n. [<batl + bolt 1.$]$ A give it a firmer hold.

batch1 (bach), n. [< ME. bacche, batche, < AS. as if "bacce, < bacan, bake; ef. Dan. bagt, G. gcbäck, a batch: see bake.] 1. A quantity produced at on $\theta$ operation; specifically, the quantity of bread made at one baking. - 2. The quantity of material prepared or required for one operation. Specifleally - $(a)$ In glass-making, the flour or dough to be used at one baking. (c) The qnantity of grain sent at one time to the mill to be ground; a grist. similar to each other; especially, a number or aggregation recoived, despatched, ete., at ono time: as, a batch of letters; a batch of pris-

The Turkish troops are being hurried to the front in When he had her all to himself, ... he would pull out his Jast batch of sonneta, and regd them in a voice tremi. 4†. Kind, sort, or lot.

One fa a rimer, gir, of your own batch, your own Jeaven.
B. Jonsom, Every Man in lis Humour, i. 1. batch 1 (bach), v. t. [< batch $\left.1, n_{0}\right]$ To mass bring together in a bateh or the quantity required.

The white calico is batched. Encyc, Brit. IV. 685. batch ${ }^{2}$ (bach), n. [E. dial., formerly also baiche $<\mathrm{ME}$. bache, bacche, perhaps for \#bcche, < AS bece, boce, a brook: see beck1. For the transfer of sense from 'stream' to 'bank, mound, vale,' cf. dike and ditch.] 1. A bank; a sandbank.-2. A field or patch of gronnd lying near a stream; the valley in which a stream flows: especially in local English names. [Local, Eing.]

batch $^{2}$ (bach), v.t. [E. dial., $\left.<b_{\text {atch }}{ }^{2}, n_{0}\right]$ To protect (the bank of a river) by facing it with stones, so as to prevent the water from eating into it. [Local, Fing.]

batch ${ }^{3}$, n. [Appar. an assibilated form of batchelor, $n$. See bachelor.

bate1 (bāt), $v$; pret. and pp. bated, ppr. bating. [Also bait; < ME. baten (only intrans.), < OF. batre, mod. F. battre, beat, flap (battre les ailes, beat the wings, flutter; reflex., se battrc, flutter), $=$ Pr. batre $=\mathrm{Sp}$. batir $=\mathrm{Ig}$. bater $=\mathrm{It}$. bat
tere, beat, ete., < ML. (IL.) batere, battere, for L. batuere, battuere, beat, strike, whence also ult. F. batter 1 , battlc 1 , ete., and prob. in part the simple bat1, $v$.: see these words. The and batter.] I.t trans. To beat: in the phrase to batc the wings, to flutter, fly. [In the passage quoted, there is an allusion to bate ${ }^{2}$ for abatc.

Till the Soule by this meanea of overbodying herseif Mitton, Church Diact

(N.E. D.)

II. intrans. 1. In falconry, to beat the wings impatiently; flutter as preparing for flight, particularly at the sight of prey; flutter away.

I am like a hawk that bates but cannot fly, because I am These kites
That bate and beat and will not be obedient

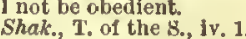

2t. To flutter; be eager or restless.-3t. To flutter or fly down. [With allusion to bate? for abate.]

bate ${ }^{2}$ (bāt), v. ; pret. and pp. bated, ppr. bating. [Early mod. E. also bait; < ME. baten, by apheresis for abaten, abate, which thus becomes in form and in some senses identical with the orig. simple form represented by bate1 : see abate and bate ${ }^{1}$.] I. trans. 1t. To beat down or away; remove by beating.

About autumn bate the earth irom about the ronts of
olives, and lay them bare. Holland, tr. of Pliny, II. 521. 2t. To beat back, or blunt.

Spite of comnorant devouring Time,

Th' endeavour of this present breath may bu Shak., I. L. I, i. 1. 
bate

3t. To weaken; impair the strength of. These griefs and losses have so bated me,
That I shait hardly spare a pound of tlesh.

4†. To lessen or decrease in amount, weight, estimation, ete.; lower; reduce.

Who bates mine honour, silall not know my coin.

5. To strike off; deduct; abate.

There is twelve sillitings to pay, and, as I am a true knight, I will not bate a penny. I would rather bate him a few strokes of his oar, than not employ an honest man that has been wounded in the I bate no jot of trust that this nolnie trial of geif-govern6. To lessen in foree or intensity; moderate; 6. To lessen in foree or intensity; moderate;
diminish: as, to bate one's breath, or with bated breath (8ee phrases, below); to bate one's or a

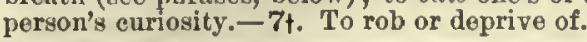
When baseness is exalted, do oot bate

The place its honour for tile person's sake.

8t. To leave out; except; bar.

Bate me the king, and, be he flesh and blood,

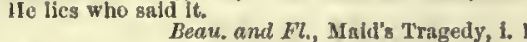

To bate off, to make a reduction in or an abatement from ;

Abate thy speed, and I wili bate of mine. restrainedly, as from fear, humillity, or deference, -With bated breath, with subdued or reatrained breathing, as rom fear or awe.

Shall I bend low, and in a bond-mana key,

With bated breath and wirispring humberess
Say this?
Shak., M. of V., 1. 3 (1623).

II. intrans. To decrease or fall away in size, amount, force, estimate, etc.

Bardolph, sm I not fallen away vilely stnce this last Shak., I Hen. IV., ili. 3.

I know "twas thia which made the envy and pride

Of the great Roman blood bate and give way
To my election.
B. Jonson, Catiline, il. 1. bate ${ }^{3}+$ (bāt), v.i. [< ME. baten, by apheresis for debaten, debate: see debatel, v.] To contend; strive; quarrel.

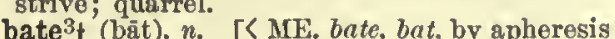

for debate, debat, debate: see debate 1 , n.] Contention; strife; debate.

Breeda no bate with teiling. Shak., 2 Hen. IV., li. 4.

bate ${ }^{4} \dagger$ (bāt), $v$. and $n$. Obsolete and less correet apelling of bait 1 .

bate $^{5}$ (bāt), v. t.; pret, and pp. bated, ppr. bat ing. [Prob. a particular use of bate 4 , properly spelled bait; cf. Sw. beta, tan, bait, = G. beizen, steep in lye, macerate, bait, lit. cause to bite: see bait ${ }^{1}$.] 1. To steep, as a hide, in an alkaline lye. See bate $, n,-2$. In jute-manuf., to separate (the raw material) into layers, and then soften by sprinkling with oil and water. bate ${ }^{5}$ (bāt) $n$. [< bate ${ }^{5}, v$.] The alkaline solnbate $^{5}$ (bāt), $n$. [<bate ${ }^{5}, v$. The alkaline soln-
tion in which hides are steeped after being limed, in order to remove or neutralize the lime. bate ${ }^{6}$. Obsolete or dialectal preterit of bite.

Yet there the ateel atayd not, but inly bate

Deepe in his flesh, and opened wide a red floodgate.

bate7 (bāt), n. [Also bait; origin unknown. Hence cross-bated.] The grain of wood or stone. [Seotch.]

bate ${ }^{8}$, n. E< LI. batus, < Gr. Bátos, < Heb. bath: see bath2.] Same as bath2.

batea (bat'ē-ä), n. [Sp. Pg.] A wooden ves8el in the form of a very flat hollow cone, abont 20 inches in diameter and 2 or 3 inches deep, used by Mexican and Californian miners for washing aurifero

In the rubbish which was thrown out of the old nine, a comfortable aubsistence is gained by washing in bateas.

batean, batteau (ba-tö $), n_{.} ;$pl. bateaux, batteaux (-tōz'). [< F. bateau, < OF. batel $=\mathrm{Pr}$. batelh $=\mathrm{Sp} . \mathrm{Pg}$. batel $=\mathrm{It}$, battello, $\langle\mathrm{ML}$. batellus, dim. of NL. batus, battus (> It. batto), a boat, prob. <AS. bät, a boat: seo boat.] 1 . a boat, prob. [AS. bät, a boat: see boat.] 1. portion to its breadth, and wider in the middle than at the ends.-2. A pontoon of a floating bridge.

batean-bridge (ba-tō'brij), n. Milit., a floating bridge supported by bateanx or boats.

bateaux, n. Plural of bateau.

bate-breedingt (bāt'brē" ding), a. $\quad\left[<b a t e^{3}+\right.$ breeding, ppr. of brced.] Breeding strife.

473

This sour informer, this bate-breeding spy This eniker tirat eats up Love's tender s\}ring, Shak., V. and A., 1. 655 . batefulł (bāt'fủl), a. [<bate $\left.e^{3}+-f u l.\right]$ Contentious; given to gtrife; exciting contention. It dild bateful question frame. Sir P. Sialney. batelesst(bait'les), $a$. [<batc ${ }^{2}+$-less.] Not to Ifaply tilat name of "chaste" unhapplly set Shak., Lucrece, 1.9. ateleur (bat'e-ler), n. [Appar. a particular application of 1. bateleur, a jugglor, buffoon.]
A name of an African eagle, the Ifelotarsus ecaudatus.

atellatet, $v$. $t$. [< ML. as if "batcllatus, $\mathrm{pp}$. batcllare, assumed from OF. bataillier, or fortify or make defensible, as a dwelling-house. batementt (bāt'ment), n. [By apheresis for abatement: 800 batis and -ment.] Abatement: diminution; lessening; specifically, among carpenters, the portion to be cut off from a piece of timber to bring it to a desired length.

batement-light (bāt'ment-lit), "r. In areh., a vertical light in the npper part of a window of

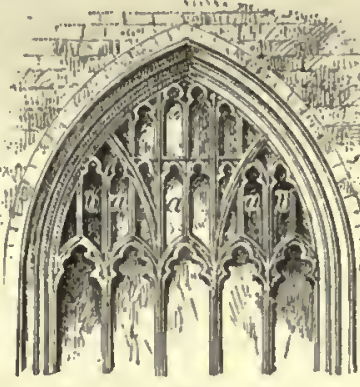
$a, a, a$, batement-lights; $\delta, \delta$, angel-lig

in bating hides. When the hidea have been properly worked with the for about twenty minntes. C. T. Davis, Lesther, p. 586 .
for at-fish (bat'fish), n. [<bat $2+f i s h 1.], 1 . A$ fish of the family Maltheida (which see). The

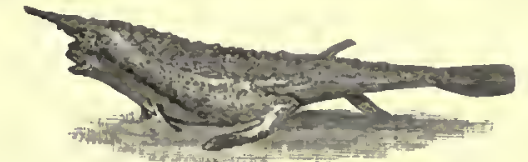

Lateral view.

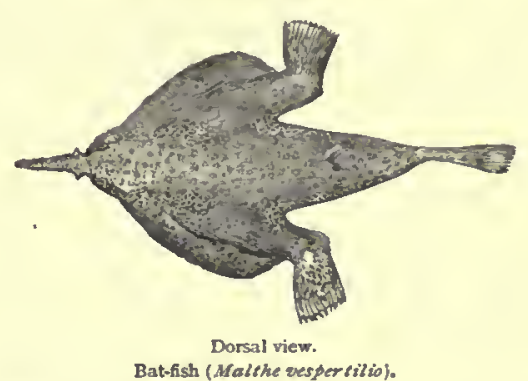

shaped trunk, produced anterioriy in a proionged mout, tentacle under the snout. It inhabits the Atlantic along 2. A name of the flying-fish or flying-robin,

Cephalaeanthus volitans.
bat-fowler (bat'fon"lér), $n$. [< ME. battforolere, < battfowlen: see bat-fowling.] 1. One who practises bat-fowling.-2†. A swindler. [Slang.

bat-fowling (bat'fou"ling), n. [<ME. battefowlynge, < battfowlen, snare birds, < batte, by gome supposed to refer to the bat or stick on which the nets were fastened, + fowlen, $\nabla$., fowl. The first element is now often associated with bat2.] A mode of catching birds at night by holding a torch or other light, and beating the bushes or trees where they roost. The birds fly toward the light, and are caught with nets or otherwise. batfulł (bat'fü), a. [< bat in battle 3 , batten 1 , ete., +-ful; possibly, like batcell, a perversion of battle or battel, fertile: see battle $3, a$.] Rich; fertile, as land: as, "batful pastures," Drayton, Polyolbion, iii. bath

bathl (båth, pl. baimiz), n. [<MF. bath, <AS. berth, pl, buthu, = OS. bnth = D. bad = OHG. IIIG. G. bal, bath, = Icel, bulh $=\mathrm{Sw}$. Dan. bad; prob., with formative -th $(-l l)$, from tho rerb represented by OHG. bajan, MHG. bajen, ban, G. bähen = LG. büen, foment, = ME. bercen, eleunse, prob. = I. fotere, foment: see foment.] 1. A washing of the body in, or an exposure of it to the action of, water or other fluid agent, for eleansing, refreshment, medial treatment, etc. : as, to take a bath; to administer a bath to a patient. -2 . A provision $r$ arrangement for bathing: as, to prepare a bath; a hot or cold bath; a vapor-bath; an electric bath. Thero are many kinds of hatha, all of which may be divided into four ciasses: $(a)$ according to the medium in which the body is inmersed, as a icuter-, oil. or mud-bath, a compressed-air bath, a medicated or min crat bathe ming-bath, etc.; (c) according to the parts bathed, as a foot ritz or eye-path, etc. (i) accorliug to temperature, as a hot, tepid, werm, or cold bath.

3. A vessel for holding water in which to plunge, wash, or bathe the body. -4 . More genrally, an apartment or apparatus by means of which the body, or a part of it, may be bathed in any medium differing in nature or ternveratnre from its natural medium. -5. An edífice containing apartmonts fitted up for bathing; a bath-house; particularly, in tho plural, one of the claborate bathing establishments of tho

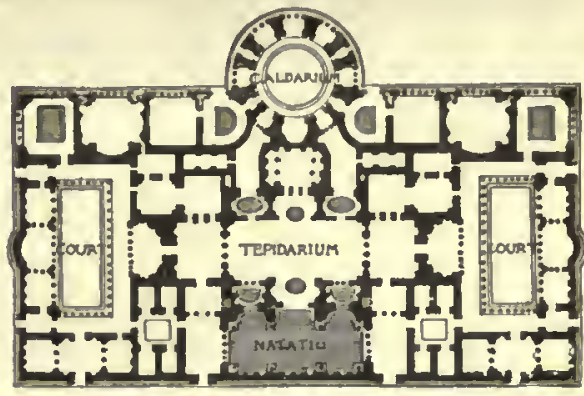

$$
\text { Plan of the Baths of Caracalla, Rome }
$$

ancients, as the Baths of Caracalla at Rome. See therme. -6. In science and the arts, any vessel containing a liquid for treating any object by immersion. (a) In photog., the vessel in which a collodionizcd plate is submitted to the action of a solu. dry piate is immersed in the developing sointion. (b) In

7. An arrangement or preparation for immersing anything, as the silver-bath in photography. -8. In chem., an apparatus for modifying and regulating the heat in various chemical processes, by interposing a quantity of sand, water, or other substance between the fire and the vessel intended to be heated. When a liquild bath of a highcr temperature than $212^{\circ}$ is required, saturated higher ths that of wster.-Companions of the Bath the Bath. - Compreased -air bath, a bath consisting in remaining for a longer or shorter time in a chsmber filted as usefui in certain diseases, in which an increased expas. give force is required to cause the air to infiate the more delicate air-passages of the lungs. - Dung-bath, a bath Bath, an order of knighthood supposed to have been insti. tated at the coronation of Heary IV in 1399 . It received this name from the fact that the candidatea for the honor were put into a bath the preceding evening, to denote a they were now to begin a new life. The present order of the Bath, however, was instituted by George I. In 1725, as a grand master and thirty-8ix companions. In 1815 the order was greatly extended, and in 1847 it was opened to clilians. It is now composed of three classes, viz: milicommanders, K. C. B.; and knights companions, C. B. The
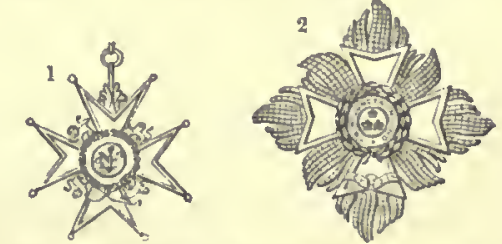

8. Badge worn suspended from the collar of a knight of the Sath.

hadge (fig. 1) is a golden Maitese cross of eight points, having in $\mathrm{a}$ circle in the center the rose, thistle, and sham. rock (representing regpectively Engiand, Scotland, and Ire.
laud), betweev three imperial crowns; motto, Tria juncta 
bath

in uno. Stars are also worn by the first two classes.
That of the knights grand-crosses (fig. 2) is of silver, with eight points of rays wayy, on which is a gold cross besring
three crowns, encircled lyy a ribbont displaying the motto of the order, while beneath is a seroll inseribed Ich dien
(I aerve), the inotto of the Prince of Wales. The star of

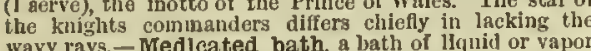
wavy rays. - Medleated bath, a lath of liquid or vapo medicine mixed in it. - Mercurial bath, a bsth used in the pneumatic trongh to collect such gases as are residily
alsorbed by water.- Metal-bath, a bath used ln chemical operations requiring a higher tenpera ture than can ive
produced by means of a water-bath. Jercury, fusible pretal, tin, and lead are enployed for such bathis.-Rusmian bath, a kind of bsth employed in Russia, snd introulueed thence in other countries. It resembles in principle the ancient anl the Turkish baths, but differs irom
the latter in that the subject, after exposnre to the in. the latter in that the subject, sifter exposnre to the in-
fluence of very hot vapor, with the attendant kneading. flutence of very hot vapor, with the attendant kneading,
lathering, etc., is suducniy and violently cooled by nieans uf a jet of ice-coidd water. It is gajd to be of service in liquid made of bran and refuse malt. It is employed to rempove the lime used in a previous process, and also to soften the skin to render it more absorbent of the tanning
materials. - Tin-bath, molten tin covered with meltei materials. - Tin-bath, molten tin covered with meter
tallow to prevent the oxldation of the metal. It is used tallow to prevent the oxidation of the metal. to lorm the go-caled thi-plate.-Turksh bath, a kly ate having undergone coplous perspiration in a heated room, is subjected to various processes, as soapling, washing,
kneading (shampooing), etc., and ultimately proceeds to an outer apartment, where he is placed on a couch to cool. Turkish baths, or modiflestions of them, are pro-
vided in all hydrotherapeutic eatablishments, and are to ve found in most towns of considerable aize. - White bath, a bath used in dyeing; sn emulsion formed by Ga]lipoll oil and the carbonates of alkaiis

bathl (báth), $v . t$. [Later form for bathe, directly from the noun.] To put into a bath; wash in a bath. [Rare.]

bath $^{2}$ (bath), $n_{\text {. }}$ [Earlier in E., as LL., batus, or else bat, bate, < LL. batus, < Gr. ßátos, < Heb. bath.] A Hebrew liquid measure $=72 \log s=$ 6 hins $=$ to cor, and correspending to the $d r y$ measure the ephah $=72 \operatorname{logs}=18$ eabs $=3$ saths $=\frac{1}{10}$ cor. There were two measures of this name, one equal to a bout two thirds of the other, as is seen by comparing 1 KJ. vil. 26 with 2 Chron. iv. 5 . The large
bath seems to have contained about 36 liters $=91$ United bath seems to have contained about 36 liters $=910$ nither
States gallons $=8$ British gallons. The smaller bath seem to have contained sbout

Bath brick, bun, chair. See the nouns.

bath-chops (báth'chops), n. pl. The cheeks or face of the hog cured or smoked.

bathe (bātr), $v_{\cdot}$; pret. and pp. bathed, ppr. bathing. [Also in var. form (now only dial.) beath, q. Y.; < ME. bathien, < AS. bathian ( $=\mathrm{D}$. baden $=\mathrm{OHG}$. badon, MHG. G. baden = Icel badha = Sw. bada = Dan. bade $),\langle$ boeth, bath immerse in water or other fluid, for cleanliness, bealth, or pleasure.

Chancing to bathe himsell in the rlver Cyduus, . . he he
fell sick, near unto death, for three days.

Others on silver lakes and rivers, bathed
Their downy breast.
Milton, $Y$. L., vii. 437 .

2. To apply water or other liquid to with a sponge, cloth, or the like, gencrally for therapeutic purposes. -3 .
fuse with any liquid.

Ier bosoun bathed in blood.

Dryden.

4. To immerse in or surround with anything aualogous to water: as, bathed in sunlight.

One sip of this
Wiil bathe tile drooping spirits in delight. Miltom, Comur, 1. 812.
Tennyson, Tithonus.

Thy rosy ahadows bathe me. Tennyson, Tithonus. The sun was past the middle of the dsy,
But bathed in food of light the world still lay.
j'illiam Morris, Farthly Paradise, it

5. In zoöl., to tint; tinge in a uniform man ner, giving the appearance of one color seen through another: as, black bathed with purple, brown bathed with rosy, ete.

II. intrans. 1. To take a bath; be in water or other liquid; go into water to bathe one's

They bathe in summer, snd in winter sllde. Waller. 2. To be immersed or surrounded as if with

bathe $(\mathrm{b} \overline{\mathrm{a}} \mathrm{TH}), n$. [< bathe, v.] The act of bathing; the immersion of the body in water: [Confined ainost entirely to Scotland, where a distinction is made between s bathe and a bath, the former being apused.] 1 (bather 1 (ber) who immerses himself in water.-2. One who bathes another.

bather ${ }^{2}$ (bath'èr), $v . i$. [E. dial.] To scrate [Prov. Eug.]
474

\section{Bathymaster}

bathetic (bā-thet'ik), u. [< bathos, on type of ized by bathos; sinking rhetorically, or in style. Coleridge.

A [stal insensibility to the ludicrous and the bathetic. The Academy, July 3,1875, p. 5.

bath-house (bath'hous), n. 1. A house fitted up with conveniences for bathing, as bath-rooms, tubs, sometimes a tauk or swimming-bath, ete. -2. A small house, or a house divided into a number of small rooms, at a bathing-place, or place for open-air bathing, where bathers change their dress.

bathing-box (bā'THing-boks), $n$. A covered shed or bath-house in which open-air bathers change their dress. [Eng.]

bathing-dress (bā'THing-dres), $n$. A partial

or loose costume used by open-air bathers, as on a searbeach.

bathing-house (bā'thing-hous), $n$. A bathhouse. [U. S.]

bathing-machine (bā'mHing-ma-shēn"), n. A covered vebicle used at the seaside resorts of Great Britain, in which bathers dress and undress. It is driven into the water to a sufficient bathing-tub (bā'THing-tub), n. Same as bathtub.

bath-kol (bath'kol), ". [Heb., < bath, daughter, + kol, voice.] A kind of oracular voice frequently referred to in the Talmud, the later grade of revelation, constituting an instrument of divine communication throughout the early history of the Israelites, and the sole prophetic manifestation which they possessed during the period of the second temple.

From the death of Haggal, Zechariah, and Malachl, the IIoly Spirit [which, according to the Jewish distinction, is only the second degree of the propheties gift] was
withdrawn Irom Israel; but they nevertheless enjoyed withdrawn from of the bath Kol

Bath metal. See metal.

bathmic (bath'mik), a. [<Gr. $\beta a \theta \mu \delta \zeta$ (see bathmism) + -ie.

I compared the transmission of bathmic toree to that of the phenomenon of combustion, which is a force converE. D. Cope, Origin of the Fittest, p. 229 .

bathmism (bath'mizm), $n$. $[<\mathrm{Gr} . \beta a \theta \mu o \delta$, also $\left.+-i s m_{0}\right]$ See extract.

It is here left open whether there be aly form of force which usy be especislly deslgnated as "vital." Mrany of
the animal functions are known to be physical and chem. the animal functions are known to be physical and chem
ical, gnd if there be any one which appears to be less ex plicable by reference to these forces than the others, it is
that of mutritlon. Probably in this instance force has been so metamorphosed through the influence of the origispecies in the category of forces. Assumlng it to he such, I have given it the name of Bathmism.
E. D. Cope, Meth. of Creatlon, p. 26.

Bathmodon (bath'mō-don), n. [NL., < Gr. $\beta a \theta$. $\mu$ s, a step, + odor's $=$ E. tonth. $]$ A genus of
fossil hoofed quadrupeds named by Cope in 1872 , subsequently identified by him with Coryphodon (which see).

bathmodont (bath'mọ-dont), $a . \quad[<B a t h m o$ don $(l-)^{-}$.] In odontog., noting a pattern of dentition in which the posterior pair of tubercles of the upper molars are approximated, connected in section, and the anterior onter tubercle is connected with the anterior inner one by an oblique crest forming a V. Such dentition is characteristic of the genus Bathmodon.

Bath note. See nole.

bathometer (ba-thom'e-tèr), n. [<Gr. Bátos, depth, + $\mu$ ćrpow, a measure.] An apparatus, consisting of a spring-balance of peculiar conwater.

Bath oölite. See Bath stone, under stone.

bathorse (bat'- or ba'hôrs), ". [< bat4 (F. bat), a pack-saddle, + horse.] In the British army, a horse for carrying baggage belonging to an officer or to the baggage-train. Also written bawhorse.

bathos (bā'thos), n. [Gr. $\beta a ́ \theta o s$, depth, < $\beta a \theta$ 's, deep. In def. 2, orig. an antithesis to iv height, the sublime.] 1. Depth; lowest part or stage; bottom. [Rare.]-2. A ludicrous descent from the elevated to the commonplace
or ridiculous in writing or speech; a sinking; anticlimax.
In his fitth sonuet he [Petrarch] may, 1 think, be said Haceulay, I'ctrarch. $=$ Syn. 2. Fustian, Turgidness, etc. See bombast.
bath-room (bath'reom), $n$. A room for bathing

bath-sponge (bảth'spunj), n. A sponge used in bathing, etc. sponges suitaj)le for this use all belong to the geuns Spongia, of which there are six commercial apecies or varieties, deriving their value from the fineness the Mediterranean is $S$. equina, resembling the woolare the zimocea, S. zimocca; the cup-sponge, $S$. adriatica, of Turkey and the Levant; the American yellow sponge, S. corlosia; and the Amerlcan lhard-head, S. dura.

Bath stone. See stone.

ath-tub (bath'tub), n. A tub to bathe in: in the usual form, approximately of the length of the body, and often permanently fixed in a bath-room. Also called bathing-tub.

bathukolpian, $a$. See bathycolpian.

athvillite (bàth'vil-it), n. [< Bathville (see def.) $+-i t e^{2}$.] A brown, dull, amorphous mineral resin, occurring in torbanite, or boghead coal, on the estate of Bathville, near Bathgate, Linlithgowshire, Scotland.

bathwort (bàth'wér.t), $n$. [Cormuption of birlhoort, after bath1.] Same as birthroot.

athybial (ba-thib'i-al), a. [<bathybius $+-a l$. of or pertaining to bathybius or the depths at which it is found; bathybian: as, "bathybial fauna," Encyc. Brit., XXI. 774

bathybian (ba-thib'i-an), $a$. [< bathybius + -an.] Pertaining to bathybius; composed of or resembling bathybius.

The use of the dredge resulted in fluding the usual bahylan forms that have Arc. Cmise of the Con un, 1881, p. 14

bathybius (ba-thib'i-us), n. [NL., < Gr. Batis, deep, + Kios, life.] A name given by Huxley to m, have been found covering the sea-bottom at have been found covering the sea-bottom at abundance as to form in some places deposits upward of 30 feet in thickness. It was described as consisting of a tengcious, viscid, slimy substance, exhibiting under the microscope a netwoik of granular, mucilaginous matter, which expands and contracts sponsponding in ali respects to protoplasm (which see). Em. bedded in it were calcareous bodies with an organlc structure, calted discoliths, coccoliths, and coccospheres, which geemed to belong to bathyblus as such. The exisbathycolpian (bath-i-kol'pi-an), a. [Also less

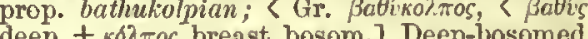
deep, $+\kappa \delta \lambda \pi$ os, breast, bosom.] Deep-boso

Bathyerginx (bath"i-èr-ji'në), $1 ., l$. [NI Bathyergus + -ince.] A subfamily of Ethiopian mole-like rodents, of the family spala cide, or mole-rats, differing from Spalacince in haviug the mandibular angle arising beside the socket of the lower incisors. There are three genera, Bathyeryus, Georychns, and Heliopho-

bathyergue (bath'i-èrg), n. A rodent quadruped of the genus Bathyergus.

Bathyergus (bath-i-ér'gus), n. [NL., after Gr.

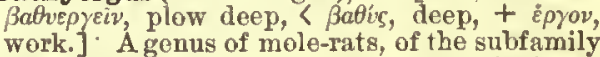
Bathyergina, having grooved upper incisors.

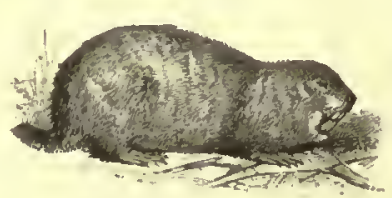

B. maritimus ls burrowing in the sand-dune (ape, an and zand. of rand-mole; it is snd in aom places the sandy
soil is honey.

combed with its extensive excavations. The fur is graylsh brown, and might possess commercial value.

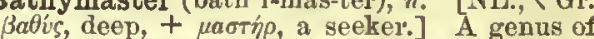
fishes, typical of the family Bathymasterida.
fishes,

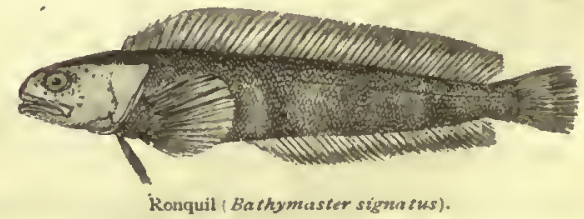

The only known species Inhshits water of moderate depth about rocks along the northern Pacific coast south to
Puget Sound, and is popufarly known as the ronguil or Puget solum.
ronchil. 


\section{Bathymasteridx}

Bathymasteridæ (bath" i-mas-ter'i-dē), n. pl. [NL., < Bathymasicr + -idce.] A family of acanthopterygian fishes, represented by the genus
Bathymastcr, and scarcely distinet from Latilido (which see)

bathymeter (ba-thim'c-tér), n。 [< Gr. Bäis, deep, + нít $\rho \circ v$, a measure.

bathymetric (bath-i-met'rik), a. [< bathymetry $+-i c$.$] Pertaining to bathymetry or the$ measurement of depths, especially at sea. Bathymetrlc zone, in zoögeog., one of the liorlzontal helts of the deptha of the sea vertically aeparated by their characteristic launa and flora. Five ancli zones are reek. nerian, from low water to about 15 fathorns : (3) the coralline, from that to abont 50 fathonis; (4) the deep-esea, 'from that to about 300 ; (5) the abyseal, from that to the
lowest depths.
bathymetrical (bath-i-met'ri-kal), u. Same as

\section{bathymetric}

bathymetrically (bath-i-met'ri-kal-i), adv. As regards bath

bathymetry (ba-thim'e-tri), [< Gr Baois

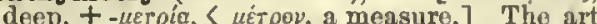
of sounding or of measuring deptlis in the sea. bathyphon (bath'i-fon), $n_{0}$ A musical instrument of the clarinet class, having a single reed and a wooden tube, and a compass of nearly three octaves from the third $\mathrm{D}$ below middle C. It was invented in 1829 in Berlin, but was soon supplanted by the tuba.

Bathythrissa (bath-i-thris'ai), n. [NL., < Gi.

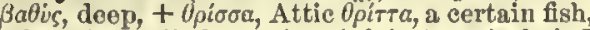
otherwise ealled r $\rho \iota \chi^{\prime} a a_{\text {, }}$ [ $\theta \rho i \xi$ (т $\rho\llcorner\chi-)$, hair.] The typical genus of the family Bathiythrissidle, containing one known species (Bathythrissa dorsalis) of deep-water fishes with some resemblance to a herring or whitefish, found off the coast of Japan.

Bathythrissidæ (bath-i-thris'i-dē), n. pl. [NL., [Bathythrissa +-ida.] A family of malacopterygian fishes, typified by the genus Bathythrissa. They have an oblong body and rounded abdo men, eovered with eyelold scales; the margin of the uppe maxillaries laterally : complete operenlar apparatus; very blind ac; nnmerous pyloric appendages; and dnctles

batiator-root (bat'i-ā-tor-röt"), n. The root of an undetermined Brazilian plant, used as an emetic and in dysentery.

Batides (bat'i-dēz), n.pl. [NL., pl. of Batis (a genus of fishes), (Gr. Garis, a flat fish, perhaps the skate or ray.] The rays, as an order of selachians. $L$. Agassiz. Seo Raia. bating ${ }^{1}$ (b $\bar{a}^{\prime}$ ting), $n$. [Verbal $\mathrm{n}$. of bate ${ }^{1}, v$.]
The act of beating the wings; fluttering; fluttering away.

bating ${ }^{2}$ (bā'ting), prep. [Orig. ppr. of bate ${ }^{2}$, for abate; now regarded as a prep.] Abating taking away; deducting; excepting.

Baling the outward respeet due to his birth, they treat-
ed him [the Prince of Condé very hardly in all hia pretened him [the Prince of Condé] very hardly in all hia preten
sions.
Bp. Burnet, Hist, Own Times, an. 1077 . bating ${ }^{3}$ (bā'ting), n. [Verbal n. of bate $\left.{ }^{5}, v.\right]$ The process of steeping hides and skins in an alkaline bath, to separate the limo, oil, and pliable, and fit for tanning.

batiste (ba-tēst'), n. [< $\mathbf{F}$. batiste, < OF. baptiste; so called, it is said, from its inventor, one Baptiste, a linen-weaver of Cambrai (see cambric) in French Flanders.] A fine linen cloth mado in Flanders and Pieardy, of threo dif-
ferent kinds or thicknesses; a kind of cambric. ferent kinds or thicknesses; a kind of eambric.
batler $\uparrow$ (bat'ler), n. [Appar. for battler ${ }^{2}, q . v$. Found only in Shakspere, with a var. batlct.] A small bat or bectle for beating clothes in wash ing; a clothes

tler, battril.

I remember the kissing of her batler (so in early edldugs that her pretty chopped handa liad miliked.

batler ${ }^{2}$. Seo batteler.

batlett (bat'let), n. [ $\left[\left\langle b^{\prime} t^{1}+\right.\right.$ dim. -let; but perhaps an error for batler $1, q . \vee$.$] Same as$ batler 1

batmanl (bat' - or bâ'man), n.; pl, balmen (-men). [Formerly also bateman; < bat $(\mathrm{F}$ bat), a pack-saddle, + man.] A person al lowed by the government to every company of a regiment on foreign service. Ilis duty is to take charge of the cooking utensils, etc., of the company. company to convey the eonking utensils from place to place. I $m p$. Dict. [Great Britain.

batman' (bat'man), ". [= Russ. batmanǔ, Turk. batman, butmān, u. weight, the same as
475

batster

tho I'ers. man: see muund2.] A Turkish weight batrachian (bu-trü'ki-an), $u_{0}$ and $n$. [< Batruvarying in amount in different localitics. Th batman formerly legal througlout the empire, now used in Constantinople and Sinyrua, is 17 pounts avolrdupois. little batman is 5.6 pounds. The batman of Tabriz is 6.4 pounds: the batman of shira.

at-money, baw-money (bat'- or b̂ी'-, bâ'mun"i), n. [<bat + money.] Money paid to a batmau.

batoid (bat'oid), $a$. and $n$. [< Batis (n geums of fishes) + -oid. $]$ I. $a$. Of or pertaining to the Batoidei.

II. n. Ono of the Batoidei.

Batoidei (ba-toi'dọ̄ī), n.pl. [NL., < Batis (a genus of fishes) +-ouleus, pl, -oidei.] In Guinther's system of classification, a suborder of plagiostomatous fishes having

Batolites (bat-ō-li'tēz), n. [NL., < F. baton, a

Batolites (bat-o-k'tez), ".o. [NL., F. baton, a staff (seo baton), $+\mathrm{Gr}$. hibos, a stone.] A genus of straight cylindrical bivalve fossil sholls, allied to the hippurites. Some aro of great length,
and form masses of rock in the high $\Lambda$ lps. Also written Batolithes and Batolithus.

batologist (ba-tol' $\overline{0}$-jist), n. [<"batology (<

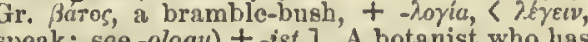
made a spocial study of the genus Rubus, or tlie brambles, tho numerous European spocies of wrambles, tho numerous European species of cult to determine.

baton (bat'on, ba-ton', or, as F., bà-tôn'), $n$. [This word appears in $\mathrm{F}$. in various forms; lirst as baston (< OF. baston $=\mathrm{Sp}$. baston $=$
$\mathrm{Pg}$. bastão = It. bastone, $<\mathrm{ML}$. basto $(n-)$, a stick staff, of unknown origin), then baton ( $<\mathrm{F}$. baton), with accent on first syllable, also spelled batton and batten (see batten ${ }^{2}$, and with F. accent baton', also spelled batoon, battoon (see baloon), and recently, esp. in the musical use, pronouuced as F.: see baston, baltonn, batten ${ }^{2}$.] 1. A staff or club; a truncheon: carried either on; (b) as a mark of anthority, as the baton of a field-marshal; or (c) as a warrant to do something, as the baton or staff carried in Something, as the baton or staff carried in single-track railway, as his authority to proceed.-2. In music: (a) The stick or wand used recting the performance.

When I went home I made myself a bafon, and went
bout the fielda condueting an orehestra. Dickens. (b) A rest of two or more measures.-3. In her., same as baston, $1(c)$.

Also spelled batton.

To wleld a good baton, to conduet a musical perform baton (bat'on), $v . t$. with a baton; cudgel.

baton-cross (bat'on-krôs), n. In her., same as cross potent (which see, under cross 1 ).

batoont (ba-tön'), n. [An older form of baton [F.baton: seebaton.] 1. A club or truncheon a baton.

\section{Although his shoulders with batoon
be elaw'd and cudgell'd to some tun}

2. A staff of office. See baton, 1.-3. In her., same as baston, $1(c)$. - 4. In areh., same as baston, 2.

at-printing (bat'prin"ting), $n$. In ceram., ware. An engraving on copper is made with fine lines, from which an inpression is taken in linaeed-oll on a thin
alab of gelatin. This impresslon la tranaferred to the glazed ware, and over it is then dusted a metallic color, which
clings to the ofl, and is afterward melted and fixed by firing. See bat 1, is.

Batrachia (ba-trā'ki-ä), n. pl. [NL., prop.

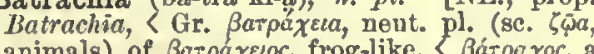
frog, with numerous dialectic variants, $\beta$ ápacos, frog, with numerous dialectic variants, Ba pakos,

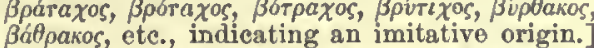
1. Formerly, as in Cuvier's system of classification, an order of reptiles, containing the frogs, toads, newts, salamanders, otc., and coextensive with the modern class Amphibia; the amphibians, or those vertebrates which breatho at first by gills, and then, generally, lose the gills and breathe by lungs. -2 . Now, an order of Amphibia, synonymous with Anura ${ }^{2}$ (which see), containing the frogs and teads only, or those amphibians which lose the tail as well as the gills. The leading familiea are the Pipida, or Sur nam toads; the Ranida, frogs ; the Bufondoe, ordinary
toads; and the IIylide, tree-frogs. See cut under Anuras

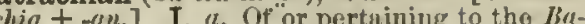
trachia, especially frogs and toads.

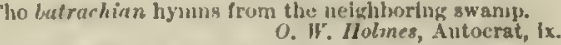

II. $n$. Ono of tho Rintruehin.

atrachid (bat'rin-kid), 21. A fish of the family Iintraclicle

atrachidæ (ba-trak'idü), u. pl. [N1.., < Bntrachus + -icke.] A family of aeanthopterygian fishes, typified by the genus Batrachus, with unurmed cheeks, a dorsal fin doveloped and com. posed of a fow sharp spines, and jngular and imperfect ventral fins. The s]recles are mostly inhab. ants of aubtropleal or temperate seas, and are known batrachite (bat'ra-kit), n. [< L. batruclites,

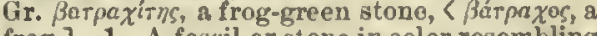
frog.] 1. A fossil or stone in color resembling a frog; toadstonc. - 2. A mineral identical with the Vesuvian monticellite (which see), belonging to tho chrysolite group.

batrachoid (bat'ra-koid), a. [<Gr. " ßaтpa zoet

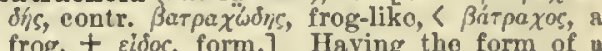
frog; pertaining to the Batrachia.

atracholite (ba-trak'o--]it), n. [<Gr. ßórpaxos frog, $+\lambda i \theta$ os, a stone.] A fossil batrachian. atrachomyomachy (bat"ra-kō-mī-om'a-ki), n. [<L. Batrachomyomachia, <Gr. Batpaxopiona xia, name of a mook-heroic poem traditionally as cribed to Homer, < $\beta$ áspaxos, a frog, + $+\mu \bar{s} s,=$ E. mousc, $+\mu a ́ x \eta$, a battle.] A battle between the frogs and mice; specifieally (cap.), the title of an ancient Greck parody on tho Iliad.

batrachophagous (bat-ra-kof'a-gus), a. [<Gr. (roger $+\phi a y i v$, eat.] Foeding on

frogs; frog-eating; ranivorous.

Batrachophidia (bat" râ-kō-fid'i-ạ.), n. pl. [NL.,

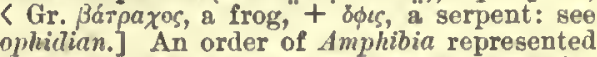
by the family Cacilide: same as Ophiomorpha. Also Batrachophidii.

batrachophobia (bat'ra-kō-fóbi-ä), n. [<Gr. Dread of batrachians; aversion to toads, frogs, etc. [Rarc.]

Batrachopsida (bat-rạ-kop'si-dä), n. pl. [NL.

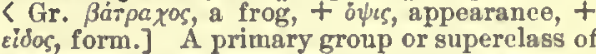
Vertebrata, conterminous with the class $A m$ phibia, contrasted with Sauropsida.

Batrachospermeæ (bat "rạ-kō-spèr'mẹ-ē), n. pl. [NL., < Batrachospermum + ea. $]^{\circ}$ A small group of fresh-water alga classed with the red seaweeds, consisting of articulated flament with whorls of necklace-like branches. The prineipal genus is Batrachospermum, sparingly represented in the United States.

Batrachospermum (bat"rạn-kō-spér'mum), n

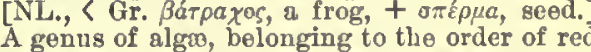
seaweeds, Floridec, and family Batrachospermea. Batrachospermum moniliforme is the commonea of the few red algav which are found in fresh water. I some ahade of red or sometlmes only grass-green, and batrachostomous (bat-ra-kos'tō-mus), a. [<

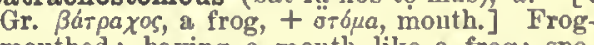
mouthed; having a mouth like a frog: spe-
cifieally applied to birds of the genus $\mathrm{Ba}$ trachostomus.

Batrachostomus (bat-rä-kos'tō-mus), $n_{\text {. [NL., }}$ [Gr. Bótpaxos, a frog, + $\sigma \tau b \mu a$, mouth.] A of the family Caprimulgida, or goatsuckers, sometimes combined with Podargus in a family (rogmouths, or frog-monthe tent of the month. The genus includes a number of anecies of India, Java, Borneo, Ceylon, Malacca, ete., which are among the very largest and noti notable of the caprimulgine aeries. B. jaramensis la a leading apeeles, BomBatrachus (bat'ra-kus) are synonyms

frog: seo Batraehia] , n. [L., KGr. Barpa zos, a cal of the family Batrachida, containing the toad-fish, B. tau, of the North Atlantic, and soveral elosely related species. See toad-fish. bat-shell (bat'shel), n. [< bat ${ }^{2}+$ shell.] A mollusk, a species of Voluta, V. vespertilio, of a dusky-brown color.

batsman (bats'man), n.; pl. batsmen (-men). the bat in base-ball, cricket, and similar games; a batter.

batster (bat'stér), n. [<batl, $\left.r_{.},+-s t e r.\right]$ A 
batt

batt, $n$. An obsoleto spelling of bat 1 , still occasionally used in some senses. See bat $1,10,11$.
battal (bat'ä), $n$. [Anglo-Ind., formerly also battee (ef. batity ${ }^{2}$ ), $\mathrm{Pg}$. bata (later in Hind., ete. bhatē, bhätā, allowance for maintenance), perhaps < Canarese bhatta, rice in the husk (see batty2), generalized to 'subsistence.'] In British India: (a) Subsistence-money given to
soldiers, witnesses, prisoners, and others. (b) An allowaneo in addition to their pay originally made to troops serving in the field.

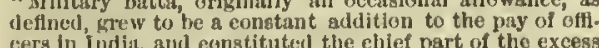

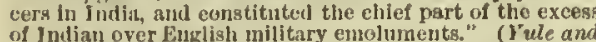
of Indian over English military emrolumerts." "(vele and
Burnell.) It was redinced one half by the governor-genbatta $^{2}$ (bat'ấ), n. [Anglo-Ind. Hind. battā, beng. battä (cerebral $t$ ).] In British India, agio; diseount; difference of exchange.

battableł (bat'a-b]), $a$. [< bat- in battlc ${ }^{3}$, bat ten 1 , etc., + -able; perhaps, like batful, a peras pasture. Also spelled batabte.

Masinissa made many inward parts of Barbary and Nu fuil aud batlable by Burton, Annat. of Mrei., 'To the Reader.

battage (ba-täzh'), n. [F., < battre, beat: see batc $\left.^{1}.\right]$ 1. Beating; the operation of beating. -2 . In agri., threshing. -3 . The operation of pulverizing or incorporating the ingredients of gumpowder by the old method of stamping witl pestles.

Also wrongly spelled batage.

battailantt, a. and $n$. [Also batteilant, batteh seo battle $1, v$.] I. a. Combatant.

$$
\text { I gaw an Elephant, }
$$

Adorn'd with bells and hossea gorgeoussle,

That on his backe did beare (as batteilant)

A giden towre, whieh enone exceedingle.
Spenser, World's Vanitie, st. B.

II. $n$. A combatant.

battailoust (bat'e-lus), $a$. [Early mod. E. also battelous, battellous, battlous, ete., < ME. batai lous, batelouse, batellous, < OH'. bataillous, bateillous, warlike, < bataille, battle.] Warlike; bellicose; ready for battle.

In sunbriglit armee, and battaitons array.

The French came foremost, battailous snd boid bairfax, tr. of T'asso, 1 .

Thoughts and images like stately fleets, 0. Bome deep With gilk and gpicery, gome brooding over the silent thun-
ders of their battailous armarents.

battaliał (ba-tā'liä), $n$. [Early mod. E. also $b a-$ talia, batallia, battaglio, etc., < It. battagtia (= $\mathrm{Sp}$. batalla $=\mathrm{Pg}$. Pr. batalha $=\mathrm{OF}$. baiaille, F. battle 1 , battle, squadron: seo battle ${ }^{1}$.] 1 . Order of battle; battle array.

1 have made all his troops and companise
Advance, and put themiselves ranget in battatia.
Chapman, Reverige of Bussy D'Ambuis, it

2. Milit.: (a) A large body of men in order of battle or on the mareb, whether a whole army or one of the great divisions of it; a host; an army.

$K$. Rich. Who hath descriet the number of the traitors? K. Rich. Why, our battalia trebles that account

[This is the reading of the folles; the quarto editiens read

In three battalias does the kIng dispose
Inls atrength, which all in ready order stand,

And to each other's reacue near at hand.
May, Edward 111.

(b) The main body or center of an army. Wee rinickly plac'd Jockey in the right wing, Sir John
in the left wing, and Old Nick tn the Battalia.

battalion (ba-tal'yon), n. [Formerly also bataltion, batcillon, ete., < $\mathrm{F}$. bataillon, < It. battaglione, battalion, aug. of battaglia, a battle squadron: see battalia, battle ${ }^{1}$.] 1t. An army in battle array.

IIe through the armed fles

Darts his experiencerd eye, and soon traverso
The whole battalion views.

2. In general, any distinct portion of an army or minor body of troops acting together: as God is on the side of the largest battalions (a
saying attributed to Turenne); a battalion of infantry, cavalry, grenadiers, voltigeurs, etc. In the United states two or more detached companies of in lantry, gquadrons of cavaliry, or batterie日 of artillery gerv. 3. Teehnically, a body of infantry composed of two or more companies forming part of a regimont, or sometimes constituting a whole regiment. In European armies an infantry regiment is
476

fonrth in reserve from which losses in the others are
filled. Formerly the regiments of the United states army, then eonsisting of twelve companies, wore divided panies constitntes a single battalion

cldioned (ba-tal'yoncl) $a$.

$[<$ battalion + tteau, $n$. Seo bateau.

battel $1, n$. and $v$. See battle 1 .

batte1 $1^{3+}, a$. and $v$. See battle ${ }^{3}$.

battel ${ }^{4}$ (bat'1), n. [Usually in pl. battcls, also battles, battells, first found in the 16 th century, use, of uncertain origin. The sense of 'provisions' appears much later than that of 'charges therefor, but, if original, suggests a connection with battel, battle ${ }^{3}, v_{0}$, feed: see battle ${ }^{3}$. $] 1$. $p l$. loge accounts for board and provisions supplice from the kitchen and buttery. (b) The whole of the college accounts for board and lodgings, funds. - 2. At Eton college, a small allowance of food which, in addition to the college allowance, the collegers receive from their dames. Richardson.

battel ${ }^{4}$ (bat' 1 ), $v \cdot i_{\text {. }}$ [< battel $4, n_{\text {. }}$ ] To stand
indebted in the college-books at Oxford for provisions and drink from the buttery.

batteler, $n_{\text {. [Also batteller, battler, batler; }}$ indebted in the college-books for provisions and drink at the buttery. -2 . One of a rank or and drink at the buttery. -2 . One of a rank or
order of students at Oxford below eommoners; a poor student.

Pieree Pennyless, exceeding poor seliolar, that hath made
ciean shoes in both ciean shoes in both universities, and been a pittiful battler
all thy lifetime.
Middleton, The Black Book, battement (bat'ment; F. pron. bat-e-moin'), $n$ $\left[\mathrm{F}^{\circ},<\right.$ battre, beat:" see batel, bat 1 , and -ment.] 1. A beating; striking; impulse.-2. In musie of a tone with the next tono below, beginning with thelatter: common in old-fashioned music batten ${ }^{1}$ (bat'n), $v$. [Not found in ME., bu prob. existent dialectally; < Icel. batna, grow better, improve, recover, = Goth. ga-batnan, be bettered, profit, avail, a neut. passive form from the pp. "batans of a lost strong verb, "batan secondarily by D. MLG. LG. baten, profit, avail, help, and in $\mathrm{E}$. by the derived forms bet ${ }^{1}$, bet ter 1 , and boot 1 : see bet 1 , better 1 , and boot 1 . A nomn, "bat, improvement, profit (ef. Icel. bati, bate, advantage, profit, gain), is implied as the formal base of tho adjectives batful, battable, but these are appar. manipulated forms of the rxin. adj. battle 3 , from the verbal root.] I. in trans. 1. To become better; improve in condi-
tion (especially by feeding); grow fat; thrive. It makes her fat, you see; she battens with it. 2. To feed gluttonously; figuratively, gratify ly, or with on or upon.

Iliave you eyes ?
Could you on this falr mountain leave to leed,
And batten on this moor? Shat., Hamlet, i1. 4.

O'er human careasses do scream and balten. J. Baillie. The meths, that were then battening upon its obsolete
lodgers and day-books, have rested Irem their deprede tions. Lamb, Sonth-Sea fouse. Melanehely sceptics ... who batten on the hideous
facts in listory. Emerson, Society and Solitude, $\mathbf{x}, 220$. 3. Figuratively, to thrive; prosper; live in ease and luxury, especially at the expense or to the detriment of others: with on, formerly And with these thoughts sa battens, as if fato Would be as easilly chested on as be

II. trans. 1. To improve by feeding; fat ten; make fat or cause to thrive with plenteous eding.

Battening our flocks with the fresh dewa of night

2t. To fertilize or enrich (the soil).

batten ${ }^{2}$ (bat'n), n. [A more English spelling of batton, baton, prevailing in the non-literary uses of the word: see baton, batoon, baston.] 1. A strip or seantling of wood. Specifleally door, allutter', etc.) to keep them together. (b) One of the or for nailing over the eracks between of a plastered wall. the narrow stripg nailed to a mast or apar, at a place of posed to friction, to prevent ehafing. (d) A narrow strip batter

way, to prevent leaking in stormy weather, (e) A wooden
har or eleat nailed to the beam of a ship, from which the geamen's larnmoeks are slung. $(f)$ One of the long slip usetl in the moldhng-loft of a slip-yard in traeing line 2. In com., squared timber of 6 or more feet in length, 7 inches in width, and 21 iuches in thickness, used in earpentry and housebuilding for various purposes. I'ieces less than 6 feet long are known as batten-ends. 3. In weaving, the beam for striking the wef home; a lathe.-Louvered or loovered battens, hattens fitted in Iramea, or between stanchlons, in parti. tions, etce, at such an angle as to admit air, and yet to pre.
vent dirt from entering. Fincham, Ship-building, iv, 83. vent dirt fits

batten ${ }^{2}\left(\right.$ bat' $\left.^{2}\right), v \cdot t$. [<batten $\left.{ }^{2}, n.\right]$ To form or fasten with battens.-To batten down the hatches of a slip, to eover them with tarpaulius and nail
battens over thetr edges, 80 as to prevent water fronl leaking helow during bad weather.

atten-door (bat'n-dōr), n. A door made of narrow boards held together by means of crossbattens nailed to them.

[IIIe] stepped cautiously up to one of the batten door with an auger, and succeeded, without arousing any one,
in boring a hole. G. W. Cable, The Grandissines, p. 407 . battening (bat'ning), n. [Verbal n. of bat$t e n^{2}$.] 1. The operation of fixing to a wall battens, to which are to be nailed laths to receive plastering. -2 . The battens fixed to a wall for this purpose.

batter ${ }^{1}$ (bat'êr), v. [< ME. bateren, batren, with freq. formative -er, < bat- (repr. in ME. by baten (only intrans.) in the sense of bate or
flutter as a hawk (see batel); in later MIE. and mod. F. regarded as freq. of bat (late ME. batten), from the noun bat1, which may be of the same ult. origin), ( OF. batre, F. battre = Pr. batre $=\mathrm{Sp}$. batir $=\mathrm{Pg}$. bater $=\mathrm{It}$. battere <ML. (LL.) batere, battere for L. batuere, bat tuere beat, strike: see batel battle1, ete. Not connected with E. beat ${ }^{1}$.] I. trans. 1. To beat upon or against; striko with repeated blows pound violently, as with the fist, a hammer of bludgeon, a battering-ram, cannon-shot, otc.: as, to batter a door for admittance; to batter the walls of a city (with or withont effect)

The thnnderer, whose iolt, you know,
Sky-planted, batters all rehelllolis cossts

Shake, Cymbeline, v. 4

[The] whigle artillery of the western blast,

Battering the Temple s

Wordsworth, Cave of Stafta

2. To bruise, break, or shatter by beating; injure the substance of by blows : pound out of form or condition: as, to batter a person's countenaneo; a battered wall or tower; to bat ter type (that is, bruise the face of it).

Now were the walls beaten with the rams, and many parts
thereof shaken and battered. Holla and, tr. of Livy, p. 397 . 3. In forging, to spread outwardly, as the ends of a metal bar or rod, by hammering; upset. E. H. Knight

II. intrans. To act by beating or striking; use repeated blows; practise pounding: as, to batter away at a door; to batter upon a wall. battering cannon.

With all her battering engines bent to rase
Some eapital eity.
Millon, P. L., ii. 923. Besiegers break ground at a safe distaneo, and advance gradually till near ellough to batter.
Abp. Whately, Elem. of Rletorle, 1. 111. 5.5 To batter at, to make attaeks upon; try to overtirow or

The tyrant has not batter'd at their peace?

To batter in breach. (a) To direet a heavy eannonade wall or rampart inelosing an enemy's fort part of the order to level or destroy it, and make a orectiven, or oppening thrould which an assantl in foree may be made. (b) Speeifeally, to attempt to breaeh an enenyy's
Worka by means of a battery mounted in the thilrd paral. Worka by means of a battery mounted in the thilrd paral-
lel. To batter in breach, a gufflecent number of gung ahould be employed to maintain a practicaliy continuous fire, so as to prevent the enemy a from repalring the dam. fring acainst as acle point. Breaching is sometimes ae complished by firing gimultaneous or aiternate volleys from two or more batterle

batter ${ }^{1}$ (bat'ér), $n$. [<batter $\left.1, v.\right]$ 1. A heavy blow.-2. In printing, a blur or defect in a ineet produced by battered type; a spot showgroken state of the type.-3. In ceram., molding. Seo batting-block.

batter ${ }^{2}$ (bat'ér), $v$. $i$. [Origin unknown; perhaps connected in some way with batter1, or with $\mathrm{F}$. abattre, beat down.] To incline from the perpendieular: said of a wall whose face recedes as it rises: opposed to overhang.

Retaining and breast walls batter towards the bank.
K. II. Knight, Anier. Mlech. Dict., I. 247. 


\section{batter}

batter'l (bat'Ar), n. [ $\mathrm{MF}$. bnter, batere, batour, buture < OF, bature, a beatinu metal beaten out thin, < batre, boat; ef. Sp. baticlo, Intter, < batir, beat: seo hatterl. Cf. batture.] 1. A mixture of several ingrodionts, as flour, eggs, salt, ete., benten togethor with some llquil, used in oookory.-2. Flour and water mado into justo; spoeifieally, the pasto used in sizing cloth. [Scoteh.]

batter ${ }^{3}$ (bat'er), v. $\iota . \quad[$ So, < butter3, n., 2.] To jaste togothor; eover with things pasted on: ins, to balfer the walls with placards. [Seoteh.] batter (but'or), $u_{0}\left[\left\langle\left\langle_{b} t^{1}, v_{,}+-e r^{1}\right]\right.\right.$. One who bats; espocinlly, in baso-ball and cricket, ono who wiolds tho bat; tho butsman.

110 [tho bewler] luwls a linll almost wlilu to tho ots: the polut is atnuling.

battered (bat'erd), p. a. [< betterl $\left.+-c l^{2}.\right]$ Iseuton down or bruised; worn or impaired, ns by beating or long servieo: as, a batteret pavement; bnttered type; a battereal jado.

I'tu Tory party, necorillng to thomo prerverted views of Toryism unhuphily too losk provalene in this country,

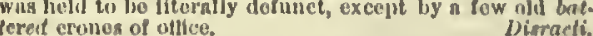

batterer (bat'er-èr), n. One who batters or beats.

batterfangt, v. t. [Appar. < balter $1+f(t) g$. 'le assail with fists and nails; boat and beclaw. [Obsolete or jrov. Iing.] N. $H_{0} .1$.

batter-head (bat'er-hed), $n$. That hond of a drum which is beaten.

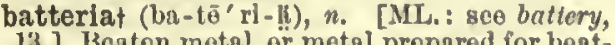
metal propared for beating: a torm used from the fourteonth to tho seventeenth contury for the thin plate-motal of which vessels and utensils were made. Seo bat tery, 13.

batterle (bat'er-1), n. [F., a beating, otc. : see battery.] 1. A roll upon the side- or suaredrum.-2. A method of playing the guitar by striking tho striugs instoad of plueking them. 3. $\Lambda n$ obsoleto designation for a staceato arpeggiation of the chords of an accompaniment. Comparo Alluerti bass (under bass ${ }^{3}$ ) and arpeggio. battering (bat'or-ing), p. a. [Ppr. of batter ${ }^{2}$.] sloping upward and inward, as a terrace or bank.

Tho nystom of it coustructlon is that known as pyran.
Idal or batterion.

battering-charge (bat' èr-ing-chărj), n. The in heavy guns; a cliargo used in battoring an onomy's works.

battering-gun (bat' er-ing-gun), n. Same as battoring-piece.

battering-piece (bat'èr-íng-pôs), n. Milit., a caunon of hoavy caliber adapted for domolish. ing defensivo works.

battering-ram (bat'or-ing-ram), n, 1. An allcient inilitary engine censisting of a large beam shod with motal, sometimes with a head somewhat resembling the hend of a ram (wheneo the name), used to batter or beat down the defensos of besieged places. In Ite almpleat form it wan enr:
rod and forctily intven agalnst the wall by the hands of Hod and forctily irlven agalnst the wall by the hands of from a benm whlch was supportod by posts, nnit balancel on as to awing linckwarl and forward, boing In this wny It walled ngalust the wall with much moro enso and offeet, cover, the asanilants belng protected by a movable shod

2. A heavy blacksmith' hammer, suspended, and workod horizontally.

battering-rule, $n$. Soe batter-rule.

battering-traln (bat'or-ing-triñ), $n$. Milit. a train of henvy ordnance for siego oporntions. batter-level (bat'er-lev"el), n. An instrument for moasuring the inclination of a slopo. Seo clinometer.

batter-rule, battering-rule (bnt'èr-rol, -ingröl), $n$. An instrument for rogulating the brttor or inclination in building a sloping wall. It conglats of a plumb-line altachet to a triangular framo, hio, the plummet linnging vertically.

Battersea enamel. Seo cnamel.

battery (bat'er-i), $n$.; pl. batterics $(-1 z)$. [Farly mod. E. also batery, batteric, < $\mathrm{F}$. batterio $(=\mathrm{Pr}$. bataria $=\mathrm{Sp} . \mathbf{P g}$. bnteria $=\mathrm{It}$. batteria; $\mathbf{M I}_{\text {. }}$. batteria), a benting, battery, < battre, beat: seo butter ${ }^{1}$ and -ery. ] it. Tho net of battering; at taek or assanlt, with the viow of beating down, as by a battering-ram or by ordnance.

At one placo abeve the reat, by continunl balteris thero

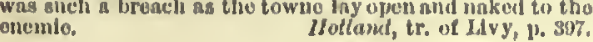

477

liring therefore all the foreen that yo may. Sinewaer, Sonneth, $x$

Iong timo you fought, reloulhet ballery bore, Dryilen, IIInd and I'anthor, I. B26.

2. In law, the unlawful benting of nnother.

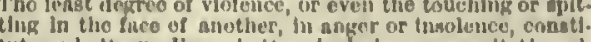
tutes a hittery. livery Imitery includes an nasanit, though an nasault doc not nevessarily fouply t

3. Tho instrument or ageney employed in battering or attreking: as, a battery of guns; a battery of abuse. Bpoeifleally - 1. Milit: $(a)$ $A$ body of ennuon for fiold ogerntions, consisting generally of from 4 to 8 guns, with conplement of wagons, artillerymon, oto. (b) 'Tho arumament of a slip of war: as, tho Coloralo's battery consiats of 46 nino-ineh guns. -5 . Tho porsonnol or complement of oflecrs aml mon attrehed to a inilitary battory. - 6. In fort., a parapet thrown up to cover the gunners und others from tho onemy's shot, with tho guns employed; a fortified werk mounting artllfory.

Adirmiral Farragut had run tho breteries at l'ort IIudson mo fron bolow Plekslurg. 7. In base-ball, the pitoher and enteher together: as, the work of tho battery wus exeollent.(n) In frictional clect., a number of Loydon

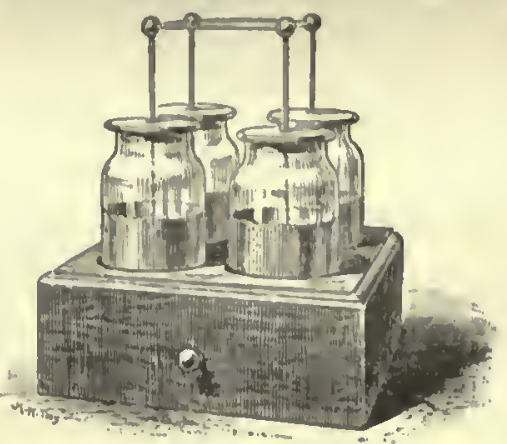

Leydenjar Battery.

jars usually arranged with their inner contings eonnected togother, and thoir outer coatings also connected, so that they may all bo chargod and discharged at the same timo. If nrranged av that the Inner centling of ono is in conjectlon with tho

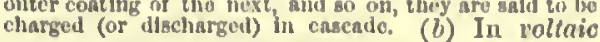

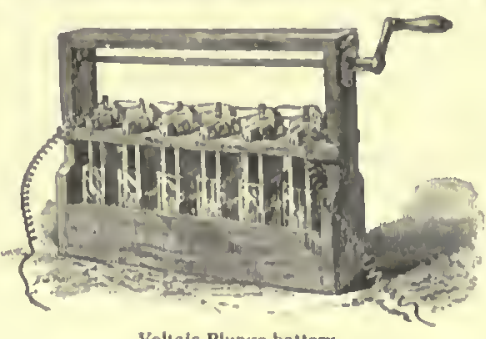

elcet., a voltaic cell, or moro properly a number of voltaic cells (sco cell) arranged togother The way In which a powerfill curront dupends upm tho unture of tho cur. rent which is clealrod nud the relation slatanco. (See remistanoe.) For exnmulio. the colls are arrangoil in sertes tho copper of the tirst with the zine of tho the maxtmum electromottve foree; nn tho other hand, if arrangod alireast, all the stues bolng conncetod together, and all tho copper plates togetlior, tho
oloctromotlvo foree la tho same as for a adngle coll, but the linternal or but ery resiatance is diminilied, ant henco ilty of uluctritelty may und conditlons, he much fincreasol. The frat nothod to sometimes apuoken of in popuinr Inngungo as the nrrangement for intentily, thio accond for guanlity. An carly form of lonitery rosune des tanses of "crown of cupn."

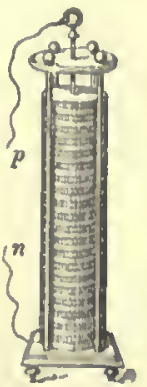

anied according to tho materiala or the form of the eells of which they are cemproned, or the wny In whildh the eclis Danielt, Grove, Bunuest of tho cotmmoner kind are tho to. For a deactiption of these anil athers, neo cett.

. In optics, a sories of lonses or of prism as in tho spectroscopo, combined in use. -10 . battery

In mach, an assemblayo of similar construotions or parts: as, a butfery of hoilers; a batfery of stmmps in n stampring-unill; \& bettery of sligrr-kettles.

The dark angar-house; the ballery of hugo caldrona, witli

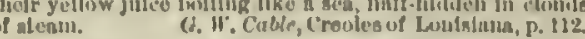
11. In tho mnnufneture of nitrio acis, a con1 as a condonsing glumaratus for the neid vapors. -12. In hat-making, $\mathrm{n}$ largo open builer eontaining water to whiel somo mulplunio acid lins been adiled. It is surrounded by planks which slono fownrl tho eenter, and is nsed in folting. - 13. Metals, or artieles of metal, especially of brass or coppor, wrought by hanmoring; hammered motnts or utensils; espocially, knparatus for jrejaring or serving inculs; all metallie utensils of servico for the kiteben. Comparo batterín.

Soon our len ballery cumo in, nnd aho [tho mald aervant]

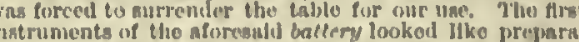

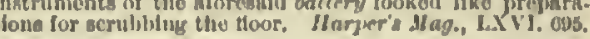
Thero aro In Mlldellurg Town-linll museum], nummg

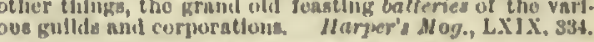
14. An oblong box submergol to the rim in the wuter, used as a boat, and for eoneoalmont, by rortons

Ono of the commoneat and most suocenaful mothola of ktlling fowl along tho meabromi lo frum ballerieg. 15. In coal-mining: (a) A strueturo built of timbor, to keop tho conl in the breast or provent it from sllding down the shute. (b) A platform on whlch miners stand while working in thin and steoply pitehing bods of corl. [Ponnsylvanla.] - Ambulant battory, a bathery of trungust them from point to potnt. Anderson batof muriate of ammonla, oxalate of elironinu, ansl poamalgamatlon, In mining, amnlwamation etfocted liy plachem mercury In the battery or murtars wtillo tho motalliforoun roek in belng stamped. - Blinded bat-

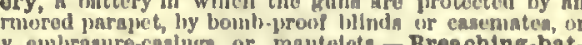
by ombranuro-cnslypa or mantelcts. - Breaching-batnesrly to to a lino of wall or parapet to lu tireaclied. it Is uned for maklug an opentng in the chemy' work through whiled an nisaultimg column may entor. Cavawo) and nrranged to deliver a plunglag fire lnto tho an arrangement for strnining the wort fruin tho vat. it Includer a dovlec for cutthe off tho llow when tho wort has attalned a sulficient dopth.- Counter-battery, $(a)$ A battery lintended to shioneo and overtirow gums of tho guns aro generally so placed as to fro along tho dituhom of the works. (t) Any linitory opponed to nuntluer. Til. Galt. - Covered battery, a inthery concenled from tho Crone-battertes, two or moro intterfes whose lines of Are intorsect. - Direct battery, a liattery wheae the 1

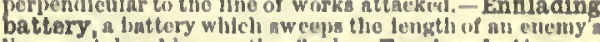
line, or takes lilim on the think. - Fascine battery, a of Pascines: naeri whiera tho enrth is loome or andy. Foating battery, n linitery erocted either on a omplo for the homburlmest of an enemy'o ports. "J'he name in aomotimen given to a lypo of alij] which, thougli it may bo provlded wlet ludependent propelling jower ls deatgmed primnrily not for navigatton, lint merely to atlord aupport wlth a parnpet formed of kabion slifed whe carth or sand.- Calvanlo battery, n ptlo or sertes of jhluted of

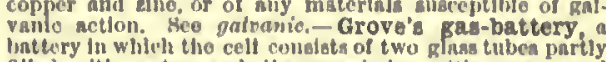
filfed with watur, and the remninder witi oxygen and trodes nro Inimerned. - Horisontal battery a battery lino Interine or terreploin of which in on the nntural battery \& crómalitéro, a linttery centetrutet with sa.

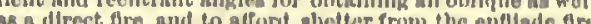
(liando firo fro lo illrecteil agalntit the enme object, - tatimer-Clark battery, sa electrie battery Intented as a stnndari, tho

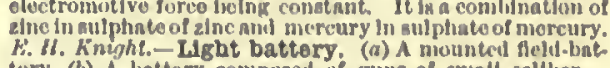
hiry. (b) A lattery composed of gumn of anill eallher.-

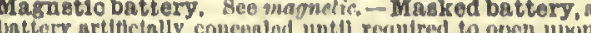
the onemy. Tulball.- Mortar-battery, a batcory linving with a parapet wlthout erilirasurea, an linterlor dopou not rovetted, but retnining the anturnl alopo of tho moll, and platfrom hurzontal lantend of Inclining slightly townrl tho tain battery, a battery of IIght guna, no hape. - Mounpleces snd tholr carringeve mny be Irnnapourted theen tho

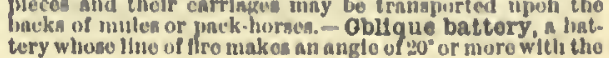


battery

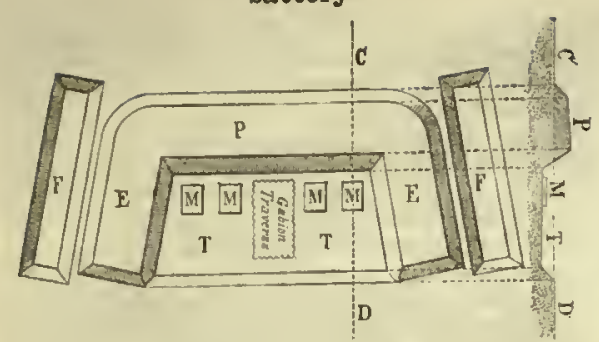

Plan and Section of Mortar-battery for four mortars. $P$, parapet $; E, E$, epaulments: $T T$, terreplein; $F, F$, ditches to
provide earth for epaulments ; $M$, $M$, mortar-platiorms; $C^{\prime} D^{2}$, section perpendicniar to the interior crest of the enemy'z works 80 calied in contradistinction to \& direct battcry.-Open
battery, a battery entirely exposed, that 18 , unprotected battery, a battery entirely exposed, that is, unprotected
by a parapet.-Plunge-battery, sn electric battery so arranged that the metals can be removed from the liquid when not in use- - Raised battery, a battery whose terre- Redan battery, a hattery giving a cross or flanking flre from a saiient or leètitrant angle of a fortiflcation.
Reverse battery, a battery which fires directly or of Reverse battery, a battery which fires directly or chet battery, a battery which fires inorizontally or at a low angle of elevation, go that the projectiles graze and bound aiong the surface of the ground or water. Smooth-bore guns firing spherical projectlles are most effective for
ricochet fire.- Síege-battery, a battery for aiege operationk. Such batteries are either fixed, comprising siegeguns and mortars of the heavlest callber snd lirgest size,
or movable, consiating of field-guna and gmall mortars. St movable, consiating of field-guna and gmall mortare. binstion of secondary cells or accumulatiora which when once charged may be used for a considerable time after gists essentially of two plates of metalific lead $\left(C, C^{2}\right)$ rolie into a sptral form, and in the Improved Faure form covered

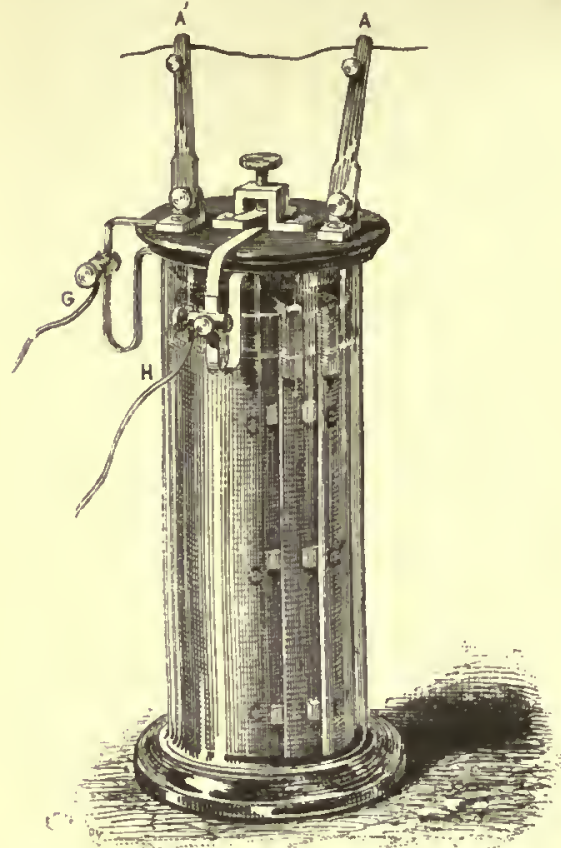

Storage or Secondary Cell, or Accumulator, Planté form.
$C_{\text {, }} C$, lead plates rolled in a spiral and separated by pieces of rub-
bers $G$, $H$, wirises from the primary or charging battery ; $A_{0}, A^{\prime}$, poles
of secondary cell.

with red oxid of lead; the primary current with which th celi is charged (by the wires $G$ and $H$ ) serves to peroxi-
dize and reduce this costing, reapectively, on the sheets connected with the two poles; the chemical energy th tored up is given back in the form of a continuous an ( $A$, A $A^{\prime}$ ) are connected and the chemical action is reversed. embrasure is on a level witl the ground, and the plattor is consequentiy sunk below it. (Tidball.) The parapet is
formed from the earth excavated from the alte constituting the platform.- Half-sunken battery, s battery of which the parapet ia formed partly from earth taken
erom the inside or terreplein, and partiy from a ditcll outside. - Urticating batteries, in zoót. the nematocyst or thread-cells of hydroid poiyps.- Water-battery, a is useless as a gource of a current, because of the high re-
siatance of the water, but, by having a large number of zincsiatace of the water, but, by having a large number. of zinc
copper couples, a high and constant difference of poten
thals is obtained at the two poles; it is thus valuabie in battery-box (bat'ér-i-boks), n. A square chest or box, filled with earth, used for making para pets for batteries where gabions or sand-bags pets for batteries where gabions or san

battery-gun (bat'err-i-gun), n. A machine-gun (which see)
478

battery-head (bat'èr-i-hed), $n$. The extreme end of a railroad cmbankment over which earth is tipped during the process of construction.

battery-shooting (bat'èr-i-shö"ting), n. The shooting of wild fowl from a battery. See battery, 14.

It wonjd be far better, however, to decide upon some plan of sction by which battery-shooting conld be wholly
done sway with. Forest and Strean, XXIII. 441 .

battery-wagon (bat'ér-i-wag"on), n. Milit., a vehicle accompanying each field-battery to carry tools, paints, oils, veterinary supplies, ete., to be used for repairs and the service of the battery,

Battey's operation. See operation.

t-tick (bat'tik), n. A small wingless tick-like of the order Dipter $a$ and family Nyeteribiide (which see): so called because it infests bats. The name is given to all the species of the family.

battil + , battill $\nmid, a$. Variant spellings of battle 3 . batting (bat'ing), $n$. [Verbal $n$. of bat $\left.{ }^{1}, t.\right] 1$. The act or process of washing or smoothing linen with a bat. -2 . The process of beating raw eotton with hazel-or holly-twigs, on a frame made of cords, for the purpose of opening the made of cords, for the -3 . matted locks, or of boating out impurities. - 3 . ted sheets for quilts or bed-covers, the quilting of garments, etc. Also called bat, batts.-4. The act or manner of using a bat in a game of ball: as, their batting was good.

batting-block (bat'ing-blok), $n$. In ceram., a block of wet plaster upon which clay is flattened out by $a$ batter before it is shaped on the potter's wheel or by a mold and templot. See batter 1,3 .

batting-machine (bat'ing-ma-shēn "), n. A machine in which cotton taken from the wilprepore it for the carding-machine.

batting-staff (bat'ing-staf), n. [Cf. battler ${ }^{2}$ and batlet.] A small mallet sometimes used and batlet.] A small mallet sometimes

battish (bat'ish), a. [<bat $\left.t^{2}+-i s h h^{1}.\right]$ Of, pertaining to, or resembling a bat. [Rare.] She clasp'd his limbs, by implous labour tired, Vernon, tr. of Ovid's Metamorpl., vili. battle ${ }^{\prime}$ (bat'1), $n$. [Early mod. E. also battel (a spelling still often used archaically, as in wager of battel), < ME. batel, batelle, batayle, bataile, batalla = It battaglia, <LL. battalia, battualia, batalla = It. battaglia, SLL. battalia, vattualia, gladiators, < battere, L. battuere, batuere, beat, fight, fence: see batter ${ }^{1}$ and batel.] 1. A fight, hostile encounter, or engagement between opposing forces on land or sea; an important and systematio engagement between independent armies or fleets. Actions and affairs are engagenents of less magnitude than battles, and are often unpremeditated, the result of surprises, or the meeting of armed reconnoitering parties, though the latter is usuaily termed
a skirmish. Battles are classed as parallel or oblique, ac cording to the rejative positiona of the contending armfe in order of battie; strategic, when fought upon sn objective point gejected in planning a campaign, as were the whole or the greater part of both armies are engaged. partial, when only brigades, divisions, or army corps arc
brought into action; offensive, when an army geeks the enemy and sttacks him wherever he is encountered; defensive, when a position is selected with the deaign of awaiting and repeliing the enenty ; mixed or defensive proper moment moves out to engage him.

2. An encounter between two persons; a due or single combat.-3. A fight or encounter between animals, especially when pitted against each other for the amnsement of spectators.

If we draw lots, he [Cregar] speeds
His cocks do win the battle stiji of mine,

When it is all to nought; and his quails ever

Beat mine, inhoop'd, at odds.

4. Warfare; hostile action; actual confliet with enemies: as, wounds received or honor gained in battle.

Who is this King of glory? The Lord strong and mighty,
the Lord mighty in battle. 5. Any contest or conflict; struggle for mas tery or victory: as, the battle of life.

Of the six genera, Drosera has been incomparably the
most successful in the battle for life; and s lsrge part o its success nay be attributed to its manner of catching
Darvin, Insectiv. Plants, p. 357 6t. An army prepared for or engaged in fight. Fire answera fire, snd through their paly flames
Each battle sees the other's umber'd face.
Shak., Hen. V., Iv. (cho. battle

7t. A body of forces, or division of an arms; a battalion.

The king divided his army into three battles, whereof the vanguard only with wings came to figh. Then the Battels were staled, and they should flght. ${ }_{J}$. Brende, tr. of Quintus Curtius, ili. 32 8t. More specifically - (a) The main or middle body of an army or fleet, as distinguished from the van and rear.

Angus led the avant-guard, himsell followed with the Aattle a good distance behind, and alter came the srrier.
Sir J. Haycard. The centre, or battle as it was called, consisting of sixty.
thrce galleys, was led by John of Austria.

The van outsailed before, by him had run

II'cn as he stayed for 11, and now indeed

William Aforris, Earthly Paradise, I. 17.

(b) That portion of the army, wherever placed and of whatever consisting, which is regarded as of main importanee.

The cavalry, by way of distinction, was called the battle, and on it alone depended the ite overy action.

8t. A formidable array similar to an army in battle order.

On his bow-back lie [the boar] hath a battle set

Shak., Venus and Adonis, 1. 619.
She,

Battie-range, the range best suited to firing on an enemilitary rifles the elevation correaponding to that range is designated by stamping the letter $\mathrm{B}$ opposite the ponding to elevation. Tha lange 16202 yards, corre sponding to a continuous dangerous space of 337 yards troops.- Battle royal. (a) A battie with fists or cudgejs, in which more than two combstants are engaged; 2 free flght. (b) A fight of game-cocks, in which more than two party gsins the victory. - Order of battle. See order.Pitched battle, s bsttle in which the armies are pre forces,- To give battle, to attack an cnemy. - To join battie, properly, to meet the sttack; commonly, to begin Wager of battle or battel, in lavo, a specics of trial for the decision of controversies used among the rude milltary peoples of Europe. It was introduced into Englan only: In the court martial, or court of clivalry or honor inger the contest was held before the judges on $\mathrm{s}$ piec of ground inclosed, and the combstants were bound to flght till the stara sppeared, unless tlie desth or defeat of one party sooner decided the contest. The weapon used were bstons or gtaves an ell long. Womcn, priests,
loen above sixty, and lame and blind persons might appear ioen above sixty, and lame and blind persons might appear $\mathrm{s}$ valid and legal mode of trial in England down to 1818 and was then formajiy abolished in consequence of the demand by the defendant in a sult lor this mode of arbitrament, and of the tact thst this demand could not fict, Fight, Combat, Contest, Aetion. Battle is a genera term, snd the most common. It is the appropriate wor for great engagementa: as, the battle of Waterloo. A battle
masy last merejy a fcw hours or for days: as, the battle o cal military usage practicaly equivalent to battle, but it is a less forcible word. Confict, literaliy, s clashing together, is a strong word, implying flerce physical encounter. Fight A msn may take part in a battle without actually fighting. A battle may incinde many fights: as, the fight at the flag as a fight. Combat, like conflict, is a word of more dignity as a fight. Combat, like conflict, is a word of more dignity
than fight; it is by its history suggestive of a struggle be. tween two, as persons, snlmals, squadrons, arniles. Contest is a very genersl word, of uncertain strength, but oiten joined with a strong adjective : as, \& gtubborn contest. An action is a minor or incidental act of war, a single act of fighting : as, the whole action lasted bit sn lour. Alt
these words apply equally to operations by land or by sea.
See encounter and strife.

The distant battle flash'd and rung.

Two thousand of the enemy were alain and taken in the Prescott, Ferd. and Isa, i. 15 About 100,000 men were engaged, and the confict raged World's Progress,
My lord is weary with the fight before,
And they will fall upon him unawses

And they will fall upon him unawsres.

Numerous were the combats which took place between level arena, as on a tilting ground.

Prescott, Ferd. and Isa., i. I5

The whole pian of the Italian campaign had been based upon the assumption that the contest between the two great Teutonic States would prove a not unequal one.
E. Dicey, Victor Emmanuel, p. 284

How many gentlemen have you lost in this action?
Shak., IIuch Ado, i.

battlel (bat'l), v. ; pret. and pp. battled, ppr. battling. [< ME. batailen, bataillen, < OF, ba tailler, < bataille, a battle: see battle $1, n$.$] I$ intrans. 1. To join or engage in battle; con-
tend in fight; fight: as, to battle with wolves. 
battle

Tis ours by craft and by sirprise to galn:

2. To struggle; contend; strive for mastery: oither absolutely or with for, will, or against: as, to battle with the winds; to battle for freedom, or aguinst adversity; to battle voith iguorance.

$$
\begin{gathered}
\text { Who battled fur the True, the Just. } \\
\text { Tennyson, In \$em }
\end{gathered}
$$

$$
\text { Tennyson, In \$lemorlam, lvi. }
$$

Regret, resolve, awe, and joy, every high human emoK. S. Phelps, Beyond the fiates, p. 94.

II. trans. 1†. To ombattle; put into battle array. $-2 \uparrow$. To fight for.

Whom thel have seyn alwey batailen and defenden cer, Bočtlíus, i. prose 4 3. To givo battle to; fight against; contend with; fight. [Rare.] He can battle theologlans witis weapons drawn from an-

Whipple, Fss, and Rev., I. 15.

battle $2+$ (bat'1), v. t.; pret. and pp. battled, ppr. batting. [Early mod. E. also battel; < ME. bataylen, batailen, < OF. bataillier, bateillier (= Pr. batalhar), fortify with battlements, < $b a-$ taille, battlement, appar. idlentical with bataille, battle; but in later OF' the verb was merged in batillier bastillier, < bastille, a fortress: see bastile, battle 1 , and battlement, and ef. embattle 1 , embattle ${ }^{2}$.] To furnish or strengthon with battlements; embattle.

$$
\begin{aligned}
& \text { feest any tyme it were assayed, } \\
& \text { ful wel abonte it was batayled. }
\end{aligned}
$$

Rom. of the Rose, 1. 4161

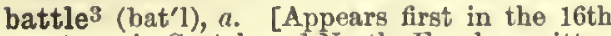
contury, in Seotch and North. E., also written battel, battil, battill, baittle, vettle, batwell, ete. in form <"bat, a verbal root appearing in tho verb battcn 1 , improve, etc., $+-e l$, $-l e$, an adj. formative suffixed to verbal roots, as in brittle, fickle, etc.: seo batten 1 , and ef. the later adjectives battable and batful, appar. modifications of battle.] In agri: (a) Improving; nutritious; fattening: as, battle grass: battle pasture. (b) Fertile; fruitful: as, battle soil; battle land. [Now only North. Eng. and Seotch.] A battel aoil for grain, for pastnre good. Fairfax.

battle ${ }^{3} \nmid$ (bat'1), v. [So, and North. E., also writtel battel, battil, ete., from the adj. Cf.
batten $1, v_{0}$. I. trans. 1. To nourish; feed.-2. To render fertile or fruitful, as the soil.

Ashes are marvellous improvements to battel barren

II. intruns. 1. To grow fat; thrive.

sleepe, thcy sayd, would make her battill better.

2. To become fertile or fruitful, as soil.

battle 4 , $u$. and $v$. See battclt

battle ${ }^{5}$ (bat'1), v.t. [Freq. of bat ${ }^{1}$ (of. batter ${ }^{1}$ ), or perhaps a var. of beetle ${ }^{1}, v$, simulatin $b a t^{1}, v$. (cf. $b a t^{1}, t$.) or perhaps from batheat (clothes) with battler or beetle in washing.

battle-ax (bat'l a.ks), n. An ax nsed as a weapon of war. It was in almost intversal tion of threarms, and atill employed awong un. aldry it is always repre. sented with a blade on on (usually the dexter) side and a potint on the other, spear-lica

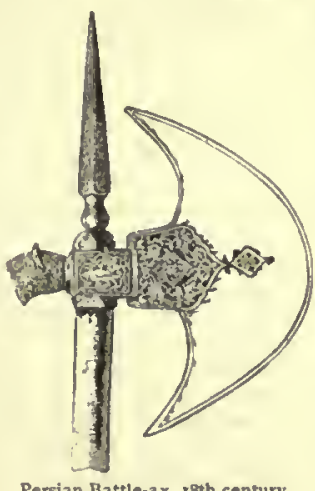

battle-bolt (bat'l-bōlt), $n$ - A bolt or missile of uny kind used in battle.

The rushing battle-bolt anng from the three-decker.

battle-brand (bat'1-brand), $n$. A sword used in battle.

Thy tather's batte-brand. Scott, In of the L., if. 15 .

battle-club (bat'l-klub), n. A club used in battle, especially by barbarians, as the Sonth Sea islanders.

The cursed Malayan crease, and battle-club

From the lsles of paim.

Ternyson, Prol. to Princeas.

battle-cry (bat'1-krī), n. A cry or shout of oops engaged in battle.

It was evident that their battle-ery was conyuer or dile.
Thoreau, Walden, $\mathrm{p} .24 \%$
479

battue

battled ${ }^{1}$ (bat'ld), p.a. 1. lianged in battlo arres disposed in order of battle -2 . Contested; fought. Sullier, rest ! thy warfare o'er,
Drean of battled ficlds no more. Scott, L. of the I., 1. 31.

battled ${ }^{2}$ (bat'ld), a. 1. Furnished or strengthrned with battlements. Batailled as it were a castel wai.

The battled tower. Chaucer, Nun's l'rieat's Tale, I. 40. Tennyzon, Falr Women.

2. In her, broken in the form of battlements: said $(a)$ of any horizontal line dividing the field; $(b)$ of a bar or fesse, when ono side only is broken in this way. Also cmbattled. Sce cut under embattled. - Battled arrondi, in her, hav. Ing the heads of the battiements curved or rounded. Battled counter, in her, same as counter-embattled.Alao called graily and battled grady.

attledore, battledoor (bat']-dōr), n. [CME. batyldore, -doure, -dure; appar. a modification (sirnulating "battle, as if dim. of bat ${ }^{1}$; ef. battlc ${ }^{5}$ ) of Pr. batedor (=Sp. batidor, a beater, formerly also batalor, a bat for beating clothes-Minsliou $)$ < batre $=\mathrm{Sp}$. batir, beat: see batter ${ }^{1}$. l'or the term., cf, steverlore. Cf. E. dial. battleton, in sense 1.] 1. A bat or beetlo used in washing clothes, or for smoothing them ont washing clothes, or for smoothing them ont while being laundered.-2. An instrument
shapod like a racket, but smaller, used in playing the game of battledore and shuttlecock.-3t. A paddle for a canoe.-4. In glass making, a flat square piece of polishod iron witl

a wooden handlo, used for flattening the bot-

toms of tumblers, or for similar purposes. -

5. A kind of paddle with a long handle, nsed for placing loaves in a baker's oven.-6t. A Battledore-boy ${ }^{\dagger}$ an abecedarian. - Battledore-barley, a apecies of cultlvated barley, Hordeum zeocriton, with battle-field (bat'l-fēld), $n$. The scene of a attle.

Oll! who would fight and march and conntermarch,
Be ahot for gixpence in a battle-field?

battle-flag (bat'l-flag), $n$. A military flag; a flag earried in battle.

Till the war-drum throbb'd no longer, and the battle-fags
were furl'd.

battle-ground (bat'l-ground), $n$. A battle-field. battle-lantern (bat'l-lan"térn), n. A lantern placed at each gun on the gun-deck of a ship of war, to light up the deck during an engagement at night.

battle-mace (bat'l-mās), $n$. A mace designed for use in war; specifically, a name given to the spiked heads for clubs, usually of bronze, which are found among ancient remains in the British islands and elsewhere.

battlement (bat'1-ment), n. [<ME. batelment batylment, of uncertain origin; perhaps due to an unrecorded OF. "bastillement, < bastiller fortify: see bastile and bastiment. The word was popularly assoeriated with battle 1 ; hence 1. In fortynge, battlement, and battle $\left.{ }^{2}, \mathrm{q} . \mathrm{v}.\right]$ series of rising cops or merlons, separated called crenelles or embrasures, the soldier shel tering himself behind the merlon while he fires through the embrasure or through a loophole in the merlon. Battle. ments, although

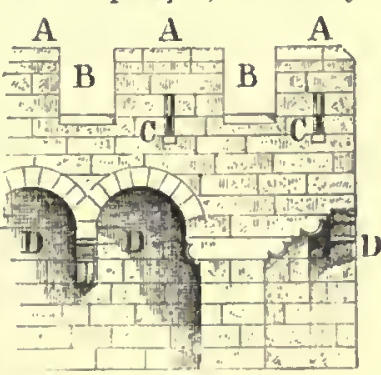
Batilement-Fortised Church of Royat,
Puy-de-Ddrue, France. military, and uae

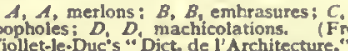

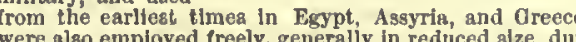
were also employed treely, generally in reduced alze, dur ing the middle agea, especially in England, upon eccles both pampets and cornces, and on tabernacle-work, transoms of windowa, etc.
Hence -2 . Any high wall for defense.

Thla was the valley of the pools of Gihon, where Solo mon was crowned, and the battlements which rose above it were the long looked-for walls of Jerusalem.
R. Curzom, Jlonast. in the Levant, p. 144

battlemented (bat'l-men-ted), $a$. Furnished with battlements, as the ramparts of a city or castle.
The walls of liabylon,, so hroad that six charlot. could well drive together at tile top, and so battlemented
hist they conld not fall. Sir T. Perbert, Travels, D. 228. The old battlemented walls of the city.

attle-piece (bat'l-pēs), n. A painting which represents a battle.

Looking at Crimean battle-pieces, in which Frenels gol are shown to liave achicved everything, we see exII. Spencer, study of Saciol., p. 214.

attler (bat'ler), n. [<battle $1+-e r^{1}$; appar.

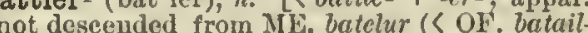
(cor), batailler, <OF. bataillier.] One who battles or fights; a warrior or contender.

attler' $\uparrow$ (bat'lèr), n. [<battle $\left.+-e r^{1}\right] 1$.

One who beats with a bat or battledore.-2. A bat or beetlo.-3. See batler 1 .

battler ${ }^{3}+n$. Seo batteler.

attle-scarred (bat'l-skinrd), a. Searred with .

The appeal of a Roman soldter, battlescarred in the ser. vice of his conntry, could aronse to vengeance the populace battle-shout (bat'l-shout), $n$. A shont raised in battle.

battle-song (bat'l-sông), u. A song sung on the battle-tield, or relating to battle; a martial song.

Tho chivairous battle-som

I'that ghe warbled alone in her joy. var. of battledore.] Same as battledore. [Prov. Eng.]

attletwig (bat'l-twig), $n$. [E. dial.] An earwig. [Prov. Eng.] II allivell.

attle-writhen (bat'l-rist"en), a [< batile + writhen, old pp. of vorithe.] Twisted or distorted by stress of battle. [Poetic.]

His battle-torithen arms and mighty han

Tennyson, Lancelot and Elalne

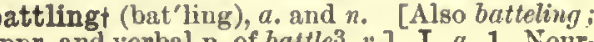
ppr. and verbal $n$.

The nieads environ'd with the sflver streams

Whose bat'ling pastnres fatten all niy flock

Fertile.

II. n. 1. A growing fat, or the process of eansing to grow fat; a fattening. - 2. That which nourishes or fattens, as food, or feed for animals, or manure for soil.

battological (bat-ō-loj'i-kal), a. [s battology tology.

battologist (ba-tol'ō-jist), $u$. $[<$ battology + -ist.] One who talks idly; one who needlessly repeats the same thing in speaking or writing. A truly dull battologist.

$$
\text { battologist. }
$$
battologize (ba-tol o-jiz), $x$; ; pret. and pp. -ize.] I. trans. To repeat needlessly; iterate. Sir T. Herbert.

II. intrans. To repeat words or phrases with needless iteration.

battology (ba-tol'ō-ji), n. [<Gr. ßaттодoyía,

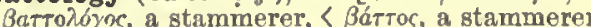
(used only as a proper name), + ityctv, speak: see -ology.] Idle talk or babbling; a needless repetition of words in speaking. [With reference to Mat. vi. 7.]

That heathenish battology of muliplying words
Milton, Def. of Humb. Remonst.

Prynne, Treachery and Disloyalty of Paplsta, if. 67

battont, n. An obsolete form of baton and bat

battoont, $n$. Same as batoon.

battory' (bat'ō-ri), n. A factory or warehouse established abroad by the Hanse towns.

battoule-board (ba-töl'bōrd), $n$. A spring board used for jumping - particularly, in circuses, for vaulting over horses, elephants, etc. It consists of a few planks fastened at one eud to a pole floor or other anrface.

battril $\nmid$ (bat'ril), $n$. [E. dial. Cf. battler ${ }^{2}$, bat ler1.] Same as batler1.

batts (bats), $u . p l$. Same as batting, 3 .

battue (ba-tū'), $n, \quad[\mathrm{~F} . \quad(=\operatorname{Pr}$. batuda $=$ It. battuta), prop, fem. pp. of battre, beat: see batel batter 1 ; 1 . A mothod of hunting in which the game is driven from cover by beaters toward a point where the sportsmen are in wait.

He bas not a word to asy against battue shooting, though for his own part he greally prefers shooting over a welltrained dog to having the game put np in drovea by a ser-
ried line of beaters. 
battue

Hence-2. Any beat-up or thorongh search, or undiscriminating slaughter, especially of defenseless or unresisting erowds. - 3. The ga

batture (ba-tür'), n. [F., a sand-bank, a shoal, < battre, beat, beat as waves: see bate ${ }^{1}$, batter ${ }^{1}$, and ef. batter ${ }^{3}$.] An alluvial elevation of the bed of a river; in particular, one of those portions of the bed of the Mississippi river which are dry or submerged according to the season. In Scptennher, 1807, cccurred the "bratture riots." The batture was the sandy deposits 1made by the MIssissippi
in front of the Fauboury Ste. Marie [in New Orleans]. in front of the Fanbourg Ste. Marie lin New Orleans]. The noted jurist, Edward Livingston, represcnting private
claimants, took possession of this ground, and was opposed by the public in two distinct ontbreaka,

battuta (båt-tö'tä), n. [It., < battere, beat. Cf. battue.] In music: (a) $\mathrm{A}$ beat in keoping time. (b) A bar or measure. See a battuta and $a$ gression of the outer voice-parts of a harmony from a tenth on the up-beat to an octave on the down-beat.

batty' (bat'i), a. [<bat ${ }^{2}+-y^{1}$.] Of or resembling a bat; battish.

Till o'er their brows death-connterfeiting sleep Shak., M. N. D., lii.

batty ${ }^{2}$ (bat'i), n.; pl. battics (-iz). [Anglo-Ind., used in southern India for northern paddy, rice; < Canarese batta, bhatta, rice: see batta growing. -2. A measure for rice in India, equal to 120 pounds. McElrath, Com. Dict.

batweed (bat'wēd), n. The burdock, Aretium

Lappa.
batz, batzen (bats, bat'sen), $n$. [Formerly also bats, taken as plural, with an assume sing., bat, < MHG. batze, G. batzen, bazen, the coin so called, < MHG. bctz, G. bätz, petz, a the coin was first issued.] A small billon coir
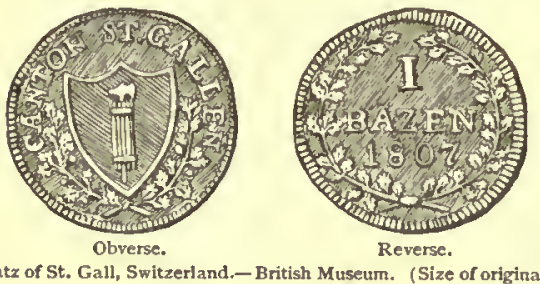

worth four kreutzers (about three cents), first issued toward the end of the fifteenth century by the canton of Bern, and afterward by other Swiss cantons, which placed their respective arms upon it. The name came to

baubee, $n$. See bawbee.

bauble ${ }^{1}\left(\mathrm{ba} \hat{a}^{\prime} \mathrm{bl}\right), n$. and $a$. [Early mod. F. bable, bauble (bâ'bl), n. and $a$. [Early mod. E. bable,
babel, < ML. bable, babylle, babulle, babcl, < OF' babel, baubel (with dim. baubelet, beubelet, > early ME. beaubelet), a child's toy, plaything, trinket. Origin doubtful; cf. mod. F. babiole, a toy, gewgaw, It. babbola, a toy, appar. connected with It. babbco, a fool, blockhead (babbano bler, fool. Cf. babble. The forms, if from the same source, show imitative variation. Bauble ${ }^{1}$ in this sense was early confused with bauble 2 appar. of different origin.] I. $n$. 1t. A child's plaything or toy. -2 . A trifling piece of finery; a gewgaw.

0, trinkets, sir, trinkets - a bauble for Lydia!

Are all these worlda, that gpeed their circling flight,

Dumb, vacant, conlless - bawbles of the night?

3. A trifle; a thing of little or no value; a

II. $+a$. Trifling; insignificant; contemptible.

The sea being amooth,
How many shallow, bauble boats dare sal

Upon her patient breast! Shak., T. and C., i. 3. Also spelled bawble.

bauble ${ }^{1}+, v . i . \quad\left[\left\langle\right.\right.$ bauble,$\left.n_{0}\right]$ To trifle.

bauble ${ }^{2}$ (bâ'bl), n. [Early mod. E. bable, babcl, (appar. bable, babulle, babcl, a fool's mace, also (appar. the same word) a stick with a heavy weight at the end, used for weighing, $<$ ME.
babelen, bablen, waver, swing to and fro, appar. a freq. form from same source as $b a b^{1}$, bob 1 .

Bauble may thus be regarded as for "bobble.

But the word was early confused with baublel,
480

bavardage

q. v.] Primarily, a sort of scepter or staff of office, the attribute of Folly personified, carried by the jesters of kings and great lords in the middle ages, and down to the seventeenth century. It is generally repreaented as eara, and with a ring of little belis, like sleigh-bells. At the other end there was gometimea a ball or bladder inflated with air, with whic

The kynges foole

Sate by the fire upon a atoole,
As he that with lis bauble plaide. Gower, Conf. Amant., vis.

Foois, who only wauted a party-coloured coat, a cap, and a bawble, to pasa for auch amongst reasonable men.
Dryden, Post. to Hist. of League.

baubleryt, $n$. [Early mod. E. also

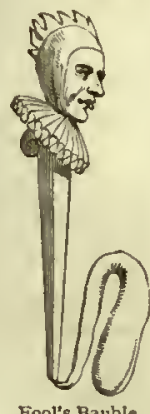

ablerie, babelry: < bauble1 + -ry.] Childish

trifling; a trifling matter. aublingt (bâ'bling),

A baubling vessel was he captain of. Shak., T. N., v. I.

bauch, baugh (bäch), a. [Se., perhaps < Icel. bāgr, uneasy, poor, hard up; cf. bagr, awkward clumsy.] Weak; pithless; shaky. [Scotch.] bauchee-seed (bấ'chē-sēd), $n$. Ś̉mo as bavchan-sced.

bauchle ${ }^{I}$, bachle $^{1}$ (bäčh'1), n. [Sc.; origin unknown. Cf. bauch.] 1. An old shoo worn down at the heel, or one with the counter turned down and worn as a slipper.-2. A slovenly, pithless, or shiftloss pers
bling good-for-nothing. [Scoteh.]

He'll he but a bauchle in this world, and a backaitter in the neiat. $\quad$ logg, Shep. Cal., II. 195. (N. E. D.)
bauchle baffle.

bauchly (bäch'li), adv. [Sc., < bauch + -ly ${ }^{2}$.] Weakly; indifferently; poorly. [Scotch.] baud2t, $v$. $t$. See barod 2

baud $3 t, n$. See bavd ${ }^{3}$.

baud 4 '(bâd), $n$. [Origin obscure. Cf. bavod3.] The fish otherwise called the rockling. [Loca] Eng. (Cornish).]

baudet, a. [ME., < OF. baud, < OLG. bald, bold, lusty, = E. bold. See bawd ${ }^{1}$.] Joyous; riotously gay. Rom. of the Rose.

baudekin, baudkin (bâ'de-kin, bâd'kin), $n$. [Obsolete, except in historical use; early mod. E. also irreg. bodkin; < ME. baudkin, baudekin, ete., < OF. baudekin, baudequin (ML. baldaki-
nus), < It. baldacchino, > also E. baldakin, baldachin: see baldachin.] A rich embroidored or brocaded silk fabric woven originally with a warp of gold thread, and properly called eloth of baudekin. It was uaed for garments, aacred veatments, altar-clotlis, canoples, etc., and is first mentioned William of Valence in 1247 by Henry III. It was proba. bly known on the continent before that date. Later the name waa applied to any rich brocade, and even to shot
silk. It is not found in use after the middle of the aix-
teenth century. Also called baldachin.

There were no fewer than "Thirty albe of old eloth of bawdkyn," that is, eloth of gold, at Peterborough.
Quoted in Rock, Church of our Fathers, 1. 431. baudekynt, $n$. See baudckin.

baudelairet, $n$. Seo badelaire.

baudkin, $n$. See baudekin.

baudreył (bâd'ri), $n$. A variant form of baldric. baudrickt, $n$. Seo baldric.

baudrons (bâd'ronz), n. [Sc., also badrans, bathrons ; of unknown, perhaps Celtic, origin.] A name for the eat (like reynard for the fox, bruin for the bear, etc.). [Scotch.]

$$
\begin{aligned}
& \text { Anld baudrons by the ingle sits, } \\
& \text { An' wi' her loof lier face a washin'. } \\
& \text { Burns, Wid }
\end{aligned}
$$

T. Martin, tr. of Heine'a "' Mein Kind, wir waren Kinder."
The baudy ${ }^{1}+$ baudy ${ }^{2} t, a$. See bavdy ${ }^{1}$, bavdy ${ }^{2}$.

baufreyt, $n$. [Origin obscure; perhaps a form of belfry.] A beam.

bauge (bōzh), n. [F.; of uncertain origin.] 1. A kind of coarse drugget made in Burgundy, France.-2. Mortar n

Bauhinia (bâ-hin'i-ä), n. [NL., named in honor of Jean and Gaspard Bauhin, eminent Swiss botanists (died in 1613 and 1624 respectively), because the leaves generally consist of two bolic of the two brothers.] A genus of plants, natural order Leguminosce. The apecies are usually ing. The wood of $B$. variegata is one of the anist Gaspard Bau-

Scotch form of bold.

aulk, $n$. and $v$. See balk $\mathbf{I}$

tretching from tree to tree like callek. The tough fibrous making ropes and bridges, and is auitable for paper-makvarieties of ebony, and
its bark is used in dyeing asd tanning. Other apecies are equally use-

hinhinian (bâlating to the Swiss anatomist and bothin (1560-1624).Bauhinian valve,
valvula Bauhinta, the jleoceecal valve. bauk (bâk), n. A Scotc $\mathbf{1}$.

bauld (bâld), $a$.

bauldricket, $n$. See balaric.

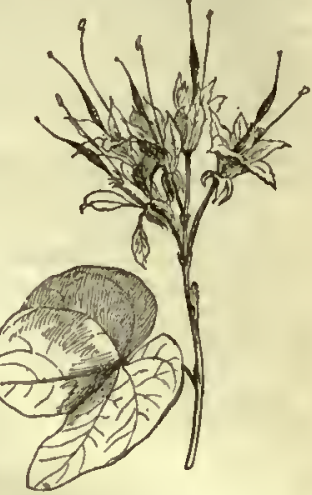

Bauhinia. - Inflorescence.

baulea (bâ'lē-ä), n. [E. Ind.] A round-bot tomed passenger-boat, having a mast and sail but generally propelled by oars, used on the shallower parts of the Ganges.

baulite (bấlit), n. [< Baula, a mountain in Iceland, + -ite 2 . The mountain prob. derives its name from Icel. baula, a cow, an imitative name; ef. mod. Icel. baula, low as a cow: see bawlI.] A white transparent mineral, found in the matter ejected by the volcano of Krabla in Iceland. It is a variety of glassy feldspar or sanadine. Also called hrablite.

baulmet, $n$. Seo balm.

baultert, $v$. See balter.

baunscheidtism (boun'shit-izm), $n$. [From the inventor, Karl Baunscheidt, a German mechanician.] A form of acupuncture, in which about 25 needlos, set in a metal disk and dipped in an irritant oil, are thrust in to the skin by a spring. Its action seems to bo accordant with that of ordinary counter-irritants.

bauset, $v$. $t$. [Appar. a var. of bass, q. v.] To kiss. Marston. [A donbtful sense.]

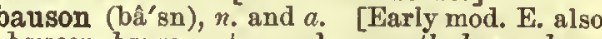
bauson, bauzon, etc., and corruptly boson, bore son, <ME. bauson, bauson, baucyn, bausen, a particular application of the adj bouson, white-spotted, in ME. bausand, mod. bausond, etc.: see bausond. The adj. is rarely found in ME., but must have preceded the noun nse. The badger has received other names in allusion to the whito mark on its face: see badger 2 .] I. $n$. An old name of the badger: sometimes applied ludicrously or in contempt to a fat or pertinacious person.

II. $a$. Same as bausond.

were of bawson's gkin.
Drayton, Dowaabell, at. 10 (1593).

bausond (b̂ी'snd), $a$. [Early mod. E. also baw sonde, bawsand, mod. dial. bawsont, bawsand also (erroneously written as if a participle bauson'd, bassen'd, baws'nt, ete.; < ME. bausand (also, as a noun, bauson, bavson, bausen, ete.), < OF. bausant, baussant, bausent, bauzant, bauçant, balcent, bauchant, ote. (with appar. unorig. -t), also bauzan, bauscn, bausain (5 ML. bausendus, bauscnnus $)=\operatorname{Pr}$. bausan $=$ It. balzano, whitespotted; ef. mod. F. (from It.) balzan, a black or bay horse with white feot. Origin unknown; possibly connected with the equiv. Celtic words mentioned as the source of $\mathbf{E}$ ball 3 , q. ..] Having white spots on a black or bay ground; having a white strip down the face, or a patch on the forehead: applied to animals. [Scotch.]

His honest, aonsie, bausint face
Aye gat him friends in 1 ka place.

Aye gat him friends in llka place.
Burns, The Twa Dogs, 1. 31.

bauson-faced (bâ'sn-fāst), a. Having a white mark on the face, like a badger; bausond.

bauteroll, $n$. Seo boterol.

bauxite (bō'zīt), n. [<Baux (see def.) + -ite ${ }^{2}$. $]$ A clay found at Les Baux, near Arles in France, and elsewhere, in concretionary grains or oölit ic. It containa about one half of its weight of alumina with iron asd water, and ailica as an Impurity. It la used as a source of alum, of the metal aluminivm, and to aome ex bavardage (ba-vär-däzh'), n. [F., < bavarder, chatter, < bavard, talkative, < bave, drivel, saliva: seo bavette.] Idle talk; chatter. [Rare.] 
Roplylng only by monosyllables to the gay bavarilayn
of the knight.
Buluer, Kienzi, Il. 133 . bavarettef (bav-a-ret'), n. Same as baxctte.

Bavarian (ba-vā'ri-an), $u$. and $n$. [<Bavaria, NI. form of NL. Boilaria, the constry of the Boii (G. Baiern), whose name is also found in Bohemia, the country of the Boiemi or Bohemi (G. Böhmen).] I. a. Of or pertaining to Bavaria, a kingdom of sonthern Germany. - Bavarlan bronze, a bronze ranging in collor from a bright
yellow to a copper-red. The yellow lironze contains about yellow to a copper-red. The yellow hronze contains abont 3. jer cent. of copper to 173 per cent. of thi

II. n. A native or an inhabitant of Bavaria. bavaroy $\nmid$ (bav'a-roi), $\pi$. [< F. Bavarois, Bavarian.] A kind of cloak.

let tho loop'l bavaroy the fol eminrace.

Gay, Trivia, 1. 53.

Baveno twins. See twin.

bavert, $n$. An obsolete form of benver 2 .

bavette (ba-vet'), n. [F., with dim. term. -ette, $<$ bave = Pr. It. bara = Sp. Pg. baba (ML. b(ta), drivel, slaver, saliva.] 1. A bib.-2. The upper part of a ehild's apron turued over The upper part

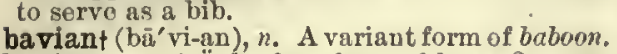
baviert, $n$. An obsolete form of beaver?

bavin' '(bav'in), n. and $a$. [E. dial. bavin, bav$\mathrm{cn}$, also babbin; of obseure origin; cf. OF. baffe, a bundle.] I. $n$. 1. A fagot of brushwood; light and combustible wood used for kindling fires. [Now rare.]

The Bauin, though It burno bright, is but a hlnze. Lyly, Euphues, Anat. of Wit, p. 73 It he outlasts not a hundred such crackling bevins as hou art, God and men neglect industry.

Marstom, Jonson, amd Chapman, Eastward Ho, I. 1. About two in the morning they felt themselves almost
ehoked wlth smoke, and rising, did find the fire coming up stalrs: go they rose to save themselves; but that, at re in the yar.

2†. Milit., a fascine.

II. $a$. Resembling bavin. [Poetic.] Sllallow jesters, and rash barin wits, soon klndled and soon burn'd. Shak., I llen. IV., lli. 2.

bavin ${ }^{1} \nmid\left(\right.$ bav'in $^{\prime}, v . t . \quad\left[<\right.$ bavin, $\left.n_{.}\right]$To make up into fagots.

Kid or bavin them, and piteh them upon their ends bavin ${ }^{2}$ (bav'in), n. [E. dial. ; orjgin obscure.] bavin 2 (bav'in), $n$. [E. dial.; orjgin obscure
Impure limestone. Halliwell. [Prov. Eng.] bavin $^{3}$ (bav'in), $n$. [Origin obsenre.] A nam on the northeastern coast of Ireland of the ballan-wrasse.

Bavouism (ba-vö’izm), $u$. Same as Babouvism. Bavouism, as Babout's system was called, was thus en.
abled to play a róle in Freneh history from 1830 to abled to play a roble in Freneh history from 1830 to 1839.
R. T. Ely, Fr. and Ger. Soeialisun, p. 34. baw ${ }^{1}$ (bâ), n. [F. dial. and Se. (Se. also ba'), $=b a l l 1$.
baw

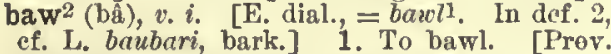
Eng.] $-2 \uparrow$. To bark. Topsell.

baw $^{3}$ (bâ), interj. [<ME. baw, bawe; a natnral exclamation of disgust, like bah.] An ejacu

bawbee, baubee (bâ-bë́), n. [Se., formerly also bawbic, baubie, rarely babie : first mentioned in pl. baubeis. Of uncertain origin; prob. an abbr. of the name of the laird of Sillebawby, mint-master mentioned at the date of the issuance of the bawbee, in connection with Atchison, another mint-master whose name was applied to the coin called atchison; ef. also bocle, Bodcell or Bothwell.] 1. A Seoteh billon coin, weighing about 29 grains troy, first issued in

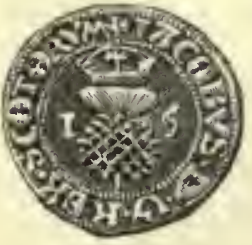

Reverse.
Bawbee of James Vo- British Museum. (Size of the original.)

1542 by James $V$. of Seotland, and worth at that time $1 \frac{1}{3} d$. Seotch. A half-bawbee, worth of $^{2}$ Seoteh, was eoined at the aame time and had sinllar types. In Scotland the name is now glven to tho
lialfpenny eurrent tliroughout the Britlsh islands. 2. $p l$. Money; cash. [Scoteh.]

bawble $1, n$. See bauble 1 .

bawble $2, n$. See bauble 2

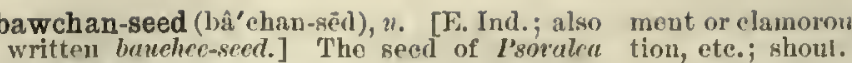
corylifolia, a laguminous plant of tho liast II1. lies, used by the natives as a tonie and in skinliseases, and exported as an oil-seod.

bawcock ( $\mathrm{b} \hat{A}^{\prime} \mathrm{kok}$ ), $n$. [<F. beau coq, fino cock: eo beu and cock.1.] A fine fellow. [Arehaic.] How now, ny barcock? Shak., T. X., Hill 4.

awd ${ }^{1}$ (bad), $n$. [Farly mod. F. also baurl, s M.5. baude, baude, in tho earliest instance varying with bawelstrot, of wlich bacd is prob. an abbr., being thus (prob.) indirectly, and not, as commonly supposed, directly, derived from the OF. baud, bold, lively, gay. The OF. adj. is not used as a nown, and does not have the sense of the E. wrord. See baicdstrot, and ef. baicdy ${ }^{1}$, baiedly ${ }^{2}$.] A procurer or procuress; a person who keeps a house of prostitution, and conly to women.

lle [Pandarus] is named Troilus' bated.

Skeltom, Poens, p. 235.

bawd ${ }^{1} \dagger($ bâd $), v . i . \quad\left[\left\langle b a c d^{1}, n_{.}\right]\right.$To pandor; act as procurer or jrocuress.

Lencippe is agcent for the klng's hist, and bazods .. bawd $d^{2} \dagger$ (bad), $v$. $t$. [Also spelled baud; $\left\langle\right.$ bavdy ${ }^{2}$, q. v.] To foul or dirty. Her shoone smered with tallow, Tresed upon dyrt yrt. bawd ${ }^{3}$ (bâd), u. [Early mod. E. also baud, perliaps abbr. from baudrons, or perhaps a var. of ME. baddc, a cat, the name boing transforred to the hare.] A hare. [In the extract there is play on bawd in this sense and bawd 1 .] Mer. A baow, a baow ! so ho
Rom. What hast thon fond? Rom. What hast tho

Shak, R. and J., if, 4 ,

bawd-born (bâd'bôrn), a. Born of a bawd; a bawd from birth. Shak., M. for MI., iii. 2.

bawdekynt, $n$. See baudekin.

awdily (ba'di-li), adv. In a bawdy manner obseenely; lewdly.

bawdiness (bâ'di-nes), n. $\quad\left[<\right.$ bawdy $\left.{ }^{1}+-n e s s.\right]$ awdmoney, $n$. Seo baldmoney.

awdrick $\dagger$ (bâd'rik), $n$. See baldric.

bawdry (bâd'ri), $n_{\text {. }}$ [< ME. baudcrye, < baude, bawd, + -ry. Cf. OF. bauderie, boldness, bawd or procuress.-2. Illicit intercourse; fornication.

We must he married, or we must live in baudry.

3. Obscenity; lewd language; smuttiness.

It is most certain that barefaced bavdry is the poorest (o wit imagiuable.

4t. Bawds collectively. Udall.

bawdship (bâd'ship), $n_{0}[<$ bawdl + -ship. $]$ The office or employment of a bawd. Ford.

bawdstrott, $n$. [ME., also baudstrot, banstrot, baldestrot, baldystrot, $\angle \mathrm{OF}$. "baudestrot, "batdestrot, found only in later form baudetro gin; possibly< OF. baud, bald, bold ( $<$ OLG. bald =E. bold ), + "strot, $($ OLG. strotten, "strutten $=$ Dan. strutte $=\mathrm{MHG} . \mathrm{G}$. strotzcn $=\mathrm{F}$. strut ef. LG. G. strutt, stiff.] A bawd; a pander. l'iers I'lowman.

bawdy ${ }^{1}$ (bấdi), a. [<barcd $\left.+-y^{1}.\right]$ Obscene ecent; unchaste.

bawdy ${ }^{2} \dagger$ (bâ'di), $a$. [Early mod. E. also bandy, MiE. bawdy, baudy, dirty, appar. from a simple form "baud, which is not found till much later, and only as a verb (see bava $d^{2}$ ); origin unknown; ef. W. bawaidd, dirty, < baic, dirt, mire; F. boue, mud. Not connected with associated.] Dirty; filthy.

IIls oversloppe ... is al baudy and to-tore also.

Chaucer, Prol. to Canon's Yeoman's Tale, 1. 82

Slovenly cooks, that .. never wash their baverly hands.
Burton, Anat. of Mll., II. 323.

bawdy-house (bâ'di-hous), n. A house of lewdness and prostitution; a house of ill-fame. bawhorse (bâ'hôrs), $n$. Same as bathorse.

bawll1 (bâl), $v$. [Early mod. E. also ball, baul, ME. barlen, bark, prob. < ML. baulare, bark (cf. L. baubari, bark); cf. mod. Icel. baula = Sw. böla, low as a cow (Ieel. baula, a eow);
ef. also Sw. bala, roar, G. bailen, bark, and see bell ${ }^{2}$, bellow, balk ${ }^{2}$, ete., all prob. orig. imitative.] I. intrans. 1t. To bark or howl, as a dog.-2. To ery out with a loud full sound; make vohe-
That haul fer freedom In their senseless mond d set then tree. l'assing under Lutgate the other day, I hearl a volce
Steele, spectator, No. 82.

II. trans. 1. To ntter or proelaim by outery;

Still must I hear? - shall hoarse Flizzerald ba wel Byron, Luglish liards and scotch Revlewers.

2. To ery for sale, as a liawker.

I saw my laluours, which harl cost me so muneh tlionglit anil watcling, baciled abont by the common liawkers of awl' (ball), $n_{0} \quad\left[<b a c l^{1}, v^{\prime}\right]$ A shout at the top of one's voice; an outery: as, the children set up a loud baul.

bawl,$+ n$. Obsoleto spelling of ball1.

bawla (bâ'lân), n. [Nativo term.] A matting made in the islands of the Pacific from the leaves of the cocoannt-paln, used for thatehing. bawler (bâ'ler), n. Ono wlıo bawls.

bawmet, $n$. An obsolete form of balm. Chauecr. baw-money, $n$. Seo butmoney.

awn (bain), $n$. [<Ir, bablum = Gael, babhunn (pron. nearly as bawn), an inclosure for cattle, a fortification.] 1. Formerly, an outer inclosure of an Irish castle: nearly equivalent to bailey and outer bailey. In the seventecnth centhry grants of government land in Freland were made on the condition that the grantee alonld hulld a eastle and
bawn, the latter for the protectlon of the cattle of the

2. In modern times, in some parts of Ireland(a) The cattle-yard near a farm-honse. (b) A large house, including all its appurtenanees, as offices, courtyard, ete. Sicift.

aWn (bân), v. t. [<bawn, u.] In Ireland, to surround or inclose with a bawn.

bawrelt, $u$. [A corresponding masc. bauret is found; appar. of F. origin. Cf. bockerel, bockeret.] A kind of liawk. Phillips.

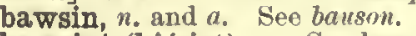

bawsint (bâ'sint), a. See bausond.

bawson, $n$. and $a$. See benson.

bawtie, bawty (bâ'ti), n. [Sc. Cf. bavol3.] In Scotland, a name for a dog, especially one of large size, and also for a liare.

baxa, baxea (bak'sä, -sē-ä), n. [L.] In Rom. antig., a sandal or low shioe of various forms, often plaited from papyrus or palm-leaves; generally, an inexpensive foot-covering worn by the poorer classes, but also referred to as occurring in rich materials and workmanship, and specifically as the shoe of comic actors, as distinguished from the eothuruus used by tragedians.

axter (bak'stér), $n$. [Also backister, < MF. baxter, bacster, bakestre, <AS. bacestre, a baker: see bakestcr. Hence the proper name Baxter, equiv. to Baker.] A baker; properly, a female baker. [Old Eng. and Scoteh.]

Baxterian (baks-tét li-an), a. Pertaining to or propounded by Richärd Baxter, a celebrated English noveonformist divine (1615-1691): as, Baxterian doctrines.

Baxterianism (baks-téti-an-izm), n. The doctrines of lichard Baxter, who amalgamated the Arminian doctrine of free grace with the Calvinistic doetrine of election.

bayl (bã), n. [Early mod. E. also baye, baic, or bay-tree, perhaps $\langle\Lambda \mathrm{S}$. beg, berry, oceurring only in pl. beger, begir, glossed baccinia, i. e. vaccinia, 'blneberries' (see Iaccinium), and in comp. begbcám, lit. 'berry-tree,' applied both to the mulberry-tree (Gr. $\mu$ opk $a$ ) and to the bramble or blackberry-bnsh (Gr. $\beta a$ tos). But the ME. form, like MD. beyc, baeye, a berry, a laurel-berry, agrees also with, and may have come directly from, OF. baie, baye, mod. F. baie = Pr. baia =Sp. baya, OSp. baca $=\mathrm{Pg}$, baga, baca $=$ It. bacca, a berry, <I. bãea, less correctly bacca, a berry; ef. Lith. bapki, a laurel-berry.] 1t. A berry, especially of the laurel-tree.

$$
\text { The bays or berrles that it heareth. }
$$

Iolland, tr. of Pliny, xv. 30 .

2. The laurel-tree, noble lanrel, or sweet-bay, Laurus nobilis. See lanrel. The name bay is also given to a number of trees and slurubs more or less re embling the noble laurel. See phrases below.

Hence (like laurel, and in reference to the ancient use of the laurel) - 3. An honorary garland or crown bestowed as a prize for victory or exment or merit: in this sense used chiefly in the 
bay

plural, with reference to the leaves or branches of laurel. Also ealled bay-leaf.

Yet as you lope hereafter to aee plays,

Beall. and $F^{\prime}$ l., Thierry and 'Theodoret, Epil.

I play'd to please myself, on rustick reed,

Way, the learned ahepherd'a meed.
11. Broume, Britannia's Pastorals, i.

In the following quotation, the offlce of poct laureate: ornerly a not uncommon use.

If you needs must write, write Cresar's pralse.

Pope, Init. of Horsce, Satire 1. 22, Bays was sonetimea used as a alngular (compare bays,
bazze, as singular).

Do plaut a sprig of cypress, not of bays.

A greener bays ahall crown Ben Jonson's name.

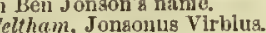

4. [Cf. bay 2.] A piece of low, marshy ground producing large numbers of bay-trees. [N. Carolina and Florida.] Bartlett. - Bull-bay, the Mlagnolia grandiflora. - Cherry-bay, Prunus Lauroceradian or royal bay, Laurus Indica.- Loblolly-bay, or tan-bay, the Gordvina Lasianthus. - Red bay, the $P$ ersea Carolinenzis.-Rose-bay, a name given $(a)$ to the States, to the great laurel, Rhododendron maximum.Sweet-bay. See above, 2 -Sweet-bay, or white bay, bay $^{2}$ (bā), n. [Early mod. E. also baye, < ME. baye, < OF. baie, baye, mod. F. baie = Pr. baia = Sp. bahia, formerly also baia, baya (> Basque baia, baiya), = Pg. bahia = It. baja (cf. G. bai, < D. baai, MD. baeye = Dan. bai, $\left\langle\right.$ E. bay $\left.{ }^{2}\right\rangle,<$ LL. D. baai, MD. baeye $=$ Dan. bai,
baia, a bay, first mentioned by Isidore, and said to have its gen. in -as, implying its existence at to have its gen. in -as, implying its existence at L. Baia, pl., a noted watering-place on the coast of Campania, hence applied also to any watering-place. Bay in this sense has been confused in E. and Rom. with bay ${ }^{3}$.] 1. A recess in the shore of a sea or lake, differing from a creel in being less long and narrow; the expanse of water between two capes or headpanse

The aea winding, and breaking in bays into the land. 2†. An anchorage or roadstead for ships; a port; a harbor.

I prithee, good Iago,
Go to the bay, and disembark my coffers
Shak, Othello, il. I. 3. A recess of land, as in a range of hills; a level space partly surrounded by heights. [Rare.]-4. An arm of a prairie extending [U. S.] Bartlett.-5. A kind of mahogany obtained from Campeachy Bay (whence the name).

bay (bā), n. [Early mod. E. also baye, baie, ME. bay, baye, < OF. baee, an opening, gap, type. Faie, a bay ( $\mathrm{ML}$. as if badata), on bayer, < LL. badare, gape (cf. L. gap, n., gape $v$.): see bay ${ }^{4}$. This word has been confused v.): see bay $y^{4}$. This word has compartment or division in the architectural arrangement of a building, marked by buttresses or pilasters o the walls, by the disposition of the main ribs (ares doubleaux) of the interior vaulting, by the placing of the main arches and pillars or of the principals of the roof, or by any other leading features that separate the design into corresponding parts. Oxford Glossary.-2 The part of a window ineluded between two mullions; a light. Also called window-bay.-3. A bay-window.

Some ladies walking with ne, see-
ing my father gltting at his writing went in through hia glorified windowg, and established themselves round his table. 4. A compartment in a barn for the storage of hay or grain. - 5. In earp., a portion of a compound or framed floo included between two girders, wall.-6. In plastering, the wall.- 6. In plastering, the
space between two sereeds. space between two sereeds.
See sereed. -7. Naut., that part of a ship between decks which lies forward of the bitts,

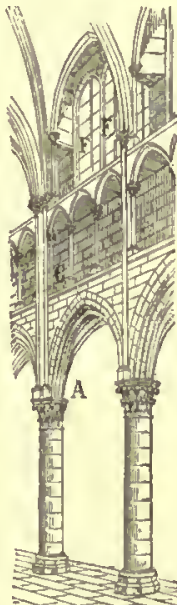

on either side; in a ship of war, the foremost messing-place between decks. See siek-bay. 8. In bridge-building, the portion between two piers-9. In coal-mining: (a) An open space for the gob or waste in a long-wall working. (b) The space between two frames or sets in a evel: synonymous with board. [Leicestershire, Eng.] - Bay of joists, the joists between tw - Bay of roofing, the small raitera and their aupporting puring hetween two principal rafters

baj ${ }^{4}+(\mathrm{ba}), v, i . \quad\left[<\mathrm{OF}^{*}\right.$, bayer, beer, baer, gape, badar = Cat. badar = lt badare < LI badare, gape, be open. Cf. bay ${ }^{3}$ and bay $y^{5}$.] To open the mouth, as for food; seek with open mouth.

Bayer a la mamelle, to seeke or baye for the dugpe.
IIollyband, Treasurie of the French Tong

bay5 (bā), $v$. [Early mod. E. also baye, < ME. bayen, $\angle \mathrm{OF}$. bayer = It. bajare (also in comp., ME. abayen, < OF. abayer, abaier, abbayer, mod. F. aboyer = It. abbajare), bark; of uncertain origin, perhaps imitative (ef. E. bawl1, bark,
L. baubari, ML. baulare, G. bailen, bark, and baw ${ }^{2}$, bov-(wov), but prob. associated in earlier use with OF. baer, beer, bayer = It. badare, < LL. badare, gape: see bay, and ef. $b a y^{5}, n$., in which the two notions unite. In some senses the verb is from the noun.] 1 . intrans. To bark, as a dog; especially, to bark with a
prolonged sound, as hounds in the chase.

The hounds at nearer listance hoarsely bayed.
Dryden, Theodore snd Honoria, 1 .

II. trans. 1. To bark at; beset with deep prolonged barking.

I had rather be s dog, and bay the moon,
Shak., J., , iv.

2. To express by barking.

"Tl's sweet to hear the watch-dog's honeat bark
Bay deep-mouthed welcome as we draw near ho

Byron, Don Juan, i. 1 at bay; chase or hunt.

'They bay'd the bear
With hounds of Sparta.

4. To hold at bay.

For we are at the atake,
And bay'd about with many enemiea

Shak., J. C., lv, 1

bay5 (bā), n. [Early mod. E. also baye, beye, < MIE. bay, baie, of different origin, aceording as
it stands $(a)$ for bay, a barking, $<$ bay, ME. bayen, bark; (b) by apheresis for abay, ২ OF. abai, abay, abbay, aboy, mod. F. aboi, a barking, ? abaycr, bark (see bay5, v.), esp. in the phrase haps always to be read at abay), to bring to bay; (c) in the phrase to hold at bay, repr. OF. tenir a bay. It. tenere a bada, hold in suspense or expectation, lit. on the gape: OF. bay (=It. bada), suspense, lit. gaping, < baer = It. badare, gape, a see above.] 1. The deep-toned barking of a dog in pursuit of game; especially, the barking of a pack of hounds. -2 . The state of being so hard pressed, as a hunted animal by dogs and hunters, as to be compelled, from impossibility or to: as, to be at bay, stand at bay, hold at bay (formerly also at a bay), bring to bay, ete.: often used figuratively, in theso and other constructions, with reference to persons beset by distress.

Unhappy Squire! what hard mialap thee brought
Into this bay of perill and diagrace?

spenser, F. Q., VI. 1. 12. Nor fight was left, nor hopes to force his way: 3. The state of being kept off by the bold attitude of an opponent; the state of being pre-
vented by an enemy, or by any kind of resistance, from making further advance: with $a t$.

We have now, for ten years together, turned the whole able to hold us at bay.

The barriers which they bullded from the soll

bay 6 (bā), a. and $n$. [I. a. Early mod. E. also baye, baie, ২ME. bay, baye, ২OF. bai, mod. F. bai

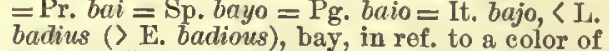
horses. II. n. 1. Rarely in sing. bay $(=\mathrm{D}$. baai = MLG. baie, LG. baje (> G. boi) = Dan. $b a i=\mathrm{Sw} . b a i)$, usually in pl. bays, early mod. E. bayes, baies, baize (whence the mod. sing. bayard

baize, q. v. ) ( OF. baies, pl. of baie, fem. of bai, di.] a Reddish or hrownish-red, inelining to ehestnut; rufous; badious; castaneons: applied most frequently to hor'ses, but also to other animals displaying the same color.

II. $n .1$ t. A light woolen fabric (originally of a bay color), the manufacture of which was introduced into Fingland in 1561 by refugees from France and the Netherlands: usually in plural bays, now, as singular, baize (which see). -2. A bay horse.

\section{The ploughmsn stopped to gaze
Whene'er his chariot awept iu view}

behind the ahining bays.

o. W. Holmes, Agnes.

$\operatorname{bay}^{7}$ (bã), $n$. [Origin uncertain; the ME. "bay, or withstondynge, obstaculum," may possibly be a uso of bays in to stand at bay, etc.: see $\left.b^{2} a y^{7}, v.\right] \Lambda \mathrm{dam}$; a pond-head; an embankment. [Eng.]

a ${ }^{7}(\mathrm{~b} \bar{a}), v_{0} . t$. [Perhaps from the related noun $\left(b^{2}{ }^{7}\right)$, or, as the source of that, < Icel. bar$a$, puslı back, hinder, < bägr, opposition, colliion; cf. fara $i$ bãg, come athwart.] To dam: s, to bay back tho water.

y ${ }^{8}$ (ba),$n$. [Short for bey-antler.] Tho bayantler or bez-antler of a stag.

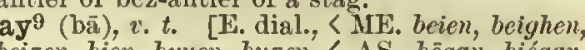
beizen, bien, buyon, buzen, < AS. beèghn, biégan, bigan, bygan (=OFries. bejja = MD. borghen= G. beugen = Icel. beygja $=$ Sw. böja $=$ Dan. böje Goth baugjan), trans bend causative of bügan ( - Goth biugan, ete $\mathrm{E}$, bow I intrans. bend: seo bow 1 , and ef. baili. '] To bend. [Prov. Eng.]

bay 10t, $v$. [Only in Spenser, who also uses emA ime.] A poetical perversion of bathe. Hee feedes upon the cooling shade, and bayes His aweatie forehesd in the breathing wynd. Spenser, F. Q., i. vii. 3.

baya (bā'yia), $n$. [Hind.] The weaver-bird, Ploeeus phitippinus, an East Indian passerine bird, somewhat like the bulfinch, remarkable for its extremely eurious nest. Soe weaverbird.

baya-bird, $n$. Same as baya

bayadere, bayadeer (ba-ya-dēr'), n. [Also pelled bajadere ( $\mathrm{F}$. bayadere); formerly ballador $=$ Sp. bailador, a dancer, $\langle$ bailar $=\mathrm{Sp}$. bailar, dance: see ball $2^{2}$.] An East Indian dancing girl.

ayal (bà $\left.\bar{s}^{\prime}\right), n$. A fine kind of cotton. Simmonds.

bayamo (bä-ÿ̈'mō), n. [Cuban.] A violent blast of wind, aceompanied by vivid lightning, Cuba, and especially from the Bight of Bayamo. bay-antler, $n$. See bez-antler.

ayard ${ }^{\mathrm{L}}$ (b̄ä ärd), $a$. and $n$. [Early mod. E. lso bayerd, baiard, bayart, < ME. bayard, bayart, < OF. bayard, baiard, baiart (= Pr. baiart), bay, a bay horse, < bai, bay: see bay ${ }^{6}$ and -ard. The adj. came to be a general appellative of a bay horse, esp. of Renaud's (Rinaldo's) magie teed in the Charlemagne romances; later of any horso, esp. in alliterative proverbial use, bold bayard, blind bayard, of ten with reference o reckless or stupid persons, perhaps associated in the latter sense with OF. bayard, gaping, staring, one who gapes or gazes, < bayer, baer, gape, gaze: see bay4.] I. $\nmid a$. Bay; of a bay

II n A bay horse; generally, any horse: formerly frequent in proverbial use, especially with the epithet blind or bold.

Blind bayard movea the mill

A person who is self-confident and ignorant: usually with the epithet blind or bold.

The more we know, the more we know we wsnt:

What Bayard boulder then the ignorant?
Marston, What you Will, Ind. Phillip the second, late king of Spain, percetving that ing of hls mines of ailver in the West Indiea, etc. Gerard Malynes, Lex Mercatoria (1622), p. 189 What are most of our paplsts, but atupld, ignorant and

[Obsolete or arehaic in all uses.]

ayard $2 \nmid, n$. [< OF. baiard, bayart, a basket ased for the earrying of earth and fastened about the neek; perhaps a faneiful application hand-barrow used for carrying heavy loads, especially of stones. 
bayardly

bayardly $\nmid$ (bā'

A blind erednlity, a bayardly conflence, or an imperion. bayberry (bā'ber"i), n.; pl. bayberries (-iz). [< bay ${ }^{1}+$ berry $\left.{ }^{1}.\right]$ 1. The fruit of tho bay-tree, or Laurus nobilis. -2. The wax-1nyrtle, Hyrice cerifera, and its fruit. The conting of wax upon tho berries is known nu bayberry-tall

3. In Jarnaica, tho Pimenta acris, from which an oil is obtained which is used in the Inanufucture of bay-rum.

bay-birds (bä'berdz), $n ., l$. A eollectivo namo of numerous sunall wading birds or shore-birds, chiofly of the snipe and plover families, which frequent the mudily shores of the bays and estuaries along the Atlantic coast of tho United States.

bay-bolt (bā'bōlt), $n$, A kind of barbed bolt. See bolt 1 .

bay-breasted (bā'bres"ted), a. Having the breast buy in color: as, the bay-brcasted warbler. Dendroca enstumea, one of the eommonest birds Dendraca enstumea, on

bay-cod (b's'kod), $n$. The name of a fish of the family Ophidide, Genypterus blacodes, of Ne Zealand, also ealled clouly bay-col and ling.

bayed (båd), $a$. [<bay $\left.{ }^{3}+e l^{2}{ }^{2}\right] 1$. Having a bay or bays, ns a building: as, "the large bay" a bay or recess.

A hardsome and substantial mansion, the mumerons gable-chds nud bayed window's of which hespoke the owner bayesł, $n$. See baizc.

bayeta (bä-ya'tii), n. [Sp., baize: see baize.] A common kind of coarse baize manufactured in Spain.

Bayeux tapestry. See tapcstry.

bay-gall (bâ'gâl), n. A watercourse covered with spongy earth, mixed with matted fibc

bay-leaf (bā'lêf), n.; pl. bay-learcs (-lēvz).

The leaf of the sweet-bay or laurel-tree, Laurus nobilis. Bay-leaves are aromatic, are reputed atimnlant and narcotic, and are used in medicine, cookery, snd conSome as

2. Same as bay ${ }^{1}, n .3$.

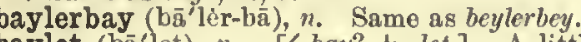

baylet (ba'let), n. $\left[<b a y^{2}+-l e t.\right]$ A little bay.

bay-mahogany (bā'mạ-hog"ạ-ni), n. Same as bay-rood.

bayman ${ }^{2}$ (bā'man), n.; pl. baymen (-men). [< bui ${ }^{2}+$ man.] 1 . One who lives on a bay, or who fishes, shoots, or pursues his oeeupation in or on a bay.

When the birds are traveling with the wind, or as bay
men call it, "free wind." 2. Spocifically, in British Honduras, a mahogany-cuttor of the coast.

bayman' (bā'man), $n_{.} ;$pl. baymon (-men). [ for sick or wounded men on a vessel of nar.

bay-oil (bä'oil), $n$. An oil manufactured from the ripe berries of the bay-tree of Italy, nsed the ripe berries of the bay-tree of
in veterinary medicine. II E

in veterinary medicine. II Elrath.
bayonet (bä'o-net), $n$. [< F. baionnette, formerly bayounette, a small flat poeket-dagger or a knife hung at the girdle, like a dagger, now a bayonet, $=$ Sp. bayoneta $=$ It. baionetta, a bayonet, nstally derived from Bayonne, in France, because bayonets are said to have been first made there (Bayonne, Sp. Bayona, is said to mean 'good harbor,' $<$ Basque baia, said to mean 'good harbor,' Basque baia,
harbor (see bay $)$, + ona, good); but ef. F' "bayonnier, as arbalestier [see arbalister]; an old word" (Cotgrave), < bayon, baion, the arrow or shaft of a erossbow.] 1t. A short flat dagger.-2. A dagger or short stabbing instrument of steel for infantry soldiers, made to be attached to the muzzle of a gun. In Its originsl form It has a sharp [E] point and thre forms havo been introdinced. (See below.) It was at
flrst lnserted in the barrel of the gun,
after the soldier wooden handle fitted to the bore; but it was afterward zasle with an iroul socket and ring passing over the muzgeldier might fle with his bayonet fixed.

3. In mach., a pin whieh plays in and out of holes mado to receive it, and which thus serves

to conneet and rlisconnect parts of the machinery. Sec bayonet-clutch.-Knife-bayonet, a com-
483

Bdella

Wimed knife and bayonet artanged to fit the muzzle of $n$
rifle, carried when not fin use in a sheath altaclicel to the waint-lsclt.-Rod-bayonet, a long steel rod with triangn-

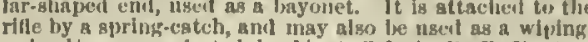

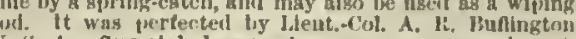
I. S. A. - spanish bayonet, a comnum name fiven to platits beionging to gevernil spectes of J'teren, with narrow,

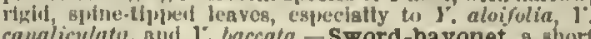

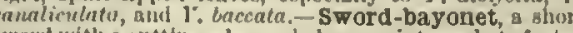
swost with a custing pelge and shary point, made to fasten liy as airing -eatch to the barrel of a ritte or enrbine. It now the usual form of military bayonet. - Trowel-bayonet, a form of bayonet with a short snil broad lint ghart. manner of a trowel, as an hutrencling toot. It was inyentefl by Col. Fidmund Rice, U. S. A., snd tas done good serNeo fin

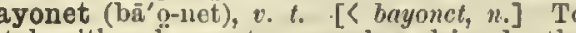
bayonet.

You send troops to sabre and to bryonel 11 into a sub. mission.

bayonet-clasp (bā'o-net-klisp), . A movable ring of metal about the socket of a bayonet which serves to strengthen it and to provent its disengagement.

bayonet-clutch (bā'n-net-kluch), $n$. In mach. a form of elutcli armed usually with two prongs (a a), which when in gear aet

lugs of a friction-strap (b)

fitted on a side-boss of the

wheel to be driven, the lat

ter being loose on the same shaft. The eluteh is attached to the shaft by a leathcr-key, and When drawn lack or ont of gear
with the strap the wheel remains at rest, and the cintch continues to rerequired to set the nucinery again

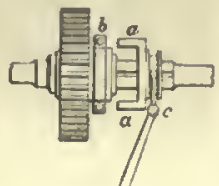
ward by the fork $c$, and its prongs, engaging wit! the bayonet-joint (bā'o-net-joint), $n$. A form of coupling or soeket-joint resembling the mode of attachment commonly adopted for fixing a bayonet on a musket.

byou (bīo $), n$. [A corrupt form of $\mathrm{F}$. boyan, a gut, a long, narrow passage (ef. a similar use

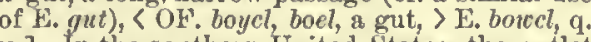
of a lake, or one of the several outlets of a river through its delta; a sluggish watercourse. For hours, in fall days, I watched the ducks eumningly
tack snd vecr and hold the middte of the pond, far from the sportsman; tricks which they wllt have less need to prac-
tise in Loulsina bayou.
Thoreau, Walden, p. 254 . Under the shore his boat was tied.

And alt her listless crew

atched the gray alligator slide

bay-porpoise (bā'pốr'pus), n. A typieal porpoise, as of the genus Phocana; a puffing-pig: so called from the frequent appearance of the animals in bays or estuaries.

bay-rum (ba' 'rum'), n. [<bay $\left.{ }^{1}+r u m^{1}.\right]$ A fragrant spirit much used as a cosmetic, ete. especially by barbers, obtained by distilling the leaves of the Pimenta acris (see bayberry,
3 , of the nat aral order Myrtacec, with rum, or by mixing the volatile oil procnred from the leaves by distillation with aleohol, water, and United States Pharmacopœia.

bays ${ }^{1}$ (bāz), n. [Prop. pl. of bay ${ }^{1}$.] See bay ${ }^{1}$ bays ${ }^{2}$, ". [Prop; pl. of bay ${ }^{6}$.] See baizc.

bai salt, basc-salt, < lato ME. baye salt; ef. Dan. baisalt $=$ G. baisalz, after E.; appar. < bay ${ }^{2}$ (some suppose orig. in ref. to the Bay of Biseay) + to salt obtained by spontaneous or natural

evaporation of sea-Water.
bay-stall (bā'stâl), $n$. In arch., the bay of a sand sre used for making silppers and as betlows-leather. window; a window-seat. bayt $t, v$, and $n$. Obsolete spelling of bait1. B. B. A common abbreviation in mineralogispcuscr.
bay-tree (bā'trē), n. [< ME. baytre (whence is infusible $B . B$.

appar. MID. baeyterc); $\left\langle b_{a y}{ }^{2}+\right.$ trec.] 1. The bbl., bbls. Abbreviations of barrcl and barrels lanrel-tree, Laurus nobilis, a native of Italy respectively: as, 1,000 bbls. flour.

and Greece, growing to the height of 30 feet.- B. C. An abbreviation of beforc Christ, used 2. In the eastern United States, a name of the in noting dates preceding the Christian era: Iagnolia glauca, and in California of the $\mathrm{Cm}$ - as, the battle of Thermopylre was fought 480 bellularia Californica.

ayur (bä-yör $\left.\mathbf{r}^{\prime}\right), n$. Javanes

I'terosperinum Javanicum.

bay-window (bā'win'dō), n. [<bay ${ }^{3}$, a recess, + B. D. An abbreviation of Bachelor of Divinity.

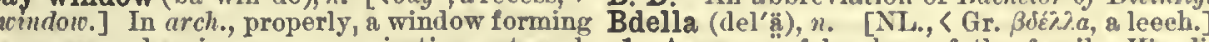
a recess or bay in a room, projecting outward, 1. A genus of leeches, of the family Hirudiand rising from the ground or basement on a nida or Gnathobdellide. Also written Bdellia. plan rectangular, semi-octagonal, or semi-hex- [Not in use.]-2. The typical genus of the agonal, but always straight-sided. The term is, family Bdellida, $B$, longicornis is an example. 


\section{bdellatomy}

bdellatomy (de-lat'ó-mi), n. [<Gr. $\beta \delta \notin \lambda \lambda n$, a leech, + roph, a cutting.] 1. The act or operation of incising a leech while sucking, so that continue to suck. -2 . The application of the bdellometer.

Bdellia (del' Bdellidæ (del'i-dē), n. pl. [NL., < Bdella + -ide.] A family of tracheate mites, of the order Acarida, class Arachnida, having the head distinct from the thorax and elongated into a proboscis, chelate cheliceres, long thin raptorial pedipalps, cursorial legs of six or more composed of sclerites embedded in soft skin. The animals are found creeping in damp places. Besides Bdella, the family contsins the genus Scirus.

Bdellinæ (de-lī'nē), n. pl. [NL., $<$ Bdella + -ince.] A

bdellium (del'i-um), $n$. [In ME. bdelyum, bidellium, < LL. bdellium, < Gr. $\beta \delta \varepsilon^{\prime} \lambda \lambda$ iow, a plant, a des, Pliny); used (also in the form $\beta \delta(\lambda \lambda \lambda \alpha)$ to translate Heb. b'dolakh, a precious article of merchandise mentioned along with gold and precious stones (Gen. ii. 12). The opinion of the rabbins, which Bochart supports, is that b'dōlakh signifies orig. a pearl, and as a collective noun pearls, which may be compared to grains of manna; hence its secondary sense of a gum.] A name given to two aromatic gumresins, similar to myrrh, but weaker. Indian bdellium is believed to be the product of Balsamodendron used for the same purposea as myrrh, but chiefly as at ingredient in plasters and as a periume. Anl Egyptian
resin also called bdellium ia obtained from the doun-palm, Hyphone Thebaica, of Upper Egyt.
Hypto leech, +-oida.] A family of rotifers that swim and creep like a leech, with the foot retractile, jointed, telescopic, and forked at the end.

bdellometer (de-lom'e-tér), $n$. [ [ Gr. $\beta \delta \varepsilon \lambda \lambda a$, a leech ( $\beta \delta \delta^{2} \lambda \lambda \varepsilon v$, milk, suck), + $\mu \varepsilon \tau p o v$, a
measure. tute for the leech. It consists of a cupping-glass, to which a scarificator and an exhausting ayringe are at.
tached. Dunglison.

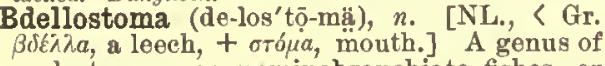
eyelostomous or mar'sipobranchiate fishes, or myzonts, referred to the family Myxinide, or made the type of a family biled from the comperison of the suctorial mouth to that of a leech. There are 7 branchial apertures or openings of the branchial aacs. B. heptatre.
$m \in$ is found at the Cape of Good Hope. Thie genua ia the

bdellostomid (de-los'tō-mid), n. A myzont of the family Bdellostomida.

Bdellostomida (del-os-tom'i-dē), n. pl. [NL., tretous myzonts, represented by the genus Bdellostoma: synonymous with Heptatremido (which see).

bds. An abbreviation of boards, in use among bookbinders and booksellers.

be $^{1}(\mathrm{~b} e \overline{)}, v$. i., substantive verb; pres. am, art (sometimes beest), is, are (sometimes be); pret. was, wast, were; subj. be, were, wert; impv, be pp. been; ppr. being. [Under the verb be are classed, as identical in sense, the surviving
forms of three orig. independent verbs, which, supplementing each other's defects, serve together to make up the substantive verb or copula; they are represented by the forms $b e, a m$, ME, be, bee, Been inf., early mod. E. also bee, pres. ind. sing. 1st pers be early mod. $\mathrm{E}$, also bee, < $\mathrm{ME}$. be, bee, beo, $<$ AS. bco, rarely bcóm, biom (retaining the suffix -m, which appears also in $a m$ ) $=$ OS. bium $=$ OFries. bem $=\mathrm{OHG}$ pim (bim), MHG. G. bin, $2 \mathrm{~d}$ pers. beest, be'st,
dial. bist, $\mathrm{M}$ ME. beest, best, beost, bist, < AS. bist $=\mathrm{OS}$. bist $=\mathrm{OHG}$. pis, pist, MHG. G. bist; 3d pers. be, dial. also beeth, bes, < ME. beth, beoth, north. bes, < AS. bith; pl. be, arehaic and dial. been, ben, bin, also beth, < ME. been, ben, bin, ete., prop. (as ind.) beeth, beth, beoth, 3 AS beoth (in all three persons) $=\mathrm{OHG}$. 1st pers. pi-
rumes, $2 \mathrm{~d}$ pirut $(\mathrm{MHG}$. birnt, bint) (3d sint); with similar forms in subj., ete.; all from a common Teut. $V$ "beu $=\mathrm{L}$. fu-in perf. fuisse, have been (ind. fui, I was, I have been), fut. part. futurus, about to be (see future), fut. inf. fore, be about to be, = Gr. фírofal, be, become, grow (act. фiztv, produce) (> ult. E. physic, physical, ete.), = Skt. $\sqrt[V]{ }$ bhü, become, come into being,
484

beach-birds

take place, exist, be; the sense 'become' being still evident in AS., and giving the present generally a future implication. 2. Am, ete., pres.
ind. (without inf.): 1st pers. am (often contr. ind. (without inf.): 1st pers. am (often contr. $m$ in $\left.I^{\prime} m\right),<$ ME. am, amm, em, < ONorth. cam, am, AS. eom = Icel. em (mod. usually er $=$ Goth. dial. $\dot{\varepsilon} \mu \mu i$ (orig. $\left.{ }^{*} \dot{\varepsilon} \sigma \mu i\right),=$ OBulg. yesmi $=$ Bohem. jsem, etc., = Lith. esmi, etc.. = Skt. asmi; $2 \mathrm{~d}$ pers, art, $<$ ME. art, ert, $<$ AS., cart, ONorth. arth

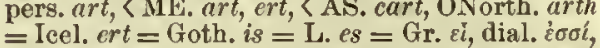
$=$ OBulg. yesi, ete., $=$ Skt. asi; $3 \mathrm{~d}$ pers. is, $<\mathrm{ME}$. $i s, c s,\langle\mathrm{AS} . i s=0 \mathrm{~S}$. $i s t=$ OFries. $i s t=\mathrm{OHG}$. MHG. G. ist $=$ Icel. $c r$, earlier $e s,=$ Sw. $a r=$ Dan. er (extended in Sw. Dan. also to 1st and $2 \mathrm{~d}$ pers. $)=$ Goth. $i s t=\mathrm{L} . e s t=\mathrm{Gr} . \dot{\varepsilon} \sigma \tau i=$ OBulg. yesti, etc., = Skt. asti; pl. are, <ME. are, aren, arne, ere, cren, erne, < ONorth. aron, caron (in al three persons) = Icel. 1st erum, $2 \mathrm{~d}$ eruth, 3d eru, $=$ Sw. 1 st äro, $2 \mathrm{~d}$ ären, $3 \mathrm{~d}$ äro, = Dan. cre: a sing. art, ete., taking the place in Seand. and ONorth., etc., of the older form, namely, AS. sind, also in double pl. sindon (in all three persons, $=O S$. sind, sinden $=$ OFries. send $=O H G$. L. L. 1st sumus, $2 \mathrm{~d}$ estis, $3 \mathrm{~d}$ sunt, $=$ Gr. 1 st $\varepsilon \sigma \mu \varepsilon v, 2 \mathrm{~d}$ 3d sant ${ }^{2}$; also in subj. (lost since early ME.), AS. 1st pers. $s \bar{i}$, pl. $s \bar{n} n==$ OFries. $s \bar{e}=$ OS. $s \bar{i}=$ OHG. MHG. $s \bar{i}$, G. $s e i=$ Icel. $s \bar{e}$, earlier $s j a \bar{a},=$ Goth. sijau, etc., = L. sim, OL. siem = Gr. eim $=$ Skt. syant, ete., with similar (in AS. identical) forms for the other persons; all from a comWas, pret. ind. (without inf. in mod. E.): sing., Was, pret. ind. (without inf. in mod. E.): sing., was $=\mathrm{OS}$, vas $=\mathrm{OH}$ was, MHG. G. var = Icel. var, earlier vas, = Sw. Dan. var = Goth. vas; $2 \mathrm{~d}$ pers. wert, earlier were, < ME. were, < AS. wēere; pl, were, < ME. were, veren, < AS. aç̄oron (so subj. were, < ME. cere, AS. veare, ete.; AS. impv. wes, of which forms in the other tongues; pp., AS. gewesen (usually beón, E. been), etc.: prop. pret. (and pp.) of the strong verb, AS. inf. wesan $=\mathrm{OS}$. wesan $=$ OFries. wes $a=\mathrm{D}$. wezen $=\mathrm{OHG}$. wesan, MHG. vesen (G. wesen, n., being, a being) = Icel. vera, earlier vesa, = Sw, vara = Dan. vare live. To the same root are referred Gr. áorv eity, dwelling-place (see asteism), L. verna (for *vesna), a household slave (see vernacular). - In mod. literary $\mathbf{E}$. the form be in the ind. is only archaio or poetical, but it still flourishes in dial. use.] 1 . To exist; have existence or being
possess reality; be the ease; be true or real.

$$
\text { To } b e \text {, or not to } b e \text {, that is the question. }
$$

Creatures which only are, and have a dull kind of being Sir T. Bronne, Religio Medici,
Tine was, Thime is, and Time shall be no more.

2. To take place; occur; happen ; come about as, the wedding will be to-morrow; his birth-
day was last week; it was to be. -3 . Usually, be is a mere copula, or sign of predication, a link between a subject and a predicate. As anch it asserts, or expresseg as fact, the jnclusion of tine anbject
among the ethings denoted by the predicate, or the posses. gion ly the subject of the characters aignified by the pred.
jcate; and thia it does with temporal and modal modift. cations, while the whole substance of the predication, or
all that is predicated, is expressed aeparately, in noun or all that is predicated, is expressed aeparately, In nown or
adjective form, or the equivalent of sucil : thus, 1 arn
rood he was a hero they will be there we should hore been beloved. Hence, every other predicating word or verb may be analyzed into a form of be, expressing the is predicated : thus, he loves into he is loving, or he is a lover, and ao on. Such a copula is possessed by many
languages, being, as in English, reduced to that value by

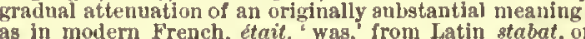
as in modern French, ctait, was,
nearly as exist, ilterally 'stand forth.

4. In metaph., to subsist in a state not necessarily amounting to actual existence ; have the rudiments of existence. See being. -5 . An jection to the mode of action or being expressed by the principal verb. (a) Joined with a present participle, it has the grammatical construction
of a predicate adjective qualifying the aubject, to make a continuoua or progressive or imperfect preaent : thus, the language has rather recently acquired a correapond

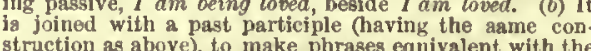
struction as above), to make phrases equivalent with the passive verb-forms or verb-phrases of other languages
thus, he is loved, Latin amatur, German er vird geliebt.
Icnce auch phrases are ordinarily viewed as making a passive confugation of the Euglish verb. They are un. with a predicate participle: : thus, he is beaten is passive when it tneans 'aomebody ia beating him,' but not when tim.' (c) Formerly, as atill to a very limited extent (much
hing

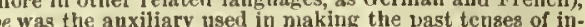
ralsitive verbs as have of transitivea: thma he is come thcy were gone (Gernan er ist gekom men, French ils étaient alles), and so on. At present, have has cone
auxiliary almost universally used in this scnse.

The heatlien are perished out of his land Ithat is, have (d) An influitive with to after be forms a sort of future, ften with a certain implication of obligation: thus, he is to come, they urere to appear, she wowild have been to hilane or to be biamed. [Be, with $l_{0}$ in perfect tenses have been, had been, etc.), is uaed in the sense of go, yet
tarilly except in collounial atyle: thua, he has been to rardly except in colloquial atyle : thna, he has been to
Paris; we had been to Bee her.]-Been and, a commoul vilgarism introduced pleonastically into the perfect and been and gone and.

Sir Pitt lias been and proposed for to marry Miss Sharp.

Let be, to omit or leave untonched; let alone; cease. Let be, said he, my prey.

Dryden. Let be thy wail and help thy fellow-men. There 1s, etc. See there.

be $\mathrm{e}^{2}$ (bē), n. [<ME. be, < AS. be = D. G. Dan. Sw., ete., $b e=\mathrm{F} . b e=\mathrm{Sp}$. Pg. It. $b e,<\mathrm{I}$. $b e$, shortened from beta (<Gr. $\beta$ ĭta: see beta), or formed from $b+e$, the usual assistant vowe in the names of the letters.] The name of the second letter of the alphabet, usually written simply $b$ or $B$. See $B$.

$\mathrm{be}^{3} \mathrm{t}$, prep. Obsolete form of by. Chaucer.

Be. In chem., the symbol for beryllium (the same

e-1. [ME. be-, in early ME. commonly bi-, As. be- $b i-,=\mathrm{OS}$. $b i-=$ OFries. be-, $b i-,=\mathrm{D}$ IHG. G. be- = Goth. $b i$ - (lengthened under stress, as in comp. with a noun, AS. bi-, bigD. bij-, OHG. MHG. bi-, G. bei-), an inseparable prefix, orig. the same as the prep., AS. $b c$, $b \bar{i}$, E. by, meaning primarily 'about,' being prob. $=\mathrm{L} .-b i, \mathrm{Gr} .-\phi \ell$, in L. ambi-, Gr. $a \mu b \ell$, An inseparable prefix of verbs, and of nouns thence derived. It means primarily 'about," 'around,' thence derived. It means primarily 'about," "around,
as in beset, begird, whenee the more general aense 'around,' "ail over," leading to a merely intensive use as in bermear, bespatter, berprinkle, etc. It is also used fog, be mire, etc., or from intransitive verbs, as belie, be howel, besing, ctc., verbs of elther class often conveying
slight contempt, as bepraise, beplaster, beponder, etc., and are lience often made for the nonce. In a few verbs, al while in many verbs this preftix, through loss of the aimple verb, or a deffection of its aense, or by mere dilution, has be-2. [ME. and AS. bc-, bi-, or separately be, $b i$, being the prep. with following adv. or noun: which may also be used as prepositions or conjunctions. It is properly the preposition by, Middie English be, bi, (a) used adverbially, as in before, behind, or (b) merged with the governed noun, as in because, be. side, that is, 'by cause, ' 'by aide' ': so also in behalf, origi-
nally a prepositional phrase, now taken as a noun. See beach (bēeh), n. [Formerly also beech, beatch, baich, baiche, bache ; first in early mod. E., appar. dial., with the meaning first given. Origin unknown.] 1. The loose pebbles of the sea-
shore; shingle. [Eng.] -2. That part of the shore of the ser. or of a lake which is washed by the tide and waves; the strand. It may be sometimea used for the ahore of large rivers. It usually Only the long waves as they broke In ripplea on the pebbly beach.

Raised beach, in geol., a shelf or terrace of ahingle, gravel, and aand, elevated ahove the sea-level, and ind and aubsegnent upheaval; the margin of an ancient gea, beach (bēch), v. [< beach, $n$.$] \quad I. trans. To$ run or haul up (a ship or boat) on the beach. We rowed ashore, dressed in our uniform, beached the boat, and went up to the fandango.
R. H. Dana, Jr., Before the Mast, p. 231.

II. intrans. To land upon a beach.

All that afternoon we drifted between sea and ahore, and beached at sunaet in a new land

c. 1'. Stoddard, South-Sea Idyls, p. 344 .

beach-birds (bēch'bérdz), n. pl. A collective name of sundry sandpipers or other small wading birds found in flocks on beaches. 
beach-clam

beach-clam (bēch'klam), ". A popular name of the Mactra solidissima. [Loeal, U.S.] beach-comber (bēeh'kō"mér), $n^{\prime \prime}$ 1. A long wave rolling in from tho ocean. Bartlett. vagrant and drunken habits, who idles about the wharves of seaports: used most frequentl This is a specimen of the life of half of the Americes and Eny'isli who are adrift along the cuasts of the l'acific

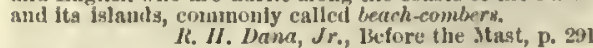

beached (bēclit), $p, a$. I. Having a beach borderal by a beach; formed by or consisting of a beach. [Rare.]

'imon hath made hs everlasting mansion
Upon tho beached verge of the salt tlood.

2. Run on a beach; strandod.

beach-flea (bēch'tlè), n. A namo of sundry small amplipod emistaceans. Also called sand hopper, shore-jumper, and sand-flea.

beach-grass (bēeh'grås), $n$. The sand-reed, Ammoplila armilinacea, a conrse grass with stout running root-stocks, growing on sandy beaclies and protecting them from the winds.

beachman (bēeh'man), $n$.; pl. benehmen (-men) A person on the coast of Africa who acts as interpreter to ship-masters, and assists in conducting the trade. Imp. Diet.

beach-master (béch'mủs"tèr), n. 1. Ninut., naval officer appointed to superintend tho discmbarkation of an attacking force.-2. A nam used in some places for a male seal.

beach-wagon (hēeh'wag'on), $n$. A light open wagon with two or more seats, used on heaches. beachy $\dagger$ (hế'chi), a. [<beach $\left.+-y^{I}.\right]$ Covered with beach or shingle; pebbly; shingly.

The beachy girdle of the ocean. Shak., 2 llen. $1 \mathrm{~V}$, ili. 1.

beacon (bë'kon or $-\mathrm{kn}$ ), $n$. [ $\langle\mathrm{ME}$. belien, bekene, <AS. beácen, bècen, bêen, a sign, signal-standard, $=\mathrm{OS}$. bökan = OFries, bēken, bäken = D. baak= LG. bäke ( $>$ G. bake) = OIIG. bouhhan, MHG. bouchen = Ieel. bākn (after AS.), a sign. Hence beckon and beck2.] 1. A guiding or warning signal; anything fixed or set up as a token especially, a signal-fire, either in a cresse and placed on a pole, or lighted on a tower or an emineuce. Such beacons were tormerly much user to signal the approach of an enemy or to spread a cali or warning for any purpose, a chas to great distances.

Mlodest doubt is call'd
The beacon of the wisc. Shak., T. and C., II. 2 Uncertain, troubled, earnest wonderers belield his intellectnal fire as a beacen burniug on a hill-top.

2. A tower or hill formerly used for such pur poses. Various hills in England and the older parts of the Uniter Statea have the name of Beacon, from

3. A lighthouse or other object placed conspic uously on a coast, or over a rock or shoal a
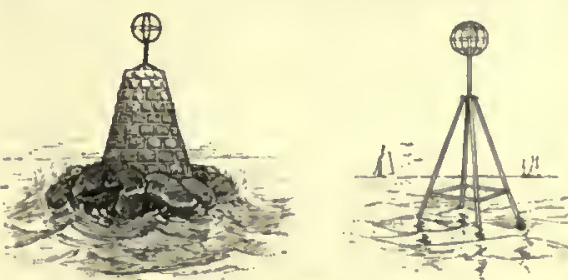

sea, to give notice of danger, or for tho guidance of vessels. -4. A painted staff about feet long, carrying a small square flag at the top, used in camps to indieate an angle of the quarters assigned to a regiment or company. wapentake; probably a distriet throughou which a beacon could he seen, or which was bound to furnish one. N. E. D.

beacon (bē'kon or -ku), v. [< beacon, $n_{\text {. Cf }}$ beckon.] I. trans. 1. To illumine or light up as a beacon. That beacons the darkness of heaven.

ampbell, Lochiel'a Wamin

2. To afford light or aid to; lead; guide as a beacon.-3. To furnish or mark with beacous as, to beacon a coast or a boundary: sometime with off. -4 . To use as a beacon; mako a beacon of.

No, if other things as great in the Church and in the inte of life both economicall and politicall be not look that Zwinglius and Calvin hath beacon'd up to us, that we are stark blind.
485

II. intrans. To serve or sline as a boacon. The sout of Adonals, like a star Beacons from the abode where the Fternal are.

Where the lighthouge beacons liright

eaconage (bë'kon-ạj), n. [< beacon + -aye. $]$ Money fraid for the inaintenance of beacons. acon-blaze (bë'kon-bläz), n. A signal-light or -fire. Tenmyson.

beaconed (b-' kond), a. Ilaving a beacon. The foss that skirts the beaconed lilli.

beacon-fire (bē'kon-tir), $u$ A fire lighted up a a beacon or signal; a signal-fire.

beacon-tower (b'j'kon-tou" èr), n. A tower on hich a beacon is raised.

A beacon-tourer above the waves, Tennyran, I'rincess, Iv.

bead (bêd), n. [<ME. becle, a prayer, also (in peire of bedes, a pair of beads) a bead used in counting prayers, $<$ AS. bedu (rare, and tho nom. is not found), in comp. bed- (= OS. bed $=$ OFries. bede $=\mathrm{D}$. bede $=$ OHG. beti, MIG. bete, G. bitte $=$ Goth. bida), fem. (also geber $=$ OS. gibed $=$ OIIG. gabet, MHIG. G. gebet neut.), a prayer, ( biddan, ete., pray: see bic. Bouds are used by Roman Catholics to koep them riglit as to tho number of their prayers, ono bead of tho rosary being dropped ever time a jrayer is said; hence tho transference of the name from that which is counted (tho prayers) to that which is used to count with. Cf. Sp. eucntas, Pg. contas, the beads of a rosary, <Sp. Pg. contar, count.] 1t. Prayer; prayer; specifically, a prayer of tho list or bead-roll, read at public ehureh-services by the preacher before lis sermon, or by the curate (see bea(-roll): usually in the plural. Yence, in this aenae, to bic

When holy and devout religieus men

Are at their beads, 'tis much to draw them thence

So aweet ia zealous contemplation. Shak., Rlch. 111., ill. ?.

2. One of the little balls, of wood, cocoanut shell, pearl, glass, jewels, or other material, strung in a preseribed order, which form the chaplet or rosary in use in the devotions of Roman Catholies, Buddhists, ete., to keep count of the number of prayers said. See pair of beads, below.

The commonest, though not the only, appliance for reckoning these prayers was, and still 1, \& atring of bead "Iall MIarya" "16 parted by a larger bead, to tell when the
"Our Father" must be recited. Rock, Church of our Fathers, 1Il. 1. 320 .

3. Anything resembling a rosary-bead, strung with others for ornament, as in necklaces or beadwork: as, glass, amber, metal, coral, or other beads.

With acarfs, and fans, and double change of bravery,
With amber bracelets, beads, and all this knavery.

4. Any small globular, eylindrical, or annular body, as the small projecting piece of metal at the end of a gun-barrel used as a sight, a drop of liquid, ete.

Beads of sweat have stood upon thy brow.

Ife ralsed his plecegradually, until the bead
barrel was brought to a line with the spot which he the
tended to hilt.
J. J. Audubon, Ornith. Biog., I. 293

5. One of the circular markings of certain diatoms. - 6. The bubble or mass of bubbles rising to the top or resting on the surface of a liquid when shaken or decanted: as, the bea of wines or spirits.

Give me the wine of thought whore bead

sparkles along the page I read.

Pleasure, that immortal hitter, Lanea on a Fy-Leat. parklng in the cup, effervescea soon and aubsides.

7. A glass globule for trying the strength of alcoholic spirits. Beada are numbered according to their speeiftc gravitien, and the strength of the apirit is
denominated by the number of that one which remains auspended in it, and velther sinka to the bot tom nor fleats on the surface. Beads, in determining the strength of hydrometer.

8. In mineral., in the blowpipe examination of minerals, a globule of borax or other flux which is supported on a platinum wire, and in which the substance under examiuation is dissolved in the blowpipe flame.-9. In areh. and join cry, a small convex molding, in section a semi circle or greater than a semicircle; properly a plain molding, but often synonymons with astragal, which is better reserved for a smal convex molding eut into the form of a striug of bead-furnace

beals. The beal is a very frectucnt ornament, nsed to the capital of a

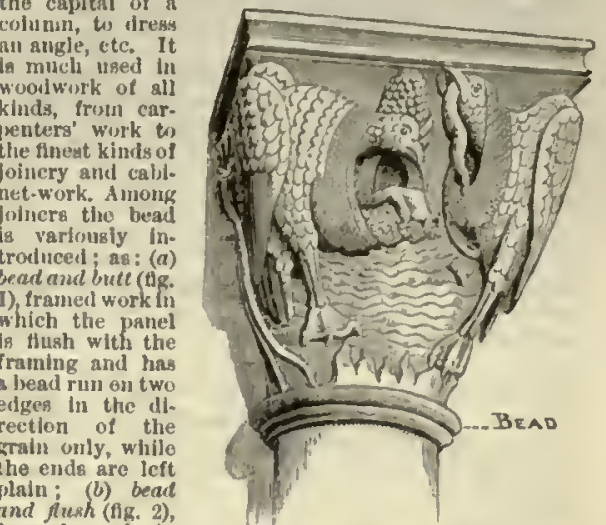
nd flush (flg. 2) which a bead to run on the edge of the fraving: (e)

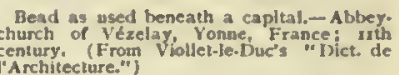
(tig. 3) the edge of a plece of stuff on which a bead la (d) bead and double quirk, or return bead (fly t) the

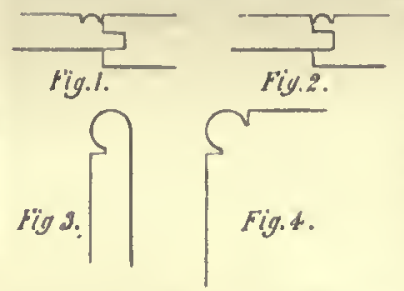

of stuff on which a bead is atuck and quirked bor relieved (e) bead, butt, and panel which has edges on one aide other alde to plain. (f) bead, flugh, and
square, framing which in beaded

10. In bookbinding, shoemaking, etc., any cordlike prominence, as the roll on the head-band of a book, the soam of a shoe, etc.-Bally's at tbe inoon'a limb in a total solar eclipge about the instant of internal contact. The phenomenon is due to diffraction and irradtation, and is much exaggerated in case th telescope la imperfect or out of tocua. So called from the Eaglish astronomer Francis Bally, who obaerved these ob.
jecta in the annular eclipse of Biay 15, 1836. - Druidical bead Same as adderotone. - Pair of beads [ME. peire
of bedes], that 18, "get of beuda" (Shak., Rtch. II., if. 8 ) a rosary; now, apeciffcally, a chaplet of five decades, that as thus reatricted, is the form in conet or pair of beads, name of the beads. The large beads between the decade were formeriy called gatedies (see gaud, gaudy); each
geparate bead, orgrain, as it to now termed, Tyndale calla Of amal coral aboute hir arm she bar
A peire of bedes gauded al with grene. "a paid tor aaying the rosary went by severa! name heada "; but never wcre they called a rosary.
Quoted in Rock', Church of our Fathers, 11. 1. 327, note. St. Cuthbert's beads, or fairy beads, the small pertorated Joints of the stems of fossll enerinites, formerly also in singuiar, to bid a bead) $13 \mathrm{E}$, bidden or beden a bede or bedesl, literaliy, to offer (one's) prayers; hence the later equivalent phrases 10 sny or recite $($ one's) beads, now with
reference, as literally in the phrase to tell (one' 8 ) beads, to The phrasea fo count and to number (une's) beads are merely literary.

A peire of bedis eke she bere
Upon a lace, alle of white threde.

on which that she hir bedes bede. Rom. of the Rose, 1. 7379

To draw a bead on, to take deliberate aim at, with a bead (bêd), $v, t$. [< bead, n.] To ormament with beads; raiso beads upon.

beaded (bé-'ded), p. a. [< bead +ed2.] 1. In the form of a bead or of a collection of beads. With beaded bubles winking at the hrin

With woolly breasts and beaded eyes.

2. Provided with or formed of beads, or of small bodies having the appearance of beads: as, a beaded necklace or bracelet.-3. In bot. moniliform: said of vessels that are deeply constricted so as to resemble strings of beads. -4. IIaving a head: as, beaded ale.-Beaded lace, lace through which beads are woven in the pattern.beader (hé'dér), $x$. A tool for raising ornamental beadwork on metal boxes.

bead-furnace (bēd'fér"nās), $n$. A furnace in which the small glass eylinders from which beads are made are rounded. The cyllnders are placed in a drum over a flre sufficiently hot to solten the 
beadhook

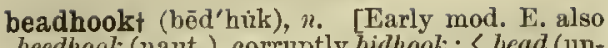
beedhook (naut.), corruptly bithook; ' bea
certain) + hook.] A kind of boat-hook.

$2 d$ Le. Arm'l men? with drum and colours?

Se.
But bright in arms, yet bear half pikes or beadhooks.

beadhouse (bēd'hous), $\eta_{0}$ [Also archaically bedehouse, north. dial. beadus (not found in ME.), < AS. bedhũs, < bedu, prayer, + hüs, house: see bead and house.] Formerly, a hospital or an almshouse for the founders and benefactors of which prayers were required to be said by the beneficiaries. Also spelled bedehouse

beadiness (b $\bar{\theta}^{\prime}$ di-nes), n. The quality of being

beading (bēediug), n. [<bead $\left.+-i n g^{1}.\right] \quad 1$. In arch. and joinery, a bead; collectively, the beads used in ornamenting a given strueture or surIn com., a preparation added to weak spirituous liquors to canse them to carry a bead, and to hang in pearly drops about the sides of the bottle or glass when poured out or shaken, it being a popular notion that spirit is strong in proportion as it shows such globules. A very small quantity of oil of vitriol or oil of almonds mixe
with rectifled spirit to olten used for this purpose.

beadle (bé'dl), n. [Early mod. E. also bedle, beedle (Sc. beddal), 〈ME. bedel, bidel, budel (with aceent on first syllable), $<$ AS. bydel $(=\mathrm{D}$, beul $=\mathrm{OHG}$. butil, MHG. buitel, G. buittcl), a beadle, $\langle$ beódan, announee, command, bid: see bid. The word merged in ME. with bedel, bedell, with accent on the last syllable (whence the bedeau = Pr. Sp. Pg. bedel = It. bidella (ML. bedellus, bidellhs s) from Teut. The reg. mod. form from ME. bidel < A.S. bydel, would be mod. biddle; it so exists in the proper name mod. biddle; it so exists in the proper name
Biddle. 1 1t. One who makes proclamation; a herald.-2. A crier or messenger of a court; a servitor; one who cites persons to appear and answer. '[Raro.] - - In universities, a subtermed a bedel (which see).

It ahall be the duty of the faculty to appoint a college day, and preserve order during the exllitilitions

4. In England, a parish officer having various subordiuate duties, such as keeping order in chureh, punishing petty offenders, waiting on the elergyman, attending meetings of vestry or session, ete.

And I, lorsooth, in love! I, that have heen love'a whil ; A very beadle to a himorous sigh, Bread and a slavish ease, with some assurance
From the base beadle's whip, crown'd all thy bopes

5. The apparitor of a trades guild or company Also spelled bedell and bedel, in senses and 3

beadledom (bē'dl-dum), n. [<beadle + -lom. $]$ Beadles collectively, and their characteristics

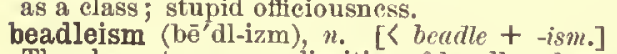
The character or peculiaritios of beadles; beadledom. Diekiens. [Rare.]

beadlery (bế'dl-ri), $n$. [< bcadle + -ry. $]$ The

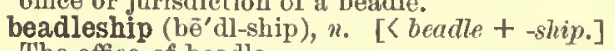
The office of beadle.

bead-loom (bēd'löm), $n$. A gauze-loom for making beadwork, the threads used being strun

beadman (bēd'man), n.; pl. beadmen (-men) [KME. beleman, <"bede, bead, a prayer, + man.] The original form of bearlsman.

They lade the lips of their beadmen, or chaplains, with
Tyndale. Tyndale.
Having thus owned the continuing sovereignty of the king, belore whom they presented themeselves as bedemen.

bead-mold (bēd'mōld), n. A name given to various species of mueedinous fungi, in which the spores are in necklace-like chains. They belong to Penicillium, Aspergillus, and similar genera,
and are fonnd on various vegetalle kinds of food and bead-molding (bēd'mōll/ding), n. In areh. same as bead, 9

bead-plane (bêd'plān), n. A form of plane used for cutting a bead. The cutting edge of the plane-iron Is a aenuicircle with a diameter equal to the diameter of
the required tnolding. bead-proof (bêd'pröf), $a .1$. Of such a nature
or quality that a crown of bubbles formed by
486

beak

shaking will stand for some time on the surface: said of spirituons liquors, and erronecertain standard of strength as ascertained by certain standard of strent. Sce bead, $n ., 7$.

bead-roll (bēd'rôl), n. [< bead, a 1rayer, + roll, a list.] 1. A list of prayers; specifically, before the Reformation, the list of the persons and objects for which prayers were said, read out by the preacher before the sermon. In "an order [of Henry V11., A. I. 1534] taken for preaching and realm" mention is made of the ehurch catholic capccially in langland, of the king and royal family, of the bishops and clergy, of the nobilitity and entire tenmporalty (laity) of the kingdom, particularly of snch as the preacher's devo.
tion may prompt him to name, and of the aonla of the laithlul departed. The bead-roll was prohibited by Jil. ward VI in 1548 . Jt has often been alypposed by later
writera to have had aomething to do with the recital of the beads or rosary.

2. Figuratively, any list or eatalogue; a long

Dan Chancer, well of English unde[yled, worthie to be fyled.

Neither in the Seripture without a pitiful beadrow of miserable torments.
Bullinger's Decades, 1587 (trans. Parker Soc.). The bead-roll of her vicious tricks, Prior, Alma, iii. 3. A rosary. -4 . $[<b e n d$, a dot, + rall, a cylinder.] In baakbinding, a brass roll with th Also cut in dots or bea
Also called bead-rono.

bead-sight (bēd'sit), $n$. A sight on a firearm consisting of a small round bead on a thin stem, placed in the lino of sight at the end of the barrel. Sometimes a small ring or porfoeadsman (bēdz'man), $n_{0}$ : pl. beadsmen (-men) [Also bedesman, eälier bedeman < ME bedeman, <bede, a prayer (see bead), + man.] 1 . A man employed in praying; especially, one who prays for another. In this aense the word was used In former times at the conclusion of petitions or letters to
great men, as we now wase "aervant " or "humble servant." Whereby ye hall bind me to be your poor beadm or ever unto almiglity God.

We your most sumble suljects, daily orators, and beads. your Clergy of Englants.

2. In England a M. Dixon's Hist. Chureh of Eng., it house or almshouse, or is suppost in a beadfunds.

In all onr old English fonndations for the sick, the old tactors living and dead - were aald every day by the inmates, who were hence also called beadsmen.
Qnoted in Rock's Clunrch ol our Fathers, III. 1. 136, note 3. Formerly, in Scotland, a public almsman one who received alms from the king, and was expected in return to pray for the royal wel. fare and that of the state; a privileged or licensed beggar. In this sense usually spelled bedesman.

A long blue gown, with a pewter badge on the right
arm; two or three wallets for holding the different kinds of meal, when he received his charity ; . . a all these at once marked a leggar by protession, and one of that privileged class which are called in Scotlanct the King's bedes-
men, or, vulgarly, Blue-gowns. Scott, Antiquary, I. Iy 4t. A petitioner.

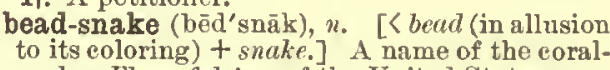
snake, Elaps fulvins, of the United States.

bead-stuff (bêd'stuf), $n$. The thin wood out of work.

beadswoman (bēdz'wùm"an), n. ; pl. beadscomen (-wim"en) [Also bedeswoman, earlie bedewoman, < MF. bede, a prayer, + woman. Cf. beadsman.] 1. A praying woman: some times used as an equivalent to "humble servant." See beadsman.

$$
\begin{aligned}
& \text { Honour done to your poor beadswoman. } \\
& B \text {. Jonson, Sad shepherd, } \\
& \text { My humbleat aervice to his grace, } \\
& \text { I am his beads-toman. }
\end{aligned}
$$

Shirley, Gratelul Servant, iii. house.

bead-tool (bēd'töl), n. 1. A turning-tool which has its cutting face ground to a concave curve so that it may produce a convex molding when applied to the work.-2. In scal-engraving, tool with an end adapted for cutting the ball and beads of coronets and other designs.

-tree (bèd'trē), n. 1. The Melia Azeda ach, natural order Meliacece. Its nuts are used lo See Melic

2. The name in Jamaica of a leuruminons tim bel-tree, Ormasia dasycarpa, with red globose A beak-iron (which see).
seeds.-Black bead-tree, of Jamaica, Pithecolobium beadwork (bēd'wèrk), $n$. 1. Ornamental work ormed of beads by embroidering, erocheting, tc. - 2. In joinery, beading (which see).

eady (bē'di), a. [ $\left\langle\right.$ bead $+-y^{\mathrm{I}}$. $]$ 1. Bead-like; small, round, and glittering: applied especially to eyes.

Miss Crawley could not look withont aeeing Mr. Bute's Thackeray, Vanity Fair, 1. xix. The titmonse turns his beady eye

Upon me as I wander hy.
Joel Bento Joel Benton, December Woods.

2. Covered with or full of beads; having a bead, as ale or other liquor.

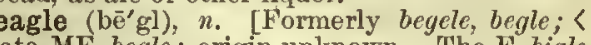
ate ME. begle; origin unknown. Tho F. bigle is from the E.] 1. A small hound, formerly kept to hunt hares, now almost superseded by the harrier, which is sometimes called by this name. The beagle is amaller than the harrier, compactly est beagles are little larger than lap-fogs.

To plains with well-breathed beagles we repair,

the circling hare.

Hence-2. Figuratively, one who makes a business of scenting out or hunting down (a person or thing); a spy; a bailiff or sheriff's officer.

\section{There beagles flew
To haud the souter lads in order.}

3. A local name for several species of the smaller sharks.

beak $^{1}$ (bēk), $n$. [Early mod. E. also beeke, and, preserving the orig. short vowel, beek, becke, $b e c=$ Pr. $b e e=$ Sp. Pg. bico = It. beceo, $<\mathrm{LL}$. beceus, a beak, of Old Celtic (Gaulish) origin; but the mod. Celtic words, Gael beic, Ir. bec, Bret. bek, are from $\mathbf{E}$. or $\mathbf{F}$. The word is notionally associated with E. peak, peck, pike, and pick, q. v.] 1. In zoöl., the rostrum, snout, muzzle, jaws, mandibles, or some similar part of an animal. Especially - (a) In ornith., the borny bill or neb of a bird. (b) In mammal., the horny jaws of the duck-billed nembers of the genus Platypus. (c) In herpet., the horny jaws of a turtle or other chelonian. (d) In jawa of a cephalopod. $(f)$ In entom.: (1) the rogtrum or snout of a rhynchophorous beetle, or weevil; (2) the rosfin or ancking mouth of a hemi blood-sucking fly, consisting of lancet-like mandibles maxillre, and lingua incloaed in the elongated and grooved labinm. (See cut under mogquito.) Tbis term is also apphe head, anch as that observed in many Coleoptera and Diptera. $(g)$ In conch. (1) the umbo or apex of a bivalve the canal. 2. Anything ending in a point like a beak. (a) Naut, a powcriul construction of metal, as ateel,

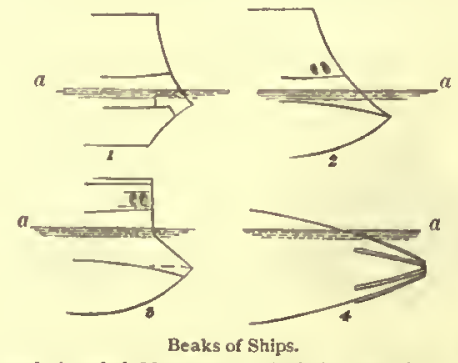

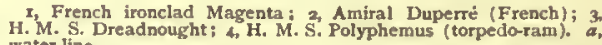

a part ol the bow of many war-ships, and extending below the water-line, for the purpose of atriking and break(which see). For a cut of the beak of an anclent war(whilch see). For a cut of the beak of an anclent war-
galley, see acrogtolium. (b) The horn of an anvil. (e) In farriery, a little ghoe about an inch long, turned up and a little apon the fore part of the hool. (d) In arch, edge of a larmier to with a channel behind it left on the water from trickling down the faces of lower areli itectura members. (e) In bot., a narrowed or prolonged tip. (f) In carp., the crooked end of the holdlast of a carpenter
bench. $(g)$ The $11 \mathrm{p}$ or spout of a vessel, as a pitcher bench. (g) The $11 \mathrm{p}$ or spout of a vessel as a pitcher
throngh which the contents are poured. (h) In chem., the rostrum of an alembic, which conducts the vapor to the worm. (i) The long point of the peculiar hoot or shoe worn at the same period, which was often longer than the shoe itsell. See solleret.

3. A gas-burner having a round smooth hole $\frac{1}{28}$ of an inch in diameter; a bird's-mouth. -4

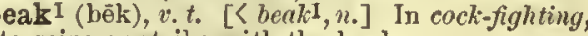
to seize or strike with the beak. 
beak

beak 2 (bēk), $n$. [Same as beck6; of obscure origin.] A magistrate; a judgo; a polieeman. [Slang.]

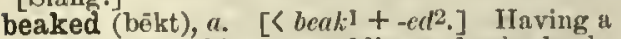
beak, or sometbing resembling a beak; beakshaped. (a) Ilaving a long beak-iike month, as some inacets, (b) In bot, rustrate; ending in a beak-iike point. of a different tincture from the reat of the birl; thus, an eagle saile, beaked or, means a biack eagia having a goili beak. When beaks and clawa aro of the ame tincture, the
term armed (which see) is used. ((i) Ending in a point,

Each beaked promontory.

Milton, Lycidas, 1. 94 .

Beaked belmet, a helmet of which the vlzor was workel to a gharp projecting point in front, in use abont $1340-70$. the right side of it. The extremely pointed form gave to the lanec of the assaifant no hold ard no opportuaity of

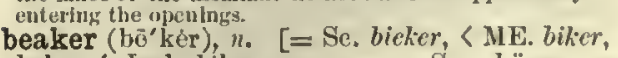
byker, < Ieel. bikur, a cup, = Sw. bägare= Dank, bager $=$ OS. biheri $=\mathrm{D}$. beher $=$ OHG. behhar, behhäri, MHG. G. beeher, < ML. bicabehhar, behhäri, MHG. G. beeher,
rium (also prob. "biccärium, > It. biechiere, pecehero $=\mathrm{OF}$. picher, pichier, $>\mathrm{ME}$. picher, E. piteher, which is thus a doublet of beaker),

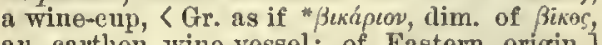
an cartlien wine-vessel; of Eastorn origin.] 1. A large drinking-vessel witl a wide mouth. $O$ for a beaker lill of the warm gouth,

Keats, Oile to a Nigitingale. 2. A glass vessel used by chemists, usually for making solutions. It is made of thin glaas to withatand heating and has a flat botton and perpendlcular

lie uaod a modiflcation of Thomson'a elcetrometer anl connceted it, with gnitable precautlons, with twelve largo
beakers whlch were covered with tinfoll and were flllei weakerg whtch were covered with tinfoll and were fllled
weith ice. 111 . 260 .

beak-head (bēk'hed), n. 1. An ornament resembling the head and beak of a bird, or, often, a grotesque human head terminating in a beak,

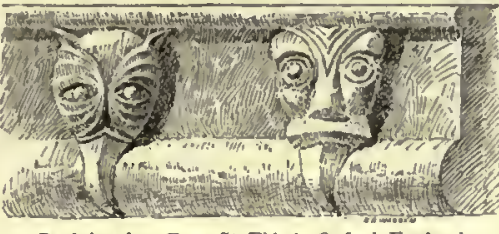

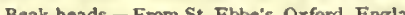

used as an enrichment of moldings in Romanesque architecture.-2. That part of a ship before the forecastle which is fastened to the stem and supported by the main knee.

beaking-joint (bé'king-joint), n. [< bcaking, verbal $\mathrm{n}$. of beal.1, + joint.] A joint formed by the junetion of several heading-joints in a continuous line,

folding doors,

floors, etc.

beak-iron (bēk'

i"érn), n. [A

further corrup-

tion, simulating

bichiron, a

ruption of bick-

$a_{1}$ tool with long beak used for rounding anvil with a two beaks which act as stakes or anvils in
long beak or the interior of ware i $d$, a conical beak in
tended to be grasped tn a vise. horm adapted to

reach the interior surfaces of sheet-metal ware; a bickern: Uaed in various forms hy blackanitha, cop-

beakmentt, $n$. [F. dial. also erroneously beatment; appar. $<\mathrm{F}$, becquer, peck, + -ment: see peck, a measure.] A measure of about a quarter of a peck. Halliwell.

beak-rush (bèk'rush), $n$. A common name for species of Rhynchospora, a genus of eyperaceous plants with conspicuously beaked achenes or seed-vessels. Also called beak-sedge.

beak-sheath (bēk'shēth), $n$. In entom., the rostral sheath or jointed extension of the labium, inclosing the mouth-orgaus of a hemipterons insect.

beaky (bé-'ki), a. [<beak + - $\left.y^{1}.\right]$ Furnished with or distinguished by a beak.

beal ${ }^{1}$ (bēl), n. [< M[E. becl, bele, a variant of bile, bule, $>\mathrm{F}$, bile1, now corrupted into boiz1: see bile 1 and boill.] A small inflammatory timor; a pustule. [Obsolete or dialectal.]

beal1 (bêl), $r$. [ ${ }^{\prime}$ [ bea $\left.7^{1}, n_{\text {. }}\right]$ To gather mat-

487

beamed

fester; suppurate. [Obsolete exeept in Seotland.]

beal ${ }^{2}$ (bēl), n. [Sc., also spelled bicl, < Gael. aud Ir. beul, earlier beal, mouth, $>$ Gael. and Ir. beulach, a defile, a mountain-pass.] A mouth; an opening, as between lills; a narrow pass. [Scoteh.]

Angus .1'Aulny mumblet over a number of lard Gaelke names teacriptive of the different passes, precipiced, cortes, and beals, through wlisch lie sald the roal lay to ln.

Seo light 1 .

eale's ganglion-cells. Seo cell.

(berbal n. of beall.] A ing part.

eall (bé'âl), n. All that is to be; the whole .

That but thia blow
sight be the be-all and the end-all liere.

Shatk., Macbeth, 1. 7.

beam (bēm), $n$. [<ME. beem, beme, ete., < AS. beam, a tree, a piece of timber, a ray of light, IILG $=$ OFries, bām $=$ D. boom $\left(>\mathrm{F} . b 00 \mathrm{~m}^{2}\right)$ G. baum, and prob. = Icel. badhmr = Goth. Gagms plajued variations of form), a tree; perhaps plained variations of form), a tree; perhaps akin to Gr. фüra, a growth, and Skt. bhumman, earth, $\leqslant \sqrt{ }$ bhi , grow, become: see bel, bouerl, boor, big $3=b i g g^{3}$, ete., and ef. the doublet boom ${ }^{2}$. Tho sense of 'ray of light' is peeuliar to AS. and E., appar. tr. L. columna (lucis), a column or pillar of light: ef. L. radius, a spoke of a wheel, a rod, a ray; G. straht, an arrow, a spoke, a ray or beam.] 1 . In areh., a long piece of stone

wood, or metal, or a construction of wood or metal, or combining wood and metal, used in tion, usually in tion, usually in others like it, all others like it, all laid parallel to one another, and at regular inter-

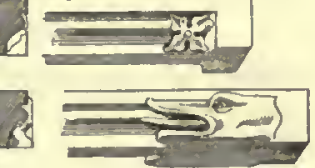
s, to support

weight, or, as a tie-beam or a collar-beam, to resist two opposite forces either pulling or compressing it in the direction of its length. -2 . A long piece fixed or movable in a structure, machine, or tool: often equivalent to girder. The word beam is used in a number of more or leas apecific aenses; as: (a) Any large piece of timber long in proporcipal horizontal timbers in a building, especially one connecting two opposite rafters; a timber serving to atrengthen any pleee of wooden frame-work. (c) The part of
from the ends of which the scales are anspended.

The doubtful beam long noda trom aide to alde.

(d†) The pole of a carriage which runs between the horses. (e) A cylindrical piece of wood, making part of a loom, the cyllnder on which the cloth ia rolled as it ia woven. The ataff of hla gpear was like a weaver'a beam. San. xvii. 7

(f) The atraight part or ahank of an anchor. (g) One of the atrong transverse pleces of timber or iron stretching decks and re-

their proper dls-

main plece of a

plow, in which

are flow-tails

drawn. (i) The

oaclllating lever of a ateam-engine reciprocating upon a center, and forning the medium of communication between the plston-rod and the crank-shaft. Also called working-beam or walking-beam. 3. The widest part of a ship's hull; the extreme breadth of a ship: from the beams extending quite across the vessel where it feet beam.

Broad in the bean, but aloping aft,

With graceful curve and slow degrees,

4. The main stem of a deer's horns bearing the snags or antlers. One of the snags themselves
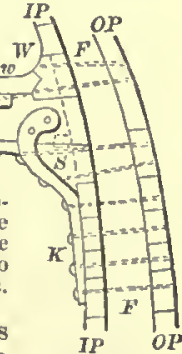
Ship's Beam and outside plane: ing:
$P_{P}$, instde plank-
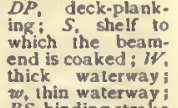

trake: $K$, forked antler. See antler. - 5. A ray of light, or more strictly a collection of parallel rays of light, emitted from the sun or other lumiuous body. The madle ray is the axis. In heraliry, beame of the aun whleh ls then said to les raliant or rayonnant.

The existenec of an trolated ray of llgint is inconcelvable. . llowever anail a portion of the wave surface nay be tiveiy form a beam or fasclculua of rays. Yon sllver beams,

Sleep they less awectly on the cottage thatch

Ienee-6. Figuratively, a ray or emanation of splendor: as, "beams of inajesty," Tillotson, Works, I. iii.-7. Sume as roocl-berm.-Abaft the beam. See aboft.-Arched beam. See arched.-
Axis of a beam of light. See axis $1,-$ Beam and acales, a islance. - Beam-center, the fulirum or pin on Weon- Beam of a car-truck a cruss beam carrginus the velght of the supported car. - Before the beam. See before.- Butit beam, a heam lormed of amailer bean notched, gcarfedi, and bolted together. - Cellular beam. a bean formed of wronghthlron platea riveted witla angle. irous in the form of longitudinal cells, with occastoual beam, an inelined post over whlch a hlde is atretched to be alaved. - Fished beam. See fish, v. - Kerfed beam, a beam witil glits aswed in onc allo to facilitate bending In that direction. - On the beam, ntut., on a On the beam-ends, in the position of a ahip which in clines so much to one alde that her beams approach a ends, to bo thrown or lytug on the gr, lo be on onesed cumstances; be at one'a last shlft. - On the weatherbeam, on the weather sids of the anip.-To kdck or strike the beam, to rise, as the lighter acale of a bal ance, so as to gtrike agajuat the leam; hence, to be of$$
\begin{gathered}
\text { In these he put two welghts, } \\
\text { The }
\end{gathered}
$$

The gequel each of parting and of fignt:

The latter quick uptlew and kick'd the beam.

beam (bēm), v. [< ME. beemen, bemen, < AS. "beamian (Somner), radiate; from the noun.] I. trans. 1t. To shed rays of light upon; irradiate.-2. To shoot forth or emit, as or like beams or rays: as, to beam love upon a person.

God beams this light into men's understandings.

3. To furnish or supply with beams; give the appearance of beams to.

The bell-towers, again, are ribbed and beamed with black 4. In currying, to stretch on the begm, as a hide.-5. In weaving, to put on the beam, as a

II. intrans. To emit beams or rays of light shed or give out radiance, literally or figuratively; shine.

$$
\text { A mighty light flew beaning every way. }
$$$$
\text { Mrore bounteous aapects on me beam, }
$$

ie mightler tranaports move and thriil

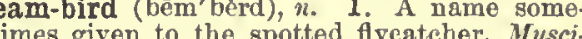
capa grisola, beequse it often builds its nest on the projecting end of a beam or rafter in a building. - 2. A provineial name for the pettychaps or garden-warbler, sylvia hortensis.

beam-board (bēm'bōrd), $n$. The platform of a steelyard or balance. Also called beam-platform. $E . H$. Knight.

beam-caliper (bēm'kal"i-pér), $n$. An instrument similar in construction to a beam-compass, but with the points turned in so as to be used as ealipers.

beam-center (bẻm'sen"tẻr), n. Tho pin upon which the working-beam of a marine engine reciprocates.

beam-compass (bēm'kum"pas), n. An iustrueonsisting of a wooden or brass beam,

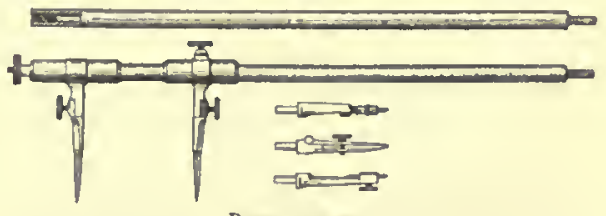

having sliding sockets that earry steel or peneil points, used for deseribing large eireles and pistances.

beamed (bēmd), $a$. Having beams or horns; having all its antlers put forth, as the head of a stag.

There were nany great beamed deer in it.
J. $F$. Campbell, Pop. Tales of West Highlands. 


\section{beam-engine}

beam-engine (bēm'en"jiin), n. A steam-engine in which the motion of the piston is transmitted to the crank by means of an overhead- or working-beam and counecting-rod, as distinet from a direct-action engine and a side-lever engine, in which the motion is communicated by twe side-levers or beams below the level of the piston cross-head. - Compound beam-engtne, a beam-engine having compond cylinders, in which the
steam is used first at a higher and then at a lower temperature.

beamer (hế'mér), n. 1. In werving, a person whose business it is to put warps on the beam. -2. Same as beaming-machine.

beam-feather (bēm'fertu"èr), $n$. One of the long feathers in a bird's wing, particularly that of a hawk; one of the remiges or flight-feathers. beam-filling (bēın'fil'ing), n. 1. Brickwork or masonry earried up from the level of the under side of a beam te the level of the top.under side of a beam te the level of the top.-
2. Naut., that pertion of the cargo whieh is stowed between the beams.

beamful (bēm'fül), $a$. [< bcam + fful.] Emitting beams; beaming; bright: as, Mseam

beam-gudgeon (bēm'guj"on), n. One of the bearing-studs on the center of a w orking-beam, or the central pivot upon which it oseillates. beamily (bé'mi-li), adv. In a beamy or beaming manner; radiantly.

Thou thy griefa dost dress
With a bright halo, ghining beamily.

eats, To Byro

beaming (bē'ming), $n$. [Verbal $n$. of beam, $v$.] 1. In cloth-manuf, the operation of winding the warp-yarn on the beam of a loom.-2. In leather-making, the operation of working hides with a slicke

beaming (be'ming), p.a. Characterized by radiance; bright; cheerful.

beamingly (bē'ming-li), adv. In a beaming manner ; brightly ; radiantly.

beaming-machine (bé' ming-ma-shēn"), $n$. A machine for winding yam upen the beams of looms. -2. An apparatus for working hides with a slioking-tool or slicker. It consists of for moving the tool over

beam-knife (bēm'nîf), $n$. A double-edged knife with a straight handle at one end of the blade, and a cross-handle fixed in the plane of the blade at the other. It is used in shaving off the thick, fleslyy parts of a hide and evening its thickness

beamless (bēm'les), a. [< bean + -less. $]$ Emitting ne rays of light; rayless.

$$
\begin{gathered}
\text { The beamless eye } \\
\text { No more with ardour llinght. } \\
\text { Thomson, Summ }
\end{gathered}
$$

beamlett (bēm'let), tle beam, as of light.

beam-light (bēm'lit), n. The light formerly kept burning in ehurehes in front of the refrom the rood-beam. [Rare.]

beam-line (bēm'liñ), $n$. In ship-building, a line showing where the tops of the beams and

beamlingt (bēm'ling), n. [< beam + -ling1. $]$ A little beam, as of light.

beam-platform (bëm'plat"fôrm), $n$. Same as beam-roll (bëm'rêl), $n$. In cloth-manuf., the spool-slaped roll upen which the warp-threads
are wound. beam-room

in a currier's establishment where the or shed or' slicking of hides is earried on.

But for unsavory odors a beam-room might pass for a
llarper's $M a g$, LXX. 274.

beamsomet (bēm'sum), a. [< beam + -some.] Shedding beams; radiant. N. E. D.

beamster (bēmn'stér), $n$. $[<$ beam + -ster. $]$ A

The beamsters bending to their tasks,

beam-trawl (bēm'trâl), n. A trawl-net the mouth of which is kept open by a beam.

beam-tree (bēm'trē), n. [Shert for vohitebeamtree.] A tree of the pear kind, Pyrus Aria of Europe (also called whiteberam), and closely
allied species of central Asia. size, bearing an abundance of white flowers and abowy red fruit. The wood is hard and tough, resembling that of the apple and pear, and is nsed for axletrees.
beam-truss (bèm'trus), $n$. A compound beam, formed generally by two main parallel mem-
488

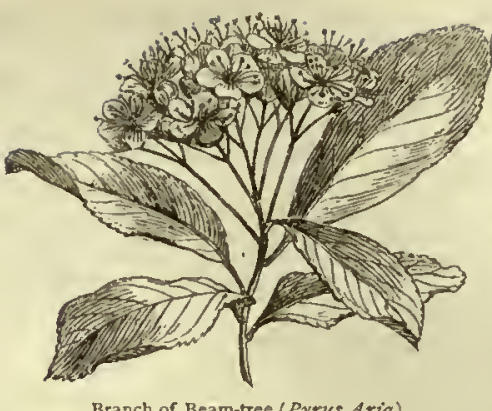

Branch of Beam-tree (Pyrus Aria).

bers which receive the stress of a load and rosist it, the one by compression and the other by tension. They are connected by braces and ties, agether, and trangmit the stress due to a load upon any one part to the points of support. See truss.

beamy (bé'mi), a. [< ME. bemy; < beam + $\left.-y y^{1}.\right]$ 1. Resembling a beam in $\operatorname{siz} \theta$ and weight; massy: as, "his . . beamy spear," Dryclen, Pal. and Are., 1. I756. - 2. Having horns or antlers: as, "beamy stags," Dryden, tr. of Virgil.-3. Naut., having much beam or breadth; broad in the beam: said of a ship whose beam is more than one tenth of its length.

The speed of beany vessels bas too often been demon-

4. Emitting rays of light; radiant; shining. Brighteuing the twilight with in Tickell, beamy gold.

In a fleid azure a sun proper, beamy.

5. Figuratively, radiant; joyous; gladsome.

Read my pardon in one beamy amile. J. Bailli beanl (bēn), n. [< ME. bene, ben, $\leq$ AS. beán D. boon = MLG. bone = OHG. bonna, MHG.

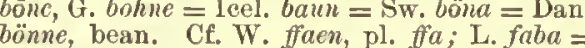
OBulg. Russ. bobu = Ofaen, pl. ffa; L. faba = 1. Originally and properly, a smooth kidney-
shaped seed, flattened at the sides, borne in long pods by a leguminous plant, Ficia Faba now extended to include the seed of the allied genus Phascolus, and, with a specific epithet, of other genera. - 2. The plant producin times was the Vicia Faba (or Faba vulgaris), a native of western Asia, and the same as the fleld-, horse-, or tick-
lean, and the broad or Windsor bean, still largely cult vated in the flelds and gardens of the old worid. It i nsed when green as a table-vegetable, and when dry a cultivated beans are of American origin, and belong chicfly to the genns Phaseolus. To $P$, vulgaris helong the con mon kiduey-bean, and the haricot and French beank, the
string-bean, and the pole-bean; to $P$. lunatus, the Lim and Carolina beans, the sugar-bean, and the butter-bean and Carolina beans, the sugar-hean, and the butter-bcan
and to $P$, nanus, the dwarf, fleld-, bush-, navy-, pea- an
gix-weeks heans. To the same genus belons the wild kid ney-bean, $P$. perenmis; the scarlet-runner bean, $P$. mult plorus, cultivated for its scarlet flowers; and the prairie-
bean of Texa, P. retusus. The asparagus-bean, Dolichos regquipedalis, with very long cylindrical pods, frequently Beans as an article of food are very nntritions, contatn. compound called legumin, analogous to the casein in cheese. The name bean is also given to many leguminous the algarroba, Calabar, and coral beans, and to certain 3. A small oval

. A small oval er roundish seed, berry, nut, ing, small coals; specifically, coals which will pass threugh a sereen with half-inch meshes. [North. Eng.] -5. pl. Money. [Slang.]-Algarroba, carob, or locust bean, the fruit of the carobSee bog-bean. - Brazllian or Pichurmm bean, the fruit o bar or ordeal bean, the geed of an African legummon climber, Physortigma renenosum, a violent poison, used and other nervous affections. In some parts of Africa it vomiting results and the poison is thrown off, the innocence of the gnspected person is regarded as estabilished.
Castor-bean, the aeed of a euphorbiaceons piant, Ricinus communis, yielding castor-ofl. - China bean ties.-Coffee-bean, a name given in conmerce to th coffee-berry. - Coral bean, of Jamaica, the seed of a leguminons shrub, Erythrina glanca; but the large coral sia dasycarpa. The coral bean of Texas ia Sophora secuntree of Brazil, Aydendran Cujumary, an esteemed ton and atimulant.- Egyptian, hyacinth, or black beans, bean-shot

beans, the aceds of Psophocarpus tetragonolobus, culti. vated for food in India.- Horse- or swo widely dis. tributed through the tropics.- Indian bean, a name John Crow or Jequirity beans, of Jamaica, the seeds the nut of an Tast Indian tree, Semcearpus Anceardium, - Mesquite bean, of Texas and sonthward, the fruit of Prosopis juliffora.-Molucca beans, or nicker-nuts, the seeds of a tropical leguminous climber, Cosalpimia Banducella. - Not to $\mathrm{kmow}$ beans, a colloquial American asknow B from a bull's foot."- - Oily bean, or bene-plant, the seed of Mucuna urens, a lerusinons clinger of the tropick. - Pythagorean or sacred bean, of the Egyptians See Nelumbium. - Sahuca or soy beans, the seeds of Glycine Soja, largely cultivated in India and China, from which the sauce known as soy is made.-- St. Ignatius' bine,

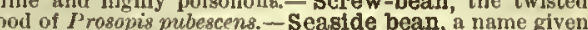
o some creeping leguminous plants of the tropics, Cana valia obfusifolia and Vigna luteola, common on rocky or andy sea-shores.-To find the bean in the cake, to succeed in defeating one 8 adversaries: an allision to the lak custoin of concealing a bean in the Twelfth-night cake and naming the person who found it as king of the f Dipteryx odorata a legurninous tree of Guians seeds in perfumery and for scenting snuff.- Vantlla bean, the fragrant pod of a climbing orchid of tropical America, Winilla planifolia, used for flavoring confectionery, etc. - Wild bean, of the United States, the Apios tuberosa. latus, with large tuberous roots, cuitivated throughout e tropics.

bean' ${ }^{2}(b \bar{e} n), a$. See bein

bean-belly (bēn'bel"i), $n$. A great eater of beans: a vulgar nickname for a dweller in Leicestersliire, England.

bean-brush (bên'brush), $n$. The stubble of beans.

bean-cake (bēn'kāk), n. A large cheese-shaped compressed cake of beans after the oil has been expressed, used largely in northern China as food for eattle, and in the sugar-plantations of southern China as manure. bean-caper (bēn'kā'pér), $n$. Zygophyllum Fa-
bago, a small tree, a native of the Levant. The flower-buds are used as capers.

bean-cod (bēn'kod), n. 1. A bean-pod.-2. A small fishing-vessel or pilot-boat used in the rivers of Portugal. It is sharp forward, and has its stem bent above inte a great eurve and plated with iron. Imp. Dict.

beancrake (bēn'krāk), $n$. A bird, Crex pratonsis; the corn-erake.

bean-curd (bēn'kèrd), $n$. A thick white jelly resembling blane-mange, made of beans, much and Japan.

bean-dolphin (bēn'dol"fin), n. The aphis or plant-louse which infests the bean.

bean-feast (bēn'fēst), $n$. 1. A feast given by an employer to those whom he empleys. Brewer. France, and afterward in Germany and England, on the evening before Twelfth day, or, as the Germans eall it, Three Kings' day. Althongh confonnded with the Christian festivai of the Eptphany, custom can be traced back to the Roman Saturnalia. bean-fed (bēn'fed), a. Fed on beans. Shak. bean-fly (bēn'flī), $n$. A beautiful fly of a palepurple color, produced from a maggot ealled nida, and found on bean-flowers.

bean-goose (bèn'gës), $n$. [So named from the likeness of the apper nail of the bill to a horsebean.] A species of wild goose, the Anser scgetum, which arrives in England in autumn and retires to the north in the end of April. Some consider it a mere variety of the European wild goose, $A$. ferus.

ean-king (bēn'king), $n$, [So called because the honor fell to him who, when the Twelfthnight cake was distributed, got the bean buried in it.] The person who presided as king over the Twelfth-night festivities.

bean-meal (bēn'mēl), n. Meal made from beans, used in some parts of Europe as feed for horses, and for fattening hogs, ote.

bean-mill (bēn'mil), $n$. A mill for splitting beans for cattle-feeding.

bean-sheller (bēn'shel "èr), $n$. A machine for removing beans from the pods.

bean-shooter (bēn'shö"tèr), $n$. A toy for shooting beans, shot, or other small missiles; a pea-shooter.

bean-shot (bēn'shot), $n$. Copper grains formed by potiring melted metal through a perforated adle into warm water. If cold water is used, flakes are formed, called feather-shot. 
bean-stalk

bean-stalk (bēn'stâk), $n$. The stern of a bean, or tho whole plant: as, Jack and tho borin-stull: bean-tree (bền'trē), ". A name given to the P'yrus intermedia of northern Europe, and to species of Bauhina: in Australia, to the Noreton Bay chestnut, Castanospermum Australe; in the United States, sometimes, to Catalyn bignonioiles; and in Jamaica, to Lrythrina Corralloclendron.

bean-trefoil (bēn'trē"foil), n. 1. The laburnum, Cytisus Laburmum, a leguminous shrub with trifoliato leaves. See laburnum.-2. The Anagyris foetida, a similar shrub of sonthern Hurope, whose violet-colored sceds aro said to Furope, whose violet-colored sceds aro said to The buckbean, Menyanties trifoliata. [Rare.]

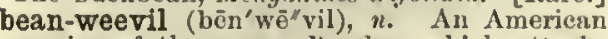
species of the genus Bruchus, which attacks beans. It lias been deacribud as Bruchus fabe (Iil-
ley), bat is held by llorn to bo I. obsuletur (Say). ITi specica aver. nges 3 millimeter in length, witin the and piceous, the whole body being covercd with rath pubcacence, anc
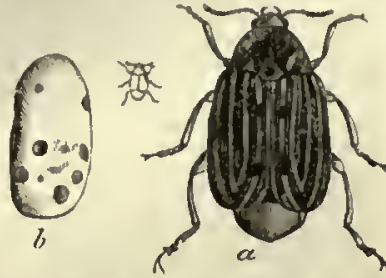

the elytra beling

a, Bean-weevil (Bruchis fabde). B. Bean
froul which the beeties have issued. (Small
figure shows natural size.) indistinctly notiled by trankverse banda of darker pulse cence. It infests stored beans, and there are ustually gevbeany (bế'ni), $a$. [< bean ${ }^{-1}+-y^{1}$.] In good condition (like a bean-fed horse); spirited fresh. [Slang.] N.E.D.

bear ${ }^{1}$ (bãr), $v_{\text {. }}$ pret. bore (formerly, and still in the arehaie style, bare), pp. borne, born (now only in a single sense: see note at end), ppr. bearing ren, pp. boren, rarely born), < AS. beran (pret. ren, pp. boren, rarely born), S AS. beran (pret.
bar, pl. bäron, pp. boren) =OS. beran = OF'ries. bera $=\mathrm{D}$. baren $=$ OHG. beron = Icel. bera $=$ Sw. bära = Dan. bere = Goth. bairan, bear (also in comp. OS. giberan = AS. geberan = qubaivan, bear, in MHG. and G. bring forth), = L. ferre $=$ Gr. $\phi \varepsilon \rho \varepsilon \imath=$ Skt. $\sqrt{ }$ bliar, bear, carry. 1. ferre $=$ Gr. $\phi \varepsilon \rho \varepsilon v=$ Skt. $\sqrt{ }$ bluar, bear, carry.
A very prolific root in all the languages, both A very prolific root in all the languages, both in form and senses. From the AS. come barburden 1 , ete.; from the L. fertile, confer, elefer, liffer, infer, etc., Lucifer, conifer, etc., aurifer. ous, rociferous, ete., and other words in -fer, -ferous; from the Gr. semaphore, hydrophore, phosphorous, electrophorus, ete., and other words in -phore, -phorous, etc.] I. trans. 1. To support; hold up; sustain: as, a pillar or a girder bears the superineumbent weight.

Sage he stooll,
With Atlantesn ahoulders fit to bear The weight of mightiest monarchics.

2. 'To support in movement; carry; convey. Whither do these bear the ephah? Zech. v. 10 From the unshaken rock the torrent hoarse Scott, Vision of Don Roderick, Concluaton, at. 3 Ant down s rocky pathway from the place There cane a fair-hair'd youth, that lin bla hand

3. To suffer; endure; undergo: as, to bcar pun ishment, blame, etc.

Alas, how many bear sucli ahameful blowa,

Which not themselves but he that giver then knows:

4. To endure the effects of; take the consequences of ; be answerable for.

Ife ahall bear their inlqultien.

Sir, let her bear her ains on her own heai

Beau. and $\mathrm{Fl}$., King and No King, I.

5. To support or sustain without sinking yielding, shrinking, or suffering injury.

A wounded spirit who can bear? Prov, xviil. 14. Console if you will, I can bear it;
'Tys a well-meant slma of breatl. Lovell, After the Buria.

Anger and jealousy can no more bear to lose sight of
thelr objects than love.
George Eliot, Mill on the Floss, 1. 10. 6. To suffer or sustain without violence, injury, or change; admit or be capable of.

In all criminal cases the moat favourable interpreta-
tion ahould be put on words that they can possibly bear.

In
Stuift.

The motives of the best actions will not bear too strict
an inquiny.
Sviff, Thoughts on Various Suhjects.
489

7. To suffer without resentment or effort to revent; endure patieutly.

It was not nn encmy that reproached me; then I couldi
have berne It. With your long-practia d patlence bear aflictions.

8. To sustain, as expense; supply the means of paying.

somewhit that will bear your charges. Dryden.

9. To have, or havo a right to; be entitled to ; have the rightful use of, as a name, a title, a oat of arms, and the like.

We are no enemles to what are commonly ealled conLoec.
Lowell, study windows, p. 330 . Who in tie Lord God'a likeness bears the kcys

. To carry, as in show; exhibit; show.

Bear welcone in your eye. Shak., Jacbelin, i. 5. Whith, like a waxen image 'gainst a fire,

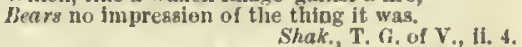

11. To bring forward; render; give; afford: as, to bear testimony.

'Thou shalt not bear false witness agalnat thy nelghbonr.

12. To earry in the mind; entertain or cherish, as love, hatred, envy, respect, etc.

II I csu eatch him once upon the hip,

I will fecil tat the ancient grudge I bear lim.

The reverent care 1 bear nnto my lord

Itade me collect theae dangers in the duke.
Shak., 211 III. VI., ii. 1.

Tle grcat and guilty love he bare the qucen. Tenmyson, Iancelot and Flaine.

13. To possess, as a property, attribute, or characteristic; have in or on; contain: as, to bear signs or traces; to bear an insc
tho contents which the letter bears.

What, think you much to pay two thousand crowns,

And bear the name and port of gentleman?

14. To possess and use, as po, bo eharged with; administer: as, to bear sway.

IIere's another letter to her: she bears the purse too Shak., II. W. of W., I. 3

Rnssla soon aliowed that she was resolved to bear part in the quarrels as well as the megotiatlons of he

15†. To carry on; deal with.

Thls can be no trick: The conference was sadly borne.

of entrance to a quarrel; but, heing in,

Of entrance to a quarrel; but, heing in,
Bear' $\mathrm{t}$, that the opposed may beware of thee.

16. To manage; direct; use (what is under the immediate control of one's will).

$$
\text { bear your body more aeeming }
$$

Hence, with a reflexive pronoun, to behave: act in any character : as, he bore himself nobly. -17. To sustain by vital connection; put forth as an outgrowth or product; produce by natural growth: as, plants bear leaves, flowers, and fruit; the heroes borne by ancient Greece.

Can the fig-tree . . . bear olive-berries? Jas, iil. 12. Here dwelt the man divine whom Samos bore. Life that bears immortal frnit. Tennyson, In Memorfan, xl.

18. To bring forth in parturition; give birth to, as young; figuratively, give rise or origin to. [The past participle born is now

And ahe conceived, and bare Cain, and aaid, I have got-

I can tell thee where that aaying was born.

19. To conduct; guide; take: as, he bore him off to his quarters.

Bear me forthwith unto his creditor.

20. To press; thrust; push; drive; urge: with some word to denote the direction in which the object is driven: as, to bear down a scale; to bear back the crowd.

The resilue were so disordered as they conld not conveniently fight or fyy, and not only justled and bore down one another, but, in their confused tnmbling back, brak
a part of the avant-guard.
Sir J. II ayward. Confldence then bore thee on; secure Either to mect no danger, or to find
Matter of glorious trial. Milton, P. L., ix. 1175 . IIow the rushing waves
Bear all before them

Bryant, Flood of Years.

21. To gain or win : now commonly with avay or off; formerly, sometimes, with an indefinite it for the object. bear

Some think to bear if by speaking a great word.
Bacun, of Seening Wise. 22. In tho game of backgammon, to throw off or renove, as the men from the board.-23. To urport; imply; import; state.

The ietters bore that anceonr was st hand. Scote.

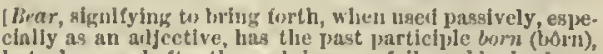

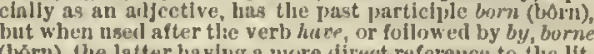
(worri), the latter having a more direct reference to tlie litcra sense. Thus, a child was born; tut, she has bome a
cliifi. In all the uther senses both partleiples are spelled borne: as, I have borne the expenses; the expensea nust ike torn, suorm. The distlnction is artifictal ancl recunt (after the middle of the eighteenth century). ]-To bear a
hand, to lend a hand quickly; take lield; give sid or as.
slatance. [Naut. and colion.]

All hands ahey! bear a hand and make sall

II. Jance, Jre, lyefore the Mast, p. 69.

To bear arms. Sce arm2, - To bear away the bell. -To bear date, to have the nark of time when written or exccuted: as, the letter bears date Sept. $30,1887$.

A public letter which bears date just a month after the Jiacaulay, Lord Bacon. To bear down, to force down; fjguratively, to overcone; vancuigh : as, to bear donen ail oppoallion. - To bear in, [1'ennsylvanla anthracle rcglou.] - To bear in handt, to keep in hope or expectation; amuse witls false pre. tcuses; decelve.

A rascally yea-torsooth knave 1 to bear a gentleman in and, and then stand upon aecurity!

$$
\text { Still bearing them in hand, }
$$

Letting the cherry knock against their lips,

And draw it by their mouttis, and back again.
B. Jonson, Voipone, 1. What I take from her, I spend npon other wenches;
bear her in hand still: : ahe las wit enough to rob ler
husband, and I waya enough to conaume the money. husband, and I waya enough to conaume the money.
Middleton and Dekker, Roaring Giri, if. 1. To bear in mind, to keep in remembrance; have fixed

With reference to the effects of intercrosing and of competition, it slould be borne in minui that most amimals
and plants keep to their preper fomes, and do not need-
iessiy wander about.
Daruin, Origin of speciea, p. 94. To bear off. (at) To snstain; endure.

Do you auppoae the atate of this realm to be now so lceble tliat it eamot bear of a greater blow than this?
Sir J. Ilayccard.

(b) Naut, to remove to a distanee; keep clear trom ruhblng against anytling: as, to bear of a boat. (c) To gain Though he bear me hard.

$$
\begin{aligned}
& \text { Though he bear me hard, } \\
& \text { I yet moust do lim rigit. }
\end{aligned}
$$

To bear out. (a) To give smpport or countenance to.

Company ouly enn bear a man out ln an ill thing. South. (b) To defend ; support ; upheld ; accond : with a personal
object. If I eannot once or twiee ln a yuarter bear out a knave
agalnst an honest man, I lave but a very little credit
with your worsinip.
Shak, 2 Hen. IV., v. I. I never suspected lin to be a man of resolution or courage sufficient to bear hin out in so deaperate an at.
tempt. Eschlnes by no means beara him out; and Plutarch directiy contradicts him.
Macalay, Mltforil's Hist. of Greece. (c) To confirm; corroborate; establish; ; jnstify : with a
thing for the olject. That atuch osclllations [of clinate] occurred during the l'ertiary period seens to be borne out by the faets of gelogy and palieontelogy.

(di) With a more or less Indefinite it for the olyect: (1)

Love alters not with his [Time's] brief hours and weeks, But bears it out even to the edge of doon.
Shak., Sonnets, cxvl.

If that the T'urkish fleet
Be not enshclter'd and embay'd, they are drown'd
It ig in possible to bear it ont. Shak. Othello, if 1.

(2) To enable to endure ; render aupportable.

Many a grood hanging preventa a had marriage; and for
turnlng away, let sunmer bear it out. Shek., T. N., 1. 5. To bear the bag. See bagl. - To bear the bell. See bell. To bear the gree. See gree 2 . - To bear throught. ( $(a)$ manage.

My hope ia,
So to bear through, and out, the consulship,

As apight shali ne'er wound you, though it inay me.
B. Jonson, Catiline, ill.

To bear up. (a) To aupport; keep from sinking.

A rellgioua hope does not only beas up the mind under (bi) To arrange ; contrive ; llevise.

Isab. 1 have made laim know
I have a servant comea with me along Thave s servant comea with me along,

1 eome shout my brother. Shak., M. for M., Iv. 1.

II. intrans. 1. To be capable of supporting or earrying: as, the floor wonld not bear. 
bear

Wyld roring Buls he would him make

To tame, and ryde their backes, not made to beare.

2. To lcan; weigh; rest fixedly or burlensomely: as, the sides of two inclining objects bear upon or agaiust one another.

In the important malter of taxation, the point in which the pressure of every governnent beers the most con-
stantly upou tlie whole people. Brougham. 3. To tend; be directed in a certain way, whether with or without violence: as, to bear away; to bear back; to bear in ; to bear out to sea; to bear unon; to bcar down upan; the fleet bore down upon the enemy.

Spinola, with his shot, did bear upon those witlin, who Sir. J. Ilayward. Who's there? bear back there! Stand from the door! The party soon set sail, and bore for England.

Down upon him bare the bandit three.

Tennyson, Geraint.

Hence-4. To have reference (to); relate (to); come into practical contact (witli); have a bearing: as There was one broad principle which lore equally upon
every class, that the laucls of England must provide for
the defense of Englani.
Froude, Sketches, p. 144. 5. To be situated as to the point of the compass, with respect to something else: as, the land bore E. N. E. from the ship.-6. To suffer, as with pain; endure.

They bore as lieroes, but they felt as men. Pope. I can not, can not bear.

Dryden.

7. To be patient. [Rare.]-8, To produce fruit; be fruitful, as opposcd to being barren as, the tree still continues to bear.

Then Abraliam fell upon his face, and laughed, and said hundred years old? snd shall Sarah, that is ninety years

9. To take effect; succeed.

Having pawned a full suit of clothes for a sum of money
which my operator assured me, was the last he should want to bring all our natters to bear. Guardian. To bear against. See above, 2. - To bear away (naut.), bears in with the land: opposed to bear of or keep at a bears in with the land ; opposed to bear off or keep at a
greater distance, - To bear on or upon. See above, 2,3 , and 4 ,- To bear up. (a) Nout, to put the helm up so as
to bring the vessel into the wind. (b) To be firm; have [If] we found evil fast as we find good
In our first years, or think that it is found

llow could the iniocent heart bear ap and live!
Wordsworth, Prelude, vili.

To bear up for (naut.), to bail or proceed toward : as, we with or under, to sustain with coursge; endure without
succumbing; be firn under: as, to bear up under aftiction.

$$
\begin{aligned}
& \text { Will bear up with this excrcise, so long } \\
& \text { I daily vow to use it. } \quad \text { Shak., W. T., til. } 2 \\
& \text { Too bold and fleree to stoop so, but bearr up, } \\
& \text { Presuming onl Jis hopes. }
\end{aligned}
$$

Fletcher, Spanish Curate, i. 1 .
To bear up witht, to keep up with; be on the same foot

What shoulde he doe? Fsin he would have the name to be religions, fain he would bear up with his neighbours
in that. To bear with, to endure; be indulgent to; forbear to Reason would that I should bear with you.

If the matter be meane, and meanly handled, I pray you
beare both with me and it. To bring to bear. See bring, The Scholentaster, p. 22 bear ${ }^{2}(\mathrm{bañ}), n$. [<ME. bere, < AS. bera $=\mathrm{D}$. beer $=1$ lG. baar $=$ OHG. bero, MHG. ber, G. bär, m.
$=$ lcel. bera, f., a bear. Cf. Icel. Sw. Dan. björn, a bear (appar. = AS. bcorn, a man, a warrior, orig. a bear? - see bern 2 ), an extended form

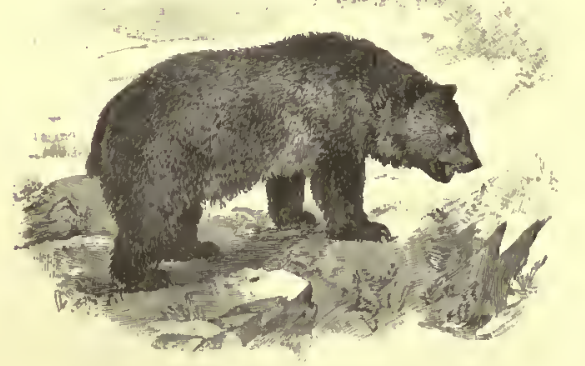

Grizzly Bear (Ursus horribilis).
490

of the same word. Perhaps ult. $=$ L. ferus, wild, fera, a wild beast: see fierce.] 1. A large plantigrade carrivorous or omnivorous mammal, of the family Crside, especially of the genus Ursus. 'The teeth of the true bears sre 42, and none of the molar's are sectorial. The snimals are less
truly carnivorous tlisn most of the order to wlich they truly carnivorous tlisn most of the order to wlich they
belong, feediug largely upon roots, fruits, etc., as well as helong, feeding largely upon roots, fruits, etc., as well as honey and insects. The tail is ridimentary, and the muz-
zle is prominent, with mobile lips and a slender, sometimes very extensile, tongue. The best-known species is the brown or bisck beal' of Europe snd Asia, Ursus arctos,
found chlefiy in northerly regions, of which several varieties are ilescribed, differing much in size and color, ant to some extcnt in shape; it is ordinarily about 4 feet long
and 21 feet high; its flesh is eaten, its peit is used for robes, and fts fat is in grcat deme. The grizzly bear of North America, $U$. horribilis, is as regards specific classification hardly separahle from the last, and like it runs into several varieties, ss the cinnamon bear, etc. It is ordinarily larger than the European, and is noted for its ferocity snd tenacity of life. It inhabits the mountainous portions of western. North
America. The common black bear of North America is a smaller and distinct species, $U$. americauns, usually black with a tawny gnout, but $\mathrm{ft}$ also runs into $\mathrm{s}$ cinnamon $\mathrm{kg}$ riety. See cut under Ursus. The polar bear or white

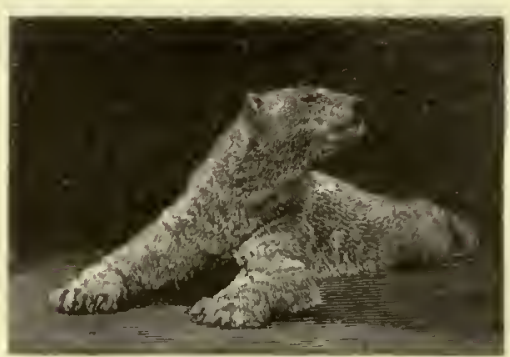

Polar Bear (Ursus marizimus).

of grent size, peculiar shape, and white or whilish color, misrine and maritime, and piscivorous to some extent,
though seals constitute much of its food. The Syrian bear, $U$. syriacus, and the Ilimalayan bear, $U$. himalayanus, respectively inhabit the regions whence they take ornat us, is the sole representative of the Ursidce in South Anerica: so cslled from the light-colored rings around the eyes, which have exactly the appearance of a pair of specHalayan bear or bruang, $U$. malayanus, is a small, black, close-halred species, with a white mark on the throat, with ar aswail of India is distinct from the other bears, and is usually placed in a different genus, Melursus labiatus. Se Uridoe, and cut under armail.

2. The Anglo-Australian name of a marsupial Sce koala.-3. [cap.] The name of two constellations in the northern hemisphere, called the Great and the little Bear. Both these figures have long taits. The principal stars of the Great Bear
comprose the figure of Charles's Wain, or the Dipper. In compose the figure of Charles's Wain, or th
the tail of the Little Bear is the pole-star.
4. A rude, gruff, or uncouth man.

You are a great bear, I'm sure, to abuse my relations.
Sheridan, School for Scandal, iil.

5. [Prob. in allusion to the proverb "to sell a bear's skin beforo one has caught the bear." (There is a similar proverb about the lion's skin.) One who sold stocks in this way was formerly called a bearshin jobbcr, later simply a bcar; now usually explained, in connection with its correlative bull, as in allusion to a bear, "which pulls down with its paws," as opposed to a bull, "which tosses with its horns."] In cxchanges: (at) Stock which future date, though not in the possession of the seller at the time the contract is made : in the phrases to buy or sell tho bcar. (b) One who sclls stocks, grain, provisions, or other nor possessed by him owned time of selling them, but which he expects to buy at a lower price before the time fixed for making delivery. (c) One who endeavors to bring down prices, in order that he may buy cheap: opposed to a bull, who tries to raise the

Every one who draws a bill or is. bear npou the rold market acts as a Jevons, Money and Mlech. of Ex.

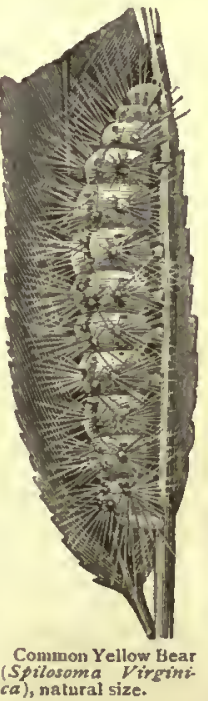

\section{bearbine}

6. A popular namo for certain common caterpillars of the family Aretiide, which are densey covered with long hair resembling the fur of a bear. They undergo their transformation under old boards or other sheltered places, forming a sligint V'irginica (Fabricius) is a common example; the moth is white with a few lilack spots, the abdomen orange-colored, black dots. See cut in preceding column.

7. In metal., one of the names given to the metallic mass, consisting of more or less malleable iron, sometimes found in the bottom of an iron furnace after it has gone out of blast.8. Naut., a square block of wood weighted with iron, or a rough mat filled with sand, dragged to and fro on a ship's decks instead of a holystone (which see).-9. In metalcorking, a portable punching-machine for iron plates. E. II. Kmight. -Bear's grease, the fst of bears, extes. sively used to promote the growth of hair. The unguents sold under this name, however, are in a great measure made of hog's

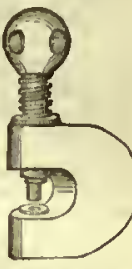
scented snil slightly colored.- Order of the Frederick Il of Gernany, and centered at the empero St. Gall, in what is now switzerland. It perished when the cantons became independent of the house of Austria.

bear $^{2}$ (bar), v. $t$. [< bear $\left.{ }^{2}, u_{.}, 5.\right]$ In the stock exchange, to attempt to lower the price of: as, to bear stocks. See bear ${ }^{2}, n ., 5$.

bear $^{3}$, bere ${ }^{3}$ (bēr), n. [Early mod. E. also beer, < ME. bere, < AS. bere, barley, = Icel. barr = North Fries. berre, bar, bär = Goth. "baris (in adj. barineins), barley, = L. far, corn. Sec bar lcy $\mathrm{I}$ and farina.] Barley: a word now used chiefly in the worth of England and in Scotland for the common four-rowed barley, Hordeum valgare. The six-rowed kind, $\boldsymbol{H}$. hexastichon, is called big.

Malt made from lere or higg only, in Seotland and Irelsind, for home consumptionl. bear 4 (bēr), n. [Also written bcer, and archaieally bere, $\langle\mathrm{ME}$. bere $=\mathrm{LG}$. büre, $\rangle \mathrm{G}$. bühre, a pillow-case.] A pillow-ease: usually in composition, pillow-bear. [Now only dialectal.] Many a pylowe and every bere
of clothe of Reynes to slepe softe.

bearable (bãr'a-bl), $a . \quad\left[<\right.$ bear $\left.{ }^{1}+-a b l e.\right] \quad \mathrm{Ca}$ pable of being borne; tolerable; endurable; supportable.

bearably (bãr'ạ-bli), adt. In a bearable manbearance (bãr'ans), $n$. [<bear $1+$-ancc. Cf. forbearance.] 1. Endurance; patient suffering. [Archaic] - 2. In mach., a bearing. bear-animalcule (bãr'an-i-mal"kūl), n. A general name for one of the minute arachnidans of the order Arctisca or Tardigrada, and family Maerobiotida. Also called uater-bear. See cut under Aretisca.

bear-baiting (bãr'bā"ting), n. The sport of setting dogs, usually mastiffs, to fight with captive bears. The practice was prohibited in Grcat Britain by Parliament in 1835 . Let hin alone: I see his vein lies only For falling out at wskes and bear-bating That may express hin

Bear-baiting, then a favourite diversion of high and low, was the abomination $\ldots$ of the austere sectarles. The Puritans hated it, not because it gave pain to the bear,
but because it gave pleasure to the spectators. bearbane (bãr'bān), $n$. A variety of the wolf'sbane, Aconitum Lycoctonum.

bearberry (bãr' 1. A tralling evergreen ericaceous shrub, Arctostaphylos uva-ursi, found throughout the arctic and mountainous portions of the northcrn hemisphere, and bearing small bright-red drupes. The leaves are very astringent and slightly bitter, snd under the nsme uva-urai are used in medicine as an astringent tonle, chiefiy in affections of the bladder. It is the, kinnikinic whlch the Indians of western America bilberry bear's-grape, and foxbermy.

2. In the Pacific States, a species of Rhamnus, R. Purshiana, named from the fondness of bears for its berries. Also called bearwood.-Alpine or black bearberry, a dwarf arctic-alpine species of the bearbine, bearbind (bêr' bỉn, -bind), $n$. [< bear ${ }^{3}$ + bine, bind: seebine ${ }^{1}$.] The name in England of several common species of Convolvulus, as $C$. arvensis, C. scpium, and C. Soldanella, from their twining about and binding together the stalks of barley. Also incorrectly written barebind. 


\section{bearbine}

The bearbine with the lllac interlaced. bear-caterpillar (bãr'kat" èr-pil-ärr), n. A larva of one of the bombycid moths: so ealled from its hairiness. See eut under bear?

bear-cloth (bũ r'klôth), $n$. Same as bearinyeloth.

beard (bērd), n. [< ME. berde, berd, < AS. beard $=\mathrm{D}$. OFries, berd $=\mathrm{OHG}$. beard $\Rightarrow$ D. baturl $=$ OFries, berd $=$ OHG. MIIG. G. bart = Ieel, bardhr, in eomp. (ef.
neut. uardh, brim, beak of a ship (seo bard ${ }^{2}$ ): the ordinary term for 'beard' is skegg $=$ E. brolla $=$ Russ. buroda $=$ Litl. baralla, bar $\approx a=$ Lett. burda $=$ OI'russ. bordus, and prob. = L. burba (> F. brabl), W. and Corn. barf, a beard. The agrocment in spelling between mod. E. and AS. beard is merely aeeidental: mod. E. and AS. beard is merely aeeidental: see ea.] 1. The close growtl of hair on the
ehin and parts of the faee lornally eharaeterehin and parts of the faee lornally eharaeterhair of tho face and ehin when allowed to remain wholly or in part unsliaved, that on the upper lip being distinguished as the mustache, and the remainder as the whiskers, or the sidewhiskers, ehin-whiskers or-beard, ote., aceording as tho beard is trimmed: as, to wear a beard,
or a fnll bcurd.-2. In zoöl., somo part or apor a fnll bcurd.-2. In zoöl., some part or appentage likened to the human beard. ( $(a)$ In ete. (b) In ornith., a clnster of tine feathers at the base of the beak, as in the bearded vulture and bearded tit. the Houdan, and the Rursian, thia appendage has been nade, by selection, very full. The feathers are supported by a pendulous fold of akin, and often extend up to the
eyer. (c) In ichth, the barbels of a flah, as the loach and cattiah. (d) In conch. : (1) The byrsus of seme bivalves, as the mussel. (2) The gills of some blvalves, as the oygter. (e) In entom., one of a pair of amall fleshy bodjes of som. 3. In bot.: (a) A erest, tuft, or eovering of
spreading hairs. (b) The awn or bristle-like appendage upon the ehaff of grain and other grasses. See eut under barley. (c) With some ringent corolla. -4 . A barb or sharp proeess of an arrow, a fish-hook, or other instrument, bent baekward from the point, to prevent it from being easily drawn out.-5. The hook for retaining the yarn at the extremity of the needle in a knitting-maehine. -6 . In organbuilding, a spring-piece on the baek of a loekbolt to hold it moderately firm and prevent it from rattling in its guides. - 7. The part of a neath the lower mandible and above the ehin.8 . The train of a comet when the comet is receding from the sun (in which ease the train preeedes the head). 9 . In printing, the outward-slop9. In printing, the outward-sloping part of a type which eonof the body. It is obsolete, type being now made with high square shoulders, to lighten the work of the eleetrotyper. $-\mathbf{1 0}$. The sharp edge of a board.False beard, in Egypt. antiq., a singllon nomments and nummy-cases, held nnder the elin by bands attached to Fearer's casque or lieal-dresa. - To False Beard, as make one's beard $\dagger$, liternally, to dress $\begin{aligned} & \text { represented upon } \\ & \text { rock-cut statue }\end{aligned}$ one'a beard; hence,

Yet can a niller make a clerkes berd,

For al his art. Chaucer, Reeve's Tale, 1. 175. Mo berdes in two houres

made, then greynes be of sondes.

Chater, llouse of Fame,

Rall'd at their covenant, and feer'd
Their rev'rend persona to my beard. beard (bērd), $\imath$. [<late ME. berdc; from tho
nomn.] I. trans. 1. To take by the board; seize, pluek, or pull the beard of, in eontempt or anger. Henee-2. Figuratively, to oppose to the faee; set at defianee.

'It is to them moat disgracefull, to be bearded of anch a Dar'st thou then
To beard the llen lit his dea

The Dourd the llon int his

Scott, Marmion, vi. 14.

3. To furnish with a beard, in any sense of the word. -4 . In carp., to ehip, plane, or otherwise diminish from a given line or to a given eurve: as, to beard elamps, plank-sheers, ete.; in shiprudder and steru-post, or the dead-wood, so as
491

\section{bearing}

to adapt them to the shaje of tho vessel. -5 . bunking and com., one who holds or preseuts To remove the beard or fringe from, as from

II. intrans. To grow a beard, or become bearded. [Rare].

Nor laugling girl, nor bearding boy,

Sor fulf-pulsed manhood, lingering here,

Shall add, to lile's abounding foy,

pose to guffering dear.
Whittier, sunmer by

bearded (bêr'ded), a. [< MIF. berled; < bear l

$\left.+-d^{2}.\right]$ 1. Having a beard.

Full of atrange oaths, and bearded like the,

Shatk., As you Like it, il. 7.

It is gooul to ateal away from the avelety of bearded inen, and even of gentler womall, and spend an hour or two with
llawthorne. T'wicc-'Told T'alea, I. IIawthorne. T'wiec-Told Talea, I. . In her.: (a) Same as barberl, 3 . (b) Having see).-3. In crlom.: (a) Having a tuft of Lairs on the elypeus, overhanging the mouth. (b) Covered on one side with short and thiekly set hairs: said of antennm.-Bearded argall. See ar. hairs: said of antennm.-Bearded argall. See $n$ beardi-Bearded titmouse, the panum

eard-grass (bērd'grás), $n$. The common name of $(a)$ some speeies of Polypogon, especially $P$. of $(a)$ some speeies of Polypogon, especially $P$.
Ifonspeliensis and $P$. littortis, from tho densely bearded appearanee of the elose panicles; (b) some common species of Aulropogon, as $A$. nutans, A. scoparius, ete.- Woolly beard-grass, name given to apeeles of Frianthus.-Naked eardie (bēr'di), n. Same as beardy, 2. bearding (bër'ding), n. [< beard + ing 1.$] 1$. The line of the intersection of the keel, deadwood, stem, and stern-post of a ship with the outer surface of the frame-timbers. Also ealled bearding-line and stepping-point. -2. The dimiuntion of the edge or surface of a piece of timber from a given line, as in the stem, deadwood, ete., of a ship. Hamersly.

earding-line (bēr'ding-lin), $n$. Sameas bearding, 1

beardless (bērd'les), a. [< ME. berdles, \AS. Wearllcás, < beard, beard, + leais, -less.] 1 . sex, immature; adoleseent: as, a beardless youth. -2 . In ornith., having no rietal vibrisse: as, the beardless flyeateher, Ornithium imberbe. -3 . In iehth., having no barbels. -4 . In bot, withont beard or awn.- Beardless drum, the redftsh or branded drum, Scia
barlels. See cut under red fish.

eardlessness (berd'les-nes), $n$. The state or condition of being beardless.

beardleted (bërd'let-ed), $a$. [<*bcarllet, dim. of beard (ef. bardule), $\left.+-e d^{2}.\right]$ In bot., having
little awns. Paxton.

beardling (bêrd'ling), $n$. One who wears a beard, formerly, in eontrast with shavelings a bear-gra layman. [Rare.] eamass, Camassiu eseulenta, of Oregon; also, beard-moss (bëra'môs), $n$. A name of the in Texas, to Dasylirion Texcmum, the young
liehen Usnea barbata, which, often intermixed pulpy stems of which are roueh eaten by bears; with others, elothes forest-trees with the and to speeies of the genus Yueea, for the same shaggy gray fleece of its pendulous thread-like branches; the "idle moss" of Shakspere (C. of bearherd (bãr'herd), $n$. A man who tends E., ii. 2).

bear-dog (bãr'dog), n. A dog for baiting bears. True. You fought high and fair.

B. Jonson, Eplecene, iv. 1.

beard-tongue (bèrd'tung), $n$. A name given to plants of the genus P'cntstemon, with referenee to the bearded sterile stamen.

beardy (bēr'di), n.; pl. bcardies (-diz). [Din. of cinered. Afacgillivray. [Loeal, British.] Sylvia Seotland, a name of the loaeh, Nemachilus barbatulus, a small fresh-water malacopterygian fish, family Cyprinide: so called from the six fish, family Cyprinide: so ealled from the six
barbules that hang from the mouth. Also spelled bearlie.

bearer (bâr'èr), n. [ME. berer, berere; <bear $1+$ - r. $^{\text {. }}$ 1. One who bears, earries, or sustains; a earrier; specifieally, one who carries anytopher, or the Christ-bearer (the meaning of tho name); a sword-bearer, an armor-bearer, a palanquin-bearer, ete.

IIia armour-bearer said unto hlm, Do all that is in thine Forgive the bearer of unhappy news: Your ruin.

Dryden. 2. One who earries a body to the grave; a pall-bearer.-3. In India: (a) A palanquin-earrier. (b) A domestie servant who has eharge
of his master's elothes, furniture, ete. -4 . In ment of whieh is not limited by the drawel. to a speeified individual or firm. Cheeks paywho wears anything, as a bailge or sword; a wearer.

Thou [the crowul, most flie, most honour'l, most ro.

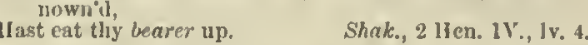
6. In old law, one who bears down or oppresses others by vexationsly assisting a third party in -7. Any part of a strueture or machine that serves as a support to somo other part (a) A anpport for the fire-f,ars of a furnace. (b) 'The support of the juppets in a lathe. (c) pl. In a rolling-mill, the housOne of the atrips whll extend over a molding-trough and erve to support the flask type-high, put in any exposed plaee in a form off impression and, for the purpose of bearing woodeuts. (b) $p l$. Typo-high pieees of metal placed in the very open spaces and over the leads of pages to bo stereotyped, and nlso typehigh strips of metal plaeed around pages or forms to be eleetrotyped, to prevent injury to quent proeesses, and eut away from the platos before printing. -9 . In her., a supporter. -10 . merly worn by women to support and distend their skirts "at their setting on at the bodies." Firholt.-11. In an organ, one of the thin sound-board, to form guides for the register-
slides whieh eommand the openings in the top of a wind-ehest leading to the pipes of the separate systems of pipes which form tho stops.
$E . H$. Knight. -12 . A tree or plant that yields ruit or flowers.

This way of procuring autumnal roaes, in some tlat are

bearer-bar (bãr'er-bär), $n$. One of the bars which support the grate-bars in a furnace.

势 length is determined. Wor. Supp.

ar-garden (bã $\mathbf{r}^{\prime}$ gär"dn), n. 1. A plaee where bears are kept for the diversion of spectators. was also ealled Paris-garlen and bear's-collegc. Hurrying me from the playhouse, and the scelses there,
to the bear-garden, to the apes, and asses, and tigers.

. Figuratively, any place of tumult or disorder. bears; a bearward.

Virtue is of so little regard in these costermonger times, Shak, 2 Hen. IV., 1. ing or baiting the bear. Few years more and the Woll-hounds shall fall aup-
preased, the Bear-hounds, the Falconry.
Carlyle, French Rev., I. iil. 1. bearing (bãr'ing), n. [〈ME. bering, beryng; erbal n. of bear ${ }^{1}$.] 1t. Support, as of a prinple or an action; maintenance; defense.

I speak against the bearing of bloodshed : this bearing Latimer, 5th Serm. bel. Edw. V1., 1549. 2. The aet of enduring, especially of enduring The two powers which constltute a wise woman are 3. The manner in which a person bears or comports himself; carriage; mien; behavior. I had reason to dread a fair outside, to mistrust a popular bearing, to ghulder helore distinetion, grace, and
courtesy. 4. The mutual relation of the parts of a whole; node of eonnection.

But of this frame the bearings and the tiea, The strong eonnectloul, nice dependencies,
Gradations just, has thy pervading soul
Look'd through?
Pope, Essay on $\mathbf{M a n}, \mathbf{1} . \mathbf{2 9}$
. In printing: (a) A strip of wood or metal, pieees of wood attached to the upper side of a A man of good repute, carriage, bearim, and estimation. 
bearing

Transactions which have $\ldots$ direct bearings on free-
dom dom, on health, on morals, on the permanent

Rae, Contemp. Socinlism, p. 213 .
5. The special meaning or application of anything said or written.

To change the bearing of a word.

Tennyson, In Memoriam, cxxviit.

6. The act or capability of producing or bringing forth: as, a tree past bearing.

In travall of his bearing, his mother was first dead.

7. In arch, the space between the two fixed extremes of a beam or timber, or between one extreme and a supporter: that is, its unsupported span. - 8. In mach., the part in contact with which a journal moves; that part of a shaft or an axle which is in contact with its supports; in general, the part of any piece supports; in general, the part of any another where it is supported, or the part of another
piece on which it rests. - 9. Same as bcaringnote. - 10. pl. In ship-building, the widest part of a vessel below the plank-sheer; the line of flotation which is formed by the water on her sides whon upright, with provisions, stores, ete., on board in proper trim.-11. In her., any single charge of a coat of arins; any one of the ordinaries, or any heraldic bird, beast, or other figure (see charge); hence, in the plural, the figure (see charge); hence, in the plural, the whole heraldie display to whe ditled. See arm $2,7 .-12$. The direction or point of the compass in which an object is scen, or the direction of one object from another, with reference to the points of the compass. In genl. and mining, used in speaking either of the outcrop of the
strata or of the direction of any nietslliferous lode or deposit, whether under ground or at the surface: nearly

"Before the sun could go his own length, the little wa. ter "will be in the lig."

"I thonght as much," returned the scout, ... "from nd the bearings of the mountsins."
Cooper, Last of the Molicans, $\times$ xxil.

Antifrlotion bearing. See antifriction.-Conlcal bearIng, an end-bearing for the spindle of s machine-tool,

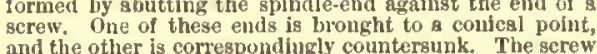
and the other is correspondingly countersunk. The serew
serves to sdjust the lessings for wear.-Continuous bearings. See continuours. - Sand-bearings, in mold. ing, the supports for the core in the sand of a mold.-
side bearngs of a car-truck, plates, blocks, or rollers
lideced placed on each side of the center-pin to prevent a too grest
rocking motion.-To bring a person to his bearings, to put him in his proper place; take linin down.-To loss one's bearings, to become uneertaln or confused in re
kgrd to one's position ; become hewildered or puzzled. gard to one's position; become hewildered or puzzed.-
To take beartngs, to ascertain on what point of the coon-
pass an object lies. The term is also spplied to ascertainpass an object lies. The term is also spplied to ascertainreference to some part of a sliph, s8 on the bean, before position; indike one's self nequainted witl the locality in which one is ; discover how natters stand; ; get rid of bewilderment or misunderstanding.

The best use that we call now make of this oecasion, it
seems to me is to look about us, take. our bearings, and seems to me, is to look about us, take our bearings, and
tell the fugitives. . Whlst course, in our opinion, they bearing (bãr'ing), a. 1. Supporting; sustaining: as, a bearing wall or partition (that is, a wall or partition supporting another).-2t. Solid; substantial: as, "a good bear

bearing-cloth (bãr'ing-klôth), n. The cloth with which a child is covered when carried to church to be baptized. Also called bear-cloth.

Thy searlet robes, as a child's bearing cloth,
Ill use to carry thee out of this place.

bearing-feeler (bãr' ing-fé "lèr), n. An automatic alarm for signaling the overheating of a journal-bearing. A plug of fusible material consud by suitable connections is masde to sond nun alarm.
bearing-neck (bâr' bearing-neck (bãr'ing-uek), n. The part which turus within the brasses of the pedestal of a car-truek,
of a shaft.

bearing-note (bãr'ing-nōt), $n$. In tuning tempered instruments, like the pianoforte, one of the notes that are first earefully tuned as a basis in tuning the others. Also called bearing. bearing-rein (bãr'ing-rān), n. The rein by
which the head of a horse is held up in driving. which the head of a horse is held up in driving. bearing-robe (bãr'ing-rōb), $n$. A garment answering the same purpose as a bearing-cloth. It was formerly enstomary for the sponsors to present such a robe to the child.

bearish (bãr'ish), a. [〈bear ${ }^{2}+-i s h^{1}$.] 1. Partaking of the qualities of a bear; morose or uncouth in manner.

In our own langusge we seem to sllude to this degen
ersey of human nature when we call men, by way of reersey of human nature when we call men, by way of re
prosch, sheepish, bearish, ete. bearish, etc.
IJarris, Three Trestises, Nutes, y. 344.
492

2. Heavy and falling: applied on the stock-

earishness (bãr' ish-nes), $n$. The state or (uality of bcing bearish iu nature, appearanee, or manner.

bear-leader (bãr'lē"dèr), n. 1. A person who leads about a trained bear for exhibition. Hence-2. A tutor or governor in charge of a youth of rank at the university or on his travols, or one in a similar relation. [Humorous.] Young gentleman, I sm the bear-leader, being appointed Cotwan the rounger. They pouneed upon the stray nobility, and seized young
lords travelling with their berr-lederers. Thackeray, Book of Snobs, vit.

bear-moss (bã̃'môs), n. Same as beurs.bed.
bear-mouse (bãr'mous), n. A book-name of a marmot or a woodehuck, translating the gemarmot or a woodehuck, translating the gebearnt (bãrn), n. [= bairn=barn'2, q.v.] An obsolete form of bairn.

bear-pig (bãr'pig), n. The Indian badger or sand-bear, Arctonyx collaris. See badger ${ }^{2}, 1$. sand-bear, Arctonyx collaris. See badger ${ }^{2}, 1^{2}$ keeping of bears in a zoölogical garden. In the center a stont pole, with cross-bars or steps at proper dis-
tances, is set up to enalble the bear to jndnlge in his intances, is set up to enable

earst, $n$. An obsolete spelling of barsc.

ear's-bed (bãrz'bed), $n$. The hair-cap moss,

a species of Polytrichum which grows in broad, soft mats. Also called bear-moss.

bear's-bilberry (bãrz'bil'ber-i), $n$. Same as bearberry, 1 .

bear's-breech (bãrz'brēch), n. 1. The English name of Acanthus spinosus. See Acanthus.2. The cow-parsnip, Heracleum Sphondylium: so called on account of its roughness.

bear's-colleget (bãrz'kol"ej), n. See bear-garden, 1

The students in bear's-college

B. Jonson, Masque of Gypsies.

bear's-ear (bãrz'ēr), n. The common name in England of the aurieula, Primula Auricula, from its early Latin name, ursi aur

bear's-foot (bãrz'fint), $n$. A plant of the genus Helleborus, II. fotidus. See Helleborus.

bear's-garlic (bãrz'gär"lik), $n$. A species of onion, Allium ursinum.

bear's-grape (bãrz'grāp), n. Same as bearberry, 1.

bearskin (bãr'skin), $n$. 1. The skin of a bear. -2. A coarse shaggy woolen cloth for overtall cap made of black fur forman of some military bodies, as of the Guards in the British army and
soldiers of various organizations elsewhere. The bearskins of the French geensdiers rose shove the
crest of the hill.
Y'onge, Life of Wellington, xxxili. Bearskin Jobber. See bear $2, n$

bear's-paw clam, root. See clam, root.

bear's-weed (bãrz'wēd), n. The yerba santa of California, Eriodiction glutinosum.

bearward (bã $\mathbf{r}^{\prime}$ wârd), n. A keeper of bears. We'll bait thy bears to death
And manacle the bearward in their clisins their clisings.

Those who worke with them co'mand them as our beare. wards to the besres, with s ring through the nose, and I entrested a bearuard one day to come down with the dogs of some four parishes that way. ${ }_{B}$. Jonson, Fepicene, i. 1.

bear-whelp (bãr'hwelp), n. [< ME. bere-hwelp; bear ${ }^{2}+v$ chelp.] The whelp of a bear.

An nnlleked bear-whelp. Shak., 3 Hen. VI., iij. 2

bearwood (bãr'wudd), $n$. The Rhamnus Purshiana, a shrub or small tree of the Paeific shand, a shrub or small
States. See bearberry, 2.

bearwort (bãr'wert), $n$. The mew or baldmoney, Meum athamanticun.

beast (bēst), n. [Early mod. E. also beest, ME. bceste, beste, $<$ OF. beste, F. béte = Sp. Pg. It. bestia = D. LG. beest, < L. bestia, an animal, ing being; an animal: in this extended sense now only in dialectal or colloquial use.

$$
\begin{aligned}
& \text { These ben the eyryssh [sirish] bestes, lo. } \\
& \text { Chaucer, Honse of Fame, L } 932 .
\end{aligned}
$$

To keepe this worlde bothe more and lesse
A skylfull beeste [manl] than will ynake
York Plays, p. 15.

2. Any four-footed animal, as distinguished from fowls, insects, fishes, and man: as, beests of burden; beasts of the chase; beasts of the forest. It is applied chiefly to large animals. The beasts, the fishes, snd the winged fowls. beast's-bane

Ouc decp ery
of great will beats. T'ennyson, Palace of Art. Beasts of chave are the buck, the doe, the tox, the mar. ten, sund the roe. Beasts of the forest are the hart, the hind, the hare, the hoar, aml the wolf. Beaxts of warren
are the liare and cony.
Corcell, Law Dictionary. 3. Any irrational animal, as opposed to man, as in tho phraso man and beast, where beast usually means horse.

O heaven! a beast, that wsints discourse of reason,
Would have monrn't longer. Shatk, Humlet, i. 2

4. $p l$. In rural ceonomy, originally all domestic nimals, but now only cattle; especially, fatting eattle as distinguished from other animals. -5 . In a limited specific use, a horse: as, my bectst is tired out. [Local, Scotland and U. S. Compare creature, critter, similarly used.] -6. Figuratively, a brutal man; a person rude,
coarse, filthy, or acting in a manner unworthy of a rational creature.

What an afticted conseience do 1 live with, Fletcher, Valentinian, iv. 1.

7t. [In this use also spelled as orig. pron., bästc, F. beste, now béte, in same sense.] (a) An old gamo of cards resembling loo. (b) A penalty or forfeit at this game, and also in ombre and quadrille. - Beast royal, the lion: used slso of And yet asconding was the beste roial,

Chancer, Squire's Tale, 1. 256.

Blatant beast, See blatent.
beasted (bês'ted), $a . \quad\left[<\right.$ beast, n., $7,+e d^{2}$.] Beaten at ombro or quadrille.

beastee, $n$. See bheesty. has not been hammered. It is used for glaziers' polishing-wheels.

beasthood (bēst'hùd), n. [< beast + -hood. $]$ The nature or condition of beasts. Carlyle.

beastíe ${ }^{1}$ (bēs'ti), $n$. [Dim. of beast.] A little animal. [Scoteh.]

beastie ${ }^{2}$ (bēs'ti), n. See bhcesty.

beastily (bēs'ti-li), adv. As a beast; bestially.

beastings, $n$. sing. or $p l$. See beestings.

beastish (bës'tish), $a$. [< ME. bestish ; < beast $+-i s h^{\mathrm{I}}$.] Like a beast; brutal.

It wonld be but a kind of anims or beatigh meeting. Mes), n. 1. The state or

beastliness (bēst'li-nes), n. 1 . 'The state or
quality of being beastly; brutality ; coarseness; vulgarity; filthiness.

Rank inumdation of luxurionsness

with such gross beastliness.

2t. Absenec of reason; stupidity.

Beastliness and lack of consideration.

North.

beastly (bèst'li), a. [< ME. becstely, bestely, mal: the opposite of spiritual.

It is sowun a beestli bodi; it shal ryse a spiritusl bodi.

2. Like a beast in form or nature; animal.

Beastly divinities and droves of gods.

Prion.

3. Like a beast in conduct or instinets; brutal; filthy; coarse.

Thon art the bersttiest, erossest baggage that ever man
met witha!! Midileton (and others), The Widow, 1.2

4. Befitting a beast; unfit for human use ; filthy; abominable.

Lewd, jrofane, snd beastly phrase.

B. Jonson.

Thrown into beattly prisons. Dickens, Hist. of Eng., xvi,

5. Nasty; disagreeable: as, beastly weather. [Slang.]

By, laying the defeat to the account of "this beastly
English weatler, you know." American, VI. 245. $=$ Syn. Brutal, Bestiul, etc. See brute

beastlył (bēst'li), adv. [< beast $+-l y^{2}$.] In the manner of a beast; filthily; abominably.

Fie on her! see how beastly she doth court him.
Shak., T. of the S., Iv. 2.

1 have seen a handsome eause so foully lost, sir,

So beastly east away, for want of witnesses.
Fletcher, Spanish Curate, iil. 1.

beastlyheadł (bēst' 'li -hed), $n$. [< beastly +

-head =-hood; one of Spenser's artificial words.] The character or quality of a beast; beastli-

: used by Spenser as a greeting to a
Sicke, steke, slas! and little lack of desd,
But I le relieved by your beastlyhead. Spenser, Shep. Cal., Msy.

beast's-bane (bēsts'bān), $n$. A variety of the wolf's-bane, dcoutitum Lycoctonum. 
beat

beat1 (bēt), $v$; ; pret. bcat, pp. beaten, bcat, ppr. beating. [<Mi. beten, <A, bedtun (pret, bcót pl. beciten $)=011 \mathrm{G}$. bözum, MIIG. bõnn = Icel, battre, $\mathrm{F}$. bat 1 , batter 1 , is aecilental, but has perlaps influoneed somo of tho meanings of periaps influoneed ${ }^{1}$. Henee bretle ${ }^{1}$.] I. trans. 1. To striko ropeatedly; lay ropeated blows upon. II'as beat mo twico, and beat me to a cowart The eagles of Mexitl shall beat the sir no more.
Ifhittir, The

2. To striko in order to produeo a sound; sound by pereussion: as, to beat a drum or a tainbourine.

Come, beat all the drums up,
And all the aolle instruments of war.

Feecher, lluworons Lleutengnt,

3. To play (a particular eall or tattoo) npon tho drum: as, to beat a charge; to beat a retreat. [The last phrase often means simply to rotire or retreat.]

The enemy was driven laack all day, as wo hal been the

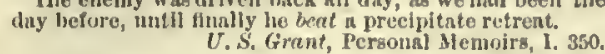
4. To break, bruiso, eomminute, or pulverize by beating or pounding, as any hard substanee. Theu shsil beat some of It very small. Fix. xxx. 36 . 5. 'To extend by beating, as gold or other mallenblo substanee, or to haminer into any form; forgo.

They dil beat the gold huto thin plates. Ex, xxxix. 3. The hammer which smote the Saracens at Tours was last auccessful in beating the Netherlundis into Cliristlanity

6. To soparate by eoneussion; strike apart; romove by striking or threshing: with out So she e. beat out that she had gleaned: and it was
mbout an epliah of barley. 7. To mix by a striking or beating motion whip into tho desired eondition: as, to beat or beat up eggs or batter, -8 . To dash or striko against, as water or wind.

Beyond this flood a frozen continent
lises, dark and wild, beal with perpetual storm.
Nhilton, P. L., i. .

9. To strike with the feet in moving; tread upor Pass awful gulls nud beat my pnintul wny.

Along the margin of the noonlight ses

We beat with thundering hoofs the level gand.

Amld the seind of steps that beat

The nurmuring walks like gutumun

Bryant, The Crowded Street.

10. To rango (fields or woods) with loud blow or other noiso in seareh of gime.

To beal the woods and rouse the bounding prey. Prior.

Together let us beat this slmple fleld,
Try what the open, what the covert ylell!

11. To overeome in battle, contest, or strife vanquislı or eonquer: as, one beats another a play.

Pyrrhus . . . beal the Carthagluians at sea. Arbuthnot. 12. To surpass; oxeel; go beyond: as, he beat them all at swimming. [Colloq.]

Many ladtes in Strasburg were beantirul, still

They were beat sll to stlcks hy the lovely Odille.
Barham, Ingoldsby Legenda, I. 239.

There is something out of common bere that beats any
thing that ever came in my way.

thing that ever came in my way.
13. To be too difficult for, whethor intellect ally or physieally; bafflo: $\mathrm{as}$, it beats me to mako it out. [Colloq.] - 14. To harass; ex ereiso severely; cudgel (one's brains)

Strrah, lay by your foolisli atudy there,

And beat your bralns about your own affairs.

Why ghould any one grammar who does not intcnd to be a critlc? Lock 15. To exhaust: as, the long and toilsome jour ney quite beat him. [Colloq.]

They hal been beaten out with the exposure and hard

16. To flutter; flap: as, to beat the wings: said of a bird. Seobate1.-17. In medieval embroi dery, to ormament with thin plates of gold or silver.

IIIr clothys weyth bestes and byrdes wer bele,

Qnoted in Rock's Textlie V'nbrics

One coat for niy lord's borly beat with gold. Dugdale, Baronage.

18. In printing: (a) To ink with beaters. (b) To impross by repeatcdly striking with a inal-
let a proof-planer pressed against the paper let a proof-planer pressed against the paper:
as, beat a proof of that form.-19. To obtain
493

\section{beat}

an unfair advantage of; defraud: as, to beat a lotel, [Slang, U.S.] - To beat a bargain. Ne bryain. - To beat a parley, to notliy the enemy l,y flag of truce.- To beat away, in mining, to cxcavate asumlly applled to hard gTound. - To beat back, to concol to retire or return. - To beat cock-nghting. Aco throw down ty beating or batterug, as a wall. (b) To press down or lay flat (gritsg, grall, etc.) hy nny prostrat fug actlon, as that of a violent wind, a current of water or the passage of persoms or anlmala. (c) To cause to lowe (a price) by importunity or angument: sluk or le:

It [usury] beats docen the prlee of land. Bacen, Usury. (d) To depress or crish : as, to beat donen elprosition. - To beat into, tu teach or instil by repetitjon of fnstruction. To extend by hanniering; hence, figuratlyely, wo work out

A man thinking on lils legs ls olliged to beat out his Ahought for lils own sske, If not for the sake of hils hearcrs,
Cornhill Mlag.

(b) To perform or execute, as a plece of mualc, by or a The clild's feet were busy beating out the tune.

l'erplext in faith, but pure in dceds, Maill Mag. At last he beat lifs muslc ont

To drive out or away. Tennyzon, In Memorim, xcvl.

Intermediate varietles, from exlating in lesser nnmber beuten the forns whileh they connect, will generally to modificatlon and improvement.

Daroin, (1)igin of swectes, p. 206.

To beat the atr, to fight to ne purpose, or againat no an. onlst or oppositlon.

I therefore so run, not as uncertalnly; so fight I, not ss To beat the bounds. See bound 1.-To beat the dust, (a) tor low, as a horse. - To beat the general, to soun the roll of the drum which calls the troops togrther.-To when ant soldlers except those alsent with permisglon are expected to be present in thulr quarters, - To beat the wind, to make a lew flourishes in the sir, and thins
be entitled to all the advantages of a victor, no was done under the medleval aystem of trial by battle when the ocisure or regulate time in nunsic by the motlon of the thand or foot. - To beat to a mummy. See nummy. To beat up. (a) To attack suddenly; alarm or dlsturt
hence, to comie to or upen unexpectedly : as, fo bent up an

A distant relstion lett him an estate in Ireland, wher he had reslded ever since, making occaslonal vlsits to the Continent and beating up his oid quarters, but rsrely con-
ing to Finglnnt. (b) To aummon or bring together as by beat of drum: ns,
to beat up recrults. (c) In hunting, to rouse and drive

Thcy beat up \& little game perad venture.

(d) In engraving to rumove (a dent or mark) ace of a plate by striking the loack with ark) (rom th lace of a plate by striking the back with a punch while
the face rests on a sheet of tin-loll on sn anvil or a atake. In thls way engravers can remove marks too deep to be ohliterated by the ecraper or burnisher. = Syn. 1. To

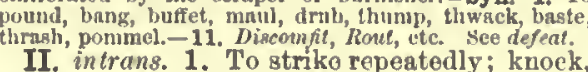
as at a door.

The men of the clty . . beat at the door. Judges xix. 22 2. To move with pulsation; throb: as, the pulse beats.

$$
\begin{aligned}
& \text { A thousand hearts beat hippily } \\
& \text { Byron, Childe ilarold, ill. } 21 .
\end{aligned}
$$

And hurrying hopes, his henrt begse to bet.

3. To act, dash or fall with foreo or violeneo as a storm, flood, passion, ete.: as, the tempest beats against the house.

And the aun beat upon the leat of Jonah, that he
Jonali Iv, 8 . Rolling tempesta valnly beat below. Dryien. For the neon Is coming on, and the sunheams flercely beat.
Bryant, Damsel of Peru. 4. To be tossed so as to strike the ground violently or frequently.

Hoating corjes lie beating on the shore. Addison. 5. To give notice by beating a drum; also, to sound on being beaten, as a drum.

But Linden saw another sight dead of night 6. To contain beats or pulsations of sound, as a tone formed by sounding together two notes
which are nearly in unison. See beat, $n ., 7 .-7$. To ponder; be incessantly engaged; be anx iously direeted to something; be in agitation or doubt.

If you be pleas'd, retire into my cell,

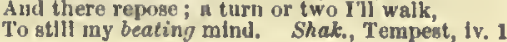

Thy haven is on earth; thine cyes and thoughts of thy henrt. VI., ii. I.

8. Naut., to anako progress aguinst tho wind by alternute tacks in a rigzag lino. A grox

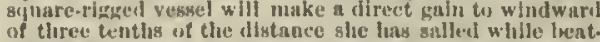
ing, while the gain to windward of an a verage Pre. And aft Higzed vessel wh
ance sillled.

We thok a pllot on loart, hove up our anchor, and he. IR. UI. Diana, Jr., licture the Must, p. 3. Many yschtsmen has yronounced it to be an impossl. In beit out in so light a brueze.

To beat about, to searuh by varlous menıs or ways;

Te llad an honest man, I beat about.

msn, I beat about.
I'ope, Einl. to Butires, II. 102.

ro beat about the bush, to appronch a matter in a conndatout or circumluentory wny. - To beat to quarto their statlons for battle. - To beat up and down, in

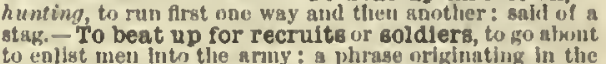
to enlist men hito the anuy : a phrase originating In the fact that a recruiting party was often preceled by a drum-
mer with hls instrument. - To beat upont, to enforce by mer with his instrum

Irow frefinently and fervently deth the seripture beat

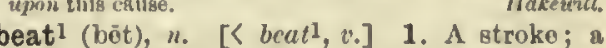
striking; a blow, wliether with the liand or with a weupon. [Rare.]

The Sullh Divinc, as with a carcless beat,

ruck eit the muto crentlon at a heat.
Dryilen, Illud and Panther, I. 253.

Thus we get but yeary and beats.

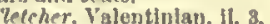

2. A recurrent stroke; a pulsation; a throb: as, tho beat of the pulse; tho heart makes from sixty to seventy beats a minute.-3. The sound made by the foot in walking or running; a footfall.

\section{The beat of her unaten feet
Whitch only the angels hear.}

4. A round or courso which is froquently gone : as, a watehman's beat; a milkman's beut. We had to descend from the sea-wall, and walk under Il, untll we got beyond the sentry's beat.
/locells, Venelian Llte, xil.

Hence - 5. A course habitually traverged, or a place to which one habitually or frequently resorts.-6. In Alabama and Mississippi, the prineipal subdivision of a county ; a voting-precinet.-7. In music: (a) The beating or pulmusical notes differing but slightly in piteh. Seo interferenee. The numher of bents per second is cqual to the difference betwcen the numbers of vibrstlons of the two notes. Thus, two notes having 256 and 255
vibratlons per second respectlvely, if sounded simultane ouly, will give riae to one beat each second, becanse once In encli secont the two wave-syatems (see sound $)$ will coln-
cide and produce a maximuni gound, snd once they will
be half a wnve-lenuth apart, and the gound will alniost be half a wnve-length apart, and the sound will almost
dtsappear. Also called beating. (b) The motion of tho hand, foot, or baton in marking the divisions of time during the perfomnance of a piees of musie. (e) Used vaguely by various English writers to denote different kinds of ornamental notes or graces. -8 . The third operation in papor-making, in which the pulp is still further divided and torn apart in the beating-engine. -9. The blow struek by a valve when falling into its soat. -10 . The bearing part or the facing of a valve.

The inlet and outlet valves in the covers of the alr-cyl. Inters are of brass provided with lenther beats.
Ure, Dict., IV. 740

11. A worthless, dishonest, shiftless fellow; a knave. [Slang.] - Beat of a watch or clock, the sald to be in beat or out of beat according as thie stroke at equal or unequal intervals. - Beat or tuek of drum (milit.), a succession of strekes on a drun, varied in different ways for particular purposea, as to regulate a march, to call aoldiera to thelr arms or quarters, to direct an at-
tack or a retreat, etc.-Dead beat. (a) Formerly, a person without money or resources; now, one who never poys, low : an Intensiffed expression of beat, 11 , above. [Slang-]
(b) $\mathrm{A}$ stroke or blow wtthoul recoll, as hi the dead.lyent
escapement. See excayement, Double beat, in wutsic, a escapement. See excapement, - Double beat, in wistic, a

or department. [Collog.] is the only form used attributively.] Exhausted by exertion, mentally or bodily; fatigued; worn ont by toil. [Colloq.]

Qulte beat and very unch vexed. Dicken. Dead beat, completely exlausted or worn ont, so as to the diflculty of a task; thoroughiy defeated in a contest 
beat

494

\section{beaupere}

beat2 (bēt), n. [Also bect, bait, < MF. bete; origin unknown, perhaps < beat $\mathrm{I}, v$, or pelliaps connected with bait, bate, steep: see bate. ${ }^{5}$. A bundle of flax or hemp made up ready for steep-

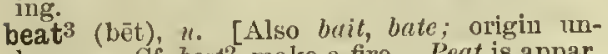
known. Cf. bect ${ }^{2}$, make a fire. Peat is appar. a different word.] The rough sod of moorland, or the matted growtl of fallow land, which is sliced or pared off, and burned, when the land is about to be

beat ${ }^{3}$ (bēt), $t$. t. and $i$. [See beat ${ }^{3}, u$.] To slice of (the beat or rough sod) from uncultivated or fallow ground with a beat-ax or breastvated or fallow ground wit, for the purpose at plow, in order to buru it, for the purpose at once of destroying it and of converting it into
manure for the land. $M . E . D . \quad$ [Prov. Eng.]

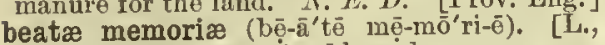
gen. of beata memoria, blessed memory: see of the dead.

beat-ax (bēt'aks), $n$. [E. dial., also bidax, bidix: < beat ${ }^{3}+a x^{1}$.] The ax or adz with which the beat is pared off in hand-beating. See beat ${ }^{3}, v . \quad$ N. E. $D$. [Prov. Eng.]

beaten $\left(\mathrm{b} \bar{e}^{-} \mathrm{tn}\right)$, p. a. [< ME. beten, < AS. beáten, pp. of becitan, beat: see beat $\mathrm{I}, v$.] 1 . Wrought upon by beating; formed or affected in any way by blows or pereussion: as, beaten work (which see, below).

This work of the candlesticks was of beaten gold.

Specifically -2. Worn by beating or treading; much trodden; hence, common from frequent use or repetition; trite: as, to follow the beaten course of reasoning.

A brosd and beaten way. Milton, P. L., i1. 1026.

Truth they profess'd, yet often left the true
And beaten prospect, for the wild and new.

3. Conquered; vanquished.

I suppose everything is right, even to Wooler's being
conqueror and I the beaten ruan.
Sytler.

4. Exhansted; worn out. - 5. Baffled, as by the difficulty of a task, intellectual or physical. - Beaten work. (a) Metal shaped by being himmered on sn anvil or a block of the requisite form. Hand-msde vessels of metal, especially those of rounded form, are conl-
monly sliaped by this process. (b) Repoussé work. See

beater (bé'tèr), n. 1. One who beats: as, carpet-beater; a drum-beater.

Enen the wisest of yeur great beaters do as oft punishe
natnre as they do correcte fsultes. Ascham, The Scholemaster, p. 32.
2. In hunting, one who rouses or beats up game. When the beaters crme up we found that the bag con-

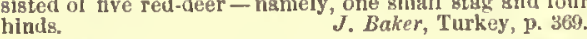

3. That which beats or is used in beating. Speciffcally $-(a)$ In basket-making, a heavy iron used for manuf, a machine for clesning snd opening the cotton preparatory to carding. This is accomplished hy beat-
lug the cotton, as it is fed through rolls, by horizental blades sttached to sn axle revolving with great rapid ity. (c) The jack of a knitting-mschine. (d) A malle
used in hat-making. (e) A tool for packing powder in a blast-liole. $(f)$ A scntching-blsde for breaking flax or hemp. ( $g$ ) In weaving, the lathe or batten of a loom makes the fabric more compact.

beater-press (bétér-pres), $n$. A machine for compacting materials for baling, by beating continued pressure.

beath (bётH), $v \cdot t$. [Now only E. dial., <ME. bethen, < AS. bethian, a parallel form of bathian, > E. bathe, q. v.] 1. To bathe; foment -2. To heat (unseasoned wood) for the purose of straightening (it).

$$
\text { Beath'd in fire for steele to be in sted. }
$$

beatific (bê-a-tif'ik), a. [<LL. beatificus, <bcatus, happy, + facere, make; ef. beatify. $]$
Blessing or making happy; imparting bliss.

The greatness and strsngeness of the beatific vision.

2. Blessed; blissful; exaltedly happy

He arrived in the most beatific frsme of mind. posed to constitute the essentisl bliss of saints snd anget beatifical (be-a-g-tif'i-kall), a. Same as beatific. [Rare.]

beatifically (bē-â-tif'i-kall-i), $a d v$. In a beatific manner.

beatificatet (bē-a-tif'i-kāt), $v$. t. To beatify.

beatification (bè̀-at"i-fi-kā'shon), n. [ $=\mathbf{F} . \dot{b} \epsilon$ atification, < LL. beatificare: see beatify.] 1 .
The act of beatifying or of rendering or pronouncing haply; the state of being blessed; blessedness.

The end of a Christian, ... the rest of a Christisn, snd

2. In the Rom. Cath. Ch., the act by which a 2. In tlie Rom. Cath. Che , the be beatified, or deceased person is declared to be beatified, or ject of a certain degree or kind of public religious honor. This is now an exclusive prerogative of the pope, but for several centuries it was also exercised by
local bisliops or metropolitans. It is usually the second
step toward canonization, and cannot take place till fitty step toward canonization, and cannot take place till fifty years after the death of the person to be beatified, except
in the case of inartyrs. The process is an elalorate one, in the case of martyrs. The process is an elalorate one,
consisting of thirteen or tonrteen stages, and extending over many years, during which the claims of the reputec scint are carefully and strictly investigated. If the fina result is favorable, the pope's decree is publichly read in
the pontifics] church, the image and rclics of the newly beatified are incensed, etc. See canonization. $\mathrm{IV}$. endeavored to procure his beatification. G. Ticknor, Span. Lit., I. 424

eatify (bē-at'i-fi),$v$. t.; pret, and pp. beatifed, ppr. beatifying. [<F. béatifier, <LL. beatificare, make happy, bless, < beatifiens, making happy, blessing, ¿ L. beatus, happy, blessed (pp. bene, woll), + facere, make.] 1. To make supremely happy; bless with the completion of celestial enjoyment: as," "beatified spirits," Iryden.-2. To pronounce or regard as happy, or as conferring happiness. [Rare.]

The common conceits and phrases which so beatify
Barrow, Works (ed. 1656), III. 161. Specifically - 3. In the Rom. Cath. Ch., to de-

The right of beatifying, that is, declsring 8 looly person a saint, and decreeing this due lonour inlght be paid him, within a particular diocese, continued to be exercised in Hence-4. To ascribe extraordiuary virtue or excellence to; regard as saintly or exalted.

His heroine is so beatified with description, that she Whipple, Es8. and Rev., I. 128. beating (b-'ting), n. [Verbal $\mathrm{n}$. of beat $\mathrm{I}, v$.] 1. The act of striking, or operating by blows; any process of working by percussion. Specifl. which they are made solt and pliable. (b) The process of hanmering gold and silver into leat. The sheets are marble block. (c) In bookbinding, the process of flatting bsdly pressed, or which hsve been

2. Punishment or chastisement by blows; a flogging. -3 . The state of being beaten or outlone; a defeat.

Our Anerican rifle-tesm has had its beating, but not a
The American, VI. 245 .

4. Regular pulsation or throbbing.

The beatings of my heart. I'ordsworth, Tintern Abbey. 5. In musie, same as beat, $7(a)$ : but in this the strings of a piano or the pipes of an organ.

beating-bracket (bē'ting-brak" et), $n$. The beating-engine (bē'ting-en"jin), $u$, 1. A machine with rotating cutters for preparing rags in paper-making.- 2 . Same as beating-maehine beating-hammer (be ting-ham er), $n$. A hammer having two slightly round

beating-machine (bē'ting-ma-shẽn"),. . A ma chine for opening and beating cotton, to loosen maehine, opener, beating-engine, ete.

beatitude (bệ-at'i-tūd), n. [< F. béatitude, L. beatitudo, < beatus, happy, blessed: see beatify.] 1. Supreme blessedness; felicity of the highest kind; consummate bliss; hence, in satisfaction. About him all the sanctities of hesven

Stood thick as stars, and from his sight received
Beatitude past uttersnce. Milton, P. Lu, iil. 62. Beatitude past uttersnce. Mitton, P. L., iil. 62.
Thonsands of the Jews find a peculiar beatitzde in hav. ing themselves interred on the opposite slope of the Moun of Olives. B. Taylor, Lands of the Saracen, p. 75. ness to those who possess particular virtues, pronounced by Christ in the Sermon on the Mount, Mat. v. 3-11: so named from the word
Ximenes has always been venerated in Spain. Plílip cree beatification. form more frequently applied to the beats of 6. Naut., the act of advancing in a zigzag line against the wind.

True beatitude groweth not on earth.
Sir T. Browne, Christ. Mor., lii. 11. in sontheastern France. "blessed" (in the Latin, beati), with which cach declaration or ascriptiou begins. - Formal beatitude, the possession of the
tive beatitude, the highest good.

[E. dial. (Exmoor and seilly Gloss.) and U. S. ; appar. < be-1 + attle for addle.] To addle the brain of; make a fool of. [Prov. U. S. (Massachusetts).]

bcau (bō), $a$. and $n$. [As an adj. long obsolete early mod. E. bow, <ME. beu, bieu, bcau, < OF beau, biau, earlier bel, beal, bial, mod. F, beau, bel, fem. belle, < L. bellus, fair, beautiful, fine: see belI, bell5. The noun is mod., and follows the $\mathrm{F}$. in pron.; the ME. adj. if still existent would be pronounced as in its deriv. beauty, q. v.] I. $\quad a$. Good; fair: used especially in address: as, "beau sir," Chaucer, House of Fame, 1. 643 . See beausire, beaupere, etc.

II. $n$.; pl. beaus or beaux (bōz). 1. One who is very neat and particular about his dress, and fond of ornaments and jewelry; a fop; a dandy: older: as, he is an old beau.

Besides thou art a beal : what's that, my child

A lop, well-dressed, cxtravagant, and wild. He is represented on his tomb by the figure of a bean dressed in a long periwig, and reposing himself npon vel.
vet enshions under a canopy of state. Addison, Thoughts in Westminster Abbey.

2. A man who is suitor to or is attentive to lady; a lover; a swain. [Now chiefly colloq. or rustic.]

Her love was sought, I do sver,

By twenty beanx and more.
Goldsmith, Elegy on IIrs. Msry Blsize.

The rural beaux their best attire put on, Crabbe, The Villsge.

=Syn. 1. Dandy, Exquisite, etc. See coxcomb.

beau $(b \bar{o}), v . t$. $\quad[<b e a n, n$.$] To act the beau$ to ; attend or escort (a lady).

beaucéantt, $n$. See beauséant.

beauclerkt' (bó'klérk or -klärk), $n$. [Early mod. E. also beauelark, < ME. beanelerk, < OF. beau, fine, + clere, elerk, scholar.] A good scholar; a learned man: known especially as a surnam of Henry I. of England (Henry Beauclerk). beaufin (bif'in), $n$. [A foreed spelling of biffin, beaufin (bif'in), $n$. [A foreed spelling of biffin,
as if $<\mathrm{F}$. beau, beautiful, $+f i n$, fine.] Same as bifin.

beaufreyt, $n$. Same as baufrey. Heale. beau-ideal (bō'i-de'-al or bō'e-dā-al'), n. [F., cont. Hene in to becu, adj qualifying ideal, n., an extaken as beau, adj., qualifying rdeal, n., an exA mental conception or image of any object, moral or physical, in its perfect typical form, free from all the doformities, defects, and blemishes accompanying its actual existence; a model of excellence in the mind or fancy; ideal excellence.

Yy ambition is to give them a beau-ideal of a welcome.

beauish (bō'ish), a. [< beau + -ishI.] Like a bean; foppish; fine: as, "a beauish young park," Byron, Beau and Bedlamite.

Beaujolais (bō-zho-la' $\left.\bar{a}^{\prime}\right), n$. [F. Bearjolais, a former division of France, now chiefly comprised in the department of Rhône.] A kind of red wine made in the department of Rhône,

beau monde (bō mônd). [F.: beau, < L. bellus, fine; monde, < L. mundus, world. See beau and mundane.] The fashionable world; people of fashion and gayety, collectively.

beaumontite (bō'mon-tit), $n$. [After Prof. Elie de Beaumont, of France.] In mineral., a variety of heulandite from Jones's Falls near Baltimore, Maryland.

beaumont-root (bō'mont-röt), $n$. Same as bouman's-root.

Beaune (bōn), n. [F.] A red wine of Burgundy. The name is given to wines produced in a large district

beauperet, beaupeert, $n$. [Early mod. E., also bevpeer, etc. (in the sense of 'companion, sometimes spelled beauphere, by confusion with phere, an erroneous spelling of ME. fere, a companion: see fere), ( $\mathbf{M E}$. bexpere, beaupere, bewpyr, etc., < (1) OF. bean pere, 'good father,' a polite form of pere, father (mod. F. beau-pere, tather-in-law, or stepfather),
+ pere, $\mathrm{F}$. pere, < L. pater $=\mathrm{E}$. father; (2) OF beau, fair, good, + per, peer (mod. F. pair), 


\section{beaupere}

peer, equal.] 1. A term of courtesy for 'father,' sed especialiy in audressing or speaking of iests.-2. A companion, compec

Now lexullng lim finto s secret ahule

$$
\text { Spender, F. \&., III. I. } 35 .
$$

beauperst, bewperst, n. [Also boupres; perhaps, like many other fabries, named from the place of its original manufacture, conjectured in this case to be Beaupréa, a town in France with mannfactures of linen and woolen.] A fabric, apparcntly of linen, used in the sixteenth and made of it.

With iny cozen Rlchard Pepys upon the 'Chnuge, about

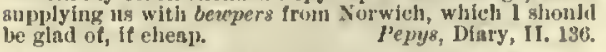

beau-peruket, $n$. A name given to periwigs of exaggerated length wom in the reign of WiIliam III.

beau-pot (bō'pot), n. [An erroneous form (simulating N. beau, beantiful) of bowpot for bouglipot, q. v.] A large ornamental vase for eut flowers.

beauseant, beauceantt, $n$. [OF. bauceant, a flag (see def.), perhaps < baucent, baueent, ete.

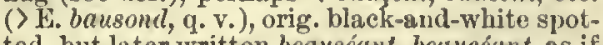
ted, but later writton beauséant, beauéant, as if < F. beal, fine, handsome, comely, + séant, suitable, lit. sitting, ppr. of seoir, sit: soe séance.] The flag of the order of the Templars, half black and half white, and bearing the inscription, "Non nobis, Domine, non nobis, sed ulomini tuo da gloriam."

beau-semblant $n_{\text {. }}$ [F.: beau, fair; semblant, appearance: see semblanee.] Fair appearance. Court of Love, 1. 1085.

beauship (bö'ship), $n . \quad[<$ bean + -ship.] The character and quality of a beau being a bean: used sometimes, as in the extract, as a title.

rou lnugh not, gallants, as by proof appears,

At what his beauship says, but what lie wears.
Congreve, Prol. to Dryden Jr.'s 11 usband hls own Cuckold.

beausiret, $n$. [ME. also beausir, bewsher, ete., $<O F$. beau sire, fair sir: seo bean and sir, and ef. beaupere. See also belsire.] Fair sir: an anciont formal mode of addross.

beauteous (bñ'tẹ-us), $a$. [Early mod. E. also beautious, benteous, bewtions, beuteus, < ME. bewteous, etc., < bevte, beaute, beauty, + -ous.] Possessing beauty; sensuously beautiful. [Chiefly poetical.]

I ean, Petruchio, help thee to s wife,

With wenth enough, and young, nild beauteous.

$=$ Syn. IIasidsome, Pretty, etc. See beautifut.
beauteously (bū'tē-us-li), adv. [<ME. bewty osely, < bewtyose, bewteous, beauteous, $\left.+-1 y^{2}.\right]$ In a beauteous manner; in a manner pleasing to the senses; beautifully.

Look upon pleasurea not npon that slde that Is next
the sun, or where they look beauteonsty. the sun, or where they look beacte日ush. Taylory Living, li. \& 1. beauteousness (bū'tẹ-ns-nes), $n$. The state or quality of being beariteous; beanty.

beautification (bñ ti-fi-ka'shon), $n$. $\quad[<$ beauti$f y$ : see-fication.] The act of beantifying or rendering beauti.

'This thing and that neceasary to the beautification of

beautified (bū'ti-fid), p. a. Adorned; made beantiful; in her., ormamented with jewels, feathers, or the like : said of a crown, a cap, or any garment used as a bearing. The blazon ahonld atate In what way the bearing is besutlfed, as, for exbeautifier (bü'ti-fi-èr), $n$. One who or that which makes beantiful.

Semirmmls, the founder of Bsbylon, according to Justin and Strabo; bnt the ent

Costard, Astron, of the Anclenta, p. 102.

beautiful (bn̄'ti-fủl), a. [Early mod. E. also beutiful, bewliful, butyful, etc. ; < beauty + -ful.] Full of beauty; possessing qualities that delight the senses, especially the eye or the ear, or awaken admiration or approval in the mind. See beruty, 1.

It was moated round sfter the old manner, but it ia now

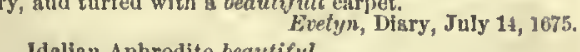
Idalian Aphrodite beautiful,
Fresh as the form, new-luath Silence, beautifut voice Be still, for yon only trouble the mind Enor Tennyson, Maud, v. 3.
It is a beautinut necessity of our nature to love some-
I). Jerrotd. We are clearly consclous of the propriety of apjiying
the eqfithet beautiful to virtuea ancli as charity, reverence, the eqifthet beautiful to vlrtuea anch as charity, reverence, irfety to dutles of perfect obligation, such as veraclty or
Lecky, Furop. Slorals, I. 84. The beautiful, that whlch possesses beauty; ieanty In the abstract: as, the beantif
the true, and the bea niful.

Cnn we conceive of a perfod of linman dievelojment at th It is very old, this srehitcelure [Duomo nt YI urano]; bint the eternal youth of the beaufiful belongss to it, and there is aesrce a atone falien from th that I would re.
Houcels, Venetinu Life, xll. $=$ Sym. Beautiful, Beruteous, Handsome, P'relly, Fair, pleasing, eajectally to the eye. Leautiful, the most gen. pleasing, eqjecially to the eye beantiful, the most gent.
eral of these words, is also often the nolleat and most spirltuai, exj/ressing that which gives the lighliest satilypoetic, nud covers the less spirltisl part of beatiful. Iandome ls founded upon the notion of proportlon, aymmetry, as the result of cultlvation or work; a handearne
llgury is strletly one that lias been developed by attention to pliyaical laws into the right proporttons. It is ess ajpiritual than beautifut is handrome tace is not or more importsnt things than pretty: as, a handxome aypliea to thist which has aymmetry snd delicscy, a dimln. ncas, disnity, feelling, purpose, etc. A thing not anall of ta kind mny be enlled pretty If It is of littic dignity or prelty is not uaced of men or their belonglngs, exeept in contenupt. Fair slarts Irom the notion of a brighitness tinat catchea the eye; it notes tinat aort of beanty which
delights the eye by coniplexion and feature; in this aense delights the eye by conplexlon and teature; in this aense
It is now leag common fin proae. Lavely is a strong word tor that which la lmmedintely plensing to the eyo; It applies primarily to that whleh exeitea admiration and love.
Comely applies rather to the humsn fgure, ehlefly in its proportlons; it is used leas commonly than handsom The moen was pallld, but not falnt;

ADd benutiful as gome fair saint. Longfellore, Orton. And there a vision canght iny eye

A handsome honse, to lodge s friend;
A river at my garden's end. Pope, Imit. of Horace, Satires, II. vi. Yothing more bearetiful - nothing prettier, st least-
was cver made than Phobe. Hauthorne, Seven Gables, ix. The lamps shone o'er fair wenten and brave men.
Byron, Childe Ilarold, ili.

$$
\begin{aligned}
& \text { Sweet Auburn, loveliest village of the plain. } \\
& \text { Goldsmith, Dea. VII. }
\end{aligned}
$$

I donbt, indeed, if the shepherda and ahepherdeases of his dsy were any comelier and any eleaner than theae ir tiescendant

C. D. I"arner, Roundabont Journey, p. 114. manner.
Fine by degrees and beautifully less. And beautifully less. beautifulness (bū'ti-full-nes), $n$. The quality beautify (bū'ti-fi), $v$; ; pret. and pp. beautified, ppr. beautifying. [Early mod. E. also beutify, bentyfy, bertify, -fie; < beauty + -fy.] I. trans.
To make or render beantiful; adorn; deck; grace; decorate; embellish.

The arts that beautify and polish life.

Jid ereeping moas and ivy's darker gree

Burke.

llow nuch thy presedee beautifies the ground !

Adorn, Ornament, ete. See adorn and decorate.

II. intrans. To become beautiful ; advance in beanty. [Rare.]

It muat be a prospect pleasing to God himself, to see
his creation for ever beautifying in his eyes. beautiless (bū'ti-les), a. $[<$ beauty + -lcss. $]$ Destitute of beauty.

Unamlable, . . beautiless, reprobate. Hammond, Worka, IV. 7.

beauty (bn̄'ti), n.; pl. beauties (-tiz). [Early beute, beaute, earliest form bealte < of biaute, bealtet, beltet, F. beauté, = Pr. beltat, beutat $=$ Sp. beldad $=\mathrm{Pg}$. beldade $=\mathrm{It}$. beltì, < $\mathrm{ML}$. Sp. beldad = Pg. beldade = It. belta, < ML.
bellita $(t-)$, beanty, < L. bellus, beantiful, fair: see beau and bell ${ }^{5}$. 1 . That quality of an object by virtue of which the contemplation of it directly excites pleasurable emotions. The word lenotes primarily that whleh pleasea the eye or enr, lut which uwakens admiration or approval : as, intelleetual beauty, moral beauty, the beauty of holiness, the beauty

IIe hath a daily beauty in hils life That makes me ugly. Shak., Othello, v. 1.
A thlng of beauty is joy for ever.
Kerts, Enilynlon, 1. 1. The homely beauty of the good old csuse is gone. beaver

It eyes were mude for secing,
Then beauly la its own excuse for being.

Brauty resulis from sdnptation to our faeuities, suil a initellectual. The aeuse of beruty and the affectton that followa it atting than to the course of slmple duty whilch constitutes a uncrely truthiful and upright man. 2. A particular graco or clarm; an embellishwhent or ornament.-3. Any particular thing urpasses in pleasing qualities that with which it is united: generally in the plural: as, the beauties of an author; the benties of nature.

lowk in thy soul, and thon slatit benuties find,

Like those whicli drown'd Yarclasus in the tlood.
Sir J. Davies, Immorta, of Soni, $x x x$

4. A beautiful person; specifically, a beautiful woman; collectively, beautiful women : as, all the beauty of the place was present.

Thls laily was not oncly a greate becuty, lut a most Évelyn, Dlary, July 8,1675 And I have alisiow'd many a grouj of beruties, that were born

In teneup-times of hood mili hoop
Or white the patcl was worn Ternywon, The Talking Oak

5†. Provailing style or taste; rage; fashion. She stalied her lialr yellow, whllcli wss then the beauty. Camberwell beauty, the laneasa Antiopa, a besutlful parts of the United States : so named from having been fonnal sometines at Camberwell, a suburl, of London. The w/ngs are deep, rlch, velvety brown, with a band of black, and an onter band or murgin of pale yellow vappled with of beauty, line of beauty. Sec curve. - Dependent jeet fa euntemplaterl in itself, but onjy when it is considered In lts silaptation to its end.

What has lyeen distinguished as dependent or relative beanty is nothing more than a beantified utility or utilized Ideal beauty, the stsndnrd of eathetic perfection which in the rules which govern those arts.- Mixed beauty, the character of an objeet which is beautiful and at the aame tíme afforda pleasure of another kind. = Syn. 1.
Lovellness, laineas, comelineas, attraetlveness; elegance, beautyt (bu''ti), v. t. [< ME. bertyen, < beuty, ete., beanty: see beauty, n.] To render beauiful; adorn, beautify, or embellish.

The harlot's cheek, beautied with plast'ring art.
Shak., lfamlet, iis. 1

beauty-of-the-night ( beanty-sleep (bñ'ti-slèp), $n$. The sleep taken before midnight, popularly regarded as the most refreshing portion of the night's rest. beauty-spot (bu'ti-spot), n. 1. A patch or spot placed on the face to heighten beanty, as formerly practised by women; hence, something that heightens beauty by contrast; a foil.

The filthluess of swine makes them the beatiy-8pot of The numberless absurditieg into whleh this eopyism has led the people, from nose-rings to ear-rings, from
painted facea to beauty-spots. 2. An especially beautiful feature or thing. Burnyon.

beauty-wash $\nmid$ (bū'ti-wosh), n. A cosmetic.

beaux, $"$. Plural of beau.

beauxite, $n$. See bauxite.

beaver ${ }^{1}$ (bē'vér), n. and a. [Early mod. E. also beator, bever, < ME. bever, < AS. beofer, biber $=$ Icel. bjōr $=$ Sw. bäfver $=$ Dan. boever $=\mathrm{L}$. fiber, OL. biber ( $>$ It. betero $=$ Sp. bibaro Pr vibre = k' bievere $=$ Gael beabhar = Corn. befr = OBuig. bebrŭ, bıbrŭ, bobrŭ, Bohem. Pol. bobr = Russ.bobrŭ= Lith. bebrus = Lett. bebris, OPruss. bebrus, a beaver, = Skt. babhru, a large ichmeumon; as adj., brown, tawny; perhaps a redupl. of $V^{* b h r u, ~ t h e ~ n l t . ~ r o o t ~ o f ~ A S . ~ b r u m, ~}$ quadruped, about two feet in length, of the family Castorida and genus Castor, C. fiber, at one time common in the northern regions of both hemispheres, now found in considerable numbers only in North Ameriea, but occurring solitary in central Europe and Asia. It has ghort ears, a blunt nose, small fore leet, Jarge weblbed hind surface. It ia valued for its fur (whlch ured to be largely is now for the most part substituted) and for an odorife- 
beaver

Its foed consists of the hark of trees, leaves, roots, and berries. The favorite haulsts of the beavers are rivers and lakes which are bordered ly thrests. When they fin acress it $\mathrm{a}$ dam constructed with great ingenuity of wood stones, and mud, gnawing down sunall trees for the purpose, and compacting the num by llows of their powerfull tails. In winter tliey live in looses, whiell are from to 4 feet high, are lovilt on the water's edge with subarnteons entrances, and afterd them protection ron wolves an other wild animals. They formerly abounled thronghout thinly populated regions. Several slightly different varieties of the European beaver have recelved special names. The North American beaver is somewhat larger than the
Enropean, ancl exlibits some slight cranial peculiarities

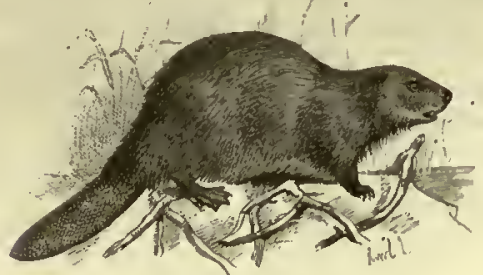

Beaver (Castor fiber)

it is eommonly rated as a distinct species or eonspecies, beaver, Castoroides ohioensis, belongs to a different family, Castoroidida (whieh see). See also Cartorida. of beaver fur.

This day I put on my half cloth black stockings and m my bever I was, after offlee was done, ready to go to my
Lord Mrayor's feast. Hence-(b) A hat of the shape of a beaver hat, but made of silk or other material, in imitation of the fur. The modern stiff silk hat was com monly called a beaver until recently.-4. A glove made of beaver's fur. Miss Austen. - 5. both sexes. The thickest quality is used for overcoats.

II. $a$. Made of beaver or of the fur of the bea ver: as, a beaver hat: beaver gloves.

beaver ${ }^{2}$ (bé'vér), $n$. [Early mod. E. also bever pever, ete. altered, by confusion with beacer in "beaver hat," from earlier bacer, bavier, late ME. baviere, $\mathrm{OOF}$. bariere (= Sp. babera = It. baviera), beaver of a helmet, prop. a bib, < bave, foam, froth, saliva: see barette.] In medieval armor, originally a protection for the lower
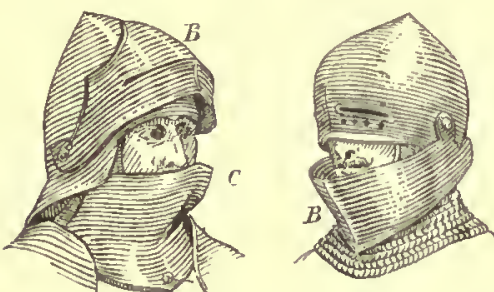

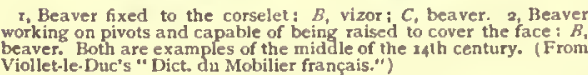

part of the face and cheeks, fixed securely to the armor of the neck and breast, and suff. eiently large to allow the head to turn behind it. In this forn it was worn throughout the flifteenth century with hesdpieces otlier than the armet. In English armor it was the movable protection for the lower part of the face, while the vizor covered the upper part; it is there-
fore nearly the same as the aventaile (which see). In the with the vizor.

So beene they both at one, and doen uprear

$$
\begin{aligned}
& \text { Their bevers bright each other for to greet. } \\
& \text { Spenser, F. Q., II. 3. } 29
\end{aligned}
$$

Their armed staves in eharge, their beavers down,

Their eyes of fire sparkling through sights of steel.

beaver ${ }^{3} t_{2} n$. and $v$. Seo bever ${ }^{3}$.

beavered (bé'vèrd), $a$. [< beaver ${ }^{2}+-e d^{2}$. $]$

His beaver'd brow a birchen garland wears.
Pope, Dunciad,

beaver-poison (bét'vèr-poin $z n), n$. The waterhemlock, Cicuta maculata.

beaver-rat (bé'ver-rat), n. 1. The name in Australia of the murine rodents of the family Muridee and genus Hydromys (which see). They are aquatic animsls of Australia and T'asmanis, inhabiting the banks bordering both salt and fresh water, swimming
and diving with ease, and in general economy resembling
496

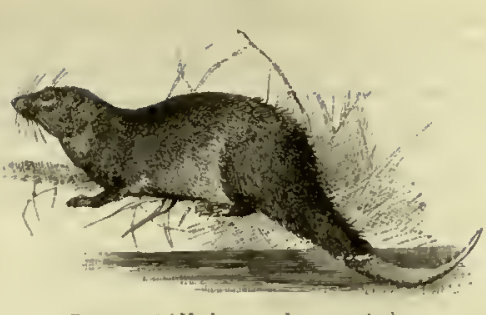

the water-vole of Enrope, Arvicola amphibius, or the musk l'at of America.

2. A name of the ondatra, muskrat, or m quash of North America, Fiber zibethicus.

beaver-root (bét ver-röt), $n$. The yellow pondlily, Nuphar advena.

beaverteen (bë'vèr-tēn), $n . \quad\left[<\right.$ beaver $^{1}+$-teen, after vclveteen.] 1. A cotton twilled fabric in which the warp is drawn up into loops, forming a pile, which is left uneut.-2. A stron cotton twilled fabric for men's wear. It is a kind of smootb fustian, shorn after being dyed. If sh

beaver-tongue (bếvèr-tung), $n$. Same as costmary.

beaver-tree (bē'vèr-trē), $n$. The sweet-bay of the United States, Magnolia glauca.

beavor $t$, beavor ${ }^{2} t, n$. Obsolete forms of bent"cr 1 , bcaver ${ }^{2}$.

beballyt, $a$. [Late ME., a corruption of OF. (AF.) "bipallé, < bi-, two, twice, + "pallé, party par-pale: a term of blazon" (Cotgrave). In her., divided into two parts by a vertica line; party per pale: said of an escutcheon. bebeastt (bẹ-bēst'), $v . t . \quad[<b e-1+b e a s t$.$] To$ make a beast of; consider as a bcast; treat as beast.

bebeeric (bē-be'trik), a. [< bebceru $+-i c$.$] Of$ or derived from bebeerin. Also written bcbiric. - Bebeeric acid, \& white, crystalline, yolatile acld bebeerin, bebeerine (bē-bé'rin), n. [< bebeer q. v.] The active principle of the bark of th bebeeru or greenheart-tree of Guiana. It is said to be Identieal with buxine, $\mathrm{C}_{8} \mathrm{H}_{2} \mathrm{NO}_{3}$, and is used as a bitter tonic and febrifuge, ehiefly in the form of the erude (0)

[Native name, also
spelled bebearu, bibiru.] spelled bebearu, bibiru.] A tree of British Guiana, Nectandra Rodicei, natural order Lauracece, chants by the name of greenheart, and is largely ims and submarine structures, being remarkably hard and durable, and not subject to injury from the ship-worm (Teredo navelis). Its bark contains bebeerin, and is uscd as a febrifuge. bebization (bē-bi-zā'slon), n. In music, the system of indicating the tones of the scale, for leference or practice, by the syllables $l a, " b e$, ee, de, $m c$, fe, ge, proposed in 1628 by Daniel scale in the abstract, but to the scale beginning on A. See bobization, solmization, etc.

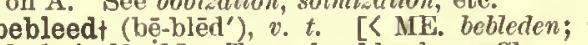
e-1 + bleed.] To make bloody. Chaucer, Knight's Tale, 1. 1144.

beblott (bē-blot'), v. $t . \quad\left[<b e-1+b l o t^{1}.\right]$ T blot all over; stain.

$$
\text { Beblotte it with thi teeris eke a lyte. }
$$

oblubbered (bō-lolónd), [< bebered.] Befouled or bleared, as with weening. Her eyes all beblubbered with tears.

Shelton, tr. of Don Quixoto, 1. iii. 13. beblurt, $v \cdot t$. [< be-1 + blur.] To blur all over. bebung (bä'bung), n. [G., a trembling, < beeffect given to a sustained note in either vocal or instrumental music, for the sake of expression. Grove.

bec $^{1} \dagger, n$. An obsolete form of beck 1 .

bec $^{2}$ (bek), n. [F., beak: see bech 4 , beak 1.$]$ A beak; in music, a mouthpiece for a musical in-

becafico, becafigo (bek-a- $\left.f \bar{e}^{\prime} k \overline{0},-g o ̄\right), n$. Same eccofico.

becall (bē-kâl'), v. t. [< ME. bicallen, bikal len, < bi-, be-, + callen, call: seo be-l and call.] 1†. To aecuse.-2†. To call upon; eall forth. challenge. -3 t. To call; summon. -4 . To call names; miscali. N. E. D.

ecalm (bẹ-käm'), v. $t .\left[\left\langle b e_{-1}+c a l m.\right] 1\right.$. To make calm or still; make quiet; ealm.

The moon shone clear on the becalmed flood. Dryden. beccafico

Banish his snrrows and becalm his soul with easy dreams. 2. Naut., to deprive (a ship) of wind; delay by or subject to a calm. A man becalned at ses, out of sight of land, in a fair
day, may look on the sun, or sea, or ship, a whole holl,
Locke. becalming (bē-kä'ming), n. The state of being becalming ( Other unlucky accidents oftentimes happen in these eas, especially in becalmings.

becalmment (bō-käm'ment), n. [< becalm + -ment.] 'The state of being becalmed. [Rare.] became (bē-kām'). Preterit of bccome.

becap (be्-kan'), $v_{.} t_{*}$; pret. and pp. becupped, ppr. becapping

becard (bek'ärd), n. [<F. *becard, <bec, beak: see beal 1 and -ard.] A name of sundry insectivorous birds of Central and South America such as those of the genera Tityra and P'saris, given on account of their large or hooked bill. becarpeted (bē-kär'pet-ed), a. $[<b e-1+c a r-$ pet $+-d^{2}$.] Furnished or covered with a carpet or carpets; carpeted. [Rare.] Is there snother country under the sun so becushioned,
becarpeted, and becurtsined with grass?
The Century, XXVII. 110. becarve (bē-kärv'), v. t. [<ME. bekerven, 〈AS. bcceorfan, eut off, $<$ be-priv. + ceorfan, eut. In
mod. use, $<$ be-1 + carre. $1+$. To cut off. - 2 . mod. use,
To cut up or open (laud).-3. To cut to pieces. N. E. D.

becasse (be-kas'), n. [< F. bécasse, a woodcock, <bec, a beak: see beah $h^{1}$.] The Furopean woodcock, Scolopax rusticula.

becassine (be-ka-sēn'), n. [<F. bécassine, < bécasse: see becasse.] The European snipe, Gallinago mcdia.

eca use (bë-kâz'), $a d v$. and conj., orig. prep. phr. Early mod. E. also by cause ; $<$ ME. because, bicause, bycause, also and prop. written apart, be causc, bi cause, by cause, being the prep. by with the governcd noun cause. The phrase by cause of, or because of (cf. the similar phrase by rcason of), was used as equiv. to a prep., and the phrase by cause that, or bccause that, afterward shortened to because (collog. and dial. cause), as a conj.] I. adv. 1. By reason (of); on account (of): followed by of.

The spirit is life, becaure of righteousness. Rom. viil, 10. Let no self-reproach weigh on you because of me. George Eliot, Jill on the Floss, vil. 3.

t. For the sake (of); in order (to)

II. conj. 1. For the reason (that); since. These wickets of the soule are plac'd on hie Because all sounds doe lightly mount aloft.
Sir $J$. Davies, Nosee Tejpsum. Why is our food so very sweet? Hen who could never be taught to do what was right because it was right, soon learned to do right because it was a becoming thing in them, as knights and nobles, to do so.
Stille, Stud. Med. Hist., xil. 2t. To the end that; in order that. And the multitude rebuked them, becaure they should
Mat. $x x .31$. [Recause introduces a elause stating some partieular cirnot ususllyy mentioned, the truth of the preceding clause neeessarily follows, or $(b)$ in consequence of a general
purpose, the agent is led to perform the act, or bring purpose, the agent is led to perform the act, or bring about the state of things, mentioned in the previous clause. ciple or major premise.] = Syn. 1. See since. beak (1.] 1. "The long point of a hood, especially in the fifteenth century, when such points reached below the waist behind.-2, A long scarf or streamer attached to a turban-shaped cap in the fifteenth century. Fairliolt. eccabunga (bek-a-bung'gä), n. [NL. ML., LG. beekebunge ( $=$ D. beckbunge $=\mathrm{G}_{\text {. bachbunge), }}$ brooklime, < becke $(=\mathrm{D}$. beek $=\mathrm{G}$. bach $=\mathrm{E}$. beck ${ }^{1}$, a brook, + bunge $=$ OHG. buengo, a bunch, bulb. Cf. Icel. bingr, a bolster, a heap: see bingi.] The brooklime, Veronica Beccabunga. eccæ $n$. Plural of becca.

eccafico (bek-a-fé-' $k \bar{o}), n$. [Also written becafico, beccafica, beccafigue, etc. (cf. F. becfigue), <It. bcccafico, <beccare = F. bccquer (Cotgrave), also becqueter, peck with the beak (< bccco = F. bce, > E. bech ${ }^{4}$, beak 1 ), + fico, a fig, < L. ficus, a fig: see $f i g$ and $f c o$.] ' 1 . An old and disused name of sundry small European birds, chiefly of the family Sylviide, or warblers, which peck figs, or were supposed to do so. The applieation of the worit is indeterminate; but it has been, perhaps, most frequentily used in conneetion with the garden-warsome anthors. 


\section{beccafico}

In extendet use -2 . One of sundry sunall Ameriean birds, as somo of those formerly included in a gonus Ficedulu. - 3. The European goltlen oriolo, Oriolus galbula.

beccot, $n$. [It., a goat.] A enekoll.

Me, thou art a bece, a cornuto.

bec-de-corbin $\nmid$ (bek' de-kor'-ban'), tt. [F', lit. erow's beak: see beak ${ }^{1}, d e^{2}$, and corbie.] 1 . A name given in the middle ages to the pointed tel-do-fer, or war - hammer. Heneo-2. Tho wholo weapon laving sueh a point or lamo given in the eighteruth century to the century to the load of a walking-cane having somewhit the form of

\section{bechamel}

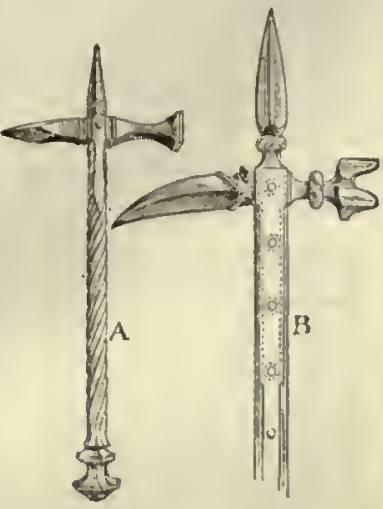

Becs-de-corlin, asth century.

(besh' a-mel), A, with handle of wrought-1ron ${ }^{B}$, with

chamel: see

caokery, a white sauce of elaborate composition, named from its invontor, Louis do Béchamol or Béchameil, marquis of Nointel, steward to Lonis XIV.

bechance $^{1}$ (bē-ehàns'), v. $\left[<b c-1+\right.$ elance, $t^{*}$. $]$

I. intrans. To happen; chanee.

II. trans. To befall; happen to.

My sons - God kuows what lath bechanced them.

bechance ${ }^{2}+$ (bō-chåns'), arlv. [For by chance, ef. bccausc.] Aceidentally; by ehance. We bechanee lost our sovereign loril. Grafton, Hen, Vill, an. It

becharm (bê-ehärm'), v. $t$. [< bc-1 + charm.] To charm; enptivate; enchain.

The lethargy wherein niy reason long

issth lieen becharmed.

Beau. and Fl, Law's of

Prithee, Interrupt not
The paradise of my becha swing thotights
Ford, Fane

Ford, Fancies, Iv. 1

bêche-de-mer (bāsh'dè-mãr'), n. [F., lit. spade of the sea (beche, <OF, besche (ML. besca; ef. equiv. becen: see beck ${ }^{3}$ ), spade; de, <L. de, of mer, <L. mare, sea, =E. mere), a namo explained as having reference to the sliape of the animals when dried and pressod, but roally an aceommodation of the $\mathrm{Pg}$. name bicho do mar, lit. worm of the sea, sea-slug : bicho = Sp. bicho, a worn, grub, slug; do, of the; mar, <1. mare, sea.] The trepang, a species of the genus Holothuria (H. argus), or sea-slugs, much esteemed by the Chinese as a eulinary delieaey. See trepang.

bechic (bé'kik), $a$. and $n$. [< L. bcchicus, < Gr. $\beta \eta \chi \iota k \delta s$, pertaining to a cough, $<\beta \eta \xi(\beta \eta \chi-)$, a

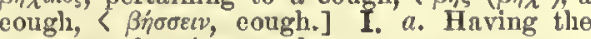
property of curing coughs.

II. $n$. A medicine for relieving eoughs; pectoral.

beckl (bok), n. [< ME. bck, becc, <AS. *bece (Bosworth $=$ Icel, bek.kr = Sw. baek = Dan. berk. but the ME . only authenticated AS. form being bece, bece, only authenticated AS, form being bece, bace,
dat. of bcce (giving mod. E. "bcteh, which prob. exists in the dial, bateh: see batch ${ }^{2}$ ) $=$ OS. beki $=$ OD. beke, D. beck = LG. beke, bäk = OHG. bah, MHG. bach, a brook.] 1. A brook; a small stream; especially, a brook with a stony bed or rugged eourso.

The brouks, the becks, the till the rills: Polyolbion, i. The reflex of a benuteous form, A glowing srrm, a gleaming neck, As when a sunbean wsvers warm
Within the dark snd dimpled beck.

Teunyson, Thie Miller's Daughter.

2. Tho valley of a beck; a field or pateh of ground adjacent to a brook. See bateh 2

beck $^{2}$ (bek), $v$. [< ME. bceken, bekken, short for beknen, beekon: see beckon.] I. intrans. 1 . To signal by a nod or other siguifieant gesturo; boekon.
497

become

Who 's ho but bowed if this great prince but becked?
Drayton, Quecu Margaret.

The becking of onr ehsuce. Let us follow

Flecher (and another), Two Noble Kinsmen, i. 2. 2. To rocognize a person by a slight bow or

II. trans. 1. To summon or intimato some command

Bell, bowk, and candle sliall not drive me lack,

When golli and silver becks ne to cone on.

2. To express by a gesture : as, to beck thanks. [liaro.]

beck ${ }^{2}$ (bok), n. [< MH. bek, < beken, brelen, beek: seo becli2, $v]$ 1. A nod of the liead or other significant gesturo intended to be understood as expressive of a desire, or as a sign of command.

Nods, ani becks, and wreathed smlles.

3 Iy guiltiness hat need of such a master,

Thiat with a beck can suppress numititule

I would wisi myself a uttle more commsnd snd goverelgnty; that all the court were subject to my alsolute 2. A gesturo of salutation or recognition; a bow; a courtesy. [Seotch.] - At one's beck, at one's beek and call, sulvject to one's slightest wist olliged or ready to olvey sll of one's orders or tesires.
It was necessary for him to have slways at his beck some men of letters from Paris to point out the golecisms anci false rhymes of which, to thie last, ho was frequently
gullty. We move, my friend,

beck ${ }^{3}$ (bek), $n$. [E. dial., not found in ME., <A.S. becca, glossed ligo, a mattoek; of. ML. becca (ef. becca, glossed ligo, a mattoek; of. ML. becca (ef.
MI. besca, $>\mathrm{OF}$. besche, mod. F. beche), a sparle; Pr. beca, a hook, Ir. bacc, a hook.] An agrieultural implement with two hooks, used in dressing turnips, ete.; a form of mattock.

beck $^{4}+$ (bek), $n$. [< ME. bek, bec, < OF. bec,

beak; the samo word, retaining the orig. short vowel, as the now more eommon beaki.] 1 . A beak. - 2. Auy pointed or projecting part of the dress, especially of a head-liess, as of tho byeoeket.

beck 5 (bek), n. [Prob. another form of back ${ }^{3}$ q. v.] A vat or vessel used in a dyc-house; a back.-Clearing-beck, in calico-printing, s vat in whlch cottons printed with

certain colors sre clentised or seutred beck $6+, n$. [Cf. beak ${ }^{2}$.] Same as beck-harman. becker (bek'èr), n. [E. dial. (also becketl, q. v.) appar < bccls + erl. Cf. F. beccard the femalo salmon.] A name of the fish sparus pagrus, otherwise called braize aud king of the pagrus, oth

beckern (bek'èrn), n. Same as bickern and beak-iron.

becket1 (bek'et), n. [F. dial.; cf. OF. bequet, bechet, a pike or pickerel, dim. of bec, beak: seo bcak1, bcck4.] Same as becker.

becket ${ }^{2}$ (bek'et), $u$. [Origin obseure.] Naut.: (a) A short piece of rope, with a knot at one

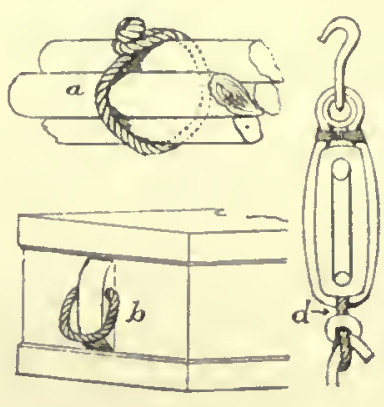
end and an eye in the other, for temporaropes or small spars. (b) A handle made of a rope grommet or ring. (c) A wooden cleat or hook, fastened on the fore- or main-rigging of a ship, for sheets to lie in when rot in use. (d) $A$ rope grommot in the bottom of a bloek for securing the standing end of the fall. (c) A cant term for a trousers-poeket. becket ${ }^{2}$ (bek'et), $t$. $t$. $\left[<\right.$ becket ${ }^{2}, n$. $]$ To fas ten or provide with beekets. Cooper.

beck-harmant, $n$. [Also harman-bcek; old slang, of obseure origin; with bcck ef. equiv. beckingt (bek'ing), $n$. [Verbal n. of beck ${ }^{2}, t$.] The aet of making a beek; the aet of bowing or nodding The Conmunion was sltogether like a poplsh mass,
with the oll apish tricks of Antichisist, bowings and beck. ings, kneelings snd knockings, the Lord's Death, stter st. By. Bale, fi $\mathrm{l}$. W. Dixun's tist. Ch, of Eng., xxi.

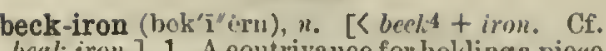
beal-iron.] 1. A eontrivanee for hollinga piece of wood firmly whilo it is planed. It is marle of the or stecel rorls fasteneit the of the wori.

2. A small anvil with a shallow groove, for rounding tho inside of the bows of seissors.

beckon (bek'n), ?. [Early mod. E. also bccken, <M1. beknen, beenen, beknien, < AS. bēenian, biécuan, later also lichenian (OS. bōkniau = OHIG. bouhnen $=$ ON. bühia , < bericen, a sigm, beacon: seo beacon.] I. intrans. To make a signifieant gesture witl tho liead or hand, intendod as a hint or an intimation, especially of a desire for approach or de parture, or for silenee. Aiexander beckned with the hand, ani would have maite

II. trans. To make a signifieant sign to; summon or direet by making signs.

I see a hand you crunot see,

Which beckons ue awsy.
Tickell, colin and Lucy. Beekoning the imagination with promises letter than suy
Lotell, study Windo ws, p. 325. fultiment. Lorcell, Study Windows, p. 320.

beckon (bek'n), ". [< bceknn, t"] A signifbroke, Parties. [Rare.]

beckoner (bok'n-ér), n. Ono who beekons or ealls by signs.

eclapł (bẹ-klap'), v. t. [< ME. beclappen; be-1 + cl( ()$\left.\left.^{1}\right)^{1}\right]$ To eatch; grasp; insnare.

Ile that with his thonsand cories ilyo continuelly us Chaucer, Second Nun's Tsle, 1. 1.

beclipt (bē-klip'), $\imath$. t. [<ME. beclippen; $\left\langle b_{c}-1\right.$ + clip 1.$]$ To embrace; elasp.

And sodenly, ere she it wlste,
Beclijt in arines he lier klste.

ecloud (bē-kloud'), t. t. $\left[<b_{-}-1+\right.$ cloud. $]$ TO overeloud; obscure; dim.

Storns of tears becloud his eyes $l$ ly the mass of writings.

become (bẹ-kum'), v.; prot. became, pp. become ppr. becoming. [Farly mod. E. also becum, be cume, <ME. becumen, bicumen, < AS. becuman, bicuman, come, happen $(=\mathrm{D}$. bekomen $=\mathrm{OHG}$. biqueman, MHG. bckomen, G. bekommien, reach, suit, = Goth. bikwiman, come upon one, befall), < be- + cuman, come: see be-f and come. In the sense of befit, suit, ef. AS. gecuême, ME. icreme, eveme, and OIIG. biquämi, MHG. be quame, $\mathrm{G}$. bequem, fit, suitable ; also AS. cymice, E. comely, and L. contenien $(t-), \mathrm{E}$. concenient.] I. intrans. 1†. To come; arrive; betako one's self; go.

But when they saw that they shoulde become vuder the oledlence of another prince, they sntfred the Greekes to
meet Alexsuder. You shall have sometimes fair houses so full of glass
that one camnot tell where to become to be out of the sums I cannot joy, until I be resolv'd
Where our riglit valiant father is become.

To come about i como into non-existence; arise. [Rare.]

The only resls for lim [11nme] were certain irrelated sen-
cations, and out of these knowledge arises or thecomes

3. To change or pass from one state of exis tenee to another; eome to bo something diffel ent; come or grow to be: as, the boy rapidly becomes the man.

The Lord God ... bresthed into his nostrils the hreati Iife ; and man became s living sonl. I rue
That errour now, whileh is becme my crime. If the Bank be uncongtltutionsl, when did it become so 4. To be fit or proper; be decorous or praisoworthy. [Rare.]

$$
\begin{aligned}
& \text { Set this dlamond safe } \\
& \text { In gollen palaces, as it becomes. }
\end{aligned}
$$
Shake, 1 Hen. VI., v. 3

To become of. (at) To come ont of ; result from. See I. (b) To be the fate of ; be the end of; be the finsl or subsequent condition: after what: as, what will become of
our conmerce? what will become of us? It applies to place as well as condition: What has becmme of my frlend? that as well as, what is his condition?

What is then becone of so huge s multitude? Raleigh. Sneer. And pray what becomes of her?

Sheridan, The Critle, iil. 1
She

II. trans. 1. To suit or be suitable to; be congruous with; befit; aceord with in charac- 
become

ter or circumstances; be worthy of or proper to: rarely said of persons.

If I become not a cart as well as another man, a plagne on my bringing up! I hope 1 shall as soon be strangled
with a hatter as another.
Shak., 1 llen. $1 V$, ii. 4. Became him like the leaving it his life Shak., Macbeth, i. 4.

1 dog't think so much learning beromes a young woman. 2. To bofit in appearanee; suit esthetieally; graee or adorn.

I have known persons so anxious to have thelr dress become thein, as to convert it at length into their proper to become the dress.

[Formerly becomed was somotimes used as the past participle.

A good reluke,
Whielt might have well becom'd the best of men

becomedt, $p . a$. [Irreg. and rare pp. of become.] Becoming.

I met the youthful lord at Laurence' cell,

And gave him what becomed love 1 might,

Shak., R. and J., iv. 2.

becomenesst, $n$. [< beeome, pp., + ness. Cf. forgiveness, similarly formed.] Becomingness. becoming (bē-kum'ing), $p_{.} a$ and $n$. [Ppr. of become, $v$.] I. 1 . $a$. 1. Fit; sutable; eongruous; proper; belonging to the charaeter, or adapted to the eireumstances: formerly sometimes followed by of.

Such [discourses] as are becoming of them.

Dryden. This condescension, my Lord, is not only becoming of your ancient fanily, but of your personal eharacter in
the world. Dryden, Ded. of Love Triumphant. 2. Suitable to the appearanee or style of; befitting esthetieally: as, a beeoming dress. = Syn

II eet, appropriate, fltting, seemly, conrely, decent.
II. If. Something worn as an ornament.

Sir, forgive me,
Since ny becomings kill me, when they do no

. That whieh is suitable, fit, or appropriate. Burnet, among whose many good qualities self-com.
mand and a fne sense of the becoming cannot be reekoned. 3. In metraph., the transition from non-existene into existence; an intermediate state betwee being and not being; a state of flux; the state of that whieh begins to be, but does not endure; ehange; development: opposed to being.

becomingly (bệ-kum'ing-li), adv. After a beeoming or proper manner.

becomingness (bẹ-kum'ing-nes), $n$. Suitableness; congruity ; propriety; deeeney; graeefulness arising from fitness: as, "beeomingness of virtue, Delany, Christmas Sermon.

becqué (be-kä'), a. [F., < bee (beequ-), beak, + $-e ́=E_{.}-c d^{2}$.] In her., same as beaked.

becripple (bẹ-krip'l), v. t. [<bc-1 + cripple. o make lame; cripple. [Rare.]

Those whom youl bed wart and becripple hy your poison-
ous medicines. Dr. II. Hore, Mlystery of Godliness, vi. 19 .

becuiba-nut (be-kwë'bä-nut), n. [< bceniba, bicuiba, or vicuiba, the native name, + nut. Biculyba, from whieh a balsam is drawn that is eonsidered of value in rhenmatism.

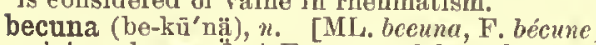
origin unknown."] A European fish of the fami
ly Sphyranida (Sphyrona spet), somewhat re-

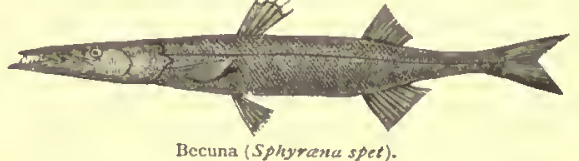

sembling a pike. From its scales and air-bladder is obtained a substance useful in the manufacture of artifl
cial pearls. The flesh is well flavored. becurl (bẹ-kérl'), v. $t$. [〈be-1+curl. $]$ To furnish or deek with eurls : as, a becurled dandy. bedI (bed), n. [Larly mod. E. also bedd, bedde, <ME. bed, bedde, < AS. bedd, bed = OS. bed $=$
OFries. bed $=\mathrm{D}$. bed $=\mathrm{OHG}$, beti, bette, bct, G. bett, beet = Ieel. bedhr = Sw. bädd $=$ Dan. $b c d=$ Goth. badi, a bed (the speeial sense of a plat of ground in a garden oceurs in AS., MHG., ete., and is the only sense of Dan. plaee dng out, a lair, and thus akin to L. fodi, dig: see foss, fossil, ete.] 1. That upon o within which one reposes or sleeps. (a) A large flat bag flled with feather's, down, hair, straw, or the like;
498

intended for shelter and warmth. (c) The maftress sod lure of wood or metal, upon which they are placed. $(d)$ ture of wood or metal,
The bedstead by itself.

The chest contrived a double debt te pay,

Henee-2. By extension, the resting-plaee of an animal.-3. Any sleeping-place; a lodging; ceommodation for the night.

That you'll vouchsafe me raiment knes I heg

Shak., Lear, ii.

4. Matrimonial conneetion; eonjngal union; matrimonial rights and duties.

George, the eldest son of his second bed.

Clarendon, Hist. Ref., I. 1. 9.

5. Offspring; progeny.-6. Anything resembling, or assumed to resemble, a bed in form or position. (a) A plat or piece of ground in a garden in which plants, especially flowers, are
raised a little above the adjoining ground.

Beds of hyacinths and roses. Miten, Comus, 1. 098.

(b) The bot tom of a river or other strean, or of any body

A uarrow guily, apparently the dry bed of a mountain Irving, Sketch-Book, p. 53 ,
(c) A layer; a stratum; an extended mass of anything, whether upon the earth or within it: as, a bed of sulphnr; ed of sanit or clay. In geology a bed is a layer of rock; and is so separated from the rock which lies over and under it, that it has a claracter of its own. This distinctness of character may be given by pecullarities of composition texture, or color, or simply by a facility of separation froni the associated bcds. Thus, there may be a bed of marble intercalated in a mass of shale; or there may be several vidualized by peculiarities of texture or color. In the latter case there would ordinarily be a distinct break solution of contlnuity between the different heds, so th When (fnarried they would separate from each other witlstratum is commoaly employed in geological writings, an 18 almost the exact erinivalent of bed. Bed, as applied to mineral deposits, implies ordinarily that the masses of
ore thus characterized lie flat, and have more or less of the character of sedimentary deposits, in distinction from 7. Anything resembling a bed in funetion; that on which anything lies, or in whieh anything is embedded. Particnlarly - ( $\alpha)$ In building: (1) Either of the horizontal surfaces of a builling-stone in position.
The surfaces are dist Inguished as the upper and the lowe bed. (2) The under surface of a brick, glingle, slate, tile in position. (b) In gun, the foundation-piece of wood, hollowed ont in the middle, to receive the breech and hat the trunnions. (c) In mach., the foundation-piece on which the machine is constructed. (d) In a grinding
mill, the lower grindstoae. (e) In printing, the talle of printing.press on which the form of types is lald. It is now or stune. $(f)$ In railway-cont ruction, the superficial earth work with the ballasting. ( $(q)$ Naut., a thick, flat pieee
of wood placed under the guarter of casks in a slip's hold to relleve the bilge or thickest part of the cask from pressure. $(h)$ The beams or shears which Bupport the puppets
or stocks of a lathe. (i) In max sonry, a layer of cement or mortar in which a stone is cmbedclec, or against which it bears. (j) In a plane, the inclined face against which the plane-iron bears, (k) The lower die in a punehing-machine, stocks. $(m)$ In bookbinding, the conch nsed in the process
of marbling the edges of books. It is a water-solution of 8. A floek or number of animals, as of wild fowl on the water, closely paeked together.9. A division of the ground in the game of hop-scoteh, also ealled loeally the game of "beds."--Aix beds, in gcol., thick fresh-water Tertiary ing of calcareous marls, caleareo-silicious grits, and gyp
sum and full of fossil tishes, insects, and plants. - Applesum, and full of fossil tishes, insects, and plants.-Apple-
pie bed. See apple-pie.-Bagshot beds, ja geol, certail beds of Eocene Tertiary age which form outliers near London, England, and occupy a considerable area aroun They are chiefly composed of sand, with occasional layers
of clay, as also of lrickearth and pebbles. The Bagshot beds rest upon the London clay. They are usually desti-
tute of fossils. Also called Bagrhot sand.-Bala beds, in geol, certain beds of Lower Silurian age which are par. ticularly well developed near the town and lake of Bala
in IIerionetlishire, Wales. - Bed of the bowsprit, a bearing formed ont of the head of the stem and the apron tice). (a) A tirrone on which the king of France was scated
the when he attended parliaruent. Hence, $(b)$ a formal visit several objects, but latteriy, when tie parliament became a power in the state, beds of justice were held principally for the purpose of compelling the parliament of Parls the king when it showed unwillingness to do so. They
were also held to try a peer, to create new taxes, to do were also held to try a peer, to create new taxes, to de-
clare the majority of the king, etc. - Bembridge beds, in geol. a f fossiliferous division of the Upper Eocene
strata, principally developed in the Jsle of Wight, Eng. land, consisting of marls and clays, resting on a compact pale-yellow or cream-colored limestone called Bem-
bridge limestone. They abound in the shells of bridge limestone. They abound in the shells of Lymnoea mammatian remains of the Palootherium and $A$ noploTale, Envoye, 1. 15. bedag

therium, One lay 2 is composed almost entirely of the rebeds, in geol. a serics of strata ocenrring near Brora in Sutherlandshire, scutland, of the age of the Lower Oolite remarkable for containing a seam of good coal 3l feet secondary strata of Great Britail. - From bed and board, a law phrase applied to a separation of man and wife without dissolving the bands of matrimony: now called a judicial separation. - Ganister beds. Sce ganister.-
Hydrostatie bed. See vater-bed. - Maestrieht beds, in geol., a member of the Cretaccons, forming the lower
division of the upperunost subgronip of that series, and espectally well developed at Maestricht in the Netherands. These heds contain a mis forms with such as are characteristic of the older Tertiary.- Parade bed, in some ceremonial fucerals, par-
ticulsrly of great personages, a bed or bier on which a

The effigy of the deceased with his hands crossed upon book, lying upon a parade bed, placed on the top of a C. C. Perkins, Italian Sculpture, p. I20. Purbeck beds, in geol., a group of rocks named from the andian and forming the hishest diviston of the portseries in England. The fossils of the Purbeck are frestic water and bracklsh, and there are in this formation dirtleds or layers of ancient soli containing stumps of trees which grew in them. The same formation is also found in Same as Osborne series (which see, under series). - To be of: as, to be brought to bed of a son. - To make a bed, bed $^{1}$ (bed), $v$; pret. and pp. bedded, ppr. bedding. [< ME. bedden, beddien, < As. beddian OHG. bettō $n=\mathrm{Sw}$. bädda), prepare a bed < bed, a bed.] I. trans. 1. To place in or as in

My son I' the ooze is bedded. Shak., 'Tempest, til. 3.

2. 'To go to bed with; make partaker of one's

$$
\begin{aligned}
& \text { They have married me: } \\
& \text { I'll to the Thiscan wars, and tuever bed her }
\end{aligned}
$$
Shake, All's Well, ii. 3

3. To provide a bed for; furnish with aceom modations for slconing. -4 . To put to bed; speeifieally, to put (a eouple) to bed together, is was formerly the eustom at weddings.

The 1rauphin and the Danphiness were bodded.
London Gaz. (1680), No. 1494.

5. To make a bed of, or plant in beds, as a mass of flowering plants or folinge-plants as a to transplant into a bed or beds, as from pots or a hothouse: often with out.

Sucin [cuttings] as are too weak to be put in the nursery closely in beds by thenselves, where they can remain fot one or two years, until they are large and strong cnough root grafting or for the nursery row's,

6. To embed; fix or set in a permanent position; furnish with a bed: as, to bed a stone.

$$
\begin{aligned}
& \text { Rites which attest that lian by nature lies } \\
& \text { Bedded for goot and evil in a gulf }
\end{aligned}
$$

7. 'T'o lay in a stratum; stratify; lay in orde or flat.

$$
\begin{aligned}
& \text { Your bedded hair. } \\
& \text { Starts up and stanils on end. }
\end{aligned}
$$

8. To make a bed for, as a horse: eommonl used with down.

Aiter bedding down the horse and fastening the barm, returned to the kitehen.

II. intrans. 1. To go to bed; retire to sleep by extension applied to animals. -2 . To eo habit; use the same bed; sleep together.

If he he married and bed with his wife.

They the wasps] never molested me serions They bedded with me.
Thoreau, Walden, p. 258. 3. To rest as in or on a bed: with on.

The rail, therefore, beds throughout on the ballast.
Ure, Dict., III. 692.

4. 'To floek elosely together, as wild fowl on the surfaee of the water.-5. To sleep; pass bed2t. An oeeasional Middlo English preterit of bid.

bedabble (bē-dab'1), v. $t . \quad[\langle b c-1+d a b b l c$.$] To$

dabble with moisture; make wet: as, "bedab bled with the dew," Shak., M. N. D., iii. 2.

bedad (bë-dad'), interj. An Irish mineed oath, eorruption of be gad, for by God?

Bedad, she'(1) conse and marry some of 'en. Thackeray. bedaff + (bē-dáf'), $v$. $t$. [ME. bedaffen (pp. by daffed $),\left\langle b e-+\right.$ daffe, a fool: see be-1 and daff ${ }^{1}$. T'o befool; make a fool of. Chaucer, Clerk's

bedaft (bē-daift'), p.a. Stupid; foolish

To bedaggle. 
bedaggle

bedaggle (bē-lag' 1$), v . t$. [<be-1 + laggle. Cf. onds in the mud, or spattering them with dirty wwater. J. Richurdson, Notes on Milton.

bed-alef (bed'āl), $n$. Alo brewed for a confincment or a cliristening.

bedare $($ bộ-dãr' $), i, t . \quad[<b c-1+$ darel. $] \quad \mathrm{T}$ dare; defy. The eagle i. is emloldenen
With eyes intentive Lo bedare tho sun.
Peele, Davla and

bedark† (bō-därk' ${ }^{\prime}, v_{0} t_{0}$ [< MF. becterlien; be-1 + durk, $v$.] To darken.

Whan the blacke winter night ..

Al priveiy they gone to londe.

Gancer, Conir. Amant., 1. 81.

bedarken (bē-där'kn), $v, t$. [<bp-l + darlien.] 'To cover with darkness; darken; obseuro.

bedarkened (bē-dïr'knd), $p_{0}$ a. 1. Obseured. -2. Niguratively, existing in mental or moral darkness; sunk in ignoranee: as, "this bedark cned race," Southey.

bedash (bē-dash' $\left.{ }^{\prime}\right), v . t .[\langle b e-1+d a s h$.$] To wet$ by throwing water or other liquid upon; bespatter with water or mud: as, "treesbedash" with rain," Shate, Rich. III., i. 2. So terribly bedashd . . that you would swear
IIe were lighted from a horse-race.
Middleton, Anything for a Quiet Life, L. 1

bedaub (bệ-dâb'), v. t. $\left[\left\langle b e_{-1}+d a u b.\right]\right.$ To daub over; besmear; soil.

Bedoub falr designs with a foul varnishl.

Bedawi (bed'a-wē), n.; pl. Bcdawin (-wēn). See Bedouin, 1

bedazzle (bē-daz'l), v. t. $[<b e-1+d a z z l e$.$] To$ dazzle by too strong a light; blind or render ineapable of seeing elearly by exeess of light.

My mistaklng eyes
That have been so bedazzled with the sun,
That everything I look on seemetin green.

Shak, T, of the $\mathrm{S}$, iv, 5 Sunrise threw a golden besm into the study and lald it Igint across the minister's bedazzled eyes.
IIcecthone, Scarlet Letter, $x x$. bedazzlingly (bẹ--daz'ling-li), $a d v$. So as to

bed-board f (bed'bōrd), n. The head-board or foot-board of a bodstead.

bed-bolt (bed'bōlt), n. Naut., a horizontal bolt passing through both the brackets of a gunearriage on whieh the forward end of the stoolbed rests.

bedbug (bed'bug), $n$. The Cimex lectularius or Acanthia lectularia, infesting beds. See bug ${ }^{2}$. bed-chair (bed'ehâr), n. An adjustable frame designed to enable invalids to sit up in bed. Also ealled chair-bed.

bedchamber (bed'ehām'bẻr), n. [< ME. bedchaumbre (= $\mathbf{M H G}$. bettekammere) ; < bed $\mathbf{1}+$ or appropriated for a bed, or for sleep and repose. Lords of the bedohamber, officers of the Britare twelve in number, snd wait a week each in turn. The groon of the stole does not take inis turn of duty, hut attends the king on all state oceaslons. There are thirteen grooms of the bedehamber, who wait likewis
in turn. In the ease of a (1neen regnant these posts ar in turn. In the ease of a (Ineen regnant these posts are
oceupied by women, ealled ladiez of the bedehamber. In oceupied by women, ealled ladiez of the bedehamber. In
either ease they are generally held by persons of the highest nobinity.

bed-clip (bed'klip), n. In coach-building, a bed of the vehiele to the spring or to the axle. bedclothes (bed'klōmHz), n. pl. The eoverings used on beds; sheets, blankets, quilts, ete., colleetively.

bed-cover (bed "kuv"èr), $n$. A bedquilt or bed-

bedded (bed'ed), p. a. [Pp. of bed', $\left.v_{0}\right] 1$. Provided with a bed.-2. Laid in a bed; embedded.-3. Existing in beds, layers, or strata; stratified, or included between stratified masses
of roek. Chlefly used in eomblnation, as thin-bedded, of rock. Clilefly used in eomblnation, as thin-bedded,
heavy-bedded, etc. Mlasses of Igneous roek formed by suecessive overllows of molten malerial are often sald to be 4. Growing in or transplanted into beds, as plauts. Dost sit and hearken

The dreary meledy of bedied reeds

In desolate places. Keats, Endymion, 1.239.

bedder (bed'èr), n. 1. One who puts to bed. -2 . One who makes beds (mattresses); an upholsterer. [Local, Eng.] -3. A bed-stone; Plillips (1706). Also bedetter.-4. A beddingplant (which see).

bedding (bed'ing), n. [ $\mathrm{C}$ ME. bedding, < AS. bcdding (for "beddung) $=\mathrm{G}$. bettung; <bedl +

499

\section{bedight}

-ing1.] 1. The aet of placing in a bed; a bedelvet, $v . t$. [M1. bedelven, < AS. bcrldfan putting to bed, ospecially of a nowly married $<$ be-, about, + delfan, dig: sce be-1 and delve.]
couple. See bed, $x . t ., 4$. To dig round or about. -2 . To bury in tho

A eircumistantial deserlption of the weilding, bedding,

2. A bed and its furniture; the materials of a bed, whether for man or beast.

Pray God he have not kept such open honse,

lings, and my bedding:
$B$. Jonson, Alchemist, v. 1 .

3. In geol., as used by most geologists, the oxact equivalent of stratifieation, or oceurrence in strata or beds. Soobed, bedded, and lamination. -4 . In building, a foundation or bottom layer of any kind. -5 . "The seat in wlich a steam-boiler rests.

bedding-molding (bed'ing-inōl ${ }^{\prime}$ ding), $n$. Same is bed-molding.

bedding-plant (bed'ing-plant), $n$. An ornamental flowering plant or foliage-plant suited by habit for growing in beds or masses, and to produce a desired effect, generally of eolor, by combination with other plants.

bedding-stone (bed'ing-stōn), n. In brielilaying, a straight piece of marble applied to tho lubbed side of the briek to prove whether the surface is straight or not.

beddy (bed'i), a. Bold; forward. [Seotch.] But ir my puppies once were resdy, iratson's Collection, I. 70.

bedel $t, n$. An obsolete form of bcad.

bede 2 (bëd), n. [Etym, unknown.] In English mining, a peculiar kind of piekax.

bedead $\dagger\left(\mathrm{b} \bar{e}-d e d^{\prime}\right), t, t$. [<be-1+dead.] To deaden.

Others that are bedeaded and stupefled as to their
Matiyuelt, JIelampronon, p. 1. bedeafen (bē-def'n), $v . \quad t_{0} \quad[<b e-1+d e a f e n$. To render deaf.

bedeck (bẹ-dek'), v. t. [< be-1 + deek. $]$ To deek out; adorn; graee: as, "bedecling ornaments," Shak., L. I. L., ii. 1 ; "bedecked, ornate, and gay," Milton, S. A., I. 712. Such wonderful and priceless gifts as these, Fit to bedeck the limbs of goddesses! Willicem Mforris, Eartilly Paradise, I. 245.

edeen (bẹ--dēn'), adv. [North. E. and Se., < MW. bedene, beden, bidene, biden; of uneertain origin; appar. < bid-, whieh seems to be an unexplained substitute for bi, E. by, prep. (less cne, $<$ AS. $\overline{c e n e}$, once, at onee, $<\vec{a} n$, one: see onee, one, and ef. anon, of somewhat similar formaone, and ef. anon, of somewhat similar formation. Bedeen is often a mere expletive.] $1 \mathrm{f}$. In one after another. - 3. Forthwith; straightway.-4. Anon; by and by.

Read on our Bibles, pray bedeen. Biackétood's IIag., XXVilt. 738

bedegar, bedeguar (bed'ēegär), n. $\quad[<\mathrm{F}$. bédegar, bedeguar, ult. < Ar. tle, lit. wind-brought, $b a d$, wind, $+\bar{a} w(a)$ âcardan, bring. Later, in tho form $b \bar{a}$ dēward, appar. taken as bäd, wind, + Ar. card, roso.] A spony excreseenee or gall, ometimes termed sweetbrier-sponge, or robin-redbreast's pineushion, found on va rious species of roses especially the sweet-

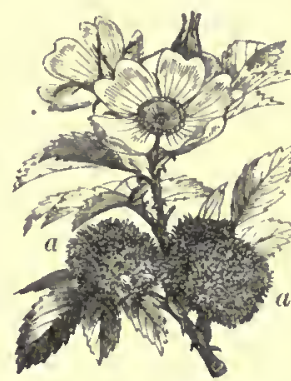

brier, produced bysev-

$a, a$, Bedegar

lites rose and $R$. bieolor, as the result of puneture and the deposit of their eggs, and contain ing their larve : once supposed to have medicinal properties.

See bcadhouse.

edel, bedell ( $b \bar{e}^{\prime} \mathrm{dl}, \mathrm{b} e \underline{-}-\mathrm{del}^{\prime}$ ), n. [<LT. bcdellus : seo beadle.] In tho medieval universities, a servant of a "nation" or faculty (each of which companies elected two, an upper and a lower, termed the csquire bedel and the yeoman bedel, terms showing the classes from which they were chosen), whose duties were to apportion the "schools" or lecture-rooms and the chapters of the colleges and halls, to ery the days and hours of the leetures, to publish and earry out the deerees of the company, to mareh before the rector, dean, or proctor with a silver mace on oecasions of ceremony, ete. See beadle.-Grand besions of ceremony, ete. See beadle.-Gr
del, the upper bedel of the facuity of theology. earth.

A man dals the erthe . . snit fund tilere a golyet of bedeman, $n$. See beudsman.

beden (bë'den), $n$. [< Ar. buden.] A kind of ibex. bedenet, alv. Sco beleen.

bederollt, $u$. Sce bead-roll.

bedesmant, $n$. Seo beulsman.

bedetter $f, n$. Same as bedder, 3 , of which it aypears to bo a corruption.

bedevil (bē-dev'l), $\imath_{\text {. }}$. ; pret. and pp. bedcriled or bederilled, ppr. bederiling or bederilling. [< be-1 + devil.] 1. To treat with diabolieal vioenee or abuse.

Dedevilled and used worse than St. Barthojomew. Sterne, Sentinental Journey, I. 34.

2. To possess with or as with a devil.

One sge, ho is hagridlien, hewltchen; the next, priest. ridden, befooled; in all ages, bederilled.
Carlyle, Sartor Resartus, ill...

3. To "play the devil with"; transform or confuse as if by the aid or ageney of evil spirits; confound; inuddle; eorrupt; spoil.

So bedevil a bottle of Gelsenhelm ... you wouldn't know it from the greenest I'oksy. Disraeli, vivian Grey, vi. 4. To bewilder with worry; torment; bother; confuse.-5. To make a devil or devils of; bring into the condition of a devil: as, to bedevil mankind.

bedevilment (bē-dev'l-ment), $u$. [< bederil + -ment.] The act of berleviling, or the state of being bedeviled; especially, a state of bewildering or vexatious disorder or confusion.

The lawyers have twisted it into sueh a state of bedevil. ment thst the original merits of the case have long dissp-
Dickens, Bleak House, vifi.

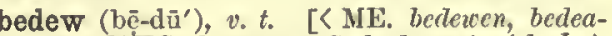
aten (= MHG. betowwen, G. bethauen); $(b e-\mathrm{I}+$

dew.] To moisten with or as with dow; moisten in a gentle manner witl any liquid.

The most preeious tears are those with whieh heavem Goldsmith, viear, xxi.

bedewer (bẹ-dū'ér), n. One who or that which bedewyt (bē-dī'i), a. [Erroneously formed from bedev, $v$; prop. dewy, < de $u, n$.] Moist wrom dew.

Dark night from her bedewy wings D. Brewer (?), Ungua, 4,18

bedfast (bed'fást), $a$. $\left[<b c d^{l}+f a s t.\right]$ Confined to bed; bedridden.

Iy old woman is bedfast.

MTs. Gaxkel, sylvia's Lovers, 11.

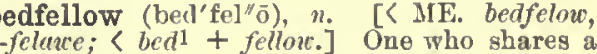
bed with another.

Jisery acqualnts a man wlth strange bedfellows.

bedfereł (bed'fēr), n. [Early mod. E. also, erroneously, bedphere, < ME. bedfere, bedifere, [bed + ferc, companion: see ferel.] A bedfellow.

Iler that I mean to ehoose for my bed-phere.

bed-frame (bed'frām), $n$. The frame of a bed; a bedstead.

bed-gown (bed'goun), n. 1. A night-gown or night-dress. - 2. A kind of jacket like a dressingsack, usually of printed calico, worm in Seotland by women of the working-elass, generally together with a drugget or colored flannel petticoat. Also called short-gown. She had wooden shoes, a short red pettleoat, s printed
eotton bed-gown; her faee was broad, lyer plyysiognony
eminently stupil. Charlotte Bromte, The Professor, vil. bed-hangings (bed'hang"ingz), n. $p l$. The valance and eurtains of a bed.

bediamonded (bē-dín âmon-ded), a. $\quad[<b c-1+$ diamond $\left.+-e d^{2}\right]^{\circ}$ Covereel or omamented with diamonds.

Astarte's bediamonded ereseent.
Poe, Ulalume, 11. 21.

bedight (bē-dit'), $v$. $t$. ; generally or always in pret. and pp. bedight or bedighted. [ME., only ray; equip; dress; triok out; bedeok; invest. [Archaie and poetical.]

A troope of men the most in armes bedight.
Jir. for Mags., p. 270 . His head and beard with sout were ill bedight.
Syenser, F. Q., 11. vit. 3. 
bedight

Many a rare and sumpluous tome

Longfellow, Wayside Inn, Prelude

bedim (bē-dim'), v. t.; pret. and pp. bedimmed ppr.bedimiming. $[\langle b c-1+d i m$.$] To make dim$ bseure or darken; becloud.

I have bedimm'd the noonticle ann. Shak., Tempest, v. 1.

Phobe, coming 80 suddenly from the sunny daylight, was altogether bedinmed in aurel clensity of shadow as
hurked in most of the passages of the old honse. Ifowthorne, Seven Gables, $\mathrm{xx}$.

bedimple (bē-dim'pl), $r$ t. $\quad[<b e-1$

bedirt (bē-dèrt') $v, t$ [<bc-1+dirt. $]$ To defile with dirt; figuratively, throw dirt at; vilify. bedismal (bē-diz'mal), v. $t$; ; pret. and pp. be bedismal (bê-diz'mal), v. t.; pret. and pp. bedismaled or bedismalled, ppr. bedismaling or be-
dismalling. [<be-1 + dismal.] To make dismal. bedizen (bẹ-diz'n or -di'zn), $v$. $t$. [Also some times bedizzen; $<$ be-1 + dizen.] To deck or dress out, especially in a tawdry manner or with vulgar finery.

Remnants of tapestried hangings, window curtains, an lireds of pictures, with which he had bedizened his tatter

A colossal image of the Virgin,... bedizened and eff ulgent, was borne aloft upon the ahoulders of her adorera. Llke clouds which bedizen

At sunset the western holizon. Browning, The Glove

bedizenment (bē-diz'n- or -dì'zn-ment), n. [< bedizen + -ment. J The act of bedizening; the The bedizenment of the great spirit's sanctuary with
Kingley. Weatward IIo! p. 451. . skulls. Kingsley, Westward 11o! p. 451. Strong Dames of the Market,, with oak-branches,
tricolor bedizenment. Carlyle, French Rev., III. iv. 4. bed-key (bed'kē), n. Same as bed-wreneh.

bedlam (bed'lam), $n$. and $a$. [Early mod. E. alse bedlem, bethlem, < ME. bedlem, bedleem, bethlem, a cormuption of Bethlehem (ME. Bethleem, Bedlem.): see Bethlehem. See def. 1.] I n. 1. [eap.] The hospital of St. Mary of Bethlehem in London, originally a priory, founded about 1247 ,

At my returne I atept into Bedlame, where I saw several poore miserable creatures in chaines, Hence-2. A madhouse; a lunatic asylum.

$$
\begin{aligned}
& \text { IIe's past } \\
& \text { Recovery ; a Bedla m eannot cure hin. }
\end{aligned}
$$

3. A scene of wild uproar and confusion.

A general division of possessions would make the coun-
try a scene of profigate extravagance for one year and of try a scene of profigate extravagance for one year and of
universal desolation the next - a bedla m for one ghor 4t. An inmate or a patient of Bethlehem Hos pital, or Bedlam; specifically, one discharged as cured (though often only partially cured) and licensed to beg. Such persons wore a tin plate as a badge on their left arm, and were known as bedlam beggars,

Let'a follow the old earl, and get the Bedlam
To lead him where he would; his roguish madness
Allows itself to anytling.
Shck., Lear, lii.

Hence - 5t. In general, a madman; a lunatic

II. $a$. Belonging to or fit for a bedlam madhouse; mad; mentally deranged.

The bedlam brain-Bick duchess. Shak., 2 JJen. VI., iii. This which followes is plaine bedlam stuffe, this is the Mitton, A pology for Smectymnuns.

bedlam beggar. See I., 4 . $n$. [< bedlam + -er ${ }^{1}$. 1t. A bedlam beggar. See bedlam, n., 4 . This country [the Border] was then much troubled with
Bedlemers. Roger North, Lord Gillford, 1. 271 . 2. The name given by seal-hunters to the booded seal, Cystophora eristata, when a year old, from its frantic cries and aetions when it

cannot escape its pursuers.
bedlamism (bed'lam-izm), n. [< bedlam + -ism.] A word or act which is characteristic of madness or

ness. Carlyle.
bedlamite (bed'lam-it), $n . \quad\left[<\right.$ bedlam $\left.+-i t e^{2}.\right]$ A madman. Seëbedlam, $n ., 4$.

What means the Bedlamite by this Ireak?

Hauthorne, Twice-Told Tales, II

bedlamitish (bed'lam-it-ish), a. [< bedlamit $+-i s h$.$] Resembling or eharacteristie of a$ bedlamite or

Their Bedlamitish creation of needless noises,
Carlyle, in Froude, II. 236.

bedlamize (bed'lam-iz), v. t.; pret. and pp. be
500

bed-sore

The Germans, on their part, cainly conscious of their pulsive bonds and sohering siraps on the Bedla mised
love, Bismarck, I. 599. bedlart, bedlawer $\nmid, n$. [<ME. bedlanere $(=\mathrm{G}$. bettlager $),<$ bed + "larer, appar. < Ieel. lag, a
lying; ef. lair.] A bedridden person. [Old English and Scoteh.]

bedless (bed'les), $a$. [<berl + -less. $]$ Without a bed.

bed-linen (bed'lin"en), $x$. Sheets, pillow-cases, ete., originally al ways of linen, now sometimes of cotton.

bed-lounge (bed'lounj), n. A combined bed nd lounge; a lounge or

open and form a bed.

edmaker (bed'mā"kẻr), n. [< ME. bedmaker.]

1. One who manufactures beds or bedsteads 2. One who prepares beds for use; especially, in English universities, a man or woman make the beds in college.- Female bedmaker were forbidden in Cambridge in 1625, but are now usiral.

The bed-makers are the women who take care of the rooms; there is about one to each stairease, that is $t$
gay, to every eiglit rooms.

bedmate (bed'māt), n. A bcdfellow. Strak.

bed-molding (bed'mōl'ding), $n$. In arch.,

melding of the cornice of an entablature, situated beneath the corona and immediately a

bedotet (bē-dōt'), $v_{\text {. } t \text {. [ME., < be-1 + dote.] }}$

To make te dete; befeol; deceive.

For to bedote this queene was her entent.

Bedouin (bed'o-in), $n$. and $a$. [Early mod. F. Bedwin, or as ML. Baduini, Beduini, pl. (ME. rarely Bedoynes); mod. E. alse freq. Bedoween, and more exactly Bedawi, sing., Bedawin, pl., after Ar., the form Bedouin being $<\mathrm{F}$. Bedoui (OF. Beduin = It. Beduino, ML. Beduimu, ete.), (OF. Beduin = It. Beduino, ML. Beduims, ete.), Ar, badawin, pl. of badawy, a dweller in the
desert (ef. badawi, rural, rustio), < badic, desert, open country.] I. n. 1. An Arab of the desert one of the nomadic Arabs, divided into many tribes, who live in tents, rear flocks and herds, especially of camels, and are seattered over Arabia, parts of Syria, and Egypt and other parts of Afriea. Also Bedawi, plural Bedawin. Prolessionally, and in the ordinary course of their lives, Bedouins are only shepherds and herdsmen : their raid ond cararana, are but oecasional, though welcome and even exciting, exceptions to the common routine.
Encye. Brit., II. 246 2. A vagabond boy; a street Arab.

II. $a$. Relating to the Bedouins.

bed-pan (bed'pan), n. 1. A pan for warming beds; a warming-pan.-2. A nceessary utensil for the use of persons eonfined to bed.

bedpheert, bedpheret, $n$. Erroneous spellings bed-plate, bed-piece (bed'plāt, -pēs), n. In meeh., the sole-plate or foundation-plate of an

bedpost (bed'pōst),.n. 1t. Same as bedstaff.2. A post forming an angle of a bedstead, in old bedsteads often rising high enough to support the canopy and rods for the curtain.- In see bedstaff.

bed-presser (bed'pres"èr), n. A lazy fellow

This angunine coward, this bed-presser, this horse-back
breaker, this huge lill of flesh. Shak., 1 Hen. IV., ii. 4 . bedquilt (bed'kwilt), $n$. A wadded and quilted covering for a bed. Also used for bedspread and eomforter.

The king [in a Sicilian fairy-story] issues a proclamatio promising a large reward to whoever shail steal the bed-
quilt of a certain ogre. $\quad N . A$. Rev., CXXIIl. 34. bedrabble (bē-drab'l), $x, t$. $[<$ be-l $+d r a b b l e$.
To make wet and dirty with rain and mud. Kingsley.

bedraggle (bẻ-drag'l), $v_{.} t_{\text {. }} \quad[<b e-1+d r a g g l e$. To son or wet by dragging in dirt, mud, moist places, etc., as the bottem of a garment in flag when rained upon.

bedral1 (bed'rgl), n. [Alse bethral, betherel; appar. a corruption of beadle, var. beddel, Sc. beddai, ete.] A beadle. [Seoteh.]

I7l hac her before presbytery and synod; I'm lialf minister mysel', now that l'm bedral in an hilhabited par
lsh. bedral ${ }^{2} \dagger$ (bed'ral), $n$. [Also bedrel, a corrup-
tion of bedred, for bedrid: see bedrid.] A ver- on who is bedridden. Luox. Also bed-thrall. [Scoteh.]

Dils father-who as Bedrel lay

dreintt. Obsoletepast participlo of (1)

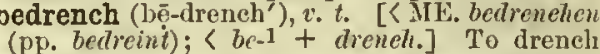
(pp. bedreint); Receyve our hilles with teres al bedremt. Sucli crimson tempest should bedren Court of Love, 1. 577. The fresh green lap of lair King Richard's land.

bedress (bē-dres'), v. t. $\quad\left[<b_{e-1}+d r e s s.\right]$ To dress up.

The Bride whose tonish inclination

Attended to the ruling lashion,

II make her entry inad bedress d

Ier upright form in all her best bedridden, bedrid (bed'rid"n, -rid), a. 1< ME.
bedred, belrede, bedreden, bedvedden, adj. and 1., < AS. bedreda, bedrida, bedryda, beddredda, n., one bedridden, lit. a bed-rider $(<$ bed, bed, + rida, vidda, a rider, a knight, < vidan, ride) Cf. LG bedderede, bedderedig, bedridden; OHG. pettiriso, G. bettrise, of same sense. The second element came to be regarded as the pp. of ride. bence the now usual form bedridden, $M \mathbf{E}$. bed reden.] Confined to bed by age, infirmity, or sickness.

Is not your father grown incapable

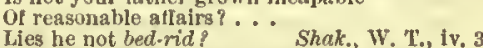
What an over-wome and bedrid Argument is this!

old bedridden palsy. Iitton, Tennyson, Aylmer's Field.

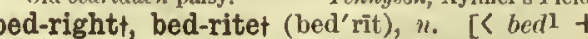

ight, rite.] The privilege of the marriage-bed. No bed-right [in some eds. bed-rite] shall be paid
THil IIymen's torch be liglited. Shak., Tempest, iv. 1 .

bedript, $n$. [ME., also bedripe, bedrepe, etc. < AS. bedrīp, < bedu, prayer, f rip, a reaping: see bead and reap. Also ealled in AS. bénrīp, [ bèn, prayer, + rip.] Boon-work at harvesttime: a service which some tenants had to perform at the bidding or request of their lord.

bed-ritet, $n$. See bed-right.

bed-rock (bed'rok), n. [<bedl + roek.] 1. In mining, the older crystalline and slaty rock which underlie the unconsolidated gravelly and volcanic beds of Tertiary and Post-tertiary ages, along the flanks of the Sierra Nevada. The term Is beginning to be usod elsewhere to designate sold roek lying under ioose detrital masses, guch as san Hence - 2. That which underlies anything else, as a foundation; bottom layer; lowest stratum Everywhere llfe and energy, working on a gigantic acale,
have plowed furrows into the institutlonal bed rock of have plowed lurrows into the institutional bed rock of C. II. Shinn, Land Laws of Mining Districts, p. 44 bedroom (bed'röm), n. 1. Room in a bed; sleoping-room in bed. [In this sense properly with a byphen.]

$$
\text { Then by your alde no bed-room me deny. }
$$

2. A room or apartment centaining or intended to contrin a bed; a sleeping-apartment.

bedrop (bẹ-drop'), $v^{\prime}$ t.; pret. and pp. bedropped (semetimes bedropt), ppr. bedropping. [CME.
bedroppen: < be-1 + drop.] 1. To drop upon fall upon in drops.

$$
\begin{aligned}
& \text { As men sene the dew bedroppe } \\
& \text { The leves and the flowers eke. }
\end{aligned}
$$

Gover, Conf. Amant., iii. 254

2. To cover, strew, or sprinkle with drops, or if with drops; bespatter; bespangle.

The yellow carp, in scales bedropp'd witlı gold.

Pope, Windsor Forest,
Ruelul cheek, Wordlowing tears.

bed-sacking (bed'sak" ing), $\dot{n}$. Canvas designed to be stretehed on the framework of a bedstead to support the mattresses and bedclothes. wrench.-2. Same as barrel-screv.

bedside (bed'sid), n. [< MF. bedsyde, orig. beddes side, i. e., bed's side.] The side of a bed; position by a bed: usually with reference to attendance on one confined to bed: as, she watched by his bedside till dawn.

bedsister ' (bed'sis"tèr), n. [< ME. bedsuster (Robert of Gloucester), $<$ bedl + suster, sister.] A coneubine.

It is not much to be wondered at that we lost bed-sister
F. IIall, Jod. Eng., D. 165, note. bed-sore (bed'sōr), $n$. A very troubleseme kind of ulcer, liable to appear on patients long confined in bed and either unable or not allowed 
to change their position. Hed-sores occur at the bedung (be-dung'), v. $t_{0} \quad[\langle b c-1+$ lluny. $]$ To inarts pressed hy the weight of the boly, ehiefly over the cover or befoul with dung.

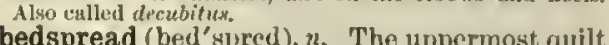
(bed spred), n. The uppermost quilt bed-spring (bel'spring), $n$. A spring, usus of spimal form, used in making spring bedstaff (bed'stif), $^{\prime}$. A staff or' stick forme ly used in some way about a berl, and freruent-

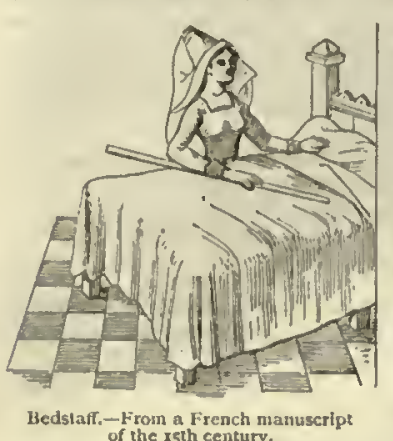
ly serving as which sense the worl most commonly oceurs. Specitically $-(a)$ A
betl-slat. (b) The stick or staff used to spreasl out the bong a bed placed l s recess. (c) A bur
or post placed at cach skile of a bed clothes from talling olf. (d) One of the Ing the "tent" In bed.

Niaw do I feel the calt of niy right lep

Tinglu, and dwindle to th' smallncss of a bet-8tad" T. Tomkis (?) Albumuzan, il s.

Ile gives ont
Ifell take a Redstaff, or an holy IVand

And laste yon listily two or thrce hours
before you go to lied, to make you líruber.

Uls the bewitched Carturight, Love's Convert, iv. ins (the bewitched bey's] bod cloathes would be pulle C. Mather, SIag. Clirtat., vi. In her lisnd slie grasped the bed-ntaff, a weapen of
milekle miglit, as lier husband's blooly cox-conib conl mickle miglit, as her husband's blooly cox-eonib conl
now well testify. Barham, Ingoldshy Legends, I, 260 . [Used In the collociuful phrase in the twinkling of a bed Uaf, In which, when bedstaff hecame ebsolate, bed port wa unolern use.

I'll do it instantly, in the twinkling of a bed-staff.

bedstead (bed'sted), n. [<ME. bedstede (= D. $\mathbf{I}(\mathbf{G}$. bedstede $=\mathrm{MHG}$. bettestat $),($ bed, bed, sterle, place, stead.] A frame or framework, more or less elaborate, for supporting a bed: most commonly made of wood, but now ofte of iron, and sometimes of brass.

bed-steps (bed'steps), n. pl. Steps for ascending an old-fashioned high bed.

bedstock (bed'stok), $n$. One of the two sidepieces or bars of a bedstead on which the rung or slats are laid. [Now chiefly used in Scotland, the north of England, and Ireland.

bedstone (bed'stōn), $n$. The lower or stationary millstone.

bedstraw (bed'strâ), n. « M MF. bedilestraice, bedstre (= OHG. bettistro, G. bettstroh), bedstraw, bed; <bed + strac.] 1 . Straw used in stuffing a mattress or bed. [In this literal sense properly with a hyphen.] -2. (a) A popula name of the different species of the genus $G a-$ lium, from the old practice of using it in beds. Our Lady's or yellow bedstraw is G. verum; whit bedstrav is G. Mollugo. See Galium. (b) name given to Desmodium Aparines.

bed-swervert (bed'swerr"verr), $n$. One who is false and unfaithful to the marriage-vow.

$$
\begin{aligned}
& \text { She's } \\
& \text { A bed-averuer, even ss bal as these } \\
& \text { That vulgars give bold'st tlties. }
\end{aligned}
$$

hak., W. T., II. 1

bed-thrall $\dagger$ (bed'thrâl), $u$. [A modification of bedral', as if $\langle$ bed $1+$ thrall.] Same as bedral2 bedtick (bed'tik), $n$. A case of strong linen or cotton cloth for containing the feathers or other materials of a bed.

bedticking (bed 'tik"ing), $n$. The material from which bedticks are rnade.

bedtime (bed'tim), n. [<ME. bedtime : < bedl + time.] Tho time to go to rest; the usual hour of going to bed.

bed-tool (bed'töl), $n$. A block with opening or holes corresponding to the shape of a die or punch, in eonneetion with whicli it is used. bedub (bề-dub'), $\imath^{\prime}$. $t$.; pret. and pp. bedubbed, ppr. bedubbing. " $\left[\left\langle b e^{-1}+d u b^{1}\right.\right.$. $]$ 1t. To adorn. -2. To designate; dub.

beduck (bẹ-duk'), v. t. $\left[\left\langle b c-1+\right.\right.$ duck $\left.^{1}.\right]$ To duck or immerso thorouglily; submerge.

$$
\begin{aligned}
& \text { To the floot he came, . . } \\
& \text { And deepe him selfe beducked lin the san }
\end{aligned}
$$

Spenser, F. Q., II. vi. 42

beduke (bō-dūk'), v. t.; pret. aud pp, beduked, ppr. berluking. [ $\left[b_{c}-1+\right.$ duke. $]$ To make a duke
of; style or dub with the title of duke. Surft. bedusk (bō-1lusk') , smutch. Cotyrere.

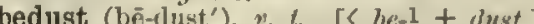
sprinkle, soil, or cover witl dust. used in yeol. and mining (as the equivalent of tho German Lagergang) to denote a Hat mass of oro liaving eharaeters intermediate between those of a vein and those of a sediment ary rleposit.

Toward (bed

$$
\text { As merry as when our muptinl lay wast lon }
$$

An merry as when our muptinl day was done,

Jeantime the two young Glendinnings were each wrspperl up in liss ou n reflectlons, and only interrupted in them by tho signal to move bedacerd.

bedwarf (bē-dwârf'), $v$. $t_{\text {. }}\left[<b_{e-1}+\right.$ tucurf. of stratifiention or pseudo-stratifleation in tho granitie rocks.

bedwind (bed'wind), $n$. [Cf. vithwind.] An English name for Convolvulus sepium.

bedwork (bed'werk), n. Work done in bed, or as in bed, that is, without toil. [Rare.]

Bedrork, mapluery, closet-war. Shak., T. and C., L.

bed-wrench (bed'rench), n. A wrench, sometimes having sockets of different sizes, used in setting up bedsteads and in taking them apart little used with moderu bedsteads. Also ealled bed-kiey.

bedye $\left(b e \bar{e}-\mathrm{di}^{\prime}\right), v, t . \quad[\langle b c-1+r y e$.$] To dye$

$$
\text { Fieldes with Saraxin blool bedyde. }
$$

bee 1 (bē), n. EEarly mod. E. also bc and been, $<\mathrm{MH}$. bee, pl. been, $<\mathrm{AS}$. beo, also bì pl. bcón, = OD. bie, D. bij, bije = LG. bigge OIIG. biu, G. dial. beic = Icel. by, generally in
comp. by-flygi, by-fluga ('bee-fly'), = Sw. Dan. bi; also with added $-n, \mathrm{OHG}$. bina, $\mathrm{MHG}$. $b \bar{n}$ f., OHG. bini, neut., MIIG. bine, bin, G. biene, f. (cf. Lith. bitis, a bee); supposed to come, through the notions 'fear, tremble, quiver, buzz, hum" (ef. bumblebec and drone), from the root "bi (= Skt. $\sqrt{ }$ bhi, OBulg. bojati Russ. bojatr = Lith, bijoti, etc.), fear, which $=\mathrm{OHG}$. bibēn, MHG. biben, G. beben = Icel bifa, tremble.] 1. An insect of the genus Apis; a hive-bee or honey-bee. See Apis 1 The common heney.bee, A. mellifica, has from the esr liest perlods been kept in hives for its wsx and honey. In is also found wild in grest numbers (now especlsil Europesn colonists), storing hone in swarms or societies of from swarms centain three elasses of bees-the perfect females or ling the worklng bees. In each female or queen, whose sole offiee is to propagate the speeies. The
'peen is nuch larger than the
other bees. When she dles, a
young worklng bee three days ol

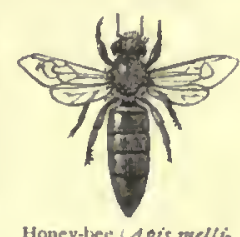
eularged by bresking dewn the partitions, its food changed to royal jelly or paste, and lt grows into a queen
The yueen lays 2,000 eggs a day. The drones serve merely

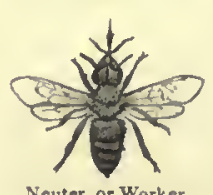

whieh they are destroyed by the neuters. These last are the laborer of the live. They collect the honey, form the cells, snd feetl the other
bees and the young. They sre fur
nished with nished with s probosels by which
they suck the honey from flowers
and a nouth by which they swallow it, cenveylng it then to the hive in gorge It Into the cells. The pollen of flewers gettles on tls leeted Into pellets hy \&' hrush on their second pair of leeted into pellets hy s hrush on their second pair of
called bee-bread, and is the food of the larvie or young. The sdult bees feed en honey. The wax was at one time supposed digestive process, hut it is now aseertained that it is formed
by secrelion froni the honey. by secrelion fromi the honey.
The females and neuters have a barbed sting attached to

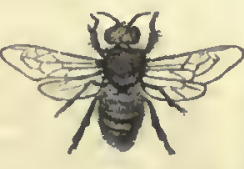

the of polson, which flows Into overstuckel a new colony is sent ont under the direcllon of a yneen beo. Thls is called suruming. Hesides tho cons.

\section{Bedunged with ealumny and tilt}

bed-vein (bed'van), ". A term oecasionally

$$
\text { Seott, Monastery, I, xiv. }
$$
To make little; stunt or hinder the growth of appears redupl, in AS bcofian = OS bibhon and the inperfect or undeveloped young worklng bee three day's old is selected, Its cell men bee, A. mellifica, there are the A. fascicata, domes. snd Greece, introduced generally into splarles in other lands; the A. unicotor of Madagasear; the A. indica, utc. 2. Any aculeate hymenopterous insect of tlie division Mcllifere or Anthophila, eomprising the families divide and Andrcnide, and inluding, besides the hive-bees of the genus Apis, the mason-bees, carpenter-becs, bumblebees, ete. Sce cuts under Anthophorn, earpenter-bee, and IIymcnoptera.-3. An assemblage of persons who meet to engage in united labor for the benefit of an individual or a family, or in some joint amusement: so called from the combined labor of the bees of a hive. as, a quilting-bce, a husking-bee, a spclling-bce, ete. [U. S.]

Now were instititecl " "ynilting bees," snil "lusklng bees," and other rurul assemblayes, where, under the luspiring intluence of the fldille, wil was enllvened ly gayety ancil
followed up by the dasce. Iroing, Knlekerbocker, p. 405. To have a bee in one's bonnet, to be a little ersukoralned or crazy ; be thiyllty or full of whims or mueasy as, to have the presidentinl bee in one's bonnet, to clierisit

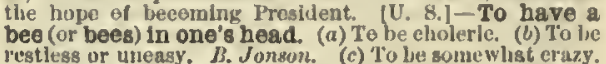
She's whiles crack-brained and has a bee in her head.

bee ${ }^{2}$ (bē), n. [Prop. North. E. dial., for reg. E. by or "bigh (ef. ligh, nigh, of like phonetic relations), (Mi. by, bye, bie, beghe, beliz, bez, beh, < AS. becih, beig (= OS. bōg, bãg = OHG. bone =Ieel. b(agr), a ring, esp. as an oruament, < būgan (pret. beálh), E. bone, bend; ef. bow ${ }^{2}$, a bend, an arch, and baill, a hoop, from the same source: see bot ${ }^{1}$.] 1†. A ring of metal, usually an ornament for the arm or neek; a cllar or brooch; sometimes, a finger-ring.

Bee or collar of gold or syluer, torques. Hutoet. 2. Naut, a ring or hoop of metal through which to reove stays. Seo bee-bloek.

beebee (bē'bē), $n$. [Anglo-Ind., 〈 Hind. bibi, Pers., orig. Turk., bibi, a lady, a lawful wife.] 1. A lady. - 2.

The soclety of the ststlen does Interfere in such eases; snd thengh it does not mind beeber or their irfends, it W. H. Russett. catcher (bell spotted flycatcher, Muscicapa yrisola, a European bird of the family Muscicavidas: so

it catches bees. [Local, Eng.] bee-block (be blok), n. bowsprit, through topmast-stays are bee-bread (bē' bred), n. [Not beóbreád, bibrecid = MHG. bie brōt, G. bienen-brot= Sw. bibröt, orig. (in AS.) the honeycomb with the + bread, bread.] 1. A brown bitter substance, the pol-

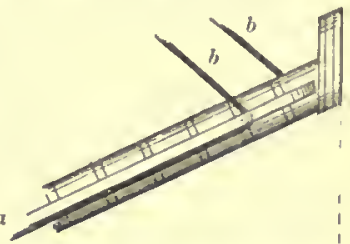

lected by bees as food for their young. See bect 1 - 2. A plant much visited by bees or cultivated for their use, as red clover, Trifolium pratense, or borage, Borago oficinalis.

beech 1 (bēch), n. [< ME. beche, < AS. bēce, ear

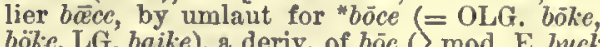
. D. beuk = Flem. boek = OHG. Ieel. bo $k=S w$. bok = Dan. $b \circ g=\mathrm{OHG}$, buolha, MHG. busche, G. buche (> OBulg. bukwi, bukve, Bulg. buk, Serv. bukva; Pol. Bohem. buk, Russ, bukŭ, Lith. buka, Hung. buik, bik, beecl1) = Goth. "boka (not recorded), beech, = L. fägus (see

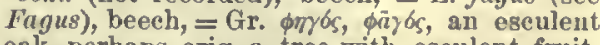
oak, perbaps orig. a tree with esculent fruit, from the root seen in Gr. фayeiv, eat, Skt. $\sqrt{ }$ bhaj, share. For the connection with book, see book.] A tree of the genus Fagus, natural order Cupulifera. The commen or Europesn beech, F. sylmatica, grows to s lsrge size, with brsnches formin and of a silvery cast. The nuts or mast are eaten by swine, poultry, oxen, snd other animals, snd yield s good ofl for lamps. The timber is not nutch used in bullding, 
beech

places where it is constantly wet. It is manufactured into a great variety of tnols, for which it is fitted on accomt of its great hariness, tonghness, and close, uniform
textule, and is also used to some extent in making furniture, taking a beantiful polish and varying much in color. Several ornamental varieties are frcuucntly seen, as the red beech and copper beeeh witl colored leaves, can bech, $F$. ferruginea, is a very similar tree, sometime 100 feet in height and 3 or 4 feet in clianleter.- Austra-
lian beech, Tectona australis, a species of teak. - Beechlian beech, Tectona australi, a species of teak- Beech-
cherry. See cherry. - Blue beech. Same as unter-beech. cherry, See cherry. - Blue beech. Same as water-becch. barum, a tree belonging to the natural order líubiacere. beech $2 t, n$. Obsolete spelling of bcach.

beech-coal (bēch'kōl), $n$. Charcoal from beechwood.

beech-drops (bēch'drops), n. A low annual plant, Epiphcyus Tirginiana, without green foliage, parasitic upon the roots of the becch in the United States. It belongs to the natural order

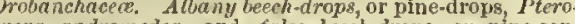
Momotropa IIypopitys, are similar parasitic plants of the natural order Ericaceo.

beechen (bē'chen), a. [< ME. bcchcn, < AS. becen (-D. bcuilen = OHG buochir $\mathrm{MHG}$.

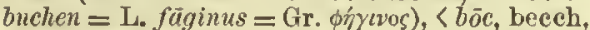
$+-c n$. te, or derived from the beech: as, bcecher boughs; bcechen shade.

$$
\begin{aligned}
& \text { His aged head, crowned with beechen wreath, } \\
& \text { Seened like a poll of ivy in the teeth } \\
& \text { Of winter hoar. } \\
& \text { Keata. }
\end{aligned}
$$

2. Made of the woed of the beech: as, beechen vessels.

A maple dish, my furniture should be

Hordsworth, Eccles. Sonnets, i. 22 .
Hern), A fern belonging

beech-fern (bēch'férn), ". A fern belonging to the genus Phegopteris (which see).

beech-finch (bēch'fiuch), $n$. The chaffinch, Fringilla colebs. Macgillivray.

beech-fungus (bëch'fung"gus), $n$. An edibl fungus, Cyttaria Darwinii, allied to the morel. It is abundant in Terra del Fuego upon the branches of the natives. formed on the beech by insects.

beech-hopper (bēch'hop"èr), n. A coleopterous insect, Orchestes fagi, family Curculionide, or weevils, injurious to beech-trees, between the two surfaces of the leaves of which the lay their eggs.

beech-marten (bēch'mär "ten), n. Mustela foina, one of two species or varieties of the Enropean marten, usually distinguished from the common pine-marten, M. martes, by the white throat and some other external features, as well as by some differences in habits. Also called stone-
marten.

beech-mast (bēch'mȧst), n. $\quad\left[<\right.$ becch $^{1}+$ mast $^{2}$ =buck-mast. $]$ The mast or nuts of the beech-
tree, from which an oil is obtaincd. The cak which remains after the oil has beentaincd. The cake fattening food for oxen, swine, and ponitry, but is inju beechnut (bēch'nut), $n$. One of the nuts fruits of the beech. The nuts are triangular, and inclosed in a spiny capsule or husk

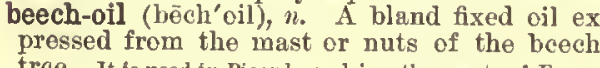
trce. It is used in Picardy and in other parts of France pains in the stomach

beech-owl (bēeh'owl), $n$. A name of the tawn owl or wood-ow

(bēch'hwèt), $n$. voheat.

beechy

(bē'chi) $-y^{1}$.] Of, pertaining to, beeches: as, "a bechy garland," Island, vi. bee-culture (bé'kul "tưr $), n$. bees in a state of domestica tion; apiculture. bee-eater (bë' $\bar{e}^{\prime \prime}$ tèr), $n$. That which eats bces, as a bird: an apiaster. Specif

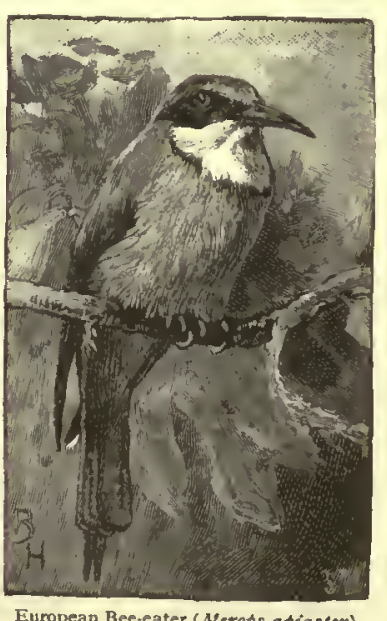

502

beehive

cally-(a) The Furopean Mcrops apriaster. (b) plt. The bee-flower (bē'tlou" è'), n. Same as bec-orchis. eef (bēf), n. [Early mod. E. also becfc, beafe, biefe, ete., $<\mathrm{ME}$. bccf, bcf c, bcof, bouf, boef, < OF. bocf, bucf, bocuf $=$ Pr. bov $=$ Sp. bucy = Pg. boi
$=$ It. boie (ef. Sw. biff, Dan. böf, beef, from E.; and see beefstcak), <1. borem, acc. of bos (see Bos and bovine $),=$ Gr. $\beta$ ovs, an $0 x$, $=$ Ir. and Gael. bo, a cow, $=$ W. buw = Skt. go, a cow, ult. identical with beef.] 1. An animal of the bovine genus, whether ox, bull, or cow, in the full-grown state. [In this, which is the original sense, full-grown state. [In this, whith is the original sense,
the word has a plural, beeves, formerly sometimes beefs.
The singular is nearly obsolete.]

These are the beasts which ye sliall eat: the beef, the A ponnd of man's flesh, taken from a man, Is not so estimable, proft table neither,

As flesh of muttons, beefs, or goats. Shak., M. of V., i. 3. A herd of beeves, fair oxen, and fair kine.

Milton, P. L., xi. 647.

2. The flesh of an ox, bull, or cow when killed. [In this seuse the word has no plural.] -3. A name given by quarrymen to certain beds of fibrous carbonate of lime occurring in Fngland in the middle division of the Purbeck series, the highest part of the Jurassic. -4 . Brawn;
muscularity; weight and strength combined: as, the erew is lacking in becf. [Colloq.] Ala mode beef. See alamode. - Baron of beef. see baron. corned, and seasoned with herbs and spices. - Hung beef. beef cured by being hung up to dry; dried beef.-Jerked beef-brained (bëf'brānd), $a$. Having the brain r wit of an ox; beef-witted: as, "the most ccf-brained sensualist," Turviers, Cure of Misprision, p. 29 (Ord MIS.).

beef-cattle (béf'kat"1), n. pl. Bovine animal adapted or intended for conversion inte beef ; bovine animals for slaughter.

beef-eater (bēf' $\bar{e}^{\prime \prime}$ tér), $n$. [ [ bcef + eatcr. In sense 2, merely a particular use of the same

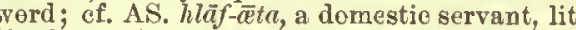
'loaf-eater,' contrasting with hläford, master, lit. 'loaf-keeper.' Servants are often thought of as eaters; Bell Jonson uses caters in th sense of 'scrvants' ("Epiccene," iii. 2). The
oft-quoted otymology from a supposed "buffetier, < buffet, a sideboard, is mere fiction.] 1 One who eats beef; hence, a well-fed fellow; a stout fleshy man.-2. One of the yeomen of the English royal guard, whe, since the accession of Henry VII. in 1485 , have attended the severeign at state banquets and on other eremonial occasions. The name is alse given to the warders of the Tower of Londen, who wear a similar uniform. Charles had begun to form a snill standing army. He
felt that without some better protection thanl that of the train-bands and beefeeaters his palace and person would with warlike Fifth Jlonarehy neen who had been jnst dis-
handed.
Macaulay, Hist. Eng. iii. 3. An African insessorial bird, of the genus $B$ t phaga, which feeds on the larve that infest th hides of oxen. It is a mere book-name, transiating $B$ whaga; the more freqnent term is axpecker. See Buphaga. ce-feed as bluebottle, 2.

fornia to an abundant free-flowering species of Eriogonum, $E$. fasciculatum, much visited by bees.

bee-feeder ( $\left.\bar{e}^{\prime} f e^{\prime \prime} d e ́ r\right), n$. An an'angement uscd for feeding bees in bad weather or very long winter's.

beefen (bēf'en), $n$. A form of biffin.

beef-herd (bëf'hérd), $n$. A drove of cattle in tended for slaughter. [Western U. S.]

Followlng the dusty trails made by the beef-herds that towns.

beefiness (bẽf'i-nes), n. 1. Beefy quality.-2. Brawniness ; muscularity; hardinoss.

beefingl (bēf'ing), n. [<beef +-ing ${ }^{1}$.] A bullock fit for slaughter. [Prov. Eng.]

beefing ${ }^{2}$ (bèf'ing), $n$. The original but later beefish (bēf'ish), a. 1. Stupid; thick [Eng.] having the brain $0 r^{\circ}$ sense of an ox.-2. Obese; solid; beefy. This degeneracy has turned him lnto that "beefish, por-
terish," lellowlng sort of a John Bull, hardly endured by
his own kind. beef-kid (bēf'kid), $n$. A mess utensil used by the crew of a merchant ship for holding cooked ncrassata, which is a formidable pest of the he disease ealled foul-brea See phoritus. beef-measle (bēf' $\left.\bar{e}^{-1 /} z l\right)$, n. The see Thle of beef the hydatid or scoleciform stage of the unarmed tapeworm of the ox, Trenia mediocunellata. eefsteak (bēf'stäk'), n. [< bcef + stcak. Adopted in other languages, D. bicfstuk (assimlated to stuk, piece), G. becfsteak, Dan. böfstcg, Sw. biffstek, F. bifteck, Sp. (Cuban) bifteq, It. biftecco, Russ. bifstehsur, etc.] A stcak or slice of beef, cut from the hind quarter, suitable for roiling or frying.

beefsteak-fungus (bēf'stāk'fung"gus), $n$. An edible hymenomycetous fungus, Fistulina hcpatica, belonging to the family Polyporei. It sometimes attains a large size, and is tliought to resemble for to

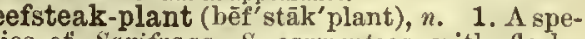
cies of Saxifraga, S. sarmentosa, with fleshy purplish leaves.-2. A name applied to species of Begonia.

beefsuet-tree (bēf'sū'et-trē), n. The buffaloshcpherdia argentca.

eef-tea (bèf'tés'), $n$. An aqucous extract of heef obtained by soaking and heating chopped beef in water, straining it, and seasoning to taste. It contains salts and extractives, a little gelatin, and fat. It is useful as a stimulant, and forms an appropeef-witted (bēf'wit"ed) Thou mongrel, beef-ritted lord! Shak., T, and C., 1i. 1. beefwood (bēf'wind), $n$. $\quad[<$ beef (in allusien to its grain and color) + wood.] 1. The timber of some species of Australian trces belonging to the genus Casuarina (which see). It is of a redlish color, hard and close-grained, with dark and whitisl 2 . In the West Indies, a name given to Pisoni btusata, with seft coarse-grained wood.-Red beefwood, of Jamaica, Arlisia eoriacea, a myrsinaceous beefy (bēf'i), $a$. [< bcef $\left.+-y^{1}.\right] \quad 1$. Ox-like; hence, fleshy; obese; solid.

He [Carlyle] was at dhner when a beefy Tory was de
The American, VIII. 390. 2. Brawny; muscular; hardy. [Colloq.] bee-garden (bë'gär/dn\}, $n$. A garden or inclosure to set beehives in; an apiary. Mortibeegerite (bē 'gêr-it), n. [After H. Beeger of Denver, Colorado.] A sulphid of bismuth and lead occurring in dark-gray masses with briliant metallic luster, rarely erystallized, found n Colorado.

bee-glue (bét'glö), $n$. A soft, unctuous matter with which bees cement the combs to the hives and close up the cells. Also called propolis. bee-gum (bé' gum), $n$. In the southern United States, a hollowed section of a gum-tree used

bee-hawk (bē'hâk), n. A name of the honeybuzzard of Europe, Pernis anivorus: so called hecause it preys npon bees, wasps, and other insects. - Bee-hawk moth, a name of varfous lepidopbeehead $\nmid$ (bé'hed), $n$. A erazy or flighty per-

beeheaded (bē'hed"ed), $a . \quad$ [= Sc. bee-hcarit.] Crazy; flight

bee-herd (he'bèrd), n. A person who takes care of bees; a bee-keeper. Phin, Dict. Api-

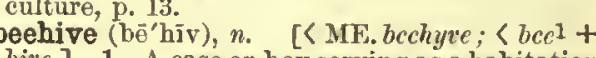
1. A case or bex serving as a habitation for bees. See hive. -2 . The common name of a species of medic, Medicago scutellata, from the shape of its spirally coiled pod.-Beehive

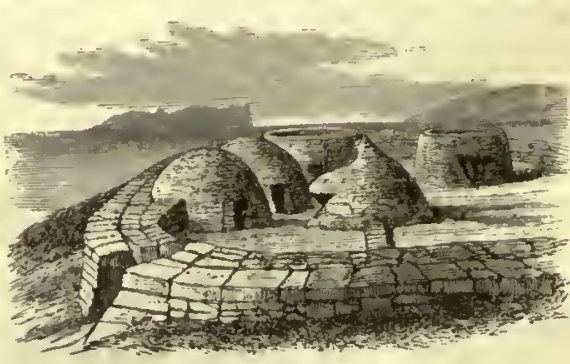
hive, formerly considered capable of producing terous insects of the families Sphingides and Sesidde, ant 
beehive

cal buildings in Treland, of smsll sizc, formed of long gtunes, $8(1)$ aid, on a clichlar flan, that each course is over Eothe and the sto re rean mo the most part in their mutural side orntories, in which case it is believed that they served as dwellines of priests, or, whe in groups, sometimes ell-
circled by a steme wall, for defense. Oceasionally they "mintain more than one almartment. Huuses of this kind "ucenr also in the Western lsles of Scotland; and the
"l'icts" houses " on the cast coast, though ditfering in be"licts under ground, resemble them in their moule of coub. struction. They are referred to a jeriod lotween the seventh snd twejth centuries.-Beehive oven, a low, sugare furnace with a dome-shapeel tops. It has an openint at the top for the eseape of gases, and a cloor in the side throush whilch to atmit air, to charge

beehouse (bé'llots), $n$. A houss or repository for bens; an apiary. Coldsmith.

beekt (bôk), r. [K. dial. (North.) and Se, also written beak, beik, beke, < Mlk. beken, warm one's self, perhaps akin to buke. Cf. busli. ${ }^{1}$.] I. trans. To warm; bask.

Go home now, and . . beek thy panpered limis at the
fre.

II. intrans. To bask; aprieate. [Seoteh,

eollog.] (bē'kil'èr), n. A kind of robber-fly,

bee-killer (bè'kil"er), n. A kind of robber-fly, frupanea apilora, a dipterons insect of the tho wing and kills them. bee-king (bé'king), $n$. A kind of drongo-shrike,
Dissemurus parndiseus, with deeply forked tail. Also called Indian bee-king.

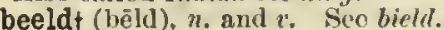

beele ${ }^{1}$ (bël), $n$. [Prob. a form of bill, a mattock (ef. E. dial. beal, tho bill of a bird): see tock (ef. E. dial. beal, tha bill of a bird): see bill 2 .] A kind of pieksx used by miners for separatin

beele $2 t, n$. [ ['crhaps a var. of bill 3 in senso of billet ${ }^{1}, \mathrm{q}$. v. $\rceil$ A cross-bar; a yoke. N. $E$. $D$. bee-line (b-'lin), n. The most direet or straight way from one point to another, as that of bees in returuing loaded with honey to their hives.

Our footmarks, scen afterward, showcll that wo hat teered a bee-line for the brig.

ane, Sec. Grimn. Exp., I. 198

bee-louse (bë'lous). n. A pupiparous dipterous insoet, of the family Broulide, parasitic upon bees. Braula caca is a parasite of the Italian boo, Apis ligustiea.

Beelzebub (bē-el'zē-bub), n. [Fomnerly also, and still in popular spoeeh, Belzebub, ME, Bel

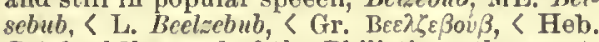
Ba'al-zebuib, a god of the Philistines, the averter of inseets, < ba'al, lord, + zebũu, $z^{2} b u \tilde{u} b$, a Hy ; ef. Ar. dhubäb, Pers. zubāb, a fly Seo inesul and bacl.] 1. A god of the Phils was worshiped as the destroyor of flieg.-2. A name of tho Mycetes ursinus, a howling monkey of South Ameriea. See cut under hoicler.

Beelzebul (bē-el'zē-bul), n. [<I. Beelzcbul, <

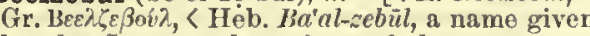
by the Jews to the prince of demons; commonly explained as either 'lord of the (heaven$=$ Ar. zibl, dung), but prob. a mere variant of Bial-zebüb, Beelzebub, the name of the Philistine god, which eame to bo applied to the prinee of demons. The best Gr. manuseripts have

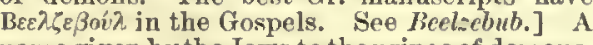
name given by the Jews to the prinee of demons, being an opprobrious alteration of the name Beelzebub.

beem $\nmid, n$. An obsolete form of bcam.

bee-martin (be 'mär'tin), n. A eommon name in tho United States of tho king-bird, Tyrammus earolinensis. See ent nnder king-bird.

bee-master (bē'mås"tẻr), n. One who keeps bees.

bee mol† (bō mol), $n$. [For $B$ mol, ML. $B$ molle, that is, 'B soft': opposed to $B$ durum, 'B hard.' See moll.] Same as bemol.

bee-moth (bē'môth), $n$. A pyralid moth of the genus Galleria, G. ecreana (Fabricius). It lays its egrs in beehives, and the Isrva when hatched fued upon the ws $x$. Aiso ealled $2 a r x$-moth (whence its speciflc

Past participle, and obbeen ${ }^{2}+, n$. Obsolete plural of bee

been $^{3}, a$. See bein.

been 4 (bēn), n. [Hind. bin, a lute, guitar, fid

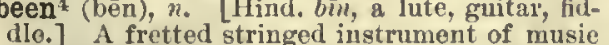
of tho guitar kind, having nineteen frets, used iu India.

bee-nettle (bë'net"1), n. A species of hempnettle, fraleopsis rersicalor. See Galeopsis.
503
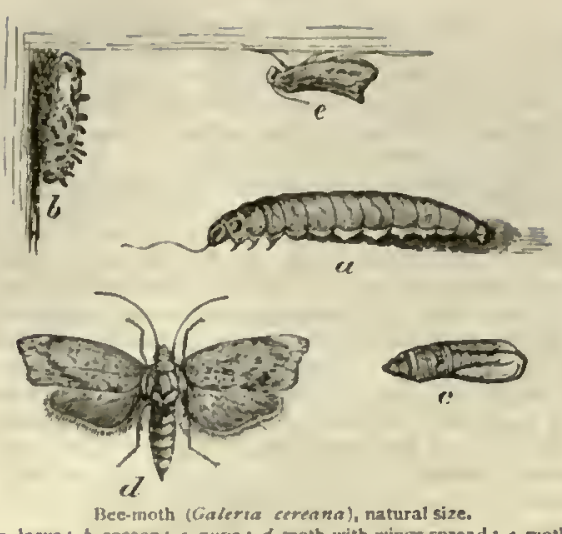

with ; wings closelt woth with

än

beënt (bē'nnt), $a$. [A foreed translation by J.
H. Stirling̈ of G. seiend.] In metaph., having boing as opposed to existenee. [Rare.]

It the Fleaties perslst in the dllemma, the worid is them, becalso it is both of ther

J. II. Stirling, tr. of Schwegler's Ifist. l'hifos., p. 20. bee-orchis (bé'ốr"kis), $n$. A Filropean orchid,
Ophrys apifera, with a bee-like flower. Also bee-parasite (bép'par"a-sit), n. 1. A stylops; an insect of the order Strepsiptera, the suceies of which are parasitie upon bees. Bees so inof whieh are parasitie upon bees. Bees 80 in-
fested aro said to be stylopized. See Ntylops. 2. Somo other inseet parasitic upon bees, as a bee-louse or bee-wolf.

beerl (bēr), n. [< ME. berc, ber, < AS. beór =

OFries. biar, bier $=$ D. bier = LG. ber, beer = ef. Icel. björr, Ir. Gael. beoir, from As, or (the Seand. word is that cognate with E. ale). Origin uneertain; some assume a loss of $r$ from orig. "breór, [AS. breb́can, ete., brew: see breic.] 1. An aleoholie liquor made from any farinaceous grain, but generally from barley, which
is first malted and ground, and its fermentable substanee extraeted by hot water. To this extre or infubion hopa or some other vegetabie product of aus agreeable bitterness is added, and it is thereupon bojled
for some time, both to concentrate it and to extract the useful matters trom the hops. The liquor is then suffere
to ferment in vats, the time allowed for lermentation d to ferment in vats, the time allowed for lermentation do 'The heers of England and France, and for the most part those of Germany, becume gradually sour by exposure to sir. Ale and beer were formeriy synonymous terms, ale name for alt inalt liquors, and ale is used speciftcally for aight than mark: thus, of a certuin strength, and rather like, are unt ale, nor are stout and porter. A distinction drawn by Andrew Boorde, in 1542 , is thst ale is made of while beer is made of malt, hops, and water.

2. A fermented extraet of the roots and other parts or produets of various plants, as ginger, spruce, molasses, beet, ete.-Beer process, in photog, a collodion dry-piate process in which the sensi. tized plate, after being washed, is treated with an intu.
sion of malt or beer. The process is of no practical value, and is disused.-Beer vinegar, a vine rar prepared from
beerwort.-Bitter beer. See abe. - Blaek beer, a kind of leer manufactured at Dantzic. It is of a black color Brolsen beer, remunts or lesvings of beer: as, "a bum-
burl of broken veer," $B$. Jomson. - Condensed beer, beer which has been reduced in a copper vacumni-peer, beer of alcohol.-Dantzle beer. Same as black beer.-Green beer, beer which is just niade. Lager-beer, or ot.ockbeer, a light German beer so called because it is stored for
ripenfug before being useil. It is extensively nianufactured in the United States- - Schenk, young, or winter beer, It was formerly brewed only between October and April, but now is manufactured at all seasons. - Small beer, or uninnortant thing or person. - Stock-beer. See lager. beer. To think small beer of, to have a low opinion of She thinks small beer of painters, J. J.- weli, well,
hill don't think sinall beer of ourselves, my noble frientl.
Thacleray, The Newcomes, $x$.

Yeast-beer, new beer with which a small quantity of beer ${ }^{1}$ (bör), $v$. $i . \quad\left[<b_{c e r}{ }^{1}, n_{\text {. }}\right]$ To drink beer; tipple. [Colloq.]

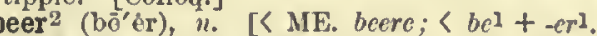
Cf. forcbear.] One who is or exists. [Rare.] beer ${ }^{3}, n$. An obsolete form of bier.
beer ${ }^{\dagger}, n$. [<D, beer, a mole, pier.] A mole or pier. $N$. $E . D$.

beer ${ }^{5}{ }$. Obsolete present and preterit of bear ${ }^{1}$. Chauecr. beestings

beer ${ }^{6} t, n$. An obsolete form of bear ${ }^{2}$.

beeregart, $"$. [Farly mod. I. also beereager, benteger, ete., s beerl + elger, sour. Cf. alegar, sour beer; vincegar formed by the aectous fernentatiou of beer.

beer-engine (bēr'en'jin), ". A hydraulie macline for raising beer aud other liquor: out of a eask in a eellar.

beer-faucet (bề' fin"set), $n$. A faucet fitted with a small air-pump, for mixing air with beer as it is Irawn.

beer-float (bēr'flòt), $n$. In distilling, an areometer or hydrometer designed to aseertain from tho observed density of a grain-mash the possible yield of spirit therefrom. The scale of the instrument is graduated to milieate directy, at the stand

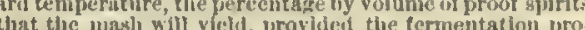
ceeds to a point where the density is equal to that of beer-garden (ber $r^{\prime} g h r^{\prime \prime} d n$ ), $n$, A garden attaehed to a brewery, tavern, or saloon, in whieh beer is server.

beer-house (bēr'lıons), $n$. A house where malt liquors aro sold; an ale-house.

eeriness (bër'i-nes), $n$. [<beery + -ness. ] The

stato of being beery or partially intoxicated; slight intoxieation from beer.

beer-measure (bēr'mezh"ür), $n$. An old English system of measures of eapacity. The galion contained 282 culhe fnches, being 10 pounds 3 ounces pounds of whest

beer-money (bēr'mun"i), n. An allowance of 1d. per day granted in 1800 to the British soldier in addition to his pay, as a substitnte for an allowance of beer or spirits; also, an allowaneo given to domestic servants in England in lien of beer, to save trouble in serving it out, or waste by leaving the eask open.

eerocracy (bēr-ok'ra-si), n. [( beer t-o-cracy, ing interest; brewers and beer-gellers collecing interest; brewers
tively. [Ludierons.]

eer-preserver (bēro prë-zêr"vêr), n. A devico

for keeping the suace abovo tho beer in a cask or barrel filled with carbonic-acid gas, which is pplied from a reservoir.

beer-pull (bēr'pủl), $n$. The handle of a beerpump; also, the pump itself.

beer-pump (bēr'pump), n. A pump for beer, especially for raising beer from tho eellar to ber-saloon (bēr'sa-lön"), n. A place where beer is sold and drunk.

beer-shop (bër'shop), n. A beer-saloon; an

beerstone (bēr'stōn), n. [< beerl + stone. $]$ In brewing, a hard inerustation like stone on the interior of the wort-coolers.

In time a preenish, or brownish, shining, thin crnst is
curmed on the sides of the coolers - no matter what terial they nay be constructed of - which adheres to them like varnish, and camnot he removed by the usual wash.
ing. This substance is called beer-gtone.

Beer stone. See stone.

beer-swilling (bēr'swil"ing), a. Drinking beer

In beer-secilling Copenhagen I have drunk your Danesman
blind.

beery (bēr'i), a. [ $\left[\left\langle\right.\right.$ becrl $\left.^{l}+-y^{1} \cdot\right]$ 1. Pertaining to or regembling beer. -2 . Stained or soiled th beer.

The sloppy, beery tatiles.

Thackera!l.

. Addieted to beer; affeeted by beer; partial-

intoxicated from drinking beer; maudlin.

There was a fril proportion of kindness in Raveloe, but

George Eliot, Silas Jarner, ix,

ITathom was not averse to ale, especialiy at another

looks pretty real in the tace."

bee-skep, bee-scap (bē'skep, -skap), n. [<bce]

+ skep, scap, a beelive, a basket: seo sliep.] A beehive. [Scoteh.]

beest (bēst), n. [Found in ME. only in deriv. beestings, q. v.; < AS. beost (also byst, after bysting, beestings) $=\mathrm{D}$. biest $=\mathrm{LG}$. best $=$ North. Fries. bjast, bjüst $=\mathrm{OHG}$. biost, MHG. G. biest, beest. Origin unknown; some suppose, from the G. dial. (Swiss) briest, Ieel. ä-brystur, pl., beestings, a conneetion with AS. breost, etc., F. breast.] Same as beestings.

eestie, $n$. See bhecsty.

eestings (bēs'tingz), n. sing. or pl. [A]so written beastings, biestings, ote., dial. beastin, bistins, biskins, ete., ME. beestynge, algo bestninge, bestynge, < AS. bȳsting, < beóst, beest, + -ing: 
beestings

see beest and -ing.] 1. The first milk given by a cow after calving.

So may the first of all our fells be thine

And both the beesting of our goats and kine.
B. Jonson, Pan'a Anniversary.

2t. A diseaso caused by drinking beestings. N. E. D.

beeswax (bēz'waks), $n$. [< bee's, poss. of bce, + wax.
their cells are constructed. See wax.

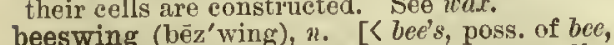
beeswing (bēz'wing), $n$. [< $\quad$ bee's, poss. of bee,
+ wing; from its appearance.] A gauzy film + wing; from its appearance.] A gauzy film hence, sometimes, the wine itself. Also written bee's-wing. Fetch'd

Ilis richest beeswing from a binn reserveri

For banquets, praised the waning red, and told
The vintage.
Temnyson, Ayluner's Field. Scott, from under bushy eyebrowa, winked at the apparition of a bees-wing.

beeswinged (bezz'wingd), $a$. So old as to be covered with beeswing: said of wine, especially port.

IIis port is not presentable, unless bees'-winged.

beet $^{1}$ (bēt), n. [< ILE. bcte, < AS. bēte (not ${ }^{*}$ betta $)=$ OFries. bete $=\mathrm{D}$. bect, bict $=\mathrm{LG}$. bete $=\overline{\mathrm{OHG}}$. bieza, MHG. bieze (G. beete, after $\mathrm{LG}_{\text {. or } \mathrm{L} .)}$. Sw. beta $=$ Dan. bede $=\mathrm{F}$. bette $=$ It. bicta, < L. becta, beet.] A plant of the genus Beta, natural order Chenopodiacere. The various forms are generally referred to a aingle apecies, B. vulgaris, the glender-rooted variety of which, known
Bus the and is occasionally used for greens. 'The common beet i extensively cultivated in many varietieg for the use of it sweetisin succulent root as a vegetable and as feed or cat clusively for cattle. The augar-beet is a large, white, and very aweet variety, from the root of which large quantities of sugar (celled beet-root sugar) are manufaetured in
trance, Germany, etc. The white or sicilian beet and the chard-beet are enlitivated for their leaves only.

beet ${ }^{2}$ (bēt), v. t. [E. dial. beet, beat, se. beet, beit, 〈 MIE. beten, ২ AS. bètan = OS. bōtian = OFries. beta $=$ D. boeten = LG. böten = OHG. buozzen, MHG. büezzen, G. büssen = Icel. bœta $=\mathrm{Sw}$. böt $a=$ Dan. böde), mend, improve, make good, < bōt, improvement, reparation, boot: good, 10 , which is related to beet as food to feed, brood to breed, ete. The word was particularly used in reference to mending, and hence by extension to kindling, fires: MIE. beten fyr $<$ AS. bétan fÿr $=\mathrm{D}$. boeten vnur $=\mathrm{LG}$. 1t. To make better; improve; alleviate or relieve (hunger, thirst, grief, the needs of a person, etc.).

All his craft we coud his aorrow bete.
Chaucer, T. and C., i. 666.

2t. To mend; repair; put to rights.

Pipen he coude, and fishe, and nettes bete.

Daily wearing neids yearly beiting. Scotch proverb.

3. To make or kindle (a fire); henee, to fire or rouse.

Two fyres on the auter gan sle beete. It warms me, it charms me, To mention but her naine An sets me $a^{\prime}$ on flane

And stiren folk to love and beten flre

4. To mend or replenish (a fire); add fuel to.

Picking up peats to beet lis ingle.

Obsolete or dialectal in all senses.]

beet ${ }^{3}, n$. Same as beat ${ }^{2}$.

beet-fly (bēt'fli)), $n$. A two-winged insect, $A n$ thomyia bete, smaller than the house-fly, infesting crops of mangel-wurzel and other varieties of beet, on whose leaves it deposits its eggs, the larve afterward devouring the soft parts.

beetle ${ }^{\mathrm{I}}$ (be $\left.\overline{\mathrm{e}}^{\prime} \mathrm{tl}\right), n . \quad$ [= Sc. bittle, bittill, < ME. betel, betylle, bitel, bittill, bytylle, < AS. biétel, bētel, bitel, by ýtel (bȳtl-) (= LG. betel, bötel = MHG. bózel), with formative -el, ( beátan, beat see beat 1.] 1. A heavy wooden mallet, used to drive wedges, consolidate earth, etc. It is made
either for awinging, with the handle aet in the middle of either for awinging, with the handle aet in the middle of
the iron-bound head, or for ramming, with the handle (provided in heavy beetles with projecting cross-pieces fo as for the use of pavers, it is sometimea heavy enough to require two or more men to operate it. Also called a
504

Ii I do, fllip me with a three-man beetle. 2. A wooden pestle-shaped utensil used for mashing potatoes, for beating linen, otc.

Aroint ye, ye limmer, out of an honest house, or ahame
Scott, lirate. 3. Same as beetling-machine.- Between the beetle and the block, in an awk wari or dangerous position.

eetle ${ }^{1}$ (bé'tl), $v_{\text {. }} t_{0}$; pret. and pp. beetled, ppr. beetling. [<bectlc, $n$.] 1. To use a beetle on; beat with a heavy wooden mallet, as linen or cotton cloth, as a substitnte for mangling.-2. beetle ${ }^{2}\left(b_{\bar{e}}^{\prime} t 1\right), n$. [The form seems to lave been influenced by that of beetle ${ }^{1}$; it would reg. be as in mod. dial. bittle, early mod. E. also betel, bittle, bittl, etc., $\mathbf{M E}$. bitle, bityl, betylle, bytylle, < AS.

bitcla, bitula (also *betel, once in pl. betlas), a beetle, appar. S*bitul, *bitol,"bitel, ME. bitel, biting (ef. ctul, etol, eating: with suffix -ol, forming seebite. Cf. bitter and beetle-browed.] Any insect belonging to the order Coleoptera (which see). Sometimes, however, the term is uaed in a more restricted this order embracing more than 3,000 speeies, eliaracterized by clavated antenne, flssile longitudinally; legs frequent-
ly dentated, and wiugs which have hard eases or aleaths y dentated, and wiugs which have hard eases or aleaths
ealied elytra. Beetles vary in aize from that of a pin'a head to nearly that of a man's fist, the iargest being the elephant. beetle of South America, 4 inehes long. "The "black beetlea" order Orthoytera. -Bloody-nose beetle, a large species of beetle of the genus Timarcha, $T$. lovigata: ao named because when disturbed it emita a red fluid from the joints.
Colorado beetle, a coleopterons inseet, Doryphora, - Colorado beetle, a coleopterons inseet, Doryphora,

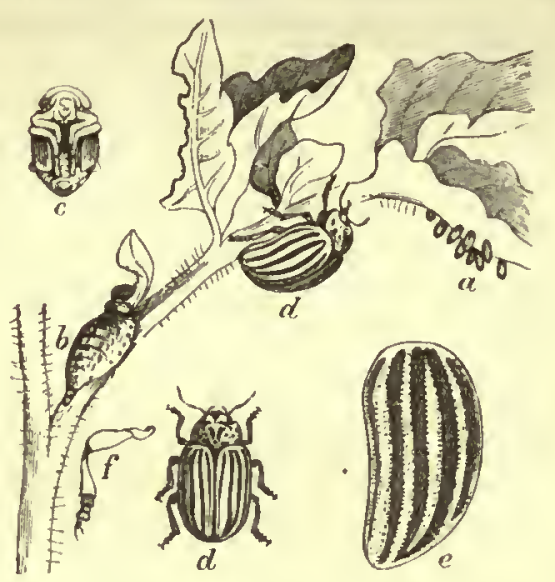

$a$, eggs; $b$, lirva, advanced ssage; $c_{\text {, pupa }}$; $d$, beetle ; $e_{1}$ wing-coves.

somelide, belonging to the tetramerons section of the or der. In size it is somewhat larger than a pea, nearly oval,
couvex, of a yellowish or ocher-yeilow color, narked with hlack spots and blotches, and on the elytra with ten black
lougitudinal atripes. T'he wings, which are folded under longitudinal atripes. The wings, which are folded under
the elytra, are of a iloori-red color. This insect works great havoc upon the leavea and flowers of the potato, ani is also destruetive to the tomato and the egg-plant
It was first observed in the Rocky Mlountain region about 1859, and has ance apread from Colorado over the whole of the United States and Canada. Also called potato-bug. a lamellicorn beetle of the genus Megalosoma and some related gewera, belonging to the cetonian group of Scara. beetle 3 (be-'tl), a. [Separate use of bectle- in beetle-browed.] Shaggy; prominent: used in beetle browo (also written beetle-brow).

Here are tine beetle brows shall bluah for me.

Bent hollow beetle browea, sharpe ataring eyes,

beetle ${ }^{3}$ (bē'tl), v.i.; pret. and pp. beetled, ppr. beetling. $\quad\left[<\right.$ beetle ${ }^{3}, a$. First used by Shakspere.] To be prominent; extend out; overang; jut.

What, if it tempt you toward the flood, my lord,

Or to the dreadful aummit of the cliff,

That beetles o'er hia base into the aea?

Each beetling rampart and each tower sublime.

beetle-brow (bē'tl-brou), $n$. See beetle ${ }^{3}, a$.

beetle-browed (bē'tl-broud), $a_{\text {. }}$ [< ME. bitelbrowed, bytclbrowed, etc. (used in "Piers Plowbrowid), as if lit. 'having biting eyebrows, that is, projecting eyebrows, < ME. bitel, adj. sharp, biting, < AS. "bitel' (see beetle ${ }^{2}$ ); but more prob. 'with eyebrows like a beetle's,' that is, projecting like the tufted antennæ of some beetles. See beetle ${ }^{2}$ and brow.] 1. Having

\section{befall}

shaggy, bushy, prominent, or overhanging eyebrows; hence, often, sullen; scowling.

A beetle-brouced sullen face.

Houcll, Letiers, ii. 25 . Its beetle-browed and gloony front.

2. Figuratively, having an overhanging or projecting top.

eetle-head (bē'tl-hed), n. 1. The monkey or a a pile-driver.-2, A beetle-headed or stupid fellow.-3. A name of the Swiss or black-bellied plover, Squatarola helvetiea. [Local, U. S.]

eetle-headed (bē "tl-hed "ed), a. [Cf. beetlehead.] Having a head like a beetle or mallet; dull; stupid.

Beetle-headed, flap-ear'd knave. Shak., T. of the S., iv. I. beetle-mite (be $\bar{e}^{\prime}$ tl-mit), n. [<beetle ${ }^{2}+$ mite $^{1}$. $]$ A mite of the family Gamaside (which see). eetle-stock (bë'tl-stok), n. [< beetle ${ }^{1}+$ The handle of a beetle.

eetle-stone (b-'tl-stōn), n. [<beetle $2+$ stone. $]$ A nodule of coprolitic ironstone, so named from the resemblance of the inclosed coprolite to he body and limbs of a beetle.

beetling (bēt'ling), $n$. [Verbal n. of beetle ${ }^{1}, v$.] A beating with a beetle.

When the desired shade is obtained, nothing remains ut to wash the silk, and give it two beetlings at the Ure, Dict., I. 209.

beetling-machine (bēt'ling-ma-shēn" machine for finishing linen or "cotton eloth by hammering it: for this purpose stamps are used, which are raised in succession and permitted to fall by their own weight. Also ealled beetle.

beet-master (bēt'mảs"tèr), n. An erroneous form of beet-mister.

beet-mister (bēt'mis"tèr), n. [Se., < beet, beit, mend, supply, + mister, want; beet a mister, supply a want: see beet 2 and mister 2 . Cf. E dial. (North.) beet-need, assistance in the hour of distress.] Whatever supplies a want; hence, a substitute. [Scotch.]

Next she eniarged on the advantage of saving old the new.

beet-press (bēt'pres), $n$. A hydraulic or steampower machine for expressing the juice from sugar.

beet-radish (bēt'rad"ish), n. A name sometimes given to red bects (Beta vulgaris) when raised or used for salad. See beet ${ }^{1}$.

beet-rave (bēt'1'āv), n. [< bect I + rave, after F bette-race, beet-root, (bette, beet (see beet ${ }^{1}$ ) + rave < L. rapa, a turnip.] Same as beet radish. In Scotland also beetraw and beetrie. bee-tree (be'triē), $n$. 1. A name of the basswood or American linden, Tilia Amerieana, from the richness of its flowers in honey, -2 . A hollow tree occupied by wild bees.

beet-root (bet'röt), $n$. The root of the beetplant. See beet ${ }^{1}$.-Beet-root sugar, sugar made Iroun beet-roota. The roots are ragped to a pulp, and tie and is then fitered and concentrated by evaporation in a vacuum-pan. See beet 1 - Beet-root vinegar, vinegar prepared from the juice of the augar-beet.

eeve (bēv), $n$. [A rare singular, erroneonsly formed from beeves, pl, of beef.] An animal of the bovine genus, as a cow, bull, or ox.

They would knoek down the firat beeve they met with. Each atately beeve bespeaks the hand

That fed hin unrepining.

eeves, $n$. Plural of beef.

bee-wolf (b- $\left.\bar{\theta}^{\prime} w u l f\right), n$. 1. An African beeeater, Mellitotheres mubieus, one of the Meropille.-2. A parasite of the bee, Triehodes apiarius.

bee-worm (bés'womn), $n$. An old name for tho larva of the bee. Ray.

befall, befal (bē-fâl'), v.; pret. befell, pp. befallen, ppr. befalling. [' MIE. befallen, fall, happen, belong, < AS. befeallan, fall (=OS. bifallan = OFries. bifalla $=\mathrm{D}$. berallen, please, $=$ OHG. bifallan, MHG. G. befallen, please), < be + fcallan, fall: see be-1 and fall.] I. trans. To fall or happen to; occur to.

But I beseech your grace that I may know The worst that may befall mie.

Shak., M. N. D., i. 1.

The worst that can befall thee, measured right

Is a sound slumber, and a long gooi night. 


\section{befall}

II. intrans. 1. To happen; come to pass. The discord which befell. Milton, i. L., vi. 897. The ground la many a little de Was broken, up and down whose steeps befel Shelley, Revolt of Islam, vi. 10.

2 t. To fall in the way; come to hand. Ilis little Givats gan drive out of their atalls, I'o feede abroud, whicre Sipenser, Virgil'a (itiat, 1. 72.

To befall oft, to be the fate of; become of

Why me the fitvour to dilate at fnll
What hath befall'n of them, anl thee, thi now.

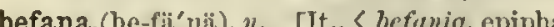
[LL. epriphenia, epiphany: seo Epiphany.] 1 . Yrimarily, in Italy, an Epiplany present or

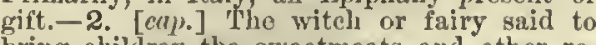
bring ehildren the sweetmeats and other rewards given them on the eve of Epiphany, or to negleet and punislı them.

In mirsery parlance the Befanu las two aspects; she

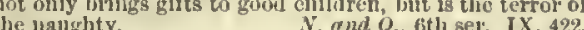
3. A large rag doll, representing tho Befana, placed on the chimneys of cottages, ete., or displayed in sliops, in Italy, where Epiphany gifts are sold, for the terror or amusement of eliildren. IThe aloore meanings and customs have reference to the gifts of gold, frankincense, and my mrrh ( Mat.
ii. 11) Irought by the 3 lagi to the clilil Jesus, which the fenst of the Epiphiany commenturates. The grotesyue biackened figures often exhlblted are explained by the
tradition that one of the three wise kings was an Ethl.

befeather (bē-feriI'er), v. t. [<be-1 + fealher. $]$ To deck witli feathers.

befell (bō-fel'). Preterit of befall.

befetter (bē-fet' èr $), v, t$. [< $b e-\mathrm{I}+$ fetter. $]$ To confine with fetters; restrain as if by fetters.

Tongue-tied, befottered, heavy-laden nations

beffroit, $n_{0}\left[F_{0}\right]$ Sce belfry.

beffroyt $n$. In her, same as vair.

befilet, $v . t$. [Early mod. E. also befylc, < ME. befylen, befilen (mixed with befulen, befoulen, whieh rest directly upon ful, foul, foul), < AS. befy̆lan, < be- + fÿlan, file, fonl, < fül, foul: seo file $e^{2}$ foul, and befoul, and ef. defile ${ }^{1}$.] To make filthy; befonl; soil.

befit (bẹ-fit'), v. t.; pret. and pp. bcfitted, ppr. befitting. $[<b c-1+f i t]$.1 . To suit; be suitable to; become.

$$
\begin{gathered}
\text { Dry up your tears, } \\
\text { Which isl befit the beauty of that face. }
\end{gathered}
$$

Beau, and Fl. Knight of Burning Pestle, Il. 3. Ont of my sight, thou aerpent! That name best

Robes befitting his degree. Drayton, Barons' Wars, Iv. 2†. To fit; furnish with something fit. [Rare.] Ife . . hat serionsly beftted him with just such a befitting (bē-fit'ing), p.a. Of a suitable kind or charaeter; fit; proper; becoming: as, befitting woras; a befitting dress or manncr.

befittingly (bề-fit'ing-li), adv. In a befitting or appropriate manner; becomingly.

beflatter (bēe-flat'èr), $v$. $t$. [< be-1 + flatter.] To tlatter; eajole.

beflea (bẹ--flèé), v. $t . \quad\left[\left\langle b e-1+f l e a^{1}.\right]\right.$ To pester, as fleas do.

Who beffec $d$ with had verses of those bores

Who befiea'd with lad versea poor Louls Quatorze.

beflecked (bê-flekt'), a. [< be-I + fleeked. $]$ Flecked; spotted or streaked; variegated. A]so spelled befleckt. Dark billows of an eartiquake atorm
Beflecked with elouds like foam. 'hittier, The IInl-top.

beflower (bẹ-flou'èr), $v, t$. $[<b c-1+$ flower. $]$ To eover or besprinkle with flowers.

lieside a befonered and garlanded precipice.

S. L. Clemens, Life on the Mlssissippi, p. 274.

beflum (bẹ-flum'), v. t.; pret. and pp. beflummed, ppr. beflumming. [Sc.; also in the appar. perverted forms blefum, blaflum, blephum, $v$. and 1i., perhaps $<b e-1+{ }^{*}$ flum, as in flummery, or u variant of flam. Words of this kind are very tiatter. Seott. [Scotcl.]

befoam (bē-fōm'), $v$. $t$. [<be-I $+f o a m$.$] To$ cover with foam. Dryden.

befog (bẹ-fog'), $v^{\prime}$ t.; pret. and pp. befogged, ppr. befogging. $[<b e .1+f \circ g$.$] To involve in$ fog; lience, figuratively, to confuse; make obsemre or meertain; bewilder: as, to befog the uind witl soplistry.
505

\section{beg}

Intentional and persiatent efforts have been ... made D. A. if efle, Merehaut Marine, p. 120.

befool (bē-föl'), r. t. [<Ml\% befolen: $<$ be-1 +

fooll.] 1. "l'o make a fool of; delude; dupe. I could burst with rape, . To treat a a fool ; eall (a person) "fool." beforen, beforn, biforen, biforn, and emy. [K MF. prep., A AS. beforan, biforan, adv. and prep., before (in place or timo: in the latter use rare, the ordinary word being $\overline{a r}$, ere) (=OS. biforan $=\mathrm{D}$, beroren $=\mathrm{OIG}$, bifore, $\mathrm{MHG}$, beror, bevorn, G. bevor), < be, by, about, + foran, adv. before, < for, for, lit. before : see fore and for, and ef. afore.] I. alle. 1. In front; on the anterior or fore side; on the side opposite the baek; in a position or at a point in advanco; ahead.

The battle was before and behind. 2 Chron. xlii. I4. Reaching forth unto those things whlch are before.

Ila!l he hia hurts before? Shak, Nacleth, v. 7 . I am aent with broom before,
To aweep the dust belind tlic door.

If you will walk before, air, I will overtake you in. 2. In time preceding; previously; formerly; already.

Ton tell me what I knew before.

Dryiden.

A flatterer is a dunce to hlm, for he can tell him nothing

The Lark, 3licro-coamographe, A selfe-concelted shan. ing eompounds, as before-eited, before-going, fore-mentioned, etc.]

II. prep. 1. In front of, in time or position; on the anterior or fore side of; in a position or at a point in advance of: as, a happy future lies
before you; before the house; before the fire.

The golden age, which a bund tradition has hitherto

Carlyle, Sartor Resartus, iti. peat reading the burial servlce. prieat reading the burial servlce.
Ilawthorne, Twlce-Told Tales, I.

2. In presence of; in sight of ; under the eognizance, jurisdiction, or consideration of.

Abraham bowed down himself before the people of the They tell me, if they nilght be brought before you,
They would reveal things of atrange consequence.
Fletcher (and another), Sea Voyage, iv. If my lady die,
I'll be aworn before a jury, thou art the cause on 't.
Beou. and F'., Scornlul Lady, 3. In precedence of; in advanee of, as regards rank, condition, development, etc.

Ife that cometh after me is preferred before me. John I. Is. 3 can shew one amost of the same nature, but much be The eldest aon is before the younger in auccession.

4. In preference to; rather than.

One joyous howre in blisfull happines

I love my friend before myself. We think poverty to be infinitely desiralie before the
turments of covetousness.
Jer. Taylor. 5. Anterior to in time; previons to: as, I shall return before six o'cloek.

Temple sprang from a famlly whlch, though ancient and honourable, had before hls time leen acarcely mentione Thcy arrived close to Alhama about two hours befor Thcy artived close to Alhama about two hours befor
Irving, Granada, p. 30 . 6. Under the action, influence, or power of. Mordecai, . . . before whom thou liast begun to fall. Tower and town, as he alvancel, Prescott, Verd. and Isa., ii. 2. Before all. See aff- - Before the beam (naul.), in a poaition or direetlon which lies before a line drawn at riglit fore (or afore) the mast, as a common sailor, the crew of a ship being berthed in the forecastle or forward of the direction in whileh the wind blows: aald of a ship.

We continued running dead before the vind, knowlng hat we gailed better so.

R. II. Dana, Jr., Before the Afast, p. 20. (b) Figuratively and colloguially, in prosperous eircuntances; out of debt or difliculty.

III. conj. 1. Provions to the time when: formerly somctimes followed by that.

Before I was aftleted, I went astray. $\quad$ P8. cxlx. 67.
Jesus answered and sald unto him, Before that l'hlilp liefore this treatlae can Jolin 1. 48. tratiae can be of use, two poluts are necesSeventy of the Noors made thelr way into the strects 2. Sooner than; rather than.

Thien take ny soul; my body, soul, and all,

liefore that Lingland give the French the fuil.

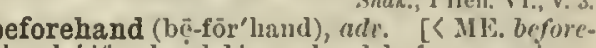
hond, bifornheind, bivorenhond, before, previously, < beforen, before, thand, liond, liand.] 1. In antieipation; in advance.

So that they . . may be tanglit beforehend the skill of $2 \nmid$. Before there is time for anything to be done; before anything is done. What Is a man's contending with insuperable tlificul.
ties but the rolling of sisyphus \& stone up the hlll, whichl is soon beforchand to return upon his agaln? S'kstrange. To be beforehand with, to antleipate; le in alvance
of; be prejared or ready lor.

Agricola ... regol vea to be beforeh and with the danger. The last-cited author has been beforehand with me.

beforehand (bẹ-fōr'hand), $a$. [< beforeliand, adv. Ci. forchinded.] In good pecuniary cireumstances; having enough to meet one's obligations and something over; forehanded: as. rich and much beforchand," Baeon. [Archaie. I now began to think of getting a little beforehand.

beforesaid (bē-fōr'sed), a. Aforesaid. Cliaucer. beforetime (bệ-för'tim), adv. [< ME. beforctyme; < before + time. Cf. aforetime.] Formerly; of old time; aforetime. [Obsoleseent.] Beforetime in Iarael, when a man went to enquire of God,

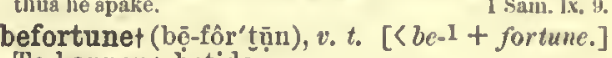
To happen; betide.

I wish all good befortune you. Shak., T. G. of V., iv. 3. befoul (bẹ-foul'), v. t. [<ME. befoulen, befulen (mixed with befylen, ete.: see befile) $<$ be + foulen, foul: see be-1 and foull, $r$.] To mako foul; cover with filth; soil; tarnisl.

Lawyers can live without befouling each other's names.
Trollope, Barchester 'Towers, xxi. Birds of prey winged their way to the stately tree, be.
fouling its purity. befreckle (bẹ-frek'l), $v . t$. [< be-I + freckle.] To freckle; spot; eolor with various spots; variegate.

Her star-befreckled face, Drayton, Polyolbion, xxli. 910. befret (bē-fret'), $v . t$; pret. and pp. befietted, ppr. befretting. " $[<b c-1+$ fret $\mathbf{I}$. $]$ To fret or gnaw away.

Accept thla ring, wherein ny heart I s set,

befriend (bē-frend'), $v, t$. [<be-1 + friend.] To act as a friend to; countenance, aid, or benefit; assist; favor: as, fortune befriended me.

That you were once unkind, befriends me now.

The climate [of Chreronea] is not much befriendud by the heavena, for the air is thick and foggy.
Dryden, Life of Plutarcis. Every little pine needle expandel and swelled with symbefriendment (bē-frend'ment), $n$. [ [ befriend + -ment.] 'The aet of befriending. Foster. [Rare.]

befrill (bō-fril'), v. $t . \quad[<b e-1+f r i l l$.$] To fur-$ or deek with a frill or frills.

The viear's white-haired mother, befrilled ... with dainbefringe (bē-frinj'), $v_{0} t_{0}\left[\left\langle b e_{-1}+f r i n g c_{0}\right]\right.$ To $_{0}$ furnish with a fringe; adorn as with fringe.

$$
\begin{aligned}
& \text { Let my dirty leaves } \\
& \text { Befringe the ralla of Betlam and solio. }
\end{aligned}
$$

befriz (bē-friz'), $v$. $t$.; pret. and pp. befrizzed, ppr. befrizzing. [< be-1 + friz. $]$ ro eurl the

Befrizzed and hepowdered coutlers. Contemporany her. befuddle (bē-fud' 1$), v$. t. $[\langle b c-1+$ fuddle. $]$ To stupefy or muddle with intoxicants; make stupidly drunk.

befur (bẹ-fér $\left.\mathbf{r}^{\prime}\right), v . t$; pret. and pp. befurred, pr. befurring. $\left[\left\langle b c_{-1}+\right.\right.$ fuer.] 1. To cover or supply with fur.-2†. To fur over; inerust. N. E. D.

begI (beg), $v_{\cdot}$; pret. and pp. begged, ppr. begging. [Early mod. E. also begg, begge, < ME. beggen, first found in the early part of the 13 th century (in the "Aneren Riwle"); origiu un- 


\section{beg}

certain. Various explanations have been offered: (1) < ME. baggc, a bag (beeause beggars carry bags: see first quotation under beggnr, n.); but this is certainly "wrong. It would imply the forms "beggen, bagge, but no such variants are found or are probable, and no suel sense as 'put into a bag,' or '(arry a bag,' whiel might eonneet the notion of 'bag' with that of 'beg,' belongs to the ME. verb baggen, whieh is bay'; the sense of 'put into a bag' is modern, and that of 'earry a bag' does not exist; baggor, moreover, the supposed antecedent of beggar, is only modern. (2) < AS. bedecian, beg gar, is only modern. par.< birljan $=$ AS. biddlan, E. bid, ask; ef. D. bedelen $=\mathrm{OHG}$. betalōn, MHG. betclen, G. bet-
teln, beg, freg. of $\mathrm{D}$. bidden $=\mathrm{G}$. bitten $=\mathrm{AS}$. biddan, E. bid, ask); but the AS. bedecian oc eurs but onee, in the 9th century, and there are no intermediate forms to eonneet it with MIE. beggen. (3) < OFlem. "beggen, beg; but there is no sueh word. (4) < OF. beg-, the eommon radieal of begard, begart, beguard, begar (ML. begardus, beggardus, beglardus, ete.), and beguin (ML. beginus, begginus, beghinus, beguimus, ete.), names given to the members of a mendieant lay brotherhood (see Beghard and Beguin); also applied to any begging friar or other beggar. Sueh mendieants were very numerous at the time of the first appearanee of the $\mathrm{E}$. verb, and the derived $O F$. verb beguiner, beguigner $(<$ beguin), with $\mathrm{AF}$. begger, is aetually guigner (रound in the sense of 'beg.' 'The $\mathrm{E}$. verb may be a baek formation from the noun beggar (ME. begger, beggere, beggar, beggare), whieh is, in this view, an adapted form (as if a noun of agent in $\left.-a r^{1},-e r 1\right)$ of the $\mathrm{OF}$. begar, begard, in iIE., though the preeise form begger is found in $W$ yelif and later as a designation of the mendieant friars (Beghards), appar. without mendieant friars (Beghards), appar. without direct referenee to their begging. I. trans. 1. alms.

Yet liave I not seen the righteous forsaken, nor his seed
Ps. Xxxvli. 25. For all thy blessed youth
Becomes as aged, and doth beg the almis Becomes as aged, and doth beg the alms
Of palsied eld. 2. To ask for earnestly; erave.

He [Joseph] . . . begyed the body of Jesus.

Mat. xxvili. 58 . treat or supplicate with humility or earnestness: as, I begged him to use his influenee in favor of my friend.

And on our knecs we beg
(As recompense of our dear services,

Past and to come) that you do cliange this purpose.

To beg a person for a foolt, to take Jim for, or regar In the old conimon law was a writ . . Inder which it man was legally provel an ifliot, the profit of his land might le granted by the king to any suljeet such a person, when this grant was asked, was said to be To beg the question, in logic, to assunne or take a granter that which is not more certain than the proposiin question: assume as a prenise what yo one who takes the opposite view of the queation will adnit.

The sophisin of begging the question is, then, when any thing is proved either by itself or sondething that is equalBurgersdicius, tr. by a Gentleman (1697) The attempt to infer his [Shakspere's] classical educa-
tion from the Internal evidence of his works is simply a

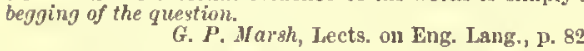
To maintain, as Sir Wyville Thonson does, that $32^{\circ}$ is
the temperature of the flool on which the Antarctic icethe thests is virtually to beg the question.

=Syn. Ask, Request, Beg, etc. (see $a s k 1$ ); to pray (for), II. intrans. 1. To ask alms or eharity; praetise begging; live by asking alms.

I cannot dig; to beg I am asliamed. Isake xvi. 3. 2 . In the game of all-fours, to ask of the dealer a eoneession of one point to be added to one's eount. The dealer must elther concede the point or deal
out three additlonal cards to each player. Should the out three additlonal cards to each player. Shonld the
suit originally turned as trump appear after this new deal, three, or fewer if so agreed, must be dealt to each pnt a different trump appears. - To beg off, to obtain relea
from a penalty, obligation, etc., by entrenty or excuses. beg $^{2}$ (beg), $n$. Same as bey 1 .

bega, biggah (bē'gä, big'ä), n. [Also written

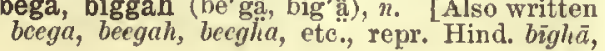

506

Marātlıi bigha..] A Hindu land-measuire, locally varying in extent, but usually regarded as equal to from one third to two thirds of an Englis yards, or about a third of an aere.

egad (bẹ-gad'), interj. [A minced oath, a coruption of by God! Cf. egad, bedad.] A sort of exelamatory oath, employed to give weight to a statement.

Begad, madam, ... 'tls the very same I net.

egall (bẹ-gâl' $), \imath . t$. [<be-1+gall².] To gall ret; chafe; rub sore. Bp. Hall.

began (bē-gan'). Preterit of begin.
begat (bẹ-gat'). Old preterit of beget, still sometimes used poetieally.

egaud $\dagger\left(b \vec{e}-g a ̂ d^{\prime}\right), v$ t. [Also written begavd; < be-1 + gaud see gaud1.] To bedeck with gaudy things. North.

begaum, $n$. See begum 2 .

egeckt (bẹ̄-gek'), $x . t$. [Sc., also begeck $(=\mathrm{D}$ begeklien); $\langle$ be-1 + geck: Cf. begunk.] To befool; gull; jilt, N. E. D.

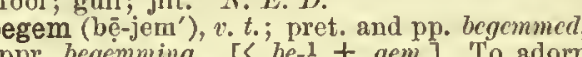
ppr. begemning. [<'be-1 + gem.] To adorn or anything suggesting them.

$$
\begin{aligned}
& \text { The lawı } \\
& \text { Begemmed with dew-drops. } \\
& \text { Scott, } \mathrm{I}_{\text {. }} \text { of the I., lii. } 2
\end{aligned}
$$

beget (bē-get'), $v$. $t$.; pret. begot, formerly be gat, pp. begotten, begot, ppr. begetting. [< ME begeten, begiten, bigiten, etc., < AS. begitan, bigitan ( $=$ OS. bigitan $=\mathrm{OHG}$. bige an), get, aequire, <be- + gitan, getan, get: see be-1 and get l.] 1. To procreate; generate: chiefly use parents.

Abralıan begat Isaac; and Isaac begat Jacob; and Jacob
begat Judas and his brethretl. Yet they a beauteous offspring shall beget.

Become stont Marsea, and beget young Cuplds. B. Jonson, Alchemist, ii.

2. To produce as an effect; cause to exist generate; oceasion: as, luxury begets vice "love is bogot by faney," Glanville.

Intellectual seience las been observed to beget invariaThentially independent of language, an Thought is essentially independent of language, an
peech could never lave begotten reasonl Thought, p. 16\%.
Wfivart, Nature and Thou =Syn. To breed, engenter.

begetter (bê-get'er), $n$. One who begets or pro creates; a father.

begetting (bẹ-get'ing), $n$. 1. The act of procreating or produeing. -2 . That whieh is begotten ; progeny.

beggable (beg'a-bl), a. $\left[\left\langle b^{\prime} g^{1}+\right.\right.$-able. $] \mathrm{Ca}$ able of being begged.

Things disyoscd of or not beggable. Butler, Claracter beggar (beg'är), n. [Early mod. E. more eom monly begger, < ME. begger, beggerc, also beggar, beggare, a beggar: for the etym., see beg ${ }^{1}$.
The reg. mod. spelling is begger; the ME. variant spelling beggar, beggare, has not neeessarily a bearing upon the conjeetured derivation fom variable to the suffix -er boing in ME. One who begs or asks alms; espeeially, one who lives by asking alms or makes it his business to beg.

Bidderes and beggeres fast about yede,

With htre belies and here bagges of brede full ycrammed.

2. One who is in indigent eircumstanees; one who has been beggared.-3t. One whu asks a favor; one who entreats; a petitioner.

Count. Wilt thou needs be a beggar?
Clo. I do beg your good-wilt in this case.

What subjects witt precarious kings regard?

One who assumes in argument what he does not prove.

These shameful beggars of principles.

5. A fellow; a rogue: used $(a)$ in eontemp

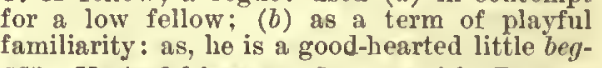
gar.-Masterful beggar. See masterful.-To go or
go bome by beggar's bush, to go to ruin. Brever. beggar (beg'är), v. t. [Early mod. E. also begreduce to beggary; impoverish.

Whose heavy land liath bow'd you to the grave,
And beggar'd yours for ever. Shak., Macbeth, li1.

\section{beggary}

Beggar'd by fools, whom still he found too late; Dryden, Abs. and Achit., i. 561

A rapacious government, and a begyared exchequer.
Buckle, Civilization, I. 653.

2. 'To exhanst the resourees of; exeeed the means or eapaeity of ; outdo.

When the two lierocs met, then began a scene of warIrving, Kuickerbocker, p. 328

Shakespeare carrles us to such a loity strain of intelligent activity as to suggest a wealth which beggars his
Emerson, Essay, 1st ger., p. 262 beggardom (beg'ậr-dum), $n$. The state of beg-

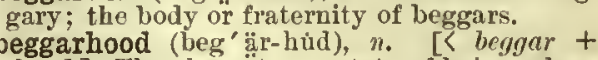
-linod.] The eharaeter or state of being a beggar; beggars eollectively.

beggarism (beg'är-izm), $n$. $\quad[<$ begyar $+-i s m$. The state or eondition of beggary.

beggarliness (beg'ijr-li-nes), $n_{0}$ [ $<$ beggarly

$+-n e s s$.] The state of being beggarly; $\theta \mathrm{x}$ treme poverty ; meanuess.

beggarly (beg'iir-]i), a. [Early mod. E. also begyerly; < beggar +-ly $1_{\text {. }}$ [. In the condition of or beeoming a beggar; extremely indigent; poor; mean; contemptible: used of persons and things. A beggarly account of empty boxes.

Beggarly sins, that is, those sins which Idleness and beggary usually betray men to, such as lying, flattery,
stealing, and dissimulatlon. IIe was an Idle, beggarly fellow, and of no use to the
public. 2. Of or for boggars. [Rare.]

But moralists, Boclologlsts, political economists, and taxe have slowly convinced me that my beggarly sympathie beggarly† (beg'är-li), adv. Meanly; indigent ly; despicably.

It is lila delight to dwell begagroly.

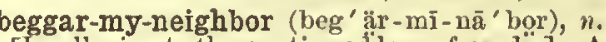
[In allusion to the continued loss of cards.'] A children's game at cards. In one variety of it the players hold the cards with the lacks upwart, and alternately lay one down till an honor is turned up, whlch
has to be paid for at the rate of four cards for an ace, three for a king, etc. : and the game goes on thus till one beggar's-basket (beg'ärz-bảs "ket), n. The European lungwort, I'ulmonuria officinalis. beggar's-lice (beg'ârz-lis), $n$. I. An English eggar s-lice (beg arz-lis), $n$. 1. An English name of Galium Aparine, or goose-grass, given to it beeause its burs stick to the elothes, and
somewhat resemble liee.-2. The name given somewliat resemble liee.-2. The name given
in the United States to speeies of Bidens and to Eehinospermum Virginieum, the seeds of whieh have barbed awns which eling persistently to clothing. Also ealled beggar's-tieks,

beggar's-needle (beg'ärz-nē"dl), n. An English popular name for the Seandix Pecten, from its long-beaked fronds.

beggar's-ticks (beg'끌-tiks), $n$. Same as beggar's-lice, 2. Also written beggarticks. It [the garden] was over-run with Roman wormwood
and beggarticks, which last stuck to my ctothes.
Thoreau, Walden, p. 282. beggar-weed (beg'ạ̈tr-wēd), n. [Cf. beggary ${ }^{2}$, 2.] A name sometimes given in England to the eommon door-weed, Polygonum avieulare, to Cuscuta Trifolii, and to some other plants. beggary ${ }^{1}$ (beg ärr-i), n. [Early mod. E. also beggery, < ME. beggerie, <beggere, beggar.] 1 The state of a beggar; a eondition of extreme indigenee.

Tis the narrowness of human nature, Our poverty and beggary of spirit, B. Jonson, The New Inn, iv. His vessel with an inestimable cargo lias just gone
down, and he is reduced in a monent from opulence to
beggary.
Macaulay, Lord Bacon. 2t. The act or praetiee of begging; the oeeu. pation of a beggar; begging.

We must be careful that our charity do not minister to idleness ant the love of beggary. Taylor, Great Exemplar.

3. Beggars eolleetively; beggardom; beggarood.

The Piazza is invaded by the legions of beggary, and eld in overpowering numbers against all comers.
Howell, Venetian Life, $x$ vill

\section{A state of bareness or deficiency.}

The freedom and the beggary of the old atudio. Thackeray.

beggary ${ }^{2}$ (beg'är-i), a. [< beggar $+-y^{1}$. $] 1$ Beggarly; poor; mean. [Rare.]-2. Full of 
beggert, beggeryt. Former and more regular spellings of beygur, begyary. begging (beg'ing), n. [<Mí. beygynge; verba] n. of begl.] The aet of asking or soliciting; the oecupation of a beggir.

beggył (beg'i), n. Same as bey $y^{1}$.

There used to be a still more powerful personage at the

Beghard (beg'iird), n. [< ML. Begharlus, begavlus, bcggardus, begfeharilus, begihardus (ef. 1t. Sp. Pg. begarlo, MIIG. beghart, begehorl, G. beghart, Flem. begyaert, ols. begard, beyart, begar, with a lator equiv. ML. beghimus, begimus, ete., OH. beguin, ete., k. Begnin), formed, with the suffix -urdus, ari (and later-inus, -in, after tho fera. Ml. beghina, begina, ete., of, beguine, etc., E. Beguin, Bcynine), from the OF. begnine, etc., F. Begwin, Beyminc), from the name of the founder of the sisterliood of Be-
guins, namely, Lambert Beyue or le Beywe: seo guins, namoly, Lambert Beyue or le Beywe: seo
Begnin, Beguine.] Ono of a body of religious cnthusiasts whieh arose in Flanders in tho thir tecnth eentury; a Beguin (which see). Also wiitten Beguurl. [Often without a eapital.] begild (bẹ-gild'), v。 t.; pret. and pp. begilled, begilt, ppr. begilling. [< be-1 + gilll.] To gild: us, "bride-laees begilt," $\boldsymbol{B}$. Jonson, King's Enas, "bride-la

The lightning-flash from sworis, casks, courtlaces,

With quivring heams begilds the neiglibour grasses.
Sulvegter, Battaile of Yivy (trans.), p.

begin (bē-gin'), $v_{.}$; pret. began, sometimes begun, pp. begun, ppr. beginuing. [< ME. beginnen, biginuen (pret. began, begon, pl. begunne, begunnen, begonne, otc., pp. begunnen, begonnen, begnnne, ete.), $<$ A S. beginnan, biginnan (pret. bcgan, pl. begunnon, pp. begunnen $)=\mathrm{OS}$. biginnan $=$ Olvies. beginna, bejenna $=\overline{\mathrm{D}}$. beginnen $=$ OHG. biginnan, MHG. G. beginnen, begin; AS. more eommonly onginnan, rarely äginnan, ME. aginnen, and by apheresis ginnen, mod. E. obs. or poet. gin; also with still different profixes, OHG inginuan, enginnen, and Goth duginnan, begin; $\left\langle b c-\left(\mathrm{E} . b c^{-1}\right)\right.$ or on-, $\bar{a}-\left(\mathrm{E} . a_{-2}\right),+$ "gin- $^{-}$ nan, not found in the simple form, prob. orig. 'open, open up' (a sense retained also by the OHG. inginnan, MHG. enginnen), being prob. eonnected with $(a)$ AS. ginian = OHG. ginēn, MHG. ginen, gonen, G. gähnen, gape, yawn, $(b)$ AS. ginan = Ieel. gina, gape, yawn, (c) AS. ganian, L. yaion = OHG, ganon, MHG. geinen, varionsly with $n$-formative from the root" $g i$, varionsly with $n$-formative from the root "gi,
seen also in OHG. gīen and giwēn, gewón, $M H G$. gicen, gercen $=\mathrm{L}$. hiare $=$ OBulg. zijati = Rnss. zijati = Bohem. zitati = Lith. zhioti, ete., gape,

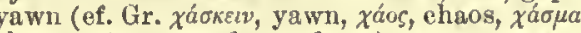
chasm, ete.: see chaos, chasm): see yaien and hiatus. Cf, open as equiv. to begin, and elose as step in; set about the performance or aceomplistment of; enter ppon; eommence.

Ye nymphs of Solyns, begin the sone. Pope, Mlessiah, 1, 1

2. To originate; be the originator of: as, to begin a dynasty.

Proud Nimrod first the savage ehase began

3. To traee from anything as the first ground date the beginning of.

The apostle beging our knowledge in the creatures
which leads us to the knowledge of God.

= Syn. 1. To set about, institute, undertake, originate,

II. intrans. 1. To come into existenee; arise; originate: as, the present German empire be gan with William I.

$$
\text { Misde a selfish war begin, }
$$

Tennyson, To F. D. Mraurice.

2. To take a first step; eornmenee in any course or operation; make a start or eommeneement. No change of disposition beging yet to show itself in
England. The contest raged from morning until night, when the
Iroors began to yielct. Granada, p. 35 . To begin the board. See board. - To begin with. (a) the Latin granumar: to begin wilh prayer. (b) At the get ; as the first thing to be considered ; flrst of ali : as, to begin with, I tio not like its color.

Animals can be trained to behave in a way in which, $t o$ begin with, they are inca pable of behaving.

begint (bē-gin'), n. [< begin, v.] A beginning. Let no whit lliee dismay

The lard beginne tiat meetes thee in the dore.

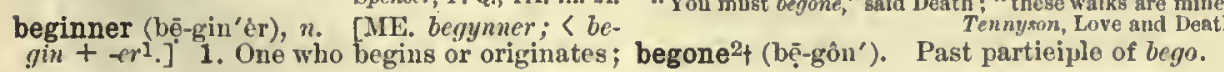

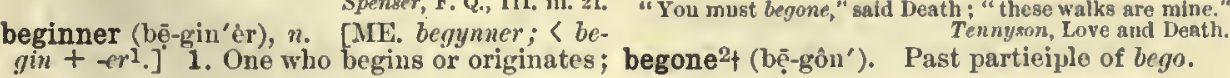

Milton, P. L, i. 581 one who starts or tirst leads off; an author or Begonía (bē-góni-ii), n. [NL., named after
originator. Where are the vile beginnerg of this fray?
Shak, K, anil J., Ili. 1. 2. One beginning to lea rn or practise; a noviee; a tyro:

There are nolje pasages in it, hut they are for the adept O. 15 . Molmes, It. W. Fimerson, xiv.

eginning (bē-gin'ing), n. [< ME. berninninge, beginnunge (= MIIG. beginnunge); verbal n. of begin.] 1. The origin; soureo; first eause.

I am . . . the bcyinniny and the ending. Itev. 1. 8. 2. The point of time or epoch at which anything begins; specifieally, the time when the niverse began to be.

In the beginning ood ereated the heaven and the earth. It was reserved for Ilution to declare for the first time that the rocks around us reveal no trace of the beginning 3. The initial stage or first part of any proeess or proeceding; the starting-point: as, a small beginning.

II was come to that liejght of honour out of base be The beginning of writing is the hieroglyphlic or symbot. ical picture, the beginning of workhip is letishism or idol. atry, the beginning of eloquence is pictorial, sensuons, and metaphorical, the beginning of philosophy is the
Lecky, Europ. BIorals, 1. 142. beginningless (bẹ̄-gin'ing-les), $a$. [<beginning +-less.] Having

begird (bề-gèrd'), $v$. $t$. ; pret. and pp. begirt, begirded, ppr. begirding. [< ME. begirden only in pret. or pp. begurt, $<\mathrm{AS}$. begyrdan (=OHG. bigurtjan; ef. Goth. bigairlan, strong
verb), < be- + gyrdan, gird : see be-1 and gird1.] 1. To bind with a band or girdle.-2. To surround; inelose ; eneompass.

Uther's son
Begirt with Britiah and Armorie knights.
Milton, $\mathbf{P}$. I.

begirdle (bē-gèr'dl), v. t. $[<b e-1+$ girdle. $]$ lo surround or eneirele as with a girdle.

Like a ring of lightning they ... benirdle lier from begirt† (bē-gèrt'), v. $t$. [A form of begird, inf., due to the frequent pp. begirt, pret. and pp. being the same as

Begirt the wood, and fire it.
Massinger, Bashtul Lover, iti. 5.

To begirt the almighty throne,
Beseeching or besieging.

beglare (bẹ-glãr $r^{\prime}, v_{0} t . \quad\left[<b e_{-1}+\right.$ glare. $]$ To

glare at or on. [A humorons eoinage.]

So thst a bystander, without heholding Mirs. Wilfer at begrease (bē-grēs'), $v . t$. [< be-1+qrease. To an, must have known at whom she was glaring by seeing soil or danb with grease or other oily matter.

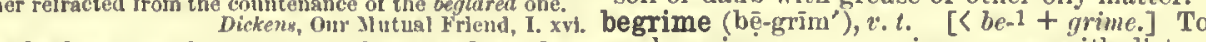
beglerbeg (beg'lèr-beg'), $n$. Same as beylerbey. beglerbeglic (beg'lèr-beg'lik), $n$. Same as beylerbeylik.

begloom (bẹ̈-glöm'), $t . t$. [<be-1 + gloom.] 'T'o make gloomy; darken. [Rare.]

begnaw (bē-ná'), v. t. [ME. not found; < AS. begnagan, gnaw, < be- + gnagan, gnaw: see $b e-1$ and gnaw.] To bite or gnaw; eat away orrode; nibble at. [Rare.]

The worm of consclence still be-mavo tliy soul.

begot (bē-gō'), v. t.; pret. bewent, pp. begone. [CM. begon, bigon, AS. begān (= D. begaan (be-, by, about, + gàn, go: see be-1 and go.] 1. To go about; eneompass; surronnd. -2 . To elothe; attire.-3. To surround or beset; affeet as a cireumstanee or influence: now gone, beset with woe (originally in tho eonstruetion him wats wo bcgon, in whiel wo is the ly made the subjeet)

$$
\text { So was } 1 \text { glad and wel begon }
$$

egod (bö fy: as, "begolded saints," South, Sermons, V. xevii.

begonel (bệ-gôn'). [Prop. two words, be gone (be, inf. or impv.; gone, pp.), irreg. nnited, as also in beure.] Be gone; go away; depart.

Begonef you are my brother; that's your ss Bear and F that's your ssiety. make grimy; cover or impress as with dirt or grime.

The justice-soom begrimed with ashes.

=Syn. Tarnish, etc. See quil. Macaulay, Ihist. Eng., $x$

begrudge (bê-grnj ${ }^{\prime}$ ), $v$. $t$. [Early mod. F. also begruich,, $\mathrm{ME}$. brgruechen: see be-1 and grudge.] T'o grudge; envy the possession of.

There wants no teacher to make a poor man begrudge
his powerful and wealthy neighbour both lis actuill sharo in the government, and his disproportionate share of the
good things of this inle.
Brongham. begruntlet (bē-grun'tl), v. $\iota . \quad[<b e-1+$ gruntle. Cf. disgruntle.] To render uneasy; diseoneert. The Spaniards were begruntled with these scruples.
Bp. Hocket, Life of Abp. WIJians, i. 131.

begrutcht, $\because . t$. Obsolete form of begrudge.

egrutten (bè--grut'n), $a$. [< be-1 + grutten, pp. of greit, greet, ery: see greet $\left.{ }^{2}.\right]$ Showing the effeets of much weeping; marred or swollen in faee through sore or eontinned reeping. [Seoteh.]

Poor things, . . . they are sae begrutten.

Begtashi (beg-tï'shẹ̄), n. [Turk.] A seeret religions order in Trikey resembling the order of Freemasons, employing passwords and signs of recognition very similar to, and in some eases identical with, those of the latter onder and ineluding many thousands of influential members. Imp. Diet.

beguan (beg'wän), $n$. [Prob. a native name.] A bezoar or eoneretion found in the intestines of the iguana.

Beguard, n. Seo Beghard. 
beguile

508

beguile (bẹ-yil'), v.t. [< ME. begilen, begylen (= ND. beghijlen), ${ }^{2}$ be- + yilen, gylen, guile, guile; deceive; impose ou by artifiee or craft. 'The serpent beguiled une, and 1 dilil eat. Gen. ifi. 13. By expeetation every day beguil' $d$,

Coverer, siy Mluther's Picture.

2. To elude or cheek by artifice or craft; foil. "Twas yet somie comport,

When misery condid beguile the tyrant's rage,

3. To deprive of irksomeness or unpleasantness by liverting the minl; render unfelt; eause to pass insensibly and pleasantly; while away.

The tedions day with sieen. Shald., Hamlet, lii. 2. Chiefs of elder Art!

Teachers of wisdom! who could once beguile
My tedious hours.
Roseoe, To ny Books.

4. To transform as if by eharm or guile; charm. Till to a sinile

The goodwife's tearful face lo did beguile. William Al orris, Earthly Yaradise, 11.

5. To entertain as with pastimes; amuse. The tales

With which this day the ehildren she beguiled
She glean'd from Breton grandianes when a chlld M. Amold, 'Tristram and IsenIt, ii. To begulle of, to deprive of hy guile or pleasing artiflce.
The writer who beguiles of their tediousness the dujl
hours of life. =Syn. 1. Cheat, mislead, inveigle.-3-5. Amise, Divert, beguilement (bē-gil'ment), $n$. [< beguile + -mont.] The act of beguiling; the state of being beguiled.

beguiler (bệ-gī'lér), n. One who or that which beguites or deceives.

beguilingly (bễ-gī'ling-li), adv. In a manner to beguile or deoeive.

beguilty† (bê-gil'ti), $v \cdot t .[\langle b e-I+g u i l t y$.$] To$ render guilty; burden with a sense of guilt.

By easy comnutations of public penance lor a private
peemiary mulct [thut] dost at onee beguilty thine own conscienee with sordid bribery. Bp. Sanderson, Sermons, p. 275 .

Beguin, Beguine (beg'in; sometimes, as mod F., bã-gañ', m., -gēn', f.), n. [(1) Beguin, Be

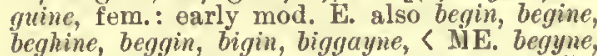
bygyme, < OF. beguine, mod. F. béguine $=\mathrm{Sp}$ Pg. beguina = It. beghina, bighina (MD. beghijne, D. begijn, LG. and G. begine), ( ML. beghina begina, beggina, beguina, bigina, ete. (cf. E. big ginl, from the same source). (2) Beguin, mase., <OF. beguin, mod. F. beguin = Sp. Pg. beguin begginus, beguinus, biginus, ete. : formed, first as begginus, beguinus, biginus, ete. : formed, first as
fem., with suffix -in, $\mathrm{ML}$. -ina, -inus, from the name of Lambert Begue or le Regue (i. e., the stammerer: OF. begue, mod. F. bègue, dial
beique, bieque, stammering; of unknown origin) a priest of Liège, who tounded the sisterhood. See also Beghard. The origin of the name was not generaliy known, and the forms varied, leading to many etymological conjectures. The eonnection with E. beggar and begl is perliaps real; in the sense of 'hypocrite' and confused with bigot, q. v.] 1. $\Lambda$ name given to the members of various religious communities of women who, professing a life of poverty and self-denial, went about in eoarse gray elothing (of undyed wool), reading the Seriptures and exhorting the people. They originsted in the tweitth or thirteenth century, and formeriy flourishedin Ger'many, the Netheriands, France, and rtaly; and guinage. [Now

$$
\text { T'oke on a robe of kamelyne, }
$$$$
\begin{aligned}
& \text { And gan her graithe [dress] as a bygynne. } \\
& \text { Rom. of the Rose, } 1 \text {. }
\end{aligned}
$$

Wanton wenches and bcguixs. World of Wonders, $I 608$. The wife of one of the ex-burgamasters and his daughter, who wss a begrian, went by his sile as be was led to
execution. $M$ Motley, Duteh Repuhlic, 1I. 442 2. [Only Beguin.] A member of a community of men founded on the same general principle of life as that of the Beguines (see 1). They be came infected with various heresies, especially with sys among the communnities of women. They were condemmed century. The faithful Beguins joined themselves in nun bers with the different orders of friars. 'The sect, gener-
aliy obmoxious and the object of severe measures, had grestly diminished by the following century, but contimuled to exist till about the midule of the sixteenth. Also as cummon nouns, without capitals.] eguinage (beg'in-âj, or', as mod. F., bā-gē(F. Aeguine. See $B e$. thin and -age.] $\mathrm{A}$ eommunity of Beguines. A begninage nsually consists of a large walled inclosure, labited ly one or two heguines; there are also some common huuses, especially for the novices and younger members of the comununity. In the center is the ehurch, where certain religious offices are perfurmed in common. Lseh Begnine keeps possession of her own properiy, and nisy suppurt herself (rom it, or from the work of her hands,
or by serving others in their honses. They are free to or by serving others in their honses. They are free to and obedience during residence. Pious women may also, under certain restrictions, rent houses and live inside the inclosure without formally joining the cummmnity. Such mmense one near Ghent, built by the Duke of Aremberg in I874, is the finest example,

begum ${ }^{1}$ (bẹ-gum'), v.t.; pret. and pp. begummed, ppr. begumming. $\left[<b e-1+g u m^{2}.\right]$ To daul or cover with gum. Swift.

begum ${ }^{2}$ (bé'gum), $\pi$. [Anglo-Ind., also beegum, begaum, < Hind. begam (ef. Pers. baigim, a lady), < Turki bigim, a prineess, fem. of big, bik = Turk. beg, bey, a prince: see bey ${ }^{1}$. The title of a Hindu prineess or lady of high rank. begun (bẹ̄-gun'). Past

times preterit of begin.
begunk (bê-gungk'), v. t. [Also spe]led begink, perhaps a nasalized variation of equiv. Sc. begeek, q. v. See also remark under beflu
To befool; deceive; balk; jilt. [Scoteh.]

Whose sweetheart has begunked hin. Blackucood's Mag., VII1. 420.

begunk (bē-gungk'), n. [<begunk, v.] An lusion; a trick; a cheat. [Scotch.]

If I havena' gien Inclsgrabbit and Jamie IIowie a honnie behad (bē-häd'), a. [Contr. of Sc. "behald = E. beholden.] Beholden; indebted. [Seotch.] behalf (bẹ-häf'), $n$. [<ME. behalve, bihalve, in the phrase on (or upon, or in) behalve, in behalf, incorrectly used for on halve ( $\mathrm{AS}$. on half, incorrectly used for on halve ( AS. On healfe, on the side or part of), owing to confu-
sion with ME. behalve, behalven, behalves, adv. and prep., by the side of, near, $\angle \mathrm{AS}$. be healfe, by the side: see $b e-2, b y^{1}$, and $h a 7 f, n$. Cf. be hoof.] 1. Advantage, benefit, interest, or defense (of somebody or something).

In the behalf of his mistress's beanty. Sir $\boldsymbol{P}$. Sidney.

I was movel to speak in behalf of the absent.

2†. Affair; cause; matter.

In an unjust behalf.

Shat, 1 II

[Always governed by the preposition in, on, or upon. See note under behoof.] - In this or behapt (bẹ-hap'), v.i. [<be-1 +hapl.] To hap-

behappent (bẹ̈-hap'n), v. $i . \quad[<b e-1+h a p p e n$, appar. suggested by befall.] To happen. That is the greatest shame, and fotlest scorne, Which unto any knight behoppen may.

behatet, $v . t$. [ME.; $<b e-1+h a t e$.$] Tọ hate;$ detest. Chaueer.

behave (bộhā $\mathrm{v}^{\prime}$ ), v.; pret. and pp. behared, ppr. behaving. [C late ME. beharen, restrain, (which thus compounded took the full inflections (pret. rarely behad and irreg. beheft) and developed reg. into the mod. pron. hãv). The word is formally identieal with AS. behabban, hold, surround, restrain (= OS. bihebbian, hold surround, = OHG. bihabên, MHG. behaben, hold, take possession of), (be, about, thabban, have, ern; manage ; conduct ; regulate.

To Florence they ean hur kenne,

To Icine hur to behave hur among men.
Le Bone Florence, 1. 156\%

11 did behave his anger ere 'twas spent Shak., 'T. of A., iil. 5.

[The old cditions read behoote in this passage.] comport, acquit, or demean. (a) In some specified way.

Those that behaved themselves manfully. 2 Hac. ii. 21. We lehaved not ourselves disorderly among you.

(b) Absolutely, in a commendable or prope way; well or properly: as, behave yourself; they occupy.

Where ease abownds yt's eath to cloe amis : Behaves with cares, cannot so easy nis. Spenser, F. Q., 11. fii. 40

\section{behavior}

II. intrans. [The reflexive pronoun omitted.] To act in any relation; lave or exhibit a mode of action or conduet: used of persons, and also of things having motion or operation. (a) In a partienlar manner, as specified: as, to behare well or ill; the ship behares well.

\section{But he was wiser and well beheft.
B. Jonzon, Love's Welcome at Welheek.}

Eleetricity behaves like an incompressible fluid.

(b) Absolutely, in a proper manner: as, why do you not behare?

behaved (bệ-hāvd'), $p$. a. Mannered; conduct. usually with some qualifying adverb: 48, a well-behaced person.

Gather l,y hinn, as he is behav'd,

Il't be the aftlietion of his love, or no,
That thus he suffers for. Shake, IIamlet, iit. I. Why, I take the French-behaved gentleman. Donson, Cyntlia's Revels, v. 2.

A very pretty behaved gentleman.

behavior, behaviour (bẹ̄-hăv' you'), n. [The
[The

latter spelling is nsual in England; early mod.

E. behavoure, behavior, behavier, behaviour, behaver, beharor, behavour, < behave + -oure, -iour, -ior, appar. in simulation of havior, haviour, havour, var. of haver for ater, possession, having (see $a v e r^{2}$ ), of $\mathbf{F}$. origin. In poetry sometimes havior, which may be taken as formed directly from have; ef. Se. have, behave, havings, behavior.] 1. Manner of behaving, whether good or bad; conduet; mode of acting; nannors; deportment: sometimes, when used ausolutcly, implying good breeding or propes deportment.

Some men's behaviour is like a verse wherein every sylBacon, Essays, of Ceremonies and Resinects. A gentjemsn that is very singular in his behatiour.

2. Figuratively, the manner in which anything acts or operates.

The behaviour of the nitrous salts of the amines is
vurtlyy of attention. Austen-finner, Org. Chem., p. 46. The phenomens of electricity and inagnetism were re duced to the same categury; and the behaviour of the jected to the influence of artifieial eleetric currents.
IJ. Spencer, Prin. of Psychol.

3t. The act of representing another person; the manner in which one personates the eharactor of another; representative character. [Very rare, possibly unique. Knigit, however, belleves the manner of having or conducting one's self.] King Joln. Now, say, Chatillon, what would France

Chat. Thus, after greeting, speaks the king of France, In my behaviour, to the najesty,

Shake, K. John, i. 1. Behavior as heir (iaw Latin, gestio pro harede), in Scots his ancestor's heritsge, ineurs a universal liability for hi (lehts and obligations.- During good behavior, as lon as one remains biameless in the discharge of one s dnties
or the conduct of one's life: as, sn uftice held during good behavior: a convict is given certain privileges during good
behavior, - On one's bebavior or good behavior. (a) behavior.- On one's bebavior or good behavior. (a) tional decorum and propriety. [Colloq.] (b) In a state of
probation; lisb]e to be called to account in case of mis conduet.

'Tyrants themselves are upos their behariour to a su=Syn. 1. Caryiage, Behavior, Condruct, Deportment, Demeanor, bearing, msmer, manners, all denote primarily tended to internsi states or activities. Carriage, the way of carrying one's self, may be mere physical attitude, or it may be personal manners, as expreasing states of mind : we spesk of a haughty or noble carriage, but not oritnarily of an ignobic, cringing, or base carrage. Behavior is tise most general expression of one's mode of acting; it
aso refery particularly to comparatively conspicuous acasso refers particularly to comparatively conspicuous ac-
tions and conduct. Comiuct is more applicsble to actions tions and conduct. Conduct is more applicsble to sctions
vewed as connected into $\mathrm{s}$ course of life especially to ac tions considered with referenee to morality. Deportment is especialiy bejıavior in the line of the proprieties or duties of life: as, Nir. Turveydrop was a model of deportment; the scholars' rank depends partly upon their deportment. Demeanor is most used for manners as expressing chsracter; it is a more deficate word than the others, and generally used in a good sense. We may speak of loot rect deportment; qujet, reflned demeanor.

Nothing can be more delicate without being fantastieal, nothing more firm and hased in uature and sentiment, than the courtship and mutual carriage of the aexes [in]
Emerson, Eng. 'Traits, p. II. Men's beliamiour should be like tileir apparel, not too strait or point-1 levice, lut free for exercise or motion.
Bacon, Essays,

It is buth more satisfactory and more safe to trist to the condect of a party tilan their professions.
Ames, Wurks, 11. 214. 


\section{behavior}

liven at dancing partics, where it wonld seen that tho poetry of motion might do something to soften the ripild
hosom of Venetian deportment, the poor young people
sepsrate after each dance. Howrells, Venetian Life, xxl. An elderiy gentleman, large and portly and of remarkaly igniled demeanor, passing slowily along. (iables, iv.

behead (bẹ-hed'), $r, t$, [< ME. beherlen, bihefden, biliereden, <AS. bcheúflian (= MHG. behoubeten; ef. G. cnt-haupten = D. on-thoof(cn), bchead, < bc-, here priv, + hedfod, head: see $b_{-1}{ }^{1}$ and head.] 1. To cut off the head of ; kill or exeeute by decapitation.

Russell aud Silney were behealed in deflamec of law
aud justice. 2. Figuratively, to deprive of the head, top, or foremost part of : as, to behead a statue or a word.

beheading (bê-her'ing), $u$. [Verbal n. of behearl.] The act of eutting off the head; speeifieally, execution by deeapitation.

In Dahomey there are frequent beheadings that the vlctims, golng to the other world to serve the dead king, may tarty messages from his living deseendant. IT. Spencer, Prin. of Soclol., \& 141.

beheld (bē-held'). Preterit and past participle of behold.

behell $\left(\mathrm{be}-\mathrm{ehel}^{\prime}\right), v \cdot t . \quad[\langle b e-1+h e l l$.$] To tor-$ as with pains of hell.

Did behell and rack lim.

Heviyt.

behemoth (bë-hē'moth), n. [< Heb. b'hemölh, appar. pl. of excellenee, 'great beast,' sing. b'hêmah, a beast, but supposed to be all adaptation of Egypt. p-ehe-mau, lit. water-ox.] An animal mentioned in Job Xl, 15-24; probably, from the details given, a hippopotamus, but from the details given, a hippopotamus, but
sometimes taken for some other animal, or for a type of the largest land-animals generally. Behold now behemoth, whileh I made with thee, he eatBehemoth in plalted mal! Thomson, Summer, 1. 710.

behen, ben ${ }^{6}$ (bē'hen, ben), n. [Also written beken, been, appar. a corruption of Ar. bahma:, behmen, a kind of root, also the flower Rosa eanina.] An old name of the bladder-eampion, silene inflata. The belzen-root of old pharmelsts is sald Silene inflata. The behen-root of old pharmselsts is sald

behest (bē-hest'), n. [< ME. behest, bihest, beheste, ete., with exerescent $t$, earlier belese, late AS. behäs, a promise, vow (equiv, to behä $=\mathrm{OHG}$. biheiz, a promise; ef. bchight, $\left.\eta_{0}\right),<b e-$ hätan, promise: see bchight, $v$., and hest.] 1 t. A vow; a promise. Chaveer; Gover; Holland.2. A command; precept; mandate.

Where I have learn'd me to repent the sin

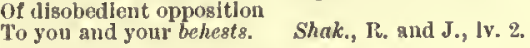
He did not pause to parley nor protest,

He did not pause to parley nor protest,

Longfellow, Torquemada.

behestt (bē-liest'), v. t. [<ME. behesten, promise, < beheste, a promise: sce behest, $n$.$] To$ promise; vow

beheter, $v$. A Middle English form of behight. behewt, v. t. [<ME, behewen, hew abont, carve $<\mathrm{AS}$. bcheawan, how off, < be-(in AS. priv. + hedwan, eut, hew.] To carve; adom; embelish.

Al with gold beherve. Chaucer, IIouse of Fame, 1. 1300.

behightt (bẹ-hit'), v. [The common spelling in Spenser and his contemporaries of both present and preterit of ME. pres. inf. bcheten, regularly behoten, earlier behaten (pret. behight, bchighte, earlier beheht, bchet, pp. behoten, later behight), < AS. behätan (pret. behèt, pp. behäten) (= OHG. bihaizan, MHG. beheizen), promise be- + lätan, eommand, call: see be-1 and hight ${ }^{2}$. The forms in ME. were eonfused, like those of the simple verb. The proper sense of bchight is 'promise'; the other senses (found only in Spenser and contemporary arehaists are forced, being in part taken from hight $\left.{ }^{2}.\right]$ I. trans. 1. To promise; vow.

The trayteresse fals and ful of gyle Chaucer, Deatli of Blanche, 1.621. Behight by vow unto the ehaste MInerve.

\section{To call; name.}

Surrey, Encid, ii.

$$
\text { That Geauntesse Argante is behight. }
$$

\section{To address.}

Spenser, F. Q., 1II. vii. 47.

Whom soone as he beheld he knew, and thus behight.

4. To pronounee; declare to be.

Why of late of English blood?

\section{beholding}

5. To mean; intend.

Words sometimes mean more than the heart behitcth.

6. To commit; intrust.

$$
\text { The koies arc to thy hand behinht. }
$$

7. To adjudge.

There was it judged, by those worthie wights,

The second was to Triamond behigh.

8. To command ; ordain.

So, taking courteous conge, he behinht

Those gates to be unbar'd, and forth he went.

II. intrans. To addross one's self. And lowly to her lowting this behight. IV. 1i. 23.

ehightt (bë-hīt') $n$. [<bchight, $v$. Cf. MF. bchet, behot, behat, \& AS. bchät, a promise. Se behest.] A promise; vow; pledgo. Surrey. hinde, bchinden, $\langle\mathrm{AS}$. behindan (= OS.bihindan), adv, and prep, behind, $<b c$, by, + hinden, ady bu hind $3^{3}$. I adv. 1. At the back of some person or thing; in the rear: opposed to before. So runn'st thou after that which flies from thee, Whilst I thy babe clase thee afar behind. look behind.

She that conld think, and neer disclose her inind, See suitors following, anil not look behind.
Shak, Othello, il. Worse things, unheard, unseen, remain behind. Shelley, Prometheus Unhound, 1.

3. Out of sight; not produecd or exhibited to view; in abeyanee or reserve.

And fill up that which is behind of the affictions of We cannot be sure that there is no evldence behind.

4. Remaining after some oceurrenee, action, or operation: as, he departed and left us behind.

Thon shalt live in this fair world belind.

, Iit. 2

Where the bee can suck no honey, she leaves her sting

5. Past in the progress of time.

Forgetting those things which are behind. Phil. ili. 13.

6. In arrear; bebindhand: as, he is bchind in his rent.

\section{So that ye come behind in no girt.}

II. prep. 1. At the back or in the rear of, as regards either the aetual or the assumed front: the opposite of before: as, the valet stood be the opposite of before: as, the valet stood

$$
\begin{aligned}
& \text { Behind yon hills where Lugar flows. } \\
& \text { Burns, Jy Nannle, } 0 . \\
& \text { A tall Brabanter behind whom I stood. }
\end{aligned}
$$

$$
\begin{aligned}
& \text { Brabanter behind whom I stood. } \\
& \text { Bp. Iloll, Acco }
\end{aligned}
$$

Bp. Hall, Account of Himsele

Behind some hedge. The lion walk'd along

Shak., Venus and Adonis, 1. I094.

2. Figuratively, in a position or at a point not so far advaneed as; in the rear of, as regards progress, knowledge, development, ete.; not on behind the others in mathematies.

For I suppose I was not a whit behind the very eliefest

In my devotion to the Union I hope I sm behind no man

3. In existenee or remaining after the removal

or disappearanee of : as, he left a large family behind him.

What he gave me to publisl 1 was but a small part of
what he left behind him.

Behind one's back. See backl. - Behind the curtain. the times, not well informed as to current events; hold ing to older illeas and ways. - Behind time, later than the proper or appointed time in doing snything. = Syn. Behind, After. Behind relates primarily to position; after,
to time. When after notes position, it is less close or ex act than behind, and it means position in motion. To say that men stood one after snother in a line was once reet (sec Chaneer, Knight's Tale, 1. 901, "kneeled . . after another, that is, somewhat irreguiariy and apart they came one behind another, that is, elose together,
one covering another. The distinction is sinilar to tliat

Out honnced a splendidly spotted creature of the cat kind. Jmmediately behind him crept ont his mate; snd On him they laid the cross, that he might bear it after
Jukus.

behindhand (bẹ-hīnd'hand), prep. phr. as adr. or $a$. [< behind + hand; ef. beforchand. $] 1$. ly advaneed; not equally alvanend with some ther person or thing: as, bchindhend in studies or work.

$$
\begin{aligned}
& \text { And these thy oflices, } \\
& \text { So rarely kind, are as interprcters } \\
& \text { of my behind-hand slackiess. }
\end{aligned}
$$
"is, and all the norning within doors, beginning to set my accomts in orler from before this the, I being fehind-
hand with them ever since.
Pepys, Diary, IJ. 480. Notlifng can exceed the evils of this spring. All agri. ciltural operations are at least s month behindhand. 2. Late; lelayed beyond the proper time; behind the time set or expected.

Government expeditions aro generally behindhand.
Comhill Ifag., Harch, 1862

3. In a state in whieh expenditure has gone beyond ineome; in a state in which means aro not adequate to the supply of wants; in arrear: as, to be behindhand in one's circumstances; you are behindhand with your payments.

IIavlug run something behindhand in the world, he ohtalned the favour of a certain lorll to recelve hin into his

4. Underhand; secret; clandestine. [Rare.] Those behindhand and paltry nuancuvres witch lestroy confidence between human beings and degrade the char Lecky, Fing. in 18tl Cent., xv.

behitherł (bē-himi'er), prep. $[<b e-2$ as in beyond, behind, ete., + hither.] On this side of.

Two mlles behither Cliflen. (6) I679.

ehold (bē-höld'), v. ; pret. and pp. behcld, ppr. beholling. [< ME. beholden, bikoldan, bihalden, hold, bind by obligation (in this sense only in pp. beholden, beholde: see bcholden), eommonly observe, see, < AS. behealdan, hold, keep, observe, see (= OS. bihaldan = OFrics. bihalda $=\mathrm{D}$. behouden $=\mathrm{OHG}$. bihaltan, $\mathrm{MHG}$. G. behalten, keep), (be- + hcaldan, hold, keep: see $b e-1$ and hold 1 . Other words combining the senses 'keep' and 'look at' are observe and regard.] I. trans. 1t. To hold by; keep; re tain.-2t. To hold; keep; observe (a comupon; look at; see with attention; observe with eare.

When he beheld the serpent of brass, he lived.

Behold the Lamb of God, which taketh awsy the sin of =Syn. Observe, Witness, ete. (see sce); look upon, con II intrans. 1. To look; direet the eyes to an objeet; view; see: in a physieal sense. Virginius gan upon the cheri beholde

And 1 beheld, and 10 in the midst of the thro And l beheld, and lo, in the midst of the throne . :
Rev. 2. To fix the attention upon an ebjeet; attend direet or fix the mind: in this sense used ehiefly in the imperative, being frequently little more than an exelamation calling attention, or expressive of wonder, admiration, and the like.

Behold, I stand at the door and knock. Rev, iii. 20. Prithee, see there! behold! look! 10 !

3t. To feel obliged or bound.

For who would behold to genle coumsell, it in eounselling
there should be any perill?

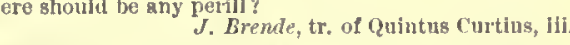
beholden (bē-hōl'dn), p. a. [Formerly often prop. ppr. of behold, $r$.] Obliged; bound in gratitude; indebted; held by obligation. Little are we beholden to your love.
Shak., Rich. II., iv. I We lad classles of our own, without being beholden to "insolent Greece or haughty Rome."

beholder (bệ-hō]'dêr), n. [< ME. beholder, biholder, -eve; <behold $+\alpha r^{1}$.] One who beholds; a spectator; one who looks upon or sees.

What, like the sun, difl niake beholders wink?
Shak. Rich. II., iv. I

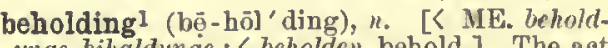
of looking at; gaze; view; sight.

The revenges we are bollnd to take upon your traitorons father are not fit for your beholding.

beholding ${ }^{2}+$ (bē-hōl'ding), a. [Corrupt form of beholden.] 1. Under obligation; obliged.

The stage is more beholding to love than the life of man. 
beholding

Oh, I thank you, I am much beholding to yous. Chapman, Blind Beggar. It is in the power of every hand to destroy ur, and we are beholding unto cvely one we meet, he doth not kill us.
Sir T. Browne, Jeligio Mledici, i. 44 . 2. Attractive; fascinatiug.

When he saw me, I assurc you, my bcauty was not more beholding to him thin my harmony. Sidney, Arcadia, 1. 50. beholdingness (bệ-hōol'ding-nes), $n$. The state of bcing boholden or under obligation to any one.

Thank me, ye gods, with much beholdingnesse. For
marke, I doe not curse you. Marston, Sophonisba, v. 2. behoney (bẹ-hun'i), $v . t$. [<be-1+honey. $]$ To cover or smear with honey; sweeten witl honey, cover or smear with hon

behoof (bē-höf'), $n$. [< ME. behōf (chicfly in behoof (bē-höf'), $n$. [ $<$ ME. behōf (chictly in the dat. behove, with prep. to, $t i l$, or for), $<$ AS.
"beh $\delta f$, advantage (in deriv. behoflie, advantageous, behëfe, useful, necessary, behofian, behoove: see bchoove) (= OFries. behof, bihof $=\mathrm{D}$. behoef = MLG. bchōf = MHG. bihnof, G. behuf, advantage, $=$ Sw. behof = Dan. behor, need, necessity; cf. Icel. hôf, moderation, measure, (pret. " ${ }^{\prime}$ behöf) = MHG. beheben, take, hold, < (pret. "behof $)=\mathrm{MHG}$. beheben, take, hold, be- + hebban, heave, raise, orig. take up, take: see be-1 and heave. In the phrase in or on be-
hoof of, the word is confused with behalf.] That which is advantageous to a person; b Accordeth nought to the behove of resunable mannes use.

Gouer, Conf. Amant., i. 15. No mean recompense it brings
To your behoof. Who wants the finer politic aense To niask, tho but in his own behoof, Tennysor, Maud, v. Is not, Indeed, every man a student, and do not all things
exist for the student's behoof? [This word Is prohably never used as a nominative, being regularly governed by one of the prepositions to, for, in, is used similarly.] The more correct form of behooveful.

behoovable (bē-hö'va-bl), a. [< behoove + -able.] Useful; profitable; needful ; fit. Also spelled behovable and behoveable. [Rare.]

All apiritual graces behoveable for our soul. Books of Homilies, ii.

behoove (bẹ-höv'), v.; pret. and pp. bchooved, ppr.bekooving. [Álso spelled, against analogy, behove; < ME. behoven, behofen, AS. behōfian, need, be necessary (= OFries. bihōria $=\mathrm{D}$. behocven = MLG. behoven, LG. behoben, bchöben = G. behufen (obs.) = Sw. behöfva = Dan. bchöra); from the noun: see behoof. Cf. Icel. hofu, aim at, hit, behoove, = Sw. höfas, beseem. The pret. behooved is worn down in Se. to bud, bid. seo bid.] I. trans. 1. To be fit or meet for with respect to necessity, duty, or convenience be necessary for; become: now used ouly i
the third person singular with it as subject.

$$
\begin{aligned}
& \text { It behoves the high, } \\
& \text { For their own aakea, to do things worthily }
\end{aligned}
$$
B. Jonson, Cynthia's Revels, v.

Indeed, it behoved him to keep on good terma with his
Irving, sketch-Book. IIe is sure of himself, and never needs to ask another what in any crisis it behooves him to do. binerson, War. $2 \nmid$. To relate to tho advantage of; concern the well-being of: formerly used with a regular nominative.

If youk know aught which doea behore ny knowledge

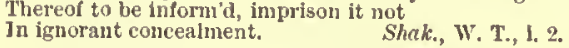

II.t intrans. To be necessary, suitable, or fit. Sometime behooveth it to be counselled.

He had all those endownents mightily at comnand which are behoved in a seholar.
Bp. Ilacket, Life of Abp. Williams, I. 39. Also spelled behove.

behoovet, $n$. An obsolete form (properly dative) of behoof

behoovefult (bẹ-höv'fül), $a$. [Prop., as in early mod. E., behoofful, < ME. bchoreful, < behof, beadvantageous.

Madam, we have cull'd auch neceasaries

Shak., R. and J., IV. 3. It may be moat behooveful for princes, in matters of behoovefullyt (bệ-höv'fủl-i), adv. Usefully; profitably; necessarily.
510

behornt (bẹ̈-hôrn'), $\tau_{\cdot} t . \quad\left[\left\langle b c_{-} 1+h o r n.\right] \quad T o\right.$ put liorns on: euckold.

ehotet, $v$. Same as behight.

ehourd, n. [OF., also written behourt, behour bihour, bohourd, etc., "a juste or tourney of mauy together with launces and batleaxes; also a bustling or blustering noise" (Cotgrave); aunces," [behourt, a lance.] A variety of the just practised in the thirteenth century, or, in some cases, a varicty of the tourney.

behovable, behoveable, $a$. See bchoovable.

ehove, $v$. Less corrcet spelling of bchoove.

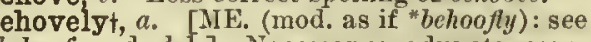
behoof and -lyt.] Necessary; advantagcous. Chaveer.

ehowl (bẹ-houl'), v. t. [<be-I +hovl. $]$ To wl at.

The wolf behouls the moon. Shak., M. X. D., v. 2. behung (bẹ-hung'), p. a. [P . of "behang, not used, ? be-1 + hang.] Draped; ornamented with something hanging

with trappings. [Rare.]

beid-el-sar (bād-el-sär'), n. [Ar.] A plant used in Africa as a remedy for various cutancous affections. It is the Calotropis procera, an asclepiadaceous shrub of tropleal Africa and aouthern

beige (bãzh), a. [F., < It. bigio, gray: see biee.] Having its natural color: said of a woolen fabric made of undyed wool.

beild, $n$. and $v$. $t$. See bield.

beildy, a. See bieldy.

ein (bēn), a. [Also been, bene, Sc. also bien, Icel. beinn, hospitable, lit. straight, is a different word, the souree of $\mathbf{F}$. bain 1 , ready, willing, ete.: see bain 1.] 1. Wealthy; well to do: as bein farmer; a bein body.-2. Well provided comfortable; cozy.

This is a gey bein place, and it's a comfort to hae sie
corner to ait in in a bad day. Scott, Antiquary, IJ. xxiv. [Now only Scoteh.]

bein (bēn), adv. [Also bien; < bein, a.] Comfortably. [Scotch.]

I grudge a wee the great folks' gift,
That live sae bien and snug. Burns, Ep. to Davie,

being (bë'ing), n. [< ME. beynge, byinge, verbal n. of been, be.] 1. Existence in its most comprehensive sense, as opposed to non-existence; existence, whether real or only in thought. -2 . rily amounting to actual existence; rudimentary existence. But the word is used in different acnaea by different philoaophera. JJegel defines it as inmediacy, proper acceptation, it is the name given by philosophica reflection to that whlch is revealer in imnediate con-
seiousneas independentiy of the distinction of aubject and seiousnegs independentiy of the distinction of aubject and
object. It nay also be defined, but with less precision, as the abstract noun corresponding to the concrete class embracing cvery object. Being is alao used In philosophy in-
fluenced by Aristotle to signify the rudinent or gern of existence, consisting in a nature, or principle of growth,
before actual existence. It da also frequently uaed to mean actual existenec, the complete preparation to produce $e$ fects on the aenses and on other objects. Psychologically,
being nuay be defined as the objectification of eonsciouanesa,
though the distinction of aubject from object logically presupposea being.

Wee may well reject a Liturgie whlch had no being that Mee can know of, but from the corruptest times.
Milton, Def. of IIumb. Remonst. First, Thou madest things whieh should have being with
out life. Consider everything as not yet in being; then consider Our noisy years geem moments in the being
of the eternal Silence. II'ordsworth, Ode to Immortality.

3. That which exists; anything that is: as, inanimate beings.

What a aweet being is an honest mind!

4. Life; conscious existence.

I will aing praises unto my Ood whtle I have any being. I fetch my jife and being.
from men of royal siege. Shak, othello, i. 2. I felt and feel, tho' left alone,

T'ennyzon, Jn Memoriam, Ixxxy.

5. Lifetime; mortal existence.

Wast follower of his fortunes in his being

It is ebstcr. It is, as far as it relates to our present being, the great end of education to raise ourseives above the vulyar. 6. That which has life; a living existence, in contradistinction to what is without life; a creature.

\section{bekiss}

It fs folly to seck the approbation of any being begides the Supreme, becanse no other being can make a right
judgnent of us.
Addison, Spectator. Accidental being, the being of an accident, mark, or
'uality.-Actual being, complete being; being really ronght to pass; actuality. - Being in itself, being apart rom the sent ient eonseiouaness; being per be.-Being of dens, being through something extrancous.-Being per se, essential and necessary being. - Connotative being, betng. See dininute - Intenttonal or spiritual being. the being of that which is in the mind.- Material being, what belongs to material bodies. - Natural being, that hich belongs to things and persons.- Objective being. an expression formerty applied to the mode of being of a ould be understool to nean the being of a real thing xisting independentiy of the mind. See objective. Potential being, that whieh belongs to sometling which satisfles the prerequisite conditions of existence, but is not yet complete or an actual lact.-Pure being, in metaph, the conception of being aa guch, that 18, devoli except that it is. - Quidditative betng, or being of esin the bosum of the etering to substantial being the heing of a anbstance. - To differ by the whole of betng. See difjer.

being-placet (bō'ing-plās), $n$. A place to exist in ; a state of existence.

Before this worlds great frame, in whieh al thlngs

Are now containd, found any being-place.

beinly (bēn'li), adv. [< bein + -ly. ] Comfortably; abundantly; happily; well. Also spelled bienly. [Scoteli.]

The chlddren were likewlse beinly apparelled.

beinness (bēn'nes), n. [Also spelled bienness, [bein, bien, +-ness.] Plenty; affuence; prosperousness; the
to do. [Scotch.]

There was a prevailing air of comfort and bienness about the people and thelr housea,

Beiram, n. See Bairam.

beistings, $n$. sing. or pl. See beestings. beit (bêt), $v . t$. [Se.] Same as bect'.

bejadet (bẹ-jâd' $d^{\prime}, v, t,[\langle b e-1+j a d e 1$.$] To$ tire.

Leat you bejade the good galloway.
Miton, Def. of Humb. Remonst.

ejan (bē'jan), $n_{\text {. }} \quad$ [Sc., < F. bejaune, $<\mathrm{OF}$ becjaune, a novice, lit. a yellow-beak, i. $e_{.}$, young bird, < bee, beak, + jaune, yellow, a yellow beak being characteristic of young birds See beakl and jaundice.] A student of the first or lowest class in the universities of $\mathrm{St}$ Andrews and Abcrdeen, Seotland.

bejapeł (bē-jāp'), v. t. [ME.; $<b e-1+j a p e$. o trick; deceive.

$$
\text { Thou... hast byja ped here duk 'lheseua. }
$$

2. To laugh at; make a mock of.

I shal byjaped ben a tliouraud tyme
lifore tlian that fool of whos folye men ryme.

bejaundice (be... bejesuit (bẹ-jez'ụ-it), $v$. $t$. [< be-1 + Jesnit.] To infect or influence with Jesuitry.

Who hath 80 bejeguited us that we ahould trouble that man with aaking license to doe so worthy a dect?

bejewel (bẹ-jö'el), v. t. [〈be-I + jewel.] To provide or adorn with jewels.

Her bejewelleut handa lay sprawling In her amber aatiu
Thackeray, Vanity Falr, J, xxt. bejuco (Sp. pron. bā-hö kō), n. [Sp.] A Spanish name for several species of the lianes or tall climbing plants of the tropics, such as Hippocratea scandens, etc.

The aerpent-like bejuco winds his apiral fold on folil

Round the tall and atately celba till it withers In lifis hold.
Whittier, Slavea of $\$$ Iartinique.

bejumble (bē-jum'bl), v. t. $\quad[<b e-1+j u m b l e$. To throw into confusion; jumble. $A s h$.

bekah (bē'kä), n. [Heb.] An ancient Hebrew unit of weight, equal to half a shekel, 7.08 grams, or 1094 grains. Ex. xxxviii. 26

beken ${ }^{3}, v, t$. [ME. bekennen, bikennen; < be-1 -3. To commit or commend to the eare of

The devil I bykenne hin.

beken $^{2} t, n$. Same as behen.

bekiss (bē-kis'), $v$. t. [<be-1 + kiss. $]$ To kiss peatedly; cover with kisses. [Rare.]

She'a sick of the young shepherd that behissed her. 


\section{bekko-ware}

bekko-ware (bek'ō-wãi), n. [< Jap. belik, tor- belamourł (bel'a-mör), n. [Also bcllamour, toise-shell (< Chinese hwei, tortoise, + kia, armor), ware $\left.{ }^{2}.\right]$ A kind of pottery aneiently veined with green, yellow, and brown.

beknave (bệ-uâv'), v. t.; jret. and pp. beknaved, ppr: bcknaving. [<be-1 + knate.] Te call (one) a kuave. [Rare.]

The lawyer beknaves the divine, Gay, Becggar's Opera.

beknight (hề-nīt'), v.t. [<be-1 + hwight. $] 1$

lo make a knight of. [Rare.]

The last beknighted booly.

T. Hnok

2. To address as a knight, or by the title Sir.

beknit (bẹ-nit'), v. l. [<be-1+knit. ] To knit; girdle or encircle. ller fithy arms beknit with snskes abont.
Gold ing, tr. of Ovfl's Metamorph. (Ord MS.).

beknotted (bē-not'ed), $a_{*}^{*}[<b e-1+$ linotled. $]$ Knotted again and again; covered with knots.
beknottedness (bē-not' ed-nes), $u$. In math., the degree of eomplication of a knot; the number of times that it is necessary to pass on part of the curve of the knot projected upon a jlane through anotlier in order to untio tlio kriot.

beknow† $\left(\mathrm{be}-\mathrm{n} \bar{e}^{\prime}\right), v . t$. [< ME. beknowen, biknowen, < $\Lambda$ s. beenăian, know, $<b_{0}+$ cnāw an, know: see be-1 and know.] 1. To know; recognize. - 2. To aeknowledge: own; eonrecognize.-2. To aeknowledge; own;
fess. Ayenty te of Inuyt (1340, ed. Morris). for I dare not beknowe min owen name.

Chaucer, Knight's Tale, 1. 698

bel't, a. [Warly mod. F. also bell; < MIs. bele bel-, $\mathrm{SOF}$. (and mod. $\mathrm{k}$.) bel, bean, fem. belle, L. bellus, fair, fine, beautiful: seo beau, beanty, bell ${ }^{5}$, ete.] 1. Fair; fine; beautiful.-2. [Lit. fair, good, as in beausire, fair sir, beaupere, good father, used in F. and ME. to indicate indirect
or adopted secondary relationship; so in mod. F. beau as a formative in relation-names, 'step-', '-in-law'; ME. bel-, 'grand-', as in beldame, grandmother, belsire, grandfather, also with purely $\mathrm{E}$. names, belmoder, belfarler, and later belehild. Cf. Se. and North. E. goodmotler, goodfather, ete., mother-in-law, father-in-law, etc.J Grand-: a formative in relation-names, as belsire, grandfather, beldam, grandmother, ete. See etymology.

$\mathrm{Bel}^{2}$ (bel), $n$. Same as Bclus.

bel $^{3}$ (bel), n. [Also written, less pro]3., bhel, bael, repr. Hind. bel.] The East Indian name of the Bengal quince-tree, Agle Marmelos. Se Agle, 1.

bela (b-'lä), n. [Hind.] The Hiudustani nanı of a species of jasmin, Jasminum Sambac, whicl is often cultivated for its very fragrant flowers. belabor, belabour (bē-lā'bor), $v$. $t$. [ be-1
+ labor.] 1f. To work hard upon; ply diligently.

If the earth is belaboured with culture, it yleldeth corn.

2. To beat soundly; thump.

They so cudgelled sind belabored him bodlly that he mot been protected by the more respectable portion of the not been protected by the more respectable portion of the
8ssembly.

bel-accoil $\nmid$, bel-accoyle $($ bel-a-koil'), $n$. [ [COF

bel acoil, fair weleome: see bell and accoil. Kindly greeting or reception. Syenser.

fasten as with, $\ell_{\text {. }}\left[\left\langle e^{-1}+\right.\right.$ lace. 1 . To with laee.

When thou lin thy bravest
And most belaced servitude dost strut Some newer fashien doth usurp.

$$
\text { J. Beaum }
$$

3t. To beat whin Tright

belace ${ }^{2} t, v, t$. An error (by misprint or con

fusion with belacel) in Bailey and subsequent dictionaries for belage or belay. See belage. belacedness (bē-lä'sed-nes), $n$. In math., the
number of times one branch of a laeing must be passed through another to undo it.

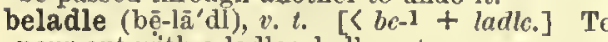

pour out with a ladle; ladle ont.

The honest masters of the roast beladling the dripping.

belady (bē-lā'di), v. t.; pret. and pp. beladied, ppr. beladying. $[<$ be- $\mathrm{t}+$ lady; ef. belord, be graec, belnight.] To address by the title Lady, or the phrase "my lady."

belaget, $v$. [Either a misprint for belaye, belay.

or less prob. a phonetic variant of that word (MF. beleggen, ete.): see belay.] Nuut., to bolay. Phillips (1678); Kersey.

belam (bē-lam'), $v_{0} t_{0}[\langle b c-1+l a m$.$] To beat$ bang. Sherwood. [North. Eng.] 1. bel amour, lit. fair love: see bel 1 and amour.]
A gallant; a consort.

fore, loe ! how hrave she decks her bonnteous houre Thereln to sirowil her sumptuserletes,

spenser, 5. Q., i1. vi. 16

. An oll name for a flower which eannot now o identified.

tter snowy lirowes, lyke budded Bellamauren.

Spenser, sonnets, Ixiv.

belamył (be]'a-mi), $n$. [Farly mod. E., also

bellamy, < ME. belany, betruni, < OF' bel ami, fair friend: used prineipally in address. Thou belamy, thou pardoner, ho seyde.

1., 1, 32 Chatcer, l'rul. to Pardoner's Tale,

lo smytte.

IIIs dearest Belamy. Spenser, F. Q., 11. vil. 52

belandre (bē-lan'dêr; F' pron, bā-londr'), n

[E., (D). bijlauler, whenee also E. bilander, q. v.] small flat-bottomed eraft, used prineipally o

belate (bề-lät'), $v$. $t$. [<bc-1 + late. $]$ To re

belate (bêklàt'), $v$; $t$.

The morn is young, quoll he,

A little tlme to old remembranee given
Will not belate us. Southey, Mtadoc, i. 10.

belated (bẹ-la'ted), p. a. Coming or staying

too late; overtaken by lateness, especially at night; benighted; delayed.

Faery elves,
Whose midnlght revels, liy s forest side,
Or fountalin, some belated peasant sees.

Ifilton, $\mathbf{P}$. Ih, 1. 783

Who were the partles? who inspected? who contested belatedness (bē-lā'ted-nes), $n$. [<belated, pp. of belate, +-ucss.] The state of being belated or of being too late; slowness; backwardness. That you may see I am sometimes suspicions of myself, the bolder to send you some of my nightward thoughts.
Nilton, Letter In Birclis Life.

belaud (bê-lâd'), v. t. [<be-1 + laud. ] To load with praise; laud high $]_{y}$

[Volmues] wlulch were commended by divines from pulis, and belcuded alt Europe over. belave (bē-lāv'), v. t. [〈ME. bilaren, bathe, bi-, be- + laven, lave: see be-1 and lavel.] To

belawgivet (bē-lâ'giv), $v$. $t$. [A foreed word, nsed only in the passage from Milton, $<b e-1+$ law to.

The lloly One of Israel hath belaugiven his own people belay (bē-lä'), v. t. [< ME. bcleggen, bileggen, AS. beleegan, lay upon, eover, charge $(=\mathrm{D}$. be lcggen, cover, overlay; as a naut. term, belay; $=\mathrm{OHG}$. bilegen, MHG. G. belegen), (be-, about, areund, by, + leegan, lay. The naut. use round,' ef. beleaguer.] 1t. To surround; en iron; inelose.-2t. To overlay; adort.

All In a woodman's jacket he was clad Spenser, F. Q., VT. 11. 5

3t. To besiege; invest; surround.

Gisynst snch strong castles needeth greater might Spenser, Sonnets,
siv.

So when Arabian thleves belayed us round.
Sandys, 1 y'mu

4t. To lie in wait for in order to attack; hence, te bloek up or obstruct.

The speedy horse all passages beluy.

5. Naut., to fasten, or make fast, by winding round a belaying pin, eleat, or cavel : applied chiefly to runining rigging. thing left but the boltrope. Dana, Jr. Before (i) 3 fast, $\mathrm{p} .256$. belaying-bitt (bẹ̄lä'ing-bit), $n$. Any bitt to which a rope

belaying (b-̄-1ã ' ing -pin), belaying-pin (bê- - Jä'ing-pin), n. Naut., a may be belayed.

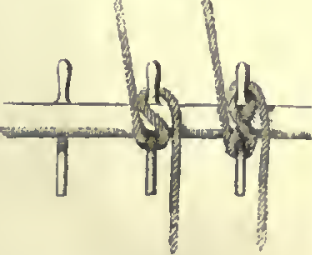
lave about; wash all over; wash. perhaps due to the $D$. In the seuse of 'surWhen we blayed the

\section{beleave}

belch (beleh), $r$. [karly mod. E., also bclehe, buclie, < $111 \%$ belelen, assibilated form of early nol. F. and K. dial.' (north.) belh, < ME. belken, AS. balcian, bralcirn, also with added formative, bcalcetlun, belch, (jaculate; allied to balk' and bolk, all prob. ult. initative: see belk, balk'2, bolk.] I. intruns. 1. To ejeet wind noisily from the stomach through the mouth; eruetate.

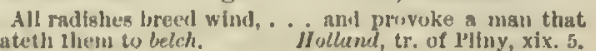
eateth lhesu to belch. in tlames," Inrylen.

II. trans. 1. To throw or eject from the vith violenee; eructate. Belehing raw goblects from lils maw.

Addirom, Fineld, lil.

2. To ejeet violently from within; east forth. Sthod open whe, belching ontrageons flu

Milton, Y. L., x. 232. and facll belch out fire.

3. To ejaeulate; vent with vehemenee: often with out: as, to belch out blasphemies; to beleh out one's fury.

belch (belch), $n$. [<belch, $\left.v_{0}\right]$ 1. The aet of throwing out from the stomach or from within; ernctation.-2†. A cant name for malt liquor, from its eausing belehing.

A surden reformatlon woule follow among all gorts of people; porters wonld no longer be drunk with belch.

belcherl (bel'cher), n. One who belehes.

belcher (bel'chér), $n$. [S 0 called from an English pugilist named Jim Belcher.] A neek-

erehief with darkish-blue ground and large white spots with a dark-blue spot in the center of each. [Slang.]

belchlld $\dagger$ (bel'child), n.; pl. belchildren (-chil" dren). [< bel-, grand-, as in beldam, belsire, ete. (see bel1), + child.] A grandehild.

To Thomas Donbledaye and Katherine his wife, my Iilill of 1564 , quoted In $\mathrm{X}$. snd $Q$., 7th ser., $11 \mathrm{r}$. 77 .

beldam, beldame (bel'dam, -däm), $n$. [<MF.

beldam, beldame, only in sense of grandmother correlative to belsire, grandfather), (ME. belgrand-, as in belsire, ete. (see bell), + dame, nother. The word was thus in E. use lit. 'good mother, used distinetively for grandmother, not as in $\mathrm{F}$. belle dame, lit. fair lady: see bel1 belle, and dame.] 1t. Grandmother: corresponding to belsire, grandfather: sometimes applied to a great-grandmother.

To show the beldame daughters of her danghter.

2. An old woman in general, espeeially an ugly eld woman; a hag.

Around the beldam sll erect they lang. Akenside. And wrlnkled beldames, satanl-sold.
Whithier, New-England

3t. [A foreed nse of the $\mathrm{F}$. belle dame.] $\mathrm{F}$. dame or lady. Spenser.

beleadt, $t . t$. [<ME. belerlen, <AS. beledan, < be + laden, lead: seo be-1 and lead1.] 1. To lead away.-2. To lead; conduct.

beleaguer (bē-lē'gèr), v. t. [< D. belegeren, besiege $(=\mathrm{G}$. belagern $=\mathrm{Sw}$. belägra $=\mathrm{Dan}$. be lagre, also belejre, perhaps ( $\mathrm{D}$. belegeren), be- + leger, a eamp, eneamping army, place to lie down, a bed (=E. lair and layer= G. lager. a camp, = Sw. laiger, a bed, ete.): see be-1 and lcaguer, ledger, lair, layer, lager.] To besiege; surround with an army so as to preelude essurround with an

The Trojan camp, then beleaguered by Turnus sud the
Dryden, tr. of Dufresnoy. =\$yn. To invest, lay siege to, beset.

beleaguerer (bè-lé'gèr-ér), $n$. One whe be-

leaguers or besieges; a besieger.

O'er the walls
The wild beleaguerers broke,
The strongholds of the plaln were forced.

Bryant, The Prairles.

beleaguerment (bẹ̄-lè 'gèr-ment), n. [< beleaguer + -ment.] Tho act of beleaguering, or the state of being beleaguered.

Falr, flckle, courtly France,

Shsttered by lard beleaguerment, and wild ire,

Ther palaces on fire.

beleaveł (bē-lè̀'), v. [< ME. beleren, bilercn, ete, also by syncope bleven, leave intrans. remain, < AS. beläfan, leave, < be- + leefan, leave; prop. the eausal of belive $1, q . v$. See beand leave ${ }^{1}$.] I. trans. To leave behind; abanlou; let go.

There was nothynge belefte. Gouver, Conf. Amant., li 


\section{beleave}

II. intrans. To remain ; continue; stay. Bot the lettres bileued ful large npon plaster.

belection (be-lek'shon), $n$. Samo as bolection. belecture (bē-lck'tựir), v. t. $\left[\left\langle b c_{-1}^{-1}+\right.\right.$ lecture. $]$ To vex with lectures:-admonish persistently. she now had somehody, or rather something, to lecture belee ${ }^{1}\left(\mathrm{bee}-\mathrm{I} \bar{e}^{\prime}\right), x^{\prime} . t . \quad\left[\left\langle b e-1+l e e^{1}.\right]\right.$ To place belee wind. [Kare.]

Iy delistor and ereditor. Shak., othello, 1.1

belee ${ }^{2}+, v t$. An apocopated form of belecve, now written believe.

Fool. Belee me, sir. beleftt. Preterit and past partieiple of beleave. belemnite (be-lem'nit), n. [= F. belemnite, Nl. belemnites, < Gr. $\beta \dot{\varepsilon} \lambda \varepsilon \mu \nu o v$, poet. for $\beta \dot{\varepsilon} \lambda o s$, dart, missile $(<\beta a ́ \lambda \lambda \varepsilon t v$ throw, east), + -ites.] 1. A straight, solid, tapering, dartshaped fossil, the internal animal of the extinet family Belemuritide, common in the Chalk and Jurassie limestone. Chalk and Jurassie limestone. J3elemnites are popularly known as their slape; also as thunderbolt. and thunder-stones, from a belief as to their origin. See Belemnitidce. a bone belonged.

Also called ecraunite.

Belemnitella (be-lem-ni tel'ä) $n$ [NL, dim. of Be lemites.] $\mathrm{A}$ genus of the family Belemnitide, characerized by having a straight fissure at the upper end of the guard, on the ventral side of the alveolus. The species are all Cretaceous.

Belemnites (bel-em-ñ̄'tēz), n. [NL.: see belemnite.] The Belemnitida.

belemnitic (bcl-em-nit'ik), $a$

of or pertaining to a belem

belcmitic animal; a belemnitic shell; belemnitic deposits.

belemnitid (be-lem'ni-tid), n. A cephalopod of the family Belemitida.

Belemnitidæ (bel-em-nit'i-dē), n. pl. [NL., Belemnites $+-i d a$.$] A family of extinet di$
branehiate cephalopods, having 10 arms near-

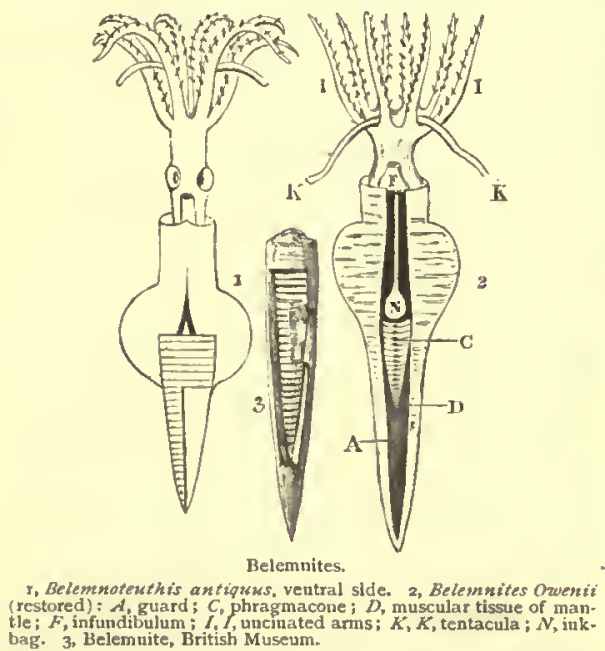

ly equally developed and provided with hooks, an internal shell terminated behind by a rostrum of variable form, and a well-developed straight phragmacone. The species are numerous the Cretaceons, and their remains are the cigar-like ghells amiliar to most persons living in regions where the Cretaceous seas once cxisted. The skeleton consists of a subcylindrical fibrous body called the rostrum or guard, which in wlich is lodged the phragmacone. This consists of a aeries of chambers, geparated by septa perforated by apertures for the passage of the siphuncle or infundibulum. The pen of the common siluid is the modern rep-
resentative, though on an inferior scale, of the ancient belie

belemnite. Some specimens have been found exhibiting other points of their anatomy. Thus we lealn that thic like processes, 8 of them hooked at the end, called the un. cinated arms, and 2 not uncinated, called the tentacula its mouth was armed with mandibles. There are four known gencra, Belemmites, Belemnotevthis, Belemnitella, and Tiphoteuthis.

belemnoid (be-lem'noid), a. [< belemn-ite + -oid.] Like a belemnite.

beleper (bē-lep'èr), v. $t_{0}[\langle b c-1+l e p e r$.$] To$ infeet witli or as with leprosy. liaz's. a worse infection than Gebel esprit (bel es-prē'); pl. beaux esprits (bēz es-prế ${ }^{\prime}$. [F., a fine spirit: see bell and esprit.] A fine genius or inan of wit.

Men wlio Jook up to me as a man of letters and a bel

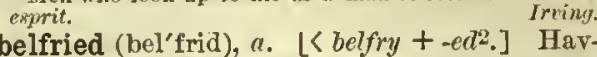
ing a belfry: as, a belfried tower. belfry (bel'fri), $n_{\text {.; }}$ pl. belfries (-friz). [Earl mod. F. also belfrey, belfery, belfrie, ete., < ME. belfray, earlier berfray, berfrey, berfreid, berfreit, $\angle$ OF. berfrai, berfray, berfrei, berefreit, berfroi, later belfrei, belefreit, belefroi, belfroi, befroi, baffray, ete., mod. F. beffroi = It. battifredo, $<\mathrm{ML}$. berefredus, berefridus, berfredus, with do, $<$ ML. berefredus, berefrillus, berfredus, with numerous variations, bel-, bil-, bal-, berte-,
balte-, bati-, butifredus, $\angle \mathrm{MHG}$, bercvrit, bercfrit, berehfrit, berhfrille, MD. bergfert, bergfrede (in sense 1), lit. "proteeting shelter,' (OHG. bergan, MHG. G. bergen (= AS. bcorgan), cover, protect, + OHG. fridu, $\mathrm{MHG}$. fride, G. friede = AS. frithu, frith, E. obs. frith, peace, security, shelter. The origin of the word was net known, or felt, in Rom., and the forms varied known, or felt, in Rom., and the forms varied; the It. battifredo (after ML. batifredus) simulates battere, beat, strike (as an alarm-bell or
a clock), and the E. form (after ML. bolfredus) a clock), and the E. form (after ML. belfredus) $\mathrm{E}$. to a bell-tower. The same first element also oceurs in bainberg and hauberl; the second, with ac-

cent, in afray.]

1t. A movable wooden tower used in tho middle ages in atplaces. It consist was mounted wheels, and was genaw liiles to protect hose under it from Tlie bowermost, etc bometines sheltered a battering-ram ; the stories intermediate uppermost were fillwith bowmen,
arhalisters, ete., to gall the defenders while the uppermost

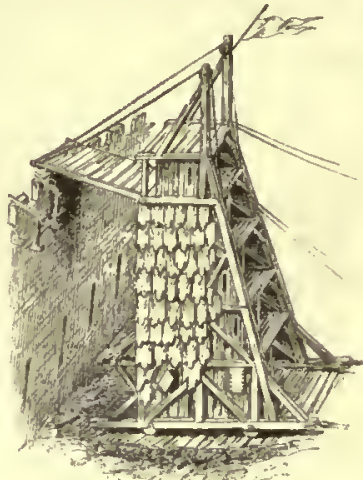
with a drawbridge to let down on the wall, over whlch $2 t$. A stationary tower near a fortified place, in which were stationed sentinels to watch th surrounding country and give notice of th approach of an nemy. It was furulshed with

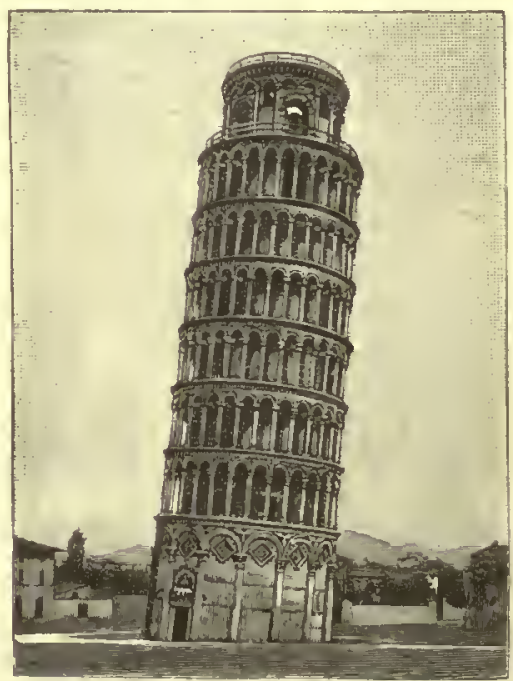

Belfry of the Duomo lu Pisa, Italy : commonly called the leell to give the alarm to the garrison, and also to sim (ireline vassilg of a felldal hrit to his rictensc. This nected with bel.

3. A bell-tower, generally attached to a church or other building, but sometimes standing a part as an independent structure.

The same dusky walls

The same cloisters and belfry and spire. den Legend, ii.

4. That part of a steeple or other structure in which a boll is hung; particularly, the frame of timberwork which sustains the bell. See eut under bell-gable. -5 . Nant., the ormarnental frame in which the ship's bell is hung. [Eng.] - 6. A shed used as a shelter for eattle or for

Eng.] barn-owl (which see), from its frequently nesting in a belfry.

belfry-turret (bel'fri-tur"ct), n. A turret at tached to an angle of a tower or belfry, to receive the stairs which give access to its upper stories. Belfry-turrets are polygonal, 8quare, or rount in external plan, but al ways rom

belgardt (bel-gärd'), $n$. [<It. bel guardo, lovely look: see bell and guard, regard.] A kind look or glance.

Upon her eyelids many Graces sate,

under the gladow of her even browes,

Spenser, F'. Q. II, tii, 25.

Belgian (bel'jian), $a$, and $n$. [See Belgic.] I. a. Belonging to Belgium, a small country of Furope, between France and Germany, formerly part of the Netherlands, erected into an independent kingdom in $1830-31$ - - Belglan syl-

II. $n$. A uative or an inhabitant of the kingdom of Belgium.

Belgic (bel'jik), a. [< I. Belgieus, <Belge. 1. Pertaining to the Belge, who in Casar's time possessed the country bounded by the Rhine, the Seine, the North Sea, the Strait of Dover, and the Englisl Channel. They were probably of mixed Tentonic and Celtic origin. At the time em Britain, whose connection with the continental Belgg

2. Pertaining to Belgium.

Belgravian (bel-grā'vi-an), $a$. and $n$. I, $a$. Belonging to Belgrayia, an aristocratie distriet of London around Pimlico; hence, aristocratic fashionable. Thackeray.

II. $n$. An inhabitant of Belgravia; an aristocrat; a member of the upper classes. Thach-

Belial (bē'lial), n. [Early mod. F. also Belyall, ME. Belial, ‘ LI. (in Vulgate) Belial, 〈Gr. B $\varepsilon$

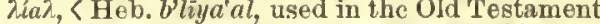
usually in phrases translated, in tho English version, "man of Belial," "son of Bclial," as if Belial were a proper name equiv. to Satan

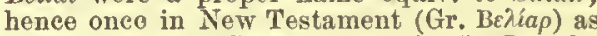
an appellative of Satan (2 Cor. vi. 15). But the $\mathrm{Heb}$. bliya'al is a common noun, meaning worth lessness or wickedness: $\left\langle b^{\prime} l i\right.$, without, + ya* $a l$ use, profit.] The spirit of evil personified; the devil. Satan; in Milton, one of the fallen angels, distinet from Satan.

What concord hath Christ with Belials 2 Cor. vi. 15 Belial came last, than whom a spirit more lewd

belibel (bē-li'bel), v. $t . \quad[<b e-1+l i b e l$.$] To$ libel or traduce.

Belideus (bē-lid'e-ens), $n$. [NL.] A genus of small flying phalangers, of the family Jhalangistida; the sugar-squirrels. These little marsupials resemble flying-aquirrels in superficial appearance, havin a large parachute, large naked ears, long busliy tail, and very soft fur. There are several apecies, auch as $B$. gciu-
reus, $B$, ariel, and $B$. faviventer, inhahiting Australia,

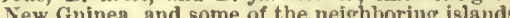

belielt $\left(\mathrm{b} \overline{\mathrm{c}}-\overline{1}^{\prime}\right), v$, $t$, betay, belie ppr. belying. [< ME. belyen, beliggen, G. beliegen), < be-, about, by, + liegan, lie: see $b c-1$ and lie 1 , and ef. belay.] To lie around encompass; especially, to lie around, as an

belie' ${ }^{2}$ (bê-li' ${ }^{\prime}$ ), $v$. t.; pret. and pp. belied, ppr. belying. [< MF. belyen, beleozen, < AS. beleógan (= OHries, biliaga = OHG, biliugan, $\mathrm{MHG}$, be liegen, G. belügen), < be-, about. by, + leógan, lie: see $b e-1$ and lie ${ }^{2}$.] 1. To tell lies concern ing; calumuiate by false reports. 


\section{belle}

Thou dost belie him, Perey, thon inst belie him: IIe never did encounter with Glendower. Who is he that belies the blood and libels the fame of

II. Hebeer Speceli, Senate, May \#, 1834

The elamor of thas belied in the hublhub of lles.

2. To give the lie to ; slow to be false; conmadict.

Their trembing hearts belie their boastini tongnes.

Novels (witness ev'ry month's review) Cothepes, Retirement.

3. To aet unworthily of ; fail to eriual or come up to; disappoint: as, to belir one's hopes or expeetations.

Shall liector, born to wa, his birthright yielc,

rnge, and forsake the fleld , 100.

Tusean Vialeriug by force o'ereane,

Drante.

4. To give a false representation of ; conceal tho trice character of.

Queen. For heaven's sake, speak comtortshle words

5t. To fill with lies.

"Tis slamier, . . . whose breath

Rliles on the posting winds, and loth belie

All corners of the world. Shak., Cymbeline, 1it. 4. 6t. To eounterfeit; mimie; feign resemblanee to.

With dust, with horses' hoots, that best the ground,

And matial brass, belic the tliunder's soun Dryden, Astren Redux.

belief (bë-löf'), n. [Early mod. E. beleef, beleeve, $\mathrm{ME}$. belece, beleafe, with prefix be- as in believe, q. v.), parallel with the earlier leve, by apheresis for ilere, $<\Lambda \mathrm{S}$. gelerifa $=\mathrm{OS}$. gilöbli $=\mathrm{D}$. geloof $=\mathrm{MLG} \cdot$ gelöte, gelō $=\mathrm{OHG}$ giloubn, MIIG. gcloube, G. glaube, mase., = Goth. galaubeins, fem., belief, ' galaubs, dear, valuable: see believc.] 1. Confidence reposed in any person or thing; faith; trust : as, a child's belief in his parents.

To make the worthy Leonstus mad, Shak., Cymbeline, v.

2. A conviction of tho truth of a given proposition or an alleged fact, resting upon ground insufficient to constitute positive knowledge. Knowiedge is a state of mind which recessarly implies a
corresponding state of things; bellel is a state of mini corresponding state of things: bellef is a state of mink tire absolute eouvietion or certaiuty which accompanies knowledge.

Noither do I lahor for a greater esteem than may in some little measile draw a velier Srom you, to do yoursel Belief ndmits of sll degrees, from the slightest suspicion to the tullest a

11e [James Mill] uses the wori belief as the most general term for every species of conviction or assursnee; the which we oniy remember or expect; of what we know by direct perception, as well as of what we accept on the

By a singuiar frenk of language we use the word belief By a singuiar \&renk of language we use the word belie
to designate both the least persistent and the mest persistent coherenee smong our ststes of conseiousness, - to ropositions of the truth of whileh wo are least certain, and to those of the truth of which we are most certsin,
J. Fiske, Cosmic Philos, 1.6

3. Persuasion of the truth of a proposition but with the consciousness that the positive evidenee for it is insufficient or wanting; especially, assuranee of the truth of what rest chiefly or solely upon anthority. (a) In this sense the word sometimes implies that the proposition is sdmitted an probable. (b) Th solse prop the proposition is almitted as being so reasonabie thist
needs no proof. (c) Sometimes used for religious taith.

Knowledge and belief differ not only in degree but in kind. Knowledge is \& certainty founded upon insight; perspicuons and ohjective : the other is obscure and sub-

One in whom persuasion and belief

A passienate intuition. 11 ordatcoth, Excursion, iv.

They [women] persuade rsther than eonvinee, and value expresston of the reslity of things.
Lecky, Europ. 3lorals, 11. 381.

4. That which is believed; an object of belief. Superstitious propheeles are the belief of foels. Bacon. We have but to read the accounts of the esrly beliefs of mankind, or the present beliefs of savages snil semi-cul-

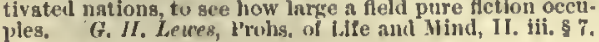

513

belive

In the csthedrals, the popular beliefn, hopes, tears, tan-

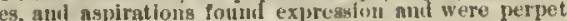
C. L. Sortom, Travel and study in 3 taly, p. 10: 5. Tho wholo body of tenets beld by tho professors of any faitl.

In the heat of persecutlon, to whleh the Christian Lelief The belief of Chrlstianity is a belief in the beauty of holl ticf his the auty of holl. ness; the creed of Hellats was a beliff hin the hesuty of the
worth and of mankind.

6. A ereed; a formula cmbodying the essential loetrines of a religion or a elinrel.

Ye ought to see them lave their belief, to know the eom. mandinents of (hol, to kecp their holy-duys, and not t lose their time ln ldicuess. Latimer, scrmous, p. 14. $=$ Syn. I and 2. Opinion, Conriction, ete. (see persin
credence, trust, credit. confldence. -4 . Doctrine.

beliefful (bö-lēf'fül), a. [< iL. bilefful, < bilef, beleve, belief, + ful. Cf. $\mathrm{AS}$. geleafiul.] Hav ing belief or faith. Iolall. [Rare.]

belieffulness (bō-lêf'finl-11es), $n_{0}[<$ belieful + The gouly beliefutnear or the heathe

The goully betiefulness of the heathen. $i$ dall, On Inke iv. There is a hopefunness and a beliefulness, so to say, on your side, which is a great compensation. who belies.

Foul-nonthed belicrs of the Christian fait]1. Coleridge, Ainls to lieflection, 1. 39

believability (bē-lō-vạ-bil'i-ti), $u . \quad[<$ belier. able: seo -bility.] Credibility; capability of being believed. J. S. Mill.

believable (bê-lé'va-bl), $a . \quad[<b$ clieve + -able. Capable of being believed; eredible.

That he sinnd, is uot betienaber

Tennyson, Merlin and Vivien.

believableness (bō-lè' va-bl-nes), n. Credi bility.

believe (bẹ-lềv'), $t$.; pret. and pp. believed, ppr. believing. [Early mod. E. belecte, <ME. beleten, bileven, bilefen, with prefix be- (as in belief, q v), parallel with the carlier leven, by apheresis for ileven, < AS. geliéfan, gelýfan, gclèfin = OS. gitöblian = D. gelooren = MLG. gelöten = OHG. gow glouben, G. gleuben, now gla galaubjan, believe, lit. hold dear or valnable or satistaetory, be pleased
with, < Goth. galaubs, dear, valuable (found only in the speeial sense of 'cestly'), ( $g a$ - (AS. ete., ge-), a generalizing prefix, + "laub, a form (pret.) of the common Tent. root *lub, whence also Goth. liubs = AS. leof, $\mathbf{E}$, lief, dear, AS lufu, F. love, etc.: see licf, leare ${ }^{2}$ lore, liberal, ete. I. intrans. 1. To have faith or confi-
dence. (a) As to a person, to have confldence in his dence. (a) As to a person, to have confldence in his
honesty, integrity, virtue, powers, sbility, etc.; trust. (b) honesty, integrlty, virtue, powers, sbility, etc. i trust.
As to a thing, to have faith in its existence, or in its genuineness, efficacy, virtue, usetuluess, soundness, and th like; eredit fts reality : as, to believe in ghosts: to belice licanisro, in ednestion, ete.: nsusily with in or on (formerly slso with $t 0$ ), rsrely absolutely.

He ssith unto the ruler of the synsgogue, Be not alrakl,
Mark v. 36 believe.

2. To exercise trust or confidence; rely throng faith: generally with an.

And they said, Delieve on the Lord Jesus Christ, anc And many believed on him there. John X. 42 . To them gave he power to become the sons of God, even
John 1. 12.

3. To be persuaded of the truth of anything; accept a doetrine, principle, system, ete., as true, or as an object of faith: with in: as, "I believe in the Holy Ghost, the holy Catholic Chureh, the communion of saints," otc., Apos-
tles' Creed; to beliere in Bnddhism. See beliey. If you will consider the nature of man, you will find that with lim it slways has been and still is true, that that thing in all his inward or out wsrd world which he see werthy of worship is essentially the thing in which he be-
Keary, Prim. Belief,

To make believe. See makel.

II. trans. 1. To eredit upon the ground of authority, testimony, argument, or any other ground than complete denonstration

as true; give eredeneo to seo belief.

We know what rests npon reason; we believe what rests pon authority.

the noment.

Sir II I mition.

We may believe what goes beyend our experienee, only when it is inferred from thst experience by the assumpknow is like what we know.
$W . K$. Clifford, Leetures, II. 210. Who kuows not what to betiere Since he sees nothing clear. mind of the truth or ehiefly poetical.]
To give eredeneo to (a person making a statement, anytling said, ete.).

Lo, I come untu thee in a thick elom, that the people Fx. xix. 0 .

You are now bound to believe him. Shak, C, of F., v. I

3. To expect or lope with confidence; trust. [Archaic.]

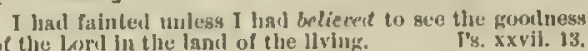
4. To be of opinion; think; understand : as believe ho has left the eity.

They are, I beliem, as high as must steeples lu Fuglani.

believer (bê-lë verr), u. [Early mod. E. belcerer

belerer (uot in ME. ol AS.); <belicve + -erI.] 1. One who believes; nuo who gives credit to other evidenco than that of personal knowledge; one who is firmly persualed in his ow

Johnson, Incredulous on all other polnts, was a realy believer in miracles and apparitions.

2. An adherent of a religious fuith; in a mor restricted sense, a Christian; one who exereises faith in Christ.

And believers were the more added to the Lom. Acts v. 14,

3. In the early churel, a baptized layman, in entradistinction to the elergy on tho one hand, and to the catechumens, whe were preparing for baptism, on the other.

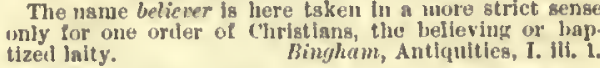
believing (bē-lē'ving), p. $a$. 1. Having faith; ready

Re not (alt]iess, but believing. John $x \times$, 25. Now, God he prais'd I that to betieving souls Gives light in darkness, confort in despair. Shak,

2. Of the number of these who are diseiples.

And they that have believing unsters, let them not de. believingly (bē-létving-li), adt. In a believing manner ( with belief:" as, to receive a doe. trine believingly.

belight (bē-lit'), v. $t,\left[<b e-1+l i g h t I_{+}\right] \mathrm{To}$ light up; illuminate. Cowley. [Rare.] belike (bể-lik'), adv. [First in early med. F. also written belyke, bylyke; also belikely, q. v. likely, i. e., by what is likely; but perhaps a rednction of an introductory phrase it may be (or will be) like or likely. Cf. maybe and likely as similarly nsed.] Perhaps; probably. [Now

Then you, belike, suspect these noblement
As guilty of Duke IIumphrey's timeless desth.
Shak., 2 Hen. VI., iil. 2

Belike this is some new kind of subscription the gallsnt
use. B. Jonson, Every If an out of his Humeur, iif. 2 If he came in tor a reekening, belike it was for better belikely $\nmid\left(b \bar{e}-l i k^{\prime} l i\right), a d t$. [See belike.] Prols-

Having belikely heard some better words of me than I belime (bē-lïm'), v. t. [<be-1+lime $\left.e^{1}\right]$ To besmear or entangle with or as with bird-lime. Bp. Hall.

belinkedness (bẹ̄-lingkt'nes), $n$. [<be-1 + $\left.l i n k^{1}+-c d^{2}+-n e s s.\right]$ In nath., the number of times one branch of a link must be passed throngh the other in order to unde it.

belittle (bē-lit'l), $v \cdot t$; pret. and pp. belittled, ppr. belittling. [First in U. S. ; $<b e-1+$ little.] 1. To make small or smaller; reduee in proportion or extent. [Rare.]-2. To cause to appear small; depreciate; lower in eharacter or importance; speak lightly or disparagingly of. elittlement (bē-lit'l-ment), n. [< belittle + inent.] The act of belittling, or detracting from the character or importance of a person or thing.

A systemstic belittlement of the essential, and exaggera. tion of the non-essential, in the story. Sci. Mto, XX. 370 .
POp. S.

belive ${ }^{1} \nmid, v, i . \quad$ [ME. (rare), < AS. belifan (pret. belãf, pl. belifon, pp. belifen) (= OS. bilibhan = OFries. biliva, blit $=\mathrm{D}$. bliven $=\mathrm{OHG}$, biliban, MHG. beliben, bliben, G. bleiben = Goth. bileiban), remain, < be- + *lifan (pret. läf), remain.

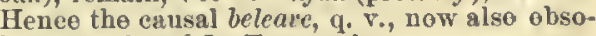
lete: see leare ${ }^{1}$.] To remain. 


\section{belive}

belive $2 t$, $a d v$., orig. prep. phr. [Now only E. dial., also written belyre, Sc. belife, belyre, beliff, <ME. belive, belyre, belife, bilife, blife blive, slso bilifes, bilives, ete.; sometimes used expletively; prop. two words, be live, be life, and lively.] 1. With speed; quickly; eagerly.

And unto battell doe Rise, rise bylive, Rir selves addresse.
Spenser, F. Q., II. vill, 18.

Thon sclialte haue delyueraunce
Be-lyne at thi list.
York

Presently; ere long; by and by: anon sometimes merely expletive.

Twenty swarm of bees,
Whilk all the summer hum abont

Whilk all the summer hum abont the
And bring mo wax and honey in bitive.

B. Jonson, Sad Shepherd, $i$.

Belyze the elder bairns come drapping in.

[Obsolete in both senses, except in Scotch.] belkt (belk), v. t. [E. dial., 〈 MIE. bellien, th unassibilated form of belehen, belch: see belch, and ef. balk.2, bolk.] To beleh; give vent to.

Till I wight belke revenge upon his eyes.
Marton, Antonio and Ilellida, II. I.

belll (bel), n. [Farly mod. E. also bel, < ME bel, belle, $<\mathrm{AS}$. belle $(=\mathrm{D}$. bel = MLG. LG. belle; ef. Icel. bjalla, < AS. belle), a bell. Perhsps connected with bell $2, v$, rosr.] 1. A hollow metsllic instrument which gives forth a ringing sound, generally of a musical quality, when struek with a clapper, hammer, or other appli ance. Its usual shape resembles that of an inverted cup with a flaring rim. If the bell is statiollary, it is often made saucer.
shaped, and in this case is commonly shaped, and in this case is combionly
termed a yong. Bells of this lorm are generally used as call-bells or signal-
beils. Bells are made for many purposes and in a great variety of porms and sizes. They usually consist of an
alloy of copper and tin, called bell. alloy of copper and tin, called bell-
metal (which see). Church-bells are known to have been in use in Italy
about $\mathrm{A}$. 1 . 400, and in France in the often tomi-sided, niade of thin plates of iron riveted together. The manufacture of the largest and finest

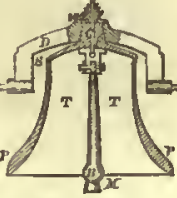
Bell (section). clapper-bolt; $;$, cannon, is, mouth ; $P$, fifteenth century. The largest ever made is the great
bell of Hoscow, called the Czar Kolokol, cast in 1733 and computed to weigh about 440,000 pounds. It is abon posed never to have been hung, and is now used as
chapel, having been raised in 1836 after lying half buried since 1737 , when a plece was broken out of its side in a fire The largest bell in actual use weighs 128 tons, and is als
in Mloscow. The bell of the Buddhist monastery Chi-on, in Kioto, Japan, was cast in 1633 , and weighs 125,000 catties,
or over 74 tous of 2,240 pounds each. Among the great

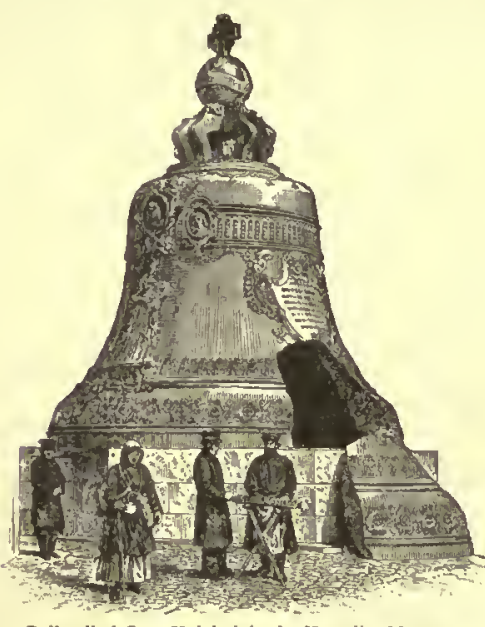

Bell called Car Kolokol, in the Kremlin, Moscow.

French belis, the bourdon of Notre Dame, Paris, weighs about 17 tons; the largest bell of Sens cathedral, 16 tons; "Big Ben " of "Westminster, weighs over 13 tons, but is the "Great Tom," at Oxford, 7 tons. The new "Kaiser-
glocke " of Cologne cathedral weighs 25 tons. For churchbelis nade to be rung in unison, sec chime. In heraldry, the bells genterally represented are hawks' bells, in shape like a small sleigh-bell; a hawk represented with these
bells attached is said to be belled. When a bell of ordinary Iorm
dlatinction.

But what art thou tbat aeyst thls tale,

That werest on thyn hose a pale

(1841 belli (bel), 2. Anything in the form of 8 bell or compred duce bells; be in bell: said of hops when the to 8 bell. Specifically $-(a)$ A bell-shaped corolla of a seed-vessels are forming. See belll, $n ., 2(d)$. to 8 bell. Specifically-(a) A bell-shaped corolla of a hawks' bells or sleigh-bells, fastened to a hanHops in the beginuing of Augnst bell.

\section{belladonna}

Where the hee sucks, there suck I;
In a cowslip's bell I lie. Shak., Teinpest, v. I. (b) In arch., the plain echings of a Corlnthian or comporauged. Also called basket. (c) The large end of a lul when the end of a pipe, tube, or any musical insirument, ble a bell. (d) The strobile, cone, or catkin containing the seed of the hop. (e) The pelidulous dermal appendage polyps, the umbrella or gelatinous disk. dle snd constituting a toy for amusing an infant.-4. $p l$. Naut, the term employed on shipdivisious of daily time, from their being marked by bells, which are struck every half-hour. The day, beginning at midnight, is divided into watche which is subdivided into two dog-watches. A full wateh thus consists of eight hall-hours, and its progress is noted by the number of atrokes on the bell. For instance, 1 watch; 3 o'clock, to six bells; 4 o'clock, to eight bells, etc. Angelus bell, Gabrjel bellt, Lady bell, a church angelus. Sce angelus. - Ave bell, Ave Maria bell, or

I could never hear the Ave Mary bell without an eleva tion, or think it a sufficient warrant because they erred lence and clumb contemp

Sir T. Browne, Religio Medicl, i. 3 Bell, book, and candle, a phrase popularly used in con nection with a mode of solemn excomniunication formerly practised in the Ronan Catholic Churcli. After tants cast the ligbted candles they held in their hand were rungr torether withor monles symbolized the disorder and going ont of grace in the oouls of the persons excommunicated.-Blessed received the solemn blessing of the church, in which the bishop prays that its sound may avall to summon the and that the powers of the air, hearing it, may tremble and flee before the standard of the holy cross of the Son of God engraved upon it, etc. - Elevation or Sanccelebration of mass to give notification of the more solems portions : now uslually a aniall hand-bell, but in prein a bell-gable erected over the nave, inmediately above une of the acolytes. Oxford Glossary, p. 74. In the bell. (a) In flower. [Scotch.] (b) In seed, or having the sacing bell. - Recording bell, a bell attached to a handpunch, or to an instrument of similar pnrpose, with whlch n, as at a bar, are recorded.- Sacring bell, a bell run the elevation of the host, at the Sanctus, and at other solenin services. When rung at the consecration it is the Sanctus bell, etc. Also called saints' bell. - Salnts bell. Same as sacring bell. The term is a corrupted lorm
of Sanctus bell, but is no longer speciffeally restricted to

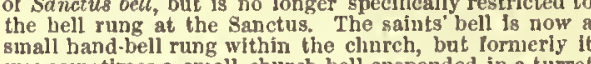
was sometimes a small church-bell suspended in a tu And it is said that his people wonld let their plough
rest when George Herbert's saints'-bell rang to prayers. Sanctus bell. See elevation bell.-To bear away (o galn, etc.) the bell, to win the prize at a race.
mer times a bell was a usual prize at a horse-race. Here lyes the man whose horse did gaine
The bell in race on Sallsbury plain.

To bear the bell, to be the first or leader: to the bell-wether of a flock, or the leading horse of

Lat ae which of you shal bere the belle

In niemory of the man but for whom had gone to whe All that France saved from the flght whence England bor To clamor bellst. See clamor.-To 1080 the bell, In aingle figlt he lost the bell.

$$
\begin{aligned}
& \text { he lost the bell. } \\
& \text { Fairfax, tr. of Tasso, xvil. } 69 .
\end{aligned}
$$

To ring the bells backward. See backward. - To priest, as was formerly done in the belief that its aoun had virtue to disperse storms, drive away a pestilence or move, or give notice or alarm: in allusion to the bells on 'a neck, which when sounded alarned its prey.

Neither the king, nor he that loves him best,

The proudest he that holds up Lancaster,
Dares stir a wing, if Warwick ghake his bell.

To take one's bells, to take one's custom in falconry of attaching bells to a bawk' from the fore letting it fly.

If ever for the Spring you do but aigh, Dekker and Ford Sun's Darling, iil. 2.
II. trans. 1. To put a bell on.-2. To swell or puff out into the shape of a bell.

Devices for belling out dresses.

IIrs, Riddell.

To bell the cat, to grapple or cope with an adversary of

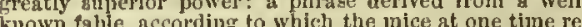
solved to put a bell on the cat to warn them of its approach; but after the resolution was passed, on inquiry daring enough to do so.

ell ${ }^{2}$ (bel), v. [Early mod. E. also bel (dial. also beal), ( ME. belle, ( AS. bellan, roar, bellow, grunt, = OHG. bellan, MHG. G. bellen, bark, $=$ orio verb (ef. D bellen, ring, MLG. bcllen, proclsim loudly), with AS. belle, E. bell , q. v. Cf. bellow, later form parallel to bell $2, v$, and see bell. belch, balk ${ }^{2}$, bolk, ete., a series of verbs of similer form assumed to be ult. imitative. Hence prob. bull1.] I. intrans. 1t. To bellow; roar.

As loud as belleth wind in hell.

1. 1803

Specifically -2 . To bellow like a deer in rutThe wlld luck bello from ferny brake.

Scott, JIarmion, iv. 15

Enjoining perfect silence, we crept from tree to tree with stealthy pace and occasionally sweeping the opposite brow of llangerton with a deer glass to discover sone of
the numerous harts which were belling and calling.
Forest and Stream, XXIV. 449.

II. trans. To bellow forth. [Rsre.]

bell 2 (bel), $n$. [<bell $2, v$.] The bellow of the wild deer in rutting-time.

In Ireland the deer-stalker has to put aside his rifle in Octoher. The first bell of the hart is a notice Ior him to quit, so that these wild denizens of the woods may carry

bellist, $v$. i. [<ME. bellen (pp. bollen), perhaps (with loss of orig. guttural) < AS. belgan (pp. bolgen) = OHG. belgan, $\mathrm{MHG}_{\text {be belgen = Icel }}$ and MiHG. also be angry). Cf. bell ${ }^{2}$ and bellow, repr. psrallel forms without and with sn orig. guttural. Seo boln 1 .] To swell up, like a boil or beal.

Jesus ... was pricked both with nail and thorn. 1t neither wealed nor belled, rankled nor boned.
Pepys, Diary, III. 96. (N. E. D.) bell4 (bel) $n \quad$ < late ME, bclle =D, bel, a bubble; cf. OD. (MD.) bellen, bubble; origin uncertain, perhaps connected with E. bells, or with L. bulla, a bubble: see bell3.] A bubble formed in a liquid.

The twinkling of a fin, the rising of an air-bell Certain qualities of coloured glass are cast by ladling the molten metal from lnige pots. . By this ladling cumstance does not affect the durability and nsefulness.
of the glass.
Encyc. Brit., X. 663. bell4 (bel), v. i. [< bell4, n.] To bubble. [Seotch.]

bell ${ }^{5}, a$. [Early mod. E. also bel, <ME. bcl, bele, <OF. (mod. F.) bel, beau, m., belle, f., = Sp. Pg. It. bello, < L. bellus, frir, beautiful, fine. This adj., the nearest representative of the L., obtained a hold in E. ehiefly in its deriv. beauty (> beautiful, etc.), and some half-French uses see bel1, belle, beau, etc.] Fair; besutiful. bellacity (be-lss'i-ti), $u$. [< L. as if "bellaci ta $(t-) s$, bellax (bellac-), warlike, < bellum, war.] Tendency to war; warlikeness. [Rare.] belladonna (bel-z-don'䓍), $n$. [NL., < bolla donna, lit. beautiful lady (the berries of the plant having been used by the Italian ladies s a cosmetic): bella, fem. of bello, beautiful (see belle) ; donna, < L. domina, lady, fem. of domi-

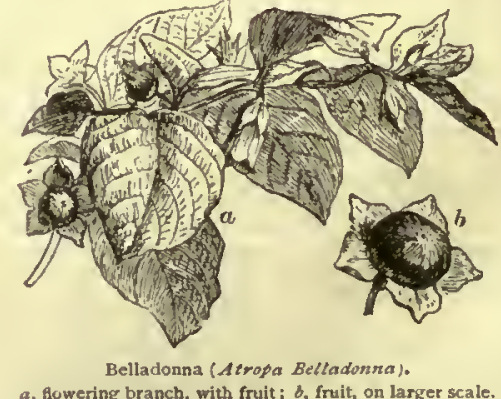

mus, lord. Ult. \& doublet of beldan, q. v.] A plant, Atropa Belladonna, or deadly nightshsde, 
natural order solanucece, a native of central bell-cote (bel'kōt), n. In areh., an ornamental and sonthern linrope. Alt parts of the plant are polaonous, and depend for their pharmacolynamic prop are largely ukalout atroplin. The plant and its alkalo and exeeaslve perspiration, and especially ln surgery to dibell-and-hopper (bel'and-hou''ér), $n$. A charging device on top of a blast-furnace. The bot piece, which, when loweresl, permits the ore to fall lnto bellandine (bel'an-dinn), n. [Sc.; cf. ballan, a figlit, combat.] "A quarrel; a squabble. Hogy. bell-animal (bol'an"i-mąl), $n$. Samo as bell animulcule.

bell-animalcule (bol' an-i-mal "kūl), n. The usual English namo of a peritrichous eiliated infusorian, of the family Vorticcllide (whic) Reo). Soo cut under Vorticella. Also called bell-polyp.

bellarmine (bel'ür-miu), $n$. [See def.] A large stonewaro jug with a capacious belly and narrow neck, decorated with the faco of a bearded man, originally designed as a earicature of Cardinal Bellarmin, who ung himself obnoxious to the Protestant party iu tho Netherlands as to tho Protestant party iu tho Netherlands as
an opponent of tho lieformation, in tho eud of the sixteeuth century and the early part of the serenteenth.

Or like a larger jug that some men call
A billurnine. W. Cartweright, The Ordinary. Largo glohular jugs, stamined in rellef with a grotesune bearded fuec and otiler ornaments, were one of the favuurite forms [hil stoneware]. Such were called "greybearda" of whom the bearded face was anpposed to be a earicature.

bellasombra-tree (bel-g-som'brị-trē), n. [< Sp. bella, beautiful, + sombra, shade.] A Soutl American tree, Plhytolacca dioica, cultivated as a shado-troo in Spain, Malta, and some of the cities of Iudia.

Bellatrix (be-lā'triks), $n$. $\left[\mathrm{I}_{\text {. }}\right.$, fem. of bellator, a warrior, < bellare, wage, < bellum, war: see bellicose, belligerent. In sense I it is the translatiou by the anthors of the Alphonsine Tables latiou by the anthors of the Alphonsine Tables
of the Ar. name Alnadshid, the real meaning of of the Ar. name Alnaidshid, the real meaning of
which is doubtful.] I. A very white glittering which is doubtful.] I. A very white glittering der of Oriou. It is $\gamma$ Orionis.-2. In ornith., genus of humming-birds. Boie, I831.

bell-bind (bel'bind), $n$. Another name of the hedge-bells or hedge-bindweed of Europe, Convolvulus sepium.

bell-bird (bel'bèrd), $n$. I. The arapunga. -2 . An Australian bird of the family Meliphagida the Mranorhina (or Ifyzantha) melanophrys, whose notes resemble the sound of a bell.-3. An Aus tralian piping erow, of the genus Strepera, as $S$ graculina. Also called bell-magpie.

bell-bloomt, $u$. [Early mod. E. belle-blome.] An eld name of the daffodil.

bell-bottle (bel'bot"l), n. Another name of ono of the two European plants called bluebell, of the two European plants

bell-boy (bel'boi), $n$, A boy who answers a bell; specifically, an omployee in a hotel who attends to tho wants of guests iu their rooms when summoned by bell.

bell-buoy (bel'boi), n. See buoy.

bell-cage (bel'kāj), n. A belfry.

bell-call (bel'kâl), n. Samo as call-bell.

bell-canopy (bel'kan"ō-pi), $n$. A eanopy-like construction of wood or stone, designed to proteet a boll und its fittings from the weatlier.

bell-chamber (bel' ehām" bèr), $n$. The portion of a tower, usually near its summit, in which bells are humg. 1t is commonly constructed with large open. ings on all sides, th permit the sound of the bells to ditfnse itself without inmediment. $\Lambda$ bell-shaped lathechuck, which, by means of set-serews, holds the viece to be turned.

bell-cord (bel'kôrd), n. A cord attached to a bell; specifically, a cord attached to a bell on a locomotive and rumuing throngh the cars of a

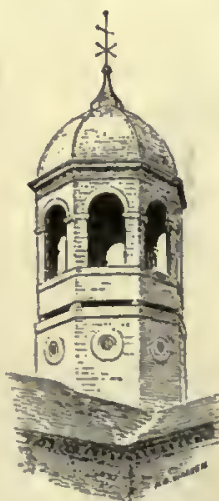

Aell-canopy, Harvard Col-
lege, Cambridge, Mass. construction de bells, und often crowned lyy lell-eote rests ujon a wall, and is some times supported hy corbeis ; lont no aeconit of its pres. ence in the arehi. tectural dispositlon of the lower part. of the builifing.
see bell-turvet. Alsis
written bell-cot. bell-crank (bel' krangk), $n$. It mach., a rectangular lover by rection of motion is changed
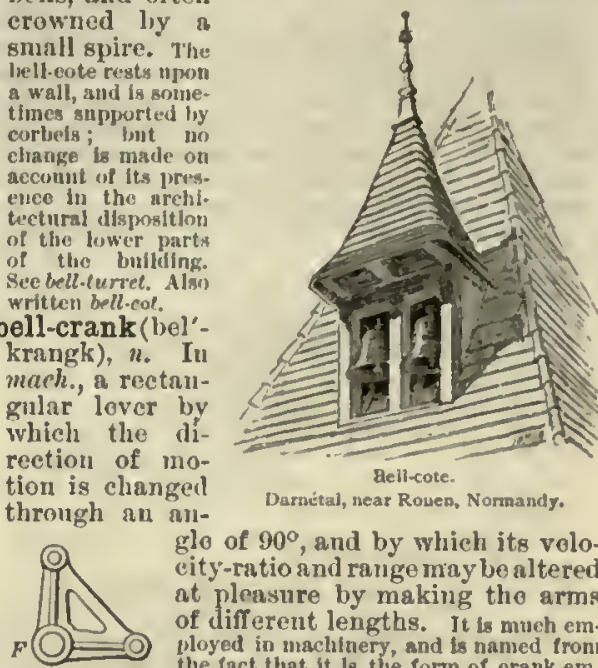

gle of $90^{\circ}$, and by which its velo eity-ratio and range may be altered at pleasure by making the arms of different lengths. It is much em ployed in machinery, and is named fromi the fact that it ls the form of erank emBell-erank. ployed ln changing the direetion of the
wires of house-bells. F in the cut la the center of mution about whish the arng oselliate. See lso cut under crank.

Ft (bel), $a$. and $n$. [<F. belle, fern. of bean , bcllus, beautiful: see bell, bell5.] I. a. Beautiful; charming; fair.-Belle cherel. [ME., $\angle O F$, belle chere: see belle snd eheer.] Good enter. That he hath had ful ofte tymea here

Chancer, Shipman's Tale, 1. 408

II. $n$, A fair lady; a handsome woman of ociety; a recognized or reigning beauty.

Where none admire, 'tls useless to exeel;

Where none are iesnx, "tia valn to be a bell

Beanty alone wlll not nake the belle; the beanty must up hy esirit.

belled (beld), p. $a$. Hung with bells; in her. having lawk-bells attached: said of a haw wheu used as a bearing.

bellelettrist, $n$. See belletrist.

belleric (be-ler'ik), n. [< F. belléric, ult. < Ar. balilaj, < Pers. balilah.] The astringent fruit of Tcrminalia Bellerica, one of the fruits imported from India, under the name of myrobalans, for tho use of calico-printers.

Bellerophon (be-ler'ō-fon), $n$. [T., 〈 Gr. Be inth, in Greek myth, the slayer of the monster

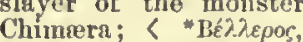
supposed to mean ' monster, $+-\phi \omega \bar{v},-\phi o ́ v \tau \eta s$,
slayer, < $\phi a v$, kill, akin to $\mathrm{E}$. bane $\left.{ }^{1}, \mathrm{q} . \mathrm{v}.\right]$ An

cxtinct genus of gastro-

ily Bellerophontida. It Is

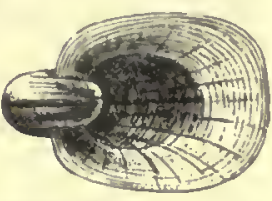
poaltion of llmestone beds of the Silurian, Devonian, and Carboniferous epochs.
bellerophontid (be-ler-o-fon'tid), n. [< Bellerophontide.] A gastropod of the family Bellerophontidle.

Bellerophontida (be-ler-ō-fon' ti - dê), n. pl. [NL L , Bcllerophon $(t$ - $)+-i d a$.$] An extinet$ lerophon. The shell was symmetrically involnte and nautillfurn, with the periphery carinatet or auleated ane notched or incised at the lip. The specles flourtshed and were numierous in the Paleozole age. Thelr affinities are thers with the heteropod Allantidoe, but they are now generally approxlmated to the Pleurolomarides, of the

belles-lettres (bel'let'r), n. pl. [F., lit. 'fine letters' (liko beaux-arts, fine arts): belle, fine, beautiful ; lettre, letter, pl. Icttres, literature: seo bclle and letter.] Polite or elegant literature: a word of somewliat indefinite application, including poetry, fietion, aud otherimaginative literature, and the studies and eriticism connected therewith; literature regarded as a form of fine art.

form of fine art.

belletrist, bellelettrist (be-let' rist), $n$. [
belles-lettres $+-i s t$.$] Ono devoted to belles-$ lettres.

bellettristic (bel-et-ris'tik), a. [く bellc(s)lettr(es) $+-i s t+-i c ; G$. belletristisch.] Of, pertaining to, or of the nature of belles-lettres. (in their nature ste genersily writtun by prof phent

bell-flower (bcl'flou"ér), n. 1. A common namo for the speeies of Campanula, from the shape of tho flower, which resembles a bell. Seo cut under Campanuln.-2. In seme parts of Eng land, the dnffodil, Narcissus I'scudn-Aareissits. - Autumn bell-flower, a species of gentlan, Gentiara

bell-founder (bel'foun"dér), $n$. A man whoso occupation is to found or cast bells.

bell-foundry (bel'foun"dri), n. A nlace whero bells nre founded or cast.

bell-gable (bel' gä"bl), n. 1. Tho contimuation upwarl of a portion of a wall terminated by a amall cable, and piereed to receivo one or more bells. Such a feature sometimes surmounts the

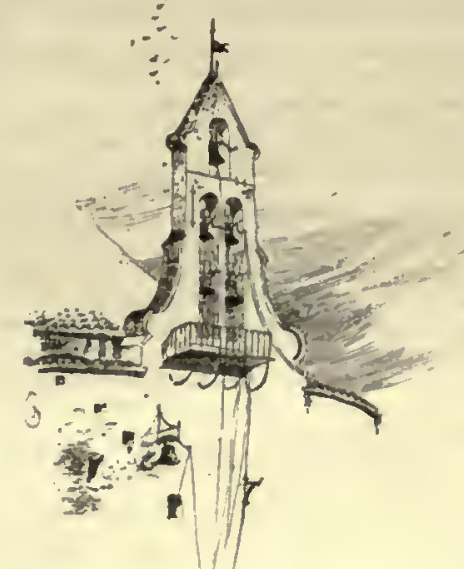

(S. S. Angurch of Slorence.

apex of a church-gable.-2. Any gable when tho wall composing it is pierced for bells. [Bell-gables of beth varieties are not uncommon in medieval architecture.]

bell-gamba (bel'gam"bä), $n$. Same as cone

bell-gastrula (bel'gas"trö-lä), n. In biol., the original, primary palingenetic form of gastrula, according to the views of Haeckel: same as archigastrula. See cut under gastrula.

bell-glass (bel'glàs), $n$. A bell-shaped glass vessel used to cover objects which requiro protection from variations of the atmosphere, dust, and influences of like character, as delieate plants, bric-à-brac, small works of art. clocks, and repairs bells.

bell-harp (bel'härp), $n$. An old stringed instrument, consisting of a wooden box about two feot long, containing a liarp or lyre with eight or mere steel strings. The player twanged the the a bell ellibonet, $n$. [One of Spenser's words, appar. F. belle ct bonne, beautiful and good. See belle, bomne, and boon ${ }^{2}$.] A bonny lass. bellict, bellicalt (bel'ik. -i-kal), $a$. [Also bel lique, < $\mathrm{F}$. bellique, < L. bellicus, warlike, < bcllum, war.] Pertaining to war; warliko: as,

lum, OL. duellum, war, orig. a combat between two, $<d u o=\mathbf{E}$. tico. Cf. ducl.] Inclined or two, < duo = E. tico. Cf. ducl.] Inclined or ticose sentiments

Arnold was in a bellicose veln.

Irving. I saw the bull alwsya alert and bellicose, charging the
tootmen, who pricked and baited, and enraged bim with their scarlet mantles.

C. D. Warner, Roundabout Journey, p. 271.

bellicosely (bel'i-kēs-li), adv. In a bellicose or warlike manner; pugnacieusly.

Anything like rallying the more bellicosely incllned of he pllgrims would, under the elrcumatances, be out of bellicoust (bel'i-kus), a. [As bellicase, < L. bcllicosus; or < L. bellicus: see bellicosc, bellic.] Bellieose: as, "bellicous nations," Sir T. Smith, Commonwealth of Eng.

bellied (bel'id), a. [<belly $+e d^{2}$.] 1. Having bolly (of the kind indicated in compesition): as, big-bellied; pot-bellied-2. In bot, ventricose; swelling out in the middle.-3. In anat., $J$. M. Ifart, German I niversiltes, b. 273.

cte. or to hold gases in chemical operations. atrings with the thumbs of both hands inserted through bellique Crsar," Feltham, Resolves, ii. 5̃. 


\section{bellied}

having a swelling fleshy part, or belly, as a muscle.-4. Rounded; bulging.

When a ralsed handlc is is used, the most rounde Toune, Pract. Nachinist, p. 270.

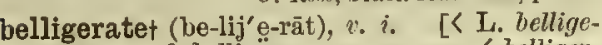
ratus, pp. of belligerare, wage war, < belliger, waging war, < bellum, war, + gerere, carry: sec gest, jest. Cf. belligerent.] To make war. coekeram.

belligerence (be-lij'e-rens), $n$. $\quad[<$ belligerent: see $-\mathrm{enc}$

Nerely diplomatic peace, which is honeycombed with suspicion, ... bristles with the apparatus and establish. required for actual belligerence.

belligerency (be-lij'e-ren-si), $n . \quad[<$ belligerent: or status as a belligerent; the state of being actually engaged in war.

They were acting for a Government whose belligerency
had been recognized. Soley, Blockade and Cruisers, p. 224.

I cannot conceive of the existence of any neutral dutles when no war exIsts. Neutrality ex vi termini implies belligerency; and a breach of meutrality can only occi with regard to s matter arising during a war.

belligerent (be-lij'e-rent), $a$, and $n$. [Ear]ier belligerant, $<\mathrm{F}$. belligérant, $<\mathrm{L}$. belligeran $(t-) s$, ppr. of belligerare, wage war: see belligerate.] acterized by a tendency to wage or carry on war.

History teaches that the nations possessing the greatest mant helligerent. Sumner, Orations, I. 97

2. Of warlike character; constituting or tending to an infraction of peace: as, a belligerent tone of debate.

Justice requires that we should commit no belligerent
act not founded in strlet right as sanctioned by public

3. Actually engaged in war: as, the belligerent 3. Actually engaged in war: as, the belligerent powers.-4. Pertaining to war, or to tho

gaged in war: as, belligerent rights, etc.
II. $n$. A nation, power, or state carrying
war; also, a person engaged in fighting.

The position of neutrals in relation to belligerents is ex. The possibllity of intercourse in war depends on the good faith; and this confidence, on the unchangeable sa-
credness of truth. Woolsey, Introd. to Inter. Law, 8249 . The rebel Poles had never risen to the rank of bellige-

belligeroust (be-lij'e-rus), a. [< L. belliger, waging war, < bellum, war, + gerere, carry on.] belling ${ }^{1}$ (bel'ing), $n$. [Verbal n. of belli, $v$.] In submarine operations, the use of the divingbell.

belling ${ }^{2}$ (bel'ing), n. [< ME. bcllynge; verbal n. of bell $2, v$.$] Formerly, bellowing; in moder$ use, the noise made by a deer in rutting-time.
bellipotent (be-lip'o-tent), $a$. [ $\mathrm{L}$. bellipoten $(t-) s,<$ bollum, war, $f$ poten $(t-) s$, powerful: [Rare.]

Bellis (bel'is), $n$. [L., < bellus, beautiful : see perennial herbs, natural order Compositce, indigenous to the temperate and cold regions of digenous to the temperate and cold regions of
the northern hemisphere. The daisy, B. perennis, is abundant in pastures nnd meadows of Europe, and is very bellitudet (bel'i-tũd), n. [< L. bellitudo, < bel lus, beautiful: see bell 5 .] Beauty of person; loveliness; elegance; neatness. Cocleram. bell-jar (bel'jär), $n$. A bell-shaped glass jar,
used by chemists in physical laboratories, etc., for receiving a gas lighter than the atmosphere or other medium in which it is plunged, and for similar uses. It is a form of bell-glass.

bell-less (bel'les), a. [<bell + -less. $]$ Havin
no bell. Scott. bell-magnet (bel'mag" net), n. An alarm in which a clapper is made to strike a bell by the

bell-magpie (bel'mag" pī), $n$. Same as bellbird, 3 .

bellman (bel'man), $n . ;$ pl. bellmen (-men). [Also written belman; < bell1 + man.] 1. A ployed to rings a bell; specifically, one emby ringing a bell; a town crier. - 2. Formerly, a night-watchman, part of whose duty it was to call out the hours, the state of the weather, and other information, as he passed.
516

bell-roof

I staid up till the bell-man eame by with his bell just under my window ss I was writing of this very line, and
cried, "P'ast one of the clock, and a cold, frosty, windy morning. yis, Diary, I.

ell-mare (bel'mãr), $n$. A mare used by muleherders as an aid in keeping their herds togother. The mules follow the bell-mal'e wherover she goes. Also called madrina in the originally Spanish parts of the United States. ell-metal (bel'met"al), $n$. A variety of bronze, made. The proportions in which the two metals are made. The proportions in which the two netals are liere is from 22 to 24 per cent. of tin and from 76 to 78 of copper. Four parts of the latter metal to one of the forest bells. See bronze. - Bell-metal ore, a name by whic the mineral stannite, or sulphid of tin, copper, and Iron, found in Cornwall, is frequently known, owing to

setell-metronome (bel met"rō-nom), $n$. A metstrike after a given number of oscillations of the pendulum, thus marking the beginning of measures as well as the pulses within measures. bell-mouth (bel'mouth), $n$. A mouthpiece expanding like a bell.

A bellmouth may also have the form of the contracted jet.
bellmouth (bel'mouth), $v . t . \quad[<$ bell-moutl, $n$. To provide with a bell-shaped

It is often desirable to bellmouth the ends of plpes.
Encyc. Brit., XII.

bell-mouthed (bel'rnoutht), a. 1. Gradually expanded at the mouth in the form of a bell.

Ilis bell-mouth'd goblet makes ne feel quite Danish, 2. Having a clear, ringing voice: said of a hound.

bell-nosed (bel'nözd), $a$. Expanded at th muzzle in the shape of a bell: said of firearms. In blunderbusses the harrels are generally bell-nosed. bellon (bel'on), $n$, [Origin unknown.] Leadcolic, or painters' colic. lum, OL. duellum, war.] 1. In Rom. myth., the goddess of war. Her temple stood in the Campus enemies territory. In it the Senate received foreign am bassadors and victorious generals entitled to a triumph. 2. [NL.] In ornith., a genus of humming-birds,
Mulsant and Verreaux, 1865.-3. [t. c.] [NL.] Mulsant and Ferreaux, $1865 .-3 .[l . c$.$] [NL.$
In herpet. the specific name of a snake, Pityo phis bellona.

bellonion (be-lō'ni-on), n. A musical instruof twenty-four trumpets and two drums, whic were played by machinory.

wellow (bel'ö), $v$. [< ME. belouren, bellewen, beluen, bellow, low, < AS. bylgean (occurring ouly once), bellow (as a bull), appar. with root as bellan, low, bellow, E. bell: see bell2. I. intrans. 1. To roar; make

$$
\text { Became a bull, and bellow'd. }
$$

2. Of persons, to make any violent outery;

iferate; clamor: used in ridicule or contempt. This gentleman . . is accusiomed to rosr and bellow
so terribly loud . . thist he frightens us. Tatler, No. 54. 3. To roar, as the sea in a tempest, or as the wind when viol

$$
\begin{aligned}
& \text { Ever overhead } \\
& \text { Bellow'd the tempest. } \\
& \text { Tennyson, Merlin and Vivien. }
\end{aligned}
$$

II. trans. To utter in a loud deep roice; vociferate: generally with out or forth.

To bellow out "Green pease" under my window. bellow (bel'ō), $n$. [< bellox, v. i. $]$ A roar, as of a bull; a loud outery.

bellower (bel'ō-èr), $n$. One who bellows.

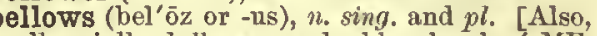
colloquially, bellowses, a double plural; < MTE. belowes, belwes, also belies, a bellows, prop. pl. of belowe, belu, also bely, beli, a bellows, a batig, belg, belig, a bag, a bellows (earlier specifically bloestbelig = Icel.blästrbelgr; cf. D. blaasbalg = Dan. blosebrelg $=\mathrm{Sw}$. blâsbalg $=\mathrm{OHG}$. blasbalg, G. blasebalg, lit. blast-bag: see blast): see belly, of which bellows is a differentiated plural.] An instrument or machine for producing a eurrent of air: principally used for blowing fire, either in private dwellings or in directed. When the airfre. Bellows of great pow. clines, and are operated by gans for producing the current of air by which the pipes and reeds are sounded. It consists essentially of an air-chnniber which can be slternately and a nozle by which the admitted through a valve pening inward. The pre are produced hy the coner closes this valve, and ves the nozle the only Bellows gre made in many different forms, a usual one being the small land-helample of which is shown in the cut, used for promoting the colnbustion of a honse $r$ are called bloming-ma. machinery driven by steam. See blindman. - Hydrostatic bellows. See hyellows-camera (bel' oz-kam" e-rä), $n_{\text {。 }}$ In

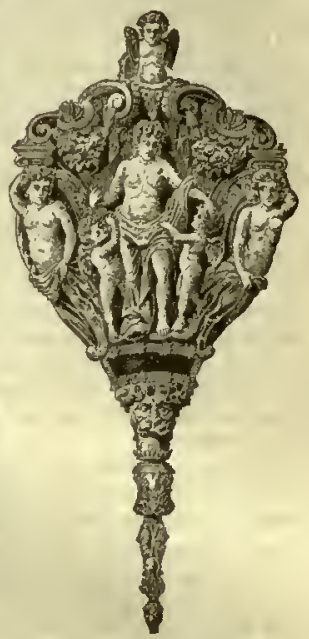

Bellows. - French, 1 th century.
(Fron " L'Art pour Tous.") photog., a form of exbodies are connected, for the sake of lightness and economy of space when the camcra is not in use, by a folding tube or chamber made of leather, rubber, or a similar light-proof material. The tube is made to fold upon itself in the same way as the air-chamber of an accordion or of bellows of olds, each carried entirely around it in a direction per. pendicular to its axis, and having their edges turned alternately inward and outward. The edges of those folds which When the tube is pulled out to its full extent, its walls are taken up hy the folits of its material. In use, the back of a canera of this form can be fixed, by a screw or other device, at any distance from the front or lens end, within the limits of the contracted or expanded tube, that the fo-
cus of the lens or tlie particulnr work in land may require. bellows-fish (bel'óz-fish), n. 1. A local name in England of the trumpet-fish, Centriscus scolopax.-2. A local name of sundry plectognath Thes, of the suborder Gymnodontes and family cetrodontide. - 3. A local name in Rhode Island of the angler, Lophins piscatorius. See cut under angler.

bellows-pump (bel 'õz-pump), n. A sort of atmospheric pump, in which the valve is in the lower side of a bellows-chamber, while the upper side performs the function of the piston. (bel'ōz-sound), $n$. In pathol., the puffing of a small bellows.

bell-pepper (bel"pep"'er), $n$. The fruit of Capsicum grossum, much used for pickling and as a vegetable; Guinea pepper.
bell-polyp (bel'pol bell-pull (bel'pul), $n$. The handle or knob by which a bell attached to a wire or rope is rung, as a door-bell.

bell-pump (bel'pump), n. A bell-shaped pump used in cleaning gas- and service-pipes.

ell-punch (bel'punch), n. A hand-punch conin a ticket, tripslip, etc., in orand call attention to the num ber of fares taken. bell-ringer (bel'ring"ér), $n$. 1. One whose ing a bell, especially a ehurch- which trip-slip or ticket is inserred $\quad C_{\text {, door }}$

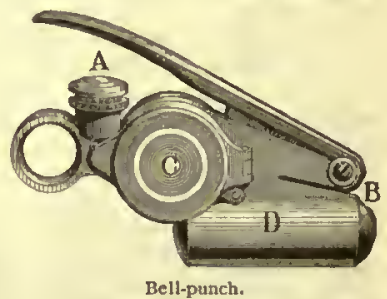
chime of bells; also, a performer with musical hand-bells. - 2. An automatic device upon a locomotive for ringing the bell.-3. Mechanism for ringing chimes by hand, by means of leverhandles which are connected by wires with the clappers or the axes of the bells, or by waterpower, compressed air, or steam operating in various ways to accomplish the same object.

ell-roof (bel'röf), $n$. A roof shaped somewhat like a bell. Its figure is generated by the revolution of an ogee curve about the apex. See out on next page. 
bell-rope

bell-rope (bel'rōp), riuging a bell. -2 A bell-cord.

bell-rose (bel'rōz), n. A namo sometimes used for the daffodil, Nürcissu. I'seudo-Nareissus. skeî) 1 rot ball of iron witl an internally tlureaded bell-sliaped end, for bell-sliaped cnd, for recovering broken or lost tools in

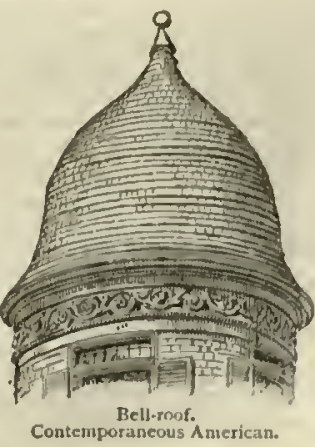

Bell's disease, finch. See disease, finch.

bell-shaped (bol'shipt), $a$. Having the form

of a bell, or of a somowliat doep vessel whose lip turns out and then begins to turn in again. specifieally, in bot., campanulato. See cut under Campanula. - Bell-shaped parabola, a divcrgent Iaraljola liaving neither crimode nor cissp. Some geometrity, regtrict the mame to those divergor parabolas to which from some polnts of the plane six real tangents can be drawn. Pure bell-shaped parabola, one which coustitutes the ciltire real part of a cubic

bell-sound (bel'sound), $n$. In auscultation, a peculiar sound indieative of pneumothorax. It may be obacrved by applying a small plece of metal, as a coin, to the affected part of the cirest, and striking it with a aecond piece. throus the athese sound lis heard

vell-telegraph (bel'tel" $\mathrm{e}$-gråf), $n$

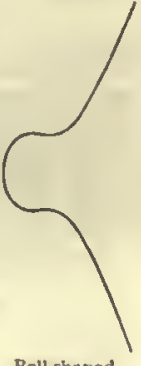

Bell-shaped
Parabola.
1. A telegraphic apparatus in which two dif ferently toned bells take the place of a vibrating needle in giving the signals, - 2. An aununciator; a fire- or burglar-alarm.

bell-tower (bel'ton'er), n. A tower of any

kind built to contain one or more bells. See cuit uniler campanile.

The unsurpassed beli

known and adnired by

all men as the Camps

nile of Giotto, [is] the most aplendid memoria

C. E. Nortom Chureh

[building in Middie

Ages, $p .222$.

bell-trap (bel'trap), $n$. A small stenchtrap, usually fixed over the waste-pipo of a sink or other in et to a draill. The from rising hy an invert ed cup or bell, the lips of which dip into a chan ber flled with water gir-

bell-turret (bel' tur" et), n. $\Lambda$ turret containing a bellchamber, and usually crowned with

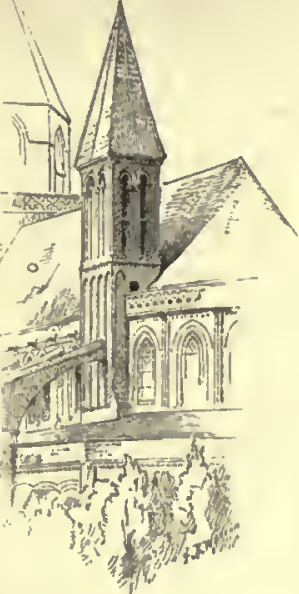

val arehitecturer ormamental feature. In medsc used as a staircase. A bell-turret is distingutshed trom a bell-cote in that the former always appears upon the ground-plan of the buinding to which it belong

Belluæ (bel'ū-ê), n. $p l$. [NL., fem. pl. of L. bellua, prop. belua, a beast, particularly a large beast.] In the Linnean system of classification (1766), the fifth of the six orders of the clas Mammalia, containing boofed quadrupeds with incisors in both jaws, and consisting of the four genera Eques, Hippopotamus, Sus, and Rhiroceros. It is occasionslly used in a modifted senae, cor responding to some extent with the Pachydermata of Cuvier, for the perissodactyl as distinguished from the
artiodactyl ungulates, though the Linnean Belluce included representatives of both these suborders of Ungu-

belluine (bel'ī-in), a. [<L. belluinus, prop. be luinus, < bellua, prop, beluca, a beast ] $1+$ Beastly; pertaining to or characteristic of beasts brutal: as, "animal and belluine life," Bp. At terbury. - 2. In zoöl., of or pertaining to the Belluex.

bellum internecinum (bel'um in-tèr-nē-si' num). [L.: bellum, war; intcrnecinum, interne cine.] A murderous war; a war of mutual cxtermination; war to the death.
517

belly-timber

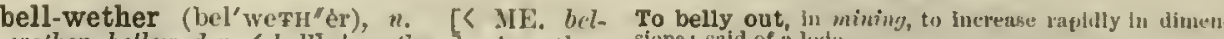
uether, belleweder; < bellI + wether.] A wether belly-ache (bel'i-ük), n. I'ain in the bowels; or shecp which leads

[Aa] a beli-wether [will] fornu the flock's connection liy tinkling aoundis, when they go forth to victual of our great inell o er fittic.

$$
\begin{gathered}
\text { The belly-ache, } \\
\text { Caused liy an Inumiation of pense-porridge }
\end{gathered}
$$

Beat, and b'lo, Juns. Thontas.

Eyron, Don Juan, vi. 48. belly-band (bel'i-band), n. 1. $\Lambda$ band that goes

bell-work (bel'wérk), n. In mining, a system round tle belly; specifieally, a sadlle-girtlı; of working flat ironstone-beds by underground also, a band fastened to the shafts of a vehiele, exeavations in the form of a bell around tho and passing under the belly of the animal drawpits or shafts; also psel on a grand seale in working the salt-mines of 'Transylvania.

bellwort (bel'wert), n. 1. A general name for be plants of the natural order C'ampanulaeca. - 2 In the United States, a common nane for species of tho genus Vvula

belly (bel'i), n.; pl. bellies (-iz). [Early mod. E. and $\mathrm{E}$. dial. also bally, $\langle\mathrm{ML}$. bely, beli, belly, stomach, womb (in early MIL. tho body), also a bellows (sce bellows), < AS. belg, beily, bielg, bylg (also buelig, belig, bylig, with intrusive i) also balge, bylge, a bag, bell, pouch, purse, bull, bellows, a bag of any kind, esp. of skin (= Orries. balga $=\mathrm{D}$. balg, skin, belly, =OHG. balg, MIIG. bale, G. balg, skin, case, bellows, paunch, = Icel. belgr (whenco perhaps böggr, a bag, baggi, a bag, whence perhaps E. bag1) = $\mathrm{Sw}$.bälg=Dan.balg, skin, ease, pod, belly, bellows, = Goth. balgs, a wine-skin, orig. a bag, lows, = Goth. balgs, a wine-skin, orig. a bag, esp. of skin), < belgan (pret. bealg) $(=\mathrm{OHG}$.
belgan), swell, swell up, be inflated. Cf. bells and boln. Doublet (orig. pl.) bellows, q. v. Similar forms are Gael. balg, bolg = Ir. balg, bolg, bag, belly, = W. bol, bola, boly, belly, appar. an old Celtic word, > LL. bulga, bag: see bulge, bouge ${ }^{1}$, budge ${ }^{2}$, etc.] 1 . That part of the human body which oxtends from the breast to the groin, and contains tho bowels; the part of the trunk between the diaphragm and the pelvis, considered as to its front and side walls and its cavity and contents; the abdomen. See cut under ablomen.- 2 . The part of any animal domen in general.

Underneatin the belly of their steeds.

3. The stomach with its adjuncts : as, a hungr belly.

II would fain have flled his belly with the huska,

4. Tho womb. - 5. The fleshy part of a muscle, as distinguished from its tendinous portion: as, the anterior belly of the digastricus muscle.6. The hollow or interior of an inclosed place. Out of the belly of hell cried 1.

7. Tho part of anything which resembles th belly in protuberanco or cavity, as of a bottle, a tool, a sail filled by the wind, a blast-fnrnace, If you were to Fall from aloft and be caught in the belly to to look at all disturbed. Neither hollow nor swelling, called a belly, is made on
the flat part of the brick. C.T. Davis, Bricks, etc., p. 129. 8. In teelnol., the inner, lower, or front surface or edge of anything. (a) In engraving, the lower edge of a graver. (b) In locks, the lower edgo of a masonsy, the batter of a wail. (d) In saddlery, a piece of of a saddle to serve as a point of attachment for valiac atraps. (e) In ship-carp., the inside or concsve side of 8 $(f)$ In carriage-making, the wooden covering of an iroul axle. (g) In archery, the finterior alde of a bow, which is
concave when the bow is bent. See back of a bow, under backl. $(h)$ The widest part of the shaft of a blast-furnace. (i) The niddle or bulging part of a cask, Also called the on the under side of an tron besrer or girder. (l) The violin, wbich is designed to increase its resonance; the volin, wbich is designed to increase its resonance; the
sounding-board of a piane. In instruments of the violin class the bridge rests upon the belly. (m) In mining, a mass of ore swelling out and occupying a large part of the belly (bel'i), v.; pret. and pp. bellied, ppr. bellying. [<belly, n.] I, trans. To fill; swell out. Your breath of full consent bellied his aalls.

Nor were they [the PiIgrim fathers] so wanting to them west wind belly the henieward sail and then tur thre pining to grappie with the terrible Unknown.
Loweil, Introd. to Biglow Pap

II intrans. To swell and become protu nt, like the belly; bulge out.

The bellying canvas atrutted with the gale. Shak. T, and C., ii.

ing it.-2. Nult., a band of cauras placer a sail to strengthen it.

elly-boards (bel'i-börlz), $n . p l$. A kind of fir and pine boards prodnced in Switzerland, used for the sounding-boards of musical instruments.

belly-bound (bel'i-bound), a. Constipated; costive. [Vulgar.]

elly-brace (bel'i-bräs), $n . \quad \Lambda$ cross-brace between the frames of a locomotive, stayed to the

elly-button (bel'i-but" $n$ ), n. The navel. [Collog.]

belly-cheatt (bel'i-chët), $n . \quad[<$ belly + eheret, also spelled ehete, a thing: see eheat ${ }^{2}$.] An apron or covering for the front of the person. Beau. and $F$. [Old slang.]

belly-cheert (bel'i-cliēr), n. Good cheer; meat and drink; food. Elyot, Dict., 1559.

Loaves and belly-cheer. Milton, Def. of II umb. Memonst.

elly-cheert (bel'i-chēr), $v$. $i$. To indulge in belly-cheer; feast; revel. and gulf the simple iaity.

, -cheering $\dagger$ (bel'i-chēr"ing), n. Feasting; Riotous banqueting and belly-cheerin.

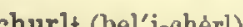
Drayton.

belly-doublett (bel'i-dub"let), n. A doublet made very long in front, and' stuffed or bombasted so as to project somewhat, as in the representation of Punch in English puppetafter. Seo doublet.

Your arms crossed on your thin beliy-doublet.

belly-fretting (bel'i-fret "ing), $n$. 1. Tho chafing of a hor'se's belly with a fore-girth. - 2 .

bellyful (bel'i-fuli), $n$. As much as fills the belly
borms. stomach) or satisfies the appetite; hence, a great abundance; more than enough.

Every jack-slave has his belly-full of flghting, and I must belly-god (bel'i-god), ". One wholine, 11. of his belly, that is, whose great business or pleasure is to gratify his appetite; a glutton; an epicure: as, "Apicius, a farnous belly-gol," Hakewill, Apology, p. 378 .

atly-guy (bel'i-gi), n. Nawt., a tackle or guy, ing support in the middle. See belly-stay. belly-plece (bel'i-pēs), n. 1 1 . The flesh ing the belly; hence, an aproy.-2. The pieco forming the belly of a violin, etc.

belly-pinched (bel'i-pincht), $a$. Pinched witl hunger; starvod: as, "the belly-pinched wolf," belly-pipe (bel'i-pip), n. A flaring nozle for a lly-pipe in a blast-furnace.

(bel'i-rāl), n. 1. In a pianoforte, a rausverse rail forming a portion of the ynain rail with a fin or web descending between the flanges which rest on the ties.

belly-roll (bel' $i$-rōl), $n$. A roller of greater diameter in the middle than at the ends, used for rolling land between ridges or in hollows. slave to his appetite.

Besstly belly-staves, which, ... not once, but continually, day and night, give themselves wholly to bibbing
and banqueting.
Konily against Giuttomy. belly-stay (bel'i-stã), n. Naut., a tackle applied from above half-mast down when the mast requires support, as the belly-guy is applied from below. See belly - guy.

belly-timber (bel'i-tim "bér), $u$. Food; that which supports the belly. [Formerly in serious Dryden, lliad, i. 65. use, but now only humorous.]
Bald-pate friars, w]rose aummum bonnm is in belly-eheer.

Let them assemhle in conaistory, ${ }_{1} \ldots$ and not ... by 
belly-timber

Through degerts vast And regions desolate they pass'd,
Where belly-timber, above ground
Or under, was not to be found.
S, Butier, iindibras, I. i. 331. S. Butier, lindibras, I. i. 331. belly-vengeance (bel'i-ven"jens), $n$. A name given

belly-wash (bel'i-wosh), n. Any kind of drink of poor quality. [Vulgar.]

belly-worm (bel'i-wérm), $n$. A worm that breeds in the belly or stomach. Ray.

belock (bē-lok'), v. t. $\quad[<b e-1+l o c k$; not directly< MiF. belouken, pp. beloken, < AS. belu-
can, pp. belocen, < be- + lüean, lock.] To lock, or fasten as with a lock.

This is the liand which, with a vow'd contrset,
Was fast belock'd in thine. Shak., II. for M., v. I

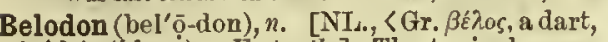
+ ódov́ $($ odovт- $)=\mathbf{E}$. tooth.] The typical genus of crocodiles of the family Belodontida, belonging to the Triassic age, and including the oldest known crocodilians, remains of which occur both in European and American formations. $B$. lepturus, the largest species, attained a length of 10 feet.

belodontid (bel-ọ-don'tid), $x$. [<Belodontida.] A crocodilian reptile of the family Belodontide. A crocodilian reptile of the family Belodontida. Belodontidæ (bel-ō-don'ti-dē), $n$. $p l$. [NL.,
Belodon $(t-)+$-ida.] A family of fossil pre-CreBelodon $(t-)+-i d a$.$] A family of fossil pre-Cre-$
taceous crocodiles, order Crocodilia. They have amphicoelous vertebre, pterygoids separate below, posterior nares bounded by the paiatines, and external nos-
trils nesr the orbits on the upper part of the base of the
snout.

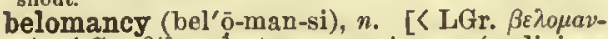

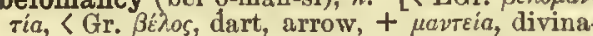
tion.] A kind of divination by means of arrows, practised by the Scythians, Babylonians, Arapractised by the Scythians, Babylenians, Arapointless arrowa were varlously niarked and put into a bag or quiver, and then drawn out st random; the marks or words on the arrow drawn were taken as indications of
what was to hsppen. Thus, Ezek. xxl. 21 (revised version): "For the king of Babylon atood at the partlng of the way, the arrows to and fro."

The arrow-divination or belomancy here mentioned [Ezek, xxi. 21] was done with pointless arrows msrked
and drawo as lots.
Encyc. Brit., XV. 201.

Belone (bel'ō-nē), n. [L., くGr. $\beta \varepsilon \lambda 6 \nu \eta$, any

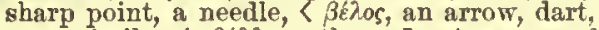
any missile, < $\beta a ́ \lambda \lambda \varepsilon \iota v$, throw.] A genus of fishes remarkable for their slender and clongated jaws, representing in some systems a beresocida; the garfishes.

belong (bệ-lông'), v. i. [<ME. belongen ( $=\mathrm{D}$ belangen, concern, = OHG. belangēn, MHG. G. belangen, reach to, attain, concern, affect; associated with the adj., early ME. belong (= OS. bilang = MD. belangh), equiv. to AS. gelang, ME. ylong, ilong, along, long, mod. E. along ${ }^{2}$ long 3 , belonging, along), < be-1 + lougen, belong (there is no AS. "belangian or *belang): see along ${ }^{2}, l_{0 n g^{2}}, l_{o n g}{ }^{3}$.] 1. To go along with anything, or accompany it as an adjunct or at tribute; pertain; appertain; be a property (of); be in the power or at the dispesal (of). [In all English by unto.]

ller hap was to Ilght on a part of the fleld belongin
Ruth ii. And David gaid unto him, To whom belongest thou?

To the Lord our God belong mercles and corgivenesses.
Dan. ix. Ile . . . careth for the things that belong to the Lord.
1 Cor. vii. 32 Most of the males subject to him [the father of the
(amily] are really his chlldren, but, even if they hsve not aprung from him, they are subject to him, they form part be used) beiong to him. Maine, Eary. Law and Custom, p. 8\%. 2. Te be the concern or proper business (of); appertain (to):
prove the title.

$$
\begin{gathered}
\text { To you it doth belong } \\
\text { Yourself to pardon of self-doing crime. } \\
\text { Shak., Son }
\end{gathered}
$$

3. To be appendant (to); be connected (with) be a special relation (to): as, a beam or rafter belongs to such a frame, or to such a place in the building.

He took them, and went aside privately into a desert

4. Te be suitable; be dne.

Strong meat belongeth to them that are of full age.

Hearing . . thy besuty sounded,

Miyself sm moval to woo thee lor $\mathrm{my}$,

Shak., T. of the $S$, ii.

518

below

Sir, monuments and eulogy beiong to the dead.
D. Webster, Speech, Bunker 1111.

5. To liave a settled residence (in); be domiiled (in); specifically, have a legal residence, settlement, or inhabitancy (in), whether by ble upon the parish or town: said of a pau per, or one likely to become such.

Bastards also are settled in the parishes to whlch the
Biackstone, Com., I. xvi. 6. To be a native (of); have original residence (in).

There is no other country in the world to whlich the 7. To have its (or one's) proper place; be resident: as, this book belongs on the top shelf dent: as, this book belongs on the top shelf;
belong here (in this house or town). [U. S.]

belonging (bẹ-lông'ing), n. [<belong $+-i n g{ }^{1}$. That which belongs to one: used generally, if net always, in the plural. (a) Qualities; endowments; facuities.

\section{Thyself and thy belongings
Are not thine own so proper, as to waste}

Thyself upon thy virtues, they on thee.

(b) Property ; possessions : as, "I carry all my belonging with ne," Trollope. (c) Members of one's fanil
hold ; relations or dependsnts. [Humorons.]

When Lady Kew sald, "sic volo, sic jubeo," I promise you they did her blddiogs, to ask her reasns.

1 have been trouble enough to my belongings in my day.
Dickens, Bleak House, II. 103

Cornhill Mag.

belonid (bel'ö-nid), n. [< Belonida. ] A fish of the family Belonida.

elonidæ (be-lon'i-dē), n. pl. [NL., < Belone $\left.-i d x_{0}\right]$ A family of fishes, represcnted by the genus Belone, containing Synentognathi with an

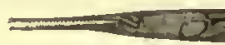

Stlver Garfit (T Tlosuris ion

elongate stout body, oblong wide head flattened above and terminating in long stout jaws, the upper of which is composed of th coalesced intermaxillaries, supramaxillaries, and facial bones, while the lower has an additional bone belind. The vertebra have zygapophyses and the bones are generally green. The speciea are calle
garpikes, garflsh, or gars. The English apecies is a nien. ber of the geons Belone, B. vulgaris, but those of the
United States belong to the genus Tylosurus, of which United States belong to the genus $T$ yiosurus, of which
there are nine species, a $T$. marinus, T. crassus, $T$, exilis, longirostris, etc.

belonite (bel'ō-nit), n. [<Gr. $\beta \varepsilon \lambda .6 v \eta$, any sharp of minute imperfect erystals, usually acicular in form, sometimes dendritic, observed in glassy volcanic rocks. The term is now limited belonoid (bel 'ó-noid), a. [< Gr. Berovoec needle-shaped, $<\beta \varepsilon \lambda \sigma \nu \eta$, a needle (see Belone) + cidos, form.] Resembling a bodkin or

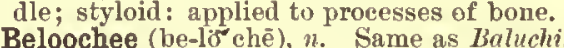

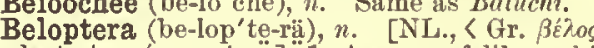
dart, + $\pi \tau \varepsilon \rho \varepsilon^{\prime}$, wing.] " 1. A genus of dibranch ate cephalopods, with a wing-like expansion of belopteron.

belopterid (bc-lop'te-rid), n. [< Belopteride. A cephalopod of the family Belopteride.

Belopteridæ (bel-op-ter'i-dē), n. pl. [NL., Beloptera + -ida.] A family of dibranchiat cephalopods, typified by the genus Beloptera closely related to the Belemnitida, and by som authors combined in the same family. The species are extinet.

belopteron (be-lop'te-ron), n.; pl. beloptera $(-\mathrm{rä}) . \quad\left[\mathrm{NL} .,<\mathrm{Gr}\right.$. $\beta \varepsilon \hat{\lambda}_{\mathrm{os}}$, a dart (see Belone)

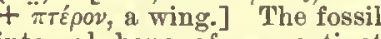
cephalepod, somewhat like a belemnite, but blunter and having a wing-like prejection on each side.

belord (bệ-lôrd'), v.t. [ $[<b e-1$ + lord.] 1. 'To apply the title Lord to; address by the phrase "my lord."-2. To demineer over. [Rare.]

Belostoma (be-los'tẹ-mä), $n$.

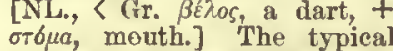
genus of heteropterous insects of the family Belostomida, for-

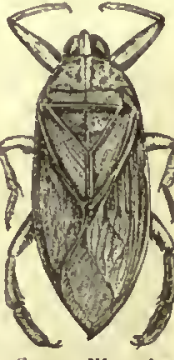

(Belastoma gaterbug merly referred to the Nepide. The largeat qpecies is $B$. grandis of South Anrerica, the great water.bug, atwhabit the Atiantic States of Sorth America. A Chinese andian apecies is $B$. indica.

Belostomidæ (bel-os-tom'i-dē), n. pl. [NL., < Belostoma + -ide. ] A family of beteropterous insects, containing the largest living members of the order IIeteroptera. They are large, broad, flat-bodied aquatic insects, with powerful swimming-Jegs and curved fore tilise, able to prey upon fisl and other aquatic animals of considerable gize. There are about 12 genera, generally distributed in teniperate and torrid re.
gions. The hesd is mucli narrower than the jrothorax, with prominent eyes, short 3 -jointed rostrum, and short al; the scutellum ls large and triangular; the elytra are ends in a pair of ligulate extensile appendages

belout $($ bẹ-lout' $), v . t . \quad\left[<b e_{-1}+\right.$ lout. $]$ To call (a person) a "lout"; address or speak of with contemptuous language.

Sieur Gaulard, when he heard a gentleman report that supper they issd not only good cheer but also savolny belowted his cook as an ignorant scnilion, thst never dressed ... him either epigrsms or anagranis.

beloret (bẹ̄-luv'), $v$. [ ME. beloren, biluren (= D. believes, please, gratify, $=\mathrm{G}$. belieben, like, luven: see be-1 and love.] I. intrans. T'o please. [Farly Middle English.]

II trans. 1. Te be pleased with; like.-2

II. trans. 1. To be pleased with; like.-2.
To love. [Little used except in the past partieiple.]

If beauty were a gtring of gilke, I would wear it ahont iNodroephe, French and Eng. Grammar, p. 322. beloved (bē-luv'ed or -luvd'), p. a. and $n$. [s 1lE. beloved, beluved, biluved, pp.: see love.] I. 1. a. Loved; greatly loved; dear to the heart. This lo my beloved Son. Jiat. ili. 17. Beloved of sll, and dying ne'er forgat. Iat. ili. 17.

II. n. One who is greatly loved; one very dear.

He giveth his belored aleep. Ps. cxxvit. 2. below (bẹ--Iō'), adv. and prep. [< ME. bilooghe (found only once), adv., < bi, be, prep., by, + older form was alow; ef. afore, before, ahind, behind.] I. adv. 1. In or to a lower place or level; beneath; downward from a higher point: as, look below; in the valley below.

Hear the rattling thunder tar belove. IVordszorth.

2 . On the earth, as opposed to in the heavens. The blessed spirits abnve rejoice at anr happincas below.
Sir T. Browne, Chriat. Mor., ili. 5.

3. In hell, or the regions of the dead: as, "the realms below," Dryden. -4. On a lower floor; downstairs.

Sir Anthony Absolute ls below, inquiring for the captain. Hence - 5. Naut., off duty: as, the watch below, in contradistinction to the wateh on deck. - 6 . At a later point in a page or writing; further on in the same part or division: as, particulars are given below; see the statistics below.-7. Lower down in a course or direction, as toward the mouth of a river or harbor, etc.: as, the ressel has just arrived from below. -8 . In a lower rank or grade: as, at the trial below, or in the court below.

II. prep. 1. Under in place; beneath; not o high as: as, below the knee.

The .... dust belono thy feet. Shak. Lear, v. 3.

All the abhorred birth belono crisp heaven

All therean Hyperion's quickening fire doth shine.
Shak., T. of A., iv, 3.

2. Lower than in position or direction; lower down: as, he lives a little betow our house, that is, a little lower down the street, read, hill, ete. The castle was now taken; hut the town belono it was in 3. Lower than in degree, amount, weight, price, value, etc. - 4. Later in time than. [Rare.] The more eminent acholars which England prodnced before and even below the twellth century, were educated in

5. Inferior in rank, excellence, or dignity: as, "one degree below kings," Addison, Remarks on Italy, Venice.-6. Too low to be worthy of ; inferior to.

They beheld, with a just loathing and diadain, ... how below all history the perzons and their actions were. The works of Petrarch were below both hls genius and
his eelebrlty. Below the salt. See salt. $=$ Syn. Betoto, Under, Beneath. 
below

pendicular line of ; beneath, close under: as, the sum sinks betow the horizon a a thing ls under a chair or tree, be benealh: as, "under whose wlugs," Rutin il. 12. Compare the oid
monnt."

[A sail] that sinks with ali we love belon the verge.

Whereon a hundred stately beeches grew,

And here and there great fiolles rroder them.

Beneath the milk-white thorn that seents the evinlug gale.
biterns, Cottar's Sat. Sight.

Bern, Cottars lit,

belsiret (bel'sir), n. [< ME. belsire, lit, good beldam, q. v.), + sive. Cf. beausire.] 1. 1 grandfather: correlative to beldam, grandmother.-2. An ancestor. Drayton.

belswagger (bel'swag"ir), $n$. [Perhaps for belly-swagger, a form given by Ash, < belly + swag, sway.] $A$ bully; a pimp.

belt (belt), n. [< MlH. belt, < AS. belt $=$ OHG. Ir. and Gael. balt, a belt, a border; prob. L. balteus, a belt.] 1. $A$ broad flat stri or strap of leatlier or other flexible inate rial, used to encirele the waist; a girdle; cincture; zone band. Ordinarily it is woln buckled or hooke hilages it has heen s com noon article of appurel, both to kcep the gar. ments in place and to purse, a writiug-case, of the like: It may be male of any materlal. The mill (a)es was sometine midale posed of small plates of juetal held to eacin other by rings, was attached to ing to the fashion of the atter, was worn mor regting below the hips upon the skirt of plate. armor. Sometimcs the sword was not secured then rather a mark of rank socessary part of the dress, (See part of the the

baldic The byond bands supporting the bayonetsheathe gud cartridge-Lox, worn by intantiy in Europe during the century ending sbout 1850 , werc slso called belts or cros

The shining belt with gold inlald.

2. Any broad band or strip of leather or other flexible material, desigued to pass round any thing, with its ends joined. (a) In mach., s fiexible cord or band passing about the periphery of wheels, irums or pulleys, for the purpose of transmitting motion from india-rubber and gutta-percha are occasionally used; also hempen cord, wire rope, and cords for small pulieys. S belting. (b) In surg., a bandage or band used by surgeon 3. Any broad band or stripe or continuou broad line distinguished in color or otherwis from adjacent objects, and encircling or ap pearing to encirele something. Specificslly - $(a)$ In astron., one of certain girdles or rings which surroun earth's surface extending over or along a surface or thegion, snd distinguished from it by difference of color, ss pect, etc.; a tract or district long in proportion to its insence of some marked physical or other peculiarity or phenomenon: ns, the ofl belt; s belt of vegetation; the

Pinks were gleamlng in every direction through the You see green trecs rising above the belt of sand.

The proposed Nicarairus Cansl has proved to lie the earthquske belt. Sci. Amer., N, S, IV, G4. The manufacturers of this favored region have decidedly the advantage of their less fortnnate competitors aws
from the gas belt. (c) In masony, a hand or string.course.

4. That which restrains or confines like a girdle.

IIe cannot buckle his distemper'd cause
Withln the belt of rule. Shak. Mlacbeth, v. 5. A diseaso ameng sheep.-Angular chainbelt. See anfular.-Belt of Orion. See Orion and ellwand. - Black beit. See black. - Chain-belt, a chain forming a band or lielt for conveying or transmitting power of various materials to form s round belt. - Crossed belt

519

belvedered

belt comecting two pulleys and crossed between them ers are piaced between the belt Endless belt. Sce endless.-Hybelt alt having Quarter-turn belt, a belt havin

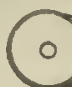
lilnced at rigit angles to esch other; a quartering-belt.--
To bold the belt, to hold the chsmplonship in pugillsus lt (bolt)

belt; specifically, to invest 1. To gird with a , spocically, to invest with a distinetive or secure with a belt; one. -2 . To fasten sword -3. To encircle surround as if witl a b belt or girule.

Belted with young children.

De Quincey. The general college of clvilization that now belted the Come from the wools that belt the grsy hill-aldc.
.

4. To strike with or as with a belt; strap; flog. [Colloq.]

Beltane (bol'tạnn), n. [Also writtell Beltein and Belten; < Gaol. Bealltainn, Beiltcine = Ir. Bealteine, Bealltaine, OIr. Belltaine, Beltene; 118ually explained as Beal's fire, < "Beal, "IBial, an alleged Celtic deity (by somo writers patriotically identified with the Oriental Belus or Baal), + teine, fire. But the origin is quite unknown. ] 1. The first day of May (old style); old Mayday, one of the four quarter-days (the others being Lammas, Hallow-mass, and Candlemas) anciently observed in Scotland.-2. An ancient Celtic festival or anniversary formerly observed on Beltane or May-day in Scotland, and in Ireland on June 21st. Bonfires were kindled on the hills, sll domestic fires haviug been previously extingnished, only to be rellghted from the elmbers of the Beltane thes. This custon is supposed to derive its origin trom the worship of the sun, or fire in genersi, which was formerly fil vogue
smong the Celts as well as among many other hesthen smong the Celts as well as among many other hesthe
nations. The practice still survives in some remote loce nations. The practice stlil survives in
itles. [Sometimes without a capitsi.]

But o'er lifs hills, on festal day,

belt-clamp (belt'klamp), $n$. An apparatus for bringing together and holding in position the ends of belts while they are being cemented, laced, or coupled.

belt-clasp (belt'klásp , $n$. A clasp for a belt; specifically, in maeh., a device for connecting the ends of belting so as to make a continuous band.

belt-coupling (belt'kup'ling), n. In mach., a devico for connecting the ends of a belt. It is them together with thongs of leather.

belt-cutter (belt'kut "er), $n$. A tool or machine for slitting tanned hides into strips for belting. belted (bel'ted), p. a. [< belt $\left.+-e d^{2}.\right] 1$ Wearing a belt; specifically, wearing a dis tinctive belt, as a knight.

$$
\begin{aligned}
& \text { A prince can niak a belted knight, } \\
& \text { A narquis, duke, snd a' that. }
\end{aligned}
$$

Burns, For A' That. The melodramatic attitude of 8 general, belled snd
plumed, with \& glittering staff of officers at lis orders. De Quincey, Essenes, 11
With puff d cheek the belted hunter blew. Tenunter blew.

2. Marked or adorned with a band or circle as, a belted stalk; the belted kingfisher.-3. Worn in the belt, or hanging from the belt:
said espeeially of a sword the sbeath of which is secured permanently to the belt.

He was dressed in his pontificsl robes, with a belted Belted plaid the plaid worn Belted plaid, the plaid worn by the Highlanders of Scot to the body by a beit : $\mathrm{ss}$ s " wl" belted plaids and glittering Beltein, Belten, $n$. See Beliane.

belting (bel'ting), $n$. [< belt + -ing. $]$ Belts collectively or in general; the material of which belts are made. See belt.-Angular belting. See fingular.- Reund belting, belting, nsually nisde from navian belting, s cotton cloth woven solld and treated with Storkholum tar. E. II. Knight.

belt-lacing (belt'lä'sing), $n$. Leather thong for lacing together the ends of a machine-belt to mako it continuous.

列

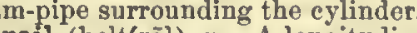

guard of (ongitudinal strip or car, beneath the windows. - Belt-rall cap a strip of wood fastened to the top of a belt-rail and forming the belt-saw (belt'sâ), $n$. Same as band-saic. belt-screw (belt'skrö), $n$. A donble clampingserew with broad, flat heads, used for joining the ends of a belt.

belt-shifter (bclt'shif"tér), n. A contrivance for shifting a machine-belt from one pulley to another, in order to stop or set in nution ecrtain parts of the machine, or to change the motion. L: II. Knight.

belt-shipper (belt'ship"ér), n. A belt-shifter. elt-speeder (belt'spē"dér), n. A contrivance in a macline for transmitting varying rates of motion by means of a belt. It is mucil used in spluning-1uachincs to vary the rate of rotation of the inclependent pulley resting on a maehine-belt, and tending by its weight to keep tho beit stretched, thus securing better adliesion.

belt-tool (belt'tol), $n$. A combined cutter, punch, awl, and nippers, used in making belts. beluga (be-lö'gä), n. [< Russ, bicluga, < bieluit, white; of. Lith. balti, be white.] 1. The large white sturgeon, Acipenser lukso, from the roe of which, sometimes wcighing 800 pounds, caviar or botarge is prepared. The fish is fronı 12 to 15 feet in length, weighing in some crses 2,000 pounds or more. . [eap.] [NL] A generie name of whales: a synonym of Delphinapterns. The only apecies found in northern seas is $b$. arctica, leucan, or whate or whicefah it is from 12 to 18 foet fit length The tail is divided into two lobes, lying horizoutslingth. there is no dorsal fin. In swimning, the animsl bends its tall under its boily like s lobster, sud thrusts itself slons with the rapidity of an arrow. It is foumd in the arctic Belus (bé'lus), n. [L., 〈Gr. Bì?.os, the traditional founder of Babylon; the Greek form of Baal, q. v.] 1. The chief deity of the Babylonians and Assyrians; Baal (which seo). Also Bel.-2. [NL.] A genus of weevils, of the family Curculionide.

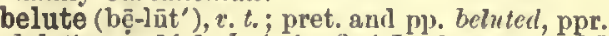
beluting. $\left[<b e-1+\right.$ lute $^{2},<\mathrm{L}$. lutum, mud. $]$ 1. To cover or bespatter with mud. [Rare.] Never was a Dr. Slop so beluted. . To coat with lute or cement of any kind lvedere (bel-ve-dēr', It. pron. bel-ve-dā're), it. also less correctly belvidere, (It. belveclere, codere, a view, <L. viderc, see: see tision, viere.] 1. In Italian aveh., an upper story of a building, or a portion of such a story, open to the

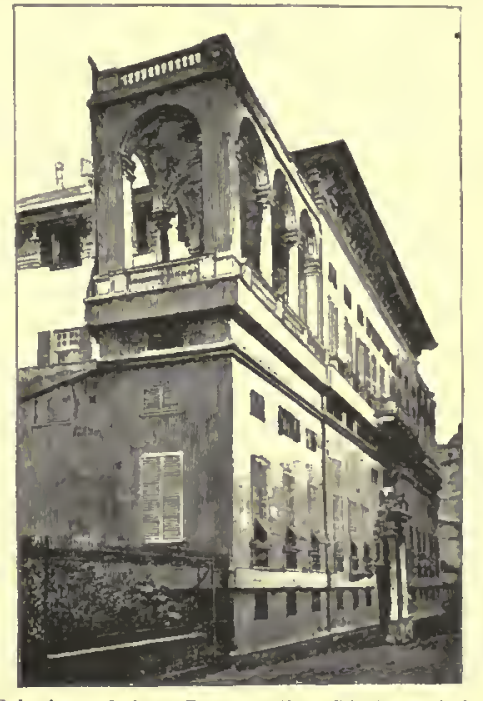

air, at least on one side, and frequently on all, for the purpose of affording a view of the counry and providing a place for enjoying the cool

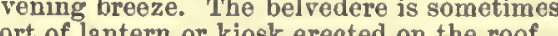
Here and there among the low rools a lofty one with cound-topped dormer windows and a breezy belvidere yond the town. G. W. Cable, The Groudissinjes, D. 220 2. In France, a summer-house on an eminence in a park or garden.

They build their palaces and belredere Fiebster, Devil's Law.Csse, 1,1

belvedered (bel-ve-dērd'), $a$. Provided with a bolvedere.

Gardencd snd belvedered villias.

G. W. Cable, The Grandlssimes, p. I4. 
Belvoisia

Belvoisia (bel-voi'si-ï), $n_{\text {. [NL, named after }}$ 11. Beaurois, a French seientist.] A genus of

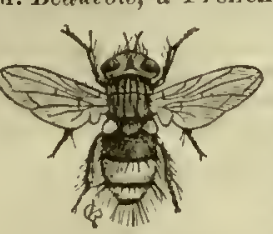
family Tachinide, eomprising numerous genera, parasitic on otlier insects. They are most difficult to distinguish on secount of the uniformity of their somber colors and the similarity of their structural
characters. The only species

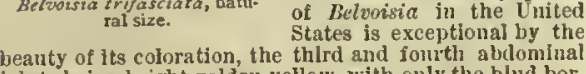
beanty of its coloration, the thlrd and fourth abilominal
joints being bright golden yellow, with ouly the hlud borders biack. It has been described as $B$. trifarciata (F'a.
bricins), and is parasitic on the green-striped maple-worn, Anisota rubicunda, and allied specie

belyet, $v$. $t$. An old spelling of beliel.

belyvet, $a d v$. An old spelling of belive 1

Belzebúb (bel'zê--bub), n. See Bcelzebub.

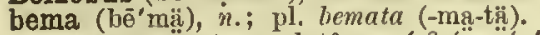

$\beta \bar{j}, u \alpha$, a step, a stage, platform, < $\beta$ aíve $v$ $\left(V^{*} \beta a\right)$, go, = E. eome, q. ४.] 1. In Gr. antiq., a stage or kind of pulpit on which speakers stood when addressing an assembly.

If a man conld be admitted as an orator, as a regular demagogus, from the popular bema, or hustings, in that
case le obtained a hcaring.
De Quincey, Style, iv.

De Quincey, Style, iv. 2. In the Gr. Church, the sanctuary or chan$\mathrm{cel}$; the inclosed space surrounding the altar. It is the part of an Orientai church furthest irom the front level of the nave. The holy tabie (the altar) gtands in Its center, aud behlnd this, near or skirting the rear wall of the

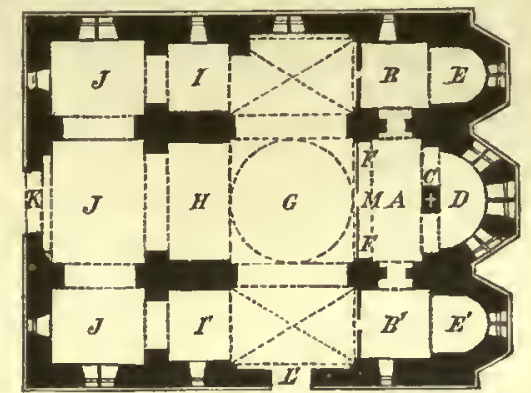

Bema. - Typical plan of Byzantine Church, $\mathrm{St}$. Theodore, Athens
$A D$, bema ; $B E$ and $B^{\prime} E^{\prime}$, parabemata $\left(B E\right.$, prothesis; $B^{\prime}$

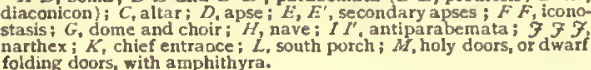

An architectural screen (iconostasis) with a curtain (amph-
thyra) at its doors, or, as was the case especially in ear times, a curtain only, separates the bema from the body bemata, called respectively the prothesis and the diacon con. These regularly communicate with the lema, and
in poor churches often have little more than an indication in poor churches often have little more than an indication
of geparation from It. Rubrically they are often counted
as part of the bema.

The Jewish type, which, if anywhere, prevails in the
Eastern Chnreh, requires a fourfold divislon: the lloly of Holies answering to the bema, the lloly r'lace to the Gentiles to the narthe

J. Ar. Neale, Eastern Churel, i. 17 .

3. A step; a rough measure of length employed were paced off, and not merely estimated by shouting. It was considered to be 21 feet, whlch for this ghouting. It was considered to be $2 \mathrm{l}$ feet, whlch for this
purpose are practically identical with English feet. In a it beeame as exact measure 2 2 feet; but these feet were of the Babylonian cubit, 8o that the benua was 0.888 meter, bemadt (bē-mad' $), v, t$. [< be-i $-1+$ mad. $]$ To bemad $\dagger$ (bē-

The patriarch herein did bewitch and bemad Godfrey.

bemangle (bẹ--mang'gl), v. t. $[<b e-1+$ mangle 1 . 'To mangle; tear asunder. Beoumont. [Rare. bemartyr (bẹ-mär'tẻr), v. t. [<bc-1 + martyr.] To put to death as a martyr. Fuller.

bemask (bẹ-másk'), v. $t$. [i be-1 + mask. $] \mathrm{T}$ mask; conceal. Shelton.

bemata, $n$. Plural of bema.

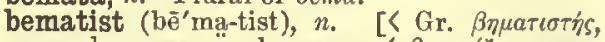
one who measures by paces, $<\beta \eta \mu a \tau i \zeta \varepsilon \iota \nu$, measure by paces, < $\beta \tilde{\eta} \mu a(\tau-)$, a step, pace.] An Great and the Ptolemies. See bema, 3.

bematter (bē-mat'èr), v. $t$. [<be.1+matter.] To smear or cover with matter. Swift.

bemaul (bẹ-mâl'), v.t. [<be-1 + maul. $]$ To maul or beat severely. Sterne.

bemaze (bē-māz'), v, $t$. [ME. bemasen ; < be-1

+ maze.] To bewilder. See maze.
520

ben

With intellects bemaz'd in endless doulht. Couper, The Task,

Bembecidæ (bem-bes'i-dē), n. pl. [NL., prop. Bembicidce, < Rcmbex, prop. Bembix (Bembic-) + -ida.] A family of solitary, aculeate or stingwasps or bces, and, along with the Sphegide and other kindred families, known as sandwasps. The female excavates cclls in the sand, in which she deposits, together with her eggs, various larvac or perfect insects stumg into insensibility, as aupport for lee progeny when latched. They are very active, fond of the jlectar of flowers, inhabitants of warm countries, and delight in sunshine. Some species emit an odor like that
of roses. Bembex is the typical genus. See cut under Bembex. Also Bembicido

Bembecinæ (bem-be-si'nē), n.pl. [NL., <BemBembecinæ (bem-be-si'nē), n. pl. [NL., $\langle$ Bem-
bex (Bembec-) + -ince.] A subfamily of diggerwasps, of the family Sphegida, typified by the genus Bembex, in which the body is large and long, the bead large, the labrum long, triangular, and exserted, and the legs are short.

Bembex (bem'beks), n. [NL., prop. Bembix, < Gr. $\beta \dot{\varepsilon} \mu \beta \iota_{\zeta}^{\xi}(\beta \varepsilon \mu \beta \iota \kappa-)$, a pool, a buzzing insect prob. imitative.] Tho typical genus of diggerwasps of tho subfamily
Bembecince. B. rostrata and the American $B$ fusciata (Fabricius) are examples. Also Bembix. dē), $n_{. p l} l$. Same as Bem-

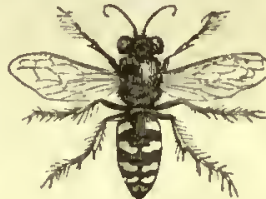

Digger.wasp (Bembex fasc
Bembididææ (bem-bi-díi-dē), n. $p l$. [NL.,

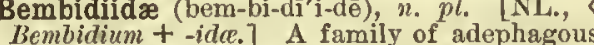
bectles, typified by the genus Bembidium: now bectles, typified by the gen

Bembidium (bem-bid'i-um), n. [NL., < Bembex + dim. -idium.] A genus of minute predatory caraboid beetles, sometimes forming the type of a family Bembidiide, sometimes plaeed in Carabida. The species are characterized by an ovate body and large eyes. Also Bembidion.

Bembix (bem'biks), n. [NL.] 1. Same as Bembex.-2. A genus of gastropods. Watson, 1876

Bembridge beds. See bed 1 .

bemet, $n_{0}$ [ME., < $\mathrm{AS}$. bēme, bȳme, a trumpet; ble, bomb1, Bembex, ete.] A trumpet. Of brasa they broughten bemes.
Chaucer, Nun's Prlest'a Tale, 1. 577.

bemet, v. [< ME. bemen, < AS. bȳmian, < bȳme a trumpet: see beme, n.] I. intrans. To sound II trans. To summon with a trumpet.

bemean ${ }^{1}, v . t$. [Early mod. E. bemene, < ME bemenen $(=\mathrm{OHG}$. bimeinan, MHG. bemeinen), mean; < be-1 + mean 1.$]$ To mean; signify; inform.

The croune of thorne that garte me blede,
It be-menes my diguite. York Plays, n. 424 bemean ${ }^{2}\left(\mathrm{bẹ}-\mathrm{mēn}^{\prime}\right), v . t$. [<be-1 $+\operatorname{mean}^{2}$.] To make mear; debase; lower: as, to bemean one's self by low associations; to bemean bu-
man nature. [Demean is commonly but incorrectly used in this sense. See demean ${ }^{2}$.]

It is a pity that men ahould ... bemean themselves ly
defending themselves acalnst charges of which the grand jury of their own heart finds them innocent.

1 felt quite ashamed that a pal of nine should have 1 felt quite ashamed that a pal of mine sh
ao bemeaned hinself for a few ounces of silver.
Jamer Payn, Can

bemercył (bē-mèr'si), v. $t . \quad[<b e-1+$ mercy. $]$ To treat with mercy.

bemetet (bē-mêt'), v. t. [ME. wanting: < AS. bemetan, measure, compare, consider ; < be-1 + mete.] To measure. Shak. [Rare.]

emingle (bē-ming'gl), $v . t . \quad[<b e-1+$ mingle.]
To mingle; mix. Mir. for Hags. [Rare.] bemire (bề-min'), $v$. t. [< be-1 + mire.] 1 . To soil or befoul with mire, as in passing through muddy or miry places.

Ifis clothes were sonewhat torn and much bemired.

2. [Chiefly in the passive.] To sink or stick 2. [Chiefly in the passive.] To sink
in the mire; be or become bogged.

Bemired and benighted in the bog.
Burke, A Regicide Peace. Bemired in the deeply rutted roadk.
The Century, $\mathrm{XXV}, 377$. bemirement (bē-mīr'ment), n. [ [ bemive +
-ment.] The state of being defiled with mud. [Rare.]

bemist (bē-mist'), v. t. $[<b e-1+$ mist. $]$ To cover or involve in or as in mist. tiny, through long years?
Ifow cau that jndge walk right that is bemirted in his
Felthan, Hesolves, ii. 4 .

bemitered, bemitred (bẹ̄-mĩ'têrd), $a$. [<be-1 miter $+-e l^{2}$. $\quad$ Crowned with or wearing a miter. Carlyle.

emoan (bệ-mōn'), $v$. t. $\quad$ [ ME. (with change of vowel; ef. moan) bemenen, bimenen, < AS. bemiēnan, bemoan, < be + mēenan, moan: sec be-1 and moan.] 1. To lament; bewail; express sorrow for: as, to bemoan the loss of a son.-2. Reflexively, to bewail one's lot.

People gricve and bewoan themselves, but it is not half 3t. To pity; feel or express sympathy with or pity for.

Bastards, ... if proving eminent. are much bemoaned, ecause merely pasaive in the blemish of their birth. Fullev. bemoanable (bē-mō'na-bl), a. [< bemoan + able.] Capable or worthy of being lamented. Sherwood.

bemoaner (bê-1nō'nèr), $n$. One who bemoans. bemock (bè-mok') v. $t$. [< be-1 + mock.] 1 . To mock repeatedly; flout.

Ifave we not seen him disappointed, bemocked of Des.

Carlyle, Sartor Reaartus, p. 111. 2. To cause to appear inock or unreal; excel or surpass, as the genuine surpasses the counterfeit.

\section{Ifer beams bemocked the sultry main} Colevidge, Anc. Mariner, iv.

A langh whicl In the woodland rang

Bemocking April's gladdest bird. Whittier, Bridal of Pennacook, jii.

bemoilt (bē-moil'), v. t. $\quad\left[\left\langle b e-1+\right.\right.$ moill $\left.{ }^{\prime}\right]$ To bedraggle; bemire; soil or encumber with mire and dirt.

Thou ghouldst have heard ... how she was bemoited.

bemoisten (bẹ̄-moi'sn), v. t. [<be-1+moisten.]

To moisten; wet.

bemol (bä'mol), $u$. [< F. bémol, <ML. $B$ molle, soft B.] In music, B flat, a half step below B natural: the general term in French for a flat on any note.

bemonster (bē-mon'stèr), v.t. $\quad[<b e-1+$ montcr.] To make monstrous. [Rare.]

Thou changed and gelt-cover'd thing, for shame,
Be-monoter not thy feature.

bemoralize (bē-mor'al-īz), $v * t$. $[<b e-1+$ moralize.] To apply to a moral purpose. Eclectic Rev. [Rare.]

bemourn (bẹ--mōrn'), v. t. [< ME. bemornen, bemurnen, <AS. bemurnan (= OS. bemornian), [be- + murnan, moum: see be-1 and mourn.] To weep or mourn ovel: as, "women that . . bemourned him," Wyelif, Luke xxiii. 27. Rare.

muddle (bē-mud'l), v. t. $[<b e-1+$ muddle. $]$ To confuse; stupefy.

The whole snbject of the statistice of lianperism is in a
hopelessly bemuldled condition. N. A. Rev., CXX. 320. bemuffle (bẹ--rnuf'l), v. t. [<be-1 +muffle. $]$ To wrap up as with a muffler.

Bemufted with the externals of religion. bemuse (bê-mūz', $t . t$. [<be-1 + muse $2 ;$ in sense perhaps affeeted by bemaze. Cf. amuse.] To put into a muse or reverie; confuse ; muddle; stupefy. We almost despair of convineing a Cabinet bemused with
the notion that danger cau only come from France.

The archdeacon must liave been slightly bemused when he defined aristarchy as we have seen.
F. II all, Mlod. Eng., p. 143, note. benl (ben), prep. and $a d v$. ए ME. ben, bene, var, of bin, binne, < AS. binnan, within: see bin2.] In, into, or toward the inner apartment of a house; in or into the parlor. See ben $1, n$. [Prov. Eng. and Seoteh.]

Wi' kindly welcome Jenny brings him ben. Ben the house, into the inner apartment, or into the

That she miglit run ben the house.

Scott, Guy Mannering, I. xxili.

To bo far ben with one, to be on terms of intimacy or familiarity with one; be in great honor with one.-To bring far ben, to treat with great respect and hospitality. ment of a house; the parlor or "room" of a dwelling consisting of a but or outer room, used as a kitehen, and a ben or inner room, used as a parlor or chamber, access to the ben being originally through the but or kitehen. 
ben

Sometimes from the hen another apartment, called the far-ben, is reaclied. The terns but and ben are now fre-

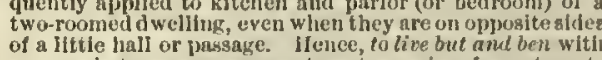
any one is to occupy an apartment or geries of apartments on tive opposite

ben $^{2}+$, bene ${ }^{7} \nmid, n$. [ME., also bene, $<$ AS. ben $n$, prayer, = Ieel. been, a prayer, parallel with bön, SE. boon 1 , q. v.] A prayer: a petition.

ben ${ }^{3}+$. Obsolete or dialeetat form of been 7 .

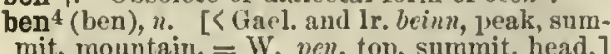
A mountain-peak: a word oecurring chiefly the names of many of the highest summits of the mountain-ranges which traverso Scotland north of the friths of Clyde and liorth: as, Ben Nevis, Ben Mae-Dhui, Ben Lawers, ete. Sweet was the red-hloming lieather
And tho rtver that flowed from the Ben ben (bon), n. [Harry mod, 2. also benn, < Ar. ban, tho troo whiel produces the ben-nut: see
ben-nut.] The ben-nut, properly the ben-nut

ben $6, n$. See behen.

benamet, $v$. $t$. ; pret, and pp. bencemed, benempt, ppr. benaming. [<ME, benemnen, < AS. benempan $(=\mathrm{G}$. benenen $=\mathrm{Sw}$, benämna $<$ < be-1 + $\operatorname{man}(=\mathrm{G}$. benennen $=$ Sw. benamna $),\langle\mathrm{be-1}+$
nemnan, name: seo be-1 and name, v.] 1. To name; denominate.

ne that is ao oft bynempt. Spenser, Shep. Cal., July.

And therefore he a conrti

2. To promise; give.

Much greater gyfts for guerdon thou shait gayne

Spenser, Sliep. Cal., November.

bench (beneh), $n$. [E. dial. and Se. also benk, bink, < ME. beneh, benk, bynk, < AS. bene (orig. *banki) $=$ OS. bank, benki $=\mathrm{D}$. bank $=\mathrm{OHG}$. banch, MHG. G. bank = Icel. bekkr = Sw. bän $=$ Dan. bonk, a bench: see bankl, bank ${ }^{2}$.] 1 . A long seat, usually of board or plank, or of
stone, differing from a stool in its greater length.

He took his place once more on the bench at the fnn door.

2. The seat where judges sit in eourt; the seat of justice.

To pinek down justice from your swini bench.

Henee-3. The body of persons who sit as pit 2 judges; the court: as, the ease is to go before earpenters or other mechanies do their work; a work-bench. In this sense bench forms an element in a number of compound words denoting toois used on a bench, such as bench-drill, bench-hammer, bench-plane.
5. The floor or ledge whieh supports muffes and retorts. - 6. A platform or a series of elevated stalls or boxes on which animals ar placed for exhibition, as at a dog-show.

Excelienee on the bench and excellence in the field may he two utterly diverse things. Forest and Strean, XXII. 361.

7. In engin., a ledgo left on the edge of a eutting in earthwork to strengthen it. -8 . In geol, and mining: (a) A natural terrace, marking the onterop of a harder seam or stratum, and thus indicating a ehange in the eharaeter of the roek.

On this rest argiliaceous, apiendent, siliceous taic schists, benches of congienterates, tuffs, and argillaceous gehists and lime-stones, which lie refers to the Potsdam sand.
atones. (b) In coal-mining, a division of a eoal-seam separated from the remainder of the bed by a parting of shale or any other kind of roek or mineral. [Pennsylvania.] -9. A small area of nearly level or gently sloping land, rising above the adjacent low region, and forming a part of a terrace or wash, disunited from the remainder by erosion. Sometimes, though rarely, used as synonymous with terrace.

After a lew amooth, grassy benches and rounded hills here come preeipitous ranges of real mountains, searcely The wide level benchea that lay between tbe foot-hills and the prairie日... were negiected. 10. The driver's seat on a eoach.-Bench of bishops, or eplseopal beneh, a collective designation of the bishops who have seats fil the English Honse of Iords.and-dividing bench, a machine for cutting wooden block kind volssolr ahapes, anch as are used in making a certai traveling bed whieh is moved by a screw, and by neeans o a systen of levers aetuated by projecting and adjustable three pulleys, causing the action to be direct or reversed,
521

bend

or to stop, as the work requires. - Free beneh. See free. leaders of a party : se cialied becunse they occupy the frout benclies
mons. It is an old and honoumble practice that in any changes
affecting the liouse itself, an understanding should bo front benches.
Fortnightly

Ministertal benehes, opposition benehes, in the Brt ish p'arlianent, the benches occulied respuetively by the bench (benel), $2, \quad[<$ beneh, n.] I. trans.

To furnish with benches.-2

"Twas benched witis turf.

bryden. 3t. To

lita eup-bearer, whom I from meaner form

4. To place on a slow-beneh for exhibition, as a dog. -5. In mining: (a) To undereut, kirve, the bottoms below the holing wlien this is done in the midale of the seam. [Leicestershire, Eng.]

II. inte.

\section{Thiou robed nian of justice, take thy place}

And thou, his yolke-fellow of equi

Shak., Lear, 111. 8 .

bench-clamp (beneh'klamp), $n$. A clamp attrebed to a work-beneh for holding firm

bench-drill (bench'dril), $n$. A hand- or machine-drill so mado that it ean be attached to a beneh.

encher (ben'ehêr), n. [〈bench,n., + erli.] 1. In England, one of the senior members of an inn of court, who have the government of the society. Benclers have been readers, and, heing ad-
mitted to plead within the bar, are called inner barrister. These were followed by a great crowd of auperannuated
benchers of the inna of court, genior fellowa of colleges, and defunct statean

Addiron, Trial of the Dead in Leason. 2. One who ocenpies an offieial beneh; a judge; sometimes, speeifically, a munieipal or loea magistrate; an alderman or justice. [Rare.] lou are well understood to be a perfecter glber for the Shak, Cor., il. i
This corporstion [New Windsor] consists of a mayor, two balliff, snd twenty-elght other persons, . il thirtee of which are esiled fellow's, and ten of them aldermen o
chicf benchers. Each town [of colonial Virginia] was to be a tree bor ough with markets and an amulual fair. For their gov lisve become thirty families, they were, upon anmmons from the Governor, to elect efght bencherg of the guild hail, who should annually elect one of their number di-
reetor. Johus Hopkins IIist. Studies, $3 d$ ser., p. 108, 3 . One who frequents the benehes of a tavern; an idler.

benchership (ben'ehèr-ship), n. $[<$ bencher + -ship.] The office or condition of a bencher. They [two benehers of the Inner Tempie] were coevais,
and had nothing but that and their bencherghip in conbench-forge (beneh'fōrj), n. A small hearth and blower adapted for use on a workman's beneh.

bench-hammer (beneh'ham"êr), $u$. A finishers' or blaeksmitlis' hammer.

bench-hook (beneh'húk), $n$. A hook with projeeting teeth used on a earpenter's bench to
keep the work from moving sidewise. It is fitted In mortise, ao that it can be placed at any reruired height.

benching (bon'ehing), $n$. [〈bench $\left.+-i n g 1^{1}\right] 1$. Benehes; seats generally. - 2. In coal-mining, one of the many names given to the proeess of hetting the cor

bench-lathe (beneh'lātн), $n$. A small lathe which can be mounted on a post placed in a socket in a bench.

bench-level (beneh'lov'el), $n$. A level used in setting up a maehine, to bring its bed into an exactly horizontal position.

bench-mark (beneh'märk), n. [< bench + mark 1 : in reference to the angle-iron which in taking a reading is inserted in the horizonta eut so as to form a support or beneh for the leveling-staff.] In surv., a mark eut in stowe or some durable material as a starting-point in a line of levels for the determination of altitudes over any region, or one of a number of similar marks made at suitable distances as the survey advanees.
They [places of the af ars] are the reference-points and
Science, IV. 202 bench-master (beneh'mas'tir), $n$. In lingland, a governor of an inn of court; an alderman. Imp, llict.

bench-plane (beneh'plān), $n$. Any form of plane used on flat surfaees, as the block-plane, the conpass-plane, tho jaek-plane, the jointer, the long plane, the smoothing-plane, and the tryilg-piane.

bench-reel (beneh'rēl), n. A spinning-wheel on tho pirn or bobbin of which a saimaker winds the yarn. E. II. Knight.

bench-screw (bench'skrö), $n$. The serew which secures the vise-jaw of a carpenter's benel.

bench-shears (beneh'shêrz), n. $p l$. Large handshears for eutting metal.

bench-show (beneh'shō), $n$. An exhibition of unimals, as of dogs or eats, which are arranged on benches for a comparison of their physieal merits aecording to a fixed seale of points: in contradistinetion to a field-shor, or ficld-trial, where awards are made for performanee.

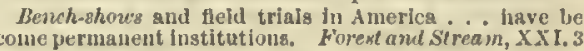

bench-stop (beneh'stop), n. A beneh-hook made to bo fastened down on a picee of work, sometimes by means of a serew.

bench-strip (beneh'strip), n. A strip of wood or metal eapable of being fixed on a workbench at any required disedge, to assist in steadying the artiele or material being worked on. ench-table (beneh'tā" bl), n. A low stone seat earrier around the interior walls of many medie

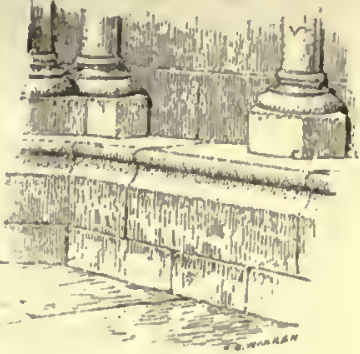

(bench'vis) n. A vise which be attached to a bench.

bench-warrant (beneh'wor"ant), $n$. In law, a warrant issued by a judge or court, or by order of a judge or court, for the appreheusion of an offender: so called in opposition to a justices warrant, issued by an ordinary justice of the peace or police magistrate. Mozley and Whiteley. bendl (bend), $n_{0}$ [< ME. bend, < AS. bend, rarely bend, fem. and masc. (= OS. bendi $=$ OFries. bende $=\mathrm{OD}$. bende $=$ Goth. bandi), a band, bond, fetter; eognate with "band, E. Bendl is praetieally identieal with bandl, the two being partly merged in use with the elosely related pair band2, bend ${ }^{2}$. In senses 4-11 bend is modern, from the eorresponding verb: see bend $1, x$.$] 1t. A band; a bond; a fetter; in$ plural, bands; bonds; confinement.-2t. A to strengthen or hold together a box or frame. In all that rowme was nothing to be seene
But lumpe great yron chests, and coffers strong,
AII bard with doubie bends.

3. Naut.: (a) That part of a rope which is fastened to another or to an anchor. (b) A knot by which a rope is fastened to another rope or to something else. The different sorts are distinguished as fisherman's bend, earrickbend, ete. See ent under earrick-bend. (e) One of the small ropes used to eonfine the elineh of a cable. (d) pl. The thick plauks in a ship's side below the waterways or the gun-deek portsills. More properly ealled cales. They are reckoned front the water as first, second, or third bend. They 4. [Seo etym.] The aetion of bending, or state of being bent or eurved; ineurvation; flexure : as, to give a bend to anything; to havo a bend of the back. -5 . An inctination of the body; 2 bow.-6t. An inclination of the eye; a tirm or glanee of the eye.

And that same eye, whose bend doth awe the world,
Did lose his lustre.

7t. Inelination of the mind; disposition; bent.

Farewell, poor swain ; thou art not for my bend

I must have a uicker souls,

8. A part that is bent; a eurve or flexure; a erook; a turn in a road or river, etc.: as, the bend of a bow, or of a range of hills. 
Just ahead of us is a grest bend in the river, heyond wich the wind drops dead and the current hurls us up un 9. A curved or elbow-shaped pipe used to change direction, as in a drain.-10. A spring; "leap; a bound. Jamieson. [Scotch.]-11. A "pull" of liquor. Jamieson. [Scoteh.] Come, gie's the other bend,
We'll driuk their lieaith, wiratever way it en Allan Ramsay, Gentle Shepherd, iil. 2

12. In mining, indurated clay, or any indurated argillaceous substance. - Close-return bend, a wronght-iron pipes. - Grecian bend, a mode of wsiking
with a slight stoop Lorward, at one time affected by some women.

bend ${ }^{1}$ (bend), $v$; pret. and pp. bent, rarely benced, ppr. bending. [< ME. benden, < AS. benrian, bind, fetter, restrain, bend a bow (= MHG. benden, fetter, $=\mathrm{Icel}$. bend $a=\mathrm{Sw}$. bänd $a=$ Dan. bende, bend; ef. OF. bender, mod. F. bander, tie, bind, bend, hoodwink, = Pr. bendar = Sp. tie, bind, bend, hoodwink, = Pr. bendar $=$ Sp.
Pg. vender, bind, hoodwink, = It. bendare, hoodwink), prop. fasten with a bend or band, < bend, E. bend1, a band, the noun being practically identical with band $n$. Tho nouns and verbs of these groups (band1, bendI, band 2 , bend 2 etc.) reacted on each other both in Tent. and Rom., developing a variety of senses which bring or strain into a state of tension by curbring or strain into a state of tension by cur-
vature, as a bow preparatory to launching an arrow.

What, are the liounds betore and all the woodmen,

Our horses ready and our bows bent?
Beau. and $F l$., Philaster, iv.

Our English archers bent their howes,

Their harts were good and trew;

Att the first flight of arrowes gent

Percy's Reliques, p, 142

Hence-2. Figuratively, to brace up or brine into tension, like a strong bow: generally with up. [Obsolete or archaie.]

Now set the teeth, and stretch the nostril wide;

Hold hard the bresth, and bend up every spirit
To his full height!
Shak., Hen. V., Iit. 1.

Her whole mind apparently bent up to the solemn in-
Scott, old Mortality, vil.

3. To curve or make crooked; deflect from a normal condition of straightness; flex: as, to bend a stick; to bend the arm.

In duty bend thy knee to me. Shak, 2 Hen. V'I., A kindly old man, . . somewhat bent hy his legal erl Longfellow, Kavanagh, $x$

4. To direct to a certain point: as, to bend one' course, way, or steps; to bend one's looks or eyes.

Towards Coventry bend we our course

Southwards, you may be smre, they bent their flight,

and harbour in a liollow rock at nigit.

How sweet are looks that lidies bend

Figuratively, to apply closely: sa mind.

It must needs be they should berul ail their intention and services to no other ends but to hils.

ro bend his mind to any public business

Sir $\mathrm{H}$. Temple.

6. To incline; determine: said of a person or of his disposition: as, to be bent on mischief.

Where will inclineth to goodnes, the mynde is bent to
troth.
Ascham, Tine Scholemaster, p. 79 . One great design on which the king's whole soul was

Still bent to make some port he know s not where. 7. To cause to bow or yield; subdue; mat Except she bend her humour.

Oh there are words and looks

Shelley, The Cencl, v, 4

8. Naut., to fasten by means of a bend or knot, as one rope to another, or to an anchor; to shackle, as a chain-cable to an anchor.-Bent lever, trimmer, graver, etc. See the nouns.- To bend a sail (naut.), to inake it last to its proper yard, gafi, or
stay, ready lor setting. - To bend the brow or brows, II. intrans. 1. To be or become eurved or crooked.

Then was 1 as a tree
Whose boughs did bend with
2. To incline; lean or tur

To whom our vows and wishes bend.

Our states daily

Our states daily
Bending to bad, our hopes to worse.
B. Jongon, Cath

Descend wbere alleys bend

Descend wher
Into the sparry hollow

There is a cliff whose high and bending head

Shakk., Lear, iv, 1.

4. To bow or be submissive: as, to bend to ate.

Most humbly therefore bending to your state. Shak., Othello, 1. 3 Niust we bend to the artist, who considers us as nothing

I. D' Israeli, Lit. Char. Men of Genius, p. 145.

5. To spring; bound. Jamieson. [Scoteh.] 6. To drink hard. Jamieson. [Scoteh.]-To bend to the oars, to row vigorously.

, [ M ME. bend, bende, partly <AS. bend, a band used as an ornament (a mod. F. bande $=\mathrm{Pr}$. benda $=\mathrm{Sp} . \mathrm{Pg}$. venda and banda = It. benda, banda, $<\mathrm{ML}$. benda binda, < OHG. binda, a band, fillet, tie, mixed with ML. (ete.) banda, < OHG. bend, ete. : see band 2 . Bend 2 is thus in part historically identical with bend1, but in part with band2. The separation is now merely formal.] 1t. A band or strip used to bind around anything; a strip, whether as a fastening or as an ornament; a fillet, strap, bandage, ete. ; specifically, a ribbon or bandeau for th

And on her legs she painted buskins wore spenser, F. Q., V. v. 3

2. A namein the leather trade fora butt or round ed crop eut in two; the half of a hide of soleloather that was trimmed and divided before tanning.- 3. In her, one of the nine ordinaries, dexter chief to the sinister base: when charged, it occupies a third of the field; when uncharged,

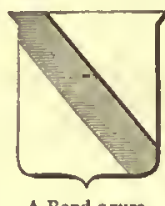
a fifth. Bearings are said to be in bend when they are placed upon the bend; the fleld is said to be divided per bend when divlded disgonaliy in that direction, usualiy by a straigint line, but dé, or the like, or by a still more com.
plicated mark of divislon. See bendplicated mark of division. See bend-
wise. Also applied to a row of charges wise. Also applied to a row of charged in bend. In bend sinister and per bend sinister are used in a
similar way.-Bend archy, In her, a balld differing from
the bend in tiat it is curved toward the sinister chief. Also calied bend enarched or botred. - Bend archy, cor-
onetty on the top, in fer., in bend arcily having the onetty on the top, in her., a bend arciby having the
points or ornaments of a crown on the upper side. This points or ornaments of a crown on the upper side. This Finglish royal arms, notably in those of the present Prince both sides broken into concave, curves. see pored.cond cottised, in her., 8 bend bsving on esch side
cettise, separated from the bend by its own widtli. bend may be double cottised or treble cottised; that is,
it may have two or three cottises on each side.-Bend it may have two or three cottises on each side.- Bend
sinister, in her. Same as bend, 3 , except that it is draw 11 rron the sinister chiel to the dexter base.

bend ${ }^{3}+$ (bend), $n$. [< late ME. bende, < OF. bende, var. of bande, a band: see bands.] An obsolete form of band $d^{3}$.

A isyre flocke of freries, and a fresh bend
Of lovely Nymphs. The Duke ot Gloucester .... and other Lords, the chiet of his bend. bendable (ben'da-bl), a. [< bend $1+-a b l e$. Capable of being bent; flexible. Sherwood.

bende (bend), $n$. [Origin unknown.] A variety of the abelmoschus, used in cookery. MeElrath. bendelt, ". [ME., < OF bendel, bandel, dim.
of bende, bande, a band; doublet of bandel, bandeau.] 1. A little band or fillet.-2. In her., a little bend.

bender (ben'dèr), n. 1. One who or that which bends.-2. A sixpence. [Fng, slang.] -3. A leg. [U. S. slang.]

The prospectus [of a new fashlonable boarding-school] has been sent to our honse. One of tile regulations is,
"Young, ladies are not aliowed to cross their benders in
school!" 4. A spree; a frolic. [U. S. slang.] -5. [Cf. bend $\left.{ }^{I}, n_{.}, 11.\right]$ A hard drinker. [Scotch.]

Now lend your lungs, ye benders fine,

Wha ken the beneft of wine. Allan Ramsay, Poems, III. I62 (1848). Shak., Cymbeline, iil. 3. Bendigo ware. See pottery. bending ${ }^{I}$ (ben'ding), $n$. [Verbal n. of bend 1 , v.] The act of causing to bend, or the state of being bent or deflected; a deflection.

II matter that will not yield st each bend is deposited while the bendings sre continually taking place, the bendings will maintain certain places of discontinuity in the
deposit.
II. Spencer, Prin. of Biol., \$ 257 .

bending ${ }^{2}+, n$. $\left[<b e n d^{2}, n .,+-i n g.\right]$ Decoration (of clothes) with stripes or horizontal bands. Chancer.

bending-machine (ben'ding-ma-shēn"), n. An pparatus for bending to shape timber, rails, ron beams for ships, plates for boilers, etc.

iron beams for ships, plates for boilers, etc. bullding, one of two strakes wrought near the deck-coverings, worked all fore and aft. They are about an incih or an inch and a haif thicker than thic remsinder of the deck, but are lowered between the beam and ledges to make the upper side even with the rest.
Their 1 se is to make a more complete tio between the

bend-leather (bend'letH"er), n. $[<$ bend + leather.] 'The strongest kind of sole-leather for shoes. See bend2, 2 .

bendlet (bend'let), $n$. [Ear]y mod. E. also bendelet, appar. < bendel + -et; but cf. OF. ए Doublet bandlet.] 1. In her., a bearing of the nature of the bend, but half as wide. Also called garter - 2 A name of the eommon British sea-anemone, Actinia nesembryanthe-

Bend between two mum.- Bendlet sinister, in her. a
Bendles gules.

Bend between two
Bendless gules.

bendsome (bend'sum), $a$. [ $<$ bend + -some. Cf. buxom.] Flexible; pliable. [Rare.] bendways (bend'wāz), adv. Same as bendwise. bendwise (bend'wīz), adv. [<bend $d^{2}+w i s e^{2}$. In her., lying in the direction of the bencl. said of any bearing: as, a sword

\section{bendwise.}

endwith $\nmid, n$. [ME. benwyt-tre later var. benewith tre - Prompt. Parv.); perhaps < bend I + with (cf. bindwith); but ef. Sw. benved, dogberry-tree, Icel. beinivdhr, beinvidhi, ebony (lit. bonewood); also Ieel. beinvidhir, a a sword nendwse. old name of a shrub not identified. Its twigs were used to tie up fagots.

bendy (ben'di), a. [<OF, bende, F, bande, pp. of bander, cross with bands: see bend2.] In her., divided into four or more diagonal parts in the direction of the bend: said of the field. This word is used, no matter how great the number of regular forms, are awkward in use.-Bendy barry, in her. See barry bendy, under barry 2 . - Bendy paly, in here, dividied by lines bendw into lozenges.

bendy-tree (ben'di-trë), n. The Thespesia populnea, all ornamental tree of rapid growth, often planted iu gardens and avenues in India. bene ${ }^{1} \dagger, n$. See ben ${ }^{2}$

bene $2 \nmid, a$. See bein.

bene ${ }^{3}, \ldots$ see benne.

bene-. [L. bene-, sometimes bent-, combining form of bene, adv., well, < bonus, good: see boon ${ }^{2}$, bonus.] An element of some words of Latin origin, meaning well, good, as in benediction, benefit, benevolence, etc.: opposed to male-, nal-.

beneaped (bë-nēpt'), a. [<bc-1 + neap $\left.+-e d^{2}.\right]$ Naut., samo as neaped.

beneath (bē-nēth'), adv. and prep. [C ME. be nethe, bineithe, binethen, adv. and prep., < AS. beneothan, binithan, prep. (= OFries. binetha $=$ D. beneden $=\mathrm{LG}$. benedden $=\mathrm{G}$. benieden $)<$ be, by, + neothan, nithon, neothone ( $=$ OS nithan $=\mathrm{OHG}$. nidana. MHG. nidene, niden, G. nieden), below, orig., like nithe, below, from compar. nither, nether: see nether. Hence by apheresis neath, 'neath.] I. adv. 1. In a lower place, position, or state, literally or figuratively.

Tilou shalt be above only, and tiou shalt not be beneath.

Every brain

That looks so many fsthoms to the sea,
And hears it roar beneath. The general's disdain'd

By him one step below; he, by the next;
That next, by him beneath. Shak., T. and C., I. 3.

2. Below, as opposed to on high, or in heaven or other superior region.

Thou shall not make .... any likeness of anything that is in heaven above, or that is in the earth beneath. 
beneath

II. vrew, 1. Below; under: witl referenee to what is overhead or towors aloft: as, beneath the same roof.

For all bencath the moon
Wonld I not leap upright. As I Iay beneath the woodlaml tree

Megon They snt

Beneath a world-old yew-tree, darkening half
Thennyson, Iloly (iral. 2. Underueath, whether in immediate contact with the under side of, or furtler down than; lower in plaee than: as, to plaeo a eushion beneath one; beneath one's teet; beneath the surface: sometimes witl verbs of motion: as he sank beneath the wave.

Aa he was rataing hla arm to make a biow, an arro plereed him, just beneath the slioulder, at the open part
of the corselet. 3. Under the weight or pressuro of; under the action or influence of: as, to sink beneath burden.

Our country sinks beneath the yoke.

It is my fate
To bear and bow beneath a thousand grier

Beau, and $F$ '., Mald'a Tragetly, lii. 1 Whercver lights appeared, the fiashing scimetar was at
its deadly work, snd all who nttenupted resistance fell beneath its elgo.
Irving, Granala, p. 21. 4. Lower than, in rank, dignity, degree, or ex celleneo; bolow: as, brutes are bencath man man is beneath the angels.

Msintalu

Witlı any beneath prince. Shirley, Bird in a Cage, 1. Beyond the limits of a vulgar fate,

Gray, Prog. of Poetry, lil.

5. Unworthy of; unbecoming; not cqual to below tho level of: as, beneath contempt.

Ile will do nothing that ls beneath his high statlon. lie lisd never sullied himselt with business, but had
benento to stnrve like a man of honour, than do snything
benech his quality.
Addison, Trial of Punctilios. Beneath the salt $\nmid$, in a subordinste or inferior positlo Ify prond lady

Admits hlm to her table: marry, ever
Beneath the salt, and there he sita the subjeet of lier contempt and scorn. Ifassinger, The Clty Madam, l.

beneathł (bệ-nēth'), a. Lower.

This beneath world.

Benedic (ben'ē-dik), $n$. [LL., prop. $2 d$ pers. sing. pres. impv. of benedicere, bless: see bene " the Lord, O my sonl," from Psalm ciii. In the merican Prayer-Book it is an alternatlve of the Den iis or Deus misereatur) at Evenling Proyer.

2. A musical setting of this canticle.

Benedicite (ben-ẹ-dîs'i-tē), n. [LL., prop. 2d pers. pl. pres. impv. of benedicere, bless: see
benedict.] 1. The canticle or hymn beginning in Latin "Benedicite omnia opera Domini," and in English " $O$ all ye works of the Lord, bless ye the Lord," taken from "The Song of the Thre Holy Children" forming part of the Apoerypha in the English Bible. It Is essentislly sn expansion peried in the Christian church. In the Angllean service 2. A musical setting of this canticle.-3. [i.c.] An invoeation of a blessing, especially a blessing before a repast, as said in religiou communities, ete., answering to the grace o: tbanksgiving after it. $-4 \nmid$. [A common uso in MF., where the word was often contraeted bendicite, benste.] Used interjectionally: (a) Bless you! expressing a wish. $(b)$ Bless ns! bless mo you! expressing a wis

benedick (ben ${ }^{-}-$dik), n. Seo benedict.

benedict (ben'- $\bar{e}-$ dikt), $a$. and $n$. [In MI. bene dight, < LL. benedictus, blessed (in MIL often as a proper name Benerlictus, whence in E. Benedict, Benedick, and (through F.) Bennet, Ben nett; ef, also benet ${ }^{2}$, bennet $\left.{ }^{2}\right)$, pp. of benedicere bless, use words of good omen, in class. L. always as two words, bene dicerc: bene, well; dicere, say, speak.] I.t a. Blessed; benign salutary; especially, in med., having mild and salubrious qualities: as, "mediei

II. $n$. [In allusion to Benedick, one of the charaeters in Shakspero's play of "Much Ado about Nothing"; esp. to the phrase, "Benedick, the married man" (i. I.). Benedick is an casy form of Benedict.] A sportive name for a
523

benefic

nowly married man, especially ono who has benedictionary (ben-ē-dik'shon-ā-ri), $n$. [< ceu lour a bachelor, or who has been in the labit of riclienling inalriage.

liaving nhandioned all his oid misogyny, and his pro-

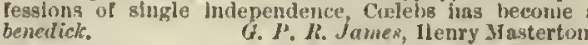

Benedictine (ben-ê-dik'tiu), a. and $n$. [<ML. Benedietinus, < Benedietus: seo benerlict.] I. ". Pertaining to St. Benedict, or to the order of him.

II $n$ 1. A member of an orler of mouk b founded at Monte Cassino, between Romo and Naples, by St. Benedict of Nursia, about A. D. 30. The rules of the order (wilich was open to persons of sll nges, conditions, and eallings) enjoinel silence sul some uselui employment when not engaged in divine ae ice. Fiery inonastery lian a hibrary, every monk a pen were elus and the learning and tile liberal arts, and the nnme of the order aynouymous with schularship and erudition. The orde was intredluced Juto England abont A. D. 600, by St. At Gustine of Canterloury. The oldest estnblishment in the United Sta tes is that of St. VIncent's Ablrey in Westmore land county, l'eunsyivania, foundell by a colony of monk
from Bavaria in 1si6. There are alao different congregatlons of muns known ns Benedlictines, and following the their foumdation to his sister, St. Scholsstieg.

2. A cordial or liqueur, resembling ehartreuse, distilled at Féeamp in Normandy. It was orl benediction (ben-ê-dik'shon), n. dictio $(n-)$, blessing, $<$ benedicere, bless, uso word of good omen: sec benedict. Benison is a shorte form of tho same word.] 1 . The act of speak ing well to or of; blessing.-2, (a) An juvocation of divine blessing, either by a private individual or a elurreh official; specifically, in the Christian chureh generally, the furm of blessing pronounced by the person officiating at the close of divine serviee and on several other occasions, as marriages, the visitation of the sick, ete.

The benedictions of the good Franciseans secompanied we rode away tron the convent The benediction. Is given In a different manner by Priest joins lis thumb and third finger, and ereets and jolns the other three: and is thua supposed to symbolis the processlon of the I1 loly Ghost Iron the Fsther alone by the position of hla fingers, When the benediction is pronounced officially by a priest
or elergymsn, he usually strnds with hands uplifted, and
the congregation recetve it with bowed hesds. Illustrsthe congregation receive it with bowed hesds. Illustra
tions of anelent benedietions are afforded by Gen. xxiv. 60 ing): Num. vi. 24-27 (a priestly blessing). The apostalic benediction is that procceding from the pope, and 18 either given personally, as at Rome, or by delegation in other
parts of the world. See blessing. (b) The rite of instituting an abbot or an abbess, and of reeeivin the profession of a nun or of a religious knight.

Thie action of the archbishops was exeluded, and the
abhots eleet sought conflrmation, if not benediction also, abbots eleet sought conflrmation, if not benedirtion 81 so,
st Rone.
Stubbs, Const. Hist., 8710. (c) An additional ceremony performed by a priest after the regular celebration of matri mony: ealled the nuptial benediction. (d) Th eeremony by which things aro set aside fo saered uses, as a church or vestments, bells as houses, ete. -3 . The advantage conferred by blessing or the invocation of blessings. Prosperity is the blessing of the Old Testament; sdver-
aity is the blessing of the Xew, whilch carrled the greate sity is the blessing of the Xew, whilch carrletl the greate Over and above this [gense for light and ahade] we have a benediction, as It were, in our sense for and enjoymen
of colour.
O. $N$. hood, Modern Chromatles, p. 304 . Benediction of the Blessed Sacrament, one of the Chureh, in whleh, after the solenu exposition, Incenslng and sdoration of the eucharist, whieh is inclosed in monstrance and placed under a canopy on the sitar, the offichating priest, taking the monstranee in his hands, kneeling faithful.- The apostollc benedietion, $a$ bene

(ben-ê-dik' dictionalis (sc. liber, book), <LL. benedictio $(n-)$ see benediction.] In tho Rom. Cath. Ch., a book containing a collection of benedietions or bless ings used in its religions services.

Psaiters, books of Gospels, Benedictionats, Canons, and the Churel. The Sarum, like the Anglo-Saxon Benedictional, con-
ained the forma for blessing the people, by the bishop, $\mathrm{st}$ ained the forma for blessing the people, by the bishop, st
high nass.
Bock, Chureh of our Fathers, III. ii. 213.
111. as if benedietionarium, $\langle\mathrm{Ll}$. benedictio $(n-)$ : seo benediction.] A collection of benedietious or blessings; a benedietional.

The benedictionary of Bishop Atletwood. By. Still. benedictive (ben-e-dik'tiv), $a$. [< I.I. bencdictus (seo benedict) + -ive.] 'Tending to bless; giving a blessing.

13 is paterual prayers sud benerlicfice comprecations.

enedictory (ben-è-dik' tọ-ri), u. [<LL. as f "benertictorius, < benedictus: seo benedict.] 13lessing; expressing a bencdiction or wishes cray.

Benedictus (ben-ể-(lik'tus), $n$. [LL., blessell: see benerlict.] 1. The short eanticle or hymn, also distinctively ealled tho Benedictus qui vemit, beginning in Latin "Benedictus qui venit mil, beginning in Latin "Benedictus qui venit is He that cometh in the name of the Lord," preceded and followed by "HIosanna in Hxcelsis," that is, "Hosama in the highest," which is usually appended in tho Koman Cathelie mass to the Sanctus, fron Psalm exviii. 26, Luke xix. 38, ete. The Benedictus qui venit was re. tained in the Prayer-Ponk of 1540, and is aung in some Angllean churches at choral or solemn celebrations of the holy communion, just belore the prayer of conseeration. 2. A musical setting of this canticle, forming a separate movement in a mass. - 3. The canticle or hynn beginning in Latin "Benedictus Dominus Deus Isrnel," and in English "Blessed we the Iuord God of Isracl"; the song of Zacharias, Luko i. 68-7I. In the English Prayer-Book it the canticle following the gecond lesson with the Jublthe first four verses are the Annerlesin Prayer-Book oniy direct the use of the whole eanticle on Sundsya in Advent, owing the fourtin verse.

1. A musieal setting of this edight ( I E. benedyght, ben-

And aoul more white
Never through martyrdom of fire was led
To its repose; ner esn in books be resd

To its repose; nor ean in books be
The legend of a lite more benedight. Longfellove, The Cross of Snow.

bene discessit ( $b \bar{e}^{\prime} n \bar{\theta}$ di-ses'it). [L., he has departed honorably.] In English nniversities, college to a student to leave that collego and enter another.

Mr. Pope, being nbout to remove Irom Trinity to Em-
manuel lyy bene discessit, was desirous of taking my rooms

bene exeat (bō'në ek'sē-at). [Is., let liim depart honorably. A certificate of good charaeter
given by a bishop to one of his elergy removing from his last bishop.

benefaction (ben-ē-fak'shon), $n$. [<LL. benefactio(n-), ( benejactus, pp. of benefacere, in do. Cf. bencfit.] 1. The aet of conferring a benefit; a doing of good; beneficence.

Worshipping God and the Lamb in the temple: God, for his benefaction in creating all things, and the Lamb, tor
his benefaction in redeeming us with hls blood. Nexiton.

2. A benefit conferred; especially, a charitable donation.

A man of true generosity will study in what manner to
ender hia benefaction most advantageous.

Syn. 1. Kilndness, - 2, Gift contribntion, alms, eharity.

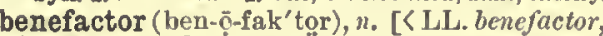
(benefacere, do good to: see benefaction.] 1 . Literally, a well-doer; sue who does good. [Rare.]

Benefactors ? Well ; what bew factory are they? are they
not majelsetors?

2. One who confers a benefit; a kindly helper: as, "the great benefactor of mankind" Milton, P. R. iii.82.

Ile is the true benefactor and alone worthy of Honor who brings coufort wher

Summer, True Grandeur of Nations.

3. One who makes a benefaction to or endows a charitable or other institution; one who makes a bequest.

benefactress (ben-ē-fak'tres), $n . \quad[<$ benefactor

+ ess.] A fermale benefactor.

beneflc (bë-nef'ik), $a$. and $n$. [Formerly bene

fique; < L. beneficus, <bene, well, + facere, do.]

I. a. 1. Beneficent. [Rare.] to another diocese: as, he brought a bene exeat lass. I. always written as two words, bene facere, do good to, benefit: bene, well; facere, 


\section{benefic}

He being equally neere to his whole Creation of Mankind, and of free power to turn his benefick and fatherly
regard to what Region or Kingdome he pleaseg, hatls ye ever had this Yland under thite speciall indulgent tye
his providence. 2. In astrol., of good or favorable influence.

The kind and truly benefique Eucolos.

II. $n$. In astrol., a favorable planet; Jupiter or Venus.

benefice (bon'ê-fis), n. $[<\mathrm{ME}$. benefice, benefise, ২OF. benefice, $\mathrm{F}$. bénéfice, <LL. bencficium, ness, < benefiens, lind liberal: see benefic ] In feudul law, originally, a fee or an estate in In feudel law, originally, a fee or all estate in bencfieio (on the mere good pleasure) of the donor. Such estates afterward becoming hereditary,
the word feud was nsed for prants to fndividnals, and the word ferd was nsed for grants to in
benefice became restricted to church livings,

The Beneficlum, or Benefice, an assignment of land by a conqnering Tentonic king as the reward or price of mill-
tary service, is allowed on alt sides to have had much to do with this great change [irom allodial to feudal] in the
legal point of view. Ilaine, Early Law and Custom, p. 345 . The kings gave their leadiug chiefs portions of conquered land or of the royal domains, nnder the name of
benefices.
Lechyl, Europ. Morals, II. 286 . 2. An ecclesiastical living; a church office endowed with a revenue for its proper fulfil ment; the revenue itself. The following terns of canon law are frequentiy found associated with this
word, which is of listorical importance: A benefice in volving no other ollligation than service in the publi oflices of the clurch is simple; if the cure of souls ir at-
tached to it, double; if with a certain rank attached, dig. nitary or major; the two forner witlout rank, nimor. Thus a chanstry, was a simple benefice; a prebend give tached to a collegiate or cathedral church ; while the bene-
fice is terpetnal and has a charge, though there are some fice is perpetual and has a clarge, though there are some
(called manual, from their being in the hands of the one conferring themi) revocable. The bencfice is sald to be regue secular if lield by a layman; and in commendain when in the charge of one commended by the proper authoried. In the last-named case the discharge of the oftice i provided for at the expense of the liolder: (See abbe).
benefice is recetved by election, for example, by a chapter benefice is recelved by election, for example, by a chapter:
or from a patron, who is properly said to present to it
or is is nominations, in the Roman Catholic Church, regutarly need confirmation from the pope. Hig action may canse
a benenece to be reserved or afected (1which see) i or the
collation is made allernative, that is, to the pope and collation is made alternative, that is, to the pope and
regular patron or guperior, according to the noniths in
which the benefice falts vacant, by definite system.

\section{Ful thredharc was his overeste conrtepy,
For he liadde geten him yet no benefice.}

For he hadde geten him yet thecr. The estates of a biahop or abbot came now to be lookert on as a fief, a benefice, held personally of the King.
L: A. Freenan, Norm. Conl.,

One priest, heing little learned, would hold ten
twelve benefices, and reside on none.

3t. Benefit.

Verely, this thyug by the benefice of philosophie was
roted in hym, that he stode in drede of no man liuging. Bénéfice de discusston, in French law, the legal right of a debtor who is secondarily liable to demand that the
creditor should be required frist to react and compel appication of the property of the principal debtor before beneficed (ben' $\bar{e}$-fist), $a_{0}\left[<\right.$ benefice $+-e d^{2}$.] Possessed of a benefice or church preferment.

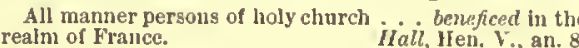
My Father sent me thither to one Mr. George Bradshaw
(nomen invisum! yet the non of (nomen invisum! yet the aon of an excellent father, bene-
ficed in Surrey).
Evelyn, Diary, May 10, 1637. Beneffced men, instead of residing, were fonnd lying at ioners, and did nothing for them. $R_{\text {. W }}$. Dixon, Hist. Church of Eng. beneficeless (ben'ẹ-fis-les), a. $\quad[<$ benefice + -less.] Having no benefice: as, "beneficeles

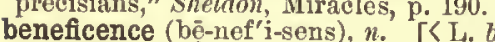

beneficence (bōenef'i-sens), $n_{0}$. [< L. berieficentia,
1 . The preficen(t) $(t)$, beneficent: see beneficent.] ness, kindness, or charity.

To spread abnudance in the land, he [Stuyvesant] obliged rule which remains a monnment of his berenticencec, golden True beneficence is that which helps a man to do the Work which he is most fitted for, not that which keeps and
encourages him in lilleness.
I. K. K. Cliford, Lectures, II. 202 2. A benefaction; a beneficent act or gift. =Syn. Benevolence, Beneficence, Bounte, Liblerality,
Generosity, Munificence, Charity. Benvolence, literally well-wishing, is expressive of the disposition to do good hence it easily came to be applied to claritable gifts.
Beneficence, iterally well-doing, is the outcome and visible expression of lenevolence. It is a strong though
524

benefit

who are in need. Benevolence may exist without the ways presupposes berzevolence. Bounty is expressive of kinid feeting, but more expressive of abundant giving Liberality is giving which is large in proportion to the
neans of the giver. Generosity adds to the notion of liberality that of largeness or nobleness of spirit in connection with the gifc. Munificenee is giving on a large
scale, not restricting itself to necessary things, hut giving scale, not restricting itselr to necessary things hint giving
lavishly, it is the one of these words most ilikely to be Mecessarity so Cherity while having the best out meaning, has conve to be a general word; as to gifts, it is wliat is lestowed upon the poor or needy, but not
with warm or kindly feelings: as, official charity.

With a bow to Ilepzibah, and a degree of paternal benevdence in his parting nod to Phobe, the Judge left th hop, and went smiliug along the street.

Few men have used the infor with such enlighthened beneficence, with such lasting recults on human culture and civilization, with such genoine simplicity and cordial loyalty [as Mrecenas]. XV.
Eneyc. Brit., XV. Descrted at his utmost need
By those his former bounty fed

By those his former bounty fed, Signtor Baptista'a liberality
I'll mend it with a largest over and beside

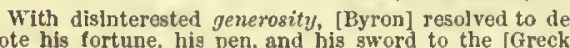
cause. Such were his temperance and noderation, such thic excelity whe hroeding, the parity of demeanor, that no one thing seemed wauting in his which belongs to a true and perfect prince. scope for action only wher there exists a large class of men at once independent an
impoverishled.
Lecky, Europ. Morals, II. 78

beneficency (bẹ-nef'i-sen-si), $n$. The quality of

beneficent (bẹ̄-nef'i-sent), a. $[<\mathrm{L}$. "bcnefi$e c n(t) s$, compar. benefieentior, assumed from the noun beneficentia, bnt the L. adj. is beneficus see benefie and bencficenee.] Doing or effecting marked by or resulting from good will.

The beneficent trutlı of Christianity.

Irescott. She longed for work which would be directly beneficent,
like the sunshine and the rain. Gee the sunshine and the rain.
George ${ }^{\prime}$ liot, Middlemarch, 11. 55. The worship of the beneficent powers of nature so per-
vades Teutonic and Scandinavian religion, that it nuay most be said to constitute that religion. World, p. 232
Faiths of the World =Syn. Bene ficent, Beneficial, bountiful, bounteons, liberal,
munificent, generous, kind. Beneficent al ways implies a kind and worthy purpose back of that to which the adjec Power of any kind readily appears in the manners; and beneficent power . . gives a majesty which caunnot be
concealcd or resisted.
E'merson, Eng. Traits, p. 187.

That such a beech can with his very bulk
Take up the ray's $0^{\prime}$ the beneficial sin.

Todide of potassium has been tried in large doses [ in ficial.
Quain, Med. Dict., p. 253. beneficential (bẹ-nef-i-sen'shạl), a. [< L. be neficcntia (see benefiecnce) $+-a l$.$] of or per-$
taining to beneficence; concerned with what is most beneficial to mankind. N. E. D.

beneficently (bẹ-nef'i-sent-li), adv. In a bebeneficia, $n$. Plural of beneficium.

beneficial (ben-ē-fish'ą), $a$. and $n . \quad[<L L$. fice.] I. a. 1. Contributing to a valuable end; conferring benefit; advantageous; profitable; useful; helpful.

The war which would have been most beneficial to us. That which is beneficial to the community as a whole, it
will become the private interest of gome part of the com
munity to accomplish. II. Spencer, Soclal Statics, D. 443.

2. Having or conferring the right to the use or benefit, as of property; pertaining or entitled to the usufruct: as, a benefieial owner (which see, below); a beneficial interest in an estate.ficed.

An engagement was tendered to all civil officers and 4ł. Kind; generous: as, a "beneficial foe," $B$. Jonson. - Beneficial owner, one who, though not having apparent legal title, is in equity entitled to enjoy the
advantage of ownership. $=$ Syn. 1 . Beneficent, Bcneficial
(see beneficent), good, salntary.

II. $n$. A benefice; a ehureh living. For that the ground.worke is, and end of all, How to obtaine a Beneficiall.
A license for the sake of the rhyme, benefice eing also used several times in the same pas sage of the poem.

beneficially (ben-ê-fish'al-i), adv. 1t. Iiberally; bountifully; with open hand. Cotgrate. profitably; helpfuly. feneficialness (ben-ê-fish'al-nes), n. [< bene-
tieial + -ness. $]$ 1t. Beneficënce.-2. The quality of being beneficial; usefulness; profitable-

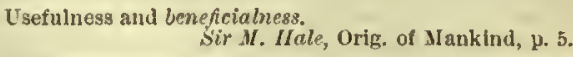
For the eternal and inevitable law in this matter is, that the beneficialnexs of the inequality depends, first, on the Ruskin, Unto this Last, ii.

beneficiary (ben-ē-fish'i-ā-ri), $a_{\text {. and }}$. $_{\text {. }}$ [< L. bencficiarius, < beneficium: seebenefice. $]$ I. a. 1 . Arising from feudal tenure; fendatory; holding under a foudal or other superior; subordinate: as, "beneficiary services," Spelman, beneficiary kiug," Bacon.-2. Connected with the receipt of benefits, profits, or advantages; freely bestowed: as, beneficiary gifts or privileges.

There is no reason whatever to suppose that Beneficiary the disruption of the Roman Empire.

II. $n . ;$ pl. benefieiaries (ben-ẹ-fish'i-ậ-1*iz) 1. One who loolds a benefice.

The beneficiary is obliged to serve the parish clurell in 2. In feudal law, a fendatory or vassal.-3. One who is in the receipt of benefits, profits, or advantages; one who receives sometbing as a free gift. Specifically - $(a)$ In American colleges, a student supported from a fund or by a religions or edu. cational society. (b) One in receipt of the profits arising from an

The fathers and the children, the benefactors and the beneficiary, shall .. hind each other in the eternal in
closures and circlings of immortality.

beneficiate (ben-ē-fish'i-āt), $v$. $t$.; pret. and $p p$. beneficiated, ppr. beneficiating. "< NL *beneficiatus, pp. of beneficiare, after $\mathrm{Sp}$. beneficiar, benefit, improve, cultivate the ground, work and improve mines, <L. beneficinm (>Sp. beneficio), benefit, improvement (in Sp. of ground, mines, etc.).] 1. To work and improve, as a mine; turn to good account; utilize.-2. To reduce (ores); treat metallurgically. Also called bencfit. [Little used except by writers on Mexican mining and metallurgy.]

There are a great number of mines located and owned by nativea, some of whon have arrastras, and others not even those, to beneficiate their minerals extracted.
Quoted in Ha milton's Yiex. Handlook, p. 230.

beneficiation (ben-ề-fish-i-ä'shon), n. [< bene. ficiate + -ion.] The reduction or metallurgieal treatment of the metalliferous ores.

beneficience, beneficient. Erroneous forms of benefieence, beneficent.

beneficions $\nmid$ (ben-ē-fish'us), a. [<L. beneficium, benefit (seo benefice), + -ous.] Beneficent.

beneficium (ben-ē-fish'i-um), n.; pl. benefieia (-ä). [<LL., L.: see benefiee.] 1. A right or privilege: a term more especially of the civil law: as, beneficiun abstinendi, that is, right of abstaining, the power of an heir to abstain from benefice.

The beneficium originated partly in gifts of land made by the kings out of their own estates to their own kins ful; partly in the surrender by landowners of their es tates to churches or powerful men, to be received back again and held by thent as tenants for rent or service. By the latter arrangement the weaker man obtained the pro-
tection of the stronger, and he who felt himself insecture tection of the stronger, and he who felt himself insecure
placed his title under the defence of the church. Stubbs, Const. Ilist., I. 275.

benefit (ben'ē-fit), n. [Early mod. E. also benifit, benyfit, ete. (also benefaet, after $\mathbf{L}$.) ; $<\mathrm{ME}$. benefet, benfeet, benfet, benfait, benfeyte, ete., AF. benfet, bienfet, OF. bienfait, $\mathbf{F}$. bienfait = It. benefatto, < LL. benefaetum, a kindness, benefit, neut. of benefactus, pp. of benefacere, do good to: see benefaction. The same terminal element occurs in counterfeit, forfeit, and sur feit.] 1 1 . A thing well done; a good deed.2. An act of kindness; a favor conferred; good done to a person.

Bless the Lord, 0 my sonl, and forget not all his benefits.

3. Advantage; profit; concretely, anything that is for the good or advantage of a person 
beneflt

or thing; a particular kind of good recoivable or received.

Men lave no right to what is not tor their benefit.

'The benefits of affection sre immense.

E'merson, Soclety and Solltude.

Certaln benefits arise [to heribvorous animals] trom liv

4ł. Bestowal, as of property, office, ete., ont of good will, grace, or favor; liberality; generosity.

Gither accept the title thou usurp'st, Ancl not proceedling from our king,

or we will plague tlee with lneessine wars.

Shak., illen. Vi., v. 4

5. A performanee at a theater or other place of public entertainment, the proceeds of which go to one or more of the actors, some indigent or deserving person, some eharitable institu tion, or tle like. In Great Britain also called a bespecti:-6. A natural advantage; entowment; aceomplishment. [Raro.]

Louk you lisp and wear strange sults; alisable [unsler valite] all the benefits of your ow Shak., As you Like it, Iv. 1.

When these so noule benefits shall prove

Not well disjos'd, the mind growhing once corrupt,
They turn to vicions forms. Shak., IIco. VIII., 1. 2. Benefit of clergy, In law. See clergy.- Benefit of dtsinventory. - Benefit play, a play acted for some one's henefit or alvantage.-Benefit society, a irlendly so-
eiety. Scc friendly.-Benefit ticket, $a$ winning tickct at a lottery. - By the benefit of thy the kininess o tavor of; ly the help of. = Syn, 2 and 3. Advantage

beneflt (ben'e-e-fit), $v$. [< benefit, n.] I. irans. 1. To do good to; be of service to; advantage: as, excreise benefits health; trade benefits a nation.

$$
\begin{aligned}
& \text { What course I mean to hold } \\
& \text { shali nothing benefit your knowledge. }
\end{aligned}
$$

2. Same as beneficiate, $\mathbf{2}$.

These ores [sllver] on sccount of the acarcity of water

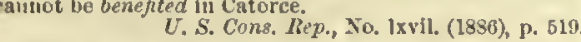

II. intrans. To gain advantage; make im provement: as, he has benefited ly good advice.

To tell you what I have benefited here

Mitton, Fducatlo

Each, therefore, benefits egoisticslly by such altruism

II. Spencer, Dsta of Ethics, 88.
.

benegrof (bẹ-nē'grō), v. t. $\quad[<b e-1+n e g r o$.

1. To render dark; blacken.

The sun shall be benegroed in darkness.

Heuryt, Sernions, p. 79

2. To people with negroes. Sir T. Browne.

benemptf. Obsolete preterit and past partic ple of bename.

beneplacitt, $a$. and $n$. [<LL. beneplaeitus, pleasjng, accoptable, pp. of beneplacere, please, < bene, well, + placere, ple
Well pleasod; satisfied.

Ood's Beneplacite wil, commonly stíled his wil of good

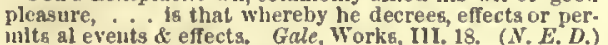

II. $n$. [< LL. bencplacitum, good pleasure, will, docree, neut. of beneplaeitus, pleasing, acceptable: see I. Cf. placitum, pleasure, what is decreed, neut. of placilus, pp. of placere, please.] Good pleasure; will; choice. Sir T. Brovene. bene placito (bā'ne plia'chē-tō). [It.: bene, L. bene (see benc-); placito, < L. placitum: see beneplacit.] In musie, at pleasure.

beneplacituret, $n$. [<beneplacit + -ure.] Same
[<entacit. In musie, at pleasure. as beneplacit.

Ilath he by his holy penmen told us, that elther of the other ways was more suitable to his bereplaciture?
Glanville, l'reèristence of Soula, iv.

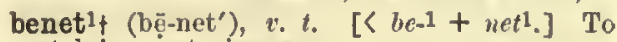
atch in a net; insnare.

lieing thus benetted rouml with villains. Shak., IIamlet, v. 2

benet2t (ben'et), n. [<MF. benet, < OF. beneit, benic (ben'ik), $a$. [< ben $5+-i e$.$] obtained$

mod. F. béni, LL. benedietus, blessed: see from oil of bell: as, benie acid.
benediet.] In the Rom. Cath. Ch., an exoreist, Beni Carlos (bä'ni kär'lōs), n. [Formerly benithe third of the four lesser orders.

benevolence (bê-nev'o-lens), n. [<ME. benevolence, benivolence, $\angle \mathrm{OF}$. benivolenee (vernacularly bienvoillance, bienvouillanee, mod. F. bienreillance), < I. benerolentia, < benerolen $(t-) s$, well-wishing: see benevolent.] 1. The disposition to do good; the love of mankind, accomness; good will; kindness; charitableness.

525

The man whom benerolence warme

blomifield, Banks of Wye. of another saint it is recorded that hia benevalence wai arch that he was never known to be hard or lnlinman to 2. An act of kindness; good done; charity
The Conrtier necdes must recompenced bee Speneer, Hother IJuh. I'alc, I. \$10. That whlch we distribute to the poor, St. Paul calleth a Oured, ti. of Cupe on Proveris, \{ol. 151 b.

3. In England, an arbitrary contribution or tax illegally exacted in the guise of a gratuity to the sovereign, from the time of Fdward IV. liam and Jary: sometimes used of similar exactions elsewhere.

The same year [1473] Fd ward hegan to collect the con.

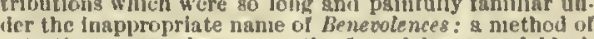
extortion worse than even the torced loans ant black
cliarters of Richard II. Stubbs, Const. IItst., 8632 . Love of benevolence, in New England theol, that s? fection or propensity of the lieart to any being which
csunes it to Incline to its well.being, or diaposes it to camses it to incline to its well.being, or dirpores it to
desire and tske pleasure in its happiness: distinguished rorn the love of complacency, or the elsposition to take daty, Charity, etc. (sce beneficence), henignity, humanity.

benevolent (bē-nev'ö-lent), $a$. [< late ME. bencolent, benjrolent, $<\mathrm{OF}$. benivolent $<\mathrm{L}$ benevolen( $t$-) s (usually benernlus), well-wishing, bene, well, + tolens, ppr. of velle, wish, = E vill.] 1. Having or manifesting a desire to do good; possessing or characterized by love toward mankind, and a desire to promots their prosperity and happiness

Beloved old $\mathrm{msn}$ ! benevolent as wisc. The benerolent sffections sre independent springs of acFowler, Shaftesbury and Hutcheson, p. 77.

disting benevolent enterprise; a benerolent institution. '=\$yn. Kind-hearted, humane, charitable, generous. benevolent manner; with good will; kindly. benevolentness (bē-nev'ō-lent-nes), $n$. Benevolence. [Rare.] lent.

A benevolous inclinstion is implanted into the very frame

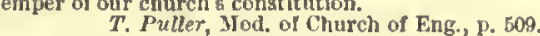
beng (beng), $n$. Same as bhang.

bengal (ben-gâl'), n. [Froin the province of
Bengal, Hind. and Beng. Bangăl: said to be named from a city called Bängùlä; in Skt. Banga.] 1. A thin stuff made of silk and hair, used for women's apparel: formerly made in Bengal.-2. An imitation of striped muslin. Also ealled Bengal stripe.

Bengalee, $a$. and $n$. See Bengali. gal, a province of British India, and also a lieutenant-governorslip comprising several other

II. $n$. sing. and $p l$. A native or natives of Bengal; a Bengali or the Bengalis.

Bengal grass, light, quince, root, etc. See the Bengali, Bengalee (ben-gâ'lē or -gä'lē), $a$. and $n$. [< Hind, and Beng. Bangäli.] I, $a$. Of or pertaining to Bengal,

II. $n$. 1. A native or an iubabitant of Benal; a Bengalese

Bengalis fled in shoals scross the Gange日.
$J . T$. Wheeler, Short Hist. India, p. 267.

earlo, beneerirlo < Beniearlo, a seanort in the province of Castellon, Spain.] A red wine of dark color and considerable strength, made on the shores of the Mediterranean, in eastern Spain. Much of it is exported to Franee, where it is mixed with lighter wine for table use.

benight (bo-nit'), v. $t$. [<be-1 + night.] 1. To overtake with night. [Rare of being bencvolent; benevolenee.

benevolous $\nmid$ (bê-nev'ō-lus), $a$. [< L, benerolus,

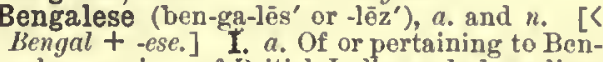

\section{benignity}

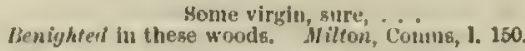
2. To involve in darkness, as with the shades of night; sliroud in gloom; overshadow; eclipse; figuratively, to involve in moral darkmess or ignorance.

And let ourselves benight our happlest day.

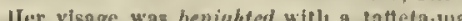
Iler visage was beniphted witli a tafteta-mask, to fray

$$
\text { lout ols! sias : what sudden cloud is spread }
$$

Alout this glorious king's eclipset liead?
it all his fame benights.
(ondey, Navideis, ii. Shall we to men benighted The iamp of llte deny? Ip. Heber, Ilissionary IIymn. benighten (bề-ni'tn), $v_{0} t_{0} \quad[<$ benight $+-e n l$, after enlighten, etc.] To benight. [Rare.]

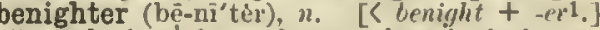
Uno who benights or keeps others in darkness. benightment (bè-nit'ment), $n$. [< beniglet + ment.] The state or condition of being be-ment.]

benign (bō-nīn'), a. [< ME. benigme, $<\mathrm{OF}$ be nigne, benin, $\mathrm{F}$. benin $=\mathrm{Sp}$. Pg. It. benignn, $<\mathrm{I}$. benignus, kind, <benus, old form of bouns, good, + -genus, born, < gignere, OL. genere, beget: sce -genous, ete. Cf. malign.] 1. Of a kind disposition; gracions; kind; benignant; favorable. Thou hast fulfilld

Thou hast fulfild
Thy words, Cresior bounteous and benign,
Glvet of all tlings Isir! Millon, l'. L., viil, 492. 2. Proceeding from or expressive of gentleness, kindness, or benignity.

To whom thus Michael, with regard beniqn.
Milton, $\boldsymbol{P}$. Lo, xI. 334. What did the benign lips seem to say? Ilawthorne, Great Stone Face.

3. Favorable; propitious: as, benign planets. Godlike exercise
of infuence benign on planets pale.
Keats, Ilyperion, i.

4. Genial; mild; salubrious : applied to weather, ote. -5 . Mild; not severe; not violent; not malignant: used especially in medicine: as, a benign medicine; a benign disease. $=\mathbf{\$ y n}$. Gracious, benignancy (bẹ̄-nig'nan-si), n. $\quad[<$ benignant: see-ancy.] Benignant quality or manner. benignant (bē-nig'nant), $a$. [In sense like benign; in form < LiL. benignan $\left(t_{-}\right) s$, ppr. of benign; in form L LL. benignan $(t-) s$, ppr; of benignari, rejoice, ML. benignare, appease, < L.
benignus, benign, kind: see benign. Cf. malignant, malign.] 1. Kind; gracious; favorable: as, a benignant sovereign.

And thank benignan nature mogt for thee

2. Exerting a good, kindly, or softening inflence; influences of Christianjty on the mind. -3 . In med., not malignant; not dangerons: said of diseases. $=$ Syn. 1. Benignant, Gracious, Benign, Kind, Good-natured. Benignant and gracious are generally applied to superiors, and imply especially a certain manuer
of kindness or favor. Bentignant 18 more tender or gentle; gracious is more civil or condeacending; both are winning. with activity or manner, and is applied especially to looks snd infuences: as, a benign smile. Find often implies gon acting : thus, we do not apesk of a gervant as being kind
to his master, unless the latter la ill or otherwise made de. to his master, unless the latter la lll or otherwise made de. pendent on his gervant for ald. A good-natured person is
one who is not only willing to oblige, but will put up with
a good des] of snnoyance. Kind implies discrimtogtion In henevolence ; good-natured does not, but often impllea a weaknesa Ior

$$
\begin{aligned}
& \text { Stern lawgiver: yet thou dost wear } \\
& \text { The Godheal's most benipnant grace; } \\
& \text { Sor know we anything ao fair } \\
& \text { As Is the smile upon tby Iace. }
\end{aligned}
$$

She, tact She, hsving the truth of honour in her, hsth made him Shak., M. for M., ill. 1.
S. Therc she lost a noble and renowned brother, in his love Shak., MI. for MI., HII. 1. An entertainment thironghout with which everybody was pleased, and the good-natured lathers seemed to be moved
with a deilght no less hearty than that of the boya them-
selves. benignantly (bē-nig'nant-li), adv. In a benignant mannor; with kindly or gracious manner or intent.

benignity (bề-nig'ni-ti), n. ; pl. benignities (-tiz). [< L. benignita $(t-) s_{1}<$ benignus, benign: see benign.] 1. The state or quality of being benign; goodness of disposition; kindness of nature; graciousness; beneficence.

The benignity of Provldence is nowhere more clearly to lee secn than in ita compensations.
Lorcell, study WIndowa, p. 349. 
benignity

2. Mildness; want of severity. Like the mildness, the aercnity, the continuing benignity 3. A benign or beneficent deed; a kindness. benignly (bề-nīu'li), ad v. In a benign maaner ; favorably ; kindly; graciously.

benimt, $v_{0} t_{0}$ [< ME. benimen, binimen, < AS. beniman $(=\mathrm{OS}$. biniman $=$ OFries. binima $=\mathrm{D}$. benemen $=\mathrm{OHG}$. bineman, $\mathrm{MHG}$. benemen, $\mathrm{G}$. benehmen = Goth. biniman $\rangle$, take away, $\langle$ be- + nimen, take: see $b e-1$ and nim, and cf. pp. and deriv, verb benum, benumb.] To take away; deriv. verive.

\section{All togider he is benome
The powcr bolh of loonde and fote.}

Ire . . benimeth the man from God. benincasa (ben-in-kā'sä), n. [NL., named after Giuseppe Benineasa, an early patron of botany, and founder of the garden at Pisa.] The white gourd-melon, Benineasa hispida, resembling the pumpkin, but covered with a waxy pulverulent coat. It is very generally cultivated in tropieal countries.

benish (bc-nēsh'), $n$. [Ar. benish.] A kind of pelisse worn by Arabs.

A beneesh, or benish, which is a robe of cloth, with benison (ben'i-zn), n. [K ME. benisoun, beneson, benesun, beneysun, <OF. beneison, beneicun, beneigon, < LL. benedictio(n-), a blessing: see benedietion, and ef. malediction, malison.]

God'a benison go with you. Shak., Mac

More precious than the benixon of friends.

Talfourd, ion, 1. 2 b

Ben-Israel (ben'iz"rạ̄-el), n. An Abyssiniaı

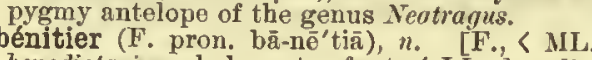
benedietarium, holy-water font, < LL. benedictus, blessed: see or vase for boly water, placed in a niche in the chief porch or chief poreh or Roman Catholic chureh, or, commonly, against one of the interior pillars door, into which the members of the congregation on entering dip the fingers of the right hand, blessing themselves by making the sign of the cross. Also called aspersorium, stoup, and holy-ivater fout (which see, under font).

benjamin ${ }^{1}$ (ben'.

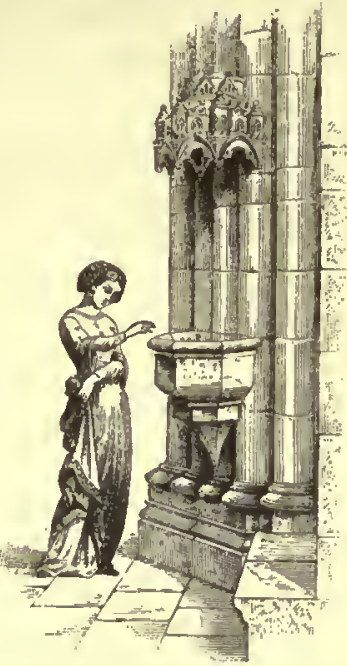
jamin.] A kind of top coat or overcoat formerly worn by men.

Sir Telegraph proceeded to peel, and emerge from his
four benjamins, like a buttertly from its chrysalis.

benjamin' (ben'ja-min), ${ }^{2}$. $[=G$, benjamin a corruption of benjoin, an earlier form of ben.
a zoin, q. v.] 1. Gum benjamin. See benzoin. -2. An essence made from benzoin.

Pure benjamin, the only spirited scent that ever awaked
a Neapolitan nostril. B. Jongon, Cynthlai benjamin-bush (ben'ja-min-bủsh), $n$. An aromatic shrub of North" America, Lindera Benzoin, natural order Lauraeex. Also called spicebuse

benjamin-tree (ben'ja-min-trē), $n$. A popular name $(a)$ of the tree Styrax Benzoin, of Sumatra (see benzoin), and (b) of Fieus Ben juminea, an East Indian tree.

benjoint (ben'jọ-in), $n$. An earlier form of ben-

benjy (ben'ji), n. [Origin obscure; perhaps A low-crowned straw hat having a very broad brim.

ben-kit (ben'kit), $n$. A large wooden vessel
526

benmost (ben'mōst), a. $[<\operatorname{ben} 1+-m o s t . \quad C$ inmost.] Innermost. See ben1. [Scoteh.] benne, bene ${ }^{3}$ (ben'e), $n$. [Of Malay origin.] A annual plant, Sesamum Indieum, natural order Pedaliaeex, a native of India, but Iargely cultivated in most tropieal and subtropical countries for the sake of the seeds and the oil expressed from it The leaves are very nuci. part this quality to The seeds liave frum an cient times been classeal with the most nutritious rains, and are still extensively used for food in Asia about lialf their weight ingill- teel- or gessmeil), which is inodorous not readily turned rancid

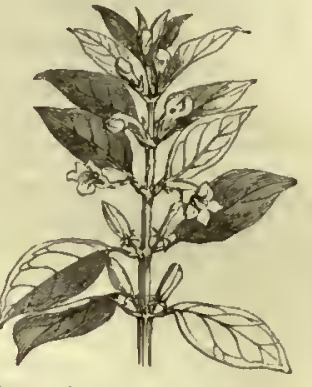

ersal use in India in cooking and anointing, for soaps etc. Large quantities of both oil and seeds are Inported into France, England, and the United States, and are used
chiety in the nuanufacture of goap and for the adultera on of ollve-oil, or as a aubstitute for it.

bennet ${ }^{1}$ (ben'et), n. [Var. of bent ${ }^{2}$, ult. < AS. *beonet: see bent ${ }^{2}$.] A grass-stalk; an old stalk of grass. [Prov. Eng.]

bennet2 (ben'et), n. [< ME. benet, beneit, in herbe beneit, < OF. *herbe beneite (mod. F. be-
noite $)=$ It. erba benedetta, < MIL herba benenoite $)=$ It. erba benedetta, < ML. herba benedicta, i. e., 'blessed herb': sce herb and benecliet.] The lierb-beanet, or commou avens, Geum urbanun.

bennick, binnick (ben'ik, bin'ik), $\mu$. [E. dia] (Somerset); origin obscure.] A local English name of the minnow.

ben-nut (ben'uut), n. [<beut + nut. $]$ The pterygosperma, yielding oil of ben, or ben-oil. See horseradish-tree.

ben-oil (ben'oil), $n$. [<ben5 + oil. $]$ The ex pressed oil of the ben-nut, bland and inodorous, and remarkable for remaining many years without becoming rancid. At a temperature near the freezing-polnt it deposits its solid fats, and the re maining liquid portion is used in extracting the perfumes cate machinery. "The truc ben-oil, however, is gaid to be derived from the aeeds of Moringa aptera of Abyssini benome $e^{1} t, p, a$. See benumb.

benome $2 t$, benoment. [See benumb, benim.] Earlier forms of benum, past participle of benim. benorth (bē-nôrth'), prep. [< ME, be (bi, by) nerthe, < AS. be-northan (= MLG. benorden), < be, prep., + northan, from the north: see beand north, and ef. besouth, ete.] North of: as, benorth the Tweed. [Scoteh.] benote (bẹ̄-nōt'), v. $t . \quad[<b e-1+$ note. $]$ To annotate or make notes upon.

benothing (bē-nuth'ing), $v \cdot t . \quad[<b e-1+n o-$ thing.] To reduce to nothing; annihilate.

bensel (ben'sel), n. [Also bensall, bensil, bensail, and bentsail (simulating bent + sail), Icel. benzl, bending, tension, < benda, bend: see bend1.] 1. Foreo; violence; impetus. - 2. A sovero stroke or blow, properly that reA sovere stroke or blow, properly that re-
ceived from a push or shove. [Scoteh and prov. Eng.]

ensel (ben'sel), v. t. $\quad[<$ bensel, n. $]$ To beat; bang. Jamieson. [Seotch.] benshie (ben'shē), $n$. Same as banshee.

ent (hent), $a$. [Pret. and pp. of bend1.] I. $-2 \nmid$. Determined; set.

The bent enemie against God and good order.

bent1 (bent), $n$. [Var. of bend1, $n_{n}$, perhaps after bent 1 , pret. and pp.; but ef. descent, $<$ descend; ascent, < useend, etc.] 1. The state of being bent; curved form or position; flexure; curvature. [Now rare.]

$$
\text { With reverence and lowly bent of knee. }
$$

Hold your rod at a Greene, Menaphon'a Eclogue.

2t. A curved part; a crook or bend Ang. gree of flexure or curvature; tension; straining; utmost force or power: an archery expression, but used figuratively of mental disposi

Her affections have their full bent.

Then let thy love be younger than thyselt

Shak., T. N., ii.

\section{ben-teak}

the discharge according to the aeveral bents, and the 4. Declivity; slope. [Rare.]

And downvard on an lill under a bente

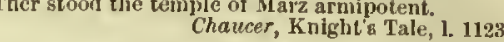
'The free hourz that we have apent Scott, Mfarnion, Int., ii.

5. Inclination; disposition; a leaning or bias of mind; propensity: as, the bent of the mind or will; the bent of a people toward an object. It is his (the legislator's] hest policy to conply wilh the My grailing at thia observation gave ler spirits to pur-
sue the bent of her inclination. Goldsmith, The Bee, No. 2 . The strong bent of nature is seen in the proportion which this topic of personal relations usurps in the con-
versation of soctety.

6. Direction taken; turn or winding.

For souls already warp'd receive an easy bent.
Dryden, Hind and Panther, iil.

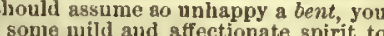
watch over and console you. Sheridan, The Rivalz, v. 1 7. In earp., a segment or section of a framed buildiug, as of a long barn or warehouse. 8. A framed portion of a wooden scaffolding or trestlework, usually put together on the ground and then raised to its place.-9. A large piece of timber.- IOt. A cast, as of the eye; direction.

Who neither looks on heaven, nor on earth,

But givea all gaze and bent of amorous view
On the fair Cressid.
Shak., T. and C., iv. 5.

= Syn. 5. Bent, Propensity, Bias, Inclination, Tendency, gronal figurativeness. Bent is the meneral and of their or of the mind as disposed toward something; a decided snd fixed turning of the mind toward a particular object of mater of the wiole Pronsity ta less deep than bent, less appetency toward that which is evil. Bias has often the aane meaning as bent, but tends specially to denote a aort of external and continued action upon the mind: as, "morality influcnces men'a nuinds and givea a bias to prejudice. Inclination is a sort of bent; a leaning, more more than inclination, atronger sad more permanent,
Proneness la by derivation a downward tendency, a strong
natural inclination toward that which is in natural inclination toward that which is in some degrce evil: as, proneness to err, to self-justification, to vice; but it is also used in a good sense. Disposition is often a
matter of claracter, with more of choice in it than in the matter of cluaracter, with more of choice in it than in the
nthers, but it is used with freedon in lighter senscs: as, They fool me to the top of my bent. Byrity to Jeer.

The bias of human nature to be slow in correspondence triumpls even over the present quickening in the geners1
pace of things. George Elivt, Middlenarch, 11. 263. 1tis so much your inclination to do good, that you stay not to be asked; which is an appraach ao nigh to the
Deity, that human nature is not eapable of $\mathrm{s}$ nearer Dryden, Ded. to ludtan Emperor.
Dring Everywhere the history of religiou betrays a tendency to
enthusiasm. Actions that promote society and mutual fellowahlp reem reduclble to a proneness to do good to others and a It eannot be denled that there la now a greater disposierty thangst men toward the assertlon of individual lib erty than existed during the feudal ages.
II. Spencer, Social Statlca, p. 187. bent2 (bent), n. [Also dial. bernet; <ME. bent, (lames, as in Beonetleáh, $>\mathrm{E}$. Bentley) $=\mathrm{OS}$. "binet (not authenticated) $=\mathrm{LG}$. behnd (Brem. Wörterb.) = OHG. binuz, binez, MHG, binz, G. binse, a bent, rush; origin unknown.] 1. Any stiff or wiry grass, such as grows on commons or neglected ground. The name is given to many speclea, as Agrostis vulgaris, Agropyrum junceum, species of 2. The culm or stalk of bent; a stalk of coarse withered grass; a dead stem of grass which has borne seed.

His spear a bent both atiff and strong. Drayton, Nymphidia.

3. A. place covered with grass; a field; nninclosed pasture-land; a heath.

the bent that that bytes on erbez.
Alliterctive Poems (ed. MIorris), ii. 532

Black bent, Alopecurus agrestis. - Dog ar brown bent, bent, dinacea.- Wire bent, vardus stricla. . To take the Take the bent, Mr. Rashleigh. Make ae pair o' legs ben-teak (ben'tēk), $n$. A close-grained, infe-
rior kind of teak, used in India for buildings 
and other ordinary purposes. It is the wood of benumbedness (bẹ-nnmd'nes), $n$. [<benumbed, benzyl (ben'zil), u. [< benz(nic) $+-y l$.] An Lagerstromia mierocarpa.

bent-grass (bent'grås), $n$. Same as bent' 1 .

benthal (ben'thal), $a$. [ $<\mathrm{Gr}$. Bivoos, tho depths of the sea, $+-a l$.$] of or pertaining to depth$ See extract.

In lis presidential address to the biologieat geetion of

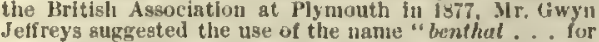
depths of one thousand fathoms and mere, "while retain

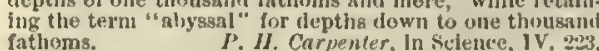

Benthamic (ben-tham'ik), a. Of or pertaining to Jeremy Bentham or to his system. See Benthanism.

The Benthamic standard of the greatest happinesa was liat which I liul always been taught to apply.

J. S. Mlill, Autwiliog., 1. 64.

Benthamism (ben'tham-izm), $n_{0}$. $<$ Bentham + -ism.] Tho political and ethical system taught by Jeremy Bentham (1748-1832), who lield thit the greatest liappiness of the greatcst number is the rational end of moral rules, and ought to be the aim of goveruments and individuals aliko; utilitarianism (which seo). My previens education [that is, hefore 1821-2] had
in a certain senge, slready a conrse of Benthamism. J. S. Mill, Antobiog., l,

Is Benthamism so absolutely the truth, that the l'ope to be denounced hecause he has not yet become a conver
to it?

Benthamite (ben'tham-īt), $x_{0} \quad$ [ Bentham + $-i t c^{2}$.] A follower of Bentliam; a believer Benthamism; an adherent of the Benthami philosopliy.

A faithful Benthamite traversing an age stll dinmedly JI. Arnold,

bentinck (ben'tingk), $n$. [From Captain Bentinek $(173 \overline{7}-75)$, the inventor.] Naut, a triangular eonrse, nsed as a trysail: now generally superseded by the storm-staysail. - Bentinck boom, a small hoom on the foot of a stuare foresail. in the weather the ship is rolling heavily. [No longer used.]

bentiness (ben'ti-nes), $n$. The state of being benty.

benting (ben'ting), $n . \quad\left[<\right.$ bent $t^{2}+$-imy. $]$ Tho act of seeking or collecting bents or bent-stalk The plgeon never knoweth woe

Ray's Proverb.

benting-time (ben'ting-tim), $n$. The time when pigeons feed on bents before peas aro ripe: as, "lare benting-times," Dryden, Hind and Panther, iii. 1283.

bentivi, bentiveo (ben-tē'vē, -tộ-vā'ọ), $u$. [Said to be Braz.] A name, said to be used in family Tyranuide, the Pitangus sulphuratus of authors in general, Tyranmus sulphwratus (Vieillot), Lanius sulphurntus (Limnæus), originally deseribed in 1760 by Brisson as la pie-griesehe jazme de Cayeme, and hence long supposed to be a shrike.

ben trovato (bān trō-vä’tọ̄). [lt.: ben, < L. benc, well; trotato (pl. trovati), pp. of trotare, find, invent: see trove.] Woll feigned; well invented: a part of a familiar Italian saying, Se non è vero, $\dot{e}$ ben trovato (If it is not tmie, it
is well imagiued), sometimes introduced, in various relations, in English.

Various anecdotes of him [Dante] are relatel by Boccacsome of them at least fitteen centuries old when revanumed. Mlost of them are neither veri nor ben trorati.
Lowell, Among my Books, 20

benty (ben'ti), a. [<bent $\left.{ }^{2}+-y^{1} \cdot\right]$ 1. Of, pertaining to, or of the nature of bent or bentgrass.-2. Covered with or abounding in bent. benumt, $p$. $a$. and $v$. $t$. An earlier form of benumb.

benumbt, benome ${ }^{1}, \nu_{\text {; }}$ a. [Farly mod. E. < niman, deprive: see benim.] Benumbed.

benumb (bẹ-num'), $v$. $t$. [Early mod. E. benu, see benumb, p.a.] 1. 'To make torpid; deprive of sensation: as, a hand or foot benumbed by cold.-2. To stupefy; render inactive.

It seizcs upon the vitals, and benumbs the senses. South. Ily mind revolts at the reverence for forelgn anthers, Wicer of the infeliectual facultes subducs ocmombs the vifer of the intellectual faculties, subducs and debases
the unind.
N. I'ebster, In Scudder, p. 230.

benumbed (bẹ--numd'), p. a. Numb or torpid, either pluysically or morally: as, benumbed limbs; benumbed faith. pp. of benumb, + -ness.] The stato of bein

enumbment (bē-num'ment), n. [<bmumb

-ment.] The act of benumbing; the stato of being berumbed ; torpor.

benweed (ben'wël), n. [Also bin-, hind-, buntecel; < ben (unecrtain) + acedl. Cf. bendwith,
bimlicece.] Ragwort. [Seot]anil and North. Irelaud.]

Irelaud.]
benzaldehyde (ben-zal'dē-hīd), $u$. [<benz(nie)
+ aldchyde.] The oil of bitter almonds, $C_{4}$ + aldchyle. The oil of bitter alnonds, $C_{i}$ $\mathrm{I}_{5} \mathrm{COH}$, a colorless liquid having a pleasant be odor and soluble in water. It is prepared artifi. as weil as variens pigments.

benzamide (ben'zan-mid ol' -mîl), $n$. [< benzoie) + amide.] A white erystalline substance, amide of benzoyl.

enzene (ben'zen), $n_{0}[\langle$ benz(oic) + ene. $] 1$. A liydrocarbon ( $\mathrm{C}_{0} \mathrm{H}_{0}$ ) formed whenever orA hyarocarbon $\left(\mathrm{C}_{6} \mathrm{H}_{6}\right)$ formed whenever organic bodies are subjected to destruetive discommercially from coal-tar. It is a clear, colorlegs liquid, of a preculiar ethereal, agrecatile odor, used in the arts as a solvent for gums, resins, fats, etc., and as the
material from which aniline and the anlline colors are material from which aniline and the
derived. Also called benzol, benzolin.

. Same as beurin or benaine.

enzll (ben'zil), n. [<benz(oiil) + -it.] A courpound $\left(\mathrm{C}_{14} \mathrm{H}_{10} \mathrm{O}_{2}\right)$ obtained by the oxidation
of benzoin, and also by heating bromotoluylene with water at $150^{\circ} \mathrm{C}$.

benzilic (ben-zil'ik), a. [<ben-it $+-i e$.$] of,$ pertaining to, or formed from benril: as, benzitic acid.

benzimide (ben' $\gamma$ i-mid or -inid), $n . \quad[<$ ben$z i(n e)+(a)$ mide.] A compound $\left(\mathrm{C}_{23} \mathrm{H}_{18} \mathrm{~N}_{2} \mathrm{O}_{2}\right)$ formed by the action of hydrocyanie acid on hydrid of benzoyl. It occurs alse in the reslueus residive of the rectiflcatien of the eil of bitter aimonda

benzin, benzine (ben'zin, ben-zën'), $n_{\text {. }}[\langle$ ben-
(oic $\left.)+-i n^{2},-i n e^{2}.\right]$ A colorless limpid liquid consisting of a mixture of volatile hydrocarbons and having a specific gravity of between $62^{\circ}$ and $65^{\circ} \mathrm{B}$. It is obtained by the fractional distillation of petwoleum. It la essentially different from benzene, being a mixture of hydrocarbons, while benzene ls a singie hy. arts is as a solvent for fats, resins, caeutchouc, and certsin benzoate (ben'zō-at), n. [<benzo(ie) $\left.+a t e^{1}.\right]$ A salt of benzoic aeid.

enzoated (ben'zō-ñ-ter

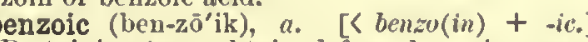
Pertaining to or obtained from benzoin.-Ben-

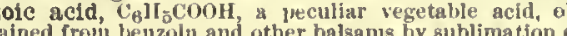
decoction. It forms light feathery needies: Its taste pungent and bitterish, and its oder slightly aromatic: substance obtained by distilling together 4 parta of alco1el, 2 parts of crystallized benzolc acid, and I part of co centrated liydrechleric acid. It is a colorless eily liq liaving a feeble aromatic smenl like that of frits, a
pungent aromatic taste. - Benzolc fermentation. benzoin (ben'zō-in or -zoin), n. [First in 16th century; also written benjoin, bengereyne, benguin, later benzion, etc. (also corruptly benju $\min 2, \mathrm{q} . \mathrm{v}.),=\mathrm{D}$. benjuin $=\mathrm{G}$. benzoe, benzoin $=$
Dan. benzoe, $<\mathrm{F}$. benjoin, $<\mathrm{Pg}$. beijoim $=\mathrm{Sp}$. Dan. benzoe,
benjui, menjui $=$ It. benzoi, < Ar. lubān jăre, lit. 'incense of Java' (Sumatra). The omission in Rom. of the syllable lu- was prob. due to its being mistaken for the def. art.] Gum benjamin; the conerete resinous juice of Styrax Benzoir, a tree of Sumatra, Java, and the Ma lay peninsula, obtained by incisions into th bark. The benzoin of commerce is obtained from both to the otiner in quality. When rubbed or heated iuperlor a tragrant and agreabie oder. It is chiefly used in cos. nuetics and perfumes, and in incense In Roman Catholi friars' or 'Turliagton's balsam, lang famens as a remedy for bronchitis and an effective application to indelent
seres, etc. It forms the medicinal ingredient of courtpiaster. See Styrax. z(oic) + -ol.] Same as benzene, 1 .

(oic) + -al.] Same as benzene, 1 .
(ben'-lin), n. $\quad\left[<\right.$ benzol $\left.+-i n^{2}.\right]$ be Same as benzenc, 1 .

To tinge or dye with a purple color. Digges.

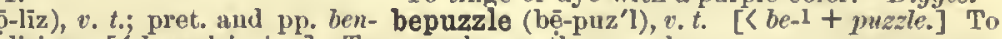
(

treat, impregnate, or cause to combine with bepuzzlement (bē-puz'

enzoyl (ben'zō-il or -zoil), n. [< benzo(ie) + bequeath (bē-kwē $\Psi^{\prime}$ ), $v, t$ [< AlE. bequethen, $-y$ l.] The radical $\left(\mathrm{C}_{7} \mathrm{H}_{5} \mathrm{O}\right)$ of benzoic acid, of oil biquethen, earlier bicicethen, AS. becteethan, f compounds derived from this oil, or connected with it by certain relations. st in the free state, but in combination forms considerable number of compounds.

enzylation (ben-zi-lā'shnn), n. [< benzyt + ino or somo similar substance.

The tentency of the benzylation being to give the colour Crace-Calert, Dyeing and Calico-prlnting, p. 390. enzylic (ben-zil'ik), u. [<benzyl +-ic. $] \mathrm{Re}$ lated to or containing the radieal benzy]. Else wonid a maiden blush beprint my cheek.
Shak., K. and $J_{\text {. }}$ ii. epale (bē-

Thuse perjur'l lips of thine, bepalef with biasting sighs. epat (bẹ-pat'), v. $t_{\text {. }}$; pret. and pp. bepatted, ppr. bepatting. [<be-1 + pat. $]$ To beat upon; As timing well the equal semul J. Baillie, The kilten. bepearl (bê̄-pẻrl'), a. t. $[\langle b c-1+$ pearl. $]$ To jearls.

This priturese all berearled with dew. Carew, The l'rimrose.

epelt (bẹ--[selt'), v.t. $\left[\left\langle b e-1+\right.\right.$ pelt $\left.t^{1}.\right]$ To pelt epepper (bē-pep'ér), $\iota t . \quad[<b e-1+$ pepper. $]$ To pepper; pelt witl thickly falling blows. To pester grently; plague; harass.

pineh or bruise all over.

In their sides, arms, shoulders, ail bepincht,
Itan tillck the weals.
Chamman, Iliad, xxill.

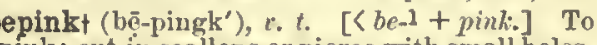
pink; cut in seallops or pierce with small holes.
bepiss (bê-pis') $v . t$. [ $\left[\right.$ be-1 $^{\prime}+$ jiss. $]$ To piss upon; wet with urine.

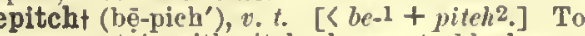
darken. Syliester.

bepity (bē-pit'i), $r$. $t . ;$ pret. and pp. bepitied, ppr. bepitying. $\left[<b e_{-}\right]+$pity. $]$To pity exeedingly.

beplait (bẹ-plāt'), r. t. $[<$ be-1+plait. $]$ To beplaster (bê-plás'tèr), t. t. [<be-1+plaster.] hickly; bedaub.

Beplasterd with rouge - Goldsmith, Retalistien. beplume (bē-plöm'), $r$ t. $[\langle b c-1+$ plume. $]$
To furnish or adorn with feathers; plume. bepommel (bẹ-pum'el), $\because \cdot t .[<b e-1+j o m-$ bepowder (bẹ-pou'dér), r.t. [<be-1 + poucder. $]$ To powder; sprinkle

Is the beaus compelled agalust his will to. . employ and becurl the outside? epraise (bē-prāz'), t. $t .[\langle b e-1+$ praise. $]$ To praise greatly or extravagant]y; puff.

Goldrmith, Essays, viil.
Ged he wspapers and niagazines. IJardly any man, and certainly no politician, has been
o bepraised as Burke. bepray (bẹ̄-prā'), v. $t . \quad[<b e-1+p r a y$.$] To$ To beprose.

Mallet, Verbal Critlelsn.

bepncker (bē-puk'er), $v$. t. $\quad[<b c-1+$ pucker. $]$ To pucker.

puff;

ever so diplomaed, be pujped, gasllghted, conbiquethen, earlier bicicethen, < AS. bectethan, declare, affirm, give by will, $<e-+$ creethan,
say. The simple verb became obsolete in tho ME. period, except in the pret. quoth, which aint; cover with paint, or as with paint. eprose (bẹe-prōz'), v.t. [<be-1+prose. $]$ To 
renains arcluaically in an idiomatic construe- berat (be-rat'), $n$. [Armen.] A warrant or berdash $\dagger, n$. See burdash,

tion (see quoth). The compound has been preserved through its technical use in wills.] 1 t. 'To give away,

sign as a gift.

Wilt thon forsake thy fortune,

Shat $K$, Jo ?

2. To give or leave by will; assign as a legacy: more commonly, but not necessarily, used of personal property, in contradistinction

$$
\begin{gathered}
\text { Mine heritage, } \\
\text { Which my dead tather did bequenth to me. }
\end{gathered}
$$

3. To hand down; transmit.

One generation has bequeathed its religious gloom and the colnterfeit of its religions ardor to the next.
IIauthme, Main Street. (ireece las bequeathed to 18 her ever living tonguc, and
the inmmortal productions of her intellect. Giladstone, dlight of Right, p. 16.

4†. To commit; commend; intrust.

We to flamea our slanghtered frlends bequeath.
Pope, Iliad, vii, 399. 5t. To give or yicld; furnish; impart.

A niggards purse shall acarce bequeath hia master a good dimuer

Parl, in IIarl. Mlisc. (Nalh.), II1. r2. (Y. E, D.) That which bequeaths it this slow pace.

6†. Reflexively, to commit; dedicate; devote. (1)phens. bequeaths himself to a solitary life in the
deserts. K. Digby, Broad Stone of IIonour, I. 166. (N,W,D.) bequeath† (bē-kwēmH'), n. [< bequeath, r.] A bequest.

bequeathable (bê-kwe'- wria-bi), a. [<bcqueath $+-a b l e$.$] Capable of being bequeathed.$

bequeathal (bẹ-kw'-'sнal), n. [< bequeath + -al.] The act of bequeathing; bequest.

The bequeathal of their savings may be a neans of giv-
The American, VI. 324 . bequeather (bē-kwē'thèr), $n$. One who bequeaths.

bequeathment (bē-kwēmH'ment), n. [< bequcath + ment. $]$ The act of bequeathing; a bequest.

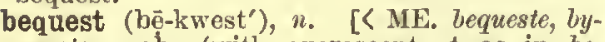
quyste, prob. (with excrescent - $t$, as in behest, and shifted accent, after the verb) < AS. *bicwis (equir. to bicwide, ME. bequide, after becwethan, ME. bequethen), (bi-, accented form, in nouns, of bi-, bc- + cwis (cwiss-), saying, s cwethan, say : see bequeath.] He elaimed the crown to himself, pretending an adop-
tion, or bequest of the klugdon unto him, by the Confes. sor.

Possession, with the right of bequest and inheritance,
the stimulant whicli raises property to its highest value.

2. That which is left by will; a legacy -3 . That which is or has been handed down or transmitted.

Our cathedrals, our creed,, our liturgies, our varled jing, are a bequest Irom the age of taith.

bequestt (bẹ-kwest'), $v$.t. [< bequest, n.] To give as a bequest; bequeath.

bequethet, $v . t$. An obsolete form of bequeath. chetucer.

bequia-sweet (bā-kēeä-swēt), $u_{\text {. }}$ [See quot.] An oscine passerine bird, of the family Icteride nosus, a grakle found in the Caribbees: so named from its note.

In Bequia [in the Carjblees], and extending thronghout the chain [of islands], is a blackbird, $a$ new specles
named the Quiscalus luminosus, which makes the air resound with its joyous cry : "Bequia sneet, sureet, Bequia
grceet." bequote (bẹ-kwöt'), v.t. $[<b e-1+q u o t e$.$] To$ quote fiequently or mucin.

beraftt, m). A Middle English past participle

of bereace.
berain $\dagger$ (bē-rän'), $v . t . \quad$ [<ME. beraynen, berei-
nen (= OHG. bireganōn, G. beregnen) < be- +

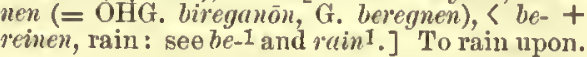
With his Leris salt lire breest byreymed.

$$
\text { Chaucer, Troilus, iv. } 1172 .
$$

Berardius (be-rär'di-us), $n$. [NL., named after of the family Physeteride and subfamily Ziphii$n$, having two functional teeth on each side of the mandibular symphysis. It is related in general characters to Ziphius and Mlesoplodon. The only apecies, New Zealand waters.
Berard steel. See steel. patent of dionity

ental monarch.

berate (bē-rāt'), $t . t . \quad\left[\left\langle b e-1+r^{2} e^{2}.\right]\right.$ To chide eliemently; scold.

Zopyrus berated Socrates as if he lial eanght a pick-
pocket. berattlet (bē-rat' 1$), v \cdot t_{0}[\langle b c-1+v a t t l e$.$] To$ cry down; abuse; run down. Shah. [Rare.] beraunite (be-râ'nit), $n_{0} \quad[\langle\operatorname{Bcr} u$ un (see def.) $+-i t e^{2}$. A hydrous phosphate of iron of a leddish-brown color, found at St. Benigna near Beraun in Bohemia.

berayt $\left(\mathrm{b} \mathrm{e}_{-}-\bar{a}^{\prime}\right), v_{0} t .\left[<b c-1+r a y^{3}.\right]$ 1. To make foul; defile; soil.

Beraying the font anl water while the bishop was baptizing him.

2. To scent.

$$
\begin{aligned}
& \text { How comes your liandkercher } \\
& \text { So aweetly thus beray'd? }
\end{aligned}
$$

Vildleton, The Witcl, i, 2 .

berbe (bèrb), $n$. The wame of an African genet, Genetta pardina.

Berber (bèr'bẻr), $n$. and $a$. [< Ar. Berber, Barbar, tho Berbers: see barbary and barb3.] I. $n$. 1. A person belonging to any one of a group of tribes inhabiting the mountainous parts of Barbary and portions of the Sahara, descended from the primitive race of those regions. -2 . The language spoken by the Berbers. It is one of the Hamitic languages.

II. $a$. Of or pertaining to the Berbers or their language.

Berberidaceæ (bèr" be-ri-dā'sē-ē), n. pl. [NL., < Bcrberis (Berberid-) + -acece.] A natural order of plants, belonging to the thalamifloral dicotyledons, distinguishod from allied orders by having the few stamens in two or three whorls and the anthers opening by valves. The genera are widely distributcd, but are small, with the genera are widely distrihutcd, but are small, with the cohosh (Carlophyllum), the mandrake (Podophyllum), and the twin-leat (Jeffersoniat) are of more or less repute in
medicine, and the Akebia is an orvamental climber. 8ee cut under Berleris.

erberidaceous (bèr"be-ri-dā'shius), $a$. Of or pertaining to the Berberidaceo.

berberine (bér'be-rin), $n . \quad[<$ NL. berberina : see Berberis and -inc ${ }^{2}$.] An alkaloid $\left(\mathrm{C}_{20} \mathrm{H}_{17}\right.$ dom, being found in the barberry and a considerable number of plants, or parts of plants, siderable number of plants, or parts of plants,
whose extracts combine a yellow color and bitter taste. It forms fine yellow aclcular crystals, sparingly soluble in water, having a bitter taste. The sul
phate and hydrochlorate are golnble, but witl difficulty. Berberis (bèr'be-ris), n. [NL.: seo Zarberry.] The prineipal genus of the natural order $\mathrm{Ber}$ beridacea, including the common barberry. It contains about 50
apeciea of shrubby species ot shrubby can, and ranging fron Fuego. The common
barkerry, B. vulgaris, the only Europcan spe.
cies and extensively naturalized in the United States, is well known which inake a pleasant
preserve. The leavea preserve. The leaves many other species, are astringent and yield a
yellow dye. The bark of the root of this an of several Asiatic spe
cics, as $B$. Lycium, $l$
Asiatica, and $B$. ari-

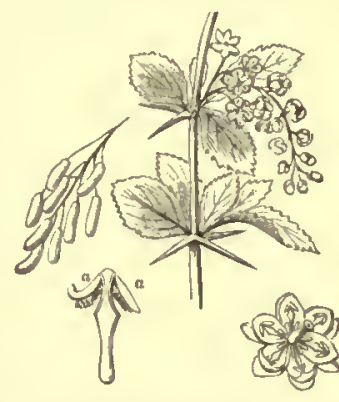
bitter tolic al tor the extraction of berlberine (which sec). Somic of the Mahonia group of species, distinguished by pinnate evergreen lcaves, and
ineluding the Oregon grape of the Pacific coast, B. Aquifolium, are frequentiy cultivated for ornament. The forward upon the pistil when the finter side of the fll juent is tonched.

berberry (bèr'ber-i), n. Same as barberry.

berbine (bèr'bin), $n_{0}$ [< Berb(eris) + -ine 2.$]$ An alkaloid extracted from the root and inner bark of the barberry. It is an amorphous white powder, bitter to the taste

berceuse (bār-sèz' ), n. [F., a rocker, a lullaby. Cf. bercean, a cradle, < bercer, rock, lull to instrumental composition of a tender, quiet, and soothing character.

bercheroot (ber' che-röt), $n$. The Russian pound, the unit of weight in Russia. The standard of 1835 equals 409.5174 grams, or 0.9028307 of a pound avoirdupois. bercowetz, $n$. See berkmets. berdet, $n$. An obsolete form of bcard.

bere $^{1} \uparrow, v$, bere ${ }^{2} \uparrow, n_{\text {. }}$, etc. An obsolete form of bcar 1 , bear ${ }^{2}$, ete., berry ${ }^{4}$, ete.

Berean (bē-rē'an), $a$. and $n$. [Also written $B e$ -

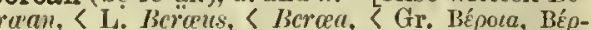
pota.] I. $a$. Of or pertaining to the ancient town of Berea (Berœa, now Verria) in Macedonia; in religious use, resembling the people of Berea as described in the Acts. See II., 2 .

II. $n$. 1. An inhabitant of ancient Berea.2. One of a sect of dissenters from the Church of Scotland, who took their name from and profess to follow the ancient Bereans mentioned in Acts xvii. 11, in building their system of faith and practice upon the Seriptures alone, without regard to human authority. Also called Barclayites, from their founder, John Barclay (1734-98), of Muthill, Perthshire. Berea sandstone. See sandstone.

bereave (bẹ̄-rêv'), v"; pret. and pp. bercarcd or bercft, ppr. bercaing. [< MF. bereven, bireven (pret. bercvede, berefte, bcreft, berafte, pp. bereved, bereft, bernft), < AS. bereafian (= OFries. birāva $=$ OS. biröbhön $=$ D. berooren $=$ OHG. biroubōn, MLHG. berouben, G. beraubcn = Goth. biraubon), rob, bereave, $<$ bc + recifian, plunder, rob: sce be-1 and reave.] I. trans. 1. To deprive by or as if by violenee; rob; strip: with of before the thing taken away.

sle have ye bereaved of ny children. Gen. xlii. 36 . The twist of lite, and hate of lite bereaven Forl, Fame' a IIemorial. Witt thou die e'en thus,

Ruined 'mldst rulu, rulning, bereft

of name and honor

Irillüm Morris, Earthly Paralíвe, 11. 18. It is annetimes used without of, more espccially in the passive, the subject of the verb he
deprived or the thing taken away.

And 'tis your fault I am bereft liim so. Shak., Venus and Adonis, I. 381.

All your interest in those territories
Is utterly bereft you. Shak., 2 Ilen. VI., iil. 1.]

2†. To take away by destroying, impairing, or poiling; take away by violence.

Shall move you to bereare my life.

I think his understanding is bereft.

Niarlone.

3t. To deprive of power; prevent. Chaucer, Trollus, I. 685

II. intrans. To destroy life ; cut off. [Rare.] bereavement (bē-rēv'ment), $n$. [< bereave t -ment.] 1. The act of bereaving.-2. The state of being bereaved; grievous loss; particularly, the loss of a relative or friend by death.

He bore his bereavement with stoical fortitude.
11. Simith, Tor Hill.

bereaver (bệ-rë'vèr), n. One who bereaves or deprives another of something valued.

bereft (bệ-1'eft'). Preterit and past participle of bercave.

Berengarian (ber-en-gā'ri-an), n. and $a_{0} \quad[<$ IL. Berengarius, Berengar, a theologian, born about A. D. 998, died about 1088.] I. $n$. One of a sect which followed Berengarius or Berengar of Tours, archdeacon of Angers in the eleventh century, who denied the doctrine of transubstantiation.

II. $a$. Of or pertaining to the Berengarians or their opinions

Berengarianism (ber-en-gā'ri-an-izm), $n$. [< Berengarian $+-i s m$.] The opinions or doctrines of Berengarius and his followers. See Beren. garian.

Berenice's hair. Sce Coma Berenices.

beresite (ber'e-sīt), $\eta_{0} \quad\left[<\operatorname{Beres}(o v s k)+-i t e^{2}.\right]$ A fine-grained granite found near Beresovsk, Russia, in the Ural, associated with gold-bearing quartz.

beret, berret ${ }^{1}$ (ber' ot), $n$. [F. béret, <ML. beretta, biretta, a cap: see barret 2 and biretta.] 1. A round flat woolen cap worn by the Basque peasantry. $\quad ., E . D .-2$. Same as birctta.

beretta, $n$. See biretta.

berettina, $n$. See berrettina.

berewickt, $n$. See berwick.

berg ${ }^{1}$ (bèrg), $u_{\text {. }} \quad$ [< Icel. Sw. Norw. berg = Dan. bjerg, a rock, G. berg = F. barrow $\mathrm{i}$, a hill.] A rock. [Shetland.]

berg 2 (bérg), $\pi$. [From -berg in ieeberg, $<G$. eisberg: see iccberg. Not from AS. beorg, a hill, which gives E. barrow ${ }^{1}$, a mound (but ef. bergh): see barrow I.] A large floating mass or mountain of ice; an iceberg.

Like glittering bergas of ice. 
bergall (bẻ re'gâl), . [Also written burgall, var. of bergell, bergle, q. v. The cummer or blueperch, a very common Now lingland fish, C'tenocunner.

Bergamask (bẻr'ga-mask), $a_{\text {, and }} n_{\text {. I I It. }}$ Bergamaseo, adj., Siergamo, a town in ltaly.

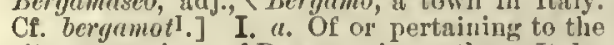
city or province of Bergamo in northern Italy, city or province of Bergamo in northern Italy, or the district of Bergamasea: as, Bergamask dance," Shak., M. N. D., v. 1.

II. $\varkappa .1$. An inlabitant of Bergamo or Bergamasca.

A gibe at the poverty of the Berqunask, anong whom, morcover, the extremes of stupidity nud cumning are Italy. 1 Houcells, Venctian Lific, v. itation of the people of Bergamasea, who were ridienlod as clownish in manners and speech.

bergamot 1 (bèr'ga-mot), $n$. [l'ornerly also burgamot, burgemott, bourgamot, appar. < licrburgamot, burgemott, bourgamot, appar. < Bergano, a town in Italy. Ct. bergamot .] 1. A variety of the lime or lemon, Citrus medien, with chancal means or by distillation, the volatile oil of bergamot (known in trade as essenec of ber gamot) is obtained. The essence is a product chiefly of southern Italy, and is much employed in perfumery. -2 . The popular mame of several labiato plants, as in Fingland of of several labiato plants, as in England of Monarda fistulosa and $M$. didyma. -3 . A kind Monarda fistulosa and M. didyma.
of snuff perfumed with bergamot.

Gives the nose its bergamol.

Couper, Task, Ii.

4. A coarse tapestry manufactured from flock of wool, silk, cotton, hemp, and from the liair of oxen and goats, said to have been made originally at Bergamo.

bergamot ${ }^{2}$ (bèr'gạ-mot), $\pi . \quad[<\mathrm{F}$. bergamote, lt. bergamatto, appar. a perversion, simulating a connection with Bergamo, a town in Italy (cf. name fürstenbirne) prince's pear, $<$ beg, a prinee (see bey ${ }^{2}$ ), + armund, a pear.] A variety of pear. bergander (bèr'gan-dér), $n$. [Early mod. E. also bergander (bèr'gan-dèr), $n$. [Early mod. E. also birpander, burgander, appar. MA. berze, a burrow (see berry ${ }^{3}$, burrow ${ }^{2}$ ), + gander (i. e., burrowbergeend = NFries. bargaand $=$ MLG. berehan $=$ G. bergente, lit. 'hill-duck,'G. erdgans, lit. 'earth-goose.'] A name of the sheldrake or burrow-duek, Tadorna vulpanser. See shcldralie. bergell, $n$. See bergle.

bergert, $n$. [Appar. < F. bergère, a négligéstyle of dressing the hair.] A lock of hair worn time of Charles II.

Bergerac (bér'je-rak; F. pron. berzh-rak'), $n$. 1. A red wine of good quality, made in the department of Dordogne in southwestern Franee, in the vicinity of the town of Bergerac. It fis seldom in the market under its own name, but is exported from Bordeanx, and confounded with claret. It is 2. A white wine from the same district, gendry wine not unlike Barsac.

bergeret, $n$. [OF., <berger, a shepherd, <ML. bcrbicarius, a shepherd, < berbex, L. vervex, a wether.] A pastoral or rustie song or dance. Also bargeret, bargaret.

$$
\begin{aligned}
& \text { There began anon } \\
& \text { A lady for to singe right womanly } \\
& \text { A bargaret in praising the dalsie. }
\end{aligned}
$$

berght, $n$. [Cf. bargh; obsolete formo (after Seand.) of barrowI, a hill.] A bill.

berglax (bérg'laks), n. [Norw. berglax, berglaks, lit. rock-salmon (= Dan. bjerglax, the common hake), ( berg = Sw. berg, Dan. bjerg, a hill, rock, + Norw. Sw. Dan. lax $=$ AS. leax $=$ G. lachs, salmon.] The Norwegian name of a gadoid fish, Coryphanoides norvegicus, of the family Maeruride.

bergle (bèr'gl), n. [Also written bergell, ber. gill (and bergall, burgall, q. v.), appar, a var. of bergylt, q. v.] A name in the Shetland

of the ballan-wrasse, Labrus maculatus.

a Swedish mineralogist $(1735-84),+-i t c^{2}$. $]$ variety of the zeolite natrolite. It occurs massive variety of the zeolite natrolite. It occurs massive
and fibrons in the zirconsyenite of Brevig in Norway. Its
colors are greenish, grayish-white, and red.

bergmaster (bèrg'más"tèr), $n$. [After G. bergmeister: see barmaster.] Same as barmaster. bergmehl (bèrg' māl), $n_{\text {. }} \quad[\mathrm{G} .,<\mathrm{berg}=\mathrm{F}$. bar row ${ }_{34}^{1}$ a mountain, + mehl $=\ddot{\mathbf{E}}_{\text {. meal }}$.] Moun- tain-meal or fossil farina, a geological deposit ut the form of an extremely tine pewiler, consisting alnost entirely of the silicious frustules or cell-walls of diatoms. It has heen caten in Iap-
land In scasons of great scarcity, mixed witl ground cenrs and bark.

bergmote (bẻrg'mōt), $n$. Same as barmote. ergy (bér'gi), a. [<ber $\left.\eta^{2}+-y^{1}.\right] \quad$ 1. Full of bergs or icebergs. -2 , Resembling or of the nature of a berg.

A conslderable bergy nuans of tce. [Also written berguylt (seo also bergle, bergall, burgah); < Norw, berggylta, dial. berggalt, appar. < berg, cliff, preciA wame in Shetland of the rose-fish, sebow.] nurinus, a fisls of the family scorpanilie. Also called Noricegian haddock. See eut under seunstes.

erhyme, $v$. $t$. See bcrime.

eriberl (ber'i-ber-i), $n$. [Singhalese; an intensive redupl. of beri, weakness.] A disease characterized by anemia, muscular and sensory paralysis, more or less pain, general dropsical symptoms, effusion into the serons caviforms are distinguished by the presence or absence of dropsy. It may be acute, or suhacute, or chironic. does not appear to be contagions, though it infects local. itles. Berberi occurs in lndis and adjacent countrica,
is frequent in Japan nnder the name of kakke, and seems
to be jdentical with the "gleeping sickness" of the west to be identical with the "gleeping sickness" of the west
const of Africa. It is sald to occur in Sontli America

Beridæ (ber'i-dē), n. $p l$. [NL., < Beri(d-)s+ ida.] A family of tetrachrotous or tanystomatons brachycerous Diptera, represented by
such genera as Beris, Iylophagus, ete. Also called Xylophagide.

beridelt, $n$. [Origin obseure.] A garment of linen, worn in Ireland in the reign of Henry VIII. Planché.

berigora (ber-i-gō'rị̂n), n. A name of an Australian falcon, the berigora hawk, Hieracided (or Ieracidea) berigora.

berime (bë-rim"), $v, t$. $\quad[<b e-1+r i m e 1$. celebrate in rime or verse. Also berliyme.
cine

She had a better love to berime [as la ofdl editions] her
Shak., $\mathbb{R}$. and J., II.

beringed (bẹ̈-ringd $d^{\prime}$, a. $[<b e-1+r i n g e d$. upplied or surrounded with rings.

A curiously beringed disc [Saturn].

[Saturn]. Beris (ber'is), $n$. [NI.] The typical genus of
the family Berida, or Xylophagide. B. elavipes is an example.

Berkeleian (bèrk'lē-an), $a$. and $n$. I. $a$. Pertaining or relating to George Berkeley, bishop of Cloyne, Ireland

The Berkeleian idealism is little more than the easy demonstration that this view Ithat the world of realit exists quite independently of being known by any know
ing befugs fn it, from a philosoplical standing point,

II. ". One who holds Bishop Berkeley's system of idealism; one

Berkeleianism (bèrk'tē-an-izm), $n$. The phi-

losophy of Bishop Berkëley. See Berleleian.

II holde that materiai things exist only in so far as they are perceived; their esse is percipi. It fa by thinkbeing createa the material universe. But lerkeley gives to oouls a snbbstmutive existence, so they must be created
otherwise. The Berkeleian idealism is intimately finterwoven with an extreme nominalism, which denies the exiswhich in a moclified form ia now generally adopted by which in a modified form ia now generally adopted ly space, the third Is recognized by touch (that fis, by the mus-
cular gense), nutii the eyes become educnted to assocint ing certain appearances with certal.

berkovets (bér'kō-vets), n. [Russ. berkovetsŭ.] A Russian weight, legally equal to 400 Russian ponnds, or 361 pounds 2 ounces avoirdupois. In other parts of Russia, where older pounds have not gone out of use, the value of this unit is somewhat greater. Also bercovet

berkowitz (bèr'kō-vitz), $n$. [G. berknvitz, repr. Russ. berkovetsti.] Same as berkovets.

berlin'1 (bèr'lin or bèr-lin'), $n$. [In first seuse, $=\mathrm{Sp}$. Pg. It. berlina $=\mathrm{G}$. berline, < F. berline; [Berlin, the capital of Prussia.] 1. A large four-wheeled carviage with a snspended body, two interior seats, and a top or hood that can be raised or lowered: so ealled because first made in Berlin, in the scventeenth century, made in Berlin, in the seventeenth century, of Brandenburg.-2. A knitted glove.
A fat uan to binck tights anul clonuly Berlin

berlin 2 berling, $n$. See birlin.

Berlin blue, iron, etc. See the nouns.

berloque (ber-lok'), $n_{0}$ [ [ ' ' . W Milit., tho tattoo upon a drum announcing a meal-time.

berm (bèrm), n. [Also written berme, rarely birm, barm; ef. F. berme, = linss. brrma, ete., SMD. berme, D. berm, berme, = MLG. berme, barn, = G. berme, a bern, jrob. = Icel. burmr, edge, border, brim, as of a river or the sea, ete. see brim $\left.{ }^{1}.\right]$ 1. I nasrow ledge; specifically, sce rim $^{1}$.] 1. A nastow ledge; specifically, in fort., a s]ace of ground or a terrace from 3 to the moat or foss, designel to receive the ruins of the rampart in the event of a bombardment and to prevent the earth from filling the foss. sometimea it is palisaded, anu in the Setierlunds it is generally planted with a quickset liedge. If we aecept the llindu Kush as our mountain fortress,

$J$. $T$. Whereer, short IIIst. India, p. ess

2. The bank or side of a canal wlich is oppo-

site to the towing-patl. Also called berm-bunk.

berme ${ }^{1} t, u$. A Midale English form of barm².

erme", $n$. See berm.

ermilliang (bér-mil'yanz), n. $p l$. [Origin un-

known.] Picces of linen or fustian.

ermuda grass, fan-palm, ete. Sce the nouns.

ermudian (bér-mū' di-an), $a$. and $n$. I. $n$.

Pertaining or relating to the Bermudas or to their inhabitants

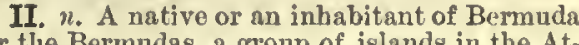
or the Bermudas, a group of islands in the Atlantic, about 600 miles east of Cape Hatteras in North Carolina, belonging to Great Britain.

bern It, $n$. A Middle English form of bamI.
bern't, bernet, n. [Early mod. E. (Se.), < ME. berne, bern, burne, burn, ete., $<$ AS. beorn, biorn, a warrior, hero, a word used only in poetry, and prob. = Icel. björn, a bear, appar. a deriv. of It was a common poetical practice to give the names of fierce animals to warriors; ef. AS. cofor, a boar, = Icel. jöfurr, a warrior, hero.] A warrior; a hero; a man of valor; in later use, a poetic term for man.

bernaclel (bér'na-kl), n. Same as barnctelel.

bernacle $2+, n$. Same as barnacle 2

Bernardine (bér'när-din), $n$. and $a$. [F.Ber nardin, < ML. Bernardinus, < Bernardus, Bernard.] I. $n$. The name given in France to the members of the Cistercian order of monks. It distingutshed menber of the order and was regarded as its II. a. Pertaining to St. Bernard or the Ber-

ardines.

bernet, $n$. Seo bern ${ }^{2}$

bernert, $n$. [<ME. berner, < OF, berner, bernier brenier (ML. bernarius), a feeder of hounds, bren, bran, bran: see bran.] An attendant in charge of a pack of hounds. $N . E . D$.

Bernese (bèr-nēs' or -nēz'), $a$. and $n_{0}[<G$.

Pertaining to Bern or its inlabitants.

II. $n$. sing. and $p l$. A citizen or citizens of Bern, the capital of Switzerland, or of the canton of the same name.

bernesque (bèr-nesk'), a. [< It. Bernesco,
Bcrni: see -esque.] In the hnmolons and burlesque style of the writings of Franeesco Berni an Italian poet, who died in 1536.

Bernesque poetry is the clearest reflexion of that reliteristics of Italian social life in the 16 th centurycwhich showed itself more or less in ali the works of that
period, that scepticism which stopped the religious Refor period, that scepticism which stopped the religious Refor-
mation in Italy, and which In Its turn was an effeet of his.

Bernicla (ber'ni-klä), n. [NL. (adopted as a genus name by Stephens, 1824), ( ML. berniela.

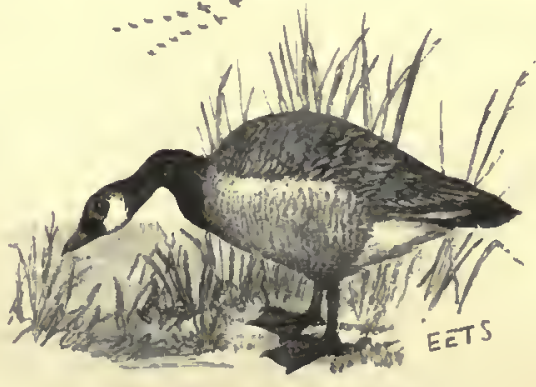

Canada Goose (Bernicla en nendensis). 
Bernicla

the barnacle: see barnacle ${ }^{1}$.] A genus of geese, containing the barnacle-goose, brent-goese, and related species, which havo black bills, black head and neck with white markings, and the general color dark, with white or light tail-coverts. The type-species is Anser bernicla, now $B$. leucopsis:
the brent-goose is $B$. brenta; the black brent of North America is $L$. nigricans; the common wild goose of North
America, or Cansda goose, is 1 . canadensis; Hutchins's America, or Cansda goose, is $\Delta$. canadensis; Hutchins's
goose is a similar but smaller species, $B$. hutchlinusic; there bernicle, bernicle-goose (bèr'ni-kl, -gös), $n$. [A for'm of barnaclet, historically obsolete, but [A form of barnacle, historically obsolete, but now oceasionally used with ref. to the $\mathrm{NL}$.
generic name Bernicla.] The barnacle or barnacle-goose. Sce barnacie $1,1$.

Bernissartia (bèr-ui-sär'ti-aí), $n$. [NL., < Bernissnrt, name of a quarry in Belginm.] A genus of extinct Wealden crocodiles, typical of the family Bernissartivile, whose remains have

Bernissartiidæ (bèr" ni-sär-tī' $\mathrm{i}-\mathrm{d} \overline{\mathrm{e}}$ ), $n$. pl. [NL.

< Bervissartia + -ida.] A family of extinet crocodilians. The technical characteristics are: the chosnz comparatively spproximated; the supratemporsl tossere smaller than the orbits; a well-defined orbitolaterotempe than two longitudinal rows; and the ventral srma. ture redicced to one buckler of imbricsted plates. The family occurs in the Weslden snd Purbeck formations. or discovered by one of several famons mathe maticians belonging to the Basle family Bernoulli, which originated in Antwerp.-Bernoullian function, \& function defined by an equistion of the form $\Delta \mathrm{F}(x)=x^{n}$. - Bernoullian numbers, a certsil series of minnbers discovered by Jacob
1705 , of which the first members sre:

$\mathrm{B}_{2}=\frac{2}{8} \quad \mathrm{~B}_{4}=\frac{1}{30} \quad \mathrm{~B}_{6}=\frac{1}{42} \quad \mathrm{~B}_{\mathrm{g}}=\frac{1}{30} \quad \mathrm{~B}_{10}=\frac{5}{6} 6$.

Bernoullian sexles, in math., the series $f \circ=f x-x f^{\prime} x$ $+\frac{x^{2}}{2+} f^{\prime \prime} x-\frac{x^{3}}{3 !} f^{\prime \prime \prime} x+$, etc.

bernouse, $n$. See burnoose.

berob $\left(b \hat{e}-\mathrm{rob}^{\prime}\right), v \cdot t . \quad[<\mathrm{MIE}$. berobben ; $<b c-1$ + rob.] To rob; plunder.

Wn you lath frownd, and pourd his inill starence bad
That of your selfe ye thus berobbed srre?

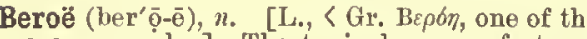
ocean nympls.] The typieal geuns of etcnophorans of the family Beroidac. B. forskali is a exsmple. The species are of the size snd shape of a sms

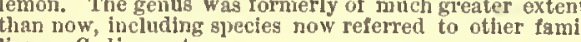
lies, as Cydippe, etc.
beroid (ber'o-id), n. A ctenophoran of the family Beroide.

Beroidæ (be-rō'i-dēe, n. pl. [NL., < Beroë + -ida. A family of the class Ctenophora, subkingdom Calenterata, having the body globular with fringed appendages of the periphery of the polar spaces. They sre transparent jelly-like ms rine orgsnisms, differing from most of the ctenophorans beroon (bē-rön'), n. [Pers. bìriñn, without, exterior.] The ehief court of a Persian dwelling
bouse. S. G.W. Benjomin, Persia and the Persians.

berret ${ }^{1}, n$. See beret.

berret2' (ber'et), n. A kind of oplal bead of the size of a marble.

It was most amusing to witness his [the clinef of Latoo-
ka's] delight at a striug of fifty little berrets I had hroughit into the country for the flrst tin.

berretta, 1 . See biretta.

berrettina (ber-e-tế'nï), n. [It., dim. of berretta: see biretta.] A scarlet skull-cap worm by cardinals. Also berettina.

berri, ". The Turkish mile, of which there are said to be 66 to a degree.

berried (ber'id), a. [<berry $\left.+-e t^{2}\right]{ }^{1}$; Keats. - 2, Of the form or nature of a bery, baceate. - 3. Having eggs or spawn, as a female lobster or other crustacean.

berry ${ }^{1}$ (ber'i i), $n_{\text {. }}$; pl. bervies (-iz). [Early mod. E. also berrie, < ME. bery, berie, < AS. berie, berige $=\mathrm{OS}$. beri (in winberi, grape) $=\mathrm{MD}$.
bere, also beze, D. bezie, bes $=\mathrm{MLG}$. bere =OHG. beri, MHG. bere, ber, G. beere = Icel ber $=\mathrm{Sw}$. bär = Dan. ber = Geth. basi (in weinabasi = OS. winberi = AS, winberie, 'wine-berry,' grape) (nent. and fem. forms mixed), a berry. Origin unknown; by some referred to the reot of bare, as if the 'bare' or 'uneovered' fruit.] 1. In bot.: (a) In ordinary use, any small pulpy
fruit, as the huekleberry, strawberry blackberry, mulberry, checkerberry, ete., of which
530

berwick

only the first is a berry in the technical sense. (b) Technically, a simple fruit in which the entire pericarp is fleshy, execpting the oute skin or epicarp, as the banana, temato, grape, currant, ete. (e) The dry keruel of certain barley, or the coffee-berv'. See cut unde wheat.-2. Something resembling a berry, as the the ov or infectorius, used in dyeing.-Avignon berry, the Irupe of Rhamnus alaternus, used in dyeing yellow. Also called French berry.

berry ${ }^{1}$ (ber'i), $v . i . ;$ pret. and pp. berried, ppr. berrying. $\left[<\right.$ berry $\left.1, n_{0}\right]$ 1. To bear or produce berries.-2. To gather berries: as, to go berrying.

berry ${ }^{2}\left(b_{c}{ }^{\prime} i\right), n . ;$ pl. berries (-iz). [Early mod. E. also berye, beric, < ME. berghe, berze (prop. dat.), a barrow: see barrow ${ }^{1}$.]
barrow. [Obsolete or dialeetal.]

\section{This little berry some ycleep}

$$
\text { II. Browne, Britanula's }
$$

The thestres are berries for the fair:

Like snts on mole-hills thither they repsir.

berry $^{3}+$ (ber'i), n. [E. dial, < late MÉ. bery: see burrow ${ }^{2}$.] 1. A burrow, especially a rabbit's burrow.-2. An exeavation; a military mine.

berry 4 (ber'i), $x$. t.; pret. and pp. berried, ppr

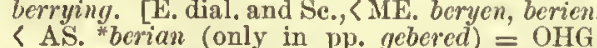
berja, MHG. berren, beren = Icel. berja $=$ ferire ( $>$ ult. E. ferule, interfere), strike.] 1 . To beat; give a beating to.

$$
\begin{aligned}
& \text { Iere this hoy is, ge bacle vs go bary } \\
& \text { With battis } \\
& \text { We are combered his corpus for to carry. }
\end{aligned}
$$

2. 'To thresh (grain, ete.)

I'll berry your crsp by the light o' the moo

berry5 5 , n. [Also berrie; a corrupt form of perrie, pirrie: see pirrie.] A gust of wind.
bersaglieri (bār-sä-lyā'ri), $n$. pl. [It., pl. of $b$ -

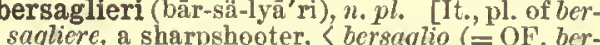
sagliere, a sharpshooter, < bersaglio (= OF. ber-
sail, berseil), a mark, butt, <"berciare, in im berciare, aim at (=OF. bercer, berser); ef. MI bersare, shoot with the bow, hnnt. Cf. ML. bercellum (var. barbizellum), a battering-ram; perhaps < berbex, L. vervex, a wether, ram.] The name for

berserk (bẻr'sérk), n. [< Icel. berserkr (omitting as nsual, the nom, suffix $-r$ ): see berserker.] Same as berserker.

berserker (bér'sér-kér), n. [Also berserkir and berserl, < Icel. berserlir (the $\mathrm{E}$. retaining the nom. suflix $-r$ ), pl. berserkir; commonly ex serkr, > E. surk, coat, shirt; but prob. rather 'bear-sark,'< "beri, m. (only in comp.) (bera, f.) = AS. bera, E. bear ${ }^{2}$ + serkr. "In olden ages $=$ AS. bera, E. bear ${ }^{2}+$ serkr. "In olden ages aears, wolves, and reindeer" (Vigfusson). The "berserker"s rage" is expressed by Icel. berserksgangr, < berserk + gangr, a going, esp. a rapid going, furious rush : see gang.] 1. A wild winavia. In battle the berserkers are gaid to have beet subject to fits of fury, when they howled like withl beasts, sulbject to fits of fury, when they howled like will beasts,
foamed at the mouth, gnawed the rim of their shields,

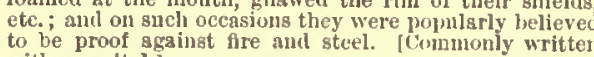
with a capltal.

Out of unhandseled savage mature, out of terrible Druid and Berserkirs, come at last Alfred and Shakspere.

The wild pirates of the North Sea have liecene con-
verted tito wariors of order and champions of peaceful verted tinto warriors of order and champions of peaceful
treedon, exlansting what still remains of the old $\mathrm{Ber}^{\text {. }}$.

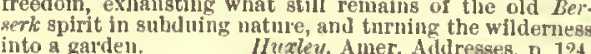
Hence-2. A persen of extreme violence and fury.

berstlet, ". A variant of bristle. Chaucer.

berth ${ }^{1}+, n$. An obsolete spelling of birth 2 .

berth ${ }^{2}$ 'berth), $n$. [First fonnd at the end of latter spelling being but recently obsolete); origin unknown (the E. dial. birth, a place, station, is but a later use of the same word) ; perhaps ult. derived (like the earlier berth ${ }^{1}=$ birth $^{1}$ ) from bear ${ }^{1}$.] 1. Naut.: (a) Sea-room; space kept or to be kept for safety or convenience
between a vessel under sail and other vessels or the shore, rocks, etc.: especially in the phrases, also used figuratively, to give a good, (to keep clear of, keep wcll away from). (b) anchor. (e) A station in which a ship lies or can lie, whether at anchor or at a wharf. (d) $A$ room or an apartment in a ship where number of officers or men mess and reside. (e) The shelf-like space allotted to a passenger in a vessel (and hence in a railroad slceping-car) as a sleeping-place; a sailor's bunk on board ship; a place for a hammock, or a repository for chests. -2 . A post or an appointment; situation ; employment: as, he has got a good berth at last. - Berth and space, in ship-brilding, the distance hetween the molding-edge o berth ${ }^{2}$ (berth), v.t. [<berth $\left.{ }^{2}, n.\right]$ Itaut.: (a) To assign or allot anchoring-ground to; give space to lie in, as a ship in a dock. (b) To allot a berth or berths to: as, to berth a ship's company.

The special object of these [changes on the approach of winterr was the economy of luel and the berthing of the
whole crew below deck. C. $F^{\prime}$. Hall, Polar Exp, p. 122

berth ${ }^{3}$ (bẻrth), v. t. [Early mod. E. byrth, perhaps <"berth, n. (not found), < Icel. byrdhi, beard or side of a ship, < bordh, board: see board.] To board; cover with boards: chiefly in ship-building.

bertha (bèr'th:̣i), $n$. [Also berthe, after F.; from the proper name Bertha.] 1. A small cape worn by women over the shoulders, usually crossed
in front and open at the throat. $-2 . \mathrm{A}$ trimming of lace or of other material in the shape of a small cape worn round the upper edge of a low-necked waist, or in a corresponding position on the body in the case of a high-necked waist.

berthage (bèr'thạjj), $u$. [<berth $\left.{ }^{2}+-a g e.\right] 1$. The dues paid by a vessel anchored in a harbor or dock, or berthed at a wharf.-2. A ccommodation for anchoring; harborage.

berth-brace (bérth'brās), $n$ A metal rod, rope, or ehaiu for supporting the upper berth of a sleeping-car.

berth-deck (berth'dek), $n$. In a man-of-war, the deck next below the gun-deck. See deck. berthe (be̊rth), n. [F.] Same as bertha.

berthierite (bẻr'thi-ér-it), $n_{\text {. }}$ [After Pierre sulphid of antimony and iron ocenrring in dark berthing ${ }^{1}$ (bèr'thing), $n$. [< berth ${ }^{2}+-i n g^{1}$. The arrangement of berths in a ship; the berths collectively. Berthing requires the earlliest attention, and the opers-
tion nay be facilitated by liaving a plan of the decks.
Luce, Searmanship, p. 294.

erthing ${ }^{2}$ (bèr'thing), $n$. [< berth $h^{3}+-i n g^{1}$. $]$ 1. The exterior planking of a ship's side abovo the sheer-strake, designated as the berthing of the quarter-deck, of the poop, or of the forecas tle, as the case may be; the bulwark. [Eng.] -2 . The rising or working up of the planks of a
ship's side. IIamersy.

berthing-rail (bèr'thing-rāl), $n$. In ship-building. See extract. The berthing-rail whicls was the uppermost rall in the
slip, was let into the lace piece and had an tron knee at

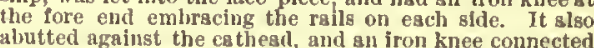
it with the cathead and shtg's side.
Thearle, Naval Arch., \& 232 berth-latch (bérth'lach), n. A spring-eatch for keeping the upper

Bertholletia (bêr-tho-lē'shi-ä) after Claude Louis Berthollet, a French chemist, 1748-1822.] A genus of Myrtacere, of which only one species, Bens of Myrtaceer, of which only one species, $B$. excelsa, is known. It is a
tree of large dimenstons, and forms vast forests on the tree of large dimenslons, and forms vast forests on the
l,gnks of the Amazon, Rio Negro, and Orinoco. It grows to s height of 150 feet, and its stem is from 3 to 4 feet in
lismeter. The fruit is known as the Brazil-nut (k-hitch

bertram, bartram (bèr'-, bär'tram) n. [A corr'uption of L. pyrethrum! see p'yrethrum.] Au old name of the plant Pyrethrum Parthenium, bastard pellitory or feverfew.

ertrandite (bèr'trand-it), [After E, Bertrand, a French erystallographer.] A hydrous silicate of glueinum, oceurring in minute orthorhombic crystals in pegmatite near Nantes in France.

berwick $\nmid$, berewick $t, n$. [Used only as a historical term, < ME. berewike, < AS. berewie, < bere, barley, + wiee, dwelling, village: see bear ${ }^{3}$ and wick $^{2}$, and ef, barton.] Same as barton, 1 . In the caurts of the Forest of Knaresborough each of the townships or berevics which form the manor of the 

pracpositus or grave, and the hedel.

STuber, Const. 11lst., 1. 120

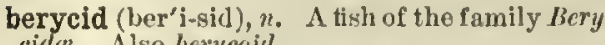
cilla. Also berycoill.

Berycidz (be-ris'i-dēe, n. $l_{\text {. }}\left[\mathrm{N}_{\text {d. }},<\right.$ Beryx (Beryo-) +-ides.] A family of acanthopterygian fislies, of which Bery $x$ is tle typieal gonus. Vury

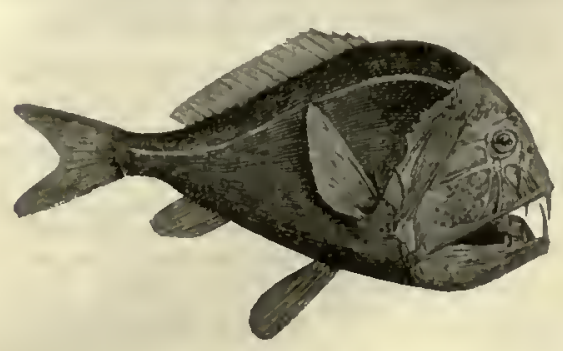

Caulolepis longidens.

tem it is the only family of the Beryciformes. (b) In Gill's system It is limited to berycuidea, with a slingle dutsul fin laving few spines in frent, and ventral fina with many soft
raya and molerate splncs. It Inctudea the genera Beryx

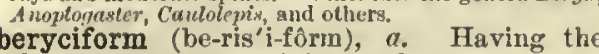
beryciform (be-ris'i-form), $a$. Having the
characters of or pertaining to the Beryciformes. characters of or pertaining to the Beryciformes,
Beryciformes (be-ris-i-fôr' môz), n. pl. [NI, [Beryx (Bcrye-) + L. forma, shapo.] In ieluth., in Ginther's system of classifieation, the second division of the order Acanthopterygii, characterized by a compressed oblong body, a head with large muciferous eavities covered with thin one spino and more than five soft rays (in Mo nocentris with only two).

berycoid (ber'i-koid), $a$. and $n$. I. $a$. Pertain ing to the superfamily Beryeoidea or family Berycidle.

II. $n$. Sanne as berycid.

Berycoidea (ber-i-koi'dē-ii), $n_{0} p l$. [NL., $<B e$ ryx (Berye-) +-oidea.] A superfamily of acan thopterygian fishes having nearly the same limits as the group Beryeiformes, and including the families Beryeide, Monocentrida, Stephanoberycide, and Holuccutride.

beryl (ber'il), n. [Early mod. E. beril, berel, ber rel, ete., < ME. beryl, beril, berel, < OF. beril,

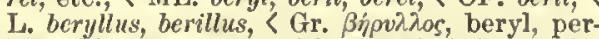
haps < Skt. vaidürya (with lingual d), beryl. Cf. Ar. Pers. ballür, bellaur, erystal.] A colorless, bluish, pinkish, yellow, or more commonly green mineral, occurring in hexagonal prisms, The precious emerald is a variety which owes its beanty
of coler to the presence of a small amount of chromiun. of coler to the presence of a small amount of chromiun. is a gilso used as a gem, theugh not hignly prized. Bery is a sticate of aluminimm and beryllium (ghucinum). The $\mathrm{kslia}$ and elsewhere in Siberia. Beryls occur also in man parts of the United States, especlally in the New Eng-

beryllia (be-ril'i-ï), n. [NL., < beryllium.] Same as glucina.

Beryllian (be-ril'ian), $n$. One of a sect founded in the third century by Beryllus, bishop of Bostra in Arabia, who taught that Christ was non-existent previous to his incarnation, and that at his birth a

berylline (ber'i-lin), $a$, [< beryl + -inel. $]$ Like a beryl; of a light- or bluish-green color.

beryllium (be-ril'i-um), n. [NL., 〈Gr. $\beta \eta \rho \dot{v} \lambda \lambda \iota 0 v$ dim. of $\beta$ h́p $2 \lambda \lambda$ s, beryl.] Same as glucinum. berylloid (ber'i-loid), $n$. [< beryl + -oid. ] A solid consisting of two twolve-sided pyramids planes of this form are common in crystals of planes

Berytidæ (be-rit'i-dē), $n, p l$. [NL., < Bcrytus $+-i d c$.$] A family of heteropterous insects,$ containing the most aberrant bugs of the series Corcoidea.

Berytus (be-ri'tus), n. [NL.] A genus of hemipterous insects, typical of the family $B e$ rytide.

Beryx (ber'iks), n. [NL.] A genus of pereoid Beryx (ber iks), $n$. [NL.] A genus of

berzelianite (bér-zé'llian-it), n. [< Bcrzelian (< Berzelius, a celebrated Swedish chemist, 1779 1848) +-ite $2^{2}$ ] A rare selenide of copper, found in thin incrustations of a silver-white color.

berzeliite (bér-zé̀'li-it), n. [< Berzelins (seo berzelianitc) $\left.+-i t e^{2}.\right]$ An arseniate of calci-
un, magnesium, and manganese occurring in

$\$ 31$

honey-yellow masses, also less frequently in isometric minerals.

berzeline (ber'ze-lin), $n$. [S Berzelius (see berzelianite $\left.+-i n e^{2} \cdot\right]$ 1. Tho copper selenid usmally called berzelianite-2. A namo enrly given to the mineral hatiyue.

bes (bes), n. [1., rare $]$ y bessis (luess-), <bi-, two + as (ass-), as, unit: see $\left(1 s^{4}\right.$. ] In Rom. metroloyy, two thircls of a unit or eight twelftis of an as; especially, eiglit cyathi or two thirds of a sextarius; also, tho namo of a small copper a sextarius; also,

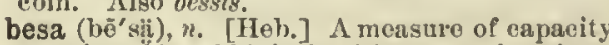
mentioned in rabbinical writings, equal to about oue sixtl of a United States pint.

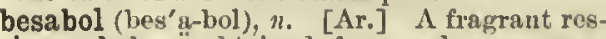
inous balsam obtained from a burseraceous tree, Commiphora L'atuf, of the Sonali country in eastern Africa. It was furmerly called Fatat Indian Also bissabol.

besagne (be-sān'), n. [OF. besange (Roquefort), a piece, bit; perhaps same as OF besant, fort), a piece, bit; perhaps same as of. besant, round plate protecting the interval between two pieces of plate-armor, as at tho knee-joint or elbow-joint. Durling the perlod from the first Introduction of plate in the earlicst rerebrace to 1he collplete sult of steel (nearly a century and a hain, the proteclen of these joluts was onc of the most difficult problems ami the use of the roundel of steel (easy to forge and to almest universal; if it disappeared for a few years, it wa only to ceme linto use agalin. See roundel. besague (bes'ä-gū), n. [OF., also bisaiguë, $\mathrm{F}$ besaiguë $=\mathrm{Pr}$. bezagudo, < L. bis, double, + acuta, aculus, pointed, sharp: see bis- and acute; and ef. E. troibill.] In medieval antiq.: (a) A twopointed weapon, especialpon, especialpick having

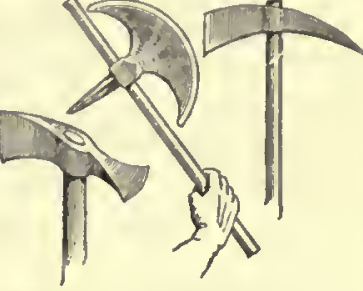

ne short point and one blunt or four-pointed head; a variety of the martelde-fer (which see). (b) A carpenter's tool with perhaps an ax-blad

besaint (bē-sānt'

make a saint of.

Their canonizing

ข. . $[<b e-1+$ saint. $]$ and besainting themselves.

besant, $n$. See bezant. bes-antler, $n$. See bez-antler.

besaylet, $n$. [ME., < OF. besayel, besaiol (F. bisaicul), a great-grandfather, < bes-, bis- (< L. bis, twice) + ayel, aiol, aieul, grandfather: see bis-and ayle.] A great-grandfather.-Writ of besayle, ln olli law, a writ by which a great.grandchild cated hla or her claim to lt.

bescatter (bê-skat'ér), $v . t_{0} \quad\left[<b e_{-1}+\right.$ seatter. To scatter over.

With flowres bescattered. Spenser, F. Q., IV. xl. 40 .
The battlemented plne-bescattered ridges on the further alde. The Century, XXVII. 39 bescorn (bẹ̈-skôrn'), v.t. [<bc-1 +seorn.] To treat with scorn; mock at.

Thell was he bescomed that enely slonild liave been hon-
chaucer, I'arson's T'ale.
oure things. bescratch (bẹ-skrach'), v. t. $[<b e-1+$ serateh. $]$ To serateh; tear with the nails. Spenser, F. Q., III. v. 3 .

bescrawl (bē-skrâl'), v. t. [< be-1 + scraucl. To serawl; seribble over.

So far is it from the kennc of these wretehed projectors
of ours that bescraull their Pamflets every day with new formes of government for our Cloure yilton, Church-Gorcrnment, i.

bescreen (bē-skrên'), v. $t$. [< be-1+ screen.] To cover with a screen, or as with a sereen shelter; conceal.

Besereenel in night.

Shak, R, and J, 11,2

bescribble (bē-skrib'1), v. $t .[\langle b c-1+$ scribble. $]$ o seribble over.

Bescriblled with a thousand trifling Impertinences, bescumberł (bộ-skum'bér), $v$. $t$. [Also beseum mer, < be-1 + scumber or scummer.] To dis charge ordure upon; befoul; besmear. Marton.

Statute's white sult with the parchment lace there? beset

A critic that all the world besemulvers inil tyoleal numbers.

B. Johum, Suetaster, v.

bescutcheon (bē-sknch'onn), r. t. $\quad\left[<b e_{-1}^{-1}+\right.$ scutchion.] To oruament witlı a senteheon: as, "bescutcheoned and betagged," Churehill The Ghost, iv.

beseet (bē-sē'), $v$ [ [ МLF, bcsen, besecon, biscom,

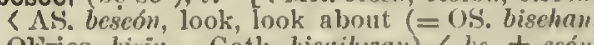
Ol'ries. bisīu $=$ Goth. bisnihurau $),<$ be- + scón, see: see be-1 and scel.] I. trmis. 1. To look at; sec.-2. 'To look to; keo to; attend to; ar rauge, -3 . lieflexiv

II. intraus. To look about; look.

beseech (bē-sèch'), $t^{\prime}, t_{\text {; }}$; pret, and pp, besonght, pir. besceching. [Far]y mod. F. (nortl.) also bescek, (ME. besechen, bisechen, also beseken (not in AS.) (= OFries, bisēka = D. bezocken = OIIG. bisuochan, MIIG. besuochen, G. besuehen $=$ Sw. besöka = Dan. besöyc, visit, go to sec), ( be- + seken, seek: see be-1 and seek.] 1. To entreat; supplicate; implore; ask or pray wit urgeney: followed by a personal object. I Paul myself beseech you by the meekneas and gentle-
ness of Cirlst. I do beseech you
(Chiefly, that I might set It in my prayers)

(Chiefly, that I might set It in my prayers),
What is your name?

2. To beg eagerly for; solicit: followed by tho thing solieited.

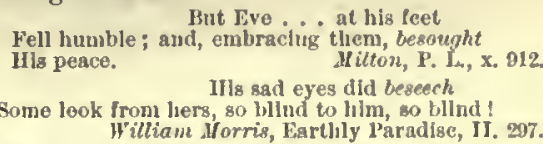

$=$ Syn. Ask, fequest, Beg, etc. (sec $a s k)$, plead for or with pelition, coujure, appeal to. $\quad[<$ bescech, $v$. $]$ A request: as, "such submiss beseeches," Hleteher (and others), Bloody Brother, iv. 2.

beseecher (bê-sét chèr), $u$. One who beseeehes. beseechingly (bẹ-sē'ehing-li), $a d v$. In a beeeching manner.

beseechingness (b-ē-sē'ching-nes), $n$. 'The state or quality of being beseeching or earnestly solicitous. Genrge Eliot.

beseechment (bē-sēch'ment), $u, \quad[<$ beseeeh + -ment.] The act of beseeching. Goodrin.

beseekt (bề-sēk'), v. t. Obsolete variant of beseceh. Chaucer.

$$
\begin{aligned}
& \text { There with yrayers meeke } \\
& \text { Anyld entreaty lodglng did for her beseeke. } \\
& \text { Spenser, F. Q., VI. I }
\end{aligned}
$$

beseem (bē-sēm'), $r$, [ <be- + semen, seem: see be-1 and scem.] I. intrans. 1. To seem.

As bereemed riglit.

2. To be seemly; be meet.

II. trans. 1. To become; bo fit for or worthy of.

In general, it has a qulet, didactlc tone, such as besecm ts subject and its age.

2†. To seem fit for.

But foure of them the lattell best beseemed.

beseemingt (bē-sē'ming), $n$. Comeliness. eseemingly (bē-sē'ming-li), adt. In a beseeming manner.

beseemingness (bẹ̄-sē'ming-nes), $n$. The qual ity of being beseeming.

beseemlyt (bō-sēm'li), a. [< beseem, confused with seemly.] Seemly; fit; suitable: as, "bescemly order," Shenstone, Schoolmistress. beseenł (bē-sēn'), pp. [< ME. beseyn, besein, bescye, byseyn, etc., provided, arrayed, having a certain appearance, pp. of besen, beseon, besee: see besee.] 1. Seen; viewed; with reference to appearance, looking: as, a well-beseen man.

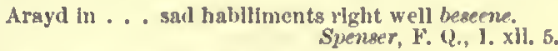

Hence-2. Clad; arrayed; equipped.

The Curate lu his best beseene solemuly recelved him at R. Carew, Survey of Cornwall, p. 137 b.

3. Provided with as accomplishments; furnished.

beseket, v. $t$. A Middle English spelling of be

besenna (be-sen'ä), n. Same as mesenna.

beset (bē-set'), $\ddot{v}_{0} t$. ; pret. and pp. beset, ppr. besetting. [<ME. besetten, bisetten, < AS. be settan (= OFries. bisetla $=\mathrm{D}$. bezetten $=\mathrm{LG}$. besetten $=\mathrm{OHG}$. bisezan, $\mathrm{MHG}$. $\mathrm{G}$. besetzen = Sw. besätta $=\mathrm{D}$. besatte $=$ Goth. bisatjan), surround, < be-, about, + settan, set: see be-1 and 
beset

set.] 1t. 'To set or place.-2. To sct or place upon; distribute orer'; bestud;
only in the perfect participle.

The garlen is so beset with all mauner of sweete slurubls,
that it perfumes the aire. A robe of azure beset with drops of gold.

pectator, No. 425 .

Beset on its external surface with splncs.

11'. B. Carpenter, yicros., \& 532

3. To come upon or against; set upon in attack, or so as to perplex, endanger, or hem in; press upon severely, vigoronsly, or from all sides : as,

Let us lay aside . . . the sin which doth so easily beset 118.

We are beset with thicves. Shch., T. of the S., iii. 2. Adam sore beset replled. Adam sore beset replled. Let thy troops beset our gates. Arifted tweenty-two niles to the sonthward.

A. 1F, Greely, Arctic Service, xxxvili. The main difficulty besetting the theory of the excavstion of the rock basins by lee is to explain how
after entering the bastin mansges to get out again.

after entering the basin mansges to get out again.
J. Croll, Climate and Cosmology, p. 254.

4t. To employ; spend; use up. Chancer.-5t. To become; suit; look well on.-To be beset ont, to be occupled with; have one's mind hixed on.

Syn thou most love thurgl thy destenee,

That thoul beset were on swich on that shold

Know al thi wo, al lakkede here pitee.

besetment (bọ̄-set'ment), $n$. [<bcset + -ment. $]$ 1. The state or cendition of being beset.

The breeze freshened off shore, breaking up and sendIng ont the foes, the leatls rapidly closing. Fearing a be Kane, Sec. Grimn. Exp., I. 33.

2. The sin or failing to which one is most liable; a besetting sin or tendency. [From the expression in $\mathrm{Heb}$. xii. 1.]

It's niy besetment to Iorget wbere I am, and everything
around me.

besetting (bẹ-set'ing), p.a. Habitually attaeking or waylaying.

We have all of us our besetting sins, our special moral danger, and our special moral strength. Self-Culture, ix

besewt (bē-sō' $), v$. t. [<ME. besewen, $<$ be- + seroen, sew: see be-I and sew ${ }^{1}$.] To sew. Gower. beseyet, $p p$. A Middle English form of bescen. besha (bé'shä), n. An ancient Egyptian measure of capacity, said to be equal to 4.5 liters, or one imperial gallon.

beshett, $p p$. A past participle of beshut. Chau-

beshinet (bë-shin'), v. t.; pret. and pp. beshone ppr. beshining. [< ME. beshinen, bisehinen, AS. bescinan $(=$ OFries. bisehinea $=\mathrm{D}$. besehijnen $=\mathrm{OHG}$. bisceinan, MHG. beschinen, G. beseheinen =Goth. biskeinan), shine upon, < be- + seinan, upon. Chaueer.

[She] was as lair a creaturc as the sun inight beshine.

beshlik (besh'lik), n. A Turkish silver coin, of the value of 21 United States cents. Also beslik. beshmet (besh'met), n. [Native term.] An article of food consisting of grapes made into the consistence of honey, used among the trits

beshonet (bệ-shōn'). Preterit and past partici-

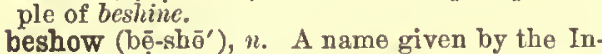
dians of the strait of Juan de Fuca te the candle-fish, Anoplopona fimbria. See cut under. eandle-fish.

beshrew (bẹ-shrö') $, v, t$. [< ME. beshrewen curse, pervert, $<b e-+$ shrew: see be- 1 an Alle suche freendis I beshrewe. Rom. of the $B$ See, a blossom from the bough; But beshrew his heart that pull'd it

Nay, guroth the cock; but I beghrew us both, Dryden, Cock and Fox

2. In modern use, a mildly imprecatory or merely expletive introductory exelamation, in the form of the imperative.

Beshrew your heart,

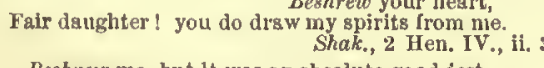
me, but it was an absolute good jest.
$B$. Jonson, Every Jan ln his Humour, iii.

Beshrew the sombre peucil ! said I vauntlugly.
532

It wag an illte bolt I sent, agalinst the villain crow; Brycut, strange Lady. beshroud (bē-shroud'), $r \cdot t . \quad[<b e-1+$ shroud. $]$
To cover with or as with a shroud; hide in darkness, as with a cloak.

darkness, as with a cloak. [< ME. beshutten, bibeshut $\dagger$ (bẹ-shut'), $v$. t. [< ME. beshutten, bi-
shetten, $(b \dot{e}-+$ sinutten, shut: see bc-1 and shut.] shetten, $<$ be- shutten, shut: see be-1 and $s$.
To shut in or inelose; shut up or confine.

besiclometer (bes-i-klom'e-tér), n. [ [ F. besieles, speetacles (modified (as if $<$ bes, L. bis, twice, $+\mathrm{L}$. oenlus, eye) < OF. bericle, crystal, brills + ( (n) linges of a pair of spectaeles; a forehead-meaure.

beside (bē-sīd'), adv. and prep., prop. prep. phlir. [< ME. beside, biside, byside, besiden, bisiden, ete., also (with adv. gen. suffix - $-s$ ) besides, bisidesiten, besitte), by (the) side: be, prep., E. by; sidan, dat. of side, side.] I. ado. San

sides, which is now the common form. II. prep. 1. At the side of ; ne
beside me, or beside the stream.

Beside hlm hung his bow. Milton, P. I, vi. 763. I walking to and fro beside s stream.

Tennyson, Holy Orall.

2. Over and above; distinct from. [In this sense now rare, besides being used instead.]

A woolten shirt is generally the only article of dress worn by the monks, beside the turban. 3t. Out of; away from. One of then taklng displeasure with his father ...
ned to him, and plucking lier [s [al leon] beside [out of] his
fist, wrong her neck. IIolinshed, Chron., Scotland (erd. 1806), 11. 60. Neleus, Son of Codrus, being put beside lont on

dom of Athenls by hls younger Brother Medon.
Stanley, Hist. Philos. (ed. 1701). (N. E. D.)

4. Apart from; not conneeted with; not aceording to.

It Is beside my present business to enlarge upon this 5†. Contrary to.

At Durham, beside all expectation, I met an old friend.
Johnson, Letters (ed. 1788), I. lxxili. 106. 6. Out of; in a state deviating from.

To put hlm quite beside his patien

7t. Without. Shak., 1 Hen. IV., Iii. I

Execut was al byside hire leve.

Chaucer, Trollus, 11i. 622

Beside the mark, away from the mark almed at; not to the point; lrreievant or irrelevantly: as, to shoot or to

To reason with such a writer is like talking to a deaf
man who catches at a stray word, makes answer beside the mark, and is led further and lurther lnto error by every attenipt to explain.

To be beside one's self, to be ont of one's wits or senses; be in a high state of mental exaltation or excitc

Paul, thon art beside thyself; much lesming doth mak thee mad.

IIe came down with a huge long naked weapon in both hils hands, and looked so dreadfully! sure he's beside him-
gelf.
B. Jonson, Epiccene, Iv. 2. To go besidet, to pass by ; pass over.-To look besidet,

Let vs but open our eyes, we csnnot looke beside a lesson.

= Syn. Beside, Besides. Beside, by the slde of; besides, in

Then went S1r Bedivere the second time

Across the ridge, and paced beside the mere.

His [Muley Abul Hassan's] kingdom now contalned fourteen cities, nluety-seven fortiffed places, besides numerous tles. besidery $\nmid$ (bē-sī'dẹ-ri), $n$. [Origin nnknown.] A species of pear. Johnson.

besides (bē-sīdz'), adv, and prep. [<ME. besides, bisides, <beside + adv. gen. suffix $-e s$ : see beside.] I. adv. 1. Moreover; more than that; furtber.

Were rich and honourable; besides, the mentlem Is full of virtue, bounty, worth, and qualities Beseening such a wile ss your fair daugliter. Shak., T. G. of V.,

2. In addition; over and above; as well. The men sald unto Lot, Hast thou here any besides? There are besides many pompous volumes, some emboss' wlth gold, and lutagllas ou achats, medailes, etc. besmear

3. Notiveluded in that mentioned; otherwise;

She does write to me

As if

4t. On one side; aside.

To gon besydes in the weye.

Thon canst not fight: the blows thou mak'st at me
Are quite besides. Beau. and Fl., Mlaid's Tragedy, v.

Sometimes beside.

II. prep. 1t. By the side of ; near. Spenser.Ovor and above; separate or distinet from; in addition to: as, besides these honors he received much money.-3. Other than; except; bating.

Fo living ereature ever walks in it besides the chaplain. dison, Spectator, No. 110 . 4†. Beyond; away from: as, quite besides the subject.-Besldes himselft, beside limselt. IIolland, tr. of Livy, p. 456.= Syn. Beside, Besides. See beside, II. besiege (bē-sēj'), $v_{\text {. }} t_{\text {. }}$; pret. and pp. besieged, segen besiege: see be-I and sicge, $v$. 1 'To lay siege to; beleaguer; beset or surround with armed forces for the purpose of compelling to armed forces for the purpose of compelling to tacks: as, to besiege a castle or city.

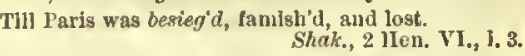

2. To beset; throng around; harass.

All frailties that besiege all kluds of blood. Shak., Sonnets, cix

The arras, rich with horseman, hawk, and houn
Flutter'd in the besieging wind's uproar,

And the long carpets rose along the gusty floor.
Keats, Eve of St. Agnes, xl.

= Syn. I. To beset, hem in, invest, blockade.

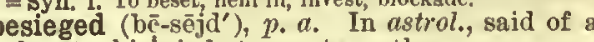

planet which is between two others.

besiegement (bệ-sēj'ment), $n$. [< besiege +

-ment.] 1. The aet of besieging.-2. A state of siege; beleaguerment.

It is not probsble, however, that Pemberton would have

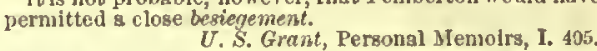

besieger (bẹ-sē'jèr), n. One who besieges.

On the 27th of November, the besiegers made a despe.

rate though hneffeetusl assault on the city.
Prescott, Ferd. and Isa., 11. 23.

besieging (bệ-s $\overline{\mathrm{e}}^{\prime} \mathrm{jing}$ ), $p$. a. Surrounding in a hostile manner; employed in a siege: as, a besieging army.

besiegingly (bệ-se' $\left.\bar{e}^{\prime} j i n g-l i\right), a d v$. In a besieging manner. [Rare.]

besillver (bë-sil'vèr), $v_{\text {. }} t_{\text {. }}[<b c-1+$ silver. $]$

To cover with or as with silver. G. Fleteher.

about; celebrate in song. Carlyle.

besitt (bē-sit'), v. t. [<ME. besitten, < AS. be

sittan, sit about, <be-, about, + sitlan, sit: see $b e-1$ and sit, and $\mathrm{cf}$. the causal form beset.] 1 .

To sit about; besiege.-2. To sit upon.-3. To sit properly upon, as elothes; suit; become.

That which is for Ladies most becitting. Spenser, F. Q., IV, 11. 19

beslabbert (bẹ-slab'èr), v. t. [< ME. beslaberen, also besioberen (= LG. beslabbern), < be- + slaberen, slabber, slobber: see be-I and slabber, slobber.] To beslaver; beslobber. Piers Plowman.

beslave (bē-slāv'), v. t. [<be-1+ slave. $]$ To make a slave of; enslave.

[Covetousness] beslaves the affections.

heslaver (bē-slav' Quarles, Judgment snd Mercy. Cf. bcsiabber.] To eover with slaver, or any thing suggestiug slaver; bence, to cover witl fulsome flattery.

beslik (bes'lik), $n$. Same as beshlik.

beslime (bè-slìm'), v. t. [<be-1+ slime. $]$ To daub with or as with slime; soil. Our fry of writers unsy beslime his fame.

(be-slob'er), same as beslaberen: see beslabber.] To besmear or befoul with spittle or anything runuing from the mouth; slobber over with effusive kisses hence, to flatter in a fulsome manner or to a fulsome degree.

beslubber (bē-slub'èr), v. t. [Var. of beslobber.] 'To besmear or befoul. Beslubber our garments with it [blood].

beslurry (bē-slur'i) v t. $[<b e-1+\mathrm{E}$ dial shu soil: see slur.] To soil. Drayton. [Rare.] besmear (bē-smēr'), v. $t$. [Early mod. E. also
besmeer, besmere, besmive, otc., < ME. bismeor 
besmear

ten, < AS. "bismerwian, besmyrian (= NIIG. besmirwen), besmear, $<$ be- + smyrran, smierwan, smear: sce be-1 aull smear.] To smear over or about; bedaub; overspreal with any viseons matter, or with any soft substanee that adheres; hence, to foul; soil; sully.

My honour would not let Ingratitude
Shak, , M, of V., vo l.

His dear friends Aeates and Acanthes

the in the fleld besnaired in their theorls Chaymant, llind Beggar.

Her fualing bleod the pavement all besmear'd.

Diryden.

besmearer (bẹ-smēr' êr), n. One who besmears.

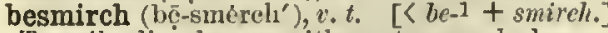
'fo soil; diseolor, as with soot or unud; henee. to sully; obseure. [The figurative uso is now tho mole common olle.]

Our gayness, and our gilt, are all besmirch'd Shinful field.
Shakk, llen. ., iv. 3 . The disbenor that besmirches the junsland of a faithless woman. II aethorne, Scarlet Letter, p. 87

besmoke (bō-smök'), $v$. $t$ [ [ MIE. besmoken, 1. To befoul or fill with smoke -2 . To harden or dry in smoke. Jolmson.-3. To fumigate. [Rare.]

besmooth (bẹ-ssmörsir'), v.t. [<be-1+smooth. $]$ To make smooth. Clajmman.

besmotered $p_{\text {, }} p$; [ME., pp. of "besmoteren; appar. freq. of besmut, which, however, docs dirty.

\section{Al bysmotered with lis habergeoun}

Chaucer, Gen. Prel. to C. T., 1. 70.

besmut (bē-smut'), $v, t_{*}$; pret. and pp. besmutted, ppr. besmutting. $\left[<\mathrm{be}^{-1}+\right.$ smut. $] \mathrm{To}$ blacken with smut; foul with soot.

besmutch (bể-smueh'), v.t. [<be-1 + smuteh.] To besmirch. Carlyle.

besnow $\left(b \bar{e}-s n \bar{o}^{\prime}\right), v_{*} t$. [With altered vowe] (after snow), for earlier besnew, < ME. besnewen, AS. besmiwan (= MHG. besnien, G. besebneien),
$\langle$ be- + snizuan, snow: see be-1 and snow.] To eover with or as with snow; whiten.

A third thy white and small hand shall besnow.
Carew, To Lady Anne IIay. besnuff (bē-snuf'), $v_{.} t_{.}\left[<b e_{-} 1+s n u f f.\right]$ To
befoul with snuff. $[$ Rare. $]$ Unwaghed her hands, and much besmufed her face.
Young, Satires, vi.

besogniot, $n$. Sce bisognio.

besoll (be--soil'), v. t. [< ME. besoylen, $<b e-1+$ sully.

Venerable too is the rugged face, all weather-tanned, besoiled, with its rude intelligence.

Carlyle, Sartor Resartus, ili. 4.

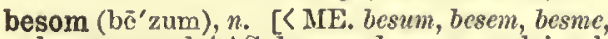
a broom, a rod, < AS. besema, besma, a rod, in pl. a bundle of twigs or rods used as a broom, also as an instrument of punishment, $=$ OFries. besma $=$ OD. bessem, D. bezem $=$ LG. bessen = OHG. besamo, MHG. beseme, G. besen, a broom, of twigs, a broom.] 1. A brush of twigs for sweeping; hence, a broom of any kind.

I wlli sweep It with the besom of destructlon, saith the
Lord of hests.

The Lord Bacon was wont to commend the advice of xton, that sold besemis.

There is little to the rake to get after the bissome. Scoteh proverb, In Ray (1678), p. 390.

2. A name given to the common breom of Eurepe, Cytisus scoparius, and to the heather, Calluna vulgaris, because botl are used for besoms. -3. [Pron. biz'um.] A conitemptuous epithet for a low, worthless woman. [Scoteh.]

besom (bë'zum), v.t. [<bcsom, n.] To sweep as with a besom. Cowper. [Rare.]

besomer (bé'zum-èr), n. One who uses a besom. besoothment (bē-sörH'ment), n. [< "besoothe (not in use) (<be-1+soothe) + -ment.] That whieh yields consolation; solace; comfort. Quarterly Rev. [Rare.]

besortt (bē-sôrt'), $v_{0} t_{\text {. }}\left[<b e_{-1}+\right.$ sort. $]$ To suit; fit; become.

Such men as nay besort your age. Shak., Lear, i. 4.

besortł (bẹ--sôrt'), n. [< besort, $v$.] Something fitting or appropriate; suitable company.

I crave fit disposition for my wife,

As levels witli her breeding. Shak., othelle, i. 3.

besot (bọ-sot'), v. $t$.; pret. and pp. besotted, ppr. besotting. $[<b e-1+$ sot. $]$ 1. To infatuate; make a dotard of.
Bessel's function

A fellow slneerely besotted on hls own wlfe.
B. Jonxon, Every $\$ a$ an ont of hils linmenr, Pret. 2. To stupefy; affect with mental or unoral tupidity or blindness.

A weak and besotted prines-who had ... producer a revolt in which six thotsand lives were lost-is per.
unitted, unnolested and In safety, to leave tle city.

3. To make sottish, as with drink; make a sot of.

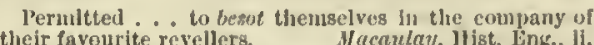
besotment (bē-sot'ment), $n_{0}[<$ besot + -ment. $]$ 'The act of making one's self sottish by drink: the state of being besotted.

The debasing habit of unsoelal besotinent is not lireught iniler tire eyes of hifs siperior.

ized by

esotted (bē-sot'ed), p.a. 1. Characterized by Besotted, base ingratitude. drilton, Comus, J. 7\%8, IIisterlen painting had sunk ... on the north Into the patient devotien of besolted lives to delineations of loricks

2. Made sottish by drink; stupefied by habitual intoxication.

besottedly (bệ-sot'ed-li), adv. In a besotted or foolish manner.

besottedness (bē-sot'ed-nes), $n$. The state of being besotted; stupidity; arrant folly; infatuation.

besottingly (bẹ-sot'ing-li), $a d x$. In a besotting

besought (bọ̄-sôt'). Preterit and past participle of beseeeh.

besour (bẹ-sour'), v. t. $[\langle b e-1+$ sour. $]$ To make sour. Hammond.

besouth (bê-south'), prep. $\quad[<\mathrm{ME}$. be-sovth: be $2+$ south. Cf. benorth.] To the south of. [Scoteh.] bespangle (bē-spang'gl), v. $t$. $[\langle b e-1+$ span-
gle. $]$ 'Lo adorn with spangles; dot or sprinkle ith small glittering objects.

Not Berenlee's lock first rose so brlyht

The heav'ns bespangling with dishevell d light,

bespat (bê-spat'). Preterit of bespit.

bespatter (bē-spat'èr), v.t. $\quad[\langle b e-1+$ spatter. $]$

1. To soil by spattering; sprinkle with any-

thing liquid, or with any wet or adhesive

substance.-2. Figuratively, to asperse with

tomy or reproach.

Whom never laction eould bespatter. Swift, on Poetry.

bespattlet (bē-spat'1), v.t. $\quad[<b e-1+$ spattlc. $]$ To spit on. Bp. Bale.

bespawl + (bô-spâl'), $v \cdot t$. $[<b e .1+$ spawt.
To soil or make foul with or as with spittle.

The conscleus time with humerons foam and braw B. Jensen, Peetaster, v. 1

This remenstrant would invest himself conditionslly
with all the rheum of the town, that he might lave sufti-

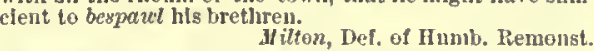
bespeak (bē-spēk'), v.; pret. bespoke (formerly bespalie), pp. bespolien, bespolie, ppr. bespeaking. [< ME. bespeken, bispeken, speak, agree upon, complain, <AS. bespreean, complain (= upon, complain, CAS. bespreean, complain (=
OS. bispretian = OFries. bisprelia = D. bespreken $=\mathrm{OHG}$. bisprehhan, $\mathrm{MHG}$. G. besprechen, bospeak), < be- + sprecan, speak: see be-1 and speak.] I. trans. 1. To speak for beforehand; engage in advance; make arrangements for: as, to bespeak a place in a theater.

Staying in Panl's Churchyard, to lespeak Ogilby's Fsop's
Fables and Tully's Officys to be bound for Fables and Tully's Officys to be bound for me.
Pepys, Diary, I. 138. 'Tis very true, na'am ; every thing is fixed, and the wed.

2. To stipulate, solicit, or ask for, as a favor: as, to bespeak a calm hearing.

This is a sinister and polltic kind of ehsrity, whereby Sir T. Brorne, Religio Mediel, ii. 2.
S. 3†. To forebode; foretell.

They started fears, bespoke dangers, and fomed omi-

4. To speak to; address. [In this sense mostly poetical.]

He thus the queen bespoke.

Dryden.

5. To betoken; show; indicate, as by signs.

When the abbet of St. Martin was borm, he had so little the figure of a man that it bespoke lin rather a monster.

$$
\begin{aligned}
& \text { IIIs face bespeaks } \\
& \text { A deep and simple meekness. } \\
& \text { W'ordkuorth, The Borderers, i. }
\end{aligned}
$$

I'ordruverth, The Borderers, i. The object, allke paltry and imposslble, of this ambi-
tien, bespoke the narrow mlnd.
Mlotley, Dutch Republic, II. 513.
II. intruns. To speak un or out; exclaim;

Cotil their Lorl hinsele bexpakr, and bid them ge. And thus the ehjef bespake. Corper, Iliad, 1i. 201. bespeak (bē-s]c̄k'), n. [<bespeak, r., I.] Among from the bespeaking of patronare by the actoris. or of the play by the patrons. See benefit, 5 . bespeaker (bë-sjoc'kér), $n$. One who bespeaks.

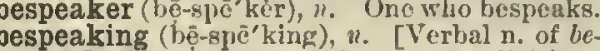
speok.] The act of speaking for or solieiting; solicitation.

A prefaee, therefore, Which is but a bespeaking of favonr,
is altogether useless, Dryden, lind and l'anther, l'ref.

bespeckle (boj-spek'1), r.t. $\quad[\langle b c-1+$ speelile. $]$ To mark witl spockles, spots, or bright jatches. Bespeckled her with. . . gandy allurements

bespendt (bē-spend'), $\tau_{\text {. }}$. $\quad[<$ be-1 + spend. $]$ To expend; bestow; eniploy.

$$
\begin{aligned}
& \text { Beapent about the beds. } \\
& \text { Chropnan, Odyssey, vili. }
\end{aligned}
$$

espett, $i$. t. [ME. bespeten (weak verb. pp. bespet, bespat $),<b e-1+$ speten, < AS. spätan, spit: see spit, and ef. bespit.] To bespit.

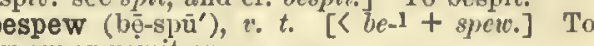
spew or vomit on.

espice (bē-spīs'), $t_{0}$. $\left[<b c_{-1}+\right.$ spice. $]$ To season with spices or drugs; henee, to drug; poisoll.

$$
\begin{aligned}
& \text { Hy, and thou, } \\
& \text { To give mine enemy a lasting wlnk. }
\end{aligned}
$$

bespirtt, $r$. See bespurt.

Shak., W. T., I. 2

bespit (bẹ-spit'), v. t.; pret. bespit, bespat, pp. bespit, bespitten, bespitter, ppr. bespitting. [< spit, and ef. bespet.] "To spit upon; soil with spittle.

bespoke (bē-spōk'). Preterit and past participle of bespeak.

bespot (bê-spot'), t. t. [< ME. bispotten, < bi+ spotten, spot: see be-1 and spot.] To make spots on ; mark with spots; cover with or as with blots or blemishes.

Bespotted so with sis. Drayton, Matilla to K. Jolm. bespread (bē-spred'), $v \cdot t_{.}[<$be-1 + spread. $]$ To spread over; cover with. His nuptial bed,
with curions needles wrought, and paluted flewers be
spryden.

bespreng (bề-spreug'), v.t. [< ME. besurengen bisprengen (pp. besprenged, bespreymt, ote.), $\Lambda S$. besprengan ( $=\mathrm{D}$. and $\mathrm{G}$. besprengen), be sprinkle, < be- + sprengan, sprinkle: see be-1 and spreng, and ef. besprinkle.] 1. To sprinkle over; besprinkle: as, "besprent with teares," Mir. for Mags., p. 26

\section{To spread; seatter.}

$$
\text { Longfellow, Wayside InH, King Ola1, iv. }
$$

$$
11 \text { is silver tresses thin besprent }
$$
sprent.]

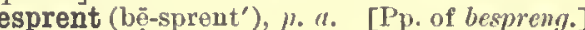

besprinkle (bē-spring'kl), $r$. t. $[<b c-1+$ sprinkle. Cf. bespreng.] To sprinkle over; seatter over: as, to besprinhile with dust.

Herodelus... hath besprinkled hls work with many

Besprinkles with Clmmerian dew. Pope, Dunclad, [II. 4. besprinkler (bọ-spring'klèr'), $n$. One who besprinkles.

bespurt, bespirtt (bē-spèrt'), $" \cdot t_{0} \quad[<b e-1+$ spurt.] To spurt out or over; throw out in a stream or streams.

Well bespurted with his own holy water.

espurtlet (bệ-spèr'tl), $r$. t. $\quad\left[\left\langle b e_{-1}+\right.\right.$ spurtle. $]$ To bespatter, as with contumely; asperse.

I give thy dogged sullemes free libertie : trot abont, and Marston and Webster, The 31 al content, 1.2

besputter (bẹ̄-sput'èx), v, t. [<bc-1+sputter. $]$ To sputter over.

Besselian (be-sel'yan), $a$. Pertaining to or originated by the German astronomer Friedrich Wilhelm Bessel (1781-1846). - Besselian function. Same as Bersel's frenction (which see, under function). 


\section{Bessemer converter}

Bessemer converter, iron, process, steel, etc. (houns.

Bessera (bes'e-rai), n. [NL., named after the Russian natuiralist Besser.] A genus of Mexican bulbous liliaceous plants, consisting of single species, $B$. elegans, frequently eultivated. Its showy erimson flowers are borne in a terminal unbel.

bessis (bes'is), $n$. Same as bes.

bessognet, n. See bisogno.

best (best), $a$. and $n$. (superlative of good). [See letter, $a_{.}$, and good.] I. $a .1$. Of the highest quality, excellence, or standing: said of both persons and things in regard to mental, moral, or physical qualities, whether inherent or ac quired: as, the best writers and speakers; the best families; the best jndgment; the best years of one's life; a house built of the best materials. When he is best, he is a little worse than a man; a

What she wills to do or say
Seems wisest, virtuousest, discreetest, best. Shak., Ml. of V., i. 2 Milton, P. Is, viiii. 550

2. Of greatest advantage, usefulness, or suitability for the purpose intended; most advantageous, suitable, appropriate, or desirable: do anything.

\section{His best companions, innocence and health,}

And his best riches, ignorance of wealth. Goldsmith, Des, Vil., 1, 61.

3. Most kind, beneficent, or good: applied to persons: as, the best husband imaginable; which of your brothers is best to yon ?-4. Largest; greatest; most: as, we spent the best part of three days in getting there.-Best man, the groomsm

I seted in the capacity of backer or best man to the ridegroon:

Dickens.

In our own marriages the best man seems originally to have been the chief sbettor of the bridegroom in the
act of cspture.
Darwin, Des. of NIan, $11 . x x$. Best work, in mining, the richest class of ore-To put ne's best foot foremost. See foot

II. $n .1$. The highest possible state of $e x$ cellence; the best quality or property of a person or thing.

$$
\begin{gathered}
\text { Yf thou wylte leve in peas \& Reste, } \\
\text { Here, \& see, \& sey the beste. } \\
\text { Prov. of Good Counsel, 52. } \\
\text { But you, O you, } \\
\text { So perfect, and so peerless, are crested } \\
\text { Of every creature's best. Shak., Tempest, iil. I. }
\end{gathered}
$$

2. All that one can do, or show in one's self: bestead ${ }^{2}+\left(\right.$ bẹe-sted $\left.^{\prime}\right), v . t .[\langle b e-1+$ stead, place. $]$ often used in this sense with the possessive To take the place of.

pronouns $m y$, thy, his, their, etc.: as, I will do my best to advance your interests; she is bent on looking her best; he did all he could to appear at his best in that performance.

Then gan 1 him to comfort all my best.

Win shall I not, but do my beat to win.

Tennyson, Laucelot and Elsine.

At best, in the utmost degree or extent spplicable to the

The Law of England is at best but the reason of ParlisFor bestt, finally; for good snd all.

Those constitutions. . . are now established for best
and not to be mended. For the best, 8088 to secure the most advantageous re-
sult; with the best intentions. - The best. (a) The best people collectively; those of the highest standing in an$$
\begin{aligned}
& \text { Throng, their rags and they, } \\
& \text { The basest, far into that council-hsll }
\end{aligned}
$$

The basest, far into that council-hsll
Where sit the best and stateliest of the land.

(b) The best things, or a thing of the best quality: as, he

$$
\begin{aligned}
& \text { The lads and lassies in their best } \\
& \text { Were dressed from top to toe. }
\end{aligned}
$$

E. Ransford, Gypsying.

The best of, the advantage in (a contest or proceeding)
or over ( $\mathrm{a}$ person) : as, from the start A. B. had the best of iit. As far as dignity is concerned, Steele has certalnly the
best of the quarrel. A. Dobson, lntrod. to Steele, p. xxxlx. To make the best of, to use to the best advantage; get Let there be freedom to carry their commodities where
they may make the best of them.
Bacon. Often used in speaking of things or events that are not so good or favorable as was expected or was to be wished: as, to make the beat of ill fortune or a bsd bargsin.-To
make the best of one's way, to travel or proceed with

best (best), adv. (superlative of well). [See better, adv.] 1. In the most excellent or most cess: as, he who runs best gets the prize; the

53.4 Speak ye, who best can tell. Milion, P. I., v. I00.

Most solicitons how best
If may compensate for a day of slotih.
Cowper, Task, iv Ife prayeth best who loveth best Coleridge, Ancient Msriner, vii. 23.

2. In or to the highest degree; to the fullest xtent; most fully: as, those who know him

Old fashions please me best. Shak., T. of the S., Iil. T. Tell whom thou lovest best. Shak., T. of the S., I1. I. I relish best the free gifts of Providence. Iawthorne, old Manse, I. best (best), v. $t$. [< best, $a$. or $n$.$] \quad I. To get$ the better of ; outdo; surpass.

1 cannot stand quilet and see the dissenters best the es 2. To overreach or ontwit: as, to best a elient. beat; hence, in pugilism, to thrash soundly; beat; hence, in pugilism,

bestadt. An obsolete preterit corresponding to the past participle bestead ${ }^{3}$.

bestain (bē-stān'), v.t. [<be-l + stain.] To mark with stains; discolor; spot.

\section{All with blood bestain his cheok.}

Percy's Reliques, p. I34.

bestand (bē-stand'), v. t. $\quad[<b e-1+$ stand. $]$ To aid. [Rare.]

Toli. D as would alwsys bestand them

best-best (best'best), $a$. The very best: somequality.

besteadI (bẹ-sted'), v. t.; pret. and pp. besteaded, bested, ppr. besteading. [< be- $1+$ stead, $v$.,

Rememher this, Gil Blas, . pay your court to Signior Rodriguez, ... his frlendship will bestead you much.
Smollett, tr. of Gil Blas, iij. In this shlp was great store of dry Newfoundlsnd fish,
. the same being so new and good as It did very greatly bestead us in the whole course of our voysge.
Sir $F$. Drake, West Indis Voyage.

\section{Hence, vsin deluding Joys,}

The hrood of Folly without father bred

How little you best ith sll your toys

Hys missing of the Vnluersitie Orstorship, wherein Doc. tor lyerne begtended him

Yash, Hsue with yol to Saffronwalden.

bestead 3 , p. a. See bested.

bested, bestead (bē-sted'), p. a. [Prop. only as a pp. or p. a.; but Spenser uses a pret. bestad and pp. bestedded, and other author have adopted present forms; < ME. bested bisted, commonly bestad, bistad, earliest forms bistathed, bisteathet, pp., without pres. or pret. (= Dan. bestedt), < be- + stad, stadd, later sted, etc., < Icel. staddr = Sw. stadd, circumstanced, pp. of stedhja, fix, appoint, $=$ AS. stceththan, set, set fast, plant, stceth, a place, related to stede, a place, stead: see stead and
steady.] 1. Placed; situated: of things.-2. Placed or circumstanced as to condition, conPlaced or circumstanced as to condition, con-
venience, benefit, and the like; situated: of versons. She salth that she shsil not be glad,
Till that she se hym so bestad.

Mlsny far worse besteod than ou

in old Bassors's schools I seemed

Hermil bested for gay bridegroo gioom,

3t Disposed mentally ; affected: as, “ fully bestad," Chancer.-4 4. Provided; furnished.

The Ladie, ill of friends bestedded.

Q., IV, 1, 3.

[This word is scarcely if at all used now, except in such phrases as ill or sore bested.

Bestiæ (bes'ti-ê), n. pl. [NT., pl. of I. bestia, a beast: see beast.] A suborder of the mammalian order Insectivora, including the true insectivores as distinguished from the frugivorous Galeopithecida, having the limbs fitted for walking, but not for flying (being devoid of der, excepting the family just named. bestorm

best-behaved boy in the school; the best-culti- bestial (bes'tią), a. and $n$. [< L. bestialis, <
vated fields. best speak highly of him; the best-abused man in town. times used in trade to indicate the very best support, help.] 1 . To help
proft; benefit; serve; avail. parachute), and the lower incisors not pectito a beast or to the class of beasts; animal.

of shape part human, part bential. Tatler, No. 49 2. Having the qualities of a beast; brutal; below the dignity of reason or humanity; carnal: as, a bestial appetite.

1 have lost the immortal part of myself, and what reBestial automaton. See automator. - Bestial sign,

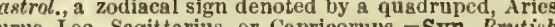
Taurus, Leo, Sagittarius, or Capricornus. = Syn

II $n$. [< LL. bestiale, cattle, neut. of L bestialis: see above.] 1. In Seots lax, the cattle on a farm taken collectively. $-2 t$. A work on zoölogy. Brewer. bestialis: see bestial.] 1. The qualities or nature of a beast; conduct or mental condition unworthy of human nature; beastliness.

What can be a greater absurdity than to affirm bestial ity to be the essence of humsulty, and dsrkness the centre
of light?

2. Unnatural connection with a beast.

bestialize (bes'tial-iz), $v$. $t$. ; pret. and pp. besialized, ppr. bestializing. [< bestial, a., + -ize.] To make like a beast; bring or reduce to the

The process of bestializing humanity.

IIare.

estially (bes'tial-i), adv. In a bestial manner; brutally; as a brute beast. beast spoken of in the Apocalypse (Rev. xiit. $\mathrm{xx}$.)

bestianism $\nmid$ (bes'tian-izm), n. [< bestian + $-i s m$.] The power of the beast. See bestian. bestiarian (bes-ti-ā'ri-an), $n_{0}$ [< L. bestia, a beast, + -arian; suggested by humanitarian.] One who is an advocate of the kind treatment of animals; specifically, in Great Britain, an antivivisectionist.

bestiary (bes'ti-ä-ri), n. [< ML. bestiarium, neut. of L. bestiarius, pertaining to wild beast (as a n., a beast-fighter), < bestia, a wild beast.] If. A fighter with wild beasts in the ancient Roman amphitheater.-2. A name fermerly sometimes given to a book treating of animals. Mr. Watkins has, however, gone further back, and com. "mences with Homer and Hesiod. His opening chapter, and satisfactory portions of his work.
N, and Q., 6th ser., XI. 260.

bestiate (bes'ti-āt), $v$. t.; pret. and pp. bestiated, ppr. bestiating. [< L. bestia, a beast, + $-a t e^{2 .}$ To make beastly; bestialize. [Rare.] Drunkenness bestiates the heart.

bestick (bē-stik') ppr. besticking. [<be-l'stiekI.] 1. To stick on the surface of; cover over.-2. To pierce Truth shsil retire
Bestuck with slanderous darts. Interpretations [valentines] no Lamb, Valentine's Day. bestill (bẹ̄-stil' $), v . t . \quad\left[<b \ell_{-\perp}+8 t i l l L^{\prime}\right]$ To make quiet or still.

Commerce bestilled her many-nationed tongue.

In the following passage uncertatn:

$$
\text { They, bestill'd }
$$

Almost to jelly with the act of fear ern editllons read distilled.

bestir (bē-stèr'), v. t.; pret. and pp. bestirred, ppr. bestirring. [< ME. bestyrien, bestirien, be sterien, bestir, < AS. bestyrian, heap up, pile up. <be- + styrian, stir: seebe-1 and stir.] To pat into brisk or vigorous action; reflexively, move with life and vigor: as, bestir yourself.

$$
\begin{aligned}
& \text { You have ... bestirred your valour. } \\
& \text { Shak., Lear, if. } 2 . \\
& \text { Come on, clowns, forsake your dumps, } \\
& \text { And bestir your hobnailed stumps. } \\
& \text { B. Jonson, The Satyr. } \\
& \text { Rouse and bestir themselves ere well a wake. } \\
& \text { Sf ilton, P. I., I. } 334 .
\end{aligned}
$$

bestness (best'nes), n. [< best + -ness. ] The quality of being best. [Rare.]

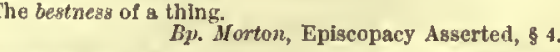

bestorm (bē-stôrma'), v. $t$. [< be- + storm; not

$=\mathrm{Sw}$. bestorma $=$ Dan. bestorme, attack with bestiality (bes-tial'i-ti), n. [<LL. bestialitas, state or condition of a beast.

estiant (bes'tian), $a$. Of or belonging to the 
bestorm

storm, agitate.] ' $\mathrm{l}$ o overtake witl a storm; W. Dacentent, Gondibert, iii. 6 .

All is sea beaides,
Sinka under us, besterms, and then devours.

Yoneng, Night 'Thoughts, iv.

bestow (bō-stō'), v. t. [<ME. bestozen, bistowen; <be-1 + stow, plaee: seo stow.] 1. To lay up in store; deposit for safo keeping; stow

I have no room where to bestow my fruits. Luke xil. 17. Ife bestawed it in a jouch thed with perfumed leather.
Scott. To all appearance I must he (engaged] for many months
to come in turning out, exanining, aorting, and bestowing

Dr. J. A. J. Nurray, 8th Ann. Add. to Plilol. Soc 2. To lodge, or find quarters for; provide with aceommodation.

Well, my masters, I'll leave him with you ; now I see him bestowed, I'll go look for my gooda.
B. Jonson, Jartholomew Fair, iv, 1.

3. To dispose of.

Give me but the name and nature of your matefactor,

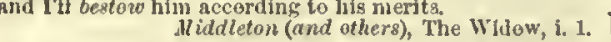
4. To give; eonfer; impart gratuitously: fol-
lowed by on or upon before the reeipient: as, to bestow praise or blame impartially.

Consecrate yoursetves.... to the Lord, . . . that he may
bestew upon you a bleasing. Thongh I bestono alt my goods to feed the poor. . and
have not charity, tt profiteth me nothing. 1 Cor. xiit. 3 .

Around its entry nodding popples grow, Dryden, Ceyx and Atcyone, 1. 287.

Did youl bestow your fortune, or did you only bend it?

5. 'To give in marriage.

I could have bestowed her upon a fine gentleman. Tatler.

6. To apply; make use of ; use; employ.

I deternine to bestono
Sone time in tearning languages abrond. Ford, Love's Sacriflce, 1. 1.

Otherwise the whole foree of the war would have been

7t. To behave or deport.

The boy ... bestows himself

Syn. 4. Conver, Grant, etc. See give. Cestowable (bē-stō'a-bl), $a$.

Capable of being bestowed.

bestowal (bẹ-stō'al), n. [< bestow $+-a l$.$] Be$ stowrment. The one did hinself honour in the bestowal, the other
in the aeceptance, of such a gratuity.

bestower (bề-stóér), $u$. One who bestows; a giver; a disposer.

bestowment (bē-stō'ment), n. $\quad[<$ bestow + -ment.] 1. The aet of giving gratuitously; a given; a donation.

They almost refuse to give due praise and crellit to
God's own bestowments. Taylor.
I8. Tay .

bestraddle (bẹ-strad'1), v. $t .[\langle b e-1+$ stradalle. $]$ To bestride. See straddle.

bestraught $\uparrow$ (bē-strât' $), p p$. [A modification of distraught, with prefix be- for dis-: see distraught.] Distraeted; mad: as, "I am not bestraught," Shak., T. of the S., Ind., ii.

bestraughted $\nmid$ (bē-strâ'ted), a. [Irreg. < bestraught.] Distracted. Norden. [Rare.] bestraw† (bẹ-strá'), $v$. $t$. [ $<$ be-1 $1+$ straw for
strew.] An obsolete form of bestreic.

bestreak (bē-strēk'), ". $t$. [<be-1 + strcak.] To mark or eover with streaks.

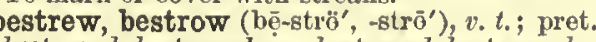
bestrewed, bestrowed, pp. bestrewed, bestreicn, bestrowed, bestrown, ppr. bestrewing, bestrowing.
[< ME. bistrewen, < A.S. bestrcówian ( $=\mathrm{D}$. bestrooijen = $\mathrm{MHG}$. beströutcen, G. bestreuen $=\mathrm{Sw}$. bestrồ = Dan. beströ), <be- + streówian, strow: see be-1 and strew, strow.] 1. To strew or seatter about; throw or drop here and there.

Those blossems alse, and those dropping gums,
That lie bestrozen.
Miltom, P. L., iv. 631.

2. To strew anything upon; cover or partially eover with things strewn or seattered.

Discord aball bestrew
The union of your bed with weeds so loathly,
That yois shall hate it both. Shak., Tempest, iv.

Strip the bough whoae mellow fruit bestrever

The ripening com beneath it.

bestrid (bē-strid'). Preterit and post partiege of bestride.
535

beteach

bestride (bē-strīl'), $v . t_{0}$; pret. bestrode or bestrid, 11]. bestridden, bestrid, improperly be-
stridedt (Sterne), ppr, bestriding. [( ME. bestridedt (Sterne), ppr, bestriding. [र ME. be-
striden (prot. bestrood, bestrode, pl). wanting) striden (pret. bestrood, bestrode, pl. wanting),
$<$ AS. bestridan (hors bestridan - lye), <be- + strilan, stride.] 1. To straddlo over; mount astrido of; streteh the legs or eorresponding parts across so as to embruee: as, to brstrille e; spectacles bestriding tlie nose.

II'ty, man, he doth best ride the narrow world hakk, J, C., t. 2

The animal he bestrode was a liruken-down plough-horse.

2. 'To step over ; eross by stepping.

Wheu I flrst my wedded uistresa snw
Bestride nyy threshold. Shak.,

bestrode (bê-strôd'). Preterit of bestride.

bestrow, $i$. See bestrer.

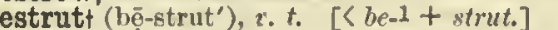
istend.

Iler pajes bestrul witi milk

P. 510 .

bestuck (bō-stuk'). Preterit and past partieiple of bestiek.

bestud (bē-stud'), v. t.; prot. and pp. bestudded ppr. bestudding. $\left[<b e-1+s t u d^{2}.\right]$ To set with as with studs; adorn with bosses.

The unarught dimuends
Woutd so imblaze the forehead of the dee

Aud so bestud witis atars, that they below

Fould grow inuret to light. Milton, Comns, 734

eswaddle (bẹ-swod'1), v. t. [<be-1+swaddle.] To envelop in swaddling-elothes. W. Whitehead.

beswiket, $v . t$. [ME. beswiken, < AS. beswican (=OS. bisicikan $=\mathrm{D}$. bezuijken $=\mathrm{OHG}$. beswillhan = Sw. bcsrik $a=$ Dan. besvige $)$, deeeive, be tray, < be- + swican $(=$ OS. swikan = OFries. swika $=$ OHG. swihhan $=$ Ieel. svikja $=$ Sw. sizia = Dau. singe), deceive, weaken.] To allure. Gouler.

beswinget (bẹ-swinj'), v. t. [ME. not found; AS. beswingai, only in pp. beswungen, seourge, beat, <be- + swingan, seourge, swinge.] To seourge; beat.

You had best to use your aword better, lest 1 beswing

yor.

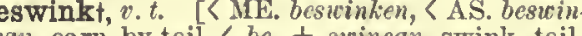
can, earn by toil, < be- + swinean, swink, toil and sicink.] To eari.

That of a polson which they drunke

Goncer, Conf. Aniant., i. 131.

besył, a. A Middle Finglish form of busy.

bet ${ }^{+}$(bet), ado. [< ME. bet, < AS. bet $=$OFries. bet $=$ OS. bat, bet $=$ OD. bat, bet $=O H G$.MHG. baz, G. bass = leel. betr = Goth. "batis (in adj.
batiza), better, orig. adj. in the neut. ace. with reg. eompar. snffix (lost in AS., ete.; henee the later form betere, betre, F. better, ado., prop. neut. of the inflected adj. betera see better 1 , appears also in Ieel. batna. E. batten 1 , beeome or make better, improve, AS. böt, E. boot, advantage, improvement, AS. bètrin, F. beet ${ }^{2}$, improve, ete.: see batten 1 bnttle 3 , boot 1 , beet ${ }^{2}$, te.] Obsoleto and earlier Middle Finglish form of better 1

$$
\begin{aligned}
& \text { "Go bet," quod he, "and axe redily" } \\
& \text { What cors is this that qasseth heer forby." }
\end{aligned}
$$
It had been bet for me atill to have kept my (Iulet ehair.
Gascoigne.

bet ${ }^{2}$ (bet), $r$; pret. and pp. bet or betted, ppr. betting. [First in early mod. E.; prob. short first as a noun, instigation, eneouragernent, support, backing, whenee the verb, to give support, ete.] I. trans. To pledge as a forfeit to another who makes a similar pledge in returu, on a future eontingeney, in support of an affir mation or opinion; stake; wager.

Jelin of Gaunt loved htm well, and betted mucll money

II. intrans. To lay a wager; stake money or anything of value upon a contingency.-You bet, cert
alang.]

"Friend," said I to a Jehu, whose breath suggested gin, "Can tilee convey me straightway to a reputabte inn?" IIis anstwer's grosa irrelevance I ahall net aoon ferget--

bet 2 (bet), n. [See the verb.] 1. The pledging of some valuable thing, as money (or of the doing of some onerous aet), to be forfeited, in case some future event happens eontrary to the assertion or belief of the one making the pledge, beteach.] Same as beteach. to another who pledges a forfeit in return on the olposite contingeney.-2. That which is wagered; also. that about whicls a wager is made.

But, on : S1x Barihary tiorses agalnat slx French swords, their assigna, and three liberal concelted carriages: that' bet ${ }^{3}+$. An obsolete preterit of lieat ${ }^{1}$.

Betai (bé'tai), n. [1., a beet: see bcet1.] A genus of apetalous plants, natural order che genus of apetalous lla

beta'2 (bē'tii), n. [1., repr. Gr. ßijra, name of tlıe eharactor $13, \beta$.$] 1. The seeond letter of the$ Greek alphabet, corresponding to Finglish $B$ or b. - 2. As a classifier in astronomy, chenistry, ete., the seeond in any series. See alpha, 3.

betacism (bè'tn-sizm), $n . \quad[<\mathrm{NL}$. bctacismus, <. beta, the (Groek) letter $\beta, b$. Cf. iotacism, rhotacism.] Conversion of other sounds to, or their eonfusion with, a $b$-sound. Even theae forms were threatened with destruction by
the spread of Betaciomus, wherely amavit was proloumced betag (bê-tag'), $v$. $t$.; pret. and pp. betagged, por. betaiging. [<be-1 + tag.] To frrnish with a tag; deek with tags.

Betagged with verse.

Churchill, lihe (ihost, iv.

betail (bẹ̄-tāl'), v.t. [< be-I + tail1. $]$ 1. To furnish with a tail: as, "betailed and bepow2. To take the tail off: a word joeularly form2 . To take the tail off : a word on the analogy of bchead.
ed

[The aportaman] puts his heavy boot on the least's borly,
and there both beileadis and betails lini. Trollope.

betain (be'ta-in), n. [Irreg. < u. beta $+-i n^{2}$.] A chemieal base found in the eommon beet and mangol-wurzel.

etake ${ }^{1}$ (bē-tãk'), v. [<be-I + take. The eorresponding ME. form bctaken, bitaken (pret. bctok, pp. bctaken) seems to have been used only in the senses of betake ${ }^{2}$ or beteach, with which it was confused. There is no AS. "betaean; but ef. Sw. betaka = Dan. betage, take, deprive, eut off.] I. trans. 1t. To seize; take hold of. take.

Then to hig handes that writt he did betake.

Spentive 25

2. Reflexively, to take one's self (to); repair; resort; have reeourse.

$$
\begin{aligned}
& \text { The rest, in initation, to like arms } \\
& \text { Wetook them. } \\
& \text { Milton, P. L., vi. 603. } \\
& \text { Betake you to your silence, and yeur sleep. } \\
& \text { B. Jonson, Volpone, i. } 1 .
\end{aligned}
$$

$$
\text { They betook themselves to treaty and subnission. }
$$

II. intrans. To take one's self.

But here by downe, and to thy rest betake.

betake $2 \nmid, \imath$. t.; pret. betook, betruglit, pp. betaught, ppr. betaking. [ME. betaken, ete., with forms prop. belonging to betake $1, q$. $\nabla$., but with $v 2$ rious senses of betceen, beteelten, beteach: see

betalk $\nmid\left(b \bar{e}-t_{a ̂ k}^{\prime}\right), r . i . \quad[\langle b e-1+t a l k$. $]$ To talk betallow (bẹ-tal'ō), v.t. $[\langle b e-1+t a l l o v e$.$] To$ eover with tallow; Ford. teach.

bete ${ }^{1} \dagger, r$, bete ${ }^{2} t, n_{\text {, }}$, bete ${ }^{3}+, r_{\text {, ete }}$, Obsolete form of bcat I, beet 1 , beet ${ }^{2}$, ete.

bête (bāt), n. [F., < OF. beste, a beast: sce beast.] In the game of solo, a forfeit.-Bete

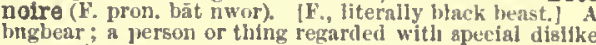
or aversion.

The newspapers have some worits of this aort dear to them, but the betes noires of all lovers of straigitforwari English, such as "peruse" nud "replete."
The Allantic, LVII. 425.

beteach $\dagger\left(\right.$ bẹ-tēeh'), $x^{\prime} t$. [ [ ME. betechen, biteeh en, betcecen (pret. betauhte, betahte, pp. betauht,

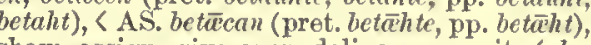
show, assign, give over, deliver, commit, < be$+t \bar{a} c a n$, show, teach: see be-I and teach. Ow ing to a similarity of form, the ME. betaken (pret. betook, betok, pp. betaken), ( be- + taken, take (see betake1), was eonfused with betcehen, and used in the same senses.] 1. To give; hand over; deliver up.

Judas Iscariot welite forth to the princis of prestis, and aatd to hem, What woten ye give to me and I Behal bitake 2. To intrust; eommit; recommend to the eare of.

Chancer, l'rol. to Tale of sielibeua, t. 6. 


\section{beteach}

And hem slic yaf hire moelles and hire thing And to the pope Urlban bitook hem thio. Tale, 1. 541.
Chancer, Second Nun's Dane Phobe to a Nymphe laer babe betooke.

3. To impart or teach.

Whereof that he was fully tanght

Gover, Conf. Amant., vil.

betear $\left(\mathrm{be}-\mathrm{e}\right.$ ē $\left.\mathrm{r}^{\prime}\right), v . t . \quad\left[\left\langle b c-I+t e u r^{2}.\right]\right.$ To wet with tears. Sir $P$. Sidney.

betechet, $v$. $t$. Same as beteaeh.

beteem ${ }^{1}+($ bè-tēm') $v, t$. $\quad[<b$

bring forth; produce; shed.

Lys. Why is your cheek so pale?

IIer. Belike for want of rain; which I ceuld wel

Beteern them trom the tenupest of mine eyes.

beteem ${ }^{2}+$ (bē-tēm'), v. t. [Appar. $<b c-1+$ teem ${ }^{2}$.] 1. To allow; permit; suffer.

\section{So loving to my mather,}

Thist he night not beteem the winds of hesven
Vhakit her face too roughly. IIamlet, 1. 2

2. Te vouchsafe; accord; give.

"So would I," said the Enchanter, "glad and tsine

Beteeme to you this sword." Spenser, F. Q., II, viil. 18. Although hee conld have well beteem'd to have thankt him of the ease liee profer'd, yet loving his owne handi-

worke, modestly refisd him, Milton, Def. of IInmb. Remonst.

betel (bế'tl), n. [Also written betle, and formerly also betele, bettel, etc.; = F. bétel $=\mathrm{Sp}$. also betle, vitele $<$ Malayalam rettila $=$ Tami

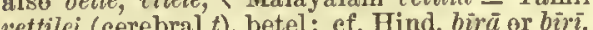
[Skt. vitika (cerebral $t$ ), betel.] 1. A species of pepper, Piper betle, a creeping or climbing plant, a native of the East Indies, natural order Piperaeece. The lesves are nsed as a wrapper for the little pellets of areca-nnt and line which are extensively
cliewed in the East. The pellet is hot and acrid, but has eliewed in the East. The pellet is hot and acrid, but ha
aromatic and astringent propertles. It tinges the saliv
red and blackens the teeth. Also called betel-pepper. 2. A piece of betel-nut.

betel-box (bē'tl-boks), $n$. A box for carryin pellets prepared of betel-leaves, lime, and areca-nuts. Such

betel-nut (b' 'tl-nut)

$n . \quad[<$ betel + nut. $]$

The nut of the areea-

palm, Areea Catechn,

bighly esteemed among the Asiatic as a masticatory. See areca-nut.

betel-pepper (bé'tl

pep"er ), n. Same as

betht,

[ME. < AS. beoth, $2 \mathrm{~d}$

pers. pl. of beón, be:

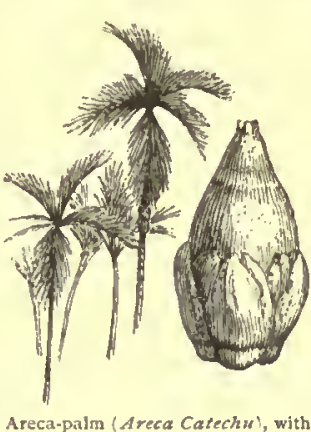

see be.] Be ye. Chali- Areca-palm Areca Catechn', with

bethankit (bệ-thang'kit), n. [Sc., humorously adapted from the formula God be thankit, where thankit =E. thanked, pp.] Grace after meat Burns.

bethel (beth'el), n. [Heb. bèth-ēl, house of God, A hallowed spot.-2. A name sometimes applied to a place of worship in Eugland, espeplied to a place of worship in Eugland, espo-
eially to a dissenting chapel. -3 . A church or chapel for seamen, whether located on shor or, as is often the case, afloat in a harber.

Bethell process. See process.

bethink (bẹ-thingk'), $v$; pret. and pp. $b e$ thought, ppr. bethinking. '[< ME. bethenken, bithinken, commonly bethenchen, < AS. bethenean, bithenean $(=\mathrm{D}$. bodentien = OHG. bidenchan, IHG. G. bedenken = Sw. betänka = Dan. be toenke), consider, think about, $<b_{e}++$ thenean. think: see be-1 and think.] I. trans. 1t. Te think: soe be-1
think; imagine.

He spak more harm tlisn herte may bethinke.
Chaucer, Prol. to Wife of Bath' Tale, 1. 779

$2+$. To think about; reflect upon; consider.

With patience csim the storm,
While we bethink a means to break it off

3. Reflexively: (a) To call to mind; take inte consideration; remind one's self: with of (formerly also on or upon) before the name of the object of thought.

Bethink yourselves beforehand what mercies yon want.
Bp. Beveridge, Sermons, II. cxiv.
536

Bethink thee of thy Lord

ho liealed again the smitten car,

Whittier, The Exiles.

(b) To reflect; deliberate; commune with one's self.

Rip bethought himself a monent snd inquired.

II. intrans. To deliberate; consider.

Bethink ere thou dismiss us Bethlehem (beth'lē-em), $n$. See bedlam.

Bethlehemite (beth"lè-em-it), n. [<Bethlehem + -ite1. See bedläm.] 1. An inhabitant of Bethlehem of Judea (2 Sam. xxi. 19). - 2 . An inmate of Bethlehem hospital or other lunatic asylum; a bedlamite. See bedlam and bedlamite.-3. Eeeles.: $(\alpha)$ One of an order of monks introduced into England in the year 1257, who were habited like the Deminicans, except that they wore a star with five rays, in memory of the comet or star which appeared over Bethlehem at the birth of Christ. (b) One of an order founded in the seventeenth century for the service of the hospitals in Spanish America.

Bethlemiteł (beth'lem-it), $n$. Same as Belhchemite.

ethought (bē-thêt' $t^{\prime}$. Preterit and past partiiple of bethinit.

bethrall (bệ-thrâl'), t. t. $[<b e-I+$ thrall. $]$ To enslave; reduce to bondage; bring into subjection.

She it is that did my Lord bethrall. Spenser, F. Q., I. viii. 2 bethroot (beth'röt), n. Same as birthroot.

bethule (beth'ìl), n. [< Bethylus.] A bird of lot).

bethump (bẹ̄-thump'), v. t. $[<b e-1+$ thump. $]$

To beat soundly.

I was never so bethump'd with words

Since I first call'd my brother's father dad.

bethwack (bẹe-tliwak'), v.t. [< be-1 + thwaek. $]$ To thrash soundly.

Bethylus (both'i-lus), n. [NL.] 1. A genus of pupivorous hymenopterous insects, of the comewhat triangular prothorax, a flattened head, and 13-jointed antennæ.-2. In ornith., a genus of South American tanagroid Passeres, based on the Lanius leverianus of Shaw, supposed to be a shrike. Antedated by Cissopis of Vielllot, 1816, based upon the same bird, and slso in enbetide (bè-tīd'), $v$ [ [<ME. bitiden, < bi-, be-, + tiden, happen: see $b e-1$ and tide, $v_{0}$.] I. trans. 1. To happen; befall; come to.

What will betide the few? Mitton, P. L., xil. 480 . Ill luck betide them all"- he cried.

2. To betoken; signify. [Rare.] Ifow could I but muse
At what such a dream shenll betide? Couper, The llorning Drean.

II. intrans. To come to pass; happen.-To If he were dead, what wonld betide on me? betidet (bō-tìd'), n. [<betide, $x$.] Hap; fortune. Bad betídet, ill hap; misfortune: a forced use.

Ny wretclied heart wounded with bad betide.

betightt (bè-tît'). An erreneously formed past participle of betide: one of Spenser's forced torms.

Why wsyle we then? why weary we the Gods with playnts,
As if aome evill were to her betight? betimet (bē-tīm'), adv., orig. prep. plir. [<ME. betyme, bitime, prop. separate, bi time, by time.] older form of betimes.

Loke thom go to bede by tyme. I I went one dsy myself betime in the morning to a great Latimer, Serm. bef. Edw. VI., 1550. betimes (bē-timz'), adv. [< MLE. betymes, bi-
tymes, < betime + adv. gen. suffix -s.] 1. Seasonably; in good season or time; before it is too late; early.

Not to be a-bed after nidnight is to be up betimes.

To messure life learn thou betimes. Metimes.

Partake we their blithe cheer

Who gathered in betimes the nnshern fleck betrap

Ifaving engaged our gulde and horses the night before, Lou set out betimes this morning for Orieside 'Travels, p. 240.
Lould, . Soon; in a short time.

IIe tires betimes, that spmirs too fast betimes.
Shak., Rich. II., ii. I. 3. Occasionally; at times. [Scotch.] = Syn. betinet, $x_{0} t$. $[\langle b c-1+$ tinc for tind, kindle. $]$ To set fire to.

betitt, $v$. Obsolete shortened form of betideth. Chaneer.

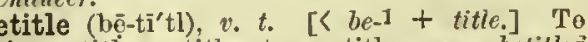
give a title or titles to; entitle: ns, a betitlea man; a "picture . . . betitled, Glorious Revolution," Carlyle, Mise., III. 82.

tle, $n$. See betel.

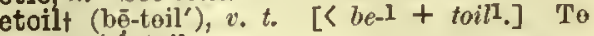
(bith toil.

etokt. Middle English preterit of betake 2 .

etoken (bē-to' $\mathrm{kn}$ ), v. l. [< ME. betokenen, bitocnen, < AS. "betuenian (not found; equiv. to getāenian, with diff. prefix; of. believe $)(=$ OFries. bitekna $=\mathrm{D}$. beteckenen $=\mathrm{LG}$. beteikbeteckna $=$ Dar. betegno $\rangle,\langle$ bc- + tāen, tāeen, token: see $b c_{-1}$ and token.] 1t. To signify; mean denote in words. - 2. To be a token of ; be a visible sign of ; give promise of. A dewy cloud, and in the cloud a bow, .... 3. To foreshow by signs; be or furnish a premonition of ; indicate the probability of: as, this fact betokens a good result.

The morning betokened fonl weather.
Buncroft, Hist. Const., IL, 261.

4. Te give evidence of ; show.

This doth betoken

The corse they follow dld with desperste hand
Forde its own life. =Syn. To signify; presage, portend, augur, loode. beton (bet'on; F. pron. bā-tốn' $\dot{n}^{\prime} n_{0}[<F$. béton, < OF, betun, rubble, of disputed origin, but prob. $<\mathrm{Pr}$, beton $=\mathrm{Sp}$. betun, < I. bitumen, but prob. $\mathrm{Pr}$. beton = Sp. betn, $\mathrm{C}$. ton, beestings, curded milk, < OF, beter, coagulate.] A mixture of lime, sand, and gravel, forming a kind of concrete. It is much used as a hydranlic cement in silhmsrin

betongue (bē-tung'), r.t. [< be- ] tongue. $]$ To scold; attack with the tongue; rail at.

How Ben Jonkon and Shs kspere betongued each other.

betonica (be-ton'i-kä), n. Same as betony.

betony (bet'o-ni), $\ddot{n}$. [Early mod. E. also beionie, bettony, etc., < ML. beiony, betany, earlier betone, betan (cf. ML. betonia), < OF' beteine, $\mathrm{F}$. bétoine $=\mathrm{Pr}, \mathrm{Sp} . \mathrm{Pg}$. It belonica $=$ G betonie = AS, betonica, L betonica, a corrupt form of rettonica, so named, according to Pliny, from the Vettones, otherwise Teetones, a people of Lusitania in the Spanish peninsuBetorica officinalis, a European labiate plant, growing in woods. It is sometimes used to dye wool growing in woods. It is sometimes used to dye wool, from vater-betony (an s sustic plant, Scrophularia aquati. ca) as wood-betomy, which name is also given in the Untted States to Pedicularis Canadensis, snd sometimes to $L y$ copus Virginicus. The Veronica serpyllifolia is called
Paul's betony, because described as a beteny by an old betook (bẹ-túk'). Preterit of betake I and beta7.e?

betorn' (bē-tōrn'), p.a. [Pp. of verb *betear' (not used), < be-I'+ tear $\left.{ }^{-1}.\right]$ 1. Torn.

Whose heart betorn out of his pantling breast.
Norton and Sackville, Gorboduc, iv. 1.

2. Torn in pieces.

betoss (bè-tos'), $v, t$. $\quad[<b e-1+$ toss. $] \quad$ To toss ; agitate; disturb; put in violent motion.

The mlserable betossed squire.

$31 y$ betossed soul Shak., R. snd J., v, 3.

betraiset, betrash $\nmid, v . t$. [ME. betraisen, betraysen, bitraisshen, bitrasshen, < be- + OF. traiss-, see betray and $-i s h^{2}$.] 'T'o betray.

They have betraised thee. Robert of Binnne.

betrap ${ }^{I}+($ bẹ-trap'), $v$. t.; pret. and pp. be trapped, ppr. betrapping. [र ME. betrappen, AS. betreppan, betreppan, insnare, $<$ be- + To entrap; insnare. Goucer.

betrap ${ }^{2}$ (bẹ-trap'), $v^{\prime} t_{.} ;$pret. and pp. beput trappings on; elothe; deck.

After them followed two other cliariots covered with red aatin, snd the horsea betrapped with the same.
Stow, Queen Mrary, an. 1553. 


\section{betrash}

betrasht, $r . t$. See betruise.

betray (bẹ-trā'), v, t. [〈ME.betrayen, betiain, $<$ be- + traien, betray, < OF. traï, F. trahir, L. tradere, deliver, give over: seo traitor, treason, tradition. The form of betruy was inflinenced by that of bewray, a quite different word.] 1. To deliver to, or expose to the power of, an enemy by treachery or disloyalty: as, an officer betrayed the eity.

The Son of man shall be betreyed into the hands of

Antness ; be 2. To violate by fraud or unfaithfulness; be tray a trust.

Betray'd her cause and wine. Tennyson, Princess, $v$ 3. To act troacherously to; bo disloyal to; disappoint the loopes or expectations of.

Do not betray ne, sil. I fear you luve Mlistress Page.
Shak, M. W. of W. iii. I will betray

'Tawny-fiun'd fishes; my bended hook ahall plerce Their sllmy jaws.
But when I rise, I shall find my legs betrayizg me. Bosiell

Yen of unquiet uinds and violent smlution followed $\mathrm{s}$ fearfully eccentric conrse jacaulay, Sir William Temple.
partiea in turn. 4. To deceive; beguile; mislead; seduce. Far, far benenth the shallow mald
Jie lef believing and betrayed. Byron, The Gisour.

Our injpatience betrays ua into rash and fooliah slli. nces which no God attends. Fivereon, Essays, lat sel , p. 195.

5. To reveal or disclose in violation of confidence; make known through breach of faith 01. obligation: as, to betray a person's secrets or designs.

Secrets are rarely betrayed or discovered according to any programne our fear has sketched out. George Eliot, Minl on the Floss, v. $\mathbf{b}$. 6. To show in true character; allow to be seen; permit to appear in spite of will or desire.

Be swift to hear, but cautious of your tongue, leat you

Anil scarcely look or tone betrays

Alow the heart strives bencath its chain. Whittier, Mlogg Mlegone, i. My own too-fearful gulit,
Simpler than any child, betrays itsels. Tennyson, Guinevere.

7. To indicate; give indication or evidence of: said of something not obvious at first view, or that would otherwise be concealed.

Yon azure amoke betrays the lurking town.

Il the names in the country betray grest antiquity. Bryant.

A turned leaf, a broken twig, the faintest film of smok agsinst the sky, betrayed to hin the passage or presence of
s. F. Clarke, self-Culture, betrayal (bẹ-trā'ạl), n. [<betray $+-a l$.$] The$ act of betraying.

Gsined his freedom by the betrayal of his country's (ause. If aeldom lost his self-control, snd ahrank with th
most sengitive pride from any noticeable betrayal of enin most sengitive pride from any noticeable betrayal of eninbetrayer (bẹ-trā'èr), n. One who betrays; a traitor; a seducer.

betraymentt (bē-tr's'ment), $n . \quad[<$ bctray + -ment.] Betrayal; the state of being betrayed. Confessing him to be innocent whose betrayment they betrend† (bē-trend'), v. t. [ME. betrenden; betrendt (bē-trend ), $v$. $t$. [ME. betrenden;
bc-1 + trend.] To wind about; twist; turn round.

Abonte s tre witly many a twiste
Bytrent and wrythe the aoote wodebynde. chacer, Troilus, iii. 1231.

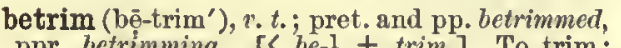
ppr. betrimming. [<be-1+trim. $]$ To trim set in order; decorate; beautify.

Thy basks with ploned and twilled brims, Shak, Tenipest, iv, 1

betroth (bē-trôth' or -trōth'), $v \cdot t$. [Early mod. E. also betrothe, betroath, betrouth, < ME. betrouthen, betreuthen, bitreuthien, betroth, < bi-, truth: see be-1 and troth, truth.] 1. To contract to give in marriage to another; promise or pledge one's troth for the marriage of ; affianco.

You, to remove that siege of griel from her

To County Paris. 2. 'To engage to take in marriage; pledge one's troth to marry.
537

betterment

What man is there that hatli befrothed a wifo and hath To lier, my lord,
Was 1 betroth'd ere I saw lieruila Shrik., M. X. D., Iv. I.

3t. To nominato to a bishopric in order to conation.

If sny person be consecrated a bishop to that clume h etrothal (bẹ-troôth' - or bē-trôtlı'al), $u$. [<betroth + al.] Tho act of betrothing; betroth-

The feast of betrothal. Longfellon, Trvangeline, is. betrothment (bẹ̄-trôth' - or bō-trōth'ment), $n$. [<betroth + ment.] A mutual and forma promise or contract made for or by a man an a woman with a view to their marriage; botrothal; the act or state of being betrothed, or romised in marringe.

IIow the strange betrothment was to end. Tennyzon, Princess.

betrust (bẹ-trust'), v. $t . \quad\left[<b e-1+\right.$ trust. $\left.^{-}\right] 1$ To intrust; commit to another in eonfidenee of fidelity.

Whatsoever you would betruat to your memory, let it
W'atts.

2. To confide in.

To estcem themselves Maisters, both of that great trust Which they serve, and of the J'eople that betrusted them.
Miltem, Exkonoklastea, xii.

[Rare in both senses.]

betrustment (bẹ-trust'ment), n. [< betrust ment.] The aet of intrusting; the thing inrusted. [Rare.]

etsot, betsat (bet'sō, -sị)), n. [<It. bezzo (pron. bet'so), farthing, piece of money ; appar. same as It. pezzo, a piece, bit (see piece); bnt ef. G. atz. A small batzen, a small Swiss coin: seo the sixteenth and seventeenth centuriesent the system established in 1750 it was equal to a quarte of a United States cent, being the fortleth part of a lira piccols ; \& bagattino.

The last and teast [coin] is the betra, which is hall $\mathrm{s}$ aol; that is, almost a farthing.

bettt, bettet, $a d v$. Middle English forms of bet ${ }^{1}$ better ${ }^{1}$ (bet'èr), $a$. and $n$. [< ME. bettere, bo tere, < AS. betera, betra = OFries. betere, betre = OSe, betara, betera $=\mathrm{D}$. beter $=\mathrm{OHG}$. bezziro,
OS. OS. betara, betera $=\mathrm{D}$. beter $=\mathrm{OHG}$. bezziro,
$\mathrm{MHG}$. bezzer, G. besser = Icel. betri $=\mathrm{Sw}$. bät tre = Dan. bedre = Goth. batisa; compar. with weak inflection; with superl. best, < ME. beste, $<\mathrm{AS}$. betst, betest $=$ OFries. beste $=$ OS. betsto $=\mathrm{D}$. best $=\mathrm{OHG}$. bezzisto, MHG. bezzist, best, G. best = Icel. beztr, older baztr, $=\mathrm{Sw}$. bäst $=$ Dan. betst = Goth. batists; with regular com par. and superl. suffixes from a positive not in use, Teut. "bat, of which the compar., with loss of the suffix, appears in the AS., ME., and comparative of good: $(a)$ Of superior quality or excellence, whether personal, physical, mental, moral, or social, essential or acquired: as, he is a better man than his brother; better time are at hand; a better position. Jan's better nature triumphed then. The Pralries. Our institutions had been so good that they had eduated us into a capacity for better institutions.

(b) Of superior value, use, fitness, acceptableness, etc.; more profitable or suitable for a purpose; more useful, eligible, or desirab

Better is a dinner of herbs where love is, than a stalled Better is a dinner of herbs where love is, than a stalled
prov. $x v, 17$. Doth, in my estimate of good, appear A better state than wsking; death than sleep.

c) Larger; greater: as, the better part of a day was spent in shopping.

You are as a candle, the better part burnt out. How have we wander'd, that the better psrt ght is perish'd!

2. As comparative of well: (a) More in accordance with one's wish or desire; more satisfactory. (b) More healthy; having sounder health. (c) More just, right, or proper.-Better arm. See arm 1.-Better halr, s wire. [Colloq. - - To be better. (a) To be improved, as in health, estate, etc.:
as, the patient is better. (b) To be quite well agsin; be as, the patient is better. (b) To be quite well agsin;
fully recovered. [Scotland.]
II. $n$. 1. That which has superior excellence

II. $n .1$. That whic

That ideal better, towards which both men and institu tlons must progress, if they would not retrograde.
2. A smperior; one who has a claim to precedenco on account of rank, age, merit, skill, power, ol office: as, give place to your betters. [In this senso generally used in the plura], and [In this senso generally userl In al Ynglelond was nou hys beter.

Their bettera wonlul hardly be found. kich. C. de L. IIooker. Thou plour shadow of a suldier, I will make thee know my master keeps servants thy better ln quallty and per-
Ford, "Tis Pity, i. 2. The better. (a) Improvement: generally in the adverinl phrase

If I have altered him anywhere for the better.

Dryden, I'retace to Fables.

(b) Advantage; supcriority ; victory : clicfly in the phrases Dionyaius, his countryman, in an cplstle to Pompey, after an express comparlson, afforis litm the better of
SThucydides.
Sir Brome, Vulg. Err. She took her lesve, clarmed with the prospect of finally getting the better of the only woman in fondon whons she acknowledged as her equal in auhtlety and Intrlgue.
J. Javerhore, Dust, p. 334.

betterl (bet'er), all. (comparative of $x c l l, a d v$.$) .$ [<ME. better, beter, betre, < AS. betere, betre; with snperl. best, <ME. best, < AS. betst, betöst; prop. neut. aee. of the adj.: see better ${ }^{-1}, a$. The older adv, was bet: see bet ${ }^{1}$.] 1. In a more exeellent way or manner: as, to behave better; the land is better eultivated and the government better administered.

The plays of Shakspeare were belter acted, better edited, and better known than they liad ever beel.

. In a superior degree: as, to know a man better than some one else knows him.

Whlch is the better able to defend himself: a strong man with nothing but lils fists, or a paralytic cripple encum. \& sword which he cannot lift? . More, without any idea of superior exeel[Colloq.]

Dorlcote IIII has been in our faunily a hundred yesr and
Getter.
George Eliot, Jlill on the Floss.

To be better off, to be in inproved circumstances

The mechanic teaches us how we may in a small degree great poinp to be as well off as we can.

Hen Jad become Romana; they were proud of the Roman name; bers of a civiliced community ordercd by law than they conld he under the dominlon of any harbarian.
E. A. Freeman, Amer. Lects., 1. 126. To go one better. See go, $v$.

better ${ }^{1}$ (bet'èr), $v$. [<ME. bettren, betren, < AS. beterian, betrian, intr., be better, ge-beterian, ge-betrian, trans., make better (= OFries. beteria $=$ Icel. betra $=$ Sw. bättra $=$ Dan. bedre $=\mathrm{OHG}$. bezzirōn, $\mathrm{MHG}$. G. bessern; ef. OS. betian, < bet, the older compar. adv, ), < betera, better: soe betterl, a.] I. tralls. 1. To make better; improve; ameliorate; increase the good qualities of: as, manure betters land; discipline may better the morals.

The cause of his taking upon hin our nature was to bet. ter the quality, and to advance the condition therent.

2. To improve upon; surpass; exceed; outdo.

He hath borne himself heyond the promise of hls age; inust expect of me to tell you how. Shak., Il uch Ado, I. 1. What you do
still betters whst ls done.

3. To advance the interest of ; suppor advantage to.

Wespons more violent, when next we meet,

Msy serve to better us and worse our foes.

=Syn. 1. Amend, Improve, Better, etc. (see amend), meli.

II. intrans. To grow better; become better improve: as, his condition is bettering. [Rare.]
better $^{2}$ (bet'er), $n$. [<bet ${ }^{2}+e r^{1}$.] One who lays bets or wagers. Also bettor.

Be able to give them the character of every bowler or

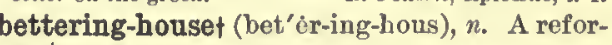
matory.

Soldiers burled in thiaground, from the hospital and
the bettering-house. Annals of Phil. and Penn., I. 406 . betterment (bet'èr-ment), $n . \quad\left[<\right.$ betterl, $v_{.},+$ -ment.] 1. A making better; improvement.2. In American lat, an improvement of real property which adds to its valne otherwise than by mere repairs: generally used in the plural. 


\section{bettermost}

bettermost (bet'èr-mōst), a. and n. $\quad[<b e t t e r 1$ +- most. $]$ I. a. Best; highest in any
as in social rank or mental qualities.

It first became opcrative in the diffnsion of knowledge among the people, at least among the bettermost elasses.
Brougham.

II. $n$. That which is best; especially, one's best clothes. [Local in England and United States.]

So II epzibah nnd her brother made themselves ready st, to go to chureh.
Hawthome, Seven Gables, xi.

betterness (bet'ér-nes), $u$. [ $<$ ME. betternes ; < better + -ness. $]$ 1. The quality of being better; superiority. Sir $\dot{P}$. Sidney.-2. In minting, the amount by which a precious metal exceeds the standard of fineness.

bettet (bet'et), n. [Native name.] A name of an Indian parrot, Palceornis pondicerianus. bettong (bet'ong), n. [Native name.] A species of the genus Bettongia, a group of small brush-tailed kangaroos.

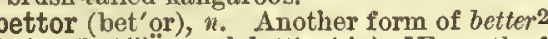
betty (bet'i), n.; pl. bettics (-iz). [From the fem. name Betty, dim. of Bet (ef. equiv. OF. Beti, Betie, also Betiaine, Betion, Betionette), abbr. of Elizabet, Elizabeth.] 1. A man who interferes with the domestic duties of women, or engages in female occupations. Also ealled ent-betty. in female occupations. Also called eot-betty.
[Used in contempt.]-2\%. A short bar used by thieves to wrench doors open. Also called a bess, a jenny, and now a jimmy or jemmy. [Thieves' slang.]

The powerful betty or the artful pickloek

Arbuthnot, Hist. John Bull.

3. A pear-shaped bottle, covered with maizeleaves or the like, in which olive-oil is exported from Italy; a F'orence flask.

Betula (bet betulla (> It. betula, betulla, also bedello, $=\mathrm{Pg}$. betulla $=$ Sp. abedul $=$ F. dim. boulcau) Corn. betho, bezo= Bret. bezo $=\mathrm{W}$. bed $v=$ Gael. beth $=$ Ir. beth, beit the birch.] A genns of hardy trees or shrubs,
natives of the north temperate and areti regions; the birches. It is the type of the order Betulneeee, and is distin-
guished from the secom. grinying genus Alnus by winged nutlet. 'There are about 30 species of Betzlala, of whieh 10 are North A merBetulaceæ (bet - $\overline{\mathrm{u}}-\mathrm{l} \overline{\mathrm{a}}^{\prime}$ sê-e), ne. pl. [NL., ral order of apetalous apetalous and shrubs, of which Betula is the typical genus, and containing

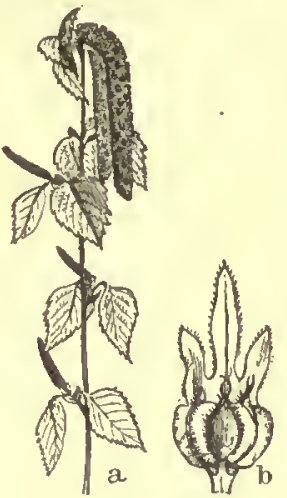

Betula.

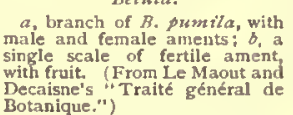
besides this only the genus Aluus, with 60 species belonging to the two genera. See eut under alder.

betulin, betuline (bet'ū-lin), $n$. [< Betula, birch, + -in $\left.{ }^{2},-i n e^{2}.\right]$ An alkaloid $\left(\mathrm{C}_{36} \mathrm{H}_{60} \mathrm{O}_{3}\right)$ obtained from the bark of the white birch. It crystallizes in the form

betumble (bē-tum'bl), v. t. $\quad[\langle b e-I+t u m b l e]$. To tumble; disarrange the parts of.

$$
\text { From her be-tunbled couch she startet }
$$

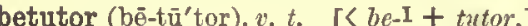
instruct; tutor. Coleridge.

between (bē-twēn'), prep. and $a d v . \quad[<(1) \mathbf{M E}$. betwene, bitwenen, etc., < AS. betweónum, betwōnum, betwimun, betwéonan, betwinan, bitweón-

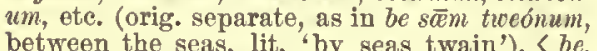
between the seas, lit. 'by seas twain'), < be, prep., by, + tweónum, dat. pl. of *tweón; (2) preceding), < AS. (ONorth.) betweón, betwēn, bitwēn, etc., < be, prep., by, + *tweón, acc. of "tweón, pl." "twēne (= OS. OFries. tuēene = OHG. MHG. zwène, G. zwcen), two, twain, orig. distrib. (=Goth. tueihnai = L. bini, OL. " duinni), two each, < twa (twi-), two: see two, and ef. twin, twain. The forms of botween have always interchanged with those of betwixt (which see).] I. prep. 1. In the space which separates (two points, places, objects, or lines); at any point of the distance from one to the other of : as, be-

538

bevel

tween the exes; betueen. Washington and Phila- betwixet, betwixent, prep. [Now only dial. delphia; the prisoner was placed between two policemen.

The sea
Swallows him with his host, bnt them lets pass

Milton, P. L., xit. 197

2. In intermediatc relation to, as regards time quantity, or degree: as, it oceurred between li incoming and outgoing; a baronet is betaeen \$6 each; between 12 and 1 o'clock. Bolus arrived, and gave a doubtfinl tsp, Colman, Broal Grins.

Her lips to mine how often hath she joined, Shak., Pass. Pilgrin, vi

3. In the mutual relations of: as, discord $\mathrm{ex}$ ists between the two families.

Frlendship requires that it be between two at least.

An intestine struggle, open or secret, betiveen anthority
and liberty.
Hume, Esssys, v. The war between Castile and Portngal had come to a close; the factions of the Spanish nobles were for the Differences of relative position ean be known only Differences of relative position ean be known only acompsnying the disclosure of the positions.

II. Spencer, Prin. of Psychol., \& 93.

4. From one to another of, as in the exchange of actions or intercourse.

If things sliould go so betreen them.
Bacon, Hist. of Hen. vII.

Thus grsceless holds he dispntation
'Tween frozen conselenee and hot-burning will Shak., Lncrece, i. 247. Franee has been the interpreter between England and
manklnd.
Macaulay, Horsee Walpole. 5. In the joint interest or possession of: as, they own the property between them.

There is between us one eommon name and sppellstion. Castor and Pollux wlth only one soul between then.

Locke. 6. $\mathrm{By}$ the

\section{Between them they will kill the eonjur}

7. In regard to the respective natures or qualities of: as, to distinguish between right and wrong.

There is an essentisl differenee between a land of which we can trace the gradnal formation from the shxth century eleventh century. E. A. Freeman, Eng. Towns, p. 120. 8. In regard to one or the other of: as, to choose betucen two things.

Between two dogs, which hsth the deeper mouth?

Between is literally applicsble only to two objeets; but it may be snd commonly is used of more than two where they are spoken of distributively, or so that they ean he
thought of as divided into two parts or estegories, or with reference to the setion or being of each individually as compared with that of sny other or all the others. When divisibly, among is tise proper word. ] - Between ourselves, not to be communicsted to others; in confidence. Between the beetle and the block. See beetle1.
To go between. See go, $=$ Syn. A midst, In the midst of II adv. In tho intermediate space; in inter II. adv. In tho intermediate space; in intermediate relation as

Your lady seeks my life ; - come yon between,
And save poor me.

between (bē-twēn'), $n$. [<between, prep.] One of a grade of necdles between sharps and blunts. between-decks (bē-twēn'deks), adv. and $n$. I. adv. In the space between two decks of a ship; on any deck but the upper one.

II. $n$. The space between two decks of a ship, or the whole space between the upper and the lowest deck.

betweenity (bẹ̄-twển'i-ti), n. [<betucen + -ity, as in extremity.] The state or quality of being between; intermediate condition; anything intermediate. [Colloq.]

To rejoin heads, tails, and betweenities. The house is not Gothic, bnt of that betucenity that in. tervened when Gothic deelined snd Pslladian was creep-
ing in. betweenwhiles (bē-twēn'hwīlz), adv., prop. prep. phr. At intervals.

betwit (bē-twit') $v, t . \quad\left[<b e-1+t^{\prime} i^{1}{ }^{1}\right.$. $]$ Totwit. Strsnge how these men, who st other times are all wise men, do now, in their drink, betwilt and reproseb one an. betwixt, prep. and adv. See betwixt. or archaic: < ME, betwixe, betwixen, betwexen, biturenen, etc., bitwixe, bituixen, etc., < AS. *betweoxan (occurs once spelled betweoxn), prob. for carlicr *betweoxum (= OFries. bitwiskum, bi twiseha), ( be, prep., by, + *tecoxum for * twihsum. "twiseum, dat. pl. of *tuise = OS. twisl: $=$ OHG. zxish, zwishi, MHG. zavise, twofold, < twa (twi-), two, + -se, -ise, E. -ishI. Forms with other prepositions appear in OS. undar tuisk, OFries. entuisla antuciska, atwisla abbr. twiska, twish, twischa, NFrjes. tuissche, D. tusschen, $\mathrm{OHG}$. in zwiskèn, unter zuishen, $\mathrm{HHG}$. in woischen, unter zoisehen, G. abbr. zwischen, between. This form was early mixed with betwix, betwixt.] Betwixt; between.

betwixt (bē-twikst'), prep. and adv. [Also by apheresis twixt, 'twixt, Se. betwisht, betweesht, < ate ME. betwixt, bytwyxte, earlicr betwix, betuxt, betuixte, betucex, betuix, bitwix, ete., < AS. betayxt, bctwuxt (with excrescent $-t$ ), betwy $x$, betweox, betweohs, betwux, betux, appar. shortened from the dat. form (or perhaps repr. an orig. ace. form) *betweoxum, > ME. betwixen, betwixe, q. v. In M[E. the words were mixed.] I. prep. Between; in the space that separates; in intermediate relation to as regards time, quantity, or degree; passing between; from one to another, etc. in most of the uses of betucen (which see)

Betuixt two aged osks. Mitton, L'Allegro, 1. 82. The morning light, lowever, soon stole into the aperThe at the foot of the bed, betwixt those faded curtains.

There was some speech of marriage
Bettrixt myself and her. Shak., M. for M., v. I. =Syn. See comparison under among.

II. $a d v$. Between, in either space or time. Betwixt and between, in an intermediate position;

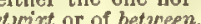

betylus, $n$. See batylus.

beudantite (bū'dan-tit), n. [After the Fronch mineralogist Beudant (1787-1850).] A hydrous phosphate and arseniate of iron, occurring in smali, closely aggregated crystals in Nassan, Prussia, and also near Cork, Ireland.

beuk (bük), n. A Seoteh form of book My grannie she bought nie a beuk,
And I held sws" to the sehoot. Burns, The Jolly Beggars. bevel (bev'el), $u$. and $a$. [Formerly also bevell, as a term of heraldry beril, bevile, < OF. "bevel or *buvel (not recorded), mod. F. birean, also spelled beveau, buveau, benveau, beaneau, etc. (cf. Sp. baivel), bevel; origin unknown.] I. $n$. 1. The obliquity or inclination of a particular surface of a solid body to another surfice of the same body: the angle contained by two adjacent sides of anything, as of a timber used in ship-building. When this angle is acute it is called an under bevel (or bevcling), and when
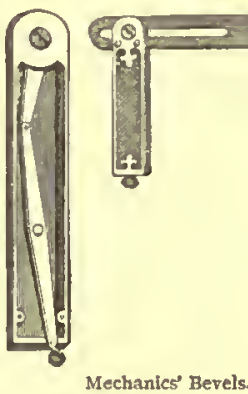
obtuse a standing sevel.-2. An inmechanies for drawing angles and for adjusting the abutting surfaces of work to the same inclination. It consists of two limbs ealled the stock or the blnde; the latter is the joint, snd can be adjusted so as to include any angle between it and the stock. The hlade is often curved on the edge to 3. A piece of type-metal nearly type-high, with a beveled edge, used by stereotypers to form the flange on the sides of the plates. W"oreester. 4. Same as bevel-angle. -5 . In her., an angular break in any

right line. Having the form of a bevel; aslant; sloping; out of the perpendicular; not upright: nsed figuratively by Shakspere.

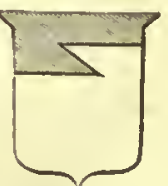

I msy be straight though they themselves be bevel.

Their houses are very ill built, the walls bevel, withont one right angle in any apartmit

$$
\text { Swift, Gnlliver's Travels, iil. } 2 .
$$

bevel (bev'el), $v$.; pret. and pp. beveled or bevelled, ppr. bereling or bevelling. [<bevel, n.] I. 
trans. To eut to a bevel-anglo: as, to bevel a bevel-ways (bev'ol-wãz), adt. Samo as berelpiece of wood.

II. intrans. To inclino toward a point or bev from a direct bevel-angle.

bevel-angle (bev'el-ang"gl), $n$. Any angle except a right angle, whethor it be acute or obtuse. Also called berel.

beveled, bevelled (bev'eld), p. $a$. 1. Having a bevel; formed with a bevel-angle. -2 . In mineral., replaced by two planes inclining equal ly upon the adjacent planes, as an edge; hav ing its edges replaced as above, ns a cube or be
other solid.-3. In her., broken by an acute other solid. - 3. In her., broken by an acute angle: thus, in the cut under berel, the blazon would be a chief vert, bereled.-Beveled bushing, a buahing in whicl the gikies are lnclined to the cnils. eled furnlture, in prining: (a) The tajering side-stlck and foot-sticks veed in inposing forms or locking up gal Beveled gearing. Sea gearing.-Beveled washer, waslier having its. $t$ wo faces not parallel to eaeh other, need to give a proper bearing to a head or nut when the rod ar bolt is not perpen

bevel-gear (bev'el-gèr), $n$. In mach., a specics of wheclwork in which the axis or shaft of the lender or driver forms an angle forms an angle with the axis or shaft of the fol-
lower or the wheel driven.

bevel-hub (bev'elhub), $n$. A hub or short connecting-pipe having a bend.

beveling, bevelling (bev'el-ing), n. Same as ber. el, 1.

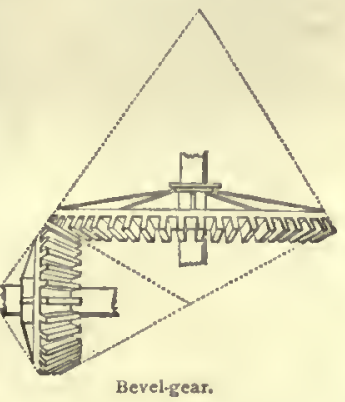

It is evident from the preceding, that by applying the bevel in the work man' osial manner, viz., with the stock against the left the bevelings will board and directed towards hia body, al . We thus find that when the flrst futtock framer are. on the amidslip side of the joint, their bevelings are always

Thearle, Naval A rchitectnre, p. 53

beveling-board (bev'el-ing-bōrd), n. 1. A board cut to any required bevel. It is used in adjusting frames or the parts of an angular construction, as in a ship.-2. A flat board upon which the bevelings of the various portions of a construction, as the framework of a ship, are marked.

beveling-frame (bev'el-ing-frâm), n. A wooden frame in which a beveling-board is placed to be marked. It consists of a wide board, on one edge of which is placed a fixed, and on the opposite a movable beveling-machine (bev'el-ing-me-shēn"), maching for beveling or angling the onter of a book-cover, or of an electrotyped plate for printing.

bevel-jack (bev'el-jak), $n$. A device used in transmitting motion from a motor to a machine. It consists of a pair of bevel-gears, one of which is con-
nected with a tunbling-ghatt turned by the motor, while

bevel-joint (bev'el-joint), $n$. A miter or sloping joint having its faces dressed to an angle, generally of $45^{\circ}$

bevelled, bevelling. See bereled, beveling.

bevelment (bev'el-ment), $n$.

[<berel + -ment.] In mineral. the replacement of an edge by ino similar planes, equally or adjacent planes.

bevel-plater (bev'el-plä"têr)

2t. A machine for rolling th bevel-edged plates of shin

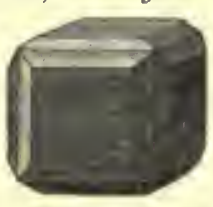
gling and veneering saws.

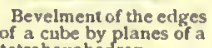

bevel-protractor (bev'el-prótrak drafting instrument with a pivoted arm sliding upon a graduated scetor, used in laying off angles.

bevel-rest (bev'el-r'est), A clamp for holding wood to a saw in making a beveled eut.

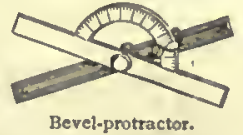

bevel-square (bev'el-skwãr), $n$. A try-square the blade of which can be adjusted to any angle with the stock, and held at such an angle by a set-screw. It is an artisan instrument for try. ing his work to see if it has been made with the proper bevel-wheel (bev'cl-liweil), In mach, a eog-wheel of which the working-face is oblique to tho axis. Such a whel is commonly used in conangles to that of the first. I'liege wileels are often called conieal wheele, aa their general form to that of frusla of Q bevel-gear.

bevel-wise (bev'el-wiz), adv. In her., in the orm or direction of a bevel: said of a ribbor or pennon charged thus upon the field. Also bevel-ucays.

bever ${ }^{3}, n$. An obsolete form of bearer ${ }^{1}$ ever $2, \mu$. An obsolete form of bearer 2 .

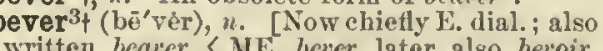
written beacer, < IIF, bever, later also beroir, bevere, bere (MI. biber), a drink, prop. inf. drink, < 1, bibere, drink: seo bibl, bibber. Honee beverage.] 1. A collation or slight de past between meals. Are. What, at your bever, gallants?
Mor. Will 't jlease your ladyghip to drink? Some twenty mark a-year! will that maintain Scarlet and gold lace, play at th' ordiuary, And bevers at the tavern? slight meal which the students received at the buttery-hateh and took to their rooms.

No acholar shall bo absent above an hour at morning bever and half an hour at evening bever. - the boys on the foundation were aupplied in tite dining hall with an intermediate meal (if meal it could be called) Which went under the name of bearer. According to my
recollection it consisted of beer only, and the hour was

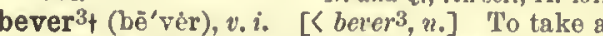
bever or slight repast between meals.

Your gallants never aup, breakfast, nor bever without
A. Brever (?), Lingua, ji. beveridge, beuvrage, ete., $<\mathrm{ML}$. beverage, beverege, beverache, beurage, ete. (ef. MIJ. beveragium, $\angle \mathrm{OF}$. bevrage, beutrage, brentraige, mod. $\mathrm{Pg}$. beberagem $=\mathrm{It}$. beveraggio; $\mathrm{MI}_{\text {. }}$ as if $*$ biberatieum $)<$ beve, boivre = It. bevere < L. bibere, drink: see bever $3, n_{\text {. }}$, and -age.] 1. Drink of any kind; liquor for drinking: as, water is the common beverage; intoxicating beverages. A pleasant beverage he prepared before

Dryden, Pal. and Arc.,

2. A name given specifically to various kinds of refreshing drinks. (a) In Devonehire, Fngland, water-elder; a drink made by passing water through the liquor made by passing water through the pressed grape after the wine has been expressed.

Touching price and quality of a liquor or drink ealled in England "bevaradge" and in France "pimpeene."

(c) In the West Indies, a drink made of sugar-cane jujee and water.

3. In Great Britain, drink-money, or a treat provided with drink-money, as on wearing a new suit of elothes, or on receiving a suit from a garnish. [Obsolete or dialectal.]

bevewt, $n$. See berue.

bevil, bevile, $n$. In her., same as berel, 5 .

evort, $n$. See beaver 2 .

bevue (be-vii'), $n$. [Formerly also bercw, < F. bérue, OF. bestue, < bé-, bes- (く L. bis-, double), + vue, view: see tiew.] An error of inadvertenee; a slip. [Rare.]

bevy (bev'i), n.; pl. beries (-iz). [Early mod. E. also beary, beavie, <ME. bery, bevey, bere, < OF, beveye ("beneye [printed deveye] des heronez, in a poem cited by Leo, Rect. Sing. Personarum, p. 40); ef. It. "beva, a beavie," Florio: applied esp. to a floek of birds and thence to a company of ladies; orig., perhaps, a drinking company, or a number of animals at a watering-place, being thus a particular use of $O F$. bevee, buvee, drink, drinking (cf. It. beva, drink), ( bevre = It. bevere, drink: see bever ${ }^{2}$, $n$, and beverage.] 1. A flock of birds, especially of larks or quails.-2. A small company or troop, as of roebueks, heifers, etc. -3 . A group or small company of persons, especially group or sinall company of persons, especially of girls or women, but also used of the male
sex: as, "a bevy of powdered coxcombs," Goldsmith; "a bevy of renegades," Macaulay, Hist. Eng.

A lovely bevy of faire Ladiles sate,
Courted of many a jolly Paramol 2. Formerly, at some colleges and scliools, a

When I was at Eton-now more thas thirty years aro

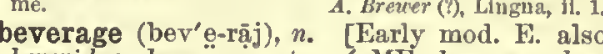

4. A small eollection of objects; an assem blage of things. [lare or obsolete.] =\$yn. 1 . bewail (bè-wãl'), $r$. [<MF. bcwailen, beceilen, biucuilen, etc., <be- + vailen, wail: see be-1 and cail.] I, truns. To mourn aloud for; bemoan lament; express deep sorrow for: as, to bercai tho loss of $a$ ehild.

Go, give your tears to those that lose their worths.

Jer anclent, hapless sorrow nightingale

iitlicm Norris, Earthiy P'aradise, 1. 394.

II. intrans, To express grief.

Hourning and bewailing exceeringly.

Ilollandi, 1r. of Livy, p. 70

bewailable (bêe-wa' $\left.\bar{a}^{\prime} \mid \mathrm{p}-\mathrm{bl}\right), a . \quad[<b c u a i l+-a b l e$. Capable or worthy of being bewailed.

bewailer (bẹ--wã'lèr), $n$. One who bewails or laments.

bewaíling (bệ-wā'ling), n. Lamentatiou.

bewailingly (bẹ--wa'ling-li), adv. In a bewail ing manner.

bewailment (bẹ-wäl'ment), n. [< bevail + Tho act of bowailing; a lamentation. "wak" (bê-wāk'), $v$. t. [<ME. bevaken, watch, wakc a dend body, wateh through ( $=\mathrm{D} . \mathrm{bc}^{-}$ waken $=\mathrm{G}$. bewachen $=\mathrm{Sw}$. beraka), $<$ be- + vouac.] To wateh, especially a dead body; observe funeral rites for. Gower.

beware (bē-wãr'), $t^{\prime}$., prop. phr. [Formerly and prop. written separately, be ware, a phrase composed of the impv. or inf. of the verb be and the d. ware; as in AS. beo war (beó, 2 d pers. sing. impv, of beon), beo the vcer (the , thee, reflexivo dative), be ware, just like E. be carcful. So ME. "be war therfor" (Chaucer); "A ha! fel awes! bcth war of such a Iape!" (Chaucer), where beth is $2 d$ pers. pl. impr., $<$ AS. bebth. (See begone, be zoare eame to be written as one word bevare, and then was classed by some authors with the numerous verbs in $b e-1$, and inflected accordingly; hence the erroneous forms be vares in Ben Jonson, and bercared in Dryden. This confusion may have been promoted by the existence of a MIE. verb becaren, show, exhibit descended, with some change of sense, from AS. bewarian, guard, keep, preserve (= OFries. biwaria $=\mathrm{D}$. bewaren $=\mathrm{OHG}$. bixarōn, MHG. bevaren, G. bevaliren = Sw. bevara $=$ Dan. bevare, kecp, guard), <be- + warian, guard, < waer, cautious, observant, $\mathrm{E}$. vares, as in be vare above. In the quotation from Claucer, below, both forms appear. See trare1.] To be wary or cautious; be on one's guard; excrcise care or vigilance: properly two words, be ware, consisting of the infinitive or imperativo of be with the adjective uare: followed by of, expressed or understood, with the force of 'against,' 'iu regard to': as, beware of evil associations; beware how you step; "beware the bear," Scott.

\section{Thus oughte wize men ben ware of folis ;
If thou do so thi witte is wele bywared [slown].}

Be ye urar of false prophets. H"yclif, Mat. vii. 15.

That 110 man no acholde . .. 2our of him ben.

Beware of all, but most beware of man.

Every one ought to be very carefnl to bevare what he

Bevare the pine-tree's withered braneh

bewash (bē-wosh'), $v$ t. [<be.1 + wash.] To

drench with water. [Rare.]

Let the majds bevash the men.

beweep (bē-wēp"), $v$.; pret. and pp. bevept, ppr.

beweeping. [< MIE. bewepen, birepen, < AS. be

cêpan (= OFries, birễpa = OS. biwöpian), < be

1. To weep over; deplore.

$$
\text { Bercep inls canke again, I'll pluck ye yen, }
$$

To bedew or wet with teans; disfigur mark with the signs of weeping.

Fast by her ayde doth wery labour stand

fere also, and sorrow all benoch

ewest (bē-west'), prep. [< ME. be trest, bi westen, (AS. be westan: be, prep., by ; westan, adv., west, from the west. 'Cf. be-east, benorth, besonth.] To the west of. [Scotch.] 
bewet

bewet ${ }^{1}$ (bē-wet'), v. t.; pret. and pp. bewetted, bewet, ppr. bewetting. [< ME. beweten, < be- + Ilis napkin with his true tears all beuet.

Shak., Tit. And., iii. 1. bewet ${ }^{2}$, bewit (bū'et, -it), ". [< late ME. bewctte, dim. of OF. beue, bue, earlier buic, boie, a collar, chaiu, fetter, < L. boio, a collar for the conry, the leatler with which the bell was at-
tached to a hawk's leg. [Commonly in the plural.]

bewhisper (bë-hwis'pér), v. t. $[<b e-1+$ whis

Keary, Prim. Belief, p. 378.
per.] To whisper. Fairfax. [Rare.] To make a whore of. Bcau, and $\mathrm{Fl}$ - -2 . To call or pronounce a whore. Shak:

bewield (bē-wēld'), $x, t$. [< ME. bewelden, < be be- + welden, wield: sce be-1 and wield.] To son. [Rare.]

bewigged (bẹ-wigd'), p. a. $[<b e-1+$ wigged. $]$ Wearing a wig.

Ancient ladies and berrigged gentlemen seemed lurry. ing to enjoy a social cup of tea.

bewilder (bọ̄-wil'dèr), $v . t . \quad[<b e-1+$ wilder see vilder.] 1. To confuse as to direction or situation; cause to lose the proper road or course: as, the intricacy of the streets $b e r$.
dered him; to be bewildered in the woods.

Can this be the bird, to man 80 good,

That, after their bevildering,

Covered witl leaves the little children,

So painfully in the wood

2. To lead into perplexity or confusion; pe plex; puzzle; confuse.

Bevildering odors floating, dulled her sense,

And killed her lear.

I'illiann Morris, Earthly Paradise, 1. 259.

We have elementary disturbances of consciousness in diseases of the nind, guch as epileptic states, ecstacy,
inentia.
ine betildered state of the mind in paralytic de-
E. C. Mann, Psychol. Mred., p. 35 . $=$ Syn, To confound, confuse, mystify, nonplus.

bewilderedness (bewilderment. bewilderingly (bệ-wil'dèr-ing-li), $a d v$. bewildering manner ; so as to bewilder. bewilderment (bë-wil'dèr-ment), n. [< bevit bewilderment (bê-wil'der-ment), $n$. $[<$ bewit
der + -ment. $]$ The state of being bewildered.

Thought was arrested by ntter bevilderment.

bewimple (bë-wim'pl), $v$. $t$. [〈ME. bewimplen (= D. bewimpelen) < be- + wimpelen, wimple: see be-1 and wimple.] To cover with a wimple; veil. Gower.

bewinter (bè-win'tèr), v.t. [<be-l + winter. $]$ To make like winter.

$$
\text { Tears that bevinter all ny year. }
$$

bewit, $n$. See bewet ${ }^{2}$

bewitch (bē-wich'), v, t. [ wicehen, < be- + wicehen, witch: see be 1 and witeh, v.] 1. To subject to the influence of witcheraft; affect by witcheraft or sorcery; throw a charm or spell over.

Look how I am bexcitclid; belold, mine arm Shak., Rich. III., iil. 4.

2. To charm; fascinate; please to such a degree as to take away the power of resistance. Love doth beritch and strangely change ua.

$$
\text { try our souls bewiteh }
$$

Dryden, tr, of Juvenal'a Satires.

His [Tennyzon's] verses still bewitch youths and artists
by their gentiments and beauty, but their thouglit takes by their sentiments and beauty, world.

bewitchedness (bē-wicht'nes), n. [<bewitehed, pp. of bewiteh, + -ness.] The state of being bewitched.

bewitcher (bẹ--wich'èr), n. One who bewitches or fascinates.

bewitchery (bẹ-wich'èr-i), n. [< bewiteh, iu imitation of witehery.] Witchery; fascination charm. [Rare.]

There is a certain beuvitehery or fascination in worda.
Sotth, Worka, II. ix.

bewitchful (bẹ-wich'fùl), a. [<bewiteh $+-f u]$ (irregularly suffixed to a verb).] Alluring fascinating. [Rare.]

Ill, more bevertch ful to enlice away. Milton, Letters. bewitching (bẹ--wich'ing), a. [Ppr. of bexiteh.]

Having power to bewitch or fascinate; fascinating; charming: as, "bewitehing tenderness," Addison, Spectator, No. 223.

540 witchingly (bẹ-wich'ing-li), adv. In a be-

witchingness (bē-wich'ing-nes), $n$. The uality w

witchment (bē-wich'ment), n. $\quad[<$ bewiteh + I'ascination; power of charming; the fiects of witcheraft.

I will counterfeit the bevitchment of some popular man,

To wall in May dew guards against bewitehment.

$\left\langle b e^{1}+\right.$ with 1 : what one an be with or do

titute. [Scotel.]

(bö-wun'dèr), v. t. $\quad[<b e-1+u o n d e r$ $\mathrm{D}$. bewonderen $=\mathrm{G}$, bewundern, admire.] 1 . To fill with wonder; amaze.
Seeing his astonishment,

2. To wonder at; admire.

F'airfax, tr. of Tasso, $x .17$

bework $\nmid\left(\right.$ bẹ-werk $\left.{ }^{\prime}\right), v . t$. [<ME. bewurehen, < AS. bewyrean (= D. bewerken $=\mathrm{G}$. bewirken $=$ Dan. bevirke), work, work in, adorn, < be- + s with thread; embroider.

The mantelle and the gyrdylle both

Sir Elamour, 1. 1152 Smocks all bewrought. B. Jonson, Jasque of Owls. bewpers, $"$. Seo beaupers.

bewrap (bē-rap'), v. t.; pret, and pp. bewrappec, bewrapt, ppr. bewrapping. [< ME. bewrappen, also bewrabben (with var. beulappen), < be- + crappen, wrap: see be-1 and wrap.] To wrap up; clothe; envelop.

$$
\begin{aligned}
& \text { His aword, } \\
& \text { Beworapt with flowers, hung idlie by his side. } \\
& \text { Fairfax, tr, of Tasso, } x \text { vi. } 30
\end{aligned}
$$

bewraył (bẹ-rā'), v. t. [<ME. beuraicn, bicreyen, disclose, reveal $(=$ OFries. biacrōgia $=\mathrm{OHG}$ biruogan, MHG. beriigen ), < be- + wraien, wrey en, obs. E. wray, disclose, reveal, < AS. wré gan, accuse (= OFries. wrögia, wreia $=\mathrm{OS}$. wroITH ruegen, $\mathrm{G}$ rügen, censure, = Icel. regjo slander, = Sw. röja, betray, = Goth. wrōhjan,

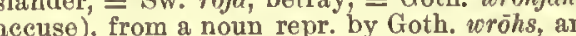
accusation, = Icel. $r \bar{o} g$, a slander. Somewhat affected in sense by betray, a quite different word.] 1. To accuse; malign.-2. To re word.] 1. To accuse; malign.-2.

Write down thy mind, bewray thy meaning.
Shak, T. of $\mathrm{A}$., ii. 5. Whoso is partner with a thiel hateth his own soul: he
heareth cursing and beverayeth it not. Prov, xxix. 24. 3. To disclose or reveal (the identity or the secrets of a person) perfidiously or prejudisecrets of a person) per
cially; betray; expose.

$$
\begin{aligned}
& \text { Thou bevreiest alle secrenesse. } \\
& \text { Chaucer, Man of Law's Tale, 1. } 675 .
\end{aligned}
$$

For feare to be enforced by torments to bewray his con-
Knolles, Hist. Turks, p. T. (N.E. D. Like slaves you sold your aouls for golden dross,

Bewraying her to death.

IIide the outcast, bevorcy not him that wandereth, the aimplest lesson of common humanity.

4. To reveal or disclose unintentionally or incidentally; show the presence or true character of; show or make visible.

The ointment of his right hand which bewrayeth itself.

Thy speech bevrayeth thee.

[Bewray is still sometimes used, especially in poetry, as an archaic word.]

ewrayer $\dagger$ (bẹ̄-rā'èr), $n$. A betrayer or. dilger.

Addison, spectator, No 225. bewrayingly $\nmid$ (bẹ̄-rā'ing-li), $a d v$. In a manner to bewray.

bewraymentf (bẹ̄-rā'ment), n. $\quad[<$ bewray + -ment.] The act of bewraying.

bewreakt (bẹ-rēk'), v. $t$. ['ME. bewreken, be- + wreken, wreak. Cf. AS. bewrecan, cxile, send forth: see be-l and wreak.] To avenge; revenge.

\section{Thus much am I bewreke.}

Chaucer, Prol. to Wife of Bath's Tale (ed. Speght), 1. 809.

bewreckt (bē-rek'), v. t. [<be-1 + wreek. Cf. AS. bevreean, drive or bring to, of ships: see be-1 and vreek.] To ruin; destroy

Yet was I, or I parted thenee, bewreckt. Mir. for Blags. bewroughtt (bẹ̄-rôt'). Obsolete past participle of bevork.

beyond

The more he considered it, the more bewitehing the bey ${ }^{1}$ (ba) $), n . \quad[=F$. Sp. bey, 〈Turk. bey, beg $=$ Sterne, Tristram Shandy, ii. 5. Pers. baig, a lord: seo bey ${ }^{2}$, beglerbeg, and be-

Pers. baig, a lord: seo bey ${ }^{2}$, beglerbeg, and begum.] 1. The governor of a minor province or sanjak of the Turkish empire.-2. A title of respect given in Turkey to members of cers above the rank of major, the wealthy gen try, and, by courtesy, to eminent foreigner's.

We therefore rode out of Beyront as a pair of Syrian 3. The title usually given by foreigners to the former Mohammedan rulers of Tunis.

Frequently written beg.

$y^{2}+, v$. A Middle English form of $b u y$.

eyetet, $v, t$. A Middle English form of beget. beylerbey (bä'lér-bä'), n. [<Turk. beylerbey, beglerbeg, prince of princes, lit. 'bey of boys.'] The title of the governor-gencral of a provine of the Turkish empire, ranking next to the grand vizir, and so called because he has under him the beys at the head of the several sanjaks or districts composing his province. Also written beglerbeg.

beylerbeylik (bä'lèr-bā'lik), n. [Turk., <beylerbey + -lik, a common noun formative; beylik.] The territory govenued by a beylerbey. Also beglerbeglik or beglerbeglic.

beylik (bā'lik), n. ['Turk., 〈bey, a bey, + -lik cf. beylerbeylik.] The district ruled by a bey. beyond (bē-yond'), prep. and adv. [<ME. be yonde, beyende, etc., < As. begeondan, < be, by, + geondan, from the further side, < geond, prep., across, over, beyond (= Goth. jäins, yonder $+-a n$, adv. suffix: sec $b c-2$ and yon, yonder.] I. prep. 1. On or to the other side of: yonder. I. prep. 1. On or to the other side of: as, beyond the river; beyond the horizon; "beyond that flaming hil We send our liest commodities beyond the aeas.
Burton, Anat. of Nel., To the Reader, p. 59.

2. Further on than; more distant than: as, a mile beyond the river; a hundred miles be yond Omaha; he never could get beyond simple equations.

So lar your knowledge all their power transcends, Dryden, Prol. to Univ. of Oxford, 1. 39. It is not necessary to look beyond Nature or beyond ex-

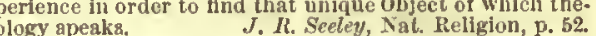
3. Past in time; later than: as, a day beyond the proper time.-4. At a place or time not yet reached by; before; ahead or in advance of.

What's fame? A fancied life lu others' breath

A thing beyond us, even before our death.
Pope, Easay on IIan, Iv. 238.

5. Out of reach of; outside of the capacity, limits, or sphere of; past: as, beyond our power; beyond comprehension; that is beyond me.

We bring a welcome to the liphest lessons of religion and of poetry out of all proportion beyond our skill to That the Antarctic continent has a flat and evell aurface, the character of the icebergs showa beyond dispute.
$J$. Croll, Climate and Cosmology, p. 74 . 6. Above; superior to; in or to a degree which rivals, exceeds, or surpasses, as in dignity, excellence, or quality of any kind.

Beyond any of the great men of my couniry. Sir P. Sidney. Dangle. Egal, we were just speaking of your tragedy.dmirable, Sir Fretiul, admirabl

Sneer. You never did anything beyond it, Sir Fretful-

She la beautiful beyond the race of women.

7. More than; in excess of; over and abor $\theta$.

And tortured with him l'veyond lorty fer $B$ Jonson, Poetaster, iii. 1

IIe [Pitt] retured to accept one farthing beyond the salIIe [Pitt] retuaed to accept one farthing beyond the sal-
ary which the law had annexed to his office.
Macaulay, William Pitt. Beyond all. See cell.-Beyond seas, out of the country; abroad.-To go beyond, to exceed in operation, ability, or circumvent.

That no man go beyond and defraud his brother in any

The king has gone beyond me; all my glories Shak., Hen. VIII., lii. 2

To go beyond one's self, to be much excited by any-

II. $a d v$. At o distance; yonder.

Beyond he lyeth, languishing. Spenser, F. Q., III. i. 38. eyond (bẹ-yond'), $n$. That place or state which lies ou the other side; an experience or 
life beyond our present life or experience: as, the great beyond.

They are the Ali, with no beyond.

281. (N.E.D.) The back of bey ond, a very distant or out-of-the.way beyond-sea (bẹ-youd'sē), $a$. From beyond the sea; forcign; outlandish: as, beyond-see words. Nay, my beyond-sea sir, we will proclsin you:
You would he king ! Bear and ${ }^{2}$, Philaster,

beyship (bā'ship), n. [<bey + ship.] The oftice of a bey; incumbency of such office.

Those small political effenees, which in the days of the Msmelukes would have Jed to a beyship or a howstring recelve four.folil punjshinent hy deportation to 'rizoghili,
the local Cayenne. bezan (bez'an), $n .[=\mathrm{F}$. bezan, prob. of F. Ind. origin.] A white or striped cotton cloth from Bengal.

bezant (bez'ant or bē-zant'), n. [ $<11 \mathrm{E}$. bezant, besant, besur" $<\mathrm{OF}$. besant, bezan, besan = $\mathrm{Pr}$ bezan $=\mathrm{Sp}$. bezante $=\mathrm{Ig}$. besante $=\mathrm{It}$. bisante, (IIL. Bezantius, L. Byzantius (sc. nummus), a Byzantine coin, < Byzantium, < Gr. Bu̧̧árcov, older name of Constantinople. Cf. florin.] 1.

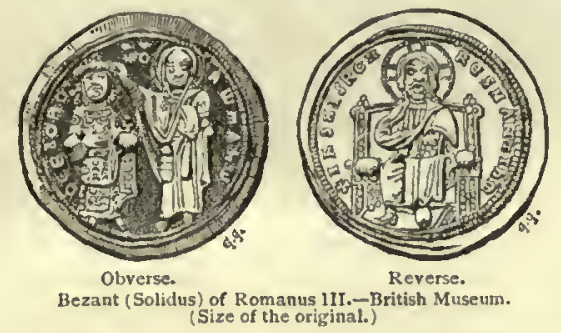

solidus) issued by the emperors at Constantinople in the middle ages. Bezants had a wide morc espeeialiy during the periol from a bout A. D. 800 to the middle of the thirteenth century, when Eurepean countries, except Spain, had no gold
own. Also ealled byzant, byzantine.

And who that did best should liave a rich circlet of gold worth a thousand bezants. Sir T. Malory, Morte d Arthur. 2. In her., a small eircle or; a gold roundel. from the colns of Constantineple, assumed as bearings by erussders.

White bezant, $\Omega$ silver eein of Byzsntium, worth sbout

bezanté, bezantée, bezanted (bez-antä', bệ-zan'ted), a. Inter.

bezantée (bez-an-tā'), n. [OF', prop. fem. seo bezanty.] A moldseo bezanty.] A moldroundels or small disks resembling bezants, of frequent occurrence in Norman architecture. Encye. Brit., II. 461.

bez-antler (bez-ant' -

lér), n. [Also bes-ant-

ler and bay-antler : OF. bez-, bes-, secondary, inferior (prob.

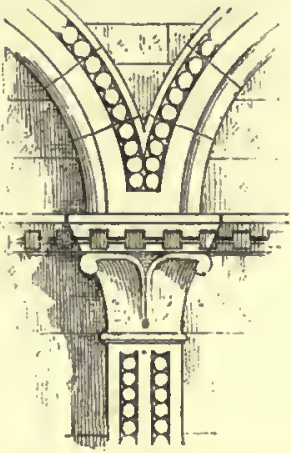
L. bis, twice), + E. antler.] The branch of a bay-antler. See antler.

bezanty (bè-zan'ti), a. [Also bezanté, bezantée, bezanty (bè-zan ti), a. [Also bezante, bezantee, or studded with bezants: said of the field, or of any charge. Also bezanted.

bezel (bez'el), n. [Also bezil, basil, and formerly beazel, bazil, bezle, etc., 〈OF. "besel, bisel (F. biseau), sloping edge, a bevel, = Sp. Pg. bisel; origin unknown; perhaps $(a)<\mathrm{L}$. bis, double, + dim. suffix -el, or $(b)<\mathrm{MI}$. bisalus, a stone with two angles or slopes, < L. bis, twice, + ala, a wing. Cf. axil and aisle.] 1. The slope at the edge of a cutting-tool, as a chisel or plane. It is generally single, but sometime double. [Iu this sense commouly basil.] -2 . The oblique side or face of a gem ; specifieally, one of four similarly situated four-sided facets on the top or crown of a brilliant, which are sometimes ealled templets. See cut under bril liant. Bezel is alse semetimes used to denote the spsce
between the table and the girdle, that is, the "erown," between the table and the girdle
with the exception of the table.
3. In jevelry: (a) That part of the setting of bezoutoid (be-zo'toirl), $n$. [< Broput (see $B c$ a precious stono which incloses it and by which zoutian) + -oill.] In math., the bezoutiant to it is held in place. (b) A flat surface of gold two homogeneous functions obtained by differengraved with any device to servo as a seal, when a stone is not used. See chuton. [Rare.] -4. In wateh-making, the grooverl flange or rim in which the erystal of a wateh is set.

bezel (bez'el), $\imath$. $t$; pret. and pp. bezeled or bezelled, ppr. bezeling or bezelling. [Also basil; <bezel,n.] To grind to an edge; eut to a sloping edge; bevel.

bezesteen (bez'es-tēn), $n$. [Also written bezestein, bezestan, < Turk. basistän, orig. Pers., a clothes-market.] An exchange, bazaar, or marelothes-market.] An exchange, b
ket-place in the East. $N$. L. D.

bezetta (bö-zet'a), $\pi$. [A corruption of It. pezzetta, red paint, prop. s picee of cloth dyed pezza, a picce, esp. of cloth: see picce.] Coarse linen rags or sacking soaked in certain pio ments, which are prepared thus for exportation; the pigment itself. Red bezetta is coleret with coehinesl, and the pigment is used as a cosmetic Bue bezetta is yrepared from the juice of some enpiner. to color the rind of Dutch cheese.

Béziers (bä-ziā'), $n$. A sweet wine, named from the town of Beziers in the department of Hérault, France.

bezique (be-zēk'), n. [Also basique ; $<\mathrm{F}$. be sigue, bezique, bcisy: of obscure origin. Some sigue, bezigne, bcsy; of obscure origin. Some compare Pers. baziehi, sport, a game, < bãzi play, sport; but the resemblance is appar. ac-
cidental.] 1. A game of cards played by two. three, or four persons, with two packs from which the cards having from two to six spots have been removed. The object of the game is to win the aees snd tens, snd to aecure various combinations of eards, which when shown or "deelared"

player to score a certaln number of polnts.
2. The queen of spades and knave of diamonds, one of the counting combinations in the game of bezique.-Double bezique, the two queens of combination in bezique.

bezoar (b-'zōr), n. [Also bezoard, early mod. E. bezor, beazor, beazer, bezar, bezer =F. bézoard, formerly bezar, bezahar, = Sp. bezoar, bczaar, bezar, = Pg. bezoar = NL. bezoar, bezaar, be bezar, = Pg. bezoar = NL. bezoar, bezaar, be-
zahar, < Ar. bazzahr, badizali, < Pers. bādzahr, $p \bar{a} d z a h r$, the bezoar-stone, < $p \bar{a} d$, expelling, + $z a h r$, poison: so called because it was considered an antidote to poison.] A name for certain calculi or coneretions found in the stomach or intestincs of some animals (especially ruminants), formerly supposed to be efficacious in preventing the fatal effects of poison, and still held in estimation in some eastern countries. They sre used in China botí as a pigment and as a drug. substance, as a bit of wood, straw, hair, ete. Many vari. etles have been mentioned, but most valne was put on tile lezasr from the East Indies and thiat front Peru.--Bezoar mineral, sn oxid of antimony, or antimonic scid, eapeeisily that preparel from butter of antimony by the animal bezosr, consisting of several layers sround some bezoardic (bez-ōöä'dik), a. and $n$. [ [ $\mathrm{F}$. bézoardique (NL. bezoardicus, bezoartieus), < béeoard, bezoar.] I. $a$. Of the nature of or pertaining to bezoar; compounded of or possessserving as an antidote.-Bezoardic acid. Same as ellaric acil (which see, under ellagic).
II. $n$. A medicine having the properties of bezoar; an antidote.

the wildoat (bēzör-göt), n. A name given to that it produces the bezoar. - See orgagrus.

bezoartict, bezoarticalt (bez-ō-är'tik, -ti-kal), a. [<NL. bezoarticus: see bezoardie.] Samë as bezoardic.

The healing bezoartical virtue of grace.
Chillinguorth, Works, p. 378. bezonian (bẹ̀-zō'ni-ạn), $\%$. [Also besonian, bi sonian, < besonio, besognio, bisogno, etc., a beggar: seo bisogno.]

Under whieh king, Bezonian! speak or die.

Bezoutian (be-zö'ti-an), a. 3. French mathematician Etienne Bezout (I73083).-Bezoutian method of elimination, a method published by Bezout in 1765

Bezoutian) + -i-ant.] In math.: (a) The homogeneous quadratic function of $n$ variables, whose discriminant is the resultant of two equations, each of the nth degree. (b) Incorrectly used for bezontoid. entiation from one homogencous function of two variables.

bezzle (bez'l), $\imath$. ; pret. and pp. bezaled, ppr. bra sling. [Now only E. dial. ; early mod. E. also bezzel, bezel, bizle, bissel, < late ML. besile, < OH besiler, beziller, besillicr, by ajheresis for cubesillier, waste, cmbezzle: sce cmbezale.] I. trans. To purloin or inake away with; embezzle.

$$
\begin{aligned}
& \text { I nust be shut up ano my sulustance bezal'd. } \\
& \text { Fletcher, Woman's Prito }
\end{aligned}
$$

2. To consume a large quantity of as food drink; waste or squander, as inoney. [Prov. ng.

II. intrans. To drink to excess. Deliter.

bezzlet (bez'l), n. [<bezsle,v.] A debaucliee; a sot. Nash.

bezzlert (bez'lér), $n$. Same as bezzle, n.

ezzling $\dagger$ (bez'liug), $n$. [<bezzle, $v$.$] Dissipa-$ cxcessive drinking.

From hauglity Spayne, what lrought'st thou els besifie But lofty lookes ani their Lacifrian prisle?

Their boote-carouse, and thelv heere-buttering? Il arston, istyres, ii.

I have proposed and determined with myself to leave Shellon, tr. of Don Quixote, fol. 158

bbadoee (bä'dō-ē), n. [< Hind. Uhätui or bhafouwi, adj., relativo to the month Bhaclou, the the last half of August and the first of September.] The earliest of the three annual erops in Hindustan, consisting of rice, maize, ete. It is lald down dinring the rsinfail in April and May, and is fourth of the food-supply in a normsl year.
[Hind. bhainsa (masc.) bhains (fem.).] An

bhang, bang ${ }^{3}$ (bang), $\%$. [Also bhung, and formerly bangue, also (after Ar.) benj; <Hind. ete. bhang, bhäng, bhang (= Pers. bang, > Ar. banj, benj), bhallg, < Skt. bhang $\bar{a}$, hemp. banj, benj), bhallg, < Skt. bhang $\vec{a}_{\text {, hemp.] The }}$ which as grown in India contain a powerfully nareotic resin and a volatile oil. In India bhang used for smeking, either with or without tobaeco, and is meat called majun (msjün). An intoxiesting drink is prepsred by infusing the ponndeci lesves in cold water. dype, hypnotie, and antispasmodic qualit tjes. One of the Gorkha chiefs who invaded Nepâl in 1768 , and parceled out the lund among themselves. The bharalars form a kind of fundal aristoc bharsiab (bär'sē-ä), n. [E. Ind.] The native name of an East Indian badger-like quadruped Ursitaxus inauritus of Hodgson. India, a man of a tribe of mixed descent, the and poets; a bard. These men in Rajputans snd Guzerat had also extraordinary privileges as the gnaran. or robbery. I'ule and Bur.

bheesty, bheestie (bēs'ti), $n$. [Anglo-Ind., also written beesty, beestie, beasty, bcastic, < Hind. bhisti, bihisti, Pers, bihisti, a water-carrier, lit. heavenly, 〈 bihist (> Hind. bihist), paradise, heaven.] An Indian water-carrier, who supthe nearest river or reservoir, earrying it in a sheepskin bucket or bag.

In psrticulsr there is a queer creature, like whot I faney s brownle should be, ealled a beestie or bhestie, whose
special eslling is to fill the baths in tlot refreshing apart ment... attsched to every Indian bedroom. $N$. Macleod. bhel (bel), n. Seo bel 3 .

Bhil (bēl), $n_{\text {. }}$ [Also spelled Bheel, repr. Hind. Bhil.] 1. A member of the aboriginal tribes budda and Tapti, and the slopes of the Vindhya and Satpura mountains.

The language of the Bhils in the Bombsy lurovinee, Rajpootana, and Central Indla, is understood to be a dis-
lect of Hiludi. 2. The language of the Bhils.

blogai (bō'gi), $n$. [E. Ind.] An inferior cotton made in India.

Bhotanese (bō-tä-nēs' or -nēz'), $a$. and $n$. See Bhutanese.

Bhutanese (bö-tạ-nēs ${ }^{\prime}$ or -nēz'), $a$. and $n$. [< Bhutān, the country (Bhutiā, a native of Bhn$\tan ),+$-ese.] I. a. Pertaining to Bhutan, its people, or their language. he bezelings of these knights and return to my vilisise. bhainsa (bīn'sä), n. [Hind. bhainsa (masc.),

bhat (bät), $n$. [Hind. bhät, also bhärata.] In 
In reality the Bhutanese authortties did not want to re- biarritz (biär'its), n. [Named from Biarritz, a biauriculate (bī-â-rik' J.T. Wheeler, Short Hist. India, p. 674. town in the department of Basses-Pyrénées,

II. $n$. 1. sing. or $p l$. A nativo or the na- lrance.] A thin corded woolen elotl.

tives Ilimalayas, having Tibet on the north, Bengal and Assam on the south, and Sikhim on the west. The Bhutunese have flat laces, lilgh cheek-bones, brown complexion, almond eyes, and black hair. They a dual government under a pontiff and a prince.

2. The languago of Bhutan.

Also written Bhotonesc and Bootancse (Bho$\tan$, Bootan).

bhyree (bi'rè), $n$. [E. Ind.] A kind of faleon used in hawking in India. Also behree.

bit, prep. [ME., S AS. be, in comp. with nouns bi: see $\left.b y^{1}, b c-1.\right]$ A common Middle English form of the preposition by.

Bi. The chemical symbol of bismuth.

bi-1 + . A Middle English and Anglo-Saxon form of $b e-1$ or $b c-2$.

bi-2. [L. bi-, combining form of bis $\left(=\mathrm{Gr}\right.$. $\delta \iota_{-}-$, $\delta_{t-}=$ Skt. lei- $=0 H \mathrm{OHG}$. MHG. zwi-, G. zwieAS. twi-, F. twi-), orig. "duis, twice, doubly, two-, $<d w 0=$ E. two: see two, twi-, di-2.] A prefix of Latin origin, cognate with di- and twi-, meaning two, two-, twice, double, twofold, as in biaxial, bicornous, bimanous, biped, bifurcate, otc. : especially in chemical terms, where it denotes two parts or equivalents of the ingredient referred to, as in bicarbonate, bich.omate, etc. Such words are properly adjectives, to be analyzed as bi- + noun + adjective auffix (for example, the (bi-axial, bi-furcate, etc). Words in bi- rest actually or theretieally upon Latin or New Latin forms, * birxialis "biacuminatus, *biangulatus, "biarticulatus, etc.; but

is often convenient to refer them to English elements.
biacid (bi-as'id), $a$. $[<b i-2+a c i d$.$] In chem.$

capable of combining with an acid in two different proportions: said of a base.

biacuminate $\left(\mathrm{b} \overline{\mathrm{i}}-\mathrm{a}-\mathrm{k} \overline{\mathrm{u}}^{\prime} \mathrm{mi}-\mathrm{na} \mathrm{a}\right), a . \quad[<b i-2+a c u-$ minatc.] In bot., having two diverging points, as the hairs on the leaves of some Mlalpighiacea. which are attached by the middle and taper toward the ends.

bialar (bi-ä'lärr), a. [< $b i-2+$ alar. $]$ Having two wings.-Bialar determinant, in math., one in bialate (bī-ā'lät), a. $\left[<b i-2+\right.$ alate $\left.^{2}.\right]$ Having two alæ ol wings; two-winged

bianco secco (biäng'kō sek'ō). [It., lit. dry white: blanco $=\mathbf{F}$. blane, white, $<$ OHG. blanch, sec, sach ${ }^{3}$.] A white pigment used in fresco painting. It consists of lime and pulverized marble til its causticity is removed. Lomazzo observes (Trattato, p. 194) that Periuo del
Vaga invented a colour formed of Verdetto and bianco
gecco, that is limewhite in seco, that is, limewhite in powder. biangular (bī-ang'gū-lär), $a$. [< bi-2 + angular.] Having two angles or corners. [Rare.]
biangulate, biangulated (bī-ang'gụ-lāt, -lầ-

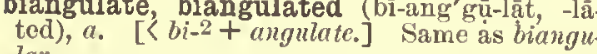

biangulous (bī-ang' gīi- $] u s), a . \quad[<b i-2+u n g u-$ lous.] Same as biangular.

biannual (bī-an' $\bar{u}-a l), a .[<b i-2+$ annual. Cf. biennial.] Occurring twice a year: arbitrarily distinguished from biennial (which see).

biannually (bī-an'ụ-ạl-i), adv. Twice a year.

Not even an aspiration toward a change in the fashion
of her clotlies bi-amnieally, at least The

biannulate (bī-an' ūi- $] a \bar{t}), a .[\langle b i-2+$ annulate. $]$ In $z o o ̈ l$., having two oncircling rings, generally of color.

biantheriferous (bī-an1-the-1rif'e-rus), $a . \quad[\langle b i-2$ + antheriferous.] Iu bot.", having two anthers. biarchy (bi'är-ki), n.; pl. biarchies (-kiz). [< ete. Cf. diarchy.] Dual government or sover-
eignty.

biarcuate, biarcuated (bī-är'kñi-āt, -ā-ted), a [<bi 2 + arcuate.] Twice curved: as, a biarcuate margin, one having a convex curve passing into a concave one.

Biar glass. See glass.

Biarmian (biär'mi-an), $n$. and $a$. $\quad[<$ Biarmia, Latinized from Icel. Bjarmaland, the land of mians: see Permian.] I. $n$. One of the Finnish inhabitants of Perm in Russia; a Permian (which see).

II. $a$. Of or pertaining to the Biarmians or ticulate.] Havin.

of some insects.

biasses (-ez). [Early mod. E. also biass, byas, biace, biais, $\angle \mathrm{F}$. (and OF.) biais, a slant, a slope, $=$ Pr. biais = OCat. diais, Cat.biax=It. s-biescio, dial. biasciu, sbias, bias (ef. also lt. bieco, squint ing, oblique, bias); origin unknown; hardly < LL. bifacem, ace. of bifax, squinting (cf. MIL. bifacius, two-faced), ( L. bi-, two-, + facies face.] I. n. 1. An oblique or diagonal line especially, a cut which is oblique to the texture of a fabric; hence, in dressmaking, a seam formed by bringing together two pieees thus cut; specifically, one of the front seams of a 2. In bowling, a bulge or greater weight on one side of a bowl; a difference in the shape and weight of the two sides or poles of a bowl, causing it to curve in its course toward the causing it to curve in its course toward the
lighter and less bulged side; hence, the curved course of such a bowl.-3. A one-sided tendency of the mind; undue propensity toward all object; a particular leaning or inclination; bent; specifieally, in law, prejudice, as of witness: used most frequently to denote prejudice and habits of thought which prevent the fair or dispassionate consideration of any subject or question.

Morality influences men's Itves, and gives a bias to all
their actions.

Alas! what years you thing consume in vain
Ruled by this wretched bias of the braln!

Crabbe, The cannot mistake the prevalling bias of her mind.
Oner. Barham, lugoldsby Legends, 1. 202

The bias of education, the bias of class-relatlonghips the bias of nationality, the politlcal bias, the theologica antipathies, lave much nore influence in determining bellefa on aocial questions than has the anall amount of On the blas, diagonally ; slantingly. $=$ Syn. 3. Propensity, medination, etc. (see bent 1), prepossession, wrediaposition, II. a. 1. Obliqu

utline or to the texlanting; diagonal to the chiefly of fabrics or dress: now used only or former use) in a drawing; a bias piece in a garment. - 2t. Loaded or swelled on one side, like a biased bowl.

Blow, villain, till thy sphercd bias cheek
Ont-gwell the colic of puff'd Aquilon.

III. ads. [< bias, a.] In a slanting man Trial did draw
Bias and thwart, not answering the atm.

bias (bī'as), $t . t$.; pret. and pp. biased or biassed, ppr. biasing or biassing. [Early mod. E. also from the noun.] 1. To give a bias to, as a bowl ; furnish with a bias. See bias, n., 2. To gine you the Morall of it [game of bowla]: It is the
Fimbleme of the world or the vorld's ambition.

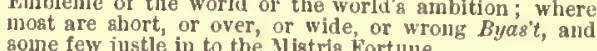
2. To Bp. Earle, Nicro-Cosmographie, xli. 2. To incline to one side; give a particular direction to the mind of; prejudice; warp; prepossess: as, the judgment is often biased My judgment

My judgment of desert hath not heen liassed by per8ons being of niy own particular judgment, in matters of
disputation, among the churches of God. No man is allowed to be a judge in his own cause; be cause his interest will certainly bias his judgment, and, bias-drawing (bī'as-drâ"ing), n. A turning awry; hence, partiälity; prepossession. Shak. biasness (bi'as-ues), $n$. [< bias + -ness.] The
state of being biased; inclination to a particustate of being biased; inclination
lar side; partiality. Sherwood.

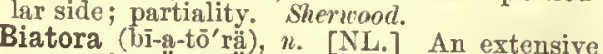
genus of lichens which have a crustaceous thallus adhering closely to the substance on which it grows, and sessile apotheeia, of which the exciple is colored or blackening.

biatorine (bī-a-tó'rin), a. [<Biatora + -inel.] In liehens, pertaining to or resembling the genus Biatora; having a proper exciple, which is not coal-black, but colored or blackening, as in many species of the tribe Lecideacei. biatoroid (bi-a-tō'roid), $a$. [< Biatora +-oid. $]$
Same as biatơine.

ulate. 1 . In coöl. and anat. having two aul ricles, in any senso of that word: especially applied to the heart of the higher vertebrates. -2. In bot., having two ear-like projections, as a leaf.

Also biaurite.

biaxal ('bī-ak'sạl), a. Same as biaxial.

'The great majority of non-isotropic aubstances are douby refracting, and in gencral are biaxal, i. e. have two equally important optre axes, whose inutrial luclination
may have any value from $0^{\circ}$ to $90^{\circ}$. Tait, Light, \& 290 . biaxial (bī-ak'si-ạl), a. [<bi-2+axial. $]$ Having two axes: as, a biaxial erystal. See optic.
biaxiality (bì-ak-si-al'j-ti), $n$. [<biaxial +-ity. $]$ Tho quality of being biaxial; biaxial character. biaxially (bi-ak'si-al-i), adv. With two axes. biaz (bé'az), n. [Native name.] A cotton cloth resembling linen, manufactured in central Asia for home use and for export to Rus. sia. MeEtrath, Com. Dict.

bibl$^{1} \nmid$ (bib), $v$. $t$. and $i$; pret. and pp. bibbed, ppr. biubing. [= North. E. beb, < ME. bilbon tipple, drink; ef. freq. bibblc, nearly $=O D$. bilcren, drink frequently. ME. bibben "must have been borrowed directly from L. bibere, to drink, and may be imagined to have been ... nsed jocularly by those familiar with a little monkish Latin" (Skeat); but perhaps of natural origin. See imbize, bibulous, bever 3 , and bevcrage.] To sip; tipple; drink frequently.

This meller [miller] hath ao wyaly bibbed ale. He was constantly bibbing, and drank more in twenty. bib2 (bib), n. [Supposed to bo derived from the verb bib1, because it absorbs moisture. Cf. barette and bavev ${ }^{2}$.] 1. A cloth worn by ehildren under the ehin to keep the front of the dress clean, especially when eating.-2. A similar article worn by aduIts, especially as forming the upper part of an apron.

We"ll Irave a bib, for spolling of thy doublet. Beau. and $F$., Captaln, iii. 5 .

3. A curved vent or nozle nsed to alter the direction of the flow of liquids. -4 . Naut., same as bibd, the usual spelling in this sense. [So called from a membrane the head, and which, when inflated, may bo compared to a bib; $<b_{i b 2}^{2}$.] The most com-
The head, and which, when infled, may bo mon name of the whiting-pout, Gadus luscus, a fish of the family Gadida. See blens, 2.

bibacious (bi-bā'shus), a. [<I. bibax (bibaci-), given to drink (< bibere, drink), +-ous.] Addicted to drinking; disposed to imbibe. [Rare.] bibacity (bi-bas $s^{\prime}$-ti), n. [Formerly bibacitie, The quality of being bibacious, or addicted to drink. Blount. [Rare.]

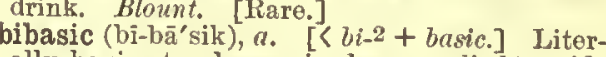
ally, having two bases: in chem., applied to acids (such as sulphuric acid, $\mathrm{H}_{2} \mathrm{SO}_{4}$ ) which have two hydrogen atoms replaceable by a base or bases. See monobasic, tribasic, dibasic, and polybasic. bibation (bi-bā'shonn), n. [Frreg. for *bibition, ML. bibitio(n-). Cf, imbibition, and see bib1.] The act of drinking; a drink or draught. Royal checr and deep bibation. Nayler, Reynard the Fox, 4.

bibativeness (bib'a-tiv-nes), n. [<bibI + -atice + -ncss.] Fondness for liquor; tendency to drink: a torm used in phrenology.

bibb (bib), n. [A particular use of bib2. A somewhat similar comparison appears in the ease of beacer2, originally a bib.] Naut., a bracket of timber bolted to the hound of a lower mast for the purpose of sup

bibber (bib

bibl $1+-e \mathbf{1}^{1}$. Cf. OD. biberer, a bibber. See bib 1.] A tippler; a person given to drinkng: chiefly used in composition: as, a wine-bibber.

Ah! Zeplyyrus! art here,

tender bibbers of the rain and dew.

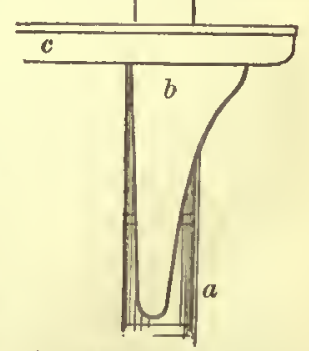

Bibb on starboard side of mast.

bibblet, $v$. [Early mod. E. also bible, dibil (ef. equiv. OD. biberen), freq. of bib1.] I, trans. To ; drink of or from.

II. intrans. 1. To drink often.-2. To sip. 
bibble-babble

bibble-babble (bib'l-bab"1), n. [Early mod. 1.. also bible-bable, a varied redupl. of babble.
Cf. tittle-tattlc, shilly-shally, ete. Idlo talk; prating to no purpose.

Thy wita the heaveng restore! endeavour thyself to sleep, bibblerł (bib'lèr), $n$. One wlıo bilbles; a bib-

l'are ye well, bibbler.

I'dall, liodster Dolster, lil. 5. bib-cock (bib'kok), $n$. [<bit 2 (in referenee to the bent-down nozle) + cock $^{1}$, 3.] A coek or faueet having a bent-down nozlo. $E$, II.

bibelot (bib'lō), n. [F.] A small objeet of euriosity, beauty, or rarity; especially, an object of this kind whieh ean be kept in a cabinet or on a shelf. See curio.

biberon (bib'rons), $n$. [F., artifieially forned, < L. bibcrc, drink, and F. suffix -on.] 1. A vessel having a spout through which to drink, designed for the use of siek persous and children.2. An infant's nursing-bottle.

Bibio (bib'i-ō), n. [NL., < LL. bibio, a small inseet said to bogenerated in wine, <L.bibere, drink.] A genus of dipterous inseets, typical of the family Bibionida. The aexes are col.
ored difterently, $B$. hor tulanus is an exnmple; the male is binek, the
female brick-red with a

Bibionidæ(bib-i-on'i-dē)

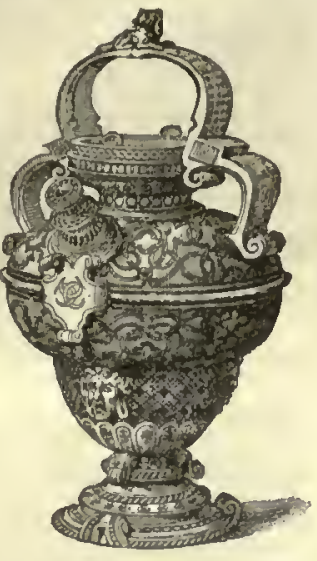
<Bibio(n-) + -ide.] A family of nemo-

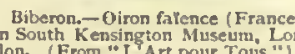

seets, typified by the genus Bibio, having the prothorax mueh developed, no transverse thoraeic suture, 7 abdominal segments, 6 to 11 antennal joints, 3 ocelli, wings without a diseal eell, and the coxe not prolonged. There are sibont 300 deseribed apeeies. The family formerly in-
cluded the genus Simulium, now separated as the type bibiru (bi-be'́rö) n. See bebccru.

bibitory (bib'i-tồ-ri), a. [<NL. bibitorius, <LL. bibitor, a drinker, toper, $\langle\mathrm{L}$. bibere, drink. ] Pertaining to drinking or tippling. [Rare.]

Bible (bi'bl), n. [< ME. bible, bibel, < OF. ble $(\mathrm{F}$. bible $=$ Pr. bibla $=\mathrm{Sp}$. Pg. biblia =1t. bibbia $=\mathrm{D}$. bijbel $=\mathrm{MHG}_{\text {, and } \mathrm{G} \text {. bibcl }=\overline{\mathrm{I}} \text { eel. }}$ biblia (usually biblia sacra) (prop. neut. pl., but in ML. taken also as fem. sing.) $<\mathrm{Gr}$.

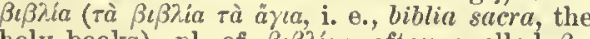
holy books), pl. of $\beta \iota \beta \lambda i o v$, ofteu spelled $\beta v$

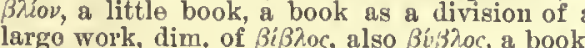
writing, seroll, lit. paper, same as $\beta \dot{v} \beta \lambda$ oc, the Egyptian papyrus, of the inner bark of whie paper was made. Cf. L. liber, a book, < liber the inner bark of a tree; E. book, < AS. bo c, book, as related to bōc, a beeeh-tree; and ef. weper. The orig. sense of IL, biblia, the book is made prominent in $\mathrm{MT}$. bibliotheca, the $\mathrm{B}$ ble, lit. a library: see bibliothect.] 1. The Book, or rather the Books (see etym.), by way
of emineneo; the Seriptures of the Old and New Testaments. The word bible is not lound in th English version, but the Greek "word occurr freguently,
being Rlways translated "book" or "books, " gonetimes dienting the books of the Old Testament. The Bible corl-
gists of two parts: the Olil Testament written lil fiebrew, sists of two parts: the Oli Testament, writtenl in liebrew
continining the Law, the Prophets, and the sacred writing

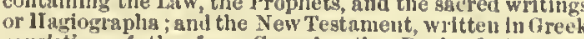
consisting of the four Gospels, the Book of Acta, thic Eipistles of Paul and other apostolie writers, and the A poc alypse or book of Revelation, the enly gatrietiy proplet

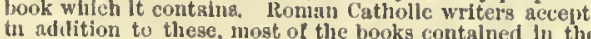
th ndclition to these, most of the books contalned in the
Apocryphat of the King Janes verslon, whlell ocenr in the

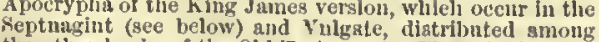
the other books of the Old Teatament. The pilncipal an. etent versioms of the Bible, or of portlons of it, are the Targums, a Chaldee or Aramaic paraplinase or hiterpret.
tion of the more aneient llebrew Seriptures: the Samat. itan Pentateuch, a dlebrew version of the first five book of the old Testament, Rancient in its eharncter, and pre-
served with fealons eare among the Samaritans; the Seplukgint, a Greek verslon of the Old Testament prepare orjueipaliy in the thind Alexandritia under the Ptolemle version of both old Testament and Now Testament, prepared by Jerome at the elose of the forrth century A. D.
and the P'cesito, a Syrisc version of the Old T'estament
543

bibliolatrous

nd the major part of the New Testament, probably preparen in the second century A. D. Trsmblations wer The first complete tranalatlon lito English wat that of Wyclif, ahont 1383; and the first printeif Enylish verslon were thiose of Tyndale and coverdale, 1524-35. Other $1 \mathrm{~m}$ portant versions are tio lupheran, in the German, by uish, Jcelandle, Dutch, mul Ftunish versiens; tlie Author ized or Kimy James, prepared ly a special eommlsslon of a pupular name given to a transation into Faglish prea pupular name givell $w$ a translation into Fiaglish lirebonay (160)-10), tho New Testament at Relms (1582); and y s conmittee of British and American protestant di vines, the New Testament appearing lin 1881 , and the old Testament In 1885. The number of minor verslons ls isible or portlons of it have been pubilshed lis upward of 225 languagca. Romsn Catholics and 1'rotestsnts liffer in the degree of antluerity whieh they attrch to the libible. Tho Roman Cnthollc Chureh "reeeives with plety ant reverence all the books of the Ohl and New Testaments, ginco onc fool is the Anthor of czeh" (Councli of Trent) writtent word of ciod over and above Seriptare" "Cath Dlet.). Protestanta generally hold thst "the suprem Jindge, by which all centroversiea of rellgion are to be de writers, and private spirlts are to be examined, and in whose sentence we are to rest, can be no other but the Ifoly spi

Hence-2. Any book or colleetion of religious writings reeoived by its adlerents as a divine revelation: as, tlic coran is the Bible of the Mohammedans the Mormon Bible. 3†. [l.c.] Any great

'lo tellen all wold passen any bible, chisurer [s. Chreveer, Prol, to Canon'a
[Yeoman'a Tale, l, 354. 4. [l. c.] A medieval military engine for throwing large stones. Grose.-Bible Christian, one of a re

igfous sect in England alled Bryanites from Bryan, \& Wesleyan local preacher, who separated

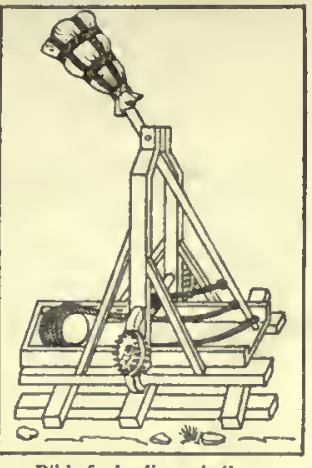

Bible for hurling missiles.
1S15. In doctriner and forms worship they do not differ wldely lrom the Arminl (whleh see). - Bible Society, an assoelation for the purBible. See Geneva Bible.-Geneva Bible, an English eral Inglish divinea who lad fled thither to eacape the perseention of the relgn of Mary. It was the first complete BIble to appear in Roman type, the first to omit the Apoeryplia, and the first to recognize the division Into verses.
Tilis tranalation was fn conmuon use in England till the version nasde by order of King James was introdueed in
1011. The Geneva Blble has slso been called the Breeches Bible, beesinse Gen. ill. 7 is translated, "Then the eyes them both were opened, and they knew that they wer tions, though the name la given especially to this one. - Ma zarin Bibie, an editlon of the Bible printed by Gintenberg movable types. It was go cslled beenuse the first known eopy of it was discovered in the Mazarin library at l'aris don press, Oxford, in 1717 , with the hesding to Luke xx. as the vineyrend."-Wleked Bible, an editjon printed in 1632 in which the word not is onitted from the seventh con

Bible-clerk (bī'bl-klèrk), $n$. 1. In Euglish universities, a student whose duty it originally was to read the Bible during meals: now often required to note absences from ehapel. -2 The holder of a eertain seholarship in Corpus Christi College, Cambridge, established in 147 . Bible-oath (bi'bl-oth), $n$. An oatli on the Bible a saered obligation.

So long as it was not a Bible-Oath, we may break it with
a cafe consclence.
Congreve, Way of the World, y.

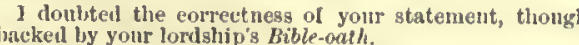

ible-press (bī'bl-pres), with thought of 'a large book bound in beavy boards,' + press.] Naut., a hand-rolling board for eartridges, and for rocket- and port-fire cases. [Eng.]

[ 1ble. In the medieval universities, the lowest ic reade of baehelor of theology. The ordinary bibnary leetures; the curgory biblic did so in extraordina conrses. See bachelor, 2.

iblical (bib'li-kal), $a_{\text {. }}$ < ML. biblicus, < LL or to the sacred writings: as, biblienl learning : biblical eritieism. -2 . In aeeord witl the teach ings of the Bible; seriptural. Heneo-3. Authoritative; true.

FIrat and last, elognenee must still ho at hottum a billi-

[Often written with a eapita], as a proper adjeetive.]

Biblical geozraphy. See geograyhy.-Biblical hermeneutics, sce hermeneulic, $=\$ y n$. Sue scriptural.
biblicality (bib-li-kal'ti-ti), $n_{0} \quad$ [< biblical + $-i t y$.$] 1. The quality of being biblieal. -2$. That which has the juality of being biblieal. [liare.]

biblically (bib'li-kall-i), adv. In a biblical manBiblicism (bib'li-sizm), [<ML, biblicus, bihlieal, $+-i s m]$.1 Adherenee to the letter of the Bible.-2. Biblical doetrine, learning, or literature. Eclectic licv.

Biblicist (bib'li-sist), n. [<ML. Viblicus, biblieal, $+-i s t$.$] 1. A professed adherent of the$ letter of tho Bible; speeifieally, in tho twelfth eentury, one who adhered to the Bible as the sole rule of faith and practiee, as opposed to a scleolastic, who professed to bring all the doc

trines of faith to the test of philosophy. -2 . biblieal seholar.

Also Biblist.

bibllochresls (bib"li-ō-krō'sis), $n$. [NL., < Gr (t) Tho use of books.

The publle librarian may aoon deserve the additional blbliognost (bib'li-og-nost), $n_{0}$ [ [ $\mathrm{F}$. biblio-

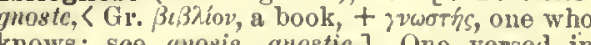
knows: see gnosis, gnostic.] One versed in
bibliography or tho history of books. I. I'Israeli, Curios. of Lit., 1V. 251.

blbliognostic (bib'li-og-nos'tik), a. [< bibliognos $t+-i c$.$] Of or pertaining to a bibliog.$ nost, or to a knowledge of bibliography.

bibllogony (bib-li-og'ō-ni), $n$. [< Gr. $\beta \iota \beta \lambda$ iov, book, + -yovia, produetion: see-gomy. $]$ The produetion of books. Southey.

ypápos: see bibliographer.] Same as bibliographer.

A thorough llbrarian must be 8 comblnation of the trio,

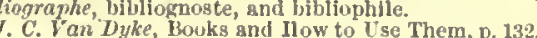

bibliographer (bib-li-og'ra-fẻr), $n$, $<\mathrm{Gr}$.

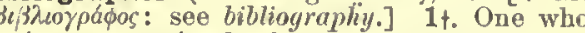
writes or eopies books. -2 . One who writes about books, espeeially in regard to their authorship, date, typography, editions, etc.; one skillod in bibliography.

bibliographic, bibliographical (bib"li-ō-graf' , -i-kal), a. [As bibliography +-ic,-ical.] Pertaining to bibliography.

bibliographically (bib"li-ō-graf'i-kal-i), adv. In a bibliographieal manner.
bibliography (bib-li-og'ra-fi), n. [

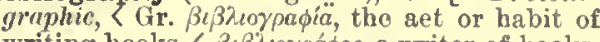

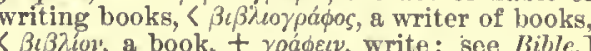
1†. The writing of books. -2 . The seienee whieh treats of books, their materials, authors, typography, editions, dates, subjeets, elassifieaion, history, ote.

Bibliography. . being the knowledge of books, which
now la not confined to ant "erluition of title-pages," but now la not confined to an "eriulitien of titie-pages," but J. C. Vain Dyke, Boeks suli tow to Lse Them, 3. A elassified list of authorities $0 r^{\circ}$ books on any theme: as, the bibliography of politieal biblioklept (bib'li-ō-klept), n. $\quad[<\mathrm{Gr} . \beta \iota \beta i$ iov, book, $+\kappa \lambda \varepsilon \pi \tau \eta s$, a thief.] A book-thief; one who purloins or steals books. [Rare.]

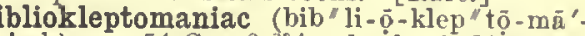

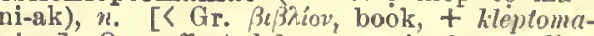
niac.] One affeeted by a mania for stealing books. [Rare.] bibliolater (bib-li-ol'A-te̊r), n. [See bibliolatry; ays undue.] 1. A book-worshiper; one who One who regard to books. Speeifically -2 . of the Bible with undue or extra vagant respeet; a worshiper of the Bible. Dc Quincey.

The mistaken zeat ot btbliblate Inuxley, Lay Sermons, p. 27S.

bibliolatrist (bib-li-ol'a-trist), $n . \quad[<$ bibliolatry + -ist.] Same as bibliolater.

bibliolatrous (bib-li-ol'a-trus), $a$. [< bibliolnliolatry. 


\section{bibliolatry}

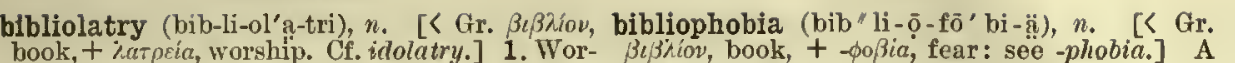

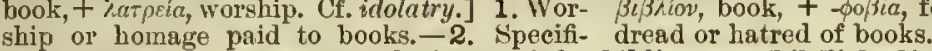

eally, excessive reverence for the letter of the bibliopoesy (bib"li-ōo-pō'e-zi), $n$. [<Gr. $\beta \iota \beta \lambda i_{0} v$, Bible.

It was on account of this exclusive reference to Scripthiration of the holy writinurs than the theolos on the ithClutrch of Rome; and that the Protestants were acense

Sir $G . \dot{C}$. . Lecris, Authority in Matters of Opinion, v. bibliolite (bib'li-ō-līt), $\pi$. [< Gr. $\beta \iota \beta \lambda i o v$, book, +20 s, stone.] A name sometimes given to certain laminated

bibliological (bib"li-ō-loj'i-kal) a [< bibliot ouy $+-i c-a l$.$] Relating to bibliology.$ bibliologist (bib-li-ol'o-j-jist), $n$. [

$-i s t$.$] One versed in bibliology.$

After so much eareful investigation by the most em Southey, The Doctor, Interchapter xvili.

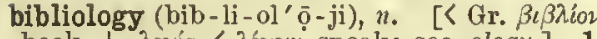

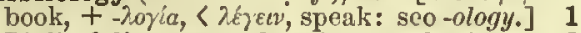
Biblical literature, doctrine, or theology._A treatise on books: bibliography.

bibliomancy (bib'li-o-man-si), $n$. [< Gr. $\beta \iota \beta \lambda i o v$ bibliomancy (bib'li-ō-man-si), $n$. [<Gr. $\beta \iota \beta \lambda i o v$,
book, $+\mu a v \varepsilon^{\prime} a$, divination.] A kind of divi nation performed by means of a book; specifically, divination by means of the Bible, consisting in selecting passages of Seripture at concerning the future.

Another kind of bibliamancy ... consisted in appeal ing to the very first words heard from any one when readbibliomane (bib'li-ō-mān), $n$. Same as biblio

bibliomania (bib"li-ō-mā'ni-ẩ), n. [NL. (> F.

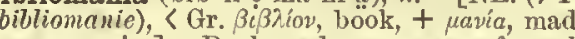
ness, mania.] Book-madness; a rage for col lecting and possessing books, especially rare and curious ones. Also bibliomany.

bibliomaniac (bib"li-ō-mā'ni-ak), $n$. and $\alpha$. [< bibliomania, after maniac.] I. $n$. One affected with bibliomania.

I found, in the owner of a choice collection of books,
well-bred gentleman and a most hearty bibliongnact Dibdin, Bibliographical 'Tour 1.

II. $a$. Affected by or pertaining to bibliomania ; book-mad.

Also bibliomanian.

bibliomaniacal (bib/1i-ō-mā-nī'a-kal), $a_{\text {a }}[<$ ing to bibliomania or bibliomaniacs.

bibliomanian (bib"li-ō-mā'ni-ạn), $n$. and $a$. [ bibliomania + -an.] Same as bibliomaniac. [Rare.]

bíbliomanianism (bib"li-ō-mā'ni-ann-izm), n. [< bibliomanian $+-i s m$.$] Book-madness; biblio-$
mania. [Rare.]

bibliomanist (bib-li-om'a-nist), $u$. [As bibliomany + -ist.] A bibliomäniac.

Not bibliomanist enough to like black-letter.
Lannb, Letter to Ains worth. bibliomany (bib-li-om'a-ni), n. [< F. biblio Same as bibliomania. Imp. Dict. bibliopegic (bib"li-ō-pej'ik), $\iota_{0}$ [ [< bibliopegy +
$-i c$.$] Of or pertaining to bookbinding. [Rare.]$

A magnificent specimen of bibliopegic art.

bibliopegist (bib-li-op'e-jist), n. [< bibliopeg + -ist.] A bookbinder. [Rare.]

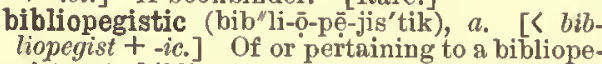
gist or to bibliopegy: as, bibliopegistic skill. bíbliopegy (bib-li-op'e-ji), n. [< Gr. $\beta \iota \beta \lambda i o v$ book, $+-\pi \eta \gamma i a,<\pi \eta v i v a l$, fasten, fix, bind: see
pact.] The art of binding books. [Rare.] During the 16 th and 17 th centuries blndings were pro-
duced in England which suffer no disgrace by comparison with contemporary masterpieces of French, Italian, and
German bibliopegy.
Encye. Brit., IV, 42 bibliophile (bib'li-ō-fil), n. [< F. bibliophile,

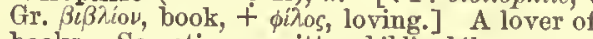
books. Sometimes written bibliophil.

bibliophilic (bib"li-ō-fil'ik), a. [ [ bibliophile + -ic. ] Of or pertaining to a bibliophile or book-

A bibliophilic curiosity is a copy of the first American
play, "The Contrast," from the library of George Washing. bibliophilism (bib-li-of'i-lizm), $n$. [< biblio plite $+-i s m$.] Love of books.

bibliophilist (bib-li-of'i-list), n. [< bibliophite $+-i s t$. $]$ A lover of books; a bibliophile.

bibliophily (bib-li-of'i-li), n. [= F. bibliophi-

lie; as bibliophile $+-y \cdot]$ Love of books. liotheca $=\mathrm{Sp}$. It. bibliotce $a=\mathrm{G}$. Dan. bibliothek,

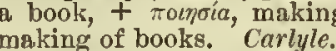

bibliopolar (bib-li-ō-pō'lịir), a. [< bibliopole + -ar.] Bibliopolic. [Rare.]

bibliopole (bib'li-ō-pōl), $n$. [< L. bibliopola, Gr. $\beta \iota \beta \lambda \iota \pi \omega \lambda \eta \eta$, a bookseller, $<\beta \iota \beta \lambda i o v$, book, a dealer in rare and curions books.

bibliopolic, bibliopolical (bib" li-ô-pol'ik, -i-kal), a. [( bibliopolc + -ic, -ical.] Relating to bookselling or booksellers.

bibliopolically (bib"li-ō-pol

bibliopolism (bib-li-op'ố-lizm), n. [<bibliopole $+-i s m$.$] Bookselling; the$

bibliopolist (bib-li-op'ó-list), n. [< bibliopole $+-i s t_{\text {. }}$ A bookseller; a bibliopole.

If civility, quickness, and intelligence be the chlef requiites of a bibliopolist, the young frere stands not in nced of parental aid for the prosperity of his lusiness.
Dibdin, Bibliographical Tour, i. 149. bibliopolistic (bib-li-op-ō-lis'tik), $a$. [< bibliopolist $+-i c$.$] Relating to a bookseller or to$ bookselling. [Rare.]

bookselling. [Rare.]
bibliotaph (bib'li-ō-taf), n. [<F. bibliotaplee,

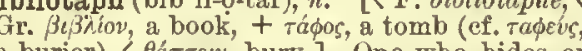
a burier), $\langle\theta a \pi \tau \varepsilon l \nu$, bury.] One who hides o buries books, or keeps them under lock and key.

A bibliotaphe buries his books by keeping them under lock, or framing them in glass eases. bibliotaphist + (bib-li-ot'a-fist), u. [As bibliotaph + -ist.] A bibliotaph. Crabbc.

bibliotbec (bib'li-ō-thek), $n$. [<L. bibliotheca : see bibliotheke, bibliotheca.] A library.

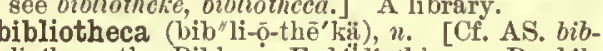
liothece, the Bible; $=\mathrm{F}$. bibliothicque $=\mathrm{Pg}$. bib a library, < L. bibliotheca, a library, colleetion of books, in LL. and MI. esp. the Bible, < Gr. $\beta \iota \beta \lambda \iota 0 \theta \hat{n} \kappa \eta$, a library, a bookease, $\left\langle\beta \iota \beta \lambda i i^{\prime} \nu\right.$, book, sce Bible and theca.] 1 . A library; a place to keep books; a collection of books.

Cairo was once celebrated for its magnificent collection of books. Besletes private libraries, each large mosque
lad its bibliotheca.
R. $F$. Burton, El-Medinah, p. 79 .

\section{2t. The Bible.}

From the circumstance of the Bible filling many rolls it
acquired such titles as pandectes and bibliotheca, the lat acquired such titles as pandectes and bibliotheca, the lat.
ter of which remained in use down to the 14th century.

It is a bibliotheca, or a copy of the Bible of the Jarge folio size, and now bound up into several large volumes. bibliothecal (bib"li-ō-the $\left.\bar{e}^{\prime} k a 1\right), a . \quad$ [< L. bibliothecalis, <bibliotheca! seo bibliotheca.] Belong-

bibliothecarian

bibliothecarian (bib "li-ō-thệ-ka'tri-an), a.

bibliothccary + -an. $]$ of or pertaining to a bibliotheeary or librarian.

We confess a bibliothecarion avarice that gives all books
a value in our eyes.
Lowell, study Windows, p. 292.

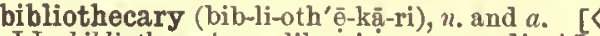
LL. bibliothecarius, a librarian, prop. adj., $<$ L. bibliotheca: see bibliotheca, and ef. apothecary.] I. $n$. 1. A librarid

II. $a$. Of or pertaining to a library or libra-

bibliothekeł (bib'li-ō-thēk), n. [Also written bibliotheh, -thec, theque, < F. bibliotheque, < L. bibliotheca: see bibliotheca.] A place for books. The king asked him how many thousand volumes he Biblist (bib'list), $n . \quad[=\mathrm{F}$. bibliste, < ML. bib lista: see Bible and -ist.] Same as Biblicist. biblus (bib'lus), n. [L. $<$ Gr. $\beta i \beta \lambda_{05}$, also $\beta$ v́

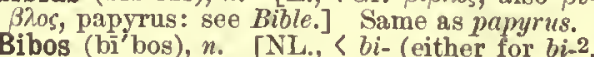
twice, here in sense of secondary, or short for bison) $+B o s$, q. v.] A genus or subgenus of bovine ruminants, of the family Botides and subfamily Bovine, with prominent front and depressed horns directed outward. It contains the Indian gayal or gaur and the banteng or Sondaic ox. See cut under gayal.

bibracteate (bī-brak'tē-āt), a. $\quad[<b i-2+b r a c$ tcate.] In bot., having two bracts.

bibracteolate (bī-brak'tẹ--ō-lāt), a. $\quad[<b i-2+$ bracteolate.] In bot, having two bractlets.

bibulose (bib'ū-lōs), $a$. Same as bibulous, 1 .

bibulous (bib'tìs), a. [< L. bibulus, < bibere, bice (bis), n. [Also written bise, < MEE. bise, absorbing or imbibing fluids or moisture; absorbent; spongy.

The soul that ascends to worship the great forl is plain ulous of the sea of light. Emerzon, Essays, 1st ser., p. 264 . The carbon is replaced by bibulous paper. ized by -3. Relating to drink or drinking: as, bibulous lore. [Rare.]

bulously (bib' $\bar{u}-1 u s-l i), a d v$. In a bibulous bicalcarate (bī-kal'ka-rāt), a. [<bi-2 + calcarate.] Armed with or having two spurs, as the limbs of some animals and the anthers of some plants.

bícallose (bī-kal'ōs), a. [<bi-2+callose. $]$ In bot., having two eallosities or hard protuberbicallous (bī-kal'us), a. Same as bicallose. bicameral (bī-kam'e-ral), a. $\quad[<b i-2+$ L. camera, a chamber: see camera.] Two-ehambered; pertaining to or consisting of two cham bers: as, a bicanicral legislature.

An increase of the number of IIouses beyond two gives Sir E. Creasy, Eng. Const., p. 179.

bicamerist (bi-kam'e-rist), n. [As bicamer-al $+-i s t$.$] One who advocates the bicameral$ system of legislation.

Not only as to the mode in which their senate is to be Cont fanlt.

bicapitate (bī-kap'i-tāt), a. $[<b i-2+$ eapitatc. $]$ Having two heads; two-headed.

bicapitated (bī-kap'i-tā-ted), a. Furnished with two lieads.

icapsular (bī-kap'sū-lar), a. $\quad[<b i-2+c a p-$ ular.] In bot., having two eapsules.

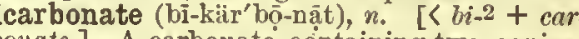
lents of carbonic acid to one of a base; one of the superearbonates.

bicarbureted, bicarburetted (bī-kär'bū-ret-ed), a. [ $b i-2+$ carbureted, carburettcd.] Combined with or containing two atoms of carbon: as, bicarbureted hydrogen, $\mathrm{C}_{2} \mathrm{H}_{4}$.

bicarinate (bi-kar'i-nāt), $a$. [< bi-2 + carimate. $]$ 1. In bot. and zoöl., two-keeled; doubly carinate; having two keel-like projections, as the upper palea of grasses. - 2. In enlom., having two earina or sharp longitudinal raised lines. pellary.] In bot., formed of two carpels or seed-vessels, whether distinet or united; dicarpellary (the more common word).

bicaudal (bī-kấdal), $a$. [<bi=2 + caudal. Cf. LL. bicodulus, having two tails.] Double-tailed terminating in two tails or prolonged extremi-

bicaudate (bī-kấdāt), $a$ : [< bi-2 + caudate.] In cntom., having two circi or jointed appendages at the end of the abdomen, or two tail like posterior processes, as the posterior wings of some insects.

bicavitary (bī-kav'i-tā-ri), a. $[<b i-2+c a v-$ ity + -ary.] Consisting of or possessing two bicchedt, a. [ME., also written bicchid, byched, becched, bicche, a word of uncertain meaning applied to the basilisk, to a body, to dice, and ater to the conseience, a burden, etc., in a vaguely opprobrious sense, appar. 'cursed,' and hence taken by some to be a contraction of ME biwicched, bewitched; but bixicched is not found in such a sense, and the contraction is improbable. Prob. at first bicche, being, in this view, an attrib. use (and hence soon with added pp. adj. formative $-e l^{2}$ : both readings occur in different MSS. in the first instance quoted) of bicche, a bitch, used opprobriously. Cf. shrexd, earlier shreiced, in sense of 'cursed, 'curst' similarly formed (but supported by a verb) from the earlier attrib. shrcue: see shrew. In the alliterative phrase bicched boncs, dice, the word has evidently the same sense (the 'cursed bones') there is no connection with $\mathrm{D}$. bikkcl $=\mathrm{G}$ bickel, astragalus, ankle, ankle-bone, a die.] Cursed: an opprobrious word of uncertain meaning.

This fruyt cometh of the bicched bones two

Chaucer, Pardoner's Tale, 1. 194.

bys, bis, < OF. (and F.) bis, fem. bise, brown, 

PLEASE DO NOT REMOVE CARDS OR SLIPS FROM THIS POCKET UNIVERSITY OF TORONTO LIBRARY 


\section{ABBREVIATIONS}

\section{USED IN THE ETYMOLOGIES AND DEFINITIONS.}

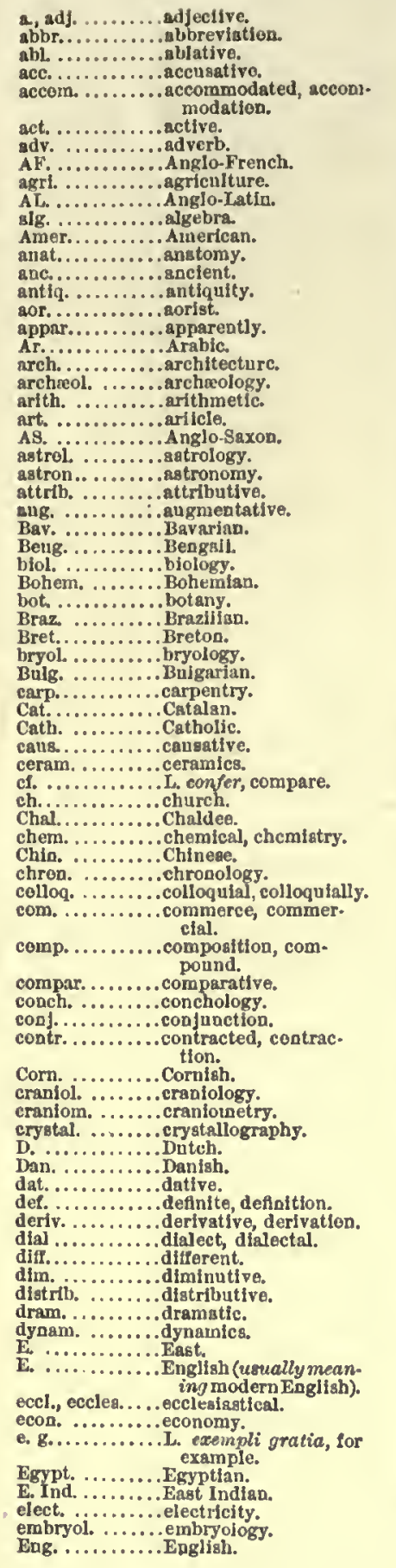

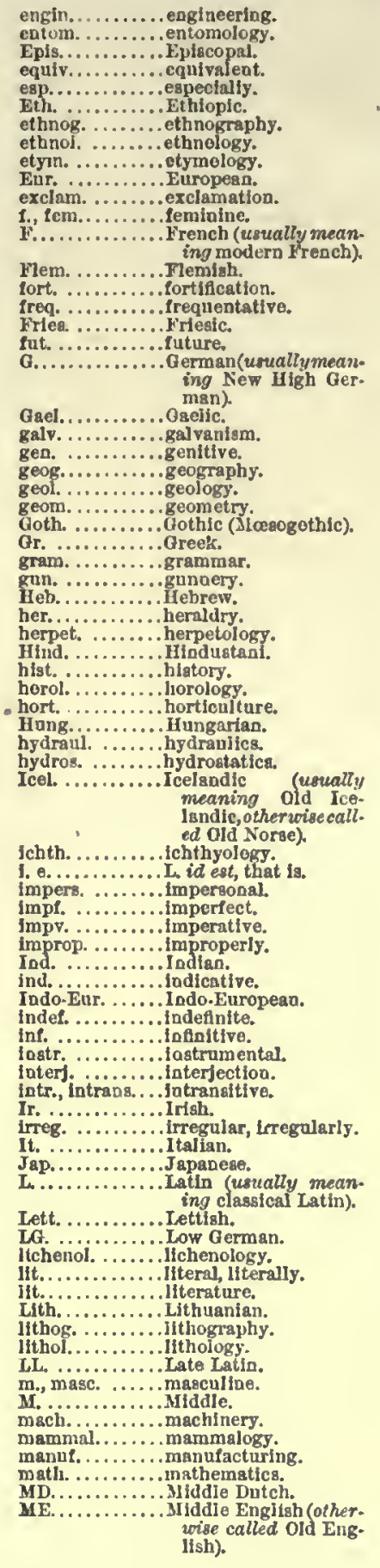

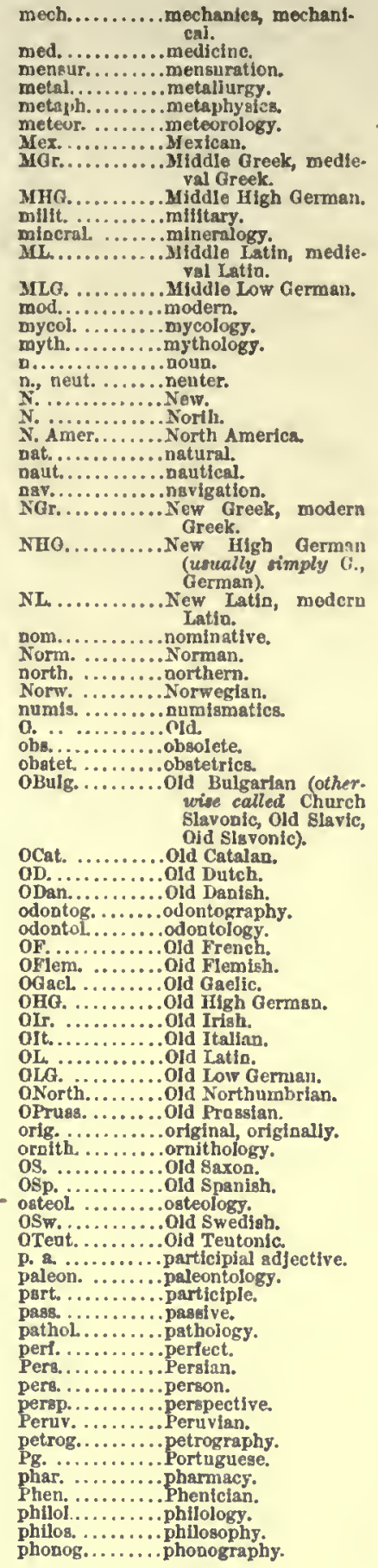

\section{KEY TO PRONUNCIATION.}

\author{
a as in fat, man, pang. \\ as in far, father, guard. \\ as in tali, talk, naught \\ gs in ask, tast, ant. \\ as in met, pen, bleas. \\ as in her, fern, heard. \\ as in pin, it, blscult. \\ as in not, on, trog. \\ as in note, poke, loor. \\ as in move, spoon, room \\ as in nor, aong, oft. \\ as mute, acute, few (alos new,
tabe, duty: aee Preface, pp. \\ ù as in pull, book, could.
}

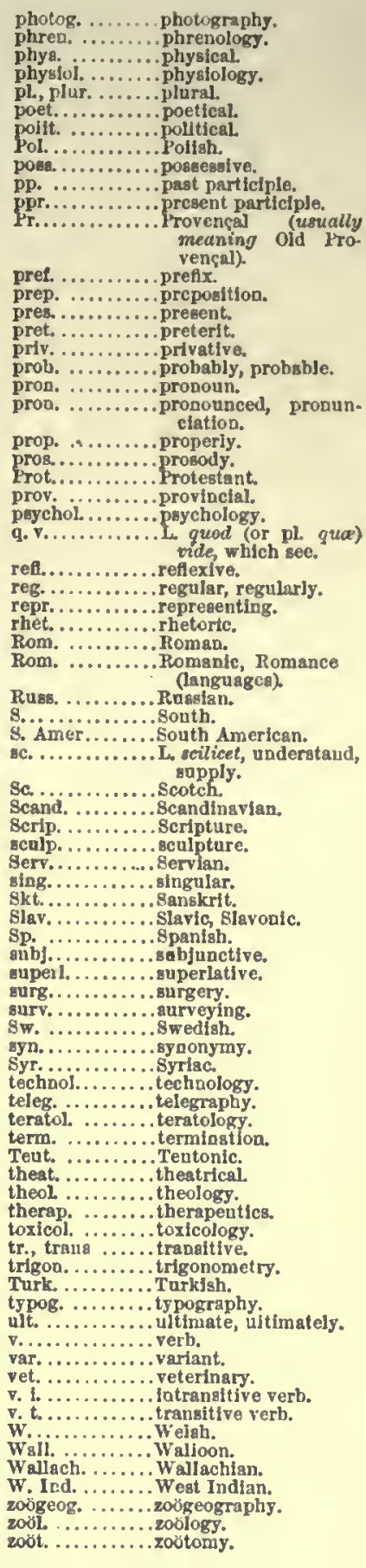

ii German it, French u.

of as in ofl, foint, boy.
on as in pound, proud, now.

A aingle dot under a rowel in an unaccented syllable fndicates it abbreviation and lightening, without absolute loas of
its diatinctire quality. See Preface, p. af.

a as in prelate, conrage, captaln.

as in ablegate, eplacopal.

$\bar{Q}$ sa in abrogate, eulogy, dem

A donhle dot nnder a vowel in an unac. cented syliable indicatea that, even in the mouths of the best speakera, its sound is varisble to, and in ordinary utterance ac. tually becomes, the short $u$-sound (ot but,
pun, etc.). See Preface, p. xl. Thua:
A as ia errant, republican.

e as in prudent, differeace.

o as in valor, actor, tdiot.

as in Persia, peolosula

as in nature, feature.

A mark ( ) under the consonanata $t, d$ $s, z$ fodicates that they In ilke manae

t. as in nature, adventure.

as in letsure.

th as in thin.

TH as in then.

ch ag in German ach, Scotch loch.
t Freach aasalizing $\mathrm{n}$, as in ton, en. 1y (in French words) Freach Itquid (monnie) 'denotea a primary, " a secondary accent. (A secondary accent is not marked if at it regular interval of two ayllablea from the
primary, or from another aecondary.)

SIGNS.

s read from; 1. e., derived from.

read whence; i. e., trom which is derived. + read and; $L$ e., compounded with, or

$=$ read cognate with; L e., etymologically $\checkmark$ read root. with

read theoretical or alleged ; $L$, theorets. cally sssumed, or asserted but anver$\uparrow$ road obsoletc. 


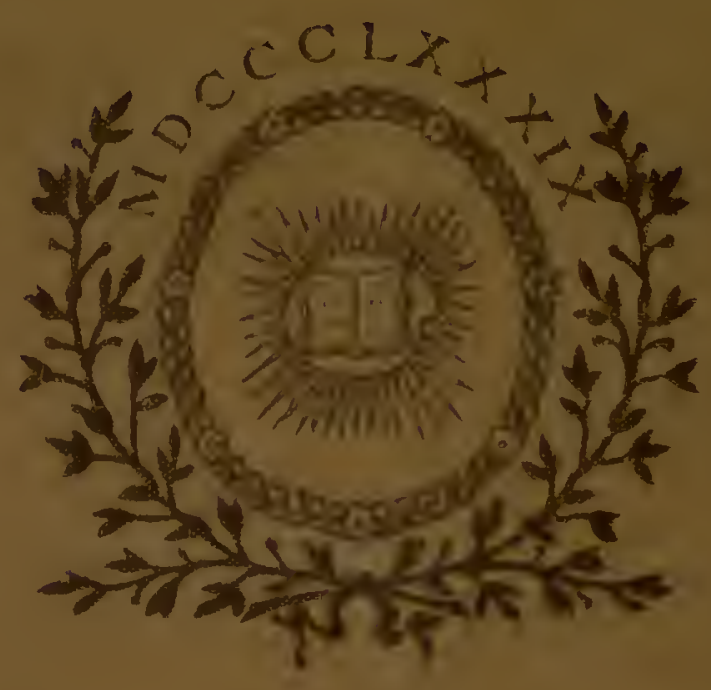

$\infty$ 